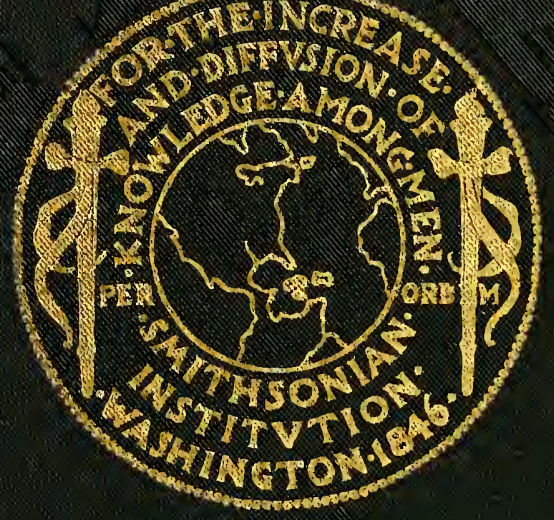


Digitized by the Internet Archive in 2010 with funding from Boston Library Consortium Member Libraries 
SMITIASONIAN INSTITUTION.

UNITED STATES NATIONAL MUSEUM:

\section{BULLETIN}

OF THE

\section{UNITED STATES NATIONAL MUSEUM.}

\section{No. 50.}

\section{PART V.}

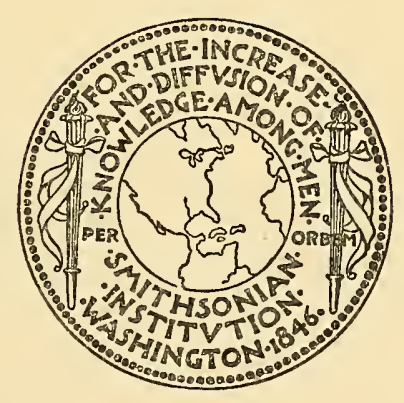

WASHINGTON:

GOVIRNMENT PRINTING OFIICE. 


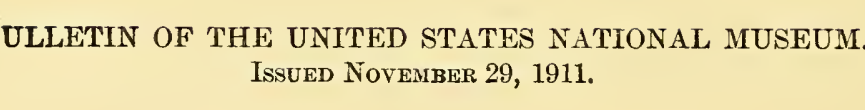




\section{THE BIRDS}

oF

\section{NORTH AND MIDDLE AMERICA:}

A DESCRIPTIVE CATALOGUE

OF THE

HIGHER GROUPS, GENERA, SPECIES, AND SUBSPECIES OF BIRDS KNOWN TO OCCUR IN NORTH AMERICA, FROM THE

ARCTIC LANDS TO THE ISTHMUS OF PANAMA, THE WEST INDIES AND OTHER ISLANDS OF THE CARIBBEAN SEA, AND THE GALAPAGOS ARCHIPELAGO.

BY

\section{ROBERT FIDGWAY,}

CURATOR, DIVISION OF BIRDS.

\section{PART V.}

Family PTEROPTOCHID E-The Tapaculos. Family DENDROCOLAPTID E-The Woodhewers. Family FORMICARIID E-The Antbirds. Tamily TROCHILID \&-The Humming Birds.

Family FURNARIID \& - The 0venbirds. Family MICROPODID E-The Swifts.

Family TROGONID E-The Trogons.

WASHINGTON:

GOVERNMENT PRINTING OFFICE. 
WIHORAWIS IPOM

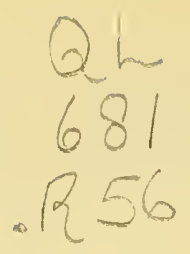

ANT.S. LIBRARY

pt. 5

O'NEILL LIBRARYY

BOSTON COLLEGE

\& 131994 


\section{PREFACE.}

Circumstances have retarded the completion of the present volume, chief among which were interruption by field work (including a second visit to Costa Rica), occasional periods of illness, and the specially difficult character of some of the included groups; furthermore, one large family (the Woodpeckers, Picidæ) was worked up and even set in type, but was finally omitted because its inclusion would increase the bulk of the volume far beyond a convenient size. It will, therefore, be included in Part VI.

The Families included in this and preceding volumes are as follows:

Part I, issued October 24, 1901, included the Family Fringillidæ (Finches) alone.

Part II, issued October 16, 1902, included the Families Tanagridæ (Tanagers), Icteridæ (Troupials), Cœrebidæ (Honey Creepers), and Mniotiltidæ (Wood Warblers).

Part III, published December 31, 1904, included the Motacillidæ (Wagtails and Pipits), Hirundinidæ (Swallows), Ampelidæ (Waxwings), Ptilogonatidæ (Silky Flycatchers), Dulidæ (Palm Chats), Vireonidæ (Vireos), Laniidæ (Shrikes), Corvidæ (Crows and Jays), Paridæ (Titmice), Sittidæ (Nuthatches), Certhiidæ (Creepers), Troglodytidæ (Wrens), Cinclidæ (Dippers), Chamæidæ (Wren-Tits), and Sylviidæ (Warblers).

Part IV, issued July 1, 1907, contained the remaining groups of Oscines, namely, the Families Turdidæ (Thrushes), Zeledoniidæ (Wren-Thrushes), Mimidæ (Mockingbirds), Sturnidæ (Starlings), Ploceidæ (Weaver Birds), and Alaudidæ (Larks), together with the Haploophonæ or Oligomyodian Mesomyodi, comprising the Families Oxyruncidæ (Sharp-bills), Tyrannidæ (Tyrant Flycatchers), Pipridæ (Manakins), and Cotingidæ (Chatterers).

The present volume contains the Tracheophone Mesomyodi, represented by the Families Pteroptochidæ (Tapaculos), Formicariidæ (Antbirds), Furnariidæ (Ovenbirds), and Dendrocolaptidæ (Woodhewers), together with the Macrochires, containing the Families Trochilidæ (Humming Birds) and Micropodidæ (Swifts), and the Heterodactylæ, represented only by the Family Trogonidæ (Trogons).

The number of species and subspecies described in the five volumes is 2,038 , with 351 additional extralimital forms characterized in the "keys." About 1,150 to 1,200 forms remain to be treated in subsequent parts of the work.

Acknowledgments for the loan of specimens for use in the preparation of the present volume are due to the same individuals and public 
institutions as have already been named in previous volumes; also to Mr. C. H. Lankester, of Cachí, Costa Rica, who kindly placed the Tracheophones of his fine collection of Costa Rican birds at the author's service.

To Señor Don José C. Zeledón, of San José, Costa Rica, the author is specially indebted for most generous help, at considerable expense to himself, in making a very fine collection of the birds of that country, which proved of incalculable value in the preparation of this work.

Dr. C. W. Richmond, Assistant Curator, and Mr. J. H. Riley, Aid, of the Division of Birds, U.S. National Museum, have rendered invaluable assistance; Dr. Richmond through his special knowledge of ornithological bibliography and his extremely useful and very complete card catalogue of generic and specific names, made at "first hand," or directly from the publication in which each name was first published, as well as by carefully scanning the proof sheets with particular reference to correctness of citations in the synonymy; $\mathrm{Mr}$. Riley, by copying references from various publications, but especially through having performed the tedious task of measuring several thousands of specimens. ${ }^{1}$

There has been some eriticism of the present work on the ground that certain books, local lists, and other publications have not been cited in the synonymies. The omission of these is very much regretted by the author, who in explanation, if not justification, would state that it has been quite impossible for him to cover the whole field; that the literature of ornithology is so vast, and increasing so rapidly, that to bring the bibliography and synonymy of all the species up to date and keep it so would require all the time that any one individual could possibly give to it; and that since much the greater part of this labor (which has justly been termed "the drudgery of ornithology") has been done by the author himself, very largely in his own time (which means during hours which should have been

\footnotetext{
1 The number of specimens examined during the preparation of this volume is as follows:

Collection of the U. S. National Museum....................... 4,846

Collection of the Biological Survey .......................... 1,118

Collection of the American Museum of Natural History .............. 2, 255

Collection of the Carnegie Museum.......................... 1, 358

Collection of the Field Museum of Natural History.................. 478

Collection of the $\Lambda$ carlemy of Natural Sciences, Philadelphia........... $\quad 170$

Collection of the Boston Society of Natural History . . . . . . . . . . . . . . 6

Collection of the Museum of Comparative Zoology ................ 2, 097

Collection of the Museo Nacionál, Costa Rica.................... 66

Collection of the Museum of Vertebrate Zoology, University of California.... 4

Collection of $A$. E. and O. Bangs, Boston................... 1,877

Collection of C. II. Lankester, Cachí, Costa Rica.................. 83
} 
given to rest or recreation), he hopes that critics may be lenient as to this shortcoming of the work.

A matter which has called forth wholly unexpected criticism is the necessarily irregular manner in which brief descriptions of nests and eggs are interspersed through the pages of this work. That the purpose of these "vague and scattered descriptions" might be misunderstood by anyone was a possibility which did not occur to the author; on the contrary, their intent seemed so self-evident that explanation was not thought of. Since, however, one writer does not "see how they can be of much use to the student of oölogy," and inquires why, "if considered of value--were they not given uniformly throughout the work," it may be stated here that these brief descriptions are given only (or at least mainly) in cases where some particular style of nest or coloration of eggs is characteristic of a group (family or genus), as a sort of accessory or supplemental group character, ${ }^{1}$ and that the numerous instances of their omission result either from the absence of anything specially characteristic or distinctive or else (as is often the case among the tropical forms) from lack of information on the subject.

Placing the accent marks to names of localities in Mexico and other parts of Spanish America may possibly be criticized on the ground of inexpediency or that of irregularity in following the rules governing such cases; but the author has been led to do so by the apparent natural tendency of English-speaking people to sadly mispronounce such names, even when spelled precisely the same in Spanish and English; for example: Bogotá (Bo-go-tah'), Davíd (Dah-veed'), Ecuadór (Ek-wah-dōr' ${ }^{\prime}$ ), Salvadór (Sal-vah-dōrón'), Generál (Hen-erahl'), and Trinidád (Tre-ne-dad'), which in English (at least commonly) are pronounced Bo-gó-tah, Dā'-vid, Ek'-wa-dor, Sal'-va-dor, Gén-er-al and Trín-i-dad, respectively. There are, of course, definite rules of accentuation in the Spanish language, but these are unknown to most Americans and other English-speaking people, and therefore the accent is frequently given where the rules do not require it. In a majority of cases, where the accent mark does not appear the accent is normal, that is, the emphasis falls on the penultimate syllable. ${ }^{2}$ Other cases where the accent is omitted are those words in which the Spanish accent agrees with the prevalent English one; as Nicaragua, Venzeuela, Yucatan, etc. In one case (that of Santa Fé) general usage is followed, although the accent mark is, of course, wholly superfluous in a word of only one syllable.

JULY 26, 1911.

Robert Ridgway.

${ }^{1}$ For example, see genera Petrochelidon, Dulus, Psaltriparus, and Regulus, and family Vireonidæ, pages 45, 126, 424, 698, and 129, in Part III.

${ }^{2}$ It should be remembered that each vowel represents a distinct syllable in every Spanish word; "pié" is not $p y$, for instance, but pe-ä". 



\section{TABLE OF CONTENTS.}

SupERTaurLY

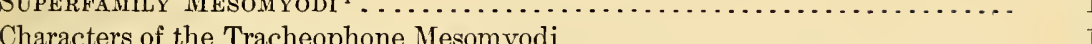

Key to the Families of Tracheophonæ. . . . . . . . . . . . . . . . . . . . 3

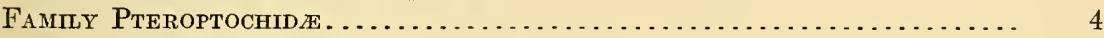

Genus 1. Scytalopus Gould .................................. 5

1. Scytalopus argentifrons Ridgway ......................... 6

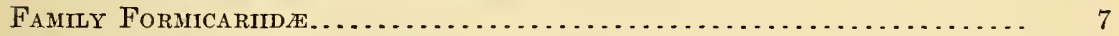

Key to the Genera of Formicariidæ. . . . . . . . . . . . . . . . . . . . . 10

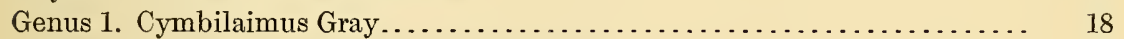

1. Cymbilaimus lineatus fasciatus Ridgway . . . . . . . . . . . . . . . 19

Genus 2. Thamnistes Sclater and Salvin......................... 21

2. Thamnistes anabatinus anabatinus Sclater and Salvin.......... 22

3. Thamnistes anabatinus saturatus Ridgway ................ 23

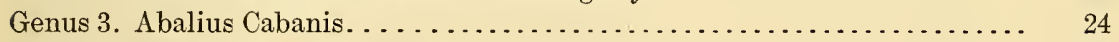

4. Abalius bridgesi (Sclater) . . . . . . . . . . . . . . . . . . . . . 25

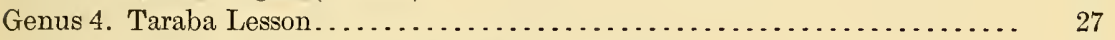

5. Taraba transandeana transandeana (Sclater) .................. 28

Genus 5. Hypolophus Cabanis and Heine..................... 32

6. Hypolophus canadensis pulchellus (Cabanis and Heine) . . . . . . . 33

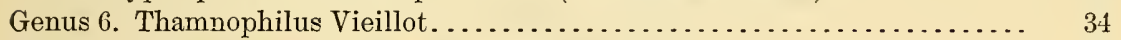

Key to the Species and Subspecies of Thamnophilus. . . . . . . . . . . . 35

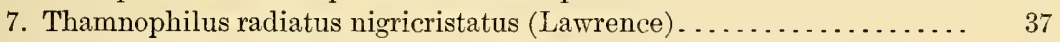

8. Thamnophilus doliatus mexicanus Allen................... 40

9. Thamnophilus doliatus pacificus Ridgway ................. 43

10. Thamnophilus doliatus yucatanensis Ridgway............... 44

11. Thamnophilus multistriatus Lafresnaye.................. 45

12. Thamnophilus virgatus virgatus Lawrence . . . . . . . . . . . . . 46

Genus 7. Erionotus Cabanis and Heine.......................... 47

Key to the Subspecies of Erionotus punctatus .................... 49

13. Erionotus punctatus atrinucha (Salvin and Godman)........... 49

14. Erionotus punctatus gorgonæ (Thayer and Bangs) ............. 52

Genus 8. Dysithamnus Cabanis............................... 52

Key to the Species and Subspecies of Dysithamnus................. 54

15. Dysithamnus mentalis septentrionalis Ridgway............. 55

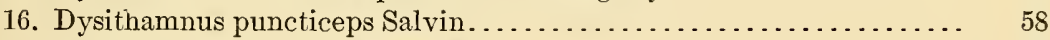

17. Dysithamnus striaticeps Lawrence. . . . . . . . . . . . . . . . 59

Genus 9. Myrmotherula Sclater.............................. 60

Key to the Species of Myrmotherula ............................ 62

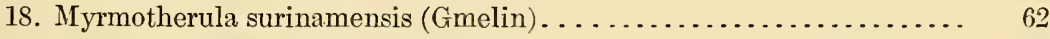

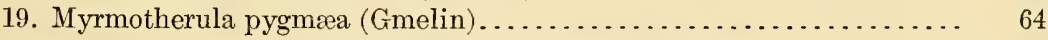


Genus 10. Myrmopagis Ridgway . . . . . . . . . . . . . . . . . . . . . 65

Key to the Species and Subspecies of Myrmopagis. . . . . . . . . . . . . . 67

20. Mr yrmopagis melæna (Sclater) . . . . . . . . . . . . . . . . . . . . . 68

21. Myrmopagis schisticolor (Lawrence) . . . . . . . . . . . . . . . . . . . 70

22. Myrmopagis fulviventris (Lawrence) ...................... 73

Genus 11. Microrhopias Sclater . . . . . . . . . . . . . . . . . . . . . . . . . 75

Key to the Species and Subspecies of Microrhopias................... $\quad 76$

23. Microrhopias boucardi boucardi (Sclater) ................... Ts

24. Microrhopias boucardi virgata (Lawrence)....................... 79

25. Microrhopias boucardi consobrina (Sclater) .................. 80

26. Microrhopias grisea alticincta (Bangs).................... 81

Genus 12. Terenura Cabanis and Heine......................... 83

27. Terenura callinota (Sclater) .......................... 84

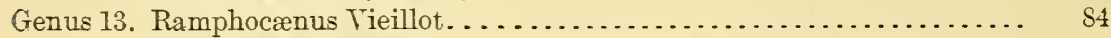

28. Ramphocænus rufiventris rufiventris (Bonaparte) .............. 85

Genus 14. Microbates Sclater and Salvin......................... $8 \delta$

29. Microbates cervineiventris semitorquatus (Lamrence) . . . . . . . . . $\$ 9$

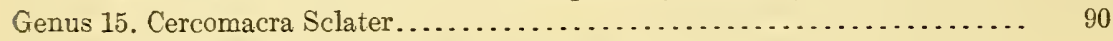

Key to the Species and Subspecies of Cercomacra. . . . . . . . . . . . . . . . . . 91

30. Cercomacra nigricans Sclater............................. 91

31. Cercomacra tyrannina tyrannina (Sclater) .................... 93

32. Cercomacra tyrannina crepera (Bangs) . . . . . . . . . . . . . . . . 95

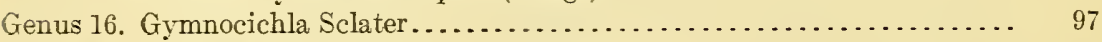

Key to the Species and Subspecies of Gymnocichla... . . . . . . . . . . . . . . . . 98

33. Gymnocichla nudiceps nudiceps (Cassin) . . . . . . . . . . . . . . . . . 99

34. Gymnocichla nudiceps erratilis Bangs. . . . . . . . . . . . . . . . . . . 101

35. Gymnocichla chiroleuca Sclater and Salvin. . . . . . . . . . . . . . . 101

Genus 17. Myrmeciza Gray . . . . . . . . . . . . . . . . . . . . . . . . . 103

Key to the Species and Subspecies of Myrmeciza . . . . . . . . . . . . . . . 105

36. Myrmeciza boucardi panamensis Ridgway . . . . . . . . . . . . . . . . . 107

37. Mrrmeciza læmosticta Salvin. . . . . . . . . . . . . . . . . . . . . . 109

38. Mirmeciza cassini (Ridgway) . . . . . . . . . . . . . . . . . . . . . . . 110

39. Myrmeciza exsul exsul Sclater. . . . . . . . . . . . . . . . . . . . . . 111

40. Myrmeciza exsul occidentalis (Cherrie) . . . . . . . . . . . . . . . . 113

41. Myrmeciza zeledoni Ridgway . . . . . . . . . . . . . . . . . . . . . . 114

Genus 18. Formicarius Boddaert. . . . . . . . . . . . . . . . . . . . . . . 115

Key to the Species and Subspecies of Formicarius . . . . . . . . . . . . . . . . 117

42. Formicarius analis nigricapillus (Ridgway) . . . . . . . . . . . . . . 118

43. Formicarius moniliger moniliger Sclater . . . . . . . . . . . . . . . . . . . 119

44. Formicarius moniliger intermedius Ridgway. . . . . . . . . . . . . . . . 121

45. Formicarius moniliger pallidus (Lawrence) . . . . . . . . . . . . . . 121

46. Formicarius moniliger umbrosus (Ridgway) . . . . . . . . . . . . . . . 122

4.. Formicarius moniliger hoffmanni (Cabanis) . . . . . . . . . . . . . . 123

48. Formicarius moniliger panamensis Ridgway . . . . . . . . . . . . . 124

49. Formicarius rufipectus Salvin. . . . . . . . . . . . . . . . . . . 125

Genus 19. Mylophylax Pidgway . . . . . . . . . . . . . . . . . . . . . . . . . 126

50. Hylophylax nævioides (Lafresnaye) . . . . . . . . . . . . . . . . . 128

Genus 20. Anoplops Cabanis and Heine. . . . . . . . . . . . . . . . . . . . 130

Key to the Species of Anoplops. . . . . . . . . . . . . . . . . . . . . . . . 131

51. Anoplops bicolor (Lawrence)........................... 132

52. Anoplops olivascens (Ridgway)........................... 132

Genus 21. Phrenostictus Ridgway.............................. 134

53. Phxenostictus mcleannani mcleannani (Lawrence)............... 135

54. Phrenostictus mcleannani saturatus (Richmond) ............... 136 


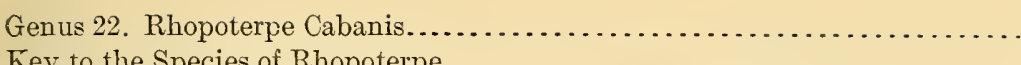

Key to the Species of Rhopoterpe

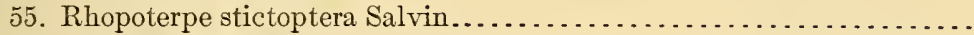

Genus 23. Pittasoma Cassin . . . . . . . . . . . . . . . . . . . . . . . . . .

Key to the Species and Subspecies of Pittasoma....................

56. Pittasoma michleri michleri Cassin. . . . . . . . . . . . . . . . . .

57. Pittasoma michleri zeledoni Ridgway . . . . . . . . . . . . . . .

Genus 24. Grallaricula Sclater................................ 143

Key to the Species of Grallaricula ............................ 144

58. Grallaricula costaricensis Lawrence...................... 145

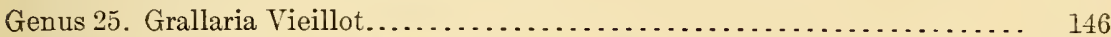

Key to the Subspecies of Grallaria guatimalensis . . . . . . . . . . . . . . . 147

59. Grallaria guatimalensis guatimalensis Prévost and Des Murs........ 148

60. Grallaria guatimalensis princeps (Sclater and Salvin)............ 149

61. Grallaria guatimalensis mexicana (Sclater) ................. 150

62. Grallaria guatimalensis ochraceiventris Nelson.............. 151

Genus 26. Hylopezus Ridgway . . . . . . . . . . . . . . . . . . . . 152

Key to the Species and Subspecies of Hylopezus..................... 153

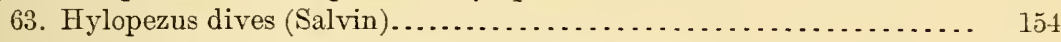

64. Hylopezus perspicillatus perspicillatus (Lawrence)............ 155

65. Hylopezus perspicillatus lizanoi (Cherrie) .................... 156

66. Hylopezus perspicillatus intermedius (Ridgway) . . . . . . . . . . . . 156

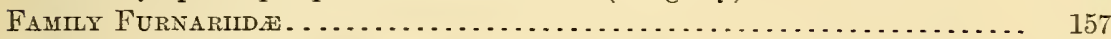

Key to the Central American Genera of Furnariidæ................... $\quad 159$

Genus 1. Sclerurus Swainson................................. 163

Key to the Species and Subspecies of Sclerurus...................... 164

1. Sclerurus canigularis Ridgway .......................... 166

2. Sclerurus mexicanus mexicanus Sclater..................... 166

3. Sclerurus mexicanus pullus Bangs......................... 168

4. Sclerurus guatemalensis (Hartlaub) .......................... 169

Genus 2. Xenops Illiger................................... 170

Key to the Species of Xenops............................... 172

5. Xenops genibarbis mexicanus (Sclater)...................... 172

6. Xenops rutilus heterurus (Cabanis and Heine) $\ldots . . . \ldots . . . . . . .175$

Genus 3. Margarornis Reichenbach.......................... 177

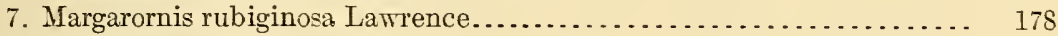

Genus 4. Premnoplex Cherrie................................. 180

Key to the Subspecies of Premnoplex brunnescens................... 181

8. Premnoplex brunnescens brunneicauda (Lawrence) . . . . . . . . . . . 181

Genus 5. Acrorchilus Ridgway . . . . . . . . . . . . . . . . . . . . . . . 183

Key to the Species of Acrorchilus. ............................. 184

9. Acrorchilus erythrops rufigenis (Lawrence)................... 184

Genus 6. Synallaxis Vieillot.................................. 186

Key to the Species and Subspecies of Synallaxis ................... 188

10. Synallaxis erythrothorax Sclater......................... 189

11. Synallaxis pudica pudica Sclater........................ 191

12. Synallaxis pudica nigrifumosa (Lawrence) . . . . . . . . . . . . . . . . . 192

13. Synallaxis albescens latitabunda Bangs....................... 194

14. Synallaxis albescens hypoleuca Ridgway .................. 195

Genus 7. Pseudocolaptes Reichenbach . . . . . . . . . . . . . . . . . . . . 196

Key to the Species of Pseudocolaptes. . . . . . . . . . . . . . . . . . . . . . . 197

15. Pseudocolaptes lawrencii Ridgway . . . . . . . . . . . . . . . . 
Genus 8. Hyloctistes Ridgway. . . . . . . . . . . . . . . . . . . . . . . 199

16. Hyloctistes virgatus (Lawrence)........................ 200

Genus 9. Philydor Spix...................................... 201

Fey to the Species of Philydor................................ 202

17. Philydor panerythrus Sclater........................... 203

18. Philydor fuscipennis Salvin........................... 204

Genus 10. Xenicopsis Cabanis................................. 205

Key to the Species of Xenicopsis.............................. 206

19. Xenicopsis variegaticeps (Sclater) ........................ 207

20. Tenicopsis subalaris lineatus (Lawrence) . . . . . . . . . . . . . . . 209

Genus 11. Automolus Reichenbach.......................... 211

Key to the Species and Subspecies of Automolus................. 213

21. Automolus rubiginosus Sclater......................... 214

22. Automolus veræpacis veræpacis Salvin and Godman............ 214

22. Automolus veræpacis umbrinus (Salvin and Godman)........... 215

23. Automolus guerrerensis Salvin and Godman ................ 216

24. Automolus fimosus Salvin and Godman.................. 216

25. Automolus cervinigularis cervinigularis Sclater............... 217

26. Automolus cervinigularis hypophæus Ridgway ................ 219

27. Automolus pallidigularis pallidigularis Lawrence............... 220

28. Automolus pallidigularis exsertus Bangs................... 221

Genus 12. Rhopoctites Ridgway............................ 222

29. Rhopoctites rufobrunneus (Lawrence) . . . . . . . . . . . . . 223

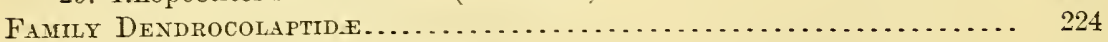

Key to the Genera of Dendrocolaptidæ....................... 226

Génus 1. Dendrocolaptes Hermann............................ 227

Key to the Species and Subspecies of Dendrocolaptes................. 229

1. Dendrocolaptes sancti-thomæ sancti-thomæ (Lafresnaye) .......... 229

2. Dendrocolaptes sancti-thome hesperius Bangs................ 232

3. Dendrocolaptes puncticollis Sclater and Salvin............... 232

4. Dendrocolaptes validus costaricensis Ridgway ................ 233

Genus 2. Xiphocolaptes Lesson............................. 235

Key to the Subspecies of Xiphocolaptes emigrans................... 236

5. Xiphocolaptes emigrans emigrans Sclater and Salvin............ 23T

6. Xiphocolaptes emigrans sclateri (Ridgway) . . . . . . . . . . . . . 238

7. Xiphocolaptes emigrans omiltemensis Nelson.................. 239

S. Xiphocolaptes emigrans costaricensis Ridgway . . . . . . . . . . . . 239

Genus 3. Xiphorhynchus Srainson......................... 239

Key to the Species and Subspecies of Xiphorhynchus................ $\quad 240$

9. Xiphorhynchus lachrymosus lachrymosus (Lawrence) . . . . . . . . . . 242

10. Xiphorhynchus lachrymosus eximius (Hellmayr) .............. 243

11. Xiphorhynclius flavigaster flavigaster Swainson............... 244

12. Xiphorhynchus flavigaster mentalis (Lawrence)................ 247

13. Xiphorhynchus flavigaster megarhynchus (Nelson)............. 248

14. Xiphorhynchus favigaster yucatanensis Ridgway ............. 248

15. Xiphorhynchus striatigularis (Richmond) .................. 249

16. Xiphorhynchus nanus nanus (Lawrence).................. 250

17. Xiphorhynchus nanus costaricensis (Ridgway).............. 252

18. Xiphorhynchus nanus confinis (Bangs).................... 253

19. Xiphorhynchus erythropygius (Sclater).................. 254

20. Xiphorhynchus punctigulus punctigulus (Ridgway)............. 255

21. Xiphorhynchus punctigulus insolitus Ridgway............... 257 
Genus 4. Picolaptes Lesson.................................... 257

Key to the Species and Subspecies of Picolaptes . . . . . . . . . . . . . . . . . . . . 259

22. Picolaptes leucogaster (Swainson) .......................... 259

23. Picolaptes affinis affinis (Lafresnaye)..................... 261

24. Picolaptes affinis neglectus Ridgway ... . . . . . . . . . . . . . . . . 263

25. Picolaptes lineaticeps lineaticeps Lafresnaye ... . . . . . . . . . . . . . . . 264

26. Picolaptes lineaticeps compressus (Cabanis) . . . . . . . . . . . . . . . 265

27. Picolaptes lineaticeps insignis (Nelson) . . . . . . . . . . . . . . . . . 266

Genus 5. Campylorhamphus Bertoni.............................. 268

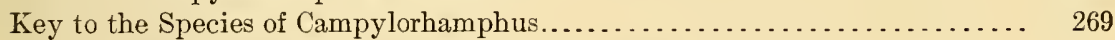

28. Campylorhamphus venezuelensis (Chapman) .................. 271

29. Campylorhamphus borealis (Carriker) . . . . . . . . . . . . . . . . . . 272

Genus 6. Glyphorhynchus Maximilian. . . . . . . . . . . . . . . . . . . . . . . . . 274

Key to the Subspecies of Glyphorhynchus cuneatus... . . . . . . . . . . . . . . 275

30. Glyphorhynchus cuneatus pectoralis (Sclater) .................. 275

Genus 7. Sittasomus Swainson............................. 277

Key to the Species and Subspecies of Sittasomus. . . . . . . . . . . . . . . . 279

31. Sittasomus sylvioides sylvioides Lafresnaye . . . . . . . . . . . . . . . . . 280

32. Sittasomus sylvioides levis (Bangs) . . . . . . . . . . . . . . . . . . . . . . 282

33. Sittasomus sylvioides jaliscensis Nelson . . . . . . . . . . . . . . . . . . 283

Genus 8. Deconychura Cherrie................................... 283

Key to the Species of Deconychura.... . . . . . . . . . . . . . . . . . . . . . . . . . 284

34. Deconychura typica Cherrie ........................... 285

Genus 9. Dendrocincla Gray . . . . . . . . . . . . . . . . . . . . . . . . . . . . . . 286

Key to the Species and Subspecies of Dendrocincla . . . . . . . . . . . . . . . . . . 287

35. Dendrocincla anabatina anabatina Sclater.................... 288

36. Dendrocincla anabatina typhla Oberholser.................... 290

37. Dendrocincla anabatina saturata Carriker....... . . . . . . . . . . . . . 290

38. Dendrocincla lafresnayei ridgwayi Oberholser. . . . . . . . . . . . . . 291

39. Dendrocincla homochroa homochroa (Sclater) . . . . . . . . . . . . . . 293

40. Dendrocincla homochroa acedesta Oberholser.... . . . . . . . . . . . . . 294

41. Dendrocincla homochroa ruficeps (Sclater and Salvin)............ 295

Order Coracimormes....................................... 295

Key to the Suborders of Coraciiformes. . . . . . . . . . . . . . . . . . . . . . . . . . 297

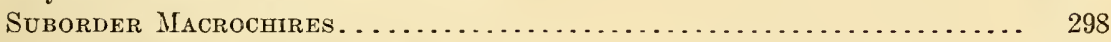

Key to the Superfamilies of Macrochires. . . . . . . . . . . . . . . . . . . . . . . . 299

Superfamily Trochili.................................... 300

Family Trochild

Key to the North and Middle American and more closely related South American Genera of Trochilidæ.

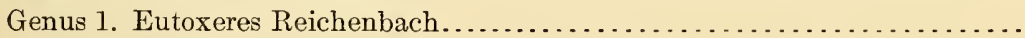

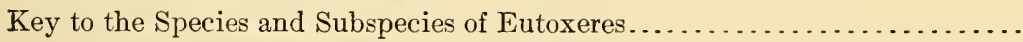

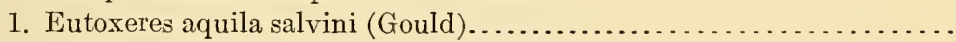

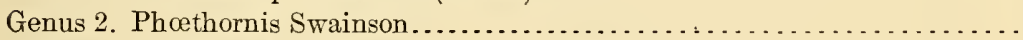

Key to the Species and Subspecies of Phothornis. . . . . . . . . . . . . . .

2. Phœthornis guyi coruscus Bangs........................

3. Phœthornis longirostris longirostris (Delattre) ..................

4. Phœethornis longirostris cephalus (Bourcier and Mulsant)...........

5. Phœthornis longirostris veræcrucis Ridgway ...................

6. Phœthornis longirostris mexicanus (Hartert) ..................

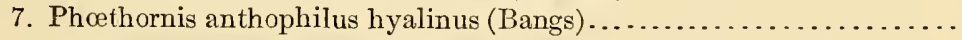

8. Phoethornis adolphi adolphi Gould .........................

9. Phœthornis adolphi saturatus Ridgway ....................

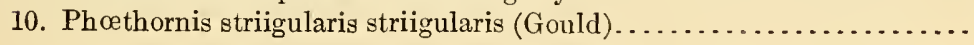




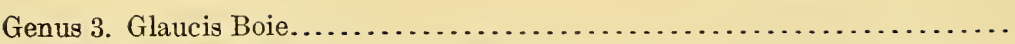

Key to the Subspecies of Glaucis hirsuta....................... 330

11. Glaucis hirsuta hirsuta (Gmelin)..................... 330

12. Glaucis hirsuta affinis (Lawrence).......................... 333

13. Glaucis hirsuta ænea (Lawrence) ......................... 334

Genus 4. Threnetes Gould................................ 336

14. Threnetes ruckeri (Bourcier) ......................... 336

Genus 5. Aithurus Cabanis and Heine......................... 338

Key to the Species of Aithurus ............................. 339

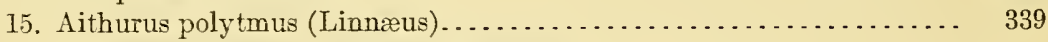

16. Aithurus scitulus Brewster and Bangs........................ 341

Genus 6. Hemistephania Reichenbach.......................... 342

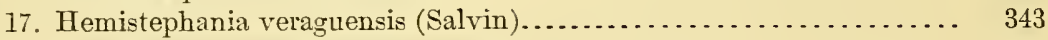

Genus 7. Anthoscenus Richmond.............................. 344

Key to the Species and Subspecies of Anthoscenus.................. 345

18. Anthoscenus longirostris longirostris (Vieillot)................. 346

19. Anthoscenus longirostris pallidiceps (Gould) ................. 349

20. Anthoscenus constantii constantii (Delattre)................. 350

21. Anthoscenus constantii leocadiæ (Bourcier)................. 352

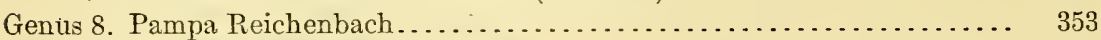

Key to the Subspecies of Pampa pampa .......................... 354

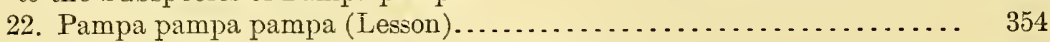

23. Pampa pampa curvipennis (Lichtenstein).................. 355

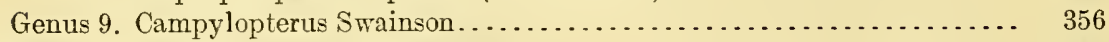

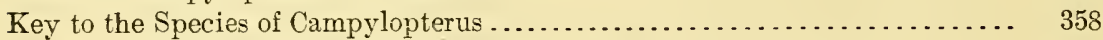

24. Campylopterus hemileucurus (Lichtenstein) $\ldots \ldots \ldots \ldots \ldots \ldots \ldots \ldots . \ldots \ldots$

25. Campylopterus rufus Lesson............................ 361

Genus 10. Phæochroa Gould................................... 362

Key to the Species and subspecies of Phæochroa ..................... 363

26. Phæochroa cuvieri cuvieri (Delattre and Bourcier)............ 363

27. Phæochroa cuvieri saturatior (Hartert) $\ldots \ldots \ldots \ldots \ldots \ldots \ldots \ldots \ldots \ldots . \ldots \ldots \ldots$

28. Phæochroa roberti (Salvin)........................... 365

Genus 11. Phæoptila Gould............................... 366

29. Phæoptila sordida Gould.............................. 367

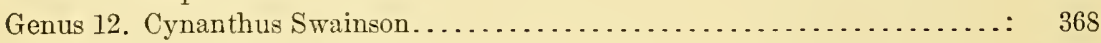

Key to the Species of Cynanthus ................................. 369

30. Cynanthus latirostris (Swainson)......................... 370

31. Cynanthus lawrencei Berlepsch.......................... 373

32. Cynanthus doubledayi (Bourcier)........................ 375

Genus 13. Basilinna Boie..................................... 377

Key to the Species and Subspecies of Basilinna................... 378

33. Basilinna leucotis leucotis (V'ieillot) ................... 378

34. Basilinna leucotis pygmæa Simon and Hellmayr............... 381

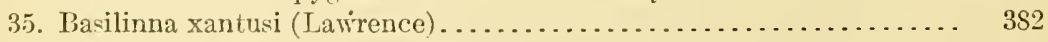

Genus 14. IIylocharis Boie................................ 384

36. Hylocharis eliciæ (Bourcier and Mulsant).................. 384

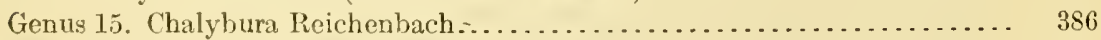

Key to the Species of Chalybura.............................. 387

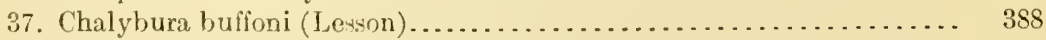

38. Chalybura urochrysa (Gould) ......................... 390

39. Chalybura isaurce (Gould) .............................. 397

40. Chalybura melauorrhoa (Salvin) .................... 392 
Genus 16. Eupherusa Gould.

Key to the Species of Eupherusa.

41. Euphorus of

41. Eupherusa eximia eximia (Delattre)......................... 394

42. Eupherusa eximia nelsoni Ridgway ....................... 396

43. Eupherusa egregia Sclater and Salvin.................... 396

44. Eupherusa poliocerca Elliot.............................. 397

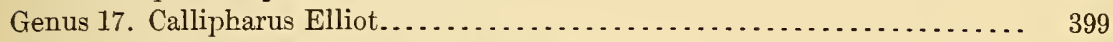

45. Callipharus nigriventris (Lawrence) ...................... 400

Genus 18. Elvira Mulsant and Verreaux.......................... 401

Key to the Species of Elvira.................................. 402

46. Elvira chionura (Gould).............................. 402

47. Elvira cupreiceps (Lawrence) ............................. 404

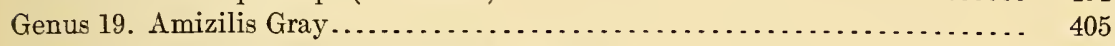

Key to the Species and Subspecies of Amizilis .................... 407

48. Amizilis tzacatl tzacatl (De la Llave)...................... 408

49. Amizilis yucatanensis (Cabot) .............................. 412

50. Amizilis yucatanensis cerviniventris (Gould).................. 414

51. Amizilis yucatanensis chalconata Oberholser................. 415

52. Amizilis forreri Boucard .............................. 416

53. Amizilis rutila rutila (Delattre) ............................ 416

54. Amizilis rutila corallirostris (Bourcier and Mulsant)............. 419

55. Amizilis graysoni (Lawrence) ............................. 419

56. Amizilis bangsi Ridgway ................................ 420

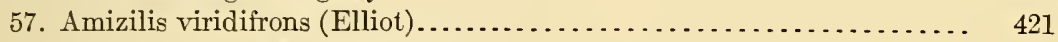

58. Amizilis verticalis (Lichtenstein) ........................ 422

59. Amizilis violiceps (Gould) . . . . . . . . . . . . . . . . . . . . . . . 424

60. Amizilis cyanocephala cyanocephala (Lesson) ................. 425

61. Amizilis cyanocephala guatemalensis (Gould) .................. 427

62. Amizilis microrhyncha (Elliot) ........................... 428

63. Amizilis salvini (Brewster) ................................ 429

Genus 20. Agyrtria Reichenbach............................... 430

Key to the Species of Agyrtria ................................... 431

64. Agyrtria candida (Bourcier and Mulsant)................... 432

65. Agyrtria luciæ (Lawrence) ................................ 434

Genus 21. Saucerottia Bonaparte............................. 434

Key to the Species and Subspecies of Saucerottia..................... 436

66. Saucerottia sophiæ sophiæ (Bourcier and Mulsant)............. 439

67. Saucerottia alfaroana (Underwood) ...................... 441

68. Saucerottia niveoventer (Gould) ....................... 441

69. Saucerottia edwardi (Delattre and Bourcier).................. 443

70. Saucerottia cyanura cyanura (Gould) .................... 445

71. Saucerottia cyanura guatemalæ Dearborn.................... 446

72. Saucerottia devillei (Bourcier and Mulsant)................... 447

73. Saucerottia beryllina beryllina (Lichtenstein) . . . . . . . . . . . . . 449

74. Saucerottia beryllina viola (Miller) . . . . . . . . . . . . . . . . . . 451

75. Saucerottia sumichrasti (Salvin) ........................... 451

76. Saucerottia ocai (Gould) ............................... 452

Genus 22. Goldmania Nelson.............................. 452

77. Goldmania violiceps Nelson........................... 453

Genus 23. Anthracothorax Boie............................... 454

Key to the Species and Subspecies of Anthracothorax.................. 455

78. Anthracothorax mango (Linnæus) .......................... 457

79. Anthracothorax nigricollis nigricollis (Vieillot) . . . . . . . . . . 459 
Genus 23. Anthracothorax-Continued.

80. Anthracothorax prevostii prevostii (Lesson).................. 463

81. Anthracothorax prevostii gracilirostris Ridgway .............. 465

82. Anthracothorax prevostii hendersoni (Cory) .................... 466

83. Anthracothorax veraguensis Reichenbach.................... 467

84. Anthracothorax dominicus (Linnæus) ............ . . . . . . . . . . . 468

85. Anthracothorax aurulentus (Audebert and Vieillot).............. 470

86. Anthracothorax viridis (Audebert and Vieillot) ............... 472

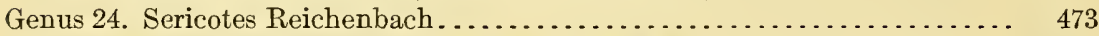

87. Sericotes holosericeus holosericeus (Linnæus) ................... 474

88. Sericotes holosericeus chlorolæmus (Gould) . . . . . . . . . . . . . . 476

Genus 25. Eulampis Boie...................................... 477

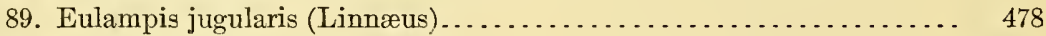

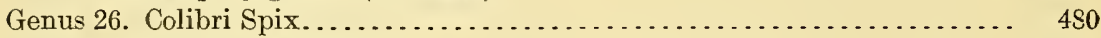

Key to the Species of Colibri.................................. 481

90. Colibri thalassinus (Swainson)............................ 482

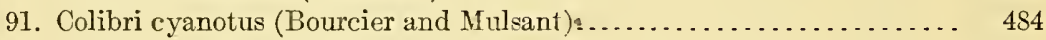

92. Colibri delphinæ (Lesson) . . . . . . . . . . . . . . . . . . . . . 486

Genus 27. Lamprolaima Reichenbach............................. 489

93. Lamprolaima rhami (Lesson) . . . . . . . . . . . . . . . . . . . . . 489

Genus 28. Cyanolæmus Stone............................. 491

94. Cyanolæmus clemenciæ (Lesson) ........................... 492

Genus 29. Lampornis Swainson.................................. 494

Key to the Species and Subspecies of Lampornis.................. 495

95. Lampornis amethystinus amethystinus Swainson............... 496

96. Lampornis amethystinus brevirostris Swainson................... 497

97. Lampornis amethystinus salvini Ridgway ................ 498

98. Lampornis margaritæ (Salvin and Godman) . . . . . . . . . . . . . . . . . . . 499

99. Lampornis pringlei (Nelson) . . . . . . . . . . . . . . . . . . . 500

Genus 30. Oreopyra Gould. .................................. . 501

Key to the Species and Subspecies of Oreopyra................... 502

100. Oreopyra castaneoventris castaneoventris (Gould)............ 502

101. Oreopyra castaneoventris calolæma (Salvin).................. 504

102. Oreopyra cinereicauda Lawrence....................... 506

103. Oreopyra hemileuca Salvin........................ 507

104. Oreopyra sybillæ (Salvin and Godman)................... 508

105. Oreopyra viridipallens (Bourcier and Mulsant) . . . . . . . . . . . . 509

Genus 31. Panterpe Cabanis and Heine........................... 511

106. Panterpe insignis Cabanis and Heine.................... 511

Genus 32. Klais Reichenbach............................... 513

107. Klais guimeti (Bourcier and Mulsant) .................... 514

Genus 33. Abeillia Bonaparte.................................. 516

108. Abeillia abeillei (Delattre and Lesson).................... 517

Genus 34. Damophila Reichenbach.......................... 518

Key to the Species and Subspecies of Damophila................... 519

109. Damophila julix julix (Bourcier)......................... 519

110. Damophila panamensis Berlejsch..................... 521

Genus 35. Polyerata Heine................................. 522

Key to the Species of Polyerata .............................. 523

111. Polyerata amabilis (Gonld) ............................. 523

112. Polyerata decora Salvin ............................... 525

Genus 36. Cyanophaia Reichenbach.......................... 526

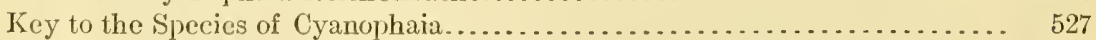

113. Cyanophaia bicolor (Gmelin) ......................... 529 
Genus 37. Thalurania Gould ................................ 530

Key to the Species and Subspecies of Thalurania . . . . . . . . . . . . . . . . 531

114. Thalurania colombica (Bourcier) . . . . . . . . . . . . . . . . . . . 532

115. Thalurania colombica venusta (Gould) .................... 534

116. Thalurania townsendi Ridgway . . . . . . . . . . . . . . . . . . . 536

117. Thalurania ridgwayi Nelson...... . . . . . . . . . . . . . . . . . 537

Genus 38. Lepidopyga Reichenbach ... . . . . . . . . . . . . . . . . . . 537

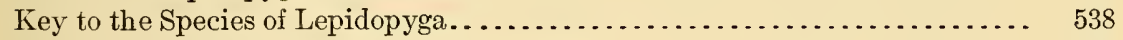

118. Lepidopyga cæruleogularis (Gould) . . . . . . . . . . . . . . . . . . . . 539

119. Lepidopyga boucardi (Mulsant) . . . . . . . . . . . . . . . . . . . 541

Genus 39. Riccordia Reichenbach ... . . . . . . . . . . . . . . . . . . . . . . 542

Key to the Species and Subspecies of Riccordia ... . . . . . . . . . . . . . . . . . 542

120. Riccordia ricordii ricordii (Gervais)....................... 543

121. Riccordia ricordii æneoviridis (Palmer and Riley) ............... 544

122. Riccordia swainsonii (Lesson) ......................... 546

Genus 40. Chlorostilbon Gould................................. 547

Key to the Species and Subspecies of Chlorostilbon. . . . . . . . . . . . . . . . . . 548

123. Chlorostilbon maugæi (Vieillot) ........................ 550

124. Chlorostilbon auriceps (Gould) ........................ 551

125. Chlorostilbon forficatus Ridgway....................... 552

126. Chlorostilbon canivetii canivetii (Lesson) $\ldots \ldots \ldots \ldots \ldots \ldots \ldots \ldots \ldots \ldots$

127. Chlorostilbon canivetii osberti (Gould) ... . . . . . . . . . . . . . 556

128. Chlorostilbon canivetii salvini (Gould) . . . . . . . . . . . . . . 557

129. Chlorostilbon assimilis Lawrence....................... 558

130. Chlorostilbon caribæus Lawrence. . . . . . . . . . . . . . . . . . . . 559

Genus 41. Heliothryx Boie................................... 561

131. Heliothryx barroti (Bourcier and Mrelsant) .................... 562

Genus 42. Eugenes Gould........................................ 564

Key to the Species of Eugenes. . . . . . . . . . . . . . . . . . . . . . . . . . 565

132. Eugenes fulgens (Swainson) .......................... 565

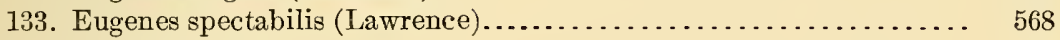

Genus 43. Heliodoxa Gould. ............. . . . . . . . . . . . . . . . . . . . . . 570

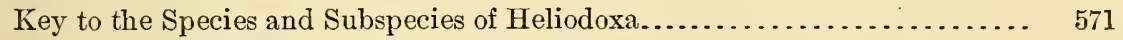

134. Heliodoxa jacula henryi (Lawrence) . . . . . . . . . . . . . . . . . . . 572

Genus 44. Florisuga Bonaparte.............................. 575

135. Florisuga mellivora (Linnæus) ........................ 576

Genus 45. Microchera Gould................................. 580

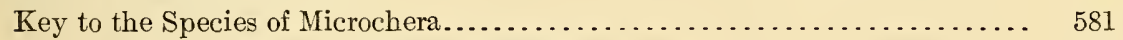

136. Microchera albocoronata (Lawrence) . . . . . . . . . . . . . . . . . . 581

137. Microchera parvirostris (Lawrence) . . . . . . . . . . . . . . . . . . . 582

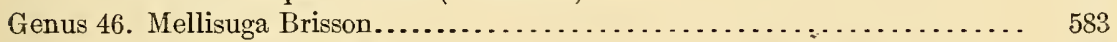

Key to the Species of Mellisuga. . . . . . . . . . . . . . . . . . . . . . . . . . 584

138. Mellisuga minima (Linnæus) . . . . . . . . . . . . . . . . . . . . . 584

139. Mellisuga catharinæ (Sallé) ... . . . . . . . . . . . . . . . . . . . . 586

Genus 47. Stellula Gould.................................... 587

140. Stellula calliope (Gould) ............................ 588

Genus 48. Atthis Reichenbach................................ 591

141. Atthis heloisa heloisa (Lesson and Delattre) . . . . . . . . . . . . . . 592

142. Atthis heloisa ellioti (Ridgway) . . . . . . . . . . . . . . . . . . . 594

143. Atthis heloisa morcomi (Ridgway) . . . . . . . . . . . . . . . . . . . 595

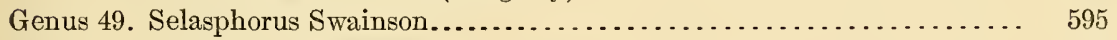

Key to the Species of Selasphorus........... . . . . . . . . . . . . . . . . . . 596

144. Selasphorus platycercus (Swainson) $\ldots \ldots \ldots \ldots \ldots \ldots \ldots \ldots \ldots \ldots \ldots \ldots$

145. Selasphorus flammula Salvin............................ 601

81255-Bull. 50-11——II 
Genus 49. Selasphorus-Continued. Page.

146. Selasphorus torridus................................ 602

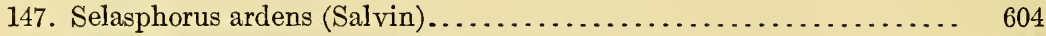

148. Selasphorus simoni Carriker.................................... 606

149. Selasphorus scintilla (Gould).............................. 607

150. Selasphorus alleni Henshaw ............................... 609

151. Selasphorus rufus (Gmelin) ................................ 612

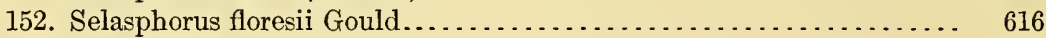

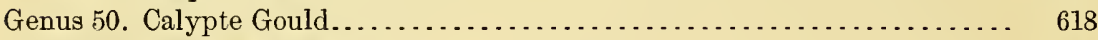

Key to the Species of Calypte................................ 619

152. Calypte anna (Lesson) ................................ 619

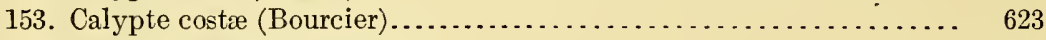

154. Calypte helenæ (Lembeye).............................. 625

Genus 51. Archilochus Reichenbach........................... 627

Key to the Species of Archilochus............................. 628

155. Archilochus colubris (Linnæus)......................... 629

156. Archilochus alexandri (Bourcier and Mulsant)............... 633

157. Archilochus violajugulum (Jeffries)........................ 636

Genus 52. Tilmatura Reichenbach............................ 637

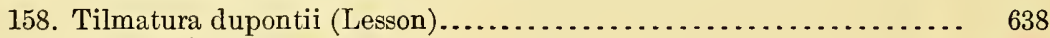

Genus 53. Nesophlox Ridgway........................................... 639

Key to the Species of Nesophlox................................ 640

159. Nesophlox evelynæ (Bourcier) .......................... 641

160. Nesophlox lyrura (Gould)............................... 643

161. Nesophlox bryantæ (Lawrence) . . . . . . . . . . . . . . . . . . 645

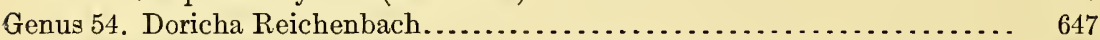

Key to the Species of Doricha. .............................. 648

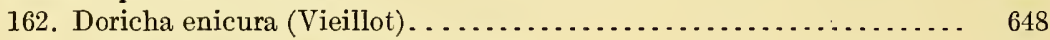

163. Doricha eliza (Lesson and Delattre)...................... 650

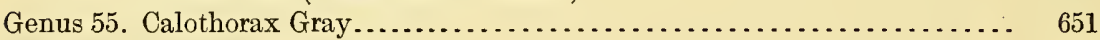

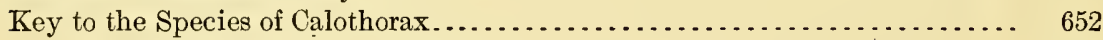

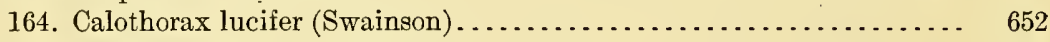

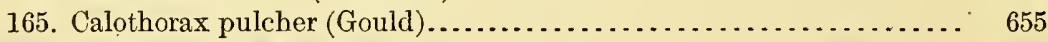

Genus 56. Orthorhyncus Lacépède............................ 656

Key to the Species and Subspecies of Orthorhyncus................. 657

166. Orthorhyncus exilis exilis (Gmelin)...................... 658

167. Orthorhyncus exilis ornatus (Gould) ..................... 661

168. Orthorhyncus cristatus cristatus (Linnæus) ............... 662

169. Orthorhyncus cristatus emigrans (Lawrence)................ 664

Genus 57. Chrysolampis Boie.............................. 665

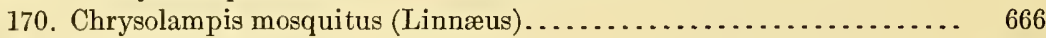

Genus 58. Lophornis Lesson................................ 669

Key to the Species of Lophornis............................. 670

171. Lophornis delattrei (Lesson) . . . . . . . ................. 671

172. Lophornis helenæ (Delattre) ............................ 673

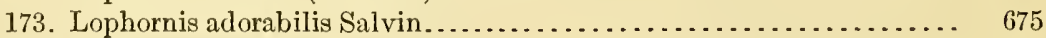

Genus 59. Popelairia Reichenbach............................ 676

Key to the Species and Subspecies of Popelairia................... 678

174. Popelairia conversii æquatorialis Berlepsch and Taczanowski..... 679

Superfamily Micropodir . . . . . . . . . . ...................... 681

Key to the Families of Microporii............................. 682

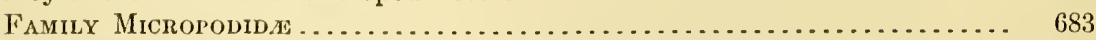

Key to the Genera of Micropodida . . . . . . . . . . . . . . . . . . . . 685

Genus 1. Aëronautes Hartert. . . . . . . . . . . . . . . . . . . . . . . 687

1. Aëronautes melanoleucus (Baird) ....................... 687 
Genus 2. Panyptila Cabanis................................. 690

Key to the Species of Panyptila................................ 691

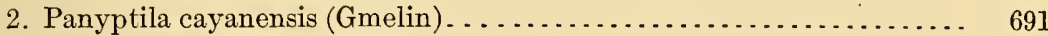

3. Panyptila sancti-hieronymi Salvin........................ 692

Genus 3. Tachornis Gosse.................................. 693

Key to the Subspecies of Tachornis phonicobia..................... 693

4. Tachornis phœnicobia phœnicobia Gosse....................... 694

5. Tachornis phœnicobia yradii (Lembeye) . . . . . . . . . . . . . . . . 695

Genus 4. Streptoprocne Oberholser............................. 696

Key to the Species and Subspecies of Streptoprocne................. 697

6. Streptoprocne zonaris albicincta (Cabanis).................... 697

7. Streptoprocne zonaris mexicana Ridgway .................... 700

8. Streptoprocne zonaris pallidifrons (Hartert) ................. 701

9. Streptoprocne semicollaris (Saussure) ........................ 702

Genus 5. Nephœcetes Baird................................. 703

Key to the Subspecies of Nephœcetes niger....................... 704

10. Nephœcetes niger niger (Gmelin) . . . . . . . . . . . . . . . . . . 704

11. Nephœcetes niger jamaicensis Ridgway..................... 705

12. Nephœcetes niger borealis (Kennerly) ...................... 707

13. Nephœcetes niger costaricensis Ridgway ..................... $\quad 710$

Genus 6. Cypseloides Streubel................................ 710

Key to the Species and Subspecies of Cypseloides.................... 711

14. Cypseloides brunneitorques brunneitorques (Lafresnaye) .......... 712

15. Cypseloides brunneitorques griseifrons Nelson.................. 714

16. Cypseloides cherriei Ridgway............................. 714

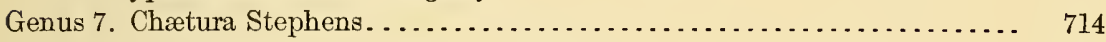

Key to the Species and Subspecies of Chætura.................... 715

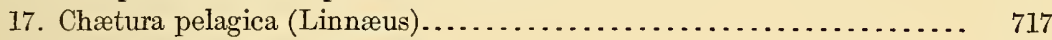

18. Chætura richmondi Ridgway........................... 719

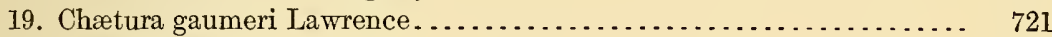

20. Chætura vauxii (Townsend) . . . . . . . . . . . . . . . . . . . 722

21. Chætura acuta (Gmelin) . . . . . . . . . . . . . . . . . . . . . . 724

22. Chætura cinereiventris fumosa (Salvin) ................... 725

23. Chætura cinereiventris lawrencei Ridgway ................... 727

24. Chætura cinereiventris phæopygos Hellmayr................ 727

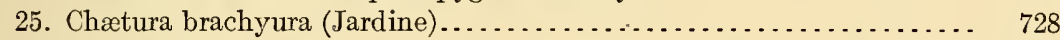

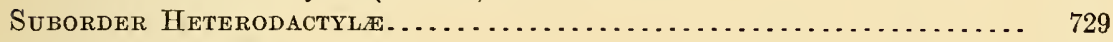

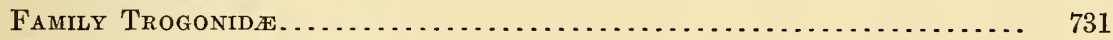

Key to the Genera of Trogonidæ............................... 732

Genus 1. Pharomachrus De la Llave........................... 733

Key to the Species and Subspecies of Pharomachrus.................. 734

1. Pharomachrus mocinno mocinno De la Llave................. 736

2. Pharomachrus mocinno costaricensis (Cabanis)............... 739

Genus 2. Leptuas Cabanis and Heine............................... 740

3. Leptuas neoxenus (Gould)............................... 741

Genus 3. Curucujus Bonaparte.................................. $\quad 742$

Key to the Species and Subspecies of Curucujus..................... 743

4. Curucujus massena (Gould) ........................... 744

5. Curucujus melanurus macrourus (Gould)................... 747

6. Curucujus clathratus (Salvin) . . . . . . . . . . . . . . . . . . . 749

Genus 4. Trogon Brisson....................................... 750

Key to the Species and Subspecies of Trogon........................ 751

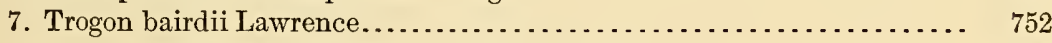

8. Trogon strigilatus chionurus (Sclater and Salvin)............. 754 
Genus 4. Trogon-Continued.

9. Trogon melanocephalus melanocephalus Gould.................. 756

10. Trogon melanocephalus illætabilis Bangs........................ 759

11. Trogon citreolus Gould ................................... 759

Genus 5. Trogonurus Bonaparte............................... 761

Key to the Species and Subspecies of Trogonurus..................... 762

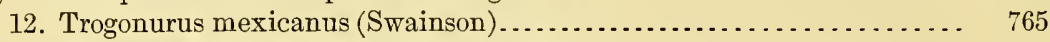

13. Trogonurus ambiguus ambiguus (Gould) .................... 768

14. Trogonurus ambiguus goldmani (Nelson) ..................... 772

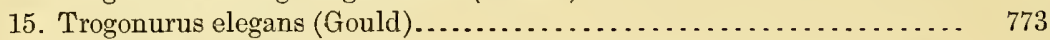

16. Trogonurus puella (Gould) ............................... 775

17. Trogonurus aurantiiventris aurantiiventris (Gould).............. 778

18. Trogonurus aurantiiventris underwoodi (Bangs) ................. 780

19. Trogon curucui tenellus (Cabanis) ........................... 781

Genus 6. Chrysotrogon Ridgway . . . . . . . . . . . . . . . . . . . . . . . 784

Key to the Species and Subspecies of Chrysotrogon................. 785

20. Chrysotrogon caligatus (Gould) ............................ 786

Genus 7. Temnotrogon Bonaparte.............................. $\quad 790$

21. Temnotrogon roseigaster (Vieillot) .......................... 791

Genus 8. Priotelus Gray..................................... 793

Key to the Subspecies of Priotelus temnurus....................... 793

22. Priotelus temnurus temnurus (Temminck) ................... 794

23. Priotelus temnurus vescus Bangs and Zappey.................. 795 


\section{LIST OF FIGURES ILLUSTRATING GENERIC DETAILS.}

\begin{tabular}{|c|c|c|c|}
\hline Genus. & Plate. & Figure. & $\begin{array}{l}\text { Page } \\
\text { of } \\
\text { text. }\end{array}$ \\
\hline 1. Scytalopus Gould. . & I & 1 & 5 \\
\hline 2. Thamnistes Sclater and Salvin. & I & 2 & 21 \\
\hline 3. Hypolophus Cabanis and Heine.. & I & 3 & 32 \\
\hline 4. Erionotus Cabanis and Heine.... & I & 4 & 47 \\
\hline 5. Cymbilaimus Gray $\ldots \ldots \ldots \ldots \ldots$ & I & 5 & 18 \\
\hline 6. Taraba Lesson .............. & II & 1 & 27 \\
\hline 7. Abalius Cabanis........... & II & 2 & 24 \\
\hline 8. Thamnophilus Vieillot...... & II & 3 & 34 \\
\hline 9. Dysithamnus Cabanis.... & II & 4 & 52 \\
\hline 10. Myrmotherula Sclater..... & III & 1 & 60 \\
\hline 11. Myrmopagis Ridgway .......... & III & 2 & 65 \\
\hline 12. Ramphocænus Vieillot....... & III & 3 & 84 \\
\hline 13. Microrhopias Sclater.......... & III & 4 & 75 \\
\hline 14. Cercomacra Selater............ & III & 5 & 90 \\
\hline 15. Microbates Sclater and Salvin.. & III & 6 & 88 \\
\hline 16. Gymnocichla Sclater............ & IV & 1 & 97 \\
\hline 17. Myrmeciza Gray............... & IV & 2 & 103 \\
\hline 18. Formicarius Boddaert ............ & IV & 3 & 115 \\
\hline 19. Anoplops Cabanis and Heine.. & $\mathrm{V}$ & 1 & 130 \\
\hline 20. Phænostictus Ridgway......... & $\mathrm{v}$ & 2 & 134 \\
\hline 21. Rhopoterpe Cabanis........... & $\mathrm{V}$ & 3 & 138 \\
\hline 22. Grallaricula Sclater............ & VI & 1 & 143 \\
\hline 23. Hylophylax Ridgway ......... & VI & 2 & 126 \\
\hline 24. Pittasoma Cassin ............... & VI & 3 & 140 \\
\hline 25. Hylopezus Ridgway............. & VI & 4 & 152 \\
\hline 26. Xenops Illiger .................... & VI & 5 & 170 \\
\hline 27. Grallaria Vieillot............... & VII & 1 & 146 \\
\hline 28. Sclerurus Swainson........... & VII & 2,3 & 163 \\
\hline 29. Margarornis Reichenbach..... & VIII & 1 & 177 \\
\hline 30. Premnoplex Cherrie ............. & VIII & 2 & 180 \\
\hline 31. Acrorchilus Ridgway........... & VIII & 3 & 183 \\
\hline 32. Synallaxis Vieillot............ & VIII & 4 & 186 \\
\hline 33. Pseudocolaptes Reichenbach... & $\mathrm{IX}$ & 1 & 196 \\
\hline 34. Hyloctistes Ridgway ........... & $\mathrm{IX}$ & 2 & 199 \\
\hline 35. Philydor Spix........... & $\mathrm{IX}$ & 3 & 201 \\
\hline 36. Xenicopsis Cabanis............. & $\mathrm{x}$ & 1 & 205 \\
\hline 37. Automolus Reichenbach..... & $\mathrm{x}$ & 2 & 211 \\
\hline 38. Rhopoctites Ridgway ......... & $X$ & 3 & 222 \\
\hline 39. Dendrocolaptes Hermann..... & $\mathrm{XI}$ & 1 & 227 \\
\hline 40. Campylorhamphus Bertoni... & $\mathrm{XI}$ & 2 & 268 \\
\hline 41. Xiphocolaptes Lesson......... & XII & $\begin{array}{l}1 \\
1\end{array}$ & 235 \\
\hline 42. Xiphorhynchus Swainson.... & XIII & $\begin{array}{l}1 \\
2\end{array}$ & 257 \\
\hline 44. Glyphorhynchus Haximilian.... & XIII & 3 & 274 \\
\hline
\end{tabular}


List of figures illustrating generic details-Continued.

45. Sittasomus Swainson

46. Deconychura Cherrie

47. Dendrocincla Gray.

48. Eutoxeres Reichenbach.

49. Phœthornis Swainson

50. Glaucis Boie.

51. Threnetes Gould.

52. Aithurus Cabanis and Heine

53. Hemistephania Reichenbach

54. Anthoscenus Richmond

55. Phæoptila Gould.

56. Pampa Reichenbach.

57. Campylopterus Swainson

58. Phæochroa Gould.

59. Cynanthus Swainson.

60. Basilinna Boie

61. Chalybura Reichenbach

62. Hylocharis Boie.

63. Eupherusa Gould.

64. Callipharus Elliot.

65. Elvira Mulsant and Verreaux.

66. Agyrtria Reichenbach

67. Saucerottia Bonaparte.

68. Goldmania Nelson.

69. Amizilis Gray

70. Anthracothorax Boie

71. Eulampis Boie.

72. Sericotes Reichenbach

73. Colibri Spix...

74. Cyanolæmus Stone

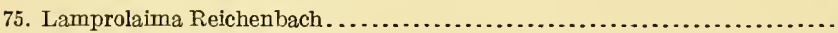

76. Panterpe Cabanis and Heine.

77. Oreopyra Gould.

78. Lampornis Swainson.

79. Klais Reichenbach.

80. Damophila Reichenbach.

81. Abeillia Bonaparte.

82. Polyerata Heine.

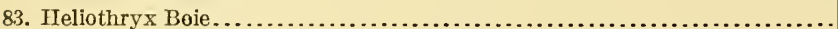

84. Cyanophaia Reichenbach

85. Lepidopyga Reichenbach.

86. Thalurania Gould.

87. Riccordia Reichenbach.

88. Chlorostilbon Gould.

89. Eugenes Gould.

90. IIeliodoxa Gould.

91. Microchera Gould.

92. Florisuga Bonaparte

93. Mellisuga J3risson...

94. $\Lambda$ this Reichenbach.

95. Stellula Gould.

96. Selasphorus Swainson

97. Archilochus Jieichenbach

98. Calyp to Gould.

\begin{tabular}{|c|c|c|}
\hline Plate. & Figure. & $\begin{array}{l}\text { Page } \\
\text { of } \\
\text { text. }\end{array}$ \\
\hline XIV & 1 & 277 \\
\hline XIV & 2 & 283 \\
\hline XIV & 3 & 286 \\
\hline $\mathrm{XV}$ & 1 & 310 \\
\hline XV & 2 & 314 \\
\hline XV & 3 & 329 \\
\hline IV & 4 & 336 \\
\hline XVI & 1 & 338 \\
\hline XVI & 2 & 312 \\
\hline XVI & 3 & 344 \\
\hline XVI & 4 & 366 \\
\hline XVII & 1 & 353 \\
\hline XVII & 2 & 356 \\
\hline XVII & 3 & 362 \\
\hline XVIII & 1 & 368 \\
\hline XVIII & 2 & 377 \\
\hline XVIII & 3 & 386 \\
\hline XVIII & 4 & 384 \\
\hline XVIII & 5 & 393 \\
\hline XVIII & 6 & 399 \\
\hline XVIII & 7 & 402 \\
\hline XIX & 1 & 430 \\
\hline IIX & 2 & 434 \\
\hline XIX & 3 & 452 \\
\hline XIX & 4,5 & 405 \\
\hline$X 1 X$ & 6 & 454 \\
\hline$\Gamma X$ & 1 & 477 \\
\hline $\mathrm{XX}$ & 2 & 473 \\
\hline$X X$ & 3 & 480 \\
\hline $\mathrm{XX}$ & 4 & 491 \\
\hline XXI & 1 & 489 \\
\hline$X X I$ & 2 & 511 \\
\hline XXI & 3 & 501 \\
\hline XXI & 4 & 494 \\
\hline$X X I$ & 5 & 513 \\
\hline$X X I$ & 6 & 518 \\
\hline XXI & 7 & 516 \\
\hline XXI & 8 & 522 \\
\hline XXI & 9 & 561 \\
\hline XXII & 1 & 526 \\
\hline XXII & 2 & 537 \\
\hline XXII & 3 & 530 \\
\hline XXII & 4 & 542 \\
\hline XXII & 5,6 & 547 \\
\hline XXII & 7 & 564 \\
\hline ХХIII & 1 & 570 \\
\hline XXIII & 2 & 580 \\
\hline XXIII & 3 & 575 \\
\hline XXIII & 4 & 583 \\
\hline XXIII & 5,6 & 591 \\
\hline XXIII & 7 & 587 \\
\hline XXIV & $1,2,3,4$ & 595 \\
\hline XXIV & $5,6,9$ & 627 \\
\hline XXIV & 7,8 & 618 \\
\hline
\end{tabular}


List of figures illustrating generic details-Continued.

\begin{tabular}{|c|c|c|c|}
\hline Genus. & Plate. & Figure. & $\begin{array}{l}\text { Page } \\
\text { of } \\
\text { text. }\end{array}$ \\
\hline 99. Tilmatura Reichenbach.. & $\mathrm{xxV}$ & 1 & \\
\hline 100. Calothorax Gray.............. & $\mathrm{xxV}$ & 2 & \\
\hline 101. Doricha Reichenbach.. & $\mathrm{xxV}$ & 3 & \\
\hline 102. Nesophlox Ridgway... & $\mathrm{xxV}$ & 4 & \\
\hline 103. Chrysolampis Boie...... & $\mathrm{XxV}$ & 5 & \\
\hline 104. Orthorhyncus Lacépède.. & $\mathrm{XXV}$ & 6 & \\
\hline 105. Lophornis Lesson.. & $\mathrm{xxV}$ & 7 & \\
\hline 106. Popelairia Reichenbach.. & $\mathrm{XXVI}$ & 1,2 & \\
\hline 107. Aëronautes Hartert.. & XXVI & 3 & \\
\hline 108. Panyptila Cabanis...... & XXVI & 4 & \\
\hline 109. Chætura Stephens......... & XXVII & 1 & 71 \\
\hline 110. Streptoprocne Oberholser.. & XXVII & 2 & 696 \\
\hline 111. Cypseloides Streubel.. . & XXVII & 3 & 710 \\
\hline 112. Tachornis Gosse...... & XXVII & 4 & 693 \\
\hline 113. Nephœcetes Baird... & XXVIII & 1 & 703 \\
\hline 114. Leptuas Cabanis and Heine.. & XXVIII & 2 & 7 \\
\hline 115. Pharomachrus De La Llave . & $\operatorname{XXIX}$ & 1 & 733 \\
\hline 116. Curucujus Bonaparte...... & $\mathrm{xxx}$ & 1 & 7 \\
\hline 117. Trogon Brisson... & $\mathrm{xxx}$ & 2 & 750 \\
\hline 118. Trogonurus Bonaparte.. & $\mathrm{XXXI}$ & 1 & 76 \\
\hline 119. Chrysotrogon Ridgway .. & $\mathrm{XXXI}$ & 2 & \\
\hline 120. Temnotrogon Bonaparte & XXXII & 1 & \\
\hline 121. Priotelus Gray..... & XXXIII & 1 & 7 \\
\hline
\end{tabular}





\title{
THE BIRDS
}

OF

\section{NORTH AND MIDDLE AMERICA.}

By Robert RIDGWAY,

Curator, Division of Birds.

Part V.

\author{
Supexfamily MESOMYODI.a
}

MESOMYODIAN PASSERES.

(Continued.) $a$

=Tracheophones MüLleR, Abh. k. Ak. Wiss. Berlin, 1846, 1847, 383 (=Formicariidæ + Pteroptochidæ + Furnariidæ + Dendrocolaptidæ).-NEwron, Dict. Birds, pt. iv, 1896, 985.

<Tracheophones CABanis, Wiegmann's Archiv für Naturg., 1847, pt. i, 209 (=Formicariidæ, part+Furnariidæ+Dendrocolaptidæ).

<Tracheophonæ Sclater, Cat. Am. Birds, 1862, 146 (includes Oligomyodi!).

=Tracheophonæ Huxuey, Proc. Zool. Soc. Lond., 1867, 471.--Sclater and Salvin, Nom. Av. Neotr., 1873, pp. vi, 61.-Garrod, Proc. Zool. Soc. Lond., 1877, 452.-Forbes, Proc. Zool. Soc. Lond., 1880, 391.-Sclater, Ibis, 1880, 349.Salvin and Godman, Biol. Centr.-Am., Aves, ii, 1891, 145.

$\times$ Tracheophonæ Garrod, Proc. Zool. Soc. Lond., 1873, 463 (Pittidæ+Rupicolidæ, +Cotingidæ+Tyrannidæ+Pteroptochidæ-Menuridæ!).

<Anabatidae Cabanis, Wiegmann's Archiv für Naturg., 1847, pt. i, 338 (=Furnariidæ+Dendrocolaptidæ).

<Anabatidae Cabanis and Heine, Mus. Hein., ii, 1860, 22.-Lilljeborg, Proc. Zool. Soc. Lond., 1866, 16 (=Furnariidæ+Dendrocolaptidæ).

=Formicaroideæ Stejnegen, Stand. Nat. Hist., iv, 1885, 476, in text.

=Formicaroidei Cope, Am. Nat., xxiii, Oct., 1889, 873.

$<$ Formicariidae Gadow, Bronn's Thier-Reichs, Vög., ii, 1893, 276, 301 (=Formicariidæ+Furnariidæ+Dendrocolaptidæ).

$<$ Dendrocolaptinae GaDow, Bronn's Thier-Reichs, Vög., ii, 1893, 276 (=Dendrocolaptidæ+Furnariidæ).

<Pteroptochidae Gadow, Bronn's Thier-Reichs, Vög., ii, 1893, 277, 301 (=Pteroptochidæ+Conopophagidæ).

The characters of the Tracheophone Mesomyodi were briefly given on pages 331 and 332, Part IV, of the present work. The group is

$a$ See Part IV, pages 328-332 of this work.

$81255^{\circ}-$ Bull. $50-11-1$ 
now considered in detail, and a new key to the families presented, based upon more extended or special study.

\section{CHARACTERS OF THE TRACHEOPHONE MESOMYODI.}

Mesomyodian Passeres with (usually) a single pair of syringeal muscles, attached to the middle portion of the bronchial semirings, the syrinx tracheal, the lower end of the trachea consisting of thin, membraneous walls, about six of the usual semirings extremely thin, sometimes obsolete, the bronchi with both outer and inner tympaniform membranes, vibratory tracheal membranes being also present, the few muscles (usually only one pair) wholly lateral (being thus specially modified as a vocal organ; $)^{a}$ feet schizopelmous; tensor patagii brevis passerine.

The Tracheophone Passeres are (excepting the small family Xenicidæ of New Zealand) a purely Neotropical group of birds, though, like many others, entirely absent from the Antillean Subregion. The various members bear a more or less close resemblance in external appearance as well as in habits to certain Oscinine families, though very distinct in their internal structure. Thus, among the Formicariidæ (Antbirds), some forms closely resemble Shrikes (Laniidæ), others Wrens (Troglodytidæ), and others again are strikingly similar to the Pittas (Pittidæ) ${ }^{b}$ in form, though lacking entirely the beautiful coloration of the latter. The Dendrocolaptidæ and Furnariidæ embrace species which, so far as external appearance goes, might pass readily for Tree Creepers (Certhiidæ), Thrushes (Turdidæ), or even Larks (Alaudidæ); the smaller Pteroptochidæ are conspicuously wrenlike, while some of the Conopophagidæ are not very unlike Pipits (Motacillidæ). While they vary greatly in size, form, and

$a$ This peculiar structure of the organs of voice is thus described by its discoverer, Johannes Müller ("Ueber die bisher unbekannten typischen der Stimmorgane der Passerinen" (title incomplete), von J. Müller, Berlin, 1847): "The lower end of the trachea is flattened anteriorly and posteriorly; its walls are thin and membranous and contain extremely fine anterior and posterior half-rings, which are fastened at the sides by long elastic bands. The position of these half-rings is altered by the muscles attached to their sides. In all these birds the cartilaginous pessulus in the furcation of the trachea is wanting, and is replaced by a tendinous strap. The membrana tympaniformis passes over from one bronchus to the other. The bronchi contain half rings only. The membranous wall of the voice organ consists of two thin transparent membranes, of which the inner one is the mucous membrane."

By Professor Alfred Newton it is described (Dictionary of Birds, Part iv, p. 940) as follows: "The lower portion of the Trachea consists of thin membranaceous walls, about six of the rings being extremely thin or, as often happens, deficient. Both inner and outer tympaniform membranes exist in the Bronchi as well as some vibratory tracheal membranes. The few muscles, generally but one pair, are wholly lateral. The birds thus furnished are the TrACHEOPHON and while it is being sounded the lower part of the throat swells out."

$b$ This, however, not an Oscinine family, but a member of the Oligomyodean or Haploophone group of Mesomyodi. 
habits, a plain coloration characterizes the entire group, not a single species possessing a brilliant plumage, while the majority are among the dullest colored of birds. They are mostly forest birds, though the Pteroptochidæ and some of the Furnariidæ inhabit bushy tracts or even more open places. The Pteroptochidæ, Conopophagidæ, and Formicariidæ are chiefly terrestrial, but the Dendrocolaptidæ and many of the Furnariidæ glean their food from the trunks of forest trees, in the manner of Woodpeckers and Creepers.

In Dr. Sclater's catalogue of the Tracheophonæ, ${ }^{a} 559$ species are recognized; but since this number represents only those that were autoptically known to the author it may safely be assumed that the actual number of recognizable forms, including subspecies, is not far from $800 .^{b}$

\section{KEY TO THE FAMILIES OF TRACHEOPHONæ.}

a. Only one pair of tracheo-bronchial muscles; metasternum 4-notched, or else (in Formicariidæ) tensor patagii brevis tendon normally passerine and nares holorhinal; tarsal envelope not exaspidean (endaspidean, taxaspidean, or holaspidean).

b. Metasternum 4-notched; tensor patagii brevis tendon quasi-picarian.c

c. Interorbital septum perforate; postorbital process small, placed low down on side of skull; maxillo-palatines long and slender, curved backward; vomer short, with long limbs; intrinsic muscles present; sterno-trachealis not attached to processus vocales; palate ægithognathous (oscinine); mesorhinium compressed and arched or else expanded into a flattened oval shield; nostrils conspicuously operculate; tarsal envelope taxaspidean or holaspidean.

Pteroptochidæ (p. 4)

$a$ Catalogue | of the | Passeriformes, | or | Perching Birds | in the | Collection | of the | British Museum. | - Tracheophonæ, | or the Families | Dendrocolaptidæ, | Formicariidæ, | Conopophagidæ, and Pteroptochidæ. | By | Philip Lutley Sclater. | London: | Printed by order of the Trustees. | 1890.-8vo, pp. xviii $\times 372$, pl. xx. (Volume XV of the "Catalogue of the Birds in the British Museum.")

$b$ In Sharpe's Hand List of the Genera and Species of Birds (vol. iii, 1901, pp. 4-87) the number of forms recognized as belonging to the American Families alone is 799, as follows:

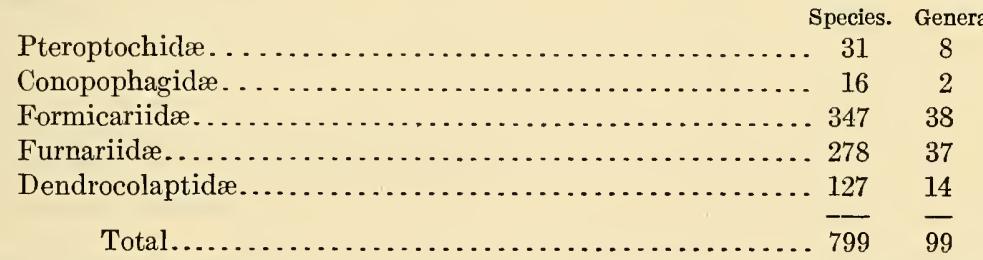

The enumeration of species, however, includes subspecies, which are not distinguished typographically or otherwise in the list. The Furnariidæ and Dendrocolaptidæ are treated as one family, as in the British Museum catalogue.

c The returning portion concealed by the muscular fibers at the origin of the extensor metacarpi muscle. (See Stejneger, Standard Nat. Hist., Birds, p. 476.) 
$c c$. Interorbital septum wanting; postorbital process wanting; maxillo-palatine long, narrow, angulated, continued backward to the level of the median descending plate of the palatine; intrinsic muscles wanting; sternotrachealis not attached to processus vocales; palate schizognathous; mesorhinium normal; nostrils not conspicuonsly operculate; tarsal envelope

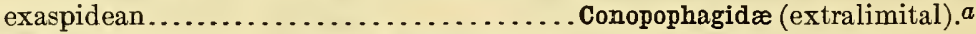

$b b$. Metasternum 2-notched; tensor patagii brevis tendon normally passerine. $b$

Formicariidæ (p. 8).

aa. Two pairs of tracheo-bronchial muscles; metasternum 2-notched; tarsal envelope endaspidean.

b. Nares schizorhinal; maxillo-palatines long and slender, continued backward to or beyond level of the free end of the median descending plate of the palatine; interorbital septum perforate; palate schizognathous; outer toe decidedly (usually much) shorter than middle toe and not conspicuously longer than inner toe (except in Sclerurus and Pygarrhicus) and united to middle toe for not more (usually less) than whole length of basal phalanx of the latter; hallux (without claw) as long as inner toe (without claw) or longer, much stouter.

Furnariidæ (p. 157).

$b b$. Nares holorhinal; maxillo-palatines short and broad, crossing posterior end of olfactory fossa and terminating immediately in front of the descending plate of the palatine; interorbital septum imperforate; palate ægithognathous or semi-desmognathous; outer toe as long as middle toe, much longer than inner toe, united to middle toe for more than whole length of basal phalanx of the latter; hallux (without claw) shorter than inner toe (without claw), little, if any, stouter....................................

\section{Family PTEROPTOCHIDE.}

THE TAPACULOS.c

=Rhinomydææ D'Orbigny Voy. Am. Mérid., iv, part 3, 1839, 192.

$>$ Pteroptochidae Cabanis and HeIne, Mus. Hein., ii, 1860, 20 (includes Menuridæ).

=Pteroptochidæ Sclater, Cat. Am. Birds, 1862, 168.-Carus, Handb. der Zool., 1863, 268.-Garrod, Proc. Zool. Soc. Lond., 1877, 452.-Stejuneger, Stand. Nat. Hist., iv, 1885, 476.-Salvin and Godman Biol. Centr.-Am., Aves, ii, 1892, 246.

=Pteroptochinae Cabanis and Heine, Mus. Hein., ii, 1860, 20.-Gadow, Bronn's Thier-Reichs, Vög., ii, 1891, 277.

=Scytalopodidæ Huxley, Proc. Zool. Soc. Lond., 1867, 471, in text.

=Scytalopodinæ Sundevall, Met. Nat. Av. Disp. Tent., ii, 1872, 65 (English translation, 1889, 134).

Tracheophone Mesomyodian Passeres with the metasternum 4-notched; interorbital septum perforate; postorbital processes small,

$a=$ Conopophaginæ Sclater and Salvin, Nom. Av. Neotr., 1873, 41; Gadow, Bronn's Thier-Reichs, Vög., ii, 1891, 277.=Conopophagidæ Garrod, Proc. Zool. Soc. Lond., 1877, 452; Forbes, Proc. Zool. Soc. Lond., 1881, 436, 438; Stejneger, Stand. Nat. Hist., iv, 1885, 476; Cope, Am. Nat., xxiii, 1889, 873; Salvin and Godman, Biol. Centr.-Am., Aves, ii, 1892, 245.

A small group of two genera and about sixteen species, peculiar to South America, from Colombia to Guiana, southeastern Brazil, Bolivia, and Peru.

$b$ The returning portion not concealed by the muscular fiber at the origin of the extensor metacarpi muscle, but the two tendons of this portion clearly exposed to view. (See Stejneger, Standard Nat. Hist., Birds, p. 459 and fig. A on p. 458.)

$c$ A Spanish (Chilean) vernacular name, from the characteristic habit of the various species of this group of carrying the tail conspicuously elevated and thrown forward. 
placed low down on side of skull; maxillo-palatines long and slender processes, curved backward; vomer short, with long limbs; nares holorhinal; tensor patagii brevis masked passerine or quasi-picarian; one pair of tracheo-bronchial muscles, the intrinsic muscles present; sterno-trachealis attached to processus vocales; palate ægithognathous (oscinine); mesorhinium compressed and arched, or expanded into a flattened oval shield; nostrils conspicuously operculate; tarsal envelope taxaspidean.

Externally, the Pteroptochidæ are characterized by their wrenlike appearance (though with the bill relatively shorter and stouter than in the true wrens), large and strong feet (which are excessively developed in some genera), short, very concave, and much rounded wing (with 10 primaries), and, usually, short or very short tail, which is usually carried erect or thrown forward. Of terrestrial or semiterrestrial habits they are well adapted to hopping or running on the ground; but their power of flight is very limited, the birds of this family being able to fly but a short distance. They are very active, inquisitive, and noisy birds, and their notes are varied and remarkable, but harsh and loud rather than musical.

The Pteroptochidæ are peculiar to the more southern portions of the Neotropical Region, the high mountains of Costa Rica, where a single representative occurs, being the northern limit; only seven of the thirty-one species and two of the eight known genera occur in the elevated districts of Colombia, the remainder occurring in the Andean district of Ecuador, Peru, and Chile, and thence to the Falkland Islands, Argentina, and southeastern Brazil, two of the Colombian species (belonging to separate genera) extending as far eastward as the higher mountains of Venezuela.

In Volume XV of the Catalogue of the Birds in the British $\mathrm{Mu}-$ seum (1890, pp. 337-352) Dr. Sclater recognizes eight genera and twenty-one species; but Dr. Sharpe, in his Hand List of the Genera and Species of Birds (Vol. III, 1901, pp. 4-7), increases the number of species to thirty-one.

\section{Genus SCYTALOPUS Gould.}

Scytalopus Gould, Proc. Zool. Soc. Lond., 1836, 89. (Type, S. fuscus Gould= Motacilla magellanica Gmelin.)

Sylviaxis Lesson, Rev. Zool., 1840, 274. (Type, S. guttatus Lesson=unidentified species).

Agathopus Sclater, Proc. Zool. Soc. Lond., 1858, 69. (Type, A. micropterus Sclater $=$ Merulaxis analis Lafresnaye?)

Small wren-like Pteroptochidæ (length about 100 to $130 \mathrm{~mm}$.) with the mesorhinium compressed and slightly arched, loral feathers short, tail much shorter than wing, tarsal envelope distinctly scutellate, and hind claw strongly curved and shorter than the digit. 
Bill much shorter than head (exposed culmen about as long as hallux, without claw), narrowly conoidal in lateral profile, its depth at base of exposed culmen equal to less than half the length of the latter; culmen flattened, very slightly to moderately decurved terminally, more or less distinctly depressed in middle portion, the basal half (mesorhinium) more compressed and more or less distinctly elevated or arched; gonys longer than mandibular rami, more than half as long as exposed culmen, rounded, slightly but distinctly convex; maxillary tomium more or less distinctly notched subterminally. Nostril narrowly cuneate or linear, longitudinal, overhung by a broad operculum. No rictal, frontal, nor mental bristles. Wing excessively rounded, very concave beneath; sixth, fifth, and seventh primaries longest (nearly equal in length), the tenth (outermost) more than half as long as the longest; all the remiges very broad, rather soft in texture; longest secondaries extending beyond tip of ninth primary. Tail decidedly to much shorter than wing to end of secondaries, excessively graduated, the rectrices (10 in number) very broad, soft, with webs semi-decomposed. Tarsus much less than half as long as wing (about twice as long as bill), its scutellation taxaspidean or semi-holaspidean (the outer series of plantar scutella much broader than the inner); middle toe, without claw, decidedly shorter than tarsus (about as long or slightly longer with claw); lateral toes about equal in length, reaching (without claw) to or very slightly beyond penultimate articulation of middle toe; hallux (without claw) longer than lateral toes and much stouter, its strongly arched claw shorter than the digit; outer toe united to middle toe only at extreme base, the inner toe entirely separated. Plumage compact but very soft (almost silky), that of the rump and flanks more elongated and lax.

Coloration.-Adult males nearly uniform gray or dusky, with hinder parts more or less rufescent and (usually) barred, sometimes with the forehead silvery gray, some species with throat or throat and breast white; adult females similar but duller in color and more barred; young very different, rusty or brown prevailing, conspicuously barred.

Nidification.- "The nest is placed in a mass of moss on a bank; it is also composed entirely of moss. The female lays two eggs, large for the size of the bird, and white." (S. magellanicus Salmon, Proc. Zool. Soc. Lond., 1879, 528.)

Range.-High mountains of Costa Rica to Falkland Islands, southern Chile and Argentina, southeastern Brazil, and mountains of Venezuela. (About eighteen species and subspecies known.) 


\section{SCYTALOPUS ARGENTIFRONS Ridgway.}

\section{SILVERY-FRONTED SCYTALOPUS.}

Adult male.-Forehead and superciliary region silvery gray (no. 6 or no. 7 gray $^{a}$ ); rest of upper parts plain sooty black, the feathers of rump tipped, more or less distinctly, with dark rusty brown or chestnut; sides of head, anterior portion of forehead, chin, throat, and chest plain deep slate color or blackish slate, the color usually darker around eye (especially between eye and the silvery gray of superciliary region); slate color of chest gradually changing to paler, or slate-gray, on breast, this into light silvery gray (sometimes tinged with fulvous) on abdomen; sides rather darker slate color than chest; flanks, anal region, and under tail-coverts sooty black, the feathers conspicuously tipped or terminally margined with deep rusty brown or russet; maxilla brownish black, mandible more brownish; legs and feet deep horn brownish (in dried skins); length (skins), 102-114 (107.5); wing, 51.5-54 (52.9); tail, 34.5-40 (35.8); culmen, 11-12 (11.6); tarsus, 20-21 (20.8); middle toe, 16.5-17.5 (17.1). ${ }^{b}$

Adult female.-Similar to the adult male but gray U-shaped frontal and superciliary mark obsolete or entirely wanting; feathers of all the upper parts broadly but indistinctly margined with dark brown; gray of under parts confined to chin, throat, and chest, the whole sides, flanks and under tail-coverts very broadly margined with russet, changing to buffy cinnamon on abdomen; bill, etc., as in adult male, but mandible lighter brownish; length (skins), 109-112 (110.5); wing, 50-52 (50.8); tail, 40-41.5 (40.7); culmen, 10.5-11.5 (11); tarsus, 19.5-21 (20.3); middle toe, $16.5-17.5(17) .^{c}$

High mountains of Costa Rica (Volcán de Irazú; Volcán de Poás; Coliblanco) and western Panamá (Boquete; Volcán de Chiriquí).

Scytalopus argentifrons Ridgway, Proc. U. S. Nat. Mus., xiv, no. 869, Oct. 31, 1891, 475 (Volcán de Irazú, Costa Rica; coll. U. S. Nat. Mus.); xvi, 1893, 613 (additional specimens described).-Salvin and Godman, 'Biol. Centr.-Am., Aves, ii, 1892, 246.-BAngs, Proc. New Engl. Zool. Club, iii, 1902, 48 (Boquete and Volcán de Chiriquí, Panamá, 5,000-7,000 ft.).-Carriker, Ann. Carnegie Mus., vi, 1910, 594 (Ujurras de Térraba, Volcán de Irazú, La Estrella de Cartago, and Volcán de Turrialba, Costa Rica; crit.; habits).—Ferry, Pub. 146, Field Mus. N. H., orn. ser., i, no. 6, 1910, 271 (Coliblanco, Costa Rica).

[Scytalopus] argentifrons Sharpe, Hand-list, iii, 1901, 5.

$a$ Ridgway's Nomenclature of Colors (ed. 1886,) plate 2.

$b$ Five specimens from Costa Rica. An adult male from Boquete, Panama, measures: Wing, 51.5; tail, 40; tarsus, 20.5; middle toe, 17.

c Three specimens, from the Volcan de Irazú, Costa Rica. 


\section{Family FORMICARIIDA.}

THE ANTBIRDS.

Myiotheridæ BoIe, Isis, 1826, 973.-Huxley, Proc. Zool. Soc. Lond., 1867, 471, in text.

$>$ Eriodoridæ CABANis, Wiegmann's Archiv für Naturg., 1847, pt. i, 209, 336 (includes Pteroptochidæ, Pittidæ, and Menuridæ!).

$>$ Formicariidæ Sclater, Proc. Zool. Soc. Lond., 1858, 202; Cat. Am. Birds, 1862 170 (includes Conopophagidæ).-CARUs, Handb. Zool., 1868, 268.

$<$ Eriodoridx Cabanis and Heine, Mus. Hein., ii, 1860, 11 (excludes Formicarii. dæ, part).

$\times$ Hypocnemididæ Cabanis and Heine, Mus. Hein., ii, 1860, 1 (includes Pittidæ and Conopophagidæ; excludes Formicariidæ, part).

=Formicariidæ Garrod, Proc. Zool. Soc. Lond., 1877, 452.-Stejneger, itand. Nat. Hist., iv, 1885, 477.-Salvin and Godman, Biol. Centr.-Am., A es, ii, 1892, 193.

=Formicariinæ GADow, Bronn's Thier-Reichs, Vög., ii, 1891, 276.

Tracheophone Mesomyodian Passeres with the metasternum 2notched, tensor patagii brevis tendon normally passerine, interorbital septum perforate, postorbital process large (sometimes joining the processus squamosi), maxillopalatines strap-shaped (crossing posterior end of the olfactory fossa and passing backward beyond the level of the median descending plate of the palatine); vomer long and broad; nares holorhinal, the anterior nares inclosed by a bony wall, leaving a wide aperture at proximal end of nasal fossa between the premaxillary and the descending process of the nasal; syrinx tracheal, one pair of tracheo-bronchial muscles arising from the trachea and attached to one or more of the bronchial semirings, or else one pair inserted on distal end of the trachea; mesorhinium normal; nostrils not conspicuously (often not at all) operculate; tarsal envelope taxaspidean or holaspidean, or fused (nonscutellate); basal phalanx of middle toe more or less united to lateral toes, usually for at least half its length to outer toe, for less than half to inner toe, in some genera also united for part of second phalanx to outer toe; outer toe decidedly shorter than middle toe and slightly longer than inner toe; hallux as long as inner toe or slightly to decidedly shorter, slightly stouter to much stouter; claws moderate in size and curvature to short and slightly curved, that of the hallux always shorter than the digit; maxilla with tip more or less conspicuously uncinate, with distinct subterminal tomial notch, the mandibular tomium also notched subterminally (this notch sometimes minute or indistinct, however). Wing moderate in size to rather large, more or less conspicuously concave beneath, always much rounded, but usually with longer primaries extending decidedly beyond secondaries; tenth (outermost) primary never more than three-fourths as long as the longest, usually about three-fifths to two-thirds as long. Tail variable as to relative length, rarely longer than wing, usually shorter 
(sometimes less than half as long), the rectrices (usually 12, but sometimes only 10) usually rounded, never acuminate, terminally.

The Formicariidæ comprise one of the larger groups of birds peculiar to the Neotropical region, but, like several others of the same class, wholly absent from the Antillean Subregion. The group is well represented in the whole of the extensive territory extending from Costa Rica to southern Brazil, but reaches its greatest development in number of species and genera in the great valley of the Amazon and the Guianas. Dr. Sclater ${ }^{a}$ recognizes 250 species belonging to 33 genera-numbers considerably less than those that are actually known at the present time. ${ }^{b}$

Among so great a number of species and genera there is, naturally, great variation in size and form. The smallest are no larger than a Gnatcatcher (Polioptila), while the largest are fully equal to an average-sized Jay; some resemble Shrikes, others Thrushes, Wrens, Dippers, or other oscinine groups in their general appearance. They are nearly all birds of plain plumage, none baving any brilliant colors, and most of the species are terrestrial, or nearly so, feeding, as their name implies, largely upon ants, though perhaps less extensively so than has been supposed; it having been stated by competent observers that some species subsist more upon various forms of insect life which the immense armies of ants, as they march across the forest floor, startle from their hiding place among the dead leaves, etc., over which they pass.

Notwithstanding their mesomyodian larynx, many of the Formicariidæ are good songsters, some of them being conspicuous for their vocal powers.

The classification of this group is very difficult, more so probably than in the case of any other American family of birds. Indeed it may be truly said that even the most recent attempts to present an orderly and natural sequence of the genera are very far from satisfactory. My effort to bring order out of chaos can be considered as only partially successful, but it is hoped that some improvement at least has been made in that direction. Undoubtedly better results would have been reached had a better representation of the genera and species been available; but unfortunately there are very many species and several recognized genera which I have not been able to examine in this connection. As in the case of many other groups, the segregation of the species into genera has been based far too much on general resemblance, and too little attention paid to structural characters. This may be said of nearly every group of birds; but in the present instance it is difficult to understand how certain associations could have been made.

$a$ Catalogue of the Birds in the British Museum, vol. xv, 1890, pp. 177-328.

$b$ In his Hand-List of the Genera and Species of Birds (vol. iii, 1901, pp. 9-45) Dr. Sharpe enumerates 347 species and 38 genera. 


\section{KEY TO THE GENERA OF FORMICARIID办.}

a. Planta tarsi compressed and more or less sharply ridged behind, consisting of two parallel rows of scutella or undivided lamina, whose line of contact forms a median posterior ridge. (Formicariinæ.)

$b$. Second phalanx of middle toe entirely free from outer toe; acrotarsium more or less distinctly scutellate (at least on inner side).

c. Nostril oval or roundish, pierced directly into the completely ossified nasal fossæ, without trace of operculum or adjacent membrane. (Thamnophileæ.)

d. Bill more swollen and relatively shorter and broader, its depth at frontal antiæ much more than one-third the length of the commissure.

$e$. Tail shorter than wing; tarsus shorter than commissure; plumage narrowly barred, above and below.................. Cymbilaimus (p. 18). $e e$. Tail much longer than wing; tarsus longer than commissure; plumage spotted above, nearly unicolored (not barred) below.

Hypœdaleus (extralimital). $b$

dd. Bill less swollen, relatively longer and narrower, or else more compressed, its depth at frontal antiæ much less than one-third the length of commissure.

e. Tail much longer than wing.

$f$. Bill relatively longer (exposed culmen longer than middle toe without claw), much stronger, less tapering terminally, the unguis larger and more abruptly hooked; upper parts transversely barred; very large (total length $300 \mathrm{~mm}$. or more) .............. Batara (extralimital).c

$f f$. Bill relatively smaller (exposed culmen not longer than middle toe without claw), much weaker, more tapering terminally, the unguis smaller and weaker; upper parts spotted (not barred) or immaculate; smaller (total length not more than $250 \mathrm{~mm}$.).

$a$ In order to show more clearly the relationship of the various groups, a number of extralimital (South American) genera are included. My efforts have been handicapped by the lack of many species desired for comparison, among which are the types of the following generic or subgeneric names:

Neoctantes Sclater. (Type, Xenops niger Pelzeln.)

Myrmophila Cabanis and Heine. (Type, Formicivora brevicauda Swainson.)

Terenura Cabanis and Heine. (Type, Myiothera maculata Maximilian.)

Psilorhamphus Sclater. (Type, Leptorhynchus guttatus Ménétriés.)

Microbates Sclater and Salvin. (Type, Rhamphocænus collaris Pelzeln.)

Myrmochanes Allen. (Type, M. hypoleucus Allen.)

Rhopornis Richmond. (Type, Myiothera ardesiaca Maximilian.)

Sclateria Oberholser. (Type, Sitta nacvia Gmelin.) See footnote on p. 16.

Percnostola Cabanis and Heine. (Type, Lanius funebris Lichtenstein.)

Thamnocharis Sclater. (Type, Grallaria dignissima Sclater and Salvin.)

Grallaria Vieillot. (Type, Formicarius varius Boddaert.)

The genus Terenura, although represented in the geographic field covered by this work, is necessarily omitted from the "key," because I have not been able to examine a specimen of any species. (See p. 83.)

b Iypoedaleus Cabanis and Heine, Mus. Hein., ii, Aug., 1859, 18. Type, Thamnophilus guttatus Vieillot. (Southeastern Brazil; monotypic.)

c Batara Lesson, Traité d'Orn., 1831, 347. Type, Vanga striata Quoy and Gaimard= Thamnophilus cinereus Vieillot.-Thamnarchus Cabanis and Heine, Mus. Hein., ii, 1859, 19. Type, Thamnophilus cinereus Vieillot. (Batara rejected on grounds of purism.) (Southeastern Brazil; monotypic.) 
g. Tail one and a half times as long as wing; not crested; spotted above in both sexes . . . . . . . . . . . . . . . . . Nisius (extralimital) ${ }^{a}$

$g g$. Tail much less than one and a half times as long as wing; conspicuously crested; not spotted above (adult male wholly dusky, female barred with blackish and rusty)... Lochites (extralimital). $b$

$e e$. Tail little if any longer (usually much shorter) than wing.

$f$. Toes relatively shorter, the middle toe (without claw) not longer than distance from nostril to tip of maxilla, or else tail not more than twothirds as long as wing, and wings and tail conspicuously spotted.

g. Tail much less than two-thirds as long as wing, truncated.

Pygiptila (extralimital). $c$

gg. Tail at least two-thirds as long as wing, much rounded or graduated.

$h$. Tail not more than two-thirds as long as wing; bill relatively smaller, the distance from nostril to tip of maxilla less than length of middle toe without claw; wings, tail, and upper tail-coverts conspicuously spotted with white (adult male) or buffy (female)................... Megastictus (extralimital). $d$

$h h$. Tail more than two-thirds as long as wing; bill relatively larger, the distance from nostril to tip of maxilla greater than length of middle toe without claw; wings, tail, and upper tail-coverts with minute white or buffy spots or none at all.

$i$. Plumage without spots, streaks or bars (plain brownish or olive above, yellowish olive below, the wings and tail rufescent; tail much shorter than wing....... Thamnistes (p. 21).

ii. Plumage more or less spotted or streaked (adult male black with white dots on wing-coverts and small white tip to lateral rectrices, female slate color or olive, streaked with whitish; tail nearly as long as wing).................

ff. Toes relatively longer, the middle toe (without claw) longer than distance from nostril to tip of maxilla; (tail more than two-thirds as long as wing).

g. Bill relatively much larger and stronger (exposed culmen equal to or longer than middle toe with claw), more strongly uncinate; crest more conspicuously developed.

$h$. Bill more compressed, its width at frontal antiæ much less than its depth at same point, and equal to less than half the distance from nostril to tip of maxilla; larger (total length about $200 \mathrm{~mm}$.); under parts white, the adult male black, the female rufousbrown, above with more or less of white on wings.

Taraba (p. 27).

$h h$. Bill less compressed, its width at frontal antiæ nearly if not quite equal to its depth at same point and equal to at least half the distance from nostril to tip of maxilla; smaller (total length not more than $170 \mathrm{~mm}$.); under parts not white (except, sometimes, in part).

a Nisius Reichenbach, Av. Syst. Nat., 1850, pl. 71. Type, Thamnophilus leachii Such. (Southeastern Brazil and northern Argentina; monotypic?)

$b$ Lochites Cabanis and Heine, Mus. Hein., ii, Aug., 1859, 18. Type, Lanius severus Lichtenstein. (Southeastern Brazil; monotypic?)

c Pygiptila Sclater, Proc. Zool. Soc. Lond., 1858, 220. Type, Thamnophilus maculipennis Sclater. (Upper Amazons; monotypic.)-Pygoptila (emendation) Cabanis and Heine, Mus. Hein., ii, 1859, 15.

d Megastictus Ridgway, Proc. Biol. Soc. Wash., xxii, Apr. 17, 1909, 69. Type, Myrmeciza margaritata Sclater. (Upper Amazons; monotypic.) 
i. Tail more graduated; larger (total length about $170 \mathrm{~mm}$.); adult male wholly black below............ Othello (extralimital) ${ }^{a}$

ii. Tail less graduated; smaller (total length less than $150 \mathrm{~mm}$.); adult males with sides and flanks white or grayish.

Hypolophus (p. 32).

gg. Bill relatively much smaller and weaker (exposed culmen shorter than middle toe with claw), less strongly uncinate; crest less conspicuously developed.

$h$. Tail at least four-fifths as long as wing; larger and stronger forms.

$i$. Bill larger and stouter, the exposed culmen much more than half as long as tarsus.

$j$. Feathers of forehead much developed, the crest occupying entire pileum; male with a white throat-patch and black jugular area, the remaining under parts fulvous.

Biatas (extralimital). $b$

$\ddot{j}$. Feathers of forehead short, semi-decomposed, the crest confined to crown and occiput; adult males with under parts barred with black and white, or else uniform gray or slate color (rarely streaked with white).

$k$. Bill more swollen, with tip less compressed, its width at frontal antiæ equal to its depth at same point, and equal to much more than half the distance from nostril to tip of maxilla; adult males conspicuously barred with black and white, or gray streaked with white, beneath, females rufous above.

Thamnophilus (p. 34).

kk. Bill less swollen laterally, more compressed terminally, its width at frontal antiæ less than its depth at same point and equal to not more than half the distance from nostril to tip of maxilla; adult males plain gray, slate color, or black below, females gray, olive, or brown above.

Erionotus (p. 47).

ii. Bill smaller and more slender, the exposed culmen not more than half as long as tarsus, its depth at frontal antiæ equal to not more than half the distance from nostril to tip of maxilla.

Rhopochares (extralimital). $c$

$h h$. Tail less than three-fourths as long as wing; smaller and weaker forms........................... Dysithamnus (p. 52).

$c c$. Nostril more or less narrow and longitudinal, more or less distinctly operculate, or if broadly oval or roundish the remainder of nasal fossæ occupied by membraneous integument.

d. Plumage softer, more lax, and semi-decomposed, especially on rump. (Formicivoræ.)

$e$. Planta tarsi distinctly scutellate, at least on inner side or posterior margin.

a Othello Reichenbach, Av. Syst. Nat., 1850, pl. 71. Type, Lanius luctuosus Lichtenstein. (Amazon Valley; monotypic?) [I have not been able to examine $T$. leuconotus Spix, T. xthiops Sclatèr, T. tschudii Pelzeln, nor T. melanochrous Sclater and Salvin, which Dr. Sclater places in the same "section" with T. luctuosus.]

b Biastes (not of Panzer, 1806) Reichenbach, Handb., 1853, 175. Type, Anabates nigropectus Lafresnaye.-Biatas Cabanis and Heine, Mus. Hein., ii, Aug., 1859, 19 (new name for Biastes Reichenbach, preoccupied). (Southeastern Brazil; monotypic.)

c Rhopochares Cabanis and Heine, Mus. Hein., ii, Aug., 1859, 17. Type, Thamnophilus torquatus Swainson. (Paraguay, Uruguay, Argentina, southeastern Brazil, and Bolivia; three species). 
f. Tail much shorter than wing (not more than three-fourths as long, usually much less).

g. Tail little if any more than half (sometimes much less than half) as long as wing.

$h$. Bill small and very slender, the exposed culmen shorter than middle toe without claw ................ Rhopias (extralimital). $a$

$h h$. Bill larger and stouter, the exposed culmen longer than middle toe without claw.

$i$. Planta tarsi scutellate on each side; maxilla slightly decurved terminally; gonydeal angle very slight; plumage streaked; no white band across rump................ Myrmotherula (p. 60.)

ii. Planta tarsi scutellate on posterior portion of outer side only; maxilla straight throughout (only the extreme tip decurved); gonydeal angle prominent; plumage spotted; a white band across rump................... Dichrozona (extralimital). $b$

gg. Tail much more than half to more than two-thirds as long as wing.

$f$. Tail nearly as long as wing, sometimes longer.

Myrmopagis (p. 65).

g. Nostril slit-like, much narrower than the broad operculum; tarsus nearly half as long as wing. (Rectrices 10.)

$h$. Rictal bristles obsolete; feathers of chin and forehead without trace of terminal setæ; tarsus much less than twice as long as middle toe without claw, the plantar scutella very distinct on both sides.

Rhoporchilus (extralimital). $c$

$h h$. Rictal bristles obvious (though small); feathers of chin and forehead with distinct terminal setæ; tarsus twice as long as middle toe without claw, the plantar scutella indistinct (especially on inner side) .................. Myrmorchilus (extralimital). ${ }^{d}$

gg. Nostril broadly oval, much broader than the narrow (sometimes obsolete) operculum; tarsus less than half as long as wing.

$h$. Rectrices 12 .

i. Pileum not black, or else back and rump also black; back, scapulars, and rump brownish slate, brown, rufescent, or black, concolor with pileum; adult male with at least chin, throat, chest, and part of breast black................ Microrhopias (p. 75).

ii. Pileum (in adult male) black, conspicuously contrasted with bluish gray of back, scapulars, and rump; chin and throat

a Rhopias Cabanis and Heine, Mus. Hein., ii, 1859, 13. Type, Thamnophilus gularis Spix. (Southeastern Brazil; monotypic?) [Possibly Myrmothera guttata Vieillot (Myrmotherula guttata Sclater), of Cayenne and Guiana, may be congeneric, but I have not been able to examine that species.]

b Dichrozona Ridgway, Proc. U. S. Nat. Mus., x, sig. 33, Aug. 6, 1888, 524, footnote. Type, D. zononota Ridgway =Cyphorinus (Microcerculus) cinctus Pelzeln.

c Rhoporchilus Ridgway, Proc. Biol. Soc. Wash. xxii, April 17, 1909, 69. Type, Formicivora speciosa Salvin. (Western Ecuador; monotypic.) The type species has been placed in both "Formicivora" (Drymophila) and Synallaxis, but is very distinct from either.

d Myrmorchilus Ridgway, Proc. Biol. Soc. Wash., xxii, April 17, 1909, 69. Type, Myiothera strigilata Maximilian. (Southeastern Brazil; monotypic.) 
grayish white; under parts without black, except sometimes a jugular area................. Herpsilochmus (extralimital) ${ }^{a}$

$h h$. Rectrices $10 \ldots \ldots \ldots \ldots \ldots \ldots \ldots$. Drymophila (extralimital). $b$ $e e$. Planta tarsi entire (fused).

$f$. Bill decidedly longer than head, more than one-third as long as wing.

g. Tail four-fifths as long as wing, graduated; exposed culmen longer than tarsus, the latter much less than half as long as wing.

Ramphocænus (p. 84).

$g g$. Tail but little more than half as long as wing, rounded; exposed culmen much shorter than tarsus, the latter nearly half as long as wing...................................

$f f$. Bill not longer than head (usually shorter), less than one-third as long as wing.

g. Rictal bristles well developed.

$h$. Rectrices 10 ; bill much narrower and relatively deeper at base; tarsus longer than commissure ............. Cercomacra (p. 90).

hh. Rectrices 12 ; bill much broader and more depressed at base; tarsus shorter than commissure...Thamnomanes (extralimital). $c$

gg. Rictal bristles indistinct (usually obsolete).

$h$. Loral and frontal regions very densely feathered, the feathering erect, plush-like................. Pyriglena (extralimital). $d$

$h h$. Loral and frontal regions normally feathered, scantily feathered, or sometimes naked.

$i$. Frontal and loral regions normally (densely) feathered.

$j$. Rictal region naked, postocular region wholly feathered; larger forms (total length about $125 \mathrm{~mm}$.), with mostly plain coloration........................ Myrmoborus (extralimital). $e$

a Herpsilochmus Cabanis, in Wiegmann's Archiv für Naturg., xiii, pt. i, 1847, 224. Type, Myiothera pileata Lichtenstein.-Dendroccia Bertoni, Aves Nuevas del Paraguay, 1901, 138. Type, D. erythroptera Bertoni=Nyiothera rufimarginata Temminck. (Nearly the whole of tropical South America east of the Andes; about eleven species recognized, of which, however, the present writer has examined only four.) I am not able to find any structural characters separating Herpsilochmus from Microrhopias.

b Formicivora (not Formicivorus Temminck, 1807) Swainson, Zool. Journ., ii, 1825, 145. Type, Myiothera squamata Lichtenstein.-Drymophila Such (ex Swainson), Zool. Journ., i, Jan., 1825, 559. Type, D. variegata Such=Myiothera ferruginea Lichtenstein.-Ellipura Cabanis, in Wiegmann's Archiv für Naturg., xiii, pt. i, 1847, 228. Type, Myiothera ferruginea Lichtenstein.-Stipituropsis Bertoni, Aves Nuevas del Paraguay, 1901, 141. Type, S. arechavaletæ Bertoni $=$ Formicivora genei De Filippi.

c Thamnomanes Cabanis, in Wiegmann's Archiv für Naturg., xiii, pt. i, 1847, 230. Type, Lanius caesius Lichtenstein. (Colombia and Guiana to southeastern Brazil and upper Amazon Valley; two species.)

d Pyriglena Cabanis, in Wiegmann's Archiv für Naturg., xiii, pt. i, 1847, 211. Type, Lanius domicella Lichtenstein=Turdus leucopterus Vieillot. (Ecuador and Peru to southeastern Brazil; five species recognized, of which the present writer has examined only $P$. leucoptera (Vieillot) and $P$. atra (Swainson).)

e Myrmoborus Cabanis and Heine, Mus. Hein., ii, July, 1859, 9. Type, Pithys leucophrys Tschudi. Besides the type species, I would refer the following to this genus: M. myiotherinus (Spix) and M. lugubris Cabanis; probably also IIypocnemis schistacea Sclater and $I I$. melanura Sclater and Salvin, and possibly $H$. melanopogon Sclater, but these three species I have not seen. 
jj. Rictal region feathered, postocular region partly naked smaller forms (total length about $100 \mathrm{~mm}$.) with coloration much variegated ............. Hypocnemis (extralimital). $a$

ii. Frontal or loral regions, or both, scantily feathered (sometimes quite bare).

$j$. Loral and suborbital regions (sometimes forehead and crown also) bare or but scantily bristled; adult males uniform black (with white markings on wing-coverts).

Gymnocichla (p. 97).

$j j$. Loral and suborbital regions feathered (only the postocular and rictal regions naked); adult males not black (or else without white markings on wing-coverts).

l. Tail less than four-fifths as long as wing; bill stouter; nostrils smaller, more rounded; forehead more thinly feathered, the feathers semi-decomposed, semi-erect.

Myrmeciza (p. 103).b

ll. Tail more than five-sixths as long as wing (sometimes longer than wing); bill more slender; nostrils larger, more longitudinal; forehead more densely feathered, the feathers more compactly webbed, decumbent.

Myrmoderas (extralimital).c

$d d$. Plumage harder, very dense and compact, only the tail-coverts semidecomposed or loose webbed.d (Formicariex.)

$e$. Tail less than two-thirds as long as wing; plumage of rump not abnormally long and dense; feathers of latero-frontal antiæ short and dense, not antrorse, not extending above nostril; bill relatively longer and less depressed basally, the exposed culmen as long as middle toe without claw; under parts neither streaked nor barred.

Formicarius (p. 115).

$e e$. Tail more than two-thirds as long as wing; plumage of rump very long and dense; feathers of latero-frontal antiæ longer, antrorse, extending anteriorly, above the nostril, to anterior end of nasal fossæ; bill relatively shorter and more depressed basally, the exposed culmen much shorter than middle toe without claw........ Chamæza (extralimital).e

a Hypocnemis Cabanis, in Wiegmann's Archiv für Naturg., xiii, pt. i, 1847, 212. Type, Turdus tintinnabulatus Gmelin=Formicarius cantator Boddaert. (Guiana and upper Amazon Valley; two species.)

$b$ Including Myrmelastes Sclater, which I am unable to separate generically.

c Myrmoderas Ridgway, Proc. Biol. Soc. Wash., xxii, April 17, 1909, 70. Type Myiothera loricata Lichtenstein.

Besides the type, the following species (placed in Myrmeciza by Dr. Sclater) also belong here: $M$. cinnamomea (Gmelin), M. ruficauda (Maximilian), M. squamosa (Pelzeln), and M. atrothorax (Boddaert); probably also Myrmeciza pelzelni Sclater and M. hemimelæna Sclater, which, however, I have not seen. The group ranges from the Guianas and Amazon Valley to southeastern Brazil.

$d$ I am not at all satisfied with these characters, but am unable to find better ones for separating these two exceedingly distinct genera from the rest, collectively. They doubtless possess marked anatomical differences, for they certainly stand clearly apart from all the rest of the family.

e Chamæza Vigors, Zool. Journ., ii, 1825, 395. Type, C. meruloides Vigors=Turdus brevicaudus Gmelin.-Chamæzosa (emendation) Cabanis, in Wiegmann's Archiv für Naturg., i, 1847, 218. (Colombia to southeastern Brazil; six species.). 
$b b$. Second phalanx of middle toe partly united to outer toe; acrotarsium fused ("booted"). (Pithyex.)

c. Tail not longer than combined length of tarsus and middle toe with claw.

d. Orbital region wholly feathered; outstretched feet reaching much beyond tip of tail; coloration varied.

$e$. Conspicuously crested and bearded; nostrils less widely separated (distance between them less than that from either to maxillary tomia); back and wings unicolored........................ Pithys (extralimital). $a$

$e e$. Neither crested nor bearded; nostrils more widely separated (distance between them greater than that from either to maxillary tomia); wings spotted or barred.

$f$. Bill relatively shorter (exposed culmen not more than one-fourth as long as wing) and broader (width at frontal antiæ muh greater than its width at same point and equal to at least half the distance from nostril to tip of maxilla); back spotted or barred, or with a concealed patch of white; tail tipped with white or cinnamon..... Hylophylax (p. 126).

$f$. Bill relatively longer (exposed culmen more than one-fourth as long as wing) and more compressed (width at frontal antiæ very little if any greater than depth at same point and equal to less than half the distance from nostril to tip of maxilla); back neither spotted nor barred, nor with concealed white patch; tail unicolored.

Sclateria (extralimital). $b$

$d d$. Orbital region partly nude; outstretched feet reaching to but little if any beyond tip of tail; coloration plain................. Anoplops (p. 130).

cc. Tail decidedly longer than combined length of tarsus and middle toe with claw.

d. Tail about two-thirds as long as wing; loral and frontal feathers dense; malar region wholly feathered; nostril narrow, longitudinal; culmen less sharply or not at all ridged; under parts unicolored.

$e$. Pileum crested; upper eyelid not feathered; culmen more contracted, slightly ridged; back and wing-coverts unicolòred.

Rhegmatorhina (extralimital).c

a Manikup Desmarest, Hist. Nat. des Tangaras, 1805, text to pl. 66. Type, Le Manikup de Cayenne Daubenton=Pipra albifrons Gmelin.-Pithys Vieillot, Nouv. Dict. d'Hist. Nat., xxiv, 1818, 112 (diagnosis but no type); xxvi, 1818, 520. Type, P. leucops Vieillot=Pipra albifrons Gmelin.-Dasyptilops Cabanis and Heine, Mus. Hein., ii, 1859, 8. Type, Pipra albifrons Gmelin. (Colombia to Guiana, Peru, and central Brazil; two or three species.)

Notwithstanding its unquestioned priority, the name Manikup is so obviously both barbarous and cacophonous that it should not be employed as the generic term.

$b$ Holocnemis (not of Schilling, 1829) Strickland, Ann. and Mag. Nat. Hist., xiii, 1844, 415. Type, H. flammulata Strickland=Sitta nævia Gmelin.-Heterocnemis (not of Albers, 1852) Sclater, Proc. Zool. Soc. Lond., 1855, 146 (new name for Holocnemis Strickland, preoccupied). Type, Sitta nxvia Gmelin.-Sclateria Oberholser, Proc. Ac. Nat. Sci. Phila., June 2, 1899, 209 (new name for Heterocnemis Sclater, preoccupied). The above diagnosis must be taken with reservation as applying to this genus, as, unfortunately, no memorandum was made of the species upon which it was based. No species of Sclateria is represented in the U. S. National Museum collection.

c Rhcgmatorhina Ridgway, Proc. U. S. Nat. Mus., x, sig. 33, Aug. 6, 18s8, 525, footnote. Type, R. gymnops Ridgway. (Lower Amazon Valley; monotypic.) 
ee. Pileum not crested; upper eyelid feathered; culmen broadly rounded; back and wing-coverts conspicuously spotted.

Phlegopsis (extralimital). $a$

$d d$. Tail nearly as long as wing; loral and frontal feathering scant; nostrils rounded; culmen more sharply ridged; malar region partly nude; under parts (as well as upper) conspicuously spotted.... Phænostictus (p. 134).

aa. Planta tarsi broadly rounded behind, composed of a single row or series of scutella, the inner edge of which is more or less prominent and convolute, separated (at least in part) from the inner edge of the acrotarsium by a narrow groove. (Grallariinæ.)

b. Tarsus shorter than commissure, shorter than middle toe with claw; feathering head very short, more scale-like; bill slender, with mesorhinium very broad and flattened basally. (Rhopoterpeæ)................. Rhopoterpe (p. 138).

bb. Tarsus much longer than commissure, much longer than middle toe with claw; feathering of head normal; bill stouter, the mesorhinium narrow and compressed (normal) basally.

c. Exposed culmen more than one-fourth as long as wing; tip of maxilla more strongly uncinate; rictal bristles obsolete; postocular region nude. (Pittasomæ) ........................................ Pittasoma (p. 140).

cc. Exposed culmen less than one-fourth as long as wing; tip of maxilla less strongly uncinate; rictal bristles obvious (sometimes very distinct); postocular region feathered. (Grallarix.)

d. Nasal fossæ short and broad (distance from their anterior end to base of exposed culmen equal to not more than half the distance from the former to tip of maxilla), more or less triangular, the nostrils more oblique and in contact with latero-frontal antiæ or separated from the latter by a very slight interval; rictal bristles obvious; bill stouter, triangular in lateral profile, relatively deeper at base; depth at frontal antiæ equal to three-fifths to two-thirds the distance from nostril to tip of maxilla, or else the nostrils partly concealed by latero-frontal feathers.

e. Tarsus only about one-third as long as wing; middle toe, without claw, three-fifths as long as tarsus; bill much broader basally, its width at frontal antiæ equal to about three-fifths the distance from nostril to tip of maxilla; rictal bristles more than half as long as bill; very small (total length less than $100 \mathrm{~mm}$.).................... Grallaricula (p. 143).

$e e$ Tarsus much more than one-third (sometimes more than half) as long as wing; middle toe, without claw, less than three-fifths as long as tarsus; bill much narrower basally, its width at frontal antiæ equal to little if any more than half the distance from nostril to tip of maxilla; rictal bristles much less than half as long as bill; larger forms (total length about $120-210 \mathrm{~mm}$.).

$f$. Tarsus decidedly less than half as long as wing, less distinctly scutellate, the inner edge of the planta scarcely convolute; upper parts squamated.................................. Grallaria (p. 146).

$f f$. Tarsus at least half as long as wing, more distinctly scutellate, the inner edge of the planta distinctly convolute; upper parts not squamated.

g. Tail at least half as long as wing; rictal bristles distinct.

$h$. Bill stouter; tarsus more than half as long as wing; coloration more varied, the pileum and hindneck rufescent in contrast with olive of back, etc., the under parts white striped laterally with brown

a Phlegopsis Reichenbach, Av. Syst. Nat., 1850, pl. 57. Type, Myothera nigromaculata Lafresnaye and D'Orbigny.-Phlogopsis (emendation) Sclater, Proc. Zool Soc. Lond., 1858, 276. (Amazon Valley and Guiana; five species and subspecies.)

$81255^{\circ}$-Bull. 50-11-2 
and black or else plain gray, very different from color of upper parts .......................Hypsibemon (extralimital). ${ }^{a}$

$h h$. Bill more slender; tarsus not more than half as long as wing; coloration plain, the pileum and hindneck concolor with the back, etc. (plain olive or rufescent), the under parts concolored (usually tawny or ochraceous)........ Oropezus (extralimital). $b$

gg. Tail decidedly less than half as long as wing; rictal bristles indistinct....................... Myrmothera (extralimital). $c$ $d d$. Nasal fossæ longer and narrower (distance from anterior end to base of exposed culmen equal to about two-thirds the distance from same point to tip of maxilla), elliptical or oblong, the nostrils more longitudinal and separated from latero-frontal antiæ by a distinct interval of naked integument; rictal bristles wanting; bill relatively longer and narrower, more terete (depth at frontal antiæ equal to not more than half the distance from nostril to tip of maxilla................... Hylopezus (p. 152).

\section{Genus CYMBILAIMUS Gray.}

Cymbilaimus Gray, List Gen. Birds, 1840, 36. (Type, Lanius lineatus Leach.) Cymbilanius (emendation) Sclater, Proc. Zool. Soc., Lond., 1854 (pub. Apr. $5,1855), 112$.

Cymbolaemus (emendation) Cabanis and Herne, Mus. Hein., ii, Aug., 1859, 18 , footnote, in text.

Medium-sized Formicariidæ (length about $160 \mathrm{~mm}$.) with short, very stout, and strongly hooked bill, rounded and exposed nostrils, and finely barred plumage.

Bill about as long as head or a little shorter, very stout, strongly hooked, its width at frontal antiæ about equal to its depth at same point and about two-thirds the distance from nostril to tip of maxilla; exposed culmen shorter than tarsus, nearly straight to near the abruptly decurved and strongly uncinate tip of maxilla; maxillary tomium straight for most of its length, distinctly notched or concave subterminally; mandible falcate, recurved terminally; gonys strongly convex, ascending terminally, broadly rounded (not ridged) beneath, decidedly longer than unfeathered portion of mandibular rami; mandibular tomium distinctly toothed and notched subterminally. Nostril exposed, small, rounded or broadly oval, with an internal tubercle showing within upper posterior portion. Rictal bristles obvious but small; feathers of chin and anterior portion of malar region with bristly points or terminal set:e. Wing rather short,

a Ifypsibemon Cabanis, in Wiegmann's Archiv für Naturg., xiii, pt. i, 1847, 217. Type, Grallaria ruficapilla Lairesnaye. (Andes of Colombia, Ecuador, and Peru; several species.)

This genus includes the first three species of Dr. Sclater's "Grallariæ flammulatæ," together with at least Grallaria ruficeps of his section "Grallarixe uniformes."

$b$ Oropezus Ridgway, Proc. Biol. Soc., Wash., xxii, April 17, 1909, 70. Type, Grallaria rufula Lafresnaye. (Mountains of Colombia, Ecuador, and Peru; several species.)

c Myrmolhera Vieillot, $\Lambda$ nalyse, 1816, 43. Type, "Béfroi $[=$ Formicarius brevieauda Boddaert] et quelques autres fourmilliers de Buffon." (Guiana and lower Amazon Valley; Venezucla?; two species?) 
much rounded, the longest primaries but little longer than secondaries; sixth and seventh or fifth, sixth, and seventh, primaries longest, the tenth (outermost) about three-fifths as long as the longest. Tail about as long as wing, graduated for about one-third its length, the rectrices (12) rather broad and rounded terminally. Tarsus more than one-third as long as wing (about as long as bill from rictus to tip of maxilla), rather slender, distinctly scutellate, the plantar scutella in two parallel, contiguous rows; middle toe, with claw, much shorter than tarsus; outer toe (without claw) reaching to or beyond middle of subterminal phalanx of middle toe, the inner decidedly shorter, reaching (without claw) about to subterminal articulation of middle toe; hallux about as long as inner toe but much stouter; middle toe united to outer toe for whole of its basal phalanx, to inner toe for about half as much; claws moderate, strongly curved, that of hallux decidedly shorter than the digit. Plumage full, blended, moderately lax, that of the rump much developed; pileum with a full decumbent crest of broad, rounded feathers.

Coloration.-Adult male black, the upper parts (except pileum) narrowly, the under parts more broadly, barred with white; adult female with pileum chestnut, the rest of plumage barred with chestnut or brown and buffy or pale fulvous.

Range.-Nicaragua to Peru and lower Amazon Valley. (Monotypic.)

\section{CYMBILAIMUS LINEATUS FASCIATUS Ridgway.}

\section{FASCIATED ANTSHRIKE.}

Similar to $C$. $l$. lineatus ${ }^{a}$ but averaging decidedly larger; adult male with black bars on under parts averaging decidedly broader (especially on throat), the adult female and young with under parts much more strongly buffy and (usually, at least,) more heavily barred.

Adult male.-Pileum black, the forehead (sometimes crown and occiput also) narrowly barred with white; rest of upper parts black, narrowly and rather distantly barred with white, the outer webs of primaries and distal secondaries with small spots of white in transverse series; sides of head and neck and entire under parts sharply barred with black and white, the bars of the two colors about equal in width; maxilla black, mandible pale grayish or dull yellowish (pale bluish gray, with whitish tip, in life); iris carmine red; legs and feet grayish or horn color (light bluish gray in life); length

a Lanius lineatus Leach, Zool. Misc., i, 1815, 20, pl. 6 (Guiana).-Thamnophilus lineatus Vieillot, Nouv. Dict. d'Hist. Nat., iii, 1816, 316.-C[ymbilaimus] lineatus Gray, List Gen. Birds, 1841, 49.-Cymbilanius lineatus Sclater, Proc. Zool. Soc., Lond., 1854, 112; Cat. Birds Brit. Mus., xv, 1890, 178, part.-Cymbilanius lineatus lineatus Hellmayr, Novit. Zool., xiv, 1907, 60, 369. (Tropical South America in general, except Pacific Coast district south to Ecuadór). 
(skins), 154-189 (165); wing, 70-78 (74); tail, 63-73.5 (67.3); culmen, 22-25 (23.4); tarsus, 24-25.5 (24.8); middle toe, 15-16 (15.5). ${ }^{a}$

Adult female.-Forehead pale buff to tawny-buff, barred with black; rest of pileum cinnamon-rufous or rufous-chestnut, usually with some of the feathers more or less distinctly barred or margined terminally with black or dusky; rest of upper parts black, or sooty black, broadly and sharply barred with buff or tawny-buff, the bars on rectrices narrower, more or less curved, and more brownish; sides of head and neck and entire under parts pale buff to tawnybuff or nearly clay color, ${ }^{b}$ narrowly barred with black or sooty black, the bars usually narrower on chin, throat, and abdomen; bill, iris, legs, and feet as in adult male; length (skins), 149-175 (169); wing, 71-78 (74); tail, 65-72.5 (69.2); culmen, 21-25 (22.6); tarsus, $24-26$ (25); middle toe, $14-16$ (15.3). ${ }^{c}$

Immature male. - Similar to the adult female (perhaps not always distinguishable) but under parts less conspicuously barred, the chin, throat, and abdomen nearly immaculate buff; iris reddish brown. ${ }^{d}$

Nicaragua (Rio Escondido; Los Sábalos), Costa Rica (Angostura; Sipúrio; Jiménez; Rio Frio; Rio Súcio; Bonilla; Guayabo; Carrillo; Cuábre; El Hogár; San Carlos; La Cristina; La Vijágua), and Panamá (Santa Fé de Verágua; Mina de Chorcha; Calovévora; Calobre; Santiago de Verágua; Lion Hill; Panamá; Pintada, Coclé;

$a$ Twenty specimens.

$b$ Sometimes the color approaches buffy white on sides of head, chin, and throat.

c Twenty specimens.

\begin{tabular}{|c|c|c|c|c|c|}
\hline Locality. & Wing. & Tail. & $\begin{array}{l}\text { Cul- } \\
\text { men. }\end{array}$ & $\begin{array}{l}\text { Tar- } \\
\text { sus. }\end{array}$ & $\begin{array}{c}\text { Middle } \\
\text { toe. }\end{array}$ \\
\hline \multicolumn{6}{|l|}{ MALES. } \\
\hline Three adult males from Nicaragua.... & 76.2 & 68.7 & 23.7 & 25 & 15.5 \\
\hline Ten adult males from Costa Rica .............. & 74.4 & 67.9 & 23.8 & 24.8 & 15. 7 \\
\hline Seven adult males from Panamá.................. & 72.5 & 66 & 23 & 24.7 & 15. 3 \\
\hline One adult male from Ecuador................... & $\$ 2$ & 67 & 24.5 & 24.5 & 15.5 \\
\hline Two adult males (C. l. lineatus) from Venezuela.......... & 74 & 68 & 21.5 & 25.2 & 15 \\
\hline One adult male ( $C$. l. lincatus) from British Guiana...... & 75 & 71 & 24.5 & 25 & 15. 5 \\
\hline Six adult males (C. l. lineatus) from Lower Amazon.... & 73.2 & 72.2 & 22.8 & 25.1 & 15.2 \\
\hline \multicolumn{6}{|l|}{ FEMALES. } \\
\hline Four adult females from Nicaragua ............... & 74. 6 & 69. 6 & 23.2 & 25.9 & 15. 7 \\
\hline Ten adult females from Costa Rica.................. & 74.6 & 70 & 22.1 & 24.7 & 15. 3 \\
\hline Six adult females from Panamá........................... & 72. 6 & 67.6 & 23.1 & 24.7 & 15 \\
\hline Two adult females (C. l. lineatus) from venczuela............. & 74.5 & 67.5 & 22.2 & 24 & 15.2 \\
\hline Two adult females (C. l. lineatus) from Cayenne.............. & 74 & 71. 2 & 22.7 & 24.2 & 15.5 \\
\hline One adult female ( $C$. l. lineatus) from Lower Amazon.......... & 75.5 & 71.5 & 23.5 & 27 & 15.5 \\
\hline
\end{tabular}

The specimen from Ecuadór agrees much better in coloration with examples from Panamá than with true C. lineatus.

d Heyde, manuscript. 
Cascajál, Coclé), and southward through Colombia and Ecuadór to northern Peru.

Cymbilanius lineatus (not Lanius lineatus Leach) Lawrence, Ann. Lyc. N. Y., vii, 1862, 293 (Lion Hill, Panamá); ix, 1868, 107 (Angostura, Costa Rica).-Sclater and Salvin, Proc. Zool. Soc. Lond., 1864, 355 (Lion Hill; crit.).-SAlvin, Proc. Zool. Soc. Lond., 1867, 144 (Santiago and Santa Fé de Verágua, Panamá); 1870, 194 (Mina de Chorcha, Calovevora, and Calobre, Panamá).-Frantzius, Journ. für Orn., 1869, 305 (Costa Rica).-Salvin and Godman, Biol. Centr. Am., Aves, ii, 1892, 194, part (excl. South Am. localities and references).

(?)Cymbilanius lineatus Sclater, Proc. Zool. Soc. Lond., 1854, 112 (Quijos, Ecuador); 1858, 65 (e. Ecuadór), 206, part (monogr.).-Sclater and Salvin, Proc. Zool. Soc. Lond., 1866, 566 (Rio Ucayali, e. Peru); 1873, 272 (Nauta and Pebas, e. Peru); 1879, 524 (Remédios and Nechi, Antioquía, Colombia).-Taczanowski, Proc. Zool. Soc. Lond., 1874, 529 (Monterico, centr. Peru); Orn. du Pérou, ii 1884, 1.-Allen, Bull. Am. Mus., ii, 1889, 74 (Rio Napo, e. Ecuadór).-Hartert, Novit. Zool., v, 1898, 492 (Cachavi, n. w. Ecuadór).-Salvadori and Festa, Boll. Mus. Zool., etc., Torino, xv, no. 362, 1899, 27 (Valle del Rio Santiago, e. Ecuadór).-Berlepsch and StolzmanN, Proc. Zool. Soc. Lond., 1902, 59 (Monterico, Peru).

[Cymbilanius] lineatus Sclater and Salvin, Nom. Av. Neotr., 1873, 69, part.ShaRPE, Hand-list, iii, 1901, 9, part.

Cymbilanius lineatus fasciatus RIdgway, Proc. U. S. Nat. Mus., vi, no. 26, April 11, 1884, 404 (Los Sábalos, Nicaragua; coll. U. S. Nat. Mus.), 415 (Rio Súcio, Costa Rica).-Zeledón, An. Mus. Nac. Costa Rica, 1887, 114 (Jiménez, Costa Rica; Panamá).-Rıснмоnd, Proc. U. S. Nat. Mus., xvi, 1893, 498, 499 (Rio Fiscondido, Nicaragua; crit.).-Bangs, Proc. New Engl. Zool. Club, ii, 1900, 24 (Loma del León, Panamá).-Carriker, Ann. Carnegie Mus., vi, 1910, 600 (Caribbean lowlands and foothills Costa Rica; habits).-Ferry, Pub. 146, Field Mus. N. H., orn. ser., i, no. 6, 1910, 271 (Guayabo, Costa Rica).

Cymbilanius lineatus (fasciatus) Ridgway, Proc. U. S. Nat. Mus., vi, 1883, 415 (Rio Súcio, Costa Rica).

(?) Thamnophilus nigricristatus (not of Lawrence) Boucard, Proc. Zool. Soc. Iond., 1878, 60 (San Carlos, Costa Rica).

\section{Genus THAMNISTES Sclater and Salvin.}

Thamnistes Sclater and Salvin, Proc. Zool. Soc. Lond., 1860, 299. (Type, T. anabatinus Sclater and Salvin.)

Medium-sized or rather small Formicariidæ (length about 130 $\mathrm{mm}$.) with rather large, stout, and strongly hooked bill, small, circular nostrils and coloration plain brown above with wings and tail more rufescent (adult male with a concealed dorsal patch of ochraceous or tawny), the under parts plain olive-buffy or yellowish.

Bill a little shorter than head, rather stout, strongly hooked, its width at frontal antiæ greater than its depth at same point and equal to about half the distance from nostril to tip of maxilla; culmen very slightly curved from base to near tip, where strongly decurved, the tip of maxilla conspicuously uncinate; maxillary tomium nearly straight, deeply notched subterminally; mandible subfalcate (slightly recurved terminally), the tomium nearly straight, distinctly toothed 
and notched subterminally; gonys distinctly convex, ascending terminally, more strongly convex and rather prominent basally. Nostril exposed, very small, circular, with an oblique tubercle in posterior half. Rictal bristles obvious but small; feathers of chin, lores, and anterior portion of malar region with distinct bristly points. Wing moderate, rather pointed, the primaries decidedly longer than secondaries; sixth and seventh, or sixth, seventh and eighth, primaries longest, the tenth (outermost) shorter, the ninth longer, than secondaries. Tail decidedly shorter than wing to end of secondaries, strongly rounded (graduation about equal to half the length of exposed culmen), the rectrices (12) rather narrow, rounded terminally. Tarsus longer than exposed culmen, less than onethird as long as wing; acrotarsium clistinctly scutellate; outer side of planta indistinctly scutellate or with scutella obsolete, the inner side with a single series of rather small roundish or oval scutella; middle toe, with claw, much shorter than tarsus; outer toe, without claw, reaching to beyond middle of subterminal phalanx of middle toe, the inner toe slightly shorter; hallux about as long as inner toe but much stouter; basal phalanx of middle toe wholly united to outer toe, for about half its length to inner toe; claws strongly curved, broad, compressed, that of hallux much shorter than the digit.

Coloration.-Above plain brown, the wings (sometimes pileum also) more rufescent, the tail chestnut or deep cinnamon-rufous; under parts plain olive-buffy or yellowish, more grayish olive on flanks; adult males with a concealed dorsal patch of ochraceous or tawny.

Range.--Southern Mexico to Peru. (Monotypic?) ${ }^{a}$

THAMNISTES ANABATINUS ANABATINUS Sclater and Salvin.

TAWNY ANTSHRIKE.

Adult male.-Above plain tawny brown (nearest raw umber or tawny olive), paler on forehead; upper tail-coverts and tail deep cinnamon-rufous or rufous-chestnut; wings (including secondaries) dull cinnamon-rufous or russet; interscapulars light cinnamon-rufous or deep ochraceous-buff beneath surface (forming a large and conspicuous patch when feathers are spread) followed immediately by a subterminal bar or spot of black; an indistinct superciliary stripe and suborbital area of pale grayish buffy, the two separated posteriorly by a postocular streak of brown; auricular region and sides of neck similar in color to back, but paler, the color deepening somewhat on malar region; general color of under parts pale brownish yellowish anteriorly, more grayish (tending more or less toward

a Although three species are recognized by authorities, it is likely that these may be in reality forms of one species. Two of these, however ( $T$. xquatorialis Sclater and T. rufescens Cabanis), I have not seen. 
olive-buff) posteriorly, the sides and flanks darker and more grayish (approaching light hair brown); under wing-coverts and broad edgings to inner webs of remiges ochraceous-buff; maxilla dusky, with paler tomia; mandible pale yellowish grayish (in dried skins); feet dusky (bluish gray in life?); length (skins), 136.5-142 (139); wing, 65-67 (66); tail, 53.5-62.5 (58); column, 18.5-19.5 (19); tarsus, 21-21.5 (21.2); middle toe, 12-12.5 (12.2). ${ }^{a}$

Adult female.-Similar to the adult male but without the concealed dorsal patch of cinnamon-rufous or ochraceous-buff, the underlying portion of the interscapulars being pale gray with whitish shaftstreaks; length (skins), 129.5-145 (138); wing, 66-67 (66.5); tail, 54-56 (55.2); culmen, 18-20 (19.2); tarsus, 19.5-20.5 (19.9); middle toe, $12-12.5(12.1) .^{b}$

Southeastern Mexico, in State of Tabasco (Teapa); Guatemala (Choctúm; Cajabón; Samayoa; Telemán); British Honduras (Toledo District).

Thamnistes anabatinus Sclater and Salvin, Proc. Zool. Soc. Lond., 1860, 299 (Choctúm, Vera Paz, Guatemala; coll. P. L. Sclater).-Salvin and Sclater, Ibis, 1860, 399 (Choctúm).-Sclater, Cat. Am. Birds, 1862, 176 (Choctum and Cajabón, Guatemala); Cat. Birds Brit. Mus., xv, 1890, 216, part (Choctum, Cajabón, and Samayoa, Guatemala).--Salvin and Godman, Biol. Centr.-Am., Aves, ii, 1892, 205, part, pl. 50, fig. I (Telemán, etc., Guatemala).

[Thamnistes] anabatinus Sclater and Salvin, Nom. Av. Neotr., 1873, 70, part.Sharpe, Hand-list, iii, 1901, 17, part.

Thamnistes anabatinus anabatinus RIDGWay, Proc. Biol. Soc. Wash., xxi, Oct. 20, 1908, 193, in text.

\section{THAMNISTES ANABATINUS SATURATUS Ridgway.}

\section{RUSSET ANTSHRIKE.}

Similar to $T$. a. anabatinus but coloration much darker and less ochraceous (more olivaceous) above, the pileum more or less distinctly rufescent (sometimes deep russet or mars brown); wings much less rufescent, especially the secondaries; size averaging smaller.

a Two specimens.

$b$ Four specimens.

\begin{tabular}{|c|c|c|c|c|c|}
\hline Locality. & Wing. & Tail. & $\begin{array}{l}\text { Cul- } \\
\text { men. }\end{array}$ & Tarsus. & $\begin{array}{c}\text { Middle } \\
\text { toe. }\end{array}$ \\
\hline MALES. & & & & & \\
\hline One adult male from Guatemala.......... & 67 & 62.5 & 18.5 & 21.5 & 12 \\
\hline $\begin{array}{l}\text { One adult male from Tabasco (Teapa).................... } \\
\text { FEMALEs. }\end{array}$ & 65 & 53.5 & 19.5 & 21 & 12.5 \\
\hline Two adult females from British Honduras (Toledo District)... & 66 & 55 & 19 & 19.7 & 12.2 \\
\hline One adult female from Guatemala................... & 67 & 55 & 18 & 19.5 & 12 \\
\hline One adult female from Tabasco (Teapa).............. & 66 & 56 & 20 & 20.5 & 12 \\
\hline
\end{tabular}


Adult male.-Length (skins), 126-135.5 (130.4); wing, 65-69.5 (67.7); tail, 48-52 (49.7); culmen, 18-19.5 (18.7); tarsus, 19-20.5 (19.6); middle toe, $11-13$ (11.8) ${ }^{a}$

Adult female.-Length 121-148 (131); wing, 61.5-69 (65.9); tail, 45.5-53.5 (50.7); culmen, 17.5-20.5 (20.1); tarsus, 19.5-20.5 (20.1); middle toe, $11-12.5$ (11.7). ${ }^{a}$

Costa Rica (Angostura; Tucurríqui; Jiménez; Volcan de Turrialba; Carrillo; La Hondura; Pacuare; Naranjo de Cartago; Guápiles; El Hogár; Bonilla; La Balsa ; Tuis; La Vijágua; Cariblanco de Sarapiquí; El Pozo de Térraba; Pozo del Pitál) and western Panamá (Calobre; Calovévora; Bugaba; Volcan de Chiriquí, 2,000-3,000 feet).

Thamnistes anabatinus (not of Sclater and Salvin) Lawrence, Ann. Lyc. N. Y., ix, 1868, 107 (Angostura and Tucurríqui, Costa Rica).-Frantzius, Journ. für Orn., 1869, 305 (Costa Rica).-SAlvin, Proc. Zool. Soc. Lond., 1870, 194 (Calovévorá and Bugaba, Panamá; crit.).-Zeledón, Anal. Mus. Nac. Costa Rica, i, 1887, 114 (Angostura, Pacuare, and Naranjo, Costa Rica).-SALvin and Godman, Biol. Centr.-Am., Aves, ii, 1892, 205, part (Costa Rican and Panaman localities and references).-Cherrie, Anal. Inst. Fis.-Geog. Costa Rica, vi, 1893, 19 (Pozo del Pitál, Costa Rica).-Bavgs, Proc. New Engl. Zool. Club, iii, 1902, 41 (Volcan de Chiriquí, Panamá, 2,000-3,000ft.).

[Thamnistes] anabatinus Sclater and Salvin, Nom. Av. Neotr., 1873, 70, part.Sharpe, Hand-list, iii, 1901, 17, part.

Thamnistes anabatinus saturatus RIDGWay, Proc. Biol. Soc. Wash., xxi, Oct. 20, 1908, 193 (Bonilla, Costa Rica, 2,600 ft.; coll. U. S. Nat. Mus.).-Carriker, Ann. Carnegie Mus., vi, 1910, 605 (Costa Rican range; crit.; habits).

\section{Genus ABALIUS Cabanis.}

Abalius $b$ Cabanis, Journ. für Orn., ix, July, 1861, 242. (Type, Thamnophilus punctatus Cabanis $=T$. bridgesi Sclater.)

Medium-sized Formicariidæ (length about $155 \mathrm{~mm}$.) with tail nearly as long as wing, pileum not crested, the adult male black (under parts of body more gray or slate colored) with small white tips to wingcoverts and lateral rectrices, adult females slate color or olive streaked with whitish.

Bill about as long as head rather stout, moderately compressed, distinctly hooked; exposed culmen about as long as tarsus, distinctly ridged, gently curved from near base to beyond middle, where more

a Ten specimens, all from Costa Rica. Costa Rican specimens compare in measurements with those from Panamá (Chiriquí, Caribbean slope) as follows:

\begin{tabular}{|c|c|c|c|c|c|}
\hline Locality. - & Wing. & Tail. & $\begin{array}{l}\text { Cul- } \\
\text { men. }\end{array}$ & $\begin{array}{l}\text { Tar- } \\
\text { sus. }\end{array}$ & $\begin{array}{c}\text { Middle } \\
\text { toe. }\end{array}$ \\
\hline MALES. & & & & & \\
\hline Ten adult males from Costa Rica.. & 67.7 & 49.7 & 18.7 & 19.6 & 11.8 \\
\hline Two adult males from Panamá (Chiriqui, Caribbean slope).... & 66 & 51.2 & 18 & $20^{\circ}$ & 12 \\
\hline
\end{tabular}

$b$ "Von $\alpha$, privativum und $\beta \alpha \lambda<b s$, scheckig, bunt." (Cabanis.) 
strongly decurved, the tip of maxilla conspicuously uncinate; maxillary tomium nearly straight, distinctly notched subterminally; tip of mandible slightly recurved or subfalcate, the tomium slightly but distinctly toothed and notched subterminally; gonys strongly convex and prominent basally, ascending and moderately convex terminally, nearly twice as long as unfeathered portion of rami. Nostril small, exposed, obliquely oval, without visible internal tubercle. Rictal bristles obvious but small; feathers of chin and anterior portion of malar region with small bristly tips, those of loral region with muchthickened shafts, and those of frontal antiæ semi-decomposed. Wing moderate, the longest primaries decidedly longer than secondaries, much rounded; fifth, sixth, and seventh primaries longest, the tenth (outermost) about three-fifths as long as the longest, the ninth about as long as secondaries. Tail slightly but decidedly shorter than wing, much rounded (graduation about equal to distance from nostril to tip of maxilla), the rectrices (12) broad, rounded terminally. Tarsus as long as exposed culmen or a little shorter (between onefourth and one-third as long as wing), distinctly scutellate, the planta consisting of two longitudinal series of scutella, the inner series of which are larger, of quadrate form, and extend around the posterior margin, the outer series much smaller, longitudinal, and irregularly hexagonal or elliptical; middle toe, with claw, much shorter than tarsus; outer toe, without claw, reaching to beyond middle of subterminal phalanx of middle toe, the inner toe decidedly but slightly shorter; hallux about as long as inner toe but much stouter; middle toe united to outer toe by whole of its basal phalanx, to inner toe by more than half its basal phalanx; claws moderately curved, rather blunt, much compressed. Plumage blended, rather lax, especially on rump; feathers of pileum moderately developed, not forming a distinct crest.

Coloration.-Adult male black (more gray or slaty on under parts of body), the wing-coverts with white terminal dots, the lateral rectrices narrowly tipped with white; adult female gray or olive, narrowly streaked with whitish.

Range.-Costa Rica and western Panamá. (Monotypic.)

\section{ABALIUS BRIDGESI (Sclater.)}

BRIDGES' ANTSHRIKE.

Adult male.-Head, neck, chest, and upper parts black, broken on wing-coverts by a small spot of white at tip of most of these feathers; outer pair of rectrices with a small terminal spot of white, the next pair sometimes with a similar but smaller spot; ${ }^{a}$ under parts of body, posterior to chest, plain slate color, the under tail-coverts similar but darker; under wing-coverts (except along margin of wing)

$a$ Very rarely there are a few very narrow streaks of white on the chest. 
yellowish white, usually flecked, more or less, with dusky; inner webs of remiges broadly edged (except terminally) with yellowish white; bill black; iris brown; legs and feet dusky (plumbeous in life); length (skins), 150-167 (157); wing, 72-80 (74.9); tail, 62-71 (67.5); culmen, 20-22.5 (21.4); tarsus, 21-23.5 (22.4); middle toe, 13.5-14.5 (13.9). ${ }^{a}$

Adult female.-Head and neck black narrowly streaked with white, the streaks much broader (sometimes spot-like) on chin and throat; back, scapulars, rump, and upper tail-coverts plain sepia-brown to slaty brown, the feathers of back slightly darker centrally; wings and tail darker (the tail brownish black or blackish brown), all, or nearly all, the wing-coverts marked with a small roundish or triangular terminal spot of white; under parts, posterior to throat or upper chest, varying from nearly slate-gray to olive-drab, the pectoral region streaked with white; under tail-coverts deeper brown, narrowly streaked (sometimes also somewhat spotted) with white; under wing-coverts and broad edgings to inner webs of remiges yellowish white or pale creamy yellow; maxilla black, mandible paler (plumbeous in life); iris dark brown or brownish gray; legs and feet plumbeous; length (skins), 148-166 (157); wing, 70-77 (72.9); tail, 60-70.5 (66.7); culmen, 19.5-22 (20.7); tarsus, 21-23.5 (22.4); middle toe, 13-15 (14). ${ }^{b}$

Young male (first plumage).- Similar to the adult male but texture of plumage much softer, black of back, etc., duller, and chest with narrow shaft-streaks of white.

Young female (first plumage).- Similar to adult female but duller in color, with black of head and neck replaced by dark sooty brown above and paler sooty brown below, and streaks much less distinct, those on pileum pale brownish or tinged with brown, instead of pure white, those of pectoral area broader but much less distinct and also suffused with pale brownish.

Southwestern Costa Rica (Pozo Azúl de Pirrís; Pozo del Pitál, Rio Naranjo; El Pozo de Térraba; Trojas de Rio Grande; El

\begin{tabular}{|c|c|c|c|c|c|}
\hline a Nineteen specimens. & \multicolumn{5}{|c|}{$b$ Eighteen specimens. } \\
\hline Locality. & Wing. & Tail. & $\begin{array}{l}\text { Cul- } \\
\text { men. }\end{array}$ & $\begin{array}{l}\text { Tar- } \\
\text { sus. }\end{array}$ & $\begin{array}{c}\text { Middle } \\
\text { toe. }\end{array}$ \\
\hline MALES. & & & & & \\
\hline Ten adult males from Costa Riea... & 75.8 & 68.6 & 21.3 & 22.1 & 13.9 \\
\hline Nine adult males from western Panamá.... & 74 & 66.3 & 21.6 & 22.7 & 13.9 \\
\hline FEMALES. & & & & & \\
\hline Ten adult females from Costa Rica............ & 73.4 & 67.8 & 20.6 & 22.5 & 14. 1 \\
\hline Eight adult females from western Panama... & 72.3 & 65.3 & 20.8 & 22.2 & 13.9 \\
\hline
\end{tabular}


Naranjo; Buenos Aires; El Generál; Tenório; Paso Reál, Boruca, Pozo del Rio Grande, and Lagarto, Boruca; Pigres; San Mateo; Esparta) and western Panamá (Divala and Davíd, Chiriquí; Verágua).

Thamnophilus bridgesi Sclater, Proc. Zool. Soc. Lond., 1856, 141 (Davíd, Chiriquí, Panamá; coll. P. L. Sclater;= $q$ ); 1858, 212 (monogr.); Cat. Birds Brit.Mus., xv, 1890, 194 (Bugaba and Mina de Chorcha, Panamá).--Salvin, Proc. Zool. Soc. Lond., 1867, 144 (Davíd, Panamá); 1870, 194 (Bugaba and Mina de Chorcha).-Lawrence, Ann. Lyc. N. Y., ix, 1868, 107 (San Mateo, Costa Rica).-Frantzius, Journ. für Orn., 1869, 305 (Costa Rica).-Zeledón, Anal. Mus. Nac. Costa Rica, 1887, 114 (Las Trojas and Pozo Azúl de Pirrís, Costa Rica).-Salvin and Godman, Biol. Centr.-Am., Aves, ii, 1892, 199, pl. 49, fig. 2.-Cherrie, Auk, x, 1893, 279, 280 (Pacific side Costa Rica, up to 2,200 ft.; crit.; habits); Anal. Inst. Fis.-Geog. Costa Rica, vi, 1893, 17 (Pozo del Pitál, Costa Rica; syn.; crit.); Expl. Zool. Merid. Costa Rica, 1893, 41 (Palmár, Boruca, Térraba, Lagarto, and Buenos Aires, s. w. Costa Rica).Bangs, Auk, xxiv, 1907, 296 (Boruca, Paso Reál, Pozo del Rio Grande, and Lagarto, s. w. Costa Rica).-CARriker, Ann. Carnegie Mus., vi, 1910, 601 (Pacific lowlands and foothills, Costa Rica; habits).

[Thamnophilus] bridgesi Sclater and Salvin, Nom. Av. Neotr., 1873, 70.SHARPE, Hand-list, iii, 1901, 12.

Thamnophilus punctatus (not Lanius punctatus Shaw, $1809^{a}$ ) CABAnis, Journ.

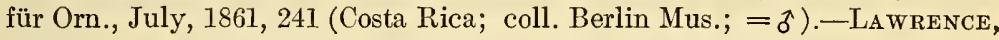
Ann. Lyc. N. Y., ix, 1868, 107 (Costa Rica).-Frantzius, Journ. für Orn., 1869, 305 (Costa Rica).-Salvin, Ibis, 1870, 110 (Costa Rica; crit); Proc. Zool. Soc. Lond., 1870, 194 (Mina de Chorcha, Bugaba, and Volcan de Chiriquí, Panamá).-Zeledón, Anal. Mus. Nac. Costa Rica, 1887, 114 (Las Trojas and Pozo Azúl de Pirrís, Costa Rica).-Sclater, Cat. Birds Brit. Mus., xv, 1890, 191 (Costa Rica; Bugaba and Mina de Chorcha, Panamá).-Salvin and Godman, Biol. Centr. Am., Aves, ii, 1892, 198, pl. 49, fig. 1.

[Thamnophilus] punctatus Sclater and Salvin, Nom. Av. Neotr., 1873, 70.SHARPE, Hand-list, iii, 1901, 12.

(?)Thamnophilus nigricristatus (not of Lawrence) Boucard, Proc. Zool. Soc. Lond., 1878, 60 (San Carlos, Costa Rica; cites "Th. punctatus Cab.")b

\section{Genus TARABA Lesson.}

Taraba Lesson, Traité d'Orn., 1831, 375. (Type, Thamnophilus major Vieillot.) Tabara (error) Sclater, Cat. Am. Birds, 1862, 172.

Diallactes Reichenbach. Av. Syst. Nat., 1850, pl. 71. (Type, Thamnophilus major Vieillot.)

Large Formicariidæ (length about $200 \mathrm{~mm}$.) with very stout but much compressed, strongly hooked bill, crested pileum, and white under parts, the adult males black above with white markings on wings, adult females chestnut or tawny brown above.

Bill nearly as long as head, very strong but compressed, strongly hooked; culmen nearly straight for most of its length, rather abruptly decurved terminally, the tip of maxilla strongly uncinate; maxillary

$a$ Usually placed in Thamnophilus, but in this work designated as Erionotus punctatus (p. 49).

$b$ Salvin and Godman, however (Biol. Centr.-Am., Aves, ii, 1892, 195), place this reference under Cymbilanius lineatus. 
tomium nearly straight, conspicuously notched subterminally; gonys moderately convex, strongly ascending terminally, prominent basally; mandibular tomium straight or slightly concave toward tip, slightly notched subterminally; width of bill at frontal antiæ about three-fourths its depth at same point. Nostril exposed, broadly longitudinally oval, with distinct internal tubercle. Rictal bristles obvious but small, the loral feathers with thickened bristly shafts. Wing moderate or rather short, excessively rounded, with longest primaries very little if any longer than secondaries; second, third, and fourth, or third, fourth, and fifth primaries longest and equal, tenth (outermost) about three-fifths as long as longest, the ninth very much, eighth slightly, shorter than secondaries. Tail three-fourths to more than five-sixths as long as wing, much rounded (graduation about equal to distance from nostril to tip of maxilla), the rectrices (12) rather broad, rounded terminally. Tarsus more than one-third as long as wing, distinctly scutellate, the elongatequadrate plantar scutella in two longitudinal series; middle toe, with claw, decidedly shorter than tarsus; outer toe, without chaw, reaching to or slightly beyond middle of subterminal phalanx of middle toe, the inner toe slightly but decidedly shorter; hallux about as long as inner toe but much stouter; basal phalanx of middle toe united for most of its length to outer toe, for about half its length to inner toe; claws moderately developed, that of the hallux decidedly shorter than the digit. Plumage blended, very full, that of rump much developed and lax; pileum with a conspicuous decumbent crest of distinctly outlined, rather narrow feathers.

Coloration.-Under parts (except, sometimes, thighs and under tail-coverts), including malar region, immaculate white; upper parts black in adult males, rufous-brown or chestnut in adult females, the wing-coverts tipped with white (primaries sometimes edged with white), the tail sometimes transversely spotted with white. ${ }^{a}$

Range.-Southern Mexico to Argentina. (About four species and subspecies.)

TARABA TRANSANDEANA TRANSANDEANA (Sclater).

HOLLAND'S ANTSHRIKE.

Adult male.-Entire upper parts, including sides of head (down to upper margin of malar region) and sides of neck, black, relieved by conspicuous white tips to all the wing-coverts ${ }^{b}$ and white edges to alula, the terminal portion of remiges duller blackish or more

a Thamnophilus rohdei Berlepsch, of Paraguay, referred to this group by Dr. Sclater, has the under parts black in the adult male with the breast varied with white. This species I have not seen and therefore do not know whether it is really a member of this genus or not.

$b$ Sometimes a few of the primaries are narrowly edged with white. 
slaty; interscapulars with concealed basal portion extensively white; under parts, including malar region, plain white (sometimes tinged with buffy), passing into grayish on flanks; tibial feathers black basally, extensively white terminally (the posterior side of thighs sometimes uniform black); under tail-coverts black, often (irrespective of locality) tipped or barred with white, rarely mostly white; bill black; iris carmine red; legs and feet dusky (bluish gray in life?); length (skins), 179-205 (194); wing, 87-99 (92.1); tail, 64-79 (71); culmen, 26-31.5 (28.5) ; tarsus, 33-37 (34.2); middle toe, 20-23.5 (21.3). ${ }^{a}$

Adult female.-Above plain chestnut, darker on pileum, paler and duller on rump, the tail and primaries more brownish chestnut; loral and orbital regions dusky, passing into chestnut on auricular region; under parts (including greater part of malar region) plain white (sometimes tinged more or less with buffy), passing through pale buffy grayish into pale buffy brown or cinnamon on flanks; under tail-coverts light chestnut; thighs mixed light chestnut and buffy whitish; bill varying from horn brown to nearly black; iris carmine red; legs and feet horn color or dusky (bluish gray in life?); length (skins), 169-220 (190); wing, 83-96 (89.4); tail, 64.5-75.5 (70.2); culmen, 25-30.5 (28.1); tarsus, 32-36.5 (34.2); middle toe. $20-23.5(21.8){ }^{b}$

Immature male.-Similar to the adult male but wing-coverts without white tips (the greater coverts sometimes narrowly tipped with

a Forty-seven specimens.

$b$ Thirty-six specimens.

\begin{tabular}{|c|c|c|c|c|c|}
\hline Locality. & Wing. & Tail. & $\begin{array}{l}\text { Cul- } \\
\text { men. }\end{array}$ & $\begin{array}{l}\text { Tar- } \\
\text { sus. }\end{array}$ & $\begin{array}{c}\text { Middle } \\
\text { toe. }\end{array}$ \\
\hline \multicolumn{6}{|l|}{ MALES. } \\
\hline Three adult males from Colombia (Rio Barratoro).. & 92.5 & 73. 3 & 27.8 & 34.7 & 21 \\
\hline Ten adult males from Panamá........................... & 89.6 & 69.9 & 28.1 & 35 & 22 \\
\hline Ten adult males from Costa Rica.... & 93.7 & 71.6 & 29.2 & 35.7 & 22.9 \\
\hline Six adult males from Nicaragua..................... & 92.5 & 70.9 & 29.2 & 34.7 & 21.8 \\
\hline Seven aduit males from Honduras..................... & 92.5 & 70.7 & 27.8 & 34.3 & 21.1 \\
\hline Six adult males from Guatemala.......... & 91.2 & 70.5 & 28 & 34.7 & 21.2 \\
\hline Five adult males from southern Mexico............... & 93.7 & 72.8 & 29 & 35 & 21.3 \\
\hline \multicolumn{6}{|l|}{ FEMALES. } \\
\hline One adult female from Colombia (Rio Lima). & 88 & 68 & 25 & 33 & 21.5 \\
\hline Two adult females from eastern Panamá (Loma del León).. & 87.2 & 66.2 & 26.2 & 34.5 & 21.7 \\
\hline Eight adult females from western Panamá (Chiriquí)... & 87.3 & 68.9 & 26.3 & 34.4 & 21.2 \\
\hline Ten adult females from Costa Rica................... & 91.6 & 70.7 & 29 & 34.6 & 22.5 \\
\hline Slx adult females from Nicaragua........ & 91 & 71.4 & 29.2 & 34.3 & 21.7 \\
\hline Two adult females from Honduras.......... & 86.5 & 67.2 & 28.5 & 33.2 & 21.2 \\
\hline Four adult females from Guatemala.......... & 87.9 & 72 & 28.4 & 34.6 & 22 \\
\hline Three adult females from southern Mexico... & 91.2 & 73 & 29.3 & 34.7 & 21.5 \\
\hline
\end{tabular}


rusty brown or buffy), white at base of interscapulars more restricted, and feathers of chest (at least lateral portions) narrowly margined terminally with black.

Young male (nestling).-Above wholly dull black, with very indistinct narrow vermiculations of rusty brown on tips of some of the feathers; throat and chest dull grayish, broken by broad bars of black (most distinct on chest) and more narrowly barred with light buffy brown; sides, flanks, and under tail-coverts nearly uniform dull black, but showing very indistinct vermiculations of light brown, especially the under tail-coverts; breast and abdomen mostly white, or grayish white, broken by broad subterminal bars of black, the tip of each feather, narrowly, pale buffy brownish. ${ }^{a}$

Southern Mexico, in States of Vera Cruz (Orizaba; Santecomapám; Playa Vicente; Omealca; Buena Vista; San Andrés Túxtla) and Tabasco (Teapa), and southward through Guatemala (Choctúm; Chiséc; Cobán; sources of Rio de la Pasión), Honduras (Omoa; San Pedro; San Pedro Sula; Céiba; Julian), Nicaragua (Greytown; Los Sábalos; Rio Escondido; San Emilis), Costa Rica (Tucurríqui; Jiménez; Las Trojas; Pacuare; Pozo Azúl de Pirrís; El Pozo de Térraba; Pozo del Rio Grande; Boruca; Paso Reál; Bolsón; El Hogår; Rio Sícsola; Guácimo; Barranca de Puntarenas; Lagarto; El Generál; Sipúrio), Panamá (Davíd; Mina de Chorcha; Divala; Agua Dulce; Lion Hill; Panamá; Sabana de Panamá), and northwestern Colombia (Rio Lima; Rio Barratoro; Turbo) to Ecuadór (Guayaquíl; Babahoyo; Santa Rita; Sarayacu; Chimbo; Vinces; Foreste del Rio Peripa). ${ }^{b}$

The very large series of Mexican and Central American birds examined in this connection shows very clearly the absence of anything like corellation between geographic distribution and the coloration of the under tail-coverts, and, therefore, in the absence of other characters (that I can discern) I am forced to recognize a single form only.

Thamnophilus transandeanus Sclater, Proc. Zool. Soc. Lond., xxxiii, April 11, 1855, 18 (Guayaquíl, w. Ecuadór; coll. Brit. Mus.); 1858, 210 (monogr.); 1860, 278 (Babahoyo, w. Ecuadór), 294 (Esmeraldas, w. Ecuadór); Edinb. Philos. Journ., new ser., i, 1855, 233; Cat. Am. Birds, 1862, 172 (Babahoyo, w. Ecuadór); Cat. Birds Brit. Mus., xv, 1890, 185 (Tucurríqui, Costa Rica; Mina de Chorcha, Verágua; Panamá; Babahoyo, Santa Rita, Guayaquíl, and Sarayacu, Ecuadór; Remédios, prov. Antioquía, Colombia).-Cassin, Proc. Ac. Nat. Sci. Philad., 1860, 188 (Turbo, Colombia).-Lawrence, Ann. Lyc. N. Y., vii, 1862, 293 (Lion Hill, Panamá).-Sclatęr and Salvin, Proc.

$a$ Described from no. 28866, Carnegie Museum; Boruca, Costa Rica, Aug. 7, 1907; M. A. Carriker, jr. (Sex given as female, but almost certainly an error.)

$b$ I have not seen a specimen from Ecuador, and therefore can not be sure that they are quite identical with those from Central America. Neither have I examined specimens from the vicinity of Bogotá or the State of Antioquía, Colombia, which have been separated by Menegaux and Hellmayr as Thamnophilus transandeanus granadensis. 
Zool. Soc. Lond., 1864, 355 (Lion Hill; crit.); 1879, 524 (Remédios and Nechi, Antioquía, Colombia).-Salvin, Proc. Zool. Soc. Lond., 1867, 144 (Davíd, Panamá; crit.).-Taczanowski, Proc. Zool. Soc. Lond., 1877, 324 (Peru); Orn. du Pérou, ii, 1884, 3.-Berlepsch and Taczanowski, Proc. Zool. Soc. Lond., 1883, 564 (Chimbo, w. Ecuadór).-Zeledón, Anal. Mus. Nac. Costa Rica, 1887, 114 (Jiménez, Las Trojas, and Pacuare, Costa Rica).Salvin and Godman, Biol. Centr.-Am., Aves, ii, 1892, 198 (Tucurríqui, Jiménez, Las Trojas, and Pacuare, Costa Rica; Davíd, Mina de Chorcha, and Lion Hill, Panamá; Turbo, Colombia; Ecuadór).-Cherrie, Expl. Zool. Merid. Costa Rica, 1893, 41 (Palmár, Boruca, and Buenos Aires, s. w. Costa Rica).-Hartert, Novit. Zool., v, 1898, 491 (Chimbo, n. w. Ecuadór).-Salvadori and Festa, Boll. Mus. Zool., etc., Torino, xv, no. 362, 1899, 27 (Vinces and Foreste del Rio Peripa, w. Ecuadór).-Bangs, Proc. New Engl. Zool. Club, ii, 1900, 24 (Loma del León, Panamá); Auk, xxiv, 1907, 296 (Boruca, Pozo del Rio Grande, Lagarto, and Barranca de Puntarenas, Costa Rica).-Thayer and Bangs, Bull. Mus. Comp. Zool., xlvi, 1906, 216 (Sabana de Panamá).-Carriker, Ann. Carnegie Mus., vi, 1910, 601 (Costa Rica; habits).

$D$ [iallactes] transandeanus Cabanis and Heine, Mus. Hein., ii, Aug., 1859, 18, footnote.

[Thamnophilus] transandeanus Sclater and Salvin, Nom. Av. Neotr., 1873, 69.Sharpe, Hand-list, iii, 1901, 10.

Thamnophilus melanurus (not of Gould) Sclater, Proc. Zool. Soc. Lond., 1856, 142 (Davíd, Panama); 1857, 203 (Santecomapám, Vera Cruz); 1859, 57 (Omoa, Honduras), 383 (Playa Vicente, Vera Cruz).-Sclater and Salvin, Ibis, 1859, 119 (Omoa, Honduras; crit.).

Thamnophilus melanurus? Moore, Proc. Zool. Soc. Lond., 1859, 57 (Omoa, Honduras; crit.).-Sclater, Proc. Zool. Soc. Lond., 1859, 383 (Playa Vicente, Vera Cruz).

(?) [Diallactes] melanurus Heine and Reichenow, Nom. Mus. Hein. Orn., 1890, 128 (Colombia).

Thamnophilus melanocrissus Sclater, Proc. Zool. Soc. Lond., 1860, 252 (Santecomapám, Orizaba, Vera Cruz, Mexico; coll. P. L. Sclater).-Cat. Am. Birds, 1862, 172 (Choctúm, Guatemala); Cat. Birds Brit. Mus., xv, 1890, 184 (Sources Rio de la Pasión and Choctúm, Guatemala; Panamá?).-Salvin, Ibis, 1866, 203 (Guatemala).--Lawrence, Ann. Lyc. N. Y., ix, 1868, 107 (Costa Rica).Frantzius, Journ. für Orn., 1869, 305 (Costa Rica).-Sumichrast, Mem. Bost. Soc. N. H., i, 1869, 556 (tierra caliente of Vera Cruz, up to 1,000 m.); La Naturaleza, v, 1881, 248 (Omealca, Vera Cruz). -Sclater and Salvin, Proc. Zool. Soc. Lond., 1870, 837 (San Pedro, Honduras).-Boucard, Liste Ois. réc. Guat., 1878, 38.-Nutring, Proc. U. S. Nat. Mus., vi, 1883, 405 (Los Sábalos, Nicaragua; habits; food).-Rrdgway, Proc. U. S. Nat. Mus., xiv, 1891, 471 (San Pedro Sula, Honduras).-Salvin and Godman, Biol. Centr.Am., Aves, ii, 1892, 197.-Rrсhмond, Proc. U. S. Nat. Mus., xvi, 1893, 500 (Rio Escondido, Nicaragua; habits, notes, etc.).

[Thamnophilus] melanocrissus Sclater and Salvin, Nom. Av. Neotr., 1873, 69.Sharpe, Hand-list, iii, 1901, 10.

$D$ [iallactes] melanocrissus Cabanis, Journ. für Orn., 1872, 234 (Mexico; crit.).

[Diallactes] melanocrissus Heine and Reichenow, Nomencl. Mus. Hein. Orn., 1890, 129 (Mexico).

Thamnophilus transandeanus+Thamnophilus melanocrissus Bangs, Bull. Mus. Comp. Zool., xxxix, 1903, 150 (Céiba, Honduras; crit.).

Thamnophilus hollandi Lawrence, Ann. Lyc. Nat. Hist. N. Y., viii, 1867, 180 (Greytown, Nicaragua; coll. U. S. Nat. Mus.).-Salvin, Ibis, 1874, 310 (crit.). 
(?) D[iallactes] granadensis CABAnIs, Journ. für Orn., May, 1872, 234 (Bogotá, Colombia; coll. Berlin Mus.?).

(?) Thamnophilus transandeanus granadensis Menegaux and Hellmayr, Bull. Soc. Philom. Paris, ser. 9, viii, 1906, 25 (Bogotá and Antioquía, Colombia; Mérida, Venezuela; crit.).

Genus HYPOLOPHUS Cabanis and Heine.

Hypolophus a Cabanis and Herne, Mus. Hein., ii, Aug., 1859, 16. (Type, Turdus cirrhatus Gmelin=Lanius canadensis Linnæus.)

Medium-sized Formicariidæ (length about $150 \mathrm{~mm}$.) with strong, compressed, and conspicuously-hooked bill, crested pileum, tail fourfifths as long as wing, and exposed culmen longer than middle toe with claw; adult males with head, neck, chest, and median portion of breast and abdomen uniform black, sides and flanks white or light gray, wings and tail black varied with white; adult females brownish above (the wings varied with buff or whitish, pileum blackish or rufescent), the under parts plain buffy.

Bill nearly as long as head (exposed culmen longer than middle toe with claw), stout, slightily to much compressed, the maxilla conspicuously hooked and notched; width at frontal antiæ decidedly less than depth at same point (H. melanonotus) or slightly greater than depth (H.canadensis), equal to less than half the distance from nostril to tip of maxilla (H.melanonotus) or more than half (H.canadensis); culmen moderately ( $H$. canadensis to rather sharply ridged ( $H$. melanonotus), nearly straight or very slightly convex for most of its length, strongly and rather abruptly decurved terminally, the tip of maxilla conspicuously uncinate; maxillary tomium nearly straight, distinctly notched and slightly toothed subterminally; mandible recurved and acute at tip, the tomium distinctly notched and toothed subterminally; gonys moderately convex, ascending terminally rather prominent basally. Nostril exposed, roundish or broadly oval, with an interior tubercle partly visible in upper posterior portion. Rictal bristles indistinct or obsolete, but loral feathers sometimes with shafts slightly elongated and thickened; feathers of chin, malar antiæ, and frontal antiæ with more or less distinct bristly tips. ${ }^{b}$ Wing moderate in length, rather pointed (primaries decidedly longer than secondaries); sixth and seventh primaries longest, tenth (outermost) more than three-fifths as long as the longest, ninth about equal to secondaries. Tail about four-fifths as long as wing, slightly ( $H$. canadensis) to much (H. melanonotus) rounded, the rectrices (12) moderately broad, with rounded tip. Tarsus decidedly longer than exposed culmen, about one-third as long as wing, distinctly scutellate, the plantar scutella in two longitudinal series; middle toe, with claw,

a "Von inó̉oфos (subcristatus)." (Cabanis and Heine.)

$b$ These bristly points are much more strongly developed in $H$. melanonotus than in H. cirrhatus, as are also those of the loral region. 
much shorter than tarsus; outer toe, without claw, reaching to beyond middle of subterminal phalanx of middle toe, the inner toe decidedly shorter; hallux about as long as inner toe but much stouter; basal phalanx of middle toe wholly united to outer toe, united for about half its length to inner toe; claws strongly curved, much compressed, that of the hallux decidedly shorter than its digit. Plumage full, lax, and blended, that of the rump much lengthened and fluffy; feathers of pileum elongated, especially on occiput, forming a distinct decumbent crest.

Coloration.-Adult males with head, neck, chest, and median portion of breast (usually of abdomen also) uniform black, the sides and flanks white or light gray; wings and tail black varied with white, the back brown or grayish, or black with a large concealed patch of white; adult females olive-brown to tawny-brown above, the wings dusky varied with buffy or whitish, the pileum blackish or rufescent; under parts plain buffy (more whitish on throat and abdomen).

Range.-Northern Colombia to Cayenne, southeastern Brazil, Bolivia, and northern Peru. (About seven species.)

\section{HYPOLOPHUS CANADENSIS PULCHELLUS (Cabanis and Heine).}

COLOMBIAN CRESTED ANTSHRIKE.

Adult male.-Pileum (including well-developed occipital crest) black, the forehead (sometimes crown also) streaked with white; back, scapulars, and rump plain cinnamon or russet, the scapulars and interscapulars with indistinct narrow mesial streaks of darker; outer row of scapulars dark brown, broadly edged with white; wingcoverts and tertials brownish black, all the former conspicuously tipped with white, the latter broadly edged with white or buffy white; secondaries and primaries dusky grayish brown (dark hair brown), the secondaries and inner primaries edged with light brown, the outer primaries edged with whitish; tail black, the rectrices broadly tipped with white, the exterior pair with outer web white (except basally); sides of head barred with black and white; chin, throat, and median portion of chest black, this sometimes continued, narrowly or brokenly, along the median line of breast, the feathers of chin and throat tipped with white; median under parts (except where occupied by the black gular-jugular area, white; lateral under parts pale gray anteriorly, passing into light cinnamon or clay color posteriorly; under wing-coverts and broad edgings to inner webs of remiges white or buffy white; maxilla brownish black, mandible sometimes more brownish (bluish gray in life?); legs and feet horn color (in dried skins); wing, 69-75 (72); culmen, 18-20 (19); tarsus, 27-27.5 (27.2); middle toe, $14.5-16$ (15.2).$^{a}$ 
Adult female.-Pileum deep cinnamon-rufous or rufous-chestnut; back, scapulars, and rump plain buffy cinnamon, the first deeper, inclining to russet; outer row of scapulars grayish brown, broadly edged with buff; wings and tail as in adult male, but the former with markings buff instead of white, and ground color of coverts less dark; sides of head, chin, and throat, pale buff or buffy white, the former barred and streaked with blackish; rest of under parts plain buff or clay color, slightly paler medially, especially on abdomen; maxilla horn color, mandible much paler; legs and feet horn color (in dried skins); wing, 69-73.5 (71.8); tail, 56-61 (58); culmen, 18-18.5 (18.2); tarsus, 26-26.5 (26.2); middle toe, $14-15$ (14.5).$^{a}$

Northern Colombia (Rio Atrato; Rio Truando; Cartagena; Sabanilla; Barranquilla; Santa Marta, Bonda, and Cienega, Santa Marta; Valencia).

H[ypolophus] pulchellus Cabanis and Heine, Mus. Hein., ii, Aug., 1859, 16 (Cartagena, Colombia; coll. Heine Mus.).

Thamnophilus pulchellus Berlepsch, Ibis, Apr., 1881, 245 (crit.).-Sclater, Cat. Birds Brit. Mus., xv, 1890, 204 (Valencia, Santa Marta, and Barranquilla, Colombia).-Salvin and Godman, Biol. Centr.-Am., Aves, ii, 1892, 201 (Rio Truando, Santa Marta, and Cartagena, n. Colombia).-Allen, Bull. Am. Mus. N. H., xiii, 1900, 161 (Bonda and Cienega, Santa Marta, Colombia).

[Thamnophilus] pulchellus SHARPE, Hand-list, iii, 1901, 15.

Thamnophilus, sp.?, Cassin, Proc. Ac. Nat. Sci. Philad., 1860, 189, no. 88 (Rio Truando).

Thamnophilus leucauchen (not of Sclater, 1855), Sclater, Cat. Am. Birds, 1862, 174, part (Santa Marta).-Salvin and Godman, Ibis, 1881, 171 (Santa Marta).

\section{Genus THAMNOPHILUS Vieillot.}

Thamnophilus $b$ Vielloot, Analyse, 1816, 40; Nouv. Dict. d'Hist. Nat., iii, 1816, 308.c (Type, Pie-Grieche rayee-Fourmillier huppé Buffon=Lanius doliatus Linnæus.)

Tamnophilus Vieillot, Analyse, 1816, 70.-D’Orbigny and Lafresnaye, Mag. de Zool., 1849 (Synop. Av., p. 10).

Medium-sized Formicariidæ (length about 150-160 mm.) with bill much shorter than head, not compressed, its terminal unguis small; adult males with under parts (usually upper parts also) conspicuously barred with black and white, or (in T. virgatus) dull slate-gray streaked with whitish; adult females and young tawny or rufous above, ochraceous or buff below. ${ }^{d}$

Bill much shorter than head (exposed culmen shorter than middle toe with claw), broader than deep at frontal antiæ, where its width is equal to much more than half the distance from nostril to tip of maxilla; culmen broad, indistinctly ridged, slightly convex from

a Three specimens. (All the specimens examined are in bad condition, and some measurements can not be made from them.)

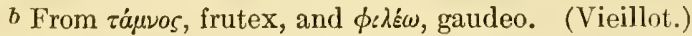

c Type given as "Lanius turdus Lath[am]."

$d$ The female and young of $T$. virgatus unknown, however. 
near base, more strongly decurved terminally, the tip of mandible distinctly but not strongly uncinate; maxillary tomium faintly concave, distinctly notched subterminally; mandibular tomium nearly straight, minutely but distinctly notched and toothed subterminally, the tip of mandible acute, recurved; gonys moderately convex, ascending terminally, rather prominent basally. Nostril exposed, broadly longitudinally oval, with the internal tubercle barely visible in upper posterior portion. Rictal bristles present but very small, shorter than the terminal setæ to feathers of chin. Wing moderate, with longest primaries projecting slightly but decidedly beyond secondaries; fifth and sixth primaries longest, the seventh but little shorter; tenth (outermost) about three-fifths as long as longest, the ninth shorter than secondaries. Tail about as long as wing (at least five-sixths as long), much rounded (graduation equal to or exceeding length of exposed culmen), the retrices (12) moderately broad. rounded terminally. Tarsus equal to or longer than commissure, about one-third as long as wing, distinctly scutellate, the plantar scutella in two longitudinal series, elongate-quadrate or lozenge shaped; middle toe, with claw, much shorter than tarsus (toe alone shorter than exposed culmen); outer toe, without claw, reaching to or a little beyond middle of subterminal phalanx of middle toc, the inner toe a little shorter; hallux about as long as inner toe, but much stouter; basal phalanx of middle toe wholly united to outer toe, united to inner toe for about half its length; claws moderate in size and curvature, that of the hallux much shorter than its digit. Plumage full, lax, and blended, that of the rump elongated, fluffy; feathers of crown and occiput (especially the latter) elongated, distinctly outlined, forming a distinct but not conspicuous decumbent crest.

Coloration.-Adult males with under parts (usually the upper also) conspicuously barred with black and white, or else (in $T$. virgatus) dull slate-gray, streaked with whitish; adult females and young tawny or rufescent above, ochraceous or buffy below.

Nidification.-Nest pensile, suspended from a fork like that of a Vireo. Eggs white or creamy white, marked with brownish spots or streaks.

Range.-Southern Mexico to Cayenne, Paraguay, Bolivia, and Peru. (About ten species, not including subspecies.)

KEY TO THE SPECIES AND SUBSPECIES OF THAMNOPHILUS. $a$

a. Plumage wholly black and white, in transverse bars.

b. Pileum wholly black. (Eastern Panamá, including San Miguél Island, and Caribbean coast of Colombia.)

Thamnophilus radiatus nigricristatus, adult male (p. 37).

$a$ Owing principally to lack of sufficient material this key is confined mainly to the forms belonging properly to the present work and is by no means as satisfactory as is desirable. 
bb. Pileum partly white.

c. Pileum with more or less of white on basal portion of feathers. (Thamnophilus doliatus.)

d. Darker, with white bars of upper parts narrower and black bars of under parts broader.

e. Wing averaging longer ( 75.5 in adult male), ${ }^{a}$ tail relatively shorter (averaging 63 in adult male). (Guianas; Venezuela?).

Thamnophilus doliatus doliatus, adult male (extralimital). $b$

ee. Wing averaging shorter (72.6 in adult male), tail relatively longer (averaging 62.8 in adult male). (Atlantic slope of Mexico, except Yucatan and Campeche, and Central America.)

Thamnophilus doliatus mexicanus, adult male (p. 40).

dd. Paler, with white bars of upper parts broader and black bars of under parts narrower.

e. Averaging smaller (wing averaging 70.1, tail 58.4), with black bars on under parts usually broader. (Pacific slope, from Chiapas to western Panama.)........ Thamnophilus doliatus pacificus, adult male (p. 43).

ee. Averaging larger (wing averaging 72, tail 63.2), with black bars on under parts usually narrower. (Yucatan and Campeche.)

Thamnophilus doliatus yucatanensis, adult male (p. 44). cc. Pileum spotted or barred with white. (Eastern Panama and Colombia.)

Thamnophilus multistriatus, adult male (p. 45).

aa. Plumage largely rufescent (back, wings, etc., plain chestnut or tawny).

b. Under parts dull slate-gray streaked with whitish. (Thamnophilus virgatus.)

c. Wings and tail clearer chestnut-tawny (more rufescent); white streaks on pileum broader, those on under parts extended over greater part of abdomen. (Northwestern Colombia.)......... Thamnophilus virgatus virgatus (p. 46). cc. Wings and tail duller chestnut-tawny (more cinnamomeous); white streaks on pileum narrower, those on under parts also narrower and on abdomen confined to median line. (Central Colombia.)

Thamnophilus virgatus nigriceps (extralimital).c

b6. Under parts buffy or tawny (with or without transverse bars).

c. Under parts distinctly barred with blackish.

Thamnophilus multistriatus, adult female (p. 45). cc. Under parts not distinctly if at all barred.

Thamnophilus radiatus and subspecies, adult female. $d$

Thamnophilus doliatus and subspecies, adult female. $d$

$a$ No females of this form have been examined by me.

$b$ [Lanius] doliatus Linnæus, Syst. Nat., ed. 12, i, 1766, 138 (South America; based on Lanius cayanensis striatus Brisson, Orn., ii, 187; etc.).-Thamnophilus doliatus Vieillot, Nouv. Dict. d'Hist. Nat., iii, 1816, 315 (Cayenne); Sclater, Cat. Birds Brit. Mus., xv, 1890, 207, part.-L[anius] (ferrugineus) (not of Gmelin, 1788) Richard and Bernard, Actes de la Soc. d'Hist. Nat. Paris, i, pt. i, 1792, 116 (Cayenne).-Lanius (ferruginatus) Reich (G. C.), Mag. des Thierreichs, i, Abth. 3, 1795, 129 (emendation of L. ferrugineus Richard and Bernard).-Lanius rubiginosus Bechstein, Allgem. Übers. de Vögel, i, 1793, 696 (new name for $L$. ferrugineus Richard and Bernard); Latham, Index Orn., Suppl., 1801, p. xix.

c Thamnophitus nigriceps Sclater, Proc. Zool. Soc. Loud., 1868, 571 (Bogotá, Colombia; coll. P. L. Sclater); Cat. Birds Brit. Mus., xv, 1890, 194, pl. 12.

$d$ The differences between adult females of the several forms of these two species are not sufficiently definite to be intelligibly expressed in a key-at least not without expenditure of much more time than I am able to give the subject. 


\section{THAMNOPHILUS RADIATUS NIGRICRISTATUS (Lawrence).}

\section{BLACK-CRESTED ANTSHRIKE.}

Similar to $T$. dotiatus, and its subspecies ${ }^{a}$ but adult males with elongated feathers of pileum entirely black. Still more like $T$. radiatus radiatus ${ }^{b}$ but coloration darker, in both sexes.

Adult male.-Pileum, except sides ol occiput (supra-auricular region) and more or less of forehead, uniform black (without concealed white, except, sometimes, a very little on the occiput); rest. of upper parts black barred, more or less broadly, with white, the white bars never as wide as the black interspaces, sometimes reduced to transverse spots; forehead usually more or less (sometimes extensively) streaked with white; sides of occiput (supra-auricular region), streaked with black and white, the black streaks usually broader than the white ones; auricular and malar regions and sirles of neck similarly streaked, but the black streaks rather narrower; under parts white, the chin and throat usually streaked (sometimes broadly) with black, the remaining under parts (except, sometimes, abdomen) barred with black, the black bars usually much narrower than the white intelspaces but sometimes nearly as broad, especially on flanks; maxilla blackish, paler on tomium; mandible grayish (sometimes whitish terminally and on tomium), bluish gray in life; iris straw color; ${ }^{c}$ legs and feet dusky (bluish gray in life?); length (skins), 138-158 (149); wing, 67.5-72 (70.2); tail, 54-61 (56.8); culmen, 17-19.5 (18.3); tarsus, 26-27.5 (26.7); middle toe, 14.5-17 (16.4).d

Adult female.-Pileum deep chestnut, becoming paler (more tawny) on forehead; hindneck broadly streaked with black and ochraceous or tawny; wings and tail uniform deep cinnamon-rufous or chestnutrufous, the back, scapulars, and rump similar but usually lighter and more tawny-rufous; sides of head (including supra-auricular region) buffy whitish, buffy, ochraceous, or pale tawny, streaked (except on lores) with black, the black streaks broader on supraauricular region, narrower (sometimes nearly obsolete) on anterior portion of malar region; chin and throat immaculate, very pale buffy

$a$ The individual variation in this form seems to include as great extremes of coloration, as regards relative width of black and white bars in the adult male and intensity of coloration in the female, as is covered by the geographic variations in T. doliatus!

$b$ Thamnophitus radiatus Vieillot, Nouv. Dict. d'Hist. Nat., iii, 1816, 315; Sclater, Cat. Birds Brit. Mus., xv, 1890, 210. Several subspecies have been described, but I have not been able to secure sufficient material to enable me to characterize them satisfactorily. They are involved in much confusion and require careful revision.

$c$ W. W. Brown, jr., on label.

$d$ Thirteen specimens from Panama (mainland). 
to ochraceous-buff; rest of under parts plain deep buff to nearly ochraceous-buff (or between ochraceous-buff and clay color); length (skins), 134-155 (147); wing, 67-71 (68.6); tail, 54-59 (56.3); culmen, 17-20 (18.7); tarsus, 25-27 (26.1); middle toe, 15-16.5 (15.8). ${ }^{a}$

$a$ Eight specimens from Panamá (mainland).

The series examined from Panamá comprises three adult males in dark, heavily barred plumage, like the type, and ten which are more or less decidedly lighter in color, some of them indistinguishable, so far as I am able to see, from Colombian examples labeled Thamnophilus albicans. In fact, unless there are two forms of the species in Panamá, which is hardly probable, the individual variation in this species is much greater than in $T$. doliatus, which is reasonably constant within definite geographic areas. At present I have neither the material nor time necessary for more satisfactorily working out the problem, which, judging from the material examined, is a very complicated one.

The following measurements of specimens belonging to the radiatus group are given below for comparison with those of Panamá examples:

\begin{tabular}{|c|c|c|c|c|c|}
\hline Locality. & Wing. & Tail. & $\begin{array}{l}\text { Cul- } \\
\text { men. }\end{array}$ & $\begin{array}{l}\text { Tar- } \\
\text { sus. }\end{array}$ & $\begin{array}{l}\text { Middle } \\
\text { toe. }\end{array}$ \\
\hline MALES. & \multirow[b]{2}{*}{70.2} & \multirow{3}{*}{56.8} & \multirow{3}{*}{18.3} & \multirow{3}{*}{26.7} & \multirow{3}{*}{16.4} \\
\hline 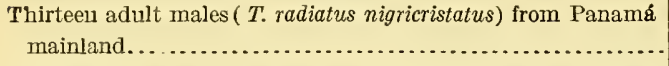 & & & & & \\
\hline $\begin{array}{l}\text { Three adult males ( } \text { T. radiatus nigricristatusg) from San Miguél } \\
\text { Island }\end{array}$ & 73.3 & & & & \\
\hline 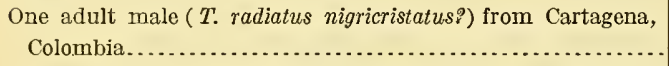 & 70.5 & 57 & 18 & 27 & 16 \\
\hline 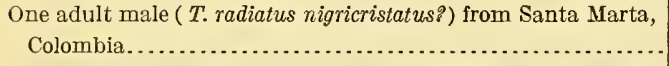 & 71.5 & 53 & 18.5 & 26 & 16 \\
\hline Four adult males ( $T$. radiatus albicans?) from Bogotá, Colombia. & 75.5 & 61.7 & 19.4 & 26 & 15.8 \\
\hline Six adult males ( $T$. radiatus subradiatus) from Upper Amazons. & 72.7 & 59.4 & 18.5 & 26.3 & 15.6 \\
\hline One adult male ( $T$. radiatus — ?) from Lower Amazon... & 78 & 64 & 19 & 25.5 & 17 \\
\hline One adult male ( $T$. radiatus difficilis) from Goyaz, Brazil....... & 74 & 64 & 19 & 27 & 16 \\
\hline Four adult males ( $T$. radiatus capistratus) from Bahia, Brazil.. & 77 & 65 & 18.5 & 26.5 & 16 \\
\hline $\begin{array}{c}\text { Ten adult males }(T \text {. radiatus radiatus) from southern Brazil } \\
\text { and Paraguay......................................... } \\
\text { FEMALEs. }\end{array}$ & 74.1 & 63.8 & 17.6 & 26.6 & 15.8 \\
\hline Eight adult females from Panamá (mainland). & 68.6 & 56.3 & 18.7 & 26.1 & 15.8 \\
\hline Five adult females from San Miguél Island.... & 72.4 & 56.9 & 18.3 & 26.6 & 15.5 \\
\hline One adult female from Cartagena, Colombia... & 67 & 52.5 & 18 & 26.5 & 15 \\
\hline One adult fennale from Bonda, Santa Marta, Colombia.. & 72.5 & 60 & 19.5 & 27.5 & 15.5 \\
\hline One adult female from Bogotá, Colombia.... & 73.5 & 59 & 18.5 & 28 & 16 \\
\hline Three adult females from Upper Amazons.... & 70.5 & 58.2 & 19.2 & 26.2 & 16.2 \\
\hline One adult female from Ceara, Brazil.................... & 75 & 62 & 17.5 & 27 & 16 \\
\hline One aduIt female from Goyaz, Brazil................... & 73.5 & 61.5 & 18 & 27 & 15.5 \\
\hline One adult female from Bahia, Brazil.................... & 72 & 63 & 17.5 & 23.5 & 14.5 \\
\hline Two adult females from Chapada, Mattogrosso, Brazil.. & 71.2 & 62.7 & 18 & 26.3 & 16 \\
\hline
\end{tabular}


State of Panamá (Panamá; Sabana de Panamá; Paraiso Station; Loma del León; Mina de Chorcha, Chitra, Calobre, and Calovévora. Verágua; San Miguél Island?); ${ }^{a}$ Caribbean coast district of Colombia (Cartagena; Santa Marta).

Thamnophilus doliatus (not Lanius doliatus Linnæus) Lawrence, Ann. Lyc. N. Y., vii, 1862, 293 (Lion Hill, Panamá).-Bangs, Proc. New Engl. Zool. Club, ii, 1900, 24 (Lion Hill).

Thamnophilus radiatus (not of Vieillot) Sclater and Salvin, Proc. Zool. Soc. Lond., 1864, 355 (Panamá; crit.).-Salvin, Ibis, 1870, 194 (Chitra and Calovévora, Verágua, Panamá).

[Thamnophilus] radiatus Sclater and Salvin, Nom. Av. Neotr., 1873, 70, part (Panama).

Thamnophilus nigricristatus Lawrence, Proc. Acad. Nat. Sci. Phila., 1865, 107 (Lion Hill, Panamá; coll. G. N. Lawrence).-Ridgway, Proc. U. S. Nat. Mus., x, 1887, 581, footnote (crit.).-Sclater, Cat. Birds Brit. Mus., xv, 1890, 209, part (Mina de Chorcha, Chitra, Paraiso Station, and Panamá, Panamá; Santa Marta, Colombia).-Salvin and Godiran, Biol. Centr.-Am., Aves, ii, 1892, 204, part (Mina de Chorcha, Chitra, Calovévora, Calobre, Paraiso Station, and Lion Hill, Panamá).-Thayer and Bangs, Bull. Mus. Comp. Zool., xlvi, 1905, 150 (San Miguél I., Panamá), 216 (Sabana de Panamá).

[Thamnophilus] nigricristatus SHarpe, Hand-list, iii, 1901, 15 (Panamá; Colombia).

Th[amnophilus] nigricristatus nigricristatus HeLLMayR, Verh. k. k. zool.-bot. Gesellsch. Wien, May 22, 1903, 217.

Thamnophilus radiatus nigricristatus Allen, Bull. Am. Mus. N. H., v, 1893, 118 (Panamá).

Thamnophilus doliatus nigricristatus Bangs, Auk, xviii, Jan., 1901, 30 (San Miguél I., Panamá).

Thamnophilus affinis (not of Spix, 1825, D'Orbigny and Lafresnaye, 1837, nor Cabanis and Heine, 1859) Sclater and Salvin, Proc. Zool. Soc. Lond., 1864, 355 (Panamá).

$a$ The birds of San Miguél Island possibly separable, perhaps referable to T. $r$. albicans, on account of their larger size. 


\section{THAMNOPHLUS DOLIATUS MEXICANUS Allen.}

\section{MEXICAN ANTSHRIKE.}

Similar in coloration to $T$. d. doliatus, ${ }^{a}$ but wing averaging much shorter and tail relatively longer.

Adult male.-Above black, the forehead spotted or streaked, more or less, with white, the elongated feathers of crown white (mostly concealed) with a large apical guttate spot of black, the remaining upper parts barred with white (the white bars always much less than half as wide as the black interspaces), the white bars on rectrices and tertials not reaching to shaft (except terminal bar on tertials); sides of head, chin, and throat streaked with black and white, the first with the two colors about equal in amount, the chin and throat with the white usually predominating; rest of underparts broadly and sharply barred with black and white, the bars of the two colors of nearly equal width, except (sometimes) on center of abdomen, where the black bars are narrower; maxilla brownish black, pale grayish blue along tomium; mandible pale grayish blue; iris yellow; legs and feet grayish dusky (grayish blue in life); length (skins), 138-167 (156.5); wing, 68.5-78.5 (72.6); tail, 57.5-69 (62.8); culmen, 18.5-20.5 (19.6); tarsus, 25-28 (26.6); middle toe, 14.5-17 (15.5). ${ }^{b}$

Immature male.-Similar to the adult male but plumage more or less strongly suffused with pale ochraceous.

Adult female.-Pileum bright chestnut or rufous-chestnut, paler on forehead; supra-auricular region, hindneck and sides of neck light ochraceous or buffy (sometimes buffy whitish on sides of neck), broadly streaked with black; rest of upper parts plain cinnamonrufous or tawny-chestnut, usually paler and tinged, more or less, with olive-ochraceous on rump and upper back; a narrow orbital ring of buff or buffy white; loral, suborbital auricular, and malar regions buff or buffy whitish, more or less streaked or flecked with black (most heavily on auricular region); chin and throat pale buff to ochraceous-buff, often more or less streaked (mostly laterally or posteriorly) with black or dusky; rest of underparts ochraceous or ochraceous-buff, deepest on chest and sides, paler on abdomen, where sometimes pale buff; usually the underparts are quite immaculate, but rarely there are indications of dusky bars on breast and tibia, and often more or less distinet blackish or dusky spots or streaks on upper chest; under wing-coverts clear buff or ochraceousbuff, the inner webs of remiges broadly edged with pinkish vinaceousbuff or vinaceous-cinnamon; maxilla dark brown or blackish brown, whitish (in dried skins) along tomium; mandible pale horn color or dull whitish in dried skins (light bluish gray in life); iris white or

a True T. doliatus is confined to Cayenne, Surinam, and British Guiana (see p. 36).

$\checkmark$ Twenty-nine specimens. 
pale yellow; legs and feet grayish dusky or horn color (bluish gray in life); length (skins), 140-166 (155); wing, 65.5-77 (71.8); tail, 56-68 (62.2); culmen, 18.5-20 (19.4); tarsus, 25.5-29 (26.8); middle toe, $14.5-17$ (15.8)..$^{a}$

Young female (first plumage).- - Somewhat like the adult female but duller rufous or rufous-tawny above; the pileum, back, scapulars, and rump rather broadly barred with blackish; underparts pale buffy, deeper on chest, everywhere (except on lower abdomen) irregularly barred (more spotted on throat) with dusky.

Eastern Mexico, in States of Tamaulipas (Tampico; Alta Mira), Vera Cruz (Playa Vicente; Jalapa; Coátepec; Córdova; Huatusco; Choapám; Misantla; Orizaba; Miradór; Tlalcotalpám; Otatitlán; Papantla; Tolosa; Buena Vista; Potrero), Puebla (Teziutlán; Met-

a Thirty-four specimens.

Locality.
MaLEs.
Ten adult males from Puebla, Vera Cruz, and Tabasco, e.

Nine adult males from Guatemala (6) and Chiapas (3) .....

Ten adult males from Honduras

Six adult males from eastern Nicaragua...................

Ten adult males ( $T$. $d$. yucatanensis) from Yucatan (9) and

Campeche (1).

One adult male ( $T . d$. pacificus?) from western Chiapas....... .

Three adult males ( $T$. $d$. pacificus) from western Nicaragua....

Ten adult males ( $T$. $d$. pacificus) from western Costa Rica.....

Five adult males from ( $T . d$. pacificus) from western Panamá..

Three adult males ( $T$. d. doliatus?) from Venezuela (mainland).

Three aduit males ( $T$. d. doliatus?) from Margarita I., Venezuela.

Fire adult males ( $T$. $d$. doliatus) from Guianas................

Ten adult males ( $T$. $d$. fraterculus) from Trinidád.............

Four adult males ( $T$. d. fraterculus) from Tobago.............

FEMALES.

Twelve adult females from Tamaulipas, Vera Cruz, Oaxaca, and Tabasco..................................... Nine adult females from Guatemala (7) and Chiapas (2)...... Seven adult females from Honduras.....................

Fire adult females from eastern Nicaragua...................

One adult female from eastern Costa Rica....................

Four adult females ( T. d. yucatanensis) from Yucatan......... One adult female ( $T$. $d$. pacificus?) from western Chiapas...... One adult female ( $T$. d. pacificus) from western Nicaragua..... Nine adult females ( $T$. $d$. pacificus) from western Costa Rica... Six adult females ( $T . d$. pacificus) from western Panamá....... Two adult females ( $T$. $d$. doliatus?) from Venezuela (mainland). Three adult females ( $T$. d. doliatus?) from Margarita I., Vene-

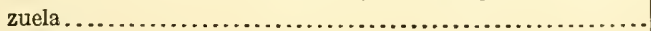
Six adult females $(T$. d. fraterculus) from Trinidád............. Three adult females ( $T . d$. fraterculus) from Tobago...........

\begin{tabular}{|c|c|c|c|c|}
\hline Wing. & Tail. & $\begin{array}{l}\text { Cul- } \\
\text { men. }\end{array}$ & $\begin{array}{l}\text { Tar- } \\
\text { sus. }\end{array}$ & $\begin{array}{l}\text { Middle } \\
\text { toe. }\end{array}$ \\
\hline 73.7 & 65.5 & 19.7 & 27.8 & 16.2 \\
\hline 70.5 & 62.1 & 19.6 & 26.6 & 15.4 \\
\hline 72.6 & 60.2 & 19.6 & 26.1 & 15.2 \\
\hline 71.4 & 58.7 & 19.2 & 26.4 & 15.4 \\
\hline 72.1 & 63.2 & 19.1 & 26.2 & 15.2 \\
\hline 74 & 65 & 19 & 27 & 16 \\
\hline 68 & 55.7 & 19.2 & 25.7 & 15.2 \\
\hline 70.6 & 59.2 & 19.5 & 26 & 15.1 \\
\hline 69.7 & 57.1 & 19.5 & 26.2 & 15.5 \\
\hline 69 & 56 & 18.8 & 26 & 14.8 \\
\hline 70.2 & 54.7 & 18.3 & 24.8 & 14.2 \\
\hline 75.5 & 63 & 19.4 & 26 & 15.9 \\
\hline 71.1 & 57.5 & 19.8 & 26.6 & 15.4 \\
\hline 74 & 59.1 & 19.7 & 27.4 & 14.9 \\
\hline 71.8 & 65.2 & 19.4 & 27.2 & 15.8 \\
\hline 68.7 & 61.5 & 19.1 & 26.6 & 15.4 \\
\hline 72.6 & 61 & 19.3 & 26.7 & 15.6 \\
\hline 68.3 & 58 & 18.9 & 26.2 & 15 \\
\hline 69 & 60.5 & 18.5 & 26 & 15.5 \\
\hline 71 & 64 & 19.6 & 27 & 16 \\
\hline 72 & 63 & 19 & 27 & 16.5 \\
\hline 71 & 59 & 19 & 26.5 & 15.5 \\
\hline 67.8 & 57.5 & 19 & 26.1 & 15.6 \\
\hline 68.2 & 57.2 & 18.7 & 26 & 15.4 \\
\hline 68.7 & 58.7 & 18.2 & 25 & 15.2 \\
\hline 69.2 & 55.7 & 18.2 & 25.5 & 15 \\
\hline 69 & 56 & 18.7 & 26.6 & 15.3 \\
\hline 73 & 57.5 & 18.8 & 26.2 & 15.2 \\
\hline
\end{tabular}


laltoyuca), San Luís Potosí (Vallés), Guanajuato?, Oaxaca (Choapám; Tomatla; Hueytalco; Tonaguia; Santa Efigénia; Tapana; Túxtepec; mountains near Santo Domingo), Tabasco (Teapa; Frontera) and Chiapas (Yajalón; Huehuetán), through Guatemala (Choctúm; Dueñas; Cajabón; San Gerónimo; Cobán; Chapulco; Los Amates, Yzabál; Rio Managua), British Honduras (Orange Walk; Belize; San Antonio; Cayo; 'Toledo District; Manatee Lagoon), Honduras (Omoa; San Pedro; San Pedro Sula; Truxillo; Santa Ana; Céiba) and eastern Nicaragua (Greytown; Los Sábalos; Rio Escondido; San Emilis, Lake Nicaragua) to eastern Costa Rica (Jiménez; Juan Viñas; Guayabo; Cartago ?; Naranjo de Cartago?; Sarchí ?; Boruca?).

(?) Thamnophilus doliatus (not Lanius doliatus Linnæus) Bonaparte, Proc. Zool. Soc. Lond., 1837, 117 (Guatemala; descr.).-Frantzius, Journ. für Orn., 1869, 305 (Costa Rica).

Thamnophilus doliatus Sclater, Proc. Zool. Soc. Lond., 1858, 217, part (monogr.); 1859, 383 (Choapám, Oaxaca; Playa Vicente, Vera Cruz); Cat. Birds Brit. Mus., Xv, 1890, 207, part.-Sclater and SAlvin, Ibis, 1859, 118 (Dueñas, Guatemala; habits).-Lawrence, Ann. Lyc. N. Y., ix, 1868, 107 (Costa Rica).-Sumichrast, Mem. Bost. Soc. N. H., i, 1869, 556 (temperate reg. Vera Cruz, up to 1250 m.).-Boucard, Liste Ois. récol. Guat., 1878, 38.Ferrari-Perez, Proc. U. S. Nat. Mus., ix, 1886, 156 (Teziutlán, Puebla; Jalapa, Vera Cruz).-ZELedón, Anal. Mus. Nac. Costa Rica, i, 1887, 144, part (Cartago, Naranjo de Cartago, and Jiménez, Costa Rica).-SALvin and GoDMaN, Biol. Centr.-Am., Aves, ii, 1891, 202, part (Tampico, Tamaulipas; Jalapa, Coátepec, Misantia, Orizaba, Huatusco, Córdova, Choapám, and Playa Vicente, Vera Cruz; Tomatla, Hueytalco, Tonaguia, Santa Efigénia, and Tapana, Oaxaca; Teapa, Tabasco; Orange Walk, Belize, San António and Cayo, Brit. Honduras; Choctúm, Cajabón, Chiséc, Cobán, and San Gerónimo, Guatemala; Omoa, San Pedro, and Truxillo, Honduras; Los Sábalos and Greytown, Nicaragua; Jiménez, Cartago, and Naranjo de Cartago, Costa Rica).-Richmond, Proc. U. S. Nat. Mus., xvi, 1893, 500 (Rio Escondido, Nicaragua; habits).-Bangs, Bull. Mus. Comp. Zool., xxxix, 1903, 150 (Céiba, Honduras; crit.).-Dearborn, Pub. 125, Field Mus. N. H., 1907, 109, part (Los Amates, Yzabál, Guatemala).

Thamnophilus doliatus? Moore, Proc. Zool. Soc. Lond., 1859, 57 (Omoa, Honduras).

[Thamnophilus] doliatus Bonaparte, Consp. Av., i, 1850, 197, part.-Sclater and Salvin, Nom. Neotr., 1873, 70, part.-Sharpe, Hand-list, iii, 1901, 15, part.

(?) Thamnophilus rutilus (not of Vieillot, 1816) Bonaparte, Proc. Zool. Soc. Lond., 1837, 117 (Guatemala; descr.;=?).

T[hamnophilus] affinis (not Thamnophilus affinis Spix, 1825, nor of D'Orbigny and Lafresnaye, 1837) Cabanis and Heine, Mus. Hein., ii, Aug., 1859, 17 (Jalapa, Vera Cruz).

Thamnophilus affinis Lawrence, Ann. Lyc. N. Y., viii, 1867, 182 'Greytown, Nicaragua); ix, 1868, 107, part (Sarchí, Costa Rica).-Frantzius, Journ. für Orn., 1869, 305 (Costa Rica).-Sclater and Salvin, Proc. Zool. Soc. Lond., 1870, 837 (Honduras).

Thamnophilus doliatus mexicanus AlLen, Bull. Am. Mus. N. H., ii, June 28, 1889, 151 (new name for Thamnophilus affinis Cabanis and Heine, preoccupied; crit.).-Richmond, Proc. U. S. Nat. Mus., xviii, 1895, 630 (Alta Mira, Tamaulipas).-Chapman, Bull. Am. Mus. N. H., x, 1898, 32 (Jalapa, Vera Cruz).- 
Ridgway, Proc. Biol. Soc. Wash., xxi, 1908, 192 (geog. range).-Carriker, Ann. Carnegie Mus., vi, 1910, 603 (Caribbean foothills, n. e. Costa Rica; habits).-Fenry, Pub. 146, Field Mus. N. H., orn. ser., i, no. 6, 1910, 271 (Guayabo, Costa Rica).

Thamnophilus intermedius Ridgway, Proc. U. S. Nat. Mus., x, Aug. 6, 18s8, 581 (Truxillo, Honduras; coll. U. S. Nat. Mus.).

\section{THAMNOPHILUS DOLIATUS PACIFICUS Ridgway.}

\section{PACIFIC ANTSHRIKE.}

Similar to T. d. mexicanus but adult male with under parts decidedly paler (black bars decidedly, sometimes very much, narrower than white interspaces, and black streaks on throat very narrow); ${ }^{a}$ adult female not constantly if at all different, but sometimes paler, either above or below.

Adult male.-Length (skins), 141-163 (149); wing, 67-74.5 (70.1); tail, 55-65 (58.4); culmen, 18-20.5 (19.4); tarsus, 25-27.5 (26.1); middle toe, $14.5-16(15.3) .^{b}$

Adult female.-Length (skins), 130-158 (145); wing, 65.5-72 (68.4); tail, 55-63 (57.8); culmen, 17-19.5 (19.3); tarsus, 24.5-27 (26.3); middle toe, $15-16.5(15.5) .^{c}$

Pacific slope of Central America, from western Panamá (Divala; Chitra; Davíd; Bugaba; Calovévora), through Costa Rica (Pozo Azúl de Pirrís; Buenos Aires; Boruca; Lagarto; Paso Reál; Puriscál; San Mateo; Bebedero; Coyolár; La Palma de Nicoya; Barranca de Puntarenas; San Carlos; Surubres; Miravalles; San José; Sarchí; Coralillo; Bolsón; El Generál; Boca de Barranca; Escazú ?), Nicaragua (Sucuyá; Chinandega; Volcan de Chinandega; 2 leagues south of Lake Manágua; Realejo) and Guatemala (Naranjo; San José; Lake Amatitlán) to Chiapas (San Bartolomé).

(?) Thamnophilus doliatus (not Lanius doliatus Linnæus) CABAnıs, Journ. für Orn., 1861, 242 (Costa Rica).

Thamnophilus doliatus Salvin, Proc. Zool. Soc. Lond., 1867, 144 (David, Panama).-Boucard, Proc. Zool. Soc. Lond., 1878, 60 (San Mateo, Costa Rica).Nutting, Proc. U. S. Nat. Mus., vi, 1884, 385 (Sucuyá, Nicaragua; habits; notes).-Zeledón, Anal. Mus. Nac. Costa Rica, i, 1887, 114, part (Pozo Azúl, Costa Rica).-Salvin and Godman, Biol. Centr.-Am., Aves, ii, 1891, 202, part (Chinandega, Volcan de Chinandega, and Sucuyá, Nicaragua; San José, San Mateo, Sarchí, Bebedero, La Palma de Nicoya, and Pozo Azúl, Costa Rica; Davíd and Bugaba, Panamá).-Cherrie, Expl. Zool. Merid. Costa Rica, 1893, 41 (Lagarto, Boruca, and Buenos Aires, s. w. Costa Rica).Underwood, Ibis, 1896, 440 (Bebedero, Costa Rica).-Dearborn, Pub. 125, Field Mus. N. H., 1907, 109 (Lake Amatitlán and San José, Guatemala, up to 4,000 ft.).-Bangs, Auk, xxiv, 1907, 296 (Boruca, Paso Reál, Lagarto, and Barranca de Puntarenas, w. Costa Rica).

a The aduit male is almost precisely similar in coloration to that of Thamnophitus doliatus fraterculus Berlepsch and Hartert (Novit. Zool., ix, April, 1902, 70; Altagracia, Venezuela; coll. Count von Berlepsch) of Venezuela and Tobago.

$b$ Nineteen specimens.

c Thirteen specimens. 
[Thamnophilus] doliatus Bonaparte, Consp. Av., i, 1850, 197, part.-Sclater and Salvin, Nom. Neotr., 1873, 70, part.-SHARPE, Hand-list, iii, 1901, 15, part.

Thamnophilus doliatus? Salvin, Proc. Zool. Soc. Lond., 1867, 144 (Davíd, Panamá).

Thamnophilus affinis (not of Spix, 1825, Lafresnaye and D'Orbigny, 1837, nor Cabanis and Heine, 1859) Lawrence, Ann. Lyc. N. Y., ix, 1868, 107 (San José, Sarchí, and San Mateo, Costa Rica).-SAlvin, Proc. Zool. Soc. Lond., 1870, 194 (Bugaba, Panamá; crit.).

Thamnophilus doliatus affinis Nutring, Proc. U. S. Nat. Mus., v, Sept. 5, 1882, 397 (La Palma de Nicoya, Costa Rica; habits).

Thamnophilus radiatus (not of Vieillot) Salvin, Proc. Zool. Soc. Lond., 1870, 194 - (Chitra and Calovévora, Panamá).

Thamnophilus nigricristatus (not of Lawrence) Boucard, Proc. Zool. Soc. Lond., 1878, 60 (San Carlos, Costa Rica).

Thamnophilus doliatus pacificus Pidgway, Proc. Biol. Soc. Wash., xxi, Oct. 20, 1908, 193 (Chinandega, Nicaragua; coll. U. S. Nat. Mus.).-Carriker, Ann. Carnegie Mus., vi, 1910, 604 (Pacific lowlands and lower slopes, rarely to $3,500 \mathrm{ft}$., Costa Rica; habits).

\section{THAMNOPHILUS DOLIATUS YUCATANENSIS Ridgway.}

\section{YUCATAN ANTSHRIKE.}

Similar to $T$. $d$. pacificus but adult male with black bars on under parts usually narrower; adult female similar to that of $T$. $d$. pacificus but upper parts (except pileum) averaging more ochraceous (less rufescent), with wings (sometimes back and tail also) showing more or less distinct indications of dusky bars; averaging larger.

Adult male.-Length (skins), 146-162 (157); wing, 69.5-75.5 (72.1); tail, 60.5-65 (63.2); culmen, 18.5-20 (19.1); tarsus, 24-27 (26.2); middle toe, $14-16$ (15.2). ${ }^{a}$

Adult female.-Length (skins), 155-163 (159); wing, 69-73.5 (71); tail, 62-67.5 (64); culmen, 19-20 (19.6); tarsus, 26.5-27.5 (27); middle toe, $15-16(15.7) .^{b}$

Yucatan (Mérida; Chichen-Itza; Buctzotz; Peto; Temáx; Meco Island; Cozumél Island) and Campeche (Yohaltán). ${ }^{c}$

Thamnophilus affinis (not of Spix, 1825, D'Orbigny and Lafresnaye, 1837, nor Cabanis and Heine, 1859) Lawrence, Ann. Lyc. N. Y., ix, 1869, 201 (Mérida, Yucatan).-NehrkorN, Journ. für Orn., 1881, 67 (Yucatan; descr. eggs).

Thamnophilus doliatus (not Lanius doliatus Linnæus) Boucard, Proc. Zool. Soc. Lond., 1883, 450 (Yucatan).-SAlvin, Ibis, 1889, 365 (Meco Island, Yuca-

- $\tan$ ).-Salvin and Godman, Biol. Centr.-Am., Aves, ii, 1891, 202, part (Mérida, Buctzotz, Peto, Meco I., and Cozumél I., Yucatan).

$a$ Ten specimens.

$b$ Four specimens.

c Specimens from Alta Mira and Tampico in Tamaulipas and Vallés, San Luís Potosí, come very near to the Yucatan form in coloration, and it is possible the latter may extend thus far northward along the narrow arid coast-belt. Specimens from Frontera, Tabasco, are intermediate in coloration between T. d. yucatanensis and $T . d$. mexicanus. 
Thamnophilus doliatus mexicamus (not of Allen) Cuapuan, Bull. Am. Mus. N. H., viii, 1S96, 284 (Chichen-Itza, Yucatan; song).-Cole, Bull. Mus. Comp. Zool., 1, 1906, 131 (Chichen-Itza).

Thamnophilus doliatus yucatanensis Rrogwax, Proc. Biol. Soc. Wash., xxi, Oct. 20, 1908, 193 (Temáx, Yucatan; coll. U. S. Nat. Mus.).

[Thamnophilus] doliatus Sclater and Salvin, Nom. Av. Neotr., 18̈73, 70, part.SHarpe, Hand-list, iii, 1901, 15, part.

\section{THAMNOPHIUS MULTISTRIATUS Lafresnaye.}

\section{BARRED-CRESTED ANTSFRIKE.}

Adult male.-Above black, rather narrowly barred with white, the bars on tips of feathers of pileum and hindneck sometimes partaking of the form of spots (a pair on tip of each feather, separated by a rather broad median space of black); sides of head, chin, and throat streaked with black and white, the streaks broadest on throat, narrower and confused or intermixed with bars on auricular and suborbital regions; under parts of body and under tail-coverts conspicuously barred with black and white, the bars of the two colors approximately equal in width, or the white ones wider, at least on the abdomen; maxilla brownish black, the tomium pale horn color (bluish gray in life?); mandible light horn color, passing into pale yellowish terminally (bluish gray in life?); legs and feet clusky (bluish gray in life?); length (skins), 148-156 (153); wing, 70-75 (72.5); tail, 61-66.5 (63.7); culmen, 18-20 (18.4); tarsus, 22.5-25 (23.9); middle toe, 14.5-16.5 (15.1). ${ }^{a}$

Adult female.-Above plain bright cinnamon-rufous or rufouschestnut, somewhat interrupted on hindneck, the back and rump sometimes duller or more tawny and with faint inclications of darker bars; sides of head and neck (including sides of hindneck), together with chin and throat, conspicuously streaked with black and white; rest of under parts white, passing into pale tawny brown or fulvous on flanks, thighs, and under tail-coverts, everywhere broadly barred with black, the bars much less distinct on flanks; bill, etc., as in adult male; length (skins), 141-151 (146); wing, 72-72.5 (72.2); tail, 64-67 (65.5); culmen, 17-18.5 (17.7); tarsus, 24; middle toe, $15-15.5(15.2) .^{b}$

Immature male.-Similar to the adult male, but plumage suffused, more or less, with pale fulvous or brownish buff.

Young (male?).- Similar in general coloration to the adult female but pileum mostly black, scapulars, interscapulars, and wing-coverts distinctly barred with dull black, and rump indistinctly barred with dusky; black bars on under parts rather narrow, the ground color very pale buff or buffy white. 
Panamá ${ }^{a}$ and Colombia (Bogotá; Remédios, Medellín and Concórdia, Antioquía; Ocaña; Bucaramanga; Rio Cauca).

Thamnophilus multistriatus Lafresnaye, Rev. Zool., vii, March, 1844, 82 (Colombia).-Sclater, Edinb. Philos. Journ., new ser., i, 1855, 238; Proc. Zool. Soc. Lond., 1855, 148 (Bogotá, Colombia); 1858, 219 (Bogotá); Cat. Am. B., 1862, 175 (Bogotá); Cat. Birds Brit. Mus., XV, 1890, 211, part (Bogotá, Medellin, and Concórdia, Colombia; "Panama;" excl. syn. T. tenuifasciatus Lawrence). $b$-WYatT, Ibis, 1871, 331 (near Ocaña, Colombia, 4,000 ft. alt.).-Sclater and Salvin, Proc. Zool. Soc. Lond., 1879, 524 (Concordia and Medellín, Antioquía, Colombia; descr. nest and eggs).-Berlepsch, Journ. für Orn., 1884, 307 (Bucaramanga, Colombia).Stone, Proc. Ac. Nat. Sci. Phila., 1899, 306 (Antioquía, Colombia; crit.).

[Thamnophilus] multistriatus Sclater and Salvin, Nom. Av. Neotr., 1873, 70.Sharpe, Hand-list, iii, 1901, 16 (Panamá; Colombia; Ecuadór).

\section{THAMNOPHILUS VIRGATUS VIRGATUS Lawrence.}

\section{TURBO ANTSHRIKE.}

Adult male.-Head and neck, above and laterally, black, each feather with a conspicuous mesial guttate streak of buffy white: under parts, including chin and throat, dull slate-gray, similarly but more broadly streaked, as far back as the lower abdomen, where the streaks become obsolete and the ground color paler and more buffy gray; under tail-coverts cinnamon with narrow shaft-streaks of paler; thighs deeper cinnamon, or russet; under wing-coverts and broad edgings to inner webs of primaries deep cinnamon-buff; back and scapulars tawny-chestnut, changing on rump to a paler and duller, more fulvous, hue; wings and tail clear chestnut; length (skin), about 1.45 ; wing, 75 ; tail, 57 ; exposed culmen (tip of bill broken off); tarsus, 25 ; middle toe, 15 .

Northwestern Colombia (Turbo), near eastern extremity of Isthmus of Panama.

This very distinct species is very unlike any other known to me. It is about the size of $T$. palliatus (Lichtenstein), and has the back, wings, and tail similar in color, but has the pileum, hindneck, and under parts conspicuously streaked with white instead of having the pileum plain black and under parts barred with white, the ground color of the under parts moreover being gray instead of black. There is a closer resemblance in coloration to Berlepschia rikeri (belonging

$a$ According to Sclater, Cat. Birds Brit. Mus., xv, 1890,211. I have seen only Colombian examples, however, and the species is omitted from the Biologia CentraliAmericana.

$b$ The type of Thamnophilus tenuifasciatus has been carefully examined and compared with specimens of $T$. multistriatus, with the result that it proves to be very distinct from the latter. If not a synonym of $T$. tenuipunctatus Lafresnaye (which I have not seen) it must stand as a distinct form. 
to the Furnariidæ), but the latter has the primaries, primary coverts, and alula sooty blackish, and under parts of the body spotted rather than streaked.

Thamnophilus, sp.? CAssin, Proc. Ac. Nat. Sci. Phila., 1860, 189 (Turbo, Colombia).

Thamnophilus virgatus Lawrence, Proc. Ac. Nat. Sci. Phila., xx, 1868, 361 (Turbo, Colombia; coll: Acad. Nat. Sci. Phila.).-Salvin and Godman, Biol. Centr.-Am., Aves, ii, 1892, 199 (Turbo).

[Thamnophilus] virgatus Sharpe, Hand-list, iii, 1901, 12.

\section{Genus ERIONOTUS Cabanis and Heine.}

Erionotus a Cabanis and Heine, Mus. Hein., ii, Aug., 1859, 15. ('Type, Thamnophilus carulescens Vieillot.)

Medium-sized or rather small Formicariidæ (length about 140-150 $\mathrm{mm}$.), with bill more compressed than in Thamnophitus and coloration very different, the plumage without bars, either above or below.

Bill variable in size (nearly as long to only about half as long as head), its width at frontal antiæ not greater than its height at same point and equal to less than one-half to decidedly more than onehalf the distance from nostril to tip of maxilla; culmen slightly to distinctly ridged, nearly straight for most of its length, strongly decurved terminally, the tip of maxilla distinctly (sometimes strongly) uncinate; maxillary tomium straight, slightly but distinctly notched subterminally; mandibular tomium straight, slightly but distinctly notched and toothed subterminally, the tip of the mandible forming a small but distinct recurved point; gonys moderately convex (more strongly so basally), recurved terminally. Nostril exposed (but posteriorly in contact with feathering of the latero-frontal antiæ), oval or roundish, without operculum, with the interior tubercle slightly visible in posterior portion. Rictal bristles present but minute (practically obsolete); feathers of chin, malar and frontal antiæ, and lores, with distinct terminal setæ. Wing moderate or rather large, with longest primaries decidedly longer than secondaries; fourth, fifth, and sixth, or fifth, sixth, and seventh primaries longest and equal (or the fifth slightly longer than fourth, the latter equal to sixth), the tenth (outermost) about three-fifths as long as the longest, the ninth equal to or shorter than secondaries. Tail four-fifths to more than fivesixths as long as wing, much rounded (graduation less than length of middle toe without claw), the rectrices (12) moderately broad or rather narrow, rounded terminally. Tarsus longer (sometimes much longer) than exposed culmen, one-third as long as wing or a little less, distinctly scutellate, the plantar scutella in two longitudinal

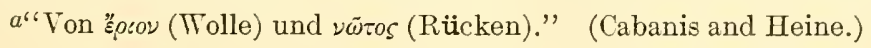


series, that on outer side sometimes indistinct, especially on upper portion; middle toe, with claw, much shorter than tarsus; outer toe, without claw, reaching to or slightly beyond middle of subterminal phalanx of middle toe, the inner toe slightly shorter; hallux about as long as inner toe but much stouter; basal phalanx of middle toe wholly united to outer toe, for about half its length to inner toe; claws moderate in size and curvature, that of the hallux decidedly shorter than the digit. Plumage full, soft, and blencled, that of the rump elongated and lax; feathers of crown and occiput (especially the latter) elongated, forming a more or less distinct decumbent crest of broad, rounded feathers.

Coloration.-Adult males with pileum, wings, and tail black, the rest of upper parts gray or gray and black, in some species wholly black, except for white concealed patch on back and white wingspots; back with a large concealed patch of white, the wings and tail with white markings; under parts gray, sometimes whitish on abdomen, etc., sometimes entirely black; adult females brown (sometimes partly rufescent) above, with whitish markings on wings and concealed white patch on back, paler brownish or rufescent below.

Nidification. -Nest pensile, vireo-like; eggs white or creamy white, spotted or streaked with brownish.

Range.-Honduras to Cayenne and southeastern Brazil. (About twelve species. $)^{a}$

a The type of Erionotus (Thamnophilus cærulescens Vieillot), together with Thamnophilus melanochrous Sclater and Salvin and probably several others referable to the same group (I have not seen T. tschudii Pelzeln, T. æthiops Sclater, T. cinereo-niger Pelzeln, T. stellaris Spix, T. tristis Sclater and Salvin, T. capitalis Sclater, nor T. cinereiceps Pelzeln), differs so much in relative size and shape of the bill from $T$. ambiguus Swainson, T. nævius (Gmelin), T. gorgonæ Thayer and Bangs, and related forms that there is some question as to whether the two groups are really congeneric; indeed, I have placed them together mainly on account of their very close resemblance to one another in style of coloration.

Another group, composed of species (referred by Dr. Sclater to the genera Thamnophilus and Dysithamnus) distinguished by their very plain (mainly gray, slate colored or sooty) coloration, without black wings or tail and destitute of white markings on wings and tail or of a distinct white dorsal (concealed) patch, I do not, at present at least, refer to Erionotus. These species (Thamnophitus murinus Pelzeln, T. simplex Sclater, T. capitalis Sclater, T. inornatus Ridgway, Dysithamnus leucostictus Sclater, Thamnophilus schistaceus D'Orbigny, Dysithamnus ardesiacus Sclater and Salvin, $D$. unicolor Sclater, D. plumbea (Maximilian), and D. subplumbeus Sclater and Salvin) differ considerably among themselves in structural details and may represent two or more distinct groups. Since they are all extralimital to the present work, however, I leave them as a problem for others to work out. 
KEY TO THE SUBSPECIES OF ERIONOTUS PUNCTATUS.

a. Smaller (wing avernging less than 71 in adult males, less than 68 in adult females); adult females with lateral under parts distinctly darker than median portion.

b. Paler; adult female more olivaceous. (South America in general.)

Erionotus punctatus punctatus (extralinital) ${ }^{a}$

b6. Darker; adult female more tawny or rufescent. (British Honduras to western

Ecuador.) .................... Erionotus punctatus atrinucha (p. 49). aa. Larger (wing areraging 72.1 in adult male, 70.1 in adult female); adult female with lateral under parts not distinctly darker than median portion. (Gorgona Island, Bay of Panama.) ............... Erionotus punctatus gorgonæ (p.52).

\section{ERIONOTUS PUNCTATUS ATRINUCHA (Salvin and Godman).}

\section{SLATY ANTSHRIKE.}

Similar to T. p. punctatus, ${ }^{b}$ but adult male with gray of both upper and under parts darker and adult female with general coloration darker and less rufescent (more olivaceous), especially the pileum.c

Adult male.-Pileum black, more or less mixed with slate-gray on forehead (the latter sometimes extensively slate-gray barred or flecked with black); hindneck mixed black and slate-gray, sometimes uniform black; back mixed black and slate-gray (the former predominating), the feathers extensively pure white basally; scapulars and rump plain slate-gray; exterior row of scapulars black, broadly edged with white; wings black, all the wing-coverts conspicuously tipped with white, tertials broadly edged with white, the other remiges narrowly edged with light gray; upper tail-coverts black, broadly tipped with white; tail black, all the rectrices tipped with a large white spot, except middle pair, which are narrowly tipped with white or else wholly black; outermost rectrix, on each side, with a quadrate spot of white crossing outer web beyond middle portion; ${ }^{d}$ superciliary region, sides of head and neck, and under parts plain gray (no.6) or slate-gray, the sides of head (often chin

a [Lanius] nævius Gmelin, Syst. Nat., i, pt. i, 1788, 308, not of p. 304.-Tityra cayanensis, female! (Cayenne); Latham, Index Orn., i, 1790, 81.-Thamnophilus nævius (not of Vieillot, 1816) Swainson, Zool. Journ., ii, no. v, April, 1825, 90; Orn. Drawings, pl. 59; Sclater, Cat. Birds Brit. Mus., xv, 1890, 197, part.-E[rionotus] naevius Cabanis and Heine, Mus. Hein., ii, 1859, 16.-Lanius punctatus Shaw, Gen. Zool., vii, pt. ii, 1809, 327 (based on "Le Tachet. Levaill[ant] Ois." [pl. 77, fig. 1]).(?) Thamnophilus nævius albiventris Taczanowski, Orn. du Pérou, ii, 1S84, 9.-T[hamnophilus] naevius naevius Hellmayr, Abh. K. B. Akad. Wiss., ii kl., xxii Bd., iii Abt., 1905, 659 (crit.).

$b$ See "Key," top of this page.

c This is an unsatisfactory subspecies, and I am doubtful as to its validity. Both very dark and light colored examples occur among specimens from Bogotá, and I find it extremely difficult to correlate the color differences with geographic distribution.

$d$ The second and third pairs (counting from outside) are sometimes similarly marked.

$$
81255^{\circ}-\text { BuIl. } 50-11-4
$$


and throat also) faintly barred or flecked with dusky, the auricular region with narrow shaft-streaks of whitish; under tail-coverts broadly tipped or terminally margined with white; maxilla brownish black, mandible grayish or brownish (bluish gray in life?); legs and feet horn color (bluish gray in life?); length (skins), 129-151 (141); wing, 66.5-74 (69.6); tail, 51.5-60 (55.1); culmen, 16.5-21 (19.7); tarsus, 19.5-22 (20.6); middle toe, 12.5-14.5 (13.2). ${ }^{a}$

Adult female.-General color of upper parts olive-brown, the pileum more rufescent (more russet or mars brown); interscapulars with much concealed white; upper tail-coverts dull chestnut-brown, usually tipped (more or less distinctly) with pale buffy brown or buffy; tail dark chestnut-brown, the rectrices tipped with white or buffy, the exterior pair with a quadrate spot of white or buffy on outer web beyond middle portion; wings dusky, all the wing-coverts conspicuously tipped with pale buff or buffy white, tertials broadly edged with the same, the remaining remiges edged with russet or brown (becoming paler and more buffy on outer primaries); sides of head, chin, and throat pale olive-buffy, the auricular region with narrow shaft-streaks of whitish or pale buffy; rest of under parts plain light buffy olive (sometimes approaching wood brown) the midale of abdomen paler and more yellowish or buffy, the under tail-coverts more rufescent or cinnamomeous; bill and feet as in adult male; length (skins), 132-150 (141.1); wing, 64-70.5 (67.5); tail, 50-58.5 (54.1); culmen, 18-20 (18.8); tarsus, 20-22 (20.9); middle toe, $12-14(13.2) .^{b}$

$a$ Twenty specimens.

$b$ Twenty-one specimens.

\begin{tabular}{|c|c|c|c|c|c|}
\hline Locality. & Wing. & Tail. & $\begin{array}{l}\text { Cul- } \\
\text { men. }\end{array}$ & $\begin{array}{l}\text { Tar- } \\
\text { sus. }\end{array}$ & $\begin{array}{c}\text { Middle } \\
\text { toe. }\end{array}$ \\
\hline MALES. & & & & & \\
\hline Foúr adult males from Honduras (3) and British Honduras (1). & 69.8 & 56.4 & 19.9 & 20.4 & 13.1 \\
\hline Two adult males from Nicaragua...................... & 69.7 & 56.5 & 19.5 & 20.7 & 13 \\
\hline Ten adult males from Costa Rica... & 69.2 & 54.3 & 19.3 & 20.7 & 13. 2 \\
\hline Two a dult males from Panamá... & 70 & 53.2 & 19.2 & 19.7 & 12.7 \\
\hline Two adult males from Colombia (Bogotá).......... & 70.7 & 57 & 17 & 22 & 14.5 \\
\hline Ten adult males (E. p. punctatus) from Colombia.. & 71 & 54.7 & 19.2 & 21.3 & 13 \\
\hline One adult male (E. p. punctatus) from Cayenne..... & 69.5 & 53 & 17.5 & 22 & 14 \\
\hline Ten adult males (E. p. punctatus) from eastern Brazi & 70.9 & 52.7 & 17 & 21.4 & 12.8 \\
\hline FEMAL & & & & & \\
\hline les from IIon & 70 & 56 & 19.2 & 20.7 & 13.5 \\
\hline males from Nicaragua.. & 6S. 2 & 54.5 & 18.7 & 20.2 & 12.7 \\
\hline Ten adult females from Costa Rica... & 67.1 & 53.3 & 18.7 & 20.9 & 13.6 \\
\hline Seven adult females from Panamá... & 67.2 & 54.7 & 18.9 & 21.4 & 12.8 \\
\hline Six adult females (E. p. punctatus) from Colombia.. & 67.9 & 55 & 19.3 & 21.2 & 13.1 \\
\hline Two adult females ( $E . p$. punctatus ) from Vene & 64.5 & 51.5 & 17.5 & 21.2 & 13 \\
\hline One adult female ( $E \cdot$ p. punctatus) from Brazil (Bahis & 69 & 58 & 18 & 24.5 & 14.5 \\
\hline
\end{tabular}


Young male.-Pileum, hindneek, back, seapulirs, and rump uniform prouts brown; under parts pale brownish gray, washed with prouts brown, the abdomen grayish white or very pale gray; wings and tail as in adult female.

loung female.-Not essentially different in coloration from the adult female but texture of plumige difierent (much softer).

British Honduris (Toledo Distriet), Honduris (Puerto Cabello; Medinal Rio Segória; Chmelieón; Rio Blaneo; Céiba), Nicaragua (Rio Escondido; San Emilis), Costa Rica (Angostura; Pacuare; San Bernardo; Sipúrio; Siquirres; Rio Reventazón; Jiménez; Old Harbor; Orosí; El Hogár; Cuábre; Guácimo; La Cristina), Panamá (Santiago de Yerágua; Chepo; Lion Hill; Panamá; Sabana de Panamá), western and central Colombia (Rio Truando; Bucaramanga; Bonda, Cacagualito, Minca, and Don Diego, Santa Marta; Nechi, Antioquía; Oñaca; Bogotá), ${ }^{a}$ and western Ecuadór ${ }^{b}$ (Babahoyo; Esmeraldas; Balzár Mts.; Santa Rita; Chimbo; Vinces; Foreste del Rio Peripa).

Thamnophilus nærius (not Lanius nævius Gmelin) Sclater, Proc. Zool. Soc., Lond., 1855, 148 (Bogotá); 1858, 213 (monogr.); 1860, 278 (Babahoyo, w. Ecuadór), 294 (Esmeraldas, w. Ecuadór; crit.); Cat. Am. Birds, 1862, 173 (Colombia; Esmeraldas, w. Ecuadór); Cat. Birds Brit. Mus., xv, 1890, 197 (Puerto Cabello and Medina, Honduras; Angostura, Costa Rica; Verágua, Chepo, and Panamá, Panamá; Minca and Nechi, Colombia; Esmeraldas, Balzár Mts., Santa Rita, and Chimbo, w. Ecuadór).-Cassin, Proc. Ac. Nat. Sci., Philad., 1860, 188 (Rio Truando, Colombia).-Sclater and Salvin, Proc. Zool. Soc., Lond., 1864, 355 (Lion Hill, Panamá; crit.); 1879, 524, Nechi, Antioquía, Colombia).-Satvin, Proc. Zool. Soc., Lond., 1867, 144 (Santiago de Terágua, Panamá).-Lawrence, Ann. Lyc., N. Y., ix, 1868, 107 (Angostura and Pacuare, Costa Rica).-Frantzius, Journ. für Orn., 1869, 305 (Costa Rica).-Boucard, Proc. Zool. Soc., Lond., 1878, 60 (San Carlos, Costa Rica).-Salvin and Gonman, Ibis, 1880, 171 (Minca, Santa Marta, Colombia, 2,000 ft.).-Berlepsch and Taczanowsei, Proc. Zool. Soc., Lond., 1883, 564 (Chimbo, w. Ecuadór; crit.).--BerLepsch, Journ. für Orn., 1884, 307 (Bucaramanga, Colombia; crit.); Zeitschr. Orn., 1887, 185 (Bogotá).-RIDGway, Proc. U. S. Nat. Mus., x, 1887, 590 (Segóvia R., Honduras).-ZELedón, Anal. Mus. Nac., Costa Rica, 1887, 114 (Angostura, Costa Rica).-Bangs, Proc. Biol. Soc., Wash., xii, 1898, 138 (Santa Marta, Colombia); Proc. New Engl. Zool. Club, ii, 1900, 24 (Loma del León, Panamá); Bull. Mus. Comp. Zool., xxxix, 1903, 150 (Céiba, Honduras).-Allew, Bull. Am. Mus., N. H., xiii, 1900, 161 (Bonda, Santa Marta, Colombia).

(?) Thamnophilus cærulescens (not of Vieillot) Lafresnaye, Rev. Zool., 1853, 338.

Thamnophilus amazonicus (not of Sclater) LAwrence, Ann. Lyc. N. Y., vii, 1862, 325 (Lion Hill, Panamá).

[Thamnophilus] nxivis Sclater and Salvin, Nom. Av. Neotr., 1873, 70, part.

Thamnophilus atrinucha Salvin and Godinan, Biol. Centr.-Am., Aves, ii, sig. 25, Feb., 1892, 200 (Panamá; coll. Salvin and Godman).-Richmond, Proc. U. S. Nat. Mus., xvi, 1893, 500 (Rio Escondido, Nicaragua; habits).-Salvadori

$a$ Specimens of beth this form and what I am not able to distinguish from true $E$. punctatus occur in Bogotá collections.

$b$ I have not seen a specimen from western Ecuadór. 
and Festa, Boll. Mus. Zool., etc., xv, no. 362, 1899, 27 (Vinces and Foreste del Rio Peripa, w. Ecuadór); no. 399, 7 (Laguna del Pita, Panamá).-Thayer and Bangs, Bull. Mus. Comp. Zool., xlvi, 1906, 216 (Sabana de Panamá).

[Thamnophilus] atrinucha SHARPE, Hand-list, iii, 1901, 14.

[Thamnophilus] nævius atrinucha Hellmayr, Abh. K. B. Akad. Wiss., ii. Kl., xxii Bd., iii. Abth., 1905, 659 (crit.).

Thamnophilus navius atrinucha CARriker, Ann. Carnegie Mus., vi, 1910, 602 (Caribbean lowlands aud foothills, Costa Rica; crit.; habits; descr. nest and eggs).

\section{ERIONOTUS PUNCTATUS GORGONE (Thayer and Bangs).}

\section{GORGONA ISLAND ANTSHRIKE.}

Similar to E. p. atrinucha but adult male with forehead more extensively grayish, ${ }^{a}$ the adult female with lateral under parts paler (nearly concolor with median portion).

Gorgona Island, Bay of Panamá.

Adult male.-Length (skins), 143-148 (146); wing, 70-75 (72.1); tail, 57-61 (59); culmen, 18.5-20 (19.4); tarsus, 20-21 (20.5); middle toe, $12.5-13(12.7) .^{b}$

Adult female.-Length (skins), 140-148 (144); wing, 68.5-72.5 (70.1); tail, 54.5-57.5 (56.1); culmen, 18.5-20 (19.1); tarsus, 21-21.5 (21.1); middle toe, $13-14$ (13.4). ${ }^{b}$

Thamnophilus gorgonæ Thayer and Bangs, Bull. Mus. Comp. Zool., xlvi, no. 5, June, 1905, 95 (Gorgona Island, Bay of Panamá; coll. E. A. and O. Bangs).

\section{Genus DYSITHAMNUS Cabanis.}

Dysithamnus c CabanIs, in Wiegmann's Archiv für Naturg., xiii, pt. i, 1847, 223. (Type, Lanius guttulatus Lichtenstein.)

Dasythamnus (emendation) Burmeister, Syst. Ueb. Th. Bras., iii, 1856, 82.

Silvestrius d Bertoni, Aves Nuevas del Paraguay, 1901, 136. (Type, Thamnophilus (Silvestrius) flavescens Bertoni=Myothera mentalis Temminck.)

Small Formicariidæ (length about 100-115 mm.) with bill much shorter than head, tail less than three-fourths as long as wing and slightly rounded, tarsus one-third as long as wing, and plainly colored plumage (olive or olive-greenish above, becoming gray or slate colored on head and neck, the pileum sometimes streaked or spotted with blackish, mostly whitish or yellowish below, sometimes with streaks on throat and chest, females more brownish, with pileum rufescent.

Bill much shorter than head, its width at frontal antiæ slightly greater than its depth at same point and equal to about half the distance from nostril to tip of maxilla; culmen distinctly but not sharply ridged, nearly straight for most of its length, strongly and rather abruptly decurved terminally, the tip of maxilla moderately

$a$ On comparison with a large series of $E . p$. atrinucha I find that most of the characters mentioned by Mr. Bangs do not hold.

$b$ Four specimens.

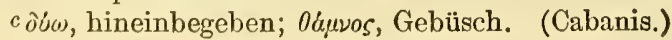

d Named for Dr. Felipe Silvestri. 
to rather strongly uncinate; maxillary tomium straight, distinctly notched subterminally; mandibular tomium nearly straight, minutely toothed and notched subterminally, the tip of mandible forming a short recurved point; gonys gently convex, slightly ascending terminally, not prominent bisally. Nostril exposed, posteriorly in contanct with feathering of latero-frontal antiae, roundish or broally oval, its upperposterior margin membraneous, the interior tubercle visible within posterior portion. Rictal bristles present but minute, the feathers of chin, anterior portion of malar region, and lores with long terminal setæ. Wing moderate, with longest primaries extending to decidedly beyond secondaries; sixth and seventh, or fourth, fifth and sccond, primaries longest, the tenth (outermost) less than three-fifths but more than half as long as the longest, the ninth about equal to or slightly shorter than secondaries. Tail a little more than half to more than two-thirds as long as wing, slightly rounded or nearly eren, the rectrices (12) narrow, subrounded or subacuminate terminally. Tarsus much longer than exposed culmen, about one-third as long as wing, slender, the acrotarsium distinctly scutellate, the plantar scutella in two longitudinal series, less distinct on outer side; middle toe, with claw, much shorter than tarsus; outer toe, without claw, reaching to slightly beyond middle of subterminal phalanx of middle toe, the inner toe a little shorter; hallux about as long as inner toe, but much stouter; basal phalanx of middle toe wholly united to outer toe, for about half its length to inner toe; claws moderate in size and curvature, that of the hallux decidedly shorter than the digit. Plumage full, soft, and blended, longer and more lax on rump; pileum not crested.

Coloration.-Adult males olive or olive-greenish above, the head and neck gray or slate-colored (sometimes streaked or spotted with blackish), the lesser wing-coverts black, spotted with white or with a white area on inner-anterior portion; under parts mostly whitish or yellowish (at least medially), the throat and chest sometimes streaked with gray or blackish. Adult females duller in color, with pileum rufescent.

Range.-Guatemala to British Guiana, southeastern Brazil, Paraguay, Bolivia, and Peru.

(About ten species.) ${ }^{a}$

$a \mathrm{I}$ have not seen $D$. guttulatus (Lichtenstein), D. tambillanus Taczanowski, $D$. xanthopterus Burmeister, nor $D$. flemingi Hartert. All these except $D$. xanthopterus appear, however, to be congeneric with $D$. mentalis, etc., so far as I am able to judge from descriptions; but the style of coloration is so different in $D$. xanthopterus (chestnut-rufous wings and lower back, white spots on sides of head, etc.) that I doubt its close relationship.

D. leucostictus Sclater, D. schistaceus (D'Orbigny), D. ardesiacus Sclater and Salvin, D. unicolor Sclater, and D. subplumbeus Sclater and Salvin, I unhesitatingly exclude, as being much more nearly related to the genus Erionotus Cabanis and Heine (=Thamnophilus, part, of Sclater).

D. plumbeus (Maximilian) I have seen but have not now at hand, and therefore can not verify my impression that it is congeneric with $D$. mentalis and allies. 


\section{KEY TO THE SPECIES AND SUBSPECIES OF DYSITHAMNUS.}

a. Pileum and hindneck at least partly slate color or slate-gray. (Adult males.)

$b$. Pileum and hindneck without black or white markings.

c. A narrow white spot or streak on lower edge of auricular region. (Southwestern Brazil; Bolivia?)........... Dysithamnus affinis, adult male (extralimital). ${ }^{a}$

$c c$. No trace of white spot or streak on lower edge of auricular region. (Dysithamnus mentalis.)

d. Under parts of body more deeply yellowish, strongly and abruptly contrasted with grayish white of throat. (Southeastern Brazil; Paraguay.)

Dysithamnus mentalis mentalis, adult male (extralimital). $b$

$d d$. Under parts of body paler yellowish (sometimes white).

e. Abdomen more or less yellowish; back more or less olivaceous, different from color of pileum and hindneck.

f. Larger (wing 63.5-66.5).

g. Paler. (Tobago.)

Dysithamnus mentalis oberi, adult male (extralimital). $c$

gg. Darker. (Colombia and Venezuela.)

Dysithamnus mentaIis semicinereus, adult male (extralimital). ${ }^{d}$ ff. Smaller (wing 57-62). (Panamá to Guatemala.)

Dysithamnus mentalis septentrionalis, adult male (p. 55).

ee. Abdomen white; back slate color, concolor with pileum and hindneck.

$f$. Lighter and clearer slate color above, more extensively white beneath, the flanks paler and less olive or buffy brownish. (Trinidád.)

Dysithamnus mentalis andrei, adult male (extralimital).e

a Dysithamnus affinis Pelzeln, Orn. Bras., ii, Abth., 1869, 80, 149 (Villa Maria, Brazil; coll. Vienna Mus.).-D[ysithamnus] a[ffinis] affinis Hellmayr, Novit. Zool., xiii, Feb., 1906, 32, in text (crit.); Dysithamnus affinis affinis Hellmayr, Novit. Zool., xv, 1908, 69 (Faz. Esperanza, Brazil; crit.).-Dysithamnus olivaceus (not Thamnophilus olivaceus Tschudi) Sclater, Cat. Birds Brit. Mus., xv, 1890, 222, excl. syn. part.-Dysithamnus mentalis (not Myothera mentalis Temminck) Allen, Bull. Am. Mus. N. H., v, 1893, 118, excl. syn. (Chapada, Matto-Grosso, Brazil; crit.).

b Myothera mentalis Temminck, Pl. Col., ii, livr. 30, Jan., 1823, text to pl. 179, fig. 3 (Brazil; coll. Vienna Mus.).--Daysthamnus mentalis Burmeister, Syst. Ueb. Th. Bras., iii, 1856, 82,-Dysithamnus mentairs Sclater, Proc. Zool. Soc. Lond., 1858, 221, part; Cat. Birds Brit. Mus., xv, 1890, 221; Allen, Bull. Am. Mus. N. H., ii, 1889, 250.-D [ysithamnus] mentalis mentalis Hellmayr, Novit. Zool., xiii, Feb., 1906, 32 , in text (crit.).-M[yiothera] poliocephala Maximilian, Beitr. Naturg. Bras.; iii, pt. ii, 1831, 1098 (s. e. Brazil; type now in coll. Am. Mus. Nat. Hist.)

c Dysithamnus mentalis oberi Ridgway, Proc. Biol. Soc. Wash., xxi, Oct. 20, 1908, 193 (Tobago; coll. U. S. Nat. Mus.).

d Dysithamnus semicinereus Sclater, Proc. Zool. Soc. Lond., 1855, 90, 147, pl. 97 (Bogotá, Colombia; coll. P. L. Sclater); Cat. Birds Brit. Mus., xv, 1890, 221, part.D[ysithamnus] mentalis semicinereus Ridgway, Proc. Bjol. Soc. Wash., xxi, Oct. 20, 1908, 193, in text.

e Dysithamnus affinis andrei Hellmayr, Novit. Zool., xiii, Feb., 1906, 31 (Caparo, Trinidád; coll. Tring Mus.).-Dysithamnus mentalis spodionotus (not D. spodionotus Salvin and Godman) Chapman, Bull. Am. Mus., N. H., vi, 1894, 50 (Trinidád). 
ff. Darker and duller slate color above, less extensively white beneath, the flanks darker and more buffy brownish. (British Guiana.)

Dysithamnus mentalis spodionotus, adult male (extralimital). ${ }^{\prime}$

$b b$. Pileum and hindneck streaked or spotted with black (sometimes also spotted with white).

c. Pileum with small rounded spots of white; throat and foreneck more narrowly streaked; tail 3-4-3S. (Costa Rica and western Panamá.)

Dysithammus puncticeps, adult male (p. 58).

cc. Pilcum withont white spots; throat and foreneck more broadly streaked; tail

30-35. (Costa Rica.)........ Dysithamnus striaticeps, adult male (p. 59).

aa. Pileum and hindneck rufescent brown, cinnamomeous, or tawny, very different from olive or olive-brown of back.

b. Pileum, throat, and chest without streaks; wing-coverts much less distinctly tipped with buff.

c. Under parts strongly bufiy, the abdomen white or pale buffy (never yellow); pileum and hindneck more strongly and more extensively rufescent, the back, etc., lighter and more buffy olive.

Dysithamnus affinis, adult female (extralimital).

cc. Under parts olivaceous (not buffy) laterally and on chest, the abdomen pale yellowish or whitish. (Dysithamnus mentalis.) $b$

d. Sides and chest much darker olivaceous.

Dysithamnus mentalis semicinereus, adult female (extralimital).

$d d$. Sides and chest much paler olivaceous.

e. Abdomen pale olive-yellowish.

Dysithamnus mentalis septentrionalis, adult female (p. 56). ee. Abdomen white..... Dysithamnus mentalis andrei, adult female (extralimital).

$b b$. Pileum, throat, and chest streaked with dusky; wing-coverts much more distinctly tipped with buffy.

c. Tail 36.5-40; under parts more strongly buffy, with chest, etc., more narrowly streaked; pileum paler tawny or cinnamomeous, more distinctly streaked with dusky............... Dysithamnus puncticeps, adult female (p. 58).

cc. Tail 29-35.5; under parts less strongly buffy (whitish medially), with chest more heavily streaked; pileum darker tawny, less distinctly streaked with dusky ................. Dysithamnus striaticeps, adult female (p. 60).

\section{DYSITHAMNUS MENTALIS SEPTENTRIONALIS Ridgway.}

NORTHERN ANTVIREO.

Similar to $D . m$. semicinereus ${ }^{c}$ but decidedly smaller; adult male lighter in color of upper parts, adult female with sides and flanks paler olive.

a Dysithamnus spodionotus Salvin and Godman, Ibis, 5th ser., ii, April, 1883, 211 (Roraima, Brit. Guiana; coll. Salvin and Godman).-D[ysithamnus] a[ffinis] spodionotus Hellmayr, Novit. Zool., xiii, Feb., 1906, 32.

$b$ Adult females of $D . m$. mentalis and $D . m$. spodionotus not seen by me.

$c$ See page 54 . 
Adult male.-Pileum and hindneck plain slate color, becoming paler (slate-gray) on supra-auricular region; back, scapulars, rump, and upper tail-coverts plain olivaceous-slate color (more decidedly olivaceous posteriorly) contrasting more or less strongly with slate color of hindneck and pileum; tail darker slaty olive or olivaceousslate, the outermost rectrices usually narrowly tipped with whitish; auricular region slate color (usually somewhat darker than pileum), sometimes with very narrow shaft-streaks of whitish; lores and subvrbital region slate-grayish indistinctly mottled or flecked with paler, the latter and posterior portion of the former sometimes uniform dark slate color; malar region pale gray or grayish white, indistinctly barred or transversely flecked with darker; outer web of exterior row of scapulars broadly edged with white, the white usually margined internally by a narrow line of dusky; lesser wing-coverts black, at least some of the feathers tipped, more or less distinctly, with white, the inner-anterior portion of the area occupied by a white patch; middle coverts black distinctly tipped with white; greater coverts slate color or slate-gray narrowly tipped with white; remiges similar in color to back, etc., the terminal portion of longer primaries more brownish; chin and throat white or grayish white; chest pale gray medially, darker (slate-gray) laterally, passing into light olive on flanks; breast (medially) white or yellowish white, passing into pale yellow (primrose to nearly straw yellow) on, abdomen and under tail-coverts; under wing-coverts mostly pale yellow, the inner webs of remiges broadly edged with the same; maxilla dusky, paler on tomium; mandible paler (plumbeous in life); iris brown; legs and feet dusky (plumbeous in life); length (skins), 101-113 (108.5); wing, 57-63 (59.4); tail, 37.5-41.5 (39.1); culmen, 14-15.5 (14.6); tarsus, 18-20 (19.2); middle toe, $11-12$ (11.4) ${ }^{a}$

Immature male.- Similar to the adult male but remiges distinctly more brownish (nearly broccoli brown to light olive-brown), and breast yellowish, like abdomen.

Adult female.-Pileum chestnut-brown or russet, the feathers with indistinct shaft-streaks of paler; hindneck similar but less rufescent brown; back, scapulars, and rump plain olive (varying from grayish to brownish olive); upper tail-coverts and tail sepia brown; general color of wings olive, the middle and greater coverts narrowly and rather indistinctly tipped with buffy or pale buffy brownish; a narrow orbital ring of whitish; auricular region dusky olive or slaty olive, with narrow shaft-streaks of whitish or pale buffy; malar region, chin, and throat white, usually more or less tinged with pale yellowish olive or dull yellowish; rest of under parts pale yellowish, passing into light olive or buffy olive on sides and flanks, the under tail-coverts buffy; bill, etc., as in adult male; length (skins), 96-112 
(106); wing, 54.5-62.5 (59.2); tail, 36-40.5 (38.6); culmen, 14.5-15.5 (14.9); tarsus, 18.5-20 (19.3); middle too, 10.5-11.5 (11.1). ${ }^{a}$

Guatemala (Choctúm; Chiséc; sources of Rio de la Pasión), Costa Rica (Dota; Naranjo de Cartago; Grécia; Guaitíl Juan Viñas; Las Mesas; El Generál; Buena Vista; Rio Platanár; Guayabo; Cariblanco de Sarapiquí; Navarro; Rio Huacúm; Laguária; Santa Maria de Dota), and Panamá (Panamá; Calovévora, Chitra, Calobre; and Santa Fe de Verágua; Boquete; Volcán de Chiriquí, and along Pacific coast to western Ecuadór (Chimbo)? (See Berlepsch and Taczanowski, Proc. Zool. Soc. Lond., 1883, 564.)

Dysithamnus semicinereus (not of Sclater, 1855) Sclater, Proc. Zool. Soc. Lond., 1S58, 222, part (monogr.); Cat. Birds Brit. Mus., xv, 1890, 221, part (Chiséc, sources of Rio de la Pasión, and Choctúm, Guatemala; Costa Rica; Santa Fé de Verágua, Calovévora, and Panamá, Panamá).-Salvin and Sclater, Ibis, 1860, 399 (Choctúm, Guatemala; crit.).—Salvin, Proc. Zool. Soc. Lond., 1867, 144 (Santa Fé de Verágua); Proc. Zool. Soc. Lond., 1870, 194 (Calovévora, Chitra, Calobre, and Volcan de Chiriquí, Panama).-Lawrence, Ann. Lyc. N. Y., ix, 1868, 107 (Turrialba, Dota, Grécia, and Guaitíl, Costa Rica).Frantzius, Journ. für Orn., 1869, 305 (Costa Rica).-Boucard, Proc. Zool. Soc. Lond., 1878, 60 (Naranjo de Cartago, Costa Rica); Liste Ois. récol. Guat., 1878, 38.-ZeLedón, Anal. Mus. Nac. Costa Rica, i, 1887, 114 (Cartago, Turrialba, and Dota, Costa Rica).-Bangs, Proc. New Engl. Zool. Club, iii, 1902, 41 (Boquete, Panamá, 4000-5000 ft.)-Salvin and Godman, Biol. Centr.-Am., Aves, ii, 1892, 206, part (excl. South American references and localities).

[Dysithamnus] semicinereus Sclater and Salvix, Nom. Av. Neotr., 1873, 70, part.-Sharpe, Hand-list, iii, 1901, 18, part.

Disithamnus semicinereus Cherrie, Expl. Zool. Merid. Costa Rica, 1893, 41 (Rio Huacúm, s. w. Costa Rica).

$a$ Fifteen specimens.

\begin{tabular}{|c|c|c|c|c|c|}
\hline Locality. & Wing. & Tail. & $\begin{array}{l}\text { Cul- } \\
\text { men. }\end{array}$ & $\begin{array}{l}\text { Tar- } \\
\text { sus. }\end{array}$ & $\begin{array}{c}\text { Middle } \\
\text { toe. }\end{array}$ \\
\hline \multicolumn{6}{|l|}{ MALES. } \\
\hline Three adult males from Guatemala. & 58.5 & 37.8 & 14.8 & 18.7 & 11.2 \\
\hline Ten adult males from Costa Rica.. & 60.6 & 39.4 & 14.6 & 19.5 & 11.4 \\
\hline Two adult males from Panamá (Chiriquí and Verágua). & 59.2 & 39.5 & 14.2 & 18.5 & 11.2 \\
\hline Four adult males ( $D$. m. semicinereus) from Colombia.. & 65.4 & 42.4 & 15 & 19.7 & 11.7 \\
\hline One adult male (D. m. semicinereus) from Venezuela ... & 64 & 41 & 14.5 & 18.5 & 11.5 \\
\hline Five adult males $(D, m$. andrei $)$ from Trinidád... & 61 & 41 & 15 & 19 & 11.3 \\
\hline One adult male $(D, m$. oberi $)$ from Tobago ............... & 64.5 & 44 & 15 & 20 & 11.5 \\
\hline One adult male ( $D . m$. spodionotus) from British Guiana. & 62.5 & 44.5 & 13.5 & 20.5 & 12.5 \\
\hline Two adult males ( $D$. m. mentalis) from southern Brazil. & 58.2 & 43.3 & 13 & 19 & 11 \\
\hline Ten adult males of $D$. affinis from southwestern Brazil. & 62.4 & 40.7 & 14.9 & 19.8 & 12.1 \\
\hline \multicolumn{6}{|l|}{ FEMALES. } \\
\hline Three adult females from Guatemala. & 56.3 & 36.8 & 14.7 & 18.5 & 10.8 \\
\hline Ten adult females from Costa Rica.. & 60.1 & 39.1 & 15 & 19.6 & 11.1 \\
\hline Two adult females from western Panamá (Verágua and Chiri- & & & & & \\
\hline $\mathrm{qu}$ & 59.2 & 38.7 & 14.5 & 19 & 11.2 \\
\hline Five adult females (D. m. semicinereus) from Colombia.. & 61.2 & 39.5 & 14.9 & 19.9 & 11.4 \\
\hline One adult female ( $D . m$. andrei) from Trinidád .... & 59 & 35.5 & 16 & 18 & 11.5 \\
\hline Six adult females of $D$. affinis from southwestern Brazil & 61.2 & 40.6 & 14.7 & 19.5 & 11.6 \\
\hline
\end{tabular}


D[ysithamnus] olivaceus semicinereus Oberholser, Proc. U. S. Nat. Mus., xxv, no. 1281, Sept. $8,1902,129$, in text (part).

Dysithamnus mentalis septentrionalis Ridgway, Proc. Biol. Soc. Wash., xxi, Oct. 20, 1908, 193 (Choctúm, Vera Paz, Guatemala; coll. U. S. Nat. Mus.).Carriker, Ann. Carnegie Mus., vi, 1910, 606 (Caribbean slope, 2000-4000 ft., and foothills of s. w. Pacific slope, Costa Rica; habits).-Ferry, Pub. 146, Field Mus. N. H., orn. ser., i, no. 6, 1910, 271 (Guayabo, Costa Rica).

\section{DYSITHAMNUS PUNCTICEPS Salvin.}

\section{SPOTTED-CROWNED ANTVIREO.}

Adult male.-Pileum and hindneck black and slate-gray, dotted with white, the black in the form of irregular ("herring-bone") mesial streaks, broader on occiput and hindneck, the white dots more transverse on forehead; back, scapulars, rump, and upper tailcoverts slate color or deep slate-gray, usually tinged, more or less, with olive, especially on rump and upper tail-coverts; tail olive-slate or slaty olive; general color of wings similar to that of back, but concealed portion of feathers more dusky, the lesser coverts dotted with white, middle and greater coverts tipped, or terminally spotted, with white (forming two distinct narrow bands), primary coverts (usually at least) minutely marked at tip with white, and alula conspicuously edged with white; auricular region slate-gray, tinged with olive and indistinctly streaked with whitish, the suborbital and malar regions white, or yellowish white, streaked and barred with dusky grayish; sides of neck and sides of chest plain slate-gray, passing posteriorly into a more buffy olive hue on flanks; median under parts (broadly) white, passing into pale buffy yellowish posteriorly, the chest (sometimes lower throat also) usually more or less streaked with dusky; under wing-corerts and broad edgings to inner webs of remiges yellowish white, the carpo-metacarpal region spotted with dusky; maxilla brownish black, mandible dull whitish (pale bluish gray in life?); legs and feet horn color (bluish gray in life?); length (skins), 10s-113 (110); wing, 58-61 (59); tail, 34--38 (36); tarsus, 20-20.5 (20.2); middle toe, 11-12 (11.5). ${ }^{a}$

Adult female.-Pileum light tawny-ochraceous, buffy cinnamon or wood brown, streaked, more or less broadly, with black, the streaks more or less cuneate or guttate and broader on occiput; back, scapulars, and rump plain light grayish olive or hair brown, the upper tailcoverts more brownish; tail dusky grayish brown with light olivebrown edgings, the lateral rectrices narrowly margined at tip with pale brownish buffy; anterior lesser wing-coverts concolor with back, but slightly darker centrally, the posterior ones and the middle coverts more dusky with a rather large terminal roundish spot of pale buffy; greater coverts dark brownish olive, edged with paler, the outer web with a roundish terminal spot of buffy; remiges olivebrown (more buffy on edges of primaries), their inner webs dusky 
grayish brown; supren-auricular region streaked or spotted with black and pale buff or buffy whitish; under parts buff, paler on throat and abdomen, more grayish or olivaceous on sides and flanks, the chest and throat (especially the former) narrowly streaked with black; bill, etc., as in adult male; length (skins), 103-107 (105); wing, 56.5-59 (57.7); tail, 36.5-40 (38.2); culmen, 15-17 (16); tarsus, 20-20.5 (20.2); middle toe, 12.5-13 (12.7). ${ }^{a}$

Costa Rica (San José; Pacuare; Rio Sícsola) and western Panamá (Santiugo de Verágua).

Dysithammus puncticeps Salvin, Proc. Zool. Soc. Lond., 1866, 72 (Santiago de Verágua, Panamá; coll. Salvin and Godman); 1867, 144 (Santiago de Verágua).-Zeledón, Anal. Mus. Nac. Costa Rica, 1887, 115 (Pacuare, Costa -Rica).-Sclater, Cat. Birds Brit. Mus., xv, 1890, 223 (Verágua).-Salvin and Godman, Biol. Centr.-Am., Aves, ii, 1892, 207, pl. 50, figs. 2, 3.-CARriker, Ann. Carnegie Mus., vi, 1910, 599 (in key; considered extralimital to Costa Rica?).

[Dysithamnus] puncticeps Sclater and Salvin, Nom. Av. Neotr., 1873, 71.Sharpe, Hand-list, iii, 1901, 19.

\section{DYSITHAMNUS STRIATICEPS Lawrence.} STREAKED-CROWNED ANTVIREO.

Adult male.-Pileum and hindneck slate-gray, broadly streaked with black, the streaks becoming obsolete on hindneck; back, scapulars, rump, and upper tail-coverts plain olive or grayish olive, the upper back sometimes inclining to slate-gray; tail russet-olive or olive-brown; lesser wing-coverts black, spotted with white, those along edge of wing mostly or wholly white; middle coverts black, tipped with a roundish spot of white or brownish white; greater coverts olive (darker on concealed portions), their outer webs tipped with brownish white (forming a narrow band across closed wing); remiges olive, with underlying portion dusky, paler on edge of primaries; alula black, the outermost feathers broadly edged with white; auricular region and sides of neck slate-gray, the former very indistinctly flecked with dusky; suborbital and malar regions paler gray, barred or flecked with dusky; chin, throat, and chest white, broadly streaked with slate-gray and with narrow blackish shaftstreaks; sides and flanks olive, more or less strongly suffused with buff; breast and abdomen white, or buffy white, passing into buff (more or less deep) on under tail-coverts; under wing-coverts mostly dull white; inner webs of remiges broadly edged with white; maxilla brownish black, mandible dull whitish (pale bluish gray, bluish horn color, or straw yellow in life) $;^{b}$ iris brown, gray, grayish white, or bluish white; $b$ legs and feet dusky or horn color (bluish gray or grayish blue in life) $;^{b}$ length (skins), 94-112 (102); wing, 56.5-61 (59.2); tail, 31.5-35 (32.7); culmen, 15.5-17 (16.1); tarsus, 19-20.5 (19.8); middle toe, $11-12.5$ (11.8). ${ }^{c}$ 
Adult female.-Pileum pale cinnamon to russet, more or less distinctly streaked with dusky; back, scapulars, rump, and upper tail coverts plain olive; tail brownish olive or olive-brown; general color of wings olive (paler on edges of primaries), the lesser and middle wing-coverts darker (sometimes blackish), each with a terminal spot of buff, the greater coverts with a buffy spot on tip of outer web; auricular region olive or buffy grayish, very narrowly streaked with whitish or buffy; suborbital and malar regions pale buffy, barred or flecked with dusky; chin and throat dull buffy whitish, usually with more or less distinct narrow streaks of dusky; rest of under parts buff (more or less deep) medially, this passing into olive on sides and flanks, the chest sometimes streaked with dusky; under wing-coverts mostly pale buff or dull buffy whitish, the inner webs of remiges broadly edged with the same; maxilla dusky brown, mandible dull whitish (in dried skins); legs and feet horn color (in dried skins); length (skins), 97-112 (103); wing, 56-60.5 (58.2); tail, 29-35.5 (32.2); culmen, 14.5-16.5 (15.4); tarsus, 18-21 (19.6); middle toe, $11-12.5(11.9){ }^{a}$

Immature male.--Similar to the adult female but grayer above and more whitish beneath.

Costa Rica (Angostura; Talamanca; San Carlos; La Balsa; Dos Novillos; Siquirres; Guácimo; Guápiles; El Hogár; Carillo; La Christina; Rio Reventazón; Rio Sícsola; Miravalles; La Vijágua).

Dysithamnus striaticeps Lawrence, Ann. Lyc. Nat. Hist. N. Y., viii, May, 1867, 130 (Angostura, Costa Rica; coll. U. S. Nat. Mus.); ix, 1868, 107 (do.).Frantzius, Journ. für Orn., 1869, 305 (Costa Rica).-Boucard, Proc. Zool. Soc. Lond., 1878, 60 (San Carlos, Costa Rica).-Zemedón, Anal. Mus. Nac. Costa Rica, 1887, 115 (Angostura, Costa Rica).-Sclater, Cat. Birds Brit. Mus., xv, 1890, 223 ("Valza," i. e., La Balsa, Costa Rica).-Salvin and Godman, Biol. Centr.-Am., ii, 1892, 208.-Underwood, Ibis, 1896, 440 (Volcan de Miravalles, Costa Rica).-Carriker, Ann. Carnegie Mus., vi, 1910, 606 (Caribbean foothills, 800-1,500 ft., Costa Rica; habits; descr. nest and eggs).

[Dysithamnus] striaticeps Sclater and Salvin, Nom. Av. Neotr., 1873, 70;Sharpe, Hand-list, iii, 1901, 19.

\section{Genus MYRMOTHERULA Sclater.}

Myrmotherula Sclater, Proc. Zool. Soc. Lond., 1858, 234. (Type, Muscicapa pygmæa Gmelin.)

Myrmotherium (emendation) Cabanis and Heine, Mus. Hein., ii, July, 1859, 12 , footnote.

Very small Formicariidæ (length less than $100 \mathrm{~mm}$.) with bill slender, nearly as long as head, tail less than two-thirds (sometimes less than half) as long as wing, and plumage either conspicuously streaked or else mostly uniform gray or slate color.

Bill slender, depressed, nearly as long as head, its width at frontal antiæ very much greater than its depth at same point, and equal to about half the distance from nostril to tip of maxilla or less; culme 
distinctly but not sharply ridged, straight for about basal half then more and nore decurved terminally, the tip of maxilla minutely but distinctly uncinate; maxilhary tomium slightly but decidedly concave, minutely but distinctly notched subterminally; mandibular tomium nearly straight, minutely notehed subterminally; gonys nearly straight terminally, gently convex basally. Nostril exposed, widely separated from feathering of frontal antie (the intervening space occupied by membrane), broadly (longitudinally) oval, the intermal tubercle visible within the posterior half. Rietal bristles present but minute. Wing morlerate, with longest primaries extending decidedly beyond secondaries; sixth and seventh, fifth, sixth, and serenth, or sixth, serenth, and eighth, primaries longest, the tenth (outermost) more than half to about three-fifths as long as the longest, the ninth shorter than secondaries. Tail decidedly less than half as long as wing ( $M$. pygmæxa) to slightly more than half as long, rery slightly to decidedly rounded, the rectrices (10 in $M$. pygmra and $M$. cinereiventris?, 12 in M. surinamensis and $M$. assimitis) rather narrow, rounded terminally. Tarsus much longer than exposed culmen, much shorter than tail and about one-third as long as wing in $M$. surinamensis, very much shorter than tail and decictedly less than one-third as long as wing in M. cinereiventris and M. assimitis, nearly as long as tail and much more than one-third as long as wing in $M$. pygmæa, distinetly scutellate, the plantar scutella in two longitudinal series; middle toe, with claw, much shorter than tarsus; outer toe, without claw, reaching to beyond middle of subterminal phalanx of middle toe, the inner toe decidedly shorter; hallux about as long as inner toe but much stouter; basal phalanx of middle toe wholly united to outer toe, for about half its length to inner toe; claws moderate in size and curvature, that of the hallux much shorter than the digit. Plumage soft and full, that of the rump much developed and fluffy; pileum not crested.

Coloration.-Adult males black above, conspicuously streaked with white, the wing with two broad white bands, or else plain gray or slate color above, with small white tips to wing-coverts, the tail with white terminal spots; the under parts white streaked with black (M. surinamensis) or immaculate pale yellow (M. pygmæa), or plain gray or slate color ( $\lambda$. cinereiventris and $M$. assimilis); adult females with head and neck tawny or cinnamomeous, streaked with black above, otherwise much like adult males, or else with under parts cinnamomeous. ${ }^{b}$

Nidification.-Nest made of fine roots and grass and suspended in a fork; eggs white or greenish-white.

$a$ According to Dr. Sclater M. pygmæa has only 10 rectrices, and a specimen of M. cinereiventris apparently has only 10.

$b$ I have not seen females of $M$. cinereiventris nor of $M$. assimilis. 
Range.--Isthmus of Panamá to Cayenne and Amazon Valley. (At least four species.) ${ }^{a}$

KEY TO THE SPECIES OF MYRMOTHERULA.

a. Under parts white, streaked with black. (Panamá to Guiana and western Ecuadór.) Myrmotherula surinamensis, adult male (p.62). aa. Under parts neither white nor streaked with black.

$b$. Under parts buffy, deepening into tawny on chest .

Myrmotherula surinamensis, adult female (p. 62).

$b b$. Under parts of body pale straw or primrose yellow.

c. Pileum narrowly streaked with pale yellow or yellowish white; throat white. - (Panamá to Cayenne and Peru).Myrmotherula pygmæa, adult male (p. 64). cc. Pileum streaked with pale rufous or tawny; throat buff or pale tawny.

Myrmotherula pygmæa, adult female (p. 64).

\section{MYRMOTHERULA SURINAMENSIS (Gmelin).}

\section{SURINAM ANTWREN.}

Adult male.-Pileum, hindneck, back, and scapulars black, narrowly streaked with white, the feathers of back extensively white basally; rump plain gray (nearly no. 6), much paler posteriorly; upper tail-coverts dusky, indistinctly margined terminally with whitish; tail black, the rectrices tipped with white and edged on middle portion with the same; wings black, the middle and greater coverts broadly tipped with white (forming two very conspicuous bands across wing), the remiges edged (except on basal portion of distal secondaries and proximal primaries) with white; under parts white, the throat narrowly, the chest, breast, sides, and flanks broadly, streaked with black; under wing-coverts and broad edgings, to inner webs of primaries white; maxilla dull black, mandible dull whitish (in dried skins); legs and feet pale yellowish gray (in dried skins); length (skins), 90-107 (96); wing, 49.5-52.5 (51); tail, 26-28.5 (26.9); culmen, 14-15.5 (15); tarsus, 16.5-18.5 (17.2); middle toe, $9.5-10.5(9.9) .^{b}$

Adult female.-Pileum bright tawny, the occiput and posterior part of crown streaked with black, the hindneck more buffy and with black streaks broader; back and scapulars black, streaked with

$a$ The following species, referred to Myrmotherula by Dr. Sclater, I have not seen and therefore have no very clear idea of the limits of the group: M. guttata (Vieillot), M. spodionota Sclater and Salvin, M. atrogularis Taczanowski, M. hæmatonota (Sclater) M. pyrrhonota Sclater and Salvin, M. erythrura Sclater, M. erythronota (Hartlaub), M. hauxwelli (Sclater), M. longipennis Pelzeln, M. brevicauda (Swainson), M. urosticta (Sclater), M. inornata Salvin, M. unicolor (Ménétriés), M. longicauda Berlepsch and Stolzmann, M. sororia Berlepsch and Stolzmann, M. guayabambæ Sharpe, M. lafresnayeana (D'Orbigny), M. viduata Hartert, M. sanctæmartæ Allen, M. behni Berlepsch and Leverkuhn, and $M$. boliviana Berlepsch. It is not unlikely that when all these species can be critically compared a further subdivision of the genus may be required.

$b$ Four specimens. 
whitish (sometimes intermixed with grayish), the median interscapulars extensively white basally, forming a conspicuous patch when feathers are parted; rump bufiy grayish, the upper tail-coverts darker, indistinctly margined with whitish; tail black, the rectrices tipped with white and edged for middle portion with same; wings black, the middle and greater coverts broadly tipped (mostly on outcr webs) with white, the remiges edged (except on basal portion of distal secondaries and proximal primaries) with white; under parts plain bufly white, deepening into buft on chest and tawny-buff on malar region, the sides and flanks tinged with pale bufly grayish and, sometimes, rery indistinctly streaked with darker; bill, etc., as in adult male; length (skins), 87-95 (90.5); wing, 48-52 (49.S); tail, $25.5-27$ (25.7); tarsus, $14-15.5$ (14.8); middle toe, $10 .^{a}$

Young female. - Similar to the adult female but without any concenled white on interscapular region and under parts more deeply colored (buff deepening into tawny on chest and sides of head and neck).

Panamá (Verágua; Panamá; Lion Hill; San Pablo), through Colombia (Turbo; Remédios, Antioquía; Bogotá), Venezuela (Munduapo; Nicare; La Prición, Rio Caura; Rio Mato; Suapuré), to British Guiana (Demerara; Camacusa; Takutu R.; Carimang R.) and western Ecuadór (Esmeraldas; Chimbo; Gualaquiza; Gualea; Foreste del Rio Peripa; San Nicolas; San Javier; Pambilár; Intac) ${ }^{b}$ Cayenne, and eastern Brazil.

[Sitta] surinamensis Guelin, Syst. Nat., i, pt. i, 1788, 444 (Surinam; based on Surinam Nuthatch Latham, Gen. Hist., iv, 72, pl. 62).

Myrmotherula surinamensis Sclater, Proc. Zool. Soc. Lond., 1858, 234, pl. 141, fig. 1 (monogr.); Cat. Am. Birds, 1862, 179 (Cayenne; Esmeraldas, w. Ecuador); Cat. Birds Brit. Mus., xv, 1890, 231, part.-Cassin, Proc. Ac. Nat. Scj. Phila., 1860, 190 (Turbo, Colombia).-Lawrence, Ann. Lyc. N. Y., vii, 1862, 293 (Lion Hill, Panamá).-Sclater and Salvin, Proc. Zool. Soc. Lond., 1864, 356 (Lion Hill); 1879, 525 (Remédios, Antioquía, Colombia; habits; descr. nest and eggs).-Salvin, Ibis, 1874, 311 (Turbo, Colombia; Panamá); 1885, 425 (Camacusa, British Guiana).-Berlepsch and Taczanowski, Proc. Zool. Soc. Lond., 1883, 564 (Chimbo, w. Ecuadór; crit.).-SAlvin and God-

a Five specimens.

\begin{tabular}{|c|c|c|c|c|c|}
\hline Locality. & Wing. & Tail. & $\begin{array}{l}\text { Cul- } \\
\text { men. }\end{array}$ & $\begin{array}{l}\text { Tar- } \\
\text { sus. }\end{array}$ & $\begin{array}{l}\text { Middle } \\
\text { toe. }\end{array}$ \\
\hline MALES. & & & & & \\
\hline Three adult males from Panamá (line of railway)............... & 50.5 & 26.3 & 15.3 & 17.3 & 10 \\
\hline One adult male from Turbo, n. w. Colombia............. & 52.5 & 28.5 & 14 & 17 & 9.5 \\
\hline FEMALES. & & & & & \\
\hline Three adult females from Panamá...... & 49 & 26.2 & 15.2 & 17.5 & 10 \\
\hline One adult female from British Guiana...................... & 50 & 23 & 14 & 17.5 & 10 \\
\hline
\end{tabular}

b I have seen specimens from Panamá, Colombia, and British Guiana only. 
man, Biol. Centr.-Am., Aves, ii, 1892, 209, part.-Salvadori and Festa, Boll. Mus. Zool., etc., Torino, xv, no. 362, 1899, 29 (Gualaquiza, e. Ecuadór; Foreste del Rio Peripa, w. Ecuadór).-Bangs, Proc. New Engl. Zool. Club, ii, 1900, 23 (Loma del León, Panamá).-Goodfeluow, Ibis, 1902, 64 (San Nicolas and Gualea, w. Ecuadór).-Berlepsch and Hartert, Novit. Zool., ix, 1902, 73 (Munduapo, etc., Venezuela; crit.).-Hartert, Novit. Zool., ix, 1902, 612 (San Javiér and Pambilár, n. w. Ecuadór; crit.).-Hellmayr, Bull. Brit. Orn. Club, xvi, 1906, 53 (Pará, Brazil).-Berlepsch, Novit. Zool., xv, 1908, 154 (Cayenne).

[Myrmotherula] surinamensis SclateR and Salvin, Nom. Av. Neotr., 1873, 71.SHARPE, Hand-list, iii, 1901, 20.

Myrmotherula surinamensis surinamensis Menegaux and Hellmayr, Bull. Soc. 'Philom., sér. 9, viii, 1906, 48 (crit.).

M[yrmotherium] surinamense Cabanis and HeIne, Mus. Hein., ii, July, 1859, 13, footnote.

M[yrmotherula] surinamensis typica Sclater, Cat. Birds Brit. Mus., xv, 1890, 232, in list of specimens (Verágua, Panamá, and San Pablo Station, Panamá; Bogotá and Remédios, Colombia; Intac and Esmeraldas, w. Ecuadór; Takutu River, Carimang River, and Camacusa, Brit. Guiana).

Myiothera pusilla Pucheran (ex Cuvier, manuscript), Archiv. Mus. Paris, vii, 1855, 335, part (Cayenne; =adult male; see Menegaux and Hellmayr, Bull. Soc. Philom., 1906, 48).

\section{MYRMOTHERULA PYGMAE (Gmelin).}

\section{PYGMY ANTWREN.}

Adult male.-Pileum and hindneck black, narrowly streaked with pale yellowish buff or buffy whitish; scapulars and interscapulars black, the former with outer web broadly edged with yellowish white, the latter with much less distinct whitish edgings; rump pale gray, slightly tinged with buffy yellowish; tail black, the rectrices narrowly edged with grayish; wings black, the middle and greater coverts broadly tipped (on outer webs) with yellowish white (forming two conspicuous wing-bands), the remiges narrowly edged (except on basal portion of distal secondaries and proximal primaries) with yellowish white; auricular and suborbital regions pale yellowish buffy, margined above and below by a rather broad postocular and a malar streak of black; chin and throat white; rest of under parts primrose or pale straw yellow, including under wing-coverts and broad edgings to inner webs of remiges; maxilla blackish brown with paler tomium, mandible dull yellowish or whitish in dried skins, gray in life; ${ }^{a}$ iris dark brown; ${ }^{a}$ legs and feet horn color in dried skins, olive-green in life ${ }^{a}$ length (skin), 65 ; wing, 38.5 ; tail, 16 ; culmen, 13; tarsus, 15.5 ; middle toe, 8.5. ${ }^{b}$

Adult female.-Similar to the adult male "but cap striped with pale rufous; throat fulvous." $c$

$a$ Cherrie; see Berlepsch and Hartert, Novit. Zool., ix, 1902, 73.

$b$ One specimen from Panamá.

$c$ Sclater, Cat. Birds. Brit. Mus., xv, 1890, 230. I have not seen the female of this species. 
Panamá (Lion Hill; Panamá) through Colombia (Rio Truando; Bogotá), Venezuela (La Pricion, Rio Caura), British Guiana (Bartica Grove; Camacusa), Ecuadór (Rio Napo; Sarayacu; Valle de Zamora) and Peru (Pebas; Yurimáguas; Chamicuros; Upper Ucayali; Xeberos; Chyavetas; Tarapata) to Cayenne and western Brazil (Borba and Humaytha, Rio Madeira).

[Muscicapa] pygmxa Guelin, Syst. Nat., i, pt. ii, 1789, 933 (Cayenne; based on Pctit Gobe-mouche tachcté de Cayenne Daubenton, PI. Enl., pl. 831, fig. 2).

Muscicapa pygmxa Latham, Index Orn., i, 1790, 488.-Vierllot, Nouv. Dict. d' Hist. Nat., xxi, 1818, 484 (Cayenne).

F[ormicivora] pygmæa Cabanis, Wiegmann's Archiv für Naturg., xiii, pt. i, $1847,227$.

[Formicivora] pygmæa Bonaparte, Consp. Av., i, 1850, 200.

Formicivora pygmæa Burmeister, Syst. Ueb. Th. Bras., iii, 1856, 77.-Sclater, Proc. Zool. Soc. Lond., 1855, 147 (Bogotá, Colombia); 1858, 67 (e. Ecuadór). Myrmotherula pygmxa Sclater, Proc. Zool. Soc. Lond., 1858, 234 (monogr.); Cat. Am. Birds, 1862, 179 (Rio Napo, e. Ecuadór); Cat. Birds Brit. Mus. xv, 1890, 230 (Bartica Grove and Camacusa, Brit. Guiana; Pebas, Yurimaguas, and Chamicuros, e. Peru; Rio Napo and Sarayacu, e. Ecuadór; Bogotá, Colombia).-Cassin, Proc. Ac. Nat. Sci. Phila., 1860, 190 (Rio Truando, Colombia).a-Lawrence, Ann. Lyc. N. Y., vii, 1862, 235 (Lion Hill, Panamá). ${ }^{a-S c l a t e r ~ a n d ~ S a l v i n, ~ P r o c . ~ Z o o l . ~ S o c . ~ L o n d ., ~ 1866, ~} 185$ (Upper Ucayali, e. Peru); 1867, 750 (Xeberos, Yurimaguas, and Chyavetas, e. Peru), 978 (Pebas, e. Peru); 1873, 274 (Upper Ucayali, Xeberos, Yurimaguas, Chyavetas, Chamicuros, and Pebas, e. Peru); 1879, 624 (Yuracares, Bolivia).-Pelzeln, Orn. Bras., ii, Abth., 1869, 80; iv, Abth., 1870, 417.-SAlvin, Ibis, 1870, 311 (Rio Truando, Colombia); 1874, 311 (synonymy); 1885, 425 (Brit. Guiana).Taczanowski, Proc. Zool. Soc. Lond., 1882, 30 (Yurimaguas, e. Peru); Orn. du Pérou, ii, 1884, 37.-Berlepsch, Journ. für Orn., 1889, 304 (Tarapata, n. Peru); Novit. Zool., xv, 1908, 154 (Cayenne).-Salvadori and Festa, Boll. Mus. Zool., etc., Torino, xv, no. 362, 1899, 29 (Valle de Zamora, Ecuadór).-Berlepsch and Hartert, Novit. Zool., ix, 1902, 73 (La Pricion, Rio Cuara, Venezuela).-Hellmayr, Novit. Zool., xiv, 1907, 382 (Borba and Humaytha, Rio Madeira, Brazil; crit.).-Snethlege, Bol. Mus. Goeldi, v, 1908, 55 (Bom Lugar, Rio Purús, n. Brazil).

[Myrmotherula] pygmæa Sclater and Salvin, Nom. Av. Neotr., 1873, 71.Sharpe, Hand-list, iii, 1901, 20.

M[yrmophila] pygmæum Cabanis and Heine, Mus. Hein., ii, July, 1859, 13, footnote.

\section{Genus MYRMOPAGIS Ridgway.}

Myrmopagis b Ridgway, Proc. Biol. Soc. Wash., xxii, Apr. 17, 1909, 69. (Type, Myrmothera axillaris Vieillot.)

(?) Myrmophilac Cabanis and Heine, Mus. Hein., ii, July, 1859, 12. (Type, Formicivora brevicauda Swainson.)

$a$ These two references, very strangely, are placed under $M$. surinamensis in the Biologia Centrali-Americana (Aves, ii, 209). I have seen the specimens on which they are based, and they are $M$. pygmæa, not $M$. surinamensis.

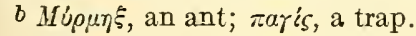

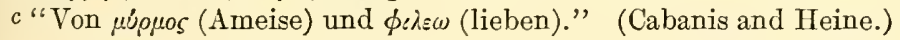

$81255^{\circ}-$ Bull. $50-11-5$ 
Small Formicariidæ resembling Myrmotherula but differing in relatively much longer tail (much more than half to more than twothirds as long as wing), much stouter and relatively shorter and less depressed bill, the adult males neither streaked nor plain gray or slaty.

Bill decidedly shorter than head, rather stout, not depressed basally, its width at frontal antiæ about equal to or very little greater than its depth at same point and equal to less to slightly more than half the distance from nostril to tip of maxilla; culmen distinctly and rather sharply ridged, straight or nearly so for most of its length, rather strongly and abruptly decurved terminally, the tip of maxilla minutely but distinctly uncinate; tomium nearly straight, that of maxilla distinctly, that of mandible slightly notched subterminally; gonys faintly convex (more decidedly so basally). Nostril exposed, posteriorly nearly (sometimes quite) in contact with feathering of latero-frontal antiæ, roundish or broadly oval, margined for basal half by the membraneous cover of nasal fossæ (this sometimes extending along upper margin as a narrow "operculum"), and with a conspicuous internal tubercle. Rictal bristles present but minute (practically obsolete); feathers of chin,-malar antiæ, and lores with slender terminal setæ. Wing moderate, with longest primaries distinctly longer than secondaries; sixth and seventh, or fifth, sixth, and seventh, primaries longest, the tenth (outermost) slightly more than one-half to nearly two-thirds as long as the longest, the ninth about as long as secondaries or a little shorter. Tail much more than half to more than two-thirds as long as wing, much rounded, the rectrices (12) moderately broad to rather narrow, rounded terminally. Tarsus decidedly longer than exposed culmen, less than one-third as long as wing (except in $M$. ornata), the acrotarsium distinctly scutellate, the planta tarsi usually fused (at least in part) or with the scutella somewhat indefinite as to form and arrangement (with a general tendency toward two longitudinal series); middle toe, with claw, decidedly shorter than tarsus; outer toe, without claw, reaching to beyond middle of subterminal phalanx of middle toe, the inner toe slightly shorter; hallux about as long as inner toe but much stouter; basal phalanx of middle toe wholly united to outer toe, for about half its length to inner toe; claws moderate in size and curvature, that of the hallux decidedly shorter than the digit. Plumage soft, lax, and blended, that of rump and flanks much elongated and fluffy; feathers of pileum not elongated.

Coloration. ${ }^{a-A d u l t}$ males plain gray or slate color above, the wings black, spotted with white, the tail black with white tip to

a Not having been able to examine much the greater number of the species referred by Dr. Sclater to Myrmotherula (see note on page 62) I am not able to define the full range of variation as to coloration in this group. 
lateral rectrices, the under parts black with flanks white or light gray; or, plain brown or olive above (sometimes with lower back and rump rufescent), the wing-coverts spotted with white, under parts paler brownish, the throat black spotted or streaked with white. Sexes very differently colored, adult females being brown or olive above, paler brownish, buffy, or whitish beneath. ${ }^{a}$

Range.-Honduras to Cayenne and Amazon Valley. (Several species.) $)^{b}$

KEY TO THE SPECIES AND SUBSPECLES OF MYRMOPAGIS.

a. General color black, or black and slate color, and white (no brown).

$b$. Flanks white; under wing-coverts immaculate white.

c. Upper parts black or slate-black. (Southern Honduras to Venezuela and western Ecuadór.)..............Myrmopagis melæna, adult male (p. 68).

cc. Upper parts slate-gray. (Guiana, Trinidád, and Amazon Valley.)

Myrmopagis axillaris, adult male (extralimital). $c$

bb. Flanks slate color, like back, etc.; under wing-coverts partly black.

c. Tail shorter (about $28 \mathrm{~mm}$.) ; lesser and middle wing-coverts partly slate color, with anterior portion of the area much more extensively white. (Bolivia to eastern Ecuadór.).......Myrmopagis menetriesii, adult male (extralimital). ${ }^{d}$ cc. Tail longer (33.5-3S mm.); lesser and middle wing-coverts black tipped with white. with anterior portion of the area much less extensively white. (Guatemala to Colombia and Venezuela.)

Myrmopagis schisticolor, adult male (p. 70).

aa. General color olive-brownish (no black except, sometimes, on throat).

b. Throat black and white. (Southern Honduras to western Ecuaclór.)

bb. Throat plain buff or buffy whitish.

Myrmopagis fulviventris, adult male (p. 73).

c. Middle and greater wing-coverts distinctly tipped with ochraceous-buff.

Myrmopagis fulviventris, adult female (p. 74).

$a$ Species examined are: Myrmopagis gutturalis (Sclater and Salvin), M. fulviventris (Lawrence), Myrmopagis ornata (Sclater), M. menetriesii (D'Orbigny), $M$. Schisticolor (Lawrence), M. axillaris (Vieillot), and M. melæna (Sclater).

$b$ The range of the group and number of species composing it are matters of uncertainty owing to poor representation of the latter in the material examined.

c Nyrmothera axillaris Vieillot, Nouv. Dict. d'Hist. Nat., xii, 1817, 113 (Guiana).Formicivora axillaris Cabanis, in Wiegm. Archiv für Naturg., 1847, pt. 1, 226.M[yrmophila] axillaris Cabanis and Heine, Mus. Hein., ii, July, 1859, 13.-Myrmotherula axillaris Sclater, Proc. Zool. Soc. Lond., 1858, 236, part; Cat. Birds Brit. Mus., xv, 1890, 238.-Myrmotherula axillaris axillaris Hellmayr, Novit. Zool., xiv, 1907, 22 (Itaituba, Brazil; crit.), 32 (Obidos, Brazil), 69 (Teffe, Brazil; crit.), 383 (Humaytha and Borba, Rio Madeira, Brazil; crit.).-M[yiothera] fuliginosa Lichtenstein, Verz. Doubl., 1823, 45, part (Cayenne; Brazil).

d Myrmothera menetriesii D'Orbigny, Voy. Am. Mérid., Ois., 1839, 184 (Cochabamba, Bolivia).-Formicivora menetriesi Cabanis, in Wiegm. Archiv für Naturg., 1847, pt. i, 226; Menegaux and Hellmayr, Bull. Soc. Philom., 1906, 51 (crit.; type from Yuracares, Bolivia, in Paris Mus.).-Myrmotherula menetriesi Sclater, Proc. Zool. Soc. Lond., 1858, 237; Cat. Birds Brit. Mus., xv. 1890, 240, part.-M[yrmophila] menetriesi Cabanis and Heine, Mus. Hein., ii, July, 1859, 13, footnote.-Myrmotherula boliviana Berlepsch, Journ. für Orn., Jan., 1901, 96 (San Mateo, n. Bolivia; coll. Count von Berlepsch). (See footnote on p. 70 of present work.) 
cc. Middle and greater wing-coverts not distinctly, if at all, tipped with buffp.

d. Pileum and hindneck dull slate-grayish; back, etc., more grayish olive; under parts paler buffy, the throat and flanks nearly white.

Myrmopagis melæna, adult female, (p. 68).

$d d$. Pileum and hindneck brown; back, etc., more brownish olive; under parts deeper (more ochraceous) buffy, the throat ochraceous-buff, the flanks buffy olive............ Myrmopagis schisticolor, adult female (p. 71).

\section{MYRMOPAGIS MELÆNA (Sclater).}

BLACK ANTWREN.

Adult male.-Above plain black or slate-black, the wing-coverts spotted or dotted with white (a roundish or subtriangular spot at tip of each feather), outer web of exterior row of scapulars broadly edged with white, and a large white patch covering inner-anterior portion of lesser wing-covert area; ${ }^{a}$ lateral rectrices (sometimes all but middle pair) tipped with white; under wing-coverts, broad edgings to inner web of remiges, and an extensive patch of soft elongated feathers covering sides and flanks, white; rest of under parts uniform black, or slate-black; bill black, the mandible sometimes more plumbeous; iris brown; legs and feet horn color (bluish gray or grayish blue in life); length (skins), 78-99 (91); wing, 50-56 (52.4); tail, 29.5-37 (32.4); culmen, 13-14.5 (13.6); tarsus, 15-17 (15.7); middle toe, $8.5-10(9) .^{b}$

Immature male.-Similar to the adult male, but the black of upper parts replaced by blackish slate, that of the under parts by slate color, clouded, more or less extensively, with black, the chin and upper throat sometimes mostly pale gray or grayish white; younger individuals with terminal spots of greater wing-coverts buffy instead of white.

Adult female.-Pileum and hindneck dark mouse gray or dull slate color, passing into olive on back and scapulars, this into brownish olive or olive-brown on rump and upper tail-coverts; tail dusky brown, the rectrices edged with russet-brown or sepia; general color of wings deep olive or olive-brown, the greater wing-coverts and secondaries more russet-brown on edges, the primaries edged with lighter and more buffy olive; middle and greater wing-coverts indistinctly tipped with russet-brown; auricular, suborbital, and malar regions, chin, and throat dull buffy whitish, the first suffused with grayish and with narrow shaft-streaks of whitish; rest of under parts, including under wing-coverts and broad edgings to inner webs of remiges, buff (more or less deep); maxilla blackish brown with paler tomia, mandible dull yellowish (bluish gray or grayish blue in life); iris brown; $\log$ s and feet horn color (bluish gray or grayish blue in

$a$ Usually there are also narrow and indistinct whitish edgings to some of the remiges.

$b$ Fifteen specimens. 
life); length (skins), s9-96 (90); wing, 47-54 (50.6); tail, 29-34 (31.5); culmen, 12.5-14 (13.3); tarsus, $15-16$ (15.3); midlle toe, 8.5-9 (8.9). ${ }^{a}$

Southern Hondurns (Rio Segóvia), Costa Rica (Angostura; Naranjo de Cartago; Rio Reventazón; Jiménez; Pacuare; Orosí; Sipúrio; La Balsa; San José; Rio Sícsola; El Hogár; Guápiles; La Junta; Carrillo; Las Trojas; Rio Frio; La Vijágua), and Panamá (Panamá; Lion Hill; Chepo), through Colombia (Rio Truando; Turbo; Nechi, Antioquía; Bogotá) and Ecuadór (Sarayacu; Foreste del Rio Peripa; Santo Domingo) to Peru (Rio IIuallaga; Lower Ucayali; Xeberos; Chyavetas; Chamicuros; Pebas; Moyabamba) and Venezuela (Maipures; Perico; Bichaco; Munduapo).

Formicivora axillaris not Myrmothera axillaris Vieillot) Schater, Proc. Zool. Soc. Lond., 1855, 147 (Bogotá).

Myrmotherula axillaris Carriker, Amn. Carnegie Mus., v, 1908, 8 (Rio Sícsola, Talamanca, Costa Pica; crit.).

Formicivora melzna Schater, Proc. Zool. Soc. Lond., 1857, 130 (Bogotá, Colombia; coll. P. L. Sclater).-Lawrence, Ann. Lyc. N. Y., viii, 1863, 484 (Lion Hill, Panamá).

Myrmotherula melæna Sclater, Proc. Zool. Soc. Lond., 1858, 237 (monogr.; Bogotá); Cat. Am. B. 1862, 180 (do.).-Sclater and Salvin, Proc. Zool. Soc. Lond., 1864, 356 (Lion Hill; crit.); 1866, 186 (Rio Ucayali, e. Peru); 186i, 750 (Rio Huallaga, e. Peru); 1873, 274 (lower Ucayali, Xeberos, Chyaretas, Chamicuros, e. Peru); 1879, 525 (Nechi, Antioquía, Colombia).Lawrence, Anu. Lyc. N. Y., ix, 1868, 107 (Angostura and Pacuare, Costa Rica).-Frantzius, Journ. für Orn., 1869, 305 (Costa Rica).-Pelzeln, Orn. Bras., ii, Abth., 1869, 82.-Salvin, Ibis, 1874, 311 (Rio Truando, Colombia; Panamá; Costa Rica; synonymy).-Boucard, Proc. Zool. Soc. Lond., 1878, 61 (Costa Rica).--Taczanowski, Orn. du Pérou, ii, 1884, 48.Zeledón, Anal. Mus. Nac. Costa Rica, 1887, 115 (Pacuare, Naranjo de Cartago, and Las Trojas, Costa Rica).-Sclater, Cat. Birds Brit. Mus., xv, 1890, 239 (Angostura, Costa Rica; Panamá and Chepo, Isthmus Panamá; Antioquía and Bogotá, Colombia; Sarayacu, e. Ecuadór; Xeberos, Yquitos, Pebas, and Chamicuros, e. Peru).-Salvin and Godman, Biol. Centr.-Am., Aves, ii, 1892, 211.-Richmond, Proc. U. S. Nat. Mus., xvi, 1893, 501 (Rio

$a$ Fifteen specimens.

\begin{tabular}{|c|c|c|c|c|c|}
\hline Locality. & Wing. & Tail. & $\begin{array}{l}\text { Cul- } \\
\text { men. }\end{array}$ & $\begin{array}{l}\text { Tar- } \\
\text { sus. }\end{array}$ & $\begin{array}{c}\text { Middle } \\
\text { toe. }\end{array}$ \\
\hline MALES. & & & & & \\
\hline Ten adult males from Costa Rica... & 51.6 & 31.5 & 13.4 & 15.3 & 9 \\
\hline One adult male from Panamá........ & 52.5 & 31 & 14 & 15.5 & 8.5 \\
\hline Two adult males from n. w. Colombia (Rio Truando)... & 53 & 33.5 & 13.5 & 16 & 9 \\
\hline Two adult males from central Colombia (Bogotâ)...... & 56 & 36 & 14.2 & 16 & 9.2 \\
\hline One adult male from Peru.................................. & 53 & 33.5 & 14 & 16.5 & 9.5 \\
\hline FEMALES. & & & & & \\
\hline One adult female from southern Honduras (Rio Segovia). & 49.5 & 32 & 13.3 & 15.3 & 8.5 \\
\hline Ten adult females from Costa Rica....... & 50 & 31 & 13.2 & 15.2 & 8.9 \\
\hline Two adult females from Panamá....... & 50.5 & 32.2 & 13 & 16 & 9 \\
\hline Two adult females from n. w. Colombia (Turbo).. & 53.7 & 32.7 & 13.5 & 15 & 8.7 \\
\hline
\end{tabular}


Frio, Costa Rica).-Salvadori and Festa, Boll. Mus. Zool., etc., xv, no. 362, 1899, 30 (Foreste del Rio Peripa, w. Ecuadór).-Goodfellow, Ibis, 1902, 64 (Santo Domingo, w. Ecuadór).-Berlepsch and Hartert, Novit. Zool., ix, 1902, 74 (Maipures, etc., Venezuela; crit.; descr. nest and eggs).Carriker, Ann. Carnegie Mus., vi, 1910, 608 (Caribbean lowlands up to 1,500 ft., Costa Rica; crit.; habits).

[Myrmotherula] melæna Pelzeln, Orn. Bras., iv, Abth., 1870, 418.-Sclater and Salvin, Nom. Av. Neotr., 1873, 72.-Sharpe, Hand-list, iii, 1901, 22.

M[yrmophila] melaena Cabanis and Heine, Mus. Hein., ii, July, 1859, 13.

Myrmotherula albigula Lawrence, Ann. Lyc. Nat. Hist. N. Y., viii, 1867, 131 (Panamá Railway; coll. G. N. Lawrence;= $\%$; see Salvin, Ibis, 1874, 317); ix́, 1868, 108 (Angostura, Costa Rica).-Frantzius, Journ. für Orn., 1869, 305 (Costa Rica).

\section{MYRMOPAGIS SCHISTICOLOR (Lawrence).}

SLATY ANTWREN.

Similar to M. menetriesii D'Orbigny (?) ${ }^{a}$ but tail much longer (both absolutely and relatively); adult male with wing-coverts much darker, the lesser and middle coverts being wholly black (except for the white terminal spots), instead of slate color with black subterminal area, and inner-anterior portion of lesser wing-covert area much less extensively white.

Adult male.-Above mainly uniform slate color; wing-coverts, which are black, each tipped with a transversely subtriangular or subrounded spot of white; primary coverts and alula also black, the former with a small white mark at tip of outer web, the latter terminally margined with white; a white patch (mostly concealed) at junction of wing and body; chin, throat, and chest (sometimes breast also, at least medially) uniform black; malar region black, barred with slate-gray; sides of head and neck, together with lateral and posterior under parts, uniform slate color, except under tail-coverts, which are margined terminally with white and barred subterminally with black; under wing-coverts mixed white and blackish; inner webs of remiges broadly edged with brownish white; bill black; iris brown; legs and feet grayish, horn color, or dusky (bluish gray or grayish blue in life); length (skins), 90-105 (96.5); wing, 54-61 (56.8); tail, 33-38 (36); culmen, 12.5-14.5 (13.3); tarsus, 15.5-17 (16.3); middle toe, $9.5-10(9.7) .^{b}$

$a$ Never having seen a specimen from Bolivia (the type locality of Myrmothera menetriesii) comparison of Colombian and Central American specimens has been made with one from Napo, eastern Ecuadór, which may or may not represent the true $M$. menetriesii. The specimen in question, while having the wing as long as the shortest-winged example of $M$. schisticolor $(54 \mathrm{~mm}$.) has the tail barely $28 \mathrm{~mm}$., the shortest-tailed adult male of $M$. schisticolor having the tail $33.5 \mathrm{~mm}$., while others range up to $38 \mathrm{~mm}$.

$b$ Twenty-two specimens from Costa Rica, Panamá, and Colombia. 
Adult female.-Pilem and hindneck plain bufly olive-brown or raw umber; the back, scapulars, rump, and upper tail-coverts lighter and less brownish olive; tail deep brown (sepia), the edges of the rectrices brighter, more russet brown; general color of wings olive, the tips of wing-coverts (broadly but indistinctly) more cinnamonbrownish; sides of head, chin, and throat buffy, the former more or less suffused with olive or olive-brown; rest of under parts tawnybufl' or clay color, deeper and browner, or tinged with olivaceous, on sides and flanks; under wing-corerts deep buff or tawny-buff; inner webs of remiges broadty edged with paler bufl; maxilla horn brown or dusky with paler tomium, mandible pale dull yellowish (grayish blue to flesh color in life); legs and feet light horn color (bluish gray or grayish blue in life); length (skins), SS-104 (96); wing, 51-56.5 (54.4); tail, 31-37.5 (34.6); culmen, 12-14 (13.1); tarsus, 15.5-17 (16.2); midlle toe, $9-10(9.7) .^{a}$

Immature male--Precisely like the adult female in coloration. (Older specimens show more or less of black on the throat, the lateral portion of which, together with more or less of sides of head, are slate-gray.)

Ioung male (first plumage).--Similar to the adult female but back tinged with dark purplish brown, and under parts of body clouded with dark purplish brown (seal brown or dark chocolate), the chest nearly uniformly of this color.

Young (nestling).-Above uniform vandyke brown, below uniform russet.

Guatemala (Choctúm and Samayoa, Vera Paz), Nicaragua (Matagalpa), Costa Rica (Turrialba; Barranca; Dota; Naranjo de Cartago; Grécia; Guayabo; Carrillo; Pozo del Pitál; Pozo Azúl de Pirrís; Boruca; Lagarto; Térraba; El Generál; La Vijágua; Tenório), Panamá (Santiago, Santa Fé, Chitra, and Calovévora, Verágua; Boquete, Divala, and Volcan de Chiriquí, Chiriquí) and through

a Fifteen specimens, from Guatemala, Costa Rica, and Panama.

\begin{tabular}{|c|c|c|c|c|c|}
\hline Locality. & Wing. & Tail. & $\begin{array}{l}\text { Cul- } \\
\text { men. }\end{array}$ & $\begin{array}{l}\text { Tar- } \\
\text { sus. }\end{array}$ & $\begin{array}{c}\text { Middle } \\
\text { toe }\end{array}$ \\
\hline MALES. & & & & & \\
\hline Ten adult males from Costa Rica... & 56.8 & 36.2 & 13.3 & 16.2 & 9.8 \\
\hline Ten adult males from Panamá....... & 56.1 & 36.2 & 13.2 & 16.3 & 9.6 \\
\hline Two adult males from Colombia............. & 60 & 34 & 14 & 16 & 9.7 \\
\hline 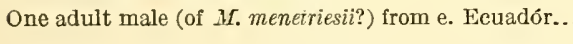 & 54 & 28 & 12.5 & 16.5 & 9.5 \\
\hline FEMALES. & & & & & \\
\hline Two adult females from Guatemala.. & 52 & 36.2 & 12.2 & 16 & 9.5 \\
\hline Ten adult females from Costa Rica.... & 54.4 & 33.9 & 13.2 & 16.3 & 9.7 \\
\hline Three adult females from Panamá.... & 55.2 & 35.9 & 13.2 & 16 & 9.7 \\
\hline
\end{tabular}




\section{Colombia (Los Tambos; Rio Conquita; Valparaiso; Bogotá) to} Venezuela (Puerto Cabello; San Esteban).

Myrmotherula menetriesi (not Myrmothera menetriesii D'Orbigny) Salvin, Proc. Zool. Soc. Lond., 1867, 144 (Santiago de Verágua, Panamá; crit.); 1869, 252 (San Esteban, Venezuela); 1870, 195 (Volcan de Chiriquí, Chitra, Calovévora, and Bugaba, Panamá; crit.); Ibis, 1874, 310 (Verágua and Chiriquí, Panamá; Costa Rica; Vera Paz, Guatemala; synonymy).-Sclater and Salvin, Proc. Zool. Soc. Lond., 1869, 252 (Venezuela).--Boucard, Proc. Zool. Soc. Lond., 1878, 61 (Naranjo de Cartago, Costa Rica).-Zeledón, Anal. Mus. Nac. Costa Rica, i, 1887, 115 (Barranca and Pozo Azúl de Pirrís, Costa Rica).-Sclater, Cat. Birds Brit. Mus., xv, 1890, 240, part (Choctúm and Samayoa, Vera Paz, Guatemala; Dota Mts., Costa Rica; Calovevora, Santa Fé de Verágua, Volcan de Chiriquí, and Bugaba, Panamá; Bogotá; Puerto Cabello and San Esteban, Venezuela).-Salvin and Godman, Biol. Centr.-Am., Aves, ii, 1892, 212, part (Matagalpa, Nicaragua; Grécia, etc., Costa Rica, and other Central American localities; Colombia; Venezuela).Berlepsch, Zeitschr. Orn., 1887, 185 (Bogotá, Colombia).-Cherrie, Anal. Inst. Fis.-Geog. Costa Rica, vi, 1893, 19 (Pozo del Pitál, Costa Rica).Bangs, Auk, xxiv, 1907, 296 (Boruca and Pozo del Rio Grande, s. w. Costa Rica).

[Myrmotherula] menetriesi Sclater and Salvin, Nom. Av. Neotr., 1873, 72, part.Sharpe, Hand-list, iii, 1901, 22, part (Guatemala to Panamá; Colombia; Venezuela).

Myrmotherula menetriesii Bangs, Proc. New Engl. Zool. Club, iii, 1902, 41 (Boquete and Volcan de Chiriquí, 3,000-7,800 ft.).

Myrmotherula menetriesi ChERRIE, Expl. Zool. Merid. Costa Rica, 1893, 41 (Lagarto, Boruca, and Térraba, s. w. Costa Rica).

Formicivora schisticolor Lawrence, Ann. Lyc. Nat. Hist. N. Y., viii, 1867, 172 (Turrialba, Costa Rica; coll. U. S. Nat. Mus.); ix, 1868, 108 (Turrialba and Barranca, Costa Rica).-Frantzius, Journ. für Orn., 1869, 305 (Costa Rica). Myrmotherula schisticolor Hellmayr, Verh. k. k. Zool.-bot. Ges. Wien, Jan., 1903, 211 (Guatemala to n. w. Venezuela and s. e. Peru).-Menegaux and Hellmayr, Bull. Soc. Philom., 9 sér., viii, 1906, 50 (crit.).

Myrmotherula menetriesi schisticolor Carriker, Ann. Carnegie Mus., vi, 1910, 609 (Costa Rica; crit.; habits).

Myrmotherula modesta Lawrence, Ann. Lyc. Nat. Hist. N. Y., ix, 1870 (pub. March, 1869), 108 (Grécia, Costa Rica; coll. U. S. Nat. Mus.;=female).-Frantzius, Journ. für Orn., 1869, 305 (Costa Rica).

Myrmotherula nigrorufa Boucard, Ann. Soc. Linn. Lyon, n. s., xxv, 1878, 38 (Guatemala; coll. Mus. Paris;=young male; see Salvin, Ibis, 1879, 215 and Menegaux and Hellmayr, Bull. Soc. Philom., 1906, 50).

ECUADOREAN AND PERUVIAN REFERENCES, $a$

Formicivora menetriesi (not Myrmothera menetriesii D'Orbigny?) ScLater, Proc. Zool. Soc. Lond., 1858, 67 (e. Ecuador).

$a$ While the only specimen from a locality south of Colombia seen by me is certainly not the same as the Colombian and Central American form, Hellmayr says (Verh. k. k. Zool.-bot. Ges. Wien, 1903, 211) that the latter extends as far as southeastern Peru. It would therefore appear that two forms occur in Ecuadór and Peru. (See also Berlepsch and Taczanowski, Proc. Zool. Soc. Lond., 1883, 564, 565, where peculiarities of specimens from northern Peru are discussed.) 
Myrmotherula menetriesi Scuater, Proc. Zool. Soc. I ond., 1s58, 237, part (monogr.); 1560, 67 (Pallatanga, w. Ecuadór), 89 (Nanegal, e. Eeuadór; crit.); (att. Am. Birds, 1862, 180 (Nanegál and Rio Napo, e. Ecuadór; Pallatanga, w. Ecuador); Cat. Mirds Brit. Mus, xv, 1890, 2-10, part (Pallatanga and Nanegal).-Taczanowski, Proc. Zool. Soc. Lond., 1874, 530 (Amable Maria and Paltaypampa, centr. Peru); 18s2, 30 (Huambo, n. e. Peru); Orn. du Pérou, ii, 18s4, 45.-Berlensch and Taczanowski, Proc. Zool. Soc. Lond., 1883, 564 (Chimbo, w. Ecuadór; crit.); 1884, 302 (Sarupata, Ecuadór).Taczanowski and Berlepscil, Proc. Zool. Soc. Lond., 1885, 101 (Machay and Mapoto, Ecundór; crit.).-Salvin and Godman, Biol. Centr.-Am., Aves, ii, 1892, 211, part (Ecuador; Peru).-Salvadoni and Festa, Boll. Mus. Zool., etc., Torino, xv, no. 362, 1899, 30 (Foreste del Rio Peripa, w. Ecuadór; crit.).-Goodfellow, Ibis, 1902, 65 (Gualea, w. Ecuadór).

[Myrmotherula] menetriesi Sclater and Salvin, Nom. Av. Neotr., 1873, 72, part.Sharpe, Hand-list, iii, 1901, 22, part (Ecuadór; Peru).-Berlersci and Stolzmax, Proc. Zool. Soc. Lond., 1902, 58 (Amable Maria, centr. Peru).

Myrmotherula menetriesi? Sclater, Proc. Zool. Soc. Lond., 1860, 67 (Pallatanga, e. Ecuadór).

Myrmotherula menetriesii Taczanowski and Berlepsch, Proc. Zool. Soc. Lond., 1855, 68 (Chimbo, Mapoto, and Machay, w. Ecuadór).

\section{MYRMOPAGIS FULVIVENTRIS (Lawrence).}

\section{LAWRENCE'S ANTWREN.}

Adult male.-Above plain olive (varying from grayish to brownish olive), becoming slightly grayer on pileum (where feathers are very indistinctly margined or flecked with dusky) and more brownish posteriorly; upper tail-coverts and tail much browner (sepia brown to prouts brown); more anterior lesser wing-coverts plain olive, the more posterior ones partly or wholly black, each with a terminal spot of buff; middle and greater coverts black with a terminal guttate or subtriangular spot of buff; remiges brownish olive to olive-brown (nearly prouts brown); auricular, suborbital, and malar regions dull grayish white, indistinctly streaked or flecked with dusky grayish; chin white; throat black, each feather tipped with a large guttate spot of white; rest of under parts light buffy olive or olive-buffy, slightly clearer and more buffy on abdomen, grayer on chest, and more olivaceous on sides and flanks; under wing-coverts and broad edgings to inner webs of remiges pale brownish buffy; mandible dark horn color with paler tomium, mandible dull whitish (pale grayish blue or bluish gray in life); iris brown, reddish brown, or straw color; ${ }^{a}$ legs and feet light horn color (bluish gray or grayish blue in life); length (skins), 86--104 (96); wing, 48.5-53.5 (50.8); tail, 30-37 (32.7); culmen, 14-15.5 (14.8); tarsus, 15.5-17 (16.1); middle toe, 10.5$11.5(11) .^{b}$ 
Adult female.-Similar to the adult male but whole throat plain buffy, and general color of wing-coverts dusky olive instead of blackish; length (skins), 86-107 (99); wing, 48-52.5 (50.5); tail, 31.5-36 (34.2); culmen, 14-15.5 (14.6); tarsus, 16-17 (16.6); middle toe, $10.5-11.5(11){ }^{a}$

Southern Honduras (Rio Segóvia) through Nicaragua (Rio Escondido; San Emilis, Lake Nicaragua), Costa Rica (Angostura; San José; San Carlos; Jiménez; Rio Reventazón; Rio Matina; Pacuare; Siquirres; Sipúrio; Cuábre; Guápiles; Carrillo; El Hogár; Guácimo; La Vijagua; La Cristina), Panamá (Lion Hill) and Colombia (Remédios, Antioquía; Naranjo, Bucaramanga; Rio Truando) to western Ecuadór (Esmeraldas; Foreste del Rio Peripa). ${ }^{b}$

Myrmotherula gularis (not Thamnophilus gularis Spix) Sclater, Proc. Zool. Soc. Lond., 1860, 294, part (Panamá).

Myrmotherula ornata (not Formicivora ornata Sclater) CAssiv, Proc. Ac. Nat. Sci. Philad., 1860, 191, part (Rio Truando, Colombia).

Myrmotherula, sp. no. 216, Lawrence, Ann. Lyc. N. Y., vii, 1862, 325 (Lion Hill, Panamá).

Myrmetherula fulviventris Lawrence, Ann. Lyc. Nat. Hist. N. Y., vii, Feb., 1862, 468 (Lion Hill, Panamá; coll. G. N. Lawrence).

Myrmotherula fulviventris Sclater and Salvin, Proc. Zool. Soc. Lond., 1864, 356 (Lion Hill; crit.); 1879, 525 (Remédios, Antioquía, Colombia).--Lawrence, Ann. Lyc. N. Y., ix, 1868, 108 (Angostura, Costa Rica).-Frantzius, Journ. für Orn., 1869, 305 (Costa Rica).-WYrat, Ibis, 1871, 331 (Naranjo, Colombia).-Salvin, Ibis, 1874, 311 (Rio Truando, Colombia; crit.).-BerLepsch, Journ. für Orn. 1884, 318 (Naranjo, Bucaramanga, Columbia).-RIDGWAY, Proc. U. S. Nat. Mus., x, 1887, 590 (Rio Segóvia, Honduras).-Zeledón, Anal. Mus. Nac. Costa Rica, 1887, 115 (Pacuare and Jiménez, Costa Rica).SclAter, Cat. Birds Brit. Mus., xv, 1890, 234 (Angostura, Costa Rica; Verágua; Panamá; Bogotá; Remédios, Antioquía; Esmeraldas, Ecuadór).Salvin and Godman, Biol. Centr.-Am., Aves, ii, 1892, 210.-Richmond, Proc. U. S. Nat. Mus., xvi, 1893, 501 (Rio Escondido, Nicaragua).-(?) SALvadori and Festa, Boll. Mus. Zool., etc., Torino, xv, 1899, no. 362, 29 (Foreste del Rio Peripa, w. Ecuadór; crit.).-Carriker, Ann: Carnegie Mus., vi, 1910, 607 (Caribbean lowlands up to 1,500 ft., Costa Rica; habits; descr. nest and eggs).

[Myrmotherula] fulviventris Sclater and Salvin, Nom. Av. Neotr., 1873, 71.Sharpe, Hand-list, iii, 1901, 21, part.

a Thirteen specimens.

\begin{tabular}{|c|c|c|c|c|c|}
\hline Locality. & Wing. & Tail. & $\begin{array}{l}\text { Cul- } \\
\text { men. }\end{array}$ & $\begin{array}{l}\text { Tar- } \\
\text { sus. }\end{array}$ & $\begin{array}{c}\text { Middle } \\
\text { toe. }\end{array}$ \\
\hline MALES. & & & & & \\
\hline Three adult males from Panamá... & 49.8 & 33 & 15.2 & 16.7 & 10.8 \\
\hline Ten adult males from Costa Rica..................... & 51 & 32.5 & 14.7 & 16.2 & 10.9 \\
\hline FEMALES. & & & & & \\
\hline 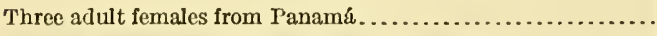 & 49.5 & 33.3 & 14 & 16.7 & 10.8 \\
\hline 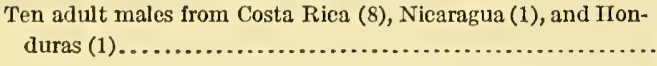 & 50.8 & 34.4 & 14.7 & 16.6 & 11.1 \\
\hline
\end{tabular}

b I have not seen a specimen from Ecuadór. 


\section{Gemus MICRORHOPIAS Sclater.}

Microrhopias Sclater, Cit. Am. Birds, 1862, 182. (Tyine, Thamnophilus quixen. sis Cormalia.)

Small to very small Formicariidie (length about 105-135. mm.) with long, graduated tail of 12 round-tipped rectrices (nearly as long as to longer than wing), tarsus much less thim half as long as wing, nostril broadly oval (much broader than the narrow, sometimes nearly obsolete, opcreulum), the adult males with at least the chin, throat, chest, and median portion of breast black, and wing-coverts tipped with white.

Bill shorter than head, moderately stout, not compressed, its width at frontal antize little if any greater than its depth at same point and equal to about half the distance from nostril to tip of maxilla; culmen distinctly but not sharply ridged, nearly straight for basal half (more or less) more and more decurved terminally, the tip of maxilla slightly though distinctly uncinate; tomia straight or nearly so, distinctly notched subterminally, the notch near tip of mandibular tomium less distinct; gonys gently convex, less so terminally. Nostril exposed, longitudinally oval, nearly in contact with feathering of latero-frontal antix, the superior operculum very narrow or practically obsolete. Rictal bristles well developed in M. boucardi and $M$. consobrina, ${ }^{a}$ very minute (practically obsolete) in M. intermedia, M. grisea, M. rufatra, and allies; feathers of chin and loral region with slender terminal setæ. Wing moderate, with longest primaries extending, more or less decidedly, beyond secondaries; fifth and sixth, sixth and seventh, or fifth, sixth and seventh, primaries longest, the tenth (outermost) one-half to three-fifths as long as the longest, the ninth shorter than secondaries. Tail nearly as long as to longer than wing, graduated (graduation equal to length of tarsus or more), the rectrices (12) rather broad, rounded terminally. Tarsus longer than whole culmen, one-third ( $M$. boucardi, M. consobrinus) to two-fifths as long as wing (M. grisea, M. intermedia, M. rufatra), distinctly scutellate, the plantar scutella in two longitudinal series but sometimes partly fused or obsolete; middle toe, with claw, much shorter than tarsus; outer toe, without claw, reaching to slightly beyond middle of subterminal phalanx of middle toe, the inner toe slightly shorter; hallux about as long as inner toe but much stouter; basal phalanx of middle toe wholly united to outer toe, for about half its length to inner toe; claws moderate in size and curvature, that of the hallux decidedly shorter than its digit. Plumage full, lax, and blended, that of the rump and flanks elongated and more fluffy; feathers of pileum not elongated.

a Probably also in the closely related $M$. quixensis and $M$. bicolor, which, however, I have not seen. 
Coloration.-(I.) Adult males black with white spots on wingcoverts, white tips to rectrices (or lateral rectrices mostly white), and interscapulars pure white basally; adult females slate color or blackish above, with white markings as in adult males, under parts cinnamon-rufous or chestnut. (II.) Adult males brownish gray, brown, or rufescent above, the wing-coverts black with terminal white spots, the lateral rectrices also tipped with white; chin, throat, chest, and median portion of breast (sometimes abdomen also) black, the sides and flanks whitish, grayish or fulvous; adult females similar but without black on under parts.

Range.-Southern Mexico to Cayenne, southeastern Brazil, Bolivia, and Peru. (About seven species.) ${ }^{a}$

KEY TO THE SPECIES AND SUBSPECIES OF MICRORHOPIAS.

a. Upper parts black, the feathers of back pure white basally. (Microrhopias boucardi.)

$b$. White tips to lateral rectrices smaller $(5-7 \mathrm{~mm}$. long on outermost rectrix).

c. Flanks usually slate color. (Southeastern Mexico to Honduras.)

Microrhopias boucardi boucardi, adult male (p. 78).

cc. Flanks usually black. (Nicaragua to Panamá.)

Microrhopias boucardi virgata, adult male (p. 79).

bb. White tip to lateral rectrices larger (9-12 mm., or more, long on outermost pair). (Colombia to Cayenne and western Ecuadór.)

Microrhopias boucardi consobrina, adult male (p. 80 ).

aa. Upper parts not black.

b. Feathers of back abruptly pure white basally; under parts wholly tawny or chestnut. (Microrhopias boucardi.)

c. White tip to lateral rectrices smaller (about 5-7 mm. long on outermost rectrix); under parts lighter than chestnut, upper parts more grayish slaty.

d. Under parts tawny... Microrhopias boucardi boucardi, adult female (p. 78). $d d$. Under parts deep cinnamon-rufous or rufous-chestnut.

Microrhopias boucardi virgata, adult female (p. 80).

$c c$. White tip to lateral rectrices larger (10-15 $\mathrm{mm}$. long on outermost rectrix); under parts deep chestnut, upper parts more blackish slaty.

Microrhopias boucardi consobrina, adult female (p. 80).

$b b$. Feathers of back not white basally; under parts not tawny or chestnut. (Microrhopias grisea.)

c. Sides of head, throat, chest, and breast uniform black. (Adult males.)

$d$. General color of upper parts darker (deep grayish sepia or purplish brownish slate color).

a I am very doubtful whether the group comprising Turdus griseus Boddaert, Formicivora intermedia Cabanis, and Thamnophilus rufater Lafresnaye and D'Orbigny should be included in this genus, for apart from the very different style of coloration, these species differ from Microrhopias proper in obsolete instead of conspicuously developed rictal bristles, much longer tarsus, and some other less marked characters. 
c. White supereiliary stripe narrower; white tip to wing-coverts smaller. (Cayenne to eastern Brazil.)

Microrhopias grisea grisea, adult male (extralimital) ${ }^{a}$

ce. White superciliary stripe broader; white tip to wing-coverts larger.

f. Flanks and sides less extensively white, the black of abdomen relatively broader. (San Miguél Island, Bay of Panamá.)

Microrhopias grisea alticincta, adult male (p. 82).

ff. Flanks and sides more extensively white, the black of abdomen relatively narrower.

g. Larger (wing 59.5, tail 52.5, tarsus 22). (Tobago.)

Microrhopias grisea tobagensis, adult male (extralimital). $b$

gg. Smaller (wing 53-54.5, tail 46-49, tarsus 20-21). (Margarita Island, Venezuela.)

Microrhopias grisea margaritensis, adult male (extralimital). $c$ dd. General color of upper parts paler (hair brown or broccoli brown). (Mainland of Venezuela and Colombia.)

Microrhopias grisea intermedia, adult male (extralimital). ${ }^{d}$ cc. Sides of head (below eyes) and under parts buffy or whitish. (Adult femalcs.) d. General color of upper parts darker (deep grayish brown); under parts distinctly buffy.

c. White tip to wing-coverts much smaller; under parts (except chin, upper throat, and under tail-coverts) deep buff or ochraceous-buff.

Microrhopias grisea grisea, adult female (extralimital).

cc. White tip to wing-coverts much larger; under parts paler buffy.

Microrhopias grisea alticincta, adult female (p. 82).

dd. General color of upper parts paler (light grayish brown); under parts dull white, tinged with buff on chest and sides.

Microrhopias grisea intermedia, adult female (extralimital). ${ }^{e}$

a Turdus griseus Boddaert, Tabl. Pl. Enl., 1783, 39 (based on Le grisin de Cayenne Daubenton, Pl. Enl., pl. 643, fig. 1).-[.1otacilla] grisea Gmelin, Syst. Nat., i, pt. 2, 1789, 964.--Thamnophilus griseus Spix, Av. Bras., ii, 1825, 29, part, pl. 41, fig. 1 (Pará).-F[ormicivora] grisea Cabanis, in Wiegm. Archiv für Naturg., 1847, pt. i, 225.-Formicivora grisea Sclater, Proc. Zool. Soc. Lond., 1858, 238; Cat. Birds Brit. Mus., xv, 1890, 249.--Ellipura grisea Burmeister, Syst. Ueb. Th. Bras., iii, 1856, 67.Drymophila grisea Richmond, Auk, xvi, Oct., 1899, 354, in text.-Formicivora nigricollis Swainson, Zool. Journ., ii, no. vi, July, 1825, 147 (catinga woods of Humildez, Brazil; coll. W. Swainson).--M[yiothera] superciliaris Lichtenstein, Verz. Doubl., 1823, 44 (Cayenne).-Formicivor $[a]$ deluzae Ménétriés, Mém. Acad. Imp. Sci. St. Petersb., ser. 6, etc., i, 1835, 484, pl. 5, fig. 2 (Serra dos Orgâoes, near Rio de Janeiro, Brazil; coll. Acad. St. Petersb.).

b Formicivora tobagensis Dalmas, Mém. Soc. Zool. France, xiii, 1900, 141 (Tobago; coll. Count Dalmas).-D[rymophila $]$ grisea tobagensis Ridgway, Proc. Biol. Soc. Wash., sxi, Oct. 20, 1908, 194, in text.

c Drymophila grisea margaritensis Ridgway, Proc. Biol. Soc. Wash., xxi, Oct. 20, 1908, 194 (Margarita I., Venezuela; coll. U. S. Nat. Mus.).

a F[ormicivora] intermedia Cabanis, in Wiegm. Archiv für Naturg., xiii, Bd. 1, Heft 2, 1847, 225 (Cartagena, Colombia, and Aragua Valley, Venezuela; coll. Berlin Mus.).--Formicivora intermedia Sclater, Cat. Birds Brit. Mus., xv, 1890, 250.-D rymophila] intermerlia Richmond, Auk, xvi, Oct., 1899, 354, in text.--Eriodora intermedia Bangs, Proc. Biol. Soc. Wash., xii, June 3, 1898, 138 (Santa Marta, Colombia).

$e$ I have not seen adult females of $M . g$. tobagensis nor $M . g$. margaritensis. In addition to the forms mentioned in the key, two others (apparently conspecific) are autoptically unknown to me: Formicivora orenocensis Hellmayr, Bull. Brit. Orn. Club, xiv, Feb. 27, 1904, 54 (Altagracia, Orinoco R., Venezuela; coll. Tring Mus.), and Formicivora cano-fumosus Cherrie, Mus. Brookl. Inst. Arts and Sci., Science Bull., i, no. 16, June 30, 1909, 387 (Las Barrancas, Orinoco R., Venezuela; coll. Mus. Brooklyn Inst.). 


\section{MICRORHOPIAS BOUCARDI BOUCARDI (Sclater).}

BOUCARD'S ANTWREN.

Adult male.-General color deep black, passing into slate color on sides and flanks; interscapulars extensively pure white beneath the surface (partly exposed); anterior portion of lesser wing-covert area (except on bend of wing) white, the other lesser coverts and middle coverts with a small roundish terminal spot of white; greater coverts broadly tipped with white, forming a very conspicuous band across wing; rectrices (except middle pair) broadly tipped with white (the white tips growing smaller toward middle rectrices); under wingcoverts (except along border of wing) and broad edgings to inner web of remiges white; bill black; iris brown; legs and feet blackish (grayish blue in life); length (skins), 98-111 (106); wing, 47-50.5 (48.6); tail, 43-49 (45.6); culmen, 13-14.5 (13.7); tarsus, 14.5-16 (15.5); middle toe, 8.5-9 (8.9). ${ }^{a}$

Adult female.-Above marked with white as in adult male (that on interscapular region more restricted, however), but black of head, neck, back, and rump replaced by dark slate color or blackish slate (more or less intermixed with black on interscapular region); under parts (including malar region) plain rufous-tawny, deepest on throat and chest; under wing-coverts and edges of inner webs of remiges white, as in adult male; bill, etc., as in adult male, but the former usually more brownish; length (skins), 96-117 (107); wing, 46.5-49 (47.7); tail, 43.5-47.5 (45.6); culmen, 12.5-14.5 (13.3); tarsus, 14.5-16 (15.4); middle toe, 8.5-9.5 (8.8). ${ }^{b}$

a Fourteen specimens.

$b$ Thirteen specimens.

\begin{tabular}{|c|c|c|c|c|c|}
\hline $\begin{array}{c}\text { Locality. } \\
.\end{array}$ & Wing. & Tail. & $\begin{array}{l}\text { Cul- } \\
\text { men. }\end{array}$ & $\begin{array}{l}\text { Tar- } \\
\text { sus. }\end{array}$ & $\begin{array}{c}\text { Middle } \\
\text { toe. }\end{array}$ \\
\hline \multicolumn{6}{|l|}{ MALES. } \\
\hline Four adult males from southeastern Mexico.............. & 48.9 & 45.2 & 14.1 & 15.5 & 9 \\
\hline Eight adult males from Guatemala.................. & 48.2 & 45.8 & 13.4 & 15.5 & 8.9 \\
\hline Two adult males from Honduras and British Honduras... & 49.3 & 46.7 & 14.3 & 15.3 & 9 \\
\hline Four adult males ( $M$. b. virginata) from Nicaragua......... & 49 & 43.6 & 14 & 15.9 & 8.9 \\
\hline Ten adult males ( $M . b$. virginata) from Costa Riea ........... & 49.7 & 44.3 & 13.7 & 15. 7 & 9 \\
\hline Seven adult males ( $M$. b. virginata) from Panamá.............. & 49.4 & 45 & 13.7 & 15. 6 & 8. \\
\hline \multicolumn{6}{|l|}{ FEMALES. } \\
\hline Six adult females from southeastern Mexico..... & 47.5 & 44.9 & 13.3 & 15.4 & 8. \\
\hline Six adult females from Guatemala ..................... & 47.9 & 46.3 & 13.2 & 15.4 & 8.7 \\
\hline One adult female from British IIonduras............... & 47.5 & 45 & 14 & 15.5 & 9 \\
\hline Ten adult females ( $M . b$. virginata) from Costa Rica....... & 48.3 & 42.5 & 13.4 & 15.6 & 9 \\
\hline Three adult females from western Panamá (Divala, Chiriqul). . & 48 & 43.8 & 14 & 16.2 & 9.5 \\
\hline One adult female from eastern Panamá (line of railway)....... & 47 & 42.5 & 13 & 16 & 9. \\
\hline
\end{tabular}


Young male (nestling).-Abovo plain sooty blackish or blackish brown (nearly clove brown), rather lighter (durk sepia) on head, the wings and tail nearly black; greater wing-coverts rather broadly tipped with white but with a narrow terminal margin of dusky; rectrices (except middle pair) tipped with white, as in adults; under parts plain dark sooty brown, tinged with chestnut-brown or vandyke brown.

Southeastem Mexico, in States of Vera Cruz (Playa Vicente; Buena Vista), Onxaca (Acátepec) and Tabasco (Teapa) through Guatemala (Choctúm; sources of Rio de la Pasión; Yzabál; Telemán; Los Amates; Uspantán, Quiché) to Honduras (Omoa; San Pedro; Rio Blanco) and British Honduras (near Manatee Lagoon; Toledo District).

Formicivora boucardi Sclater, Proc. Zool. Soc. Lond., 1858, 241, 300 (Acátepec, Oaxaca; coll. P. L. Sclater); 1859, 383 (Playa Vicente, Vera Cruz); Cat. Am. Birds, 1862, 183, pl. 16 (Oaxaca; Choctúm, Guatemala); Cat. Birds Brit. Mus., xv, 1890, 254, part (Acátepec, Oaxaca; Choctúm and sources of Rio de la Pasión, Guatemala).-Moore, Proc. Zool. Soc. Lond., 1859, 55 (Omor, Honduras).-Sclater and Salvin, Ibis, 1859, 119 (Omoa, Honduras; Proc. Zool. Soc. Lond., 1870, 837 (San Pedro, Honduras).-SAlvin and GodMAx, Biol. Centr.-Am., Aves, ii, 1892, 216, part (Acátepec; Playa Vicente; Choctúm, Yzabál, and Telemán, Guatemala; Omoa and San Pcdro, Honduras).-Dearbors, Pub. 125, Field Mus. Nat. Hist., 1907, 109 (Los Amates, c. Guatemala).

[Formicirora] boucardi Sclater and Salvin, Nom. Ar. Neotr., 1873, 72, part.Sharpe, Hand-list, iii, 1901, 26, part.

Formicirora boucardii Boucard, Ann. Soc. Linn. Lyon, 1878, 39 (Guatemala; Playa Vicente, Vera Cruz).

D[rymophila] boucardi Richmond, Auk, xvi, Oct., 1899, 354, in text.

\section{MICRORHOPIAS BOUCARDI VIRGATA (Lawrence).}

PANAMÁ ANTWREN.

Similar to $M . b$. boucardi but adult male more intensely and extensirely black (even the sides and flanks usually black or slateblack), ${ }^{a}$ the adult female with color of under parts much darker (rufous-chestnut instead of rufous-tawny) and upper parts darker.

Adult male.-Length (skins), 96-113 (106); wing, 47.5-51 (49.5); tail, 40-49 (45.9); culmen, 13-14.5 (13.8); tarsus, 15-16 (15.7); middle toe, $8.5-9.5(8.9) .^{b}$

$a_{\mathrm{A}}$ few specimens from Nicaragua and Costa Rica have the flanks slate color, much as in northern examples ( $M . b$. boucardi), but all of the females seen from Costa Rica belong unmistakably to the Panamá form. (I have not seen any females from Nicaragua.)

The white mesial streaks showing on the adult male described by Mr. Lawrence (and on which the name virgata was based) are an individual peculiarity, which I do not find repeated in any other specimen examined, even from Panamá.

This form is distinctly intermediate in coloration between $M . b$. boucardi and M. b. consobrina of Colombia and Ecuadór.

b Twenty-one specimens, 
Adult female.-Length (skins), 96-109 (103); wing, 45-52 (48.2); tail, 40-46.5 (42.1); culmen, 12.5-14 (13.5); tarsus, 15-17 (15.8); middle toe, $8.5-10(9.1){ }^{a}$

Nicaragua (Chontales; Los Sábalos; Rio Escondido; San Emilis), Costa Rica (San Carlos; Pejé; Pacuare; La Balsa; Talamanca; Sipúrio; Rio Sícsola; Jiménez; Angostura; Guápiles; Guácimo; Siquirres; La Cristina; Tuís; El Hogár; San José; La Concepción; La Florída; Pozo Azúl de Pirrís; Pozo del Pitál; Pozo del Rio Grande; Paso Reál; Lagarto; Boruca; Buenos Aires; Palmár; El Generál; La Vijágua), and Panamá (Divala and Bugaba, Chiriquí; Panamá; Lion Hill).

Formicivora boucardi (not of Sclater, 1858) Sclater and Salvin, Proc. Zool. Soc. Lond., 1864, 356 (Panamá; crit.).-Salvin, Proc. Zool. Soc. Lond., 1870, 195 (Bugaba, Panamá); Ibis, 1872, 318 (Chontales, Nicaragua).-Boucard. Proc. Zool. Soc. Lond., 1878, 61 (San Carlos, Costa Rica).-Nutring, Proc, U. S. Nat. Mus., vi, 1884, 405 (Los Sábalos, Nicaragua; habits).-Sclater, Cat. Birds Brit. Mus., xv, 1890, 254, part (Chontales, Nicaragua; Pejé and Angostura, Costa Rica; Panamá, Bugaba, and Chiriquí, Panamá).-Salvin and Godman, Biol. Centr.-Am., Aves, ii, 1892, 216, part (Chontales and Los Sábalos, Nicaragua; Angostura, Pacuare, Pejé, San Carlos, Jiménez, La Balsa, and Pozo Azúl de Pirrís, Costa Rica; Chiriquí, Bugaba, and Lion Hill, Panamá).-Richmond, Proc. U. S. Nat. Mus., xvi, 1893, 501 (Rio Escondido, Nicaragua; habits).-Cherrie, Expl. Zool. Merid. Costa Rica, 1893, 43 (Palmár, Lagarto, Boruca, and Buenos Aires, s. w. Costa Rica; habits).-Bangs, Auk, xxiv, 1907, 296 (Boruca, Paso Reál, Pozo del Rio Grande, and Lagarto, s. w. Costa Rica).

[Formicivora] boucardi Sclater and Salvin, Nom. Av. Neotr., 1873, 72, part.Sharpe, Hand-list, iii, 1901, 26, part.

Formicivora boucardii Lawrence, Ann. Lyc. N. Y., ix, 1868, 108 (Angostura, San José, and Pacuare, Costa Rica).-Frantzius, Journ. für Orn., 1869, 305 (Costa Rica).-Zeledón, Anal. Mus. Nac. Costa Rica, i, 1S87, 115 (Pozo Azúl, Pacuare, Jiménez, and La Balsa, Costa Rica).

Formicivora boucardi Cherrie, Anal. Inst. Fis.-Geog. Costa Rica, vi, 1893, 19 (Pozo del Pitál, Costa Rica).

Formicivora quixensis (not Thamnophilus quixensis Cornalia) LAwrence, Ann. Lyc. N. Y., vii, 1862, 325 (Lion Hill Station, Panamá).

Formicivora virgata Lawrence, Ibis, v, April, 1863, 182 (Lion Hill Station, Panamá; coll. G. N. Lawrence); Ann. Lyc. N. Y., viii, 1863, 484 (Lion Hill).-Salvin and Godman, Biol. Centr.-Am., Aves, ii, 1892, 217 (Chontales, Nicaragua; Lion Hill, Panamá).

$D$ [rymophila] virgata Richmond, Auk, xvi, Oct., 1899, 354, in text.

[Formicivora] virgata Sharpe, Hand-list, iii, 1901, 26 (Panamá to Nicaragua).

Formicivora boucardi virgata CARriker, Ann. Carnegie Mus., vi, 1910, 610 (Costa Rica; crit.; habits).

\section{MICRORHOPIAS BOUCARDI CONSOBRINA (Sclater).}

ECUADORIAN ANTWREN.

Similar to M. b. virgata, but adult male with rectrices more broadly tipped with white, the adult female with under parts deep chestnut 
instead of rufous- or tawny-chestnut, the upper parts also slightly darker.

Adult male.-Length (skin), 109; wing, 49.5; tail, 46; culmen, 12.5 ; tarsus, $16 .^{a}$

Adult female.-Length (skin), 116-121 (118); wing, 48.5-51.5 (50); tail, 45.5-52 (48.7); tarsus, 16.5 ; middle toe, $10 .^{b}$

Northwestern Colombia (Rio Truando) to western Ecuadór (Babahoyo; Esmeraldas; Balzár Mts.; Sarayacu; Chimbo) and Cayenne.

Formicivora consobrina Sclater, Proc. Zool. Soc. Lond., 1860, 279, 294 (Babahoyo, w. Ecuadór; coll. P. L. Sclater); Cat. Am. Birds, 1862, 183 (Babahoyo); Cat. Birds Brit. Mus., xv, 1890, 255 (Babahoyo, Esmeraldas, Balzár Mts., and Sarayacu, Ecuadór; Pocune and Medellin, Antioquía, and Bogotá, Colombia; Cayenne).-Sclater and Salvin, Proc. Zool. Soc. Lond., 1879, 525 (Pocune, Antioquía, Colombia).-Berlepsch and Taczanowski, Proc. Zool. Soc. Lond.. 1883, 565 (Chimbo, w. Ecuadór).

[Formirivora] consobrina Sclater and Salvin, Nom. Av. Neotr., 1873, 72.Sharpe, Hand-list, iii, 1901, 26.

$D$ [rymophila] consobrina Richuond, Auk, xvi, Oct., 1899, 354, in text.

Formicivora quixensis (not Thamnophilus quixensis Cornalia) CAssin, Proc. Acad. Nat. Sci. Phila., 1860, 190 (Rio Truando, n. w. Colombia).

Formicivora boucardi (not of Sclater) Salvin and Godman, Biol. Centr.-Am., Aves, ii, 1892, 216, part (Rio Truando).

\section{MICRORHOPIAS GRISEA ALTICINCTA (Bangs).}

\section{SAN MIGUELL ANTWREN.}

Similar to $M . g$. intermedia ${ }^{c}$ of Colombia and Venezuela, but adult male much darker above (deep grayish sepia, purplish slate color, or deep brownish slate instead of hair brown or broccoli brown) and more extensively black beneath, the adult female darker brown above and much more strongly buffy beneath.

$a$ One specimen, from Rio Truando, Colombia.

$b$ Two specimens.

\begin{tabular}{|c|c|c|c|c|}
\hline Locality. & Wing. & Tail. & $\begin{array}{l}\text { Tar- } \\
\text { sus. }\end{array}$ & $\begin{array}{c}\text { Middle } \\
\text { toe. }\end{array}$ \\
\hline FEMALES. & & & & \\
\hline One adult female from Rio Truando, Colombia.......... & 48.5 & 45.5 & 16.5 & 10 \\
\hline One adult female from Ecuadór........... & 51.5 & [52?] & 16.5 & 10 \\
\hline
\end{tabular}

Besides having a longer wing and, apparently, much longer tail than the Rio Truando specimen, that from Ecuadór has the white tips to the rectrices much more extensive. The specimens examined, however, are all imperfect, and a much better series would be necessary to show whether the Colombian and Ecuadorian birds are really different or not.

$c$ See p. 77 .

81255-Bull. $50-11-6$ 
Adult male.-Above plain purplish slate color (between slate color and seal brown), deep grayish sepia or deep brownish slate; wings and tail black; anterior portion of lesser wing-covert area white, the remaining lesser coverts, together with middle coverts, with a small terminal roundish spot of white; greater coverts broadly tipped with white, forming a very conspicuous band across wing; remiges narrowly and indistinctly edged (except basally) with grayish brown, the edgings broader on tertials, where sometimes whitish terminally; three outermost rectrices (on each side) broadly tipped with white, this extending much farther on outer than on inner web, the extent of the white greatest (on both webs) on second rectrix; a broad superciliary stripe of white extending from sides of forehead to sides of nape, where confluent with a white area extending from sides of neck to flanks; loral, suborbital, auricular, and malar regions, chin, throat, chest, breast, abdomen, and under tail-coverts uniform black, the sides and flanks immaculate white outwardly, streaked black and white along exterior margin of the black median area; under wing-coverts black (the under primary coverts white, tipped with black); inner web of remiges broadly edged with grayish white; bill black, paler on tomia; legs and feet grayish black (plumbeous in life?); length (skin), 113-116 (115); wing, 54.5-59 (55.7); tail, 45-49 (46.5); culmen, 14-15 (14.5); tarsus, 20-21.5 (20.3); middle toe, 11-12 (11.5). ${ }^{a}$

Adult female.-Above much as in adult male, but the general color decidedly more brownish (deep broccoli brown on back, etc., more grayish brown on pileum and hindneck), the remiges more distinctly edged with brown; sides of head (including superciliary stripe, which is less sharply defined than in adult male) pale grayish buffy or dull buffy whitish, interrupted by a narrow postocular streak of dusky, the suborbital region with very narrow and indistinct bars of dusky, the auricular region with fine shaft-streaks of whitish; chin and upper throat white, passing into buff on chest, this into paler buff on other lower parts, the under tail-coverts (some-

$a$ Six specimens.

\begin{tabular}{|c|c|c|c|c|c|}
\hline Locality. & Wing. & Tail. & $\begin{array}{l}\text { Cul- } \\
\text { men. }\end{array}$ & $\begin{array}{l}\text { Tar- } \\
\text { sus. }\end{array}$ & $\begin{array}{c}\text { Middle } \\
\text { toe. }\end{array}$ \\
\hline MALES. & & & & & \\
\hline Six adult males from San Miguél Island.. & 55.7 & 46.5 & 14.5 & 20.3 & 11.5 \\
\hline 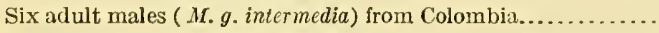 & 53.5 & 48 & 14.8 & 20.3 & 11.5 \\
\hline 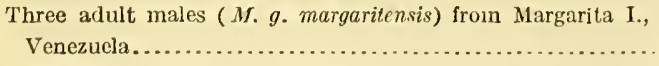 & 53.7 & 47.8 & 14.3 & 20 & 11.3 \\
\hline 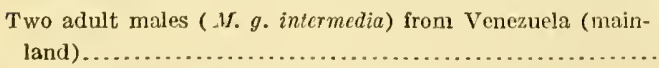 & 54.7 & 49.5 & 14 & 21 & 11.5 \\
\hline One adult male ( $M_{.} g$. tobagensis) from Tobago.. & 59.5 & 52.5 & & 22 & 12.5 \\
\hline
\end{tabular}


times flanks also) and center of abdomen nearly white; bill and feet as in adult male, but mandible pale grayish brown (bluish gray in life ?); length (skin), 112-116 (114); wing, 50-52.5 (51.5); culmen, $43-45$ (43.S); tarsus, $14-1+.5$ (14.1); middle toe, $11-11.5$ (11.2) ${ }^{a}$

Immature male.-Similar to the adult female, but whitish superciliary stripe more distinct, and with throat, chest, and breast intermixed with black.

San Miguél Island, Bay of Panamá.

Drymophila intermedia (not Fomnicivora intermedia Cabanis) BANGs, $\Lambda u k$, xviii, Jan., 1901, 30 (San Miguél I.. Bay of Panamá).

Formicivora alticincta Bangs, Proc. New Engl. Zool. Club, iii, Mar. 31, 1902, 71 (San Miguél I., Bay of Panamá; coll. E. A. and O. Bangs).-Thayer and BANgs, Bull. Mus. Comp. Zool., xlvi, 1905, 150 (San Miguél I., crit.).

\section{Genus TERENURA Cabanis and Heine.}

Terenura $b$ Cabanis and Heine, Mus. Hein., ii, July, 1859, 11. (Type, Myiothera maculata Maximilian.)

Phyllobates c Bertoni, Aves Nuevas del Paraguay, 1901, 142. (Type, P. erythronotus Bertoni= Myiothera maculata Maximilian.)

Small Formicariidæ (length about 90-100 mm.) with long tail, slender bill, no trace of rictal bristles, and bright coloration.

. This little group leads away from Formicivora [i.e. Microrhopias] to Psitorhamphus and Rhamphocænus. The bill is hardly longer than in Formicivora, but smaller; the nostrils are more elongated, and hare a slight membraneous operculum as in Psilorhamphus. The tail is rather long, thin, and delicate; the tarsi are more like those of Formicivora, and show the divisions of the scutes." $d$

"Terenura is a peculiar genus of doubtful affinities, but remarkable for the bright colours of its members. These colours (black, bright yellow, chestnut, and olive), it is true, are all to be found in different species of Formicariidæ, but in Terenura alone are they associated in a single bird.

"Cabanis and Heine, who founded the genus, placed it between Ramphocænus and Ellipura (=Formicivora), and in this position it was left by Mrr. Sclater. We can not see that it has much in common with either of these forms, which, different as they are, both possess well-defined rictal bristles, not a trace of which can we see in Terenura. Mr. Sclater speaks of the presence in the latter genus of a slightly membraneous nasal operculum such as is found in Rhamphocænus, but the specimens of Terenura callinota before us have open nostrils without any overhanging membrane.

a Three specimens.

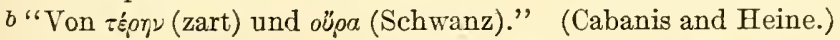

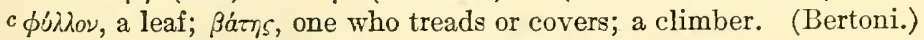

$d$ Sclater, Cat. Birds Brit. Mus., xv, 1890, 257. 
"On the whole, and in the absence of any information as to the habits of any species of Terenura, we are inclined to place the genus near Myrmotherula, notwithstanding the difference of coloration and the much longer tail.

"The bill is longer than that of Myrmotherula surinamensis, but is otherwise very similar. The wings are decidedly longer and less rounded. The tarsi are covered behind with large scutella, the sutures of which are, however, rather indefinite.

"Four or five species constitute the genus Terenura, all more or less rare birds. These are distributed over a wide area of Tropical America-one or two in Southeastern Brazil, one in Guiana, one in Eastern Ecuador, and T. callinota, a western and northwestern bird the range of which is given below"a [Veragua to Peru].

\section{TERENURA CALLINOTA (Sclater).}

\section{RUFOUS-RUMPED ANTWREN.}

Adult male.-Above greenish olive; cap black; lores and sides of head whitish; lower back bright chestnut; wings and tail blackish, with olivaceous edgings; wing-coverts black, broadly tipped with white; bend of wing and adjoining coverts bright yellow; beneath pale greenish yellow; throat and breast pale cinereous; under wingcoverts sulphur-yellow; whole length 4 inches, wing 2.2 , tail $1.7 .^{b}$

Western Panamá (Calobre, Verágua) through Colombia (Bogotá) and Ecuadór (Nanegál; Pallatanga) to central Peru (Roypaybamba).

Formicivora callinota Sclater, Proc. Zool. Soc. Lond., 1855, 89, pl. 96 (Bogotá, Colombia; coll. Brit. Mus.,) 147 (Bogotá); 1858, 242 (Bogotá).

Terenura callinota Taczanowski, Proc. Zool. Soc. Lond., 1874, 530 (Roypaybamba, centr. Peru); Orn. du Pérou, ii, 1884, 52.-Taczanowski and BerLepscr, Proc. Zool. Soc. Lond., 1885, 118 (Pallatanga, Ecuadór).-Sclater, Cat. Birds Brit. Mus., xv, 1890, 257 (Calobre, Verágua; Bogotá; Nanegál, Ecuador).-Salvin and Godman, Biol. Centr.-Am., Aves, ii, 1892, 213.-BerLepsch and Stolzmann, Proc. Zool. Soc. Lond., 1902, 58 (Ropaybamba, Peru).

[Terenura] callinota Sclater and Salvin, Nom. Av. Neotr., 1873, 72.-Sharpe, Hand-list, iii, 1901, 27.

\section{Genus RAMPHOCANUS Vieillot.}

Ramphocænus c Vierllot, Nouv. Dict. d'Hist. Nat., xxiv, 1818, 112 (diagnosis but no type given). Ramphocenus Vieillot, Nouv. Dict. d'Hist. Nat., xxix, 1819, 5. (Type, R. melanurus Vieillot.)

Rhamphocænus (emendation) StrickLand, Ann. Mag. N. H., vi, 1841, 421.

Acontistes Sundevall, Kgl. Vet.-Ak. Handl., 1835 (1836), 95. (Type, Ramphocænus melanurus Vieillot.)

Scolopacinus Bonaparte, Proc. Zool. Soc. Lond., 1837, 119. (Type, S. rufiventris Bonaparte.)

$a$ Salvin and Godman, Biol. Centr.-Am., Aves, ii, 1892, 213.

$b$ Sclater, Cat. Birds Brit. Mus., xv, 1890, 257, 258.

c japфòs, rostrum, kaı̀̀s, novus. (Vieillot.) 
Very small Formicariidie (length about 120-135 mm.) with long, slender bill (longer than head), long, slender tarsi (nearly as long as exposed culmen) and with tail four-fifths as long as wing.

Bill very long (longer than head), straight, and slender, its width at frontal antive decidedly greater than its depth at same point and equal to about one-fourth the distance from nostril to tip of maxilla; culmen sharply rilged, strilight, the extreme end abruptly and rather strongly decurved, the tip of maxilla very minutely uncinate; maxillary tomium faintly concave for anterior half or more, very faintly (obsoletely) notched subterminally; mandibular tomium straight, faintly decurred terminally, without trace of subterminal notch, the tip of mandible very slightly decurved; gonys nearly straight, very slightly prominent basally. Nostril exposed, widely separated from feathering of latero-frontal antiæ, narrow, longitudinal, overhung by a broad, convex operculum. Rictal bristles distinct, but rather few and slender; feathers of chin without terminal setæ. Wing moderate or relatively rather large, with longest primaries extending slightly but decidedly beyond secondaries; fifth, sixth, and seventh primaries longest, the tenth (outermost) less than half as long as longest, the ninth much shorter than secondaries. Tail about fourfifths as long as wing, graduated (graduation less than distance from nostril to tip of maxilla), the rectrices (10) rather narrow, rounded terminally. Tarsus about as long as bill from frontal antiæ, twofifths as long as wing, slender, the scutella of acrotarsium fairly distinct, those of the planta tarsi undivided; middle toe, with claw, about two-thirds as long as tarsus; outer toe, without claw, reaching to beyond middle of subterminal phalanx of middle toe, the inner toe decidedly shorter; hallux about as long as inner toe but much stouter; basal phalanx of middle toe wholly united to both outer and inner toes, the second phalanx partly united to outer toe; claws moderate in size and curvature, that of the hallux shorter than its digit. Plumage full, soft, and blended, that of rump and flanks elongated, more lax or fluffy; feathers of pileum not elongated.

Coloration.-Above plain brownish (back, etc., sometimes more grayish), the tail blackish, with or without whitish tip to rectrices; beneath whitish, more or less strongly buffy or rufescent laterally: sexes alike.

Range.-Guatemala to southeastern Brazil. (Four species.)

\section{RAMPHOCENUS RUFIVENTRIS RUFIVENTRIS (Bonaparte).}

NORTHERN LONG-BILIED ANTWREN.

Adults (sexes alitie).-Pileum and hindneck plain olive-brown (between prouts brown and raw umber); rest of upper parts (except tail) plain deep grayish olive or olive-slaty, the concealed portion of 
wing-feathers darker; tail dull slate-black or blackish slate, the three outer rectrices (on each side) with an apical or subapical area of dull white, this most developed on inner web of two outermost, which have a narrow longitudinal area of dusky on terminal or subterminal portion of outer web; sides of head and neck plain cinnamon or russet, broken by an indistinct postocular streak of olive-brownish; chin and throat white, more or less broken by partly exposed dusky basal portion of feathers; rest of under parts plain buff, or pinkish buff, deepest (sometimes nearly ochraceous-buff) laterally, paler medially (sometimes nearly white on abdomen); thighs mostly dusky olive-gray; under wing-coverts pale cream buff or buffy white; inner webs of remiges edged with white or buffy white; maxilla horn brown (sometimes darker terminally), mandible much paler (pale bluish gray to flesh color in life); iris brown; legs and feet horn color (bluish gray or grayish blue in life).

Adult male.-Length (skins), 109-127 (120); wing, 46-54.5 (51.2); tail, 36.5-43.5 (40.9); culmen, 22-26 (24); tarsus, 20-21.5 (20.9); middle toe, $10.5-12$ (11.1). ${ }^{a}$

Adult female.-Length (skins), 105-119 (113); wing, 45.5-53 (49.2); tail, 36-41 (38.6); culmen, 20-24.5 (23.1); tarsus, 20-22 (21.3); middle toe, $11-11.5$ (11.2). ${ }^{b}$

Young.-Essentially like adults, but back, rump, etc., soft grayish brown (nearly concolor with pileum and hindneck), and under parts pale grayish brown, approaching dull buffy whitish on throat and abdomen.

Southeastern Mexico, in States of Vera Cruz (Playa Vicente; Buena Vista; San Andrés Tuxtla), Oaxaca (mountains near Santo Domingo),

$b$ Sixteen specimens.

\begin{tabular}{|c|c|c|c|c|c|}
\hline Locality. & Wing. & Tail. & $\begin{array}{l}\text { Cul- } \\
\text { men. }\end{array}$ & Tarsus. & $\begin{array}{c}\text { Middle } \\
\text { toe. }\end{array}$ \\
\hline \multicolumn{6}{|l|}{ MALES. } \\
\hline Two adult males from southern Mexico.. & 50 & 40 & 22 & 21.2 & 10.7 \\
\hline Two adult males from Chiapas and Guatemala.... & 50.7 & 43 & 24.5 & 20.7 & 11.2 \\
\hline One adult male from Honduras.............................. & 54 & 40 & 26 & 21 & 11 \\
\hline One adult male from British Honduras................... & 46 & 42 & 24 & 21 & 10.5 \\
\hline Ten adult males from Nicaragua ( 4 ) and Costa Rica (6)... & 51.7 & 41 & 24 & 20.9 & 11.3 \\
\hline Two adult males from Panamá (line of railway)............ & 51.5 & 39.2 & 23.2 & 20.7 & 10.7 \\
\hline Four adult males (R.r. sanct $x-m a r t x)$ from Colombia .......... & 51.6 & 44.5 & 25.1 & 21.9 & 11.4 \\
\hline \multicolumn{6}{|l|}{ FEMALES. } \\
\hline Two adult females from southern Mexico (Vera Cruz).. & 48.2 & 39.2 & 24 & 21 & 11 \\
\hline One adult female from Chiapas................. & 49 & 37.5 & 23 & 22 & 11.5 \\
\hline Two adult females from British Honduras............... & 47.5 & 39.5 & 22.5 & 21 & 11 \\
\hline Ten adult females from Nicaragua (3) and Costa Riea (7). & 49.4 & 38.4 & 23.1 & 20.8 & 11.2 \\
\hline One adult female from Panamá (Verágua) .................. & 51.5 & 39 & ....... & 22 & 11 \\
\hline One adult female (R. r. sanct $x$-mart $x$ ) from Colombia........ & 47 & 38 & 24.5 & 22 & 12 \\
\hline
\end{tabular}


and Chiapas (Palenque; San Benito) and sonthward through Guatemala (Cobán; Cloctúm; Chiséc; Lanquín; Retalhuleu; Los Amates, Yzabál), British Honduras (Orange Walk; Cayo; near Soldiers Creek; near Manatee Lagoon), Honduras (Truxillo), Salvadór (La Libertád; Volcan de San Miguél), Nicaragua (Chinandegar Greytown; Los Sábalos; Sucuýá ; Rio Escondido), and Costa Rica (Orosí; Lagarto; Bebedero; Miravalles; Pozo Azúl de Pirrís; Pozo de Térraba; Pozo del Pitál; Pozo del Río Grande; Paso Reál; Boruca; El Hogár; Carrillo; Guícimo; Cuábre; Laguária; Santa Maria de Dota; Tenório; El Generál; Bolsón) to Panamá (Santa Fé de Verágua; Calobre; Bugaba; Lion Hill; Panamá; Sabana de Panamá).

Scolopacinus rufiventris Bonaparte, Proc. Zool. Soc. Lond., 1837, 119 (Guatemala; coll. Velasquez).

R[hamphocinus] rufiventris Gray and Mitchell, Gen. Birds, i, March, 1847, 157, pl. 47 , fig. 2 .

Rhamphocænus mufiventris Sclater, Proc. Zool. Soc. Lond., 1857, 202 (San Andrés Tuxtla, Vera Cruz); 1858, 244 (monogr.); Cat. Am. Birds, 1862, 184 (Choctúm, Guatemala); Ibis, 1883, 95, part (Guatemala to Panamá; descr.; crit.); Cat. Birds Brit. Mus., xv, 1890, 261, part (Cobán, Choctúm, Chiséc, Lanquín, and Retalhuleu, Guatemala; Bebedero, Costa Rica; Bugaba, Calobre, and Santa Fé de Verágua, Panamá).-Sclater and Salvin, Proc. Zool. Soc. Lond., 1864, 356 (Panamá; crit.).-Nutring, Proc. U. S. Nat. Mus., vi, 1883, 386 (Sucuyá, Nicaragua), 405 (Los Sábalos, Nicaragua).-Ridgway, Proc. U. S. Nat. Mus., x, 1885, 581 (Truxillo, Honduras).-Salvin and Godman, Biol. Centr.-Am., Ares, ii, 1892, 219, part (San Andrés Tuxtla and Playa Vicente, Tera Cruz; Orange Walk, Brit. Honduras; Choctúm, Chiséc, Lanquín, and Retalhuleu, Guatemala; Truxillo, Honduras; La Libertád and Volcan de San Miguél, Salvadór; Chinandega, Sucuyá, Los Sábalos, and Greytown, Nicaragua; Bebedero, Costa Rica; Bugaba, Santa Fé de Verágua, Calobre, and Lion Hill, Panamá).-Thayer and Bangs, Bull. Mus. Comp. Zool., xlvi, 1906, 217 (Sabana de Panamá).-Dearborn, Pub. 125, Field Mus. Nat. Hist., 1907, 109 (Los Amates, Guatemala).-Carriker, Ann. Carnegie Mus., vi, 1910, 611 (Costa Rica; habits).

[Rhamphocænus] rufiventris Sharpe, Hand-list, ii, 1901, 27, part (s. Mexico to Panamá).

[Rhamphocaenus] rufiventer Heine and Reichenow, Nomencl. Mus. Hein. Orn., 1890, 126, part (Cobán, Guatemala).

Ramphocænus rufiventris Sclater, Proc. Zool. Soc. Lond., 1859, 383 (Playa Vicente, Vera Cruz; crit.).-Salvin and Sclater, Ibis, 1860, 399 (Choctúm and Lanquín, Guatemala).-Lawrence, Ann. Lyc. N. Y., viii, 1863, 484 (Lion Hill, Panamá); viii, 1865, 182 (Greytown, Nicaragua).-Salvin, Proc. Zool. Soc. Lond., 1867, 145 (Santa Fé de Verágua, Panamá); 1870, 195 (Calobre and Bugaba, Panama); Ibis, 1869, 319 (Bebedero de Nicoya, Costa Rica).Boucard, Ann. Soc. Linn. Lyon, 1878, 39 (Guatemala).-Richyond, Proc. U. S. Nat. Mus., xvi, 1893, 501 (Greytown and Rio Escondido, Nicaragua; habits).-Underwood, Ibis, 1896, 440 (Volcan de Miravalles, Costa Rica).Lantz, Trans. Kansas Acad. Sci. for 1896-97 (1899), 221 (Cayo, Brit. Honduras).

[Ramphocaenus] rufiventris Bonaparte, Consp. Av., i, 1850, 201.

[Ramphocænus] rufiventris Sclater and Salvin, Nom. Av. Neotr., 1873, 73.

Rhamphocenus rufiventris Cherrie, Anal. Inst. Fis.-Geog. Costa Rica, vi, 1893, 19 (Pozo del Pitál, Costa Rica). 


\section{Genus MICROBATES Sclater and Salvin.}

Microbates $a$ Sclater and Salvin, Nom. Av. Neotr., 1873, 155. (Type, M. torquatus Sclater and Salvin=Rhamphocænus collaris Pelzeln.)

Very small, long-billed, long-legged Formicariidæ, similar in appearance to Ramphocænus but with shorter and broader bill, longer tarsi, relatively longer toes (especially the hallux), narrower nostrils with differently shaped operculum, and much shorter tail (only about half, instead of four-fifths) as long as wing.

Bill about as long as head, nearly straight, its width at laterofrontal antiæ much greater than its depth at same point and equal to much more than one-third the distance from nostril to tip of maxilla; culmen sharply ridged, straight for basal half (more or less), then very gradually decurved until near end, where more strongly decurved, the tip of maxilla minutely but distinctly uncinate; maxillary tomium faintly concave, minutely notched subterminally; mandibular tomium very faintly convex, at least terminally, without trace of subterminal notch; gonys faintly convex basally, straight terminally. Nostril exposed, distinctly separated from feathering of latero-frontal antiæ, narrow, longitudinal (slit-like), overhung by a broad but not convex membraneous operculum. Rictal bristles distinct but rather few and slender; feathers of chin without terminal setæ. Wing rather large, with longest primaries extending slightly beyond secondaries, much rounded; fifth and sixth primaries longest, the tenth (outermost) less than half as long as the longest, the ninth very much shorter than, the eighth about equal to, secondaries. Tail slightly more than half as long as wing, rounded (graduation equal to much less than half the distance from nostril to tip of maxilla), the rectrices (10) rounded at tip. Tarsus very long (decidedly longer than whole culmen, nearly half as long as wing), slender, the acrotarsium faintly scutellate, the planta tarsi completely fused; middle toe, with claw, decidedly shorter than tarsus (equal to or slightly longer than exposed culmen); outer toe, with claw, reaching to about middle of subterminal phalanx of middle toe, the inner toe decidedly shorter; hallux much longer than inner toe (about as long as outer toe), much stouter; basal phalanx of middle toe wholly united to both lateral toes; claws moderate in size and curvature, that of the hallux much shorter than its digit. Plumage full, soft, and blended, that of rump and flanks elongated, more lax or fluffy; feathers of pileum not elongated.

Coloration.-Above plain brown; sides of head blackish and white, or tawny; beneath white passing into dusky on flanks and under tailcoverts, the chest crossed by a band of black ( $M$. collaris) or under parts of body gray, chest streaked with black and white, and throat white bordered on each side by a black stripe; sexes alike. 
Range.-Southwestern Costa Rica to Cayemne and Ecuadorr. (Two species. $)^{a}$

\section{MICROBATES CINEREIVENTRIS SEMITORQUATUS (Lawrence).} HALF-COLLARED ANTWREN.

Adults (sexes alike).-Pileum and hindneck plain warm-sepia brown; rest of upper parts plain sepia, the edges of greater wingcorerts and secondaries (especially the tertials) more rufescent, the rectrices decidedly darker terminally; sides of head (except lores) plain ochraceous-buff to deep tawny-buff, this color extending more or less orer sides of neck; lores dull whitish broken by dusky bristlelike tips to feathers; anterior portion of malar region whitish; chin and throat white or grayish white, the latter bordered along each side by a broad but more or less broken streak of black; rest of under parts plain gray (no. 6 to mouse gray) passing into olive on flanks and under tail-coverts, the upper chest broadly streaked with black; maxilla brownish black with paler tomium, mandible dull whitish (horn color, flesh color, or straw yellowish in life); iris brown; legs and feet horn color (dark bluish gray in life).

Adult male.-Length (skins), 95-106 (100); wing, 51-57 (53.9); tail, 26.5-29.5 (27.7); culmen, 17.5-19 (18.1); tarsus, 22-24.5 (23.7); middle toe, $13-14.5(13.6){ }^{b}$

Adult female.-Length (skins), 92-101 (96); wing, 50.5-53.5 (51.5); tail, 24-28 (26.3); culmen, 17-19 (18.1); tarsus, 20.5-24.5 (23.1); middle toe, 12.5-13.5 (12.9). ${ }^{c}$

Costa Rica (Jiménez; San Carlos; La Balsa; Rio Súcio; Pacuare; Guápiles; Guácimo; Cuábre; El Hogár; Carrillo; La Vijágua) and Panamá (Volcan de Chiriquí; Santiago de Verágua; Lion Hill; Panamá); Colombia (Antioquía)?

Ramphocænus semitorquatus Lawrence, Ann. Lyc. Nat. Hist. N. Y., vii, 1862, 469, (Lion Hill Station, Panamá; coll. G. N. Lawrence); ix, 1868, 108 ("Valza," i.e. La Balsa, Costa Rica; crit.).-SAlvin, Proc. Zool. Soc. Lond., 1867, 145 (Santiago de Verágua, Panamá; crit.); 1870, 195 (Calovévora, Panamá).-Frantzivs, Journ. für Orn., 1869, 305 (Costa Rica).-Boucard, Proc. Zool. Soc. Lond., 1878, 61 (San Carlos, Costa Rica).-Zeledón, Anal. Mus. Nac. Costa Rica, i, 1887, 115 (Rio Súcio, Costa Rica).

$a$ I have not seen $M$. collaris (Pelzeln), the type of the genus, and the above generic description is drawn up from $M$. cinereiventris and its subspecies semitorquatus.

$b$ Thirteen specimens.

c Ten specimens, from Costa Rica.

\begin{tabular}{|c|c|c|c|c|c|}
\hline Locality. & Wing. & Tail. & $\begin{array}{l}\text { Cul- } \\
\text { men. }\end{array}$ & $\begin{array}{l}\text { Tar- } \\
\text { sus. }\end{array}$ & $\begin{array}{c}\text { Middle } \\
\text { toe. }\end{array}$ \\
\hline MALES. & & & & & \\
\hline Ten adult males from Costa Rica.. & 53.9 & 27.6 & 18.1 & 23.7 & 13.6 \\
\hline Two adult males from western Panamá (Chiriquí).. & 53.7 & 28.7 & 18.5 & 23 & 13 \\
\hline One adult male from eastern Panamá (line of railway) & 54 & 26.5 & & 22.5 & 14 \\
\hline
\end{tabular}


[Ramphocænus] semitorquatus Sclater and Salvin, Nom. Av. Neotr., 1873, 73.

Rhamphocænus semitorquatus Sclater, Ibis, 1883, 96 (Veragua, Panama; Antioquia, Colombia; crit.); Cat. Birds Brit. Mus., xv, 1890, 262 (Veragua; Antioquia).--Salvin and Godman, Biol. Centr.-Am., Aves, ii, 1892, 219 (La Balsa, Rio Sucio, and San Carlos, Costa Rica; Santiago de Veragua, Calovevora, and Lion Hill, Panama; Colombia).-Bangs, Proc. New Engl. Zool. Club, iii, 1902, 42 (Volcan de Chiriquí, Panama, 1,000-2,000 ft.).Carriker, Ann. Carnegie Mus., vi, 1910, 612 (Caribbean lowlands to 1,500 ft., Costa Rica; habits).

[Rhamphocænus] semitorquatus SHARPE, Hand-list, iii, 1901, 28.

(?)Rhamphocænus cinereiveniris (not of Sclater?) Sclater and Salvin, Proc. Zool. Soc. Lond., 1879, 525 (Antioquia, Colombia; crit.).

\section{Genus CERCOMACRA Sclater.}

Cercomacra Sclater, Proc. Zool. Soc. Lond., 1858, 244. (Type, Myrmothera cærulescens Vieillot.)

Medium-sized Formicariidæ (length about 120-135 mm.) with 10 rectrices, distinct rictal bristles, and color plain gray or blackish with concealed white dorsal patch and narrow white tips to wingcoverts (sometimes with broad white tips to lateral rectrices), the adult female of some species brown above, tawny or ochraceous below.

Bill shorter than head, morlerately stout, rather broad and depressed basally, its width at frontal antiæ much greater than its depth at same point and equal to at least half the distance from nostril to tip of maxilla; culmen distinctly ridged, straight basally, gently decurved for about terminal half, the tip of maxilla distinctly but not conspicuously uncinate; maxillary tomium nearly straight, minutely notched subterminally; mandibular tomium nearly straight, minutely (very indistinctly) notched subterminally; gonys faintly convex (more decidedly so basally), moderately ascending terminally. Nostril exposed, posteriorly in contact with feathering of laterofrontal antiæ, small, broadly oval, margined above and posteriorly by very narrow membrane, with an internal tubercle showing within posterior portion. Rictal bristles distinct; feathers of chin and malar apex with distinct terminal setæ. Wing moderate, with longest primaries distinctly longer than secondaries; sixth, fifth and fourth, or fourth and fifth primaries longest, the tenth (outermost) one-half to nearly three-fifths as long as the longest, the eighth about as long as secondaries. Tail as long as wing or a little shorter, graduated (grarluation about equal to length of tarsus), the rectrices (10) broad, rounded terminally. Tarsus much longer than whole culmen (a little more than one-third as long as wing), slender, the acrotarsium rather distinctly scutellate, the planta tarsi completely fused; middle toe, with claw, much shorter than tarsus (about as long as exposed culmen); outer toe, without claw, reaching to beyond middle of subterminal phalanx of middle toe, the inner toe 
decidedly shorter; hallux about as long as inner toe but much stouter; basial phalanx of middle toe mnited to outer toe for most of its length, to immer toe by about half its length (or less); claws moderate or rather weak, that of the hallux decidedly shorter than its digit. Plumage full and blended, that of rump and flanks more elongated and lix; feather's of pileum not elongated.

Coloration.-Plain gray, slate color, or blackish, the back with a concealed patch of white, the wing-coverts narrowly tipped with white (lateral rectrices sometimes broadly tipped with white); adult females of some species similar but throat streaked with white, of others brown above, tawny or ochraceous below.

Nidification.-Nest (of $C$. nigricans) composed of dry grasses, placed in fork of a low bush. Eggrs mahogany color, mottled with darker shades of the same color. ${ }^{a}$

Range.-Southern Mexico to Cayenne, southeastern Brazil, and Peru. (About 10 species.) ${ }^{b}$

KEY TO THE SPECIES AND SUBSPECIES OF CERCOMACRA.

a. General color black or slaty.

b. Lateral rectrices broadly tipped with white. (Cercomacra nigricans.)

c. General color deep black, the throat without white streaks. (Eastern Panama to Tenezuela, Trinidád, and western Ecuadór.)

Cercomacra nigricans, adult male (p. 91).

cc. General color blackish slate (more blackish beneath), the throat streaked with white................ Cercomacra nigricans, adult female (p. 92).

bb. Lateral rectrices very narrowly if at all tipped with whitish. (Cercomacra tyrannina.)

c. Paler (slate color above, slate-gray below). (Eastern Pauamá to British Guiana, western Ecuadór, etc.)

Cercomacra tyrannina tyrannina, adult male (p. 93).

cc. Darker (slate-blackish above, slate color or blackish slate below). (Western Panamá to southeastern Mexico.)

Cercomacra tyrannina crepera, adult male (p. 95).

aa. General color olive-brownish above, tawny below.

b. Paler... . . . . . . . . . . . Cercomacra tyrannina tyrannina, adult female (p. 93). bb. Darker................. . Cercomacra tyrannina crepera, adult female (p. 96).

\section{CERCOMACRA NIGRICANS Sclater.}

BLACK TYRANNINE ANTBIRD.

Adult male.-Uniform deep black, relieved by white tips to wingcoverts (anterior half of lesser covert area wholly white), broad white edging to outermost feather of alula, and broad white tips to rectrices (except middle pair); feathers of back extensively white beneath surface; under wing-coverts uniform black for anterior half or more, white for posterior portion; inner webs of remiges broadly edged (except terminally) with white; bill black; iris dark brown; legs and

$a$ Sclater and Salvin, Proc. Zool. Soc. Lond., 1879, 526.

$b$ Some of these doubtless only subspecies. 
feet dusky (bluish gray or grayish blue in life); length (skins), 132-160 (148); wing, 61.5-71.5 (67.8); tail, 62.5-71 (67.1); culmen; 15.5-19 (17.4); tarsus, 22-24.5 (23.5); middle toe, $12-15$ (13.4) ${ }^{a}$

Immature male. - Similar to the adult male but black less intense (more or less tinged with slate color), throat broadly streaked with whitish, and (sometimes) chest and breast very narrowly streaked with white; mandible pale horn color (in dried skins).

Adult female.-Above plain slate color, the wings and tail marked with white, as in adult male; chin and throat mixed black and white; chest (except laterally) slate-black; breast (except laterally) black, irregularly streaked or otherwise marked with white; rest of underparts (including sides of chest and breast), plain slate-gray, tinged with olive posteriorly; maxilla brownish black with paler tomia; mandible dull whitish (in dried skin); legs and feet horn color (bluish gray in life?); length (skin), 132-145 (138); wing, 60.5-63 (61.6); tail, 52.5-64 (60); culmen, 16-17 (16.5); tarsus, 22-24 (22.8); middle toe, $12-14(13.1) .^{b}$

Eastern Panamá (Lion Hill; Paraiso Station; Panamá; Sabana de Panamá; San Miguél Island), through Colombia (Remédios, Antioquía; Santa Marta; Bucaramanga; Bogotá; Rio Cauca) to western Ecuadór (Babahoyo; Esmeraldas; Balzár Mountains; Pambilár; Chimbo), Venezuela (Altagracia) and Trinidád.

Cercomacra nigricans Sclater, Proc. Zool. Soc. Lond., 1858, 245 (Santa Marta, Colombia; coll. P. L. Sclater); Cat. Am. Birds, 1862, 184 (Bogotá and Santa Marta, Colombia; Babahoyo, Ecuadór); Cat. Birds Brit. Mus., xv, 1890, 267 (Paraiso Station, Panamá; Santa Marta, Remédios, Bogotá, and Bucaramanga, Colombia; Balzár Mts. Santa Rita, Babahoyo, and Esmeraldas, w. Ecuadór).-Sclater and Salvin, Proc. Zool. Soc. Lond., 1879, 526 (Antioquía, Colombia).-Berlepsch, Journ. für Orn., 1884, 308 (Bucaramanga, Colombia).--Taczanowsí and Berlepsch, Proc. Zool. Soc. Lond., 1885, 100 (Ecuadór).-Salvin and Godman, Biol. Centr.-Am., Aves, ii, 1892, 215 (Lion Hill and Paraiso Station, Panamá; Ecuadór; Venezuela; Trinidád; etc.).-Berlepsch and Hartert, Novit. Zool., ix, 1892, 76 (Altagracia, Venezuela; crit.), 612 (Pambilár, n. w. Ecuadór).-Thayer and Bangs,

$a$ Seventeen specimens.

b Ten specimens.

\begin{tabular}{|c|c|c|c|c|c|}
\hline Locality. & Wing. & Tail. & $\begin{array}{l}\text { Cul- } \\
\text { men. }\end{array}$ & $\begin{array}{l}\text { Tar- } \\
\text { sus. }\end{array}$ & $\begin{array}{c}\text { Middle } \\
\text { toe. }\end{array}$ \\
\hline MALES. & & & & & \\
\hline Seven ąult males from eastern Panamá (mainland).......... & 66.6 & 05.9 & 17.4 & 23.3 & 13.5 \\
\hline Seven adult males from San Miguél Island, Panama.. . & 68.4 & 68 & 17.7 & 23.4 & 13.1 \\
\hline $\begin{array}{l}\text { Three adult males from Colombia........................... } \\
\text { FEMALES. }\end{array}$ & 70 & 67.7 & 16.8 & 24 & 13.8 \\
\hline Two adult females from eastern Panamá (mainland)......... & 61.2 & 60 & 17 & 23.5 & 13.7 \\
\hline Seven adult females from San Miguél Island............... & 61.9 & 61.1 & 16.4 & 22.6 & 13 \\
\hline One adult female from western Ecuador . ................. & 60.5 & 52.5 & 16.5 & $\cdots$ & \\
\hline
\end{tabular}


Bull. Mus. Comp. Zool., xlvi, 1905, 150 (San Miguél T., Bay of Panamá); xlvi, 1906, 217 (Sabana de Panamá).

[Ceremacra] nigricans Schater and S.uprin, Nom. Av. Neotr., 1873, 73.-Sunrpe, Hand-list, iii, 1901, 29 (Panamá to Ecuadór).

Pymiglena maculicaudis Sclater, Proc. Zool. Soc. Lond., 1S58, 66, 247 (Trinidúd; coll. P. L. Sclater); Cat. An. Birds, 1862, I85 (do.).-Lawrence, Ann. Lyc. N. Y., vii, 1862, 325 (Lion Hill, Panamí).-Schater and Salvin, Proc. Zool. Soc. Lond., 1861, 356 (Lion IIill; crit.).

[Coromacra] maculicaudis Schater and Salvin, Nom. Av. Neotr., 1S73, 73.

Corcomacra macnlicaudis Sclater. Cat. B. Brit. Mus., xv, 1890, 268 (Paraiso Station and Panamá, Panamá; Bogotá; Trinidád).-Hantert, Novit. Zool., v, 1S98, 492 (Chimbo, 1,000 ft., n. w. Ecuadór; crit.).-Bangs, $\Lambda u k$, xviii, 1901, 30 (San Miguel I., Bay of Panama).

Corcomacra maculicauda B.Angs, Proc. New Engl. Zool. Club, ii, 1900, 24 (Loma del Lcón, Panamá).

Cercomacra maculosa Schater, Proc. Zool. Soc. Lond., 1S60, 279 (Babahoyo, w. Ecuadór: coll. P. L. Sclater); Cat. Am. Birds, 1862, 184.

\section{CERCOMACRA TYRANNINA TYRANNINA (Sclater).}

TYRANNINE ANTBIRD.

Adult mate.-Above plain slate color, sometimes tinged, more or less, with olive on rump and upper tail-coverts, the feathers of interscapular region darker centrally and extensively white basally; interior portion of lesser wing-covert area white, the remaining lesser coverts, together with middle and greater coverts, narrowly tipped or terminally margined with white, the alulæ (sometimes outermost primaries also) edged with white; rectrices (except middle pair) usually narrowly tipped with white, this preceded by an indistinct bar or area of dusky; under parts plain slate-gray, sometimes tinged with olive posteriorly; under wing-coverts yellowish white, spotted or mottled with dusky on carpal region; inner webs of remiges broadly edged with yellowish white; bill brownish black or blackish brown; iris brown; legs and feet horn color or dusky (bluish gray or grayish

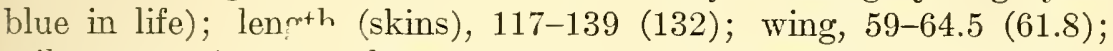
tail, 52.5-59 (56.2); culmen, 15.5-17.5 (16.4); tarsus, 21.5-23 (22.6); middle toe, $12.5-13(12.9) .^{a}$

Adult female.-Above plain light olive to grayish olive, the tail browner (sepia), the wings also browner, with outer primaries edged with pale clay color or olive-buff, the wing-coverts (in part, at least) more or less distinctly margined terminally or narrowly tipped with the same or pale fulvous; under parts, including sides of head, plain ochraceous or tawny ochraceous, strongly tinged with olive on flanks, the auricular region also tinged or clouded with olive and with very narrow and indistinct shaft-streaks of paler ochraceous; maxilla dusky brown with paler tomium, mandible dull whitish (in dried skins); legs 
and feet brownish or horn color (in dried skins); length (skins), 125-141 (131); wing, 57-61 (59.2) tail, 50-60 (54.7); culmen, $15.5-17$ (16.3): tarsus, $21.5-23$ (21.9); middle toe, $11.5-13(12 . \bar{t}) .^{a}$

Immature male. - Similar to the adult female but ochraceous of under parts more or less intermixed, especially on anterior portions, with slate-grar, and anterior upper parts more grayish.

Eastern Panamá (Lion Hill; Chepo; Panamá; Sabana de Panamá; Cascajál, Coclé; Rio Lara), and southward through Colombia (Bogotá; Rio Cauca: Remédios, Antioquía; Bucaramanga), Venezuela (Munduapo; Maripa; Suapuré; La Union, Caura; Bichaco), British Guiana (Roraima: Camacusa; Bartica Grore; Takutu Rirer), Ecuadór (Esmeraldas; Babahoyo; Chimbo; Yaguachi; San Jariér; Pambilár; Foreste del Rio Peripa), to Peru (Roparbamba; Huambo; Chirimoto) and northern Brazil (Rio Negro; Pará; Obidos).

Pyriglena tyrannina Sclater, Proc. Zool. Soc. Lond., 1855, 90, 147, pl. 98 (Bogotá, Colombia; coll. Brit. Mus.).

Cercomacra tyrannina Sclater, Proc. Zool. Soc. Lond., 1Săs, 24ว̃ (monogr.; Bogotá); 1860, 294 (Esmeraldas, ஈ. Ecuadór; crit.); Cat. Am. Birds, 1862, 1S4, part (Bogotá, Colombia; Esmeraldas, w. Ecuadór); Cat. Birds Brit. Mus., xr, 1890, 184, part (Lion Hill, Paraiso, Chepo, and Panamá, Panamá; Esmeraldas, Ecuadór; Roraima, Camacusa, Bartica Grote, and Takutu R., Brit. Guiana; Rio Negro and Pará, Brazil).-Sclater and SAltix, Proc. Zool. Soc. Lond., 1564, 3556 (Panamá; crit.); 1Sॅ9, 526 (Remédios, Antioquía; Colombia; descr. nest and eggs).-Pelzelx, Orn. Bras., ii, Abth., 1869, 81.Lafard, Tbis, 1873, 387 (Pará, Brazil; food).--TAczAxowski, Proc. Zool. Soc. Lond., 1874, 530 (Ropaybamba, centr. Peru); 1882, 31 (Huambo and Chirimoto, n. e. Peru); Orn. du Pérou, ii, 18S4, 54.-Salvir, Proc. Zool. Soc. Lond., 18\$3, 424 (Panamá); 18S5, 427 (Bartica Grove, Camacusa, and Roraima, 3,000 ft., Brit. Guiana).-Berlepsch and Tacza.jowsin, Proc. Zool. Soc. Lond., 1883, 565 (Chimbo, ஈ. Ecuadór; crit.).-BERLePscH, Journ. für Orn., 1SSt, 308 (Bucaramanga, Colombia; crit.).-TACZATowski and BerLePsch, Proc. Zool. Soc. Lond., 18s5, 68 (Chimbo, w. Ecuadór), 100 (Yaguachi, Ecuadór).-SAlfadori and Festa, Boll. Mus. Zool., etc., Torino, xiv, 1899, no. 339. - (Rio Lara, Panamá; crit.); xv, 1899, no. 362, 30 (Foreste del Rio

$a$ Eleren specimens.

\begin{tabular}{|c|c|c|c|c|c|}
\hline Locality. & Wing. & Tail. & $\begin{array}{l}\text { Cul- } \\
\text { men. }\end{array}$ & $\begin{array}{l}\text { Tar- } \\
\text { sus. }\end{array}$ & $\begin{array}{l}\text { Middle } \\
\text { toe. }\end{array}$ \\
\hline MALES. & & & & & \\
\hline Seven adult males from eastern Panamá. & 62.3 & 55.6 & 16 & 22.5 & 12.9 \\
\hline $\begin{array}{l}\text { Two adult males from Venezuela......... } \\
\text { FEMales. }\end{array}$ & 60 & 58.3 & 17.5 & 22.7 & 13 \\
\hline Five adult females from eastern Panamá. & 59.6 & 51.9 & 16.1 & 22.2 & 12.6 \\
\hline Six adult females from Venezuela........ & 58.9 & $5 \overline{1}$ & $16 . j$ & 21.7 & 12.7 \\
\hline
\end{tabular}


Peripa, w. Ecuador; crit.).-Salvin and Godman, Biol. Centr.-Am., Aves, ii, 1892, 214, part (Lion Hill, Panama, and Chepo, Panama; Colombia; Ecuador; Peru; Guiana).-Bangs, Proc. New Engl. Zool. Club, ii, 1900, 23 (Loma del Leon, Panama).--Hartert, Novit. Zool., ix, 1902, 612 (San Javier and Pambilár, n. w. Ecuador; crit.).-Berlepsch and Hartert, Novit. Zool., ix, 1902, 76 (Munduapo, etc., Venezuela).-Heldmayr, Novit. Zool., xii, 1905, 286 (near Pará, Brazil; crit.); xiii, 1906, 370 (Prata, near Pará); xiv, 1907, 32 (Obidos, Brazil; crit.).--Thayer and Bangs, Bull. Mus. Comp. Zool., xlvi, 1906, 217 (Sabana de Panama).

[Cercomacra] tyrannina Pelzeln, Orn. Bras., iv, Abth., 1870, 419.-Sclater and Salvin, Nom. Av. Neotr., 1873, 73, part.-Sharpe, Hand-list, iii, 1901, 28, part (Panama; Colombia; Ecuador; Guiana; Amazonia).

Hypocnemis schistacea (not of Sclater) Lawrence, Ann. Lyc. N. Y., vii, 1862, 325 (Lion Hill, Panama).

Disythamnus rufiventris Lawrence, Ann. Lyc. Nat. Hist. N. Y., viii, 1867, 131 (Lion IIill, Panama; coll. G. N. Lawrence; =young male; see Salvin, Ibis, 1874, 316).

\section{CERCOMACRA TYRANNINA CREPERA (Bangs).}

\section{DUSKY TYRANNINE ANTBIRD.}

Similar to C.t. tyrannina but adult male with coloration averaging much darker, the general color of upper parts blackish slate to slateblack, under parts slate color to blackish slate; adult female and, young male not always distinguishable from those of $C$. t. tyrannina, but usually with color of upper parts darker and more brownish olive, the under parts decidedly deeper tawny. ${ }^{a}$

Adult male.-Length (skins), 124-148 (137); wing, 60-67 (63.4); tail, 54.5-62.5 (57.2); culmen, 15-18 (16.6); tarsus, 21.5-24 (22.9); middle toe, $12.5-14(13.5){ }^{b}$

a There is much variation in intensity of coloration among specimens from Costa Rica and northward. As a rule, specimens from the Caribbean slope are much darker than those from the Pacific side, and were the differences strictly geographical two well-marked forms could easily be made out; but unfortunately both slate-colored and blackish examples sometimes occur in the same locality, as in eastern Nicaragua (Rio Escondido), Honduras (Rio Blanco and San Pedro Sula), while extreme dark specimens come from Bebedero, northwestern Costa Rica, and light colored ones from British Honduras. A large majority of the specimens from southwestern Costa Rica are so light colored that they could almost be referred to true C. tyrannina; but much darker ones occasionally occur there also. Specimens from Venezuela agree exactly with those from Bogotá and Panamá; but two adult males from Reyes and Mapiri, Bolivia, respectively, are quite as dark as the darkest examples of C. $t$. crepera. On the whole, I consider our present understanding of this species, with reference to its geographic variations, far from satisfactory.

$b$ Forty-four specimens. 
Adult female.-Length (skins), 123-148 (134); wing, 57-63 (60); tail, 51-64 (57.4); culmen, 14-17 (15.9); tarsus, 20.5-23.5 (22.4); middle toe, $12.5-14$ (13.2). ${ }^{a}$

Southeastern Mexico, in States of Vera Cruz (Playa Vicente; Sochiapa; Santa Lucrécia; Buena Vista), Tabasco ('I'eapa), and Chiapas (Palenque), and southward through Guatemala (Cobán; Choctúm; sources of Rio de la Pasión; Yzabál; Los Amates, Yzabál; Telemán; Chiséc), British Honduras (Belize; near Manatee Lagoon), Honduras (Omoa; San Pedro; San Pedro Sula; Rio Blanco; La Bomba), Nicaragua (Matagalpa; Los Sábalos; Greytown; Rio Escondido; Sucuyá; San Emilis; 4 leagues south of Lake Manágua) and Costa Rica (Tucurríqui; Pacuare; San Carlos; Jiménez; El Hogár; Guácimo; Guápiles; Carrillo; Turrialba; Guayabo; Angostura; Juan Viñas; Rio Sícsola; Talamanca; Naranjo de Cartago; Pozo Azúl de Pirrís; Pozo del Rio Grande; Pozo de Térraba; Térraba; Buenos Aires; Boruca; Barranco, Boruca; Tenório; El Generál; Pigres; Lagarto; Bebedero; Miravalles; La Vijágua; Cerro Santa Maria) to western Panamá (Santa Fé de Verágua; Divala; Bugaba; Mina de Chorcha).

Cercomacra tyrannina (not Pyriglena tyrannina Sclater) Sclater, Proc. Zool. Soc. Lond., 1859, 383 (Playa Vicente, Vera Cruz); Cat. Am. Birds, 1862, 184, part (Choctúm, Guatemala; Omoa, Honduras); Cat. Birds Brit. Mus., xv, 1890, 265, part (Chiséc, Choctúm, and sources of Rio de la Pasión, Guatemala; Omoa, Honduras; Tucurríqui, Costa Rica; Santa Fé, Bugaba, and Mina de Chorcha, w. Panamá).-Moore, Proc. Zool. Soc. Lond., 1859, 55 (Belize, Brit. Honduras; crit.).-Sclater and Salvin, Ibis, 1859, 119

a Thirty-nine specimens.

\begin{tabular}{|c|c|c|c|c|c|}
\hline Locality. & Wing. & Tail. & $\begin{array}{l}\text { Cul- } \\
\text { men. }\end{array}$ & $\begin{array}{l}\text { Tar- } \\
\text { sus. }\end{array}$ & $\begin{array}{c}\text { Middle } \\
\text { toe. }\end{array}$ \\
\hline MALES. & & & & & \\
\hline Three adult males from southeastern Mexico (Vera Cruz). & 63.5 & 60.5 & 16 & 22.5 & 12.8 \\
\hline Ten adult males from Guatemala.................. & 63.7 & 59 & 16.9 & 22.7 & 13.2 \\
\hline Five adult males from Honduras......... & 63.1 & 60.5 & 17.2 & 23 & 13.4 \\
\hline Four adult males from eastern Nicaragua............ & 62.4 & 58.6 & 16.7 & 23 & 13.2 \\
\hline One adult male from western Nicaragua..... & 63 & 58.5 & 17.5 & 22.5 & 13.5 \\
\hline One adult male from British Honduras....... & 63 & 55.5 & ..... & ...... & 14 \\
\hline Ten adult males from eastern Costa Rica....... & 63.3 & 56. 8 & 16.2 & 23.3 & 13.8 \\
\hline Ten adult males from western Costa Rica..... & 63.4 & 58.4 & 16.4 & 23.2 & 13.7 \\
\hline FEMALES. & & & & & \\
\hline Two adult females from southeastern Mexico..... & 61 & 55 & 16 & 21.3 & 13 \\
\hline Nine adult females from Guatemala........... & 60.4 & 60.8 & 16.2 & 22.3 & 13.1 \\
\hline Three adult females from British Honduras... & 59 & 60.8 & 15 & 22.5 & 13.2 \\
\hline Three adult females from Honduras............ & 61.2 & 55.5 & 16.8 & 23 & 13 \\
\hline One adult female from eastern Nicaragua..... & 57.5 & 52.5 & 17 & 22 & 13 \\
\hline One adult female from western Nicaragua.......... & 58 & 53.5 & 16 & 22.5 & 13 \\
\hline Ten adult females from eastern Costa Rica.............. & 60.2 & 56.4 & 15.6 & 22.8 & 13.4 \\
\hline Ten adult fomales from western Costa Rica......... & 59.6 & 56 & 14.2 & 22.3 & 13.2 \\
\hline
\end{tabular}


(Cobán, Guatemala; Belize); Proe. Zool. Soe. Lond., 1870, 837 (San Pedro, Monduras).-Salvin and Sclatek, Ibis, 1860, 36 (Yzabál, Guatemala).Salvin, Proc. Zool. Soc. Lond., 1867, 145 (Santa Fé de Verágul, w. Panamá); 1870, 195 (Mina de Chorcha and Bugaba, w. Panamá). -Lawrence, Ann. Ixyc. N. Y., ix, 1868, 109 (Angostura, Cosia Rica).-Frantzius, Journ. für Orn., 1869, 305 (Costa Rica).-Boucard, Proc. Zool. Soc. Lond., 1878, 61 (San Carlos, Costa Rica); Ann. Soc. Limn. Lyon, 1878, 39 (Guatcmila).Nutrixg, Proc. U. S. Nat. Mus., vi, 1883, 386 (Sucuyá, Nicaragua), 405 (Los Sábalos, Nicaragua).-Zeuedón, Anal. Mus. Nac. Costa Rica, i, 1887, 115 (Pacuare, Jiménez, and Pozo Azúl, Costa Rica).-Salvin and Godman, Biol. Centr.-Am., Ares, ii, 1892, 214, part (Playa Vicente and Sochiapa, Vera Cruz; Belize, Brit. Honduras; Chiséc, etc., Guatemala; San Pedro, Honcluras; Matagalpa, etc., Nicaragua; Tucurríqui, etc., Costa Rica; Bugaba, Miua de Chorcha, and Santa Fé de Verágua, Panamá).-Richmond, Proc. U. S. Nat. Mus., xvi, 1893, 501 (Rio Escondido, Nicaragua; habits).Chenrie, Expl. Zool. Merid. Costa Rica, 1893, 42 (Lagarto, Boruca, Térraba, and Buenos Aires, s. W. Costa Rica).-Underwood, Ibis, 1896, 440 (Volcan de Miravalles, Costa Rica).

[Cercomacra] tyrannina Sclater and Salvin, Nom. Av. Neotr., 1873, 73, part.Sharpe, Hand-list, iii, 1901, 28, part.

Cercomacra tyrannina tyrannina Carriker, Ann. Carnegie Mus., v, no. 1, Oct. 1, 1908, 9, in text (s. w. Costa Rica).

Cercomacra crepera Bangs, Auk, xviii, Oct., 1901, 365 (Divala, Chiriquí, Panamá; coll. E. A. and O. Bangs).-Dearborn, Pub. 125, Field Mus. Nat. Hist., 1907, 109 (Los Amates, e. Guatemala; crit.).

Cercomacra tyrannina crepera Bangs, Auk, xxiv, 1907, 296 (Boruca, Paso Reál, Pozo del Rio Grande, and Barranca, s. w. Costa Rica).-Carriker, Ann. Carnegie Mius., v, 1908, \& (e. Costa Rica; crit.); vi, 1910, 612 (Costa Rica; crit.; habits).-Ferry, Pub. 146, Field Mus. N. H., orn. ser., i, no. 6, 1910, 271 (Guayabo, Costa Rica).

\section{Genus GYMNOCICHLA Sclater.}

Gymnocichla Sclater, Proc. Zool. Soc. Lond., 1858, 274. (Type, Myiothera nudiceps Cassin.)

Medium-sized Formicariidæ (length about 140-160 mm.) resembling the larger and stouter species of Myrmeciza, but with bill weaker, less compressed anteriorly and less strongly uncinate, the culmen less distinctly ridged; nostril smaller; relatively shorter tarsus (only two-fifths as long as wing), with acrotarsium distinctly scutellate; tail shorter (not more than four-fifths as long as wing), the adult males with loral and suborbital regions (sometimes whole pileum) naked.

Bill about as long as head, narrowly wedge-shaped in vertical profile (with nearly straight lateral outlines), its width at posterior end of nostrils about equal to its depth at same point and equal to a little less than half the distance from nostril to tip of maxilla; culmen slightly ridged, straight to near tip where abruptly decurved, the point of maxilla slightly or minutely uncinate; tomium straight, with small subterminal notch, that of the mandible less distinct; gonys

$81255^{\circ}-$ Bull. $50-11-7$ 
strongly convex and prominent basally, faintly convex and ascending terminally. Nostril exposed, small, longitudinally broadly oval, margined above by a narrow extension of the membraneous integument of nasal fossa, an internal tubercle showing conspicuously in posterior portion. No trace of rictal bristles, and feathers of chin without terminal setr. Wing moderate, very much rounded, but longest primaries extending decidedly beyond secondaries; sixth and seventh, fifth and sixth, or fourth, fifth, and sixth primaries longest, the tenth (outermost) between one-half and three-fifths as long as the longest, the eighth slightly longer, the ninth decidedly shorter, than secondaries. Tail about four-fifths as long as wing, much rounded (graduation not greater than length of culmen), the rectrices (12) broad, rounded terminally. Tarsus about two-fifths as long as wing, rather slender, the acrotarsium distinctly scutellate, the planta fused (sometimes indistinctly scutellate on outer side); middle toe, with claw, much shorter than tarsus, but decidedly longer than whole culmen; outer toe, without claw, reaching to or slightly beyond middle of subterminal phalanx of middle toe, the inner toe slightly shorter; hallux shorter than inner toe but much stouter; basal phalanx of middle toe wholly or for much the greater part united to outer toe, about half united to.inner toe; claws moderate in size and curvature, that of the hallux decidedly shorter than the digit. Plumage full and blended, that of rump and flanks more lengthened and lax; loral, rictal, and orbital regions-sometimes forehead and crown also-naked, the crown with sparse hair-like feathers or bristles.

Coloration.-Adult males uniform black, the wing-coverts (at least some of the lesser corerts) tipped with white, the back sometimes with a small concealed patch of white; adult females and young males brown above, tawny or rufescent below; bare skin of head light blue in life (in both sexes).

Range.-Honduras to Colombia. (Two species.)

KEY TO THE SPECIES AND SUBSPECIES OF GYMNOCICHLA.

a. General color black. (Males.)

b. Forehead, lores, and more or less of crown nude. (Adult males.)

c. Anterior margin of lesser wing-covert area mostly black; bill black. (Gymnocichla nudiceps.)

d. Deeper black, the posterior under parts black; smaller under wing-coverts mostly wholly black.

e. Smaller (averaging: wing 76.4, tail 57.7, culmen 20.6, tarsus 29.4). (Eastern Panamá and adjacent parts of northwestern Colombia.)

Gymnocichla nudiceps nudiceps, adult male (p. 99).

$e e$. Larger (averaging: wing 78.9, tail 61.7, culmen, 20.9, tarsus 30 ). (Northwestern Panamá and western Costa Rica.)

Gymnocichla nudiceps erratilis, adult male (p. 101). 
dd. Duller black, the posterior under parts blackish slate; smaller under wingcoverts broadly tipped with white. (Coast district of northeastern Colombia.)

Gymnocicha mudiceps sancta-martre, adult male (extralimital). ${ }^{a}$ cc. Anterior margin of lesser wing-covert area broadly white; bill whitish or light rellowish. (Eastern Costa Rica to eastern Guatemala.)

Gymnocichla chiroleuca, adult male (p. 101).

bb. Forehead, lores, and crown feathered. (Immature males.) $b$ $a$. General color brown above, deep tawny below. (Adult females.)

b. Wing-coverts brown, indistinctly tipped with rufous-tawny. (Gymnocichla nudiceps.)

c. Slightly paler and smaller (wing averaging 73.6, tail 55.4, culmen 19.7, tarsus

29.2) ............. Gymnocichla nudiceps nudiceps, adult female (p. 99).

cc. Slightly darker and larger (wing averaging 75.1, tail 59.3, culmen 19.9, tarsus

$29.4 \ldots . . . . . . .6$. Gymnocichla nudiceps erratilis, adult female (p. 101).c

$b b$. Wing-coverts blackish, broadly tipped with bright tawny.

Gymnocichla chiroleuca, adult female (p. 102).

\section{GYMNOCICHLA NUDICEPS NUDICEPS (Cassin).}

\section{BARE-CROWNED ANTBIRD.}

Adult male.-Uniform black, slightly duller on rump, upper tailcoverts, and posterior under parts, the latter inclining to slate-black; all the wing-coverts margined terminally with white, alulæ and outermost primary edged with white, and rectrices (except middle pair) narrowly tipped with white; smaller under wing-coverts uniform black, the under primary coverts slate color or slate-gray, broadly margined with white; inner webs of remiges broadly edged with pale gray or grayish white; naked skin of head bright light blue in life; bill black; iris brown; legs and feet horn color or dusky (bluish gray or grayish blue in life?) ; length (skins), 143-157 (152); wing, 73.5S0.5 (76.1); tail, 54-60 (57.1); culmen, 19.5-21.5 (20.6); tarsus, 2S.5-30.5 (29.6); middle toe, $18-20.5$ (18.9). ${ }^{d}$

Immature male $(=$ Myrmelastes corinus Lawrence and $M$. ceterus Bangs).- Similar to the adult male but whole pileum feathered (only the loral and orbital regions being naked) and greater wing-coverts wholly dark sooty brown or sooty black (without white tips).

Adult female.-Above plain olive-brown, russet-brown or mummy brown, the wings more rufescent (chestnut-brown), with tips of wingcoverts (rather broadly) deep cinnamon-rufous, rufous-chestnut or deep tawny; tail dark russet-brown or vandyke brown, the rectrices (except middle pair) sometimes (usually ?) narrowly tipped with pale

a Gymnocichla nudiceps sancta-martæ Ridgway, Proc. Biol. Soc. Wash., xxi, Oct. 20, 1908, 194 (Santa Marta, Colombia; coll. U. S. Nat. Mus.).

$b$ The different forms distinguished by same characters as those given for adult males $(c$ to $c c)$.

$c$ The adult female of $G$. nudiceps sancta-martæ not seen by me.

$d$ Eight specimens. 
rusty or whitish; interscapulars extensively white basally; under parts plain deep tawny or rufous-tawny to nearly chestnut, the color deepest on chest, palest on abdomen, the flanks tinged with olive; maxilla blackish, becoming more horn colored terminally; mandible horn color, paler (sometimes whitish) terminally; iris brown; legs and feet horn color (bluish gray or grayish blue in life); length (skins), 148-152 (150); wing, 72-76 (73.6); tail, 53.5-57 (55.4); culmen, 19-20.5 (19.7); tarsus, 28-30 (29.2); middle toe, 18-19.5 (18.8). ${ }^{a}$

Eastern Panamá (Loma del León; Panamá) and adjacent portion of northwestern Colombia (Rio Atrato).

Myiothera nudiceps Cassiv, Proc. Ac. Nat. Sci. Phila., 1850, 106, pl. 6 (Isthmus Panamá; coll. Acad. Nat. Sci. Phila.).

Pyriglena nudiceps Sclater, Proc. Zool. Soc. Lond., 1854, 113, part (Isthmus Panamá); 1857, 47, in text.

Gymnocichla nudiceps Sclater, Proc. Zool. Soc. Lond., 1858, 274 (monogr.); Cat. Birds Brit. Mus., xv, 1890, 272, part (Lion Hill; Panamá).-Lawrence, Ann. Lyc. N. Y., vii, 1862, 295 (Lion Hill; Panamá). - Sclater and Salvin, Proc. Zool. Soc. Lond., 1864, 356 (Lion Hill, crit.; descr. female).-SALvin and Godman, Biol. Centr.-Am., Aves, ii, 1892, 223, part (Lion Hill, Panamá).Bangs, Proc. New Engl. Zool. Club, ii, 1900, 24 (Lion Hill, Panamá).

[Gymnocichla] nudiceps Sclater and Salvin, Nom. Av. Neotr., 1873, 73, part.Sharpe, Hand-list, iii, 1901, 32, part.

G[ymnocichla] nudiceps nudiceps RiDGWAy, Proc. Biol. Soc. Wash., xxi, 1908, 194, in text.

Pithys rufigularis (not of Sclater, ex Turdus rufigula Boddaert) LaWRence, Ann. Lyc. N. Y., vii, 1862, 293 (Lion Hill, Panamá; =adult female).

Myrmeciza ferruginea Lawrence, Ann. Lyc. Nat. Hist. N. Y., vii, 1862, 470

(Lion Hill, Panamá; =adult female; see Sclater and Salvin, Proc. Zool. Soc. Lond., 1864, 356).

Myrmelastes corvinus (not Thamnophilus corvinus Gould) Lawrence, Ibis, v, April, 1863, 182 (Lion Hill, Panamá Railway; coll. G. N. Lawrence); Ann. Lyc. N. Y., viii, 1863, 485 (Lion Hill).

Myrmelastes lawrencii, part, Salvin and Godman, Biol. Centr.-Am., Aves, ii, 1892, 226, part (Lion Hill, Panamá).

$a$ Six specimens.

\begin{tabular}{|c|c|c|c|c|c|}
\hline Locality. & Wing. & Tail. & $\begin{array}{l}\text { Cul- } \\
\text { men. }\end{array}$ & $\begin{array}{l}\text { Tar- } \\
\text { sus. }\end{array}$ & $\begin{array}{c}\text { Middle } \\
\text { toe. }\end{array}$ \\
\hline MALES. & & & & & \\
\hline Eight adult males from eastern Panamá................ & 76.1 & 57.1 & 20.5 & 29.6 & 18.9 \\
\hline 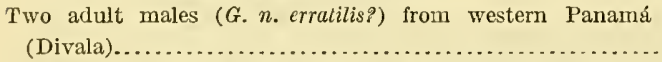 & 77.7 & 60.5 & 21.2 & 28.7 & 19 \\
\hline Ten adult males ( $G$. n. erratilis) from southwestern Costa Riea. & 78.9 & 61.7 & 20.9 & 30 & 19.4 \\
\hline $\begin{array}{l}\text { One adult male ( } G . n . \text { sanctæ-mart } \text { ) from Colombia.......... } \\
\text { FEMALES. }\end{array}$ & 81 & 60.5 & 21.5 & 30 & 18.5 \\
\hline Six adult females from eastern Panamá................. & 73.6 & 55.4 & 19.7 & 29.2 & 18.8 \\
\hline Ten adult females ( $G$. n. erratilis) from southwestern Costa Riea. & 75.1 & 59.3 & 19.9 & 29.4 & 18.9 \\
\hline One adult female ( $G$. n. sanct $x$-mart $x$ ) from Colombia.......... & 74 & 58 & 18.5 & 30.5 & 19.5 \\
\hline
\end{tabular}


Myrmelastes ceterus Bangs, Proc. New Engl. Zool. Club, ii, Sept. 20, 1900, 25 (Loma del I.cón, i. e., Lion Hill, Panamá; coll. E. A. and O. Bangs).

[. Hyrmelastes] cctorus Sirarpe, Uand-list, iii, 1901, 32.

\section{GYMNOCICHLA NUDICEPS ERRATILIS Bangs.}

\section{COSTA RICAN BARE-CROWNED ANTBIRD.}

Similar to $G$. n. mudiceps but areraging slightly larger, the adult female averaging more intense in coloration. ${ }^{a}$

Adult male.-Length (skins), 147-163.5 (153.5); wing, 75.5-S3 (7S.9); tail, 59.5-64.5 (61.7); exposed culmen, 20-22 (20.9); tarsus, $29.5-30.5$ (30): middle toe, 19-20 (19.4). ${ }^{b}$

Adult female.-Lengtl (slins), 137.5-153 (14S); wing, 72.5-77.5 (75.1); tail, 56-62 (59.3); exposed culmen, 19-21 (19.9); tarsus, 29-30 (29.4); middle toe, $18-19.5$ (1S.9). ${ }^{b}$

Southwestern Costa Rica (Boruca; Pozo del Rio Grande, Boruca; Térraba; Paso Reál de Térraba; Buenos Aires; El Generál; Pigres), and northwestern Panamá (Divala; ${ }^{c}$ Mina de Chorcha; Bugaba; (hitr'a)?

(?) Gymnocichla nudiceps (not Myiothera nudiceps Cassin?) Salvin, Proc. Zool. Soc. Lond., 1870, 195, part (Mina de Chorcha and Bugaba, Verígua, Panamá; crit.).-Sclater, Cat. Birds Brit. Mus., xv, 1890, 272, part (Mina de Chorcha, Bugaba, Chiriquí, and Chitra, Panamá).-Salvin and Goduan, Biol. Centr.Am., Ares, ii, 1892, 223, part (Chiriqui, Bugaba, Mina de Chorcha, and Chitra, Panamá).

Gymnocichla nudiceps (not Myiothera nudiceps Cassin) Cherrie, Expl. Zool. Merid. Costa Rica, 1593, 42 (Boruca, Térraba, and Buenos Aires, s. w. Costa Rica; crit.).

Gymnocichla nudiceps erratilis Bangs, Auk, xxiv, no. 3, July, 1907, 297 (Boruca, s. W. Costa Pica; coll. E. A. and O. Bangs).-Carriker, Ann. Carnegie Mus., vi, 1910, 620 (Costa Rica; crit.; habits).

\section{GYMNOCICHLA CHIROLEUCA Sclater and Salvin.}

BARE-FRONTED ANTBIRD.

Similar to G. nudiceps but adult male with bend of wing white and white tips to wing-coverts broader, much less of concealed white on back, and bill paler (plumbeous in life, whitish-at least terminally-in dried skins); adult female with wing-coverts very much darker, contrasting much more strongly with their tawny or rufescent tips.

Adult male.-General color uniform black; bend of wing, broad tips to all the wing-coverts, and broad edging to outermost feather of alula and outermost primary, white; feathers of anterior portion

$a$ The diffrence in coloration of temales is by no means constant, but the average difference is very obvious.

b Ten specimens.

$c$ Having only adult males from that locality, I am not able to determine whether specimens of this species from Divala belong to the present form or true G. nudiceps. No specimens from other localities in Chiriqui have been seen by me. 
of interscapular area with more or less of white at base; lateral rectrices sometimes narrowly tipped with white; bare skin of head pale blue (azure or campanula blue back of eyes); bill, tarsi, feet, and claws plumbeous; iris dark red; ${ }^{a}$ length (skins), 147-170 (160); wing, 76.5-81.5 (79) ; tail, 58-64 (60.9); culmen 20-23 (21.7); tarsus, 29-32 (31.1); middle toe, 18.5-20.5 (19.4). ${ }^{b}$

Immature male (= Myrmelastes lawrencii Salvin and Godman).Similar to the adult male but entire pileum feathered (only the loral and orbital regions being naked) and greater wing-coverts wholly black.

Adult female.-Pileum and hindneck rufescent brown (nearly mummy brown), somewhat more rufescent anteriorly and laterally; back, scapulars, and rump plain deep olive, the upper tail-coverts more rufescent; tail dark warm-sepia brown; lesser wing-coverts and margin of wing deep tawny-ochraceous, the former with concealed base of feathers dusky; middle coverts black, broadly and sharply tipped with tawny-ochraceous; greater coverts bistre brown, passing into black subterminally, their tips sharply and rather broadly tawnyochraceous; remiges russet-brown or vandyke brown, the edges of outermost primaries lighter (more russet); sides of head and neck and general color of under parts, including under wing-coverts, plain bright cinnamon-rufous or rufous-tawny, somewhat paler on abdomen and passing into olive-tawny on flanks and under tail-coverts; "naked skin of head pale blue (azure back of eye); bill, tarsi, feet, and claws plumbeous; iris dark red;" c length (skins), 151-163 (156); wing, 71-79 (75.9); tail, 59-60.5 (59.4); culmen, 19.5-21.5 (21.1); tarsus, 28.5-30.5 (29.6); middle toe, 19-19.5 (19.1). ${ }^{d}$

Young male.-Similar to the adult female, but pileum and hindneck duller and less rufescent brown, middle and greater wing-coverts without ochraceous or tawny tips, and the tawny-ochraceous which

$a$ C. W. Richmond.

$b$ Ten specimens.

$c$ C. W. Richmond, manuscript.

$d$ Six specimens.

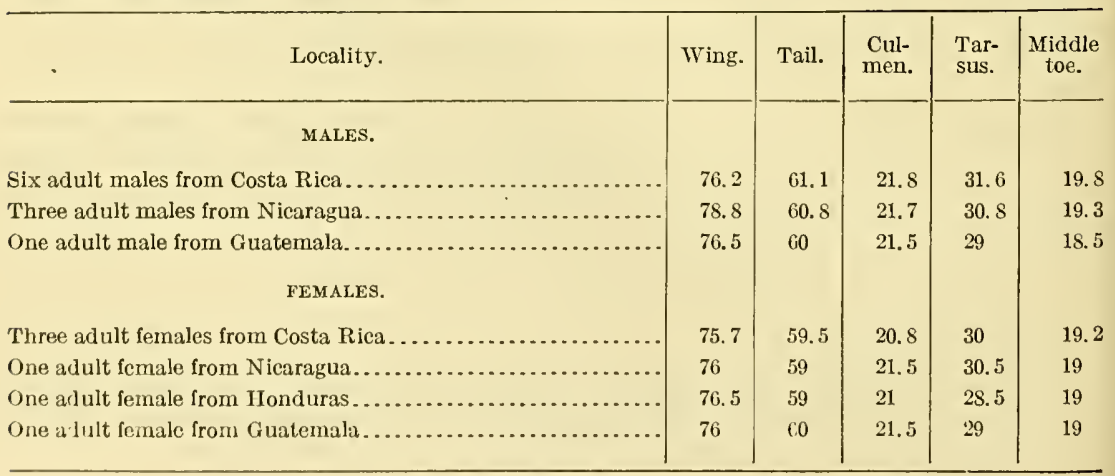


covers solidly the exposed surface of lesser wing-covert area paler. (Older specimens slowing admixture of black, according to age.)

Immature female.-Similar to the immature male.

Northwestern Panamá (Mina de Chorcha, Chiriquí); eastern Costa Rica (Tucurríqui; Jiménez; “San José;” El Mogár; Cuábre; Guápiles; Rio Sícsola ; La Cristina; Talamanca), through Nicarngua (Matagalpa; Rio Escondido; San Emilis, Lake Nicaragua) and Honduras (Omoa; Sinta Ana) to Guatemala (Los Amates, Yzabál).

Gymnocichla mudiceps (not Myiothera nudiceps Cassin) Moore, Proc. Zool. Soc. Lond., 1859, 55 (Omoa, Honduras; habits).-Sclater and Salvin, Proc. Zool. Soc. Lond., 1859, 119 (Omoa).-Lawrence, Ann. Lyc. N. Y., ix, 1S68, 109 (Tucurríqui, Costa Rica).-Frantzius, Journ. für Orn., 1869, 305 (Costa Rica).

Gymnocichla chiroleuca Schater and Salvin, Proc. Zool. Soc. Lond., 1869, 417 (Tucurríqui, Costa Rica; coll. Salvin and Godman).-Sclater, Cat. Birds Brit. Mus., xv, 1890, 272 (Tucurríqui, Costa Rica; Honduras).-Ridgwar, Proc. U. S. Nat. Mus., xiv, 1891, 469 (Santa Ana, Honduras; descr. female and young male).-Salvin and Godman, Biol. Centr.-Am., Aves, ii, 1892, 224.-Richmond, Proc. U. S. Nat. Mus., xvi, 1893, 501 (Rio Escondido, Nicaragua; habits, notes, etc.).-Dearborn, Pub. 125, Field Mus. Nat. Hist., 1907, 109 (Los Amates, Guatemala).

G[ymnocichla $]$ chiroleuca SaLvin, Ibis, 1869, 314, 318.

[Gymnocichla] chiroleuca Sclater and Salvin, Nom. Av. Neotr., 1873, 73.Sharpe, Hand-list, iii, 1901, 32.

Gymnocichla cheiroleuca Carriker, Ann. Camegie Mus., vi, 1910, 621 (Caribbean lowlands to about 1,000 ft., Costa Rica; habits).

Myrmelastes lawrencii Salvin and Godman, Biol. Centr.-Am., Aves, ii, sig. 29, March, 1892, 226 (Mina de Chorcha, Chiriquí, Panamá; coll. Salvin and Godman).

Myrmelastes lawrencei Richuond, Proc. U. S. Nat. Mus., xvi, 1893, 502 (Rio Escondido, Nicaragua).

[Myrmelastes] lawrencei Sharpe, Hand-list, iii, 1901, 32.

\section{Genus MYRMECIZA Gray.}

Myrmeciza Gray, List Gen. Birds, 1841, 34. (Type, Myrmothera longipes Vieillot.) Myrmonax a CABANIs, in Wiegmann's Archiv für Naturg., xiii, pt. i, 1847, 210. (Type, Myrmothera longipes Vieillot.)

Myrmelastes Sclater, Proc. Zool. Soc. Lond., 185S, 274. (Type, Mr. plumbeus Sclater.)

Medium-sized Formicariidæ (length about 130-165 mm.) resembling Gymnocichla but loral and suborbital regions feathered (only the postocular and rictal regions naked), tail relatively shorter (twothirds to three-fourths, instead of four-fifths, as long as wing), the adult males not black (or else without white tips to wing-coverts).

Bill shorter than head, rather slender to moderately stout, its width at frontal antiæ equal to or slightly greater than its depth at same point and equal to nearly if not quite half the distance from nostril to tip of maxilla; culmen distinctly (sometimes rather sharply) 
ridged, straight or nearly so for basal half or more, then gradually more and more decurved to the distinctly uncinate tip of maxilla; tomia nearly straight, minutely but distinctly notched subterminally (more slightly so on mandibular tomium); gonys distinctly convex and prominent basally, gently convex or nearly straight and ascending terminally, the tip of mandible forming a minute slightly recurved point. Nostril exposed, separated more or less widely from feathering of latero-frontal antiæ, longitudinally oval, with an internal tubercle showing distinctly within posterior portion, margined above by a more or less broad extension of the membraneous integument of the nasal fossa. Rictal bristles absent; feathers of chin, etc., without distinct terminal setæ, but their webs semidecomposed, bristle-like. Wing moderate, much rounded, the longest primaries projecting very little (sometimes not at all) beyond secondaries; fourth, fifth and sixth, fifth, sixth and seventh, or fifth and sixth, primaries longest, the tenth (outermost) a little more than half ( $M$. plumbea) to two-thirds ( $M$. boucardi) as long as the longest, the eighth slightly shorter to decidedly longer than secondaries. Tail two-thirds to slightly more than three-fourths as long as wing, strongly rounded (graduation equal to less than distance from nostril to tip of maxilla), the rectrices (12) rather narrow to rather broad ( $M$. plumbea), rounded terminally. Tarsus much longer than whole culmen, two-fifths as long as wing or a little more, the acrotarsium distinctly scutellate, the planta fused (nonscutellate); middle toe, with claw, much shorter than tarsus; outer toe, without claw, not reaching to middle of subterminal phalanx of middle toe, the inner toe slightly shorter; hallux about as long as inner toe, but much stouter; basal phalanx of middle toe united to outer toe for much the greater part, to inner toe for not more than basal half (for less than basal half in M. boucardi); claws moderate in size and curvature, much compressed, that of the hallux decidedly shorter than its digit. Plumage full and blended, that of rump (and to a less extent that of flanks also) much lengthened, more lax; feathers of pileum short and blended in $M$. plumbea, more elongated and distinctly outlined in other species; rictal and postocular regions naked, the loral and frontal regions more or less scantily feathered.

Coloration.-(I) Adult males uniform black, including outer surface of wings; adult females brown, the head more dusky. Adult male plain slate color, the wing-coverts spotted with white; adult female similar but under parts bright tawny. (III) Adult males brown above, the head and neck slate color or olive, the wing-coverts with or without white spots; under parts gray or slate color, darker (sometimes black) on throat, the flanks brownish; adult females duller, brownish or rufescent below, or (in M. lxmosticta) similar to the male but the black throat barred with white. (IV) Adult males 
bright cinnamon-rufous, more grayish (sometimes wholly gray) on pileum and hindneck, the wing-coverts sometimes spotted with black; sides of head, throat, and chest black, rest of under parts white medially, grayish and fulvescent laterally; adult females similar but without black on under parts.

Range.-Nicaragua to western Ecuadór, Amazon Valley, and British Guiana. (About six species.) ${ }^{a}$

\section{KEY TO THE SPECIES OF MYRMECIZA.}

a. Under parts partly black.

b. Back, wings, etc., brown or cinnamon-rufous.

c. Abdomen white; back, wings, etc., cinnamon-rufous or rufous-chestnut. (Myrmeciza boucardi.)

d. Whole chest gray.

e. Pileum and hindneck wholly gray; no black spots or bars on wing-coverts. (Central Colombia.)

Myrmeciza boucardi boucardi, adult male (extralimital). $b$

ee. Pileum and hindneck mostly rufous-brown; wing-coverts with conspicuous bars or transverse spots of black. (Central Venezuela.)

Myrmeciza boucardi griseipectus, adult male (extralimital). $c$

dd. Upper chest black, like throat, the lower chest white medially.

$e e$. Sides of chest paler and less extensively gray. (Coast district of Venezuela; Trinidád.)

Myrmeciza boucardi swainsoni, adult male (extralimital). ${ }^{d}$

ee. Sides of chest darker and more extensively gray. (Eastern Panamá and Caribbean coast district of Colombia.)

Myrmeciza boucardi panamensis, adult male (p. 107).

a I have not seen Thamnophilus leuconotus Spix, referred to Myrmelastes by recent authors.

I am quite unable to appreciate any reasons for retaining a genus Myrmelastes as distinguished from Myrmeciza, unless the former is restricted to the type (M. plumbeus). The latter differs from other species in much greater development of the plumage of the lower back and rump, stouter bill, more rounded wing, and narrower, more broadly operculate nostrils. On the other hand, $M$. boucardi and its allies have a longer and more slender bill, longer tail, with relatively narrower rectrices, longer ontermost primary, and very different style of coloration. While not so homogeneous as most genera, however, the group, after the elimination of the longtailed and otherwise very different species constituting the genus Drymophila Swainson (see page 15), may, on the whole, be considered a fairly natural group.

b Ifyrmeciza boucardi Berlepsch, Ibis, 5th ser., vi, no. xxi, Jan., 1888, 129 (Bogotá, Colombia; coll. Count von Berlepsch); Sclater, Cat. Birds Brit. Mus., xv, 1890, 279, part (Bogotá).-[Drymophila] boucardi Sharpe, Hand-list, iii, 1901, 34.

c Myrmeciza suainsoni griseipectus Berlepsch and Hartert, Novit. Zool., ix, no. 1, April 10, 1902, 76 (Caicará, Orinoco R., Venezuela; coll. Tring Mus.).

d Myrmeciza suainsoni Berlepsch, Ibis, 5th ser., vi, no. xxi, Jan., 1888, 130, in text (based on Myrmothera longipes Swainson, but not of Vieillot).-M[yrmeciza] boucardi swainsoni Ridgway, Proc. Biol. Soc. Wash., xxi, Oct. 20, 1908, 194, in text.-Myrmeciza longipes albiventris Chapman, Auk, x, no. 4, Oct., 1893, 343; Bull. Am. Mus. N. H., vi, Feb., 1894, 51 (Princestown, Trinidád; coll. Am. Mus. N. H.).-[Drymophila] albiventris Sharpe, Hand-list, iii, 1901, 34 (Trinidád).-Myrmeciza longipes longipes (not Myrmothera longipes Swainson?) Hellmayr, Novit. Zool., xiii, 1906, 33 (Trinidád; crit.). 
cc. Abdomen slate color or gray.

d. Back with a large concealed patch of white; sexes nearly alike in color.

e. Throat uniform black. (Costa Rica and western Panamá.)

$e e$. Throat spotted or barred with white.

Myrmeciza læmosticta, adult male (p. 109).

Myrmeciza læmosticta, adult female (p. 109).

$d d$. Back without a concealed white patch; sexes very different in color.

$e$. All the wing-coverts with a white apical spot or dot; tail relatively shorter.

$f$. Darker, the back, rump, etc., deep mummy or vandyke brown, head (all round) black, chest, breast, and abdomen blackish slate. (Nortlwestern Ecuadór)... Myrmeciza maculifer, adult male (extralimital). ${ }^{a}$

ff. Paler, the back, rump, etc., mars brown, head (all round) blackish slate, chest, breast, and abdomen slate-gray. (Eastern Panamá and adjacent portion of Colombia).....Myrmeciza cassini, adult male (p. 110).

ee. Wing-coverts (except, sometimes, a few of the more anterior lesser coverts) without white spots or dots. (Myrmeciza exsul.)

$f$. Slightly darker or duller in general coloration, with slate color of under parts usually not paler on abdomen. (Caribbean slope of Panamá, Costa Rica, and Nicaragua.)

Myrmeciza exsul exsul, adult male (p. 111).

ff. Slightly brighter in coloration, with slate color of under parts usually paler on abdomen. (Pacific slope of Costa Rica and western Panamá).

Myrmeciza exsul occidentalis, adult male (p. 113).

$b b$. Back, wings, etc. (whole upper parts), also entire under parts, uniform black, the anterior lesser wing-coverts white.

c. Forehead and lores densely (normally) feathered; white area on anterior margin of wing narrower; tarsus 31.5-32. (Central Colombia.)

Myrmeciza immaculata, adult male (extralimital). $b$

$c c$. Forehead and lores scantily feathered; white area on anterior margin of wing broader; tarsus $33.5-36$.

d. White area on anterior portion of wing smaller, invólving only marginal lesser coverts; tarsus 33.5-34.5. (Costa Rica and western Panamá.)

Myrmeciza zeledoni, adult male (p. 114).

$d d$. White area on anterior portion of wing much larger, involving nearly the whole of the lesser covert area; tarsus 36 . (Western Ecuadór to central Colombia.)............Myrmeciza berlepschi, adult male (extralimital).c aa. Under parts without any black.

$b$. Throat and chest buff or ochraceous-buff (the former sometimes whitish); abdomen white. (Myrmeciza boucardi.)

c. Wing-coverts distinctly spotted or barred with black.

d. Spots or bars on wing-coverts larger, very conspicuous.

Myrmeciza boucardi griseipectus, adult female (extralimital). $d d$. Spots or bars on wing-coverts smaller; inconspicuous.

Myrmeciza boucardi panamensis, adult female (p. 108).

a Myrmelastes exsul maculifer Hellmayr, Novit. Zool., xiii, no. 2, July 10, 1906, 340, 342 (Paramba, n. w. Ecuadór, 3,500 ft.; coll. Tring Mus.).-M[yrmelastes] maculifer Ridgway, Proc. Biol. Soc. Wash., xxi, Oct. 20, 1908, 194, in text.

b T [hamnophilus] immaculatus Lafresnaye, Rev. Zool., viii, Sept., 1845, 340 (Bogotá, Colombia; types now in coll. Bost. Soc. N. H.). See Ridgway, Proc. Biol. Soc. Wash., xxii, 1907, 74, under Myrmeciza berlepschi.

c Myrmeciza berlepschi Ridgway, Proc. Biol. Soc. Wash., xii, April 17, 1909, 74 (Chimbo, n. w. Ecuador; coll. U. S. Nat. Mus.). This form (of which I have not seen Colombian specimens) may prove to be only subspecifically distinct from M. zeledoni. 
ce. Wing-coverts not distinctly, if at all, spotted or barred with black.

INyrmeciza boucardi swainsoni, adult female and young (extralimital).

Myrmeciza boucardi panamensis, young male (p. 108). ${ }^{a}$

bb. Throat gray or dusky; chest and abdomen brown or tawny.

c. Smaller (wing 62-71, tarsus 26-31); pileum slaty or blackish, in contrast with chestnut or chestnut-brown of back; tail brown.

d. All the wing-coverts with a terminal spot or dot of white; under parts paler, becoming buffy on abdomen.... Myrmeciza cassini, adult female (p. 110).

dd. Wing-coverts uniform browu (except, sometimes, a few small dots of white near bend of wing); under parts darker, the abdomen brown. (Myrmeciza exsul.)

c. General color of under parts much duller, the chest vandylie brown.

Myrmeciza exsul exsul, adult female (p. 111).

cc. General color of under parts much brighter, the chest bright chestnut or

tawny-chestnut... Myrmeciza exsul occidentalis, adult female (p. 113).

c. Larger (wing 75-81, tarsus 32-35); tail blackish; pileum dark brown, like back, etc.

d. Forehead and lores densely (normally) feathered; chin to auricular region grayish dusky; throat dull grayish, chest slaty olive; back chestnutbrown; tail blackish brown; culmen, 19.5.

Myrmeciza immaculata, adult female (extralimital).

dd. Forehead and lores scantily feathered; chin to auricular region dull black; lower throat, chest, and other under parts deep vandyke brown; back, etc., dark randyke brown; tail black; culmen, 20.5-22.

Myrmeciza zeledoni, adult female (p. 114).

\section{MYRMECIZA BOUCARDI PANAMENSIS Ridgway.}

\section{WHITE-BELIIED ANTBIRD.}

Adult male.-Pileum and hindneck gray or slate-gray, at least anteriorly and laterally, the gray paler on sides of occiput (supraauricular region), the crown, occiput, and hindneck usually more or less overlaid by chestnut-brown (burnt-umber or vandyke), sometimes uniformly of this color; rest of upper parts plain bright cinnamon-rufous or chestnut-rufous, the color paler and more tawny on primaries; anterior margin of lesser wing-covert area white or pale buffy, immediately followed by more or less of black spotting; middle wing-coverts sometimes with an indistinct subterminal bar of dusky; loral, suborbital, auricular, and malar regions, chin, throat, and chest uniform black, the first mixed with gray anteriorly; Iower chest and breast (except medially) and sides of upper chest plain gray (no. 6 or no. 7), passing posteriorly into tawny-buff or clay color on flanks; median portion of lower chest and breast, together with abdomen, white; under tail-coverts tawny or tawnyochraceous; smaller under wing-coverts white or buffy white, those on carpal region with more or less distinct central or mesial marks of dusky; inner webs of remiges broadly edged with vinaceouscinnamon; bill black; legs and feet dull yellowish or pale yellowish

a The distinctive characters of the several forms of this species are not very evident in fernales and immature birds. I have not seen the adult female of $M . b$. boucardi. 
brown (in dried skins); length (skins), 145-152 (150); wing, 65.571.5 (69.3); tail, 51-57.5 (53.8); culmen, 18.5-20.5 (19.6); tarsus, 28-31.5 (30.5); middle toe, $16.5-18.5$ (17.5) ${ }^{a}$

Adult female.-Pileum and hindneck brown (nearly mummy brown), passing into grayish (more or less extensively) on forehead and into light buffy grayish on supra-auricular region; rest of upper parts plain cinnamon-rufous, somewhat darker and duller on tail, paler and more tawny or cinnamomeous on primaries; lesser wingcoverts mixed black and cinnamon-brown; middle coverts crossed by a broad subterminal bar of black, the tip lighter cinnamonrufous than general color; the greater coverts and tertials similarly marked but black subterminal bar narrower; auricular region dark brown or dusky, with narrow shaft-streaks of buffy or whitish; malar region, throat, and chest plain ochraceous-buff, passing into white or buffy white on chin; sides and flanks paler ochraceous-buff, somewhat tinged with grayish; breast and abdomen white; under tailcoverts tawny-ochraceous; maxilla dark horn color, mandible paler; legs and feet dull yellowish or light yellowish brown (in dried skins); length (skins), 133-154 (141); wing, 62-69.5 (64.8); tail, 49-58.5 (52.2); culmen, 18.5-20 (19.2); tarsus, 28.5-31 (30): middle toe, $16-18.5(16.8) .^{b}$

Immature male.-Similar to the adult female, but without distinct, if any, black markings on wings.

Panamá (Lion Hill; Panamá; Sabana de Panamá; Verágua) to northeastern Colombia (Santa Marta, Cacagualito, Don Diego, and Bonda, Santa Marta; Cartagena).

(?) Myrmeciza longipes (not Myrmothera longipes Vieillot) Sclater, Proc. Zool. Soc. Lond., 1858, 249, part ("New Granada").

Myrmeciza longipes Lawrence, Ann. Lyc. N. Y., vii, 1862, 325 (Lion Hill, Panamá).-Sclater and Salvin, Proc. Zool. Soc. Lond., 1864, 357 (Lion Hill).

Myrmeciza swainsoni (not of Berlepsch) Salvin and Godman, Biol. Centr.-Am., Aves, ii, 1892, 229, part (Verágua and Lion Hill, Panamá).

\begin{tabular}{|c|c|c|c|c|c|}
\hline$a$ Eleven specimens. & $b$ Nine & specin & Iens. & & \\
\hline Locality. & Wing. & Tail. & $\begin{array}{l}\text { Cul- } \\
\text { men. }\end{array}$ & $\begin{array}{l}\text { Tar- } \\
\text { sus. }\end{array}$ & $\begin{array}{c}\text { Middle } \\
\text { toe. }\end{array}$ \\
\hline \multicolumn{6}{|l|}{ MALES. } \\
\hline Five adult males from eastern Panamá. . & 68.5 & 52.5 & 19.7 & 30.7 & 17.2 \\
\hline Six adult males from Santa Marta, Colombia......... & 70 & 55.5 & 19.5 & 30.2 & 17. 7 \\
\hline Two adult males ( $M$. b. swainsoni) from Venezuela........... & 66.7 & 52.7 & 18.5 & 29.5 & 16. 7 \\
\hline Ten adult males $(M . b$. swainsoni) from Triniáad......... & 66.6 & 53.5 & 19.4 & 29.2 & 16.9 \\
\hline \multicolumn{6}{|l|}{ FEMALES. } \\
\hline Four adult females from eastern Panamé................. & 63.9 & 50.4 & 18.9 & 29.5 & 16.4 \\
\hline Five adult females from Sauta Marta, Colombia......... & 65.5 & 54 & 19.4 & 30.4 & 17.1 \\
\hline Four adult females (M. $b$. swainsoni) from Venezuela.......... & 66 & 53.4 & 17.3 & 28.6 & 16.4 \\
\hline Six adult females (M. b. swainsoni) from Trinidád............ & 66.3 & 52.5 & 18. 7 & 28.2 & 16.5 \\
\hline
\end{tabular}


Drymophila swainsoni Thayer and Bangs, Bull. Mus. Comp. Zool., xIvi, 1906, 217 (Sabana de Panamá).

[Drymophila] swainsoni Shanpe, Hand-list, iii, 1901, 33, part (Colombia; Panamá).

Myrmeciza boucardi (not of Berlepsch) Sclater, Cat. Birds Brit. Mus., xv, 1890, 279, part (Verígua; Panamá).-Bangs, Proc. Biol. Soc. Wash., xii, 1898, 138 (Santa Marta, Colombia).-Allen, Bull. Am. Mus. N. H., xiii, 1900, 160 (Bonda, etc., Santa Marta, Colombia).

Myrmeciza boucardi panamensis Ridgway, Proc. Biol. Soc. Wash., xxi, Oct. 20, 1908, 144 (line of Panamá Railway; coll. U. S. Nat. Mus.).

\section{MYRMECIZA LEMOSTICTA Salvin.}

SALVIN'S ANTBIRD.

Adult male ( $=M$. stictoptera Lawrence).-Head and neck plain slate-black or blackish slate, becoming black on chin and throat; upper back dark brownish olive, the feathers black centrally and extensively white basally; lower back, rump, and upper tail-coverts dark chestnut or chestnut-brown, the tail similar but slightly darker; lesser and middle wing-coverts black, each with a roundish apical spot of white, some of the coverts along anterior border of wing with outer web wholly white; greater coverts and secondaries dark chestnut-brown, some of the former with indistinct small apical spots of fulvous; alula and primary-coverts uniform dusky grayish brown; primaries prouts brown, the outermost without white edging; chest, breast, anterior portion of sides, and upper abdomen, deep slate-gray or slate color, the feathers blackish centrally; posterior portion of sides, flanks, and under tail-coverts plain vandyke brown; maxilla black, mandible brownish (dark bluish horn color in life); ${ }^{a}$ iris carmine red, scarlet, or crimson; ${ }^{a}$ legs and feet horn brown (leaden bluish or dark purplish lead color in life); ${ }^{a}$ length (skins), 120-141 (131); wing, 62-65.5 (64.3); tail, 44-49 (46.5); culmen, 17.5-20 (18.5); tarsus, 25.5-28 (26.7); middle toe, 16-18 (17.1). ${ }^{b}$

Adult female ( $=M$. Trmosticta Salvin).-Similar to the adult male, but throat conspicuously spotted with white, and pileum and hindneck mostly dark sepia brown instead of wholly slate-black or blackish slate; length (skins), 121-145 (131); wing, 62.5-65 (63.3); tail, 42-49 (44.8); culmen, 17-18.5 (18); tarsus, 26-28 (26.8); middle toe, $17-18(17.2) .^{b}$

Costa Rica (Tucurríqui; Angostura; San Carlos; La Florída; Turrialba; Peralta; Guápiles; Cuábre; Carrillo; La Vijágua; Rio Súcio) and western Panamá (Santa Fé de Verágua).

Myrmeciza læmosticta SALvin, Proc. Zool. Soc. Lond., 1864 (pub. Apr. 1, 1865) 582 (Tucurríqui, Costa Rica; coll. Salvin and Godman); 1867, 145 (Santa Fé de Verágua, Panamá; crit.).-Lawrence, Ann. Lyc. N. Y., ix, 1868, 109

$a$ M. A. Carriker, jr., on labels.

$b$ Ten specimens, from Costa Rica. 
(Tucurríqui).-Frantzius, Journ. für Orn., 1869, 305 (Costa Rica).-Sclater, Cat. Birds Brit. Mus., xv, 1890, 280.--Salvin and Godman, Biol. Centr.-Am., Aves, ii, 1892, 230, pl. 51, fig. 1.-Carriker, Ann. Carnegie Mus., vi, 1910, 617 (Caribbean slope, 1,000-2,500 ft., Costa Rica; crit.; habits).

[Myrmeciza] læmosticta Sclater and Salvin, Nom. Av. Neotr., 1873, 74. Myrmeciza læmosticta læmosticta Hellmayr, Novit. Zool., xiii, 1906, 343 (crit.). [Drymophila] læmosticta SHARPe, Hand-list, iii, 1901, 34.

Drymophila læmosticta Carriker, Ann. Carnegie Mus., v, 1908, 9, in text.

Myrmeciza stictoptera Lawrence, Ann. Lyc. Nat. Hist. N. Y., viii, 1867, 132

(Angostura, Costa Rica; coll. U. S. Nat. Mus.); ix, 1868, 109 (do.).-Frant-

ziUs, Journ. für Orn., 1869, 306 (Costa Rica).-Cherrie, Proc. U. S. Nat. Mus., xiv, 1891, 532 (San Carlos, Costa Rica; crit.).-Salvin and Godman,

Biol. Centr.-Am., Aves, ii, 1892, 230.

[Drymophila] stictoptera SHARPe, Hand-list, iii, 1901, 34.

Drymophila stictoptera CarriKer, Ann. Carnegie Mus., v, 1908, 9 (crit.).

MYRMECIZA CASSINI (Ridgway).

CASSIN'S ANTBIRD.

Adult male.-Head and neck, all round, uniform slate-black or blackish slate; back, scapulars, rump, upper tail-coverts, tail, and secondaries plain bright mummy brown or mars brown; edge of wing white; lesser wing-coverts brownish black or blackish brown, each with a conspicuous apical spot of white; ${ }^{a}$ alula dusky brown, the outermost feather broadly edged with white; primary-coverts uniform dusky brown; primaries grayish brown basally passing terminally into light olive-brown, the outermost edged with white; under parts, except chin, throat, and under tail-coverts, plain slategray, somewhat paler posteriorly, where slightly tinged with fulvous; under tail-coverts light mummy brown; bill black; legs and feet light yellowish gray (in dried skin); wing, 69; tail, 42; culmen (bill defective); tarsus, 29 ; middle toe, $18 .^{b}$

Adult female?.-Upper parts as in the adult male, but brown of back, etc., much deeper (chestnut-brown); chin and most of throat uniform slate color; median portion of lower throat, chest, and breast chestnut, the remaining under parts slightly paler and duller (more russet); wing, 64; tail, 39; culmen (bill defective); tarsus, 26; middle toe, $18 .^{c}$

Immature maled-Similar to the supposed adult female, as described above, but brown of upper parts lighter and less castaneous (deeper, however, than in the adult male described), and general color of under parts much lighter (dull cinnamon-rufous on chest

$a$ In the single specimen that $\mathrm{I}$ have been able to examine the middle and greater coverts are wanting.

$b$ One specimen (the type).

c One specimen, from Turbo, Colombia.

d Described from no. 150,920, U. S. Nat. Mus., Cascajál (Coclé), Panamá; Heyde. 
passing into ochraceous-buff on abdomen), the sides and flanks more brownish (nearly raw umber), the slate-gray restricted to chin and upper throat; wing, 63; tail, 41; culmen, 19; tarsus, 27; middle toe, 17.

Easteru Panamá (Cascajál, Coclé) and adjacent portion of northwestern Colombia (Turbo).

Myrmeciza exsul a (not of Sclater, 1858) Cassin, Proc. Ac. Nat. Sci. Phila., 1860, 191 (Turbo, Colombia).

Myrmelastes cassini Ridgway, Proc. Biol. Soc. Waslı., xxi, Oct. 20, 1908, 194 (Turbo, n. w. Colombia; coll. U. S. Nat. Mus.).

\section{MYRMECIZA EXSUL EXSUL Sclater.}

\section{SCLATER'S ANTBIRD.}

Adult male.-Head and neck, all round, uniform slate-black; upper parts (except pileum and hindneck) plain deep chestnut; lesser wingcoverts at least partly black, those along anterior margin of wing more or less extensively white, and behind this white margin often a few small dots of white; the carpo-metacarpal region also streaked with white, and outermost feather of alula sometimes edged with white; under parts (except chin, throat, flanks, anal region and under tail-coverts), plain blackish slate color; flanks, anal region, and under tail-coverts plain mummy or vandyke brown; bill black; iris brown; bare skin of postocular region and chin sky blue; legs and feet dusky (blackish horn color or dark bluish gray in life); length (skins), 126-148 (134); wing, 64-71 (67.4); tail, 44-49 (46.8); culmen, 1S.5-21.5 (20.2); tarsus, 27-29.5 (28.2); middle toe, 17.5-19 (17.9). ${ }^{b}$ Adult female.-Upper parts as in adult male, but slate-black of pileum and hindneck slightly duller; chin and throat slate-blackish, but usually duller than in adult male; rest of under parts plain vandyke or mummy brown; bill, etc., as in adult male, but mandible

a The following citations of Myrmcciza (or Myrmelastes) exsul refer to one or more allied forms:

Myrmeciza exsul (not of Sclater, 1858) Sclater, Proc. Zool. Soc. Lond., 1860, 294 (Esmeraldas, w. Ecuadór; crit.); Cat. Am. Birds, 1862, 187 (Esmeraldas); Cat. Birds Brit. Mus., xv, 1890, 279 (Esmeraldas and Intac, Ecuadór; Nechi, Colombia).--Sclater and Salvin, Proc. Zool. Soc. Lond., 1879, 526 (Nechi, Antioquía, Colombia).-Berlepsch and Taczanowsri, Proc. Zool. Soc. Lond., 1883, 566 (Chimbo, w. Ecuadór; crit.).-Salvadori and Festa, Boll. Mus. Zool., etc., Torino, xv, 1899, no. 362, p. 31 (Foreste del Rio Peripa, w. Ecuadór).-Harterx, Novit. Zool., v, 1898, 493 (Cachavi, n. w. Ecuador).-Goodfellow, Ibis, 1902, 65 (Santo Domingo and Guanacillo, n. w. Ecuadór; habits, etc.).

[Myrmeciza] exsul Sclater and Salvin, Nom. Av. Neotr., 1873, 74.

[Myrmelastes] exsul Sharpe, Hand-list, iii, 1901, 32 (Colombia to Ecuadór).

(The bird from Nechi, Colombia, may possibly be M. cassini.)

$b$ Sixteen specimens. 
sometimes brownish; length (skins), 124-140 (132); wing, 64-69.5 (66.4); tail, 42.5-50 (45.2); culmen, 19-21 (20); tarsus, 27.5-31 (28.3); middle toe, $16.5-19$ (17.9). ${ }^{a}$

Caribbean slope of Panamá (Lion Hill; Frijole station; Chepo; Panamá; Cascajál, Coclé), Costa Rica (Jiménez; Sipúrio; Talamanca; Angostura; Rio Reventazón; Guácimo; Guápiles; Cuábre; Rio Sícsola; Siquirres; La Cristina; Carrillo; Limón; La Balsa; Turrialba; Volcan de Turrialba; El Hogár; Rio Banana; La Vijágua; Pacuare) and Nicaragua (Los Sábalos; Rio Escondido; Chontales; San Emilis, Lake Nicaragua).

Myrmeciza exsul Sclater, Proc. Zool. Soc. Lond., 1858 (pub. 1859), 540 (Panamá; coll. Derby Mus.).--Carriker, Ann. Carnegie Mus., vi, 1910, 614 (Caribbean lowlands up to 2,000 ft., Costa Rica; crit.; habits; descr. nest and eggs).

M[yrmeciza] exsul Hellmayr, Verh. k. k. zool.-bot. Gesellsch. Wien, 1903, 215 (diagnosis).

Myrmelastes exsul exsul Heldmayr, Novit. Zool., xiii, 1906, 341 (Panamá; e. Costa Rica; Rio Escondido and Chontales, Nicaragua; crit.; synonymy).

Myrmeciza immaculata (not Thamnophilus immaculatus Lafresnaye) Sclater and Salvin, Proc. Zool. Soc. Lond., Oct. 1, 1864, 357 (Lion Hill, Panamá; coll. Salvin and Godman).-Lawrence, Ann. Lyc. N. Y., ix, 1868, 109 (Pacuare and Angostura, Costa Rica; crit.).-Frantzius, Journ. für Orn., 1869, 305 (Costa Rica).--Nutring, Proc. U. S. Nat. Mus., vi, 1883, 405 (Los Sábalos, Nicaragua; habits).-Zeledón, Aual. Mus. Nac. Costa Rica, i, 1887, 115, part (Pacuare and Jiménez, Costa Rica).-Sclater, Cat. Birds Brit. Mus., xv, 1890, 279, part (Panamá and Chepo, Panamá; "Valza," i. e. La Balsa, Costa Rica).-Salvin and Godman, Biol. Centr.-Am., Aves, ii, 1892, pl. 5l, figs. 2, 3. [Myrmeciza] immaculata Sclater and Salvin, Nom. Av. Neotr., 1873,74 .

Myrmeciza intermedia Cherrie, Proc. U. S. Nat. Mus., xiv, no. 355, Sept. 4, 1891, 345 (Sipúrio, Talamanca, Costa Rica; coll. U. S. Nat. Mus.).

Myrmelastes intermedius Salvin and Godman, Biol. Centr.-Am., Aves, ii, 1892, 227, part (Los Sábalos, Nicaragua; Pacuare, Angostura, La Balsa, Jiménez, and Carrillo, Costa Rica; Lion Hill and Chepo, Panamá).-Richmond, Proc. U. S. Nat. Mus., xvi, 1893, 502 (Rio Escondido, Nicaragua; habits).Bangs, Proc. New Engl. Zool. Club, ii, 1900, 25 (Loma del León, Panamá). [Myrmelastes] intermedius Sharpe, Hand-list, iii, 1901, 32.

Myrmelastes occidentalis intermedius CARriker, Ann. Carnegie Mus., v, no. 1, Oct. 1, 1908, 10, in text.

$a$ Fourteen specimens.

\begin{tabular}{|c|c|c|c|c|c|}
\hline Locality. & Wing. & Tail. & $\begin{array}{l}\text { Cul- } \\
\text { men. }\end{array}$ & $\begin{array}{l}\text { Tar- } \\
\text { sus. }\end{array}$ & $\begin{array}{l}\text { Middle } \\
\text { toe. }\end{array}$ \\
\hline MALES. & & & & & \\
\hline $\begin{array}{l}\text { Six adult males from eastern Panamá........................... } \\
\text { Ten adult males from eastern Costa Rica }(8) \text { and Nicaragua }(2) . \\
\text { FEMALES. }\end{array}$ & $\begin{array}{l}67.4 \\
67.4\end{array}$ & $\begin{array}{l}47.2 \\
46.5\end{array}$ & $\begin{array}{l}19.4 \\
20.6\end{array}$ & $\begin{array}{l}28.4 \\
28.1\end{array}$ & $\begin{array}{l}17.8 \\
18\end{array}$ \\
\hline $\begin{array}{l}\text { Four arlult females from eastern Panamá. ............................ } \\
\text { Ten adult females from eastern Costa } R \text { ica }(8) \text { and Nicagua }\end{array}$ & $\begin{array}{l}66.6 \\
66.3\end{array}$ & $\begin{array}{l}45.4 \\
45.2\end{array}$ & $\begin{array}{l}20.1 \\
20.1\end{array}$ & $\begin{array}{l}27.9 \\
28.5\end{array}$ & $\begin{array}{l}18 \\
17.9\end{array}$ \\
\hline
\end{tabular}




\section{MYRMECIZA EXSUL OCCIDENTALIS (Cherrie).}

\section{CHERRIE'S ANTBIRD.}

Adult male.-Head and neck, all round, plain black or slate-black; rest of upper parts plain chestnut, the tail slightly (larker; anterior lesser wing-coverts black (those along margin of wing white), the posterior ones more brownish; outermost feather of alula sometimes edged with white; chest, breast, sides, and abdomen plain blackish slate (rather darker anteriorly, where usually shading gradually into the black of throat, slightly paler, or clearer slate color, posteriorly); flanks, anal region, and under tail-coverts plain chestnut-brown or vandyke brown; bill black; iris brown; bare skin of postocular region and chin sky blue (in life); legs and feet dusky (blackish horn color or dark bluish gray in life); length (skins), 125-143 (133); wing, 65-71 (68.3); tail, 47-51.5 (48.1); culmen, 20-22 (20.7); tarsus, 27-29.5 (27.8); middle toe, 17.5-19.5 (18.2).$^{a}$

Young male (nestling).-Nuch like the adult male but coloration much duller, the chestnut of back mixed or tinged with sooty brown, the head, neck, and chest sooty blackish or brownish slate-black, and under parts of body mixed sooty brown and tawny brown.

Adult female.-Upper parts as in adult male, but color of back, etc., usually rather lighter, more tawny, chestnut, and less sharply defined against the dusky slate color of pileum and hindneck, which are usually more or less tinged with brown; sides of head, chin, and upper throat slate color, the latter sometimes tinged with tawny brown; lower throat and chest bright tawny-chestnut or rufouschestnut, passing into russet or tawny-russet on breast and abdomen, the flanks, anal region, and under tail-coverts tawny-brown (between mars brown and russet); bill, etc., as in adult male; length (skins), 131-140 (135); wing, 62-69 (65.7); tail, 44.5-49 (46.8); culmen, 18.5-21.5 (20.1); tarsus, $27-29.5$ (28.1) ; middle toe, $17-18(17.7){ }^{a}$

Pacific slope of Costa Rica (Pozo del Pitál, Rio Naranjo; Pozo Azúl de Pirrís; Pozo del Rio Grande; Pozo de Térraba; El Generál; Paso Reál; Boruca; Buenos Aires; Barranca, Boruca; Las Trojas; Palmár; Lagarto; La Palma de Nicoya; Esparta; San Mateo; San Carlos), and western Panamá (Divala; Bugaba).

Iyrmeciza immaculata (not of Sclater and Salvin) SALvin, Proc. Zool. Soc. Lond., 1870, 195 (Bugaba, Panamá; crit.).-Boucard, Proc. Zool. Soc. Lond., 1878, 61 (San Carlos and San Mateo, Costa Rica).-Ridgway, Proc. U. S. Nat. Mus., v, 1882, 398 (La Palma de Nicoya, Costa Rica; crit.).Zeledón, Anal. Mus. Nac. Costa Rica, 1887, 115, part (Las Trojas and Pozo Azúl, w. Costa Rica).

Myrmeciza immaculata occidentalis Cherrie, Auk, viii, April, 1891, 191 (Pozo Azúl, s. W. Costa Rica; coll. U. S. Nat. Mus.). 
Myrmeciza occidentalis Cherrie, Anal. Inst. Fis.-Geog. Costa Rica, vi, 1893, 19 (Pozo del Pitál, s. w. Costa Rica).-Carriker, Ann. Carnegie Mus., vi, 1910, 616 (Pacific lowlands and foothills, Costa Rica; crit.; descr. nest and eggs).

Myrmelastes occidentalis Salvin and Godman, Biol. Centr.-Am., Aves, ii, 1892, 228 (Bebedero, etc., w. Costa Rica).-Cherrie, Expl. Zool. Merid. Costa Rica, 1893, 43 (Palmár, Lagarto, Boruca, and Buenos Aires, s. w. Costa Rica).-Carriker, Ann. Carnegie Mus., v, 1908, 10 (crit.).

[Myrmelastes] occidentalis Sharpe, Hand-list, iii, 1901, 32.

Myrmelastes exsul occidentalis Hellmayr, Novit. Zool., xiii, 1906, 341 (Pozo Azúl, etc., s. w. Costa Rica; Bugaba, Panamá; crit.).-Bangs, Auk, xxiv, 1907, 296 (Boruca, Paso Reál, Pozo del Rio Grande, and Barranca, s. w. Costa Rica).-Carriker, Ann. Carnegie Mus., v, 1908, 10, in text.

M[yrmelastes] exsul occidentalis Ridgway, Proc. Biol. Soc. Wash., xxi, 1908, 194 , in text.

Myrmelastes intermedius (not Myrmeciza intermedia Cherrie) Salvin and Godman, Biol. Centr.-Am., Aves, ii, 1892, 227, part (San Carlos and San Mateo, Costa Rica; Bugaba, Panamá).

\section{MYRMECIZA ZELEDONI Ridgway.}

ZELEDÓN'S ANTBIRD.

Adult male.-Uniform black, relieved only by a white patch on inner-anterior portion of lesser wing-covert area, a narrow white margin thence around bend of wing, and white edging to alulæ; bill and feet black; iris chestnut; bare skin of lores and orbits blue, becoming white behind eye; ${ }^{a}$ length (skins), 168-188 (178); wing, 78-86 (80.9); tail, 70-82 (76.8); culmen, 21-23 (22); tarsus, 33.534.5 (34); middle toe, 20-22 (21.2). ${ }^{b}$

Adult female.-Above plain dark chocolate brown (or between chocolate and seal brown), the tail blackish brown or brownish black; loral, orbital, and auricular regions, chin, and upper throat, blackish brown or brownish black; under parts lighter chocolate brown or vandyke brown; maxilla blackish brown, mandible pale yellowish brown or dull yellowish (in dried skins); legs and feet dusky brown (in dried skins); length (skins), 166-193 (175); wing, 75-81 (78.6); tail, 71.5-78 (75); culmen, 20.5-22 (21.1); tarsus, 32-35 (33.6); middle toe, 20-22 (21.1). ${ }^{c}$

Costa Rica (Naranjo de Cartago; Guayabo; Guápiles; Carrillo; La Hondura; Tucurríqui; Cariblanco de Sarapiquí) and western Panamá (Boquete de Chitra; Calobre; Calovévora; Caribbean slope, Volcan de Chiriquí). Western Colombia.

Thamnophilus immaculatus (not of Laf resnaye) Salvin, Ibis, 1870, 114 (Tucurríqui, Costa Rica; crit.); Proc. Zool. Soc. Lond., 1870, 194 (Volcan de Chiriquí, Calovévora, and Calobre, Panamá).-Sclater, Cat. Birds Brit. Mus., xv, 1890, 189, part (Tucu ríqui, Costa Rica; Boquete de Chitra, Calobre, Calovévora, and Volcan àe Chiriquí, Panamá).

a Zeledón, manuscript.

$b$ Five specimens, from Costa Rica.

c Eight specimens from Costa Rica (7) and western Panamá (1). 
[Thamnophilus] immaculatus Sclater and Salvin, Nom. Av. Neotr., 1873, 69, part.

Myrmelastes immaculatus Salvin and Godman, Biol. Centr.-Am., Aves, ii, 1892, 225, part (Costa Rica and Panama localities and references).-Bangs, Proc. New Engl. Zool. Club, iii, 1902, 42 (Volcan de Chiriqui, 2,000 ft.).

[.1.yrmelastes] immaculatus Sharpe, Hand-list, iii, 1901, 32, part.

Mymaciza immaculata Carriker, Ann. Carnegie Mus., vi, 1910, 618 (Caribbean slope Costa Rica, 1,000-1,000 ft.; crit.) ${ }^{a}$.

Myrmeciza zclcdoni Ridgway, Proc. Biol. Soc. Wash., xxii, April 17, 1909, 74 (Guayabo, Costa Rica; coll. U. S. Nat. Mus.).

\section{Genus FORMICARIUS Boddaert.}

Formicarius Boddaent, Tabl. P1. Enl., 1783, 43. (Type, F. cayanensis Boddaert $=F$. colma Boddaert.)

(?).Myrmecophaga LacÉPÈDE, Tableaux Oiseaux, 1799, 6. (Type undeterminable, no species being named; nomen nudum.)

Myotthera Spix, Av. Sp. Nov. Brazil, i, 1824, 72. (Type, M. ruficeps Spix= Turdus colma Gmelin.

Myothera D'Orbigny and Lafresnaye, Mag. de Zool., 1839 (Synopsis Avium, p. 14). (Type, M. analis D'Orbigny and Lafresnaye.)

Myrmothera, part, Vieillot, Analyse, 1816, 43, 70. (Type, none specified, and no species named; includes "Befroi, et quelques antres fourmilliers de Buffon").

Myocincla Swainson, Classif. Birds, ii, 1837, 230. (Type, Turdus colma Gmelin $=$ Formicarius colma Boddaert.)

Rather large Formicariidæ (length about $150-180 \mathrm{~mm}$.) with very dense, compact plumage; bill much shorter than head, depressed basally; short, rounded tail (less than two-thirds as long as the short and concare, rather pointed wing); latero-frontal antiæ with feathering short and dense; scutellate tarsi, short anterior claws, and plain coloration.

Bill shorter than head (exposed culmen about as long as distance from nostril to posterior angle of eye), with straight lateral outlines, slightly depressed basally, its width at latero-frontal antiæ greater than its depth at same point and equal to half the distance from nostril to tip of maxilla, or slightly less; culmen distinctly ridged, straight or nearly so for most of its length, decurved terminally, the tip of maxilla inconspicuously and rather obtusely uncinate; maxillary tomium slightly convex posteriorly, straight anteriorly, slightly notched subterminally; mandibular tomium faintly concave posteriorly, nearly straight or very faintly convex anteriorly, very indistinctly notched subterminally; gonys decidedly to rather

a Mr. Carriker erroneously concludes that because six skins of "Myrmeciza immaculata (Lafresnaye)" from western Colombia agree closely with Costa Rican specimens of $M$. zeledoni, the latter is not a tenable form. He quite overlooked the fact that the specimens from western Colombia which he examined are мот Thamnophilus immaculatus of Lafresnaye, which is so different that their confusion would be almost impossible if specimens are actually compared. His observations simply extend the range of $M$. zeledoni to western Colombia. 
strongly convex basally, nearly straight and ascending terminally. Nostril exposed, broadly oval, margined above by narrow membrane, posteriorly in contact with the short and very dense feathering of latero-frontal antiæ. Rictal bristles present but small; feathers of chin, malar antiæ, etc., short, without trace of terminal setæ. Wing rather short but pointed, very concave beneath, the outer primaries rather strongly arcuate, the longer ones projecting decidedly beyond secondaries; sixth, seventh, or eighth primaries longest, the tenth (outermost) nearly three-fourths as long as the longest, the ninth decidedly longer than secondaries. Tail about three-fifths as long as wing, rounded (graduation less than distance from nostril to tip of maxilla), the rectrices (12) rather broad and firm, rounded terminally. Tarsus about two and a half times as long as bill from nostril, decidedly less than two-fifths as long as wing, distinctly scutellate, the plantar scutella quadrate, in two longitudinal series; middle toe, with claw, a little more than two-thirds as long as tarsus (longer than commissure); outer toe, without claw, reaching to about middle of subterminal phalanx of middle toe, the inner toe very slightly shorter; hallux much shorter than inner toe, slightly stouter; basal phalanx of middle toe united for more than half its length to outer toe, for less than half its length to inner toe; anterior claws very short, relatively broad, slightly curved; claw of hallux slightly curved, nearly as long as its digit. Plumage compact, dense, that of rump and flanks not elongated nor lax; feathers of pileum not elongated.

Coloration.-General color uniform brown or blackish (the head sometimes rufescent) above, dusky, grayish, or brownish below, sometimes with chest rufescent or tawny, the under tail-coverts usually rufescent and throat black (sometimes margined posteriorly with a narrow band of cinnamon or chestnut); inner webs of remiges with basal portion (abruptly) buff, ochraceous, or tawny, the under wingcoverts similar but tipped with black; sexes alike; young similar but throat usually more or less variegated with white.

Range.-Southern Mexico to western Ecuadór, Peru, Bolivia, southeastern Brazil, and Cayenne. (About fifteen species and subspecies.)

This genus is very distinct from any other, its nearest relative being the genus Chamæza Vigors, ${ }^{a}$ of South America, which differs in longer tail (more than two-thirds as long as wing), much greater development of plumage of lower back and rump, different character of feathering of anterior portion of head, shorter and more depressed bill, variegated plumage, and other features. 
KEY TO THE SPECHES AND SUBSPECIES OF FORMICARIUS.

a. Pileum and hindneck ruiescent or tawny, conspicuously different from color of back; outer web of exterior feather of alula light tawny or buff.

b. Forehead bright tawny or rufescent, like crown, etc. (Southeastern Brazil.)

Formicarius colma (extralimital) $a^{a}$

bb. Forehead black or dusky. (Amazon Valley to Cayeune and Colombia.)

Formicarius nigrifrons (extralimital). $b$ aa. Pileum dull brownish, not very different from color of back, or else black; outer web of exterior feather of alula grayish brown.

b. Chest black, brownish gray, or slaty.

c. Sides of neck similar in color to hindneck, not rufescent or cinnamomeous.

d. Pileum brown, like back, with only centers of feathers blackish; chest slategray in contrast with black of throat. (Polivia to northeastern Peru.)

Formicarius analis (extralimital).c dd. Pileum and chest black. (Costa Rica and western Panamá.)

Formicarius analis nigricapillus (p. 118).

cc. Sides of neck rufescent or cinnamomeous. (Formicarius monitiger.)

d. Under tail-coverts only partly, if at all, rusty, tawny, or cinnamomeous, the longer (posterior) ones being dusky margined with brown.

e. A distinct rusty or cinnamomeous collar across foreneck.

f. Darker, the back, etc., bright mummy brown to chestnut-brown, the chest sooty slate-gray. (Southeastern Mexico, except Yucatan, to Guatemala)................Formicarius moniniger moniliger (p. 119).

ff. Paler, the back, etc., raw-umber to light olive-brown, the chest mouse gray to drab-gray.

a Formicarius colma Boddaert, Tabl. Pl. Enl., 1783, 44 (=young; based on Le Colma, de Cayenne Daubenton, Pl. Enl., pl. 703, fig. 1); Sclater, Cat. Birds Brit. Mus., xi. 1890, 302.-[Turdus] colma Gmelin, Syst. Nat., i, pt. 2, 1789, 827.-Myrmothera colma Tieillot, Tabl. Enc. Méth., 1822, 681, 683.-Myiother a colma Cahanis, in Schomburgl's Reis. Brit. Guiana, iii, 1848, 686.-Formicarnus cayanensis Boddaert, Tabl. Pl. Enl., 1783, 50 (= adult; based on Le Tetêma, de Cayenne Daubenton, Pl. Enl., pl. 821); Ridgway, Proc. U. S. Nat. Mus., xvi, 1893, 670 (monogr.).-M[yrmornis] cayanensis Cabanis and Heine, Mus. Hein., ii, 1859, 7.--Myiothera tetema Burmeister, Syst. Ueb. Th. Bras., iii, 1856, 46.-Myioturdus tetema Maximilian, Beitr. Naturg. Bras., iii, 1831, 1030.-Myrmothera fuscicapilla Vieillot, Nouv. Dict. d'Hist. Nat., xii, 1817, 112.-Myothera ruficeps Spix. Av. Bras., i, 1825, 72, pl. 72, fig. 1 (locality not given; coll. Munich Mus.).-Formicarius ruficeps Pelzeln, Orn. Bras., ii Abth., 1869, 90, part.-Formicanus ruficeps ruficeps Hellmayr, Orn. Monats., x, March, 1902, 35 (geog. range).

o Formicarius nigrifrons Gould, Ann. and Mag. N. H., ser. 2, xv, May, 1855, 344 Chamicuros, e. Peru; coll. J. Gould); Proc. Zool. Soc. Lond., 1855 (pub. May 16),) 68; Sclater, Cat. Birds Brit. Mus., xv, 1890, 303; Ridgway, Proc. U. S. Nat. Mus., xvi, 1893, 672 (monogr.).--Formicarius colma nigrifrons Snethlege, Journ. für Orn., Jan., 1908, 17 (Rio Purús, w. Brazil).-(?) Formicarius nigrifrons glaucopectus Ridgway, Proc. U. S. Nat. Mus., xvi, no. 961, Nov. 28, 1893, 673, in text (British Guiana; coll. U. S. Nat. Mus.).

c M[yothera] analis D'Orbigny and Lafresnaye, Synop. Av., in Mag. de Zool., 1837, 14; cl. ii, pls. 7i-79 (Yuracares and Chiquitos, Bolivia); D'Orbigny, Voy. Amér. Mérid., Ois., 1839, pl. 6 bis, fig. 1.-Formicarnus analis Sclater, Proc. Zool. Soc. Lond., 1857, 46; Cat. Birds Brit. Mus., xv, 1890, 304, part; Ridgway, Proc. U. S. Nat. Mus., xvi, 1893, 673 (monogr.).-Formicarius analis analis Hartert, Novit. Zool., ix, Dec., 1902, 613 (Bolivia to e. Peru; diagnosis).-M[yrmornis] analis Cabanis and Heine, Mus. Hein., ii, 1859, 7. 
g. Darker, the back, etc., raw-umber brown, the chest mouse gray. (British Honduras).....Formicarius moniliger intermedius (p. 121).

gg. Paler, the back, etc., light olive-brown (or between broccoli brown and isabella color), the chest drab-gray. (Yucatan.)

Formicarius moniliger pallidus (p. 121).

ee. No rusty or cinnamomeons collar across foreneck. (Eastern Costa Rica and eastern Nicaragua)..... Formicarius moniliger umbrosus (p. 122).

dd. Under tail-coverts wholly, or for much the greater part, rusty, tawny, or cinnamomeous.

e. Forehead lighter and more rufescent or cinnamomeous brown than crown.

$f$. Larger (wing averaging 93.5 in adult male, 91 in adult female); color of under parts more slaty, the under tail-coverts darker rusty. (Sonthwestern Costa Rica and western Panamá.)

Formicarius moniliger hoffmanni (p. 123).

ff. Smaller (wing averaging 87 in adult male, 86.9 in adult female); color of under parts more brownish or more strongly suffused with olive or buffy, the under tail-coverts paler, more tawny. (Eastern Panamá.)

Formicarius moniliger panamensis (p. 124).

$e e$. Forehead concolor with crown (not more rufescent or cinnamomeous).

$f$. White loral spot small, sometimes obsolete; under parts nearly uniform deep brownish gray; under tail-coverts rufous-tawny. (Trinidád, Venezuela, and adjacent coast district of Colombia.)

Formicarius moniliger saturatus (extralimital) $a$

$f f$. White loral spot large, conspicuous; under parts clear brownish gray, fading into nearly white on lower abdomen; under tail-coverts clear tawny. (British Guiana.)

Formicarius moniliger crissalis (extralimital). $b$

$b b$. Chest chestnut or rufous-tawny.

c. Pileum rusty brown or chestnut. (Western Panamá to eastern Costa Rica; northwestern Colombia?).................. Formicarius rufipectus (p. 125).

cc. Pileum black. (Eastern Ecuadór.)...Formicarius thoracicus (extralimital). c

\section{FORMICARIUS ANALIS NIGRICAPILLUS (RidgWRy).}

\section{BLACK-HEADED ANTTHRUSH.}

Adult male.-Head, all round, and chest uniform sooty black, this gradually passing through sooty blackish slate on upper breast into brownish slate-gray on abdomen, where (in fresh plumage) the feathers are margined terminally with dull buffy whitish; sides and flanks similar in color to breast, but faintly tinged with olive; hindneck, sides of neck and general color of upper parts plain dark van-

a Formicarius saturatus Ridgway, Proc. U. S. Nat. Mus., xvi, no. 961, Nov. 28, 1893, 677 (Princestown, Trinidád; coll. Am. Mus. N. H.).-Formicarius analis saturatus Chapman, Bull. Am. Mus. N. H., vi, Feb. 16, 1894, 53 (Trinidád).-Formicarius hoffmanni saturatus Hellmayr, Novit. Zool., xiii, 1906, 33 (Trinidád; crit.).

b Myrmornis crissalis Cabanis, Journ. für Orn., Mar., 1861, 96, in text (Roraima, Brit. Guiana).-Formicarius crissalis Sclater and Salvin, Proc. Zool. Soc. Lond., 1867, 576 (Pará); Ridgway, Proc. U. S. Nat. Mus., xvi, 1893, 676 (monogr.).-F[ormicarius] a[nalis] crissalis IIellmayr, Novit. Zool., xiv, Nov., 1907, 392 (geog. range).

c Formicarius thoracicus Taczanowski and Berlepsch, Proc. Zool. Soc. Lond., 1885, 101 (Machay, e. Ecuador; coll. Branicki Mus.); Sclater, Cat. Birds Brit. Mus., xv, 1890, 301, footnote; Ridgway, Proc. U. S. Nat. Mus., xvi, 1893, 685 (monogr.). 
dyke brown, or approaching seal brown, the upper tail-coverts seal brown or dark chocolate; tail blackish brown or brownish black; shorter under tail-coverts light rufous-chestnut or chestnut-tawny, the longer ones sooty black; under wing-coverts blackish at tip (broadly) and base, ochraceous in middle portion, the axillars similarly marked, but middle portion buff instead of ochraceous; inner webs of remiges crossed near base by a broad but not sharply defined band of dull ochraceous; bill black; legs and feet dusky horn color (in dried skins); length (skin), 168-175 (171); wing, 90.5-94 (92.3); tail, 49-51.5 (50.3); culmen, 23-24.5 (23.7); tarsus, 32; middle toe, $20.5-21(20.7) .^{a}$

Adult female.-Similar to the adult male, and probably not always distinguishable, but usually(?) with color of under parts of body slightly tinged with olive, the sides and flanks strongly olivaceous; length (skins), 163.5-164 (163.7); wing, 90-93.5 (91.7); tail, 48.549.5 (49); culmen, 24-25.5 (24.7); tarsus, 30-31.5 (30.7); middle toe, $21 .^{a}$

Costa Rica (Tucurríqui; Carrillo; Cariblanco de Sarapiquí; Cerro de Santa Maria; Buena Vista) and western Panamá (Santiago de Verágua).

Formicarius analis (not Myothera analis Lafresnaye) Salvin, Proc. Zool. Soc. Lond., 1866, 74, part (Tucurríqui, Costa Rica; Verágua, Panamá); 1867, 145 (Santa Fe de Verágua, Panamá; crit.).-Lawrence, Ann. Lyc. N. Y., ix, 1868, 110 (Costa Rica; crit.).-Frantzius, Journ. für Orn., 1869, 306 (Costa Rica).-Zeledón, Anal. Mus. Nac. Costa Rica, i, 1887, 115 (Costa Rica).Salvin and Godman, Biol. Centr.-Am., Aves, ii, 1892, 235, part (Tucurríqui, Costa Rica; Santiago de Verágua, Panamá).

[Formicarius] analis Sclater and Salvin, Nom. Av. Neotr., 1873, 75, part.

Formicarius nigricapillus "Cherrie" Rrdgway, Proc. U. S. Nat. Mus., xvi, no.961, Nov. 28, 1893, 675 (Buena Vista, Costa Rica; coll. U. S. Nat. Mus.).-CARRiker, Ann. Carnegie Mus., vi, 1910, 623 (Carrillo, Cariblanco de Sarapiquí, and Cerro de Santa Maria, Costa Rica).

[Formicarius] nigricapillus ShaRpe, Hand-list, iii, 1901, 38, part (Costa Rica; Panama).

Formicarius analis nigricapillus Hartert, Novit. Zool., ix, Dec., 1902, 614 (Cariblanco de Sarapiquí, Costa Rica; crit.).

\section{FORMICARIUS MONILIGER MONILIGER Sclater.}

\section{MEXICAN ANTTHRUSH.}

Adults (sexes alike).-Pileum dull black, the feathers broadly tipped or terminally margined with prouts brown, this often the prevailing color (the black being mostly concealed); rest of upper parts plain mummy brown, more castaneous (vandyke brown) on lower rump, upper tail-coverts, and hindneck; tail darker and duller brown basally, passing into dull slate-blackish terminally; loral and suborbital regions, anterior half of auricular region, malar region, 
chin, and throat uniform black, the first with a small central spot of white; band across foreneck and extending thence to hindneck and supra-auricular region and terminal portion of auricular region chestnut, duller laterally; under parts plain deep sooty grayish, darkest on chest (where sometimes strongly tinged with olive), paler on abdomen (where sometimes inclining to buffy whitish), the sides and flanks olive or mixed sooty gray and olive; under tailcoverts light brown (nearly raw-umber), the longer ones mostly blackish, margined terminally with light brown; under wing-coverts buff, broadly tipped with dark sooty brown; inner webs of remiges crossed by a broad band of tawny-buff anterior to their middle portion; bill black; iris brown; legs and feet brownish (in dried skins).

Young.-Essentially like adults but black of throat, etc., replaced by dark sooty brown; chestnut band across foreneck narrow and more or less broken, and general color of under parts more sooty.

Adult male.--Length (skins), 150-181 (173); wing, 87.5-94 (90.6); tail, 50-55 (52.9); culmen, 20.5-22 (21.2); tarsus, 30.5-33 (31.7); middle toe, $19-21(20){ }^{a}$

Adult female.-Length (skins), 155-175 (167); wing, 85.5-92.5 (89.2); tail, 51-56 (53.5); culmen, 20-21 (20.7); tarsus, 30-33 (31.3); middle toe, $20 .^{b}$

Southeastern Mexico, in States of Vera Cruz (Córdova; Playa Vicente; Cerro de la Defensa; Atoyác; Motzorongo; Buena Vista), Oaxaca (mountains near Santo Domingo) and Tabasco (Teapa) and Guatemala (Choctúm; Chiséc; Cobán; sources of Rio de la Pasión; Kampamác; Tactíc; Nehaj, Quiché).

Formicarius moniliger Sclater, Proc. Zool. Soc. Lond., 1856, 294 (Córdova, Vera Cruz, Mexico; coll. A. Sallé, now in coll. Brit. Mus.); 1858, 278, part (Vera Cruz); 1859, 383 (Playa Vicente, Vera Cruz); Cat. Am. Birds, 1862, 191 (Oaxaca); Cat. Birds Brit. Mus., xv, 1890, 303, part (Córdova, Vera Cruz; Oaxaca; sources Rio de la Pasión and Choctúm, Guatemala).-Salvin, Ibis, 1861, 353 (Chiséc, centr. Guatemala); Proc. Zool. Soc. Lond., 1866, 75 (Mexico; Guatemala; monogr.).-Sumichrast, Mem. Bost. Soc. N.H., i, 1869, 556 (hot region Vera Cruz, up to $800 \mathrm{~m}$.; habits; notes); La Naturaleza, v, 1881, 248 (do.).-SAL-

a Nine specimens.

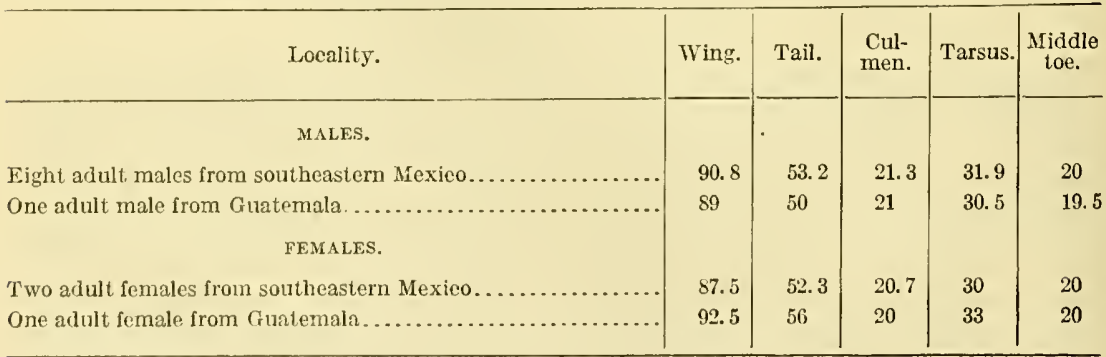


riv and Gonmax, Biol. Centr.-Am., Aves, ii, 1592, 233, part (Córdova, Cerro de la Defensa, Atoyác, and Playa Vicente, Vera Cruz; Vera Paz, Chiséc, Kampamíc, Choctúm, and Tactic, Guatemala).-limbiwar, Proc. U. S.

Nat. Mus., xvi, 1593, 693 (monogr.).

[Formicarius] moniliger Sclater, Proc. Zool. Soc. Jond., 1557, 47, in text.-

Sclater and Salvin, Nom. Av. Neotr., 1873, 75, part.-Sharpe, Hand-list, iii, 1901, 39, part (s. Mexico; Guatemali).

Myrmornis moniliger CABANis, Journ. für Orn, 1S61, 96.

[Jymomis] moniliger Heine and Rercirenow, Nomencl. Mus. Hein. Orn., 1890, 124 (Mexico).

Formicarius moliniger Boucand, Ann. Soc. Linn. Lyon, 1878, 49 (Guatemala).

\section{FORMICARIUS MONILIGER INTERMEDIUS Ridgway.}

\section{INTERMEDIATE ANTTHRUSH.}

Much paler and less rufescent above than $F$. m. monitiger, darker and more rufescent than $F . m$. pallidus; ${ }^{a}$ under parts pale as in $F . m$. pallidus, but the color decidedly clearer (less buffy) gray.

Adult male.-Length (skins), 163-1S0 (170); wing, S6-91 (8S); tail, 51-5S (54); culmen, 19.5-22 (21); tarsus, 30-32 (31); middle toe, $19-20.5(19.9){ }^{b}$

Adult female.-Length (skin), 169.5; wing, 90; tail, 51.5; culmen, 20; tarsus, 30.5; middle toe, $19{ }^{c}$

British Honduras (forest near Manatee Lagoon; Manatee River; Toledo District: Cayo).

Formicarius moniliger (not of Sclater, 1856) Sclater, Cat. Birds Brit. Mus., xv, 1890, 303, part (Brit. Honduras).--Salvin and Godman, Biol. Centr.-Am.,

Aves, ii, 1892, 233, part (Cayo, Brit. Honduras).

[Formicarius] moniliger SHa RPE, Hand-list, iii, 1901, 39, part (Brit. Honduras).

Formicarius monitiger intermedius Ridgway, Proc. Biol. Soc. Wash., xxi, Oct. 20, 1908, 194 (forest near Manatee Lagoon, British Honduras; coll. Carnegie Mus.).

Formicarius monileger Lantz, Trans. Kansas Acad. Sci. for 1896-97 (1899), 221 (Cayo, Brit. Honduras).

\section{FORMICARIUS MONILIGER PALLIDUS (Lawrence).} YUCATAN ANTTHRUSH.

Similar to F.m. intermedius but coloration still paler, the general color of upper parts light olive-brown (between broccoli brown and isabella color, brightening into raw-imber on upper tail-coverts), the abdominal region (extensively) grayish white or very pale buffy gray.

a In $F$. m. monitiger the color of the back varies from bright mummy brown to chestnut-brown; in $F . m$. intermedius it is deep raw-umber, while in $F . m$. pallidus it is light olive-brown or between broccoli brown and isabella color. In $F$. m. pallidus the color of the chest is drab-gray, in $F$. m. intermedius mouse gray.

$b$ Four specimens.

c One specimen. 
Adult (sex not determined).-Length (skin), 173.5; wing, 93; tail, 55 ; culmen, 22; tarsus, 31 ; middle toe, 20.

Yucatan (Tizimin).

Furnarius pallidus Lawrence, Ann. N. Y. Acad. Sci., ii, no. 9, May 29, 1882, 288 (Yucatan; coll. G. N. Lawrence).

Formicarius pallidus Lawrence, Ann. N. Y. Acad. Sci., ii, no. 9, 1882 (index).Boucard, Proc. Zool. Soc. Lond., 1883, 450 (Tizimin, Yucatan; crit.).Retchenow and Schalow, Journ. für Orn., 1884, 388 (reprint of orig. descr.).-Ridgway, Proc. U. S. Nat. Mus., xvi, 1893, 684 (monogr.).

[Formicarius] pallidus Sharpe, Hand-list, iii, 1901, 39.

F[ormicarius] m[oniliger] pallidus Ridgway, Proc. Biol. Soc. Wash., xxi, Oct. 20, 1908,194 , in text.

[Myrmornis] pallidus Heine and Reichenow, Nomencl. Mus. Hein. Orn., 1890, 124.

Formicarius moniliger (not of Sclater, 1856) Sclater, Cat. Birds Brit. Mus., xv, 1890, 303, part (Tizimin, Yucatan).- Salvin and Godman, Biol. Centr.-Am., Aves, ii, 1892, 233, part (Tizimin).

\section{FORMICARIUS MONILIGER UMBROSUS (Ridgway).} NICARAGUAN ANTTHRUSH.

Similar to F. m. monitiger but without any chestnut across foreneck, the black of throat giving way, more or less abruptly, on chest to dull slate color or sooty gray; under tail-coverts darker, more castaneous, brown; terminal portion of auricular region, together with supraauricular region (sides of occiput) and sides of neck, varying from chestnut to vinaceous-cinnamon.

Young.-Much like adults but malar region, chin, and throat dull whitish or buffy, transversely mottled or barred with dusky, or else uniform dull sooty blackish; whitish abdominal area transversely spotted or clouded with grayish dusky.

Adult male.-Length (skins), 158-180 (164); wing, 86-93 (90.2); tail, 49.5-57 (53.7); culmen, 19-23.5 (21.4); tarsus, 31-36 (33.5); middle toe, $18-20.5$ (19.1). ${ }^{a}$

Adult female.-Length (skins), 146-170 (161); wing, 86-91.5 (88.3); tail, 48-55 (51.7); culmen, 19-22 (20.3); tarsus, 31.5-33.5 (32.3); middle toe, $17.5-20$ (18.8). ${ }^{b}$

a Fourteen specimens.

$b$ Twelve specimens.

\begin{tabular}{|c|c|c|c|c|c|}
\hline Locality. & Wing. & Tail. & $\begin{array}{l}\text { Cul- } \\
\text { men. }\end{array}$ & Tarsus. & $\begin{array}{c}\text { Middle } \\
\text { toe. }\end{array}$ \\
\hline MALES. & & & & & \\
\hline Ten adult males from eastern Costa Rica... & 90.6 & 54.4 & 20.9 & 33.9 & 19.2 \\
\hline Four adult males from Niearagua.... & 89 & 52.1 & 22.5 & 32.6 & 18.9 \\
\hline FEMALES. & & & & & \\
\hline Ten adult females from eastern Costa Rlca. & 88 & 51.4 & 20.1 & 29 & 18.7 \\
\hline Two adult females from Niearagua.... & 89.7 & 53 & 21.3 & 32.3 & 19.3 \\
\hline
\end{tabular}


Eastern and northern Costa Riea (Talamanea; Bouilla; Jiménez; Rio Matina; Cuábre; Guácimo; Guápiles; La Vijágua; Ia Florída; Volean de Miravalles; Pacuare; San Carlos) and Nicaragua (Mosquito coast; Los Sábalos; Rio Escondido; San Emilis, Lake Nicaragua).

Formicarius moniliger (not of Sclater, 1856) Sclater, Proc. Zool. Soc. Lond., 185s, 27S, part (Mosquito coast, Nicaragua).

Formicarius hoffmanni (not Myrmornis hofmanni Cabanis) Bovcard, Proc. Zool. Soc. Lond., 1878, 62 (San Carlos, Costa Rica; labits).-Zeledón, Proc. U. S. Nat. Mus., viii, 1585, 105 (Costa Rica); Anal. Mus. Nac. Costa Rica, 1S57, 115, part (Jiménez, Costa Rica).-Salvin and Godman, Biol. Centr.Am., Aves, ii, 1S92, 234, part (Los Sábalos, Nicaragua; San Carlos, Jiménez, and Pacuare. Costa Rica).-Richmond, Proc. U. S. Nat. Mus., xvi, 1893, 502 (Rio Escondido, Nicaragua; habits).

Formicarius hoffmani NutTing, Proc. U. S. Nat. Mus., vi, 1883, 405 (Los Sábalos, Nicaragua: habits; notes).

[Formicarius] hoffmanni Sclater and Salvin, Nom. Av. Neotr., 1873, 75, part. Formicarius umbrosus Ridgway, Proc. U. S. Nat. Mus., xvi, no. 961, Nov. 28, 1S93, 6S1 (Talamanca, Costa Rica; coll. U. S. Nat. Mus.).-Underwood, Ibis, 1896, 441 (Volcan de Miravalles, Costa Rica; habits; notes).-CARRiker, Ann. Carnegie Mus., vi, 1910, 624 (Caribbean and northern Pacific lowlands of Costa Rica, up to 1,200 ft.; habits; deser. nest and eggs).

[Formicarius] umbrosus Sharpe, Hand-list, iii, 1901, 39.

\section{FORMICARIUS MONILIGER HOFFMANNI (Cabanis.)}

\section{HOFFMANN'S ANTTHRUSH.}

Similar to $F$. m. umbrosus, but under tail-coverts clear tawny or tawny-chestnut (as in $F$. m. panamensis), and black of throat usually more sharply defined and abruptly contrasterl with the dark slate color of chest. Differing from F.m. panamensis in larger size and less brownish coloration. ${ }^{a}$

Adult male.--Length (skins), 153-173 (163); wing, 90-98.5 (93.5); tail, 51.5-56.5 (54.1); culmen, 19.5-23 (21.2); tarsus, 31.5-34 (33.5); middle toe, 19-21.5 (20.4). ${ }^{b}$

Adult female.-Length (skins), 155-170 (161); wing, 88-95 (91); tail, 47-55 (51.1); culmen, 21-22.5 (21.7); tarsus, 31.5-34.5 (33.5); middle toe, $19-20.5(19.9) .^{b}$

As in the young of $F . m$. umbrosus, the young of this form frequently have the malar region, chin, and throat white barred or transversely spotted with black.

a As in $F . m$. panamensis, there is in this form sometimes a more or less distinct indication of a chestnut or russet collar across the lower throat. Such specimens may be easily distinguished from $F . m$. moniliger by the very different color of the under tail-coverts (clear tawny or tawny-chestnut instead of light olive-brown and dusky), and much lighter, as well as more extended, color (deep vinaceous-cinnamon to cinnamon-rufous, instead of dull chestnut) of sides of neck and occiput and terminal portion of auricular region.

$b$ Ten specimens, from Costa Rica. 
Southwestern Costa Rica (Pozo del Rio Grande, Paso Reál, Lagarto, Boruca, and Barranca, Boruca; Buenos Aires; El Generál; Pozo del Pitál, Rio Naranjo; Pozo de Térraba; Pozo Azúl de Pirrís; Las Trojas) and western Panamá (Divala; Bugaba; Chiriquí).

Myrmornis hoffmanni CABanis, Journ. für Orn., Mar., 1861, 95 (Costa Rica; coll. Berlin Mus.).

Formicarius hoffmanni Lawrence, Ann. Lyc. N. Y., ix, 1868, 110 (Costa Rica).Frantzius, Journ. für Orn., 1869, 306 (Costa Rica).-Salvin, Proc. Zool. Soc. Lond., 1866, 75, part (Costa Rica); 1870, 195 (Bugaba, Panamá).Zeledón, Anal. Mus. Nac. Costa Rica, i, 1878, 115, part (Las Trojas and Pozo Azúl de Pirrís, Costa Rica).—Sclater, Cat. Birds Brit. Mus., xv, 1890, 304, part (Bugaba, Verágua, and Chiriquí, Panamá).-SAlvin and GodMan, Biol. Centr.-Am., Aves, ii, 1892, 234, part (Las Trojas, Costa Rica; Chiriquí and Bugaba, Panamá).-Carriker, Ann. Carnegie Mus., vi, 1910, 623 (s. w. Costa Rica, up to 1,500 ft.; crit.; habits).

[Formicarius] hoffmanni Sclater and Salvin, Nom. Av. Neotr., 1873, 75, part (Costa Rica).-Sharpe, Hand-list, iii, 1901, 39, part (s. w. Costa Rica).

Formicarius hoffmanni hoffmanni Bangs, Auk, xxiv, July, 1907, 298 (Boruca, Paso Reál, Pozo del Rio Grande, Lagarto, and Barranca, s. w. Costa Rica; crit.).

F[ormicarius] moniliger hoffmanni RIDGway, Proc. Biol. Soc. Wash., xxi, Oct. $20,1908,195$, in text.

Formicarius umbrosus (not of Ridgway) BAngs, Auk, xviii, 1901, 366 (Divala, Panamá).

\section{FORMICARIUS MONILIGER PANAMENSIS Ridgway.}

PANAMÁ ANTTHRUSH.

Similar to F. m. hoffmanni but averaging smaller, and coloration much lighter, the under parts more strongly suffused with olive and buffy, and color of under tail-coverts lighter, more tawny; black gular area more frequently(?) bordered posteriorly with a more or less distinct collar of deep vinaceous-cinnamon or dull cinnamonrufous, or indication of one.

Adult male.--Length (skins), 153-172 (162); wing, 86-88 (87); tail, 50-55 (52.4); culmen, 20.5-21.5 (20.7); tarsus, 30-32 (30.9); middle toe, $18-19.5(18.9){ }^{a}$

Adult female.-Length (skins), 144-161 (154); wing, 84-88.5 (86.9); tail, 48-51.5 (49.7); culmen, 1S.5-20.5 (19.9); tarsus, 30-32 (31); middle toe, 17-20 (1S). ${ }^{a}$

Eastern Panamá (Lion Hill, Obispo, and Paraiso stations, Panamá railway; Chepo; Laguna del Pita ; Cascajál, Coclé) ; Colombia (Remédios, Antioquía)?

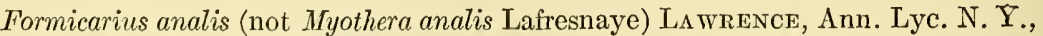
vii, 1862, 326 (Lion Hill station, Panamá).

Formicarius hoffmanni (not Myrmornis hoffmanni Cabanis) Sclater and Salvin, Proc. Zool. Soc. Lond., 1864, 357 (Lion Hill, Panamá);(?) 1879, 526 (Remé- 
dios, Antioquía, Colombia).-Salvin, Proc. Zool. Soc. Lond., 1866, 75, part (Panamí; monogr.).-Sclatek, Cat. Birds Brit. Mus., xv, 1890, 304, part (Panamá and Chepo, Panamá).-Sabrin and Gonuan, Biol. Centr.-Am., Aves, ii, 1892, 234, part (Lion Ilill, Obispo, and Paraiso stations, and Chepo, Pananí; Colombia?).-Liddwar, Proc. U. S. Nat. Mus., xvi, 1893, 679, part (monogr.).-Salrabort and Flsta, Boll. Mus. Zool., ete., Torino, xir, 1S99, no. 339, 7 (Lagrma del Pita, Panamí).-BAngs, Proc. New Engl. Zool. Club, ii, 1900, -4 (Loma del Leon, Panamá).

[Formicarius] hoffmanni Sclaten and Salvin, Nom. Av. Neotr., 1873, 75, part (Panamá).-Sharpe, Hand-list, iii, 1901, 39, part (Panamá; Colombia?).

Formicarius moniliger panamensis Ridgwar, Proc. Biol., Soc. Wash., xxi, Oct. 20, 1908, 195 (Lion Hill station, Panamá; coll. U. S. Nat. Mus.).

\section{FORMICARIUS RUFIPECTUS Salvin.}

\section{RUFOUS-BREASTED ANTTHRUSH.}

Adult male. ${ }^{\text {a-Pileum }}$ and hindneck dark chestnut, the feathers dull black beneath the surface (partly exposed on crown); rest of upper parts dark olive or olive-sepia, passing into deep reddish chestnut or bay on upper tail-coverts; tail dull black, the rectrices edged (especially toward base) with olive-brown; remiges, primary coverts, and alula dark sooty brown; loral, orbital, auricular, suborbital and malar regions, chin, and throat uniform black; whole chest uniform chestnut, passing into tawny-chestnut on breast, this into tawny on abdomen, the chestnut of chest extended laterally as a. narrow band behind auricular region to merge into the dark chestnut of hindneck; sides and flanks olive, indistinctly streaked on inner portion with dull tawny or tawny-chestnut; under tail-coverts bright chestnut; bill black; iris brown; legs and feet dark horn color; length (skin), 182; wing, 90; tail, 56; culmen, 21; tarsus, 38.5; middle toe, $23{ }^{b}$

Adult female. - Similar to the adult male, as described above, but color of back, etc., less olivaceous (more slaty) sides and flanks dull slate color or dark mouse gray instead of olive, and chestnut of chest lighter (tawny-chestnut), passing through tawny or tawny-olivaceous on lower breast into deep buff or clay color on abdomen; under tail-coverts also lighter chestnut; length (skin), 163.5; wing, 88.5; tail, 56.5; culmen, 23.5; tarsus, 38; middle toe, 23.

Western Panamá (Santiago de Verágua); Costa Rica (Juan Viñas); northwestern Colombia (San Antonio)?

a Description from no. 28,203, Carnegie Museum; Juan Viñas, Costa Rica (Atlantic slope), May 7, 1907; M. A. Carriker, jr. (Type of Formicarius castaneiceps Carriker.)

$\checkmark$ One specimen (type of $F$. castaneiceps Carriker).

c Described from no. 20,656, coll. E. A. and O. Bangs; San Antonio, Rio Cali, northwestern Colombia; Nov. 8, 1907; Mervyn G. Palmer. (Possibly representing a distinct subspecies). 
Formicarius rufipectus a SAlvin, Proc. Zool. Soc. Lond., 1866, 73, pl. 8 (Santiago de Verágua, Panamá; coll. Salvin and Godman); 1867, 145 (Santiago de Verágua; habits).—Sclater, Cat. Birds Brit. Mus., xv, 1890, 306, part (Verágua, Panamá).-Salvin and Godian, Biol. Centr.-Am., Aves, ii, 1892, 235, part (Santiago de Verágua).-Ridgway, Proc. U. S. Nat. Mus., xvi, 1893, 685 part (Santiago de Verágua; monogr.).-Bangs, Proc. Biol. Soc. Wash., xxi, 1908, 157 ([San Antonio], n. w. Colombia).-Carriker, Ann. Carnegie Mus., vi, 1910, 625 (Juan Viñas, e. Costa Rica; crit.).

F[ormicarius] rufipectus Salvin, Proc. Zool. Soc. Lond., 1866, 74.

[Formicarius] rufipectus Sclater and Salvin, Nom. Av. Neotr., 1873, 75.Sharpe, Hand-list, iii, 1901, 39, part (Panamá).

Formicarius castaneiceps Carriker, Ann. Carnegie Mus., iv, April 1, 1908, 301 (Juan Viñas, Costa Rica; coll. Carnegie Mus.).

\section{Genus HYLOPHYLAX Ridgvay.}

Hylophylax b Ridgway, Proc. Biol. Soc. Wash., xxii, Apr. 17, 1909, 70. (Type, Conopophaga nævioides Lafresnaye.)

Small Formicariidæ (length about $100 \mathrm{~mm}$.) with second phalanx of middle toe partly united to outer toe, outstretched feet reaching to beyond tip of tail, tail not more than three-fifths as long as wing, planta tarsi fused (nonscutellate) and acrotarsium indistinctly scutellate.

Bill shorter than head (sometimes nearly as long), rather stout, rather broad and depressed basally, with straight or (in part) even slightly convex lateral outlines, its width at frontal antiæ much greater (sometimes twice as great) as its height at same point and equal to from a little less than half to a little more than two-thirds the distance from nostril to tip of maxilla; culmen distinctly ridged, nearly straight basally (sometimes for most of its length), gradually to rather abruptly decurved terminally, the tip of maxilla slightly but distinctly uncinate; maxillary tomium straight or slightly concave, minutely but distinctly notched subterminally; mandibular tomium straight or faintly convex, minutely notched subterminally, the tip of mandible forming a short, more or less recurved, point; gonys more or less strongly convex and prominent basally, more gently convex and more or less decidedly ascending terminally. Nostril exposed, more or less widely separated from feathering of laterofrontal antiæ (nearly in contact with the latter in $H$. nævioides), longitudinally ovate, more or less pointed anteriorly, margined above

a The following citations of $F$. rufipectus refer to a different form:

Formicarius rufipectus (not of Salvin) Sclater, Cat. Birds Brit. Mus., xv, 1890, 306, part (Baisa, w. Ecuadór).-Salvin and Godman, Biol. Centr.-Am., Aves, ii, 1892, 235 (Baisa, w. Ecuadór).-Salvadori and Festa, Boll. Mus, Zool., etc., Torino, xv, 1899, no. 362, 33 (Gualea, w. Ecuadór).-Menegaux and Hellmayr, Bull. Soc. Philom., 1906, 52 (Esmeraldas, Pachijál, and Oyacachi, w. Ecuadór; crit.).

$b^{\prime \prime} r i \eta$, a wood, forest; $\phi \dot{u} \lambda a \xi$, a watcher, guard, sentinel. 
(at least posteriorly) by an extension of the membraneous integument of the nasal fossa, an internal tubercle or facet visible within the posterior portion. Rictal bristles present, but inconspicuous; feathers of chin, malar antia, and loral region with distinct terminal seta. Wing moderinte or rather large, with longest primaries extending decidedly berond secondaries; sixth and seventh, or seventh, primaries longest, the tenth (outermost) three-fifths as long as the longest, or slightly more, the ninth equal to or slightly longer than secondaries. Tail slightly more than one-half to three-fifths as long as wing, slightly rounded, the rectrices (12) rather broad, rouncled terminally. Tarsus much longer than whole culmen, a little less than two-fifths as long as wing, the acrotarsium indistinctly scutellate (scutella sometimes obsolete except on lower portion), the planta fused, at least for greater part; middle toe, with claw, much shorter than tarsus; outer toe, without claw, reaching to about middle of subterminal phalanx of middle toe, the inner toe decidedly shorter; hallux equal to or slightly longer than inner toe; basal phalanx of middle toe wholly united, the second phalanx partly united, to outer toe (the adhesion involving the first two phalanges of outer toe), united for half its length or more to inner toe; claws rather large, moderately curved, extremely compressed, that of the hallux shorter than the digit (but sometimes nearly as long). Plumage full, soft, and blended, that of rump and flanks more elongated and lax; feathers of pileum not elongated.

Coloration.-Adult males gray and black above, the back with white spots or lunulate bars, the wing-coverts, tertials, and tail tipped with white; or back rufous or chestnut, with a concealed patch of white, the wing-coverts, tertials, and tail tipped with cinnamonrufous; throat black, rest of under parts white, passing into gray or buffy on flanks, the chest spotted with black, or whole under parts plain gray. Adult females somewhat like males, but browner above with markings fulvous or buffy instead of white, the throat whitish, and black markings of chest replaced by brownish, or (in slatecolored species) head and under parts rufescent or the general color of under parts gray, with white throat and dusky flanks. ${ }^{a}$

Range-Costa Rica to western Ecuadór, Amazon Valley, and Guiana. (Six species. ?) ${ }^{b}$

a On account of insufficiency of material, I am not able to give the full range of color variation in this group.

$b$ Of the species referred to the genus Hypocnemis by Dr. Sclater and other recent authors I have seen in this connection only $H$. cantator (type of the genus), H. poecilonota (Cuvier), H. lepidonota Sclater and Salvin, H. leucophrys (Tschudi), H. myiotherina (Spix), H. lugubris (Cabanis and Heine), H. nævia (Gmelin), and H. nævioides (Lafresnaye). The second, third, seventh, and eighth of these I have removed from Hypocnemis on account of the very different amount of adhesion of the anterior toes 


\section{HYLOPHYLAX NEVIOIDES (Lafresnaye).}

SPOTTED ANTBIRD.

Adult male.-Pileum and hindneck grayish brown or olive-brown, passing into gray laterally and on forehead, the feathers usually with darker shaft-streaks and terminal margins; back plain chestnut, the feathers extensively white basally; scapulars, rump, and upper tailcoverts plain russet-brown, the first tinged with chestnut; wingcoverts black, the lesser with terminal spots of white (those along anterior margin mostly white), the middle and greater corerts very broadly tipped with cinnamon-rufous, forming two very conspicuous bands; remiges dull black, the outer web and tip of tertials largely cinnamon (more or less deep) or dull cinnamon-rufous, the secondaries and primaries with outer half or more of outer web light brown or grayish brown; tail grayish brown (deep drab or broccoli brown to sepia), the rectrices tipped with pale cinnamon (sometimes whitish on outermost) and crossed by a band (more or less broad) of dull black; sides of head plain dull slate-gray or slate color, like superciliary region and forehead; malar region, chin, and throat uniform black; rest of lower parts white, passing into buffy gray on flanks and pale brownish buff on under tail-coverts, the latter sometimes brownish beneath surface; upper breast and anterior portion of sides heavily spotted with black, separating the immaculate white jugular and pectoral areas; bill black, the mandible sometimes more brownish; legs and feet light horn color (in dried skins); length (skins), 96-113 (106); wing, 61-65.5 (63.1); tail, 32-36 (35); culmen, 16-17.5 (16.7); tarsus, 21.5-23 (22.4); middle toe, 13.5-16 (14.5). ${ }^{a}$

Adult female.-Above much as in adult male, but pileum and hindneck decidedly browner (deep broccoli brown to prouts brown), back duller chestnut, rump and upper tail-coverts more rufescent brown, and markings on larger wing-coverts and tertials tawny or ochraceous instead of cinnamon-rufous; under parts very different, however, the chin and throat white or buffy, like chest, upper breast spotted (less heavily) with olive or grayish instead of black, and whole sides and flanks olive or buffy olive; mandible dull whitish (in dried skins); length (skins), 98-114 (108); wing, 59.5-64.5 (62.1); tail, 30-35

and other excellent structural characters, while the fourth, fifth, and sixth I also remove as a distinct genus, Myrmoborus Cabanis and Heine. (See p.14.)

There is much difference in the form of the bill between the three species of Hylophylax which I now have before me, H. nævia having this member very broad and very much depressed basally, while that of $H$. pœcilonota is much narrower, less depressed, and with the base of the gonys more prominent, II. nævioides being, however, intermediate between these extremes.

$a$ Seventeen specimens. 
(33.4); culmen, 16-17 (16.7); tarsus, 21.5-23 (22.4); middle toe, $14-15(14.6) .^{a}$

Immature male. - Similar in coloration to adult female.

Nicaragua (Rio Escondido; San Emilis, Lake Nicaragua), Costa Rica (Tucurríqui; Angostura; Pacuare; Jiménez; Rio Reventazón; Rio Sícsola; Sipúrio; Orosí; San Carlos; Volcan de Turrialba; Volcan de Miravalles; Cuábre; Carrillo; Guácimo; Guápiles; La Concepción; La Cristina; La Vijágua; Tenório; Cerro Santa Maria; Panamá (Lion Hill; Paraiso; Chepo; Panamá; Sabana de Panamá), Colombia (Rio Atrato; Rio Truando; Truando Falls) and western Ecuadór (Esmeraldas; Chimbo; Foreste del Rio Peripa; San Javier) ${ }^{b}$

Conopophaga nævioides Lafresnaye, Rev. Zool., 1847, 69 (type locality not given; Bolivia, Colombia, and Panamá; coll. Acad. Nat. Sei. Philad.).

C[onopophaga] naevioides Bonaparte, Consp. Av., i, 1850, 203.

Hypocnemis nævioides Sclater, Proc. Zool. Soc. Lond., 1858, 254 (monogr.); 1860, 294 (Esmeraldas, w. Ecuadór); Cat. Am. Birds, 1862, 189 (Esmeraldas, w. Ecuadór); Cat. Birds Brit. Mus., xv, 1890, 293 (Tucurríqui and Angostura, Costa Rica; Paraiso Station, Chepo, and Panamá, Panamá; Esmeraldas, w. Ecuadór).-Cassin, Proc. Ac. Nat. Sci. Phila., 1860, 190 (Rio Truando, Colombia).-Lawrence, Ann. Lyc. N. Y., vii, 1862, 326 (Lion Hill, Panamá); ix, 1868, 109 (Angostura and Turrialba, Costa Rica).Sclater and Salvin, Proc. Zool. Soc. Lond., 1864, 357 (Lion Hill).-Berlepsch and Taczanowski, Proc. Zool. Soc. Lond., 1883, 566 (Chimbo, w. Ecuadór).-Salvin and Godman, Biol. Centr.-Am., Aves, ii, 1892, 231.Richmond, Proc. U. S. Nat. Mus., xvi, 1893, 502 (Rio Escondido, Nicaragua).-Underwood, Ibis, 1896, 440 (Volcan de Miravalles, Costa Rica).Salvadori and Festa, Boll. Mus. Zool., etc., Torino, xv, 1899, no. 362, 32 (Foreste del Rio Peripa, w. Ecuadór).-Bangs, Proc. New Engl. Zool. Club, ii, 1900, 24 (Loma del León, Panamá).-Hartert, Novit. Zool., ix, 1902, 613 (San Javier, n. w. Ecuadór).-Thayer and Bangs, Bull. Mus. Comp. Zool., xłvi, 1906, 217 (Sabana de Panamá).

[Hypocnemis] nxioides Sclater and Salvin, Nom. Av. Neotr., 1873, 74.Sharpe, Hand-list, iii, 1901, 37.

$?$ Fourteen specimens.

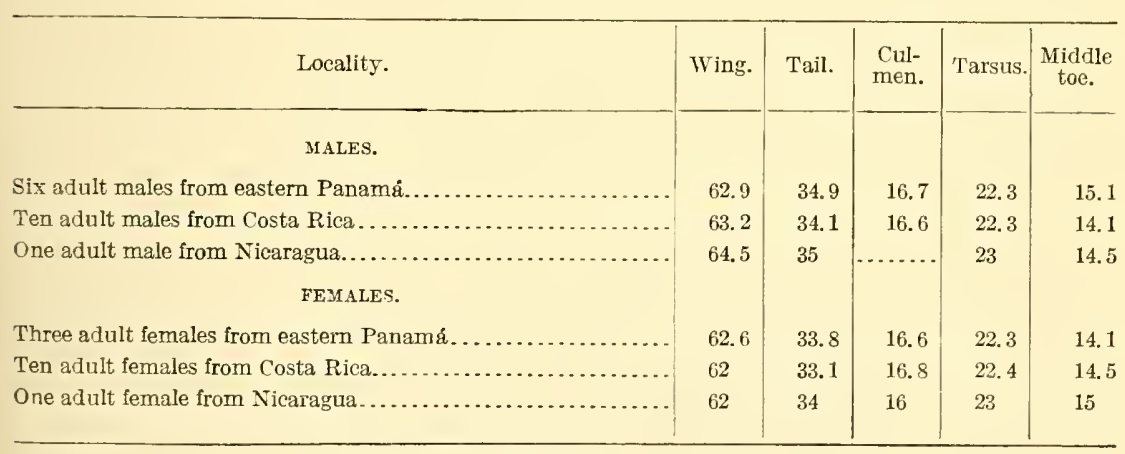

$b$ I have not seen a specimen from Ecuadór.

$81255^{\circ}-$ Bull. 50-11—9 
Hypocnemis naevoides Frantzius, Journ. für Orn., 1869, 306 (Costa Rica).

Hypocnemis nævoides ZeLEDón, Anal. Mus. Nac. Costa Rica, i, 1887, 115 (Jiménez, Pacuare, and Angostura, Costa Rica).

Hylophylax nævioides Carriker, Ann. Carnegie Mus., vi, "Aug. 29" (=Sept. 7), 1910, 619 (Costa Rica; crit.; habits).

Hypocnemis nævioides capnitis Bangs, Proc. Biol. Soc. Wash., xix, July 30, 1906, 107 (Volcan de Miravalles, n. w. Costa Rica; coll. E. A. and O. Bangs).

Genus ANOPLOPS Cabanis and Heine.

Gymnopithys "Schiff” Bonaparte, Ann. Sci. Nat., sér. iv, i, 1854, 132. (Type not mentioned; nomen nudum.)

Anoplops a Cabanis and Heine, Mus. Hein., ii, July, 1859, 9. (Type, Turdus rufigula Boddaert.)

Medium-sized Formicariidæ (length about 135-145 mm.) with second phalanx of middle toe partly united to outer toe, tail less than two-thirds (scarcely more than three-fifths) as long as wing, suborbital and postocular regions naked, outstretched feet reaching little if any beyond tip of tail, and plain coloration.

Bill shorter than head, narrow, wedged shaped in vertical profile (lateral outlines nearly straight), its width at frontal antiæ equal to or greater than its depth at same point and equal to half the distance from nostril to tip of maxilla, or less; culmen distinctly ridged, straight to near tip, where abruptly decurved, the tip of maxilla more or less distinctly (but not strongly) uncinate; tomia straight, slightly but distinctly notched subterminally; gonys strongly convex and prominent basally, gently or faintly convex and ascending terminally. Nostril exposed, posteriorly in contact with feathering of loral antiæ, narrow and longitudinally ovate (slit-like in $A$. rufigula) overhung by a broad membraneous operculum. Rictal bristles obsolete. Wing moderate or rather large, with longest primaries projecting decidedly beyond secondaries; sixth and seventh, or sixth, seventh and eighth, primaries longest, the tenth (outermost) about three-fifths as long as the longest, the ninth about as long (sometimes a little longer or shorter than) secondaries. Tail slightly more than three-fifths as long as wing, slightly rounded, the rectrices (12) rather narrow (A. rufigula) to rather broad ( $A$. bicolor, etc.), rounded terminally. Tarsus about one-third as long as wing, booted (nonscutellate) or with scutella of acrotarsium very indistinct; middle toe, with claw, nearly as long as tarsus; outer toe, without claw, not reaching to middle of subterminal phalanx of middle toe, the inner toe slightly shorter; hallux about as long as inner toe but much stouter; midlle toe united for whole of basal and part of second phalanx to outer toe, for half or more of basal phalanx to inner toe; claws rather large and strongly curved, that of the hallux decidedly shorter than the digit. Plumage full and blended, that of rump and flanks more elongated and lax; feathers 
of pileum short; anteorbital and postocular regions (A. rufigula) or suborbital, postocular, and lower portion of loral regions (A. bicolor and allies) naked; latero-frontal feathers short and erect (denser, more plush-like in $A$. rufigula).

Coloration.-Plain brown or olive, with throat tawny or rufescent, or with throat and median under parts white; ${ }^{a}$ sexes alike or nearly so.

Range.-Honduras to Amazon Valley and Cayenne. (Eleven or more species recognized. ${ }^{b}$ )

KEY TO THE SPECIES OF ANOPLOPS.

a. Underparts brown (no white), becoming tawny or rufous on throat and auricular region. (British Guiana to lower Amazon Valley.)

Anoplops rufigula (extralimital). $c$

aa. Underparts broadly white medially, including throat; auricular region black or dusky.

b. Above bright tawny-chestnut, more rufescent on forehead.

c. Sides and flanks chestnut or rufous-chestnut. (Colombia.)

Anoplops ruficeps (extralimital).d

$c c$. Sides and flanks olive-brown, becoming slate-grayish next to white of breast, etc. (Colombia and upper Amazon Valley.)

Anoplops leucaspis (extralimital). $e$

$b b$. Above vandyke brown, not more rufescent on forehead.

c. Forehead and postauricular regions slate color. (Eastern Panamá.)

Anoplops bicolor (p. 132).

$c c$. Forehead and postauricular region brown, like pileum, etc. (TTestern Panamá to eastern Honduras.).................. Anoplops olivascens (p. 132).

a A. lunulata (Sclater and Salvin), a species which I have not seen, has black and ochraceous lunulations on the back, and whitish spots on inner webs of rectrices.

$b$ Of these I have not seen the following: $A$. lunulata (Sclater and Salvin), $A$. salvini (Berlepsch), A. griseiventris (Pelzeln), A. cristata (Pelzeln), A. berlepschi Snethlage, A. hoffmannsi Hellmayr, A. pallidus Cherrie, and A. melanosticta (Sclater and Salvin). Anoplops lunulata differs from $A$. bicolor and its allies in more slender bill, much narrower and more broadly operculate nostrils, and very much denser as well as longer feathering of the loral region. The style of coloration is somewhat different, there being no white on the under parts, the chin and throat being rufous-tawny and the under parts of the body brown. The naked skin on sides of head, together with the legs and feet, are yellow, instead of blue and dusky horn color, respectively, as in $A$. bicolor, etc.

c Turdus rufigula Boddaert, Tabl. Pl. Enl., 1783, 39 (based on Petit merle brun à gorge rousse de Cayenne Daubenton, Pl. Enl., pl.644, fig. 2).-Anoplops rufigula Cabanis, Wiegmann's Archiv für Naturg., 1847, pt. i, 214.-Pithys rufigula Sclater, Proc. Zool. Soc. Lond., 1858, 273.-Gymnopithys rufigula Sclater, Cat. Birds Brit. Mus., xv, 1890, 297.-Turdus pectoralis Latham, Index Orn., i, 1790, 357.-Myothera pectoralis Temminck, Tabl. Méth., 183-?, 17.-Myrmothera pcctoralis Lesson, Traité d'Orn., 1831, 396.

l Gymnopithys ruficeps Salvin and Godman, Biol. Centr.-Am., Aves, ii, sig. 2S, Feb., 1892, 222, footnote (Cauca Valley, Colombia; coll. Brit. Mus.).

e Nyrmeciza leucaspis Sclater, Proc. Zool. Soc. Lond., 1855 (pub. Apr. 11), 253, aves, pl. 70 (Chamicuros, e. Peru; coll. J. Gould)-Dithys leucaspis Sclater, Proc. Zool. Soc. Lond., 1858, 274; Cat. Birds Brit. Mus., xv, 1890, 295.-G[ymnopithys] leucaspis Salvin and Godman, Biol. Centr.-Am., Aves, ii, sig. 2S, Feb., 1892, 221. in text. 


\section{ANOPLOPS BICOLOR (Lawrence).}

BICOLORED ANTBIRD.

Adults (sexes alike).-Above plain chestnut-brown or vandyke brown, the forehead, lores, and sides of occiput slate color or slategray, the hindneck partly the same color; malar, suborbital, and auricular regions black; sides of neck and thence to flanks (broadly) lighter brown (prouts brown to nearly sepia), sometimes with indistinct dusky spots or streaks along outer edge, especially on sides of neck; chin, throat, chest, breast, and abdomen immaculate white; under tail-coverts brown (like flanks), tipped or margined with whitish or buffy; maxilla blackish, paler (sometimes dull whitish in dried skins) terminally and along tomium; mandible dull whitish or pale dull yellowish (in dried skins), darker basally; legs and feet horn color (in dried skins).

Adult male.-Length (skins), 136-139 (138); wing, 74.5-79.5 (76.8); tail, 45.5-52 (47.8); culmen, 18.5-20.5 (19.5); tarsus, 27-28.5 (27.7); middle toe, $17.5-19$ (18.2) ${ }^{a}$

Adult female.-Length (skins), 125-126 (125.5); ${ }^{b}$ wing, 73-74 $(73.5) ;^{b}$ tail, $47-47.5(47.2) ;^{b}$ culmen, $18.5 ;^{c}$ tarsus, $26.5 ;^{c}$ middle toe, $17 .{ }^{c}$

Panamá (Lion Hill; Chepo; Paraiso; Panamá; Cascajál, Coclé; Santa Fé de Verágua).

Pithys leucaspis (not Myrmeciza leucaspis Sclater) Lawrence, Ann. Lyc. N. Y., vii, 1862, 326 (Lion Hill, Panamá).

Pithys bicolor Lawrence, Ann. Lyc. Nat. Hist. N. Y., vii, 1862, 484 (Lion Hill Station, Panamá Railway; coll. G. N. Lawrence); viii, 1867, 6 (Lion Hill).Sclater and Salvin, Proc. Zool. Soc. Lond., 1864, 357 (Lion Hill).-Salvin, Proc. Zool. Soc. Lond., 1867, 145 (Santa Fé de Verágua, Panamá).-Sclater, Cat. Birds Brit. Mus., xv, 1890, 296, part (Panamá, Chepo, and Santa Fe de Verágua, Panamá).

[Pithys] bicolor Sclater and Salvin, Nom. Av. Neotr., 1873, 74, part (Panamá). Gymnopithys bicolor Salvin and Godman, Biol. Centr.-Am., Aves, ii, 1892, 221 (Santa Fé de Verágua, Lion Hill Station, Paraiso Station, and Chepo, Panamá). [Gymnopithys] bicolor Sharpe, Hand-list, iii, 1901, 30, part (Panamá).

\section{ANOPLOPS OLIVASCENS (Ridgway).}

OLIVE-SIDED ANTBIRD.

Similar to $A$. bicolor, but pileum and hindneck wholly chestnutbrown, like rest of upper parts.

Adults (sexes alike).-Above plain chestnut-brown (prouts brown to vandyke brown or even nearly burnt-umber), including entire pileum and hindneck; narrow line immediately above bare orbital region, suborbital region, auricular region, and malar region black; sides of neck and thence (broadly) to flanks plain brown (varying from olive-brown 
to vandyke brown), usually with more or less distinct spots or broad streaks of blackish or dusky along onter edge, some of the brown feathers sometimes margined with whitish; under tail-coverts brown, tipped or margined with whitish or bufly; chin, throat, chest, breast, and abdomen immaculate white; maxilla brownish black, paler (sometimes whitish) terminally and along tomia; mandible dull whitish or pale dull yellowish (in dried skins), usually dusky basally; legs and feet horn color (in (lried skins).

Adult male.-Longth (skins), 126-143 (135); wing, 71-7S (75.1); tail, 41.5-49.5 (45.9); culmen, 17-19 (18.2); tarsus, 25.5-27.5 (26.7); middle toe, $15.5-18.5$ (17.4). ${ }^{a}$

Adult female.-Length (skins), 126-138.5 (132); wing, 70-75.5 (72.9); tail, 43-46.5 (44.4); culmen, 17-19 (17.3); tarsus, 25.5-27.5 (26.6); middle toe, $16-18.5$ (17.6). ${ }^{\circ}$

Immature male. - Similar to adults but chest mostly light mummy brown, and white of breast, etc., more or less intermixed with the same.

Honduras (Santa Ana; Chaloma), Nicaragua (Chontales; Rio Escondido; San Emilis, Lake Nicaragua), Costa Rica (Angostura; Navarro de Cartago; La Balsa; Jiménez; San José; Pacuare; San Carlos; Boruca; El Generál; Pozo del Rio Grande; Pozo Reál de Térraba; Pozo Azúl de Pirrís; Volcán de Turrialba; El Hogár; Guápiles; Cuábre; La Florída; La Cristina; La Vijágua) and westem Panamá (Divala; Volcan de Chiriquí; Boquete).

Pithys bicolor (not of Lawrence, 1863) Lawrence, Ann. Lyc. N. Y., viii, 1868, 109 (Angostura, Costa Rica).-Frantzius, Journ. für Orn., 1869, 306 (Costa Rica).-Salvin, Proc. Zool. Soc. Lond., 1870, 195 (Volcan de Chiriquí and and Bugaba, Panamá; crit.).-Sclater, Ibis, 1873, 373 (Chontales, Nicaragua); Cat. Birds Brit. Mus., xv, 1890, 296, part (Bugaba and Volcan de Chiriquí, Panamá; La Balsa, Costa Rica; Chontales, Nicaragua).-Boucard, Proc. Zool. Soc. Lond., 1878, 62 (San Carlos, Costa Rica).-ZELedón, Anal. Mus. Nac. Costa Rica, i, 1887, 115 (Navarro de Cartago, Costa Rica)._LAntz, Trans. Kansas Acad. Sci. for 1896-97 (1899), 221 (Chaloma, Honduras).

$a$ Nineteen specimens.

$b$ Thirteen specimens.

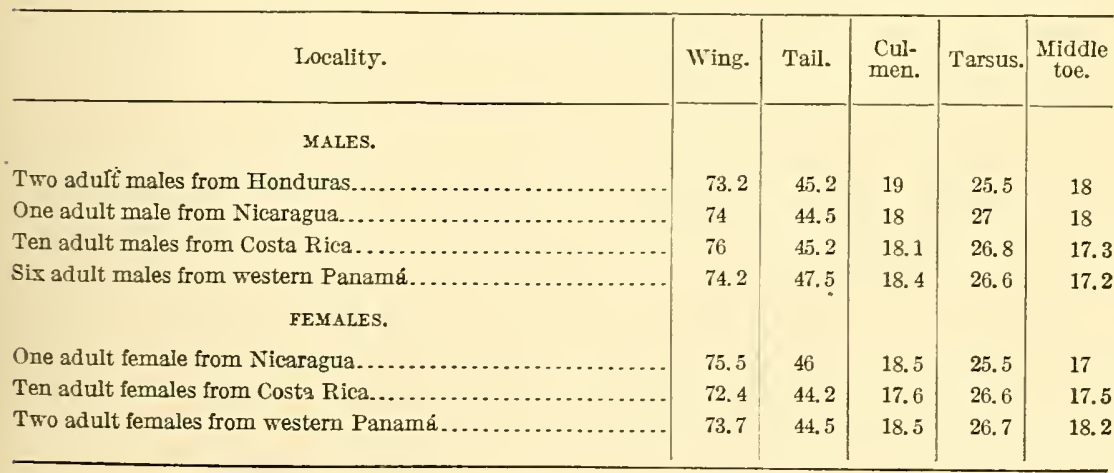


[Gymnopithys] bicolor ShaRPe, Hand-list, iii, 1901, 30, part (Nicaragua).

Pithys bicolor olivascens Ridgway, Proc. U. S. Nat. Mus., xiv, no. 868, Oct. 26, 1891, 469 (Santa Ana, Honduras; coll. U. S. Nat. Mus.).

Gymnopithys olivascens Salvin and Godman, Biol. Centr.-Am., Aves, ii, 1892, 222 (Santa Ana, Honduras; Chontales, Nicaragua; Angostura, La Balsa, Navarro de Cartago, and San Carlos, Costa Rica; Volcan de Chiriquí and Bugaba, Panamá).-Richmond, Proc. U. S. Nat. Mus., xvi, 1893, 501 (Rio Escondido, Nicaragua).-Cherrie, Expl. Zool. Merid. Costa Rica, 1893, 42 (Boruca, Costa Rica; crit.).

[Gymnopithys] olivascens SHarpe, Hand-list, iii, 1901, 30 (Honduras).

Gymnopithys bicolor olivascens Bangs, Proc. New Engl. Zool. Club, iii, Jan. 30, 1902, 42 (Boquete, Panamá, 4,000-6,000 ft.).-Cairriker, Ann. Carnegie Mus., vi, 1910, 614 (Costa Rica; crit.; habits).

Gymnopithys bicolor olivaceus BANGs, Auk, xviii, Oct., 1891, 366 (Divala, Panamá); xxiv, 1907, 296 (Boruca and Pozo del Rio Grande, s. w. Costa Rica).

\section{Genus PHANOSTICTUS Ridgway.}

Phænostictus a Ridgway, Proc. Biol. Soc. Wash., xxii, Apr. 17, 1909, 70. (Type, Phlogopsis mcleannani Lawrence.)

Medium-sized or rather large Formicariidæ (length about $190 \mathrm{~mm}$.) with bill stout and about as long as head, tail nearly as long as wing, tarsal scutella fused, sides of head naked, and with back and under parts conspicuously spotted with black.

Bill about as long as head, rather stout, moderately compressed terminally, its width at latero-frontal antiæ decidedly less than its depth at same point; culmen distinctly (almost sharply) ridged, nearly straight for most of its length or very slightly convex subbasally, decurved terminally, the tip of maxilla moderately uncinate; maxillary tomium nearly straight, slightly notched subterminally; mandibular tomium straight, minutely notched subterminally; gonys decidedly convex and prominent basally, faintly convex and ascending terminally. Nostril exposed, posteriorly in contact with thin feathering of latero-frontal antiæ, broadly oval, margined above by a rather broad extension of the membraneous integument of the nasal fossæ, an internal tubercle showing distinctly within posterior portion. Rictal bristles absent, but feathers of loral region with stiffened, bristle-like shafts. Wing moderate or rather large, with longest primaries extending considerably beyond secondaries; sixth, or fifth, sixth and seventh, primaries longest, the tenth (outermost) nearly two-thirds as long as the longest, the ninth about as long as secondaries. Tail of 12 rectrices, nearly as long as wing, graduated (graduation equal to length of tarsus or for about two-fifths its length), the rectrices rather narrow, rounded terminally. Tarsus a little more than one-third as long as wing, stout, booted (nonscutellate); middle toe, with claw, decidedly shorter than tarsus; outer toe, without claw, reaching to about middle of subterminal phalanx of middle

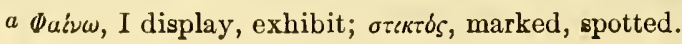


toe, the inner toe slightly but decidedly shorter; hallux as long as inner toe, much stouter; basal phalanx and half of second phalanx of middle toe united to outer toe, the former united for a little more than half its length to inner toe; claws moderate in size and curvature, that of the hallux much shorter than the digit. Plumage full, the scapulars, interscapulars, and feathers of under parts broad, distinctly outliner, and compactly webbed, those of rump and flanks more elongated and lax; feathers of pileum short; loral, suborbital, and postocular regions naked, the ear quite exposed; a tuft or spot of short velvety feathers on upper cyelid.

Coloration.-Pileum grayish brown; throat and chest black; back, scapulars, and wing-coverts olive-brown or tawny-brown with large roundish black spots, the under parts with similar but smaller spots on a more rufescent ground; tail black.

Range.-Nicaragua to Panamá. (Monotypic. ${ }^{a}$ )

\section{PHÆNOSTICTUS MCLEANNANI MCLEANNANI (Lawrence).}

MC'IEANNAN'S ANTTHRUSH.

Adults (sexes alike).-Pileum plain grayish brown (sepia to dark. broccoli brown); hindneck chestnut or rufous-chestnut; general color of upper parts light olive-brown (between raw-umber and broccoli brown), each feather of back, scapulars, wing-coverts, and tertials very conspicuously marked with a large roundish or transverse broadly elliptical subterminal spot of black, and broadly margined terminally with pale brownish buff or clay color; tail black or brownish black; loral, orbital, and auricular regions unfeathered, except for scattered bristly feathers on the first and a small patch of black feathers immediately above and another beneath eye, the naked skin azure blue in life; malar region, chin, throat, and upper chest uniform black; lower chest deep cinnamon-rufous, the lower chest similar but slightly paler or duller, each feather with a large roundish, subcordate, or broadly elliptical transverse spot of black;

a The genus Phlegopsis Reichenbach (type Myothera nigromaculata Lafresnaye and D'Orbigny), to which the type of Phænostictus has hitherto been referred, differs conspicuously in shorter and slightly rounded tail (only two-thirds as long as wing, graduated for less than one-seventh its length) of, apparently, only 10 rectrices; very dense, plush-like, feathering of forehead and anterior half of loral region; wholly (and densely) feathered malar region; covered ears; weaker bill, with less sharply ridged culmen and less elevated as well as broadly rounded mesorhinium, and wide, smooth, naked space between nostril and loral feathering. The coloration, too, while somewhat similar is really very different, the head, neck, and under parts being uniform black, the remiges and tail chestnut, the feet black instead of yellow, and the naked skin on sides of head yellow instead of blue (in life).

I have not seen Formicarius trivittatus Sclater nor F. erythropterus Gould, both of which are referred by recent authors to Phlegopsis, but, according to descriptions, these are so different in their style of coloration that the matter of their structural characters should be carefully looked into. 
breast and abdomen similarly spotted with black, but ground color less rufescent, the feathers broadly margined terminally with buff or brownish buff; flanks and lower abdomen plain olive-brown; under tail-coverts olive-brown, with a large subterminal spot of blackish and terminally margined with buffy brown or brownish buff; bill black, horn color or brownish at tip; iris brown; legs and feet yellowish (in dried skins-probably pinkish in life).

Young.-Pileum black, broadly barred with light gray; otherwise essentially like adults, but markings of back, etc., much less regular in form and less sharply contrasted, the feathers broadly tipped or terminally margined with tawny-buff, the under parts much darker, without any jugular area of cinnamon-rufous, the chest being black spotted with brownish tawny or cinnamon.

Adult male.--Length (skins), 174-200 (191); wing, 86-97 (92); tail, 80-92.5 (86.3); culmen, 21.5-22.5 (22.1); tarsus, 32-33.5 (32.7); middle toe, $19-21.5$ (20.6) ${ }^{a}$

Adult female.-Length (skins), 184-203 (194); wing, 88-91 (89); tail, 82.5-88 (84.8); culmen, 22-23 (22.7); tarsus, 31-32.5 (31.8); middle toe, $20-21.5(20.7) .^{b}$

Eastern Panamá (Lion Hill; Panamá; Cascajál, Coclé; Santiago de Verágua ?). ${ }^{c}$

Phlogopsis mcleannani Lawrence, Ann. Lyc. Nat. Hist. N. Y., vii, 1862 (pub. May, 1860), 285, 294 (Lion Hill Station, Panamá Railway; coll. U. S. Nat. Mus.).

Phlogopsis macleannani Sclater and Salvin, Proc. Zool. Soc. Lond., 1864, 357 (Lion Hill); Exotic Orn., pt. ii, pl. 9 (vol. ii, 1867, 17, pl. 15).--Salvin, Proc. Zool. Soc. Lond., 1867, 145 (Santiago de Verágua).-Sclater, Cat. Birds Brit. Mus., xv, 1890, 300, part (Panamá; Santiago de Verágua).Salvin and Godman, Biol. Centr.-Am., Aves, ii, 1892, 236, part (Lion Hill, Panamá; Santiago de Verágua).-Bangs, Proc. New Engl. Zool. Club, ii, 1900, 24 (Loma del Leon, Panamá).

[Phlogopsis] macleannani Sclater and Salvin, Nom. Av. Neotr., 1873, 75.-

Sharpe, Hand-list, iii, 1901, 37, part (Panamá).

(?)Phlegopsis macleannani Hartert, Novit. Zool., ix, 1902, 613 (Bulún, Rio Bogotá, n. w. Ecuadór; crit.).

\section{PHÆNOSTICTUS MCLEANNANI SATURATUS (Richmond).}

RICHMOND'S ANTTHRUSH.

Similar to P. m. mcleannani, but coloration decidedly brighter, the general color of upper parts more tawny brown, with margins to feathers of back, etc., tawny or light tawny-brown instead of buffy,

$a$ Five specimens.

$b$ Three specimens.

$c$ I have not seen specimens from Verágua. They may be referable to $P . m$. saturatus. 
the under parts also much more tawny brown, with cinnamon-rufous of chest brighter. ${ }^{a}$

Adult male.-Length (skins), 1S3-202 (191); wing, 91.5-96 (93.4); tail, S1-\$S.5 (\$4.6); culmen, 21-23 (22.1); tarsus, 30.5-34 (32.9); middle toe, $20-21.5(20.7){ }^{b}$

Adult female.--Length (skins), 177-194 (184); wing, S6-90.5 (88.7); tail, 76.5-83 (79.1); culmen, 20.5-23 (21.8); tarsus, 29-33 (31.5); middle toe, $15.5-21(20.2) .^{b}$

Costa Rica (Tucurríqui; Angostura; Rio Súcio; Rio Reventazón; El Hogár; Guápiles; La Cristina; San Carlos; Cariblanco de Sarapiquí; Cerro Santa Míaria; Tenório; La Vijágua; Volcan de Miravalles) and Nicaragua (Chontales; Rio Escondido).

Phlogopsis macleannani (not of Lawrence, 1862) LAwrence, Ann. Lyc. N. Y., ix, 1868, 109 (Angostura, Costa Rica).-SAlvin, Proc. Zool. Soc. Lond., 1872, 313, 318 (Chontales, Nicaragua).-Ridgway, Proc. U. S. Nat. Mus., vi, 1883, 415 (Rio Súcio, Costa Rica).-Zeledón, Anal. Mus. Nac. Costa Rica, 1887, 115 (Rio Súcio).-Sclater, Cat. Birds Brit. Mus., xv, 1890, 300, part (Chontales, Nicaragua; Tucurríqui, Costa Rica).-SAlvin and Godman, Biol. Centr.-Am., Aves, ii, 1892, 236, part (Chontales, Nicaragua; Tucurríqui, Angostura, and Rio Súcio, Costa Rica).-Richmond, Proc. U. S. Nat. Mus., xvi, 1893, 502 (Rio Escondido, Nicaragua; habits, etc.).-Underwoon, Ibis, 1896, 441 (Volcan de Miravalles, Costa Rica).

[Phlogopsis] macleannani Sharpe, Hand-list, iii, 1901, 37, part (Nicaragua).

Phlegopsis macleannani Frantzius, Journ. für Orn., 1869, 306 (Costa Rica).

Phlegopsis saturata Richмond, Proc. U. S. Nat. Mus., xviii, Aug. 12, 1896, 625

(Rio Escondido, $50 \mathrm{~m}$. from Bluefields, Nicaragua; coll. U. S. Nat. Mus.).

[Phlogopsis] saturata Sharpe, Hand-list, iii, 1901, 37 (Nicaragua).

Phænostictus macleannani saturatus CARRIKER, Ann. Carnegie Mus., vi, 1910, 622

(Caribbean lowlands and foothills of Costa Rica, 600-1,500 ft.; crit.; habits).

$a$ "Naked skin on head azure blue, around ears and along lower jaw campanula blue; bill black; tarsi, feet, and claws pinkish vinaceous." (C. W. Richmond.)

$b$ Eleven specimens.

\begin{tabular}{|c|c|c|c|c|c|}
\hline Locality. & Wing. & Tail. & $\begin{array}{l}\text { Cul- } \\
\text { men. }\end{array}$ & Tarsus. & $\begin{array}{l}\text { Middle } \\
\text { toe. }\end{array}$ \\
\hline MALES. & & & & & \\
\hline One aduit male from Nicaragua.... & 95.5 & 88.5 & 21 & 32.5 & 20 \\
\hline Ten adult males from Costa Rica ............ & 93.1 & 84.2 & 22.1 & 32.9 & 20.7 \\
\hline Five adult males (P. m. mcleannani) from Panamá... & 92 & 86.3 & 22.1 & 32.7 & 20.6 \\
\hline FEMALES. & & & & & \\
\hline One adult female from Nicaragua.. & 87.5 & 76.5 & 22 & 32 & 21 \\
\hline Ten adult females from costa Rica.................... & 88.8 & 79.3 & 21.6 & 31.3 & 20.1 \\
\hline Three adult females (P. m. mcleannani) from Panamá. & 89 & 84.8 & 22.7 & 31.8 & 20.7 \\
\hline
\end{tabular}


Genus RHOPOTERPE Cabanis.

(?) Myrmornis Hermann, Tab. aff. Anim., 1783, 188, 235. (Type, Fourmillier Buffon.) $a$

Formicivorus Temminck, Cat. Syst. Cab. Orn., 1807, 92. (Type, by tautonomy, Formicivorus palikour Temminck=Turdus formicivorus Gmelin=Formicarius torquatus Boddaert.)

(?) Urotomus Swainson, Zool. Journ., i, no. 3, Oct., 1824, 302, in text (nomen nudum); iii, no. 10, Sept., 1827, 166 (diagnosis, but no species named).

Rhopoterpe 6 CaBanis, in Wiegmann's Archiv für Naturg., xiii, pt. i, 1847, 227, 337. (Type, Turdus formicivorus Gmelin=Formicarius torquatus Boddaert.)

Medium-sized Formicariidæ (length about 130-150 mm.) with planta tarsi broadly rounded (not ridged) behind; tarsus only onefourth as long as wing; tail only two-fifths as long as wing, nearly even; bill as long as or longer than head (commissure longer than tarsus), with mesorhinium broad and flattened basally; coloration variegated, with a white or fulvous band across subbasal portion of remiges, and outer web of primaries crossed by an oblique subterminal band of buff or fulvous.

Bill as long as or longer than head, rather slender, rather broad and depressed basally, its width at loral antiæ greater than its depth at same point and equal to less than half the distance from nostril to tip of maxilla; culmen distinctly ridged (except extreme base, where broad and flattened), straight for most of its length, abruptly decurved terminally, the tip of maxilla moderately uncinate; tomia straight, slightly but distinctly notched subterminally; gonys slightly convex, rather prominent basally. Nostril exposed, separated rather widely from loral feathering, narrow, longitudinal (slit-like) overhung by a rather broad convex operculum. Rictal bristles obsolete, and feathers of chin, malar apex, loral antiæ, etc., short, without terminal setæ. Wing large, very concave beneath, rather pointed, the longest primaries projecting considerably beyond secondaries; sixth and seventh, or sixth, seventh, and eighth primaries longest, the tenth (outermost) three-fourths as long as the longest, the ninth longer than secondaries. Tail very short (only two-fifths as long as wing), nearly even, the rectrices rather narrow, soft, with subacuminate tip. Tarsus shorter than commissure, only one-fourth as long as wing, rather stout, distinctly scutellate, the planta rather broadly rounded

$a$ The "Fourmillier" of Buffon comprises thirteen species, belonging to eleven recognized genera and four families (Formicariidæ, Conopophagidæ, Pittidæ, and Troglodytidæ). So far as I can determine no one has ever fixed a type, and to do so by any other method than the "process of elimination" would involve an amount of time and labor which is not at my disposal. Under the circumstances, I prefer to retain the generic name Rhopoterpe, notwithstanding the unquestioned priority and pertinence of Formicivorus, leaving the final solution of the question to some one who has both the time and taste for such investigation.

$\checkmark$ " $\dot{\rho} \dot{\omega} \psi$ Gesträuch; $\tau \hat{\varepsilon} \rho \pi \omega$, erquicken." (Cabanis.) 
(not ridged) posteriorly, the plantar scutella forming a single series which bends around from the outer to the inner side, where separated from the inner edge of the acrotarsium by a distinct groove; middle toe, with claw, longer than tarsus; outer toe, without claw, not reaching to middle of subterminal phalanx of niddle toe, the inner toe very slightly shorter; hallux as long as outer toe, but much stouter; basal phalanx of middle toe wholly united to outer toe, for about half its length to imner toe; claws moderate in size and curvature, that of the hallux shorter than the digit. Plumage rather thin, but feathers mostly broad and distinctly outlined, those of rump and flanks more elongated and lax; feathering of head very short (scalelike on superciliary region and sides of neck), the rictal and postocular regions naked.

Coloration.-Above brownish, with a concealed white dorsal patch; wings black with two buffy or fulvous bands (tips of middle and greater coverts) and an oblique band of same across subterminal portion of primaries; a broad white band across inner webs of remiges near base; under parts of body gray, the throat and upper chest black in male, rufous-tawny in female.

Range.-Nicaragua to Cayenne and Ecuadór. (Two species. ${ }^{a}$ )

KEY TO THE SPECIES OF RHOPOTERPE.

a. Inner webs of remiges crossed by a band of white; remiges without buff or tawny terminal spots; upper tail-coverts and tail cinnamon-rufous. (Cayenne and British Guiana to eastern Ecuadór.).........Rhopoterpe torquata (extralimital).b $a a$. Inner webs of remiges crossed by a band of buff or tawny; remiges tipped with a buff or tawny spot; upper tail-coverts and tail brown. (Eastern Nicaragua.)

Rhopoterpe stictoptera (p. 139).

\section{RHOPOTERPE STICTOPTERA Salvin.}

RICHARDSON'S ANTTHRUSH.

Allied to R. torquata and of the same size and for the most part similar in coloration; but top of head darker, rump and tail more fuscous, outer web of remiges with a distinct terminal spot of fawn

a The above description is based entirely on the type of the genus, $R$. torquata (Gmelin). R. stictoptera Salvin, of Nicaragua, which I have not seen, is apparently very similar in coloration, but has the band across inner webs of remiges fulvous instead of white.

b Formicarius torquatus Boddaert, Tabl. Pl. Enl., 1783, 43 (Cayenne; based on Le Fourmillier de Cayenne Daubenton, Pl. Enl., pl. 700, fig. 1).-Rhopoterpe torquata Sclater, Proc. Zool. Soc. Lond., 1858, 275; Cat. Birds Brit. Mus., xv, 1890, 298.[Turdus] formicivorus Gmelin, Syst. Nat., i, pt. 2, 1788, 828 (based on Fourmillier de Cayenne Daubenton, PI. Enl., pl. 700, fig. 1).-Myrmothera formicivora Vieillot, Nouv. Dict. d'Hist. Nat., xii, 1817, 114, pl. D. 26.-Rhopoterpe formicivora Cabanis, Wiegmann's Archiv für Naturg., 1847, pt. i, 228.-Formicivorus palikour Temminck, Cat. Syst. Cabinet d'Orn., 1807, 93 (new name for Turdus formicivorus Gmelin).-Myioturdus palikour Ménétriés, Mém. Acad. St. Petersburg, sér. vi (Sci. Nat.), 1 (Livr. 5), 1835,470 . 
color, the inner webs with a spot of fawn color (not white) , and greater wing-coverts tipped with clear fawn color. ${ }^{a}$

Nicaragua (Santo Domingo, Chontales).

Rhopoterpe stictoptera Salvin, Bull. Brit. Orn. Club, no. vi, March 1, 1893, p. xxxii; Ibis, 6th ser. v, no. 18, April, 1893, 264 (Santo Domingo, Chontales, Nicaragua; coll. Salvin and Godman).

[Rhopoterpe] stictoptera SHARPE, Hand-list, iii, 1901, 31.

\section{Genus PITTASOMA Cassin.}

Pittasoma Cassin, Proc. Ac. Nat. Sci. Phila., 1860, 189. (Type, P. michleri Cassin.)

Pittisoma (emendation) Sclater and Salvin, Proc. Zool. Soc. Lond., 1864, 357.

Calobamon b Heine, in Heine and Reichenow, Nomencl. Mus. Hein. Orn., 1890, 123. (New name for Pittasoma Cassin, on grounds of purism.)

Very large Formicariidæ (length about 160-180 mm.) with excessively short tail (shorter than commissure, only one-third as long as the short, much-rounded wing), stout, distinctly uncinate, bill, very long tarsi (half as long as wing), and conspicuously variegated coloration.

Bill nearly as long as head, stout, rather broad and slightly depressed basally, its width at loral antiæ much greater than its height at same point and equal to half the distance from nostril to tip of maxilla, or slightly more; culmen distinctly but not sharply ridged, slightly curved from near base to near tip, where more strongly decurved, the tip of maxilla strongly uncinate; maxillary tomium straight or very faintly concave, distinctly notched subterminally; mandibular tomium faintly convex, slightly but distinctly notched subterminally; gonys strongly convex and prominent basally, nearly straight for most of its length, ascending terminally, the tip of the mandible forming an obtuse, slightly recurved, point. Nostril exposed, posteriorly in contact with loral feathering, longitudinally oval, with a thin, pointed, internal tubercle or splint in upper posterior portion. Rictal bristles present but short and inconspicuous. Wing rather short, much rounded, the longest primaries scarcely if at all extending beyond secondaries; fifth and sixth, or fourth, fifth, and sixth, primaries longest, the tenth (outermost) less than two-thirds as long as the longest, the ninth much shorter than secondaries. Tail excessively short, shorter than commissure, only one-third as long as wing, the rectrices relatively broad. Tarsus much longer than commissure, half as long as wing, stout, rounded posteriorly, distinctly scutellate, the plantar scutella indistinct (fused on upper half or more); middle toe, with claw, about three-fourths as long as tarsus; outer toe, without claw, reaching to a little beyond subterminal articulation of mid-

b Kaגos, beautiful; $\beta \tilde{a} \mu a(\beta \tilde{\eta} \mu a)$, a step, pace. 
Ile toe, the inner toe reaching about to the joint; hallux about as long as imner toe, but much stouter; basal phalanx of middle too united to outer too for greater part of its length, to inner toe for less than half its length; claws moderate in size and curvature, that of the hallux shorter than the digit. Plumage full, with feathers broad and distinctly outlined, those of rump and flanks more elongated, blended, and lax; feathers of pileum rather stiff, slightly elongated; an elongated, narrow, naked postocular space.

Coloration.-Head black, with more or less of chestnut on lateral portion, the throat sometimes spotted with brown and whitish; above brown, the back streaked with black, wing-coverts with subapical spots of buff or light fulvous margined with black; under parts broadly barred or squamated with white and black.

Range.-Eastern Costa Rica to northwestern Ecuadór. (Two species.)

KEY TO THE SPECIES AND SUBSPECIES OF PITTASOMA.

a. Pileum, including superciliary and supra-auricular regions, uniform black.

b. Smaller (wing 93-99.5 in adult male, 93.5-95.5 in adult female); auricular and suborbital regions wholly chestnut. (Panamá.)

Pittasoma michleri michleri (p. 141).

b6. Larger (wing 99.5-115 in adult male, 97.5-100.5 in adult female); auriculars and suborbital regions black, or mostly so. (Costa Rica.)

Pittasoma michleri zeledoni (p. 142).

aa. Pileum rufous, bordered laterally by a black superciliary stripe. (Northwestern Ecuadór.)

Pittasoma rufopileatum (extralimital). ${ }^{a}$

\section{PITTASOMA MICHLERI MICHLERI Cassin.}

MICFLER'S ANTPITTA.

Adult male.-Pileum, including upper half of lores and whole of superciliary region, uniform black (slightly glossy); back, scapulars, rump, and upper tail-coverts olive-brown to vandyke brown, the first broadly but not sharply streaked with black (the feathers sometimes also narrowly squamately margined with the same), and with narrow buffy shaft-streaks; tail deep chestnut-brown; wings deep chestnutbrown, the middle and greater coverts with a small subterminal transverse spot of whitish or buffy, inclosed between a small black spot and a narrow terminal bar; ${ }^{b}$ tertials with a more or less distinct apical spot of buff or tawny; outer webs of primaries lighter chestnutbrown than the general color; lower half of lores dull white, usually somewhat flecked with dusky; auricular and malar regions uniform deep chestnut, the latter, however, partly mixed with black, especially

a Pittasoma rufopileatum Hartert, Novit. Zool., viii, no. 3, Oct. 5, 1901, 370 (Salidero, Bulún, n. w. Ecuadór; coll. Tring Mus.); ix, 1902, 615, pl. 8.

This species I have not seen.

$b$ Sometimes a few of the lesser coverts have similar but smaller markings. 
the posterior portion; sides of neck mummy brown; chin and throat black (chin sometimes mostly white), broken, more or less, by narrow shaft-streaks or small spots of white or chestnut, the feathers of lower throat sometimes tipped with chestnut; rest of under parts mostly white, heavily marked with broad U-shaped bars of black, the flanks light mummy or chestnut-brown, indistinctly barred with dusky, the under tail-coverts brownish white or pale tawny barred or lunulated with black; maxilla brownish black or blackish brown, paler on tomium; mandible pale yellowish (in dried skins); legs and feet pale yellowish horn color (in dried skins); length (skins), 160-175 (167); wing, 93-99.5 (97.1); tail, 33-37.5 (35.5); culmen, 26.5-27.5 (27); tarsus, 47-52 (49.7); middle toe, 26-29.5 (27.6). ${ }^{a}$

Adult female.-Above similar to the adult male; chin and throat mixed white and light chestnut irregularly spotted or barred with black; remaining under parts as in adult male, but black U-shaped markings narrower, and the white general color more or less suffused or tinged with buff, the chest sometimes washed with rusty; length (skins), 155-178 (164); wing; 93.5-95.5 (94.4); tail, 32-35 (33.1); culmen, 26 ; tarsus, 46.5-49 (48.1); middle toe, $27-29$ (28). ${ }^{b}$

Immature female.--Similar to the adult female, but lower throat tawny, chin and upper throat white, with a few narrow streaks of black.

Panamá (Lion Hill; Panamá; Laguna del Pita; Santa Fé and Calovévora, Verágua ? ${ }^{c}$ ) and adjacent portion of northwestern Colombia (Rio Truando).

Pittasoma michleri Cassin, Proc. Ac. Nat. Sci. Phila., 1860, 189 (Rio Truando, Colombia; coll. U. S. Nat. Mus.); 1864, 257, pl. 3.-Lawrence, Ann. Lyc. N. Y., vii, 1862, 326 (Lion Hill, Panamá).-Salvin, Proc. Zool. Soc. Lond., 1867, 146 (Santa Fé de Verágua, Panamá); 1870, 196 (Calovévora, Panama).-Sclater, Cat. Birds Brit. Mus., xv, 1890, 309.-Salvin and Godman, Biol. Centr.-Am., Aves, ii, 1892, 237.-Salvadori and Festa, Boll. Mus. Zool., etc., Torino, xiv, 1899, no. 339, 7 (Laguna del Pita, Panamá).

[Pittasoma] michleri Sclater and Salvin, Nom. Av. Neotr., 1873, 75.-Sharpe, Hand-list, iii, 1901, 40.

Pittisoma michleri Sclater and Salvin, Proc. Zool. Soc. Lond., 1864, 357 (Panamá; crit.).

PITTASOMA MICHLERI ZELEDONI Ridgway.

ZELEDÓN'S ANTPITTA.

Similar to $P . m$. michleri but decidedly larger; adult male with head entirely black, except for a tinge of chestnut on auricular region.

$a$ Seven specimens.

$b$ Four specimens.

$c$ I have not seen specimens from Verágua. They may be referable to $P$. $m$. zeledoni. 
Adult male--Length (skins), 175-179 (177); wing, 99.5-115 (105.1); tail, 31.5-34 (33); culmen, 29-31 (30); tarsus, 50-51.5 (50.7); middle toe, $2 S .5-31(30.2){ }^{a}$

Adult female.-Length (skins), 166-1S1 (172); wing, 97.5-100.5 (9S.7); tail, 33.5-36 (34.3); culmen, 27-30 (2S.5); tarsus, 46-52 (4S); middle toe, 29-31 (30). ${ }^{a}$

Eastern Costa Rica (Rio Súcio; Rio Sícsola; Jiménez; Carrillo).

Pittasoma michleri zeledoni Ridgway, Proc. U. S. Nat. Mus., vi, Apr. 11, 1884, 414 (Rio Súcio, Costa Rica; coll. U.S. Nat. Mus.).-Zelenón, Anal. Mus., Costa Rica, i, 1S57, 115 (Jiménez, Costa Rica).-Carriker, Ann. Carnegie Mus., vi, 1910, 626 (Caribbean foothills of Costa Rica, to about 2,500 ft.; habits).

Pittasoma zeledoni Sclater, Cat. Birds Brit. Mus., xv, 1890, 310.-SAlvin and Godman, Biol. Centr.-Am., Aves, ii, 1892, 238.

[Pittasoma] zeledoni Sharpe, Hand-list, iii, 1901, 40.

\section{Genus GRALLARICULA Sclater.}

Grallaricula Sclater, Proc. Zool. Soc. Lond., 1858, 283. (Type, Grallaria flavirostris Sclater.)

Small Formicariidæ (length about 90-115 mm.) with very short, emarginate tail (only about one-third as long as wing), short and broad but rather thick bill, long and conspicuous rictal bristles, rather long, slender tarsi (about one-third as long as wing), the color plain brown or olive above, whitish or tawny below, usually more or less streaked or squamated with black or dusky-sometimes plain gray, with head and neck chestnut.

Bill much shorter than head, rather stout, broadly wedge-shaped in vertical profile, its width at loral antiæ decidedly greater than its depth at same point and equal to about three-fifths the distance from nostril to tip of maxilla; culmen distinctly ridged, gradually and rather strongly decurved from near base, the tip of maxilla distinctly but rather minutely uncinate; maxillary tomium slightly concave, distinctly but minutely notched subterminally; mandibular tomium faintly convex (at least distally), faintly notched subterminally; gonys faintly or gently convex, not prominent basally. Nostril partly exposed, partly hidden by antrorse feathering of loral antiæ, small, longitudinal, narrowly oval or elliptical, overhung by a rather broad extension of the membraneous integument of the nasal fossæ. Rictal bristles conspicuously developed, nearly (sometimes quite) as long as bill, the feathers of chin, malar antiæ, and loral region with distinct terminal setæ. Wing rather long, with longest primaries much longer than secondaries; sixth and seventh primaries longest, the tenth (outermost) two-thirds as long as longest, or slightly more, the ninth decidedly longer than secondaries. Tail about one-third as long as 
wing, even, slightly double rounded, or slightly emarginate, the rectrices (10 ?) very narrow, rounded or minutely subacuminate terminally. Tarsus much longer than commissure, about one-third as long as wing, slender, distinctly scutellate, the plantar scutella in a single longitudinal series, bending around to the inner side, where separated from the inner edge of the acrotarsium by a rather broad shallow groove; middle toe, with claw, much shorter than tarsus, decidedly shorter than commissure; outer toe, without claw, reaching very nearly to middle of subterminal phalanx of middle toe, the inner toe very slightly shorter; hallux about as long as inner toe but much stouter; basal phalanx of middle toe united for more than half its length to outer toe, for about half its length to inner toe; claws moderate in size and curvature, that of the hallux shorter than the digit, acute, much compressed. Plumage full, soft, and (mostly) blended, that of rump and flanks more elongated and fluffy or lax; feathers of pileum slightly elongated, distinctly outlined.

Coloration.-(I) Above plain brown or olive; beneath white, or white and ochraceous, tawny, or rufescent, usually more or less streaked or squamated with black or dusky. (II) Head (all round) chestnut; rest of plumage plain brownish gray above, lighter and clearer gray beneath, with patch of white on lower abdomen and foreneck.

Range.-Costa Rica to mountains of British Guiana and Ecuadór. $\left(\right.$ Six species. $^{a}$ )

\section{KEY TO THE SPECIES OF GRALLARICULA.}

a. Under parts without streaks or other markings (tawny or tawny-ochraceous, the throat and abdomen sometimes white or whitish). (Santa Marta district of Colombia to Venezuela.).......... Grallaricula ferrugineipectus (extralimital). $b$ aa. Under parts more or less streaked or spotted with blackish or dusky.

$b$. Paler olive-brown above; under parts with less of ochraceous and with black streaks or squamations much heavier. (Colombia to eastern Ecuadór.)

Grallaricula flavirostris (extralimital).c

$b b$. Darker olive-brown above; under parts with more ochraceous or ochraceoustawny (mostly so) with blackish streaks or squamations indistinct. (Costa Rica and western Panamá.)............... . Grallaricula costaricensis (p. 145).

$a$ Of these I have seen only $G$. flavirostris (Sclater), G. ferrugineipectus (Sclater), and $G$. costaricensis Lawrence.

b Grallaria ferrugineipectus Sclater, Proc. Zool. Soc. Lond., 1857 (pub. Oct. 21), 129 (near Carácas, Venezuela; coll. Paris Mus.); Ann. and Mag. N. H. (2), xx, 1857, 462 (reprint).-Grallaricula ferrugineipectus Sclater, Proc. Zool. Soc. Lond., 1858, 284 (monogr.); Cat. Birds Brit. Mus., xv, 1890, 326.-Conopophaga browni Bangs, Proc. Biol. Soc. Wash., xiii, Nov. 11, 1899, 100 (Chirua, Santa Marta, Colombia, 7,000 ft.; coll. E. A. and O. Bangs).

c Grallaria flavirostris Sclater, Proc. Zool. Soc. Lond., 1855 (pub. Apr. 26), 68 (Rio Napo, e. Ecuadór; coll. Verreaux).-Grallarimula favirostris Sclater, Proc. Zool. Soc, Lond., 1858, 283 (monogr.); Cat. Birds Brit, Mus., xv, 1890, 326. 


\section{GRALLARICULA COSTARICENSIS Lawrence.}

\section{COSTA RICAN GRALLARICULA.}

Adults (sexes alike.)-Pileum and hindneck plain grayish olive, more brownish on forehead; rest of upper parts plain brownish olive, the general color of wings, together with tail, decidedly browner (sometimes nearly prouts brown); outer web of exterior feather of alula buff or ochraceous-buff; wing-coverts sometimes with an indistinct terminal spot or terminal margin of light tawny or rufescent brown; an indistinct orbital ring of tawny ; lores buffy or ochraceous, suffused with black or dusky in middle portion; suborbital and auricular regions olive tinged with tawny, the latter" with very indistinct narrow shaft-streaks of paler; malar region, chin, throat, chest, and sides ochraceous or tawny-ochraceous, usually somewhat paler on chin and throat, the chest usually more or less distinctly marked (irregularly) with black or dusky; abdomen and median lower part of breast white or buffy white, the latter, as well as sides of abdomen, usually flecked with black or dusky; under tail-coverts pale buff or buffy whitish; under wing-coverts clear ochraceous, those over carpo-metacarpal joint, more or less extensively, dusky; inner webs of remiges rather indistinctly edged with brownish buff or pale wood brown; maxilla horn brown (more or less dark), mandible pale dull yellowish (wax yellow in life) ${ }^{a}$ iris brown ${ }^{b}$ or red; ${ }^{a}$ legs and feet pale yellowish brown (yellowish olive in life). ${ }^{a}$

Adult male.--Length (skin), 97; wing, 66; tail, 26; culmen, 13.5; tarsus, 21.5 ; middle toe, 13.5 .

Adult female.-Length (skins), 86.5-100.5 (92); wing, 61.5-64 (62.8); tail, 18-24.5 (21.7); culmen, 13.5-14.5 (14); tarsus, 20.5-21 (20.7); middle toe, $13.5-14(13.7){ }^{c}$

Costa Rica (Navarro; Barranca; Buena Vista; Rio Súcio; Cariblanco de Sarapiquí; base of Volcán de Turrialba, 2,000 ft.) and western Panamá (Chitra; Calovévora; Calobre; Cordillera de Tolé; Caribbean slope, Chiriquí).

Grallaricula costaricensis Lawrence, Ann. Lyc. Nat. Hist. N. Y., viii, 1867, 346 (Barranca, Costa Pica; coll. U. S. Nat. Mus.); ix, 1868, 110 (Barranca).Saltix, Proc. Zool. Soc. Lond., 1867, 146 (Cordillera de Tolé, Panamá);

a J. C. Zeledón, on label.

$b \mathrm{~F}$. Carmiol, on label.

c Three specimens.

\begin{tabular}{|c|c|c|c|c|c|}
\hline Locality. & Wing. & Tail. & $\begin{array}{l}\text { Cul- } \\
\text { men. }\end{array}$ & Tarsus. & $\begin{array}{l}\text { Middle } \\
\text { toe. }\end{array}$ \\
\hline Two adult females from Costa Rica & 62.3 & 20.3 & 14 & 20.7 & 13.7 \\
\hline One adult female from western Panamả (Chiriquí).......... & 64 & 24.5 & 14 & & \\
\hline
\end{tabular}


1870, 196 (Chitra and Calovévora, Panama).-Frantzius, Journ. für Orn., 1869, 306 (Costa Rica).-Ridgway, Proc. U. S. Nat. Mus., vi, 1883, 415 (Navarro, Costa Rica).

Grallaricula flavirostris costaricensis CARRIKER, Ann. Carnegie Mus., vi, 1910, 630 (Cariblanco de Sarapiquí and base of Volcán de Turrialba, 2,000 ft., Costa Rica).

[Grallaricula] flavirostris (not Grallaria flavirostris Sclater, 1858) Sclater and Salvin, Nom. Av. Neotr., 1873, 76, part (Costa Rica; Verágua).-SHARpe, Hand-list, iii, 1901, 44, part (Costa Rica; Panamá).

Grallaricula flavirostris Sclater, Cat. Birds Brit. Mus., xv, 1890, 326, part (Buena Vista, Costa Rica; Calovévora and Cordillera de Tolé, Panamá).-Salvin and Godman, Biol. Centr.-Am., Aves, ii, 1892, 245, part (Barranca, Buena Vista, and Rio Súcio, Costa Rica; Chitra, Cordillera de Tolé, Calovévora, and Calobre, Panamá).

(?) Grallaricula vegeta Bangs, a Proc. New Engl. Zool. Club, iii, Jan. 30, 1902, 42 (Caribbean slope of Volcán de Chiriquí, 4,000ft., Panamá; coll. E. A. and O. Bangs).

\section{Genus GRALLARIA Vieillot.}

Grallaria Vierldot, Analyse, 1816, 43. (Type, Roi des Fourmilliers Buffon=Formicarius varius Boddaert.)

Myioturdus Bore, Isis, 1826, 972. (Type, Formicarius varius Boddaert.)

Myiotrichas BoIe, Isis, 1831, 542. (Type, Formicarius varius Boddaert.)

Colobathris $b$ Gloger, Hand- und Hilfsb. der Natürg., 1842, 304. (New name for "Grallina" = Grallaria Vieillot.)

Chamæbates $c$ Bertoni, Aves Nuevas del Paraguay, 1901, 150. (Type, C. rufiventris Bertoni= Myiothera grallaria Lichtenstein.)

Very large terrestrial Formicariidæ (length about 160-210 mm.) with the slender tarsus less than half as long as wing, tail less than half (usually only two-fifths) as long as wing, and plumage of upper parts more or less distinctly squamated with dusky.

Bill shorter than head, stout, much deeper than broad at base, its width at loral antiæ decidedly less than its height at same point and equal to a little to considerably less than half the distance from nostril to tip of maxilla; culmen very indistinctly if at all ridged, gradually but rather strongly curved from base, the tip of maxilla distinctly but not abruptly uncinate; maxillary tomium very slightly concave, distinctly notched subterminally; mandibular tomium nearly straight or very faintly convex, with faint subterminal notch; gonys slightly to very faintly convex, very ascending terminally, not prominent basally. Nostril exposed, posteriorly in contact with loral feathering, obliquely broadly oval, with an internal tubercle or septum showing within upper posterior portion. Rictal bristles distinct but very slender;

$a \mathrm{I}$ am not satisfied as to the distinctness of $G$. vegeta. The individual variation among Costa Rican specimens (of which, however, I have seen but few) is considerable, and I strongly suspect that a larger series of specimens would show the hirds from western Panamá to be inseparable.

$\checkmark$ See also Colobalhris Cabinis, Wiegmann's Archiv, 1847, i, 216.

$c$ Xopać, on the ground; $\beta \dot{a} \tau \eta \zeta$, one who treads or covers. (Bertoni.) 
feathers of chin and upper throat with long, slender, terminal setæ. Wing moderate or rather large, with longest primaries projecting considerably beyond secondaries; sixth and seventh, or fifth, sixth, seventh, and eighth primaries longest, the tenth (outermost) about two-thirds to three-fourths as long as the longest, the ninth decidedly to much longer than secondaries. Tail two-fifths to nearly half as long as wing, even, or very slightly rounded, the rectrices (12) rounded terminally. Tarsus less than half as long as wing, slender, the planta fused (non-scutellate) or with scutella indistinct, its inner edge scarcely if at all convolute, the acrotarsium with 12-14 scutella; middle toe, with claw, about two-thirds as long as tarsus, longer than whole culmen; outer toe, without claw, reaching to a little beyond subterminal articulation of middle toe, the inner toe slightly shorter; hallux shorter than inner toe, not conspicuously stouter; basal phalanx of middle toe united for more than half its length to outer toe, for less than half to inner toe; claws short to moderately long, not strongly curved, moderately compressed, not grooved laterally, that of the hallux shorter than the digit. Plumage very full, that of rump and flanks (especially the former) elongated and more lax; a small naked postocular space (except in G. squamigera ${ }^{a}$ and allies).

Coloration.-Above olive, the hindneck and part of pileum grayish, distinctly squamated with black (squamations indistinct in $G$. squamigera, which has the under parts conspicuously barred or lunulated with black); tail rufescent brown or russet (except in G. squamigera); under parts rufescent or tawny, sometimes more or less variegated, especially on throat, sometimes mixed olive and buffy with indistinct bars of darker.

Range.-Southern Mexico to Cayenne, southeastern Brazil, Bolivia, and Peru. (About ten species, including subspecies.)

KEY TO THE SUBSPECIES OF GRALLARIA GUATIMALENSIS.

a. Coloration darker, the general color of under parts ochraceous to tawny; black squamations of upper parts much heavier; gray of hindneck and pileum much clearer (more bluish) much more extended, the forehead much less extensively (sometimes not at all) brownish; size averaging considerably smaller (maximum average measurements: wing 113.3 , tail 41.8 , culmen, 27.2 , tarsus 49.6 , middle toe 25.3 ).

b. Darker; under parts tawny to chestnut-tawny; larger (averaging: wing 111.7 or more, tarsus 48.2 or more, middle toe 24.4 or more), except tail and bill.

c. Slightly paler, with black squamations of upper parts narrower; averaging slightly larger, except bill and middle toe (wing averaging 113.3, tail 41.5, culmen 25.8, tarsus 49.6, middle toe 24.4). (Chiapas to northern Nicaragua.)

Grallaria guatimalensis guatimalensis (p. 148).

$\alpha G$. squamigera also differs in having the planta tarsi partly scutellate, the tail nearly half instead of only two-fifths as long as wing, with firmer rectrices, relatively longer outermost primary, and other minor characters, and may not be congeneric. 
cc. Slightly darker, with black squamations of upper parts heavier; averaging slightly smaller, except bill and middle toe (wing averaging 111.7 , tail 41 , culmen 27.2, tarsus 48.2, middle toe 25.3). (Costa Rica and western Panamá.)..................Grallaria guatimalensis princeps (p. 149).

bb. Paler; under parts ochraceous, deepening into brownish tawny on chest; smaller, except tail and bill (averaging: wing 109.5, tarsus 40.4, middle toe 20.8).

(Southeastern Mexico.)........... Grallaria guatimalensis mexicana (p. 150).

aa. Coloration paler, the general color of under parts dull buff to clay color; black squamations of upper parts much narrower; gray of hindneck, etc., much duller, much more restricted, the whole forehead (sometimes crown.also) light olivebrownish; size averaging larger (average measurements: wing 116.5, tail 48.3, culmen 27.3, tarsus 51.8, middle toe 26.5). (Southwestern Mexico.)

Grallaria guatimalensis ochraceiventris (p. 151).

\section{GRALLARIA GUATIMALENSIS GUATIMALENSIS Prévost and Des Murs.}

\section{GUATEMALAN ANTPITTA.}

Adults (sexes alike?). ${ }^{a-}$-Pileum and hindneck slate color or slategray, the feathers margined with black, producing a squamate effect; back, scapulars, and rump olive, the feathers rather broadly margined with black; upper tail-coverts and tail russet-brown to chestnut; wings olive or olive-brown, the remiges more russet brown, lighter on primaries, the outer of which have their outer webs much paler (nearly wood brown) terminally; greater coverts edged with russet, sometimes (also occasionally the middle coverts) with more or less distinct terminal spots of tawny; lores dull whitish, sometimes slightly intermixed with dusky or grayish; a narrow line of white on posterior half (more or less) of upper eyelid; the posterior portion of lower eyelid also whitish; suborbital and auricular regions dark olive with narrow but distinct shaft-streaks of whitish or pale tawny; malar region whitish, buffy or tawny; chin and upper throat olive-brown, suffused, more or less strongly, with tawny-ochraceous, sometimes mixed somewhat with dusky, the feathers with pale ochraceous or buffy shaft-streaks; lower throat tawny or tawnyochraceous to ochraceous-white, usually immaculate but sometimes more or less broken by dusky spots or bars, usually bounded posteriorly by a more or less distinct narrow semicircular line of dusky or sooty blackish spots; rest of under parts plain bright tawny or tawny-ochraceous, slightly paler on abdomen, deeper on sides and flanks; under wing-coverts immaculate tawny-ochraceous, the inner webs of remiges broadly edged with a paler tint of same or ochraceousbuff; maxilla dusky horn color, paler toward culmen; mandible pale brownish (in dried skins); legs and feet horn brownish (in dried skins).

$a$ While considerable variations in color-pattern are observable among spccimens of all the forms of this species, in none of them do I find any differences that can be corellated with difference of sex-provided, of course, the lafter has in all cases been correctly determined. 
Young.-Pileum and hindneck dull slate color, with narrow mesial guttate streaks of buff; chest and breast similar but ground color rather lighter brownish slate and streaks broader; otherwise like adults, but middle and greater wingr-coverts with distinct (though not sharply defined) terminal or subterminal spots of tawny, and with a rery narrow terminal margin of black.

Adult male--(No specimens with sex determined examined.)

Adult female.-Length (skins), 163-175 (169); wing, 114-116.5 (115.3); tail, 42-44 (43); culmen, 25.5-26 (25.7); tarsus, 46-50.5 (4S.3); middle toe, $24-25.5(24.3) .^{a}$

Southern Mexico, in State of Chiapas (Tumbalá), Guatemala (forests of northern Vera Paz; Cobán; Choctúm; Calderas; Yaxcamnál; Savana Grande; Barranca Honda and Pajál Grande, Volcán de Fuego), Honduras (Santa Ana), and northern Nicaragua (Matagalpa).

Grallaria guatimalensis Prévost and Des Murs, Zool. Voy. 'Venus,' Atlas, "1S46"=1842, pl. 4 (Guatemala).-Lafresnaye, Rev. Zool., 1842, 334.Sclater, Proc. Zool. Soc. Lond., 1858, 280 (monogr.).

Grallaria guatemalensis Prévost and Des Murs, Zool. Voy. 'Venus,' "1855"= 1849, 199.-Sclater and Salvin, Ibis, 1859, 119 (Cobán, Guatemala).Salvin, Ibis, 1861, 354, in text (Vera Paz, Guatemala).--Sclater, Cat. Am. Birds, 1S62, 191 (Guatemala); Cat. Birds Brit. Mus., xv, 1890, 313 (Choctúm, Yaxcamnál, Savana Grande, Calderas, Volcán de Fuego, Barranca Honda, Volcan de Fuego, and Pajál Grande, Volcán de Fuego).-SAlvin and Godman, Biol. Centr.-Am., Aves, ii, 1892, 240 (localities in Guatemala; Santa Ana, Honduras; Matagalpa, Nicaragua).

[Grallaria] guatemalensis Sclater and Salvin, Nom. Av. Neotr., 1873, 75.Sharpe, Hand-list, iii, 1901, 41 (Guatemala to Nicaragua).

(?) Grallaria guatemalensis ? RIDGway, Proc. U. S. Nat. Mus., xiv, 1891, 470 (Santa Ana, Honduras; descr. young).

[Chamaeza] guatimalensis Bonaparte, Consp. Av., i, 1850, 204.

Grallaria princeps (not of Sclater and Salvin) Boucard, Ann. Soc. Linn. Lyon, 1878, 39 (Guatemala).

\section{GRAILARIA GUATIMALENSIS PRINCEPS (Sclater and Salvin).}

COSTA RICAN ANTPITTA.

Similar to $G$. g. guatimalensis but smaller and more deeply colored, the black squamations of upper parts broader, the general color of under parts bright tawny to rufous-tawny.

Adult male.-Length (skins), 165-181 (172); wing, 110-115 (111.7); tail, 40-43 (41.3); culmen, 24.5-28.5 (27.4); tarsus, 44.5-52 (48); middle toe, $23-27(25.2) .^{b}$

a Two specimens. Five specimens with sex undetermined measure as follows: Wing, 104-120 (112.6); tail, 37-44 (40.9); culmen, 24-28 (26); tarsus, 49-51.5 (50.1); middle toe, 24-25.5 (24.3).

$b$ Twelve specimens. 
Adult female.-Length (skins), 167-181 (172); wing, 106.5-113.5 (111.1); tail, 37.5-42.5 (40); culmen, 25-27.5 (26.7); tarsus, 46.5-50 (48.6); middle toe, $25-26$ (25.4) ${ }^{a}$

Costa Rica (La Estrella de Cartago; Faldas del Volcán de Barba; Volcan de Irazú; Turrialba; Juan Viñas; Carrillo; Escazú; Tenório) and western Panamá (Volcán de Chiriquí; Boquete; Santa Fé de Verágua; Calovévora).

Grallaria guatemalensis (not of Prévost) SALvin, Proc. Zool. Soc. Lond., 1867, 146 (Santa Fé de Verágua, Panamá; crit.)-Lawrence, Ann. Lyc. N. Y., ix., 1868, 89 (Verágua).

Grallaria princeps Sclater and Salvin, Proc. Zool. Soc. Lond., 1869, 418 (Calovévora, Verágua, Panamá; coll. Salvin and Godman).-Salvin, Proc. Zool. Soc. Lond., 1870, 196 (Volcán de Chiriquí and Calovévora).-Sclater, Ibis, 1877, 441 (Verágua; Chiriquí; monogr.); Cat. Birds Brit. Mus., xv, 1890, 314 (Irazú district, Costa Rica; Calovévora, Santa Fé, and Volcán de Chiriquí, Panama).-Zeredón, Anal. Mus. Nac. Costa Rica, i, 1887, 115 (Turrialba, Costa Rica).-Salvin and Godman, Biol. Centr.-Am., Aves, ii, 1892, 241, pl. 52.-Bangs, Proc. New Engl. Zool. Club, iii, 1902, 42 (Boquete and Volcán de Chiriquí, Panamá, 7,000-11,000ft.).

[Grallaria] princeps Sclater and Salvin, Nom. Av. Neotr., 1873, 75.-Sharpe, Hand-list, iii, 1901, 41.

Grallaria guatemalensis princeps CARRIKer, Ann. Carnegie Mus., vi, 1910, 627 (Costa Rica; crit.; habits).

\section{GRALLARIA GUATIMALENSIS MEXICANA (Sclater).}

\section{MEXICAN ANTPITTA.}

Similar to G. g. guatimalensis but slightly larger and paler in color, the back, etc., less brownish olive, the general color of under parts ochraceous instead of tawny-ochraceous or tawny; slate color of pileum and hindneck, however, rather darker.

Adult male.-Length (skins), 161-180 (170); wing, 104.5-111 (109.1); tail, 38-44.5 (42); culmen, 25.5-27 (26); tarsus, 43.5-49.5 (47.3); middle toe, $23-25(24.3){ }^{b}$

Adult female. -Length (skins), 160-175 (166); wing, 107-113 (110); tail, 40.5-43 (41.5); culmen, 26.5-27 (26.7); tarsus, 46.5-47.5 (47); middle toe, $24-24.5(24.2) .^{c}$

Southeastern Mexico, in States of Vera Cruz (Córdova; Potrero, near Córdova; Uvero; San Andrés Tuxtla; Omealca; Jalapa; Moyoapám; Playa Vicente; Buena Vista; Motzorongo), and Tabasco (Teapa).

a Four specimens, from Costa Rica.

\begin{tabular}{|c|c|c|c|c|c|}
\hline Locality. & Wing. & Tail. & $\begin{array}{l}\text { Cul- } \\
\text { men. }\end{array}$ & Tarsus. & $\begin{array}{c}\text { Middle } \\
\text { toe. }\end{array}$ \\
\hline 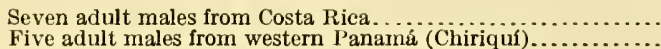 & $\begin{array}{l}112 \\
111.8\end{array}$ & $\begin{array}{l}41.3 \\
41.3\end{array}$ & $\begin{array}{l}27.1 \\
27.6\end{array}$ & $\begin{array}{l}48.3 \\
47.6\end{array}$ & $\begin{array}{l}25.3 \\
25.1\end{array}$ \\
\hline
\end{tabular}

$b$ Four specimens.

c Three specimens. 
Grallaria guatimalensis (not of Prévost) Sclater Proc. Zool. Soc. Lond., 1856, 294 (Córdova, Vera Cruz; crit.); 1858, 280, part (monogr.).

Grallaria guatemalensis Sclater, Proc. Zool. Soc. Lond., 1859, 366 (Jalapa, Vera Cruz), 383 (Playa Vicente, Veril Cruz).-Sumichrast, La Naturaleza, v, 1881, 248 (Uvero, San Andrés Tuxtla, and Potrero, Vera Cruz).

Grallaria guatemalensis? Sumichrast, Ṁem. Bost. Soc. N. H., i, 1869, 556 (Uvero near San Andres Tuxtla, Potrero, and Omealca, Vera Cruz).

[Myiotrichas] guatemalensis HeIne and ReIchenow, Nomencl. Mus. Hein. Orn., 1590, 123 (Mexico).

Grallaria mexicana Sclater, Proc. Zool. Soc. Lond., 1861, 381 (Jalapa, Vera Cruz; coll. P. L. Sclater); 1864, 175 (near City of Mexico); Cat. Am. Birds, 1862, 191 (Jalapa); Ibis, 1877, 440 (tierra caliente of s. Mexico; monogr.; crit.); Cat. Birds Brit. Mus., xv, 1890, 313, part (Jalapa).-Sumichrast, La Naturaleza, v, 1881, 248 (Omealca, Vera Cruz).-SAlvin and Godman, Biol. Centr.-Am., Aves, ii, 1892, 241, part (Moyoapám, Córdova, Omealca, Uvero, San Andrés Tuxtla, Potrero, Córdova, Playa Vicente, and Jalapa, Vera Cruz). Grallaria —? Sumichrast, Mem. Bost. Soc.. N H., i, 1869, 556 (Moyoapám, Vera Cruz, 2,500 m.; crit.).

[Grallaria] mexicana Sclater and Salvin, Nom. Av. Neotr., 1873, 75.-Sharpe, Hand-list, iii, 1901, 41.

\section{GRALLARIA GUATIMALENSIS OCHRACEIVENTRIS (Nelson).}

\section{NELSON'S ANTPITTA.}

Most like G.g. mexicana but coloration decidedly paler and much duller, the blackish squamations of upper parts narrower and less distinct (especially on pileum and hindneck, where sometimes nearly obsolete), forehead more extensively olive, and general color of under parts dull tawny-ochraceous to dull buff or clay color.

Adult male.-Length (skins), 180-198 (189); wing, 111-119.5 (115.2); tail, 46-49.5 (47.7); culmen, 25.5-26.5 (26); tarsus, 48.5-51 (49.7); middle toe, $25.5-26(25.7) .^{a}$

Adult female.-Length (skins), 178-199 (190); wing, 110.5-120 (115.7); tail, 45-52 (47.7); culmen, 27.5-29.5 (28.1); tarsus, 49-55 (52.1); middle toe, $25-28(26.7) .^{b}$

a Two specimens. $b$ Four specimens.

\begin{tabular}{|c|c|c|c|c|c|}
\hline Locality. & Wing. & Tail. & $\begin{array}{l}\text { Cul- } \\
\text { men. }\end{array}$ & Tarsus. & $\begin{array}{c}\text { Middle } \\
\text { toe. }\end{array}$ \\
\hline MALES. & & & & & \\
\hline One adult male from Omilteme, Guerrero.................... & 119.5 & 49.5 & 26.5 & 51 & 26 \\
\hline $\begin{array}{l}\text { One adult male from San Sebastián, Jalisco.......................... } \\
\text { FEMALES. }\end{array}$ & 111 & 46 & 25.5 & 48. 5 & 25.5 \\
\hline Two adult females from Omilteme, Guerrero.................. & 117.5 & 48.7 & 28.2 & 53.2 & 27 \\
\hline One adult female from mountains of Morelos................. & 110.5 & 45 & 28 & 49 & 26 \\
\hline
\end{tabular}


Southwestern Mexico, in States of Jalisco (San Sebastián), Morelos (mountains) and Guerrero (Omilteme); Mexico (Valley of Mexico; Chimalpa; Ajusco)?

(?) Grallaria mexicana (not of Sclater, 1861?) Sclater, Proc. Zool. Soc. Lond., 1864, 175 (Valley of Mexico); Cat. Birds Brit. Mus., xv, 1890, 313, part (western Mexico).-Salvin and Godman, Biol. Centr.-Am., Aves, ii, 1892, 241, part (Valley of Mexico, Chimalpa, and Ajusco, Mexico).

Grallaria mexicana Salvin and Godman, Biol. Centr.-Am., Aves, ii, 1892, 241, part (Omilteme, Guerrero).

Grallaria ochraceiventris Nelson, Proc. Biol. Soc. Wash., xii, Mar. 24, 1898, 62 (San Sebastián, Jalisco; coll. U. S. Nat. Mus.).

[Grallaria] ochraceiventris SHARPE, Hand-list, iii, 1901, 41.

\section{Genus HYLOPEZUS Ridgway.}

Hylopezus a Ridgway, Proc. Biol. Soc. Wash., xxii, Apr. 17, 1909, 71. (Type, Grallaria perspicillata Lawrence.)

Medium-sized terrestrial Formicariidæ (length about 120-125 mm.) with very long, slender, booted (nonscutellate) tarsi (more than two-fifths as long as wing), very short tail (one-third to about two-fifths as long as wing), slender bill, no rictal bristles, and under parts partly white, with chest more or less streaked with black.

Bill shorter than head, slender, rather broad and depressed basally, its width at loral antiæ greater than its depth at same point and equal to half or more the distance from nostril to tip of maxilla; culmen distinctly but not sharply ridged, straight basally, then gradually decurved, the tip of maxilla slightly uncinate; tomia nearly straight, that of maxilla distinctly notched subterminally, the mandibular notch very indistinct or obsolete; gonys convex and prominent basally, nearly straight and ascending terminally. Nostril exposed, horizontally oval, posteriorly nearly in contact with loral feathering, margined above by a narrow extension of the membranous integument of the nasal fossæ, an internal tubercle or septum showing within the upper posterior portion. Rictal bristles obsolete, but feathers of malar and loral regions with bristly shafts. Wing moderate, with longest primaries projecting decidedly beyond secondaries; sixth and seventh, fifth, sixth, and seventh, or fifth and sixth, primaries longest, the tenth (outermost) a little less than three-fifths to slightly more than two-thirds as long as the longest, the ninth much shorter than secondaries $(H$. dives)b or longer than secondaries (other species). Tail one-third (H. perspicillatus) to about two-fifths (H. macularius) as long as wing, very slightly rounded, the rectrices (12) rather broad, rounded terminally. Tarsus slightly more than two-fifths to nearly half as long as wing, slenter,

$a^{\prime \prime} r_{\lambda r}$, a wood, forest; $\pi \varepsilon \zeta d s$, walking.

$b$ In $I I$. dives even the eighth primary (third from outside) is much shorter than the secondaries. 
booted (nonscutellate) or with scutella of acrotarsium faintly defined; middle toe, with claw, slightly more than three-fifths as long as tarsus (as long as or slightly longer than whole culmen); outer toe, without claw, reaching to or slightly beyond subterminal articulation of middle toe, the imner toe slightly shorter; hallux shorter than inner toe, considerably but not conspicuously stouter; basal phalanx of middle toe united for about half its length to outer toe, for less thim half to inner toe; claws rather short, slightly curved, that of hallux decidedly shorter than the digit. Plumage full, soft, and blended, that of rump and flanks (especially the former) more elongated and lax, that of pileum short, with feathers distinctly outlined; a very small naked postocular space.

Coloration.-Above olive (more grayish or dusky. on pileum) the back sometimes streaked with buff, the wings sometimes varied with buff or tawny; a buff orbital ring (indistinct or obsolete in H. dives); under parts with at least throat and abdomen white, the chest, sides, and flanks more or less buffy, ochraceous, or tawny, the first (at least) more or less streaked with black; sexes alike.

Range.-Nicaragua to Cayenne, southeastern Brazil, and western Ecuador.

(About nine species. ${ }^{a}$ )

KEY TO THE SPECIES AND SUBSPECIES OF HYLOPEZUS.

a. Ming-coverts unspotted; chest deep tawny-ochraceous, very narrowly streaked with black. (Caribbean slope of Nicaragua and Costa Rica.)

Hylopezus dives (p. 154).

aa. Wing-coverts conspicuously spotted with buff or ochraceous; chest white or buffy, very heavily streaked with black.

b. Flanks light grayish buffy, streaked with dusky. (Hylopezus perspicillatus.)

c. Back and scapulars conspicuously streaked with buff. (Eastern Panamá.)

Hylopezus perspicillatus perspicillatus (p. 155).

cc. Back and scapulars inconspicuously or not at all streaked. (Western Panamá and southwestern Costa Rica.)... Hylopezus perspicillatus lizanoi (p. 156).

bb. Flanks bright buffy or tawny-buff, unstreaked.

c. Chest more heavily and more extensively streaked with black; buffy spots on wing-coverts more sharply defined; outer web of primaries brownish tawny. (Caribbean slope of Costa Rica and Nicaragua.)

Hylopezus perspicillatus intermedius (p. 156).

$c c$. Chest less heavily and less extensively streaked with black; buffy spots on wing-coverts less sharply defined; outer web of primaries olive-brown. (Guiana and Amazon Valley.).......Hylopezus macularius (extralimital). $b$

$a$ Of these I have examined only $H$. dives (Sclater), $H$. intermedius (Ridgway), H. lizanoi (Cherrie), H. perspicillatus (Lawrence) and $H$. macularius (Temm ck).

b Pitta macularia Temminck, PI. Col., ii, livr. 85, July, 1830, in text to Genus Pitta, sp. 11 (Brazil).-C[olobathris] macularia Cabanis, in Wiegm. Archiv für Naturg., 1847, pt. i, 217.-Grallaria macularia Lafresnaye, Rev. Zool., 1842, 334; Sclater, Cat. Birds Brit. Mus., xv, 1890, 324. 


\section{HYLOPEZUS DIVES (Salvin).}

\section{DIVES ANTPITTA.}

Adults (sexes alike).-Pileum and hindneck dull slate color, indistinctly streaked or squamated with slate-blackish; rest of upper parts dull slate color anteriorly passing into olive posteriorly, the feathers (especially the scapulars) with very narrow and mostly indistinct shaft-streaks of pale buffy; upper tail-coverts and tail russet-brown or vandyke brown; general color of wings deep olive-brown, the outer webs of primaries paler and more rufescent brown; outermost feather of alula edged with buff or ochraceous-buff; loral, orbital, and suborbital regions buff, more or less flecked with dusky, the lower-anterior portion of auricular region deeper buffy; upper-posterior portion of auricular region dull slate color, more or less tinged with olive; malar region, chin, and throat white or buffy white, the first more or less flecked with dusky; chest and sides of breast ochraceous, the feathers with median or central portion paler and edged with black, producing a streaked effect; sides, flanks, under tail-coverts and under wing-coverts plain ochraceous to rufous-tawny; inner webs of remiges passing into dull vinaceous-cinnamon on edges; maxilla brownish, paler along tomia, darker (sometimes nearly black) on culmen; mandible pale dull yellowish (in dried skins), usually tinged with brownish laterally or terminally; legs and feet pale yellowish or yellowish brown (in dried skins).

Adult male.-Length (skins), 118-129 (124); wing, 73.5-78 (75.8); tail, 29-31 (30); culmen, 19-19.5 (19.3); tarsus, 37 ; middle toe, 18-20.5 (19.2). ${ }^{a}$

Adult female.-Length (skin), 119; wing, 75; tail, 30 ; culmen, 18; tarsus, 36 ; middle toe, 19.

Caribbean slope of Costa Rica ('Tucurríqui; Jiménez; Guácimo; La Vijágua) and Nicaragua (Chontales; Greytown; Rio Escondido; Los Sábalos).

Grallaria dives Salvin, Proc. Zool. Soc. Lond., 1864 (pub. April 1, 1865), 582 (Tucurríqui, e. Costa Rica; coll. Salvin and Godman); Ibis, 1872, 313 (Chontales, Nicaragua).-Lawrence, Ann. Lyc. N. Y., viii, 1865, 182 (Greytown, Nicaragua); ix, 1868, 110 (Tucurríqui, Costa Rica).-Frantzius, Journ. für Orn., 1869, 306 (Costa Rica).-Sclater, Ibis, 1877, 450 (Tucurríqui, Costa Rica; Chontales, Nicaragua; monogr.; crit.); Cat. B. Brit. Mus., xv, 1890, 323 (do.).-Nutring, Proc. U. S. Nat. Mus., vi, 1883, 406 (Los Sábalos, Nicaragua).-RIdgway, Proc. U. S. Nat. Mus., vi, 1883, 406, footnote (crit.; Greytown and Los Sábalos).-Cherrie, Proc. U. S. Nat. Mus., xiv, 1891, 534 (Costa Rica; descr. young).-Salvin and Godman, Biol. Centr.-Am., Aves, ii, 1892, 243, pl. 53, fig. 1.-Richmond, Proc. U. S. Nat. Mus., xvi, 1893, 504 (Rio Escondido, Nicaragua).

[Grallaria] dives Sclaten and Salvin, Nom. Av. Neotr., 1873, 76.-SharPe, Hand-list, iii, 1901, 43.

a Three specimens. 
Hylopezus dives Carriker, Ann. Carnegie Mus., vi, 1910, 628 (Costa Rica).

Grallaricula perspicillata (not Grallaria perspicillata Lawrence) Sclater, Ibis, 1S73, 373 (Chontales, Nicaragua).

\section{HYLOPEZUS PERSPICILLATUS PERSPICILLATUS (Lawrence).}

\section{LAWRENCE'S ANTPITTA.}

Adults (sexes alike).-Pileum and hindneck plain slate color, passing into light olive on forehead, the feathers sometimes with very narrow and indistinct shaft-streaks of paler; rest of upper parts olive, the scapulars and interscapulars with more or less distinct mesial (usually guttate) streaks of buff, these sometimes margined with blackish; general color of wings rather browner olive than back, etc., the wing-coverts with terminal (usually triangular) spots of buff or ochraceous, outer web of exterior feather of alula buff, the outer webs of primaries with a basal area of dull ochraceous followed by a space of olive, the remaining portion pale ochraceous-brown; a broad and conspicuous orbital ring of buff or ochraceous-buff; lores buff, with middle portion (vertically) black or dusky; suborbital region and anterior portion of auricular region buff, the former barred or flecked with black; auricular region (except lower-anterior portion) olive, with narrow shaft-streaks of buff; malar region and under parts whice, the chest, breast (except median portion), and sides broadly streaked with black and tinged or suffused with buff, the flanks olive with indistinct broad streaks or flammulations of pale yellowish buff; under tail-coverts buff; under wing-coverts and broad edgings to inner web of remiges bright ochraceous or ochraceousbuff, the coverts near edge of wing more or less streaked with dusky; maxilla dark brown, usually paler terminally; mandible pale dull yellowish (in dried skins), brownish terminally; iris light brown; ${ }^{a}$ legs and feet light brownish (in dried skins).

Adult male.-Length (skins), 118-129 (125); wing, 77.5-82.5 (79.9); tail, 26.5-30 (28.7); culmen, 18-20 (18.8); tarsus, 34-37.5 (35.2); middle toe, $16-18.5$ (17.1). ${ }^{b}$

Adult female.-Length (skins), 125-126 (125.5); wing, 78-79.5 (78.7); tail, 28-30 (29); culmen, 19; tarsus, 34-36.5 (35.2); middle toe, $16.5-18(17.4) .^{c}$

Panamá (Lion Hill; Panamá; Natá, Coclé; Divala; Santa Fé de Verágua; Santiago de Verágua; Mina de Chorcha; Volcán de Chiriquí).

Grallaria perspicillata Lawrence, Ann. Lyc. Nat. Hist. N. Y., vii, 1862, 303, 326 (Lion Hill, Panamá; coll. G. N. Lawrence).-Sclater and Salvin, Proc. Zool. Soc. Lond., 1864, 357 (Lion Hill).-Salvin, Proc. Zool. Soc. Lond., 1867, 146 (Santa Fé and Santiago de Verágua, Panamá); 1870, 196 (Volcán de Chiriquí and Mina de Chorcha, Panamá).-Sclater, Ibis, 1877,

\footnotetext{
$a$ Heyde, manuscript.

$b$ Five specimens.

c Four specimens.
} 
449 (Panamá; monogr.; crit.); Cat. Birds Brit. Mus., xv, 1890, 325, excl. - syn. part (Panamá; Santa Fé, Mina de Chorcha, and Volcán de Chiriquí, Panama).-Ridgway, Proc. U. S. Nat. Mus., vi, 1884, 406, footnote (crit.).Salvin and Godman, Biol. Centr.-Am., Aves, ii, 1892, 242, pl. 53, fig. 2.

[Grallaria] perspicillata Sclater and Salvin, Nom. Av. Neotr., 1873, 76, part (Panamí).-Sharpe, Hand-list, iii, 1901, 44, part (Panamí).

\section{HYLOPEZUS PERSPICILLATUS LIZANOI (Cherrie).}

\section{LIZANO'S ANTPITTA.}

Similar to $H . p$. perspicitlatus but back and scapulars plain olive (or with only a few very narrow streaks of buff on extreme upper back), the olive much more grayish, brown, or olive area on middle of primaries much less distinct (sometimes obsolete), and chest and sides usually more strongly suffused with yellowish buff.

Adult male.-Length (skins), 120-135 (126); wing, 79-84.5 (81.7); tail, 26.5-32 (30.2); culmen, 19-20.5 (19.6); tarsus, 34-37.5 (35.8); middle toe, $16.5-18.5$ (17.3). ${ }^{a}$

Adult female.-Length (skins), 115-132 (125); wing, 79-84.5 (82.4); tail, 27.5-32 (30.2); culmen, 19-21 (19.8); tarsus, 32.5-37 (34.8); middle toe, $16.5-18$ (17.5). ${ }^{a}$

Southwestern Costa Rica (Pozo Azúl de Pirrís; Pirrís; Pozo del Pitál, Rio Naranjo; Pozo de Térraba; Térraba; Boruca, Paso Reál and Pozo del Rio Grande, Boruca; Lagarto; Buenos Aires; Las Trojas; El Generál) and western Panamá (Divala).

Grallaria intermedia (not of Ridgway) Zeledón, Anal. Mus. Nac. Costa Rica, i, 1887, 115, part (Pozo Azúl de Pirrís, s. w. Costa Rica).

Grallaria lizanoi Cherrie, Proc. U. S. Nat. Mus., xiv, no. 855, Sept. 4, 1891, 342 (Las Trojas, s. w. Costa Rica; coll. U. S. Nat. Mus.); Anal. Inst. Fis.-Geog. Costa Rica, vi, 1893, 19 (Pozo del Pitál, s. w. Costa Rica); Expl. Zool. Merid. Costa Rica, 1893, 44 (Lagarto, Boruca, Térraba, and Buenos Aires, s. w. Costa Rica).-Salvin and Godman, Biol. Centr.-Am., Aves, ii, 1892, 243.Bangs, Auk, xxiv, 1907, 298 (Boruca, Paso Reál, and Pozo del Rio Grande, s. w. Costa Rica).

[Grallaria] lizanoi Sharpe, Hand-list, iii, 1901, 44.

Hylopezus lizanoi Carriker, Ann. Carnegie Mus., vi, 1910, 629 (Pacific slope Costa Rica, up to $1,500 \mathrm{ft}$.).

\section{HYLOPEZUS INTERMEDIUS (Ridgway).}

TALAMANCA ANTPITTA.

Similar to H. p. lizanoi but flanks and posterior portion of sides clear plain ochraceous or ochraceous-buff.

Adult male.-Length (skins), 114-137 (128); wing, 78-83 (80.5); tail, 25.5-32 (29.4); culmen, 17-20 (19); tarsus, 34-37 (35.7); middle toe, $17-18.5(17.3) .^{a}$ 
Adult female.-Length (skins), 113-134 (123); wing, 77-82 (79.6); tail, 27-35 (29); culmen, 18-20 (19.2); tarsus, 35-38.5 (36.2); midllle toe, $16.5-18(17.2){ }^{a}$

Caribbean slope of Costa Rica (Angostura; Talamanca; Santa Clara; Jiménez; San Carlos; La Balsa; El Hogár; Guápiles; Cuábre; Guácimo; Voleán de Turrialba ; La Florida; La Cristina; La Vijágua) and Nicaragua (San Emilis, Lake Nicaragua).

Grallaria perspicillata (not of Lawrence, 1861) Lawrence, Ann. Lyc. N. Y., ix, 1868, 110 (Angostura, Costa Rica).-Frantzius, Journ. für Orn., 1869, 306 (Costa Rica).-Boucard, Proc. Zool. Soc. Lond., 1878, 62 (San Carlos, Costa Rica).-Sclater, Cat. Birds Brit. Mus., xv, 1890, 325, part (syn. part; "Yalza," i. e., La Balsa, Costa Rica).

[Grallaria] perspicillata Sclater and Salvin, Nom. Av. Neotr., 1873, 76, part (Costa Rica).-Sharpe, Hand-list, iii, 1901, 44, part (Costa Rica).

G[rallaria] intermedia Ridgway, Proc. U. S. Nat. Mus., vi, no. 26, April 11, 1884, 406, footnote (Talamanca, Costa Rica; coll. U. S. Nat. Mus.).

Grallaria intermedia Zeledóx, Anal. Mus. Nac. Costa Rica, i, 1887, 115, part (Jiménez, Costa Rica).-Cherrie, Proc. U. S. Nat. Mus., xiv, 1891, 534 (Jiménez; crit.).-Salvin and Godman, Biol. Centr.-Am., Aves, ii, 1892, 243 (Angostura, La Balsa, Talamanca, Jiménez, and San Carlos, Costa Rica). [Grallaria] intermedia SHARPE, Hand-list, iii, 1901, 44.

Hylopezus intermedius CARriker, Ann. Carnegie Mus., vi, 1910, 629 (Caribbean lowlands of Costa Rica up to 800 or $900 \mathrm{ft}$; crit.; habits).

\section{Family FURNARIIDÆ.}

THE OVEN BIRDS.

Tracheophone Mesomyodian Passeres, with the metasternum 2-notched, interorbital septum perforate, maxillo-palatines very long and slender (and continued backward to or beyond the level of the free end of the median descending plate of the palatine), tensor patagii brevis tendon normally passerine, nares schizorhinal, syrinx tracheal (with two pairs of short tracheo-bronchial muscles), palate schizognathous, mesorhinium normal, tarsal envelope endaspidean, outer toe much shorter than middle toe, hallux (without claw) not shorter than inner toe (without claw), and middle toe united to outer toe by less than the whole of its second phalanx (usually for more or less of first phalanx only).

$>$ Anabatidæ CABAvis, Wiegmann's Archiv für Naturg., 1847, pt. i, 230, 338 (includes Dendrocolaptidæ).-Cabanis and Eeine, Mus. Hein., ii, 1860, 22.-Carvs, Handb. Zool., 1868, 266.

=Anabatidæ Bonaparte, Consp. Av., i, 1850, 210.-Huxley, Proc. Zool. Soc. Lond., 1867, 471, in text.

=Anabatinæ CABavis, Wiegmann's Archiv für Naturg., 1847, pt. i, 338 .

<Furnariinæ CABANIS, Wiegmann's Archiv für Naturg., 1847, pt. i, 339.Sundevall, Met. Nat. Av. Disp. Tent., ii, 1872, 55 (English translation, 1889, 121).-GARrod, Proc. Zool. Soc. Lond., 1877, 452. 
XFurnariinæ CABANIS and Heine, Mus. Hein., ii, 1860, 22 (includes Rhodinocichla!).-Sclater, Cat. Am. Birds, 1862, 146.

=Furnariidæ Stejneger, Stand. Nat. Hist., iv, 1885, 479, in text.

<Synallaxinæ Cabanis and Heine, Mus. Hein., ii, 1860, 26.-Sclater, Cat. Am. Birds, 1862, 149.-Sundevall, Met. Nat. Av. Disp. Tent., ii, 1872, 55 (English translation, 1889, 122).

The Furnariidæ are closely related to the Dendrocolaptidæ and have usually been included in the same family, as Subfamilies Furnariinæ, Synallaxinæ, Philydorinæ, and Sclerurinæ ${ }^{a}$ three Furnariine genera being even referred to the "Subfamily Dendrocolaptinæ. Prof. Garrod and Dr. Stejneger, however, have shown ${ }^{c}$ that in their schizorhinal, instead of holorhinal, skull and dissimilar feet they differ sufficiently to warrant their recognition as a distinct family.

Although distributed throughout the continental portions of the Neotropical Region, the Furnariidæ are most developed in the Patagonian and South-Brazilian Subregions, to which many of the genera, among them the most typical ones, are peculiar, comparatively few of them passing to the northward of the Isthmus of Panama, only 25 of the more than 278 species and 10 of the 37 genera $^{d}$ belonging to the Central American district.

While some of the genera resemble Dendrocolaptine forms in external appearance, and presumably in habits also, the majority of the Furnariidæ are more terrestrial; some of them eminently so, and strongly recalling in their appearance and general habits the Larks (Alaudidæ) and Stone-chats. Many of them inhabit reedy marshes, and bear a superficial likeness to the marsh-wrens (genera Telmatodytes and Cistothorus), while certain small long-tailed short-billed forms, as Leptasthenura, recall the Parine genus Psaltriparus, others again resembling Creepers (Certhüidæ).

Many of the species, particularly those belonging to the so-called Subfamily Furnariinæ, are remarkable for the unusual character of their nests, which, in some cases, consist of massive oven-like structures built of mud or clay, in others immense heaps of twigs, whence the builders have received the name of "fagot-gatherers" from the human inhabitants of the country.

What has been said concerning the unsatisfactory classification of the Formicariidæ ${ }^{e}$ and my efforts to devise a better one applies as well to the present group.

$a$ See Catalogue of the Birds in the British Museum, vol. xv., pp. xi-xiii, 2-126. (By Philip Lutley Sclater.)

$b$ Genera Margarornis, Premnoplex, and Pygarrhicus.

$c$ See Garrod, Proc. Zool. Soc. Lond., 1877, pp. 449-452, and Stejneger, Standard Natural History, vol. iv, Birds, 1885, pp. 478, 481.

$d$ As enumerated in Sharpe's Hand-list of the Genera and Species of Birds, vol. iii, 1901, pp. 45-74, under Dendrocolaptidæ.

$e$ See p. 9 . 


\section{KEY TO THE CENTRAL AMERICAN GENERA OF FURNARIIDA. ${ }^{a}$}

a. Maxillary tomium with a distinct (though small) subterminal notch; outer toe united to middle toe by the whole of its first and second phalanges and at least half of its third phalanx; tarsus indistinctly scutellate (smooth on inner side); tail less than three times as long as tarsus, the rectrices with very rigid shafis, whose denuded tips are not protruded. (Sclcurinx.)........ Sclerurus (p. 163). aa. Maxillary tomium without trace of notch; onter toe united to middle toe by not more than whole of its first and second phalanges (usually by less than whole of its first phalanx); tarsus distinctly scutellate; tail more than three times as long as tarsus, $b$ the rectrices without rigid shafts or else with the attenuated or acuminate tips not denuded but protruded. (Furnariinæ.)

b. Maxilla with tip not at all decurved, but with tomia ascending (more or less strongly) terminally; mandible strongly recurved (falcate) terminally.

c. Outer toe not conspicuously (though distinctly) longer than inner toe, reaching (without claw) only to middle of subterminal phalanx of middle toe; outer toe with first and second phalanges united to middle toe; bill relatively shorter and stouter, the exposed culmen decidedly shorter than tarsus; tip of rectrices normal............................. Xenops (p. 170).

$c c$. Outer toe conspicuously longer than inner toe, reaching (without claw) much beyond middle of subterminal phalanx of middle toe; outer toe with only its first phalanx united to middle toe; bill relatively longer and more slender, the exposed culmen as long as tarsus; tips of rectrices (except lateral ones) attenuated, stiffened, and decurved.

Pygarrhicus (extralimital).c

$b b$. Maxilla with tip more or less distinctly decurved, the tomia more or less decurved or descending terminally; mandible not recurved terminally (or else tip of maxilla decurved).

c. Nostril narrow, longitudinal, distinctly operculate.

d. Tarsus shorter than middle toe with claw; outer toe with first phalanx and at least part of second phalanx united to middle toe. (Margarornithes.)

e. Wing longer (nearly four times to more than four times as long as tarsus) and more pointed, the primaries exceeding secondaries by at least length of exposed culmen, sometimes by length of tarsus; bill relatively. shorter, the exposed culmen much shorter than middle toe without claw; inner webs of remiges crossed by a broad band or with an extensive basal area of buff or ochraceous.

$f$. Tail graduated for only about one-third its length, with tip of rectrices (except outer ones) excessively acuminate, the slender points conspicuously protruded; wing more than four times as long as tarsus; inner webs of remiges crossed by a broad sub-basal band of buff or

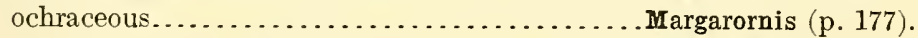

ff. Tail excessively graduated (for much more than half its length), with tips of rectrices not distinctly acuminate, the minute slender points

a Including, for comparison, a few related extralimital genera.

$b$ The proportionate length of tail and tarsus, as a subfamily character, will probably not apply to some of the exclusively South American genera.

c Pygarrhicus Burmeister, Handb. der Naturg., 1837, 769. Type, Dendrocolaptes albigularis King.-Dendrodramus Gould, Zool. Voy. "Beagle," iii, 1841, 82. Type, Dendrocolaptes albigularis King.-Dromodendron Gray, List Gen. Birds, 1842, App., p. 6. Type, Dendrocolaptes albigularis King. (Southern Chile and southwestern Argentina; monotypic.) 
very slightly protruded; wing less than four times as long as tarsus; inner webs of remiges with an extensive basal area of ochraceous or pale tawny...................... Premnornis (extralimital). ${ }^{a}$

ee. Wing shorter (less than three and a half times as long as tarsus) and more rounded, the primaries exceeding secondaries by less, than length of exposed culmen; bill relatively longer, the exposed culmen as long as middle toe without claw; inner webs of remiges without buff or ochraceous cross-band or basal area..............Premnoplex (p. 180).

$d d$. Tarsus longer than middle toe with claw; outer toe with second phalanx entirely free from middle toe, the first phalanx also often partly free.

$e$. Basal phalanx of middle toe partly free from outer toe; bill more subulate or terete, with culmen more or less distinctly curved (at least terminally), the mesorhinium more or less rounded or else much compressed; wing relatively shorter and more rounded, the longer primaries exceeding secondaries by less than length of exposed culmen; no tuft on sides of neck; smaller forms (wing less than $80 \mathrm{~mm}$.) (Synallaxex.)

f. Rectrices 12 .

$g$. Tail much shorter than wing; hallux (without claw) longer than outer toe (without claw); wing four times as long as tarsus.

Siptornis (extralimital). $b$

$g g$. Tail longer (sometimes very much longer) than wing; hallux (without claw) not longer than outer toe (without claw); wing not more than three and a half times as long as tarsus (usually much less).

$h$. Tarsus at least one-third as long as wing; frontal feathers extending farther forward, covering most of nasal operculum and concealing greater part of nostril.

$i$. Bill much stouter, with culmen much more strongly curved, more compressed, and sharply ridged; rictus abruptly and strongly deflected.

$j$. Tarsus decidedly more than one-third as long as wing; wing about two-thirds as long as tail; mesorhinium elevated, extremely compressed............ Drioctistes (extralimital).c

$j j$. Tarsus not more than one-third as long as wing; wing more than three-fourths as long as tail; mesorhinium not elevated nor unusually compressed.

$k$. Wing only four-fifths as long as tail, the latter graduated for nearly two-thirds its length; tarsus not longer than middle toe with claw; bill relatively longer and narrower; feathers of chest with thickened or widened shafts.

Phaceloscenus (extralimital).d

a Premnornis Ridgway, Proc. Biol. Soc. Wash., xxii, April 17, 1909, 71. Type, Margarornis guttata Lawrence. (Colombia and Ecuador; monotypic.)

This genus presents a very close superficial resemblance to the automoline genus Heliobletus Reichenbach (see p. 162) but may easily be distinguished by the very different nostrils and other structural characters.

b Siptornis Reichenbach, Handb. der Spec. Orn., 1853, 171. Type, Synallaxis striaticollis Lafresnaye. (Colombia and Ecuadór; monotypic.)

c Drioctistes Ridgway, Proc. Biol. Soc. Wash., xxii, April 17, 1909, 71. Type, Thripophaga sclateri Berlepsch. (Southeastern Brazil; Bolivia?; three species?.)

I have not seen Anabates erythrocephalus Maximilian nor Thripophaga fusciceps Sclater, one or both of which may be congeneric with Drioctistes sclateri. The genus is exceedingly distinct from Thripophaga.

d Phaceloscenus Ridgway, Proc. Biol. Soc. Wash., xxii, April 17, 1909, 71. Type, Anumbius striaticollis D'Orbigny and Lafresnaye. (Argentina and Uruguay; monotypic?.) 
$k \%$. Wing very nearly as long as tail (more than eight-ninths as long), the latter graduated for only half its length; tarsus longer than middle toe with claw; bill relatively shorter and deeper; feathers of chest without thickened or widened shafts.................. Phacellodomus (extralimital). $a$

ii. Bill much more slender, with culmen much less strongly curved (usually nearly straight), less compressed, less sharply ridged; rictus not deflected .............. Asthenes (extralimital). $b$

hh. Tarsus much less than one-third as long as wing; frontal feathers not extending so far forward, the nostrils and nasal operculum being uncovered for much the greater part.

$i$. Larger (wing more than $70 \mathrm{~mm}$., exposed culmen more than 15 $\mathrm{mm}$.); conspicuously streaked both above and below.

Thripophaga (extralimital). $c$

ii. Smaller (wing less than $70 \mathrm{~mm}$., exposed culmen less than 15 $\mathrm{mm}$.); without streaks (except sometimes, on pileum.)

Acrorchilus (p. 183)

ff. Rectrices 10 .

g. Tail not more than one and a half times as long as wing (usually much

less, sometimes shorter than wing); upper parts not streaked.

Synallaxis (p. 186)

gg. Tail nearly twice as long as wing; upper parts streaked.

Sehœniophylax (extralimital).d

ee. Basal phalanx of middle toe wholly united to outer toe; bill more wedgeshaped, with culmen nearly straight (if curved more so toward base than terminally), the mesorhinium flattened; wing relatively longer

a Phacellodomus Reichenbach, Handb. der Spec. Orn., 1853, 169. Type, Anabates ruffrons Maximilian.-Phacelodomus (emendation) Sclater, Cat. Birds. Brit. Mus., $\mathrm{xv}, 1890,79 .-$ Placellodomus (emendation) Sclater and Salvin, Proc. Zool. Soc. Lond., May, 1868, 141.-Phacellodromus (emendation) Bonaparte, Ann. Sci. Nat. (Zool.), 4 sér., i, 1854, 132.

b Asthenes Reichenbach, Handb. der Spec. Orn., 1853, 168. Type, Synallaxis sordida Lesson. (Andes of Colombia to Chile, Argentina, etc.; at least eight species.)

This group unquestionably requires subdivision, but I have not a sufficient representation of the species to justify an attempt to do so. Besides the type-species I have examined the following: A. humicola (Kittlitz), A. modesta (Eyton), A. anthoides (King), A. wyatti (Sclater and Salvin), A. sulphurifera (Burmeister), A. striaticeps (D'Orbigny and Lafresnaye), and $A$. maluroides (D'Orbigny and Lafresnaye). The three last are almost certainly distinct generically. Probably nearly related to Asthenes, if not actually belonging to it, are the following species, referred, like the others, to Siptornis by recent authorities: $S$. orbignii (Reichenbach), S. arequip (Sclater and Salvin), S. humilis (Cabanis), and S. pudibunda (Sclater). How nearly related may be $S$. albiceps (Lafresnaye and D'Orbigny) and $S$. albicapilla (Cabanis)the former being the type of Cranioleuca Reichenbach (Handb. der Spec. Orn., 1853, 167)-I am unable to say, not having seen either.

c Thripophaga Cabanis, Wiegmann's Archiv für Naturg., xiii, pt. i, 1847, 338. Type, Sphenura striolata Lichtenstein. (Southeastern Brazil; Colombia?; two species?.)

I have not seen T. guttuligera Sclater, from Colombia, which may or may not be congeneric with $T$. striolata.

d Schoeniophylax Ridgway, Proc. Biol. Soc. Wash., xxii, April 17, 1909, 71. Type, Sylvia phryganophila Vieillot. (Southern Brazil, Paraguay, Uruguay, and Argentina; monotypic?.) 
and more pointed, the longest primaries exceeding secondaries by more than length of exposed culmen; a tuft of elongated soft feathers on each side of neck; larger (wing $95 \mathrm{~mm}$. or more). (Pseudocolaptex.)

Pseudocolaptes (p. 196).

cc. Nostril oval or roundish, not distinctly operculate. (Automolex.)

$d$. Basal phalanx of middle toe wholly united to both outer and inner toes.

$e$. Bill much longer, the exposed culmen longer than tarsus, its length from nostril equal to two and a half times its depth at loral antiæ.

Hyloctistes (p. 199).

$e e$. Bill much shorter, the exposed culmen shorter than tarsus, its length from nostril equal to but little more than twice its depth at loral antiæ.

$f$. Bill relatively broader basally and more compressed terminally, the tip of maxilla abruptly and strongly uncinate; upper parts conspicuously streaked............................. Ancistrops (extralimital). ${ }^{a}$

$f f$. Bill relatively narrower basally and less compressed terminally, the tip of maxilla not abruptly not strongly, if at all, uncinate; upper parts not streaked.

g. Bill excessively compressed, its width at loral antiæ equal to only about two-thirds its depth at same point and less than one-third the distance from nostril to tip of maxilla; claw of hallux very large, as long as the digit.............Anabazenops (extralimital). $b$

gg. Bill only moderately compressed, its width at loral antiæ equal to more than two-thirds its depth at same point and more than onethird the distance from nostril to tip of maxilla; claw of hallux smaller, decidedly shorter than the digit......... Philydor (p. 201).

dd. Basal phalanx of middle toe not wholly united to lateral toes.

$e$. Bill relatively smaller, more slender, more compressed, its width at loral antiæ much less than its depth at same point, not distinctly if at all uncinate; shafts of rectrices softer at tip.

f. Bill smaller, the culmen (from base) shorter than tarsus; anterior toes more extensively united basally.

g. Bill smaller and more slender, more decurved terminally, with gonys not ascending terminally ............. Heliobletus (extralimital).c

gg. Bill larger and stronger, less decurved terminally (except at extreme tip), with gonys strongly ascending terminally.

Xenicopsis (p. 205).

$f f$. Bill larger, the culmen (from base) longer than tarsus; anterior toes less extensively united basally........................Automolus (p. 211).

$e e$. Bill larger and stouter, less compressed, its width at loral antiæ nearly equal to its depth at same point, distinctly uncinate; shafts of rectrices more rigid at tip ........................... Rhopoctites (p. 222).

a Ancistrops Sclater, Cat. Am. Birds, 1862, 157. Type, Anabates lineaticeps Sclater $=$ Thamnophilus strigilatus Spix. (Upper Amazon Valley; monotypic.)

b Anabazenops Lafresnaye, Dict. Univ. d'Hist. Nat., i, 1841, 411. Type, Sitta fusca Vieillot.-Anabatoides Burmeister, Syst. Ueb. Th. Bras., iii, 1856, 23. Type, Sitta fusca Vieillot. (Southeastern Brazil; monotypic.)

c Heliobletus Reichenbach, Handb. der Spec. Orn., 1853, 201. Type, Dendrocolaptes superciliosus Lichtenstein. (Southeastern Brazil; monotypic.) 
Genus SCLERURUS Swainson.

Sclerurus Swainson, Zool. Jouru., iii, 1827, 356. (Type, Nyiothera umbretta Lichtenstein.)

Scelurus (typographical error?) Burmeister, Syst. Ueb. Th. Bras., iii, 1856, 45.

Tinactor Maxinillan, Beitr. Naturg. Bras., iii, pt. ii, 1831, 1106. (Type, T. fuscus Maximilian.)

Oxypyga a Ménétriés, Mem. de l'Acad. St. Pétersb., sér. vi, Sci. Nat., i, 1835. 519. ('Type, O. scansor Ménétriés=Myiothera umbretta Lichtenstein.)

Oxypiga Lesson, 1839.

Geoccia Bertoni, Aves Nuevas del Paraguay, 1901, 79. (Type, G. orryctera Bertoni $=$ Myiothera umbretta Lichtenstein.)

Medium sized Furnariidæe (length about 150-160 mm.) with long slender bill (as long as or longer than head), tail much shorter than wing, with rectrices broad and rounded terminally and with very rigid but not protruded shafts; hallux much longer than inner toe, the latter conspicuously shorter than outer toe, middle toe united to outer toe for whole of first and part of second phalanx, and plain brownish coloration.

Bill about as long as head, or longer, slender, straight or slightly decurved, its width at loral antiæ equal to or greater than its depth at same point and equal to a little less than one-fourth to nearly one-third the distance from nostril to tip of maxilla; culmen distinctly ridged, straight.basally, gradually decurved terminally, or straight for most of its length and terminal portion rather abruptly decurved; maxillary tomium nearly straight to decidedly concave, minutely but distinctly notched subterminally; mandibular tomium more or less convex, at least terminally, without trace of notch; gonys faintly convex basally, faintly concave terminally (the tip of mandible slightly but distinctly decurved in S. mexicanus). Nostril exposed, posteriorly in contact with loral feathering, broadly oval, horizontal, margined above by narrow membrane, a conspicuous internal tubercle or septum occupying nearly the posterior half. Rictal bristles absent, and feathers of chin, etc., without distinct (if any) terminal setæ. Wing rather large and pointed, the longest primaries considerably longer than secondaries; eighth, or sixth, seventh, and eighth, primaries longest, the tenth (outermost) twothirds to three-fourths as long as the longest, the ninth equal to or longer (sometimes much longer) than secondaries. Tail between two-thirds and three-fourths as long as wing, strongly rounded, the rectrices (12) broad, rounded terminally, with very rigid shafts, which are denuded but not protruded terminally. Tarsus shorter than culmen, about one-fourth as long as wing, scutellate anteriorly (sometimes indistinctly so), the planta fused (nonscutellate); middle toe, with claw, a little longer than tarsus; outer toe, without claw,

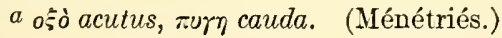


reaching to beyond middle of subterminal phalanx of middle toe, the inner toe conspicuously shorter, reaching (without claw) only to subterminal articulation of middle toe; hallux longer than inner but shorter than outer toe; claws moderate in size and curvature to rather large and strongly curved, much compressed, that of the hallux shorter than the digit.

Coloration.-Plain brownish, the rump and upper tail-coverts usually more rufescent, sometimes bright or deep chestnut; under parts paler than upper, the throat sometimes gray or whitish or squamated. Sexes alike.

Nidification.-Nest (of S. umbretta) composed of leaf-ribs placed in a rounded chamber at the end of a gallery in the ground. Eggs white. ${ }^{a}$

Range.-Southern Mexico to Cayenne, Argentina, and Peru. (About twelve species.)

KEY TO THE SPECIES AND SUBSPECIES OF SCLERURUS.

a. Lower rump and upper tail-coverts chestnut, distinctly different from color of back.

b. Chin and throat whitish or grayish, distinctly different from color of chest.

c. Chin and throat dull white or grayish white, the feathers margined or tipped with dusky. (Southern Brazil.)......... Sclerurus umbretta (extralimital). $b$

$c c$. Chin dull white deepening into gray on throat, the feathers without distinct, if any, darker margin or tip.

d. Back, etc., brown; chest tawny brown or dull rusty. (Sclerurus albigularis.)

e. Back, etc., olive-brown; chest tawny brown; throat grayish white, deepening into pale gray on lower portion. (Venezuela; Tobago.)

Sclerurus albigularis albigularis (extralimital). $c$

ee. Back, etc., burnt-umber brown; chest dull rusty; throat smoke gray. (Northeastern Colombia.)

Sclerurus albigularis propinquus (extralimital). $d$

$a$ Goeldi, Ibis, 1896, 305 .

b M[yiothera] umbretta Lichtenstein, Verz. Doubl., 1823, 43 (Bahia, Brazil).Myioturdus umbretta Ménétriés, Mem. de l'Acad. St. Petersb., ser. 6, Sci. Nat., i, 1835, 468 (Bahia).-F[ormicarius] umbretta Gray, Gen. Birds, i, 1840, 211.-Sclerurus umbretta Sclater and Salvin, Proc. Zool. Soc. Lond., 1867, 574 (lower Amazon Valley); Burmeister, Syst. Ueb. Th. Bras., iii, 1856, 45; Ridgway, Proc. U. S. Nat. Mus., xii, 1890, 22 (monogr.); Sclater, Cat. Birds Brit. Mus., xv, 1890, 114.-Sclerurus caudacutus umbretta Hellmayr, Novit. Zool., xiv, 1907, 56 (crit.).-Oxypyga scansor Ménétriés, Mém. de l'Acad. St. Petersb., ser. 6, Sci. Nat., i, 1835, 520, pl. 11 (Rio de Janeiro, Brazil).-T[inactor] fuscus Maximilian, Beitr. Naturg. Bras., iii, 1831, 1106, part (female only).

c Sclerurus albigularis "Sw[ainson] Braz. B. t. 78" Bonaparte, Consp. Av., i, 1850, 210 (nomen nudum); Sclater and Salvin, Proc. Zool. Soc. Lond., 1868, (pub. April, 1869), 630 (Venezuela; diagnosis); Sclater, Cat. Birds Brit. Mus., xv, 1890, 114, part (excl. syn. S. canigularis).-Sclerurus albogularis Ridgway, Proc. U. S. Nat. Mus., xii, 1889 (1890), 24 (monogr.; Venezuela; Tobago).

d Sclerurus albigularis propinquus Bangs, Proc. Biol. Soc. Wash., xiii, Nov. 11, 1899, 99 (Chirua, Santa Marta, Colombia, 7,000 ft.; coll. E. A. and O. Bangs). 
dd. Back., etc., deep chestnut-brown or vandyke brown; chest clear chestnut. (Costa Rica and western Panamá)......... Sclerurus canigularis (p. 166).

$b b$. Chin and throat bright russet or rufous-tawny, like chest. (Sclerurus mexicanus.)

c. Coloration lighter, the back, etc., warm-sepia brown, the lower rump and upper

tail-coverts chestnut. (Southeastern Mexico to Amazon Valley.)

Sclerurus mexicanus mexicanus (p. 166).

cc. Coloration darker, the back, etc., dark sepia brown, the lower rump and upper tail-coverts deep vandyke to deep chocolate or walnut brown. (Caribbcan slope of western Panamá and castern Costa Rica.)

Sclerurus mexicanus pullus (p. 168). aa. Lower rump and upper tail-coverts similar in color to back or but slightly more rufescent.

b. Chin and throat tawny or russet, like chest. (Guiana and lower Amazon Valley.)

Sclerurus caudacutus (extralimital).$^{a}$

$b b$. Chin and upper throat with basal portion of feathers whitish or very pale brownish, the tip or terminal margin dark brown or dusky.

c. General color umber or sepia brown.

d. Throat brown, with basal portion of feathers dull brownish white or very pale brownish. (Upper Amazon Valley.)

Sclerurus fuscus (extralimital). $b$

$d d$. Chin and upper throat white, the feathers tipped or margined with brown or dusky.

e. Chest without spots or distinct streaks of tawny, and general coloration lighter brown.

f. General color deep chocolate brown; smaller (wing 83 8-86.4, tail 53.355.4). (Colombia.) .............. Sclerurus brunneus (extralimital).c

ff. General color vandyke brown, more olive-brown on under parts, the sides of head and neck and upper chest brownish tawny; larger (wing 100.3, tail 78.7). (Southeastern Brazil.)

Sclerurus lawrencei (extralimital). $d$

$e e$. Chest with distinct streaks or spots of tawny, and general color much darker brown. (Southern Mexico to Panamá; western Ecuadór?).

cc. General color olivaceous. (Western Peru.)

Sclerurus guatemalensis (p. 169).

Sclerurus olivascens (extralimital).e

a Thamnophilus caudacutus Vieillot, Nouv. Dict. d'Hist. Nat., iii, 1816, 310 (Cayenne).-[Sclerurus] caudacutus Bonaparte, Consp. Av., i, 1850, 210.-Sclerurus caudacutus Sclater and Salvin, Proc. Zool. Soc. Lond., 1867, 573 (Capim R., lower Amazon Valley); Ridgway, Proc. U. S. Nat. Mus., xii, 1889 (1890), 27 (monogr.); Sclater, Cat. Birds Brit. Mus., xv, 1890, 116.-Sclerurus caudacutus caudacutus Hellmayr, Novit. Zool., xiv, 1907, 56 (crit.).

b T[inactor] fuscus Maximilian, Beitr. Naturg. Bras., iii, 1831, 1106, part (male; locality not stated; type now in coll. Am. Mus. Nat. Hist.).-Sclerurus fuscus Ridgway, Proc. U. S. Nat. Mus., xii, 1889, no. 762 (pub. Feb. 5, 1890), 28 (monogr.).

c Sclerurus brunneus Sclater, Proc. Zool. Soc. Lond., 1857, 17 (Bogotá, Colombia; coll. P. L. Sclater); Cat. Birds Brit. Mus., xv, 1890, 116; Ridgway, Proc. U. S. Nat. Mus., xii, 1889 (1890), 29 (monogr.).-Sclerumus caudacutus brunneus Hellmayr, Novit. Zool., xiv, 1907, 56, 58 ('Teffé, Brazil; crit.; geog. range).

d Sclerurus lawrencei Ridgway, Proc. U. S. Nat. Mus., xii, 1889, no. 762 (pub. Feb. 5, 1890), 29 ("Bahia" [Brazil], but locality probably erroneous; coll. Am. MIus. Nat. Hist.).

e Sclerurus olivascens Cabanis, Journ. für Orn., Jan., 1873, 67 (Monterico, w. Peru); Ridgway, Proc. U. S. Nat. Mus., xii, 1889 (1890), 31 (monogr.). 


\section{SCLERURUS CANIGULARIS Ridgway.}

GRAY-THROATED SCLERURUS.

Adults (sexes alike).-Pileum deep to dark sepia (sometimes lighter and browner on forehead), the feathers sometimesindistinctly margined with dusky; back, scapulars, and wing-coverts plain deep warm-sepia or vandyke brown, passing into chestnut on rump and upper tailcoverts, the wing-coverts inclining to chestnut or margined with that color; tail dark seal brown basally, passing into brownish black terminally; remiges dark sepia brown, the primary coverts more dusky; chin and throat light mouse gray, deeper on lower throat, paler (sometimes inclining to dull white) on chin; chest (broadly) dark dull cinnamon-rufous or tawny-chestnut; rest of under parts dark grayish brown or brownish slate color, tinged or suffused with tawnychestnut, the under tail-coverts inclining to chestnut, with concealed portion dusky; maxilla brownish black, passing into horn color terminally; mandible dull pale yellowish or whitish (in dried skins), dusky along tomia; legs and feet dusky horn color (in dried skins).

Young.-Similar to adults but general color of upper parts more castaneous (less strongly contrasted with chestnut of rump and upper tail-coverts) and color of chest duller (between mummy brown and vandyke).

Adult male.-Length (skins), 151-168 (158); wing, 86-93 (89.2); tail, 58.5-62.5 (60.4); culmen, 21.5-22.5 (22.4); tarsus, 22-22.5 (22.2); middle toe, $18-19.5$ (18.6). ${ }^{a}$

Adult female.--Length (skins), 140-166 (155); wing, 85-89 (86.8); tail, 57-60.5 (58.6); culmen, 21.5-24 (22.2); tarsus, 21-22.5 (21.8); middle toe, $17.5-19$ (18.6). ${ }^{a}$

Costa Rica (Turrialba; Cariblanco de Sarapiquí; Tenório; Buena Vista; Cerro Santa Maria) and western Panamá (Boquete).

Sclerurus canigularis Ridgway, Proc. U. S. Nat. Mus., xi, sig. 34, Sept. 20, 1889, 542 (Turrialba, Costa Rica; coll. U. S. Nat. Mus.); xii, 1890, 24 (monogr.); xvi, 1893, 613 (Buena Vista, Costa Rica; crit.).-Zeledón, Anal. Mus. Nac. Costa Rica, i, 1887, 114.-Sclater, Ibis, 1889, 354 (crit.).-Salvin and Godman, Biol. Centr.-Am., Aves, ii, 1891, 166.-Bangs, Proc. New Engl. Zool. Club, iii, 1902, 45 (Boquete, Panamá, 5,600-5,800 ft.).-Carriker, Ann. Carnegie Mus., vi, 1910, 645 (Costa Rica; crit.).

[Sclerurus] canigularis SHARPE, Hand-list, iii, 1901, 72.

Sclerurus albigularis (not S. albogularis Swainson) Sclater, Cat. Birds Brit. Mus., $\mathrm{xv}, 1890,114$, part (in synonymy).

\section{SCLERURUS MEXICANUS MEXICANUS Sclater.}

MEXICAN SCLERURUS.

Adults (sexes alike).-Above plain deep warm-sepia brown (sometimes approaching prouts or vandyke brown), duller and rather 
darker on pileum, and passing into chestnut on lower rump and upper tail-coverts; tail darker sepia brown, passing into blackish brown terminally; chin and throat dull tawny-rufous or rufous-tawny (the chin sometimes decidedly paler, rarely dull whitish), passing into deeper tawny-rufous or tawny-chestnut on chest; rest of under parts plain brown (nearest mummy brown), sometimes tinged with more rufescent brown, especially on breast and under tail-coverts; under, wing-coverts mixed tawny and grayish brown; maxilla dusky horn color or blackish, mandible pale yellowish or dull whitish (in dried skins), dusky or horn colored terminally and along tomia; iris hazel ${ }^{a}$ legs and feet horn color or dusky (in dried skins).

Young.-Similar to adults, but colors rather duller, especially on throat and chest, which are dull tawny or tawny-brown, some of the feathers with very indistinct shaft-streaks of paler and (sometimes) with narrow and indistinct terminal margins of duller brown or dusky.

Adult male.-Length (skins), 142-163 (154); wing, 78-83 (80.5); tail, 51-62 (56.2); culmen, 23-27 (24.7); tarsus, 20-22 (21.2); middle toe, $16-17.5(17) .^{b}$

Adult female.-Length (skin), 158; wing, 80; tail, 56.5; culmen, 24; tarsus, 20.5 ; middle toe, $17.5 .^{c}$

Southeastern Mexico, in States of Vera Cruz (Córdova; Potrero, near Córdova; Jico; Jalapa; Orizaba), and Mexico (City of Mexico), Guatemala (Cobán; Raxché; Savana Grande; Volcán de Agua), Honduras (Volcán de Puca, Department of Copán), Costa Rica (Cariblanco de Sarapiquí), Panamá (Lion Hill; Panamá; Calovévora; Cordillera de Tolé; Santiago de Veragua) and southward through Colombia (Bogotá; Frontino) and Ecuadór (Intaj; Sarayacu) to Peru (Yurimaguas; Chyavetas) and lower Amazon (Rio Capím). ${ }^{d}$

(?) "Sclerurus ruficollis Swainson, Birds Brazil, ["1834-41"], pl. 79."

Sclerurus mexicanus Sclater, Proc. Zool. Soc. Lond., 1856 (pub. Jan. 26, 1857), 290 (Córdova, Vera Cruz, Mexico; coll. P. L. Sclater); 1859, 365 (Jalapa, Vera Cruz); 1864, 175 (City of Mexico); Cat. Am. Birds, 1862, 145, pl. 12

$a$ T. W. Brown, jr., on label.

$b$ Seven specimens.

c One specimen.

\begin{tabular}{|c|c|c|c|c|c|}
\hline Locality. & Wing. & Tail. & $\begin{array}{l}\text { Cul- } \\
\text { men. }\end{array}$ & Tarsus. & $\begin{array}{c}\text { Middle } \\
\text { toe. }\end{array}$ \\
\hline MALES. & & & & & \\
\hline Two adult males from Vera Cruz, Mexico... & 80.2 & 58.5 & 26 & 20.7 & 16.7 \\
\hline One adult male from Honduras............... & 83 & 62 & 27 & 21 & 17.5 \\
\hline Four adult males from Panamá (Lion Hill) ............. & 80 & 53.6 & 23.2 & 21.5 & 17 \\
\hline
\end{tabular}

$d$ South American specimens not seen by me. 
(Córdova; Cobán, Guatemala); Cat. Birds Brit. Mus., xv, 1890, 115 (Córdova; Raxché, Cobán, Savana Grande, and Volcán de Agua, Guatemala; Calovévora, Cordillera de Tolé, and Santiago de Verágua, Panamá; Bogotá and Frontino, Colombia; Intaj and Sarayacu, Ecuadór; Yurimáguas, e. Peru; Capím R., lower Amazons; Bahia?).-SAlvin and Sclater, Ibis, 1860, 35 (Cobán; crit.).-Sclater and Salvin, Proc. Zool. Soc. Lond., 1867, 574 (Capim R.; crit.), 750, 755 (Yurimaguas and Chyavetas, e. Peru); 1873, 269 (Yurimaguas, e. Peru).-Salvin, Ibis, 1861, 143 (Raxché, Guatemala); Proc. Zool. Soc. Lond., 1867, 142 (Santiago and Cordillera de Tolé Panamá; crit.); 1870, 191 (Calovévora, Panamá).-Sumichrast, Mem. Bost. Soc. N. H., i, 1869, 555 (tierra caliente of Vera Cruz, up to $1300 \mathrm{~m}$.); La Naturaleza, v, 1881, 247 (Orizaba and Protrero, Vera Cruz).-SAnchez, Anal. Mus. Nac. Mex., i, 1877, 97 (Vera Cruz).-Taczanowski, Orn. du Pérou, ii, 1884, 115 (Yurimaguas).-Ridgway, Proc. U. S. Nat. Mus., xii, 1890, 25 (monogr.); xiv, 1891, 471 (Volcán de Puca, Honduras).-Salvin and Godman, Biol. Centr.-Am., Aves, ii, 1891, 167.-Carriker, Ann. Carnegie Mus., vi, 1910, 645 (Costa Rica).-Chapman, Bull. Am. Mus. N. H., x, 1898, 32 (Jalapa).-Bangs, Proc. New Engl. Zool. Club, ii, 1900, 26 (Loma del León, Panamá).-Goeldi, Ibis, 1903, 499 (Capím R., n. e. Brazil).

[Sclerurus] mexicanus GraY, Hand-list, i, 1869, 167, no. 2219.-Pelzeln, Orn.

Bras., iv, Abth., 1870, 419.-Sclater and Salvin, Nom. Av. Neotr., 1873, 62.--Sharpe, Hand-list, iii, 1901, 72.

(?) Sclerurus rufigularis Pelzeln, Orn. Bras., ii Abth., 1869, 161 (Maribatanas; ex "Tinactor rufigularis, Natterer, Catal. msc."). ${ }^{a}$

Sclerurus caudacutus (not Thamnophilus caudacutus Vieillot) ScLATER and SALviN, Proc. Zool. Soc. Lond., 1879, 520 (Antioquía, Colombia).-TACZanowski, Orn. du Pérou, ii, 1884, 114.

\section{SCLERURUS MEXICANUS PULLUS Bangs.}

DUSKY SCLERURUS.

Similar to $S . m$. mexicanus but coloration much darker, the back, etc., dark sepia, the lower rump and upper tail-coverts deep vandyke to deep chocolate or walnut brown.

Adult male.-Length (skins), 146-160 (153); wing, 76.5-81 (78.7); tail, 56-57 (56.5); culmen, 21-24 (22.5); tarsus, 21-21.5 (21.2); middle toe, $18-19(18.5) .^{b}$

Adult female.-Length (skins), 146-156 (151); wing, 75-78 (76.5); tail, 50-54.5 (52.2); culmen, 20-21.5 (20.7); tarsus, 20-22 (21); middle toe, $18-19.5$ (18.7). ${ }^{b}$

Caribbean slope of western Panamá (Boquete, Chiriquí) and Costa Rica (Cariblanco de Sarapiquí).

Sclerurus mexicanus pullus Bangs, Proc. New Engl. Zool. Club, iii, Jan. 30, 1902, 45 (Boquete, Chiriquí, Panama, 5,000 ft.; coll. E. A. and O. Bangs).

a Brown, the lower back rufescent, throat and upper neck ochraceous, breast washed with ferruginous, tail blackish. Length (dried skin), $6^{\prime \prime}$, wing $3^{\prime \prime} 1^{\prime \prime \prime}$, tail $2^{\prime \prime} 3^{\prime \prime \prime}$, bill, to rictus, $11^{\prime \prime \prime}$, tarsus $9 \frac{1}{2}^{\prime \prime \prime}$. (Translation of original description.)

o Two specimens. 


\section{SCLERURUS GUATEMALENSIS (Hartlaub).}

GUATEMALAN SCLERURUS.

Adults (sexes alike).-Above plain deep vandyke brown, the feathers of pileum very indistinctly margined with dusky; tail darker brown, passing into blackish brown terminally; chin and throat white, the feathers broadly margined with dusky (at least on lower throat), producing in squamate effect; rest of under parts bister or sepia brown, brighter, more tawny, brown on chest, where the feathers are paler centrally and have a narrow shaft-streak of light tawny; under wing-corerts pale brownish gray or grayish brown, narrowly margined with dusky; bill black or blackish brown, the basal portion dull whitish or yellowish (in dried skins); iris brown; legs and feet dusky horn color to brownish black (in dried skins).

Young.-Essentially like adults but chin and throat darker, streaked rather than squamated with dusky and with ground color pale brown or brownish gray instead of white, and color of chest less tawny (nearly mummy brown).

Adult male.-Length (skins), 150-1S1 (164); wing, 85.5-92 (88.7); tail, 57-66.5 (60.9); culmen, 21-25 (22.7); tarsus, 20.5-23 (22); middle toe, $17-19.5(18.2) .^{a}$

Adult female.-Length (skins), 148-165 (157); wing, 83-91 (86.9); tail, 54.5-59.5 (57.6); culmen, 21.5-23.5 (22.4); tarsus, 21-23 (21.9); middle toe, $18-19.5$ (18.3). ${ }^{b}$

a Eighteen specimens.

$b$ Ten specimens.

\begin{tabular}{|c|c|c|c|c|c|}
\hline Locality. & Wing. & Tail. & $\begin{array}{l}\text { Cul- } \\
\text { men. }\end{array}$ & Tarsus. & $\begin{array}{c}\text { Middle } \\
\text { toe. }\end{array}$ \\
\hline \multicolumn{6}{|l|}{ MaLES. } \\
\hline One adult male from Tabasco, Mexico............ & 87 & 57 & 21.5 & 22 & 18.5 \\
\hline Three adult males from Honduras......... & 89.7 & 61.5 & 23 & 21.8 & 18.7 \\
\hline Two adult males from British Honduras........... & 90.5 & 61.2 & 22 & 21.7 & 18.2 \\
\hline One adult male from Nicaragua................. & 90 & 61 & 22 & 20.5 & 18 \\
\hline Ten adult males from Costa Rica....... & 88.5 & 57.5 & 23 & 21.5 & 18 \\
\hline 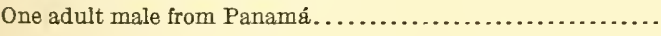 & 85 & 57.5 & 23 & 21.5 & 18 \\
\hline \multicolumn{6}{|l|}{ FEMALES. } \\
\hline One adult female from Guatemala........ & 86.5 & 58 & 22 & 21 & 18 \\
\hline One adult female from Honduras.............. & 89.5 & 58.5 & 22.5 & 21.5 & 18.5 \\
\hline 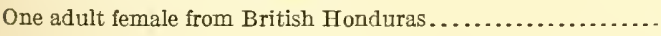 & 91 & 59 & 23 & 22.5 & 19 \\
\hline Five adult females from Costa Rica....................... & 86.9 & 57.1 & 22.7 & 22 & 18.5 \\
\hline Two adult females from Panamá....................... & 84 & 57.5 & 21.7 & 22 & 18.2 \\
\hline
\end{tabular}


Southeastern Mexico, in States of Vera Cruz (Jico), Tabasco (Teapa), and southward through Guatemala (Choctúm), British Honduras (Toledo District), Honduras (Santa Ana; La Puerta; Chaloma), Nicaragua (Rio Escondido; San Emilis, Lake Nicaragua), Costa Rica (Sibahue, Talamanca; Jiménez; La Concepción; Bonilla; El Hogár; El Generál; Pozo Azúl de Pirrís; Pozo del Rio Grande; El Pozo de Térraba; Boruca; Paso Reál, Boruca; La Vijágua; Palmár; Volcán de Miravalles; Cerro Santa Maria), and Panamá (Lion Hill; Panamá; Boquete).

Tinactor guatemalensis Hartlaub, Rev. Zool., 1844, 370 (Guatemala).

Sclerurus guatemalensis Sclater and Salvin, Ibis, 1859, 118 (Guatemala); Proc. Zool. Soc. Lond., 1864, 354 (Lion Hill, Panamá; crit.).-Salvin, Ibis, 1861, 352 (Choctúm, Guatemala).-Zeledón, Anal. Mus. Nac. Costa Rica, i, 1887, 114 (Jiménez and Pozo Azúl de Pirrís, Costa Rica; Panama).-Ridgway, Proc. U. S. Nat. Mus., xii, 1890, 30 (monogr.); xiv, 1891, 471 (Santa Ana and La Puerta, Honduras).-Sclater, Cat. Birds Brit. Mus., xv, 1890, 117, part (Choctúm, Guatemala; Panamá; not spec. $c$, which $=S$. brunneus Sclater).Salvin and Godman, Biol. Centr.-Am., Aves, ii, 1891, 168, pl. 44, fig. 1.Richmond, Proc. U. S. Nat. Mus., xvi, 1893, 498 (Rio Escondido, Nicaragua).-Cherrie, Expl. Zool. Merid. Costa Rica, 1893, 38 (Palmár and Boruca, s. w. Costa Rica).-Underwood, Ibis, 1896, 440 (Volcán Miravalles, Costa Rica).-Lantz, Trans. Kansas Acad. Sci. for 1896-97 (1899), 221 (Chaloma, Honduras).-Bangs, Proc. New Engl. Zool. Club, ii, 1900, 26 (Loma del León, Panamá); Auk, xxiv, 1907, 299 (Boruca, Paso Reál, and Pozo del Rio Grande, s. w. Costa Rica).-Carriker, Ann. Carnegie Mus., vi, 1910, 646 (Costa Rica; crit.).

S[clerurus] guatimalensis Bonaparte, Consp. Av., i, 1850, 210.

[Sclerurus] guatemalensis Grax, Hand-list, i, 1869, 167, no. 2221.-Sclater and Salvin, Nom. Av. Neotr., 1873, 62.-Sharpe, Hand-list, iii, 1901, 73.

Scleurus guatemalensis Lawrence, Ann. Lyc. N. Y., vii, 1863, 482 (Isthmus Panamá).

Scleurus caudacutus (not Thamnophilus caudacutus Vieillot) LAwrence, Ann. Lyc. N. Y. vii, 1862, 320 (Lion Hill, Panamá).

Scleurus mexicanus? (not Sclerurus mexicanus Sclater) Lawrence, Ann. Lyc. N. Y., vii, 1862, 465 (Lion Hill).

\section{Genus XENOPS Illiger.}

Xenops Illiger, Prodr. Orn., 1811, 213. (Type, $X$. genibarbis Illiger.)

Neops a Vieillot, Analyse, 1816, 45. (Type, $N$. ruficaudus Vieillot=Xenops genibarbis Illiger.)

Anecorhamphus $b$ Brllberg, Synop. Faunæ Scand., i, pt. ii, 1828, tab. A. (To replace Xenops Illiger.)

Small scansorial Furnariidæ (length about $115 \mathrm{~mm}$.) with short, stout, wedge-shaped bill with strongly recurved, falcate mandible; tail (black and cinnamon-rufous) shorter than wing, with round- 
tipped rectrices, and inner webs of remiges crossed by a broad oblique band of light tawny or ochraceous-buft.

Bill decidedly shorter than head, stout, wedge-shaped, compressed, its width at loral antia much less than its depth at same point and equal to a little less than half to one-third the distance from nostril to tip of maxilla; culmen scarcely ridged, straight to extreme tip; maxillary tomium slightly convex, without trace of notch; mandibular tomium distinctly concave for terminal half, without trace of notch; gonys distinctly convex, strongly ascending terminally, the mandible strongly recurved terminally (falcate) with tip acute. Nostril exposed, posteriorly in contact with loral feathering, very small, longitudinally ovate or elliptical, slightly operculate. Rictal bristles absent. Wing moderate, rather pointed, the longest primaries exceeding secondaries by length of culmen, or more; serenth and eighth primaries longest, the tenth (outermost) about four-fifths as long as longest and decidedly longer than secondaries. Tail a little more than two-thirds to four-fifths as long as wing, strongly rounded or moderately graduated (graduation not greater than length of tarsus), the rectrices (12) soft and rounded terminally. Tarsus as long as or slightly longer than culmen, one-fourth as long as wing or slightly less, distinctly scutellate; middle toe, with claw, about as long as tarsus; outer toe, without claw, reaching to middle of subterminal phalanx of middle toe, the inner toe slightly but decidedly shorter; hallux as long as outer toe, decidedly stouter; middle toe united to outer toe by all of its first and half or more of its second phalanx, to inner toe by whole of its first phalanx; claws large, strongly curved, acute, that of the hallux much shorter than the digit.

Coloration.-Plain brown or rufescent above, the head darker, sometimes streaked; tail cinnamon-rufous with much black on third and fourth, or second, third, and fourth rectrices; primaries blackish and dull cinnamon-rufous; inner webs of remiges crossed obliquely by a broad band of pale tawny or ochraceous; under parts light olive, whitish on throat, the chest, etc., sometimes streaked with whitish. Sexes alike.

Range.-Southern Mexico to Cayenne, Brazil, Bolivia, and Peru. (About five species.) ${ }^{a}$

$a$ The following I have not seen: $X$. littoralis Sclater; $X$. tenuirostris Pelzeln. 


\section{KEY TO THE SPECIES OF XENOPS. $a$}

a. Breast plain brown, brownish gray, or grayish olive. '(Xenops genibarbis.)

b. Basal portion of rectrices more extensively black. (Tropical South America.)

Xenops genibarbis genibarbis (extralimital). $b$

bb. Basal portion of rectrices less extensively black. (Southern Mexico to Panama.)

Xenops genibarbis mexicanus $c$ (p. 172.)

aa. Breast conspicuously streaked with whitish. (Xenops rutilus.)

b. Under parts more broadly streaked; back, etc., brighter rufous-brown. (Brazil,

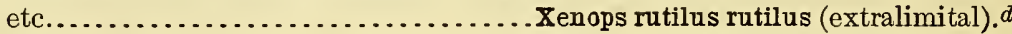

bb. Under parts more narrowly streaked; back, etc., duller rufous-brown. (Costa Rica to Colombia, Venezuela, Trinidad, and Peru.)

Xenops rutilus heterurus (p. 175).

\section{XENOPS GENIBARBIS MEXICANUS (Sclater).}

\section{MEXICAN XENOPS.}

Similar to $X . g$. genibarbis ${ }^{e}$ but with much less of black on basal portion of lateral rectrices.

Adults (sexes alike).-Pileum brown (nearly bister), the feathers sometimes with very indistinct shaft-streaks of paler (these usually

$a$ Both species of Xenops almost certainly require further subdivision than is here made, but from want of sufficient material, especially of $X$. rutilus and South American representatives of $X$. genibarbis, I must leave a satisfactory treatment of the genus to some one who has both more material and time. (See, however, Hellmayr, in Novit. Zool., xiv, 1907, 54, 55, whose paper I did not, unfortunately, see in time to utilize it in this work.)

b Xenops genibarbis Illiger, Prodromus Orn., 1811, 213 (Cametà, Brazil); Sclater, Cat. Birds Brit. Mus., xv, 1890, 110.-Neops ruficaudus Vieillot, Analyse, 1816, 68 (Guiana).-(?)Xenops littoralis Sclater, Proc. Zool. Soc. Lond., 1861, 379 (Esmeraldas, w. Ecuador; coll. P. L. Sclater).-(?)Xenops approximaus Pelzeln, Sitz. Akad. Wien, xxxiv, 1859, 113.

In the paper referred to above Hellmayr (than whom there is no better authority), divides $X$. genibarbis into three subspecies (besides $X . g$. mexicanus), as follows: (1) Xenops genibarbis genibarbis (Colombia to Cayenne and Amazon Valley); (2) Xenops genibarbis littoralis (western Ecuador); (3) Xenops genibarbis pelzelni (southeastern Brazil, from Bahia to S. Paulo; new subspecies, described on p. 55, the type, in coll. Vienna Mus., being from Ypanema, S. Paulo).

$c$ This probably separable into about three subspecies. (See p. 174, footnote.)

$d X$ [enops] rutilus Lichtenstein, Verz. Doubl., 1823, 17 (Bahia, Brazil; coll. Berlin Mus.); Sclater, Cat. Birds Brit. Mus., xv, 1890, 111, part.-Xenops rutilus rutilus Hellmayr, Novit. Zool., xiii, 1906, 29 (Trinidad; crit.); xv, 1908, 62 (Goiaz, etc., Brazil; crit.).-Xenops rutilans Temminck, Pl. Col., livr., 12, July, 1821, pl. 72, fig. 2.-Xenops affinis Swainson, Anim. in Menag., pt. iii, Jan. 1, 1838, 352 (Brazil; coll. W. Swainson).-Xenops argyobronchus Bertoni, Aves Nuevas del Paraguay, Jan , 1901, 75 (Djaguarasapá, lat. $26^{\circ}$ 53', upper Rio Paraná, Paraguay; coll. A. de W. Bertoni; see Arribálzaga, An. Mus. Nac. Buenos Aires, vii, 1902, 352, 358 and Ihering, Rev. Mus. Paulista, vi, 1904, 328).

e See p. 172 . 
obsolete); hindneck, back, scapulars, and lesser wing-coverts plain cinnamon-brown or between russet and raw-umber; lower rump, upper tail-coverts, and greater part of tail clear cinnamon-rufous; fourth and fifth rectrices (from outside), greater part of inner web of third rectrix, and basal portion of inner web of second, black, the inner web of outermost rectrix usually with a dusky spot at extreme base; wing-coverts russet-brown, the inner webs of greater coverts 'dusky; primary coverts dull black or dusky at base (narrowly) and tip (broadly), the middle portion (broadly) russet-brown; secondaries dull cinnamon-rufous with a large subterminal area of black (mostly concealed in the closed wing), the basal portion of inner web (extensively) ochraceous-buff; proximal (shorter) primaries dull black, tipped (more or less broadly and distinctly) with cinnamon-brown, crossed obliquely on the middle portion by a broad band of clear cinnamon-rufous; distal (longer) primaries dusky, their inner webs with a broad median area of ochraceous-buff, except on two or three outermost quills, the outer webs of which are mostly light russetbrown; a narrow supra-auricular streak of brownish buff; loral region mostly dark brownish; malar, suborbital, and auricular regions dark brown (much like pileum), narrowly and indistinctly streaked with paler; a conspicuous subauricular streak of white; chin and throat pale brownish buffy (sometimes nearly buffy white on chin), the throat indistinctly flammulated with pale buffy brown, at least on lower portion; rest of under parts plain light brown (varying from buffy hair brown to isabella color), tinged, more or less strongly, with pale russet-brown posteriorly; under wing-coverts ochraceous-buff; maxilla dusky, the lower-basal portion paler; mandible pale horn color or dull whitish (in dried skins) becoming darker on upper or terminal portions; iris brown; legs and feet dark horn color (in dried skins).

Young.-Similar in coloration to adults but dusky on basal portion of inner webs of lateral rectrices more extensive and texture of plumage different.

Adult male.-Length (skins), 108-125 (117); wing, 58.5-67.5 (64.2); tail, 43.5-53 (48.9); culmen, 12-14.5 (13.1); tarsus, 14-15.5 (14.7); middle toe, $11.5-13(12){ }^{a}$ 
Adult female.-Length (skins), 104-120 (113); wing, 58-66 (61.2); tail, 43.5-48 (46); culmen, 11-14 (13.1); tarsus, 14-15 (14.1); middle toe, $11-13(11.9) .^{a}$

Southeastern Mexico, in States of Vera Cruz (Córdova; Playa Vicente; Uvero; Buena Vista), Oaxaca, Tabasco (Teapa), and Yucatan (La Vega), and southward through Guatemala (Choctúm; sources of Rio de la Pasión), British Honduras (Orange Walk; Cayo; Toledo District; near Manatee Lagoon), Honduras (San Pedro; Montañas; Santa Ana; Rio Blanco; Rio Segóvia), Nicaragua (Castillo; Rio San Juan; San Emilis, Lake Nicaragua) and Costa Rica (Grécia; Angostura; San José; 'Tucurríqui; Guápiles; Carrillo; Corallillo; Guayabál; Orosí; El Hogár; Guayabo; Jiménez; Pozo Azúl de Pirrís; Pozo del Pitál; Pozo del Rio Grande; Lagarto; Boruca; Paso Reál; El Generál; Tenório; Buenos Aires; El Pozo de Térraba; Pigres; Pacuare; Palmár; Bebedero; Cerro Santa Maria; Miravalles; La Vijágua; Bolsón), to Panamá (Santa Fé de Verágua; Calovévora; Bugaba; Bibalaz; Volcan de Chiriquí; Boquete; Divala; Panamá; Lion Hill).

Xenops mexicanus Sclater, Proc. Zool. Soc. Lond., 1856 (pub. Jan. 26, 1857), 289 (Córdova, Vera Cruz, Mexico; coll. A. Sallé); 1859, 382 (Playa Vicente, Vera Cruz); Cat. Am. Birds, 1862, 159 (Oaxaca).-Salvin, Ibis, 1861, 353

$a$ Eighteen specimens.

\begin{tabular}{|c|c|c|c|c|c|}
\hline Locality. & Wing. & Tail. & $\begin{array}{l}\text { Cul- } \\
\text { men. }\end{array}$ & Tarsus. & $\begin{array}{c}\text { Middle } \\
\text { toe. }\end{array}$ \\
\hline \multicolumn{6}{|l|}{ MALES. } \\
\hline Two adult males from Vera Cruz, Mexico...... & 64 & 50 & 13 & 14.5 & 12.5 \\
\hline Three adult males from British Honduras . ............ & 63.5 & 48.5 & 13.2 & 14.8 & 12 \\
\hline Five adult males from Honduras . . . . . . . . . . . . . . . . . & 63.1 & 47.2 & 13.3 & 14.5 & 11. 8 \\
\hline Ten adult males from Nicaragua (1) and Costa Rica (9) ........ & 65.2 & 49.6 & 13.3 & 14.9 & 12.1 \\
\hline Two adult males from western Panamá (Divala, Chiriquí)..... & 66.2 & 52.2 & 13.5 & 14.7 & 12.2 \\
\hline Two adult males from eastern Panamá (line of railway)...... & 60.7 & 45.5 & 12.7 & 14.5 & 12 \\
\hline One adult male ( $X$. g. genibarbis) from Surinám............. & 67 & 52.5 & 15 & 14.5 & 12 \\
\hline One aduit male ( $X$. g. genibarbis) from Brazil (Maribatanas)... & 63.5 & 41.5 & 14 & 15 & 11.5 \\
\hline \multicolumn{6}{|l|}{ FEMALES. } \\
\hline One aduit female from Vera Cruz... & 61 & 46 & 13 & 14.5 & 12 \\
\hline 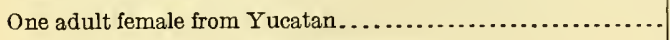 & 62 & 46 & 13.5 & 14 & 11.5 \\
\hline Two adult females from British Honduras.......... & 60 & 46 & 12.7 & 14 & 11.2 \\
\hline One adult female from Honduras................. & 60 & 46 & 13 & 14 & 11.5 \\
\hline Ten adult females from Costa Rica................ & 61.6 & 45.7 & 13 & 14.5 & 12.2 \\
\hline Two adult females from western Panamá............ & 62.5 & 47 & 13.7 & 14.5 & 11.7 \\
\hline One adult female from eastern Panamá.................... & 58 & 46.5 & 12.5 & 14 & 12 \\
\hline
\end{tabular}

Specimens from British Honduras are more buffy (less olivaceous) below and more rufescent above than those from Costa Rica, etc., the latter being much more olivaceous (less brownish) below as well as above, than those from Mexico. Those from the Santa Marta district of Colombia are paler above, with middle rectrices cinnamomeous rather than rufescent, the under parts paler and grayer, wing shorter, and tail longer. The species almost certainly requires further subdivision. 
(Choctúm, Guatemala); Proc. Zool. Soc. Lond., 1867, 143 (Santa Fe de Verágua); 1870, 192 (Calovévora and Bugabá, Panamá),-Lawrence, Ann. Lyc. N. Y., vii, 1862, 320 (Lion Hill, Panamá); ix, 1868, 106 (Angostura, San José, Pacuare, and Grécia, Costa Rica).-Sclater and Salvin, Proc. Zool. Soc. Lond., 1864, 354 (Lion Hill; crit.).-Frantzius, Journ. für Orn., 1869, 304 (Costa Rica).-Sumichrast, Mem. Bost. Soc. N. H., i, 1869, 555 (hot region Vera Cruz); La Naturaleza, v, 1881, 247 (Uvero, Vera Cruz).-Sanchez, Anal. Mus. Nac. Mexico, i, 1877, 97 (Vera Cruz).-Boucard, Ann. Soc. Linn. Lyons, 1878, 37 (Guatemala).

[Xenops] mexicanus GraY, Hand-list, i, 1869, 174, no. 2356.

$X$ [enops] genibarbis mexicanus Berlepsch and Stolzmann, Proc. Zool. Soc. Lond., 1896, 375, in text.-Hellmayr, Novit. Zool., xiv, 1907, 55 (crit.).

Xenops genibarbis mexicanus Carriker, Ann. Carnegie Mus., vi, 1910, 643 (Costa Rica).

Xenops genibarbis (not of Illiger), Zeledón, Anal. Mus. Nac. Costa Rica, i, 1887, 113 (Jiménez, Angostura, and Pozo Azúl de Pirrís, Costa Rica).-Ridgway, Proc. U. S. Nat. Mus., x, 1888, 590 (Rio Segóvia, Honduras).-Sclater, Cat. Birds Brit. Mus., xv, 1890, 110, part (Córdova, Vera Cruz; Oaxaca; sources Rio de la Pasión, and Choctúm, Guatemala; Tucurríqui and San José, Costa Rica; Santa Fé, Calovévora, and Bugaba, Verágua; Panamá).Salvin and Godman, Biol. Centr.-Am., Aves, ii, 1891, 164, part (Teapa, Tabasco; Orange Talk and Cayo, Brit. Honduras; Angostura, Pacuare, and Grécia, Costa Rica; Bibaláz, Verágua; etc.).-Richmond, Proc. U. S. Nat. Mus., xvi, 1893, 497 (Castillo, Nicaragua).-Cherrie, Expl. Zool. Merid. Costa Rica, 1893, 39 (Palmár, Boruca, etc., Costa Rica); Anal. Inst. Fis.Geog., vi, 1893, 17 (Pozo del Pitál, Costa Rica).--Underwood, Ibis, 1896, 440 (Volcán Miravalles and Bebedero, Costa Rica).-Bangs, Proc. New Engl. Zool. Club, ii, 1900, 26 (Loma del León, Panamá); iii, 1902, 45 (Volcán de Chiriquí, 6,200 ft.).-Ferry, Pub. 146, Field Mus. N. H., orn. ser., i, no. 6, 1910, 270 (Guayabo, Costa Rica).

[Xenops] genibarbis Sclater and Salvin, Nom. Av. Neotr., 1873, 66, part.SHarPe, Hand-list, iii, 1901, 71, part (s. Mexico to Panamá).

\section{XENOPS RUTLUS HETERURUS (Cabanis and Heine).}

STREAKED XENOPS.

Adults (sexes alike).-Pileum dark sepia or sooty brown streaked with pale brownish buff or cinnamon; hindneck and back dull cinnamon-brown (or between russet and raw-umber) the former broadly streaked with cinnamon-buff, the upper back sometimes with narrower and indistinct streaks of the same; rump, upper tail-coverts, and tail clear deep cinnamon-rufous, the inner web of third and fourth rectrices (from outside) mostly black, that of second dusky basally; wing-coverts nearly concolor with back, the middle and greater series with terminal portion paler and more cinnamomeous or tawny; secondaries dull cinnamon-rufous with a large subterminal area of black (concealed in the closed wing), the basal portion (extensively) of inner web clear ochraceous-buff; proximal (shorter) primaries black, tipped with dull cinnamon-rufous and crossed by a broad subbasal area of the same (lighter, more ochraceous-buff, on inner webs); distal (longer) primaries, except three outermost, similar 
but with cinnamon-rufous area confined to inner web; three outermost primaries with inner web wholly dusky, the outer web mostly dull cinnamon-rufous; a narrow but conspicuous superciliary streak of buffy white, indistinct anteriorly; lores mostly dull grayish or dusky; a broad postocular streak of brownish black or dark sooty brown; auricular region dusky, streaked with pale brownish buff or whitish, and bordered below by a conspicuous subauricular streak of white; chin and throat dull white or yellowish white, the lower throat sometimes streaked, more or less, with olive; rest of under parts light grayish brown (hair brown to light isabella color), passing into a more rufescent or cinnamomeous hue posteriorly, streaked with dull white, the streaks broadest on chest; under wing-coverts deep ochraceous-buff; maxilla dusky horn color, paler on lower-basal portion; mandible dull pale yellowish or whitish (in dried skins), passing into dusky or horn color terminally; iris dark brown; legs and feet dusky horn color (dark bluish gray in life).

Male.-Length (skins) 112-121 (115); wing, 63-71.5 (67.6); tail, 43.5-50 (47.9); culmen, 12-13 (12.6); tarsus, 14.5 ; middle toe, 13-14 $(13.3){ }^{a}$

Costa Rica (Juan Viñas; Guayabo) and Panamá (Boquete, 4,500$5,000 \mathrm{ft}$.; Volcán de Chiriquí), and southward through Colombia (San Antonio, Rio Cali; Rio Chiquitos; Rio Lima; Bogotá; Cauta; Medellín, Antioquía; Los Tambos; Santa Elena and Las Nubes, Santa Marta) and Ecuadór (Guayaquíl; Macháy; Balzár Mountains; Sarayacu; Baeza; Vinces) to Peru (Chamicuros; Ropaybamba; Anquimarca; Tambillo; Guajango; Chirimoto; Cococho; Huambo; Nauta; Rio Ucayali; La Gloria; Borgoña; Garita del Sol; Idma; Santa Ana). ${ }^{b}$

Xenops rutilans (not of Temminck) Sclater, Proc. Zool. Soc. Lond., 1856, 27 (Bogotá, Colombia; crit.).

Xenops rutilus (not of Lichtenstein) WyatT, Ibis, 1871, 331 (Cauta, Colombia).-

Sclater and Salvin, Proc. Zool. Soc. Lond., 1873, 270 (Chamicuros, e. Peru;

$a$ Four specimens.

\begin{tabular}{|c|c|c|c|c|c|}
\hline Locality. & Wing. & Tail. & $\begin{array}{l}\text { Cul- } \\
\text { men. }\end{array}$ & Tarsus. & $\begin{array}{l}\text { Middle } \\
\text { toe. }\end{array}$ \\
\hline MALES. & & & & & \\
\hline $\begin{array}{l}\text { Two adult males from western Panamá (Boquete, Chiriquí)... } \\
\text { Two adult males from northwestern Colombia (Rio Cali and }\end{array}$ & 65.5 & 46. 7 & 12.7 & 14.5 & 13 \\
\hline Rio Limón) ....................... & 69.7 & 49 & 12.5 & 14.5 & 13. \\
\hline 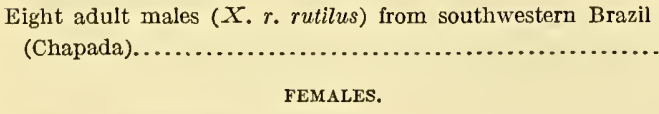 & 66.2 & 47.8 & 12.5 & 14 & 13. \\
\hline aale from Trinidád. & 63 & 43 & 12 & 14 & 13 \\
\hline Four adult females ( $X . r$.rutilus) from Brazil ( & 65.2 & 46.1 & 12.2 & 14 & 13 \\
\hline
\end{tabular}

$b$ I have not seen specimens from Ecuadór or Peru. 
habits).-Taczanowski, Proc. Zool. Soc. Lond., 1874, 529 (Ropaybamba and Anquimarca, centr. Peru); 1879, 231 (Tambillo and Guajango, Peru); 18s2, 26 (Chirimoto, Cococho, and Huambo, Peru); Orn. du Pérou, ii, 1884, 160.-Berlepscir and Taczanowsini, Proc. Zool. Soc. Lond., 1883, 562 (Guayaquíl, w. Ecuadór; crit.).-Berlepsch, Journ. für Orn., 1884, 318 (Cauta, Colombia).-Taczanowski and Berlepsch, Proc. Zool. Soc. Lond., 1885, 97 (Machíy, Ecuadór; crit.).-Schater, Cat. Birds Brit. Mus., xv, 1890, 111, part (Costa Rica; Volcan de Chiriquí, Panamá; Medellín, Santa Elena, and Bogotí, Colombia; Balzár Mountains and Sarayacu, Ecuadór; Nauta and Tambillo, Peru).-Salvin and Godnan, Biol. Centr.-Am., Aves, ii, 1891, 165, part (Volcan de Chiriquí; Colombia).-ALLen, Bull. Am. Mus. N. H., xiii, 1900, 159 (Las Nubes, Santa Marta, Colombia).-Goodfellow, Ibis, 1902, 61 (Baeza, e. Ecuadór).-Ferry, Pub. 146, Field Mus. N. H., orn. ser. i, no. 6, 1910, 270 (Guayabo, Costa Rica).

[Xenops] rutilus Sclater and Salvin, Nom. Av. Neotr., 1873, 66, part.-Sharpe, Hand-list, iii, 1901, 71, part (Costa Rica; Panamá; Colombia; Peru).

$X$ [enops] heterurus Cabanis and Heine, Mus. Hein., ii, Aug., 1859, 33 (Colombia; coll. Heine Mus.).

Xenops heterurus Sclater, Cat. Am. Birds, 1862, 159 (Bogotá).-Sclater and Salvin, Proc. Zool. Soc. Lond., 1866, 566 (Rio Ucayali, e. Peru).-Salvin, Ibis, 1869, 319 (Costa Rica); Proc. Zool. Soc. Lond., 1870, 192 (Volcan de Chiriquí; crit.).-Salvadori and Festa, Boll. Mus. Zool., etc., Torino, xv, 1899, no. 362, 23 (Vinces, w. Ecuadór; crit.; synonymy).

[Xenops] heterurus Sharpe, Hand-list, iii, 1901, 71 (Ecuadór; Peru).

Xenops rutilus heterurus Berlepsch and Stolzmann, Proc. Zool. Soc. Lond., 1896, 375 (La Gloria, Borgoña, and Garita del Sol, centr. Peru); Ornis, 1906, 92 (Idma, Santa Ana, Peru).-Berlepsch, Novit. Zool., xv, 1908, 147 (Cayenne; crit.).

\section{Genus MARGARORNIS Reichenbach.}

Margarornis Reichenbach, Handb. Spec. Orn., 1853, 119. (Type, Anabates squamigera Lafresnaye and D'Orbigny.)

Anabasitta Lafresnaye, Rev. et Mfag. de Zool., Nov., 1853, 492. (Type, Anabates squamigera Lafresnaye and D'Orbigny.)

Small scansorial Furnariidæ (length about 130-150 mm.) with small bill (much shorter than head), long spine-tipped tail, very long hallux, middle toe united to outer toe by whole of its first phalanx (sometimes a small part of its second phalanx also), and color of upper parts (except, sometimes, pileum and hindneck) uniform bright cinnamon-rufous.

Bill very much shorter than head, rather slender, moderately compressed, its width at loral antiæ about equal to its depth at same point and equal to about half the distance from nostril to tip of maxilla; culmen rather sharply ridged, gradually but decidedly decurved from base; maxillary tomium nearly straight or slightly decurved (concave) terminally, without trace of subterminal notch; mandibular tomium slightly but decidedly decurved (convex) terminally, without trace of notch; gonys nearly straight, scarcely if at all ascending terminally, not prominent basally. Nostril exposed, posteriorly in contact with loral feathering, narrow, longitudinal,

$81255^{\circ}$-Bull. 50-11-12 
distinctly operculate. Rictal bristles absent, and feathers of chin, etc., without terminal setæ. Wing long and pointed, the longer primaries exceeding secondaries by much more than length of exposed culmen; sixth, seventh, and eighth primaries longest, the tenth (outermost) two-thirds to nearly three-fourths as long as the longest, the ninth much longer than secondaries. Tail nearly as long as wing, graduated for more than one-fourth its length, the rectrices (12) abruptly and excessively acuminate terminally, with slender tip conspicuously protruded. Tarsus very much longer than culmen, at least one-fourth (but less than one-third) as long as wing, distinctly scutellate; middle toe, with claw, as long as tarsus; outer toe, without claw, reaching to much beyond middle of subterminal phalanx of middle toe, the inner toe decidedly shorter; hallux as long as outer toe; middle toe united to outer toe by the whole of its first and part of its second phalanx, to inner toe for greater part of its first phalanx; claws rather large, strongly curved, sharp, that of the hallux decidedly shorter than the digit.

Coloration.-Upper parts (except, sometimes, pileum and hindneck) uniform bright cinnamon-rufous or chestnut-rufous; under parts similar but paler, with whitish throat and spots or streaks on lower throat or chest, or else under parts of body with conspicuous guttate spots of buffy white margined with black. Sexes alike.

Range.-Costa Rica to Venezuela, Bolivia, and Ecuadór. (Four species. $\left.{ }^{a}\right)$

\section{MARGARORNIS RUBIGINOSA Lawrence.}

COSTA RICAN MARGARORNIS.

Adults (sexes alike).-Pileum plain chestnut-brown, usually paler and more buffy brown on forehead and passing into buffy brown or raw-umber on hindneck; rest of upper parts, including wings and tail, plain deep cinnamon-rufous or rufous-chestnut, the outer webs of two or three outermost primaries and most of inner webs of all the remiges (except tertials) deep grayish brown; a superciliary stripe of buff, indistinct or obsolete above lores; auricular, suborbital, and malar regions plain wood brown or tawny-olive; chin and throat dull white or yellowish white; rest of under parts light buffy cinnamon medially deepening into rufous-cinnamon laterally and on under tail-coverts, the feathers of median portion of chest (sometimes of breast also) with more or less distinct small spots of pale buff, these usually margined posteriorly by a very narrow line of black, the extreme upper chest with ground color paler, and, together with extreme lower throat usually with more or less distinct narrow bars of grayish or dusky; under wing-coverts pale buffy, mottled or tinged with light cinnamon-brownish, and sometimes more or less

$a$ I have not seen $M$. squamigera (D'Orbigny and Lafresnaye), from Bolivia. 
barred with dusky; inner webs of remiges (except two or three outer primaries) edged with light ochraceous-buff and with a broad subbasal area of the same extending entirely across the web; maxilla light brownish, mandible paler; iris brown; legs and feet light brownish (in dried skins).

Adult male.-Length (skins), 131-159 (149); wing, 71-81.5 (76.9); tail, 69.5-81 (75.5); culmen, 11-13 (12.5); tarsus, 19-20.5 (19.8); middle toe, $14-16(15.2){ }^{a}$

Adult female.-Length (skins), 141-155 (149); wing, 71-79.5 (74.8); tail, 66-S0 (73.2); culmen, 11-13 (12.1); tarsus, 19-20 (19.6); middle toe, $14-15.5$ (14.8). ${ }^{b}$

Highlands of Costa Rica (Burgos and El Roble, Volcán de Irazú; Quebrada Honda; San José; La Palma de San José; Volcán de Turrialba; Coliblanco; La Estrella de Cartago; Cachí, Cartago; Navarro de Cartago; Carrillo; La Hondura; San Mateo; Los Reyes, Las Tueltas, and Laguária, Santa Maria de Dota; Laguna Tapada de Birrís; Ojuras de Térraba) and western Panamá (Boquete, 5,0006,000 ft.; Volcán de Chiriquí, 7,500-11,000 ft.; Lomo Cheno, 7,000 ft.; Calobre).

Margarornis rubiginosa Lawrence, Ann. Lyc. Nat. Hist. N. Y., viii, 1867, 128 (San José, Costa Rica; coll. U. S. Nat. Mius.); ix, 1868, 106 (San José and San Mateo, Costa Rica).—Frantzius, Journ. für Orn., 1869, 304 (Quebrada Honda, Costa Rica).-Boucard, Proc. Zool. Soc. Lond., 1878, 60 (Navarro, Costa Rica).-Zeledón, Anal. Mus. Nac. Costa Rica, i, 1887, 113 (San Mateo, Costa Rica).-Sclater, Cat. Birds Brit. Mus., xv, 1890, 122 (San José and Irazú distr., Costa Rica; Calobre, Panamá).--Salvin and Godman, Biol. Centr.Am., Aves, ii, 1891, 170, pl. 47, fig. 1.-Bangs, Proc. New Engl. Zool. Club, iii, 1902, 46 (Boquete and Volcán de Chiriquí, 5,000-11,000ft., Panamá).Carriker, Ann. Carnegie Mus., vi, 1910, 646 (Costa Rica; habits).-Ferry, Pub. 146, Field Mus. N. H., orn. ser., i, no. 6, 1910, 270 (Coliblanco and Volcán de Turrialba, Costa Rica).

[Margarornis] rubiginosa Sclater and Salvin, Nom. Av. Neotr., 1873, 67.Sharpe, Hand-list, iii, 1901, 73.

[Sittasomus] rubiginosus GRAY, Hand-list, i, 1869, 180, no. 2475.

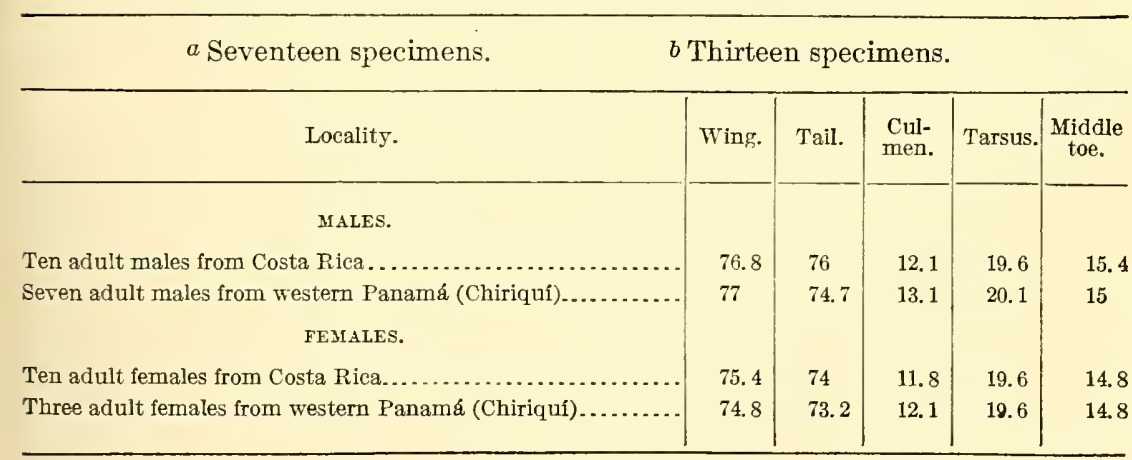




\section{Genus PREMNOPLEX Cherrie.}

Premnoplex a Cherrie, Proc. U. S. Nat. Mus., xiv, no. 855, Sept. 4, 1891, 339. (Type, Margarornis brunnescens Lawrence.)

Small scansorial Furnariidæ (length about $135 \mathrm{~mm}$.) with second phalanx of outer toe partly joined to middle toe, tarsus shorter than middle toe with claw, wing less than three and a half times as long as tarsus, exposed culmen as long as middle toe without claw, and inner webs of remiges without any buff or ochraceous area.

Bill nearly as long as head, slender, its width at loral antiæ greater than its depth at same point and equal to decidedly less than half the distance from nostril to tip of maxilla; culmen distinctly ridged, slightly and gradually curved from near base, the tip of maxilla very slightly decurved, not uncinate; tomia nearly straight for terminal half or more but strongly deflected basally, without trace of subterminal notch; gonys nearly straight, slightly prominent basally, slightly ascending terminally. Nostril exposed, posteriorly in contact with loral feathering, very narrow (a horizontal slit), overhung by a broad, convex, membraneous operculum. Rictal bristles absent, and feathers of chin, etc., without terminal setæ. Wing rather short, excessively rounded, the longest primaries exceeding secondaries by much less than length of exposed culmen; sixth, seventh, and eighth primaries longest, the tenth (outermost) about three-fifths as long as the longest, the ninth much longer than secondaries. Tail about as long as wing, graduated for more than half its length, the rectrices (12) abruptly acuminate, with slender but barbed points conspicuously protruded (but less developed on lateral than on middle rectrices). Tarsus longer than whole culmen, onethird as long as wing, distinctly scutellate; middle toe, with claw, longer than tarsus; outer toe, without claw, reaching to about middle of subterminal phalanx of middle toe, the inner toe distinctly shorter; hallux as long as outer toe, much stouter; basal phalanx of middle toe wholly united to outer toe, for more than half to inner toe; claws rather large and strongly curved, very acute, that of the hallux much shorter than the digit.

Coloration.-Above brown, the head darker and duller; throat buff or ochraceous; rest of under parts brown with broad guttate streaks of buff or ochraceous-buff; no buff or ochraceous on inner webs of remiges.

Range.-Costa Rica to Peru and Bolivia. (Two species ? ${ }^{b}$ )

$a$ From $\pi \rho \varepsilon \varepsilon \nu \nu \nu$, trunk of tree, and $\pi \lambda \dot{\eta} \sigma \sigma \alpha$, strike (erroneously $\pi \eta \eta \sigma \sigma \omega$ in original).

$b$ I have not seen $P$. stictonota (Berlepsch), from western Bolivia. 
KEY TO THE SUBSPECIES OF PREMNOPLEX BLUNNESCENS.

a. Throat more rufescent; general color darker, with black margins to feathers of under parts broader.

b. Throat paler (ochraceous to tawny-ochraceous). (Central to northwestern Colombia.)........... Premnoplex brunnescens brunnescens (extralimital.) ${ }^{a}$

$b b$. Throat darker (deep tawny-ochraceous to rufous-tawny.) (Santa Marta district of Colombia.)........ Premnoplex brunuescens coloratus (extralimital). $b$ aa. Throat paler (buff to ochraceous-buff); general color paler, with black margin to feathers of under parts narrower. (Costa Rica and Panamá.)

Premnoplex brunnescens brunneicauda (p. 181).

\section{PREMNOPLEX BRUNNESCENS BRUNNEICAUDA (Lawrence).}

COSTA RICAN PREMNOPLEX.

Adults (sexes alike).-Pileum olive or deep grayish olive, the feathers margined with dusky, those of the forehead with rather broad mesial streaks of buff; rest of upper parts mummy brown passing into vandyke brown on rump and upper tail-coverts, the scapulars and interscapulars indistinctly margined with dusky, the latter (especially on upper back) sometimes with narrow and mostly indistinct shaft-streaks of buff; tail darker or duller vandyke brown than rump, sometimes nearly seal brown; loral, superciliary, and supra-auricular regions buff, the latter streaked with dusky; auricular and suborbital regions dusky or dark sooty brown, streaked (the latter spotted or flecked) with buffy; malar region, chin, and throat deep buff, the feathers of throat usually indistinctly margined with blackish; rest of under parts olive, conspicuously variegated with large spots and streaks of light buff and black or dusky margins to the feathers, the former largest on chest, where occupying all of each feather except a broad black margin, narrower, more streak-like on sides, more indistinct on abdomen and flanks, indistinct or obsolete on under tail-coverts; maxilla black, mandible dull whitish or yellowish (in dried skins) with a sharply defined stripe of blackish along tomia; iris brown; legs and feet dusky or horn color (in dried skins).

Young.-Similar to adults in coloration but under parts of body with margins to feathers rather broader and more blackish and mesial spots and streaks rather deeper buff.

a Margarornis brunnescens Sclater, Proc. Zool. Soc. Lond., June 16, 1856, 27, pl. 116 (Bogotá, Colombia; coll. P. L. Sclater); Cat. Birds Brit. Mus., xv, 1890, 123, part.-Premnoplex brunnescens brunnescens Bangs, Proc. Biol. Soc. Wash., xxi, July 27, 1908, 159 (centr. and w. Colombia to Peru; crit.).

¿ Premnoplex coloratus Bangs, Proc. New Engl. Zool. Club, iii, Mar. 31, 1902, 84 (San Miguel, Santa Marta, Colombia, 7,500 ft.; coll. E. A. and O. Bangs).-Premnoplex brunnescens coloratus Bangs, Proc. Biol. Soc. Wash., xxi, July 27, 1908, 159 (Sierra Nevada de Santa Marta; crit.). 
Adult male.-Length (skins), 128-149 (137); wing, 59.5-70.5 (63.8); tail, 58.5-65 (61.6); culmen, 12-15.5 (13.9); tarsus, 18.5-20 (19.1); middle toe, $15-16$ (15.7) ${ }^{a}$

Adult female.-Length (skins), 125-144 (133); wing, 57.5-65.5 (61.2); tail, 55.5-65 (59.3); culmen, 13-15.5 (14.3); tarsus, 18-19.5 (18.9); middle toe, $14.5-16$ (15.5). ${ }^{b}$

Highlands of Costa Rica (San José; Rancho Redondo de San José; San Mateo; Rio Súcio; Quebrada Honda; Birrís, Azahár, and La Estrella, Cartago; La Hondura; Carrillo; Volcán de Irazú; Guayabo; Barranca; Coliblanco; Turrialba; Laguária; Santa Maria de Dota) and western Panamá (Cordillera de Tolé; Cordillera del Chucu; Volcán de Chiriquí, 7,000-7,700 ft.; Boquete; Chitra; Calobre; Calovévora).

Margarornis brunnescens (not of Sclater, 1856) Salvin, Proc. Zool. Soc. Lond., 1867, 143 (Cordillera de Tolé, Verágua, Panamá; crit.); 1870, 192 (Chitra and Cordillera del Chucu, Verágua, Panamá; crit.).-LAwrence, Ann. Lyc. N. Y., ix, 1868, 106 (San José, Rancho Redondo, Barranca, San Mateo, and Birrís, Costa Rica).-Frantzius, Journ. für Orn., 1869, 304 (Costa Rica).-Ridgway, Proc. U. S. Nat. Mus., vi, 1884, 415 (Rio Súcio, Costa Rica).-Zeledón, Anal. Mus. Nac. Costa Rica, i, 1887, 113 (Turrialba, Costa Rica).-Sclater, Cat. Birds Brit. Mus., xv, 1890, 123, part (Rancho Redondo, Costa Rica; Calovévora, Panamá).--Salvin and Godman, Biol. Centr.-Am., Aves, ii, 1891, 170, pl. 47, fig. 2, part (San José, Quebrada Honda, Rancho Redondo, Barranca, San Mateo, Birrís, and Rio Súcio, Costa Rica; Chiriquí, Chitra, Tolé, Cordillera del Chucu, Calovévora, and Calobre, Panamá).

[Margarornis] brunnescens Sclater and Salvin, Nom. Av. Neotr., 1873, 67, part. [Sittasomus] brunnescens Gray, Hand-list, i, 1869, 180, no. 2476.

Premnoplex brunnescens Bangs, Proc. New Engl. Zool. Club, iii, 1902, 46 (Boquete and Volcan de Chiriquí, 4,000-7,700 ft., Panamá).-Ferry, Pub. 146, Field Mus. N. H., orn. ser., i, no. 6, 1910, 270 (Guayabo and Coliblanco, Costa Rica).

$a$ Fourteen specimens.

$b$ Seventeen specimens.

\begin{tabular}{|c|c|c|c|c|c|}
\hline Locality. & Wing. & Tail. & $\begin{array}{l}\text { Cul- } \\
\text { men. }\end{array}$ & Tarsus. & $\begin{array}{l}\text { Middle } \\
\text { toe. }\end{array}$ \\
\hline \multicolumn{6}{|l|}{ MALES. } \\
\hline Ten adult males from Costa Rica.................. & 63.1 & 61.5 & 13.6 & 19.1 & 15.7 \\
\hline Four adult males from western Panamá (Chiriquí).......... & 65.6 & 61.8 & 15 & 19.1 & 15.7 \\
\hline 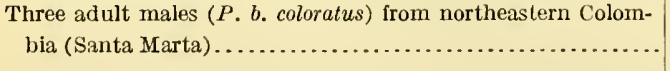 & 61.2 & 60.7 & 15.8 & 19.3 & 15.8 \\
\hline \multicolumn{6}{|l|}{ FEMALES. } \\
\hline Ten adult females from Costa Rica...................... & 60.8 & 59.3 & 14.2 & 18.9 & 15.7 \\
\hline Seven adult females from western Panamá (Chiriquí).......... & 61.6 & 59.2 & 14.6 & 18.9 & 15.2 \\
\hline 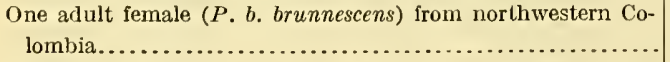 & 60 & 53 & 15 & 19.5 & 16 \\
\hline 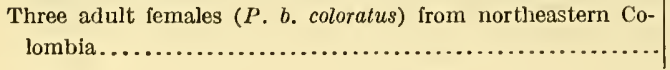 & 59.5 & 55.5 & 15.5 & 19.2 & 15.7 \\
\hline
\end{tabular}


[Premnoplex] brunnescens Shanpe, Hand-list, iii, 1901, 74, part (Costa Rica; Panamí).

[Margaromis] brunneicauda Lawrence, Aun. Lyc. Nat. Hist. N. Y., viii, 1867, 130, in text (Costa Rica; coll. U. S. Nat. Mus.).

Premnoplex brunncscens brunncicauda Bangs, Proc. Biol. Soc. Wash., xxi, July 27, 190S, 159 (Costa Rica, Chiriquí and Verágua, Panamá; crit.)-CArriker, Ann. Carnegie Mus., vi, 1910, 647 (highlands of Costa Rica, 2,000 ft. to timber-line; crit.).

\section{Genus ACRORCHILUS Ridgway.}

Acrorchilus a Ridgway, Proc. Biol. Soc. Wash., xxii, April 17, 1909, 71. (Type Synallaxis erythrops Sclater.)

Small wrenlike Furnariidx (length about 130-140 mm.) with tail about as long as wing (sometimes longer), graduated, the rectrices (12) usually acuminate at tip; tarsus much less than one-third as long as wing; basal phalanx of middle toe not wholly united to outer toe, and tail and wings rufescent and plumage without streaks (except, sometimes, on pileum).

Bill much shorter than head, rather stout, slightly decurved, and moderately compressed, its width at loral antiæ slightly greater than its depth at same point and equal to about one-third the distance from nostril to tip of maxilla; culmen distinctly ridged, gradually and rather strongly decurved from near base, the tip of maxilla not uncinate; maxillary tomium more or less distinctly concave, mandibular tomium similarly convex, both without trace of subterminal notch; gonys nearly to quite straight, not prominent basally. Nostril exposed, posteriorly in contact with loral feathering, narrow (a longitudinal slit), overhung by a broad, convex, membraneous oper:culum. Rictal bristles absent, and feathers of chin, etc., without terminal setæ. Wing rather large and pointed, the longest primaries exceeding secondaries by about distance from nostril to tip of maxilla; seventh and eighth, sixth, seventh, and eighth, or sixth and seventh primaries longest, the tenth (outermost) about two-thirds as long as the longest, the ninth longer than secondaries. Tail very nearly as long as wing to decidedly longer, graduated for nearly to more than half its length, the rectrices (12) usually abruptly attenuated terminally, sometimes with tips acute (but not denuded). Tarsus much longer than whole culmen, less than one-third as long as wing, stout, very distinctly scutellate; middle toe, with claw, decidedly shorter than tarsus; outer toe, without claw, not reaching to middle of subterminal phalanx of middle toe, the inner toe slightly shorter; hallux about as long as inner toe, but much stouter; basal phalanx of middle toe united for half or more (sometimes for nearly the whole) of its length to outer toe, for nearly as much to inner toe; claws mod- 
erate to rather large, strongly curved, acute, that of the hallux decidedly shorter than the digit.

Coloration.-Wings and tail (usually pileum also) cinnamon-rufous rest of upper parts plain brown; under parts plain pale brownish gray, light grayish brown, or dull buffy. Sexes alike.

Range.-Costa Rica to Ecuadór (at least). ${ }^{a} \quad$ (Many species.) $^{a}$

KEY TO THE SPECIES OF ACRORCHILUS.

a. Pileum, at least, rufous. (Adults.)

b. Loral, orbital, auricular, and malar regions rufous; crown without black streaks (Acrorchilus erythrops.)

c. Middle pair of rectrices russet-brown. (Ecuadór.)

Acrorchilus erythrops erythrops (extralimital). $b$

$c c$. Middle pair of rectrices bright cinnamon-rufous, like rest of tail.

d. Rufous of head less extended, the occiput and nape brown, like back; chest and lower throat light buffy olive. (Costa Rica and Panamá.)

Acrorchilus erythrops rufigenis, adults (p. 185).

$d d$. Rufous of head more extended, involving occiput and nape; chest mouse gray fading into nearly ash gray on throat. (Northwestern Colombia.)

Acrorchilus erythrops griseigularis (extralimital).c

$b b$. Loral, orbital, auricular, and malar regions buffy brownish, the superciliary region narrowly streaked with whitish; forehead and crown streaked with black. (Colombia to Ecuadór.)...... Acrorchilus antisiensis (extralimital). $d$ aa. Pileum without rufous...........Acrorchilus erythrops rufigenis, young (p. 185).

\section{ACRORCHUUS ERYTHROPS RUFIGENIS (Lawrence).}

\section{IAWRENCE'S SPINETAIL.}

Similar to A. e. erythrops Sclater, ${ }^{e}$ of Ecuadór, but middle pair of rectrices bright cinnamon-rufous (like other rectrices), instead of russet brown, cinnamon-rufous of head deeper and more extended (occupying whole of auricular and greater part of malar regions, as well as orbital, loral, superciliary, and supra-auricular regions as well as forehead and crown), general coloration darker, and size larger.

$a$ On account of the very poor representation of species referred to the genus Siptornis. by Dr. Sclater and other recent authorities, in the material which I have been able to examine, I can not give a very definite statement of the number of species or extent of the geographic range of this genus, which is so exceedingly distinct, structurally, from Siptornis that it is difficult to imagine why the fact has not sooner been realized. The only species examined by me in this connection are the following: A. erythrops (Sclater), A. hellmayri (Bangs), and A. pallida (Maximilian).

b Synallaxis erythrops Sclater, Proc. Zool. Soc. Lond., pt. xxviii, pt. i, May, 1860, 66 (Pallatanga, w. Ecuadór; coll. P. L. Sclater). Siptornis erythrops Sclater, Cat. Birds Brit. Mus., xv, 1890, 60, part.-A[crorchilus] erythrops erythrops Ridgway, Proc. Biol. Soc. Wash., xxii, April 17, 1909, 72, in text.

c Acrorchilus erythrops griseigularis Ridgway, Proc. Biol. Soc. Wash., xxii, April 17, 1909, 72 (San Antonio, Rio Cali, n. w. Colombia; coll. E. A. and O. Bangs).

d Synallaxis antisiensis Sclater, Proc. Zool. Soc. Lond., 1859, 457 (Cuenca, Ecuador; coll. P. L. Sclater).-Siptornis antisiensis Sclater, Cat. Birds Brit. Mus., xv, 1890, 59.

$e$ See Key to the Species, this page. 
Differing from A. e. griseigularis Ridgway ${ }^{a}$ of northwestern Colombia in much less grayish underparts (especially throat and chest), darker coloration of upper parts, and larger size.

Adults (sexes alike).-Forehead and crown, together with entire loral, orbital, superciliary, supra-auricular, and auricular regions and anterior half or more of malar region bright cinnamon-rufous, the supra-auricular region sometimes paler, forming a more or less distinct postocular streak; mape, hindneck, back, scapulars, rump, and upper tail-coverts plain olive-brown (between sepia and raw umber), the nape and hindneck sometimes duller; tail and wings cinnamonrufous, this passing into brown on terminal portion of remiges and on tertials, the primary coverts tipped with more grayish brown; underparts light olive or buffy olive, passing into dull whitish on upper throat and chin, inclining to raw umber on flanks, the abdomen sometimes tinged with tawny; under wing-coverts deep ochraceousbuff, the inner webs of remiges broadly edged with deep pinkish buff; maxilla blackish brown, mandible pale brownish (in dried skins) darker terminally; legs and feet horn color (in dried skins).

Young.-Pileum and hindneck olive-brown, nearly concolor with back, etc.; sides of head similar, relieved by a more dusky broad streak occupying upper portion of auricular region and a paler superciliary or supra-auricular streak, the latter sometimes rufous-tawny, the lower portion of auricular region, suborbital region, and malar region also sometimes rufous-tawny or suffused with that color; coloration otherwise essentially as in adults, but underparts tinged with ochraceous, or sometimes with indistinct narrow bars of dusky.

Adult male.-Length (skins), 140-153 (146); wing, 64-72 (66.8); tail, 66.5-75.5 (71.5); culmen, 12-14.5 (13.4); tarsus, 18-19.5 (18.6); middle toe, $13-14.5(13.7) .^{b}$

Adalt female.-Length (skins), 136-162 (146); wing, 62-69.5 (65.8); tail, 63-75 (70); culmen, 12.5-14 (13.4); tarsus, 18-19 (18.6); middle toe, $13-14.5(13.6){ }^{c}$

$a$ See p. 184.

$b$ Nineteen specimens.

c Twelve specimens.

\begin{tabular}{|c|c|c|c|c|c|}
\hline Locality. & Wing. & Tail. & $\begin{array}{l}\text { Cul- } \\
\text { men. }\end{array}$ & Tarsus. & $\begin{array}{l}\text { Middle } \\
\text { toe. }\end{array}$ \\
\hline MaLES. & & & & & \\
\hline Ten adult males from Costa Rica.. & 66.7 & 71.8 & 13.1 & 18.7 & 13.8 \\
\hline Nine adult males from western Panamá(Chiriquí).... & 66.8 & 71.5 & 13.4 & 18.6 & 13.7 \\
\hline $\begin{array}{l}\text { One adult male (A. e. erythrops?) from northwestern Colombia.. } \\
\text { FEMALES. }\end{array}$ & 65.7 & 62.7 & 13.2 & 18 & 14 \\
\hline Eight adult females from costa Rica............... & 65.2 & 70.7 & 13.2 & 18.6 & 13.6 \\
\hline Four adult females from western Pazamá(Chiriquí)... & 66.9 & 68.7 & 13.8 & 18.6 & 13.6 \\
\hline
\end{tabular}


Costa Rica (Navarro, Birrís, Azahár, and La Estrella, Cartago; Volcán de Irazú; Escazú; Jiménez; Barranca; La Carpintera; Guayabo; La Hondura; Juan Viñas; Rio Súcio; Copéy; Dota; Dota Mts.; Santa Maria de Dota; Laguária) and western Panamá (Boquete; Volcan de Chiriquí, 7,500-10,300 ft.; Caribbean slope, Volcan de Chiriquí).

Synallaxis erythrops (not of Sclater, 1860) LAWRence, Ann. Lyc. N. Y., ix, 1868, 105 (Barranca, Dota Mts., and Birrís, Costa Rica).-Frantzius, Journ. für Orn., 1869, 304 (Costa Rica).-Salvin, Proc. Zool. Soc. Lond., 1870, 191 (Volcan de Chiriquí, Panamá; crit.).-Boucard, Proc. Zool. Soc. Lond., 1878, 59 (Volcán de Irazú and Navarro, Costa Rica).-Zeledón, Anal. Mus. Nac. Costa Rica, i, 1887, 113 (Rio Súcio, Costa Rica).-Salvin and Godman, Biol. Centr.-Am., Aves, ii, 1891, pl. 45, fig. 1.

[Synallaxis] erythrops Gray, Hand-list, i, 1869, 168, no. 2237.-ScLAter and Salvin, Nom. Av. Neotr., 1873, 64, part.

Siptornis erythrops Sclater, Cat. Birds Brit. Mus., xv, 1890, 60, part (Irazú distr., Costa Rica; Volcán de Chiriquí, Panamá).--Salvin and Godman, Biol. Centr.-Am., Aves, ii, 1891, 151, part (Barranca, Dota Mts., "Pirris," i. e., Birrís, Irazú, and Navarro, Costa Rica; Volcan de Chiriquí, Panamá).Ferry, Pub. 146, Field Mus. N. H., orn. ser., i, no. 6, 1910, 270 (Guayabo, Costa Rica).

[Siptornis] erythrops SHARPe, Hand-list, iii, 1901, 59, part (Costa Rica; Panamá). Synallaxis rufigenis Lawrence, Ann. Lyc. Nat. Hist. N. Y., ix, April, 1868, 105

(Costa Rica; coll. G. N. Lawrence;=young).-Frantzius, Journ. für Orn., 1869, 304 (Costa Rica).-SAlvin, Proc. Zool. Soc. Lond., 1870, 191 (Costa Rica).-Sclater, Proc. Zool. Soc. Lond., 1874, 19 (monogr.; Costa Rica).

[Synallaxis] rufigenis Sclater and Salvin, Nom. Av. Neotr., 1873, 64.

Siptornis rufigenis Sclater, Cat. Birds. Brit. Mus., xv, 1890, 60 (Costa Rica).Salvin and Godman, Biol. Centr.-Am., Aves, ii, 1891, 152, pl. 45, fig. 2.Bangs, Proc. New Engl. Zool. Club, iii, 1902, 43 (Boquete and Volcán de Chiriquí, 4,000-7,500 ft., Panamá; crit.).

[Siptornis] rufigenis SHARPE, Hand-list, iii, 1901, 59.

A[crorchilus] erythrops rufigenis Ridgway, Proc. Biol. Soc. Wash., xxii, April 17, 1909,72 , in text.

Acrorchilus erythrops rufigenis Carriker, Ann. Carnegie Mus., vi, 1910, 636 (Costa Rica; crit.; habits).

\section{Genus SYNALLAXIS Vieillot.}

Synallaxis Vieillot, Nouv. Dict. d'Hist. Nat., xxiv, 1818, 117 (diagnosis, but no type indicated); xxxii, 1819, 309. (Type, S. ruficapilla Vieillot.)

Anabates Temminck, Man. d'Orn., i, 1820, p. lxxxii. (Type, "Rouge-queue de la Guiane Buffon= Motacilla guianensis Gmelin.)

Parulus Six, Av. Sp. Nov. Bras., i, 1824, 85. (Type, P. ruficeps Spix=Synallaxis spixi Sclater.)

(?) Leptoxyura Reichenвach, Handb. Spec. Orn., 1853, 170. (Type, Certhia cinnamomea Gmelin.)

Melanopareia Reichenbach, Handb. Spec. Orn., 1853, 164. (Type, Synallaxis maximiliani D'Orbigny.)

(?) Certhiaxis a Lesson, Compl. (Euvres de Buffon (éd. Lévêque), xx, Apr., 1847, 287. (Type, Certhia cinnamomea Gmelin.) 
Barnesia a Bertoni, Aves Nuevas del Paraguay, 1901, 77. (Type, Synallaxis cururuvi Bertoni $=S$. ruficapilla Vieillot.)

Small, wrenlike, long-tailed Furnariidie (length about 130-150 $\mathrm{mm}$.) with only 10 rectrices, and with tail not more than one and a half times as long as wing.

Bill much shorter than head, rather stout, moderately compressed, its width at loral antire about equal to its depth at same point and from one-third to one-half the clistance from nostril to tip of maxilla; culmen gradually decurved from near base, the tip of maxilla not uncinate; tomia slightly decurved terminally, without trace of subterminal notch; gonys nearly straight, ascending terminally, at base forming a slight angle with lower edge of mandibular rami. Nostril exposed, posteriorly in contact with loral feathering, narrow (a longitudinal slit), overhung by a broad operculum. Rictal bristles wanting, and feathers of chin, etc., without terminal setæ. Wing rather short, very concave beneath, much rounded, the longer primaries exceeding secondaries by less (usually very much less) than length of exposed culmen; sixth and seventh, fifth, sixth, and seventh, or sixth, serenth, and eighth, primaries longest, the tenth (outermost) about two-thirds as long as the longest, the ninth shorter than secondaries (S. pudica, S. eryithrothorax) or very much longer (S. ruficapilla, S. albescens). Tail decidedly longer than wing to nearly one and a half times as long, graduated for more than half its length, the rectrices (10) usually acuminate, sometimes with webs thin or semidecomposed. Tarsus nearly to much more than twice as long as bill from nostril, nearly to quite three-fifths as long as wing, stout, distinctly scutellate; middle toe, with claw, very slightly to decidedly shorter than tarsus; outer toe, without claw, reaching to slightly beyond subterminal articulation of middle toe, the inner toe very slightly shorter; hallux about as long as inner toe, but much stouter; basal phalanx of middle toe united for a little more than basal half to outer toe, for slightly less to inner toe; claws moderate in size and curvature, acute, that of the hallux much shorter than the digit.

Coloration.-Color partly cinnamon-rufous, this either on pileum, wings, or tail, sometimes on all three, occasionally on chest; otherwise plain olive, brown, gray, or sooty, usually paler (sometimes partly whitish) on under parts; no streaks, spots, nor bars. Sexes alike.

Nidification.-Nest an extremely bulky retort-shaped structure composed outwardly of coarse sticks, built in bushes or low trees; eggs white, bluish-white, or pale bluish green.

\footnotetext{
a Named for Carlos St. Barnes. (Bertoni.)
} 


\section{Range.-Southeastern Mexico to southeastern Brazil. (Many species. ${ }^{a}$ )}

KEY TO THE SPECIES AND SUBSPECIES OF SYNALLAXIS.

a. Pileum partly rufous, or else chest rufous. (Adults.)

b. Pileum dull brown; chest cinnamon-rufous or chestnut-rufous. (Southeastern Mexico to Honduras)............... . Synallaxis erythrothorax, adults (p. 189).

bb. Pileum partly cinnamon-rufous or rufous-chestnut; chest grayish or white.

c. Greater wing-coverts and basal portion of primaries cinnamon-rufous or chestnut-rufous; chest slate-gray to blackish slate. (Synallaxis pudica.)

d. Paler, the back, etc., olive-brown, tail brown, chest dull slate color or slategray. (Eastern Panamá to western Ecuadór.)

Synallaxis pudica pudica (p. 191).

dd. Darker, the back, etc., dark sooty brown, tail blackish brown, chest dark slate to blackish slate. (Western Panamá to southern Honduras.)

Synallaxis pudica nigrifumosa, adult (p. 192).

cc. Greater wing-coverts and basal portion of primaries light brown or broccoli brown; chest light gray to white. (Synallaxis albescens.)

d. Chest distinctly gray; brown of back, etc., darker.

$e$. Larger (wing averaging 54 or more in male, more than 53 in female; tail averaging more than 69 in male, more than 66 in female).

$f$. Slightly paler and smaller (wing averaging 54 in male, 55 in female; tail 69.7 in male, 73.5 in female). (Margarita Island, Venezuela.)

Synallaxis albescens nesiotis (extralimital). $b$

ff. Slightly darker and larger (wing averaging 56 in male, 54.7 in female; tail averaging 73 in male, 70.4 in female). (Colombia to Cayenne and Amazon Valley.)

Synallaxis albescens albigularis (extralimital).c

$e e$. Smaller (wing averaging 52.2 in male, 49.9 in female; tail averaging 658 . in male, 62.9 in female). (Southwestern Costa Rica and western Panamá)................... Synallaxis a'bescens latitabunda (p. 194).

$a$ In Sharpe's Hand-List of the Genera and Species of Birds, Vol. III, pp. 53-58 (1901), forty-nine species are referred to this genus. Of these I have examined about one-half, but the above generic diagnosis and description are based on the three Central American species and S. ruficapilla (type of the genus) alone. I am nearly convinced that the group requires subdivision, but it should not be attempted with so poor a representation of the species, and I therefore leave the problem for others to work out.

b Synallaxis albescens nesiotis Clark (A. H.), Auk, xIx, July, 1902, 264 (Margarita Island, Venezuela; coll. E. A. and O. Bangs).

c Synallaxis albigularis Sclater, Proc. Zool. Soc. Lond., 1858, 63 (eastern Ecuador; coll. Verreaux).-Synallaxis albescens albigularis Berlepsch and Hartert, Novit. Zool., ix, April, 1902, 59 (Caicará, Altagracia, and Suapuré, Venezuela; descr. nest and eggs).Synallaxis albescens (not of Temminck) Sclater, Cat. Birds Brit. Mus., xv, 1890, 43, part.

I am not able to examine a specimen of $S$. albescens albescens during preparation of this key; indeed, the material available is, for all the forms, exceedingly scanty and unsatisfactory. The synonymy of S. a. albescens is as follows: Synallaxis albescens Temminck, Pl. Col., iii, livr. 38, Sept., 1823, pl. 227, fig. 2 (Brazil; coll. Mus. Pays-Bas); Sclater, Cat. Birds Brit. Mus., Xv, 1890, 43, part.-Synallaxis albescens albescens Hellmayr, Novit. Zool., xv, 1908, 59 (crit.). 
dd. Chest white medially, shading into pale gray laterally; brown of back, etc., lighter, more buffy. (Eastern Panamá.)

Synallaxis albescens hypoleuca (p. 195). aa. Pileum without any rufous (uniform dark brown); chest not ruious. (Young.)

b. Chest brown .................... Synallaxis erythrothorax, young (p. 189). $b b$. Chest dull slate-grayish or olive-slaty.

Synallaxis pudica nigrifumosa, young (p. 192).

\section{SYNALLAXIS ERYTHROTHORAX Sclater.}

RUFOUS-BREASTED SYNALIAXIS.

Adults (sexes alite).-Above plain sepia or bister brown, the pileum and hindneck usually somewhat duller (approaching grayish brown in worn plumage); tail more chestnut brown, the shafts of rectrices black; wings chestnut, passing into brown on terminal portion of remiges and on tertials; sides of head and neck similar in color to pileum and hindneck; chin and upper throat blackish slate or slate-black, streaked (more or less broadly) with white, the lower throat uniform blackish slate or slate-black, or with feathers tipped with slate color; chest, upper breast, sides of breast, and under wing-coverts uniform chestnut-rufous or deep cinnamon-rufous, passing into light brown (nearly raw-umber) on flanks; abdomen and median portion of lower breast transversely mottled or barred with whitish and mouse gray, more or less suffused with olive; under tail-coverts similar in color to flanks but rather paler and grayer; bill black, the mandible sometimes brownish or horn colored basally; legs and feet dusky horn color (in dried skins).

Young.-Upper parts as in adults, but chestnut of wings broken by brown tips to middle and greater wing-coverts; chin and upper throat transversely mottled or barred with grayish white and dull slate color, the lower throat nearly uniform dull slate color; chest, upper breast, sides, flanks, and under tail-coverts light brown (between isabella color and raw umber), the abdomen and median portion of lower breast pale grayish transversely mottled or barred with brown; basal half or more of mandible light colored.

Adult male.-Length (skins), 132-157 (146); wing, 53.5-61.5 (57); tail, 58-70.5 (65.7); culmen, 12.5-14.5 (13.8); tarsus, 19-21 (20.4); middle toe, $13.5-16(14.9) .^{a}$ 
Adult female.-Length (skins), 144-157 (148); wing, 53-58.5 (56.3); tail, 62-67 (65.1); culmen, 13.5-14.5 (13.9); tarsus, 19.5-21 (20.3); middle toe, $14.5-15$ (14.9). ${ }^{a}$

Southeastern Mexico, in States of Vera Cruz (Playa Vicente; Córdova; Potrero, near Córdova; Orizaba; Uvero; Omealca; Atoyác; Sochiapa; Buena Vista; Pasa Nueva; Tlalcotalpám; Motzorongo; Jaltipán), Oaxaca (Túxtepec), Tabasco (Frontera; Teapa); Chiapas (Palenque; Huehuetán; Yojalón) and Yucatan (Chichen-Itza) and southward through Guatemala (Cobán; Choctúm; Chiséc; Kamkhál; Yzabál; Retalhuleu; Naranjo; Los Amates, Yzabál; Patulúl, Sololá; San José) and British Honduras (Belize; Orange Walk; Cayo; Sittee River; Toledo District; near Manatee Lagoon) to Honduras (San Pedro; San Pedro Sula).

Synallaxis erythrothorax Sclater, Proc. Zool. Soc. Lond., June 26, 1855, 75, pl. 86 (Cobán, Guatemala; coll. Derby Mus.); 1856, 288 (Córdova, Vera Cruz); 1859, 192, 382 (Playa Vicente; Vera Cruz); 1874, 17 (monogr.; Mexico; Guatemala; Honduras); Cat. Am. Birds, 1862, 153 (Honduras; Choctúm, Guatemala); Ibis, 1873, 373; Cat. Birds Brit. Mus., xv, 1890, 55 (Orizaba, Vera Cruz; n. Yucatan; Choctúm, Kamkhál, Chiséc, and Retalhuleu, Guatemala; Belize, Brit. Honduras; Honduras).-Sclater and Salvin, Ibis, 1859, 117 (Cobán, Guatemala; Córdova, Vera Cruz); Proc. Zool. Soc. Lond., 1870, 837 (San Pedro, Honduras).-Salvin and Sclater, Ibis, 1860, 35 (Yzabál, Guatemala).-Sumichrast, Mem. Bost. Soc. N. H., i, 1869, 555 (tierra caliente of Vera Cruz); La Naturaleza, v, 1881, 247 (Uvero and Omealca, Vera Cruz).--Sanchez, Anal. Mus. Nac. Mex., i, 1877, 97 (Vera Cruz).-Boucard, Proc. Zool. Soc. Lond., 1883, 449 (e. Yucatan; descr. nest).-Salvin and Godman, Biol. Centr.-Am., Aves, ii, 1891, 150 (Atoyác and Sochiapa, Vera Cruz; Teapa, Tabasco; Orange Walk and Cayo, Brit. Honduras; etc.).-Cole, Bull. Mus. Comp. Zool., 1, 1906, 131 (ChichenItza, Yucatan).-Dearborn, Pub. 125, Field Mus. N. H., 1907, 107 (Los Amates, Patulúl, and San José, Guatemala; habits; crit.).

$a$ Thirteen specimens.

\begin{tabular}{|c|c|c|c|c|c|}
\hline Locality. & Wing. & Tail. & $\begin{array}{l}\text { Cul- } \\
\text { men. }\end{array}$ & Tarsus. & $\begin{array}{c}\text { Middle } \\
\text { toe. }\end{array}$ \\
\hline \multicolumn{6}{|l|}{ MALES. } \\
\hline Ten adult males from Vera Cruz, Mexico...... & 56.3 & 67 & 13.6 & 20.5 & 15. 1 \\
\hline One adult male from Guatemala....................... & 53.5 & 58 & ...... & 19 & 13.5 \\
\hline Three adult males from British Honduras................ & 57 & 63.7 & 14 & 19.8 & 14. 8 \\
\hline Four adult males from Honduras.......................... & 59.5 & 66 & 14.2 & 20.7 & 15 \\
\hline \multicolumn{6}{|l|}{ FEMALES. } \\
\hline Seven adult females from Vera Cruz... & 56.6 & 65.9 & 14.1 & 20.4 & 14.9 \\
\hline Two adult females from Tabasco................... & 58.2 & 64.7 & 14.2 & 20.5 & 15 \\
\hline One adult female from Guatemala..... & 53 & 65 & 14 & ….. & $\ldots$. \\
\hline Three adult females from Honduras. ..................... & 55.3 & 63.5 & 13.7 & 19.8 & 14.8 \\
\hline
\end{tabular}


S[ynallaxis] erythrothorax Sclater and Salvin, Proc. Zool. Soc. Lond., 1859, 192 (s. Mexico; Guatemala).

[Synallaxis] crythrothorax Gray, Hand-list, i, 1869, 168, no. 2228.-Sclater and

Salvin, Nom. Av. Neotr., 1873, 63.-Sharpe, Mand-list, iii, 1901, 57.

Synallaxis erytrothorax Boucard, Ann. Soc. Linn. Lyons, 1878, 37 (Guatemala).

Synallaxis cinerascens (not of Temminck) Bonaparte, Proc. Zool. Soc. Lond., 1837, 118 (Guatemala).

\section{SYNALLAXIS PUDICA PUDICA Sclater.}

\section{SLATY SYNALLAXIS.}

Adults (sexes alike).-Forehead, sides of head (including loral, superciliary, auricular, suborbital and malar regions) and sides of neck plain dull slate color or dark mouse gray, the first rather darker and slightly tinged with brownish; whole crown and occiput deep cinnamon-rufous or reddish chestnut; hindneck, back, scapulars, rump, and upper tail-coverts plain olive, grayer on hindneck, more strongly olive posteriorly; tail olive-brown or warm-sepia, the shafts of rectrices black; wings bright cinnamon-rufous or rufous-chestnut, the terminal portion of remiges (extensively) and whole of tertials deep olive-brown or sepia, the outermost primaries also mostly of this color; underparts mostly plain dull slate color or dark mouse gray, paler posteriorly, where strongly tinged with olive on flanks and under tail-coverts, the chin and upper throat narrowly streaked with white; in certain lights, a darker spot at junction of lower throat and chest; under wing-coverts light ochraceous-rufous, paler and duller on under primary-coverts; inner webs of remiges (except outermost primaries) broadly edged with vinaceous-cinnamon for basal half (approximately); maxilla blackish horn color, mandible light grayish horn color; iris brown; legs and feet dark horn color (in dried skins). Length (skins), 148-164 (155); wing, 55-60 (57.8); tail, 67.5-75 (71); culmen, 14.5-16 (15.2); tarsus, 20.5-22 (21.2); middle toe, $15-16.5$ (15.9) ${ }^{a}$

Adult female.-Length (skins), 151; wing, 55-55.5 (55.2); tail, 65-67 (66); culmen, 14-15 (14.5); tarsus, 21 ; middle toe, 15-15.5 $(15.2) .^{b}$

Eastern Panamá (Lion Hill; Panamá) and southward through Colombia (Bogotá; Remédios, Antioquía) to Ecuadór (Babahoyo; Nanegál; Esmeraldas; Chimbo; Cayandeléd; Yaguachi; Paramba; Foreste del Rio Peripa). ${ }^{c}$

$a$ Five specimens, from Panamá.

b Two specimens, from Panamá.

c The birds of this species from western Ecuadór may be different from true $S$, pudica of Colombia, but I am unable to compare specimens. 
(?) Synallaxis brachyura LAFresnaye, Rev. Zool., 1843, 290 (Colombia; types now in coll. Boston Soc. N. H.).-Sclater, Proc. Zool. Soc. Lond., 1855, 141 (Bogotá, Colombia); 1874, 26 (Bogotá, Colombia; crit.).-SALVIN, Ibis, 1874, 322 (crit.).

Synallaxis pudica Sclater, Proc. Zool. Soc. Lond., 1859, 191 (Bogotá, Colombia; coll. P. L. Sclater); 1860, 88 (Nanegal,w. Ecuadór), 278 (Babahoyo, w. Ecuadór; crit.), 294 (Esmeraldas, w. Ecuadór; crit.); 1874, 10, part (monogr.); Cat. Am. Birds, 1862, 151 (Bogotá; Nanegal and Babahoyo, w. Ecuadór); Cat. Birds Brit. Mus., xv, 1890, part.-Sclater and Salvin, Proc. Zool. Soc. Lond., 1864, 354 (Panamá; crit.); 1879, 521 (Remédios, Antioquía, Colombia; descr. eggs).-Berlepsch and Taczanowski, Proc. Zool. Soc. Lond., 1883, 560 (Chimbo, w. Ecuadór; crit.); 1884, 298 (Cayandeléd, w. Ecuadór, 4,000 ft.).-Taczanowski and Berlepsch, Proc. Zool. Soc. Lond., 1885, 94 (Yaguachi, Ecuadór).-Hartert, Novit. Zool., v, 1898, 490 (Chimbo and Paramba, n. w. Ecuadór; crit.).-Saluadori and Festa, Boll. Mus. Zool., etc., Torino, xv, 1899, no. 362, 19 (Foreste del Rio Peripa, w. Ecuadór).Bangs, Proc. New Engl, Zool. Club, ii, 1900, 26 (Loma del León, Panamá).

S[ynallaxis] pudica Sclater, Proc. Zool. Soc. Lond., 1859, 192 (Colombia).

[Synallaxis] pudica Sclater and Salvin, Nom. Av. Neotr., 1873, 63, part.Sharpe, Hand-list, iii, 1901, 55, part (Panamá; Colombia; Ecuadór).

Synallaxis brunneicaudalis (not of Sclater) Lawrence, Ann. Lyc. N. Y., vii, 1862, 319 (Lion Hill, Panamá).

\section{SYNALLAXIS PUDICA NIGRIFUMOSA (Lawrence).}

\section{SOOTY SYNALLAXIS.}

Similar to $S . p$. pudica but coloration decidedly darker, the tail very dark sooty brown or brownish black, back, etc., deep sepia brown, slate color of anterior under parts decidedly darker, and rufous-chestnut of pileum and wings deeper.

Young. a-Above, including whole pileum, deep olive-brown, the wings, however, mostly rufescent but the color either duller or more tawny than in adults; tail dark sooty brown (as in adults); chin and upper throat dull yellowish white or pale yellowish gray, the lower throat dark yellowish gray or olive-gray; rest of under parts light olive or grayish olive, paling into pale yellowish gray on abdomen, and changing into olive-brown or brownish olive on sides, flanks, and under tail-coverts.

Adult male.-Length (skins), 135-158 (150); wing, 52.5-62 (56.4); tail, 61.5-72.5 (69.6); culmen, 14-15.5 (14.6); tarsus, 20-22 (20.9); middle toe, $15-16(15.3){ }^{b}$

a I have not been able to examine the young of $S . p$. pudica.

$b$ Fifteen specimens. 
Adult female.-Length (skins), 130-155 (145); wing, 50.5-56.5 (54.1); tail, 63.5-74.5 (70.7); culmen, 13-15 (14.1); tarsus, 19.5-22 (20.7); middle toe, $14.5-16$ (15.3). ${ }^{a}$

Southern Honduras (Rio Segóvia), Nicaragua (Greytown; Chontales; Los Sábalos; San Emilis, Lake Nicaragua) and Costa Rica (Naranjo de Cartago; San José; Pacuare; Siquirres; Jiménez; Boca Matina; Pejé; Guayabo; Bonilla; Guápiles; Carrillo; El Hogár; Buenos Aires; Lagarto; Pozo del Rio Grande; Boruca; Pozo Azúl de Pirrís; El Pozo de Térraba; El Generál; Las Trojas); western Panamá (Chiriquí)?

Synallaxis nigrifumosa Lawrence, Ann. Lye. Nat. Hist. N. Y., viii, 1867, 181 (Greytown, Nicaragua; coll. U.S.Nat. Mus.); ix, 1868, 105 ("Payna," =Pacuare, Costa Rica).-Salvin, Ibis, 1870, 110 (crit.).-Frantzius, Journ. für Orn., 1869, 304 (Costa Rica).

S[ynallaxis] nigrifumosa Salvin, Proc. Zool. Soc. Lond., 1867, 143, in text (Greytown).

[Synallaxis] nigrofumosa GraY, Hand-list, i, 1869, 169, no. 2266.

Synallaxis pudica (not of Sclater, 1859) Salvin, Ibis, 1872, 213 (Nicaragua).Sclater, Ibis, 1873, 373 (Chontales, Nicaragua); Proc. Zool. Soc. Lond., 1874, 10, part (Chiriqui?; Costa Rica); Cat. Birds Brit. Mus., xv, 1890, 45, part (Chontales, Nicaragua; Pejé, Costa Rica; Chiriqui?).-Boucard, Proc. Zool. Soc. Lond., 1878, 59 (Naranjo de Cartago, Costa Rica).-Nutrina, Proc. U. S. Nat. Mus., vi, 1883, 404 (Los Sábalos, Nicaragua; habits; notes).Zeledón, Anal. Mus. Nac. Costa Rica, i, 1887, 113 (Las Trojas, Pozo Azúl de Pirrís, Naranjo de Cartago, and Pacuare, Costa Rica).-Ridgway, Proc. U. S. Nat. Mus., x, 1888, 590 (Rio Segóvia, Honduras).-Salvin and Godman, Biol. Centr.-Am., Aves, ii, 1891, 149, part, pl. 44, fig. 2.-Richmond, Proc: U. S. Nat. Mus., xvi, 1893, 496 (Rio Escondido, Nicaragua; habits; descr. nest, etc.).-Ferry, Pub. 146, Field Mus. N. H., orn. ser., i, no. 6, 1910, 270 (Guayabo, Costa Rica).-Cherrie, Expl. Zool. Merid. Costa Rica, 1893, 38 (Lagarto and Buenos Aires, Costa Rica).--BANgs, Auk, xxiv, 1907, 299 (Boruca

$a$ Fourteen specimens.

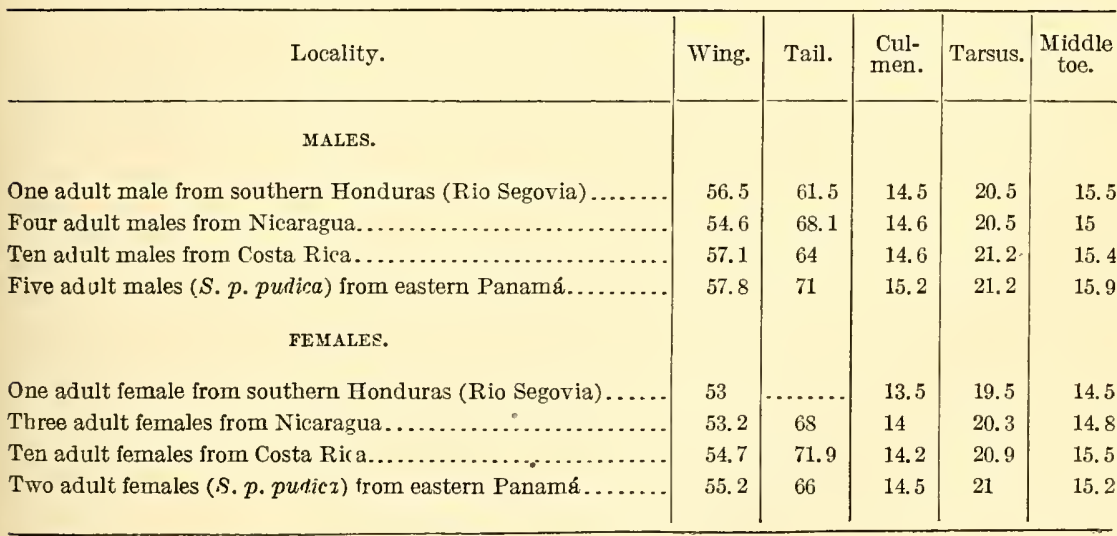

$81255^{\circ}-$ Bull. $50-11-13$ 
and Pozo del Rio Grande, Costa Rica; descr. young).-Carriker, Ann. Carnegie Mus., vi, 1910, 635 (Costa Rica; crit.; habits; descr. nest and eggs).

[Synallaxis] pudica Sclater and Salvin, Nom. Av. Neotr., 1873, 63, part.Sharpe, Hand-list, iii, 1901, 55, part (Honduras, etc.).

\section{SYNALLAXIS ALBESCENS LATITABUNDA Bangs.}

COSTA RICAN GRAY-BREASTED SYNALLAXIS.

Similar to S. a. albigularis (Sclater), ${ }^{a}$ of Colombia and Venezuela, but smaller, gray of chest averaging deeper and purer (less brownish), cinnamon-rufous of occiput more extended, and greater wing-coverts brighter cinnamon-rufous.

Adults (sexes alike).-Forehead (back to at least middle of eyes) mouse gray, the feathers with indistinct mesial streaks of darker; crown, occiput, and nape plain cinnamon-rufous; back, scapulars, rump, upper tail-coverts, tail, and remiges plain grayish brown (hair brown), the shafts of rectrices darker, the outer webs of secondaries and sub-basal portion of that of inner primaries usually slightly tinged with cinnamon; lesser and middle wing-coverts uniform cinnamon-rufous (somewhat lighter than color of crown and occiput), the greater coverts similar but (usually) slightly paler and duller; loral region grayish white anteriorly, passing into pale mouse gray posteriorly, the suborbital and malar regions similar; auricular region deeper mouse gray, narrowly streaked with white; supra-auricular region, hindneck, sides of neck, chest, and sides of breast plain mouse gray, slightly paler on median portion of chest; chin and throat white, the lower throat with a more or less concealed patch of dusky or dark slate color, the feathers tipped with white or pale gray and marked by a narrow mesial streak of the same; abdomen and median portion of lower breast white; sides, flanks, and under tail-coverts light broccoli brown or drab; under wing-coverts pale pinkish buff, the inner webs of remiges indistinctly edged with the same; bill black, the lower-basal portion of mandible whitish (in dried skins); iris brown; legs and feet light horn color (in dried skins).

Young.-Above plain brown (between sepia and raw-umber), the occipital region tinged (more or less) with more rufescent brown, the tail more russet brown, the middle and greater wing-coverts margined or edged with russet; lesser wing-coverts cinnamon or russet; general color of under parts pale buffy brown, passing into pale brownish buff on throat and chin and into brownish buff on flanks, the sides of chest and breast shaded with deeper and more grayish brown, the abdomen inclining to buffy white.

Adult male.-Length (skins), 129-139 (135); wing, 51.5-54 (52.2); tail, 66-7G (68.5); culmen, 11-12 (11.7); tarsus, 18.5-19.5 (18.9); middle toe, $12.5-13.5(12.9) .^{b}$ 
Adult female.-Length (skins), 126-136 (130); wing, 48.5-51 (49.9); tail, 60-67.5 (62.9); culmen, 11-12.5 (11.7); tarsus, 17.5-19 (18.5); middle toe, $13 .^{a}$

Southwestern Costa Rica (Buenos Aires; Boruca, Paso Reál, and Barranca, Boruca; Térraba); western Panamá (Santa Fé de Verágua) ? ${ }^{b}$

Synallaxis albescens (not of Temminck) Salvin, Proc. Zool. Soc. Lond., 1867, 143 (Santa Fe de Verágua, Panama; crit.).-Sclater, Proc. Zool. Soc. Lond., 1874, 9, part (Verágua; monogr.); Cat. Birds Brit. Mus., xv, 1890, 43, part (Santa Fe de Verágua).-Salvin and Godman, Biol. Centr.-Am., Aves, ii, 1891, 147, part (Santa Fé de Verágua).-Cherrie, Expl. Zool. Merid. Costa Rica, 1893, 38 (Térraba and Buenos Aires, s. w. Costa Rica).

[Synallaxis] albescens Sclater and Salvin, Nom. Av. Neotr., 1873, 63, part.Sharpe, Hand-list, iii, 1901, 54, part (Panamá).

Synallaxis albescens latitabunda BANGS, Auk, xxiv, July, 1907, 298 (Boruca, s. w. Costa Rica; coll. E. A. and .O. Bangs).-Carriker, Ann. Carnegie Mus., vi, 1910, 634 (s. w. Costa Rica; habits).

\section{SYNALLAXIS ALBESCENS HYPOLEUCA Ridgway.}

\section{WIITE-BREASTED SYNALLAXIS.}

Similar to S. a. latitabunda but under parts (including chest) nearly pure white (only the upper portion and sides of chest very faintly shaded with pale brownish gray, passing into pale buffy brown or light wood brown on sides and flanks and pale brownish buff on under tail-coverts); general color of upper parts lighter and more buffy brown.

$a$ Four specimens.

\begin{tabular}{|c|c|c|c|c|c|}
\hline Locality. & Wing. & Tail. & $\begin{array}{l}\text { Cul- } \\
\text { men. }\end{array}$ & Tarsus. & $\begin{array}{c}\text { Middle } \\
\text { toe. }\end{array}$ \\
\hline MALES. & & & & & \\
\hline Eight adult males from Costa Rica....... & 52.2 & 68.5 & 11.7 & 18.9 & 12.9 \\
\hline Nine adult males (S. a. albigularis) from Colombia.... & 56.3 & 74.3 & 11.7 & 19.3 & 14.1 \\
\hline Five adult males (S. a. albigularis) from Venezuela... & 56.4 & 74.9 & 12.2 & 19.7 & 13.8 \\
\hline Nine adult males (S. a. albigularis) from Trinidad.............. & 55.3 & 70 & 12.4 & 19.6 & 13.6 \\
\hline 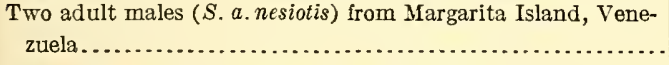 & 54 & 69.7 & 12.2 & 18.2 & 13.2 \\
\hline $\begin{array}{l}\text { One adult male (S. a. albescens) from Argentina........ } \\
\text { FEMALES. }\end{array}$ & 53.5 & 68.5 & 11 & 18 & 11.5 \\
\hline Four adult females from Costa Rica... & 49.9 & 62.9 & 11.7 & 18.5 & 13 \\
\hline Five adult females ( $S$. a. albigularis) from Colombia.. & 55 & 68.8 & 11.7 & 19.3 & 13.7 \\
\hline Two adult females ( $S$. a. albigularis) from Venezuela..... & 53.2 & 66.5 & 12.2 & 19.2 & 13.5 \\
\hline Three adult females ( $S$. a. albigularis) from Trinidad... & 53.3 & 69.5 & 12.7 & 19 & 14.2 \\
\hline One adult female ( $S$. a. albigularis?) from British Guiana & 57 & 77 & 13 & 19.5 & 13.5 \\
\hline One adult female ( $S$. a. nesiotis) from Margarita Island. & 55 & 73.5 & 12.5 & 19 & 14.5 \\
\hline
\end{tabular}

b No Panamá specimens seen by me. 
Adult (sex not determined).-Length (skin), about 125; wing, 60; tail, 59 (middle rectrices imperfect); exposed culmen, 11; tarsus, 18; middle toe, $14{ }^{a}$

Eastern Panamá (Natá, Coclé).

Synallaxis albescens hypoleuca Ridgway, Proc. Biol. Soc. Wash., xxii, April 17, 1909, 73 (Natá, Coclé, Panamá; coll. U. S. Nat. Mus.).

\section{Genus PSEUDOCOLAPTES Reichenbach.}

Pseudocolaptes Reichenbach, Handb. Spec. Orn., 1853, 209. (Type, P. semicinnamomeus Reichenbach $=$ Anabates boissonneautii Lafresnaye.)

Otipne b Cabanis and Heine, Mus. Hein., ii, Aug., 1859, 30. (Type, Anabates boissonneautii Lafresnaye.)

Large scansorial Furnarïdæ (length about $200 \mathrm{~mm}$.) with narrow (slit-like), broadly operculate nostrils, wedge-shaped compressed bill, acuminate, rigid-shafted rectrices, and with a tuft of elongated soft (white or buff) feathers on each side of neck.

Bill decidedly shorter to longer than head, nearly elongate-cuneate in lateral profile, much compressed, its width at loral antiæ decidedly less than its depth at same point and equal to less than one-third the distance from nostril to tip of maxilla, the latter scarcely if at all decurved; culmen rather indistinctly ridged anteriorly, the mesorhinium distinctly flattened, sometimess lightly arched above nostrils, and thence to tip nearly straight or but slightly decurved; maxillary tomium strongly deflected basally, the anterior half straight or very faintly concave, without trace of subterminal notch; the mandibular tomium also straight (or very nearly so) and without trace of notch; gonys straight, slightly ascending terminally, the mandibular rami sometimes strongly deflected basally. Nostril exposed, posteriorly in contact with latero-frontal feathering, very narrow (slit-like), broadly operculate, the posterior portion of the operculum invaded by the short feathering of the latero-frontal antiæ. Rictal bristles wanting, and feathers of chin, etc., without terminal setæ. Wing large and pointed, with the longest primaries exceeding secondaries by more than length of bill from nostril; sixth, seventh, and eighth primaries longest and nearly equal, the tenth (outermost) more than two-thirds as long as the longest, the ninth intermediate between fourth and fifth. Tail about six-sevenths as long as wing, graduated for about one-fourth its length (graduation much less than length of tarsus), the rectrices (12) broad, acuminate, with rigid but slender shafts. Tarsus about one-fourth as long as wing, stout, distinctly scutellate (endaspidean); middle toe, with claw, decidedly shorter than tarsus; outer toe, without claw, reaching to beyond middle of subterminal phalanx of middle toe, the inner toe slightly, but dis-

$a$ One specimen (the type).

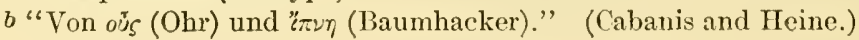


tinctly, shorter; hallux about as long as inner toe but much stouter; basal phalanx of middle toe wholly united to outer toe, united for most, if not the whole, of its length to imner toe; claws large and strong, acute, that of the hallux nearly as long as the digit.

Coloration.- Tawny or rufescent brown above, the rump, upper tailcoverts, and tail cinnamon-rufous; wings sometimes partly black; pileum and hindneck (sometimes back also) streaked; chin, throat, and tuft on sides of neck white or buff; under parts of body tawny or light ocher-brownish, the chest more or less distinctly flammulated or squamated.

Nidification.-Nests placed in holes of trees; eggs white.

Range.-Costa Rica to Peru and Bolivia. (Three species.) ${ }^{a}$

KEY TO THE SPECIES OF PSEUDOCOLAPTES.

a. Neck-tufts white; primaries and wing-coverts rusty brown. (Colombia to Ecuadór, Peru, and Bolivia)............... Pseudocolaptes boissonneautii (extralimital). $b$ aa. Neck-tufts buff; primaries and wing-coverts brownish black. (Costa Rica and western Panamá.) ......................Pseudocolaptes lawrencii (p. 197).

\section{PSEUDOCOLAPTES LAWRENCII RidgWay.}

LAWRENCE'S PSEUDOCOLAPTES.

Adults (sexes alike).-Pileum with feathers dusky basally and laterally (and sometimes on terminal margin), the mesial and terminal or subterminal portions light brown, with a narrow shaft-streak of paler (buffy or buffy whitish); hind-neck similarly marked but with the pale mesial streaks much broader; back and scapulars tawny-brown or russet, the feathers usually with narrow and mostly indistinct terminal margins of dusky; rump and upper tail-coverts plain rufous-tawny, the tail clear cinnamon-rufous, with shafts of rectrices chestnut; lesser wing-coverts tawny-brown or russet, dusky centrally (this mostly concealed); middle and greater coverts black or brownish black, tipped with tawny-buff or ochraceous; secondaries plain tawny-brown or russet, the distal ones passing into black basally; primaries grayish brown, the shorter (proximal) ones more blackish; lores dusky grayish brown; auricular region blackish brown or dusky, narrowly streaked with dull whitish or buffy, margined above by a narrow (usually indistinet) superciliary and supra-auricular streak of dull buffy or whitish; chin, throat, and malar region im-

$a$ I have not seen $P$. flavescens Berlepsch and Stolzmann, from central Peru.

b Anabates boissonneautii Lafresnaye, Rev. Zool., iii, Apr., 1840, 104 (Bogotá, Colombia; coll. A. Boissonneau).-Ph[ilydor $]$ boissoneautii Reichenbach, Handb. Spec. Orn., 1853, 200.-O[tipne] boissonneaui Cabanis and Heine, Mus. Hein., ii, Aug., 1859, 30 (Caracas, Venezuela).-Pseudocolaptes boissoneauti Sclater, Proc. Zool. Soc. Lond., 1860, 88 (Puellaro, Ecuadór); Cat. Birds Brit. Mus., xv, 1890, 78, excl. syn. part.-Anabates auritus Tschudi, Wiegm. Archiv für Naturg., xiii, pt. i, 1844, 294; Fauna Peruana, Aves, 1845, 239.-P[seudocolaptes] semicinnamomeus Reichenbach, Handb. Spec. Orn., 1853, 210 (Bogotá). 
maculate pale buff or buffy white, passing into clear buff on subauricular region and sides of upper neck, where feathers are developed into a short but distinct tuft; rest of under parts pale yellowish buff, passing into light tawny-brown or cinnamon on sides, flanks, and under tail-coverts, the feathers of chest and lower throat edged and (usually) terminally margined with dusky or dark olive, producing a more or less squamate effect, these dusky edgings much broader on sides of chest; under wing-coverts ochraceous-buff; inner webs of remiges broadly but not sharply edged with pale brownish buffy; maxilla brownish black, paler on tomium; mandible dull whitish (in dried skins) with a broad dusky streak along upper portion; legs and feet horn color (in dried skins).

Young.-Similar to adults but pileum and auricular region nearly (sometimes quite) uniform black or brownish black, chest heavily squamated with black or dusky, feathers of whole throat more or less broadly margined with blackish, and under parts of body more tawny.

Adult male.-Length (skins), 187-203 (197); wing, 98-114 (106.3); tail, 85-97.5 (91.6); culmen, 20.5-23.5 (21.9); tarsus, 23.5-27 (25.4); middle toe, $17-18.5$ (17.7).$^{a}$

Adult female.-Length (skins), 185-201 (195); wing, 96.5-102.5 (99.7); tail, 84-92.5 (88.2); culmen, 21.5-25 (23.6); tarsus, 23.5-25.5 (24.3); middle toe, $16.5-18.5(17.2){ }^{a}$

Highlands of Costa Rica (Navarro de Cartago; La Palma de San José; El Roble, Volcán de Irazú; Volcán de Turrialba; Escazú; Las Vueltas, Los Reyes, and Santa Maria, Dota; Ojuras de Térraba) and western Panamá (Cordillera del Chucu; Calobre; Volcán de Chiriquí, 10,000-10,300 ft.; Boquete, 7,500 ft.).

Pseudocolaptes boissoneauti (not Anabates boissonneautii Lafresnaye) SALvin, Proc. Zool. Soc. Lond., 1870, 192 (Cordillera del Chucu, Verágua; crit.).

Pseudocolaptes boissoneauti? Boucard, Proc. Zool. Soc. Lond., 1878, 59 (Navarro, Costa Rica; crit.).

Pseudocolaptes lawrencii Ridgway, Proc. U. S. Nat. Mus., i, sig. 16, Dec. 10, 1878, 253, 254 (Navarro and La Palma de San José, Costa Rica; coll. U. S. Nat. Mus.).-Sclater, Cat. Birds Brit. Mus., xv, 1890, 79 (Cordillera del Chucu

$a$ Twelve specimens.

\begin{tabular}{|c|c|c|c|c|c|}
\hline Locality. & Wing. & Tall. & $\begin{array}{l}\text { Cul- } \\
\text { men. }\end{array}$ & Tarsus. & $\begin{array}{c}\text { Middle } \\
\text { toe. }\end{array}$ \\
\hline MALES. & & & & & \\
\hline Ten adult males from Costa Riea ..................... & 107.2 & 92.7 & 21.5 & 25.5 & 17.5 \\
\hline Two adult males from western Panamá (Chiriquí)......... & 101.5 & 86.2 & 23.5 & 24 & 17. 7 \\
\hline FEMALES. & & & & & \\
\hline Ten adult females from Costa Rica... & 97.5 & 88.3 & 23.5 & 24.2 & 17 \\
\hline Two adult females from western Panamá (Chiriquí).......... & 100.2 & 87.7 & 24 & 24.7 & 18.2 \\
\hline
\end{tabular}


and Calobre, Verágua).-Salyin and Gomman, Biol. Centr.-Am., Aves, ii, 1891, 153.-Bangs, Proc. New Engl. Zool. Club, iii, 1902, 44 (Boquete and Volcán de Chiriquí, 4,000-10,300 ft., Panamá).-Menegaux and Hellanar, Mém. Soc. Hist. Nat. d'Autun, xix, 1906, 83 (crit.; type of $P$. costaricensis Boucard=juv.).-Canriker, Ann. Carnegie Mus., vi, 1910, 637 (Costa Rica; crit.; habits).

[Pseudocolaptes] laurencei SHARPe, Hand-list, iii, 1901, 62.

Pseudocolaptes costaricensis Boucard, Bull. Soc. Zool. France, 5 année, pt. 5-6, 1850, 230 (Navarro, Costa Rica; coll. A. Boueard; =young).

Pseudocolaptes laurenci Ferry, Pub. 146, Field Mus. N. H., orn. ser., i, no. 6, 1910, 270 (Volcán de Turrialba, Costa Rica).

\section{Genus HYLOCTISTES Ridgway.}

Hyloctistes a Ridgwar, Proc. Biol. Soc. Wash., xxii, Apr. 17, 1909, 72. (Type, Philydor virgatus Lawrence.)

Rather large Furnariidx (length about $185 \mathrm{~mm}$.) with bill nearly as long as head (exposed culmen longer than tarsus), basal phalanx of middle toe wholly adherent to both lateral toes, and with pileum, hindneck, back, foreneck, and chest streaked.

Bill about as long as head, rather narrow, straight, compressed, its width at loral antiæ decidedly less than its width at same point and equal to less than one-third the distance from nostril to tip of maxilla; culmen broadly ridged, nearly straight, slightly but decidedly decurved terminally, the tip of maxilla not uncinate; maxillary tomium faintly concave distally, without trace of subterminal notch; mandibular tomium nearly straight to near tip, where very slightly decurved; gonys nearly straight, ascending terminally slightly prominent and convex basally. Nostril exposed, posteriorly in contact (or nearly so) with loral feathering, rather broadly oval, longitudinal, non-operculate, with an inner oblique septum showing within the upper posterior portion. Rictal bristles wanting, and feathers of chin, etc., without terminal setæ. Wing moderate, rather pointed, the longest primaries exceeding secondaries by less than length of bill from nostril; sixth, seventh, and eighth primaries longest and nearly equal, the tenth (outermost) about two-thirds as long as the longest, the ninth intermediate between fourth and firth and very much longer than secondaries. Tail a little less than five-sixths as long as wing, graduated for more than one-fourth its length, the rectrices (12) rather narrow, minutely acuminate terminally. Tarsus shorter than exposed culmen, about one-fourth as long as wing, rather stout, distinctly scutellate; middle toe, with claw, about as long as tarsus; outer toe, without claw, reaching to slightly beyond middle of subterminal phalanx of middle toe, the inner toe slightly but distinctly shorter; hallux about as long as inner toe, but decidedly stouter; basal phalanx of middle toe completely adherent to both lateral toes; 
claws rather large, strongly curved, that of the hallux shorter than the digit.

Coloration.--Olive-brown (paler below), the upper tail-coverts and tail chestnut; pileum, hindneck, and back more dusky, narrowly streaked with paler; chin and throat buff. the chest indistinctly streaked or flammulated with the same.

Range.-Costa Rica and western Panamá. (Monotypic.)

\section{HYLOCTISTES VIRGATUS (Lawrence).}

\section{STRIPED HYLOCTISTES.}

Adults (sexes alike).-Pileum and hindneck dark sooty brown or brownish black, broadly streaked with pale olive, each feather with a narrow shaft-streak of pale buffy; back and scapulars olive-brown, sometimes suffused with dusky, usually narrowly streaked (at least on upper back) with pale buffy; lower rump, upper tail-coverts, and tail chestnut; wings chestnut-brown, usually lighter and more rufescent on basal portion of primaries; sides of head rather broadly streaked with dull grayish buff and dusky; chin and throat buff, the feathers usually edged or margined (more or less distinctly) with olive or dusky, at least on lower throat; rest of under parts light buffy olive, passing into a more rufescent hue on under tail-coverts, the chest, upper breast, and sides (especially the first) more or less distinctly streaked with paler (dull buffy); under wing-coverts and broad edging to inner webs of remiges ochraceous-buff; maxilla dark horn color (sometimes nearly black on culmen), mandible paler, especially on under side; iris brown; legs and feet horn color (in dried skins).

Adult male.-Length (skins), 158-188 (165); wing, 79.5-86.5 (83.5); tail, 65-70 (67.7); culmen, 22-24.5 (23.4); tarsus, 19-21 (20.1); middle toe, $15.5-16.5$ (15.9). ${ }^{a}$

Adult female.-Length (skins), 152-190 (170); wing, 79-85.5 (82); tail, 63-73 (69.2); culmen, 21-24.5 (23.2); tarsus, 19.5-21.5 (20.5); middle toe, $15-16.5$ (15.7). ${ }^{b}$

Costa Rica (Angostura; San Carlos; Jiménez; Carrillo; El Hogár; La Cristina; Pozo del Rio Grande; Pozo del Pitál; El Pozo de Térraba; Palmár; Boruca; La Vijágua) and Panamá (Natá, Coclé).

Philydor virgatus Lawrence, Ann. Lyc. Nat. Hist. N. Y., viii, May, 1867, 468 (Angostura, Costa Rica; coll. U. S. Nat. Mus.); ix, 1868, 106 (Angostura).Frantzius, Journ. für Orn., 1869, 304 (Costa Rica).-Berlepsch, Proc. U. S. Nat. Mus., xi, 1888, 565 (crit.).-Sclater, Cat. Birds Brit. Mus., xv, 1890, 96,

a Ten specimens from Costa Rica. An adult male from Natá, Coclé, Panamá, measures as follows: Length (skin), 164; wing, 84; tail, 69; tarsus, 21 ; middle toe, 16. The bill is broken.

$b$ Eight specimens from Costa Rica. 
footnote (synonymy).-Cinerrie, Proc. U. S. Nat. Mus., xiv, 1891, 534 (San

Carlos, Costa Rica); Anal. Inst. Fis.-Geog. Costa Rica, vi, 1893, 17 (Pozo del

Pitál, Costa Rica; crit.).

[Philydor] virgatus Gray, Hand-list, i, 1869, 172, no. 2317.

Automolus virgatus Salvis and Gonman, Biol. Centr.-Am., Aves, ii, sig. 19, July, 1S91, 155 (Angosturi, Costa Rica):-Crnerrie, Expl. Zool. Merid. Costa Rica, 1S93, 39 (Palmár, s. w. Costa Rica).-Bangs, Auk, xxiv, 1907, 299 (Pozo del Rio Grande, s. w. Costa Rica).

[Automolus] virgatus Sharpe, Hand-list, iii, 1901, 66.

Hyloctistes virgatus Carriker, Amm. Camegie Mus., vi, 1910, 639 (Costa Rica; habits).

\section{Genus PHILYDOR Spix.}

Philydor Spix, Av. Sp. Nov. Bras., i, 1824, 73. (Type, Sphenura superciliaris Lichtenstein $=$ Anabates atricapillus Maximilian.)

Phytidor (emendation?) Lesson, Traité d'Orn., 1831, 317.

Dendroma Swainson, Classif. Birds, ii, 1837, 316. (Type, D. caniceps Swainson= Dendrocopus rufus Tieillot.)

Medium sized Furnariidæ (length about 145-190 mm.) with bill much shorter than head (culmen shorter than tarsus), basal phalanx of middle toe wholly united to lateral toes, and plain (unstreaked) plumage.

Bill much shorter than head, moderately compressed, its width at loral antire decidedly less than its depth at same point and equal to slightly less to much more than one-third the distance from nostril to tip of maxilla; culmen slightly to distinctly ridged, usually more or less strongly curved from near base, sometimes (P. rufus) nearly straight to near tip, where abruptly decurved, the tip of maxilla minutely uncinate; tomia straight or nearly so for most of their length, usually more or less (but, except in P. rufus, always slightly) decurved distally, without trace of subterminal notch; gonys nearly to quite straight, ascending terminally, slightly convex and prominent basally. Nostril exposed, posteriorly in contact with loral feathering, small, longitudinally oval, nonoperculate or with narrow superior membrane. Rictal bristles wanting, and feathers of chin, etc., without terminal setæ. Wing moderate to rather long, rather pointed, with longest primaries exceeding secondaries by at least length of gonys; seventh and eighth, sixth, seventh, and eighth, or sixth and seventh, primaries longest, the tenth (outermost) about three-fourths as long as the longest, the ninth equal to or longer than fifth and much longer than secondaries. Tail three-fourths as long as wing ( $P$. pyrrhodes) to as long as wing ( $P$. rufus), slightly rounded (P. fuscipennis, $P$. erythrocercus) to graduated for more than onefourth its length ( $P$. pyrrhodes, $P$. rufus), the rectrices (12) subrounded to subacuminate terminally. Tarsus longer than culmen, less than one-fourth as long as wing (P. lichtensteini, P. fuscipennis) to more than one-fourth as long ( $P$. rufus), rather stout, 
distinctly scutellate; middle toe, with claw, equal to tarsus ( $P$. fuscipennis) or more or less shorter (other species); outer toe, without claw, reaching to or beyond middle of subterminal phalanx of middle toe, the inner toe slightly shorter; hallux about as long as outer toe but much stouter; basal phalanx of middle toe wholly united to lateral toes; claws moderate in size and curvature, that of the hallux decidedly shorter than the digit.

Coloration.-Plain brown, brown and gray, or rufescent above, the tail and upper tail-coverts usually cinnamon-rufous or rufous-tawny; a more or less distinct superciliary stripe of rufous-tawny, ochraceous, buff, or whitish; under parts plain tawny, ochraceous, or buffy. Sexes alike.

Range.-Costa Rica to Peru, Bolivia, southeastern Brazil, and Cayenne. (About fifteen species.) ${ }^{a}$

KEY TO THE SPECIES OF PHILYDOR. $b$

a. Upper tail-coverts buffy brown, like back but lighter; wings cinnamon-rufous, contrasting strongly with color of back.

b. Pileum distinctly gray, the forehead broadly and abruptly buffy. (Southeastern Brazil) ............................... Philydor rufus (extralimital).c

$b b$. Pileum not distinctly, if at all, gray, the forehead neither broadly nor abruptly buffy.

c. Coloration much paler, the back, etc., light buffy brown, under parts buff; pileum brownish gray or grayish brown. (Venezuela.)

Philydor columbianus (extralimital). ${ }^{d}$

$a$ Of the fifteen species enumerated under Philydor in Dr. Sharpe's Hand-List of the Genera and Species of Birds (vol. iii, 1901, pp. 68, 69), I have examined only P. atricapillus (Maximilian), P. rufus (Vieillot), P. lichtensteini Cabanis, P. pyrrhodes (Cabanis), $P$. fuscipennis Salvin, $P$. panerythrus Sclater, and P. erythrocercus (Pelzeln)-leaving eight species, or more than one-half, unknown to me autoptically. A careful comparison of all the species would, I feel quite sure, result in subdivision of the genus, which is certainly far from being a homogeneous or natural group.

$b$ Including only the more closely allied extralimital forms that are available at this time.

c Dendrocopus rufus Vieillot, Nouv. Dict. d'Hist. Nat., xxvi, 181S, 119.-P[hilydor] rufus Cabanis and Heine, Mus. Hein., ii, Aug., 1859, 29.-Philydor rufus Sclater, Proc. Zool. Soc. Lond., 1861, 378; Cat. Birds Brit. Mus., xv, 1890, 97.-S[phcnura] poliocephala Lichtenstein, Verz. Doubl., 1823, 41 (S. Paulo, s. Brazil; coll. Berlin Mus.).Philydor ruficollis Spix, Av. Bras., "1824," 74, pl. 75 (int. prov. Bahia, Brazil).$D$ [endroma] caniceps Swainson, Classif. Birds, ii, 1837, 316 (based on "Braz. Birds, pl. 80").-Xenops rufifrons Lesson, Traité d'Orn., 1831, 317 (ex Valenciennes, manuscript; new name for Philydor ruficollis Spix).

d P [hilydor] columbianus Cabanis and Heine, Mus. Hein., ii, Aug., 1859, 29, footnote (Puerto Cabello, Venezuela; coll. Berlin Mus.).-Philydor columbianus Sclater and Salvin, Proc. Zool. Soc. Lond., 1868, 170 (Carácas, Venezuela).-Philydor colombianus Sclater, Cat. Birds Brit. Mus., xv, 1890, 98. 
c. Coloration much darker, the back, otc., deep tawny-brown, under parts dull ochraceous (clear ochraceous on throat). (Costa Rica to Colombia.)

Philydor panerythrus (p. 203).

aa. Upper tail-coverts bright chestnut, like tail; wings not cinnamon-rufous.

b. IVings rusty brown. (Southeastern Brazil.)

Philydor atricapillus (extralimital). ${ }^{a}$

$b b$. Wings brownish slate color. (Panami.)....... Philydor fuscipennis (p. 204).

\section{PHILYDOR PANERYTHRUS Sclater.}

\section{OCHRACEOUS PHILYDOR.}

Adults (sexes alite).-Crown and occiput grayish cinnamon-brown or buffy grayish brown, passing into dull cinnamon on forehead and tawny-brown (nearly raw-umber) on hindneck, back, and scapulars, the rump and upper tail-coverts lighter, more buffy brown or wood brown; tail dull cinnamon-rufous, the wings brighter cinnamonrufous, except primary coverts, which are dull russet, and tips of primaries, which are dusky; superciliary stripe, sides of head, chin, and throat clear ochraceous, relieved by a more or less distinct brown or dusky postocular streak (occupying upper part of auricular region); rest of under parts lighter and duller ochraceous, becoming gradually duller and somewhat paler (nearly pale isabella color, but more yellowish) on flanks, under tail-coverts, and lower abdomen; under wing-coverts and broad edgings to inner webs of remiges clear ochraceous-buff; maxilla horn color, darker on terminal portion of culmen, paler on tomia; mandible dull whitish (in dried skins) dusky or horn color on rami; iris brown $;^{b}$ legs and feet deep horn color (in dried skins).

Adult male.-Length (skins), 190-191 (190.5); wing, 96-103 (99.5); tail, 88-90 (89); culmen, 19-19.5 (19.2); tarsus, 23.5-24 (23.7); middle toe, $14 .^{c}$

a Anabates atricapillus Maximilian, Reis. Bras., ii, 1821, 147.-Philydor atricapillus Sclater, Cat. Birds Brit. Mus., xv, 1890, 96.-S[phenura] superciliaris Lichtenstein, Verz. Doubl., 1823, 41 (Bahia, Brazil; coll. Berlin Mus.).-Anabates superciliaris Burmeister, Syst. Ueb. Th. Bras., iii, 1856, 28.-Philydor superciliaris Spix, Av. Bras., i, "1824," 73, pl. 73, fig. 1.-Xenops canivetii Lesson, Cent. Zool., livr. ii, Sept., 1830, 60, pl. 16 (Brazil).--Xenops melanocephalus Lesson, Traité d'Orn., livr. 4, Sept., 1830, 318 (new name for Philydor superciliaris Spix).

$b$ W. W. Brown, jr., on label.

$c$ Two specimens. 
Adult female.-Length (skins), 180-187 (182.3); wing, 92-98 (95.2); tail, 86-87 (86.3); culmen, 17.5-19.5 (18.7); tarsus, 23.5; middle toe, $13.5-15$ (14.3) ${ }^{a}$

Costa Rica (Birrís and Cervantes, Cartago; Laguária and Los Reyes, Santa Maria de Dota) and western Panamá (Boquete, 6,500 feet, Volcán de Chiriquí, 6,500-7,000 feet, and Caribbean slcpe, 7,000 feet, Chiriquí) to Colombia (Bogotá, etc.).

Philydor panerythrus Sclater, Proc. Zool. Soc. Lond., 1862, 110 (Bogotá, Colombia; coll. P. L. Sclater); 1870, 329 (do.); Cat. Birds Brit. Mus., xv, 1890, 100 (Bogotá; Isth. Panamá; Costa Rica).-Salvin, Ibis, 1870, 110 (Costa Rica; crit. nom.).-BerLepsch, Proc. U. S. Nat. Mus., xi, 1888, 565, in text (crit.).-Salvin and Godman, Biol. Centr.-Am., Aves, ii, 1891, 160 ("Pirris," i. e., Birrís, and Cervantes, Costa Rica; Verágua; Panamá; Colombia).

Philydor rufus panerythrus Zeledón, Anal. Mus. Nac. Costa Rica, i, 1887, 113 (Cervantes de Cartago, Costa Rica).

[Philydor] panerythrus Gray, Hand-list, i, 1869, 172, no. 2315.-Sclater and Salvin, Nom. Av. Neotr., 1873, 66.-Sharpe, Hand-list, iii, 1901, 69.

Philydor semirufus (lapsus) Sclater, Cat. Am. Birds, 1862, 360 (Bogotá).

Automolus rufescens Lawrence, Ann. Lyc. Nat. Hist., viii, 1867, 345 (Birrís, Costa Rica; coll. U. S. Nat. Mus.); ix, 1868, 106 (Costa Rica).-Frantzius, Journ. für Orn., 1869, 304 (Costa Rica).-SAlvin, Ibis, 1870, 110 (crit.).Ridgway, Proc. U. S. Nat. Mus., vi, 1883, 414 (Cervantes, Costa Rica).Berlepsch, Proc. U. S. Nat. Mus., xi, 1888, 565 (crit.).

Philydor panerythrus rufescens CARriker, Ann. Carnegie Mus., vi, 1910, 641 (Costa Rica).

[Philydor] rufescens GraY, Hand-list, i, 1869, 173, no. 2339.

Philydor panerythrus rufus (not Dendrocopus rufus Vieillot) Bangs, Proc. New Engl. Zool. Club, iii, Jan. 30, 1902, 44 (Boquete and Volcán de Chiriquí, Panamá, 6,500-7,000 feet).

\section{PHILYDOR FUSCIPENNIS Salvin.}

DUSKY-WINGED PHILYDOR.

Adults (sexes alike).-Pileum deep chestnut-brown (between mummy brown and prouts brown), the feathers with indistinct shaftstreaks of grayish; hindneck, back, and scapulars plain chestnut, passing into rufous-chestnut or dark cinnamon-rufous on rump, upper tail-coverts, and tail; wings wholly grayish brown (grayish

$a$ Three specimens.

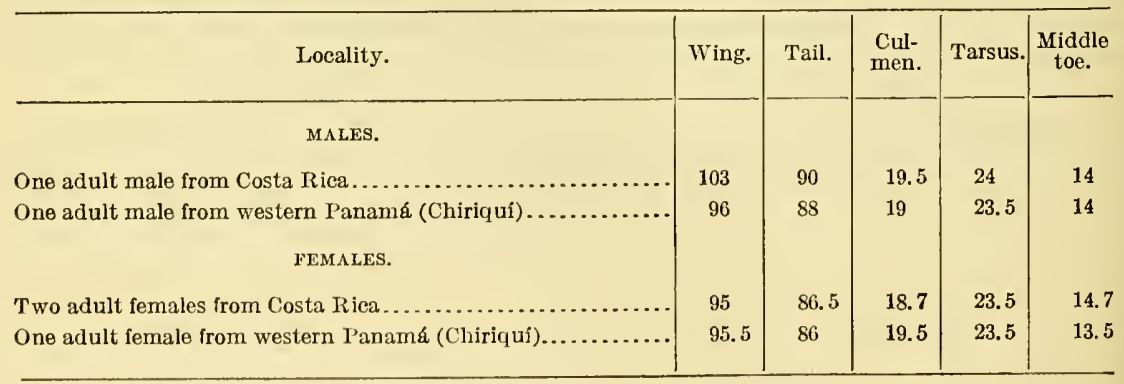


hair brown), in strong contrast with general coloration of upper and under parts; a conspicuous supra-auricular (postocular) streak of tawny-ochraceous; lores pale grayish or dull grayish white flecked with dusky; under parts plain dull tawny-ochraceous or raw-sienna, paler on chin and throat (where feathers are whitish sub-basally), deeper laterally, passing into more grayish brown on thighs and cinnamon-rufous or rufous-tawny on under tail-coverts; under wingcoverts ochraceous-buff, the inner webs of remiges broadly edged with dull white or buffy white; maxilla horn color, darker on culmen; mandible horn color with gonys (broadly) whitish (in dried skins); iris dark brown; ${ }^{a}$ legs and feet light yellowish horn color (in dried skin).

Adult male.-Length (skin), 151.5; wing, 90; tail, 69.5; culmen, 18.5; tarsus, 20 ; middle toe, $14.5 .^{b}$

Panamá (Santiago de Verágua; Cascajál, Coclé).

Philydor fuscipennis SAlvr, Proc. Zool. Soc. Lond., 1866, 72 (Santiago de Verágua, Panamá; coll. Salvin and Godman); 1867, 143 (Santiago de Verágua).-Sclater, Cat. Birds Brit. Mus., xv, 1890, 99.-Salvin and Godvan, Biol. Centr.-Am., Aves, ii, 1891, 161, pl. 46, fig. 1.

[Philydor] fuscipennis Gray, Hand-list, i, 1869, 172, no. 2310.-Sclater and Salvin, Nom. Av. Neotr., 1873, 66.-Sharpe, Hand-list, iii, 1901, 68.

\section{Genus XENICOPSIS Cabanis.}

Syndactyla (not Syndactylus Boitard, 1842) Reichenbach, Handb. Spec. Orn., 1853, 171. (Type, Xenops rufo-superciliatus Lafresnaye.)

Xenicopsis c Cabanrs and Herne, Mus. Hein., ii, Aug., 1859, 32. (Type, Xenops rufo-superciliatus Lafresnaye.)

Medium sized Furnariidæ (length about 145-190 mm.) with small, roundish, non-operculate nostrils, culmen (from base) shorter than tarsus, and basal phalanx of middle toe not wholly united to lateral toes.

Bill much shorter than head, relatively rather deep and compressed, its width at loral antiæ much less than its depth at same point and equal to one-third to much more than one-third the distance from nostril to tip of maxilla; culmen (from base) shorter (usually much shorter) than tarsus, broadly and rather indistinctly ridged, nearly straight for basal half (more or less), more or less strongly decurved terminally, the tip of maxilla slightly uncinate or sub-uncinate; maxillary tomium straight or very nearly so to near tip, where more or less (for a very short distance) decurved, without trace of subterminal notch; mandibular tomium straight or slightly convex (the

a Heyde, on label.

$b$ One specimen, from Cascajál, Coclé, Panamá. An adult with sex undetermined from Panama (Lion Hill?) measures as follows: Wing, 92.5; tail, 70; culmen, 18.

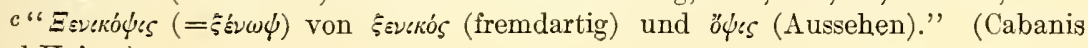
and Heine.) 
mandible then recurved or subfalcate), the extreme tip sometimes slightly decurved; gonys gently convex, strongly ascending terminally, more strongly convex and sometimes rather prominent basally. Nostril exposed, posteriorly in contact with loral feathering, very small, broadly oval or roundish, non-operculate, but margined above by a very narrow concave membrane. Rictal bristles wanting, and feathers of chin, etc., without terminal setæ. Wing moderate, rather pointed, the longest primaries exceeding secondaries by less than length of bill from nostril to more than length of exposed culmen; sixth and seventh, sixth, seventh, and eighth, or fifth, sixth, seventh, and eighth, primaries longest, the tenth (outermost) between twothirds and three-fourths as long as the longest, the ninth much longer than secondaries. Tail four-fifths as long as wing to very slightly longer than wing, rounded or graduated (graduation equal to from about one-ninth to more than one-third its total length), the rectrices (12) subacuminate. Tarsus longer than culmen, less than one-fourth to nearly one-third as long as wing, distinctly scutellate; middle toe, with claw, slightly shorter to slightly longer than tarsus; outer toe, without claw, reaching to about middle of subterminal phalanx of middle toe, the inner toe slightly shorter; hallux about as long as outer toe but decidedly stouter; basal phalanx of middle toe united for much the greater part to outer toe, for at least half to inner toe; claws rather large, strongly curved, and acute, that of the hallux decidedly shorter than the digit.

Coloration.-Above brown or olive, the pileum and back sometimes narrowly streaked with buffy or whitish, the former usually much duller (grayer) or more dusky; upper tail-coverts and tail cinnamonrufous or chestnut; a more or less distinct (usually conspicuous) superciliary stripe (often an orbital ring also) of buff or ochraceous; under parts plain light buffy brown or yellowish brown, paler (yellowish or buffy) on throat, or conspicuously streaked or flammulated. Sexes alike.

Range.-Southern Mexico to Peru, Bolivia, southeastern Brazil, and Venezuela. (About thirteen species.) ${ }^{a}$

KEY TO THE SPECIES OF XENICOPSIS.

a. Throat buffy or yellowish, chest light buffy brownish.

$b$. Hindneck, upper back, and chest not streaked; upper tail-coverts brown, concolor with back; smaller (wing less than 90).

$a$ Of these the following have been examined in this connection: $X$. rufosuperciliatus (Lafresnaye), $X$. oleagineus Sclater, $X$. subalaris (Sclater), $X$. percnopterus Oberholser, $X$. variegaticeps Sclater, $X$. striaticollis (Sclater), X. temporalis (Sclater), and $X$. anxius (Bangs). The last four of these differ from typical Xenicopsis in much less graduated tail, relatively much longer wing and shorter tarsus, and unstreaked lower parts, and constitute a very well defined group, possibly a distinct genus. 
c. Superciliary stripe buff or ochraceous-bufi, different from color of throat.

(Southern Mexico to western Panamá.)..Xenicopsis variegaticeps (p. 207). $c c$. Superciliary stripe pale yellowish buff, concolor with throat.

d. Throat pale dull buffy or buffy whitish.

$e$. Chest broadly streaked or flammulated with pale buffy; color of pileum browne1. (Colombia to Peru and Bolivia.)

Xenicopsis striaticollis (extralimital) $a$

$e e$. Chest plain light buffy brown, or with very indistinct (obsolescent) streaks; color of pileum more olivaceous. (Western Colombia to Ecuadór and Bolivia.)......... Xenicopsis temporalis (extralimital). $b$ dd. Throat light buff-yellow. (Santa Marta district of Colombia.)

Xenicopsis anxius (extralimital).c

$b b$. Hindneck, upper back, and chest, conspicnously streaked; upper tail-coverts chestnut, like tail. (Xenicopsis subalaris.)

c. Pileum and back more distinctly streaked, under parts more broadly streaked, chestnut of upper tail-coverts and tail much darker; slightly smaller. (Northwestern Colombia to western Ecuadór.)

Xenicopsis subalaris subalaris, adults (extralimital). $d$

$c c$. Pileum and back much less distinctly streaked (the former much browner), under parts more narrowly streaked, and chestnut of upper tail-coverts and tail much lighter; slightly larger. (Costa Rica and Panamá.)

Xenicopsis subalaris lineatus, adults (p. 209).

aa. Throat and chest tawny or tawny-ochraceous.

Xenicopsis subalaris lineatus, young (p. 210).

\section{XENICOPSIS VARIEGATICEPS (Sclater).}

\section{SCALY-THROATED XENICOPSIS.}

Adults (sexes alike).-Pileum and hindneck grayish olive, the feathers with narrow shaft-streaks of dull whitish or buffy (at least on crown) and very indistinctly margined terminally with dusky; back, scapulars, rump, upper tail-coverts and wings plain brown (between mummy and raw-umber), the secondaries more russet-

a(?) Anabates montanus Tschudi, Fanna Peruana, Aves, 1845, 240, pl. 20, fig. 1.(?) I[poborus] montanus Cabanis and Heine, Mus. Hein., ii, 1859, 31 ("Brasilien," i. e., Bolivia).-(?) Philydor montanus Taczanowski, Proc. Zool. Soc. Lond., 1874, 528 (centr. Peru); Orn. du Pérou, ii, 1884, 153.-Anabates striaticollis Sclater, Proc. Zool. Soc. Lond., June 6, 1857, 17 (Bogotá, Colombia; coll. P. L. Sclater).-Philydor striaticollis Sclater, Proc. Zool. Soc. Lond., 1861, 378.-Anabazenops striaticollis Sclater, Cat. Birds Brit. Mus., xv, 1890, 108.-[Xenicopsis] striaticollis Sharpe, Hand-list, iii, 1901, 71.

$b$ Anabates temporalis Sclater, Proc. Zool. Soc. Lond., 1859, 141 (Pallatanga, w. Ecuador; coll. P. L. Sclater).-Anabazenops temporalis Sclater, Cat. Am. Birds, 1862, 159; Cat. Birds Brit. Mus., xv, 1890, 107.-[Xenicopsis] temporalis Sharpe, Hand-list, iii, 1901, 70.

c Xenicopsis anxius Bangs, Proc. New Engl. Zool. Club, iii, March 31, 1902, 83 (Chirua, Sierra Nevada de Santa Marta, Colombia, 7,000 ft.; coll. E. A. and O. Bangs).

d Anabates subalaris Sclater, Proc. Zool. Soc. Lond., Aug., 1859, 141 (Pallatanga, w.

Ecuadór; coll. P. L. Sclater).-Anabazenops subalaris Sclater, Cat. Am. Birds, 1862, 159; Cat. Birds Brit. Mus., xv, 1890, 108, part.-(?) Anabazenops mentalis Taczanowski and Berlepsch, Proc. Zool. Soc. Lond., June 1, 1885, 96 (Machay, w. Ecuadór; coll. Branicki Mus.).-[Xenicopsis] subalaris Sharpe, Hand-list, iii, 1901, 71, part. 
brown, the primary-coverts dusky terminally and primaries passing into grayish brown or dusky at tips; tail clear chestnut; broad orbital ring and supra-auricular stripe buff or ochraceous-buff; lores mostly dusky or dark grayish, paler and more buffy (sometimes distinctly buffy) along upper margin; auricular region dusky, more or less broadly streaked with paler (except along upper portion) and with very narrow shaft-streaks of buffy, this dusky auricular area passing, in a more or less well-defined stripe, to the anterior portion of the malar region; chin and throat, together with middle and posterior portions of malar region, pale yellowish buff or cream-buff, the feathers of lower throat narrowly margined, more or less distinctly, with dusky; rest of under parts plain light buffy brown (sometimes approaching wood brown but more yellowish or cinnamomeous), passing into darker brown (between raw-umber and isabella color) on flanks, the under tail-coverts more rufescent; under wing-coverts and broad edgings to inner webs of remiges ochraceous-buff; maxilla dusky horn color, paler toward tomium; mandible paler, whitish on gonys (broadly); iris brown; legs and feet horn color (in dried skins).

Adult male.-Length (skins), 151-167 (160); wing, 78.5-91 (89.8); tail, 64-75 (70.4); culmen, 15.5-17.5 (16.5); tarsus, 18-20 (19.1); middle toe, $14-16$ (15.1). ${ }^{a}$

Adult female.-Length (skins), 146-160 (154); wing, 76-88.5 (81.2); tail, 63-72 (65.8); culmen, 14.5-17.5 (16.1); tarsus, 17.5-19.5 (18.7); middle toe, $14.5-16$ (15). ${ }^{b}$

Southern Mexico, in States of Vera Cruz (Córdova; Jalapa; Uvero; Omealca; Motzorongo), Guerrero (Omilteme), Oaxaca (Choapám; Totóntepec), and Chiapas (Tumbalá; Chicharros), Guatemala (Barranca Honda; Savana Grande; Choctúm), Costa Rica (San Marcos;

$a$ Twenty-one specimens.

$b$ Thirteen specimens.

\begin{tabular}{|c|c|c|c|c|c|}
\hline Locality. & Wing. & Tail. & $\begin{array}{l}\text { Cul- } \\
\text { men. }\end{array}$ & Tarsus. & $\begin{array}{l}\text { Middle } \\
\text { toe. }\end{array}$ \\
\hline MALES. & & & & & \\
\hline Two adult males from Vera Cruz, Mexico... & 87.5 & 71.7 & 16.7 & 19.2 & 14.7 \\
\hline Four adults from Guerrero, Mexico............ & 87.5 & 70.7 & 16.5 & 19.4 & 15.2 \\
\hline Two adult males from Chiapas, Mexico...... & 83 & 67.5 & 16 & 18.7 & 15 \\
\hline Two adult males from Guatemala.............. & 86.7 & 70.5 & 16.7 & 19 & 14.7 \\
\hline Five adult males from Costa Rica............... & 83.7 & 68.7 & 16 & 18.8 & 15.2 \\
\hline Six adult males from western Panamá (Chiriquí). & 88.7 & 72.2 & 16.9 & 19.2 & 15.2 \\
\hline FEMALES. & & & & & \\
\hline Two adult females from Guerrero, Mexico. & 81.5 & 65 & 16.7 & 18.5 & 15.5 \\
\hline Eight adult females from Costa Rica............ & 81 & 65.3 & 15.7 & 18.7 & 14.9 \\
\hline Three adult females from western Panamá (Chiriqquí) & 81.7 & 67.7 & 16.8 & 18.7 & 15 \\
\hline
\end{tabular}


Rio Naranjo; Naranjo de Cartago; Azahár de Cartago; Turrialba; Candelárin; Juan Viñas; Rio Súcio; Barranca; Dotal, Dota Mountains, Los Reyes, Laguária, and Santa Maria, Dotar Ojuras de Térraba), and western Panamá (Boquete; Voleńn do Chiriquí).

Anabazenops variegaticeps Sclater, Proc. Zool. Soc. Lond., 1856 (pub. Jan. 26, 1857), 2s9 (Córdova, Vera Cruz, Mexico; coll. A. Sallé); 1859, 382 (Choapám and Totóntepec, Oaxaca); Cat. Am. Birds, 1862, 159 (Córdova); Cat. Birds Brit. Mfus., xv, 1890, 106 (Jalapa, Vera Cruz; Barranca Honda, Savana Grande, and Choctúm, Guatemala; Costa Rica; Volcán de Chiriquí; Verágua).-SAlitix and Sclater, Ibis, 1860, 398 (Choctúm, Guatemala).LA Wrence, Ann. Lyc. N. Y., ix, 1868, 106 (Dota and Barranca, Costa Rica).Frattzius, Journ. für Or'n., 1869, 304 (Costa Rica).-Sumichrast, La Naturaleza, v, 1881, 247 (Uvero and Omealca, Vera Cruz).-Salvin, Proc. Zool. Soc. Lond., 1870, 192 (Volcán de Chiriquí, Panamá).-Boucard, Proc. Zool. Soc. Lond., 1878, 59 (Candelária, Costa Rica); Ann. Soc. Linn. Lyon, 1878, 37 (Guatemala).-SAnchez, An. Mus. Nac. Mex., i, 1877, 97 (Yera Cruz).-Ridgway, Proc. U. S. Nat. Mus., vi, 1883, 414 (Rio Sucio, Costa Rica).-Salvin and Godman, Biol. Centr.-Am., Aves, ii, 1891, 162.Cherrie, Anal. Inst. Fis.-Geog. Costa Rica, vi, 1893, 17 (San Marcos and Rio Naranjo, s. w. Costa Rica).

[Anabazenops] variegaticeps Sclater and Salvin, Nom. Av. Neotr., 1873, 66.

[Xenicopsis] variegaticeps Heine and Reichenow, Nomencl. Mus. Hein. Orn., 1890, 134 (Córdova, Vera Cruz).-Sharpe, Hand-list, iii, 1901, 70.

Xenicopsis variegaticeps Bangs, Proc. New Engl. Zool. Club, iii, 1902, 44 (Boquete and Tolcán de Chiriquí, Panamá, 4,000-4,800 ft.).—CARriker, Ann. Carnegie Mus., vi, 1910, 642 (Costa Rica; habits).

Anabaztenops variegaticeps Sumichrast, Mem. Bost. Soc. N. H., i, 1869, 555 (tierra caliente of Vera Cruz, up to $1,300 \mathrm{~m}$.).

[Xenops] variegaticeps Gray, Hand-list, i, 1869, 175, no. 2363.

Xenicopsis variegaticeps idoneus Bangs, Proc. Biol. Soc. Wash., xix, July 30, 1906, 108 (Boquete, Chiriquí, Panamá; coll. E. A. and O. Bangs).

\section{XENICOPSIS SUBALARIS LINEATUS (Lawrence).}

\section{LINEATED XENICOPSIS.}

Similar to $X$. s. subalaris (Sclater), ${ }^{a}$ of Ecuadór, but pileum much browner and much less distinctly streaked, back less distinctly streaked, chestnut of upper tail-coverts and tail much lighter, and under parts more narrowly streaked.

Adults (sexes alike).-Pileum sepia brown, usually with very narrow shaft-streaks of pale brown or buffy, at least on forehead, but these sometimes obsolete; hindneck more dusky brown, distinctly streaked with buff; back, scapulars, and wings brown (between mummy and raw umber), the back (at least upper portion) with more or less distinct narrow shaft-streaks of buff; lower rump, upper tail-coverts, and tail clear chestnut or deep chestnut-rufous; sides of head and neck (including malar region) dark sepia or dusky, 
rather broadly streaked with light yellowish buff or buff-yellow; chin and upper throat immaculate yellowish buff or buff-yellow; rest of under parts light raw-umber brown (darker on lower throat and upper chest, passing posteriorly into a more tawny-olive hue on flanks and a more rufescent hue on under tail-coverts), narrowly streaked with pale yellowish buff, these streaks broader on chest and lower throat, sometimes obsolete on flanks and under tail-coverts; under wingcoverts and broad edgings to inner webs of remiges ochraceous-buff; bill dusky horn color, the gonys (broadly) whitish or pale yellowish horn color (in dried skins); iris brown; legs and feet horn color (in dried skins).

Young.-Upper parts essentially as in adults but color of pileum and hindneck more dusky, the latter with streaks rufescent instead of buffy yellowish; a more or less distinct narrow superciliary stripe of tawny; malar region (except anterior portion), sides of neck, chin, throat, and chest, tawny-ochraceous, tawny, or rufous-tawny (deepest on chest, paler on chin), the feathers with narrow and indistinct shaft-streaks of paler; rest of under parts similar medially in color to throat and chest but paler and duller, passing into a more olive hue on sides and flanks, the under tail-coverts more rufescent; under wing-coverts tawny or tawny-ochraceous, the inner webs of remiges broadly edged with ochraceous-buff; bill, etc., as in adults, or with mandible wholly dusky.

Adult male.-Length (skins), 178-195 (186); wing, 89-94 (91.9); tail, 78-86 (82.5); culmen, 18.5-20 (19.3); tarsus, 22-24 (22.9); middle toe, $17-19$ (17.8). ${ }^{a}$

Adult female.-Length (skins), 172-187 (182); wing, 81.5-92 (87.2); tail, 73.5-83 (79.6); culmen, 19-21 (20); tarsus, 21.5-23.5 (22.6); middle toe, $17-18.5(17.6){ }^{b}$

$a$ Eleven specimens.

$b$ Nine specimens.

\begin{tabular}{|c|c|c|c|c|c|}
\hline Locality. & Wing. & Tail. & $\begin{array}{l}\text { Cul- } \\
\text { men. }\end{array}$ & Tarsus. & $\begin{array}{c}\text { Middle } \\
\text { toe. }\end{array}$ \\
\hline MALES. & & & & & \\
\hline Nine adult males from Costa Rica... & 91.6 & 83.2 & 19.4 & 22.9 & 17.7 \\
\hline Two adult males from western Panamá (Chiriquí)............ & 93 & 78.5 & 19.5 & 22.7 & 18.2 \\
\hline Two adult males ( $X$. s. subalaris) from northwestern Colombia. & 89.7 & 80 & 19.2 & 22 & 17.7 \\
\hline $\begin{array}{l}\text { One adult male }(X . \text { s. subalaris }) \text { from western Ecuador......... } \\
\text { FEMALEs. }\end{array}$ & 86.5 & 70.5 & 19 & 23.5 & 20 \\
\hline Seven adult females from Costa Rica.. & 86.8 & 78.9 & 20.1 & 22.4 & 17.6 \\
\hline Two adult females from western Panamá (Chiriquí) ............ & 88.5 & 81.7 & 19.7 & 23 & 17.5 \\
\hline
\end{tabular}


Costa Rica (Angostura; Cartago, Birrís, La Estrella, Naranjo, and Azahár, Cartago; Volean de Irazú; Cervantes; Coliblanco; Juan Viñas; La Hondura; Cariblanco de Sarapiquí; Santa Maria, Laguaria, and Los Reyes, Dota) and western Panamá (Calovévora; Calobre; Boquete; Voleán de Chiriquí, 4,500-7,800 feet).

Anabazenops lineatus Lawrence, Ann. Lyc. Nat. Hist. N. Y., viiii, 1867, 127 (Angostura, Costa Rica; coll. U. S. Nat. Mus.); ix, 1868, 106 (Angostura, Birrís, and Cervantes, Costa Rica).-Frantzıus, Journ. für Orn., 1869, 304 (Costa Rica).-SAlvin, Ibis, 1870, 110 (crit.).-Berlepsch, Proc. U. S. Nat. Mus., xi, 188s, 565 (crit.).

[. Yenops] lineatus GraY, Hand-list, i, 1869, 175, no. 2368.

Anabazenops subalaris lineatus Berlepsch, Proc. U. S. Nat. Mus., xi, sig. 36, Sept. 25, 1889, 566 (diagnosis).

Anabazenops subalaris (not Anabates subalaris Sclater) SALviv, Ibis, 1870, 110 (Costa Rica; crit.); Proc. Zool. Soc. Lond., 1870, 192 (Calovévora, Verágua).Sclater, Cat. Birds Brit. Mus., xv, 1890, 108, part (Calovévora, Verágua; Irazú distr., Costa Rica).-Salvin and Godman, Biol. Centr.-Am., Aves, ii, 1891, 163, part (Angostura, "Pirris," i. e., Birrís, Cervantes, and Volcan de Irazú, Costa Rica; Calobre and Calovévora, Verágua).

[Xenicopsis] subalaris Sharpe, Hand-list, iii, 1901, 71, part (Costa Rica; Panamá). Xenicopsis subalaris lineatus Bangs, Proc. New Engl. Zool. Club, iii, Jan. 30, 1902, 44 (Boquete and Volcán de Chiriquí, 4,500-7,800 ft., Panamá).Carriker, Ann. Carnegie Mus., vi, 1910, 643 (Costa Rica; crit.).-Ferry, Pub. 146, Field Mus. N. H., orn. ser., i, no. 6, 1910, 270 (Coliblanco, Costa Rica; crit.).

\section{Genus AUTOMOLUS Reichenbach.}

Automolus (not Automolis Hübner, 1816), Reichenbach, Handb. Spec. Orn., 1853, 174. (Type, Sphenura sulphurascens Lichtenstein=Anabates leucophthalmus Maximilian.)

Cichlocolaptes Reichenbach, Handb. Spec. Orn., 1853, 174. (Type, Anabates ferruginolentus Maximilian.)

Ipoborus a Cabanis and Heine, Mus. Hein., ii, Aug. 26, 1859, 31. (Type, Sphenura sulphurascens Lichtenstein=Anabates leucophthalmus Maximilian.)

Large Furnariidæ (length about 180-200 mm.) with roundish, nonoperculate nostrils, basal phalanx of middle toe not wholly united to lateral toes, rather long and narrow bill (culmen, from base, longer than tarsus), and unstreaked coloration.

Bill nearly as long as hearl, narrow, compressed, its width at loral antiæ much less than its depth at same point and contained two and a half to more than three times in distance from nostril to tip of maxilla; culmen longer than tarsus, broadly and rather indistinctly ridged, nearly straight or very slightly curved for basal half or more, moderately and gradually decurved terminally, the tip of maxilla distinctly decurved but not uncinate; tomia straight for most of their length, slightly but distinctly decurved terminally, without trace of notch;

$a$ "Von " $\psi$ (Holzwurm) und $\beta \varepsilon \beta \rho \omega ́ \sigma k \omega$ (fressen)." (Cabanis and Heine.) 
gonys faintly convex basally, straight or faintly concave terminally, the tip of maxilla sometimes slightly decurved. Nostril exposed, posteriorly in contact with loral feathering, rather small, roundish or broadly oval, non-operculate, but margined above by very narrow membranous rim. Rictal bristles wanting, and feathers of chin, etc., without terminal setæ. Wing moderate, much rounded, the longest primaries exceeding secondaries by much less than length of bill from nostril (except in A. leucophthalmus, in which the difference between tip of secondaries and longest primaries nearly equals length of exposed culmen); sixth, seventh, and eighth, sixth and seventh, fifth, sixth, and seventh, or fifth and sixth primaries longest, the tenth (outermost) less than two-thirds to three-fourths (A. leucophthalmus) as long as the longest, the ninth longer than fourth ( $A$. leucophthalmus) to shorter than second (A. rubiginosus). Tail sixsevenths as long as wing ( $A$. leucophthalmus) to as long as wing, graduated (graduation equal to from less than one-fourth, in $A$. leucophthalmus to more than one-third, in A. veræ-pacis, its total length), the rectrices (12) rather broad, with tip rounded or slightly subacuminate. Tarsus shorter than culmen (from base), a little more than one-fourth (in $A$. leucophthalmus) to nearly one third (in A. veræ pacis) as long as wing, distinctly scutellate; middle toe, with claw, shorter than tarsus; outer toe, without claw, reaching to or slightly beyond middle of subterminal phalanx of middle toe, the inner toe slightly shorter; hallux nearly as long as outer toe, but much stouter; basal phalanx of middle toe united for about half its length to outer toe, for less than half to inner toe; claws moderate to rather large, strongly curved, that of the hallux decidedly shorter than the digit.

Coloration.-Above plain brown (sometimes darker on pileum and hindneck), the upper tail-coverts and tail (sometimes rump also) cinnamon-rufous or chestnut; beneath plain tawny, cinnamon-brown, or pale buffy (more brownish laterally), the throat light russet, tawny, ochraceous, buff, or whitish; foreneck sometimes faintly squamated with brown or dusky; sometimes a tawny or ochraceous supraauricular stripe. Sexes alike.

Range.-Southern Mexico to British Guiana, Peru, and southeastern Brazil. (About eighteen species.) ${ }^{a}$

$a$ Of these I have examined, in this connection, only the following: A. rubiginosus (Sclater), A. veræpacis Salvin and Godman, A. guerrerensis Salvin and Godman, $A$. umbrinus Salvin and Godman, A. cervinigularis (Sclater), A. ochrolæmus (Tschudi), A. pallidigularis Lawrence, A. leucophthalmus (Maximilian), and A. rufipectus Bangs. All these agree very well in structural characters except $A$. leucophthalmus, which is conspicuously different in its relatively longer and much more pointed wing, much less graduated tail, and much shorter gonys. 
KEY TO THE SPECIES AND SUBSPECIES OF AUTOMOLUS.

a. Throat and upper chest strongly rufescent (tawny to chestnut); no trace of supraauricular streak.

b. Wings deep russet or chestnut-brown, more rufescent than back.

c. Tail clear chestnut or rufous-chestnut.

d. Pileum and hindneck decidedly darker and more chestnut brown than back.

e. Throat and upper chest deep cinnamon-rufous or rufous-chestnut (whole of under parts darker). (Southeastern Mexico.)

Automolus rubiginosus (p. 214).

$e e$. Throat and upper chest tawny-ochraceous to rufous-tawny (whole of under parts lighter). (Automolus veræpacis.)

f. Pileum and hindneck dark vandyke brown or seal brown, back deep vandyke brown, throat and upper chest rufous-tawny. (Central Guatemala.)..............Automolus veræpacis veræpacis (p. 214).

ff. Pileum and hindneck light vandyke or deep russet brown, back deep tawny-brown, throat and upper chest tawny-ochraceous. (Western Guatemala.)...............Automolus veræpacis umbrinus (p. 215).

dd. Pileum and hindneck tawny-brown or russet-brown, concolor with back.

(Southwestern Mexico.)...............Automolus guerrerensis (p. 216).

cc. Tail dark chestnut (otherwise very much like $A$. guerrerensis). (Santa Marta district of Colombia.)...............Automolus rufipectus (extralimital). ${ }^{a}$

$b b$. Wings deep sooty brown, concolor with back. (Western Panamá.)

Automolus fumosus (p. 216).

aa. Throat buff, chest buffy or light buffy grayish; a more or less distinct supraauricular streak of buffy.

b. Supra-auricular streak distinct; feathers of upper chest more or less distinctly margined with darker; under wing-coverts tawny-ochraceous; under tailcoverts more or less strongly rufescent. (Automolus cervinigularis.)

c. Coloration more rufescent above, darker and more buffy below, the buff of throat merging gradually into the dull brownish buff or clay color of chest, etc. (Southeastern Mexico to eastern Nicaragua.)

Automolus cervinigularis cervinigularis (p. 217). $b$

$c c$. Coloration less rufescent (more olivaceous) above, darker and more olivaceous below, the buff of throat abruptly contrasted with the buffy olive of chest, etc. (Eastern Costa Rica; western Panamá?)

Automolus cervinigularis hypophæus (p. 219).

bb. Supra-auricular streak indistinct; under wing-coverts ochraceous-buff; feathers of chest without darker margin; under tail-coverts slightly if at all rufescent. (Automolus pallidigularis.)

c. Coloration slightly darker above (back deep olive-brown); chest indistinctly flammulated with pale buffy. (Eastern Panamá; Colombia?; Ecuadór?)

Automolus pallidigularis pallidigularis (p. 220).

cc. Coloration slightly paler above (back lighter and more olivaceous brown); chest uniform pale buffy grayish brown. (Western Panamá and western Costa Rica.)................Automolus pallidigularis exsertus (p. 221).

a Automolus rufipectus Bangs, Proc. Biol. Soc. Wash., xii, Aug. 10, 1898, 158 (Puebla Vieja, Santa Marta, Colombia; coll. E. A. and O. Bangs); xiii, 1899, 99 (Santa Marta, $3,000-\bar{\tau}, 500 \mathrm{ft}$.$) .$

$b$ This probably requires subdivision within the geographic area indicated。 


\section{AUTOMOLUS RUBIGINOSUS (Sclater).}

\section{RUDDY AUTOMOLUS.}

Adults (sexes alike).-Pileum and hindneck uniform dark chestnutbrown or vandyke brown; back, scapulars, and rump plain deep tawny-brown or mummy brown, the wings similar but more rufescent (nearly burnt umber); upper tail-coverts rufous-chestnut, tail chestnut; sides of head chestnut or brownish chestnut, the auricular region more grayish; chin, throat, and chest deep cinnamon-rufous; rest of under parts cinnamon-tawny or dull tawny-ochraceous medially, passing into deep raw-umber or light mummy brown on sides and flanks and into light chestnut or cinnamon-rufous on under tail-coverts; under wing-coverts uniform cinnamon-rufous, the inner webs of remiges broadly edged with vinaceous-cinnamon; maxilla brown, darker toward culmen; maxilla pale dull yellowish (in dried skins) with a stripe of pale brown along upper portion; legs and feet light horn color (in dried skins).

Adult male.-Length (skins), 199-225 (212); wing, 95.5-97.5 (96.5); tail, 90.5; culmen, 23-23.5 (23.2); tarsus, 26-27 (26.5); middle toe, $20.5-21(20.7){ }^{a}$

Southeastern Mexico, in State of Vera Cruz (Córdova; Jalapa; Coátepec; Uvero).

Anabates rubiginosus Sclater, Proc. Zool. Soc. Lond., 1856 (pub. Jan. 26, 1857), 288 (Córdova, Vera Cruz, Mexico; coll. P. L. Sclater); 1859, 365 (Jalapa, Vera Cruz).-Sumichrast, Mem. Bost. Soc. N. H., i, 1869, 555 (tierra caliente of Vera Cruz, up to 1,300 m.).-Sanchez, Anal. Mus. Nac. Mexico, i, 1877, 97 (Vera Cruz).

Automolus rubiginosus Sclater, Cat. Am. Birds, 1862, 157 (Córdova); Cat. Birds Brit. Mus., xv, 1890, 91, part (Mexico).-Salvin and Godman, Biol. Centr.Am., Aves, ii, 1891, 155 (Córdova, Jalapa, Coátepec, and Uvero, Vera Cruz).-

Chapman, Bull. Am. Mus. N. H., x, 1898, 32 (Jalapa, Vera Cruz).

[Automolus] rubiginosus Sclater and Salvin, Nom. Av. Neotr., 1873, 65, part.SHarpe, Hand-list, iii, 1901, 66.

[Philydor] rubiginosus GRAY, Hand-list, i, 1869, 172, no. 2323.

\section{AUTOMOLUS VERAPACIS VERAPACIS Salvin and Godman.}

\section{VERA PAZ AUTOMOLUS.}

Similar to A. rubiginosus in coloration of upper parts, but under parts much paler, the chin, throat, and chest tawny-ochraceous instead of deep cinnamon-rufous; wing shorter, bill longer.

Adults (sexes alike).-Pileum and hindneck dark chestnut-brown, sometimes a little lighter or brighter on forehead; back, scapulars, and rump tawny-brown or mummy brown, the wings more rufescent brown (between russet and burnt umber); upper tail-coverts and tail clear chestnut or rufous-chestnut; sides of head deep chestnut- 
brown passing into chestmut on malar region, the auricular region tinged with grayish and with indistinet shaft-streaks of paler; chin, throat, and ehest deep tawny-ochraceous; rest of under parts light tawny-ochraceous medially, passing into tawny-brown or tawnyolive on sides and flanks and into light chestmut or deep cimmamonrufous on under tail-coverts; under wing-coverts uniform tawnyochraceous, the inner webs of remiges broadly edged with pinkish tawny-ochraceous or yellowish vinaceous-cimnamon; maxilla dark horn brown, becoming paler toward tomia; mandible light horn brown, the under portion (broadly) pale dull yellowish (in dried skins); legs and feet horn color (in dried skins).

Adults.-Length (skin), $215 ;^{a}$ wing, 91-93 (92); tail, 82-86 (84.5); culmen, 2t-25 (24.7); tarsus, 26-27.5 (27); middle toe, 20.5-22 $(21.2) .^{b}$

Highlands of central Guatemala (Cobán, Vera Paz).

Anabates rubiginosus (not of Sclater) Sclater and Salvin, Ibis, 1859, 5, 117 (Guatemala).

Automolus rubiginosus (not of Sclater, 1S62) Salvin, Cat. Strickland Coll., 1882, 337.-Sclater, Cat. Birds Brit. Mus., xv, 1890, 91 (Cobán, Vera Paz, Guatemala).

[Automolus] rubiginosus Sclater and Salvin, Nom. Av. Neotr., 1873, 65, part (Guatemala).

Automolus veræpacis Salvin and Godman, Biol. Centr.-Am., Aves, ii, sig. 20, July, 1891, 156 (Cobán, Vera Paz, Guatemala; coll. Salvin and Godman). [Automolus] veræpacis Sharpe, Hand-list, iii, 1901, 66.

\section{AUTOMOLUS VERAPACIS UMBRINUS (Salvin and Godman).}

\section{TAWNY AUTOMOLUS.}

Similar to $A$. $v$. veræpacis but coloration lighter throughout, the throat and chest ochraceous instead of tawny-ochraceous.

Adult female.-Length (skin), 207; wing, 89; tail, 88; culmen, 24.5 ; tarsus, 27.5 ; middle toe, $21.5 .^{c}$

Highlands of western Guatemala (Santa Maria, near Quezaltenango; Barranca Honda, Volcán de Fuego).

Automolus rubiginosus (not Anabates rubiginosus Sclater) Sclater, Cat. Birds Brit. Mus., xv, 1890, 91, part (Savana Grande, Barranca Honda, Volcan de Agua, and Volcan de Fuego, Pacific side, Guatemala).

Automolus umbrinus Salvin and Godman, Biol. Centr.-Am., Aves, ii, sig. 20, July, 1891, 157 (Santa Maria, near Quezaltenango, Pacific side, Guatemala; coll. Salvin and Godman).

[Automolus] umbrinus SHARPE, Hand-list, iii, 1901, 66.

a One specimen.

$b$ Four specimens, with sex undetermined.

c One specimen, the only one of the form seen by me. 


\section{AUTOMOLUS GUERRERENSIS Salvin and Godman.}

GUERRERO AUTOMOLUS.

Most like A. rubiginosus but coloration of upper parts and under parts of body much paler, the back, etc., raw-umber brown instead of tawny-brown or mummy brown, the pileum concolor with back instead of decidedly darker.

Adults (sexes alike).-Pileum, hindneck, back, scapulars, and rump plain raw-umber brown, passing into cinnamon-rufous on upper tailcoverts; tail clear rufous-chestnut; wings more rufescent than color of back, etc., sometimes rufous-brown or russet, the secondaries and proximal greater coverts sometimes nearly concolor with back; sides of head nearly concolor with pileum but rather more rufescent, especially on supra-auricular region, the auricular region rather duller or more grayish brown, with very narrow and indistinct shaftstreaks of paler; malar region, sides of neck, chest, and throat plain dull cinnamon-rufous or tawny-rufous, the chin (sometimes upper throat also) paler (more tawny-ochraceous or ochraceous-buff); abdomen and median portion of breast deep buff or clay color, shading into light raw-umber or tawny-olive on sides of breast, sides, and flanks, the under tail-coverts more rufescent (shorter coverts cinnamon, passing into russet or rufous-tawny on the longer ones); axillars and under wing-coverts clear buff-tawny, the inner webs of remiges with basal half or more similar but slightly paler; maxilla dark horn color becoming paler toward tomium, darker on basal portion of culmen; mandible horn color, the lower portion (broadly) pale dull yellowish (in dried skins); legs and feet horn color (in dried skins).

Adult male.-Length (skins), 203-213 (206); wing, 91.5-95 (93.2); tail, 83-84 (83.3); culmen, 23.5-24 (23.8); tarsus, 26-27.5 (26.5); middle toe, $21.5-22(21.7) .^{a}$

Adult female.-Length (skin), 212; wing, 88; tail, 80; culmen, 23; tarsus, 25.5; middle toe, $20 .^{b}$

Mountains of southwestern Mexico, in States of Guerrero (Omilteme) and western Oaxaca (Pluma).

Automolus guerrerensis Salvin and Godman, Biol. Centr.-Am., Aves, ii, sig. 20, July, 1891, 157 (Omilteme, Guerrero, s. w. Mexico; coll. Salvin and Godman).

[Automolus] guerrerensis SHARPE, Hand-list, iii, 1901, 66.

Automolus pectoralis Nelson, Auk, xiv, Jan., 1897, 54 (Pluma, Oaxaca, s. w. Mexico; coll. U. S. Nat. Mus.).

\section{AUTOMOLUS FUMOSUS Salvin and Godman.}

\section{SOOTY AUTOMOLUS.}

Above deep smoke brown, pileum darker, rump deep rufescent ("saturate rubiginoso"), tail darker; wings externally concolor 
with back; under parts fawn color ("cervino-brunneus"), throat and breast more rufeseent, flanks smoke brown, under tail-coverts rufescent ("rubiginosis"), under wing-coverts cimnamon; bill and leet dusky hazel ("corylinus"), the mandible paler beneath. 'Total length [adult malc] 8.0 [inches $=201 \mathrm{~mm}$.], wing $3.25[=82.5 \mathrm{~mm}$.], tail, middle rectrices, 3.1 [ $78.5 \mathrm{~mm}$.], lateral rectrices, 2.25 [57 mm.], bill to rictus, 1.5 [3S mm.], tarsus, 1.1 [2S $\mathrm{mm}$.]. (Translation of original description.)

This species, of which only one example is known, is said to be "the darkest of all the forms of Automolus, darker even than $A$. rubiginosus, and has much darker wings. On the underside it is more like the Guatemalan A. umbrinus, but the sides of the head and the flanks are much darker and the wings outwardly very differently coloured."

Western Panamá (Bibaláz, Volcán de Chiriquí).

Automolus cervinigularis (not Anabates cervinigularis Sclater) Sclater, Cat. Birds Brit. Mus., xv, 1890, 91, part (spec. n, Bibaláz, Chiriquí).

Automolus fumosus Salvin and Godman, Biol. Centr.-Am., Aves, ii, sig. 20, July, 1891, 158 (Bibaláz, Chiriquí, Panamá; coll. Salvin and Godman). [Automolus] fumosus Sharpe, Hand-list, iii, 1901, 66.

\section{AUTOMOLUS CERVINIGULARIS CERVINIGULARIS (Sclater).}

\section{BUFF-THROATED AUTOMOLUS.}

Adults (sexes alike).-Pileum and hindneck deep sooty brown or dark sepia, the forehead paler; back, scapulars, and upper rump plain warm-sepia or deep olive-brown, the wings similar but more russet or chestnut brown, the outer webs of primaries more or less paler; lower rump, upper tail-coverts, and tail chestnut; loral region, a distinct though narrow superciliary stripe, suborbital region, lower portion of auricular region, anterior portion of sides of neck, chin, and throat, deep buff or ochraceous-buff; upper portion of auricular region dark sooty brown, forming a conspicuous postocular stripe; median portion of chest and breast, together with abdomen, dull grayish buff, passing laterally into olive-brown or raw-umber on sides and flanks and into cinnamon-rufous on under tail-coverts; feathers of upper chest (sometimes those of sides of neck and sides of lower throat also) more or less distinctly margined with olivebrown or dusky; under wing-coverts and broad edgings to inner webs of remiges ochraceous-buff; maxilla horn color (more or less dark) more blackish basally and on culmen; mandible pale brownish or dull whitish (in dried skins), darker terminally, especially along tomia; iris brown; legs and feet horn color (in dried skins).

Young.-Similar to adults but texture of plumage different. 
Adult male.-Length (skins), 171-192 (185); wing, 84-95 (90.9); tail, 66.5-85.5 (73); culmen, 22.5-25.5 (24.1); tarsus, 22.5-25.5 (23.9); middle toe, $17.5-20$ (19) ${ }^{a}$

Adult female.-Length (skins), 176-193 (185); wing, 82.5-93 (88.1); tail, 66-80 (73.5); culmen, 22.5-25 (23.4); tarsus, 22-25 (22.7); middle toe, $16.5-19.5$ (18.8). ${ }^{b}$

Southeastern Mexico, in States of Vera Cruz (Córdova; Playa Vicente; Omealca; Atoyác; Orizaba; Miradór; Buena Vista), Mexico (near City of Mexico)?, Oaxaca (mountains near Santo Domingo), and Tabasco (Teapa), and southward through Guatemala (Cobán; sources of Rio de la Pasión; Choctúm), British Honduras (Manatee Lagoon; near Soldier Creek; near Quamius Creek; Toledo District) and Honduras (Santa Ana; Yaruca) to eastern Nicaragua (Los Sábalos; Rio Escondido).

Anabates cervinigularis Sclater, Proc. Zool. Soc. Lond., 1856 (pub. Jan. 26, 1857), 288 (Córdova, Vera Cruz, Mexico; coll. A. Sallé); 1859, 382 (Playa Vicente, Vera Cruz).-Salvin and Sclater, Ibis, 1860, 35 (Cobán, Guatemala).

Automolus cervinigularis Sclater, Cat. Am. Birds, 1862, 158 (Córdova); Proc. Zool. Soc. Lond., 1864, 175 (City of Mexico); Cat. Birds Brit. Mus., xv, 1890, 91, part (Córdova; near City of Mexico; sources Rio de la Pasión, and Choctúm, Guatemala; Honduras).-Sumichrast, Mem. Bost. Soc. N. H., i, 1869, 555 (tierra caliente of Vera Cruz); La Naturaleza, v, 1881, 247 (Omealca, Vera Cruz).-Boucard, Ann. Soc. Linn. Lyon, 1878, 37 (Guatemala).Sanchez, Anal. Mus. Nac. Mex., i, 1877, 97 (Vera Cruz).-SAlvin and Godman, Biol. Centr.-Am., Aves, ii, 1891, 158, part (Atoyác, Vera Cruz; Chim-

$a$ Fifteen specimens.

$b$ Seventeen specimens.

\begin{tabular}{|c|c|c|c|c|c|}
\hline Locality. & Wing. & Tall. & $\begin{array}{l}\text { Cul- } \\
\text { men. }\end{array}$ & Tarsus. & $\begin{array}{c}\text { Middle } \\
\text { toe. }\end{array}$ \\
\hline MALES. & & & & & \\
\hline Nine adult males from southeastern Mexico.......... & 92.4 & 73 & 24.4 & 24.1 & 19.3 \\
\hline Four adult males from British Honduras............... & 89.7 & 75.5 & 23.7 & 24 & 18.7 \\
\hline One adult male from Honduras. ....................... & 88.5 & 70 & 24 & 23 & 19 \\
\hline One adult male from Nicaragua.......................... & 84.5 & 66.5 & 22.5 & 23 & 18 \\
\hline Ten adult males (A.c. hypophæus) from Costa Rica.... & 91.7 & 72.9 & 23.6 & 23.2 & 18.8 \\
\hline FEMALES. & & & & & \\
\hline Nine adult females from southeastern Mexico.. & 89.1 & 74.8 & 23.6 & 23.1 & 19.5 \\
\hline Four adult females from British Honduras........ & 86.2 & 73.6 & 23.1 & 23.4 & 18 \\
\hline Three adult females from Houduras...................... & 89.5 & 73.7 & 22.8 & 23.7 & 18.5 \\
\hline One adult female from Nicaragua.......................... & 82.5 & 66 & 23.5 & 23 & 16.5 \\
\hline Ten adult females (A. c. hypophæus) from Costa Rica....... & 85.3 & 69.6 & 22.8 & 23.3 & 18 \\
\hline
\end{tabular}

Mexican specimens average decidedly deeper in color than others, especially the buff of superciliary stripe, throat, ete., and brown of pileum, the latter almost sooty in its darkness. Guatemalan examples have the back, etc., more rufescent or castaneous, those from Honduras, British Honduras, and Nicaragua more olivaceous than Mexican specimens. The series examined is, however, inadequate. 
alapa, Oaxaca; Cobán and Choctum, Guatemala).-Bangs, Bull. Mus. Comp. Zool., xxxix, 1903, 150 (Yaruca, Honduras).

[Automolus] cervinigularis Sclater and Salvin, Nom. Av. Neotr., 1S73, 65, part.-Sharpe, Hand-List, iii, 1901, 67, part.

[Ipoborus] corvinigularis Heine and Reicuenow, Nomencl. Mus. Meiu. Orn., 1590, 134 (Mexico).

[Philydor] cervinigularis GraY, Hand-list, i, 1S69, 172, no. 2321.

Automolus pallidigularis (not of Lawrence) Nutring, Proc. U. S. Nat. Mus., vi, 1S84, t04 (Los Síbalos, Nicaragua).-Ridgway, Proc. U. S. Nat. Mus., xiv, 1S91, 471 (Santa Ana, Honduras).-Richmond, Proc. U. S. Nat. Mus., xvi, 1S93, 497 (Rio Escondido, Nicaragua; habits; crit.).

\section{AUTOMOLUS CERVINIGULARIS HYPOPHEUS Ridgway.}

\section{DARK-BREASTED AUTOMOLUS.}

Similar to A. c. cervinigularis but coloration decidedly darker, especially under parts of the body, which are isabella color medially darkening laterally into deep buffy olive, contrasting strongly and abruptly with the buff or ochraceous-buff of chin and throat.

Adult male.-Length (skins), 168-189 (181); wing, 88-94 (91.7); tail, 70-76.5 (72.9); culmen, 22-25 (23.6); tarsus, 22.5-25 (23.2); middle toe, $18-20$ (18.8). ${ }^{a}$

Adult female.-Tength (skins), 167-185 (176); wing, 83.5-89 (85.3); tail, 64.5-75 (69.6); culmen, 21.5-24 (22.8); tarsus, 22-24 (23.3); middle toe, $17.5-19.5$ (18) ${ }^{a}$

Caribbean slope of Costa Rica (Angostura; Sipúrio; Talamanca; Rio Sícsola; Pacuare; Rio Reventazón; Jiménez; Carrillo; Tucurríqui; La Balsa; Guayabo; Guápiles; Cuábre; El Hogár; Peralta; Turrialba; Cariblanco de Sarapiquí; La Vijágua); western Panamá (Santa Fé de Verágua; Boquete de Chitra)?

Automolus cervinigularis (not Anabates cervinigularis Sclater) SAlvin, Proc. Zool. Soc. Lond., 1867, 143 (Santa Fé de Verágua, Panamá).-Lawrence, Ann. Lyc. N. Y., viii, 1868, 106 (Angostura, Costa Rica).-Frantzius, Journ. für Orn., 1S69, 304 (Costa Rica).-ZZeledón, Anal. Mus. Nac. Costa Rica, i, 1887, 113, part (Rio Súcio and Jiménez, Costa Rica).-Sclater, Cat. Birds Brit. Mus., xv, 1890, 91, part (Tucurríqui and La Balsa, Costa Rica; Santa Fé de Verágua, except specimen n.).-Salvin and Godman, Biol. Centr.-Am., Aves, ii, 1891, 158, part (Tucurríqui, Angostura, and La Balsa, Costa Rica; Boquete de Chitra and Santa Fé de Verágua, Panamá).

[Automolus] cervinigularis Sclater and Salvin, Nom. Av. Neotr., 1873, 65, part.Sharpe, Hand-list, iii, 1901, 67, part.

Automolus cervinigularis hypophæus Ridgway, Proc. Biol. Soc. Wash., xxii, April 17, 1909, 72 (Rio Reventazón at Guayabo Station, Costa Rica; col!. U. S. Nat. Mus.).-Carriker, Ann. Carnegie Mus., vi, 1910, 640 (Caribbean lowlands of Costa Rica, up to about 2,000 ft.; habits; descr. nest and eggs).-Ferry, Pub. 146, Field Mus. N. H., orn. ser., i, no. 6, 1910, 270 (Guayabu, Costa Rica). 


\section{AUTOMOLUS PALLIDIGULARIS PALLIDIGULARIS Lawrence.}

PALE-THROATED AUTOMOLUS.

Somewhat like $A$. cervinigularis but superciliary stripe much less distinct (the supra-auricular portion more or less obsolete), general coloration paler, feathers of chest without darker margins, and size smaller.

Adults (sexes alike).-Pileum and hindneck sepia brown, paler on forehead, where the feathers have indistinct narrow mesial streaks or shaft-streaks of brownish buffy; back and scapulars plain deep olivebrown, passing into chestnut on lower rump, tail-coverts, and tail and into deep russet-brown or prouts brown on wings, this passing into dusky on tips of remiges and primary coverts; an indistinct narrow superciliary stripe of brownish buff, becoming obsolete above posterior portion of auricular region; auricular and suborbital regions sepia brown, with indistinct shaft-streaks of dull buffy; malar region, chin, and throat immaculate pale dull cream buff; rest of under parts light wood brown medially, passing laterally into tawny-olive or raw-umber on sides and flanks and into light chestnut or tawny on under tail-coverts, the chest with median portion of feathers pale cream buffy, producing an indistinctly flammulated effect; under wing-coverts and broad edgings to inner webs of remiges ochraceousbuff; maxilla horn color, the upper-basal portion dusky or blackish; mandible horn color with lower-basal portion dull whitish (in dried skins); legs and feet horn color (in dried skins).

Young.-Similar to adults but texture of plumage very different and feathers of lower throat narrowly margined terminally with dusky.

Adult male.-Length (skin), 188; wing, 85.5; tail, 70.5; tarsus, 21 ; middle toe, $19 .^{a}$

Adult female.-Length (skin), 176.5; wing, 87; tail, 75; culmen, 22 ; tarsus, 22.5 ; middle toe, $16.5 .^{a}$

Eastern Panamá (Panamá; Lion Hill); Colombia (Remédios, Antioquía) $?^{b}$ Ecuadór ? ${ }^{b}$

Anabates cervinigularis (not of Sclater) Lawrence, Ann. Lyc. N. Y., vii, 1862, 294 (Lion Hill Station, Panamá).

Anabates ochrolæmus (not of Tschudi) Lawrence, Ann. Lyc. N. Y., vii, 1862, 319 (Lion Hill).

Automolus pallidigularis Lawrence, Ann. Lyc. Nat. Hist. N. Y., vii, 1862, 465 (Lion Hill Station, Panamá; coll. G. N. Lawrence).-Sclater and SalviN, Proc. Zool. Soc. Lond., 1864, 354 (Lion Hill; crit.); (?) 1879, 522 (Remédios, Antioquía, Colombia).-Sclater, Cat. Birds Brit. Mus., xv, 1890, 94, part (Panamá; Remédios, Colombia?).-Salvin and Godman, Biol. Centr.-Am., Aves, ii, 1891, 159, part (Lion Hill, Panamá; Colombia?).-Bangs, Proc. New Engl. Zool. Club, ii, 1900, 26 (Loma del León, Panamá). 
[Automolus] pallidigularis Sclater and SAlvin, Nom. Av. Neotr., 1873, 65, part.Sharpe, Hand-list, iii, 1901, 67, part (Panamá; Colombia?).

[Philydor] pallidigularis GraY, Hand-list, i, 1869, 173, no. 2328, part.

\section{AUTOMOLUS PALLIDIGULARIS EXSERTUS (Bangs).}

\section{CHIRIQUi AUTOMOLUS.}

Similar to $A$. p. paltidigularis but slightly larger, with relatively longer bill, color of back, etc., more olivaceous, chest uniform in color, and buff of throat, etc., deeper.

Adult male.-Length (skins), 158-186 (174); wing, 85-93 (88.6); tail, 69-76.5 (72.4); culmen, 20.5-24 (22.6); tarsus, 22-23.5 (22.7); middle toe, $17-1 S .5(17.9) .^{a}$

Adult female.-Length (skins), 161-180 (174); wing, 85-94 (89); tail, 66.5-77 (71.7); culmen, 21-24 (22.5); tarsus, 21.5-23.5 (22.7); middle toe, $17-18.5(17.9){ }^{b}$

Pacific slope of Costa Rica (Cartago; Boruca; Guaitíl; Pozo del Rio Grande; Pozo del Pitál; Pozo Azúl de Pirrís; El Pozo de Térraba; Térraba; Buenos Aires; El Generál) and western Panamá (Divala; Calobre; Boquete de Chitra; Bugaba; El Banco).

Automolus pallidigularis (not of Lawrence, 1862) Lawrence, Ann. Lyc. N. Y., ix, 1868, 106, part (Guaitíl, and Cartago, Costa Rica).-Frantzius, Journ. für Orn., 1869, 304 (Costa Rica).-Salvin, Proc. Zool. Soc. Lond., 1870, 192 (Boquete de Chitra and Bugaba, Panamá).-Sclater, Cat. Birds Brit. Mus., xv, 1890, 94, part (Costa Rica; Bugaba and Boquete de Chitra, Panamá).Salvin and Godman, Biol. Centr.-Am., Aves, ii, 1891, 159, part (Guaitil, and Angostura, Costa Rica; Bugaba, Boquete de Chitra, and Calobre, Panamá).Cherrie, Expl. Zool. Merid. Costa Rica, 1893, 38 (Boruca, Térraba, and Buenos Aires, Costa Rica); Anal. Inst. Fis.-Geog. Costa Rica, vi, 1893, 16 (Pozo del Pitál, Costa Rica; crit.).

[Automolus] pallidigularis Sclater and Salvin, Nom. Av. Neotr., 1873, 65, part.-Sharpe, Hand-list, iii, 1901, 67, part.

[Philydor] pallidigularis GrAY, Hand-list, i, 1869, 173, no. 2328, part.

Automolus exsertus Bangs, Auk, xviii, Oct., 1901, 367 (Divala, Chiriquí, Panamá; coll. E. A. and O. Bangs); xxiv, 1907, 299 (Boruca, Lagarto, and Pozo del Rio Grande, s. w. Costa Rica).

$a$ Eleven specimens. $b$ Seventeen specimens.

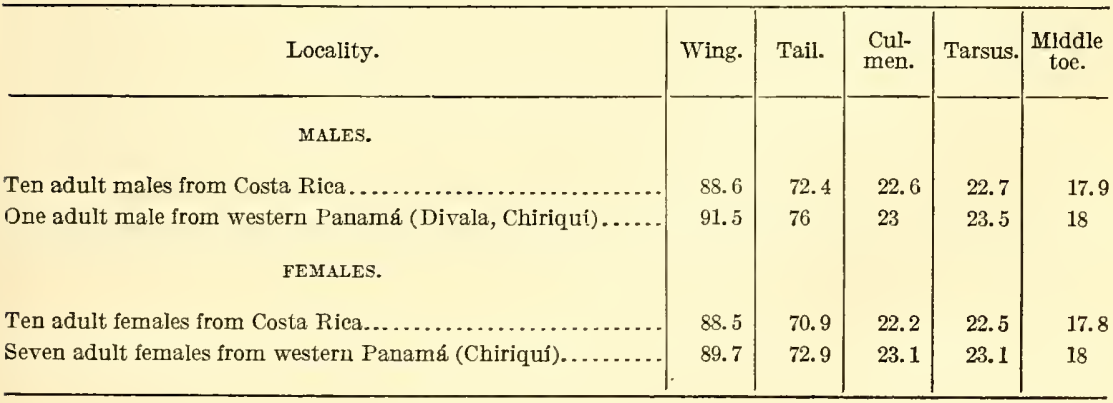


(?) Automolus cervinigularis (not Anabates cervinigularis Sclater?) ZELEdón, Anal. Mus. Nac. Costa Rica, i, 1888, 113, part (Cartago, Costa Rica).

Automolus cervinigularis exsertus CARriker, Ann. Carnegie Mus., vi, 1910, 641 (s. w. Costa Rica; crit.).

\section{Genus RHOPOCTITES Ridgway.}

Rhopoctites a Ridgway, Proc. Biol. Soc. Wash., xxii, April 17, 1909, 72. (Type, Philydor rufo-brunneus Lawrence.)

Medium sized to large Furnariidæ (length about 165-210 mm.) somewhat resembling the genus Automotus but with much stouter, less compressed, and distinctly uncinate bill, culmen decidedly shorter than tarsus, rigid and protruding shafts to rectrices, and streaked coloration.

Bill nearly as long as head, stout, moderately compressed, its width at loral antiæ decidedly less than its depth at same point and contained slightly more than twice to about two and a half times in distance from nostril to tip of maxilla; culmen decidedly shorter than tarsus, distinctly ridged, nearly straight for basal half (more or less) strongly decurved terminally, the tip of maxilla distinctly uncinate; tomia nearly straight but slightly though distinctly decurved terminally, without trace of notch; gonys convex and rather prominent basally, ascending terminally, the tip sometimes faintly decurved. Nostril exposed, posteriorly in contact with loral feathering, roundish or broadly oval, nonoperculate but margined above by a very narrow membraneous rim. Rictal bristles absent, and feathers of chin, etc., without terminal setæ. Wing moderate, much rounded, the longest primaries exceeding secondaries by less than distance from nostril to tip of maxilla; sixth and seventh, or fifth, sixth, and seventh, primaries longest, the tenth (outermost) about two-thirds as long as the longest, the ninth about as long as secondaries. Tail about as long as wing (decidedly shorter in $R$. ignobilis $?^{b}$ ), graduated for about one-third its length, the rectrices (12) rather loosely webbed or semi-decomposed, with rigid and protruded shafts. Tarsus longer than culmen, about one-third as long as wing, rather stout, distinctly scutellate; middle toe, with claw, slightly shorter than tarsus; outer toe, without claw, reaching to about middle of subterminal phalanx of middle toe, the inner toe slightly shorter; hallux about as long as inner toe but much stouter;

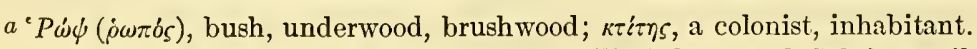

$b$ In the only specimen of Automolus ignobilis Sclater and Salvin available for comparison, the tips of the rectrices are so much worn that the real length of the tail can not be ascertained. 
basal phalanx of middle toe mnited for more than half its length to lateral toes; claws moderate to rather large, strongly curved, that of hallux decidedly shorter than the digit.

Coloration.-Above brown, usually darker and duller (sometimes more grayish) on pileum and hindneck, the tail and upper tail-coverts chestnut or chestnut-brown; under parts brown or olive, more or less distinctly streaked with tawny, ochraceous, or buffy-the pileum and hindneck, or even the back, sometimes similarly streaked. Sexes alike.

\section{Nidification.-Unknown?}

Range.-Costa Rica to Ecuadór (to Peru, Bolivia, and southeastern Brazil ? $\left.{ }^{a}\right)$. (Sereral species..$\left.^{a}\right)$

\section{RHOPOCTITES RUFOBRUNNEUS (Lawrence).}

\section{STREAKED AUTOMOLUS.}

Adults (sexes alike).-Pileum and hindneck dark grayish brown or brownish gray, the feathers margined with blackish; back, scapulars, and wings deep warm-sepia or mummy brown, passing into chestnut on lower rump, upper tail-coverts, and tail, the shafts of rectrices much darker; lores mixed dusky and grayish; suborbital and auricular regions streaked with dusky and dull ochraceous or light brownish; malar region, sides of neck (anteriorly), chin, and throat ochraceous (more or less deep), the feathers more or less distinctly edged or narrowly margined with dusky olive or blackish; rest of under parts light tawny-olive, more olive on chest, where more or less broadly streaked with ochraceous, usually more ochraceous on abdomen, the under tail-coverts more rufescent; under wing-coverts tawny-ochraceous, the inner webs of remiges broadly edged with pale ochraceousbuff or deep pinkish buff; bill black, the mandible usually brownish basally; legs and feet horn color (in dried skins).

a The above diagnosis and description are based exclusively on Philydor rufobrunneus Lawrence and Automolus ignobilis Sclater and Salvin, but several other species referred to Automolus by Sclater and others seem to be nearly related and perhaps are-some of them at least-congeneric. These are: Automolus ferruginolentus (Maximilian), A. holostictus Sclater and Salvin, A. striaticeps Taczanowski, A. subulatus (Spix) and $A$. stictoptilus (Cabanis), none of which have been examined by me.

Rhopoctites ignobilis differs considerably from $R$. rufo-brunneus (type of the genus) in shorter, deeper, and relatively more compressed bill, and, apparently, in relatively shorter tail; but the differences are within the usual normal limits of variation. 
Adult male.-Length (skins), 195-218 (207); wing, 87-100 (92.6); tail, 82-92.5 (88.9); culmen, 22-25.5 (23.6); tarsus, 25.5-29 (27.5); middle toe, $20-22.5(21) .^{a}$

Adult female.--Length (skins), 186-217 (202); wing, 85.5-92 (88.9); tail, 83.5-91 (86.9); culmen, 23-24.5 (23.7); tarsus, 26.5-29 (27.9); middle toe, $20-22(21.1) .^{b}$

Costa Rica (Barranca; Navarro, La Estrella, and Azahár, Cartago; Faldas de Irazú; Escazú; San José; La Hondura; Carrillo; Coliblanco; Ojuras de Térraba; Los Reyes, Santa Maria de Dota) and western Panamá (Boquete, 4,500-6,000 ft., Volcán de Chiriquí, and Caribbean slope, Chiriquí).

Philydor rufobrunneus Lawrence, Ann. Lyc. Nat. Hist. N. Y., viii, 1867, 127 (San José, Costa Rica; coll. U. S. Nat. Mus.); ix, 1868, 106 (San José and Barranca, Costa Rica).-Frantzius, Journ. für Orn., 1869, 304 (Costa Rica).Berlepsch, Proc. U. S. Nat. Mus., xi, 1888, 565 (crit.; diagnosis).

Philydor rufo-brunneus Boucard, Proc. Zool. Soc. Lond., 1878, 59 (Navarro, Costa Rica).

[Philydor] rufobrunneus GRAY, Hand-list, i, 1869, 172, no. 2316.

Automolus rufo-brunneus Sclater, Cat. Birds Brit. Mus., xv, 1890, 89 (Irazú distr., Costa Rica).

Automolus rufobrunneus Salvin and Godman, Biol. Centr.-Am., Aves, ii, 1891, 154, pl. 46, fig. 2 (Philydor rufobrunneus on plate).-Bangs, Proc. New Engl. Zool. Club, iii, 1902, 44 (Boquete and Volcán de Chiriquí, 4,500-7,700ft., Panamá).

Rhopoctites rufo-brunneus CARriker, Ann. Carnegie Mus., vi, 1910, 638 (Costa Rica; habits).

\section{Family DENDROCOLAPTID办.} THE WOODHEWERS.

$>$ Dendrocolaptinæ CABANIs, Wiegmann's Archiv für Naturg., 1847, pt. i, 339 (includes Sclerurus).-Bonaparte, Consp. Av., i, 1850, 206.-Sundevald, Met. Nat. Av. Disp. Tent., ii, 1872, 56 (English translation, 1889, 123).

$=$ Dendrocolaptin $x$ Cabanis and Heine, Mus. Hein., ii, 1860, 33.-Sclater, Cat. Am. Birds, 1862, 160.-Sclater and Salvin, Nom. Av. Neotr., 1873, 66.Salviv and Godman, Biol. Centr.-Am., Aves, ii, 1891, 146, 176.

$>$ Dendrocolaptidæ Bonaparte, Consp. Av., i, 1850, 206 (includes Sclerurus).Sclater, Cat. Am. Birds, 1862, 146 (includes Furnariidæ and Oxyruncidæ!).-Sclater and Salvin, Nom. Av. Neotr., 1873, 66 (includes Furna-

$a$ Fifteen specimens.

$b$ Eight specimens.

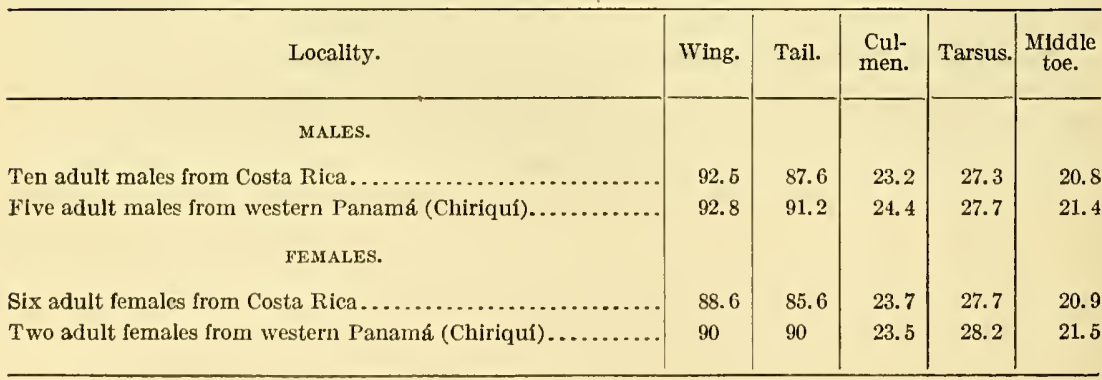


riidæ).-Salvin and Godman, Biol. Centr.-Am., Aves, ii, 1891, 145 (includes Furnariidie).

=Dendrocolaptida Garrod, Proc. Zool. Soc. Lond., 1877, 452.-Stejneger, Stand. Nat. Hist., iv, 1855, 478, in text.

Tracheophone Mesomyodian Passeres with the metasternum 2notched, interorbital septum imperforate, postorbital process small, maxillo-palatines short and broad (crossing posterior end of the olfactory fossa and terminating immediately in front of the descending plate of the palatine), romer short, tensor patagii brevis tendon typically passerme, nares usually holorhimal (but occasionally schizorhinal); syrinx tracheal, with two pairs of short tracheo-bronchal muscles, palate compound regithognathous or semi-desmognathous (the palatines fused at anterior end and with the internasal septum); mesorhinium normal; tarsal enrelope endaspidean; outer toe about as long as middle toe (much longer than inner toe), the three anterior toes united for full length of the basal phalanx; the middle adherent to the outer by nearly, if not quite, the full length of the second phalanx also; hallux (without claw) shorter than inner toe (without claw).

Like the allied Furnariidæ the Dendrocolaptidæ are peculiar to the continental portions of the Neotropical Region, but unlike the latter they belong almost exclusively to the intertropical portions, and are, proportionally, better developed in the Central American district. The family is far less numerous and varied, however, than the Furnariidæ, consisting of only about 14 genera and 127 species, or considerably less than half as many as are contained in the allied family.

The Dendrocolaptidæ are more arboreal than the Furnariidæ, all being distinctly "scansorial," while comparatively few of the Furnariidæ are thus adapted. They represent and more or less resemble, superficially, the Woodpeckers (Picidæ) and Tree-Creepers (Certhiidæ), more especially the latter, most of the species having similarly curved and compressed bills, a more or less varied brownish coloration, and lengthened, graduated, and stiff-pointed tails. Like the Certhiidæ and unlike the Picidæ they have three toes in front and one behind, but the former, instead of -being cleft to the base are united for the length of their first and second phalanges; and the middle toe, instead of being much longer than the outer one, barely, or not at all exceeds the latter in length. Like the Woodpeckers, however, and unlike the Creepers, the Woodhewers have the habit of loudly tapping or hammering on the trunks and branches of trees. Some genera have the bill enormously developed as to length and greatly curved, sometimes in the shape of a bow-a modification evidently adapted to the purpose of probing the burrows of woodboring insects. In others the bill is straight and quite woodpecker- 
like in form, though without a chisel-shaped tip and well adapted to hammering or chipping the decayed wood, as in the case of the Woodpeckers. In size the Dendrocolaptidæ vary from the dimensions of a true Creeper (Certhia) to those of a Flicker (Colaptes). There is little range in the variety of their coloration, rufous or chestnut and olivaceous hues prevailing throughout the group, often unvaried but sometimes relieved by streaks or bars of darker and lighter hues.

The family as properly restricted is equal to the "Subfamily Dendrocolaptinæ" of Dr. Sclater, ${ }^{a}$ minus the genera Margarornis and Pygarrhicus, which belong to the Furnariidæ, and plus the genera Glyphorhynchus and Dendrornis, which constitute Dr. Sclater's "Subfamily Glyphorhynchinæ."

\section{KEY TO THE GENERA OF DENDROCOLAPTID . $^{b}$}

a. Nostril roundish, without distinct operculum. (Dendrocolaptinæ.)

$b$. Bill moderately elongated (much less than twice as long as tarsus) or rather short.

c. Bill depressed (at least as broad as deep at nostril); maxillary tomium more or less distinctly notched subterminally. (Dendrocolaptex.)

d. Bill relatively short and stout, the distance from nostril to tip of maxilla not greater than length of tarsus, its depth at nostril equal to one-third the length of exposed culmen and nearly half the distance from nostril to tip of maxilla.................... Dendrexetastes (extralimital). $c$

$d d$. Bill relatively longer and more slender, the distance from nostril to tip of maxilla greater than length of tarsus, its depth at nostril less than one-fourth the length of exposed culmen and less than one-third the distance from nostril to tip of maxilla....... Dendrocolaptes (p. 227).

cc. Bill compressed (much deeper than broad at nostril); maxillary tomium without trace of subterminal notch. (Xiphocolaptex.)

d. Bill straight ............................ Dendroplex (extralimital). ${ }^{d}$ dd. Bill more or less decurved.

e. Larger (wing 120-152 mm.); bill relatively shorter and deeper, with gonydeal angle more prominent and base of gonys with a narrow but distinct median ridge...................... Xiphocolaptes (p. 235.)

$e e$. Smaller (wing less-usually much less-than $120 \mathrm{~mm}$.); bill relatively longer and less deep, with tip of maxilla more decidedly decurved, gonydeal angle less prominent, and base of gonys without median ridge.

$f$. Bill nearly straight (only the tip of maxilla decidedly decurved), relatively much deeper (depth at nostril equal to nearly one-fourth to about one-third the distance from nostril to tip of maxilla).

Xiphorhynchus (p. 239).

$a$ Catalogue of the Birds in the British Museum, vol. xv, 1890, pp. 117-175.

$b$ The genus Hylexetastes Sclater (type, Dendrocolaptes perrotii Lafresnaye) I have not examined, and therefore is omitted.

c Dendrexetastes Eyton, in Jardine's Contr. Orn., 1851, 76. (Type, D. capitoides Eyton $=$ Dendrocolaptes temminckii Lafresnaye.-Cladoscopus Reichenbach, Handb. Spec. Orn., 1853, 192. Type, Dendrocolaptes temminckii Lafresnaye. (Cayenne and upper Amazon Valley; two species.)

d Dendroplex Swainson, Zool. Journ., iii, 1827, 354. Type, Oriolus picus Gmelin. (Colombia and Venezuela to Bolivia, southeastern Brazil, and lower Amazon Valley; two species.) 
If. Bill decidedly though slightly decurved throughout, relatively more slender (depth at nostril not more than ono-third the distance from nostril to tip of maxilla) ................... Picolaptes (p. 257).

bb. Bill excessively elongated (more than twice as long as tarsus).

c. Bill nearly straight, much stouter................ Nasica (extralimital). ${ }^{\prime}$ ce. Bill strongly arched or decurved, slender.......... Campylorhamphus (p. 268). aа. Nostril narrow, distinctly operculate. (Glyphorhynchina.)

b. Bill long, slender, and distinctly (though not strongly) arehed or decurved, conspicuously louger than head (about twice as long as tarsus); nasal operculum densely feathered; outer toe distinctly (though slightly) shorter than middlo toe. (Drymornithes.).................. Drymornis (extralimital). $b$ $b b$. Bill shorter thau head or at least not distinctly longer, much less than twice as long as tarsus, not distinctly, if at all, decurved; nasal operculum naked; outer toe as long as middle toe.

c. Bill much shorter than head, the exposed culmen only about two-thirds as long as tarsus; inner webs of remiges crossed by a broad sub-basal band of ochraceous-buff.

d. Bill very stout, wedge-shaped, with tip of maxilla broad and flattened; nasal operculum very broad. (Glyphorhynchex.).. Glyphorhynchus (p. 274).

dd. Bill slender, almost subulate, with tip of maxilla narrow, pointed, and slightly decurved; nasal operculum narrow. (Sittasomx.).

Sittasomus (p. 277).

$c c$. Bill nearly as long as head, the exposed culmen as long as (sometimes longer than) tarsus; inner webs of remiges without any cross-band, but uniform cinnamon-rufous (more or less deep) except terminally. (Dendrocinclæ.)

d. Tail as long as or longer than wing, graduated for half its length, the rectrices conspicuously acuminate and very strongly decurved subterminally (as in Glyphorhynchus and Sittasomus), the attenuated tips distinctly webbed throughout; bill more slender, relatively broader and more depressed basally.............................. Deeonychura (p. 283).

dd. Tail decidedly shorter than wing, graduated for only one-third its length, the rectrices inconspicuously acuminate and not strongly decurved terminally or subterminally, the attenuated tips with shaft denuded or the barbs very short; bill stouter, relatively narrower and deeper basally. Dendrocincla (p. 286).

\section{Genus DENDROCOLAPTES Hermann.}

Dendrocolaptes Hermanx, Obs. Zool., 1804, 135. (Type, Picus certhia Boddaert.)

Dendrocalaptes (emendation) Vorgt, Thierreich, i, 1831, 624.

Dendrocopus Vieillot, Analyse, 1816, 45. (Type, Talapiot Buffon=Picus certhia Boddaert.)

Dendrocops Swamson, Classif. Birds, ii, 1837, 314. (Type, Dendrocolaptes platyrostris $\mathrm{Spix}=$ Dendrocolaptes picumnus Lichtenstein.)

Orthocolaptes Lesson, Rev. Zool., 1840, 267. (Type, O. communis Lesson= Dendrocolaptes picumnus Lichtenstein.)

Premnocopusc Cabanis, in Wiegmann's Archiv für Naturg., xiii, pt. i, 1847, 339. (Type, Picus certhia Boddaert.)

a Nasica Lesson, Traité d'Orn., 1831, 311. Type, N. nasalis Lesson=Dendrocopus longirostris Vieillot. (Guianas and Amazon Valley; monotypic.)

b Drymornis Eyton, in Jardine's Contr. Orn., 1852, 23. Type, Nasica bridgesii Eyton. (Uruguay and northern Argentina; Bolivia?; monotypic.)

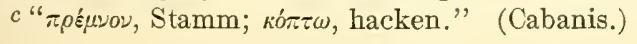


Large Dendrocolaptidæ (length about $250-275 \mathrm{~mm}$.) with roundish, nonoperculate nostril, and nearly straight, depressed bill with distance from nostril to tip of maxilla greater than length of tarsus, and more than three times its depth at nostril.

Bill about as long as or slightly longer than head, nearly straight, broad and depressed basally, its width at frontal antiæ very slightly to much greater than its depth at same point and equal to less than one-third the distance from nostril to tip of maxilla; culmen very much longer than tarsus, distinctly (sometimes sharply) ridged, gradually (usually very slightly) curved to near tip, where abruptly decurved, the tip of maxilla distinctly uncinate; maxillary tomium nearly straight to slightly but distinctly concave, distinctly notched subterminally; mandibular tomium very faintly to rather distinctly convex, with faint trace of subterminal notch; gonys practically straight for most of its length but convex and slightly prominent basally, sometimes slightly decurved terminally. Nostril exposed, posteriorly in contact with latero-frontal feathering, roundish or broadly oval, nonoperculate. Rictal bristles absent, but feathers of chin and lores with loose, semidecomposed, setaceous webs. Wing large, pointed, the longest primaries exceeding secondaries by nearly to quite the distance from nostril to tip of maxilla; seventh, seventh and eighth, or sixth, seventh, and eighth primaries longest, the tenth (outermost) two-thirds or more as long as the longest, the ninth longer than fourth, sometimes longer than fifth. Tail nearly as long as wing, graduated for about the length of culmen, the rectrices (12) conspicuously acuminate, with very strong and extremely rigid shafts, which are more or less strongly decurved terminally. Tarsus shorter than exposed culmen, a little more than one-fifth as long as wing, rather slender, distinctly scutellate (endaspidean); middle toe, with claw, slightly shorter than tarsus; outer toe (with or without elaw) as long as middle toe or very slightly longer; inner toe (without claw) reaching to a little beyond subterminal articulation of middle toe, its claw reaching to base of middle claw (D. certhia) or falling far short (D. validus); hallux decidedly shorter than inner toe, little if any stouter; middle toe united to outer toe by whole of basal and part of second phalanx, to inmer toe by at least half the basal phalanx; claws large, very strongly curved, very acute, that of the hallux less strongly curved, longer than the digit.

Coloration.-Brown or olive, the tail, upper tail-coverts and remiges deep cinnamon-rufous or chestnut; pileum streaked, or spotted witlı paler brown or buffy or barred with black; under parts paler brown, olive, or brownish buffy more or less distinctly barred with darker or blackish, the chest sometimes streaked, the throat usually mostly dull whitish or pale brownish buffy. Sexes alike.

Nidification.-Nesting in holes of trees; eggs white. 
Range.-Southern Mexico to Cayenne, southeastern Brazil, Bolivia, and Ecuadór. (About twelve species. ${ }^{a}$ )

KEY TO THE SPECIES AND SU1BSPECIES OF DENDIROCOLAPTES.

a. Pileum barred or transversely lunulated with black. (Dendrocolaptes sanctithoma')

b. Pileum distinctly more rufescent or tawny than color of back; back more broadly or more distinctly barred; bars on under parts broader. (Southeastern Mexico to western Panamá.)..... Dendrocolaptes sancti-thomæ sancti-thomæ (p. 229). 6b. Pileum nearly (sometimes quite) concolor with back; back more narrowly or less distinctly barred; bars on under parts narrower. (Southwestern Costa Rica and adjacent part of westeru Panamá.)

Dendrocolaptes sancti-thomæ hesperius (p. 232). aa. Pileum streaked with buffy or whitish.

b. Pileum blackish, with narrow (and indistinet?) buffy streaks; chest with pale buffy or whitish predominating (the mesial streaks broader). (Guatemala.)

Dendrocolaptes puncticollis (p. $\left.232^{b}\right)$.

bb. Pileum grayish brown, with broader and more distinet streaks; chest with brown predominating, the buffy mesial streaks narrower. (Dendrocolaptes validus.)

c. Chest more distinctly and regularly streaked; under parts less extensively barred. (Colombia, etc.)...Dendrocolaptes validus validus? (extralimital). $c$ $c c$. Chest less distinctly or more irregularly streaked (the streaks broken along edges by black dots or bars) and under parts more extensively streaked. (Costa Rica and Panamá; Nicaragua?; northwestern Colombia?).

Dendrocolaptes validus costaricensis (p. 233).

\section{DENDROCOLAPTES SANCTI-THOME SANCTI-THOM尼 (Lafresnaye).}

\section{BARRED WOODHEWER.}

Adults (sexes alike).-Pileum and hindneck dull cinnamon-rufous or russet marked with crescentic bars or lunules of black; back, scapulars, and smaller (lesser and middle) wing-coverts olive-brown (nearly raw-umber to mars brown), barred, more or less distinctly, with black; rump, upper tail-coverts, tail, and proximal secondaries deep cinnamon-rufous or chestnut (the tail usually darker, more chestnut, than other parts), the shafts of rectrices darker; primaries and distal secondaries deep cinnamon-rufous edged, more or less broadly, with grayish brown or olive, the inner webs of longer prima-

$a$ Of these the following have been examined in this connection: $D$. picumnus Lichtenstein, D. validus Tschudi, D. certhia (Boddaert), D. obsoletus Ridgway, D. radiolatus Sclater and Salvin, and $D$. sancti-thomæ (Lafresnaye).

$b$ I have not seen a specimen of this form, and, as stated on p. 233, the published descriptions do not clearly indicate the differences from $D$. validus.

c Dendrocolaptes validus Tschudi, Fauna Peruana, Aves, 1845, 242, pl. 21, fig. 2 (Peru); Sclater, Cat. Birds Brit. Mus., xv, 1890, 172, part.-Dendrocolaptes multistrigatus Eyton, Jardine's Contr. Orn., 1851, 75 (locality not indicated; coll. Derby Mus.).

I have not seen a Peruvian specimen of this species, and am therefore not at all sure that the Colombian specimens (chiefly from the Santa Marta district), with which I have compared Costa Rican examples, are subspecifically the same. 
ries grayish brown or dusky terminally; lores plain gray or dusky; suborbital, auricular, and malar regions brownish buff or clay color narrowly barred with blackish; chin and upper throat dull grayish, the latter indistinctly barred with darker; rest of under parts brownish buff or light buffy cinnamon, everywhere barred with black or dusky, the bars more lunulate or crescentic on foreneck and chest, narrower and less blackish on posterior parts; under wing-coverts light ochraceous or ochraceous-buff, narrowly and irregularly barred with black; inner webs of remiges light cinnamon-rufous, the outer primaries passing into grayish brown terminally; bill dusky horn color, sometimes nearly black terminally, paler brown basally, especially on mandible; iris brown; legs and feet horn color or dusky (in dried skins).

Young.-Similar to adults, but bars on under parts less sharply defined, especially on posterior portions, the under tail-coverts more rufescent.

Adult male.--Length (skins), 248-289 (260); wing, 119-134 (127.2); tail, 105-121.5 (112.9); culmen, 35-44 (37.9); tarsus, 26-30 (27.9); middle toe, $19-23.5(21.2){ }^{a}$

Adult female.-Length (skins), 250-276 (261); wing, 120.5-136 (127); tail, 105-122.5 (115.3); culmen, 35-38 (37); tarsus, 27-29.5 (28); middle toe, $20-23.5(21.3) .^{b}$

Southeastern Mexico, in States of Vera Cruz (Pasa Nueva) and Campeche (Apazote), and southward through Guatemala (Vera Paz), British Honduras (Belize; Orange Walk; Toledo District; near Mana-

a Twenty-one specimens.

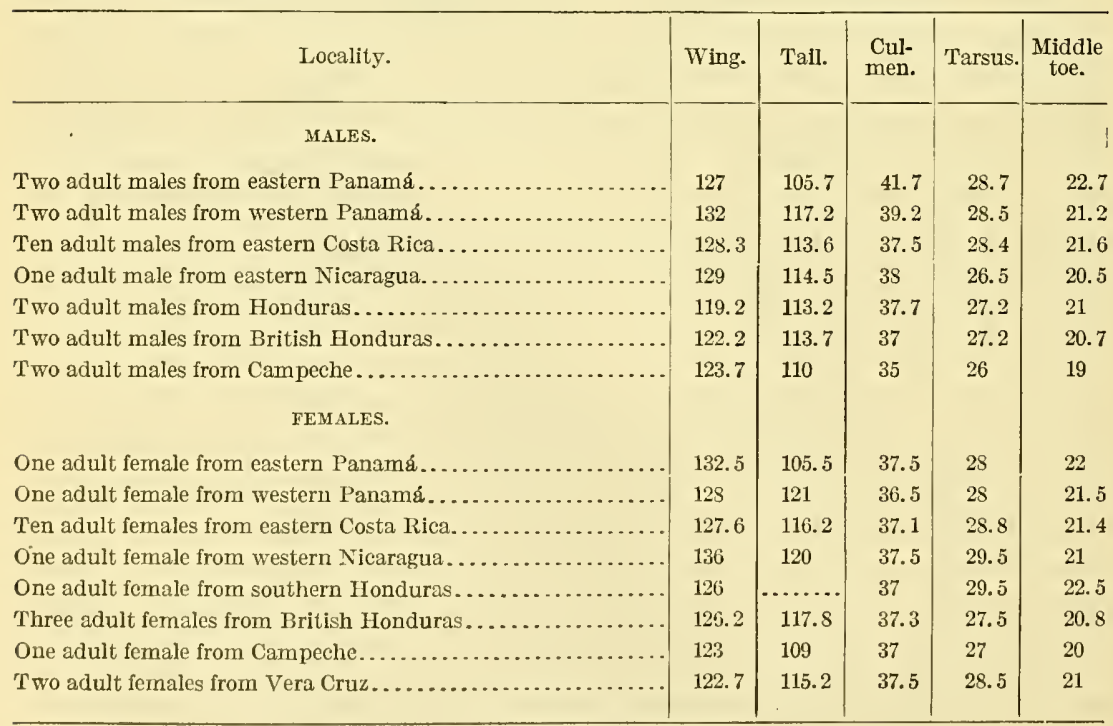


tee Lagoon; Quamin Creek), Honduras (Omoa; Santo Tomas; Santa Ana; Yaruca; Rio Segóvia), Nicaragua (Mosquito coast; Greytown; Rio Escondido; Sucuyá; Momotombo; Sin Gerónimo, Chinandega), northern and eastern Costa Rica (Navarro; Cuábre; Limón; Talamanea; Rio Matina; Pacuare; Tucurríqui; Bonilla; Naranjo de Cartago; Rio Súcio; Guácimo; Guápiles; Juan Viñas; La Cristina; El Hogár; Cariblanco de Sitrupiquí; Bebedero; Bolsón; Boruca!; La Vijágua; Coralillo; Tenório; Cerro Santa Maria; Santa Maria; Miravalles; ${ }^{a}$ Aguacate Mountains ?) ${ }^{b}$ and Panamá (Lion Hill; Panamá; Punta de Sabana; Divala).

Dendrocops sancti-thomæ Lafresnaye, Rev. et Mag. Zool., Oct., 1852, 466 (Santo Tomas, Honduras. ${ }^{c}$

Dendrocolaptes sancti-thomæ Sclater, Proc. Zool. Soc. Lond., 1S58, 96 (s. Mexico; Honduras; Mosquito coast, Nicaragua); Cat. Am. Birds, 1862, 163 (Honduras); Cat. Birds Brit. Mus., xv, 1890, 174, part (near Belize, Brit. Honduras; Vera Paz, Guatemala; Honduras; Tucurríqui, Costa Rica; Panama).-Moore, Proc. Zool. Soc. Lond., 1859, 54 (Omoa, Honduras; Belize, Brit. Honduras).Sclater and Salvin, Ibis, 1859, 118 (Santo Tomas, Honduras); Proc. Zool. Soc. Lond., 1864, 355 (Lion Hill, Panamá; crit.).-Lawrence, Ann. Lyc. N. Y., vii, 1862, 320 (Lion Hill); viii, 1867, 181 (Greytown, Nicaragua); ix, 1868, 106 (San José, Costa Rica).-Frantzius, Journ. für Orn., 1869, 305 (Aguacate Mts., Costa Rica).-Wratr, Ibis, 1871, 331 (Colombia).-BouCArd, Proc. Zool. Soc. Lond., 1878, 60 (Navarro, Costa Rica); Ann. Soc. Linn. Lyon, 1878, 38 (Guatemala).-Nutring, Proc. U. S. Nat. Mus., vi, 1883, 385 (Sucuyá, Nicaragua).-Zeuedón, Anal. Mus. Nac. Costa Rica, i, 1887, 113 (Pacuare, Costa Rica).-Ridgway, Proc. U. S. Nat. Mus., x, 1887, 589 (Segóvia R., Honduras).-Salvin and Godiran, Biol. Centr.-Am., Aves, ii, 1891, 192, part (Orange Walk and Belize, Brit. Honduras; Vera Paz, Guatemala; Omoa and Segóvia R., Honduras; Greytown, Sucuyá, and Momotombo, Nicaragua; Navarro and Tucurríqui, Costa Rica; Lion Hill, Panamá).-Richuond, Proc. U. S. Nat. Mus., xvi, 1893, 498 (Rio Escondido, Nicaragua).-Underwood, Ibis, 1896, 440 (Volcan Miravalles, Costa Rica).Salvadori and Festa, Boll. Mus. Zool., etc., Torino, xiv, 1899, no. 339, 7 (Punta de Sabana, Panamá).

Dendrocolaptes sanctithomae Bangs, Bull. Nus. Comp. Zool., xxxix, 1903, 151 (Yaruca, Honduras).

[Dendrocolaptes] sancti-thomæ GraY, Hand-list, i, 1869, 175, no. 2374.-Sclater and Salvin, Nom. Av. Neotr., 1873, 67.-Sharpe, Hand-list, iii, 1901, 87, part (Mexico to Panamá).

$D$ [endrocolaptes] sancti-thomæ Sclater and Salvin, Proc. Zool. Soc. Lond., $1868,56$.

$D$ [endrocolaptes] $c$ [erthia] sancti-thomæ Menegaux and Hellimayr, Mém. Soc. N. H. d'Autun, xix, 1906, 125, in text.

Dendrocolaptes sancti-thomæ sancti-thomæ Carriker, Ann. Carnegie Mus., vi, 1910, 659 (Costa Rica, up to 2,000 ft.).

$a$ Some specimens from Miravalles are intermediate between the typical form and D. s. hesperius.

$b$ Specimens from Aguacate Its. not seen by me. Possibly they are referable to D. s. hesperius.

c In original, island of St. Thomas; but this obviously an error; see Salvin and Godman, Biol. Centr.-Am., Aves, ii, p. 192. 


\section{DENDROCOLAPTES SANCTI-THOM五 HESPERIUS BangS.}

\section{BORUCA WOODHEWER.}

Similar to $D$. s. sancti-thomæ but pileum duller, much less rufescent (nearly concolor with back), back less distinctly barred (bars often obsolete), and bars on under parts much narrower.

Adult male:-Length (skins), 241-272 (253); wing, 119.5-130.5 (127); tail, 103-120.5 (112); culmen, 37.5-41.5 (39.5); tarsus, 27-30 (28.5); middle toe, $21-22$ (21.5) ${ }^{a}$

Adult female.-Length (skins), 243-275 (260); wing, 117.5-135 (126.9); tail, 104-117.5 (112.4); culmen, 36-39 (37.7); tarsus, 27.5-29 (28.4); middle toe, $21-22.5(21.6){ }^{b}$

Southwestern Costa Rica (Boruca, ${ }^{c}$ Pozo del Rio Grande, Lagarto, and Paso Reál, Boruca; El Pozo de Térraba; Buenos Aires; Pigres; Aguacate Mountains?) and adjacent portion of western Panamá (Chiriquí; Santiago de Verágua; Bugaba); western Nicaragua (San Gerónimo, Chinandega)?

Dendrocolaptes sancti-thomæ (not of Sclater, 1858) Salvin, Proc. Zool. Soc. Lond., 1867, 144 (Santiago de Verágua, Panamá); 1870, 193 (Bugaba, Panamá).Sclater, Cat. Birds Brit. Mus., xv, 1890, 174, part (Santiago and Bugaba, Panamá).-Salvin and Godman, Biol. Centr.-Am., Aves, ii, 1891, 192, part (Aguacate Mts., Costa Rica?; Bugaba and Santiago de Verágua, Panamá).Cherrie, Expl. Zool. Merid. Costa Rica, 1893, 41 (Boruca, Costa Rica).

Dendrocolaptes sancti-thomæ hesperius BANGS, Auk, xxiv, July, 1907, 299 (Lagarto, s. w. Costa Rica; coll. E. A. and O. Bangs).-Carriker, Ann. Carnegie Mus., vi, 1910, 660 (Térraba Valley, s. w. Costa Rica; crit.).

\section{DENDROCOLAPTES PUNCTICOLLIS Sclater and Salvin.}

\section{SPOTTED-NECKED WOODHEWER.}

"Above fulvous-brown; head rather darker, with pale fulvous linear shaft-stripes, which are sparingly continued over the upper back; outer secondaries and tail ferruginous; beneath paler; throat pale fulvous, with slight blackish variegations; breast with broad shaftspots of pale fulvous laterally edged with black; belly marked with numerous fine black cross-bands; under wing-coverts ochraceous slightly flecked with black; bill pale horn-colour: whole length 10.5 inches [266.5 mm.], wing 5.1 [129.5 mm.], tail 4.5 [114.5 mm.]." $d$

Above olive-brown, upper tail coverts, outer surface of wings, and tail rufescent ["rubiginosis"], wing-coverts concolor with back, head

$a$ Ten specimens from southwestern Costa Rica .

$b$ Seven specimens.

$c$ Among specimens from Boruca are some that I can not distinguish from typical $D$. sancti-thomx; in fact, while the difference of coloration in the two forms is quite obvious when extreme examples are compared, the absence of strict corellation between the color-differences and geographic distribution is difficult to understand.

$d$ Sclater's description in Cat. Birds Brit. Mus., xv, 1890, 171. 
black and, together with hindneck and upper back, marked with obsolete shaft-stripes of fawn color ["cervinis"]; beneath paler, all the feather's of throat to middle of breast whitish margined with fuscous, streaks on breast narrower, abdomen and crissum transversely barred with brownish black, under wing-coverts and inner webs of remiges cimnamon, the former variegated with fuscous, the latter with terminal portion fuscous; bill horn color, mandible paler, feet plumbeous. Total length 10.5 [inches $=266.5 \mathrm{~mm}$.] wing 5.2 [132 mm.], tail $4.5[114.5 \mathrm{~mm}$.], bill to rictus $1.65[42 \mathrm{~mm}$.$] , tarsus$ $1.05\left[26.5 \mathrm{~mm} . .^{a}\right.$

Both Sclater and Salvin and Godman compare this form with the South American D. picumnus, but the characters wherein it differs from the Costa Rican form of $D$. validus are not clear from either of the descriptions quoted or the context thereof. The form is probably a subspecies of $D$. validus.

Highlands of Guatemala (Tactíc; San Gerónimo).

Dendrocops multistrigatus (not Dendrocolaptes multistrigatus Eyton) Salvin and Sclater, Ibis, IS60, 275 (Tactíc and San Gerónimo, Guatemala; crit.).

Dendrocolaptes multistrigatus (not of Eyton) Sclater, Cat. Am. Birds, 1862, p. 162, no. 995 (San Gerónimo).

Dendrocolaptes puncticollis Sclater and Salvin, Proc. Zool. Soc. Lond., 1868, 54, pl. 5 (Tactíc and San Gerónimo, Vera Paz, Guatemala; coll. Salvin and Godman and coll. P. L. Sclater).-Sclater, Cat. Birds Brit. Mus., xv, 1890, 171, excl. syn. part (Tactíc and San Gerónimo).--Salvin and Godulan, Biol. Centr.-Am., Aves, ii, 1891, 190.

[Dendrocolaptes] puncticollis Gray, Hand-list, i, 1869, 176, no. 2378.-Sclater and Salvin, Nom. Av. Neotr., 1873, 67.-Sharpe, Hand-list, iii, 1901, 87.

\section{DENDROCOLAPTES VALIDUS COSTARICENSIS Ridgway.}

COSTA RICAN WOODHEWER.

Similar to D. v. validus, ${ }^{b}$ but chest less distinetly streaked or with streaks less regular (broken along edges by black dots or bars), and under parts much more extensively barred.

Adults (sexes alike).--Pileum and hindneek dull grayish brown or sepia, with narrow mesial streaks of very pale brownish buffy or dull buffy whitish, the supra-auricular region, lower portion of auricular region, and sides of neck similar but with the streaks much broader, the upper portion of aurieular region dark sooty brown or blackish with very narrow shaft-streaks of pale buffy or dull whitish; malar region with feathers dark sooty brown on margin, with a central ovate spot of pale brownish buffy; back, scapulars, and wing-coverts plain olive-brown (between bister and raw-umber), the back usually

$a$ Biol. Centr.-Am., Aves, ii, 1891, 190; free translation.

$b$ See p. 229. (Comparison is made with specimens from State of Santa Marta, Colombia, which, however, probably do not represent true $D$. validus.) 
with very indistinct narrow shaft-streaks of paler; rump, upper tailcoverts, and proximal secondaries deep cinnamon-rufous, the first intermixed, more or less, with olive-brown; tail chestnut, with shafts of rectrices more or less darker; primaries and distal secondaries deep cinnamon-rufous, edged, more or less broadly, with olivebrownish, the terminal portion of inner webs of longer primaries grayish brown or dusky; chin and throat light brownish buffy or pale clay color, the feathers edged with brown, producing a rather confused streaked appearance, those of the lower throat with broader brownish edgings and sometimes narrowly margined terminally with dusky; feathers of foreneck similarly marked but with small transverse spots in the brown edgings; chest light olive-brown or buffy grayish brown (varying from nearly broccoli brown to nearly rawumber), with broad mesial streaks of pale buffy, these margined with a narrow line of blackish, these lines sometimes partially broken into small spots; rest of under parts light buffy brown, everywhere marked with narrow crescentic bars of black, these bars less distinct on flanks, thighs, and anal region; under wing-coverts ochraceous-buff or light ochraceous, with narrow, more or less crescentic, bars of blackish; inner webs of remiges light cinnamon-rufous, the outer primaries with terminal portion dusky; bill brown or horn color (more or less deep), paler (sometimes whitish) terminally and along tomia; iris brown; legs and feet dark horn color or dusky (in dried skins).

Young.-Similar to adults but general coloration darker and more rufescent, the pileum sooty blackish, with streaks broader and more tawny, the black bars on under parts indistinct or obsolete.

Adult male.-Length (skins), 238-280 (251); wing, 126-130 (127.6); tail, 115.5-119.5 (116.7); culmen, 33-35 (34.1); tarsus, 26-28.5 (27); middle toe, $20-22(21.1)^{a}$

Adult female.-Length (skins), 250-273 (261); wing, 120-126 (123); tail, 112-121 (116); culmen, 33.5-34 (33.7); tarsus, 27; middle toe, 20-21 (20.5). ${ }^{b}$

Costa Rica (Cartago, Naranjo, and Navarro, Cartago; Volcán de Irazú; Rio Súcio; Laguária, Los Reyes, Santa Maria, Dota) and

$b$ Two specimens.

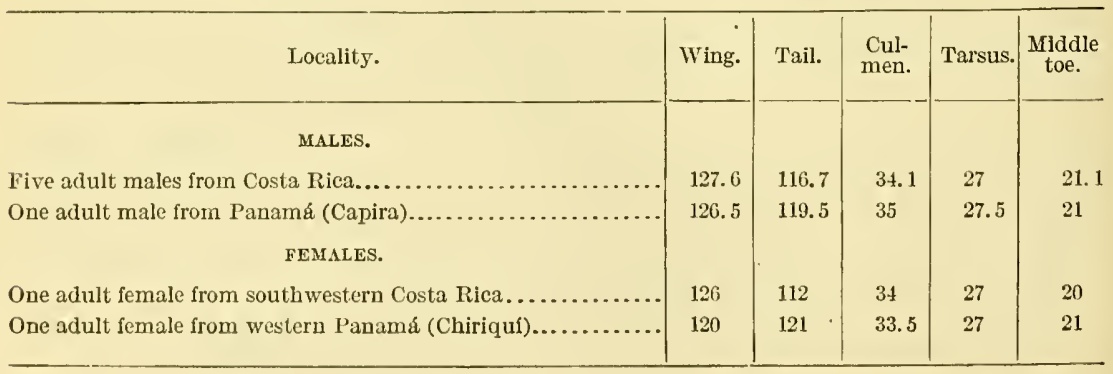


Panamá (Boquete, Chiriquí; Capira); Nicaragua ?; State of Antioquía, Colombia (Medellin; Frontino)?

(?) Dendrocops multistrigatus (not Dendrocolaptes multistrigatus Eyton) Bonaparte, Notes Orn. Coll. Delattre, 1854, 87 (Nicaragua).

Dendrocolaptes multistrigatus (not of Eyton) Lawrence, Ann. Lyc. N. Y., ix, 1S68, 106, 146 (Navarro, Costa Rica; crit.).-FrantzıUS, Journ. für Orn., 1869,305 (Navarro).

Dendrocolaptes puncticollis (not of Sclater and Salvin) Lawrence, Ann. Lyc. N. Y., ix, 1868, 146 (Navarro).-Boucard, Proc. Zool. Soc. Lond., 1878, 60 (Naranjo de Cartago, Costa Rica; habits).-Zéledón, Anal. Mus. Nac. Costa Rica, i, 1887, 113 (Cartago, Costa Rica).-Ridgway, Proc. U. S. Nat. Mus., xi, 1889, 545 (Navarro; crit.).-BANGs, Proc. New Engl. Zool. Club, iii, 1902, 48 (Boquete, 7,000 it., Panamá).

Dendrocolaptes validus (not of Tschudi) Sclater, Cat. Birds Brit. Mus., xv, 1890, 172, part (Panamá; Medellín and Frontino, prov. Antioquía, Colombia?).Salvin and Godman, Biol. Centr.-Am., Aves, ii, 1S91, 191, part (Navarro and Naranjo, Costa Rica; Panamá; Colombia?).

[Dendrocolaptes] validus Sharpe, Hand-list, iii, 1901, 87, part (Costa Rica; Panamá).

Dendrocolaptes validus costaricensis Ridgway, Proc. Biol. Soc. Wash., xxii, April 17, 1909, 73 (Laguária, Santa Maria de Dota, s. w. Costa Rica; coll. U. S. Nat. Mus.).-Carriker, Ann. Carnegie Mus., vi, 1910, 658 (Costa Rica; crit.).

\section{Genus XIPHOCOLAPTES Lesson.}

Xiphocolaptes Lesson, Rev. Zool., 1840, 269. (Type, Dendrocopus albicollis Vieillot.)

Very large Dendrocolaptidæ (length about 280-320 mm.) with bill longer than head, stout, more or less (but never strongly) decurved, and compressed (much deeper than broad at nostrils).

Bill longer than head (commissure nearly twice as long as tarsus), slightly decurved, much compressed, its depth at nostril much greater than its width at same point; culmen scarcely ridged, gradually decurved from base, the tip of maxilla not uncinate; tomia gradually decurved, without trace of subterminal notch; gonys straight or (sometimes) slightly decurved terminally, slightly prominent and convex basally, where there is a more or less distinct narrow median ridge on under side. Nostril exposed, posteriorly in contact with latero-frontal feathers or nearly so, obliquely oval, non-operculate. Rictal bristles absent; feathers of chin and loral region with open or semi-decomposed webs. Wing rather large and pointed, with longest primaries exceeding secondaries by less than length of bill from nostril; sixth, seventh, and eighth, fifth, sixth, and seventh, or sixth and seventh, primaries longest, the tenth (outermost) a little more than two-thirds as long as the longest, the ninth longer than fourth. Tail about six-sevenths as long as wing, graduated for more than one-third its length, the rectrices (12) acuminate, with the excessively strong and rigid shafts decurved and twisted terminally. Tarsus about as long as bill from nostril, 
about one-fourth as long as wing, stout, very distinctly scutellate (endaspidean); middle toe, with claw, about as long as tarsus or slightly longer; outer toe (with or without claw) as long as middle toe or barely shorter; inner toe (without claw) reaching to subterminal articulation of middle toe, its claw falling considerably short of terminal articulation of middle toe; hallux much shorter than inner toe and slightly thicker; middle toe united for whole of its first and part of its second phalanx to outer toe, for about half its first phalanx to inner toe; claws large, very strongly curved, very acute, that of the hallux less strongly curved, equal to or slightly longer than the digit.

Coloration.-Tail and remiges cinnamon-rufous or chestnut, the inner webs of longer primaries tipped with dusky; rest of plumage brownish (sometimes cinnamon-rufous), the cliest, pileum, and hindneck (sometimes back also) streaked with paler, the throat at least partly dull whitish. Sexes alike.

Nidification.-Nests in holes; eggs white.

Range.-Southern Mexico to southeastern Brazil, Paraguay, Argentina, Bolivia, and Peru. (About eighteen species, including subspecies. ${ }^{a}$ )

\section{KEY TO THE SUBSPECIES OF XIPHOCOLAPTES EMIGRANS. $b$}

a. Smaller (wing averaging 137.5 in male, 134.7 in female; culmen averaging 46.9 in male, 48.7 in female). (Highlands of Guatemala.)

Xiphocolaptes emigrans emigrans (p. 237).

$b b$. Larger (wing averaging 140 or more in males, 136 or more in females; culmen averaging 52 or more in males, usually more than 55 in females).

c. Coloration darker and brighter (much as in $X$.e. emigrans).

$d$. Wing averaging shorter (140 in male, 138 in female) but bill larger (culmen averaging 53 in male, 55 in female); pileum darker, with streaks paler. (Highlands of southeastern Mexico.)

Xiphocolaptes emigrans sclateri (p. 238).

$d d$. Wing averaging longer (145.5 in male, 136 in female) but bill smaller (culmen averaging 52 in male, 47.7 in female); pileum lighter or browner, with streaks more buffy. (Highlands of Costa Rica.)

Xiphocolaptes emigrans costaricensis (p. 239).

$c c$. Coloration paler and duller. (Wing averaging 143.3 in male, 140.5 in female; culmen averaging 54.2 in male, 56.5 in female.) (Highlands of southwestern Mexico) .......... Xiphocolaptes emigrans omiltemensis (p. 239).

a The following have been examined in the preparation of this work: $X$. albicollis (Vieillot), $X$. argentinus Ridgway, $X$. emigrans Sclater (and its several subspecies), $X$. promeropirhynchus (Lesson), $X$. crassirostris Taczanowski and Berlepsch, $X$. fortis Heine, $X$. virgatus Ridgway, $X$. ignotus Ridgway, $X$. compressirostris Taczanowski, $X$. saturatus Ridgway, $X$. major Vieillot, $X$. castaneus Ridgway, and $X$. cinnamomeus Ridgway.

$b$ All the Mexican and Central American forms of this genus are evidently very closely related to $X$. promeropirhynchus (Iesson) and other forms of northern South America; but material available for study is so scant that their exact status can not be worked out at the present time. 


\section{XIPHOCOLAPTES EMIGRANS EMIGRANS Sclater and Salvin.} GUATEMALA WOODHEWER.

Adults (seires atitie).-Pileum and hindneck sepia brown to nearly clove brown narrowly streaked with pale buff; back, scapulars, and wing-coverts plain brown (nearly raw-umber or between raw-umber and light olive), the upper back sometimes with narrow shaft-streaks of buffy; rump and upper tail-coverts plain cinnamon-rufous; tail chestnut, the shafts of middle rectrices darker; remiges lighter chestnut, or rufous-chestnut, the primaries and distal secondaries edged (more or less broadly) with brown, the inner webs of longer and outer primaries grayish brown terminally; superciliary region dark brown, rather broadly streaked with pale dull buff or buffy whitish; lores pale grayish buffy or dull brownish whitish; suborbital region dull buffy whitish, the feathers narrowly edged with dark brown; upper portion of auricular region narrowly streaked with dull whitish or pale dull buffy on a dark brown or sepia ground, the lower portion dull whitish or pale dull buffy narrowly streaked with dark brown; malar region dark brown streaked (more or less narrowly) with dull whitish or pale dull buffy; chin and upper throat dull brownish white or pale brownish buffy, the latter faintly streaked (broadly) with pale brownish; rest of under parts raw-umber brown (paler and more fulrescent than back, etc.), more or less tinged with tawny posteriorly (especially on flanks and under tail-coverts), the lower throat, chest, and breast (sometimes abdomen and sides also), with narrow shaft-streaks of pale brownish buffy or dull buffy whitish, the abdomen (more or less distinctly and extensively) usually barred with dusky and buffy whitish or dull pale buffy; under wing-coverts ochraceous or ochraceous-buff, barred with black or dusky; inner webs of remiges cinnamon-rufous, the terminal portion of outer primaries (extensively) grayish brown; bill light horn color, more dusky basally; feet dusky or horn color (in dried skins).

Adult male.-Length (skins), 310-340 (318); wing, 135-140 (137.5); tail, 118-123 (120.7); culmen, 44-50 (46.9); tarsus, 31-31.5 (31.4); middle toe, $25-27(25.7){ }^{a}$

Adult female.-Length (skins), 290-324 (313); wing, 131-142 (134.7); tail, 112-131.5 (120.1); culmen, 45-51 (48.7); tarsus, 31-32 (31.5); middle toe, $25-28(26.3){ }^{5}$

a Four specimens, from Chiapas.

$b$ Six specimens.

\begin{tabular}{|c|c|c|c|c|c|}
\hline Locality. & Wing. & Tail. & $\begin{array}{l}\text { Cul- } \\
\text { men. }\end{array}$ & Tarsus. & $\begin{array}{l}\text { MIddle } \\
\text { toe. }\end{array}$ \\
\hline FEMALES. & & & & & \\
\hline Four adult females from Chiapas (San Cristóbal). & 135.2 & 123 & 47.9 & 31.2 & 26 \\
\hline One adult female from Guatemala (Gualán)... & 131.5 & 112 & 49.5 & 32 & 28 \\
\hline One adult female from Nicaragua (San Rafaél del Norte)....... & 136 & 116.5 & 51 & 32 & 26 \\
\hline
\end{tabular}


Southern Mexico, in State of Chiapas (San Cristóbal); highlands of Guatemala (San Gerónimo; Cajabón; pine ridge of Poctúm; Gualán); British Honduras; northern Nicaragua (Matagalpa; San Rafaél del Norte).

Xiphocolaptes emigrans Sclater and Salvin, Ibis, April, 1859, 118, 127 (San Gerónimo, Vera Paz, Guatemala; coll. Salvin and Godman); Exotic Orn., pt. v, 1867, 69, pl. 35.-Sclater, Cat. Am. Birds, 1862, 163 (Guatemala); Cat. Birds Brit. Mus., xv, 1890, 145 (Brit. Honduras; Cajabón, San Gerónimo, and pine ridge of Poctúm, Guatemala).-Ridgway, Proc. U. S. Nat. Mus., xii, 1890, 7 (monogr.).-Salvin and Godman, Biol. Centr.-Am., Aves, ii. 1891, 183, part (Guatemalan localities; Brit. Honduras).

$X$ [iphocolaptes] emigrans Cabanis and Heine, Mus. Hein., ii, 1859, 36 (Guatemala).-(?) Salvin and Godman, Ibis, 1892, 327 (Matagalpa, Nicaragua).

[Xiphocolaptes] emigrans Sclater and Salvin, Nom. Av. Neotr., 1873, 68, part (Guatemala).-Sharpe, Hand-list, iii, 1901, 81.

[Dendrocolaptes] emigrans Gray, Hand-list, i, 1869, 176, no. 2389.

\section{XIPHOCOLAPTES EMIGRANS SCLATERI (Ridgway).}

\section{SCLATER'S WOODHEWER.}

Similar to $X$.e. emigrans but slightly larger; color of pileum darker (more blackish) with streaks slightly less buffy (more whitish); throat more extensively whitish; chest, etc., rather more distinctly streaked.

Adult male?-Length (skin), 325; wing, 140; tail, 123; culmen, 53; tarsus, 33 ; middle toe, 28.5. ${ }^{a}$

Adult female.-Length (skin), 326; wing, 138; tail, 123; culmen, 55 ; tarsus, 33.5 ; middle toe, $28 .^{\circ}$

Southeastern Mexico, in States of Vera Cruz (Orizaba; Jalapa) and Oaxaca (Tonaguia; La Parada; Reyes).

Xiphocolaptes albicollis? (not Dendrocopus albicollis Vieillot) Sclater, Proc. Zool. Soc. Lond., 1857, 202 (Jalapa, Vera Cruz).

Xiphocolaptes emigrans Sclater and Salvin, Ibis, 1859, 118, part (Jalapa).-

Sclater and Salvin, Exotic Orn., pt. v, 1867, 69, part (Jalapa).-Sumichrast, Mem. Bost. Soc. N. H., i, 1869, 554 (Orizaba, Vera Cruz; habits; food); La Naturaleza, v, 248 (1881).-Sanchez, Anal. Mus. Nac. Mexico, i, 1877, 97 (Vera Cruz).-Salvin and Godman, Biol. Centr.-Am., Aves, ii, 1891, 183, part (Orizaba, Vera Cruz; La Parada and Tonaguia, Oaxaca).

Xiphocolaptes sclateri Ridgway, Proc. U. S. Nat. Mus., xii, no. 761, Feb. 5, 1890, 6 (Orizaba, Vera Cruz; coll. U. S. Nat. Mus.).-Sclater, Cat. Birds Brit. Mus., xv, 1890, 143 (La Parada, Oaxaca).

[Xiphocolaptes] sclateri SHARPE, Hand-list, iii, 1901, 81.

a One specimen, from Orizaba, Vera Cruz.

$b$ One specimen, from Reyes, Oaxaca. 


\section{XIPHOCOLAPTES EMIGRANS OMILTEMENSIS Nelson.}

\section{GUERRERO WOODHEWER.}

Similar to $X$. e. sclateri but still larger; general coloration duller and slightly paler, the under parts less rufescent, and lower throat more streaked (as in $X$. e. emigrans).

Adult male.-Length (skins), 311-327 (319); wing, 138-148.5 (143.2); tail, 126; culmen, 53-55.5 (54.2); tarsus, 31.5-33 (32.2); middle toe, $27.5-29(28.2){ }^{a}$

Adult female.-Length (skins), 307-316 (311); wing, 137-144 (140.5); tail, 110-110.5 (110.2); culmen, 56-57 (56.5); tarsus, 29.532.5 (31); middle toe, 26-27.5 (26.7). ${ }^{a}$

Southwestern Mexico, in State of Guerrero (Omilteme).

Xiphocolaptes emigrans (not of Sclater and Salvin) Salvin and Godman, Biol. Centr.-Am., Ares, ii, 1891, 183, part (Omilteme, Guerrero).

Xiphocolaptes emigrans omiltemensis Nelson, Proc. Biol. Soc. Wash., xvi, Nov. 30, 1903, 153 (Omilteme, Guerrero, s. w. Mexico; coll. U. S. Nat. Mus.).

\section{XIPHOCOLAPTES EMIGRANS COSTARICENSIS Ridgway.}

\section{CARTAGO WOODHEWER.}

Similar to $X$. e. emigrans but slightly larger (except bill) and with under parts more extensively (or more distinctly) streaked.

Adult male.-Length (skin), 305; wing, 145.5; tail, 117; culmen, 52 ; tarsus, 32 ; middle toe, $27.5 .^{b}$

Adult female.-Length (skins), 285-308 (295); wing, 134-140 (136); tail, 102-117 (108); culmen, 44.5-50 (47.7); tarsus, 32; middle toe, $27.5-28.5(28){ }^{c}$

Highlands of Costa Rica (Naranjo and Azahár, Cartago; Juan Viñas; Guayabo).

Xiphocolaptes emigrans costaricensis Ridgway, Proc. U. S. Nat. Mus., xi, sig. 34, Sept. 20, 1889, 541 (Naranjo de Cartago, Costa Rica; coll. U. S. Nat. Mus.); xii, 1890, 8 (monogr.).-Zeledón, Anal. Mus. Nac. Costa Rica, i, 1887, 114.Carriker, Ann. Carnegie Mus., vi, 1910, 655 (Costa Rica).-Ferry, Pub. 146, Field Mus. N. H., orn. ser., i, no. 6, 1910, 271 (Guayabo, Costa Rica).

[Xiphocolaptes] costaricensis SHARPE, Hand-list, iii, 1901, 81.

Xiphocolaptes emigrans (not of Sclater and Salvin) Sclater, Cat. Birds Brit. Mus., xv, 1890, 145, part (Costa Rica).-Salvin and Godman, Biol. Centr.Am., Aves, ii, 1891, 183, part (Naranjo de Cartago, Costa Rica).

\section{Genus XIPHORHYNCHUS Swainson.}

Xiphorhynchus Swannson, Philos. Mag., i, June, 1827, 440. (Type, X. flavigaster Swainson; see Oberholser, Smithson. Misc. Coll., xlviii, no. 1579, 1905, 62.) Dendrornis Eуток, Jardine's Contr. Orn., 1852, 23. (Type, D. susurrans Jardine.)

Large Dendrocolaptidæ (length about 200-260 mm.) with roundish, nonoperculate nostrils, nearly straight bill, and wing less than $120 \mathrm{~mm}$. 
Bill about as long as head to decidedly longer, nearly straight, much compressed, its width at latero-frontal antiæ much less than its depth at same point and contained from three and a half to nearly six times in distance from nostril to tip of maxilla; culmen distinctly to obsoletely ridged, straight for basal half (more or less), gently decurved terminally, the tip of maxilla rather strongly decurved but scarcely uncinate; tomia more or less decurved terminally, without trace of subterminal notch; gonys straight or (sometimes) very faintly concave, slightly prominent basally, sometimes very faintly decurved at tip. Nostril exposed, posteriorly in contact with latero-frontal feathering, roundish or broadly oval, nonoperculate. Rictal bristles absent. Wing moderate, rather pointed, the longest primaries exceeding secondaries by less than to decidedly more than length of tarsus; seventh and eighth, sixth, seventh, and eighth, or sixth and seventh, primaries longest, the tenth (outermost) about three-fourths as long as the longest, the ninth longer than fourth, usually (?) longer than fifth. Tail less than four-fifths to more than six-sevenths as long as wing, graduated for about one-third its length, the rectrices (12) conspicuously acuminate, with the very strong and rigid shafts decurved and somewhat twisted terminally. Tarsus shorter to slightly longer than bill from nostril, less than one-fourth as long as wing, rather slender, distinctly scutellate (endaspidean); middle toe, with claw, slightly longer than tarsus; outer toe (with or without claw) as long as middle toe; inner toe (without claw) reaching to subterminal articulation of middle toe, its claw falling short of base of middle claw; hallux decidedly shorter than inner toe, scarcely stouter; middle toe united for whole of first and part of second phalanx to outer toe, for whole of first phalanx to inner toe; claws large, those of anterior toes very strongly curved and acute, that of hallux less strongly curver, less acute, as long as or longer than the digit.

Coloration.-Rump, upper tail-coverts, tail, and remiges (at least partly) plain cinnamon-rufous or chestnut; pileum, hindneck, and back brown, olive, or black, usually streaked or spotted with buff; under parts brown, buffy grayish, or olive, striped or spotted with buffy, sometimes squamated with black on a buffy ground; chin and throat buff, sometimes immaculate, sometimes spotted or barred with olive. Sexes alike.

Range.--Southern Mexico to Cayenne, eastern and central Brazil, Bolivia, and Peru. (About thirty species and subspecies. ${ }^{a}$ )

KEY TO THE SPECIES AND SUBSPECIES OF XIPHORHYNCHUS.

a. Under parts striped or streaked with buffy.

$b$. Back black, with broad streaks of buff; under parts striped with black and buff. (Xiphorhynchus lachrymosus.)

a About half of them have not been examined in this connection. 
c. Posterior under parts obsoletely striped. (Nicaragua to northwestern Colombia.)............... . xiphorhynchus lachrymosus lachrymosus (p. 242). cc. Posterior under parts distinctly striped with black and buff. (Southwestern Costa Rica and western Panamá.)

Xiphorhynchus lachrymosus eximius (p. 243).

bb. Back brown, with streaks of buff margined with black (or with these streaks obsolete).

c. Back conspicuously streaked; general color lighter and grayer.

d. Throat immaculate buff, or with dusky squamations on lower or middle portion. (Tiphorhynchus flavigaster.)

e. Darker and browner, the throat immaculate. (Eastern Mexico, except

Yucatan, to Nicaragua.). Xiphorhynchus flavigaster flavigaster (p. 244).

ce. Paler and grayer, the lower throat usually squamated with grayish brown.

$f$. Lower throat squamated with grayish brown.

g. Smaller; averaging, wing 114.4 in male, 106.1 in female; exposed culmen 40.4 in male, 39.7 in female. (Western Mexico.)

Xiphorhynchus flavigaster mentalis (p. 247).

gg. Larger; averaging, wing 117.4 in male, 110.5 in female; exposed culmen 43.2 in male, 42.2 in female. (Southwestern Mexico.)

Xiphorhynchus flavigaster megarhynchus (p. 248).

ff. Throat immaculate. (Yucatan.)

Xiphorhynchus flavigaster yucatanensis (p. 248).

dd. Throat conspicuously streaked with blackish. (Eastern Mexico.)

Xiphorhynchus striatigularis (p. 249).

cc. Back obsoletely streaked (the streaks mostly confined to upper back); general color darker and browner. (Xiphorhynchus nanus.)

d. Chin and throat deeper buff.

e. General coloration slightly lighter. (Eastern Panamá to Colombia.)

Xiphorhynchus nanus nanus (p. 250).

$e e$. General coloration slightly darker. (Western Panamá to southern Honduras.).............. Xiphorhynchus nanus costaricensis (p. 252).

$d d$. Chin and throat paler buff or buffy white. (Northern Honduras and eastern

Guatemala.)................. Xiphorhynchus nanus confinis (p. 253).

aa. Under parts spotted with buffy.

b. Pileum and back distinctly streaked (but streaks small).

c. Back rufescent brown; under parts browner. (Southeastern Mexico to Honduras)...................... Xiphorhynchus erythropygius (p. 254).

cc. Back and under parts olive. (Colombia and Venezuela.)

Xiphorhynchus triangularis (extralimital). ${ }^{\omega}$

a Dendrocolaptes triangularis Lafresnaye, Rev. Zool., v, May, 1842, 134 ("Bolivia"; coll. Lafresnaye); Mag. de Zool., 1843, Ois., pI. 32.--Nasica triangularis Lafresnaye, Rev. Zool., 1850, 418.-Dendrornis triangularis Sclater, Proc. Zool. Soc. Lond., 1855, 142 (Bogotá, Colombia); Cat. Birds Brit. Mus., xv, 1890, 132.-Picolaptes triangularis Eyton, Contr. Orn., 1852, 22.-Xiphorhynchus triangularis triangularis Oberholser, Smithson. Misc. Coll., xlviii, pt. i, no. 1579, May 13, 1905, 63.-D[endrornis] $t[$ riangularis] bogotensis Berlepsch and Stolmmann, Proc. Zool. Soc. Lond., 1896, 376, in text.-Xiphorhynchus triangularis bogotensis Oberholser, Smithson. Misc. Coll., xlviii, pt. i, no. 1579, May 13, 1905, 63 .

The above synonymy includes two or more subspecies, but the characters given in the key are taken from Bogotá specimens. Another name possibly pertaining to a form of this species is Dendrornis erythropygia æquatorialis Berlepsch and Taczanowski, Proc. Zool. Soc. Lond., 1883, 563 (Chimbo, w. Ecuadór); Dendrornis æquatorialis Salvadori and Festa, Boll. Mus. Zool., etc., Torino, xv, 1899, no. 362, p. 25 (Foreste del Rio Peripa, w. Ecuadór; syn.; crit.); but this may be a form of $X$. punctigulus.

$$
81255^{\circ}-\mathrm{Bull} .50-11-16
$$


bb. Pileum and back not streaked (except forehead and extreme upper back, where streaks are mostly concealed). (Xiphorhynchus punctigulus.)

c. Pileum and back olive; general color of under parts olive, the throat with heavier and more numerous triangular spots of the same. (Costa Rica and western Panamá.)......... .xiphorhynchus punctigulus punctigulus (p. 255).

cc. Pileum and back sepia brown to burnt umber; general color of under parts brownish olive, the throat with smaller and fewer spots of the same. (Eastern Panamá and adjacent portion of Colombia.)

Xiphorhynchus punctigulus insolitus (p. 257).

\section{XIPHORHYNCHUS LACHRYMOSUS LACHRYMOSUS (Lawrence).}

\section{BLACK-STRIPED WOODHEWER.}

Adults (sexes alike).-Pileum and hindneck brownish black, each feather with a conspicuous mesial broad guttate streak of light buff; back and seapulars similar, but the mesial streaks much larger and deeper buff; rump, upper tail-coverts, remiges, proximal greater wing-coverts and inner-anterior portion of lesser covert area deep cinnamon-rufous, the longer primaries dark grayish brown or dusky terminally; tail, including shafts of rectrices, deep chestnut; middle wing-coverts and outer webs of distal greater coverts black or brownish black, the former with a broad mesial streak of buff or with a U-shaped mark of the same; primary coverts cinnamon-rufous, their outer webs more or less distinctly edged with grayish brown; sides of head light buff, the auricular region broadly streaked with brownish black, the feathers of suborbital and malar regions margined with the same; chin and throat light buff, the feathers of lower throat narrowly margined terminally with brownish black or dusky; chest, breast, and median portion of abdomen buff, the first and second with feathers broadly margined or squamated with brownish black, the last streaked with dusky; sides and flanks pale buffy grayish brown (pale broccoli brown), indistinctly streaked with pale buff and dusky; under tailcoverts similar, but with broad mesial streaks of buffy margined with a line of dusky; under wing-coverts deep ochraceous-buff or tawnybuff, the inner webs of remiges deeper (inclining to cinnamon-rufous), the longer primaries dusky terminally; maxilla horn color (more or less deep), sometimes darker on culmen; mandible pale horn color passing into dull pale yellowish or whitish (broadly) on gonys; legs and feet horn color (in dried skins).

Adult male.-Length (skins), 219-248 (233); wing, 111.5-131.5 (125); tail, 88-106 (99.8); culmen, 33-38.5 (34.9); tarsus, 22.5-24.5 (23.4); middle toe, $18-20$ (19.2) ${ }^{a}$

Adult female.-Length (skins), 21S-250 (231); wing, 114-125 (119); tail, S6-103 (92.3); culmen, 35-3S (36); tarsus, 22-24 (23); middle toe, $18.5-20.5(19.6){ }^{b}$ 
Nicaragua (Bluefields; Chontales; Rio Escondido), northern, eastern, and central Costa Ricr (Puerto Limón; Rio Sícsola; Talamanca; Cuábre; El Hogár; La Vijágua; Rio Reventazón; Bonilla; La Florída; Pacuare; San José; Voleán de Miravalles), and Panamá (Divala; Lion Hill) to extreme northwest portion of Colombia (Rio Truando).

Dendromis sp.? Cassin, Proc. Acad. Nat. Sci. Phila., 1860, 194 (Rio Truando, 11. W. Colombia).-Lawrence, Ann. Lyc. N. Y., vii, 1862, 292 (Lion Hill, Panamá).

Dendrornis lachrymosus Lawrence, Ann. Lyc. Nat. Hist. N. Y., vii, 1862, 467 (Lion Hill station, Panamá Railway; coll. G. N. Lawrence).

$D$ [endrornis] lachrymosa Sclater and Salvin, Proc. Zool. Soc. Lond., 1870, 839 (Nicaragua; Costa Rica; Panamá).

Dendrornis lachrymosa Zeledón, Cat. Aves de Costa Rica, 1882, 11; Anal. Mus. Nac. Costa Rica, i, 1887, 114; part (Pacuare, Costa Rica).

D[endrornis] lachrymosa lachrymosa Hellmayr, Journ. für Orn., Oct., 1903, 537, in text (crit.).

Dendrornis lacrymosa Sclater and Salvin, Proc. Zool. Soc. Lond., 1864, 355 (Panamá; crit.); 1867, 279 (Bluefields R., Nicaragua); (?) 1879, 523 (Remédios, Antioquía, Colombia).-SAlvin, Proc. Zool. Soc. Lond., 1867, 144, part (Bluefields, Nicaragua); Ibis, 1872, 317 (Chontales, Nicaragua).Elliot, Auk, vii, 1890, 181 (monogr.).-Sclater, Cat. Birds Brit. Mus., xv, 1890, 133 (Chontales, Nicaragua; Panamá).-Salvin and Godman, Biol. Centr.-Am., Aves, ii, 1891, 182, part, pl. 48, fig. 1 (Bluefields and Chontales, Nicaragua; Costa Rica; Lion Hill and Rio Truando, Panamá; Colombia?).Richmond, Proc. U. S. Nat. Mus., xvi, 1893, 498 (Rio Escondido, Nicaragua).-Uxderwood, Ibis, 1896, 440 (Volcán de Miravalles, Costa Rica).

[Dendrornis] lacrymosa Sclater and Salvin, Nom. Av. Neotr., 1873, 68.-Sharpe, Hand-list, iii, 1901, 79, part (Nicaragua to Panamá).

[Dendrocolaptes] lacrymosus GRAY, Hand-list, i, 1869, 178, no. 2420.

Xiphorhynchus lacrymosus lacrymosus Oвerholser, Smithsonian Misc. Coll., xlviii, no. 1579, Маy 13, 1905, 63.

Tiphorhynchus lacrymosus eximius (not Dendrornis lachrymosa eximia Hellmayr) Carriker, Ann. Carnegie Mus., vi, 1910, 654, part (Bonilla, Reventazón, Guácimo, Cuábre, Rio Sícsola, El Hogár, and La Vijágua, Costa Rica; habits).

\section{XIPHORHYNCHUS LACHRYMOSUS EXIMIUS (Fiellmayr).}

STRIPED-BELLIED WOODHEWER.

Similar to X.7.7achrymosus, but under parts of body more distinctly marked with black and buff (the whole abdomen conspicuously striped with these colors).

Adult male.-Length (skins), 233-252 (242); wing, 127-131.5 (129.1); tail, 98-110 (104); culmen, 35.5-36.5 (36.1); tarsus, 23-24 (23.4); middle toe, $19-20$ (19.5).$^{a}$

Adult female.-Length (skins), 223-231 (227); wing, 114.5-124 (117.8); tail, 87.5-93.5 (90.3); culmen, 35-40 (38); tarsus, 24.5-25 (24.7); middle toe, $19-20(19.7) .^{b}$ 
Southwestern Costa Rica (Pozo Azúl de Pirrís; Pozo del Rio Grande; El Pozo de Térraba) and adjacent portion of western Panamá (Divala).

Dendrornis lacrymosa (not D. lachrymosus Lawrence) Salvin, Proc. Zool. Soc. Lond., 1867, 144, part (Santiago de Verágua, Panamá); 1870, 193 (Volcán de Chiriquí and Bugaba, Panamá).-Sclater, Cat. Birds Brit. Mus., xv, 1890, 133, part (Bugaba and Santiago de Verágua, Panamá).-SAlvin and Godman, Biol. Centr.-Am., Aves, ii, 1891, 182, part (Volcán de Chiriquí, Bugaba, Bibaláz, and Santiago de Verágua, Panamá).

Dendrornis lachrymosa Zeledón, Anal. Mus. Nac. Costa Rica, i, 1887, 114, part (Las Trojas, Costa Rica).

Dendrornis lachrimosa Cherrie, Expl. Zool. Merid. Costa Rica, 1893, 40 (Palmár and Boruca, s. w. Costa Rica).

Dendrornis lachrymosa eximia Hellma yr, Journ. für Orn., Oct., 1903, 537 (Boruca, s. w. Costa Rica; coll. Vienna Mus.).-Bangs, Auk, xxiv, 1907, 299 (Pozo del Rio Grande, s. w. Costa Rica).

Xiphorhynchus lacrymosus eximius Oberholser, Smithsonian Misc. Coll., xlviii, no. 1579, May 13, 1905, 63.-Carriker, Ann. Carnegie Mus., vi, 1910, 654, part (Pozo Azúl de Pirrís and El Pozo de Térraba, s. w. Costa Rica).

\section{XIPHORHYNCHUS FLAVIGASTER. FLAVIGASTER Swainson.}

SWAINSON'S WOODHEWER.

Adults (sexes alike).-Pileum and hindneck sooty black, each feather with a conspicuous mesial broad guttate streak or spot of buff or clay color; back and scapulars raw-umber brown, each feather with a conspicuous broad mesial streak of buff or clay color, inclosed within a narrower bordering streak of black; rump more tawny brown passing into dull tawny or tawny-ochraceous on upper tail-coverts, the longer feathers of which are tinged with cinnamonrufous and with more or less distinct narrower mesial streaks of paler, sometimes margined with blackish; tail uniform deep cinnamon-rufous or rufous-chestnut; lesser wing-coverts rufous-brown, with very indistinct mesial streaks of paler; middle coverts rawumber brown (nearly like color of back), with mesial streaks of buff or clay color, margined laterally with black; greater and primary coverts plain raw-umber brown, slightly more rufescent than color of black; remiges plain dull cinnamon-rufous, becoming paler and more brownish (less rufescent) on outer primaries; superciliary region buff, the feathers narrowly margined with blackish; suborbital and auricular regions buff, the feathers of the former margined, those of the latter streaked, with black; malar region, chin, and throat clear buff, the feathers of extreme lower throat usually narrowly margined with dusky; a conspicuous but more or less interrupted broad submalar streak of sooty black; chest buff' (usually slightly paler than color of throat, the feathers margined with dusky or blackish, producing a squamate effect; rest of under parts light bufly brown (nearly isabella color) broadly streaked with light buff, 
these buffy streaks often margined laterally with a line of blackish or dusky; under wing-coverts uniform ochraceous-bufl; inner webs of remiges light tawny-ochraceous, the terminal portion (extensively) of five onter primaries grayish brown or dusky; bill pale yellowish horn color or dull buffy whitish, darker (more horn colored) on basal portion of maxilla; iris brown; legs and feet dusky horn color (in dried skins).

Iounq.-Similar to adults but general coloration darker, with blackish streaks on back and under parts heavier; feathers of chest more broadly and distinctly margined with black and texture of plumage more lax.

Adult male.-Length (skins), 219-259 (237); wing, 100.5-120 (113.3); tail, SS-104.5 (95.2); culmen, 37-42.5 (39.9); tarsus, 21-25 (23.3); middle toe, $16.5-19$ (18.3). ${ }^{a}$

Adult female.-Length (skins), 20s-255 (231); wing, 102.5-121.5 (110); tail, \$4-102 (92.5); culmen, 35-43.5 (39.7); tarsus, 21.5-24.5 (22.9); middle toe, $16.5-19.5$ (17.S). ${ }^{b}$

Southeastern Mexico, in States of Tamaulipas (Alta Mira; Tampico; Tamesi), Tera Cruz (Playa Vicente; Rivera; Jalapa; Orizaba; Miradór; Córdova; San Lorenzo near Córdova; Misantla; Colipa; Plan del Rio; Otatitlán; Santa Lucrécia; Tega del Casadero; Hacienda Tortugas; Pasa Nueva; Buena Vista; Tolosa; Carrizál; Mot-

a Thirty-eight specimens. $b$ Twenty-five specimens.

\begin{tabular}{|c|c|c|c|c|c|}
\hline Locality. & Wing. & Tail. & $\begin{array}{l}\text { Cul- } \\
\text { men. }\end{array}$ & Tarsus. & $\begin{array}{c}\text { Middle } \\
\text { toe. }\end{array}$ \\
\hline \multicolumn{6}{|l|}{ MALES. } \\
\hline Eight adult males from Tamaulipas.. & 116.1 & 98.9 & 40.9 & 23.3 & 18 \\
\hline Five adult males firom Vera Cruz....... & 112.7 & 98 & 39.8 & 23.3 & 18.4 \\
\hline Four adult males from San Luís Potosí... & 112.1 & 92 & 40.4 & 23.1 & 18.7 \\
\hline Three adult males from Puebla............. & 114.3 & 96.3 & 39.7 & 23.7 & 18 \\
\hline Four adult males from Oaxaca......... & 116.1 & 93.6 & 40.2 & 24.2 & 18.4 \\
\hline Two adult males from Guatemala........ & 119.7 & 99.5 & 39.7 & 23.7 & 19.7 \\
\hline Eight adult males from British Honduras.... & 107.9 & 91 & 38.5 & 22.9 & 18.1 \\
\hline T wo adult males from Honduras............ & 116 & 96.2 & 40 & 23.7 & 19 \\
\hline Two adult males from Nicaragua............ & 111.2 & 91.2 & 42 & 22.5 & 17.2 \\
\hline \multicolumn{6}{|l|}{ FEMALES. } \\
\hline EIght adult females from Tamaulipas... & 112.4 & 94.2 & 40.2 & 22.9 & 18.2 \\
\hline Six adult females from Vera Cruz and Puebla. & 109.8 & 92.2 & 40.2 & 23.5 & 17.1 \\
\hline Three adult females from Oaxaca.. & 112.5 & 95.8 & 39.8 & 23.2 & 18.8 \\
\hline One adult female from Tabasco.... & 108 & 85.5 & 41 & 23.5 & 17.5 \\
\hline One adult female from Chiapas..... & 105 & 86.5 & $\ldots$ & 21.5 & 18 \\
\hline One adult female from Guatemala......... & 102.5 & 87 & 38 & 21.5 & 17 \\
\hline Two adult females from British Honduras. & 108.7 & 91.5 & 36.7 & 22.2 & 17 \\
\hline One adult female from Honduras............ & 111 & 95.5 & 39 & 22 & 16.5 \\
\hline One adult female from Salvadór........... & 107 & 86.5 & 40 & 23 & 18 \\
\hline One adult female from Nicaragua..... & 116 & 95.5 & 39 & 22.5 & 18 \\
\hline
\end{tabular}


zorongo; Llave), Puebla (Chietla; Metlaltoyuca), Mexico (Temíscáltepec), San Luís Potosí (Vallés), Oaxaca (Santa Efigénia; Tehuántepec; Tapana; Guichicovi; Cacoprieto; Chimalapa; Ishuatlán; Túxtepec; mountains near Santo Domingo), Guerrero (Papayo), Tabasco (Teapa; Frontera), Campeche (Apazote; Yohaltán; Canasayat), and Chiapas (San Benito), and through Guatemala (Choctúm; sources of Rio de la Pasión; Sabana Grande; Volcán de Agua; Retalhuleu; Los Amates, Yzabál; Patulúl, Sololá; Telemán), British Honduras (Belize; Orange Walk; Cayo; Southern Pine Ridge; Toledo District; near Manatee Lagoon), Honduras (San Pedro; Truxillo; Santa Ana) and Salvadór (Acajutla; Volcán San Miguél; La Libertád) to Nicaragua (Realejo; Chinandega; Sucuyá; Managua; San Juan del Sur).

Xiphorhynchus flavigaster Swannson, Philos. Mag., new ser., i, 1827, 440 (Temiscáltepec, Mexico).

X[iphorhynchus] flavigaster Bonaparte, Consp. Av., i, 1850, 208 (Realejo, Nicaragua).

Dryocopus flavigaster DंEs MURs, Icon. Orn., livr. 9, July, 1847, text to pl. 52 (Mexico).

Nasica flavigaster Lafresnaye, Rev. et Mag. Zool., 1850, 383.

Dendrornis flavigastra Sclater, Proc. Zool. Soc. Lond., 1856, 289 (Córdova, Vera Cruz); 1859, 381 (Playa Vicente, Vera Cruz).-Salvin and Sclater, Ibis, 1860, 398 (Choctúm, Guatemala).-Sumichrast, La Naturaleza, v, 1881, 248 (Cacoprieto, Tapana, and Sta. Efigénia, Oaxaca).-Chapman, Bull. Am. Mus. N. H., x, 1898, 32 (Jalapa, Vera Cruz).-Dearborn, Pub. 125, Field Mus. N. H., 1907, 108 (Los Amates and Patulúl, Guatemala; crit.).

Dendrornis flavigaster Ferrari-Perez, Proc. U. S. Nat. Mus., ix, 1886, 156 (Chietla, Puebla).-Elliot, Auk, vii, 1890, 178, part (monogr.; excl. syn. D. mentalis Lawrence).-RIchmond, Proc. U. S. Nat. Mus., xviii, 1896, 630 (Alta Mira, Tamaulipas).

Xiphorhynchus favigaster flavigaster Oberholser, Smithsonian Misc. Coll., xlviii, no. 1579, May 13, 1905, 63.

Dryocopus eburneirostris "Lesson, Echo du Monde Savant, 1843" [Des Murs, Icon. Orn., livr. 9, July, 1847, pl. 52 and in synonymy of Dryocopus favigaster] (Realejo, Nicaragua).-Des Murs, Icon. Orn., livr. 9, July, 1847, pl. 52 .

Dendrornis eburneirostris Eyton, Jardine's Contr. Orn., 1852, 23.-Bonaparte, Consp. Voluc. Anisod., 1854, 11.-Cabanis and Heine, Mus. Hein., ii, 1859, 37.-Sclater, Cat. Am. Birds, 1862, 164 (Guatemala; Mexico); Cat. Birds Brit. Mus., xv, 1890, 130, part (Cacoprieto and Sta. Efigénia, Oaxaca; Belize, Brit. Honduras; sources Rio de la Pasión, Choctúm, Sabana Grande, Volcán de Agua, and Retalhuleu, Guatemala; San Pedro, Honduras).-Sclater and Salvin, Proc. Zool. Soc. Lond., 1870, 834, 840 (San Pedro, Honduras).Lawrence, Bull. U. S. Nat. Mus., no. 4, IS76, 25 (Guichicovi, Ishuatlán, Tapana, and Sta. Efigénia, Oaxaca).-Boucard, Ann. Soc. Linn. Lyon, 1878, 38 (Guatemala).-Nutring, Proc. U. S. Nat. Mus., vi, 1883, 375, 385 (San Juan del Sur and Sucuyá, Nicaragua).-Rrdgway, Proc. U. S. Nat. Mus., x, 1887, 580 (Truxillo, Honduras).-Salvin and Godman, Biol. Centr.Am., Aves, ii, 1891, 178, part (Alta Mira, Tamesi, and Tampico, Tamaulipas; and numerous other Mexican localities, etc.; excl. syn. D. mentalis Law- 
rence).-Menegaux and Hellyayr, Mem. Soc. N. H. d'Autun, xix, 1906, 101, part (type, from Realejo, Nicaragua, in Paris Mus.; crit.).

Iiphorhynchus flaigaster cbumeirostris OberHouser, Smithsonian Misc. Coll., xlviii, no. 1579, Maty 13, 1905, 63.

Premnocopus cbumcirostris Reicinenbach, Mandb. Spec. Orn., 1853, 186, pl. 603, fig. 4059 .

Dendrocolaptes eburneirostris Gray, Hand-list, i, 1869, 177, no. 2403.

[Dendrornis] eburneirostris Sclater and Salvin, Nom. Av. Neotr., 1873, 68, part.-Sharpe, Hand-list, iii, 1901, 78, part.

D[endromis] eburneirostris CABANIS and HeIne, Mus. Hein., ii, 1859, 37 (Mexico).-Sclater and Salvin, Proc. Zool. Soc. Lond., 1870, 839 (Mexico; Guatemala; Honduras).

Picolaptes validirostris ErToN, Jardine's Contr. Orn., 1851, 75 (no locality given; coll. Knowsley Mus.).

[Picolaptes] validirostris Gray, Hand-list, i, 1869, 179, no. 2447.

\section{XIPHORHYNCHUS FLAVIGASTER MENTALIS (Lawrence).}

GRAYSON'S WOODHEWER.

Similar to $X$. $f$. flavigaster but decidedly paler throughout, the prevailing color of pileum and hindneck deep grayish brown instead of blackish, that of back, etc., light grayish buffy brown (nearly broccoli brown) instead of raw-umber, streaks paler buff, and feathers on middle of throat usually distinetly margined or edged with grayish brown, often producing a broken patch of that color.

Adult male.-Length (skins), 222-243 (231); wing, 103-119 (114.4); tail, 81-100 (91); culmen, 38-42.5 (40.4); tarsus, 22-23.5 (22.9); middle toe, $17-19.5(18.2){ }^{a}$

Adult female.-Length (skins), 200-220 (214); wing, 99.5-109.5 (106.1); tail, 75.5-90 (82.7); culmen, 38.5-42 (39.7); tarsus, 21-23 (22.3); middle toe, $17-18.5$ (17.7). ${ }^{b}$

Western Mexico, in States of Durango (Chacalá), Jalisco (Las Palmas; Barranca Veltrán; San Sebastián), Sinaloa (Mazatlán; Presídio de Mazatlán; Juan Lisiarraga Mountains, 5,500 feet; Los Pieles; Arroyo de Limones, 3,500 feet; Quotla, near Rosário; Culiacán; Plomosas; Escuinapa; Rio Juan Gomez), Colima (Manzanillo; Santiago; Sierra Madre), Michoacán (Cayaco), Guerrero (Papayo), Durango (Chacalá), and Territory of Tepíc (Santiago; Rio Santiago; San Diego; Tepíc).

Dendromis mentalis Baird, MS. LAWrence, Ann. Lyc. Nat. Hist. N. Y., viii, May, 1867, 481 (Mazatlán, Sinaloa, w. Mexico; coll. U. S. Nat. Mus.); Mem. Bost. Soc. N. H., ii, 1874, 285 (Mazatlán; Tepíc).-SaNcriez, An. Mus. Nac. Mexico, i, 1877, 97 (Mazatlán)._Sclater, Cat. Birds Brit. Mus., xv, 1890, 131 (Presídio, near Mazatlán).-Jouy, Proc. U. S. Nat. Mus., xvi, 1893, 784 (Barranca Veltrán, s. Jalisco).

Dendrornis flavigaster mentalis Mrluer (W. De W.), Bull. Am. Mus. N. H., xxi, Nov. 24, 1905, 355 (Los Pieles, etc., s. Sinaloa; crit.). 
Xiphorhynchus flavigaster mentalis OBERHOLSER, Smithsonian Misc. Coll., xlviii, no. 1579, May 13, 1905, 63.

[Dendrocolaptes] mentalis GRAY, Hand-]ist, i, 1869, 177, no. 2413.

Dendrornis flavigaster (not Xiphorhynchus flavigaster Swainson) ELLIOT, Auk, vii, 1890, 178, part (Mazatlán; Manzanillo; monogr.).

Dendrornis eburneirostris (not Dryocopus eburneirostris "Lesson") SaLvin and Godman, Biol. Centr.-Am., Aves, ii, 1891, 178, part (Mazatlán; Tepíc; Santiago de Tepíc; Santiago de Colima; Tecolapa).

[Dendrornis] eburneirostris Sclater and Salvin, Nom. Av. Neotr., 1873, 68, part.-Sharpe, Hand-list, iii, 1901, 78, part.

\section{XIPHORHYNCHUS FLAVIGASTER MEGARHYNCHUS (Nelson).}

\section{LARGE-BILIED WOODHEWER.}

Similar in coloration to $X . f$. mentalis but larger, especially the bill. Adult male.-Length (skins), 239-265 (249); wing, 114-123 (117.4); tail, 89.5-96 (92.3); culmen, 42-45.5 (43.2); tarsus, 23-25 (23.8); middle toe, $18.5-19$ (18.8). ${ }^{a}$

Adult female.-Length (skins), 232-253 (242); wing, 110-111 (110.5); tail, 88-90 (89); culmen, 42-42.5 (42.2); tarsus, 22.5-23 (22.7); middle toe, $18-18.5$ (18.2). ${ }^{b}$

Dendrornis flavigaster megarhynchus Nelson, Auk, xvii, July, 1900, 265 (Puerto Angel, Oaxaca; coll. U. S. Nat. Mus.).

[Dendrornis] megarhyncha SHARPE, Hand-list, iii, 1901, 78.

Xiphorhynchus flavigaster megarhynchus OBERHolser, Smithsonian Misc. Coll., xlviii, no. 1579, May 13, 1905, 63.

Southwestern Mexico, in States of Guerrero (El Naranjo; Acahuitzotla; Sihuataenjo; La Unión) and western Oaxaca (Puerto Angel).

\section{XIPHORHYNCHUS FLAVIGASTER YUCATANENSIS Ridgway.}

\section{YUCATAN WOODHEWER.}

Very similar in coloration to $X . f$. mentalis, but averaging very slightly smaller (with slightly larger bill and feet), and throat always immaculate pale buff; much paler and grayer than $X$. $f$. flavigaster.

Adult male.-Length (skins), 228-248 (238); wing, 104-118 (110.2); tail, 84-100 (90.9); culmen, 40-42 (40.8); tarsus, 22.5-24 (23.2); middle toe, $17-18.5(17.5){ }^{c}$

Adult female.-Length (skins), 217-232 (226); wing, 100-111 (106.4); tail, 85-94.5 (89.4); culmen, 39-43 (40.6); tarsus, 21-23 (22.1); middle toe, $17 .^{a}$

Yucatan (Chichen-Itza; Puerto Morelos; Izalám; La Vega; Temáx; Mérida; Tuloom; Peto; Buctzotz; Tabi; Meco Island). ${ }^{d}$

Dendrornis eburneirostris (not Dryocopus eburneirostris "Lesson") LAwrence, Ann. Lyc. N. Y., ix, 1869, 201 (n. Yucatan).-Boucard, Proc. Zool. Soc. Lond., 1883, 450 (Yucatan; habits).-Selater, Cat. Birds Brit. Mus., xv, 1890,

$a$ Five specimens.

$b$ Two specimens. $c$ Nine specimens.

$d$ Specimens from Meco Island not seen by me. 
130, part (Tuloom and Meco I., Yucatan).-Salyin and Godman, Biol. Centr.-Am., Aves, ii, 1s91, 17s, part (Peto, liuctzotz, Tuloom, Tabi, Meco I., etc., Yucatan).-Menegaux and Heldiayr, Mem. Soc. N. H. d'Autun, xix, 1906, 101, part (Izamál, lucatan).

[Dendrornis] cbumeirostris Sclater and Salvin, Nom. Av. Neotr., 1873, 68, part.SuArpe, Hand-list, iii, 1901, 78, part.

Dendrornis flavigaster (not Tiphorhynchus flavigaster Swainson) SALvin, Ibis, 1859, 364 (Tuloom and Meco I., Yucatan).-EцLот, Auk, vii, 1890, 178, part (Temáx and Mérida, Yucatan).-Cole, Bull. Mus. Comp. Zool., ], 1906, 132 (Chichen-Itza, Yucatan).

Iiphorhynchus favigaster yucatancnsis Ridgway, Proc. Biol. Soc. Wash., xxii, Apr. 17, 1909, 73 (Temáx, Yucatan; coll. U. S. Nat. Mus.).

\section{XIPHORHYNCHUS STRIATIGULARIS (Richmond).}

STRIPED-THROATED WOODHEWER.

Slightly resembling $\mathrm{I}$. flavigaster but differing greatly in having the whole throat conspicuously streaked; buff streaks of chest, etc., margined laterally with a chain-like streak of blackish; wing-coverts conspicuously streaked with black and buff, and buff streaks of back much broader.

Adult female. ${ }^{a}$-Pileum and hindneck sooty black, each feather with a broad mesial guttate streak of buff or clay color; back and scapulars brown (between light olive and raw-umber) each feather with a broad mesial streak of brownish buff or clay color, broadly margined with black; lesser and middle wing-coverts similar, but buffy mesial streaks much narrower; greater coverts similar but with still narrower streaks; remiges plain deep cinnamon-rufous or rufous-chestnut, the terminal portion of inner webs of primaries (except the innermost) grayish brown; rump plain light cinnamonrufous or rufous tawny, the upper tail-coverts deeper cinnamonrufous, with indistinct shaft-streaks of paler; tail (including shafts of rectrices) plain deep cinnamon-rufous or rufous-chestnut; sides of head and neck broadly streaked with buff and sooty blackish; chin, throat, and foreneck similarly streaked, the streaks becoming gradually broader and more sharply defined, and the feathers edged with light buffy grayish brown, on lower foreneck; chest, breast, etc., similarly streaked, but the blackish streaks narrower and more irregular and grayish brown edgings to the feathers broader, the streaks becoming gradually narrower and less distinct posteriorly; under wing-coverts mixed pale cinnamon-rufous and light buffy brownish (the latter prevailing along edge of wing, where streaked with buffy and blackish); inner webs of remiges pale cinnamon-rufous or vinaceous-cinnamon, the terminal portion (extensively) of outer primaries grayish brown; bill pale yellowish horn color, the maxilla more brownish basally; feet light horn brownish (in dried skins);

$a$ The adult male is unknown, but judging from the general rule in this group the sexes are probably alike in color. 
length (skin), 230; wing, 105; tail, 87; exposed culmen, 37.5; tarsus, 23 ; middle toe, 17.

Eastern Mexico, in southern part of State of Tamaulipas (Alta Mira).

Dendrornis striatigularis Richmond, Proc. U. S. Nat. Mus., xxii, no. 1200, May, 1900, 317 (Alta Mira, Tamaulipas; coll. U. S. Nat. Mus.).

[Dendrornis] striatigularis SHARPE, Hand-list, iii, 1901, 78.

Xiphorhynchus striatigularis Oberholser, Smithsonian Misc. Coll., xlviii, no. 1579, May.13, 1905, 63.

\section{XIPHORHYNCHUS NANUS NANUS (Lawrence). \\ LAWRENCE'S WOODHEWER.}

Adults (sexes atike).-Pileum and hindneck dark sooty brown or sooty blackish, each feather with a broad mesial guttate streak or mark of brownish buff; back and scapulars olive-brown (between raw-umber and mummy), the feathers of upper back with a broad mesial streak of brownish buff or pale tawny, margined with blackish; rump and upper tail-coverts plain cinnamon-rufous; tail, including shafts of rectrices, chestnut; remiges deep cinnamon-rufous, the primaries and distal secondaries edged (more or less distinctly) with grayish brown or olive; wing-coverts plain brown, nearly if not quite concolor with back; supra-auricular region pale brownish buff or dull buffy whitish, the feathers narrowly margined with dusky; auricular region streaked with light brown and dusky; suborbital region with feathers light buff margined with dusky, the malar region similar but with dusky margins to feathers much less distinct (partly obsolete); chin and throat plain light brownish buff or dull pinkish buff, the feathers of extreme lower throat narrowly margined with dusky; feathers of chest light brownish buff or dull pinkish buff centrally, those of upper chest wholly of this color except for a narrow but distinct margin of dusky, those of lower chest with a broad median ovate or elliptical stripe of buff margined laterally by a blackish line, the edges (more or less broadly) light buffy brown; rest of under parts light buffy brown (nearly wood brown or isabella color), the median portion of breast and abdomen usually with narrow and indistinct streaks of paler; under wing-coverts ochraceousbuff, the inner webs of remiges deeper, inclining to cinnamon-rufous, the longer primaries with terminal portion dusky; maxilla blackish brown, mandible pale horn color or dull yellowish (in dried skins); feet horn color or dusky (in dried skins).

Young.-Similar to adults but markings of under parts rather more strongly contrasted; only to be distinguished with certainty, however, by the softer and more lax texture of the plumage. 
Adult male.-Length (skins), 211-226 (222); wing, 97-111 (105.7); tail, 77.5-0.2.5 (\$7.7); culmen, 34-39 (36.6); tarsus, 21.5-23.5 (22.6); middle toe, $17-19$ (17.9). ${ }^{a}$

Adult female.-Length (skins), 210-227 (217); wing, 98-109 (104); tail, S1-91 (\$5); culmen, 34.5-39.5 (36.8); tarsus, 22-23.5 (22.9); middle toe, $17-1 \mathrm{~s}(17.5) .^{b}$

Eastem Panamá (Lion Hill; San Pablo Station; Colón; Panamá; Sabana de Panamá; Natá, Coclé) and Colombia (Ninca, Don Diego, and Cacagualito, Santa Marta; Rio Lima; Bogotá?).

Dendrornis guttatus (not Dendrocolaptes guttatus Lichtenstein) Cassin, Proc. Ac. Nat. Sci. Phila., 1860, 193 (Lion Hill, Panamá).-Lawrence, Ann. Lyc. N. Y., vii, 1862, 292 (Lion Hill).

Dendrornis pardalotus (not Dendrocopus pardalotus Vieillot) Lawrence, Ann. Lyc. N. Y., viii, 1863, 482 (Isth. Panamá).

Dendrornis nana LAwrence, Ibis, April, 1863, 181 (Lion Hill, Panamá; coll. G. N. Lamrence); Ann. Lyc. Nat. Hist. N. Y., viii, 1863, 4, 482 (do.).Sclater and Salvin, Proc. Zool. Soc. Lond., 1864, 355 (Lion Hill; crit.).Elliot, Auk, vii, 1890, 174, part (Panamá; monogr.).-SAlvin and Godman, Biol. Centr.-Am., Aves, ii, 1891, 180, part (Lion Hill, San Pablo Station, and Panamá, Isth. Panamá).-Bangs, Proc. New Engl. Zool. Club, ii, 1900, 25 (Loma del León, Panamá).

[Dendrornis] nana Sharpe, Hand-list, iii, 1901, 78, part (Panamá).

Dendrornis nana nana Bavgs, Bull. Mus. Comp. Zool., xxxix, no. 6, July, 1903, 151 (Panamá; diagnosis).

Xiphorhynchus nanus nanus OвerHolser, Smithsonian Misc. Coll., xlviii, no. 1579, May 13, 1905, 63.-Thayer and Bangs, Bull. Mus. Comp. Zool., xlvi, 1906, 217 (Sabana de Panamá).

[Dendrocolaptes] nanus GrAY, Hand-list, i, 1869, 177, no. 2408.

Dendrornis susurrans (not Dendrocolaptes susurrans Jardine) Sclater and SAlvin, Proc. Zool. Soc. Lond., 1870, 839, part (Panamá; crit.).-_SALvin, Proc. Zool. Soc. Lond., 1883, 424 (Panamá).-Sclater, Cat. Birds Brit. Mus., xv, 1890, 133, part (San Pablo and Paraiso stations and Panamá City, Panamá).

[Dendrornis] susurrans Sclater and Salvin, Nom. Av. Neotr., 1873, 68, part.

Dendrornis lawrencei Ridgway, Proc. U. S. Nat. Mus., x, sig. 32, Aug. 6, 1888, 509 (Panamá; coll. U. S. Nat.Mus.).-Sclater, Ibis, 1889, 353 (crit.).

a Twelve specimens.

$b$ Five specimens, from eastern Panamá.

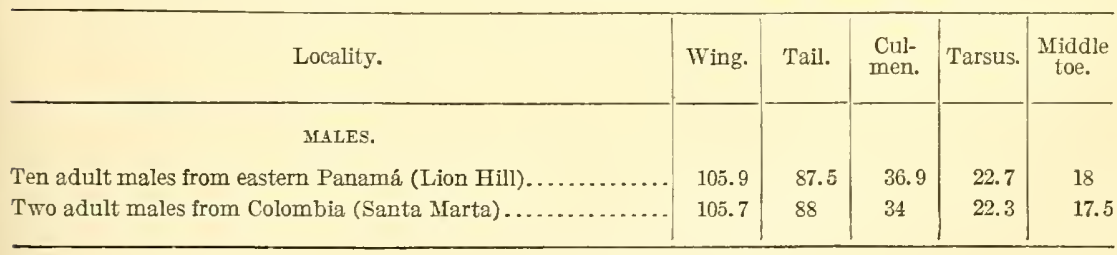




\section{XIPHORHYNCHUS NANUS COSTARICENSIS (Ridgway).}

TUCURRIQUI WOODHEWER.

Similar to $X$. n. nanus, but coloration averaging slightly deeper.

Adult male.-Length (skins); 200-243 (220); wing, 95.5-114.5 (105.8); tail, 83-104 (90.3); culmen, 34.5-39 (36.7); tarsus, 21.5-24 (22.8); middle toe, $17-19$ (17.7). ${ }^{a}$

Adult female.-Length (skins), 185-222 (205); wing, 94-102 (97.9); tail, $77-85.5$ (81.8); culmen, 29.5-39 (36); tarsus, 21-23 (22); middle toe, $16-18$ (17). ${ }^{b}$

Western Panamá (Calovévora; Bugaba; Divala), through Costa Rica (Angostura; San Carlos; San Juan Valley; Tucurríqui; Guayabo; Rio Reventazón; Rio Sícsola; Talamanca; Puerto Limón; Siquirres; Guácimo; Guápiles; Cuábre; El Hogár; Jiménez; Bonilla; Pacuare; Volcán de Turrialba; Volcán de Miravalles; Tenório; Barranca de Puntarenas; Barranca de Boruca; Bebedero; Pozo del Rio Grande; Pozo Azúl de Pirrís; El Pozo de Térraba; Térraba; Buenos Aires; El Generál; Boruca, Paso Reál, and Lagarto, Boruca), eastern Nicaragua (Greytown; Rio Escondido), and southeastern Honduras (Rio Segóvia).

Dendrornis pardalotus (not Dendrocopus pardalotus Vieillot) Lawrence, Ann. Lyc. N. Y., viii, 1867, 180 (Greytown, Nicaragua); ix, 1868, 107 (Tucurríqui, Costa Rica).-Frantzius, Journ. für Orn., 1869, 305 (Costa Rica).

Dendrornis nana (not of Lawrence) Sclater and Salvin, Proc. Zool. Soc. Lond., 1870, 837 (Calovévora, Panamá).-Salvin, Proc. Zool. Soc. Lond., 1870, 193 (Calovévora and Bugaba, Panamá; crit.).-Salvin and Godian, Biol. Centr.Am., Aves, ii, 1891, 180, part (Rio Segóvia, Honduras; Tucurríqui and San Carlos, Costa Rica; Bugaba and Calovévora, Panamá).-Rıснмond, Proc. U.S. Nat. Mus., xvi, 1893, 498 (Greytown and Rio Escondido, Nicaragua; crit.).Underwood, Ibis, 1896, 440 (Volcán de Miravalles, Costa Rica).-Eliıot, Auk, vii, 1890, 174, part.

a Twenty-nine specimens.

$b$ Eighteen specimens.

\begin{tabular}{|c|c|c|c|c|c|}
\hline Locality. & Wing. & Tail. & $\begin{array}{l}\text { Cul- } \\
\text { men. }\end{array}$ & Tarsus. & $\begin{array}{l}\text { Middle } \\
\text { toe. }\end{array}$ \\
\hline \multicolumn{6}{|l|}{ MALES. } \\
\hline Three adult males from eastern Nicaragua...... & 102.8 & 91.2 & 36 & 22.7 & 17.3 \\
\hline Nine adult males from eastern Costa Rica....... & 106 & 90.8 & 37.6 & 23.2 & 17.5 \\
\hline Eleven adult males from western Costa Rica................ & 107.6 & 90.4 & 36.8 & 22.8 & 17.9 \\
\hline Six adult males from western Panamá.............. & 103 & 88.9 & 36.6 & 22.6 & 17. 8 \\
\hline Ten adult males (X. n. nanus) from eastern Panamá......... & 105.9 & 87.5 & 36.9 & 22.7 & 18 \\
\hline Two adult males (X.n. nanus) from Colombia (Santa Marta). & 105.7 & 88 & 34 & 22.3 & 17.5 \\
\hline Two adult males ( $X . n$. confinis) from Honduras... & 104.7 & 90 & 36.5 & 22 & 17.3 \\
\hline \multicolumn{6}{|l|}{ FEMALES, } \\
\hline Two adult females from eastern Nicaragua.... & 94.7 & 81 & 31.7 & 22 & 17.5 \\
\hline Eight adult females from eastern Costa Rica...... & 99.2 & 82.3 & 37.1 & 22.1 & 17.1 \\
\hline Eight adult females from western Costa Rica. . .............. & 97.5 & 81.4 & 35.9 & 22 & 16.9 \\
\hline One adult female ( $X . n$. confinis) from Guatemala........ & 93.5 & 74 & 36 & 20.5 & 16.5 \\
\hline
\end{tabular}


[Iendrornis] nana Srarpe, Hand-list, iii, 1901, 78, part.

Dendrornis susurrans (not Dendrocolaptes susumans Jardine) Sclater and Salvin, Proc. Zool. Soc. Lond., 1S70, S39, part (Terágua; Costa Rica; crit.).-BouCard, Proc. Zool. Soc. Lond., 1S7s, 60 (San Carlos, Costa Rica).-Sclater, Cat. Birds Brit. Mus., xv, 1890, 133, part (Angostura, Costa Rica; Calovévora and Bugaba, Panamí).

[Dendrornis] susumans Sclater and Salvin, Nom. Av. Neotr., 1S73, 68, part.

Dendrornis lawrencei costaricensis Ridgway, Proc. U. S. Nat. Mus., x, sig. 32, Aug. 6, 1Sss, 510 (Tucurríqui, Costa Rica; coll. U. S. Nat. Mus.).-Zeledón, Anal. Muss. Nac. Costa Rica, i, 1Ss8, 114.

Dendrornis laurencii costaricensis SCLATER, Ibis, 1889, 353 (crit.).

Dendrornis lawrenceï costaricensis Lantz, Trans. Kansas Acad. Sci. for 1896-97 (1S99), 221, part (San Juan Valley, Costa Rica).

Dendrornis nana costaricensis Cherrie, Proc. U. S. Nat. Mus., xiv, 1891, 532 (crit.).-Bangs, Bull. Mus. Comp. Zool., xxxix, 1903, 151 (diagnosis); Auk, xxiv, 1907, 299 (Boruca, Paso Reál, Pozo del Rio Grande, Barranca, Lagarto, and Barranca de Puntarenas, w. Costa Rica).-Ferry, Pub. 146, Field Mus. N. H., orn. ser., i, no. 6, 1910, 270 (Guayabo, Costa Rica).

Dendrornis nana (costaricensis?) Cherrie, Expl. Zool. Merid. Costa Rica, 1893, 40 (Palmár, Lagarto, Boruca, Térraba, and Buenos Aires, s. w. Costa Rica).

Xiphorhynchus nanus costiricensis OBerHolser, Smithsonian Misc. Coll., xIviii, no. 1579, May 13, 1905, 63.

Xiphorhynchus nanus costaricensis Carriker, Ann. Carnegie Mus., vi, 1910, 652 (Costa Rica; habits).

\section{XIPHORHYNCHUS NANUS CONFINIS (Bangs).}

WHITE-THROATED WOODHEWER.

Similar to $X$.n. nanus, but color of chin and throat very much paler dull buffy white or very pale buff.

Adult male.-Length (skins), 217-232 (224); wing, 101.5-108 (104.7); tail, 86-94 (90); culmen, 35.5-37.5 (36.5); tarsus, 21.5-22.5 (22); middle toe, $17-17.5(17.2){ }^{a}$

Adult female.-Length (skin), 200; wing, 93.5; tail, 74; culmen, 36 ; tarsus, 20.5 ; middle toe, $16.5 .^{b}$

Honduras (Medina; Céiba) and Guatemala (Santo Tomas; Los Amates, Yzabál; Chapulco).

Dendrornis susurrans (not Dendrocolaptes susurrans Jardine) SCLATER and SALvin, Proc. Zool. Soc. Lond., 1S70, 839 (Honduras).-Sclater, Cat. Birds Brit. Mus., xv, 1890, 133, part (Medina, Honduras).

Dendrornis nana (not of Lawrence) Salvin and Godman, Biol. Centr.-Am., Aves, ii, 1891, 180, part (Medina, Honduras).

[Dendrornis] nana SHARPE, Hand-list, iii, 1901, 78, part (Honduras).

Dendrornis lawrenceii costaricensis (not of Ridgway) Lantz, Trans. Kansas Acad. Sci. for 1896-97 (1899), 221, part (Santo Tomas, Guatemala).

Dendrornis nana confinis Bangs, Bull. Mus. Comp. Zool., xxxix, no. 6, July, 1903, 150 (Céiba, Honduras, sea-level; coll. E. A. and O. Bangs).-DeARBorn, Pub. 125, Field Mus. N. H., 1907, 108 (Los Amates, e. Guatemala; crit.).

Xiphorhynchus nanus confinis OBerHoLser, Smithsonian Misc. Coll., xlviii, no. 1579, May 13, 1905, 63.

$a$ Two specimens, from Honduras. $b$ One specimen, from Guatemala (Chapulco). 


\section{XIPHORHYNCHUS ERYTHROPYGIUS (Sclater).}

\section{SPOTTED WOODHEWER.}

Adults (sexes alike):--Pileum and hindneck deep olive, the feathers margined, more or less distinctly, with dusky and with narrow mesial streaks of pale buffy; back and scapulars olive-brown (nearly raw-umber), the feathers (at least the more anterior ones) marked with a mesial guttate or broadly fusiform streak of pale buff; rump and upper tail-coverts deep cinnamon-rufous, the tail similar but slightly darker (chestnut); wing-coverts concolor with back but immaculate; secondaries chestnut, the primaries also mostly chestnut but outer webs edged with light olive-brown (those of the several more outer ones wholly or mostly of the latter color) and with terminal portion deep grayish brown or dusky; lores nearly uniform dusky; an indistinct superciliary stripe (obsolete anterior to eye) of pale yellowish buff, broken by dusky olive margins or edges to the feathers; auricular region streaked with dusky olive and light yellowish buff; suborbital and malar regions light yellowish buff, the feathers margined with dusky; chin and throat buff, or yellowish buff, the latter (sometimes chin also) with feathers narrowly tipped with olive; rest of under parts light olive or buffy olive, each feather with a large central guttate spot of light buff or yellowish buff, these markings smaller (sometimes obsolete) on flanks; shorter under tailcoverts light buff mesially broadly edged with light buffy brown, the longer ones nearly uniform cinnamon to cinnamon-rufous; under wing-coverts buff (more or less deep,) the inner webs of remiges cinnamon-rufous, with terminal portion of longer primaries grayish brown or dusky, that of outermost primary mostly of the latter color; maxilla blackish or dusky brown to nearly black, with a tomial stripe of pale dull yellowish or whitish; mandible pale dull yellowish or whitish (in dried skins); legs and feet horn color or dusky (in dried skins).

Adult male.-Length (skins), 204-241 (227); wing, 109.5-125 (119.5); tail, 91-102 (96); culmen, 31.5-37.5 (34.3); tarsus, 23-24 (23.5); middle toe, 17.5-18.5 (18).$^{a}$

Adult female.-Length (skin), 215; wing, 108; tail, 91.5; culmen, 30.5 ; tarsus, 21.5 ; middle toe, $17 .{ }^{b}$

Southeastern Mexico, in States of Vera Cruz (Córdova; Jalapa; Coátepec; Huatusco; Jico; Cofre de Perote), Oaxaca, Guerrero (Chilpancingo; Omilteme) and Chiapas (Tumbala), and through Guatemala (Choctúm; Cobán; Chiséc; Rio de la Pasión; El Rincón, San Marcos; Las Nubes, Cerro Zunil) to Honduras (Yaruca).

\footnotetext{
a Three specimens, from Vera Cruz and Guerrero.

$b$ One specimen, from Chiapas. An adult female from Yaruca, Honduras, measures as follows: Length (skin), 195; wing, 104; tail, 82.5; culmen, 30.5; tarsus, 22; middle toe, 18 .
} 
Dendrornis triangularis (not Dendrocolaptes triangularis Lafresnaye) SCLATER, Proc. Zool. Soc. Lond., 1856, 289 (Córdova, Tera Cruz).

Dendrornis erythropygia Sclater, Proc. Zool. Soc. Lond., 1859, 366 (Jalapa, Vern Cruz, Mexico; coll. P. L. Sclater), 3S1 (Oaxaca); Cat. Am. Birds, 1862; 165 (Jalapa); Cat. Birds Brit. Mus., xv, 1890, 131, part (Jalapa; sources Rio de la Pasión, Chiséc, and Choctúm, Guatemala).-Salvin and Sclater, Ibis, 1860, 35 (Cobín, Guatemala).-Boucard, Ann. Soc. Iinn. Iyons, 1878, 38 (Guatemala).-Elliot, Auk, vii, 1890, 187, part (Jalapa, Mexico, Guatemala; excl. syn. D. e. xquatoriatis Berlepsch and Taczanowski).Salvin and Godman, Biol. Centr.-Am., Aves, ii, 1891, 181, part (Jalapa, Cośtepec, Huatusco, Córdova, Cofre de Perote, Vera Cruz; Chilpancingo, Guerrero; Oaxaca; El Rincón, Las Nubes, Cobán, Chiséc, and Choctúm, Guatemala)-BANGs, Bull. Mus. Comp. Zool., xxxix, 1903, 151 (Yaruca, Honduras).

D[endrornis] erythropygia Schater and Salvin, Proc. Zool. Soc. Lond., 1870, 839, part (monogr.).

[Dendrornis] erythropygia Sclater and Salvin, Nom. Av. Neotr., 1873, 68, part.-Sharpe, Hand-list, iii, 1901, 78, part.

[D[endromis] triangularis erythropygia Berlepsch and Stolzmann, Proc. Zool. Soc. Lond., 1896, 376, in text.

[Dendrocolaptes] erythropygius Grax, Hand-list, i, 1869, 177, no. 2405.

Xiphorhynchus erythropygius OBerHorser, Smithsonian Misc. Coll., xlviii, no. 1579, Мау 13, 1905, 63.

\section{XIPHORHYNCHUS PUNCTIGULUS PUNCTIGULUS (Ridgway).}

\section{SPOTTED-THROATED WOODHEWER.}

Somewhat like $X$. erythropygius, but color of pileum, back, and under parts greenish or ocherous olive instead of olive-brown, back without streaks or with very narrow ones on anterior portion only, and throat spotted rather than barred with dusky.

Adults (sexes alike).-Pileum deep olive, the feathers more or less broadly tipped or terminally margined with dusky, and usually (some of them at least) with a narrow shaft-streak of pale buff; hindneck, back, and scapulars deep ocherous olive, the more anterior scapulars and interscapulars sometimes with a very narrow mesial streak of light buff; rump, upper tail-coverts, and tail chestnut, the shafts of rectrices darker; wing-coverts and most of outer webs of primaries olive, the secondaries chestnut, but outer webs of distal ones edged with olive; an indistinct superciliary stripe of light buff (obsolete anterior to eye) broken by dusky olive margins or edgings to the feathers; lores nearly uniform dusky; auricular region streaked with dusky olive and light buff or yellowish buff, the suborbital and malar regions dusky olive spotted or speckled with buffy; chin and throat buff, the latter with a triangular or diamond-shaped spot of deep olive on tip of each feather; rest of under parts clear, somewhat greenish, olive, each feather with a central cuneate, guttate or fusiform spot of buff, these markings narrower (streak-like) on sides, less distinct on flanks; under tail-corerts buff mesially (broadly), edged with olive, the longer ones nearly uniform rusty; under wing-coverts 
mostly ochraceous-buff, tinged or faintly mottled with pale brown, the marginal coverts light buff, spotted or blotched with pale brown or olive; inner webs of remiges dull cinnamon-rufous, paler on edges, the longer primaries with terminal portion (extensively) deep grayish brown or dusky; maxilla horn color, blackish basally, pale horn color or dull whitish along tomia; mandible pale horn color or dull whitish or yellowish (in dried skins); iris brown; legs and feet dusky (in dried skins).

Adult male.-Length (skins), 200-233 (213); wing, 101-120 (112.1); tail, 75-100 (90.8); culmen, 29-36 (32.7); tarsus, 20-23.5 (22.5); middle toe, $17.5-19.5$ (18.4) ${ }^{a}$

Adult female.-Length (skins), 194-233 (216); wing, 100-116 (108.6); tail, 82.5-96 (89.5); culmen, 29-35 (32.1); tarsus, 21-23 (22.1); middle toe, $18-19$ (18.3). ${ }^{b}$

Nicaragua (San Rafaél del Norte), Costa Rica (Naranjo de Cartago; Tucurríqui; Rio Reventazón; Bonilla; Guayabo; Tuís; Angostura; Carrillo; Rio Súcio; Pacuare; La Hondura; El Hogár; Juan Viñas; San Carlos; Candelária; Barranca; Cariblanco de Sarapiquí; La Vijágua; Cerro Santa Maria; Laguária, and Los Reyes, Dota; Tenório; El Generál), and Panamá (Boquete, 4,000-4,500 feet; Boquete de Chitra; Bugaba; Castillo; Calovévora; Cordillera del Chucu; Volcán de Chiriquí; Santiago de Verágua; Lion Hill).

Dendrornis erythropygia (not of Sclater) Cabanis, Journ. für Orn., 1861, 242 (Costa Rica).-Sclater and Salvin, Proc. Zool. Soc. Lond., 1864, 355 Panamá; crit.).-Salvin, Proc. Zool. Soc. Lond., 1867, 144 (Santiago de Verágua, Panamá); 1870, 193 (Calovévora, Boquete de Chitra, Cordillera del Chucu, Bugaba, and Volcán de Chiriquí, Panamá).-Lawrence, Ann. Lyc. N. Y., ix, 1868, 107 (Angostura, Pacuare, and Barranca, Costa Rica).Frantzius, Journ. für Orn., 1869, 305 (Costa Rica).-Ridgway, Proc. U. S. Nat. Mus., vi, 1883, 414 (Rio Súcio, Costa Rica).-Sclater, Cat. Birds Brit. Mus., xv, 1890, 131, part (Angostura, Costa Rica; Castillo, Santiago, Calovévora, Volcán de Chiriquí, and Bugaba, Panamá).-Elııot, Auk, vii, 1890, 187, part (Cósta Rica; Verágua; Panamá).

[Dendrornis] erythropygia Sclater and SaLvin, Nom. Av. Neotr., 1873, 68, part.Sharpe, Hand-list, iii, 1901, 78, part.

$a$ Nineteen specimens.

$b$ Seveuteen specimens.

\begin{tabular}{|c|c|c|c|c|c|}
\hline Locality. & Wing. & Tail. & $\begin{array}{l}\text { Cul- } \\
\text { men. }\end{array}$ & Tarsus. & $\begin{array}{c}\text { Middle } \\
\text { toe. }\end{array}$ \\
\hline MALES. & & & & & \\
\hline Nine adult males from Panamá.... & 110.9 & 90.2 & 32.7 & 22.6 & 18.3 \\
\hline Ten adult males from Costa Rica... & 113.1 & 91.2 & 32.7 & 22.3 & 18.5 \\
\hline FEMALES. & & & & & \\
\hline Seven adult females from Panamá. & 109.1 & 89.9 & 33 & 21.9 & 18.2 \\
\hline Nine adult females from Costa Rica... & 107.9 & 89 & 31.2 & 22.2 & 18.3 \\
\hline One adult female from Nicaragua (San Rafaél del Norte). & 112 & 90.5 & 33 & 22.5 & 18.5 \\
\hline
\end{tabular}


D[chdrormis] crythropygia Sclater and Salvin, Proc. Zool. Soc. Lond., 1870, 839, part.

Dendromis punctigula Ringway, Proc. U. S. Nat. Mus., xi, sig. 31, Sept. 20, 1S59, $5+4$ (Naranjo, Costa Rica; coll. U. S. Nat. Mus.).-Sclatere, Ibis, 1889,

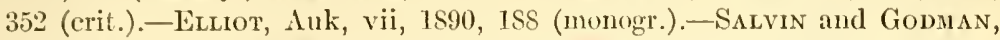
Biol. Centr.-Am., Aves, ii, 1891, 182 (Angostura, Pacuare, Barranca, Rio Súcio, Naraijo, and Tucurríqui, Costa Rica; Chiriquí, Bugaba, Castillo, Cordillera del Chucu, Boquete de Chitra, Calovévora, and Santiago, Pamamá).-Cherrie, Anal. Inst. Fis.-Geog. Costa Rica, vi, 1893, 17 (Pozo del Pital, Costa Rica).-Banas, Proc. New Engl. Zool. Club, iii, 1902, 48 (Boquete, Panamá, 4,000-5,000 ft.).

[Dendrornis] punctigula Snarpe, Hand-list, iii, 1901, 79, part (Costa Rica; Panamá).

Tiphorhynchus punctigulus OвerHolser, Smithronian Misc. Coll., xlviii, no. 1579, May 13, 1905, 63.

Iiphorhynchus punctigula Carrıker, Ann. Carnegie Mus., vi, 1910, 653 (Costa Rica; habits).

\section{XIPHORHYNCHUS PUNCTIGULUS INSOLITUS Ridgway.} TRUANDO WOODHEWER.

Similar to $X$. p. punctigulus, but color of pileum and back much darker, the latter browner (nearly chestnut-brown), and general color of under parts much browner (brownish olive instead of greenish olive).

Adult male.-Wing, 111; tail, 94; exposed culmen, 29; tarsus, 22; middle toe, 18.

Adult female.-Length (skin), 190; wing, 101; tail, 86; exposed culmen, 30 ; tarsus, 22 ; middle toe, 18.5 .

Eastern Panamá (Cascajál, Coclé) and adjacent portion of northwestern Colombia (Truando).

Dendrornis triangularis (not Dendrocolaptes triangularis Lafresnaye) CAssin, Proc. Acad. Nat. Sci. Phila., 1860, 193 (Rio Truando, n. w. Colombia).

Xiphorhynchus punctigula insolitus Ridgway, Proc. Biol. Soc. Wash., xxii, April 17, 1909, 73 (Cascajál, Coclé, e. Panamá; coll. U. S. Nat. Mus.).

\section{Genus PICOLAPTES Lesson.}

Picolaptes Lessox, Traité d'Orn., 1831, 313. (Type, Dendrocolaptes tenuirostris Lichtenstein.)

Lepidocolaptes Reichenbach, Handb. Spec. Orn., 1853, 183. (Type, Dendrocolaptes squamatus Lichtenstein.)

Dacryophorus Bonaparte, Ann. Sci. Nat., sér. 4, Zool., i, 1854, 133. (Type, Dendrocolaptes lacrymiger Des Murs.)

Thripobrotus a CABAnis, in Wiegmann's Archiv für Naturg., xiii, pt. i, 1847, 339. (Type, Dendrocolaptes bivittatus Lichtenstein.)

Medium-sized Dendrocolaptidæ (length about 160-190 mm.) with roundish, nonoperculate nostrils, and rather long, decidedly (but not conspicuously) decurved, compressed bill.

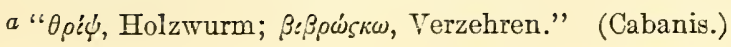

S1255ำBull. $50-11-17$ 
Bill as long as or longer than head (but much less than twice as long as tarsus), decidedly though not conspicuously decurved throughout, rather slender, much compressed, its width at latero-frontal antiæ slightly to decidedly less than depth at same point and contained from four and a half to seven times in distance from nostril to tip of maxilla; culmen and tomia gradually decurved from base, the latter without trace of subterminal notch; gonys very faintly to rather strongly concave, sometimes slightly prominent basally. Nostril exposed, posteriorly in contact with latero-frontal feathering, longitudinally oval, nonoperculate, but margined above by a narrow membrane. Rictal bristles absent, and feathers of chin, etc., without terminal setæ. Wing moderate or rather large, rather pointed, the longest primaries exceeding secondaries by nearly to much more than length of tarsus; eighth, seventh and eighth, sixth, seventh, and eighth, or seventh, eighth, and ninth primaries longest, the tenth (outermost) nearly to a little more than three-fourths as long as the longest, the ninth longer than fifth, sometimes equal to the longest. Tail three-fourths to (usually) decidedly more than three-fourths as long as wing, graduated for about one-fourth its length, the rectrices (12) acuminate, their strong and very rigid shafts decurved, sometimes twisted, terminally. Tarsus much shorter to slightly longer ( $P$. tenuirostris) than length of bill from nostril, one-fourth $(P$. tenuirostris) to much less than one-fourth as long as wing, distinctly scutellate (endaspidean); middle toe, with claw, equal to tarsus or decidedly longer; outer toe, without claw, equal to or slightly longer than middle toe; inner toe, without claw, reaching to subterminal articulation of middle toe; hallux decidedly shorter than inner toe, scarcely if at all stouter; middle toe united to outer toe for whole of first and part of second phalanx, to inner toe by greater part of first phalanx; anterior claws large, very strongly curved, acute, that of the hallux much less curved, equal to or shorter than the digit.

Coloration.-Rump, upper tail-coverts, tail, and at least part of remiges cinnamon-rufous or rufous-chestnut; back, scapulars, and wing-coverts olive-brown, russet, or cinnamon-rufous; pileum and hindneck brown or dusky, streaked or spotted with paler (sometimes the back also streaked), or feathers margined with dusky; chin and throat white or buffy (feathers of throat sometimes narrowly margined with dusky), the rest of under parts more or less distinctly streaked or striped.

Nidification.-Nest in holes of trees or stumps; eggs plain white.

Range.-Southern Mexico to Cayenne, Paraguay, Uruguay, Bolivia, and Peru. (About twenty species.) ${ }^{a}$

$a$ Of these the following have not been examined in this connection: $P$. falcinellus (Cabanis and Heine), P. oblectus Allen, P. warscewiczi (Cabanis and Heine), P. parvirostris Sclater, $P$. puncticeps Sclater and Salvin, $P$. albolineatus (Lafresnaye), $P$. saturatior Underwood, and P. fuscicapillus Pelzeln. 
KEY TO THE SPECIES AND SUBSPECIES OF PICOLAPTES.

a. Breast essentially bicolored, the very pale buff or buffy white median area on each feather very broad, the edges of the feathers mostly or wholly black; buffy or whitish streaks on pileum and hindueck broader; back more grayish brown.

(Western and central Mexico.)................Picolaptes leucogaster (p. 259). aa. Breast distinctly tricolored, the feathers broadly edged with brown, this much broader than the black line edging the narrower buffy mesial area; buffy streaks on pileum narrower; back more cinnamomeous brown.

b. Markings on pileum guttate or rhomboid (spot-like). (Picolaptes affinis.)

c. Under parts with stripes narrower, less distinct posteriorly; throat paler buff (not deeper than color of stripes on breast, etc.). (Southern Mexico to Guatemala.)....................... Picolaptes affinis affinis (p. 261). $c c$. Under parts with stripes broader, more distinct posteriorly; throat deeper buff than color of stripes on breast, etc. (Costa Rica and western Panamá.)

Pieolaptes affinis negleetus (p. 263).

bb. Markings on pileum linear (streak-like). (Picolaptes lineaticeps.)

c. Pale buffy streaks on back and under parts narrower, the former more acicular; throat paler and less extensively buffy.

d. Coloration paler, the ground color of pileum lighter sepia brown, back, etc., light cinnamon-brown; streaks on upper back smaller, without distinct blackish edges. (Eastern Panamá.)

Picolaptes lineaticeps lineaticeps (p. 264).

$d d$. Coloration darker, the ground color of pileum dark sooty brown, back russet-brown; streaks on upper back larger, distinctly edged with blackish. (Western Panamá to Nicaragua.)

Picolaptes lineaticeps compressus (p. 265).

cc. Pale buffy streaks on back and under parts broader, the former more cuneate; throat more deeply and extensively buff. (Northern Honduras to southern Mexico.)...................... Picolaptes lineaticeps insignis (p. 266).

\section{PICOLAPTES LEUCOGASTER (Swainson).}

\section{WHITE-STRIPED WOODHEWER.}

Adults (sexes alike).-Pileum and hindneck deep olive-brown or sepia, each feather with a broad guttate or elliptical streak of buff or buffy white, margined with blackish; back, scapulars, and wingcoverts buffy olive-brown (nearly broccoli brown), the upper back usually with a few streaks of buff (with or without blackish margins); rump, upper tail-coverts, tail, and remiges deep cinnamon-rufous or rufous-chestnut, the remiges, however, passing basally into brownish (like color of wing-coverts, etc.), and terminal portion of inner webs of primaries dusky; orbital ring and supra-auricular stripe white or buffy white, the feathers of the latter narrowly margined with black; a narrow postocular stripe of blackish or dusky, narrowly streaked with white or pale buff; the greater portion of auricular region buffy white or very pale buff, narrowly streaked with dusky; suborbital and malar regions, chin, and throat buffy white, the lower throat margined on each side by one or more streaks of black or dusky; the feathers of extreme lower throat (sometimes those of suborbital region and posterior portion of 
malar region also), narrowly margined with the same; foreneck and chest buffy white or very pale buff, the feathers broadly margined with black or dusky, producing a squamate effect; rest of under parts similar but with mesial buffy or whitish area on each feather narrower, the blackish lines submarginal instead of marginal, the feathers broadly edged with light grayish olive or grayish brown, this gradually increasing (at expense of the whitish or buffy mesial stripes and blackish lines) posteriorly, where, on flanks, lower abdomen, and under tail-coverts the light grayish brown predominates; under wing-coverts ochraceous-buff, paler on margin of wing; inner webs of remiges light cinnamon-rufous, the longer primaries grayish brown terminally; maxilla deep horn brown, darker basally; mandible paler, especially toward base; legs and feet horn color or dusky (in dried skins).

Young.-Similar to adults but blackish margins and edgings to feathers of lower parts more irregular or broken, and color of back more olivaceous (less tawny) brown.

Adult male.--Length (skins), 219-235 (226); wing, 108.5-123 (116.9); tail, 93-103.5 (97.4); culmen, 32-37.5 (35.4); tarsus, 20-21.5 (20.8); middle toe, $15.5-17$ (16.5).$^{a}$

Adult female.-Length (skins), 219-225 (222); wing, 108.5-115.5 (112); tail, 90-98 (94.9); culmen, 29.5-37 (34.4); tarsus, 20-21 (20.6); middle toe, $16-16.5$ (16.2). ${ }^{b}$

Western and central Mexico, in States of Sonora (Nuri), Durango (Coyotes; El Salto; Ciudád Durango), Guanajuato, San Luís Potosí (Sierra de San Luís Potosí), Vera Cruz (alpine zone of Orizaba), Puebla (Tenango del Valle; Rio Frio; Ixtaccihuátl; San Salvadór el Verde), Zacatecas (Plateado), Mexico (near City of Mexico; Temascáltepec), Morelos (Huitzilác), Michoacán (Mt. Tancítaro; Patzcuaro; Quiroga, Lake Patzcuaro; Morelia; Nahuátzin), Jalisco (Sierra de Bolaños; Sierra de Nayarít; Zapotlán; Hacienda de San Marcos; San Sebastián; Tonila), Colima (Sierra Nevada), Guerrero (Amula; Omilteme), and Oaxaca (La Parada; Cerro San Felipe), and Territory of Tepíc (Santa Teresa).

Xiphorhynchus leucogaster Swanson, Philos. Mag., new ser., i, 1827, 440 (Temascáltepec, Mexico; coll. Bullock Mus.).

X[iphorhynchus] leucogaster Bonaparte, Consp. Av., i, 1850, 208.

Picolaptes leucogaster Lafresnaye, Rev. et Mag. Zool., March, 1850, 150.Sclater, Proc. Zool. Soc. Lond., 1858, 297 (La Parada, Oaxaca); Cat. Am. Birds, 1862, 166; Cat. Birds Brit. Mus., xv, 1890, 147 (near City of Mexico; La Parada, Oaxaca; Ciudád Durango).-Sumichrast, La Naturaleza, v, 1881, 
24s (alp. reg. Orizaba, Vera Cruz).-Salvin and Gomman, Biol. Centr.Am., Aves, ii, 1S91, 185 (Nuri, Sonora; Ciudád, Durango; Sierra de Sin Luís Potosí; Sierra de Bolaños and Sierma de Nayaríl, Jalisco; Sierra Nevada de Colima; Tenango del Valle, Rio Frio, Ixtacciłnáll, and San Salvador el Verde, Puebla; Temíscaltepec; La Parada, Oaxaca; Omilteme and Amula, Guerrero).

[Picolaptes] leucogaster Grax, Hand-list, i, 1869, 179, no. 2441.-Sclater and Salvin, Nom. Av. Neotr., 1S73, 6S.-Sirarpe, Hand-list, iii, 1901, 83.

Thripobrotus] leucogaster Cabanis and Heine, Mus. Hein., ii, 1859, 37, footnote.

[Thripobrotus] leucogaster Heine and Reichenow, Nom. Mus. Hein. Orn., 1890, 137.

Picolaptes atripes Erтos, Jardine's Contr. Orn., 1S51, 76 ("South America").

[Picolaptes] atripes Gray, Hand-list, i, 1S69, 179, no. 2446.

\section{PICOLAPTES AFFINIS AFFINIS (Lafresnaye).}

\section{ALLIED WOODHEWER.}

Adults (sexes alike).-Pileum and hindneck brown (light sepia or dark raw-umber), each feather margined terminally with black or dusky and with a central guttate or diamond-shaped spot of dull buffy; back, scapulars, and wing-coverts plain raw-umber brown, the upper back sometimes with a few narrow streaks of pale buffy; rump and upper tail-coverts plain cinnamon-rufous; tail and remiges chestnut or rufous-chestnut, the primaries and distal secondaries edged, more or less distinctly, with brown, the exposed (terminal) portion of inner webs of longer primaries dusky grayish brown; sides of head and neck buff, streaked (the feathers edged or margined) with dusky; chin and throat immaculate buff, the extreme lower throat and upper chest also buff, but the feathers margined with black; rest of under parts light raw-umber brown, each feather with a broad central elliptical or obtusely cuneate streak of buff, margined with black, these markings becoming gradually less distinct posteriorly, the black marginal lines nearly obsolete on flanks and under tailcoverts, the general color of the latter more fulvescent or cinnamomeous; under wing-coverts ochraceous-buff (passing into buff on margin of wing) slightly flecked with dusky; inner webs of remiges light cinnamon-rufous, with terminal portion (extensively) dusky brownish gray; bill pale grayish or yellowish horn color, usually somewhat darker or more brownish basally; iris brown; legs and feet dusky horn color (in dried skins). 
Adult male.-Length (skins), 207-222 (212); wing, 100.5-116 (107.5); tail, 87-100 (93.9); culmen, 28-31.5 (29.6); tarsus, 19-22 (20.8); middle toe, $15-17$ (15.6). ${ }^{a}$

Adult female.-Length (skins), 193-219 (209); wing, 103-112 (106); tail, 82-97.5 (90); culmen, 29-32.5 (30.7); tarsus, 20-21.5 (20.7); middle toe, $15-17(16.3) .^{b}$

Southern Mexico, in States of Vera Cruz (Córdova; Potrero, near Córdova; Omealca; Cofre de Perote; Jalapa; Pasa Nueva), Puebla (Hueytamalco; Teziutlán), Mexico (Valley of Mexico), Guerrero (Omilteme; mts. near Chilpancingo), Oaxaca (Mt. Zempoáltepec; Totóntepec; Villa Alta; $15 \mathrm{~m}$. west of Oaxaca), and Chiapas (Tumbalá; San Cristóbal; Pinabete), and Guatemala (Santa Bárbara; Calderas, Volcán de Fuego; Volcán de Agua; Santa Maria and Chuipaché, Quezaltenango; Tolimán; Tecpám; Santa Bárbara de Vera Paz; Todos Santos; Sierra Santa Elena).

Dendrocolaptes affinis LAFresnaye, Rev. Zool., 1839, 100 (Mexico).

P[icolaptes] affinis Gray, Gen. Birds, i, 1847, 140.

Picolaptes affinis Lafresnaye, Rev. Zool., ser. 2, ii, May, 1850, 275 (monogr.).Sclater, Proc. Zool. Soc. Lond., 1856, 289 (Córdova, Vera Cruz); 1859, 365 (Jalapa, Vera Cruz), 381 (Totóntepec, Oaxaca); 1864, 175 (City of Mexico); Cat. Am. Birds, 1862, 166 (Jalapa); Cat. Birds Brit. Mus., xv, 1890, 149, part (Jalapa, Vera Cruz; Sta. Bárbara, Volcán de Fuego, and Volcán de Agua, Guatemala).Sclater and Salvin, Ibis, 1859, 117 (Pacific side Guatemala).-SAlvin and Sclater, Ibis, 1860, 35 (CaIderas, Volcán de Fuego, Guatemala; crit.).-SumiChrast, Mem. Bost. Soc. N.H., i, 1869, 555, part (hot, temperate, and alpine regions, Vera Cruz); La Naturaleza, v, 1881, 248 (Omealca, Vera Cruz).-(?) Sanchez, An. Mus. Nac. Mexico, i, 1877, 97, part (Vera Cruz).-FerrariPerez, Proc. U. S. Nat. Mus., ix, 1886, 156 (Hueytamalco, Teziutlán, Puebla; Jalapa, Vera Cruz).-Salvin and Godman, Biol. Centr.-Am., Aves, ii, 1891,

$a$ Fifteen specimens.

$b$ Eighteen specimens.

\begin{tabular}{|c|c|c|c|c|c|}
\hline Locality. & Wing. & Tail. & $\begin{array}{l}\text { Cul- } \\
\text { men. }\end{array}$ & Tarsus. & $\begin{array}{c}\text { Middle } \\
\text { toe. }\end{array}$ \\
\hline \multicolumn{6}{|l|}{ MALES. } \\
\hline Three adult males from Vera Cruz. & 105.2 & 94 & 29.8 & 21.7 & 16.7 \\
\hline Two adult males from Oaxaca... & 103.7 & 98.2 & 28.7 & 20.7 & 15 \\
\hline Four adult males from Guerrero.. & 112.2 & 91.1 & 30.4 & 20.7 & 15.9 \\
\hline Two adult males from Chiapas.... & 107.5 & 93.5 & 29 & 20 & 15.2 \\
\hline Two adult males from Guatemala.... & 105.5 & 95.2 & 28.7 & 20.5 & 16.2 \\
\hline Ten adult males $(P . a$. neglectus $)$ from Costa Riea. & 107.7 & 91.3 & 30.3 & 20.7 & 16.7 \\
\hline Ten adult males $(P, a$. neglectus $)$ from western Panam & 109.1 & 94.2 & 31.2 & 20.8 & 16.5 \\
\hline \multicolumn{6}{|l|}{ FEMALES. } \\
\hline Four adult females from Vera Cruz & 104.6 & 92.4 & 29.7 & 20.9 & 15.7 \\
\hline Two adult females from Oaxaca... & 106.5 & 95.2 & 31 & 20.5 & 16 \\
\hline Nine adult females from Guerrero. & 106.7 & 87.7 & 31.4 & 20.6 & 16.2 \\
\hline Two adult females from Chiapas... & 104.2 & 90 & 29.2 & 20.5 & 15.7 \\
\hline One adult female from Guatemala. & 107 & 95.5 & 30 & 21.5 & 16 \\
\hline Ten adult females ( $P . a$. neglcctus) fror & 104.8 & 90.2 & 31 & 20.5 & 16.6 \\
\hline Three adult females $(P, a$. neglectus from western Panam & 108 & 92.5 & 31 & 20.8 & 16.2 \\
\hline
\end{tabular}


185, part (Valley of Mexico; alpine reg., Omealca, Cofre de Perote, Jalapa, and Córdova, Vera Cruz; Hueytamalco, Puebla; Villa Alta, and Totóntepec, Oaxaca; Omilteme, Guerrero; Santa Maria, Chuipaché in Quezaltenango, Tolimán, Volcán de Fuego, Volcán de Agua, and Sinnta Bárbara, Vera Paz, Guatemala).-Chapman, Bull. Am. Mus. N. H., x, 1898, 32 (Jalapa).-DearBors, Pub. 125, Field Mus. N. H., 1907, 108 (Tecpím, Guatemala, 9,500 ft.).

Lepidocolaptes affinis Reichenbach, Handb. der Spec. Orn., i, 1850, 184, pl. 603; fig. 4058 .

Dacryophom affinis Bonaparte, Consp. Voluc. Anisod., 1854, 11.

T[hripobrotus] a.finis Cabanis and IIErne, Mus. Hcin., ii, 1859, 38 (Jalapa).

[Thripobrotus] affinis Heine and Reicuenow, Nom. Mus. IIein. Orn., 1890, 136 (Jalapa).

[Picolaptes] affinis Bonaparte, Consp. Av., i, 1850, 208.-Gray, IIand-list, i, 1869, 179, no. 2449 (Jalapa).-Sclater and Salvin, Nom. Av. Neotr., 1873, 68, part.-Sharpe, Hand-list, iii, 1901, 83, part.

\section{PICOLAPTES AFFINIS NEGLECTUS Ridgway.}

\section{SOUTHERN ALLIED WOODHEWER.}

Similar to $P$. a. affinis, but stripes on under parts broader, more distinct on posterior portions; chin and throat more deeply buff, always more so than the stripes on under parts of body.

Adult male.-Length (skins), 196-223 (208); wing, 102.5-116.5 (109.1); tail, 87-97.5 (92.7); culmen, 27-33 (30.8); tarsus, 20-21.5 (20.8); middle toe, $16-17.5$ (16.8) ${ }^{a}$

Adult female.-Length (skins), 197-215 (203); wing, 101.5-110 (105.6); tail, 85-94 (90.7); culmen, 29-32.5 (31); tarsus, 20-21.5 (20.6); middle toe, $16-17(16.5) .^{b}$

Costa Rica (Volcán de Irazú; Volcán de Turrialba; Cartago, Azahár, and La Estrella, Cartago; Escazú; Tobosi; Juan Viñas; Coliblanco; Guayabo; Barranca; Dota Mts., Santa Maria, Copéy, Las Vueltas, Los Reyes, and Laguária, Dota; El Generál; Ojuras de Térraba) and western Panamá (Boquete; Chiriquí).

Thripobrotus affinis (not Dendrocolaptes affinis Lafresnaye) CABANIs, Journ. für Orn., 1861, 242 (Costa Rica).

Picolaptes affinis Lawrence, Ann. Lyc. N. Y., ix, 1868, 107 (San José, Dota, and Barranca, Costa Rica).-Frantzius, Journ. für Orn., 1869, 305 (Costa Rica).Salvin, Proc. Zool. Soc. Lond., 1870, 193 (Volcán de Chiriquí, Panamá).-Ridgway, Proc. U. S. Nat. Mus., v. 1882, 497 (Volcán de Irazú, Costa Rica).-

a Twenty specimens.

$b$ Thirteen specimens.

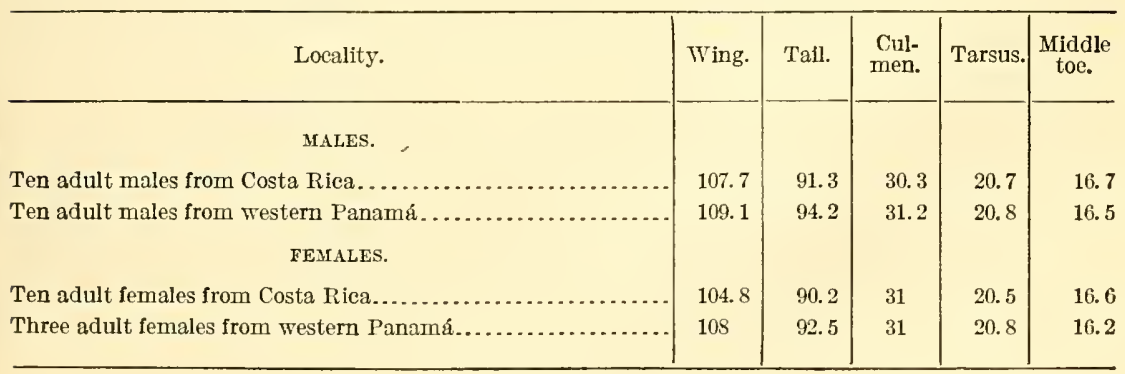


Sclater, Cat. Birds Brit. Mus., xv, 1890, 149, part (San José and San Francisco, Costa Rica; Volcán de Chiriquí, Panamá).-Salvin and Godman, Biol. Centr.-Am., Aves, ii, 1891, 185, part (Dota, Barranca, San José, and San Francisco, Costa Rica; Volcán de Chiriquí, Panamá).-Cherrie, Anal. Inst. Fis.-Geog. Costa Rica, vi, 1893, 17 (San Marcos and Rio Naranjo, Costa Rica).Bangs, Proc. New Engl. Zool. Club, iii, 1902, 48 (Boquete, 4,000-6,000 ft., Panamá).-Ferry, Pub. 146, Field, Mus. N. H., orn. ser., i, no. 6, 1910, 271 (Guayabo, Coliblanco, and Volcán de Turrialba, Costa Rica).

[Picolaptes] affinis Sclater and Salvin, Nom. Av. Neotr., 1873, 68, part.-SharPe, Hand-list, iii, 1901, 83, part.

Picolaptes affinis neglectus Ridgway, Proc. Biol. Soc. Wash., xxii, April 17, 1909, 73 (Coliblanco, e. Costa Rica; coll. U. S. Nat. Mus.).-Carriker, Ann. Carnegie Mus., vi, 1910, 655 (highlands of Caribbean slope, Costa Rica, above 2,500 ft.; crit.).

\section{PICOLAPTES LINEATICEPS LINEATICEPS Lafresnaye.}

STREAKED-HEADED WOODHEWER.

Adult (sexes alike).-Pileum brown (sepia or light sepia), passing into lighter and warmer brown (nearly prouts brown) on hindneck, each feather with a rather broad mesial streak of pale brownish buff; back, scapulars, and wing-coverts light cinnamon-brown (between cinnamon and raw-umber), the upper back usually (?) with a few narrow, pointed streaks of pale brownish buff or dull buffy whitish; rump, upper tail-coverts, tail, and remiges plain cinnamon-rufous or rufous-chestnut, the outer webs of primaries and distal secondaries indistinctly edged with grayish brown, the terminal portion of inner web of longer primaries deep grayish brown or dusky; sides of head and neck streaked with sepia brown and pale brownish buff; chin and throat pale dull buff, the feathers of extreme lower throat narrowly margined with dusky; rest of under parts pale buffy grayish brown (pale broccoli brown or isabella color), each feather with a broad mesial stripe of pale buff, margined laterally by a narrow streak of dusky - these markings becoming gradually narrower and less distinct (the dusky edgings obsolete) posteriorly; under wing-coverts ochraceous-buff, those near edge of wing pale buff with a few flecks of dusky; inner webs of remiges vinaceous-cinnamon, the outer primaries with terminal portion (extensively) grayish brown or dusky; bill pale brown or dull brownish buffy, the basal portion of maxilla slightly darker; iris brown; legs and feet dusky horn color or dusky olive (in dried skins).

Adult male.-Length (skins), 172-190 (181); wing, 90-98 (94); tail, 72-73 (72.5); culmen, 30; tarsus, 18-20 (19); middle toe, $16{ }^{a}$

Eastern Panamá (Lion Hill; Panamá; Punta de Sabana).

Picolaptes lineaticeps Lafresnaye, Rev. Zool., ser. 2, ii, May, 1850, 277 (locality unknown; type now in coll. Boston Soc. Nat. Hist.).-Banas, Proc. New Engl. Zool. Club, ii, 1900, 25 (Loma del León, Panamá). 
Dendrornis temuirostris (not Dendrocolaptes temuirostris Tafresnaye) I/AWREnce, Ann. Lỵc. N. Y., vii, 1862, 292 (Panamá).

l'icolaptes compressus (not Thripobrotus compressus Cabanis) Sarvabori and Festa, Boll. Mus. Zool., etc., T'orino, xiv, 1899, no. 339, 7 (Punta de Sabana, P:ınแá).

\section{PICOLAPTES LINEATICEPS COMPRESSUS (Cabanis).}

\section{THIN-BILLED WOODHEWER.}

Similar to P. 7. Tincaticeps but coloration decidedly darker, the ground color of pileum dark sooty brown, the back, etc., decper, russet brown, with streaks on upper back larger, distinetly edged with blackish; ground color of under parts darker, more strongly contrasted with the broader and conspicuously blackish-edged buffy stripes, and feathers of lower throat (sometimes of nearly whole throat) narrowly margined with dusky.

Adult male.-Length (skins), 177-197 (190); wing, 89-101 (95.3); tail, $71.5-85$ ( 80$)$; culmen, 27-33.5 (29.1); tarsus, 18-20 (18.8); middle toe, $14-16$ (15). ${ }^{a}$

Adult female.-Length (skins), 173-194 (185); wing, 84.5-95.5 (90.7); tail, 71.5-81.5 (77); culmen, 26-29.5 (2S); tarsus, 17-19 (18); middle toe, $13.5-15(14.5) .^{b}$

Testern Panamá (Bugaba; Mína de Chorcha; Davíd; Divala; Boquete), Costa Rica (Puerto Limón; Navarro de Cartago; Juan Viñas; Turrialba; El Hogár; Guayabál; Guápiles; Guayabo; Orosí; Coralillo; Jiménez; Bonilla; Monte Redondo; Cobia de Salinas; Bolsón; Tenório; El Generál; Boca Barranca, Punta Arenas; Barranca, Boruca, and Paso Reál, Boruca; Pozo Azúl de Pirrís; Pozo del Rio

a Fifteen specimens. $b$ Twelve specimens.

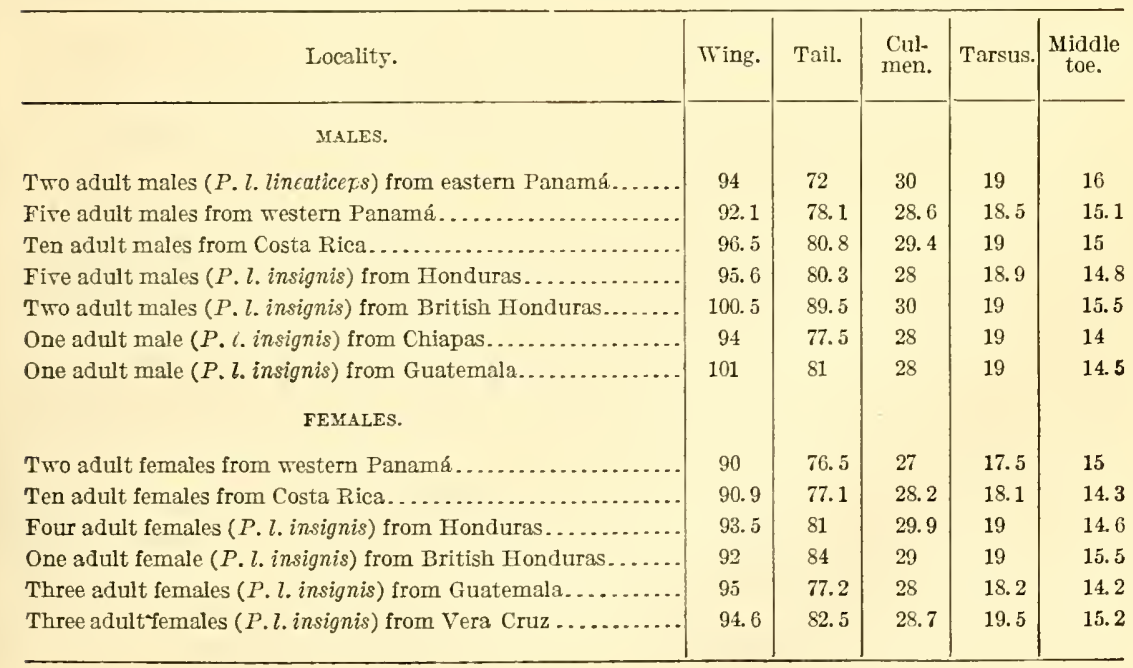


Grande; El Pozo de Térraba; Buenos Aires; Pigres; La Palma de Nicoya; Bebedero; Volcán de Miravalles), and Nicaragua (San Carlos; Chinandega; San Gerónimo).

Picolaptes lineaticeps (not of Lafresnaye) Lawrence, Ann. Lyc. N. Y., ix, 1868, 107 (Gulf of Nicoya, Costa Rica).--Salvadori, Atti Soc. Ital. Torino, iv, 1868, 179 (Costa Rica).-Frantzius, Journ. für Orn., 1869, 305 (Costa Rica).

Thripobrotus compressus Cabanis, Journ. für Orn., July, i861, 243 (Costa Rica; coll. Berlin Mus.).

Picolaptes compressus Lawrence, Ann. Lyc. N. Y., ix, 1868, 107 (Costa Rica).Frantzius, Journ. fün Orn., 1869, 305 (Costa Rica).-Salvin, Ibis, 1869, 314, in text (crit.); Proc. Zool. Soc. Lond., 1870, 193 (Bugaba and Mina de Chorcha, Panamá; crit.).-Bovcard, Proc. Zool. Soc. Lond., 1878, 60 (Navarro, Costa Rica).-Nutting, Proc. U. S. Nat. Mus., v, 1882, 397 (La Palma de Nicoya, Costa Rica; habits).-Sclater, Cat. Birds Brit. Mus., xv, 1890, 153, part (Bebedero de Nicoya, Costa Rica; Bugaba and Mina de Chorcha, Panamá).-Salvin and Godman, Biol. Centr.-Am., Aves, ii, 1891, 186, part (Chinandega, Nicaragua; Navarro, La Palma de Nicoya, and Bebedero, Costa Rica; Bugaba and Mina de Chorcha, Panamá).-Cherrie, Proc. U. S. Nat. Mus., xiv, 1891, 533 (Costa Rica; crit.); Expl. Zool. Merid. Costa Rica, 1893, 40 (Boruca and Buenos Aires, Costa Rica).-Richmond, Proc. U. S. Nat. Mus., xvi, 1893, 498 (San Carlos, Nicaragua).-Underwood, Ibis, 1896, 440 (Volcán Miravalles, Costa Rica).-Bangs, Proc. New Engl. Zool. Club, iii, 1902, 48 (Boquete, Panamá, 4,500 ft.).-Ferry, Pub. 146, Field Mus. N. H., orn. ser. i, no. 6, 1910, 271 (Guayabo and Puerto Limón, Costa Rica).

[Picolaptes] compressus Sclater and Salvin, Nom. Av. Neotr., 1873, 68, part.SharPe, Hand-list, iii, 1901, 84, part.

Picolaptes compressus compressus BAngs, Auk, xxiv, July, 1909, 299 (Boruca, Paso Reál, Pozo del Rio Grande, Barranca, and Barranca de Puntarenas, w. Costa Rica).-Carriker, Ann. Carnegie Mus., vi, 1910, 656 (lowlands of Costa Rica; crit.).

Picolaptes gracilis Ridgway, Proc. U. S. Nat. Mus., xi, sig. 34, Sept. 20, 1889, 542 (Monte Redondo, Costa Rica; coll. U. S. Nat. Mus.;=young female); xiv, 1891, 475 (Cobia de Salinas, Costa Rica; crit.).-Zeledón, Anal, Mus. Nac. Costa Rica, i, 1888, 114.-Sclater, Ibis, 1889, 353 (crit.).

[Picolaptes] gracilis SHARPE, Hland-list, iii, 1901, 84.

\section{PICOLAPTES LINEATICEPS INSIGNIS (Nelson).} NORTHERN STREAKED-HEADED WOODHEWER.

Similar to $P$. $l$. compressus, but buffy streaks on back broader, more cuneate, those of under parts also broader, and throat more extensively buffy as well as (usually at least) deeper buff.

Adult male.--Length (skins), 187-223 (199); wing, 92-104 (97.9); tail, 72.5-8S (82.8); culmen, 27-33.5 (28.8); tarsus, 18.5-20 (19.1); middle toe, $14-16.5$ (14.8). ${ }^{a}$

Adult female.-Length (skins), 187-209 (194); wing, 91.5-99 (93.1); tail, 74-86 (80.6); culmen, 27-31.5 (2S.9); tarsus, 18-20 (18.9); midllle toe, $13-15.5$ (14.8). ${ }^{b}$ 
Honduras (Puerto Cabello; Yaruea; Céiba; Santa Ana; Rio Segóvia), British ITonduras (Belize; Cayo; Toledo District; Sabune District; Yacacos Lagoon; pine ridge near Manatee Lalgoon), Salvadór (Voleám Sam Mignél), and through Guatemala (pine ridge of Poctún; Chiséc; Choctúm; sources of Rio de la Pasión; Retalhuleu; Voleán de Agua; Toleán de Fuego; El Baul, near Santa Lucia Cosamalguapa; San José; Gualán?; Naranjo; Patulúl, Sololá; Mazatenango) to southern Mexico, in States of Chiapas (Palenque), Tabasco (Teapa), Oaxaca (mountains near Santo Domingo), Guerrero (Rincón) and Vera Cruz (Playa Vicente; Alvarado; San Lorenzo, near Córdova; Orizaba; Otatitlún; Motzorongo; Pasa Nueva).

Picolaptes lineaticeps (not of Lafresnaye) Sclater, Proc. Zool. Soc. Lond., 1860, 252 (Orizaba, Vera Cruz); Cat. Am. Birds, 1862, 166 (Orizaba).-Salvin, Ibis, 1861, 353 (Pacific slope Guatemala).

Picolaptes affinis (not Dendrocolaptes affinis Lafresnaye) Sclater and Salvin, Ibis, 1859, 117 (Guatemala).-(?) Sumichrast, Mem. Bost. Soc. N. H., i, 1869, 555, part (hot, temperate, and alpine regions, Vera Cruz).

Picolaptes compressus (not Thripobrotus compressus Cabanis) Sclater and SALvin, Proc. Zool. Soc. Lond., 1870, 837 (Puerto Cabello, Honduras).-Sclater, Cat. Birds Brit. Mus., xv, 1890, 153, part ("Mexico;" Belize, Brit. Honduras; pine ridge of Poctún, Chiséc, sources of Rio de la Pasión, Retalhuleu, Volcán de Agua, Volcán de Fuego, and Baul, Guatemala; Puerto Cabello, Honduras).-Shavin and Godman, Biol. Centr.-Am., Aves, ii, 1891, 186, part (Orizaba, San Lorenzo near Córdova, Alvarado, and Playa Vicente, Vera Cruz; Rincón, Guerrero; Teapa, Tabasco; Belize and Cayo, Brit. Honduras; pine ridge of Poctún, Chiséc, Volcán de Agua, Volcán de Fuego, El Baul, near Santa Lucia Cosamalguapa, and Retalhuleu, Guatemala; Volcán San Miguél, Salvadór; Puerto Cabello, Honduras).-Iantz, Trans. Kansas Acad. Sci. for 1896-97 (1899), 221 (Naranjo, Guatemala).-Bangs, Bull. Mus. Comp. Zool., xxxix, 1903, 151 (Céiba and Yaruca, Honduras crit.).-Dearborn, Pub. 125, Field Mus. N. H., 1907, 108 (Mazatenango, San José, and Patulúl, Guatemala; crit.).

[Picolaptes] compressus Sclater and Salvin, Nom. Av. Neotr., 1873, 68, part.Sharpe, Hand-list, iii, 1901, 84, part.

Picolaptes compressus insignis Nelson, Auk, xiv, Jan., 1897, 54 (Otatitlán, Vera Cruz; coll. U. S. Nat. Mus.).

P[icolaptes] compressus insignis Bangs, Bull. Mus. Comp. Zool., xxxix, 1903, 151 (diagnosis).

[Picolaptes] insignis Sharpe, Hand-list, iii, 1901, 84.

(?)Picolaptes saturatior Underwood, Bull. Brit. Orn. Club, vii, no. lv, June 30, 1898, p. lix (Gualán, Guatemala; coll. ——?;=Young?); Ibis, 1898, 613 (reprint).

(?)[Picolaptes] saturatior Sharpe, Hand-list, iii, 1901, 84. 


\section{Genus CAMPYLORHAMPHUS Bertoni.}

Xiphorhynchus (not of Swainson, 1827 a) Authons.

Xiphorynchus (emendation) Maximilian, Beitr. Naturg. Bras., iv, pt. iii, 1831, 1139.

Ziphorhynchus (emendation?) Swarnson, Classif. Birds, ii, 1837, 313.

Campylorhamphus $b$ Bertoni, Aves Nuevas del Paraguay, 1901, 70. (Type, C. longirostris Bertoni=Dendrocolaptes procurvus Temminck.)

Xiphornis c OberHolser, Smithsonian Misc. Coll., Quart. Issue, xlviii, no. 1579, May 13, 1905, 64, in text. (Type, Dendrocolaptes procurvus Temminck.)

Medium sized Dendrocolaptidæ (length about 200-250 mm.) with excessively elongated, slender, compressed, and strongly arched bill and broadly oval nonoperculate nostrils.

Bill very much longer than head, more than twice as long as tarsus, slender, compressed, conspicuously decurved or arched, its width at latero-frontal antiæ much less than its depth at same point and equal to less than one-twelfth the distance from nostril to tip of maxilla; culmen rounded (not ridged), very strongly decurved from base; tomia strongly decurved, without trace of subterminal notch; gonys deeply concave and decurved, though nearly straight terminally. Nostril exposed, posteriorly in contact with latero-frontal feathering, more or less broadly oval, nonoperculate. Rictal bristles absent, and feathers of chin, etc., without terminal setæ. Wing moderate, rather rounded, the longest primaries exceeding secondaries by much less than length of tarsus; seventh and eighth, or sixth, seventh, and eighth, primaries longest, the tenth (outermost) two-thirds to nearly three-fourths as long as the longest, the ninth intermediate between third and fourth ( $C$. venezuelensis) or between fifth and sixth (C. pusillus). Tail nearly as long as wing, graduated onefourth to more than one-third its length, the rectrices (12) acuminate, with their very strong and rigid shafts decurved terminally. Tarsus about one-fourth as long as wing, distinctly scutellate (endaspidean); middle toe, with claw, a little longer than tarsus; outer toe (with or without claw) as long as middle toe; inner toe, without claw, reaching to a little beyond subterminal articulation of middle toe; hallux decidedly shorter than inner toe, decidedly (but not conspicuously) stouter; middle toe united to outer toe for whole of its first and about half of its second phalanx (for first and second phalanges of outer toe), to inner toe for whole of its first phalanx;

a As Mr. Oberholser states (Smithsonian Misc. Coll., xlviii, 1905, 62) while "Swainson evidently intended to make Dendrocolaptes procurvus Temminck the type of Xiphorhynchus, he defeated his purpose by allowing the previous publication of Xiphorhynchus in combination with the name of a species of another group, such publication being quite sufficient to fix the name of a genus."

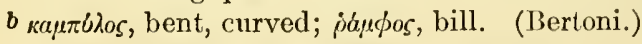

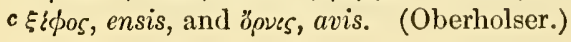


anterior claws large, very strongly curved and acute, that of the hallux less strongly curved, shorter than the digit.

Coloration.-Rump, upper tail-coverts, tail, and greater part of wings chestnut; back and scapular's brown, olive, or rufescent, the former sometimes narrowly strcaked with paler, under parts lighter brown, more or less distinctly streaked, at least on chest, with paler, the throat sometimes dull whitish or bufty.

Nidification.-Nests in holes of trees; eggs plain white.

Range.-Costa Rica to Cayenne, southeastern Brazil, Paraguay, Bolivia, and Peru. (About twelve species. ${ }^{a}$ )

KEY TO THE SPECIES OF CAMPYLORFAMPHUS.

a. Bill light reddish brown.

b. Streaks on back and chest margined with black. (Western Ecuadór.)

Campylorhamphus thoracicus (extralimital). $b$

$b b$. Streaks on back and chest without black margins.

c. Back cinnamon-rufous, under parts dull tawny or ochraceous. (Southwestern Brazil; Paraguay.).......... Campylorhamphus rufodorsalis (extralimital).c

cc. Back olive-brown to cinnamon-brown; under parts light buffy brown to olivebrown.

d. Streaks on pileum, hindneck, and chest much broader.

$e$. Remiges and rectrices cinnamon-rufous; under parts paler, more buffy, brown. (Campylorhamphus trochitirostris.)

f. Bill and tail much longer (culmen 69, tail $87 \mathrm{~mm}$.); lower throat more broadly streaked. ("Brazil.")

Campylorhamphus trochilirostris major (extralimital). $d$

ff. Bill and tail much shorter (culmen 55-59, tail 77-83 mm.), the former much more slender; lower throat more narrowly streaked. (Bahia to lower Amazon Valley, eastern Brazil.)

Campylorhamphus trochilirostris trochilirostris (extralimital). $e$

$a$ The following have not been examined in this connection: C. thoracicus (Sclater), C. lafresnayeanus (D'Orbigny), and C. dorso-immaculatus (Chapman).

$b$ Xiphorhynchus thoracicus Sclater, Proc. Zool. Soc. Lond., Aug., 1860, 277 (Babahoyo, w. Ecuadór; coll. P. L. Sclater); Chapman, Bull. Am. Mus. N. H., ii, 1889, 160 (monogr.).-Xiphornis thoracicus Oberholser, Smithson. Misc. Coll., xlviii, no. 1579, May 13, 1905, 64.-Xiphorhynchus trochilirostris thoracicus Hartert, Novit. Zool., ix, Dec., 1902, 616 (San Javier and Pambilár, n. w. Ecuadór).

c Xiphorhynchus rufodorsalis Chapman, Bull. Am. Mus. N. H., ii, no. 3, July 5, 1889, 160 (Corumbá, Matto Grosso, s. w. Brazil; Coll. Am. Mus. Nat. Hist.).-Xiphornis rufodorsalis Oberholser, Smithson. Misc. Coll., xlviii, no. 1579, May 13, 1905, 64.

d Campylorhamphus trochilirostris major Ridgway, new subspecies. (Type, no. 32819, coll. U. S. Nat. Mus.; adult male; "Brésil;" from Maison Verreaux.)

e D [endrocolaptes] trochilirostris Lichtenstein, Abh. Königl. Akad. Wissensch. Berlin, for 1818-19 (1820), 207, pl. 3 (Brazil; coll. Berlin Mus.; type locality given as Bahia in next vol., p. 263).-X[iphorhynchus] trochilirostris Maximilian, Beitr. Naturg. Bras., iii, 1831, 1140 (excl. syn. part).-Xiphorhynchus trochilirostris Sclater, Cat. Birds Brit. Mus., xv, 1890, 159, part; Chapman, Bull. Am. Mus. N. H., ii, 1889, 155 (monogr.; excl. syn. Dendrocolaptes procurvus Temminck?); Menegaux and Hellmayr, Mém. Soc. Hist. Nat. d'Autun, xix, 1906, 117 (Bahia; crit.; synonymy).-Xiphornis trochilirostris Oberholser, Smithson. Misc. Coll., xlviii, no. 1579, May 13, 1905, 64. 
$e e$. Remiges and rectrices chestnut; under parts deeper, more olive, brown.

(Venezuela to easíern Panamá.)

Campylorhamphus venezuelensis (p. 271).

$d d$. Streaks on pileum, hindneck, and chest much narrower.

e. Pileum, hindneck, back, and under parts more cinnamomeous or russet brown; throat mostly unstreaked; streaks on pileum, chest, etc., more distinct. (Eastern Brazil.)

Campylorhamphus procurvus? (extralimital). $a$

$e e$. Pileum, hindneck, back, and under parts darker and more olive-brown; throat mostly streaked; streaks on pileum, chest, etc., less distinct. (Guianas.)........... Campylorhamphus procurvoides (extralimital). $b$

aa. Bill horn brown or dusky.

b. Throat buff, streaked with dusky brown; pileum sooty (more or less dark) streaked with brownish buff; rump rufescent, like upper tail-coverts; bill paler horn brown.

c. Coloration darker, the pileum blackish brown, remiges and rectrices dark chestnut; streaks on pileum, hindneck, and under parts narrower.

d. Paler, with under parts less olivaceous and less extensively streaked, the back unstreaked. (Central Colombia.)

Campylorhamphus pusillus (extralimital).c

$d d$. Darker, with under parts more olivaceous and more extensively streaked, and back narrowly streaked. (Western Panamá; Costa Rica.)

Campylorhamphus borealis (p. 272).

$c c$. Coloration lighter, the pileum sepia brown, remiges and rectrices clear chestnut; streaks on pileum, hindneck, and under parts broader. (Range unknown.)............... Campylorhamphus chapmani (extralimital).d

$b b$. Throat immaculate dull white; pileum and hindneck black, streaked with brownish white or pale brownish buff; rump olive-brown, like back; bill darker brown. (Brazil.)..... Campylorhamphus falcularius (extralimital). $e$

Noте.-Until a much greater amount of material than has been available in the preparation of this key can be examined, it would be quite useless to more than guess at which of the above-defined forms are specifically and which only subspecifically distinct.

$a$ (?) Dendrocolaptes procurvus Temminck, Pl. Col., iv, livr. 5, Aug., 1820, text to pl. 28 (Brazil).

All specimens of this form that I have seen are from Bahia.

b Xiphorhynchus procurvoides Lafresnaye, Rev. et Mag. de Zool., 1850, 376 (Cayenne); Chapman, Bull. Am. Mus. N. H., ii, 1889, 158 (monogr.).-Xiphorhynchus trochilirostris (not Dendrocolaptes trochilirostris Lafresnaye) Sclater, Cat. Birds Brit. Mus., xv, 1890, 159, part.-Xiphorhynchus subprocurvus Reichenbach, Handb. Spec. Orn., 1853, 183.-Xiphornis subprocurvus Oberholser, Smithson. Misc. Coll., xlviii, no. 1579, May 13, 1905, 64 .

c Xiphorhynchus pusillus Sclater, Proc. Zool. Soc. Lond., 1860, 278 (Colombia; coll. P. L. Sclater); Cat. Birds Brit. Mus., xv, 1890, 160, part (Bogotá and Concordia, Colombia; Ecuadór?); Hartert, Novit. Zool., ix, 1902, 616 (Ventana, n. w. Ecuadór; crit.).

d Campylorhamphus chapmani Ridgway, Proc. Biol. Soc. Wash., xxii, April 17, 1909, 74 ("unknown lncality in South America;" coll. $\Lambda \mathrm{m}$. Mus. Nat. Hist.).

e Dendrocopus falcularius Vieillot, Tabl. Enc. Méth., 1822, 626 (Brazil).-X[iphorhynchus] falcularius Gray, Gen. Bircls, i, Feb., 1847, 140.-Xiphorhynchus falcularius Chapman, Bull. Am. Mus. N. II., ii, 1889, 161 (monogr.); Menegaux and Hellmayr, Mém. Soc. Ilist. Nat. d'Autun, xix, 1906, 115 (crit.; synonymy).-Xiphornis falcularius Oberholser, Smithson. Misc. Coll., xlviii, no. 1579, May 13, 1905, 64. 


\section{CAMPYLORHAMPHUS VENEZUELENSIS (Chapman).}

VENEZUELAN SICKLE BILL.

Adults (seres alite).-Pileum deep sepia or bister brown, each feather with a mesial guttate streak of dull buff or clay color, the hindneck similar but the ground color slightly lighter brown; back and scapulars lighter, more fulvous or russet, brown (between rawumber and russet or mars brown), the upper back usually with more or less distinct narrow mesial streaks of pale dull buffy; rump more rufescent brown than back, the upper tail-coverts still more strongly rufescent (nearly cinnamon-rufous); tail and remiges, including shafts, plain chestnut, the wing-coverts similar but duller (intermediate between color of remiges and that of back); sides of head and neck rather broadly streaked with deep sepia brown and pale dull buffy; chin and throat pale dull buffy or dull buffy whitish, the feathers of throat rather broadly edged with sepia brown, producing distinct streaks; foreneck and chest light brown (between raw-umber and isabella color), with rather broad mesial linear streaks of pale buffy or dull buffy whitish, the breast similar but with the streaks narrower and less distinct; rest of under parts similar but slightly paler and with streaks obsolete (absent on flanks and thighs); under wingcoverts deep ochrnceous-buff, paler and usually indistinctly flecked with pale brownish along edge of wing; inner webs of remiges vinaceous-cinnamon, the outer primaries passing into grayish brown terminally; bill light reddish brown (nearly cinnamon-rufous); iris brown; legs and feet dusky horn color or olive (in dried skins).

Adult male.-Length (skins), 226-252 (239); wing, 92-96.5 (94); tail, 72-81 (78); culmen (chord), 60-66 (62); tarsus, 21.5-22 (21.8); middle toe, $16.5-18(17.5) .^{a}$

Adult female.-Length (skins), 224-227 (225); wing, 88-96 (91.3); tail, 73.5-82.5 (78.3); culmen (chord), 5S-64 (60.7); tarsus, 21-22 (21.5); middle toe, $17-18(17.5) .^{b}$

a Three specimens, from Panamá.

$b$ Three specimens-one from Venezuela, two from Panamá.

\begin{tabular}{l|c|c|c|c|c|c}
\hline Locality. & Wing. & Tall. & $\begin{array}{c}\text { Cul- } \\
\text { men. }\end{array}$ & Tarsus. & $\begin{array}{c}\text { Mlddle } \\
\text { toe. }\end{array}$ \\
\hline FEMrALES. & & & & & \\
One adult female from Venezuela ............................ & 96 & $\$ 2.5$ & 58 & 22 & 17.5 \\
Two adult females from eastern Panamé (Lion Hill).......... & 89 & 76.2 & 62 & 21.2 & 17.5 \\
\hline
\end{tabular}

In all probability, comparison of good series of specimens will show that the Panamá bird is separable from that of Venezuela. 
Venezuela (San Esteban; Carácas; Cumanacoa, Bermudez), Colombia (Bogotá; Remédios, Antioquía), and eastern Panamá (Lion Hill and Frijole stations; Panamá).

Xiphorhynchus lafresnayanus (not Dendrocolaptes lafresnayanus D'Orbigny) LAwRence, Ann. Lyc. N. Y., vii, 1862, 292 (Lion Hill, Panamá).

Xiphorhynchus trochilirostris (not Dendrocolaptes trochilirostris Lichtenstein) Sclater and Salvin, Proc. Zool. Soc. Lond., 1879, 524 (Remédios, Antioquía, Colombia; descr. nest and eggs).-Sclater, Cat. Birds Brit. Mus., xv, 1890, 159, part (Lion Hill, Panamá; Remédios and Bogotá, Colombia; San Esteban and Carácas, Venezuela).-Salvin and Godman, Biol. Centr.-Am., Aves, ii, 1891, 188, excl. syn. part (Lion Hill; Colombia; Venezuela).Bangs, Proc. New Engl. Zool. Club, ii, 1900, 26 (Loma del León, Panamá).

[Xiphorhynchus] trochilirostris Sclater and Salvin, Nom. Av. Neotr., 1873, 69, part.-SHARPE, Hand-list, iii, 1901, 86, part.

Xiphorhynchus venezuelensis Chapman, Bull. Am. Mus. N. H., ii, no. 3, July, 1889, 156 (Venezuela?; type in coll. Bost. Soc. N. H.; ex Lafresnaye, MS., Gray, Hand-list, i, 1869, 178, no. 2423, and Giebel, Thes. Orn., 1877, 766=nomen nudum).

Xiphornis venezuelensis Oberholser, Smithsonian Misc. Coll., xlviii, no. 1579, May 13, 1905, 64.

Xiphorhynchus isabella "Verr.," Gray, Hand-list, i, 1869, 178, no. 2429 (nomen nudum; ex Verreaux, MS.; =isabelline or semi-albinistic variety; see Chapman, Bull. Am. Mus. N. H., ii, no. 3, 1889, 157).

\section{CAMPYLORHAMPHUS BOREALIS (Carriker).}

\section{COSTA RICAN SICKLE BILL.}

Similar to $O$. venezuelensis, but coloration much darker, under parts much more olivaceous with streaks much narrower, and bill horn color instead of light reddish brown.

Adults (sexes alite).-Pileum dark sooty brown to sooty black, each feather with a narrow (usually guttate) streak of buff, the hindneck similar but with the ground color slightly less dark; back and scapulars deep brown (between raw-umber and mummy brown), with very narrow mesial streaks or shaft-streaks of light buff, at least on upper back; rump cinnamon-rufous, passing into rufous-chestnut on upper tail-coverts, the tail and remiges deep chestnut; wing-coverts similar in color to remiges but duller (tinged with color of back); sides of head and neck streaked with sooty brown or blackish and buff, the markings on malar region broader, more spot-like; chin and throat deep buff, the feathers of the latter edged (sometimes terminally margined also) with sooty brown or blackish, the streaks thus produced increasing in width posteriorly; rest of under parts deep raw-umber brown, slightly paler (sometimes slightly rufescent) posteriorly, the foreneck, chest, and breast with narrow mesial streaks of buff, the under tail-coverts (sometimes abdomen also) with much narrower and moro indistinet streaks; under wing-coverts ochraceous or tawny-ochraceous, the inner webs of remiges light cinnamon-rufous, passing into dull grayish brown terminally (exten- 
sively on outer primaries); bill horn brownish, darker on basal and teminal portions of maxilla, paler on mandible (at least on lower midlle portion); iris brown; legs and feet dusky horn color or dark olive (in dried skins).

Young.-Similar to adults, but coloration darker, streaks darker buff or clay color (those on back broader), exposed surface of remiges (in closed wing) mostly olive-brown, and bill nearly black.

Adult male.-Length (skins), 202-233 (223); wing, 89.5-103 (96.9); tail, S1-100.5 (\$9.6); culmen (chord), 4S-57 (54.4); tarsus, 20-21.5 (21); middle toe, 17.5-19 (1S.1). ${ }^{a}$

Adult female.-Length (skins), 215-230 (223); wing, 90.5-99 (94.1); tail, 79-91 (St.6); culmen (chord), 55-61 (57.5); tarsus, 21-22.5 (21.6); middle toc, $17-19$ (17.9). ${ }^{b}$

Costa Rica (Naranjo, La Estrella, Azahúr, and Birrís, Cartago; Guápiles; Guácimo; La Hondura; El Hogár; Carrillo; Jiménez; Guayabo; Cariblanco de Sarapiquí; El Generál; Cervantes; Rio Súcio) and western Panamá (Volcán de Chiriquí, 700 feet, and Caribbean slope; Chitra; Boquete de Chitra).

Iiphorhynchus pusillus (not of Sclater, 1860?) Sclater, Cat. Birds Brit. Mus., xv, 1590, 160, part (Boquete de Chitra, Chitra, and Chiriquí, Panamá; Costa Rica).-Salvin, Proc. Zool. Soc. Lond., 1870, 193 (Boquete de Chitra, Panamá; crít.).-Boucard, Proc. Zool. Soc. Lond., 1878, 60 (Naranjo de Cartago, Costa Rica).-Zeledón, Anal. Mus. Nac. Costa Rica, i, 1888, 114 (Birrís de Cartago and Jiménez, Costa Rica).-Chapman, Bull. Am. Mus. N. H., ii, 1889, 157, part (monogr.).-Salvin and Godman, Biol. Centr.-Am., Aves, ii, 1891, 159, pl. 48, fig. 2.

[Xiphorhynchus] pusillus Gray, Hand-list, i, 1869, 178, no. 2430.-Sclater and Salvin, Nom. Av. Neotr., 1873, 69, part.-Sharpe, Hand-list, iii, 1901, 86 (Costa Rica; Panamá).

Niphornis pusillus Oberholser, Smithsonian Misc. Coll., xlviii, no. 1579, May 13, $1905,64$.

Tiphorhynchus grandis "Cherrie" Bangs, Proc. New Engl. Zool. Club, iii, Jan. 30, 1902, 48 (Volcán de Chiriquí, 700 ft., Panamá; =nomen nudum!).

Campylorhamphus pusillus borealis CARriKer, Ann. Carnegie Mus., vi, "Aug. 29" (=Sept. 7), 1910, 657 (El Hogár, e. Costa Rica; coll. Carnegie Mus.).

a Twelve specimens.

$b$ Nine specimens, from Costa Rica.

\begin{tabular}{|c|c|c|c|c|c|}
\hline Locality. & Wing. & Tail. & $\begin{array}{l}\text { Cul- } \\
\text { men. }\end{array}$ & Tarsus. & $\begin{array}{c}\text { Middle } \\
\text { toe. }\end{array}$ \\
\hline MALES. & & & & & \\
\hline Ten adult males from Costa Rica. & 97.3 & 90.7 & 54.2 & 21 & 18.1 \\
\hline Two adult males from western Panamá... & 94.7 & 85 & 55.5 & 21.2 & 18 \\
\hline
\end{tabular}

\$1255ำBull. 50-11-18 


\section{Genus GLYPHORYNCHUS Maximilian.}

Glyphorynchus Maxmminan, Beitr. Naturg. Bras., iii, pt. ii, 1831, 1149. (Type, G. ruficaudus Maximilian=Dendrocolaptes cuneatus Lichtenstein.)

Glyphorhynchus (emendation) Strickland, Proc. Zool. Soc. Lond., 1841, 28, in text.

Sphenorhynchus Maximilian, Beitr. Naturg. Bras., iii, pt. ii, 1831, 1278. (Type, Glyphorynchus ruficaudus Maximilian=Dendrocolaptes cuneatus Lichtenstein.)

Zenophasia Swainson, Anim. in Menag., 1838, 351. (Type, Z. platyryncha Swainson $=$ Dendrocolaptes cuneatus Lichtenstein.)

Sittacilla Lesson, Compl. de Buffon, ix, 1837, 135. (Type, Dendrocolaptes cuneatus Lichtenstein.)

Small Dendrocolaptidæ (length about $140 \mathrm{~mm}$.) with bill much shorter than head, stout, wedge-shaped, with maxilla broad and flattened terminally; nostril narrow, broadly operculate, and tail (nearly as long as wing) with the very rigid rectrices very strongly decurved terminally.

Bill much shorter than head, stout, wedge-shaped, its width at latero-frontal antiæ decidedly greater than its depth at same point and equal to about half the distance from nostril to tip of maxilla; culmen broad and rounded (not ridged), straight basally, rather suddenly depressed terminally, the tip of maxilla broad and rounded in vertical profile but acute in lateral aspect; maxillary tomium nearly straight, but slightly incised or faintly notched terminally; mandibular tomium straight or very faintly concave (the mandible very slightly recurved terminally); gonys strongly convex and rather prominent basally, nearly straight and strongly ascending terminally. Nostril exposed, posteriorly in contact with latero-frontal feathering, narrow (slit-like), longitudinal, overhung by a very broad and conspicuous operculum and. also margined below by the integument of the nasal fossa. Rictal bristles present but minute, and feathers of chin and lores with minute terminal setæ. Wing moderate, rather pointed, the longer primaries exceeding secondaries by more than length of exposed culmen; seventh and eighth primaries longest, the tenth (outermost) about three-fourths as long as the longest, the ninth about equal to sixth. Tail nearly as long as wing, graduated for one-third, or more, of its Iength, the rectrices (12) acuminate, with the very strong and excessively rigid shafts very strongly decurved terminally. Tarsus much longer than culmen (from base); about one-fourth as long as wing, distinctly scutellate (endaspidean); middle toe, with claw, decidcdly shorter than tarsus; outer toc, with or without claw, as long as middle toe; inner toe, without claw, reaching to middle of subterminal phalanx of middle toe; hallux conspicuously shorter than inner toe, not stouter; middle toe united to outer toe for whole of first and part of second phalanx, to inner toe for whole of its first phalanx; anterior claws large, very strongly curved and acute, that of the hallux much less curved, about as long as the digit. 
Coloration.-Above plain olive-brown, the tail, upper tnil-coverts, and secondaries chestunt; bencath light olive, the chest with cuneate spots of pale buff or whitish, the throat buff spotted or flecked with olive; inner webs of remiges crossed by a broad band of buff or ochraceous.

Nidification.-Nests in holes; eggs white.

Range.-Southern Mexico to Cayenne, Brazil and Ecuadór. (Two species. ${ }^{a}$ )

KEY TO THE SUBSPECIES OF GLYPHORYNCHUS CUNEATUS.

a. Under parts paler, with chest indistinctly streaked or nearly uniform grayish brown, the chin and throat paler buffy. (Brazil, etc.)

Glyphorynchus cuneatus cuneatus (extralimital). $b$ aa. Under parts darker, with chest more conspicuously marked with triangular or wedge-shaped spots or streaks of buffy; chin and throat deeper buff. (Southeastern Mexico to Panamá.)........ . Glyphorynchus cuneatus pectoralis (p. 275).

\section{GLYPHORYNCHUS CUNEATUS PECTORALIS (Sclater).}

NORTHERN WEDGEBILL.

Similar to G. c. cuneatus Lichtenstein, of Brazil, but under parts darker, chin and throat more deeply buffy and triangular or wedgeshaped markings on chest larger and more distinct.

Adults (sexes alite).-Pileum sooty brown or sepia, the forehead usually indistinctly streaked or flecked with paler brown or dull buffy; back and scapulars plain raw-umber or russet-brown, passing into cinnamon-rufous on rump and upper tail-coverts; tail deeper cinnamon-rufous or rufous-chestnut, the shafts of rectrices bright cinnamon-rufous or orange-rufous; wings similar in color to back but slightly more rufescent, the proximal secondaries (tertials) dull cinnamon-rufous; a narrow superciliary stripe of dull buff or buffy whitish, broken by small streaks of brown; auricular region sooty brown, narrowly streaked with dull buff or buffy whitish, the suborbital region with small spots or flecks of the same; chin and throat buff to tawny-buff, the feathers (except, sometimes, those of chin)

$a$ I have not seen $G$. castelnaudi Des Murs, which possibly is only a subspecies of G. cuneatus (Lichtenstein). (Glyphorhynchus castelnaudi Des Murs, in Castelnau's Expéd., Ois., 1855, 47, pl. 15, fig. 2.)-Glyphorhynchus cuneatus castelnaudi Berlepsch and Taczanowski, Proc. Zool. Soc. Lond., 1883, 563 (Chimbo, n. w. Ecuador; crit.).

$b$ [endrocolaptes] cuneatus Lichtenstein, Abh. Königl. Ak. Wissensch, Berlin for 1818-19 (1820), 204, pl. 2, fig. 2 (locality not given, but in vol. for 1822, p. 266, given as Bahia, Brazil; coll. Berlin Mus.).-Glyphorhynchus cuneatus Strickland, Proc. Zool. Soc. Lond., 1841, 28, in text; Sclater, Cat. Birds Brit. Mus., xv, 1890, 124, part.-Glyphorhynchus cuneatus cuneatus Menegaux and Hellmayr, Mém. Soc. Hist. Nat. d'Autun, xix, 1906, 97 (crit.).-G[lyphorynchus] ruficaudus Maximilian, Beitr. Naturg. Bras., iii, pt. ii, 1831, 1150 (Brazil; type now in coll. Am. Mus. Nat. Hist.; see Allen, Bull. Am. Mus. N. H., ii, 1889, 248).-Zenophasia platyryncha Swainson, Anim. in Menag., pt. iii, Jan. 1, 1838, 352 (Brazil; coll. W. Swainson).-Sittasomus flammulatus Lesson, Traité d'Orn., 1831, 315 (Brazil?; coll. Paris Mus.). 
margined with sooty brown or dusky; rest of under parts light rawumber or tawny-olive, darker on chest, where the feather's have a large and conspicuous mesial cuneate or broadly fusiform mark of light buff, the feathers of breast with more or less distinct narrow mesial streaks, or shaft-streaks, of the same; under tail-coverts cinnamomeous with narrow mesial streaks of paler; under wingcoverts mostly white or pale yellowish buff, the carpo-metacarpal area brown; inner webs of remiges (except three outer primaries) crossed obliquely, near middle portion, by a broad band of ochraceous-buff (usually passing into paler buff toward edge of the web); maxilla dusky brown, mandible paler brown or horn color; iris brown; legs and feet horn color or dusky (in dried skins).

Adult male.-Length (skins), 133-156 (145); wing, 69.5-80.5 (75.5); tail, 65-76.5 (70); culmen, 11-13.5 (13); tarsus, 16-18 (17); middle toe, $9.5-11(10.2) .^{a}$

Adult female.-Length (skins), 130-151 (140.7); wing, 65-74 (70.3); tail, 57.5-67 (63); culmen, 11-13.5 (12.6); tarsus, 16-17 (16.6); middle toe, $9.5-10.5$ (10.1). ${ }^{b}$

Southeastern Mexico, in State of Vera Cruz (Tolosa; Buena Vista); Guatemala (Choctúm; Yzabál; Los Amates, Yzabál; sources of Rio de la Pasión), British Honduras (forest near Manatee Lagoon), Honduras (Rio Segóvia), Nicaragua (Greytown; Rio San Juan; Los Sábalos; Rio Escondido), Costa Rica (Tucurríqui; Naranjo de Cartago; Rio Reventazón; Rio Frio; Boca de Rio Matina; Rio Sícsola; Pacuare; Cuabre; Guápiles; Carrillo; La Cristina; La

a Nineteen specimens.

$b$ Seventeen specimens.

\begin{tabular}{|c|c|c|c|c|c|}
\hline Locality. & Wing. & Tail. & $\begin{array}{l}\text { Cul- } \\
\text { men. }\end{array}$ & Tarsus. & $\begin{array}{l}\text { Mldddle } \\
\text { toe. }\end{array}$ \\
\hline MALES. & & & & & \\
\hline Two adult males from Vera Cruz, Mexico.. & 73.3 & 69 & 13.5 & 17 & 10.5 \\
\hline Two aduit males from southern IIonduras. . & 75 & 66.3 & 13 & 17.3 & 10.3 \\
\hline Five adult males from Nicaragua........... & 75.6 & 70.6 & 13.1 & 16.9 & 9.8 \\
\hline Ten adult males from Costa Riea. & 75.8 & 70.6 & 12.9 & 17 & 10.3 \\
\hline One adult male (G. c. $\longrightarrow$ ?) from northwestern Colombia. & 73 & 65 & 11 & 15.5 & 10 \\
\hline Four adult males ( $G . c . \longrightarrow$ ?) from Venezuela. & 70.6 & 65.2 & 11.9 & 15.7 & 9 \\
\hline Two adult males (G. c. cuncatus) from Brazil..... & 69.3 & 64 & 13.5 & 17 & 11 \\
\hline FEMALES. & & & & & \\
\hline Two adult females from Vera Cru & 73 & 66.3 & 13.5 & 16.3 & 10 \\
\hline One adult $f$ & 69 & 65 & 13 & 16.5 & 10.5 \\
\hline Two adult females from Nicaragn & 70.5 & 64 & 13.3 & 16.3 & 10.5 \\
\hline Ten adult females from Costa 1 & 70.6 & 62 & 12.4 & 16.6 & 10 \\
\hline One adult female from western Pana & 69.9 & 57.5 & 12 & 16.5 & 10 \\
\hline One adult female from eastern I'anamá......... & 67.5 & 60 & 12 & 17 & 10 \\
\hline One adult female (G.c. — ?) from Venezucla.. & 65 & 58 & 12 & 15.5 & 9.5 \\
\hline Two arlult females (G.c. cuncatus) from Brazil.. & 67.8 & 63 & 13 & 16 & 10 \\
\hline
\end{tabular}


Florida; El Hogár; La Hondura; Jiménez; Turralba; Bonilla; El Generál; La Vijágua; Palmár; Pozo Azúl de Pirrís; Pozo del Rio Grande; Pozo del Pitál; Buenos Aires), and Panamá (Bugaba; Mina de Chorcha; Voleán de Chiriquí, 7,000 feet; Chitra; Panamá).

Glyphorhynchus cuncatus (not Dendrocolaptes cuncatus Lichtenstein) Scuater, Proc. Zool. Soc. Lond., 1S58, 63 (s. Mexico); Cat. B. Brit. Mus., xv, 1890, 124, part (Yzabíl, sources Rio de la Pasión, and Choctúm, Guatemala; Tucurríqui, Costa Rica; Bugaba and Mina de Chorcha, Verágua; Panamá).Sclater and Salvin, Ibis, 1860, 35 (Yzabál, Guatemala); Nom. Av. Neotr. 1873, 67, part.-Lawrence, Ann. Lyc. N. Y., vii, 1862, 320 (Lion Hill, Panamí).-Sumichrast, La Naturaleza, v, 1881, 248 (Uvero, Vera Cruz).Salvin, Ibis, 1866, 205 (Guatemala).-Boucard, Proc. Zool. Soc. Lond., 1878, 60 (Naranjo, Costa Rica).-Nutring, Proc. U. S. Nat. Mus., vi, 1883, 404 (Los Sábalos, Nicaragua; habits).-Zeledón, Anal. Mus. Nac. Costa Rica, i, 1888, 113 (Pacuare, Pozo Azúl de Pirrís, and Naranjo do Cartago, Costa Rica).-Salvin and Godman, Biol. Centr.-Am., Aves, ii, 1891, 175, part (Mexican and Central American references and localities).-CnerRIE, Expl. Zool. Merid. Costa Rica, 1893, 40 (Palmár, Costa Rica); Anal. Inst. Fis.-Geog. Costa Rica, vi, 1893, 17 (Pozo del Pitál, Costa Rica).Richmond, Proc. U. S. Nat. Mus., xvi, 1893, 497 (Rio Escondido, Nicaragua; habits; descr. nest and eggs).-Bangs, Proc. New Engl. Zool. Club, iii, 1902, 46 (Volcán de Chiriquí, 7,000ft., Panamá); Auk, xxiv, 1907, 299 (Pozo del Rio Grande, Costa Rica).-Dearborn, Pub. 125, Fiold Mus. N. H., 1907, 107 (Los Amates, Guatemala; crit.).-Carriker, Ann. Camegie Mus., vi, 1910, 648 (Costa Rica; habits; descr. nest and eggs).

Glyphorhynchus cuneatus? Salvin and Sclater, Ibis, 1860, 35 (Yzabál, Guatemala).

[Glyphorhynchus] cuneatus Sclater and Salvin, Nom. Av. Neotr., 1873, 67, part.-Sharpe, Hand-list, iii, 1901, 74, part (Mexico to Panamá).

Glyphorhincus cuneatus Boucard, Ann. Soc. Linn. Lyon, 1878, 38 (Guatemala).

Glyphorhynchus pectoralis Sclater and Salvin, Proc. Zool. Soc. Lond., 1860, 299

(Choctúm, Vera Paz, Guatemala; coll. Salvin and Godman); 1864, 354 (Lion Hill, Panamá; crit.).-Lawrence, Ann. Lyc. N. Y., viii, 1867, 181 (Greytown, Nicaragua); ix, 1868, 106 (Costa Rica).-Frantzius, Journ. für Orn., 1869, 305 (Costa Rica).-Salvin, Proc. Zool. Soc. Lond., 1870, 192 (Bugaba, Mina de Chorcha, and Volcán de Chiriquí, Verágua).

Glyphorhynchus major Sclater, Cat. Am. Birds, 1862, 161 (Choctúm, Vera Paz, Guatemala; coll. P. L. Sclater); Proc. Zool. Soc. Lond., 1862, 369 (s. Mexico).

Glyphorynchus major Sumichrast, Mem. Bost. Soc. N. H., i, 1869, 555 (hot zone, Vera Cruz).

[Glyphorhynchus] major GRAY, Hand-list, i, 1869, 181, no. 2481.

Xiphorhynchus mayor SAnchez, Anal. Mus. Nac. Mex., i, 1877, 97 (Vera Cruz).

\section{Genus SITTASOMUS Swainson.}

Sittasomus Swanson, Zool. Joum., iii, 1827, 355. (Type, Dendrocolaptes sylviellus Temminck $=D$, erithacus Lichtenstein.)

Sittosomus (emendation) Cabanis and Heine, Mus. Hein., ii, Aug., 1859, 33.

Acanthurus a (not Acanthura Guilding, 1827) Bertoni, Aves Nuevas del Paraguay, 1901, 72. (Type, A. microrhynchus Bertoni=Dendrocolaptes erithacus Lichtenstein.)

Sylosella Lesson, Traité d'Orn., 1830, 314. (New name for Sittasomus Swainson.) 
Small Dendrocolaptidæ (length about 140-160 mm.) with small slender bill, long, graduated tail with acuminate tips of very rigid rectrices strongly decurved, and inner webs of remiges crossed by a broàd band of buff or ochraceous.

Bill much shorter than head, nearly subulate, rather broad and depressed basally, its width at latero-frontal antiæ much greater than its depth at same point and equal to half the distance from nostril to tip of maxilla or a little less; culmen distinctly ridged, gently decurved from near base; maxillary tomium nearly straight for most of its length, distinctly but slightly decurved terminally, without trace of subterminal notch, the tip of maxilla forming a fine, more or less distinctly decurved, point; gonys nearly straight and slightly ascending terminally, faintly convex basally. Nostril exposed, posteriorly in contact with latero-frontal feathering, narrow, nearly horizontal, margined above by a rather broad membraneous operculum. Rictal bristles obvious but minute; feathers of chin and loral region with small terminal setæ. Wing rather long and pointed, the longest primaries exceeding secondaries by about length of tarsus; eighth and ninth, or seventh and eighth, primaries longest, the tenth (outermost) about two-thirds as long as the longest. Tail equal to or longer than wing, graduated for one-third its length, or more, the rectrices (12) abruptly acuminate, with their very rigid shafts very strongly decurved and twisted subterminally. Tarsus much longer than culmen, slender, distinctly scutellate (endaspidean); middle toe, with claw, slightly shorter than tarsus; outer toe, with or without claw, as long as or very slightly longer than middle toe; inner toe, without claw, reaching to slightly beyond subterminal articulation of middle toe; hallux much shorter than inner toe, not stouter; middle toe united to outer toe by the whole of its first and about half its second phalanx, to inner toe by greater part of first phalanx; anterior claws large, very strongly curved and acute, that of the hallux much less curved, longer than the digit.

Coloration.-Rump, tail-coverts, tail, and secondaries cinnamonrufous, chestnut, or rufous-tawny; pileum and hindneck grayish olive to tawny brown, the back similar or browner; under parts plain grayish olive to olive-ochraceous; inner webs of remiges crossed obliquely by a broad band of ochraceous-buff, and secondaries with an extensive subterminal (mostly concealed) area of black. Sexes alike.

Nidification.-Nests in holes; eggs white.

Range.-Southern Mexico to Venezuela, Tobago, southeastern Brazil, Paraguay, Argentina, Bolivia, and Ecuadór. (About ten species and subspecies.) 
KEY TO TIF SPECIES AND SUBSPECIES OF SITIASOMUS.

a. Pale band across inner web of remiges very sharply defined, very distinct on secondaries as well as on primaries, and in color distinctly yellowish.

b. Tail and secondaries rufous-chestnut or deep eimnamon-rufous.

c. Under parts olive-yellowish. (Southeastern Brazil, etc.)

cc. Under parts grayish olive or olive-grayish.

Sittasomus erithacus (extralimital). d. Back mixed rusty and olive.

e. More olivaceous, with much smallor bill: under wing-coverts and band across inner web of remiges deeper yellowish. (Southwestern Brazil,

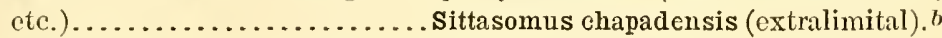

ec. More grayish, with much larger bill; under wing-coverts and band across inner webs of remiges paler yellowish. (Upper Amazon Valley.)

Sittasomus amazonus (extralimital).c

dd. Back uniform russet brown. (Sittasomus sylvioides.)

e. Smaller (male averaging, wing, 77.1; tail, 73.5; exposed culmen, $14 \mathrm{~mm}$.). (Southeastern Mexico to Costa Rica.)

Sittasomus sylvioides sylvioides (p. 280).

ee. Larger (male averaging, wing, 84; tail, 77.5 or more; exposed culmen, 15.4 or more).

f. Tail and bill shorter (tail averaging 77.5, exposed culmen 15.4). (Panama.)..................... Sittasomus sylvioides levis (p.282).

ff. Tail and bill longer (tail averaging 81, exposed culmen 16.5). (Western Mexico.)................ Sittasomus sylvioides jaliscensis (p. 283).

$b b$. Tail and secondaries clear tawny. (Western Ecuadór.)

Sittasomus æquatorialis (extralimital). $d$ aa. Pale band across inner web of remiges not sharply defined, very indistinct on secondaries, in color white or yellowish white. (Tobago.)

Sittasomus griseus (extralimital).e

a D[endrocolaptes] erithacus Lichtenstein, Abh. Königl. Akad. Wissensch. Berlin, for 1820-21 (1822), 259, 266, pl. 1, fig. 2 (Province of São Paulo, s. Brazil; coll. Berlin Ius.).-[Sittasomus] erythacus Bonaparte, Consp. Av., i, 1850, 209.-Sittasomus erithacus Lafresnaye, Rev. Zool., 1850, 589; Sclater, Cat. Birds Brit. Mus., xv, 1890, 119; Ridgway, Proc. U. S. Nat. Mus., xiv, 1891, 508 (monogr.).-Sittasomus sylviellus Temminck, Pl. Col., livr. 12, Sept. 27, 1823, text to pl. 72, fig. 1; Menegaux and Hellmayr, Mém. Soc. Hist. Nat. d'Autun, xix, 1906, 95 (Goyaz, Brazil; crit.).-Sittasomus sylviellus sylviellus Hellmayr, Novit. Zool., xv, 1908, 63 (Goyaz and Faz. Esperança, Brazil).-Acanthurus microrhynchus Bertoni, Aves Nueves del Paraguay, 1901, 72.-S[ittasomus] olivaceus Maximilian, Beitr. Naturg. Bras., iii, 1831, 1146.

b Sittasomus chapadensis Ridgway, Proc. U. S. Nat. Mus., xiv, no. 877, Oct. 31, 1891, 509 (Chapada, Matto Grosso, s. w. Brazil; coll. Am. Mus. Nat. Hist.); Menegaux and Hellmayr, Mém. Soc. Hist. Nat. d'Autun, xix, 1906, 95 (Chiquitos, Bolivia; crit.).-Sittasomus sylviellus chapadensis Hellmayr, Novit. Zool., xv, 1908, 63 (Rio Thesouras, Brazil; crit.).

c Sittasomus amazonus Lafresnaye, Rev. et Mag. de Zool., 1850, 509; Ridgway, Proc. U. S. Nat. Mus., xiv, 1891, 509 (monogr.); Menegaux and Hellmayr, Mém. Soc. Hist. Nat. d'Autun, xix, 1906, 96 (Yungas, Bolivia; up. Amazon).--Sittasomus olivaceus amazonus Hartert, Kat. Vogelsamml. Senckenb., 1891, 110 (Bolivia).

d Sittasomus æquatorialis Ridgway, Proc. U. S. Nat. Mus., xiv, no. 877, Oct. 31, 1891, 509 (Guayaquíl, w. Ecuadór; coll. U. S. Nat. Mus.).

e Sittasomus griseus Jardine, Ann. and Mag. N. H., xix, 1847, 82 (Tobago); Ridgway, Proc. U. S. Nat. Mus., xiv, 1891, 510 (monogr.). 


\section{SITTASOMUS SYLVIOIDES SYLVIOIDES Lafresnaye.}

MEXICAN SITTASOMUS. $a$

Adults (sexes alike).-Pileum and hindneck plain grayish olive, the sides of head and under parts (except under tail-coverts) similar but lighter; back and scapulars uniform russet, sometimes slightly tinged with olive, passing on rump, upper tail-coverts, and tail into clear deep cinnamon-rufous; wing-coverts similar in color to back and scapulars, but with an indistinct central area of grayish olive; secondaries deep cinnamon-rufous, with a large subterminal area (not crossing outer web) of dull black or dusky, this sharply defined anteriorly against a basal area of clear buff or ochraceous-buff on inner web; proximal (shorter) primaries similarly colored, but dusky subterminal area not so dark (more sooty brownish), cinnamon-rufous tip narrower and duller, and basal portion of outer web duller (dull ochraceous or cinnamon); distal (longer) primaries with outer web cinnamon, the three outermost with inner webs wholly dusky; alula and primary coverts grayish brown; axillars buff; under wing-coverts and broad oblique band across inner webs of remiges deep cream-buff or light ochraceous-buff; under tail-coverts cinnamon-rufous, the flanks sometimes tinged with the same; maxilla dusky horn color, paler along tomium; mandible paler with terminal portion dusky; iris brown; legs and feet horn color or dusky (in dried skins).

$a$ The utter impossibility of inventing English names for all of the thousands of species and subspecies of birds found in Tropical America necessitates the occasional use of the Greek or Latin generic name in cases where there is no native vernacular name to take the place of an English one. Unfortunately the native language is often very poor in bird-names, many diverse kinds being often grouped under one term, as cóme-maiz (corn-eater) for sparrows in general, or else the names in general use are borrowed from extremely different European birds. In Costa Rica, for example, the Spanish name gorrion (sparrow) is universally applied and practically restricted to hummingbirds, that of calandria (lark) to the three-caruncled bell-bird, and that of jilguéro (linnet) to the Myadestes of that country.

The author is well aware that there are persons who imagine that the English language is equal to any emergency and resent the use of anything else; but the views of such would surely change were they to attempt the task of naming in English terms all of the American birds alone that are not already thus named. 
Adult male.-Length (skins), 145-160 (152); wing, 65.5-82 (77.1); tail, 65.5-7S (73.5); culmen, 13-15.5 (14); tarsus, 15-18 (16.9); midlllo toc, 11-13.5 (12.1). ${ }^{a}$

Adult female.-Length (skins), 131-156 (142); wing, 66-80 (70.8); tail, 61.5-75 (67.1); culmen, 13-15 (13.9); tarsus, 15-17.5 (16.2); midille toc, $10.5-13(11.7){ }^{b}$

Southeastern Mexico, in States of Vera Cruz (Córlova; Potrero, near Córdova; Jalapa; Miradór; Coátepec; Cofre de Perote; Cuesta de Misantla; Sochiapa; Pasa Nueva), Puebla (Metlaltoyuca), Mexico (ncar City of Mexico)?, Oaxaca (Santa Efigénia), Tabasco (Teapa), Campeche (Apazote), anel Yucatan (La Vega; Izalám; ChichenItza), and southward through Guatemala (Chiséc; Choctúm; Savana Grande; Pie de la Cuesta in San Marcos; Naranjo; Patulúl, Sololá; Mazatenango; Los Amates, Yzabál), British Honduras (Orange Walk; forest near Manatee Lagoon; Ycacos Lagoon; forest near Quamius Creek), Honduras (Santa Ana), and Nicaragua (Sucuyá) to Costa Rica ${ }^{c}$ (Naranjo de Cartago; Monte Redondo; La Cedrál, Aserrí; Coralillo; Bonilla; Guayabo; Mojica; Dota; Santa Maria de Dota; Cerro Santa Maria; Tenório; Bolsón; Volcán de Miravalles).

Sittasomus sylvioides Lafresnaye, Rev, et Mag. Zool., 1850, 590 (Mexico).Reichenbach, Handb. Spec. Orn., 1853, 177.-Sclater, Proc. Zool. Soc. Lond., 1856, 290 (Córdova, Vera Cruz); 1859, 365 (Jalapa, Vera Cruz); 1864, 175 (near City of Mexico); Cat. Am. Birds, 1862, 160 (do.).-Salvin, Ibis,

a Twenty-three specimens. a Twenty-two specimens.

\begin{tabular}{|c|c|c|c|c|c|}
\hline Locality. & WVing. & Tail. & $\begin{array}{l}\text { Cul- } \\
\text { men. }\end{array}$ & Tarsus. & $\begin{array}{l}\text { Middle } \\
\text { toe. }\end{array}$ \\
\hline MALES. & & & & & \\
\hline Four adult males from Vera Cruz (3) and Puebla (I).... & 77.5 & 76 & 13.6 & 16.9 & 11.9 \\
\hline Two adult males from Guatemala.................. & 75.5 & 71 & 14.5 & 16 & 11.5 \\
\hline One adult male (?) from British Honduras...... & 65.5 & 65.5 & 14 & 16 & 12 \\
\hline One adult male from Honduras......... & 76.5 & 72.5 & 13.5 & 17.5 & 12.5 \\
\hline Four adult males from Yucatan .................... & 74.4 & 73 & 14 & 16.5 & 11.6 \\
\hline One adult male from Nicaragua.......... & 77.5 & 73 & 15 & 17 & 11.5 \\
\hline Ten adult males from Costa Rica............... & 78.9 & 74 & 14.4 & 17.2 & 12.5 \\
\hline Six adult males (S. s. levis) from western Panamá....... & 84 & 77.4 & 15.4 & 17.7 & 13 \\
\hline One adult male (S. s. jaliscensis) from Jalisco, Mexico...... & 84 & 81 & 16.5 & 18.5 & 12 \\
\hline FEMALES. & & & & & \\
\hline Three adult females from Puebla.. & 70.7 & 68.8 & 13.7 & 16.2 & 11.3 \\
\hline Two adult females from Campeche.... . . . . . . . . & 67.2 & 66.2 & 13.5 & 15 & 11 \\
\hline Two adult females from Yucatan ............ & 67.7 & 65.7 & 13.5 & 15.5 & 10.7 \\
\hline One adult female from Guatemala..................... & 71 & 66.5 & 14.5 & 16.5 & 12.5 \\
\hline Four adult females from British Honduras...... & 67.2 & 64.1 & 14 & 16.1 & 11.6 \\
\hline Ten adult females (S. s. levis) from Costa Rica.... & 73.6 & 68.4 & 14 & 16.7 & 12.2 \\
\hline Three adult females (S. s. levis) from Panamá..... & 76 & 73.5 & 14.7 & 17.3 & 12.7 \\
\hline
\end{tabular}

$c$ Costa Rican examples are intermediate between $S$. s. sylvioides and S. s. levis, agreeing best with the former in measurements and with the latter in coloration. In fact, they may be as well referred to one form as to the other. 
1861, 353 (Chiséc, Guatemala).-Lawrence, Ann. Lyc. N. Y., ix, 1868, 106 (Dota Mts., Costa Rica).-Frantzius, Journ. für Orn., 1869, 304 (Costa Rica).-Sumichrast, Mem. Bost. Soc. N. H., i, 1869, 555 (tierra caliente of Vera Cruz).-Sanchez, An. Mus. Nac. Mex., i, 1877, 97 (Vera Cruz).Zeledón, Anal. Mus. Nac. Costa Rica, i, 1888, 113 (Dota and Monte Redondo, Costa Rica).-Rrdgway, Proc. U. S. Nat. Mus., xiv, 1891, 509 (crit.).-CoLe, Bull. Mus. Comp. Zool., 1, 1906, 131 (Chichen-Itza, Yucatan; crit.).-Dearborn, Pub. 125, Field Mus. N. H., 1907, 108 (Los Amates and Patulúl, Guatemala).-Carriker, Ann. Carnegie Mus., vi, 1910, 651 (Costa Rican range).

[Sittasomus] sylvioides Lafresnaye, Rev. et Mag. Zool., 1849, 331 (nomen nudum).-Gray, Hand-list, i, 1869, 180, no. 2466.-SHARPe, Hand-list, iii, 1901, 77, part.

Sittasomus pectinicaudus Caban[is] ReIchenbach, Handb. Spec. Orn., 1853, 177.

S[ittosomus] pectinicaudus Cabanis and Herne, Mus. Hein., ii, Aug., 1859, 33 (Mexico; coll. Heine).

[Sittosomus] pectinicaudus Herne and Rerchenow, Nom. Mus. Hein. Orn., 1890, 135 (Mexico).

Sittasomus olivaceus (not of Maximilian) Sclater and Salvin, Proc. Zool. Soc. Lond., 1869, 363 (near City of Mexico).-Sumichrast, La Naturaleza, v, 1881, 247 (Potrero, Vera Cruz).-Nutting, Proc. U. S. Nat. Mus., vi, 1883, 385 (Sucuyá, Nicaragua).-Boucard, Proc. Zool. Soc. Lond., 1883, 450 (Yucatan).-Ferrari-Perez, Proc. U. S. Nat. Mus., ix, 1886, 156 (Jalapa, Vera Cruz).-Under wood, Ibis, 1896, 440 (Volcán de Miravalles, Costa Rica). [Sittasomus] olivaceus Sclater and Salvin, Nom. Av. Neotr., 1873, 66, part.

Sittosomus olivaceus Sclater, Cat. Birds Brit. Mus., xv, 1890, 119, part (Jalapa; n. Yucatan; Savana Grande and Choctúm, Guatemala; Tempate, Costa Rica).-Salvin and Godman, Biol. Centr.-Am., Aves, ii, 1891, 176, part (Coátepec, Cofre de Perote, Cuesta de Misantla, and Córdova, Vera Cruz; Sochiapa; Teapa, Tabasco; Sta. Efigénia, Oaxaca; Orange Walk, Brit. Honduras; Pié de la Cuesta in San Marcos, Choctúm, and Savana Grande, Guatemala; Sucuyá, Nicaragua; Tempate de Nicoya and Dota Mts., Costa Rica).

\section{SITTASOMUS SYLVIOIDES LEVIS (Bangs).}

PANAMA SITTASOMUS.

Similar to S. s. sylvioides, but larger and with cinnamon-rufous color of rump and under tail-coverts lighter.

Adult male.-Length (skins), 156-165 (160); wing, 81.5-86 (84); tail, 75-81.5 (77.4); culmen, 15-16 (15.4); tarsus, 17-18 (17.7); middle toe, $12.5-13.5$ (13). ${ }^{a}$

Adult female.-Length (skins), 147-158 (152); wing, 73.5-83 (76.S); tail, 68-82.5 (73.5); culmen, 14-15.5 (14.7); tarsus, 17-17.5 (17.3); middle toe, $12.5-13(12.7) .^{b}$

Panamá (Calovévora; Chitra; Volcán de Chiriquí; Boquete, 4,000 feet; Cascajál, Coclé).

Sittasomus olivaceus (not of Maximilian) Salvin, Proc. Zool. Soc. Lond., 1870, 192 (Calovévora and Volcán de Chiriquí, Panamá).

[Sittasomus] olivaceus Sclater and Salvin, Nom. Av. Neotr., 1873, 66, part.

Sittosomus olivaceus Sclater, Cat. Birds Brit. Mus., xv, 1890, 119, part (Calovévora, Chitra, and Volcán de Chiriquí, Panamá).-Salvin and Godman, Biol. 
Centr.-Am., Ares, ii, 1891, 176, part (Chiriquí, Chitra, and Calovévora, Panamí).

[Sittasomus] sylvioides Shanpe, Hand-list, iii, 1901, 77, part (Panamá).

Sittasomus levis Bangs, Proc. New Engl. Zool. Club, iii, Jan. 30, 1902, 46 (Boquete, Chiriquí, Panama, alt. 4,000 ft.; coll. E. A. and O. Bangs).

\section{SITTASOMUS SYLVIOIDES JALISCENSIS Nelson.}

JALISCO SITTASOMUS.

Similar to S. s. sylvioides but much larger, and color of under parts slightly darker.

Adult male.-Length (skin), 167; wing, 84; tail, 81; culmen, 16.5; tarsus, 18.5 ; middle toc, $12 .^{a}$

Southwestern Mexico, in State of Jalisco (San Sebastián).

Sittasomus sylvioides (not of Lafresnaye) NELson, Auk, xv, 1898, 156 (San Sebastián, Jalisco).

Sittasomus sylvioides jaliscensis Necson, Auk, xvii, July, 1900, 264 (San Sebastián, n. w. Jalisco; coll. U. S. Nat. Mus.).

[Sittasomus] jaliscensis Sharpe, Hand-list, iii, 1901, 77.

Genus DECONYCHURA Cherrie.

Deconychura b Cherrie, Proc. U. S. Nat. Mus., xiv, no. 855, Sept. 4, 1891, 338. (Type, D. typica Cherrie.)

Medium sized or rather small Dendrocolaptidæ (length about 170 $\mathrm{mm}$.) with narrow operculate nostrils, tail equal to or longer than wing, graduated for about half its length, with the very rigid shafts of rectrices strongly decurved subterminally, and with culmen (from base) longer than tarsus, and inner webs of remiges without any buffy or ochraceous cross-band.

Bill nearly as long as head, straight, rather stout, broad and depressed basally, its width at latero-frontal antiæ much greater than its depth at same point and equal to a little less than half the distance from nostril to tip of maxilla; culmen distinctly ridged, straight for basal half or more, gradually but decidedly decurved terminally; tomia slightly but distinctly decurved terminally, without trace of notch; gonys faintly convex basally, straight or even very faintly concave distally. Nostril exposed, posteriorly in contact with latero-frontal feathering, narrowly ovate or elliptical, longitudinal, margined above by a rather narrow membraneous operculum. Rictal bristles obvious but very small, and feathers of chin and lores with minute terminal setæ. Wing rather long and pointed, with longest primaries exceeding secondaries by less than length of exposed culmen; eighth primary longest, the seventh and sixth, successively, but little shorter, the tenth (outermost) nearly three-fourths as long as the longest, the ninth shorter than sixth. Tail equal to or slightly longer than wing, graduated for

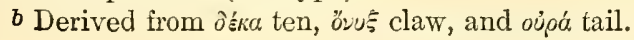


about half its length, the rectrices $\left(12^{a}\right)$ abruptly and conspicuously acuminate, with their very rigid shafts twisted and strongly decurved subterminally. Tarsus about as long as exposed culmen, less than one-fourth as long as wing, slender, distinctly scutellate (endaspidean); middle toe, with claw, shorter than tarsus; outer toe, with or without claw, equal to or very slightly longer than middle toe; inner toe, without claw, reaching to a little beyond subterminal articulation of middle toe; hallux much shorter than inner toe, not stouter; middle toe united to outer toe by whole of its first and about half of its second phalanx, to inner toe by greater part of its first phalanx; anterior claws rather large, very strongly curved and acute, that of the hallux slightly curved, as long as or longer than the digit.

Coloration.-Tail-coverts, tail, and remiges chestnut or rufouschestnut; pileum and back olive-brown, the former with narrow indistinct streaks of paler; beneath light olive-brown, throat brownish buff or clay color, the chest sometimes spotted with the same.

Nidification.-Nests in holes; eggs glossy white.

Range.-Costa Rica to British Guiana and upper Amazon Valley. (Four species. ${ }^{b}$ )

This genus is distinctly intermediate between Sittasomus and Dendrocincla, and I quite agree with Hellmayr that it is more nearly related to the latter than to the former; but I can not believe that it is "perhaps barely separable" from Dendrocincla (see Hellmayr, Bull. Brit. Orn. Club, xiv, 1904, 52), the difference in the character of the tips of the rectrices (in which character Deconychura is precisely likeGlyphorynchus and Sittasomus and very unlike Dendrocincla), even apart from the difference in the form of the bill, being, in my opinion, quite sufficient to justify generic separation. I have not, however, seen Dendrocincla longicauda Pelzeln, which Hellmayr refers to Deconychura, and which may possibly bridge the gap apparently separating the two genera as understood by me.

\section{KEY TO THE SPECIES OF DECONYCHURA. $c$}

a. Rump brown like back (only the upper tail-coverts chestnut-rufous); bend of wing washed with cinnamon-rufous.

b. Smaller (wing 95-102 in male, $86-90$ in female; bill, from rictus, 24-25.5); breast spotted or streaked with buff. (Southwestern Costa Rica and Panamá.)

Deconychura typica (p. 285).

bb. Larger (wing 107-111 in male, 102 in female; bill, from rictus, 27-29 in male, 25 in female); breast plain, like abdomen. (British Guiana to Rio Negro and Rio Madeira.)............... Deconychura longicauda (extralimital).d

$a$ Hellmayr was the first to call attention to the fact that this genus possesses twelve rectrices, not ten, as stated by its describer. (See Bull. Brit. Orn. Club, xiv, 1904, 52.)

b According to Hellmayr (Novit. Zool., xiv, 1907, 368). I have, however, seen only $D$. typica, from which alone the above diagnosis and description are taken.

c Adapted from Hellmayr, Novit. Zool., xiv, 1907, 368.

a Dendrocincla longicauda Pelzeln, Orn. Bras., i Abth., 1868, 42, 60 (Borba; Marabitanas; Barra do Rio Negro); Sclater, Cat. Birds Brit. Mus., xv, 1890, 165.-Deconychura longicauda Hellmayr, Novit. Zool., xiv, no. 2, Nov., 1907, 367 (crit.). 
aa. Rump chestnut-rufous; bend of wing olive-brown.

b. Larger (wing of female 84.5, tail, 90, bill, from rictus, 20). (Eastern Ecuadór.) Deconychura secunda (extralimital). ${ }^{a}$

6b. Smaller (wing of female 75, tail 72, bill, from rictus, 16). (Rio Madeira, northwestern Brazil to eastern Peru.).... Deconychura stictolæma (extralimital). $b$

\section{DECONYCHURA TYPICA Cherrie.}

CHERRIE'S DECONYCHURA.

Adults (sexes alite).-Pileum olive or brownish olive, indistinctly streaked with darker, and with indistinct narrow shaft-streaks of buffy (at least on forehead); back, scapulars, rump, and wingcoverts plain olive-brown or raw-umber, passing into chestnut on upper tail-coverts, tail, secondaries, and outer webs of proximal (inner) primaries, the outer webs of distal primaries lighter and less rufescent brown; shafts of rectrices dark chestnut, those of remiges black, or nearly so; a narrow superciliary stripe of buff; auricular and submalar regions streaked with dull buff and dusky, the latter predominating on upper portion of auricular region, forming an indistinct postocular streak; malar region, chin, and throat dull buff, the first indistinctly streaked with dusky; feathers of chest dark olive or dusky marked with a large central, more or less guttate spot of buff; rest of under parts light olive-brown or buffy grayish brown (nearest isabella color), the breast (sometimes abdomen and under tail-coverts also) more or less distinctly streaked with buff; uncler wing-coverts clear ochraceous-buff; inner webs of remiges deep cinnamon-rufous passing into buffy on edge, the terminal portion, abruptly, dusky; maxilla dusky horn color or blackish, paler along tomia; mandible dull whitish or pale yellowish (plumbeous in life);c iris brown; ${ }^{c}$ legs and feet dusky (plumbeous in life). ${ }^{c}$

Adult male.--Length (skins), 1S3-194 (1S8); wing, 94-102 (97.2); tail, 89.5-96 (93.9); culmen, 19.5-23 (22.1); tarsus, 20.5-22 (21.1); middle toe, $13.5-15$ (14.3). ${ }^{d}$

Adult female.-Length (skins), 174-180 (176); wing, 86-90 (88); tail, 83.5-S8 (\$6.5); culmen, 20-21.5 (20.6); tarsus, 19-20 (19.6); middle toe, $13-13.5(13.2) e^{e}$

a Deconychura secunda Hellmayr, Bull. Brit. Orn. Club, xiv, no. civ, Feb. 27, 1904, 51 (Rio Coca, upper Rio Napo, e. Ecuadór; coll. Tring Mus.).-D[econychura] secunda Hellmayr, Novit. Zool., xiv, 1907, 368 (diagnosis).

b Sittasomus stictolæmus Pelzeln, Oru. Bras., i, Abth., 1868, 42, 59 (Borba, Rio Madeira, w. Brazil; coll. Vienna Mus.).-Sittosomus stictolæmus Sclater, Cat. Birds Brit. Mus., xv, 1890, 120.-D [econychura] stictolaemus Hellmayr, Novit. Zool., xiv, no. 2, Nov., 1907, 368 (Borba, Brazil; diagnosis).

c Zeledón, manuscript.

d Six specimens.

$e$ Four specimens. 
Southwestern Costa Rica (Pozo Azúl de Pirrís; Pozo del Pitál, Rio Naranjo; El Pozo de Térraba; Tuís; Palmár; El Generál) and Panamá (Lion Hill; Divala, Chiriquí).

Deconychura typica Cherrie, Proc. U. S. Nat. Mus., xiv, no. 855, Sept. 4, 1891, 339 (Pozo Azúl de Pirrís, s. w. Costa Rica; coll. U. S. Nat. Mus.); Expl. Zool. Merid. Costa Rica, 1893, 39 (Palmár, s. w. Costa Rica); Anal. Inst. Fis.Geog. Costa Rica, vi, 1893, 17 (Pozo del Pitál, s. w. Costa Rica; descr. nest and eggs).-Bangs, Auk, xviii, 1901, 367 (Divala, Chiriquí, Panamá).-CARriker, Ann. Carnegie Mus., vi, 1910, 652 (s. w. Costa Rica, up to 1,000 ft.).

[Deconychura] typica Sharpe, Hand-list, iii, 1901, 77 (Costa Rica; Panamá).

D[econychura] typica Hellmayr, Novit. Zool., xiv, 1907, 368 (Chiriquí; Pozo Azúl, Costa Rica; diagnosis).

\section{Genus DENDROCINCLA Gray.}

Dryocopus (not of Boie, 1826) Maxmilian, Beitr. Naturg. Bras., iii, pt. ii, 1831, 1111. (Type, Dendrocolaptes turdinus Lichtenstein.)

Dendrocincla GraY, List Gen. Birds, 1840, 23. (Type, Dendrocolaptes turdinus Lichtenstein.)

Dendromanes Sclater, Proc. Zool. Soc. Lond., 1859, 382. (Type, Dendrocincla anabatina Sclater.)

Medium-sized to rather large Dendrocolaptidæ (length about 175-235 mm.), with narrow, conspicuously operculate nostril, bill as long as or longer than head, with distinctly recurved (almost uncinate) tip, and with tail shorter than wing, graduated for about one-third its length, the tips of rectrices inconspicuously acuminate and with the nearly denuded projecting tips of the very rigid shafts but slightly decurved.

Bill about as long as, sometimes slightly shorter than, head, rather stout, nearly straight (but distinctly decurved, almost uncinate, at tip), its width at latero-frontal antiæ equal to or greater than its depth at same point, and contained from less than two and a half to a little more than three times in the distance from nostril to tip of maxilla; culmen more or less distinctly ridged, straight for most of its length, rather abruptly decurved terminally, the tip of maxilla almost uncinate; maxillary tomium straight for the most part, rather strongly concave (decurved) terminally, without trace of notch; gonys more or less strongly convex and prominent basally, straight and ascending terminally, the extreme tip sometimes slightly decurved. Nostril exposed, posteriorly in contact with feathering of latero-frontal antiæ, narrow (slit-like), longitudinal, overhung by a broad membranous operculum, this sometimes partly covered by feathers of the latero-frontal antix. Rictal bristles present but very small, and feathers of chin and lores with fine terminal setæ. Wing moderate to rather long, rather pointed, the longest primaries exceeding secondaries by from less the distance from nostril to tip of maxilla to nearly length of exposed culmen; sixth, seventh, and eighth, or sixth and seventh, primaries longest, the tenth (outermost) a little more 
than two-thirds (D. tyrannina) to nearly four-fifths (D. homochroa) as long as the longest, the ninth equal to or shorter than fifth. Tail a little more thatn two-thirls (D. homochroa) to more than five-sixths (D. tyrannina) as long as wing, graduated for less than to considerably more than two-thirds its length, the rectrices (12) rather broad, rounded terminally, but with the very rigid shafts nearly denuded at tip, and forming projecting, more or less (sometimes rather strongly) decurved points. Tarsus shorter than exposed culmen to slightly longer, about one-fourth as long as wing (only one-fifth as long in $D$. tyrannina) rather slender (stouter in D. homochroa), distinctly scutellate (endaspidean); middle toe, with claw, shorter than tarsus (except in D. tyrannina); outer toe (with or without elaw) as long as middle toe, or very slightly shorter; inner toe, without claw, reaching to subterminal articulation of middle toe; hallux decidedly shorter than inner toe, scarcely, if at all, stouter; middle toe united to outer toe for whole of its first and part of its second phalanx, to inner toe for about half its first phalanx; anterior claws large, very strongly curved and acute, that of hallux less strongly curved, about as long as the digit.

Goloration.-Tail-coverts, tail, and secondaries chestnut or rufouschestnut; rest of upper parts brown (nearly olive to tawny-brown or russet), the pileum sometimes narrowly and indistinctly streaked with paler; under parts lighter brown or olive-brown, sometimes paler and grayer, or eren dull whitish, on chin and upper throat, the chest or foreneck sometimes narrowly streaked with paler. One species wholly rufous-chestnut, duller on back and under parts. Sexes alike.

Range.-Southern Mexico to Cayenne, southeastern Brazil, Bolivia, and Ecuadór. (About sixteen species. ${ }^{a}$ )

\section{KEX TO THE SPECIES AND SUBSPECIES OF DENDROCINCLA.}

a. Secondaries mostly tawny or tawny-ochraceous, contrasting strongly with their dusky tips and the umber brown of wing-coverts. (Dendrocincla anabatina.)

b. Nape suffused with tawny; rump lighter, or more tawny, brown; secondaries clearer tawny or tawny-ochraceous.

c. Darker and browner. (Southeastern Mexico, except Campeche and Yucatan, to eastern Nicaragua)........... . Dendrocincla anabatina anabatina (p. 288).

cc. Lighter and more buffy. (Campeche and Yucatan.)

Dendrocincla anabatina typhla (p. 290).

bb. Nape not suffused with tawny; rump darker brown; secondaries darker and duller tawny. (Southwestern Costa Rica and western Panamá.)

Dendrocincla anabatina saturata (p. 290).

aa. Secondaries brown or rufescent (not tawny or tawny-ochraceous), concolor with wing-coverts, or at least not contrasting strongly with them.

$b$. Wing-coverts brown (not rufescent); throat dull light buffy grayish; pileum dull olive-brown. (Dendrocincla lafresnayei.)

$a$ The following have not been examined in this connection: $D$. macrorhyncha Salvadori and Festa, D. fuliginosa (Vieillot), and D. minor Pelzeln. 
c. Coloration lighter. (Colombia to eastern Ecuadór.)

Dendrocincla lafresnayei lafresnayei (extralimital). ${ }^{a}$

cc. Coloration darker. (Eastern Panamá to southeastern Honduras.)

Dendrocincla lafresnayei ridgwayi (p. 291).

$b b$. Wing-coverts deep cinnamon-rufous or chestnut, like remiges; throat clear tawny-brown or dull tawny; pileum rufous-brown to rufous-chestnut. (Dendrocincla homochroa.)

c. General color more rufescent, the pileum rufous-chestnut, back and under parts nearly chestnut or tawny-chestnut. (Southern Mexico to Guatemala and British Honduras)............. Dendrocincla homochroa homochroa (p. 293).

cc. General color less rufescent, the pileum dull tawny-chestnut or burnt umber, back and under parts nearly mummy brown.

d. Back and under parts deeper in color and more rufescent; slightly larger (male averaging: Wing, 104.7; tail, 78). (Southwestern Nicaragua to western Panamá)............. Dendrocincla homochroa acedesta (p. 294).

$d d$. Back and under parts lighter, more olivaceous; slightly smaller (male averaging: Wing, 101.7; tail, 73.4). (Panamá.)

Dendrocincla homochroa ruficeps (p. 295).

\section{DENDROCINCLA ANABATINA ANABATINA Sclater.}

\section{NORTHERN DENDROCINCLA.}

Adults (sexes alike).-Pileum and hindneck sepia brown to nearly raw-umber, the feathers usually with very narrow and indistinct shaft-streaks of paler, those of the occiput and nape usually paler and more cinnamomeous centrally (sometimes conspicuously so); back, scapulars, and wing-coverts plain deep raw-umber (sometimes nearly mummy) brown, the rump lighter and more rufescent, passing into cinnamon-rufous on upper tail-coverts; tail deep cinnamonrufous or rufous-chestnut, the shafts of rectrices darker; remiges dull tawny, or russet-tawny (the outer primaries with outer webs more brownish or isabella color), with terminal portion (broadly and on inner web abruptly) dusky; a more or less distinct but broken supra-auricular streak of pale tawny or buffy; auricular and suborbital regions sooty brown or sepia, with narrow shaft-streaks of paler, the malar region similar but speckled or flecked instead of streaked; lores dull grayish buffy, with bristly tips of feathers dusky; chin and throat buff, the lower throat more or less intermixed or barred with light brownish; rest of under parts light raw-umber brown, paler and more buffy or cinnamomeous on abdomen, slightly darker and more olivaceous on chest, where the feathers have narrow, usually indistinct, shaft-streaks of buff; under tail-coverts dull cinnamon-rufous; axillars and under wing-coverts tawny-ochraceous, the greater part of inner webs of remiges similar but slightly paler;

a Dendrocincla lafresnayei Ridgway, Proc. U. S. Nat. Nus., x, Jan. 6, 1888, 492 ("Upper Amazon?"; coll. Bost. Soc. Nat. Hist.); Oberholser, Proc. Ac. Nat. Sci. Phila., 1904, 457 (monogr.).-Dendrocincla olivacea anguina Bangs, Proc. Biol. Soc. Wash., xii, June 3, 1898, 138 (Santa Marta, Colombia, 5,000 ft.; coll. E. A. and O. Bangs). 
maxilla deep horn color to nearly black; mandiblo pale horn color or dull pale yellowish or whitish (in dried skins), usually with a stripe (more or less distinct) of horn color along tomium; iris brown; legs and feet horn color (in dried skins).

Adult male.-Length (skins), 176-191 (184); wing, 95-100 (98.5); tail, 6S-7S (73.7); culmen, 22.5-24.5 (23.8); tarsus, 23-24 (23.6); middle toe, $16-17(16.5) .^{a}$

Adult female.-166-193 (179); wing, 89-100.5 (94.1); tail, 63.5-81 (70.8); culmen, 21-25 (23.2); tarsus, 22-24 (23.4); middle toe, 15-16 $(15.7) .^{b}$

Southeastern Mexico, in States of Vera Cruz (Playa Vicente; Miradór; Potrero, near Córdova; Buena Vista), Oaxaca, and Tabasco (Teapa), and southward through Guatemala (Cobán; Choctúm; Cajabón-Peten road; Rancho Tuilhá; Samayoa; Los Amates, Yzabál), British Honduras (Orange Walk; Toledo District; near Manatee Lagoon) and Honduras (Omoa; San Pedro; Santa Ana; Rio Segóvia; La Puerta) to Nicaragua (Los Sábalos; Rio Escondido).

Dendrocincla anabatina Sclater, Proc. Zool. Soc. Lond., 1859, 54, pl. 150 (Omoa, Honduras; coll. Derby Mus.); Cat. Birds Brit. Mus., xv, 1890, 162 (Oaxaca; San Pedro, Honduras; Choctúm, Samayoa, etc., Vera Paz, Guatemala).Sclater and Salvin, Proc. Zool. Soc. Lond., 1868, 54 (Mexico; Guatemala).Boucard, Ann. Soc. Linn. Lyon, 1878, 38 (Guatemala).-Nutting, Proc. U. S. Nat. Mus., vi, 1883, 404 (Los Sábalos, Nicaragua).-Ridgway, Proc. U. S. Nat. Mus., x, 1888, 490 (syn.; crit.), 590 (Segóvia R., Honduras).Salvin and Godman, Biol. Centr.-Am., Aves, ii, 1891, 172, part (Miradór,

$a$ Eight specimens.

$b$ Fourteen specimens.

\begin{tabular}{|c|c|c|c|c|c|}
\hline Locality. & Wing. & Tail. & $\begin{array}{l}\text { Cul- } \\
\text { men. }\end{array}$ & Tarsus. & $\begin{array}{c}\text { Middle } \\
\text { toe. }\end{array}$ \\
\hline MALES. & & & & & \\
\hline One adult male from Guatemala.. & 100 & 75 & 24 & 23 & 16.5 \\
\hline Five adult males from British Honduras..... & 98.1 & 73.6 & 23.9 & 23.8 & 16.5 \\
\hline One adult male from Honduras........................ & 97.5 & 71 & 22.5 & 23.5 & 16.5 \\
\hline One adult male from Nicaragua ........................ & 100 & 74 & 24.5 & 23.5 & 16.5 \\
\hline Ten adult males ( $D$. a. saturata) from Costa Rica........ & 100.7 & 76.6 & 24.1 & 23.9 & 16.7 \\
\hline Three adult males ( $D$. a. saturata) from western Panamá....... & 96.8 & 69.8 & 25 & 24 & 16.8 \\
\hline $\begin{array}{c}\text { Three adult males }(D . \text { a. typhla) from Yucatan (2) and Cam- } \\
\text { peche (1) ......................................... } \\
\text { FEMALES. }\end{array}$ & 99.2 & 73.8 & 23 & 23.8 & 16.5 \\
\hline One adult female from Vera Cruz & 92.5 & 68.5 & 23 & 22.5 & 16 \\
\hline Two adult females from Tabaseo.... & 95.5 & 67.5 & 23 & 22.7 & 15.7 \\
\hline One adult female from Guatemala......... & 92 & 68 & 23 & 22.5 & 15.5 \\
\hline Six adult females from British Honduras..... & 95.7 & 73.6 & 23.2 & 23 & 15.6 \\
\hline Two adult females from Honduras...................... & 90.5 & 65.5 & 23 & 22.5 & 15 \\
\hline Ten adult females (D. a. saturata) from Costa Rica.... & 96.6 & 71.8 & 23.5 & 23.2 & 16 \\
\hline One adult female ( $D$. o. saturata) from western Panam & 102 & 80 & 24.5 & 23.5 & 16.5 \\
\hline One adult female (D. a. typhla) fr & 95.5 & 71.5 & 23 & 23 & 16.5 \\
\hline
\end{tabular}


Potrero, and Playa Vicente, Vera Cruz; Teapa, Tabasco; Orange Walk, Brit. Honduras; Rancho Tuilhá, Cajabón-Petén road, Choctúm, and Cobán, Guatemala; Omoa, San Pedro, and Segóvia R., Honduras; Los Sábalos, Nicaragua).-Richmond, Proc. U. S. Nat. Mus., xvi, 1893, 498 (Rio Escondido, Nicaragua; habits; notes).-Dearborn, Pub. 125, Field Mus. N. H., 1907, 108 (Los Amates, e. Guatemala).

D[endrocincla] anabatina Sclater and Salvin, Proc. Zool. Soc. Lond., 1868, 54.

[Dendrocincla] anabatina Grax, Hand-list, i, 1869, 180, no. 2459.-Sclater and

Salvin, Nom. Av. Neotr., 1873, 67, part.-Sharpe, Hand-list, iii, 1901, 74, part.

Dendrocincla anabatina anabatina Oberholser, Proc. Acad. Nat. Sci. Phila., April, 1904, 452 (monogr.).

Dendromanes anabatinus Sclater, Proc. Zool. Soc. Lond., 1859, 382 (Playa Vicente, Vera Cruz; crit.); Cat. Am. Birds, 1862, 161 (Oaxaca).-Salvin and Sclater, Ibis, 1860, 35 (Cobán, Guatemala); Proc. Zool. Soc. Lond., 1870, 837 (San Pedro, Honduras).

Dendrocops anabatinus Sclater and Salvin, Ibis, 1859, 118 (Omoa).

\section{DENDROCINCLA ANABATINA TYPHLA Oberholser.}

YUCATAN DENDROCINCLA.

Similar to $D$. a. anabatina but slightly paler, especially the under parts.

Adult male.-Length (skins), 190-193 (192); wing, 95.5-103.5 (99.2); tail, 70-78 (73.8); culmen, 22-24 (23); tarsus, 23.5-24 (23.8); middle toe, $15.5-17$ (16.5). ${ }^{a}$

Adult female.-Length (skin), 179; wing, 95.5 ; tail, 71.5 ; culmen, 23; tarsus, 23 ; middle toe, $16.5 .^{b}$

Yucatan (Puerto Morelos; Calotmúl; Chichen-Itza) and Campeche (Apazote; Canasayát).

Dendrocincla anabatina (not of Sclater) Boucard, Proc. Zool. Soc. Lond., 1883, 450 (Yucatan).-Sclater, Cat. Birds Brit. Mus., xv, 1890, 162, part (n. Yucatan).-Salvin and Godman, Biol. Centr.-Am., Aves, ii, 1891, 172, part (n. Yucatan).-Chapman, Bull. Am. Mus. N. H., viii, 1896, 284 (ChichenItza, Yucatan).

Dendrocincla anabatina typhla Oвerholser, Proc. Acad. Nat. Sci. Phila., April, 1904, 452 (Puerto Morelos, Yucatan; coll. U. S. Nat. Mus.).-Cole, Bull. Mus. Comp. Zool., l, 1906, 131 (Chichen-Itza, Yucatan).

\section{DENDROCINCLA ANABATINA SATURATA Carriker.}

\section{CARRIKER'S DENDROCINCLA.}

Similar to D. a. anabatina but general coloration (except remiges and rectrices) darker and more olivaceous brown.

Adult male.-Length (skins), 175-193 (181); wing, 95-105 (99.8); tail, 68-80 (75.1); culmen, 22-25.5 (24.2); tarsus, 23-25 (23.9); middle toe, $15.5-17$ (16.8). ${ }^{c}$ 
Adult female.-Length (skins), 162-1S6 (175); wing, 92.5-102 (97.1); tail, 63.5-S0 (72.6); culmen, 21-25 (23.5); tarsus, 22-24 (23.2); middle toe, 15-17 (16). ${ }^{a}$

Southwestern Costa Rica (Pozo Azúl de Pirrís; Pozo del Rio Grande; El Pozo de Térraba; Térraba; Paso Reál; Boruca; Buenos Aires; Palmár; El Generál; Pigres) and western Panamá (Divala; Bugaba; Chiriquí).

Dendromanes anabatinus (not Dendrocincla anabatina Sclater) SALvin, Proc. Zool. Soc. Lond., 1S70, 192 (Bugaba, Verágua, Panamá).

Dendrocincla anabatina (not of Sclater, 1859) ScLater, Cat. Birds Brit. Mus., xv, 1890, 162, part (Bugaba, Panamá).-Salvin and Godman, Biol. Centr.-Am., Aves, ii, 1891, 172, part (Bugaba, Panamá).-Cherrie, Expl. Zool. Merid. Costa Rica, 1893, 39 (Palmár, Boruca, and Térraba, s. w. Costa Rica).

[Dendrocincla] anabatina Sharpe, Hand-list, iii, 1901, 74, part (Panama).

Dendrocincla anabatina saturata CARriker, Ann. Carnegie Mus., vi, 1910, 649

(El Pozo de Térraba, s. w. Costa Rica; coll. Carnegie Mus.; habits).

\section{DENDROCINCLA LAFRESNAYEI RIDGWAYI (Oberholser).}

\section{BROWN DENDROCINCLA.}

Adults (sexes alike).-Above plain brown (between raw-umber and mummy to nearly russet-brown), duller (grayer or more olive) on pileum, passing into deep cinnamon-rufous or rufous-chestnut on upper tail-coverts and tail, the latter with shafts of rectrices darker chestnut; wing-coverts usually concolor with back, or very nearly so, sometimes a little more rufescent; remiges decidedly more rufescent, especially on proximal primaries which are dull cinnamonrufous; six or seven outer primaries with terminal portion grayish brown or dusky (abruptly so on inner web); supra-auricular region narrowly streaked with buffy; loral region pale grayish brown or buffy grayish, with indistinct shaft-streaks of paler; auricular and suborbital regions dull olive or dusky, narrowly streaked with buff; malar region nearly uniform dull olive; chin and upper throat pale brownish buffy, usually indistinctly barred or flecked with dusky or dull grayish, the lower throat more brownish, with narrow shaft-

$a$ Eleven specimens.

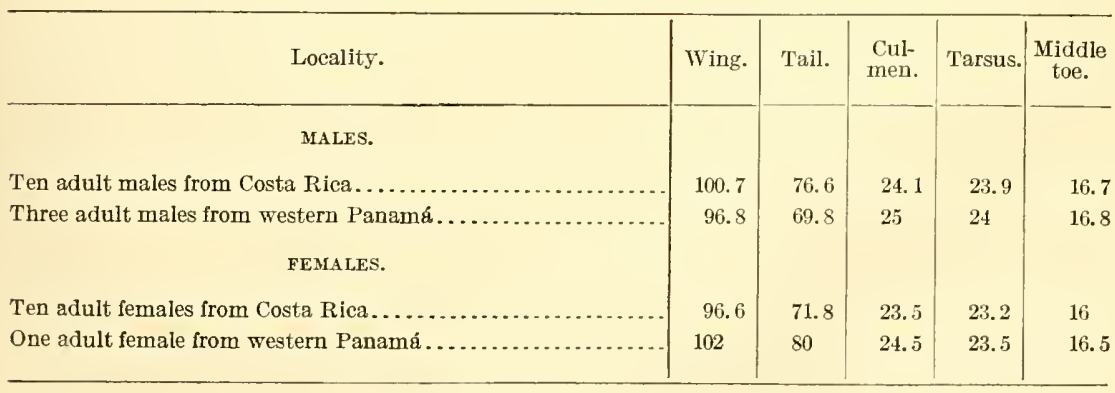


streaks of pale buffy; rest of under parts plain light olive-brown (nearly raw-umber) to nearly cinnamon-brown, usually slightly more cinnamomeous posteriorly, where passing into dull cinnamonrufous on longer under tail-coverts; under wing-coverts clear light ochraceous or ochraceous-buff; inner webs of remiges tawny-rufous or rufous-tawny, passing into ochraceous-buff on edges, the outer six or seven more or less extensively grayish brown or dusky terminally; bill dusky brown to brownish black, the under portion of mandible (broadly) whitish or pale dull yellowish (in dried skins); legs and feet horn brown or dusky (in dried skins).

Adult male.--Length (skins), 191-222 (209); wing, 110-116 (113.2); tail, 87-94 (90.3); culmen, 28-30.5 (29.2): tarsus, 24-25.5 (25.1); middle toe, $17-18.5$ (17.8). ${ }^{a}$

Adult female.-Length (skins), 18s-208 (199); wing, 100.5-109.5 (105.6); tail, 77-89 (83.9); culmen, 27-28.5 (27.6); tarsus, 23-24.5 (23.5); middle toe, $17-17.5(17.2){ }^{b}$

Panamá (Iion Hill; Panamá; Chitra, Verágua), eastern Costa Rica (Talamanca; Rio Sícsola; Pacuare; Rio Reventazón; Angostura; La Cristina; Carrillo; Guayabál; Cartago; La Vijágua), eastern Nicaragua (Rio Escondido), and southeastern Honduras (Rio Segóvia).

Dendrocincla fumigata (not Dendrocolaptes fumigatus Lichtenstein) LAwrENCE, Ann. Lyc. N. Y., vii, 1862, 320 (Lion Hill, Panamá).

Dendromanes atrirostris Sclater and Salvin, Proc. Zool. Soc. Lond., 1864, 355 (Panamá).-Salvin, Proc. Zool. Soc. Lond., 1870, 193 (Chitra, Verágua, Panamá).

Dendrocincla atrirostris (not Dendrocops atrirostris Lafresnaye) Sclater and Salvin, Proc. Zool. Soc. Lond., 1868, 54, part (Panamá).-Zeledón, Anal. Mus. Nac. Costa Rica, i, 188s, 114 (Pacuare and Cartago, Costa Rica).

[Dendrocincla] atrirostris Sclater and Salvin, Nom. Av. Neotr., 1873, 67, part. Dendrocincla olivacea (not Dendrocops olivaceus Eyton c) Lawrence, Ann. Lyc.

N. Y., vii, Feb., 1862, 12 (Lion Hill, Panamá; coll. G. N. Lawrence).Ridgway, Proc. U. S. Nat. Mus., x, 1888, 492, part (Costa Rica; Panamá; syn.; crit.), 592 (Segóvia R., Honduras).-Sclater, Cat. Birds Brit. Mus., xv, 1890, 166, part (Angostura, Costa Rica; Chitra de Verágua, Panamá).Salyin and Godman, Biol. Centr.-Am., Aves, ii, 1891, 174, part (Segóvia R., Honduras; Talamanca, Cartago, Pacuare, and Angostura, Costa Rica;

\begin{tabular}{|c|c|c|c|c|c|}
\hline$a$ Nine specimens. & \multicolumn{5}{|c|}{$b$ Six specimens. } \\
\hline Locality. & Wing. & Tail. & $\begin{array}{l}\text { Cul- } \\
\text { men. }\end{array}$ & Tarsus. & $\begin{array}{l}\text { Middle } \\
\text { toe. }\end{array}$ \\
\hline FEMALES. & & & & & \\
\hline One adult female from Panamá....... & 100.5 & 83.5 & 27 & 23 & 17 \\
\hline Four adult females from Costa Rica... & 107.5 & 85.8 & 27.6 & 23.8 & 17.2 \\
\hline One adult female from Niearagua..... & 103 & 77 & 28 & 23 & 17 \\
\hline
\end{tabular}

$c=$ Dendrocincla tyrannina (Lafresnaye), fide Sclater, Cat. Birds Brit. Mus., xv, 1890,164 . 
Chitra and Lion Ilill, Panamá).-Rrenmond, Proc. U. S. Nat. Mus., xvi, 1893, 495 (Rio Escondido, Nicaraguia).

[Dendrocinela] olinaced Shanpe, Hand-hist, iii, 1901, 75 (Honduras to P'anamá; Culombia).

Dendrocincla rilguayi Onennolser, Proc. Acad. Sci. Phila., Apr., 190-4, 458 (Talamanca, Costa Rica; coll. U. S. Nat. Mus.).

Dendrocincla ridgwayi ridguayi Camnken, Ann. Carnegie Mus., vi, 1910, 651 (Caribbean lowlands, Costa Rica, up to 2,000 ft.; crit.; habits).

Dendrocincla olivacea olivacea OBerrolsen, Proc. Ac. Nat. Sci. Phila., Apr., 1904, 456 (monogr.).

\section{DENDROCINCLA HOMOCHROA HOMOCHROA (Sclater).}

\section{RUDDY DENDROCINCLA.}

Adults (sexes alitie).-Above, including sides of head (except lores), plain clear chestnut or rufous-chestnut, the back and scapulars duller; lores light grayish; under parts plain dull tawny-ochraceous, darker (tawny-brown or deep brownish tawny) on chest, the under tail-coverts more rufescent; under wing-coverts clear tawnyochraceous; inner webs of remiges vinaceous-cinnamon, the longer primaries dusky termimally; bill brownish horn color (more or less deep), paler on tomia and (sometimes) on mandible; legs and feet light brownish (in dried skins).

Adult male.-Length (skins), 175-193 (185); wing, 93-102 (97.9); tail, 68.5-80 (71.9); culmen, 23-25.5 (24.5); tarsus, 24.5-26.5 (25.6); middle toe, $16-17(16.4){ }^{a}$

Adult female.-Length (skins), 185-191 (187); wing, 95-104 (100); tail, 75.5-80 (78.2); culmen, 24-26.5 (25); tarsus, 24-26.5 (25.3); middle toe, $15.5-17.5(16.3) .^{b}$

Southern Mexico, in States of Oaxaca (Teotalcingo; Chimalapa), Campeche (Apazote), and Yucatan (Izalám; Chichen-Itza; Puerto

a Seven specimens. b Three specimens.

\begin{tabular}{|c|c|c|c|c|c|}
\hline Locality. & Wing. & Tail. & $\begin{array}{l}\text { Cul- } \\
\text { men. }\end{array}$ & Tarsus. & $\begin{array}{l}\text { Middle } \\
\text { toe. }\end{array}$ \\
\hline \multicolumn{6}{|l|}{ MALLES. } \\
\hline One adult male from Campeche... & 101.5 & 73.5 & 25.5 & 25.5 & 16.5 \\
\hline Two adult males from Yucatan... & 97.2 & 71 & 25 & 25.2 & 16.2 \\
\hline Four adult males from British Honduras........ & 97 & 72 & 23.8 & 25.7 & 16.4 \\
\hline Ten adult males $(D . h$. acedesta $)$ from Costa Rica.......... & 104.4 & 77.9 & 25.5 & 26.3 & 17.2 \\
\hline Two adult males $(D . h$. acedesta) from western Panamá... & 106 & 78 & 25.5 & 26.5 & 17.3 \\
\hline Nine adult males (D. h. ruficeps) from Panamá......... & 101 & 73.4 & 25.2 & 25.8 & 17.6 \\
\hline \multicolumn{6}{|l|}{ FEMALES. } \\
\hline One adult female from Campeche.. & 95 & 75.5 & 24 & 24 & 15.5 \\
\hline Two adult females from British Honduras................ & 103 & 79 & 25.5 & 26 & 16.7 \\
\hline 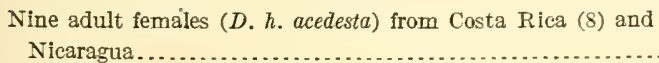 & 99.6 & 71.1 & 24.3 & 25.8 & 17.2 \\
\hline Two adult females (D. h. ruficeps) from Panamá... & 99.3 & 76.3 & 25.7 & 25 & 17.7 \\
\hline
\end{tabular}


Morelos; Meco Island; Mugeres Island; Cozumél Island) and southward through Guatemala (Chiséc; sources of Rio de la Pasión; Volcán de Agua; Savana Grande; Naranjo) to British Honduras (Orange Walk; Toledo District; near Manatee Lagoon).

Dendromanes homochrous Sclater, Proc. Zool. Soc. Lond., 1859, 382 (Teotalcingo, Oaxaca, s. Mexico; coll. P. L. Sclater); Cat. Am. Birds, 1862, 162 (Oaxaca).-Salvin, Ibis, 1861, 353 (Chisec, Guatemala).-Lantz, Trans. Kansas Acad. Sci. for 1896-97 (1899), 221 (Naranjo, Guatemala).

Dendrocincla homochroa Sclater and Salvin, Proc. Zool. Soc. Lond., 1868, 54 (Mexico; Guatemala); Nom. Av. Neotr., 1873, 67.--Boucard, Proc. Zool. Soc. Lond., 1883, 450 (Izalám, n. Yucatan).-Ridgway, Proc. U. S. Nat. Mus., x, 1888, 491 (syn. crit.; Guatemala).-SALvin, Ibis, 1889, 365 (Mugeres 1. and Meco I., Yucatan).-Sclater, Cat. Birds Brit. Mus., xv, 1890, 163, part (Oaxaca; Cozumél I., Mugeres I. and Meco I.; n. Yucatan; Savana Grande, sources Rio de la Pasión, Choctúm, and Volcan de Agua, Guatemala).-Salvin and Godman, Biol. Centr.-Am., Aves, ii, 1891, 172, part (Chimalapa, Oaxaca; Orange Walk, Brit. Honduras, etc.).-Chapman, Bull. Am. Mus. N. H., viii, 1896, 284 (Chichen-Itza, Yucatan).-Cole, Bull. Mus. Comp. Zool., 1, 1906, 131 (Chichen-Itza).

[Dendrocincla] homochroa Gray, Hand-list, i, 1869, 180, no. 2460.-Sclater and Salvin, Nom. Av. Neotr., 1873, 67, part.-Sharpe, Hand-list, iii, 1901, 75, part.

D[endrocincla] homochroa Sclater and Salvin, Proc. Zool. Soc. Lond., 1868, 54. Dendrocincla homochroa homochroa Oberholser, Proc. Ac. Nat. Sci. Phila., Apr., 1904, 462 (monogr.).

\section{DENDROCINCLA HOMOCHROA ACEDESTA Oberholser.}

\section{COSTA RICAN RUDDY DENDROCINCLA.}

Similar to $D$. $h$. homochroa but larger and coloration darker throughout, the wings, tail, and pileum deep chestnut, the under parts deep russet brown, only slightly paler on throat and abdomen. ${ }^{a}$ Adult male.-Length (skins), 180-198 (188); wing, 101-108 (104.7); tail, 71.5-82 (78); culmen, 24-27 (25.5); tarsus, 25-27.5 (26.4); middle toe, $16.5-18$ (17.2). ${ }^{b}$

Adult female.-Length (skins), 173-190 (180); wing, 95.5-104.5 (99.6); tail, 68-75.5 (71.1); culmen, 22.5-26.5 (24.3); tarsus, 24.5-26.5 (25.8); middle toe, $16.5-18$ (17.2). ${ }^{c}$

Southwestern Nicaragua (Chinandega; Sucuyá; San Emilis, Lake Nicaragua), western Costa Rica (Volcán de Miravalles; La Vijágua; Tenório; Bolsón; Boruca; Las Trojas; Navarro; Naranjo de Cartago) and western Panamá (Volcán de Chiriquí).

Dendromanes homochrous (not of Sclater) SALvin; Proc. Zool. Soc. Lond., 1S70, 193 (Volcán de Chiriquí, Panama).

$a$ I am somewhat doubtful whother this supposed form is really separable from D. h. ruficeps.

$b$ Twelve specimens.

c Nine specimens. 
Dendrocincla homochroa Nutring, Proc. U. S. Nat. Mus., vi, 1884, 385, (Sucuyá, Nicaragua).-Ridgway, Proc. U. S. Nat. Mus., vi, 1884, 414 (Navarro, Costa Rica).-Sclater, Cat. Birds Brit. Mus., xv, 1890, 163, part (Nicaragua; Costa Rica; Volcán de Chiriquí, Panamá).-Salvin and Godman, Biol. Centr.-Am., Aves, ii, 1891, 172, part (Chiuandega, El Volcáu, and Sucuyá, Nicaragua; Navarro, Costa Rica; Volcán de Chiriquí).-Cherrie, Expl. Zool. Merid. Costa Rica, 1893, 40 (Boruca, Costa Rica).-Underwood, Ibis, 1896, 440 (Volcán Miravalles, Costa Rica).

[Dendrocincla] homochroa Sharpe, Hand-list, iii, 1901, 75, part (Panamá).

Dendrocincla homochroa ruficeps (not Dendrocincla ruficeps Sclater and Salvin) Ridgway, Proc. U. S. Nat. Mus., x, sig. 31, Jan. 6, 1888, 489, 491, excl. syn. part (Sucuyá, Nicaragua; Navarro, Costa Rica; Chiriquí, Panamá).Zeledón, Anal. Mus. Nac. Costa Rica, i, 1888, 114 (Las Trojas, Costa Rica). Dendrocincla homochroa acedesta Oberholser, Proc. Ac. Nat. Sci. Phila., Apr., 1904, 462 (Chiriquí, Panamá; coll. U. S. Nat. Mus.).-Carriker, Ann. Carnegie Mus., vi, 1910, 650 (Nicoya peninsula, Guanacaste, and Boruca, w. Costa Rica).

\section{DENDROCINCLA HOMOCHROA RUFICEPS (Sclater and Salvin).}

\section{PANAMA RUDDY DENDROCINCLA.}

Similar to $D$. h. acedesta but coloration slightly lighter throughout, especially the under parts, which are also slightly less rufescent, with the throat less different from the general color.

Adult male.-Length (skins), 172-196 (188); wing, 97.5-107.5 (101.7); tail, 68.5-79 (73.4); culmen, 24-26.5 (25.2); tarsus, 24.527.5 (25.8); middle toe, $17-19$ (17.6) ${ }^{a}$

Adult female.-Length (skins), 188-207 (197); wing, 95-103.5 (99.3); tail, 68-84.5 (76.3); culmen, 25-26.5 (25.7); tarsus, 25-26 (25.5); middle toe, $17.5-18$ (17.7). ${ }^{b}$

Panamá (Panamá; El Banco and Boquete, Chiriquí).

Dendrocincla ruficeps Sclater and Salvin, Proc. Zool. Soc. Lond., 1868, 54 (Panamá City, Panamá; coll. P. L. Sclater).-Sclater, Cat. Birds Brịt. Mus., xv, 1890, 164, excl. syn. part (Panamá).-Salvin and Godman, Biol. Centr.-Am., Aves, ii, 1S91, 173, excl. syn. part? (Panamá).-Bangs, Proc. New Engl. Zool. Club, iii, 1902, 46 (Boquete, Panamá, 4,000-4,500 ft.).Oberholser, Proc. Acad. Nat. Sci. Phila., 1904, 461 (monogr.).

[Dendrocincla] ruficeps Gray, Hand-list, i, 1869, 180, no. 2463.--Sclater and Salviv, Nom. Av. Neotr., 1873, 67.-Sharpe, Hand-list, iii, 1901, 75.

\section{Order CORACIIFORMES.}

\section{CORACIINE BIRDS.}

XPicæ Linnæus, Syst. Nat., ed. 10, i, 1758, 96. (Includes Cuculiformes, Buphagidæ, Corvidæ, Oriolidæ, Graculidæ, Paradiseidæ, Sittidæ, and Certhiidæ; excludes Striges.)

$\times$ Picariæ Nıtzsch, Deutsch. Archiv für Physiol., vi, 1820, 255. (Includes Cuculiformes; excludes Striges); Syst. Pterylog., 1840, 121. (Includes Cuculiformes and Opisthocomus; excludes Striges.) 
XPicariæ Coues, Key N. Am. Birds, 2d ed., 1884, 444. (Includes Cuculidæ; excludes Striges.)

<Picarix Seевoнm, Classif. Birds, 1890, pp. vii, xi, 19. (Excludes Striges, Trochilidæ, Colii, and Alcedines.)

$<$ Macrochires (not of Nitzsch, 1829) CABANIs, in Wiegmann's Archiv für Naturg., 1847, 345. (=Macrochires + Caprimulgi.)

<Strisores Lillueborg, Proc. Zool. Soc. Lond., 1866, 12, 14. (Excludes Pici and Striges.)

X Coccygomorphæ Huxlex, Proc. Zool. Soc. Lond., 1867, 466. (Includes Cuculidæ; excludes CaprimuÎi and Macrochires.)

$\times$ Anomalogonatæ GARrod, Proc. Zool. Soc. Lond., 1874, 117. (Includes Passeriformes; excludes Striges.)

$<$ Piciformes Fonbes, Ibis, 1884, 119. (Excludes Todidæ, Meropidæ, Striges, Caprimulgi, Coraciæ, and Macrochires.)

XPicariz Sclater, Ibis, 1880, 399, 410. (Includes Cuculi; excludes Striges.)

X Picariz Stejneger, Stand. Nat. Hist., iv, 1885, 368. (Includes Cuculi; excludes Striges.)

$>$ Coracornithes FürBringer, Unters. Morph. Syst. Vög., ii, 1888, 1567. （Includes Cuculi.)

$\times$ Pico-Passeres Sеєвонм, Classif. Birds, 1890, 2. (Includes Passeriformes and Cuculi; excludes Striges, Coraciæ, Bucerotes, and Alcedines.)

$\times$ Coraciiformes Sеєвонм, Classif. Birds, 1890, 7, 19. (Includes Sarcorhamphi; excludes Macrochires, Pici, Upupæ, Trogones, Columbæ, Cuculi, and Striges.)

$\times$ Passeriformes Sесвонм, Classif. Birds, 1890, vii, 1. (Includes Passeriformes, Columbæ, and Cuculi; excludes Anisodactylæ, Pamprodactylæ, and Coraciæ.)

$<$ Coraciiformes Sharpe, Rev. At. Classif. Birds, 1891, 79, 80. (Excludes Striges, Trogones, and Pici.)

$<$ Coraciæ Sеввонм, Classif. Birds, 1890, pp. vii, xi, 21. (=Macrochires+Caprimulgi+Coraciæ+Meropidæ.)

<Halcyones Seевонm, Classif. Birds, 1890, pp. vii, xi, 20. (=Colii+Alcedines.)

<Anisodactylæ Sclater, Ibis, 1880, 401, in text. (=Colii+Alcedines+Coraciæ+Caprimulgi.)

$>$ Dendrornithes FürBRINGER, Unters. Morph. Syst. Vög., ii, 1888, 1567. (Includes Cuculi.)

<Coracoidex Stejneger, Stand. Nat. Hist., iv, 1885, 371, 384. (=Caprimulgi+ Coraciæ.)

<Coraciiformes Fürbringer, Unters. Morph. Syst. Vög., ii, 1888, 1567. (=Coraciæ + Caprimulgi + Striges.)

=Coraciiformes GADOw, in Bronn's Thier-Reichs, Vög., ii, 1893, 223, 301; Classif. Vertebr., 1898, 36.-KNowlton, Birds of the World, 1909, 50.

$\times$ Coraciïdx Cabanis, in Wiegmann's Archiv für Naturg., 1847, pt. i, 342. (Includes Eurylaimi; excludes Pici, Macrochires, Caprimulgi, and Striges.)

<Coraciid $æ$ Garrod, Proc. Zool. Soc. Lond., 1874, 117. (=Coraciæ+Momoti+ Tōdi.)

$<$ Cuculinæ caloplerae Nıтzsch, Syst. Pterylog., 1840, 126. (=Coraciæ+Momoti+ Todi+Galbulæ.)

<Todidx Nitzsch, Syst. Pterylog., 1840, 126. (=Coraciæ+Momoti+Todi+ Galbulæ.)

XPiciformes Garrod, Proc.Zool. Soc. Lond., 1874, 117. (=Pici+Ramphastides+ Capitones + Upupre+Bucerotes + Halcyones.)

$<$ Coracix Bednand, Struct. and Classif. Birds, 1898, 204. (=Coracix+Meropes+ Momoti+'Todi+Galbulæ.) 
Anomalogonatous ${ }^{a}$ nonpasserine binds with deep plantar tendons of types I, V, Va, Vb, VI, VII, or VIII, or else palate desmogrnathous, or sehizognathous in combination with raptorial feet (Striges) (saurognathous? in Pici), bronchial syrinx (Caprimulgi), or with not more than seven secondaries (Trochiti), or agithognathous in combination with short triangular bill, fissirostral gape, and ten greatly elongated primaries (Micropodii) or pointed manubrial process and forked romer (Capitones, part); feet synpelmous, desmopelmous, heteropelmous, or antiopelmous, or if schizopelmous (Upupæ), the palate desmognathous; basipterygoid processes absent or present (rudimentary?); cervical vertebræ 13-15; nasals usually holorhinal.

\section{KEY TO THE SUBORDERS OF CORACIIFORMES,}

a. Feet neither desmopelmous nor raptorial (the flexor tendons never of type I); coracoids not connected; hypotarsus complex (except in Macrochires); myological formula with $\mathrm{X}$ (except in Macrochires); only one carotid (except in Superfamily Caprimulgi); cæca (if present) short, usually absent; syrinx tracheo-bronchial (except in Caprimulgi); aftershaft present (sometimes rudimentary in Caprimulgi and Pici); young gymnopæedic (except in Nycticoraciæ).

b. Myological formula without X (i. e., A); hypotarsus simple; spina interna

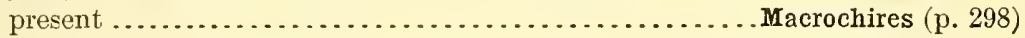

bb. Myological formula with X; hypotarsus complex; spina interna absent.

c. Not synpelmous.

d. Not schizopelmous; dorsal pteryla not forked between shoulders.

e. Heteropelmous; feet heterodactylous, the flexor tendons of type VIIT.

Heterodactylæ (p. 729).

$e e$. Antiopelmous; feet zygodactylous, the flexor tendons of type VI.

Zygodactylæ (to be included in Part VI). dd. Schizopelmous; dorsal pteryla forked between shoulders.

Upupæ (extralimital). $b$

cc. Synpelmous.

d. Dorsal pteryla not forked between shoulders.

e. Feet anisodactylous............ Anisodactylæ (to be included in Part VI).

$a$ Anomalogonatous birds are those which lack the ambiens muscle. Besides the Coraciiformes, the Passeriformes also are anomalogonatous, all other birds, according to Garrod (Proc. Zool. Soc. Lond., 1874, 116-118), being homalogonatous. The morphological value of this character was so greatly overestimated by Garrod that he made it the basis of his primary division of the Class Aves into two "Subclasses," Anomalogonatæ and Homalogonatæ.

b> Upupinæ Cabanis, in Wiegmann's Archiv für Naturg., 1847, pt. i, 343 (includes genus Falculia, an oscinine form usually referred to Corvidœ).-=Upupidæ Cabanis and Heine, Mus. Hein., ii, 1860, 127; Fürbringer, Uebers. Syst. Morph. Vög., ii, 1888, 1364.—=Upupoidex Stejneger, Stand. Nat. Hist., iv, 1885, 408, in text.$>$ Bucerotes Fürbringer, Unters. Morph. Syst. Vög., ii, 1888, 1567 (includes Bucerotes).-= Upupæ Seebohm, Classif. Birds, 1890, 7; Sharpe, Rev. Classif. Birds, 1891, 80; Hand-List, ii, 1900, 70.

The Upupæ comprise two families, Upupidæ (Hoopoes) and Irrisoridæ (Wood Hoopoes), the former common to the Palæarctic, Ethiopian, and Indian Regions, the latter confined to the Ethiopian Region. 
$e e$. Feet pamprodactylous. Pamprodactylæ (extralimital). $a$

$d d$. Dorsal pteryla forked between shoulders.

$e$. Feet syndactyle or eleutherodactyle, the flexor tendons of type $\mathrm{V} a$, or outer toe reversible; spina externa sterni well developed; syrinx tracheo-bronchial; only one (the left) carotid artery; young gymnopædic...................................... (extralimital).b

$e e$. Feet anisodactyle, the flexor tendons of type $\mathrm{Va}$ (as in Macrochires), the outer toe never reversible; spina externa sterni vestigial; primaries 10; two carotid arteries, syrinx bronchial, and young ptilopædic (as in Striges.).................. Nycticoraciæ (to be included in Part VI). $a a$. Feet desmopelmous and raptorial, the flexor tendons of type I; coracoids connected; hypotarsus simple; myological formula A; two carotid arteries; cæca long; syrinx bronchial; aftershaft absent or (rarely) rudimentary; primaries 11; young ptilopædic............. Nyctiharpages (to be included in Part VI).

\section{Suborder MACROCHIRES.} HUMMING BIRDS AND SWIFTS.

= Macrochires Nitzsch, Obs. Av. art. carot. com., 1829, 15; Syst. Pterylog., 1840, 122.-BEddard, Struct. and Classif. Birds, 1898, 224.

$>$ Macrochires Cabanis and Henne, Mus. Hein., iii, 1860, 3 (includes Caprimulgidæ and Steatornithidæ).-Sclater, Cat. Am. Birds, 1862, 278 (includes Caprimulgidæ).-Garrod, Proc. Zool. Soc. Lond., 1873, 463 (includes Caprimulgidæ and Steatornithidæ).

= Makrochires (emendation) Fürbringer, Unters. Morph. Syst. Vög., 1888, 1567.

$>$ Strisores Cabanis in Wiegmann's Archiv für Naturg., 1847, pt. i, 308, 345, 346 (includes Caprimulgidæ, Opisthocomidæ, and Musophagidæ!).

$>$ Cypselomorphæ Huxley, Proc. Zool. Soc. Lond., 1867, 468 (includes Caprimulgidæ).

=Cypseliformes Garrod, Proc. Zool. Soc. Lond., 1874, 118.

= Micropodii KNowlton, Birds of the World, 1909, 50 .

= Micropodoideæ SteJneger, Stand. Nat. Hist., iv, 1885, 435, in text.

= Micropodoidei Cope, Am. Nat., xxiii, 1889, 871, 872, 873 .

=Cypseli (not of Ridgway, 1881) GaDow, Bronn's Thier-Reichs, Vög., iii, 1893, 245, 301; Classif. Vertebr., 189S, 37.

$a=$ Coliomorph (not of Sundevall, 1856) Murie, Ibis, July, 1S72, 278.=Pamprodactylæ Murie, Ibis, iii, April, 1873, 190, foot-note.=Colioideæ Stejneger, Stand. Nat. Hist., iv, 1885, 371, 393, in text.=Colii Fürbringer, Unters. Morph. Syst. Vög., ii, 1888, 1567; Sharpe, Rev. Classif. Birds, 1891, 82; Hand-list, ii, 1900, 145; Gadow, in Bronn's Thier-Reichs, Vög., ii, 1893, 252, 301; Classif. Vertebr., 1898, pp. xv, 37.Beddard, Struct. and Classif. Birds, 1898, 201; Knowlton, Birds of the World, 1909, 50.=Colioidei Cope, Am. Nat., xxiii, Oct., 1889, 871, 873.

The Pamprodactylæ comprise a single family, Coliidæ (the Colies), represented by the genera Colius and Urocolius only, and are peculiar to the Ethiopian Region.

$b<$ Coraciadx Gray, Gen. Birds, i, June, 1845, 61; Hand-List, i, 1869, 75.- = Coracix Fürbringer, Unters. Morph. Syst. Vög., ii, 1888, 1567.—<Coracix Sharpe, Rev. Classif. Birds, 1891, 79 (=Coraciidæ); Hand-list, ii, 1900, 45.-<Leptosomati Sharpe, Rev. Classif. Birds, 1891, 79 (=Leptosomatidæ); Hand-list, ii 1900, 45.=Coraciidæ Gadow, Classif. Vertebr., 1898, 36.=Coraciæ Fürbringer, Uebers. Syst. Morph. Vög., ii, 1888, 1567 .

An exclusively Old World group, comprising the families Coraciidæ and Leptosomatidæ, the former common to the Ethiopian, Indian, Indo-Malayan, and AustroMalayan Subregions, the latter peculiar to Madagascar. 
Medium-sized to extremely small Coraciilorm birls with the myological formula $\Lambda$, hypotarsus simple, spina externa and spina interna present (but short); palate regithognathous (Micropodii) or schizognathous ('Trochili), humerus extremely short and manus relatively very long; bill either short and broadly triangular with gape deeply cleft and nostrils opening vertically, near together, and nonoperculate (Micropodii) or long and slender with nostrils opening laterally and broadly operculate and tongue extensile (Trochili).

Basipterygoid processes absent (rudimentary in some Micropodii); temporal fossæ deep; end of mandible truncated; vomer absent or rudimentary; nares holorhinal, impervious; coracoids separated; metasternum usually entire and convex (truncate or emarginate, with two foramina, in Macropterygidæ), the carina sterna very high; only the left carotid artery developed (except in Micropodii, part); cæca absent; oil-gland (if present) nude; syrinx tracheal (Micropodii) or tracheo-bronchial (Trochili); intestinal convolutions of type VI; flexor tendons of type $\mathrm{V}$ or $\mathrm{Va}$, the hallux connected with the flexor perforans digitorum ; semitendinosus, accessory semitendinosus, accessory femoro-caudal, and sterno-coracoideus museles and biceps slip absent, the femoro-caudal muscle present; tensor patagii brevis peculiar, no tendon being developed and the fleshy belly running on to a special tendon which springs from the lower end of the outer surface of the humerus and is continued, parallel to the forearm, along the radial margin of the manus. Spinal pteryla well defined on neck, forked on upper back; lateral cervical pterylæ present, lateral cervical apterium absent; lateral cervical, nuchal, and spinal apteria present; occipital apterium present (indistinct in Micropodii); adult downs present (on apteria, only, in Trochili); aftershaft present; wing-coverts nonoscinine (the inverted middle series wanting); secondaries $6-11$; primaries 10 , the tenth, ninth, and eighth (usually the tenth) longest; the fifth cubital remex present (except in some Micropodii); rectrices 10 ; alula of 0-3 feathers; rictal bristles absent; skin of manus dark. Young nidicolous and gymnopædic.

\section{KEY TO THE SUPERFAMILIES OF MACROCHIRES. ${ }^{a}$}

a. Palate schizognathous; toes anisodactylous, the deep plantar tendons passerine; ribs, 8 pairs; cervical hæmapophyses " $U=$ "; humero-coracoid groove or fossa present; tibial bridge absent; flexor tendons of type Vc; syrinx tracheo-bronchial; bill long and slender, the gape not deeply cleft; nostrils lateral, broadly operculate; tongue extensile; secondaries 6-7; alular feathers 0-1; frontal apterium present; femoral pterylæ small, connected with the dorsal pteryla; aftershaft small (sometimes rudimentary or, apparently, wanting)...... Trochili (p. 300).

aa. Palate ægithognathous; toes pamprodactylous, the deep plantar tendons coraciine; ribs, 6-7 pairs; cervical hæmapophysis " $=\mathrm{T} "$; humero-coracoid groove or

a Anatomical characters chiefly from Gadow in Bronn's Thier-Reich, Birds, Syst. Theil, p. 83. 
fossa absent; tibial bridge present; flexor tendons of type Va; syrinx tracheal; bill short and broadly tiangular, the gape deeply cleft; nostrils opening vertically, close together, nunuperculate; tongue not extensile; secondaries 8-11; alular feathers 2-3; frontal apterium wanting; femoral pterylæ large, separated from dorsal pteryla; aftershaft large.......................

\section{Superfamily TROCHILI.}

\section{THE HUMMING BIRDS.}

=Suspensi Illiger, Prodr. Orn., 1811, 209.

$=$ Trochili Wagler, Nat. Syst. Amph., Säugth. und Vögel, 1830, 82.-Sеввонм, Classif. Birds, 1890, pp. vii, xi, 5.-Sharpe, Rev. Classif. Birds, 1891, 81; Hand-list, ii, $1900,97$.

Small to extremely small Macrochires with slender bill, extensile tongue, lateral, operculate nostrils, schizognathous palate, eight pairs of ribs, alula absent or, when present, composed of a single feather, and not more than seven secondaries.

Metasternum entire, convex, the carina sterna greatly developed; humero-coracoid fossa present; cervical hæmapophyses " $U=$ "; flexor tendons of type $\mathrm{V} c$; toes anisodactylous, the front plantar leading to the three anterior toes, the hind plantar leading to the hallux, the feet relatively very small; a frontal apterium; femoral pterylæ small, connected with the dorsal pteryla; aftershaft (if present) small or rudimentary; adult downs (if present) on apteria only.

\section{Family TROCHILID王.}

\section{THE HUMMING BIRDS.}

$=$ Trochilidæ Vigons, Trans. Linn. Soc. Lond., 1825, 468.-CaBanis, in Wiegmann's Archiv für Naturg., 1847, pt. i, 345.-Bonaparte, Consp. Av., i, 1849, 67.-Cabanis and Heine, Mus. Hein., iii, 1860, 3.-Fürbrincier, Unters. Morph. Syst. Vög., ii, 1888, 1381, 1382.-SharPe, Hand-list, ii, 1900, 97.

As mostly additional to the characters given above under the heading of Superfamily Trochili, the following may be mentioned: Palate schizognathous; nares holorhinal; neck very long, forming four-sevenths of the vertebral column; three free dorsal vertebræ, succeeded by a sacrum of twelve fused vertebræ, terminated by six caudal vertebræ; bones supporting the tail provided with long recurved processes "to furnish ample attachment for the welldefined caudal muscles;" eight pairs of ribs, the first three pairs joined to the three free dorsal vertebræ, the succeding four pairs attached to the first four vertebræ of the sacral series, the eighth pair entirely free at upper end; coracoids peculiar, the usual notch in upper end being bridged over, forming a perforation through which the tendon from muscles that raise the wing play securely; sternum relatively very large, with keel extremely deep, the metasternum strongly convex and entire; bill slender, usually subulate, 
sometimes compressed and often somewhat widened and depressed basally, extremely viriable as to relative length (from decidedly shorter than head to longer than head, neck, and body together), usually straight or more or less (sometimes excessively) decurved, rarely recurved terminally; mandible with a more or less distinct median lateral groove or sulcus; nostrils basal, lateral, broadly operculate, but often completely hidden by dense frontal feathering; tongue extremely long, slender, extensile, split terminally, euch lateral division with the outer edge curled upward and inward for part of its length, forming, in effect, two parallel tubes; ${ }^{a}$ only one carotid artery (the left); feet small and usually relatively weak, the tarsus not longer than middle toe with claw; anterior toes all directed forward, subequal in length, the hallux well developed (nearly as large as anterior toes), the claws strongly curved and sharp; deep plantar tendons not Coraciine but much as in Eurylaimidæ (Desmodactyli ${ }^{b}$ ), the front tendon leading to the three anterior toes, the hinder one to the hallux; wing much as in the Micropodii, the primaries excessively developed and the secondaries correspondingly reduced, the latter not longer than the first (innermost) primary and only six to seven in number, the former ten in number, with the outermost (tenth) longest or (rarely) equal to the ninth (in genra Aithurus and Goldmania) distinctly shorter than ninth; rectrices ten, the tail excessively variable in relative length, form, etc.; ${ }^{c}$ young nidicolous and gymnopædic; nest open above, variable as to form and position but usually cup-shaped and attached to a twig, composed of plant-downs or other soft materials, usually stuccoed exteriorly with bits of moss, lichen, or fragments of .bark and spiders' webs; eggs one or (usually) two, broadly elliptical, immaculate white.

Inhabitants exclusively of America, the Humming Birds constitute not only the most charming element in the wonderfully varied birdlife of the Western Hemisphere, but, also, without doubt, the most remarkable group of birds in the entire world. No other group of birds is so brilliant in plumage or so different from all others in their mode of flight and manner of feeding. The general habits of Humming Birds are not dissimilar to those of birds in general. They are both aërial and arboreal, but are unable to progress upon the ground or any flat surface by means of their legs and feet alone. They perch readily and frequently upon trees or bushes, or may

$a$ The tongue of Trochilidæ is described in detail by Dr. F. A. Lucas in Proc. U. S. Nat. Mus., xiv, 1891, 169-172, pl. iv, and Rep. U. S. Nat. Mus., 1892, 293, 294, where the reader is referred for further information on the subject.

$b$ See Part I, p. 14.

c More so than in any other group of birds. For a detailed account of variations in the form of the tail, etc., in the Trochilidæ see Riep. U. S. Nat. Mus., 1892, 294-301. 
even cling to rocks or other vertical surfaces; and their nidification presents nothing that may be deemed peculiar or even specially characteristic. In their flight and manner of procuring their food, however, they differ strikingly from all other birds, in these respects closely resembling certain insects, especially the crepuscular hawkmoths (Sphingidæ). Their food, consisting mainly of small insects but in part also of the nectar of flowers, is mostly gleaned from blossoms, before which they poise, with wings so rapidly vibrating as to be invisible except as a dim haze or halo partly surrounding the body and producing the humming sound from which these birds derive their vernacular name, the bill thrust inside the flower and the slender, semitubular tongue extended into the depths of the blossom. Some species, instead of feeding from flowers, glean their insect food from the bark of forest trees, following along the branches in suspended flight in the same manner that the others pass from flower to flower. In their feeding from flower to flower, Humming Birds, like bees, butterflies, and moths, perform the same office in the economy of nature as insects by transferring pollen from one bloom to another, and thus assisting in the fertilization of plants. In flying from one point to another, the flight of Humming Birds, while essentially direct, is usually more or less undulating, and so extremely rapid that the eye can scarcely follow. Often this flight is accompanied (at least in the case of males of some species) by a more or less remarkable screeching or grating sound, produced mechanically by some peculiarity of wing-structure.

Diminutiveness of size and metallic brilliancy of coloring are the chief external characteristics of Humming Birds, though exceptions to both occur; and in these respects they, as a group, have no rivals. Unfortunately stuffed specimens convey but a faint idea of their splendid coloring, for the perfection of their changeable refulgence can be fully realized only in the living bird, whose every change of position flashes to view a different hue-emerald green replacing ruby red, sapphire blue succeeding fiery orange, or either becoming opaque velvety black-according to the angle at which the sun's rays touch the feathers, an eflect which can only partially be imitated with the stuffed specimen by artificially changing its position with reference to the light. Many species have a spot of the most luminous or brilliantly metallic color (usually green) that it is possible to imagine on the forchead at the base of the bill, this spot being surrounded by the most intense velvety black-evidently to enhance the brilliancy of the ornament by contrast, just as a jeweler would, for the sime purpose, display a diamond or other gem against a background of black velvet. Often there is a spot of brilliant color and one of a contrasting hue just below it, the result 
being that first one color, then the other, is flashed forth as the bird changes slightly its position.

Note to Trocnumb.-(1) In descriptions of some of the species certain positions of the bird with reference to the eye and the angle of light are designated as "position $a$," etc. $a$ These positions may be described as follows:

(2) The veruacular names are mostly taken, with or without modification, from Gould's "Monograph of The Trochilide." In some cases it has seemed desirable, for the sake of greater brevity or euphony, to clange or modify the names bestowed by Gould, while in the case of forms described since the publication of that magnificent work it has, of course, been necessary to invent new ones. At the best, however, it must be said that (as in the case of other groups of birds) many of these vernacular names are more or less fancilul and of slight utility.

KEY TO THE NORTH AND MIDDLE AMERICAN AND MORE CLOSELY RELATED SOUTH AMERICAN GENERA OF TROCHILIDA.

a. Nasal operculum well-developed (though sometimes concealed by frontal feathering); no white or buffy band across rump; adult males with outer web of ninth primary normal.

b. Nasal operculum higher, the lower edge of the posterior portion about midway between culmen and tomia, or nearer to the former. (Phothornithinæ.)

c. Bill excessively decurved, forming about one-third of a circle; feet very stout; under parts conspicuously streaked....................Eutoxeres (p. 310).

$c c$. Bill only moderately or slightly decurved; feet much weaker; under parts not streaked.

d. Nasal operculum decumbent, with lower edge distinctly convex, at least posteriorly; bill more slender, compressed.

$e$. Tail graduated for at least half its length, with middle pair of rectrices more or less elongated....................... Phœthornis (p. 314).

$e e$. Tail graduated for less than half its length, with middle rectrices not elongated............................................

$d d$. Nasal operculum excurrent, its lower edge more or less concave or arched;

bill stouter, depressed........................ Threnetes (p. 336).

$b b$. Nasal operculum lower, the lower edge of its posterior portion much nearer to tomia than to culmen. (Trochilinx.)

c. Nasal operculum partly exposed.

d. Outermost (tenth) primary distinctly shorter than ninth; adult male with next to outer pair of rectrices greatly elongated and head with a double occipital crest ................................

$d d$. Outermost (tenth) primary equal to or longer than ninth (or else with tips attenuated).

$e$. Frontal feathering extending as far forward as that of chin; exposed culmen at least as long as tail, the bill very slender, faintly recurved terminally.

Hemistephania (p. 342).

a These positions, it should be stated, do not correspond with those similarly numbered by Gadow in his article on the color of feathers in Proc. Zool. Soc. Lond., 1882, 409-421 (see especially diagram on p. 420), which, so far as metallic coloring is concerned is based chiefly on sun-birds (Nectarinidæ) and other non-Trochiline forms, which seem to require more or less different positions.

(a) The eye between bird and light, bird's bill toward eye, bird nearly horizontal.

(b) Eye directly above bird, the latter's bill toward light, and position of its body nearly horizontal.

(c) Same as position $a$, but bird reversed (tail, instead of bill, toward eye).

(d) Bird between eye and light, tail toward eye, body inclined, with bill pointing upward. 
$e e$. Frontal feathering not extending as far forward as that of chin; exposed culmen shorter than tail, or else (Anthoscenus, part) the bill much stouter and not at all recurved terminally.

$f$. Exposed culmen nearly to quite as long as tail; a white spot or streak on center of rump....................... Anthoscenus (p. 344).

ff. Exposed culmen much shorter than tail; no white on center of rump.

$g$. Shafts of outer primaries with a more or less distinct median ridge on

basal half (or more), or else the shaft conspicuously enlarged and bent in middle portion.

$h$. Adult males with shafts of outer primaries conspicuously enlarged and bent in middle portion; bill relatively broader terminally and narrower basally (the lateral outlines more nearly parallel).

$i$. Tail graduated, more than two-thirds as long as wing.

Pampa (p. 353).

ii. Tail truncate or slightly rounded, not more (usually less) than two-thirds as long as wing............ Campylopterus (p. 356).

$h h$. Adult males with shaft of outer primary not conspicuously thickened nor bent; bill relatively narrower terminally, broader basally (narrowly wedge-shaped in vertical profile).

Phæochroa (p. 362).

$g g$. Shafts of outer primaries without trace of median ridge, and never enlarged nor bent in middle portion.

$h$. Base of maxilla more denuded, the frontal feathering not extending as far as middle of nasal operculum (the latter almost wholly exposed).

$i$. Tail emarginate or forked in adult males, emarginate or doublerounded in females and young.

$j$. Under parts brownish gray in both sexes, and upper parts much duller in color.................. Phæoptila (p. 366).

jj. Adult males metallic green or green and blue below, the upper parts much brighter in color........... Cynanthus (p. 368).

ii. Tail truncate or very slightly rounded or double-rounded.

$j$. Wing three times as long as exposed culmen; adult males with a broad black auricular and white postocular stripe.

Basilinna (p. 377).

jj. Wing less than three times as long as exposed culmen; adult males without black or white on sides of head.

Hylocharis (p. 3S4).

$h h$. Base of maxilla less denuded, the frontal feathering extending forward to or beyond middle of nasal operculum (the latter with at least the upper basal portion concealed).

$i$. Under tail-coverts all decomposed, plume-like.

j. Larger (wing 62-72 mm.); tarsus naked; no white on tail.

Chalybura (p. 386).

jj. Smaller (wing 45-60 mm.); tarsus feathered; tail partly white; $k$. Maxillary tomium distinctly (but minutely) serrate terminally. secondaries partly rufous; bill longer (from base of nasal operculum one-fourth as long as wing).

l. Outermost (tenth) primary much longer than ninth; adult males with under parts green...... Eupherusa (p. 393).

1l. Outermost (tenth) primary not longer than ninth; adult male with under parts black...... Callipharus (p. 399).

k7. Maxillary tomium not serrate terminally; secondaries without rufous; bill shorter (from nasal operculum less than one-fouth as long as wing)......... Elvira (p. 401). 
ii. Under tail-coverts not all plume-like (all normal except in Goldmania.

j. Nasal operculum mostly exposed.

$k$. Bill stouter, broader, abruptly widened at base; nasal operculum thicker, broader, more conspicuously exposed.

l. Tarsus mostly naked; lateral rectrices broadly tipped with white................. Leucippus (extralimital) ${ }^{a}$

ll. Tarsus mostly naked; lateral rectrices without white.

Amizilis (p. 405).

$k k$. Bill more slender, narrower, not distinctly widened basally; nasal operculum thinner, narrower, with inner-posterior portion more extensively feathered.

l. Under tail-coverts well developed, normal; outermost primary longer than next(?), never attenuated at tip.

$m$. Under parts with at least lower abdomen white; tail olive-bronzy, usually darker subterminally.

Agyrtria (p. 430).

$m m$. Under parts without white, or else tail purplish black or purplish bronze; tail usually black or dark steel blue ....................... Saucerottia (p. 434).

$l l$. Under tail-coverts small and short, the three median ones stiff and plume-like; outermost primary not longer than ninth, in adult male shorter and with tip attenuated ...................... Gold mania (p. 452).

jj. Nasal operculum mostly concealed.

$k$. Bill decidedly decurved; tarsi mostly naked.

l. Frontal feathering not extending to anterior end of nasal operculum, the latter more exposed; rectrices and upper tail-coverts relatively narrower, the former more narrowly rounded at tip, the latter concolor with rump and back.

Anthracothorax (p. 454).

ll. Frontal feathering extending to anterior end of nasal operculum, the latter more concealed; rectrices and upper tail-coverts relatively much broader, the former more broadly rounded or subtruncate at tip, the latter different in color from rump and back.

$m$. Remiges not metallic-colored; tail slightly rounded; pileum, back, rump, and throat green, chest blue or violet, upper tail-coverts blue and green.

Sericotes (p. 473).

nm. Remiges brightly metallic green, like wing-coverts; tail emarginate; pileum, back, and rump velvety black, throat and chest reddish purple, upper tailcoverts bright metallic green.... Eulampis (p. 477).

a Leucippus Bonaparte, Consp. Av., i, 1850, 73. Type, as fixed by Gray, 1855, Trochilus fallax Bourcier.-Doleromyia Bonaparte, Rev. et Mag. de Zool., May, 1854, 249; Ann. Sci. Nat. (Zool.), 4 sér., 1, 1854, 136. New name for Leucippus Bonaparte?-Dolerisca Cabanis and Heine, Mus. Hein., iii, Feb., 1860, 6. New name for "Doleromyia(!) Bp. 1854"' and 'Leucippus Gray, 1855 (nec Bp. 1849)." (Venezuela, including Margarita Island, and Colombia; monotypic?).

I would exclude from this genus Trochilus chionogaster Tschudi, Leucippus pallidus Taczanowski, Thaumatias? chlorocercus Gould, and L. viridicauda Sclater and Salvin. The last two of these I have not seen, but they seem to be closely allied to the first and second, which differ in many structural details and also (conspicuously) in coloration from Leucippus fallax. The generic name which they should bear is probably Talaphorus Mulsant (Hist. Nat. Ois.-Mouch., i, 1874, 257), the type of which is Thaumatias? chlorocercus Gould. 
$k k$. Bill not decidedly if at all decurved; tarsi mostly feathered; upper tail-coverts normal (covering less than basal half of tail).

l. An auricular tuft of blue, violet, or reddish purple; tail blue, green, or bronzy olive, with a darker subterminal band ............................... Colibri (p. 480).

$l l$. No auricular tuft; tail not blue, green, or bronzy with darker subterminal band.

$m$. Exposed culmen only one-fourth as long as wing, less than two-fifths as long as tail; remiges rufous-chestnut basally .................... Lamprolaima (p. 489).

$m m$. Exposed culmen more than one-fourth as long as wing, more than one-third as long as tail (or else the latter long and deeply forked); remiges wholly dusky.

n. A white postocular spot or streak (if this minute (Panterpe), the pileum metallic blue and throat bright metallic orange or orange-red.

o. Larger (wing more than $55 \mathrm{~mm}$.).

p. Postocular white spot or streak conspicuous; bill broader; throat never orange or orange-red; sexes different in color.

$q$. Larger (wing $70 \mathrm{~mm}$. or more); exposed culmen longer than head; under parts of body gray.

$r$. Tail less deeply emarginate, the lateral rectrices broadly tipped with white; adult male with throat metallic blue.

Cyanolæmus (p. 491).

$r r$. Tail more deeply forked, the lateral rectrices without white tips; adult males with throat reddish purple to violet.

Lampornis (p. 494).

$q q$. Smaller (wing not more than $65 \mathrm{~mm}$.); exposed culmen shorter than head; under parts not gray .................. Oreopyra (p. 501).

$p p$. Postocular white spot minute; throat metallic orange or orange-red, the sexes alike in color.

Panterpe (p. 511)

oo. Smaller (wing less than $50 \mathrm{~mm}$.).

$p$. Exposed culmen nearly half as long as tail, the latter much less than two-thirds as long as wing in male, only half as long in female; pileum metallic blue, the throat also blue in adult male.

Klais (p. 513).

$p p$. Exposed culmen but little more than one-third as long as tail, the latter two-thirds as long as wing in male, nearly two-thirds as long in female; pileum metallic green, the upper throat metallic emerald green in adult male.

Abeillia (p. 516).

$n n$. No white postocular mark, or else (Riccordia) tail deeply forked and adult male with under parts wholly green.

o. Tail graduated ................ Damophila (p. 518). oo. Tail not graduated. 
p. Lateral pair of rectrices not longer than middle pair; wing not less than $50 \mathrm{~mm}$.

Polyerata (p. 522).

$p p$. Lateral pair of rectrices longer than middle pair, or else (Chlorostilbon, female, part) wing less than $45 \mathrm{~mm}$.

$q$. Bill relatively broader, distinctly depressed in middle portion, deeper subterminally; tail forked for much less than one-fourth its length, the rectrices relatively much broader; adult male with whole head dark metallic blue................ Cyanophaia (p. 526).

$q q$. Bill narrower, not at all depressed in middle portion, not deeper subterminally; tail forked for at least one-fourth its length or else (Chlorostilbon, part) the bill not as in $q$.

$r$. Nasal operculum with only the edge exposed; adult males with under parts of body at least partly blue or violet, or else pileum violet............... Thalurania (p. 530).

$r$. Nasal operculum with much more than edge exposed; adult males with under parts of body never partly blue or violet, the pileum always green.

s. Bill slightly decurved, the exposed culmen more than half as long as tail; tail nearly to quite two-thirds as long as wing, forked for not more than five-sevenths its length................ Lepidopyga (p. 537).

ss. Bill straight, the exposed culmen less than half as long as tail and tail forked for more than five-sevenths its length, or else (Chlorostilbon, part) the tail much less than two-thirds as long as wing.

$t$. Frontal feathering not extending much beyond middle of nasal operculum; adult male with tail more than twothirds as long as wing, forked for at least two-fifths its length, the lateral rectrices not narrowing terminally; a small white postocular spot.....Riccordia (p. 542).

$t t$. Frontal feathering extending nearly if not quite to middle of nasal operculum; adult male with tail less than two-thirds as long as wing and forked for less than two-fifths its length, or else lateral rectrices narrowing terminally; no white postocular spot.. Chlorostilbon (p. 547).

cc. Nasal operculum entirely concealed by closely appressed frontal feathering.

d. Base of maxilla less extensively feathered, the distance from frontal antiæ to tip of maxilla more than twice (usually several times) the distance from the same point to base of nasal operculum.

$e$. Bill excessively compressed anteriorly (acutely wedge-shaped in vertical profile); tomia distinctly serrate terminally........Heliothryx (p. 561). 
$e e$. Bill not excessively compressed terminally (more linear or parallel-edged in vertical profile); tomia not serrate terminally.

f. Larger (wing more than $60 \mathrm{~mm}$.).

g. Tarsal feathering short, not forming a fringe-like tuft posteriorly; rectrices relatively narrower, with tip rounded.

$h$. Exposed culmen two-thirds to three-fourths as long as tail; tail not more than three-fifths as long as wing in adult male, less than three-fifths as long in female; deeply emarginate in adult male, slightly rounded or double-rounded in female; adult female not spotted below .......................... Eugenes (p. 564).

$h h$. Exposed culmen slightly more than to less than half as long as tail, the latter more than two-thirds as long as wing in adult male, more than three-fifths as long in female, forked in male, deeply emarginate in female; adult female spotted with green below.............................. Heliodoxa (p. 570).

gg. Tarsal feathering much developed posteriorly, forming a conspicuous fringe-like tuft; rectrices relatively broader, with tip subtruncate.

$h$. Longest upper tail-coverts reaching to end of middle rectrices in adult male, nearly as far in female............ Florisuga (p. 575).

$h h$. Longest upper tail-coverts reaching but little more than halfway to tip of tail..............Melanotrochilus (extralimital). ${ }^{a}$

ff. Smaller (wing not more than $50 \mathrm{~mm}$.).

g. Tail less than half as long as wing; adult male with white pileum and dark purplish or blackish under parts......... Microchera (p. 580).

$g g$. Tail not less than half as long as wing; adult males with pileum metallic green and under parts not dark purplish or blackish.

$h$. Exposed culmen less than one-third as long as wing; tail not more than half as long as wing; adult male without metallic color on throat . . . . . . . . . . . . . . . . . . . . . . . . Mellisuga (p. 583).

$h h$. Exposed culmen not less (usually more) than half as long as wing; tail more than half as long as wing; adult males with throat metallic red, purple, or violet.

$i$. Rectrices broader subterminally (subspatulate); adult male with feathers of throat very narrow, pure white basally.

Stellula (p. 587).

ii. Rectrices not broader subterminally, but more or less tapering; adult males with feathers of throat broader, gray, dusky, or buffy basally.

$j$. Bill straight, less than half as long as wing.

$k$. Lateral rectrices little if any longer than middle pair, or else (males of Calypte and Archilochus) tail forked for less than half its length; adult males with tail less than three-fourths wing, not forked, or else (adult males of Calypte and Archilochus) forked for less than half its length.

l. Plumage with more or less of rufous; tail rounded or graduated in males, strongly rounded in females.

$m$. Tail less strongly rounded, none of the rectrices pointed or contracted terminally; adult males with lateral rectrices broadly tipped with white and with basal half rufous....................... Athis (p. 591).

a Melanotrochilus Deslongchamps, Guide d. Naturaliste, 1880, 7. (Type, Trochilus fuscus Vieillot.) 
$\mathrm{mm}$. Tail more strongly rounded or graduated, at least some of the rectrices pointed or contracted terminally in adult males; adult males withont white tips to lateral rectrices, their basal half not rufous or else tail mostly rufous............. Selasphorus (p. 595).

$l l$. Plumage without any rufous; tail forked in males, doublerounded in females.

$m$. Inner primaries normal; adult males with pileum brilliant metallic purplish red or violet, like throat; the lateral feathers of the latter elongated; lateral rectrices not pointed ................ Calypte (p. 618).

$m m$. Inner primaries with a small subterminal tooth on inner web; adult males with inner primaries abruptly reduced in size; pileum dull or dusky metallic green; feathers of sides of throat not elongated; lateral rectrices pointed................ Archilochus (p. 627).

$k k$. Lateral rectrices conspicuously longer than middle pair; adult males with tail at least three-fourths as long as wing, forked for more than half its length.

l. A conspicuous white or buffy spot on each side of rump; adult male with lateral rectrices broadly banded with white, adult female wholly light cinnamon-rufous below.

Tilmatura (p. 637).

$\imath l$. No white or buffy spot on side of rump; adult males without white on lateral rectrices, adult females partly whitish below.

$m$. Wing relatively larger, with outer primary not attenuated terminally; adult males with lateral rectrices broadly edged with rufous on inner webs; adult female with tail more than half as long as wing.

Nesophlox (p. 639).

$m m$. Wing relatively smaller, with outermost primary narrower and attennated terminally; adult males with lateral rectrices wholly purplish dusky; adult females with tail not more than half as long as wing.

Calliphlox (extralimital). $a$

jj. Bill distinctly decurved; exposed culmen more than half as long as wing (except in Calothorax, part).

k. Adult male with tail much longer than wing, forked for more than half its length, the lateral rectrices of uniform width thronghout or slightly expanded terminally, with tip broadly rounded, and with lateral feathers of throat little if any elongated; adult female with tail nearly two-thirds as long as wing.......................... Doricha (p. 647).

$k k$. Adult male with tail shorter than wing, forked for less than half its length, the lateral rectrices narrowing terminally and pointed or narrowly rounded, the lateral feathers of throat much elongated; adult female with tail but little more than half as long as wing...... Calothorax (p. 651).

a Calliphlox Boie, Isis, 1831, 544 (type, Trochilus amethystinus Gmelin).-Philodice Mulsant and Verreaux, Classif. Troch., 1865, 86 (type, Trochilus mitchelli Bourcier).

Venezuela and Trinidád to Brazil and Ecuadór. (Two species.) 
$d d$. Base of maxilla more extensively feathered, the distance from frontal antiæ to tip of maxilla not more than twice the distance from same point to base of nasal operculum (much less than twice in adult males).

$e$. Distance from frontal antiæ to tip of maxilla scarcely greater than from same point to base of nasal operculum; adult males with feathers of pileum developed into a conspicuous flattened pointed crest, brilliant golden or emerald green, sometimes passing into blue or violet posteriorly, the throat and chest sooty grayish, the tail uniform blackish; adult females with pileum dark metallic green, under parts light gray, and lateral rectrices tipped with gray............ Orthorhyncus (p. 656).

$e e$. Distance from frontal antiæ to tip of maxilla considerably greater than from same point to base of nasal operculum; adult male with whole pileum and nape brilliantly metallic red (the pileum not crested), throat and chest brilliantly metallic golden orange, the tail rufous, narrowly tipped with dark bronzy brown; adult female with pileum grayish brown or dull bronzy, under parts grayish white, and lateral rectrices tipped with white................. Chrysolampis (p. 665).

$a a$. Nasal operculum almost rudimentary; a white or buffy band across rump; adult males with outer web of ninth primary abruptly excised or narrowed for terminal third or more. (Lophornilhinæ.)

b. Tail not forked or else (Polemistria) forked for much less than half its length, the rectrices broader, with rounded tip, their shafts not white beneath; adult males with a conspicuous ornamental crest or auricular or neck tufts (sometimes both).

c. Base of maxilla more extensively feathered, the distance from frontal antiæ to rictus nearly equal the distance from same point to tip of maxilla; tail relatively longer (more than two-thirds as long as wing), deeply emarginate, with outermost pair of rectrices longest; throat not metallic-colored; rectrices without rufous. ........................ Polemistria (extralimital) ${ }^{a}$

cc. Base of maxilla less extensively feathered, the distance from frontal antiæ to rictus much less than distance from same point to tip of maxilla; tail relatively shorter (not more than two-thirds, usually only three-fifths, as long as wing), double-rounded, with outermost pair of rectrices shorter than middle pair; tail partly rufous; throat bright metallic green in adult males....................................... Lophornis (p. 669).

$b b$. Tail forked for more than half its length, the rectrices narrower with pointed tip, their shafts white beneath-in adult males much longer than wing, very deeply forked, the lateral rectrices slender and attenuate; adult males without auricular tufts or neck tufts and without crest, or else the latter very long and slender.....................................

Genus EUTOXERES Reichenbach.

Eutoxeres Reichenbach, Av. Syst. Nat., 1849, pl. 40. (Type, Trochilus aquila Bourcier.)

Myiaetina Bonaparte, Rev. et Mag. de Zool., vi, pt. 2, 1854, 249. (Type, Trochilus aquila Bourcier.)

Rather large Trochilidæ (length about 110-130 mm.) with the bill very abruptly and excessively decurved (the culmen forming approximately one-third of a circle) and plumage of under parts conspicuously streaked.

a Polemistria Cabanis and Heine, Mus. Hein., iii, 1860, 63 (type, Trochilus verreauxi Bourcier).-Aurinia Mulsant, Cat. Ois.-Mouch., 1875, 27 (type, Trochilus verreauxi Bourcier). 
Bill sickle-shaped, compressed except at base, where broad and depressed, the curve of the culmen forming nearly one-third of a circle; tomia smooth; maxilla with a narrow lateral groove parallel to culmen and a narrow ridge near tomium; culmen rounded, somewhat ridged basally. Nostril narrow, slit-like, overhung by a broad, convex, tumid naked operculum. Tarsus very stout, feathered for upper anterior portion, longer than anterior toes; toes all very stout, the middle and inner ones of equal length, the outer slightly but decidedly shorter; middle toe equally united to outer and inner toes, the extent of cohesion involving slightly less than basal phalanx; hallux very strong, slightly longer than outer toe (without claw). Wing decidedly more than twice as long as exposed culmen (chord), the outermost primary longest. Tail nearly to quite three-fourths as long as wing, graduated, the rectrices broad but tapering to an obtuse point terminally.

Coloration.-Above rather dull metallic green, the pileum dull dusky (sometimes a band of metallic greenish blue across hindneck); tail dull bronze or bronze-dusky, the rectrices tipped with whitish, or the three lateral pairs cinnamon, fading into whitish at tip; under parts conspicuously streaked with dusky and whitish or pale tawny. Sexes alike.

\section{Range.-Costa Rica to northern Peru. (Four species.)}

\section{KEY TO THE SPECIES AND SUBSPECIES OF EUTOXERES.}

a. Pileum wholly feathered; lateral rectrices bronzy olive or grayish, with or without white tip.

b. Tail bronzy olive (more greenish on middle rectrices), the lateral rectrices extensively white terminally. (Eutoxeres aquila.)

c. White tips to rectrices longer, wedge-shaped basally, the shaft white for more than the white portion of the webs. (Central Colombia to eastern Ecuadór.)

Eutoxeres aquila aquila (extralimital). ${ }^{a}$

cc. White tips to rectrices shorter, more truncated basally, the shaft white only as far as white portion of webs.

d. Tail-spots nearly pure white; larger (male averaging: wing 73.7 , tail 53.3 , culmen 25.9). (Costa Rica to Colombia.). Eutoxeres aquila salvini (p. 312).

$d d$. Tail-spots dull brownish white or pale buffy; smaller, with larger bill (male averaging: wing 71.5, tail 49.5, culmen 26.8). (Western Ecuadór.)

Eutoxeres aquila heterura (extralimital). $b$

a Troch[ilus] aquila Bourcier, Proc. Zool. Soc. Lond., xv, 1847, 42 (Bogotá, Colombia; coll. Loddiges)._Eutoxeres aquila Reichenbach, Aufz. der Colibr., 1854, 15; Mulsant and Verreaux, Hist. Nat. Ois.-Mouch., i, 1873, 27, pl. 1; Elliot, Synop. and Classif. Hum. Birds, 1879, 3, part; Salvin, Cat. Birds Brit. Mus., xvi, 1892, 261.-E[utoxeres] aquila (typicus) Hartert, Das Tierreich, Troch., 1900, 29.

$b$ E[utoxeres] heterura Gould, Ann. and Mag. N. H., ser. 4, i, no. vi, June, 1868, 456, in text (Quito, Ecuadór; coll. J. Gould).-Eutoxeres heterura Gould, Introd. Troch., oct. ed., 1861, 36; Elliot, Classif. and Synop. Troch., 1879, 3.-Eutoxeres aquila var. heterura Mulsant and Verreaux, Hist. Nat. Ois.-Mouch., i, 1873, 27.-Eutoxeres aquila heterura Taczanowski and Berlepsch, Proc. Zool. Soc. Lond., 1885, 102.-E[utoxeres] aquila heterura Hartert, Das Tierreich, Troch., 1900, 29. 
$b b$. Tail olive-grayish, the lateral rectrices with very minute (if any) whitish tips. (Ecuadór.) ............................ Eutoxeres baroni (extralimital). ${ }^{a}$ aa. Pileum with median line unfeathered; lateral rectrices tawny-ochraceous (paler terminally) .................... Eutoxeres condamini (extralimital). ${ }^{b}$

\section{EUTOXERES AQUILA SALVINI (Gould).}

\section{SALVIN'S SICKIE-BILL.}

Similar to $E$. a. heterura, but white tips to rectrices averaging larger and always much purer white. ${ }^{c}$

Adults (sexes alike).-Above metallic bronze-green or greenish bronze, darker and duller on pileum, where feathers are narrowly and indistinctly margined with dusky, the upper tail-coverts (sometimes feathers of lower rump also) margined terminally with pale dull buffy; tail dull metallic bronze-green, the rectrices tipped with white, this most extended on lateral pair, where the basal outline of the white area on outer web is more or less transverse; remiges blackish slate or dusky, very faintly glossed with violaceous, the innermost secondary is usually marked with a narrow shaft-streak or subterminal spot of dull white; chin, throat, and chest sooty black sharply streaked with pale buff or buffy white, the breast and abdomen similarly marked, but streaks narrower and less strongly contrasted (the darker streaks more brownish); sides and flanks washed with metallic bronze-green; under tail-coverts dusky (glossed, more or less, with bronze-green), margined with brownish buff or pale cinnamon and with a narrow shaft-streak of the same; maxilla black, mandible pale dull yellowish (in dried skins), passing into dusky terminally; iris dark brown; legs and feet pale brownish (in dried skins), the scutella darker, more horn colored.

Young.-Similar to adults, but feathers of pileum, hindneck, back, and rump more or less distinctly tipped with buffy, the upper tailcoverts margined with the same, the greater wing-coverts very narrowly tipped with buffy, and remiges with a minute apical spot of dull whitish (larger on secondaries).

a Eutoxeres baroni Hartert (E. and C.), Novit. Zool., i, Jan., 1894, 12, 54 (Rio Pescado, near Naranjál, w. Ecuadór; coll. Tring Mus.).-E[utoxeres] baroni Hartert (E.), Das Tierreich, Troch., 1900, 29.

$b \operatorname{Tr}$ [ochilus] condamini Bourcier, Compt. Rend., xxxii, 1851, 187 (Archidona, e. Ecuadór).--Eutoxeres condaminii Gould, Mon. Troch., i, Nov., 1851, pl. 4; Intr. Troch., oct. ed., 1831, 37; Mulsant and Verreaux, Hist. Nat. Ois.-Mouch., i, 1873, 29, pl. 2; Elliot, Classif. and Synop. Troch., 1879, 3; Salvin, Cat. Birds Brit. Mus., xvi, 1892, 263, part.-E[utoxeres] condaminei Hartert, Das Tierreich, Troch., 1900, 28, part.(?) Eutoxeres condaminei gracilis Berlepsch and Stolzman, Proc. Zool. Soc. Lond., 1902, 19 (Vitoc, Garita del Sol, centr. Peru; coll. Mus. Branicki).

$c$ Compared with sixteen adults of $E$. a. heterura from Ecuadór, twenty adults of $E$. $a$. salvini (including one from Bogotá) differ constantly and conspicuously in having pure white tips to the rectrices, all the others having these markings dull brownish white as well as less in extent. 
Adult male.-Length (skins), 12S-133 (130); wing, 68-77 (73.7); tail, 52.5-55.5 (53.3); culmen (chord), 25.5-26(25.9). ${ }^{a}$

Adult female.-Length (skins), 120-129 (127); wing, 64.5-70.5 (68.5); tail, 48.5-55 (52.2); culmen (chord), 26-27.5 (26.7). ${ }^{b}$

Costa Rica (Carrillo; Turrialba; Tucurríqui; Róvalo; Pozo Azúl de Pirrís) and Panamá (Calovévora; Chitra; Calobre, and Belén, Verágua).

Eutoxeres aquila (not Trochilus aquila Bourcier) Gould, Mon. Troch., part ii, Nov. 1, 1851 (vol. i, pl. 3); Introd. Troch., oct. ed., 1861, 36.-SAlvin, Proc. Zool. Soc. Lond., 1867, 152 (Belén, Verágua, Panamá).-Lawrence, Ann. Lyc. N. Y., ix, 1868, 120 (Tucurríqui, Costa Rica), 146 (crit.).-F Fantzius, Journ. für Orn., 1869, 315 (Costa Rica).-Boucard, Notes quelques Troch., 1Si3, 1, part (Costa Rica); The Hum. Bird, ii, 1892, 84, part (Verágua).Elliot, Classif. and Synop. Troch., 1879, 3, part (Costa Rica; Verágua). Eudes-Deslongchamps, Ann. Mus. Caen, i, 1850, 72.-Ridgway, Proc. U. S. Nat. Mus., iii, 1850, 30 s (Verágua).-Zeledón, Cat. Aves de Costa Rica, 18S2, 19.

[Eutoxeres] aquila Sclater and Salvin, Nom. Av. Neotr., 1873, 78, part (Verágua; Costa Rica).-Sinos, Cat. Troch., 1897, 7, part.

Trochilus aquila (not of Bourcier) LAwrence, Ann. Lyc. N. Y., vi, 1858, 139 (Verágua).

Eutoxeres salvini Gould, Ann. and Mag. N. H., i, 1868, 456 (Verágua, Panamá; coll. J. Gould).-SAlvin, Proc. Zool. Soc. Lond., 1870, 204 (Calovévora, Panamá; crit.); Cat. Birds Brit. Mus., xvi, 1892, 262.-Salvin and Godman, Biol. Centr.-Am., Aves, ii, 1892, 314 (Turrialba and Róvalo, Costa Rica; Belén, Chitra, Calobre, and Calovévora, Panamá).

[Gryphus] salvini Gray, Fand-list, i, 1869, 123, no. 1547.

Eutoxeres aquila, var. salvini Mulsant and Verreaux, Hist. Nat. Ois.-Mouch., i, $1873,27, \mathrm{pl} .1$.

Eutoxeres heterura (not of Gould) HarTert (E. and C.), Novit. Zool., i, 1894, 53 part (crit.).

[Eutoxeres] heterura Sharpe, Hand-list, ii, 1900, 101, part (Costa Rica; Panamá).

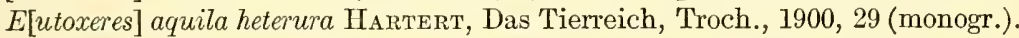

Eutoxeres aquila heterura CARrIKer, Ann. Carnegie Mus., vi, 1910, 521 (Costa Rica; habits).

a Six specimens (five from Costa Rica, one from Verágua).

$b$ Nine specimens (all from Costa Rica).

\begin{tabular}{|c|c|c|c|}
\hline Locality. & Wing. & Tail. & $\begin{array}{l}\text { Ex- } \\
\text { posed } \\
\text { cul- } \\
\text { men. }\end{array}$ \\
\hline MALES. & & & \\
\hline Five adult males of $E$. $a$. salvini from Costa Rica.... & 73.2 & 53.9 & 25.9 \\
\hline One adult male of E. a. salvini from Panamá (Chitra, Verágua). & 76.5 & 52.5 & 26 \\
\hline One adult male of $E$. a. aquila from Colombia (Bogotá)......... & 77.5 & 56 & 26.5 \\
\hline Nine adult males of $E$. $a$. heterura from w. Ecuadór .......... & 71.5 & 49.5 & 26.8 \\
\hline FEMIALES. & & & \\
\hline Nine adult females of $E$. a. salvini from Costa Rica........... & 68.5 & 52.5 & 26.7 \\
\hline Four adult females of $E$. a. heterura from w. Ecuadór......... & 68.9 & 47 & 27 \\
\hline
\end{tabular}




\section{Genus PHCETHORNIS Swainson.}

Phothornis Swainson, Zool. Journ., iii, no. xi, Dec., 1827, 357. (Type, Trochilus superciliosus Linnæus.)

Phaëthornis (emendation) SwaInson, Fauna Bor.-Am., ii, 1831, 322.

Phrethornis (typ. error?) BoIE, Isis, 1831, 548.

Phaethornis (emendation) Salvin, Cat. Birds Brit. Mus., xvi, 1892, 267.

Phrthornis (emendation) Lesson, Man. d'Orn., ii, June, 1828, 429.-Elliot, Classif. and Synop. Troch., 1879, 10.

Photornis Ferussac, in Ferussac's Bull., xxiv, Feb., 1831, 201.-Lesson, Index Gen. et Synop. Troch., 1832, p. xiv.

Phætornis Lesson, L'Echo du Monde Sav., viii, sér. 2, 1843, col. 756.-BonaPARTe, Rev. et Mag. de Zool., 1854, 249.

Phaetornis Voigt, Das Thierreich, i, 1831, 640.-Lichtenstein, Syst. Verz., 1844, 21.

Phaëtornis Bonaparte, Consp. Av., i, 1850, 67.

Phæthornus Jardine and Selby, Illustr. Orn., ser., i, iii, pt. 10, Dec., 1835, 77.

Ptyonornis Reichenbach, Aufz. der Colibr., 1854, 14. (Type, Trochilus eurynome Lesson.)

Ametrornis Reichenbach, Aufz. der Colibr., 1854, 14. (Type, A. abnormis Reichenbach $=$ Trochilus bourcieri Lesson.)

Ametornis (emendation?) Mulsant, Ann. Soc. Linn. Lyon, n. s., xxii, 1876, 201.

Orthornis Bonaparte, Rev. et Mag. de Zool., vi, pt. 2, 1854, 249. (Type, Trochilus bourcieri Lesson.)

Guyornis Bonaparte, Rev. et Mag. de Zool., vi, pt. 2, 1854, 249. (Type, Trochilus guyi Lesson.)

Toxoteuches a Cabanis and Heine, Mus. Hein., iii, Feb., 1860, 11. (Type, Trochilus guyi Lesson.)

Mesophila Mulsant and Verreaux, Mém. Soc. Imp. Sci. Cherb., xii (sér. 2, ii), 1866, 161 (Classif. Troch., 17). (Type, Trochilus yaruqui Lesson.)

Anisoterus Mulsant and Verreaux, Hist. Nat. Ois.-Mouch., i, 1873, 72. (Type, Trochilus pretrii Lesson and Delattre.)

Milornis Mulsant and Verreaux, Hist. Nat. Ois.-Mouch., i, 1873, 77. (Type, Trochilus squalidus Temminck.)

Pygmornis Bonaparte, Rev. et Mag. de Zool., vi, pt. 2, 1854, 250. (Trochilus intermedius Lesson $=T$. longuemareus Lesson.)

Pygornis (emendation?) Mulsant and Verreaux, Mém. Soc. Imp. Sci. Nat. Cherb., xii (sér. 2, ii), 1866, 162 (Classif. Troch., 18).

Momus Mulsant and Verreaux, Mém. Soc. Imp. Sci. Nat. Cherb., xii, (sér. 2, ii), 1866, 162 (Classif. Troch., 19). (Type, Pygmornis obscura Gould= Trochilus idaliæ Bourcier.)

Eremita (not of Cocteau, 1837) Reichenbach, Aufz. der Colibr., 1854, 14. (Type, Trochilus rufigaster Vieillot=T. pygmæus Spix.)

Rather large to small Trochilidæ (length about 90-155 mm.) with very long, more or less decurved bill, long, graduated tail with middle rectrices at least twice as long as lateral pair, middle toe united to outer except for its terminal phalanx, tarsi feathered, and coloration usually very dull, devoid of metallic hues except on upper parts (where rarely brilliant), the under parts rarely with any metallic coloring.

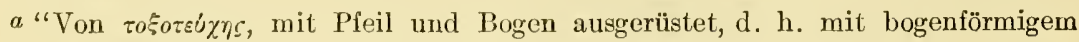
Schnabel und pfeilförmigen Schwanzfedern." (Cabanis and Heine.) 
Bill very long (nearly twice to nearly three times as long as head), more or less decidedly decurved, broader than deep at base, the culmen rounded except for mesorhinal portion, where compressed into a narrow ridge; mandible with a broad and distinct lateral groove, the maxilla sometimes faintly grooved; tomia smooth. Nostril narrow, slit-like, overhung by a broad, tumid, mostly unfeathered opereulum. 'Tarsus feathered (more or less completely), longer than anterior toes (without claw), these about equal in length, the hallux shorter and weaker; middle toe united to outer toe except for its terminal phalanx. Wing decidedly longer than bill, the outermost primary longest. Tail about as long as wing (sometimes decidedly longer), excessively graduated, the middle pair of rectrices at least twice as long as lateral pair, sometimes several times as long, often attenuated terminally.

Coloration.-Above usually olivaceous, more or less glossed with metallic green or bronze, the upper tail-coverts rufescent or tipped with tawny, buffy, or whitish; rectrices dusky, tipped or terminally margined with whitish, buffy, or rusty, the elongated middle pair whitish, or at least paler, terminally; under parts buffy grayish, ochraceous, or tawny, the throat sometimes with a broad median area of striped grayish or plain buffy whitish. Sexes alike. (One or two species have the sexes decidedly different in coloration, the adult male being glossy metallic green above, more bluish on upper tail-coverts, the under parts glossed laterally with the same.)

Range.-Southern Mexico to Cayenne, southeastern Brazil, Bolivia, and Ecuadór. (About fifty species and subspecies.)

KEY TO THE SPECIES AND SUBSPECIES OF PHETHORNIS.

a. Larger (wing more than $50 \mathrm{~mm}$.). (Phoethornis.)

$b$. Under parts mostly slate-gray or metallic bluish green; upper parts bright bluish green passing into green, bluish green, or blue on upper tail-coverts. (Phothornis guyi.)

c. Rump and upper tail-coverts decidedly greenish (green or bluish green); adult males with under parts mostly gray (more or less dark).

d. Rump and upper tail-coverts green, the back bronze-green or greenish bronze. (Venezuela and Trinidád.)

Phøthornis guyi guyi (extralimital) ${ }^{a}$

a Trochilus guy Lesson, Hist. Nat. Troch., 1829, 119, pl. 44.-[Phaëthornis] guy Bonaparte, Consp. Av., i, 1850, 67.-Phæthornis guyi Gould, Mon. Troch., i, 1852, pl. 26; Elliot, Classif. and Synop. Troch., 1879, 13; Salvin, Cat. Birds Brit. Mus., xvi, 1892, 268.-P[haëthornis] guy (typicus) Hartert, Das Tierreich, Troch., 1900, 19 (mon.).-T[oxoteuches] guyi Cabanis and Heine, Mus. Hein., iii, 1860, 11, part.Phaetornis guy Léotaud, Ois. Trinidad, 1866, 129.-Guyornis typus Bonaparte, Rev. et Mag. de Zool., 1854, 249. 
$d d$. Rump and upper tail-coverts bluish green, the back less bronzy; general coloration darker. (Colombia; Ecuadór?; Peru?)

Phœthornis guyi emiliæ (extralimital). $a$

$c c$. Rump and upper tail-coverts decidedly blue (greenish blue); adult males with under parts mostly metallic green. (Costa Rica and Panamá.)

Phæthornis guyi coruscus (p. 317).

$b b$. Under parts neither slate-gray nor metallic; upper parts dull greenish or bronzy, much broken by buffy margins to feathers; upper tail-coverts mostly greenish bronze or buffy.

c. Upper tail-coverts buffy or tawny, barred with dusky or dark brouzy; under parts mostly buffy. (Phothornis longirostris.)

d. Lateral rectrices margined terminally with buff.

$e$. Under parts less strongly buffy, the median throat-stripe narrower.

$f$. Under parts paler (especially sides of throat), not distinctly if at all barred. (Guatemala to northern Honduras.)

Phœthornis longirostris longirostris (p. 319).

ff. Under parts darker (especially sides of throat), more or less distinctly barred with darker. (Southern Honduras to Panamá.)

Phœthornis longirostris cephalus (p. 321).

$d d$. Lateral rectrices margined terminally with white.

$e$. Paler and smaller (adult male, wing 60-65.5, tail 65-70, culmen 39-42.5).

(Southeastern Mexico.)..Phœthornis longirostris veræcrucis (p. 323).

$e e$. Darker and larger (adult male, wing 67-69.5, tail 83-87, culmen 45.5-47).

(Southwestern Mexico.)... Phœthornis longirostris mexicanus (p. 323).

cc. Upper tail-coverts bronze-green margined with buffy; under parts dull grayish

white, slightly if at all tinged with buffy. (Phothornis anthophilus.)

$d$. Green of upper parts paler and more bronzy; upper tail-coverts more broadly margined with buffy; under parts slightly buffy. (Colombia and Venezuela.)............ Phœthornis anthophilus anthophilus (extralimital). $b$

$d d$. Green of upper parts deeper and less bronzy, the upper tail-coverts less broadly margined with buffy; under parts more grayish white. (San Miguél Island, Bay of Panamá.)

Phœthornis anthophilus hyalinus (p. 324).

aa. Smaller (wing less than $45 \mathrm{~mm}$.). (Pygmornis.)

$b$. Chin and throat not streaked; lateral rectrices broadly margined terminally with deep cinnamon-buff or ochraceous-buff. (Phœthornis adolphi.)

c. Paler, especially the throat and chest, the chin not dusky. (Southeastern Mexico.)................ Phœthornis adolphi adolphi, adult male (p. 324).

$c c$. Darker, especially throat and chest, the chin distinctly more dusky. (Guatemala to Panamá.)...............Phœthornis adolphi saturatus (p. 326).

a T[rochilus] emilix Bourcier and Mulsant, Ann. Sci. Phys. et Nat. Lyon, ix, 1846, 317 (Bogotá, Colombia).-[Phaëthornis] emiliæ Bonaparte, Consp. Av., i, 1850, 67.Phæthornis emiliæ Gould, Introd. Troch., oct. ed., 1861, 44; Elliot, Classif. and Synop. Troch., 1879, 13, part; Salvin, Cat. Birds Brit. Mus., xvi, 1892, 368, part.-Toxoteuches emiliae Heine, Journ. für Orn., 1863, 177.-Phaetornis guyi var. emilix Mulsant and Verreaux, Classif. Troch., 1866, 17.-Phaëthornis guyi emiliae Berlepsch, Journ. für Orn., 1887, 314 (Bogotá).-(?) Trochilus apicalis Tschudi, Fauna Peruana, 1845-'46, 243.-(?) [Phaëthornis] apiculis Bonaparte, Consp. Av., i, 1850, 68.-P[haëthornis] guy emilix Hartert, Das Tierreich, Troch., 1900, 19 (monogr.).

b Trochilus anthophilus Bourcier, Rev. Zool., vi, March, 1843, 71 (Upper Magdalena Valley, Colombia; coll. J. Bourcier).-[Phaëthornis] anthophilus Bonaparte, Consp. Av., i, 1850, 68.-Phxthornis anthophilus Gould, Mon. Troch., i, 1854, pl. 24; Elliot, Classif. and Synop. Troch., 1879, 16; Salvin, Cat. Birds Brit. Mus., xvi, 1892, 275. 
$b b$. Chin and upper throat streaked with dusky; lateral rectrices more narrowly edged with whitish (sometimes buffy on outermost ones). (Ihothornis striigularis.)

c. Throat and clrest more grayish; sides and flanks paler; outermost rectrices margined terminally with pale buffy or whitish. (Colombia.)

Phœthornis striigularis striigularis (p. 327).

$c c$. Throat and chest more buffy; sides and flanks darker (nearly cinnamonrufous); outermost rectrices margined terminally with light cinnamonrufous or tawny ochraceous. (Westeru Ecuadór.)

Phœthornis striigularis atrimentalis (extralimital) ${ }^{a}$

\section{PHETHORNIS GUYI CORUSCUS Bangs.}

BANGS' HERMIT.

Similar to P.g. emilix, ${ }^{b}$ of Colombia, but much brighter in coloration, the green of upper parts more bluish, passing into blue (instead of green or bluish green) on upper tail-coverts and base of tail, the fully adult males with under parts mostly metallic bluish green; tail averaging shorter.

Adult male.-Above bright metallic bluish green, duller on pileum, passing into bright metallic blue or violet-blue on upper tail-coverts and basal portion of tail; longer upper tail-coverts with a subterminal bar of blackish and a narrow terminal bar or margin of pale grayish buffy or dull buffy whitish; terminal half (approximately) of tail black, the contracted terminal portion of elongated middle rectrices pale grayish with whitish tips and shafts; remiges purplish dusky, the inner secondaries glossed with bluish green; under parts mostly bright metallic bluish green, this usually somewhat duller along median line and passing into, or inclining to, dull slate color on lower abdomen, the median portion of chin and throat, more or less distinctly, tawny; under tail-coverts metallic greenish blue, or dusky grayish glossed with greenish blue, centrally, broadly margined with grayish white; indistinct femoral tufts grayish white; maxilla black, mandible pale (reddish or yellowish in life?), with terminal portion dusky; iris dark brown; feet brownish (in dried skins); length (skins), 131-153 (143); wing, 59.5-63.5 (61.5); tail, 47-64.5 (42.6); culmen, 41-45 (42.6). ${ }^{c}$

Adult female.-Upper parts as in adult male but upper tail-coverts more broadly tipped or terminally margined with pale grayish buffy, feathers of rump also very narrowly margined terminally with the same, and with narrowed portion of middle pair of rectrices much

a Phæthornis atrimentalis Lawrence, Ann. Lyc. Nat. Hist. N. Y., vi, 1858, 260 (bet. headwaters of Rio Napo and Quito, Ecuadór; coll. G. N. Lawrence).-[Phaethornis] strïg[ularis] atrimentalis Simon, Cat. Troch., 1897, 7.-Phoethornis striigularis atrimentalis Oberholser, Proc. U. S. Nat. Mus., xxiv, no. 1258, Jan. 18, 1902, 313 (Milligalli, w. Ecuador; crit.).

$b$ See p. 316.

c Twenty specimens. 
longer and broader, with rounded instead of acuminate tip; a broad postocular (supra-auricular) streak, long rictal (subauricular) streak, of buff (more or less deep); auricular region dull blackish; median portion of chin and throat (broadly) ochraceous-buff to almost tawny, the lateral portions dusky; rest of under parts (except under tail-coverts) plain mouse gray or slate-gray, the sides usually glossed, more or less, with metallic bluish green; under tail-coverts grayish white, with a central $V$-shaped mark of grayish (sometimes glossed with bluish green or greenish blue); lateral rectrices margined terminally with white, especially on outer web; bill, etc., as in adult male; length (skins), 154-168 (158); wing, 57-62.5 (60); tail, 61-72 (67.7); culmen, 38-42.5 (40.8). ${ }^{a}$

Immature male.-Similar in coloration to the adult female but having the narrowed tip of middle rectrices much smaller, narrower, and (usually) more pointed, as in adult males.

Young male.-Similar to the immature male (as described above) but feathers of rump and lower back, also those of hindneck (sometimes those of whole upper surface) margined terminally with brownish buffy, those of sides of throat and chest also with indistinct buffy or paler tips or margins.

Young female.-Similar in coloration to the young male but middle pair of rectrices with the narrowed terminal portion much longer and broader and more rounded at tip.

Costa Rica (Angostura; Tucurríqui; Turrialba; Coliblanco; Peralta; Carrillo; Volcán de Irazú; Juan Viñas; La Estrella de Cartago; Naranjo de Cartago; Tres Rios; La Hondura; Cariblanco de Sarapiquí; La Vijágua; Peorsnada; Ojuras de Térraba; Dota Mountains; Los Reyes, Santa Maria de Dota; El Generál; Pozo del Rio Grande; Barranca) and Panamá (Boquete; Volcán de Chiriquí; Laguna del Castillo; Calovévora; Cordillera del Chucu; Santa Fé de Verágua); northwestern Colombia (Truando Falls)?

$a$ Fourteen specimens.

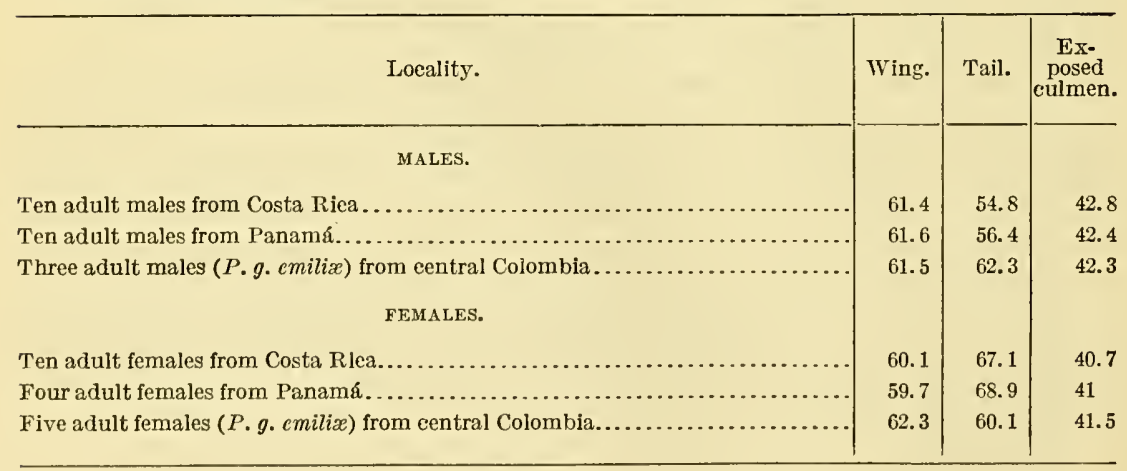


Phaëthornis cmilia (not Trochilus cmilix Bourcier and Mulsant) Salvin, Proc. Zool. Soc. Lond., 1867, 152 (Santa Fé de Verígua, Panamá; crit.); 1870, 205 (Calovévora, Boquete de Chitra, and Cordillera del Chucu, Panamá).Frantzius, Journ. für Orn., 1869, 315 (Costa Rica).—Boucard, Proc. Zool. Soc. Lond., 1878, 67 (Tres Rios and Naranjo de Cartago, Costa Rica).

[Phaëthornis] emilix Sharpe, Hand-list, ii, 1900, 98, part (Costa Rica; Panamá). Phrthornis cmitix Lawrence, Ann. Lyc. N. Y., ix, 1868, 121 (Angostura and Barranca, Costa Rica).-Elliot, Classif. and Synop. Troch., 1879, 13, part (Costa Rica; Verígua).-Ribgway, Proc. U. S. Nat. Mus., iii, 18s0, 309, part (Costa Rica).-Zeledón, Anal. Mus. Nac. Costa Rica, i, 1887, 121 (Costa Rica).

Phaethornis emilix Salvin and EluIot, Ibis, 1873, 13, part (Verágua; Costa Rica; synon.; crit.).-Zeledón, Cat. Aves de Costa Rica, 1882, 19.-Salvin, Cat. Birds Brit. Mus., xvi, 1892, 268, 662, part (Volcán de Irazú and Tucurríque, Costa Rica; Boquete de Chitra, Laguna del Castillo, Calovévora, and Santa Fé de Verágua, Panamá).-Salvin and Godian, Biol. Centr.-Am., Aves., ii, 1892, 317 (San José, Peorsnada, Turrialba, etc., Costa Rica; localities in Panamá; Truando Falls, n. Colombia?).

[Phaethornis] emilix Sclater and Salvin, Nom. Av. Neotr., 1873, 78, part (Verágua; Costa Rica).

Toxateuches emiliae Boucard, The Hum. Bird, ii, 1892, S4, part (Verágua); Gen. Hum. Birds, 1895, 374, part (Costa Rica; Veragua).

P[hä̈thornis] guyi emiliæ HARTERT, Ibis, 1897, 429, part (Costa Rica).

(?)Phaethornis yaruqui (not Trochilus yaruqui Bourcier) CAssis, Proc. Ac. Nat. Sci. Phila., 1860, 194 (Truando Falls, n. Colombia).

Phaëthornis guy coruscus Bangs, Proc. New Engl. Zool. Club, iii, Jan. 30, 1902, 26 (Boquete, Chiriquí, Panamá, 4,500 ft. alt.; coll. E. A. and O. Bangs); Auk, xxiv, 1907, 295 (Pozo del Rio Grande, Costa Rica).-Carriker, Ann. Carnegie Mus., vi, 1910, 519 (Costa Rica; habits).-Ferrx, Pub. 146, Field Mus. N. H., orn. ser., i, no. 6, 1910, 264 (Coliblanco, Costa Rica).

\section{PHETHORNIS LONGIROSTRIS LONGIROSTRIS (Delattre).}

\section{GUATEMALAN HERMIT.}

Adults (sexes alike).-Pileum plain dusky (nearly clove brown) faintly glossed with bronze-green, the hindneck similar but feathers margined terminally with brownish buff or cinnamon; back, scapulars, and lesser wing-coverts rather dull metallic bronze-green, the feathers sometimes indistinctly margined terminally with dull buffy; rump and upper tail-coverts buff or clay color, barred with dusky (glossed faintly with bronze-green), the bars broader (transverse spots) on rump, narrower on upper tail-coverts; basal (mostly concealed) portion of tail dull bronze-greenish, passing subterminally into dull black, the tip pale buff or buffy whitish-the middle pair of rectrices with narrowed and elongated portion mostly white, passing anteriorly into the blackish part through a grayish shading; remiges dusky, faintly glossed with violaceous; a broad postocular streak (extending to above eye) dull white; loral, suborbital, and auricular regions dull black or dusky, bordered below by a rather ill-defined rictal streak of dull whitish; chin and throat with a broad median stripe of pale buff or dull cream-buff, bordered on each side by a 
lateral stripe of darker brownish buff, the feathers of which are dusky beneath the surface; rest of under parts pale dull grayish buffy, paler (sometimes dull whitish) on abdomen, the under tail-coverts with a few indistinct $V$-shaped marks of grayish; maxilla black, mandible pale yellowish or buffy (yellow in life?), with terminal third (more or less) dusky; iris dark brown; feet pale brownish (in dried skins).

Young.--Similar to adults, but feathers of back broadly margined terminally with brownish buff, those of the pileum usually marked in same manner, but more narrowly.

Adult male.-Length (skins), 144-158 (150.5); wing, 59-64.5 (62); tail, 64-68 (66.5); culmen, 39-44 (40.7). ${ }^{a}$

Adult female.-Length (skins), 142-156 (149); wing, 60; tail, 63.5-67 (65.2); culmen, 37.5-40 (38.7). ${ }^{b}$

Guatemala (Choctúm, Cobán, and Las Salinas, Vera Paz; Los Amates, Yzabál; track to Petén; Guatemala City), British Honduras (Cayo; San Felipe; Toledo District; forest near Manatee Lagoon; forest on Soldiers Creek), and northern Honduras (Céiba).

Ornismya longirostris Delattre, Echo du Monde Savant, June 15, 1843, no. 45, col. 1070 (Guatemala).

Phaëthornis longirostris Gould, Introd. Troch., oct. ed., 1861, 42, part ("Central America").-Sclater, Cat. Am. Birds, 1862, 285, part (Las Salinas, Vera Paz, Guatemala).

Phæthornis longirostris ElLiot, Classif. and Synop. Troch., 1879, 15, part.-DeARвоRл, Pub. 125, Field Mus. N. H., 1907, 96 (Los Amates, e. Guatemala).

P[haëthornis] longirostris Cabanis and Hetne, Mus. Hein., iii, 1860, 9 (Guatemala).--Hartert, Ibis, 1897, 425, 429, part (crit.); Das Tierreich, Troch., 1900,20 , part (Guatemala).

[Phaëthornis] longirostris SHARPe, Hand-list, ii, 1892, 99, part.

\begin{tabular}{|c|c|c|c|}
\hline$a$ Four specimens. & len. & & \\
\hline Locality. & Wing. & Tall. & $\begin{array}{c}\text { Ex- } \\
\text { posed } \\
\text { culmen. }\end{array}$ \\
\hline \multicolumn{4}{|l|}{ MALES. } \\
\hline Four adult males of $P . l$. mexicanus from $\mathrm{s}$. w. Mexico.. & 68.1 & 84.6 & 46.1 \\
\hline Six adult males of $P . l$. veræcrucis from s. e. Mexico... & 62.9 & 67.9 & 40.3 \\
\hline One adult male of $P . l$. longirostris from Guatemala.... & 59 & 64 & 40.5 \\
\hline Two adult males of $P . l$. longirostris from British Honduras... & 62.2 & 67 & 39.2 \\
\hline One adult male of $P . l$. longirostris from n. Honduras (Céiba)....... & 64.5 & 68 & 44 \\
\hline Three adult males of $P . l$. cephalus from s. Honduras (Santa Ana)... & 64.6 & 68 & 42.9 \\
\hline Two adult males of $P . l$. ccphalus from Nicaragua................... & 61.2 & 68 & 38.5 \\
\hline Sixteen aduit males of $P . l$. cephalus from Costa Rica.......... & 61.9 & 67.2 & 38.5 \\
\hline Nine adult males of $P . l$. cephalus from Panamá.............. & 61.1 & 66 & 38.9 \\
\hline Eight adult males of $P . l$. susurrus from Colombia (Santa Marta district). & 64.7 & 72.2 & 42.2 \\
\hline \multicolumn{4}{|l|}{ FEMALES. } \\
\hline One adult female of $P . l$. longirostris from Guatemala... & 60 & 67 & 37.5 \\
\hline One adult female of $P . l$. longirostris from British Honduras... & 60 & 63.5 & 40 \\
\hline Ten adult females of $P . l$. cephalus from Costa Rica............ & 60.5 & 66.6 & 38.5 \\
\hline 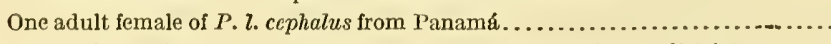 & 57.5 & 63.5 & 37.5 \\
\hline One adult female of $P . l$. susurrus from Colombla (Santa Marta district). . .. & 63 & 70 & 41 \\
\hline
\end{tabular}


Phaethornis longirostris SALvin and Eluot, Ibis, 1873, 5, part (Choetúm, Guatemalar; crit.).-Boucarn, Liste Ois. récol. Guat., 1878, 44.-Salvin, Cat. Birds Brit. Mus., xvi, 1892, 273, 663, part (Choctún, Guatemaka; San Felipe, Brit. Honduras).-Salvin and Godman, Biol. Centr.-Am., Aves, ii, 1892, 318, part (San Felipe, British Honduras; Yzabál, Choctúm, and track to Petén, Guatemala).

[Phathornis] longirostris Sclaten and Salvin, Nom. Av. Neotr., 1873, 78, part.

Phathornus longirostris LAntz, Trans. Kansals Ac. Sci. for 1896-97 (1899), 221 (Cayo, British Honduras).

Phocthornis longirostris longirostris OBerholser, Proc. U. S. Nat. Mus., xxiv, no. 125s, Jan., 1902, 312, in text, 313, part.

Phathornis longirostris longirostris Bangs, Bull. Mus. Comp. Zool., xxxix, July, 1903, 144 (Céiba, n. Honduras).

Phathornis cephalus (not Trochilus cephalus Bourcier and Mulsant) Sclater and Salvin, Ibis, 1859, 126 (Guatemala).-Salvin, Ibis, 1866, 204 (Guatemala).

[Phä̈tornis] cephale Boucard, Notes quelques Troch., 1873, 1, part (Cobán, Guatemala; habits).

Phac̈thornis cephalus Gould, Mon. Troch., pt. xvi, 1858 (vol. i, 1861), pl. 19, part (Guatemala).

Phaetornis cephalus Mulsant and Verreaux, Hist. Nat. Ois.-Mouch., i, livr. 1, 1873, 64, part (Guatemala).

\section{PHETHORNIS LONGIROSTRIS CEPHALUS (Bourcier and Mulsant).}

\section{NICARAGUAN HERMIT.}

Similar in coloration to $P$. . longirostris but coloration darker, the under parts usually distinctly, though faintly, barred with brownish gray.

Aault male.--Length (skins), 127-165 (159); wing, 58-66.5 (61.9); tail, 61-75 (67); culmen, 36.5-44 (39.8). ${ }^{a}$

Adult female.-Length (skins), 136-154 (147); wing, 57.5-62.5 (60.2); tail, 63.5-70 (66.3); culmen, 37-41.5 (38.5). ${ }^{b}$

Honduras (Santa Ana), Nicaragua (Rio San Juan; Chontales; Rio Escondido; San Emilis, Lake Nicaragua), Costa Rica (San José; Naranjo de Cartago; La Balsa; Palmár; Jiménez; El Hogár; Guápiles; Rio Sícsola; Cuábre; La Vijágua; Tenório; Volcán de Miravalles; Boruca; Pozo del Pitál; Pozo Azúl de Pirrís; Pozo del
a Thirty specimens.
$b$ Eleven specimens.

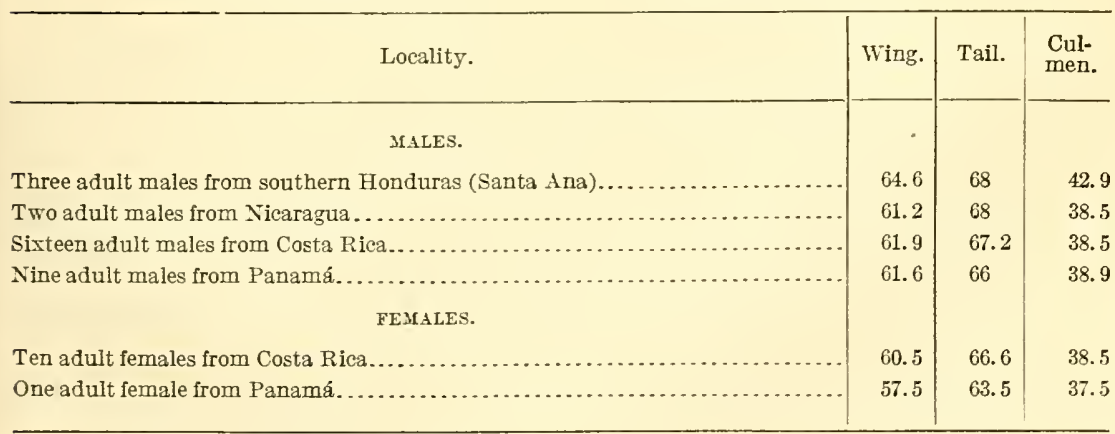


Rio Grande; El Pozo de Térraba; Buenos Aires; Laguária; Santa Maria de Dota), Panamá (Loma del León; Panamá; Obispo; Chepo; Agua Dulce; Bugaba; Divala), and northwestern Colombia (Turbo).

Trochilus cephalus Bourcier and Mulsant, Rev. Zool., 1848, 269 (Rio San Juan, Nicaragua; coll. J. Gould).

[Ptyonornis] cephalus ReICHENBaCH, Aufz. der Colibr., 1854, 14.

[Ptyonornis] cephala ReICHENBACH, Troch. Enum., 1855, 12.

Phä̈tornis cephalus Bonaparte, Rev. et Mag. de Zool., 1854, 249.

Phaetornis cephalus Mulsant and Verreaux, Hist. Nat. Ois.-Mouch., i, livr. 1, 1873, 64, part (Nicaragua; Panamá); iv, livr. 2, 1877, 140.

[Phaetornis] cephalus Mulsant, Ann. Soc. Linn. Lyon, xxii, 1876, 200.

Phaëthornis cephalus Gould, Mon. Troch., i, pt. xvi, 1858; vol. i, 1861, text to pl. 19, part (Rio San Juan, Nicaragua; Veragua; crit.).

Pha ëthornis longirostris (not Ornismya longirostris Delattre) Gould, Mon. Troch., Introd., p. xl, part ("Central America”); Introd. Troch., oct. ed., 1861, 42, part ("Central America").-Sclater and Salvin, Proc. Zool. Soc. Lond., 1864, 364 (Panamá).-Frantzius, Journ. für Orn., 1869, 315 (Costa Rica).Salvin, Proc. Zool. Soc. Lond., 1870, 205 (Bugaba, Panamá).-Boucard, Proc. Zool. Soc. Lond., 1878, 67 (Naranjo de Cartago, Costa Rica; habits).Richmond, Proc. U. S. Nat. Mus., xvi, 1893, 516 (Rio Escondido, Nicaragua; habits).-Underwood, Ibis, 1896, 442 (Volcán de Miravalles, Costa Rica).Bangs, Proc. New Engl. Zool. Club, ii, 1900, 19 (Loma del León, Panamá).

P[haëthornis] longirostris HARTERT, Ibis, 1897, 425, 429, part (crit.); Das Tierreich, Troch., 1900, 20, part.

[Phaëthornis] longirostris SHARPE, Hand-list, ii, 1900, 99, part.

Phæthornis longirostris Lawrence, Ann. Lyc. N. Y., vii, 1862, 319 (Lion Hill, Panama); ix, 1868, 128 ("Valza," i. e. La Balsa, Costa Rica).-Eulıot, Classif. and Synop. Troch., 1879, 15, part.-Zeledón, Cat. Aves de Costa Rica, 1882, 19; Anal. Mus. Nac. Costa Rica, i, 1887, 121 (Jiménez, Costa Rica).-BouCARD, The Hum. Bird, ii, 1892, 83 (Panamá).

Phaethornis longirostris SAlvin, Ibis, 1872, 319 (Chontales; Nicaragua); Cat. Birds Brit. Mus., xvi, 1892, 273, 663, part (Nicaraguan, Costa Rican, and Panaman localities).-Salvin and Elliot, Ibis, 1873, 5, part (Chontales, Nicaragua; Costa Rica; Bugaba and Lion Hill, Panamá; synon.; crit.).Salvin and Godman, Biol. Centr.-Am., Aves, ii, 1892, 318, part (Santa Ana, s. Honduras; Rio San Juan and Chontales, Nicaragua; La Balsa, Jiménez, San José, and Naranjo de Cartago, Costa Rica; Bugaba, Lion Hill, Obispo, and Chepo, Panamá; Turbo, n. Colombia).-Cherrie, Expl. Zool, Merid. Costa Rica, 1893, 45 (Palmár, Boruca, and Buenos Aires, Costa Rica).Boucard, Gen. Hum. Birds, 1895, 377, part (Costa Rica).-Bangs, Auk, xviii, 1901, 359 (Divala, Panamá; crit.).

[Phaethornis] longirostris Sclater and Salvin, Nom. Av. Neotr., 1873, 78, part.

Phaetornis longirostris Cherrie, Anal. Inst. Fisico-Geog. Costa Rica, vi, 1893, 19 (Pozo del Pitál, s. w. Costa Rica).

Phoethornis longirostris longirostris Oberholser, Proc. U. S. Nat. Mus., xxiv, 1902, 312 in text, 313, part.

Phaëthornis longirostris longirostris Bangs, Auk, xxiv, 1907, 295 (Boruca and Pozo del Rio Grande, Costa Rica).-Carriker, Ann. Carnegie Mus., vi, 1910, 520 (Costa Rica; habits; descr. nest and eggs).

Phæthornis panamensis Boucaro, The Humming Bird, ii, no. 9, Sept., 1892, 83 (Panamá City and Agua Dulce, Verágua, Panamá; coll. A. Boucard).

Phaethornis panamensis Boucard, Gen, Hum. Birds, 1895, 377 (Panamá; Agua Dulce). 


\section{PHETHORNIS LONGIROSTRIS VERÆCRUCIS Ridgway.}

VERA CRUZ HERMIT.

Similar to P. l. longirostris but tips of lateral rectrices pure white, or merely tinged with buff on imer wob.

Adult male.-Length (skins), 150-15S (154); wing, 60-65.5 (62.9); tail, $65-70$ (67.9); culmen, 39-42.5 (40.3). ${ }^{a}$

Southeastern Mexico, in States of Vera Cruz (Córdova; San Andrés Túxtla; Santecomapám; Buena Vista; Motzorongo) ; Oaxaca (Chimalapa), and Tabasco (Teapa).

Phaethornis longirostris (not Ornismya longirostris Delattre) Sclater, Proc. Zool. Soc. Lond., 1857, 227 (San Andrés Túxtla, Vera Cruz).-Salvin and Elliot, Ibis, 1873, 5, part (Mexico; synon.; crit.).-Salvin, Cat. Birds Brit. Mus., xvi, 1892, 273, 663, part (Chimalapa, Oaxaca).-Salvin and Godman, Biol. Centr.-Am., Aves, ii, 1892, 318, part (Córdova and San Andrés Túxtla, Vera Cruz; Chimalapa, Oaxaca).-Boucard, Gen. Hum. Birds, 1895, 377, part (Mexico).

[Phaethornis] longirostris Sclater and Salvin, Nom. Av. Neotr., 1873, 78, part. Phæthornis longirostris Elliot, Classif. and Synop. Troch., 1879, 15, part (Mexico). Phaëthornis cephalus (not Trochilus cephalus Bourcier and Mulsant) Gould, Mon. Troch., pt. xvi, 1858, text to pl. 19, part (Mexico).

Phaetornis cephalus Mulsant and Verreaux, Hist. Nat. Ois.-Mouch., i, livr. 1, 1873, 64, part (Mexico).

Phaëtornis cephalus D'OcA, Troq. de Mex., 1875, 48, pl. (10), fig. 37.

[Phaetornis] cephale Boucard, Notes quelques 'Troch., 1873, 1 (Santecomapám, Vera Cruz; habits).

Phæthornis longirostris veræcrucis Ridgway, Proc. Biol. Soc. Wash., xxiii, April 19, 1910, 54 (Buena Vista, Vera Cruz, e. Mexico; coll. U. S. Nat. Mus.).

\section{PHETHORNIS LONGIROSTRIS MEXICANUS (Hartert).}

GUERRERO HERMIT.

Similar to $P . l$. veræcrucis in white margins to rectrices but coloration of under parts much darker, superciliary stripe and anterior portion of rictal stripe ochraceous-buff instead of cream-buff, and size decidedly larger.

Adult male.-Length (skins), 182-187 (185); wing, 67-69.5 (68.1); tail, 83-87 (84.6); culmen, 45.5-47 (46.1). ${ }^{b}$

Southwestern Mexico, in States of Guerrero (Dos Arroyos; Chilpancingo; Acahuitzotla; Papayo) and western Oaxaca (Pluma).

Phaethornis longirostris (not Ornismya longirostris Delattre) HARTERT (E. and C.), Novit. Zool., i, 1894, 21 (Dos Arroyos, near Chilpancingo, Guerrero; crit.).

Phä̈thornis mexicanus Hartert, Ibis, iii, ser. 7, July, 1897, 425 (Dos Arroyos, near Chilpancingo, Guerrero, s. w. Mexico; coll. Tring Mus.).

P[haëthornis] mexicanus HARTERT, Ibis, 1897, 429; Das Tierreich, Troch., 1900, 21 (monogr.).

[Phä̈thornis] mexicanus Sharpe, Hand-list, ii, 1900, 99. 
Phoethornis longirostris mexicanus Oberholser, Proc. U. S. Nat. Mus., xxiv, no. 1258, Jan., 1902, 312 in text, 313 (s. Mexico).

$P$ [hoethornis] l[ongirostris] mexicanus Ridgway, Proc. Biol. Soc. Wash., xxiii, 1910,54 , in text.

\section{PHCETHORNIS ANTHOPHILUS HYALINUS (Bangs).}

ISLAND HERMIT.

Similar to $P$. a. anthophitus but green of upper parts deeper and less bronzy, and feathers of rump and upper tail-coverts less broadly margined with brownish buffy; averaging slightly larger (except tail.)

Adults (sexes alike).-Pileum plain dusky (nearly clove brown); hindneck, back, scapulars, rump, and upper tail-coverts metallic green (nearest bice green), slightly tinged with bronze, the feathers very narrowly and indistinctly margined terminally with pale brownish buffy, except on upper tail-coverts, where these markings are broader and more distinct; tail metallic bluish green (French green), crossed subterminally by a broad band of black, the middle pair of rectrices with narrowed and elongated portion white apically, dull grayish basally, the other rectrices with median portion of tip dull gray and lateral portions white; remiges dusky, faintly glossed with violaceous; a broad postocular or supra-auricular elongated spot of dull brownish white; loral, orbital, and auricular regions black; rictal and malar regions dull white or buffy white; chin and throat buffy grayish, indistinctly streaked with pale buffy or buffy whitish; rest of under parts dull brownish white, deeper and suffused with brownish buff on sides, the flanks distinctly buffy; maxilla black, mandible pale dull yellowish or buffy (in dried skins); iris dark brown; feet light brownish (in dried skins), the claws dusky.

Adult male.-Length (skins), 135-139 (138.5); wing, 58.5-61.5 (59.2); tail, 55-58.5 (56.5); culmen, 35-36.5 (35.7). ${ }^{a}$

Adult female.-Length (skins), 138; wing, 55.5-58.5 (57); tail, 58.5; culmen, $33-34.5(33.7) .^{b}$

San Miguél Island, Bay of Panamá.

Phaëthornis hyalinus Bangs, Auk, xviii, Jan., 1901, 27 (San Miguél Island, Bay of Panamá; coll. E. A. and O. Bangs).-Thayer and Bangs, Bull. Mus. Comp. Zool., xlvi, 1905, 149 (San Miguél I.).

\section{PHETHORNIS ADOLPHI ADOLPHI Gould.}

BOUCARD'S HERMIT.

Adult male.-Above rather dull metallic bronze or greenish bronze, darker and duller on pileum; lower rump and upper tail-coverts

$a$ Four specimens.

b Two specimens.

Specimens of $P$. a. anthophilus measure as follows: Four adult males, length (skins), 128-153 (136); wing, 54.5-61 (57.7); tail, 56-59.5 (58); culmen, 30.5-36 (34.5); one adult female, length (skin), 132; wing, 54; tail, 56; culmen, 33. 
plain chestnut; tail metallic bronze or greenish bronze, the rectrices broadly tipped with pale chestnut or cinnamon-rufous, paler on middle pair, which are sometimes nearly white terminally; remiges dusky, faintly glossed with violaceous; suborbital and auricular regions dusky, margined above by an indistinct supra-auricular streak of cinnamon and below (anteriorly) by a more distinct rictal streak of the same; chin, throat, and chest light dull grayish cinnamon or isabella color, passing on other lower parts into pale cinnamon-rufous; bill dull black, the basal half (more or less) of mandible dull yellowish (yellow in life); iris dark brown; feet dull yellowish (flesh colored or whitish in life); length (skins), 91-98 (95); wing, 38.5-42 (39.5); tail, 33-37.5 (35.4); culmen, 21-22.5 (21.7). ${ }^{a}$

Adult female.-Similar to the adult male but chin, throat, and chest pale cinnamon-rufous or pale cinnamon, sometimes quite concolor with posterior under parts; length (skins), 92-99 (94); wing, 37 ; tail, 33-35 (34); culmen, 21-22 (21.5). ${ }^{b}$

Southeastern Mexico, in States of Vera Cruz (Córdova; Tospám, near Córdova; Playa Vicente; Jalapa; San Andrés Túxtla; Buena Vista; Pasa Nueva), Oaxaca (Teotalcingo), Tabasco (Frontera), and Chiapas (Palenque).

Phaethornis adolphi Sclater, Proc. Zool. Soc. Lond., 1856, 287 (nomen nudum; Córdova, Vera Cruz).

Phaëthornis adolphi Gould, Mon. Troch., pt. xiv, Sept., 1857 (vol.i, 1861), pl. 35 and text, part (Córdova, Vera Cruz; coll. J. Gould; ex Bourcier, manuscript).-Sclater, Proc. Zool. Soc. Lond., 1859, 367 (Jalapa, Vera Cruz), 385 (Teotalcingo, Oaxaca; Playa Vicente, Vera Cruz).-D'Oca, Troq. de Mex., 1875, 24, pl. (4), fig. 15.

[Phaëthornis] adolphi Gray, Hand-list, i, 1869, 122, no. 1532, part.-SharPe, Hand-list, ii, 1900, 100, part.

P[haëthornis] adolphi Hartert, Ibis, 1897, 430, part (s. e. Mexico); Das Tierreich, Troch., 1900, 25, part.

P[hothornis] a[dolphi] adolphi Ridgway, Proc. Biol. Soc. Wash., xxiii, April 19, 1910, 54, in text.

P[ygmornis] adolphi Cabanis and Heine, Mus. Hein., iii, 1860, 7, footnote, part (Mexico).

Pygmornis adolphi Salvin and Elliot, Ibis, 1873, 271, part (Mexico).-Bodcard, Notes quelques Troch., 1873, 2, part (Córdova and San Andrés Túxtla, Vera Cruz).-Mursant and Verreaux, Hist. Nat. Ois.-Mouch., i, livr. 2, 1873, 102, pl. 9; iv, livr. 2, 1877, 144; Ann. Soc. Linn. Lyon, xxii, 1876, 201.-Salvin, Cat. Birds Brit. Mus., xvi, 1892, 282, part (Córdova; Playa Vicente; Teapa).-Salvin and Godman, Biol. Centr.-Am., Aves, ii, 1892, 319, part (Córdova; Jalapa; Playa Vicente; Teotalcingo; Teapa).

[Pygmornis] adolphi Sclater and Salvin, Nom. Av. Neotr., 1873, 79, part.

Pygornis adolphi Mulsant and Verreaux, Classif. Troch., 1866, 19, part.

Eremita adolphi BoucARD, Gen. Hum. Birds, 1895, 392, part ('Tospám, near Córdova). 


\section{PHETHORNIS ADOLPHI SATURATUS Ridgway.}

\section{DUSKY HERMIT.}

Similar to P. a. adolphi, but coloration of adult decidedly darker, especially the under parts, the chin and upper throat decidedly dusky.

Adult male.-Length (skins), 86-97 (89); wing, 36-40 (38.3); tail, 31-37 (34.4); culmen, 20.5-23.5 (21.8). ${ }^{a}$

Adult female.-Length (skins), 78-96 (89); wing, 36-39 (37.9); tail, 32-37 (34.5); culmen, 20-23 (21.5). ${ }^{a}$

Central America, from Guatemala ${ }^{a}$ (Cobán; Kamkál, near Cobán; Yzabál; Guatemala City; Lanquín, Vera Paz; Puerto Bárrios; Secanquín) and British Honduras (forest near Manatee Lagoon) through Honduras (Rio Segóvia), Nicaragua (Chontales; Rio Escondido; San Emilis, Lake Nicaragua) and Costa Rica (Angostura; Jiménez; Carrillo; Turrialba; El Hogár; Guápiles; Rio Sícsola; Talamanca; La Vijágua; Tenório; San Carlos; Bolsón; Azahár de Cartago; Lagarto; Boruca; Buenos Aires; Pozo Azúl de Pirrís; Pozo del Pitál; Paso Reál, Boruca) to Panamá (Colón;

$a$ Seventeen specimens.

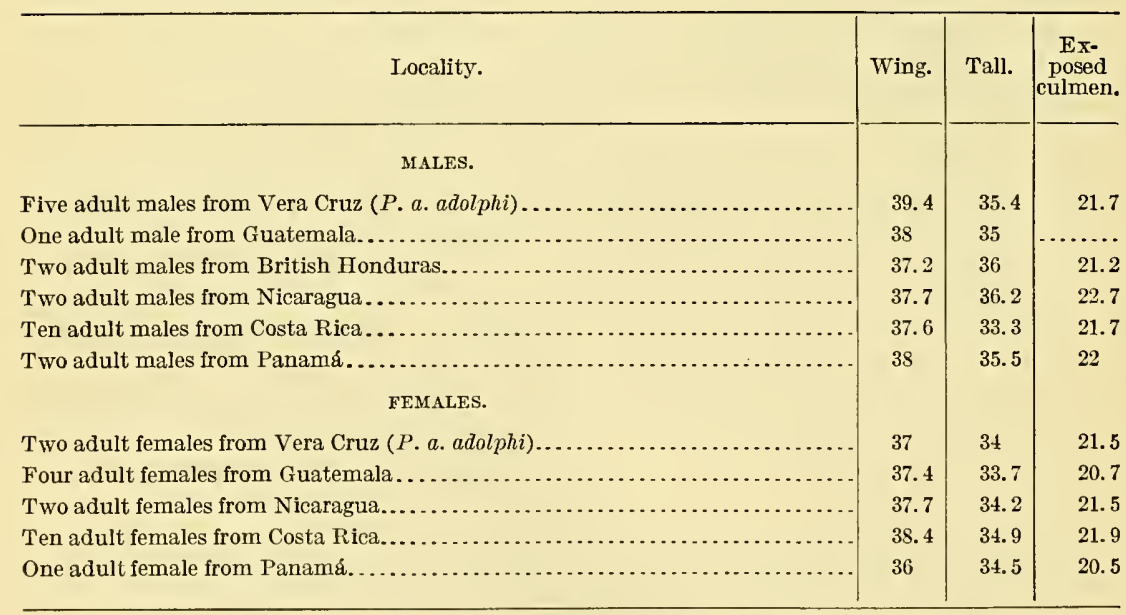

The series examined indicates that at least specimens from southern Honduras, Nicaragua, and Costa Rica require subspecific separation, $P$. adolphi proper being restricted to the birds from southeastern Mexico. Examples from Guatemala and British Honduras are intermediate, but with the small number of specimens available for comparison I am unable to decide whether they are nearer the typical or the southern form. Costa Rican and other southern birds are darker than those from southeastern Mexico, especially the adult males, which have the throat much darker and the chest much duller in color. 
Paraiso and Obispo stations; Panamá; Lion IHill; El Chiquito; Santiago de Verágua).

Phaethornis adolphi (not of Gould) Sclater and Salvin, Ibis, 1859, 126 (Yzabál, Guatemula; habits).—SALvin and ScLATER, Ibis, 1860, 38 (Yzabál; habits).Carriker, Ann. Camegie Mus., vi, 1910, 520 (Costa Rica; habits).

Phä̈thornis adolphi Salvin, Ibis, 1860, 195, 260 (Cobán and Yzabál; habits); 1872, 319 (Chontales, Nicaragua); Proc. Zool. Soc. Lond., 1867, 152 (Santiago de Verígua, Panamá).-Sclater, Cat. Am. Birds, 1862, 286 (Coban).-Sclater and Salvin, Proc. Zool. Soc. Lond., 1864, 365 (Panamá).-Bangs, Auk, xxiv, 1907, 295 (Boruca, Costa Rica).

Phæthornis adolphi Lawrence, Ann. Lyc. N. Y., vii, 1862, 291 (Lion Hill, Panama); ix, 1868, 121 (Angostura, Costa Rica).-Elliot, Classif. and Synop. Troch., 1879, 18, part (Central America; Panamá).-Zenedón, Cat. Aves de Costa Rica, 1882, 19.-Ridgway, Proc. U. S. Nat. Mus., x, 1887, 591 (Rio Segóvia, Honduras).-Dearborn, Pub. 125, Field Mus. N. H., 1907, 96 (Puerto Bárrios, e. Guatemala).

Phaetornis adolphi Cherrie, Anal. Inst. Fis.-Geog. Costa Rica, vi, 1893, 19 (Pozo del Pitál, s. w. Costa Rica).

P[haëthornis] adolphi HarterT, Ibis, 1897, 430, part (Central America); Das Tierreich, Troch., 1900, 25, part.

[Phaëthornis] adolphi SHARpe, Hancl-list, ii, 1900, 100, part.

P[ygmornis] adolphi Cabanis and Heine, Mus. Hein., iii, 1860, 7, footnote, part (Central America).

Pygmornis adolphi Gould, Introd. Troch., oct. ed., 1861, 47 (Central America).Lawrence, Ann. Lyc. N. Y., ix, 1868, 121 (Angostura, Costa Rica).-Frantzius, Journ. für Orn., 1869, 315 (Costa Rica).-SALvin and Elliot, Ibis, 1873, 271, part (Cobán, Guatemala; Costa Rica; Panamá; crit.).-MulsAnt and Verreaux, Hist. Nat. Ois.-Mouch., i, livr. 2, 1873, 102, part; iv, livr. 2, 1877, 144, part; Ann. Soc. Linn. Lyon, xxii, 1876, 201, part.-Boucard, Notes quelques Troch., 1873, 2, part (Cobán; habits); Ois. récol. Guat., 1878, 44; Proc. Zool. Soc. Lond., 1878, 67 (San Carlos, Costa Rica; habits; song).Salvin, Cat. Birds Brit. Mus., xvi, 1892, 282, part (Cobán; Kamkál, near Cobán; Chontales, Nicaragua; Costa Rica; Santiago de Verágua, Paraiso, and Lion Hill, Panamá), 663 (La Libertád, Chontales, Nicaragua).-Salvin and Godman, Biol. Centr.-Am., Aves, ii, 1892, 319, part (Central American and Panaman localities and references).-Richmond, Proc. U. S. Nat. Mus., xvi, 1893, 516 (Rio Escondido, Nicaragua).-Cherrie, Expl. Zool. Merid. Costa Rica, 1893, 45 (Lagarto, Boruca, and Buenos Aires, s. w. Costa Rica).Underwood, Ibis, 1896, 442 (Miravalles, Costa Rica).

[Pygmornis] adolphi Sclater and Salvin, Nom. Av. Neotr., 1873, 79, part. Pygornis adolphi Mulsant and Verreaux, Classif. Troch., 1866, 19, part.

Eremita adolphi Boucard, The Hum. Bird, ii, 1892, 84 (Verágua; Panamá); Gen. Hum. Birds, 1895, 392, part (Guatemala; Costa Rica).

Phothornis adolphi saturatus Ridgway, Proc. Biol. Soc. Wash., xxiii, April 19, 1910, 54 (El Hogár, e. Costa Rica; coll. E. A. and O. Bangs).

\section{PHETHORNIS STRIIGULARIS STRIIGULARIS Gould.}

\section{STRIPE-THROATED HERMIT.}

Adults (sexes alike).-Above dull metallic bronze-green or greenish bronze, passing into dull blackish brown or dusky on pileum, and into dull chestnut or rusty on rump and upper tail-coverts; rectrices dull metallic bronze-green or bronze, margined terminally with dull 
white (more buffy on outer rectrices), the middle pair more broadly tipped with white and brownish gray subterminally; remiges dusky, faintly glossed with violaceous; a supra-auricular stripe of pale brownish buff, extending to immediately above eye, where narrower and more rufescent; loral, suborbital, and auricular regions plain blackish brown or dusky; an ill-defined malar stripe of pale brownish buff; chin, throat, and chest pale brownish gray, more or less tinged with buffy, the chin and upper throat indistinctly streaked with dusky; rest of under parts cinnamon-buffy, deepening la terally into cinnamonrufous; bill dull black, the basal half (approximately) of mandible whitish (pink or reddish in life?); iris dark brown; feet dull yellowish or buffy (in dried skins).

Adult male.-Length (skins), 100-102 (101); wing, 37-37.5 (37.2); tail, 35-36 (35.5); culmen, 23-23.5 (23.2). ${ }^{a}$

Adult female.-Length (skin), 101; wing, 39; tail, 35.5; culmen, $21.5 .^{b}$

Northern and central Colombia (Turbo; La Concepción, Santa Marta; Bogotá); Venezuela (San Esteban).

Phaëthornis striigularis Gould, Mon. Troch., pt. viii, Oct., 1854 (vol. i, 1861), pl. 37 (Bogotá, Colombia; coll. J. Gould).-Sclater, Proc. Zool. Soc. Lond., 1855, 139 (Bogotá, Colombia); Cat. Am. Birds, 1862, 286 (Bogotá, Colombia).-Berlepsch, Journ. für Orn., 1887, 316 (Bogotá, Colombia; synonymy); Proc. U. S. Nat. Mus., xi, 1888, 560 (Turbo, n. Colombia).Srmon, Mém. Soc. Zool. France, ii, 1889, 219 (San Esteban, Venezuela; crit.).

[Phaëthornis] striigularis GRAY, Hand-list, i, 1869, 122, no. 1534.-ShaRPE, Hand-list, ii, 1900, 100, part (Colombia).

P[haëthornis] striigularis Hartert, Ibis, 1897, 430 (Colombia to Peru).

Phæthornis striigularis ELLiot, Classif. and Synop. Troch., 1879, 19, part (Colombia).--Simon and Dalmas, Ornis, xi, 1901, 218 (Naranjo, w. Colombia).

P[ygmornis] striigularis Cabanis and Heine, Mus. Hein., iii, 1860, 7 (Colombia). Pygmornis striigularis Gould, Introd. Troch., oct. ed., 1861, 48.-SALvin and EцLiot, Ibis, 1873, 273, part (Bogotá, Colombia; Rio Napo, e. Ecuador; crit.).-Mulsant and Verreaux, Hist. Nat. Ois.-Mouch., i, livr. ii, 1874, 96; iv, livr. ii, 1877, 144; Ann. Soc. Linn. Lyon, xxii, 1876, 201.-SALvin, Cat. Birds Brit. Mus., xvi, 1892, 281, part (Bogotá, Colombia).-SALvin and Godman, Biol. Centr.-Am., Aves, ii, 1892, 321, part (Turbo, Colombia).Bangs, Proc. Biol. Soc. Wash., xiii, 1899, 93 (La Concepción, Santa Marta, Colombia, 3,000 ft.).

[Pygmornis] striigularis Sclater and Salvin, Nom. Av. Neotr., 1873, 79.

Eremita striigularis, Boucard, The Hum. Bird, ii, 1892, 84 (Bogotá); v, 1895, 7 (Rio Dagua, n. w. Colombia); Gen. Hum. Birds, 1895, 391.

Phaethornis sp.? CAssin, Proc. Ac. Nat. Sci. Phila., 1860, 194 (Turbo, Colombia). Pygmornis amaura Bourcier, Rev. et Mag. de Zool., 1856, 552.

Phaëthornis amaura Gould, Mon. Troch., i, pt. xvii, 1859, pl. 32 (vol. i, 1861). P[ygmornis] amaura CabanIs and HeINe, Mus. Hein., iii, 1860, 7.

Pygmornis amaura Gould, Introd. Troch., oct. ed., 1861, 46.-Herne, Journ. für Orn., 1863, 176. 
Phathornis adolphi (not of Gould) Rngwar, Proc. U. S. Nat. Mus., iii, 1880, 309, part ('Turbo, 11. Colombia; see Berlepsch, Proc. U. S. Nat. Mus., xi, $1 S S S, 560)$.

\section{Genus GLAUCIS Boie.}

Glaucis BoIe, Isis, 1831, 545. (Type, Trochilus hirsutus Gmelin.)

Medium-sized Trochilide (length about 100-110 mm.) very similar to Threnetes but differing in more strongly decurved, much less depressed (narrower), and relatively longer bill, wholly nude nasal operculum, unicolored under parts, and basal half of rectrices chestnut or rufous instead of white or buff.

Bill rather slender, compressed, scarcely if at all broader than deep basally, distinctly to rather strongly decurved, about twice as long as head, the eulmen rounded except for mesorhinal portion, where narrowly ridged; tomia smooth; maxilla and mandible with narrow median grooves. Nostril narrow, slit-like, overhung by a broad, tumid, operculum, feathered only on extreme upper basal portion. Tarsus mostly naked (feathered on upper portion in front), longer than middle toe without claw, the latter slightly longer than both lateral toes; hallux shorter than lateral toes, relatively weak. Wing less than twice as long as exposed culmen, the outermost primary longest. Tail equal to (sometimes longer than) exposed culmen, strongly rounded or nearly graduated, the rectrices narrowly rounded terminally.

Coloration.-Above metallic bronze or bronze-green, the pileum dull dusky; rectrices (except middle pair) with basal half rufous or chestnut, then black tipped with whitish; under parts plain grayish brown to cinnamon-rufous. Sexes essentially alike.

Range.-Costa Rica to Guiana, Grenada (Lesser Antilles), Brazil, and Ecuadór. (Several species. ${ }^{a}$ )

a Owing to insufficiency of material I am not able to express an opinon as to the exact number of species which should be recognized; but careful examination of a considerable series (71 specimens) shows that $G$. hirsula is by no means uniform in characters throughout its range, and that three well-marked forms occur within the geographic limits of this work; namely, (1) a very small form (perhaps specifically distinct), in which (alone) the sexes are apparently always alike in coloration of the under parts and the color of the upper parts always decidedly bronzy, confined to Nicaragua and Costa Rica; (2) a larger form with the adult male always much duller in color of the under parts than the adult female and the upper parts less bronzy, found in Panamá and adjacent parts of South America; and (3) a very large form, essentially like the last in coloration, but more closely resembling (and here not separated from) the smaller true $G$. hirsuta of the adjacent mainland, peculiar to the islands of Trinidád, Tobago, and Grenada.

A very much larger series of specimens from various parts of South America is required for the proper working out of the geographic variations in this species, and the arrangement here given is to be considered as tentative only. 
KEY TO THE SUBSPECIES OF GLAUCIS HIRSUTA.

a. Larger (wing averaging more than 56, tail more than 34 , culmen more than 31 $\mathrm{mm}$.; upper parts bronze-green or decidedly greenish bronze; sexes different, the adult females rufescent beneath, adult males dull russet brownish.

b. Larger (adult male averaging: Wing 65.1, tail 41.2, culmen 33.3; adult female, wing 61.8 , tail 39.5, culmen 33.1); color of under parts slightly browner. (Eastern South America, including islands of Grenada, Tobago, and Trinidád.)

Glaucis hirsuta hirsuta (p. 330).

bb. Smaller (adult male averaging: Wing 58.6, tail 36.3, culmen 31.3 ; adult female, wing 56.5, tail 34.9 , culmen 31.9 ); color of under parts slightly more rufescent. (Panamá to the Rio Negro and eastern Peru.)

Glaucis hirsuta affinis (p. 333). aa. Smaller (wing less than 54, tail less than 32, culmen less than $31 \mathrm{~mm}$.); upper parts bronze or coppery bronze; sexes alike, the adult male as well as female rufescent beneath. (Eastern Costa Rica and eastern Nicaragua.)

Glaucis hirsuta ænea (p. 334).

\section{GLAUCIS HIRSUTA HIRSUTA (Gmelin).}

\section{HAIRY HERMIT.}

Adult male.-Above metallic bronze-green or greenish bronze, duller on pileum, where, especially on forehead and crown, the feathers are dusky basally and on margins, sometimes wholly dusky; upper tailcoverts rather broadly margined terminally with pale buffy grayish or grayish buffy; middle pair of rectrices metallic bronze-green, tipped (usually narrowly) with dull white, the subterminal portion more or less dusky; remaining remiges clear chestnut, crossed by a broad subterminal band of dull black (outer web of lateral rectrix also mostly black), the tip, narrowly, dull white; remiges dusky, faintly glossed with violet-purple; loral, suborbital, and auricular regions dusky, the last faintly glossed with bronze or bronze-green; under parts dull russet or mars brown (at least on chest), the chin dull whitish, the abdomen pale grayish cinnamon or buffy grayish; under tail-coverts pale cinnamon, becoming still paler on margin, sometimes with an indistinct central area of grayish or olive faintly glossed with bronzegreenish; dusky brown or dull blackish, mandible whitish (pink or reddish in life), passing into dusky at tip; iris dark brown; feet dull yellowish or buffy (in dried skins); length (skins), 109-131 (123); wing, 57.5-68.5 (65.1); tail, 34.5-44.5 (41.2); culmen, 31-35.5 (33.3). ${ }^{a}$

Adult female.-Similar to the adult male but under parts wholly and almost uniformly light russet or rusty cinnamon; length (skins), 
111-125 (11S); ${ }^{a}$ wing, 56-65.5 (61.S); tail, 34.5-41.5 (39.5); culmen, $31-35.5(33.1) .^{b}$

Young.-Similar to adults, but feathers of back, rump, etc., narrowly margined terminally with pale grayish buff or bufly grayish; pileum nearly uniform dusky or sooty, black band across tail and white tips to rectrices broader, and tip of rectrices narrower, nore pointed.

Eastern South America, including islands of Grenada, Tobago, and Trinidád.c

[Trochilus] hirsutus Gmelin, Syst. Nat., i, 1788, 490 (based on Polytmus brasiliensis Brisson, Orı., ii, 670).

Trochilus hirsutus Audebert and Vieillot, Ois. Dor., i, 1801, 40, pl. 20.-Temmisck, Cat. Syst., 1807, 80.-Vieillot, Nouv. Dict. d'Hist. Nat., vii, 1817, 352.-Lesson, Hist. Nat. Colibr., 1830-31, 80, pl. 21 (Brazil); Traité d'Orn., 1830, 290; Index Gen. and Synop. Troch., 1832, p. xiii (Brazil).-Jardine, Humming Birds, ii, 1833, 155, pl. 29.

T[rochilus] hirsutus Vieillot, Tabl. Enc. Méth., ii, 1822, 556.

[Glancis] hirsutus BoIe, Isis, 1831, 545.-Gray, List Gen. Birds, 1841, 17.Bonaparte, Consp. Av., i, 1850, 67; Rev. et Mag. de Zool., 1854; 249.Sclater and Stlvin, Nom. Av. Neotr., 1873, 78, part.

Glaucis hirsutus Mulsant and Verreaux, Hist. Nat. Ois.-Mouch., i, livr. 1, 1873, 39, part (Cayenne; Trinidád; Tobago).-Lawrence, Proc. U. S. Nat. Mus., i, 1879, 266, 271, 487 (Grenada).-Wells, Proc. U. S. Nat. Mus., ix, 1887, 619 (Grenada; descr. nest and eggs).-Chapman, Bull. Am. Mus. N. H., vi, 1894, 54 (Trinidád; habits).-Phelps, Auk, xiv, 1897, 366 (Cumanacoa and San Antonio, Venezuela).-Robinson and Richmond, Proc. U. S. Nat. Mus., xxiv, 1901, 171 (La Guayra, and San Julian, Venezuela).

Glaucis hirsuta Reichenвach, Aufz. der Colibr., 1854, 15; Troch. Enum., 1855, 12.-Buryeister, Syst. Ueb. Th. Bras., ii 1856, 321.-Gould, Mon. Troch., pt. xi, 1856 (vol. i, 1861), pl. 5; Introd. Troch., oct. ed., 1861, 38 (e. Brazil;

$a^{\prime}$ Two specimens.

$b$ Eleven specimens.

\begin{tabular}{|c|c|c|c|}
\hline Locality. & Wing. & Tail. & $\begin{array}{c}\text { Ex- } \\
\text { posed } \\
\text { culmen. }\end{array}$ \\
\hline MALES. & & & \\
\hline Two adult males from Brazil (Bahia and Chapada).... . & 63.2 & 40 & 31.2 \\
\hline Two adult males from Venezuela...... & 63.2 & 40 & 32 \\
\hline 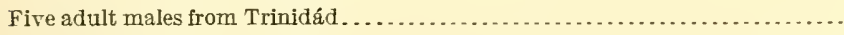 & 63.8 & 39.9 & 32.4 \\
\hline Two adult males from Tobago............... & 68 & 44.2 & 33.7 \\
\hline Five adult males from Grenada............. & 66 & 41.8 & 34.9 \\
\hline FEMALES. & & & \\
\hline Two adult females from Brazil (Bahia). & 65.2 & 40.7 & 31.7 \\
\hline One adult female from Venezuela....... & 57.5 & 33 & 31 \\
\hline Three adult females from Trinidád..... & 60.3 & 37.2 & 32.2 \\
\hline 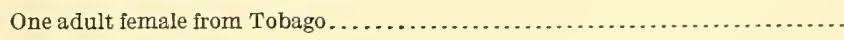 & 65 & 44.5 & 34 \\
\hline Five adult females from Grenada........... & 60.6 & 37.3 & 33.8 \\
\hline
\end{tabular}

$c$ Specimens examined are from Brazil (Bahia; Chapada, Matto Grosso), Cayenne, Venezuela (San Antonio, Bermudez; Merida), Trinidad, Tobago, and Grenada. 
Venezuela; Trinidád).-Pelzeln, Orn. Bras., i. Abth., 1868, 27; iv. Abth., 1870, 406.-Sclater and Salvin, Proc. Zool. Soc. Lond., 1868, 628 (Venezuela).-Boucard, Notes quelques Troch., 1873, 1 (Brazil; Trinidád); Gen. Hum. Birds, 1895, 516 (Brazil; Trinidád; Grenada).--Salvin and EцLiot, Ibis, 1873, 276, part (Bahia, etc., Brazil; Trinidád; Merida and Caracas, Venezuela).-LAYARD, Ibis, 1873, 388 (Pará, Brazil).-Elliot, Classif. and Synop. Troch., 1879, 6, part (Tobago; Trinidád; Brazil).-Ridgway, Proc. U. S. Nat. Mus., iii, 1880, 308, part (Grenada; Brazil).--Salvin, Ibis, 1885, 431 (Roraima, Brit. Guiana, 3,500 ft.).-Cony, Auk, 1886, 347 (Grenada); Birds West Ind., 1889, 142 (Grenada); Cat. West Ind. Birds, 1892, 106 (Grenada).-Allen, Bull. Am. Mus. N. H., ii, 1889, 257 (concerning type of Trochilus ferrugineus Maximilian); v, 1893, 122 (Chapada, Matto Grosso, Brazil).-Simon, Mém. Soc. Zool. France, ii, 1889, 218 (San Esteban, Venezuela).-Salvin, Cat. Birds Brit. Mus., xvi, 1892, 41, part (Carácas, Venezuela; Roraima, Brit. Guiana; Cayenne; Trinidád; Tobago; Grenada; Pará, etc., Brazil).-Salvin and Godman, Biol. Centr.-Am., Aves, ii, 1892, 255, part.-Lodge, Ibis, 1896, 518 (Grenada; habits).-Hartert, Ibis, 1897, 423, part (crit.).-Ihering, Rev. Mus. Paul., iv, 1900, 70 (descr. nest and eggs).Dalmas, Mém. Soc. Zool. France, xiii, 1900, 142 (Tobago).-Berdepsch and Hartert, Novit. Zool., ix, 1902, 80 (Munduapo, Tembladór, and La Pricion, Venezuela).--Ihering, Rev. Mus. Paul., vi, 1904, 357 (São Sebastião, São Paulo, s. e. Brazil).-Nicholl, Ibis, 1904, 565 (Grand Étang, Grenada; habits).-Menegaux, Bull. Mus. d'Hist. Nat. Paris, 1904, 113 (Mahury, Cayenne).-Clark (A. H.), Proc. Bost. Soc. N. H., xxxii, 1905, 273 (Grenada).-Fellmayr, Novit. Zool., xiii, 1906, 374 (near Pará, Brazil; crit.).Berlepsch, Novit. Zool., xv, 1908, 261 (Cayenne).

G[laucis] hirsuta Cabanis and Heine, Mus. Hein., iii, 1860, 4 (Carácas, Venezuela; Brazil).-Hartert, Das Tierreich, Troch., 1900, 15, part.

[Glaucis] hirsuta Cory, List Birds West Ind., 1885, 17 (Grenada).-SharPe, Hand-list, ii, 1900, 98, part.

Glaucis hirsuta hirsuta Oв евноцser, Proc. U. S. Nat. Mus., xxiv, Jan., 1902, 311, in text.

P[hæthornis $]$ hirsutus JARDINe, Hum. Birds, ii, 1833, 177.

Phæthornis hirsutus JA RDine and SeLby, Illustr. Orn., iii, 1835, pl. 143 (Tobago).

Phaethornis hirsutus JARDine, Ann. and Mag. N. H., xx, 1847, 372 (Tobago; Trinidad).

P[olytmus] hirsutus Gray, Gen. Birds, i, Dec., 1848, 108.

[Polytmus] hirsutus Gray, Hand-list, i, 1869, 126, no. 1590.

Polytmus hirsutus LÉotaud, Ois. Trinidad, 1866, 139.

[Trochilus] brasiliensis Latнaм, Index Orn., i, 1790, 308 (=Trochilus hirsutus Gmelin).

Trochilus brasiliensis Vreillot, Nouv. Dict. d'Hist. Nat., vii, 1817, 357 (Brazil; Cayenne).-Maximilan, Beitr. Naturg. Bras., iv, 1831, 111.-Cabanis, in Schomburgk's Reis. Brit. Guiana, iii, 1848, 708.-Burmeister, Syst. Ueb. Th. Bras., ii, 1856, 327.

Trochilus ferrugineus Maxmmuan, Beitr. Naturg. Bras., iv, pt. ii, 1832, 120 (s. e. Brazil; type now in coll. Am. Mus. N. II. see Allen, Bull. Am. Mus. N. H. ii, 1889, 257).

$T$ [rochilus] dominicus (not of Linnæus) Lich'tens'tein, Verz. Doubl., 1823, 13 (Brazil).

Trochilus dominicus CaBanis, in Schomburgk's Reis. Brit. Guiana, iii, 1848, 708. Trochilus superciliosus (not of Linnæus) Lesson, Hist. Nat. Col., 1831, 38, pl. 7; Traite d'Orn., 1830, 289.-JARDine, IIum. Birds, ii, 1833, 145, part, pl. 27.Burmeister, Syst. Ueb Th. Bras., ii, 1856, 324 . 
Trochilus mazeppa Lesson, Hist. Nat. Col., 1831, 18, pl. 3 (Guiana); Index Gen. and Syn. Troch., 1832, p. xiii (Cayeune).-Jardene, Hum. Birds, ii, 1S33, 156.

[Glancis] mazeppa Rercuenbacu, Aufz. der Colibr., 1854, 15; Troch. Enum., 1855, 12.-Bonaparte, Rev. et Mag. de Zool., 1854, 249.

Glaucis mazeppa Gould, Mon. Troch,, pt. xxiv (vol. i, 1861), pl. 6; Introd. Troch., oct. ed., 1S61, 38 (Cayenne; Trinidád; Tobago).-TAYLor, lbis, 186t, 90 (Trinidíd).-Boucard, Gen. Hum. Birds, v, 1895, 363 ('Tobago; Guiana; Brazil).

[Glaucis hirsutus] var. mazeppa Mulsant, Ann. Soc. Linn. Lyon, n. s., xxii, 1876, 200.

P[olytmus] mazeppa GraY, Gen. Birds, i, Dec., 1S4S, 10 S.

[Polytmus] mazeppa GraY, Hand-list, i, 1S69, 126, no. 1591.

P[haethornis] mazeppa JARDINE, Hum. Birds, ii, 1S33, 178.

Glancis lanceolata Gould, Mon. Troch., pt. xxiv, Sept. 1, 1S61, pl. 8 (Parí, lower Amazon; coll. J. Gould); Introd. Troch., oct. ed., 1861, 39.

[Glancis hirsutus] var. lanceolatus Mulsant, Ann. Soc. Limn. Lyon, 11. s., xxii, $1876,200$.

\section{GLAUCIS HIRSUTA AFFINIS (Lawrence).}

\section{LESSER HAIRY HERMIT.}

Similar to $G$. h. hirsuta but decidedly smaller, and color of under parts averaging duller (more rufescent).

Adult male.-Length (skins), 101-121 (111) ${ }^{a}$; wing, 53-61.5 (58.6); tail, 32.5-39 (36.3); culmen, 30.5-31.5 (31.3). ${ }^{b}$

Adult female.-Length (skins), $109^{c}$; wing, 56-57 (56.5); tail, 34-36 (34.9); culmen, 30-33 (31.9). ${ }^{b}$

Panamá (Lion Hill; Chepo; Panamá) and southward through Colombia (Bogotá; lower Magdalena; Medina; Santa Elena; Don Diego, Santa Marta; Rio Cali; Rio Dagua), and eastern Ecuadór (Rio Napo) to Rio Negro and eastern Peru (Pebas; upper Ucayali; Santa Cruz; Yurimáguas; Chyavetas; Chamicuros).

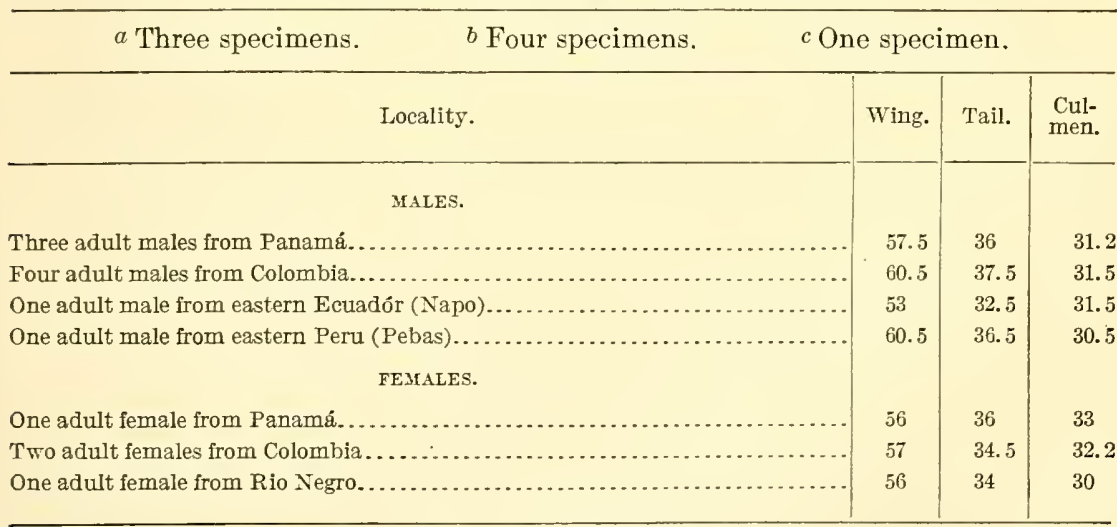


Glaucis hirsuta (not Trochilus hirsutus Gmelin) Mulsant and Verreaux, Hist. Nat. Ois.-Mouch., i, livr. 1, 1873, 39, part (Colombia).-SAlvin and Elliot, Ibis, 1873, 276, part (Pebas and Xeberos, e. Peru; Bogotá, Colombia; Barro do Rio Negro?; Panamá).-Elliot, Classif. and Synop. Troch., 1879, 6, part.-Sclater and Salvin, Proc. Zool. Soc. Lond., 1879, 528 (Santa Elena, Colombia).-Ridgway, Proc. U. S. Nat. Mus., iii, 1880, 308, part (Pebas; Panamá).-Berlepsch, Journ. für Orn., 1887, 314 (Bogotá).-Salvin, Cat. Birds Brit. Mus., xvi, 1892, 41, part (Lion Hill, etc., Panamá; Santa Elena, Bogotá, and Medina, Colombia; Barro do Rio Negro?; Rio Javari, Iquitos, Pebas, etc., e. Peru; Rio Napo, e. Ecuadór).-Salvin and Godman, Biol. Centr.-Am., Aves, ii, 1892, 255, part (Lion Hill and Chepo, Panamá).Bangs, Proc. Biol. Soc. Wash., xii, 1898, 134 (Santa Marta).-Ihering, Rev. Mus. Paul., iv, 1904, 357, part (Bogotá).-Allen, Bull. Am. Mus. N. H., xvi, 1905, 276 (Don Diego, Santa Marta, Colombia;) 281 (Don Diego; descr. nest and eggs).-(?) Hellmayr, Novit. Zool., xiv, 1907, 392 (Humaytha and Borba, Rio Madeira, w. Brazil).

G[laucis] hirsuta Hartert, Das Tierreich, Troch., 1900, 15, part.

[Glaucis] hirsuta SHARPE, Hand-list, ii, 1900, 98, part.

[Glaucis] hirsutus Sclater and Salvin, Nom. Av. Neotr., 1873, 78, part.

Glaucis hirsutus Taczanowski, Orn. du Pérou, i, 1884, 261.

Glaucis affinis LA Wrence, Ann. Lyc. Nat. Hist. N. Y., vi, 1858, 261, 262 (Ecuadór; coll. G. N. Lawrence).-Gould, Mon. Troch., i, 1861, pl. 7; Introd. Troch., oct. ed., 1861, 38 (Bogotá).-Sclater and Salvin, Proc. Zool. Soc. Lond., 1864, 364 (Panamá); 1873, 286 (Yurimaguas, Xeberos, Chyavetas, Chamicuros, and Pebas, e. Peru).

[Glaucis hirsulus] var. affinis MUlSaNt, Ann. Soc. Linn. Lyon, n. s., xxii, 1876, 200. Glaucis hirsuta affinis Oberholser, Proc. U. S. Nat. Mus., xxiv, no. 1258, Jan., 1902, 311 (Napo, e. Ecuadór; crit.).

[Polytmus] affinis Gray, Hand-list, i, 1869, 126, no. 1592.

Glaucis melanura Gould, Proc. Zool. Soc. Lond., 1860, 304 (upper Rio Negro; Rio Napo, e. Ecuadór; coll. J. Gould); Mon. Troch., i, 1861, pl.9; Introd. Troch., oct. ed., 1861, 39.-Sclater and Salvin, Proc. Zool. Soc. Lond., 1866, 193 (upper Ucayali, e. Peru); 1873, 286 (upper Ucayali).

[Glaucis hirsutus] var. melanura Mulsant, Ann. Soc. Linn. Lyon, n. s., xxii, 1876, 200.

[Polytmus] melanura Gray, Hand-list, i, 1869, 126, no. 1595.

Glaucis xnea (not Glaucis xneus Lawrence) Boucard, The Hum. Bird, ii, 1892, 84 (Bogotá, Colombia); v, 1895, 7 (Cali, Colombia); Gen. Hum. Birds, 1895, 365, part (Panamá; Colombia; upper Amazons; Ecuadór).

(?) Glaucis columbiana Boucard, The Hum. Bird, v, 1895, 7 (Rio Dagua, n. w. Colombia; nomen nudum here); v, Dec., 1895, 402 (Rio Dagua, n. w. Colombia; coll. A. Boucard).-HARTERT, Ibis, 1897, 423 (crit.).

(?) G[laucis] columbiana Harter'T, Das Tierreich, Troch., 1900, 16.

\section{GLAUCIS HIRSUTA RNEA (Lawrence).}

\section{BRONZY HERMIT.}

Somewhat like G.h. hirsuta but much smaller (smaller even than $G$. h. affinis), the upper surface always metallic bronze or copperbronze (never green or bronze-green), and under parts (in both sexes) much more rufescent. 
Adult male.- Above metallic bronze (varying from copper-bronze to slightly greenish bronze), except pileum, which is uniform dusky; upper tail-coverts broally margined with cinnamon or (sometimes) with pale bufly grayish on longer coverts; middle pair of rectrices metallic greenish bronze or bronze-green, tipped with white or pale grayish buff, and crossed by a narrow subterminal band of black; other rectrices clear chestnut or rulous-chestnut, broadly tipped with white and crossed by a broad subterminal band of black, the outer web of lateral rectrix also mostly black; remiges dusky, faintly glossed with violaceous; chin pale grayish cinnamon or dull buffy whitish; throat, chest, sides, flanks, and under tail-coverts light russet or rusty cinnamon, fading on breast and abdomen into pale grayish buffy; maxilla dull black, mandible dusky terminally, paler (sometimes dull whitish) basally; iris dark brown; feet dull yellowish or buffy (in dried skins); length (skins), 95-104 (101); wing, 50.5-56 (53.6); tail, 30-34 (31.7); culmen, 30-31.5 (30.6) ${ }^{a}$

Adult female.-Similar to the adult male, but under parts almost wholly and nearly uniformly light russet or rusty cinnamon; length (skins), 94-105 (97); wing, 51-54 (52.4); tail, 29.5-33 (31.3); culmen, 30-31.5 (30.7). ${ }^{b}$

Costa Rica (San José; Talamanca; Rio Frio; El Hogár; Pozo Azúl de Pirrís; Pozo del Rio Grande; El Pozo de Térraba) and Nicaragua (Rio Escondido).

Glaucis æneus Lawrence, Proc. Ac. Nat. Sci. Phila., 1867, 232 (Costa Rica coll. U. S. Nat. Mus.); Ann. Lyc. N. Y., ix, 1868, 121 (Costa Rica).Frantzius, Journ. für Orn., 1869, 315 (Costa Pica).

Glaucis aenea Boucard, Gen. Hum. Birds, 1895, 365, part (Costa Rica).

[Glaucis hirsutus] var. aeneus Mulsant, Ann. Soc. Linn. Lyon, n. s., xxii, $1876,200$.

Glaucis hirsuta æneus Bangs, Auk, xxiv, July, 1907, 288, 295 (Pozo del Rio Grande, s. w. Costa Rica; crit.).-Carriker, Ann. Carnegie Mus., vi, 1910, 518 (Costa Rica; crit.; habits).

Glaucis hirsuta (not Trochilus hirsutus Gmelin) SAlvin and Ellıot, Ibis, 1873, 273, part (Costa Rica; synon.; crit.).-Ridaway, Proc. U. S. Nat. Mus., iii, 1880, 308, part (Costa Rica).-Elliot, Classif. and Synop. Troch., 1879, 6, part (Costa Rica).-Zeledóx, Cat. Aves de Costa Rica, 1882, 19; Anal. Muf. Nac. Costa Rica, i, 1887, 121 (Pozo Azúl de Pirrís, s. w. Costa Rica).Salvis, Cat. Birds Brit. Mus., xvi, 1892, 41, 655, part (Costa Rica).-SAlvin and Godman, Biol. Centr.-Am., Aves, i, 1892, 255, part (Costa Rica).Richyord, Proc. Zool. Soc. Lond., xvi, 1893, 516 (Rio Escondido, e. Nicaragua).-Hartert, Ibis, 1897, 423, part (crit.).

[Glaucis] hirsutus Sclater and Salvin, Nom. Av. Neotr., 1873, 78, part. G[laucis] hirsuta Hartert, Das Tierreich, Troch., 1900, 15, part (monogr.). [Glaucis] hirsuta SHARPE, Hand-list, ii, 1900, 98, part. 


\section{Genus THRENETES Gould.}

Threnetes a Gould, Mon. Troch., pt. iv, Oct., 1852, pl. 13; Introd. Troch., oct. ed., 1861, 40. ('Type, Trochilus leucurus Linnæus.)

Dnophera $b$ Heine, Journ. für Orn., 1863, 175, in text. (Type, Trochilus antonix Bourcier and Mulsant.)

Medium-sized Trochilidæ (length about 110-120 mm.) with the long, rather stout, depressed and distinctly decurved bill less than twice as long as head, tail more than half as long as wing, graduated, with rectrices more or less subacuminate terminally, the rectrices (except middle pair) white or buff basally.

Bill rather stout, much broader than deep basally, distinctly (though not conspicuously) decurved, less than twice as long as head, the culmen distinctly ridged, at least basally, where constricted and elevated into a rather conspicuous narrow ridge; mandible grooved laterally for basal half or more. Nostril narrow, slitlike, overhung by a broad, tumid, mostly unfeathered operculum, but frontal feathering extending, in a narrow line, nearly to its anterior end; unfeathered inter-ramal space long and broad. Tarsus naked, about as long as middle toe without claw, the latter about equal to inner toe, the outer toe slightly shorter; hallux slightly shorter than outer toe. Wing about twice as long (more or less) as exposed culmen, the outermost primary longest. Tail longer than exposed culmen, decidedly more than half as long as wing, graduated, with rectrices distinctly cuneate or subacuminate at tip or (in $T$. cervinicauda) moderately rounded with rectrices broadly rounded terminally.

Coloration.-Rather dull metallic bronze-green or bronze above, the rectrices (except middle pair) abruptly white for basal half (more or less), then blackish, the tip whitish, or (in T. cervinicauda) buff with or without dusky at tip; chin and upper throat black or dusky, lower throat buff or tawny, under parts of body dull grayish (chest dull metallic green in $T$. cervinicauda). Sexes nearly alike, but females duller in color.

Range.-Guatemala to Guiana and Bolivia, mostly in lowlands. (Five species.)

\section{THRENETES RUCKERI (Bourcier).}

\section{RUCKER'S HERMIT.}

Adults (sexes alike).-Above metallic bronze-green or greenish bronze, duller on pileum, where feathers are narrowly margined with dusky and with a dusky shaft-streak; upper tail-coverts margined terminally with pale cinnamon or pale grayish buffy, this bordered anteriorly by a narrow curved line of dusky; middle pair of rectrices 
bronze-creen, tipped with dull white or pale buffy, the other rectrices white for basal half (more or less), then dull black, glossed on outer web with bronze-green, the tip white or pale bufy; remiges dusky, faintly glossed with violaceous; suborbital and auricular regions blackish brown or dusky, margined above by a postocular spot or short stripe of pale cinnamon or buffy and below by a malar stripe of the same; chin and upper throat dusky, the feathers margined or tipped with grayish buffy or pale cimnamon; lower throat and upper chest cinnamon-rufous, changing gradually to pale buffy grayish on lower chest, breast, and abdomen (the last tinged with cinnamon-rufous), the sides and flanks deeper buffy grayish, more or less tinged (especially the flanks) with pale cinnamon-rufous; under tail-corerts olive-bronze, broadly margined with cinnamon or cinnamon-buff; maxilla dull black, mandible whitish (pink or reddish in life?), passing into dusky at tip; iris dark brown; feet pale brownish or dull yellowish (in dried skins).

Young (first plumage).-Essentially like adults but lower throat and chest dull buffy grayish instead of tawny, and feathers of upper surface narrowly margined terminally with dull brownish buffy.

Adult male.-Length (skins), 107-120 (113); wing, 52.5-60 (57.7); tail, 31-3S (34.4); culmen, 2S-31 (30.5). ${ }^{a}$

Adult female.-Length (skins), 101-116 (108); wing, 52-57.5 (54.4); tail, 31-35.5 (32.9); culmen, 26.5-32 (29.7). ${ }^{b}$

Nicaragua (Rio Escondido), Costa Rica (Angostura; Jiménez; El Hogár; Carrillo; Guácimo; Turrialba, 2,000 feet; Guápiles; Cuábre; Talamanca; Pozo Azul de Pirrís; Pozo del Rio Grande) and Panamá (Lion Hill; Panamá; Paraiso; Bibaláz; Mina de Chorcha; Verágua); northwestern Colombia (Rio Dagua) ?; Guatemala?

Troch[ilus] ruckeri Bouncien, Proc. Zool. Soc. Lond., 1847, 46 (Iocality unknown; coll. M. Loddiges).

Glaucis ruckeri Gould, Mon. Troch., i, Nov., 1851, pl. 11; Introd. Troch., oct. ed., 1861, 39 (Verágua, Panamá).-Lawrence, Ann. Lyc. N. Y., vii, 1862, 319 (Lion Hill, Panamá); ix, 1868, 121 (Costa Rica).--Sclater and Salvin, Proc. Zool. Soc. Lond., 1864, 364 (Lion Hill).-Mulsant and Verreaux, Classif. Troch., 1866, 14; Hist. Nat. Ois.; Mouch., i, livr. 1, 1873, 47, part (Verágua).Salvis, Froc. Zool. Soc. Lond., 1870, 204 (Mina de Chorcha, Panamá).Frantzius, Journ. für. Orn., 1869, 315 (Costa Rica).-Elliot, Classif. and Synop. Troch., 1879, 8, part ("Central America").-Ridgway, Proc. U. S. Nat. Mus., iii, 1880, 308 (Panamá; Costa Rica).-Zeledón, Cat. Aves de Costa Rica, 1882, 19; Anal. Mus. Nac. Costa Rica, i, 1887, 121 (Angostura and Jiménez, Costa Rica).

G[laucis] ruckeri CABANIS and Heine, Mus. Hein., iii, 1860, 4, footnote (Veragua).

P[olytmus] ruckeri Gray, Gen. Birds, i, Dec., 1848, 108.

[Polytmus] ruckeri GrAY, Hand-list, i, 1869, 126, no. 1573. 
Threnetes ruckeri Reichenbach, Aufz. der Colibr., 1854, 15; Troch. Enum., 1855, 12.-Bonaparte, Rev. et Mag. de Zool., 1854,.249; Ibis, 1873, 428 (Guatemala).-SAlvin and Elliot, Ibis, 1873, 278, part (Costa Rica; Panamá; synon.; crit.).-Mulsant and Verreaux, Hist. Nat. Ois.-Mouch., i, livr.1, 1873, 47.-Mulsant, Ann. Soc. Linn. Lyon, xxii, 1875, 200.-Salvin, Cat. Birds Brit. Mus., xvi, 1892, 265 (Guatemala; Angostura, Costa Rica; Mina de Chorcha, Paraiso, and Lion Hill, Panamá).-Salvin and Godman, Biol. Centr.-Am., Aves, ii, 1892, 316.-Boucard, The Hum. Bird, ii, 1892, 84 (Veragua); Gen. Hum. Birds, 1895, 371, part (Verágua)--Richmond, Proc. U. S. Nat. Mus., xvi, 1893, 516 (Rio Escondido, Nicaragua).-Bangs, Auk, xxiv, 1907, 295 (Pozo del Rio Grande, Costa Rica).-Carriker, Ann. Carnegie Mus., vi, 1910, 518 (Caribbean lowlands of Costa Rica; habits; descr. nest and eggs).

[Threnetes] ruckeri Sclater and Salvin, Nom. Av. Neotr., 1873, 79.-Sharpe, Hand-list, ii, 1900, 98 (Panamá; Costa Rica; Guatemala).

Threnetes] ruckeri Hartert, Das Tierreich, Troch., 1900, 14 (monogr.).

(?) Threnetes ruckeri Boucard, The Hum. Bird, v, 1895, 7 (Rio Dagua, n. w. Colombia).

\section{Genus AITHURUS Cabanis and Heine.}

Polythmus (not Polytmus Brisson) Lesson, Tabl. Esp. Ois.-Mouch., 1829, p. xviii. (Type, Trochilus polytmus Linnæus.)

Polytmus (not of Brisson) Reichenbach, Av. Syst. Nat., 1849, pl. 39. (Type, Trochilus polytmus Linnæus.)

Aïthurus a Cabanis and Herne, Mus. Hein., iii, March, 1860, 50. (Type, Trochilus polytmus Linnæus.)

Aethurus (emendation) Simon, Cat. Troch., 1897, 24.

Medium-sized Trochilidæ (length, not including elongated rectrices, about $100 \mathrm{~mm}$.) with outermost (tenth) primary shorter than the next, ${ }^{b}$ nasal operculi nude, and tail about two-thirds as long as wing, double-rounded in female but in male forked and with the next to outermost pair of rectrices excessively elongated; adult male with a crest on each side of occiput, top and sides of head (including crests) together with tail black, back, etc., and under parts metallic green; the female dull white below, and lateral rectrices broadly tipped with whitish.

Bill a little longer than head, broad and depressed basally, faintly decurved; culmen rounded anteriorly, posteriorly contracted into a ridge, especially on mesorhinal portion (ridged only at extreme base in females); tomia smooth throughout; mandible with a broad longitudinal groove above middle portion. Nasal operculum rather narrow, moderately tumid, nude except for upper-posterior portion, the frontal feathering extending to about its middle portion with a narrowly convex or nearly truncate anterior outline. Tarsus very stout, feathered on upper-anterior portion; lateral toe about equal

a "Von de'Toupos (stets kampflustig)." (Cabanis and Heine.)

$b$ Aithurus is the only genus in the entire family in which the tenth primary is shorter than the ninth, except Goldmania (adult male, see p. 452.) 
in length, slightly shorter than middle toe, the hallux shorter than lateral toes. Wing, about three times as long as exposed culmen, the ninth (next to outermost) primary longest. 'Tail about two-thirds as long as wing, in adult male forked and with the next to outermost pair of rectrices excessively elongated, in adult female double-rounded, with lateral rectrices shorter than middle pair. Adult males with a conspicuous crest on each side of occiput.

Coloration.-Adult male with top and sides of head, including crests, together with tail, black; rest of plumage metallic green, brighter on under parts; adult female metallic green or bronze-green above (including middle rectrices), dull white beneath, spotted with green laterally.

Range.-Island of Jamaica. (Two species.)

KEY TO THE SPECIES OF AITHURUS.

a. Bill with at least greater part of mandible pale brownish or yellowish (red or pink in life); adult male with under parts purer (less yellowish) green. (Southern slope of Jamaica.)............................. a. Bill wholly black (in both sexes); adult male with under parts more yellowish green. (Northern slope of Jamaica.)............Aithurus scitulus (p. 341).

\section{AITHURUS POLYTMUS (Linnæus).}

\section{STREAMER-TAILED HUMMING BIRD.}

Adult male.-Pileum dull black or blue-black; occiput and nuchal crest deep velvety black; back, scapulars, wing-coverts, rump, and upper tail-coverts bright metallic green, bronze-green, or greenish bronze; tail (including elongated rectrices) black, the middle pair of rectrices more or less strongly glossed with bronze-green or greenish bronze, the other rectrices sometimes similarly but less strongly glossed, at least basally; primaries dark brownish slate or dusky, glossed with purplish bronze; secondaries darker (nearly black), faintly glossed with violaceous, the innermost ones with outer web mostly metallic green or bronze-green; malar region, sides of neck, and under parts (except under tail-coverts) luminous metallic yellowish green (nearest apple green, but much purer in hue); under tail-coverts and under surface of tail blue-black or black faintly glossed with bluish; bill pale brownish or dull yellowish (pink or red in life), dusky at tip; iris dark brown; feet dusky; length (skins), including elongated rectrices, 211-256 (234); wing, 64.5-68.5 (66.4), tail (elongated second rectrix), 152-184 (167.5); middle rectrices 28-32 (29.9); culmen, 20-21.5 (20.6) ${ }^{a}$

Immature male.-Similar to the adult male, but without elongated rectrices; rectrices tipped with bronze-green or greenish bronze, and under tail-coverts strongly glossed with greenish bronze. 
Young male (nestling).-Essentially like immature males, but coloration duller, the under parts rather dull metallic bronze-green (like upper parts), the pileum and nape dusky, faintly glossed with bronzegreen (no nuchal crest).

Adult female.-Above bright metallic bronze-green or greenish bronze, becoming much duller on pileum, where the green or bronze is confined to a terminal spot on each feather, the remaining portion being grayish dusky; middle pair of rectrices bright bronze-green or greenish bronze, the other rectrices black, more or less glossed with bronze-green on basal portion of outer web, the two outermost (on each side) extensively tipped with white; remiges dusky, faintly glossed with bronzy purple, the innermost secondaries with outer webs more or less extensively metallic bronze-green (mostly on terminal portion); primary coverts dusky, glossed on outer web with bluish green; loral and auricular regions grayish dusky; malar region and under parts white, the sides, flanks, sides of neck and chest heavily spotted with metallic bronze-green or greenish bronze, the sides of throat sometimes with similar but smaller spots; maxilla dusky, sometimes becoming brownish (dull reddish in life?) basally; mandible pale brownish or dull yellowish (pink or reddish in life), passing into dusky terminally; iris dark brown; feet dusky; length (skins), 97-112 (105); wing, 54.5-58 (56.9); tail, 35.5-40 (37.6), middle rectrices, 30-33.5 (31.4); culmen, 19-21.5 (21). ${ }^{a}$

Southern slope, island of Jamaica (vicinity of Kingston; Cinchona, 5,000 feet; Spanishtown; Hope Gardens, 700 feet; Flanstead; Moneague; Port Henderson); accidental or occasional on northern slope (Priestmans River).

[Trochilus] polytmus Linnæus, Syst. Nat., ed. 10, i, 1758, 120 (based on Polytmus viridans Brown, Jamaica, 145; Long-tailed Black-cap Humming Bird, Avis mellivora, macroura, capite nigro, Edwards, Nat. Hist., i, pl. 34); ed. 12, i, 1766, 189.-Gmein, Syst. Nat., i, pt. 1, 1788, 486.-Latham, Index Orn., i, $1790,302$.

T[rochilus] polytmus Vienlot, Tab. Enc. Méth., ii, 1822, 554.

Trochilus polytmus Vieillot, Nouv. Dict., d'Hist. Nat., vii, 1817, 355.-Gosse, Birds Jamaica, 1847, 97; Illustr. Birds Jam., 1849, pls. 19, 20.-Gould, Mon. Troch., ii, 1849, pl. 98.

A[ithurus $]$ polytmus Cabanis and Heine, Mus. Hein., iii, March, 1860, 50.-Heine, Journ. für Orn., 1863, 205.-Newton, Handb.Jamaica, 1881, 108.-HaRtert, Das Tierreich, Troch., 1900, 106 (monogr.).

Aithurus polytmus Gould, Introd. Troch., oct. ed., 1861, 75.-Sclater, Cat. Am. Birds, 1862, 293.-March, Proc. Ac. Nat. Sci. Phila., 1863, 284.-Elliot, Ibis, 1872, 353 (synon.; crit.); Classif. and Synop. Troch., 1879, 96.-MuLsant and Verreaux, Hist. Nat. Ois.-Mouch., i, livr. 4, 1874, 335; iv, livr. 3, 1878, 185.-Cory, Auk, iii, 1886, 352; Birds West Ind., 1889, 147; Cat. West Ind. Birds, 1892, 13, 106, 130.-Scotr , $\Lambda$ uk, ix, 1892, 277, part.-SAlviN, Cat. 
Birds 13rit. Mus, xvi, 1892, 64.-lined, Auk, xi, 1894, 125 (Port Henderson, Jamaica).-Rotuscum, Ibis, 1\$94, 547 (crit.).-Boucard, Gen. Hum. Birds, 1895,168 .-Lodge, lhis, 1896,496 (habits).

[Athurns] polytmus GraY, Hand-list, i, 1869, 134, no. 1717.-SCLATEll and SALVin,

Nom. Ar. Neotr., 1873, s2.-Corr, List Birds West Ind., 1855, 17.-Shampe,

Hand-list, ii, 1900,120 .

Aiturus polytmus Boucard, Notes quelques Troch., 1873, 15.

Aiturus polytmus Mulsant and Verreaux, Hist. Nat. Ois.-Mouch., i, livr. 3, 1sit, pl. 13.

Ayturus polytmus Hartert, Kat. Vogelsamml. Mus. Senckenb., 1891, 115.

Ornismya ecphalatra lesson, Hist. Nat. Ois.-Nouch., 1829, pp. xviii, 78, pl. 17;

Index Gen. and Synop. Troch., 1832, p. xvi.

[Polytmus] cephalatra Bonaparte, Consp. Ar., i, 1850, 72.

Polytmus ceplaalatra Boxapante, Rev. et Mag. de Zool., 1854, 354.

Polytmus cephalater Sclater, Proc. Zool. Soc. Lond., 1861, 79.-Albrecht, Journ. für Orn., 1862, 201.-Mulsant and Verreaux, Classif. Troch., 1866, 36.

Trochilus maria Gosse, Ann. and Mag. N. H., iii, 1849, 258.-Gosse, Illustr. Birds Jam., 1849, pl. 22.

Aithurus fuliginosus March, Proc. Ac. Nat. Sci. Phila., 1863, 285 (St. Ann's).

[Aithurus] fuliginosus Gray, Hand-list, i, 1869, 134, no. 1718.

Polytmus viridans (ex Brisson) Reichen bach, Aufz. der Colibr., 1854, 11; Troch. Enum., 1855, 9, pl. 799, figs. 4858-4860.

(?) Trochilus forficatus (not of Linnæus) Vieıllot, Nouv. Dict. d'Hist. Nat., vii, 1817, 366 (Jamaica; based on Ois. Dorés, pl. 16).

(?) Ornismya furcata (not Trochilus furcatus Gmelin) Lesson, Index Gen. and Synop. Troch., 1832, p. xxii, part (Jamaica).

(?) Aithurus taylori a Rothschild, Bull. Brit. Orn. Club, no. xix, June 30, 1894, p. xlvii, in text (St. Andrews, Jamaica; coll. Tring Mus.); Ibis, 1894, 548 (reprint).-Boucard, Gen. Hum. Birds, 1895, 402.

[Aethurus] polyt[mus] taylori Simon, Cat. Troch., 1897, 24.

\section{AITHURUS SCITULUS Brewster and Bangs.}

\section{BLACE-BILIED STREAMER-TAIL.}

Similar to $A$. polytmus but slightly smaller, and with bill wholly black, the adult male with green of under parts less yellowish, that of back, etc., more grass-green (less bronzy).

Adult male.-Pileum (including latero-occipital crests), together with loral, orbital, and postocular regions, opaque velvety black; back, scapulars, wing-coverts, rump, and upper tail-coverts, metallic grass-green; remiges dull blackish or dusky, faintly glossed with purplish, the inner secondaries partly metallic green; tail uniform black, very faintly glossed with bluish; under parts bright metallic green, the feathers of throat and chest white basally (mostly concealed), those of abdomen, etc., more grayish basally; under tail-coverts bluish black; bill wholly black; iris dark brown; feet dusky; length (skins), including elongated rectrices, 211-250 (236); wing, 62.5-65

a Apparently a rariety or "sport" of $A$. polytmus distinguished by possession of a ruby-red spot on the throat. See also Brewster and Bangs, Proc. New Engl. Zool. Club, ii, 1901, 49. 
(63.9); tail, 147-184 (167.5); middle rectrices, 26.5-29.5 (28.3); culmen, 19-20.5 (19.5). ${ }^{a}$

Adult female.-Above metallic, slightly bronzy green, duller on pileum, where the feathers are dark sooty grayish tipped with metallic green; remiges dusky, faintly glossed with purplish, the outermost narrowly edged with whitish; middle pair of rectrices metallic bronzegreen, the other rectrices metallic bronze-green basally, then bluish black, the two outermost broadly tipped with dull white; under parts white, the sides of neck, and thence to flanks, spotted with metallic green; bill wholly black; iris brown; feet dusky; length (skins), 96-108 (103); wing, 52.5-56.5 (54.8); tail, 33.5-39.5 (36.4); middle rectrices, 29-32 (30.5); culmen, 18.5-21 (20.3). ${ }^{a}$

Northern slope, island of Jamaica (Priestmans River; Port Antonio); accidental or casual on southern slope (vicinity of Kingston).

Aithurus polytmus (not Trochilus polytmus Linnæus) ScoтT, Auk, ix, 1892, 277, part.

Aithurus scitulus Brewster and Bangs, Proc. New Engl. Zool. Club, ii, Feb. 8, 1901, 49 (Priestmans River, Portland Parish, Jamaica; coll. Mus. Comp. Zool.).

\section{Genus HEMISTEPHANIA Reichenbach.}

Doryfera (not Doryphora Illiger, 1809) Gould, Proc. Zool. Soc. Lond., 1847, 95. (Type, "Trochilus (Doryfera) louise"=Trochilus ludovicix Bourcier and Mulsant.)

Dorifera Bonaparte, Consp. Av., i, 1850, 68; Rev. et Mag. de Zool., 1854, 251. Doryphora (emendation; not of Illiger) Cabanis and Heine, Mus. Hein., iii, April, 1860, 77.

[Helianthea. $\alpha$. Hemistephania Reichenbach, Aufz. der Colib., 1854, 9. (Type, Trochilus ludoviciæ Bourcier and Mulsant.)

Medium-sized Trochilidæ (length about 100-125 mm.) with the very long, subulate, slightly recurved bill about as long as body, tail shorter than bill, decidedly rounded, the rectrices broad, and rather dull coloration (nearly uniform dusky, the adult males, at least, with a frontal patch of metallic green or blue).

Bill very long (about as long as body, more than twice as long as head), slender-subulate, nearly straight but usually appreciably recurved, the tip compressed, the tomia smooth. Nostril slit-like, overhung by a broad, tumid, unfeathered operculum. Tarsus unfeathered, about as long as middle toe without claw; middle and inner toes equal in length, the outer decidedly shorter; hallux about equal to outer toe or slightly shorter. Wing less than twice as long as bill, the outermost primary longest. Tail half as long as wing to decidedly more, decidedly rounded, the rectrices broad, with rounded or sub-acuminate tip. 
Coloration.-Plumage in general soft and blended; coloration plain dusky bronze-green (sometimes black on under parts), brightest on posterior upper parts, the upper tail-coverts usually bluish; tail black, the rectrices usually tipped with dull grayish. Adult males with a frontal patch of bright metallic green, blue, or violet, the feathers scale-like.

Range.-Costa Rica to Venezuela, Ecuadór, and Bolivia, in mountains. (Four species.)

\section{HEMISTEPHANIA VERAGUENSIS (Salvin).}

VERAGUAN LANCE-BILL.

Adult male.-Forehead bright metallic green or bluish green (emerald green to viridian); crown, occiput, and hindneck dark bronze (varying from greenish to coppery); back, scapulars, rump, and lesser wing-coverts rather dark metallic green (dark parrot green to bottle green); upper tail-coverts dark metallic greenish blue or bluish green (indigo to nearly myrtle green); tail black, faintly glossed with greenish, the rectrices (except middle pair) tipped with deep brownish gray; larger wing-coverts dull black more or less glossed with metallic green, especially at tip; remiges blackish slate or slate-black, faintly glossed with purplish blue; chin and throat dark sooty gray or dusky, faintly glossed with green or bluish green; under tail-corerts sooty gray or dusky, more or less glossed with metallic bluish; femoral tufts grayish white; rest of under parts rather dull metallic bronze-green, the feathers deep sooty gray beneath surface; bill dull black; iris dark brown; feet light brownish (in dried skins), claws blackish; length (skins), 110-117 (116); wing, 57-60.5 (58.8); tail, 30.5-33.5 (32.8); culmen, 33.5-37 (35.2). ${ }^{a}$

Adult female.-Similar to the adult male but forehead dusky bronze, like rest of pileum, instead of greenish, and general coloration slightly duller, especially the under parts; length (skins), 113-116 (114); wing, 54.5-60.5 (56.7); tail, 30-32 (31.4); culmen, 33-35 (34.3). ${ }^{b}$

a Eight specimens.

$b$ Six specimens.

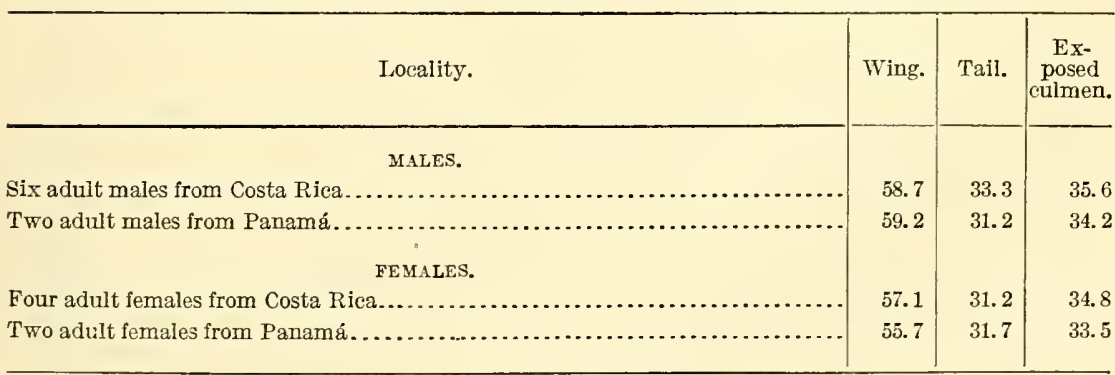


Costa Rica (Cervantes de Cartago; Volcán de Irazú; Coliblanco; La Hondura; San Isidro de La Palma) and western Panamá (Boquete, Chiriquí; Cordillera de Tolé).

Dorifera ludovicix (not Trochilus ludoviciæ Bourcier and Mulsant) SALvin, Proc. Zool. Soc. Lond., 1867, 153 (Cordillera de Tolé, Panamá; crit.).

Doryfera ludovicix? Lawrence, Ann. Lyc. N. Y., ix, 1868, 121 (Cervantes de Cartago, Costa Rica; crit.).

Doryfera ludovicia? Frantzius, Journ. für Orn., 1869, 315 (Costa Rica).

Hemistephania ludoviciæ Zeledón, Cat. Aves de Costa Rica, 1882, 20.

Dorifera veraguensis SAlvin, Proc. Zool. Soc. Lond., 1867, 154 (Cordillera de Tolé, Verágua, Panamá; coll. Salvin and Godman).

[Doryphora] veraguensis Sclater and Salvin, Nom. Av. Neotr., 1873, 82.

Doryfera veraguensis Mulsant and Verreaux, Hist. Nat. Ois.-Mouch., i, livr. 3, 1874, 199 (Costa Rica; Verágua); iii, livr. 1, 1876, 17.-Mulsant, Ann. Soc. Linn. Lyon, xxii, 1875, 217.-Gould, Mon. Troch., Suppl., 1883, pl. 22.-BAngs, Proc. New Engl. Zool. Club, rii, 1902, 26 (Boquete, Panamá, 7,000-7,500 ft.).-Eudes-Deslongchamps, Bull. Soc. Linn. Normandie, v, 1881, 180.-CArriker, Ann. Carnegie Mus., vi, 1910, 517 (Caribbean slope, Costa Rica; habits).

D[oryfera] veraguensis Hartert, Das Tierreich, Troch., 1890, 11 (monogr.).

Hemistephania veraguensis Elliot, Classif. and Synop. Troch., 1879, 82.-ZeleDón, Cat. Aves de Costa Rica, 1882, 20; Anal. Mus. Nac. Costa Rica, i, 1887, 121.-Salvin, Cat. Birds Brit. Mus., xvi, 1892, 40 (Volcán de Irazú, Costa Rica; Chiriquí and Cordillera de Tolé, Panamá).-Salvin and Godman, Biol. Centr.-Am., Aves, ii, 1892, 253, pl. 55, fig. 1.-Boucard, The Hum. Bird, ii, 1892, 86 (Verágua); Gen. Hum. Birds, 1895, 307 (Veragua).Salvadori and Festa, Boll. Mus. Zool., etc., Torino, xiv, 1899, no. 339, 7 (Chiriquí).-Ferry, Pub. 146, Field Mus. N. H., orn. ser., I, no. 6, 1910, 263 (Coliblanco, Costa Rica).

[Hemistephania] veraguensis Sharpe, Hand-list, ii, 1900, 97 (Panamá; Costa Rica). [Hemistephania] lud[oviciae] veraguensis Simon, Cat. Troch., 1897, 5.

\section{Genus ANTHOSCENUS Richmond.}

Floricola (not of Gistel, 1848a) Elliot, Classif. and Synop. Troch., Sept., 1878 (=1879?) 82. (Type, Trochitus longirostris Vieillot.)

Heliomastes Bonaparte, Rev. et. Mag. de Zool., vi, pt. 2, 1854, 251. (Type, Trochilus longirostris Vieillot.)

Anthoscenus b Richmond, Proc. Biol. Soc. Wash., xv, April 25, 1902, 85. (Type, Trochilus longirostris Vieillot.)

Anthoscaenus (emendation) Helluayr, Novit. Zool., xiii, no. 1, Feb. 24, 1906, 36.

Medium-sized or rather large Trochilidæ (length, including the very long bill, about 110-125 mm.) with bill very long (more than half to three-fifths as long as wing), straight, terete; tail about half as long as wing, truncate or slightly rounded; and with a white spot or streak on rump, and white tips to outer rectrices

Bill very long, more than half to three-fifths as long as wing, straight, terete, but broader and more depressed at base; culmen rounded except for basal third, or less, where contracted into a nar- 
row ridge; tomia smooth; maxilla with a rather broad longitudinal groove above middle line. Nasal opereulum rather narrow, nearly straight along edge, mostly nude, the frontal feathering extending to or beyond the mildle of operculum (sometimes nearly to its anterior end), forming a short point or antia on cach side of the mesorhinium. Tarsus naked; lateral toes about equal, slightly shorter than micklle toe, the hallux about as long as lateral toes. Wing less than half to more than twice as long as exposed culmen, the outermost primary longest. Tail about half as long as wing, truncated or slightly rounded, the rectrices very firm, rounded or, sometimes, rather pointed at tip.

Coloration.-Above bronze, greenish bronze or bronze-green, or olive glossed with metallic bronze, etc., the rump with a white spot or streak; adults with throat (at least its lower portion) metallic red or purple, the remaining under parts grayish (sometimes glossed with bronze or greenish laterally) paler (sometimes white) along median line; under tail-coverts white terminally and laterally, dusky grayish centrally; outer rectrices tipped with white. Some species with pileum bright metallic blue or green.

Range.-Mexico to Guiana, Bolivia, and Ecuadór. (About six species.)

KEY TO THE SPECIES AND SUBSPECIES OF ANTHOSCENUS.

a. Feathers of throat without paler margins; adult males with forehead and crown bright metallic blue or bluish green, very different from color of back, etc.

b. Under tail-coverts mostly white. (Ecuadór.)

$b b$. Under tail-coverts mostly dusky. (Anthoscenus longirostris.)

c. Adult males with forehead and crown blue or greenish blue. (Amazon Valley, Guiana, and Trinidád to Costa Rica.)

Anthoscenus longirostris longirostris (p. 346).

$c c$. Adult male with forehead and crown bluish green. (Guatemala and southern

Mexico.................. Anthoscenus longirostris pallidiceps (p. 349).

aa. Feathers of throat narrowly margined with pale grayish or dull whitish (very conspicuous when viewed from behind); adult males with forehead and crown dull metallic green or bronze-green, concolor with back or duller. (Anthoscenus constantii.)

$b$. Coloration darker; metallic red of throat more extensive, occupying most if not all of throat; chin sooty blackish. (Guatemala to Costa Rica.)

Anthoscenus constantii constantii (p. 350).

$b b$. Coloration paler, at least below; metallic red of throat more restricted, confined to extreme lower portion; chin and upper throat grayish. (Southwestern and western Mexico.)...... Anthoscenus constantii leocadiæ (p. 352).

a Heliomaster albicrissa Gould, Proc. Zool. Soc. Lond., 1871, 504 (Citado, Ecuadór; coll. J. Gould).--Heliomastes albicrissa Mulsant and Verreaux, Hist. Nat. Ois.-Mouch., ii, 1876, 274.-Floricola albicrissa Elliot, Classif. and Synop. Troch., 1879, 83; Salvin, Cat. Birds Brit. Mus., xvi, 1892, 231.-F[loricola] albicrissa Hartert, Das Tierreich, Troch., 1900, 192.-[Floricola] long [irostris] albicrissa Simon, Cat. Troch., 1897, 37. 


\section{ANTHOSCENUS LONGIROSTRIS LONGIROSTRIS (Vieillot).}

\section{LONG-BILLED STAR-THROAT.}

Adult male.-Forehead and crown bright metallic blue to greenish blue; occiput and hindneck dark bronze or coppery bronze, appearing nearly black when viewed from in front; back, scapulars, wingcoverts, rump, upper tail-coverts and middle rectrices metallic bronze or bronze-green, the last sometimes blackish terminally; center of rump with an elongated white patch, spot, or broad streak; lateral rectrices metallic bronze or bronze-green basally, blackish terminally, the two outermost usually with a terminal spot of white (smaller on second rectrix); remiges dark brownish slate or dusky, faintly glossed with purplish; a small (usually indistinct) postocular spot of whitish; a broad and conspicuous rictal streak or stripe of dull white; chin dull black; throat metallic reddish purple (pomegranate to magenta), the feathers dusky basally; foreneck, sides of neck, chest, and breast, brownish gray (nearly mouse gray laterally, paler medially), fading into white on abdomen; sides and flanks metallic bronze or bronze-green, the feathers gray basally and, usually, margined with the same; under tail-coverts dusky, broadly and sharply tipped or terminally margined with white; a large and conspicuous tuft of silky white feathers between flanks and rump; bill dull black; iris dark brown; feet dusky; length (skins), 104-126 (112); wing, 57-63 (59.7); culmen, 30-36 (33.4). ${ }^{a}$

Adult female.-Similar to the adult male but forehead and crown dull metallic green (similar to but duller and darker than color of back), blackish of chin more extended, sometimes occupying greater part of throat, where the metallic reddish purple is sometimes restricted to a few feathers on extreme lower portion, and gray of under parts slightly paler, especially along median line; length (skins), 106-119 (112); wing, 56.5-61 (59.3); tail, 28.5-34.5 (31.3); culmen, 32-35.5 (33.7). ${ }^{b}$

a Twenty-six specimens.

$b$ Fifteen specimens.

\begin{tabular}{|c|c|c|c|}
\hline Locality. & Wing. & Tail. & $\begin{array}{l}\text { Cul- } \\
\text { men. }\end{array}$ \\
\hline MALES. & & & \\
\hline One adult male from British Guiana....... & 58 & 29.5 & 33 \\
\hline Six adult males from Trinidád....................... & 58.2 & 32.2 & 32.6 \\
\hline Four adult males from Colombia (Bogotá, etc.)........................ & 61.6 & 32.7 & 34.7 \\
\hline 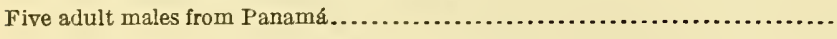 & 59.9 & 32.7 & 33 \\
\hline Ten adult males from Costa Rica................................... & 59.8 & 31.5 & 33.6 \\
\hline Seven adult males ( $A . l$. pallidiceps) from Guatemala.......... & 59.9 & 32.6 & 31.6 \\
\hline Four adult males (A.l. pallidiceps) from Mexico.......... & 55.8 & 32.2 & 32.2 \\
\hline FEMALES. & & & \\
\hline Three adult females from Trinidád........... & 58.2 & 30.5 & 34 \\
\hline Two adult females from Panamá........................... & 58 & 30.7 & 33 \\
\hline Nine adult females from Costa Rica................................ & 60.2 & 31.8 & 33.5 \\
\hline 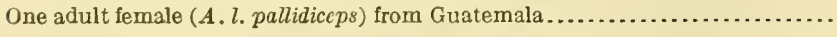 & 57 & 32 & 32.5 \\
\hline
\end{tabular}

With the material examined I am unable to make out satisfactorily any geographic variations sufficiently marked or constant to warrant the recognition of two or more subspecies. Costa Rican specimens, however, vary more or less toward A.l. pallidiceps, some examples being hardly distinguishable from the latter. 
Immature? - Similar to the adult female but without any metallic purple feathers on throat, which is wholly (centrally at least) dusky, the feathers usually tipped with dull white or grayish.

Foung.-Similar to the supposed immature plumage, as described above, but feathers of upper parts (especially those of rump) more or less distinctly tipped with pale rusty brown or buffy; throat sometimes mostly dull white.

Costa Rica (San José; Rancho Redondo; Cerro de la Candelária; San Pedro del Mojón; Angostura; Eseazú; Volcán de Irazú; Tucurríqui; Bortuca ; Paso Reál, and Barranca, Boruca; Térraba; El Generál; Pozo Azúl de Pirrís; Bebedero), Panamá (Cordillera del Chucu; Cordillera de Tolé; Calovévora; Calobre; Chitra; Santa Fé de Verágua; Laguna del Castillo; Davíd; Divala; Boquete; El Banco; Loma del León; Paraiso; Chepo; Panamá; Saboga Island) and southward through Colombia, Venezueli, and the Guianas to lower Amazon Valley.

Trochilus longirostris Audebert and Viemlot, Ois. Dorés, i, livr. 10, 1801, 107, pl. 59 (Trinidád).-Vienlot, Nouv. Dict. d'Hist. Nat., vii, 1817, 366 (Trinidád).

T[rochilus] longirostris Viemlot, Tabl. Enc. Méth., ii, 1822, 566.

Ornismya longirostris D'Orbigny and Lafresnaye, Hag. de Zool., 1854 (Synop. Av., ii, 29).

[Heliomaster] longirostris Bonaparte, Consp. Av., i, 1850, 70.-Pelzeln, Orn. Bras., iv. Abth., 1870, 408.-Sclater and Salvin, Nom. Av. Neotr., $1873,90$.

Heliomaster longirostris Gould, Mon. Troch., pt. v, 1853 (vol. iv), pl. 259; Introd. Troch., oct. ed., 1861, 138.-Sclater, Proc. Zool. Soc. Lond., 1856, 140 (Davíd, Panamá); 1857, 16 (Bogotá, Colombia); Cat. Am. Birds, 1862, 310 (South America).-Salvin, Ibis, 1885, 435 (Merumé Mts. and Roraima, Brit. Guiana); Proc. Zool. Soc. Lond., 1867, 155 (Cordillera de Tolé and Santa Fé de Verágua, Panamá; crit.); 1870, 210 (Cordillera del Chucu, Laguna del Castillo, Calovévora, and Chitra, Panamá).-TAYlor, Ibis, 1864, 92 (Trinidád).-Pelzeln, Orn. Bras., i. Abth., 1868, 31.-Lawrence, Ann. Lyc. N. Y., ix, 1868, 126 (Costa Rica).-Frantzıus, Journ. für Orn., 1869, 317 (Costa Rica).-Finsch, Proc. Zool. Soc. Lond., 1870, 562 (Trinidád).Sclater and Salvin, Proc. Zool. Soc. Lond., 1867, 752 (Chyavetas, e. Peru), 979 (Pebas, e. Peru); 1873, 288 (Chyavetas, Chamicuros, and Pebas, e. Peru); 1879, 530 (Colombia).-Mulsant, Ann. Soc. Linn. Lyon, xxii, 1875, 215.Elliot, Ibis, 1877, 138 (Guarayos, Bolivia).-Eudes-Deslongchamps, Bull. Soc. Linn. Normandie, v, 1881, 262.-Taczanowski, Proc. Zool. Soc. Lond., 1882, 38 (Yurimaguas, e. Peru).-Berlepsch, Journ. für Orn., 1887, 321 (Bogotá; crit.).-Boucard, The Hum. Bird, ii, 1892, 86 (Bogotá).

H[eliomaster] longirostris CABANrs and Herne, Mus. Hein., iii, 1860, 54 (Cayenne).-Salvin, Ibis, 1869, 316, in text (Costa Rica; crit.).

[Heliomastes] longirostris Boxaparte, Rev. et Mag. de Zool., 1854, 251.

Heliomastes longirostris Mulsant and Verreaux, Hist. Nat. Ois.-Mouch., ii, livr. 4, 1876, 271 (Trinidád; the Guianas; Venezuela; Amazonia; Colombia; Costa Rica); iv, livr. 3, 1878, 211 (synonymy).

[Selasphorus. r. Heliomaster] longirostris ReichenBach, Aufz. der Colibr., 1854, 13. Mellisuga longirostris LÉotaud, Ois. Trinidad, 1866, 137. 
Floricola longirostris Eudiot, Classif. and Synop. Troch., 1879, 83, part.-ZeLEDón, Cat. Aves de Costa Rica, 1882, 20.-Taczanowski, Orn. du Pérou, i, 1884, 391.-Srmon, Mém. Soc. Zool. France, ii, 1889, 221 (San Esteban, Venezuela; crit.).-SAlvin, Cat. Birds Brit. Mus., xvi, 1892, 229, part (Bebedero and Tucurríqui, Costa Rica; Cordillera del Chucu, etc., Panamá; South American localities).-Salvin and Godman, Biol. Centr.-Am., Aves, ii, 1892, 304, part (Costa Rican, Panaman, and South American localities).-Cherrie, Expl. Zool. Merid. Costa Rica, 1893, 45 (Boruca and Térraba, s. w. Costa Rica).-Chapman, Bull. Am. Mus. N. H., vi, 1894, 57 (Trinidád).-Bangs, Proc. Biol. Soc. Wash., xii, 1898, 135 (Santa Marta, Colombia).-Allen, Bull. Am. Mus. N. H., xiii, 1900, 139 (Bonda, etc., Santa Marta, Colombia).-Smon and Dalmas, Ornis, xi, 1901, 215 (Trinidád; Yacua, Andes de Cumaná, Venezuela).-Berlepsch and Hartert, Novit. Zool., ix, 1902, 88 (Suapuré, La Pricion, and Maipures, Venezuela).Anthoscenus longirostris Berlepsch, Novit. Zool., xv, Nov., 1908, 265 (Cayenne). Trochilus superbus SHAw, Nat. Misc., xiii, No. 7, March, 1802, pl. 517 ("Southern parts of America"); Gen. Zool., viii, 1811, 323, pl. 41, fig. 2.-Темміnск, Pl. Col., iv, livr. 50, Sept. 1824, pl. 299, fig. 1.-Lesson, Index Gen. et Syn. Troch., 1832, p. xix (Trinidád).

Ornismya superba Lesson, Hist. Nat. Ois.-Mouch., 1829, pp. xxv, 40, pl. 2; Suppl. Ois.-Mouch., 1830-31, 164, pl. 33.

[Floricola] superba Sharpe, Hand-list, ii, 1900, 138.

Floricola superba Bangs, Auk, xxiv, 1907, 296 (Boruca, Paso Reál, and Barranca, s. w. Costa Rica).

Floricola superba superba Carriker, Ann. Carnegie Mus., vi, 1910, 544 (Costa Rica; crit.; habits).

H[eliomaster] sclateri Cabanis and Heine, Mus. Hein., iii, March, 1860, 54 (Venezuela; coll. Heine Mus.).

Heliomaster sclateri Gould, Introd. Troch., oct. ed., 1861, 139.-LAwrence, Ann. Lyc. N. Y., viii, 1867, 482 (Isthmus Panamá); ix, 1868, 126 (San José and Angostura, Costa Rica; crit.).-Frantzius, Journ. für Orn., 1869, 317 (Costa Rica).

[Heliomaster longirostris] var. sclateri Mulsant, Ann. Soc. Linn. Lyon, n. s., xxii, 1876, 215.

Heliomaster stuartæ Lawrence, Ann. Lyc. Nat. Hist. N. Y., vii, 1860, 108 (Bogotá, Colombia; coll. G. N. Lawrence).-Gould, Introd. Troch., oct. ed., 1861, 138.-Sclater, Cat. Am. Birds, 1862, 310 (Bogotá).-Sclater and Salvin, Proc. Zool. Soc. Lond., 1864, 365 (Panamá).

[Heliomaster longirostris] var. stuartae Mulsant, Ann. Soc. Linn. Lyon, n. s., xxii, 1876, 215.

[Floricola] long[irostris] stuartae Snon, Cat. Troch., 1897, 37.

F[loricola] superba siewartae Hartert, Das Tierreich, Troch., 1900, 192 (Andes of Colombia).

Heliomaster pallidiceps (not of Gould) Lawrence, Ann. Lyc. N. Y., ix, 1868, 126 (Gulf of Nicoya, Costa Rica).-Frantzius, Journ. für Orn., 1869, 317 (Costa Rica).-Boucard, The Hum. Bird, ii, 1892, 86 (Verágua; Panamá).

Floricola superba pallidiceps Bıngs, Auk, xviii, Oct., 1901, 360 (Divala, Panama);

Proc. New Engl. Zool. Cl., iii, 1902, 31 (Boquete, Panamá, 3,000 ft.).

F[loricola] superba (typica) II ARTent, Das Tierreich, Troch., 1900, 192. 


\section{ANTHOSCENUS LONGIROSTRIS PALLIDICEPS (Gould).}

\section{PALE-CROWNED STAR-THROAT.}

Similar to A.7. Tongirostris, but adult male with forehead and crown metallic green or bluish green instead of blue or greenish blue.

Adult male.-Length (skins), 103-11S (111); wing, 57-61.5 (58.9); tail, 31-34.5 (32.5); culmen, 30-33.5 (31.S). ${ }^{a}$

Adult female.-Length (skin), 105; wing, 57 ; tail, 32 ; culmen, $32.5 .^{b}$

Nicaragua (Chontales), Salvadór (Volcán de San Miguél; La Libertád), Guatemala (Santa Ana, Petén; Patulúl, Sololá; Dueñas; Gualín; Mazatenango; Las Salinas; Retalhuleu; Naranjo) and southeastern Mexico, in States of Chiapas (Gineta Mountains), Oaxaca (Santa Efigénia; Tehuántepec; Sierra de Santo Domingo; Tonila) Vera Cruz (Jalapa; Tospám, near Córdova), and Guerrero (Chilpancingo).

[Heliomaster] pallidiceps Gould, Introd. Troch., oct. ed., 1861, 139 (Jalapa, Vera Cruz; coll. J. Gould).-Sclater and Salvin, Nom. Av. Neotr., $1873,90$.

Heliomaster pallidiceps Gound, Introd. Troch., oct. ed., 1861, 139 (Mexico; Guatemala).-Sclater, Cat. Am. Birds, 1862, 310 (Las Salinas, Vera Paz, Guatemala).-(?) SALvin, Ibis, 1866, 205 (Dueñas); 1872, 313, 320 (Chontales, Nicaragua; crit.); Cat. Strickl. Coll., 1881, 367 (Guatemala).-D'OcA, Troq. de Mex., 1875, 17, pl. (3), fig. 9.-Boucard, Notes Troch. du Mex., 1875, 11 (Tospám, near Córdova, Vera Cruz); Liste Ois. récol. Guat., 1878, 45.-Lamrexce, Bull. U. S. Nat. Mus., no. 4, 1876, 32 (Santa Efigénia, Oaxaca).-Mulsant, Ann. Soc. Linn. Lyon, xxii, 1876, 215.

H[eliomaster] pallidiceps SALviv, Ibis, 1869, 316, in text (Guatemala).

Heliomastes pallidiceps Mulsant and Verreaux, Hist. Nat. Ois.-Mouch., ii, livr. 4, 1876, 275 (Mexico to Nicaragua); iv, livr. 3, 1878, 211 (synonymy).

Floricola longirostris pallidiceps Hartert (E. and C.), Novit. Zool., i, Jan., 1894, 20 (Chilpancingo, Guerrero, 4,000 ft.; crit.).

[Floricola] long[irostris] pallidiceps Simon, Cat. Troch., 1897, 36.

F[loricola] superba pallidiceps Hartert (E.), Das Tierreich, Troch., 1900, 192. Anthoscenus superbus pallidiceps Dearborn, Pub. 125, Field Mus. N. H., Nov., 1907, 99 (Mazatenango and Patulúl, Guatemala).

[Floricola] pallidiceps Sharpe, Hand-list, ii, 1900, 138.

Heliomaster longirostris (not Trochilus longirostris Audebert and Vieillot) SaLvin, Ibis, 1860, 263 (Dueñas, Guatemala).-Salvin and Sclater, Ibis, 1860, 195, 263, 276 (Dueñas).-Elliot, Classif. and Synop. Troch., 1879, 83, part.

Floricola longirostris ElLiot, Classif. and Synop. Troch., 1879, 83, part.-SALviN, Cat. Birds Brit. Mus., xvi, 1892, 229, part (Jalapa, Vera Cruz; Oaxaca and Sierra de Santo Domingo, Oaxaca; Santa Ana, Las Salinas, Retalhuleu,
$a$ Eleven specimens.
$b$ One specimen (from Guatemala).

\begin{tabular}{|c|c|c|c|}
\hline Locality. & Wing. & Tail. & $\begin{array}{c}\text { Ex- } \\
\text { posed } \\
\text { culmen. }\end{array}$ \\
\hline MALES. & & & \\
\hline Seven adult males from Guatemala... & 59.9 & 32.6 & 31.6 \\
\hline Four adult males from Mexico............. & 55.8 & 32.2 & 32.2 \\
\hline
\end{tabular}


and Dueñas, Guatemala; Chontales, Nicaragua?).-SALvin and Godman, Biol. Centr.-Am., Aves, ii, 1892, 304, part (Jalapa; Santa Efigénia, Tapana, Tonila, etc., Oaxaca; Guatemalan localities; Volcan de San Miguél and La Libertád, Salvadór; Chontales, Nicaragua).

\section{ANTHOSCENUS CONSTANTII CONSTANTII (Delattre).}

\section{CONSTANT'S STAR-THROAT,}

Adult male.-Above metallic bronze or bronze-green, somewhat duller on pileum, especially on forehead; rump with a longitudinal median patch or broad streak of white; middle rectrices usually dusky terminally, the other rectrices extensively blackish terminally, the inner web tipped with a spot of white; remiges brownish slate or dusky, faintly glossed with purplish; a postocular spot and a conspicuous rictal stripe dull white, the auricular, suborbital, and loral regions dusky; chin sooty or blackish; throat bright metallic red or purplish red (varying from orange-red or scarlet to rose-red) ${ }^{a}$ the feathers narrowly margined terminally with pale grayish or dull whitish (invisible except when viewed from behind); under parts of body brownish gray (deep smoke gray or nearly mouse gray), fading to white on abdomen and anal and femoral regions; under tail-coverts pale gray basally, dusky subterminally (in form of a V-or U-shaped bar), broadly white terminally; a large and conspicuous tuft of silky white feathers on sides, between flanks and back; bill dull black; iris dark brown; feet dusky; length (skins), 113-130 (119); wing, 63-70.5 (66.9); tail, 28.5-37 (34.1); culmen, 33.5-36.5 (34.5). ${ }^{b}$

Adult female. - Very similar to the adult male and not always distinguishable, but usually (?) with the blackish of chin slightly more extended; length (skins), 113-128 (117); wing, 64-68.5 (65.7); tail, 31-34 (32.6); culmen, 34-37.5 (35.5). ${ }^{c}$

$a$ The more orange hue characterizes specimens in older or more worn plumage, the more purplish or rosy hue those in fresh livery.

$b$ Fifteen specimens.

$c$ Ten specimens, from Costa Rica.

\begin{tabular}{|c|c|c|c|}
\hline Locality. & Wing. & Tail. & $\begin{array}{c}\text { Ex- } \\
\text { posed. } \\
\text { culmen. }\end{array}$ \\
\hline MALES. & & & \\
\hline Ten adult males from Costa Rica.... & 68 & 34.4 & 35.2 \\
\hline One adult male from Salvadór............... & 70 & 34.5 & 35.5 \\
\hline Seven adult males from Guatemala ...................... & 64.9 & 33.7 & 33.3 \\
\hline 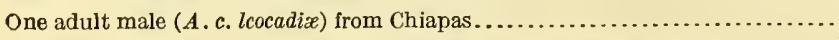 & 65.5 & 33 & 35 \\
\hline Fifteen adult males (A.c. leocadix) from Oaxaca, Guerrero, etc., Mexico........ & 67.1 & 33 & 34.4 \\
\hline FEMALES. & & & \\
\hline Ten adult females from Costa Rica............ & 65.7 & 32.6 & 35.5 \\
\hline 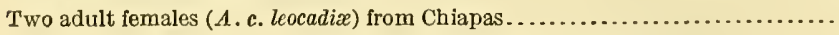 & 59.5 & 30.2 & 34.2 \\
\hline Three adult females ( $A$. c. leocadi $x$ ) from Guerrero, etc., Mexico............... & 65 & 31.3 & 33.8 \\
\hline
\end{tabular}

With the exception of the type, which is said to be from Guatemala, all Guatemalan examples examined are much paler below than those from Costa Rica and Nicaragua; 
Immature. - Similar to adults, but greater part (sometimes whole) of throat dark sooty brown or dusky, the feathers margined terminally with grayish white.

Young.-Similar to the immature plumage, as described above, but feathers of upper parts narrowly tipped or margined terminally with buffy.

Costa Rica (San José; San Isidro; San Pedro de Mojón; Angostura; Corralillo; Orosí; Bolsón; Bebedero; Voleán de Miravalles, up to 2,000 feet; Tempate; Tenório; Boruca), Nicaragua (Matagalpa; Momotombo; boundary line between Nicaragua and Honduras, 180 miles from Pacific coast), Salvadór (San Salvadór; La Libertád; Volcán de San Miguél), and Guatemala (Amatitlán; San Gerónimo; Gualán; Toyabáj, Quitché).

Ornismya constantii Delattre, Echo du Monde Savant, $10^{\ominus}$ ann., ser. 2, vii, no. 45 , June 15, 1843, 1069, in text (Guatemala; coll. A. Delattre; type now in coll. Am. Mus. N. H.).

[Selasphorus. $\gamma$. Heliomaster] constantii Reichenbach, Aufz. der Colibr., 1854, 13. [Heliomastes] constantii Bonaparte, Rev. et Mag. de Zool., 1854, 251.

Heliomastes constanti Mulsant and Verreaux, Hist. Nat. Ois.-Mouch., ii, livr. 4, 1876, 269 (Guatemala; Costa Rica); iv, livr. 2, 1877, pl. 57; iv, livr. 3, 1878, 210 (synonymy).

Heliomaster constanti Gould, Mon. Troch., pt. v, May, 1853 (vol. iv), pl. 260; Introd. Troch., oct. ed., 1861, 140.-Sclater and SAlvin, Ibis, 1859, 129 (Guatemala).-Salvin, Ibis, 1860, 263 (San Gerónimo, Guatemala).Cabanis, Journ. für Orn., 1862, 164 (Costa Rica).-Mulsant and Verreaux, Classif. Troch., 1866, 26.-Lawrence, Ann. Lyc. N. Y., ix, 1868, 126 (Costa Rica).-Frantzius, Journ. für Orn., 1869, 317 (Costa Rica).-Boucard, Proc. Zool. Soc. Lond., 1878, 69 (San José, Costa Rica).-Eudes-DeslongCHAMps, Bull. Soc. Linn. Normandie, v, 1881, 267.

H[eliomaster] constanti Cabanis and Heine, Mus. Hein., iii, 1860, 54 (Costa Rica).

[Heliomaster] constanti Sclater and Salvin, Nom. Av. Neotr., 1873, 90.-MulSant, Ann. Soc. Linn. Lyon, xxii, 1876, 215.

[Selasphorus] constantii Reichenbach, Troch. Enum., 1855, 11.

[Trochilus] constanti GraY, Hand-list, i, 1869, 137, no. 1762.

Floricola constanii Elliot, Classif. and Synop. Troch., 1879, 84.-Zeledón, Cat. Aves de Costa Rica, 1882, 20; Anal. Mus. Nac. Costa Rica, 1887, 121 (San José).-Salvin, Cat. Birds Brit. Mus., xvi, 1892, 231, 661 (San Gerónimo, Guatemala; La Libertád, Salvadór; Bebedero, Costa Rica).-Salvin and Godmax, Biol. Centr.-Am., Aves, ii, 1892, 306 (San Salvaclór, Volcán de San Miguél, and La Libertád, Salvadór; Matagalpa and Momotombo, Nicaragua, etc.).-Cherrie, Auk, ix, 1892, 324 (San José, Costa Rica).-Boucard, Gen. Hum. Birds, 1895, 304, part (Guatemala; San José, Costa Rica).-Underwood, Ibis, 1896, 442 (Volcán de Miravalles, Costa Rica).-Lantz, Trans. Kans. Ac. Sci. for 1896-97 (1899), 221 (Amatitlán, Guatemala).

indeed, in the coloration of the under parts (except throat) they are quite like A. $c$. leocadiæ of Mexico. It is possible there may have been an error in ascribing the type to Guatemala, for in the dark-colored under parts it is exactly like Costa Rican specimens and very different from other Guatemalan ones examined; in which case there would be three geographic forms of this species: A. c. constantii of Costa Rica and Nicaragua, A. c. —— of Guatemala and Salvador, and A. c. leocadiæ of Mexico. 
[Floricola] constanti SHARPe, Hand-list, iii, 1900, 138.

F[loricola $]$ constanti (typica) HaRtert, Das Tierreich, Troch., 1900, 193 (monogr.). Anthoscenus constanti Miller (W. DeW.), Bull. Am. Mus. N. H., xxi, Nov. 24, 1905,355 , in text.

Floricola consianti constanti CARriker, Ann. Carnegie Mus., vi, 1910, 545 (central plateau and Guanacaste, Costa Rica).

\section{ANTHOSCENUS CONSTANTII LEOCADIÆ (Bourcier).}

PINE STAR-THROAT.

Similar to A. c. constantii, but general coloration paler, especially below; metallic red of throat much more restricted (occupying lower throat only), the chin and upper throat dull sooty grayish (instead of blackish), with paler margins to the feathers.

Adult male.-Length (skins), 113-130 (121); wing, 64.5-70.5 (67.1); tail, 31-36.5 (33); culmen, 32-36 (34.4). ${ }^{a}$

Adult female.-Length (skins), 112-121 (116); wing, 59.5-66 (63.6); tail, 28.5-32 (30.9); culmen, 33-35 (34). ${ }^{b}$

Southern and western Mexico, in States of Chiapas (Gineta Mountains; Ocuilapa; San Vicente), Oaxaca (Chimalapa; Tehuántepec), Guerrero (Acapulco; Tlapa; Iguala; Papayo; Dos Arroyos; Rio Papagaio; Alto de Camarón; Venta de Pelegrino), Michoacán (La Salada), Jalisco (Bolaños; Huejuquilla), and Sinaloa (Mazatlán; Presídio de Mazatlán; Sierra de Álamos; Los Pieles; Escuinapa; Rosario; Mount Juan Lisiarraga), and Territory of Tepíc (San Blas; Santiago).

Trochilus leocadiæ Bourcier and Mulsant, Ann. Sci. Phys. et Nat. d'Agric., etc., Lyon, ser. 2, iv, 1852, 141 (Mexico).

Heliomaster leocadiæ Gould, Introd. Troch., oct. ed., 1861, 140.-Sclater, Cat. Am. Birds, 1862, 310.-Mulsant and Verreaux, Classif. Troch., 1866, 26.Lawrence, Mem. Bost. Soc. N. H., ii, 1874, 292 (Mazatlán).-Boucard, Notes Troch. du Mex., 1875, 12.-Sumichrast, La Naturaleza, v, 1881, 250 (Tehuántepec).

[Heliomaster] leocadia Sclater and Salvin, Nom. Av. Neotr., 1873, 90.

[Heliomaster] leocadiae Mulsant, Ann. Soc. Linn. Lyon, xxii, 1876, 215.

Heliomasies leocadiae Mulsant and Verreaux, Hist. Nat. Ois.-Mouch., ii, livr. 4, $1875,276$.

[Trochilus] leocadix Gray, Hand-list, i, 1869, 137, no. 1763.

Floricola leocadiæ ElLiot, Classif. and Synop. Troch., 1879, 84.-Salvin and Godman, Biol. Centr.-Am., Aves, ii, 1892, 306.

[Floricola] leocadix Sharpe, Hand-list, ii, 1900, 138.

F[loricola] constanti leocadiae Hartert, Das Tierreich, Troch., 1900, 193.

Anthoscenus leocadiæ Milder (W. De W.), Bull. Am. Mus. N. H., xxi, Nov. 24, 1905, 355 (Escuinapa, etc., s. Sinaloa; crit.).

[Heliomasies] leocadia Bonaparte, Rev. et Mag. de Zool., 1854, 251.

Heliomaster leocadia I.Awrence, Bull. U. S. Nat. Mus., no. 4, 1876, 32 (Tehuántepec City, Oaxaca). 
Floricola leocardia: Salvin, Cat. Birds Brit. Mus., xvi, 1892, 232 (Sierra de Álamos, Sonora; Presídio de Mazatlín; Bolaños, Jalisco; Valley of Mexico; Dos Arroyos, Rio Papagaio, Alta de Camarón, and Venta de Pelegrino, Guerrero; Chimalapa, Oaxica).

Heliomaster pinicola Gould, Mon. Troch., iv, pt. v, May, 1853, pl. 261.-De OcA, La Naluraleza, iii, 1875, 299; Troq. de Mlex., 1875, 53, pl. (11), fig. 42.

[Heliomaster] pinicolı Sanchez, Aual. Mus. Nac. Mex., i, 1877, 96 (pine region in. Mexico).

[Selasphorus. $\gamma$. Heliomaster] pinicola Reicuenbacir, Aufz. der Colib., 1854, 13. [Selasphorus] pinicola Reichenbacu, Troch. Enum., 1855, 11.

Heliomaster constantii (not Omismya constantii Delatire) Sclater, Proc. Zool. Soc. Lond., 1856, 287 (Mexico).

Heliomaster constanti Lawrence, Bull. U. S. Nat. Mus., 110. 4, 1876, 32 (Gineta Mts., Chiapas).

Floricola constanti BoucaRd, Gen. Hum. Birds, 1595, 304, part (Mexico).

Genus PAMPA Reichenbach.

Pampa Reichenbach, Aufz. der Colib., 1854, 11. (Type, P. campyloptera Reichenbach=Ornismya pampa Lesson.)

Sphenoproctus a Cabanis and Heine, Mus. Hein., iii, Feb., 1860, 11. (Type, Ornismya pampa Lesson.)

Rather large Trochilidæ (length about 115-125 mm.) with thickened shafts to outer primaries, straight, stout bill much longer than head, long graduated or cuneate tail, and under parts plain light gray.

Bill about one and a half times as long as head, straight or very nearly so, stout, broad and depressed basally; tomia smooth; mandible with a median lateral groove, the maxilla with a less distinct lateral groove. Nostril narrow, slit-like, overhung by a very broad, convex, tumid, unfeathered operculum. Tarsus densely feathered, slender, about as long as middle toe, the latter about as long as inner and slightly longer than outer toe; hallux decidedly shorter than outer toe; toes all slender and weak, and claws relatively small, especially that of the hallux. Wing much more than twice as long as bill, the outermost primary longest, the three outermost with shafts thickened basally, especially the outer one, which in adult males has the shaft greatly swollen in middle portion. Tail threefourths (more or less) as long as wing, graduated for more than onefourth its length, the rectrices broad but decreasing in width terminally, especially the middle pair, which in adult males are abruptly longer than the rest.

Coloration.-Forehead and crown metallic blue or violet, the rest of upper parts metallic green or bronze-green; lateral rectrices dusky, tipped with dull grayish in females; under parts wholly pale gray.

Range.--Southern Mexico to Guatemala. (Two species.)

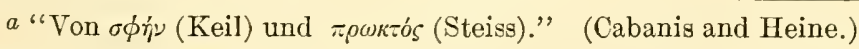
S1255 $5^{\circ}-\mathrm{Bull} .50-11-23$ 
KEY TO THE SUBSPECIES OF PAMPA PAMPA.

a. Under parts drab-gray; pileum metallic violet; bill shorter (culmen averaging 24.5 in adult male, 24 in adult female). (Guatemala to Yucatan.)

Pampa pampa pampa (p. 354). $a a$. Under parts very pale gray or grayish white; pileum metallic blue or greenish blue; bill longer (culmen averaging 27.3 in adult male, 26.6 in adult female). (Vera Cruz, San Luís Potosí, etc., to Campeche and Oaxaca.)

Pampa pampa curvipennis (p. 355).

\section{PAMPA PAMPA PAMPA (Lesson).}

\section{WEDGE-TAILED SABRE-WING.}

Adult male.-Pileum bright metallic violet or royal purple; rest of upper parts metallic green or bronze-green, the upper tail-coverts more bluish green; tail dull metallic bluish green, ${ }^{a}$ passing into purplish black or blackish violet terminally, this occupying most of inner web (except on middle pair of rectrices), the outer web of lateral rectrix brownish gray in middle portion, dusky basally; remiges purplish dusky; under parts, including malar and loral regions, brownish gray or drab-gray, the auricular region similar but darker; a postocular spot of dull white; maxilla dull black; mandible brownish (in dried skins), dusky terminally; feet brownish (in dried skins); length (skins), 115-131 (123); wing, 66-72 (68); tail, 48-59.5 (53.2); culmen, $23-25.5(24.5){ }^{b}$

Adult female.- Similar to the adult male, but two outer rectrices (on each side) broadly tipped with brownish gray, the outermost with terminal third, or more, of outer web also brownish gray, and with violet of crown slightly duller; length (skins), 116; wing, 62-64.5 (62.8); tail, 43.5-45 (44.3); culmen, $24 .^{c}$

Guatemala (Cobán; Choctúm; Cliséc; Guatemala City) and Yucatan (Izalám; Tizimín; La Vega).

Ornismya pampa Lesson, Hist. Nat. Colibr., Suppl. Ois.-Mouch., 1830-31, 127, pl. 15 ("Paraguay"; error); Index Gen. and Syn. Troch., 1832, p. vi ("Paraguay").

P[olytmus] pampa Gray, Gen. Birds, i, Dec., 1848, 107.

[Polytmus] pampa Grax, Hand-list, i, 1869, 125, no. 1568.

[Campylopterus] pampa Bonaparte, Consp. Av., i, 1850, 71 ("Paraguay").

Campylopterus pampa Bonaparte, Rev. et Mag. de Zool., 1854, 250.-Gould, Mon. Troch., pt. x, 1855, p1. 43 (vol. ii, 1861, pl. 43), part (Guatemala).Sclater and Salvin, Ibis, 1859, 127 (Guatemala).--Salvin, Ibis, 1860, 260 (Cobán, Guatemala).-Mulsant and Verreaux, Classif. Troch., 1866, 22, part (Guatemala); Hist. Nat. Ois.-Mouch., i, livr. 2, 1874, 115, part (Guatemala).

Sphenoproctus pampa (not of Cabanis and Heine, 1860) Gousd, Introd. Troch., oct. ed., 1861, 51.-Mulsant, Ann. Soc. Linn. Lyon, xxii, 1876, 201.Elisot, Classif. and Synop. Troch., 1879, 23.-Boucard, Liste Ois. récol. Guat., 1878, 44; Proc. Zool. Soc. Lond., 1883, 450 (Izalám and Tizimín, Yucatan; habits); Gen. Hum. Birds, 1895, 349 (Guatemala).-RidgwaY, Proc. U. S. Nat. Mus., iii, 1880, 309 (Guatemala).-SAlvin, Cat. Birds Brit. 
Mus., xvi, 1892, 286 (Choctúm, Chisec, and Cobán, Guatemala).-SAlvin and Godman, Biol. Centr.-Am., Aves, ii, 1892, 321.

Pampa pampa Elitor, Classif. and Synop. Troch., 1879, 22, in text.

[Sphenoproctus] pampa Sclater and Salvin, Nom. Av. Neotr., 1873, 79.

Sphenoproetus (Campylopterus) pampa Mulsant and Verreaux, Mist. Nat. Ois.-Mouch., iv; livr, 2, 1877, 147 (Guatemala).

Pampa campyloptera Reichenbach, Aufz. der Colibr., 1854, 11; Troch. Enum., 1855, 9, pl. S00, figs. 4861, 4862 .

[Pampa] lessoni Simon, Cate Troch., 1897, 8 (Guatemala).-Sharpe, IIand-list, ii, 1900, 101 (Guatemala; n. Yucatan).

P[ampa] lessoni Hartert, Das Tierreich, Troch., 1900, 30 (monogr.).

\section{PAMPA PAMPA CURVIPENNIS (Lichtenstein).}

CURVE-WINGED SABER-WING.

Similar to P. p. pampa but bill decidedly longer, under parts much paler (dull grayish white instead of drab-gray), and pileum duller and more greenish or less violaceous blue.

Adult male.-Pileum rather dull metallic violet-blue, varying to greenish blue; rest of upper parts bright metallic bronze or bronzegreen, the middle pair of rectrices varying from bronze-green to bluish green, the next pair similar but passing into blackish terminally, the rest mostly dull black (faintly glossed) with basal portion of outer web bronze-green, the outermost edged for terminal half (more or less) with grayish brown (sometimes with outer web mostly of this color) and sometimes with a streak of the same near shaft; remiges dark brownish slate or dusky, very faintly glossed with purplish bronzy; auricular and suborbital regions brownish gray; loral and malar regions, together with whole of under parts very pale gray or dull grayish white, the under tail-coverts inclining more or less to brownish buff (sometimes decidedly of this color) with the central or mesial portion indistinctly dull grayish; bill dull black; iris dark brown; feet dusky brownish (in dried skins); length (skins), 129-143 (136); wing, 65-68.5 (66.8); tail, 50-55.5 (52.5); culmen, 26-29.5 (27.3). ${ }^{a}$

Adult female. - Similar to the adult male but middle rectrices less elongated, lateral rectrices broadly tipped with dull gray, and blue of pileum usually duller, sometimes replaced on forehead with dull dusky grayish; length (skins), 120-130 (125); wing, 60-68 (63.6); tail, 46-50 (47.4); culmen, 26-27.5 (26.6). ${ }^{b}$

Young.-Similar to adults but under parts tinged or suffused with brownish buffy. ${ }^{c}$

$a$ Nine specimens.

$b$ Four specimens.

c A specimen in the Biological Survey Collection (no. 158756, coll. U. S. Nat. Mus.) from Metlaltoyuca, Puebia, with sex determined as male by the collector but probably a female or immature male, differs from all other specimens examined in having the green of back, etc., much more bronzy and blue of pileum decidedly greenish. 
Southeastern Mexico, in States of San Luís Potosí (Jilitla), Puebla (Metlaltoyuca), Vera Cruz (Jalapa; Córdova; Miradór; Orizaba; Coátepec; Colipa; Atoyác; Misantla; Cuesta de Misantla), Oaxaca (Teotalcingo), and Campeche (Apazote). ${ }^{a}$

Trochilus curvipennis Lichtenstein, Preis-Verz. Mex. Vög., 1830, i, no. 32; Journ. für Orn., 1863, 55 (Mexico).

Sphenoproctus curvipennis Gould, Introd. Troch., oct. ed., 1861, 51.-Mulsant and Verreaux, Hist. Nat. Ois.-Mouch., iv, ${ }^{\bullet 1877,} 147$ (Mexico).-Mulsant, Ann. Soc. Linn. Lyon, xxii, 1876, 201.-Eluıot, Classif. and Synop. Troch., 1879, 23.-Ridgway, Proc. U. S. Nat. Mus., iii, 1880, 309 (Miradór, Vera Cruz).-Ferrari-Perez, Proc. U. S. Nat. Mus., ix, 1886, 156 (Jalapa, Vera Cruz).-Salvin, Cat. Birds Brit. Mus., xvi, 1892, 287 (Misantla, Colipa, Cuesta de Misantla, Coátepec, Jalapa, and Atoyác, Vera Cruz).-SalviN and Godman, Biol. Centr.-Am., Aves, ii, 1892, 322.-Boucard, Gen. Hum. Birds, 1895, 350.-Chapman, Bull. Am. Mlus. N. H., x, 1898, 33 (Jalapa; habits; notes).-La Latz, Trans. Kans. Ac. Sci. for 1896-97 (1899), 221 (Coátepec, Vera Cruz).

[Sphenoproctus] curvipennis Sclater and SAlvin, Nom. Av. Neotr., 1873, 79.Boucard, Notes quelques Troch., 1873, 4 (Córdova and Jalapa; habits).Mulsant and Verreaux, Hist. Nat. Ois.-Mouch., i, liv. ii, 1874, 117 (in text).

P[ampa] curvipennis HARTERT, Das Tierreich, Troch., 1900, 30 (monogr.).

[Pampa] curvipennis Simon, Cat. Troch., 1897, 8.-Sharpe, Hand-list, ii, $1900,101$.

Campylopterus pampa, var. curvipennis Mulsant and Verreadx, Classif. Troch., 1866, 22.

[Polytmus] curvipennis Grat, Hand-list, i, 1869, 125, no. 1569.

Campylopterus pampa (not Ornismya pampa Lesson) Sclater, Proc. Zool. Soc. Lond., 1856, 287 (Córdova); 1859, 367, 385 (Teotalcingo, Oaxaca); Cat. Am. Birds, 1862, 287 (Mexico).-Mudsant and Verreaux, Hist. Nat. Ois. Mouch., i, livr. 2, 1874, 115, part (Mexico)-D'Oca, Proc. Ac. Nat. Sci. Phila., 1860, 551 (habits); La Naturaleza, iii, 1875, 30; Troq. de Mex., 1875, 25, pl. (3), fig. 12.-SANChez, An. Mus. Nac. Mex., i, 1877, 96 (Orizaba). S[phenoproctus] pampa Cabanis and Herne, Mus. Hein., iii, 1860, 11 (Jalapa). Uranomitra quadricolor (not Trochilus quadricolor Vieillot) Ridgway, Proc. U. S. Nat. Mus., iii, 1880, 317, part (Orizaba; =very young; see Berlepsch, Proc. U. S. Nat. Mus., ix, 1888, 562).

\section{Genus CAMPYLOPTERUS Svainson.}

Campylopterus Swainson, Zool. Journ., ii, 1826, 358. (Type, Trochilus largipennis, Boddaert.)

Saepiopterus Reichenbach, Aufz. der Colib., 1854, 11. (Type, Trochilus lazulus Vieillot.)

Platystylopterus Reichenbach, Aufz. der Colib., 1854, 11. (Type, Campylopterus rufus Lesson.)

Loxopterus ${ }^{b}$ Cabanis and Herne, Mus. Hein., iii, Feb., 1860, 13. (Type, Campylopterus hyperythrus Cabanis.)

a The specimen from Apazote, Campeche, is intermediate between $P$. pampa pampa and $P$. pampa curvipennis, but nearer the latter.

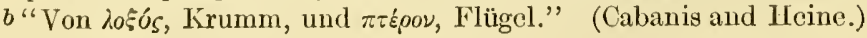


Large Trochilida (length about 115-140 $\mathrm{mm}$.) with bill much longer than head, straight to decidedly decurved; tail two-thirds to threefourths as long as wing, slightly rounded; very weak feet; and shafts of outer primaries thickened basally (in adult males excessively so).

Bill slightly longel than head (in C. hyperythrus) to one and a half times as long, straight (C. hyperythrus, C. rufus, C. Zargipennis, and C. obscurus) to decidedly decurved (C. ensipennis, C. hemileucurus, C. lazulus, and $C$. villavicencio); tomia smooth; both mandible and maxilla with a distinct lateral groove, the former on basal half, mainly. Nostril narrow, slit-like, overhung by a broad, convex, tumid, mostly unfeathered membrane, but frontal feathering reaching to or beyond middle of upper portion. Tarsus densely feathered, slender, about as long as anterior toes; middle and inner toes equal in length, the inner very slightly shorter; hallux decidedly shorter than outer toe; middle toe united to outer for whole of its basal phalanx, to inner toe for less that distance; all the toes weak and slender, and claws relatively small. Wing about three times as long as exposed culmen, the outermost primary longest; three outer primaries with shafts more or less thickened basally, especially in adult males, in which the shaft of the outermost is greatly enlarged and strongly bowed toward middle portion. Tail two-thirds to three-fourths as long as wing, slightly rounded, the rectrices very broad, rounded terminally (in C. obscurus tapering and pointed terminally).

Coloration.-a. Saepiopterus: Metallic green or green and violet above, the tail black, with lateral rectrices extensively white terminally, or (in C. lazulus) chestnut tipped with green; adult males with under parts metallic blue or violet, or green with violet throat; adult females with under parts gray mixed with green on sides and blue on throat. $b$. Campylopterus: Above metallic bronze green, including middle rectrices, the outer rectrices blackish with broad white tips; beneath wholly light gray; sexes alike. (C.largipennis, C.obscurus.) c. Platystylopterus: Above metallic bronze green, the middle rectrices greenish bronze or golden bronze; other rectrices (at least in part) light cinnamon-rufous; under parts wholly light cinnamonrufous. Sexes alike, or very nearly so.

Although for present purposes it may be as well to retain the genus Campylopterus with its generally recognized limits I am convinced that the genus as so recognized is not a natural group, but a combination of at least two and probably three generic groups, as indicated in the paragraph describing coloration. The species with uniform gray under parts (in both sexes) closely resemble those of the genus Pampa in coloration (except for the absence of a blue or violet frontal patch), and the relationship is still further indicated by the form of the rectrices in C. obscurus, for, while the tail is slightly rounded (not gradu- 
ated, as in Pampa) the rectrices are distinctly narrowed terminally. The bill, moreover, in all the species of the group (true Campylopterus) is straight, as in Pampa, though less broad and depressed basally.

KEY TO THE SPECIES OF CAMPILOPTERUS.

a. Under parts metallic blue or violet (adult male), dusky (young male), or gray with blue on throat (female); lateral rectrices broadly tipped with white. (Southeastern Mexico to western Panamá.) ...... Campylopterus hemileucurus (p. 35s).

aa. Under parts light cinnamon-rufous or vinaceous-cinnamon (in both sexes); lateral rectrices broadly tipped with light cinnamon-rufous. (Guatemala.)

Campylopterus rufus (p. 361).

\section{CAMPYLOPTERUS HEMILEUCURUS (Lichtenstein).}

DE IATTRE'S SABRE-WING.

Adult male.-Forehead and crown duskr, faintly glossed with bluish green; occiput, hindneck, upper back (at least partly), auricular, suborbital. and malar regions, and under partsofrom chin to anal region (inclusive), bright metallic riolet-blue to bluish violet, occasionalls rarring, in places, to more greenish blue, the feathers dusky or blackish subterminally, grarish basally; lower back mixed rioletblue and green or bluish green; scapulars, wing-corerts, rump, and upper tail-corerts metallic green or bluish green, the feathers of rump sometimes tipped with blue; tail bluish black, the middle pair of rectrices usually tinged with green, the three outermost (on each side) very broadly tipped with white, this on lateral pair occupying much more than terminal third; remiges dull blackish or dusky, faintly glossed with purplish; under tail-coverts dull dark metallic green or (partly) greenish blue: conspicuous femoral tufts white or grayish white; bill black; iris dark brown; legs and feet dusky; length (skins), 136-15t (142); wing, 76.5-\$2.5 (79.5); tail, 52.5-60 (56.S); culmen, 26-31 (2S.9). ${ }^{a}$

Adult female.-Abore bright metallic green or bronze-green, much duller (sometimes dusky glossed with bronze) on forehead and cromn, appearing more bluish green when riewed from in front, especially on upper tail-coverts; middle rectrices duller and more bluish green; lateral rectrices and remiges as in adult male, but former glossed with bluish green on basal portion of outer webs; under parts gray, paler on abdomen, glossed with metallic green laterally (especially on sides and flanks), the throat spotted with bright metallic blue or violet-blue, often forming a solid patch of this color; bill, etc., as in adult male; 
length (skins), 12s-14.3 (136); wing, 6s.5-7s (73.9); tail, 50.5-56 (53.6); culmen, 30-35.5 (32.1). ${ }^{a}$

Young male.-Above similar in coloration to adult female; below dusky, glossed with bluish green, older specimens showing blue or violet feathers of the adult dress appearing first on median line of throat and center of breast.

Ioung female.-Similar to adult female but green of upper parts more bronzy and throat with little if any metallic blue.

Southern Mexico, in States of Tera Cruz (Jalapa; Córdora; Orizaba; Huatusco; Coátepec; Playa Ticente), Mexico (near City of Mexico), Guerrero (Chilpancingo: Omilteme), Oaxaca (Teotalcingo; Chimalapa; Tehuántepec; Sierra de Santo Domingo), Tabasco (Teapa), and Chiapas (Tumbalá; Gineta Mountains), and southward through Guatemala (Choctúm; Cobán; Dueñas; Guatemala City; Gualán; Kamkál; Tolcán de Fuego; Tolcán de Agua; Totonicapám; Retalhuleu), British Honduras (Manatee Lagoon), Honduras (Santa Ana), Nicaragua (Matagalpa; San Rafaél, Lake Nicaragua), and Costa Rica (Cerro de la Candelária; Escazú; Tolcán de Irazú; La Estrella de Cartago; Navarro de Cartago; Azahár de Cartago; La Palma de San José; Tucurríqui; La Hondura; Juan Vinas; Tres Rios; Rancho Redondo; Cerro de Santa Maria; San Pedro; Santa Maria de Dota; Ojuras de Térraba) to western Panamá (Boquete; Tolcán de Chiriquí; Calorérora: Chitra; Cordillera del Chucu).

Trochilus hemileucurus Lichtexstern, Preis.-Terz. Mex. Tög., 1830, 1 (Mexico): Journ. für Orn., 1S63, 56.

a Thirty specimens.

\begin{tabular}{|c|c|c|c|}
\hline Locality. & Wing. & Tail. & $\begin{array}{c}\text { Ex- } \\
\text { posed } \\
\text { culmen. }\end{array}$ \\
\hline MALES. & & & \\
\hline Ten adult males from southeastern Mexico.... & 79.7 & 56 & $2: .6$ \\
\hline Seren adult males from Chiapas (3) and Guatemala ( 1 )........ & 80.7 & 5.5 .6 & 28.5 \\
\hline One adult male from British Honduras.................... & 82 & 5.5 & 27.5 \\
\hline Ten adult males from Costa Rica................................ & 79.9 & 59.2 & 29.9 \\
\hline 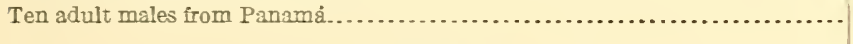 & $\pi .6$ & 56.9 & 29.5 \\
\hline FEMALES. & & & \\
\hline Five adult females irom southeastern Merico... & 75.2 & 33.1 & 31.3 \\
\hline Six adult females from Chiapas (1) and Guatemala (5) ............. & $i \pm .5$ & 52.7 & 31.4 \\
\hline Two adult females irom Honduras and British Honduras..... & 76.7 & 54 & 30.7 \\
\hline Ten adult females from Costa Rica............ & 73.9 & $5 \pm$ & 33 \\
\hline Seren adult females from Panamá... & 71.6 & 33.9 & 32.5 \\
\hline
\end{tabular}

After careful comparison of seventy adult males and thirty-two adult females I am unable to appreciate any constant color differences betreen specimens from difierent geographic areas. 
C[ampylopterus' hemileucurus Cabanis and Heine, Mus. Hein., iii, 1860, 13 (Mexico; Guatemala).-Hartert, Das Tierreich, Troch., 1900, 32 (monogr.).

Campylopterus hemileucurus Gould, Introd. Troch., oct. ed., 1861, 52.-CaBanis, Journ. für Orn., 1862, 162 (San José, Costa Rica).-Sclater, Cat. Am. Birds, 1862, 288 (Cobán, Guatemala); Proc. Zool. Soc. Lond. 1864, 176 (near City of Mexico).-Salvin, Proc. Zool. Soc. Lond., 1870, 205 (Cordillera del Chucu, Chitra and Calovévora, Panamá); Cat. Birds Brit. Mus., xvi, 1892, 291, 664 (Jalapa, Huatusco, and Playa Vicente, Vera Cruz; Omilteme, Guerrero; Tehuántepec, Chimalapa, and Sierra San Domingø, Oaxaca; Cobán, Kamkál, Volcán de Fuego, V. de Agua, Totonicapám, and Retalhuleu, Guatemala; Costa Rica; Calovévora, Cordillera del Chucu, and Boquete del Chitra, Panamá).-Lawrence, Ann. Lyc. N. Y., ix, 1868, 121 (Costa Rica).Frantzius, Journ. für Orn., 1869, 315 (Costa Rica).-Lawrence, Bull. U. S. Nat. Mus., no. 4, 1876, 32 (Gineta Mts., Chiapas)-_Boucard, Liste Ois. récol. Guat., 1878, 45 (Guatemala); Proc. Zool. Soc. Lond., 1878, 68 (Tres Rios and Rancho Redondo, Costa Rica; habits); Gen. Hum. B., 1895, 356.Sumichrast, La Naturaleza, v, 1881, 250 (Orizaba, Vera Cruz; Gineta Mts., Chiapas).-Elliot, Classif. and Synop. Troch., 1879, 26.-Ridgway, Proc. U. S. Nat. Mus., iii, 1880, 310 (Jalapa, Vera Cruz; Honduras; Guatemala; Costa Rica; Verágua).-Zeledón, Cat. Aves de Costa Rica, 1882, 20; Anal. Mus. Nac. Costa Rica, i, 1887, 121 (La Palma de San José, Costa Rica).Nutting, Proc. U. S. Nat. Mus., v, 1882, 501 (San José, Costa Rica).Ferrari-Perez, Proc. U. S. Nat. Mus., ix, 1886, 157 (Jalapa).-Salvin and Godman, Biol. Centr.-Am., Aves, ii, 1892, 323.-Hartert (E. and C.), Novit. Zool., i, 1894, 21 (Chilpancingo, Guerrero).-Lantz, Trans. Kans. Ac. Sci. for 1896-97 (1899), 221 (Coátepec, Vera Cruz).

[Campylopterus] hemileucurus Sclater and Salvin, Nom. Av. Neotr., 1873, 79.-

Sharpe, Hand-list, ii, 1900, 102.

[Polytmus] hemileucurus GRAY, Hand-list, i, 1869, 124, no. 1559.

Sxpiopterus hemileucurus Boucard, The Hum. Bird, ii, 1892, 86 (Verágua).

Ornismyia de lattrei "Lesson" Delattre and Lesson, Rev. Zool., ii, 1839, 19 (Jalapa, Vera Cruz, Mexico).

M[ellisuga] delatrei Gray, Gen. Birds, i, Dec. 1848, 113.

[Campylopterus] delattrei Reichenbach, Aufz. der Colibr., 1854, 11; Troch. Enum., 1855, 9, pl. 804, figs. 4869, 4870.-Boucard, Notes quelques Troch., 1873, 4 (Córdova and Jalapa, Vera Cruz; Cobán, Guatemala; habits).

Campylopterus delattrei Gould, Mon. Troch., pt. x, 1855 (vol. ii, pl. 45).D'Oca, Proc. Ac. Nat. Sci. Phila., 1868, 47 (habits).-Mulsant and VerReAux, Hist. Nat. Ois.-Mouch., i, livr. 2, 1874, 134 (Córdova, Jalapa, Orizaba, and Coátepec, Vera Cruz; Cobán, Guatemala); iv, livr. 2, 1877, 149.Mulsant, Ann. Soc. Linn. Lyon, xxii, 1876, 202.

Campylopterus delattrii Sclater, Proc. Zool. Soc. Lond., 1856, 287 (Mexico); 1859, 367 (Jalapa), 385 (Teotalcingo, Oaxaca).-Moore, Proc. Zool. Soc. Lond., 1859, 53 (Guatemala).-Sclater and Salvin, Ibis, 1859, 127 (Cobán, Guatemala).-Salvin, Ibis, 1860, 195 (Cobán; habits), 260 (Cobán, Guatemala; habits).

[Campylopterus] delattre Bonaparte, Consp. Av., i, 1850, 71.

[Campylopterus] delattrii Bonapar'te, Rev. et Mag. Zool., 1S54, 250.

Campylopterus delattrie D'Oca, Troq. de Mex., 1875, pl. (1.), fig. 4.

Campylopterus hemileucurus mellitus Bangs, Proc. New Engl. Zool. Club, iii, Jan. 30, 1902, 28 (Boquete de Chiriquí, Panamá, 4,800 ft.; coll. E. $\Lambda$. and O. Bangs).-Carriker, Ann. Carnegie Mus., vi, 1910, 521 (plateau region Costa Rica; habits). 


\section{CAMPYLOPTERUS RUFUS LesSOn.}

\section{RUFOUS SABRE-WING.}

Adult male.-Above bright metallic bronze-green or greenish bronze, becoming more bronzy on upper tail-coverts and middle rectrices, the pileum slightly darker and duller, with feathers narrowly and indistinctly margined with dusky; middle pair of rectrices wholly metallic bronze or greenish bronze, the next pair similar but with a broad, ill-defined, subterminal band of blackish and tipped with cinnamon; next pair similar but with basal half or more of outer web (less on imner web) deep vinaceous-cinnamon or cinnamon-rufous, the blackish subterminal band more sharply defined and the cinnamon tip broader; next pair with outer web cinnamon-rufous almost if not quite to the black subterminal band and inner web with the same color proportionally increased in extent, the cinnamomeous tip still broader; outermost pair with outer web wholly cinnamon-rufous (paling slightly terminally), the inner web the same color but interrupted by a broad subterminal band of black preceded anteriorly by a narrow one of greenish bronze; remiges dusky, faintly glossed with violaceous; under parts plain vinaceous-cinnamon, slightly paler medially, the downy femoral tufts white; maxilla dull black, mandible dusky brownish (in dried skins); iris dark brown; feet light grayish brown (in dried skins); length (skins), 127-138 (132); wing, 71-76 (73.5); tail, 47.5-51.5 (49.2); culmen, 25-27.5 (26.3). ${ }^{a}$

Adult female.-Similar in coloration to the adult male but black subterminal area on inner web of lateral rectrix roundish instead of quadrate, and shafts of outer primaries not conspicuously thickened; length (skins), 121-135 (128); wing, 68.5-74.5 (71.5); tail, 49.5-50 (49.7); culmen, 26-26.5 (26.2). ${ }^{b}$

Highlands of Guatemala, 5,000-7,000 feet altitude (Guatemala City; Dueñas; Atitlán; Volcán de Fuego; plains near Pacicia and Patzúm).

Campylopterus rufus Lesson, Rev. Zool., 1840, 73 (loc. ignot.).-Bonaparte, Consp. Av., i, 1849, 71; Rev. et Mag. de Zool., 1854, 250.-Gourd, Mon. Troch., pt. iii, 1852 (vol. ii, 1861), pl. 50; Introd. Troch., oct. ed., 1861, 54.Sclater and Salvin, Ibis, 1859, 127 (Dueñas and Atitlán, Guatemala).Salvin and Sclater, Ibis, 1860, 38 (Dueñas; habits).-Salvin, Ibis, 1860, 195, 263, 264; Cat. Birds Brit. Mus., xvi, 1892, 294, 664.-Sclater, Cat. Am. Birds, 1862, 288 (Dueñas, Guatemala).-Mursant and Verreaux, Classif. Troch., 1866, 22; Hist. Nat. Ois.-Mouch., i, livr. 2, 1874, 133.-Mulsanr, Ann. Soc. Linn. Lyon, xxii, 1876, 202.-Elliot, Classif. and Synop. Troch., 1879, 25.-Salvin and Godman, Biol. Centr.-Am., Aves, ii, 1892, 324 (Dueñas, Volcán de Fuego, and plains near Pacicia and Patzúm, Guatemala; Volcan de San Miguél, Salvador).-Ridgway, Proc. U. S. Nat. Mus., iii, 1880, 310 (Dueñas; Guatemala City).-Dearborn, Pub. 125, Field Mus. N. H., 1907, 96 (Lake Atitlán, Guatemala). 
[Campylopterus] rufus Sclater and Salvin. Nom. Av. Neotr., 1873, 79.Sharpe, Hand-list, ii, 1900, 102.

C[ampylopterus] rufus Hartert, Das Tierreich, Troch., 1900, 33 (monogr.).

P[olytmus] rufus Gray, Gen. Birds, i, Dec., 1848, 107.

[Polytmus] rufus Gray, Hand-list, i, 1869, 124, no. 1565.

Platystylopterus rufus Reichenbach, Aufz. der Colibr., 1854, 11; Troch. Enum., 1855, 8, pl. 789, figs. 4834-5.

Saepiopterus rufus Boucard, Gen. Hum. Birds, 1895, 360.

\section{Genus PH EOCHROA Gould.}

Phrochroa a Gould, Introd. Troch., oct. ed., 1861, 55. (Type, Trochilus cuvieri Delattre and Bourcier.)

Rather large Trochilidæ (length about 115-120 mm.) with bill slightly longer than head, strong, nearly straight, narrowly cuneate in vertical profile; wing about three times as long as exposed culmen, the outer primary longest, its shaft more or less thickened toward base, especially in adult males; tail more than three-fifths as long as wing, slightly or moderately rounded, the rectrices rather broad but contracted terminally where narrowly rounded; plumage very dull-dull metallic bronze-green above, pale dull bronze-greenish on anterior under parts, the posterior under parts pale grayish buffy; lateral rectrices dull black, broadly tipped with white or whitish. Sexes alike in color.

Bill slightly to decidedly longer than head, stout, nearly straight, broader than deep (except terminally), narrowly cuneate in vertical profile; tomia smooth; culmen indistinctly ridged (distinctly so basally); maxilla and mandible with lateral sulci rather indistinct. Nostril narrow, slit-like, overhung by a rather narrow, straightedged (or at least not distinctly convex) operculum, feathered on its upper and posterior portions. Tarsus feathered only on upper anterior portion, rather stout, slightly shorter than middle and inner toes, these equal in length, the outer slightly shorter; hallux slightly shorter than anterior toes; middle toe united to outer for whole of its basal phalanx, to inner toe for nearly as much; toes and claws moderately strong. Wing at least three times as long as exposed culmen, the outermost primary longest, its shalt very rigid, more or less thickened basally (especially in adult males). Tail nore than three-fifths as long as wing, slightly to moderately rounded, the rectrices rather broad but somewhat abruptly contracted terminally into a rounded point.

Coloration.-Dull bronze-green above, paler dull bronze-green anteriorly beneath, with pale dull buffy margins to feathers, the abdomen plain dull buffy, the under tail-coverts bronzy grayish, margined with white; lateral rectrices black, broadly tipped with white or whitish. Sexes alike in color. 
Range.-Guatemala to Colombia and Venczuch. (Two species.)

While closely resembling, superficially, the type species of Aphantochroa Gould, this gremus differs in relatively longer tail (more, instead of less, than three-filths as long as wing), ridged instead of rounded culmen, and less distinct lateral sulei of maxilla and mandible. The coloration is very similar but Aphantochroa lacks the white tips to the lateral rectrices, so conspicuous in both sexes of both species of Phrochroa. The two groups are, however, very closely related, and Phxochroa undoubtedly is more nearly allied to Aphantochroa than to Campylopterus.

KEY TO THE SPECIES AND SUBSPECIES OF PHAOCHROA.

a. Basal half (approximately) of mandible pale brownish or whitish (reddish or pinkish in life); lateral rectrices extensively bronze-greenish basally. (Phæochroa cuvieri.)

b. Green of under parts paler; abdomen paler, more buffy; bill slightly shorter. (Western Costa Rica to northern Colombia; coast of Venezuela?)

Phæochroa cuvierii cuvierii (p. 363).

bb. Green of under parts darker; abdomen darker and more brownish; bill slightly longer. (Coiba Island, Bay of Panamá.)

Phæochroa cuvierii saturatior (p. 365).

aa. Mandible wholly dusky; lateral rectrices with little if any bronze-green on basal portion. (Guatemala and British Honduras to eastern Nicaragua.)

Phæochroa roberti (p. 365).

\section{PHAOCHROA CUVIERII CUVIERII (Delattre and Bourcier).}

CUVIER'S HUMMING BIRD.

Adults (sexes alike).-Above metallic bronze-green (sometimes more bronzy posteriorly), the tail usually more bluish or silvery green; lateral pair of rectrices extensively grayish white terminally (usually tinged on outer web with gray), ${ }^{a}$ this separated from the bronzegreenish basal portion by an ill-defined band of dull blackish or dusky, the second pair with a less extensive, but still conspicuous, whitish tip, the third sometimes slightly tipped with grayish; remiges dark brownish slate or dusky, faintly glossed with purplish; chin, throat, chest, and sides of breast rather dull metallic bronze or bronzegreen, the feathers narrowly margined with dull grayish buffy or pale buffy grayish; flanks, abdomen, and median line of breast pale isabella color or pale, dull brownish buffy, the first glossed with bronze or bronze-green; femoral tufts and tuft on each side of rump white, the latter usually intermixed with pale grayish; under tailcoverts dull metallic bronze or bronzc-greenish, broadly margined with white; bill dull black, the basal half (more or less) of mandible pale brownish or whitish (fleshy or pinkish in life); iris dark brown, feet dusky.

a Sometimes there is a bronze-dusky spot at tip of outer web. 
Adult male.-Length (skins), 113-122 (118); wing, 66.5-75.5 (72.2); culmen, 21-24 (22.4). ${ }^{a}$

Adult female.-Length (skins), 110-124 (117); wing, 63.5-73 (68.6); tail, 40.5-46.5 (43.7); culmen, 21.5-24.5 (23). ${ }^{b}$

Young.--Similar to adults, but feathers of upper parts (especially the rump) margined terminally with pale buffy brownish.

Western Costa Rica (Miravalles; Bebedero; Punta Arenas; Esparta; Pigres; Bolsón; Boruca; Buenos Aires; Pozo Azúl de Pirrís; El Generál; San Pedro), Panamá (David; Bugaba; Panamá; Paraiso; Loma del León), and north coast of Colombia (Barranquilla); coast of Venezuela?

T[rochilus] cuvierii Delattre and Bourcier, Rev. Zool., 1846, 310, part (Isthmus of Panamá; coll. Delattre, now in Phila. Acad.).

[Campylopterus] cuvieri Bonaparte, Consp. Av., i, 1850, 71.

[Campylopterus] cuvierii Reichenbach, Troch. Enum., 1855, 9, pl. 805, fig. 4871. Campylopterus cuvieri Gould, Mon. Troch., pt. xii, 1856, pl. 52 (vol. ii, 1861, pl. 52).-La wrence, Ann. Lyc. N. Y., vii, 1862, 319 (Lion Hill, Panamá).Mulsant and Verreaux, Classif. Troch., 1866, 22.-Elliot, Classif. and Synop. Troch., 1879, 27.-Zeledón, Cat. Aves de Costa Rica, 1882, 20; Anal. Mus. Nac. Costa Rica, 1887, 121 (Pozo Azúl de Pirrís, Costa Rica).-Boucard, The Hum. Bird, ii, 1892, 86 (Verágua).

[Aphantochroa] cuvieri Bonaparte, Rev. et Mag. de Zool., 1854, 250.-Simon, Cat. Troch., 1S97, 9.-SHARPe, Hand-list, ii, 1900, 103.

Aphantochroa cuvieri Mulsant and Terreaux, Hist. Nat. Ois.-Mouch., i, livr. 2, 1874, 137 (Venezuela; Colombia; Panamá; Verágua); iv, livr. 2, 1877, 150.-Bangs, Auk, xxiv, 1907, 295 (Boruca, Costa Rica).-Carriker, Ann. Carnegie Mus., vi, 1910, 523 (Pacific coast, Costa Rica; habits).

A[phantochroa] cuvieri Cabanis and Heine, Mus. Hein., iii, 1860, 14 (Verágua).Hartert, Das Tierreich, Troch., 1900, 37 (monogr.).

Phæochroa cuvieri Gould, Introd. Troch., oct. ed., 1861, 55.-Sclater and Salvin, Proc. Zool. Soc. Lond., 1864, 365 (Lion Hill, Panamá.)-Salvin, Proc. Zool. Soc. Lond., 1867, 153 (David, Panama); 1870, 205 (Bugaba, Panamá); Cat. Birds Brit. Mus., xvi, 1892, 299 (Punta Arenas, Miravalles, and Bebedero, Costa Rica; Bugaba, Davíd, Panamá, Lion Hill, and Paraiso Station, Panamá).-Lawrence, Ann. Lyc. N. Y., ix, 1868, 121 (Gulf of Nicoya, Costa Rica).-Mulsant, Ann. Soc. Linn. Lyon, xxii, 1876, 202.-Frantzius, Journ. für Orn., 1869, 315 (Costa Rica).-Berlepsch, Journ. für Orn., 1887,

a Thirteen specimens.

$b$ Nineteen specimens.

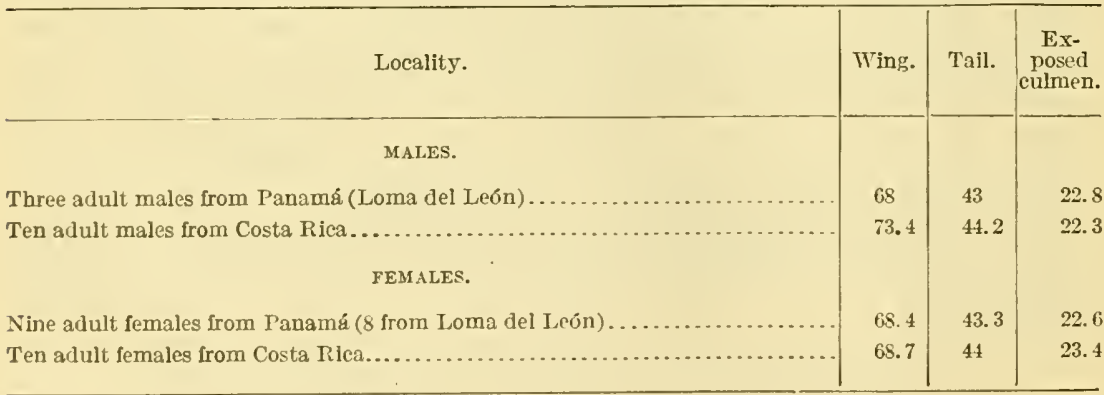


335 (Barranquilla, Colombia)--Cherrie, Expl. Zool. Merid. Costa Rica, 1S93, 45 (Boruca and Bucnos Aires, s. w. Costa Rica). -Salvin and Godmax, Biol. Centr.-Am., Aves, ii, 1892, 326 (Colombia?; Venezuela?, etc.).--BouCard, Gen. Hum. Birds, 1595, 353, part (Costa Rica; Chiriquí; Colón).Ridgwar, Coultor, vii, 1905, 154, in text (Pigres, Costa Rica).

[Phxochroa] cuileri Sclater and Salvin, Nom. Av. Neotr., 1S73, S0.

[Polytmus] curieri Grar, Hand-list, i, IS69, 125, no. 1573.

[Caligene] clemencix (not Ornismya clemencix Lesson) Reichensach, Troch.

Enum., 1S55, 3, pl. 687, fig. 4517, part (supposed female).

Aphantochroa cirrhochloris (not Trochilus cirrhochloris Gmelin) Bangs, Proc. New Engl. Zool. Club, ii, 1900, 19 (Loma del León, Panamá).

\section{PHAOCHROA CUVIERII SATURATIOR (Hartert).}

\section{COIBA ISLAND HUMMING BIRD.}

Similar to P. c.cuvierii, but green of throat, chest, and breast much deeper, abdomen darker (browner), and bill slightly longer.

Coiba Island, Bay of Panamá.

This form I have not seen, but it seems, judging from the original description (which omits measurements), to be quite well marked.

A phantochroa cuvierii saturatior HarTerT, Bull. Brit. Orn. Club, xii, no. lxxxiv, Dec. 30, 1901, 33 (Coiba Island, Bay of Panamá; coll. Tring Mus.).

\section{PHAOCHROA ROBERTI (Salvin).}

OWEN'S HUMMING BIRD.

Similar to $P$. cuvierii but mandible wholly dusky and lateral rectrices (except for whitish tip) wholly dusky or with bronze-greenish at base only.

Adults (sexes alike).-Above metallic bronze or bronze-green, the middle pair of rectrices usually more bluish or silvery green; rectrices next to middle pair bronze-green tipped with dusky; next pair similar but more extensively dusky terminally, sometimes with a small apical spot of white; next pair with less than basal half bronzegreen, the rest blackish, with a large terminal cuneate or guttate spot of white; lateral pair black to or near extreme base, the white terminal spot still larger (sometimes with a small dusky area on outer terminal portion of outer web); remiges dusky or dark brownish slate, faintly glossed with purplish; chin, throat, chest, and sides rather dull metallic bronze or bronze-green, the feathers narrowly margined with pale grayish buffy; rest of under parts pale dull cinnamonbuff or pale isabella color, the under tail-corerts dull bronze-greenish (or grayish dusky glossed with bronze-greenish), broadly-margined with white; femoral tufts and tuft on each side of rump white; bill dull black, the mandible indistinctly more brownish basally; iris dark brown; feet dusky.

Adult male.--Length (skins), 115-122 (118); wing, 66.5-70 (68.4); tail, 41-43.5 (42.6); culmen, 20-21 (20.6). ${ }^{a}$ 
Adult female.-Length (skin), 110; wing, 66.5; tail, 43; culmen, $22.5 .^{a}$

Guatemala (mountains of Vera Paz; Choctúm; Cantoöloc; Telemán), British Honduras (Belize River; Cayo; San Felipe), Honduras (Santa Ana; San Pedro Sula), and eastern Nicaragua (Los Sábalos).

Trochilus cuvieri Delattre and Bourcier, Rev. Zool., 1846, 310, part (Telemán, Guatemala).

Phacochroa cuvieri Boucard, Gen. Hum. Birds, 1895, 353, part (Guatemala).

A phantochroa roberti Salvin, Proc. Zool. Soc. Lond., 1861, 203 (tierra caliente of Vera Paz, e. Guatemala; coll. O. Salvin); Ibis, 1861, 354 (Guatemala; crit.).-Heine, Journ. für Orn., 1S63, 178.

Aphantocrhoa roberti Mulsant and Verreaux, Hist. Nat. Ois.-Monch., i, livr. 2, 1874, 138 (mts. of Vera Paz, Guatemala).

[A phantochroa] roberti Simon, Cat. Troch., 1897, 9.

A[phantochroa] roberti HaRtent, Das Tierreich, Troch., 1900, 37 (monogr.).

Campylopterus roberti Gould, Mon. Troch., pt. xxiii, Sept., 1861, pl. 53 (vol. ii, 1861, pl. 53).-Mulsant and Verreaux, Classif. Troch., 1866, 22.-Elliot, Classif. and Synop. Troch., 1879, 28.-Ridgway, Proc. U. S. Nat. Mus., iii, 1880, 310 (Choctúm, Vera Paz, Guatemala).

Phrochroa roberti Gould, Introd. Troch., oct. ed., 1861, 55.-Mulsan', Ann. Soc. Linn. Lyon, xxii, 1876, 202.-Nutring, Proc. U. S. Nat. Mus., vi, 1884, 406 (Los Sábalos, Nicaragua).-Ridgway, Proc. U. S. Nat. Mus., xiv, 1891, 471 (San Pedro Sula and Santa Ana, Honduras).-Salvin, Cat. Birds Brit. Mus., xvi, 1892, 300 (San Felipe, Belize R., and Cayo, Brit. Honduras; Choctum and Cantoöloc, Guatemala).-Salvīn and Godman, Biol. Centr.-Am., Aves, ii, 1892, 326.-Lantz, Trans. Kansas Ac. Sci. for 1896-97 (1899), 221 (Cayo, Brit. Honduras).

[Phæochroa] roberti Sclater and Salvin, Nom. Av. Neotr., 1873, 80.

[Polytmus] roberti Gray, Hand-list, i, 1869, 125, no. 1574.

\section{Genus PHAOPTILA Gould.}

Phæoptila $b$ Gould, Mon. Troch., v, July, 1861, text to pl. 340; Introd. Troch., oct. ed., 1861, 169. (Type, Cyanomyia(?) sordida Gould.)

Similar to Cynanthus but tail relatively longer, feet relatively stouter, under parts brownish gray in both sexes, and coloration of upper parts very dull.

Bill much longer than head, depressed, broad at base, faintly decurved; culmen broadly rounded but contracted into a narrow ridge basally; tomia smooth; both maxilla and mandible with a narrow lateral median sulcus, that of the former indistinct, however. Nasal operculum broad, tumid, unfeathered, the frontal feathering forming a transverse line across base of forehead. Tarsus slender, with upper portion feathered; anterior toes about equal in length, the hallux slightly shorter, all the toes slender, with claws relatively small. Wing less than three times as long as exposed culmen, the 
outermost primary longest. Tail more than half as long as wing, slightly double-rounded, the rectrices broad, rounded at tip.

Coloration.--Nhove, including tail, plain olivaceous glossed with bronze or bronze-green; beneath plain brownish gray; a dusky auricular or suborbital spot; sexes essentially alike, but female with a broad subterminal area of black and terminal area of gray or brown on lateral rectrices.

Range--Mexican plateau. (Monotypic.)

Authorities have disagreed widely as to the relationship of this form, Elliot placing it near Doleromyia (=Leucippus) (a South American genus) and placing by fir the greater number of genera between it and Cynanthus ("Iache"), while Hartert unites it with the latter. I agree with Hartert in considering it most closely related to the latter, but would separate it generically on account of the differences mentioned in the above diagnosis.

\section{PHÆOPTILA SORDIDA (Gould).}

DUSKY HUMMING BIRD.

Adult male.-Above dull metallic bronze-green or greenish bronze, usually much duller (sometimes dull brownish gray or grayish brown) on forehead and crown and on upper tail-coverts; tail dull greenish bronze or grayish brown glossed with greenish bronze, the rectrices dusky basally, this occupying more than basal half of lateral rectrix; remiges purplish dusky, the outermost primary narrowly edged with pale gray or grayish white; a pale gray or grayish white postocular spot, and beneath this a poorly defined dusky area extending to beneath eye; under parts deep sooty gray (nearly mouse gray), deepest on throat, the feathers of which usually have a darker subterminal (concealed) area; femoral tufts and tuft on each side of rump white; shorter under tail-coverts brownish gray, the longer ones mostly buffy; bill brownish (reddish in life), passing into dusky terminally (more or less extensively); iris dark brown; feet dusky; length (skins), 98-106 (101); wing, 56.5-57. (56.8); tail, 35-35.5 (35.3); culmen, $27.5-29$ (28.3) ${ }^{a}$

Adult female.-Similar to the adult male but four lateral rectrices (on each side) bronzy green (duller and more grayish on lateral rectrix) crossed by a broad subterminal band of dull blue-blackish and tipped with pale brownish gray or grayish brown (most broadly on outermost rectrix); remiges paler and less purplish dusky, and gray of under parts averaging slightly paler than in adult male; length (skins), 101-103 (102); wing, 55; tail, 31.5-32 (31.7); culmen, $29 .^{\circ}$ 
Young male.-Similar to the adult male but general coloration slightly duller, feathers of upper parts (especially on lower back and rump) tipped or terminally margined with pale brown, rectrices usually tinged terminally with brownish buffy, under parts of body tinged with buffy brownish, and an indistinct malar or rictal stripe of pale brownish.

Western and southern Mexico, in States of Oaxaca (Oaxaca City; Tamazulapám; Huajuapám), Guerrero (Chilpancingo; Omilteme; El Limón; Tlapa; Iguala; Sierra Madre del Sur; Tepetlapa; Vente de Zopilote; Zumbango del Rio), Puebla (Tehuacán; Atlixco), Morelos (Cuernavaca; Yaútepec), Jalisco (Bolaños), and Sonora (Opodepe; La Chumata).

Cyanomyia (?) sordida Gould, Ann. and Mag. N. H., iv, 1859, 97 (Oaxaca, Mexico; coll. J. Gould).

Cyanomyia sordida Sclater, Proc. Zool. Soc. Lond., 1859, 386 (Oaxaca).

U[ranomitra] sordida Cabanis and Heine, Mus. Hein., iii, 1860, 41, footnote (Oaxaca).

Phæoptila sordida Gould, Mon. Troch., pt. xxii, July, 1861, pl. 340 (vol. v, pl. 340); Introd. Troch., oct. ed., 1861, 169.-D'OcA, La Naturaleza, iii, 1875, 210; Troq. de Mex., 1875, 52, pl. (11), fig. 41.-Elurot, Classif. and Synop. Troch., 1879, 10.--Ridgway, Proc. U. S. Nat. Mus., iii, 1880, 309 (Oaxaca).Salvin, Cat. Birds Brit. Mus., xvi, 1892, 63 (Sierra Madre del Sur, Chilpancingo, Tepetlapa, Vente de Zopilote, and Omilteme, Guerrero; Oaxaca).Salvin and Godyan, Biol. Centr.-Am., Aves, ii, 1892, 260 (Bolaños, Jalisco?; Cuernavaca, Morelos; Atlixco, Puebla; etc.).-Hartert, Novit. Zool., i, 1894, 61 (Zumbango del Rio and Chilpancingo, Guerrero).-Boucard, Gen. Hum. Birds, 1894, 109 (Oaxaca; Puebla).-Hartert (E. and C.), Novit. Zool., i, 1894, 19 (Zumbango del Rio and Chilpancingo, Guerrero).-THAYer and Bangs, Proc. Biol. Soc. Wash., xix, 1906, 18 (Opodepe and La Chumata, n.-centr. Sonora).

[Phæoptila] sordida Sclater and Salvin, Nom. Av. Neotr., 1873, 93.-Sharpe, Hand-list, ii, 1900, 110.

P[haeoptila] sordida Hartert, Das Tierreich, Troch., 1900, 64 (monogr.).

Leucolia sordida Mulsant and Verreaux, Classif. Troch., 1865, 35.

[Hylocharis] sordida GraY, Hand-list, i, 1869, 152, no. 1957.

Doteromya sordida Boucard, Notes quelques Troch., 1873, 14 (Oaxaca City; Atlixco, Puebla; habits); Ann. Soc. Linn. Lyon, xx, 1873, 282 (Atlixco).Mulsant and Verreaux, Hist. Nat. Ois.-Mouch., i, livr. 3, 1874, 207 (Oaxaca; Atlixco; etc.); iv, livr. 3, 1878, 168.

[Doleromya] sordida Mulsant, Ann. Soc. Linn. Lyon, xxii, 1876, 204.

Phxoplila zonura Gould, Introd. Troch., oct. ed., 1861, 170 (Bolaños, Jalisco; Loddiges coll.).-D'OcA, La Naturaleza, iii, 1875, 304; Los Colibris Mex., 1875, 58 (cites fig. 47).

[Hylocharis] zonura GRAY, Hand-list, i, 1869, 152, no. 1958.

[Doleromya sordida] var. zonura Mulsant, Ann. Soc. Linn. Lyon, n. s., xxii, $1876,204$.

\section{Genus CYNANTHUS Swainson.}

Cynanthus Swarnson, Philos. Mag., n. s., i, June, 1827, 441. (Type C. latirostris Swainson; see Stone, Auk, xxiv, 1907, 192; Allen, Bull. Am. Mus. N. H., xxiii, 1907, 347; xxiv, 1908, 34.) 
Circe a (not of Mertens, 1835) Gould, Monogr. Troch., pt. xiii, May 1, 1857; 1861, 168. (Type, Cynanthus latirostris Swainson.)

Iache Eldiot, Classif. and Synop. Troch., March, 1879, 234. (Type, Cynanthus latirostris Swainson.)

Rather small Trochilidæ (length about $80-90 \mathrm{~mm}$.) with bill decidedly longer than head, very faintly decurved, broader than deep, broad and depressed basally, with the broad nasal operculi unfeathered (except at extreme base) and frontal feathering forming a transverse line; tail distinctly forked (sometimes for more than onc-third its length in adult males), the middle rectrices broad and all rounded terminally; adult males metallic green below, sometimes with chin or chin and throat blue, the tail blue-black with deep gray tips to middle rectrices, adult females brownish gray below, with gray tips to lateral rectrices.

Bill decidedly longer than head, broader than deep, broad and depressed basally, very faintly decurved; culmen broadly rounded but contracted to a narrow ridge at base; tomia smooth; maxilla and mandible (especially the latter) each with a distinct narrow median groove. Nasal operculum broad, tumid, completely nude, the frontal feathering forming a transverse line across base of forehead. Tarsus naked except upper portion, slender; anterior toes about equal in length, the hallux slightly shorter; all the toes slender, with claws relatively small. Wing about two and a half to three times as long as bill, with outermost primary longest. Tail nearly to quite half as long as wing, deeply emaginate or forked in adult males, less deeply emarginate in females, the middle rectrices very broad, the lateral ones narrower, all rounded terminally.

Coloration.-Above rather dull metallic bronze-green, the forehead more brilliant green or blue; adult males with tail blue-black, the middle rectrices tipped with brownish gray, the under parts metallic green, usually passing into blue on chin or chin and throat; lumbar and femoral tufts white; adult female with middle rectrices metallic greenish, lateral (but not middle) rectrices tipped with gray, and under parts brownish gray.

Range.-Mexico and adjacent portions of Arizona and New Mexico. (Three species.)

\section{KEY TO THE SPECIES OF CYNANTHUS.}

a. Under parts metallic green (with or without blue on throat); rectrices blue-black, the middle ones tipped with brownish gray. (Adult males.)

b. Tail forked for not more than one-fourth its total length; wing, 49-54.5; exposed culmen, 18.5-22; forehead and crown not brilliant metallic green or blue.

c. Larger, with longer bill (wing averaging 52.5, culmen 21); back and rump more decidedly green; chin and throat greenish blue or decidedly bluish 
green; under tail-coverts grayish centrally. (Northern and western Mexico and southern Arizona.).......... Cynanthus latirostris, adult male (p. 370). cc. Smaller, with relatively shorter bill (wing averaging 51.7, culmen 18.2), back and rump bronze; chin and throat emerald green or slightly bluish green; under tail-coverts dusky centrally. (Tres Marias Islands.)

Cynanthus lawrencei (p. 373).

$b b$. Tail forked for more than one-third its length; wing, 46-51; exposed culmen,

16.5-19.5; forehead and crown brilliant metallic blue or bluish green. (Southwestern Mexico.)....................... Cynanthus doubledayi (p. 375).

$a a$. Under parts brownish gray; rectrices metallic green basally, blue-black subterminally, the lateral ones tipped with brownish gray. (Adult females.)

$b$. Wing $49.5-54$, averaging much more than 50 ; culmen $19-23.5$, averaging much more than 20 ; tail slightly emarginate.

c. Lateral under parts with little of green; basal portion of rectrices brighter green...................... Cynanthus latirostris, adult female (p. 370).

$c c$. Lateral under parts conspicuously spotted or washed with metallic green; basal portion of rectrices darker and duller green.

Cynanthus lawrencei, adult female (p. 374).

$b b$. Wing 45-49, averaging 47.2; culmen 18-19.5, averaging 18.5; tail deeply emarginate.................... Cynanthus doubledayi, adult female (p. 375).

\section{CYNANTHUS LATIROSTRIS Swainson.}

BROAD-BILLED HUMMING BIRD.

Adult male.-Above metallic bronze-green, usually duller on pileum, where sometimes passing into dull grayish brown on forehead; tail glossy blue-black or dark steel blue, the four middle rectrices tipped (more or less broadly) with deep brownish gray, the remaining rectrices sometimes narrowly margined with the same; remiges dusky brownish gray or dull slate color, faintly glossed with purplish, the outermost primary narrowly edged with pale gray or grayish white; chin and throat bright metallic greenish blue or bluish green (the color more blue anteriorly, more green posteriorly), passing into metallic bronze-green on breast, sides, flanks, and abdomen; under tail-coverts dull white, usually more or less distinctly grayish centrally, the shorter ones sometimes with dusky, slightly metallic, spots; anal tufts and tuft on each side of rump white; bill brownish (purplish red or carmine in life), dusky terminally; iris dark brown; feet dusky; length (skins), 88-105 (92); wing, 49-57 (51.6); tail, 28-36 (32.3), the middle rectrices 23-29.5; culmen, 18.5-22 (20.4) ${ }^{a}$

Adut female.-Above similar in color to adult male but duller, especially on pileum, which is usually dull grayish brown or brownish gray anteriorly; remiges paler grayish brown; middle pair of rectrices bronze-green passing into blue-black or greenish black terminally (the extreme tip sometimes green or bronzy); other rectrices with basal half (more or less) bronze-green, the remaining portion blue-black tipped with brownish gray (most broadly on lateral pair); under parts sooty gray or dark drab-gray (browner than mouse gray), 
the sides of chest glossed (nore or less) with metallic green or bronzegreen; under tail-coverts mostly dull white (griby $x_{-1}$, centrally); anal tufts and tuft on each side of rump white; a white or gratyi-1, white postocular spot, and below this a dusky area extending to beneatu eyo; maxilla dull black, sometimes brownish basally; mandible dusky for terminal half (more or less), brownish (reddish in life) basally; iris and feet as in adult male; length (skins), 85-104 (93); wing, 49.5-54 (51.6); tail, 27.5-33 (30.3); culmen, 19.5-23.5 (21.4). ${ }^{a}$

Young male.-Similar to the alult female but feathers of pileum, hindneck, back, scapulars, rump, etc., tipped or terminally margined with pale buffy brown or grayish buff; rectrices as in adult male; chin and throat (in older specimens) intermixed with metallic bluish green or greenish blue fenther's, these margined terminally with pale grayish or buffy brown.

Young female.--Similar to the adult female but feathers of upper parts margined terminally or tipped with pale bufly brown (sometimes more cinnamomeous on pileum and rump).

Mexico in general, except extreme southern States of Oaxaca, Tabasco, Chiapas, Campeche, and Yucatan, north to southern Arizona (Santa Rita, Huachuca, Chiricáhua, and Santa Catalina moun-

a Nineteen specimens.

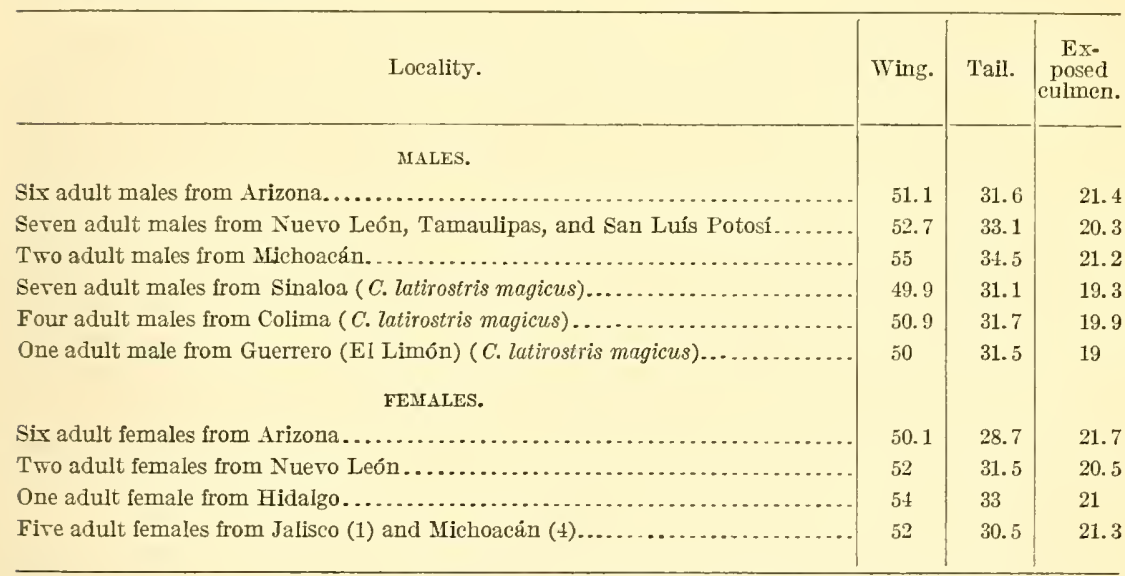

Three adult males from the extreme southeastern portion of the range of the species (Jaumave, Tamaulipas; Hacienda Angostura, San Luís Potosí, and Valley of Mexico) differ from all others in the collection in the decidedly greenish blue of the throat, which is colored nearly as in the adult male of $C$. lawrencei. Should other specimens from the same geographic area agree with these in this respect, a southeastern form would undoubtedly require recognition. Unfortunately no other specimens are available for examination.

Specimens from the state of Sinaloa average considerably smaller than those from other localities, but those from Colima, Guerrero, and Arizona are nearly as small, and at present, in the light of material examined, I hardly feel justified in accepting a subspecies C. l. magicus for the Sinaloa birds. It may be, however, that more satisfactory material will show that two, possibly three, forms can be satisfactorily defined. 
tains; Santa Cruz River, west of Patagona Mountains; mountains near Crittender quadalupe Cañon; Tucsón; Pinál County), Sonora (Diolrict of Montezuma; Nurí; Ysleta; Guaymas; Opodepe; La Chumata), Sinaloa (Mazatlán; Escuinapa; Los Pieles), Jalisco (Barranca Ibarra; Plains of Colima; La Barca; Bolaños; Guadalajara; Atemajac; Santa Ana; Lake Chapala), Colima (Colima), Michoacán (Querendero; Los Reyes; La Salada; Patzcuaro; near Ahuacana), Guerrero (El Limón), Mexico (Valley of Mexico; Hacienda Eslava; Tetelco; Chimalcoyoc), Vera Cruz (alpine region of Orizaba; Jalapa?), Hidalgo (Tula), Guanajuato (Guanajuato), Aguas Calientes (Cavillo), San Luís Potosí (Hacienda Angostura), Tamaulipas (Jaumave; Sierra de Victoria; Santa Leonora; Realito), Nuevo León (Monterey), Territory of Tepíc (San Blas).

Cynanthus latirostris Swainson, Philos. Mag., n. s., i, 1827, 441 ("table lands" of Mexico).-American Ornithologists' Union Committee, Auk, xxv, July, 1908, 375; Check List, 3rd ed., 1910, 206.-Visher, Auk, xxvii, 1910, 282 (Santa Catalina Mts., Arizona, breeding 3,500 to above 7,000 ft.).

[Amazilius] latirostris Bonaparte, Consp. Av., i, 1850, 77; Rev. et Mag. de Zool., 1854, 254.

Amazilia latirostris Reichenbach, Aufz. der Colib., 1854, 10; Troch. Enum., $1855,8$.

Circe latirostris Gould, Mon. Troch., pt. xiii, 1857, (vol. v, 1861, pl. 338); Introd. Troch., oct. ed., 1861, 169.-Sclater, Proc. Zool. Soc. Lond., 1858, 297 (Oaxaca); 1859, 367 (Jalapa); 1864, 177 (City of Mexico); Cat. Am. Birds, 1S62, 317 (Mexico).-Heine, Journ. für Orn., 1863, 196 (crit.).-DugÈs, La Naturaleza, i, 1870, 141 (Guanajuato).-DE OcA, La Naturaleza, iii, 1875, 65 (Valley of Mexico); Ens. Orn. Troq. Mex., 1875, 28, pl. (5), fig. 1S.-Henshaw, Rep. Orn. Spec. Wheeler's Survey, 1873 (1874), 162 (Santa Rita Mts., Arizona); Zool. Wheeler's Survey, 1875, 380 (do.).-Boucard, Ann. Soc. Linn. Lyon, xx, 1S74, 281 (Valley of Mexico).-Lawrence, Mem. Bost. Soc. N. H., ii, 1874, 292 (Mazatlán).-Sumichrastr, La Naturaleza, v, 1881, 250 (alp. reg. Orizaba).-Sanchez, An. Mus. Nac. Mexico, i, 1877, 96, part (Valley of Mexico and Guanajuato).-Mulsant and Verreaux, Hist. Nat. Ois.Mouch., ii, livr. 1, 1875, 46; iv, livr. 3, 1878, 192.

Circe latirostris Vlluada, La Naturaleza, ii, 1875, 366 (Valley of Mexico).

[Circe] latirostris Mulsant, Ann. Soc. Linn. Lyon, xxii, 1876, 208.-Sclater and Salvin, Nom. Av. Neotr., 1873, 93.

Hylocharis latirostris Mulsant and Verreaux, Classif. Troch., 1866, 38.

[Hylocharis] latirostris GraY, Hand-list, i, 1S69, 151, no. 1955.

Iache latirostris Elliot, Classif. aud Synop. Troch., 1879, 235.-Boucard, Notes quelques Troch., 1873, 13 (near City of Mexico); Gen. Hum. Birds, 1894, 110.-Allen, Bull. Nutt. Orn. Club, v, 1880, 90; Auk, iii, 18s6, 432 (descr. young).-Ridgway, Proc. U. S. Nat. Mus., ii, 1Ss1, 15, 188, 319 (Colima; Mazatlán; Arizona); Nom. N. Am. Birds, 18s1, no. 348; Rep. U. S. Nat. Mus. for 1890 (1891), 373, pl. 45 (monogr.; habits).-Brewster, Bull. Nutt. Orn. Club, vii, 1882, 211 (Santa Rita and Chiricáhua Mts., Arizona; habits).Belding, Proc. U. S. Nat. Mus., vi, 1883, 344 (Guaymas, Sonora).-Scotт, Auk, iii, 1886, 432 (Santa Catalina Mts., Arizona, 3,500-5,000 ft., breeding).American Ornithologists' Union, Check List, 1886, no. 441.一Herrera, La Naturaleza, (2), i, 1891, 322 (Valley of Mexico; descr. nest).-SAlvin, Cat. Birds Brit. Mus., xvi, 1892, 60 (Sierra de Victoria, Tamaulipas; Bolaños, 
Lake Chapala, and Santa Ana, Jalisco; San Blas, Tepíc; Lake Patzcuaro,

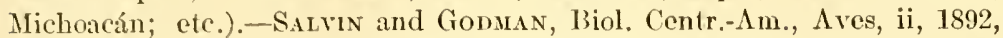
256.-Jour, Proc. U. S. Nat. Mus., xvi, 1893, 784 (Hacienda Angostura, San Luís Potosí; Barranca Ibarra, Jaliseo).-Bendire, Life Hist. N. Am. Birds, ii, 1895, 228.-BAiley (Florence M.), Handb. Birds W. U. S., 1902, 244, fig. 322.-Swarti, Pacific Coast A vifauna, no. 4, 1904, 20 (Huachuca Mts., Arizona).-Mllter, (W. De W.), Bull. Am. Mus. N. H., xxi, 1905, 354 (Escuinapa, etc., Sinaloa; crit.).

I [ache] latirostris Coues, Key N. Am. Birds, $2 d$ ed., 1884, 467.-Ridgway, Man.

N. Am. Birds, 18s7, 319 .

[Jache] latirostris Heine and Reichenow, Nom. Mus. Hein. Orn., 1890, 181 ("Rio Negro").

P[hacoptila] latirostris Hartert, Das Tierreich, Troch., 1900, 63 (monogr.).

[Phacoptila] latiostris Sumon, Cat. Troch., 1897, 15.

[Phaoptila] latirostris SHARPE, Hand-list, ii, 1900, 110.

Phroptila latirostris Thayer and Bangs, Proc. Biol. Soc. Wash., xix, 1906, 18

(Opodepe and La Chumata, Sonora, breeding).-Philirps, Auk, xxviii, 1911,

77 (Santa Leonora and Realito, Tamaulipas).

O[mysmia] lessonii Delattre, Rev. Zool., 1839, 15 ("Jalapa";=female).

[Hylocharis. $\beta$. Cyanophaia] lazula Reichenbaci, Aufz. der Colibr., 1854, 10

("Chrinatilla," i. e., Chinantla?, Mexico; ex "Tr.-us Vieill. 1822").

[ Hylocharis] lazula Pieichenbach, Troch. Enum., 1855, 8, pl. 770, figs. 4783, 4784.

[Sapphironia] circe Bonaparte, Rev. et Mag. de Zool., 1854, 256.

[Hylocharis] circe Reichenbach, Troch. Enum., 1855, 8, pl. 771, figs. 4786-4788.

H[ylocharis] doubledayi (not Trochilus doubledayi Bourcier) Cabanis and Heine,

Mus. Hein., iii, 1860, 44, part.

Hylocharis magica a Mulsant and Verreaux, Classif. Troch., 1866, 38 (nomen nudum!; Mazatlán, Sinaloa, w. Mexico; type now in coll. Am. Mus. Nat. Hist.); Ann. Soc. Linn. Lyon, xviii, 1872, 110.

Circe magica Mulsant and Verreaux, Hist. Nat. Ois.-Mouch., ii, livr. 1, 1875, 49 (Mazatlán); Suppl., pl. 12.

[Circe] magica Sclater and Salvin, Nom. Av. Neotr., 1873, 93.-Mulsant, Ann. Soc. Linn. Lyon, xxii, 1s76, 208.

Iache magica ElLiot, Classif. and Synop. Troch., 1879, 235 (Mazatlán; "Lower California;" first description?).-SAlvin, Cat. Birds Brit. Mus., xvi, 1892, 61 (Mazatlán).-Salvin and Godman, Biol. Centr.-Am., Aves, ii, 1892, 258 (Mazatlán).-Boucard, Gen. Hum. Birds, 1894, 110.-Mrrler (W. DeW.), Bull. Am. Mus. N. H., xxi, 1905, 354, in text (crit.).

I [ache] magica Ridgway, Man. N. Am. Birds, 1887, 320; Rep. U. S. Nat. Mus. for 1890 (1891), 373 (diagnosis, etc.).

\section{CYNANTHUS LAWRENCEI (Berlepsch.)}

\section{LAWRENCE'S HUMMING BIRD.}

Similar to C. latirostris but smaller, with shorter bill; adult male with chin and throat slightly bluish green (never blue), back and rump more bronzy, and under tail-coverts dusky centrally; adult

a The type of Hylocharis magica (in the collection of the American Museum of Natural History) is a mounted specimen, and differs very much in coloration from other specimens, the usual bronze-green of the upper parts being replaced by a rather dull purplish or coppery bronze, that of the under parts strongly tinged with the same, and the blue of the throat replaced by bluish green. The plumage has, however, every appearance of having been affected by the action of light or, possibly, immersion in spirits; at any rate, the coloration is certainly abnormal. 
female with basal half (more or less) of lateral rectrices brownish gray instead of bronze-green and middle rectrices darker and much duller bronze-green.

Adult male.--Pileum and hindneck metallic bronze-green passing into greenish bronze, bronze, or coppery bronze on back, scapulars, wing-coverts, and rump; upper tail-coverts dusky brownish gray (sometimes partly bronzy); tail slightly glossy blue-black, the four middle rectrices tipped with deep brownish gray, the remaining rectrices narrowly edged and terminally margined with the same; remiges dull slate color, faintly glossed with purplish, the outermost primary narrowly edged with pale gray or grayish white; chin and throat bright metallic emerald green (more bluish green, but never blue, anteriorly), passing into metallic bronze-green on rest of under parts; anal tufts and tuft on each side of rump white; under tailcoverts grayish white with a large subterminal spot of slightly glossy bluish dusky or blue-blackish; terminal half (more or less) of maxilla dull black, the basal portion brownish (reddish in life); mandible pale brownish (reddish in life), passing into blackish terminally; iris dark brown; feet dusky; length (skins), S6-94 (91); wing, 51-53. 5 (51.7); tail, 31-35.5 (33.1); middle rectrices, 23-25.5 (24.2); culmen, $17.5-19(18.2) .^{a}$

Adult female.-Above metallic bronze-green, duller (sometimes dull brownish gray) on forehead; remiges as in adult male; middle pair of rectrices dusky metallic bronze-green, darker terminally or subterminally; remaining rectrices with basal half (more or less) dull bronze-green, then bluish black, the tip (broadly on outermost) brownish gray-the outermost rectrix with brownish gray (darker basally) replacing bronze-green; under parts sooty gray or deep drab-gray, slightly paler on chin, the sides (including sides of neck) conspicuously glossed or spotted with metallic bronze-green; femoral tufts and tuft on each side of rump white; under tail-coverts brownish gray passing into grayish white on margins, sometimes with a subterminal mesial streak of dusky; a small pale gray or grayish white postocular spot, and beneath this a dusky space extending to beneath eye; bill, etc., as in adult male, but maxilla mostly (sometimes wholly) blackish; length (skins), 87-93 (89); wing, 49.5-50.5 (50); tail, 28-30 (29.4); the middle rectrices, 25.5-27 (26.4); culmen, $19-21(20.1) .^{b}$

Tres Marias Islands (Maria Madre and Cleofa Islands), western Mexico.

Circe latirostris (not Cynanthus latirostris Swainson) Grayson, Proc. Bost. Soc. N. II., xiv, 1871, 282, part (Tres Marias).-Lawrence, Mem. Bost. Soc. N. H., ii, 1874, 292, part (Tres Marias; habits). 
Tache laurencei Berlepscr, This, 5th ser., v, July, 1857, 292 (Tres Marias Islands, w. Mexico; coll. Count von Berlepsch).-Rıdaway, Man. N. Am. Birds, 1857, 592; 2d ed., 1896, 613.-Boucard, Gen. Hum. Birds, 1894, 112.Nelson, North American Fauma, no. 14, 1899, 46 (Tres Marias; habits; crit.).-Ballex (H. H.), Auk, xxiii, 1906, 389 (Cleofa Island, Tres Marias). Iache laurencii Salvin, Cat. Birds Brit. Mus., xvi, 1892, 61.-Salvin and GodMan, Biol. Centr.-Am., Aves, ii, 1892, 258.

I ache] laurencei Ridgway, Man. N. Am. Birds, 1887, 320; Rep. U. S. Nat.

Mus. for 1890 (1891), 373 (diagnosis, etc.).

[Phacoptila] laurencei Sinon, Cat. Troch., 1897, 15.

P[hacoptila] laurencei Hartert, Das Tierreich, Troch., 1900, 64 (monogr.).

[Phroptila] lawrencei Sharpe, Hand-list, ii, 1900, 110.

\section{CYNANTHUS DOUBLEDAYI (Bourcier).}

DOUBLEDAY'S HUMMING BIRD.

Much smaller than C. latirostris or $C$. lawrencei (wing not more than $51 \mathrm{~mm}$.); adult male with pileum much more brilliant metallic green than back, under parts more extensively and decidedly blue, and under tail-coverts black (glossed with blue or green), with or without pale gray or grayish white margins; adult female with basal half of rectrices less distinctly bronze-greenish.

Adult male.-Forehead and crown brilliant metallic bluish green, usually decidedly more bluish on forehead, sometimes wholly uniform emerald green; ${ }^{a}$ occiput and hindneck metallic grass-green (more bronzy in worn plumage); back, scapulars, wing-coverts, and rump bronze-green, usually duller (sometimes inclining to brownish gray) on rump; upper tail-coverts varying from dull bronze-green to dusky; tail glossy blue-black, the six middle rectrices tipped with deep brownish gray (more broadly on middle pair); remiges purplish dusky; chin and throat bright metallic bhe or violet-blue, passing into less bright metallic bluish green on under parts of body, usually more decidedly bluish along median line, the sides of breast more bronzy green; femoral tufts and tuft on each side of rump white; under tail-coverts varying from uniform blue-black to dusky glossed with green or bluish and more or less margined or tipped with pale gray or grayish white; bill brownish (reddish in life) passing into dusky terminally; iris dark brown; feet dusky; length (skins), 75-92 (84); wing, 46-51 (47.8); tail, 28-34 (30.7); middle rectrices 20-23 (21.4); culmen, $16.5-19.5(17.8){ }^{b}$

Adult female.-Above metallic bronze-green, usually much duller (often dull grayish brown or brownish gray) on forehead and crown;

a This variation in color of the forehead and crown appears to be principally if not wholly due to difference in age of the plumage, all specimens examined in which the plumage is evidently old or considerably affected by wear or exposure having the forehead and crown uniform green, while those in fresh plumage have the forehead distinctly blue and the crown bluish green.

$b$ Twelve specimens. 
remiges as in adult male; middle rectrices rather dull bronze-green or greenish bronze, usually darker (sometimes blue-blackish) subterminally; other rectrices with basal half (more or less) dull bronzegreen (at least on outer web), the remaining portion blue-black tipped with brownish gray or grayish brown, this gray tip disappearing toward inner pair; a small pale gray or grayish white postocular spot or streak, and beneath this a dusky area extending to beneath eye; under parts dull sooty gray or deep drab-gray, sometimes slightly paler on chin and upper throat; femoral tufts and tuft on each side of rump white; under tail-coverts paler brownish gray, usually darker mesially, at least toward base; bill as in adult male but usually more extensively dusky, sometimes mostly so; iris and feet as in adult male; length (skins), 78-87 (82); wing, 45-49 (47.2); tail, 25-28 (26.5); middle rectrices, 22-25 (23.2); culmen, $18-19.5$ (18.8). ${ }^{a}$

Young male.-Similar to the adult female but tail as in adult male, except that the lateral as well as the middle rectrices are tipped with gray, and throat (in older specimens) intermixed with metallic greenish-blue feathers.

Southwestern Mexico, in States of Guerrero (Dos Arroyos; Acapulco; Tecpán; Egido Nuevo; Chinantla; Rincón; Vente de Pelegrino; Rio Papagaio) and Oaxaca (Tehuántepec; Chihuitán; Juchitán; Salina Cruz; Puerto Angel).

Troch[ilus] doubledayi Bourcien, Proc. Zool. Soc. Lond., 1847, 46 ("Rio Negro;" coll. G. Loddiges); $b$ Rev. Zool., 1847, 259.

a Ten specimens.

\begin{tabular}{|c|c|c|c|}
\hline Locality. & Wing. & Tail. & $\begin{array}{c}\mathrm{Ex}- \\
\text { posed } \\
\text { culmen. }\end{array}$ \\
\hline MALES. & & & \\
\hline Six adult males from Oaxaca.... & 48.5 & 31.9 & 18.7 \\
\hline Flve adult males from Guerrero.. & 47.1 & 29.2 & 17 \\
\hline FEMALES. & & & \\
\hline One adult female from Oaxaca........ & 47.5 & 26 & 19.5 \\
\hline Nine adult females from Guerrero.......... & 47.2 & 26.5 & 18.8 \\
\hline
\end{tabular}

Besides being smaller than those from localities in the State of Oaxaca (Tehuantepec, Puerto Angel, and Chihuitán) the adult males from the State of Guerrero (Dos Arroyos, Tecpán, and Acapulco) have the rump bronze-green, while the former have the rump grayish olive, with little if any metallic gloss; other color-characters, however, vary so much in both series that I am not able to detect other constant differences. The alleged type of Trochilus doubledayi Bourcier, in the collection of the American Museum of Natural History, agrees with the Guerrero series, both in size and coloration; consequently if two forms are to be recognized that from Oaxaca requires a new name, Iache nitida Salvin being unquestiouably a synonym of $T$. doubledayi.

$b$ See Hartert, Novit. Zool., iv, 1897, 530. A cotype (probably) is in the collection of the American Museum of Natural History, New York City. 
M[ylocharis] doublcdayi Gray, Gen. Birds, i, Dee., 1848, 114.-Cabanis and Heine, Mus. Hein., iii, 1860, 14, part ("Rio Negro").

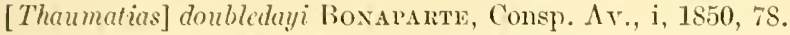

[Hylocharis. $\beta$. Cyanophaia] doublcduyi Reıcnenbach, Auiz. der Colibr., 1854, 10. [Suphironia] doubleduyi Bonapante, Rev. et Mag. de Zool., ]854, 256.

Circe doubledayi Gound, Mon. Troch., pt. xx, Sept. 1, 1860 (vol. v), pl. 339 (Chinantla, Guerrero); Introd. Troch., oct. ed., 1861, 169.-D'OCA, La Naturaleza, iii, 1875, 302, pl.; Troq. de Mex., 1875, pl. (12), fig. 45.-Mulsant and Verreaux, Hist. Nat. Ois.-Mouch., ii, livr. 1, 1875, 44 (Chinantla).-LAwrexce, Bull. U. S. Nat. Mus., no. 4, 1876, 33 (Chihuitán, Oaxaca).-Sumichrast, La Naturaleza, v, 1881, 250 (Chihuitán and Juchitán, Oaxaca).

[Cire] doubledcayi Mulsant, Ann. Soc. Linn. Lyon, xxii, 1S76, 208.

[Circe] doubledayi Sclater and Salvin, Nom. Av. Neotr., 1S73, 93.

Iache doubledayi Elliot, Classif. and Synop. Troch., 1S79, 235.-SAlvin, Cat. Birds Brit. Mus., xvi, 1892, 62 (Chinantla, Guerrero).-SAlvin and GodMan. Biol. Centr.-Anı., Aves, ii, 1892, 259 (Venta del Pelegrino, Rineon, Dos Arroyos, and Acapulco, Guerrero; Chihuitán, Juchitán, Salina Cruz, and Tehuántepec, Oaxaca).-Boucard, Gen. Hum. Birds, 1894, 111 (Chihuitán).-HaRtert, Novit. Zool., iv, 1897, 530 (crit.).

I ache] doubledayi Ridgway, Man. N. Am. Birds, 1887, 320; Rep. U. S. Nat Mus. for 1890 (1891), 373 (diagnosis, etc.).

P[haeoptila] doublcdayi Hantert, Das Tierreich, Troch., 1900, 64 (monogr.).

[Phroptila] doubledayi SHARPe, Hand-list, ii, 1900, 110.

[Phaeoptila] doubledayi Snos, Cat. Troch., 1897, 15.

Iache nitida Salvin and Godman, Ibis, April, 1889, 240 (Acapulco and Rio Papagaio, Guerrero; coll Salvin and Godman).-SALvin, Cat. Birds Brit. Mus., xvi, 1892, 62 (Venta del Pelegrino, Rincón, Dos Arroyos, and Acapulco, Guerrero; Salina Cruz and Tehuántepec, Oaxaca).-Boucard, Gen. Hum. Birds, 1894, 111.

Jache nitida Hartert (E. and C.), Novit. Zool., i, 1894, 61 (Dos Arroyos, near Acapulco, Guerrero).

[Phaeoptila] nitida Smon, Cat. Troch., 1897, 15.

I [ache] nitida RidgWay, Rep. U. S. Nat. Mus. for 1890 (1891), 373 (diagnosis, etc.)

Genus BASILINNA Boie.

Basilinna Bore, Isis, 1831, 546. (Type, Trochilus leucotis Vieillot.)

Basilina (emendation?) Reichendach, Av. Syst. Nat., 1849, pl. xxxix.

Heliopædica a Gould, Mon. Troch., pt. xv, May, 1858. (Type, Trochilus melanotis Swainson $=T$. leucotis Vieillot.)

Meliopedica (emendation) Sclater and Salvin, Ibis, April, 1S59, 130.

Similar to Hylocharis, but wing relatively longer (three times as long as exposed culmen) and style of coloration very different, the side of head with a broad white postocular streak and a black (male) or dusky (female) auricular stripe.

Bill longer than head, broad and depressed basally, faintly decurved; culmen broadly rounded but contracted basally into a narrow mesorhinal ridge; tomia smooth; mandible with a rather distinct median lateral groove. Nasal operculum broad, very tumid, wholly nude, the frontal feathering forming a transverse line across base of forehead. Tarsus feathered; anterior toes about equal in length, the

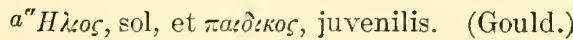


hallux slightly shorter. Wing three times as long as exposed culmen, the outermost primary longest. Tail more than half as long as wing, truncated or slightly double-rounded, all the rectrices very broad, rounded at tip.

Coloration.-Above metallic bronze-green, including middle rectrices, the other rectrices blackish or chestnut. Adult males with forehead and chin metallic violet-blue or velvety black, a black auricular stripe and white postocular stripe, the throat brilliant metallic green; adult females with the forehead sooty grayish brown, chin and other under parts dull whitish or buffy, the throat sometimes spotted with green; auricular stripe grayish brown or dusky instead of black.

Range.-Mexico (including Lower California) to Nicaragua. (Two species.)

KEY TO THE SPECIES AND SUBSPECIES OF BASILINNA.

a. Lateral rectrices blackish (tipped with grayish in female); center of abdomen white. (Basilinna leucotis.)

b. Bill larger (exposed culmen 14.5-18.5); green of throat more extended posteriorly, and white of abdomen more restricted. (Southern Mexico to Guatemala.) .................... . Basilinna leucotis leucotis, adult male (p. 378).

$b b$. Bill smaller (exposed culmen 14.5-15); green of throat more restricted posteriosly and white of abdomen more extended. (Northern Nicaragua.)

Basilinna leucotis pygmæa, adult male (p. 381).

aa. Lateral rectrices chestnut or cinnamon-rufous; abdomen light cinnamon-rufous or buffy cinnamon. (Cape San Lucas district, Lower California.)

Basilinna xantusi (p. 382).

\section{BASILINNA LEUCOTIS LEUCOTIS (Vieillot).}

WHITE-EARED HUMMING BIRD.

Adult male.-Forehead, loral and malar regions, chin, and upper throat rich metallic violet or violet-blue, passing into velvety black on suborbital and auricular regions, and into cluller black, faintly glossed with bluish or greenish, on crown; occiput and hindneck dark metallic bronze or bronze-green; back, scapulars, wing-coverts, and rump varying from bright metallic green to bronze-green or golden green, the upper tail-coverts similar but usually more bronzy (sometimes golden bronze), and, together with feathers of rump, more or less distinctly margined with rusty; middle pair of rectrices bright bronze-green, bronze, or golden bronze, the next pair similar but darker, the remaining rectrices bronzy black, tipped (more or less distinctly) with bright bronze or bronze-green; remiges purplish dusky, the inner secondaries glossed with bronze-green; a broad white postocular stripe, extending backward and downward above and behind upper margin of auricular region to side of neck; middle and lower throat brilliant metallic emerald green (more yellowish green posteriorly) abruptly defined against the dark violet or violet- 
blue of upper throat and chin; chest, breast (except medially), sides, and flanks metallic bronze or bronze-green, interrupted by grayish margins to the feathers, the basal grayish also showing where feathers are disarranged; median line of breast and abdomen dull grayish white, sometimes tinged with brownish bufly; femoral tufts dull white; under tail-coverts grayish brown, faintly glossed with bronze, centrally, broadly margined with dull whitish; basal half (more or less) of bill pale brownish (coral red in life), terminal portion dull blackish; iris dark brown; feet dusky; length (skins), 89-102 (92); wing, 52.5-59.5 (55.3); tail, 30.5-35.5 (33); culmen, 14.5-18.5 (16.6). ${ }^{a}$

Adult femate.-Above similar to the adult male, but pileum dusky brown, the feathers (especially on forehead) sometimes margined with pale rusty brown, and lateral pair of rectrices broadly tipped with brownish gray; a broad black suborbital and auricular patch and white postocular stripe, as in adult male; under parts pale brownish gray or dull grayish white, spotted with metallic bronzegreen, this predominating laterally; median line of breast and abdomen plain dull grayish white or pale brownish gray; under tailcoverts grayish centrally (the shorter ones bronzy or bronze-green) broadly margined with dull grayish white; maxilla dull black, mandible pale brownish (reddish in life), with terminal portion dusky; iris and feet as in adult male; length (skins), 78-96 (88); wing, 49-55 (51.9); tail, 30-33.5 (31.3); culmen, 16-18.5 (17.4). ${ }^{b}$

Young male.-Pattern of coloration as in adult, but no blue on head, and brilliant emerald-green of throat merely indicated; pileum dull dusky greenish, the feathers margined with dull tawny, this prevailing on occiput; chin and upper throat dull grayish white spotted with dusky; lower throat metallic emerald-green, the feathers distinctly margined with grayish white; prevailing color of rump, superficially, dull tawny, the upper tail-coverts distinetly margined with

$a$ Seventeen specimens.

$b$ Fifteen specimens.

\begin{tabular}{|c|c|c|c|}
\hline Locality. & Wing. & Tail. & $\begin{array}{c}\text { Ex- } \\
\text { posed } \\
\text { culmen. }\end{array}$ \\
\hline MALES. & & & \\
\hline One adult male from Arizona......... & 59.5 & 34.5 & 18.5 \\
\hline Ten adult males from Mexico.......... & 56.1 & 33.6 & 17.2 \\
\hline six adult males from Guatemala... & 53.2 & 31.7 & 15.3 \\
\hline FEMALES. & & & \\
\hline Three adult females from Arizona.. & 53.8 & 33.2 & 17.7 \\
\hline Eight adult females from Mexico... & 52.1 & 31.1 & 17.7 \\
\hline Four adult females from Guatemala....... & 50.2 & 30.4 & 16.6 \\
\hline
\end{tabular}


the same; outer pair of rectrices broadly tipped with light brownish gray, the next pair more narrowly tipped with same.

Young female.-Similar to the adult female, but general coloration duller; feathers of pileum margined with rusty, and spotting of under parts much duller (less metallic).

Southern Arizona (Huachuca, Chiricáhua, Santa Catalina, and Santa Rita mountains), over nearly the whole of Mexico to highlands of Guatemala (Guatemala City; Chilasco; Amatitlán; Cobán; Totonicapám; near Tecpám; Volcán de Fuego; Volcán de Agua; Santa Rosa above Salamá; Santa Barbara; San Gerónimo; Quezaltenango; Santa Maria near Quezaltenango; Chuipaché). Sonora (Tetuaca), Sinaloa (Mazatlán), Jalisco (Sierra Nevarla de Colima; Sierra de Bolaños; Bolaños; Sierra de Nayarít), Colima (Volcán de Colima; Nevada de Colima), Michoacán (Patzeuaro; Mount Tancítaro), Guerrero (Omilteme; Chilpancingo; Amula), Morelos (Huitzilác; Titela del Volcán), Mexico (Valley of Mexico; Temascáltepec; Tlaxcala; Tenango del Valle; Amecameca; Rio Frio, Ixtaccihuátl; Ixtapalapa; Hacienda Eslava; Chimalapa; Tetelco; San Antonio Coapa; Las Cruces), Hidalgo (Reál del onte). Guanájuato, Zacatecas (Sierra de Valparaiso), Durango (Ciudád Durango), Chihuáhua (Tatuaca), Tamaulipas (Sierra de Victoria; Galindo; Realito), Vera Cruz (Jalapa; Miradór; Orizaba; Mount Orizaba, 11,000 ft.; Córdova; Las Vigas; Cofre de Perote; Maltrata), San Luís Potosí (Sierra de San Luís Potosí), Puebla (Chalchicomula; Tochimilco; Pinál), Oaxaca (Mount Zempoáltepec; 15 miles west of Oaxaca City; Totóntepec; Villa Alta; Toniaguia), Chiapas (San Cristóbal).

Trochilus leucotis Vieillot, Nouv. Dict. d'Hist. Nat., ed. 2, xxiii, 1818, 428 ("Brazil"; coll. M. Laugier).

T[rochilus] leucotis VieiLlot, Tabl. Enc. Méth., ii, 1822, 559.

H[ylocharis] leucotis Gray, Gen. Birds, i, Dec., 1848, 114.-Hartert, Das Tierreich, Troch., 1900, 66.

[Hylocharis] leucotis Gray, Hand-list, i, 1869, 151, no. 1949.-Sharpe, Hand-list, ii, $1900,110$.

Mylocharis leucotis Dearborn, Pub. 125, Field Mus. N. H., 1907, 98 (Lake Atitlán, 5,000 ft. and above Tecpám, 9,500 ft., Guatemala).-Prillırs, Auk, xxviii, 1911, 78 (Galindo and Realito, Tamaulipas).

[Thaumatias] leucotis Bonaparte, Consp. Av., i, 1850, 78.

Basilinna leucotis Reichenbach, Aufz. der Colibr., 1854, 13; Troch. Enum., 1855, 11.-Sclater, Proc. Zool. Soc. Lond., 1856, 287 (Córdova, Vera Cruz).-Elliot, Classif. and Synop. Troch., 1879, 227.-SAlvin, Cat. Birds Brit. Mus., xvi, 1892, 252, 662.-Salvin and Godman, Biol. Centr.-Am., Aves, ii, 1892, 312.-Fisher (A. K.), Auk, xi, 1894, 325 (Chiricáhua Mts., Arizona).-Hartert (E. and C.), Novit. Zool., i, 1894, 21 (Chilpancingo, Guerrero, 6,000-8,000 ft.; descr. nest).-Boucard, Gen. IIum. Birds, 1894, 177.-Cox, Auk, xi, 1895, 357 (Mt. Orizaba, 11,000 ft.).-American OrNiTirologists' Union, Auk, xii, 1895, 164; Check-List, 2d ed., 1895, no. 440.1; 3rd ed., 1910, 206.-Bendire, Life IIist. N. Am. Birds, 1895, 227.-BAILEY 
(Florence M.), Handb. Birds IV. U. S., 1902, 243.-Swarmi, Condor, vii, 1905, 79 (Santa Rita Mts., Arizona).-Visner, Auk, xxvii, 1910, 282 (Santa Rita Mls., Arizona, 1 spec.; Santa Catalina Mts., Arizona, 1 spec., May 4). B[asilima] leucotis Cabanis and Heine, Mus. Hcin., iii, 1860, 45 (Mexico).Ringway, Man. N. Am. Birds, 1857, 319; Rep. U. S. Nat. Mus. for 1890 (1591), 369 (diagnosis, etc.).

Basillina leucotis Sctater, Proc. Zool. Soc. Lond., 1856, 287 (Córdova, Vera Cruz).-Swartir, Pacific Coast Avifauna, 110. 4, 1904, 19 (Huachuca Mts., Arizona, $5,500-7,000 \mathrm{ft}$.).

Coeligena leucotis Mulsant and Verreaux, Ilist. Nat. Ois.-Mouch., i, livr. 3, 1874, 187 (Temascáltepec, Mexico; Guatemala).

Heliopaedica leucotis Mulsant and Verreaux, Hist. Nat. Ois.-Mouch., ii, livr. 1, $1875,3$.

Heliopacdica (Coeligena) leucotis Mulsant and Verreaux, Hist. Nat. Ois.Mouch., iv, livr. 3, 1878, 186 (synonymy).

(?) Trochilus lucidus Sнаw, Gen. Zool., viii, pt. 1, 1812, 327 (based on "Le plus beau des becfleurs, Azara Par.")

(?) Mcllisuga lucida Strephens, Shaw's Gen. Zool., xiv, pt. i, 1826, 247.

(?) [Sapphironia] lucida Bonaparte, Rev. et Mag. de Zool., 1S54, 256.

Sapphironia lucida Sclater, Proc. Zool. Soc. Lond., 1858, 297 (Oaxaca); 1859, 386 (Totóntepec, Oaxaca).

Trochilus melanotis Swannson, Philos. Mag., n. s., i, 1827, 441 (Reál del Monte, Hidalgo).

Heliopædica melanotis Gould, Mon. Troch., ii, pt. xv, 1858, pl. 64; Introd. Troch., oct. ed., 1S61, 60.-SALviN, Ibis, 1S60, 195, 263, 270 (Volcan de Fuego, Cobán, and San Gerónimo, Guatemala; habits).-Sclater, Cat. Am. Birds, 1862, 289 (Mexico); Proc. Zool. Soc. Lond., 1864, 176 (Valley of Mexico).-Sanchez, Anal. Mus. Nac. Mex., i, 1877, 96 (Jalapa; Valley of Mexico; Guanájuato).-Villada, La Naturaleza, ii, 1874, 365 (Valley of Mexico).-Boucard, Ann. Soc. Linn. Lyon, xxii, 1876, 14 (Mexico; Puebla; Oaxaca); Notes Troch. du Mex., 1875, I (Mexico; Puebla; Oaxaca; habits, etc.).-D’OCA, La Naturaleza, iii, 1875, 28; Troq. de Mex., 1875, 19, pl. (3), fig. 11.

[Heliopædica] melanotis Sclater and Salvin, Nom. Av. Neotr., 1873, 81.

H[eliopxdica] melanotis Barrd, Brewer, and Ridgway, Hist. N. Am. Birds, ii, $1874,466$.

Heliopedica melanotis Sclater and Salvin, Ibis, 1859, 130 (Guatemala).Dugìs, La Naturaleza, i, 1873, 141 (Guanajuato).

Hæliopædica melanotis Herrera, La Naturaleza, (2), i, 1891, 322 (Valley of Mexico).

Hylocharis melanotis Mulsant and Verreaux, Classif. Troch., 1866, 38.

Trochilus cuculliger Lrchtenstern, Preis-Verz. Mex. Vög., 1831, 1; Journ. für Orn., 1863, 55.

Ornismya arsennii Lesson, Hist. Nat. Ois.-Mouch., 1829, pp. xxvii, 60, pl. 9 ("Brazil;" coll. Rivoli); Suppl., 1831, 152, pl. 27; Index Gen. and Synop. Troch., 1832, p. xxxix (Reál del Monte; Temascáltepec).

T[rochilus] xicotencal DE LA Llave, Piegistro Trimestre, ii, no. 5, Jan., 1833, 48 (Mexico; see Richmond, Auk, xvi, 1899, 324).

\section{BASIINNA LEUCOTIS PYGMÆA Simon and Hellmayr.} LESSER WHITE-EARED HUMMING BIRD.

Differing from $B$. $l$. leucotis in smaller size with relatively longer wings; green of throat more restricted posteriorly; breast. and abdo- 
men with much more white; rectrices blackish blue below, the lateral ones with a grayish white apical spot; wing, 55-57; culmen, $14.5-15 .^{a}$ Nicaragua (Matagalpa).

Basilinna leucotis (not Trochilus leucotis Vieillot) Salvin and Godman, Biol. Centr.-Am., Aves, ii, 1892, 312, part (Matagalpa, Nicaragua).

Basilinna leucotis pygmaea Simon and Hellmayr, Novit. Zool., xv, June 25. 1908, 12 (Matagalpa, Nicaragua; coll. E. Simon).

\section{BASILINNA XANTUSII (Lawrence).}

\section{XANTUS'S HUMMING BIRD.}

Differing from $B$. leucotis in having the tail mostly chestnut and under parts vinaceous-cinnamon; adult male with forehead, chin, etc., black (sometimes faintly glossed with bluish) instead of bright metallic violet or violet-blue.

Adult male.-Forehead (sometimes crown also) loral, suborbital, auricular and malar regions and chin black, the first and last sometimes faintly glossed with blue in certain lights; rest of upper parts metallic bronze-green, the feathers of rump and the upper tailcoverts more or less distinctly margined with rusty; middle pair of rectrices chestnut margined with metallic bronze-green, sometimes mostly of the latter color; rest of tail chestnut, the rectrices sometimes margined terminally with dull bronzy; remiges purplish dusky; a white or buffy white postocular stripe, following upper and posterior margins of black auricular area to side of neck; throat brilliant metallic emerald green, passing into more yellowish green on chest, the feathers more or less distinctly margined (very narrowly) with dull whitish; rest of under parts vinaceous-cinnamon or pale cinnamon-rufous, the breast (especially laterally) and sides spotted with metallic green; femoral tufts white; bill pale brownish (coral red or pinkish red in life), dusky terminally; iris dark brown; feet dusky; length (skins), 86-96 (93); wing, 50-54 (52.3); tail, 30-32.5 (31.1); culmen, $17-19$ (17.7). ${ }^{b}$

Adult female.-Above similar to the adult male but forehead dull brownish gray, instead of black, and rectrices (except middle pair and outer web of lateral pair) with a more or less extensive blackish subterminal area on each web; auricular area dusky grayish brown instead of black, the whitish postocular stripe more cinnamomeous or buffy; whole under parts pale vinaceous-cinnamon or cinnamon-buff, except the white femoral tufts; maxilla wholly dusky, the mandible dusky for terminal half (more or less); iris and feet as in adult male; length (skins), 79-90 (84); wing, 43.5-52.5 (48.9); tail, 27-31 (28.7); culmen, $17-19(17.8) .^{b}$ 
Young male.-Similar to the adult female but pileum tingea with rusty brown, and throat spotted with metallic emerald green or rellowish green.

Young female.-Similar to the young male but without green on throat.

Southern Lorrer California (Cape San Lucas; San José del Cabo; San José del Rancho; Pearco's Ranch ; El Sauz; La Laguna; Comondú; Triunfo; Santa Anita; Sierra de la Laguna; Agua Escondida; Cacachiles Mountains).

Amazilia xantusii Lamrence, Amu. Lyc. Nat. Hist. N. Y., vii, April, 1860, 109 (Cape St. Lucas; coll. U. S. Nat. Mus.; =adult female).

Heliopadica xantusi Govld, Ibis, 1860, 309; Mon. Troch., pt. xxi, 1861, pl. 2 (rol. ii, 1861, pl. 65); Introd. Troch., oct. ed., 1861, 61.-ELLiot, Illust. Birds N. Am., i, 1865, pl. 23.-Cooper, Orn. Cal., i, 1870, 365.-Baird, Breter, and Ridghax, Hist. N. Am. Birds, ii, 1874, 467, pl. 47, fig. 3.D`Oca, La Naturaleza, iii, 1875, 161; Troq. de Mex., 1875, 39.-Mursant and Terreaux, Hist. Nat. Ois.-Mouch., i, 1877, pl. 16.-Mulsant, Ann. Soc. Linn. Lyon, xxii, 1876, 207.

[Heliopædica] xantusi Coues, Key N. Am. Birds, 1872, 184.

Heliopodica xantusi D’OcA, Troq. de Mex., 1875, pl. 8, fig. 28.

Heliopaedica (Coligena) xanthusi Mulsant and Verreaux, Hist. Nat. Ois.Mouch., ir, livr. 3, 1878, 186.

[Heliopaedica] xanthusi Mfulsant, Ann. Soc. Linn. Lyon, n. s., xxii, 1876, 207.

Coeligena xanthusi Mulsant and Terreaux, Hist. Nat. Ois.-Mouch., i, livr. 3, 1874, 190, pl. 16 (Helioprdica xantusi on plate).

Hellopaedica xanthusi Mulsant and Verreaux, Hist. Nat. Ois.-Mouch., suppl. plates, pl. 29.

Basilinna xanthusi Euliot, Classif. and Synop. Troch., 1879, 227.-Boucard, Gen. Hum. Birds, 1894, 178.

Basilinna xantusi Ridgway, Proc. U. S. Nat. Mus., iii, Aug. 24, 1880, 6, 188, 219, 229, 319; r, 1883, 542 (descr. nest and eggs); Nom. N. Am. Birds, 1881, no. 347; Rep. U. S. Nat. Mus. for 1890 (1891), 369, pl. 44 (monographic).American Ornithologists' Union, Check List, 1886, no. 440.-Belding, Proc. U. S. Nat. Mus., v, 1882, 542 (w. base Cacachiles Mts. and San José del Cabo, Lower California; descr. nest, etc.); vi, 1883, 349 (high mts. of s. Lower California).-Bryant (W. E.), Proc. Calif. Ac. Sci., ser. 2, 1889, 289 (Comondu, Lower California and n. to lat. 29 ${ }^{\circ}$ ). - Salvin, Cat. Birds Brit. Mus., xvi, 1892, 255 (Agua Escondida, 20 m. s. of La Paz, Triunfo, and San José del Cabo).-Bendire, Life Hist. N. Am. Birds, ii, 1895, 226.-Brewster, Bull. Mus. Comp. Zool., xli, 1902, 113 (Cape San Lucas district; descr.; descr. nest and eggs, habits, etc.).

B[asilinna] xantusi Henne, Journ. für Orn., 1863, 196.-Coves, Key N. Am. Birds, 2d ed., 1884, 460.-Ridgway, Man. N. Am. Birds, 1887, 318.

Hylocharis xantusi Mulsant and Verreaux, Classif. Troch., 1866, 38.

H[ylocharis] xantusi HARTERT, Das Tierreich, Troch., 1900, 66 (monogr.).

[Hylocharis] zantusii GRAY, Hand-list, i, 1869, 151, no. 1950.

[Hylocharis] xantusi SHARPE, Hand-list, ii, 1900, 110.

[Helioprdica] xanthusi Sclater and Salvin, Nom. Av. Neotr., 1873, 81.

Heliopaedica castaneocauda Lawrence, Ann. Lyc. Nat. Hist. N. Y., vii, April, 1860 (pub. 1862), 145 (Cape San Lucas, Lower California; coll. U. S. Nat. Mus.; =adult male).-ElL1oT, Illust. Birds N. Am., i, 1869, pl. 22. 


\section{Genus HYLOCHARIS Boie.}

Hylocharis Bore, Isis, 1831, 546. (Type, Trochilus saphirinus Gmelin.) Sapphironia Bonaparte, Rev. et Mag. de Zool., vi (2), May, 1854, 256. (Type, as fixed by Gray, 1855, Trochilus sapphirinus Gmelin.)

Rather small Trochilidæ (length about 80-100 mm.) with bill longer than head, broad and depressed basally, the broad nasal operculi very tumid and completely naked, frontal feathering forming a transverse line across base of forehead, tail slightly rounded or double-rounded, no black or white markings on head, ${ }^{a}$ and tail uniform bright metallic golden, bronze, coppery, or blue-black.

Bill decidedly longer than head, depressed, broad basally, very slightly decurved; culmen broadly rounded, but contracted into a narrow ridge basally; tomia smooth; a more or less distinct narrow median groove along sides of mandible, and more or less distinct indication of a similar groove on maxilla. Nasal operculum broad, tumid, completely nude, the frontal feathering forming a transverse line across base of forehead or (in $H$. grayi) forming two very slight antiæ. Tarsus feathered for upper portion, at least in front; middle and inner toes about equal in length, the outer slightly shorter; hallux shorter than outer toe. Wing nearly three times as long as exposed culmen, the outermost primary longest. Tail more than half as long as wing, slightly rounded or double-rounded, the rectrices broad, with rounded tip.

Coloration.--Above metallic green or bronze-green (sometimes with head or at least forehead blue or violet), the tail very bright metallic golden, golden-green, bronze, or dark chestnut with middle rectrices and upper coverts copper bronze, or else uniform blueblack; adult males with under parts of body metallic green or bronze, the throat bronze, green, blue, or violet, the chin sometimes rufous. Sexes different (except in $H$. grayi), the female with under parts mostly dull whitish medially.

Range.-Guatemala to Guiana, Paraguay, northern Argentina, Bolivia, and eastern Peru. (About ten species and subspecies, but only one in Middle America.)

\section{HYLOCHARIS ELICIE (Bourcier and Mulsant).}

\section{ELICIA'S GOLDEN-TAIL.}

Adult male.-Pileum, hindneck, back, scapulars, and wing-coverts metallic green (varying from nearly pure green to more or less golden green), passing, through a more golden or bronzy hue on rump, into bright golden or coppery bronze on upper tail-coverts; tail brilliant golden bronze, more or less tinged with golden green in certain lights,

$a$ The females of some species have the chin and throat intermixed with white. 
rarely ${ }^{a}$ varying to bright golden green; remiges dark brownish slate or dusky, faintly glossed with violaceous; chin and extreme upper throat dull whitish, the feathers (except, sometimes, on apex of chin) with a terminal spot of metallic violet-blue; rest of throat, together with upper chest, bright metallic violet-blue; breast, sides, and flanks metallic bronze-green (the upper breast or lower chest usually purer or more bluish green); abdomen and median portion of breast buffy grayish or pale broccoli brown, slightly more buffy on lower abdomen; femoral tufts white; under tail-coverts grayish brown, broadly edged and tipped with cinnamon; bill pale brownish (pinkish or reddish in life), more or less extensively dusky terminally; iris dark brown; feet grayish brown or dusky; length (skins), 78-90 (88); wing, 47.5-52 (49.6); tail, 24.5-29 (26.6); culmen, 17-18.5 (17.6). ${ }^{b}$

Adult female.-Essentially like the adult male, but under parts paler, usually with the violet-blue of throat much more restricted and broken by dull whitish margins to feathers; length (skins), 74-83 (77); wing, 44.5-48.5 (46.8); tail,24-26 (25); culmen, 17-19 (17.9).c

Extreme southern Mexico in State of Chiapas (Ocuilapa) and southward through Guatemala (Cobán; Choctúm; Masagua; Retalhuleu; Gualán), Salvadór (La Libertád), Honduras (Santa Ana; Rio Segóvia), Nicaragua (Sucuyá; La Libertád and Santo Domingo, Chontales), and Costa Rica (Miravalles; Coralillo; La Vijagua; El Generál; Bolsón; Lagarto; Tenório; Boruca; Pozo del Rio Grande; Pozo Azúl de Pirrís; Rio Turubales; Pigres; Bagaces; San Pedro del Mojón), to western Panamá (Boquete; Volcán de Chiriquí; Divala; Bugaba; Chitra; Davíd).

Trochilus] elicix Bourcier and Mulsant, Ann. Sci. Phys. et Nat. Lyon, ix, 1846, 314 (locality unknown); Rev. Zool., 1846, 316.

P[olytmus] eliciæ Gray, Gen. Birds, i, Dec., 1848, 109.

[Polytmus] elicix GraY, Hand-list, i, 1869, 133, no. 1706.

[Chrysuronia] eliciæ Bonaparte, Consp. Av., i, 1850, 75.-Reichenbach, Aufz. der Colibr., 1854, 9; Troch. Enum., 1855, 5, pl. 722, figs. 4644, 4645.

[Chrysuronia] elicia Bonaparte, Rev. et Mag. de Zool., 1854, 254.

$a$ In only one among eleven specimens examined.

$b$ Twenty specimens.

\begin{tabular}{|c|c|c|c|}
\hline Locality. & Wing. & Tail. & $\begin{array}{l}\text { Cul- } \\
\text { men. }\end{array}$ \\
\hline MALES. & & & \\
\hline Five adult males from Guatemala... & 49.7 & 27.1 & 18.1 \\
\hline Two adult males from Honduras............ & 48.5 & 25.2 & 18 \\
\hline Ten adult males from Costa Rica........................ & 49.8 & 26.8 & 17.3 \\
\hline 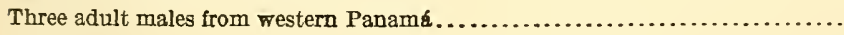 & 49.3 & 26.3 & 17.3 \\
\hline
\end{tabular}

c Ten specimens, from Costa Rica. 
Chrysuronia eliciæ Gould, Mon. Troch., pt. xvi, 1858 (vol. v), pl. 328; Introd. Troch., oct. ed., 1861, 165.-Sclater and SalviN, Ibis, 1859, 130 (Guatemala).-Sclater, Cat. Am. Birds, 1862, 316 (Cobán, Guatemala).-LAwRence, Ann. Lyc. N. Y., vii, 1862, 465 (Isthmus of Panamá); ix, 1868, 128 (Costa Rica).--Frantzius, Journ. für Orn., 1869, 317 (Costa Rica).--Salvin, Proc. Zool. Soc. Lond., 1870, 211 (Bugaba and Chitra, Panamá); Ibis, 1872, 320 (Chontales, Nicaragua); Cat. Birds Brit. Mus., xvi, 1892, 251, 662 (Cobán, Choctúm, and Masagua, Guatemala; La Libertád, Salvadór; La Libertád and Santo Domingo, Chontales, Nicaragua; Costa Rica; Volcán de Chiriquí, Bugaba, Chitra, and Davíd, Panamá).-Mulsant and Verreaux, Hist. Nat. Ois.-Mouch., ii, livr. i, 1876, 4, 13 (Guatemala, etc.); iv, livr. 3, 1878, 186.Mulsant, Ann. Soc. Linn. Lyon, xxii, 1876, 207.-Boucard, Liste Ois. récol. Guat., 1878, 47; The Hum. Bird, ii, 1892, 83 (Verágua); Gen. Hum. Birds, 1894, 140 (Guatemala; Nicaragua; Verágua).-Zeledón, Cat. Aves de Costa Rica, 1882, 21.-Elliot, Classif. and Synop. Troch., 1879, 169.-RIDGway, Proc. U. S. Nat. Mus., vi, 1883, 386 (Sucuyá, Nicaragua; crit.); x, 1887, 591 (Rio Segóvia, Honduras); Condor, vii, 1905, 154, in text (Pigres, Costa Rica).-Salvin and Godman, Biol. Centr.-Am., Aves, ii, 1892, 311 (La Libertád and Santo Domingo, Nicaragua; etc.).-Cherrie, Expl. Zool. Mérid. Costa Rica, 1893, 44 (Lagarto and Boruca, s. w. Costa Rica).

[Chrysuronia] elicix Sclater and Salvin, Nom. Av. Neotr., 1873, 93. C[hrysurisca] eliciae Cabanis and Heine, Mus. Hein., iii, 1860, 42 (Honduras).

[Chrysurisca] eliciae Heine and Reichenow, Nom. Mus. Hein. Orn., 1890, 180 (Guatemala; Honduras).

Hylocharis elicix Mulsant and Verreaux, Classif. Troch., 1866, 38.-Bangs, Auk, xviii, 1901, 359 (Divala, Panamá); xxiv, 1907, 295 (Boruca and Pozo del Rio Grande, Costa Rica); Proc. New Engl. Zool. Club, iii, 1902, 29 (Boquete, Panamá, 3,000 ft.).-Carriker, Ann. Carnegie Mfus., vi, 1910, 530 (Pacific slope, Costa Rica, 1,000-2,000 ft.).

[Hylocharis] eliciz Simon, Cat. Troch., 1897, 15.--Sharpe, Hand-list, ii, 1900, 111. H[ylocharis] eliciae HarTent, Das Tierreich, Troch., 1900, 68.

\section{Genus CHALYBURA Reichenbach.}

[Agyrtria.] o. Chalybura Reichenbach, Aufz. der Colib., March (?), 1854, 10. (Type, Trochilus buffoni Lesson.)

Hypuroptila Gould, Mon. Troch., pt. vii (vol. ii), May, 1854, pl. 89. (Type, Trochilus buffoni Lesson.)

[Hylocharis.] o. Cyanochloris Reichenвach, Aufz. der Colib., 1854, 10. (Type, Trochilus (Glaucis?) cæruleogaster Gould.)

Methon Mulsant, Ann. Soc. Linn. Lyon, n. s., xxii, 1876, 203 (Cat. Ois. Mouch., 1875, 7). (Type, Chalybura caeruleiventris Reichenbach = Trochilus (Glaucis?) cæruleogaster Gould.)

Rather large Trochilidæ (length about 105-115 mm.), with peculiarly modified or specialized under tail-coverts (these downy, semidecomposed, plume-like), stout, straight, or slightly decurved bill much longer than head, the tail long (about two-thirds as long as wing), emarginate, with broad rectrices, and coloration rather plain.

Bill much longer than head, stout, straight, or faintly decurved, nearly terete but slightly depressed, especially at base; culmen rounded except for basal portion, where compressed into a narrow 
ridge; tcrminal portion of both maxillary and mandibular tomia minutely serrate; mandible with a longitudinal median groove, the maxilla with more or less faint indication of a similar groove. Nasal operculum moderately broad and convex, mostly nude, the frontal feathering reaching to or beyond its middlc portion, forming a short antin or angle on each side of mesorhinium. Tarsus stont, naked; middle and inner toes about equal in length, the outer slightly shorter, the hallux shorter than outer toe; toes rather stout, with claws relatively short but very acute. Wing about three times as long as exposed culmen, the outermost primary longest. Tail about twothirds as long as wing, emarginate, the rectrices broad, with rounded or broadly subcuneate tip.

Coloration.-Above metallic green, in some species changing into dark bronze or copper-bronze on upper tail-coverts. Adult males with under parts (except under tail-corerts) metallic green or blue, the under tail-coverts white, or (in one species) dusky, the tail plain blue-black, bronzy black, or bronzy; adult females with under parts grayish medially, greenish laterally, the lateral rectrices tipped with gray.

Range.-Nicaragua to Venezuela and Ecuadór. (Six species.)

KEY TO THE SPECIES OF CHALYBURA.

a. Under parts (except under tail-coverts) metallic green or blue. (Adult males.)

b. Under tail-coverts white.

c. Mandible wholly black.

d. Under parts metallic green. (Panamá to Colombia and Venezuela.)

dd. Under parts metallic blue. (Colombia.)

Chalybura buffonii, adult male (p. 388).

Chalybura cæruleogaster, adult male (extralimital). ${ }^{a}$ cc. Mandible pale colored (reddish or flesh colored in life) for at least basal half.

d. Under parts green, without blue tinge. (Panamá and northwestern Colombia.)................. Chalybura urochrysa, adult male (p. 390). dd. Under parts tinged with blue.

e. Throat and chest bluish green, abdomen green. (Panamá.)

Chalybura isauræ, adult male (p. 391).

a Trochilus (Glaucis?) cæruleogaster Gould, Proc. Zool. Soc. Lond., 1847, 96 (locality unknown).-[Lampornis] caeruleigaster Bonaparte, Consp. Av., i, 1850, 72.-Hypuroptila cæruleogaster Gould, Mon. Troch., pt. vii, May, 1854 (vol. ii), pl. 91.-Chalybura cæruleogaster Gould, Introd. Troch., oct. ed., 1861, 72.-C[halybura] caeruleogaster Hartert, Das Tierreich, Troch., ii, 1900, 92.-[Hylocharis. o. Chalybura] caeruleiventris Reichenbach, Aufz. der Colibr., 1854, 10.-[Agyrtria. $\delta$. Chalybura] caeruleiventris Reichenbach, Troch. Enum., 1855, 7, pl. 767, figs. 4775, 4776.-C[halybura] caeruleiventris Cabanis and Heine, Mus. Hein., iii, 1860, 20.-Lampornis coeruleiventris Mulsant and Verreaux, Hist. Nat. Ois.-Mouch., i, livr. 3, 1874, 168 (Andes of Colombia)._Chalybura (Lampornis) coeruleiventris Mulsant and Verreaux, Hist. Nat. Ois.-Mouch., iv, livr. 2, 1877, 156.-Chalybura cæruleiventris Elliot, Classif. and Synop. Troch., 1879, 47.-Hypuroptila cæruleiventris Salvin, Cat. Birds Brit. Mus., xvi, $1892,88$. 
ee. Throat golden green, abdomen greenish blue. (Western Ecuadór.)

Chalybura intermedia, adult male (extralimital). $a$

$b b$. Under tail-coverts dusky. (Eastern Nicaragua to western Panamá.)

Chalybura melanorrhoa, adult male (p. 392).

aa. Under parts mostly pale grayish. (Adult females. ${ }^{b}$ )

b. Under tail-coverts white.

c. Lateral under parts with little green admixture; lateral rectrices more broadly tipped with pale gray or grayish white.

Chalybura buffonii, adult female (p. 381).

cc. Lateral under parts extensively spotted or overlaid by green; lateral rectrices more narrowly tipped with pale gray or grayish white.

Chalybura cæruleogaster, adult female (extralimital).

$b b$. Under tail-coverts gray ......... Chalybura melanorrhoa, adult female (p. 392).

\section{CHALYBURA BUFFONII (Lesson).}

BUFFON'S PLUMELETEER.

Adult male.-Above deep metallic grass green, slightly duller on pileum, the upper tail-coverts more bronzy, the middle rectrices metallic bronze or greenish bronze, sometimes blackish, more or less glossed with bronzy; rectrices (except middle pair) blue-black, usually edged more or less broadly with bronzy, at least toward base, the outer web of pair next to middle sometimes almost wholly bronzy; remiges dull brownish slate or dusky, faintly glossed with purplish, the inner secondaries mostly metallic grass green; under parts metallic dark emerald green or clear metallic grass green, the feathers grayish basally and crossed by a subterminal bar (concealed) of white or grayish white, and narrowly margined with pale grayish, forming a squamated appearance when viewed from behind; femoral tufts, anal region, and under tail-coverts pure white; bill dull black; iris dark brown; feet brownish (in dried skins); length (skins), 110-129 (119); wing, 67.5-73 (69.9); tail, 39.5-48.5 (43.3); culmen, $23-27$ (24.6). ${ }^{\circ}$

Adult female.-Above similar to adult male, but lateral rectrices rather broadly tipped with pale gray; under parts, including malar and suborbital regions, pale gray, usually glossed or spotted, more or less, with metallic green laterally, sometimes over whole surface;

a Chalybura intermedia Hartert (E. and C.), Novit. Zool., i, Jan., 1894, 44 (road from Guayaquil to Loja, bet. Pogio and Santa Rosa, w. Ecuadór; coll. Tring Mus.).C[halybura $]$ intermedia Hartert (E.), Das Tierreich, Troch., 1900, 92.-Hypuroptila intermedia Boucard, The Hum. Bird, v, 1895, 325 (synonymy; descr.).

$b$ Females of $C$. urochrysa and $C$. isauræ not seen by me.

c Fifteen specimens. 
femoral tufts, anal region, and under tail-coverts pure white, as in adult male; length (skins), 100-112 (105); wing, 59.5-65 (62); tail, $36.5-39(37.5)$; culmen, $23.5-27(24.6) .^{a}$

Immature male.-Similar to the adult male but bright green of under parts less continuous or appearing in patches on a dull grayish green ground color (representing the earlier plumage).

Eastern Panamá (Lion Hill, Paraiso, and Obispo Stations; Chepo; Panamá; Punta de Sabana), Colombia (Bogotá; lower Magdalena; Rio Dagua; Naranjo; Valencia; Santa Elena and Remédios, Antioquía; Santa Marta, Doña Amo, Manuare, Bonda, Minca, Don Diego, and Cacagualito, Santa Marta) and Venezuela (La Guaira; Maracay, Aragua; Valéncia; Puerto Cabello; Guanta; San Julian; Carácas).

Trochilus buffonii Lesson, Hist. Nat. Troch., 1831, 31, pl. 5 ("Brasil"); Index Gen. et Synop. Troch., 1832, p. xii ("Brasil").

P[olytmus] buffonii GraY, Gen. Birds, i, Dec., 1848, 108.

[Polytmus] buffonii Gray, Hand-list, i, 1869, 126, no. 1584.

[Lampornis] buffoni Bonaparte, Consp. Av., i, 1850, 72; Rev. et Mag. de Zool., 1854, 250.

Lampornis buffoni Mulsant and Verreaux, Hist. Nat. Ois.-Mouch., i, livr. 3, 1874, 170 (San Antonio, near Bogotá, Colombia, 6,000-7,000ft.; La Guaira, Venezuela).

a Nine specimens.

\begin{tabular}{|c|c|c|c|}
\hline Locality. & Wing. & Tail. & $\begin{array}{l}\text { Cul- } \\
\text { men. }\end{array}$ \\
\hline MALES. & & & \\
\hline Two adult (?) males from Panamá. & 69.2 & 42 & 24 \\
\hline Ten adult males from Colombia... & 69.9 & 43 & 24.3 \\
\hline Three adult males from Venezuela.. & 70.2 & 45 & 25.7 \\
\hline FEMALES. & & & \\
\hline One adult female from Panamá.. & 60.5 & 38 & 23.5 \\
\hline Seven adult females from Colombia.... & 62.4 & 37.5 & 24.3 \\
\hline One adult female from Venezuela........ & 61 & 37 & 27 \\
\hline
\end{tabular}

I am by no means satisfied that all the above-mentioned specimens represent a single form. Six males (three fully adult, three evidently immature) from the Santa Marta district of Colombia have the middle rectrices wholly metallic bronze or greenish bronze and the remaining rectrices (except the outermost) broadly edged with the same, at least basally. On the other hand, fully adult as well as immature males from the lower Magdalena and Bogotá districts and those from Venezuela have the middle rectrices either very dull bronzy or blackish faintly glossed basally with bronzy, while two from Panamá (the only ones seen from that district) have the middle pair of rectrices wholly blue-black like the rest of the tail, and the upper tail-coverts purplish bronze. The series examined is, however, much too small to enable one to decide the question properly. 
Hypuroptila buffoni Gould, Mon. Troch., pt. vii, 1854 (vol. ii), pl. 89.-LAwrence, Ann. Lyc. N. Y., vii, 1862, 319 (Lion Hill, Panamá).-Salvin, Cat. Birds Brit. Mus., xvi, 1892, 87 (Lion Hill, Paraiso, and Chepo, Panamá; Minca, Sierra de Santa Marta, Manuare, and Bogotá, Colombia; Venezuela).-Salvin and Godman, Biol. Centr.-Am., Aves, ii, 1892, 274 (Obispo, Panamá; etc.).-Boucard, The Hum. Bird, 1895, 7 (Rio Dagua, n. w. Colombia); Gen. Hum. Birds, 1895, 322 (Colombia).-Robinson, Proc. U. S. Nat. Mus., xviii, 1896, 682 (Guanta, Venezuela).-Bangs, Proc. Biol. Soc. Wash., xii, 1898, 135 (Santa Marta, Colombia).-Salvadori and Festa, Boll. Mus. Zool., etc., Torino, xiv, 1899, no. 339, 7 (Punta de Sabana, Panamá).-Allen, Bull. Am. Mus. N. H., xiii, 1900, 141 (Bonda, Minca, etc., Santa Marta, Colombia).-Robinson and Richmond, Proc. U. S. Nat. Mus., xxiv, 1901, 172 (La Guaira and San Julian, Venezuela).

[Agyrtria] o. Chalybura buffonii Reichenвach, Aufz. der Colibr., 1854, 10.

[Agyrtria] buffonii Reichenbach, Troch. Enum., 1855, 7, pl. 766, figs. 4773, 4774. C[halybura] buffoni CaBanis and Heine, Mus. Hein., iii, 1860, 20 (Caracas, Venezuela; Veragua).

Chalybura buffoni Gould, Introd. Troch., oct. ed., 1861, 72.-Sclater and Salvin, Proc. Zool. Soc. Lond., 1864, 365 (Lion Hill, Panamá); 1868, 628 (Venezuela); 1879, 529 (Remédios and Santa Elena, Antioquía, Colombia).Salvin and Godman, Ibis, 1879, 205 (Manuare, Santa Marta, Colombia, 2,700 ft.); 1880, 171 (Minca, Santa Marta, 2,000 ft.).-Euliot, Classif. and Synop. Troch., 1879, 45.--Berlepsch, Journ. für Orn., 1884, 309 (Bucaramanga, Colombia; crit.); 1887, 316 (Bogotâ).-Snon, Mém. Soc. Zool. France, ii, 1889, 219 (San Esteban, Venezuela).-Boucard, The Hum. Bird, ii, 1892, 84 (Bogotá).-Simon and Dalmas, Ornis, xi, 1901, 222 (Naranjo, w. Colombia).

[Chalybura] buffoni Sclater and Salvin, Nom. Av. Neotr., 1873, 82.-Mulsant, Ann. Soc. Linn. Lyon, xxii, 1876, 203.-SharPe, Hand-list, ii, 1900, 117.

C[halybura] buffoni HarTerT, Das Tierreich, Troch., 1900, 91.

Chalybura buffonii Sclater, Cat. Am. Birds, 1862, 292.-Pelzeln, Orn. Bras., iv. Abth., 1870, 408.

Chalybura (Lampornis) buffoni Mulsant and Verreaux, Hist. Nat. Ois.-Mouch., iv, livr. 2, 1879, 156.

Chalybura æneicauda Lawrence, Proc. Ac. Nat. Sci. Phila., 1865, 38 (Venezuela; coll. Am. Mus. N. H.).-Boucard, The Hum. Bird, ii, 1892, 84 (Valéncia, Colombia).

[Polytmus] æneicaudus Grax, Hand-list, i, 1869, 126, no. 1588.

Hypuroptila æneicauda Boucard, Gen. Hum. Birds, 1895, 323 (Puerto Cabello, Venezuela; Valéncia, Colombia).

\section{CHALYBURA UROCHRYSA (Gould.)}

GOLDEN-TAILED PLUMELETEER.

"Adult male.-Upper surface dark grass-green; rump and upper tail-coverts bronzy; tail rich golden bronze; under surface emeraldgreen, almost the same shade as in $H$. buffoni; abdomen dull grey washed with green; maxilla black, mandible flesh-color, tip black. Total length about 5 inches [127 mm.], wing 2.75 [69.8 mm.], tail, central rectrices 1.6 [40.6], lateral 1.8 [45.7]; bill 1.15 [29.2].

"Female unknown." a 
Panamá and northwestern Colombia (Medellín and Remédios, Antioquía).

Hypuroptila wrochrysa Gould, Proc. Zool. Soc. Lond., xxix, 1861, 198 (Panamá; coll. J. Gould); Ann. and Mag. N. H., 3d ser., viii, IS61, 268.

Hypuroptila urochrysia Gould, Mon. Troch., pt. xxii (vol. ii), 1861, pl. 90.Salvin, Cat. Birds Brit. Mus., xvi, 1892, 89 (Panamá, Medellín, and Remédios, Colombia).-Salvin and Godman, Biol. Centr.-Am., Aves, ii, 1892, 275.-Boucard, Gen. Hum. Birds, 1895, 325 (Panamá; Verágua).

Chalybura urochrysea Gould, Introd. Troch., oct. ed., 1861, 72.-ElLıot, Classif. and Synop. Troch., 1879, 46.-Boucard, The Hum. Bird, ii, 1892, 85 (Panamá).-Hartert, Novit. Zool., v, 1S98, 494 (Cachaví, n. w. Ecuadór).

[Chalybura] urochrysia Mulsant, Ann. Soc. Linn. Lyon, n. s., xxii, 1876, 203.

Lampornis urochrysia Mulsant and Verreaux, Classif. Troch., 1866, 24; Hist. Nat. Ois.-Mouch., i, livr. 3, 1874, 176 (Panamá; Verágua).

[Polytmus] urochryseus Gray, Hand-list, i, 1869, 126, no. 1587.

[Chalybura] urochrysea Sclater and Salvin, Nom. Av. Neotr., 1873, 82.-Sharpe, Hand-list, ii, 1900, 117.

C[halybura] urochrysea HaRtent, Das Tierreich, Troch., 1900, 92 (monogr.).

\section{CHALYBURA ISAUR止 (Gould.)}

\section{BARONESS DE LAFRESNAYE'S PLUMELETEER.}

Adult male.-Pileum and (usually) hindneck metallic greenish bronze, usually tinged or intermixed with coppery bronze, the feathers with a small central area of dusky, producing a more or less distinct squamate effect; back, scapulars, and wing-coverts metallic bronzegreen, usually more or less tinged or intermixed with bronze or coppery; rump coppery bronze, passing into darker and more purplish bronze on upper tail-coverts; tail uniform dark purplish bronze (less violaceous than upper tail-coverts); remiges dusky, faintly glossed with violaceous; malar region, chin, throat, chest, and breast rather dark metallic green (bluish grass green to viridian), the feathers abruptly dusky gray beneath the surface; femoral tufts and under tail-coverts dull white; rest of under parts dusky grayish, strongly glossed or overlaid by bronze-green or bronze; maxilla dull black, mandible pale dull yellowish (pink or reddish in life?); iris dark brown; legs and feet pale brownish (pink or reddish in life?); length (skins), 105; wing, ${ }^{a}$ 64.5-68.5 (66.6); tail, 39-43.5 (41.4); culmen, $22.5-25.5(24.1)^{b}$.

Adult female.- "Under surface from the chin to the vent grey, the under tail-coverts white; the two lateral rectrices on either side are tipped with dull grey preceded by a dark subterminal band." $c$

Panama (Boca del Toro; Santa Fé and Santiago, Verágua) and Caribbean coast district of Costa Rica (Talamanca; Puerto Limón).

Hypuroptila isauræ Gould, Proc. Zool. Soc. Lond., xxix, 1861, 199 (Boca del Toro, "Costa Rica," i. e., Panamá; coll. J. Gould).-Salvin, Cat. Birds Brit.

$b$ Four specimens. 
Mus., xvi, 1892, 89 (Boca del Toro; Santa Fe and Santiago de Verágua).Salvin and Godman, Biol. Centr.-Am., Aves, ii, 1892, 275.-Boucard, Gen. Hum. Birds, 1895, 324.

[Hypuroptila] isaurae Mulsant, Ann. Soc. Linn. Lyon, xxii, 1876, 203.

Hypuroptila (Lampornis) isauræ Mulsant and Verreaux, Hist. Nat. Ois.Mouch., iv, livr. 2, 1877, 158 (synon.)

Chalybura? isauræ GouLd, Introd. Troch., oct. ed., 1861, 72.

Chalybura isauræ Salvin, Proc. Zool. Soc. Lond., 1867, 152 (Santiago and Santa Fé de Verágua, Panamá; descr. female).-Lawrence, Ann. Lyc. N. Y., ix, 1868, 122 (Boca del Toro).-FrantziUs, Journ. für Orn., 1869, 315 (Costa Rica).-Elliot, Classif. and Synop. Troch., 1879, 46.-Zeledón, Cat. Aves de Costa Rica, 1882, 20; Anal. Mus. Nac. Costa Rica, i, 1887, 122.-Boucard, The Hum. Bird, ii, 1892, 85 (Verágua).-Carriker, Ann. Carnegie Mus., vi, 1910, 537 (Costa Rica).

[Chalybura] isauræ Sclater and Salvin, Nom. Av. Neotr., 1873, 82.-Sharpe, Hand-list, ii, 1900, 117.

C[halybura] isaurae HaRTERT, Das Tierreich, Troch., 1900, 92 (monogr.).

[Polytmus] isauræ Gray, Hand-list, i, 1869, 126, nò. 1586.

Lampornis isauræ Mulsant and Verreaux, Hist. Nat. Ois.-Mouch., i, livr. 3, 1874, 174 (Boca del Toro, Santa Fe, and Santiago, Panamá).

\section{CHALYBURA MELANORRHOA Salvin.}

\section{DUSKY PLUMELETEER.}

Adult male.-Above dark metallic grass-green, passing into bronze on rump and into bronze-green or greenish bronze on wing-coverts; upper tail-coverts dusky bronzy purplish; tail purplish bronze; remiges dusky purplish brown, the inner secondaries bronze-green or greenish bronze; primary coverts darker, indistinctly tipped with dull bronze-green; under parts deep metallic grass-green, passing into dusky bronze on abdomen and flanks; under tail-coverts dull black or dusky, glossed with bronzy purple; anal tufts dull grayish; maxilla black, mandible pale brownish (flesh color in life) dusky terminally; iris dark brown; feet pale brownish (purplish red or lake red in life); length (skins); 111-119 (115); wing, 68.5-72.5 (70.2); tail, 44-48 (46.2); culmen, 22.5-24 (23.3). ${ }^{a}$

Adult female. - Similar to the adult male in color of upper parts, but under parts dull brownish gray, with sides (especially sides of breast) mostly metallic green, the chest sometimes spotted with the same; lateral rectrices broadly tipped with brownish gray; bill, etc., as in adult male; length (skins), 102-108 (105); wing, 61-65.5 (63.2); tail, 36.5-41 (38.5); culmen, 22-24.5 (23.3). ${ }^{a}$

Caribbean slope of Nicaragua (Chontales; Los Sábalos) and Costa Rica (Angostura; Tucurríqui; Turrialba; Juan Viñas; Jiménez; Bonilla; El Hogár; Rio Sícsola; Cuábre; Guápiles; La Junta; La Vijágua; Pacuare; Talamanca) to western Panamá (Verágua).

Chalybura melanorrhoa Salvin, Proc. Zool. Soc. Lond., 1864 (pub. April 1, 1865), 585 (Tucurríqui, Costa Rica; coll. Salvin and Godman); Ibis, 1872, 313, 319 
(Chontales, Nicaragua; crit.).-Lawrence, Ann. Lyc. N. Y., ix, 1868, 122 (Angostura and Pacuare, Costa Rica).-Frantzius, Journ. für Orn., 1869, 315 (Costa Rica).-Elliot, Classif. and Symop. Troch., 1879, 47.-M ulsant and Verreaux, Hist. Nat. Ois.-Mouch., Suppl., pl. 9.-Zeuedón, Cat. Aves de Costa Rica, 1852, 20; Anal. Mus. Nac. Costa Rica, i, 1887, 121 (Jiménez, Costa Rica).-Nutring, Proc. U. S. Nat. Mus., vi, 1883, 406 (Los Sábalos, Nicaragua).-Salvin and Godman, Biol. Centr.-Am., Aves, ii, 1892, pl. 55, figs. 2, 3.-Carriker, Ann. Carnegie Mus., vi, 1910, 536 (Caribbean lowlands, Costa Rica; habits).

Chalybura melanorhoa Boucard, The Hum. Bird, ii, 1892, 84 (Verígua).

[Chalybura] melanorrhoa Sclater and Salvin, Nom. Av. Neotr., 1873, 82.-MulSAxt, Ann. Soc. Linn. Lyon, xxii, 1876, 203.-Sharpe, Hand-list, ii, 1900, 117.

C[halybura] melanorrhoa Hartert, Das Tierreich, Troch., 1900, 93 (monogr.).

[Polytmus] melanorrhous Gray, Hand-list, i, 1869, 126, no. 1585.

Lampornis melanorrhoa Mulsant and Verreaux, Hist. Nat. Ois.-Mouch., i, livr. 3, 1874, 174, pl. 14 (Verágua; Angostura and Pacuare, Costa Rica).

Hypuroptila (Lampornis) melanorrhoa Mulsant and Verreaux, Hist. Nat. Ois.Mouch., iv, livr. 2, 1877, 157.

Hypuroptila melanorrhoa Gould, Suppl. Troch., 1881, pl. 10.-SAlvin, Cat. Birds Brit. Mus., xvi, 1892, 90 (Chontales, Nicaragua; Tucurríqui and Turrialba, Costa Rica).-Salvin and Godman, Biol. Centr.-Am., Aves, ii, 1892, 276.Boucard, Gen. Hum. Birds, 1895, 324 (Costa Rica; Verágua).

Chalybura carnioli Lawrence, Proc. Ac. Nat. Sci. Phila., 1865, 39 (Angostura, Costa Rica; coll. U. S. Nat. Mus.).

\section{Genus EUPHERUSA Gould.}

Eupherusa a Gould, Mon. Troch., pt. xiv, Sept., 1857, pl. 324. (Type, Ornismya eximia Delattre.)

Rather small Trochilidæ (length about 90-95 mm.) with bill about as long as head, maxillary tomium serrate terminally, nasal operculum mostly nude, tail more than half as long as wing, rounded, with broad rectrices, secondaries rufous, and lateral rectrices mostly white (at least the inner web), the adult males bright metallic green below, with under tail-coverts white, the females pale gray or grayish white below.

Bill about as long as head, straight, nearly terete; culmen rounded but basally contracted into a distinct narrow ridge; terminal portion of maxillary tomium minutely serrate; mandible and maxilla without distinct lateral median sulci. Nasal operculum narrow, mostly nude, the frontal feathering extending to or beyond its middle portion, and forming a slightly emarginate median antia. Tarsus feathered; middle and inner toes about equal in length, the outer slightly shorter, the hallux shorter than outer toe. Wing a little more than three times as long as exposed culmen, the outermost primary longest. Tail more than half as long as wing, truncated or slightly rounded, the rectrices broad, with rounded tip.

Coloration.-Above metallic bronze-green, the middle rectrices dark bronze-green or blackish; secondaries cinnamon-rufous, usually

a Eu, benè, feliciter, et $\phi \varepsilon \rho o v \sigma \alpha$, gestans. (Gould.) 
tipped with green or dusky; lateral reetrices extensively white, at least on inner web. Adult males with under parts bright metallic green, the under tail-coverts white; females with under parts pale gray or grayish white, glossed with green on sides.

Range.-Southern Mexico to western Panamá. (Three speeies.)

KEY TO THE SPECIES OF EUPHERUSA.

a. Under parts (except under tail-coverts) metallic green. (Adult males.)

$b$. Only two pairs of lateral rectrices with white on inner webs, the outer webs black or partly black.

c. Outermost rectrices with outer web wholly black. (Eupherusa eximia.)

d. Smaller (wing averaging 58.7, tail 33.5, culmen 17.6); line of demarcation between black and white on inner web of lateral rectrices sharply defined, nearly transverse. (Guatemala to Nicaragua.)

Eupherusa eximia eximia, adult male (p. 394).

$d d$. Larger (wing averaging 60.7 , tail 34.7 , culmen 18.7); line of demarcation between black and white on inner web of lateral rectrices indistinct, oblique. (Southeastern Mexico.).

Eupherusa eximia nelsoni, adult male (p. 396). $c c$. Outermost rectrices with outer web white next to shaft, the edge black. (Costa Rica and western Panamá.)

Eupherusa egregia, adult male (p. 396).

$b b$. Four pairs of rectrices with white on inner web, the outer web and tip of inner web gray. (Southwestern Mexico.)

Eupherusa poliocerca, adult male (p. 397).

aa. Under parts dull white or pale gray. (Adult females.)

b. Lateral pair of rectrices with a broad blackish tip, extending entirely across both webs and including shaft.

Eupherusa eximia eximia, adult female (p. 395). ${ }^{a}$

bb. Lateral pair of rectrices white, including tip, narrowly edged, in part, with dusky, the shaft entirely white.

c. Middle rectrices bronzy passing into dusky terminally; outermost rectrix white, the outer web edged terminally with dusky; second rectrix broadly margined for terminal half with black.

Eupherusa egregia, adult female (p. 397).

$c c$. Middle rectrices bronze-green narrowly margined with dusky; outermost rectrix white, the outer web narrowly edged subterminally with dusky, the second similar, but with dusky subterminal spot on edge of inner web.

Eupherusa poliocerca, adult female (p. 398.)

\section{EUPHERUSA EXIMIA EXIMIA (Delattre).}

\section{STRIPE-TAILED HUMMING BIRD.}

Adult male.-Above bright metallic grass green, usually becoming more bronzy posteriorly, the upper tail-coverts sometimes distinctly bronze; middle rectrices dark bronze-green or greenish bronze; two lateral rectrices (on each side) with outer web black, faintly glossed with bronzy, inner web pure white very broadly and abruptly tipped with black; remaining rectrices with outer web dark bronze or bronzegreen, inner web black; primaries purplish dusky, the innermost with 
basal portion cimnamon-rufous; secondaries cinnamon-rufous tipped with dusky (with bronze-green on innermost); under parts bright metallic grass green (more ycllowish green in position $a$ ), the feathers deep gray basally, this separated from the metallic green tip by a narrow bar of grayish white; f'emoral tufts grayish white; under tailcoverts pure white; bill dull black, the mandible sometimes slightly brownish basally; iris dark brown; feet light brownish (reddish in life ?) ; length (skins), \$4-93 (89); wing, 56.5-61 (58.7); tail, 32.5--34.5 (33.5); culmen, 16-19 (17.6). ${ }^{a}$

Adult female.-Above similar to the adult male but secondaries scarcely if at all tipped with dusky, middle rectrices black or dusky terminally, and two lateral rectrices (on each side) partly white (next to shaft); under parts (except femoral tufts and under tailcorerts) light brownish gray, the sides spotted or glossed with metallic green; bill, etc., as in adult male; length (skins), 80-90 (S5); wing, 50.5-54.5 (53.1); tail, $27-31$ (29.9); culmen, 16-19.5 (17.6). ${ }^{b}$

Immature male.-Similar to the adult male but bright green of under parts more restricted, the abdomen and flanks mostly grayish brown.

Guatemala (Cobán; Choctúm; Kamkhál; track between Cajabón and San Luís; Guatemala City); Nicaragua (Matagalpa; San Rafaél del Norte).c

Ornismya eximia Delattre, Echo du Monde Savant, 1843, 1069, (Cobán, Guatemala).

[Chlorestes. $\gamma$. Saucerottia] eximia Reichenbach, Aufz. der Colib., 1854, 8.

[Saucerottia] eximia Bonaparte, Rev. et Mag. de Zool., 1854, 255.

[Amazilia] eximia Reichenbach, Troch. Enum., 1855, 8, pl. 776, fig. 4802.

Eupherusa eximia Gould, Mon. Troch., v, pt. xiv, 1857, pl. 324; Introd. Troch., oct. ed., 1861, 163.-Sclater and Salvin, Proc. Zool. Soc. Lond., 1859, 130 (Guatemala).-Salvin, Ibis, 1860, 195, 271 (Cobán); Cat. Birds Brit. Mus., xvi, 1892, 72, part (Choctúm, Kamkhál, and Cobán, Guatemala), 656 (Matagalpa, Nicaragua).-Sclater, Cat. Am. Birds, 1S62, 316.-Mulsant and Verreaux, Classif. Troch., 1866, 32; Hist. Nat. Ois.-Mouch., i, livr. 4, 1874, 272, part (Vera Paz, Guatemala); ii, livr. 1, 1875, pl. 20; iv, livr. 3, 1878, 179.-Boucard, Ann. Soc. Linn. Lyon, xx, 1874, 280; Liste Ois. réc. Guat., 1878, 46; Gen. Hum. Birds, 1894, 169 (Guatemala).-Elirot, Classif. and Synop. Troch., 1879, 212.--Salvin and GodMan, Ibis, 1892, 327 (Matagalpa, Nicaragua); Biol. Centr.-Am., Aves, ii, 1892, 271 (Cobán, Kamkhál, Choctúm, and bet. Cajabón and San Luís, Guatemala; Matagalpa, Nicaragua).

[Eupherusa] eximia Sclater and Salvin, Nom. Av. Neotr., 1873, 92 (Guatemala).-SharPe, Hand-list, ii, 1900, 116 (Guatemala).

$a$ Eleven specimens (ten from Guatemala, one from Nicaragua).

$b$ Eight specimens, from Guatemala.

The single specimen from Nicaragua (San Rafaél del Norte) does not differ, either in coloration or dimensions, from Guatemalan examples, though the length of the culmen is half a millimeter shorter than the minimum of the same measurement in the latter series.

c There are apparently no records of this species for Salvador nor Honduras. 
[Euphrerusa] eximia Mulsant, Ann. Soc. Linn. Lyon, xxii, 1876, 205.

E[upherusa] eximia HARTERT, Das Tierreich, Troch., 1900, 89, part.

E[upherusa] e[ximia] eximia RIDGWay, Proc. Biol. Soc. Wash., xxiii, April 19, 1910, 54 , in text.

[Polytmus] eximius Gray, Hand-list, i, 1869, 133, no. 1700.

\section{EUPHERUSA EXIMIA NELSONI Ridgway.}

\section{NELSON'S HUMMING BIRD.}

Similar to E. e. eximia, but larger, especially the bill; adult male with green of under parts more yellowish green, and black tip to inner web of two lateral rectrices (on each side) with line of demarcation against white of basal portion decidedly oblique and much less sharply defined.

Adult male.-Length (skins), 93-103 (98); wing, 60.5-61 (60.7); tail, 34-35.5 (34.7); culmen, 18.5-19 (18.7). ${ }^{a}$

Southeastern Mexico, in States of Vera Cruz (Motzorongo) Oaxaca (Chimalapa and Sierra de Santo Domingo, Tehuántepec), and Puebla (Chinantla).

Eupherusa eximia (not Ornismya eximia Delattre) Boucard, Ann. Soc. Linn. Lyon, xx, 1874, 280; Notes quelques Troch., 1873, 12 (Chinantla, Puebla).Salvin, Cat. Birds Brit. Mus., xvi, 1892, 72, part (Chimalapa and Sierra Santo Domingo, Oaxaca).-Salvin and Godman, Biol. Centr.-Am., Aves, ii, 1892, 271, part (Chinantla, Puebla; Chimalapa and Sierra Santo Domingo, Oaxaca).

E[upherusa] eximia Hartert, Das Tierreich, Troch., 1900, 89, part.

Eupherusa eximia nelsoni RIDGway, Proc. Biol. Soc. Wash., xxiii, April 19, 1910, 54 (Motzorongo, Vera Cruz, e. Mexico; coll. U. S. Nat. Mus.).

\section{EUPHERUSA EGREGIA Sclater and Salvin.}

\section{EGREGIOUS HUMMING BIRD.}

Similar to $E$. eximia, but larger; adult male with outer webs of two outer rectrices (on each side) white (except terminally), edged with dusky; adult female with outermost rectrix wholly white, or with merely a dusky edging for terminal portion of outer web.

Adult male.-Above bright metallic bronze-green or greenish bronze; middle pair of rectrices dark dull bronzy, sometimes more dusky terminally, the next two pairs similar but with inner web dull black or dusky, the two outer pairs white broadly tipped and (except inner web) edged with bronzy black or dusky; primaries purplish dusky, the innermost ones becoming cinnamon-rufous basally; secondaries cinnamon-rufous tipped with dusky (the innermost with metallic bronze-green); under parts bright metallic grass green or yellowish green, the feathers deep gray basally, with a subterminal bar of pale gray or grayish white; femoral tufts dull white or grayish white; under tail-coverts pure white; bill dull black, the mandible sometimes brownish basally; iris dark brown; feet light 
grayish brown (in dried skins); length (skins), s\$-100 (96); wing, 5S-62 (60.1); tail, 33-37 (34.9); culmen, 17-19.5 (18.6). ${ }^{a}$

Adult female.-Above similar to the adult male, but outermost rectrix white without blackish tip, the outer web merely edged with dusky terminally; secondaries less extensively cinnamomeous; under parts pale brownish gray, glossed or spotted with metallic bronze-green laterally, the under tail-coverts, etc., as in adult male; length (skins), 87-95 )91); wing, 53.5-56 (54.9); tail, 30-34 (31.9); culmen, $17.5-20(18.9){ }^{a}$

Young male.-Similar to the adult male but bright green of under parts more restricted, first appearing in spots on throat and chest, the general surface being grayish glossed with bronze-green, fading into whitish posteriorly.

Costa Rica (Cervantes; Cervantes de Cartago; Azahár de Cartago; Barranca; Navarro; Volcán de Irazú; Coliblanco; Juan Viñas; Tenório; Cerro de Santa Maria; Las Cruces de Candelária; Volcán de Barba; San Cristóbal; Ojuros de Térraba) and western Panamá (Volcán de Chiriquí; Boquete; Castillo; Calovévora).

Eupherusa egregia Sclater and Salvin, Proc. Zool. Soc. Lond., 1868, 389 (Castillo and Calovévora, Panamá; coll. Salvin and Godman).-SAlvin, Ibis, 1869, 316 (crit.); Proc. Zool. Soc. Lond., 1870, 210 (Verágua; crit.); Cat. Birds Brit. Mus., xvi, 1892, 73 (Costa Rica; Volcán de Chiriquí, Castillo; Calovévora).-Mulsant and Verreaux, Hist. Nat. Ois.-Mouch., i, livr. 4, 1874, 274; iv, livr. 3, 1878, 179.-Boucard, Notes quelques Troch., 1873, 13 (Verágua); Proc. Zool. Soc. Lond., 1878, 71 (Navarro, Costa Rica); The Hum. Bird, ii, 1892, 81 (Verágua); Gen. Hum. Birds, 1895, 170 (Verágua;'Costa Rica).-Elliot, Classif. and Synop. Troch., '1879, 213.-Zeledón, Cat. Aves de Costa Rica, 1882, 21; Anal. Mus. Nac. Costa Rica, i, 1887, 122 (Cervantes de Cartago, Costa Rica).-Sharpe, Suppl. Gould's Mon. Troch., 1885 (text).-Salvin and Godyan, Biol. Centr.-Am., Aves, ii, 1892, 272.BangS, Proc. New Engl. Zool. Club, iii, 1902, 29 (Boquete and Volcán de Chiriquí, Panamá, 6,000-7,000 ft.).-Carriker, Ann. Carnegie Mus., vi, 1910, 534 (Costa Rica).-Ferry, Pub. 146, Field Mus. N. H., orn. ser., i, no. 6, 1910, 263 (Coliblanco, Costa Rica).

[Eupherusa] egregia Sclater and Salvin, Nom. Av. Neotr., 1873, 92.-Sharpe, Hand-list, ii, 1900, 116.

E[upherusa] egregia HARTert, Das Tierreich, Troch., 1900, 89.

[Polytmus] egregius GraY, Hand-list, i, 1869, 133, no. 1701.

[Euphrerusa] egregia Mulsant, Ann. Soc. Linn. Lyon, xxii, 1876, 205.

Eupherusa eximia (not Ornismya eximia Delattre) Lawrence, Ann. Lyc. N. Y., ix, 1868, 127 (Cervantes and Barranca, Costa Rica; crit.), 146 (crit.).Frantzius, Journ. für. Orn., 1869, 317 (Costa Rica).

\section{EUPHERUSA POLIOCERCA Elliot.}

\section{WHITE-TAILED HOMMING BIRD.}

Differing conspicuously from its congeners in having the inner webs of four (instead of only two) pairs of rectrices white, their outer web and tip of inner web gray instead of blackish. 
Adult male.-Above bright metallic bronze-green, including middle pair of rectrices; secondaries and four innermost primaries hazelrufous, the inner secondaries with a metallic green spot at tip of outer web and the rufous of primaries passing into purplish brown terminally; longer primaries uniform dusky, faintly glossed with purplish; lateral rectrix with inner web grayish white (purer white basally), crossed near tip by a bar of grayish dusky, the outer web hoary gray, darker along edge and at tip; second, third, and fourth rectrices (counting from each side) similar, but second with the white tip occupying both webs, and third and fourth dusky at tip (without any white terminal spot); under parts bright metallic yellowish green, the anal region and under tail-coverts pure white; bill black; iris dark brown; feet dusky brown (in dried skin); length (mounted specimen), 94; wing, 70 ; tail, 38.1 ; culmen, $18.3 .^{a}$

Adult female.-Above bright metallic golden green, the four middle rectrices paler, more silvery green; the pair next to middle tipped with white; two outer pairs of rectrices white, the outermost slightly edged with dusky on subterminal portion of outer web, the next similarly but more extensively edged with dusky and with a dusky grayish spot on subterminal portion of inner web, next to edge; third rectrix with greater part of outer web light bronze-green, broadly tipped with white and grayish basally, the inner web more grayish bronzy green subterminally, white terminally, and pale gray or grayish white basally; secondaries and innermost primaries dull cinnamon-rufous, the latter passing into dusky purplish bronze terminally, the longer primaries uniform purplish dusky; under parts grayish white, the sides of breast spotted with metallic green; femoral tufts and under tail-coverts white or grayish white; bill, etc., as in adult male; length (skin), 96; wing, 54.5; tail, $34 .^{b}$

Southwestern Mexico, in States of Oaxaca (Putla) and Guerrero (Omilteme; Chilpancingo); Puebla (Chinantla)?

Eupherusa poliocerca ElLiot, Ann. and Mag. N. H., 4th ser., viii, Oct., 1871, 266 (Putla, Oaxaca; coll. D. G. Elliot); Classif. and Synop. Troch., 1879, 212.Botcard, Notes quelques Troch., 1873, 13 (Putla); Gen. Hum. Birds, 1895, 170 (Putla; Chinantla, Puebla).-D'OcA, La Naturaleza, iii, 1875, 302, fig. 44; Troq. de Mex., 1875, 55, pl. (12), fig. 44.-Mulsant and Verreaux, Hist. Nat. Ois.-Mouch., i, livr. 4, 1874, 271, pl. 24.-Gould, Suppl. Troch., 1881, pl. 55.-Salvin, Cat. Birds Brit. Mus., xvi, 1892, 74 (Putla; Omilteme, Guerrero, 8,000 ft.).-Salvin and Godman, Biol. Centr.-Am., Aves, ii, 1892, 272.-Hartert (E. and C.), Novit. Zool., i, 1894, 19, 61 (Chilpancingo, Guerrero, 5,000-7,000 ft.; descr. adult female).

$a$ Described from a specimen from Chilpancingo, Guerrero, collected by O. T: Baron, and examined through courtesy of Mr. Frank Ward.

$b$ Description and measurements from no. 186475, coll. U. S. Nat. Mus. (Biological Survey coll.), from Omilteme, Guerrero, May 23, 1903, Nelson and Goldman. The tip of maxilla is broken off. 
[Eupherusa] poliocerca Sclatel and Salvin, Nom. Av. Neotr., 1873, 92.-Sharpe, Hand-list, ii, $1900,116$.

E[upherusa] poliocerca Hartert, Das Tierreich, Troch., 1900, 89 (monogr.).

[Euphrerusa] poliocerca Mulsax', Ann. Soc. Linn. Lyon, xxii, 1876, 205.

Genus CALLIPHARUS Elliot.

Clotho (not of Faujas, 1808, nor Walckenaer, 1809, nor Gray, 1840) Mulsant, Ann. Soc. Linn. Lyon, 11. s., xxii, 1876, 205 (Cat. Ois.-Mouch., 1875, 9). (Type, Eupherusa nigriventris Lawrence.)

Callipharies Elliot, Classif. and Synop. Troch., 1879, 211. (Type, Eupherusa nigriventris Lawrence.)

Small Trochilidie (length about $75-78 \mathrm{~mm}$.) related to Eupherusa, but tail more strongly rounded, the adult male with head and under parts relrety black.

Bill about as long as head, straight, terete, but rather broad and depressed basally; culmen rounded but basally (between nasal operculi) contracted into a distinct ridge; terminal portion of maxillary tomium minutely serrate; mandible with a distinct lateral median groore or sulcus. Nasal operculum very broad and tumid, mostly unfeathered, only the upper-posterior portion covered by frontal feathering, which, anteriorly, forms a convex line across base of forehead. Tarsus densely clothed with short feathers; middle toe apparently very slightly longer than both lateral toes, the hallux shorter than the latter. Wing three times as long as culmen, or a little more, the outermost primary longest. Tail more than half as long as wing, rounded, the rectrices moderately broad, rather soft.

Coloration.-Hindneck, back, scapulars, wing-coverts, and rump metallic bronze-green or greenish bronze; secondaries cinnamonrufous or chestnut, tipped with dusky (as in Eupherusa); lateral rectrices white. Adult male with head and under parts (except under tail-coverts) uniform velvety black, the under tail-coverts white; adult female with under parts pale gray, the pileum dusky, faintly glossed with greenish.

Range.-Costa Rica and western Panamá. (Monotypic.)

Although referred to Elvira by Dr. Hartert, the single species constituting the genus Callipharus differs in the presence of minute serrations to the terminal portion of the maxillary tomium, rufous secondaries, and rounded tail, in all of which characters it agrees with Eupherusa and not with Elvira. Were it not for the strikingly different and quite unique coloration of the adult male, involving structural differences in the feathers of the pileum and under parts (which are beautifully blended and velvety instead of harsh and conspicuously imbricated and squamate), and the decidedly more rounded tail, it might well be merged with Eupherusa. Considering all its peculiarities, I feel sure that Callipharus should stand alone in any arrangement of the family which does not involve a very great reduction in the number of genera. 


\section{CALLIPHARUS NIGRIVENTRIS (Lawrence).}

\section{BLACK-BELIIED HUMMING BIRD.}

Adult male.-Forehead, crown, and under parts velvety black, the under tail-coverts white; occiput, hindneck, back, scapulars, and wing-coverts metallic bronze-green, the upper tail-coverts duller and more bronzy; four middle rectrices dusky bronze or dull blackish glossed with bronze; three lateral rectrices (on each side) white, sometimes margined terminally with dusky; secondaries cinnamonrufous tipped with brownish dusky (the innermost with metallic bronze-green); primaries dusky purplish bronze, the innermost becoming cinnamon-rufous basally; primary coverts dusky; bill black, the mandible more or less brownish (pale dull flesh color in life) basally; iris dark brown; feet dusky (in life white, with scutella pale brownish); length (skins), 72-87 (79); wing, 46-50.5 (48.3); tail, 26.5-30 (27.9); culmen, 13.5-15 (14.5). ${ }^{a}$

Adult female.-Above metallic bronze-green; four middle rectrices dull greenish bronze or dull blackish, becoming bronzy basally; two outer rectrices (on each side) white, the third mostly white, but with more or less of dusky on edges, especially terminally; remiges dusky, faintly tinged with purplish bronze, the secondaries and inner primaries passing into cinnamon-rufous basally; under parts dull grayish white or pale brownish gray, the sides and flanks mostly metallic bronze-green; bill, etc., as in adult male, but feet paler; length (skins), 73-87 (79); wing, 44-47 (45.8); tail, 25.5-29 (27.1); culmen, $14.5-16(14.9) .^{b}$

Immature male.-Similar to the adult male, but forehead and crown dull metallic bronze-green (instead of velvety black), and black of under parts duller and more restricted, the under parts of body (except medially) mostly dull dusky bronze-greenish.

Costa Rica (Peorsnada; Naranjo de Cartago; Cervantes; La Hondura; Coliblanco; Cariblanco de Sarapiquí) and western Panamá (Verágua; Lomo Lleno; Cordillera del Chucu; Calobre; Caribbean slope Volcán de Chiriquí, 6,000-7,000ft.).

a Thirteen specimens. $b$ Eight specimens.

\begin{tabular}{|c|c|c|c|}
\hline Locality. & Wing. & Tail. & $\begin{array}{l}\text { Cul- } \\
\text { men. }\end{array}$ \\
\hline MALES. & & & \\
\hline Ten adult males from Costa Rica ................................. & $\begin{array}{l}48.2 \\
48.5\end{array}$ & 28.1 & 14.5 \\
\hline $\begin{array}{l}\text { Three adult males from western Panamá (Verégua) } \ldots \ldots \ldots \ldots \ldots \ldots \ldots \\
\text { FEMALES. }\end{array}$ & 48.5 & 27 & 14.3 \\
\hline 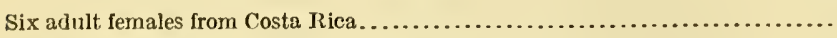 & 46 & 27.6 & 15 \\
\hline Two adult females from western Panamá (Verágua)..... & 45. 2 & 25.7 & 14. 7 \\
\hline
\end{tabular}


Eupherusa nigrientris Lawrence, Proc. Ac. Nat. Sci. Phila., 1867, 232 (Costa Rica; coll. U. S. Nat. Mus.); Ann. Lyc. N. Y., ix, 1868, 127 (Costa Rica).Frantzius, Journ. für Orn., 1869, 317 (Costa Rica).-Salvin, Proc. Zool. Soc. Lond., 1870, 210 (Cordillera del Chucu, Verágua; descr. female).Mulsaxt and Venreaux, Hist. Nat. Ois.-Mouch., i, livr. 4, 1S74, 270, pl. 23 (Costa Rica); iv, livr. 3, 1878, 179 (Cordillera del Chucu; descr. female).-Salvin and Godman, Biol. Centr.-Am., Aves, ii, 1592, pl. 57, figs. 3,4 .

[Euphrerusa] nigriventris Mulsant, Ann. Soc. Linn. Lyon, xxii, 1876, 205; Cat. Ois.-Mouch, 1875, 6.

[Eupherusa] nigriventris Smon, Cat. Troch., 1897, 21.

Callipharus nigriventris Elliot, Classif. and Synop. Troch., 1879, 211.-Zeledón, Cat. Aves de Costa Rica, 1882, 21; Anal. Mus. Nac. Costa Rica, i, 1887, 122 (Naranjo de Cartago, Costa Rica).-Sharpe, in Gould's Suppl. Troch., 1887, pl. 54.-Salvin, Cat. Birds Brit. Mus., xvi, 1892, 67 (Cordillera del Chucu and Calobre, Verígua; Costa Rica).-Salvin and Godman, Biol. Centr.-Am., Aves, ii, 1892, 270 (Cervantes and Peorsnada, Costa Rica, etc.).-Boucard, The Hum. Bird, ii, 1892, 81 (Verágua); Gen. Hum. Birds, 1894, 171 (Naranjo, Costa Rica; Verágua).

[Polytmus] nigriventris GRAY, Hand-list, i, 1869, 133, no. 1702.

[Thaumatias] nigriventris Sclater and Salvin, Nom. Av. Neotr., 1873, 92.

E[lvira] nigriventris HA RTERT, Das Tierreich, Troch., 1900, 90 (monogr.).

Elvira nigriventris Bangs, Proc. New Engl. Zool. Club, iii, 1902, 29 (Volcán de

Chiriquí, 6,000-7,000 ft.).-Carriker, Ann. Carnegie Mus., vi, 1910, 534

(Caribbean slope, Costa Rica).-Ferry, Pub. 146, Field Mus. N. H., crn. ser., i, no. 6, 1910, 263 (Coliblanco, Costa Rica).

[Elvira] nigriventris SHARPE, Hand-list, ii, 1900, 116.

\section{Genus ELVIRA Mulsant and Verreaux.}

Elvira Mulsant and Verreaux, Classif. Troch., 1865, 32. (Type, Trochilus (Thaumatias) chionura Gould.)

Laurencius (not Lawrencia Ridgway, 1886) Boucard, Gen. Hum. Birds (in Humming Bird, iv, pt. 3), sig. s, Sept., 1894, 173. (Type, Eupherusa cupreiceps Lawrence.)

Small Trochilidæ (length about $75 \mathrm{~mm}$.) closely resembling Eupherusa, but with maxillary tomium entirely smooth, ${ }^{a}$ the bill relatively smaller (rather shorter than head), tail double-rounded or emarginate and secondaries green and dusky, instead of cinnamon-rufous.

Bill rather shorter than head, nearly terete, straight (E. chionura) or distinctly decurved (E.cupreiceps); culmen rounded except basally, where contracted into a distinct ridge; tomia smooth; ${ }^{a}$ mandible with lateral median groove indistinct. Nasal operculum rather narrow, tumid, mostly unfeathered, the frontal feathering extending on each side of culmen to about the middle of nasal operculi. Tarsus feathered; middle and inner toes about equal in length, the outer slightly shorter, the hallux slightly shorter than outer toe. Wing decidedly more than three times as long as exposed culmen, the outermost

a Apparently, however, sometimes there are, when a magnifying glass is used, faint indications of serrations.

$81255^{\circ}-$ Bull. $50-11-26$ 
primary longest. Tail half as long as wing (E. cupreiceps) to more than half as long ( $E$. chionura), emarginate, double-rounded, or rounded (in female of $E$. cupreiceps), the rectrices rather broad and soft.

Coloration.-Above metallic green, bronze-green or (in E. cupreiceps) bronze passing into purple or copper bronze on head and upper tail-coverts; lateral rectrices white, tipped with black or gravish or (in females) crossed by a subterminal band of the same. Adult males with under parts bright metallic green, the under tail-coverts (abdomen also in E.chionura) white; adult females grayish white beneath, spotted or spangled with metallic green.

Range.-Costa Rica and western Panamá. (Two species.)

The two species which, so far as known, constitute this group are quite different in certain structural details, and are scarcely strictly congeneric. Except for its green and dusky (instead of cinnamonrufous) secondaries and emarginate (instead of truncate or slightly rounded) tail and absence of minute serrations on maxillary tomium E. chionura might well be placed in Eupherusa. E. cupreiceps, on the other hand, has a distinctly decurved as well as much more slender bill, and the tail is relatively shorter (not more than half as long as wing).

KEY TO THE SPECIES OF ELTIRA.

a. Bill very slightly if at all decurved; lateral rectrices broadly tipped with black (male) or crossed by a broad subterminal band of black (female); adult male with pileum metallic grass-green, the lower abdomen and hinder flanks white; adult female with lateral under parts more extensively green. (Testern Panamá and southwestern Costa Rica.).................... Elvira chionura (p. 402).

aa. Bill strongly decurved; lateral rectrices tipped with pale gray (male) or crossed by a narrow subterminal bar of dusky (female); adult male with pileum coppery bronze, the lower abdomen and hinder flanks metallic green; adult female with lateral under parts less extensively green. (Costa Rica.)

Elvira cupreiceps (p. 404).

\section{ELVIRA CHIONURA (Gould)。}

\section{WHTE-TAILED EMERAID.}

Adult male.-Above metallic bronze-green, the upper tail-coverts and middle rectrices usually more bronzy; three outer rectrices (on each side) pure white, broadly (for about $5-7 \mathrm{~mm}$. on outermost) and abruptly tipped with black (passing into dull bronzy terminally); remiges purplish slaty brown, the secondaries tinged with chestnut, the innermost ones more or less green; chin, throat, chest, breast (except medially), sides, and flanks bright metallic green (more yellowish green anteriorly), the feathers pale gray or dull grayish white beneath surface, becoming darker grayish basally; abdomen, middle line of lower breast, anal region, and under tail-corerts pure white, the shorter lateral under tail-corerts sometimes spotted with 
metallic green; bill black, the mandible pale brownish basally; iris dark brown; feet dusky; length (skins), 74-SS (S0); wing, 49-54.5 (50.3); tail, 26.5-30.5 (2S.3); culmen, 14-15.5 (14.7). ${ }^{a}$

Adult female.- Lbove bright metallic grass green or bronze-green, the longer upper tail-coverts and four middle rectrices metallic bronze or greenish bronze; three lateral pairs of rectrices white, the third very broadly tipped with black, the fourth and fifth crossed by a broad subterminal band of the same; remiges dusky, faintly glossed with purplish; chin, throat, median line of chest and breast, abdomen, hinder flanks, anal region, and under tail-coverts pure white, the lower throat and chest sometimes flecked with metallic green; rest of under parts metallic emerald green, the feathers grayish beneath surface; bill blackish, the mandible paler basally; iris dark brown; feet brownish (in dried skins); length (skins), 74-80 (76); wing, 45.5-4S (46.S); tail, 24-26.5 (25.4); culmen, 14.5-15.5 $(15.1) .^{b}$

Western Panamá (Calorérora; Daríd; Boquete; Volcán de Chiriquí) and southwestern Costa Rica (Dota; Santa Maria and Laguaria, Dota; Boruca).

Trochilus (Thaumatias) chionura Gould, Proc. Zool. Soc. Lond., 1850, 162

(Daríd, Chiriquí, Panamá, alt. 2,000-3,000 ft.; coll. J. Gould).

Thaumatias chionurys Gould, Mon. Troch., v, pt. iil, 1852, pl. 300; Introd.

Troch., oct. ed., 1861, 153.-LAWrexce, Ann. Lyc. N. Y., viii, 1868, 349

(crit.).-Elliot, Ibis, 1878, 48 (Costa Rica; synon.; crit.).-Boucard,

Notes quelques Troch., 1873, 11 (Costa Rica; Panamá).

[Thaumatias] chionurus Sclater and SALrix, Nom. Av. Neotr., 1873, 92.

[Thaumantias] chionura Borap.arte, Rev. et Mag. de Zool., 1854, 255.

Thaumantias chionurus SAlvin, Proc. Zool. Soc. Lond., 1867, 156 (Davíd, etc., Panama; crit.); 1870, 210 (Tolcán de Chiriquí and Calovévora, Panamá).

[Leucippus] chionurus ReicheNвach, Aufz. der Colib., 1854, 11; Troch. Enum., 1855, s, pl. 780, figs. 4313-4315.

A[gyrtria] chionura CABANis and Heñe, Mus. Hein., iii, 1860, 32, footnote (Terágua).-Heise, Journ. für Orn., 1863, 183.

Elrira chianura Mulsavt and Terreaux, Classif. Troch., 1866, 32.

Eupherusa chionura Lawrexce, Ann. Lyc. N. Y., ix, 1868, 127 (Dota, Costa Rica).-Fravtzios, Journ. für Orn., 1869, 317 (Costa Rica).

\begin{tabular}{|c|c|c|c|}
\hline a Thirteen specimens. & $b$ Eight specimens. & & \\
\hline Locality. & Wing. & Tail. & $\begin{array}{c}\text { Ex- } \\
\text { posed } \\
\text { culmen. }\end{array}$ \\
\hline $\begin{array}{l}\text { Fire adult males from Costa Rica............ } \\
\text { Fir. }\end{array}$ & 49.9 & 27.4 & 14.6 \\
\hline $\begin{array}{l}\text { Eight adult males from western Panamá..... } \\
\text { FEMALES. }\end{array}$ & 50.7 & 28.8 & 14.7 \\
\hline $\begin{array}{l}\text { Sir adult females from Costa Rica.............. } \\
\text { Two adult females from western Panamá.... }\end{array}$ & $\begin{array}{l}46.8 \\
46.7\end{array}$ & $\begin{array}{l}25.4 \\
25.5\end{array}$ & $\begin{array}{l}15.1 \\
15\end{array}$ \\
\hline
\end{tabular}


[Eupherusa] chionura Srmon, Cat. Troch., 1897, 21.

[Polytmus] chionurus Gray, Hand-list, i, 1869, 129, no. 1637.

Elvira chionura Mulsant and Verreaux, Hist. Nat. Ois.-Mouch., i, livr. 4, 1874, 266; iv, livr. 3, 1878, 179.-Euliot, Classif. and Synop. Troch., 1879, 210.-Zeledón, Cat. Aves de Costa Rica, 1882, 21; Anal. Mus. Nac. Costa Rica, i, 1887, 122.-Salvin, Cat. Birds Brit. Mus., xvi, 1892, 74 (Costa Rica; Chiriquí and Calovévora, Verágua).-Salvin and Godman, Biol. Centr.-Am., Aves, ii, 1892, 273.-Boucard, The Hum. Bird, ii, 1892, 81 (Verágua); Gen. Hum. Birds, 1894, 172.-Bangs, Proc. New Engl. Zool. Club, iii, 1902, 29 (Boquete and Volcan de Chiriquí, 4,000-7,700 ft.); Auk, xxiv, 1907, 296 (Boruca, Costa Rica).-Carriker, Ann. Carnegie Mus., vi, 1910, 535 (Costa Rica).

[Elvira] chionura Mulsant, Ann. Soc. Linn. Lyon, xxii, 1876, 205.-Sharpe, Hand-list, ii, 1900, 116.

E[lvira] chionura HarterT, Das. Tierreich, Troch., 1900, 90 (monogr.).

Eupherusa niveicauda Lawrence, Ann. Lyc. Nat. Hist. N. Y., viii, 1867, 134 (Dota, Costa Rica; coll. U. S. Nat. Mus.).

\section{ELVIRA CUPREICEPS (Lawrence).}

COPPERY-HEADED EMERALD.

Similar to E. chionura, but bill distinctly decurved and adult male with upper tail-coverts bright copper-bronze, pileum and middle rectrices bronze instead of green, no white on abdomen, and lateral rectrices tipped (less extensively) with light gray instead of black.

Adult male.-Pileum dull coppery bronze; hindneck, back, scapulars, rump, and wing-coverts bronze-green; upper tail-coverts bright coppery bronze; middle pair of rectrices bronze (much less coppery than upper tail-coverts); four outer rectrices (on each side) pure white, the three outer tipped with pale gray, the fourth tipped (more abruptly) with black; remiges dusky purplish brown, the inner secondaries mostly bronze-green; under parts bright yellowish metallic green, the under tail-coverts pure white, the anal tufts grayish white; maxilla black; mandible pale (flesh color in life?), dusky terminally; iris dark brown; feet grayish brown (in dried skins); length (skins), 74-79 (77); wing, 46-51 (48.4); tail, 24-27 (25.4); culmen, $13.5-15$ (14.1). ${ }^{a}$

Adult female.-Above metallic green (less bronzy than in adult male), duller on pileum; upper tail-coverts and middle pair of rectrices bright bronze (the former usually more coppery); four outer rectrices white with a $\mathrm{V}$-shaped subterminal bar of gray or dusky, the fourth tipped with black or black and gray and edged for terminal half (more or less) with blackish; remiges as in adult male; under parts dull white or grayish white, passing into pure white posteriorly, the sides more or less (sometimes extensively) ${ }^{b}$ spotted

$b$ Occasionally the green spotting extends across chest or breast. 
with metallic green; bill, etc., as in adult male; length (skins), 74-81 (76.6); wing, 41-46 (44.6); tail, 22.5-25.5 (23.1); culmen, 13.5-15.5 $(14.6) .^{a}$

Immature(?) male.-Similar to the adult male, but coloration slightly duller (especially on under parts of body), and four lateral rectrices (on each side) tipped with black or grayish black. ${ }^{b}$

Costa Rica (Barranea; Naranjo de Cartago; Tucurríqui; Bonilla; Carrillo; Cariblanco de Sarapiquí).

Eupherusa cupreiceps Lawrence, Amu. Lyc. Nat. Hist. N. Y., viii, 1867, 348 (Barrauca, Costa Rica; coll. U. S. Nat. Mus.); ix, 1868, 127 (Barranca).-Frantzius, Journ. für Orn., 1869, 317 (Costa Rica).-Boucard, Notes quelques Troch., 1873, 13 (Costa Rica).

Elvira cupreiceps Mulsant and Verreaux, Hist. Nat. Ois.-Mouch., i, livr. 4, 1S74, 268; iv, livr. 3, 1878, 179.-Elliot, Classif. and Synop. Troch., 1879, 210.-Gould, Suppl. Troch., 1Ss0, pl. 53.-Zeledón, Cat. Aves de Costa Rica, 1882, 21; Anal. Mus. Nac. Costa Rica, 1887, 122 (Naranjo de Cartago, Costa Rica).-Salvin, Cat. Birds Brit. Mus., xvi, 1892, 75 (Tucurríqui, Costa Rica).-Salvin and Godman, Biol. Centr.-Am., Aves, ii, 1892, 273.-CarriKer, Ann. Carnegie Mus., vi, 1910, 535 (Caribbean slope, Costa Rica).

E[tvira] cupreiceps Hartert, Das Tierreich, Troch., 1900, 91 (monogr.).

[Elvira] cupreiceps Smon, Cat. Troch., 1897, 21.-Sharpe, Hand-list, ii, 1900, 116.

[Polytmus] cupreiceps Gray, Hand-list, i, 1869, 128, no. 1625.

[Thaumatias] cupreiceps Sclater and Salvin, Nom. Av. Neotr., 1873, 92.

Thaumatias cupreiceps Boucard, Proc. Zool. Soc. Lond., 1878, 71 (Naranjo de Cartago, Costa Rica).

Lawrencius cupreiceps BodCard, Gen. Hum. Birds, Sept., 1894, 173.

[Elvira] caeruleiceps (error) Mulsant, Ann. Soc. Linn. Lyon, xxii, 1876, 328.

\section{Genus AMIZILIS Gray.}

Amizilis Gray, List Gen. Birds, 1840, 14. (Type, "A. latirostris, (Sw.) n. Ois. M., pl. 12. Or. amizili Less."=Orthorhynchus amazilia Lesson; see Oberholser, Proc. Ac. Nat. Sci. Phila., 1899, 206, 207.)

Amizillis Bangs, Proc. New Engl. Zool. Club, ii, Sept. 20, 1900, 20.

Amazilia Lesson, L'Echo du Monde Sav., sér. 2, viii, no. 32, Oct. 22, 1843, col.

757. (Type ?c.)

Amazilius (emendation) Bonaparte, Consp. Av., i, 1850, 77. (Type, Orthorhynchus amazilia Lesson.)

Amazilis (ex Lesson, 1832) Gray, List Gen. Birds, 1855, 23. (Type, Ornismya amazili Lesson.)

Amazillia (emendation) Sclater and Salvin, Ibis, 1859, 130.

Amazilicus (emendation) Bonaparte, Compt. Rend., 1850, 382.

Amazilina Eudes-Deslongchamps, Ann. Mus. Hist. Nat. Caen, i, 1880, 391, 405.

(Type, Trochilus fuscicaudatus Fraser.)

a Ten specimens.

$b$ Three specimens (two of them from Cariblanco de Sarapiqui, the other from an unknown locality in Costa Rica) agree in the above characters. It is possible that they may indicate intergradation or hybridism with $E$. chionura.

cThe species mentioned are: "Ornismia" lumachella Lesson, O. eximia Delattre, O. cinnamomea Lesson(=Amizilis rutila), O. rufula Delattre, and O. clarissæ Longuemare, only one of which, 0 . cinnamomea, is a member of this genus! 
Pyrrhophaena a Cabanis and Heine, Mus. Hein., iii, March, 1860, 35. (Type, Orthorhynchus amazilia Lesson.)

Eranna $b$ Heine, Journ. für Orn., xi, May, 1863, 187. (Type, Ornismya cinnamomea Lesson.)

Myletes Mulsant and Verreaux, Hist. Nat. Ois.-Mouch., i, livr. 4, 1874, 284. (Type, Trochilus yucatanensis Cabot.)

Cyanomyia Bonaparte, Rev. et Mag. de Zool., May, 1854, 254. (Type, as designated by Gray, 1855, "Trochilus quadricolor Vieillot," i. e., T. verticalis Lichtenstein.)

Uranomitra Reichenbach, Journ. für Orn., 1853, Extraheft, 1854, Aufz. der Colibr., 10. (Type, as fixed by Gray, 1855, "Trochilus quadricolor Vieillot," i. e., T. verticalis Lichtenstein.)

Medium-sized Trochilidæ (length about 95-110 mm.), with the straight or very faintly decurved stout bill much broader than deep, longer than head, distinctly widened basally; nasal operculum thick or tumid, with more than anterior half exposed; tail nearly truncated to slightly double-rounded or emarginate, and tail rufous-chestnut, olive-bronzy, or dull greenish bronze, darker subterminally.

Bill decidedly longer than head (more than one-third but much less than one-half as long as wing), straight or very faintly decurved, stout, much broader than deep, abruptly widened basally; nasal operculum rather thick or tumid, exposed for much the greater part; wing normal; tail between one-half and two-thirds as long as wing, nearly truncate, slightly double-rounded, or emarginate; tarsi feathered; outer toe nearly as long as middle toe, the inner decidedly shorter.

Coloration.-Above metallic green, bronze-green, or bronzy, the pileum sometimes violet-blue; tail rufous-chestnut, olive-bronzy, or dark bronze-greenish; under parts varying from mostly green, with cinnamon-rufous or white abdomen to wholly cinnamon-rufous or entirely white. Sexes alike.

Range.-Northern Mexico to Peru. (Twenty-three species.)

I am not able to give a better diagnosis of this genus for the reason that its limits are very indefinite, and its relations to Agyrtria and Saucerottia uncertain. Either the three so-called genera must be combined into one, or each of them must be further restricted and a considerable number of genera recognized before their definition can be made more precise. Even as here restricted I have been obliged to place in Amizilis not only certain species formerly referred to Uranomitra Reichenbach (e.g. U.violiceps and U. viridifrons), in this following Hartert, but also two species of Agyrtria (A. tephrocephala and $A$. maculicauda), which, so far as I am able to see, while agreeing with true Agyrtria in coloration, at the same time agree minutely in shape of the bill and nasal operculi with typical Amizilis. In short,

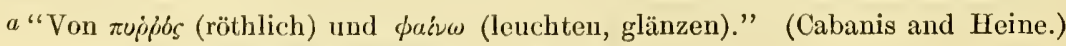

$b$ "Von Épavsos (lieblich, anmuthig)." (Heine.) 
the group of species eomposing the three so-called genera here tentatively recognized constitute a very difficult problem, for, apparently, no matter whether they are combined into a single genus or divided into several the definition of the group or groups is equally difficult in either case.

KEY TO THE SPECIES AND SUBSPECIES OF AMIZILIS.

a. Chin and throat not white.

b. Throat and chest metallic green .

c. Breast and abdomen not white.

d. Lores chestnut; sides, anterior flanks, and under wing-coverts uniform metallic green or bronze-green; abdomen grayish (sometimes tinged with buffy). (Amizilis tzacatl.)

e. Abdomen brownish-gray. (Andes of Ecuadór and Venezuela through Colombia to southeastern Mexico.).... Amizilis tzacatl tzacatl (p. 408).

ce. Abdomen decidedly buffy grayish (much paler in females). (Western Ecuadór and southwestern Colombia.)

Amizilis tzacatl jueunda (extralimital). ${ }^{a}$

$d d$. Lores not chestnut; sides, anterior flanks, and under wing-coverts at least partly cinnamon-rufous or cinnamon-buff. (Amizilis yucatanensis.)

$e$. Under parts of body deeper cinnamon-rufous, the sides without mixture of metallic bronze or bronze-green. (Tabasco, Campeche, Yucatan, and British Honduras.)... . . . . Amizilis yucatanensis yueatanensis (p. 412).

$e c$. Under parts paler cinnamon-rufous or cinnamon-buff, the sides glossed or intermixed with greenish bronze or bronze-green.

$f$. Under parts of body light cinnamon-rufous or vinaceous-cinnamon; upper parts more greenish bronze. (States of Vera Cruz, Puebla, Oaxaca, and Chiapas.).. Amizilis yucatanensis eerviniventris (p. 414).

ff. Under parts of body light cinnamon-buff to pale pinkish buff; upper parts more bronzy. (Southern Mexico, Tamaulipas, and Nuevo León.)................. Amizilis yueatanensis chalconota (p. 415). $c c$. Breast and abdomen white; tail glossed with metallic purple. (Western

Mexico.)................................. Amizilis forreri (p. 416).

$b b$. Throat and chest cinnamon-rufous (more or less deep), like rest of under parts.

c. Sides of neck cinnamon-rufous.

d. Smaller (wing 51-60, tail 31-37, culmen 19.5-23.5). (Amizilis rutila.)

$e$. Coloration pale, the under parts vinaceous-rufous or light cinnamon-rufous. (State of Sinaloa, western Mexico, to Yucatan and eastern Guatemala and thence to western Costa Rica.)...... Amizilis rutila rutila (p. 416).

$e e$. Coloration darker, the under parts deep cinnamon-rufous. (Pacific slope of Chiapas and Guatemala.)...... Amizilis rutila corallirostris (p. 419). dd. Larger (wing 66-69.5, tail 42-45.5, culmen 23.5-27). (Tres Marias Islands, western Mexico.) . . . . . . . . . . . . . . . . . . . Amizilis graysoni (p. 419).

cc. Sides of neck metallic greenish bronze. (Northwestern Costa Rica.)

Amizilis bangsi (p. 420).

a E[ranna] jucunda Heine, Journ. für Orn., 1863, 188 (Babahoyo and Esmeraldas, w. Ecuador; coll. Hoine Mus.).-[Ariana riefferi] var. jucunda Mulsant, Ann. Soc. Linn. Lyon, xxii, 1876, 206.-Amazilia riefferi jucunda Berlepsch and Taczanowski, Proc. Zool. Soc. Lond., 1883, 568 (Chimbo, w. Ecuadór); 1884, 306 (Cayandeléd and Pinampunga, w. Ecuadór).-Amazilia fuscicaudata jucunda Hartert, Novit. Zool., v, 1898, 496 (Chimbo; habits).-A[mazilia] fuscicaudata jucunda Hartert, Das Tierreich, Troch., 1900, 58.-Amizilis tzacatl jucunda Oberholser, Proc. U. S. Nat. Mus., xxiv, no. 1258, Jan., 1902, 317 (Santo Domingo, w. Ecuadór). 
aa. Chin and throat white.

$b$. Sides of neck without metallic blue; tail bronzy olive to coppery bronze.

c. Sides of neck mostly white; under tail-coverts white, and under parts of body almost wholly white.

d. Forehead and crown dusky greenish or dull bluish. (Southwestern Mexico.) Amizilis viridifrons (p. 421).

$d d$. Forehead and crown bright metallic blue or violet.

e. Tail dull greenish bronze. (Western Mexico.)

$e e$. Tail bronze to coppery bronze. (Southwestern Mexico.)

Amizilis verticalis (p. 422).

Amizilis violiceps (p. 424).

cc. Sides of neck metallic green; under tail-coverts dull olive-bronze to coppery bronze margined with white; under parts of body with only the median line white.

d. Bill larger (culmen 18.5-23); tail, sides, flanks, and under tail-coverts more greenish or olive bronze. (Amizilis cyanocephala.)

$e$. Tail duller bronzy, the rump and upper tail-coverts more faintly glossed with bronze. (Southeastern Mexico, including State of Chiapas.)

Amizilis cyanocephala cyanocephala (p. 425).

ee. Tail brighter bronzy, the rump and upper tail-coverts more strongly glossed with bronze. (Guatemala, Honduras, and British Honduras.)

Amizilis cyanocephala guatemalensis (p. 427).

$d d$. Bill smaller (culmen 13.5); tail, sides, flanks, and under tail-coverts more coppery bronze. (Honduras?).......... Amizilis microrhyncha (p. 428).

$b b$. Sides of neck metallic blue; tail dark metallic green or bronze-green. (Northwestern Mexico and southern Arizona.)........... Amizilis salvini (p. 429).

\section{AMIZILIS TZACATL TZACATL (De la Llave).}

RIEFFER'S HUMMING BIRD.

Adult male.-Above metallic bronze-green or greenish bronze, the pileum darker and duller; upper tail-coverts and tail chestnut, the rectrices margined terminally with dusky bronze, the coverts sometimes partly bronze or bronze-green; remiges dusky, faintly glossed with violet; lores chestnut; malar region, chin, throat, chest, upper breast, and sides of lower breast bright metallic yellowish emeraldgreen, the feathers of chin and upper throat pale buff or buffy white basally, this much exposed on chin; abdomen and median portion of lower breast brownish gray; sides and flanks bronze-green; under tail-coverts cinnamon-rufous; femoral tufts white; bill brownish (reddish in life), dusky terminally, the maxilla sometimes mostly (rarely wholly?) blackish; iris dark brown; feet dusky (in dried skins); length (skins), 86-105 (97); wing, 46-61 (58.3); tail, 29.5-35 (32.8); culmen, 18-23 (20.8). ${ }^{a}$

Adult female.-Similar to the adult male and perhaps not always distinguishable, but usually with the green of under parts more broken by whitish margins to the feathers, gray of abdomen paler, and cinnamon-rufous loral streak less distinct, sometimes obsolete; 
length (skins), s6-102 (95); wing, 52-5s (54.9); tail, 30-35 (32.7); culmen, $20-24(21.3){ }^{a}$

Young.-Essentially like adults, but anterior under parts much duller metallic green, the chin and upper throat (at least) sometimes grayish brown or brownish gray, with little if any metallic gloss, and feathers of pileum, rump, etc., tipped (more or less distinctly) with rusty.

Lower Rio Grande Valley in Texas (Fort Brown ${ }^{b}$ ) and southward through eastern Mexico, in States of Tamaulipas (Tampico), Vera Cruz (Playa Vicente; Córdova; Orizaba; Xochiapa; Choapám; Buena Vista), Oaxaca (Guichicovi; Túxtepec), Tabasco (Teapa; Frontera; San Juan Bautista), and Chiapas (Tumbalá; Yajalón), Guatemala (Dueñas; Cobán; Choctúm; Lanquín; Guatemala City; Los Amates, Yzabál; Santa Ana, Petén), British Honduras (Orange Walk; Corosál; Belize; Cayo), Honduras (Rio Segóvia; Céiba; Yaruca), Nicaragua (Chontales; Los Sábalos; Greytown; Matagalpa; La Libertád; San Emilis; Rio Escondido), Costa Rica (San

a Thirty-six specimens.

\begin{tabular}{|c|c|c|c|}
\hline Locallty. & Wing. & Tail. & $\begin{array}{c}\text { Ex- } \\
\text { posed } \\
\text { culmen. }\end{array}$ \\
\hline \multicolumn{4}{|l|}{ MALES. } \\
\hline Ten adult males from southeastern Mexico.... & 55.4 & 32.2 & 20.7 \\
\hline Six adult males from Guatemala............. & 56.3 & 31.9 & 19. 2 \\
\hline Seven adult males from British Honduras . . . . . . . . . . . . . . . & 59.7 & 33.1 & 20.1 \\
\hline One adult male from Honduras........ & 58 & 32.5 & 20 \\
\hline Eight adult males from Nicaragua................ & 56.7 & 31.7 & 20.2 \\
\hline Ten adult males from eastern Costa Rica................ & 59.5 & 33.9 & 22 \\
\hline Four adult males from western Costa Rica.... & 57.4 & 34.3 & 22.2 \\
\hline Three adult males from Panamá................... & 56.2 & 32.7 & 20.3 \\
\hline Ten adult males from Colombia........................ & $5 \pm .5$ & 33.4 & 21.2 \\
\hline 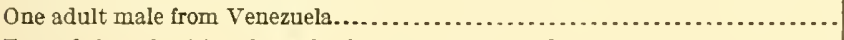 & 55.5 & 32.5 & 21.5 \\
\hline 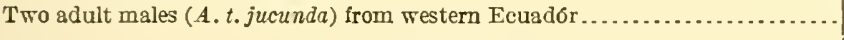 & 56 & 32.7 & 21.5 \\
\hline \multicolumn{4}{|l|}{ FEMALES. } \\
\hline Three adult females from southeastern Mexico... . & 54.2 & 32 & 21.5 \\
\hline One adult female from Guatemala... & 54.5 & 33.5 & 20.5 \\
\hline Ten adult females from Nicaragua.................. & 54.9 & 32 & 21. 1 \\
\hline Ten adult females from eastern Costa Rica.......... & 56.1 & 33.4 & 22.9 \\
\hline Three adult females from western Costa Rica. . & 55.3 & 33.3 & 22. 7 \\
\hline Three adult females from Panamá. & 54.2 & 33 & 21 \\
\hline Six adult females from Colombia................... & 53.5 & 31.2 & 21. 7 \\
\hline One adult female (A.t. jucunda) from western Ecuador....................... & 56 & 32 & 23.5 \\
\hline
\end{tabular}

With exception of specimens from western Ecuador, which differ from all others in the decidedly more buffy and (especially in females) slightly paler color of the abdomen, I am not able to distinguish satisfactorily specimens from any of the geographic areas indicated above, and therefore, for the present at least, consider them all as representing a single subspecies.

$b$ Apparently of purely accidental occurrence on north side of Rio Grande. 
José; San Pedro de Mojón; Tucurríqui; Carrillo; Bonilla; Guayabo; Juan Viñas; Volcan de Irazú; Jiménez; Isla Uvita, Puerto Limón; Talamanca; Boca Matina; Escazú; Cerro de la Candelária; Guápiles; El Hogár; Rio Frio; Orosí; Boruca; Barranca, Boruca; Boca Barranca, Punta Arenas; Pozo Azúl de Pirrís; Pigres; Esparta; El Generál; Santa Maria de Dota; Bolsón; Miravalles), Panamá (Davíd; Chitra; Boquete de Chitra; Calovévora; Cordillera del Chucu; Paraiso; Colón; Lion Hill; Boca del Toro), Colombia (Bogotá; Santa Marta, Cacagualito, Bonda, and Don Diego, Santa Marta; Don Amo; lower Magdalena; Buritaca; Barranquilla; Medellin; San Nicolás; Fusagasugá), to Venezuela (Mérida).

T[rochilus] tzacatl DE LA Llave, Registro Trimestre, ii, no. 5, Jan., 1833, 48 (Mexico; see Richmond, Auk, xvi, 1899, 324).

Amazilia or Amazilis tzacatl Richmond, Auk, xvi, Oct., 1899, 324, in text.

[Amazilia] tzacatl SHARPE, Hand-list, ii, 1900, 108, part.

Amizillis tzacatl Bangs, Proc. New Engl. Zool. Club, iii, Jan. 30, 1902, 29 (Volcán de Chiriquí, Panama, 5,000 ft.).

Amizilis tzacatl Balley (Florence M.), Handb. Birds W. N. Am., [Nov.?] 1902, 243.-Thayer and Bangs, Bull. Mus. Comp. Zool., xlvi, 1905, 94 (Gorgona I., Colombia); 216 (Sabana de Panamá).-American Ornithologists' Union, Check List, 3rd ed., 1910, 205.-Ferry, Pub. 146, Field Mus. N. H., orn. ser., i, no. 6, 1910, 263 (Guayabo, Costa Rica).

Amazilis tzacatl Dearborn, Pub. 125, Field Mus. N. H., 1907, 98 (Los Amates, Guatemala).

(?) Trochilus fuscicaudatus Fraser, Proc. Zool. Soc. Lond., 1840, 17 (Chachapoyas, e. Peru; ${ }^{a}$ coll. Derby Mus.).

H[ylocharis] fuscicaudatus Gray, Gen. Birds, i, Dec., 1848, 114.

Amazilia fuscicaudata Ridgway, Proc. U. S. Nat. Mus., i, Oct. 2, 1878, 147 (Ft. Brown, Texas; synonymy; descr., etc.); iii, 1880, 187, 219, 233, 318; x, 1887, 591 (Rio Segóvia, Honduras); Nom. N. Am. Birds, 1881, no. 345; Rep. U. S. Nat. Mus. for 1890 (1891), 366, pl. 43 (monogr.; habits); Condor, vii, 1905, 154, in text (Pigres, Costa Rica).-Euliot, Classif. and Synop. Troch., 1879, 220.-Allen, Bull. Nutt. Orn. Club, v, 1880, 90 (Ft. Brown, Texas).-Nutting, Proc. U. S. Nat. Mus., v, 1882, 398 (La Palma de Nicoya, Costa Rica; habits); v, 1883, 406 (Los Sábalos, Nicaragua).-Zeledón, Cat. Aves de Costa Rica, 1882, 21; Proc. U. S. Nat. Mus., viii, 1885, 110 (Costa Rica); Anal. Mus. Nac. Costa Rica, i, 1887, 122 (Naranjo de Cartago; San José).American Ornithologists' Union, Check List, 1886, no. 438.--Boucard, The Hum. Bird, ii, 1892, 80 (Bogotá, Colombia); v, 1895, 7 (Rio Dagua, Colombia); Gen. Hum. Birds, 1895, 198.-Rıснмоnd, Proc. U. S. Nat. Mus., xvi, 1893, 517 (Rio Escondido, Nicaragua; habits).-Bendire, Life Hist. N. Am. Birds, ii, 1895, 223.-Bangs, Proc. Biol. Soc. Wash., xii, 1898, 135 (Santa Marta, Colombia)._Lantz, Trans. Kansas Ac. Sci. for 1896-97 (1899), 221 (Santo Tomás, Guatemala).

A[mazilia] fuscicaudata Ridgway, Man. N. Am. Birds, 1887, 317.

Amazilis fuscicaudatus Eudes-Dessongchamps, Ann. Mus. Caen, i, 1880, 405.

Amizillis fuscicaudata Allen, Bull. Am. Mus. N. H., xiii, Aug. 25, 1900, 139

(Bonda and Cacagualito, Santa Marta, Colombia).-Bangs, Proc. New Engl. Zool. Club, ii, Sept. 20, 1900, 20 (Loma del León, Panamá).

$a$ The type-locality has been questioned, and the opinion expressed that the type is of Bogotá make; but I have mislaid the slip containing the reference. 
[Eranna] fuscicaudata Heine and Reichenow, Nom. Mus. Hein. Orn., 1890, 179 (Colombia; Verígua?).

Amizilis fuscicaudata Oberholser, Proc. Ac. Nat. Sci. Phila., June 2, 1899, 208.-Bangs, Auk, xviii, 1901, 359 (Divala, Panamá).

A[mazilia] fuscocaudata Coues, Key N. Am. Birds, 2d ed., 18st, 466.

[Chlorcstes. r. Saucerottia] fuscicauda Reichenibach, Aufz. der Colibr., 1854, 8.

[Chlorestes] fuscicauda Reichenbaci, Troch. Enum., 1855, 4, pl. 696, figs. 4552, 4553.

Amazilia fuscicaudata fuscicaudata Hartert, Novit. Zool., v, 1898, 18 (crit.).

Trochilus] riefferi Bourcier and Mulsant, Ann. Sci. Phys. et Nat. Lyon, vi, livr. 1, 1843, 45 (Fusagasugá, Colombia).-Bourcier, Rev. Zool., 1843, 103.

P[olytmus] riefferi Gray, Gen. Birds, i, Dec., 1848, 108.

[Polytmus] riefferi GraY, Hand-list, i, 1869, 132, no. 1680.

[Amazilius] riefferi Bonaparte, Consp. Av., i, 1850, 78; Rev. et Mag. de Zool., 1S54, 254.

Amazilius riefferi Sclater, Proc. Zool. Soc. Lond., 1S56, 140 (Chiriquí); 1857, 16 (Bogotá).

[Amazilia] riefferii Reichenbach, Aufz. der Colibr., 1854, 10; Troch. Enum., 1855, 8, pl. 775, figs. 4798, 4799.

[Amazilia] reifferi Simon, Cat. Troch., 1897, 13.

Amazilia riefferi Gould, Mon. Troch., pt. xix, 1860, pl. 14 (vol. v, 1861, pl. 311).-Sclater, Proc. Zool. Soc. Lond., 1860, 94 (Colombia); Cat. Am. Birds, 1862, 314, part (Cobán, Guatemala; Barranquilla, Colombia).-Sclater and Salvin, Ibis, 1864, 365 (Panamá); Proc. Zool. Soc. Lond., 1879, 530 (Colombia; descr. nest).-Salvin and Sclater, Ibis, 1860, 40 (Yzabál, Guatemala).-SAlvin, Ibis, 1860, 270 (Cobán and Yzabál, Guatemala); 1872, 320 (Chontales, Nicaragua); Proc. Zool. Soc. Lond., 1867, 156 (Davíd, Panamá); 1870, 210 (Calovévora and Cordillera del Chucu, Panamá); Cat. Birds Brit. Mus., xvi, 1892, 216, part (Mexican, Central American, Colombian, and Venezuelan localities and references).-Wyatт, Ibis, 1871, 378 (San Nicolás, Colombia, 3,000 ft.).-Lawrence, Ann. Lyc. N. Y., vii, 1862, 292 (Panamá).-Mulsant and Verreaux, Classif. Troch., 1866, 35.Berlepsch, Journ. für Orn., 1884, 311 (Bucaramanga, Colombia; crit.).Salvin and Godman, Biol. Centr.-Am., ii, 1892, 300.--Cherrie, Expl. Zool. Merid. Costa Rica, 1893, 44 (Buenos Aires, Costa Rica).-Underwood, Ibis, 1896, 442 (Volcán de Miravalles and Bagaces, Costa Rica).Simon and Dalmas, Ornis, xi, 1901, 221 (Naranjo, w. Colombia).

Amazillia riefferi Sclater and Salvin, Ibis, 1859, 130 (Guatemala).

E[ranna] riefferi Heine, Journ. für Orn., 1863, 188 (Colombia).

Ariana riefferi Mulsant and Verneaux, Hist. Nat. Ois.-Mouch., i, livr. 4, 1874, 316 (Fusagasugá, Colombia); iv, livr. 3, 1878, 184 (synonymy).

[Ariana] riefferi Mulsant, Ann. Soc. Linn. Lyon, xxii, 1876, 206.

[Amazilia] riefferi Sclater and Salvin, Nom. Av. Neotr., 1873, 92.

P[yrrhophaena] riefferi Cabanis and Heine, Mus. Hein., iii, March, 1860, 36 (Verágua; Colombia).

Pyrrhophæna riefferi Gould, Introd. Troch., oct. ed., 1861, 158.-LAWREnCE, Ann. Lyc. N. Y., viii, 1867, 183 (Greytown, Nicaragua); ix, 1868, 127 (Costa Rica); Bull. U. S. Nat. Mus., no. 4, 1876, 33 (Guichicovi, Oaxaca).Frantzius, Journ. für Orn., 1869, 317 (Costa Rica).-Merrill, Bull. Nutt. Orn. Club, i, 1876, 88 (Ft. Brown, Texas).-Boucard, Proc. Zool. Soc. Lond., 1878, 71 (San José and Cartago, Costa Rica).-Sumichrast, La Naturaleza, v, 1881, 250 (Guichicovi).-Berlepsch, Journ. für Orn., 1887, 331 (Bogotá; synonymy). 
T[rochilus] aglaiæ Bourcier and Mulsant, Ann. Sci. Phys. et Nat. Lyon, ix, 1846, 329-(locality unknown); Rev. Zool., 1846, 316.

Trochilus aglaiæ Mulsant and Verreaux, Hist. Nat. Ois.-Mouch., i, livr. 4, $1874,319$.

[Chlorestes. $\gamma$. Saucerottia] aglaia Reichenbach, Aufz. der Colibr., 1854, 8.

[Chlorestes] aglaia ReIchenbach, Troch. Enum., 1855, 4.

H[emithylaca] aglaiae Cabanis and Heine, Mus. Hein., iii, 1860, 38, footnote.

[Amazilius] aglaiae Bonaparte, Consp. Av., i, 1850, 78.

$P$ [olytmus] aglaiæ Grax, Gen. Birds, i, 1848, 109.

[Ariana riefferi] var. aglaiae Mulsant, Ann. Soc. Linn. Lyon, n. s., xxii, 1876, 207.

Ornismya amazili? (not of Lesson) Delattre, Echo du Monde Savant, no. 45, 1843, col. 1069.

Trochilus dubusi Bourcier, Ann. Sci. Phys. et Nat. Lyon, (2), iv, 1852, 141 (Honduras).

[Amazilia] dubusi Reichenbach, Aufz. der Colibr., 1854, 10; Troch. Enum., 1855, 8, pl. 778, figs. 4809, 4810.

[Amazilia] dubusi Sharpe, Fand-list, ii, 1900, 108.

[Amazilius] dubusi Bonaparte, Rev. et Mag. de Zool., 1854, 254.

Amazilius dubusi Sclater, Proc. Zool. Soc. Lond., 1856, 287 (Córdova, Vera

Cruz; crit.); 1859, 386 (Coapám, Oaxaca; Playa Vicente, Vera Cruz; crit.).

P[yrrhophaena] dubusi Cabanis and Heine, Mus. Hein., iii, March, 1860, 36 (Verágua).

Pyrrhophaena dubusi Cabanis, Journ. für Orn., 1862, 163 (Costa Rica; crit.).

E[ranna] dubusi HeINE, Journ. für Orn., 1863, 188 (Verágua to s. Mexico).

[Eranna] dubusi Heine and Reichenow, Nom. Mus. Hein. Orn., 1890, 179 (Costa Rica; Verágua).

$A$ [mazilia] $f$ [uscicaudata] dubusi HARTert, Novit. Zool., v, Dec. 31, 1898, 518 (Panamá northward).

A[mazilia] fuscicaudata dubusi Hartert, Das Tierreich, Troch., 1900, 58.

Amazilia tzacatl dubusi Bangs, Bull. Mus. Comp. Zool., xxxix, July, 1903, 144 (Céiba and Yaruca, Honduras).

Amizilis tzacatl dubusi Bangs, Auk, xxiv, July, 1907, 295 (Boruca, Barranca, and Boca Barranca de Punta Arenas).-Carriker, Ann. Carnegie Mus., vi, 1910, 528 (Costa Rica; habits; descr. nest and eggs).

P[yrrhophaena] suavis Cabanis and Heine, Mus. Hein., iii, March, 1860, 36 (Cartagena, Colombia; coll. Berlin Mus.).

E[ranna] suavis HeIne, Journ. für Orn., 1863, 188.

[Polytmus] suavis Grax, Hand-list, i, 1869, 132, no. 1688.

[Ariana riefferi] var. suavis Mulsant, Ann. Soc. Linn. Lyon, n. s., xxii, 1876, 206. A[mazilia] fuscicaudata (typica) Hartert, Das Tierreich, Troch., 1900, 58.

\section{AMIZIIS YUCATANENSIS YUCATANENSIS (Cabot).}

\section{YUCATAN HUMMING BIRD.}

Adults (sexes alike).-Above metallic bronze-green or greenish bronze, duller and darker on pileum; the upper tail-coverts more or less tinged or intermixed with cinnamon-rufous, sometimes mostly of the latter color; middle pair of rectrices mostly or with at least terminal fourth metallic bronze, the basal portion chestnut; remaining rectrices chestnut, margined terminally with metallic bronze; remiges dusky, faintly glossed with violet; chin, throat, and chest bright metallic yellowish emerald green, the feathers pale buff basally or 
(on chest) subterminally; under parts of body, including under tailand wing-coverts and axillars, cinnamon-rufous; femoral tufts white; bill brownish (rosy reddish in life), dusky terminally; iris dark brown; feet dusky (in dried skins).

Adult male.-Length (skins), ss-102 (96); wing, 51-57.5 (53.8); tail, 31-35 (32.8); culmen, 19-21 (20.2). ${ }^{a}$

Adult female.-Length (skins), 94-100 (97); wing, 52-52.5 (52.2); tail, 32-34 (33); culmen, 21-21.5 (21.2). ${ }^{b}$

Extreme southeastern Mexico, in States of Tabasco (San Juan Bautista), Campeche (Canasayat), and Yucatan (Mérida; Labna; Chichen-Itza; Tabi), through British Honduras (forest near Manatee Lagoon) to eastern Guatemala (Santa Ana, Petén).

Trochilus yucatanensis САвот, Proc. Bost. Soc. N. H., ii, 1845, 74 (Yucatan; coll. Dr. S. Cabot).

Amazilia yucatanensis Gould, Mon. Troch., pt. xxiii, Sept., 1861 (vol. v), pl. 308.-Mulsant and Verreaux, Classif. Troch., 1866, 35; Hist. Nat. Ois.Mouch., i, livr. 4, 1874, 295; iv, livr. 3, 1878, 181.-DE OCA, La Naturaleza, iii, 1875, 303; Troq. de Mex., 1875, pl. (12), fig. 46.--Elliot, Classif. and Synop. Troch., 1879, 219, part.-Ridgway, Proc. U. S. Nat. Mus., i, 1879, 148, part (Yucatan); Rep. U. S. Nat. Mus., 1890 (1891), 364.-Boucard, Proc. Zool. Soc. Lond., 1883, 451 (Mérida, Yucatan); Gen. Hum. Birds, 1895, 196.--Stone, Proc. Ac. Nat. Sci. Phila., 1890, 207 (Labna, Yucatan).Salvin, Cat. Birds Brit. Mus., xvi, 1892, 214 (Mérida, Yucatan; Santana, Peten, Guatemala).-Salvin and Godman, Biol. Centr.-Am., Aves, ii, 1892, 299.-ChapMan, Bull. Am. Mus. N. H., viii, 1896, 284 (Chichen-Itza, Yucatan).

[Amazilia] yucatanensis Sclater and Salvin, Nom. Av. Neotr., 1873, 92.Mulsant, Ann. Soc. Linn. Lyon, xxii, 1876, 206.-Sharpe, Hand-list, ii, 1900, 108.

A[mazilia] yucatanensis Ridgway, Proc. U. S. Nat. Mus., iv, 1881, 25 (diagnosis; crit.); Man. N. Am. Birds, 1887, 317; Rep. U. S. Nat. Mus., 1890 (1891), 364 (diagnosis, etc.).-Hartert, Das Tierreich, Troch., 1900, 59 (monogr.).

Pyrrhophæna yucatanensis Gould, Introd. Troch., oct. ed., 1861, 157.

E[ranna] yucatanensis HeINE, Journ. für Orn., 1863, 187.

Amazilis yucatanensis Eudes-Deslongchamps, Ann. Mus. Caen, i, 1880, 402.

Amizilis yucatanensis Oberholser, Proc. Ac. Nat. Sci. Phila., 1899, 208.

[Polytmus] yucatanensis GraY, Hand-list, i, 1869, 132, no. 1690.

Pyrrhophæna cerviniventris (not Amazilia cerviniventris Gould) SALvin, Ibis, 1866, 195 (Santa Ana, Petén, Guatemala).

$a$ Five specimens.

\begin{tabular}{|c|c|c|c|}
\hline Locality. & Wing. & Tail. & $\begin{array}{c}\text { Ex- } \\
\text { posed } \\
\text { eulmen }\end{array}$ \\
\hline MALES. & & & \\
\hline Three adult males from Tabaseo, Campeehe, and Yucatan. & 55 & 34 & 20.8 \\
\hline Two adult males from British Hcnduras................. & 51.7 & 31 & 19.2 \\
\hline
\end{tabular}

$b$ Two specimens, from Campeche and Yucatan. 


\section{AMIZILIS YUCATANENSIS CERVINIVENTRIS (Gould).}

\section{FAWN-BREASTED HUMMING BIRD.}

Similar to A. y. yucatanensis, but under parts of body, under tailcoverts, etc., paler cinnamon-rufous or nearly vinaceous-cinnamon (less pinkish, however, than the latter color) and sides glossed or spotted with metallic bronze-green or greenish bronze; slightly larger (except bill).

Adult male.-Length (skins), 98-104 (101); wing, 51.5-57 (55.2); tail, 30.5-37 (34.6); culmen, 20-21.5 (20.6). ${ }^{a}$

Adult female.-Length (skins), 91-104 (97); wing, 52-55 (53.4); tail, 31-34 (32.7); culmen, 20-21.5 (21). ${ }^{b}$

Southeastern Mexico, in States of southern Tamaulipas (Hidalgo; Tampico?; Alta Mira?; Presas de Aldama?; Tantina?), San Luís Potosí (Válles) ?, Puebla (Metlaltoyuca), Vera Cruz (Córdova; Tospám, near Córdova; Tomatla; Sochiapa; Jalapa; San Andrés Tuxtla; Tlalc̣otalpám; Coatzocoalcos; Laguna; Catemaco; Misantla; Colipa; Vega de Casadero; Xochiapa), and Chiapas (Ocozucuantla)?

Amazilius cerviniventris Gould, Proc. Zool. Soc. Lond., Nov. 11, 1856, 150 (Córdova, Vera Cruz; coll. J. Gould).-Sclater, Proc. Zool. Soc. Lond., 1856, 287 (near Córdova).

Amazilia cerviniventris Gould, Mon. Troch., pt. xiii, May, 1857 (vol. v, 1861), pl. 309.-Sclater, Cat. Am. Birds, 1862, 314 (Tlalcotalpám, Vera Cruz).Mulsant and Verreaux, Classif. Troch., 1866, 35; Hist. Nat. Ois.-Mouch., i, livr. 4, 1874, 296; iv, livr. 3, 1878, 182.-D'OcA, La Naturaleza, iii, 1875, 209; Troq. de Mex., 1875, 51, pl. (11), fig. 39.-Salvin, Cat. Birds Brit. Mus., xvi, 1892, 214, part (except specimens from Brownsville, Texas).Salvin and Goduan, Biol. Centr.-Am., Aves, ii, 1892, 300 (except Texas specimens).-Boucard, Gen. Hum. Birds, 1895, 197 (Tospám, near Córdova, Vera Cruz).

[Amazilia] cerviniventris Sclater and Salvin, Nom. Av. Neotr., 1873, 92.Mulsant, Aun. Soc. Linn. Lyon, xxii, 1876, 209.-SHarpe, Hand-list, ii, $1900,108$.

P[yrrhophaena] cerviniventris Cabanis and HeIne, Mus. Hein., iii, 1860, 36, footnote (Córdova).

Pyrrhophæna cerviniventris GouLd, Introd. Troch., oct. ed., 1861, 157.

E[ranna] cerviniventris HeINe, Journ. für Orn., 1863, 187 (Córdova).

[Eranna] cerviniventris Heine and Reichenow, Nom. Mus. Hein. Orn., 1890, 179 (s. Mexico).

[Polytmus] cerviniventris Gray, Hand-list, i, 1869, 132, no. 1079.

Amazilis cerviniventris Eudes-Deslongchamps, Ann. Mus. Caen, i, 1880, 404.

Amizilis cerviniventris Oberholser, Proc. Ac. Nat. Sci. Phila., June 2, 1899, 208.

Amazilia cerviniventris cerviniventris Oberholser, Auk, xv, Jan., 1892, 36.

Amizilis cerviniventris cerviniventris AMERICAN Ornithologists' UnIon, Check List, 3d ed., 1910, 205.

Amila cerviniventris Boucard, Notes quelques Troch., 1873, 12 (Córdova).

Amazilia yucatanensis (not Trochilus yucatanensis Cabot) Eurot, Classif. and Synop. Troch., 1879, 219, part.-Ridgwax, Proc. U. S. Nat. Mus., i, 1879, 148, part (Jalapa); iii, 1881, 187, 318, part (Jalapa).

$\Lambda$ [mazilia] cerviniventris (typica) HARTERT, Das Tierreich, Troch., 1900, 59. 


\section{AMIZILIS YUCATANENSIS CHALCONOTA (Oberholser).}

\section{BUFF-BELLIED HUMMING BIRD.}

Similar to A. \%. cerviniventris, but uncler parts of body much paler (light cinnamon buff to pale pinkish bufl) and green of upper parts areraging more bromzy.

Adult male.-Length (skins), 95-105 (100); wing, 52.5-59 (55.8); tail, 32-37.5 (3t); culmen, 20-21.5 (20.7). ${ }^{a}$

Adult female.-Length (skins), 91-101 (96); wing, 52.5-55.5 (53); tail, 30-35 (32.S); culmen, 20.5-22.5 (21.3). ${ }^{a}$

Lower Rio Grande Valley in Texas (Ft. Brown; Brownsville), and southward into States of Tamaulipas (Tampico; Alta Mira; Xicotencatl; Boque Negro; Victoria; Rio Corono; Sota La Marina; Matamoras; Santa Leonora; Rio de la Cruz) and Nuevo León (Saltillo; San Pedro Mines), northeastern Mexico.

Amazilia cervineiventris (not Amazilia cerviniventris Gould) Merrill, Bull. Nutt. Orn. Club, ii, 1877, 26 (Ft. Brown, Texas).

Amazilia cerviniventris Brewer, Ibis, 1878, 116 (Ft. Brown; descr. nest).Coues and Sennetr, Bull. U. S. Geol. and Geog. Surv. Terr., iv, no. i, 1878, 3 (Brownsville, Texas; descr.; habits).-Allen, Bull. Nutt. Orn. Club, v, 1850, 90 (Ft. Brown).-Ridgway, Nom. N. Am. Birds, 1881, no. 346; Proc. U. S. Nat. Mus., iii, 1881, 187, 318, part (Texas); iv, 1881, 25, part (crit.); Rep. U. S. Nat. Mus. for 1890 (1891), 364, part (monogr.; habits).-Coues, Check List, 2 d ed., 1882, no. 420.-American Ornithologists' Union, Check List, 1886, no. 439.-Salvin, Cat. Birds Brit. Mus., xvi, 1892, 214, part (Brownsville; localities in Tamaulipas?).--Salvin and Godman, Biol. Centr.-Am., Ares, ii, 1892, 300, part (Rio Grande Valley; localities in Tamaulipas?).-Bendre, Life Hist. N. Am. Birds, ii, 1895, 225.

A[mazitia] ceriniventris Ridgway, Proc. U. S. Nat. Mus., iv, 1881, 25, 126 (diagnosis; crit.); Man. N. Am. Birds, 1887, 317, part.-Coues, Key N. Am. Birds, 2d ed., 1884, 466, part.

Amazilia yucatanensis (not Trochilus yucatanensis Cabot) Ridgway, Proc. U. S. Nat. Mus., i, 1879, 148, excl. syn. part (Ft. Brown, Texas; descr.); iii, 1880, 187, 219, 233; Nom. N. Am. Birds, 1881, no. 346.-Merrill, Proc. U. S. Nat. Mus., i, 1879, 149 (Ft. Brown; habits).

Amazilia cerviniventris chalconota OBERHolser, Auk, xv, Jan., 1898, 32 ("Beeville"=Brownsville, Texas; coll. U. S. Nat. Mus.), 188 (correction of type locality).-American Ornithologists' Union Committee, Auk, xvi, $1899,112$.

A[mazilia] cenviniventris chalconota HARTERT, Das Tierreich, Troch., 1900, 59.

[Amazilia] chalconota Sharpe, Hand-list, ii, 1900, 108.

Amizilis cerviniventris chalconota Oberholser, Proc. Ac. Nat. Sci. Phila., June 2, 1899, 208.-Banley (Florence M.), Handb. Birds W. U. S., 1902, 243.Ayericax Ornithologists' Union, Check List, 3d, ed., 1910, 205.-Phillips, Auk, xxviii, 1911, 77 (Alta Mira, Matamoras, Santa Leonora, and Rio de la Cruz, Tamaulipas). 


\section{AMIZILIS FORRERI Boucard.}

FORRER'S HOMMING BIRD.

Adult male.-Above bright metallic golden green, duller or more brownish on pileum, the rump and upper tail-coverts chestnut; median rectrices purplish chestnut passing into reddish bronze terminally, the remaining rectrices purplish chestnut edged terminally or subterminally with reddish black, the outermost pair wholly purplish chestnut; throat and sides of neck metallic golden green; breast, abdomen, and anal region white; flanks pale rufous; under tail-coverts pale chestnut margined with white; remiges brown, more purplish on secondaries; maxilla black, mandible flesh color with black tip; length (skin), 200; wing, 54; tail, 38; culmen, $19 .^{a}$

Western Mexico, in State of Sinaloa (Mazatlán).

Amazilia forreri Boucard, The Humming Bird, iii, no. 1, March, 1893, 7 (Mazatlan, Mexico; coll. A. Boucard); Gen. Hum. Birds, 1894, 193.

A[mazilia] forreri Hartert, Das Tierreich, Troch., 1900, 63 (monogr.).

[Amazilia] forreri SHARPE, Hand-list, ii, 1900, 109.

\section{AMIZILIS RUTILA RUTILA (Delattre).}

CINNAMOMEOUS HUMMING BIRD.

Adults (sexes alike).-Above metallic bronze, varying from slightly greenish bronze to golden; upper tail-coverts metallic bronze mesially, broadly margined with light cinnamon-rufous or tawny-rufous, the shorter lateral coverts mostly of this color; tail deep cinnamonrufous or rufous-chestnut, the rectrices broadly tipped with dark metallic bronze, the outer web of outermost rectrix edged for most of its length with the same; remiges dark brownish slate or dusky, faintly glossed with violaceous; under parts deep vinaceous-cinnamon or light dull cinnamon-rufous, slightly paler on chin and upper throat; femoral tufts and inconspicuous lumbar tufts white; bill pale brownish (carmine red or deep pinkish red in life) dusky at tip; iris dark brown; feet dusky.

Adult male.-Length (skins), 85-109 (99); wing, 52.5-60 (56.5); tail, 31-37 (34.6); culmen, 19.5-23.5 (21.2). ${ }^{b}$

$a$ I have not seen this species, which seems to be very distinct. The above description is adapted from that by Boucard in "Genera of Humming Birds" (p. 193).

$b$ Thirty-three specimens. 
Adult female.-Length (skins), 90-109 (97); wing, 51-5s (55.3); tail, 31-37 (33.2); culmen, 20-23.5 (21.6). ${ }^{a}$

Western and southern Mexico, in States of Sinaloa (Mazatlán; Presídio de Mazatlán; Escuinapa; Plomosas; Arroyo de Limones), Colima (Manzanillo; Colima; Tacolapa; Culata), Guerrero (Papayo; Acapulco; Ometepec; El Limón; Dos Arroyos; Coquilla; Tierra Colorado; Rio Papagaio; Acahuitzotla; La Venta; Venta de Pelegrino; Alto de Camarón), Oaxaca (Chimalapa; Tapana; Putla; Chicapa; Tehuántepec; Santa Efigénia), Chiapas (Tonalá), and Yucatan (Chichen-Itza; La Vega; Tunkas; Mérida; Tekanto; Sitilpech; Ticúl; between Ticúl and Uxmál; Mujeres I.; Holbox I.) and Territory of Tepic (Santiago; San Blas), and southward through central and eastern Guatemala (San Gerónimo; Gualán; Zacapa; El Rancho ?), British Honduras (Belize; Orange Walk; Wild Cave Cay), Salvadór (Acajutla; La Libertád?), Honduras (Tigre I.; Comayágua) and Nicaragua (Sucuyá; Matagalpa; San Gerónimo; Chinandega; Volcán de Chinandega; Volcan de Momotombo) to western Costa Rica (Volcán de Miravalles; Bagaces; Guanacaste; Bebedero; Punta Arenas; Barranca de Punta Arenas; Esparta; San Lucas; San Mateo; Santo Domingo de San Mateo; Tenório; Bolsón).

Ornismya cinnamomea (not Ornismya cinnamomeus Gervais, 1835 b) LEsson, Rev. Zool., 1842, 175 (Acapulco, Guerrero).

a Seventeen specimens.

\begin{tabular}{|c|c|c|c|}
\hline Locality. & Wing. & Tail. & $\begin{array}{c}\text { Ex- } \\
\text { posed } \\
\text { culmen. }\end{array}$ \\
\hline MALES. & & & \\
\hline Ten adult males from Sinaloa, Colima, Guerrero, and Oaxaca................... & 56.6 & 34.5 & 21.9 \\
\hline Seren adult males from Yucatan................................... & 56.1 & 34.3 & 20.4 \\
\hline Four adult males from eastern Guatemala (3) and Salvador (1)............... & 56.5 & 34.6 & 21.3 \\
\hline Two adult males from British Honduras................................. & 57 & 36.2 & 20.2 \\
\hline 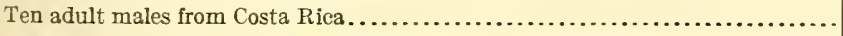 & 55.9 & 34.6 & 21.8 \\
\hline $\begin{array}{l}\text { Seren adult males from western Chiapas (3) and Guatemala }(4)(A, r \text { coral- } \\
\text { lirostris) } \ldots \ldots \ldots \ldots \ldots \ldots \ldots \ldots \ldots \ldots \ldots \ldots \ldots \ldots \ldots \ldots \ldots \ldots \ldots \ldots \ldots \ldots \ldots \ldots \ldots \ldots \ldots \ldots \ldots \ldots \ldots\end{array}$ & 56.5 & 34.4 & 21 \\
\hline $\begin{array}{l}\text { Five adult males of } A \text {. graysoni from Tres Marias Islands................ } \\
\text { FEMALES. }\end{array}$ & 68.1 & 43.5 & 25.1 \\
\hline Four adult females from Sinaloa, Colima, and Guerrero............ & 55.1 & 34.4 & 23 \\
\hline Two adult females from Yucatan..................... & 53.2 & 32.2 & 21.5 \\
\hline Eleven adult females from Costa Rica............................ & 53 & 34 & 23 \\
\hline One adult female ( $A . r$. corallirostris) from western Guatemala........... & 54.8 & 33 & 21.1 \\
\hline Four adult females of $A$. graysoni from Tres Marias Islands........ & 66.4 & 44 & 25.7 \\
\hline
\end{tabular}

I am not able to detect any differences of coloration according to geographic area except that specimens from Sinaloa, Colima, and Yucatan average slightly paler, those from Guerrero and Costa Rica slightly deeper in coloration, these latter approaching in intensity of coloration specimens of $A$. $r$. corallirostris from western Chiapas and western Guatemala.

$b=$ Sephanoides fernandensis (King).

$81255^{\circ}-$ Bull. 50-11-27 
Pyrrhophæna cinnamomea Gould, Introd. Troch., oct. ed., 1861, 156.-LAwrence, Ann. Lyc. N. Y., ix, 1869, 204 (Mérida, Yucatan); Mem. Bost. Soc. N. H., ii, 1874, 292 (Mazatlán, Sinaloa; habits); Bull. U. S. Nat. Mus. no. 4, 1876, 32 (Santa Efigénia, Oaxaca).-Sanchez, Anal. Mus. Nac. Mex., i, 1877, 96.Sumichrast, La Naturaleza, v, 1881, 250 (Santa Efigénia and Tapana, Oaxaca; Potrero [Vera Cruz?]).

Amazilia cinnamomea Sclater, Cat. Am. Birds, 1862, 314, part (in synonymy).SAlvin, Ibis, 1870, 115 (Costa Rica); 1889, 365 (Holbox I., Yucatan); Cat. Birds Brit. Mus., xvi, 1892, 207, 660, part.-Mulsant and Verreaux, Classif. Troch., 1866, 35, Hist. Nat. Ois.-Mouch., i, livr. 4, 1874, 284, part; iv, livr. 3, 1878, 180 (synonymy).-Boucard, List Ois. récol. Guat., 1878, 46; Proc. Zool. Soc. Lond., 1878, 71 (San Mateo and Punta Arenas, Costa Rica); 1883, 451 (Yucatan).-Euliot, Classif. and Synop. Troch., 1879, 219, part.-ZELEDón, Cat. Aves de Costa Rica, 1882, 21.-Nutring, Proc. U. S. Nat. Mus., vi, 1883, 386 (Sucuyá, Nicaragua).-Stone, Proc. Ac. Nat. Sci. Phila., 1890, 207 (Tekanto, Sitilpech, and Ticúl, Yucatan).-Salvin and Godman, Biol. Centr.-Am., Aves, ii, 1892, 293, part.-Hartert (E. and C.), Novit. Zool., i, 1895, 20 (Dos Arroyos, Guerrero).-Chapman, Bull. Am. Mus., N. H., viii, 1896, 284 (Chichen-Itza, Yucata ).-Underwoov, Ibis, 1896, 441 (Volcan de Miravalles and Bagaces, Costa Rica).-Lantz, Trans. Kansas Ac. Sci. for 1896-97 (1899), 221 (Granada, "Mex."=Nicaragua?).-Cole, Bull. Mus. Comp. Zool., 1, 1906, 128 (Chichen-Itza).

A[mazilia] cinnamomea Mulsant, Ann. Soc. Linn. Lyon, xxii, 1876, 206.-Ridgway, Man. N. Am. Birds, 1887, 318; Rep. U. S. Nat. Mus. for 1890 (1891), 364 (diagnosis, etc.).-HARTERT, Das Tierreich, Troch., 1900, 61.

[Amazilia] cinnamomea Sclater and Salvin, Nom. Av. Neotr., 1873, 92, part.-

SharPe, Hand-list, ii, 1900, 109.

Amazilis cinnamomea Eudes-Deslongchamps, Ann. Mus. Caen, i, 1880, 400.

Amazilis cinnamomeus Dearborn, Pub. 125, Field Mus. N. H., 1907, 98 (Gualán and El Rancho, Guatemala).

Amazillia cinnamomea Salvin, Ibis, 1864, 380 (Half Moon Cay, Brit. Honduras). Amizilis cinnamomea Oberholser, Proc. Ac. Nat. Sci. Phila., June 2, 1899,

207.-Carriker, Ann. Carnegie Mus., vi, 1910, 530 (lowlands of n. w. Costa Rica).

Amizilis cinnamomea cinnamomea Mrller (W. De W.), Bull. Am. Mus. N. H., xxi, Nov. 24, 1905, 354 (Escuinapa, etc., Sinaloa).-BANGs, Auk, xxiv, 1907, 295

(Barranca de Punta Arenas, Costa Rica).

A[mizilis] cinnamomea cinnamomea Ridgway, Proc. Biol. Soc. Wash., xxiii, 1910, 54 , in text.

[Polytmus] cinnamomea Gray, Hand-list, i, 1869, 132, no. 1678.

E[ranna] cinnamomea HeIne, Journ. für Orn., 1863, 187.

[Eranna] cinnamomea Heine and Reichenow, Nom. Mus. Hein. Orn., 1890, 179

(Mexico).

Ornismya rutila Delatrre, Echo du Monde Savant, sér. 2, vii, no. 45, June 15, 1843, col. 1069 (new name for $O$. cinnamomea Lesson, preoccupied).

Amazilius corullirostris (not Trochilus corallirostris Bourcier and Mulsant) ScLater,

Proc. Zool. Soc. Lond., 1858, 358 (Tigre I., Honduras); 1859, 386 (Oaxaca).

Amazillia corallirostris Sclater and SALvin, Ibis, 1859, 130, part (Tigre Island,

Honduras; Guatemala, part; habits).-TAYLor, Ibis, 1860, 115 (Tigre I.,

Comayagua, etc., Honduras; habits).

[Amazilius] erythrorhynchus Bonaparte, Compt. Rend., xxx, 1850, 382. Amazilius hacmalorhynchus Bonaparte, Compt. Rend., xxx, 1850, 382. 


\section{AMIZILIS RUTILA CORALLIROSTRIS (Bourcier and Mulsant).}

CORAL-BILLED HUMMING BIRD.

Sinilar to A.r. rutila, but much more deeply colored, the under parts deep cinnamon-rufous, the tail chestnut, and green or bronze of back, etc., deeper and brighter.

Adult male.-Length (skins), 91-105 (99); wing, 53-58.5 (55.9); tail, 31.5-37 (34.6); culmen, 20.5-22.5 (21.8). ${ }^{a}$

Adult female.-Length (skin), 103; wing, 53 ; tail, 34 ; culmen, $23 .^{b}$ Pacific slope of Guatemala (Escuintla; Escuinapa; Mazatenango; Patulúl; Retalhuleu; Santa Ana Mixtán) and Chiapas (Huehuetán).

T[rochilus] corallirostris Bourcier and Mulsant, Ann. Sci. Phys. et Nat. Lyon, ix, 1846, 328 (Escuintla, w. Guatemala).

[Amazilius] corallirostris Bonaparte, Consp. Av., i, 1850, 77; Rev. et Mag. de Zool., 1854, 254.

[Amazilia] corallirostris Reichen bach, Aufz. der Colibr., 1854, 10; Troch. Enum., 1855, 8, pl. 776, figs. 4800, 4801.-Gould, Mon. Troch., pt. xiii, May, 1857, (vol. v), pl. 307.

Amazilia corallirostris Salvin, Ibis, 1860, 100 (Pacific slope Guatemala), 196, 268 (San Gerónimo, Guatemala; habits).

Amazillia corallirostris Sclater and Salvin, Ibis, 1859, 130, part (Guatemala; habits).

P[yrrhophaena] corallirostris Caban1s and Heine, Mus. Hein., iii, 1860, 35, footnote (Guatemala).

Amazilia cinnamomea saturata Nelson, Proc. Biol. Soc. Wash., xii, March 24, 189S, 63 (Huehuetán, Chiapas; coll. U. S. Nat. Mus.).

Amizilis cinnamomea saturata Oвerholser, Proc. Ac. Nat. Sci. Phila., June 2, 1899, 207.

Amazilis cinnamomeus saturatus Dearborn, Pub. 125, Field Mus. N. H., 1907, 98 (San José, Mazatenango, and Patulúl, w. Guatemala; coast up to 2,000 ft.).

[Amazilia] saturata Sharpe, Hand-list, ii, 1900, 109.

Amazilia cinnamomea (not Ornismya cinnamomea Lesson, 1842, nor O. cinnamomeus Gervais, 1835) Sclater, Cat. Am. Birds, 1862, 314, part (San Gerónimo, Guatemala).-Elliot, Classif. and Synop. Troch., 1879, 219, part.-Salvin, Cat. Birds Brit. Mus., xvi, 1892, 207, part (Escuintla, Santa Ana Mixtán, and Retalhuleu, Guatemala).-Salvin and Godman, Biol. Centr.-Am., Aves, ii, 1892, 293, part (San Gerónimo, Escuintla, Santa Ana Mixtán, and Retalhuleu, Guatemala).

[Amazilia] cinnamomea Sclater and Salvin, Nom. Av. Neotr., 1873, 92, part.

\section{AMIZILIS GRAYSONI (Lawrence).}

GRAYSON'S HUMMING BIRD.

Similar in coloration to $A$. rutila rutila, but darker, throughout, and much larger.

Adult male.-Length (skins), 116-122 (120); wing, 66-69.5 (68.1); tail, 42-45.5 (43.5); culmen, 23.5-27 (25.1). ${ }^{\circ}$ 
Adult female.-Length (skins), 115-124 (120); wing, 66-67 (66.4); tail, 42.5-45.5 (44); culmen, 25-27 (25.7). ${ }^{a}$

Tres Marias Islands (Maria Madre Island), western Mexico.

Amazilia (Pyrrhophæna) graysoni Lawrence, Ann. Lyc. Nat. Hist. N. Y., viii, 1866, 404 (Tres Marias Islands, w. Mexico; coll. U. S. Nat. Mus.).

Pyrrhophæna graysoni Lawrence, Proc. Bost. Soc. N. H., xiv, 1871, 283 ; Mem. Bost. Soc. N. H., ii, 1874, 292.

Amazilia graysoni Gould, Ibis, 1867, 247.-Mulsant and Verreaux, Hist. Nat. Ois.-Mouch., i, livr. 4, 1874, 286; iv, livr. 3, 1878, 180.-Ellıot, Classif. and Synop. Troch., 1879, 219.-D'Hamonville, Bull. Soc. Zool. France, xi, 1886, 313 (reprint, p. 11; descr.; crit.).-Sharpe, in Gould's Mon. Troch., Suppl., 1887.-Ridgway, Rep. U. S. Nat. Mus., 1890 (1891), 364.-Salvin, Cat. Birds Brit. Mus., xvi, 1892, 209.-Salvin and Godman, Biol. Centr.Am., Aves, ii, 1892, 294.-Boucard, Gen. Hum. Birds, 1894, 195.-Nelson, North Am. Fauna, no. 14, 1899, 45 (habits; crit.).

[Amazilia] graysoni Sclater and Salvin, Nom. Av. Neotr., 1873, 92.-Mulsant, Ann. Soc. Linn. Lyon, xxii, 1876, 206.-Sharpe, Hand-list, ii, 1900, 109.

A[mazilia] graysoni Ridgway, Man. N. Am. Birds, 1887, 318; Rep. U. S. Nat. Mus., 1890 (1891), 364 (diagnosis, etc.).-HarTerT, Das Tierreich, Troch., 1900,61 (monogr.).

[Eranna] graysoni Heine and Reichenow, Nom. Mus. Hein. Orn., 1890, 179.

[Polytmus] graysoni GraY, Hand-list, i, 1869, 132, no. 1689.

Amazilis graysoni Eudes-Deslongchamps, Ann. Mus. Caen, i, 1880, 402.-Bailey

(H. H.), Auk, xxiii, 1906, 388 (Cleofa Island, Tres Marias).

Amizilis graysoni Oberholser, Proc. Acad. Nat. Sci. Phila., 1899, 207.

\section{AMIZILIS BANGSI Ridgway.}

BANGS' HUMMING BIRD.

Similar to $A$. rutila rutila, but whole side of neck metallic greenish bronze instead of cinnamon-rufous.

Adult male.-Above bright metallic bronze-green, changing to greenish bronze, the pileum duller, inclining on forehead to dull coppery bronze; upper tail-coverts cinnamon-rufous, with a large median spot of metallic bronze; tail chestnut, the rectrices broadly margined terminally with metallic bronze; remiges dusky, faintly glossed with purplish; auricular region and whole side of neck metallic greenish bronze; chin and throat pale cinnamon-rufous, the feathers margined with pale cream-buffy; rest of under parts buffy vinaceouscinnamon medially, deepening into cinnamon-rufous laterally; bill pale brownish (rosy red in life?); fcet brownish (in dried skins); length (skin), 97; wing, 60 ; tail, 37 ; culmen, $22 .^{b}$

Northwestern Costa Rica (Volcán de Miravalles).

Amizilis bangsi Ridgway, Proc. Biol. Soc. Wash., xxiii, April 19, 1910, 54 (Volcán de Miravalles, n. w. Costa Rica; coll. E. $\Lambda$. and O. Bangs). 


\section{AMIZILIS VIRIDIFRONS (Elliot).}

\section{GREEN-FRONTED HUMMING BIRD.}

Adult male. ${ }^{a}$ - Forehead and median portion of crown dark, slightly metallic, indigo blue; sides of crown, auricular region, occiput, and hindneck dusky metallic bronze-green, the upper back, scapulars, and wing-corerts rather brighter and more bronzy; lower back and rump grayish brown or olive, glossed with bronze; upper tail-coverts dull coppery bronze, narrowly margined with dull buffy whitish; tail metallic bronze, tinged with coppery bronze, the rectrices narrowly and indistinctly tipped with buffy; remiges dusky, faintly glossed with violet; suborbital region (anteriorly), rictal and malar regions, and under parts (including under tail-coverts), immaculate white, the sides partly grayish brown glossed with bronze; bill brownish (rosy red in life?), dusky terminally; iris dark brown; legs and feet dusky (in dried skins); length (skins), 99-103 (101); wing, 58-61.5 (60.1); tail, 31.5-35 (33.2); culmen, 22-24.5 (23.2). ${ }^{b}$

Adult female.--Similar to the adult male (as described above), but forehead and crown dull dusky green, and rectrices without buffy tip; length (skins), 96-106 (100); wing, 55-60.5 (58.5); tail, 30.5-35 (32.5); culmen, 20-24.5 (22.7). ${ }^{c}$

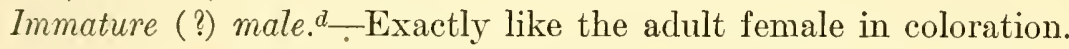

Young.-Essentially like the adult female, but forehead and crown sooty, without trace of greenish or bluish gloss, and feathers of lower back, rump, and upper tail-coverts narrowly tipped or terminally margined with pale buffy grayish.

Southwestern Mexico, in States of Guerrero (Rincón; Tierra Colorado; Zumpango del Rio; Chilpancingo; Coquilla; Acahuitzotla; Sierra Madre del Sur), Oaxaca (Putla; Tehuántepec; Santa Efigénia; Tapana), and Chiapas (Tonalá).

Cyanomyia viridifrons Eluiot, Ann. and Mag. N. H., ser. 4, viii, 1871, 266 (Putla, Oaxaca; coll. D. G. Elliot); Ibis, 1876, 314 (Putla; synon.; crit.).-DE OCA, La Naturaleza, iii, 1875, 304.-SAlvin, Cat. Birds Brit. Mus., xvi, 1892, 196 (Putla and Tehuántepec, Oaxaca; Rincón, Acahuitzotla, and Tierra Colorado,

$a$ The only specimen examined corresponding in plumage to the fully adult male as described above is from Acahuitzotla, Guerrero, and represents the so-called Cyanomyia guerrerensis Salvin and Godman. All others examined lack both the dark blue forehead and buffy tip to the rectrices. I am fully convinced, however, that these bluish fronted specimens are neither specifically nor subspecifically distinct from the greenish fronted ones, for the reason that the two occur in the same locality, both being represented from Acahuitzotla. Whether the apparently adult males with greenish forehead are in reality females wrongly sexed, are younger males, or merely represent individual variation can be determined only from more ample material.

$b$ Three specimens.

c Six specimens.

d Possibly representing merely individual variation in the fully adult male. 
Guerrero; Tonalá, Chiapas).-Salvin and Godman, Biol. Centr.-Am., Aves, ii, 1892, 289 (Putla and Tehuántepec, Oaxaca; Tonalá, Chiapas).-Boucard, Gen. Hum. B. 1894, 164 (Putla).-Hartert (E. and C.), Novit. Zool., i, 1894, 62 (Zumpango del Rio and Chilpancingo, Guerrero).

Cyanomya viridifrons Boucard, Ann. Soc. Linn. Lyon, $\mathrm{xx}, 1874,277$ ("Puebla"=Putla ?).

Uranomitra viridifrons Elliot, Classif. and Synop. Troch., 1879, 197.-SharPe, in Gould's Mon. Troch., Suppl., 1885, pl. 49.-Berlepsch, Proc. U. S. Nat. Mus., xi, 1888, 562 (Sta. Efigénia, Oaxaca).

[Cyanomyia] viridifrons Sclater and Salvin, Nom. Av. Neotr., 1873, 91.

Cyanomia viridifrons D'OcA, Los Colibr. Mex., 1875, 58.

Leucolia viridifrons Mulsant and Verreaux, Hist. Nat. Ois.-Mouch., i, livi. 3, 1874, 224 (Putla).

Leucolia viridi-frons Mulsant and Verreaux, Hist. Nat. Ois.-Mouch., Suppl. plates (no date), pl. 27.

[Leucolia] viridifrons Mulsant, Ann. Soc. Linn. Lyon, n. s., xxii, 1876, 204. A[mazilia] viridifrons Hartert, Das Tierreich, Troch., 1900, 62 (monogr.).

[Amazilia] viridifrons Sharpe, Hand-list, ii, 1900, 109.

[Uranomitra] violiceps viridifrons Srmon, Cat. Troch., 1897, 14.

Cyanomyia guerrerensis Salvin and Godman, Biol. Centr.-Am., ii, sig. 37, July, 1892, 290 (Rincón, Acahuitzotla, and Tierra Colorado, Sierra Madre del Sur, Guerrero, Mexico; coll. Salvin and Godman).-Boucard, Gen. Hum. Birds, 1894, 165 (Putla, Oaxaca).

[ Uranomitra] guerrerensis Srmon, Cat. Troch., 1897, 14.

A[mazilia] guerrerensis Hartert, Das Tierreich, Troch., 1900, 63 (monogr.).

[Amazilia] guerrerensis Sharpe, Hand-list, ii, 1900, 109.

\section{AMIZILIS VERTICALIS (Lichtenstein).}

BLACK-BILIED AZURE-CROWN.

Adult male.-Pileum bright metallic blue or violet-blue; hindneck, upper back, scapulars, and wing-coverts, dull bronze-green or olive glossed with bronze-green, the first usually more or less tinged or intermixed with blue on upper portion and along junction with white of foreneck; lower back, rump, and upper tail-coverts grayish brown or olive faintly glossed with bronze-greenish, the feathers sometimes narrowly and indistinctly paler on terminal margin, especially the upper tail-coverts, which are usually slightly more bronzegreenish; tail rather dull metallic greenish bronze; remiges dusky, faintly glossed with violet; rictal and malar regions and under parts (including under tail-coverts) immaculate white, the sides mostlylight olive glossed with bronze-greenish; bill light brownish (rosy or carmine red in life?), dusky at tip; iris dark brown; feet dusky (in dried skins); length (skins), 98-105 (102); wing, 53-59.5 (57); tail, 29-32 (30.9); culmen, 21-23.5 (22.6). ${ }^{a}$

Adult female.-Similar to the adult male and not always distinguishable but usually with coloration slightly duller; length (skins), 98-104 (100); wing, 52-57 (54.9); tail, 27-31.5 (29.6); culmen, $21.5-24.5(23.1) .^{b}$ 
Young.-Similar to adults, but feathers of upper parts (inchuding pileum) narrowly tipped or terminally margined with buffy, these markings broadest on rump and upper tail-coverts, sometimes obsolete on back.

Western and central Mexico, in Sates of Sonora (Ālamos), Sinaloa (Culiacán; Plomosas; Escuinapa; Mazatlán; Mount Juan Lisiarraga), Jalisco (Chapala; Lake Chapala; Bolaños; Sierra Bolaños; Etzatlán; Zapotlán; Barranca Ibarra), Michoacán (La Salada; Querendero; Los Reyes), Morelos (Cuernavaca), Aguas Calientes (Calvillo), Guanajuato, Mexico (Valley of Mexico; Choapán), and Puebla (Volcán de Orizaba), and Territory of Tepíc (San Blas).

Trochilus verticalis Lichtenstern, Preis-Verz. Mex. Vög., 1830, 1 (Mexico); Journ. für Orn., 1863, 55.

[Cyanomyia] verticalis Bonaparte, Rev. et Mag. de Zool., 1854, 254.

Cyanomyia verticalis SALvin, Cat. Birds Brit. Mus., xvi, 1892, 194 (Mazatlán; San Blas; Zapotlán, Lake Chapala, Bolaños, and Sierra Bolaños, Jaliseo; Calvillo, Aguas Calientes).-SAlvin and Godman, Biol. Centr.-Am., Aves, ii, 1S92, 287 (localities in Sinaloa, Jalisco, Guanajuato, Aguas Calientes, Mexico, and Puebla).

Amazilia verticalis Hartert, Journ. für Orn., 1900, 360 (Volcán de Orizaba; crit.).

A[mazilia] verticalis Hartert, Das Tierreich, Troch., 1900, 62.

[Amazilia] verticalis Sharpe, Hand-list, ii, 1900, 109.

Ornismya cyanocephala (not of Lesson, 1829) Lesson, Suppl. Ois.-Mouch., 1830, 132, pl. 17.

[Agyrtria] cyanocephala Reichensach, Troch. Enum., 1855, 7, pl. 760, figs. $4754,4755$.

[Agyrtria, $\beta$. Uranomitra] quadricolor (not Trochilus quadricolor Vieillot) ReIcHENBACH, Aufz. der Colibr., 1854, 10.

[Agyrtria] quadricolor Reichenbach, Troch. Enum., 1855, 7, pl. 761, figs. 4758, 4759 .

[Cyanomyia] quadricolor Bonaparte, Rev. et Mag. de Zool., 1854, 254.

Cyanomyia quadricolor Gould, Mon. Troch., pt. ix, 1855, (vol. v), pl. 284; Introd. Troch., oct. ed. 1861, 147.-Sclater, Proc. Zool. Soc. Lond., 1856, 287; 1859, 386 (Choapám [Mexico?]); Cat. Am. Birds, 1862, 311.-VilLadA, La Naturaleza, ii, 1874, 362 (Valley of Mexico).-D’OcA, La Naturaleza, iii, 1875, 209 (Valley of Mexico); Troq. de Mex., 1875, 51, pl. (11), fig. 40.Lawrence, Mem. Bost. Soc. N. H., ii, 1874, 292 (Mazatlán; Guadalajara).Elliot, Ibis, 1876, 312 (synonymy; crit.).-Herrera, La Naturaleza, (2), i, 1891, 322 (Valley of Mexico).

Cyanomya quadricolor Boucard, Ann. Soc. Linn. Lyon, xx, 1874, 276 (Volcán de Orizaba [Puebla?]); Notes quelques Troch., 1873, 8 (Volcán de Orizaba; habits); Gen. Hum. Birds, 1894, 163.

Cianomyia quadricolor DuGÈs, La Naturaleza, i, 1870, 141 (Guanajuato).

[Cyanomyia] quadricolor Sclater and Salvin, Nom. Av. Neotr., 1873, 91.Sanchez, Anal. Mus. Nac. Mex., i, 1877, 96 (Valley of Mexico; Jalisco; Mazatlán; Guanajuato).

[Cyanomya] quadricolor Mulsant, Ann. Soc. Linn. Lyon, n. s., xxii, 1876, 204. U[ranomitra] quadricolor Cabanis and Heine, Mus. Hein., iii, 1860, 41.-Heine, Journ. für Orn., 1863, 195. 
Uranomitra quadricolor ElLIot, Classif. and Synop. Troch., 1879, 196.-BeRLEPSCH, Proc. U. S. Nat. Mus., xi, 1889, 561 (crit.).-Lantz, Trans. Kansas Ac. Sci. for 1896-97 (1899), 221 (Culiacán, Sinaloa).

Cyanomya (Leucolia) quadricolor Mulsant and Verreaux, Hist. Nat. Ois.Mouch., iv, livr. 3, 1878, 169 (crit.).

Leucolia quadricolor Mulsant and Verreaux, Classif. Troch., 1866, 31: Hist. Nat. Ois.-Mouch., i, livr. 3, 1874, 215 (Orizaba).

[Polytmus] quadricolor GRAY, Hand-list, i, 1869, 133, no. 1710.

U[ranomitra] ellioti Berlepsch, Proc. U. S. Nat. Mus., xi, Sept. 25, 1889, 562, in text (Mazatlán, Sinaloa; coll. U. S. Nat. Mus.).

Cyanomyia ellioti Jouy, Proc. U. S. Nat. Mus., xvi, Apr. 18, 1894, 784 (Guadalajara, Lake Chapala, and Barranca Ibarra, Jalisco).

\section{AMIZILIS VIOLICEPS (Gould).}

\section{VIOLET-CROWNED HOMMING BIRD.}

Adult male.-Pileum bright metallic blue, violet-blue, or bluish violet; hindneck, upper back, scapulars, and wing-coverts dull metallic bronze-green, becoming brighter green or bronze-green next to white of foreneck, passing into olive glossed with bronze or bronzegreen on lower back and rump, the feathers of which are indistinctly margined terminally with paler; upper tail-coverts bronzy olive to dull coppery bronze, margined terminally with dull whitish or pale dull grayish buffy; tail olive-bronze to coppery bronze, the rectrices margined with bronze; remiges dusky, faintly glossed with violet; suborbital, rictal, and malar regions and under parts (including under tail-coverts) immaculate white, the extreme outer portion of sides brownish gray or drab; bill pale brownish (rosy or carmine red in life), the tip dusky; iris dark brown; feet dusky; length (skins), 101-109 (104); wing, 56-60 (58.5); tail, 31-35 (33.4); culmen, $20.5-23.5(21.6) .^{a}$

Adult female.-Similar to the adult male and not always distinguishable, but usually slightly duller in coloration, especially the pileum, which is usually duller and less violaceous, sometimes partly greenish blue; length (skins), 100-107 (104); wing, 54.5-59.5 (57); tail, 31-33 (32.3); culmen, 21.5-23.5 (22.4). ${ }^{b}$

Young.-Essentially like adults, but pileum dusky or duller blue, the feathers tipped with rusty brown, feathers of rump tipped with buffy, upper tail-coverts margined with buffy, rectrices narrowly tipped with buffy or pale cinnamon, and sides suffused with buffy.

Southern Mexico, in States of Puebla (Atlixco), Morelos (Cuernavaca; Puenta de Ixtla), Michoacán (La Salada), Guerrero (Chilpancingo; Acahuitzotla; Iguala; Venta de Zopilote; Sierra Madre del Sur), and Oaxaca (Putla; Oaxaca; Santa Efigénia; Tapana).

Cyanomyia violiceps Gould, Ann. and Mag. N. H., 1859, iv, 97 (Atlixco, Puebla; coll. J. Gould); Mon. Troch., v, 1860, pl. 285; Introd. Troch., oct. ed., 1861, 147.-Sclater, Proc. Zool. Soc. Lond., 1859, 386 (Atlixco).-D'OcA, La 
Naturaleza, iii, 1875, 208; 'Troq. de Mex., 1875, 50.-Lawrence, Bull. U. S.

Nat. Mus., no. 4, 1876, 32 (Tapana and Sta. Efigénia, Oaxaca).-Eulıo', Ibis, 1876, 313 (Oaxaca; synon.; crit.).-Sanchez, An. Mus. Nac. Mex., i, 1877, 96 (Oaxaca).-Salin, Cat. Birds Brit. Mus., xvi, 1892, 196 (Chilpancingo, Venta de Zopilote, and Sicra Madre del Sur, Guerrero; Atlixco, Puebla; Oaxaca).-Salvin and Godman, Biol. Centr.-Am., $\Lambda$ ves, ii, 1892, 288.Jour, Proc. U. S. Nat. Mus., xvi, 1894, 784 (Cuernavaca, Morelos).-Boucard, Gen. Hum. Birds, 1894, 164 (Oaxaca).

[Cyanomya] violiceps Mulsant, Ann. Soc. Linn. Lyon, xxii, 1876, 204.

Cyanomya violiceps Boucard, Ann. Soc. Linn. Lyon, xx, 1874, 276 (Cuernavaca,

Morelos; Atlixco, Puebla; Oaxaca; habits); Notes quelques Troch., 1873, 8

(Cuernavaca; Atlixco; Oaxaca; habits).-Sumichrast, La Naturaleza, v, 1881, 250 (Sta. Efigénia and Tapana).

[Cyanomyia] violiceps Sclater and Salvin, Nom. Av. Neotr., 1873, 91.

Cianomyia violiceps D'OcA, Los Colibris Mex., 1875, pl. 10, fig. 38.

Cyanomya (Leucolia) violiceps Mulsant and Verreaux, Hist. Nat. Ois.-Mouch., iv, livr. 3, 1878, 170 (crit.).

U[ranomitra] violiceps Cabanis and Herne, Mus. Hein., iii, 1860, 41, footnote (Oaxaca).

Uranomitra violiceps Elliot, Classif. and Synop. Troch., 1879, 196.

Leucolia violiceps Mulsant and Verreaux, Classif. Troch., 1866, 31; Hist. Nat.

Ois.-Mouch., i, livr. 3, 1874, 213 (Puebla; Oaxaca; Morelos).

[Polytmus] violiceps GraY, Hand-list, i, 1869, 133, no. 1711.

A[mazilia] violiceps Hartert, Das Tierreich, Troch., 1900, 62 (monogr.).

[Amazilia] violiceps Sharpe, Hand-list, ii, 1900, 109.

\section{AMIZILIS CYANOCEPHALA CYANOCEPHALA (LesSON).}

RED-BILLED AZURE-CROWN.

Adult male.-Pileum bright metallic blue (varying from slightly violet blue to greenish blue); hindneck, back, scapulars, and wingcoverts metallic bronze-green, passing on rump, upper tail-coverts, and tail into olive faintly glossed with greenish bronze or bronzegreen, the nape sometimes tinged with blue, the upper tail-coverts usually narrowly or indistinctly margined with paler; remiges dusky, faintly glossed with purplish; rictal and suborbital regions metallic bluish emerald-green, the feathers narrowly margined with white; auricular region and sides of neck mostly metallic bluish green, less bluish posteriorly; sides of chest metallic bronze-green, the feathers usually narrowly margined with white, passing into duller bronzegreen or olive glossed with bronze-green or greenish bronze; chin, throat, malar region, median portion of chest and breast, abdomen, and femoral tufts immaculate white; under tail-coverts olive-gray, faintly glossed with bronze and margined with white; maxilla dull black; mandible whitish (carmine red in life), blackish at tip; iris dark brown; feet dusky or blackish; length (skins), 96-106 (101); wing, 57.5-62 (59.7); tail, 31-34.5 (33.2); culmen, 19-22 (20.3). ${ }^{a}$

Adult female.-Similar to the adult male and not always distinguishable, but usually with blue of pileum slightly less brilliant or 
more greenish, sometimes nearly bluish green; length (skins, 95-103 (100); wing, 54-61 (57.9); tail, 31.5-34 (32.6); culmen, 19.5-23 $(21.2) .^{a}$

Young.-Essentially like adults, but coloration much duller; pileum very dull greenish blue, the feathers margined, more or less distinctly, with light brownish; feathers of rump and upper tailcoverts narrowly but distinctly tipped or terminally margined with pale grayish buffy; rectrices narrowly margined at tip with whitish; under parts more or less suffused with buffy, especially on chin, throat, and sides.

Southeastern Mexico, in States of Vera Cruz (Córdova; Coátepec; Orizaba; Miradór; Huatusco; Jalapa; Jico; Téxolo), Oaxaca (Chimalapa; Guichicovi; Tehuántepec; mountains near Santo Domingo), and Chiapas (Gineta Mountains; Yajalón).

Ornismya cyanocephalus Lesson, Hist. Nat. Ois.-Mouch., 1829, p. xlv ("Brésil"). Ornismya cyanocephala Lesson, Suppl. Ois.-Mouch., 1830-31, 132, pl. 17, 134, pl. 18 ("Brésil").

Trochilus cyanocephalus Lesson, Index Gen. et Synop. Troch., 1832, p. xxii, part. Cyanomyia cyanocephala Bonaparte, Rev. et Mag. de Zool., 1854, 254.-Gould, Mon. Troch., v, 1856, pl. 286; Introd. Troch., oct. ed., 1861, 147.-Sclater, Proc. Zool. Soc. Lond., 1857, 212 (Orizaba, Vera Cruz); 1859, 367 (Jalapa, Vera Cruz).-D'OcA, Proc. Ac. Nat. Sci. Phila., 1868, 80 (habits); La Naturaleza, iii, 1875, 159 (Jalapa, Coátepec, and Córdova, Vera Cruz); Troq. de Mex., 1875, 37, pl. (7), fig. 26.-Lawrence, Bull. U. S. Nat. Mus., no. 4, 1876, 32 (Guichicovi, Oaxaca).--Elliot, Ibis, 1876, 314, part (synon.; crit.).Mulsant, Ann. Soc. Linn. Lyon, xxii, 1876, 204.-Salvin, Cat. Birds Brit. Mus., xvi, 1892, 197 (Jalapa, Coátepec, Orizaba, and Córdova, Vera Cruz; Oaxaca and Chimalapa, Oaxaca).-Salvin and Godman, Biol. Centr.-Am., Aves, ii, 1892, 291 (Huatusco, etc., Vera Cruz; Gineta Mts., Chiapas; etc.).Boucard, Gen. Hum. Birds, 1895, 163, part (Mexico).

[Cyanomyia] cyanocephala Sclater and Salvin, Nom. Av. Neotr., 1873, 91, part (Mexico).-SAnchez, Anal. Mus. Nac. Mex., i, 1877, 96 (Jalapa, Córdova, Orizaba).

[Agyrtria. $\beta$. Uranomitra] cyanocephala ReIchensach, Aufz. der Colibr., 1854, 10. [Agyrtria] cyanocephala Reichenbach, Troch. Enum., 1855, 7.

Leucolia cyanocephala Mulsant and Verreaux, Classif. Troch., 1866, 31; Hist. Nat. Ois.-Mouch., i, livr. 3, 1874, 219.

[Polytmus] cyanocephalus GraY, Hand-list, i, 1869, 133, no. 1712.

Uranomitra cyanocephala Elurot, Classif. and Synop. Troch., 1879, 197.-Ferrarr-

Perez, Proc. U. S. Nat. Mus., ix, 1886, 158 (Jalapa).-Chapman, Bull. Am.

Mus. N. H., x, 1898, 33 (Jalapa).-LANTz, Trans. Kansas Ac. Sci. for 1896-97 (1899), 221 (Coátepec).

[Amazilia] cyanocephala Sharpe, Hand-list, ii, 1900, 109.

Cyanomya cyanocephala Boucard, Notes quelques Troch., 1873, 8 (Córdova, Jalapa, and Orizaba, Vera Cruz); Ann. Soc. Linn. Lyon, xx, 1874, 276 (do.).Sumichrast, La Naturaleza, v, 1881, 250 (Orizaba, Vera Cruz; Guichicovi, Oaxaca).

Cyanomya (Leucolia) cyanocephala Mulgant and Verreaux, Hist. Nat. Ois.Mouch., iv, livr. 3, 1878, 170 (crit.). 
A[mazilia] cyanocephala (typica) Hanter'r, Das 'Tierreich, Troch., 1900, 61 (unonogr.).

$P$ [olytmus] verticalis (not Trochilus verticalis Lichtenstein) Grux, Gen. Birds, i, Dec., 1S4s, 109.

Agyrtria faustinae Reichen baci, 'Troch. Enum., 1855, 7, pl. 760, figs. 4756, 4757. [Uranomitra] faustinae Cabanis and Heine, Mus. Hein., iii, 1860, 180 (Jalapa).

[Cyanomya cyanocephala] var. faustinae Múlsant, Ann. Soc. Limn. Lyon, n. 8., xxii, 1576, 204.

U[ranomitra] lessoni Cabanis and Herne, Mus. Hein., iii, 1860, 41 (Jalapa, Vera Cruz; coll. Heine Mus.).-Heine, Journ. für Orn., 1863, 195 (crit.).

\section{AMIZILIS CYANOCEPHALA GUATEMALENSIS (Gould).}

GUATEMALAN AZURE-CROWN.

Similar to A. c. cyanocephata, but tail much brighter bronzy, the rump and upper tail-coverts also much more strongly glossed with bronzy.

Adult male.-Length (skins), 94-102 (98); wing, 57.5-63 (60.3); tail, 31-36.5 (33.9); culmen, 18.5-20 (19.4). ${ }^{a}$

Adult female.-Length (skins), 95-101 (98); wing, 53-63 (58.3); tail, 31-33.5 (32.3); culmen, 20-21.5 (20.5). ${ }^{b}$

Guatemala (pine ridge of Poctún; mountains of Chilasco; San Gerónimo, etc., Vera Paz; Dueñas; Cobán; Panajachál; Gualán; Toyabáj, Quitché; Guatemala City; Amatitlán), British Honduras (pine ridge near Manatee Lagoon; southern pine ridge, Western District), Honduras (Siquátepec; San Pedro Sula; Yaruca). and northern Nicaragua (Matagalpa).

Cyanomyia cyanocephala (not Ornismyia cyanocephalus Lesson) SCrATer and Salvin, Ibis, 1859, 127 (Dueñas, Guatemala).-Salvin and Sclater, Ibis, 1S60, 39 (Dueñas; habits).-SALvin, Ibis, 1860, 195, 261, 264, 269 (Dueñas and Cobán, Guatemala).-TAYLor, Ibis, 1860, 114 (Siquátepec, Honduras).Elliot, Ibis, 1876, 314, part (Guatemala; Honduras; synon.; crit.).-BouCARD, Gen. Hum. Birds, 1895, 163, part (Guatemala).

[Cyanomyia] cyanocephala Sclater and Salvin, Nom. Av. Neotr., 1873, 91, part. Cyanomya cyanocephala Boucard, Liste Ois. récol. Guat., 1878, 46.

a Ten specimens.

$b$ Four specimens.

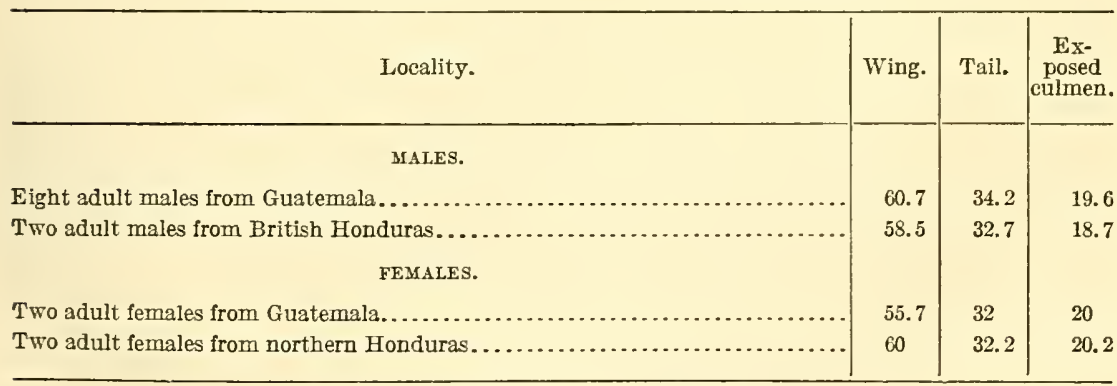


Uranomitra cyanocephala Eutor, Classif. and Synop. Troch., 1879, 197, part.Ridgway, Proc. U. S. Nat. Mus., xiv, 1891, 471 (San Pedro Sula, Honduras). Amazilia cyanocephala Bangs, Bull. Mus. Comp. Zool., xxxix, 1903, 144 (Yaruca, Honduras; crit.).

Cyanomyia guatemalensis Gould, Introd. Troch., oct. ed., 1861, 148 (Guatemala; coll. J. Gould).--Sclater, Cat. Am. Birds, 1862, 312 (Cobán, Guatemala).Salvin, Cat. Birds Brit. Mus., xvi, 1892, 198, 660 (southern pine ridge, Brit. Honduras; Poctún, Cobán, mts. of Chilasco, Panajachál, and Dueñas, Guatemala; Matagalpa, Nicaragua).-Mulsant, Ann. Soc. Linn. Lyon, xxii, 1876, 31.-Lawrence, Proc. Bost. Soc. N. H., xiv, 1871, 284 (Tres Marias Islands; error).-Salvin and Godman, Biol. Centr.-Am., Aves, ii. 1892, 291.

Cyanomia guatemalensis Lawrence, Mem. Bost. Soc. N. H., ii, 1874, 292 ("Tres Marias;" error).

Cyanomya guatemalensis Boucard, Notes quelques Troch., 1873, 9 (Vera Paz, Guatemala); Anal. Soc. Linn. Lyon, xx, 1874, 277 (do.).

[Cyanomya] guatemalensis Mulsant, Ann. Soc. Linn. Lyon, n. s., xxii, 1876, 204. C[yanomyia] guatemalensis SAlvin, Ibis, 1866, 204.

U[ranomitra] guatemalensis HeIne, Journ. für Orn., 1863, 195.

Uranomitra guatemalensis Berlepsch, Proc. U. S. Nat. Mus., xi, 1888, 562 (as to alleged Tres Marias specimen).

[Uranomitra] cyanocephala guatemalensis Simon, Cat. Troch., 1897, 14.

[Polytmus] guatemalensis Gray, Hand-list, i, 1869, 133, no. 1714.

A[mazilia] cyanocephala guatemalensis Hantert, Das Tierreich, Troch., 1900, 62 (monogr.).

[Amazilia] guatemalensis SHARPE, Hand-list, ii, 1900, 109.

\section{AMIZILIS MICRORHYNCHA (Elliot).}

\section{SMALL-BILLED AZURE-CROWN.}

Similar to $A$. cyanocephala guatemalensis, but bill conspicuously smaller, and tail, as well as sides and under tail-coverts, more reddish bronze.

Adult? ${ }^{a}$-Pileum bright metallic blue, inclining, in places, to violetblue and greenish blue; hindneck, upper back, sides of neck, and auricular region metallic bronze-green; wing-coverts, scapulars, and lower back rather dull metallic greenish bronze; rump and upper tailcoverts olive, faintly glossed with bronze, the feathers narrowly and indistinctly tipped with dull brownish buffy; tail metallic bronze, tinged with coppery bronze; remiges dusky, faintly glossed with purplish; malar region, chin, throat, most of chest, median line of breast, and abdomen, white; sides and flanks broccoli brown or drab glossed with coppery bronze; under tail-coverts pale dull coppery bronze margined with dull white; maxilla dull black, mandible pale brownish (reddish in life?) basally, dusky terminally; iris dark brown; feet brownish (in dried skin); length (skin), 88 ; wing, 58 ; tail, 28; culmen, $13.5 .^{b}$

$a$ The specimen described shows traces of immaturity.

$b$ One specimen (tyre of the species). 
Honduras.

Cyanomyia microrhyncha Ellot, Ibis, 3d ser., vi, July, 1876, 316 (Ionduras?; coll. D. G. Elliot).-Salvin, Cat. Birds Brit. Mus., xvi, 1892, 197.-SALvin and Gonmax, Biol. Centr.-Am., Aves, ii, 1592, 290.-Boucard, Gen. Ium. Birds, 1894, 165.

Uranomitra microrhyncha Elliot, Classif. and Synop. 'Troch., 1879, 197.-Sirarpe, in Gould's Mon. Troch., Suppl.,18S5.

Cyanomya microrhyncha Mulsant and Verreaux, Hist. Nat. Ois.-Mouch., iv, livr. 3, 1878, 172; Suppl. plates, pl. 53.

A[gyrtria] microrhyncha Hantent, Das Tierreich, Troch., 1900, 49.

[Agyrtria] microrhyncha SHarpe, Hand-list, ii, 1900, 106.

[Agyrtria] microrrhyncha Smos, Cat. Troch., 1897, 11.

\section{AMIZILIS SALVINI (Brewster).}

SALVIN'S AZURE-CROWN.

Adult male.-Pileum bright metallic blue, more greenish posteriorly, the sides of head (behind and beneath eyes) and sides of neck also bright metallic blue; hindneck, upper back, anterior scapulars, and wing-coverts metallic bluish green; lower back, posterior scapulars, and rump dull grayish green, the feathers showing pale brownish gray margins in certain lights; upper tail-coverts and tail deeper metallic green, inclining to bottle green, with a faint bronzy cast, the outer pair of rectrices with a rather indistinct darker subterminal bar and more distinct broad brownish gray tip; remiges dusky, very faintly glossed with violet; chin, throat, chest (except laterally), median line of breast, abdomen, thighs, anal region, and under tailcoverts immaculate white; sides of throat and chest spotted with bright metallic blue, the terminal or subterminal portion of some of the feathers being of this color; sides of breast nearly uniform metallic bluish green (like hindneck), the sides and flanks purer green, the feathers with indistinct pale grayish or grayish white margins; lores dusky; maxilla blackish brown, paler (reddish in life) basally; mandible paler (reddish flesh color in life) with dusky tip; iris dark brown; length (skin), 91.5; wing, 53.8; tail, 33; culmen, 22.8. ${ }^{a}$

Young female. ${ }^{b}$-Pileum dull metallic smalt blue, passing into greenish blue or bluish green on hindneck and upper back, this into greenish bronze on lower back, rump, and upper tail-coverts, the feathers all margined terminally with pale buffy brown or brownish buff, these buffy margins becoming much broader and more conspicuous on rump and upper tail-coverts; wing-coverts deep grayish brown or brownish slatc faintly glossed with greenish bronze and very narrowly tipped with paler; remiges similar but faintly glossed

a One specimen (the type: no. 24125, coll. William Brewster; Nacosari, Sonora, March 31, 1887; J. C. Cahoon).

b No. 13964, coll. Louis B. Bishop, Palmerlee, Cochise County, Arizona, July 4,1905 . 
with purplish; rectrices greenish bronze, indistinctly tipped with pale buffy grayish and narrowly margined terminally with dull whitish; sides of head and neck dull metallic bluish, the feathers with narrow pale brownish buffy margins; under parts, including malar region, white, the sides of chest tinged with metallic greenish blue and spotted with pale olive, the median portion of under tailcoverts tinged with pale grayish or olive; maxilla dusky, more brownish basally; mandible whitish (in dried skin) with tip dusky; length (before skinning), 109; extent (before skinning), 139: wing, 54; tail, 30; exposed culmen, 21.5.

Northwestern Mexico, in State of Sonora (Nacosari) and southern Arizona (Palmerlee, Cochise County).

Cyanomyia salvini Brewster, Auk, x, No. 3, July, 1893, 214 (Nacosari, Sonora; coll. W. Brewster).

Uranomitra salvini Boucard, The Hum. Bird, v, part iv, Dec., 1895, 400 (Sonora).-Bisнop, Auk, xxiii, 1906, 337 (Palmerlee, Chochise Co., Arizona, 1 spec., July 4, 1905; descr. young female).-AMerican Ornithologists' Union Committee, Auk, xxv, 1908, 348 (Arizona); Check List, 3d ed., 1910, 206.

A[mazilia] salvini Hartert, Das Tierreich, Troch., 1900, 62 (monogr.).

[Amazilia] salvini SHARPE, Hand-list, ii, 1900, 109.

[Agyrtria] salvini Simon, Cat. Troch., 1897, 11.

Genus AGYRTRIA Reichenbach.

Agyrtria Reichenbach, Aufz. der Colibr., 1854, 10; Troch. Enum., 1855, 7. (Type, Ornismya brevirostris Lesson.)

Leucodora Mulsant, Hist. Nat. Ois.-Mouch., i, 1873, 309. (Type, Trochilus norrisii Bourcier.)

[Agyrtria] $\beta$. Uranomitra Reichenbach, Journ. für Orn., 1853, extra-heft, 1854 (Aufz. der Colibr.), 10. (Type, Trochilus franciæ Bourcier and Mulsant.)

Cyanomyia Bonaparte, Rev. et Mag. de Zool., vi, part 2, 1854, 254. (New name for Uranomitra Reichenbach.)

Cyanomya (emendation) Mulsant and Verreaux, Hist. Nat. Ois.-Mouch., iv, livr. 3, 1878, 169.

Leucolia Mulsant and Verreaux, Mém. Soc. Imp. Sci. Nat. Cherb., xii, (sér. 2, tom. ii), 1866, 175; Hist. Nat. Ois.-Mouch., i, 1874, 211. (Type, ?)

Medium-sized to rather small Trochilidæ (length about 75-95 mm.) with straight, depressed bill longer than head, nasal operculum with outer and anterior half exposed, tail more or less emarginate, abdomen (sometimes whole of median under parts) white, and tail never black, stecl blue, nor purplish bronze (usually olive-bronze, with subterminal portion darker).

Bill straight, decidedly broader than deep, slightly to moderately expanded basally, the exposed culmen slightly less than one-third to nearly one-half as long as wing, the interramal space narrow and relatively short; nasal operculum rather thin (not tumid), with rather less than anterior and outer halves exposed; wing normal (tenth primary decidedly longer than ninth and none of the pri- 
maries attenuated or otherwise modified); tail slightly more than half to two-thirds as long as wing, shallowly to deeply emarginate, the lateral reetrices sometimes slightly narrowed terminally; tarsi feathered; outer toe nearly as long as middle toe, the inner decidedly shorter.

Coloration.-Above metallic green or bronze-green, the pileum usually darker and duller, but sometimes brilliant metallic green or blue; tail olive-bronzy, sometimes with an indistinct subterminal band of darker; under parts, except sides, varying from wholly white to almost entirely metallic green, but always with some white on abdomen. Sexes alike.

Range.-Southern Mexico to Peru, Bolivia, Brazil, and Cayenne. (About twenty-five species, mostly South American.)

KEY TO THE SPECIES OF AGYRTRIA.

a. Under parts mostly white.

b. Pileum dull metallic green or bronze; maxilla pale with dusky tip; sides and flanks white slightly mixed on outer portion with metallic green; under tailcoverts white. (Southeastern Mexico to Costa Rica.)

Agyrtria candida (p. 432).

bb. Pileum brilliant metallic green (emerald green); mandible black or dusky; sides and flanks metallic green; under tail-coverts light brownish gray margined with white. (Trinidád and Venezuela.)

Agyrtria chionopectus (extralimital). ${ }^{a}$

aa. Under parts mostly metallic green.

b. Rectrices (except middle pair) bronze crossed by a subterminal band of dusky and tipped with grayish; throat and chest metallic bluish green changing to greenish blue. (Honduras?).......................... . . . . . . .

bb. Rectrices (except middle pair) mostly blackish; throat and chest metallic yellowish green. (Venezuela and Trinidad to lower Amazon Valley.)

Agyrtria viridissima (extralimital). $b$

a Thaumatias chionopectus Gould, Mon. Troch., v, Sept., 1859, pl. 293 (Trinidad).Polytmus chionopectus Léotaud, Ois. Trinidad, 1866, 140.-Leucolia chionopectus Mulsant and Verreaux, Classif. Troch., 1866, 31.-A[gyrtria] niveipectus Cabanis and Heine, Mus. Hein., iii, 1860, 33, footnote (new name for T. chionopectus).-Agyrtria niveipectus Elliot, Classif. and Synop. Troch., 1879, 202; Salvin, Cat. Birds Brit. Mus., xvi, 1892, 180.-A[gyrtria] chionopectus (typica) Hartert, Das Tierreich, Troch., 1900, 42.-Leucolia niveipectus Mulsant and Verreaux, Hist. Nat. Ois.-Mouch., i, 1874, 227; iv, 1878, 173.

In the collection of the Museum of Comparative Zoology are four specimens of this species labeled "Grenada, W. I. Peter Gellineau." As these are of the well-known "make" of Trinidád "trade" skins, and the species has not been recorded from Grenada, I conclude that a wrong locality has been assigned the specimens in question.

$b$ (?) Trochilus maculatus Vieillot, Ois. Dor., i, 1801, 87, 117, pl. 44; Nouv. Dict. d'Hist. Nat., vii, 1817, 361.-_ Agyrtria maculata Maynard, Birds E. Mass., 1870, 128 (Cambridge, Massachusetts).-Ornismya viridissima Lesson, Hist. Nat. Ois.-Mouch., 1829, pp. xxxiv, 207, pl. 75 ("Brésil").-Trochilus viridissimus Lesson, Ind. Gen. et Synop. Troch., 1832, p. xxvi.-(?) Thaumatias viridissimus Burmeister, Syst. Ueb. Th. Bras., ii, 1856, 344.-Agyrtria viridissima Salvin, Cat. Birds Brit. Mus., xvi, 1892, 186.A[gyrtria] viridissima Hartert, Das Tierreich, Troch., 1900, 45.-[Chlorestes] malvina Reichenbach, Aufz. der Colibr., 1854, 7; Troch. Enum., 1855, 4, pl. 696, figs. 4550, 4551.-A[gyrtria] malvinae Cabanis and Heine, Mus. Hein., iii, 1860, 33, footnote.-[Chlorestes] $\beta$. Saucerottia viridipectus Reichenbach, Aufz. der Colibr., 1854, 


\section{AGYRTRIA CANDIDA (Bourcier and Mulsant).}

\section{WHITE-BEILIED EMERALD.}

Adult male.-Above metallic bronze or bronze-green, the back usually more decidedly green or greenish; tail metallic bronze crossed (except on middle rectrices) by a broad subterminal band of dark purplish bronze or blackish glossed with purplish bronze, the terminal portion of two outer pairs of rectrices dull brownish gray; remiges dark brownish slate or dusky, faintly glossed with violaceous; under parts white, overlaid or spotted with metallic bronze-green, from malar region to flanks, inclusive, the under tail-coverts usually faintly tinged with pale brownish gray; maxilla dull black; mandible pale brownish (carmine or pink in life), with dusky tip; feet dusky; length (skins), 81-92 (86); wing, 49-52.5 (51.1); tail, 27.5-31 (28.9); culmen, $15-17.5(16.1){ }^{a}$

Adult female.-Very similar to the adult male and probably not always distinguishable, but usually (?) with terminal portion of outer rectrices paler grayish; ${ }^{b}$ length (skins), 80-91 (86); wing, 48.5-52 (49.9); tail, 27-30.5 (28.3); culmen, 16-19 (17.3). ${ }^{c}$

7; Troch. Enum., 1855, 4, 702, figs. 4573, 4574.-Thaumatias linnæi (not of Bonaparte, 1854) Gould, Mon. Troch., v, 1856, pl. 302; Introd. Troch., oct. ed., 1861, 153.-Leucochloris linnæi Mulsant and Verreaux, Classif. Troch., 1866, 32.-[Polytmus] linnæi Gray, Hand-list, i, 1869, 128, no. 1623.-[Agyrtria] linnæi Coues, Key N. Am. Birds, 1872, 186.-Thaumatias tobaci (not Trochilus tobaci Gmelin) Elliot, Ibis, 1878, 49.-Agyrtria tobaci Elliot, Classif. and Synop. Troch., 1879, 206; Ridgway, Rep. U. S. Nat. Mus. for 1890 (1891), 382.

This species has been recorded as a North American bird on account of its alleged accidental occurrence at Cambridge, Massachusetts; but the circumstances, as related, strongly indicate substitution (perhaps accidental), by the taxidermist, of a trade skin of this species for a specimen of the common Archilochus colubris.

$a$ Twenty-three specimens.

$b$ According to the material examined, the majority of adult females are absolutely similar in coloration to adult males.

c Twelve specimens.

\begin{tabular}{|c|c|c|c|}
\hline Locality. & Wing. & Tail. & $\begin{array}{c}\text { Ex- } \\
\text { posed } \\
\text { culmen. }\end{array}$ \\
\hline MaLes. & & & \\
\hline Four adult males from Vera Cruz (3) and Puebla (1)................ & 51.5 & 29.7 & 17 \\
\hline 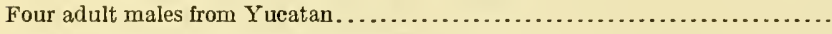 & 50.4 & 27.9 & 15.7 \\
\hline One adult male from British Honduras.......... & 50.5 & 28.5 & 15.5 \\
\hline Four adult males from Honduras................ & 51.2 & 28.2 & 16. 1 \\
\hline Nine adult males from Guatemala ................ & 51.3 & 29.5 & 15.9 \\
\hline One adult male from Costa Rica............... & & & 15.5 \\
\hline FEMALES. & & & \\
\hline Five adult females from Vera Cruz (3) and Oaxaca (2). & 50.8 & 28.5 & 18 \\
\hline One adult female from Yucatan.............. & 50 & 29 & 17 \\
\hline One adult female from British IIonduras.... & 50.5 & 28 & 17 \\
\hline Three adult females from Honduras........... & 49 & 27.8 & 17.3 \\
\hline One arlult female from Guatemala...... & 48.5 & 29 & 16 \\
\hline One adult female from Costa Rica...... & 49 & 27.5 & 16 \\
\hline
\end{tabular}


Young.-Similar to adults, but fenthers of pileum, rump, and upper tail-coverts narrowly and indistinctly tipped with brownish.

Sontheastern Mexico, in States of Vera Cruz (Cordóva; Orizaba; Misantla; Nochiapa; Playa Vicente; Buena Vista; Pasa Nueva; Sochiapa), Oaxaca (Guichicovi; Chimalapa; mountains near Santo Domingo), Tabasco (Teapa), Chiapas (Palenque; Ocuilapa), Campeche (Canasayit), and Yucatan (Temax; La Vega), and southward through Guatemala (Guatemala City; Cobán; Choctúm; Cobán to Chiséc; Gualán; Los Amates, Yzabál), British Honduras (Belize; Corosál; Cayo; Southern Pine Ridge), Honduras (Truxillo; Santa Ana; San Pedro Sula; Potrerillos) and Nicaragua (Matagalpa; La Libertád and Santo Domingo, Chontales), to western Costa Rica (San Pedro del Mojón; Coronado de Térraba).

T[rochilus] candidus Bourcier and Mulsant, Ann. Soc. Phys. et Nat., ix, 1846, 326 (Cobán, Guatemala); Rev. Zool., 1846, 319.

P[olytmus] candidus Gray, Gen. Birds, i, Dec., 1848, 108.

[Polytmus] candidus Gray, Hand-list, i, 1869, 128, no. 1617.

[Thaumatias] candidus Bonaparte, Consp. Av., i, 1850, 78.-Sclater and Salvin, Nom. Av. Neotr., 1873, 91.

Thaumatias candidus Sclater, Proc. Zool. Soc. Lond., 1856, 287 (Mexico).Sclater and Salvin, Ibis, 1859, 130 (Guatemala).-Gould, Mon. Troch., v, 1860, pl. 292; Introd. Troch., oct. ed., 1861, 151.-TAYLOR, Ibis, 1860, 116 (Honduras).-D'OCA, La Naturaleza, iii, 1875, 206; Troq. de Mex., 1875, 48, pl. (10), fig. 36.-Sumichrast, La Naturaleza, v, 1881, 250 (Guichicovi, Oaxaca).-Sarchez, Anal. Mus. Nac. Mex., i, 1877, 96 (s. e. Mexico).-BouCard, Liste Ois. récol. Guat., 1878, 46.-Lawrence, Bull. U. S. Nat. Mus., iv, 1876, 33 (Guichicovi, Oaxaca).-Ellot, Ibis, 1878, 43 (Mexico to Honduras; crit.).

[Thaumantias] candidus Bonaparte, Rev. et Mag. de Zool., 1854, 255.

Thaumantias candidus Sclater, Proc. Zool. Soc. Lond., 1858, 358 (near Potrerillos, Honduras); 1859, 386 (Playa Vicente, Vera Cruz).-Salvin and Sclater, Ibis, 1860, 40 (Yzabál, e. Guatemala).-Salvin, Ibis, 1859, 467 (Yzabál, e. Guatemala); 1860, 197, 270 (Cobán and Yzabál, Guatemala; habits); 1872, 313, 320 (Chontales, Nicaragua).

A[gyrtria] candida Cabanis and Heine, Mus. Hein., iii, 1860, 33, footnote (Guatemala).-Heine, Journ. für Orn., 1863, 183.-Hartert, Das Tierreich, Troch., 1900, 46 (monogr.).

Agyrtria candida Sclater, Cat. Am. Birds, 1862, 312 (Cobán, Guatemala).-Eluiot, Classif. and Synop. Troch., 1879, 203.-Zeledón, Cat. Aves de Costa Rica, 1882, 21; Anal. Mus. Nac. Costa Rica, i, 1887, 122 (Guatemala).-Ridgway, Rep. U. S. Nat. Mus. for 1890 (1891), 382.-Salvin, Cat. Birds Brit. Mus., xvi, 1892, 190, 660 (Misantla and Xochiapa, Vera Cruz; Chimalapa, Oaxaca; Temáx, Yucatan; Belize, Corosál, Cayo, and southern pine ridge, Brit. Honduras; Honduras; Cobán and Choctúm, Guatemala; Matagalpa, La Libertád, and Santo Domingo, Nicaragua).-Salvin and Godman, Biol. Centr.Am., Aves, ii, 1892, 285 (Truxillo and Santa Ana, Honduras; Chontales, etc., Nicaragua, etc.).-LANTz, Trans. Kans. Ac. Sci. for 1896-97 (1899), 221 (Cayo, Brit. Honduras).-Dearborn, Pub. 125, Field Mus. N. H., 1907, 97 (Los Amates, e. Guatemala).-CArrizer, Ann. Carnegie Mus., vi, 1910, 523 (San Pedro del Mojón, Costa Rica).

$81255^{\circ}-$ Bull. $50-11-28$ 
[Agyrtria] candida Sharpe, Hand-list, ii, 1900, 105.

Leucolia candida Mulsant and Verreaux, Classif. Troch., 1866, 31; Hist. Nat. Ois.-Mouch., i, livr. 3, 1874, 233, pl. 21; iv, livr. 3, 1878, 174.-Boucard, Notes quelques Troch., 1873, 9 (Córdova, Vera Cruz; Vera Paz, Guatemala; habits); Ann. Soc. Linn. Lyon, xx, 1874, 277 (do.).

Leucollia candida Mulsant and Verreaux, Hist. Nat. Ois.-Mouch., Suppl., 1878?, pl. 54 .

[Leucolia] candida Mulsant, Ann. Soc. Linn. Lyon, n. s., xxii, 1876, 205.

[Agyrtria] margaritacea (not Trochilus margaritaceus Gmelin) REICHENBACH, Troch. Enum., 1855, 7, pl. 758, figs. 4747, 4748.

(?) Ornismyia senex Lesson, Rev. Zool., 1838, 315 (=albino?, according to Elliot).

\section{AGYRTRIA LUCIE (Lawrence).}

LUCY'S EMERALD.

Adult (male?).-Above metallic bronze-green, much duller on pileum, purer green on rump; upper tail-coverts and tail greenish bronze, the rectrices (except middle pair) crossed by a broad subterminal band of dusky and tipped with bronzy grayish; remiges dusky, faintly glossed with purplish; chin, throat, and chest bright metallic bluish emerald green, changing to greenish blue, the feathers narrowly margined with whitish and with a subterminal bar of the same, the basal portion grayish; sides and flanks rather dull bronzegreenish; abdomen, anal region, and femoral tufts white; under tailcoverts light brownish gray centrally, broadly margined with dull white; maxilla dull black; mandible pale brownish (pinkish or reddish in life), dusky at tip; feet dusky (in dried skin); length (skin), 95; wing, 55; tail, 34; culmen, 22.

"Honduras."

Thaumatias luciæ Lawrence, Proc. Ac. Nat. Sci. Philad., 1867, 233 (Honduras; coll. Am. Mus. Nat. Hist.).-Mulsant and Verreaux, Hist. Nat. Ois.-Mouch i, livr. 3, 1874, 241 (Honduras).-Elliot, Ibis, 1878, 52 (crit.).

[Thaumatias] luciae Mulsant, Ann. Soc. Linn. Lyon, n. s., xxii, 1876, 205.

[Polytmus] luciæ Gray, Hand-list, i, 1869, 128, no. 1636.

Agyrtria luciæ Elliot, Classif. and Synop. Troch., 1879, 208.-Ridgway, Rep.

U. S. Nat. Mus., 1890 (1891), 382.-Salvin, Cat. Birds Brit. Mus., xvi, 1892, 188.-Salvin and Godman, Biol. Centr.-Am., Aves, ii, 1896, 285.

Agyrtria (?) luciae Boucard, Gen. Hum. Birds, 1894, 153.

A[gyrtria] luciae Hartert, Das Tierreich, Troch., 1900, 46 (monogr.).

[Agyrtria] luciæ SHARPE, Hand-list, ii, 1900, 105.

\section{Genus SAUCEROTTIA Bonaparte.}

Saucerottia Bonaparte, Consp. Av., i, 1849, 77; Compt. Rend., xxx, 1850, 381. (Type, Trochilus saucerottii Bourcier and Delattre.)

Saucerottea (emendation) Simon, Cat. Troch., 1897, 12.-Hartert, Das Tierreich, Troch., 1900, 51.

Hemithylaca a Cabanis and Heine, Mus. Hein., iii, March, 1860, 37. (Type, Trochilus nivcoventer Gould.)

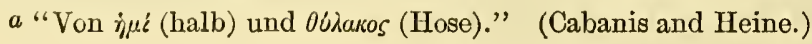


Hemistilbon a Gouln, Introd. Troch., oct. ed., 1861, 149. ('Type, Amazilia ocai Gould.)

Erythronota b Gould, Introd. Troch,, oct. ed., 1861, 160. (Type, Ornismya erythronota I.esson.)

Eratina c Heıne, Journ. für Orn., xi, May, 1863, 190. ('Type, Trochilus iodurus Saucerotte.)

Eratopis d II elne, Journ. für Orn., xi, May, 1863, 191. (Type, Trochilus cyanifrons Bourcier.)

Lramia e Hewne, Journ. für Orn., xi, May, 1863, 191. (Type, Erythronota? elegans Grould.)

Ariana Mulsant and Verreaux, Mém. Soc. Imp. Sci. Nat. Cherb., xii (sér. 2, ii), 1866, 180 (Classif. Troch., 1866, 35). (Type, Trochilus niveoventer Gould.)

Lisoria Mílsant, Ann. Soc. Linn. Lyon, n. s., xxii, 1876, 207 (Cat. Ois.-Mouch., 1876, 11). (Type, Hemithylaca warszewiczi Cabanis and Heine.)

Leneodora Mulsant, Ann. Soc. Linn. Lyon, n. s., xxii, 1876, 206. (Type, Trochilus eduard Bourcier and Delattre.)-Mulsant and Verreaux, Hist. Nat. Ois.-Mfouch., i, 1874, 309.

Medium-sized to rather small Trochilidæ (length about 85-95 mm.) closely related to Amizilis and Agyrtria, but differing (especially from the former) in narrower bill, scarcely widened at base, thinner (less tumid) and less exposed nasal operculi, and (usually) more deeply emarginate, black or dark steel blue (but sometimes bronzy) tail.

Bill slightly to decidedly longer than head, straight or very faintly decurred, rather slender, narrow (not conspicuously wider than deep), not noticeably widened basally; nasal operculi thin, with only outer and anterior halres exposed; wing normal; tail slightly to decidedly more than half as long as wing, more or less deeply emarginate, with outermost pair of rectrices usually longest, but sometimes shorter than next pair; tarsi feathered; outer toe about equal to middle toe, the inner toe slightly shorter, or lateral toes about equal and both slightly shorter than middle toe.

Coloration.-Above rather dark metallic green, the upper tailcoverts or rump (or both) sometimes coppery or reddish bronze, the pileum sometimes (in one species) dark metallic blue; tail usually dark steel blue or blackish, sometimes bronzy; under parts (except under tail-coverts) metallic green, the femoral tufts and leg feathers (sometimes whole abdomen) white. Sexes alike.

Range.-Mexico to Ecuadór, Venezuela, Tobago, and Granada. (About twenty-two species.)

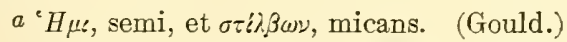

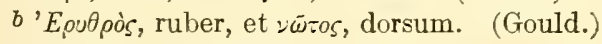

$c$ żoarsuos. (Heine.)

$d$ "Epazw̄as (lieblichen Blick's)." (Heine.)

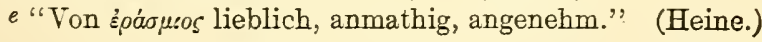


KEX TO THE SPECIES AND SUBSPECIES OF SAUCEROTTLA.

a. Remiges wholly blackish.

$b$. Abdomen not white.

c. Tail blue-black or dark steel blue.

d. Pileum dark metallic blue. (Colombia.)

Saucerottia cyanifrons (extralimital). $a$

$d d$. Pileum metallic green or green and bronze (more or less bright).

$e$. Under tail-coverts dark metallic blue, or dusky grayish glossed with blue, margined with pale grayish.

f. Smaller (wing 50-56.5, tail 29-32.5, culmen 18-20.5); bill straighter; green of upper parts less bluish. (Saucerottia sophix.)

g. Rump more bronzy, passing into coppery or purplish bronze posteriorly. (Costa Rica and Nicaragua.)

Saucerottia sophiæ sophiæ (p. 439).

gg. Rump wholly green.

$h$. Under tail-coverts dusky grayish glossed with blue. (Northwestern Colombia.)

Saucerottia sophiæ saucerrottei (extralimital). $b$

$h$. Under tail-coverts dark steel blue centrally.

$i$. Coloration darker green (both above and below); wing averaging shorter. (Eastern Colombia.)

Saucerottia sophiæ warscewiczi (extralimital).c

a T[rochilus] cyanifrons Bourcier, Rev. Zool., vi, April, 1843, 100 (Ybagué, Colombia); Bourcier and Mulsant, Ann. Sci. Phys. et Nat. d'Agric., etc., Lyon, vi, 1843, 42.-[Thalurania] cyanifrons Bonaparte, Consp. Av., i, 1850, 77.-[Chlorestes, $\gamma$. Saucerottia] cyanifrons Reichenbach, Aufz. der Colibr., 1854, 8.-Saucerottia cyanifrons Bonaparte, Rev. et Mag. de Zool., 1854, 255; Gould, Mon. Troch., v, 1866, pl. 323.S[aucerottea] cyanifrons Hartert, Das Tierreich, Troch., 1900, 52 (monogr.).-Chlorestes cyanifrons Reichenbach, Troch. Enum., 1855, 4, pl. 701, figs. 4571, 4572.$H$ [emithylaca] cyanifrons Cabanis and Heine, Mus. Hein., iii, 1860, 39 ("Veragua").Eratopis cyanifrons Heine, Journ. für Orn., 1863, 191, in text.-Ariana cyanifrons Mulsant and Verreaux, Classif. Troch., 1866, 36; Hist. Nat. Ois.-Mouch., i, 1874, 332; iv, 1877, 185.-[Polytmus] cyanifrons Gray, Hand-list, i, 1869, 131, no. 1669.Amazilia cyanifrons Elliot, Classif. and Synop. Troch., 1879, 225; Salvin, Cat. Birds Brit. Mus., xvi, 1892, 227.-Pyrrhophaena cyaneifrons Berlepsch, Journ. für Orn., 1887,332 .

b T[rochilus] saucerrottei Delattre and Bourcier, Rev. Zool., ix, Sept. (=Nov.), 1846, 311 (Cali, n. w. Colombia; coll. Delattre).-H[emithylaca] sauceroitei Cabanis and Heine, Mus. Hein., iii, 1860, 38, footnote.-Ariana saucerottei Mulsant and Verreaux, Classif. Troch., 1866, 36; Hist. Nat. Ois.-Mouch., i, 1874, index; iv, 1877, 185.Amazilia saucerottii Elliot, Classif. and Synop. Troch., 1879, 225; Salvin, Cat. Birds Brit. Mus., xvi, 1892, 223.-Saucerottia saucerottii Eudes-Deslongchamps, Ann. Mus. Caen, i, 1880, 424.-Pyrrhophaena saucerottei Berlepsch, Journ. für Orn., 1887, 332.Saucerottia typica Bonaparte, Consp. Av., i, 1850, 77; Gould, Introd. Troch., 1861, 162.-Chlorestes typica Reichenbach, Troch. Enum., 1855, 4, pl. 701, figs. 4569, 4570.-Eryihronota typica Gould, Mon. Troch., v, 1861, pl. 321.-Erythronota saucerottei Mulsant and Verreaux, Hist. Nat. Ois.-Mouch., i, 1874, 331.

c H[emithylaca] warscewiczi Cabanis and Heine, Mus. Hein., iii, March, 1860, 38 ("Veragua;" coll. Heine Mus.).-Saucerottia warszewiczi Gould, Introd. Troch., 1861, 163.-Ariana warszwiczi Mulsant and Verreaux, Hist. Nat. Ois.-Mouch., i, 1874, 327; iv, 1877, 185.-[Polytmus] warsewiczi Gray, Hand-list, i, 1869, 131, no. 1671.-Amazilia warszewiczi Elliot, Classif. and Synop. Troch., 1879, 225.-Amazilia warszewiezi Salvin, Cat. Birds Brit. Mus., xvi, 1892, 222, part.-Amizilis warszewiezi Oberholser, Proc. Ac. Nat. Sci. Phila., 1899, 208.-S[aucerottea] warscewiczi (typica) Hartert, Das Tierreich, Troch., 1900, 52. 
ii. Coloration lighter (more yellowish) green; wing averaging longer. (Andes of Venezuela.)

Saucerottia sophiæ braccata (extralimital). $a$ f. Larger (wing 56, tail 43.3, culmen 25.4); bill more curved; green of upper parts more bluish. (Northwestern Costa Rica.)

Saucerottia alfaroana (p. 441).

ce. Under tail-coverts bronzy or chestnut. (Saucerottia tobaci.)

$f$. Tail black or dull violet-black.

$g$. Above mostly green or bronze-green, the upper tail-coverts purplish bronze; larger: male with wing 55.5, tail 33, culmen 19; female, wing 54-54.5 (54.2), tail 32-32.5 (32.2), culmen 18-19.5 (18.8). (Island of Tobago.)....... Saucerottia tobaci tobaci (extralimital). $b$

$g g$. Above with whole rump coppery bronze, the upper tail-coverts sometimes light chestnut; smaller: male with wing 50-51 (50.3), tail 30-30.5 (30.2), culmen 16.5-18 (17.2); female, wing 48-50 (49.3), tail 29-30 (29.3), culmen 18-19.5 (18.8). (Island of Trinidád.)........... Saucerottia tobaci erythronota (extralimital).c

ff. Tail bright blue-black or dark steel blue.

$g$. Wing-coverts, back, and rump green or bronze-green; under tailcoverts usually bronze centrally; smaller: male with wing 49-51 (50.2), tail 29-31 (29.7), culmen 17-18 (17.7); female, wing 48-49 (48.8), tail 28-29 (28.4), culmen 18-19 (18.4). (Coast district of Venezuela.)............ Saucerottia tobaci feliciæ (extralimital). ${ }^{d}$

a H[emithylaca] braccata Heine, Journ. für Orn., May, 1863, 193 (Mérida, Venezuela; coll. Berlin Mus.).-H[emithylaca] caligata (not Trochilus caligatus Gould) Cabanis and Heine, Mus. Hein., iii, 1860, 39 (Mérida, Venezuela).--S[aucerottea] warscewiczi braccata Hartert, Das Tierreich, Troch., 1900, 52 (monogr.).

$b$ (?) [Trochilus] tobaci Gmelin, Syst. Nat., i, pt. 1, 1788, 498 (based on Tobago Humming-bird Latham, Synopsis, i, pt. 2, 781; Tobago).-Amazilia tobaci Salvin, Cat. Birds Brit. Mus., xvi, 1892, 226.-Trochilus erythronotus (not Ornismya erythronotos Lesson) Jardine, Ann. and Mag. N. H., xx, 1847, 374 (Tobago).-Saucerottia wellsi Boucard, The Hum. Bird, iii, pt. i, March, 1893, 8 ("Grenada;" coll. A. Boucard); Dalmas, Bull. Soc. Zool. France, xiii, 1900, 142 (Tobago; crit.).-S[aucerottea] tobaci (typica) Hartert, Das Tierreich, Troch., 1900, 55.-Amizilis tobaci Oberholser, Proc. Ac. Nat. Sci. Phila., 1899, 208.

c Ornismya erythronotos Lesson, Hist. Nat. Ois.-Mouch., 1829, pp. xxxii, 181, pl. 61 ("Brésil").-P[olytmus] erythronotus Gray, Gen. Birds, i, 1848, 108.-[Polytmus] erythronotos Gray, Hand-list, i, 1869, 132, no. 1695.-Polytmus erythronotus Léotaud, Ois. Trinidad, 1866, 137.-[Saucerottia] erythronota Bonaparte, Consp. Av., i, 1850, 77.-Chlorestes erythronota Reichenbach, Troch. Enum., 1855, 4, pl. 699, figs. 4562, 4563.-H[emithylaca] erythronota Cabanis and Heine, Mus. Hein., iii, 1860, 37.Ariana erythronota Mulsant and Verreaux, Classif. Troch., 1866, 36; Hist. Nat. Ois.Mouch., i, 1874, 323.-Amazilia erythronota Elliot, Classif. and Synop. Troch., 1879, 224; Salvin, Cat. Birds Brit. Mus., xvi, 1892, 225.-Amizilis tobaci erythronota Oberholser, Proc. Ac. Nat. Sci. Phila., June 2, 1899, 208. -S[aucerottea] tobaci erythronota Hartert, Das Tierreich, Troch., 1900, 55 (monogr.).-Erythronota antiqua Gould, Mon. Troch., v, May, 1860, pl. 316; Introd. Troch., oct. ed., 1861, 160.

d O[rnismya] felicix Lesson, Rev. Zool., iii, March, 1840, 72 ("Ie Brésil, le district de San José;" coll. Abeillé).-[Chlorestes, ץ. Saucerottia] feliciae Reichenbach, Aufz. der Colibr., 1854, 7.-[Saucerottia] feliciæ Bonaparte, Rev. et Mag. de Zool., 1854, 255.-Chlorestes feliciæ Reichenbach, Troch. Enum., 1855, 4, pl. 697, figs. 4556, 4557.Erythronota feliciæ Gould, Mon. Troch., v, Sept., 1849, pl. 317; Introd. Troch., oct. ed., 1861, 161.- - H[emithylaca] felicix Cabanis and Heine, Mus. Hein., iii, 1860, 38.Ariana feliciæ Mulsant and Verreaux, Classif. Troch., 1866, 36; Hist. Nat. Ois.-Mouch., i, 1874, 325; iv, 1877, 185.-[Polytmus] felicix Gray, Hand-list, i, 1869, 132, no. 1696.- 
gg. Wing-coverts and back bright coppery bronze; rump and upper tail-coverts chestnut; under tail-coverts chestnut; larger: male with wing 53, tail 29.5, culmen 20; female, wing 50-51.5 (50.8), tail 29.5-31 (30.2), culmen 20.5-21.5 (20.8). (Margarita Island, Leeward group.)......... Saucerottia tobaci aliciæ (extralimital). $a$

cc. Tail not blue-black or dark steel blue.

d. Upper tail-coverts and rectrices chestnut basally; under tail-coverts chestnut. (British Guiana.)......... Saucerottia cupreicauda (extralimital). $b$

$d d$. Upper tail-coverts and tail without chestnut; under tail-coverts not chestnut.

e. Tail dark metallic violet, more purplish basally, more bluish terminally. (Central Colombia.)............. Saucerottia viridigaster (extralimital). $c$ $e e$. Tail bright metallic purplish bronze. (Central Colombia.)

Saucerottia iodura? (extralimital). $d$

Amazilia feliciæ Elliot, Classif. and Synop. Troch., 1879, 234; Salvin, Cat. Birds Brit. Mus., xvi, 1892, 226.-Amizilis tobaci felicix Oberholser, Proc. Ac. Nat. Sci. Phila., June 2, 1899, 208.-S[aucerottea] tobaci feliciae Hartert, Das Tierreich, Troch., 1900, 55 (monogr.).-Ornismya feliciana Lesson, Rev. Zool., vii, Dec., 1844, 433 ("Guayaquil;" coll. Abeillé).

a Amazilia aliciæ Richmond, Auk, xii, Oct., 1895, 368 (Margarita Island, Venezuela; coll. U. S. Nat. Mus.).-Amizitis tobaci alicix Oberholser, Proc. Ac. Nat. Sci. Phila., June 2, 1899, 208.-S[aucerottea] tobaci aliciae Hartert, Das Tierreich, Troch., 1900, 55.

b Amazilia cupreicauda Salvin and Godman, Ibis, Oct., 1884, 452 (Roraima, Brit. Guiana; coll. Salvin and Godman); Salvin, Cat. Birds Brit. Mus., xvi, 1892, 220; Sharpe, Suppl. Gould's Mon. Troch., 1887, pl. 56.-S[aucerottea] cupreicauda Hartert, Das Tierreich, Troch., 1900, 54 (monogr.).

c T[rochilus] viridigaster Bourcier, Rev. Zool., vi, April, 1843, 103 (Fusagasugá, Colombia); Bourcier and Mulsant, Ann. Sci. Phys. et Nat., etc., Lyon, vi, 1843, 42.-H[ylocharis] viridigaster Gray, Gen. Birds, i, 1848, 115.-Saucerottia viridigaster Bonaparte, Rev. et Mag. de Zool., 1854, 255.-Amazilia viridigaster Gould, Mon. Troch., v, 1860, pl. 314.-Pyrrhophæna viridigaster Gould, Introd. Troch., oct. ed., 1861, 159.-Ariana viridigaster Mulsant and Verreaux, Classif. Troch., 1866, 36; Hist. Nat. Ois.-Mouch., i, 1874, 320; iv, 1877, 185.-[Polytmus] viridigaster Gray, Handlist, i, 1869, 132, no. 1683.-[Chlorestes $\gamma$. Saucerottia] viridiventris Reichenbach, Aufz. der Colibr., 1854, 8.-Chlorestes viridiventris Reichenbach, Troch. Enum., 1855, 4, pl. 699, figs. 4564, 4565.-H[emithylaca] viridiventris Cabanis and Heine, Mus. Hein., iii, 1860, 38.-Amazilia viridiventris Sclater, Cat. Am. Birds, 1862, 315; Elliot, Classif. and Synop. Troch., 1879, 220; Salvin, Cat. Birds Brit. Mus., xvi, 1892, 219, part.-E[ratina] viridiventris Heine, Journ. für Orn., 1863, 191.-Pyrrhophaena viridiventris Berlepsch, Journ. für Orn., 1887, 332.-S[aucerottea] viridigaster Hartert, Das Tierreich, Troch., 1900, 53 (monogr.).-Saucerottia nunezi Boucard, The Hum. Bird, ii, 1892, 81 (melanistic variety).

$d$ ?[Chlorestes $\gamma$. Saucerottia] iodura ("Tr[ochilus iodur] us Sauc[erotte] 1843") Reichenbach, Aufz. der Colibr., 1854, 8 (Colombia; nomen nudum!).-?[Chlorestes] iodura Reichenbach, Troch. Enum., 1855, 4, pl. 698, figs. 4560, 4561.-?H[emithylaca] iodura Cabanis and Heine, Mus. Hein., iii, 1860, 39.-?Pyrrhophxna iodura Gould, Introd. Troch., oct. ed., 1861, 159; Mulsant and Verreaux, Hist. Nat. Ois.-Mouch., i, 1874, 299.-E[ratina] iodura Heine, Journ. für Orn., 1863, 190.-Amazilia iodura Elliot, Classif. and Synop. Troch., 1879, 223; Sharpe, Suppl. Gould's Mon. Troch., 1887; Salvin, Cat. Birds Brit. Mus., xvi, 1892, 219.

While doubtful whether the bird whose characters are given above is the true $S$. iodura, which, judging from the colored figures on which the name is based and descriptions by authors, seems more like $S$. viridigaster, I nevertheless feel sure that it can not represent an extreme variation of the latter, being much too different in coloration of the tail. I have seen but one specimen, a "Bogota" skin, in the collection of the U. S. National Museum. 
bb. Abdomen white.

c. Tail purplish black; under tail-coverts grayish. (Northwestern Colombia to southern Costa Rica.).................. Saucerottia niveoventer (p. 441).

cc. Tail metallic coppery bronze; under tail-coverts cinnamomeous. (Panama to western Ecuadór.).................... Saucerottia edwardi (p. 443).

aa. Reniges (except outer primaries) cinnamon-rufous or chestnut basally.

b. Tail dark steel blue or metallic blue-black. (Saucerottia cyanura.)

c. Secondaries cinnamon-rufous tipped with black; primaries mostly dusky glossed with purplish; general coloration lighter. (Costa Rica and Nicaragua.).......................... Saucerottia cyanura cyanura (p. 445).

$c c$. Secondaries with at least terminal half blue-black, the basal portion chestnut; primaries mostly blue-black; general coloration darker. (Guatemala and Chiapas.).................... Saucerottia cyanura guatemalæ (p. 446).

bb. Tail bronzy or partly clestnut.

c. Tail extensively chestnut basally.

d. Abdomen wholly green, like anterior under parts; middle rectrices and tips of other rectrices rich metallic purplish bronze or bronzy purple. (Guatemala and Chiapas.)...................... Saucerottia devillei (p. 447).

$d d$. Abdomen cinnamomeous or grayish; middle rectrices and tips of other rectrices duller coppery bronze or dull metallic violet. (Saucerottia beryllina.)

$e$. Middle rectrices and tips of other rectrices coppery bronze or reddish bronze; abdomen more cinnamomeous; green of upper and under parts more yellowish. (Eastern and central Mexico.)

Saucerottia beryllina beryllina (p. 449).

$e e$. Middle rectrices and tips of other rectrices purplish or violaceous bronze; abdomen more grayish; green of upper and under parts less yellowish.

(Western Mexico.)................ Saucerottia beryllina viola (p. 451).

$c c$. Tail without chestnut or with only shafts and basal portion of outer web of lateral rectrices chestnut.

d. Tail bright metallic coppery bronze; under tail-coverts pale cinnamonrufous; throat mostly green. (State of Oaxaca, southern Mexico.)

Saucerottia sumichrasti (p. 451).

dd. Tail metallic bronzy olive-green, with shafts and basal portion of outer webs of lateral rectrices chestnut; under tail-coverts pale greenish bronze; throat mostly white. (State of Vera Cruz, Mexico.)

Saucerottia ocai (p. 452).

\section{SAUCEROTTIA SOPHIF SOPHIE (Bourcier and Mulsant).}

\section{SOPHIA'S HUMMING BIRD.}

Adult male.-Above deep metallic green (nearly grass green) the lower rump more bronzy, sometimes coppery bronze or purple; upper tail-coverts and tail dark steel blue; remiges very dark brownish slate or dusky, glossed with bluish or violet; under parts bright metallic green, the feathers of chin and upper throat more or less edged or margined with grayish white, especially along median line; femoral and lumbar tufts white; under tail-coverts dark steel bluish, margined with pale grayish; maxilla dull black, mandible pale brownish or dull whitish (pink or reddish in life), blackish or dusky terminally; iris dark brown; feet dusky; length (skins), 91-97 (94); wing, 53-56.5 (55); tail, 29.5-32.5 (30.9); culmen, 18-20.5 (19.1). ${ }^{a}$ 
Adult female.-Similar to the adult male, but slightly duller, the green of throat, etc., more broken by grayish white subbasal bars and pale grayish margins to the feathers, and under tail-coverts with broader grayish margins and duller or paler bluish central areas; length (skins), 88-96 (92); wing, 50-55 (52.7); tail, 29-31 (30); culmen, $18-20.5(19.3) .^{a}$

Young.-Similar to adults, but decidedly duller in coloration, especially the under parts, and feathers of rump tipped or terminally margined with brown.

Nicaragua (San Emilis, Lake Nicaragua; boundary line between Nicaragua and Honduras, 180 miles from Pacific coast) and Costa Rica (San José; Las Cruces de Candelária; Escazú; Monte Redondo; Cartago; Tucurríqui; Bonilla; Carrillo; Cerro Santa Maria; Volcán de Miravalles; Bebedero; Barranca de Punta Arenas; Esparta; Rio Turubales; Pigres; San Miguél; San Pedro de Mojón; Tenório; Orosí; Bolsón).

Trochilus] sophiae Bourcier and Mulsant, Ann. Sci. Phys. et Nat. Lyon, ix, 1846, 318 ("Bogota"); b Rev. Zool., 1846, 316.

P[olytmus] sophiæ Gray, Gen. Birds, i, Dec., 1848, 109.

[Polytmus] sophiæ Gray, Hand-list, i, 1869, 131, no. 1670.

[Amazilius] sophiæ Bonaparte, Consp. Av., i, 1850, 78.

[Chlorestes. r. Saucerottia] sophiae Reichenbach, Aufz. der Colibr., 1854, 8.

[Saucerottia] sophia Bonaparte, Rev. et Mag. de Zool., 1854, 255.

Saucerottia sophiæ Gould, Introd. Troch., oct. ed., 1861, 162.-SCLATER, Cat. Am. Birds, 1862, 315 ("Central America").-Lawrence, Ann. Lyc. N. Y., ix, 1868, 127 (San José and Dota, Costa Rica).-Boucard, Proc. Zool. Soc. Lond., 1878, 71 (San José and Cartago, Costa Rica); (?) The Hum. Bird, v, 1895, 7 (Cali, n. w. Colombia).-Eudes-Deslongchamps, Ann. Mus. Caen, i, 1880, 425.-Carriker, Ann. Carnegie Mus., vi, 1910, 526 (Pacific slope and highlands of Costa Rica; habits).

[Saucerottia] sophiæ Sclater and Salvin, Nom. Av. Neotr., 1873, 92.

[Saucerottea] sophiae Simon, Cat. Troch., 1897, 12.

S[aucerottea] sophiae Hartert, Das Tierreich, Troch., 1900, 53 (monogr.).

Saucerottea sophiæ BAngs, Auk, xxiv, 1907, 295 (Barranca de Punta Arenas).

[Saucerottea] sophiæ SHARPE, Hand-list, ii, 1900, 107.

Saucerothia sophiæ Frantzius, Journ. für Orn., 1869, 317 (Costa Rica).

(??) Saucerotia sophix BoucArd, The Hum. Bird, ii, 1892, 81 (Santa Marta and Barranquilla; Valencia, Venezuela; crit.).

[Chlorestes] sophiae Reichenbach, Troch. Enum., 1855, 4, pl. 697, figs. 4554, 4555. Erythronota sophiæ Gould, Mon. Troch., v, pt. xxii, July, 1s61, pl. 322.

H[emithylaca] sophiae Cabanis and Heine, Mus. Hein., iii, 1860, 38, footnote ("Colombia").-Heine, Journ. für Orn., 1863, 192.

[Hemithylaca] sophiae Heine and Reichenow, Nom. Mus. Hein. Orn., 1890, 179 (Costa Rica; "Guatemala").

Ariana sophiæ Mulsant and Verreaux, Classif. Troch., 1866, 36; Hist. Nat. Ois.Monch., i, livr. 4, 1874, 328, pl. 28 ("Colombia;" Veragua; Costa Rica); iv, livr. 1, 1877, pl. 54, livr. 3, 1878, 185.

$b$ The alleged type in the Elliot collection, American Museum of Natural History, bears, on the original label, the locality Nicaragua! 
[Ariana] sophiae Muldant, Ann. Soc. Linn. Lyon, n. s., xxii, 1876, 207.

Amazilia sophix Ellotot, Classif. and Synop. Troch., 1879, 224.-Zeledón, Cat. Aves de Costa Rica, 1852, 21; Anal. Mus. Nac. Costa Rica, i, 1887, 122 (San José, Costa Rica).-Salvin, Cat. Birds Brit. Mus., xvi, 1892, 224 (Bebedero and Tucurríqui, Costa Rica).-SAlvin and Godman, Biol. Centr.-Am., Aves, ii, 1892, 303 (Nicaragua; Las Cruces de Candelária, etc., Costa Rica).Underwood, Ibis, 1896, 442 (Bebedero and Volcán de Miravalles, Costa Rica).

A[mazilia] sophiz Ridqway, Rep. U. S. Nat. Mus. for 1890 (1891), 363 (diagnosis, etc.).

Amizilis sophiae Oberholser, Proc. Ac. Nat. Sci. Phila., June 2, 1899, 208.

(?) Trochilus (- ?) caligatus Gould, Proc. Zool. Soc. Lond., 1848, 14 (Colombia).

(?) [Saucerottia] caligatus Bonaparte, Consp. Av., i, 1850, 77.

(?) [Chlorestes] $r$. Saucerottia caligata Reichenbach, Aufz. der Colibr., 1854, 8.

(?) [Chlorestes] caligata Reichenbach, Troch. Enum., 1855, 4.

(?) E[ [emithylaca] caligata Cabanis and Heine, Mus. Hein., iii, 1860, 39 (Mérida, Venezuela).

H[emithylaca] hoffmannii Cabanis and Heine, Mus. Hein., iii, March, 1860, 38 (Costa Rica; coll. Heine Mus.).-Cabanis, Journ. für Orn., 1862, 163 (San José, Costa Rica).

Saucerottia hoffmanni Boucard, Gen. Hum. Birds, 1894, 188 (San José).

\section{SAUCEROTTIA ALFAROANA (Underwood.)}

\section{ALFARO'S HUMMING BIRD.}

"Similar to A. sophiæ, but larger, and the bill rather longer and more curved. On the underside there is little difference, but the under tail-coverts are dark steel-blue, with a narrow white margin. On the upper surface the green of the plumage has a distinct blue tint, which becomes more intense on the crown and forehead. The upper tail-coverts are as in $A$. sophix. The mandible is pale for about its basal half, the rest and the maxilla black. Total length about 4.0 inches [102 mm.]; wing, 2.2 [55.9]; tail-outer rectrices 1.35 [34.3], middle rectrices 0.25 [6.3] shorter; bill, 1.0 [25.4]." a

Northwestern Costa Rica (Volcán de Miravalles).

Amazilia alfaroana UNdertrood, Ibis, 4th ser., ii, Oct., 1896, 441 (Volcán de Miravalles, Costa Rica; coll. —_? ).

Amizilis alfaroana Oвerholser, Proc. Ac. Nat. Sci. Phila., 1899, 208.

S[aucerottea] alfaroana HARTERT, Das Tierreich, Troch., 1900, 53 (monogr.).

[Saucerottea] alfaroana SHARPE, Hand-list, ii, 1900, 107.

Saucerottia cyanifrons alfaroana CARRIKER, Ann. Carnegie Mus., vi, 1910, 527 (crit.).

SAUCEROTTIA NIVEOVENTER (Gould).

SNOWY-BREASTED HUMMING BIRD.

Similar to S. edwardi, but tail purplish black or riolaceous-black (instead of bronze), and under tail-coverts grayish (instead of rufescent) centrally.

Adult male.-Pileum, hindneck, and upper back metallic green (nearly grass green); lower back, scapulars, and wing-coverts metallic 
bronze, more or less coppery; rump and shorter upper tail-coverts grayish brown or olive, glossed with bronze, the longer upper tailcoverts dusky purplish bronze; tail slightly glossy violaceous-black, the middle rectrices sometimes glossed with purplish basally; remiges dark brownish slate or dusky, faintly glossed with violaceous; malar region, chin, throat, sides of neck, breast, and sides bright metallic green (yellowish emerald green), the feathers of chin, throat, and chest grayish white beneath surface, dusky grayish basally, those of other parts brownish gray beneath surface; abdomen, anal region, femoral tufts, and lumbar tufts white; under tail-coverts brownish gray, with darker shaft-streaks, margined with whitish; maxilla dull black; mandible pale brownish (reddish in life), dusky, or blackish terminally; iris dark brown; feet dusky; length (skins), 86-94 (89); wing, 50-56 (53.5); tail, 29-31 (29.9); culmen, 17.5-19.5 (18.3). ${ }^{a}$

Adult female.-Similar to the adult male and frequently not distinguishable, but usually (?) very slightly duller in coloration; length (skins), 84-89 (87); wing, 49.5-52.5 (51); tail, 28-30 (29); culmen, $18-19.5$ (18.8). ${ }^{b}$

Panamá (Lion Hill; Panamá; Bugaba; Davíd; Chitra; Boquete; Calobre; Cordillera del Chucu; Calovévora; Santiago de Verágua), southern Costa Rica (Talamanca; El Generál; Buenos Aires de Térraba; Boruca), and northern Colombia (Boquerón).

Trochilus (-?) niveoventer Gould, Proc. Zool. Soc. Lond., 1850, 164 (near Davíd, Verágua, Panamá; coll. J. Gould).

[Chlorestes. Y. Saucerottia] niveiventer ReIChenbach, Aufz. der Colibr., 1854, 8.

[Thaumantias] niveiventer Bonaparte, Rev. et Mag. de Zool., 1854, 255.

[Chlorestes] niveiventris Reichenвach, Troch. Enum., 1855, 4, pl. 700, figs. $4566,4567$.

Erythronota niveiventris Gould, Mon. Troch., pt. xv, May, 1858 (vol. v), pl. 319; Introd. Troch., oct. ed., 1861, 161.-SALvin, Proc. Zool. Soc. Lond., 1867, 155 (Davíd and Santiago, Panamá; crit.); 1870, 210 (Volcán de Chiriquí, Chitra, Cordillera del Chucu, and Calovévora, Panamá).-Boucard, Notes quelques Troch., 1873, 12 (Verágua).

H[emithylaca] niveiventris Cabanis and Heine, Mus. Hein., iii, 1860, 37 (Veragua).-Heine, Journ. für Orn., 1863, 192.

$a$ Sixteen specimens. $b$ Ten specimens, from Costa Rica.

\begin{tabular}{|c|c|c|c|}
\hline Locality. & Wing. & Tail. & 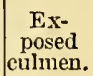 \\
\hline MALES. & & & \\
\hline Ten adult males from Costa Rica..... & 54.3 & 30 & 17.9 \\
\hline Five adult males from Panamá... & 51.8 & 29.7 & 19 \\
\hline One adult male from northwestern Colombia (Boqueron) $\ldots \ldots \ldots \ldots \ldots \ldots$ & 50.5 & 30 & 19 \\
\hline
\end{tabular}


[Hemithylaca] niveirentris II esve and Reicuesow, Nom. Mns. Hein. Orn., 1890, 179 (Teríguia).

Saucerottia miveiventris Sclater and Salvin, Proc. 'Zool. Soc. Iond., 1864, 365

(Lion Hill, Panamí).-Eudes-Deslongchamps, Ann. Mus. Caen, i, 1880, 429.

[Saucerottia] niveiventris Sclater and Salvin, Nom. Av. Neotr., 1873, 92.

S[aucrottea] niverenter IIARTERT, Das Tierreich, Troch., 1900, 54.

[Saucerottea] niveiventris Suon, Cat. Troch., 1897, 13.--Suarpe, Hand-list, ii, $1900,107$.

Saucerottea miveoventer BAngs, Proc. New Engl. Zool. Club, iii, 1902, 29 (Boquete, Panama, 4,000 ft.); Auk, xxiv, 1907, 295 (Boruca, s. w. Costa Rica).

Saucerottia niveoventer Carriker, Ann. Carnegie Mus., vi, 1910, 528 (Boruca and Buenos Aires de Térraba, Costa Rica; habits).

Ariana nivciventris Mulsant and Verreaux, Classif. Troch., 1866, 36.

[Polytmus] niveiventris Gray, Hand-list, i, 1869, 133, no. 1698.

Leucodora niveiventris Mulsant and Terreaux, Hist. Nat. Ois.-Mouch., i, livr.

4, 18it, 313; iv, livr. 3, 1878, 184 .

[Leucodora] niveiventris Mulsant, Ann. Soc. Linn. Lyon, n. s., xxii, 1876, 206.

Amazilia niveiventris Elliot, Classif. and Synop. Troch., 1879, 222.-ZEeledón,-

Cat. Aves de Costa Rica, 18s2, 21.--Salvin, Cat. Birds Brit. Mus., xvi,

1892, 221.-Salvin and Godman, Biol. Centr.-Am., Aves, ii, 1892, 302.-

Boucard, The Hum. Bird, ii, 1892, 81; Gen. Hum. Birds, 1895, 202.

A[mazilia] niveoventer RIdgway, Rep. U. S. Nat. Mus. for 1890 (1891), 363

(diagnosis, etc.).

\section{SAUCEROTTIA EDWARDI (Delattre and Bourcier).}

\section{WILSON'S HUMMING BIRD.}

Similar to S. niveoventer but tail metallic bronze instead of violetblackish, and under tail-coverts rufescent, instead of grayish, centrally.

Adult male.-Pileum, hindneck, and upper back metallic green (nearly grass-green); lower back and scapulars metallic bronze or coppery bronze, the wing-coverts usually more decidedly coppery; rump and upper tail-coverts much duller bronze; tail wholly metallic bronze or coppery bronze; remiges dark brownish slate or dusky, faintly glossed with purplish; malar, suborbital, and auricular regions, chin, throat, sides of neck, breast, and sides bright metallic green (yellowish emerald green), the feathers of chin and throat grayish white, those of other parts light brownish gray beneath surface; abdomen, anal region, femoral tufts and lumbar tufts white; under tail-coverts light grayish chestnut margined with paler; maxilla dull black; mandible pale brownish or whitish (reddish in life), dusky terminally; iris dark brown; feet dusky; length (skins), 
83-97 (91); wing, 47-56.5 (50.7); tail, 28-30.5 (29.9); culmen, 17.5-20 (18.7). ${ }^{a}$

Adult female.-Similar to the adult male but very slightly duller, the under tail-coverts paler and more grayish with broader pale (often whitish) margins; length (skins), 87-95 (91); wing, 50-54.5 (52.2); tail, 27.5-32.5 (29.4); culmen, 17.5-20 (19). ${ }^{b}$

Panamá (Lion Hill and Paraiso stations, Panamá Railway; Panamá; Verágua; San Miguél Island; Saboga Island); northwestern Ecuadór (Santo Domingo).

Trochilus] edward Delattre and Bourcier, Rev. Zool., 1846, 308 (Panamá; type now in coll. Ac. Nat. Sci. Phila.).

[Amazilius] edward Bonaparte, Consp. Av., i, 1850, 78.

[Thaumantias] edward Bonaparte, Rev. et Mag. de Zool., 1854, 255.

[Polytmus] edward Grax, Hand-list, i, 1869, 132, no. 1697.

Amizilis edward Obernolser, Proc. Ac. Nat. Sci. Phila., June 2, 1899, 208.

Saucerottia edward Oвеrнolser, Proc. U. S. Nat. Mus., xxiv, no. 1258, Jan., 1902, 316 (Santo Domingo,.n. w. Ecuadór; crit.).

P[olytmus] edwardsii Gray, Gen. Birds, i, Dec., 1848, 109.

[Chlorestes. r Saucerottia] edwardsii ReICHenbach, Aufz. der Colibr., 1854, 8.

[Chlorestes] edwardsii Reichenbach, Troch. Enum., 1855, 4, pl. 698, figs. 4558, 4559.

Erythronota edwardi Gould, Mon. Troch., pt. xv, 1858 (vol. v), pl. 318; Introd. Troch., oct. ed., 1861, 161.-LaWrence, Ann. Lyc. N. Y., vii, 1862, 292 (Lion Hill, Panamá); 1868, 317 ("Costa Rica").-Frantzius, Journ. für Orn., 1869, 317 ("Costa Rica").

H[emithylaca] edwardi Cabanis and Heine, Mus. Hein., iii, 1860, 37, footnote (Panamá).

E[ratina] edwardi HeINe, Journ, für Orn., 1863, 191.

Saucerottia edwardi Eudes-Deslongchamps, Ann. Mus. Caen, i, 1880, 427.

[Saucerottia] edwardi Sclater and Salvin, Nom. Av. Neotr., 1873, 92.

[Saucerottea] edwardi Simon, Cat. Troch., 1897, 13.-Sharpe, Hand-list, ii, 1900, 107.

Saucerottea edwardi Thayer and Bangs, Bull. Mus. Comp. Zool., xlvi, 1905, 149 (San Miguél and Saboga islands, Bay of Panamá).

Leucodora edwardi Mulsant and Verreaux, Hist. Nat. Ois.-Mouch., i, livr. 4, 1874, 311 (Panamá; Verágua; "Costa Rica”); iv, livr. 3, 1878, 184.

a Eighteen specimens.

$b$ Eight specimens.

\begin{tabular}{|c|c|c|c|}
\hline Locality. & Wing. & Tail. & $\begin{array}{c}\text { Ex- } \\
\text { posed } \\
\text { culmen. }\end{array}$ \\
\hline MALES. & & & \\
\hline Five adult males from Panamá......... & 52.3 & 29.7 & 18.7 \\
\hline Nine adult males from San Miguél Island, Panamá. & 54.4 & 30.1 & 18.6 \\
\hline Two adult males from Saboga Island, Panamá...... & 54.5 & 30.2 & 18.5 \\
\hline Two adult males from western Ecuadór...... & 53 & 29.2 & 19.5 \\
\hline FEMALES. & & & \\
\hline Two adult fernales from Panamá......... & 50.5 & 27.5 & 18.7 \\
\hline Five adult females from San Miguél Island.. & 53.1 & 30.2 & 19 \\
\hline One adult female from Saboga Isiand........... & 51.5 & 29.5 & 19.5 \\
\hline
\end{tabular}


[Leucodora] eduardi Mulsant, Ann. Soc. Linn. Lyon, xxii, n. A., 1876, 206.

Saucerottic ediardi Sclater and Salvin, Proc. Zool. Soc. Lond., 1864, 365 (Panantí).

S[aucerottea] chward Hantert, Das Tierreich, Troch., 1900, 5t.

Amazilia eduardi Mfulsant and Verreaux, Classif. Troch., 1866, 35.-Elliot, Classif. and Synop. Troch., 1879, 221.-Zeledón, Cat. Aves de Costa Rica, 1882, 21; Anal. Mus. Nac. Costa Rica, i, 1887, 122.-Salvin, Cat. Birds Brit. Mus., xvi, 1892, 221 (Lion Hill, Panamá, and Paraiso, Panamá).Salvin and Goduan, Biol. Centr.-Am., Aves, ii, 1892, 302.-Boucard, The Hum. Bird, ii, 1892, 81 (Verígua; Panamá); Gen. Hum. Birds, 1895, 202. A[mazilia] eduardii Ridgway, Rep. U. S. Nat. Mus. for 1890 (1891), 363 (diagnosis, ete.).

Amizilis cdwardi Bangs, Auk, xviii, Jan., 1901, 28 (San Miguél I., Panamá).

SAUCEROTTIA CYANURA CYANURA (Gould). BLUE-TAILED HUMMING BIRD.

Adult male.-Pileum, hindneck, back, scapulars, and lesser wingcorerts deep metallic green; rump rather dull purplish bronze, deepening into dark metallic bluish on upper tail-coverts; tail wholly dark metallic violet-blue; remiges dusky, faintly glossed with violaceous, the secondaries and inner primaries chestnut or rufous-chestnut broadly tipped with violet-dusky; under parts mostly bright metallic green (between grass green and yellowish emerald green), sometimes slightly broken by very narrow and indistinct dull whitish or pale grayish margins to the feathers (especially on lower abdomen) and by an exposure of the pale grayish basal areas and edgings to feathers of throat; under tail-coverts rather dull steel blue or dark metallic violet-blue, sometimes partly coppery bronze, narrowly margined with pale grayish or light chestnut; femoral and lumbar tufts white; maxilla dull black, mandible dull whitish (reddish in life?) with dusky tip; iris dark brown; feet dusky; length (skins), 89-92.5 (91); wing, 51-54 (52.9); tail, 27.5-30 (28.9); culmen, 18-19.5 (18.8). ${ }^{a}$

Adult female. - Similar to the adult male, but duller in color, the feathers of under parts, especially those of chin, throat, and chest, usually narrowly margined with whitish, and those of chin and upper throat showing more or less of the subterminal white, the lower abdomen mixed with dull buffy whitish, the under tail-coverts more grayish, and rump duller, less purplish; length (skins), 87-89 (88); wing, 51; tail, 28-30 (28.7); culmen, 18.5-19 (18.8). ${ }^{b}$

Nicaragua (Realejo; Chontales; Volcán de Chinandega; Matagalpa; San Gerónimo, Chinandega; boundary line between Nicaragua and Honduras, 180 miles from Pacific coast), and Costa Rica (San Pedro).

Amazilia cyanura Gould, Mon. Troch., pt. xviii, Sept., 1859 (vol. v, 1861), pl. 315 (Realejo, Nicaragua; coll. J. Gould).-Elliot, Classif. and Synop. Troch., 1879, 223, part (Nicaragua).-Salviv, Cat. Birds Brit. Mus., xvi, 1892, 212, part (Realejo, Chontales, Volcán de Chinandega, and Matagalpa, Nicaragua).Salvin and Godman, Biol. Centr.-Am., Aves, ii, 1892, 297, part (Nicaraguan localities).-Boucard, Gen. Hum. Birds, 1895, 206, part (Nicaragua).

$a$ Four specimens (three from Nicaragua, one from Costa Rica). $b$ Three specimens. 
[Amazilia] cyanura Sclater and Salvin, Nom. Av. Neotr., 1873, 92, part (Nicaragua).

A[mazilia] cyanura Ridgway, Man. N. Am. Birds, 1887, 318, part (Nicaragua);

Rep. U. S. Nat. Mus. for 1890 (1891), 363, part (Nicaragua; diagnosis, etc.).

Amizilis cyanura Oberholser, Proc. Ac. Nat. Sci. Phila., June 2, 1899, 207.

H[emithylaca] cyanura Cabanis and Heine, Mus. Hein., iii, 1860, 38, footnote (Realejo).

Pyrrhophæna cyanura Gould, Introd. Troch., oct. ed., 1861, 160.-Mulsant and

Verreaux, Hist. Nat. Ois.-Mouch., i, livr. 4, 1874, 307 (Realejo).

[Pyrrhophaena] cyanura Mulsant, Ann. Soc. Linn. Lyon, n. s., xxii, 1876, 206.

E[ratina] cyanura HeIne, Journ. für Orn., 1863, 191.

Ariana cyanura Mulsant and Verreaux, Classif. Troch., 1866, 36.

[Polytmus] cyanurus GraY, Hand-list, i, 1869, 132, no. 1684.

Saucerottia cyanura Eudes-Deslongchayps, Ann. Mus. Caen, i, 1880, 417.

S[aucerottea] cyanura Hartert, Das Tierreich, Troch., 1900, 52, part (Nicaragua).

[Saucerottea] cyanura Simon, Cat. Troch., 1897, 13.-Sharpe, Hand-list, ii, 1900,

107.

Amizilis cyanura Oberholser, Proc. Ac. Nat. Sci. Phila., June 2, 1899, 207.

Saucerottea cyanura impatiens a Bangs, Proc. Biol. Soc. Wash., xix, July 30,

1906, 104 (San Pedro de Mojón, Costa Rica; coll. E. A. and O. Bangs).

Saucerottia cyanura impatiens CARriker, Ann. Carnegie Mus., vi, 1910, 526

(Costa Rica; crit.).

\section{SAUCEROTTIA CYANURA GUATEMALAE Dearborn.}

\section{GUATEMALAN BLUE-TAILED HUMMING BIRD.}

Similar to $S$. c. cyanura, but much darker in color, especially the wings; primaries blue-black instead of violet-dusky; chestnut on basal portion of remiges darker and much more restricted; green of upper parts darker, and blue of tail more violaceous, especially on basal portion of outer webs of rectrices, where the color sometimes inclines to metallic purple, the under tail-coverts almost wholly blueblack or dark steel blue, or else margined with darker grayish or chestnut.

Adult male.-Length (skins), 92-100 (97); wing, 53-56 (54.5); tail, 30-31.5 (30.8); culmen, 18.5-19 (18.8). ${ }^{b}$

Adult female.-Length (skins), 94-100 (97); wing, 50-52 (51); tail, 30 ; culmen, 19.5-20 (19.7). ${ }^{c}$

Pacific slope of Guatemala (Mazatenango, Suchitepequez; Patulúl; ${ }^{d}$ Retalhuleu; Pie de la Cuesta, San Marcos) and Chiapas (Huehuetán).

Amazilia cyanura (not of Gould) SAlvin, Ibis, 1863, 239 (Pacific coast, Guatemala), 1866, 195 (Retalhuleu and Mazatenango, Guatemala); Cat. Birds Brit. Mus.; xvi, 1892, 212, 661, part (Retalhuleu and Pie de la Cuesta, Guatemala).Elliot, Classif. and Synop., Troch., 1879, 223, part (Guatemala).-SAlvin and Godman, Biol. Centr.-Am., Aves, ii, 1892, 297, part (Retalhuleu and Mazatenango, Guatemala).-Boucard, Gen. Hum. Birds, 1895, 206, part (Guatemala).

$a$ I am not able to distinguish the type of $S . c$. impatiens from Nicaraguan examples of true $S$. cyanura, except by the very slightly less violaceous blue of the tail, all the characters mentioned in the original description failing to hold good.

b Three specimens.

$c^{\prime}$ Two specimens.

$d$ See p. 448 , footnote. 
[Amazilia] cyamura Sclater and SAlvin, Nom. Av. Neotr., 1873, 92, part (Guatemala).

A[mazilia] cyanura RrDaway, Man. N. Am. Birds, 1887, 318, part (Guatemala); Rep. U. S. Nat. Mus., 1890, 363, part (Guatemala).

S[aucerollea] cyamura Hartert, Das Tierreich, Troch., 1900, 52, part (Guatemala). Saucerottea cyamura guatemalx Dearnonn, Pub. 125 (Onn., i, no. 3), Ficld Mus. N. H., Nor., 1907, 97 (Mazatenango, Dept. Suchitepequez, Guatemala; coll. Field Mus. N. II.).

\section{SAUCEROTTIA DEVILLEI (Bourcier and Mulsant).}

\section{DEVILLE'S HUMMING BIRD.}

Similar to S. beryllina beryllina, but primaries wholly dusky or with only the extreme basal (concealed) portion rufescent, and secondaries dusky for at least terminal half of exposed portion, abdomen usually (at least in adult males) wholly metallic green, and bronze color of tail usually more strongly purplish.

Adult male.-Pileum, hindneck, back, and scapulars bright metallic green (nearly grass green), the pileum usually darker or duller; rump olive-bronzy, bronze, purplish bronze, or purplish, deepening into more decided purple or violet-purple on upper tail-coverts; middle rectrices metallic purplish bronze (usually darker and more purplish terminally), the remaining rectrices dark chestnut or maroon margined with metallic reddish or purplish bronze or bronze-purple; ${ }^{a}$ remiges dusky, faintly glossed with violet, the basal half of exposed portion of secondaries chestnut, the extreme basal portion of inner primaries sometimes tinged with the same; under parts, including abdomen, mostly bright metallic green (between grass green and yellowish emerald green); under tail-coverts light chestnut or vinaceous-chestnut, usually indistinctly margined with paler; femoral and lumbar tufts white; maxilla dull black, mandible whitish (reddish in life) with dusky tip; iris dark brown; feet dusky; length (skins), 86-100 (92); wing, 49-55.5 (52.6); tail, 29-31 (30.2); culmen, 17-20 (18.5). ${ }^{b}$

Adult female.-Similar to the adult male, but duller in color, especially the under parts, the lower abdomen sometimes pale buffy grayish; the under tail-coverts paler and more grayish chestnut, with (usually) broad and distinct whitish margins, and green of under parts broken by narrow pale grayish or dull whitish margins to the feathers, as weli as whitish on basal and lateral portion of feathers on gular region; length (skins), 87-95 (91); wing, 51-53 (51.8); tail, 29.5-30 (29.7); culmen, 26-27.5 (26.8). ${ }^{c}$

$a$ In some specimens (possibly representing another form) all the rectrices, except sometimes the middle pair, are clear chestnut margined terminally, more or less broadly, with metallic golden, coppery, or purplish bronze.

$b$ Ten specimens.

c Three specimens. 
Guatemala (Dueñas; Choctúm; Yzabál; Gualán; Guatemala City; Amatitlán; Lake Amatitlán; Patulúl, ${ }^{a}$ Sololá; Volcán de Fuego; La Trinidád; Vera Paz); Yucatan; Chiapas (Gineta Mts.); Salvadór (Volcán de San Miguél; La Libertád).

T[rochilus] devillei Bourcier and Mulsant, Rev. Zool., 1848, 272 (Guatemala).Gray, Gen. Birds, iii, 1849, App., 30a.

[Amazilia] devillei Reichenbach, Aufz. der Colibr., 1854, 10; Troch. Enum., 1855, 8, pl. 778 , figs. 4807, 4808 .

Amazilia devillei Gould, Mon. Troch., pt. xix, 1860 (vol. v, 1861), pl..313.Mulsant and Verreaux, Classif. Troch., 1866, 35.

Amazilia devillii Sclater, Cat. Am. Birds, 1862, 315 (Dueñas, Guatemala).Boucard, Proc. Zool. Soc. Lond., 1883, 451 (Yucatan).-Salvin, Cat. Birds Brit. Mus., xvi, 1892, 211, 660 (Dueñas, Volcán de Fuego, and Choctúm, Guatemala; La Libertád and Volcán de San Miguél, Salvadór).-SaLvin and Godman, Biol. Centr.-Am., Aves, ii, 1892, 296.

[Amazilia] devillii Sclater and Salvin, Nom, Av. Neotr., 1873, 92.

A[mazilia] devillii Ridgway, Man. N. Am. Birds, 2d ed., 1896, 317.

[Amazilius] devillei Bonaparte, Rev. et Mag. de Zool., 1854, 254.

Amizilis devillii Eudes-Deslongchamps, Ann. Mus. Caen, i, 1880, 412.-OberHolser, Proc. Ac. Nat. Sci. Phila., 1899, 207.

Pyrrhophæna devillii SaLvin, Ibis, 1860, 204.

Pyrrhophæna devillei Gould, Introd. Troch., oct. ed., 1861, 158.-Mulsant and

Verreaux, Hist. Nat. Ois.-Mouch., i, livr. 4, 1874, 305, pl. 27.-Lawrence,

Bull. U. S. Nat. Mus., no. 4, 1876, 33 (Gineta Mts., Chiapas)--Boucard,

Liste Ois. récol. Guat., 1878, 47 (Cobán).

[Pyrrhophaena] devillei Mulsant, Ann. Soc. Linn. Lyon, n. s., xxii, 1876, 206.

E[ranna] devillei HerNe, Journ. für Orn., 1863, 188.

[Polytmus] devillei Grax, Hand-list, i, 1869, 132, no. 1682.

S[aucerottea] devillei HARTERT, Das Tierreich, Troch., 1900, 57.

[Saucerottea] devillei Srmon, Cat. Troch., 1897, 13.-Sharpe, Hand-list, ii, 1900, 108.

Saucerottea devillii Dearborn, Pub. 125, Field Mus. N. H., 1907, 98 (Patulúl and Lake Amatitlán, Guatemala).

Amazilia arsinoe (not Ornismya arsinoe Lesson) Sclater and Salvin, Ibis, 1859, 130 (Guatemala).-Salvin and Sclater, Ibis, 1860, 40 (Yzabál and Dueñas, Guatemala).-SAlvis, Ibis, 1860, 195 (Yzabál and Dueñas).

Amazilia dumerillii (not Ornismya dumerili Lesson) Salvin, Ibis, 1860, 270 (Dueñas; habits).

Amazilia mariæ (not Trochilus mariæ Bourcier) EluIot, Classif. and Synop. Troch., 1879, 222.-BoucARD, Gen. Hum. Birds, 1895, 205.

A[mazilia] mariæ Ridgway, Man. N. Am. Birds, 1887, 317.

[Eranna] mariae Heine and Reichenow, Nom. Mus. Hein. Orn., 1890, 179.

A[mazilia] maria Rrdgway, Rep. U. S. Nat. Mus. for 1890 (1891), 363.

(?) Pyrrhophaena beryllina (not Trochilus beryllinus Lichtenstein?) Boucard, Liste Ois. récol. Guat., 1878, 47 (Cobán).

a A specimen from Patulúl, in the collection of the Field Museum of Natural History (No. 22627), placed by Mr. Dearborn with S. devillii in his list "Catalogue of a Collection of Birds from Guatemala" (Pub. 125, Field Mus. Nat. Hist., 1907, 98), is exactly intermediate between that species and $S$. cyanura (which occurs in the same locality) and is undoubtedly a hybrid between the two. 


\section{SAUCEROTTIA BERYLLINA BERYLLINA (Lichtenstein).}

\section{BERYLLINE HUMMING BIRD.}

Adult male.-Above bright metallic green or bronze-green, passing into duller purplish bronzy on rump, the upper tail-coverts rather dull bronzy purple or violet-purple; middle rectrices metallic purplish or coppery bronze or bronzy purple, the remaining rectrices chestnut, tipped, or broadly margined at tip, with purplish bronze (this sometimes wanting or obsolete on outermost rectrix); secondaries chestnut, or dull rufous-chestnut, broadly tipped with dusky, the innermost ones (tertials) mostly of the latter color; primaries chestnut or dull rufous-chestnut, with terminal portion (extensively) dusky, faintly glossed with purplish; malar region, chin, throat, sides of neck, chest, breast, sides, flanks, and upper abdomen bright metallic green (brighter and more yellowish than grass green), the feathers of chin and throat abruptly grayish white, those of under parts of body dusky brownish gray, beneath surface; lower abdomen pale buffy gray, grayish cinnamon, or isabella color; femoral and lumbar tufts white; under tail-coverts pale chestnut broadly edged basally and (usually) narrowly margined terminally with white; maxilla dull black; mandible pale brownish or dull brownish white (reddish in life), dusky at tip; iris dark brown; feet grayish brown or dusky; length (skins), 90-103 (97); wing, 52-56.5 (54.7); tail, 30-32 (31.3); culmen, $18-20(18.7){ }^{a}$

Adult female.-Similar to the adult male, but slightly duller in color, especially the under parts, nearly the whole abdomen being dull cinnamon-buffy, the feathers of chin and throat showing more or less of the basal or subterminal white; length (skins), 88-98 (92); wing, 52-55 (53.6); tail, 29.5-32 (30.2); culmen, 18-20 (19). ${ }^{b}$

Eastern and east-central Mexico, in States of Vera Cruz (Jalapa; Córdova; Orizaba; Jico; Playa Vicente; Cofre de Perote; Coátepec; Omealca; Tospán), Mexico (Valley of Mexico), Morelos (Cuernavaca), Oaxaca (Pluma; Oaxaca; Villa Alta; Totóntepec; Chimalapa), and Guanajuato (Moro León). ${ }^{c}$

Trochilus beryllinus Lichtenstein, Preis-Verz. Mex. Vög., 1830, 1 (Mexico); Journ. für Orn., 1863, 55 .

P[yrrhophaena $]$ beryllina Cabanis and Heine, Mus. Hein., iii, 1860, 36.

Pyrrhophrna beryllina Mulsant and Verreaux, Hist. Nat. Ois.-Mouch., i, livr. 4, 1874, 303; iv, livr. 3, 1878, 182 (Córdova, Tospán, and Orizaba, Vera Cruz).-Gould, Introd. Troch., oct. ed., 1861, 158.-Boucard, Notes quelques Troch., 1873, 12 (Córdova; Orizaba; Oaxaca).

a Ten specimens.

b Four specimens.

$c$ Specimens from Guanajuato are intermediate between the typical form and S.b. viola. 
[Pyrrhophaena] beryllina Mulsant, Ann. Soc. Linn. Lyon, n. s., xxii, 1876, 206. Amazilia beryllina GouLD, Mon. Troch., pt. xxii, July, 1861 (vol. v), pl. 312.Sclater, Cat. Am. Birds, 1862, 314; Proc. Zool. Soc. Lond., 1864, 177 (Valley of Mexico).-Dugès, La Naturaleza, i, 1870, 141 (Guanajuato).Viluada, La Naturaleza, ii, 1874, 364 (Valley of Mexico).-D'OcA, La Naturaleza, iii, 1875, 23 (Valley of Mexico; Orizaba; Córdova; Jalapa); Troq. de Mex., 1875, pl. (2), fig. 6.-Elliot, Classif. and Synop. Troch., 1879, 221.-RIdgway, Rep. U. S. Nat. Mus. for 1890 (1891), 363.-Salvin, Cat. Birds Brit. Mus., xvi, 1892, 209, part.-Salvin and Godman, Biol. Centr.-Am., Aves, ii, 1892, 295, part.-Jour, Proc. U. S. Nat. Mus., xvi, 1894, 784 (Cuernavaca, Morelos).-Boucard, Gen. Hum. Birds, 1895, 204.Chapman, Bull. Am. Mus. N. H., x, 1898, 33 (Jalapa).

[Amazilia] beryllina Sclater and Salvin, Nom. Av. Neotr., 1873, 92. A[mazilia] beryllina Ridgway, Man. N. Am. Birds, 1887, 317; Rep. U. S. Nat.

Mus. for 1890 (1891), 363 (diagnosis, etc.).

Amizilis beryllinus Eudes-Deslongchamps, Ann. Mus. Caen, i, 1880, 40.

Amizilis beryllina Oberholser, Proc. Ac. Nat. Sci. Phila., 1899, 207.

Amizilis beryllina beryllina Mulder (W. De W.), Bull. Am. Mus. N. H., xxi,

Nov. 24, 1905, 353, in text.

Amazilia berilina D'Oca, Los Colibris de Mex., 1875, 14, pl. (2), fig. 6.-Herrera, La Naturaleza, (2), i, 1891, 322 (Valley of Mexico).

[Amazilia] berilina Sanchez, Anal. Mus. Nac. Mex., i, 1877, 961 (Valley of Mexico; Orizaba; Córdova).

E[ranna] beryllina Heine, Journ. für Orn., 1863, 188.

[Eranna] beryllina Heine and Reichenow, Nom. Mus. Hein. Orn., 1890, 179.

[Polytmus] beryllinus Gray, Hand-list, i, 1869, 132, no. 1681.

$S[$ aucerottea] beryllina HarTerT, Das Tierreich, Troch., 1900, 56, part.

[Saucerottea] beryllina Simon, Cat. Troch., 1897, 13.-Sharpe, Hand-list, ii, 1900, 108.

Ornismya arsinoe Lesson, Hist. Nat. Colibris (Suppl. Ois.-Mouch.); 1829, 154, 156, pls. 28, 29 (Mexico); Index Gen. et Synop. Troch., 1832, p. xxviii,

Rev. Zool., 1838, 314; 1839, 18.

P[olytmus] arsinoe Gray, Gen. Birds, i, Dec., 1848, 109.

[Amazilius] arsinoe Bonaparte, Consp. Av., i, 1850, 77; Rev. et Mag. de Zool., 1854, 254.

Amazilius arsinoe Sclater, Proc. Zool. Soc. Lond., 1856, 287; 1858, 297 (Oaxaca); 1859, 297 (Jalapa), 386 (Playa Vicente).

A[mazilia] arsinoë Reichenbach, Aufz. der Colibr., 1854, 10; Troch. Enum., 1855, 8, pl. 774, figs. 4794-4797.

Amazilia arsinoe Mulsant and Verreaux, Classif. Troch., 1866, 35.

(?) T[rochilus] mariæ Bourcier, Ann. Sci. Phys. et Nat. Lyon, ix, 1846, 319 ("Venezuela;" error?); Rev. Zool., 1846, 316.

(?)H[ylocharis] marix Gray, Gen. Birds, i, Dec., 1848, 115.

(?)[Hylocharis] mariae Bonaparte, Consp. Av., i, 1850, 74.

(?)[Chlorestes. $\beta$. Smaragditis] mariae Reichenbach, Aufz. der Colibr., 1854, 7.

(?)[Chlorestes] mariae Reichenbach, Troch. Enum., 1855, 4, pl. 695, fig. 4549.

(?)[Saucerottia] maria Bonaparte, Rev. et Mag. de Zool., 1854, 255.

(?) $P[$ anychlora $]$ mariae Cabanis and Heine, Mus. Hein., iii, 1860, 49, footnote.

Amazilia marix (not of Elliot) Ferrari-Perez, Proc. U. S. Nat. Mus., ix, 1876, 158 (Jalapa). 


\section{SAUCEROTTIA BERYLLINA VIOLA (Miller).}

\section{VIOLACEOUS HUMMING BIRD.}

Similar to S. b. beryllina, but upper tail-coverts decidedly violet or bluish violet, middle rectrices more purplish bronze (sometimes violet), and abdomen usually much less cinnamomeous (buffy grayish or cinnamon-grayish).

Adult male.-Length (skins), 92-100 (97); wing, 52-57.5 (55.5); tail, 27.5-32.5 (31.2); culmen, 1S-20.5 (19.1). ${ }^{a}$

Adult female.-Length (skins), 91-100 (97); wing, 50.5-55.5 (53.9); tail, 2S.5-31.5 (30.S); culmen, 19-21 (20). ${ }^{b}$

Western Mexico, in States of Sinaloa (Plomosas; Mount Lisiarraga; Jalpa; Los Pieles; Los Limones; La Balla; Choix), Jalisco (Tonila; Bolaños; Zapotlán; San Marcos; Beltrán; Voleán de Colima), Michoacán (Patzcuaro; Los Reyes), and Guerrero (Omilteme; El Rincón; Acahuitzotla; Chilpancingo; Amula; Xautipa) and Territory of Tepíc (Sierra Madre; Sierra de Tepíc; Tepíc; San Blas; Huayimo).

Amazilia beryllina (not Trochilus beryllinus Lichtenstein) Salvin, Cat. Birds Brit. Mus., xvi, 1892, 209, part (Choix, Sinaloa; San Blas, Tepíc, Huayimo, etc., Tepic; Bolaños, Zapotlan, Tonila, San Marcos, Beltran, and Volcán de Colima, Jalisco; Chilpancingo, Xautipa, Amula, and Omilteme, Guerrero).Salvin and Godman, Biol. Centr.-Am., Aves, ii, 1892, 295 (localities in Sinaloa, Tepíc, Jalisco, and Guerrero).-Hartert (E. and C)., Novit. Zool., i, 1895, 20 (Chilpancingo, Guerrero, 5,000-7,000 ft.; descr. nest and eggs).

Amizilis beryllina viola Mrreer (IT. De W.), Bull. Am. Mus. N. H., xxi, Nov. 24, 1905, 353 (Jalpa, Sinaloa; coll. Am. Mus. N. H.).

\section{SAUCEROTTIA SUMICHRASTI (Salvin).}

\section{SUMICHRAST'S HUMMING BIRD.}

Adult male.-Above bright metallic grass green, darker on pileum, more golden or bronzy on rump and upper tail-coverts; tail bright metallic coppery bronze; remiges purplish dusky, with basal portion of secondaries and inner (proximal) primaries chestnut; under parts bright metallic grass green, more brilliant on throat and chest, where the feathers are white basally; under tail-coverts pale rufous; maxilla black, mandible flesh color with blackish tip; length (skin), 96; wing, 53; tail, 30.5 ; culmen, $23 .^{c}$

Southern Mexico, in State of Oaxaca (Santa Efigénia, Tehuántepec).

Amazilia sumichrasti SALvin, Ann. and Mag. N. H., vii, 1891, 376 (Santa Efigénia, Oaxaca; coll. Salvin and Godman); Cat. Birds Brit. Mus., xvi, 1892, 213, 661, pl. 7, fig. 2.-Salvin and Godnan, Biol. Centr.-Am., Aves, ii, 1892, 298.-Boucard, Gen. Hum., Birds, 1895, 205.

$a$ Fourteen specimens.

$b$ Ten specimens.

$c$ Unknown to me, the above description being adapted from those in the Biologia Centrali-Americana and "Genera of Humming Birds," as cited below. The differences from $S$. beryllina are not very obvious in the descriptions consulted. 
Amizilis sumichrasti Oberholser, Proc. Ac. Nat. Sci. Phila., June 2, 1899, 208. S[aucerottea] sumichrasti HaRtert, Das Tierreich, Troch., 1900, 208 (monogr.).

[Saucerottea] sumichrasti Simon, Cat. Troch., 1897, 13.-Sharpe, Hand-list, ii, 1900, 108.

\section{SAUCEROTTIA OCAI (Gould).}

DE OCA'S HUMMING BIRD.

Adult male._- "Upper surface shining golden green, crown glittering grass-green, lower back and upper tail-coverts greenish bronze; throat and breast glittering grass-green, each feather being white with a green discal spot, those of the throat being small and the white of the feathers appearing; middle of the abdomen grey, flanks washed with golden green; under tail-coverts pale greenish bronze, broadly edged with dull white; tail bronzy olive-green, the lateral rectrices with the shafts and outer webs toward the base chestnut; bill black, mandible toward the base flesh-color. Total length about 4 inches [101.6 $\mathrm{mm}$.], wing 2.3 [58.4], tail 1.35 [34.3], bill 0.85 [21.6]." "a

Southeastern Mexico, in State of Vera Cruz (Jalapa; Paso del Macho ?).

Amazilia ocai Gould, Ann. and Mag. N. H., ser. 3, iv, 1859, 96 (Jalapa, Vera Cruz; coll. J. Gould); Mon. Troch., pt. xxii, 1861 (vol. v), pl. 289.-D'OcA, La Naturaleza, iii, 1875, 16; Troq. de Mex., 1875, 6, pl. (1), fig. 1.-Mulsant and Verreaux, Classif. Troch., 1866, 35.-Elliot, Classif. and Synop. Troch., 1879, 221.-Ridgway, Rep. U. S. Nat. Mus. for 1890 (1891), 363.-Salvin, Cat. Birds Brit. Mus., xvi, 1892, 213.-Salvin and Godman, Biol. Centr.-Am., Aves, ii, 1892, 298.-Boucard, Gen. Hum. Birds, 1895, 204.

$A$ [mazilia] ocai Rmgway, Man. N. Am. Birds, 1887, 317; Rep. U. S. Nat. Mus. for 1890 (1891), 363 (diagnosis, etc.).

Amazilius ocai Sclater, Proc. Zool. Soc. Lond., 1859, 367.

Amizilis ocai Eudes-Deslongchamps, Ann. Mus. Caen, i, 1880, 414.-OberholSER, Proc. Ac. Nat. Sci. Phila., 1899, 208.

P[yrrhophaena] ocai Cabanis and Herne, Mus. Hein., iii, 1860, 36, footnote.

Pyrrhophaena ocai Mulsant and Verreaux, Hist. Nat. Ois.-Mouch., i, livr. 4, 1874, 301; iv, livr. 3, 1878, 182.-Boucard, Notes Troch. du Mex., 1875, 12.

[Pyrrhophaena] ocai Mulsant, Ann. Soc. Linn. Lyon, xxii, n. s., 1876, 206.

Hemistilbon ocai Gould, Introd. Troch., oct. ed., 1861, 150.

[Hemistilbon] ocai Sclater and Salvin, Nom. Av. Neotr., 1873, 91.

[Polytmus] ocai Gray, Hand-list, i, 1869, 132, no. 1693.

S[aucerottea] ocai Hartent, Das Tierreich, Troch., 1900, 56.

[Saucerottea] ocai Simon, Cat. Troch., 1897, 13.-Sharpe, Hand-list, ii, 1900, 108.

(?) Thaumatias lerdi D'OcA, La Naturaleza, iii, 1875, 24 (Paso del Macho, Vera Cruz; coll. Señor Blasio); Troq. de Mex., 1875, pl. (2), fig. 7.

\section{Genus GOLDMANIA Nelson.}

Goldmania Nebson, Smiths. Misc. Coll., lvi, no. 21, July 8, 1911, 1. (Type, Goldmania violiceps Nelson.)

Similar in general form to Saucerottia, but under tail-coverts very small and short, the three median ones remarkably specialized, forming a tuft of interlocking stiff plumes which are very narrow 
proximally, broad and strongry reeurved distally, and different in color (pure white) from the other coverts (bright metallic green); outermost (tenth) primary not longer than ninth, in adult male shorter and with terminal portion abruptly attenuated; and with the sexes very different in color.

Bill longer than head, slender, terete, but with base slightly expanded; nasal opereulum overlapping maxillary tomium, but the greater part covered by latero-frontal feathers; maxilla with a distinct lateral groove extending about halfway (more or less) from nostril to tip. Wing about three times as long as exposed culmen, the tenth (outermost) primary, in adult male, slightly shorter than ninth, its incurved terminal portion abruptly attenuated, in adult female and young male equal, or nearly equal, to ninth, and not attenuated. Tail nearly three-fifths as long as wing, in adult male deeply emarginate and with rectrices very broad, in adult female rounded, with rectrices much narrower. Tarsal feathering short, the inner side of tarsus wholly exposed.

Coloration.-Adult male metallic green (brighter below), the forehead and crown bright violet-blue, the rectrices deep chesnut broadly margined with metallic bronze; adult female green above (including forehead and crown), under parts grayish white (spotted with green laterally), the lateral rectrices dusky distally, with a median terminal cuneate spot of dull whitish and a median fusiform area of chestnut on proximal portion.

Range.-Eastern Panamá (Cerro Azúl, 3,000ft.). (Monotypic.)

\section{GOLDMANIA VIOLICEPS Nelson.}

\section{GOLDMAN'S HUMMING BIRD.}

Adult male.-Forehead and crown bright metallic blue, the feathers pale grayish buff or dull buffy white beneath surface, passing into pale gray basally; rest of upper parts, from occiput and postocular region to upper tail-coverts, inclusive, bright metallic grass green; tail deep chestnut, the remiges broadly margined (except on proximal portion of inner web) with metallic bronze; remiges slateblackish, faintly glossed with violaceous; under parts bright metallic pure green, the feathers gray basally and with a rather broad subterminal bar of white (mostly concealed); femoral tufts white; under tail-coverts with specialized median tult wholly pure white, the remainder bright metallic green; maxilla dull black; mandible dull whitish in dried skin (pinkish in life?), passing into dusky terminally; feet dusky; length (skin), 91; wing, 52.5; tail, 32.5; exposed culmen, $19 .^{a}$

Immature male.-Similar to the adult male, but green of under parts less uniform (more broken by exposure of white subterminal 
bars), and lateral rectrices narrowly tipped with pale buffy grayish, and with bronzy border to middle rectrices broader.

Young male.-Similar to the immature male, but violet-blue of crown replaced by dark metallic green, and under parts pale grayish, more or less spotted (except on abdomen and anal region) with metallic green; length (skin), 87-90 (88.5); wing, 51-54.5 (52); tail, 29-31 (29.2); exposed culmen, 17-18 (17.7)..$^{a}$

Adult female.-Above, including forehead and crown, metallic grass green; remiges blackish slate, faintly glossed with violaceous; middle rectrices dull metallic green proximally passing into dull bronze terminally; next pair similar but with a wedge-shaped median space of chestnut for proximal two-thirds, the remaining rectrices with the chestnut area increasing in width (but not in Jength) toward outermost, which is black subterminally and tipped with a diamondshaped spot of pale brownish buff or dull brownish white, the next two rectrices (on each side) with a similar but successively smaller and more cuneate terminal spot; malar region, chin, throat, and rest of under parts dull white, or grayish white, the malar region, chin and throat, with small spots of grayish (paler and less distinct on chin and throat), the sides and flanks spotted with metallic green, especially on sides of breast, where the spots are larger and partly coalesced; under tail-coverts metallic green with basal portion white, the specialized median tuft entirely white, as in adult male; length (skin), 81; wing, 47.5; tail, 25.5; exposed culmen, 19.

Cerro Azúl, Eastern Panamá, 3,000 ft. alt.

Goldmania violiceps Nelson, Smiths. Misc. Colls., Ivi, no. 21, July 8, 1911, 1 (Cerro Azúl, N. W. of Chepo, Panamá, 3,000 ft. alt.; coll. U. S. Nat. Mus.).

\section{Genus ANTHRACOTHORAX Boie.}

Lampornis (not of Swainson, June, 1827 b) Swarnson, Zool. Journ., iii, Dec., 1827, 358. (Type, Trochilus mango Linnæus.)

Anthracothorax BoIE, Isis, 1831, 545. (Type, Trochilus violicauda Boddaert, i. e., T. nigricollis Vieillot.)

Smaragdites Bore, Isis, 1831, 547. (Type, Trochilus dominicus Linnæus.)

[Anthracothorax.] B. Floresia Reichenbach, Aufz. der Colib., 1854, 11. (Type, Trochilus porphyrurus Shaw $=T$. mango Linnæus.)

[Anthracothorax.] o. Hypophania Reichen bach, Aufz. der Colib., 1854, 11. (Type, Trochilus dominicus Linnæus.)

Margarochrysis ReICHenBach, Aufz. der Colib., 1854, 11. (Type, Trochilus aurulentus Vieillot.)

Endoxac Heine, Journ. für Orn., 1863, 179, in text. (Substitute for Floresia Reichenbach.)

Rather large Trochilidx (length about 110-120 mm.), with broad, rounded or emarginate tail more than half as long as wing, bill

$a$ Six specimens, including one immature male with blue crown.

$b$ Philos. Mag., n. s., i, no. 6, June, 1827, 442; type, Lampornis amethystinus Swainson=Ornismya henrica Lesson and Delattre.

c"Von "้วоรоธ (berühmt)." (Heine.) 
decidedly longer than head, stout, more or less decurved, terminal portion of maxillary tomium minutely serrate, and color of tail mainly cither chestnut glossed with purple, or else (in $A$. viridis) bright bluish green or steel blue.

Bill decidedly longer than head, stout, rather broad and depressed basally, faintly to decidedly decurved; culmen rounded but at base contracted into a distinct narrow ridge; terminal portion of maxillary tomium minutely serrate; mandible with a broad lateral median sulcus or groove, which basally involves the greater part of upper half of the ramus. Nasal operculum very narrow anteriorly, nude for anterior and exterior portion, the frontal feathering extending anteriorly much beyond middle of nasal operculum, forming a more or less distinct but sometimes very short and obtuse point or antia on each side of the mesorhinium. Tarsus naked, rather stout; lateral toes nearly equal in length (or the outer one slightly longer), both slightly shorter than middle toe, the hallux shorter than lateral toes; claws relatively small. Wing less than three times as long as exposed culmen, the outermost primary longest. Tail more than half as long as wing, slightly rounded or emarginate, the rectrices broad, firm, rounded, or broadly subangular terminally.

Coloration.-Above metallic green, bronze-green, bronze or olive glossed with coppery bronze; tail (except middle rectrices) chestnut glossed with metallic violet or purple and margined with blackish, or else dark steel blue, greenish blue, or bluish green; adult males with under parts metallic green (with or without black on throat or chest), black medially bordered laterally with greenish blue or (on neck) with metallic violet-red, or else chin and throat greenish golden bronze, breast black; adult females (except of $A$. mango and $A$. viridis, in which sexes are alike in color), wholly dull whitish beneath ( $A$. dominicus and $A$.aurulentus), or with a black, green, or bluish median stripe bordered laterally with a whitish one.

Range.-Southern Mexico to Cayenne, eastern Brazil, Bolivia, and Peru; Greater Antilles (Jamaica, Haiti, Porto Rico, and St. Thomas). (Nine species.)

KEY TO THE SPECIES AND SUBSPECIES OF ANTHRACOTHORAX.

a. Tail not steel blue; under parts not uniform green (if green the chest more bluish, in contrast with emerald green of throat and bronze-green of sides).

b. Sides of neck metallic reddish purple or purplish red; under parts wholly black, or else chin and throat (only) dark metallic greenish or bluish. (Jamaica.)

Anthracothorax mango, both sexes (p. 457).

$b b$. Sides of neck not metallic purple or reddish; under parts not wholly black, nor with chin and throat dark metallic greenish or bluish.

c. Under parts without white (except femoral tufts). (Adult males.)

d. Throat black, at least medially.

e. Throat and under parts of body broadly (mostly) black. (Anthracothorax nigricollis.) 
f. Smaller (wing of adult male averaging 66.9, tail 37.2, culmen 23.5; female, wing 65.2, tail 35.2, culmen 24.1); metallic color bordering black of throat and chest more bluish. (South America east of Andes to Panamá; St. Andrews Island, Caribbean Sea.)

Anthracothorax nigricollis nigricollis, adult male (p. 459).

ff. Larger (wing of adult male averaging 67.2, tail 37, culmen 25.3; female, wing 69.5 , tail 37 , culmen 27.2); metallic color bordering black of throat and chest more greenish. (Western Ecuadór.)

Anthracothorax nigricollis iridescens (extralimital). ${ }^{a}$

$e e$. Throat and under parts of body narrowly black (medially), the latter sometimes merely darker green or bluish along median line. (Anthracothorax prevosti.)

f. Bill longer (culmen averaging 26.2); under parts of body usually more distinctly blackish along median line. (Southern Mexico to Honduras.) ......... Anthracothorax prevostii prevostii, adult male (p. 463).

ff. Bill shorter (culmen averaging less than 25); under parts of body less distinctly blackish along median line.

$g$. Bill more slender, the culmen 23.5-25.5; upper parts and lateral under parts metallic green or bronze-green. (Nicaragua and Costa Rica.)

Anthracothorax prevostii gracilirostris, adult male (p. 465).

gg. Bill stouter and shorter, the culmen 22-23.5; upper parts and lateral under parts bronze or golden bronze. (Old Providence Island, Caribbean Sea.)

Anthracothorax prevostii hendersoni, adult male (p. 466).

$d d$. Throat metallic green or bronze.

$e$. Chest only partly black or without black, throat emerald green or bright golden green.

f. A black spot on chest; center of abdomen blackish. (Trinidád and Venezuela to Lower Amazon.)

Anthracothorax gramineus (extralimital). $b$

ff. No black on chest.

(Panamá and southern Costa Rica.)

Anthracothorax veraguensis, adult male (p. 467).

$e e$. Chest wholly black.

$f$. Under parts of body mostly (sometimes whollyc) black; upper parts dark or deep bronze-green; larger (wing averaging 67.9 , tail 42.9 , culmen 23.8). (Island of Haiti.)

Anthracothorax dominicus, adult male (p. 468).

a Lampornis iridescens Gould, Introd. Troch., oct. ed., 1861, 65 (Guayaquil, w. Ecuador; coll. J. Gould).-Anthraeothorax violicaudus iridescens Oberholser, Proc. U. S. Nat. Mus., xxiv, no. 1258, Jan., 1902, 321 (Nanegal, w. Ecuador; crit.).

$b$ [Trochilus] gramineus Gmelin, Syst. Nat., i, pt. 1, 1788, 488 (based on Hausse col vert Buffon, Hist. Nat. Ois., vi, 58; Blaek-breasted Hummingbird Latham, Synopsis, i, pt. 2, 756).-Trochilus gramineus Audebert and Vieillot, Ois. Dorés, i, 1801, 23, pl. 9.-Lampornis gramineus Gould, Mon. Troch., ii, 1858, pl. 77; Introd. Troch., oct. ed., 1861, 65; Elliot, Classif. and Synop. Troch., 1879, 40; Salvin, Cat. Birds Brit. Mus., xvi, 1892, 95.-L[ampornis] gramineus Hartert, Das Tierreich, Troch., 1900, 98 (monogr.).-[Polytmus] gramineus Gray, Hand-list, i, 1869, 125, no. 1581.-Anthracothorax gramineus Berlepsch, Novit. Zool., xv, 1908, 263 (Cayenne; crit.).-[Trochilus] maculatus Gmelin, Syst. Nat., i, pt. 1, 1788, 488 (based on Colibri à cravate verte Buffon, Hist. Nat. Ois., vi, 56; Colibri à gorge verte de Cayenne Buffon, PI. Enl., pl. 671, fig. 1; Green-throated IJummingbird Latham, Synopsis, i, pt. 2, 755).-[Trochilus] peetoralis Latham, Index Om., i, 1790, 306 (=T. gramineus Gmelin).-Polytmus dominicus (not Trochilus dominicus Gmelin) Léotaud, Ois. Trinidad, 1866, 132.

c Except for white femoral tufts. 
(fi. Inder parts of body with black confined to chest and upper breast; upper parts more bronzy; smaller (wing averaging 62.5, tail 36.7, culmen 22.9). (Island of Porto Rico, St. Thomas, St. Johns, and Anegada.)........... Anthracothorax aurulentus, adult male (p. 470).

cc. Under parts partly white.

d. Under parts with a median stripe of black, black and bluish green, or bluish green, bordered laterally (on each side) by a stripe of white.

e. Median stripe wholly black.

f. Smaller (wing averaging 65.2, tail 35.2, culmen 24.1).

Anthracothorax nigricollis nigricollis, female and young (pp. 459, $460)$.

ff. Larger (wing averaging 69.5, tail 37, culmen 27.2).

Anthracothorax nigricollis iridescens, female and young (extralimital). ce. Median stripe only partly black or without black.

f. Median stripe black on throat, bluish green on chest and breast. g. Bill longer (culmen 25-31, averaging 28.1).

Anthracothorax prevostii prevostii, female and young (pp. 463, 464). gg. Bill shorter (culmen 22-28, averaging much less than 28).

$h$. Culmen 22.5-28, averaging 25.4 .

Antracothorax prevostii gracilirostris, female and young (p. 465). $h h$. Culmen 22-23.5, averaging 22.7.

Anthracothorax prevostii hendersoni, female and young (p. 466). ff. Median stripe green on throat, black on chest, breast, and abdomen.

Anthracothorax gramineus, female and young (extralimital).

ee. Median stripe wholly bluish green.

Anthracothorax veraguensis, female and young (p. 467).

$d d$. Under parts pale grayish without any black or greenish median stripe.

e. Larger (wing averaging 65.3 , tail 37.5 , culmen 25.6); lateral rectrices extensively chestnut basally; lateral under parts conspicuously spotted with metallic green; green of upper parts less bronzy.

Anthracothorax dominicus, female and young (pp. 468, 469).

$e e$. Smaller (wing averaging 58.1, tail 32.7, culmen 23.6); lateral rectrices with little if any chestnut; lateral under parts with little if any metallic green spotting; green of upper parts more bronzy.

Anthracothorax aurulentus, female and young (pp. 470, 471). aa. Tail steel blue; under parts uniform green. (Island of Porto Rico.)

Anthracothorax viridis, both sexes (p. 472).

\section{ANTHRACOTHORAX MANGO (Linnæus).}

MANGO HUMMING BIRD.

Adult male.-Pileum dull dusky bronze, the feathers narrowly and indistinctly margined with darker; occiput, hindneck, upper back, anterior scapulars, and lesser wing-coverts metallic coppery purple, the feathers grayish dusky at base and with a concealed subterminal band of greenish bronze; lower back, posterior scapulars, rump, and upper tail-coverts dull dusky greenish bronze, more or less tinged with coppery bronze or purplish, the lower back sometimes strongly so; middle pair of rectrices varying from dusky greenish bronze to dull black; remaining rectrices deep chestnut, margined terminally with dark bluish green, dusky bronze-green, or blackish (the outermost rectrix also edged along outer web with the same), the chestnut portion of rectrices glossed with metallic purple, violet, or bluish; 
greater wing-coverts dusky bronze or very dark bronze-greenish; remiges dull brownish slate or dusky, the secondaries usually faintly glossed with bronze-greenish; under parts plain velrety black, glossed with bluish green when riewed from behind, the under tailcoverts more strongly glossed with greenish; loral, rictal, and auricular regions and sides of neck bright metallic purple or reddish purple (aster purple to violet); femoral and lumbar tufts white; bill dull black; iris brown; feet dusky; length (skins), 117-130 (126); wing, 69-77 (73.5); tail, 38.5-44.5 (41.6); culmen, 25-30 (26.8). ${ }^{a}$

Adult female. - Similar to the adult male, but coloration decidedly duller (especially the black of under parts), tail less brilliant, and rectrices margined terminally (more or less distinctly) with pale grayish or dull whitish; length (skins), 123-136 (127); wing, 69.5-75 (71.2); tail, 40.5-43.5 (41.7); culmen, 26-29 (27.6). ${ }^{a}$

Immature? - Similar to adults, as described above, but chin and throat dull metallic bluish green (viewed from in front), middle rectrices more blackish (less metallic), and outer two or three rectrices (on each side) tipped, more or less, with whitish. ${ }^{b}$

Island of Jamaica, Greater Antilles (Metcalfe Parish; Hope Gardens; Port Antonio; Port Henderson; Kingston; Spanishtown; Priestmans River; Moneague).

[Trochilus] mango Linxeus, Syst. Nat., ed. 10, i, 1758, 128 (based on Mellivora mango Albin, Av., iii, 45, pl. 49, fig. 1); ed. 12, i, 1766, 191 (cites Mellivora avis maxima Sloane, Nat. Hist. Jam., ii, 305, pl. 264, fig. 3).-GMeln, Syst. Nat., i, pt. i, 1788, 491.-LathaMr, Index Orn., i, 1790, 307.

Trochilus mango Lessox, Index Gen. et Synop. Troch., 1832, p. x, part (Jamaica). Lampornis mango Gosse, Birds Jam., 1847, 88; Illustr. Birds Jam., 1849, pl. 18.March, Proc. Ac. Nat. Sci. Phila., 1863, 284.-Elliot, Ibis, 1872, 350 (crit.); Classif. and Synop. Troch., 1879, 39.-Mulsait and Verreaux, Hist. Nat. Ois.-Mouch., iv, livr. 2, 1877, 155 (crit.).-Ridgway, Proc. U. S. Nat. Mus., iii, 1880, 311.-Cory, Auk, iii, 1886, 349; Birds West Ind., 1889, 144; Cat. Tiest Ind. Birds, 1892, 12, 106, 130.-Salvis, Cat. Birds Brit. Mus., xvi, 1892, 91.-ScotT, Auk, ix, 1892, 277.-Field, Auk, xi, 1894, 125 (Port Henderson).-Bodcard, Gen. Hum. Birds, 1895, 327.-Lodge, Ibis, 1896, 497 (habits).

[Lampornis] mango Sclater and Salvin, Nom. Av. Neotr., 1S73, 81.-Cory, List Birds West Ind., 1885, 17.-Sharpe, Hand-list, ii, 1900, 118.

L[ampornis] mango Newtox, Handb. Jam., 1881, 108.-Hartert, Das Tierreich, Troch., 1900, 97.

a Ten specimens.

$b$ This green-throated plumage was considered by Gould that of the adult female; but, judging from the material examined, I am inclined to agree with Mr. Salvin (Cat. Birds Brit. Mus., xvi, 92) in considering that it represents birds of both sexes in immature dress. 
[Endora] mango Herne and Reichexow, Nom. Mus. Ifein. Orn., 1890, 175.

Trochilus porphyrurus Siraw, Nat. Misc., ix, no. 9, May, 1798, pl. 333 ("South America and neighboring islands"); Gen. Zool., viii, 1811, 296.

[Anthracothorax. 3. Florcsia] porphyrurus Reichex Bach, Auiz. der Colibr., 1854,11. [Anthracothorax] porphyrurus ReichenBach, Troch. Enum., 1855, 8, pl. 795, figs. 4849,4850 .

[Lampornis] porphyrurus Boxaparte, Rev. et Mag. de Zool., 1854, 250.-MIULSAxt, Ann. Soc. Linn. Lyon, xxii, 1876, 203.

Lampornis porphyrurus Gould, Mon. Troch., pt. xv, May, 1858 (vol. v, 1861), pl. 81; Introd. Troch., oct. ed., 1861, 67.-Sclater, Cat. Am. Bircle, 1862, 291.-Mulsayt and Verreaux, Classif. Troch., 1866, 24; Hist. Nat. Ois.Mouch., i, livr. 2, 1874, 163.

Lampornis porphyrura Sclater, Proc. Zool. Soc. Lond., 1561, 79.--Albrecht, Journ. für Orn., 1862, 201.

L[ampornis] porphyrura CABANrs and Henve, Mus. Hein., iii, 1860, 19.

P[olytmus] porphyrurus Grar, Gen. Birds, i, Dec., 1848, 108.

[Polytmus] porphyrurus GRAY, Hand-list, i, 1869, 126, no. 1589.

E[ndoxa] porphyrura HeINe, Journ. für Orn., 1863, 179.

Trochilus] floresii Bourcier and Mulsant, Ann. Sci. Phys. et Mat. d'Agric. Lyon, ix, 1846, 327 (Jamaica); Rev. Zool, 1846, 316.

[Lampornis].floresi Bonaparte, Consp. Av., i, 1850, 72; Rev. et Mag. de Zoul., $1854,250$.

\section{ANTHRACOTHORAX NIGRICOLLIS NIGRICOLLIS (Vieillot).}

BLACK-THROATED MANGO.

Adult male-Abore metallic bronze-green, darker and duller on pileum, more decidedly bronzy (sometimes pure golden or coppery bronze) on rump; middle pair of rectrices varying from dull greenish bronze to dusky, slightly glossed with bronze or greenish; remaining rectrices deep maroon-chestnut, glossed with metallic purple, and margined terminally with dark metallic greenish blue, or black glossed with bluish or greenish, this extending along edge of outer web of outermost rectrix for more than terminal half (sometimes nearly to base); remiges dusky brownish slate; chin, throat, and median portion of chest, breast, and abdomen plain velvety black, faintly glossed with bluish when viewed from behind; loral and rictal regions, and thence along each side of the black area of middle under parts as far as flanks, metallic greenish blue or bluish green next to the black, passing outwardly through pure green into yellowish green; under tail-corerts mixed metallic green and blackish; femoral and lumbar tufts white; bill dull black; iris brown; feet dusky; length (skins), 103-129 (113); wing, 61.5-70.5 (66.9); tail, 34-40.5 (37.2); culmen, 21.5-25.5 (23.5). ${ }^{a}$

Adult female.-Abore similar to the adult male but lateral rectrices with blackish terminal portion more extended, the tip (at least of 
two or three outermost rectrices), more or less extensively, whitish; median under parts, from chin to anal region, velvety black, this forming a broad stripe, along each side of which extends a broad stripe of white, from base of mandible to thighs, the sides of neck, sides of chest and breast, sides and flanks metallic bronze or bronze-green; under tail-coverts bronze-green centrally, passing into grayish basally, margined terminally or tipped (more or less broadly) with whitish or pale grayish; femoral and lumbar tufts white; bill, etc., as in adult male; length (skins), 103-125 (112); wing, 62.5-67.5 (65.2); tail, 33-.37 (35.2); culmen, 22-27 (24.1). ${ }^{a}$

Young.-Similar to the adult female, but feathers of upper parts, including wing-coverts, tipped with pale brownish buffy, those of sides and flanks similarly but less distinctly marked, and sometimes with the white along each side of median black stripe of under parts intermixed with light brown.

Panamá (Loma del León; Paraiso; Panamá) and southward through Colombia (Bogotá; Masinga, Bonda, Don Amo, and Sierra Nevada, Santa Marta; Cartagena; Cauca Valley; lower Magdalena; Bucaramanga), Venezuela (Cumanacoa; Maipures; Munduapo; Cariban; Suapuré; Tembladór; Andes de Cumaná; Mérida), British Guiana (Demerara; Roraima; Aunai), Cayenne and Brazil (Mexiana Island; Pará; Santarem; Bahia; Rio de Janeiro; Pernambuco; Santa Clara, Goiaz; Tonantins; Humaytha, Rio Madeira; Teffé; Piquete,

\section{a Twenty-three specimens.}

\begin{tabular}{|c|c|c|c|}
\hline Locality. & Wing. & Tail. & $\underset{\begin{array}{c}\text { Ex- } \\
\text { posed } \\
\text { culmen. }\end{array}}{.}$ \\
\hline MALES. & & & \\
\hline Five adult males from Panamá... & 66.5 & 36.7 & 22.8 \\
\hline Ten adult males from Colombia.. & 66.7 & 36.9 & 23.8 \\
\hline Five adult males ( $A . v$. iridescens) from western Eeuadór.. & 67.2 & 37 & 25.3 \\
\hline One adult male from eastern Peru....... & 68 & 36 & 22.5 \\
\hline One adult male from St. Andrews Island.. & 70 & 37.5 & \\
\hline Three adult males from Venezuela...... & 67.5 & 37.2 & 24.7 \\
\hline Seven adult males from Trinidád............ & 67.4 & 38.6 & 23.6 \\
\hline Two adult males from British Guiana and Cayenue........ & 66 & 36 & 24.5 \\
\hline Five adult males from eastern Brazil (mostly from Bahia)... & 66.3 & 37.2 & 22.7 \\
\hline FEMALES. & & & \\
\hline Four adult females from Panamá. & 64.5 & 34.7 & 22.6 \\
\hline Six adult females from Colombia........ & 65.1 & 35.2 & 24.7 \\
\hline Two adult females $(A, v$. iridescicns) from western Fcuadór.. & 69.5 & 37 & 27.2 \\
\hline 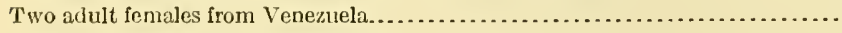 & 65.5 & 35.5 & 26.2 \\
\hline F'our adult females from Trinidád...................... & 65.4 & 34.9 & 24 \\
\hline 'I wo adult females from Cayenne and British Guiana.. & 65.5 & 35.7 & 23.5 \\
\hline Five adult females from eastern Brazil (Bahia, ete.) ............ & 65.5 & 35.2 & 24 \\
\hline
\end{tabular}


São Paulo; Chapada, Matto Grosso) to Paraguay (Lambaré), Bolivia (Moxos; Guarayos), eastern Peru (Pebas; Yurimaguas; Xeberos), and eastern Eeuadór (Sarayacu); Trinidád; St. Andrews Island, Caribbean Sea.

(?) Trochilus violicauda Bopdaert, Tabl. Pl. Enl., 1783, 41 (based on Le Colibri à queue violette de Cayenne Buffon, Pl. Enl., pl. 671, fig. 2.

Lampornis violicauda Ellor, Ibis, 1872, 351; 1877, 141 (Moxos and Guarayos, Bolivia); Classif. and Synop. Troch., 1879, 38.-LAYARD, Ibis, 1873, 388 (Parí, Brazil; food).-Sclater and Salvin, Proc. Zool. Soc. Lond., 1875, 235 (Mérida, Venezuela); 1879, 528 (Colombia), 626 (Moxos and Guarayos, Bolivia).-Boucard, The Hum. Bird, ii, 1892, 85 (Bogotá, Colombia).Ridgway, Proc. U. S. Nat. Mus., iii, 1880, 310 (specimens in coll. U. S. Nat. Mus.).-Shlvin, Cat. Strickland Coll., 1881, 361; Ibis, 1885, 432 (Roraima, Brit. Guiana, 3,500 ft.); Cat. Birds Brit. Mus., xvi, 1892, 92, part (Lion Hill and Paraiso, Panamá; Cauca Valley and Bogotá, Colombia; Roraima, Brit. Guiana; Mexiana I., Santarém, Pará, Pernambuco, Bahia, etc., Brazil; Trinidád; Cobati, Rio Negro; upper Amazons).-TAczanowski, Orn. du Pérou, i, 1884, 281.-Salvin and Godman, Biol. Centr.-Am., Aves, ii, 1892, 277 (Lion Hill and Paraiso, Panamá).-Chapman, Bull. Am. Mus. N. H., vi, 1894, 56 (Trinidád).-Phelps, Auk, xiv, 1897, 366 (Cumanacoa, Venezuela).-LoAt, Ibis, 1898, 565 (Brit. Guiana).-BAngs, Proc. Biol. Soc. Wash., xii, 1898, 135 (Santa Marta, Colombia); Proc. New Engl. Zool. Club, ii, 1900, 19 (Loma del León, Panamá).-Ihering, Aves de S. Paulo, 1899, 255 (Piquete); Rev. Mus. Paulista, iv, 1900, 72 (descr. nest and eggs); iv, 1900, 159 (Cantogallo and Novo Friburgo, s. Brazil).-Stone, Proc. Ac. Nat. Sci. Phila., 1899, 301, in text (St. Andrews Is., Caribbean Sea).Allen, Bull. Am. Mus. N. H., v, 1893, 122 (Chapada, Matto Grosso); xiii, 1900, 141 (Bonda, etc., Santa Marta).-Hagman, Zool. Jahrb., 1907, 34 (Mexiana I.).

[Lampornis] violicauda Sclater and Salvin, Nom. Av. Neotr., 1873, 81.Sharpe, Hand-list, ii, 1900, 118.

(?)[Trochilus] punctulatus Gmelin, Syst. Nat., i, pt. i, 1788, 488 ("Nova Hispania").-Lathay, Index Orn., i, 1790, 306.

(?) Trochilus punctulatus Vieillot, Nouv. Dict. d'Hist. Nat., vii, 1817, 358; Tabl. Enc. Méth., 1822, 552.

(?)[Trochilus] albus Gmenin, Syst. Nat., i, pt. i, 1788, 488.

(?)[Trochilus] nitidus LathaM, Index Orn., i, 1790, 305 (new name for T. albus Gmelin).

(?) Trochilus nitidus VienLot, Nouv. Dict. d'Hist. Nat., vii, 1817, 354 (cites Ois. Dor., pl. 11).

(?) Trochilus punctatus Audebert and Vielllot, Ois. Dorés, i, 1801, 21, pl. 8 -Vienlot, Nouv. Dict. d'Hist. Nat., vii, 1817, 357; Tabl. Enc. Méth., 1822,550 .

(?) Trochilus fasciatus SHAw, Gen. Zool., viii, part i, 1812, 303 (Paraguay).

Trochilus nigricollis Vıепlot, Nouv. Dict. d'Hist. Nat., vii, 1817, 349 (Brazil); Tabl. Enc. Méth., 1822, 553.

Lampornis nigricollis Berlepsch, Journ. für Orn., 1884, 309 (Bucaramanga, Colombia; crit. nomencl.); 1887, 17 (Lambaré, Paraguay), 120 (Paraguay), 316 (Bogotá; synonymy); 1889, 100 (Tonantins, n. w. Brazil; n. e. Peru), 305 (Yurimaguas, e. Peru); Zeitschr. Orn., 1887, 186 (Bogotá).-Srmon, Mém. Soc. Zool. France, ii, 1889, 219 (San Esteban, Venezuela).--Berelpsch 
and Ihering, Zeitschr. Orn., 1885, 152 (crit.).-Ridgway, Rep. U. S. Nat Mus. for 1890 (1891), 377 (monogr.).-Boucard, Gen. Hum. Birds, 1895, 331.-Koenigswald, Journ. für Orn., 1896, 370 (São Paulo, s. Brazil).Simon and Dalmas, xi, 1901, 215 (Trinidád; Andes de Cumaná, Venezuela).-Berlepsch and Hartert, Novit. Zool., ix, 1902, 87 (Maipures, Munduapo, Caribán, Suapuré, Temblador, and La Pricion, Venezuela).(?)Berlepsch and Stolzmann, Proc. Zool. Soc. Lond., 1902, 22 (La Mercéd, centr. Peru; crit.).-Ihering, Rev. Mus. Paul., vi, 1904, 331 (Paraguay).

L[ampornis] nigricollis HARTERT, Das Tierreich, Troch., 1900, 97.

Anthracothorox nigricollis Hellmayr, Novit. Zool., xiv, 1907, 78 (Teffé, Brazil), 396 (Humaytha, Rio Madeira, Brazil).-Berlepsch, Novit. Zool., xv, 1908, 263 (Cayenne).

Anthracothorax nigricollis nigricollis Hellmayr, Novit. Zool., xv, 1908, 77 (Leopoldina, Brazil).

Trochilus mango (not of Linnæus) Audebert and Vieillot, Ois. Dorés, i, 1801, 20, pl. 7.-Temminck, Cat. Syst., 1807, 81.-Vieillot, Nouv. Dict. d'Hist. Nat., vii, 1817, 353.-Lesson, Hist. Nat. Colibr., 1830-31, 58, 62, 64, pls. 13, 13 bis, 14; Index Gen. et Synop. Troch., 1832, p. x.-A udubon, Orn. Biog., ii, 1834, 480, pl. 184 ("Key West, Florida"); Synopsis, 1839, 170; Birds Am., oct. ed., iv, 1842, 186, pl. 251.

T[rochilus] mango Lichrenstein, Verz. Doubl., 1823, 13 (Brazil).

[Lampornis] mango Bonaparte, Consp. Av., i, 1850, 71; Rev. et Mag. de Zool., 1854, 250.-Mulsant, Ann. Soc. Linn. Lyon, xxii, 1876, 202.

L[ampornis] mango Swainson, Birds Brazil, etc., "1834-1841," pl. 28.-CaBanis and Heine, Mus. Hein., iii, 1860, 19 (Brazil).

Lampornis mango Bonaparte, Geog. and Comp. List, 1838, 10.-Gould, Mon. Troch., pt. xii, Sept., 1856 (vol. ii), pl. 74; Introd. Troch., oct. ed., 1861, 64.-Burmeister, Syst. Ueb. Th. Bras., ii, 1856, 331; Journ. für Orn., 1865, 229.-Sclater, Proc. Zool. Soc. Lond., 1857, 16 (Bogotá, Colombia), 263 (Santarém, lower Amazon); Cat. Am. Birds, 1862, 290 (Trinidád).-BAIrd, Rep. Pacific R. R. Surv., ix, 1858, 130 ("Key West, Florida").-Lawrence, Ann. Lyc. N. Y., vii, 1862, 319 (Panamá).-Sclater and Salvin, Proc. Zool. Soc. Lond., 1864, 365 (Panamá); 1866, 193 (Sarayacu, e. Ecuadór); 1867, 584 (Mexiana I.; Cobati, Rio Negro), 752 (Xeberos, e. Peru), 979 (Pebas, e. Peru); 1868, 169 (Venezuela), 628 (Venezuela); 1873, 287 (Sarayacu, Xeberos, and Pebas, e. Peru).-Taylor, Ibis, 1864, 91 (Trinidád; habits).-Mulsant and Verreaux, Classif. Troch., 1866, 24; Hist. Nat. Ois.-Mouch., i, livr. 2, 1874, 155, livr. 3, 1874, pl. 10; iv, livr. 2, 1877, 155 (crit.).-Euler, Journ. für Orn., 1867, 221 (Brazil; descr. nest and eggs).-Pelzel , Orn. Bras., i, Abth., 1868, 28; iv, Abth., 1870, 407.-Reinhardt, Vid. Medd. Nat. For. Kjöb., 1870, 103 (Brazil).-Finsch, Proc. Zool. Soc. Lond., 1870, 562 (Trinidád).—Wyatт, Ibis, 1871, 376 (Bucaramanga, Colombia).-Cabanis, Journ. für Orn., 1874, 225 (Brazil).-Baird, Brewer, and Ridgway, Hist. N. Am. Birds, ii, 1874, footnote.-Allen, Bull. Essex Inst., viii, 1876, 80 (Santarém); Bull. Nutt. Orn. Club, v, 1880, 88.-Eudes-Deslongcha ups, Ann. Mus. Caen, i, 1880, 189.

[Lampornis] mango? Coues, Key N. Am. Birds, 1872, 184.

Anthracothorax mango Reichen BaCh, Aufz. der Colibr., 1854, 11; Troch. Enum., 1855, 8, pl. 791, figs. 4839-4841.

Polytmus mango LÉotaud, Ois. Trinidad, 1866, 131.

[Polytmus] mango Gray, Hand-list, i, 1869, 125, no. 1576.

Trochilus mango var. Vieillot, Nouv. Dict. d'Hist. Nat., vii, 1817, 353 (cites Ois. Dorés, pl. 7).

(?) Trochilus quadricolor Vieillot, Nouv. Dict. d'Hist. Nat., vii, 1817, 353 (Paraguay; based on Turqui de Baxo Azara). 
(?) Trochilus alricapillus Viemlot, Nonv. Dict. d'Ilist. Nat., vii, 1817, 354 (Paraguay; based on del faxa negra a lo largo Azara).

(?) Lampornis obscura Bovcand, The Hum. Bird, i, no. 4, $\Lambda$ pril 1, 1891, 25 (Brazil; coll. A. Boucard; =melanism?).

'?) Lampornis violicauda var. Boucaro, Proc. Zool. Soc. Lond., 1879, 178 (=melanism?).

\section{ANTHRACOTHORAX PREVOSTII PREVOSTII (LesSOn).}

\section{PREVOST'S MANGO.}

Adult male.-Above metallic bronzc-green or greenish bronze; middle pair of rectrices dull dusky bronze-green, varying to dull coppery bronze, the other rectrices deep purplish maroon strongly glossed with metallic violet-purple, margined terminally (rather broadly) with black; remiges dusky brownish slate; median portion of chin and throat (broadly) velvety black; sides of chin and throat (narrowly), malar region, lower foreneck, chest, and median portion of breast and abdomen metallic bluish green, the feathers dull black or dusky beneath surface, auricular region, sides of neck, sides of chest and breast, sides, and flanks bronze-green; under tail-coverts dusky, often intermixed with deep purplish chestnut (the latter sometimes prevailing); femoral and lumbar tufts white; bill dull black; iris dark brown; feet dusky; length (skins), 110-120 (115); wing, 63.5-68.5 (66); tail, 34-37 (35.6); culmen, 24-29 (26.2). ${ }^{a}$

Adult female.-Above much less bronzy than adult male, often nearly pure metallic green; lateral rectrices with brownish gray and

a Twenty-four specimens.

\begin{tabular}{|c|c|c|c|}
\hline Locality. & Wing. & Tail. & $\begin{array}{c}\text { Ex- } \\
\text { posed } \\
\text { culmen. }\end{array}$ \\
\hline MALES. & & & \\
\hline Ten adult males from Tamaulipas, Vera Cruz, and Oaxaca.. & 66.4 & 36 & 26.5 \\
\hline Two adult males from Yucatan............................. & 66.2 & 35.2 & 25.2 \\
\hline Ten adult males from Cozumél Island............................ & 65.4 & 35.2 & 26 \\
\hline One adult male from British Honduras.......................... & 66.5 & 35.5 & 26 \\
\hline One adult male from eastern Guatemala................... & 65.5 & 36 & 27 \\
\hline Three adult males from Nicaragua $(A . p$. gracilirostris $) .. . \ldots \ldots \ldots . . .$. & 66 & 35 & 24.7 \\
\hline Six adult males from Costa Rica (A.p. gracilirostris) ..................... & 65.9 & 35.4 & 24.3 \\
\hline Four adult males ( $A . p$. hendersoni) from old Providence Island..... & 67 & 36.7 & 22.9 \\
\hline FEMALES. & & & \\
\hline Five adult females from Tamaulipas, Vera Cruz, and Oaxaca.. & 64.3 & 34.1 & 29.5 \\
\hline One adult female from Yucatan........................ & 66 & 35 & 28 \\
\hline Four adult females from Cozumél Island................. & 64.9 & 34.9 & 28.2 \\
\hline One adult female from British Honduras................ & 64 & 34.5 & 28.5 \\
\hline One adult female from eastern Guatemala................ & 67 & 34 & 25 \\
\hline One adult female from Chiapas (Palénque)............... & 65.5 & 35 & 26.5 \\
\hline Two adult females from Nicaragua $(A . p$. gracilirostris $) \ldots \ldots \ldots \ldots \ldots \ldots . . . . . .$. & 66.5 & 36 & 25.5 \\
\hline Eight adult females from Costa $\mathrm{Rica}(A . p$. gracilirostris) ............... & 64.9 & 35.3 & 25.4 \\
\hline Two adult females ( $A . p$. hendersoni) from Old Providence Island... & 66.2 & 35 & 22.7 \\
\hline
\end{tabular}


dusky usually replacing purplish on basal portion of outer webs, or with the purplish more restricted (on both webs), the tip (broadly on outermost rectrix) abruptly grayish white; primaries dusky brownish slate; median portion of chin and throat velvety black (this sometimes broken or irregular), the median portion of chest and breast metallic bluish green, passing into dusky on median line of abdomen; sides of chin and throat, malar region, and thence posteriorly to thighs, white; sides of neck, sides of chest, sides of breast, sides, and flanks metallic greenish bronze, sometimes washed or intermixed with purplish bronze; under tail-coverts grayish bronzy, tipped or terminally margined with white; femoral and lumbar tufts white; bill, etc., as in adult male; length (skins), 103-121 (114); wing, 62-69 (64.7); tail, 32-38 (34.3); culmen, 25-31 (28.1). ${ }^{a}$

Immature male and female.-Similar to the adult female, but chin and upper throat white, and sides of chin and throat (sometimes sides of chest and breast also) spotted or overlaid with chestnut (the feathers white beneath surface).

Southeastern Mexico in States of Tamaulipas (Tampico; Tantina; Alta Aira), Vera Cruz (Córdova; Jalapa; Misantla; Choapám; Catemaco; Tlalcotalpám; Coatzocoalcos; Antigua), Oaxaca (Santa Efigénia; Tehuántepec), Chiapas (Palénque), and Yucatan (La Vega; Chichen-Itza; Labna; between Ticúl and Uxmál; Cozumél, Meco, Mugeres, and Holbox islands), southward through British Honduras (Belize; Half Moon Cay; Isabella; Manatee Lagoon) and Guatemala (Santa Ana, Petén; Lake Petén; Escuintla; Hacienda de la Concepción) to Honduras (San Pedro; Bonaca Island).

Trochilus prevostii Lesson, Hist. Nat. Colibr., 1830-31, 87, pl. 24 (locality unknown); Index Gen. et Synop. Troch., 1832, p. xii (Surinam?).-? BourCIER, Rev. Zool., vi. 1843, 99 ("Caracas").

(?) T[rochilus] prevostii Bourcier and Mulsant, Ann. Soc. d'Agr. Lyon, vi, 1843, 39 ("Caracas").

P[olytmus $]$ prevostii Gray, Gen. Birds, i, Dec., 1848, 108.

[Polytmus] prevostii SRAY $_{\mathrm{R}}$ Hand-list, i, 1869, 125, no. 1577.

[Lampornis] prevosti Bonaparte, Consp. Av., i, 1850, 72; Rev. et Mag. de Zool., 1854, 250.-Sclater and Salvin, Nom. Av. Neotr., 1873, 81, part.-Mulsant, Ann. Soc. Linn. Lyon, xxii, 1876, 203.-Sharpe, Hand-list, ii, 1900, 118, part.

Lampornis prevosti Gould, Mon. Troch., pt. xv, 1858,(vol. ii), pl. 75, part; Introd. Troch., oct. ed., 1861, 65, part.-Sclater, Proc. Zool. Soc. Lond., 1856, 287 (Mexico); 1859, 367 (Jalapa, Vera Cruz), 385 (Choapám, Vera Cruz).-Sclater and Salvin, Ibis, 1859, 127 (Guatemala); Proc. Zool. Soc. Lond., 1870, 837 (Atlantic coast Honduras).-Mulsant and Verreaux, Classif. Troch., 1866, 24; Hist. Nat. Ois.-Mouch., i, livr. 3, 1874, 160 (Guatemala; IIonduras; Mexico); iv, livr. 2, 1877, 156.-SALvin, Ibis, 1860, 272 (Escuintla, Guatemala); 1864, 380 (Ialf Moon Cay, Brit. Honduras); 1889, 
365 (Meco, Mugeres, Holbox, and Cozmmél islands, Yucatan; crit.); (at. Birds Brit. Mus., xvi, 18!2, 9S, part (Alta Mira, Tampico, and Tantina, s. Tamaulipas; Misantla, Vera Cruz; Cozumél I., ete., Yucatan; Bonaca I., Honduras; Belize, Brit. Ionduras; Santa Ana and Escuintla, Guatemala).Bovcaro, Notes quelques Troch., 1873, 7 (Córdova and Jalapa, Vera Cruz); Proc. Zool. Soc. Lond., 1883, 451 (Yucatan); Anm. Soc. Linm. Lyon, xx; 1874, 275 (Córdora); Gen. IIum. Birds, 1895, 332, part (excl. syn. hendersoni Cory).-Lawrexce, Bu!l. U. S. Nat. Mus., no. 4, 1876, 32 (Santa Etigénia, Oaxalea).-Elliot, Classif. and Synop. Troch., 1879, 39, part.-Stone, Proc. Ac. Nat. Sci. Plila., 1590, 207 (between Ticúl and Uxmál and at Labna, Iucatan).-Salvin and Godman, Biol. Centr.-Am., Aves, ii, 1892, 278 , part (localities in Tamaulipas, Oaxaca, Yucatan, and Brit. Honduras; Uvero, etc., Vera Cruz; Hacienda de la Concepción, etc., Guatemala; San Pedro, etc., Honduras).-Chapman, Bull. Am. Mus. N. H., viii, 1896, 284 (Chichen-Itza, Iucatan).-Lantz, Trans. Kansas Ac. Sci. for 1896-97 (1899), 221, part (Isabella, Brit. Honduras).

L[ampornis] prevosti RIDGWAY, Rep. U. S. Nat. Mus. for 1890 (1891), 377, part.-

Simox, Rev. Franç. d'Orn., no. 1, 1909, 9, 10, in text, part (crit.).

[Anthracothorax] prevostii Reichenbach, Aufz. der Colibr., 1854, i1; Troch. Enum., 1855, 8, pl. 792, figs. 4842-4844.

A[nthracothorax $]$ p [revosti] prevosti Ridgway, Proc. Biol. Soc. Wash., xxiii, April $19,1910,55$, in text.

Lampornis thalassinus Ridgway, Proc. Biol. Soc. Wash., iii, Feb. 26, 1885, 3 (Cozumél Island, Yucatan; coll. U. S. Nat. Mus.).

Lampornis prevosti thalassinus Ridgway, Proc. U. S. Nat. Mus., viii, no. 36, Oct. 17, 18s5, 573 (Cozumél; descr.; crit.).

Lampornis mango (not Trochilus mango Linnæus) D'Oca, La Naturaleza, iii, 1875, 62; Troq. de Mex., 1875, 25, pl. (4), fig. 16.-Sanchez, Anal. Mus. Nac. Mex., i, 1877, 96.

L[ampornis] prevosti (typicus) HARTERT, Das Tierreich, Troch., 1900, 98, part.

\section{ANTHRACOTHORAX PREVOSTII GRACILIROSTRIS Ridgway.} SLENDER-BILLED MANGO.

Similar to A. p. prevostii, but with decidedly shorter and more slender bill; upper parts and sides decidedly less bronzy or golden green, and under tail-coverts averaging darker.

Adult male.-Length (skins), 105-119 (110); wing, 64-68 (65.9); tail, 34.5-37 (35.3); culmen, 23.5-25.5 (24.4) ${ }^{a}$

Adult female.-Length (skins), 105-118 (111); wing, 63.5-69 (65.2); tail, 33-38 (35.4); culmen, 22.5-28 (25.4). ${ }^{b}$

Nicaragua (Los Sábalos; San Emilis, Lake Nicaragua; San Carlos; Grenada; Matagalpa?) and Costa Rica (Bolsón; Bebedero; San Pedro; Rio Turubales); Venezuela? ${ }^{c}$

Lampornis prevostii (not Trochilus prevostii Lesson) LAwrence, Ann. Lyc. N. Y., ix, 1868, 121 (Gulf of Nicoya, Costa Rica).-Frantzius, Journ. für Orn., 1869, 315 (Costa Rica).

a Nine specimens.

$b$ Ten specimens.

$c$ See Salvin and Godman, Biol. Centr.-Am., Aves, ii, 1892, 279.

S1255ำBull. $50-11-30$ 
[Lampornis] prevosti Sclater and Salvin, Nom. Av. Neotr., 1873, 81, part (Costa Rica).-Sharpe, Hand-list, ii, 1900, 118, part (Costa Rica).

Lampornis prevosti Elliot, Classif. and Synop. Troch., 1879, 39, part (Costa Rica).-Zeledón, Cat. Aves de Costa Rica, 1882, 20.-Salvin, Cat. Birds Brit. Mus., xvi, 1892, 98, part (Bebedero, Costa Rica).-Salvin and Godman, Biol. Centr.-Am., Aves, ii, 1892, 278, part (Bebedero).-Richmond, Proc. U. S. Nat. Mus., xvi, 1893, 517 (Los Sábalos and San Carlos, Nicaragua).-Boucard, Gen. Hum. Birds, 1895, 332, part.-Lantz, Trans. Kansas Ac. Sci. for 1896-97 (1899), 221, part (Grenada, Nicaragua).

L[ampornis] prevosti Ridgway, Rep. U. S. Nat. Mus. for 1890 (1891), 377, part (Costa Rica).-Simon, Rev. Franç. d'Orn., no. 1, 1909, 9, 10, in text, part (Costa Rica; crit.).

(?)Lampornis violacauda (not Trochilus violicauda Boddaert) LANTz, Trans. Kansas Ac. Sci. for 1896-97 (1899), 221 (Grenada, Nicaragua).

L[ampornis] prevosti (typicus) HARTERT, Das Tierreich, Troch., 1900, 98, part.

Anthracothorax prevosti prevosti CARRIKer, Ann. Carnegie Mus., vi, 1910, 538 (Costa Rica).

Anthracothorax prevosti gracilirostris Ridgway, Proc. Biol. Soc. Wash., xxiii, April 19, 1910, 55 (Bolsón, Costa Rica; coll. E. A. and O. Bangs).

\section{ANTHRACOTHORAX PREVOSTII HENDERSONI (Cory).}

\section{HENDERSON'S MANGO.}

Similar to A. p. gracitirostris in smallness of bill, but upper parts, sides, and flanks conspicuously more bronzy (greenish bronze to almost golden bronze) and green color bordering black throat-stripe much less bluish.

Adult male.-Length (skins), 104-112 (109); wing, 65.5-68.5 (67) tail, 35.5-38 (36.7); culmen, 22-23.5 (22.9). ${ }^{a}$

Adult female.-Length (skins), 106-107 (106.5); wing, 63.5-69 (66.2); tail, 33-37 (35); culmen, 22-23.5 (22.7). ${ }^{b}$

Island of Old Providence, Caribbean Sea.

Lampornis hendersoni CoRY, Descr. Six New Sp. B. Isl. Old Providence and St. Andrews, May 27, 1887, 1; Auk, iv, July, 1887, 177, 180 (Old Providence I., Caribbean Sea; coll. C. B. Cory).-Salvin, Cat. Birds Brit. Mus., xvi, 1892, 99.-Salvin and Godman, Biol. Centr.-Am., ii, 1892, 279.-Boucard, The Hum. Bird, ii, 1892, 85.-Simon, Revue Frarç. d'Orn., no. 1, 1909, 9 (crit.).

[Lampornis] hendersoni Sharpe, Hand-list, ii, 1900, 118.

L[ampornis] prevosti hendersoni RIDGway, Rep. U. S. Nat. Mus. for 1890 (1891), 377 (diagnosis, etc.).-Hartert, Das Tierreich, Troch., 1900, 98 (monogr.). Lampornis prevosti (not Trochilus prevostii Lesson) Boucard, Gen. Hum. Birds, 1895, 332, part (Old Providence).

$A[$ nthracothorax $] p[$ revosti $]$ hendersoni Ridgway, Proc. Biol. Soc. Wash., xxiii, April 19, 1910, 55, in text. 


\section{ANTHRACOTHORAX VERAGUENSIS Reichenbach.}

VERAGUAN MANGO.

Similar to A. prevostii, but adult male with chin and throat wholly bright metallic green.

Adult male.-Above metallic bronze, greenish bronze, or bronzegreen, the middle pair of rectrices usually more coppery bronze; other rectrices rich purplish maroon, glossed with violet-purple, margined terminally with purplish or bluish black, this extending along edge of outer web for terminal half (more or less); remiges brownish slate or dusky; loral and malar regions, chin, and throat brilliant metallic yellowish emerald green varying to more golden green; chest and median portion of breast and abdomen duller and more bluish green, the lateral under parts metallic bronze or bronzegreen; under tail-coverts blackish or dusky, more or less glossed with greenish; femoral and lumbar tufts white; bill dull black; iris dark brown; feet dusky; length (skins), 99-111 (105); wing, 64.5-72 (67.1); tail, 34-37.5 (35.3); exposed culmen, 23.5-26.5 (24.7) ${ }^{a}$

Adult female.-Above similar in color to the adult male; chin and a broad stripe extending therefrom along sides of throat and chest to anal region, white, these two white stripes inclosing one of metallic bluish green, the feathers of which are dusky beneath the surface; sides of neck and thence to flanks metallic bronze-green; under tailcoverts light bronze-green narrowly tipped or terminally margined with white, the longer ones with an indistinct subterminal bar of dusky; lateral rectrices broadly tipped with white and crossed by a broad band of glossy blue-black, the remaining portion chestnut glossed with metallic purple; length (skin), 111; wing, 65; tail, 36.5; culmen (tip of maxilla broken off). ${ }^{b}$

Panamá (Volcán de Chiriquí; Davíd; Calobre; Cordillera del Chucu; Agua Dulce; Natá, Coclé; Panamá); Costa Rica?

[Anthracothorax, r. Sericotes] veraguensis Reichenbach, Aufz. der Colibr., 1854, 11 (Verágua; nomen nudum).

[Anthracothorax] veraguensis ReICHenbach, Troch. Enum., 1855, 9, pl. 794, fig. 4848 (Verágua).

[Lampornis] veraguensis Bonaparte, Rev. et Mag. de Zool., 1854, 250.-Sclater and Salvix, Nom. Av. Neotr., 1873, 81.-Mulsant, Ann. Soc. Linn. Lyon, xxii, 1876, 202.-Sharpe, Hand-list, ii, 1900, 118.

a Six specimens.

\begin{tabular}{|c|c|c|c|}
\hline Loeality. & Wing. & Tail. & $\begin{array}{c}\text { Ex- } \\
\text { posed } \\
\text { culmen. }\end{array}$ \\
\hline Six adult males from Panamá. & 66.2 & 35 & 24.9 \\
\hline One adult male from Costa Rica.... & 72 & 37.5 & 23.5 \\
\hline
\end{tabular}

b One specimen. 
Lampornis veraguensis Sclater, Proc. Zool. Soc. Lond., 1856, 140 (David, Panama); Cat. Am. Birds, 1862, 291.-Gould, Mon. Troch., pt. xv, May, 1858 (vol. ii, 1861), pl. 76 (Volcan de Chiriquí, Panamá); Introd. Troch., oct. ed., 1861, 65.-Mulsant and Verreaux, Classif. Troch., 1866, 24; Hist. Nat. Ois.-Mouch., i, livr. 2, 1874, 146; iv, livr. 2, 1877, 153.-Lawrence, Ann. Lyc. N. Y., viii, 1867, 177 (Davíd); ix, 1868, 121 (Cósta Rica; error?).Salvin, Proc. Zool. Soc. Lond., 1867, 153 (Davíd); 1870, 207 (Cordillera del Chucu and Calobre); Cat. Birds Brit. Mus., xvi, 1892, 99.-Frantzius, Journ. für Orn., 1869, 315 (Costa Rica; error?).-Elliot, Classif. Troch., 1879, 40.-Zeledón, Cat. Aves de Costa Rica, 1882, 20; Anal. Mus. Nac. Costa Rica, i, 1887, 121.-Salvin and Godman, Biol. Centr.-Am., Aves, ii, 1892, 280 (Agua Dulce, etc., Panamá).-Boucard, The Hum. Bird, ii, 1892, 85; Gen. Hum. Birds, 1895, 333 (Colón, etc.).

L[ampornis] veraguensis CABANis and HeIne, Mus. Hein., iii, 1860, 18.-RidgWAy, Rep. U. S. Nat. Mus. for 1890 (1891), 377 (diagnosis, etc.).-HarterT, Das Tierreich, Troch., 1890, 99 (monogr.).

[Polytmus] veraguensis GrAx, Hand-list, i, 1869, 125, no. 1578.

\section{ANTHRACOTHORAX DOMINICUS (Linnæus).}

HAITIAN MANGO.

Adult male--Above dark, rather dull, metallic bronze-green, sometimes intermixed with metallic grass green; middle pair of rectrices dull metallic bronze, coppery bronze or violaceous-black; ${ }^{a}$ remaining rectrices broadly margined terminally with violaceous-black, this extending along the edge of each web for (approximately) the terminal half, on the outer web of lateral rectrix to or near base; remiges dusky brownish slate or dull violaceous-black; chin and throat metallic bronze, or brassy bronze, usually passing laterally and posteriorly into a more greenish hue, or uniform greenish bronze or bronze-green; chest, breast, and abdomen--sometimes entire under parts of bodyopaque velvety black, sometimes duller or more sooty on lower abdomen; sides and flanks sometimes (narrowly) dark metallic green or bronze-green; under tail-coverts dusky or dark sooty basally, darker and faintly glossed with bronze or greenish terminally, sometimes wholly violaceous black; femoral and lumbar tufts white; bill dull black; iris brown; feet dusky; length (skins), 115-124 (119); wing, 65.5-70.5 (67.9); tail, 40-46 (42.9); culmen, 23-25 (23.8). ${ }^{b}$

Adult female.-Above rather bright bronze-green or greenish bronze; middle pair of rectrices rather dull dusky greenish bronze or bronze-green; other rectrices with basal half or more chestnutrufous, glossed with purple, the remainder (approximately the terminal third) first black, then white, the latter in form of a terminal spot, largest on outermost rectrix; remiges dusky brownish slate;

$a$ Salvin (Cat. Birds Brit. Mus., xvi, 97) describes the color of the middle rectrices as "steel blue;" but I have never seen a specimen in which the color even distantly approached that hue!.

$b$ Ten specimens. 
under parts very pale gray, passing into white, or grayish white, on malar region, the sides and flanks faintly washed with bronze; bill, etc., as in adult male; length (skins), 112-116 (114); wing, 64-67 (65.3); tail, 35.5-39 (37.5); culnen, 24-27 (25.6). ${ }^{a}$

Island of Haiti, Greater Antilles (Port au Prince, La Vega, and Le Coup, Haiti; Samaná, Santo Domingo, Puerto Plata, La Camita, and Sanchez, Santo Domingo).

[Trochilus] dominicus Linnzus, Syst. Nat., ed. 12, i, 1766, 191 (based on Polytmus dominicensis Brisson, Orn., iii, 672, pl. 35, fig. 1).-Gmenn, Syst. Nat., i, 1788, 489.-Lathan, Index Orn., i, 1790, 309.

Trochilus dominicus Auderent and Vieillot, Ois. Dorés, i, 1802, 128.-Vienllot, Nouv. Dict. d'Hist. Nat., vii, 1817, 358.

[Lampornis] dominicus Bonaparte, Consp. Av., i, 1850, 71; Rev. et Mag. de Zool., 1854, 250.-Sharpe, Hand-list, ii, 1900, 119.

Lampornis dominicus ElLiot, Ibis, 1872, 349, part (Santo Domingo; synonymy; crit.); Classif. and Synop. Troch., 1879, 41, part (Santo Domingo).-MUusant and Verreaux, Hist. Nat. Ois.-Mouch., iv, livr. 2, 1877, 154.-Cory, Birds Haiti and St. Dom., 1885, 90, pl. (22), figs. 7, 8; Auk, iii, 1886, 348, part; Birds West Ind., 1889, 143, part; Cat. West Ind. Birds, 1892, 12, 106, part (Haiti).-Salvin, Cat. Birds Brit. Mus., xvi, 1892, 96 (Samaná and Puerto Plata, Santo Domingo; Port au Prince, Haiti).-Boucard, Gen. Hum. Birds, 1895, 328.-Cherrie, Contr. Orn. St. Dom., 1896, 18.-Christy, Ibis, 1897, 329 (Samaná and La Vega, Santo Domingo).

L[ampornis] dominicus Hartert, Das Tierreich, Troch., 1900, 99 (monogr.).

[Anthracothorax, ò. Hypophania] dominica Reichenbach, Aufz. der Colibr., 1854, 11.

[Anthracothorax] dominicus Reichenbach, Troch. Enum., 1855, 9, pl. 793, figs. $4845,4846$.

[Trochilus] margaritaceus Gmelin, Syst. Nat., i, pt. 1, 1788, 490 (based on Plastron blanc Buffon, Hist. Nat. Ois., vi, 61; Colibri de St. Domingue Buffon, Pl. Enl., pl. 680, fig. 1; Grey-necked Humming-bird Latham, Synop., i, pt. 2, 761).Latham, Index Orn., i, 1790, 308.

Trochilus margaritaceus Viemlot, Nouv. Dict. d'Hist. Nat., vii, 1817, 353.

$P$ [olytmus] margaritaceus Gray, Gen. Birds, i, Dec., 1848, 108.

Polytmus aurulentus (not Trochilus aurulentus Audebert and Vieillot) VIEILLot, Ois. Am. Sept., ii, 1807, 72.

Trochilus aurulentus (not of Audebert and Vieillot) SHAw, Gen. Zool., viii, 1811, 306.-Bryant, Proc. Bost. Soc. N. H., xi, 1867, 95 (Santo Domingo).

T[rochilus] aumulentus Vieillot, Tabl. Enc. Méth., ii, 1822, 555.

[Trochilus] aurulentus Sclater and Salvin, Nom. Av. Neotr., 1873, 81, part (Haiti).

Margarochrysis aurulenta Reichenbach, Aufz. der Colibr., 1854, 11; Troch. Enum., 1855 , 8, pl. 784, figs. 4822, 4823.

[Eulampis] aurulentus Bonaparte, Rev. et Mag. de Zool., 1854, 250.

Lampornis aurulenta Sallé, Proc. Zool. Soc. Lond., 1857, 233 (Santo Domingo). 
Lampornis aurulentus GouLd, Mon. Troch., pt. xv, 1858 (vol. ii), pl. 79; Introd. Troch., oct. ed., 1861, 66.-Mulsant and Verreaux, Classif. Troch., 1866, 14; Hist. Nat. Ois.-Mouch., i, livr. 2, 1874, 152, part (Santo Domingo).Cory, Bull. Nutt. Orn. Club, vi, 1881, 153 (Haiti, above 1,000 ft.).-Tristram, Ibis, 1884, 168 (Santo Domingo).

[Lampornis] aurulentus Mulsant, Ann. Soc. Linn. Lyon, xxii, 1876, 202, part (Santo Domingo).

\section{ANTHRACOTHORAX AURULENTUS (Audebert and Vieillot).}

FORTO RICAN MANGO.

Similar to $A$. dominicus but decidedly smaller; adult male with black of under parts confined to chest and breast, and middle rectrices usually much more coppery bronze; adult female with basal portion of lateral rectrices light grayish, or partly so, instead of more than basal half wholly chestnut-rufous, ${ }^{a}$ black of subterminal portion brightly glossed with bluish green, and under parts more extensively and uniformly grayish, the sides without green spotting or intermixture.

Adult male.-Above metallic greenish bronze, golden bronze, or (more rarely) coppery bronze or bronze-green, the middle rectrices dull blackish bronze to bright coppery bronze; tail (except middle rectrices) dark violet-chestnut or maroon-violet glossed with metallic violet-purple, the rectrices broadly margined terminally with glossy steel-blue; remiges dull slate-blackish or dusky faintly glossed with violet-bluish; chin and throat metallic greenish bronze to golden bronze; chest and upper breast opaque velvety black, passing into dull brownish gray on sides, flanks, and lower abdomen; under tailcoverts dusky brownish gray, usually more blackish subterminally, usually margined (more or less distinctly) with paler, and faintly glossed with violet; conspicuous femoral and lumbar tufts white; bill black; iris dark brown; feet blackish; length (skins), 105-111 (108); wing, 59-65 (62.5); tail, 32-39 (36.7); culmen, 21-25 (22.9). ${ }^{b}$ Adult female.-Above metallic bronze-green to golden bronze, usually much duller on forehead and crown; middle rectrices dull bronze-green to bright bronze (rarely coppery bronze), usually darker (sometimes blackish) terminally; other rectrices brownish gray (rarely partly chestnut on inner webs) basally, steel blue subterminally, and tipped with white (broadly on lateral rectrices); remiges slate-blackish or dusky, faintly glossed with violet-bluish; under parts pale brownish gray, paler (sometimes dull white) on chin and throat, passing into white on abdomen and anal region, the sides sometimes slightly intermixed with metallic bronze or bronze-green; under tail-coverts pale gray centrally, margined with white; bill, etc., as in

$a \Lambda$ few specimens have the basal half of the lateral rectrices mostly chestnut-rufous, but these I think are immature males; one of them certainly is, the collector having taken pains to emphasize the determination of sex.

$b$ Seventeen specimens. 
adult male; length (skins), 99-110 (104); ${ }^{a}$ wing, 54-63 (5S.1); tail, $31.5-34(32.7)$; culmen, $21-25.5(23.6){ }^{b}$

lmmature male. - Similar to the adult female, but basal portion of lateral rectrices mostly chestnut (glossed with violet-purple), and throat and ehest showing, along median line, more or less of the metallic bronze or bronze-green and black of the adult plumage.

Islands of Porto Rico (Catano; Luquillo; Aguadilla; Arroyo; Ponee; Hucares; Coamo; Añasco; El Yúnque), Culebra, St. Thomas, St. Johns, and Anegada, Greater Antilles.

Trochilus aurulentus Aunebert and Vieillot, Ois. Dorés, i, 1801, 29, 31, pls. 12, 13 (Porto Rico; coll. Paris Mus.).-Yieillot, Nouv. Dict. d'Hist. Nat., vii, 1817, 350 (Porto Rico).-Lesson, Hist. Nat. Colibr., 1830-31, 68, 71, 73, 74, pls. 16-19 (Porto Rico); Index Gen. et Synop. Troch., 1832, p. xi, (Porto Rico). Lampornis aurulentus Cassin, Proc. Ac. Nat. Sci. Phila., 1860, 377 (St. Thomas).Mulsant and Verreaux, Hist. Nat. Ois.-Mouch., i, livr. 2, 1874, 152, part (St. Thomas; Porto Rico).-Gundlach, Journ. für Orn., 1878, 181 (Porto Rico; crit.); Anal. Soc. Esp. Hist. Nat., vii, 1878, 233 (Porto Rico).

[Lampornis] aurulentus Sclater and Salvin, Nom. Av. Neotr., 1873, 81, part (Porto Rico; St. Thomas).-Gundlach, Journ. für Orn., 1874, 312 (Porto Rico); 1878, 160 (Porto Rico).-Mulsant, Ann. Soc. Linn. Lyon, xxii, 1876, 202, part (St. Thomas; Porto Rico).

Trochilus (Lampornis) aurulentus Sundevall, Oefv. K. Vet. Ak. Förh., 1869, 600 (Porto Rico).

Lampornis virginalis Gould, Mon. Troch., ii, pt. xxiv, Sept., 1861, pl. 80 (St. Thomas, Greater Antilles; coll. J. Gould); Introd. Troch., oct. ed., 1861, 66.-Sclater, Cat. Am. Birds, 1862, 291.-Cory, Cat. West Ind. Birds, 1892, 12, 108, 143 (Anegada; Porto Rico; St. Thomas?).-Salvin, Cat. Birds Brit. Mus., xvi, 1892, 97 (Porto Rico; St. Thomas).-Bouchrd, Gen. Hum. Birds, 1895, 329 (St. Thomas).-Bowdish, Auk, xix, 1902, 366 (Porto Rico; habits).

[Lampornis aurulentus] var. virginalis MuLSANT, Ann. Soc. Linn. Lyon, n. s., xxii, 1876, 202 (St. Thomas).

L[ampornis] virginalis Hartert, Das Tierreich, Troch., 1900, 99 (monogr.).

[Lampornis] virginalis SHARPE, Hand-list, ii, 1900, 119.

[Polytmus] virginalis GraY, Hand-list, i, 1869, 126, no. 1583.

Lampornis ellioti CorY, Auk, vii, Oct., 1890, 374 (Anegada I., W. I.; coll. C. B. Cory)._Bodcard, Gen. Hum. Birds, 1895, 329 (Anegada).

a Two specimens.

$b$ Eleven specimens.

\begin{tabular}{|c|c|c|c|}
\hline Locality. & Wing. & Tail. & $\begin{array}{c}\text { Ex- } \\
\text { posed } \\
\text { culmen. }\end{array}$ \\
\hline MaLES. & & & \\
\hline Ten adult males from Porto Rico....... & 63 & 36.5 & 23.5 \\
\hline One adult male from Culebra Island... & 62 & 36 & 24 \\
\hline Four adult males from St. Thomas.... & 62.1 & 37.3 & 22.2 \\
\hline Two adult males from Anegada..... & 60.7 & 36.7 & 22.9 \\
\hline FEMALES. & & & \\
\hline Six adult females from Porto Rico.... & 58.2 & 32.6 & 24.3 \\
\hline Three adult females from St. Thomas. & 58.8 & 32.7 & 23.3 \\
\hline Two adult females from St. Johns....................... & 56.5 & 33.2 & 23.2 \\
\hline
\end{tabular}


Lampornis dominicus (not Trochilus dominicus Linnæus) Ellıot, Ibis, 1872, 349, part (St. Thomas; Porto Rico; synon.; crit.); Classif. and Synop. Troch., 1879, 41, part (Porto Rico; St. Thomas).

(?) Trochilus mango (not of Linnæus) Lesson, Hist. Nat. Colibr., 1830-31, 66, pl. 15 (Porto Rico).

[Lampornis] margaritaceus Bonaparte, Consp. Av., i, 1850, 72 (Porto Rico).

Lampornis viridis (not Trochilus viridis Audebert and Vieillot) Gould, Mon. Troch., pt. xxi, 1861 (vol. ii), pl. 78, part (supposed female!); Introd. Troch., oct. ed., 1861, 66, part.-EцLiot, Ibis, 1872, 348, part (supposed female); Classif. and Synop. Troch., 1879, 40, part (supposed female!).-CorY, Auk, iii, 1886, 349, part (supposed female!); Birds West Ind., 1889, 144, part (supposed female!); Cat. West Ind. Birds, 1892, 12, 106, 132.--Salvin, Cat. Birds Brit. Mus., xvi, 1892, 100, part (supposed female!).-Boucard, Gen. Hum. Birds, 1895, 334, part (supposed female!).

L[ampornis] viridis HaRTERT, Das Tierreich, Troch., 1900, 99, part (supposed female!).

\section{ANTHRACOTHORAX VIRIDIS (Audebert and Vieillot).}

\section{GREEN MANGO.}

Adults (sexes alike). ${ }^{a}$-Above metallic green, bronze-green, or (rarely) bronze, duller on pileum, the lower rump and upper tailcoverts purer green (metallic grass green or sea green); tail metallic blue-black or dark steel blue, the lateral rectrices sometimes very narrowly margined at tip with grayish or grayish white; remiges dusky brownish slate, very faintly glossed with violet; under parts metallic bluish green (french green or between grass green and sea green), the under tail-coverts sometimes narrowly margined terminally with whitish; femoral and lumbar tufts white (the latter small and concealed); bill black; iris dark brown; feet dusky.

Young.-Not materially different in coloration from adults, but some specimens, at least, have the feathers of the under parts narrowly and very indistinctly margined terminally with pale grayish brown, or else have the green of the anterior under parts darker and duller. ${ }^{b}$

Adult male.- Length (skins), 107-116 (111); wing, 60-67 (63.9); tail, 35.5-38.5 (37); culmen, $23-25(24.2){ }^{c}$

Adult female.-Length (skins), 104-117 (112); wing, 58.5-63 (60.1); tail, 33.5-37 (35.1); culmen, 25-27 (25.9).d

Island of Porto Rico, Greater Antilles (El Yúnque; Adjuntas; Utuado; Lares; Mayaguéz).

a Not only have Gould (Monog. Troch., ii) but also Elliot, Cory, Salvin (Cat. Birds Brit. Mus., xvi, 100), and Hartert (Tierreich, Aves, Lief. 9, 100) described the adult female of this species as being pale gray beneath. Undoubtedly they are wrong, for all the specimens sexed as female in the U. S. National Museum (one of them with the determination of sex emphasized) are precisely like adult males in coloration, and even a young bird which had not yet left the nest (a male, however) is not appreciably different! Numerous specimens in the U. S. National Museum corresponding with the descriptions of the alleged female of $A$. viridis by the authors mentioned undoubtedly belong to $A$. aurulentus, the adult female of which has little if any chestnut or rufous on the rectrices.

$b \mathrm{~A}$ nestling (determined to be a male by dissection) is in this plumage.

$c$ Ten specimens.

d Four specimens. 
Trochilus viridis Aunener' and Vienlot, Ois. Dorés, i, 1801, 34, pl. 15 ("îles de l'Amérique Septentriouale").-Viemlot, Nouv. Dict. d'Hist. Nat., vii, 1817, 354 ("Guyane;" "Ia Trinité"), 357 (Porto Rico; "St. Domingo").Temminck, Cat. Syst., 1807, 81, 8t.-Lesson, Hist. Nat. Colibr., 1830-31, 50, pl. 11; Index Gen. el Synop. Troch., 1832, p. x.-Sundevall, Gefv. k. Vet.-Ak. Förh., 1869, 600.

Trochilus] viridis Yinillot, Tabl. Enc. Méth., i, 1822, 551.

[Lampornis] viridis Bonaparte, Consp. Av., i, 1850, 71.-Scla'ten and Salvin, Nom. Av. Neotr., 1873, 81.-Cory, List Birds West Ind., 1885, 17.-Sharpe, Hind-list, ii, 1900, 119.

Lampornis viridis Gould, Mon. Troch., pt. xxi, 1861 (vol. ii), pl. 78, part (male only!); Introd. Troch., oct. ed., 1861, 66.-Mulsant and Verreaux, Classif. Troch., 1866, 24; Hist. Nat. Ois.-Mouch., i, livr. 3, 1874, 172 (Porto Rico; "St. Thomas").-Ellior, Ibis, 1872, 348, part (male only; synon.; crit.); Classif. and Synop. Troch., 1879, 40, part (male only).-Gundlach, Journ. für Orn., 1878, 160, 180 (Porto Rico; crit.); 1874, 312 (Porto Rico); Anal. Soc. Esp. Hist. Nat., vii, 1878, 222.-Cory, Auk, iii, 1886, 349, part (male only!) ; Birds West Ind., 1889, 144, part (male only!); Cat. West Ind. Birds 1S92, 12, 106, 132.-SÁlvin, Cat. Birds Brit. Mus., xvi, 1892, 100, part (male only!; Porto Rico; St. Thomas).-Boucard, Gen. Hum. Birds, 1895, 334, part (male only!; Porto Rico).

L[ampornis] viridis HarterT, Das Tierreich, Troch., 1900, 99, part (male only!). [Agyrtria, o. Chalybura] viridis ReIchenbach, Aufz. der Colibr., 1854, 10.

[Agyrtria] viridis Reichenbach, Troch. Enum., 1855, 7, pl. 765, figs. 4771, 4772.

[Chalybura] viridis Mulsant, Ann. Soc. Linn. Lyon, xxii, 1876, 203.

Chalybura (Lampornis) viridis Mulsant and Verreaux, Hist. Nat. Ois.-Mouch., iv, livr. 2, 1878, 157.

[Polytmus] viridis Gray, Hand-list, i, 1869, 125, no. 1579.

\section{Genus SERICOTES Reichenbach.}

‘Anthracothorax ] $\gamma$. Sericotes Reichenbach, Aufz. der Colib., 1854, 11. (Type, Trochilus holosericeus Linnæus.)

Rather large Trochilidæ (length about 100-120 mm.) very closely related to Eutampis, but differing in more naked tarsi, rounded, instead of emarginate, tail and very different coloration, the remiges nonmetallic, and general coloration green, the upper tail-coverts blue and a blue or violet patch on chest.

Bill longer than head, rather stout, nearly terete but broader than deep at base, distinctly decurved; culmen rounded but basally contracted into a narrow ridge; terminal portion of maxillary tomium minutely serrate; mandible with a broad longitudinal median groove. Nasal operculum narrow, concealed by dense appressed frontal feathering, which extends to or slightly beyond anterior end of nostril, forming a short and narrow point or antia on each side of mesorhinium. Tarsus naked except for upper frontal portion; middle and inner toes about equal in length, the outer slightly shorter, the hallux shorter than outer toe. Wing about three times as long as exposed culmen, the outermost primary longest. Tail decidedly more than half as long as wing, slightly but distinctly rounded, the rectrices broad, with nearly truncate tip, the lateral rectrices strongly incurved.

Coloration.-General color green (brighter below), but this relieved by a blue or violet jugular patch, the tail-coverts also blue or greenish blue; tail blue-black or violet-black. Sexes alike. 
Range.-Lesser Antilles and adjacent small islands of the Greater Antilles (St. Thomas, Tórtola, Virgin Gorda, Anegada, and St. Croix); also island of Tobago. (Monotypic.)

\section{SERICOTES HOLOSERICEUS HOLOSERICEUS (LinnæUS).} GREEN CARIB.

Adult male.-Above metallic-green or bronze-green (often suffused with bronze or coppery bronze), passing into bluish-green (sometimes into greenish blue or, rarely, violet-olive) on upper tail-coverts; tail slightly glossy blue-black (the middle rectrices sometimes more greenish), the under surface more violaceous-black, tipped with blueblack or dark steel blue; remiges dusky, faintly glossed with violaceous, the inner secondaries more strongly glossed with greenish; malar region, chin, throat, and foreneck bright metallic yellowish green (apple green to light grass green), passing on sides of chest into a more bluish green and this on center of chest into blue or greenish blue, forming a more or less well-defined patch; under parts of body black, glossed, more or less distinctly, with bluish green, green, or bronzy; under tail-coverts bright metallic green or bluish green, with a subterminal area of blue or violet-blue; femoral and lumbar tufts white; bill dull black; iris dark brown; feet dusky; length (skins), 99-121 (111); wing, 57-63 (61); tail, 31.5-36.5 (33.8); culmen, 20-26 (21.9). ${ }^{a}$

$a$ Thirty-three specimens.

\begin{tabular}{|c|c|c|c|}
\hline Locality. & Wing. & Tail. & $\begin{array}{c}\text { Ex- } \\
\text { posed } \\
\text { culmen. }\end{array}$ \\
\hline MALES. & & & \\
\hline One adult male from St. Thomas... & 60.5 & 34 & 21.5 \\
\hline Two adult males from St. Johns...... & 60.7 & 32.5 & 22.2 \\
\hline One adult male from St. Eustatius.............. & 59.5 & 33.5 & … \\
\hline One adult male from St. Christopher................. & 59 & 34.5 & 20.5 \\
\hline One adult male from Nevis....... & 61.5 & 35 & 21 \\
\hline Six adult males from Barbuda.............. & 58.3 & 33.3 & 22.1 \\
\hline Four adult males from Antigua........... & 60.1 & 32.6 & 21 \\
\hline Four adult males from Guadeloupe...... & 61.2 & 33.9 & 22.2 \\
\hline 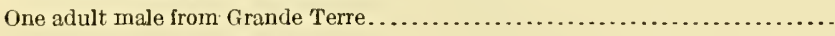 & 61 & 33 & 22.5 \\
\hline Two adult males from Dominica........... & 59.2 & 34.7 & 21.7 \\
\hline Seven adult males from Martinique......................... & 60.8 & 34.3 & 21.9 \\
\hline Two adult males from Santa Lucia......... & 60.2 & 34 & 23.7 \\
\hline One adult male from St. Vincent........ & 63 & 35.5 & 21.5 \\
\hline 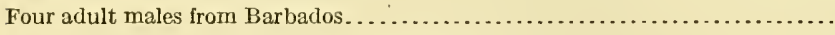 & 62.7 & 34.1 & 21.5 \\
\hline FEMALES. & & & \\
\hline Two adult females from Culebra.... & 58.7 & 32.5 & 23.5 \\
\hline One adult female from St. Johns.......... & 59.5 & 34 & 26 \\
\hline One adult female from St. Christopher........... & 58.5 & 32.5 & 24 \\
\hline Four adult females from Barbuda........... & 59.4 & 33 & 22.7 \\
\hline Two adult females from Antigua...................... & 59.2 & 33.7 & 23.7 \\
\hline One adult female from Guadeloupe....... & 58.5 & 33.5 & 26 \\
\hline 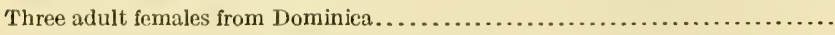 & 61 & 34.5 & 23.8 \\
\hline One adult female from Martinique...... & 59.5 & 34.5 & 25.5 \\
\hline 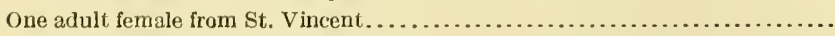 & 59.5 & 33.5 & 24.1 \\
\hline Ten adult females from Barbados...... & 61.3 & 33.9 & 24.4 \\
\hline
\end{tabular}


Adult female.-Similar to the adult male, and perhaps not aiways distinguishable, but usually with the blue jugular area smaller and more greenish blue, and bill longer; length (skins), 110-121 (115); wing, 57.5-62 (59.5); tail, 32-35 (33.5); culmen, 21.5-26.5 (24.1). ${ }^{a}$

Young.-Similar to adults, but color of under parts much duller, the chin, throat, and chest wholly dull metallic bronze-green, with underlying portion of feathers grayish dusky.

Lesser Antilles (islands of Barbados, Union, Carriacou, Canounn, Bequia, St. Vincent, Santa Lucia, Martinique, Dominica, Marie Galante, Desirade, Grand Terre, Guadeloupe, Montserrat, Antigua, Barbuda, Nevis, St. Christopher, St. Eustatius, Saba, St. Bartholomew, and Sombrero), and Virgin group (islands of St. Croix, Anegada, Virgin Gorda, Tórtola, St. Johns, St. Thomas, and Culebra).

[Trochilus] holosericens Lrnnæus, Syst. Nat., ed. 10, i, 1758, 120 (based on Blackbellied Green Humming-bird Edwards, Gleanings, i, pl. 36, etc.); ed. 12, i, 1766, 191.-Guelix, Syst. Nat., i, pt. i, 1788, 491.-Lathan, Index Orn., i, 1790, 305.-Temanck, Cat. Syst., 1807, 81.

Trochilus holosericeus Audebert and Vielulot, Ois. Dorés, i, 1801, 19, pl. 6 ("Porto Rico").-Tienlot, Nouv. Dict. d'Hist. Nat., vii, 1817, 357 ("Mexico;" "Guiana;" "Porto Rico;" "St. Domingo").-Lesson, Hist. Nat. Colibr., 1830-31, 76, pl. 20 (St. Thomas; "Porto Rico;" Martinique); Index Gen. et Symop. Troch., 1832, p. xi.

T]rochilus] holosericeus ViemLot, Tabl. Enc. Méth., ii, 1822, 551.

P[olytmus] holosericeus Gray, Gen. Birds, i, Dec., 1848, 108.

[Polytmus] holosericeus GraY, Hand-list, i, 1869, 130, no. 1649.

[Eulampis] holosericens Bonaparte, Consp. Av., i, 1850, 72; Rev. et Mag. de Zool., 185̃4, 250.-Sclater and Salvin, Nom. Av. Neotr., 1873, 81, part.Mulsant, Ann. Soc. Linn. Lyon, xxii, 1876, 211, part.-Cory, List Birds West Ind., 1885, 17, part.-Sclater, Proc. Zool. Soc. Lond., 1889, 395 (Santa Lucia).

Eulampis holosericeus GouLD, Mon. Troch., pt. xiv, 1857 (vol. ii, 1861), pl. 83; Introd. Troch., oct. ed., 1861, 68.-CAssin, Proc. Ac. Nat. Sci. Phila., 1860, 377 (St. Thomas).-Sclater, Cat. Am. Birds, 1862, 291; Froc. Zool. Soc. Lond., 1871, 272 (Santa Lucia); 1874, 175 (Barbados); 1883, 499 (Anguilla); 1892，499 (Anguilla).-TAYLOR, Ibis, 1864, 170 (Martinique; Dominica; habits).-Mulsant and Verreaux, Classif. Troch., 1866, 42; Hist. Nat. Ois.-Mouch., ii, livr. 2, 1875, 134; Suppl., pl. 41.-Semper, Proc. Zool. Soc. Lond., 1872, 651 (Santa Lucia; descr. nest).-Elцrot, Ibis, 1872, 35 (St. Thomas; St. Croix; Martinique; Dominica; Santa Lucia; synon.; crit.); Classif. and Synop. Troch., 1879, 42 (excl. syn. part). - SAlviN, Cat. Birds Brit. Mus., xvi, 1892, 105 (excl. syn. part).-Lawrence, Proc. U. S. Nat. Mus., i, 1878, 60 (Dominica; habits), 192 (St. Vincent), 234 (Antigua); i, 1879, 358 (Martinique), 458 (Guadeloupe), 487, part (Barbuda; Antigua; Guadeloupe; Dominica; Martinique; St. Vincent).-Alten, Bull. Nutt. Orn. Club, v, 1880, 167 (Santa Lucia).-Lister, Ibis, 1880, 42 (St. Vincent).-Grisdale, Ibis, 1882, 486 (Montserrat; habits).-Conx, Auk, iii, 1886, 351, part; iv, 1887, 96 (Martinique); vii, 1890, 374 (Anegada), 375 (Tortola; Virgin Gorda); viii, 1891, 47 (Antigua; St. Eustatius), 48 (St. Croix; St. Christopher; Guadeloupe); Birds West Ind., 1889, 146, part; Cat. West Ind. Birds, 1892, 13, 106, 
155, part; Ibis, 1886, 472 (Barbados), 474 (Marie Galante; Desirade), 475 (Grand Terre).-FeildeN, Ibis, 1889, 486 (Barbados; habits).--RidgwaY, Proc. U. S. Nat. Mus., xii, 18\$0, 130 (Santa Lucia).-Verrilu (G. and A. H.), Trans. Conn. Ac. Arts and Sci., viii, 1892, 331 (Dominica; habits; descr. nest and eggs).-Lodge, Ibis, 1896, 510 (Dominica; habits).-Nicoll, Ibis, 1904, 558 (Barbados; crit.), 562 (Santa Lucia), 570 (Dominica), 573 (St. Christopher; crit.), 574 (St. Croix; St. Thomas).-Wells, Auk, xix, 1902, 345 (Carriacou; descr. nest).

E[ulampis] holosericeus SAlvin, Ibis, 1873, 334 (Barbados).-HaRTERT, Novit. Zool., v, 1898, 520 (crit.).

Eulampis holocericeus Mulsant and Verreaux, Hist. Nat. Ois.-Mouch., iv, livr. $3,1878,200$.

[Anthracothorax] $\gamma$. Sericotes holosericeus Reichen bach, Aufz. der Colibr., 1854, 11. [Anthracothorax] holosericeus RetchenBach, Troch. Enum., 1855, 9, pl. 794, fig. 4847.

Sericotes holosericeus Eudes-Deslongchamps, Ann. Mus. Caen, i, 1880, 185.Boucard, Gen. Hum. Birds, 1895, 337 (St. Thomas; Martinique; Dominica; Santa Lucia; St. Croix).--Riley, Smithson. Misc. Coll., xlvii, 1904, 287 (Barbuda; Antigua).-Clark (A. H.), Proc. Bost. Soc. N. H., xxxii, 1905, 274, part (Barbados; St. Vincent; Bequia; Canouan; Union I.; Carriacou; crit.; descr. nest and eggs).

[Sericotes] holosericeus Hartert, Novit. Zool., v, 1898, 520 (crit.).-Sharpe, Handlist, ii, 1900, 120.

S[ericotes] holosericeus HARTERT, Das Tierreich, Troch., 1900, 103.

L[ampornis] holosericeus Cabanis and Heine, Mus. Hein., iii, 1860, 17 ("Porto Rico").

[Lampornis] holosericeus GundLACH, Journ. für Orn., 1874, 312 (Porto Rico); 1878, 160 (Porto Rico).

Lampornisholosericeus GundhacH, Anal. Soc. Esp. Hist. Nat.; vii, 1878, 224 (Porto Rico); Journ. für Orn., 1878, 181 (Porto Rico; crit.).

Trochilus (Lampornis) holosericeus Sundevalu, Efv. k. Vet.-Ak. Förh., 1869, 600 (Porto Rico).

Eulampis chlorolæmus (not of Gould) NewTon (A. and E.), Ibis, 1859, 138 (St. Croix; habits).-Sclater, Cat. Am. Birds, 1862, 291, excl. syn. (St. Thomas).Lawrence, Ann. Lyc. N. Y., viii, 1864, 99 (Sombrero).

L[ampornis] chlorolaema Cabanis and Heine, Mus. Hein., ii, 1860, 17, footnote ("Insel Nevis, St. Croix, St. Thomas, St. Johns, etc.").

\section{SERICOTES HOLOSERICEUS CHLOROLAMUS (Gould).}

\section{DARKER GREEN CARIB.}

Similar to $S . h$. holosericeus, but green of throat, etc., much darker (metallic grass green) and blue jugular area larger and more violaceous. Adult male.-Length (skins), 106-112 (109); wing, 59.5-62.5 (61.1); tail, 33.5-35 (34); culmen, 22-22.5 (22.2). ${ }^{a}$

Adult female.-Length (skins), 110-128 (117); wing, 62-62.5 (62.2); tail, 34-36 (35.2); culmen, 26.5-27 (26.7). ${ }^{a}$

Islands of Grenada and Tobago.

Eulampis Gould nov. sp. Bonaparte, Consp. Av., i, 1850, 72 (nomen nudum).

[Eulampis] chlorolxmus (ex Gould, manuscript) Bonaparte, Rev. et Mag. de Zool., 1854, 250 (nomen nudum!). 
Eulumpis chlorolacmus Gould, Mon. Troch., pt. xiv, 1857 (vol. ii, 1861), pl.84 (locality unknown;" coll. J. Gould); Introd. Troch., oct. ed., 1861, 68 ("St. Thomas;" "St. Croix").—Boucamn, The IIum. Bird, i, 1891, 25 ("Trinidad," i. e., Tobago?; deser.; (erit.).

[Anthracothorax. r. Sericotes] chlorolaimus ReIcnenbacu, Aufz. der Colibr., 1854, 11 (nomen nudum).

[Anthracothorax| chlorolaimus Reruenbach, Troch. Enum., 1855, 9 (nomen nudum).

[Polytmus] chlorolimus Grar, Hand-list, i, 1869, 130, no. 1650.

Sericotes chlorolamus Boucard, Gen. Hum. Birds, 1895, 337 (Grenada).

S[ericotes] chlorolacmus Hartert, Das Tierreich, Troch., 1900, 103.

[Sericotes] chlorolamus Sharpe, Hand-list, ii, 1900, 120.

C[?] chlorolaemus Har'tert, Novit. Zool., v, 1898, 520 (crit.; Grenada).

Eulam pis longirostris GoulD, Introd. Troch., oct. ed., 1861, 69 (locality unknown; coll. J. Gould).

[Polytmus] longirostris Gray, Hand-list, i, 1869, 130, no. 1651.

Sericotes longirostris Eudes-Deslongchaups, Ann. Mus. Hist. Nat. Caen, i, 1880, 186.

[Eulampis] longirostris HARtert, Novit. Zool., v, 1898, 520 (crit.).

[Eulampis] holosericeus Sclater and Salvin, Nom. Av. Neotr., 1873, 81, part.

Eulampis holosericeus (not Trochilus holosericeus Linnæus) Lawrence, Proc. U. S.

Nat. Mus., i, 1879, 272 (Grenada), 487, part (Grenada).-- Wells, Proc. U. S.

Nat. Mus., ix, 1887, 619 (Grenada; descr. nest and eggs).-Cory, Cat. West

Ind. Birds, 1892, 13, 106, 155, part (Grenada).-Lodge, Ibis, 1896, 519 (Grenada).

Sericotes holosericeus Chark (A. H.), Proc. Bost. Soc. N. H., xxxii, 1905, 274, part (Grenada; crit.).

\section{Genus EULAMPIS Boie.}

Eulampis Bore, Isis, 1831, 547. (Type, Trochilus jugularis Linnæus.)

Culampis (typographical error?) Lesson, Ind. Gen. Troch., 1832, p. vii.

Rather large Trochilidæ (length about 115-125 mm.); upper parts and under parts of body velvety black, tail-coverts bright metallic bluish green, wings bright metallic bronze-green, and throat and chest soft metallic reddish purple.

Bill longer than head, rather stout, strongly decurved, nearly terete, but decidedly broader than deep basally; culmen rounded but basally contracted into a narrow ridge; terminal portion of maxillary tomium minutely serrate; mandible with a distinct lateral median broad groove or sulcus. Nasal operculum narrow, hidden by dense frontal feathering, the latter extending to or slightly beyond anterior end of nostril, forming a distinct point or antia on each side of mesorhinium. Tarsus stout, densely feathered, except lower and posterior portions; lateral toes equal in length, decidedly shorter than middle toe, the hallux as long as lateral toes or very slightly shorter. Wing more than three times as long as exposed culmen, the outermost primary longest. Tail about half as long as wing, emarginate, the rectrices very broad, with broadly rounded tip, the lateral ones strongly incurved; upper tail-coverts very large and broad.

a A specimen said to be from the Island of Nevis is mentioned in the text, but the locality is certainly erroneous. 
Coloration.-Pileum, back, and under parts of bods velvety black; upper tail-coverts bright metallic bluish green; tail dark metallic green or greenish black; wings (including remiges) bright metallic bronze-green; chin, throat, and chest soft reddish purple. Sexes alike.

Range.-Lesser Antilles. (Monotypic.)

\section{EULAMPIS JUGULARIS (Linnæus). PURPLE CARIB.}

Adults (sexes alike).-Upper parts, except wings, upper tail-coverts, and tail, uniform velvety black; upper tail-coverts metallic bluish green or greenish blue; tail greenish black, glossed with metallic bluish green; wings bright metallic green, the wing-coverts and secondaries more yellowish or golden green, the primaries more bluish green, duller (nearly black on the two outermost); malar region, chin, throat, and chest uniform metallic reddish purple (maroon purple to nearly burnt carmine), this color encroaching on sides of neck; under tail-coverts bright metallic bluish green or greenish blue; rest of under parts velvety black; under surface of wings metallic green, brightest on coverts; bill black; iris dark brown; feet dusky.

Immature.-Essentially like adults, but reddish purple of throat, etc., narrower, restricted to a broad median stripe, the lateral portions (including malar region) black; black of upper parts glossed, more or less, with bluish green (in younger individuals intermixed, more or less, with brown feathers).

Adult male.-Length (skins), 114-136 (124); wing, 67-78.5 (74.3); tail, 35-45 (39.9); culmen, 21-27.5 (22.8). ${ }^{a}$

Adult female.-Tength (skins), 114-132 (124); wing, 65-78 (71.1); tail, 33.5-42.5 (38); culmen, 19-30 (25.2). ${ }^{b}$

a Thirty specimens.

$b$ Fifteen specimens.

\begin{tabular}{|c|c|c|c|}
\hline Locality. & Wing. & Tail. & $\begin{array}{c}\text { Ex- } \\
\text { posed } \\
\text { culmen. }\end{array}$ \\
\hline MALES. & & & \\
\hline Two adult males from St. Christopher... & 76 & 39 & 24 \\
\hline One adult male from Nevis.............. & 75 & 41 & 24 \\
\hline Four adult males from Guadeloupe......... & 72.6 & 39.5 & 23.3 \\
\hline Seven adult males from Dominica......... & 75.6 & 40.7 & 22.5 \\
\hline Seven adult males from Martinique......... & 75.6 & 41.6 & 22.3 \\
\hline Eight adult males from $\mathrm{Si}$. Vincent....... & 72 & 38 & 22.8 \\
\hline One adult male from Barbados..... & 78 & 41 & 23 \\
\hline FEMALES. & & & \\
\hline One adult female from St. Christopher... & 70.5 & 36.5 & 30 \\
\hline Two adult females from Guadeloupe...... & 69.2 & 35.7 & 25.7 \\
\hline Seven adult females from Dominica........ & 73.1 & 39.6 & 24 \\
\hline Two adult females from $\mathrm{S} t$. Vincent....... & 66.5 & 34.5 & 25 \\
\hline One adult female from Martinique....... & 71 & 39 & 27 \\
\hline Two adult females from Santa Lucia..... & 70.5 & 38.5 & 26 \\
\hline
\end{tabular}


Lesser Antilles (islands of St. Christopher, Nevis, Barbuda, Montserrat, Guadeloupe, Grand Terre, Dominica, Martinique, Santa Lucia, Bequia, St. Vincent, and Barbados).

[Trochitus] jugularis Linswus, Syst. Nat., ed. 12, i, 1766,190 (based on Redbrcasted Humming-bird Edwards, Gleanings, ii, pl. 266, fig. 2; etc.).Gulelix, Syst. Nat., i, pt. 1, 178S, 4S9.-Latham, Index Orn., i, 1790, 305.

Trochilus jugularis Mïller, Syst. Nat. Suppl., 1776, 100 (cites Buff. Pl. Enl. 27 , fig. 3).-Audebert and Vieillot, Ois. Dorés, i, 1801, 17, pl. 4; ii, 1S02, 126.-Temmack, Cat. Syst., 1807, 79.

$I$ [olytmus] jugularis Grar, Gen. Birds, i, Dec., 1S4S, 10 .

[P'olytmus] jugularis Grar, Hand-list, i, 1869, 130, no. 1648.

Eulampis jugularis Reichenвach, Auiz. der Colibr., 1854, 11; Troch. Enum., 1S55, 9, pl. 796, figs. 4851, 4852.-Gould, Mon. Troch., pt. xiv, 1857 (vol. ii, 1S61), pl. 82; Introd. Troch., oct. ed., 1S61, 67.-Sclater, Cat. Am. Birds, 1862. 291; Proc. Zool. Soc. Lond., 1871, 272 (Santa Lucia); 18s9, 326 (Dominica), 395 (Santa Lucia).-TAYlor, Ibis, 1864, 169 (Martinique; Dominica; habits).-Mulsant and Verreaux, Classif. Troch., 1866, 45; Hist. Nat. Ois.-Mouch., ii, livr. 2, 1875, 131 (Martinique, etc.; "north Brazil"); iv, livr. 3, 1S7S, 200.-Semper, Proc. Zool. Soc. Lond., 1872, 651 (Santa Lucia).-Elliot, Ibis, 1872, 352 (synon.; crit.); Classif. and Synop. Troch., 1879, 43.-Lawrence, Proc. U. S. Nat. Mus., i, 1878, 60 (Dominica), 192 (St. Vincent), 240 (Barbuda); i, 1879, 358 (Martinique), 458 (Guadeloupe), 487 (Guadeloupe; Dominica; Martinique; St. Vincent).-Allen, Bull. Nutt. Orn. Club, v, 1880, 167 (Santa Lucia).-Lister, Ibis, 1880, 42 (St. Vincent).-Grisdale, Ibis, 1SS2, 489 (Montserrat).-Cory, Auk, iii, 1856, 351, 473 (St. Vincent); iv, 1887, 96 (Martinique); viii, 1891, 48 (St. Christopher; Guadeloupe); Ibis, 1886, 475 (Grand Terre); Birds West Ind., 1889, 145; Cat. West Ind. Birds, 1S92, 13, 106, 143.-SAlvin, Cat. Birds Brit. Mus., xvi, 1592, 102.-Verrill (G. and A. H.), Trans. Conn. Ac. Arts and Sci., viii, 1892, 330, pl. 25, fig. 1 (Dominica; habits; descr. nest).Bodcard, Gen. Hum. Birds, 1895, 336).-Lodge, Ibis, 1896, 509 (Dominica; habits).-Nicoll, Ibis, 1904, 562 (Santa Lucia), 570 (Dominica).-Clark (A. H.), Proc. Bost. Soc. N. H., xxxii, 1905, 273 (St. Vincent; Bequia).

E[ulampis] jugularis Cabanis and Heine, Mus. Hein., iii, 1860, 17 (Martinique).-Hartert, Das Tierreich, Troch., 1900, 102.

[Eulampis] jugularis Bonaparte, Consp. Av., i, 1850, 72 ("St. Thomas;" "Gujana;" "Cayenna"); Rev. et Mag. de Zool., 1854, 250.-Sclater and Salvin, Nom. Av. Neotr., 1873, 81.-Mulsant, Ann. Soc. Linn. Lyon, xxii, 1S76, 210.-Sharpe, Hand-list, ii, 1900, 119.

Eulampes jugularis Hartert, Kat. Vogelsamml. Mus. Senckenb., 1891, 114 (Martinique).

[Trochilus] auratus Guelis, Syst. Nat., i, pt. 1, 1788, 487 (based on Garnetthroated Humming-bird Latham, Synop., i, pt. 2, 752).

Trochilus auratus Lesson, Hist. Nat. Colibr., 1830-31, 46, pl. 10; Index Gen. et Synop. Troch., 1832, p. vii.

Trochilus (Culampis) auratus Lesson, Index Gen. et Synop. Troch., 1832, 7.

[Trochilus] auratus, var. B. Gurelin, Syst. Nat., i, pt. 1, 1788, 487 (based on Grenat Buffon, Hist. Nat. Ois., vi, 48).

[Trochilus] violaceus GuenIn, Syst. Nat., i, pt. 1, 1788, 488 (based on Colibri violet Buffon, Hist. Nat. Ois., vi, 57; Colibri violet de Cayenne Buffon, Pl. Enl., pl. 600, fig. 2; Polytmus cayennensis violaceus Brisson, Orn., iii, 683, pl. 35, fig. 3).-Lathaм, Index Orn., i, 1790, 306.

Trochilus violaceus Vienlot, Nouv. Dict. d'Hist. Nat., vii, 1817, 358. 
T[rochilus」 violaceus Vieillot, Tabl. Enc. Méth., ii, 1822, 552.

T[opaza] violacea Gray, Gen. Birds, i, Dec., 1848, 110.

Trochilus (Culampis) violaceus Lesson, Index Gen. et Synop. Troch., 1832, p. vii.

(?)[Trochilus] venustissimus Gmelin, Syst. Nat., i, 1788, 490 (based on Polytmus mexicanus cyaneus Briss. Av. 3, p. 681, n. 9; Avicula mexicana cyaneo colore venutissima Seb. Mus. I, p. 102, t. 65, f. 3 ; etc.).

(?)[Trochilus] cyanomelas GMelin, Syst. Nat., i, 1788, 498 (based on Black and blue Humming-bird Bancr. Guj. p. 167; Latham, Syn. i, 2, p. 782, n. 50).

[Trochilus] granatinus LatHaM, Index Orn., i, 1790, 305 (based on Trochilus auratus Gmelin; Garnet-throated Humming-bird Latham, Synop., ii, 752, 9, pl. 34).

Trochilus granatinus VieiLlot, Nouv. Dict. d'Hist. Nat., vii, 1817, 350 (cites Trochilus auratus Gmelin, and Ois. Dorés, "pl. 4, de 1'Hist. Colibris d'Audebert").

(?)[Trochilus] cyaneus Latham, Index Orn., i, 1790, 309 (based on Trochilus venustissimus Gmelin; Polytmus mexicanus cyaneus Brisson, Orn., iii, 681, 3; Le Colibri bleu Buffon, Ois., vi, 61; etc.).

(?)[Trochilus] bancrofti Latham, Index Orn., i, 1790, 317 (based on Trochilus cyanomelas Gmelin; Black and blue Humming-bird Bancroft, Guiana, p. 167; Latham, Synop., ii, 782).

Trochilus bancrofti Vieillot, Nouv. Dict. d'Hist. Nat., vii, 1817, 359.

Certhia prasinoptera Sparrman, Mus. Carls., fasc. 4, no. lxxxi, 1789, pl. 81 (based on Souimanga prasinoptére Vieillot, Ois. Dor., ii, 1802, 65).

Eulampis jugularis eximius BERLEPSCH, Ibis, July, 1887, 294 (Nevis, Lesser Antilles; coll. Count von Berlepsch).

[Eulampis jugularis] eximius HaRtert, Novit. Zool., v, 1898, 520 (crit.).

\section{Genus COLIBRI Spix.}

Colibri SpIx, Av. Bras., i, 1824, 80. (Type, C. crispus $\mathrm{Spix}=$ Trochilus serrirostris Vieillot.)

Petasophora Gray, List Gen. Birds, 1840, 13. (Type, Trochilus serrirostris Vieillot.)

Petasophorus (emendation) Mulsant and Verreaux, Classif. Troch., 1866.

[Petasophora] 3. Telesiella Reichenbach, Aufz. der Colib., 1854, 13. (Type, Ornismya delphinæ Lesson.)

[Petasophora] r. Praxilla ReIchenbach, Aufz. der Colib., 1854, 13. (Type, Ornismya anais Lesson, i. e., Petasophora iolota Gould.)

Telesilla (emendation) Cabanis and Heine, Mus. Hein., iii, 1860, 27.

Delphinella "Reich[enbach]" Bonaparte, Ann. Sci. Nat. (Zool.), sér. 4, i, 1854, 137 (new name for Telesiella Reichenbach).

Medium-sized to large Trochilidæ (length about 100-125 mm.) with a post-auricular tuft of violet, violet-blue, or violet-red broad and rounded, imbricated feathers, and the broad, rather long, tail metallic blue, green, or olive crossed by a subterminal band of dark metallic bluc, green, black, or bronze-dusky.

Bill shorter than head to decidedly longer, straight or slightly decurved, nearly terete but slightly depressed basally; culmen rounded, but contracted at base into a narrow ridge; tomia sometimes smooth, sometimes with minute serrations near tip of maxillary tomium; mandible with a distinct longitudinal median groove 
or sulcus. Nasal opereulum moderately broad and convex, unfeathered, but mostly concealed by orerhanging frontal feathers, which extend anteriorly beyond anterior end of nostrils, forming a more or less prominent point or antia on cach side of the mesorhinium. Tarsus clothed with short feathers; middle and inner toes about equal in length, the outer slightly shorter, the hallux shorter than outer toe; feet relatively very small. Wing more than three times (sometimes four times) as long as exposed culmen, the outermost primary longest. Tail nearly to quite two-thirds as long as wing, emarginate, the rectrices broad, with broadly rounded tip.

Coloration.-Above metallic green or (in one species only) grayish brown or olive, the tail metallic green or blue, or (in $C$. delphinæ) olive, crossed by a subterminal band of darker green, blue, blackish, or bronze-dusky; a conspicuous post-auricular tuft of violet, violetblue, or (in $C$. serrirostris) violet-red broad, rounded and imbricated feathers; under parts mostly metallic green, this broken by darker centers to the strongly individualized feathers (producing an effect quite peculiar to the genus), sometimes relieved by a violet or violetblue pectoral or jugular area, the chin and suborbital region also sometimes violet or violet-blue; in $C$. delphinæ the under parts brownish (more or less spotted or mottled), the throat with metallic green, bluish, or bronzy feathers, the tail-coverts broadly margined with light cinnamon. Sexes alike in coloration, but females usually decidedly smaller than males.

Range.-Southern Mexico to Guiana, southern Brazil, Bolivia, and Peru. (Nine species.)

KEY TO THE SPECIES OF COLIBRI.

a. General color metallic green.

b. A patch of violet-blue on center of chest or breast.

c. Larger (wing 70-84.5, tail 45-55, culmen 23-28.5); whole chin blue. (Colombia to Venezuela, Bolivia, and Peru.)......... Coliori iolotus (extralimital). $a$ cc. Smaller (wing 60-70, tail 35.5-45, culmen 18-22); chin wholly green or with only extreme upper margin blue. (Guatemala and southern líexico.)

Colibri thalassinus (p. 482).

66. No blue on under parts. (Costa Rica to Venezuela, Bolivia, and Ecuador.)

Colibri cyanotus (p. 484).

aa. General color grayish brown or olive, the upper tail-coverts (in young other upper parts) margined terminally with cinnamon, rusty, or buffy. (Guatemala to Peru, Trinidad and Guiana.).................... Colibri delphinæ (p. 486).

a Rhamphodon anais (not Ornismya anais Lesson, 1830) Lesson, Hist. Nat. Troch., 1832, I46, pl. 55.--Petasophora anais Gould, Proc. Zool. Soc. Lond., 1847, 8; Mon. Troch., pt. iv, 1853, pl. 224; Introd. Troch., oct. ed., 1861, 124; Elliot, Classif. and Synop. Troch., 1879, 50.-Petasophora iolota Gould, Proc. Zool. Soc. Lond., 1847, 9 (Bolivia).-Fetasophora iolata Gould, Mon. Troch., pt. iv, I853, pl. 225; Introd. Troch., oct. ed., I861, 124; Salvin, Cat. Birds Brit. Mus., xvi, 1892, 107.-C[olibri] iolotus Hartert, Das Tierreich, Troch., 1900, 94 (monogr.).

This species undoubtedly requires subdivision into two or more subspecies.

$81255^{\circ}-\mathrm{Bu} 11.50-11-31$ 


\section{COLIBRI THALASSINUS (Swainson).}

MEXICAIN VIOLET-EAR.

Adult male.-Above metallic green or bronze-green, darker or duller on pileum; tail metallic bluish green or greenish blue (middle rectrices sometimes green or even bronze-green) crossed by a broad subterminal band of blue-black; remiges dark brownisl slate or dusky, very faintly glossed with bronzy purplish or violet, the secondaries more or less glossed at tip and on edges with metallic green or bronze-green; loral, suborbital, and auricular regions rich metallic dark violet-blue, this sometimes invading, somewhat, sides of neck; malar region, chin, and throat bright metallic green (varying from slightly bluish to yellowish emerald green), each feather with a darker mesial streak or spot; center of chest dark metallic blue or violet-blue, this passing into metallic-green laterally; breast, sides, flanks, and abdomen metallic green or bronze-green, duller posteriorly, where sometimes slightly broken by faint pale grayish brown or pale grayish buff tips or margins to the feathers; under tail-coverts metallic green or bronze-green, margined or edged with pale buffy brownish or grayish buffy; bill dull black; iris dark brown; feet dusky grayish brown; length (skins), 103-122 (114); wing, 63-70 (66.9); tail, 39-45 (42.3); culmen, 18-22 (20.2). ${ }^{a}$

Adult female.-Similar to the adult male, but smaller and slightly duller in coloration; length (skins), 103-112 (107); wing, 60-63 (61); tail, 35.5-40 (37.5); culmen, 19-22 (20.3). ${ }^{b}$

Young.-Similar to adult female, but much duller in coloration, the upper tail-coverts and feathers of rump (sometimes pileum also) narrowly and indistinctly margined with pale grayish buffy; green of under parts much duller and suffused with grayish, the feathers indistinctly margined terminally with pale grayish, and blue of chest absent or slightly indicated.

Southern Mexico, in States of Guanajuato, Mexico (Temascáltepec; Ajusco; Tetelco; Chimalapa; Valley of Mexico; Hacienda Eslava), Hidalgo (Reál del Monte), Puebla, Vera Cruz (Jalapa; Córdova;

\begin{tabular}{|c|c|c|c|}
\hline Locality. & Wing. & Tail. & $\begin{array}{c}\text { Ex- } \\
\text { posed } \\
\text { culmen. }\end{array}$ \\
\hline MALES. & & & \\
\hline Nine adult males from southern Mexico..... & 67.3 & 42.9 & 20.8 \\
\hline $\begin{array}{l}\text { Seven adult males from Guatemala } \ldots \ldots \ldots \ldots \ldots \ldots \ldots \ldots \ldots \ldots \ldots \\
\text { FEMALES. }\end{array}$ & 66.3 & 41.6 & 19.3 \\
\hline Five adult females from southern Mexico (Vera (ruz, Michoacán, and Oaxaca).. & 60.6 & 37.4 & 20.6 \\
\hline 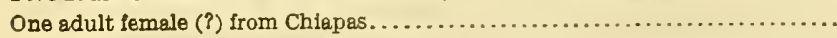 & 63 & 38 & 19 \\
\hline
\end{tabular}


Coátepec; Mount Orizaba), Oaxaca (Totóntepec; Oaxaca City), Guerrero (Chilpancingo, 6,000-8,000 feet), Michoacán (Patzcuaro; Mount Tancítaro), Jalisco (Bolaños) and Chiapas (San Cristóbal) and Territory of Tepíc (San Blas) and highlands of Guatemala (San Martín, Santa Maria, Quipaché, ete., Quezaltenango; Montañas de Chilasco; Dueñas; Cobán; Tolimán; Guatemala City; Hacienda Chancól; Tolcán de Fuego).

Trochilus thalassinus Swanson, Philos. Mag., n. s., i, 1827, 441 (Temascáltepec, Mexico; Bullock coll.).

P[olytmus] thalassinus GraY, Gen. Birds, i, Dec., 1848, 108.

[Polytmus] thalassinus Gray, Hand-list, i, 1869, 127, no. 1606.

Petasophora thalassina Gould, Proc. Zool. Soc. Lond., 1847, 8 (Mexico; crit.); Mon. Troch., iv, 1853, pl. 227; Introd. Troch., oct. ed., 1861, 125.-Sclater, Proc. Zool. Soc. Lond., 1858, 297 (Oaxaca); 1859, 367 (Jalapa), 368 (Totontepec, Oaxaca); 1864, 177 (near City of Mexico); Cat. Am. Birds, 1862, 306.Sclater and Salvin, Ibis, 1859, 127 (Guatemala).-Salvin, Ibis, 1859, 468 (above the plains of Dueñas, Guatemala); 1860, 195, 260 (Dueñas and Volcán de Fuego, Guatemala), 263 (Volcán de Fuego, Guatemala); Cat. Birds Brit. Mus., xvi, 1892, 109.-Mulsant and Verreaux, Classif. Troch., 1866, 48; Hist. Nat. Ois.-Mouch., ii, livr. 2, 1875, 148 (Mexico; Guatemala); iv, livr. 3, 1878, 202.-Lawrence, Proc. Bost. Soc. N. H., xiv, 1871, 284 ("Tres Marias"; error); Mlem. Bost. Soc. N. H., ii, 1874, 292 ("Tres Marias").-Boucard, Notes Troch. du Mex., 1875, 11 (Mexico; Puebla; Oaxaca; Guatemala); Liste Ois. récol. Guat., 1878, 45; Gen. Hum. Birds, 1895, 318. - De OCA, La Naturaleza, iii, 1875, 64 (Hacienda Eslava, Chimalapa, and Tetelco, Valley of Mexico; Montañas del Orizaba and Coátepec, Vera Cruz); Troq. de Mex., 1875, 27, pl. (5), fig. 17.-Elliot, Ibis, 1876, 404 (synon.; crit.); Classif. and Synop. Troch., 1879, 51.-Sumichrast, La Naturaleza, v, 1881, 250 (Orizaba).-Ferrari-Perez, Proc. U. S. Nat. Mus., ix, 1886, 157 (Puebla).-Herrera, La Naturaleza, (2), i, 1891, 322 (Valley of Mexico).-Salvin and Godman, Biol. Centr.-Am., Aves, ii, 1892, 281.-Hartert (E. and C.), Novit. Zool., i, 1894, 20 (Chilpancingo, Guerrero, 6,000-8,000 ft.; descr. nest and eggs).-Cox, Auk, xii, 1895, 357 (Mt. Orizaba, 11,000 ft.).-Dearborn, Pub.125, Field Mus. N. H., 1907, 99 (near Tecpám, Guatemala, $9,500 \mathrm{ft}$.).

[Petasophora] thalassina Bonaparte, Rev. et Mag. Zool., 1854, 2500,-ReichenBaCH, Troch. Enum., 1855, 11.-Sclater and Salvin, Nom. Av. Neotr., 1873, 89.-Mulsant, Ann. Soc. Linn. Lyon, xxii, 1876, 211.-Sharpe, Hand-list, iii, 1900, 117.

C[ynanthus] thalassinus JARdine, Nat. Libr., Humming Birds, ii, 1833, 174. [Colibri] thalassinus Bonaparte, Consp. Av., i, 1850, 69.

Colibri thalassinus Oberholser, Proc. U. S. Nat. MIus., zxiv, 1902, 319, in text. C[olibri] thalassinus Hartert, Das Tierreich, Troch., 1900, 94 (monogr.).

Colibris thalassina Sclater, Proc. Zool. Soc. Lond., 1856, 287 (Mexico).

[Petasophora. $;$. Praxilla] thalassina. Reichenbach, Aufz. der Colibr., 1854, 13.

Ornismya anais Lesson, Hist. Nat. Colibr., Suppl. Ois.-Mouch., 1831, 104, pl. 3

("Chile"); Index Gen. et Synop. Troch., 1832, p. ix, part (Temascáltepec, Mexico).

Rhamphodon anais Lesson, Les Trochilidées, 1831, 146, 148, pls. 55 , 56 (Mexico). Trochilus anais Swainson, Birds Brazil and Mex., 1841?, pl. 75. 


\section{COLIBRI CYANOTUS (Bourcier and Mulsant).}

LESSER VIOLET-EAR:

Similar to C. thalassinus, but without blue on chest or lores.

Adult male.-Above metallic green or bronze-green; tail more bluish green (the middle rectrices usually more bronzy), crossed by a broad subterminal band of blue-black; remiges dark brownish slate or dusky, very faintly glossed with purplish; suborbital and auricular (but not loral) region rich dark metallic violet-blue; chin and throat bright metallic green (varying from slightly bluish to yellowish emerald green) each feather with a darker median streak or spot; rest of under parts duller metallic green, the center of chest sometimes slightly tinged with bluish green; under tail-coverts metallı green or bronze-green, margined (broadly toward base) with pale brownish or grayish buffy; femoral tufts brownish white; bill dull black; iris dark brown; feet grayish brown or dusky; length (skins), 98-118 (109); wing, 59.5-68.5 (65.2); tail, 35-45.5 (40.4); culmen, 19.5-23.5 (21.2). ${ }^{a}$

Adult female.-Similar to the adult male, but smaller and slightly duller in color; length (skins), 96-113 (103); wing, 58-68 (62.3); tail, 34-43 (38.3); culmen, 16-23 (20.5). ${ }^{b}$

Young.-Essentially like adults, but feathers of upper parts conspicuously tipped or margined with rusty brown or cinnamon, those of under parts similarly but less distinctly margined, the chin and throat dull metallic green (the brilliant feathers of the adult plumage first appearing on center of throat).
a Thirty specimens.
$b$ Twelve specimens.

\begin{tabular}{|c|c|c|c|}
\hline Locality. & Wing. & Tail. & $\begin{array}{c}\text { Ex- } \\
\text { posed } \\
\text { culmen. }\end{array}$ \\
\hline MaLes. & & & \\
\hline Teu adult males from Costa Rica...... & 65.3 & 40.6 & 21.3 \\
\hline Six adult males from Panamá.......... & 64.9 & 40 & 21.8 \\
\hline Five adult males from Colombia.......................... & 63.4 & 39.4 & 20.6 \\
\hline One adult male ( $C . c . \longrightarrow$ ?) from eastern Ecuador............... & 68.5 & 40.5 & 19 \\
\hline 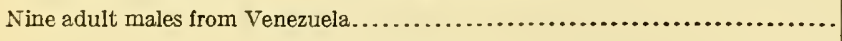 & 66.2 & 40.9 & 20.9 \\
\hline FEMALES. & & & \\
\hline Seven adult females from Costa Rica.......... & 60.5 & 37.7 & 20.3 \\
\hline Two adult females (C.c. — ? ) from eastern Ecuador..... & 61.2 & 36.7 & 20.7 \\
\hline Five adult females from Venezuela..... & 64.9 & 39.2 & 20.8 \\
\hline
\end{tabular}

I feel quite sure that several of the alleged females from Venezuela are in reality males with the sex wrongly determined. If these were eliminated the average dimensions of the female would be considerably reduced.

Specimens from Costa Rica, Panamá, Colombia, and Venezuela seem to be quite alike; but those from eastern Ecuadór (Baeza) are easily distinguished by their conspicuously buffy under tail-coverts and (at least in males) larger size. 
Costa Rica (Grécia; Las Cruees de Candelária; Escazú; San José; Voleán de Irazú; Voleán de Turrialba; La Estrella de Cartago; Cartago; Orosí; Barranca; San Pedro; Dota; Copéy, Santa Maria de Dota) and southward through Panama (Boquete; Volcan de Chiriquí; Chitra; Calorérora) to Colombia (Bogotá; Valparaiso, El Libano, Minea, San Sebastiun, and El Mamón, Santa Marta; Alto; Canuto; Santa Elena) and Tenezucla (Carácas; Conejos Escorial and Culata, near Mérida; Méricla; Aragua Valley; Andes de Cumaní); Ecuadór (Bateza; Pallatanga; Cayandeled; Cechec; Pogio; Ibarra; La Concepción; Baños)a? Peru (Idma; Tambillo; Huasampilla; Maraynioc; Culinachay) ?; Bolivia (Yungas; Tilotilo)?

(?) Ornismya anais Lesson, Hist. Nat. Troch., 1830-31, 151, pl. 57.

Trochilus] cyanotus Bourcier and Mulsant, Anu. Sci. Phys. et Nat. Lyon, vi, 1843, 41 (Carácas, Tenezuela); Rev. Zool., vi, April, 1843, 101 (Carácas).

Petasophora cyanotus Gould, Proc. Zool. Soc. Loud., 1847, 8 (Bogotá, Colombia; crit.); Mon. Troch., pt. v, May, 1853 (vol. iv), pl. 228.-(?) Whitely, Proc. Zool. Soc. Lond., 1873, 784 (Peru).

(?) Colibris cyanotus Berlepsch and Stolzmann, Proc. Zool. Soc. Loud., 1902, 21 (Maraynioc, Culinachay, centr. Peru).

C[olibri] cyanotus Hartert, Das Tierreich, Troch., 1900, 94.

(?) Colibri cyanotus Oberholser, Proc. U. S. Nat. Mus., xxiv, 1902, 319 (Baeza, e. Ecuador; crit.).-Berlepsch and! Stolzmann, Ornis, 1906, 95 (Idma, Peru).

[Colibri] cyanotis Bonaparte, Consp. Av., i, 1850, 69

[Petasophora. $\gamma$. Praxilla] cyunotis Reichenbach, Aufz. der Colibr., 1854, 13.

[Petasophora] cyanotis Boraparte, Rev. et Mag. de Zool., 1854, 251.-Sclater and Salvis, Nom. Av. Neotr., 1873, 89.

(?) Petasophora cyanotis Sclater, Proc. Zool. Soc. Lond., 1859, 145 (Pallatanga, Ecuadór).-Whitely, Proc. Zool. Soc. Lond., 1873, 784 (Peru).-Taczanowski, Proc. Zool. Soc. Lond., 1879, 237 (Tambillo, Peru); Orn. du Pérou, i, 1884, 369.-Berlepsch and Taczanowski, Proc. Zool. Soc. Lond., 1884, 303 (Cayandeled and Cechce, w. Ecuadór).-Hartert (E. and C.), Novit. Zool., i, 1894, 4 (Pogio, Ecuador).-Hartert (E.), Novit. Zool., v, 1898, 495 (Ibarra, n. W. Ecuador).-Salvadori and Festa, Boll. Mus. Zool., etc., Torino, xr, 1900, 9 (La Concepción, centr. Ecuadór).

(?) P[etasophora] cyanotis Cabanis and Heine, Mús. Hein., iii, 1860, 26, part (Peru).

(?) [Petasophora] cyanotis Gould, Proc. Zool. Soc. Lond., 1870, 803 (Baños, Ecuadór).

$P[$ etasophora $]$ cyanotis Cabanis and Heine, Mus. Hein., iii, 1860, 26, part (Verágua, Panamá).

Petasophora cyanotis Gould, Introd. Troch., oct. ed., 1861, 125.-CaBAnIS, Journ. für Orn., 1862, 162 (Costa Rica; crit.).-Lawrence, Ann. Lyc. N. Y., ix, 1868, 125 (Barranca, Dota, and Cartago, Costa Rica).-Frantzius, Journ. für Orn., 1869, 316 (Costa Rica).-Salvin, Proc. Zool. Soc. Lond., 1870, 210 (Volcán de Chiriquí, Chitra, and Calovévora, Panamá); Cat. Birds Prit. Mus., xvi, 1892, 110 (Orosí and Volcán de Irazú, Costa Rica; localities in

a As stated in footnote on p. 484 the birds from eastern Ecuadór (I have not seen any from central or western Ecuador) are probably subspecifically distinct. In this case it is hardly possible that those from Peru and Bolivia should represent true C. cyanotus, but I have seen none from either of those countries. 
Panamá; Minca and San Sebastián in Santa Marta, and Bogotá, Colombia; Mérida and Aragua Valley, Venezuela; Baños, Ecuadór?; Huasampilla, Peru?; Yungas and Tilotilo, Bolivia?).-Wуатт, Ibis, 1871, 377 (Alto and Canuto, Colombia, 5,000-6,000 ft.).-Mulsant and Verreaux, Hist. Nat. Ois.-Mouch., ii, livr. 2, 1875, 151 (Costa Rica; Colombia; Venezuela; Ecuadór?; Peru?); iv, livr. 3, 1878, 202 (synonymy); Suppl. pl. 40.-Elliot, Ibis, 1876, 404 (Costa Rica; Panamá; Colombia; Venezuela); Classif. and Synop. 'Troch., 1879, 51.-Boucard, Proc. Zool. Soc. Lond., 1878, 69 (Volcán de Irazú, 8,000 ft.; habits); The Hum. Bird, ii, 1892, 85 (Bogotá).—Sclater and Salvin, Proc. Zool. Soc. Lond., 1879, 530 (Santa Elena, Colombia).Salvin and Godman, Ibis, 1880, 173 (Minca, Santa Marta, Colombia, 2,000 ft.); Biol. Centr.-Am., Aves, ii, 1892, 282 (Las Cruces de Candelária, etc., Costa Rica; localities in Panamá; Colombia, etc.).-Nutting, Proc. U. S. Nat. Mus., v, 1882, 500 (San José, Costa Rica).-Zeledón, Cat. Aves de Costa Rica, 1882, 20; Anal. Mus. Nac. Costa Rica, i, 1887, 121 (Faldas de Irazú).Ridgway, Proc. U. S. Nat. Mus., v, I883, 500 (Volcán de Irazú).-BerLEPSCH, Journ. für Orn., 1884, 319 (Alto and Canuto, Colombia); 1887, 318 (Bogotá; synonymy).-Bangs, Proc. New Engl. Zool. Club, i, 1899, 76 (San Sebastián and El Mamón, Santa Marta, Colombia).-Allex, Bull. Am. Mus. N. H., xiii, 1900, 140 (Valparaiso and El Libano, Santa Marta).-Simon and Dalmas, Ornis, xi, 1901, 214 (Andes de Cumaná, Venezuela).

[Petasophora] cyanota SHARPe, Hand-list, ii, 1900, 117.

P[etasophora] thalassina (not Trochilus thalassinus Swainson) CABANIS and FeINE, Mus. Hein., iii, 1860, 27 (Verágua, Panamá).

(?) Petasophora cabanidis a Heine, Journ. für Orn., 1863, 182 (Costa Rica).

(?) [Polytmus] cabanidis GRAY, Hand-list, i, 1869, 127, no. 1608.

(?) [Petasophora] cabanidis Heine and Reichenow, Nom. Mus. Hein. Orn., 1890, 177.

Petasophora cyanotis cabanidis (not Petasophora cabanidis Heine?) Bangs, Proc. New Engl. Zool. Club, iii, Jan. 30, 1902, 30 (Boquete, Panamá, 4,000-5,800 ft.; crit.).

Petasophora cyanotus cabanidis OвerHolser, Proc. U. S. Nat. Mus., xxiv, no. 1258, Jan., 1902, 319, in text.

Colibri cyanotus cabanidis Carriker, Ann. Carnegie Mus., vi, 1910, 538 (mts. of Costa Rica; crit.).

Petasophora cabanisii Lawrence, Ann. Lyc. N. Y., ix, 1868, 126 (Costa Rica; coll. G. N. Lawrence).-Boucard, The Hum. Bird, ii, 1892, 85 (Verágua); Gen. Hum. Bird, 1895, 318 (Irazú, Costa Rica; Verágua).

[Petasophora] cyan[otis] cabanisi Simon, Cat. Troch., 1897, 22.

\section{COLIBRI DELPHINA (Lesson).}

\section{BROWN VIOLET-EAR.}

Adults (sexes alike).-Above dull grayish brown or olive, very faintly glossed (in certain lights) with greenish bronze, bronze, or purplish bronze, the feathers of rump and upper tail-coverts margined terminally with cinnamon or cinnamon-buffy; tail greenish olive, faintly but distinctly glossed with bronze, crossed by a broad subterminal band of blackish or dusky, glossed with purplish bronze; remiges dark brownish slate or dusky, faintly glossed with purplish;

a According to Hartert (Novit. Zool., iv, 148), C' cabanidis Heine is C. delphinæ (Lesson). 
lores pale cimmamon or dull whitish; malar region dull white to pale brownish gray or pale brown, forming a more or less conspicuous stripe; suborbital and auricular regions and patch on upper portion of side of neck rich dark metallic violet-blue or bluish violet; general color of under parts dull grayish brown, the feathers usually more or less distinctly edged or margined with paler (forming a somewhat streaked appearance), the throat mostly (sometimes wholly) covered by a patch of metallic green, this often passing at lower extremity into blue or riolet-blue; under tail-coverts cinnamon or cinnamonbuff, with a subbasal or central spot of light grayish brown or olive; femoral tufts (inconspicuous) dull white, tinged with cinnamon; bill dull black, the mandible somewhat more brownish, at least basally; iris dark brown; feet dusky grayish brown.

Young. - Similar to adults, but feathers of back, scapulars, hindneck and pileum broadly tipped or terminally margined with rusty brown or dull cinnamon, wing-corerts narrowly tipped with the same, and (in earlier stage) without any blue on side of head or neck. ${ }^{a}$

Adult male.-Length (skins), 99-114 (106); wing, 67.5-76.5 (71.9); tail, 36.5-47 (41.6); culmen, 16-20 (17.5). ${ }^{b}$

Adult female.-Length (skins), 93-116 (105); wing, 66-76 (69.3); tail, $37-\frac{1}{4} 5$ (40); culmen, 16-18 (16.9). ${ }^{\circ}$

Guatemala (Cobán, Tera Paz), British Honduras (forest near Manatee Lagoon) and southward through Honduras (San Pedro), Nicaragua (Chontales), Costa Rica (Escazú; San Pedro de Mojón; Bonilla; Miravalles; Boruca), Panamá (Calovévera, Verágua), Colombia (Bogotá; Bonda and Ninca, Santa Marta; Rio Dagua; Bucara-

a In what are apparently younger birds there is no metallic blue whatever on sides of neck, the auricular region being dusky (nonmetallic); in apparently older individuals there is a patch of metallic violet-blue on upper side of neck, immediately behind the auricular region.

$b$ Twenty-three specimens.

$c$ Eleren specimens.

\begin{tabular}{|c|c|c|c|}
\hline Locality. & Wing. & Tail. & $\begin{array}{c}\text { Ex- } \\
\text { posed } \\
\text { culmen. }\end{array}$ \\
\hline MALES. & & & \\
\hline One ảdult male from Guatemala......... & 74.5 & 43 & 20 \\
\hline One adult male from British Honduras.... & 71 & 39.5 & 17.5 \\
\hline Ten adult males from Costa Rica.......... & 70.6 & 40.5 & 16.7 \\
\hline Six adult males from Colombia .......... & 71.8 & 42.2 & 17.3 \\
\hline Five adult males from western Ecuador..... & 74.3 & 43.2 & 18.7 \\
\hline FEMALES. & & & \\
\hline Four adult females from Costa Rica.. & 66.5 & 39.5 & 16.6 \\
\hline Two adult females from Colombia..... & 66 & 38 & 16.5 \\
\hline Three adult fomales from western Ecuador... & 72.3 & 40.2 & 17.3 \\
\hline Two adult females from British Guiana... & 72.5 & 43.2 & 18 \\
\hline
\end{tabular}


manga), Ecuadór (Quito; Mindo; Gualea; Citado; Zamora; Pogio; Sarayacu; Paramba; Ibarra), Trinidád (Aripo), and Venezuela (Carácas; Parima Mountains) to British Guiana (Roraima; Merumé Mountains) and Peru (Cosnipata; Huambo).

Ornismya delphinæ Lesson, Rev. Zool., ii, Feb., 1839, 44 (unknown; coll. Longuemare).

P[olytmus] delphinæ Gray, Gen. Birds, i, Dec., 1848, 108.

[Polytmus] delphin: GRAy, Hand-list, i, 1869, 127, no. 1610.

Polytmus delphinæ LÉotaud, Ois. Trinidad, 1866, 134.

Petasophora delphinæ Gould, Proc. Zool. Soc. Lond., 1847, 9; Mon. Troch., iv, pt. v, 1853, pl. 229; Introd. Troch., oct. ed., 1861, 125.-Salvin, Ibis, 1860, 194, 195, 261 (Cobán, Guatemala; habits); 1872, 320 (Chontales, Nicaragua); 1885, 434 (Merumé Mts. and Roraima, Brit. Guiana, 3,000-5,500 ft.); Proc. Zool. Soc. Lond., 1870, 210 (Calovévora, Panama); Cat. Birds Brit. Mus., xvi, 1892, 111, 657 (Cobán, Guatemala; Chontales, Nicaragua; Calovévora, Panamá; Minca in Santa Marta, Fusagasugá, Bogotá, and Llanos del Rio Mata, Colombia; Quito and Sarayacu, Ecuadór; Peru; Carácas, Venezuela; Trinidád?; Merumé Mts. and Roraima, Brit. Guiana).-Salvin and Sclater, Ibis, 1860, 276 (Cobán).-Mulsant and Verreaux, Classif. Troch., 1866, 49; Hist. Nat. Ois.-Mouch., ii, livr. 2, 1875, 157; iv, livr. 3, 1878, 202.Sclater and Salvin, Proc. Zool. Soc. Lond., 1870, 837 (Guatemala; San Pedro, Honduras; Costa Rica; Guiana).--Whitely, Proc. Zool. Soc. Lond., 1873, 784 (Cosnipata, Peru).-Elliot, Ibis, 1876, 406 (synon.; crit.); Classif. and Synop. Troch., 1879, 52.-SAlvin and Godman, Ibis, 1880, 173 (Minca, Santa Marta, Colombia, 2,000 ft.); Biol. Centr.-Am., Aves, ii, 1892, 282.Zeledón, Cat. Aves de Costa Rica, 1882, 20; Anal. Mus. Nac. Costa Rica, i, 1887, 121 (Bogotá).-Taczanowski, Proc. Zool. Soc. Lond., 1882, 37 (Huambo, Peru); Orn. du Pérou, i, 1884, 371.-Berlespsch, Journ. für Orn., 1884, 309 (Bucaramanga, Colombia; crit.); 1887, 318 (Bogotá; synonymy); Proc. Zool. Soc. Lond., 1885, 118 (Citado, Ecuadór).-Boucard, The Hum. Bird, ii, 1892, 85 (Verágua; Bogotá); v, 1895, 7 (Rio Dagua, n. w. Colombia); Gen. Hum. Birds, 1895, 321.-Hartert (E. and C.), Novit. Zool., i, 1894, 4 (Zamora and Pogio, Ecuadór).-Сhapman, Bull. Am. Mus. N. H., vi, 1894, 57 (Trinidád).-Cherrie, Bull. Brooklyn Inst. Arts and Sci., 1906, 6 (Aripo, Trinidád).-Hartert, Novit. Zool., iv, 1897, 148 (crit.); v, 1898, 496 (Paramba and Ibarra, n. w. Ecuadór).-BAngs, Proc. Biol. Soc. Wash., xii, 1898, 135 (Santa Marta).-Allen, Bull. Am. Mus. N. H., xiii, 1900, 140 (Bonda, Santa Marta).

[Petasophora] delphinæ Bonaparte, Rev. et Mag. de Zool., 1854, 251.-ReIchenBACH, Troch. Enum., 1855, 11.-Gould, Proc. Zool. Soc. Lond., 1870, 803 (Citado, Ecuadór).-Sclater and Salvin, Nom. Av. Neotr., 1873, 89.Sharpe, Hand-list, ii, 1900, 117.

[Petasophora] delphinae Mulsant, Ann. Soc. Linn. Lyon, xxii, 1876, 211.

[Colibri] delphinae Bonaparte, Consp. Av., i, 1850, 69.

C[olibri] delphinae Hartert, Das Tierreich, Troch., 1900, 93 (monogr.).

Colibri delphinae Berlepsch and Hartert, Novit. Zool., ix, 1902, 87 (Parima

Mts., Venezuela).-Oвerholser, Proc. U. S. Nat. Mus., xxiv, 1902, 319 (Mindo and Gualea, w. Ecuadór).-Banas, Auk, xxiv, 1907, 296 (Boruca, Costa Pica).-Carriker, Ann. Carnegie Mus., vi, 1910, 537 (Costa Rica).

[Petasophora. 3. Telesiella] delphinae Reichendach, Aufz. der Colib., 1854, 13. T[elesilla] delphinae CaBanis and Herne, Mus. Hein., iii, 1860, 27 (Colombia).

[Telesiella] delphinae Heine and Reichenow, Nom. Mus. Hein. Orn., 1890, 177 (Colombia). 
Genus LAMPROLAIMA Reichenbach.

[Heliodoxa] ò. Lamprolaima Rercinennacir, Aufz. der Colib., 1854, 9. (Type, Omismya rhami Lesson.)

Lamprolama (emendation) Gould, Mon. Troch., pt. xi, May, 1856, text to pl. 61 (rol. ii, 1S61, text to pl. 61).

Lamprolaima Cabaxis and Herne, Mus. Heine, iii, March, 1860, 30.

Large Trochilide (length about 110-120 mm.) with straight bill about as long as head; wing four times as long as exposed culmen; tail nearly two-thirds as long as wing, emarginate; remiges extensively deep cinnamon-rufous or chestnut, the adult male with chin and throat rosy purple between lateral areas of velvety black, chest metallic riolet-blue, and tail violet-black, the female with under parts deep brownish gray, glossed with green laterally.

Bill about as long as head, straight, slender, terete; culmen rounded terminally, narrowly ridged basally; tomia smooth; mandible with the usual longitudinal groove, but this narrow and rather indistinct. Nasal operculum rather narrow, convex and tumid posteriorly, mostly concealed by frontal feathering, which extends to or a little beyond anterior end of nostrils, forming a very short point or antia on each side of culmen. Tarsus rather stout, densely feathered except along posterior side; toes strong, the outer slightly, the inner decidedly, shorter than middle toe, the stout hallux about as long as inner toe. Wing four times as long as exposed culmen, the ontermost primary longest. Tail nearly two-thirds as long as wing, deeply emarginate, the rectrices broad, with rounded tip.

Range.-Mountains of southern Mexico and Guatemala. (Monotypic.)

\section{LAMPROLAIRA RHAMI (LesSOn).}

\section{GARNET-THROATED HUMMING BIRD.}

Adult male.-Above bright metallic green or bronze-green, slightly duller and more decidedly bronzy posteriorly; tail entirely purplish black or very dark violet-purple; remiges and greater wing-coverts deep cinnamon-rufous or rufous-chestnut, margined terminally with purplish dusky, the longer primaries extensively of the latter color terminally, the inner secondaries partly dull bronze-greenish; a small white postocular spot; loral, auricular, suborbital, and malar regions and sides of lower throat velvety black in position $a$, glossed with purplish bronze in position $c$; chin and throat bright metallic reddish purple or purplish red (varying from solferino to nearly crimson); chest and upper breast rich metallic violet or violet-blue in position $a$, more decidedly violet in position $b$, much duller and more greenish in position $c$; rest of under parts grayish black or dusky, the breast, sides, and flanks strongly glossed with metallic bronze-green, the abdomen more slaty; under tail-coverts dull blue-black or purplish 
black, more or less distinctly margined with grayish white; femoral tufts and very inconspicuous (mostly concealed) tuft between sides and upper rump grayish white; bill black; iris dark brown; feet dusky; length (skins), 113-127 (120); wing, 73.5-81 (77.2); tail, 45-51.5 (47.5); culmen, $15-19$ (17.9). ${ }^{a}$

Adult female.-Above similar to the adult male, but the green slightly more bronzy, especially on pileum; rufous-chestnut of remiges and greater wing-coverts more restricted, the dusky purplish or bronzy brown proportionally more extended; lateral rectrices tipped, more or less broadly, with brownish gray, all the rectrices except middle pair narrowly edged with the same; under parts deep sooty brown (dark broccoli or hair brown), the chest usually tinged with buffy brown or cinnamon, the sides and flanks glossed or spotted with metallic green, the breast sometimes faintly glossed with bluish green or greenish blue, the throat often with an admixture of metallic reddish purple feathers; femoral tufts white, as in adult male; under tail-coverts grayish dusky or sooty, more or less distinctly margined with whitish; bill, etc., as in adult male; length (skins), 97-113 (109); wing, 64-67.5 (66.2); tail, 40-44 (41.7); culmen, 15.5-18.5 (16.7). ${ }^{b}$

Highlands of southern Mexico, in States of Vera Cruz (Jalapa; Coátepec; Jico; Córdova; Orizaba; Niradór; Cofre de Perote), Mexico ("near City of Mexico"), Guerrero (Chilpancingo; Omilteme), Oaxaca (La Parada; Tonaguia; Totóntepec; Mount Zempoáltepec; near Oaxaca City) and Chiapas (San Cristóbal) and Guatemala (Santa Maria and San Martín, Quezaltenango; El Rincón, San Marcos; Calderas, Volcán de Fuego; Volcán de Agua; Chilasco; Cobán; Cajabón; Guatemala City; above Tecpám).

O[rnismya] rhami Lesson, Rev. Zool., i, 1838, 315 (Mexico).

Ornysmia rhami Delattre and Lesson, Rev. Zool., ii, 1839, 13.

M[ellisuga] rhami Gray, Gen. Birds, i, Dec., 1848, 112.

[Lampornis] rhami Bonaparte, Consp. Av., i, 1850, 72 (Mexico).

[Delattria] rhami Bonaparte, Rev. et Mag. de Zool., 1854, 353.

a Twenty-three specimens.

$b$ Nine specimens.

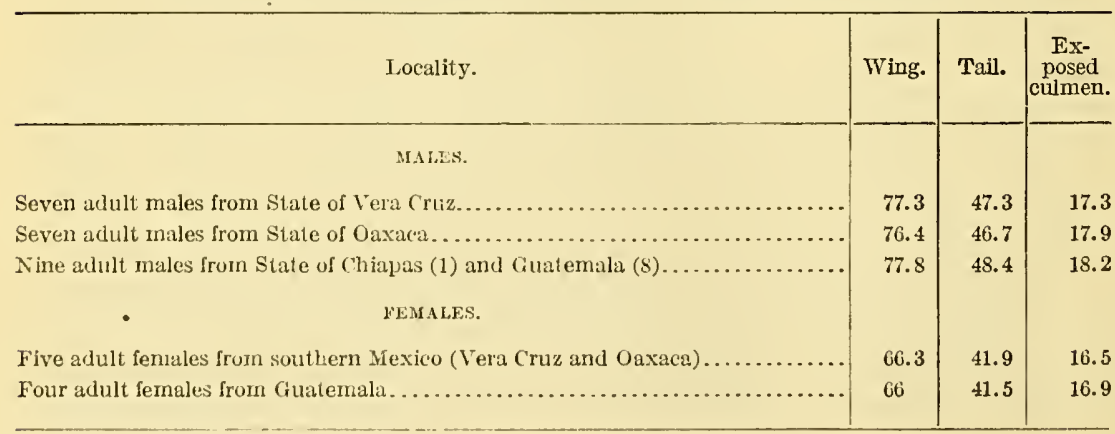


Delattria rhami Sclater, Proc. Zool. Soc. Lond., 1856, 287 (Mexico); 1858, 297 (Oaxaca); 1859, 367 (Jalapa, Vera Cruz).

[Heliodora.] 0. Lamprolaima thami Reichenbach, Aufz. der Colibr., 1854, 9.

[Hetiodoxa] rhami Reichenbacr, Troch. Enum., IS55, 6, pl. 746, figs. 4712, 4713.

Lamprotama thami Gould, Mon. Troch., pt. xi, May, 1866 (vol. ii, 1S61, pl. 61);

Introd. Troch., oct. ed., 1861, 59.-Sclater and Salvin, Ibis, 1859, 129

(Guatemala).-Salvin, Ibis, 1859, 468 (Calderas, Volcán de Fuego, Guatemala); 1860, 196 (Calderas); Cat. Birds Brit. Mus., xvi, 1892, 314 (Cofre de Perote, Coátepec, Jalapa, and Córdova, Vera Cruz; Omilteme, Guerrero; Tonaguia and Totóntepec, Oaxaca; Santa Maria and San Martín, in Quezaltenango, Volcán de Fuego, Chilasco, and Cajabón, Guatemala).-Sclater, Cat. Am. Birds, 1862, 289; Proc. Zool. Soc. Lond., 1864, 176 ("near City of Mexico").-Elliot, Classif. and Synop. Troch., 1879, 32.-Sumichrast, La Naturaleza, v, 1881, 250 (alpine region, Orizaba).-Salvin and Godman, Biol. Centr.-Am., Aves, ii, 1892, 338.-Ridgway, Proc. U. S. Nat. Mus., iii, 1880, 310 (Orizaba and Miradór, Vera Cruz; Guatemala City).-Dearborn, Pub. 125, Field Mus. N. H., 1907, 99 (above Tecpám, Guatemala).

[Lamprolæma] thami Sclater and Salvin, Nom. Av. Neotr., 1873, S0.-Sharpe, Hand-list, ii, 1900, 123.

L[amprolaema] rhami Cabanis and Heine, Mus. Hein., iii, 1860, 30 (Guatemala).Hartert, Das Tierreich, Troch., 1900, 117.

Lamprolaima rhami D'OcA, La Naturaleza, iii, 1875, 25 (Coátepec, Córdova, and Orizaba, Vera Cruz); Troq. de Mex., 1875, 16, pl. (2), fig. 8.--Ridgway, Man. N. Am. Birds, 1887, 304, in text.

Lamprolaema rhami Boucard, Notes quelques Troch., 1873, 7 (Jalapa; La Parada; Cobán; habits); Ann. Soc. Linn. Lyon, xx, 1874, 275; Liste Ois. récol. Guat., 1878, 45; Gen. Hum. Birds, 1895, 216.-Mulsant and Verreaux, Hist. Nat. Ois.-Mouch., ii, livr. 3, 1876, 218 (Mexico; Guatemala); iv, livr. 3, 1878, 206 (synonymy).-Hartert (E. and C.), Novit. Zool., i, 1894, 63 (Chilpancingo, Guerrero, 6,000-8,000 ft.).

Clytolaema rhami Mulsant and Verreaux, Classif. Troch., 1866, 59.

[Trochilus] rhami Gray, Hand-list, i, 1869, 140, no. 1805.

Lamprolæma rami Mulsant and Verreaux, Hist. Nat. Ois.-Mouch., ii, livr. 2, 1875, pl. 24.

\section{Genus CYANOLAEMUS Stone.}

Cyanolæmus a Stone, Auk, xxiv, April, 1907, 197, in text. (Type, Ornismyia clemenciæ Lesson.)

Large Trochilidæ (length about $125 \mathrm{~mm}$.) with bill longer than head, straight, slender; wing three times as long as exposed culmen; tail three-fifths as long as wing, slightly emarginate or (in female) double-rounded; feathered tarsi, and rather dull coloration, the under parts grayish (adult male with throat metallic blue).

Bill longer than head, straight, terete; culmen rounded except basally, where contracted into a narrow ridge; tomia smooth; mandible with a broad longitudinal median groove. Nasal operculi broad and convex posteriorly (when edge descends to or below the tomia), only its upper-posterior portion covered by frontal feathering; 
the latter extending nearly as far as its anterior end, forming a very short point or antia on each side of culmen. Tarsus clothed, except behind, with short feathers; lateral toes about equal in length, slightly shorter than middle toe, the hallux about as long as lateral toes. Wing more than three times as long as exposed culmen in adult male, less than three times as long in adult female, the outermost primary longest. Tail about three-fifths as long as wing, slightly emarginate in adult male, slightly double-rounded (with lateral rectrices shorter than middle pair) in adult female.

Coloration.-Above rather dull bronze-green or greenish bronze, duller (grayish brown) on pileum, the tail dull bluish black, with lateral rectrices broadly tipped with white; a white postocular streak and whitish rictal streak, inclosing a dusky auricular space; under parts gray, the adult male with feathers of throat tipped with metallic blue.

Range.-Southwestern United States, near Mexican border, to Guatemala. (Monotypic.)

\section{CYANOLEMUS CLEMENCIAE (Lesson).}

BLUE-THROATED FUMMING BIRD.

Adult male.-Above rather dull metallic bronze-green, passing into olive-bronze or bronzy olive on rump, where the feathers have narrow terminal margins of pale brownish gray or buffy grayish; upper tailcoverts dusky (sometimes faintly glossed with greenish or bluish), narrowly and indistinctly margined with paler; tail black, faintly glossed with bluish, the outermost rectrix with terminal third (or less) abruptly white, the second less extensively tipped with white, the third usually with a small median white streak or mark (usually more or less fusiform or diamond-shaped) near tip; remiges dark brownish slate color or dusky, very faintly glossed with purplish; a conspicuous white postocular streak, extending obliquely backward and downward behind upper posterior margin of auricular region, the latter, together with the suborbital and loral regions, plain dusky; a more or less distinct rictal streak of whitish (this sometimes obsolete); chin and throat metallic blue (varying from a greenish to a slightly violet hue), the feathers very narrowly and indistinctly margined with brownish gray and with concealed portion of the latter color; rest of under parts plain deep brownish gray or brownish slate color, the under tail-coverts broadly margined with white; femoral and anal tufts and tuft on each side of rump white; bill dull black; iris dark brown; feet dusky; length (skins), 116-136 (119); wing, 72-79 (76.7); tail, 43.5-50 (46.6); culmen, 21.5-25 (23.3). ${ }^{a}$

a Twenty-three specimens. 
Adult female. - Similar to the adult male, but blue of throat replaced by the general dull brownish gray of under parts; length (skins), 111-126 (11S); wing, 6S.5-71 (69.7); tail, 41-45.5 (43.2); culmen, $24-27.5(25.8))^{a}$

Highlands of Mexieo, in States of Tamaulipas (Galindo), Chihuáhua (Sierra Madre), Durango (Cindád Durango; Sierra Valparaiso; Rancho Baillón; Arroyo del Buéy), Zacatecas (Sierra Valparaiso), Jalisco (Barranea Ibarra), Michoacán (Mount Taneítaro; Nahuatzín; Patzcuaro), Guerrero (Omilteme), Oaxaca (La Parada; Cerro San Felipe), Puebla (Tehuacán), Mexico (Ajusco; Amecameca; Ixtapalapa; Rio Frio, Lxtaccihuatl; Tetelco; Hacienda Eslava), Ḿorelos (Cuernavaca), Vera Cruz (Córdora; Coátepec; Las Vegas; Jalapa; Miradór; Orizaba), Tlaxcala (Huehuantla), Guanajuato, San Luís Potosí (Sierra San Luís Potosí), and Nuevo León (Santa Catarina), and northward into western Texas (Chisos Mountains) and southern Arizona (Huachuca, San Luís, Chiricáhua, and Santa Catalina mountains).

Ornismya clemenciae Lesson, Hist. Nat. Ois.-Mouch., 1829, pp. xlv, 216, pl. 80 (Mexico; coll. Rivoli); Suppl. Ois.-Mouch., 1830-31, 115, pl. 8; Index Gen. et Synop. Troch., 1832, p. xviii; Traité d'Orn., 1831, 279.

[Coeligena . Coeligena] clemenciae Reichenbach, Aufz. der Colibr., 1854, 7.

[Coeligena] clemenciae Reichenbach, Troch. Enum., 1855, 3, pl. 687, figs. 4516, 4ว̄17.-Mulsaxt, Ann. Soc. Linn. Lyon, xxii, 1876, 203.

Coeligena clemencix Gould, Introd. Troch., oct. ed., 1861, 59.-Sclater, Cat. Am. Birds, 1862, 289.-Boucard, Notes quelques Troch., 1873, 6 (Oaxaca; habits); Gen. Hum. Birds, 1895, 217.-Mulsant and Verreaux, Hist. Nat. Ois.-Youch., i, livr. 3, 1874, 180; iv, livr. 3, 1877, 158.-VrlladA, La Naturaleza, ii, 1875, 350 (Valley of Mexico).-EuLıot, Classif. and Synop. Troch., 1879, 30.-Ridgway, Proc. U. S. Nat. Mus., iii, 1880, 310 (Miradór, Vera Cruz); Rep. U. S. Nat. Mus. for 1890 (1891), 324, pl. 36 (monogr.; habits).-Sumichrast, La Naturaleza, v, 1881, 250 (Orizaba).-Brewster,

$a$ Eight specimens.

\begin{tabular}{|c|c|c|c|}
\hline Locality. & Wing. & Tail. & $\begin{array}{c}\text { Ex- } \\
\text { posed } \\
\text { culmen. }\end{array}$ \\
\hline MALES. & & & \\
\hline Ten adult males from Arizona.......... & 76.1 & 45.8 & 22.9 \\
\hline Five adult males from southwestern Texas (Chisos Mountains)........... & 76.1 & 45.9 & 23.1 \\
\hline Four adult males from Michoacán.......... & 77.9 & 48.2 & 24.2 \\
\hline Two adult males from Vera Cruz........... & 77.5 & 48.2 & 23.7 \\
\hline One adult male from Oaxaca........................ & 79 & 49 & 24.5 \\
\hline FEßALES. & & & \\
\hline Five adult females from Arizona including Mexican boundary line)....... & 69.8 & 42.5 & 25.4 \\
\hline 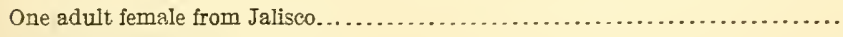 & 69.5 & 41 & 27.5 \\
\hline 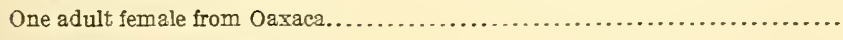 & 68.5 & 43.5 & 26.5 \\
\hline One adult female from Vera Cruz............. & 71 & 45.5 & 25.5 \\
\hline
\end{tabular}


Auk, ii, 1885, 85 ("Camp Lowell," i. e., Santa Catalina Mts., Arizona), 199 (correction of locality).-AMERICAN ORNithologists' Union, Check List, 1886, no. 427.-Salvin, Cat. Birds Brit. Mus., xiv, 1892, 304.-Salvin and Godman, Biol. Centr.-Am., Aves, ii, 1892, 331.-Jour, Proc. U. S. Nat. Mus., xvi, 1893, 784 (Cuernavaca, Morelos).-Bendre, Life Hist. N. Am. Birds, ii, 1895, 190.-Cox, Auk, xii, 1895, 357 (Mt. Orizaba, 11,000 ft.).-Clark (J. H.), Auk, xvii, 1900, 294 (Las Vegas, Vera Cruz; descr. nest and eggs).-BAILEY (Florence M.), Handb. Birds W. U. S., 1902, 234, fig. 304.-Oberholser, Auk, xix, 1902, 300 (Chisos Mts., w. Texas).Breninger, Auk, xx, 1903, 435 (Huachuca Mts., Arizona; descr. nest and eggs).-Swarth, Pacific Coast Avifauna, no. 4, 1904, 17 (Huachuca Mts., summer res.).-Miller (W. De W.), Bull. Am. Mus. N. H., xxii, 1906, 167 (Rancho Baillón and Arroyo del Buéy, Durango; measurements).-PHiLlips, Auk, xxviii, 1911, 78 (Galindo, Tamaulipas).

[Coligena] clemenciz Sclater and Salvin, Nom. Av. Neotr., 1873, 80.-Sharpe, Hand-list, ii, 1900, 122.

C[oeligena] clemenciae Cabanis and Heine, Mus. Hein., iii, 1860, 15 (Mexico).Hartert, Das Tierreich, Troch., 1900, 114.

Coeligena clemenciae Willard, Condor, xiii, 1911, 46-48, figs. 19-22 (Huachuca Mts.; descr. nest and eggs, etc.).

C[eligena] clemenciæ Ridgway, Man. N. Am. Birds, 1887, 310.

Cœligena clementiœ Dugès, La Naturaleza, i, 1870, 141 (Guanajuato).

M[ellisuga] clemencix Gray, Gen. Birds, i, Dec., 1848, 112.

Campylopterus clemenci⿱ J J $1833,154$.

[Delattria] clemenciae Bonaparte, Consp. Av., i, 1850, 70.

Delattria clemenciæ Gould, Mon. Troch., pt. ix, 1855 (vol. ii, 1861, pl. 60).Sclater, Proc. Zool. Soc. Lond., 1856, 287 (Mexico); 1858, 297 (Oaxaca); 1859, 367 (Jalapa).-D'OcA, La Naturaleza, iii, 1875, 100; Troq. de Mex., 1875, 30, pl. (5), fig. 20.

[Lampornis] clemencia Bonaparte, Rev. et Mag. de Zool., 1854, 251.

Cyanolæmus clemenciæ American Ornithologists' Union Committee, Auk, xxv, July, 1908, 374; Check List, 3d ed., 1910, 202.

Coeligena clementiae Srmon, Cat. Troch., 1897, 25.

T[rochilus] topiltzin DE LA Llave, Registro Trimestre, ii, no. 5, Jan., 1833, 49 (Mexico' see Richmond, Auk, xvi, 1899, 325).

\section{Genus LAMPORNIS Svainson.}

Lampornis Swarnson, Philos. Mag., n. s., i, June, 1827, 442. (Type, by monotypy, L. amethystinus Swainson.)

Delattria Bonaparte, Consp. Av., i, 1850, 70. (Type, Ornismya henrica Lesson and Delattre=Lampornis amethystinus Swainson.)

Chariessa HeIne, Journ. für Orn., May, 1863, 178. (Type, Ornismya henrica Lesson and Delattre=Lampornis amethystinus Swainson.)

Himelia Mulsant, Ann. Soc. Linn. Lyon, n. s., xxii, 1876, 203 (Cat. Ois.-Mouch., p. 7). (Type, as fixed by Elliot, 1879, Ornismya henrica Lesson and Delattre= Lampornis amethystinus Swainson.)

Large Trochilidæ (length about 120-125 mm.) resembling Cyanolamus but bill relatively more depressed and broader basally, and very faintly decurved, tail more deeply emarginate and without 
white tips to lateral rectrices, the adult male with throat purple or purplish red instend of blue.

Bill longer than head, depressed, very fautly decurved; culmen rounded except basally, where contracted into a narrow ridge; maxillary tomium very minutely serrate terminally; mandible with a lateral median groove. Nasal opereuhm rather narrow (its convex edge not descending to tomium), the posterior and inner portions covered by frontal feathering, which extends not quite to anterior end of the operculi, forming a very short point or antia on each side of mesorhinium. Tarsus clothed with short feather's, except lower and extreme posterior portions; middle and outer toes nearly equal in length, the inner slightly shorter, the hallux about as long as inner toe. Wing about three times as long as exposed culmen, the outermost primary longest. Tail about threc-fifths as long as wing, rather deeply emarginate in adult male, slightly double-rounded in adult female, the rectrices firm, with rounded tip.

Coloration.--Above metallic bronze-green or greenish bronze, duller on rump and upper tail-corerts, the tail blackish with tips of outer rectrices grayish; a dull whitish postocular streak and a similar (or buffy) rictal one, enclosing a broader auricular space of dusky; under parts brownish gray, adult males with feathers of throat broadly tipped with violet, purple or rosy.

Range.-Highlands of Mexico and Guatemala. (Three species.)

KEY TO THE SPECIES AND SUBSPECIES OF LAMPORNIS.

ـ. Throat metallic reddish purple, purple, violet, or violet-blue. (Adult males.)

b. Throat purple to reddish or pinkish purple. (Lampornis amethystinus.)

c. Throat reddish or pinkish purple, the feathers more broadly and distinctly margined with whitish; under parts paler; averaging larger, with longer bill (wing averaging 67.6, tail 42.3, culmen 21.5). (Southeastern Mexico.)

Lampornis amethystinus amethystinus, adult male (p. 496).

$c c$. Throat magenta purple, the feathers more narrowly and indistinctly margined with pale grayish; under parts darker; averaging smaller, with shorter bill. (Average measurements less than the above.)

d. Dusky suborbital and auricular area less blackish and white postocular streak duller; averaging slightly larger (wing 68, tail 42.2, culmen 20). (Testern Mexico.)

Lampornis amethystinus brevirostris, adult male (p. 497).

dd. Dusky suborbital and auricular area more blackish and postocular streak purer white; a veraging slightly smaller (wing 65.2, tail 39.5, culmen 19.5). (Guatemala and Chiapas.)

Lampornis amethystinus salvini, adult male (p. 498).

$b b$. Throat violet or violet-blue.

c. Throat violet; green of upper parts less bronzy. (Mountains of central Guerrero.).................... Lampornis margaritæ, adult male (p. 499).

$c c$. Throat violet-blue (royal purple or more bluish); green of upper parts more bronzy. (Mountains of eastern Guerrero to central Oaxaca.)

Lampornis pringlei, adult male (p. 500). 
aa. Throat brownish gray, more or less strongly suffused with buffy or cinnamon. (Adult females. ${ }^{a}$ )

$b$. Green of upper parts less bronzy; throat less strongly cinnamomeous.

Lampornis margaritæ, adult female (p. 499).

$b b$. Green of upper parts more bronzy; throat more strongly cinnamomeous.

Lampornis pringlei, adult female (p. 500).

\section{LAMPORNIS AMETHYSTINUS AMETHYSTINUS Swainson.}

\section{CAZIQUE HUMMING BIRD.}

Adult male.-Above metallic bronze-green, greenish bronze, or bronze, usually duller (sometimes faintly metallic olive) on rump, the feathers of pileum usually darker centrally; upper tail-coverts dull black, usually faintly glossed with bluish; tail black, very faintly glossed with bluish, the lateral rectrices tipped with brownish gray; remiges dusky, faintly glossed with violaceous; loral, suborbital, and auricular regions brownish black or dusky, the last margined above by a postocular (supra-auricular) line of white or grayish white, the first and second margined beneath by a rictal streak (more or less distinct) of cinnamon or cinnamon-buff; chin grayish, usually more or less suffused with cinnamon or buffy, the feathers slightly darker centrally; throat bright metallic reddish purple (solferino to wine purple), the feathers conspicuously margined with pale buffy gray or grayish white, producing a distinctly squamate effect; rest of under parts brownish gray, the sides and flanks overlaid by metallic bronzegreen, greenish bronze, or bronze; under tail-coverts deeper brownish gray centrally, broadly margined with dull white or grayish white; femoral and lumbar tufts white; bill dull black, the mandible sometimes brownish; iris dark brown; feet pale brownish (in dried skins), the claws and end of toes darker; length (skins), 109-121 (114); wing, 65-71 (67.6); tail, 39-45 (42.3); culmen, 20-23 (21.5). ${ }^{b}$

Adult female.-Similar to the adult male, but pileum darker and duller (sometimes dusky, faintly glossed with bronze-green or bronzy); chin and throat dull cinnamon (the feathers abruptly dusky grayish basally), and sides and flanks very faintly, if at all, glossed with metallic green or bronze; tips of lateral rectrices paler gray and more sharply defined.

Southeastern Mexico, in States of Mexico (Temascáltepec; Valley of Mexico; Hacienda Eslava), Hidalgo (Reál del Monte), Vera Cruz (Jalapa; Córdova; Coátepec; Montañas de Orizaba; Playa Vicente), and Oaxaca (Oaxaca; Mount Zempoáltepec; Totóntepec).

a No adult female of $L$. amethystinus, in any of its forms, is available at the time of preparing this "Key;" and since the differences between the females of $L$. margaritæ and $L$. pringlei, as given above, are based on a single specimen of each they may not hold good.

$b$ Nine specimens. 
Lampornis amethystimus Swanson, Philos. Mag., n. s., i, June, 1827, 442 Temascaltepec, Re:íl del Monte, Mexico; Bullock coll'n).

D [elattria] amcthystina Simon, Rev. Franç. d'Orn., no. 1, May, 1909, 10, in text.

Ornismyia hemica l.esson and Delattre, Rev. Zool., 1839, 17 (Coátepec, near Jalapa, Vera Cruz, Mexico).

T[opaza] henrica GrAY, Gen. Birds, i, Dec., 1848, 110.

[Topaza] henrica Gray, Hand-list, i, 1869, 134, no. 1726.

[Delaltria] henrica Bonaparte, Consp. Av., i, 1850, 70.

[Delattria] henrici Bonaparte, Rev. et Mag. de Zool., 1854, 253.

Delattria hemica DE OCA, Los Colibris Mex., 1875, 23.

[Heliodoxa o. Lamprolaima] henrica Reichenbach, Aufz. der Colibr., 1854, 9.

[Heliodoxa] henrica Reichenbach, Troch. Enum., 1855, 6, pl. 742, figs. 4701-4703.

D [elattria] henrica henrica Ridgway, Proc. Biol. Soc. Wash., xxi, Oct. 20, 1908, 195 , in text.

Cæligena henrica Ferrari-Perez. Proc. U. S. Nat. Mus., ix, 1886, 157 (Jalapa).

C[œligena] henrica Ridgway, Man. N. Am. Birds, 1887, 310, part (Mexico); Rep.

U. S. Nat. Mus. for 1890 (1891), 324, part (Mexico).

[Coeligena] henrici Mulsant, Ann. Soc. Linn. Lyon, n. s., xxii, 1876, 203.Simon, Cat. Troch., 1897, 25.

[Coligena] henrici Sharpe, Hand-list, ii, 1900, 122, part.

Delattria henrici Gould, Mon. Troch., pt. viii, Oct., 1854 (vol. ii, 1861, pl. 62); Introd. Troch., oct. ed., 1861, 60.-Sclater, Proc. Zool. Soc. Lond., 1856, 287 (Mexico); 1858, 297 (Oaxaca); 1859, 367 (Jalapa), 386 (Totóntepec, Oaxaca); Cat. Am. Birds, 1862, 289, part (in synonymy).--Villada, La Naturaleza, ii, 1875, 351 (Valley of Mexico).-Herrera, La Naturaleza, (2) i, 1891, 322 (Valley of Mexico).-Salvin, Cat. Birds Brit. Mus., xvi, 1892, 308, part (Jalapa, Montañas de Orizaba, and Coátepec, Vera Cruz; Valley of Mexico).Salvin and Godyan, Biol. Centr.-Am., Aves, ii, 1892, 335, part (Hacienda Eslava, Jalapa, Montañas de Orizaba, and Playa Vicente, Vera Cruz; Valley of Mexico; Totóntepec, Oaxaca).-Boucard, Gen. Hum. Birds, 1895, 218, part (Mexico).

Delatria henrici D'Oca, Los Colibris Mex., 1875, pl. 4, fig. 14.

[Delattria] henrici Sclater and Salvin, Nom. Av. Neotr., 1873, 80, part.

C[oeligena] henrici Cabanis and Henne, Mus. Hein., iii, 1860, 15, footnote, part (Mexico).

Coeligena henrici Boucard, Notes quelques Troch., 1873, 7 (Córdova, Jalapa, and Playa Vicente, Vera Cruz); Ann. Soc. Linn. Lyon, xx, 1874, 275 (Córdova).Mulsant and Verreaux, Hist. Nat. Ois.-Mouch., i, livr. 3, 1874, 182, part (Mexico).-Erliot, Classif. and Synop. Troch., 1879, 30 part (Mexico).

Coeligena henricii Mulsant and Verreaux, Hist. Nat. Ois.-Mouch., iv, livr. 2, $1877,159$.

C[hariessa] henrici HeINe, Journ. für Orn., 1863, 178 (synonymy).

Lampornis hentici Mulsant and Verreaux, Classif. Troch., 1866, 24.

C[oeligena] henrica (typica) HARTert, Das Tierreich, Troch., 1900, 114, part (Mexico).

\section{LAMPORNIS AMETHYSTINUS BREVIROSTRIS (Ridgway).}

\section{SHORT-BILLED CAZIQTE.}

Similar to $L$. a. amethystinus, but bill relatively shorter, throat darker and less pinkish purple, color of under parts darker and more uniform (deep mouse gray or brownish slate-gray), and feathers of throat with whitish margins much narrower and less distinct. 
Adult male.-Length (skins), 113-118 (116); wing, 66-70 (68); tail, 40.5-44 (42.2); culmen, 19-21 (20). ${ }^{a}$

Highlands of western Mexico, in States of Jalisco (San Sebastián) and Colima (Sierra Nevada) and Territory of Tepíc (Santiago).

(?) Delattria henrici (not Ornismyia henrica Lesson and Delattre?) SAlvin, Cat. Birds Brit. Mus., xvi, 1892, 308, part (Sierra Nevada de Colima).--SalviN and Godman, Biol. Centr.-Am., Aves, ii, 1892, 335, part (Sierra Nevada de Colima).

[Coligena] henrici SHARPe, Hand-list, ii, 1900, 122, part.

Delattria henrica brevirostris Ridgway, Proc. Biol. Soc. Wash., xxi, Oct. 20, 1908, 195 (San Sebastian, Jalisco; coll. U. S. Nat. Mus.).

\section{LAMPORNIS AMETHYSTINUS SALVINI (Ridgway).} GUATEMALAN CAZIQUE.

Much darker, both above and below, than L. a. amethystinus. Similar in coloration to L. a. brevirostris, but with dusky auricularsuborbital area much darker (brownish black), white postocular (supra-auricular) area broader, pure white, and margined above by a black line; smaller than either L. a. amethystinus or L. a. brevirostris. Adult male.-Length (skins), 106-116 (111); wing, 63.5-67 (65.2); tail, 38.5-40 (39.5); culmen, 19-20 (19.5). ${ }^{b}$

Highlands of Guatemala (Dueñas; Calderas, Volcán de Fuego; Totonicapám; El Rincón, San Marcos; San Martín and Cuipaché, Quezaltenango); State of Chiapas (San Cristóbal), southern Mexico?

Delattria henrici (not Ornismyia henrica Lesson and Delattre) Gould, Mon. Troch., pt. viii, Oct., 1854 (vol. ii, 1861, pl. 62), part (Guatemala); Introd. Troch., oct. ed., 1861, 60, part (Guatemala).-Sclater and Salvin, Ibis, 1859, 129 (Guatemala).-Salvin, Ibis, 1860, 196 (Dueñas, Guatemala); 1862, 96 (Volcán de Fuego and Calderas, Guatemala); Cat. Birds Brit. Mus., xvi, 1892, 308, part (Volcán de Fuego, Calderas, Totonicapám, Quezaltenango, El Rincón, etc., Guatemala).-Sclater, Cat. Am. Birds, 1862, 289, part (Guatemala; excl. syn. part).-Mulsant and Verreaux, Fist. Nat. Ois.-Mouch., i, livr. 3, 1874, 182, part (Guatemala).-Boucard, Liste Ois. récol. Guat., 1878, 45; Gen. Hum. Birds, 1895, 218, part (Guatemala).-Silvin and Godman, Biol. Centr.-Am., Aves, ii, 1892, 335, part (Cuipaché, San Martín, etc., Guatemala).

$a$ Two specimens.

I am somewhat doubtful as to the validity of this form, which at present rests on two specimens. In these the color of the throat is distinctly different from that in the only two adult males of true L. amethystinus now before me (from Vera Cruz), being a more decided purple or less pinkish (nearly phlox purple, the color in L.a. amethystinus being rather more pinkish than solferino). A specimen from San Cristóbal, Chiapas (provisionally referred to $L$. a. salvini, though by no means typical of the latter) has the throat colored precisely as in these specimens from western Mexico, while one from Mt. Zempoáltepec, in northeastern Oaxaca, has it colored very much as in true $L$. amethystinus. Before the geographic variations in this species and the character of relationship between $L$. amethystinus and the two local Guerrero forms (L. margaritx and $L$. pringlei) can be satisfactorily understood, a much larger number of specimens must be carefully compared.

$b$ Two specimens, one of them (irom San Cristóbal, Chiapas) not typical. 
[Delatria] henrici Sclater and Salvin, Nom. Ar. Neotr., 1873, 80, part (Guatemala).

C[oeligena] hemrici Cabants and Henne, Mns. Hein., iii, 1860, 15, footnote, part (Guatemala).

Coeligena henrici Mulsant and Yerreaux, Hist. Nat. Ois.-Mouch., i, livr., 3, 18.4, 182, part (Guatemala).-Elliot, Classif. and Synop. Troch., 1879, 30, part (Guatemala).-Ridgwax, Proc. U. S. Nat. Mus., iii, 1880, 310 (Guatemala).

C[celigena] henrica Ridgwar, Man. N. Anı. Birds, 1857, 310, part (Guatemala); Rep. U. S. Nat. Mus. for 1890 (1891), 324, part (Guatemala).

[Coeligena] hemrici Sharpe, Haud-list, ii, 1900, 122, part.

Lampornis amethystinus (not of Swainsou) Dearborn, Pub. 125, Field Mus. N. H., 1907, 99 (above Tecpám, Guatemala, 9,600ft.).

C[oeligena] henrica (typica) Hartert, Das Tierreich, Troch., 1900, 114, part (Guatemala).

Delattria henrica salvini Rıdgway, Proc. Biol. Soc. Wash., xxi, Oct. 20, 1908, 195 (Calderas, Volcán de Fuego, Guatemala, 7,000-8,000 ft.; coll. Am. Mus. N. H.).

\section{LAMPORNIS MARGARIT E (Salvin and Godman).}

\section{MARGARET'S CAZIQUE.}

Similar to L. amethystinus, but much darker; adult male with throat metallic violet (violet to royal purple) instead of reddish purple, the metallic feathers without distinct grayish or whitish margins.

Adult male.-Above metallic bronze-green, becoming dull bronze on rump; upper tail-coverts and tail black, faintly glossed with bluish, the lateral rectrices broadly (but not abruptly) tipped with dark brownish gray; remiges brownish slate or dusky, very faintly glossed with purplish; suborbital and auricular regions dusky, the latter margined above by a broad postocular (supra-auricular) streak of dull white, the former margined below by an indistinct rictal streak of cinnamomeous; chin brownish gray, the feathers darker centrally; throat bright metallic violet (varying from violet or violet-purple to royal purple), the feathers narrowly margined with pale grayish; rest of under parts plain deep mouse gray or brownish slate color, more or less glossed with bronze green, especially on chest, sides, and flanks, the under tail-coverts broadly margined with whitish; femoral and lumbar tufts white; bill dull black, the mandible sometimes more brownish; iris dark brown; feet pale brownish (in dried skins), the claws and terminal portion of toes darker; length (skins), 109-123 (118); wing, 67-69.5 (68.4); tail, 43.5-45 (44.2); culmen, 20-22 (21). ${ }^{a}$

Adult female.-Similar to the adult male, but chin and throat with feathers deep mouse gray centrally, broadly margined with pale cinnamon or buffy wood brown. (Differing from the adult female of $L$. amethystinus in decidedly larger size, darker and more uniform under parts, and more bronzy color of rump.) Length (skins), 99-113 (106); wing, 63-64 (63.5); tail, 41-41.5 (41.2); culmen, 21-23 (22). ${ }^{6}$ 
Southwestern Mexico, in State of Guerrero (Chilpancingo; Omilteme).

Delattria margaritæ Salvin and Godman, Ibis, April, 1889, 239 (Omilteme, Guerrero, alt. 8,000 ft.; coll. Salvin and Godman.)

Delattria margaritae BoucARd, Gen. Hum. B., 1895, 219 (Omilteme).

C[eligena] margaritæ RidGWAY, Rep. U. S. Nat. Mus. for 1890 (1891), 324 (diagnosis, etc.).

Delattria margarethæ Salvin and Godman, Biol. Centr.-Am., Aves, ii, 1892, 336, pl. 54a, figs. 1, 2.-SALvin, Cat. Birds Brit. Mus., xvi, 1892, 310 .

Delattria margarethae HARTERT (E. and C.), Novit. Zool., i, 1894, 63 (Chilpancingo, Guerrero, 6,000-8,000 ft.).

[Coeligena] margarethae Simon, Cat. Troch., 1897, 25.

[Celigena] margarethæ SHARPe, Hand-list, ii, 1900, 122.

C[oeligena] henrica margarethae HARTERT, Das Tierreich, Troch., 1900, 115 (monogr.).

\section{LAMPORNIS PRINGLEI (Nelson).}

\section{PRINGLE'S CAZIQUE.}

Similar to $L$. margaritæ, but color of upperparts much more bronzy, the adult male with pileum, hindneck, and back metallic bronze instead of bronze-green, and throat violet-blue instead of violet or violet-purple, the feathers with grayish margins much less distinct.

Adult male.-Forehead dull metallic coppery bronze, the feathers darker centrally; crown dusky metallic bronze-greenish; occiput, hindneck, back, scapulars, and wing-coverts metallic bronze (brighter and somewhat coppery on occiput and hindneck), passing into much duller bronzy, or olive-bronze, on rump; upper tail-coverts and tail black, faintly glossed with bluish, the lateral rectrices broadly, but not sharply, tipped with dark gray or slate color; remiges dusky, very faintly glossed with purplish; auricular region dusky, faintly glossed with bronze, margined above by a white postocular (supraauricular) streak; a rictal streak of buffy, cinnamomeous, or grayish brown; chin brownish gray, the feathers darker centrally; throat bright metallic violet-blue (hyacinth blue tinged with royal purple), the feathers without grayish margins, except on upper throat; rest of under parts deep mouse gray or brownish slate-gray, glossed laterally with bronze or coppery bronze, the under tail-coverts broadly margined with white; femoral and lumbar tufts white; bill dull black; iris dark brown; feet pale brownish (in dried skins), the claws and upper side of toes dusky; length (skins), 114-115 (114.7); wing, 68-69 (68.3); tail, 43.5-44 (43.7); culmen, 21-22 (21.3) ${ }^{a}$

Adult female.-Similar in coloration to adult females of $L$. amethystinus and $L$. margaritx, but general color of upper parts bronze or greenish bronze instead of bronze-green; length (skin), 108; wing, 62; tail, 40.5 ; culmen, $23 .^{b}$ 
Southwestern Mexieo, in States of Guerrero (mountains near Chilpancingo) and Oaxaca (15 miles west of Onxaca (ity).

Delattria pringlei Nelsox, Auk, xiv, Jan., 1897, 51 (Oaxaca City, Oaxaca, s. w. Mexico; coll. U. S. Nat. Mus.).

[Coligena] pringlei Sharee, Hand-list, ii, 1900, 122.

C[oeligena] henrica pringlei HarTerT, Das Tierreich, Troch., 1900, 115 (monogr.).

\section{Genus OREOPYRA Gould.}

Oreopyra a Gould, Proc. Zool. Soc. Lond., 1860, 312; Introd. Trochil., 1861, 141. (Type, O. leucaspis Gould = Trochilus (-?) castaneoventris Gould.)

Medium-sized Trochilidæ (length about 90-110 mm.) closely related to Lampornis and Cyanolæmus, but with relatively shorter bill, nasal operculum narrower and more concealed, and more feathered tarsi; under parts not gray, and coloration more brilliant, the adult males green, white, or green and white beneath, with pure white, brilliant green, or violet throat-patch, usually with forehead and crown glittering green or blue, adult females with under parts light einnamonrufous or white.

Bill about as long as head, moderately slender, straight, terete; culmen rounded except basally, where contracted into a narrow ridge; tomia smooth; mandible with a lateral median groove. Nasal opereulum rather narrow, its outer edge straight or but slightly convex basally, mostly hidden by frontal feathering, which extends about as far as anterior end of nostrils, forming a short point or antia on each side of mesorhinium. Tarsus clothed with short feathers, except posterior edge; inner toe very slightly shorter than middle toe, the outer toe still shorter, the hallux about as long as outer toe. Wing more than three times as long as culmen in adult males, about three times as long in females, the outermost primary longest. Tail about three-fifths as long as wing, rather deeply emarginate in adult males, slightly double-rounded or truncate in females, the rectrices moderately broad, rounded or subcuneate at tip.

Coloration.-Above metallie green, bronze-green or bronze, the upper tail-coverts sometimes dusky; tail plain gray, blackish passing into gray on lateral rectrices, or dull bronzy with paler tip in adult males (sometimes in females also), bronze-green with blackish tip or subterminal band and pale gray tip to lateral rectrices in females of some species. Adult males usually with forehead and crown glittering green or blue, a throat-patch of metallic violet or pure white or else throat spotted with bright metallic green, the remaining under parts mostly white (O. hemileuca, O. sybillæ, and $O$. viridipallens) or metallic green (in other species). Adult females with under parts light cinnamon-rufous, or white $(O$. hemileuca, $O$. sybillæx, and $O$. viridipallens). 
Range.-Southern Mexico to western Panama, in higher mountains. (Seren species.)

The proper disposition of Trochitus viridipallens Bourcier and Mulsant which both Elliot and Hartert place in "Coligena" (=Cyanolæmus)--both authors uniting Cocligena and "Delattria" - -and its near relative, "Delattria" sybillæ Salvin, is a matter of difficulty and uncertainty; but I am convinced that unless a new genus is made for their accomodation they fit far better in Oreopyra than in "Delattria." The only alternative is to consider Oreopyra as also a synonym of "Delattria" = Lampornis.

KEY TO THE SPECIES AND SUBSPECIES OF OREOPYRA.

a. Under parts mostly green or mostly white.

b. A conspicuous patch of white or purple on throat; pileum brilliantly metallic green.

c. Chest bright metallic green; chin white or purple, like throat.

d. Tail black or blue-black. (Oreopyra castaneoventris.)

$e$. Throat white; or if purple the feathers white beneath surface. (Volcan de Chiriquí, Panamá.)

Oreopyra castaneoventris castaneoventris, adult male (p. 502)

ee. Throat metallic purple, the feathers gray beneath surface. (Costa Rica to western Panamá.)

Oreopyra castaneoventris calolæma, adult male (p. 504).

$d d$. Tail gray (the throat white). (Southwestern Costa Rica.)

Oreopyra cinereicauda, adult male (p. 506).

cc. Chest white; chin metallic green. (Costa Rica.)

Oreopyra hemileuca, adult male (p. 507).

$b b$. No throat-patch of white or purple; pileum not brilliantly metallic.

c. Throat metallic green squamated or otherwise broken by white.

d. Chest and foreneck green like throat. (Nicaragua.)

Oreopyra sybillæ, adult male (p. 508).

$d d$. Chest and foreneck white. (Guatemala and Chiapas.)

Oreopyra viridipallens, adult male (p. 509).

$c c$. Throat white or buff, or mostly so.

d. Throat white; outermost rectrix pale gray.

Oreopyra viridipallens, adult female (p. 510).

dd. Throat buff; outermost rectrix white, the inner web crossed by a subterminal bar of dusky gray........ Oreopyra sybillæ, adult female (p. 509).

aa. Under parts tawny-ochraceous.

$b$. Lateral rectrices with a well-defined broad subterminal area of blackish.

Oreopyra castaneoventris castaneoventris, adult female (p. 503).

Oreopyra castaneoventris calolæma, adult female (p. 505).

$b b$. Lateral rectrices without a well-defined (if any) subterminal area of dusky.

Oreopyra cinereicauda, adult female (p. 506).

OREOPYRA CASTANEOVENTRIS CASTANEOVENTRIS (Gould).

CHIRIQUi MOUNTAIN GEM.

Adult male.-Forehead and crown glittering metallic emerald green, varying to yellowish green and bluish green; rest of upper parts duller metallic bronze-green, becoming more bluish green or 
dark metallic grass green on upper tail-eoverts; tail dull blue-black; remiges dusky purplish brown, the inner secondaries mostly bronzegreenish, especially on outer webs; primary coverts dull black, faintly glossed with bronze-greenish; suborbital and auricular regions dusky bronze-green, the latter margined above by a conspicuous postocular streak of white; chin and throat unilorm grayish white (the feathers dusky gray at extreme base), this white area with a sharply defined convex posterior outline, usually with some of the feathers round the margin tipped with metallic phlox purple or metallic blue, rarely with chin and thioat entirely purple or violet superficially: ${ }^{a}$ chest, sides of neck, and sides of breast bright motallic green (rarring from emerald to golden), passing into duller and more bronzy green on flanks and into brownish gray on abdomen; under tail-corerts deep bronzy gray margined with paler gray; anal tufts grayish white; bill dull black; iris dark brown; feet grayish brown or dusky; length (skins), 99-10s (104); wing, 62-66 (64.3); tail, 35.5-38 (36.5): culmen, 18.5-21.5 (20.2). ${ }^{b}$

Adult female.-Above bright metallic green, usually more bronzy green anteriorly (sometimes distinctly so) and more bluish green on upper tail-coverts; middle rectrices much duller metallic green or bronze-green, the other rectrices similar for more than basal half, blackish subterminally or (pair next to middle rectrices) terminally, the two or three onter pairs rather broadly tipped with pale gray; remiges dusky, faintly glossed with violaceous; a blackish area on side of head, involving loral and auricular regions (narrowly connected beneath eye), the auricular portion margined above by a broad streak of white or pale buffy extending from posterior angle of eye obliquely backward and downward; rictal and malar regions, chin, throat, and under parts of body plain tawny-ochraceous, paler on lower or median portion of abdomen; femoral tufts white; under tail-corerts dull white to pale tawny buff, with central portion pale grayish; bill black; iris dark brown; feet brownish or dusky (in dried skins); length (skins), 93-102 (96); wing, 56-59.5 (57.6); tail, 30.5-34 (32.2); culmen, 19.5-23 (21.3). ${ }^{c}$

Western Panamá (Cordillera de Chiriquí; Volcán de Chiriquí; Boquete).

Trochilus (_-?) castaneoventris Gould, Proc. Zool. Soc. Lond., 1850, 163 (Cordillera cie Chiriquí, Panamá, 6,000 ft. alt.; coll. J. Gould).

[Trochilus]? castaneiventris GRAY, Hand-list, i, 1869, 142, no. 1831.

[Jetallura] castaneiventris Peichenbact, Aufz. der Colibr., 1854, 8; Troch. Enum., 1855, 5 .

Adelomyia? castaneiventris Gould, Mon. Troch., vol. iii, 1861 (pt. x, Sept., 1855), pl. 203 (Cordillera of Chiriquí, 6,000 ft.).

$a$ The feathers white immediately beneath the surface.

$b$ Ten specimens.

c Nine specimens. 
Anthocephala? castaneiventris Gould, Introd. Troch, oct. ed., 1861, 115.-Mulsant and Verreaux, Classif. Troch., 1866, 71; Hist. Nat. Ois.-Mouch., iii, livr. 2, 1876, 123; iv, livr. 3, 1878, 219.

Oreopyra castaneiventris Salvin, Proc. Zool. Soc. Lond., 1867, 153 (Volcán de Chiriquí; synon.; crit.); Ibis, 1869, 316 (crit.).

O[reopyra] castaneiventris Salvin, Proc. Zool. Soc. Lond., 1864, 585.

Oreopyra castaneiventris castaneiventris Bangs, Proc. Biol. Soc. Lond., xix, July 30, 1906, 107 (crit.).

Oreopyra leucaspis Gould, Proc. Zool. Soc. Lond., 1860, 312 (Volcán de Chiriquí, Panamá, 9,000-10,000 ft. alt.; coll. J. Gould); Mon. Troch., iv, pt. xxi, 1861, pl. 264; Introd. Troch., oct. ed., 1861, 141.-SALvin, Proc. Zool. Soc. Lond., 1867, 153 (Volcan de Chiriquí); 1870, 205 (Volcán de Chiriquí; crit.); Cat. Birds Brit. Mus., xvi, 1892, 306.-IAawrence, Ann. Lyc. N. Y., ix, 1868, 125 (Volcán de Chiriquí).-Frantzius, Journ. für Orn., 1869, 316 (Costa Rica; error!).-Mulsant and Verreaux, Hist. Nat. Ois.-Mouch., iv, livr. 2, 1877, 160 (Yolcán de Chiriquí); Suppl., 1885, pl. 55.--Elliot, Classif. and Synop. Troch., 1879, 33.-RIdgway, Proc. U. S. Nat. Mus., iii, 1880, 310 (Chiriquí).-Zesenón, Cat. Aves de Costa Rica, 1882, 20; Anal. Mus. Nac. Costa Rica, i, 1887, 121.-Sharpe, Gould's Mon. Troch. Suppl., 1885.Salvis and Goduran, Biol. Centr.-Am., Aves, ii, 1892, 332 (Cordillera de Chiriquí; Volcán de Chiriquí).—Boucard, The Hum. Bird, ii, 1892, 77 ("Veragua"); Gen. Hum. Birds, 1895, 221 (Volcán de Chiriquí).-SALvadori and Festa, Boll. Mus. Zool., etc., Torino, 1899, no. 339, 7 (Chiriquí).-Bangs, Proc. New Engl. Zool. Club, iii, 1902, 30 (Boquete de Chiriquí and Volcán de Chiriquí, 4,000-7,700 ft.).

O[reopyra] leucaspis Salvin, Proc. Zool. Soc. Lond., 1864, 585; 1870, 206 (Volcán de (hiriquí; crit.).

[Oreopyra] leucaspis Sciater and Salvin, Nom. Av. Neotr., 1873, 80.-Mulsant, Ann. Soc. Linn. Lyon, xxii, 1876, 203.-Sharpe, Hand-list, iii, 1900, 123.

O[reopyra] leucaspis (typica) HARTERT, Das Tierreich, Troch., 1900, 116 (monogr.).

Diphloguena leucaspis Mulsant and Verreaux, Classif. Troch., 1866, 61.

[Trochilus] leucaspis Grar, Hand-list, i, 1869, 138, no. 1769.

Oreopyra calolxma (not of Salvin, 1864) Salvin, Proc. Zool. Soc. Lond., 1870, 205 (Volcán de Chiriquí).-SAlvadori and Festa, Boll. Mus. Zool., etc., Torino, xiv, 1899, no. 339, 7 (Chiriquí).-Bangs, Proc. New Engl. Zool. Club, iii, 1902, 30 (Boquete, Panamá, 4,000 ft.).

O[reopyra] calolæma Salvin, Proc. Zool. Soc. Lond., 1870, 206, part (Volcán de Chiriquí; crit.).

\section{OREOPYRA CASTANEOVENTRIS CALOLAMA (Salvin).} COSTA RICAN MOUNTAIN GEM.

Similar to O.c. castaneoventris, but adult male with chin and throat always metallic violet or purple, ${ }^{a}$ the feathers gray, instead of white, immediately beneath the surface. ${ }^{b}$

Young male.-Upper parts, including tail, as in adult female; chin and throat dusky, the latter with a few tawny-ochraceous feathers along middle line, the dusky color gradually passing into

$a$ Varying, in different specimens, from royal purple to phlox purple.

$b$ The supposed difference in coloration of the upper parts in females mentioned by Salvin (Proc. Zool. Soc. Lond., 1870, 205, 206) proves to be inconstant; in fact does not, so far as I am able to see, exist in even a considerable proportion of specimens. 
dull metallic bronze-green on lower throat, chest, and sides of breast; lower breast and abdomen tawny-ochraceous, passing into dull grayish on sides and flanks; under tail-coverts brownish gray broadly margined with dull white.

Adult male.-Length (skins), S7-113 (99); wing, 60.5-65 (61.7); tail, 29.5-37 (35.6); culmen, 1S-20.5 (19.5). ${ }^{a}$

Adult female.-Length (skins), 91-107 (96); wing, 55-58.5 (57.5); tail, 30.5-34 (32.5); culmen, 20-23 (20.9). ${ }^{b}$

Highlands of Costa Rica (San José; La Palma de San José; Escazú; Las Cruces de Candelária; Cerro de la Candelária; Cartago; Azahár de Cartago; Naranjo de Cartago; Volcán de Irazú; Rancho Redondo; Peorsnada; Navarro; Coliblanco; Juan Viñas; Carrillo; La Hondura; Tenório; Copéy, Santa Maria de Dota; Dota Mountains) and western Panamá (Cordillera de Tolé; Cordillera del Chucu; Calorérora; Calobre).

Oreopyra calolæma SAlvin, Proc. Zool. Soc. Lond., 1864 (pub. April 1, 1865), 584 ("Tolcan de Cartago," i. e. Volcán de Irazú, Costa Rica; coll. Salvin and Godman); Cat. Birds Brit. Mus., xvi, 1892, 307 (Irazú district, etc., Costa Rica).-Salvadori, Atti R. Acc. Torino, 1868, 183 (Costa Rica).-Frantzius, Journ. für Orn., 1869, 316 (Costa Rica).-Boucard, Proc. Zool. Soc. Lond., 1878, 69 (Naranjo de Cartago, Navarro, and Rancho Redondo, Costa Rica; crit.).-Elliot, Classif. and Synop. Troch., 1879, 33, part (Volcán de Irazú).-Ridgway, Proc. U. S. Nat. Mus., iii, 1880, 310 (Costa Rica).-ZeleDós, Cat. Aves de Costa Ricá, 1882, 20; Anal. Mus. Nac. Costa Rica, i, 1887, 418 (Costa Rica).-Nutting, Proc. U. S. Nat. Mus., v, 1882, 500 (San José, Costa Rica).-Sharpe, Gould's Mon. Troch. Suppl., 1885, pl. 6.-Salvin and Goduan, Biol. Centr.-Am., Aves, ii, 1892, 333, part, pl. 54, figs. 1, 2 (Volcán de Irazú, Rancho Redondo, San José, Dota, "La Palma"=San José, Peorsnada, Las Cruces de Candelária, and Naranjo de Cartago, Costa Rica).Ferry, Pub. 146, Field Mus. N. H., orn. ser., i, no. 6, 1910, 264 (Coliblanco, Costa Rica).

(?) Oreopyra calolæma Salvin, Proc. Zool. Soc. Lond., 1867, 153 (Cordillera de Tolé, Panamá; crit.); 1870, 205, part (Calovévora and Cordillera del Chucu, Panamá); Cat. Birds Brit. Mus., xvi, 1892, 307, part (Cordillera del Chucu and Calovévora).-Mulsant and Verreaux, Hist. Nat. Ois.-Mouch., iv, livr. 3, 1878, 164, part (Cordillera de Tolé and Cordillera del Chucu, Panamá).--Boucard, The Hum. Bird, ii, 1892, 77 (Verágua); Gen. Hum. Birds,

a Fourteen specimens.

$b$ Eleven specimens.

\begin{tabular}{|c|c|c|c|}
\hline Locality. & Wing. & Tail. & $\begin{array}{c}\text { Ex- } \\
\text { posed } \\
\text { culmen. }\end{array}$ \\
\hline MALES. & & & \\
\hline Ten adult males from Costa Rica... & 63.7 & 36 & 19.5 \\
\hline Four adult males from western Panamá (Cordillera de Tolé, etc.)............... & 61.7 & 34.5 & 19.4 \\
\hline FEMALES. & & & \\
\hline Ten adult females from Costa Kica..................... & 57.2 & 32.5 & 21 \\
\hline One adult female from western Panamá (Cordillera de Tolé)............. & 55 & 33 & 20.5 \\
\hline
\end{tabular}


1895, 223 (Verágua).-Salvin and Godman, Biol. Centr.-Am., Aves, ii, 1892, 333, part (Cordillera de Tolé, Cordillera del Chucu, Calovévora, and Calobre, Panamá).

[Oreopyra] calolæma Sclater and SAlvin, Nom. Av. Neotr., 1873, 80, part.

[Oreopyra] calolaema Mulsant, Ann. Soc. Linn. Lyon, xxii, 1876, 203.

(?) O[reopyra] calolæma SALvin, Proc. Zool. Soc. Lond., 1870, 206, part (Cordillera de Tolé, Cordillera del Chucu, and Calovévora, Panamá; crit.).

O[reopyra] calolæma Salvin, Proc. Zool. Soc. Lond., 1870, 206, part (Volcán de Irazú and La Candelária, Costa Rica; crit.).

Oreopyra salolæma Lawnence, Ann. Lyc. N. Y., ix, 1868, 125 (Rancho Redondo and Las Cruces de Candelária, Costa Rica).

[Trochilus] calolæmus GRAX, Hand-list, i, 1869, 138, no. 1767.

O[reopyra] castaneoventris calolæma BanGs, Proc. Biol. Soc. Wash., xix, July 30, 1906, 107 (crit.).

Oreopyra castaneiventris calolæma CARR1KER, Ann. Carnegie Mus., vi, 1910, 541 (centr. and n. Costa Rica; crit.).

O[reopyra] calolaema (typica) HARTERT, Das Tierreich, Troch., 1900, 117 (monogr.).

Oreopyra venusta Lawrence, Ann. Lyc. Nat. Hist. N. Y., viii, 1867, 484 (Costa Rica; coll.).

Anthocephala castaneiventris (not Trochilus castaneoventris Gould) LAwrEnce, Ann. Lyc. N. Y., ix, 1868, 124 (La Candelária, San José, and Irazú, Costa Rica; crit.).-Frantzius, Journ. für Orn., 1869, 316 (Costa Rica).

(?) Oreopyra castaneiventris SALviN, Proc. Zool. Soc. Lond., 1867, 153, part (Cordillera de Tolé, Panamá).

Oreopyra castaneiventris Salvin, Ibis, 1869, 316 (Costa Rica; crit.).

Panterpe insignis, supposed female (not of Cabanis and Heine) Lawrence, Ann. Lyc. N. Y., viii, 1867, 48 (Costa Rica).

(?) Oreopyra pectoralis Salvin, Ann. and Mag. N. H., vii, 1891, 377 (Costa Rica; coll. Salvin and Godman); Cat. Birds Brit. Mus., xvi, 1892, 308, 664.--Salvin and Godman, Biol. Centr.-Am., Aves, ii, 1892, 334.-Boucard, Gen. Hum. Birds, 1895, 223 (Navarro, Rancho Redondo, and Volcán de Irazú, Costa Rica).

(?) [Oreopyra] pectoralis Sharpe, Hand-list, iii, 1900, 123.

(?) O[reopyra] pectoralis Bangs, Proc. New Engl. Zool. Club, xix, 1906, 107 (crit.). [Oreopyra] cal[olaema] pectoralis Simon, Cat. Troch., 1897, 25.

(?) O[reopyra] calolaema pectoralis Hartent, Das Tierreich, Troch., 1900, 117 (monogr.).

\section{OREOPYRA CINEREICAUDA Lawrence.}

\section{GRAT-TAILED MOUNTAIN GEM.}

Precisely like the white-throated phase of $O$. castaneoventris castaneoventris except in color of tail, which in the adult male is ash gray (usually darker terminally) instead of blue-black, the shafts of rectrices whitish instead of dusky or dark grayish, the female.with the dusky subterminal portion of the lateral rectrices much less welldefined, grading gradually into the dull grayish bronzy of the basal portion.

Adult male.-Length (skins), 99-107 (103); wing, 62-65 (64); tail, 36-39.5 (37.6); culmen, 19.5-21.5 (20.4). ${ }^{a}$

Adult female. - Length (skins), 94-98 (96); wing, 52.5-59.5 (56.7); tail, 32-35 (33.4); culmen, 21-23 (21.9). ${ }^{a}$ 
Highlands of southern and central Costa Rica (Cartago; Ia Estrella de Cartago; Escazú; Dota Mfountains; Sinnta Maria, Copéy, Languária, Los Reyes, and Las Vucltas, Dota; Ojuras de Téraba) and adjacent portion of western Panamá (Voleán de Chiriquí).

Oropyra cinercicanda Lawrexce, Ann. Lyc. Nat. Hist. N. Y., viii, May, 1867, 455 (Costa Rica; coll. (7. N. Lawrence); ix, 1868, 125 (Costa Rica).-FrantzıUs, Journ. für Orm., 1869, 316 (Costa Rica).-SAlvin, Proc. Zool. Soc. Lond,, 1870, 206; Cat. Birds Brit. Mus., xvi, 1892, 307.-Boucard, Proc. Zool. Soc. Lond., 1S78, 68 (Navarro, Costa Rica); Gen. Ilum. 13irds, 1895, 225 (Navarro and Cartago, Costa Rica).-Mulsant and Verneaux, Ilist. Nat. Ois.-Mouch., iv, live. 3, 187s, 163, pl. 116 (Cartago); Suppl., pl. 2.-Ellıot, Classif. and Symop. Troch., 1879, 34.-Zerenón, Cat. Ares de Costa Rica, 1882, 20; Anal. Mus. Nac. Costa Rica, i, 1S87, 121.-Sharpe, Suppl. Gould's Mon. Troch., 1855, pl.7.-Salvix and Godman, Biol. Centr.-Am., Aves, ii, 1892, 333.-Carriker, Ann. Carnegie Mus., vi, 1910, '540 (s. w. Costa Rica; crit.; habits).

O[reopyra] cinereicauda SAlvis, Proc. Zool. Soc. Lond., 1870, 206 (Costa Rica; crit.).-Baxgs, Proc. Biol. Soc. Wash., xix, 1906, 107 (Dota Mts.; crit. on pp. 105, 106).

[Oreopyra] cinereicauda Sclater and Saltin, Nom. Av. Neotr., 1873, 80.-MulSaxt, Ann. Soc. Linn. Lyon, xxii, 1S76, 203.-Sharpe, Hand-list, ii, 1900,123. O[reopyra] leucaspis cinereicauda Hartert, Das Tierreich, Troch., 1900, 117.

[Trochilus] cinereicaudus GraY, Hand-list, i, 1869, 138, no. 1770.

Anthocephala castaneiventris (not Trochilus castaneoventris Gould) Lawrence, Ann. Lyc. N. Y., ix, 1S68, 124, part.

\section{OREOPYRA HEMILEUCA Salvin.}

WHITE-BELLIED MOUNTAIN GEM.

Adult male.-Forehead and crown, together with auricular, suborbital, and malar regions, brilliant metallic emerald green; occiput and nape duller, more bronzy green, changing to opaque black in position $a$, at least laterally; back, scapulars, wing-coverts, and rump metallic bronze-green (more bronzy posteriorly), the upper tail-coverts metallic bronze or greenish bronze; tail rather dull metallic bronze or greenish bronze, becoming still duller (more grayish) on lateral rectrices, the rectrices (except middle pair) tipped with pale buffy grayish and crossed by an indistinct subterminal band of darker bronzy or dusky; remiges purplish dusky, the inner secondaries glossed with bronze-greenish; edge of wing (metacarpal portion) pale cinnamon; a postocular streak of white extending obliquely backward and downward between the blackish of latero-occipital region and emerald green of auricular region; chin metallic emerald green, the feathers light gray basally and margined with pale gray or grayish white; throat soft metallic light violet-purple or mauve; rest of under parts white, spotted laterally, especially on sides of breast, with metallic bronze-green, the under tail-coverts pale brownish gray centrally; bill dull black; iris dark brown; feet grayish brown (in dried 
skins); length (skins), 99-109 (105); wing, 62-64.5 (63.3); tail, 36-39 (37.5); culmen, 16.5-19.5 (18.8). ${ }^{a}$

Adult female.--Similar to the adult male, but chin and throat white spotted laterally with metallic green, rectrices (except middle pair) crossed by a distinct subterminal band of dusky, and metallic emerald green of forehead, etc., less brilliant; length (skins), 92-105 (98); wing, 55-60 (57.9); tail, 32.5-36 (34); culmen, 18.5-21 (19.6) ${ }^{a}$

Young male.-Essentially like the adult male, but without the purple throat-patch, the sides of throat being brownish dusky, the chin and upper median portion of throat much as in adult male; white of under parts duller, and upper parts more bronzy, with feathers of lower back and rump indistinctly margined with rusty.

Highlands of Costa Rica (Turrialba; Tucurríqui; Juan Viñas; Carrillo; La Hondura; Navarro; Rancho Redondo; Naranjo de Cartago; Cariblanco de Sarapiquí; Las Cruces de Candelária) and western Panamá (Chiriquí). ${ }^{b}$

Oreopyra hemileuca Salvin, Proc. Zool. Soc. Lond., 1864 (pub. April 1, 1865), 584 (Turrialba and Tucurríqui, Costa Rica; coll. Salvin and Godman).Lawrence, Ann. Lyc. N. Y., ix, 1868, 125 (Turrialba; Tucurríqui).Frantzius, Journ. für Orn., 1869, 316 (Las Cruces de Candelária and Rancho Redondo, Costa Rica).--Boucard, Proc. Zool. Soc. Lond., 1878, 69 (Naranjo de Cartago, Costa Rica); Gen. Hum. Birds, 1895, 222 (Navarro and Turrialba, Costa Rica).-Mulsant and Verreaux, Hist. Nat. Ois.-Mouch., iv, livr. 3, 1878, 167 (Turrialba; Tucurríqui); Suppl., pl. 15.

[Oreopyra] hemileuca Sclater and Saltin, Nom. Av. Neotr., 1873, 80.-Mulsant, Ann. Soc. Linn. Lyon, xxii, 1876, 203.

Cæligena hemileuca Erlıot, Classif. and Synop. Troch., 1879, 31.-Ridgway, Proc. U. S. Nat. Mus., iii, 1880, 310.

Caeligena hemileuca Zeledón, Cat. Aves de Costa Rica, 1882, 20.

Coligena hemileuca Sharpe, Suppl. Gould's Mon. Troch., 1885, pl. 5.-Zeledón, Anal. Mus. Nac. Costa Rica, i, 1887, 121 (Naranjo de Cartago)--Hartert, Journ. für Orn., 1900, 366 (Chiriquí, Panamá; crit.).-Carriker, Aun. Carnegie Mus., vi, 1910, 540 (Caribbean slope, Costa Rica, 2,000-4,000 ft.; habits).

C[øligena] hemileuca Ridgway, Rep. U. S. Nat. Mus. for 1890 (1891), 324 (diagnosis, etc.).

[Coligena] hemileuca Sharpe, Hand-list, ii, 1900, 122.

[Coeligena] hemileuca Srmon, Cat. Troch., 1897, 25.

C[oeligena] hemileuca Hartert, Das Tierreich, Troch., 1900, 115.

[Trochilus] hemileucus Gray, Hand-list, i, 1869, 138, no. 1766.

Delattria hemileuca Salvin, Cat. Birds Brit. Mus., xvi, 1892, 311.-Salvin and Godman, Biol. Centr.-Am., Aves, ii, 1892, 337, pl. 54, figs. 3, 4.

OREOPYRA SYBILLAE (Salvin and Godman).

SYBIL'S MOUNTAIN GEM.

Adult male.-Above deep metallic grass green, becoming slightly more bronzy on rump; upper tail-coverts black; four middle rectrices grayish black, the other rectrices pale gray or grayish white margined

a Ten specimens.

b According to Hartert, Journ. 1ür Orn., 1900, 366. 
(on both webs) with dusky; remiges dusky, faintly glossed with violet; a conspicuous postocular streak of white passing obliquely backward and downward along upper margin of auricular region; auricular region and sides of neck deep green, like upper parts; under parts mostly metallic grass-green, but this much broken by white or grayish white margins to the feathers and by a white subterminal bar to feathers of throat; femoral and lumbar tufts, anal recrion, and extreme lower abdomen (medially) white; under tailcoverts white with a central area of gray; bill black; iris dark brown; feet brownish (in dried skins); length (skins), 104-113 (108); wing, 62.5-67.5 (65.2); tail, 38.5-42 (39.8); culmen, 20-22 (21.1). ${ }^{a}$

Adult female.-Above as in adult male, but outermost rectrix white or grayish white (without gray margin), the inner web with a subterminal bar (more or less distinct) of dusky gray, the second rectrix with a similar bar across both webs; chin and throat buff, or white tinged with buff; rest of under parts mainly grayish white, the sides of breast mostly metallic green; length (skins), 99-102 (101); wing, 56.5-60 (58.4); tail, 34-37.5 (35.7); culmen, $22 .{ }^{b}$

Highlands of northern Nicaragua (Matagalpa; San Rafaél del Norte; Ocotál).

Delattria sybillæ SAlvin and Godman, Ibis, April, 1892, 327 (Matagalpa, Nicaragua; coll. Salvin and Godman); Biol. Centr.-Am., Aves, ii, 1892, 337, pl. 54A, figs. 3, 4 (Matagalpa and San Rafaél del Norte, Nicaragua).-Salvin, Cat. Birds Brit. Mus., xvi, 1892, 664.

Delattria sybille Boucard, Gen. Hum. Birds, 1895, 220 (Matagalpa).

[Coeligena] sybillae Simox, Cat. Troch., 1897, 25.

C[oeligena] sybillae Hartert, Das Tierreich, Troch., 1900, 115 (monogr.).

[Coligena] sybillæ SHarpe, Hand-list, ii, 1900, 123.

\section{OREOPỴRA VIRIDIPALLENS (Bourcier and Mulsant).}

\section{GREEN-THROATED MOUNTAIN GEM.}

Adult male.-Forehead and crown metallic grass green, changing to brilliant, more emerald, green in position $a$, the occiput and hindneck more bronzy green; back, scapulars, and wing-coverts bronzegreen or greenish bronze, passing into bronze or coppery bronze on rump; upper tail-coverts dull blackish, faintly glossed with bluish or bronzy purplish; four middle rectrices dusky slate or slate-blackish, faintly glossed with bluish, the rest of tail similar but paler and grayer (especially the outermost pair), indistinctly darker terminally and along edge; remiges purplish dusky; a conspicuous postocular streak of white, extending obliquely backward and downward, and below this an auricular area of dusky metallic bronze-green (more brilliant in position $a$ ), continued beneath eye to loral region; malar region, chin, throat, chest, median portion of breast, and abdomen 
dull white or grayish white, the feathers of chin and throat with a subterminal roundish or subcrescentic spot of brilliant emerald green, the base and margin of each feather being whitish; sides of breast metallic bronze-green, the flanks brownish gray glossed with bronzegreen; under tail-coverts brownish gray margined with dull whitish; bill dull black; iris dark brown; feet grayish brown (in dried skins); length (skins), 100-109 (104); wing, 63-67 (65.1); tail, 39-43 (41); culmen, 19-21 (19.9). ${ }^{a}$

Adutt female.-Similar to the adult male, but chin and throat immaculate dull white or grayish white, lateral rectrices with a broad terminal, ill-defined area of pale brownish gray, middle rectrices more bronzy, and upper tail-coverts bronze-green instead of blackish; length (skins), 94-107 (98); wing, 57-61 (58.9); tail, 34-38.5 (36.3); culmen, 18.5-21 (20.4)..$^{b}$

Highlands of Guatemala (Guatemala City; Cobán; Tolimán; Chilasco, Volcán de Fuego; Santa Maria, Quezatelnango; Pié de la Cuesta, San Marcos), and southern Mexico, in State of Chiapas (Tumbalá).

T[rochilus] viridi-pallens Bourcier and Mulsant, Ann. Sci. Phys. et Nat. Lyon, ix, 1846, 321 (Cobán, Vera Paz, Guatemala).

P[olytmus] viridipallens Gray, Gen. Birds, i, Dec., 1848, 108.

[Delattria] viridi-pallens Bonaparte, Consp. Av., i, 1850, 70.

Delattria viridipallens Gould, Mon. Troch., ii, pt. ix, May, 1855, pl. 63; (vol. ii, 1861, pl. 63); Introd. Troch., oct. ed., 1861, 60.-Sclater and Salvin, Ibis, 1859, 129 (Guatemala).-SALvin, Ibis, 1859, 468 (above the plains of Dueñas, Guatemala); 1860, 40, 195,-263 (Volcán de Fuego, Guatemala; habits); Cat. Birds Brit. Mus., xvi, 1892, 310, 664 (Sta Maria, near Quezaltenango; Pié de la Cuesta, San Marcos; Volcán de Fuego, Chilasco, and Cobán, Guatemala).--Sclater, Cat. Am. Birds, 1862, 289 (Cobán, Guatemala).-Boucard, Liste Ois. récol. Guat., 1878, 45; Gen. Hum. Birds, 1895, 219.-Salvin and Godman, Biol. Centr.-Am., Aves, ii, 1892, 336.

Delattria viridi-pallens Salvin and Sclater, Ibis, 1860, 40 (Volcán de Fuego).

[Delattria] viridipallens Sclater and Salvin, Nom. Av. Neotr., 1873, 80.

[Agyrtria] viridipallens Reichenbach, Aufz. der Colib., 1854, 10; Troch. Enum., 1855, 7, pl. 758 , figs. $4746-7$.

[Thaumantias] viridipallens Bonaparte, Rev. et Mag. de Zool., 1854, 255.

C[hariessa] viridipallens Heıne, Journ. für 'Orn., 1863, 178.

Lampornis viridipallens Mulsant and Verreaux, Classif. Troch., 1866, 24.

Coeligena viridipallens Mulsant and Verreaux, Hist. Nat. Ois.-Mouch., i, livr. 3, 1874, 185 (Cobśn, Guatemala); iv, livr. 2, 1877, 159.

[Coeligena] viridipallens Mulsant, Ann. Soc. Linn. Lyon, n. s., xxii, 1876, 203.-

Srmon, Cat. Troch, 1897, 25.

C[oeligena] viridipallens Hartert, Das Tierreich, Troch., 1900, 115 (monogr.).

C[øligena] viridipallens Ridgway, Man. N. Am. Birds, 1887, 310; Rep. U. S.

Nat. Nus. for 1890 (1891), 324 (diagr., etc.).

[Coligena] viridipallens Sharpe, Hand-list, ii, 1900, 123.

Cxligena viridipallens Ellıo', Classif. and Synop. Troch., 1879, 31.-Ridaway,

Proc. U. S. Nat. Mus., iii, 1880, 310 (Cobán; Guatemala City; "Mexico").

[Topaza] viridipallens Gray, Hand-list, i, 1869, 134, no. 1727. 
Genus PANTERPE Cabanis and Heine.

Panterpe Cabaxis and Heive, Mlus. Hein., iii, March, 1560, 43, footnote. (Type, $P$. insignis Cabanis and Heine.)

Rather large Trochilidie (length about $105-110 \mathrm{~mm}$.) with the slender, compressed bill slightly longer than head, nasal opercuhm inconspicuous or mostly covered by frontal feathering, feet rather stout with tarsus mostly naked, tail about two-thirds as long as wing, emarginate or double-rounded, with broad and rather soft rectrices, and very brilliant coloration, the pileum brilliant blue or violet, throat brilliant golden, orange, or scarlet, a blue or violet pectoral patch, upper tail-corerts blue, the tail uniform blue-black or violet-black.

Bill slightly longer than head, straight, very slender, compressed; culmen rounded but basally contracted into a well-defined ridge; tomia smooth; mandible with a distinct lateral median groove or sulcus, the maxilla with indication of a similar groove. Nasal operculum inconspicuous, being mostly covered by the overhanging frontal feathers, which anteriorly form a truncated or slightly emarginate antia. Tarsus rather stout, its upper half clothed with short feathers; anterior toes about equal in length, the hallux slightly shorter, all the toes rather stout, with well-developed and very acute claws. Wing three times (more or less) as long as exposed culmen, the outermost primary longest. Tail about two-thirds as long as wing, emarginate or slightly double-rounded, the rectrices rery broad, rather soft.

Coloration.-Pileum brilliant metallic blue, violet-blue or violet bordered posteriorly by velvety black; back, etc., metallic green, passing into blue on upper tail-coverts; tail uniform blue-black or violet-black; under parts mostly brilliant metallic green but this relieved by a violet jugular area and brilliant golden orange or scarlet on throat. Sexes alike.

Range.-High mountains of Costa Rica and western Panamá. (Monotypic.)

\section{PANTERPE INSIGNIS Cabanis and Heine.}

\section{IRAZÚ HUNMING BIRD.}

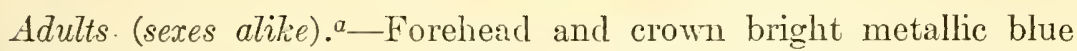
(varying from greenish to a slightly purplish hue), the feathers dusky gray basally with a bar of velvety black (concealed) between the gray basal portion and the metallic blue tip; loral and supra-auricular regions, occiput, and nape velvety black $(a)$ changing to bronze or dull coppery bronze in position $c$; back, scapulars, and wing-coverts

a After careful examination of a very large series of specimens I can not find that there is even an average difference of coloration betreen the sexes, some of the most brightly colored specimens being females, while some of the dullest are males. 
metallic, more or less bronzy, green, the rump similar but purer or more bluish green, the upper tail-coverts metallic bluish green; remiges dusky, faintly glossed with purplish; tail entirely blueblack (slightly metallic); chin and throat (more or less extensively) brilliant metallic orange-red or scarlet centrally, passing into a more orange or golden hue exteriorly, this passing gradually into the golden or bronzy green color of sides of neck and chest; a spot of metallic violet, passing into blue exteriorly (or of the two colors intermixed) on center of chest; rest of under parts less golden or more bluish metallic green, the anal tufts grayish white; bill black, the basal half (more or less) of mandible flesh color (in life); iris dark brown; legs and feet dusky brown.

Adult male.-Length (skins), 102-119 (106.2); wing, 62-69 (66.6); tail, 39-48 (43.7); culmen, 18-22 (20.2). ${ }^{a}$

Adult female.-Length (skins), 100-113 (105); wing, 58-65 (61.1); tail, 37-43 (40.3); culmen, 19.5-23 (20.7). ${ }^{b}$

Young.-Essentially like adults in coloration but the colors duller (crown more greenish, throat more coppery) and texture of plumage different (more blended or fluffy).

Highlands of Costa Rica (Volcán de Irazú; Volcán de Turrialba; Volcán de Barba; Volcán de Poás; Cerro de la Candelária; La Palma de San José; Rancho Redondo; Escazú; Ojuras de Térraba; Coliblanco; Las Vueltas, Santa Miaria de Dota) and western Panamá (Boquete; Volcán de Chiriquí; Verágua).

Panterpe insignis Cabanis and Herne, Mus. Hein., iii, March, 1860, 43 ("San José," i. e. Volcán de Irazu?, Costa Rica; coll. Berlin Mus.).-Gould, Mon. Troch., v, pt. xxi, 1861, pl. 336; Introd. Troch., oct. ed., 1861, 167.-CABANIS, Journ. für Orn., 1862, 164 ("San Jose").--Lawrence, Ann. Lyc. N. Y., ix, 1868, 124 (La Candelária and "Volcan Yrazei"=Irazú, Costa Rica).Frantzius, Journ. für Orn., 1869, 316 (La Candelária).-Mulsant and Verreaux, Hist. Nat. Ois.-Mouch., ii, livr. 1, 1875, 25 (Costa Rica; Volcán

$a$ Twenty-nine specimens.

$b$ Eighteen specimens.

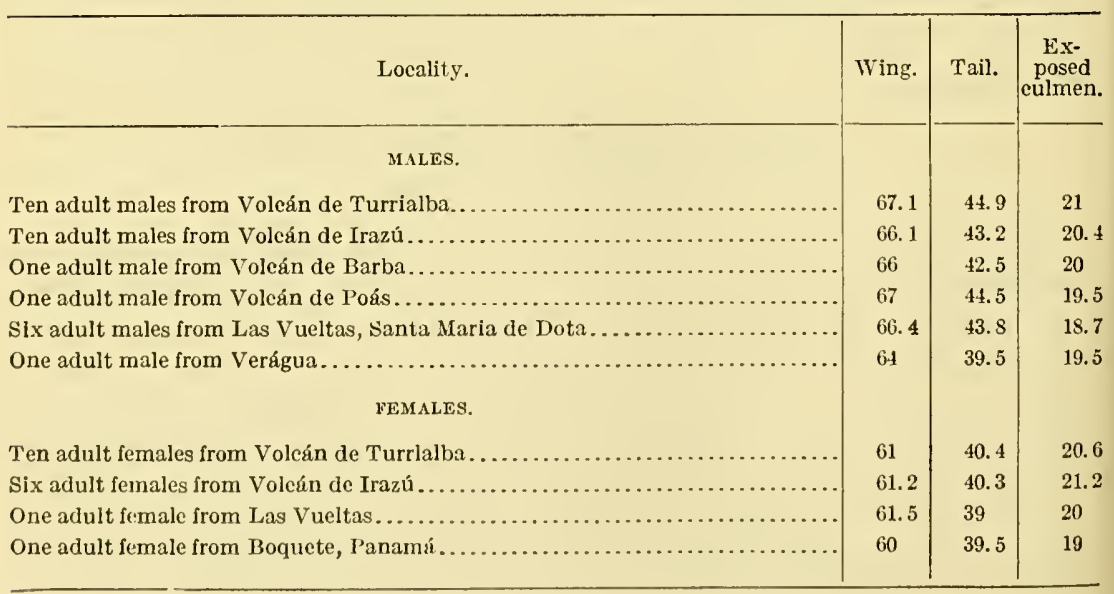


de Chiriquí, Pauamá); iv, livr.3, 1878, 1Ss; Suppl., pl. 31.-Boucaro, Proc. Zool. Soc. Lond., 1878, 71 (Volcán de Irazú; habits); The Hum. Bird, ii, 1892, 77 (Tolcán de Chiriquí); Gen. Hum. Bird, 1895, 235.--Elliot, Classif. and Synop. Troch., 1S79, 195.-Zeledón, Cat. Aves de Costa Rica, 1882, 21; Anal. Mus. Nac. Costa Rica, i, 1887, 122 (Faldas de Irazú).-Salvin, Cat. Birds Brit. Mus., xvi, 1892, 159.-Salvin and Godman, Biol. Centr.Am., Aves, ii, 1892, 283 (La Candelária, Volcán de Irazú, Faldas de Irazú, and La Palma de San José, Costa Rica; Volcán de Chiriquí).-Salvador and Festa, Boll. Mus. Zool., etc., Torino, xiv, 1899, no. 339, 7 (Chiriquí, Panamá).-Baxas, Bull. New Engl. Zool. Club, iii, 1902, 29 (Boquete and Volcán de Chiriquí, 6,000-7,600 ft.); iv, 1908, 25 (descr. of melanistic or abnormally colored specimen).-RIDGwaY, Condor, vii, 1905, 158, in text (Volcán de Turrialba, Costa Rica, 9,000 ft.).-Carriker, Ann. Carnegie Mus., vi, 1910, 532 (highlands of Costa Rica).-Ferry, Pub. 146, Field Mus.

N. H., orn. ser., i, no. 6, 1910, 263 (Volcán de Turrialba, Costa Rica; habits). [Panterpe] insignis Sclater and Salvin, Nom. Av. Neotr., 1873, 93.-Mulsant,

Ann. Soc. Linn. Lyon, xxii, 1876, 208.-Sharpe, Hand-list, ii, 1900, 114.

$P$ [anterpe] insignis HARTERT, Das Tierreich, Troch., 1900, 82 (monogr.).

[Trochilus] insignis GraY, Hand-list, i, 1S69, 135, no. 1768.

Clytolama insignis Mulsant and Verreaux, Classif. Troch., 1866, 59.

\section{Genus KLAIS Reichenbach.}

[Basilinna.] 3. Klais Reichenbach, Aufz. der Colib., 1854, 13. (Type, Trochilus guimeti Bourcier and Mulsant.)

Clais (emendation) Sclater, Cat. Am. Birds, 1862, 304.

Guimetia "Reich[enbach]" Bonaparte, Ann. Sci. Nat., sér. 4, i, 1854, 137. (Type, Trochilus guimeti Bourcier and Mulsant.)

Small Trochilidæ (length about $75 \mathrm{~mm}$.) with bill shorter than head, straight, nasal operculi mostly exposed, tarsi feathered (except behind), tail a little more than half to nearly three-fifths as long as wing, truncate or slightly emarginate in adult male, double-rounded in female, the rectrices broadly rounded terminally (in both sexes), the coloration mostly grayish beneath; adult male with pileum, chin, and throat metallic violet-blue and tail greenish passing into black terminally; adult female paler gray beneath (including chin and throat), pileum greenish blue, the lateral rectrices tipped with pale gray.

Bill shorter than head, straight, slender, terete; culmen rounded except basally, where contracted into a distinct ridge; tomia smooth; mandible with the usual lateral median groove. Nasal operculum rather narrow, only the upper posterior portion concealed by frontal feathering, the latter extending scarcely as far forward as anterior end of nostril, forming a short point or antia on each side of culmen. Tarsus feathered, except on posterior side; anterior toes about equal in length, or the lateral ones just appreciably shorter than the middle one. Wing nearly to quite four times as long as exposed culmen, the outermost primary longest, normal in shape. Tail of adult male about three-fifths as long as wing, truncate or faintly emarginate, that of female a little more than half as long as wing, rounded, with middle rectrices shorter than next pair, the rectrices broadly rounded at tip in both sexes.

$81255^{\circ}-$ Bull. $50-11-33$ 
Coloration.--Back, etc., metallic bronze-green, the middle rectrices and basal portion of other rectrices less bronzy or more bluish green, the outer rectrices blackish terminally or subterminally; under parts partly or wholly grayish; a white postocular spot. Adult male with head mostly metallic violet or violet-blue, under parts of body glossed with metallic greenish, and without grayish tips to lateral rectrices; adult female with pileum greenish blue, whole under parts pale gray, and outer rectrices tipped with pale gray.

Range.-Nicaragua to Venezuela and Ecuadór. (Monotypic.)

\section{KLAIS GUIMETI (Bourcier and Mulsant).} GUIMET'S HUMMING BIRD.

Adult male.-Pileum bright metallic violet or violet-blue, becoming more decidedly blue (sometimes even greenish) posteriorly; rest of upper parts metallic bronze-green or greenish bronze, the upper tail-coverts purer green or bluish green; middle rectrices metallic silvery bronze-green or bluish green, the remaining rectrices similar basally, but with terminal half (approximately) dull black or dusky, narrowly tipped with light brownish gray; remiges purplish dusky; a postocular spot of white; chin, throat, and malar region rich metallic violet or violet-blue; rest of under parts brownish gray, spotted or flecked (except on abdomen) with metallic green or bronze-green, the under tail-coverts brownish gray margined with dull white or pale gray; bill dull black; iris dark brown; feet grayish brown (in dried skins); length (skins), 70-82 (75); wing, 45-52.5 (49.5); tail, 25.5-31 (28.4); culmen, 12-13.5 (12.8). ${ }^{a}$

Adult female.-Above similar to adult male, but with metallic blue of pileum lighter, decidedly blue (not violaceous) or even greenish in hue, lateral rectrices more abruptly tipped with pale gray, and middle rectrices sometimes blackish terminally; under parts pale gray, the sides and flanks glossed or spotted with metallic green or bronzegreen; length (skins), 73-79 (76); wing, 44-48.5 (45.9); tail, 23-27 (25.1); culmen, $11.5-14$ (13). ${ }^{b}$

Young.-Similar to the adult female, but pileum dull metallic green instead of bright blue or bluish green.

a Twenty-six specimens.

$b$ Seventeen specimens.

\begin{tabular}{|c|c|c|c|}
\hline Locality. & Wing. & Tail. & $\begin{array}{c}\text { Ex- } \\
\text { posed } \\
\text { culmen. }\end{array}$ \\
\hline MALES. & & & \\
\hline Ten adult males from Costa Rica.. & 48.6 & 28.2 & 12.9 \\
\hline Five adult males from Panamá........... & 49 & 27.9 & 12.9 \\
\hline Nine adult males from eentral Colombia.... & 50.6 & 28.8 & 12.7 \\
\hline One adult male from castern Ecuadór (Napo)........ & 52 & 29 & 13 \\
\hline One adult male from northern Pcru (Chanehamoyo)....... & 48.5 & 27.5 & 12 \\
\hline FEMALES. & & & \\
\hline Eleven adult females from Costa Rlca.. & 45.5 & 25 & 13 \\
\hline Five adult females from eentral Colombia.... & 46.7 & 25.4 & 12.9 \\
\hline One adult female from eastern Ecuadór (Napo)......... & 45 & 24 & 14.5 \\
\hline
\end{tabular}


Nicaragua (Chontales), Costa Rica (Navarro de Cartago; Carrillo; Bonilla; Escazú; San Pedro; Gúpiles; Miravalles; Térraba; El Generál; Boruca; Buenos Aires), Panama (Santa Fé and Santiago, Verágua; Bugaba; Volcán de Chiriquí; Calovévora; Chitra; Castillo; Laguna de Castillo; Chepo; Ventorillo, Coclé), and southward through Colombia (Bogotá; Llanos de Meta) and Ecuarlór (Napo; Báeza; Gualaquiza; Zamora) to Peru (Chanchamoyo; Chyavetas; Huambo) and Venezuela (Carácas; San Esteban).

Trochilus] guimeti Bourcier and Mulsant, Ann. Sci. Phys. et Nat. Lyon, vi, livr. 1, 1843, 38, pl. 2 (no locality given).

Trochilus guimeti Bourcier, Rev. Zool., 1843, 72 (Colombia; Carácas, Venezuela). H[ylocharis] guimeti GraY, Gen. Birds, i, Dec., 1848, 114.

[Hylacharis] guimeti GraY, Hand-list, i, 1869, 152, no. 1959.

[Basilinna] $\beta$. Klais guimeti Reichenbach, Aufz. der Colibr., 1854, 13.

[Basilinna] guimeti ReICHENBaCH, Troch. Enum., 1855, 11.

B[asilinna] guimeti Cabanis and Heine, Mus. Hein., iii, 1860, 45 (Verágua; (arácas).

[Myiabeillia] guimeti Bonaparte, Rev. et Mag. de Zool., 1854, 253.

nyyiabellia guimeti Sclater, Proc. Zool. Soc. Lond., 1857, 7 (Bogotá, Colombia).

Klais guimeti Gould, Mon. Troch., pt. xiv, Sept., 1857; vol. iv, 1861, pl. 210;

Introd. Troch., oct. ed., 1861, 119.-Lawrence, Ann. Lyc. N. Y., ix, 1868, 145 (Costa Rica).-Mulsant and Verreaux, Hist. Nat. Ois.-Mouch., ii, livr. 1, 1875, pl. 19; iii, livr. 2, 1876, 139, pl. 82 (Tenezuela; Colombia).Bovcard, Proc. Zool. Soc. Lond., 1878, 69 (Navarro de Cartago, Costa Rica); The Hum. Bird, ii, 1892, 74 (Bogotá); Gen. Hum. Birds, 1895, 49 (Colombia).-Elliot, Classif. and Synop. Troch., 1879, 184.-Cherrie, Expl. Zool. Mérid. Costa Rica, 1882, 45 (Boruca and Térraba, s. w. Costa Rica).-ZeteDóx, Cat. Aves de Costa Rica, 1882, 21; Anal. Mus. Nac. Costa Rica, i, 1887, 122 (Navarro de Cartago).-TAczanowski, Orn. du Pérou, i, 1884, 364.-BerLEPSCH, Zeitschr. Orn., 1887, 186 (Bogotá); Journ. für Orn., 1887, 319 (Bogotá; synonymy).-SaLvin, Cat. Birds Brit. Mus., xvi, 1892, 359, 666 (Chontales, Nicaragua; Costa Rica; Laguna de Castillo, Santiago, Santa Fé de Verágua, and Chepo, Panamá; Bogotá; Ecuadór; upper Amazons; San Esteban, Venezuela).-Salvin and Godman, Biol. Centr.-Am., Aves, ii, 1892, 343.Salvadori and Festa, Boll. Mus. Zool., etc., Torino, xv, 1900, 8 (Gualaquiza, e. Ecuadór).-Hartert (E. and C.), Novit. Zool., i, 1894, 17 (near Zamora, Ecuadór).-CArriker, Ann. Carnegie Mus., vi, 1910, 551 (Costa Rican range).

[Klais] guimeti MulsaNT, Ann. Soc. Linn. Lyon, n. s., xxii, 1876, 221.

Claïs guimeti Sclater, Cat. Am. Birds, 1862, 304 (Bogotá).-Salvin, Proc. Zool. Soc. Lond., 1867, 155 'Santiago and Santa Fé de Verágua, Panamá).-Scla ter and Salvix, Proc. Zool. Soc. Lond., 1867, 752 (Chyavetas, e. Peru).-Taczanowsir, Proc. Zool. Soc. Lond., 1882, 37 (Huambo, Peru)._Siмon, Mém. Soc. Zool. France, ii, 1889, 224 (San Esteban, Venezuela).-BANGs, Auk, xxiv, 1907, 296 (Boruca, Costa Rica).

C[lais] guimeti Heine, Journ. für Orn., 1863, 196.-HARTERT, Das Tierreich, Troch., 1900, 181.

[Clais] guimeti Sclater and Salvin, Nom. Av. Neotr., 1873, 88.-Heine and Reichenow, Nom. Mus. Hein. Orn., 1890, 181 (Caracas).-Sharpe, Handlist, ii, 1900, 143.

Adelomya guimeti Mulsant and Verreaux, Classif. Troch., 1866, 70. 
Mellisuga merrettii Lawrence, Ann. Lyc. Nat. Hist. N. Y., vii, April, 1860, 110 (District of El Minerál, 15 miles west of District of Belén, Verágua, Panamá; coll. Dr. J. K. Merritt; =adult female).-Gould, Ibis, 1860, 309.

Clais merretti Salvin, Ibis, 1870, 209 (Castillo, Calovévora, Chitra, Laguna de Castillo, Bugaba, and Volcán de Chiriquí, Panamá; crit.).

Klais merritti Boucard, The Hum. Bird, ii, 1892, 74 (Verágua); Gen. Hum. Birds, 1895, 50 ("Guatemala"; Costa Rica; Panamá).

[Klais guimeti] var. merritti Mulsant, Ann. Soc. Linn. Lyon, n. s., xxii, 1876, 221.

Klais guimeti merritti Berlepsch and Stolzmann, Proc. Zool. Soc. Lond., 1902, 29 (Borgoña, centr. Peru); Ornis, 1906, 120 (Huaynapata, Cuzco, centr. Peru).

\section{Genus ABEILLIA Bonaparte.}

Abeillia Bonaparte, Consp. Av., i, 1849, 79. (Type, A. typica Bonaparte =Ornismya abeillei Delattre and Lesson.)

[Basilinna.] ץ. Baucis Reichenbach, Aufz. der Colibr., 1854, 13. (Type, Ornismya abeillei Delattre and Lesson.)

Myiabeillia Bonaparte, Rev. et Mag. de Zool., vi, May, 1854, 253. (Type, Ornismya abeillei Delattre and Lesson.)

Small Trochilidæ (length about $68-75 \mathrm{~mm}$.) very closely related to Klais, but with tail relatively longer (three-fifths to nearly twothirds as long as wing), more distinctly emarginate or double-rounded in adult male, the latter with pileum metallic green (concolor with back, etc.) the chin and upper throat bright metallic emerald green.

Bill shorter than head, straight, terete; culmen rounded except basally, where contracted into a rather distinct ridge; tomia smooth; mandible with the usual lateral median groove. Nasal operculum moderately broad, strongly convex, only the inner portion hidden by the decumbent frontal feathering, which extends anteriorly nearly to anterior end of nostril, forming a single broad, rounded, frontal antia. Tarsus feathered, except on posterior side; anterior toes about equal in length, but the outer apparently appreciably shorter. Wing about four times as long as exposed culmen, the outermost primary longest, normal in shape. Tail of adult male nearly two-thirds as long as wing, deeply emarginate, with lateral rectrices slightly shorter than the next, that of adult female moderately rounded, with middle rectrices slightly shorter than the next, the rectrices (in both sexes) broadly rounded terminally.

Coloration.-Above metallic bronze-green, including middle rectrices and basal portion of other rectrices, which are blackish subterminally and grayish terminally; a small white postocular spot. Adult male with chin and upper throat bright metallic emerald green, the remaining under parts olive-grayish strongly glossed with bronzegreen (more dusky on lower throat); adult female with under parts pale gray, the outer rectrices more abruptly tipped with gray.

Range.-Southern Mexico to Guatemala. (Monotypic.) 


\section{ABEILLIA ABEILLEI (Delattre and Lesson).}

ABEILIE'S HUMMING BIRD.

Adult male.-Above metallic bronze-green or greenish bronze, including middle pair of rectrices; rest of tail black, faintly glossed with bluish or bronzy, the rectrices tipped with brownish gray (most broally on outermost), and with basal half (more or less) of outer web rather dull greenish bronze or bronze-green; remiges purplish dusky or dull dusky- slate faintly glossed with purplish; a small postocular spot of white; chin and upper throat brilliant metallic emerald green or yellowish green; lower throat velvety black in position $a$, dusky metallic bronze-green in position $c$, passing into duller black or dusky on chest, the remaining under parts deep brownish gray more or less glossed or overlaid with metallic bronze-green, except on abdomen; under tail-coverts metallic bronze-green centrally, broadly margined with deep brownish gray; bill dull black; iris dark brown; feet brownish (in dried skins); length (skins), 73-86 (80); wing, 44-50.5 (47.8); tail, 27.5-33 (30.3); culmen, 10-11.5 (10.6). ${ }^{a}$

Adult female.-Similar to the adult male, but lateral rectrices distinctly tipped with pale brownish gray, and under parts pale gray, spotted or glossed with metallic green or bronze-green on sides; length (skins), 71-72 (71.3); wing, 41.5-46 (43.8); tail, 26.5-27 (26.8); culmen, $11-12(11.5){ }^{b}$

Southeastern Mexico, in States of Vera Cruz (Jalapa; Córdova; Orizaba) and Chiapas (Tumbalá); Guatemala (Cobán; Guatemala City; Volcán de Fuego; Pié de la Cuesta, San Marcos; 'Tolimán, Sololá); northern Nicaragua (Matagalpa).

Ornismya abeillei Delattre and Lesson, Rev. Zool., 1839, 16 (Jalapa, Vera Cruz, Mexico).

M[ellisuga] abeillei Gray, Gen. Birds, i, Dec., 1848, 112.

[Ramphomicron] abeilleii Bonaparte, Consp. Av., i, 1850, 79.

[Basilinna] †. Baucis abeillei Reichenbach, Aufz. der Colibr., 1854, 13.

Basilinna abeillei Reichenbach, Troch. Enum., 1855, 11.

B[aucis] abeillei Cabanis and Herne, Mus. Hein., iii, 1860, 72 (Guatemala).

Baucis aheillei Boucard, Ann. Soc. Linn. Lyon, xxii, 1876, 23 (Córdova, Vera Cruz); Notes Troch. du Mex., 1875, 10 (Córdova; Guatemala).-Mulsant and Verreaux, Hist. Nat. Ois.-Mouch., iii, livr. 2, 1876, 143; iv, livr. 3, $1878,219$.

a Sixteen specimens.

$b$ Three specimens.

\begin{tabular}{|c|c|c|c|}
\hline Locality. & Wing. & Tail. & $\begin{array}{c}\text { Ex- } \\
\text { posed } \\
\text { culmen. }\end{array}$ \\
\hline MALES. & & & \\
\hline 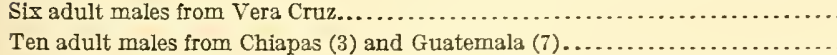 & $\begin{array}{l}47.9 \\
47.7\end{array}$ & $\begin{array}{l}30.3 \\
30.2\end{array}$ & $\begin{array}{l}10.6 \\
10.6\end{array}$ \\
\hline
\end{tabular}


[Baucis] abeillæi Sclater and Salvin, Nom. Av. Neotr., 1873, 88.

[Baucis] abeillei Mulsant, Ann. Soc. Linn. Lyon, n. 8., xxii, 1876, 221.-Heine and Reichenow, Nom. Mus. Hein. Orn., 1890, 187 (Guatemala).

Daucis abeillei BouCARD, Liste Ois. réc. Guat., 1878, 46.

Adelomya abeillei Mulsant and Verreaux, Classif. Troch., 1866, 71.

[Trochilus] abeillei Grax, Hand-list, i, 1869, 142, no. 1840.

A[beillea] abeillei Hartert, Das Tierreich, Troch., 1900, 215 (monogr.).

[Abeilleia] abeillei Sharpe, Hand-list, ii, 1900, 143.

Abeillia typica? Bonaparte, Consp. Av., i, 1850, 79, in text under Ramphomicron abeillei.

Abeillia typica Elurot, Classif. and Synop. Troch., 1879, 184.-Zeledón, Cat. Aves de Costa Rica, 1882, 21; Anal. Mus. Nac. Costa Rica, i, 1887, 122.Salvin, Cat. Birds Brit. Mus., xvi, 1892, 358, 666 (Mexico; Cobán, Volcán de Fuego, and Pié de la Cuesta, San Marcos, Guatemala).-SAlvin and Godman, Biol. Centr.-Am., Aves, ii, 1892, 342 (Jalapa and Córdova, Vera Cruz; Tolimán in Sololá, etc., Guatemala; Matagalpa, Nicaragua).-BouCARD, Gen. Hum. Birds, 1895, 55 (Jalapa; Cobán).

Myiabeillia typica Gould, Mon. Troch., iv, pt. viii, Oct., 1854 (vol. iv, 1861), pl. 211; Introd. Troch., oct. ed., 1861, 119.-Sclater, Proc. Zool. Soc. Lond., 1856, 287 (Mexico); Cat. Am. Birds, 1862, 304.-Sclater and Salvin, Ibis, 1859, 128 (Cobán).-SALvin, Ibis, 1860, 195, 262, 263 (Cobán and Volcán de Fuego; habits).

[Myiabeillia] typica Bonaparte, Rev. et Mag. Zool., 1854, 253.

Myiabiellia typica D’Oca, La Naturaleza, iii, 1875, 205 (Jalapa); Troq. de Mex., 1875, pl. (10), fig. 35 .

Myiabiellia tipica D’OcA, Troq. de Mex., 1875, 47.

\section{Genus DAMOPHILA Reichenbach.}

[Coeligena.] ß. Damophila Reichenbach, Aufz. der Colib., March(?), 1854, 7. (Type, Ornismya juliæ Bourcier.)

Juliamyia Bonaparte, Rev. et Mag. de Zool., vi, May, 1854, 255. (Type, J. typica Bonaparte=Ornismya juliæ Bourcier.)

Rather small Trochilidæ (length about $78-90 \mathrm{~mm}$.) with bill about as long as head, straight, and terete; nasal operculi feathered; tail about two-thirds as long as wing (in female) to three-fourths as long (adult males), graduated, blue-black in both sexes; adult males with under parts of body bright metallic violet-blue, the chin and throat brilliant metallic green, in abrupt contrast.

Bill as long as head, straight, terete; culmen broadly rounded but basally contracted into a narrow mesorhinal ridge; tomia smooth; mandible with a narrow median lateral groove and maxilla with a faint indication of a similar groove. Tarsus feathered; middle and inner toes about equal in length, the outer slightly shorter, the hallux slightly shorter than lateral toes; all the toes slender. Wing about three times as long as exposed culmen, the outermost primary longest. Tail about two-thirds as long as wing (in females) to three-fourths as long (in adult males), graduated, the rectrices rather narrow, the lateral ones contracted terminally but all with rounded tip. 
Coloration.-Above metallic green (darker in adult males), the tail blue-black (middle rectrices sometimes dark greenish in females); adult males with chin and throat brilliant metallic green, the under parts of body, abruptly, bright violet-blue; tail wholly blue-black; adult females with under parts pale gray or grayish white (the throat sometimes spotted with green), the lateral rectrices tipped with gray.

Range.-Panamá to western Ecuadór. (Three species or subspecies.)

KEY TO THE SPECIES AND SUBSPECIES OF DAMOPHILA.

a. Chin, throat, and chest brilliant metallic green, under parts of body metallic violet-blue; tail uniform blue-black. (Adult males.)

b. Pileum brilliant metallic green. (Damophila juliæ.)

c. Bill averaging shorter (14.5); pileum usually less glittering green and blue of under parts usually(?) less violaceous. (Colombia to Chiriquí.)

Damophila juliæ juliæ, adult male (p. 519).

cc. Bill averaging longer (15.1); pileum usually more glittering green and blue of under parts usually(?) more violaceous. (Testern Ecuadór.)

Damophila juliæ feliciana, adult male (extralimital). $a$

bb. Pileum dull metallic green, like back. (Panamá and adjacent part of Costa Rica?)................... Damophila panamensis, adult male (p. 521). aa. Chin, throat, and chest pale gray or grayish white, or only spotted with green; under parts of body pale gray, passing into white posteriorly; lateral rectrices tipped with gray. (Adult females.)

b. Throat usually heavily spotted with green.

Damophila juliæ feliciana, adult female (extralimital). $b$

bb. Throat usually immaculate..... Damophila panamensis, adult female p. 521).)

\section{DAMOPHILA JULIE JULIA (Bourcier).}

\section{JULIE'S HUMMING BIRD.}

Adult male.-Pileum brilliant metallic green (yellowish emerald green to golden green); rest of upper parts duller metallic bronzegreen, usually more bronzy on rump; tail glossy blue-black; remiges very dark brownish slate or dusky, faintly glossed with violaceous; malar, suborbital, and auricular regions, chin, throat, and sides of neck brilliant metallic green (like pileum); rest of under parts rich metallic violet-blue (deep smalt blue to hyacinth blue), the flanks intermixed with metallic green; under tail-coverts glossy blue-black; femoral tufts white; maxilla dull black, mandible pale brownish or

a Ornisny feliciana Lesson, Rev. Zool., vii, Dec., 1844, 433 (Guayaquíl, w. Ecuadór; coll. Abeillé).-Juliamya feliciana Gould, Introd. Troch., oct. ed., 1861, 168.Damophila feliciana Sclater, Cat. Am. Birds, 1862, 316.-[Hylocharis] feliciana Gray, Hand-list, i, 1869, 151, no. 1948.-D[amophila] julie feliciana Hartert, Das Tierreich, Troch., 1900, 71 (monogr.).-Damophila juliæ (not Ornismya juliae Bourcier) Salvin, Cat. Birds Brit. Mus., xvi, 1892, 236, part.-Juliamyia typica (not of Bonaparte) Sclater, Proc. Zool. Soc. Lond., 1860, 283 (Babahoyo, w. Ecuadór), 296 (Esmeraldas, w. Ecuadór).

The adult female of $D$. juliæ julix not seen by me. 
dull whitish (pink or reddish in life); iris dark brown; feet dusky; length (skins), 75-83 (80); wing, 42.5-45.5 (43.8); tail, 29-33 (31.5); culmen, $13.5-15.5(14.5) .^{a}$

Adult female.-(Not seen by me.)

Panama (Bugaba, Chiriquí) and Colombia (Tunja, near Bogotá; Bogotá; Agua Chica; Antioquía; Lower Magdalena; Turbo; Buca ramanga).

Ornismya juliae Bourcier, Ann. Sci. Phys. et Nat. Lyon, v, 1842, 345, pl. 21 ('Tunja, near Bogotá, Colombia).

Ornismya julie Bovrcier, Rev. Zool., 1842, 373 (Tunja).

H[ylocharis] juliz Grax, Gen. Birds, i, Dec., 1848, 114.

[Hylocharis] julix GRAY, Hand-list, i, 1869, 151, no. 1947.

[Coeligena] 3. Damophila julia Reichenbach, Aufz. der Colibr., 1854, 7.

[Coeligena] juliae Reichenbach, Troch. Enum., 1855, 3, pl. 681, figs. 4494, 4495.

D[amophila] juliae Cabanis and Heine, Mus. Hein., iii, 1860, 40 (Colombia).-

HeINe, Journ. für Orn., 1863, 194.

Damophila julix Sclater, Cat. Am. Birds, 1862, 316 (Bogotá).-Wyatt, Ibis, 1871, 378 (Agua Chica, Colombia).-Mulsant and Verreaux, Hist. Nat. Ois.-Mouch., ii, livr. 1, 1875, 56, part (Tunja, Colombia); livr. 3, 1876, pl. 29; iv, livr. 3, 1878, 193, part.-Mulsant, Ann. Soc. Linn. Lyon, xxii, 1876, 208.-Berlepsch, Journ. für Orn., 1884, 312 (Bucaramanga, Colombia; crit.); 1887, 333 (Bogotá).-Salvin, Cat. Birds Brit. Mus., xvi, 1892, 236, part (Bogotá).-Salvin and Godman, Biol. Centr.-Am., Aves, ii, 1892, 309, part (Turbo, etc., Colombia).

[Damophila] julix Sharpe, Hand-list, ii, 1900, 112.

[Juliamyia] typica Bonaparte, Rev. et Mag. de Zool., 1854, 255.-Sclater and Salvin, Nom. Av. Neotr., 1873, 93, part.

Juliamyia typica Gould, Introd. Troch., oct. ed., 1861, 168, part.-Sclater, Proc. Zool. Soc. Lond., 1857, 17 (Tunja, Colombia).-Sclater and Salvin, Proc. Zool. Soc. Lond., 1879, 530 (Antioquía, Colombia).--Berlepsch, Proc. U. S. Nat. Mus., xi, 1888, 563 (Turbo, Colombia; crit.).-Boucard, The Hum. Bird, ii, 1892, 80 (Bogotá).

Juliamya typica Gould, Mon. Troch., pt. xviii, Sept., 1859; vol. v, 1861, pl. 337. Damophila typica Boucard, Gen. Hum. Birds, 1895, 133 (Colombia). D[amophila] julie (typica) Hartert, Das Tierreich, Troch., 1900, 71.

a Eight specimens.

\begin{tabular}{|c|c|c|c|}
\hline Locality. & Wling. & Tail. & $\begin{array}{c}\text { Ex- } \\
\text { posed } \\
\text { culmen. }\end{array}$ \\
\hline MALES. & & & \\
\hline Seven adult males from Colombia (mostly from Bogotâ).. & 43.9 & 31.4 & 14.5 \\
\hline One adult male from Panama (Bugaba, Chiriquí)......... & 43 & 32.5 & 14.5 \\
\hline
\end{tabular}

The Chiriqui specimen has the color of the pileum exceedingly brilliant, quite as much 80 , in fact, as any specimen of $D$. j. feliciana. 


\section{DAMOPHILA PANAMENSIS Berlepsch.}

\section{PANAMA HUMMING BIRD.}

Similar to $D$. julize, but adult male with pileum dull or dark metallic green. similar to or darker than color of back, instead of brilliant yellowish emerald green, like throat.

Adult male.-Above metallic green or bronze-green, usually more bronzy on rump, darker (or at least not brighter) on pileum; tail glossy blue-black; remiges very dark brownish slate or blackish, faintly glossed with violaceous; malar, suborbital, and auricular regions, chin, throat, and sides of neck brilliant metallic green, more yellowish or golden anteriorly, purer green or sometimes even bluish green posteriorly; rest of under parts rich deep metallic violet-blue (dark smalt blue or hyacinth blue), the under tail-coverts slightly glossy bluish or greenish black, the femoral tufts white; maxilla dull black, mandible pale brownish or dull whitish (pink or reddish in life) ; iris dark brown; feet dusky; length (skins), 78-93 (S6); wing, 41.5-44 (43.1); tail, 29-31 (30.4); culmen, 14-15.5 (14.7). ${ }^{a}$

Adult female.-A bove bright metallic bronze-green, more decidedly bronzy on rump and upper tail-coverts; tail blue-black, the middle pair of rectrices usually more or less tinged with dark bluish green, sometimes wholly of this color, the outer pair of rectrices broadly tipped with pale gray, the next pair more narrowly tipped with the same; remiges dusky, faintly glossed with violaceous; under parts pale gray, passing into white posteriorly, the sides of throat sometimes spotted with metallic green; bill, etc., as in adult male; length (skins), 74-78 (77); wing, 41.5-44 (42.6); tail, 25-27.5 (26.4); culmen, $15-16(15.5) .^{b}$

Panamá (Lion Hill; Panamá; Camerón; Paraiso; Chepo, on Rio Bayano; Calovérora, Terágua); Costa Rica?

Juliamyia typica (not of Bonaparte) LAwrence, Ann. Lyc. N. Y., vii, 1862, 292 (Lion Hill, Panamá); ix, 1868, 128 (Costa Rica).-Frantzius, Journ. für Orn., 1869, 317 (Costa Rica).-Elliot, Classif. and Synop. Troch., 1879, 233, part (Panama).-Zeledós, Cat. Aves de Costa Rica, 1882, 21.
a Nine specimens.
$b$ Five specimens.

\begin{tabular}{|c|c|c|c|}
\hline Locality. & Wing. & Tail. & $\begin{array}{c}\text { Ex- } \\
\text { posed } \\
\text { culmen. }\end{array}$ \\
\hline MaLES. & & & \\
\hline Eight adult males from Panamá... & 43.4 & 30.4 & 14.6 \\
\hline One adult male said to be from Costa Rica... & 41 & 30.5 & 15.5 \\
\hline Eight adult males of $D$. juliæ juliæ........... & 43.8 & 31.5 & 14.5 \\
\hline Ten adult males of $D$. julix feliciana... & 43.7 & 31.1 & 15.1 \\
\hline FEMALES. & & & \\
\hline Five adult females of $D$. panamensis... & 42.6 & 26.4 & 15.5 \\
\hline Four adult females of $D$. juliæ feliciana .... & 42.4 & 27.2 & 15.4 \\
\hline
\end{tabular}


[Juliamyia] typica Sclater and Salvin, Nom. Av. Neotr., 1873, 93, part.

Damophila juliæ (not Ornismyia juliae Bourcier) Sclater and Salvin, Proc. Zool. Soc. Lond., 1864, 365 (Panamá).-Salvin, Proc. Zool. Soc. Lond., 1870, 211 (Calovévora, Panamá).--Mulsant and Verreaux, Hist. Nat. Ois.-Mouch., ii, livr. 1, 1875, 56, part (Panamá).

D[amophila] panamensis Berlepsch, Journ. für Orn., 1884, 312 (Panamá and Verágua); Proc. U. S. Nat. Mus., xi, 1888, 563, in text.

Damophila panamensis Salvin, Cat. Birds Brit. Mus., xvi, 1892, 237 (Lion Hill, Paraiso, Panamá, and Chepo, Panamá).-Salvin and Godman, Biol. Centr.Am., Aves, ii, 1892, 309 (Calovévora, Lion Hill, Paraiso, and Chepo, Panamá; Costa Rica?).-Bangs, Proc. New Engl. Zool. Club, ii, 1900, 20 (Loma del León, Panamá).

Juliamyia panamensis Boucard, The Hum. Bird, ii, 1892, 80 (Panamá). D[amophila] julie panamensis Hartert, Das Tierreich, Troch., 1900, 71 (monogr.). [Damophila] panamensis Sharpe, Hand-list, ii, 1900, 112.

\section{Genus POLYERATA Heine.}

Polyerata a Heine, Journ. für Orn., March, 1863, 194, in text. (Type, Trochilus amabilis Gould.)

Rather small Trochilidæ (length about $80-90 \mathrm{~mm}$.) related to Agyrtria, but differing in broader median and relatively narrower lateral rectrices, narrower and relatively longer bill, and more varied coloration; adult males with pileum brilliant emerald green and throat bright metallic violet-blue; adult female essentially similar but much duller, with no blue on throat or at most with merely spots of that color, pileum less brilliantly green, and rectrices tipped with gray.

Bill nearly half as long as wing, straight, narrow (terete), not distinctly if at all widened basally, the culmen broadly rounded except mesorhinal portion, where narrowly ridged; tomia smooth; median lateral sulci of maxilla and mandible fairly distinct. Nostril narrow, slit-like, overhung by a rather narrow, partly (sometimes mostly) feathered operculum. Tarsus completely covered with short feathers; middle and inner toes equal in length, the outer decidedly shorter; hallux decidedly shorter than outer toe; toes small, but claws relatively large. Wing more than twice as long as exposed culmen, the outermost primary longest. Tail more than half as long as wing, slightly to decidedly rounded, the middle rectrices rather broad, the lateral rectrices (especially outermost pair) much narrower, all contracted terminally into a rounded point.

Coloration.-Above metallic green or bronze-green, the upper tailcoverts bronzy, the middle rectrices dull bronze or greenish bronze, the lateral rectrices dull black, more grayish terminally; abdomen grayish white. Adult male with pileum brilliant metallic green, throat metallic violet-blue; adult female with pileum less brilliant green and throat spotted with dull green or blue.

Range.-Costa Rica to western Ecuadór. (Four species, including subspecies.) 
KEY TO THE SPECIES OF POLYERATA. ${ }^{\alpha}$

a. Bill shorter (culmen 17-19.5 in male, 18.5-20 in female); middle rectrices purplish bronze; adult male with violet or violet-blue throat-patch broader and more violaceous. (Eastern Nicaragua, Costa Rica, and Panamá to western Ecuadór.)

Polyerata amabilis (p. 523). aa. Bill longer (culmen $21-23$ in male, $21-24$ in female); middle rectrices greenish bronze adult male with throat-patch narrower and more bluish. (Western Costa Rica and Panamá.)...................... Polyerata decora (p. 525).

\section{POLYERATA AMABILIS (Gould).}

LOVELT HUMMING BIRD.

Adult male.-Forehead and crown brilliant metallic green (yellowish emerald green); oeciput, sides of head and neck, hindneck, back, scapulars, and wing-coverts metallic bronze-green, changing to bronze, greenish bronze, or purplish bronze on rump, the upper tailcoverts deep bronze or (usually) purplish bronze; middle pair of reetrices dark metallic bronze or (usually) purplish bronze; rest of tail black, glossed with bluish, the reetrices next to middle pair dark bronze or purplish bronze basally, the exterior ones usually narrowly margined at tip with pale grayish; remiges dark brownish slate or dusky, glossed with violaceous; chin and upper throat opaque black viewed from in front, rather dull metallie green or bronze-green, the feathers margined with dusky, when viewed from behind; lower throat and upper chest bright metallic violet-blue, this area purer blue (sometimes greenish blue) exteriorly; lower ehest rather dull metallic green or bluish green, the feathers margined with pale gray or grayish white (especially along median line), the sides and flanks similar, but the green more bronzy; abdomen and median portion of breast pale brownish gray; under tail-coverts clusky gray, faintly glossed with bronze, and margined (more or less broadly) with pale gray or grayish white; femoral tufts white; maxilla dull black, mandible pale brownish or dull whitish (pink or reddish in life), the tip dusky; iris dark brown; feet grayish brown or dusky; length (skins),

$a$ In addition to the two species (or subspecies) found within the geographic limits of this work, three additional ones havo been described, but they are all autoptically unknown to me.

(1) Polyerata rosenbergi Boucard.-Polyerata rosenbergi Boucard, Genera Hum. Birds, Dec., 1895, 399 (Rio Dagua, n. w. Colombia; coll. A. Boucard).-Polyerata rosenbergii Boucard, The Hum. Bird, v, 1895, 6 (Rio Dagua; crit.).-A[gyrtria] rosenbergi Hartert, Novit. Zool., v, 1898, 517 (crit.); Das Tierreich, Troch., 1900, 48.

(2) Polyerata reini Berlepsch.-Polyerata reini Berlepsch, Oru. Monatsber., April, 1897, 58 (w. Ecuadór; coll. Count von Berlepsch).

(3) Polyerata cyaneotincta Gounelle.-Polyerata cyaneotincta Gounelle, Rev. Frans. d'Orn., no. 2, June 7, 1909, 17 (Colombia; coll. E. Gounelle). 
80-94 (87); wing, 53-55.5 (54); tail, 27.5-31 (29.6); culmen, 17$19.5(18.1){ }^{a}$

Adult female.-Above similar in coloration to adult male, but forehead and crown not brighter in color than back, etc., the feathers metallic bronze-green at tip, dusky basally; three outer rectrices (on each side) tipped with brownish gray; under parts very pale brownish gray or dull grayish white, spotted (except on abdomen and median portion of breast) with metallic green, these spots sometimes more bluish on chest; otherwise like adult male; length (skins), 82-90 (86); wing, 47.5-51.5 (49.5); tail, 26.5-28 (27.4); culmen, 18.5-20 (19). ${ }^{b}$

Caribbean slope of Nicaragua (Rio Escondido) and Costa Rica (Rio Frio; Talamanca; Pacuare; San Carlos; Bonilla; Jiménez; Guápiles; El Hogár), eastern Panamá (Colón; Lion Hill; Paraiso; Chepo), and southward through Colombia (Turbo; Lower Magdalena; Antioquía; Andes de Quindiú; Bogotá) to western Ecuadór (Guayaquíl; Esmeraldas; Balzár Mountains).

Trochilus (—-?) amabilis Govid, Proc. Zool. Soc. Lond., 1851, 115 ("New Granada"=Colombia; coll. J. Gould).

[Coeligena, 3. Damophila] amabilis Reichenbach, Aufz. der Colibr., 1854, 7.

[Coeligena] amabilis Reichenbach, Troch. Enum., 1855, 3, pl. 681, pls. 4496, 4497.

[Juliamyia] amabilis Bonaparte, Rev. et Mag. de Zool., 1854, 255.

Juliamyia amabilis Sclater, Proc. Zool. Soc. Lond., 1857, 17 (Bogotá, Colombia); 1860, 296 (Esmeraldas, w. Ecuadór).

Damophila amabilis Gould, Mon. Troch., pt. xviii, Sept., 1859; vol. v, 1861, pl. 341; Introd. Troch., oct. ed., 1861, 170.-La Wrence, Ann. Lyc. N. Y., vii, 1862, 292 (Lion Hill, Panamá); ix, 1868, 128 (Pacuare, Costa Rica).-Sclater and Satvin, Proc. Zool. Soc. Lond., 1864, 365 (Lion Hill).-Mulsant and Verreaux, Classif. Troch., 1866, 38.-Frantzius, Journ. für Orn., 1869, 317 (Costa Rica).-Boucard, Proc. Zool. Soc. Lond., 1878, 71 (San Carlos, Costa Rica); The Hum. Bird, ii, 1892, 80, part (Bogotá).-Euliot, Classif. and Synop. Troch., 1879, 234.-Zeledón, Cat. Aves de Costa Rica, 1882, 21.

a Twenty-six specimens.

b Ten specimens.

\begin{tabular}{|c|c|c|c|}
\hline Locality. & Wing. & Tail. & $\begin{array}{c}\text { Ex- } \\
\text { posed } \\
\text { culmen. }\end{array}$ \\
\hline MALES. & & & \\
\hline One adult male from eastern Nicaragua............ & 53.5 & 28 & 17 \\
\hline Ten adult males from eastern Costa Rica (Bonilla)... & 54 & 30 & 18.1 \\
\hline Seven adult males from eastern Panamá........ & 53.9 & 29.9 & 18.4 \\
\hline Six adult males from central Colombia (Bogotá)... & 54.2 & 28.9 & 18.1 \\
\hline Two adult males from western Ecuadór (Guayaquil). . & 53.7 & 29.5 & 18 \\
\hline FEMALES. & & & \\
\hline One adult female from eastern Nicaragua..... & 48.5 & 28 & 18.5 \\
\hline Two adult females from eastern Costa Rica........ & 50.5 & 27 & 10.2 \\
\hline Five adult females from castern Panamá........... & 49.5 & 27.8 & 19.1 \\
\hline One adult female from central Colombia (Bogotí)... & 51.5 & 27 & 19.5 \\
\hline One adult female from western Ecuadór (Guayaquil). & 49.5 & 26.5 & 18.5 \\
\hline
\end{tabular}


D[amophila] amabilis Cabanis and Heine, Mus. Hein., iii, 1860, 40 (Colombia). [Damophila] amabilis Sclater and Salvin, Nom. Av. Neotr., 1873, 93, part.

Polyerata amabilis Heine, Journ. für Orn., 1863, 194, in text.-Mulsant and Verreaux, Hist. Nat. Ois.-Mouch., ii, livr. 1, 1875, 52 (Costa Rica; Colombia; Ecuadór); iv, livr. 3, 1878, 193 (crit.).-BeRLepsch, Journ. für Orn., 1884, 312 (Bucaramanga, Colombia); 1887, 333 (Bogotá, Colombia); Proc. Zool. Soc. Lond., 1885, 118 (Esmeraldas, w. Ecuadór).-SAlvin, Cat. Birds Brit. Mus., xvi, 1892, 237 (Costa Rica; Lion Hill, Paraiso Station, and Chepo, Isth. Panamá; Antioquía, Quindiú Mits., and Bogotá, Colombia; Esmeraldas and Balzár Mts., w. Ecuadór).-Salvin and Godman, Biol. Centr.-Am., Aves, ii, 1892, 310.-Richmond, Proc. U. S. Nat. Mus., xvi, 1893, 517 (Rio Frio, Costa Rica, and Rio Escondido, Nicaragua).-Boucard, Gen. Hum. Birds, 1894, 142, part (Colombia; Ecuadór; San Carlos, Costa Rica).-Harтеrт (E. and C.), Novit. Zool., i, 1894, 10 (Nanegál, Ecuadór).

[Polyerata] amabilis Mulsant, Ann. Soc. Linn. Lyon, n. s., xxii, 1876, 208.Heine and Reichenow, Nom. Mus: Hein. Orn., 1890, 180 (Bogotá).

[Hylocharis] amabilis GrAY, Hand-list, i, 1869, 150, no. 1946.

Agyrtria amabilis Hartert, Novit. Zool., v, 1898, 517 (crit.).-OBerholser,

Proc. U. S. Nat. Mus., xxiv, 1902, 316 (Guayaquíl, w. Ecuadór; crit.).

A[gyrtria] amabilis Hartert, Das Tierreich, Troch., 1900, 48 (monogr.).

[Agyrtria] amabilis Sharpe, Hand-list, ii, 1900, 105.

Agyrtria amabilis amabilis Carriker, Ann. Carnegie Mus., vi, 1910, 525 (Caribbean lowlands, Costa Rica; habits).

\section{POLYERATA DECORA Salvin.}

\section{CHARMING HUMIING BIRD.}

Similar to $P$. amabilis, but bill much longer (both relatively and absolutely); adult male with whole pileum (that is, occiput as well as forehead and crown) brilliant metallic green, chin and upper throat dull bronzy or greenish (not appearing black when viewed from in front), blue area of lower throat and upper chest narrower and decidedly less violaceous, upper tail-coverts usually less purplish bronze, middle rectrices olivaceous bronze (never purplish), and rest of tail much duller blackish, glossed with bronzy rather than bluish.

Adult male.-Pileum brilliant metallic green (burnished emerald green or slightly yellowish or golden emerald); hindneck, sides of head and neck, back, scapulars, and wing-coverts metallic bronzegreen or greenish bronze, the rump usually more decidedly bronzy; upper tail-coverts rather dull bronze or olive-bronze (more rarely dull coppery bronze); middle pair of rectrices dull olive-bronze, the remaining rectrices dusky, faintly glossed with bronze, the gloss becoming more violaceous terminally, especially on outer rectrices; remiges dark brownish slate or dusky, glossed with purplish; chin and upper throat dull dusky or sooty, the feathers with terminal portion metallic green when viewed in certain lights; lower throat and upper chest bright metallic blue (cobalt to ultramarine exteriorly, more violaceous centrally); lower chest dull metallic green or bluish green, the feathers margined with pale brownish gray; sicles and 
flanks metallic bronze-green, the feathers margined with pale brownish gray; abdomen and median portion of breast plain pale brownish gray, fading to dull white toward anal region; femoral tufts white; under tail-coverts deep gray or olive-gray, broadly margined with pale gray or grayish white; maxilla dull black, mandible pale brownish or dull whitish (pink or reddish in life), with dusky tip; iris dark brown; feet grayish brown or dusky; length (skins), 87-95 (91); wing, 52-56.5 (54); tail, 27.5-30 (29.2); culmen, 21-23 (21.6). ${ }^{a}$

Adult female.-Above similar to adult male, but pileum concolor with hindneck, back, etc.; middle rectrices much duller bronzy, the remaining rectrices dull olivaceous-bronze passing into dusky terminally or subterminally, and tipped (broadly on two outer) with brownish gray; under parts as in adult male, but chin, throat, and chest mostly very pale brownish gray or dull grayish white, spotted with metallic green, these spots usually more or less bluish on lower throat or upper chest; otherwise like adult male; length (skins), 86-95 (90); wing, 50-54 (51.2); tail, 26.5-29 (27.9); culmen, 21-24 $(22.8) .^{b}$

Western Panamá (Volcán de Chiriquí; Bugaba; Divala) and southwestern Costa Rica (Pozo Azúl de Pirrís; El Pozo de Térraba; Pozo del Rio Grande; Boruca; Paso Reál, Boruca; Buenos Aires; El Generál; San Pedro; Rio Turubales).

Damophila amabilis (not of Gould) Salvin, Proc. Zool. Soc. Lond., 1870, 211 (Volcán de Chiriquí and Bugaba, Panamá).-Zeledón, Anal. Mus. Nac. Costa Rica, i, 1887, 122 (Pozo Azúl de Pirrís, Costa Rica).

[Damophila] amabilis Sclater and Salvin, Nom. Av. Neotr., 1873, 93, part.

Polyerata amabilis Cherrie, Expl. Zool. Merid. Costa Rica, 1893, 45 (Lagarto and Boruca, s. w. Costa Rica).-Boucard, Gen. Hum. Birds, 1894, 142, part (Chiriquí).

Polyerata decora Salvin, Ann. and Mag. Nat. Hist., vii, 1891, 377 (Volcán de Chiriquí, Panamá; coll. Salvin and Godman); Cat. Birds Brit. Mus., xvi, 1892, 238.-Salvin and Godman, Biol. Centr.-Am., Aves, ii, 1892, 311.Boucard, Gen. Hum. Birds, 1895, 399.

A[gyrtria] decora HARTERT, Das Tierreich, Troch., 1900, 48 (monogr.).

[Agyrtria] decora SHaRPe, Hand-list, ii, 1900, 106.

Agyrtria decora Bangs, Auk, xviii, 1901, 359 (Divala, Panamá); xxiv, 1907, 295

(Boruca, Paso Reál, and Pozo del Rio Grande, s. w. Costa Rica).

Agyrtria amabilis decora Carriker, Ann. Carnegie Mus., vi, 1910, 525 (s. w. Costa Rica; crit.).

\section{Genus CYANOPHAIA Reichenbach.}

[Hylocharis] $\beta$. Cyanophaia Reichenbach, Aufz. der Colibr., 1854, 10. (Type, as fixed by Gray, Cat. Gen. and Subgen. Birds, 1855, 142, Trochilus bicolor "Linn." =Gmelin.)

Augasma (not Augasmus Motsch[?], 1858) Gould, Proc. Zool. Soc. Lond., pt. xxviii, pt. ii, Aug., 1860, 305. (Type, A. smaragdineum Gould.) 
Timolia Mulsant, Ann. Soc. Linn. Lyon, n. s., xxii, 1876, 219 (Cat. Ois.-Mouch., 1876, 23). (Type, Thalurania lerchi Mulsant and Verreaux.)

Gmelinius a BouCARD, Genera of Humming Birds (in Humming Bird, iv, pt. 1), March, 1894, 108. (Type, Trochilus bicolor Gmelin.)

Medium-sized or rather large Trochilidæ (length about $100 \mathrm{~mm}$.) with bill about as long as head, straight, rather broad and depressed basally, thicker (in vertical section) subterminally than in middle portion, nasal operculum mostly unfeathered, tail nearly two-thirds as long as wing, emarginate, with rather broad rectrices, the adult male metallic-green above and below, passing into dark blue on head and upper tail-coverts and dark steel-blue on tail; the female light brownish gray below, middle rectrices bronze-green, lateral rectrices gray or bronze-greenish basally, steel-blue (broadly) subterminally, and tipped with light gray.

Bill about as long as head, straight, narrowly cuneate in rertical profile, contracted vertically in middle portion, or thickened, vertically, toward tip; culmen broadly rounded but basally contracted into a rather distinct ridge; tomia smooth; mandible with a rather distinct longitudinal groove or sulcus nearer to tomium than to gonys, the maxilla with a similar but less distinct sulcus along each side of culmen. Nasal operculum broad, strongly convex and decumbent basally, mostly unfeathered; frontal feathering forming two narrow antiæ (one on each side of mesorhinium), extending to beyond middle of nasal operculum. Tarsus feathered on upper anterior portion; middle and inner toes equal in length, the outer (apparently) slightly shorter; hallux shorter than outer toe. Wing a little more than three times as long as exposed culmen, the outermost primary longest. Tail nearly two-thirds as long as wing, emarginate, the rectrices rather broad.

Coloration.-Adult male rather dark metallic-green above and below, passing into deep blue on head and upper tail-coverts, the tail uniform dark steel-blue; adult female light brownish gray beneath, bronze-green above (including middle rectrices), the outer rectrices gray or bronze-greenish basally, steel-blue (broadly) subterminally, and tipped with pale gray or grayish white.

Range.-Colombia to Brazil; Lesser Antillean islands of Dominica and Martinique. (Seven species. ${ }^{b}$ )

KEY TO THE SPECIES OF CYANOPHAIA.C

a. Upper tail-coverts bluish black, like rectrices. (Islands of Dominica and Martinique, Lesser Antilles.)...................... Cyanophaia bicolor (p. 529).

a Named for Johann Friedrich Gmelin.

$b$ Of these I have seen only one ( $C$. bicolor) on which the above diagnosis and description are based exclusively.

c Adapted from Hellmayr, Novit. Zool., v, no. 1, June, 1908, 7, 8. Of the seren species recognized by Hellmayr I have seen only $C$. bicolor. 
aa. Upper tail-coverts not bluish black.

b. Upper tail-coverts coppery red.

c. Upper parts with a supra-scapular area of blue; pileum dark green like back.

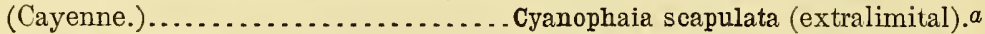
cc. Upper parts without any blue supra-scapular band; pileum brilliant blue.

d. Under parts golden green (sometimes bluish on chin); under tail-coverts bronzy olive, narrowly margined with white; upper tail-coverts (less extensively) coppery red; middle rectrices bluish black. (Colombia.)

Cyanophaia lerchi (extralimital). $b$

dd. Under parts bluish green; under tail-coverts violaceous golden bronze; upper tail-coverts (more extensively) golden bronze; margined with coppery red; middle rectrices violaceous golden bronze. (Southern Brazil.) .................. Cyanophaia cæruleo-lavata (extralimital).c

bb. Upper tail-coverts not coppery.

c. Upper tail-coverts bronzy olive. (Southeastern Brazil.)

cc. Upper tail-coverts golden green, like back.

Cyanophaia chlorocephala (extralimital). ${ }^{d}$

d. Under tail-coverts brilliant green; head brilliant light greenish blue. (Brazil; Colombia?) .............Cyanophaia smaragdinea (extralimital).e $d d$. Under tail-coverts white; head golden green. (Eastern Brazil.)

Cyanophaia chlorophana (extralimital). $f$

a Eucephala scapulata Gould, Introd. Troch., oct. ed., 1861, 166 (Cayenne?; coll. J. Gould); Elliot, Classif. and Synop. Troch., 1879, 229; Salvin, Cat. Birds Brit. Mus., xvi, 1892, 243.-Thalurania scapulata Simon, Feuille Natural., xxvii, 1897, 174.-T[halurania] scapulata Hellmayr, Novit. Zool., xv, 1908, 8.

b Thalurania lerchi Mulsant and Verreaux, Ann. Soc. Linn. Lyon, n. s., xviii, Jan., 1872, 108 (Colombia); type now in coll. Am. Mus. Nat. Hist.; Hellmayr, Novit. Zool., xv, 1908, 9 (crit.).-Timolia lerchi Mulsant, Ann. Soc. Linn. Lyon (2), xxii, 1876, 219; Elliot, Classif. and Synop. Troch., 1879, 232.-Eucephala lerchi Elliot, Ibis, 1874, 264; Mulsant and Verreaux, Hist. Nat. Ois.-Mouch., iv, 1877, 191, with plate.-Agyrtria tenebrosa Hartert, Bull. Brit. Orn. Club, x, no. lxv, Oct. 31, 1899, p. xv (Bogotá, Colombia; coll. Tring. Mus.).-A[gyrtria] tenebrosa Hartert, Das Tierreich, Troch., 1900, 229.

c Eucephala crruleo-lavata Gould, Proc. Zool. Soc. Lond., 1860, 306 (São Paulo, s. Brazil; coll. J. Gould); Mon. Troch., v, 1861, pl. 333; Salvin, Cat. Birds Brit. Mus., xvi, 1892, 244.-T[halurania] caeruleolavata Hartert, Das Tierreich, Troch., 1900, 84.-T[halurania] caeruleo-lavata Hellmayr, Novit. Zool., xv, 1908, 8 (diagnosis; crit.).

'Hylocharis chlorocephalus Bourcier, Rev. et Mag. de Zool., ser. 2, vi, 1854, 457. ("Guaranda, Ecuador," i. e., Rio de Janeiro, Brazil, according to Hellmayr.)[Agyrtria] chlorocephala Reichenbach, Troch. Enum., 1855, 7.-Eucephala chlorocephala Gould, Mon. Troch., v, 1861, pl. 332; Salvin, Cat. Birds Brit. Mus., xvi, 1892, 241.-[Saucerottea] chlorocephala Simon, Cat. Troch., 1897, 12.-T[halurania] chlorocephala Hellmayr, Novit. Zool., xv, 1908, 8 (diagnosis; crit.).

e Augasma smaragdineum Gould, Proc. Zool. Soc. Lond., 1860, 305 ("Brazil;" coll. J. Gould).-A[ugasma] smaragdineum Hartert, Das Tierreich, Troch., 1900, 82.-Eucephala smaragdinea Salvin, Cat. Birds Brit. Mus., xvi, 1892, 240, part (adult male and young male).-[Timolia] smaragdinea Simon, Cat. Troch., 1897, 19.Thalurania smaragdinea Hellmayr, Novit. Zool., xv, June, 1908, 10 (crit.).-Eucephala smaragdo-cxrulea Gould, Mon. Troch., v, 1861, pl. 331.-Timolia lerchi (not Thalurania lerchi Mulsant and Verreaux) Salvin and Godman, Ibis, 1881, 596; Sharpe, Suppl. Gould's Mon. Troch., 1885, pl. 57.

$f$ Th[alurania $]$ chlorophana Simon, Cat. Troch., 1897, 20, footnote (Bahia, Brazil; coll. E. Simon).-T[halurania] chlorophana Hartert, Das Tierreich, Troch., 1900, 84; Hellmayr, Novit. Zool., xv, 1908, 8 (diagnosis). 


\section{CYANOPHAIA BICOLOR (Gmelin).}

WAGLER'S WOOD-NYMPH.

Adult male.-Head, all round (including forehead, crown, loral and malar regions, chin, and upper throat), dark metallic violet-blue (hyacinth blue), the posterior portion of crown more greenish blue, passing into bluish green on occiput, this into bronze-green on hindneck, back, scapulars, wing-coverts, and upper rump, the lower rump and shorter upper tail-coverts more bluish green, the longer upper tail-coverts dark greenish steel blue; tail wholly deep or dark steel blue; remiges glossy bluish black, or black glossed with violet-blue; lower throat and chest bright metallic bluish green, passing into rather dark bronze-green or more golden green on rest of under parts; femoral tufts (small) pale gray or grayish white; maxilla dull black, mandible dull black for terminal half (more or less), pale brownish (pinkish or reddish in life ?) basally; iris dark brown; feet dusky; length (skins), 95-108 (102); wing, 58-62.5 (60.1); tail, 34.5-42.5 (38.1); culmen, $15.5-18.5(17) .^{a}$

Adult female.-Pileum metallic green (varying from bluish green to slightly bronzy green); hindneck, upper back, scapulars, and wingcoverts golden bronze or golden green, passing through more greenish bronze on lower back and rump into golden green on upper tailcoverts; middle pair of rectrices metallic bronze, passing into bluish green or greenish blue terminally; second, third, and fourth pairs of rectrices dark greenish steel blue, metallic bronze basally, the third slightly, the fourth broadly, tipped with pale brownish gray; fifth (outermost) pair similar to fourth but pale grayish tip still broader and basal portion brownish gray instead of bronzy; remiges dusky slate glossed with violet or violet-blue; loral and auricular regions dusky; malar region and under parts pale brownish gray, passing into golden green or bronze on sides and flanks; bill, etc., as in adult male, but mandible wholly dusky; length (skins), 91-108 (101); wing, 55.5-58 (56.7); tail, 32.5-38 (35.6); culmen, 17-18 (17.7). ${ }^{b}$

$a$ Fourteen specimens.

$b$ Eight specimens.

\begin{tabular}{|c|c|c|c|}
\hline Locality. & Wing. & Tail. & $\begin{array}{c}\text { Ex- } \\
\text { posed } \\
\text { culmen. }\end{array}$ \\
\hline MALES. & & & \\
\hline Ten adult malcs from Dominica... & 60.5 & 38.1 & 16. 6 \\
\hline 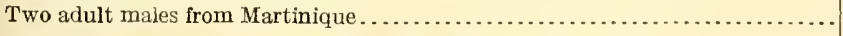 & 59 & 38 & 18 \\
\hline 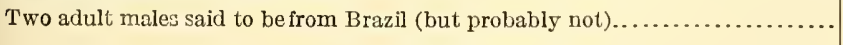 & 59.2 & 38.2 & 17.7 \\
\hline FEMALES. & & & \\
\hline Six adult females from Dominica.. & 57 & 36.3 & 17.6 \\
\hline One adult female from Martinique..................... & 56 & 34.5 & 18.5 \\
\hline One adult female said to be from Brazil........... & 56 & 32.5 & $\ldots$ \\
\hline
\end{tabular}


Islands of Dominica and Martinique (also Guadeloupe?), Lesser Antilles; Brazil ?; Guiana?.

[Trochilus] bicolor Gmelin, Syst. Nat., i, pt. 1, 1788, 496 (based on Colibri Nr. 2, Fermin, Surin. 2, p. 195; Saphir-émeraude, Buff. Hist. Nat. Ois. 6, p. 26; Sapphire-and Emerald-Hummingbird Latham, Syn. i, pt. 2, p. 775, n. 40.)LATHAM, Index Orn., i, 1790, 314.

Trochilus bicolor Audebert and Vieillot, Ois Dorés, i, 1801, 75, pl. 36.-Vieillot, Nouv. Dict. d'Hist. Nat., vii, 1817, 373 (Guadeloupe; Martinique).

$T$ [rochilus] bicolor Vieillot, Tab. Enc. Méth., ii, 1822, 571.-Lichtenstein, Verz. Doubl., 1823, 14 ("Brazil").

[Hylocharis] 3. Cyanophaia bicolor ReIChenbach, Aufz. der Colibr., 1854, 10.

Hylocharis bicolor Reichenbach, Troch. Enum., 1855, 8.-Burneister, Syst. Ueb. Th. Bras., ii, 1856, 348.

[Polytmus] bicolor Gray, Hand-list, i, 1869, 130, no. 1661.

Ornismya bicolor Lesson, Hist. Nat. Ois.-Mouch., 1829, pp. xxix, 161, pls. 49, 50; Les Troch., 1831, 58, 60, pls. 16, 17 (Guiana; Brazil); Index Gen. and Synop. Troch., 1832, p. xxxviii.

C[hlorostilbon] bicolor CABanis and Heine, Mus. Hein., iii, 1860, 46 (Brazil).

Thalurania bicolor Elliot, Classif. and Synop. Troch., 1879, 102 (Brazil; Dominica).-Cory, Auk, iii, 1886, 353 (descr. and synonymy); 1887, 96 (Martinique); Birds West Ind., 1889, 148; Cat. West Ind. Birds, 1892, 106, 133 (Dominica).Salvin, Cat. Birds Brit. Mus., xvi, 1892, 86 (Dominica).-Verrill (G. and A. H.), Trans. Conn. Ac. Arts and Sci., viii, 1892, 333 (Dominica; habits; descr. nest and eggs).

Gmelinius bicolor Boucard, Gen. Hum. Birds, March, 1894, 108 (Dominica).

[Timolia] bicolor Simon, Cat. Troch., 1897, 19.

Augasma bicolor Hartert, Journ. für Orn., 1900, 361 (crit.).

A[ugasma] bicolor HARTert, Das Tierreich, Troch., 1900, 82 (monogr.).

[Augasma] bicolor SHARPE, Hand-list, ii, 1900, 115.

Ornismya wagleri Lesson, Hist. Nat. Ois.-Mfouch., 1829, pp. xvii, 203, pl. 73 (Brazil); Index Gen. and Synop. Troch., 1832, p. xxi (Brazil).

H[ylocharis] wagleri Gray, Gen. Birds, i, Dec., 1848, 114.

[Thalurania] wagleri Bonaparte, Consp. Av., i, 1850, 77 (Brazil).-Pelzeln, Orn. Bras., iv, Abth., 1870, 408.-Sclater and Salvin, Nom. Av. Neotr., 1873, 83.-Mulsant, Ann. Soc. Linn. Lyon, n. s., xxii, 1876, 219.-Conx, List Birds West Ind., 1885, 17.

Thalurania wagleri Gould, Proc. Zool. Soc. Lond., 1852, 9; Mon. Troch., ii, 1857, pl. 109.-Bonaparte, Rev. et Mag. de Zool., 1854, 254.-Mulsant and VerReaux, Classif. Troch., 1866, 51; Hist. Nat. Ois.-Mouch., iii, livr. 1, 1876, 80.-Salvin and Elliot, Ibis, 1873, 360 (Brazil; crit.).-Lawrence, Ann. N. Y. Ac. Sci., i, 1878, 46 (Dominica); Proc. U. S. Nat. Mus., i, 1878, 61, 487 (Dominica; descr. female).-Sclater, Proc. Zool. Soc. Lond., 1889, 326, 327 (Dominica).-Verrill (G. and A. H.), Trans. Conn. Ac. Arts and Sci., viii, 1892, 333, pl. 26, fig. 5 (Dominica; habits; descr. nest and eggs).

Thalurania] wagleri Ca Banis and Heine, Mus. Hein., iii, 1860, 24 (Pará).

Thalurania? wagleri Gould, Introd. Troch., oct. ed., 1861, 79 (Brazil).

[Coeligena. $\alpha$. Thalurania] wagleri Reichenbach, Aufz. der Colibr., 1854, 7.

Coeligena wagleri ReichenBach, Troch. Enum., 1855, 3, pl. 702, figs. 4576-4577.

\section{Genus THALURANIA Gould.}

Thalurania a Govld, Proc. Zool. Soc. Lond., 1848, 13. (Type, as fixed by Gray, Cat. Gen. and Subgen. Birds, 1855, 21, Trochilus furcatus Gmelin.) 
Thaluronia (misprint?) GrAy, Gen. Birds, i, App., 1849, 5, in text.

Glaucopes "Less[on]" Gray, Gen. Birds, i, Dec., 1848, 108, in text. (Type, Trochilus glaucopis Gmelin.)

Glaucopis Burmeister, Syst. Ueb. Th. Bras., ii, 1856, 333. (Type, Trochilus glaucopis Gmelin.)

Medium-sized Trochilidæ (length about $95-115 \mathrm{~mm}$. in adult males, 90-98 in adult females) with bill about as long as head, straight or slightly decurved, the terminal portion of maxillary tomium serrated; nasal operculum mostly concealed, tail forked or (in females) emarginate, with relatively broad lateral rectrices, the adult males with under parts bright metallic green or (often) with under parts of body violet and tail uniform blue-black or violet-black, the adult females with under parts pale gray (under parts of body sometimes metallic greenish), and lateral rectrices tipped with pale grayish (sometimes greenish or grayish basally).

Bill about as long as head, straight or slightly decurved, terete or slightly broader than deep basally; culmen broadly rounded, but basally contracted into a distinct narrow ridge; terminal portion of maxillary tomium serrated; mandible with a distinct lateral groove or sulcus, the maxilla with indication of the same. Nasal operculum rather narrow, mostly covered by frontal feathering, which forms distinct antiæ on each side of mesorhinium, extending forward at least to middle of nasal operculum. Tarsus completely clothed with short feathers; middle and inner toes about equal in length, the outer slightly shorter, the hallux shorter than outer toe. Wing about three times as long as culmen, the outermost primary longest. Tail nearly as long as wing to less than two-thirds as long, forked in adult males, emarginate or slightly forked in females, the lateral rectrices relatively broad, all rather rigid, with rounded tip.

Coloration.-Adult males metallic green or green with violet or black (sometimes both) above, the forehead and crown sometimes brilliantly metallic green or violet; tail uniform black, blue-black or violet-black; chin and throat, sometimes chest also-in some species whole or most of under parts-rery bright metallic green, the under parts of body usually rich metallic riolet, in abrupt contrast. Adult females metallic green or bronze-green above, pale gray beneath, the lateral rectrices tipped with pale gray and sometimes gray or greenish basally.

Range.-Western Mexico to Cayenne, southeastern Brazil, Bolivia, and Peru. (About sixteen species.)

KEY TO THE SPECIES AND SUBSPECIES OF THALURANIA.

c. Throat and chest bright metallic green; under parts of body metallic green, violetblue, or blackish. (Adult males.)

b. Lesser wing-coverts and anterior scapular region (sometimes upper back also) violet or violet-blue; tail dark steel blue or dark violaceous-blue. 
c. Under parts of body violet-blue. (Thalurania colombica.)

d. Upper back green or bronze-green medially; lower back and rump brighter green, the occiput and hindneck bronze-green or bronze. (Colombia and eastern Panamá.). . Thalurania colombica colombica, adult male (p. 532).

$d d$. Upper back wholly violet or violet-blue; lower back and rump darker and duller green, the occiput and hindneck blackish green. (Costa Rica and western Panamá.)

Thalurania colombica venusta, adult male (p. 534).

$c c$. Under parts of body bright metallic green (like throat and chest) except laterally. (Eastern Guatemala to southeastern Honduras.)

Thalurania townsendi, adult male (p. 536).

$b b$. Lesser wing-coverts and whole of scapular region bronze-green; breast and abdomen blackish; tail black. (State of Jalisco, western Mexico.)

Thalurania ridgwayi, adult male (p. 537).

aa. Throat and chest pale gray or grayish white. (Adult females.)

$b$. Sides and flanks more extensively green or bronze-green. (Thalurania colombica.)

c. Under parts of body broadly pale gray medially.

Thalurania colombica colombica, adult female (p. 533).

$c c$. Under parts of body very narrowly grayish medially (usually wholly green).

Thalurania colombica venusta, adult female (p. 535).

$b b$. Sides and flanks less extensively green or bronze-green.

Thalurania townsendi, adult female (p. 536).

\section{THALURANIA COLOMBICA COLOMBICA (Bourcier).}

COLOMBIAN WOOD-NYMPE.

Adult male.-Forehead and anterior portion of crown bright metallic bluish violet or royal purple; rest of pileum dull bronze-green, bronze, or coppery bronze, the feathers narrowly and indistinctly margined with dusky; lower hindneck and upper back metallic bluish green or greenish blue, with a lateral patch (mostly on anterior scapulars) of intense violet-blue (confluent with the similar color of the lesser wing-coverts and under parts), the two patches of opposite sides sometimes narrowly but brokenly connected; lower back, rump, and upper tail-coverts deep metallic bluish green, ${ }^{a}$ varying to more bronzy green; tail glossy blue-black or black glossed with blue (sometimes slightly violaceous); greater wing-coverts metallic bluish green; remiges dark brownish slate or dusky, faintly glossed with violaceous; chin, throat, and chest bright metallic yellowish emerald green, with a convex posterior outline, the feathers pale gray or grayish white beneath surface, dark gray basally; breast and abdomen rich metallic violet-blue or bluish violet (between hyacinth blue and royal purple), the feathers dark gray beneath surface; sides and flanks mixed dark metallic violet-blue and bluish green; under tail-coverts broadly white laterally and basally, bluish black or dark steel blue medially and terminally, the latter in form of a broad wedge-shaped area; bill dull

$a$ Near terre-verte in hue, but much brighter. 
black; iris dark brown; feet dusky; length (skins), 89-109 (99); wing, 52.5-59 (55.7); tail, 36-45.5 (40); culmen, 17.5-20 (19). ${ }^{a}$

Adult female.-Above metallic green, duller and more bronzy on pileum (where feathers show more or less of the dusky grayish of basal portion), brighter and more bluish green posteriorly; middle pair of rectrices darker metallic green or bluish green, sometimes passing into blackish terminally; other rectrices glossy blue-black, or black glossed with steel blue (sometimes slightly violaceous), the passing into metallic green basally, two outermost broadly tipped with pale brownish gray or dull grayish white; remiges dusky brownish slate, faintly glossed with violaceous; malar region, chin, throat, and chest very pale brownish gray; ${ }^{b}$ breast and abdomen deeper brownish gray, the sides and flanks spotted with metallic green; under tailcoverts, anal region, and femoral tufts white; bill dull black, the mandible sometimes more brownish; iris dark brown; feet grayish brown or dusky; length (skins), 78-101 (92); wing, 50-53.5 (51.9); tail, 29-33 (30.8); culmen, 17.5-21 (18.1). ${ }^{c}$

Immature male.-Above similar to the adult female, but tail as in adult male; chin, throat, and chest sooty grayish, glossed with bronzegreen, paler gray feathers, with a terminal spot of metallic yellowish emerald green, indicating the adult plumage, appearing along the median line; breast and abdomen darker sooty gray, varying to nearly sooty brown, the metallic violet-blue feathers of the adult dress appearing first on anterior or median portions; under tail-coverts as in adult male.

Colombia (Bogotá; Valparaiso, Oñaca, El Libano, Don Amo, Las Nubes, Minca, San José, Pueblo Viejo, Chinchicua Valley, San Miguél, Bonda, Palomina, and Sierra Nevada, Santa Marta; Herradura; Buca-

a Twenty-two specimens.

$b$ About no. 9 or no. 10 in tone, but much browner, approaching drab-gray in hue. c Twelve specimens.

\begin{tabular}{|c|c|c|c|}
\hline Locality. & Wing. & Tail. & $\begin{array}{c}\text { Ex- } \\
\text { posed } \\
\text { culmen. }\end{array}$ \\
\hline MALES. & & & \\
\hline Ten adult males from central Colombia (Bogotâ)....... & 54.9 & 41.6 & 18.3 \\
\hline Ten adult males from northeastern Colombia (Santa Marta)... & 56.5 & $3 \mathrm{~S} .6$ & 18.5 \\
\hline Two adult males from Pauamá.......................... & 54.7 & 39 & 19.5 \\
\hline Two adult males of $T$. c. venusta from Panamá....... & 52 & 37.2 & 18.2 \\
\hline Ten adult males of $T$. c. venusta from Costa Rica...... & 54.5 & 40.2 & 19.9 \\
\hline FEMALES. & & & \\
\hline Four adult females from Bogotá................................... & 51.7 & 31.7 & 18.7 \\
\hline Eight adult females from Santa Marta........... & 51.9 & 30.4 & 18.9 \\
\hline Three adult females of $T . c$. venusta from Panamá.. & 49 & 28.7 & 20.8 \\
\hline Ten adult females of $T$. c. venusta from Costa Rica.................... & 49.8 & 30 & 20.8 \\
\hline
\end{tabular}




\section{ramanga; Ibague), Venezuela (San Cristóbal), and eastern Panamá} (Colón; Panamá).

Ornismya colombica Bourcier, Rev. Zool., vi, Jan., 1843, 2 (Colombia; coll.?); Ann. Sci. Phys. et Nat. Lyons, vi, 1844, pl. 6.

$P$ [olytmus] columbicus Gray, Gen. Birds, i, Dec., 1848, 108.

[Polytmus] columbicus GraY, Hand-list, i, 1869, 130, no. 1658.

Thalurania columbica Gould, Proc. Zool. Soc. Lond., 1852, 8; Monogr. Troch., ii, 1858, pl. 106; Introd. Troch., oct. ed., 1861, 78.-Bonaparte, Rev. Zool., 1854, 254.--Sclater, Cat. Am. Birds, 1862, 294 (Bogotá, Colombia).-MuLSant and Verreaux, Classif. Troch., 1866, 51; Hist. Nat. Ois.-Mouch., iii, livr. 1, 1876, 63; iv, livr. 2, 1877, pl. 56; livr. 3, 1878, 217 (crit.).-WYATT, Ibis, 1871, 376 (Herradura, Colombia, 4,000 ft.).-SALvin and Elliot, Ibis, 1873, 355, part (monogr.).-Sclater and Salvin, Proc. Zool. Soc. Lond., 1875, 237 (San Cristóbal, Venezuela).-Mulsant, Ann. Soc. Linn. Lyons, xxii, 1876, 218.--Eцliot, Classif. and Synop. Troch., 1879, 99, part (Colombia).--Salvin and Godman, Ibis, 1880, 17 (Sierra Nevada de Santa Marta, and Minca, Colombia, 2,000 ft.).-Berlepsch, Journ. für Orn., 1884, 310 (Bucaramanga, Colombia); 1887, 319 (Bogotá, Colombia; synonymy).Salvin, Cat. Birds Brit. Mus., xvi, 1892, 79, 652, part (Colombian and Venezuelan localities and references).-BoucARD, The Hum. Bird, ii, 1892, 75 (Bogotá); Gen. Hum. Birds, 1893, 101.-Bangs, Proc. Biol. Soc. Wash., xii, 1898, 135 (Santa Marta, Colombia), 174 (San Miguél and Palomina, Santa Marta).-Stone, Proc. Ac. Nat. Sci. Phila., 1899, 306 (Ibague, centr. Colombia).-Allen, Bull. Am. Mus. N. H., xiii, 1900, 141 (Bonda, etc., Santa Marta).

Thalurania] columbica CABanis and Heine, Mus. Hein., iii, 1860, 24 (Colombia). [Thalurania] columbica Sclater and Salvin, Nom. Av. Neotr., 1873, 83, part (Colombia).

[Coetigena. $\alpha$. Thalurania] columbica Reichenbach, Aufz. der Colibr., 1854, 7.

Coeligena columbica Reichen Bach, Troch. Enum., 1855, 3, pl. 685, figs. 4511, 4512.

Thalurania colombica Boucard, The Hum. Bird, i, no. 4, 1901, 26 (descr. of aberrant or discolored male).-SALvin and Godman, Biol. Centr.-Am., Aves, ii, 1892, 266, part (Colombia; Venezuela).

T[halurania] colombica Hartert, Das Tierreich, Troch., 1900, 86 (monogr.).

[Thalurania] colombica SHARPE, Hand-list, ii, 1900, 116.

[Coeligena. $\alpha$. Thalurania] puella Reichenbach, Aufz. der Colibr., 1854, 7.

Coeligena puella Reichen Bach, Troch. Enum., 1855, 3.

Thalurania puella Bonaparte, Rev. et Mag. de Zool., 1854, 254.

Th[alurania] columbica typica HARTERT, Novit. Zool., iv, April, 1897, 149, in text (crit.).

\section{THALURANIA COLOMBICA VENUSTA (Gould).}

\section{COSTA RICAN WOOD-NYMPH.}

Similar to T. c. colombica, but bill and tail averaging decidedly longer; adult male with color of upper parts very much darker, with the violet-blue of anterior scapulars much more extended and often crossing the upper back (sometimes as a broad band); color of tail decidedly more violaceous, and under tail-coverts with much less of white, sometimes wholly blue-black or dark steel blue; adult female with middle rectrices averaging much more bluish (usually dusky metallic blue) and under parts with sides and flanks much more 
extensively metallic green, the gray confined to the median line of breast and abdomen, and even there sometimes obsolete.

Adult male.-Length (skins), 99-109 (102); wing, 52-55.5 (54.1); tail, 34-42.5 (39.6); culmen, 18-20.5 (19.7). ${ }^{a}$

Adult female.-Length (skins), 82-94 (90); wing, 47.5-52 (49.6); tail, 28-31 (29.7); culmen, 20-22.5 (20.8). ${ }^{b}$

Panamá (Volcán de Chiriquí; Chitra; Boquete de Chitra; Santiago and Santa Fé, Verágua; Divala; Calovévora; Castillo; Laguna; Paraiso ?; ${ }^{c}$ Lion Hill ? ${ }^{c}$ ), Costa Rica (Angostura; Tucurríqui ; Jiménez; Naranjo de Cartago; San Carlos; Bonilla; Guayabo), and Nicaragua (La Libertád, Chontales).

Trochilus (Thalurania) venusta Gould, Proc. Zool. Soc. Lond., 1850, 163 (Volcán de Chiriquí, Panamá; coll. J. Gould).

Thalurania venusta Gould, Proc. Zool. Soc. Lond., 1852, 9; Monogr. Troch., ii, 1858, pl. 105; Introd. Troch., oct. ed., 1861, 78.-Bonaparte, Rev. et Mag. de Zool., 1854, 254.-Lawrence, Ann. Lyc. N. Y., vii, 1862, 292 (Lion Hill, Panamá); ix, 1868, 122 (Angostura and Tucurríqui, Costa Rica).-Sclater and Salvin, Proc. Zool. Soc. Lond., 1864, 365 (Panamá; crit.).-Mulsant and Verreaux, Classif. Troch., 1866, 51; Hist. Nat. Ois.-Mouch., iii, livr. i, 1876, 65, in text.-Salvin, Proc. Zool. Soc. Lond., 1867, 153 (Santa Fé, Santiago, and Volcán de Chiriquí, Panamá; crit.); 1870, 207 (Calovévora, Chitra, and Boquete de Chitra, Panamá); Ibis, 1872, 313, 319 (Chontales, Nicaragua).-Frantzius, Journ. für Orn., 1869, 315 (Costa Rica).

[Coeligena. $\alpha$. Thalurania] venusta Reichensach, Aufz. der Colibr., 1854, 7.

Coeligena venusta Reichenbach, Troch. Enum., 1855, 3.

[Polytmus] venustus Gray, Hand-list, i, 1869, 130, no. 1657.

[Thalurania columbica] var. venusta Mulsan', Ann. Soc. Linn. Lyon, n. s., xxii, 1876, 219.

Thalurania colombica var. venusta Boucard, Proc. Zool. Soc. Lond., 1878, 69 (San Carlos and Naranjo, Costa Rica).

Th[alurania] columbica venusta Hartert, Novit. Zool., iv, April, 1897, 149, in text (crit.).

Thalurania columbica venusta HARTERT, Journ. für Orn., 1900, 362 (crit.).-BANGS, Auk, xviii, 1901, 360 (Divala, Panamá; crit.); xxiv, 1907, 296 (Boruca, Barranca, and Pozo del Rio Grande, s. w. Costa Rica).-Ferry, Pub. 146, Field Mus. N. H., orn. ser., i, 1910, 263 (Guayabo, Costa Rica).

Thalurania colombica venusta CARriker, Ann. Carnegie Mus., vi, 1910, 533 (Costa Rica; crit.; habits).

Thalurania columbica (not Ornismya colombica Bourcier) SALvin and ElLiot, Ibis, 1873, 355, part (Costa Rica; Verágua).-Zeledón, Cat. Aves de Costa Rica, 1882, 20; Anal. Mus. Nac. Costa Rica, i, 1887, 121, part (Naranjo de Cartago and Jiménez, Costa Rica).-Salvin, Cat. Birds Brit. Mus., xvi, 1892, 79, 652, part (Chontales, Nicaragua; Tucurríqui, Costa Rica; Volcán de Chiriquí, Boquete de Chitra, Castillo, Laguna, Calovévora, Santiago, Paraiso, and Lion Hill, Panamá).

Thalurania colombica SaLvin and Godman, Biol. Centr.-Am., Aves, ii, 1892, 266, part (Nicaraguan, Costa Rican, and Panaman localities and references).

a Twelve specimens.

$b$ Thirteen specimens.

$c$ Without specimens in hand it is impossible to say which of the two forms occurring in Panamá occur in certain localities. 


\section{THALURANIA TOWNSENDI Ridgway.}

HONDURAS WOOD-NYMPH.

Adult male similar in color of upper parts to $T$. colombica, but under parts with breast and abdomen green instead of violet-blue or bluish violet; similar in coloration of under parts to T. hypochlora (of Ecuador), but forehead bluish violet or violet-blue instead of emerald green.

Adult male.-Forehead bright metallic violet-blue or bluish violet (royal purple); rest of pileum dull dusky metallic green, the hindneck more bronzy green, varying to bronze; upper back crossed by a band of opaque velvety black, immediately succeeded by one of bright violet-blue, this involving also the anterior scapular region; lesser wing-coverts metallic greenish blue or bluish green, the greater coverts black glossed with bluish or bluish green; lower back, rump, and upper tail-coverts metallic green (varying from slightly bluish green to bronze-green); tail dark violaceous steel blue or black glossed with violet-blue; remiges dusky slate faintly glossed with violaceous; malar region, chin, throat, and chest bright metallic yellowish emerald green; breast and abdomen similar, but less yellowish green, changing to bluish green in certain lights, the sides of breast and under wing-coverts metallic greenish blue; under tail-coverts glossy blue-black, broadly edged basally with grayish white; bill dull black; iris dark brown; feet grayish brown or dusky; length (skins), 98-107 (103); wing, 53.5-55.5 (54.3); tail, 36.5-42 (39); culmen, 19.5-20 (19.7). ${ }^{a}$

Adult female.-Above metallic green, more bronzy anteriorly (especially on hindneck), duller on pileum, where only tips of the feathers are metallic; middle pair of rectrices metallic bluish green, usually darker (sometimes blackish) terminally; other rectrices glossy blueblack terminally or subterminally, metallic green basally, the two outer pairs broadly tipped with pale gray or dull grayish white; remiges dusky slate, faintly glossed with violaceous; under parts, including malar region, pale brownish gray, passing on sides of neck into golden green or bronze, into metallic green or bronze-green on sides and flanks; anal region, under tail-coverts, and femoral tufts dull grayish white; bill, etc., as in adult male; length (skins), 91-94 (92); wing, 48-51.5 (49.7); tail, 27-29.5 (28.7); culmen, 20-20.5 (20.1). ${ }^{b}$

Honduras (Rio Segóvia; Yaruca) and eastern Guatemala (Gualán).

Thalurania townsendi Ridgway, Proc. U. S. Nat. Mus., x, Aug. 6, 1888, 590 (Seg6́via R., Honduras; coll. U. S. Nat. Mus.).-Salvin, Cat. Birds Brit. Mus., xvi, 1892, 78.-Salvin and Godman, Biol. Centr.-Am., Aves, ii, 1892, 266.Boucard, Gen. Hum. Birds, 1895, 102.-Bangs, Bull. Mus. Comp. Zool., xxxix, 1903, 144 (Yaruca, Honduras).

Thalurania] townsendi Hartert, Das Tierreich, Troch., 1900, 85 (monogr.).

[Thalurania] townsendi SHARPE, Hand-list, ii, 1900, 115. 
THALURANIA RIDGWAYI Nelson.

MEXICAN WOOD-NYMPE.

Adult male.-Forehead and crown metallic violet-blue; occiput, nape, and sides of hinder crown (superciliary region) dark metallic bluish green, appearing nearly black when viewed from in front; hindneck, back, scapulars, wing-coverts, and rump uniform metallic bronze-green, the upper tail-coverts darker; tail uniform black, faintly glossed with bluish; remiges dusky, faintly glossed with violaceous; malar and rictal regions, chin, throat, and chest bright metallic yellowish emerald green; rest of under parts dull blackish, the sides and flanks glossed with metallic bronze-green; bill black; iris dark brown; feet blackish; length (skin), 96; wing, 56; tail, 35.5; culmen, $17 .^{a}$

Adult female unknown.

Western Mexico, in State of Jalisco (San Sabastián).

Thalurania ridgwayi Nelson, Auk, xvii, no. 3, July, 1900, 262 (San Sabastián, Jalisco, s. w. Mexico; coll. U. S. Nat. Mus.).

\section{Genus LEPIDOPYGA Reichenbach.}

Lepidopyga Reichenbach, Troch. Enum., 1855, 7. (Type, Trochilus goudoti Bourcier.)

Emilia Mulsant and Verreaux, Mém. Soc. Imp. Sci. Nat. Cherb., xii (ser. 2, ii), 1866, 165, in text (Classif. Troch., 1866, 41). (Type, Trochilus goudoti Bourcier.)

Arinia (not of Adams, 1858, nor Schin [?], 1862) Mulsant, "Ann. Soc. Linn. Lyon, 1877, Oct. 12." b (Type, A. boucardi Mulsant.)

Arena (not of Fauv[ier?], 1862) Mulsant, Descr. d'une esp. nouv. de Troch., Oct. 12, 1877, 5. (Type, A. boucardi Mulsant.)

Rather small Trochilidæ (length about 85-95 mm.) related to Agyrtria, but differing in relatively much longer and distinctly forked tail, much narrower lateral rectrices, and more naked tarsi.

Bill longer than head, rather stout, terete, very faintly decurved; culmen broadly rounded, but mesorhinal portion distinctly ridged; tomia smooth; median lateral sulci of maxilla and mandible rather indistinct. Nasal operculum moderately broad, feathered for upperposterior portion or inner half (more or less). Tarsus feathered for upper half (more or less), rather slender; middle and inner toes equal in length or the former slightly the longer, outer toe slightly but distinctly shorter; hallux shorter than outer toe. Wing nearly three times as long as exposed culmen, the outer primary

$a$ One specimen (the type).

$b$ "'Thus quoted in 'The Ibis' and 'Zool. Rec.' (1878) from a specimen copy of this paper, but not published in the work alluded to." (Salvin, Cat. Birds Brit. Mus., xvi, 1892, 193, footnote.) 
longest. Tail nearly to quite two-thirds as long as wing, distinctly forked, the rectrices (except middle pair) rather narrow, with rounded tip.

Coloration.-Above metallic green, bronze-green, or greenish bronze, the middle rectrices sometimes blackish, the lateral rectrices always black or blackish; beneath metallic green or green with violet-blue throat and chest, the abdomen and under tail-coverts sometimes white. Adult females with under parts white, more or less greenish laterally (the throat sometimes spotted with green), the lateral rectrices tipped with pale grayish.

Range.-Western Costa Rica to western and central Colombia. (Four species.)

KEY TO THE SPECIES OF LEPIDOPYGA.

a. Under parts mostly metallic green or violet-blue. (Adult males.)

b. Throat and chest violet-blue. (Panamá and southwestern Costa Rica.)

$b b$. Throat and chest green.

Lepidopyga cæruleogularis, adult male (p. 539).

c. Abdomen metallic green; under tail-coverts green medially.

d. Under tail-coverts metallic green margined with white; feathers of throat and chest with subterminal (concealed) bar gray. (Northeastern Colombia.).................. Iepidopyga cœlina, adult male (extralimital)., ${ }^{a}$

$d d$. Under tail-coverts white with a mesial streak of green; feathers of throat and chest with subterminal (concealed) bar white. (Central and northern Colombia.).......... Lepidopyga goudoti, adult male (extralimital). $b$

cc. Abdomen and under tail-coverts immaculate white. (Pacific coast of Costa Rica.)...................... Lepidopyga boucardi, adult male (p. 541).

aa. Under parts mostly white.

$b$. Chin, throat, and chest white or mostly white.

a Thalurania colina Bourcier, Rev. et Mag. de Zool., 1853, 553 (Santa Marta, Colombia).-Lepidopyga colina Simon, Rev. Franç. d'Orn., nos. 5, 6, Sept.-Oct., 1909, 66 (crit.).-Sapphironia luminosa Lawrence, Ann. Lyc. N. H. N. Y., vii, 1862, 458 (Barranquilla, Colombia; coll. G. N. Lawrence?).-L[epidopyga] luminosa Heine, Journ. für Orn., 1863, 194 (crit.); Hartert, Das Tierreich, Troch., 1900, 50 (monogr.).Cyanophaia luminosa Elliot, Classif. and Synop. Troch., 1879, 235; Salvin, Cat. Birds Brit. Mus., xvi, 1892, 235.-[Emilia] luminosa Mulsant, Ann. Soc. Linn. Lyon, n. s., xxii, 1876, 208.-L[epidopyga] (Cyanophaia) luminosa Simon, Rev. Franç. d'Orn., nos. 5, 6, Sept., Oct., 1909, 66, in text (crit.).

b T[rochilus] goudoti Bourcier, Rev. Zool., vi, April, 1843, 100 (Ibagué, Colombia); Bourcier and Mulsant, Ann. Sci. Phys. et Nat., etc., Lyon, vi, 1843, 47.-[Saucerottia] goudoti Bonaparte, Consp. Av., i, 1850, 77.-[Agyrtria. $\delta$. Chalybura] goudoti Reichenbach, Aufz. der Colibr., 1854, 10.-Hylocharis goudoti Bonaparte, Rev. Zool., 1854, 255.-[Agyrtria] goudotii Reichenbach, Troch. Enum., 1855, 7, pl. 763, figs. 4765, 4766.-Sapphironia goudoti Gould, Mon. Troch., pt. v, 1860, pl. 345; Introd. Troch., oct. ed., 1861, 172.—L[epidopyga] goudoti Cabanis and Heine, Mus. Hein., iii, 1860, 40, footnote.-Chrysolampis (Emilia) goudoti Mulsant and Verreaux, Classif. Troch., 1866, 41.-Emilia goudoti Mulsant and Verreaux, Hist. Nat. Ois.-Mouch., ii, 1875, 64.-[Polytmus] goudoti Gray, Hand-list, i, 1869, 131, no. 1673.-Cyanophaia goudoti Elliot, Classif, and Synop. Troch., 1879, 239; Salvin, Cat. Birds Brit. Mus., xvi, 1892, 234.-L[epidopyga] goudoti Hartert, Das Tierreich, Troch., 1900, 50. 
c. Flanks mostly metallic green or bronze-green; lateral rectrices broadly tipped with pale gray and with basal portion bluish black.

Lepidopyga cærulettgolaris, adult female (p. 539).

cc. Flanks mostly white; lateral rectrices narrowly tipped with pale gray and with basal portion extensively bronze or bronze-green.

Lepidopyga boucardi, adult female (p. 541).

$b b$. Chin, throat, and chest mostly green.

c. Green of chest strongly bluish.

cc. Green of chest not strongly bluish.

Lepidopyga cœlina, adult female (extralimital).

Iepidopyga goudoti, adult female (extralimital).

\section{LEPIDOPYGA CARULEOGULARIS (Gould).}

\section{DUCHASSAIN'S HUMMING BIRD.}

Adult male.-Above rather bright metallic green or bronze-green, the upper tail-coverts with basal portion usually more decidedly bronzy; middle pair of rectrices varying from bronze-green to bronze, sometimes darker (rarely blackish) terminally; rest of tail dull blueblack or black glossed with bluish; remiges dark brownish slate or dusky, faintly glossed with violaceous; chin, throat, and chest bright metallic violet-blue, more decidedly violaceous centrally, less so (sometimes greenish blue) exteriorly; breast, sides, flanks, and abdomen metallic green or bluish green; under tail-coverts bright metallic green or bronze-green, broadly margined with white or grayish white; femoral tufts white; maxilla dull black, mandible pale brownish or dull whitish (pink or reddish in life) with terminal portion dusky; iris dark brown; feet dusky; length (skins), 84-97 (90); wing, 46.5-52 (49.8); tail, 27-34 (31.8); culmen, 16-19 (17.8). ${ }^{a}$ Adult female.-Above metallic bronze-green, the middle pair of rectrices more bronzy, darker terminally; other rectrices black, faintly glossed with bluish, and broadly tipped with grayish white, this more or less clouded with gray, especially on outer web; remiges brownish slate or dusky, faintly glossed with violaceous; malar region, chin, throat, median portion of chest and breast, abdomen, flanks, anal region, and under tail-coverts plain white, faintly tinged with pale grayish; sides of chest and breast and anterior portion of sides metallic green; bill, etc., as in adult male; length (skin), 89.5; wing, 48 ; tail, 30 ; culmen, $20 .^{b}$

Panamá (near Davíd; Calobre; Castillo; Laguna del Castillo; Cordillera del Chucu; Santa Fé de Verágua; Panamá; Punta de Sabana, near Panamá; Lion Hill; Paraiso; Colón; Natá, Coclé) and northern Colombia (Cartagena; Cienega).

Trochilus (—?) cæruleogularis Gould, Proc. Zool. Soc. Lond., 1850, 163 (Davíd, Chiriquí, Panamá; coll. J. Gould). 
[Agyrtria. o. Cyanochloris] coeruleigularis Reichenbach, Aufz. der Colibr., 1854, 10. [Sapphironia] coeruleigularis Bonaparte, Rev. et Mag. de Zool., 1854, 256.

Sapphironia cæruleogularis Lawrence, Ann. Lyc. N. Y., vii, 1862, 319 (Lion Hill, Panamá).-WyatT, Ibis, 1871, 378 (Cienega, n. Colombia).-Salvin, Proc. Zool. Soc. Lond., 1883, 425 (Colón, Panamá).

Sapphironia cæruleigularis Sclater, Proc. Zool. Soc. Lond., 1856, 140 (Davíd, Panamá).-Gould, Mon. Troch., v, 1860, pl. 346; Introd. Troch., oct. ed., 1861, 172.-Sclater and Salvin, Proc. Zool. Soc. Lond., 1864, 365 (Lion Hill).-SAlvin, Proc. Zool. Soc. Lond., 1867, 156 (Santa Fé de Veragua, Davíd, and Chiriquí, Panamá); 1870, 211 (Laguna del Castillo, Castillo, Cordillera del Chucu, and Calobre, Panamá).-Frantzius, Journ. für Orn., 1869, 317 (Costa Rica).

[Sapphironia] cæruleigularis Sclater and Salvin, Nom. Av. Neotr., 1873, 94.

[Agyrtria] coeruleigularis Reichenbach, Troch. Enum., 1855, 7, pl. 764, figs. $4768-4770$.

L[epidopyga] caeruleigularis Cabanis and Heine, Mus. Hein., iii, 1860, 40 (Verágua).

[Lepidopyga] cæruleigularis Sharpe, Hand-list, ii, 1900, 106.

Lepidopyga cxruleo-gularis Mulsant and Verreaux, Hist. Nat. Ois.-Mouch., ii, livr. 1, 1875, 68 .

[Lepidopyga] caeruleogularis Mulsant, Ann. Soc. Linn. Lyon, xxii, 1876, 208.

Lepidopyga caeruleogularis Mulsant and Verreaux, Hist. Nat. Ois.-Mouch., iv, livr. 3, 1878, 197 (synon.).

[Lepidopyga] caeruleigularis Heine and Rerchenow, Nom. Mus. Hein. Orn., 1890, 180 (Verágua).-Sryon, Cat. Troch., 1897, 12.

Lepidopyga coeruleigularis BerLePsCH, Journ. für Orn., 1887, 336 (Cartagena, Colombia).

L[epidopyga] caeruleogularis HARTERT, Das Tierreich, Troch., 1900, 50 (monogr.). L[epidopyga] (Cyanophaia) coeruleigularis Simon, Rev. Franç. d'Orn., nos. 5-6, Sept.-Oct., 1909, 66, in text (crit.).

Hylocharis caeruleigularis Mulsant and Verreaux, Classif. Troch., 1866, 38.

[Polytmus] cæruleogularis Gray, Hand-list, i, 1869, 131, no. 1674.

Cyanophaia cæruleigularis Eldiot, Classif. and Synop. Troch., 1879, 238.-ZeleDóN, Cat. Aves de Costa Rica, 1882, 21; Anal. Mus. Nac. Costa Rica, i, 1887, 122.-Salvin, Cat. Birds Brit. Mus., xvi, 1892, 233 (Costa Rica; Paraiso, Colón, etc., Panamá).-Salvin and Godman, Biol. Centr.-Am., Aves, ii, 1892, 307.-Boucard, The Hum. Bird, ii, 1892, 80 ("Bogotá"); Gen. Hum. Birds, 1895, 134 (Verágua; Panamá; Colon).-Salvadori and Festa, Boll. Mus. Zool., etc., Torino, xiv, 1899, no. 339, 7 (Punta de Sabana, Panamá; crit.).

$\operatorname{Tr}$ [ochilus] duchassaini Bourcien, Compt. Rend., xxxii, 1851, 187 ("les bois entre la Gorgone et Panama"). ${ }^{a}$

[Hylocharis. $\beta$. Cyanophaia] duchassainii Reichenbach, Aufz. der Colibr., 1854, 10. [Hylocharis] duchassainii ReICHen BaCH, Troch. Enum., 1855, 8.

[Sapphironia] duchassaingi Bonapárte, Rev. et Mag. de Zool., 1854, 256.

[Hylocharis] $\beta$. Cyanophaia caerulescens ReichenBaCh, Aufz. der Colibr., 1854, 10. [IIylocharis] coerulescens ReIchenBACH, Troch. Enum., 1855, 8, pl. 770, fig. 4785.

a Type now in coll. Am. Mus. Nat. Hist., New York City. 


\section{LEPIDOPYGA BOUCARDI (Mulsant).}

BOUCARD'S HUMMING BIRD.

Adult male.-Above metallic bronze-green, passing into a more decided bronze hue on upper tail-coverts and middle rectrices; rectrices (except middle pair) bronze or greenish bronze basally and dull blackish or dusky terminally, the dusky decreasing in extent from the outermost rectrix, on which it occupies approximately the terminal half, to the fourth, on which it is confined to the tip; remiges dusky or dull brownish slate, very faintly glossed with bluish, the primary coverts similar but slightly darker and sometimes faintly glossed with green terminally; chin, throat, and chest brilliant metallic emerald green, the feathers pure white beneath surface, this more or less exposed, especially on upper throat; sides more bronzy green, the feathers grayish white or pale gray basally; rest of under parts white, the breast, at least laterally, more or less spotted with metallic green; maxilla dull black; mandible pale (flesh colored in life), dusky terminally; iris dark brown; legs and feet dusky; length (skins), 93-99 (95); wing, 52-55 (53.9) ; tail, 31-35 (32.4); culmen, 19-19.5 (19.3)..$^{a}$

Adult female.-Similar to the adult male, but chin, throat, and chest white, the throat usually sparsely spotted with dull metallic emerald green; under parts of body more extensirely white; lateral rectrices extensively but indistinctly tipped with pale brownish gray; length (skins), 90-96 (94); wing, 50.5-55 (52.8); tail, 30-32.5 (31.6); culmen, 19-21.5 (20.1). ${ }^{a}$

Pacific coast of Costa Rica (Punta Arenas; Pigres; Coronada de Térraba; Palo Verde, Guanacaste).

Arena boucardi Mulsant, Descr. espéce nouv. Troch. [présentée Soc. Linn. Lyon, Oct. 12, 1877], 6 (Punta Arenas, Costa Rica; coll. Paris Mus.).-Mulsant and Verreaux, Hist. Nat. Ois.-Mouch., iv, livr. 3, 1878, 194, pl. 121.

Arinia boucardi Mulsant and Verreaux, Hist. Nat. Ois.-Mouch., Suppl. plates, pl. 18.-Elliot, Classif. and Synop. Troch., 1879, 209.-SAlvin, Cat. Birds Brit. Mus., xvi, 1892, 193.-Salvin and Godnan, Biol. Centr.-Am., Aves, ii, 1892, 286.-Boucard, Gen. Hum. Birds, 1895, 136.-Zeledón, Cat. Aves de Costa Rica, 1882, 21; Anal. Mus. Nac. Costa Rica, i, 1887, 122.-Ridgway, Condor, vii, 1905, 154, in text (Pigres, Costa Rica).

Sapphironia boucardi Boucard, Proc. Zool. Soc. Lond., 1878, 71 (Punta Arenas). [Polyerata] boucardi Srmon, Cat. Troch., 1897, 12.

A[gyrtria] boucardi HaRTERT, Das Tierreich, Troch., 1900, 47 (monogr.).

[Agyrtria] boucardi Sharpe, Hand-list, ii, 1900, 105.

Agyrtria boucardi Carriker, Ann. Carnegie Mus., vi, 1910, 524 (Palo Verde, Guanacaste, and El Corona de Térraba, Costa Rica; habits). 


\section{Genus RICCORDIA Reichenbach.}

[Chlorestes.] o. Riccordia Reichenbach, Aufz. der Colib., March?, 1854, 8. (Type, Riccordia ramondii Reichenbach $=$ Trochilus ricordii Gervais.)

Ricordia (emendation) Srmon, Cat. Troch., 1897, 18.

Sporadinus Bonaparte, Rev. et Mag. de Zool., vi, May, 1854, 255. (Type, as fixed by Gray, 1855, Trochilus ricordii Gervais.)

Sporadicus (emendation, on grounds of purism) Cabanis and Heine, Mus. Hein., iii, March, 1860, 25.

Small Trochilidæ (length about 95-105 mm.) resembling the longer tailed species of Chlorostilbon, but with lateral rectrices relatively much wider.

Bill about as long as head, straight, slightly depressed; culmen broadly rounded, but basally contracted into a more or less distinct narrow ridge; tomia smooth; mandible with a distinct median lateral groove, the maxilla with a faint indication of a similar one. Nasal operculum broad and convex posteriorly, feathered on upper posterior portion, the frontal feathering forming two obtuse antiæ which extend about as far as middle of nasal operculum. Tarsus clothed with short feathers; lateral toes about equal, slightly shorter than middle toe, the hallux shorter than lateral toes. Wing more than three times as long as exposed culmen (slightly less in females), the outer primary longest. Tail nearly as long as wing in adult males, about threefourths as long in females, deeply forked, the lateral rectrices broad, all rounded at tip.

Coloration.-Above metallic green or bronze-green; adult males with under parts bright metallic green (one species with a velvety black jugular spot), the tail black with middle rectrices more or less bronzy; adult females with under parts brownish gray, the tail much as in adult males.

Range.-Bahama Islands, Cuba, and Haiti. (Two species.)

This genus is very close to Chlorostilbon, and differs mainly, if not solely, in the relatively broader lateral rectrices, the form of the tail being very similar to that of some species of Thalurania. As stated under Chlorostilbon, it has been found necessary to transfer from this genus to the latter $R$. maugxi, of Porto Rico, in order that it may be possible to characterize the two groups.

KEY TO THE SPECIES AND SUBSPECIES OF RICCORDIA.

a. Under parts mostly metallic green. (Adult males.)

b. No black on under parts. (Riccordia ricordii.)

c. Tail averaging longer and relatively more deeply forked (average length 43.9, average dejth of fork 23.2); rectrices less distinctly bronzy. (Cuba, including Isle of Pines.)........... Riccordia ricordii ricordii, adult male (p. 543).

$c c$. Tail averaging shorter and relatively less deeply forked (average length 41.6, average depth of fork 19); rectrices more distinctly bronzy. (Bahamas.)

Riccordia ricordil æneoviridis, adult male (p. 544).

bb. A velvety black spot on center of chest and breast. (Haiti.)

Riccordia swainsonii, adult male (p. 546). 
aa. Under parts mostly gray. (Adult females.)

b. Lateral rectrices blackish to extreme base; gray of under parts paler; under tailcoverts white. (Riccordia ricordii.)

c. Tail averaging 38.5, average depth of fork 15.8 .

Riccordia ricordii ricordii, aduit female (p. 543).

cc. Tail averaging 36.9 , average depth of fork 12.8 .

Riccordia ricordii æneoviridis, adult female (p. 545).

$b b$. Lateral rectrices with basal half or more bronzy; gray of under parts darker; under tail-coverts brownish gray.

Riccordia swainsonii, adult female (p. 546).

\section{RICCORDIA RICORDII RICORDII (Gervais).}

\section{RICORD'S EMERALD.}

Adult male.-Above rather dark metallic bronze-green, darker and decidedly duller on pileum; four middle rectrices dark metallic bronze or greenish bronze, the next pair similar but with inner webs greenish black; two outer pairs of rectrices greenish black, or black faintly glossed with bluish green or greenish blue, the outer web of next to outer pair slightly bronzed; remiges dark brownish slate or dusky, faintly glossed with violaceous; under parts brilliant metallic green (yellowish emerald green); femoral tufts and under tail-coverts white, the latter sometimes with a few small spots or streaks of grayish on lateral feathers; maxilla dull black; mandible brownish (pinkish or reddish in life ?), with tip dusky; iris dark brown; feet dusky; length (skins), 97-105 (100); wing, 50-55 (52.3); tail, 36-47.5 (43.4); middle rectrices, 18.5-22 (20.4); culmen, 14.5-18.5 (17.1). ${ }^{a}$

Adult female.-Above similar in color to adult male; beneath brownish gray (between drab-gray and smoke gray), the sides, from neck to flanks inclusive, metallic green, with feathers gray beneath surface; anal tufts white; a grayish white postocular spot; bill, etc., as in adult male; length (skins), 92-101 (96); wing, 4S-52.5 (50 .7); tail, 36-42.5 (38.5) ; middle rectrices, 21-24.5 (22.7); culmen, 17.5-19 (18.1). ${ }^{b}$

a Thirteen specimens.

$b$ Twelve specimens.

\begin{tabular}{|c|c|c|c|c|}
\hline Locality. & Wing. & $\begin{array}{c}\text { Lateral } \\
\text { rec- } \\
\text { trices. }\end{array}$ & $\begin{array}{c}\text { Middle } \\
\text { rec- } \\
\text { trices. }\end{array}$ & $\begin{array}{c}\text { EX- } \\
\text { posed } \\
\text { culmen. }\end{array}$ \\
\hline \multicolumn{5}{|l|}{ MALES. } \\
\hline Ten adult males from eastern Cuba.. & 52.6 & 43.2 & 20.4 & 17.2 \\
\hline One adult male from western Cuba... & 52 & 44 & 22.5 & 18 \\
\hline Two adult males from Isle of Pines............... & 51 & 44.5 & 19.2 & 16.2 \\
\hline Fifteen adult males of $R . r$. xneoviridis from Jahamas. & 52.8 & 41.6 & 22.6 & 17.4 \\
\hline \multicolumn{5}{|l|}{ FEMALES. } \\
\hline Two adult fomales from eastern Cuba.... & 49.5 & 39.5 & 21.5 & 17.5 \\
\hline Eight adult females from western Cuba.......... & 50.9 & 38.6 & 22.8 & 18.1 \\
\hline Two adult females from Isle of Pines..................... & 51.5 & 37.2 & 23.2 & 18.2 \\
\hline Nine adult females of $R . r . æ$ neoviridis from Bahamas.. & 51.8 & 36.9 & 24.4 & 18.4 \\
\hline
\end{tabular}


Island of Cuba (Santiago de Cuba; Figuabas; Palmarito; Pinár del Rio; Monte Verde; El Guamá; Cabañas; Trinidád; Holquín; San Diego de los Baños; Batabano; Matanzas; San Cristóbal; near Havana); Isle of Pines (Almacigos; Santa Fé).

O[rnismya] ricordii Gervars, Mag. de Zool., 1835, cl. ii, pls. 41, 42 (Santiago, Cuba).

Trochilus ricordii GervaIs, Mag. de Zool., 1835, errata.

Trochilus ricordi Bonaparte, Consp. Av., i, 1850, 81.

Orthorhynchus ricordi D'OrBignY, in La Sagra's Hist. Nat. Cuba, iii, 1839, 100, pl. 21, fig. 2 .

H[ylocharis] ricordi GRAY, Gen. Birds, i, Dec., 1848, 114.

[Hylocharis] ricordi GRAY, Hand-list, i, 1869, 150, no. 1942.

Sporadinus ricordi Gould, Mon. Troch., v, pt. xx, 1860, pl. 348; Introd. Troch., oct. ed., 1861, 173.-Elliot, Ibis, 1872, 356 (Cuba).-Mulsant and VerREAUX, Hist. Nat. Ois.-Mouch., ii, livr. 1, 1875, 74 (Cuba); iv, livr. 3, 1878, 197.-SAlvin, Cat. Birds Brit. Mus., xvi, 1892, 57, part (San Cristóbal, Cuba; "part of Florida").-Сhapman, Bull. Am. Mus. N. H., iv, 1892, 302 (near Trinidád, s. Cuba; descr. nest and eggs).-Gundlach, Orn. Cub. ed. 1895, 130.-Boucard, Gen. Hum. Birds, 1895, 116, part (Cuba).

[Sporadinus] ricordi Bonaparte, Rev. et Mag. de Zool., 1854, 255.-Sclater and Salvin, Nom. Av. Neotr., 1873, 94, part (Cuba).-Mulsant, Ann. Soc. Linn. Lyon, xxii, 1876, 209.

Sporadinus riccordi ElLiot, Classif. and Synop. Troch., 1879, 241, part (Cuba).Cory, Auk, iii, 1886, 358, part (Cuba); Birds West Ind., 1889, 153, part (Cuba); Cat. West Ind. Birds, 1892, 57, part (Cuba).

[Sporadinus] riccordi Cony, List Birds West Ind., 1885, 18, part (Cuba). S[poradicus] ricordi Cabanis and Heine, Mus. Hein., iii, 1860, 25, footnote. Chlorolampis ricordi Mulsant and Verreaux, Classif. Troch., 1866, 40.

Chlorestes ricordii Cabanis, Journ. für Orn., 1856, 99 (Cuba; habits).-GundLACH, Journ. für Orn., 1874, 142 (Cuba; habits); Repert. Fisico-Nat. Cuba, i, 1866, 291; Orn. Cub., ed. 1895, 108, 272.-Brewer, Proc. Bost. Soc. N. H., vii, 1860, 306.

[Chlorestes] ricordii GundLAch, Journ. für Orn., 1861, 334 (Cuba).

$R[$ icordia $]$ ricordi HaRTert, Das Tierreich, Troch., 1900, 81, part (Cuba; monogr.).

[Ricordia] ricordi Simon, Cat. Troch., 1897, 19.-Sharpe, Hand-list, ii, 1900, 114, part (Cuba).

Ricordia ricordi Menegaux, Rev. Franç. d'Orn., no. 2, 1909, 25 (Figuabas, e. Cuba).

Riccordia ricordii BANGS and ZAPPEx, Am. Nat., xxxix, April, 1905, 203 (Isle of Pines, Cuba).

O[rnismya] parzudhaki Lesson, Rev. Zool., 1838, 315 ("Cuba, circà Havanam"). [Chlorestes] o. Riccordia ramondii Reichendach, Aufz. der Colibr., 1854, 8.

[Chlorestes] raimondii Reichendach, Troch. Enum., 1855, 4, pl. 704, figs. 45844586 .

\section{RICCORDIA RICORDII \&NEOVIRIDIS $a$ (Palmer and Riley).}

BAHAMAN EMERALD.

Similar to $R$. r. ricordii, but tail averaging shorter and relatively. less deeply forked, and more bronzy, especially on lateral rectrices.

a In case Sporadinus bracci Lawrence should prove not different from the ordinary Bahaman bird, the namo of this form would then be Riccordia ricordii bracei. 
Adult male.-Length (skins), 95-106 (102); wing, 49-54.5 (52.8); tail, 38-44 (41.6); middle rectrices, 20-25 (22.6); culmen, 17-19 (17.4). ${ }^{a}$

Adult female.--Length (skins), 91-104 (99); wing, 49-54 (51.8); tail, 34-38 (36.9); middle rectrices, 23-25.5 (24.4); culmen, 17-19.5 (18.4). ${ }^{b}$

Bahama Islands (Abaco; Little Abaco; Great Bahama; Elbow Cay; Andros; New Providence?)

(?)Sporadinus bracei Lawrence, Ann. N. Y. Acad. Sci., i, Dec., 1877, 50 (New Providence, Bahamas; coll. U. S. Nat. Mus.).-Elııт, Classif. and Synop. Troch., 1879, 240, footnote.-Corx, Birds Bahama I., 1880, 113.

[Sporadinus] ricordi Sclater and Salvin, Nom. Av. Neotr., 1873, 94, part (Abaco I., Bahamas).

Sporadinus ricordi Cony, Birds Bahama Is., 1880, 11 (Andros; Long Bay Cay); Auk, viii, 1891, 298 (Abaco), 350 (Great Bahama; Abaco).-Ridgway, Auk, viii, 1891, 334 (Abaco).-Northrop, Auk, viii, 1891, 74 (Andros).

Salvin, Cat. Birds Brit. Mus., xvi, 1892, 57, part (in synonymy).

[Sporadinus] riccordi (not Ornismya ricordï Gervais) CoRx, List Birds West Ind. 1885, 18, part (Bahamas).

Sporadinus riccordi Elliot, Classif. and Synop. Troch., 1879, 241, part (Abaco, Bahamas).-Cory, Auk, iii, 1886, 259, part; Birds West Ind., 1889, 153, part; Cat. West Ind. Birds, 1892, 13, part.-Bолноте, Ibis, 1903, 293 (Andros and Little Abaco islands, Bahamas; crit.).

Sporadinus riccordii Conx, Cat. West Ind. Birds, 1892, 107, 144, part (Bahamas). $R[$ icordia $]$ ricordi HaRtent, Das Tierreich, Troch., 1900, 81, part (Bahamas; monogr.).

[Ricordia] ricordi Sharpe, Hand-list, ii, 1900, 114, part (Bahamas).

Riccordia æneoviridis Palmer and Riley, Proc. Biol. Soc. Wash., xv, March 5, 1902, 34 (Abaco, Bahamas; coll. U. S. Nat. Mus.).-Allen (G. M.), Auk, xxii, 1905, 127 (Great Abaco; Little Abaco; Great Bahama; and "all the outer cays" with bushes).

Riccordia ricordii æneoviridis Riley, Auk, xxii, 1905, 356 (Abaco; crit.).
$a$ Fifteen specimens.
$b$ Nine specimens.

\begin{tabular}{|c|c|c|c|c|}
\hline Locality. & Wing. & Tail. & $\begin{array}{c}\text { Middle } \\
\text { rec- } \\
\text { trices. }\end{array}$ & $\begin{array}{l}\text { Cul- } \\
\text { men. }\end{array}$ \\
\hline \multicolumn{5}{|l|}{ MALES. } \\
\hline Ten adult males from $\mathrm{A}$ baco island ............ & 53 & 42.1 & 22.7 & 17.3 \\
\hline Two adult males from Great Bahama island ........... & 53 & 42 & 25 & 17.2 \\
\hline 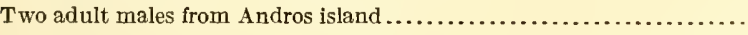 & 51.5 & 38.5 & 21 & 17.5 \\
\hline \multicolumn{5}{|l|}{ FEMALES. } \\
\hline Six adult females from $A$ baco............ & 52.7 & 37.5 & 25 & 18.8 \\
\hline One adult female from Little Abaco........ & 52.5 & 37 & 24.5 & 18 \\
\hline 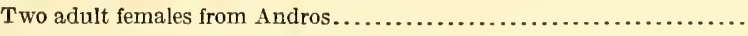 & 49 & 35.2 & 23 & 17.2 \\
\hline
\end{tabular}

$81255^{\circ}-$ Bull. $50-11-35$ 


\section{RICCORDIA SWAINSONII (LesSOn).}

\section{HAITIAN EMERALD.}

Adult male.-Above metallic bronze-green to grass-green, usually duller on pileum, the upper tail-coverts decidedly more bronzy; tail dark greenish bronze, becoming darker (dull blackish) on lateral rectrices; remiges dusky, faintly glossed with purplish; chin, throat, and sides of chest brilliant metallic emerald green or yellowish green; center of chest and upper breast opaque velvety black; rest of under parts metallic green or bronze-green, darker (sometimes blackish) along median line, especially on abdomen; femoral and lumbar tufts pale brownish gray; maxilla dull black; mandible pale (reddish or flesh color in life), dusky terminally; iris dark brown; feet dusky (in dried skins); length (skins), 102-110 (106); wing, 54.5-58 (55.7); tail, 41-49 (43.6); culmen, 16-18 (16.9)..$^{a}$

Adult female.-Above as in the adult male, but lateral rectrices bronze or bronze-green for basal two-thirds (approximately) the subterminal or terminal portion black, the one or two outermost pairs tipped (more or less broadly) with brownish gray; under parts light brownish gray (nearest drab-gray), the sides and flanks overlaid by metallic green or bronze-green; length (skins), 97-105 (100); wing, 49-55 (53.2); tail, 35--39.5 (37.5); culmen, 17-19 (18.1). ${ }^{6}$

Island of Haiti (Le Coup and Gautier, Haiti; Samaná, Catare, Aguacate, El Valle, La Canita, Sanchez, and La Vega, Santo Domingo).

Trochilus elegans (not of Reich, 1795) Audebert and Vieillot, Ois. Dorés, i, 1801, 32, pl. 14.-Vieillot, Nouv. Dict. d'Hist. Nat., vii, 1817, 351.-Lesson, Suppl. Ois.-Mouch., 1830-31, 99.-Bryant, Proc. Bost. Soc. N. H., xi, 1867, 95 (Santo Domingo).

T[rochilus] elegans Vieillot, Tabl. Enc. Méth., ii, 1822, 556.

$H[y$ locharis $]$ elegans Gray, Gen. Birds, i, Dec., 1848, 114.

[Hylocharis] elegans Gray, Hand-list, i, 1869, 150, no. 1943.

[Lampornis] elegans Bonaparte, Consp. Av., i, 1850, 72.

[Chlorestes. o. Riccordia] elegans Reichenbach, Aufz. der Colibr., 1854, 8.

[Chlorestes] elegans ReIchenBach, Troch. Enum., 1855, 4, pl. 704, fig. 4587.

[Sporadinus] elegans Bonaparte, Rev. et Mag. de Zool., 1854, 255.-Sclater and Salvin, Nom. Av. Neotr., 1873, 94.-Mulsant, Ann. Soc. Linn. Lyon, xxii, 1876, 209 (Haiti)._CoRY, List Birds West Ind., 1885, 18.

Sporadinus elegans Sallé, Proc. Zool. Soc. Lond,, 1857, 233 (Santo Domingo).Gould, Mon. Troch., pt. xviii, 1859; vol. v, 1861, pl. 347; Introd. Troch., oct. ed., 1861, 173.-Ellior, Classif. and Synop. Troch., 1879, 241.-MuLSANt and Verreaux, Hist. Nat. Ois.-Mouch., ii, livr. 1, 1875, 72 (Santo Domingo); iv, livr. 3, 1878, 197.-Cory, Bull. Nutt. Orn. Club, vi, 1881, 153 (Gautier and Le Coup, Haiti); Birds Haiti and St. Dom., 1885, 93, pl. 22, figs. 9, 10; Auk, iii, 1886, 358 (descr.; synon.); Birds West Ind., 1889, 152; Cat. West Ind. Birds, 1892, 13, 107, 131.-Salvin, Cat. Birds Brit. Mus., xvi, 1892, 59 (Samaná, Santo Domingo).-Boucard, Gen. Hum. Birds, 1895, 117.-Cherrie, Contr. Orn. San Dom., 1896, 18 (habits)-Christy, Ibis, 1897, 329 (Sanchez and La Vega, Santo Domingo). 
S[poradicus] elegans Cabanis and Heine, Mus. Hein., iii, 1860, 25 (Haiti).

[Sporadicus] elegans Heine and Reichenow, Nom. Mus. Hein. Orn., 1890, 176.

Chlorolampis elegans Mulsant and Verreaux, Classif. Troch., 1866, 40.

$R[$ icordia $]$ elegans Hartert, Das Tierreich, Troch., 1900, 80.

[Ricordia] elegans Simon, Cat. Troch., 1897, 19.-Sharpe, Hand-list, ii, 1900, 114.

Ormismya swainsonii Lesson, Hist. Nat. Ois.-Mouch., 1829, pp. xvii, Tableau,

p. xvii (p. 197, pl. 70) ("Brésil;" new name for Trochilus elegans Audebert and Vieillot).

Trochilus swainsonii Lesson, Index Gen. et Synop. Troch., 1832, p. xxiii.

Sporadinus incertus Mulsant and Verreaux, Hist. Nat. Ois.-Mouch., ii, livr. 1, 1875, 76 (new name for "Erythronota? elegans Gould;" but see Boucard, The Hum. Bird, iv, 1894, 118!).

[Sporadinus] incertus Mulsant, Ann. Soc. Linn. Lyon, n. s., xxii, 1876, 209.

\section{Genus CHLOROSTILBON Gould.}

Chlorostilbon a Gould, Mon. Troch., pt. v, May, 1853, sub. pl. 355; Introd. Troch., oct. ed., 1861, 175. (Type, Ornismya prasina Lesson.)b

Chlorolampis c Cabanis and Heine, Mus. Hein., iii, March, 1860, 47. (Type, Trochilus chrysogaster Bourcier $=T$. angustipennis Fraser.)

Prasitis d Cabanis and Heine, Mus. Hein., iii, March, 1860, 49. (Type, Ornismya prasina Lesson.)

Chloauges Heine, Journ. für Orn., xi, May, 1863, 200. (Type, Trochilus auriceps Gould.)

Merion Mulsant and Verreaux, Hist. Nat. Ois.-Mouch., ii, 1875, 92. (Type, Chlorestes haeberlini Reichenbach.)

Marsyas Mulsant, Ann. Soc. Linn. Lyon, n. s., xxii, 1876, 209. (Type, Trochilus maugæus Vieillot.)

Chrysomirus Mulsant, Ann. Soc. Linn. Lyon, n. s., xxii, 1876, 209. (Type, as fixed by Elliot, 1879, Trochilus angustipennis Fraser.)

(?) Panychlora e Cabanis and Heine, Mus. Hein., iii, March, 1860, 49. (Type, Smaragditis euchloris Reichenbach.)

Small Trochilidæ (length about 70-100 $\mathrm{mm}^{f}$ ) with straight, narrow bill about as long as head, tail more or less forked or emarginate (rarely nearly truncate or slightly double-rounded in female), with lateral rectrices decidedly narrower than middle pair, the adult males with under parts wholly brilliant metallic green and tail (except in species of "Panychlora" group) blue-black, the middle rectrices sometimes tipped with gray; adult females gray beneath, lateral rectrices green or grayish basally, blue-black terminally or subterminally, the outermost (at least) tipped with pale gray.

Bill slender, straight, nearly terete, about as long as head; culmen broadly rounded but basally contracted into a more or less distinct

$a " X \lambda \omega \rho o ́ s$, viridis, et $\sigma \tau \imath \lambda \beta \omega$, corusco." (Gould.)

$b$ See Introduc. Troch., 1861, 175.

c"Von $\chi \lambda \omega \rho o ́ s$ (grün) und $\lambda \dot{a} \mu \pi \omega$ (leuchten, glänzen)." (Cabanis and Heine.)

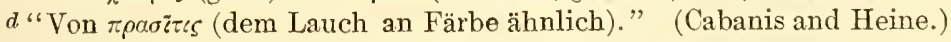

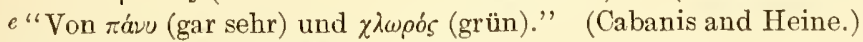

$f$ The variation in length is caused by varying length of the tail, which in some species equals nearly half the total length. 
ridge; tomia smooth; maxilla and mandible (especially the latter) each with a more or less distinct median lateral groove. Nasal operculum broad and convex posteriorly, the upper basal portion feathered; frontal feathering forming two narrow antiæ, extending nearly (sometimes quite) as far forward as anterior end of nasal operculum. Tarsus clothed with short feathers; lateral toes about as long as middle toe, the hallux shorter. Wing three to nearly four times as long as culmen, the outer primary longest. Tail less than half as long as wing to nearly as long as wing in adult males of some species, emarginate or forked in adult males, forked, emarginate, or slightly double-rounded in females, the rectrices straight, the outer ones narrower than middle pair, sometimes much narrower, but always with rounded tip.

Coloration.-Above metallic green or bronze-green. Adult males brilliant metallic green below, the tail blue-black, green, bronze, or copper-bronze, sometimes with middle rectrices tipped with gray. Females with under parts pale gray or grayish white, middle rectrices greenish (usually blackish terminally or subterminally), the lateral rectrices greenish or gray basally, black terminally or subterminally, the outermost tipped with pale grayish.

Range.-Southern Mexico to Cayenne, Paraguay, northern Argentina, Bolivia, and Peru; one species in Porto Rico. (About twentyone species, including subspecies.).

For the present, I follow von Berlepsch and Hartert in uniting Panychlora Cabanis and Heine with this genus. Panychlora seems at first examination to be a very well circumscribed group, the males of all the species having brightly metallic (never blue-black) rectrices, and the tail relatively shorter than in most species of Chlorostilbon (not more than half as long as wing); but $C$. prasinus has the tail even shorter (decidedly less than half as long as wing). In short, when all the species of the two groups are carefully compared it is found that there is no character, apparently, that will serve to separate them.

If Riccordia is to be kept separate from Chlorostilbon, as I believe it should, it is necessary to remove $R$. maugæi from the former and transfer it to the present genus.

KEY TO THE SPECIES AND SUBSPECIES OF CHLOROSTILBON.

a. Under parts brilliant metallic green. (Adult males.)

$b$. Forehead and crown brilliant metallic green, much brighter than color of back. $a$

c. Bill pale brownish (pinkish or reddish in life) basally, the mandible with at least basal half thus colored; middle rectrices usually tipped, more or less distinctly, with gray.

d. Tail nearly as long as to slightly longer than wing.

$e$. Smaller, with relatively smaller bill and longer and more deeply forked tail, the lateral rectrices narrower terminally; wing, 43-44, tail, 38.5-45, middle rectrices, 14-15, culmen, 13-13.5. (Western Mexico.)

Chlorostilbon auriceps, adult male (p. 551).

$a$ This character is evident only in fully adult males. 
$e e$. Larger, with relatively larger bill and shorter and less deeply forked tail, the lateral rectrices broader terminally; wing, 47-50.5, tail, 39-44, middle rectrices, 16-18.5, culmen, 14-15.5. (Cozumél Island, Yuca$\tan$.)................. Chlorostilbon forficatus, adult male (p. 552).

dd. Tail much shorter than wing. (Chlorostilbon canivetii.)

$e$. Tail longer and more deeply forked, the middle rectrices always distinctly tipped with gray; tail averaging 34.6 , middle rectrices averaging 18.1. (Southeastern Mexico, including Yucatan, to British Honduras.)

Chlorostilbon canivetii canivetii, adult male (p. 553).

$e e$. Tail shorter and less deeply forked, the middle rectrices less distinctly (sometimes obsoletely) tipped with gray; tail averaging less than 32 , middle rectrices averaging more than 18.5.

f. Maxilla more extensively brownish (or reddish) basally, never wholly blackish; middle rectrices usually with gray tip distinct; tail averaging longer and more deeply forked; wing averaging 45.8, tail 31.1, middle rectrices 18.6. (Guatemala, Honduras, and Salvadór.)

Chlorostilbon canivetii osberti, adult male (p. 556).

ff. Maxilla less extensively brownish (or reddish) basally, sometimes wholly blackish; middle rectrices usually with gray tip indistinct, sometimes obsolete; tail averaging shorter and less deeply forked; wing averaging 46, tail 27.9, middle rectrices 19.2. (Nicaragua and Costa Rica.)

Chlorostilbon canivetii salvini, adult male (p. 557).

cc. Maxilla wholly black; middle rectrices without trace of gray tip.

d. Mandible pale (pink or reddish in life) basally; tail 32.5-38.5. (Porto Rico.)

Chlorostilbon maugæi, adult male (p. 550).

dd. Mandible wholly black, like maxilla; tail 25.5-30. (Coast of Venezuela and islands of Trinidád, Margarita, Aruba, Bonaire, and Curaçao.)

Chlorostilbon caribæus, adult male (p. 559).

bb. Forehead and crown dull metallic green, like back, etc. (Bill wholly black; wing averaging 45.6, tail 27.8, middle rectrices 19.4.) (Panamá and southwestern Costa Rica.).......... Chlorostilbon assimilis, adult male (p. 558).

aa. Under parts pale gray. (Adult females.)

$b$. Outermost rectrix with a band of gray across middle portion.

c. Whitish postocular streak minute; mandible wholly dusky; lateral rectrices narrower, with basal area of dusky not well-defined.

Chlorostilbon maugæi, adult female (p. 550).

$c c$. Whitish postocular streak conspicuous; mandible extensively pale basally; lateral rectrices broader, with basal dusky area well-defined.

d. Tail averaging more than 31 .

e. Culmen 13-15.5 (14.2), tail 30-33.5 (31.7), the lateral rectrices narrower (about $4 \mathrm{~mm}$.)............Chlorostilbon auriceps, adult female (p. 551).

ee. Culmen 15.5-16.5 (15.8), tail 31-35 (32.8), the lateral rectrices broader (about 5-5.5 mm.)...... Chlorostilbon forficatus, adult female (p. 553). $d d$. Tail averaging less than 30 .

$e$. Tail averaging more than 29 , the middle rectrices averaging less than 22 .

Chlorostilbon canivetii canivetii, adult female (p. 554).

ee. Tail averaging less than 28 , the middle rectrices averaging more than 22 . $f$. Tail 27.5 , the middle rectrices 23 .

Chlorostilbon canivetii osberti, adult female (p. 556).

ff. Tail 25-28 (26.6), the middle rectrices 21-24 (22.7).a

Chlorostilbon canivetii salvini, adult female (p. 557).

$b b$. Outermost rectrix without any gray band across middle portion.

c. Culmen 13-15.5 (14.3)......... Chlorostilbon assimilis, adult female (p. 558).

cc. Culmen 16.5-17 (16.7)......... Chlorostilbon caribæus, adult female (p. 560).

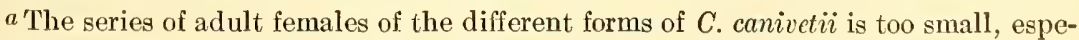
cially of $C . c$. osberti and C. c. salvini to admit of their satisfactory differentiation. 


\section{CHLOROSTILBON MAUGAI (Audebert and Vieillot).} PORTO RICAN EMERALD.

Adult male.-Above rather dark metallic green or bronze-green; tail uniform glossy blue-black, or black glossed with steel blue; remiges very dark brownish slate or dusky, faintly glossed with violaceous; under parts wholly brilliant metallic golden green, the chest slightly purer green (less golden); femoral and lumbar tufts white; maxilla dull black; mandible pale brownish (pink or reddish in life?), with blackish tip; iris dark brown; feet dusky; length (skins), 84-95 (87); wing, 45-50 (48.6); tail, 32.5-38.5 (35.8), middle rectrices, 20-23 (21.5); culmen, 13-14 (13.6). ${ }^{a}$

Adult female.-Above metallic green or bronze-green, including middle pair of rectrices, these sometimes more bronzy; second pair of rectrices bronze-green with terminal portion black, the third pair similar, but the black more extensive and a small pale gray spot at apex of inner web; fourth pair with more than basal half bronzegreen (duller than on middle pair), crossed by a broad subterminal area of blue-black and with a large terminal spot of pale gray; fifth (outermost) pair similar, but with terminal gray spot still larger and the basal area gray faintly glossed with bronze-green; remiges very dark brownish slate or dusky, faintly glossed with violaceous; loral and suborbital regions dusky; malar region and under parts very pale gray or grayish white, the sides and flanks mostly metallic green, with feathers deep brownish gray beneath surface; femoarl and lumbar tufts white; bill dull black, the base of mandible usually slightly more brownish; iris and feet as in adult male; length (skins), 77-88 (83); wing, 44.5-48 (45.7); tail, 26-32.5 (28.9), middle rectrices, 22-25 (23.6); culmen, $14-16$ (14.8). ${ }^{b}$

Immature male.-Similar to the adult male, but green of under parts darker and much duller, with brilliant green feathers, indicating the adult plumage, first appearing on lower throat; mandible mostly dusky.

Porto Rico, Greater Antilles (Adjuntas; Mayaguéz; Lares; Ponce; El Yúnque; Utuado).

Trochilus maugaeus Audebert and Vieillot, Ois. Dorés, i, 1801, 71-79, 80, 93, pls. 37, 38 (Porto Rico; coll. Paris Mus.).-Tenminck, Cat. Syst. du Cab. d'Orn., 1807, 84.-Vieillot, Nouv. Dict. d'Hist. Nat., vii, 1817, 368.

T[rochilus] maugæus Vieılıot, Tabl. Enc. Méth., ii, 1822, 567.

Ornismya maugaei Lesson, Hist. Nat. Ois.-Mouch., 1829, pp. xiv, 194, pls. 68, 69; Index Gen. and Synop. Troch., 1832, p. xxii.

Trochilus maugei Sundevald, Effv. k. Vet.-Ak: Förh., 1869, 600.

Sporadinus maugei GunduACH, Journ. für Orn., 1874, 312.

[Sporadinus] maugeus Bonaparte, Rev. et Mag. de Zool., 1854, 255.

Sporadinus maugaeus Gundlach, Journ. für Orn., 1878, 160, 182 (crit.). 
Sporadinus? maugæi Gould, Mon. Troch., v, 1861, pl. 349; Introd. Troch., oct. ed., 1861, 173.

Sporadinus maugaei Elııot, Ibis, 1872, 356 (synon.); Classif. and Synop. Troch., 1879, 242.-Mulsant and Verreaux, Hist. Nat. Ois.-Mouch., ii, livr. 1, 1875, 77; iv, livr. 3, 1878, 198.-Cony, Auk, iii, 1886, 359; ix, 1892, 229, in text; Birds West Ind., 1889, 154; Cat. West Ind. Birds, 1892, 13, 107, 132.Salvin, Cat. Birds Brit. Mus., xvi, 1892, 58.-Bowdish, Auk, xix, 1902, 366. [Sporadinus] maugæi Sclater and Salvin, Nom. Av. Neotr., 1873, 94.-Cory, List Birds West Ind., 1885, 18.

C[ynanthus] maugerii Jardine, Nat. Libr., Hummingbirds, ii, 1833, 174.

[Hylocharis] maugæi GRAY, Hand-list, i, 1869, 150, no. 1944.

Sporadinus maugei Boucard, Gen. Hum. Birds, 1894, 118.

Chlorolampis maugæus Mulsant and Verreaux, Classif. Troch., 1866, 40.-

Gundlach, Anal. Soc. Esp. Hist. Nat., vii, 1878, 225.

[Ricordia] maugei Simon, Cat. Troch., 1897, 19.

$R[$ icordia $]$ maugaeus Hartert, Das Tierreich, Troch., 1900, 80 (monogr.).

[Ricordia] maugæi SHARPE, Hand-list, ii, 1900, 114.

[Sporadinus (Marsyas)] maugaei Mulsant, Ann. Soc. Linn. Lyon, xxii, 1876, 209; Cat. Ois.-Mouch., 1875, 13.

(?)[Thaumatias] ourissia Bonaparte, Consp. Av., i, 1850, 79, part.

[Coeligena] ourissia Reichenbach, Troch. Enum., 1855, 3, pl.688, figs. 45194521.

Chlorestes gertrudis GundlacH, Journ. für Orn., 1874, 312 (nomen nudum), 315 (îrst characterized).

Chlorolamois gertrudis CABANIs, Journ. für Orn., 1875, 223.

\section{CHLOROSTILBON AURICEPS (Gould).}

GOLDEN-CROWNED EMERALD.

Adult male.-Pileum brilliantly metallic golden green; rest of upper parts, including wing-coverts, cluller golden green or bronzegreen; tail black, faintly glossed with violet-bluish, the six middle rectrices broadly and abruptly tipped with brownish gray, the fourth (on each side, from middle) with terminal fourth (more or less) of inner web broadly edged with the same; remiges brownish slate or dusky, faintly glossed with violaceous; under parts brilliantly metallic golden green, more strongly golden posteriorly, the chin and throat purer (less yellowish) green; femoral tufts white; maxilla dull black, more brownish basally; mandible pale brownish (pinkish of flesh colored in life?), with terminal third (more or less) dusky; iris dark brown; feet dusky; length (skins), 88-93.5 (91); wing, 43-44 (43.4); tail, 38.5-45 (42.5); middle rectrices, 14-15 (14.6); culmen, $13-13.5(13.2){ }^{a}$

Adult female.-Above bright metallic green or bronze-green; middle rectrices metallic bluish green to bronze-green, the second, third, and fourth rectrices bluish green for basal two-thirds (approximately), black subterminally, tipped with brownish gray, the outermost (fifth) pair with a broader brownish gray tip and a large median space of light brownish gray between the black subterminal 
and dusky (glossed with greenish blue) basal areas; remiges dusky, faintly glossed with purplish; a dusky suborbital-auricular area, margined above by a grayish white postocular streak; under parts light gray, paler on abdomen and anal region; femoral and lumbar tufts white; maxilla dusky, mandible pale brownish (in dried skins), dusky at tip; feet dusky; length (skins), 83-85 (84); wing, 43-44 (43.5); tail, 30-33.5 (31.7); middle rectrices, 17-20.5 (18.7); culmen, $13-15.5(14.2) .^{a}$

Southwestern and west-central Mexico, in States of Mexico (Valley of Mexico), Guerrero (Acahuitzotla; Chilpancingo) and Jalisco (San Marcos; Tonila) and Territory of Tepíc (Santiago; San Blas; Tepíc).

Trochilus (—?) auriceps Gould, Jardine's Contr. Orn., 1852, 137 (Mexico; coll. J. Gould).

[Sporadinus] auriceps Bonaparte, Rev. et Mag. de Zool., 1854, 225.

Chlorostilbon auriceps Gould, Mon. Troch., v, pt. xiii, May, 1857, pl. 350.Sanchez, An. Mus. Nac. Mexico, i, 1877, 96 (Valley of Mexico).-Villada, La Naturaleza, ii, 1874, 361 (Valley of Mexico).-D’OcA, Troq. de Mex., 1875, 38, pl. (8), fig. 27; La Naturaleza, iii, 1875, 160 (Valley of Mexico).Elliot, Ibis, 1875, 168 (synon.; crit.); Classif. and Synop. Troch., 1879, 243.Herrera, La Naturaleza, (2), i, 1891, 322 (Valley of Mexico).-Salvin and Godman, Biol. Centr.-Am., Aves, ii, 1892, 262.-SAlvin, Cat. Birds Brit. Mus., xvi, 1892, 45 (Santiago and San Blas, Tepíc; Tonila, Jalisco; Chilpancingo and Acahuizotla, Guerrero).-Jour, Proc. U. S. Nat. Mus., xvi, 1893, 784 (San Marcos, s. Jalisco).-Hartert (E. and C.), Novit Zool., i, 1894, 61 (Chilpancingo, Guerrero; descr. nest and eggs).

C[hlorostilbon] auriceps Salvin, Ibis, 1889, 366, in text.

[Chlorostilbon] auriceps Sclater and Salvin, Nom. Av. Neotr., 1873, 94.Sharpe, Hand-list, ii, 1900, 112.

C[hlorostilbon] auriceps HeIne, Journ. für Orn., 1863, 200.-Hartert, Das Tierreich, Troch., 1900, 74 (monogr.).

C[hlorolampis] auriceps Cabanis and Heine, Mus. Hein., iii, 1860, 48, footnote.Heine, Journ. für Orn., 1863, 200.

Chlorolampis auriceps Gould, Introd. Troch., oct. ed., 1861, 174.-MulsanT and Verreaux, Hist. Nat. Ois.-Mouch., ii, livr. 1, 1875, 79; iv, livr. 3, 1878, 198.-Boucard, Notes Troch. du Mex., 1875, 13; Gen. Hum. Birds, 1894, 113.

[Chlorolampis] auriceps Mulsant, Ann. Soc. Linn. Lyon, n. s., xxii, 1876, 209.

[Hylocharis] auriceps Gray, Hand-list, i, 1869, 149, no. 1934.

\section{CHLOROSTILBON FORFICATUS Ridgway.}

COZUMEL EMERALD.

Similar to $C$. auriceps, but larger; adult male with lateral rectrices broader and less tapering, and middle rectrices less broadly tipped with brownish gray.

Adult male.-Pileum brilliantly metallic golden green or golden; rest of upper parts, including wing-coverts, duller, but still bright, golden green; tail glossy blue-black or black glossed with metallic blue, the six middle rectrices abruptly tipped with deep brownish gray; remiges 
dark brownish slate or dusky, faintly glossed with violaceous; under parts brilliantly metallic golden green, purer (less yellowish) green anteriorly; femoral tufts white; maxilla blackish or dusky for terminal half or more, fading into light brownish (reddish in life?) basally; mandible pale brownish (pinkish or flesh-colored in life), passing into dusky at tip; iris dark brown; feet dusky; length (skins), 95-105 (99); wing, 47-50.5 (48.3); tail, 39-45 (42.5), middle rectrices, 16-18.5 (17.2); culmen, 14.5-15.5 (14.9). ${ }^{a}$

Adult female.-Above metallic green or golden green, the pileum not more brilliant than back, etc.; four middle rectrices metallic green or golden green, sometimes darker terminally or subterminally; third rectrix with terminal third or fourth of outer web blue-black or black glossed with violet-blue, the remaining portion metallic green, the inner web with terminal portion blackish, middle portion brownish gray, basal portion metallic greenish; fourth rectrix (from middle) dusky metallic greenish basally, middle portion light brownish gray, subterminal portion (extensively) glossy blue-black, tip pale brownish gray or grayish white; fifth (outermost) rectrix similar, but whitish tip more extensive, and blackish subterminal area correspondingly more restricted; remiges dark brownish slate or dusky, faintly glossed with violaceous; under parts plain grayish white or very pale gray; femoral tufts white; bill, etc., as in adult male, but maxilla more extensively blackish and mandible with more of dusky at tip; length (skins), 83-91 (88); wing, 46-48.5 (47.2); tail, 31-35 (32.8), middle rectrices, 21.5-24 (22.6); culmen, 15-16.5 (15.8). ${ }^{b}$

Islands of Cozumél, Mugeres, and Holbox, off coast of Yucatan.

Chlorostilbon forficatus Ridgway, Descr. New Sp. B. Cozumel, Feb. 26, 1885, 3 (Cozumél I., Yucatan; coll. U. S. Nat. Mus.); Proc. Biol. Soc. Wash., iii, 1885, 3; Proc. U. S. Nat. Mus., viii, 1885, 574 (descr.; crit.).-Salvin, Ibis, 1889, 366 (Mugeres I., Holbox I., and Cozumél I., Yucatan; crit.); Cat. Birds Brit. Mus., xvi, 1892, 46.-Salvin and Goduan, Biol. Centr.-Am., Aves, ii, 1892, 263.

C[hlorostilbon] forficatus HaRtent, Das Tierreich, Troch., 1900, 74 (monogr.).

[Chlorostilbon] forficatus SHARPE, Hand-list, ii, ]900, 112.

Chlorolampis forficata Boucard, Gen. Hum. Birds, 1894, 113 ("Yucatan").

Chlorostibon caniveti (not Ornismya canivetii Lesson) Salvin, Ibis, 1885, 119 (Cozumél I.; crit.).

\section{CHLOROSTILBON CANIVETII CANIVETII (Lesson).}

CANIVET'S EMERALD.

Similar to $C$. forficatus, but tail much less deeply forked and wing decidedly shorter.

Adult male.-Pileum bright metallic golden green or golden; rest of upper parts less brilliant golden green, varying to almost golden bronze; tail glossy blue-black or black glossed with blue, the four to 
six middle rectrices abruptly tipped with deep brownish gray; ${ }^{a}$ remiges dark brownish slate or dusky, faintly glossed with violaceous; under parts bright metallic golden green (varving much in relative yellowness of the green, the hue sometimes decidedly golden, sometimes nearly pure green); femoral tufts white; maxilla with terminal half (more or less) dusky, the basal portion pale brownish (carmine red in life) $;^{b}$ mandible pale brownish (carmine red in life), ${ }^{b}$ dusky at tip; iris dark brown; feet dusky; length (skins), 78-93 (81); wing, 41-48 (45.1); tail, 30.5-37.5 (34.6); middle rectrices, 15.5-21.5 (18.1); culmen, $13-15$ (14.4). ${ }^{c}$

Adult female.-Above bright metallic green or bronze-green, usually duller or more bronzy on pileum; middle rectrices metallic green or bluish green; second, third, and fourth pairs of rectrices metallic green or bluish green for basal two-thirds or more, abruptly black terminally or subterminally (the fourth usually narrowly tipped with gray), the outermost pair broadly tipped with pale brownish gray, and with a broad median area or band of the same between the broad subterminal black band and the dusky basal area; remiges dusky, faintly glossed with purplish; a dusky auricular area margined above and behind by a postocular streak of grayish white; under parts light brownish gray, somewhat paler posteriorly, the sides and flanks glossed or overlaid with metallic green or bronze-green; maxilla dull black, mandible pale brownish (pinkish in life ?) basally, dusky terminally; length (skins), 75-86 (81); wing, 42.5-46.5 (44.6); tail, 27-31.5 (29.4), middle rectrices. 19.5-23.5 (21.7); culmen, 15-16 (15.3). ${ }^{d}$

Southeastern Mexico, in States of Tampico (Alta Mira; Tampico), Vera Cruz (Jalapa; Córdova; Tospán; Coátepec; Atoyác; Orizaba;

$a$ When present on the third rectrix, the gray is usually in form of a broad edging to the terminal portion of the outer web.

$b$ According to Sumichrast.

$c$ Eighteen specimens.

d Nine specimens.

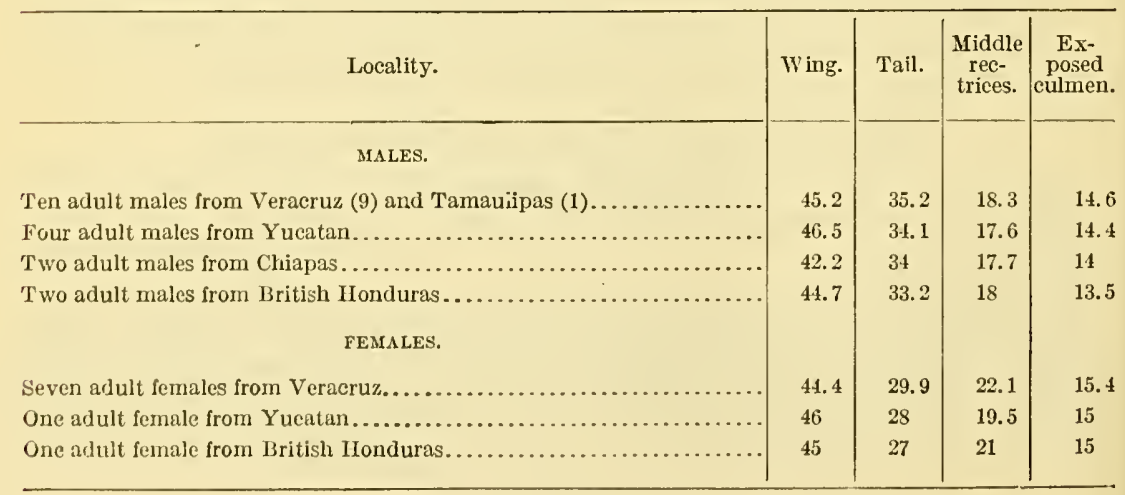


Miradór; Papantla; San Andrés Tuxtla; Buena Vista; Catemaco; Jaltipán; Nisantla; Playa Vicente), Puebla (Atlixco), Oaxaca (Chimalapa; Guichicovi; Túxtepec), Chiapas (Yajalón), and Yucatan (Mérida; Chichen-Itza; Tunkas; Shkolak; Tabí), and southward along Caribbean coast to British Honduras (Belize; Orange Walk; forest near Manatee Lagoon).

Ornismya canivetii Lesson, Hist. Nat. Colibr., Suppl. Ois.-Mouch., 1830-31, 174, 177, pls. 37, 38 ("Brésil"); Index Gen. et Synop. Troch., 1832, p. xxii; Rev. Zool., 1839, 15 (Jalapa, Vera Cruz).

H[ylocharis] canivetii Gray, Gen. Birds, i, Dec., 1848, 114.

[Hylocharis] canivetii GrAY, Hand-list, i, 1869, 149, no. 1931.

[Thaumatias] caniveti Bonaparte, Consp. Av., i, 1850, 78.

[Chlorestes. o. Riccordia] canivetii Reichenbach, Aufz. der Colibr., 1854, 8. [Chlorestes] canivetii Reichen bach, Troch. Enum., 1855, 4, pl. 703, figs. 4581-4583. [Sporadinus] caniveti Bonaparte, Rev. et Mag. de Zool., 1854, 225.

Sporadinus caniveti Sclater, Proc. Zool. Soc. Lond., 1856, 287 (Córdova, Vera Cruz); 1859, 367 (Jalapa).

Ornismia canivetii Савот, Proc. Bost. Soc. N. H., ii, 1845, 55 (Yucatan).

C[hlorolampis $]$ caniveti Cabanis and HeIne, Mus. Hein., iii, 1860, 47, footnote.

Chlorolampis caniveti Gould, Introd. Troch., oct. ed., 1861, 174.-Mulsant and Verreaux, Hist. Nat. Ois.-Mouch., ii, livr. 2, 1875, 81, part (Tospán, Vera Cruz); iv, livr. 3, 1878, 198, part.--Sumichrast, La Naturaleza, v, 1881, 250 (Guichicovi, Oaxaca).-Boucard, Troch. de Mex., 1875, 13 (Córdova and San Andrés Tuxtla, Vera Cruz); Gen. Hum. Birds, 1894, 114 (Tospán, near Córdova).

C[hlorolampis] caniveti Heine, Journ. für Om., 1863, 200.

[Chlorolampis] caniveti Mulsant, Ann. Soc. Linn. Lyon, n. s., xxii, 1876, 209.

Chlorolampis canaveti Lawrence, Bull. U. S. Nat. Mus., no. 4, 1876, 33 (Guichicovi, Oaxaca).

Chlorostilbon caniveti Gould, Mon. Troch., v, 1860, pl. 351.-Sclater, Cat. Am. Birds, 1862, 318 (southeru Mexico).-D'OcA, Troq. de Mex., 1875, 22, pl. 4(1), fig. 13; La Naturaleza, iii, 1875, 59 (Jalapa).-Elliot, Classif. and Synop. Troch., 1879, 243, part.-Boucard, Proc. Zool. Soc. Lond., 1883, 451 (Izalím, Yucatan).-Stone, Proc. Ac. Nat. Sci. Phila., 1890, 206 (Aguada de Shkolak, Yucatan).-Merrera, La Naturaleza, (2), i, 1891, 322 (Valley of Mexico).Salvin, Cat. Birds Brit. Mus., xvi, 1892, 46, part (Mexican and British IIonduran localities and references).--Salvin and Godman, Biol. Centr. Am., Aves, ii, 1892, 263, part (Mexican and British Honduran localities and references).-Сhapman, Bull. Am. Mus. N. H., viii, 1896, 284 (Chichen-Itza, Yucatan).-Richmond, Proc. U. S. Nat. Mus., xviii, 1896, 629 (Alta Mira, Tamaulipas).-Lantz, Trans. Kansas Ac. Sci. for 1896-97 (1899), 221 (Coátepec, Vera Cruz).-Cole, Bull. Mus. Comp. Zool., 1, 1906, 128 (Chichen-Itza, Yucatan).

[Chlorostilbon] caniveti Sclater and Salvin, Nom. Av. Neotr., 1873, 94.-Sharpe, Hand-list, ii, 1900, 112.

C[hlorostilbon] caniveti Herne, Journ. für On'n., 1863, 200 (crit.).

Chlorostilbon caniveti caniveti HARTERT, Journ. für Oru., 1900, 361.

[Chloauges] caniveti Heine and Reichenow, Nom. Mus. Hein. Om., 1890, 181 (Córdova, Vera Cruz).

Chloristilbon caniveti Ellior, Ibis, 1875, 168, part (Mexico; synonymy; crit.). Chlorostilbon canivete Cirapman, Bull. Am. Mus. N. II., x, 1898, 33 (Jalapa). C[hlorostilbon $\mid$ caniveti (typicus) Hantent, Das Tierreich, Troch., 1900, 74 (monogr.). 


\section{CHLOROSTILBON CANIVETII OSBERTI (Gould).}

GUATEMALAN EMERALD.

Similar to C. c. canivetii, but tail shorter and less deeply forked, that of adult male with gray tips to middle rectrices much less distinct (being both narrower and darker), sometimes obsolete.

Adult male.-Length (skins), 74-86 (79); wing, 43-49 (45.8); tail, 28.5-33.5 (31.1); middle rectrices, 17-20 (18.6); culmen, 13.5-15.5 (14.3). ${ }^{a}$

Adult female.-Length (skins), 75-76.5 (76); wing, 45-46.5 (45.7); tail, 27.5 ; middle rectrices, 23 ; culmen, $15-15.5$ (15.2). ${ }^{b}$

Guatemala (Guatemala City; Cobán; Dueñas; San Gerónimo; Lanquín; Amatitlán; San António; San José; Gualán; Volcán de Fuego), Salvadór (Acajutla; La Libertád; Volcán de San Miguél), and Honduras (San Pedro Sula; Bonaca and Ruatán islands ?). ${ }^{c}$

Chlorostilbon osberti Gould, Proc. Zool. Soc. Lond., 1860, 309 (Guatemala; coll. J. Gould); Mon. Troch., pt. xxii, vol. v, 1861, pl. 354.-Salvin and Sclater, Ibis, 1860, 40 (Dueñas and Volcán de Fuego, Guatemala, 5,000ft.).-SALvin, Ibis, 1860, 195, 263, 271 (Dueñas and San Gerónimo).

[Chlorostilbon] osberti Sclater and Salvin, Nom. Av. Neotr., 1873, 94.-Sharpe, Hand-list, ii, 1900, 112.

Chlorostilbon osbertii Sclater, Cat. Am. Birds, 1862, 318 (Dueñas).

Chlorolampis osberti Gould, Introd. Troch., oct. ed., 1861, 174.-SALvin, Ibis, 1866, 204.-Boucard, Gen. Hum. Birds, 1894, 115, part (Guatemala).

C[hlorolampis] osberti HeIne, Journ. für Orn., 1863, 200.

[Hylocharis] osberti GRAY, Hand-list, i, 1869, 149, no. 1933.

[Chlorostilbon caniveti] var. osberti Mulsant, Ann. Soc. Linn. Lyon, n. s., xxii, 1876, 209.

[Chlorostilbon] caniveti osberti HARTERT, Journ. für Orn., 1900, 361.

[Chlorostilbon] caniv[eti] osberti Srmon, Cat. Troch., 1897, 17.

C[hlorostilbon ] caniveti osberti HARTERT, Das Tierreich, Troch., 1900, 74.

Chlorostilbon canivetii (not Ornismya canivetii Lesson) Sclater and Salvin, Ibis, 1859, 130 (Guatemala).

Chloristilbon caniveti ElLIOT, Ibis, 1875, 168, part (Guatemala; Honduras; crit.; synonymy).

Chlorostilbon caniveti Elııot, Classif. and Synop. Troch., 1879, 243, part (Guatemala).-Salvin, Cat. Birds Brit. Mus., xvi, 1892, 46, part (Lanquín, San Gerónimo, Cobán, Volcán de Fuego, and Dueñas, Guatemala; Volcán de San Miguél and La Libertád, Salvadór; Bonaca and Ruatán islands, Honduras?).-Salvin and Godman, Biol. Centr.-Am., Aves, ii, 1892, 263, part (Guatemalan and Salvadorean localities).-Dearborn, Pub. 125, Field Mus. N. H., 1907, 99 (Gualán and San José, Guatemala).

(?) Chlorostilbon caniveti Salvin, Ibis, 1889, 366 (Bonaca and Ruatán islands).

Chlorolampis caniveti Mulsant and Verreaux, Hist. Nat. Ois.-Mouch., ii, livr. 2, 1875, 81, part (Dueñas, Guatemala).-Boucand, Liste Ois. récol. Guat., 1878,47 .

a Ten specimens.

$\checkmark$ Two specimens.

$c$ Specimens from these islands not seen by me. According to Salvin (Ibis, 1889, 366) they present some peculiarities, and it is possible they may represent a definable local form. 


\section{CHLOROSTILBON CANIVETII SALVINI (Gould).}

SALVIN'S EMERALD.

Similar to $C$. $c$. osberti, but maxilla less extensively brownish (or reddish) basally (sometimes wholly dusky), and middle rectrices of adult male with gray tips (when present--usually they are quite obsolete) narrower and darker (dark sooty grayish).

Adult male.-Length (skins), 76-85 (80); wing, 43-49 (46); tail, 30-32.5 (31.5); middle rectrices, 18-21 (19.2); culmen, 13-15.5 $(14.4)^{a}$

Adult female.-Length (skins), 71-80 (76); wing, 42.5-49 (45.5); tail, 25-28 (26.6); middle rectrices, 21-24 (22.7); culmen, 14.5-16 (15.1). ${ }^{a}$

Costa Rica (San José; Rancho Redondo; Escazú; Cartago; La Estrella de Cartago; Tucurríqui ; San Pedro ; Alajuela; Volcán de Miravalles; Tenório; Liberia; Guanacaste; Cerro Santa Maria; Coralillo; Mount Aguacate; Bolsón; Dota Mountains) and Nicaragua (Omotepe; San Juan del Sur; Grenada; Chinandega; Volcán de Chinandega).

C[hlorolampis] salvini Cabanis and Heine, Mus. Hein., iii, March, 1860, 48 (Costa Rica; coll. Heine Mus.).-Heine, Journ. für Orn., 1863, 200 (crit.).

Chlorolampis salvini Cabanis, Journ. für Orn., 1862, 164 (Costa Rica).-Gould, Introd. Troch., oct. ed., 1861, 174.-Lawrence, Ann. Lyc. N. Y., ix, 1868, 128 (San José, Costa Rica).-Frantzius, Journ. für Orn., 1869, 317 (Costa Rica).-Boucard, Gen. Hum. Birds, 1894, 115 (Costa Rica).

[Hylocharis] salvini GraY, Hand-list, i, 1869, 149, no. 1932.

Chlorostilbon salvini Berlepsch, Proc. U. S. Nat. Mus., xi, 1888, 564, in text (Cartago, Costa Pica).-Zeledón, Anal. Mus. Nac. Costa Rica, i, 1887, 122 (San José and Libéria, Costa Rica).

[Chlorostilbon] salvini SHarpe, Hand-list, ii, 1900, 113.

[Chlorostilbon caniveti] var. salvini Mulsant, Ann. Soc. Linn. Lyon, n. s., xxii, 1876, 209.

Chlorostilbon caniveti salvini Ridgway, Proc. U. S. Nat. Mus., v, Feb. 28, 1883, 501 (San José).-Carriker, Ann. Carnegie Mus., vi, 1910, 531 (highlands on Pacific slope, Costa Rica; crit.).

[Chlorostilbon] caniv[eti] salvini Simon, Cat. Troch., 1897, 17.

C[hlorostilbon] c[aniveti] salvini HARTERT, Journ. für Orn., 1900, 361.

C[hlorostilbon] caniveti salvini HaRtert, Das Tierreich, Troch., 1900, 75.

[Chloranges] salvini Heine and Reichenow, Nom. Mus. Hein. Orn., 1890, 182 (Costa Rica).

Chlorolampis caniveti (not Ornismya canivetii Lesson) Mulsant and Terreaux, Hist. Nat. Ois.-Mouch., ii, livr. 2, 1875, 81, part (Costa Rica).-Boucard, Proc. Zool. Soc. Lond., 1878, 71 (San José and Cartago, Costa Rica).

Chlorostilbon caniveti Elliot, Classif. and Synop. Troch., 1879, 243, part (Costa Rica).-Zeledón, Cat. Aves de Costa Rica, 1882, 22.-Salvin, Cat. Birds Brit. Mus., xvi, 1892, 46, part (Costa Rican and Nicaraguan localities).-Salvin and Godran, Biol. Centr.-Am., Aves, ii, 1892, 263, part (Costa Rica; Nicaragua).-Underwood, Ibis, 1896, 441 (Volcán de Miravalles, Costa Rica).-Alfaro, Pag. Illustr., ii, 1905, 795 (habits; descr. nest and eggs; fig. of nest).

Chloristilbon caniveti Elliot, Ibis, 1875, 168, part (Costa Rica; crit.; synonymy).

Chlorostilbon osberti (not of Gould) Nutring, Proc. U. S. Nat. Mus., vi, 18s3, 375, 394 (San Juan del Sur and Omotepe, Nicaragua).

(?)Chlorolampis osberti BoucARD, Gen. Hum. Birds, 1894, 115, part (Nicaragua). 


\section{CHLOROSTILBON ASSIMILIS Lawrence.}

\section{ALIIED EMERALD.}

Somewhat resembling C.canivetii salvini, but smaller (wingdecidedly so), green of upper parts darker and less golden, tail more strongly glossed with blue, and bill wholly black.

Adult male.-Above uniform deep metallic grass green, the upper tail-coverts sometimes slightly more bluish green; tail uniform glossy blue-black or black strongly glossed with steel blue; remiges dark brownish slate or dusky, faintly glossed with violaceous; under parts bright metallic green (much more brilliant and decidedly more yellowish than upper parts); femoral tufts white; bill wholly dull black, the basal portion of mandible sometimes slightly more brownish; iris dark brown; feet dusky; length (skins), 67-84 (77); wing; 44-48.5 (45.6); tail, 25.5-30 (27.8); middle rectrices, 17-21 (19.4); culmen, 12.5-15 (14). ${ }^{a}$

Adult female.-Above bright metallic green or bronze-green, usually more bronzy anteriorly, purer green posteriorly, especially on upper tail-coverts; tail glossy blue-black (the middle rectrices sometimes dark metallic green), the lateral rectrices with basal third (approximately) of outer web dull metallic green (or grayish glossed with green), the two or three outermost tipped (more broadly on lateral pair) with pale gray; remiges dusky, faintly glossed with purplish; loral, suborbital, and auricular regions dusky, the latter margined above by a postocular streak of pale gray or grayish white; rictal and malar regions and under parts plain pale gray, the outer portion of sides and flanks overlaid by metallic green or bronzegreen; femoral and lumbar tufts white; bill black; feet dusky; length (skins), 69-77 (74); wing, 42-46 (44.1); tail, 23.5-26 (25); middle rectrices, 20.5-24 (22.1); culmen, $13-15.5$ (14.3). ${ }^{b}$

a Thirty specimens.

$b$ Thirteen specimens.

\begin{tabular}{|c|c|c|c|c|}
\hline Locality. & Wing. & $\begin{array}{c}\text { Lateral } \\
\text { rec- } \\
\text { trices. }\end{array}$ & $\begin{array}{l}\text { Middle } \\
\text { ree- } \\
\text { trices. }\end{array}$ & $\mid \begin{array}{c}\mathrm{Ex}- \\
\text { posed } \\
\text { culmen. }\end{array}$ \\
\hline MALES. & & & & \\
\hline Seven adult males from Panamá (mainland).. & 45.3 & 28 & 18.9 & 14.1 \\
\hline Three adult males from Saboga Island........... & 45.7 & 28.3 & 19.3 & 14 \\
\hline Ten adult males from San Miguél Jsland....................... & 46.4 & 28.1 & 19.8 & 14.4 \\
\hline 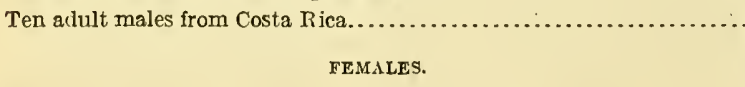 & 45 & 27.4 & 19.3 & 13.4 \\
\hline 'Three adult females from Panamá (mainland).. & 43.7 & 25 & 22.3 & 14.5 \\
\hline One adult female from Saboga Island.......... & 45 & 25 & 22 & 14 \\
\hline 'Two adult females from San Miguél Island.. & 46 & 24.7 & 21.2 & 15.2 \\
\hline Seven adult females from Costa Riea......... & 43.6 & 25.1 & 22.4 & 13.9 \\
\hline
\end{tabular}


Panamá (Colón; Paraiso; Rio Grande Station; Lion Hill; Panamá; Calobre; Chitra; Calovévora; Castillo; Boquete; Divala; Volcán de Chiriquí; Cordillera del Chucu; Santiago and Santa Fé, Verágua) and southwestern Costa Rica (Boruca; Buenos Aires; Dota Mountains).

Chlorostilbon assimilis Lawrence, Ann. Lyc. Nat. Hist. N. Y., vii, 1862, 292 (Lion Hill Station, Panamá Railway; coll. G. N. Lawrence?); ix, 1868, 128 (Cartago, Costa Rica).-Gould, Introd. Troch., oct. ed., 1861, 178.-Salvin, Proc. Zool. Soc. Lond., 1867, 156 (Santa Fé de Verágua, Panamá); Cat. Birds Brit. Mus., xvi, 1892, 54 (Volcan de Chiriquí, Chitra, Santa Fé, Calovévora, Lion Hill, and Paraiso, Panamá).-Frantzius, Journ. für Orn., 1869, 317 (Costa Rica).-Salvin and Godman, Biol. Centr.-Am., Aves, ii, 1892, 265 (Cordillera del Chucu, Calobre, etc., Panamá).-Boucard, The Hum. Bird, ii, 1892, 79 (Verágua; Colón); Gen. Hum. Birds, 1894, 124 (Colón; Panamá; Veragua).-Cherrie, Expl. Zool. Merid. Costa Rica, 1893, 44 (Boruca, s. w. Costa Rica; crit.).-Bangs, Auk, xviii, 1891, 28 (San Miguel I., Bay of Panama); xxiv, 1907, 295 (Boruca); Proc. New Engl. Zool. Club, iii, 1902, 29 (Boquete, Panamá, 4,000-4,800 ft.).-Thayer and Bangs, Bull. Mus. Comp. Zool., xlvi, 1905, 150 (San Miguél and Saboga islands, Bay of Panamá).Carriker, Ann. Camegie Mus., vi, 1910, 532 (Dota Mts., Boruca, and Buenos Aires, Costa Rica).

C[hlorostilbon assimilis Hartert, Das Tierreich, Troch., 1900, 76.

[Chlorostilbon] assimilis Sharpe, Hand-list, ii, 1900, 113.

C[hlorolampis] assimilis HeIne, Journ. für Orn., 1863, 201 (Panamá).

Chlorolampis assimilis Sclater and Salvin, Proc. Zool. Soc. Lond., 1864, 365 (Lion Hill).-Salvin, Proc. Zool. Soc. Lond., 1867, 156 (Santiago and Santa Fé de Verágua, Panamá; crit.); 1870, 211 (Volcán de Chiriquí, Calovévora, Castillo, and Cordillera del Chucu, Panamá).

[Hylocharis] assimilis Gray, Hand-list, i, 1869, 149, no. 1929.

Chlorostilbon angustipennis (not Trochilus angustipennis Fraser) ELLIot, Ibis, 1875, 153, part (Panamá; Verágua; crit.; synon.); Classif. and Synop. Troch., 1879, 245, part (Panamá; Verágua).-Zeledón, Cat. Aves de Costa Rica, 1882, 22; Anal. Mus. Nac. Costa Rica, i, 1887, 122 (Panamá).

[Chlorostilbon] angustipennis Sclater and Salvin, Nom. Av. Neotr., 1873, 94, part (Panamá; Veraguá).

Chrysomirus angustipennis Mulsant and Verreaux, Hist. Nat. Ois.-Mouch., ii, livr. 2, 1875, 102, part (Panamá; Veraguá); iv, livr. 3, 1878, 199, part.

Chlorostilbon panamensis Boucard, Gen. Hum. Birds, sig. o, March, 1894, 124, in text (Panamá; name proposed "if it should prove new;" see Hartert, Novit. Zool., iv, 1897, 152).

\section{CHLOROSTILBON CARIBEUS Lawrence.}

CARIBBEAN EMERALD.

Similar to $C$. assimilis, but wing and tail much shorter and bill longer, the adult male with pileum brilliant metallic golden instead of dull metallic grass green.

Adult male.-Pileum brilliant metallic golden green; rest of upper parts varying from metallic golden green to nearly grass green, the upper tail-coverts sometimes slightly more bluish green; tail glossy blue-black or black glossed with steel-blue; remiges dark brownish slate or dusky, faintly glossed with violaceous; under parts brilliant metallic golden green, usually appreciably more golden posteriorly, purer (less yellowish) green anteriorly; femoral tufts white; bill 
wholly black; iris dark brown; feet dusky; length (skins), 70-79 (75); wing, 41.5-45 (43.1); tail, 23.5-26 (24.4), middle rectrices, 17-22.5 (19); culmen, 14.5-16 (15.4). ${ }^{a}$

Adult female.-Above rather dull metallic green or bronze-green, the upper tail-coverts and middle pair of rectrices more bluish green; tail (except middle pair of rectrices) glossy blue-black or black glossed with greenish blue (this more greenish toward middle pair), two outer rectrices tipped (second very narrowly) with pale brownish gray or dull grayish white; remiges brownish slate, faintly glossed with purplish; under parts pale brownish gray, fading into white on abdomen; femoral tufts white; bill, etc., as in adult male; length (skins), 72-77 (75); wing, 41.5-45.5 (43.5); tail, 22.5-24 (23.2), middle rectrices, 21 ; culmen, $16.5-17$ (16.7). ${ }^{b}$

Immature male.-Similar to the adult female, but tail wholly glossy blue-black (as in adult male) and pale gray of under parts intermixed with metallic green.

Islands of Curaçao, Aruba, Bonaire, Margarita, and Trinidád, and adjacent coast district of Venezuela (La Guayra).

Chlorostilbon atala (not Ornismya atala Lesson) Gould, Mon. Troch., pt. xx, Sept., 1860; vol. v, 1861, pl. 356; Introd. Troch., oct. ed., 1861, 177 (crit.).Elliot, Ibis, 1875, 159 (synon.; crit.; Trinidád; Curaçao); Classif. and Synop. Troch., 1879, 246 (Trinidád).-Salvin, Cat. Birds Brit. Mus., xvi, 1892, 55 (excl. syn. part).-Chapman, Bull. Am. Mus. N. H., vi, 1894, 58 (Trinidád).-Boucard, Gen. Hum.-Birds, 1894, 124 (monogr.).

H[ylocharis] atala Gray, Gen. Birds, i, Dec., 1848, 115.

(?) [Saucerottia] atala Bonaparte, Consp. Av., i, 1850, 77 (Brazil).

[Chlorestes] atala Reichenbach, Troch. Enum., 1855, 4, pl. 700, fig. 4568.

Chrysomirus atala Mulsant and Verreaux, Hist. Nat. Ois.-Mouch., iv, livr. 3, 1878, 199.

Prasitis atala Boucard, The Hum. Bird, ii, 1892, 79 (Valencia, Colombia).

Chlorostilbon caribæus Lawrence, Ann. Lyc. Nat. Hist. N. Y., x, 1874 (pub. March, 1871!), 13, 14 (Island of Curaçao, Dutch West Indies; coll. G. N. Lawrence).-BERLEPSCH, Journ. für Orn., 1892, 87 (Curaçao; crit.).Peters, Journ. für Orn., 1892, 119 (Curaçao).-Hartert, Ibis, 1893, 299 (Aruba; crit.), 319 (Curaçao; crit.; habits; descr. nest and eggs), 328 (Bonaire); Novit. Zool., ix, 1902, 301 (islands of Aruba, Curaçao, and Bonaire).-Cory, Pub. 137, Field Mus. N. H., 1909, 200 (Aruba), 206 (Curaçao), 212 (Bonaire), 245 (Margarita).

C[hlorostilbon] caribaeus HARTERT, Das Tierreich, Troch., 1900, 76 (monogr.).

$a$ Sixteen specimens.

$b$ Two specimens, from Margarita Island.

\begin{tabular}{|c|c|c|c|c|}
\hline Locality. & Wing. & Tail. & $\begin{array}{c}\text { Middle } \\
\text { rec- } \\
\text { trices. }\end{array}$ & $\mid \begin{array}{c}\text { Ex- } \\
\text { posed } \\
\text { culmen. }\end{array}$ \\
\hline MaLES. & & & & \\
\hline Three adult males from coast of Venezuela (LaGuayra). & 43.8 & 25.3 & 18.7 & 15.5 \\
\hline Five adult males from Margarita Island... & 42.4 & 23.8 & 18 & 15.2 \\
\hline Six adult males from Curaçao.... & 43.2 & 24.6 & 20.9 & 15.6 \\
\hline Two adult males from Trinidád............ & 43.5 & 24.2 & 17.5 & 15 \\
\hline
\end{tabular}


[Chlorostilbon] caribæus SHARpe, Hand-list, ii, 1900, 113 (w. Venezuela; Trinidád; Aruba, Curaçao, Bonaire, and Margarita islands).

Chlorostilbon caribbæa RobINson, Proc. U. S. Nat. Mus., xviii, 1896, 672 (Margarita I.), 682 (Guanta, Venezuela), 684 (La Guayra, Venezuela).-Robinson and Richmond, Proc. U. S. Nat. Mus., xxiv, 1901, 173 (coast of Venezuela).Clark (A. H.), Auk, xix, 1902, 263 (Margarita I.).

Chlorostilbon caribbeus Simon and Dalmas, Ornis, xi, 1901, 212 (Curaçao).

Chlorostilbon caribbæus Lowe, Ibis, 1907, 559 (Margarita I.).

[Chlorostilbon] caribeus Simon, Cat. Troch., 1897, 18.

(?) Chlorostilbon caribbeus lessoni Srmon and Dalmas, Ornis, xi, 1901, 212, 213 (Carúpano, Cariaco, Andes de Cumaná, and Ciudád Bolivár, Venezuela).

[Chrysomiras atala] var. caribaeus Mulsant, Ann. Soc. Linn. Lyon, n. s., xxii, $1876,210$.

(?) Chlorostilbon caribaeus nanus Berlepsch and Hartert, Novit. Zool., ix, April, 1902, 86 (Caicará, Venezuela; coll. Tring Mus.).

\section{Genus HELIOTHRYX Boie.}

Heï̌thryx BoIE, Isis, 1831, 547. (Type, Trochilus auritus Linnæus.)

Heliothrys (emendation) Gray, List Gen. Birds, 1840, 14.

Heliothrix (emendation) Strickland, Ann. Nat. Hist., vi, 1841, 419.-Cabanis and Heine, Mus. Hein., iii, March, 1860, 28.

Heliotrix (emendation) Bonaparte, Consp. Av., i, 1850, 69.

Rather large Trochilidx (length about 100-120 mm.) with the straight bill excessively compressed (finely wedge-shaped) anteriorly, tail more or less graduated (but rectrices broadly rounded terminally), under parts white, and with a black stripe on side of head.

Bill (unfeathered portion) about as long as head, straight, rather broad and depressed basally, excessively compressed terminally, narrowly cuneate with finely acuminate tip, in vertical profile; culmen distinctly ridged throughout (but less sharply so posteriorly); tomia smooth; mandible with a longitudinal, median narrow groove on basal half only. Nasal operculum very narrow, completely hidden by the dense, closely appressed frontal feathering, which extends to or beyond anterior end of the nostrils, forming a short obtuse point or antia on each side of culmen or these merged into a single, broader, median antia. Feet excessively small; tarsus feathered on upper portion, except on inner side; lateral toes about equal in length, slightly shorter than middle toe; hallux much shorter than lateral toes. Wing about four times as long as exposed culmen, the outermost primary longest. Tail about three-fifths as long as wing in adult males to five-sixths as long in adult females, graduated, the rectrices rather soft, with broadly rounded tip.

Coloration.-Metallic grass-green or bronze-green above, the middle rectrices bluish black, lateral rectrices and under parts pure white (faintly spotted with grayish on chest in young); a black loral, suborbital and auricular stripe. Adult males with a stripe of brilliant metallic emerald green beneath the black stripe on side of head, a violet post-auricular tuft, sometimes with the pileum metallic violet.

Range.-Guatemala to Guiana and Peru.

(Three species.)

$81255^{\circ}-$ Bull. $50-11-36$ 


\section{HELIOTHRYX BARROTI (Bourcier and Mulsant).}

BARROT'S FAIRY.

Adult male.-Forehead and crown bright metallic violet or blueviolet ("royal purple"); loral, suborbital, and auricular regions opaque velvety black, the last terminated by a spot or short tuft of metallic bluish violet; a band extending from malar apex to side of neck, immediately beneath the black loral-suborbital-auricular stripe, very brilliant metallic emerald green; occiput, hindneck, back, scapulars, wing-coverts, rump, and upper tail-coverts uniform soft metallic green; four middle rectrices slightly glossy blue-black; remaining rectrices pure white; under parts, from chin to under tailcoverts, inclusive, immaculate pure white; bill black; feet light brownish (in dried skins); length (skins), 94-121 (108); wing, 63-69 (65.9); tail, 35.5-54.5 (45.4); culmen, 15-18 (16.7). ${ }^{a}$

Adult female. - Similar to the adult male, but forehead and crown green, like rest of upper parts, white of under parts extending up to the black loral-suborbital-auricular stripe, and violet post-auricular spot wanting; chest sometimes (in younger individuals) spotted or streaked with brownish gray; tail averaging much longer; length (skins), 117-134 (124); wing, 63-70.5 (66.6); tail, 43-73 (60.9); culmen, 15.5-19 (17.1). ${ }^{b}$

$a$ Twenty-six specimens.

$b$ Twenty-seven specimens.

\begin{tabular}{|c|c|c|c|}
\hline Locality. & Wing. & Tail. & $\begin{array}{c}\text { Ex- } \\
\text { posed } \\
\text { culmen. }\end{array}$ \\
\hline MALES. & & & \\
\hline One adult male from Guatemala... & 66.5 & 49.5 & 17 \\
\hline Four adult males from Honduras...... & 67.3 & 51.7 & 16.2 \\
\hline Ten adult males from Honduras........... & 66 & 45.6 & 16.6 \\
\hline 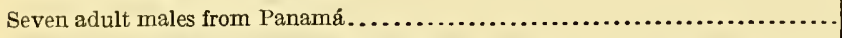 & 65.8 & 46.6 & 17.2 \\
\hline Four adult males from western Ecuadór.............................. & 64.1 & 37.1 & 16.2 \\
\hline FEMALES. & & & \\
\hline One adult female from Guatemala. & 70.5 & 58 & 17 \\
\hline One adult female from Honduras......... & 67.5 & 72 & 19 \\
\hline Ten adult females from Costa Rica........ & 66.6 & 63.5 & 16.4 \\
\hline Eight adult females from Panamá........... & 67.1 & 60.6 & 17.5 \\
\hline Seven adult females from western Ecuadór... & 65.1 & 56.1 & 17 \\
\hline
\end{tabular}

I am unable to subtantiate the claims of a subspecies, H.b. alincius, for Guatemala to Costa Rica, as proposed by Mr. Oberholser, since the characters ascribed do not hold good. It is possible the bird from western Ecuador should be separated on account of its much shorter tail, usually more bluish violet crown, and apparently broader subauricular green stripe; but a much larger series is necessary to determine the question.

The individual variation in length of tail is very great, especially among females. 
Immature female. - Similar to the adult female, but pileum (especially forehead) and sides of head partly (sometimes mostly) dull brown.

Guatemala (Choctúm; Chiséc; Las Salinas; Rio Polochíc between Telemán and Panzos; track between Cajabón and San Luís), British Honduras (Belize; San Felipe; Cayo) and southward through Honduras (Yaruca; Céiba; Chamelicón), Nicaragua (La Libertád, Chontales), Costa Rica (Angostura; Cervantes; Tucurríqui; Jiménez; Carrillo; Bonilla; Guayabo; La Hondura; San José; La Vijágua; El Generál; Paso Reál, Boruca; Pozo Azúl de Pirrís), Panama (Volcán de Chiriquí; Boquete; Boquete de Chitra; Calovévora; Santa Fé de Veragua; Castillo; Laguna del Castillo; Bugaba; Lion Hill; Obispo; Panamá) and Colombia (Cartagena; Popayán; Bogotá; Remédios, Antioquía) to western Ecuadór (Santo Domingo; Citado; Chimbo; Esmeraldas; west side of Pichincha; Rio Pescado, near Nanegál; Gualabamba; Foreste del Rio Peripa).

O[rnismya barroti Bourcier and Mulsant, Ann. Soc. d'Agric. Lyon, vi, 1843, 48, pl. 4 (Cartagena, Colombia).

T[rochilus] barroti Bourcier, Rev. Zool., vi, March, 1843, 72.

H[eliothryx $]$ barroti Gray, Gen. Birds, i, Dec., 1848, 115.

[Heliothryx] barroti Gray, Hand-list, i, 1869, 153, no. 1978.

[Heliothrix] barroti Bonaparte, Consp. Av., i, 1850, 69 (Cartagena); Rev. et Mag. de Zool., 1854, 251. Sclater and Salvin, Nom. Av. Neotr., 1873, 88.Sharpe, Hand-list, ii, 1900, 137.

Heliothrix barroti Gould, Mon. Troch., pt. iv, 1853; vol. iv, 1861, pl. 217; Introd. Troch., oct. ed., 1861, 121; Proc. Zool. Soc. Lond., 1870, 803 (Citado, w. Ecuadór).-Salvin, Ibis, 1860, 272 (tierra caliente, Guatemala), 400 (Las Salinas, Choctúm, and Polochíc Valley, Guatemala); 1872, 320 (Chontales, Nicaragua); Proc. Zool. Soc. Lond., 1867, 155 (Santa Fé de Verágua, Panamá; crit.); 1870, 209 (Volcán de Chiriqui, Bugaba, and Boquete de Chitra, Panamá; crit.); Cat. Birds Brit. Mus., xvi, 1892, 32, 655்.- SAlvin and Sclater, Ibis, 1860, 400 (Choctúm, Chiséc, and Rio Polochíc, Guatemala).-Sclater, Cat. Am. Birds, 1862, 305.-Lawrexce, Ann. Lyc. N. Y., vii, 1861, 291 (Lion Hill Station, Panamá); ix, 1868, 125 (Angostura and Cervantes, Costa Rica).-Sclater and Salvin, Proc. Zool. Soc. Lond., 1864, 365 (Panamá); 1879, 529 (Remédios, Antioquía, Colombia).--Mulsant and Verreaux, Classif. Troch., 1866, 58; Hist. Nat. Ois.-Mouch., ii, livr. 4, 1876, 242, pl. 52 (Guatemala; Colombia; Ecuadór); iv, livr. 3, 1878, 209 (crit.).-Frantzius, Journ. für Orn., 1869, 316 (Costa Rica).-Elliot, Ibis, 1876, 397 (synonymy; crit.); Classif. and Synop. Troch., 1879, 175.-ZELEdóN, Cat. Aves de Costa Rica, 1882, 21; Anal. Mus. Nac. Costa Rica, i, 1887, 122.Berlepsch and Taczanowski, Proc. Zool. Soc. Lond., 1883, 567 (Chimbo, w. Ecuadór; crit.).-Taczanowski, Orn. du Pérou, i, 1884, 258.-BerLEPSCH, Journ: für Orn., 1887, 335 (Cartagena, Popayán, and Antioquía, Colombia).-Boucard, The Hum. Bird, ii, 1892, 86 (Bogotá, Colombia); Gen. Hum. Birds, 1895, 314 (Colombia; Ecuadór).-Salvin and Godman, Biol. Centr.-Am., Aves, ii, 1892, 251.-Hartert (E. and C.), Novit. Zool., i, 1894, 1 (Rio Pescado, near Nanegál, w. Ecuadór).-Lantz, Trans. Kansas Ac. Sci. for 1896-97 (1899), 220 (Cayo, Brit. Honduras).-SAlvadori and Festa, Boll. Mus, Zool., etc., Torino, xv, 1900, 8 (Gualabamba and Foreste 
del Rio Peripa, w. Ecuadór).-Oberholser, Proc. U. S. Nat. Mus., xxiv, 1902, 339 (Santo Domingo, w. Ecuadór; crit.).-Bangs, Proc. New Engl. Zool. Club, iii, 1902, 31 (Boquete and Volcán de 'Chiriquí, 4,500-7,000 ft., Panamá); Bull. Mus. Comp. Zool., xxxix, 1903, 144 (Céiba and Yaruca, Honduras).-CARriker, Ann. Carnegie Mus., vi, 1910, 543 (lowlands of Costa Rica, up to 4,000 ft.).-Ferry, Pub. 146, Field Mus. N. H., orn. ser., i, no. 6, 1910, 263 (Guayabo, Costa Rica).

H[eliothrix] barroti Cabanis and Heine, Mus. Hein., iii, 1860, 28, footnote (Colombia; Ecuadór; Verágua).-Heine, Journ. für Orn., 1863, 183.Hartert, Das Tierreich, Troch., 1900, 187.

[Heliothrix] barrotii Reichenbach, Aufz. der Colibr., 1854, 13; Troch. Enum., $1855,11$.

Heliothrix purpureiceps Gould, Proc. Zool. Soc. Lond., 1855, 87 (Popayán, Colombia; coll. J. Gould); Mon. Troch., iv, 1861, pl. 216.-Sclater, Proc.

Zool. Soc. Lond., 1860, 296 (Esmeraldas, w. Ecuadór).

$H$ [eliothrix] purpureiceps Cabanis and Heine, Mus. Hein., iii, 1860, 28, footnote.

[Heliothrix barroti] var. purpureiceps Mulsant, Ann. Soc. Linn. Lyon, n. s., xxii, 1876, 214.

Heliothrix violifrons Gould, Introd. Troch., oct. ed., 1861, 122 ("Cartagena"= Verágua, Panamá; coll. J. Gould; cites Mon. Troch., iv, pl. 217.)-Salvin. Proc. Zool. Soc. Lond., 1870, 210.-Boucard, The Hum. Bird, ii, 1892, 86 (Verágua); Gen. Hum. Birds, 1895, 314 (Verágua; Panamá).

[Heliothryx] violifrons GRAY, Hand-list, i, 1869, 153, no. 1979.

[Heliothrix barroti] var. violifrons Mulsant, Ann. Soc. Linn. Lyon, n. s., xxii, $1876,214$.

Heliothrix barroti alincius Oberholser, Proc. U. S. Nat. Mus., xxiv, no. 1258, Jan. 18, 1902, 339, in text (Choctúm, Guatemala; coll. U. S. Nat. Mus.).

\section{Genus EUGENES Gould.}

Eugenes a Gould, Mon. Troch., pt. xii, Sept., 1856, text to pl. 59; Introd. Troch., oct. ed., 1861, 57. (Type, Trochilus fulgens Swainson.)

Large Trochilidæ (length about 120-130 mm.) with bill much longer than head, straight, terete; culmen rounded but basally contracted into a narrow ridge; tomia smooth; mandible with a lateral median groove. Nasal operculum nude, but hidden (except extreme edge) by dense oppressed frontal feathers, which extend considerably beyond its anterior end, forming a short angle or antia on each side of culmen. Tarsus feathered in front, except for lower portion; outer toe slightly shorter than middle toe, the inner still (but very slightly) shorter. Wing about three times as long as exposed culmen in adult males, relatively much shorter ${ }^{b}$ (sometimes only twice as long) in females, the outermost primary longest. Tail a little more than half (in females) to three-fifths (in alult males) as long as wing, decply emarginate in adult males, faintly emarginate or doublerounded in females, the rectrices moderately broad, with rounded tip.

Coloration.-Back, ete., metallic green or bronze-green; a small white postocular spot; tail bronzy. Arlult male with forehead and 
crown bright metallic violet, chin and throat brilliant metallic green, remaining under parts dark metallic bronze-green or blackish. Adult females with pileum dull bronze-greenish or dusky, under parts grayish, lateral rectrices blackish subterminally and tipped with pale gray.

Range.-Southwestern United States (near Mexican boundary) to Costa Rica, in higher mountains. (Two species.)

KEY TO THE SPECIES OF EUGENES.

a. Pileum metallic violet, throat metallic emerald green. (Adult males.)

b. Chest velvety black; smaller: Wing 69.5-76 (73), culmen 25.5-31 (27.4). (Guatemala to southern Arizona.)............. Eugenes fulgens, adult male (p. 565).

$b b$. Chest dull metallic green or bronze-green; larger: Wing 76-81 (77.8); culmen, 29-33 (31). (Costa Riça and western Panamá.)

Eugenes spectabilis, adult male (p. 568). aa. Pileum dull metallic greenish or dusky; throat dull brownish white or pale brownish gray, streaked or spotted with darker. (Adult females.)

b. Smaller: Wing, 66.5-70.5 (68.7); culmen, 27-30.5 (29.1).

Eugenes fulgens, adult female (p. 566).

bb. Larger: Wing, 68-74.5 (73.5); culmen, 35-37.5 (36.3).

Eugenes spectabilis, adult female (p. 569).

\section{EUGENES FULGENS (Swainson).}

\section{RIVOLI HUMMING BIRD.}

Adult male.--Pileum rich metallic violet or royal purple, the forehead (at least anteriorly) blackish, usually glossed with green or bluish green; hindneck, sides of occiput, and auricular region velvety black in position $a$, metallic bronze, bronze-green, or golden green in position $c$; rest of upper parts metallic bronze, bronze-green, or golden green, including tail, the latter sometimes with rectrices passing into pale grayish at tip; remiges dark brownish slate or dusky, faintly glossed with purple or purplish bronze; chin and throat brilliant metallic emerald green (more yellowish in position $a$, more bluish in position $b$ ), this brilliant green area extending much farther backward laterally than medially; chest and upper breast velvety black in position $a$ (bronze or bronze-green in position $c$ ), passing into dusky bronze or bronze-green on lower breast, this into grayish brown or sooty grayish on abdomen and flanks; femoral and anal tufts white; a small white postocular spot or streak (sometimes a whitish rictal streak also); under tail-coverts light brownish gray (sometimes glossed with bronze or bronze-green) margined (more or less distinctly) with whitish; bill dull black; iris dark brown; feet dusky; length (skins), 114-136 (125); wing, 69.5-76 (73); tail, 40.5-48 (43.2); middle rectrices, 32.5-41 (36.5); culmen, 25.5-31 (27.4). ${ }^{a}$ 
Adult female.-Above, including four middle rectrices, metallic bronze, bronze-green, or golden green, the pileum duller (sometimes dull grayish brown anteriorly); three outer rectrices (on each side) with basal half (more or less) bronze-green, then black, the tip brownish gray or grayish brown, this broadest on outermost rectrix, much smaller on third; ${ }^{a}$ remiges as in adult male; a postocular streak of white and below this a dusky auricular area; under parts brownish gray or buffy grayish, glossed laterally with metallic bronze or bronze-green, the feathers of chin and throat margined with paler or with dull grayish white, producing a squamate appearance; femoral and anal tufts white; under tail-coverts brownish gray (sometimes glossed with bronze-green) margined with pale brownish gray or dull whitish; bill, etc., as in adult male; length (skins), 110-125 (119); wing, 66.5-70.5 (68.7); tail, 37.5-41.5 (39.4); culmen, 27-30.5 (29.1). ${ }^{b}$

Immature male.-Intermediate in coloration between the adult male and adult female, the crown partly violet, the throat only partly green, and chest slightly intermixed with black, the tail exactly intermediate, both in form and color.

Young female.-Similar to the adult female, but feathers of upper parts narrowly margined terminally with pale grayish buffy and under parts slightly darker and suffused, more or less, with pale brownish buffy.

Southern Arizona (Chiracáhua, Santa Rita, Huachuca, Santa Catalina, and San Luís Mountains; Mount Graham; Camp Grant; Carr's Cañon) and southward through highlands of Mexico, in States of Chihuáhua, Tamaulipas (Miquihuana; Boque Negro), San Luís Potosí (Sierra San Luís Potosí), Guanajuato, Durango (Rancho Baillón; Arroyo del Buéy), Jalisco (Sierra de Bolaños; Sierra de Valparaiso; Sierra de Nayarít), Michoacán (Patzcuaro; Mount

$a$ Sometimes the fourth rectrix also has a small grayish terminal spot, the subterminal portion being blackish.

$b$ Fourteen specimens.

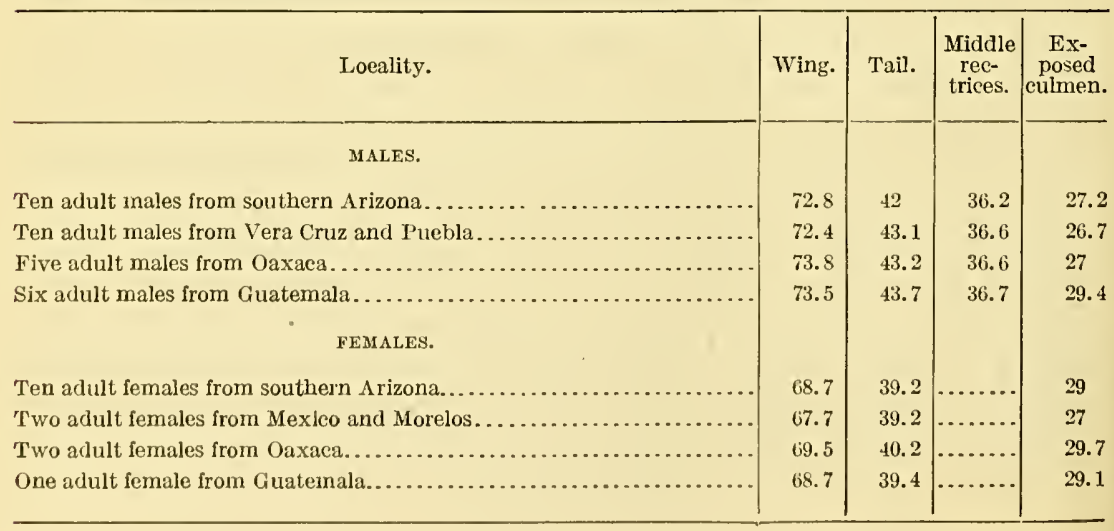


Tancítaro), Morelos (Huitzilác), Mexico (Salazár; "Valley of Mexico"; Ajusco; Tenango; Chimalpa; Hacienda Eslava; Temascáltepec; Rio Frio, Ixtaccihuátl), Puebla (Huachinango; Chalchicomula), Vera Cruz (Orizaba; Miradór; Jalapa; Córdova; Coátepec; Las Vigas; Téxolo), Oaxaca (Cerro San Felipe; Mitla; Oaxaca; Tonaguia; Totóntepec; La Parada), Guerrero (Omilteme; Chilpancingo; Xucumanatlán), and Colima (Sierra Nevada) and Territory of Tepíc, to highlands of Guatemala (Santa Maria, San Martín, and Chuipaché; Quezaltenango; El Rincón, San Marcos; Volcán de Fuego; Tactíc; Dueñas; Cobán; near Tecpám; Montañas de Chilasco); northern Nicaragua (San Rafaél del Norte).

Trochilus fulgens Swarnson, Philos. Mag., n. s., i, 1827, 441 (Temascáltepec, Mexico; coll. Bullock Mus.).

[Trochilus] fulgens GRAY, Hand-list, i, 1869, 137, no. 1749.

M[ellisuga] fulgens GraY, Gen. Birds, i, Dec., 1848, 112.

[Delattria] fulgens Bonaparte, Consp. Av., i, 1850, 70.

[Coligena] fulgens Bonaparte, Rev. et Mag. de Zool., 1854, 252.-Reichenbach, Troch. Enum., 1855, 3, pl. 686, figs. 4513, 4514.

[Coeligena. n. Coeligena] fulgens Reichenbach, Aufz. der Colibr., 1854, 7.

Coeligena fulgens Sclater, Proc. Zool. Soc. Lond., 1856, 287 (Córdova, Vera Cruz); 1858, 297 (Oaxaca); 1859, 367 (Jalapa, Vera Cruz), 386 (Totóntepec, Oaxaca).

Eugenes fulgens Gould, Mon. Troch., pt. xii, Sept., 1856; vol. v, 1861, pl. 59; Introd. Troch., oct. ed., 1861, 58.-Moore, Proc. Zool. Soc. Lond., 1859, 53 (Guatemala).-Sclater and Salvin, Ibis, 1859, 128 (Guatemala).SAlvin, Ibis, 1860, 197, 261 (Dueñas, Cobán, and Tactíc, Guatemala; habits).-Sclater, Cat. Am. Birds, 1862, 228 (Dueñas); Proc. Zool. Soc. Lond., 1864, 176 (City of Mexico).-Boucard, Notes quelques Troch., 1873, 5 (Mexico; Puebla; Oaxaca; Cobán, Guatemala; habits); Liste Ois. récol. Guat., 1878, 45; Gen. Hum. Birds, 1895, 296.-DuGès, La Naturaleza, i, 1873, 141 (Guanajuato).-VIILADA, La Naturaleza, ii, 1874, 349, pl. 1, fig. 5.-D'Oca, La Naturaleza, iii, 1875, 164 (Jalapa and Coátepec, Vera Cruz); Troq. de Mex., 1875, 41, pl. (8), fig. 30.-Henshaw, Am. Nat., viii, 1874, 241 (Mt. Graham, Arizona); Rep. Orn. Spec. Wheeler's Surv. for 1873 (1874), 132, 162 (Camp Grant, Arizona); Zool. Expl. W. 100th Merid., 1875, 379.Coues, Check List, 1874, no. 274 bis; 2 d ed., 1882, no. 408.-Mulsant and Verreaux, Hist. Nat. Ois.-Mouch., ii, livr. 3, 1876, 212, pl. 47 (Mexico; Guatemala); iv, livr. 3, 1878, 206 (synonymy), livr. 4, 1878, pl. 64.-Еццioт, Classif. and Synop. Troch., 1879, 60.-Ridgway, Proc. U. S. Nat. Mus., iii, 1880, 187, 218, 233, 312; Nom. N. Am. Birds, 1881, no. 334; Rep. U. S. Nat. Mus. for 1890 (1891), 319, pl. 35 (monogr.; habits).-Brewster, Auk, ii, 1885, 199 (Santa Rita Mts., Arizona).-Ferrari-Perez, Proc. U. S. Nat. Mus., ix, 1886, 157 (Puébla; Jalapa).-American Ornithologists' Union, Check List, 1886, no. 426; 3d ed., 1910, 201.-Herrera, La Naturaleza, (2), i, 1891, 322 (Valley of Mexico).-Poling, Auk, vii, 1890, 402 (Huachuca Mts., Arizona; habits; descr. nest and eggs).-RHоAds, Proc. Ac. Nat. Sci. Phila., 1892, 117 (Santa Catalina Mts., Arizona, in pine belt).Salvin, Cat. Birds Brit. Mus., xvi, 1892, 302.-Salvin and Godman, Biol. Centr.-Am., Aves, ii, 1892, 328 (San Rafaél del Norte, Nicaragua; etc.).Hartert (E. and C.), Novit. Zool., i, 1894, 21 (Chilpancingo, Guerrero, 6,000 ft., Oct.).-Bendire, Life Hist. N. Am. Birds, ii, 1895, 188.-Lantz, 
Trans. Kansas Ac. Sci. for 1896-97 (1899), 220 (Coátepec, Vera Cruz).Loomis, Auk, xix, 1902, 83 (San Gorgónio Pass, Riverside Co., California, 1 spec., July 15, 1899).-Barley (Florence M.), Handb. Birds W. U. S., 1902, 233, fig. 303.-Swarth, Pacific Coast Avif., no. 4, 1904, 17 (Huachuca Mts., bet. 5,500-7,500 ft.; habits).-Miller (W. DeW.), Bull. Am. Mus. N. H., xxii, 1906, 17 (Rancho Baillón and Arroyo del Buéy, Durango).Wrllard, Condor, xi, 1909, 102 (Ramsey Cañon, Huachuca Mts.; behavior of young bird).-Dearborn, Pub. 125, Field Mus. N. H., 1907, 99 (near Tecpám, Guatemala, 9,500 ft.).-Visher, Auk, xxvii, 1910, 282 (Santa Catalina Mts., breeding above 6,000 ft.).-PhiLLIPs, Auk, xxviii, 1911, 78 (Rampahuila, Galindo, and Realito, Tamaulipas)

E[ugenes] fulgens Cabanis and Heine, Mus. Hein., iii, 1860, 20 (Mexico).Coues, Key N. Am. Birds, 2 d ed., 1884, 461.-Ridgway, Man. N. Am. Birds, 1887, 309.-Hartert, Das Tierreich, Troch., 1900, 113.

[Eugenes] fulgens Sclater and Salvin, Nom. Av. Neotr., 1873, 80.-Mulsant Anu. Soc. Linn. Lyon, xxii, 1876, 213.-Sharpe, Hand-list, ii, 1900, 122.

Clytolæma fulgens Mulsant and Verreaux, Classif. Troch., 1866, 59.

Ornismya rivolii Lesson, Hist. Nat. Ois.-Mouch., 1829, pp. xxvi, 48, pl. 4 (Mexico; coll. Rivoli); Index Gen. et Synop. Troch., 1832, p. xviii (Temascáltepec).

Trochilus rivolii Swainson, Birds Brazil, Mex., etc., [1841?], pl. 76.-Jardine, Nat. Libr., Humming-birds, ii, 1833, 96, pl. 18.

T[rochilus] papantzin DE LA LLAVE, Registro Trimestre, ii, no. 5, Jan., 1833, 48 (Mexico; see Richmond, Auk, xvi, 1899, 325).

(?)Eugenes viridiceps Bouca RD, Ann. Soc. Linn. Lyon. (2), xxv, 1878, 55 (Cobán, Guatemala; see Salvin and Godman, Biol. Centr.-Am., Aves, ii, 1892, 329, 330); Liste Ois. récol. Guat., 1878, 45.

\section{EUGENES SPECTABILIS (Lawrence).}

\section{ADMIRABLE HUMMING BIRD.}

Similar to E. fulgens, but larger; adult male with chest dull bronzegreen or bronzy (the feathers dull brownish gray beneath surface), the under tail-coverts more greenish or bronzy brownish gray margined with pale buffy; adult female with outer rectrices more narrowly tipped with darker brownish gray.

Adult male.-Forehead black (a) becoming dull dusky green in position $b$; crown and occiput metallic violet-blue (a) changing to violet or royal purple (b); superciliary, supra-auricular, auricular, and suborbital regions and nape velvety black (a) changing to bronze-green or greenish bronze (c); back, scapulars, wing-coverts, rump, and upper tail-coverts rather dull metallic bronze-green, the feathers dusky immediately beneath surface, brownish gray basally; tail dull bronze, more dusky toward edge of inner webs of rectrices; remiges dusky faintly glossed with bronzy purplish, the innermost secondaries with outer web mostly bronze-green; primary coverts dull black faintly glossed with dusky green; a small white spot at posterior angle of eye; throat bright metallic emerald green (a), more bluish green posteriorly, changing to more bluish green in position $b$, the feathers brownish gray beneath surface, this gray more or less exposed on 
upper throat and chin; chest, breast, sides, and flanks rather dull metallic bronze-green $(b, c)$, changing to nearly black (a), passing into dull grayish brown on abdomen; anal tufts grayish white; under tail-coverts dull bronze-green, or bronzy grayish brown, margined with brownish buff; bill blackish or dull black, with mandibular tomia dull flesh color (in life); iris dark brown; feet dusky brown (in life); length (skins), 124-135 (130); wing, 76-81 (77.8); tail, 43.5-48.5 (46.8), middle rectrices, 37.5-41.5 (42.8); culmen, $29-33$ (31). ${ }^{a}$

Adult female.-Pileum, together with loral, suborbital and auricular regions, dark sooty or dusky, the first faintly glossed with greenish, at least posteriorly; rest of upper parts as in adult male, but tail duller bronze, the two or three outer rectrices tipped with brownish gray and all becoming dull blackish terminally or subterminally; a conspicuous postocular spot of white; under parts buffy or brownish gray, the feathers of chin and throat conspicuously margined with pale dull grayish buffy (especially on edges) producing a streaked and more or less squamate appearance, the other lower parts with much less distinct paler margins to feathers; sides and flanks mostly bronzy green; anal tufts white, as in adult male; bill, iris, and feet as in adult male; length (skins), 127-141 (135); wing, 68-74.5 (73.5); tail, 36-43.5 (42.3), middle rectrices, 33-40 (37.7); culmen, $35-37.5(36.3) .^{a}$

Highlands of Costa Rica (Rancho Redondo; Volcán de Irazú; Volcán de Turrialba; Coliblanco; Escazú; Cerro de la Candelária; La Estrella de Cartago; San Juan; Ojuras de Térraba) and western Panamá (Volcán de Chiriquí).

Heliomaster spectabilis Lawrence, Ann. Lyc. Nat. Hist. N. Y., viii, May, 1867, 472 (Costa Rica; coll. G. N. Lawrence;=female).-SALvin, Ibis, 1868, 251 (crit.).

[Trochilus] spectabilis Gray, Hand-list, i, 1869, 137, no. 1750.

Eugenes spectabilis Salvin, Ibis, 1869, 316 (Volcán de Irazú, Costa Rica); Cat. Birds Brit. Mus., xvi, 1892, 304.-Frantzius, Joum. für Orn,, 1869, 315 (Costa Rica).-Lawrence, Ann. Lyc. N. Y., x, 1871, 140 ("near San José," Costa Rica; crit.).-Mulsant and Verreaux, Hist. Nat. Ois.-Mouch., ii, livr. 3, 1876, 215; iv, livr. 3, 1878, 206 (crit.).-BoucARd, Proc. Zool. Soc. Lond., 1878, 68 (Volcán de Irazú, 6,000-8,000 ft.; descr. adult male; crit.; habits); Gen. Hum. Birds, 1895, 297 (Rancho Redondo, Costa Rica).Elliot, Classif. and Synop. Troch., 1879, 61.-Zeredón, Cat. Aves de Costa Rica, 1882, 20; Anal. Mus. Nac. Costa Rica, i, 1887, 121 (Faldas de Irazú).-Sharpe, Suppl. Gould's Mon. Troch., 1885, pl. 13.-SAlvin and Godman, Biol. Centr.-Am., Aves, ii, 1892, 330.-Bangs, Proc. New Engl. Zool. Club, iii, 1902, 30 (Volcán de Chiriquí, Panamá, 8,000ft.).-RIdGway, Condor, vii, 1905, 157, in text (Coliblanco, Costa Rica, 6,500 ft.).-CArriker, Ann. Carnegie Mus., vi, 1910, 539 (Costa Rica, above 6,000 ft.).-Ferry, Pub. 146, Field Mus. N. H., orn. ser., i, no. 6, 1910, 264 (Coliblanco, Costa Rica). 
[Eugenes] spectabilis Sclater and Salvin, Nom. Av. Neotr., 1873, 80.-MuLSANT, Ann. Soc. Linn. Lyon, xxii, 1876, 213.-Sharpe, Hand-list, ii, 1900, 122.

E[ugenes] spectabilis Ridgway, Man. N. Am. Birds, 1887, 310; Rep. U. S. Nat. Mus. for 1890 (1891), 319 (diagnosis, etc.).-Hartert, Das Tierreich, Troch., $1900,113$.

(?)Eugenes spectabilis chiriquensis Neнrkorn, Orn. Monatsb., ix, Sept., 1901, 132 (Chiriquí, Panamá).

\section{Genus HELIODOXA Gould.}

Heliodoxa a Gould, Proc. Zool. Soc. Lond., 1849, 95; Introd. Troch., oct. ed., 1861, 74. (Type, H. jacula Gould.)

Leadbeatera Bonaparte, Consp. Av., i, 1850, 70. (Type, L. grata Bonaparte $=$ Trochilus leadbeateri Bourcier and Mulsant.)

Aspasta $b$ Heine, Journ. für Orn., xi, May, 1863, 179, in text. (Type, Trochilus leadbeateri Bourcier and Mulsant.)

Hypolia (not of Ridgway, May 11, 1875) Mulsant, Ann. Soc. Linn. Lyon, xxii, 1876, 212 (Cat. Ois.-Mouch., p. 17). (Type, Trochilus leadbeateri Bourcier and Mulsant.)

Xanthogenyx (typographical error) D'Hamonville, Bull. Soc. Zool. France, viii, 1883, 77. (Type, Heliodoxa xanthogenys Salvin.)

Xanthogenys D'Hamonville, Bull. Soc. Zool. France, xi, 1886, 318 (correction).

Large Trochilidæ (length about 115-125 mm.) with straight and rather stout bill about as long as head, nostrils completely hidden by appressed, imbricated, frontal feathering, wing three to nearly four times as long as exposed culmen; adult males with tail more than two-thirds as long as wing, forked, the under parts very brilliant metallic green, a blue spot on throat or else forehead and crown brilliant violet-blue; adult females with tail less than two-thirds as long as wing, less deeply forked, the under parts whitish, spotted with bright metallic green.

-Bill (unfeathered portion) about as long as head, straight, terete or slightly compressed, rather stout; culmen rounded except at extreme base, where contracted into a rather broad ridge; tomia smooth; mandible with a narrow, rather indistinct, longitudinal median groove. Nasal operculum narrow, straight along edge, wholly covered by the closely appressed and imbricated frontal feathering, which advances over base of maxilla to beyond anterior end of nostril, forming a short obtuse point or antia on each side of culmen. Tarsus slender, feathered, except along posterior side; toes slender, the lateral toes about equal in length and slightly shorter than middle toe, the hallux about as long as lateral toes. Wing three to nearly four times as long as exposed culmen, the outermost primary longest. Tail more than two-thirds as long as wing in adult males,

$\alpha^{\prime \prime} I I \lambda \iota s$, sol et $\delta \delta \xi \alpha$, gloria. (Gould.)

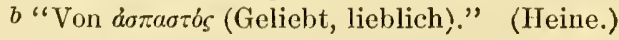


less than two-thirds as long in females, forked in the former, deeply emarginate in the latter, the rectrices broad, rounded or subangular at tip.

Coloration.-Above mainly metallic green or bronze-green, the tail blackish (sometimes with middle rectrices greenish or bronzy). Adult males with forehead and crown glittering metallic green or violet-blue, under parts metallic green (very brilliant or glittering anteriorly), the throat sometimes with a small spot of bright metallic blue. Adult females whitish beneath (sometimes buffy posteriorly) spotted with bright metallic green, the lateral rectrices tipped with whitish.

Range.-Costa Rica to British Guiana, Bolivia, and Peru, in higher mountains. (Seven species.)

KEY TO THE SPECIES AND SUBSPECIES OF HELIODOXA.

a. Under parts brilliant metallic green (with or without blue or violet spot on throat). (Adult males.)

b. Pileum glittering metallic emerald green; a blue or violet spot on lower throat. (Heliodoxa jacula.)

c. Middle rectrices bronze or bronze-green; smaller (wing 72.5-76, averaging 74.3; culmen, 20.5-22.5, averaging 21.3). (Colombia.)

Heliodoxa jacula jacula, adult male (extralimital). ${ }^{a}$

oc. Middle rectrices blue-black (rarely slightly glossed with green or bronzegreen); larger (wing 73.5-79, averaging more than 75 ; culmen 23-26, averaging more than 21.5).

d. Bill longer (exposed culmen 23-26, averaging 24.8); tail shorter and less deeply forked (49-52, averaging 51.8; middle rectrices $32.5-36$, averaging $34)$; green of pileum rather narrower; under parts of body duller green. (Ecuadór.).........Heliodoxa jacula jamersoni, adult male (extralimital). $b$

a Heliodoxa jacula Gould, Proc. Zool. Soc. Lond., 1849, 96 (Bogotá, Colombia; coll. J. Gould); Mon. Troch., pt. ii, 1858, pl. 94; Introd. Troch., oct. ed., 1861, 74; Mulsant and Verreaux, Hist. Nat. Ois.-Mouch., ii, 1875, 202, pl. 46; Elliot, Classif. and Synop. Troch., 1879, 64, part; Salvin, Cat. Birds Brit. Mus., xvi, 1892, 319, part.$H[$ eliodoxa] jacula (typica) Hartert, Das Tierreich, Troch., 1900, 122.-[Leadbeatera] jacula Bonaparte, Consp. Av., i, 1850, 70.-[Coeligena. o. Leadbeatera] jacula Reichenbach, Aufz. der Colibr., 1854, 7.-[Coeligena] jacula Reichenbach, Troch. Enum., 1855, 4, pl. 688, fig. 4522.-Clytolæma jacula Mulsant and Verreaux, Classif. Troch., 1866, 59.-[Trochilus] jacula Gray, Hand-list, i, 1869, 137, no. 1752.

b Trochilus jamersoni Bourcier, Compt. Rend., xxxii, 1851, 187.-[Coeligena. o. Leadbeatera] jamersoni Reichenbach, Aufz. der Colibr., 1854, 7.-[Leadbeatera] jamesoni Bonaparte, Compt. Rend., 1854, 251.-II [eliodoxa] jacula jamersoni Hartert, Das Tierreich, Troch., 1900, 123.--Heliodoxa jacula jamersoni Oberholser, Proc. U. S. Nat. Mus., 1902, 324 (Santo Domingo, w. Ecuadór; crit.).-Heliodoxa jamesoni Gould, Mon. Troch., ii, 1861, pl. 95; Introd. Troch., oct. ed., 1861, 74; Elliot, Classif. and Synop. Troch., 1879, 65; Salvin, Cat. Birds Brit. Mus., xvi, 1892, 320.-Heliodoxa jacula jamesoni Hartert, Kat. Vogelsamml. Mus. Senckenb., 1891, 115.-Clytolæma jamesoni Mulsant and Verreaux, Classif. Troch., 1866, 59. 
dd. Bill shorter (exposed culmen 20.5-23, averaging 21.7); tail longer and more deeply forked (53-59, averaging 54.9, middle rectrices $28.5-32.5$, averaging $30.2)$; green of pileum rather broader; under parts of body brighter green. (Costa Rica and western Panamá.)

Heliodoxa jacula henryi, adult male (p. 573).

$b b$. Pileum brilliant metallic violet or violet-blue; no blue or violet spot on throat. (Heliodoxa leadbeateri.)

c. Bill longer (21-22 mm.); general green color more bluish or less golden. (Coast district of Venezuela to Ecuadór, Peru, and Bolivia.)

Heliodoxa leadbeateri leadbeateri, adult male (extralimital). ${ }^{a}$

$c c$. Bill shorter (18-19 mm.); general green color more golden or bronzy. (Colombia and Venezuela.)..Heliodoxa leadbeateri parvula, adult male (extralimital. $)^{b}$

aa. Under parts mixed green and white. (Adult females.)

b. Abdomen white or mostly white (without buff). (Heliodoxa jacula.)

c. Bill larger (exposed culmen 25.5-28, averaging 26.8); under parts of body always (?) with green predominating.

Heliodoxa jacula jamersoni, adult female (extralimital).

cc. Bill smaller (exposed culmen 21.5-24, averaging 22.9); under parts of body usually (?) with white predominating.

Heliodoxa jacula henryi, adult female (p. 573). bb. Abdomen buff...... Heliodoxa leadbeateri parvula, adult female (extralimital).c

a T[rochilus] leadbeateri Bourcier, Rev. Zool., vi, April, 1843, 102 (Caracas, Venezuela); Bourcier and Mulsant, Ann. Sci. Phys. et Nat., etc., Lyon, vi, 1843, 43.Heliodoxa leadbeateri Gould, Mon. Troch., ii, 1860, pl. 97; Elliot, Classif. and Synop. Troch., 1879, 65, part; Salvin, Cat. Birds Brit. Mus., xvi, 1892, 317, part.-A[spasta] leadbeateri Heine, Journ. für Orn., 1863, 179.-Hypolia leadbeateri Mulsant and Verreaux, Hist. Nat. Ois.-Mouch., ii, livr. 3, 1876, 207.-Clytolæma leadbeateri Mulsant and Verreaux, Classif. Troch., 1866, 59.-H[eliodoxa] leadbeateri (typica) Hartert, Das Tierreich, Troch., 1900, 122.-(?) Trochilus otero Tschudi, Wiegmann's Archiv für Naturg., 1844, i, 298; Fauna Peruana, Aves, 1845-46, 249, pl. 23, fig. 2.-(?) Leadbeatera otero Bonaparte, Rev. Zool., 1854, 251; Gould, Introd. Troch., oct. ed., 1861, 75.(?) Heliodoxa otero Gould, Mon. Troch., ii, 1860, pl. 96.-(?) A[spasta] otero Heine, Journ. für Orn., 1863, 180.-(?) Clytolæma leadbeateri, var. otero Mulsant and Verreaux, Classif. Troch., 1866, 59.-(?) Hypolia otero Mulsant and Verreaux, Hist. Nat. Ois.Mouch., ii, 1876, 209.-Leadbeatera grata Bonaparte, 'Consp. Av., i, 1850, 70; Gould, Introd. Troch., oct. ed., 1861, 75.-(?) [Coeligena. o. Leadbeatera] sagitta Reichenbach, Aufz. der Colibr., 1854, 7.-(?) [Coeligena] sagitta Reichenbach, Troch. Enum., 1855, 4, pl.689, fig. 4525, pl.690, figs. 4527, 4528.-(?) H[eliodoxa] sagitta Cabanis and Heine, Mus. Hein., iii, 1860, 22.-[Coeligena. ò. Leadbeatera] typica Reichenbach, Aufz. der Colibr., 1854, 7.-(?) Leadbeatera splendens Gould, Introd. Troch., oct. ed., 1861, 74 (Venezuela).-(?) A[spasta] splendens Heine, Journ. für Orn., 1863, 180.-(?) Hypolia splendens Mulsant and Verreaux, Hist. Nat. Ois.-Mouch., ii, 1876, 211.-(?) Heliodoxa splendens Eudes-Deslongchamps, Ann. Mus. Caen, i, 286.

b Heliodoxa leadbeateri parvula Berlepsch, Journ. für Orn., xxxv, July, 1887, 320 (Bogotá, Colombia; coll. von Berlepsch).-H[eliodoxa] leadbeateri parvula Hartert, Das Tierreich, Troch., 1900, 122.

I follow Hartert in recognizing two forms of this species; but, owing to lack of sufficient material, I have no personal opinion as to the number of forms into which the species is divisible.

$c$ Females of $H$. jacula jacula and $H$. leadbeateri leadbeateri not seen by me. 


\section{HELIODOXA JACULA HENRYI (Lawrence).}

HENRY'S HUMMING BIRD.

Similar to H. j. jacula, ${ }^{a}$ of Colombia, but slightly larger; adult male with general color of upper parts much less bronzy green, middle pair of rectrices blue-black or very (rarely) slightly bronzy, instead of decided bronze or bronze-green, and green of under parts of body much brighter and less bronzy.

Adult male.-Pileum very brilliant metallic emerald green, the area thus colored becoming narrower posteriorly; sides of crown and occiput, hindneck, back, scapulars, wing-coverts, and rump deep metallic green (nearly grass green) sometimes tinged with bronze, especially on hindneck or upper tail-coverts; tail slightly glossy blue-black, the middle rectrices sometimes (rarely) slightly bronzy; remiges slateblackish, faintly glossed with violaceous; sides of head and neck, chin, throat, and chest brilliant metallic emerald green, the breast, abdomen, sides, and flanks similar in color but less brilliant; a transverse spot of bright metallic blue or (usually) violet-blue on center of throat; under tail-coverts rather dark or dull metallic green, the longer ones (at least) narrowly margined with pale grayish or dull whitish; femoral tufts white; bill black; iris dark brown; feet dusky; length (skins), 125-139 (130); wing, 73.5-79 (75.8); tail, 53-59 (54.9); middle rectrices, $28.5-32.5$ (30.4); culmen, 20.5-23 (21.7). ${ }^{b}$

Adult female.-Above metallic green, sometimes tinged with bronze, especially on hindneck; tail slightly glossy blue-black, the middle rectrices usually more or less bronzy or bronze-greenish, the two or three outer pairs narrowly tipped or terminally margined with white; remiges slate-blackish, faintly glossed with violaceous; a postocular spot of white and a rictal spot or short streak of the same; a black or dusky triangular spot immediately in front of eye; chin, throat, and chest white, with large rounded spots of bright metallic green; the median line of breast and abdomen similar, but abdomen more sparsely spotted, sometimes immaculate; sides and flanks nearly uniform metallic green; femoral tufts white; under tail-coverts dusky grayish glossed (more or less) with green, and margined (more or less broadly) with white; bill, etc., as in adult male; length (skins), 
105-121 (114); wing, 64-68 (66.2); tail, 38-43.5 (40.8), middle rectrices, 28.5-31.5 (30.1); culmen, 21.5-24 (22.9). ${ }^{a}$

Immature male.-Similar to the adult male, but pileum dull metallic green (nearly concolor with back, etc.), green of under parts duller, and chin, together with a suborbital space and small postocular spot, light brown or cinnamon.

Highlands of Costa Rica (Tucurríqui; Angostura; Naranjo de Cartago; Birrís de Cartago; Volcán de Turrialba; Volcán de Irazú; Coliblanco; Bonilla; Guayabo; Tuís; San José Valley; San Pedro de Mojón; Cariblanco de Sarapiquí; Rancho Redondo; Juan Viñas; La Hondura; El Generál; Pozo del Pitál; Los Reyes, Santa Maria de Dota) and western Panamá (Volcán de Chiriquí; Boquete; Boquete de Chitra; Calobre; Calovévora; Castillo; Santiago de Verágua; Lomo Lleno; Cordillera de Tolé).

Heliodoxa jacula (not of Gould, 1849) SALvin, Proc. Zool. Soc. Lond., 1867, 154 (Santiago de Verágua and Cordillera de Tolé, Panamá; crit.); 1870, 207 (Calovévora and Boquete de Chitra, Panamá); Ibis, 1869, 283, 316 (Castillo, Panama); Cat. Birds Brit. Mus., xvi, 1892, 319, 665, part (Panamá localities; Tucurríqui, Costa Rica).-Lawrence, Ann. Lyc. N. Y., ix, 1868, 122 (Angostura and Tuís, Costa Rica; crit.).-Frantzius, Journ. für Orn., 1869, 315 (Costa Rica).-Mulsant and Verreaux, Hist. Nat. Ois.-Mouch., ii, livr. 3, 1876, 202, part (Verágua, Panamá; Costa Rica).-Boucard, Proc. Zool. Soc. Lond., 1878, 69 (Naranjo de Cartago and Volcán de Irazú, Costa Rica; crit.).-Elııoт, Classif. and Synop. Troch., 1879, 64, part (Costa Rica; Verágua).-Zeledón, Cat. Aves de Costa Rica, 1882, 20; Anal. Mus. Nac. Costa Rica, i, 1887, 121 (Birrís de Cartago, Costa Rica).-SALvin and Godman, Biol. Centr.-Am., Aves, ii, 1892, 339, part (Costa Rica and Panamá localities).-Cherrie, Anal. Inst. Fisico-Geog. Costa Rica, vi, 1893, 19 (Pozo del Pitál, Costa Rica).

[Heliodoxa] jacula Sclater and Salvin, Nom. Av. Neotr., 1873, 82, part (Verágua; Costa Rica).

Heliodoxa henryi Lawrence, Ann. Lyc. Nat. Hist. N. Y., viii, 1867, 402 (Angostura, Costa Rica; coll. U. S. Nat. Mus.).

[Trochilus] henryi Gray, Hand-list, i, 1869, 137, no. 1753.

H[eliodoxa] jacula henryi HARTERT, Das Tierreich, Troch., 1900, 123 (monogr.).

$a$ Fifteen specimens.

\begin{tabular}{|c|c|c|c|c|}
\hline Locality. & Wing. & Tail. & $\begin{array}{c}\text { Middle } \\
\text { rec- } \\
\text { trices. }\end{array}$ & $\begin{array}{c}\text { Ex- } \\
\text { posed } \\
\text { culmen. }\end{array}$ \\
\hline MIALES. & & & & \\
\hline Ten adult males from Costa Rica.................... & 76 & 54.8 & 30.4 & 21.7 \\
\hline One adult male from western Panamá (Verágua)................... & 74.5 & 55.5 & 28 & 21.5 \\
\hline $\begin{array}{l}\text { Three adult males ( } I . j . j a c u l a) \text { from central Colombia (Bogotá)....... } \\
\text { ГEM LES. }\end{array}$ & 74.3 & 52 & 30.5 & 21.3 \\
\hline Ten adult females from Costa Rica.............. & 65.9 & 40.4 & 29.8 & 22.7 \\
\hline Five adult females from western Panamá........... & 66.8 & 41 & 30.7 & 23.1 \\
\hline
\end{tabular}


Heliodoxa jacula henryi Bangs, Proc. New Engl. Zool. Club, iii, Jan. 30, 1902, 30 (Boquete and Volcán de Chiriquí, Panamá, 4,000-7,500ft.).-OвеRHolser, Proc. U. S. Nat. Mus., xxiv, no. 1258, Jan., 1902, 324, in text (Costa Rica).-Carriker, Ann. Carnegie Mus., vi, 1910, 543 (Caribbean slope, 1,000-4,000 ft., San José Valley, and Dota Mts., Costa Rica).-Ferry, Pub. 146, Field Mus. N. H., orn. ser., i, no. 6, 1910, 264 (Coliblanco, Costa Rica).

[Heliodoxa] henryi SHarpe, Hand-list, iii, 1900, 124.

Heliodoxa henrici BouCARD, Gen. Hum. Birds, 1895, 287 (Navarro de Cartago and Volcán de Irazú; Verágua).

(?) Heliodoxa berlepschi Boucand, The Humming Bird, ii, no. 9, Sept., 1892, 75 (Verágua, Panamá; coll. A. Boucard).

\section{Genus FLORISUGA Bonaparte.}

Florisuga Bonaparte, Consp. Av., i, 1850, 73. (Type, Trochilus mellivorus Linnæus.)

Rather large Trochilidæ (length about 95-110 mm.) with apparently twelve rectrices (the longer upper tail-coverts so elongated and specialized as to simulate the middle rectrices), tail equal to or longer than combined length of head and bill, emarginate, with rectrices broad, firm, and (at least in adult male) nearly truncated at tip, tarsi densely clothed with rather long feathers (especially behind), and abdomen white.

Bill a little longer than head, rather stout, straight, nearly terete; culmen rounded except basally, where narrowly ridged; tomia smooth; maxilla and mandible each with a rather indistinct narrow median lateral groove. Nostril narrow, slit-like, overhung by a broad, tumid, almost wholly feathered operculum, only the edge of which is exposed. Tarsus wholly feathered, the feathering long on posterior portion; middle and inner toes about equal in length, the outer toe slightly shorter; hallux slightly shorter than outer toe; all the toes small and weak, with claws relatively small. Wing about four times as long as exposed culmen, the outermost primary longest. Tail a little more than half (female) as long as wing to nearly threefifths as long (adult male), emarginate, the rectrices firm, very broad, broadly rounded or (in adult male) nearly truncated at tip; the rectrices apparently 12 in number (at least in adult male) through specialization of the two longest upper coverts, which are as long as and differently colored from the middle rectrices.

Coloration.-Adult male with head and neck metallic violet-blue, back, scapulars, rump, and upper tail-coverts metallic green; breast, abdomen, flanks, under tail-coverts, and tail (including middle rectrices) white, the latter narrowly tipped with black; a white line across hindneck. Adult female and young with throat, chest, sides, and under tail-coverts dusky squamated with grayish white, pileum green, like back, etc., and tail dark metallic green crossed at or near 
tip by a rather broad band of bluish black (the lateral rectrix mainly the latter color), and (in unworn plumage) with a narrow terminal margin of white.

Range.-Southern Mexico to Amazon Valley. (Monotypic.)

\section{FLORISUGA MELLIVORA (Linnæus).}

JACOBIN HUMMING BIRD.

Adult male.-Head, neck, and chest uniform dark metallic blue or violet-blue, becoming more greenish blue on hindneck and (sometimes) on lower portion of chest; a pure white bar or crescent across lower part of hindneck or extreme upper back, this sometimes obsolete (concealed) ; ${ }^{a}$ back, scapulars, wing-coverts, rump, and upper tail-coverts metallic green, bronze-green, or bronze; tail white, the rectrices narrowly tipped (or terminally margined) and usually edged (more or less) with black; ${ }^{b}$ remiges slate-blackish, faintly glossed with violaceous; breast, abdomen, flanks, and under tail-coverts immaculate pure white; sides metallic green, bronze-green, or bronze, this color invading sides of breast, where sometimes extending entirely across the upper portion; bill dull black; iris dark brown; feet dusky; length (skins), 95-124 (118); wing, 62-71.5 (68.4); tail, 32-43 (38.1); culmen, 16.5-22 (19.3). ${ }^{c}$

Adult female.-Above metallic bronze-green or greenish bronze, slightly duller or darker on pileum; tail usually more bluish green (sometimes decidedly bluish), the rectrices broadly blackish subterminally and tipped or terminally margined with white, this broad and conspicuous on outermost pair but reduced to a narrow edging on middle pair, the outer web of outer pair broadly edged with grayish white or pale gray basally; remiges slate-blackish or dusky slate, faintly glossed with violaceous; chin white (at least in part); throat and chest with feathers dusky centrally, broadly margined with white (producing a scaled effect), the dark central spots usually more or less glossed with metallic green or bluish green, especially on chest; sides of breast and sides mottled or squamated with white and bronze or bronze-greenish; median portion of breast, abdomen, and flanks immaculate white; under tail-coverts dusky grayish glossed with bronze-greenish basally, slightly glossy blueblack subterminally, and tipped or terminally margined (broadly)

$a$ This white marking varies greatly in development, even in specimens from the same locality; sometimes it is entirely concealed, the tips of the feathers being metallic green; again it is broad and conspicuous. The "make" of the skin has much to do with its apparent development, since specimens with the head crowded close to the body have the white mark entirely covered or obliterated.

$b$ The middle rectrices, which are white, black-tipped, like the rest, are almost wholly covered and hidden by the elongated upper tail-coverts.

c Forty-six sper:imens. 
with white; bill, etc., as in adult male; length (skins), 94-109 (100); wing, 62-70 (65.2); tail, 31-37 (34.1); culmen, 17.5-22 (19). ${ }^{a}$

Immature male.-Essentially like adult male but coloration duller; middle rectrices with only basal portion white, the terminal half or more being dusky dull metallic greenish or bronzy broadly tipped with black; rictal region (more or less extensively) light buffy brown or cinnamon. ${ }^{b}$

Southeastern Mexico, in States of Vera Cruz (Orizaba) and Oaxaca (Lana, Choapám) and southward through Guatemala (Guatemala City; Choctúm; near Petén), British Honduras (Belize; forest near Manatee Lagoon), Honduras (San Pedro), Nicaragua (Greytown; Rio San Juan; Chontales), Costa Rica (San Pedro; Guápiles; Bonilla; El Hogár; Turrialba; Carrillo; La Vijágua; El Generál; Bebedero; Pozo del Pitál; Pozo Azúl de Pirrís; Boruca), Panamá (Divala; Volcán de Chiriquí; Cordillera de Tolé; Cordillera del Chueu; Santiago de Verágua; Lion Hill; Paraiso), Colombia (Don Diego, Sierra Nevada, Cacagualito, Bonda, Don Amo, and Minca, Santa Marta; Bogotá;

$a$ Sixteen specimens.

\begin{tabular}{|c|c|c|c|}
\hline Locality. & Wing. & Tail. & $\begin{array}{c}\text { Ex- } \\
\text { posed } \\
\text { culmen. }\end{array}$ \\
\hline \multicolumn{4}{|l|}{ MALES. } \\
\hline Three adult males from Guatemala... & 69.3 & 39.5 & 18.2 \\
\hline Five adult males from British Honduras............ & 67.8 & 36.4 & 20.1 \\
\hline One adult male from Nlcaragua.............. & 67 & 36 & 18.5 \\
\hline Ten adult males from Costa Rica............... & 67.5 & 37.4 & 17.8 \\
\hline Four adult males from Panamá.................................. & 67.7 & 37 & 19.2 \\
\hline Five adult males from northeastern Colombia (Santa Marta district)... & 68.4 & 37.7 & 20.9 \\
\hline 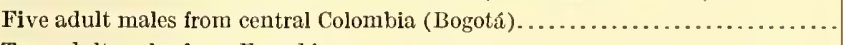 & 69.2 & 39 & 19.7 \\
\hline 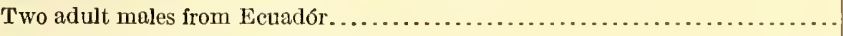 & 69.2 & 40.7 & 19.7 \\
\hline Four adult males from eastern Peru....... & 69.7 & 40.2 & 19.2 \\
\hline One adult male from British Guiana.............. & 66 & ......... & 20 \\
\hline 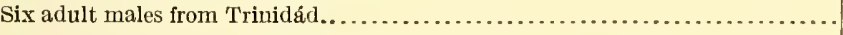 & 68.9 & 37.9 & 20 \\
\hline Four adult males $(F$, m. tobagcnsis $c)$ from Tobago............ & 73.1 & 44.5 & 22.7 \\
\hline \multicolumn{4}{|l|}{ FEMALES. } \\
\hline Ten adult females from Costa Rica.... & 64.6 & 37.4 & 18.5 \\
\hline Two adult females from Pauamá....................... & 64 & 32 & 18.7 \\
\hline Two adult females frolu Santa Marta district, Colombia.... & 68.7 & 35 & 21.5 \\
\hline One adult female from Ecuador....................... & 66.5 & 33 & 20 \\
\hline 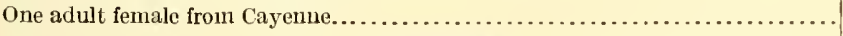 & 64 & 31 & 19.5 \\
\hline One adult female $(F, m$. tobagcnsis $)$ from Tobago............. & 70.5 & 38.5 & ........ \\
\hline
\end{tabular}

$b$ Younger specimens have the dark dull metallic blue of throat and chest confined to a median stripe, margined along each side by a narrower, ill-defined stripe of pale brownish, and there is a stripe of pale buff or cinnamon along middle of back and rump.

c Florisuga mellivora tobagensis Ridgway, Proc. Biol. Soc. Wash., xxiii, April 19. 1910, 55 (Tobago; coll. U. S. Nat. Mus.). 
Remédios, Antioquía; Las Cruces), Ecuadór (Báeza; Quito; Sarayacu; Nanegál; Chimbo; Parambo), Venezuela (Yauca, Caura; Nericagua; Munduapo; Suapuré; La Priẹion), Trinidád, Tobago, ${ }^{a}$ Aruba, Carriacou, British Guiana (Demerara; Merumé Mountains; Atapuroni River), and Cayenne to Brazil (Pernambuco; Pará; Rio Negro; Humaytha; Borba; Arumatheua, Tocantins; Rio de Janeiro, and Peru (Pebas; Iquitos; Xeberos; Chamicuros; Yurimaguas; Rio Javari; Callacate).

[Trochilus] mellivorus Linneus, Syst. Nat., ed. 10, i, 1758, 121; ed. 12, i, 1766, 193 (based on White-bellied Humming Bird, Avis mellivora, ventre albo Edwards, Nat. Hist., i, pl. 35, upper fig.).-GmeLin, Syst. Nat., i, pt. 1, 1788, 499.LATHAM, Index Orn., $i, 1790,310$.

Trochilus mellivorus Audebert and Vieillot, Ois. Dorés, i, 1801, 55, pl. 23 (Cayenne; Guiana).-Temminck, Cat. Syst., 1807, 82.-Vieillot, Nouv. Dict. d'Hist. Nat., vii, 1817, 360.-Vigors, Zool. Beechey's Voy., 1839, 25 (Rio Janeiro, Brazil; habits; food).-Cabanis, in Schomburgk's Reis. Brit. Guiana, iii, 1848, 706.-Burmeister, Syst. Ueb. Th. Bras., ii, 1856, 339.

T[rochilus] mellivorus Vıеillot, Tabl. Enc. Méth., ii, 1822, 562.

Ornismya mellivora Lesson, Hist. Nat. Ois.-Mouch., 1829, pp. xxiii, 90, pls. 21, 22 ; Index Gen. et Synop. Troch., 1832, p. xx (Guiana; Brazil; "Martinique").

[Florisuga] mellivorus Bonaparte, Consp. Av., i, 1850, 73; Rev. et Mag. de Zool., 1854, 253.

[Florisuga] mellivora Sclater and Salvin, Nom. Av. Neotr., 1873, 83.-MulSANT, Ann. Soc. Linn. Lyon, xxii, 1876, 212.-Sharpe, Hand-list, ii, 1900, 102.

Florisuga mellivora Gould, Mon. Troch., pt. ii, 1851; vol. ii, 1861, pl. 113; Introd. Troch., oct. ed., 1861, 80.-Reichenbach, Aufz. der Colibr., 1854, 14; Troch. Enum., 1855, 12.-Moore, Proc. Zool. Soc. Lond., 1859, 53 (Belize, Brit. Honduras).-Sclater and Salvin, Ibis, 1859, 128 (Guatemala); Proc. Zool. Soc. Lond., 1864, 365 (Lion Hill, Panamá); 1867, 584 (Pará and Cobati, Rio Negro, Brazil); 1868, 628 (Venezuela); 1870, 837 (San Pedro, Honduras); 1873, 287 (Xeberos, Chyavetas, Chamicuros, and Pebas, e. Peru); 1879, 529 (Remédios, Antioquía, Colombia).-Sclater, Proc. Zool. Soc. Lond., 1860, 95 (Nanegál, Ecuadór); Cat. Am. Birds, 1862, 295 (Cayenne).-Taylor, Ibis, 1863, 91 (Trinidád).-Mulsant and Verreaux, Classif. Troch., 1866, 47; Hist. Nat. Ois.-Mouch., ii, livr. 3, 1876, 176 (n. Brazil to e. Peru, Ecuadór, and Mexico); iv, livr. 4, 1878, 204 (synonymy).-Salvin, Proc. Zool. Soc. Lond., 1867, 155 (Cordillera de Tolé and Santiago de Verágua, Panamá); Ibis, 1872, 319 (Chontales, Nicaragua); Cat. Birds Brit. Mus., xvi, 1892, 329, 665 (Belize, etc., Brit. Honduras; Choctúm, Guatemala; Chontales, Nicaragua; Costa Rica; Volcán de Chiriqué, Cordillera de Tolé, Santiago, Lion Hill, and Paraiso, Panamá; etc.).-Lawrence, Ann. Lyc. N. Y., vii, 1862, 292 (Lion Hill, Panamá); ix, 1868, 122 (Costa Rica); Proc. Bost. Soc. N. H., xiv, 1871, 284 ("Tres Marias," error; see Berlepsch, Proc. U. S. Nat. Mus., xi, 1888, 561); Mem. Bost. Soc. N. H., ii, 1874, 291 ("Tres Marias").-LayARD, Ibis, 1863, 388 (Pará, Brazil).-Pelzeln, Orn. Bras., i. Abth., 1868, 30; iv. $\Lambda$ bth., 1870, 481.-Frantzius, Journ. für Orn., 1869, 315 (Costa Rica).Boucard, Notes Troch. du Mex., 1875, 2 (Lana, Choapám, Oaxaca; Guato-

a The Tolsago bird has, however, been separated on account of its much larger size. (Florisuga mellivora tobagensis Ridgway, Proc. Biol. Soc. Wash., xxiii, $\Lambda$ pril 19, 1910, 55 ('Tobago; coll. U. S. Nat. Mus.). 
mala; habits; etc.); Liste Ois. récol. Guat., 1878, 45; Gen. Hum. Birds, 1895, 338.-Elliot, Classif. and Synop. Troch., 1879, 48.-Taczanowski, Proc. Zool. Soc. Lond., 1880, 304 (Callacate, n. Peru); Orn. du Pérou, i, 1884, 297.Sumichrast, La Naturaleza, v, 1881, 250 (Orizaba, Vera Cruz).-Zeledón, Cat. Aves de Costa Rica, 1882, 20; Anal. Mus. Nac. Costa Rica, i, 1887, 121 (Panamá).-Taczanowski and Berlepsch, Proc. Zool. Soc. Lond., 1883, 566 (Chimbo, w. Ecuadór).-Berlepsch, Journ. für Orn., 1887, 317 (Bogotá, Colombia; crit.); 1889, 305 (Yurimaguas, e. Peru); Zeitschr. Orn., 1887, 186 (Bogotá); Proc. U. S. Nat. Mus., xi, 1888, 561 (crit. as to alleged Tres Marias spec.).-Srmon, Mém. Soc. Zool. France, ii, 1889, 220 (San Estéban, Venezuela; crit.).-Salvin and Godman, Biol. Centr.-Am., Aves, ii, 1892, 340.Richmond, Proc.U.S. Nat. Mus., xvi, 1893, 517 (near Grey town, Nicaragua).Cherrie, Anal. Inst. Físico-Geog. Costa Rica, vi, 1893, 19 (Pozo del Pitál, Costa Rica).-Chapman, Bull. Am. Mus. N. H., vi, 1894, 56 (Trinidád; crit.).-Bangs, Proc. Biol. Soc. Wash., xii, 1898, 135 (Santa Marta, Colombia).-Hartert, Novit. Zool., v, 1898, 494 (Paramba, n. w. Ecuadór).Dalmas, Soc. Zool. France, xiii, 1900, 142 (Tobago; crit.).-Allen, Bull. Am. Mus. N. H., xiii, 1900, 138 (Bonda, etc., Santa Marta, Colombia).Simon and Dámas, Ornis, xi, 1901, 209 (Yacura, Caura, Venezuela), 218 (Las Cruces, w. Colombia).-Berlepsch and Hartert, Novit. Zool., ix, 1902, 82 (Nericagua, Munduapo, Suapuré, La Pricion, etc., Venezuela).Oberholser, Proc. U. S. Nat. Mus., xxiv, 1902, 315 (Báeza, e. Ecuador).Clark (A. H.), Proc. Bost. Soc. N. H., xxxii, 1905, 275 (Carriacou, Lesser Antilles).-Helluayr, Novit. Zool., xiii, 1906, 375 (Pará); xiv, 1907, 395 (Humaytha and Borba, Rio Madeira, w. Brazil).-SNethlage, Journ. für Orn., 1908, 583 (Arumatheua, Tocantins, Brazil).-BERlepsch, Novit. Zool., xv, 1908, 264 (Cayenne).-Cory, Pub. 137, Field Mus. N. II., 1909, 200 (Aruba; crit.).-Carriker, Ann. Carnegie Mus., vi, 1910, 522 (Costa Rica).

F[lorisuga] mellivora Caban1s and Heine, Mus. Hein., iii, 1860, 29 (Guiana).Hartert, Das Tierreich, Troch., 1900, 35.

F[lorisuga] m[ellivora] mellivora Ridgway, Proc. Biol. Soc. Wash., xxiii, Apr. $19,1910,55$, in text.

Lampornis mellivora JARdine, Nat. Libr., Humming-Birds, ii, 1833, 155.

T[opaza] mellivora Gray, Gen. Birds, i, 1848, 110.

Topaza mellivora LÉotaud, Ois. Trinidad, 1866, 141.

[Topaza] mellivora Gray, Hand-list, i, 1869, 134, no. 1721.

Mellisuga mellivora Sclater and Salvin, Ibis, 1880, 171 (Minca, Santa Marta, Colombia, 2,000 ft.).

Mellisuga surinamensis Stephens, Shaw's Gen. Zool., xiv, pt. 1, 1826, 243 (based on "Trochilus mellivorus Shaw, v, viii, p. 320").

(?) [Trochilus] fimbriatus Linnwus, Syst. Nat., ed. 12, i, 1766, 193 (based on Mellisuga cayennensis gutture naevia Brisson, Orn., iii, 706; etc.).-GMelin, Syst. Nat., i, pt. 1, 1788, 493.-Latian, Index Orn., i, 1790, 312.

T[opaza] fimbriata Gray, Gen. Birds, i, Dec., 1848, 110.

Trochilus (—? flabelliferus Gould, Proc. Zool. Soc. Lond., July, 1846, 45 (Mexico; coll. J. Gould).

T[opaza] flabellifera Gray, Gen. Birds, i, Dec., 1848, 110.

[Topaza] flabellifera Gray, Hand-list, i, 1869, 134, no. 1722.

[Florisuga] flabelliferus Bonaparte, Consp. Av., i, 1850, 74.

[Florisuga] flabellifera Bonaparte, Rev. et Mag. de Zool., 1854, 253.

Florisuga flabellifera Gould, Mon. Troch., pt. ii, Nov., 1857; vol. ii, 1861, pl. 114;

Introd. Troch., oct. ed., 1861, 81.-Reichenbaci, Aufz. der Colibr., 1854, 14; Troch. Enum., 1855, 12.-Sclater, Cat. Am. Birds, 1862, 295.-Mulsant and Verreaux, Classif. Troch., 1866, 47. 
F[lorisuga] flabellifera Cabanis and Heine, Mus. Hein., iii, 1860, 29, footnote.

[Florisuga mellivora] var. flabellifera Mulsant, Ann. Soc. Linn. Lyon, n. s., xxii, $1876,212$.

Florisuga sallei BouCARD, The Hum. Bird, i, no. 3, Mar. 1, 1891, 18 ("South Mexico;" coll. A. Boucard); Gen. Hum. Birds, 1895, 341.

Florisuga sallæi HARTERT, Ibis, 1897, 434, in text (crit.; = "golden" variety of F. mellivora).

F[lorisuga] guianensis BoucARD, Genera Hum. Bird, Sept., 1895, 340, in text (Demerara and Atapuroni R., Brit. Guiana; coll. A. Boucard).-HARtert, Ibis, 1897, 434, in text (crit.).

F[lorisuga] peruviana Boucard, Genera Hum. Bird, Sept., 1895, 340, in text (Pebas, e. Peru; coll. A. Boucard).-Hartert, Ibis, 1897, 434, in text (crit.).

Trochilus mellivorus varius Audebert and Vieillot, Ois. Dorés, i, 1801, 56, pl. 24 (Cayenne and Guiana; =immature male).

\section{Genus MICROCHERA Gould.}

Microchera ${ }^{a}$ Gould, Mon. Troch., pt. xvi, Sept., 1858 (vol. ii, 1861), text to pl. 116; Introd. Troch., oct. ed., 1861, 82. (Type, Mellisuga albo-coronata Lawrence.)

Very small Trochilidæ (length about $60-70 \mathrm{~mm}$.) with the straight bill shorter than head, wing about four times as long as exposed culmen, tail less than half as long as wing, with rectrices (except middle pair) white basally, the adult males with general color plain dark metallic purplish relieved by a pure white pileum.

Bill shorter than head, straight, rather slender, terete or slightly compressed; culmen rounded except basally, where contracted into a narrow ridge; tomia smooth; . mandible with the usual lateral median groove. Nasal operculum narrow, completely hidden by the appressed frontal feathering, which extends forward considerably beyond anterior end of nostrils, forming a single broad, rounded, or truncate antia on base of culmen. Tarsus feathered, except on inner side; inner and middle toes about equal in length, the outer very slightly shorter. Wing about four times as long as exposed culmen, the outermost primary longest, normal in shape. Tail a little less than half as long as wing, slightly double-rounded, the rectrices broadly rounded at tip.

Coloration.--Adult males with whole pileum satiny white; rest of plumage dark metallic blackish purple or coppery purple, the chin and throat bronzy blackish (whole under parts, except under tailcoverts, blackish in one species), the under tail-coverts and basal porrtion of tail (except middle rectrices) white; adult females metallic bronze-green above, including pileum, the middle rectrices more bronzy, the under parts wholly grayish white, the tail as in adult male, but lateral rectrices tipped with white.

Range.-Highlands of Nicaragua, Costa Rica, and western Panamá. (T'wo species.) 
KEY TO TIIE SPECIES OF MICROCHERA.

a. Under parts purplish black or dark metallic reddish purple; pileum white. (Adult males.)

b. Under parts and anterior upper parts purplish black; tail more extensively white basally. (Western Panamá.)

Microchera albo-coronata, adult male (p. 581).

bb. Under parts and upper parts (except pileum) metallic reddish purple; tail less extensively white basally. (Costa Rica.)

Microchera parvirostris, adult male (p. 582).

aa. Under parts very pale gray or grayish white; pileum metallic greenish.

$b$. Lateral rectrices with basal half white and white tip broader.

Microchera albo-coronata, adult female (p. 581).

$b b$. Lateral rectrices mostly black (only the extreme base whitish or grayish) and white tip narrower............ Microchera parvirostris, adult female (p.582).

\section{MICROCHERA ALBO-CORONATA (Lawrence).}

VERAGUAN SNOW-CAP.

Adult male.-Entire pileum immaculate satiny white, the feathers distinctly outlined, producing a squamate or imbricated effect; nape and hindneck purplish black, passing into very dark metallic reddish coppery purple on back, scapulars, and wing-coverts, this into much brighter coppery purple on rump and upper tail-coverts; middle pair of rectrices dark coppery bronze; other rectrices white for basal twothirds (approximately), black terminally, the outermost narrowly margined at tip with grayish; remiges dusky faintly glossed with purplish; under parts (except under tail-coverts) and sides of head black, glossed with metallic reddish purple when viewed from behind; under tail-coverts white; bill black; iris dark brown; feet lusky; length (skins), 61-63 (62); wing, 39-41.5 (40.5); tail, 20-20.5 (20.2); culmen, 11-11.5 (11.2). ${ }^{a}$

Adult female.-Pileum and hindneck dark metallic green; rest of upper parts brighter green, passing into bronze on upper tail-coverts and middle rectrices; other rectrices white for basal half and black terminally or subterminally, the two outermost pairs broadly tipped with white; reniges as in adult male; under parts plain pale gray anteriorly, fading into white posteriorly; bill, etc., as in adult male; length (skin), 66; wing, 40.5; tail, 19.5; culmen (bill broken). ${ }^{b}$

Immature male. - Similar to the adult female, but pileum bordered laterally by a superciliary stripe of white (forehead sometimes grayish), and under parts mixed more or less (according to age) with blotches or areas of purplish black.

Western Panamá (Belén, Cordillera del Chucu, and Santiago, Verágua); Costa Rica? 
Mellisuga albo-coronata Lawrence, Ann. Lyc. Nat. Hist. N. Y., vi, 1855, 137, pl. 4 (Belén, Verágua, Panamá; coll. G. N. Lawrence).-Salvin, Proc. Zool. Soc. Isond.; 1870, 207 (Cordillera del Chucu, Panamá).

Microchera albocoronata Gould, Mon. Troch., ii, pt. xvi, 1858, pl. 116; Introd. Troch., oct. ed., 1861, 82.-Lawrence, Ann. Lyc. N. Y., ix, 1868, 122 ("Costa Rica").-Salvin, Proc. Zool. Soc. Lond., 1867, 154 (Santiago, Verágua; crit.); 1870, 207 (Cordillera del Chucu, Verágua); Cat. Birds Brit. Mus., xvi, 1892, 66.-Frantzius, Journ. für Om., 1869, 315 ("Costa Rica").Mulsan't and Verreaux, Hist. Nat. Ois.-Mouch., ii, livr. 4, 1876, pl. 32; iii, livr. 2, 1876, 134, pl. 81.-Elliot, Classif. and Synop. Troch., 1879, 104.Zeledón, Cat. Aves de Costa Rica, 1882, 20; Anal. Mus. Nac. Costa Rica, i, 1887, 121.-Ridgway, Rep. U. S. Nat. Mus., for 1890 (1891), pl. 34, fig. 2.-Salvin and Godman, Biol. Centr.-Am., Aves, ii, 1892, 268.-Boucard, The Hum. Bird, ii, 1892, 74 (Verágua); Gen. Hum. Birds, 1892, 51.

[Microchera] albo-coronata Sclater and Salvin, Nom. Av. Neotr., 1873, 83. [Microchera] albocoronata Mulsant, Ann. Soc. Linn. Lyon, n. s., xxii, 1876, 220. $M[$ icrochera] albocoronata HaRtert, Das Tierreich, Troch., 1900, 215 (monogr.). [Microchera] albicoronata SHarpe, Hand-list, ii, 1900, 143.

Chrysolampis albocoronata Mulsant and Verreaux, Classif. Troch., 1865, 57. [Topaza] albocoronata GraY, Hand-list, i, 1869, 134, no. 1724.

\section{MICROCHERA PARVIROSTRIS (Lawrence).}

\section{COSTA RICAN SNOW-CAP.}

Similar to $M$. albocoronata, but white at base of lateral rectrices more restricted and less sharply defined, the adult male with the general color brighter coppery purple.

Aduli male.-Forehead and crown wholly pure silky white; rest of upper parts (except tail, remiges, and primary coverts) metallic coppery purple; ${ }^{a}$ middle rectrices bronze or coppery bronze, the other rectrices with basal half or more pale gray or grayish white (shafts pure white), the terminal portion blackish, more or less glossed with bronzy, and (except in worn plumage) with a narrow terminal margin of white; chin and throat dull dusky greenish bronze; under tail-coverts white; rest of under parts rich dark coppery purple; remiges purplish dusky, the primary coverts similar but darker; bill black; iris dark brown; feet dusky; length (skins), 62-70 (66); wing, 41-43 (42); tail, 19-21 (20.1); exposed culmen, $11-12(11.6) .^{b}$

Adult female.-Above, including forehead and crown, metallic bronzy green; tail and remiges as in the adult male but lateral rectrices broadly tipped with white; lores and auricular region grayish; under parts grayish white, tinged with pale brownish gray laterally; bill, etc., as in adult male; longth (skins), 61-70 (65); wing, 39-42 (40.3); tail, 17.5-20.5 (19.3); exposed culmen, 11-13 $(12.1) \cdot{ }^{b}$ 
Immature male.-Similar to the adult female but upper parts more bronzy (intermixed with coppery feathers in older specimens); tail as in adult male; median under parts coppery purple (more or less extensively).

Caribbean slope of Costa Rica (Angostura; Tucurríqui; Turrialba; Bonilla; Carrillo; Rio Súcio; Puerto Limón; La Balsa; La Vijagua) and Nicaragua (Chontales; Matagalpa).

Panychlora parvirostris Lawrence, Proc. Ac. Nat. Sci. Philad., 1865, 39 (Angostura, Costa Rica; coll. U. S. Nat. Mus.).

Microchera parvirostris Salvin, Proc. Zool. Soc. Lond., 1867, 154, in text (Tucurríqui, Costa Rica; crit.); Ibis, 1872, 313, 319 (Chontales, Nicaragua; crit.); 1892, 327 (Matagalpa, Nicaragua); Cat. Birds Brit. Mus., xvi, 1892, 67, 656 (La Balsa, Costa Rica, etc.).-Lawrence, Ann. Lyc. N. Y., ix, 1868, 122 (Angostura, Costa Rica; descr. adult male).-Frantzius, Journ. für Orn., 1869, 315 (Costa Rica).-Mulsant and Verreaux, Hist. Nat. Ois.-Mouch., iii, livr. 2, 1876, 136.-Boucard, Proc. Zool. Soc. Lond., 1878, 69 (Costa Rica); Gen. Hum. Bird, 1892, 51 (Chontales, Nicaragua; Limón, Costa Rica).-Elliot, Classif. and Synop. Troch., 1879, 104.-Gould, Suppl. Troch., 1880, pl. 30.-Zeledón, Cat. Aves de Costa Rica, 1882, 20; Anal. Mus. Nac. Costa Rica, i, 1887, 121 (Rio Súcio, Costa Rica).-Ridgway, Proc. U. S. Nat. Mus., vi, 1884, 415 (Rio Súcio, Costa Rica); Condor, vii, 1905, 157, in text (Bonilla, Costa Rica).-SAlvin and Godman, Biol. Centr.-Am., Aves, ii, 1892, 269.-Carriker, Ann. Carnegie Mus., vi, 1910, 551 (Caribbean slope of Costa Rica, 1,000-3,000 ft.; descr. nest).

[Microchera] parvirostris Sclater and Salvin, Nom. Av. Neotr., 1873, 83.Mulsant, Ann. Soc. Linn. Lyon, 1. s., xxii, 1876, 221.-Sharpe, Handlist, ii, 1900,143 .

M[icrochera] parvirostris Hartert, Das Tierreich, Troch., 1900, 216 (monogr.).

[Topaza] parvirostris Gray, Hand-list, i, 1869, 134, no. 1725.

\section{Genus MELLISUGA Brisson.}

Mellisuga Brisson, Orn., iii, 1760, 694. (Type, Trochilus minimus Linnæus.) Dyrinia Mulsant and Verreaux, Mém. Soc. Imp. Sci. Nat. Cherb., xii (sér. 2, ii), 1866, 232 (Classif. Troch., 1866, 88). (Type, Trochilus minimus Limmæus.)

Very small Trochilidæ (length about $55-60 \mathrm{~mm} .^{a}$ ) with bill shorter than head, straight, wing more than three times as long as exposed culmen, tail about half as long as wing, emarginate in adult male, rounded in female and young, the adult male without brilliant coloring on throat, which is dull whitish or grayish in both sexes.

Bill shorter than head, straight, relatively rather stout, broader than deep basally; culmen rounded except basally, where contracted into a rather distinct ridge; tomia smooth; mandible with the usual lateral median groove. Nasal operculum rather broad, convex, and tumid, nude, but hidden by appressed frontal feathering, which anteriorly extends about as far as anterior end of nostrils, forming a short obtuse point or antia on each side of culmen. Tarsus feathered, except on posterior side; lateral toes about equal in length, 
slightly shorter than middle toe. Wing decidedly more than three times as long as exposed culmen, the outermost primary longest, normal in shape. Tail about half as long as wing, in the adult malo emarginated, in adult female and young rounded, the rectrices (in both sexes) rounded at tip.

Coloration.-Above rather dark metallic green or bronze green, the tail blackish; beneath dull whitish or grayish, the under parts of body, especially laterally somewhat dusky; adult males without white on rectrices, females and young with lateral rectrices tipped with white.

Range.-Islands of Haiti and Jamaica, Greater Antilles. (Two species.)

KEY TO THE SPECIES OF MELLISUGA.

a. Tail deeply emarginate, the lateral rectrices wholly black. (Adult males.)

$b$. Much paler, the chest and median portion of breast and abdomen (broadly) white or grayish white, the upper parts, including rump and upper tail-coverts, clear metallic green; wiug, 35.5-38 (36.5); tail, 18-19.5 (18.7), middle rectrices, 14-15.5 (15). (Jamaica.)............ Mellisuga minima, adult male (p. 584).

$b b$. Much darker, the chest and median line of breast and abdomen (narrowly) light gray, the upper parts dark and dull metallic green, passing into blackish on rump and upper tail-coverts; wing, 34-36.5 (35.1); tail, 16.5-19 (17.9), middle rectrices, 12-14 (12.8). (Haiti.)

Mellisuga catharinæ, adult male (p. 586). aa. Tail rounded or double-rounded, the lateral rectrices broadly tipped with white.

(Adult females and young males.)

b. Lighter or more bronzy green above, clearer white beneath; wing, 36-39 (37.8); tail,19-21 (19.9); exposed culmen, 10-11.5 (11).

Mellisuga minima, adult female (p. 585).

$b b$. Darker or more blnish green above, more grayish white or pale gray below; wing, 36-40 (37.1); tail, 18.5-21 (19.5); exposed culmen, 10-11.5 (10.8).

Mellisuga catharinæ, adult female (p. 586).

\section{MELLISUGA MINIMA (Linnæus).}

VERVAIN HUMMING BIRD.

Adult male.-Above rather dull metallic bronze-green or greenish bronze, usually more or less darker or duller on pileum; middle pair of rectrices metallic bronze-green or greenish bronze, darker (sometimes blackish) subterminally; rest of tail black, faintly glossed with bluish or greenish; remiges dusky, faintly glossed with violet or bluish; under parts dull white (purer white on chest and abdomen), the sides and flanks metallic bronze-green or greenish bronze; chin (occasionally throat also) sometimes flecked with grayish or dull bronzy, and under tail-coverts sometimes with a central spot (more or less large) of grayish bronzy; bill dull black; iris dark brown; feet dusky; length (skins), 57-64 (61); wing, 35.5-3S (36.5); tail, 1S-19.5 (18.7), midllle rectrices, 14-15.5 (15); exposed culmen, 10-10.5 $(10.1) .^{a}$ 
Adult female.-Similar to the adult male, but two lateral rectrices (on each side) broadly tipped with white, the third usually with a small white or grayish white terminal spot; length (skins), 59-68 (63); wing, 36-39 (37.8); tail, 19-21 (19.9); exposed culmen, 10-11.5 (11). ${ }^{a}$

Island of Jamaica (Kingston; Spanishtown; Priestmans River; Port Henderson; Hope Gardens).

[Trochilus] minimus LinNæus, Syst. Nat., ed. 10, i, 1758, 121 (based on Mellisuga avis minima Sloane, Jamaica, 307, pl. 364, fig. 1; Polytmus minimus variegatus Brown, Jamaica, 475, pl. 364, fig. 1; Least Humming Bird Edwards, Nat. Hist., i, pl. 105); ed. 12, i, 1766, 193.—GMeLiN, Syst. Nat., i, pt. 1, 1788, 500.Lathaм, Index Orn., i, 1790, 320.

(?) Trochilus minimus Audenert and Vienlot, Ois. Dorés, i, 1802, 113, pl. 64, part.-Vieillot, Nouv. Dict. d'Hist. Nat., vii, 1817, 369, part.-Lesson, Index Gen. et Synop. Troch., 1832, p. xxvii.

T[rochilus] minimus Vieillot, Tab. Enc. Meth., ii, 1822, 568, part.

Ornismya minima Lesson, Hist. Nat. Ois.-Mouch., 1829, pp. xxxii, 213.

[Mellisuga] minimus Bonaparte, Consp. Av., i, 1850, 81, part ("Antilles").

Mellisuga minima Reichenbach, Aufz. der Colibr., 1854, 6, part; Troch. Enum., 1855, 3, pl. 680, fig. 4490.-Gould, Mon. Troch., iii, pt. ii, Nov., 1851 (vol. iii, 1861, pl. 133), part; Introd. Troch., oct. ed., 1861, 87, part.-Sclater, Cat. Am. Birds, 1862, 297 (Jamaica).-MARch, Proc. Ac. Nat. Sci. Phila., 1863, 285 (Jamaica).-Eццiot, Ibis, 1872, 354, part (Jamaica; synon.; crit.); Classif. and Synop. Troch., 1879, 103, part (Jamaica).-Mulsant and VerREAUX, Hist. Nat. Ois.-Mouch., iv, livr. 2, 1877, 82, part, pl. 106, figs. 1, 2 (Jamaica).-Cory, Auk, iii, 1886, 354, part (Jamaica); Birds West Ind., 1889, 149, part (Jamaica); Cat. West Ind. Birds, 1892, 13, 107, part (Jamaica).Ridgway, Rep. U. S. Nat. Mus. for 1890 (1891), pl. 17 (bird, nest, and eggs; Jamaica).-Salvin, Cat. Birds Brit. Mus., xvi, 1892, 409, part (Jamaica).Sсотт, Auk, ix, 1892, 277 (Jamaica).-Frein, Auk, xi, 1894, 126 (Port Henderson, Jamaica; descr. nest).-Boucard, Gen. Hum. Birds, 1892, 6, part (Jamaica).-Lodge, Ibis, 1896, 503 (Jamaica; habits).-Nicoll, Ibis, 1904, 577 (Kingston, Jamaica; notes).

[Mellisuga] minima Bonaparte, Rev. et Mag. de Zool., 1854, 257.-Sclater and Salvin, Nom. Av. Neotr., 1873, 84, part (Jamaica).-Mulsant, Ann. Soc. Linn. Lyon, n. s., xxii, 1876, 227, part (Jamaica).-Corr, List Birds West Ind., 1885, 18, part (Jamaica).-Sharpe, Hand-list, iii, 1900, 142, part (Jamaica).

M[ellisuga] minima Newton (A. and E.), Handb. Jamaica, 1881, 108.-Hartert, Das Tierreich, Troch., 1900, 212, part (Jamaica).

Zephyritis (Dyrinia) minima Mulsant and Verreaux, Classif. Troch., 1866, 88, part (Jamaica).

[Hylocharis] minima GRAY, Hand-list, i, 1869, 150, no. 1941, part (Jamaica).

Trochilus minutulus Vieillot, Ois. Am. Sept., ii, 1807, 73 (new name for " $T$. minutus L. Gm.," i. e., T. minimus Linnæus).

Mellisuga humilis Gosse, Birds Jamaica, 1847, 127; Illustr. Birds Jam., 1849, pl. 21.-March, Proc. Ac. Nat. Sci. Phila., 1863, 285 (Jamaica).

Mellisuga humila Albrecht, Journ. für Orn., 1862, 201 (Jamaica).

Trochilus pygmaeus (not of Spix, 1824) SwaInson, Birds of Brazil, Mex., etc., [1841?], pl. 78. 


\section{MELLISUGA CATHARINE (Salle).}

HAITIAN VERVAIN HUMMING BIRD.

Similar to $M$. minima but adult male much darker (both above and below), with wing and tail longer, the latter more deeply forked, the adult female slightly darker below.

Adult male.-Above dark dull metallic green, darker (sometimes nearly black) on rump and upper tail-coverts; tail black, including middle rectrices; remiges dusky, very faintly glossed with purplish; auricular and suborbital regions deep sooty gray; chin, throat, and chest pale gray, the first two with feathers dusky gray centrally producing a spotted effect; under parts of body dark metallic green, intermixed along median line with gray; under tail-coverts dark metallic green narrowly margined with pale gray and with base of feathers grayish; femoral and lumbar tufts white; bill dull black; iris dark brown; feet dusky; length (skins), 57-66 (62); wing, 34-36.5 (35.1); tail, 16.5-19 (17.9), middle rectrices, 12-14 (12.8). ${ }^{a}$

Adult female.-Above rather dark metallic green, bluish green or (rarely) bronze-green, including basal two-thirds (approximately) of middle rectrices; lateral and terminal or subterminal portion of middle rectrices black, the outermost pair broadly, the next less broadly tipped with dull white, the third sometimes narrowly tipped with the same; remiges dusky, faintly glossed with purplish; under parts pale gray, paler (nearly grayish white) on chin, throat, and abdomen, deepening into sooty gray laterally (especially on auricular and suborbital regions and sides of neck), the sides and flanks glossed with metallic green; bill, etc., as in adult male; length (skins), 65-71 (68); wing, 36-40 (37.1); tail, 18.5-21 (19.5); culmen, 10-11.5 (10.8). ${ }^{b}$

Immature male.-Similar to the adult female but feathers of chin and throat with a darker gray mesial streak, and sides more strongly or extensively glossed with green.

Island of Haiti (Le Coup and Port au Prince, Haiti; Catare, Samaná Bay, Sanchez, La Vega, Honduras, Caña Honda, La Canita, San Francisco Mountains, and Rio San Juan, Santo Domingo).

(??) [Trochilus] niger Linnæeus, Sys. Nat., ed. 10, 1758, 121 (Indiis); ed. 12, pt. 1, 1766, 192.-Guelis, Syst. Nat., i, pt. i, 1788, 496.

Trochilus niger (not of Linnæus?) VierLlot, Ois. Am. Sept. i, 1807, 73 (L'Oiseaumouche à ventregris).

Trochilus mellisugus (not of Latham) Vreillot, Nouv. Dict. d'Hist. Nat., vii, 1817, 363, part (Santo Domingo $c$ ).

II[ylocharis] nigra Gray and MitchelL, Gen. Birds, i, 1844, 114.

[Ornismya] niger Bonaparte, Consp. Av., i, 1850, 81 (Santo Domingo).

Trochilus minimus (not of Linnæus) Audebert and Vieillot, Ois. Dorés, i, 1802, 113, pl. 64, part.-Vieillot, Nouv. Dict. d'Hist. Nat., vii, 1817, 369, part.Lesson, Index Gen. et Synop. Troch., 1832, p. xxvii, part.-Bryant, Proc.

$a$ Seven specimens.

$b$ Six specimens.

c Cites also Cayenne and Porto Rico! 
Bost. Soc. N. H., 1867, 95 (Santo Domingo).-Mulsant and Verreaux, Hist.

Nat. Ois.-Mouch., Suppl., pl. 46, figs. 1, 2.

T[rochilus] minimus Vieılot, Tab. Enc. Méth., ii, 1822, 568, part.

[Mellisuga] minimus Bonaparte, Consp. Av., i, 1850, 81, part ("Antilles").

Ornismya minima (not Trochilus minimus Linnæus) Lesson, Hist. Nat. Ois.-

Mouch., 1829, pp. xxxii, 213, pl. 79 (Santo Domingo); Index Gen. et Synop.

Troch., 1832, p. xxvii (Santo Domingo).

Mellisuga minima Gould, Mon. Troch., pt. ii, Nov., 1851 (vol. iii, 1861, text to pl. 133), part (Santo Domingo); Introd. Troch., oct. ed., 1861, 87, part (Santo Domingo).-Reichenbach, Aufz. der Colibr., 1854, 6, part (Santo Domingo); Troch. Enum., 1855, 3, pl. 680, fig. 4490, part (Santo Domingo).—Sallé, Proc. Zool. Soc. Lond., 1857, 233 (Santo Domingo).-Sclater, Cat. Am. Birds, 1862, 297, part (synonymy only).-Elurot, Ibis, 1872, 354, part (Santo Domingo; synon.; crit.); Classif. and Synop. Troch., 1879, 103, part (Santo Domingo).-Mulsant and Verreaux, Hist. Nat. Ois.-Mouch., iv, livr. 2, 1877, 82, part (Santo Domingo).-Cory, Birds Haiti and San Dom., 1855, 92, pl. (22), fig. 6; Auk, iii, 1886, 354, part (Santo Domingo); Birds West Ind., 1889, 149 (Santo Domingo); Cat. West Ind. Birds, 1S92, 103, 107, part (Santo Domingo).-Salvin, Cat. Birds Brit. Mus., xvi, 1892, 409, part (Santo Domingo).-Boucard, Gen. Hum. Birds, 1895, 6, part (Haiti and Santo Domingo).-Cherrie, Contr. Orn. San Dom., 1896, is (song).-Chris'ry, Ibis, 1897, 329 (Sanchez and La Vega, Santo Domingo; habits).

[Mellisuga] minima Sclater and Salvin, Nom. Av. Neotr., 1873, 84, part (Haiti).-Mulsant, Ann. Soc. Linn. Lyon, xxii, 1876, 227, part (Haiti).Cory, List Birds West Ind., 1885, 18, part (Haiti).--Sharpe, Hand-list, ii, 1900, 142, part (Haiti).

M[ellisuga] minima Hartert, Das Tierreich, Troch., 1900, 212, part (Haiti and Santo Domingo).

Zephyritis (Dyrinia) minima Mulsant and Verreaux, Classif. Troch., 1866, 8S, part.

[Hylocharis] minima Grax, Hand-list, i, 1869, 150, no. 1941, part (Santo Domingo). Trochilus vielloti SHAw, Gen. Zool., viii, pt. 1, 1812, 347 (based on 'L'Oiseaumouche à ventre gris Viell., pl. 53." Santo Domingo).

Ornismia catharina SAllé, Rev. et Mag. de Zool., Oct., 1849, 498 (Santo Domingo).

\section{Genus STELLULA Gould.}

Stellula GousD, Introd. Troch., oct. ed., 1861, 90. (Type, Trochilus calliope Gould.)

Stellura (emendation?) Mulsant and Verreaux, Classif. Troch., 1865, 88; Hist. Nat. Ois.-Mouch., iv, 1877, 87. (Type, Trochilus calliope Gould.)

Small Trochilidx (length about $65-75 \mathrm{~mm}$.) resembling Atthis but differing in longer tenth primary, relatively shorter and differently shaped and differently colored tail, with subspatulate middle rectrices (in both sexes), and in the very narrow and much elongated throat ("gorget") feathers of the adult male.

Bill about as long as head or slightly longer, slender, straight, nearly terete; culmen rounded but at extreme base contracted into a rather distinct ridge; tomia smooth; mandible with the usual lateral median groove or sulcus. Nasal operculum covered by the appressed frontal feathering, which anteriorly extends considerably beyond nostrils, forming a very short obtuse point or antia on each side of culmen. 
Tarsus feathered, except on posterior side; lateral toes about equal in length, slightly shorter than middle toe. Wing about three times as long as exposed culmen, the outermost primary longest, not attenuated at tip. Tail about half as long as wing, double-rounded, the rectrices broadest subterminally, subspatulate (especially the middle pair) in adult male, in adult female rounded, with rectrices less distinctly subspatulate.

Coloration.-Above metallic bronze-green; beneath dull whitish medially and on chest, cinnamon-buffy laterally; adult male with narrow, elongated feathers of throat pure white basally, metallic reddish purple terminally, the tail (including middle rectrices) blackish passing into sooty grayish terminally and edged with cinnamon-rufous basally; adult female with throat whitish, sometimes flecked with dusky, middle rectrices bronze-greenish, other rectrices grayish basally (with shaft of that portion pale cinnamon) black subterminally or terminally, the two or three outermost tipped with white.

Range.-British Columbia to central Mexico. (Monotypic.)

\section{STELLULA CALLIOPE (Gould).}

\section{CALLIOPE HUMMING BIRD.}

Adult male.-Above metallic bronze-green, usually rather duller on forehead; middle pair of rectrices subspatulate or with subterminal portion contracted, dull purplish black or dusky, edged basally (more or less distinctly) with cinnamon-rufous, and broadly tipped with dull brownish gray; remaining rectrices similar in coloration, but cinnamomeous basal edgings less distinct (sometimes obsolete) and grayish tip less distinct; remiges dull brownish slate or dusky, very faintly glossed with purplish; feathers of gorget narrow and distinctly outlined, much elongated posteriorly, pure white basally and metallic reddish purple (solferino) terminally, the basal white much exposed, especially on chin and upper throat; foreneck and chest white, or grayish white; rest of under parts more grayish, strongly tinged or suffused with cinnamon-buff laterally, the sides glossed, or overlaid, with metallic bronze-green, the under tail-coverts white, tinged with cinnamon-buff toward anal region; maxilla dull black or dusky; mandible dusky terminally, more brownish (flesh-color in life) basally; iris dark brown; feet dusky; length (skins), 66-73 (69); wing, 37-40 (38.7); tail, 19.5-20.5 (20); exposed culmen, 13.5-15 (14.3). ${ }^{a}$

Adult female.-Above metallic bronze-green or greenish bronze (usually much more bronzy than in adult male); remiges brownish slate or dusky, very faintly glossed with purplish; middle pair of rectrices dull bronze-green or greenish bronze, sometimes with terminal portion (more or less extensively) purplish dusky or 
blackish; next pair dull bronze-green with terminal third (more or less) black, the subbasal portion edged (on both webs), more or less distinctly, with cinnamon-buff; next pair similar but with the black relatively more extended and with an apical spot (usually small and wedge-shaped) of white; next similar but white apical spot larger and basal half mostly brownish gray; outermost rectrix like the last but only about the basal third grayish and white apical spot still larger; auricular region light brownish gray; a dusky triangular space in front of eye; chin and throat dull brownish white, usually more or less streaked or flecked with dusky or bronzy brownish; chest pale grayish cinnamon-buff or dull whitish, the median portion of breast and abdomen similar; sides and flanks cinnamon or deep cinnamon-buff, the under tail-coverts similar but paler; femoral tufts and tuft on each side of rump white; bill, etc., as in adult male; length (skins), 69-80 (75); wing, 41-44 (42.8); tail, 19.5-22.5 (21.5); exposed culmen, 15-16 (15.6). ${ }^{a}$

Young male.-Apparently not essentially if at all different from the adult female but older individuals with some metallic purple or purplish red feathers on middle of throat.

Young female.-Similar to the adult female but general color of upper parts more decidedly bronzy, with feathers very narrowly and indistinctly margined terminally with dull brownish or grayish buffy.

Western United States and British Columbia, south in winter over western and central Mexico; north to British Columbia (both sides of Cascade range, southern Rocky Mountains, and interior districts), and northern Idaho (Fort Sherman); east to Montana (Belt Mountains; Fort Ellis; Bear Creek; McDonald County), Colorado (Cheyenne Canyon; near Breckinridge, 9,500 feet; Antonito), New Mexico (Inscription Rock; Santa Fé Mountains; Pecos River; Pecos Baldy; El Moro; Hondo Canyon), and extreme western Texas (El Paso); breeding in mountains, chiefly above 5,000 feet, nearly to southern border of United States. Mexican localities: Sinaloa (Los Pieles); Michoacán (Patzcuaro, October); Guerrero (Amula); Mexico (near City of Mexico; Ajusco; Tetelco; Cerro de Guadalupe Pedregál); Aguas Calientes (Calvillo).

Trochilus (Calothorax) calliope Goubd, Proc. Zool. Soc. Lond., 1847, 11 (Mexico; coll. J. Gould?).

C[alothorax $]$ calliope Gray, Gen. Birds, i, Dec., 1848, 110.

[Calothorax] calliope Bonaparte, Consp. Av., i, 1850, 85.-Gray, Hand-list, i, 1869,135 , no. 1735 .

Calothorax calliope Gould, Mon. Troch., pt. xv, Sept., 1857; vol. iii, 1861, pl. 142.-Xantus, Proc. Ac. Nat. Sci. Phila., 1859, 190 (Ft. Tejon, California).-D'Oca, La Naturaleza, iii, 1875, 27 (Valley of Mexico); Troq. de Mex., 1875, 18, pl. (3), fig. 10. 
[Callothorax] calliope Bonaparte, Rev. et Mag. de Zool., 1854, 257.

Callothorax calliope Felloner, Ann. Rep. Smithson. Inst. for 1864 (1865), 429 (Yreka, n. California, breeding).

[Lucifer. o. Calothorax] calliope Reichenbach, Aufz. der Colibr., 1854, 13.

[Lucifer] calliope Reichenbach, Troch. Enum., 1855, 10.

Stellula calliope Gould, Introd. Troch., oct. ed., 1861, 90.-Elliot, Illustr.

New and Unfig. N. Am. Birds, i, 1869, pl. 23; Classif. and Synop. Troch., 1879, 115.-Cooper, Orn. Cal., 1870, 363; Proc. Calif. Ac. Sci., 1875, 12 (Haywards, Alameda Co., California); 1876, 90 (Haywards).-Coues, Check List, 1873, no. 282; 2d ed., 1882, no. 417.-Merriam, Sixth An. Rep. U. S. Geol. Surv. Terr., 1872, 693 (Ft. Ellis, Montana); North Am. Fauna, no. 16, 1899, 117 (Mt. Shasta, California).-Baird, Brewer, and Ridgway, Hist. N. Am. Birds, ii, 1874, 445, pl. 47, fig. 9.-Yarrow and Henshaw, Rep. Orn. Spec. Wheeler's Surv. for 1871-73 (1874), 35 (Nevada).-Henshaw, Rep. Orn. Wheeler's Surv. for 1873 (1874), 130, 162 (Camp Grant, White Mts., and Apache, Arizona; Inscription Rock, New Mexico); Zool. Expl. W. 100th Merid., 1875, 372 (localities in Nevada, Arizona, and New Mexico); Orn. Wheeler's Surv., 1876, 256 (mts. of California); 1879, 311 (range; habits); Auk, iii, 1886, 78 (upper Pecos R., New Míexico; habits).-RidgwAy, Bull. Essex Inst., vi, 1874, 174 (Sierra Nevada, near Carson City); vii, 1875, 21 (Ruby Mts., Nevada), 33 (Parleys Park, Utah); Orn. 40th Parallel, 1877, 563 (localities in Nevada and Utah); Proc. U. S. Nat. Mus., iii, 1880, 187, 314; Nom. N. Am. Birds, 1881, no. 343; Rep. U. S. Nat. Mus. for 1890 (1891), 354, pls. 1, 2, 3, 41 (monogr.); Man. N. Am. Birds, 2d ed., 1896, 598.-Villada, La Naturaleza, ii, 1874, 359 (Cerro de Guadalupe Pedregál, Mexico).-Boucard, Notes Troch. du Mex., 1875, 5; Gen. Hum. Birds, 1895, 13 (near City of Mexico).-Belding, Proc. U. S. Nat. Mus., i, 1879, 391, 393, 426 (Murphys and Big Trees, Calaveras Co., California).Hofrman, Bull. U. S. Geol. and Geog. Surv. Terr., vi, 1881, 237 (Prospect Hill, Nevada; Owens Valley, California).-Williams, Bull. Nutt. Orn. Club, viii, 1883, 59 (Belt Mts., Montana).-Salvin, Cat. Birds Brit. Mus., xvi, 1892, 413 (lat. $48^{\circ} 40^{\prime}$ N.; Amula, Guerrero, etc.).-SALvin and GodmaN, Biol. Centr.-Am., Aves, ii, 1892, 362.-Fisher (A. K.), N. Am. Fauna, no. 7, 1893, 59 (Crockers, near Yosemite Valley; Tejon Mts.).-RHoAds, Proc. Ac. Nat. Sci. Phila., 1893, 44 (s. Rocky Mts. and interior distr. Brit. Columbia).-American Ornithologists' Union Committee, Auk, $x$, 1893, 62; Check List, 2d ed., 1895, no. 436; Check List, 3d ed., 1910, 204.Richmond and Knowlton, Auk, xi, 1894, 304 (Bear Creek, s.-centr. Montana, Aug.).-Bendire, Life Hist. N. Am. Birds, ii, 1895, 219.-McGregor, Auk, xiv, 1897, 92 (Oakland, California, April).-Merrill, Auk, xiv, 1897, 355 (Ft. Sherman, Idaho, breeding).-Cooke, Bull. 44 Col. Agric. Coll., 1898, 163 (Cheyenne Canyon, Colorado, July); no. 56, 1900, 208 (near Breckinridge, Colorado, 9,500 ft., June 30); $\Lambda u k$, xxvi, 1909, 413 (Antonito, Colorado, Aug.).-Grinneli (J.), Pub. 2, Pasadena Ac. Sci., 1898, 28 (Los Angeles Co., California, breeding above 5,000 ft.); Auk, xxii, 1905, 384 (Mt. Piños, California, 6,500-8,500 ft.); Univ. Calif. Pub. Zool., v, 1908, 72 (San Bernardino Mts., California, breeding in Canadian zone; habits).Silloway, Bull. Univ. Mont., no. 3, 1901, 54 (McDonald Lake, etc., Montana, breeding.-DAwson, Auk, xviii, 1901, 401 (Okanogan, Chelan Co., Washington).-BAILEY (Florence M.), Handb. Birds W. U. S., 1902, 241, fig. 320;

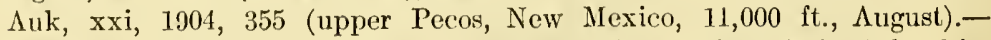
Brooks, $\Lambda$ uk, xx, 1903, 282 (w. of Clinton, Lilloet Distr., Brit. Columbia, breeding).-Wroman , $\Lambda u k$, xxi, 1904, 69(Yosemite Valley).-Miller(L. II.), Condor, vi, 1904, 103 (John Day R., Oregon).--Swar'm, Pacific Coast $\Lambda$ vi- 
fauna, no. 4, 1904, 19 (Huachuca Mts., Arizona, above 9,000 ft., in migration).-Miller (W. De W.), Bull. Am. Mus. N. H., xxi, 1905, 355 (Dos Pieles; s. Sinaloa, 1 spec., April 17).-Bowles, Auk, xxiii, 1906, 144 (Tacoma, Washington, 1 spec., May 10); Condor, x, 1908, 192 (Lake Chelan, Washington, breeding).-JoHsson, Condor, viii, 1906, 27 (Cheney, Washington, transient).-Sheldon, Condor, ix, 1907, 189 (Eagle Lake, n. California, July).-Ebson, Auk, xxv, 1908, 434 (Bellingham Bay, Washington, rare).Kermode, Prov. Mus., 1909, 52 (both sides of Cascade range, Brit. Columbia). [Stellula] calliope Sclater and Salvin, Nom. Av. Neotr., 1873, 84.

S[tellula] calliope Coues, Key N. Am. Birds, 2d ed., 1884, 465.

Zephyritis (Stellura) calliope Mulsant and Verreaux, Classif. Troch., 1866, 88. [Stellura] calliope Mulsant, Ann. Soc. Linn. Lyon, n. s., xxii, 1876, 227.

Stellura calliope Mulsant and Verreaux, Hist. Nat. Ois.-Mouch., iv, livr. 2, $1877,87$.

Selasphorus calliope Xantus, Proc. Ac. Nat. Sci. Phila., 1859, 190 (Ft. Tejon, California).

Trochilus calliope American Ornithologists' Union, Check List, 1886, no. 436.-Scotr, Auk, iii, 1886, 431 (Santa Catalina Mts., Arizona, 5,000 ft., April, August).-Townsend (C. H.), Proc. U. S. Nat. Mus., x, 1887, 209 (lower McCloud R., California; descr. nests, etc.).-Merrill, Auk, v, 1888, 257 (Ft. Klamath, Oregon; habits, etc.; descr. nest).-F ANn IN, Check List, Birds Brit. Col., 1891, 30 (both sides of Cascade Range).-LAwrence (R. H.), Auk, ix, 1892, 44 (Grays Harbor, Washington, summer resid.).

T[rochilus] calliope Ridgway, Man. N. Am. Birds, 1887, 316. A[tuis] calliope Hartert, Das Tierreich, Troch., 1900, 211.

[Atthis] calliope Sharpe, Hand-list, ii, 1900, 142.

\section{Genus ATTHIS Reichenbach.}

[Trochilus.] o. Atthis Reichenbach, Aufz. der Colibr., 1854, 12. (Type, Ornismya heloisa Lesson and Delattre.)

Small Trochilidæ (length about $65-70 \mathrm{~mm}$.) related to Selasphorus but differing in form and coloration of the tail in the adult male, which is slightly rounded, with rectrices broadly rounded at tip, the lateral rectrices with basal half (more or less) cinnamon-rufous, succeeded by a black band and white terminal spot; gorget with feathers rather more strongly individualized and relatively longer, especially the lateral ones.

Bill about as long as head or slightly shorter, slender, straight, nearly terete; culmen rounded, slightly contracted or indistinctly ridged at extreme base; tomia smooth; mandible with the usual lateral median groove. Nasal operculum hidden by appressed frontal feathering, which anteriorly extends beyond nostrils, forming a very short obtuse point or antia on each side of culmen. Tarsus feathered, except along posterior side; outer toe slightly shorter than middle toe, the inner toe decidedly shorter, hallux (apparently) shorter than outer toe. Wing about three times as long as exposed culmen, the outermost primary, or two outermost, longest, the outermost narrower and abruptly more or less attenuated (but not acuminate) terminally, Tail about three-fifths as long as wing, rounded, the 
rectrices broadly rounded terminally (similar in form, and essentially so in coloration, in the two sexes).

Coloration.-Abore metallic bronze-green, greenish bronze, or bronze, including middle rectrices; tail (except middle rectrices) cinnamon-rufous or rufescent basally, black subterminally, white or whitish at tip, in both sexes; chest dull whitish. Adult male with chin and throat brilliant metallic reddish purple, changing to violet or blue; rufous of lateral rectrices occupying basal half or more. Adult female with throat whitish, flecked with bronze or dusky; sides, flanks, and under tail-corerts suffused with cinnamon buffy, and rufous of lateral rectrices duller and inrolving less than basal half.

Range.-Mexico (including adjacent parts of Arizona) to highlands of Guatemala. (Three species or subspecies.)

\section{ATTHIS HELOISA HELOISA (Lesson and Delattre).}

\section{HELOISE'S HUMMING BIRD.}

Adult male.-Above metallic bronze-green, greenish bronze, or golden bronze (sometimes tinged with copper-bronze on back); middle pair of rectrices metallic bronze-green or greenish bronze (sometimes dusky at tip), both webs edged for basal half or more with cinnamon-rufous; next pair of rectrices with basal half or more cinnamon-rufous, the terminal portion black, this usually separated from the cinnamon-rufous by a space of bronze-green or greenish bronze; other rectrices with basal half or more cinnamon-rufous, the subterminal portion (extensively) black (usually with more or less of bronze-green or greenish bronze between the black and the cinnamon-rufous portion), the tip (broadly) white; remiges brownish slate color or dusky, rery faintly glossed with riolaceous; sides of head brownish gray or grayish brown, passing into dull white on anterior portion of malar region and on postocular region; chin and throat brilliant metallic magenta purple, changing to bluish purple and eren, partly, to greenish blue, according to different inclinations of the light, the more posterior feathers of the throat much elongated, especially laterally; chest, sides of neck, breast (medially), abdomen, and under tail-corerts dull white, or grayish white; sides and flanks light cinnamon-rufous, orerlaid, more or less extensively, by metallic bronze or bronze-green; bill dull blackish; iris dark brown; feet dusky; length (skins), 59-71 (68); wing, 32.5-38 (34.6); tail, 19-22.5 (20.7); exposed culmen, $11.5-13$ (12.1). ${ }^{a}$

Adult female.-Above similar to the adult male, but tail with relatively much more black and less cinnamon-rufous, the latter also duller, especially on lateral rectrices, the middle pair of rectrices 
without cinnamon-rufous edgings, the white tips also less purèly white, those of inner rectrices sometimes cinnamomeous; chin and throat white, conspicuously spotted with metallic bronze; rest of under parts as in the adult male, but sides and flanks more extensirely and uniformly cinnamon-rufous, and under tail-coverts more or less strongly tinged with the same; length (skins), 64-75 (69); wing, 35.5-38 (36); tail, 19-23 (21.2); exposed culmen, 11.5-13 (12.4). ${ }^{a}$

Young male.-Similar to the adult female, but tail, sides, and flänks as in adult male (the middle pair of rectrices, howerer, wholly bronze-green or greenish bronze).

Central and southern Mexico, in States of Tamaulipas (Galindo; Realito), Guanajuato, San Luís Potosí (Sierra San Luís Potosí), Aguas Calientes(Calvillo), Vera Cruz (Jalapa; Córdora; Orizaba; San Lorenzo; Cuesta de Misantla; Cofre de Perote; San Andrés Tuxtla), Mexico (Valley of Mexico), Oaxaca (15 miles west of Oaxaca Citr; Totóntepec), Guerrero (Omilteme; Chilpancingo) and Territory of Tepíc (Tepíc).

O[rnysmia] heloisa Lessox and Delattre, Rev. Zool., ii, no. 1, Jan., 1S39, 15 (Jalapa and Coátepec, Vera Cruz, Mexico).

M[ellisuga] heloisa Grar, Gen. Birds, i, Dec., 1848, 113.

T[ryphrna] heloisa Boxaparte, Rev. et Mag. de Zool., 1854, 257.

Tryphæna heloisæ Sclater, Proc. Zool. Soc. Lond., 1855, 297 (Oaxaca); -1859, 367 (Jalapa).

[Trochilus.] ò. Atthis heloisa Retchexвach, Aufz. der Colibr., 1854, 12.

[Trochilus] heloisa PieIcheNBACH, Troch. Enum., 1855, 10, pl. 835, figs. 49664968.-GRAY, Hand-list, i, 1869, 145, no. 1870.

Trochilus heloisa Ayericax Orsithologists' Uxiox, Check List, 1886, no. 435.Herrera, La Naturaleza, (2), i, 1891, 322 (Valley of Mexico).

T[rochilus] heloisa Ridgway, Man. N. Am. Birds, 1887, 315.

Selasphorus? heloisæ Gould, Mon. Troch., pt. viii, Oct., 1854, pl. 2; vol. iii, 1861, pl. 141.

Selasphorus heloisæ Sclater, Proc. Zool. Soc. Lond., 1856, 288 (Córdova, Tera Cruz); 1859, 386 (Totóntepec, Oaxaca); 1864, 177 (Talley of Mexico); Cat. Am. Birds, 1862, 298.-Mulsaxt and Terreaux, Classif. Troch., 1866, 89.Coues, Check List, 1873, no. 281.-D'OcA, La Naturaleza, iii, 1875, 19 (Jalapa); Troq. de Mex., 1S75, pl. (1), fig. 3.

[Selasphorus] heloisæ Coues, Key N. Am. Birds, 1872, 185.

Selasphorus heloisa D'OcA, Troq. de Mex., 1875, 9.

Atthis heloisæ Gould, Introd. Troch., oct. ed., 1861, S9.-Reichexbach, Auiz. der Colibr., 1854, 12.-Elliot, Illustr. New and Unfig. Birds N. Am., pt. xii, 1868, pl. (vol. i, 1869, pl. 21); Classif. and Synop. Troch., 1879, 113.Cooper, Orn. Calif., 1870, 361 ("Southern New Mexico;' error).-Botcard, Notes Troch. du Mex., 1875, 7, part (Córdova, Jalapa, Orizaba, and San Andrés Tuxtla, Vera Cruz); Gen. Hum. Birds, 1895, 12 (Jalapa; San Andrés Tuxtla).-Mulsaxt and Terreaux, Hist. Nat. Ois.-Mouch., iv, livr. 2, 1877, 91.- Villada, La Naturaleza, ii, 1874, 357 (Valley of Mexico).Ridgway, Proc. U. S. Nat. Mus., i, 1s7s, 10 (descr.; synon.; crit.); iii, 1s\$0, 
187, 314; Nom. N. Am. Birds, 1881, no. 342; Man. N. Am. Birds, 2 d ed., 1896, 598.-Coues, Check List, 2d ed., 1882, no. 416.-SAlvin, Cat. Birds Brit. Mus., xvi, 1892, 411 (Valley of Mexico; Sierra de San Luís Potosí; Cofre de Perote, Jalapa, and Cuesta de Misantla, Vera Cruz; Calvillo, Aguas Calientes; Tepíc; Oaxaca; Chilpancingo, Guerrero).-Salvin and Godman, Biol. Centr.-Am., Aves, ii, 1892, 360 (Patzcuaro, Michoacán; Totóntepec, Oaxaca; etc.).-Hartert (E. and C.), Novit. Zool., i, 1894, 64 (Chilpancingo, Guerrero, 7,000 ft.).-Сhapman, Bull. Am. Mus. N. H., x, 1898, 34 (Jalapa).

Atthis eloisoe Dugìs, La Naturaleza, i, 1870, 141 (Patzcuaro, Michoacán).

$A[t$ this] heloisæ Ridgway, Proc. U. S. Nat. Mus., i, 1878, 9 (diagnosis).-Coues,

Key N. Am. Birds, 2d ed., 1884, 465.

[Atthis] helois:e Sclater and Salvin, Nom. Av. Neotr., 1873, 84, part (Mexico).--

Mulsant, Ann. Soc. Linn. Lyon, n. s., xxii, 1876, 227.

Atthis heloisa Baird, Brewer, and Ridgway, Hist. N. Am. Birds, ii, 1874, 465,

pl. 47, fig. 6.-Ridgway, Rep. U. S. Nat. Mus. for 1890 (1891), 380, pl.

46 (monogr.).-Phillips, Auk, xxviii, 1911, 78 (Galindo and Realito,

Tamaulipas).

$A[t$ this $]$ heloisa Hartert, Das Tierreich, Troch., 1900, 210 (monogr.).

[Atthis] heloisa Sharpe, Hand-list, ii, 1900, 142.

\section{ATTHIS HELOISA ELLIOTI (Ridgway).}

ELLIOT'S HUMMING BIRD.

Similar to $A$. h. heloisa, but averaging smaller (especially the bill); adult male with tip of outermost primary not contracted in width, sides of head much darker grayish brown (without whitish on malar region), and purple of throat decidedly more reddish. (Adult female not seen.)

Adult male.-Length (skin), 58-69 (63); wing, 34-37.5 (34.9); tail, 19-21 (20.3); exposed culmen, 10.5-11.5 (10.9). ${ }^{a}$

Guatemala (Calderas, Volcán de Fuego; Cuipaché and Volcán de Santa Maria, Quezaltenango; Cobán; El Rincón, San Marcos; Chilasco; Dueñas; Cobán; Guatemala City; Vera Paz).

Selasphorus heloisæ (not Ornismya heloisa Lesson and Delattre) Sclater and SALvin, Ibis, 1859, 129 (Guatemala).-Salvin, Ibis, 1860, 195 (Dueñas, Guatemala), 266 (tierra caliente and Volcán de Fuego, Guatemala); 1862, 96 (Volcán de Fuego).

Atthis heloisa Batrd, Brewer, and Ridgway, Hist. N. Am. Birds, ii, 1874, 465, part (Guatemalan references).

Atthis heloisæ Boucard, Notes Troch. du Mex., 1875, 7, part (Cobán, Guatemala); Liste Ois. récol. Guat., 1878, 46.-Mulsant and Verreaux, Hist. Nat. Ois.Mouch., iv, livr. 2, 1877, 91, part (Guatemala).

Atthis ellioti Ringway, Proc. U. S. Nat. Mus., i, sig. 1, July 1, 1878, 9 (Volcan de Fuego, Guatemala; coll. U. S. Nat. Mus.); Rep. U. S. Nat. Mus. for 1890 (1891), 380; Man. N. Am. Birds, 2d ed., 1896, 598.-Elliot, Classif. and Synop. Troch., 1879, 114.-Salvin, Cat. Birds Brit. Mus., xvi, 1892, 412, 667 (El Rincón, San Marcos; Cuipaché and Volcán de Sta Maria, Quezaltenango; Calderas, Volcán de Fuego; Chilasco, Cobán, and Atitlín, Guatemala).-Salvin and Godman, Biol. Centr. $\Lambda$ m., $\Lambda$ ves, ii, 1892, 361.-BouCARD, Gen. Hum. Birds, 1895, 12, part (Guatemala). 
A[this] ellioti Ridgway, Rep. U. S. Nat. Mus., 1890, 380 (mon.).-Hartert, Das

Tierreich, Troch., 1900, 211 (mon.).

[Atthis] ellioti Sharpe, Hand-list, ii, 1900, 142.

T[rochilus] ellioti Ridgway, Man. N. Am. Birds, 1887, 315.

\section{ATTHIS HELOISA MORCOMI (Ridgway).}

MORCOM'S HUMMING BIRD.

Similar to A. h. heloisa, but smaller (except bill); adult female paler below, with bronzy spots on chin and throat much smaller, sides less extensively cinnamon-rufous, and under tail-coverts pure white. (Adult male not seen.)

Adult female.-Length (skin), 66; wing, 36; tail, 19.5; exposed culmen, 12.5. ${ }^{a}$

Southern Arizona (Ramsey Cañon, Huachuca Mountains).

Atthis morcomi Rrdgway, Auk, xv, Oct., 1898, 325 (Huachuca Mts., Arizona; coll. U. S. Nat. Mus.).-American Ornithologists' Union, Auk, xvi, 1899, 111; Check List, 3d ed., 1910, 204.-Ballex (Florence M.), Handb. Birds W. U. S., 1902, 241.-Swarth, Pacific Coast Avif. no. 4, 1904, 19 (Ramsey Cañon, Huachuca Mits.).

A[tthis] morcomi Hartert, Das Tierreich, Troch., 1900, 211 (monogr.).

[Atthis] morcomi Sharpe, Hand-list, ii, 1900, 142.

\section{Genus SELASPHORUS Swainson.}

Selasphorus Swarnson, Fauna Bor.-Am., ii, 1831, 324, 496. (Type, Trochilus rufus Gmelin.)

Selosphorus (emendation) Bonaparte, Consp. Av., i, 1850, 82.

Selaspherus (emendation) Rerchenвach, Troch. Enum., 1855, 11.

Selasforus (error) DugÈs, La Naturaleza, i, 1870, 141.

Selatophorus (emendation) Newton, Dict. Birds, pt. ii, 1893, 448, in text.

Small Trochilidæ (length about $65-85 \mathrm{~mm}$.), related to Archilochus and Calypte, but differing from both in having the tail more or less rounded or graduated in adult males, strongly rounded in adult females and young; adult males also differing from those of Archilochus in having the "gorget" elongated laterally, and from those of Calypte in having the pileum concolor with the back; adult males of most species with outermost primary attenuated and acute terminally.

Bill about as long as head to decidedly longer, straight, slender, terete; culmen rounded except basally, where contracted into a more or less distinct ridge; tomia smooth; mandible with the usual lateral median groove or sulcus. Nasal operculum rather broad and convex, tumid posteriorly, nude, but hidden by appressed frontal feathering, which anteriorly extends considerably beyond anterior edge of nostrils, forming a short obtuse point or antia on each side of culmen. Tarsus feathered, except on posterior side; lateral toe slightly shorter than middle toe, but (apparently) slightly longer than hallux. Wing about three times as long as exposed culmen, the outermost 
primary or two outermost longest, and in adult males usually ${ }^{a}$ attenuated and accuminate terminally (in S. platycercus slightly excurved, in other species strongly incurved). Tail of adult male about two-thirds as long as wing, more or less rounded or graduated (nearly truncate in S. platycercus), the rectrices more or less contracted and obtusely pointed terminally, the lateral ones sometimes very narrow; in adult females and young a little less than threefifths to two-thirds as long as wing, rounded, the rectrices broader and rounded terminally.

Coloration.-Above metallic bronze-green or bronze, or else (in S. rufus) mostly cinnamon-rufous; chest white or whitish. Adult males with chin and throat metallic scarlet, rose red, wine purple, or heliotrope, the "gorget" elongated laterally; rectrices mostly dusky, edged, more or less broadly (at least on one web), with cinnamon-rufous, or else cinnamon-rufous with a mesial streak (at least near end) of dusky. Adult females and young with throat whitish, usually flecked with bronze or dusky, sometimes spotted with metallic red, etc., the lateral rectrices cinnamon-rufous basally and broadly tipped with white, cinnamon-buff, or cinnamon-rufous.

Range.-Southern Alaska to western Panamá. (Eight species. ${ }^{b}$ )

KEY TO THE SPECIES OF SELASPHORUS.

a. Throat metallic red or purple. (Adult males.)

b. Pileum metallic greenish.

c. Throat metallic purple (reddish purple to greenish purple); rectrices mostly purplish black or dark bronzy purple.

d. Larger (wing more than 45 , tail 30 or more, exposed culmen 16 or more); tip of outermost primary attenuated and recurved; throat bright solferino. (Western United States to Guatemala.)

Selasphorus platycercus, adult male (p. 597$)$.

$d d$ : Smaller (wing less than 45 , tail less than 30 , exposed culmen much less than 16); tip of outermost primary neither attenuated nor recurved; throat not solferino.

$e$. Throat dull rose purple to greenish heliotrope; middle rectrices mostly metallic green; under wing-coverts and axillars with little if any cinnamon-rufous.

f. Throat dull rose purple or wine purple. (Costa Rica and western Panamá.)............... Selasphorus flammula, adult male (p. 601).

ff. Throat dull grayish or greenish purple (greenish heliotrope). (Costa Rica and western Panamá.)

Selasphorus torridus, adult male (p. 602).

ee. Throat bright reddish purple (pomegranate purple to nearly crimson); middle rectrices mostly purplish black or dark bronzy purple; under wing-coverts and axillars with much cinnamon-rufous.

$f$. Middle rectrices very broadly edged with cinnamon-rufous and inner webs of lateral rectrices broadly edged with same; under tail-coverts

a The tip of the outermost primary in S. flammula, $S$. ardens, and $S$. torridus is obtusely pointed and the quill less attenuated than in other species.

$b$ The ninth species of Sharpe's Hand-List (vol. ii, p. 141), S. floresii Gould, is undoubtedly a hybrid of Selasphorus rufus (or S. alleni) and Calypte anna. 
very pale rufous-buff or buffy whitish; wing 40-40.5, tail 28-29, exposed culmen 11.5-12. (Western Panamá.)

Selasphorus ardens, adult male (p. 604).

ff. Middle rectrices narrowly edged with cinnamon-rufous, the inner webs of lateral rectrices without rufous edging; under tail-coverts light cinnamon-rufous or vinaceous-cinnamon; wing 36.5-40 (38.4), tail 26.5-28.5 (27.7), exposed culmen 10-11.5 (10.5). (Costa Rica.)

Selasphorus simoni, adult male (p. 606).

cc. Throat brilliant metallic orange-red or scarlet; rectrices mostly cinnamonrufous.

d. Smaller (wing less than 35, tail less than 25, exposed culmen less than 12). (Costa Rica and western Panamá.)

Selasphorus scintilla, adult male (p. 607).

$d d$. Larger (wing more than 36), tail not less than 25, exposed culmen 15 or more.

$e$. Back and rump metallic green; rectrices much narrower (the outermost much less than 2 wide), the middle pair not notched near tip. (Pacific coast from British Columbia to northwestern Mexico.)

Selasphorus alleni, adult male (p. 609).

$e e$. Back and rump cinnamon-rufous; rectrices much broader, the outermost not less than 2 wide, the middle pair notched near tip. (Western North America, from Guatemala to Alaska.)

Selasphorus rufus, adult male (p. 612).

bb. Pileum brilliant metallic red, like throat. (California to northwestern Mexico.)

Selasphorus floresii, ${ }^{a}$ adult male (p. 616).

aa. Throat whitish, usually flecked with dusky, sometimes with a few feathers of metallic red or purple. (Adult females.)

b. Middle rectrices wholly metallic green or else merely edged with cinnamonrufous.

c. Larger (wing 45.5-52, exposed culmen 17-20); tips of lateral rectrices pure white.................. Selasphorus platycercus, adult female (p. 598).

cc. Smaller (wing 39.5-43.5, exposed culmen 11-13.5); tips of lateral rectrices more or less rufescent.

Selasphorus flammula (p. 602), Selasphorus torridus (p. 603), Selasphorus ardens (p. 605), and Selasphorus simoni (p. 606), adult females. $b$

$b b$. Middle rectrices extensively cinnamon-rufous basally.

c. Smaller (wing 34-37.5, exposed culmen 11.5-12.5); tips of lateral rectrices cinnamon-rufous.............. Selasphorus scintilla, adult female (p. 608).

$c c$. Larger (wing 41-45, exposed culmen 17-19); tips of lateral rectrices white.

d. Lateral rectrices much narrower (not more than $2 \mathrm{~mm}$.); wing 41-42 (41.6); tail, 23-26 (24.7) ... . . . . . . . . . Selasphorus alleni, adult female (p. 610).

$d d$. Lateral rectrices broader (more than $3 \mathrm{~mm}$. wide); wing 43-45 (44.4); tail $24.5-28(26.4) \ldots \ldots \ldots$..... Selasphorus rufus, adult female (p. 612).

\section{SELASPHORUS PLATYCERCUS (Swainson).}

BROAD-TAILED FIUMMITG BIRD.

Adult male.-Above metallic bronze-green or greenish bronze; middle pair of rectrices metallic bronze-green (sometimes more bluish green); rest of tail dull purplish or bronzy black, the pair

a This is undoubtedly a hybrid between Sclasphorus alleni and Calypte anna.

$b$ Before it is possible to give a key showing satisfactorily the differential characters of these species, the very careful examiuation and comparison of a much larger number of specimens is necessary. 
next to middle pair usually glossed, more or less, with bronzy green (sometimes mostly of this color), the outer web edged (except terminally) with cinnamon-rufous, the next pair sometimes also narrowly edged with the same; remiges dark brownish slate or dusky, faintly glossed with purplish; chin and throat bright metallic reddish purple (usually more reddish than solferino), the feathers crossed by a broad subterminal (concealed) bar of dull white, their basal portion dusky gray; chest grayish white, passing into very pale gray on breast and abdomen; sides and flanks darker grayish, tinged (especially the flanks) with pale cinnamon, the sides and sides of breast overlaid by metallic bronze-green; femoral tutts white; under tail-coverts white with a central area of pale cinnamon or cinnamon-buff (sometimes partly bronze-green); bill dull black; iris dark brown; feet dusky; length (skins), 83-96 (90); wing, 46.5-50.5 (48.4); tail, 30-35 (31.7); exposed culmen, 16-19 (17.6). ${ }^{a}$

Adult female.-Above metallic bronze-green, including middle pair of rectrices, the latter sometimes blackish or dusky terminally; second rectrix (from middle) metallic bronze-green with terminal portion more or less extensively dusky; three outer rectrices, on each side, broadly tipped with white, cinnamon-rufous basally (more or less extensively), the remaining portion purplish or bronzy black with more or less of metallic bronze-green between the blackish subterminal and cinnamon-rufous basal areas; chin and throat dull white, the feathers with small mesial streaks or guttate spots of dusky or dusky bronze; chest dull brownish white or buffy grayish white, the breast and abdomen similar but, usually, more decidedly tinged with buffy; sides and flanks light cinnamon or pale cinnamonrufous; under tail-coverts pale cinnamon or cinnamon-buff (sometimes partly grayish) centrally, broadly margined with white; femoral tufts white; bill, etc., as in adult male; length (skins), 83-97 (91); wing, 45.5-52 (49.9); tail, 27-32.5 (30.5); exposed culmen, $17-20(18.6) .^{b}$

\begin{tabular}{|c|c|c|c|}
\hline$a$ Nineteen specimens. & $b$ Sixteen specimens. & & \\
\hline Locality. & Wing. & Tail. & $\begin{array}{l}\text { Cul- } \\
\text { men. }\end{array}$ \\
\hline MALES. & & & \\
\hline Ten adult males from western United States. & 49.5 & 32.2 & 17.7 \\
\hline Eight adult males from Mexico ............... & 48.6 & 31.3 & 17.6 \\
\hline One adult male from Guatemala....... & 46.5 & 30.5 & 16 \\
\hline FEMALES. & & & \\
\hline Ten adult females from western United Stat & 49.9 & 30.3 & 18.6 \\
\hline Six adult females from Mexico...$\ldots \ldots \ldots$ & 49.8 & 30.7 & 18.6 \\
\hline
\end{tabular}


Young male.-Similar to the adult female but feathers of upper parts (especially rump and upper tail-coverts) indistinctly margined terminally with pale brownish buff or cinnamon, and lateral rectrices with much less of cinnamomeous on basal portion.

Young female.-Similar to the young male but rectrices as in adult female.

Mountain districts of western United States; north to Idaho (Big Butte), Montana (Gallatin County); east to eastern base of Rocky Mountains in Wyoming (Cheyenne), western Nebraska (Glen, Sioux County), Colorado, New Mexico, and western Texas (Chisos Mountains; Davis Mountains); west to the Sierra Nevada (casually to Oakland, California); southward over greater part of Mexico, in States of Sonora (Micoba), Nuevo León (Cerro de la Silla), Tamaulipas (Miquihuana), Aguas Calientes (Sierra de Calvillo), Durango (Guanacavi), Zacatecas (Sierra de Valparaiso), Michoacán (Patzcuaro), Jalisco (Sierra de Bolaños), Colima (Volcán de Colima; Sierra Nevada de Colima), Hidalgo (Reál del Monte), Mexico (City of Mexico; Tenango del Valle; Ajusco; Popocatépetl; Rio Frio, Ixtaccihuátl; Hacienda Eslava; north slope Volcán de Toluca), Puebla (Chalchicomula; Pinál), Vera Cruz (Cofre de Perote; Córdova; Jalapa; Miradór), and Oaxaca ('Tonaguia) to highlands of Guatemala (mountains above Totonicapám; Paramos; Cuipaché and San Martín, Quezaltenango; El Rincón, San Marcos); apparently breeding throughout its general range.

Troshilus platycercus Swainson, Philos. Mag., n. s., i, 1827, 441 (Mexico).American Ornithologists' Union, Check List, 1886, no. 432.-Scott, Auk, iii, 1886, 431 (Santa Catalina Mts., Arizona; breeding?).-Stone, Proc. Ac. Nat. Sci. Phila., 1890, 214 (Chalchicomula, Puebla).-Mearns, Auk, vii, 1890, 255 (San Francisco Mts., A rizona, breeding in spruce belt; habits).Merriam, North Am. Fauna, no. 3, 1890, 39 (Grand Cañon of Colorado), 93 (San Francisco Mts., breeding in balsam and upper part of pine belt; habits); no. 5, 1891, 98 (Big Butte, Idaho).-Anthony, Auk, ix, 1892, 363 (s. w. New Mexico).-Rhodds, Proc. Ac. Nat. Sci. Phila., 1892, 118 (Santa Catalina Mts., Arizona, breeding).-Lowe, Auk, xi, 1894, 268 (Wet Mts., Colorado, breeding at $10,000 \mathrm{ft}$.).

T[rochilus] platycercus Ridgway, Man. N. Am. Birds, 1887, 313.

M[ellisuga] platycercus Grax, Gen. Birds, i, Dec., 1848, 113.

[Selosphorus] platycercus Bonaparte, Consp. Av., i, 1850, 82.

Selasphorus platycercus Gould, Mon. Troch., pt. iii, May, 1852, pl. 7; vol. iii, 1861, pl. 140; Introd. Troch., oct. ed., 1861, 89.-Sclater, Proc. Zool. Soc. Lond., 1856, 288 (Córdova, Vera Cruz); 1858, 297 (Oaxaca); 1864, 177 (City of Mexico); Cat. Am. Birds, 1862, 298 (Mexico).-Baind, Rep. Pacific R. R. Surv., ix, 1858, 135, 922 (El Paso, 'Texas; Cantonment Burgwyn, New Mexico; Ft. Bridger, Wyoming); ed. 1860 ("Birds N. Am."), 922, atlas, pl. 43, figs. 1, 2; Rep. U. S. and Mex. Bound. Surv., ii, pt. 2, 1859, 6, pl. 5, figs. 1, 2 (El Paso, Texas; Cantonment Burgwyn, New Mexico); Cat. N. Am. Birds, 1859, no. 104.--Henry, Proc. Ac. Nat. Sci. Phila., 1859, 106 (New Mexico).Sclater and Salvin, Ibis, 1859, 129 (Guatemala).-Salvin, Ibis, 1860, 196 
(Quezaltenango and Mts. above Totonicapám, Guatemala); Cat. Birds Brit. Mus., xvi, 1892, 396.-Mulsant and Verreaux, Classif. Troch., 1866, 89; Hist. Nat. Ois.-Mouch., iv, livr. 2, 1877, 94.-Coues, Proc. Ac. Nat. Sci. Phila., 1866, 57 (Ft. Whipple, Arizona); Check List, 1873, no. 278; 2d ed., 1882, no. 413; Birds North West, 1874, 271; Bull. Nutt. Orn. Club, ii, 1878, 95 (Colorado; descr. nest).-Cooper, Proc. Calif. Ac. Sci., 1868, 68 (Lake Tahoe, California); Orn. Cal., 1870, 357.-Allen, Bull. Mus. Comp. Zool., iii, 1872, 146 (Cheyenne, Wyoming), 151 (e. base Rocky Mts. in Colorado), 158 (South Park, Colorado), 163 (Mt. Lincoln, Colorado), 169 (Ogden, Utah), 180.-Ridgway, Bull. Essex Inst., v, 1873, 185 (Colorado); vii, 1875, 21 (Ruby Mts., Nevada), 22 (East Humboldt Mts., Nevada), 30 (Salt Lake City, Utah), 34 (Parleys Park, Utah); Orn. 40th Parallel, 1877, 560 (localities in Utah and Nevada; habits); Proc. U. S. Nat. Mus., iii, 1880, 187, 314; Nom. N. Am. Birds, 1881, no. 339; Rep. U. S. Nat. Mus. for 1890 (1891), 341, 350 (monogr.; habits); Man. N. Am. Birds, 2d ed., 1896, 598.-Merriam, Sixth Ann. Rep. U. S. Geol. Surv. Terr., 1872 (1873), 714 (Utah).-Henshaw, Ann. Lyc. N. Y., ix, 1874, 47 (Ogden, Utah); Rep. Orn. Spec. Wheeler's Surv., 1871-73 (1874), 47 (Ogden), 88 (Ft. Garland, Colorado), 132, 162 (Apache, White Mts., and Camp Grant, Arizona; Inscription Rock, New Mexico); Zool. Expl. W. 100th Merid., 1875, 377 (localities in Arizona, New Mexico, and Colorado; habits); Auk, iii, 1886, 75 (upper Pecos R., New Mexico, breeding; habits).-Baird, Brewer, and Ridgway, Hist. N. Am. Birds, ii, 1874, 462, pl. 47, fig. 5.-Nelson, Proc. Bost. Soc. N. H., xvii, 1875, 347 (Salt Lake City).-De OcA, La Naturaleza, iii, 1875, 204 (Valley of Mexico); Troq. de Mex., 1875, 46, pl. (9), fig. 34.-Sumichrast, La Naturaleza, v, 1881, 250 (Valley of Mexico; alpine region of Orizaba).Boucard, Ann. Soc. Linn. Lyon, xxii, 1876, 19 (Puebla); Notes Troq. du Mex., 1875, 6 (Oaxaca; Puebla; Mexico; Guatemala); Gen. Hum. Birds, ii, 1892, 9.-Elliot, Classif. and Synop. Troch., 1879, 109.-Scotт, Bull. Nutt. Orn. Club, iv, 1879, 95 (Twin Lakes, Colorado).-Mınoт, Bull. Nutt. Orn. Club, v, 1880, 232 (Colorado, from 2,000 ft. to above timber line).-DREw, Bull. Nutt. Orn. Club, vi, 1881, 140 (Colorado, 4,000-13,000 ft.).-Brewster, Bull. Nutt. Orn. Club, vii, 1882, 211 (Santa Rita Mts., Arizona, May).Allen and Brewster, Bull. Nutt. Orn. Club, viii, 1883, 196 (Colorado Springs, Colorado).-Hernera, La Naturaleza, (2), i, 1891, 322 (Valley of Mexico).-Salvin and Godman, Biol. Centr.-Am., Aves, ii, 1892, 355.Fisher (A. K.), North Am. Fauna, no. 7, 1893, 58 (Juniper Mts., Nevada; opp. head of Owens R., w. slope Sierra Nevada; Sequoia National Park).American Ornithologis's' Union Committee, Auk, x, 1893, 62; Check List, 2 d ed., 1895, no. 432; 3d ed., 1910, 203.-Bendire, Life Hist. N. Am. Birls, ii, 1895, 210.-Cox, Auk, xii, 1895, 357 (Mt. Orizaba, up to 11,000 ft. summer).-Cooke, Bull. Col. Agric. Coll., no. 37, 1897, 86 (Colorado up to $2,000 \mathrm{ft}$. above timber line, breeding up to 11,000 ft.); Auk, xxvi, 1900, 413 (Springfield and Yuma, Colorado).-McGregor, Auk, xiv, 1897, 91 (Oakland, California, 1 spec., May 8, 1890).—CARY, Auk, xviii, 1901, 234 (Black Hills, Wyoming, 2 specs., May).-Bailey (Florence M.), Handb. Birds W. U. S., 1902, 238; Auk, xxi, 1904, 354 (upper Pecos R., New Mexico, 7,00011,600 ft., breeding).-Swarth, Pacific Coast Avifauna, no. 4, 1904, 18 (Huachuca Mts., Arizona, breeding; habits).-Swenk, Auk, xxiii, 1906, 109 (Glen, Sioux Co., w. Nebraska, 1 pair, Aug.).-Mrluer (W. De W.), Bull. Am. Mus. N. II., xxii, 1906, 167 (Guanacavi, Durango, Oct.).-SAunders, Condor, xi, 1909, 197 (Gallatin Co., Montana, breeding; habits).-Visher, Auk, xxvii, 1910, 282 (Santa Catalina Mts., Arizona, breeding). 
S[elasphorus platycercus Cabanis and Heine, Mus. Hein., iii, 1860, 56 (Mexico).Coues, Key N. Am. Birds, 2 d ed., 1884, 463.--Hartert, Das Tierreich, Troch., 1900, 206.

[Selasphorus] platycercus Reichenbach, Aufz. der Colibr., 1854, 13; Troch. Enum., 1855, 10, pl. 854, figs. 5027-5029.-Bonaparte, Rev. et Mag. de Zool., 1854, 257.-Sclater and Salvin, Nom. Av. Neotr., 1873, 84. Mulsant, Ann. Soc. Linn. Lyon, n. s., xxii, 1876, 227.-Sharpe, Hand-list, ii, 1900, 141.

[Selasphorus platycercus] var. platycercus BAIRd, Brewer, and Ridgway, Hist. N. Am. Birds, ii, 1874, 458.

Selasforus platycercus Dùges, La Naturaleza, i, 1870, 141 (Patzcuaro, Michoacan).-Vinlada, La Naturaleza, ii, 1874, 253 (Valley of Mexico).

Ornismya tricolor Lesson, Suppl. Ois.-Mouch., 1830-31, 125, pl. 14 ("Brésil"); Les Troch., 1831, 156, pl. 60 (Mexico); Index Gen. et Synop. Troch., 1832, p. xxxiv.-Jardine, Nat. Libr., Humming birds, ii, 1833, pl. 13.

C[ynanthus]? tricolor JARDINE, Nat. Libr., Humming birds, ii, 1833, 170.

Ornismya montana Lesson, Les Troch., 1831, 161, 163, pls. 63, 64 (Mexico) Index Gen, et Synop. Troch., 1832, p. xxxiv.

Trochilus montana JARDINe, Nat. Libr., Humming birds, ii, 1833, 93.

Trochilus montanus Swarnson, Birds Brazil, Mex., etc. [1841?], pl. 74.

\section{SELASPHORUS FLAMMULA Salvin.}

\section{LESSER BROAD-TAILED HUMMING BIRD.}

Somewhat like $S$. platycercus, but much smaller; adult male with outermost primary not attenuated, middle pair of rectrices edged (on both webs) with cinnamomeous, and color of gorget much duller; adult female with middle rectrices broadly edged with cinnamonrufous, the outer ones broadly tipped with pale cinnamon-rufous or cinnamon-buff instead of white.

Adult male.-Above metallic bronze-green, somewhat darker and duller on pileum; middle pair of rectrices bronze-green broadly edged on both webs (except terminally) with cinnamon-rufous; other rectrices purplish dusky or black glossed with bronzy purple, the third and fourth (from outside) with both webs broadly edged (except terminally) with cinnamon-rufous, the outermost with a spot of cinamonrufous at tip of inner web (which is also indistinctly edged with cinnamomeous), the next (second) with greater part of inner web (except terminally) cinnamon-rufous; remiges and primary coverts purplish dusky, the inner secondaries glossed with bronze-green; lores dark cinnamon-rufous or chestnut; gorget rather dull metallic purple (between heliotrope purple and wine purple, the feathers dusky gray basally, then crossed by a broad bar of cinnamon-buff, a narrow dusky bar separating this from the metallic tip; chest dull white, the median portion of breast and abdomen similar but slightly darker or more grayish; sides pale rusty or cinnamon-buff, spotted with metallic bronze-green, especially on sides of breast; under tailcoverts pale cimnamomeous or cimnamon-buff, passing into paler on margins, the longer coverts sometimes mostly dull whitish; bill dull black, the mandible paler basally; iris dark brown; feet grayish 
brown or dusky; length (skins), 69-74 (72); wing, 38.5-41.5 (40.2); tail, 26-28.5 (27.5); exposed culmen, 11-12.5 (11.7). ${ }^{a}$

Adult female.-Above similar in color to the adult male, but three outer rectrices (on each side) broadly tipped with pale cinnamonrufous or cinnamon-buff, and with the basal portion extensively cinnamon-rufous; chin and throat dull white (often more or less tinged with cinnamomeous) streaked or spotted with grayish brown or dusky; rest of under parts as in adult male, but sides without green spotting; length (skins), 71-78 (74); wing, 41-43.5 (42); tail, 25-27 (26.2); exposed culmen, 12-13.5 (12.9). ${ }^{a}$

Highlands of Costa Rica (Volcán de Irazú; Volcán de Turrialba; Sabana de Cartago; La Estrella de Cartago; Cerro de la Candelária; Santa Maria de Dota; Rancho Redondo).

Selasphorus flammula Salvin, Proc. Zool. Soc. Lond., 1864, 586 (Volcán de Cartago, i. e., Volcán de Irazú, Costa Rica; coll. Salvin and Godman); Cat. Birds Brit. Mus., xvi, 1892, 398.-Lawrence, Ann. Lyc. N. Y., ix, 1868, 123 (Volcán de Irazú)._Frantzius, Journ. für Orn., 1869, 315 (Costa Rica).Mulsant and Verreaux, Hist. Nat. Ois.-Mouch., iii, livr. 3, 1876, pl. 44; iv, livr. 2, 1877, 99 (Cartago); livr. 3, 1878, 220, 221, pl. 107.-BoucARD, Proc. Zool. Soc. Lond., 1878, 70 (Volcán de Irazú, 10,000ft.; habits); Gen. Hum. Birds, ii, 1892, 10 (Volcán de Irazú).-Elliot, Classif. and Synop. Troch., 1879, 110.-Ridgway, Proc. U. S. Nat. Mus., v, 1882, 497 (Volcán de Irazú).-Zeredón, Cat. Aves de Costa Rica, 1882, 20; Anal. Mus. Nac. Costa Rica, i, 1887, 121.-Sharpe, Suppl. Gould's Mon. Troch., 1883, pl. 31.Salvin and Godman, Biol. Centr.-Am., Aves, ii, 1892, 357.-Hartert, Novit. Zool., ii, 1895, 68 (Faldas de Irazú, La Estrella de Cartago, and Santa Maria de Dota, Costa Rica; descr. adult male and female).

[Selasphorus] flammula Sclater and Salvin, Nom. Av. Neotr., 1873, 84.-Mulsant, Ann. Soc. Linn. Lyon, n. s., xxii, 1876, 227.-Sharpe, Hand-list, ii, 1900, 141.

S[elasphorus] flammula Ridgway, Rep. U. S. Nat. Mus. for 1890 (1891), 341 (diagnosis, etc.).-Hartert, Das Tierreich, Troch., 1900, 205.

Selasphorus flammula flammula CARriker, Ann. Carnegie Mus., vi, 1910, 547 (high mts. of central Costa Rica).

[Selasphorus platycercus] var. flammula BAIRD, BREwer, and Ridgway, Hist. N. Am. Birds, ii, 1874, 459.

Selasphorus (platycercus, var.?) flammula BaIrd, Brewer, and RIdgway, Hist. N. Am. Birds, ii, 1874, 459, footnote.

[Trochilus] flammula Gray, Hand-list, i, 1869, 144, no. 1866.

Selasphorus torridus (not of Salvin) Ridgway, Proc. U. S. Nat. Mus., vi, 1884, 415 (Costa Rica); vii, 1884, 14 (Volcán de Irazú).-Salvin and Godman, Biol. Centr.-Am., Aves, ii, 1892, 354, part (citation of $S$. flammula Nutting and loc. Volcán de Cartago).

\section{SELASPHORUS TORRIDUS Salvin.}

\section{HELIOTROPE-THROATED HUMMING BIRD.}

Very similar to S. flammula, but adult male with throat ("gorget") very different in color (dull metallic grayish green faintly glossed with purple or dull grayish purple faintly glossed with dull green); 
adult female possibly not distinguishable from that of $S$. fammula, but apparently less suffused with pale vinaceous-cinnamon beneath, tips to lateral rectrices more whitish, and basal portion of lateral rectrices less extensively cinnamon-rufous.

Adult male.-Above metallic bronze-green, darker and duller on pileum; middle pair of rectrices with outer web bronze-green, the inner web dusky faintly glossed with bronze-green (sometimes mostly bronze-green), both webs broadly edged, except terminally, with cinnamon-rufous; other rectrices purplish black, the two (on each side) next to middle pair broadly edged (except terminally) with cinnamon-rufous, ${ }^{a}$ the two outermost (sometimes second also) with a spot of same on terminal portion of inner web; remiges and primary coverts purplish dusky or dull brownish slate faintly glossed with purplish, the inner secondaries glossed with bronze-green; lores dark rusty or chestnut; gorget dull metallic grayish purple or heliotrope purple, changing to dull grayish green (or the latter changing to dull purplish), the feathers crossed beneath surface with a broad bar of cinnamon-buff, separated from the metallic tip by a narrow bar of dusky, the base dusky gray; chest dull white tinged with cinnamon-buffy, the median portion of breast and abdomen similar but darker (more grayish); sides and flanks similar but more suffused with pale rusty or cinnamon and (especially on sides of breast) intermixed with metallic bronze-green; under tail-coverts cinnamon or cinnamon-buff margined with pale buff or buffy whitish; bill dull black, the mandible paler basally; iris dark brown; feet grayish brown or dusky; length (skins), 67-76 (72); wing, 39.5-42 (40.3); tail, 27-28.5 (27.7); exposed culmen, 11.5-12.5 (12.1). ${ }^{b}$

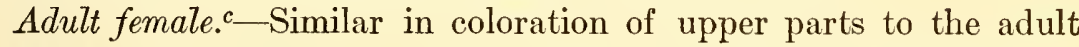
male, but both webs of middle rectrices metallic bronze-green, the next to middle pair bronze-green, passing into black terminally, the outer web broadly edged for most of its length with cinnamon-rufous; outermost rectrix very broadly tipped with white (the white sometimes tinged with cinnamon-rufous or buffy), the subterminal portion (extensively) black, passing into grayish brown basally, the basal portion of shaft usually rufescent; second rectrix (from outside) similar, but with basal half (more or less) of inner web cinnamonrufous, the corresponding part of outer web metallic bronze-green; third rectrix similar to second, but with basal half (more or less) of outer web broadly edged with cinnamon-rufous; chin and throat dull

¿The second and third (from outside) have the inner web also similarly edged.

$b$ Five specimens.

c It is not absolutely certain that the females on which this description is based are of this species. They agree, however, with Salvin's description, and certainly are different in the coloration of the tail from an equal number of undoubted females of S. flammula. 
white streaked or spotted with dusky; rest of under parts as in adult male, but sides more strongly suffused with pale cinnamon-rufous and without intermixture of green; length (skins), 67-77 (72); wing, 40.5-41.5 (41); tail, 24-26 (25.2); exposed culmen, 11-12.5 (11.7). ${ }^{a}$

Immature male.-Similar to the adult female, but sides and flanks glossed with metallic bronze-green; older specimens with one or more dull grayish purple or dull purplish green feathers on throat.

Highlands of Costa Rica (Volcán de Irazú; Volcán de Turrialba; Las Cruces de Candelária?; Dota Mountains) and western Panamá (Voleán de Chiriquí).

Selasphorus torridus Salvin, Proc. Zool. Soc. Lond., 1870, 208 (Volcán de Chiriquí, Panamá; coll. Salvin and Godman); Cat. Birds Brit. Mus., xvi, 1892, 395.Mulsant and Verreaux, Hist. Nat. Ois.-Mouch., iv, livr. 2, 1877, 101.Elliot, Classif. and Synop. Troch., 1879, 112.-Zeledón, Anal. Mus. Nac. Costa Rica, i, 1887, 122 (Volcán de Irazú, Costa Rica).-Salvin and Godman, Biol. Centr.-Am., Aves, ii, 1892, 354, pl. 56, figs. 2, 3 (excl. syn. part).-BouCARD, The Hum. Bird, ii, 1892, 73 (Volcán de Chiriquí); Gen. Hum. Birds, ii, 1892, 10 (Volcán de Chiriquí).-Bangs, Proc. New Engl. Zool. Club, iii, 1902, 31 (Volcán de Chiriquí, 10,300 ft.).-Ferry, Pub. 146, Field Mus. N. H., orn. ser., i, no. 6, 1910, 264 (Volcán de Turrialba, Costa Rica; habits). [Selasphorus] torridus Sclater and Salvin, Nom. Av. Neotr., 1873, 84.-Mulsant, Ann. Soc. Linn. Lyon, n. s., xxii, 1876, 227.-Sharpe, Hand-list, ii, 1900, 141. S[elasphorus] torridus Ridgway, Rep. U. S. Nat. Mus. for 1890 (1891), 341 (diagnosis, etc.).-Hartert, Das Tierreich, Troch., 1900, 206.

Selasphorus flammula torridus CARRIKER, Ann. Carnegie Mus., vi, 1910, 547 (Volcán de Irazú and Dota Mts., Costa Rica; crit.).

\section{SELASPHORUS ARDENS Salvin.}

\section{GLOW-THROATED HUMMING BIRD.}

Most like $S$. flammula but smaller, especially the bill; adult male with middle rectrices mostly if not wholly purplish black (except for the cinnamomeous edging to both webs) and gorget intense (but not brilliant) reddish purple instead of dull rose purple; adult female with lateral rectrices more extensively tipped with pale cinnamonrufous, middle rectrices broadly edged (for more than basal half) with cinnamon-rufous, and sides of head partly cinnamon-rufi....

$a$ Three specimens.

\begin{tabular}{|c|c|c|c|}
\hline Locality. & Wing. & Tail. & $\begin{array}{c}\text { Ex- } \\
\text { posed } \\
\text { culmen. }\end{array}$ \\
\hline MALES. & \multirow{4}{*}{$\begin{array}{l}40 \\
40.7\end{array}$} & \multirow{4}{*}{$\begin{array}{l}27.8 \\
27.5\end{array}$} & \multirow{4}{*}{$\begin{array}{l}12.3 \\
11.7\end{array}$} \\
\hline Three adult males from Costa Rica.. & & & \\
\hline Two adult males from westcrn Panama.... & & & \\
\hline FEMALES. & & & \\
\hline One adult female from Costa lica...... & 41.5 & 25.5 & 11 \\
\hline Two adult females from western Panamá.. & 40.7 & 25 & 12.5 \\
\hline
\end{tabular}


Adult male.-Above deep metallic bronze-green, darker anteriorly, brighter and more bronzy posteriorly; middle rectrices broadly cinnamon-rufous laterally, glossy purplish black medially, this black median stripe sometimes passing into metallic green on edge of terminal portion on one web; remaining rectrices purplish black, the inner web broadly edged with cinnamon-rufous, this edging interrupted subterminally; loral, rictal, and postocular regions and point of chin cinnamon-rufous; chin and throat (gorget) bright metallic purplish red (between crimson or burnt carmine and pomegranate purple), the feathers with a concealed broad buffy whitish bar across middle portion and pale grayish base; chest white, tinged (especially on posterior portion) with pale vinaceous-cinnamon or pinkish buff; sides and flanks rather dull metallic bronze-green, slightly suffused with cinnamon-rufous, the two lateral areas nearly confluent on upper breast; median line of breast (narrowly) and abdomen pale gray or grayish white; under tail-coverts buffy white or pale buff, deeper buff, or cinnamon-buff, mesially; femoral and lumbar tufts buffy white; bill dull blackish, the basal half, more or less, of mandible brownish (in dried skins); iris dark brown; feet dusky; length (skins), 69-72 (70.5); wing, 40-40.5 (40.2); tail, 28-29 (28.5); exposed culmen, 11.5-12 (11.7). ${ }^{a}$

Adult female.-Above metallic greenish bronze, much duller on pileum, the lower rump slightly suffused with cinnamon-rufous; middle rectrices metallic bronze-green, the outer web broadly tipped with blackish, the basal half or more of both webs broadly edged with cinnamon-rufous; outermost rectrix light cinnamon-rufous, crossed in middle portion by a broad band of purplish black; intermediate rectrices intermediate in coloration, according to position; remiges dusky, faintly glossed with purplish; loral, superciliary, and postocular regions deep cinnamon-rufous or chestnut; auricular region dusky, suffused with cinnamon-rufous; suborbital and malar regions and sides of chin and throat cinnamon-buff, flecked with dusky; fading into paler buff, more sparsely flecked, on median portion of chin and throat; chest immaculate bufly white; under parts of body light cinnamon-rufous laterally, pale buff or buffy white along median line; under tail-coverts pale cinnamon-buff; femoral and lumbar tufts buffy white; bill, etc., as in adult male; length (skin), 67; wing, 39.5; tail, 24; exposed culmen, $13 .^{b}$

Highlands of western Panamá (Castillo and Calovévora, Verágua; Volcán de Chiriquí).

Selasphorus ardens Salvin, Proc. Zool. Soc. Lond., 1870, 209 (Castillo, Verágua, Panamá; coll. Salvin and Godman); Cat. Birds Brit. Mus., xvi, 1892, 398.-

a Two specimens.

$b$ One specimen. I am very doubtful, however, whether this is not in reality a temale of S. scintilla. 
Mulsant and Verreaux, Hist. Nat. Ois.-Mouch., ii, livr. 1, 1875, 22; iv, livr. 2, 1877, 103, pl. 108 (Castillo and Calovévora, Panama).-Eurrot, Classif. and Synop. Troch., 1879, 110.-Sharpe, Suppl. Gould's Mon. Troch., 1883, 31.-Salvin and Godman, Biol. Centr.-Am., Aves, ii, 1892, 356, part, pl. 56, fig. 1 (Castillo and Calovévora).-Boucard, The Hum. Bird, ii, 1892, 73 (Verágua); Gen. Hum. Birds, ii, 1892, 9 (Volcán de Chiriquí).

[Selasphorus] ardens Sclater and Salvin, Nom. Av. Neotr., 1873, 84.-MulSant, Ann. Soc. Linn. Lyon, n. s., xxii, 1876, 227.-Sharpe, Hand-list, ii, $1900,141$.

S[elasphorus] ardens Ridgway, Rep. U. S. Nat. Mus. for 1890 (1891), 341, part (Verágua).-Hartent, Das Tierreich, Troch., 1900, 206, part (Verágua).

\section{SELASPHORUS SIMONI Carriker.}

\section{SIMON'S HUMMING BIRD.}

Similar to $S$. ardens but smaller, especially the bill; adult male with middle rectrices much less broadly edged with cinnamon-rufous, inner webs of lateral rectrices without distinct (if any) cinnamonrufous edging, under tail-coverts more strongly rufescent, and color of throat slightly more purplish (less reddish); adult female with much less rufous on tail (the outermost rectrix purplish black for much the greater part), no rufous on upper tail-coverts nor sides of head, sides less clear (more brownish) cinnamon-rufous, throat less tinged with rufous-buff, and under tail-coverts deeper rufous-buff.

Adult male.--Above deep metallic green, slightly darker on pileum, slightly more bronzy on rump and upper tail-coverts; tail bronzy purplish black or dark bronzy purple, the middle pair of rectrices narrowly edged (except terminally) on both sides with cinnamonrufous, and usually with inner web partly dark metallic green; next pair also edged with cinhamon-rufous, at least on outer web; outermost pair usually with a small subterminal spot of cinnamon-rufous on edge of inner web; remiges dusky, faintly glossed with violaceous; chin and throat (gorget) bright (but not brilliant) metallic reddish purple (nearest pomegranate purple), the feathers dusky grayish at base and crossed in middle portion by a broad bar (concealed) of pale cinnamon-buff; chest dull white anteriorly, passing into grayish cinnamon-buffy posteriorly; sides and flanks metallic bronze-green, suffused (especially on flanks) with rusty, passing into pale buffy grayish on median portion of breast and abdomen; under tail-coverts light cinnamon-rufous (deepest toward anal region); femoral and lumbar tufts white or buffy white; bill dull blackish, the mandible more brownish basally; iris dark brown; feet dusky; length (skins), 66-73 (71); wing, 37-40 (38.4); tail, 26.5-28.5 (27.7); exposed culmen, $10-11.5(10.5) .^{a}$

Adult female.-Above bright metallic bronze-green or greenish bronze, including upper tail-coverts; middle rectrices similar, but 
outer web darker and less bronzy green, becoming purplish black terminally and rather broadly edged with cinnamon-rufous, the inner web very narrowly edged with the same; outermost rectrix purplish black, with basal third of shaft, basal portion of inner web, and edge of inner web for about basal two-thirds, together with a broad tip, pale cinnamon-rufous; the remaining rectrices mostly purplish black, rather broadly edged on outer web (nearly to tip) with cinnamon-rufous; remiges dusky, faintly glossed with violaceous; chin and throat dull white, tinged or suffused with buffy (the anterior and lateral portions of chin pale cinnamon-rufous or rusty buff), the whole throat flecked with small guttate streaks or spots of dusky; chest dull buffy white; passing into duller, more grayish, white on median portion of breast and abdomen; sides and flanks light rusty brownish (nearly russet) slightly glossed or intermixed with bronzy; under tail-coverts pale cinnamon-rufous or vinaceous-cinnamon; femoral and lumbar tufts buffy white; bill, feet, etc., as in adult male; length (skin), 69; wing, 41.5; tail, 26.5; exposed culmen, 11.5. ${ }^{a}$

Immature male.-Similar to the adult female but (at least in older individuals) with one or more feathers of metallic reddish purple on throat.

Highlands of Costa Rica (Volcán de Poás; Volcán de Barba; Las Cruces de Candelária).

Selasphorus ardens (not of Salvin, 1870) Ridgway, Proc. U. S. Nat. Mus., vi, 1884, 415 (Costa Rica).-Salvin, Cat. Birds Brit. Mus., xvi, 1892, 398.Salvin and Godman, Biol. Centr.-Am., Aves, ii, 1892, 356, part (Volcán de Poás and Las Cruces de Candelária, Costa Rica).

S[elasphorus] ardens Ridgway, Rep. U. S. Nat. Mus. for 1890 (1891), 341, part (Costa Rica).-Hartert, Das Tierreich, Troch., 1900, 206, part (Costa Rica).

S[elasphorus] underwoodi (not of Salvin) Hartert, Das Tierreich, Troch., 1900, 206.

Selasphorus simoni Carriker, Ann. Carnegie Mus., vi, Aug. 29 (i. e., Sept. 7), 1910, 550 (Volcán de Barba, Costa Rica; coll. E. A. and O. Bangs).

\section{SELASPHORUS SCINTILLA (Gould).}

SCINTILLANT HUMMING BIRD.

Similar in coloration to $S$. alleni, but much smaller; rectrices much broader and more obtuse (especially lateral pair) and with median blackish area much broader and extending to base; adult female and young with lateral rectrices broadly tipped with cinnamon instead of white.

Adult male.-Above metallic golden or bronzy green, the upper tail-coverts mostly cinnamon-rufous basally and laterally; rectrices cinnamon-rufous, the middle pair with a broad, fusiform mesial stripe of purplish black, extending for nearly the entire length, the next 
two (on each side) with a similar but broader and more cuneate stripe, the two outer pairs (on each side) with outer web and part of inner web purplish black; remiges purplish dusky, the inner secondaries glossed with bronze-green, the primary coverts similar in color to primaries but darker; loral and orbital regions deep cinnamonrufous; chin and throat (gorget) brilliant metallic orange-red or orange (less scarlet than in S. rufus and S. alleni), changing to golden green in position $d$; chest dull white, tinged with cinnamon-buff posteriorly, the feathers dusky gray beneath surface; rest of under parts pale cinnamon-rufous or cinnamon-buff, paler medially, the sides (especially sides of breast) spotted with metallic bronze-green; bill dull black, the mandible paler basally; iris dark brown; feet grayish brown or dusky; length (skins), 61-68 (66); wing, 31-34 (32.7); tail, 22-24.5 (23.5); exposed culmen, 10-11 (10.5). ${ }^{a}$

Adult female.-Above similar in color to adult male, but slightly duller (especially on pileum); middle rectrices metallic bronze-green margined with cinnamon or pale cinnamon-rufous, the remaining rectrices cinnamon-rufous for basal half, the terminal half crossed by a broad subterminal band of black and broadly tipped with pale cinnamon-rufous or cinnamon-buff; chin and throat varying from dull buffy white to pale cinnamon-rufous, more or less streaked or spotted with dusky grayish brown or dull bronzy; rest of under parts as in adult male, but sides without green spotting; bill, etc., as in adult male; length (skins), 65-69 (67); wing, 34-37.5 (35.7); tail, 21-23.5 (22.5); exposed culmen, 11.5-12.5 (11.9). ${ }^{b}$

Young male.--Similar to the adult female, but middle rectrices mainly cinnamon-rufous.

Young female.--Similar to the adult female, but under parts strongly suffused with pale cinnamon-rufous, especially on throat, and feathers of upper parts indistinctly margined terminally with rusty.

Highlands of Costa Rica (Volcán de Irazú; Volcán de Turrialba; Coliblanco; Cartago; Rancho Redondo; Tucurríqui; Barranca; Cervantes; Tabacales; San José; Escazú; Cerro de la Candelária; Las Cruces de Candelária; Santa Maria de Dota; Copéy, Laguária, and San Lucas, Dota) and western Panamá (Volcán de Chiriquí; Boquete).

$a$ Thirteen specimens.

$b$ Ten specimens, from Costa Rica.

\begin{tabular}{|c|c|c|c|}
\hline Tocality. & Wing. & Tail. & $\begin{array}{c}\text { Ex- } \\
\text { posed } \\
\text { culmen. }\end{array}$ \\
\hline MALES. & & & \\
\hline Ten adult males from Costa lica.......... & 32.7 & 23.4 & 10.5 \\
\hline Three adult males from western Panamí. & 32.7 & 24 & 10.7 \\
\hline
\end{tabular}


Trochilus (Selosphorus) scintilla Gould, Proc. Zool. Soc. Lond., 1850, 162 (Volcán de Chiriquí, 9,000 it., Panamá; coll. J. Gould).

Selasphorus scintilla Gould, Mon. Troch., pt. iii, May, 1852; vol. iii, 1861, pl. 138; Introd. Troch., oct. ed., 1861, 89.-CABANIS, Journ. für Orn., 1863, 165 (Costa Rica).-Mulsant and Verreaux, Classif. Troch., 1866, 89; Hist. Nat. Ois.-Mouch., ii, livv. 3, 1876, pl. 27; iv, livr. 2, 1877, 104, pl. 109 (Costa Rica; Verágua).-Salvin, Proc. Zool. Soc. Lond., 1867, 155 (Volcán de Chiriquí); 1870, 209 (Volcán de Chiriquí); Cat. Birds Brit. Mus., xvi, 1892, 395 (Volcán de Irazú, Barranca, and Tucurriqui, Costa Rica; Chiriquí).Lawrence, Ann. Lyc. N. Y., ix, 1868, 123 (Barranca, Cervantes, and Las Cruces de la Candelaria, Costa Rica).-Frantzius, Journ. für Orn., 1869, 315 (Costa Rica).-Boucard, Proc. Zool. Soc. Lond., 1878, 70 (Cartago and Volcán de Irazú, 10,000 ft., Costa Rica); The Hum. Bird, ii, 1892, 73 (Veragua); Gen. Hum. Birds, ii, 1895, 8 (Cartago; Chiriquí).--Elliot, Classif. and Synop. Troch., 1879, 111.-Zeledón, Cat. Aves de Costa Rica, 1882, 20; Anal. Mus. Nac. Costa Rica, i, 1887, 121.--Salvin and Godman, Biol. Centr.Am., Aves, ii, 1892, 353.-Salvadori and Festa, Boll. Mus. Zool., etc., Torino, xiv, 1899, no. 339, p. 7 (Chiriquí)._Bangs, Proc. New Engl. Zool. Club, iii, 1902, 31 (Boquete, Panamá, 4,000 ft.).-Carriker, Ann. Carnegie Mus., vi, 1910, 548 (highlands of Costa Rica, above 3,500 ft.; habits).

S[elasphorus] scintilla Cabanis and Heine, Mus. Hein., iii, 1860, 56 (Verágua).Ridgway, Rep. U. S. Nat. Mus. for 1890 (1891), 340 (diagnosis, etc.).Hartent, Das Tierreich, Troch., 1900, 206.

[Selasphorus] scintilla Reichenbach, Aufz. der Colibr., 1854, 13; Troch. Enum., 1855, 10, pl. 853, figs. 5024-5026.-Bonapar'te, Rev. et Mag. de Zool., 1854, 257.-Sclater and Salvin, Nom. Av. Neotr., 1873, 84.-Mulsant, Ann. Soc. Linn. Lyon, n. s., xxii, 1876, 227.-Sharpe, Hand-list, ii, 1900, 141.

[Selasphorus rufus] var. scintilla BaIrd, Brewer, and Ridgway, IIist. N. Am. Birds, ii, 1874, 459.

Selasphorus (rufus, var.?) scintilla BaIrd, Brewer, and RIDGWay, Hist. N. Am. Birds, ii, 1874, 459, footnote.

[Trochilus] scintilla Gray, Hand-list, i, 1869, 144, no. 1864.

(?) Selasphorus underwoodi Salvin, Bull. Brit. Orn. Club, vi, no. xliv, April 30, 1897, p. xxxviii (Volcán de Irazú, Costa Rica; coll. Salvin and Godmau); Ibis, 1897, 441 (reprint).-Carriker, Ann. Carnegie Mus., vi, 1910, 519 (Costa Rica; crit.).

(?) [Selasphorus] underwoodi SHaRpe, Hand-list, ii, 1900, 141.

\section{SELASPHORUS ALLENI Henshaw.}

ALLEN'S a HUMMING BIRD.

Similar to S. rufus, but smaller and with rectrices much narrower (the outermost much less than 2.5 wide in adult male, not more than 2.5 wide in adult fenale); adult male with upper parts (exeept upper tail-coverts and tail) metallic bronze-green (instead of cinnamonrufous), and rectrices next to middle pair tapering gradually, without notch or sinuation near tip.

Adult male.-Above metallic bronze-green, the feathers of rump with basal portion (mostly concealed) deep cinnamon-rufous; upper

a Named for Cliarles A. Allen, of Nicasio, California, who first called attention to the specific distinctness of this species from $S$. rufus.

$81255^{\circ}-13111.50-11-39$ 
tail-coverts and tail deep cinnamon-rufous, the rectrices with a terminal, more or less fusiform, streak of purplish black or dusky, the lateral ones with this dusky confined mostly to outer web; remiges dark brownish slate or dusky, faintly glossed with purplish; loral, orbital, auricular, and postocular regions deep cinnamon-rufous, this sometimes extending, brokenly, across nape; chin and throat brilliant metallic scarlet or orange-red, changing in position $b$ to golden and greenish, the latero-posterior feathers of the gorget elongated; chest white, passing gradually into pale cinnamon-rufous or cinnamonbuff on breast and abdomen, this into deep cinnamon-rufous on sides and flanks; femoral tufts white; under tail-coverts cinnamon-rufous, paler basally; bill dull black; iris dark brown; feet dusky; length (skins), 82-90 (86); wing, 36.5-38.5 (37.8); tail, 25-26.5 (25.6); exposed culmen, $15-16.5$ (15.9). ${ }^{a}$

Adult female.-Above metallic bronze-green, the upper tail-coverts with basal portion light cinnamon-rufous (partly exposed); middle pair of rectrices with basal half (laterally, at least) cinnamon-rufous, the terminal half (more or less) metallic bronze-green; next pair similar, but terminal portion (extensively) black, the tip of inner web sometimes with a small spot of white; three outer rectrices (on each side) broadly tipped with white, crossed by a broad subterminal area of black, the basal portion cinnamon or dull light cinnamon-rufous, this separated from the subterminal black (at least on third rectrix) by more or less of metallic greenish; remiges dark brownish slate or dusky, faintly glossed with purplish; under parts dull white (sometimes slightly tinged with pale cimmamon-buffy), passing into light cinnamon-rufous on sides, flanks, and under tail-coverts, the throat usually spotted, more or less, with metallic orange-red or scarlet; bill, etc., as in adult male; length (skins), 78-90 (85); wing, 41-42 (41.6); tail, 23-26 (24.7); exposed culmen, 17-18.5 (17.8). ${ }^{b}$

Young male.-Similar to the adult female, but upper tail-coverts mostly (sometimes wholly) cinnamon-rufous, rectrices more extensively cinnamon-rufous, and throat strongly tinged with cinnamonrufous and spotted or speckled with dark bronzy.

Pacific coast district of California and southern British Columbia (15S-mile House, Caribou District; east side of Cascade range and southern Rocky Mountain district), eastward through southern California to southern Arizona (Bisbee; Santa Catalina Mountains; IIuachuca Mountains), and to northern Lower California (Piñon, San Pedro Martir Mountains); breeding, locally (in Upper Sonoran and Transition zones), nearly throughout its range, as well as on Santa Bárbara Islands (San Clemente; Santa Catalina; Santa Cruz); in minration extending to Los Coronados Islands, Lower California, 
Sonora, and Chihuáhua (Santa Barbara, September); also resident throughout greater part of its range, as far northward (at least) as Bellingham Bay, Washington.

(?) Ornismya sasin Lesson, Hist. Nat. Ois.-Mouch., 1829, pp. xxx, 190, pls. 66, 67 (based on Le Sasin Audebert, Ois. Dorés, i, 133, pl. 62); Suppl. Ois.-Mouch., 1831-32, 121, 123, 124, pls. 11, 12, 13 (California); Les Troch., 1831, 117, pl. 43 (California); Index Gen. et Synop. Troch., 1832, p. xxxv (California).

Selasphorus sasin Hartert (E. and C.), Novit. Zool., i, no. 1, Jan., 1894, 22, 64 (California; crit.).

Selasphorus rufus (not Trochilus rufus Gmelin) Gould, Mon. Troch., pt. iii, 1854, pl. 5; vol. iii, 1861, pl. 141, part; Introd. Troch., oct. ed., 1861, 88, part.BAIRd, Rep. Pacific R. R. Surv., ix, 1858, 134, part (spec. no. 6059, Steilacoom, Washington).-Cooper and Suckley, Rep. Pacific R. R. Surv., xii, pt. 2, 1860, 164, part (Washington).-Cooper, Orn. Cal., 1870, 355, part.Baird, Brewer, and Ridgwax, Hist. N. Am. Birds, ii, 1874, 459, part.Mulsant and Verreaux, Hist. Nat. Ois.-Mouch., iv, 1877, 106, part.Eldiot, Bull. Nutt. Orn. Club, ii, 1877, 101, excl. syn. (crit.); Classif. and Synop. Troch., 1879, 110, excl. syn., part.-Boucard, Gen. Hum. Birds, ii, 1892, 7, part.

Selasphorus alleni Henshaw, Bull. Nutt. Orn. Club, ii, July, 1877, 53-58 (Nicasio, Marin Co., California; coll. H. W. Henshaw); iii, 1878, 11-15 (crit.); Field and Forest, iii, 1877, 95-98 (habits).-Elliot, Bull. Nutt. Orn. Club, ii, 1877, 97-102 (crit.).-Ridgway, Proc. U. S. Nat. Mus., iii, 1880, 187, 218, 314 (Nicasio to Santa Cruz, California); Nom. N. Am. Birds, 1881, no. 341; Rep. U. S. Nat. Mus. for 1890 (1891), 347 (monogr.; habits); Man. N. Am. Birds, $2 d$ ed., 1896, 598.-Crowell, Ornith. and Oölog., vii, 1883, 126-128 (habits in confinement).-Emerson, Ornith. and Oölog., xi, 1886, 37 (nesting habits).-Coues, Check List, 2 d ed., 1882, no. 412.-Salvin, Cat. Birds Brit. Mus., xvi, 1892, 394 (Nicasio, Tejon, and Coahuila Valley, California).American Ornithologists' Union Committee, Auk, $\mathrm{x}, 1893,62$; Check List, 2 d ed., 1895, no. 434; 3d ed., 1910, 204.-Allen, Bull. Am. Mus. N. H., v, 1893, 36 (Bisbee, Arizona, Aug., Sept.; Santa Barbara, Chihuahua, Sept. 21).-HARTERT (E. and C.), Novit. Zool., i, 1894, 63 (crit.; descr. nest and eggs).-Bendire, Life Hist. N. Am. Birds, ii, 1895, 216.-Grinnell (J.), Pub. no. 1, Pasadena Ac. Sci., 1897, 15 (San Clemente I.; descr. nest and eggs); Pub. no. 2, 1898, 28 (Los Angeles Co., Cal., March, April); Condor, iii, 1901, 128 (breeding range); Auk. xxii, 1905, 384 (Seymour Canyon, Mt. Piños, California, 6,500 ft.; habits); xv, 1898, 235 (Santa Catalina I., Dec. abundant); Univ. Cal. Pub. Zool., v, 1908, 71 (San Bernardino Mts., June 28-Aug. 29; not breeding).-Orerholser, Proc. U. S. Nat. Mus., xxii, 1900, 230 (Santa Cruz I., July).-BaIley (Florence M.), Irandb. Birds W. U. S., 1902, 241.-Rathiun, Auk, xix, 1902, 135 (Seattle, Washington, rare summer res.).-Brooks, Auk, xx, 1903, 282 (158-mile House, Caribou Distr., Brit. Columbia, breeding).-STone, Proc. Ac. Nat. Sci. Phila., 1904, 582 (Mt. Sanhedrin, Mendocino Co., California).-Richardson, Condor, iv, 1904, 135 (Piute Mts., s. e. California); x, 1908, 66 (Santa Catalina I., breeding).Swartir, Pacific Coast Avifauna, no, 4, 1904, 19 (IIuachuca Mits., Arizona, July).-Jenkins, Condor, viii, 1906, 126 (Monterey Co., California).Bowles, Auk, xxiii, 1906, 144 (Tacoma, Washington, epring).-Linton, Condor, x, 1908, 84 (San Clemente I., breeding), 127 (Santa Cruz I., Nov.).EDson, Auk, xxv, 1908, 434 (Bellingham Bay, Washington, resident).Wright, Condor, xi, 1909, 100 (Los Coronados Islands, Lower California).Torney, Condor, xi, 1909, 173 (San Diego, Jan.).-Van Rossem, Condor, xi, 
1909, 208 (Los Coronados Islands, April, common).-Kernode, Prov. Mus.

1909, 52 ("eastern Cascades and Rocky Mts.," Brit. Columbia).

S[elasphorus] alleni Coues, Key N. Am. Birds, 2d ed., 1884, 463.-Hartert,

Das Tierreich, Troch., 1900, 205.

[Selasphorus] alleni Sharpe, Hand-list, ii, 1900, 140.

Trochilus alleni Ridg way, Proc. U. S. Nat. Mus., viii, sig. 23, Sept. 2, 1885, 355.-

American Ornithologists' Union, Check List, 1886, no. 434.-Scott, Auk, iii, 1886, 431 (Santa Catalina Mts., Arizona, 4,500 ft., 1 spec., July).Fannin, Check List Birds Brit. Col., 1891, 30 (e. Cascade and Rocky Mit. districts).-Lawrence (R. H.), Auk, ix, 1892, 44 (Grays Harbor, Washington, summer resid.).

T[rochilus] alleni RIDGWay, Man. N. Am. Birds, 1887, 314.

\section{SELASPHORUS RUFUS (Gmelin).}

\section{RUFOUS HUMMING BIRD.}

Adult male.-Pileum dull metallic bronze or bronze-green; rest of upper parts, including loral, orbital and auricular regions, sides of occiput, and greater part of tail, plain cinnamon-rufous, the back sometimes glossed with metallic bronze-green; rectrices with a terminal median, more or less fusiform or cuneate, area of purplish or bronzy dusky; remiges dark brownish slate or dusky, faintly glossed with purplish; chin and throat brilliant metallic scarlet; changing to golden green in position $b$; chest white, passing through cimnamon-buff posteriorly into cinnamon-rufous on rest of under parts (paler medially); the under tail-coverts whitish basally; femoral tufts white; bill dull black; iris dark brown; feet dusky; length (skins), 73-91 (84); wing, 38-41.5 (40.3); tail, 26-29 (27.9); exposed culmen, $15-17.5$ (16.5).$^{a}$

Adult female.-Above metallic bronze-green, usually slightly duller on pileum; remiges dark brownish slate or dusky, faintly glossed with purplish; middle pair of rectrices metallic bronze-green (usually more dusky terminally), both webs broadly edged basally with cinnamon-rufous (sometimes with whole basal half or more of this color); next pair with more than basal half cinnamon-rufous, then metallic bronze-green, the terminal portion purplish black; three outer pairs broadly tipped with white, the subterminal portion (extensively) purplish black, the basal half (approximately) cinnamon-rufous, the latter usually separated from the black by more or less of metallic bronze-green; chin, throat, and chest dull white, the throat usually with tips of some of the feathers metallic orange-red or scarlet (changing to golden and greenish), sometimes with a large patch of this color; rest of under parts cinnamon-rufous laterally, fading into dull buffy whitish on breast and abdomen; femoral tufts white; under tail-coverts pale cinnamon-rufous or cinnamon-buff centrally, broadly margined with white or buffy white, the longer 
ones sometimes with the central area pale grayish or brownish terminally; bill, etc., as in adult male; length (skins), 79-90 (85); wing, 43-45 (44.4); tail, 24.5-28 (26.4); exposed culmen, 17-19 (18). ${ }^{a}$

Young male.-Similar to the adult female but upper tail-coverts cinnamon-rufous, with a terminal spot of metallic bronze-green; middle pair of rectrices cinnamon-rufous with terminal portion metallic bronze-green (sometimes partly blackish) the lateral rectrices with white tip smaller and cinnamon-rufous deeper and more extensive, and feathers of throat with a terminal mesial spot or streak of dusky metallic bronze or bronze-green.

Young female. - Similar to the adult female but feathers of upper parts (especially rump and upper tail-coverts) narrowly and indistinctly margined terminally with pale dull cinnamon or buffy, and throat spotted or streaked with dark bronzy, as in young male.

Western North America; north to coast district of Alaska as far as latitude $61^{\circ}$ (Eagle Lake; Glacier; Lake Bennett); east to Alberta (Banff, headwaters of Peace River, and 15 miles south of Henry House, breeding), Montana (Flathead Lake, breeding; Chief Mountain Lake; Nyack, June 22; Columbia Falls), Wyoming (Carbon, July), Colorado (breeding at from 6,500-10,500 feet), and New Mexico (upper Pecos River, 7,500-9,000 feet, breeding; Deer Springs and Inscription Rock, July); breeding southward to higher mountains of New Mexico and Arizona (Santa Catalina range), northern California (lower MeCloud River; Mount Shasta; Camp Bidwell; Humboldt Bay and northward along coast) and southward along coast to Santa Clara County and in Sierra Nevada at least to Calaveras County (Big Trees), as well as, locally (in Transition and Canadian zones), throughout the general range; in winter some migrating southward to Lower California (San Quintín; Cerros Island), Santa Barbara Islands, and over highlands of Mexico, through States of Sonora (San José Mountains, August), Zacatecas (Plateado, September; Xeres, September; Sierra de Valpariaso, August), Michoaeán (Patzcuaro, August), Colima (Volcán de Colima, January), Mexico (near City of Mexico; Ajusco; Tetelco; Tlalpán, December; Volcán de Toluca, September), San Luís Potosí (mountains near Jesús Maria, September) and Vera Cruz (Miradór) to Oaxaca (La Parada; 15 miles west of Oaxaca City, September).

[Trochilus] rufus Gmelin, Syst. Nat., i, pt. 1, 1788, 497 (Nootka Sound, British Colombia; based on Ruffed Iloneysucker Pennant, Arctic Zool., ii, 290; Ruf-necked Ifumming Bird Latham, Gen. Synop., i, pt. 2, 785).--Аaтmaм, Index Orn., i, 1790, 315.

Trochilus rufus Jardine, Nat. Libr., Humming birds, ii, 1833, 97, pl. 11.Audubon, Orn. Biog., iv, 1838, 555, pl. 379.-Nuttaln, Man. Orn. U. S. and Can., 2d ed., i, 1840, 714.-American Ornithologists' Union, Check 
List, 1886, no. 433.-AnтHony, Auk, iii, 1886, 166 (Washington Co., Oregon, breeding).-Evermann, Auk, iii, 1886, 180 (Ventura Co., California; "breeding;" error?).- Scotт, Auk, iii, 1886, 431 (Santa Catalina Mts., Arizona, 4,000-6,000 ft.; breeding?).-Nelson, Nat. Hist. Coll. Alaska, 1887, 161 (Sitka).-Townsend (C. H.), Proc. U. S. Nat. Mus., x, 1887, 209 (lower McCloud R., n. California, breeding; habits).-MerrmL, Auk, v, 1888, 257 (Ft. Klamath, Oregon, transient).-Bryant (W. E.), Proc. Calif. Ac. Sci., ser. 2, 1889, 289 (San Quintín, Lower California).-Merriam, North Am. Fauna, no. 3, 1890, 93 (San Francisco Mt., Arizona).-Fannin, Check List Birds Brit. Col., 1891, 30 (both sides Cascade range).-Lawrence (R. H.), Auk, ix, 1892, 44 (Grays Harbor, Washington, summer resid.).

T[rochilus] rufus Jardine, Nat. Libr., Humming birds, ii, 1833, 167.-Ridgway, Man. N. Am. Birds, 1887, 314.

Trochilus (Selasphorus) rufus Swainson, Fauna Bor.-Am., ii, 1831, 324. S[elasphorus] rufus Swainson, Fauna Bor.-Am., ii, 1831, 496.-Coues, Key N. Am. Birds, 2 d ed., 1884, 462.--HARtert, Das Tierreich, Troch., 1900, 204.

Selasphorus rufus Audubon, Synopsis, 1839, 171; Birds Am., oct. ed., iv, 1842, 200, pl. 254.-Gould, Mon. Troch., pt. iii, 1854, pl. 5, part; vol. iii, 1861, pl. 141, part; Introd. Troch., oct. ed., 1861, 88, part.-HeErmann, Journ. Ac. Nat. Sci. Phila., 2d ser., ii, 1853, 269 (San Francisco, California).-Newberry, Rep. Pacific R. R. Surv., vi, pt. iv, chapt. ii, 1857, 648 (California; Oregon).BaIrd, Rep. Pacific R. R. Surv., ix, 1858, 134; Cat. N. Am. Birds, 1859, no. 103; Rep. U. S. and Mex. Bound. Surv., ii, pt. ii, 1859, 6 (El Paso, Texas).-Xantus, Proc. Ac. Nat. Sci. Phila., 1859, 190 (Ft. Tejon, California).-Cooper and Suckley, Rep. Pacific R. R. Surv., xii, pt. 2, 1860, 164, part (Washington; habits, etc.).-Sclater, Cat. Am. Birds, 1862, 297 (Mexico); Proc. Zool. Soc. Lond., 1864, 177 (City of Mexico).-Cassin, Proc. Ac. Nat. Sci. Phila., 1863, 319 (Sitka, Alaska).-Coues, Proc. Ac. Nat. Sci. Phila., 1866, 57 (Ft. Whipple, Arizona, breeding); Check List, 1873, no. 277; 2d ed., 1882, no. 411; Bull. U. S. Geol. and Geog. Surv. Terr., iv, 1878, 614 (Chief Mt. Lake, Montana, August).-Brown, Ibis, 1868, 419 (Vancouver I.).-Dall and Bannister, Trans. Chicago Ac. Sci., i, 1869, 275 (Sitka).Cooper, Orn. Cal., 1870, 355, part; (?) Proc. Calif. Ac. Sci., 1870, 58 (Santa Barbara and Santa Catalina islands).-Finsch, Abth. Nat. Mus. Brem., iii, 1872, 29 (Sitka, Alaska).-Batrd, Brewer, and Ridgway, Hist. N. Am. Birds, ii, 1874, 459, pl. 47, fig. 4.-Henshaw, Rep. Orn. Spec. Wheeler's Surv., 1873 (1874), 131, 162 (Deer Springs and Inscription Rock, New Mexico, July; Apache, Arizona, July, August; Camp Grant, Arizona, Sept.); 1876, 256 (Santa Barbara, California, June; Tejon Mts., Aug.); 1879, 312 (near Camp Bidwell, California, breeding); Zool. Expl. W. 100th Merid., 1875, 375 (localities in Colorado, New Mexico, and Arizona; habits); Bull. Nutt. Orn. Club, ii, 1877, 52-57 (crit.); Aun. Rep. Wheeler's Survey, 1877, 1310, 1318 (mts. near Carson City, Nevada); Auk, iii, 1S86, 76 (upper Pecos R., New Mexico, 7,500-9,000 ft., breeding; habits).-Ridgway, Bull. Essex Inst., vii, 1875, 10 (Truckee Valley, Nevada), 22 (East Humboldt Mts., Nevada); Field and Forest, 1877, 209 (Colorado); Orn. 40th Parallel, 1877, 559; Proc. U. S. Nat. Mus., iii, 1880, 187, 314; Nom. N. Am. Birds, 1881, no. 340; Rep. U. S. Nat. Mus. for 1890 (1891), 343, pl. 40 (monogr.; habits); Man. N. $\Lambda \mathrm{m}$. Birds, 2 d ed., 1896, 598.-De OcA, La Naturaleza, iii, 1875, 9, pl. 5, fig. 19; Troq. de Mex., 1875, 29, pl. 5, fig. 19.-Boucard, Ann. Soc. Linn. Lyon, xxii, 1876, 18; Notes Troch. du Mex., 1875, 5 (La Parada, Oaxaca; habits); Gen. Hum. Birds, ii, 1892, 7, part (includes S. alleni!).-Mulsant and Verrenux, Hist. Nat. Ois.-Mouch., iv, livr. 2, 1877, 106, part.Bebding, Proc. U. S. Nat. Mus., i, 1879, 427 (Stockton, April; Big Tree,, 
July).-Sumichrast, La Naturaleza, v, 1881, 250 (Valley of Mexico).Herrera, La Naturaleza, (2), i, 1891, 322 (Valley of Mexico).-Bendire, Proc. Bost. Soc. N. H., xix, 1877, 128 (Camp Harney, Oregon); Life Hist. N. Am. Birds, ii, 1895, 213.-Belding, Proc. U. S. Nat. Mus., i, 1879, 393, 427 (Stockton, etc., California; breeding at Big Trees, Calaveras Co.).Drew, Bull. Nutt. Orn. Club, vi, 1881, 140 (San Juan Co., Colorado, breeding); Auk, ii, 1885, 17 (Colorado, breeding from 6,500-10,500 ft.).-BEAN, Proc. U. S. Nat. Mus., v, 1882, 161 (Sitka).-Hartlaub, Journ. für Orn., 1883, 265 (Alaska).-SAlvin, Cat. Birds Brit. Mus., xvi 1892,392 (Patzcuaro, Michoacán; Oaxaca; Volcán de Colima; etc.).-Salvin and Goduan, Biol. Centr.-Am., Aves, ii, 1892, 353.-Rhодds, Proc. Ac. Nat. Sci. Phila., 1893, 44 (Brit. Columbia).-American Ornithologists' Union Committee, Auk, x, 1893, 62; Check List, 2d ed., 1895, no. 433; 3d ed., 1910, 204.-HARTERT (E. and C.), Novit. Zool., i, 1894, 21 (California; descr. nest and eggs).Dawson, Auk, xiv, 1897, 175 (Okanogan Co., Washington, 8,000 ft.).Merrill (J. C.), Auk, xiv, 1897, 335 (Ft. Sherman, Idaho; breeding?).Cooke, Bull. Col. Agric. Coll., no. 37, 1897, 86 (s. w. Colorado, breeding at 7,000-10,000 ft.); no. 44, 1898, 162 (Carbon, Wyoming, July 24); Auk, xxvi, 1909, 413 (near Antonito, Colorado, 1 spec., Aug. 27).-Grinnelu (J.), Ank, xv, 1898, 128 (Sitka; breeding); Pub. 2, Pasadena Ac. Sci., 1898, 28 (Los Angeles Co., California, Feb. 20-Oct. 5; not breeding); Condor, iii, 1901, 128 (breeding along coast of California north of Humboldt Bay); Univ. Calif. Pub. Zool., v, 1909, 219 (Admiralty, Baranof, and Chichagoff islands, Idaho Inlet, etc., Alaska); v, 1910, 392 (Cordova, Hawkins I., etc., Prince William Sound).-Merriam, North Am. Fauna, no. 16, 1899, 117 (Mt. Shasta, breeding).-Van Denburg, Proc. Am. Philos. Soc., xxxviii, 1899, 166 (Santa Clara Co., California, breeding).-Bishop, North Am. Fauna, no. 19, 1900, 79 (Eagle I., Glacier, and Lake Bennett, Alaska).-Osgood, North Am. Fanna, no. 21, 1901, 46 (Queen Charlotte Islands).-Silloway, Bull. Univ. Montana, no. 3, 1901, 54 (Flathead Lake, Montana, breeding).-BAILEY (Florence M.), Handb. Birds W. U. S., 1902, 239, fig. 316; Auk, xxi, 1904, 354 (upper Pecos, New Mexico, 10,200-12,600 ft., July).-Rathbun, Auk, xix, 1902, 135 (Seattle, Washington, summer res.).-RAY, Auk, xx, 1903, 184 (Glen Alpine, centr. Sierra Nevada, breeding).-Swarth, Pacific Coast Avifauna, no. 4, 1904, 18 (Huachuca Mts., Arizona, migratory; habits).Fintey, Condor, vii, 1905, 59 (habits).-Johnson, Condor, viii, 1906, 27 (Cheney, Washington, transient).-Thayer and Bavgs, Condor, ix, 1907, 78 (Cerros I., Lower California).-Preble, North Am. Fauna, no. 27, 1908, 391 (15 miles s. of Henry House, July, Banff, breeding, and headwaters of Peace R., Alberta).-Eoson, Ank, xxv, 1908, 434 (Bellingham Bay, Washington, summer res.).-Rockwell, Condor, x, 1908, 165 (Mesa Co., s. w. Colorado, migratory).-Henderson, Univ. Cal. Stud., vi, 1909, 232 (Boulder, Colorado).-Kermode, Prov. Mus., 1909, 52 (Vancouver I. and Okanogan, Brit. Columbia).-Swarth, Univ. Calif. Pub. Zool., vii, 1911, 73 (Kuiu, Prince of Wales, Coronation, Warren, Dall, and Revillagigedo islands, etc., s. Alaska).

[Selasphorus] rufus Sclater and Salvin, Nom. Av. Neotr., 1873, 84.-Mulsant, Ann. Soc. Linn. Lyon, n. s., xxii, 1876, 227.-Sharpe, Hand-list, ii, 1900, 140.

[Selasphorus rufus] var. rufus Batrd, Brewer, and Ridgway, Hist. N. Am. Birds, ii, 1874, 459.

Selasforus mefus Dugés, La Naturaleza, i, 1870,141 (Guanajuato).-Villada, La Naturaleza, ii, 1874, 355 (Valley of Mexico).

Sclatophorus rufus Newron, Dict. Birds, pt. ii, 1893, 448, in text. 
Calliphlox rufa Bonaparte, Comp. and Geog. List, 1838, 10.-Gamber, Proc. Ac. Nat. Sci. Phila., 1846, 111; Weigmann's Archiv für Naturg., xiv, 1848, 82.

Polytmus rufus Woodhouse, Rep. Sitgreaves' Expl. Zuñi and Col. R., 1853, 66 (New Mexico).

Trochilus ruffus Audebert and Vieillot, Ois. Dorés, i, 1802, 110, 111, pls. 61,62 .

[Trochilus] collaris Latham, Index Orn., i, 1790, 318 (based on T. rufus Gmelin; cites also Sassineer sasin Cook's Last Voy., ii, 297, etc.).

Trochilus collaris .Vienllot, Ois. Am. Sept., ii, 1807, 75; Nouv. Dict. d'Hist. Nat., vii, 1817, 374 (cites Ois. Dorés, pls. 61, 62).-SHAw, Gen. Zool., viii, $1811,343$.

T[rochilus] collaris Vieillot, Tabl. Enc. Méth., ii, 1822, 571.

[Selosphorus] ruber (not Trochilus ruber Linnæus) a Bonaparte, Consp. Av., i, $1850,82$.

[Selasphorus] ruber Bonaparte, Rev. et Mag. de Zool., 1854, 256.

Selasphorus ruber Reichenbach, Aufz. der Colibr., 1854, 13; Troch. Enum., 1855, 10, pl. 852, figs. 5021-5023.-Sclater, Proc. Zool. Soc. Lond., 1857, 126 (San José Valley, California); 1858, 297 (Oaxaca).

S[elasphorus] ruber Cabanis and Heine, Mus. Hein., iii, 1860, 56 (California).

Sclasphorus henshawi Eluot, Bull. Nutt. Orn. Club, ii, Oct., 1877, 97, 102 (crit.); Classif. and Synop. Troch., 1879, 111.

"Trochilus sitkensis RathkE (Bonaparte)."

\section{SELASPHORUS FLORESII Gould. $b$}

\section{FLORESI'S HUMMING BIRD.}

Adult male.-Forehead and crown, chin, and throat glittering metallic rose red, changing to scarlet, especially on chin and upper throat; occiput, hindneck, back, scapulars, wing-coverts, rump, and upper tail-coverts metallic bronze-green; remiges dusky, or dull brownish slate, faintly glossed with purplish; middle pair of rectrices metallic green (much less bronzy than back, etc.), the outer web broadly edged with rufous-chestnut nearly to the tip, the inner web similarly marked for basal half; next rectrix chestnut-rufous with a median stripe of purplish-black, this stripe gradually coming to a point before the base of the feather is reached, but in the other direction widening so as to reach the edge of each web about 6.3 $\mathrm{mm}$. from the tip; next rectrix similar, but the black occupying whole width of outer web to a distance of half an inch from the tip, but much restricted on inner web; next with the black extending about as far along the edge of the outer web, but not reaching farther along the shaft, while on the inner web it follows the shaft no farther than $5 \mathrm{~mm}$. from the tip; lateral rectrix dusky, with shaft chestnut-rufous nearly to the tip and inner web a paler

"Syst. Nat., ed. 12, i, 1766, 193; based on Little Brown Humming Bird Edwards, pl. 32; Oiseau-Mouche Pourpre Buffon, IIist. Nat. Ois., vi, 24; Mcllisuga surinamensis Brisson, Orn., iii, 701.

b Alunosi ceriainly a hybrid of S. alleni and Calypte anna. 
tint of the same for about the basal half; chest pale brownish gray, paler anteriorly against the lower margin of the metallic gorget; middle line of breast and belly similar; sides and flanks metallic bronze-green, the feathers margined with pale brownish gray; axillars and adjacent smaller under wing-coverts light chestnut or cinnamon-rufous; femoral downy tufts white; under tail-coverts pale cinnamon-rufous, becoming grayish white on latero-basal portion; bill black; wing, 43.2; middle rectrices 25.4, longest rectrices (third pair), 30.5, shortest (outer pair), 24.1; exposed culmen, 16.5. ${ }^{a}$

Bolaños, Jalisco, 1845 ; $^{b}$ San Francisco, California, 1885; Haywards, Alameda Co., California, Feb. 20, 1901; near Nicasio, Marin Co., California, Feb. 26, 1909.

Selasphorus floresii (not Trochilus floresii Bourcier, 1846 c) Gould, Mon. Troch., pt. xxiii, Sept. 1, 1861, pl. 10; vol. iii, 1861, pl. 139 (Bolaños, Jalisco, Mexico; coll. J. Gould; ex Trochilus floresii Loddiges, manuscript); Introd. Troch., oct. ed., 1861, 89.-Mulsant and Verreaux, Classif. Troch., 1866, 89; Hist. Nat. Ois.--Mouch., iv, livr. 2, 1877, 98 (Bolaños).-Villadd, La Naturaleza, ii, 1874, 356.-DE OCA, La Naturaleza, iii, 1875, 101, pl. 6, fig. 21; Troq. de Mex., 1875, 31, pl. (6), fig. 21.-Boucard, Ann. Soc. Linn. Lyon, xxii, 1876, 20; Notes Troch. du Mex., 1875, 7.-Eunot, Classif. and Synop. Troch., 1879, 109.-Bryant, Forest and Stream, xxvi, no. 22, July 24, 1886, 426 (San Francisco, Cal.).-RIdGWay, Rep. U. S. Nat. Mus. for 1890 (1891), 340, pl. 38, fig. 1; Man. N. Am. Birds, 2d ed., 1896, 598.-SAlvin, Cat. Birds Brit. Mus., xvi, 1892, 392.-Salvin and Godman, Biol. Centr.Am., Aves, ii, 1892, 352.-American Ornithologists' Union Committee, Auk, x, 1893, 62; Check List, 2d ed., 1895, no. 431.1.-Bendire, Life Hist. N. Am. Birds, ii, 1895, 209.-Enerson, Condor, iii, 1901, 68 (Haywards, Alameda Co., California, 1 spec., Feb. 20, 1901).-Grinneld (J.), Pacific Coast Avifauna, no. 3, 1902, 41 (California records).-BAILEy (Florence M.); Handb. Birds W. U. S., 1902, 238.-TAYLor (W. P.), Auk, xxvi, 1909, 291, in text (near Nicasio, Marin Co., California, 1 spec., Feb. 26, 1909; crit.).

$a$ Description from no. 2620, coll. Walter E. Bryant, from San Francisco, California. This specimen agrees exactly with Mr. Gould's description and colored figures except in some minor and unessential points, and since Mr. Gould's description and figures, though from the same specimen, do not agree with one another, it is altogether likely that neither is quite correct. Mr. Gould describes the color of the middle pair of rectrices as "green with purple reflexions," and the lateral ones as having the outer webs "purple" and the "inner webs deep reddish buff," but they are not so colored in the plate, which represents the middle pair as green with a continuous broad border of rufous, and the outer pair as uniform purplish dusky, the intermediate rectrices being rufous with a narrow median stripe of purplish dusky, expanding into a wedge-shaped space near the tip. The coloration of the tail as represented in the plate agrees very well with that of the San Francisco specimen, except that the latter has the basal half of the inner web of the outermost rectrix rufous, and lacks the rufous border around the end of the middle rectrices the rufous running out to the edge a little past the middle of the feather, and thus confined to a little more than the basal lialf.

$b$ It is possible that the specimen (Gould's type) in reality came from California, since Floresi collected there as well as in Mexico.

c Trochilus florcsii Bourcier, Rev. Zool., 1846, 316 (Jamaica); =Anthracothorax mango (Linnæeus). 
[Selasphorus] floresii Sclater and Salvin, Nom. Av. Neotr., 1873, 84.-Mulsant, Ann. Soc. Linn. Lyon, n. s., xxii, 1876, 227.-Sharpe, Hand-list, ii, $1900,141$.

S[elasphorus] floresii HaRTERT, Das Tierreich, Troch., 1900, 207 (monogr.).

[Trochilus] floresii (not of Bourcier, 1846) GrAY, Hand-list, i, 1869, 144, no. 1865. T[rochilus] floresii RIDGWAY, Man. N. Am. Birds, 1887, 315.

Trochilus floresii Chapman, Auk, v, 1888, 396.-American Ornithologists' Union, Suppl. Check List, 1889, 10; Abridged Check List, 1889, no. 431.1. Calypte floresi Baird, Brewer, and Ridgway, Hist. N. Am. Birds, ii, 1874, 453. Calypte floresii Boucard, Gen. Hum. Birds, ii, 1892, 5.

Trochilus (Selasphorus) floresii Ridgway, Man. N. Am., Birds, 1887, 593.

Trochilus rubromitratus or Selasphorus rubromitratus RidGWAY, Auk, viii, Jan., 1891, 114 (proposed as substitute for specific name floresii, if considered preoccupied).

Selasphorus rubromitratus Ridaway, Rep. U. S. Nat. Mus. for 1890 (1891), 341 (monogr.).

\section{Genus CALYPTE Gould.}

Calypte a Gould, Monogr. Troch., pt. xi, May, 1856, vol. iii, 1861, text to pl. 134; Introd. Troch., oct. ed., 1861, 87. Type, Ornismya costæ Bourcier.)

Leucaria Mulsant, Ann. Soc. Linn. Lyon, xxii, 1876, 227 (Cat. des Ois.-Mouch., 1875, 29). (Type, Ornismya costæ Bourcier.)

Zephyritis Mulsant and Verreaux, Mém. Soc. Imp. Sci. Nat. Cherb., xii (sér. 2, ii), 1866, 231 (Classif. Troch., 1866, 87). Type, Ornismya anna Lesson or o. costae Bourcier.)

Small to extremely small ${ }^{b}$ Trochilidæ (length about $55-95 \mathrm{~mm}$.), resembling and closely related to Architochus, but differing in normal inner (proximal) primaries, round-tipped instead of pointed rectrices, lateral rectrices more strongly incurved, the adult males with the "gorget" elongated laterally and the pileum glittering metallic red or violet, like the "gorget."

Bill about as long as head or (in C. helenæ) slightly shorter, straight, rather slender, terete or (in $C$. helenæ) broader than deep basally; culmen rounded, except basally, where contracted into a distinct ridge; tomia smooth; mandible with the usual lateral median groove. Nasal operculum rather broad and convex, but hidden by appressed frontal feathering, which anteriorly extends much beyond anterior end of nostrils, forming a short obtuse point or antia on each side of culmen. Tarsus feathered, except along posterior side; outer toe slightly, the inner more decidedly, shorter than middle toe, the hallux about as long as inner toe. Wing about three times as long as exposed culmen, the outermost primary longest; all the primaries normal in shape. Tail of adult males one-half to nearly three-fifths as long as wing, emarginate (but three outermost rectrices, on each side, subequal in length), the lateral rectrices narrow (less so in $C$. helen $x)$, incurved $(C$. cost $x)$, or the reverse (C. anna) terminally, all

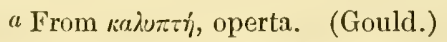

$b$ One species, $C$. helenx (Lembeye), the smallest of known birds! 
rounded at tip; in adult females about half as long as wing, rounded, the lateral rectrices broad and rounded.

Coloration.-Above metallic bronze-green, including middle rectrices, or (in C. helenæ) bluish green passing into blue on middle rectrices; beneath mostly, or in large part, whitish or pale grayish. Adult male with entire head glittering metallic purplish red or (in $C$. costr) violet, the feathers of sides of throat much elongated, and lateral rectrices plain dusky; adult females and young with pileum brownish gray (sometimes faintly bronzy or greenish), the chin and throat dull white (sometimes flecked or streaked with dusky or spotted with metallic red or violet), the lateral rectrices grayish basally and broadly tipped with white.

Range.--Southwestern United States and northwestern Mexico (two species) and island of Cuba (one species). (Three species.)

KEY TO THE SPECIES OF CALYPTE.

a. Throat brilliantly metallic purplish red or violet, the pileum of same color. (Adult males.)

b. Larger (wing more than 40, tail more than 20, exposed culmen more than 15); middle rectrices metallic green or bronze-green.

c. Head metallic purplish red; wing 48.5-51 (49.7), tail 30.5-32.5 (31.3). (California to northwestern Mexico.).......... Calypte anna, adult male (p. 619). cc. Head metallic violet, changing to blue; wing 43-45.5 (44.4), tail 22-24.5 (22.6). (Northwestern Mexico to southern California and Nevada.)

Calypte costæ, adult male (p. 623).

$b b$. Smaller (wing less than 30 , tail less than 17 , exposed culmen 10); middle rectrices metallic blue. (Cuba.)........... Calypte helenæ, adult male (p. 625).

$a a$. Throat pale gray or dull whitish (sometimes flecked with dusky or with a few metallic red or violet feathers); pileum greenish, like back, or grayish. (Adult females.)

$b$. Larger (wing more than 40, tail more than 20, culmen 17 or more); middle rectrices metallic green or bronze-green.

c. Wing 48-51 (49.6); under parts darker grayish; lateral rectrices broader and more rounded, $5 \mathrm{~mm}$. wide at base of deeper gray tip.

Calypte anna, adult female (p. 620).

cc. Wing 43.5-46 (44.7); under parts paler grayish; lateral rectrices narrower and more pointed, not more than $4 \mathrm{~mm}$. wide at base of paler gray tip.

Calypte costæ, adult female (p. 623).

$b b$. Smaller (wing less than 35 , tail less than 20, exposed culmen less than 12); middle rectrices metallic blue or greenish blue.

Calypte helenæ, adult female (p. 626).

\section{CALYPTE ANNA (Lesson).}

ANNA HUMMING BIRD.

Adult male.-Whole head except occiput and auricular region brilliant metallic rose red, changing to solferino and violet in certain lights (more golden or even greenish in position $b$ ), the latero-posterior feathers of throat elongated; a small postocular spot or streak of white; occiput (except laterally, where at least partly metallic 
purplish red), hindneck, back, scapulars, wing-coverts, and rump metallic bronze-green, the upper tail-coverts and middle pair of rectrices similar but usually less bronzy, or more bluish, green; tail (except middle pair of rectrices) dark grayish, faintly glossed with greenish bronze, the rectrices blackish terminally and medially; remiges brownish slate or dusky, faintly glossed with purplish; chest pale brownish gray or dull grayish white, the feathers darker brownish gray beneath surface; rest of under parts deeper grayish, strongly glossed with metallic bronze-green laterally, the feathers more or less distinctly margined with paler grayish; femoral tufts and conspicuous tuft on each side of rump white; under tail-coverts brownish gray glossed with bronze-green or greenish bronze (especially on shorter coverts) and broadly margined with pale gray or grayish white; bill dull black; iris dark brown; feet dusky; length (skins), 90-102 (96); wing, 48.5-51 (49.7); tail, 30.5-32.5 (31.3); middle rectrices, 23.525.5 (24.4); exposed culmen, 17.5-20 (18.2). ${ }^{a}$

Adult female.-Above metallic bronze or bronze-green, duller on pileum, the forehead sometimes dull grayish brown; middle pair of rectrices metallic green or bronze-green, sometimes dusky terminally, the next pair similar, but with terminal portion (broadly) blackish; third pair similar to second, but more extensively blackish terminally and narrowly tipped with white; two outer pairs with basal half (more or less) brownish gray, the tip pale brownish gray or dull grayish white (broader on outermost rectrix), the intermediate (subterminal) portion black; remiges brownish slate or dusky, faintly glossed with purplish; chin and throat pale brownish gray or dull grayish white, the center of throat usually with an admixture of metallic red or purplish red feathers, sometimes with a considerable patch of metallic reddish; the lower throat, at least, with mesial guttate spots or broad streaks of dusky grayish brown or dull bronzy; rest of under parts as in the adult male, but slightly paler and less extensively glossed with metallic greenish; bill, etc., as in adult male; length (skins), 84-99 (91); wing, 48-51 (49.6); tail, 25-28.5 (27.2); exposed culmen, 17-22 (18.8). ${ }^{a}$

Young male.-Similar to the adult female, but tail $\mathrm{......} \mathrm{rounded,}$ lateral rectrices with dark subterminal portion duller blackish and less sharply contrasted with dull grayish of basal portion, feathers of upper parts very narrowly and indistinctly margined with pale buffy grayish and (at least older individuals) with metallic purplish red feathers on crown as well as on throat.

Young female.-Similar to the adult female, but fcathers of upper parts narrowly margined with pale brownish or dull buffy and throat without metallic red feathers. 
California in general (except parts of northern coast district?), north to Shasta County (Wagon Camp, Mount Shasta; McCloud River), Siskiyou County (Yreka), and Mendocino County (Mount Sanhedrin), east to Sierra Nevada (near Pyramid Peak; Nevada, etc.), and southward (as a resident) to coast district of northern Lower California; during migration to Santa Barbara Islands (Santa Catalina Island, December; Santa Cruz Island), Guadalupe Island, Cerros Island, Todos Santos Island, and Los Coronados Islands, San Pedro Martir Mountains, near Tia Juana, etc., Lower California, and southeastward to southern Arizona (Camp Grant, September; Santa Catalina Mountains, October), and northern Sonora (San José Mountains, August).

Ornismya anna Lesson, Hist. Nat. Ois.-Mouch., 1829, pp. xxxi, xlvi, 205, pl. 74 (California; coll. Rivoli); Suppl. Ois.-Mouch., 1831, 115, pl. 7; Traité d'Orn., i, 1831, 281; ii, 1831, pl. 74; Index Gen. et Synop. Troch., 1832, p. xxxvi.

Trochilus anna Jardine, Nat. Libr., Humming-birds, i, 1834, 137, pl. 6.-BonaParte, Comp. and Geog. List, 1838, 10.-Audubon, Orn. Biog., v, 1839, 238, pl. 425; Synopsis, 1839, 170; Birds Am., oct. ed., iv, 1842, 188, pl. 252.Heermann, Journ. Ac. Nat. Sci. Phila., 2d ser., ii, 1853, 269 (California); Rep. Pacific R. R. Surv., x, pt. iv, no. 2, 1859, 56 (San Diego and Cosumnes R., California).-Cassin, Illustr. Birds Cal., Tex., etc., 1854, 147.-NewBerry, Rep. Pacific R. R. Surv., vi, pt. ii, 1857, 79 (California).-American Ornithologists' Union, Check List, 1886, no. 431.-Scotт, Auk, iii, 1886, 431 (Santa Catalina Mts., Arizona, 5,000 ft., 1 spec., Oct. 1).-Bryant (W. E.), Bull. Calif. Ac. Sci., ii, 1887, 292 (Guadalupe I., Lower California); 1889, 289 (Villaderes, between Tia Juana and San Pedro Martir Mts., Cerros I. and Guadalupe I., Lower California).-Townsend, Proc. U. S. Nat. Mus., x, 1887, 208 (McCloud R., n. California; habits; descr. nest).-Thayer and Bangs, Condor, ix, 1907, 78 (Cerros I.).

T[rochilus] anna Ridgway, Man. N. Am. Birds, 1887, 312.-Hartert, Das Tierreich, Troch., 1900, 203.

[Trochilus] anna Reichenbach, Troch. Enum., 1855, 10, pl. 834, figs. 4963-4965.Gray, Hand-list, i, 1869, 145, no. 1867.-Sharpe, Hand-list, ii, 1900, 140.

Trochilus annæ Evermann, Auk, iii, 1886, 180 (Ventura Co., California).

[Trochilus. 0. Atthis] anna Reichenbach, Aufz. der Colibr., 1854, 12.

C[rochilus $]$ anna JARdine, Nat. Libr., Hummingbirds, ii, 1833, 167.

M[cllisuga] anna Gray, Gen. Birds, i, Dec., 1848, 113.

Calliphlox anna Gamber, Proc. Ac. Nat. Sci. Phila., 1846, 3; Journ. Ac. Nat. Sci.

Phila., 2d ser., i, 1847, 32 (California; habits).-CaBANIs, in Wiegmann's

Archiv für Naturg., xiv, pt. i, 1849, 94.

[Selosphorus] anna Bonaparte, Consp. Av., i, 1850, 82.

[Selasphorus] anna Bonapante, Rev. et Mag. de Zool., 1854, 257.

Selasphorus anna Sclater, Proc. Zool. Soc. Lond., 1857, 126 (San José Valley, California); Cat. Am. Birds, 1862, 297 ("Mexico").-Coues, Check List, 1873, no. 279.-Nelson, Proc. Bost. Soc. N. H., xvii, 1875, 361 (Nevada, California).

Calypte annæ Gould, Mon. Troch., pt. xi, May, 1856, pl. 5; vol. iii, 1861, pl. 135; Introd. Troch., oct. ed., 1861, 88.-Hensuaw, Rep. Orn. Spec. Wheeler's Surv., 1873 (1874), 130, 162 (Camp Grant, Arizona, Sept.); 1867, 257 (Tejón Mts. and Ft. Tejón, California); Zool. Expl. W. 100th Merid., 1875, 375 (Camp Grant).-Ridgway, Bull. Essex Inst., vi, 1874, 171 (Sacramento, 
California); Orn. 40th Parallel, 1877, 558 (Sacramento); Proc. U. S. Nat. Mus., iii, 1880, 187, 314, 338; Nom. N. Am. Birds, 1881, no. 338.-Boucard, Notes Troch. du Mex., 1875, 7; Ann. Soc. Linn. Lyon, xxii, 1876, 20 ("Mexico;" California); Gen. Hum. Birds, ii, 1892, 5.-Mulsant and Verreaux, Hist. Nat. Ois.-Mouch., iv, livr. 1, 1877, 73 (California).Eluiot, Classif. and Synop. Troch., 1879, 107.-Belding, Proc. U. S. Nat. Mus., i, 1879, 393, 427 (Murphys, Big Trees, and Copperopolis, California, resident); v, 1883, 531 (Cerros I., April).-Salvin, Cat. Birds Brit. Mus., xvi, 1892, 403.--Salvin and Godman, Biol. Centr.-Am., Aves, ii, 1892, 359.Anthony, Zoë, iv, 1893, 237 (San Pedro Martir Mts., Lower California, May; resident on coast).

C[alypte] annae HeINe, Journ. für Orn., 1863, 208.

C[alypte] annæ Coues, Key N. Am. Birds, 2d ed., 1884, 464.

[Calypte] annæ Sclater and Salvin, Nom. Av. Neotr., 1873, 84.

[Calypte] annae Mulsant, Ann. Soc. Linn. Lyon, n. s., xxii, 1876, 227.

Calypte anna Cooper, Orn. Cal., 1870, 358; Proc. Calif. Ac. Sci., 1870, 78 (Santa

Catalina I.); Proc. U. S. Nat. Mus., iii, 1880, 250 (dates of arrival at Haywards, California).-Batrd, Brewer, and Ridgway, Hist. N. Am. Birds, ii, 1874, pl. 47, fig. 7.-Ridgway, Rep. U. S. Nat. Mus. for 1890 (1891), 334 (monogr.; habits); Man. N. Am. Birds, 2d ed., 1896, 598.-American Orniтhologists' Union Committee, Auk, x, 1893, 62; Check List, 2d ed., 1895, no. 431; 3d ed., 1910, 203.-Fisher (A. K.), North Am. Fauna, no. 7, 1893, 58 (Reche Cañon and Morro Bay, California).-Hartert (E. and C.), Novit. Zool., i, 1894, 22 (descr. nest and eggs).-Bendire, Life Hist. N. Am. Birds, ii, 1895, 206.-Grinnell (J.), Auk, xv, 1898, 235 (Santa Catalina I., Dec.); Pub. 2, Pasadena Ac. Sci., 1898, 28 (Los Angeles Co., resident); Condor, vi, 1904, 42 (Palm Springs, Riverside Co., Dec.); Univ. Calif. Pub. Zool., v, 1908, 71 (San Bernardino Mts. up to 5,000 ft., breeding).-VAN Denburg, Proc. Am. Philos. Soc., xxxviii, 1899, 164 (Santa Clara Co.; habits).-MerRIAM, North Am. Fauna, no. 16, 1899, 117 (Wagon Camp, Mt. Shasta, breeding).-Balley (Florence M.), Handb. Birds W. U. S., 1902, 237.-RAY, Auk, xx, 1903, 124 (near Pyramid Peak, centr. Sierra Nevada, 1 spec., July).-Stone, Proc. Ac. Nat. Sci. Phila., 1904, 582 (Mt. Sanhedrin, Mendocino Co.).-Childs, Warbler, i, 1905, 45 (habits).-Kaeding, Condor, vii, 1905, 134 (Todos Santos I., Lower California, March).-Sharpe, Condor, ix, 1907, 88 (San Diego Co., breeding).-Richardson, Condor, x, 1908, 66 (Santa Catalina I.).-Linton, Condor, x, 1908, 127 (Santa Cruz I.).-Osburn, Condor, xi, 1909, 137 (Los Coronados Islands).

Calypte annæ DE OcA, Troq. de Mex., 1875, pl. (8), fig. 29.

Calipte annae De Ocs, La Naturaleza, iii, 1875, 163; Troq. de Mex., 1875, 40.

Atthis anna Baird, Rep. Pacific R. R. Surv., ix, 1858, 137; Cat. N. Am. Birds, 1859, no. 105.-Xantus, Proc. Ac. Nat. Sci. Phila., 1859, 190 (Ft. Tejon).Feilner, Ann. Rep. Smithson. Inst. for 1864, 429, in text (Yreka, Siskiyou Co., breeding).

A[uhis] annae Cabanis and Heine, Mus. Hein., iii, 1860, 55.

"Calliope anna Montes De OCA, in Natural., p. 163, pl. 8, fig. 29." (Mulsant and Verreaux.)

Zephyritis annae Mulsant and Verreaux, Classif. Troch., 1866, 88.

Trochilus icterocephalus Nuttald, Man. Orn. U. S. and Can., ed. 2, i, 1840, 712 (=male with forehead stained with yellow pollen). 
CALYPTE COSTE (Bourcier).

COSTA'S HUMMING BIRD.

Adult male.-Head, except postocular region, very brilliant metallic violet or amethyst purple, changing to violet-blue or even greenish and more reddish purple (magenta) in certain lights, the lateroposterior feathers of throat much elongated; rest of upper parts, including four middle rectrices, rather dull metallic bronze-green or greenish bronze; tail (except four middle rectrices) grayish brown or brownish gray, faintly glossed with bronze-greenish, the rectrices darker on shafts and toward tip; remiges brownish slate or dusky, faintly glossed with purplish; foreneck very pale brownish gray or grayish white, passing into more decidedly grayish on chest and median line of breast and abdomen; rest of under parts metallic bronzegreen or greenish bronze, the feathers more or less distinctly margined with dull grayish; femoral tufts and conspicuous tuft on each side of rump white; under tail-coverts light brownish gray or bronzy centrally, margined with whitish; bill dull black; iris dark brown; feet dusky; length (skins), 77-90 (83); wing, 43-45.5 (44.4); tail, 22-24.5 (22.6); middle rectrices, 17.5-20 (18.6); exposed culmen, $16-19(17.2){ }^{a}$

Adult female.-A bove rather dull metallic bronze-green or greenish bronze, much duller on pileum, where (at least on forehead) sometimes dull grayish brown; middle pair of rectrices bronze-green, the next pair similar but with terminal portion black; third pair tipped with dull white or pale brownish gray, extensively black subterminally and dull brownish gray basally, the gray and black separnted (at least on outer web) by more or less of metallic bronze-green; fourth and outermost pairs with whitish tip broader, basal grayish more extended, and with little if any metallic greenish between the gray and black; remiges brownish slate or dusky, faintly glossed with purplish; under parts pale brownish gray, paler (dull whitish) on chin, upper throat, and under tail-coverts; femoral tufts and tuft on each side of rump white; bill, etc., as in adult male; length (skins), 74-91 (81); wing, 43.5-46 (44.7); tail, 21.5-25.5 (23.6); culmen, $17-20(18.2){ }^{b}$

Young male.-Similar to the adult female but feathers of upper parts more or less distinetly margined with pale grayish buffy, tail double-rounded instead of rounded, and throat with a central patch of metallic purple or violet feathers (in older individuals similar feathers on crown also).

Young female.-Similar to the adult female but feathers of upper parts margined with pale grayish buffy. 
Southern California and whole of Lower California, including islands of San Benito, Todos Santos, Santa Margarita, and Cerros; north, regularly, to Ventura, Los Angeles, and Inyo Counties, casually to San Francisco, Haywards, and Oakland; east to southern Nevada (Panaca; Charleston Mountains; Mount Magruder; Ash Meadows; Pahranagat Valley; Vegas Wash; Muddy Mountains; Bend of Colorado River), southern Utah (Beaver Dam Mountains), Arizona (Camp Grant; Santa Rita, Santa Catalina, Huachuca, and Cócopah Major Mountains; Tinejas; Atlas; Tucsón; San Pedro River; Bill Williams Fork, etc.), and southern New Mexico; ${ }^{a}$ breeding, locally, throughout its general range; during migration southward through northwestern Mexico as far as Mazatlán.

Ornismya costae Bourcier, Rev. Zool., 1839, 294 (California); Ann. Sci. Phys. et Hist. Nat. Lyon, iii, March, 1840, 225, pl. 2 (California).-Longuemare and Parzudaki, Rev. Zool., 1840, 71 ("Madeline Bay, California").BAird, in Stansbury's Gt. Salt Lake, 1852, 326.-Prévost and Des Murs, Voy. "Vénus," 1855, 194, atlas, pl. 2, figs. 1, 2.

$M[$ ellisuga] costæ Gray, Gen. Birds, i, Dec., 1848, 113.

[Selosphorus] costae Bonaparte, Consp. Av., i, 1850, 82.

[Selasphorus] costae Bonaparte, Rev. et Mag. de Zool., 1854, 257.-Coues, Key N. Am. Birds, 1872, 185.

Selasphorus costæ Sclater, Cat. Am. Birds, 1862, 297.-Coues, Check List, 1873, no. 280.

[Trochilus. o Atthis] costae Reichenbach, Aufz. der Colibr., 1854, 12.

[Trochilus] costae ReIchenbach, Troch. Enum., 1855, 10.

[Trochilus] costæ Gray, Hand-list, i, 1869, 145, no. 1868.-SharPe, Hand-list. ii, $1900,140$.

T[rochilus] costæ Ridgwax, Man. N. Am. Birds, 1887, 312.

T[rochilus] costae Hartent, Das Tierreich, Troch., 1900, 202.

Trochilus costæ AMERICAN ORnithologists' Union, Check List, 1886, no. 430.Evermann, Auk, iii, 1886, 180 (Ventura Co., California, rare).-Scott, Auk, iii, 1886, 430 (Santa Catalina Mts., San Pedro R., and Riverside, Arizona).-Morcom, Bull. Ridgw. Orn. Club, no. 2, 1877, 42 (Cohuilla Valley, s. California, breeding; habits).-Bryant (W. E.), Proc. Calif. Ac. Sci., ser. 2, 1889, 289 (Santa Margarita I., Cerros I., and bet. Tia Juana and San Pedro Martir Mts., Lower California, up to 10,000 ft.).-Thayer and Bangs, Condor, ix, 1907, 78 (Cerros I.), 81 (San Benito I.).

Calypte costæ Gound, Mon. Troch., pt. xi, May, 1856, pl. 7; vol. iii, 1861, pl. 134; Introd. Troch., oct. ed., 1861, 88.-Cooper, Orn. Cal., 1870, 360; Proc. Calif. Ac. Sci., 1870, 74 (Colorado Valley); 1876, 90 (Haywards, Alameda Co., 1 spec.).-Baird, Brewer, and Ridgwax, Ilist. N. Am. Birds, ii, 1874, 457, pl. 47, fig. 8.-Henshaw, Rep. Orn. Spec. Wheeler's Surv., 1873 (1874), 162 (Arizona).-Boucard, Notes Troch. du Mex., 1875, 7; Gen. Hum. Birds, 1895, 4.-De OcA, La Naturaleza, iii, 1875, 166; Troq. de Mex., 1875, 44, pl. (9), fig. 32.-Elliot, Classif. and Synop. Troch., 1879, 107.-Ridaway, Proc. U. S. Nat. Mus., iii, 1880, 187, 314 ("Guatemala"error; Mazatlán; Ft. Tejon; Cape San Lucas; $\Lambda$ rizona); v, 1883, 542 (descr. nost and eggs); Nom. N. $\Lambda$ m. Birds, 1881, no. 337; Rep. U. S. Nat. Mus. for 1890 (1891), 337, pl. 39 (monogr.); Man. N. $\Lambda \mathrm{m}$. Birds, $2 d$ ed., 1896, 598.-Beldino, Proc. U. S. Nat. Mus., v, 1882, 528 (San Quintín Bay, 
Lower California, May), 530 (Santa Rosalia Bay), 531 (Cerros I., breeding), 542 (San José del Cabo, Cape San Lucas, Miraflores, and La Paz, Lower California, breeding); vi, 1883, 343 (Guaymas, Sonora), 348 (mts. Lower California below 2,000 ft.).-Brewster, Bull. Nutt. Orn. Club, vii, 1882, 210 (Tucsón, Arizona); Bull. Mus. Comp. Zool., xli, 1902, 112 (Cape San Lucas district; crit., habits, etc.).-Coues, Check List, 2 d ed., 1882, no. 415.-Stephens, Auk, i, 1884, 354 (Colorado Desert).-Gault, Auk, ii, 1885, 309-311 (San Bernardino Co.; descr. nest and eggs).-Salvin, Cat. Birds Brit. Mus., xvi, 1892, 404.-Salvin and Godman, Biol. Centr.-Am., Aves, ii, 1892, 359.-Allen, Bull. Am. Mus. N. H., v, 1893, 36 (El Pinita, Sonora, Oct.).--Anthony, Zoë, iv, 1893, 237 (San Pedro Martir Mts., Lower California, up to 7,500 ft., breeding); Auk, xii, 1895, 140 (San Fernando, Lower California).-American Ornithologists' Union Committee, Auk, $x$, 1893, 62; Check List, 2d ed., 1895, no. 430; 3d ed., 1910, 203.-HarTerT (E. and C.), Novit. Zool., i, 1894, 22 (California; descr. nest and eggs).Bendrre, Life Hist. Birds N. Am., ii, 1895, 202.-Grinnell (J.), Pub. no. 1, Pasadena Ac. Sci., 1897, 15 (San Clemente I., 1 spec., March 30); Pub. no. 2, 1878, 28 (Los Angeles Co., summer res.); Condor, vi, 1904, 42 (Palm Springs, Riverside Co., Dec.); Univ. Calif. Pub. Zool., v, 1898, 71 (base of San Bernardino Mts., 2,500 ft., breeding).-BAILEy (Florence M.), Handb. Birds W. U. S., 1902, 236, fig. 310.-Fisher (A. K.), North Am. Fauna, no. 7, 1893, 56 (Amaragosa Desert, Coso, Argus, Funeral, Panamint, and Grapevine Mts., Death Valley, etc., s. e. California; Mt. Magruder, Ash Meadows, Pahranagat Valley, Charleston Mts., Vegas Wash, Muddy Mts., Bend of Colorado R., etc., s. Nevada, breeding; Beaver Dam Mits., s. Utah; habits).-Stone, Proc. Ac. Nat. Sci. Phila., 1905, 682 (Cocopah Major Mts., Arizona, breeding).-Swarth, Pacific Coast Avifauna, no. 4, 1904, 17 (Huachuca Mts., Arizona, up to 5,500 ft., breeding chiefly in valleys); Condor, vii, 1905, 79 (Santa Rita Mts., Arizona).-Kaeding, Condor, vii, 1905, 134 (Todos Santos and San Benito islands and Turtle Bay, Lower California, March, April).-Sharp, Condor, ix, 1907, 88 (San Diego Co., breeding).-Visher, Auk, xxvii, 1910, 282 (Tucsón, Arizona, summər res.). C[alypte] costae Heine, Journ. für Orn., 1863, 208.

[Calypte] costæ Sclater and Salvin, Nom. Av. Neotr., 1873, 84.

C[alypte] costæ Coues, Key N. Am. Birds, 2 d ed., 1884, 464.

Atthis costr BaIRD, Rep. Pacific R. R. Surv., ix, 1858, 138; ed. 1860 (Birds N. Am.), 138, pl. 19; Cat. N. Am. Birds, 1859, no. 106; Rep. U. S. and Mex. Bound., ii, pt. 2, 1859, 22, pl. 19 (Bill Williams Fork, Arizona).Xantus, Proc. Ac. Nat. Sci. Phila., 1859, 190 (Ft. Tejon)--Coues, Proc. Ac. Nat. Sci. Phila., 1866, 57 (Bill Williams Fork and Ft. Mojave); 1868, 82 (s. Arizona).-Boucard, Ann. Soc. Linn. Lyon, xxii, 1875, 20.

Zephyritis costae Mulsant and Verreaux, Classif. Troch., 1866, 88.

[Leucaria] costae Mulsant, Ann. Soc. Linn. Lyon, n. s., xxii, 1876, 227.

Leucaria costae Mulsant and Verreaux, Hist. Nat. Ois.-Mouch., iv, livr. 1, 1877, 69, pl. 104; Suppl., pl. 6.

[Calypte] costai Simon, Cat. Troch., 1897, 39.

\section{CALYPTE HELENAE (Lembeye).}

HELENA'S HUMMING BIRD.

Adult male.-Whole head, except postocular region (narrowly) very brilliant metallic rose red (slightly more purplish red on pileum), the feathers on sides of throat much elongated; hindneck, back, scapuS1255 - Bull. 50-11- 40 
lars, wing-coverts, rump, and upper tail-coverts bright metallic bluish green or greenish blue; tail metallic greenish blue (decidedly more bluish than back, etc.), the lateral rectrices blackish terminally; remiges dull black or dusky, faintly glossed with violet; chest grayish white, passing posteriorly into more decided gray on median portion of breast and abdomen; sides and flanks metallic bluish green, more or less intermixed with grayish; under tail-coverts grayish white with a subterminal spot of metallic bluish green; femoral tufts and tuft on each side of rump white; bill dull black; iris dark brown; feet dusky; length (skins), 55-62 (58); wing, 27.5-29 (28.4); tail, 16-16.5 (16.2); exposed culmen, $10 .^{a}$

Adult female.-Above metallic bluish green, duller on pileum, more bluish posteriorly; middle rectrices bright metallic greenish blue, the remaining rectrices bright greenish blue basally (for more than half their length), black terminally or subterminally, the two or three outermost tipped with white (broadly on lateral rectrix); remiges dusky, faintly glossed with violaceous; superciliary, auricular, and suborbital regions brownish gray (nearly drab-gray); a blackish loral spot or streak and a small whitish postocular spot; under parts pale brownish gray, fading into white on anal region and under tail-coverts; femoral tufts white; bill, etc., as in adult male; length (skins), 57-66 (62); wing, 32-34.5 (33.1); tail, 16.5-19.5 (17.9); exposed culmen, $10.5-11.5(11.1) .^{b}$

Immature male.-Similar to the adult female, but usually more bluish above.

Island of Cuba (Cardenas; Santiago; Bayate; Holquín; Figuabas).

Orthorhynchus helenx Lembeye, Aves de la Isla de Cuba, 1850, 70, pl. 10, fig. 2

(Cardenas, Cuba; ex Gundlach, manuscript).-Brewer, Proc. Bost. Soc.

N. H., vii, 1860, 306.

Orthorhynchus helenae GuNDLACH, Journ. für Orn., 1861, 414.

[Orthorhynchus] helenae GuNDLACH, Journ. für Orn., 1861, 334.

Calypte helenæ Gould, Mon. Troch., pt. xi, May, 1856; vol. iii, 1861, pl. 136; Introd. Troch., oct. ed., 1861, 88.-GundLACH, Repert. Fisico-Nat. Cuba, 1866, 291; Journ. für Orn., 1874, 144 (habits); Contr. Orn. Cuba, 1876, 109, 272; Auk, viii, 1891, 187 (crit.; habits, etc.); Orn. Cub., ed. 1895, 132.Eliıot, Ibis, 1872, 354 (synonymy); Classif. and Synop. Troch., 1879, 108.Mulsant and Verreaux, Hist. Nat. Ois.-Mouch., iv, livr. 1, 1877, 77, pl. 105; Suppl., pl. 7.-Cory, Auk, iii, 1886, 354; Birds West Ind., 1889, 149; Cat. West Ind. Birds, 1892, 13, 107, 128, 144.-Salvin, Cat. Birds Brit. Mus., xvi, 1892, 405.-Boucard, Gen. Hum. Birds, ii, 1892, 6.-Ridgway, Man. N. Am. Birds, 2d ed., 1896, 598.

C[alypte] helenae HeINe, Journ. für Orn., 1863, 208.

C[alypte] helenæ Batrd, Brewer, and Ridgway, Hist. N. Am. Birds, ii, 1874, 453 -Ridgway, Rep. U. S. Nat. Mus. for 1890 (1891), 334 (diagnosis, etc.).

[Calypte] helenæ Sclater and Salvin, Nom. Av. Neotr., 1873, 84.-Corx, List Birds West Ind., 1885, 18. 
[Calypte] helenae Mulsant, Ann. Soc. Linn. Lyon, n. s., xxii, 1876, 227.

Atthis helenae LAwrence, Ann. Lyc. N. Y., vii, 1860, 263 (crit.).

[Trochilus] helenæ Gray, Hand-list, i, 1869, 145, no. 1869.-Sharpe, Hand-list, ii, 1900, 140.

Trochilus] helenæ Ridgwax, Man. N. Am. Birds, 1887, 313.

Trochilus] helenae Hartert, Das Tierreich, Troch., 1900, 203.

Trochilus helenæ Menegaux, Rev. Franç. d'Orn., no. 2, 1909, 26 (Figuabas, e. Cuba).

Orthorhynchus boothi GundlacH, Journ. für Orn., 1856, 99; 1859, 347 (Santiago, e. Cuba).

Zephyrites (Calypte) elvirae Mulsant and Verreaux, Classif. Troch., 1866, 88.

Genus ARCHILOCHUS Reichenbach.

Trochilus (not of Linnæus, 1758? a) of AvtHors.

Cynanthus (not of Swainson, 1827) BoIE, Isis, 1831, 547. (Type, Trochilus colubris Linnæus.)

Colubris (not of Hübner, 1793) Wood (T. C.), Orn. Guide, Jan., 1837, 137. (Type, C. rubens Wood=Trochilus colubris Linnæus.)--ReichenвaCH, Syst. Av. Nat., 1849, pl. 40. (Type, Trochilus colubris Linnæus.)

[Selasphorus] $\beta$. Archilochus Reichenbach, Journ. für Orn., 1853, Extra heft, 1854 ("Aufz. der Colibr."), 13. (Type, Trochilus alexandri Bourcier and Mulsant.)

Ornismia (not Ornismya Lesson, 1829) Mulsant and Verreaux, Mém. Soc. Imp. Sci. Nat. Cherb., xii (sér. 2, ii), 1866, 235 (Classif. Troch., 1865, 91). (Type, Trochilus alexandri Bourcier and Mulsant.)

Mellisuga (not of Brisson) Sundevali, Av. Met. Nat. Disp. Tent., pt. ii, 1873, 91. (Type, Trochilus colubris Linnæus.)

Small Trochilidæ (length about 75-100 mm.) with bill as long as or longer than head, rather slender, straight; six innermost primaries abruptly narrower than the rest, with the edge of inner web forming a more or less prominent angle subterminally; adult males with the "gorget" not elongated laterally, pileum concolor with the back or more dusky, the tail deeply emarginate, but with outer pair of rectrices shorter than the next, all the rectrices except middle pair pointed terminally.

Bill as long as or longer than head, rather slender, straight, terete; culmen rounded except at base where contracted into a narrow ridge; tomia smooth; mandible with the usual lateral median groove. Nasal operculum moderately broad and convex, mostly (sometimes wholly) covered by the appressed frontal feathering, which anteriorly extends to beyond anterior end of nostrils, forming a short angle or antia on each side of culmen. Wing a little more than twice to nearly two and a half times as long as exposed culmen; outermost primary longest, strongly incurved terminally, in adult male of $A$. colubris much narrower than the next and obtusely pointed terminally; six innermost (proximal) primaries abruptly, and in adult males con-

a The type of Trochilus Linnæus, according to recent authorities, is Trochilus polytmus Linnæus (type of Aithurus Cabanis and Heine), as designated by Gray in 1840; see Allen, Bull. Am. Mus. Nat. Hist., xxiv, 1908, 12. 
spicuor isly, smaller than the rest, with a more or less prominent angle on edge of inner web near tip. Tail of adult males about three-fifths to two-thirds as long as wing, slightly forked or deeply emarginate (but with outermost rectrix shorter than the next pair), the middle rectrices very broad, with rounded tip, the others gradually decreasing in width to the lateral pair, all contracted or narrowed terminally and obtusely pointed; in adult females less than three-fifths as long as wing, double-rounded, the lateral rectrices subcuneate terminally, the outer pair not distinctly incurved.

Coloration.-Above metallic bronze-green, including middle rectrices, the pileum duller or darker; beneath mostly dull whitish or grayish. Adult males with chin (sometimes upper throat also) opaque black, the throat (at least lower portion) bright metallic red or violet, the lateral rectrices wholly purplish black; adult females with chin and throat whitish (sometimes flecked or streaked with dusky), and lateral rectrices tipped with white (the outer pair sometimes wholly white), black subterminally, grayish or bronze-greenish basally.

Range.-Temperate and subtropical North America; one species migratory in winter as far as western Panamá. (Two species.)

KEY TO THE SPECIES OF ARCHILOCHUS.

$a$. Throat (at least partly) bright metallic red or violet, the chin (sometimes upper throat also) velvety black; tail forked, the lateral rectrices wholly purplish black. (Adult males.)

b. Throat bright metallic red. (Eastern North America; south in winter over nearly whole of Mexico and Central America to western Panamá and to Cuba.)

bb. Throat purple or violet.

Archilochus colubris, adult male (p. 629).

c. Lower half of throat violet to violet-blue; tail shorter, the lateral rectrices 23.5-28 (25.6), middle rectrices 20.5-23.5 (21.9). Southern British Columbia to northern and western Mexico.)

Archilochus alexandri, adult male (p. 633).

$c c$. Greater part of throat magenta purple; tail longer, the lateral rectrices 30 , middle rectrices 23. (Santa Barbara, California.)

Archilochus violajugulum, $a$ adult male (p. 636).

$a a$. Throat and chin dull white (sometimes flecked with dusky); tail double-rounded, the lateral rectrices broadly tipped with white and with a basal area of gray or greenish. (Adult females.)

b. Smaller; wing 43.5-45.5 (44.5), tail 25-26.5 (25.6), exposed culmen 17-18.5 (18.2); under parts more whitish. . Archilochus colubris, adult female (p. 629).

bb. Larger; wing 46-48.5 (47), tail 26-27.5 (26.8), exposed culmen 24-26 (24.8); under parts more grayish...... Archilochus alexandri, adult female (p. 633).

a Probably a hybrid of Archilochus alexandri and Calypte anna. 


\section{ARCHILOCHUS COLUBRIS (Linnæus).}

\section{RUBY-THROATED HUMMING BIRD.}

Adult male.-Above metallic bronze-green, including middle pair of rectrices; remiges dark brownish slate or dusky, faintly glossed with purplish; tail (except middle pair of rectrices) dark bronzy purplish or purplish bronzy black; chin, malar region, suborbital region, and auricular region velvety black; a small postocular spot of white; whole throat brilliant metallic red (nearest geranium red in position $a$ ) changing to golden or even greenish in position $b$; chest dull brownish white or very pale buffy brownish gray, passing gradually into deeper brownish gray on breast and abdomen, the sides and flanks darker and overlaid by metallic bronze-green; femoral tufts and tuft on each side of rump white; under tail-coverts brownish gray (sometimes glossed with greenish bronze) centrally, broadly margined with dull white; bill dull black; iris dark brown; feet dusky; length (skins), 76-89 (83); wing, 37-40 (38.5); tail, 25.5-28.5 (27) ; middle rectrices, 18-20.5 (19); exposed culmen, 15-17 (15.9). ${ }^{a}$

Adult female.-Above metallic bronze-green, golden green, or greenish bronze, including middle pair of rectrices; three outer rectrices, on each side, broadly tipped with white (the white tip on third rectrix smaller and mostly confined to inner web), metallic bronze-green for basal half (more or less) the intervening portion black; remiges dark brownish slate or dusky, faintly glossed with purplish; a small postocular spot of dull white; auricular region deep dull grayish; lores dusky; malar region and under parts dull grayish white or very pale brownish gray (usually more decidedly whitish on chin, throat, and malar region), the flanks and shorter under tailcoverts usually more or less tinged with pale buffy brownish; femoral tufts and tuft on each side of rump white; bill, etc., as in adult male; length (skins), 78-S9 (85); wing, 43.5-45.5 (44.5); tail, 25-26.5 (25.6); middle rectrices, 22-24.5 (23); exposed culmen, 17-19.5 (18.2). ${ }^{a}$

Young male.-Similar to the adult female, but feathers of upper parts very narrowly and indistinctly margined terminally with pale grayish buffy, throat with small mesial streaks of dusky, and under parts usually more strongly tinged with buffy brownish, especially on sides and flanks.

Young female.-Similar to the young male, but throat without dusky streaks.

Eastern North America; north, regularly to southern Labrador (casually to Davis Inlet), Quebec, Ontario, and Keewatin (to about latitude $52^{\circ}$ ), and in the interior to northern Alberta (near Lake 
Athabaska, latitude $59^{\circ}$ ) and central Alberta; west to about middle portion of Great Plains (along streams); breeding southward to middle Florida (Tarpon Springs) and along the Gulf coast to westcentral Texas (Bexar, Tom Green, and Concho counties); wintering from middle and southern Florida (Tarpon Springs, Punta Rassa, Key West, Dry Tortugas, etc.) and southern Texas (Bexar, Lee, and Cameron counties, etc.) southward over greater part of Mexico, in States of Tamaulipas (Sierra de Victoria; Tamasi; Tampico; Escandón), Puebla, Vera Cruz (Miradór; Jalapa; Córdova: Orizaba; Coátepec; Maltrata; Catemaco; Misantla; Playa Vicente), Mexico (Valley of Mexico; Ajusco; Amecameca), Morelos (Cuernavaca; Turrúceres), Michoacán (La Salada), Jalisco (Bolaños; Volcán de Colima), Sinaloa (Escuinapa), Guerrero (Chilpancingo; Acahuitzotla; near Ometepec; El Limón; Tecpán; Venta de Zopilote), Oaxaca (Tehuántepec; 15 miles west of Oaxaca; Santa Efigénia; Tonaguia), Tabasco (Frontera), Chiapas (Comitán), and Yucatan (Mérida; Labna; Tabí; La Vega; Schkolak; Progreso; Chichen-Itza; Cozumél Island; Holbox Island), Guatemala (Dueñas; Cobán; San Gerónimo; Acatenango; Guatemala City; Salamá; Gualán; Panajachál; Lake Amatitlán; Rincon de San Marcos; Santa Ana de Petén; between Cobán and Chiséc), Nicaragua (Omotepe) and Costa Rica (Las Cruces de la Candelária; Volcán de Irazú; San José; Turrúcares; Santo Domingo de San Mateo; Juan Viñas; Bebedero; Bagaces) to western Panamá (Volcán de Chiriquí, Verágua); also Bahamas (New Providence Island), Cuba, Porto Rico, and Bermudas.

[Trochilus] colubris Linnsus, Syst. Nat., ed. 10, i, 1758, 120 (based on Redthroated Humming Bird, Avis mellivora, minor, gutture rubro, Edwards, Nat. Hist., i, pl. 38; Humming Bird Catesby, Carolina, i, 65, pl. 65); ed. 12, i, 1766, 191.-Gmelin, Syst. Nat., i, 1788, 492.-Latham, Index Orn., i, 1790, 312.

Trochilus colubris Viemlot, Ois. Dor., i, 1801, 66, 69, 70, pls. 31, 32, 33; Ois. Am. Sept., i, 1807, 73, pls. 31, 32; Nouv. Dict. d'Hist. Nat., vii, 1817, 371.Temminck, Cat. Syst., 1807, 83.-Wilson, Am. Orn., ii, 1810, 26, pl. 10, figs. 3, 4.-JArdine, Nat. Libr., Humming-birds, i, 1833, 85, pl. 5.-BonAPAR'Te, Synop. Birds U. S., 1828, 98; Geog. and Comp. List, 1838, 10; Consp. Av., i, 1850, 81; Rev. et Mag. de Zool., 1854, 256.-Swainson and Richardson, Fauna Bor.-Am., ii, 1831, 323.-Nuttall, Man. Orn. U. S. and Can., i, 1832, 588.-Audubon, Orn. Biog., i, 1831, 248, pl. 47; v, 1839, 544; Synop., 1839, 170; Birds Am., iv, 1842, 190, pl. 253.-Giraud, Birds L. I., 1844, 169.-Hurdis, Jardine's Contr. Orn., 1850, 37 (Bermndas).-ReichENBACH, Aufz. der Colibr., 1854, 12; Troch. Enum., 1855, 10, pl. 826, figs. 4939-44.-Cabanis, Journ. für Orn., 1856, 98 (Cuba).-Sclater, Proc. Zool. Soc. Lond., 1856, 287 (Córdova, Vera Cruz); 1859, 367 (Jalapa, Vera Cruz), 386 (Oaxaca); 1864, 176 (City of Mexico); Cat. Am. Birds, 1862, 297 (Dueñas, Guatemala).-Barrd, Rep. Pacific R. R. Surv., ix, 1858, 131; Cat. N. $\Lambda \mathrm{m}$. Birds, 1859, no. 101; Rep. U. S. and Mex. Bound. Surv., ii, pt. 2, 1859, 6 (Brownsville, Texas).-Gould, Mon. Troch., pt. xv, 1858; vol. iii, 1861, pl. 131; Introd. Troch., oct. ed., 1861, 86 (crit.).-MARTENs, Journ. für Orn., 1859, 216 (Bermudas).-Sclater and Salvin, 1bis, 1859, 
129 (Acatenango, Guatemala, 3,000-4,000 ft., winter).-SALvin, Ibis, 1860, 195, 263, 266 (Cobán, Dueñas, San Gerónimo, and Salamá, Guatemala; habits); Proc. Zool. Soc. Lond., 1870, 208 (Volcán de Chiriquí, Panamá); 1889, 365 (Holbox and Cozumél Islands, Yucatan); Cat. Birds Brit. Mus., xvi, 1892, 399, 667.-Dresser, Ibis, 1865, 470 (s. Texas).-Gundlach, Journ. für Orn., 1861, 414 (Cuba); 1871, 293 (Cuba); 1874, 141 (Cuba), 318 (Porto Rico); 1878, 160, 180 (Porto Rico); Repert. Fisico-Nat. Cuba, i, 1866, 291; Anal. Soc. Esp. Hist. Nat., vii, 1878, 221 (Porto Rico); Orn. Cub., ed. 1895, 129.-Lawrence, Ann. Lyc. N. Y., ix, 1868, 123 (Las Cruces de Candelária, Costa Rica); Bull. U. S. Nat. Mus., no. 4, 1876, 32 (Santa Efigénia and Tehuántepec, Oaxaca, Oct.-Dec.).-Frantzius, Journ. für Orn., 1869, 315 (Costa Rica).-Allen, Bull. Mus. Comp. Zool., ii, 1871, 301 (e.Florida, winter); iii, 1872, 180 (e.Kansas).—Elııот, Ibis, 1872, 354; Classif. and Synop. Troch., 1879, 105.-Coues, Check List, 1873, no. 275; 2d ed., 1882, no.409; Birds North West, 1874, 271; Bull. U. S. Geol. and Geog. Surv. Terr., iv, 1878, 614 (Pembina, North Dakota).-Villada, La Naturaleza, ii, 1875, 352 (Valley of Mexico; breeding?).-Baird, Brewer, and Ridgway, Hist. N. Am. Birds, ii, 1874, 448, pl. 47, fig. 2; special ed.,ii, 1875, plate facing p. 545.-GENTry, Proc. Ac. Nat. Sci. Phila., 1874, 106 (habits).-D'OCA, La Naturaleza, iii, 1875, 22 (Valley of Mexico); Los Colibr. de Mex., 1875, 12, pl. (2), fig. 5.-BouCARD, Proc. Zool. Soc. Lond., 1878, 70 (San José, Costa Rica); Liste Ois. réc. Guat., 1878, 46 (Guatemala); The Hum. Bird, ii, 1892, 73 (Volcán de Chiriquí, Panamá); Gen. Hum. Birds, 1895, 2.-Merrirl, Proc. U. S. Nat. Mus., i, 1878, 146 (Fort Brown, Texas, Dec.-Mar.).-Sennett, Bull. U. S. Geol. and Geog. Surv. Terr., iv, 1878, 35 (Hidalgo, Texas, Apr.-May); v, 1879, 411 (Lomita Ranch, Texas, Apr.).-Brown (N. C.), Bull. Nutt. Orn. Club, iv, 1879, 11 (Coosada, Alabama).-Looms, Bull. Nutt. Orn. Club, iv, 1879, 215 (Chester Co., South Carolina, summer).-Eutrot, Classif. and Synop. Troch., 1879, 105.-Ridgway, Proc. U. S. Nat. Mus., iii, 1880, 187, 314; viii, 1885, 573 (Cozumél I., Yucatan, Jan.); Nom. N. Am. Birds, 1881, no. 335; Orn. Illinois, 1889, 361; Rep. U. S. Nat. Mus. for 1890 (1891), 327, pl. 37 (monogr.).Mundt, Ornith. and Oolog., vi, 1881, 29 (habits in captivity).-Jones and Schulze, Nests and Eggs of Ohio Birds, viii, 1881, pl. 25, fig. 1.-Zeledón, Cat. Aves de Costa Rica, 1882, 20; Proc. U. S. Nat. Mus., viii, 1885, 110 (Costa Rica); Anal. Mus. Nac. Costa Rica, i, 1878, 121.-Ogilby, Sci. Proc. Roy. Dublin Soc., iii, 1882, 55 (Navarro Co., Texas, summer resid.).Batchelder, Bull. Nutt. Orn. Club, vii, 1882, 150 (upper St. Johns R., New Brunswick).-Nehrling, Bull. Nutt. Orn. Club, vii, 1882, 169 (s. e. Texas, summer resid.).-Nutring, Proc. U. S. Nat. Mus., vi, 1884, 394 (Omotepe, Nicaragua).-Wilмoт, Forest and Stream, xxiii, 1884, 3 (nesting habits).-Turner, Proc. U. S. Nat. Mus., viii, 1885, 242 (Davis Inlet, I spec., July 17, 1882).-Willard, Auk, ii, 1885, 218 (food).-Agersborg, Auk, ii, 1885, 283 (s. e. South Dakota).-Willard, Auk, ii, 1885, 218 (food).American Ornithologists' Union, Check List, 1886, no. 428.-Cory, Auk, iii, 1886, 353 (West Indian localities and references); Birds West Ind., 1889, 148; Cat. West Ind. Birds, 1892, 107 (New Providence, Bahamas; Cuba; Porto Rico).-Ferrari-Perez, Proc. U. S. Nat. Mus., ix, 1886, 157 (Jalapa, Vera Cruz).-Brewster, Auk, iii, 1886, 105 (mts. North Carolina, 2,000-5,000 ft.).-Seton, Auk, iii, 1886, 320 (Qu 'Appelle, Red Deer R., and Red R., w. Manitoba).-Lloyd, Auk, iv, 1887, 191 (Tom Green and Concho counties, w. Texas, breeding).-Beckнam, Proc. U. S. Nat. Mus.. x, 1887, 637, 666 (Bexar Co., Texas, resident).-Cooke, Bird Migr. Miss, Val., 1888, 140.-Allen (F. H.), Auk, vi, 1889, 79 (Bridgewater, New Hampshire).-FAxon, Auk, vi, 1889, 99 (Mt. Graylock, Massachusetts).- 
Scoтt, Auk, vi, 1889, 252 (Punta Rassa and Key West, Florida, winter; Tarpon Springs, resident); vii, 1890, 310 (Dry Tortugas, winter).-SToNe, Proc. Ac. Nat. Sci. Phila., 1890, 207 (Shkolak, Labna, and Progreso, Yucatan, Mar.).-Thompson, Proc. U. S. Nat. Mus., viii, 1890, 557 (Winnipeg, etc., Manitoba).-Salvin and Godman, Biol. Centr.-Am., Aves, ii, 1892, 357, (Sierra de Victoria Tamasí, Tampico, and Escandón, Tamaulipas; Misantla, Coátepec, Jalapa, Miradór, Orizaba, and Playa Vicente, Vera Cruz; Ajusco and Amecameca, Mexico; Puebla; Volcán de Colima, Jalisco; Chilpancingo, Venta de Zopilote, Amula, and Acahuitzotla, Guerrero; Tonaguia, La Parada, Tuxtla, Santa Efigénia, Chimalapa, and Tehuántepec, Oaxaca; Mérida, Progreso, Holbox I., and Cozumél I., Yucatan; Santa Ana de Petén, Cobán, San Gerónimo, Dueñas, Acatenango, Rincón de San Marcos, and Panajachál, Guatemala; Omotepe, Nicaragua; Bebedero, Las Cruces de Candelária, and San José, Costa Rica; Volcán de Chiriquí, Panamá).Coоmbs, Auk, ix, 1892, 205 (Louisiana, breeding).-Aттwater, Auk, ix, 1892, 235 (San Antonio, Texas, transient).-Dwight, Auk, x, 1893, 9 (Prince Edward I.).-Jouy, Proc. U. S. Nat. Mus., xvi, 1894, 784 (Cuernavaca, Morelos).-Hartert (E. and C.), Novit. Zool., i, 1894, 64 (Chilpancingo, Guerrero, 5,000 ft., Oct.-Dec.).-Singley, Rep. Geol. Surv. Tex., 1894, 350 (Lee Co., Texas, sum. resid.).-Bendire, Life Hist. N. Am. Birds, ii, 1895, 192, pl. 1, fig. 1.-Allen (F. H.), Auk, xii, 1895, 89 (Cape Breton, Nova Scotia).-Underwood, Ibis, 1896, 442 (Bagaces, Costa Rica).-Coubeaux, Ottawa Nat., 1900, 28 (s. Saskatchewan, rare).-CARroll, Auk, xvii, 1900, 344 (Refugio Co., Texas, transient; breeding?).-Beyer, Proc. Louisiana Soc. Nat. for 1897-99 (1900), 103 (Louisiana, breeding, sometimes wintering).-BAiley (Florence M.), Handb. Birds W. U. S., 1902, 235, fig. 306.Williams, Auk, xxi, 1904, 456 (León Co., Florida, summer resid.).-Allison, Auk, xxi, 1904, 478 (Baton Rouge Parish, Louisiana, summer resid.).Montgomerx, Auk, xxii, 1905, 14 (Altudo and Green Gulch, Brewster Co., Texas, common).-Minler (W. De W.), Bull. Am. Mus. N. H., xxi, 1905, 355 (Escuinapa, Sinaloa, Oct.).-Cole, Bull. Mus. Comp. Zool., 1, 1906, 128 (Chichen-Itza, Yucatan, Feb.-Apr.).-Dearborn, Pub. 125, Field Mus. N. H., 1907, 99 (Gualán and Lake Amatitlán, Guatemala, Feb., Apr.).Townsend and Allen, Proc. Bost. Soc. N. H., xxxiii, 1907, 378 (Labrador, rare sum. visit).-TAVERNER and Swales, Wilson Bull., no. 61, 1907, 137 (Point Pelee, Ontario, May-Sept. 21; habits).-Preble, North Am. Fauna, no. 27, 1908, 390 (near Lake Athabaska, lat. 59²).-CArriker, Ann. Carnegie Mus., vi, 1910, 546 (plateau region and Guanacaste, Costa Rica, in winter).

$\operatorname{Tr}$ [ochilus] colubris Maximilian, Journ. für Orn., 1858, 103 (Pennsylvania).

T[rochilus] colubris Vieillot, Tabl. Enc. Méth., ii, 1822, 569.-Cabanis and Heine, Mus. Hein., iii, 1860, 57.-Coues, Key N. Am. Birds, 2d ed., 1884, 461.-Ridgway, Man. N. Am. Birds, 1887, 311.-Hartert, Das 'Tierreich, Troch., 1900, 201 (monogr.).

[Trochilus] colubris Gundlach, Journ. für Orn., 1861, 334 (Cuba).-Gray, Handlist, i, 1869, 136, no. 1744.-Coues, Key N. Am. Birds, 1872, 184.-Sclater and Salvin, Nom. Av. Neotr., 1873, 84.-Cony, List Birds West Ind., 1885, 18.-Sharpe, Hand-list, ii, 1900, 140.

Trochillus colubris $\mathrm{DE}_{\mathrm{E}} \mathrm{OcA}$, Troq. de Mex., 1875, pl. (2), fig. 5.

Ormismya colubris Lesson, IIisi. Nat. Ois.-Nouch., 1829, pp. xvi, 151, pls. 48, 48 bis; Ies Trochil., 1831, 1, pl. 1; Index Gen. and Synop. Troch., 1832, p. xxxiv.-Deville, Rev. et Mag. de Zool., 1852 (habits).-Mulsant and Verreaux, Classif. Troch., 1866, 91; Hist. Nat. Ois.-Mouch., iv, livr. 1, 1877,52 . 
[Ornismya] colubris Mulsant, Ann. Soc. Linn. Lyon, n. s., xxii, 1876, 226.-BouCARD, Notes Troch. du Mex., 1875, 4.

Me[llisuga] colubris Stephens, Shaw's Gen. Zool., xiv, pt. i, 1826, 247.

Mellisuga colubris Woodнouse, in Rep. Sitgreaves' Expl. Zuñi and Col. R., 1853, 65 (Indian Territory; Texas).

M[ellisuga] colubris Gray and Mitchell, Gen. Birds, i, Dec., 1848, 113.

Melisuga colubris Brewer, Proc. Bost. Soc. N. H., vii, 1860, 306 (Cuba).

"Cynanthus colubris, JARD[INE], Nat. Libr. Humming-Birds, vol. ii, p. 143." (Elliot.)

Orthorhynchus colubris D'OrbignY, in La Sagra's Hist. Nat. Cuba, Ois, , 1840, 126. Archilochus colubris American Ornithologists' Union Committee, Auk, xxvi, July, 1909, 298; 3d ed., 1910, 202.-STansiLl, Auk, xxvi, 1909, 395 (central Alberta, rare).

Trochilus aurigularis a Lawrence, Ann. Lyc. Nat. Hist. N. Y., vii, 1862, 458 (locality unknown; coll. U. S. Nat. Mus.; =discolored alcoholic specimen). [Trochilus] aureigularis GrAx, Hand-list, i, 1869, 136, no. 1746.

T[rochilus] aureigularts HEINE, Journ. für Orn., 1863, 208.

\section{ARCHILOCHUS ALEXANDRI (Bourcier and Mulsant).}

\section{BLACK-CHINNED HUMMING BIRD.}

Adult male.-Above rather dull metallic bronze-green, darker and duller on pileum, the forehead sometimes dull dusky; remiges dark brownish slate or dusky, faintly glossed with purplish; tail (except middle pair of rectrices) bronzy purplish black; loral, suborbital, auricular, and malar regions, chin, upper throat, and sides of throat uniform opaque or velvety black; lower throat metallic violet or violetpurple, changing to black in position $b$; chest dull grayish white or very pale brownish gray, the under parts of body similar, but usually more decidedly grayish medially, the sides and flanks darker and glossed or overlaid with metallic bronze or bronze-green; under tail-coverts brownish gray (sometimes glossed with bronzy) centrally or medially, broadly margined with white; femoral tufts and tuft on each side of rump white; bill dull black; iris dark brown; feet dusky; length (skins), 80-88 (86); wing, 41.5-44 (42.7); tail, 23.5-28 (25.6); middle rectrices, 20.5-23.5 (21.9); exposed culmen, 18-20.5 (19.2). ${ }^{b}$

Adult female.-Above rather dull metallic bronze-green, the pileum much duller, usually dull grayish brown or brownish gray, at least on forehead and crown; remiges dark brownish slate or dusky, faintly glossed with purplish; three outer rectrices (on each side) broadly tipped with white, the subterminal portion (extensively) black, the basal half (more or less) metallic bronze-green (sometimes grayish basally); under parts dull white or grayish white (more purely white on abdomen and under tail-coverts), the throat sometimes streaked or guttately spotted with dusky; femoral tufts and tuft on each side

$a$ Wrongly cited as "Trochilus aureigaster (aureigula?)" in Hist. N. Am. Birds, ii, 1874, 448, in text, and as "Trochilus aureigaster Lawrence, Ann. Lyc. N. Y., vii, p. 58" by Salvin in Cat. Birds Brit. Mus.

$b$ Ten specimens. 
of rump white; bill, etc., as in adult male; length (skins), 86-102 (91); wing, 46-48.5 (47); tail, 26-27.5 (26.8); middle rectrices, 24-26 (24.8); exposed culmen, 19.5-22 (20.6). ${ }^{a}$

Young male.-Similar to the adult female, but feathers of upper parts margined terminally with pale grayish buffy, under parts more or less strongly tinged or suffused with pale buffy brownish, and throat always (?) streaked or spotted with dusky.

Young female.--Similar to the young male, but throat usually immaculate or with the dusky spots or streaks smaller and less distinct.

Western United States and southern British Columbia (both sides of Cascade range; Chilliwack); east to southern Alberta (?), western Montana (Columbia Falls), western Colorado (La Plata Co.), and western and middle Texas (Gillespie, Concho, Tom Green, San Saba, Bexar, Mason, and Refugio counties); breeding, locally (in Transition and Upper Sonoran zones), throughout its general range (except in Pacific coast district from middle California northward?), south to southern California (San Diego, San Bernardino, and Riverside counties), northern Lower California (Hardy River; Rancho San Antonio), Arizona (Santa Rita, Santa Catalina, and Huachuca mountains, Tucsón, Camp Lowell, Oracle, etc.), southern New Mexico (Grant and Otero counties), Nuevo León (Montemorelos; Monteréy; Sierra Madre), Tamaulipas (Jaumave), Chihuáhua (San Diego), and Sonora (Guaymas); in winter farther southward, in States of Durango (Rio Setín, April), Zacatecas (Xeres, September), Sinaloa (Culiacán), Jalisco (Ocotlán, January; Plains of Colima, January), Michoacán (Querendero, August; La Salada, March), Guerrero (Venta de Zopilote, October), and Mexico (City of Mexico).

T[rochilus] alexandri Bourcier and Mulsant, Ann. Sci. Agric. Lyon, ix, 1846, 330 (Sierra Madre, Mexico).-Bourcier, Rev. Zool., 1846, 316.-Cabanis and Heine, Mus. Hein., iii, 1860, 57 (Mexico).-Coues, Key N. Am. Birds, 2d ed., 1884, 462; 5th ed., ii, 1903, 548.-Rrdgway, Man. N. Am. Birds, 1887, 312.-Hartert, Das Tierreich, Troch., 1900, 202.

Trochilus alexandri Heermann, Journ. Ac. Nat. Sci. Phila., 2d ser., ii, 1852, 269 (near Guaymas, Sonora, breeding; Sacramento, California, breeding); Rep. Pacific R. R. Surv., x, pt. iv, no. 2, 1859, 56 (Guaymas; Sacramento, Dry Creek, and Cosumnes R., California).-CAssin, Illustr. Birds Cal., Tex., etc., 1854, 141, pl. 22.-Gound, Mon. Troch., pt. xiv, 1857, pl. 4; vol. iii, 1861, pl. 132; Introd. Troch., oct. ed., 1861, 87.-BAIRD, Rep. Pacific R. R. Surv., ix, 1858, 133; ed. 1860 ("Birds N. Am."), 133, pl. 14, fig. 3; Cat. N. Am. Birds, 1859, no. 102; Rep. U. S. and Mex. Bound. Surv., ii, pt. 2, 1859, 6, pl. 5, fig. 3.-Xantus, Proc. Ac. Nat. Sci. Phila., 1859, 190 (Ft. Tejon, Califormia).-Sclater, Cat. Am. Birds, 1862, 297 (n. Mexico); Proc. Zool. Soc. Lond., 1864, 177 (City of Mexico).-Coues, Proc. Ac. Nat. Sci. Phila., 1866, 56 (Colorado Desert); 1868, 82 (Tuscón, Arizona); Check-list, 1873, no. 276; 2 d ed., 1882, no. 410.-Cooper, Orn. Cal., 1870, 353; Proc. Cal. Ac. Sci., 1876, 
90 (Haywards, Alameda Co.).-Merriam, Sixth An. Rep. U. S. Geol. Surv., 1872, 693, 714 (Ogden, Utah).-Ridgway, Bull. Essex Inst., v. 1873, 173 (Wahsatch Mts., Utah), 185 (Colorado); vi, 1874, 171 (Sacramento); vii, 1875, 10, 15, 17 (Truckee Valley, Nevada), 21 (East Humboldt Mts., Nevada), 30 (Salt Lake Valley), 33 (Parleys Park, Utah); Orn. 40th Parallel, 1877, 559; Proc. U. S. Nat. Mus., iii, 1880, 187, 314; Nom. N. Am. Birds, 1881, no. 336; Rep. U. S. Nat. Mus. for 1890 (1891), 331 (monogr.; habits).-BAIRD, Brewer, and Ridgway, Hist. N. Am. Birds, ii, 1874, 450, pl. 47, fig. 1.Yarrow and Henshaw, Rep. Orn. Spec. Wheeler's Surv., 1871-73 (1874), 23, 47 (Provo, Utah).-Henshaw, Rep. Orn. Spec. Wheeler's Surv., 1873 (1874), 130, 162 (Apache and Camp Grant, Arizona); 1876, 256 (Tejon Mts., California); 1879, 312 (Honey Lake and Camp Bidwell, n. California); Ann. Lyc. N. Y., xi, 1874, (8) (Utah); Zool. Expl. W. 100th Merid., 1875, 373 (localities in Utah and Arizona).-Villada, La Naturaleza, ii, 1874, 351 (Valley of Mexico).-De Oca, La Naturaleza, iii, 1875, 102 (Valley of Mexico); Troq. de Mex., 1875, 32, pl. (6), fig. 22.-Elliot, Classif. and Synop. Troch., 1879, 106.-Belding, Proc. U. S. Nat. Mus., i, 1879, 390, 391, 393, 426, 496 (Marysville, Murphys, and Calaveras Big Trees, California).-Purdie, Bull. Nutt. Orn. Club, iv, 1879, 60 (Gillespie, Bosque, and San Saba counties, Texas).Brewster, Bull. Nutt. Orn. Club, vii, 1882, 210 (Tucsón, Santa Rita Mts., and Camp Lowell, Arizona, breeding; descr. nest and eggs).-Brown (N. C.), Auk, i, 1884, 123 (Kendall Co., Texas).-Gault, Auk, ii, 1885, 310 (San Bernardino Co., California, breeding).-Evermann, Auk, iii, 1886, 180 (Ventura Co., California, breeding).--Scotr, Auk, iii, 1886, 430 (Santa Catalina Mts. and Ft. Lowell, Arizona, breeding).-A Merican ORNITHologists' Union, Check List, 1886, no. 429.-Lloyd, Auk, iv, 1887, 192 (Concho and Tom Green counties, w. Texas, breeding).-Townsend, Proc. U. S. Nat. Mus., x, 1887, 207 (lower McCloud R., etc., n. California; habits; descr. nest).-Bескнам, Proc. U. S. Nat. Mus., x, 1887, 666 (Bexar Co., Texas, March, common).-Morcom, Bull. Ridgw. Orn. Club, no. 2, 1887, 42 (San Bernardino, California, breeding).-Emerson, Bull. Cal. Ac. Sci., ii, 1887, 427 (Poway Valley, San Diego Co., California, breeding).-Cooke, Bird Migr. Miss. Val., 1888, 141 (Mason, Concho, Tom Green, Kendall, Gillespie, Bexar, and San Saba counties, Texas); Bull. Col. Agr. Coll., no. 37, 1897, 86 (w. and s. w. Colorado below 6,000 ft.).-Bryant (W. E.), Proc. Cal. Ac. Sci., ser. 2, 1889, 289 (n. w. coast Lower California).-Mearns, Auk, vii, 1890, 225 (San Francisco Mt., Arizona, breeding in pine belt).-Fannin, Check List Birds Brit. Col., 1891, 30 (both sides of Cascade range).-RHoads, Proc. Ac. Nat. Sci. Phila., 1892, 117 (Santa Catalina Mits., Tucsón, and Oracle, Arizona, breeding).--AтTwater, Auk, ix, 1892, 235 (San Antonio, Texas, common summer res.).-Anthony, Auk, ix, 1892, 363 (Apache Hills, s. w. New Mexico; breeding?).-SAlvin, Cat. Birds Brit. Mus., xvi, 1892, 402 (Montemorelos, Monteréy, and Sierra Madre, Nuevo León; Nuri, Sonora; Xeres, Zacatecas; Plains of Colima; Vente de Zopilote, Guerrero; Valley of Mexico).Salvin and Godman, Biol. Centr.-Am., Aves, ii, 1892, 359 (San Diego, Chihuáhua, etc.).-Boucard, Gen. Hum. Birds, 1895, 3.-Fisher (A. K.), North Am. Fauna, no. 7, 1893, 56 (Owens Valley, Walker Basin, etc., s. e. California, breeding; Beaver Dam Creek, Arizona, and Santa Clara Valley, Utah, breeding).-Hartert (E. and C.), Novit. Zool., i, 1894, 22 (California; descr. nest and eggs).-Bendre, Life Hist. 'N. Am. Birds, ii, 1895, 198.Merriam (Florence A.), Auk, xiii, 1896, 118 (San Diego Co., California, breeding; habits; descr. nest and eggs).-DAwson, Auk, xiv, 1897, 175 (Okanogan Co., Washington).-Merrill (J. C.), Auk, xiv, 1897, 355 (Ft. Sherman, n. Idaho, breeding).-Mitchell, Auk, xv, 1898, 308 (San Miguél 
Co., New Mexico, breeding up to 8,000 ft.).-Grinnell (J.), Pub. 2, Pasadena Ac. Sci., 1898, 27 (Los Angeles Co., California, sum. resid.); Condor, vi, 1904, 42 (Palm Springs, Riverside Co., California, Dec.); Univ. Calif. Pub. Zool., v, 1908, 70 (San Bernardino Mts., breeding on foothills).Lantz, Trans. Kansas Ac. Sci. for 1896-97 (1899), 221 (Culiacán, Sinaloa).Snyder, Auk, xvii, 1900, 244 (Blue Lake, Idaho, July).-Carroll, Auk, xvii, 1900, 344 (Refúgio Co., Texas, transient).-Ballex (Florence M.), Handb. Birds W. U. S., 1902, 235.-Stone and ReHN, Proc. Ac. Nat. Sci. Phila., 1903, 27 (Dry Cañon, Otero Co., New Mexico, breeding).-SwartH, Pacific Coast Avifauna, no. 4, 1904, 17 (Huachuca Mts., Arizona, up to 7,000 ft.).-Johnson, Condor, viii, 1906, 28 (Cheney, e. Washington, breeding).Mrller (W. De W.), Bull. Am. Mus. N. H., xxii, 1906, 167 (Rio Setín, n.w. Durango, April).-Sharp, Condor, ix, 1907, 88 (San Diego Co., California, breeding).-Kermode, Prov. Mus., 1909, 51 (Chilliwack, Brit. Columbia).

[Trochilus] alexandri Bonaparte, Rev. et Mag. de Zool., 1854, 256.-Coues,

Key N. Am: Birds, 1872, 184.-Sclater and Salvin, Nom. Av. Neotr., 1873, 84.-SHARPE, Hand-list, ii, 1900, 140.

$M[e l l i s u g a]$ alexandri Grax, Gen. Birds, i, Dec., 1848, 113.

[Selasphorus] $\beta$. Archilochus alexandri Reichenbach, Aufz. der Colibr., 1854, 13. [Selasphorus] alexandri Reichenbach, Troch. Enum., 1855, 10, pl. 855, figs. $5030-5032$.

Ornismya alexandri Mulsant and Verreaux, Classif. Troch., 1866, 91; Hist.

Nat. Ois.-Mouch., iv, livr. 1, 1877, 61.-BoucarD, Notes Troch. du Mex., 1875,4 (coast of Chiapas).

[Ornismya] alexandri Mulsant, Ann. Soc. Linn. Lyon, n. s., xxii, 1876, 227.

[Trochilus] alexandrei Sumon, Cat. Troch., 1897, 38.

Archilochus alexandri American Ornithologists' Union Committee, Auk, xxvi, July, 1909, 29s; Check List, 3d ed., 1910, 202.

\section{ARCHILOCHUS VIOLAJUGULUM $a$ (Jeffries).}

VIOLET-THROATED HUMMING BIRD.

Adult male. ${ }^{b}$-Pileum dull dusky green-almost black when viewed from in front, more metallic from behind; rest of upper parts, except remiges and rectrices (but including middle pair of the latter), bronzy green; remiges and primary coverts dull purplish dusky; tail (except middle pair of rectrices) dull black, the feathers tinged at tips with metallic green; a small white spot behind eye; chin and a rather indistinct stripe thence backward beneath eye and along upper margin of gorget opaque dull black; gorget metallic auricula purple (much less violaceous than in A.alexandri), the posterior and lateral feathers not elongated; chest dull grayish white; rest of under parts dull light bronzy green, nearly uniform on sides and flanks, elsewhere broken by whitish margins to the feathers, these particularly distinct on the lower tail-coverts and along middle line of the belly; bill black, feet dusky; length (skin), 86; wing, 47; tail, 33; middle

a Probably a hybrid of Archilochus alexandri and Calypte anna.

$b$ Description from type, no. 1616, coll. Dr. J. Amory Jeffries, (now in coll. Mus. Comp. Zool.). 
pair of rectrices 6.3 shorter, the lateral one only 3.8 wide in middle portion. ${ }^{a}$

Trochilus violajugulum JefFries, Auk, v, no. 2, April, 1888, 168 (Santa Barbara, California; coll. J. Amory Jeffries); vi, 1889, 223.-Chapman, Auk, v, 1888, 396.-American Ornithologists' Union, Suppl. Check List, 1888, 10, no. 429.1; Auk, v, 1888, 396; Abridged Check List, 1889, no. 429.1; Check List, 2d ed., 1895, no. 429.1.-Ridgway, Rep. U. S. Nat. Mus. for 1890 (1891), 329, pl. 38, fig. 2 (monogr.); Man. N. Am. Birds, 2 d ed., 1896, 598.-Boucard, Gen. Hum. Birds, ii, 1892, 3.-Bendire, Life Hist. N. Am. Birds, ii, 1895, 201.

T[rochilus] violajugulum Hartert, Das Tierreich, Troch., 1900, 202.

[Trochilus] violijugulum Sharpe, Hand-list, ii, 1900, 140.

\section{Genus TILMATURA Reichenbach.}

Tryphæna ${ }^{b}$ (not of Ochsenheimer, 1816) Gould, Mon. Troch., pt. i, June, 1849; Introd. Troch., oct. ed., 1861, 96. (Type, Ornismya dupontii Lesson.)

Tilmatura Reichendach, Aufz. der Colibr., c 1854, 8; Troch. Enum., 1855, 5. (Type, T. lepida Reichenbach=Ornismya dupontii Lesson.)

Small Trochilidæ (length, including long tail of adult male, about 58-100 mm.), resembling Nesophlox, but with bill shorter than head, a conspicuous white or buffy patch on each side of rump, the adult male with lateral pair of rectrices abruptly contracted near tip, and three outer rectrices tipped and banded with white.

Bill (unfeathered portion) shorter than head, straight, slender, terete; culmen rounded, scarcely contracted basally; tomia smooth; mandible with the usual lateral median groove. Nasal operculum broad and convex, nude, but covered by decumbent frontal feathering, which extends anteriorly to about anterior end of nostril, forming a very short obtuse point or antia on each side of culmen. Tarsus naked on inner and posterior sides, feathered on anterior and outer sides; outer toe apparently about as long as middle toe, the inner slightly shorter; hallux about as long as inner toe or slightly shorter. Wing about three times as long as exposed culmen, the outermost primary longest. Tail of adult male nearly one and a half times as long as wing, forked for about three-fourths its length, the outer pair of rectrices abruptly contracted terminally, but with rounded, slightly expanded tip; in adult female about half as long as wing, deeply emarginate, but with outermost rectrix shorter than the next.

Coloration.-Above rather dark metallic bronze-green, including middle rectrices; a conspicuous spot of white or buff on each side of rump. Adult male with chin and throat black, the feathers tipped with dark violet-blue, chest white, the longer rectrices tipped and at

a The tip of the bill having been shot away, the length of the culmen can not be given; the length of the bill from the base of the culmen to the tip of the mandible, however, is $17.2 \mathrm{~mm}$.

b Tрúфaєva, nom. prop. (Gould.)

c A nomen nudum in "Aufz, der Colibr." 
wide intervals banded with white; adult female with under parts light cinnamon-rufous, the lateral rectrices black tipped with whitish.

Range.-Southern Mexico to Guatemala. (Monotypic.)

\section{TIIMATURA DUPONTII (Lesson).}

\section{DUPONT'S HUMMTYG BIRD.}

Adult male.-Abore metallic bronze or bronze-green; remiges dull brownish slate or dusky, faintly glossed with purplish; middle pair of rectrices metallic bronze-green the next pair with outer web (in part at least) bronze-green, the inner web purplish black; remaining rectrices mostly purplish black, broadly tipped with white, the two outer ones (on each side) crossed, about one-third the distance from tip, by a white band, this preceded by a band of chestnut or chestnutrufous, the third (from outside) with a white spot on middle portion of inner web; a conspicuous white patch on each side of rump; chin and throat black, the feathers tipped or terminally margined with metallic riolet-blue, their basal portion dusky grayish; chest grayish white; rest of under parts dark metallic bronze-green, the feathers sometimes margined terminally with pale grayish; femoral tufts white; bill dull black; iris dark brown; feet dusky; length (skins), 82-101 (90); wing, 33-35 (34); tail, 38-47 (43); middle rectrices, 9-12 (10.5); exposed culmen, 12.5-13.5 (12.9). ${ }^{a}$

Adult female.-Abore metallic bronze or bronze-green, duller on pileum, especially the forehead; middle pair of rectrices metallic bronze-green, blackish terminally or subterminally; remaining rectrices metallic bronze-green basally, purplish or bronzy black subterminally (broadly) and tipped with light cinnamon-rufous (sometimes passing into white proximately); a conspicuous patch of pale cinnamon-buff or buffy white on each side of rump; remiges as in adult male; under parts buffy cinnamon or cinnamon-rufous, deepest laterally and posteriorly; bill, etc., as in adult male; length (skins), 58-67 (63); wing, 33.5-36 (34.7); tail, 16.5-18, middle rectrices, 13.5-16 (14.5); exposed culmen, 12-14.5 (13.6). ${ }^{b}$

Southern Mexico, in States of Tera Cruz (Córdora; Orizaba; Jalapa; Los Cerrillos, near Jalapa; Coátepec; Cuesta de Misantla), Mexico (Valley of Mexico), Jalisco (Volcán de Colima ${ }^{c}$ ), and Guerrero $^{c}$ (Amula; Chilpancingo), and highlands of Guatemala (Guatemala City; Volcán de Santa Maria, Quezaltenango; Cobán, Vera Paz; San Gerónimo); northern Nicaragua c (Matagalpa).

Ornismya dupontii Lesson, Hist. Nat. Colibr., Suppl. Ois.-Nouch., 1830-31, 100, pl. I (Mexico); Index Gen. et Synop. Troch., 1832, p. xxiv.-D OcA, La Naturaleza, iii, 1875, 103 (Jalapa, Vera Cruz; Valley of Mexico).

a Ten specimens.

$b$ Eight specimens.

c I have not seen specimens from Jalisco, Guerrero, nor Nicaragua. 
Ornismya duponti De OcA, Los Colibris, Mex., 1875, 33.

Trochilus duponti JARDINe, Nat. Libr., Humming-birds, i, 1833, 131, pl. 26.

M[ellisuga] duponti Grax, Gen. Birds, i, Dec., 1848, 113.

[Trochilus] duponii Gray, Hand-list, i, 1869, 146, no. 1883.

Tryphæna dupontii Gould, Mon. Troch., pt. i, June, 1849; vol. iii, 1861, pl. 158;

Introd. Troch., oct. ed., 1861, 97.-Sclater and SAlvin, Ibis, 1859, 129

(Guatemala).-Salvin, Ibis, 1860, 266 (San Gerónimo, Guatemala).Mulsant and Verreaux, Classif. Troch., 1866, 79.

Triphæna duponti Herrera, La Naturaleza (2), i, 1891, 322 (Valley of Mexico). Tryphaena dupontii Villada, La Naturaleza, ii, 1874, 360 (Valley of Mexico).

Triphaena duponti $\mathrm{De}_{\mathrm{OCA}}$, Troq. de Mex., 1875, pl. (7), fig. 23.

[Tryphaena] duponti Bonaparte, Consp. Av., i, 1850, 84.

[Thaumastura] duponti Bonaparte, Rev. et Mag. de Zool., 1854, 257.

Thaumastura duponti Sclater, Proc. Zool. Soc. Lond., 1856, 288 (Córdova, Vera Cruz).

Tilmatura] duponti Cabanis and Heine, Mus. Hein., iii, 1860, 59, footnote (Mexico; Guatemala).-Heine, Journ. für Orn., 1863, 205.-Hartert, Das Tierreich, Troch., 1900, 200 (monogr.).

Tilmatura duponti Sclater, Cat. Am. Birds, 1862, 300 (Guatemala).-Mulsant and Verreaux, Hist. Nat. Ois.-Mouch., iv, livr. 1, 1877, 11, pl. 101 (Mexico; Guatemala).-Boucard, Notes Troch. du Mex., 1875, 10 (Córdova and Jalapa, Vera Cruz; Oaxaca; Guatemala); Liste Ois. réc. Guat., 1878, 46; Gen. Hum. Birds, 1895, 20.--Euliot, Classif. and Synop. Troch., 1879, 128.Ferrari-Perez, Proc. U. S. Nat. Mus., ix, 1886, 157 (Jalapa).-Ridgway, Rep. U. S. Nat. Mus. for 1890 (1891), pl. 12 (nest).-SAlvin, Cat. Birds Brit. Mus., xvi, 1892, 385, 667 (Volcán de Colima; Amula and Chilpancingo, Guerrero; Jalapa, etc., Vera Cruz; Volcán de Santa Maria, Cobán, San Gerónimo, and Vera Paz, Guatemala); Ibis, 1892, 327 (Matagalpa, Nicaragua).-Salvin and Godman, Biol. Centr.-Am., Aves, ii, 1892, 348.-Hartert (E. and C.), Novit. Zool., i, 1894, 21, 63 (Chilpancingo, Guerrero).

[Tilmatura] duponti Sclater and Salvin, Nom. Av. Neotr., 1873, 85.-MulSant, Cat. Ois.-Mouch., 1875, 28; Ann. Soc. Linn. Lyon, n. s., xxii, 1876, 225.-Sharpe, Hand-list, ii, 1900, 140.

Ornismya coelestis Lesson, Traité d'Orn., 1831, 276 (Mexico).

Ornismya zémès Lesson, Rev. Zool., 1838, 315 (Mexico).

Tilmatura lepida Reichenbach, Aufz. der Colibr., 1854, 8; Troch. Enum., 1855, 5, p. 711, figs. 4610-4614.

\section{Genus NESOPHLOX Ridgway.}

Nesophlox a Ridgway, Proc. Biol. Soc. Wash., xxiii, April 19, 1910, 55. (Type, Trochilus evelynæ Bourcier.)

Egolia (not of Erichson, 1842) Mulsant and Verreaux, Mém. Soc. Imp. Sci. Nat. de Cherbourg, xii, (sér. 2, tome ii), 1866, 230, in text (Classif. Troch., 1866, 86). (Type, Trochilus evelynæ Bourcier.)

Small Trochilidæ (length about 75-90 mm.) resembling Doricha, but differing in relatively much shorter and nearly to quite straight bill (exposed culmen less than half as long as wing), and tail of adult male shorter than wing.

Bill about as long as head or slightly longer, straight or at most very faintly decurved, terete; culmen rounded except basally, where 
more contracted, sometimes forming a rather distinct narrow ridge; tomia smooth; mandible with the usual longitudinal median sulcus. Nasal operculum rather broad and convex, more or less (sometimes wholly) hidden by the decumbent frontal feathering, which extends forward to beyond anterior end of nostril, forming a short and obtuse point or antia on each side of culmen. Tarsus feathered for upper portion except behind; inner toe about as long as middle toe, the outer very slightly shorter, the hallux shorter than outer toe. Wing more than twice as long as exposed culmen, the outermost primary longest, rather narrow, but not attenuated nor acuminate. Tail in adult male shorter than wing, forked for more than half its length, the lateral rectrices rather narrow but rounded at tip; in adult females at least half as long as wing, strongly double rounded or rounded with middle pair of rectrices abruptly shorter than the rest.

Coloration.-Above rather dull or dark metallic bronze or bronzegreen, including middle rectrices; under parts of body more or less rufescent, sometimes glossed with green or bronze laterally, the chest whitish or buffy. Adult male with chin and throat bright metallic reddish purple sometimes passing into violet or blue posteriorly, the lateral rectrices purplish black broadly edged on inner web with cinnamon-rufous; adult females with chin and throat dull white or cinnamon-buffy, lateral rectrices rufescent with a subterminal band of black.

Range.--Bahrama Istands ; Costa Rica and western Panamá. (Three species.)

While acknowledging the very close relationship of this group to Calliphlox Boie, I believe it is better to keep it apart, the type of Calliphlox having the lateral rectrices contracted and obtusely pointed terminally, the middle rectrices much broader, and the primaries very much narrower, the outer one very narrow terminally. The coloration is very similar, but in Calliphlox there is no rufous on the tail, which (except the middle rectrices) is uniform purplish black. $N$. bryantæ is intermediate in coloration between the typical species of the present genus and Calliphlox, the female agreeing with that of the latter in the conspicuous dusky auricular area, while both sexes agree with the species of Nesophlox in coloration of the tail. It is also, to a certain extent, intermediate in form, but seems nearer the present group.

\section{KEY TO THE SPECIES OF NESOPHLOX.}

a. Throat bright metallic reddish purple; tail deeply forked, the longer rectrices edged on inner web with cinnamon-rufous but not tipped with that color. (Adult males.)

b. Bill slightly decurved from middle portion; under parts of body more rufescent; purple of throat passing into violet on posterior border; a conspicuous lumbar tuft of white. 
c. Forehead dusky or dark metallic greenish, like crown; lateral rectrices straight, broader. (Bahamas, except island of Inágua.)

Nesophlox evelynæ, adult male (p. 641).

cc. Forehead metallic reddish purple, like throat; lateral rectrices doubly curved, narrower. (Island of Inagua, Bahamas.)

Nesophlox lyrura, adult male (p. 644).

$b b$. Bill straight; under parts of body more greenish; purple of throat not passing into violet posteriorly. (Costa Rica and western Panamá.)

Nesophlox bryantæ, adult male (p. 645).

aa. Throat pale gray, pale rufous-buff, or whitish; tail double-rounded, the longer rectrices tipped with light cinnamon-rufous. (Adult females.)

b. No distinct auricular patch of dusky; no white lumbar tuft; throat pale grayish; axillars and under wing-coverts cinnamon-rufous; tail more than 26.

c. Slightly larger; wing, 41.5-45.5 (43.3); tail, 26.5-30.5 (28.5), middle rectrices, 23-28.5 (25.5); exposed culmen, 15.5-18 (16.6). ${ }^{a}$

Nesophlox evelynæ, adult female (p. 642).

cc. Slightly smaller; wing, 40.5-13 (41.9); tail, 27.5-29.5 (28.5), middle rectrices, 23.5-26 (25); exposed culmen, 16-17 (16.6). ${ }^{a}$

Nesophlox lyrura, adult female (p. 644).

$b b$. A distinct auricular patch of dusky and a conspicuous lumbar tuft of white; axillars and under wing-coverts olive-bronzy; tail less than 25.

Nesophlox bryantæ, adult female (p. 645).

\section{NESOPHLOX EVELYNAE (Bourcier).}

BAHAMA WOOD-STAR.

Adult male.-Above rather dull metallic green or bronze-green, including middle pair of rectrices; remiges dark brownish slate or dusky, very faintly glossed with purplish; tail (except middle pair of rectrices) purplish black, the second and third rectrices with inner web cinnamon-rufous (except for a narrow space along shaft toward tip), the third (from outside) with basal portion of outer web (extensively) also cinnamon-rufous, the fourth with outer web (sometimes basal portion of inner web also) mostly cinnamon-rufous $;^{b}$ a small postocular spot (sometimes a rictal spot also) of dull white; chin and throat brilliant metallic solferino purple passing into violet or violetblue posteriorly and laterally, the chin and anterior portion of throat decidedly reddish purple or purplish red; chest white, passing into light buffy grayish posteriorly; rest of under parts cinnamon-rufous, paler medially, the sides and flanks glossed with metallic bronze or bronze-green; under tail-coverts cinnamon-rufous medially, passing into cinnamon-buff or white laterally; femoral tufts white; bill dull black; iris dark brown; feet grayish brown (in dried skins); length

$a$ I am not able to discover any positive characters distinguishing females of these two species.

$b$ Sometimes the fourth rectrix passes into metallic bronze-green terminally, at least on edge.

$81255^{\circ}-\mathrm{Bu} 11.50-11-41$ 
(skins), 79-93 (87); wing, 37-40.5 (38.9); tail, 31-34 (32.2), middle rectrices, 13.5-17 (15.2); exposed culmen, 15.5-16.5 (15.9). ${ }^{a}$

Adult female.-Above as in the adult male, but slightly duller metallic bronze-green, especially on pileum, where sometimes dull grayish brown, at least on forehead; three outer rectrices (on each side) extensively light cinnamon-rufous basally, broadly tipped with pale cinnamon-rufous or vinaceous-rufous, and crossed by a very broad subterminal band of purplish black, the latter separated from the rufescent basal portion on outer web by more or less of metallic green; third rectrix (from outside) mostly metallic bronze-green, extensively black terminally, the concealed basal portion light cinnamon-rufous; chin and throat dull grayish white, sometimes tinged with pale cinnamon or cinnamon-buff; chest grayish white; rest of under parts cinnamon-rufous, paler medially, the under tail-coverts paler cinnamon-rufous or cinnamon-buff, sometimes indistinctly whitish along edges; femoral tufts white; bill, etc., as in adult male; length (skins), 76-89 (85); wing, 41.5-45.5 (43.3); tail, 26.5-30.5 (28.5), middle rectrices, 23-28.5 (25.5); exposed culmen, 15.5-18 $(16.6)^{b}$

Young male.-Similar to the adult female, but lateral rectrices relatively longer and narrower and with the black relatively more extended; in older individuals the throat with a greater or less number of metallic reddish purple feathers.

Young female.-Similar to the adult female, but feathers of upper parts (especially rump) indistinctly margined with rusty.

$a$ Seventeen specimens.

$b$ Nineteen specimens.

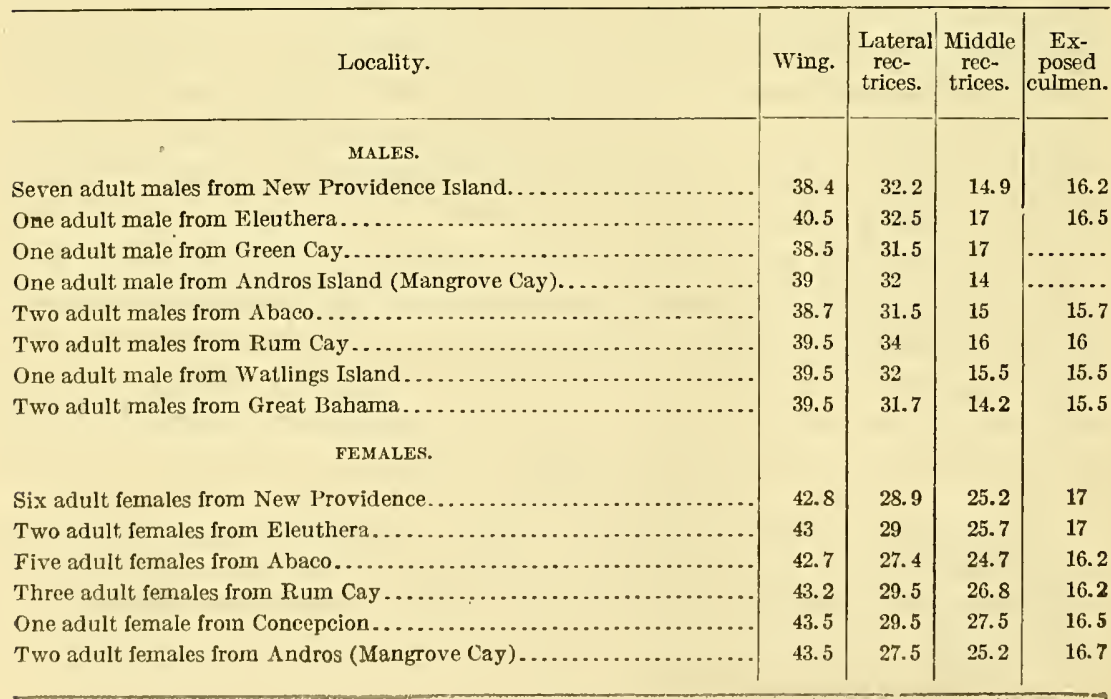


Bahama Islands (New Providence; Biminis; Berry Islands; Eleúthera; Andros; San Salvadór; Concepción; Watling; Acklin; Crooked Island; Long Island; Current Island; Grand Caicos; North Caicos; East Caicos; Cay Sal; Green Cay; Mangrove Cay; Elbow Cay; Stranger Cay; Moraine Cay; Rum Cay; Cay Lobos; Great Bahama).

Troch[ilus] evelynæ Bourcier, Proc. Zool. Soc. Lond., 1847, 44 (Nassau, New Providence I., Bahamas; coll. M. Loddiges).

C[alothorax $]$ evelynæ GraY, Gen. Birds, i, Dec., 1848, 110.

[Calothorax] evelynæ Gray, Hand-list, i, 1869, 135, no. 1733.

[Lucifer. ò. Calothorax] evelynae Reichenbach, Aufz. der Colibr., 1854, 13.

[Lucifer] evelynae Reichenbach, Troch. Enum., 1855, 10.

[Callothorax] evillinæ Bonaparte, Rev. et Mag. de Zool., 1854, 257.

Thaumastura evelynæ Gould, Mon. Troch., pt. xxi, May, 1856; vol. iii, 1861, pl.156.

Doricha evelynæ Gould, Introd. Troch., oct. ed., 1861, 95.--ЕцLiot, Ibis, 1872,

353 (New Providence; synonymy; crit.); Classif. and Synop. Troch., 1879, 125.-Mulsant and Verreaux, Hist. Nat. Ois.-Mouch., iv, livr. 1, 1877, " 83 "=38; Suppl., pl. 46, fig. 3.-Cory, Birds Bahama Is., 1880, 108; Auk, iii, 1886, 355; viii, 1891, 294 (New Providence), 295 (Berry Is.), 296 (Biminis), 297 (Caicos Is.), 298 (Abaco), 350 (Abaco), 351 (Eleúthera); Birds West Ind., 1889, 150; Cat. West Ind. Birds, 1892, 13, 107, 127 (Abaco; Biminis; Berry Islands; Eleúthera; New Providence; Andros; San Salvador; Concepción; Watlings; Rum Cay; Long I.; Acklin I; North Caicos; Grand Caicos; East Caicos; Cay Sal).-Northrop, Auk, viii, 1891, 73 (Andros; habits).-RidGway, Auk, viii, 1891, 334 (Abaco), 335 (New Providence), 336, (Eleuthera), 337 (Cat I.; Watlings I.), 338 (Rum Cay), 339 (Green Cay; Concepción I.).Salvin, Cat. Birds Brit. Mus., xvi, 1892, 383 (Nassau).-Bonнote, Ibis, 1899, 514 (New Providence); 1903, 292 (habits); Auk, xx, 1903, 174 (Cay Lobos).Bangs, Auk, xvii, 1900, 288 (Nassau; Current I.; Eleúthera).-Allen (G. M.), Auk, xxii, 1905, 127 Great Bahama; New Providence; Elbow Cay; Stranger Cay).-Riley, Auk, xxii, 1905, 355 (New Providence; Andros; Eleúthera; Cat I.; Rum Cay; Long I.).

[Doricha] evelynæ Sclater and Salvin, Nom. Av. Neotr., 1873, 85.-Cory, List Birds West Ind., 1885, 18.

[Doricha] evelynae Mulsant, Ann. Soc. Linn. Lyon, n. s., xxii, 1876, 226.

Dorycha evelynæ Boucard, Gen. Hum. Birds, ii, 1892, 28 (Long I.).

Amathusia (Egolia) evelynae Mulsant and Verreaux, Classif. Troch., 1866, 86. C[alliphlox] evelynae Hartert, Das Tierreich, Trach., 1900, 198.

[Calliphlox] evelynæ SHarpe, Hand-list, ii, 1900, 139.

[Philodice] evelynae Simon, Cat. Troch., 1897, 38.

Nesophlox evelynæ Ridgway, Proc. Biol. Soc. Wash., xxiii, April 19, 1910, 55.

Trochilus bahamensis Bryant, Proc. Bost. Soc. N. H., vii, 1859, 106 (Nassau, New

Providence I., Bahamas; coll. U. S. Nat. Mus.), 317 (crit.).-Albrecht, Journ. für Orn., 1861, 51.

\section{NESOPHLOX LYRURA (Gould).}

INAGUA WOOD-STAR.

Similar to $N$. evelynæ, but adult male with forehead metallic reddish purple (instead of dull metallic green), and lateral rectrices longer, relatively narrower, and their terminal portion curved outward; adult female similar to that of $N$. evelynx, but tail longer, with rela- 
tively less of cinnamon-rufous on lateral rectrices, and next to middle pair mostly (sometimes wholly) green.

Adult male.-Forehead metallic reddish purple, varying to violet; rest of upper parts, including middle pair of rectrices, rather dull metallic green or bronze green; remiges dull brownish slate or dusky, faintly glossed with purplish; outermost rectrix entirely purplish black, the next with outer web purplish black, inner web cinnamon-rufous; third with most of inner web and basal portion of outer web cinnamon-rufous, the remainder purplish black; fourth purplish black (usually glossed with or passing into dull metallic bronze-green terminally), the outer web edged basally with cinnamon-rufous; a small postocular (sometimes also a rictal) spot of white; chin and throat bright metallic solferino purple, passing into violet or violet-blue posteriorly, the chin and anterior portion of throat more decidedly reddish purple or purplish red; chest grayish white, more decidedly grayish posteriorly; rest of under parts cinnamon-rufous, paler medially, this overlaid, more or less strongly, by metallic bronze or greenish bronze; under tail-coverts light cinnamonrufous, sometimes partly white especially at base); femoral tufts white; bill dull black; iris dark brown; feet grayish brown or dusky; length (skins), 83-92 (88); wing, 37-38.5 (37.9); tail, 36-40 (38.4); middle rectrices, 12.5-14 (13.2); exposed culmen, 13.5-16 (15.4). ${ }^{a}$

Adult female.-Above dull metallic bronze-green or greenish bronze, still duller on pileum, where becoming dull grayish brown or brownish gray on forehead; middle pair of rectrices metallic bronze-green, the next pair.similar but with basal portion of outer web (sometimes of both webs) cinnamon-rufous, the terminal portion sometimes blackish; two outer rectrices (on each side) with basal half, or more, light grayish brown, the inner web tinged with light cinnamon-rufous or partly of that color, the tip broadly light grayish brown, brownish gray, or grayish cinnamon, the subterminal portion (broadly) black; third rectrix similar, but with terminal spot smaller and more cinnamomeous and basal area more decidedly cinnamomeous; auricular region light brownish gray, fading gradually into dull grayish white, pale buffy grayish, or cinnamon-buff on chin and throat; chest dull grayish white; rest of under parts cinnamon-rufous (more or less deep), paler medially; femoral tufts white; bill, etc., as in adult male; length (skins), 77-78 (77.7); wing, 41-42 (41.4); tail, 27.529.5 (28.5) ; middle rectrices, 23.5-26 (25); exposed culmen, 16-17 $(16.6)^{b}$

Young male.-Similar to the adult female, but lateral rectrices longer and relatively narrower, with more black on outer webs and less on inner webs. 
Immature male (not quite adult).--Similar to the adult male, but with forehead dull grayish brown or dull bronze-green, instead of metallic purple.

Inágua Island, Bahamas.

Trochilus evelynæ (not of Bourcier) Bryanx, Proc. Bost. Soc. N. H., 1866, 65, part (Inágua, Bahamas).

Doricha lyrura Gould, Ann. and Mag. N. H., 4th ser., iv, Aug., 1869, 111, 112 ("Long Id.," i. e., Inágua, Bahamas; coll. J. Gould).—Elurot, Ibis, 1872, 354 ("Long Island," error; synonymy; crit.); Classif. and Synop. Troch., 1879, 126.-Cory, Birds Bahama I., 1880, 110; Auk, iii, 1886, 355; viii, 1891, 297, 351 (Inágua); Birds West Ind., 1889, 150; Cat. West Ind. Birds, 1892, 13, 107, 127, 144 (Inágua; Long I.?).--Salvin, Cat. Birds Brit. Mus., xvi, 1892, 382 ("Long Island").

[Doricha] lyrura Sclater and Salvin, Nom. Av. Neotr., 1873, 85.-Mulsant, Ann. Soc. Linn. Lyon, n. s., xxii, 1876, 226.-Conx, List Birds West Ind., $1885,18$.

Doriche lyrura Mulsant and Verreaux, Hist. Nat. Ois.-Mouch., iv, livr. 1, 1877, 41 ("Long Island").

Dorycha lyrura Boucard, Gen. Hum. Birds, ii, 1892, 28 (Inagua).

C[alliphlox] lyrura Hartert, Das Tierreich, Troch., 1900, 199.

[Calliphlox] lyrura Sharpe, Hand-list, ii, 1900, 139.

[Philodice] lyrura Srmon, Cat. Troch., 1897, 38.

Nesophlox lyrura Ridgway, Proc. Biol. Soc. Wash., xxiii, April 19, 1910, 55.

\section{NESOPHLOX BRYANTA (Lawrence).}

\section{COSTA RICAN WOOD-STAR.}

Adult male.-Above dark, rather dull, metallic bronze-green; four middle rectrices duller bronze-green passing into dusky terminally, the remaining rectrices black glossed with purplish bronze, the shafts and broad edging to inner webs pale cinnamon or cinnamon-buff; remiges dull purplish black or purplish dusky; a small whitish or pale cinnamon-buff postocular spot; gorget bright metallic magenta purple; chest dull white, passing posteriorly into deep brownish gray, glossed with metallic bronze or bronze-green except along median line, on lower parts of body; flanks cinnamon-rufous; anal tufts white; tufts on sides of rump pale cinnamon-buff or buffy white; under tail-coverts greenish bronzy margined with pale cinnamon or cinnamon-buff, cinnamon or cinnamon-buff basally; bill dull black; iris dark brown; feet dusky grayish brown; length (skins), 82-94 (89); wing, 40.5-43 (41.6); tail, 32-36.5 (34.6), middle rectrices 12-13.5 (12.8); exposed culmen, 14.5-16.5 (15.6). ${ }^{a}$

Adult female.-Above metallic bronze or bronze-green; middle pair of rectrices bronze-green passing into dusky terminally; other rectrices cinnamon-rufous basally, crossed by a broad subterminal band of black and broadly tipped with paler cinnamon-rufous (except next to middle pair); wings as in adult male; lores dull grayish 
cinnamon becoming dusky next to eye; suborbital and auricular regions dusky faintly glossed with bronze or bronze-green, this color extending downward from posterior portion of auricular region toward posterior portion of throat; chin and throat cinnamon-buff passing into cinnamomeous-white on chest, or wholly buffy white; rest of underparts cinnamon-rufous, paler along median line of breast and abdomen, or the cinnamon-rufous confined to sides, flanks and under tail-coverts, the breast (except laterally) and abdomen dull white; sides of breast glossed with bronze-green; anal tufts buffy white; bill, etc., as in adult male; length (skins), 75-85 (79); wing, 40.5-43 (41.9); tail, 21-23.5 (22.5), middle rectrices 15-17 (16.2); exposed culmen, 15.5-17 (16.2). ${ }^{a}$

Young male.-Similar to the adult female but tail more deeply forked and with less cinnamon-rufous (except outer rectrices) and (in older individuals) with a greater or less number of metallic purple feathers on throat.

Highlands of Costa Rica (Las Cruces de Candelária; Escazú; San José; San Pedro de San José; San Pedro de Mojón; El Mojón; Volcán de Irazú; Naranjo de Cartago; Cerro Santa Maria; Dota) and western Panamá (Volcán de Chiriquí; Boquete; Boquete de Chitra; Cordillera del Chucu; Castillo; Laguna del Castillo; Chiha, Coclé).

Doricha bryantæ Lawrence, Ann. Lyc. Nat. Hist. N. Y., viii, May, 1867, 483 (Costa Rica; coll. U. S. Nat. Mus.); ix, 1868, 123 (Dota and Las Cruces de Candelária, Costa Rica; descr. female).-Frantzius, Journ. für Orn., 1869, 316 (Costa Rica).-Salvin, Proc. Zool. Soc. Lond., 1870, 209 (Volcán de Chiriquí, Cordillera del Chucu, Castillo and Laguna del Castillo, Panamá); Cat. Birds Brit. Mus., xvi, 1892, 384 (Boquete de Chitra, etc.).-Mulsant and Verreaux, Hist. Nat. Ois.-Mouch., iii, livr. 4, 1877, pl. 49; iv, livr.1, 1877, 42, pl. 103.-Elliot, Classif. and Synop. Troch., 1879, 125.-Gould, Mon. Troch., Suppl., 1881, pl. 53.-Zeledón, Cat. Aves de Costa Rica, 1882, 21; Anal. Mus. Nac. Costa Rica, i, 1887, 122 (Naranjo de Cartago, Costa Rica).-Salvin and Godman, Biol. Centr.-Am., Aves, ii, 1892, 347.

[Doricha] bryantr Sclater and SAlvin, Nom. Av. Neotr., 1873, 85.

[Doricha] briantae Mulsant, Ann. Soc. Linn. Lyon, n. s., xxii, 1876, 226.

Dorycha bryantæ Boucard, Proc. Zool. Soc. Lond., 1878, 70 (San José and Volcan de Irazú, Costa Rica); The Hum. Bird, ii, 1892, 73 (Verágua).

C[alliphlox] bryantae Hartert, Das Tierreich, Troch., 1900, 198 (monogr.).

[Calliphlox] bryantæ Sharpe, Hand-list, ii, 1900, 139.

Calliphlox bryantæ Bangs, Proc. New Engl. Zool. Club, iii, 1902, 31 (Boquete and Volcán de Chiriquí, 4,000-5,800 ft.).-Carriker, Ann. Carnegie Mus., vi, 1910, 545 (highlands of Costa Rica; habits).

[Philodiee] bryantae Snion, Cat. Troch., 1897, 37.

Nesophlox bryantx Ridgway, Proc. Biol. Soc. Wash., xxiii, April, 1910, 55.

[Calothorax] bryantx GraY, IIand-list, i, 1869, 135, no. 1732.

Dorycha bryanthae Boucard, Gen. Hum. Birds, 1892, 27. 


\section{Genus DORICHA Reichenbach.}

[Calliphlox.] 3. Doricha Reichenbach, Aufz. der Colibr., 1854, 12; Troch. Enum., 1855. (Type, Trochilus enicurus Vieillot.)

Dolicha a (emendation) Heine, Journ. für Orn., vi, May, 1863, 208, in text.

Elisa "Reich[enbach]" Bonaparte, Ann. Sci. Nat., 1854, 138. (Type, by tautonomy, Trochilus eliza Lesson and Delattre.)

Amathusia (not of Fabricius, 1808, nor Rafinesque, 1815) Mulsant and VerReaux, Mém. Soc. Imp. Sci. Nat. Cherb., xii (sér. 2, ii), 1866, 229 (Classif. Troch., 1866, 85). (Type, Trochilus enicurus Vieillot.)

Amalasia Mulsant, Ann. Soc. Linn. Lyon, n. s., xxii, 1876, 225 (Cat. Ois.Mouch., 29). (Type, Trochilus enicurus Vieillot.)

Amalusia (emendation?) Mulsan't and Verreaux, Hist. Nat. Ois.-Mouch., iv, $1877,15$.

Small Trochilidæ (length, including long bill and tail, about 72-121 mm.) resembling Calothorax in the long, slender, decurved bill and in coloration, but adult males with tail longer than wing, the lateral rectrices rounded terminally and gorget not elongated laterally, the adult females with tail deeply forked or strongly double-rounded.

Bill much longer than head, slender, terete, rather strongly decurved; culmen rounded except basally, where contracted into a rather indistinct ridge; tomia smooth; mandible with the usual longitudinal median groove. Nasal operculum broad and strongly convex (especially anteriorly) nude, but mostly concealed by the decumbent frontal feathering, which extends forward considerably beyond anterior end of nostril, forming a short and obtuse point or antia on each side of culmen. Tarsus feathered, except on posterior and lower portions; middle and outer toes about equal in length, the inner slightly shorter, the hallux shorter than inner toe. Wing less than twice as long as exposed culmen, the outer primary longest, normal in shape. Tail in adult male slightly longer than wing (D. eliza) to more than one and a half times as long (D. enicura), forked for nearly two-thirds (D. eliza) to more than three-fourths its length ( $D$. enicura), the lateral rectrices rounded terminally (slightly expanded in D. etiza); in adult females tail nearly twothirds (D. eliza) to more than two-thirds (D. enicura) as long as wing, forked (but with third rectrix longest) in D. enicura, strongly double-rounded in D. eliza.

Coloration.-Above, including middle rectrices, metallic bronzegreen or bronze. Adult males with throat metallic violet or reddish purple (the chin dusky greenish in D. enicura), chest and median line of body beneath buffy whitish, sides greenish or bronzy, lateral rectrices purplish black edged, more or less, with light cinnamonrufous; females dull whitish (D. eliza) or cinnamon-buff beneath 
(D. enicura), the lateral rectrices cinnamon-rufous basally and tipped with white.

Range.-Southeastern Mexico to Guatemala. (Two species.)

KEY TO THE SPECIES OF DORICHA.

a. Throat bright metallic purple or violet; tail deeply forked, the lateral restrices without whitish tip. (Adult males.)

$b$. Chin black, throat violet; outermost rectrices wholly black; wing not more than 34, tail more than 50. (Guatemala.).... Doricha enicura, adult male (p. 648).

$b b$. Chin and throat reddish purple (solferino); outermost rectrices with inner web broadly edged with light cinnamon-rufous; wing more than 34 , tail less than 40. (Southeastern Mexico.)............. Doricha eliza, adult male (p. 650). aa. Throat whitish or buffy; tail slightly forked, the lateral rectrices broadly tipped with whitish. (Adult females.)

$b$. Under parts cinnamon-buff or vinaceous-cinnamon; lateral rectrices cinnamonrufous basally; middle rectrices less than 19, exposed culmen less than 22 .

Doricha enicura, adult female (p. 648).

$b b$. Under parts dull buffy whitish; lateral rectrices grayish cinnamon basally; middle rectrices more than 19 , exposed culmen 22 or more.

Doricha eliza, adult female (p. 650).

? ORICHA INICURA (Vieillot).

SLENDER SHEAR-TAIL.

Adult male.-Above metallic bronze-green, the back sometimes decidedly bronze or golden; four middle rectrices bronze-green, the next pair bronze-green terminally, purplish black or dusky basally; other rectrices dull black, with a faint gloss of bronzy purplish, the inner web of pair next to the outermost edged with pale rusty or cinnamon; remiges purplish dusky, the inner secondaries glossed with bronze-greenish; chin and upper throat, together with malar, suborbital, and auricular regions, dusky metallic bronze-greenish; throat (except upper part) bright metallic violet or phlox purple; chest varying from dull brownish white to pale vinaceous-cinnamon; sides and flanks (broadly) metallic bronze-green; median line of breast and abdomen pale dull brownish gray; under tail-coverts metallic bronze or bronze-green centrally, margined with pale brownish gray or dull whitish; femoral tufts white; bill dull black; iris dark brown; feet dusky; length (skins), 103-121 (110); wing, 31-34 (32.7); tail, 55-61.5 (5S.4), middle rectrices 9.5-14 (11.5); exposed culmen, $18-20.5$ (19) ${ }^{a}$

Adult female.-Above similar to the adult male, but two outer rectrices (on each side) broadly and abruptly tipped with white, this preceded by a broad subterminal area of blackish, the remainder mostly light cinnamon-rufous or vinaceous-cinnamon, the third rectrix similar but (usually at least) without any white at tip; a post- 
ocular spot of buff, and beneath this an indistinct auricular area of dusky grayish; under parts, including malar region, pale cinnamonrufous or vinaceous-cinnamon; femoral tufts white; bill, etc., as in adult male; length (skins), 72-\$9 (\$1); wing, 35-39 (36.6); tail, 24-30 (26.6), middle rectrices 13.5-18 (15.8); exposed culmen, $18.5-21.5(20.4){ }^{a}$

Highlands of Guatemala (Guatemala City; Cobán, Vera Paz; Dueñas; Atitlán; Panajachel).

Trochilus enicurus VienLot, Nouv. Dict. d'Hist. Nat., xxiii, 1818, 429 ("Brazil"error; coll. M. Laugier).-Теммгоск, P1. Col., iv, livr. 2, 1831, pl. 66, fig. 3. T[rochilus] enicurus Vieillot, Tabl. Enc. Méth., ii, 1822, 560.

C[alothorax] enicurus GraY, Gen. Birds, i, Dec., 1848, 110.

[Calothorax] enicurus Bonaparte, Consp. Av., i, 1850, 85.-Gray, Hand-list, i, 1869,135 , no. 1730 .

Thaumastura enicura Goutd, Mon. Troch., pt. iv, Oct., 1852; vol. iii, 1861, pl. 157.-Sclater and Salvin, Ibis, 1859, 129 (Dueñas, Guatemala; habits).

Taumastura enicura De OcA, La Naturaleza, iii, 1875, 203; Troq. de Mex., 1875, 45, pl. (9), fig. 33.

[Lucifer] enicurus Bonaparte, Rev. et Mag. de Zool., 1854, 257.

M[yrtis] enicura Cabanis and Herne, Mus. Hein., iii, 1860, 59 (Guatemala).

Doricha enicura Gould, Introd. Troch., oct. ed., 1861, 95.-ElLiot, Classif. and Synop. Troch., 1879, 124.-SALvin, Cat. Birds Brit. Mus., xvi, 1892, 381, 667 (Dueñas, Cobán, Panajachel, and Atitlán, Guatemala).-SALvin and Godman, Biol. Centr.-Am., Aves, ii, 1892, 345.-Boucard, Gen. Hum. Birds, ii, 1392, 25 (Cobán).

Amathusia enicura Mulsant and Verreaux, Classif. Troch., 1866, 85.

Amalusia enicura Mulsant and Verreaux, Hist. Nat. Ois.-Mouch., iv, livr. 1, $1877,16$.

[Amalasia] enicura Mulsant, Ann. Soc. Linn. Lyon, n. s., xxii, 1876, 225.

[Calliphlox.] 3. Doricha henicura Reichenbach, Aufz. der Colibr., 1854, 12.

[Calliphlox] henicura Reichenbach, Troch. Enum., 1855, 10, pl. 840, figs. 49814983.

Thaumastura henicura Salvin and Sclater, Ibis, 1860, 40 (Dueñas; habits).Salvin Ibis, 1860, 196, 263, 264 (Dueñas; habits); 1864, 376.-Sclater, Cat. Am. Birds, 1862, 299 (Dueñas).

[Doricha] henicura Sclater and Salvin, Nom. Av. Neotr., 1873, 85.-Sharpe, Hand-list, ii, 1900, 140.

Doricha henicura Salvin, Cat. Strickl. Coll., 1881, 365.

$D$ [oricha] henicura Herne and Reichenow, Nom. Mus. Hein. Orn., 1890, 184 (Guatemala).- Нантеrт, Das Tierreich, Troch., 1900, 199.

[Doricha] henicura Srmos, Cat. Troch., 1897, 38.

Amalasia henicura Boucard, Liste Ois. récol. Guat., 1878, 46.

Ornismya heteropygia Lesson, Hist. Nat. Ois.-Mouch., 1829, pp. xxi, 72, pl. 15 (locality not given; coll. Laugier); Index Gen. et Synop. Troch., 1832, p. xxxii ("Trinidad"); Suppl. Ois.-Mouch., 1830-31, 97.

Ornismya swainsonii Lesson, Hist. Nat. Ois.-Mouch., 1829, 197, pl. 70 (= female). 


\section{DORICHA ELIZA (Lesson and Delattre).}

MEXICAN SHEAR-TAII.

Adult male.-Above metallic bronze or bronze-green, duller on pileum, the forehead sometimes dull brownish gray; three lateral rectrices (on each side) purplish bronzy black, the inner web of second and third broadly edged with light cinnamon; remiges deep brownish gray, very faintly glossed with purplish; chin (except anterior portion) and throat bright metallic solferino purple, tinged with violet laterally or posteriorly; chest white; median portion of breast, abdomen, and under tail-coverts dull white, the latter (and sometimes lower abdomen) tinged with cinnamon-buff; sides and flanks (broadly) metallic bronze or bronze-green; femoral tufts white; bill dull black; iris dark brown; legs and feet dusky; length (skins), 86-97 (93); wing, 34.5-36.5 (35.5); tail, 35.5-38 (37.1), middle rectrices 10-12.5 (11); exposed culmen, 20.5-22.5 (21.3). ${ }^{a}$

Adult female.-Above similar to the adult male, but three outer rectrices (on each side) with basal half (more or less) light cinnamonrufous, the two outermost broadly tipped with white and crossed by a broad subterminal area of black, the third with terminal half black, with or without a small white tip; the second and third with more or less of metallic bronze-green between the cinnamon-rufous and black areas; under parts dull grayish white, more or less tinged with brownish buffy, especially on flanks and under tail-coverts, the sides and flanks (broadly) glossed with metallic bronze or bronze-green; bill, etc., as in adult male; length (skins), 82-85 (83); wing, 37.5-4C (38.7); tail, 23-25 (24.4), middle rectrices 19.5-23 (20.S); exposed culmen, 22-23 (22.4). ${ }^{b}$

Southeastern Mexico, in States of Vera Cruz (Jalapa; Barranca de Jico, near Jalapa; Miradór; Córdova; Llano de Camerones, near Vera Cruz) and Yucatan (Mérida; Progreso; Sisál; Holbox Island).

Trochilus eliza Lesson and Delattre, Rev. Zool., 1839, 20 (between Vera Cruz and Jalapa, Vera Cruz, Mexico).

C[alothorax] eliza Gray, Gen. Birds, i, Dec., 1848, 110.

Calothorax eliza Sclater, Proc. Zool. Soc. Lond., 1856, 288 (Córdova, Vera Cruz).

[Doricha] eliza Sclater and Salvin, Nom. Av. Neotr., 1873, 85.-Sharpe, Handlist, ii, 1900, 140.

Doricha eliza Ferrari-Perez, Proc. U. S. Nat. Mus., ix, 1886, 157 (Jalapa).

D[oricha] eliza Hartert, Das Tierreich, Troch., 1900, 200.

[Lucifer] $\beta$. Myrtis elisa Rerchen Bach, Aufz. der Colibr., 1854, 13.

[Lucifer] clisa Reichenbach, Troch. Enum., 1855, 10, pl. 845, figs. 4996-4998.Bonaparte, Rev. et Mag. de Zool., 1854, 257.

Thaumastura elizæ Gould, Mon. Troch., pt. xiii, May, 1857; vol. iii, 1861, pl. 155.-Sclater, Cat. Am. Birds, 1862, 299 (Mexico).-De Oca, Proc. Ac. Nat. Sci. Phila., 1860, 552 (habits); La Naturaleza, iii, 1875, 17. 
Taumastura elisæ De OcA, Troq. de Mex., 1875, 7, pl. (1), fig. 2.

Doricha elisæ Gould, Introd. Troch., oct. ed., 1861, 94.-ELLiot, Classif. and Synop. Troch., 1879, 125.-Boucard, Ann. Soc. Linn. Lyon, xxii, 1876, 22; Notes Troch. du Mex., 1875, 9 (Jalapa); Gen. Hum. Birds, ii, 1892, 26 (Jalapa; Progreso, Yucatan).--Salvin, Ibis, 1889, 365 (Holbox I., Yucatan); Cat. Birds Brit. Mus., xvi, 1892, 382 (Jalapa and Córdova, Vera Cruz; Sisál and Holbox I., Yucatan).-Salvin and Godman, Biol. Centr.-Am., Aves, ii, $1892,346$.

Amathusia (Doricha) elizae Mulsant and Verreaux, Classif. Troch., 1866, 85.

[Calothorax] elizæ GRAx, Hand-list, i, 1869, 135, no. 1731.

Amalusia elizae Mulsant and Verreaux, Hist. Nat. Ois.-Mouch., iv, livr. 1, $1877,20$.

[Amalasia] elizae Mulsant, Ann. Soc. Linn. Lyon, n. s., xxii, 1876, 225.

Doricha elisæ Boucard, Proc. Zool. Soc. Lond., 1883, 451 (Progreso, Yucatan; habits).

[Doricha] elisae Simon, Cat. Troch., 1897, 38.

\section{Genus CALOTHORAX Gray.}

Calothorax Grax, List Gen. Birds, 1840, 13. (Type, Cynanthus lucifer Swainson.) Callothorax (emendation) Bonaparte, Rev. et Mag. Zool., May, 1854, 257.a

Callithorax (emendation) Simon, Cat. Troch., 1897, 37.

Lucifer Reichenbach, Synop. Av. Nat., 1849, pl. 39. (Type, Cynanthus lucifer Swainson.)

Cyanopogon "Reich[enbach]" Bonaparte, Ann. Soc. Nat., ser. 4, i, 1854, 138. (Nomen nudum.)

Manilia Mulsant and Verreaux, Mém. Soc. Imp. Sci. Nat. Cherb., xii (sér. 2, ii), 1866, 230, in text (Classif. Troch., 1866, 86). (Type, Calothorax pulchra Gould.)

Small Trochilidæ (length, including very long bill, about 80-95 $\mathrm{mm}$.) with long, slender and more or less decurved bill, the adult males with tail three-fourths as long as wing, forked and lateral rectrices stiff and narrow (acicular in one species), uniform blackish, and with a gorget of bright metallic purple (changing to violet), the posterior lateral feathers of which are much elongated, the chest white; the adult females with tail less than two-thirds as long as wing, rounded or double-rounded, the lateral rectrices not narrow, broadly tipped with white, black subterminally, and rufous basally, the under parts buffy passing into white on abdomen or dull white with sides and flanks buffy.

Bill decidedly to very much longer than head, slender, more or less decurved, terete; culmen rounded except basally, where contracted into a rather distinct ridge; tomia smooth; mandible with a distinct longitudinal median narrow groove. Nasal operculum broad and convex but covered by the appressed frontal feathering, which extends forward to beyond anterior end of nostrils, forming a short point or antia on each side of culmen. Tarsus feathered except on posterior' side and extreme lower portion; lateral toes about equal in length,

$a$ But the name used in a different sense generically. 
very slightly shorter than middle toe, the hallux shorter than lateral toes. Wing relatively small, less than twice as long as exposed culmen in adult males, about twice as long in females, the outermost primary longest and distinctly narrowed and incurved terminally in adult males. Tail about three-fourths as long as wing in adult males, rather deeply forked but with outermost rectrix not longer than next pair, all the longer rectrices narrow (the lateral ones acicular in one species); in adult female tail less than two-thirds as long as wing, rounded or double-rounded, all the rectrices normally broad.

Coloration.-Above metallic bronze-green, greenish bronze, or bronze, including middle rectrices; under parts mostly whitish medially, greenish, bronzy, or buffy laterally. Adult males with chin and throat brilliantly metallic reddish purple changing to violet or even blue (the posterior-lateral feathers of the "gorget" much elongated), the chest dull white, the lateral rectrices wholly blackish; adult female with throat and chest buffy or whitish, and lateral rectrices cinnamon-rufous basally, then blackish, the two or three outermost pairs tipped with white.

Range.-Mountains of Mexico, including adjacent parts of Texas, New Mexico, and Arizona. (Two species.)

KEY TO THE SPECIES OF CALOTHORAX.

a. Throat brilliant metallic purple; tail deeply forked, the lateral rectrices narrow, pointed, wholly purplish black. (Adult males.)

b. Bill longer, the exposed culmen 20-22.5 (21.2), strongly decurved; outermost rectrix very narrow, attenuate-acuminate or acicular terminally. (Whole of Mexico and adjacent portion of United States.)

Calothorax lucifer, adult male (p. 652).

bb. Bill shorter, the exposed culmen 18.5-19 (18.7), very slightly if at all decurved; outermost rectrix broader, rounded at tip. (Southern Mexico.)

Calothorax pulcher, adult male (p. 655).

aa. Throat buff (more or less deep); tail double-rounded, the lateral rectrices broadly tipped with white. (Adult females.)

b. Bill longer, exposed culmen 19.5-22 (averaging 21.1), decidedly decurved.

Calothorax lucifer, ${ }^{a}$ adult female (p. 653).

bb. Bill shorter (17-18.5, averaging 17.9), slightly if at all decurved.

Calothorax pulcher, $a$ adult female (p. 655).

\section{CALOTHORAX LUCIFER (Swainson).}

\section{LUCIFER HUMMING BIRD.}

Adult male.-Above metallic bronze, bronze-green, or golden green, usually duller on pileum, especially on forehead; remiges dull brownish slate or dusky, faintly glossed with purplish; four middle rectrices metallic green or bronze-green, the rest of tail purplish or

$a$ I do not know of any other character which will serve to invariably distinguish between the females of these two species. All the measurements inosculate, except length of bill, but average decidedly less in C. pulcher than in C. lucifer except length of tail, which is slightly greater. 
bronzy dusky or blackish; a small postocular spot (sometimes also a rictal spot) of dull whitish; chin and throat brilliant metallic solferino or magenta purple, changing to violet, the posterior feathers of sides of throat much elongated; chest dull white; sides and flanks mixed light cinnamon and metallic bronze or bronze-green, the median portion of breast and abdomen pale grayish or dull grayish white; under tail-coverts dull white with a central area of pale brownish gray; femoral tufts white; bill dull black; iris dark brown; feet dusky; length (skins), 84-96 (89); wing, 36-39 (37.6); tail, 27-31 (28.6), middle rectrices 14-16.5 (15.3); exposed culmen, 19.5-22 (21.1). ${ }^{a}$

Adult female.-Above as in adult male but lateral rectrices much broader, the three outermost (on each side) with basal half (approximately) light cinnamon-rufous, then (distally) purplish black, the two outermost broadly tipped with white, the black terminal or subterminal area on second and third separated from the cinnamonrufous of basal portion by a narrow space of metallic bronze-green; fourth rectrix (from outside) mostly metallic bronze-green but terminal or subterminal portion blackish and outer web edged basally with light cinnamon-rufous; a postocular spot or streak of cinnamonbuff, and beneath this a narrow auricular area of grayish brown; malar region and underparts dull light vinaceous-cinnamon or cinnamon-buff, passing into dull whitish on abdomen, the under tailcoverts mostly (sometimes almost wholly) whitish; femoral tufts white; bill, etc., as in adult male; length (skins), 83-92 (87); wing, 39-44 (41.2); tail, 23-27 (24.7), middle rectrices 16-21 (20); exposed culmen, 20-22.5 (21.2). ${ }^{b}$

Mexico, in States of Sinaloa (Mazatlán; Sierra Madre), Jalisco (Bolaños; Lake Chapala), Durango (Rancho Baillón), Guanajuato (Tupátaro), Nuevo León (Monteréy), San Luís Potosí (Sierra de San Luís Potosí; Hacienda La Parada), Vera Cruz (Miradór; Jalapa; Orizaba; Córdova; San Andrés Tuxtla), Puebla (Chalchicomula), Mexico (Temascáltepec; Valley of Mexico; Ajusco; Tetelco; San Antonio, Coapa; Hacienda Eslava; Ixtapalapa), Hidalgo (Reál del Monte), Guerrero (Chilpancingo), and Chiapas (Ocozucuantla), and northward into southern Arizona (Camp Bowie) and southwestern Texas (Chisos Mountains, breeding).

Cynanthus lucifer Swainson, Philos. Mag., n. s., i, 1827, 442 (Temascáltepec, Mexico).-Banrd, Brewer, and Ridgway, Hist. N. Am. Birds, ii, 1874, 444 , in text.

C[alothorax] lucifor Gray, Gen. Birds, i, Dec., 1848, 110.-Cabanis and Heine, Mus. Hein., iii, 1860, 55.-Herne, Journ. für Orn., 1863, 207.-Coves, Kiey N. Am. Birds, 2d ed., 1884, 466.-Hartert, Das Tierreich, Troch., 1900, 193. 
[Calothorax] lucifer Bonaparte, Consp. Av., i, 1850, 85.-Gray, Hand-list, i, 1869, 135, no. 1728.-Sclater and Salvin, Nom. Av. Neotr., 1873, 84.Mulsant, Ann. Soc. Linn. Lyon, n. s., xxii, 1876, 226.-Sharpe, Handlist, ii, 1900, 139.

Calothorax lucifer Sclater, Proc. Zool. Soc. Lond., 1856, 288 (Córdova, Vera Cruz); 1864, 177 (City of Mexico); Cat. Am. Birds, 1862, 298.-Gould, Introd. Troch., oct. ed., 1861, 90.-Lawrence, Mem. Bost. Soc. N. H., ii, 1874, 291 (Sierra Madre, Sinaloa); Bull. Nutt. Orn. Club, ii, 1877, 108, 109 (Camp Bowie, Arizona).-Mulsant and Verreaux, Hist. Nat. Ois.-Mouch., , iv, livr. 1, 1877, 26.-Erriot, Classif. and Synop. Troch., 1879, 118 (Jalapa; Córdova).-Allen, Bull. Nutt. Orn. Club, v, 1880, 90 (Arizona).-Ridgway, Proc. U. S. Nat. Mus., iii, 1880, 187, 219, 233, 314; Nom. N. Am. Birds, 1881, no. 344; Rep. U. S. Nat. Mus. for 1890 (1891), 359, pl. 42 (monogr.; habits); Man. N. Am. Birds, 2 d ed., 1896, 598.-Coues, Check List, 2d ed., 1882, no. 418.-Sumichrast, La Naturaleza, v, 1881, 250 (Valley of Mexico; Orizaba, Vera Cruz).-Salvin, Cat. Birds Brit. Mus., xvi, 1892, 390 (Sierra de San Luís Potosí; Reál del Monte, Hidalgo; localities in Valley of Mexico; Córdova).-Salvin and Godman, Biol. Centr.-Am., Aves, ii, 1892, 350.-Boucard, Gen. Hum. Birds, ii, 1892, 14.-American Ornithologists' Union Committee, Auk, x, 1893, 62; Check List, 2d ed., 1895, no. 437; 3d ed., 1910, 205.-Bendre, Life Hist. N. Am. Birds, ii, 1895, 222.-Bailey (Florence M.), Handb. Birds W. U. S., 1902, 242, fig. 321.Oberholser, Auk, xix, 1902, 300 (Chisos Mts., s. w. Texas).-Mrller (W. DeW.), Bull. Am. Mus. N. H., xxi, 1906, 167 (Rancho Baillón, n. w. Durango).

[Callithorax] lucifer Simos, Cat. Troch., 1897, 37.

Trochilus lucifer Finsch, Abth. Nat. Mus. Brem., 1870, 329 (Mazatlán, Sinaloa).American Ornithologists' Union, Check List, 1886, no. 437.-Herrera, La Naturaleza, (2), i, 1891, 322 (Valley of Mexico).

T[rochilus] lucifer RIDGway, Man. N. Am. Birds, 1887, 316.

Ornismya cyanopogon Lesson, Hist. Nat. Ois.-Mouch., 1829, pp. xvi, xlvi, 50, pl. 5 (Mexico; coll. Rivoli); Suppl. Ois.-Mouch., 1830-31, 117, 119, pls. 9, 10; Traité d'Orn., 1831, 274; Index Gen. et Synop. Troch., 1832, p. xxiii.

Trochilus cyanopogon Swainson, Birds Brazil, Mex., etc., [1841?], pl. 77.

Lucifer cyanopogon Reichenвach, Aufz. der Colibr., 1854, 13; Troch. Enum., 1855, 10, pl. 843, figs. 4990, 4991.

[Lucifer] cyanopogon Bonaparte, Rev. et Mag. de Zool., 1854, 257.

C[alothorax $]$ cyanopogon Gray, Gen. Birds, i, Dec., 1848, 13.

Calothorax cyanopogon Gould, Mon. Troch., pt. xvi, Sept., 1857, pl. 1; vol. iii, 1861, pl. 143; Introd. Troch., oct. ed., 1861, 90.-Villada, La Naturaleza, ii, 1874, 357, fig. 4.-Boucard, Ann. Soc. Linn. Lyon, xxii, 1876, 21 (San Andrés Chalchicomula, Puebla); Notes Troch. du Mex., 1875, 8 (Puebla; San Andrés Tuxtla, Vera Cruz; Mexico; habits).-DE OcA, La Naturaleza, iii, 1875, 104, pl. 7, fig. 24; Troq. de Mex., 1875, 34, pl. (7), fig. 24.

Ornismya (Lucifer) cyanopogon Mulsant and Verreaux, Classif. Troch., 1866, 91. Trochilus simplex Lesson, Hist. Nat. Colibris, 1830-31, 86, pl. 23 ("Brésil";= female); Traité d'Orn , 1831, 291 ("Brésil"); Index Gen. et Synop. Troch., 1832, p. xiii.

Trochilus corruscus Lichtenstein, Preis-Verz. Mex. Vög., 1830, 1; Journ. für Orn., 1863, 55.

(?)[Lucifer. $\delta$. Calothorax] tendali Reichenbach, Aufz. der Colibr., 1854, 13 ("Peru;" ex Trochilus tendali Tschudi).

Ornismya labrador Bourcier, Ann. Sci. Phys, et Nat. d'Agric. Lyon, ii, March, 1839, pl, 8 (Mexico). 
[Lucifer] labrador Bonaparte, Rev. et Mag. de Zool., 1854, 257.

Doricha enicura (not Trochilus enicurus Vieillot) Henshaw, Rep. Orn. Spec. Wheeler's Surv., 1873 (1874), 162 (Camp Lowell, Arizona); Am. Sportsman, v, 1875, 328 (Camp Bowie); Zool. Expl. W. 100th Merid., 1875, 381 (Camp Bowie; see Lawrence, Bull. Nutt. Orn. Club, ii, 1877, 108).

T[rochilus] cohuatl DE LA Llave, Registro Trimestre, ii, no. 5, Jan., 1833, 47 (Mexico; see Richmond, Auk, xvi, 1899, 324).

\section{CALOTHORAX PULCHER (Gould).}

\section{BEAUTIFUL HUMMING BIRD.}

Similar to C. Tucifer, but bill much more slender and less decurved; adult male with lateral rectrices much broader (nearly as wide as next pair), rounded (instead of acuminate) at tip, the tail much longer; adult female with under parts much less rufescent (more buffy grayjsh).

Adult male.-Above metallic bronze or bronze-green, including four middle rectrices, the rest of tail plain purplish bronzy black; remiges dull brownish slate or dusky, faintly glossed with purplish; a small postocular spot of whitish; chin and throat brilliant metallic magenta purple, changing to violet and blue, the more posterior feathers on sides of throat much elongated; chest dull white or grayish white, the median portion of breast similar, passing into metallic bronze or bronze-green on sides and into light cinnamon-rufous on flanks; femoral tufts and under tail-coverts white; bill dull black; iris dark brown; feet dusky; length (skins), 77-89 (84); wing, 35-39 (36.7); tail, 28-31.5 (29.2), middle rectrices 12-16.5 (13.9); exposed culmen, $17-18.5(17.9) .^{a}$

Adult female.-Above metallic bronze or bronze-green, duller (sometines dull grayish brown) on pileum or forehead; middle pair of rectrices bright bronze-green, the next pair similar but becoming blackish terminally or subterminally; three lateral rectrices (on each side) with basal half (approximately) light cinnamon-rufous, then (distally) black, the two outermost broadly tipped with white (the third sometimes with a small apical spot of white); remiges dull brownish slate or dusky, faintly glossed with purplish; under parts pale dull grayish buffy, deepening on sides and flanks into more decided cinnamon-buff; femoral tufts white; bill, etc., as in adult male; length (skins), 81-82 (81.5); wing, 36.5-40.5 (38.5); tail, 22-24 (23); exposed culmen, 18.5-19 (18.7). ${ }^{b}$

Southern Mexico, in States of Puebla (Tehuacán; Chalchicomula), Oaxaca (Putla; Tehuántepec; Oaxaca; Tamazulapám) and Guerrero (Venta de Zopilote).

Calothorax pulchra Gould, Ann. and Mag. Nat. Hist., 3d ser., iv, 1859, 97 (Oaxaca, Mexico; coll. J. Gould); Mon. Troch., pt. xix, May, 1860; vol. iii, 1861, pl. 144; Introd. Troch., oct. ed., 1861, 91.-Sclater, Proc. Zool. Soc. Lond., 
1859, 386 (Oaxaca).-De Oca, La Naturaleza, iii, 1875, 105; Troq. de Mex., 1875, 36, pl. (7), fig. 25.-Boucard, Ann. Soc. Linn. Lyon, xxii, 1876, 22 (Putla, Oaxaca); Notes Troch. du Mex., 1875, 9 (Putla); Gen. Hum. Birds, ii, 1892, 14 (Oaxaca).-Lawrence, Bull. Nutt. Orn. Club, ii, 1877, 109, in text (remarks on coloration of female).-ELLiot, Classif. and Synop. Troch., 1879, 118 (Oaxaca)._Salvin, Cat. Birds Brit. Mus., xvi, 1892, 391 (Oaxaca; Tehuántepec; Venta de Zopilote, Guerrero).-Ridgway, Man. N. Am. Birds, 2d ed., 1896, 59s.

[Calothorax] pulchra Gray, Hand-list, i, 1869, 135, no. 1734.

C[alothorax] pulchra RIDGway, Rep. U. S. Nat. Mus. for 1890 (1891), 358 (diagnosis, etc.).

C[alothorax $]$ pulcher Heine, Journ. für Orn., 1863, 207.-Hartert, Das Tierreich, Troch., 1900, 194.

[Calothorax] pulcher Sclater and Salvin, Nom. Av. Neotr., 1873, 84.-Sharpe, Hand-list, ii, 1900, 139.

Calothorax pulcher Salvin and Godman, Biol. Centr.-Am., Aves, ii, 1S92, 351. [Callithorax] pulcher Simox, Cat. Troch., 1897, 37.

Amathusia (Manilia) pulchra Mulsant and Verreaux, Classif. Troch., 1S66, S6.

Manilia pulchra Mulsant and Verreaux, Hist. Nat. Ois.-Mouch., ii, livr. 2, 1875, pl. 23; iv, livr. 1, 1877, 30.

[Manilia] pulchra Mulsant, Ann. Soc. Linn. Lyon, n. s., xxii, 1876, 226

T[rochilus $\rceil$ pulcher RIDGWAy, Man. N. Am. Birds, 1887, 316.

Calliphlox mitchelli (not Trochilus mitchelli Bourcier) DE OCA, Los Colibris, Mex., 1875, 43, pl. (9), fig. 31 .

\section{Genus ORTHORHYNCUS Lacépède.}

Orthorhyncus LACÉPł̀DE, Tabl. Ois., 1799, 9. (Type, as fixed by Gray, List Gen. Birds, 1840, 14, Trochilus cristatus Linnæus; see Oberholser, Smithson. Misc. Coll., xlviii, 1905, 60,61.)

Orthorhynchus (emendation) Bonaparte, Consp. Av., i, 1850, 83.

Bellona (not of Reichenbach, 1852) Mulsant and Verreaux, Mém. Soc. Imp.

Sci. Nat. Cherbourg, xii, 1866, 219; Classif. Troch., 1865, 75. (Type, Trochilus cristatus Linnæus.)

Microlyssa Riley, Auk, xxi, Oct., 1904, 485. (Type Trochilus exilis Gmelin.)

Smail Trochilidæ (length about 73-95 mm.) with basal half (more or less) of maxilla feathered, tarsus naked, tail three-fifths to nearly two-thirds as long as wing, rounded, the adult male with a flat, pointed occipital crest, which, with forehead and crown is brilliant metallic green or else the crest (at least terminally) violet or violetblue.

Bill straight, terete, rather slender, longer from rictus than head, but the unfeathered portion much shorter than head, the frontal feathering advancing over base of maxilla to nearly half the distance from rictus to tip of maxilla in adult females, to considerably more in adult males; culmen rounded except basally, where contracted into a more or less distinct ridge; tomia smooth; mandible with the usual lateral median groove very distinct. Nasal operculum narrow, nude, but wholly concealed by the closely appressed frontal feathering, which extends far anterior to nostrils, forming a distinet point or antia on each side of culmen. Tarsus wholly unfeathered; 
inner toe about as long as middle toe, the outer slightly shorter. Wing more than four to more than five times as long as exposed culmen, the outermost primary longest, strongly incurved and broadly rounded terminally. Tail three-fifths to nearly two-thirds as long as wing, slightly rounded in adult males, more strongly rounded, with middle rectrices usually shorter than second pair, in adult females, the rectrices rather broad, rounded terminally.

Coloration.-Adult males with pileum, including occipital crest, brilliant metallic green (the crest more bluish terminally) or the crest metallic blue or violet (at least in part); rest of upper parts rather dark metallic green, the tail purplish black; under parts sooty blackish, passing into sooty gray on chin and throat. Adult females and young bronze-green above, including middle rectrices, gray beneath; lateral rectrices purplish black, more or less bronzy or greenish basally, tipped with gray.

Range.-Lesser Antilles; island of Tobago. (Three species, or subspecies.)

This genus is so evidently closely related to Chrysolampis that it is difficult to understand why they should be so widely separated in most classifications of the group.

KEY TO THE SPECIES AND SUBSPECIES OF ORTHORHYNCUS.

a. Pileum and pointed occipital crest brilliantly metallic. (Adult males.)

b. Occipital crest green or mostly green, like crown and forehead. (Orthorhyncus exilis.)

c. Occipital crest very faintly, if at all, tinged with blue at tip. (Porto Rico, St. Thomas, etc., of Greater Antilles, and Lesser Antilles except St. Vincent, Barbados, Grenada, and Grenadines.)

Orthorhyncus exilis exilis, adult male (p. 658).

$c c$. Occipital crest distinctly blue terminally. (St. Vincent.)

Orthorhyncus exilis ornatus, adult male (p. 661).

$b b$. Occipital crest (abruptly) violet or violet-blue. (Orthorhyncus cristatus.)

c. Crest more decidedly violet; throat darker gray. (Barbados.)

Orthorhyncus cristatus cristatus, adult male (p. 662).

$c c$. Crest more bluish violet to violet-blue; throat paler gray. (Grenada and Grenadines)....... Orthorhyncus cristatus emigrans, adult female (p. 664).

aa. Pileum metallic green (not brilliant); no crest.

$b$. Under parts of body dark sooty; lateral rectrices without distinct gray tip. (Immature males.) ${ }^{a}$

bb. Under parts of body gray. (Adult females.) ${ }^{a}$

$a$ I am unable to give characters for certain identification of immature males and ฉdult females.

81255ㅇ-Bull. 50-11-42 


\section{ORTHORHYNCUS EXILIS EXILIS (Gmelin).}

\section{GILT-CRESTED HUMMING BIRD.}

Similar to 0 . e. ornatus, but adult male with crest wholly green or merely tinged with blue terminally, and under parts paler.

Adult male.-Forehead and whole crown, including much the greater part of occipital crest, very bright metallic green, golden green, or golden, the longer feathers of the crest usually more bluish green, but never distinctly nor abruptly blue; hindneck and sides of head behind eye and beneath crest dark metallic green or bronze-green, appearing nearly black when viewed from in front; back, scapulars, wing-coverts, rump, and upper tail-coverts metallic bronze-green or bronze; tail black, glossed with purplish bronze; remiges dusky, faintly glossed with purplish; loral, suborbital, and auricular regions and under parts of body (including under tail-coverts) very dark sooty grayish, ${ }^{a}$ becoming paler sooty gray• on chin and throat; sides glossed with bronze or bronze-green or mostly of this color; femoral tufts mixed sooty gray and whitish; bill dusky; iris dark brown; feet grayish brown or dusky; length (skins), 73-91 (86.2); wing, 46-51.5 (49.6); tail, 26-32 (27.9); exposed culmen, 7.5-10 (8.8)..$^{b}$

$a$ In a specimen from Anegada Island approaching sooty black, as in O.e. ornatus and 0 . cristatus.

$b$ Seventy-two specimens. 
Adult female.-Above metallic bronze-green or greenish bronze, including middle rectrices; other rectrices purplish black, the two or three outer pairs rather broadly tipped with light brownish gray and with basal portion rather dull metallic greenish or bronzy, the one next to middle pair with greenish or bronzy basal area more extended; remiges dusky, faintly glossed with violaceous; under parts sooty gray, slightly deeper laterally and posteriorly, paler on chin and throat; bill, etc., as in adult male; length (skins), 71-91 (78); wing, 44-49 (46.3); tail, 26-31 (28.6); exposed culmen, 9-12 (10.6). ${ }^{a}$

Immature male.-Similar to the adult male, but without any crest, the pileum being rather dull metallic green, with feathers dusky basally.

$a$ Thirty-five specimens.

\begin{tabular}{|c|c|c|c|}
\hline Locality. & Wing. & Tail. & $\underset{\begin{array}{c}\text { Ex- } \\
\text { posed } \\
\text { culmen. }\end{array}}{.}$ \\
\hline MALES. & & & \\
\hline One adult male from Porto Rico..... & 47 & 27.5 & \\
\hline Nine adult males from $\mathrm{St}$. Thomas.... & 48.4 & 28.2 & 9.2 \\
\hline Two adult males from Anegada....... & 47.5 & 26 & 9.2 \\
\hline Seven adult males from Antígua........ & 48.1 & 27.4 & 8.6 \\
\hline Two adult males from Barbuda.......... & 47.5 & 27.5 & 9 \\
\hline One adult male from Sombrero......... & 47 & 29.5 & 8 \\
\hline Ten adult males from Santa Lucia...... & 49 & 28.9 & \\
\hline Three adult males from Martinique...... & 47.8 & 28.5 & \\
\hline Ten adult males from Domínica......... & 48.1 & 28.2 & \\
\hline Four adult males from Virgin Gorda..... & 47.5 & 28 & \\
\hline Seven adult males from Guadeloupe.......... & 48 & 28.9 & \\
\hline Two adult males from Saba................... & 48 & 28.7 & 8.7 \\
\hline Four adult males from St. Eustatius........ & 48.5 & 28.7 & 8.9 \\
\hline One adult male from Marie Galante...... & 46.5 & 28 & 8.5 \\
\hline One adult male from Desirade................ & 47.5 & 28 & 8 \\
\hline Eight adult males from St. Christopher....... & 48.6 & 28.2 & 8.5 \\
\hline FEMALES. & & & \\
\hline Three adult females from St. Thomas. & 44.8 & 28.5 & 11.7 \\
\hline One adult fernale from Anegada... & 46 & 26 & 12 \\
\hline One adult fernale from Antigua...... & 45 & 29 & 10 \\
\hline Two adult females from Barbuda....... & 44.7 & 30.5 & 10.7 \\
\hline Ten adult females from Santa Lucia... & 46.4 & 28.4 & \\
\hline Four adult females from Martinique... & 47.7 & 29.4 & 11.2 \\
\hline Two aduit females from Domínica.... & 46.5 & 28.5 & 10.7 \\
\hline One adult female from Virgin Gorda.... & 47 & 28.5 & 11 \\
\hline Six adult females from Guadeloupe...... & 47 & 28.6 & 11.5 \\
\hline One adult female from Saba............ & 45 & 28 & 10.5 \\
\hline One adult female from Marie Galante.... & 47.5 & 29 & 10 \\
\hline One adult female from Desirade......... & 45.5 & 28 & 12 \\
\hline One adult female from St. Christopher.... & 45 & 29.5 & 11 \\
\hline One adult fernale from St. Bartholomew.......... & 46 & 28 & \\
\hline
\end{tabular}

Occasional specimens from Martinique and Santa Lucia have the tip of the crest nearly as blue as examples from St. Vincent (O.e. ornatus), and those from Dominica have the tip of the crest more often tinged with blue than those from more northern islands. 
Lesser Antilles, except St. Vincent, Barbadoes, Grenada, and Grenadines (recorded from Sombrero, St. Bartholomew, Saba, St. Eustátius, St. Christopher, Nevis, Barbuda, Antígua, Montserrat, Guadeloupe, Grand Terre, Desirade, Marie Galante, Dominíca, Martinique, and Santa Lucía), and Virgin group of Greater Antilles (Virgin Gorda, Anegada, St. Croix, St. Thomas); Porto Rico.

[Trochilus] exilis GmeLIN, Syst. Nat., i, pt. 1, 1788, 484 (based on Humming bird of a black color Bancroft, Guj., p. 166; Little Humming bird Latham, Synopsis, i, pt. 2, 764).-Latham, Index Orn., i, 1790, 310.-Gray, Hand-list, i, 1869, 147, no. 1902.

Trochilus exilis Audebert and Vieillot, Ois. Dorés, i, 1802, 125.-Vienllot, Nouv. Dict. d'Hist. Nat., vii, 1817, 356 ("Guyane").

Trochilus] exilis Viemlıot, Tabl. Enc. Méth., ii, 1822, 550.

M[ellisuga] exilis GrAY, Gen. Birds, i, Dec., 1848, 113.

[Orthorhynchus] exilis ReichenBach, Aufz. der Colibr., 1854, 11; Troch. Enum., 1855, 9, pl. 807, fig. 4879.-Bonaparte, Rev. et Mag. de Zool., 1854, 256.Sclater and Salvin, Nom. Av. Neotr., 1873, 88.

Orthorhynchus exilis Gould, Mon. Troch., pt. xiii, 1857; vol. iv, 1861, pl. 207; Introd. Troch., oct. ed., 1861, 117.-Newrow (A. and E.), Ibis, 1859, 141 (St. Croix; crit.).-Sclater, Cat. Am. Birds, 1862, 304 (St. Thomas); Proc. Zool. Soc. Lond., 1889, 326 (Dominíca); 1892, 499 (Anguilla).-TAYLor, Ibis, 1864, 170 (Martinique; Dominíca).-Lawrence, Ann. Lyc. N. Y., viii, 1864, 99 (Sombrero); Proc. U. S. Nat. Mus., i, 1878, 61 (Dominíca), 234 (Antígua), 240 (Barbuda), 358 (Martinique), 458 (Guadeloupe), 487 (Barbuda; Antígua; Guadeloupe; Dominíca; Martinique).-Mulsant and Verreaux, Classif. Troch., 1866, 75.-Elliot, Ibis, 1872, 355 (Dominíca; Nevis; St. Thomas; St. Croix; synonymy).-GundLAch, Journ. für Orn., 1874, 312 (Porto Rico); 1878, 182 (Porto Rico)--Allen, Bull. Nutt. Orn. Club, v, 1880, 167 (Santa Lucia; crit.).-Grisdale, Ibis, 1882, 490 (Montserrat; habits).

O[rthorhynchus] exilis CaBANIs and HeINe, Mus. Hein., iii, 1860, 61 (Martinique; Nevis; St. Croix).

Orthorhyncus exilis Oвerholser, Smithson. Misc. Coll., xlviii, May 13, 1905, 60. Trochilus (Orthorhynchus) exilis Sundevald, Efv. k. Vet.-Ak. Förh., 1869, 600 (St. Bartholomew).

Bellona exilis Mulsant and Verreaux, Hist. Nat. Ois.-Mouch., iii, livr. 3, 1876, 196 (St. Croix; Nevis; Martinique; etc.).-Elloт, Classif. and Synop. Troch., 1879, 179 (Dominíca; Nevis; St. Thomas; St. Croix).-Cory, Auk, iii, 1886, 357; vi, 1889, 218 (crit.; range); vii, 1890, 374 (Anegada), 375 (Virgin Gorda); viii, 1891, 47 (Antígua; St. Eustátius), 48 (St. Croix; St. Christopher; Guadeloupe); Birds West Ind., 1889, 152; Cat. West Ind. Birds, 1892, 13, 107, 144.-Verrill (G. E.), Trans. Conn. Ac. Arts and Sci., viii, 1892, 334, pl. 26, fig. 6 (Dominíca; habits; descr. nest and eggs).-Salvin, Cat. Birds Brit. Mus., xvi, 1892, 354.-Boucard, Gen. Hum. Birds, ii, 1892, 53 (Dominíca; St. Croix; Montserrat; Nevis; Martinique).-Lodge, Ibis, 1896, 511 (Dominíca; habits).-Nicoll, Ibis, 1904, 562 (Santa Lucia; crit.), 570 (Dominíca).

[Bellona] exilis Mulsant, Ann. Soc. Linn. Lyon, n. s., xxii, 1876, 222.-Corx, List Birds West Ind., 1885, 18.-Sharpe, Hand-list, ii, 1900, 142.

$B[$ êlona $]$ cristata exilis Hartert, Das Tierreich, Troch., 1900, 213.

Microlyssa exilis RiLex, Smithson. Misc. Coll., xlvii, Nov. 8, 1904, 287 (Barbuda: Antígua). 
(?) [Trochilus] cristatellus Latham, Index Orn., Suppl., 1801, p. xxxix (no locality given; based on Gilt-crested Hummingbird Latham, Synopsis, Suppl., ii, 172).

(?) Trochilus cristatellus Vieillot, Nouv. Dict. d'Hist. Nat., vii, 1817, 352.

Orthorhynchus chlorolophus Bonaparte, Consp. Av., i, 1850, 83 (Martinique).Audebert and Vieillot, Ois. Dorés, i, 1801, 91-93, pls. 47, 48 (Martinique).

Trochilus cristatus (not of Linnæus) Vieillot, Nouv. Dict. d'Hist. Nat., vii, 1817, 365, pl. B. 19, fig. 3 ("Cayenne;" Martinique; Guadeloupe).

T[rochilus] cristatus Vieillot, Tabl. Enc. Méth., ii, 1822, 565.

Ornismya cristata Lesson, Les Trochilidées, 1831, 153, pl. 58 (Martinique); Index Gen. et Synop. Troch., 1832, p. xxx ("Trinidad;" Martinique).

Bellona cristata ELLiot, Classif. and Synop. Troch., 1879, 178, part (Martinique; Santa Lucia).-Cory, Ibis, 1886, 474 (Desirade; Marie Galante), 475 (Grand Terre); Auk, iv, 1887, 96 (Martinique).-Sclater, Proc. Zool. Soc. Lond., 1889, 395 (Santa Lucia).-Ridgway, Proc. U. S. Nat. Mus., xii, 1890, 130 (Santa Lucia).

Orthorhynchus ornatus (not of Gould) Sclater, Proc. Zool. Soc. Lond., 1871, 272 (Santa Lucia; crit.).-Semper, Proc. Zool. Soc. Lond., 1872, 651 (Santa Lucia: habits).

\section{ORTHORHYNCUS EXILIS ORNATUS (Gould).}

ST. VINCENT BLUE-CREST.

Similar to $O$. e. exitis, but terminal portion of crest extensively and abruptly blue; similar also to $O$. cristatus, but adult male with blue of crest much more restricted, and greenish blue instead of violet-blue.

Adult male.-Forehead and whole crown very bright metallic green or golden, passing into more bluish green posteriorly, the longer feathers of the crest bright metallic blue or greenish blue; hindneck and sides of head behind eyes and beneath crest dark metallic green, appearing nearly black when viewed from in front; back, scapulars, wing-coverts, rump, and upper tail-coverts metallic bronze-green or greenish bronze; tail black, glossed with purplish bronze; remiges dusky, faintly glossed with purplish; loral, suborbital, and auricular regions and under parts of body (including under tail-coverts) sooty blackish (the sides of breast faintly glossed with green), fading into sooty gray on chin and throat; femoral tufts whitish; bill dull black or dusky; iris dark brown; feet grayish brown or dusky; length (skins), 77-93 (83); wing, 47-51 (48.1); tail, 26.5-31 (28.9); exposed culmen, 9-11 (10.2). ${ }^{a}$

Adult female.-Above metallic bronze-green or greenish bronze, including middle rectrices; other rectrices blackish or purplish black terminally or subterminally, the two or three outer ones (on each side) rather broadly iipped with light brownish gray and with basal portion rather dull metallic greenish or bronzy, the one next to middle pair with greenish or bronzy at base more extended; remiges dusky, faintly glossed with violaceous; under parts deep sooty gray, 
deeper laterally, paler on chin and throat; bill, etc., as in adult male; length (skin), 83; wing, 47; tail, 28; exposed culmen, $12 .^{a}$

Island of St. Vincent, Lesser Antilles; occasional straggler to Martinique? ${ }^{b}$

Orthorhynchus ornatus GoucD, Mon. Troch., pt. xxiv, Sept., 1861; vol. iv, 1861, pl. 206 (locality unknown; coll. J. Gould); Introd. Troch., oct. ed., 1861, 117.-EлLiot, Ibis, 1872, 355 ("Martinique and Santa Lucia"-error?).Lawrence, Proc. U. S. Nat. Mus., i, 1878, 192, 487 (St. Vincent).-Lister, Ibis, 1880, 42 (St. Vincent; habits).

Orthorhyncus ornatus OвеRHolser, Smithson. Misc. Coll., xlviii, May 13, 1905, 60.

[Trochilus] ornatus Gray, Hand-list, i, 1869, 148, no. 1903.

Bellona ornatus CoRY, Auk, vi, July, 1889, 218 (St. Vincent; crit.).

Bellona ornata Ridgway, Proc. U. S. Nat. Mus., iii, Oct. 27, 1880, 316 (St. Vincent).-SALvin, Cat. Birds Brit. Mus., xvi, 1892, 354 (St. Vincent).

[Bellona] ornata Sharpe, Hand-list, ii, 1900, 142 (St. Vincent).

Bellona exilis ornatus CoRy, Cat. West Ind. Birds, 1892, 13, 107, 134, 144 (St. Vincent).

Bellona exilis ornata Clank (A. H.), Proc. Bost. Soc. N. H., xxxii, 1905, 275 (St. Vincent; descr. nest and eggs).

B[ellona] cristata ornata Hartert, Das Tierreich, Troch., 1900, 213.

Bellona cristata (not Trochilus cristatus Linnæus) Mulsant and Verreaux, Hist. Nat. Ois.-Mouch., iii, livr. 3, 1876, 193, part (St. Vincent).--Euııoт, Classif. and Synop. Troch., 1879, 178, part (St. Vincent).-Cory, Auk, iii, 1886, 356, part (St. Vincent); Ibis, 1886, 473 (St. Vincent); Birds West Ind., 1889, 151, part (St. Vincent).

Orthorhynchus cristatus Eц̣тoт, Ibis, 1872, 355, part (St. Vincent; synonymy; crit.).

[Orthorhynchus] cristatus Scrater and Salvin, Nom. Av. Neotr., 1873, 88, part (St. Vincent).

Bellona hectoris Mulsant and Verreaux, Classif. Troch., 1866, 75.

Bellona superba Boucard, The Hum. Bird, i, June 1, 1891, 43 (St. Vincent; coll. A. Boucard); Gen. Hum. Birds, 1892, 53 (St. Vincent).

\section{ORTHORHYNCUS CRISTATUS CRISTATUS (LinnæUS).}

\section{BLUE-CRESTED HUMMING BIRD.}

Adult male.-Forehead and crown brilliant metallic green, changing (according to inclination of light) from pure emerald green to golden green; occipital crest (abruptly) rich metallic violet; hindneck and sides of head behind eyes dark and rather dull metallic bluish green; back, scapulars, wing-coverts, rump, and upper tail-coverts rather dark metallic grass green; tail black, glossed with purplish bronze; remiges dusky, faintly glossed with purplish; loral, suborbital, and auricular regions and under parts sooty blackish, fading into sooty gray on chin and throat; femoral tufts pale grayish or whitish; bill dull black; iris dark brown; feet grayish brown or dusky; length

\footnotetext{
a One specimen.

$b \Lambda$ specimen in the Bangs collection said to be from Martinique is typical of this form, and some specimens from Santa Lucia approach it more or less.
} 
(skins), 77-82 (80); wing, 45.5-51.5 (48.4); tail, 27-30.5 (28.8); exposed culmen, 9-11 (9.6). ${ }^{a}$

Adult female.-Above metallic green, bronze-green, or bronze, including middle rectrices, the latter becoming dusky terminally; remaining rectrices black, faintly glossed with purplish, the three outer pairs broadly tipped with pale gray, and with basal portion dull grayish glossed with bronze-green or greenish bronze, the pair next to middle pair similar but without gray tip and with basal portion more extensively greenish or bronzy; remiges dusky, faintly glossed with purplish; under parts pale gray, slightly darker laterally, especially on sides of neck, the chin and median portion of throat sometimes inclining to dull whitish; bill, etc., as in adult male; length (skins), 80-83 (81); wing, 45-48.5 (46.6); tail, 28-31.5 (29.3); exposed culmen, $9.5-12(10.9){ }^{b}$

Immature male.-Similar to the adult male, but without crest, the pileum dark and rather dull metallic bluish green.

Island of Barbádos, Lesser Antilles.

[Trochilus] cristatus Linnwus, Syst. Nat., ed. 10, i, 1758, 121 (based on Crested Humming Bird, Avis mellivora, minor, cristata Edwards, Nat. Hist., i, pl. 37); ed. 12, i, 1766, 192.-Gmelin, Syst. Nat., i, pt. 1, 1788, 498.-LAтHAм, Index Orn., i, 1790, 317.

Trochilus cristatus Audebert and Vieillot, Ois. Dorés, i, 1801, 91-93, pls. 47, 48, part.-Temminck, Cat. Syst., 1807, 83.-Vieillot, Nouv. Dict. d'Hist. Nat., vii, 1817, 365, pl. B. 19, fig. 3, part?-SсномвURGк, Hist. Barbados, 1848,681 .

T[rochilus] cristatus Swainson, Birds Brazil, etc., pt. 2 (1834-35?), pl. 21.

Ornismya cristata Lesson, Hist. Nat. Ois.-Mouch., 1829, pp. xxxix, 113, pls. 31, 32; Les Trochilidées, 1831, 20, pl. 4 ("Santo Domingo"); Traité d'Orn., 1831, 285; Index Gen. et Synop. Troch., 1832, p. xxx, part ("Trinidad")?

M[ellisuga] cristata Gray, Gen. Birds, i, Dec., 1848, 113.

[Orthorhynchus] cristatus Bonaparte, Cousp. Av., i, 1850, 83.-Sclater and Salvin, Nom. Av. Neotr., 1873, 88, part (Barbados).

Orthorhynchus cristatus ReICHEN BACH, Aufz. der Colibr., 1854, 11; Troch. Enum., 1855, 9, pl. 807, figs. 4876, 4877.-Gould, Mon. Troch., pt. xiii, May, 1857; vol. iv, 1861, pl. 205; Introd. 'Troch., oct. ed., 1861, 116.-Pelzeln, Orn. Bras., iv, Abth., 1870, 408 ("Brazil" on authority of Swainson).-Elliot, Ibis, 1872, 355, part (Barbádos; synonymy; crit.).-Salvin, Ibis, 1873, 334, in text (Barbádos).—Sclater, Proc. Zool. Soc. Lond., 1874, 175 (Barbádos).Feilden, Ibis, 1889, 487 (Barbádos; habits; descr. nest and eggs).

O[rthorhynchus] cristatus CABANIS and HeIne, Mus. Hein., iii, 1860, 61 (Barbádos).

Orthorhyncus cristatus cristatus OberHolser, Smithson. Misc. Coll., xlviii, May 13, 1905, 60 .

Bellona cristata Mulsant and Verreaux, Classif. Troch., 1866, 75; Hist. Nat. Ois.-Mouch., iii, 1876, 193, part (Barbádos), pl. 89; Suppl., pl. 21.-Elliot, Classif. and Synop. Troch., 1879, 178, part (Barbádos).-Conx, Auk, iii, 1886, 356, part (Barbádos); vi, 1889, 218, part (Barbádos); Ibis, 1886, 472 (Barbádos); Birds West Ind., 1889, 151, part (Barbádos); Cat. West Ind. Birds, 1892, 13, 107, 144, part (Barbádos).-Salvin, Cat. Birds Brit. Mus., xvi, 1892, 353, part (Barbádos).-Boucard, Gen. Hum. Birds, ii, 1892, 52, part (Barbádos). 
[Bellona] cristata Mulsant, Ann. Soc. Linn. Lyon, n. s., xxii, 1876, 222, part (Barbádos).-Sharpe, Hand-list, ii, 1900, 142, part (Barbádos).

[Trochilus] puniceus GMelin, Syst. Nat., i, pt. 1, 1788, 497 (based on Crested Brown Humming-bird Latham, Synopsis, i, pt. 2, 784).

[Trochilus] pileatus Latham, Index Orn., i, 1790, 318 (new name for T. puniceus Gmelin).

Trochilus pileatus Viemlot, Nouv. Dict. d'Hist. Nat., vii, 1817, 365 (cites Ois. Dorés, pl. 63, fig. 1).

T[rochilus] pileatus Vieillot, Tabl. Enc. Méth., ii, 1822, 566.

Orthorhynchus exilis (not Trochilus exilis Gmelin) Sclater, Proc. Zool. Soc. Lond., 1874, 175 (Barbádos).

B[ellona] cristata (typica) Hartert, Das Tierreich, Troch., 1900, 213.

Bellona cristatus emigrans (not Orthorhynchus emigrans Lawrence) CLARK (A. H.), Auk, xxii, April, 1905, 216 (Barbádos).

Bellona cristata emigrans Clark (A. H.), Proc. Bost. Soc. N. H., xxxii, 1905, 276 (Barbádos; descr. nest and eggs).

\section{ORTHORHYNCUS CRISTATUS EMIGRANS (Lawrence). GRENADA BLUE-CREST.}

Similar to $O$. c. cristatus, but adult male with crest averaging more bluish violet and throat paler gray; adult female with under parts decidedly paler (grayish white instead of light gray).

Adult male.-Length (skins), 75-93 (82); wing, 47.5-51 (49.1); tail, 26.5-30.5 (29.1); exposed culmen, 9.5-11 (10.4). ${ }^{a}$

Adult female.-Length (skins), 77-83 (81); wing, 43-47 (45.2); tail, 27-29.5 (27.7); exposed culmen, 12-13.5 (12.7). ${ }^{b}$

Islands of Grenada, Unión, Carriacoú, and Mustíque, Lesser Antilles.

Orthorhynchus emigrans Lawrence, Ann. N. Y. Ac. Sci., i, 1878, 50 ("Venezuela," i. e., Grenada?; coll. G. N. Lawrence).

Orthorhyncus cristatus emigrans OBerHolser, Smithson. Misc. Coll., xlviii, May $13,1905,60$.

Bellona emigrans Boucard, Gen. Hum. Birds, sig. i, July, 1892, 54 (Venezuela?; Grenada; crit.).

Orthorhynchus cristatus (not Trochilus cristatus Linnæus) Lawrence, Proc. U. S. Nat. Mus., i, 1878, 272, 487 (Grenada).

a Twenty specimens.

$b$ Ten specimens, from Grenada.

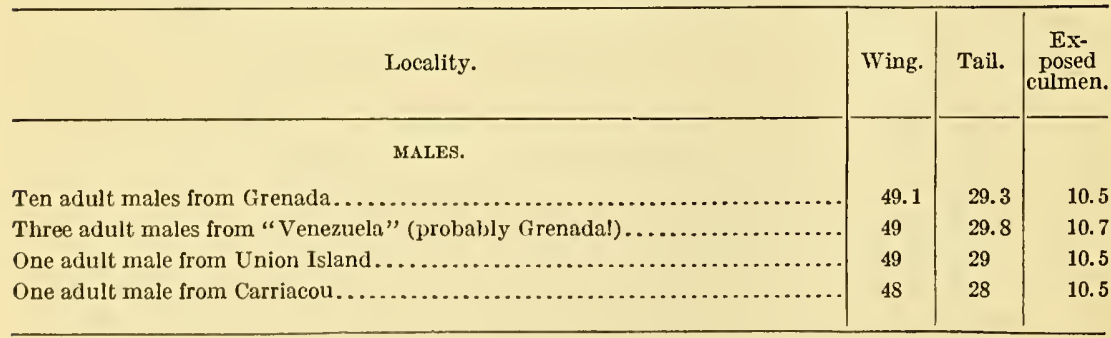


Bellona cristata Elliot, Classif. and Synop. Troch., 1879, 178, part (Grenada).Cory, Auk, vi, 1889, 218, part (Grenada); Cat. West Ind. Birds, 1892, 13, 107, 144, part (Grenada).-Salvin, Cat. Birds Brit. Mus., xvi, 1892, 353, part (Grenada;. Mustíque; Venezuela?).-Boucard, Gen. Hum. Birds, ii, 1892, 54 (Venezuela?; Grenada).-LodGe, Ibis, 1896, 518 (Grenada; habits; notes).-Wells, Auk, xix, 1902, 345 (Carriacoú; habits; descr. nest).Nicoli, Ibis, 1904, 566 (Grenada, up to 2,000 ft.).

[Bellona] cristata SHa RPE, Hand-list, ii, 1900, 142, part (Grenada; Grenadines).

Bellona cristatus cristatus Clark (A. H.), Auk, xxii, April, 1905, 216 (Grenada; Grenadines).

Bellona cristata cristata Cla RK (A. H.), Proc. Bost. Soc. N. H., xxxii, 1905, 275 (Grenada; Grenadines; habits; descr. nest and eggs).

Orthorhynchus exilis (not Trochilus exilis Gmelin) Wells, Proc. U. S. Nat. Mus., ix, 1887, 620 (Grenada; habits; descr. nest and eggs).

\section{Genus CHRYSOLAMPIS Boie.}

Chrysolampis Bore, Isis, 1831, 546. (Type, Trochilus mosquitus Linnæus.)

Rather small Trochilidæ (length about 85-98 mm.) with dense frontal feathering covering basal third (approximately) of maxilla, entirely concealing nostrils, exposed culmen much shorter than head, tail more than half as long as wing, broad, and rounded, the adult male with pileum brilliant metallic ruby red, chin, throat and chest brilliant metallic golden orange, and tail bright rufous.

Bill straight, nearly terete, about as long as head or slightly longer, but unfeathered portion of maxilla decidedly shorter, the basal third, more or less, being completely covered by the dense frontal feathering, which entirely conceals nostrils; culmen rounded anteriorly, narrowly ridged posteriorly; terminal portion of maxillary tomium very minutely serrate; mandible with a distinct narrow longitudinal median lateral groove. Tarsus naked; middle and outer toes about equal in length, the inner decidedly shorter, the hallux about as long as inner toe. Wing more than four times as long as exposed culmen, the outermost primary longest. Tail more than half as long as wing, rounded, the rectrices broad, rounded at tip.

Coloration.-Adult male with pileum very brilliant metallic ruby red, chin and throat brilliant metallic golden orange, and tail rufous, with rectrices margined terminally with dark bronzy brown; adult female dull metallic bronze-greenish above, pale gray or dull grayish white below, the tail grayish, glossed with greenish bronze basally, dusky subterminally or terminally, the lateral rectrices broadly tipped with white.

Range.-Eastern and central Colombia, to Cayenne, and southeastern Brazil; Caribbean Islands of Trinidád, Tobago, Curaçao, Bonaire, Aruba, etc.; southwestern Costa Rica? (Monotypic.) 
CHRYSOLAMPIS MOSQUTTUS (Linnæus).

RUBY-AND-TOPAZ HUMMING BIRD.

Adult male.-Entire pileum, from frontal antiæ to occiput, inclusive, intense metallic red (rose red to carmine); chin, throat, and chest bright metallic orange or golden; hindneck, sides of neck, and extreme upper back velvety black, passing into dark bronzy olive on lower back, rump, upper tail-coverts, scapulars, and wing-coverts; tail clear chestnut-rufous, faintly glossed with purplish, the rectrices margined terminally with dark bronzy olive; remiges dusky, faintly glossed with violaceous; under parts of body plain grayish brown or sepia, the femoral tufts white; under tail-coverts cinnamon-rufous; bill dull black; iris dark brown; feet dusky; length (skins), 85-98 (87); wing, 52-58 (53.2); tail, 30.5-36 (31.4); exposed culmen, 9.5-13 (11). ${ }^{a}$

Adult female.-Above metallic bronze-green or greenish bronze, more decidedly bronzy (often coppery bronze) on hindneck and upper back, passing into dull grayish brown on forehead; middle pair (sometimes two middle pairs) ${ }^{b}$ of rectrices bronze-green or greenish bronze, usually more dusky at extreme tip; remaining rectrices chestnut-rufous basally, blackish subterminally (more or less broadly), and tipped with a large triangular spot of white-the outermost rec-

a Thirty-one specimens.

$b$ Occasionally specimens agreeing in every other respect as regards coloration have the middle rectrices (like the others) chestnut-rufous broadly tipped with dusky and dark metallic green.

\begin{tabular}{|c|c|c|c|}
\hline Locality. & Wing. & Tail. & $\begin{array}{c}\text { Ex- } \\
\text { posed } \\
\text { culmen. }\end{array}$ \\
\hline \multicolumn{4}{|l|}{ MALES. } \\
\hline 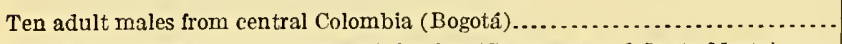 & 55.2 & 32.5 & 10.7 \\
\hline Four adult males from north coast Colombia (Cartagena and Santa Marta)... & 53.5 & 31.5 & 12 \\
\hline 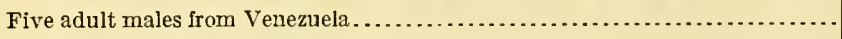 & 54 & 31.7 & 11.9 \\
\hline Three adult males from Trinidád................. & 56.8 & 33 & 11.3 \\
\hline Two adult males from Tobago ..................... & 56.1 & 34.2 & 11.5 \\
\hline Two adult males from Curaçao..................... & 54.5 & 34.2 & 11 \\
\hline One adult male from British Guiana............... & 56.5 & 32 & 11 \\
\hline One adult male from Cayenne.................... & 55.5 & 32.5 & 11.5 \\
\hline Four adult males from Brazil.................. & 55 & 33 & 11.5 \\
\hline \multicolumn{4}{|l|}{ FEMALES. } \\
\hline One adult female from central Colombia (Bogotâ).... & 54 & 30 & 15.5 \\
\hline Four adult females from northern Colombia............ & 52 & 30.2 & 14.4 \\
\hline Three adult females from Venezuela................. & 53.7 & 29.5 & 15.2 \\
\hline Two adult feınales froin Trinidád......................... & 54.7 & 30.8 & 14.5 \\
\hline 'Two adult females from Tobago................... & 56.7 & 34.2 & 15.5 \\
\hline One adult female from Surinam............. & 52.5 & 31 & 13.5 \\
\hline One adult female from Cayenne.... & 53.5 & 30.5 & 13 \\
\hline One adult female from Brazil.... & 52.5 & 31 & 17 \\
\hline
\end{tabular}


trix sometimes (in younger birds?) with light gray replacing chestnutrufous, except on part of inner web; remiges dusky, faintly glossed with violaceous; under parts pale brownish gray laterally, whitish medially, the throat usually with a darker median stripe, often intermixed with metallic orange or golden feathers; bill, etc., as in adult males; length (skins), 84-96 (92); wing, 51-58 (53.7); tail, 29-35 (30.9); exposed culmen, 13-17 (14.8).$^{a}$

Immature.-Similar to the adult female, as described above, but without any rufous on tail, the basal half, or more, of rectrices (except middle pair) being brownish gray, faintly glossed with greenish or bronzy, the shaft of that portion being whitish. Immature males to be distinguished by a greater or less number of scattered metallic red feathers on pileum and a median stripe of metallic orange or golden on throat or throat and chest.

Young.-General color of upper parts cinnamon-rufous, this uniform on rump, but broken elsewhere by exposed dusky basal portion of feathers, the hindneck glossed with metallic bronze; otherwise like the immature stage, described above, but under parts of body and under tail-coverts suffused with pale cinnamon-rufous and whitish tips to outer rectrices tinged with the same.

Northern and eastern South America, from Colombia (Bogotá; Bonda, Santa Marta; Rio Lima; Rio Cauquita; Cauca; Ocaña; Cartagena; Bucaramanga), through Venezuela (Ciudád Bolivár; Carácas; Conejos; Cucurutí; Guaria; Cariaco; Cáura; Caicará; mouth of Rio Meta; La Prición), islands of Margarita, Blanquilla, Los Testigos, Bonaire, Aruba, Curaçao, Tobago, and Trinidád, British Guiana (Georgetown, Demerara; Annai River), Cayenne (Sinnamary), to Brazil (Macuca; Pernambuco; Pará; Bahia; Rio de Janeiro; Serra dos Organos; Minas Geraez; Goiaz; Porto Reál); southwestern Costa Rica (San Pedro).

[Trochilus] mosquitus Linneus, Syst. Nat., ed. 10, i, 1758, 120 ("Indiis"); ed. 12, i, 1766, 192 ("America").-GraY, Hand-list, i, 1869, 147, no. 1900.

[Trochilus] moschitus Guelin, Syst. Nat., i, pt. 1, 1788, 494.-Latнaм, Index Orn., i, 1790, 316.

Trochilus moschitus Audebert and Vieillot, Ois. Dorés, i, 1801, 62, pl. 29 (Brazil; Guiana).-Temminck, Cat. Syst., 1807, 82.-Vieillot, Nouv. Dict. d'Hist. Nat., vii, 1817, 372, pl. 13, 19, fig. 2 (Cayenne; Brazil).-JArdine, Ann. and Mag. N. H., xx, 1847, 373 (Tobago).-Cabanis, in Schomburgk's Reis. Brit. Guiana, iii, 1848, 705.

T[rochilus] moschitus Lichtenste1n, Verz. Doubl., 1823, 14 (Brazil).-Swarnson, Birds Brazil, Mex., etc., [1841?], pl. 30.

Ornismya moschita Lesson, Hist. Nat. Ois.-Mouch., 1829, pp. xxviii, 166, pls. 52-54 (Guiana); Les Trochilidées, 1831, 55, pi. 15; Index Gen. et Synop. Troch., 1832, p. xxxvi.

Mellisuga moschita Stephens, in Shaw's Gen. Zool., xiv, 1826, 253.--LÉotaud, Ois. Trinidad, 1866, 145. 
$M[$ ellisuga] moschita Gray, Gen. Birds, i, 1848, 113.

Chrysolampis moschitus BoIE, Isis, 1831, 546._Des Murs, in Casteln. Voy., Ois., 1855, 40 (Serra dos Organos near Paraïba; Province Minas Geraez; Province Goiaz; Bahia; Guiana).-Gould, Mon. Troch., pt. xii, 1856; vol. iv, 1861, pl. 204; Introd. Troch., oct. ed., 1861, 115.-Burmerster, Syst. Ueb. Th. Bras., ii, 1856, 332.--Hartlaub, Journ. für Orn., 1857, 44.-Cassin, Proc. Ac. Nat. Sci. Phila., 1860, 194 (Cartagena).-Sclater, Cat. Am. Birds, 1862, 303 (Venezuela).-Taylor, Ibis, 1864, 92 (Trinidád).-Sclater and Salvin, Proc. Zool. Soc. Lond., 1868, 629 (Carácas, Venezuela); 1870, 782 (Mérida, Venezuela).Reinhardt, Vid. Medd. Nat. For. Kjöb., 1870, 104.-Finsch, Proc. Zool. Soc. Lond., 1870, 562 (Trinidád).-Fonbes, Ibis, 1871, 348 (Macuca, n. e. Brazil); 1881, 348 (Garanhúns, n. e. Brazil).-Mulsant and Verreaux, Hist. Nat. Ois.-Mouch., ii, livr. 4, 1876, 254; iv, livr. 3, 1878, 210 (synonymy).-Elurot, Classif. and Synop. Troch., 1879, 176.-Salvin, Cat. Strickland Coll., 1881, 365 (Brazil; Trinidád); Ibis, 1885, 434 (Brit. Guiana); Cat. Birds Brit. Mus., xvi, 1892, 113.-Boucard, The Hum. Bird, i, no. 4, 1891, 26 (descr. aberrant males); ii, 1892, 74 (Bogotá, Colombia); Gen. Hum. Birds, 1895, 55, 56 bis (monogr.).-Boucard and Berlepsch, The Hum. Bird, ii, 1892, 45 (Porto Reál, Brazil).-Allen, Bull. Am. Mus. N. H., iv, 1892, 55 (Carúpano, Venezuela); xiii, 1900, 140 (Bonda, Santa Marta, Colombia).Lodge, Ibis, 1896, 514 (Tobago; habits).-Loat, Ibis, 1898, 565 (Brit. Guiana).-Robinson and Richmond, Proc. U. S. Nat. Mus., xxiv, 1901, 172 (Cucurutí, Venezuela).-Nicold, Ibis, 1904, 40 (Bahia).-Menegaux, Bull. Mus. d'Hist. Nat. Paris, 1904, 113 (Sinnamary, French Guiana).-Lowe, Ibis, 1907, 118 (Blanquilla I.); 1909, 317 (Los Testigos I.).

[Chrysolampis] moschitus Bonaparte, Consp. Av., i, 1850, 82; Rev. et Mag. de Zool., 1854, 256.-Mulsant, Ann. Soc. Linn. Lyon, xxii, 1876, 214.-Sclater and Salvin, Nom. Av. Neotr., 1873, 87.

C[hrysolampis] moschita Cabanis and Heine, Mus. Hein., iii, 1860, 21 (Guiana).Heine, Journ. für Orn., 1863, 179.

Chrysolampis moschita Pelzeln, Orn. Bras., i. Abth., 1868, 32; iv. Abth., 1870, 408.-Wyatт, Ibis, 1871, 378 (Ocaña, Colombia).

Chrysolampis mosquita Mulsant and Verreaux, Classif. Troch., 1866, 57.

Chrysolampis mosquitus Reichenbach, Aufz. der Colibr., 1854, 9; Troch. Enum., 1855,5 , pl. 753, figs. 4646-4649.-Mulsant and Verreaux, Hist. Nat. Ois.Mouch., iv, livr. 2, 1877, pl. 55.-Berlepsch, Journ. für Orn., 1884, 310 (Bucaramanga, Colombia; crit.); 1887, 319 (Bogotá; synonymy); 1892, 86 (Curaçao; crit.); Zeitschr. Orn., 1887, 186 (Bogotá).-Peters, Journ. für Orn., 1892, 119 (Curaçao; habits).-HARTert, Ibis, 1893, 299 (Aruba; crit. as to plumages of female and young), 319 (Curaçao; habits), 328 (Bonaire); Novit. Zool., ix, 1902, 301 (Aruba; Curaçao; Bonaire).-Chapman, Bull. Am. Mus. N. H., vi, 1894, 57 (Trinidád).-Dalmas, Soc. Zool. France, xiii, 1900, 141 (Tobago).-Sinon, Ornis, xi, 1901, 215 (Trinidád; Guaria, Cariaco, and Caura, Venezuela).-Berlepsch and Hartert, Novit. Zool., ix, 1902, 87 (Caicará, mouth of Rio Meta, Ciudád Bolivár, and La Prición, Venezuela).Cherrie, Bull. Brooklyn Inst. Arts and Sci., 1906, 6 (Aripo, Trinidád).Lowe, Ibis, 1907, 559 (Margarita I.; Blanquilla I.).-Cony, Pub. 137, Field Mus. N. H., 1909, 200 (Aruba), 206 (Curaçao), 212 (Bonaire), 221 (Tortuga), 224 (Blanquilla), 245 (Margarita).

C[hrysolampis] mosquitus Hartert, Das Tierreich, Troch., 1900, 101.

[Chrysolampis] mosquitus SHARPE, Hand-list, ii, 1900, 119.

Chrysolampis moschatus Stone, Proc. Ac. Nat. Sci. Phila., 1899, 312 (near Cartagena, Colombia).

(?)[Trochilus] pegasus LinNæus, Syst. Nat., ed. 12, i, 1766, 192 (Cayenne; based on Mellisuga cayanensis, ventre griseo Brisson, Orn., iii, 709, pl. 36, fig. 4).Gmelin, Syst. Nat., i, pt. 1, 1788, 495.-Latham, Index Orn., i, 1790, 315. 
[Trochilus] elatus Linnæus, Syst. Nat., ed. 12, i, 1766, 192 ("India orientali;" based on Mellivora cristata rubra Edwards, Nat. Hist., Birds, pl. 344, upper fig.).-Gmelrn, Syst. Nat., i, pt. 1, 1788, 499.-Lathar, Index Orn., i, $1790,316$.

Chrysolampis elatus Berlepsch, Novit. Zool., xv, Nov., 1908, 264 (Cayenne).

[Trochilus] carbunculus Gmelin, Syst. Nat., i, pt. 1, 1788, 498 (Cayenne; based on Escarboucle Buff. Hist. Nat. Ois., vi, 28; Carbuncle Humming-bird Latham, Synop., i, pt. 2, 782).-Latham, Index Orn., i, 1790, 317.

Trochilus carbunculus Viemlot, Nouv. Dict. d'Hist. Nat., vii, 1817, 361 (cites Ois. Dorés, pl. 5).

[Chrysolampis] carbunculus Reichenbach, Aufz. der Colibr., 1854, 9; Troch. Enum., 1855, 5.

(?)[Trochilus] gujanensis Gmelin, Syst. Nat., i, pt. 1, 1788, 498 (based on Small Green and Crimson Humming-bird Bancroft, Guiana, p. 168; Guiana Hummingbird Latham, Synopsis, ii, 781).

(?)[Trochilus] guianensis LathaM, Index Orn., i, 1790, 317.

Trochilus guianensis Vieillot, Nouv. Dict. d'Hist. Nat., vii, 1817, 375.

(?)[Trochilus] hypophæus LatraM, Index Orn., i, 1790, 314 (new name for Trochilus striatus Gmelin, based on Brown-crowned Humming-bird Latham, Synopsis, ii, 776).

(?) Trochilus hypophæus SHaw, Gen. Zool., viii, pt. 1, 1811, 333.

(?) C[hrysolampis] reichenbachi Cabanis and Heine, Mus. Hein., iii, Feb., 1860, 21 (Colombia).

(?)[Chrysolampis] reichenbachi Heine and Reichenow, Nom. Mus. Hein. Orn., $1890,176$.

(?) Chr[ysolampis] infumatus Berlepsch, Zeitschr. Orn., iv, 1858, 182, in text (Bogotá, Colombia; coll. Count von Berlepsch?; = color variety or melanism?).

(?) Chrysolampis infumatus Boucard, Gen. Hum. Birds, 1895, 55, 57, in text (crit.).

\section{Genus LOPHORNIS Lesson.}

Lophornis Lesson, Hist. Nat. Ois.-Mouch., 1829, p. xxxvii; Index Gén. et Synop. Troch., 1832, p. xli. (Type, Trochilus ornatus Boddaert.)

Bellatrix Bole, Isis, 1831, 545. (Type, Trochilus ornatus Boddaert.)

Lophorhinus (not Lophorhina Vieillot, 1816) Bonaparte, Rev. et Mag. de Zool., 1854, 257. (Type, Ornismya (Lophorinus) delattrei Lesson.)

Lophomyia Futzinger, Sitzungsb. Ak. Wissensch. Wien, xlvi, pt. 1, 1862 ?, 235. (Type, Trochilus magnificus Vieillot.)

Telamon Mulsant and Verreaux, Mém. Soc. Imp. Sci. Nat. Cherb., xii (sér. 2, ii), 1866, 219 (Classif. Troch., 1866, 75). (Type, Ornismya (Lophorinus) delattrei Lesson.)

Paphosia Mulsant and Verreaux, Mém. Soc. Imp. Sci. Nat. Cherb., xii (sér. 2, ii), 1866, 219 (Classif. Troch., 1866, 75). (Type, Ornismya helenæ Delattre.) Paphiosa (emendation?) Mulsant, Ann. Soc. Linn. Lyon, n. 8., xxii, 1876, 222. Dialia Mulsant, Ann. Soc. Linn. Lyon, n. s., xxii, 1876, 223 (Cat. Ois.-Mouch., p. 27). (Type, Lophornis adorabilis Salvin.)

Idas Mulsant, Ann. Soc. Linn. Lyon, n. s., xxii, 1876, 223 (Cat. Ois. Mouch., p. 27). (Type, Trochilus magnificus Vieillot.)

Small Trochilidæ (length about 65-80 mm.) with nasal operculum very narrow, almost rudimentary, mandibular groove indistinct, a more or less distinct whitish or buffy bar across rump, naked tarsi, tail double-rounded or rounded, with rectrices broadly rounded at tip (three-fifths to about two-thirds as long as wing), the adult males with 
conspicuous crest or neck-tufts or ruffs (sometimes both), and with outer web of ninth primary abruptly narrowed (almost obliterated) terminally.

Bill shorter than head, stout, nearly terete (broad and depressed basally in $L$. adorabilis); culmen rounded terminally, narrowly ridged (for a greater or less distance) basally; tomia smooth; mandible with the usual lateral median groove or sulcus indistinct or obsolete. Nasal operculum narrow, almost rudimentary, hidden by appressed frontal feathering, which anteriorly extends nearly to (sometimes considerably beyond) anterior end of nostrils, forming a single broadly rounded or very faintly emarginate antia on base of culmen. Tarsus naked; lateral toes about equal in length, slightly but distinctly shorter than middle toe. Wing more than three to about four times as long as exposed culmen, the outermost (tenth) primary longest or equal to ninth, narrow but not acuminate, the ninth primary in adult males with outer web abruptly excised or narrowed (almost obliterated) for about terminal third or fourth. Tail in adult male about three-fifths to a little more than two-thirds as long as wing, double-rounded, the outermost rectrices sometimes longer, sometimes shorter, than middle pair-in females and young about half as long as wing, rounded, the rectrices broadly rounded at tip in both sexes.

Coloration.-Back, etc., metallic green, bronze-green, or bronze; a more or less distinct bar of white or buffy across rump. Adult males extremely variable in coloration of head, neck, and under parts but always with the chin and throat brilliant metallic green; the head often conspicuously crested, and frequently with a conspicuous tuft of elongated, usually spangled or otherwise brilliantly colored feathers springing from the auricular region; adult females without crest or tufts, the chin and throat whitish or buffy, sometimes spotted or flecked with dusky or bronzy.

Range.-Southern Mexico to Cayenne, southern Brazil, Bolivia, and Peru. (About ten species.)

KEY TO THE SPECIES OF LOPHORNTS.

a. Head conspicuously crested or tufted; rectrices (except middle pair) wholly cinnamon-rufous or merely edged with dusky. (Adult males.)

b. No elongated auricular tuft, nor white patch on crown; forehead not coppery; no distinct white patch on chest.

c. Whole pileum, including bushy crest, cinnamon-rufous; whole throat metallic green; under parts of body not spotted. (Central Costa Rica to northern Colombia.)....................... Lophornis delattrei, adult male (p. 671).

cc. Pileum dark metallic green, the slender crest blackish; lower throat velvety black; under parts of body spotted with bronze on a white ground. (Southeastern Mexico to Costa Rica.)

Lophornis helenæ, adult male (p. 673). 
$b b$. An auricular tuft of elongated acicular (dark metallic green) feathers; a white patch on crown and a large white patch on chest; forehead coppery. (Costa

Rica and western Panama.)........ Lophornis adorabilis, adult male (p. 675). aa. Head without crest or tufts; rectrices crossed by a broad band of black. (Adult females and immature males.)

$b$. Forehead light cinnamon-rufous or cinnamon-buff.

Lophornis delattrei, adult female and immature male (pp. 671,672).

$b b$. Forehead dusky or dark metallic greenish.

c. Under parts of body whitish spotted with bronze; throat buffy or pale cinnamomeous...... Lophornis helenæ, adult female and immature male (p. 673). cc. Under parts of body uniform cinnamon-rufous; throat white.

Lophornis adorabilis, adult female and immature male (pp. 675,676).

\section{LOPHORNIS DELATTREI (LesSON).}

\section{DE IATTRE'S COQUETTE.}

Adult male.--Pileum, including very conspicuous crest of much elongated, acicular, rather rigid, feathers, uniform cinnamon-rufous; nape, hindneck, back, scapulars, and lesser wing-coverts metallic bronze-green; a band of white, pale buff, or cinnamon-buff across upper rump; lower rump and upper tail-coverts dark purplish bronze; middle pair of rectrices with edges and terminal portion (more or less extensively) dark bronzy, the basal-median portion deep cinnamon-rufous; rest of tail deep cinnamon-rufous, the outer webs of rectrices edged with dusky bronze; remiges dull purplish black or dusky glossed with violet-purple; loral, auricular, and malar regions, chin, and throat brilliant metallic yellowish emerald green, the feathers abruptly cinnamon-buff basally (this slightly exposed on latero-posterior portion of throat); beneath the posterior margin of the green gular area a few narrow feathers, white terminally, pale cinnamonbuff basally; under parts of body rather dull metallic bronze-green or greenish bronze, more or less broken or intermixed with light rusty brownish; under tail-coverts bright cinnamon-rufous; bill pale brownish (in dried skins), dusky terminally; iris dark brown; feet grayish brown (in dried skins); length (skins), 66-68 (67); wing, 35-38.5 (36.8); tail, 22-22.5 (22.2); exposed culmen, 8.5-10 (9.1) ${ }^{a}$

Adult female.-Forehead and anterior portion (sometimes greater part) of crown dull cinnamon-rufous or russet; rest of pileum, hindneck, back, scapulars, and wing-coverts metallic bronze or bronzegreen, usually darker on occiput and posterior portion of crown; a band of cinnamon-buff or whitish across upper rump; lower rump and upper tail-coverts dusky purplish bronze or dull copper-bronze; middle pair of rectrices pale cinnamon-rufous basally, middle portion greenish bronze, terminal portion (broadly) purplish bronzy black (sometimes with a small chestnut or cinnamon-rufous apical spot); remaining rectrices broadly tipped with cinnamon-rufous and crossed by a broad subterminal band of black, the basal portion cinnamon- 
rufous; remiges purplish dusky or dull purplish black; chin and throat cinnamon-rufous or cinnamon-whitish, the lower portion of the latter spotted or flecked with dusky, these spots coalescing posteriorly into a transverse patch of dusky purplish bronzy on extreme lower throat; under parts of body brownish gray, glossed with metallic bronze, especially on sides; under tail-coverts clear cinnamon-rufous to pale cinnamon; bill as in adult male, but more extensively dusky terminally; iris and feet as in adult male; length (skins), 65-70 (67); wing, 38-39 (38.5); tail, 18.5; exposed culmen, 9.5-11 $(10.2){ }^{a}$

Young male?.- Similar to the adult female, but fore part of head, including forehead, lores, chin, and upper throat, light cinnamonrufous.

Immature male.-Similar to the adult female, but chin and throat bright metallic green or else (younger individuals) dull black with green on lower-middle portion and a whitish spot or bar between the bright green of throat and duller green of chest.

Southwestern Costa Rica (San Pedro) through Panamá (Verágua; Castillo; Laguna del Castillo; Chitra; Chepo; Lion Hill; Panamá) to Colombia (Bogotá; Prado, Tolima).

(O[rnysmia] Lophorinus) de lattrei LEsson, Rev. Zool., ii, Jan., 1839, 19 (locality unknown).

$M[e l l i s u g a]$ de lattrei Grax, Gen. Birds, i, Dec., 1848, 113.

Lophornis delattrei Gould, Mon. Troch., pt. xxiv, Sept., 1861; vol. iii, 1861, pl. 121; Introd. Troch., oct. ed., 1861, 84.-Lawrence, Ann. Lyc. N. Y., vii, 1862, 465 (Lion Hill, Panamá).-Boucard, Gen. Hum. Birds, 1892, 39.

L[ophornis] delattrei HARTERT, Das Tierreich, Troch., 1900, 218.

[Lophornis] delattrei Sharpe, Hand-list, ii, 1900, 143.

Telamon delattrei Mulsant and Verreaux, Classif. Troch., 1866, 75; Hist. Nat. Ois.-Mouch., iii, livr. 3, 1876, 199, part (Panamá; Colombia).

[Telamon] delattrei Mulsant, Ann. Soc. Linn. Lyon, xxii, 1876, 222.

[Trochilus] delattrei Gray, Hand-list, i, 1869, 146, no. 1892.

[Lophornis] delattrii Bonaparte, Consp. Av., i, 1850, 83; Rev. et Mag. de Zool., 1854, 257.-Reichenbach, Aufz. der Colibr., 1854, 12; Troch. Enum., 1855, 9.-Sclater and Salvin, Nom. Av. Neotr., 1873, 83.

Lophornis delattrii Sclater, Proc. Zool. Soc. Lond., 1857, 17 (Bogotá, Colombia).Sclater and Salvin, Proc. Zool. Soc. Lond., 1864, 365 (Lion Hill).-Salvin,

$a$ Two specimens.

\begin{tabular}{|c|c|c|c|}
\hline Iocality. & Wing. & Tail. & 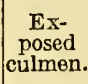 \\
\hline MALES. & & & \\
\hline Three adult males from central Colombia (Bogot $\hat{x}) . .$. & 36.2 & 22 & 8.8 \\
\hline 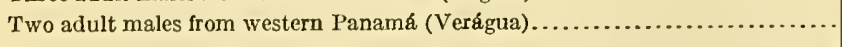 & 37.7 & 22.2 & 9.5 \\
\hline FEMALES. & & & \\
\hline 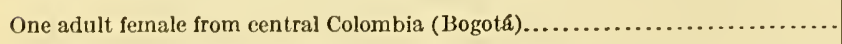 & 38 & 18.5 & 9.5 \\
\hline One adult female from eastern Panamá ( $\Lambda$ tlantic side).............. & 39 & 18.5 & 11 \\
\hline
\end{tabular}


Proc. Zool. Soc. Lond., 1870, 207 (Castillo and Laguna del Castillo, Panamá); Cat. Birds Brit. Mus., xvi, 1892, 423, 668 (Castillo, Laguna del Castillo, Chitra, Lion Hili, and Chepo, Panamá; Bogotá and Prado, Tolima, Colombia).-Elliot, Classif. and Synop. Troch., 1879, 133, part (Verágua; Panamá; Colombia).-Berlepsch, Journ. für Orn., 1887, 329 (Bogotá).-Ridgway, Rep. U. S. Nat. Mus. for 1890 (1891), pl. 32, fig. 1.-SALviN and Gomman, Biol. Centr.-Am., Aves, ii, 1892, 363.-Boucard, The Hum. Bird, ii, 1892, 73 (Verágua; Panamá, Bogotá).-Bangs, Proc. New Engl. Zool. Club, iv, 1908, 25 (San Pedro, s. w. Costa Rica).-Carriker, Ann. Carnegie Mus., vi, 1910, 552 (Costa Rica).

\section{LOPHORNIS HELENÆE (Delattré).}

\section{PRINCESS HELENA'S COQUETTE.}

Adult male.-Pileum dark metallic green, the long, acicular, or filamentous feathers of occipital crest greenish black; nape, hindneck, back, scapulars, and wing-coverts metallic bronze-green; lower rump and upper tail-coverts sooty blackish, more or less glossed with bronzy, this separated from the green of upper rump and back by a narrow band of white or light dull buffy, across middle of rump; middle rectrices dull greenish bronze or olive-bronze, passing into dusky terminally and into cinnamon-rufous, more or less extensively, basally; other rectrices cinnamon-rufous, edged on outer web with bronzy blackish; remiges dusky, faintly glossed with violaceous; chin and upper throat brilliant metallic yellowish green abruptly defined, with a convex or semicircular outline, posteriorly against a patch of elongated, velvety black feathers on extreme lower throat; on each side of this shield-like velvety black patch a tuft of elongated feathers, mostly buff (more or less deep) but with upper web of some velvety black, forming sharply defined streaks; chest metallic bronze (varying from greenish to bright golden), the breast, abdomen, sides, and flanks of white spotted with metallic bronze; under tail-coverts cinnamon-rufous, more or less distinctly grayish brown centrally; bill light brownish or whitish (in dried skins), usually dusky terminally; iris dark brown; feet brownish (in dried skins); length (skins), 63-77 (67.5); wing, 38-42.5 (39.8); tail, 22-25.5 (23.7); exposed culmen, 10-12.5 (11.3). ${ }^{a}$

Adult female.-Above dark metallic green or bronze-green, brightest on back, etc.; a narrow white band across middle of rump; extreme lower rump and upper tail-coverts black, glossed with bronze; middle rectrices olive-bronzy, blackish terminally, cinnamon-rufous at base, the remaining rectrices cinnamon-rufous crossed by a broad subterminal band of black; remiges dusky, faintly glossed with violaceous; loral, suborbital, and auricular regions uniform blackish; malar region, chin, and throat varying from pale grayish or brownish buft to deep cinnamon-buff or pale cinnamon-rufous, sometimes minutely flecked with dusky or bronzy; chest nearly uniform metallic bronze, 
the remaining under parts (except under tail-coverts) white spotted with metallic bronze; under tail-coverts cinnamon-rufous; maxilla dusky, mandible pale brownish basally, dusky terminally; length (skins), 60-71 (65); wing, 37.5-41 (38.9); tail, 18.5-21.5 (20.2); exposed culmen, 11-12.5 (11.3). ${ }^{a}$

Southeastern Mexico, in States of Vera Cruz (Córdova; Jalapa; Santecomapám; Chiquilmita; Catemaco; Tospám; San Andrés Tuxtla) and Chiapas, southward through Guatemala (Cobán; Chisec; Guatemala City; Chiquilmitra, Vera Paz; Petén) and Honduras (San Pedro Sula) to Costa Rica (Turrialba; Tucurríqui; Bonilla; Juan Viñas; Guayabál; Guayabo; El Naranjo; San Pedro; Las Pavas; Cachí; San Carlos).

Ornismya helenae Delatrré, Echo du Monde Savant, 1843, 991, in text (Vera Paz, Guatemala); Rev. Zool., 1843, 133.

M[ellisuga] helenx Gray, Gen. Birds, i, Dec., 1848, 113.

[Lophornis] helenae Bonaparte, Consp. Av., i, 1850, 83.-Reichenbach, Aufz. der Colibr., 1854, 12; Troch. Enum., 1855, 9, pl. 811, fig. 4892.

Lophornis helenæ GouLd, Mon. Troch., pt. x, Sept., 1855; vol. iii, 1861, pl. 123; Introd. Troch., oct. ed., 1861, 84.-Sclater, Proc. Zool. Soc. Lond., 1856, 288 (Córdova, Vera Cruz); Cat. Am. Birds, 1862, 295 (Cobán, Vera Paz, Guatemala).-Sclater and Salvin, Ibis, 1859, 130 (Cobán, Guatemala).Salvin, Ibis, 1860, 194, 196, 267 (Cobán; habits); Cat. Birds Brit. Mus., xvi, 1892, 425 (Cobán and Chiséc, Guatemala; Turrialba and Tuccurique, Costa Rica).-Lawrence, Ann. Lyc. N. Y., ix, 1868, 145 (Costa Rica).De OCA, La Naturaleza, iii, 1875, 300 (Chiapas); Troq. de Mex., 1875, 54.Boucard, Notes Troch. du Mex., 1875, 2 (Jalapa, Córdova, and Chiquilmita, Vera Cruz; habits, etc.); Ann. Soc. Linn. Lyon, xxii, 1876, 15 (Córdova, Santecomapám, and Catemaco, Vera Cruz); Gen: Hum. Birds, 1892, 34 (Tospám, San Andrés Tuxtla, etc., Vera Cruz).-Zeledón, Cat. Aves de Costa Rica, 1882, 21; Anal. Mus. Nac. Costa Rica, i, 1887, 122.-Ridgway, Rep. U. S. Nat. Mus. for 1890 (1891), pl. 30, fig. I; Condor, vii, 1905, 157, in text (Bonilla, Costa Rica).-Salvin and Godman, Biol. Centr.-Am., Aves, ii, 1892, 364 (San Pedro Sula, Honduras; El Naranjo, Costa Rica; etc.).-Carriker, Ann. Carnegie Mus., vi, 1910, 552 (Caribbean slope Costa Rica, $1,000-4,000 \mathrm{ft}$.).

[Lophornis] helenæ Sclater and Salvin, Nom. Av. Neotr., 1873, 83.-Sharpe, Hand-list, ii, 1900, 144.

L[ophornis] helenae HавтеRт, Das Tierreich, Troch., 1900, 219.

a Twelve specimens.

\begin{tabular}{|c|c|c|c|}
\hline Loeality. & Wing. & Tail. & $\begin{array}{c}\text { Ex- } \\
\text { posed } \\
\text { culmen. }\end{array}$ \\
\hline MALES. & & & \\
\hline Two adult males from Vera Cruz (Cordora), Mexico. . & $\$ 1.2$ & 24.2 & 10.2 \\
\hline Nine adult males from Guatemala.............. & 39.7 & 23.8 & 11.4 \\
\hline Ten adult males from Costa Rica........... & 39.6 & 23.5 & 11.4 \\
\hline FEMALES. & & & \\
\hline Three adult females from Guatemala...... & 39.5 & 21 & 12.2 \\
\hline Nine adult females from Costa Riea....... & 38.7 & 19.9 & 11.7 \\
\hline
\end{tabular}


Paphosia helenae Mulsant and Verreaux, Classif. Troch., 1866, 75; Hist. Nat. Ois.-Mouch., ii, livr. 2, 1875, pl. 25, fig. 2; iii, livr. 3, 1876, 205, pl. 91, fig. 2 (Mexico; Guatemala; Costa Rica).

Paphiosa helenæ Boucard, Proc. Zool. Soc. Lond., 1878, 70 (San Carlos and Turrialba, Costa Rica).

[Paphiosa] helenae Mulsant, Ann. Soc. Linn. Lyon, xxii, 1876, 222.

Paphiosa helenae Boucard, Liste Ois. récol. Guat., 1878, 46.

[Trochilus] helenæ GrAy, Hand-list, i, 1869, 146, no. 1891.

[Lophornis] helena Bonaparte, Rev. et Mag. de Zool., 1854, 257.

Lophornis elenæ $\mathrm{DE}_{\mathrm{E}} \mathrm{OcA}$, La Naturaleza, iii, 1875, pl. (8), fig. 43; Troq. de Mex., 1875, pl. (12), fig. 43 .

\section{LOPHORNIS ADORABILIS Salvin.}

\section{ADORABLE COQUETTE.}

Adult male.-Frontal, ioral, and orbital regions metallic copperbronze, the feathers pure white beneath surface; a cuneate crest of pure white, elongated, narrowly pointed feathers springing from posterior portion of forehead and center of crown; sides of crown, occiput, hindneck, back, scapulars, and wing-coverts rather dark bronze-green; rump and shorter upper tail-coverts dark metallic coppery purple, this area separated from green of back by a narrow band of white, pale cinnamon, or buffy across upper rump; longer upper tail-coverts pale grayish cinnamon or dull brownish buffy broadly tipped with dusky purplish bronze; tail chestnut-rufous, the outer webs of rectrices edged with dusky bronze or bronze-green, the middle pair broadly tipped with the same; remiges and primary coverts dull black, the secondaries and inner primaries more purplish dusky; chin and throat bright metallic emerald green, this color extending over the auricular region, from the posterior portion of which there springs a much elongated tuft of very long narrowly lanceolate or acicular - almost filamentous-plumes of metallic green; chest white, tinged with cinnamon or buffy grayish laterally and posteriorly; rest of under parts cinnamon-rufous, passing into metallic bronze-green on sides of breast; bill pale brownish (coral red in life) the terminal third (more or less) dusky; feet dusky grayish brown (in dried skins); length (skins), 71-80 (74); wing, 36.540.5 (39); tail, 25.5-29 (27.3); exposed culmen, 10.5-12 (11.1). ${ }^{a}$

Adult female.-Forehead, and crown, together with loral, suborbital, and auricular regions, dark sooty, faintly glossed with bronze; occiput, nape, hindneck, back, scapulars, and wing-coverts metallic bronze-green; a broad band of cinnamon-buff (more or less deep) or buffy white across middle of rump; upper tail-coverts dark sooty or sooty black, strongly glossed with bronze or coppery bronze; middle rectrices pale cinnamon-rufous basally, bronze-green in middle portion, black (broadly) subterminally or terminally, usually tipped with light cinnamon-rufous; lateral rectrices similar but broadly tipped with light cinnamon-rufous, and bronze-green band 
across middle portion greatly reduced in width or obsolete; remiges dusky, faintly glossed with violaceous; malar region, chin, throat, and chest white, the chin and throat usually flecked or punctulated with dusky bronze; rest of under parts light cinnamon-rufous, the sides of breast glossed with bronze or bronze-green; bill blackish or dusky, the mandible usually more brownish for basal half or more; iris dark brown; feet dusky; length (skins), 64-67 (66); wing, 36.5-39 (37.8); tail, 17.5-22 (20.4); exposed culmen, 11-12 (11.4). ${ }^{a}$

Immature male.-Similar to the adult female but lower throat with greater or less admixture of metallic green feathers, and rump-band narrower.

Costa Rica (San José; San Pedro de San José; Escazú; Volcán de Irazú; Juan Viñas; Barranca; Boruca; San Pedro) and western Panamá (Bugaba, Volcán de Chiriquí; Bibaláz).

Lophornis adorabilis Salvin, Proc. Zool. Soc. Lond., 1870, 207 (Bugaba, Volcán de Chiriquí, Panamá; coll. Salvin and Godman); Cat. Birds Brit. Mus., xvi, 1892, 425 (Bugaba and Bibaláz, Panamá).-Elurot, Classif. and Synop. Troch., 1879, 135.-Sharpe, Suppl. Gould's Mon. Troch., 1880, pl. 35.Zetedón, Anal. Mus. Nac. Costa Rica, i, 1887, 122 (San José, Costa Rica).Ridgway, Proc. U. S. Nat. Mus., xi, 1888, 542 (San José); Rep. U. S. Nat. Mus. for 1890 (1891), pl. 30, fig. 2.-Cherrie, Expl. Zool. Merid. Costa Rica, 1882, 45 (Boruca, s. w. Costa Rica); Auk, ix, 1892, 324 (Boruca; San José).Salvin and Godman, Biol. Centr.-Am., Aves, ii, 1892, 365, pl. 57, figs. 1, 2.Boucard, The Hum. Bird, ii, 1892, 73 (Chiriquí, Panamá); Gen. Hum. Birds, 1892, 34 (Bugaba).-SAlvadori and Festa, Boll. Mus. Zool., etc., Torino, xiv, 1899, no. 339, 7 (Chiriquí).-BANGS, Auk, xxiv, 1907, 296 (Boruca).-Carriker, Ann. Carnegie Mus., vi, 1910, 553 (Costa Rica).

[Lophornis] adorabilis ScLATER and SALvin, Nom. Av. Neotr., 1873, 83.--STHARPE, Hand-list, ii, 1900, 143.

L[ophornis] adorabilis HARTERT, Das Tierreich, Troch., 1900, 219.

Dialia adorabilis Mulsant and Verreaux, Hist. Nat. Ois.-Mouch., ii, livr. 2, 1875, pl. 25, fig. 1; iii, livr. 3, 1876, 208 (Bugaba).

[Dialia] adorabilis Mulsant, Ann. Soc. Linn. Lyon, xxii, 1876, 223.

\section{Genus POPELAIRIA Reichenbach.}

Gouldia (not of Adams, 1847) Bonaparte, Consp. Av., i, 1850, 86. (Type, Trochilus langsdor $f f i$ Bonnaterre and Vieillot.)

Popelairia Reich en bach, Aufz. der Colibr., 1854, 12. (Type, Trochilus popelairii Du Bus.)

Popelairea (emendation) Srmon, Cat. Troch., 1897, 41.-Hartert, Das Tierreich, Troch., 1900, 222.

Gouldomyia Bonaparte, Rev. et Mag. de Zool., vii, pt. 2, 1854, 257. (Type, Trochilus langsdor $/ f$ Bonnaterre and Vieillot.)

Prymnacantha $b$ CABanis and HeIne, Mus. Hein., iii, April, 1860, 64. (Type, Trochilus popelairii Du Bus.)

Primnacantha (error) Mursant, Ann. Soc. Linn. Lyon, n. s., xxii, 1876, 223.

Tricholopha c IIEIne, Journ. für Orn., 1863, 209, in text. (Type, Popelairia tricholopha Reichenbach = Trochilus popelairii Du Bus.)

a Ten specimens from Costa Rica.

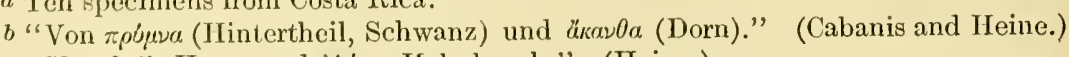

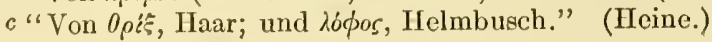


Mytinia Mulsant, Ann. Soc. Linn. Lyon, n. s., xxii, 1876, 224 (Cat. Ois.-Mouch., p. 28); Hist. Nat. Ois.-Mouch., iii, 1876, 235. (Type, Trochilus letitixe Bourcier.)

Mythinia (emendation?) Mulsant and Verreaux, Hist. Nat. Ois.-Mouch., iii, 1876, 235.

Small Trochilidæ (length, including long tail of adult males, about 70-120 mm.) related to Lophornis, but differing in forked tail (in adult male greatly elongated, with lateral rectrices attenuated terminally), absence of ornamental head plumes (except a slender, lapwing-like crest in one species), and more uniform coloration.

Bill (unfeathered portion) shorter than head, straight, nearly terete; culmen rounded except basally, where more or less distinctly ridged; tomia smooth; mandible with the usual lateral median groove. Nasal operculum moderately broad to rather narrow, nude, but hidden by appressed frontal feathering, which anteriorly extends considerably beyond anterior end of nostrils, forming a short, obtuse point or antia on each side of culmen. Tarsus naked; inner toe about as long as middle toe, the outer toe slightly shorter. Wing between three and four times as long as exposed culmen, the outermost (tenth) primary longest, rather narrow but with tip rounded, the ninth with outer web abruptly incised (almost obliterated) for terminal third or fourth, in one species ( $P$. popelairi) entire outer web of both ninth and tenth primaries obsolete. Tail in adult males about one and a half times as long as wing to more than twice as long, forked for much the greater part of its length, the lateral rectrices narrow and attenuated terminally; in adult females about three-fifths as long as wing, forked, but with lateral pair of rectrices shorter than the next.

Coloration.-Above metallic green or bronze-green, including pileum, the rump crossed by a narrow band or bar of white, this often succeeded by a blackish area. Adult males with chin, throat, and chest metallic green, the remaining under parts mostly green or blackish, or else chin and throat metallic green, chest and middle of breast and abdomen black, sides and flanks sooty; tail with longer rectrices blue-black, violet-black or grayish, the shafts white on under side; one species with a band of metallic orange-reddish, another with a spot of white, on chest. Adult females with under parts mixed black, green, and white, the lateral rectrices tipped with white and grayish basally.

Range-Costa Rica to Peru, Bolivia, and Brazil. (Five species.)

It is probable that this genus should be restricted to $P$. popelairii, which differs from all the others in its very conspicuous, long and slender, lapwing-like crest, almost complete obliteration of outer web of ninth and tenth primaries, more strongly curved primaries, and relatively much shorter wing, the latter only about three times as long as the exposed culmen instead of nearly to quite four times as 
long. In case two genera are recognized $P$. conversi and its allies would constitute a genus the earliest name for which appears to be Gouldomyia Bonaparte (1854).

\section{KEY TO THE SPECIES AND SUBSPECIES OF POPELAIRIA.}

a. Tail excessively forked, the lateral rectrices slenderly attenuate; no white on head nor anterior under parts. (Adult male.)

b. Conspicuously crested; thighs cinnamon-rufous. (Colombia to Peru.)

Popelairia popelairii, adult male (extralimital). ${ }^{a}$

$b b$. Without crest; thighs not cinnamon-rufous.

c. No white pectoral spot; rectrices blue-black or dark steel blue, the lateral ones more than $40 \mathrm{~mm}$. long, their shafts white beneath.

d. Flanks metallic green; only center of breast black, the feathers tipped with metallic green or blue; throat and chest metallic grass-green; lateral rectrices strongly doubly curved. (Popelairia conversi.)

$e$. Feathers of center of breast tipped with green; upper tail-coverts dark metallic green; wing 41-43.5 (42.6), tail 54.5-56.5 (55.2). (Central Colombia.) .. . . Popelairia conversii conversii, adult male (extralimital). $b$

$e e$. Feathers on center of breast tipped with bluish green or greenish blue; upper tail-coverts dark bronzy (at least in part); wing, 40-43 (41.4); tail, 46-61 (56.6). (Costa Rica to western Ecuador.)

Popelairia conversii æquatorialis, adult male (p. 679).

$d d$. Flanks pale brownish gray; whole breast uniform black; throat and chest metallic yellowish green; lateral rectrices curved ontwardly only.

Popelairia langsdorffi, adult male (extralimital).c

a Trochilus popelairii Du Bus, Esquis. Orn., livr. 2, 1846, pl. 6, and text (Peru; coll. Royal Mus. Belgium).-[Gouldia] popelairii Bonaparte, Consp. Av., i, 1850, 86.Gouldia popelairii Gould, Mon. Troch., iii, 1854, pl. 127; Elliot, Classif. and Synop. Troch., 1879, 138.-P $[$ rymnacantha $]$ popelairei Cabanis and Heine, Mus. Hein., iii, 1860, 64.--Prymnacantha popelairei Gould, Introd. Troch., oct. ed., 1861, 86; Salvin, Cat. Birds Brit. Mus., xvi, 1891, 428.-T[richolopha] popelairei Heine, Journ. für Orn., 1863, 209, in text.-Popelairia tricholopha Reichenbach, Aufz. der Colibr., 1854, 12; Troch. Enum., 1855, 9, pl. 815, figs. 4905-4907.-Popelaria tricholopha Ridgway, Proc. U. S. Nat. Mus., iii, Oct. 27, 1880, 315 (Colombia).-[Popelairea] popelairei Sharpe, IIand-list, ii, 1900, 144.

b T[rochilus] conversii Bourcier and Mulsant, Ann. Sci. Phys. et Nat., etc., Lyon, ix, 1846, 313 (Bogotá, Colombia).-[Gouldia] conversi Bonaparte, Consp. Av., i, 1850, 86; Gould, Mon. Troch., iii, 1854, pl. 129; Introd. Troch., oct. ed., 1861, 86; Elliot, Classif. and Synop. Troch., 1879, 139, part.-P [rymnacantha $]$ conversi Cabanis and Heine, Mus. Hein., iii, 1860, 65.-Prymnacantha conversi Salvin, Cat. Birds Brit. Mus., xvi, 1891, 430, part.-Mellisuga conversi Mulsant and Verreaux, Classif. Troch., 1866, 79.-[Popelairea] conversi Simon, Cat. Troch., 1897, 41.-P[opelairea] conversi (typica) Hartert, Das Tierreich, Troch., 1900, 223.

c Trochilus langsdorffi "Vieill [ot]" Temminck, Nouv. Pec. Planches Coloriées, iv, livr. 11, June, 1821, pl. 66, fig. 1 (Brazil; coll. Laugsdorff).-Ornismya langsdorffi Lesson, IIist. Nat. Ois.-Mouch., 1829, pp. xx, 102, pl. 26; Suppl. Ois.-Mouch., 1830-3I, 129, pl. 16; Les Troch., 1832, 101, pl. 35.-Orthorhynchus langsdorffi Lesson, Man. d'Orn., ii, 1828, 77.-[Gouldia] langsdorffi Bonaparte, Consp. Av., i, 1850, 86.-Gouldia langsdor fi Gould, Mon. Troch., iii, 1854, pl. 128; Introd. Troch., oct. ed., 1861, 86; Elliot, Classif. and Synop. 'Troch., 1879, 138.-P[rymnacantha] langsdorffi Cabanis and fleine, Mus. Hein., iii, 1860, 65.-Prymnacantha langsdorffi Mulsant and Verreaux, 
cc. A white pectoral spot; rectrices purplish black, their shafts rufous beneath, $a$ the lateral ones less than $40 \mathrm{~mm}$. (Bolivia.)

Popelairia letitiæ, adult male (extralimital). $b$

$a a$. Tail slightly forked or double rounded, the lateral rectrices not attenuated; head and anterior under parts partly white. (Adult females.)

$b$. Thighs not rufescent; throat and chest not uniform sooty black.

c. Thighs black......... Popelairia conversii æquatorialis, $c$ adult female (p. 680).

$c c$. Thighs white............ Popelairia langsdorff, adult female (extralimital).

bb. Thighs rufescent; throat and chest uniform sooty blackish.

Popelairia popelairii, adult female (extralimital).

\section{POPELAIRIA CONVERSII EQQUATORIALIS (Berlepsch and Taczanowski).}

\section{SALVIN'S THORN-TAIL.}

Adult male.-Above deep metallic green (brightest on pileum), the lower rump and shorter upper tail-coverts usually dark coppery bronze or partly of this color; a narrow white band across upper rump; tail slightly glossy blue-black, the shafts of the rectrices white basally, passing into brownish gray terminally, pure white for entire length on under surface, the webs brownish gray immediately next to shaft; remiges and primary coverts dusky, very faintly glossed with purplish; chin, throat, and chest bright metallic grass green; rest of under parts duller metallic green, the center of breast with a patch of metallic bluish green or greenish blue, intermixed centrally with dark blue or bluish black; femoral tufts white; bill black; iris dark brown; feet dusky; length (skins), 93-110 (104); wing, 40-43

Hist. Nat. Ois.-Mouch., iii, 1877, 238, pl. 94; Salvin, Cat. Birds Brit. Mus., xvi, 1891, 429.-Mellisuga langsdorffi Mulsant and Verreaux, Classif. Troch., 1866, 79.-Popelaria langsdorfi Ridgway, Proc. U. S. Nat. Mus., iii, Oct. 27, 1880, 315 (Brazil; Pebas, e. Peru).-P[opelairea] langsdorffi Hartert, Das Tierreich, Troch., 1900, 223.(?) Gouldia melanosternon Gould, Ann. and Mag. N. H., ser. 4, i, May, 1868, 323 (Napo, Pebas, and Ucayali, e. Peru; coll. J. Gould).-[Trochilus] melanosternon Gray, Handlist, i, 1869, 146, no. 1879.

a. According to Elliot; but Salvin says they are white beneath.

$b$ Trochilus letitix Bourcier and Mulsant, Ann. Sci. Phys. et Nat., etc., Lyon, iv, 1852, 143 (Bolivia).-[Gouldia] laetitia Reichenbach, Aufz. der Colibr., 1854, 12.Gouldia letitix Gould, Mon. Troch., iii, 1855, pl. 130; Introd. Troch., oct. ed., 1861, 86; Elliot, Classif. and Synop. Troch., 1879, 139.-P[rymnacantha] laetitiae Cabanis and Heine, Mus. Hein., iii, 1860, 64, footnote.-Mellisuga letitiæ Mulsant and Verreaux, Classif. Troch., 1866, 79.-Prymnacantha letitiæ Salvin, Cat. Birds Brit. Mus., xvi, 1891, 431.-Mythinia letitiæ Mulsant and Verreaux, Hist. Nat. Ois.-Mouch., iii, 1877, 245.-[Mytinia] letitiæ Mulsant, Ann. Soc. Linn. Lyon, xxii, 1876, 224.-P[opelairea] letitiae Hartert, Das Tierreich, Troch., 1900, 224.

c I have no females of $P$. c. conversii nor $P$. letitix for comparison. 
(41.4); tail, 46-61 (56.6), middle rectrices 10-18 (11.9); exposed culmen, 11.5-12.5 (11.8)..$^{a}$

Adult female.-Upper parts as in adult male, but lower rump and upper tail-coverts darker (mostly purplish black or blackish bronze); four middle rectrices bluish black with basal portion of outer web bronze-green, the tip with a very narrow mesial streak of whitish; outermost rectrix with outer web white basally, passing into pale brownish gray distally, crossed by a broad subterminal band of blueblack and broadly tipped (across both webs) with white; second and third rectrices blue-black, with middle portion of outer web greenish or bronzy gray, the second with a distinct, the third with a minute (mesial) white tip; chin and throat opaque black (sometimes intermixed with whitish) bordered along each side by a broad white stripe, covering malar region; other under parts mostly black medially (the feathers of chest usually tipped with green), the sides of breast, sides, and flanks mostly metallic green, the space between this and black along middle line of abdomen white; bill, etc., as in adult male; length (skins), 70-75 (72); wing, 38.5-40.5 (39.5); tail, 22-24.5 (23.5), middle rectrices, $12.5-14.5$ (13.6); exposed culmen, $11-13(12.2) .^{b}$

Young male.-Similar to the adult female, but tail longer and more deeply forked, and with more green on under parts.

Immature male.-Similar to adult male (including tail), but with a white rictal stripe and flank-patches, and green of under parts more broken.

a Ten specimens from Costa Rica.

$b$ Eight specimens.

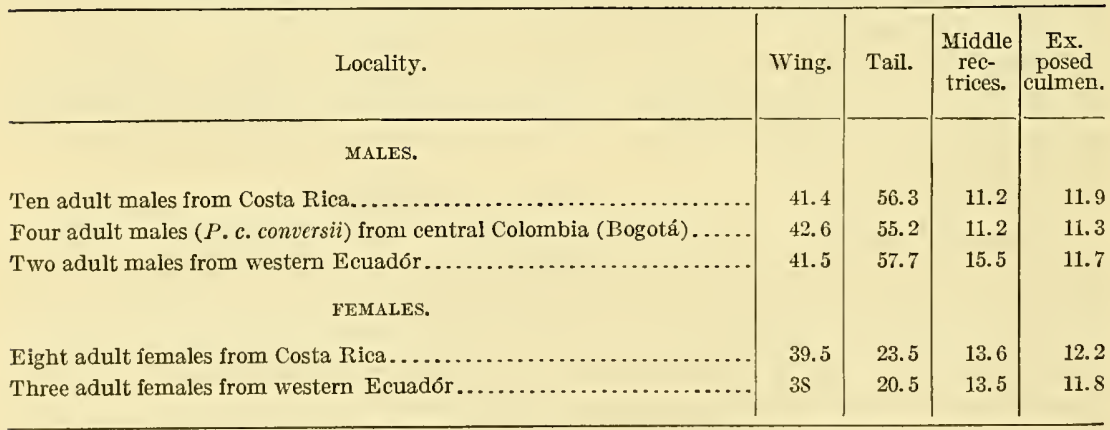

Except that they have longer bills, and that the females usually have the subterminal black band of lateral rectrices narrower, I am unable to distinguish Costa Rican and Panaman examples from those from western Ecuador; but they are, if anything, more differen $\boldsymbol{t}$ than the latter from Bogotá specimens, representing true $P$. conversii. The series from Ecuador is, unfortunately, too small for satisfactory comparison, consisting of only two males and three females. Should a larger series prove the Costa Rican specimens to be separable, I suggest that they bear the name Popelairia conversii salvini Zeledón (manuscript), Mr. Zeledón having at one time contemplated so naming the Costa Rican bird. (Type, no. 199271, coll. U. S. Nat. Mus., Bonilla, Costa Rica, April 4, 1905; R. Ridgway.) 
Costa Rica (Tucurríqui; Angostura; Naranjo de Cartago; Bonilla; Carrillo; La Hondura; Cariblanco de Sarapiquí), Panamá (Santa Fé de Verágua; Calovévora; Cordillera del Chucu; Lion Hill; Panamá), and western Ecuadór (Baisa; Citado; Chimbo; Quito; Naranjál; Nanegál; Santo Domingo).

Gouldia conversi (not Trochilus conversii Bourcier and Mulsant) LAwrence, Ann. Lyc. N. Y., vii, 1862, 319 (Lion Hill, Panamá); ix, 1868, 123 (Tucurríqui, Costa Rica).-SAlvin, Proc. Zool. Soc. Lond., 1867, 154 (Santa Fé de Verágua, Panamá); 1870, 208 (Calovévora, Panamá).-Frantzius, Journ. für Orn., 1869, 315 (Costa Rica).-Gould, Proc. Zool. Soc. Lond., 1870, 803 (Citado, Ecuadór).-Zeledón, Cat. Aves de Costa Rica, 1882, 21; Anal. Mus. Nac. Costa Rica, i, 1887, 122.-Boucard, The Hum. Bird, ii, 1892, 74, part (Verágua); Gen. Hum. Birds, 1895, 42, part (Verágua; Ecuadór).

[Gouldia] conversi Sclater and Salvin, Nom. Av. Neotr., 1873, 84, part (Costa Rica; Verágua; Ecuadór).

Prymnacantha conversi (not of Cabanis and Heine) Mulsant and Verreaux, Hist. Nat. Ois.-Mouch., iii, livr. 4, 1877, 242, part (Verágua; Costa Rica; Ecuadór).-Salvin, Cat. Birds Brit. Mus., xvi, 1892, 430, part (Tucurríqui and Angostura, Costa Rica; Cordillera del Chucu, Calovévora, and Santa Fé de Verágua, Panamá; Baisa, Citado, Quito, and Chimbo, Ecuadór).-SALvin and Godman, Biol. Centr.-Am., Aves, ii, 1892, 366, part (Naranjo de Cartago, etc., Costa Rica; Lion Hill, etc., Panamá; Ecuadór).

[Primnacantha] conversi Mulsant, Ann. Soc. Linn. Lyon, xxii, 1876, 223, part.

Popelaria conversi Ridgway, Proc. U. S. Nat. Mus., iii, Oct. 27, 1880, 315 (Costa Rica).

Popelairia conversi Hartert (E. and C.), Novit. Zool., i, 1894, 19 (Naranjál, w. Ecuadór; crit.).-Ridgway, Condor, vii, 1905, 157, in text (Bonilla, Costa Rica).

P[opelairea] conversi (typica) Hartert, Das Tierreich, Troch., 1900, 223, part.

[Popelairea] conversi SHARPE, Hand-list, ii, 1900, 144, part.

Popelairea conversi conversi Carriker, Ann. Carnegie Mus., vi, 1910, 553 (Caribbean slope of Costa Rica, 1,000-3,000 ft.).

Gouldia conversi zquatorialis Berlepsch and Taczanowski, Proc. Zool. Soc. Lond., 1883, 567 (Chimbo, w. Ecuadór; coll. Count von Berlepsch).

Popelairia conversi aequatorialis HARtert, Novit. Zool., v, 1898, 494 (Chimbo; crit.).-Oberholser, Proc. U. S. Nat. Mus., xxiv, 1902, 342 (Santo Domingo and Nanegál, w. Ecuadór; crit.).

P[opelairea $]$ conversi aequatorialis Hartert, Das Tierreich, Troch., 1900, 223.

[Popelairea] æquatorialis Sharpe, Hand-list, ii, 1900, 144.

\section{Superfamily MICFOPODII.}

THE SWIFTS.

=Cypselidae Cabanis, in Wiegmann's Archiv für Naturg., 1847, pt. i, 345.Bonaparte, Consp. Av., i, 1850, 64.-Cabanis and Heine, Mus. Hein., iii, 1860, 82.-Carus, Handb., Zool., i, 1868-75, 253.-Garrod, Proc. Zool. Soc. Lond., 1873, 463.-Fuerbringer, Unters. Morph. Syst. Vög., ii, 1888, 1381.

=Cypselinae (not of Bonaparte, 1838) CABanis, in Wiegmann's Archiv für Naturg., 1847, part i, 345.-Bonaparte, Consp. Av., i, 1850, 64.-Sundevall, Met. Nat. Av. Disp. Tent., ii, 1873, 87 (English translation, 1889, 164). =Cypseli Ridgway, Bull. Ills. State Lab. N. H., no. 4, May, 1881, 185.-ShuFELDT, Linn. Soc. Journ., Zool., xx, 1888, 300; Ibis, 1893, 84-100.-Sharpe, Rev. Classif. Birds, 1891, 81; Hand-list, ii, 1900, 88.-Salvin and Godman, Biol. Centr.-Am., Aves, ii, 1892, 367. 
$==$ ?Ocyptilinæ Mune-Edwards, Ois. Foss., ii, 1867-1871.

= Micropodoideæ Stejneger, Stand. Nat. Hist., iv, 1885, 437, in text.

= Micropodoidea LucAs, Auk, vi, Jan., 1889, 12.

= Macropterygidæ (not of Lucas, 1895) Hartert, Das Tierreich, Podarg., Caprim., Macropt., 1897, 63.

Small to rather large swallow-like Macrochires with bill short, flat, and broadly triangular; gape deeply cleft and without rictal bristles; nostrils opening vertically, near together, and non-operculate; tongue not extensile; palate ægithognathous; six to seven pairs of ribs and with eight to eleven secondaries and two to three feathers composing the alula.

Palate ægithognathous; maxillo-palatines unciform; basipterygoid processes absent; metasternum convex and entire (Micropodidæ except Tachornis) or slightly concave with two foramina (Dendrochelidonidæ and Tachornis); costal process small, manubrium rudimentary, keel very high; coracoid short, not implanted in a groove, the humero-coracoid fossa absent, the epicoracoid feebly developed; furcula widely $U$-shaped, with hypoclidium small and epiclidium obsolete; ribs, 6-7 on each side, the second to sixth pairs articulating with the margin of the sternum proper and not with the costal process; humerus very short, radius longer, metacarpals very long (except in Dendrochelidonidæ); cæca absent; only the left carotid artery present (except in Micropodidæ, part) $;^{a}$ semitendinosus muscle absent; anterior toes subequal, cleft to the base, the inner toe more or less reversible, ${ }^{b}$ the hallux relatively small, directed inward or sometimes forward; deep plantar tendons coraciine (of type Va); tarsi never conspicuously longer than middle toe (with claw), always nonscutellate, sometimes feathered (occasionally the toes also); primaries 10, greatly elongated, either the tenth or ninth longest; secondaries relatively very short, 8-11 in number; alula composed of 2-3 feathers; rectrices 10 , always shorter than primaries, the tail very variable in shape but usually more or less forked or emarginate, never graduated or distinctly rounded, the shafts of rectrices (in Subfamily Chæturinæ) often very rigid and extruded, or "spinetipped."

\section{KEY TO THE FAMILIES OF MICROPODII.}

a. Tarsus longer than first digit; head without crest or ornamental plumes, flanks without a downy or silky patch, and general plumage hard; rostral portion of cranium broad; nasals triradiate, overlapping frontals; ecto-ethmoid wide; vomer T-shaped, much expanded anteriorly; palatines notched exteriorly; metasternum convex, entire (with foramina in Tachornis); ulna shorter than second metacarpal; phalanges (except ultimate and penultimate) very short or obsolete; shoulder muscles and deep plantar tendons strictly cypseline. (Cosmopolitan, except colder regions.)..................... Micropodidæ (p. 683).

a According to Garrod (Proc. Zool. Soc. Lond., 1873, 471) both carotids are present in Cypseloides fumigatus.

$b$ Said to be permanently reversed (the toes in pairs) in some genera, but I can not find that this is true from examination of specimens. 
$a a$. Tarsus shorter than first digit; head with a crest or with mystacial or superciliary plumes, flanks with a patch of downy or silky feathers, and general plumage soft; rostral portion of cranium moderate; nasals forked, abutting against frontals; ecto-ethmoid narrow; vomer scarcely expanded; palatines unnotched; metasternum slightly concave, perforated by two foramina; ulna longer than second metacarpal; phalanges not shortened; shoulder muscles passerine; deep plantar tendons characteristic. (Indo-Malayan Subregion and Papuan portion of Australian Region.).................. Dendrochelidonidæ (extralimital). ${ }^{a}$

\section{Family MICROPODID $Æ$.}

\section{THE TRUE SWIFTS. $b$}

= Micropodidæ Lucas, Auk, vi, 1889, 13 .

=A podinae + Chaeturinae Hartert, Das Tierreich, Podarg., Caprim., Macropt., $1897,62,63,65,80$.

=Cypselidx Sharpe, Hand-list, ii, 1900, 89.

Micropodii with the tarsus longer than the first digit; head without crest or plumes, flanks without downy or silky feathers, and general plumage hard; rostral portion of cranium broad; nasal triradiate, overlapping frontals; ecto-ethmoid wide; vomer T-shaped, much expanded anteriorly; palatines notched anteriorly; metasternum convex, usually entire (with foramina in Tachornis only?); ulna shorter than second metacarpal; phalanges (except ultimate and penultimate) very short or obsolete; shoulder muscles and deep plantar tendons strictly cypseline.

Bill very small, broadly triangular, depressed, the culmen rather strongly decurved, the maxillary tomium without notch; gape deeply cleft, without rictal bristles; nostrils opening vertically, near together, longitudinally elliptical or oval, nearly parallel, or more or less divergent posteriorly; frontal feathering usually extending over lower portion of nasal fossæ, sometimes nearly to anterior end of nostril, sometimes also extending forward medially, between base of nostrils; anterior toes subequal (but one or both of the lateral ones usually very slightly shorter than the middle), cleft to the base, and covered with skin or feathers (non-scutellate); hallux conspicuously smaller than lateral toes (sometimes less than half as long

a Dendrochetidonidx Lucas, Auk, vi, 1889, 12.-Macropterygida Lucas, Auk, xii, 1895, 156.-Macroptcryginæ Hartert, Das Tier., Podarg., Caprim., Macr., 1897, 63.Hemiprocnida Oberholser, Proc. Biol. Soc. Wash., xix, May 1, 1906, 68, in text.

This very well-characterized family of Swifts comprises a single genus (Hemiprocne Nitzsch, Obs. Av. Carot. Com., 1829, 15, type, Cypselus longipennis Temminck; see Oberholser, Proc. Biol. Soc. Wash., xix, 1906, 67, 68), containing about seven species. The nidification of the Dendrochelidonidæ is also peculiar, the nest being attached to the upper sicle of a branch, composed of bits of bark, etc., held together by the bird's saliva, and barely large enough to hold the single egg. They also perch freely upou branches, while none of the Micropodidæ do, so far as known.

$b$ As distinguished from the Tree Swifts, family Dendrochelidonidæ. 
as inner toe), directed inward, more or less versatile or capable of being directed forward, the inner toe also more or less versatile, or capable of being directed backward.

The Swifts are eminently aërial birds and, so far as known, are the only ones among all birds of flight which do not perch upon the branches of trees-a remarkable characteristic when their similarity in general habits in other respects to the Swallow is considered. They cling easily against the side of vertical surfaces, as a rock or the inside of a hollow tree trunk or a chimney, pressing the tail against the surface as an additional support (as in the case of woodpeckers), but apparently they are not able to grasp a branch with their feet in such a way as to maintain a fixed position thereon. ${ }^{a}$

Like the Swallows (Hirundinidæ) the Swifts are insectivorous and take their prey while flying; but their manner of flight is different, as might be expected from the very different structure of their wings. In this respect, however, there is much difference between different genera, the flight of some being characterized by a velocity perhaps unequaled among other birds, while that of others (as for example the species of Chætura) is much less rapid and more fluttering.

There are many interesting peculiarities connected with the nidification of Swifts, some of which may be briefly described. In this connection it may be mentioned that the salivary glands are often highly developed, and the glutinous or mucilaginous substance which they secrete enters more or less into the composition of the nest. In the oriental genus Collocatia (belonging to the subfamily Chæturinæ) the nest is sometimes composed entirely of this substance, and constitutes an important delicacy among Chinese and Japanese epicures. The nest of the common Chimney Swift (Chætura pelagica) of the eastern United States and related species of the same genus is of similar form to that of the "edible birds' nests" above mentioned, but is composed of dead twigs glued together by the saliva. The beautiful large black and white swift of Guatemala, Panyptila sancti-hieronymi, attaches to the under side of an overhanging rock a tube some feet in length, constructed of the pappus or seed-down of plants, caught flying in the air. Entrance to this is from the lower end, and the eggs are laid on a kind of shelf near the top. A smaller but otherwise similar species ( $P$. cayanensis) found from Nicaragua southward attaches a similar nest to the under side of a large branch of a forest tree. ${ }^{b}$ Chxtura brachyura is said to make

a The Tree Swifts (Dendrochelidonidæ), however, are said to perch upon trees in the manner of Swallows and other birds.

$b$ See Richmond, Auk, xv, 1898, 7-10, pl. 1. 
a somewhat similar nest, but with the tube more contracted below, out of seeds of Trixis divaricata, suspends it to a horizontal branch, and covers the outside with feathers; as there is no shelf on the inside, it is believed that the eggs are glued against the side and brooded on by the bird while in an upright position. ${ }^{a}$

Owing to the extreme velocity of their flight and the great height at which they usually fly, Swifts are very difficult birds to collect, and consequently comparatively few species of the family are well represented in collections. On this account it is not easy to obtain a correct understanding of their geographic range and variations; consequently our present knowledge is, in the case of many species, imperfect and tentative.

\section{KEY TO THE GENERA OF MICROPODIDA.}

$a$. Toes with the number of phalanges abnormal $(2,3,3,3)$; hallux lateral (on inner side of foot), capable of being directed forward (the foot then pamprodactylous), the inner toe sometimes reversible (capable of being directed backward), the toes then paired; tarsi (sometimes toes also) feathered. (Subfamily Micropodinx.b)

$b$. Outer and middle toes directed forward, in line with axis of tarsus; feet very strong, the tarsi relatively shorter.

c. Toes naked ...............................

$c c$. Toes feathered.

$d$. Tail slightly fe:ked (for less than one-fourth its length), the rectrices not attenuated terminally; toes more sparsely feathered; feathers of pileum and under parts distinctly outlined, broadly rounded.

Aëronautes (p. 687).

$d d$. Tail deeply forked (for at least half its length), the lateral rectrices attenuated terminally; toes more densely feathered; feathers of pileum and under parts blended.......................... Panyptila (p. 690).

$b b$. Outer and middle toes inclined outwards, at more or less of an angle with axis of tarsus; feet proportionately much weaker, with tarsus relatively longer.

$a$ This style of nest is so different from that of the species of Chrtura, whose nidification is known, that the proper identification of the species is very questionable. At the same time, it may be remarked that the suggested mode of securing the eggs is highly improbable.

b Cypselinæ (not of Bonaparte, 1838) Sclater, Proc. Zool. Soc. Lond., 1865, 579; Carus, Handb. Zool., i, 1868-75, 253.-Micropodinæ Stejneger, Stand. Nat. Hist., iv, 1885, 437, in text.-A podinæ Hartert, Das Tier., Podarg., Caprim., Macropt, 1897, 80.

c Apus (not Apos Scopoli, 1777, prior by anteriority) Scopoli, Intr. Nat. Hist., 1777, 483 (type, Mirundo apus Linnæus).-Micropus Meyer and Wolf, Taschenb. Deutschl. Vög., i, 1810, 280 (type, Hirundo apus Linnæus).-Cypselus Illiger, Prodr. Orn., 1811, 229 (type, Hirundo apus Linnæus).-Cipselus (emendation) Vieillot, Analyse, 1816, 38.-Brachypus Meyer, Vög. Liv.-u. Esthl., 1815, 142 (type, Hirundo apus Linnæus).-Cypcelus (emendation?) D’Orbigny, Voy. Am. Mérid., iv, pt. 3, $1839,357$.

This genus is numerously represented in the Eastern Hemisphere, but, so far as known, there are only two American species, both of which belong to the southern continent. 
c. Toes naked; tail forked for less than half its length $a . .$. . Tachornis (p. 693).

cc. Toes feathered; tail forked for more than half its length.

Claudia (extralimital). $b$

$a a$. Toes with the number of phalanges normal $(2,3,4,5)$; hallux more posterior, not reversible, the foot never pamprodactylous nor toes paired; tarsi and toes naked. (Subfamily Chæturinæ.) $c$

$b$. Hallux relatively longer, more than half as long as inner toe.

c. Tarsus not longer (usually shorter) than middle toe with claw.

$d$. Size very large (wing not less than $190 \mathrm{~mm}$.); tenth (outermost) primary longest, or at least not distinctly shorter than ninth; distance from tips of longest secondaries to tip of longest primary not more than two-thirds the total length of wing; tail two-ninths to one-fourth as long as wing; bill relatively much stouter; under tail-coverts and a flank-stripe white.

Hirundapus (extralimital). $d$

$d d$. Size smaller (wing less than $170 \mathrm{~mm}$., the wing relatively very long); tenth (outermost) primary distinctly shorter than ninth; distance from tips of longest secondaries to tip of longest primary much more than two-thirds the total length of wing; tail only one-sixth as long as wing, the longest coverts reaching nearly to its tip; no white on under tail-coverts or flanks.

Mearnsia (extralimital).e

cc. Tarsus longer than middle toe with claw.

d. Size very large (wing 190-230 mm.); rectrices more firm, with very rigid shafts; adults with a white collar (at least on hindneck).

Streptoprocne (p. 696).

$d d$. Size much smaller (wing less than $180 \mathrm{~mm}$.); rectrices softer, with less rigid shafts; adults without white collar.

$e$. Tail distinctly emarginate, the rectrices soft, with shafts not at all rigid nor produced.........................................

$e e$. Tail truncate or slightly rounded or double-rounded, the rectrices firm, with shafts rigid and, sometimes, slightly produced.

Cypseloides (p. 710).

bb. Hallux relatively much smaller, not more (usually less) than half as long as inner toe.........................................

a According to Gosse (Birds of Jamaica, p. 59) the sternum of Tachornis phonicobia (type of the genus) has two large metasternal foramina and also a foramen perforating the anterior portion of the keel. In this respect Tachornis differs from all other Micropodinæ, so far as known, all the latter having both the metasternum and carina sterni entire.

b Claudia Hartert, Cat. Birds Brit. Mus., xvi, 1892, 469 (type, Cypselus squamatus Cassin.

The single known species belonging to this genus occurs in Guiana, Brazil, and eastern Peru.

$c=$ Chxturinæ Sclater, Proc. Zool. Soc. Lond., 1865, 597; Stejneger, Stand. Nat. Hist., iv, 1885, 437; Hartert, Das Tierreich, Podarg., Caprim., Macropt., 1897, 63, 65. $>$ Chaturinae Carus, Handb. Zool., i, 1868-75, 253 (includes Dendrochelidonidæ).

d Hirund-apus Hodgson, Journ. Asiat. Soc. Bengal, v, no. 60, Dec., 1836, 780, in text. (Type, Chxtura nudipes Hodgson.)-Hirundinapus (emendation) Sclater, Proc. Zool. Soc. Lond., 1865 (March, 1866), 607.-Pallene Lesson, Compl. Buffon, viii, 1837, 493. (Type, Cypselus giganteus Temminck.)

$e$ New genus. Dedicated to Dr. Edgar A. Mearns, U. S. A., not only in recognition of his valuable services to ornithology, but also as a token of the author's high esteem. (Type, Chrotura picina Tweeddale.) 


\section{Genus A $\ddot{E}$ RONAUTES Hartert.}

Aëronautes a Hartert, Cat. Birds Brit. Mus., xvi, 1892, 459. (Type, Cypselus melanoleucus Baird.)

Medium-sized Cypselinæ (length, about 135-152 mm.) with toes (as well as tarsus) feathered, outer and middle toes directed forward on line with axis of tarsus, tail forked for less than one-fourth its length, and feathers of pileum and under parts distinctly outlined (broadly rounded).

Tail about half as long as wing, moderately forked (for less than one-fourth its length), the lateral rectrices not attenuated terminally, the outermost pair little if any longer than next pair; tenth (outermost) primary shorter than ninth, but equal to or longer than eighth; feet very stout, the toes short and thick and claws strong; tarsi and toes feathered (except on soles of latter); middle toe slightly longer than tarsus, but scarcely longer than inner toe, which is slightly longer than the outer; hallux very short, inserted laterally on inner side of foot.

Coloration.-Dusky above and on lateral under parts; throat, chest, median line of breast and abdomen, and a patch on upper flanks or sides of rump, dull white.

Nidification.-Nest placed in crevices of vertical cliffs or walls of old buildings, composed of feathers, bark, grass, wool, cotton, etc., glued to its support by salivary excretion.

\section{AËRONAUTES MELANOLEUCUS (Baird).}

WHITE-THROATED SWIFT.

Adults (sexes alike).-Pileum and hindneck grayish brown to very dark sooty brown, sometimes uniform but usually becoming paler on forehead, and with feathers indistinctly margined with paler, especially on frontal region, the projecting edges of crown dull whitish, forming a distinct narrow superciliary streak; back, scapulars, wing-coverts, rump, and upper tail-coverts plain sooty blackish, the tail similar but rather more sooty (less blackish); a large patch of white or brownish white on each side of rump, more or less pointed anteriorly; remiges dark sooty brown or sooty blackish, the secondaries broadly tipped on outer web with dull or brownish white, the inner webs of primaries passing into pale grayish brown on edges (except on longer quills); a dusky spot immediately in front of eye, the loral region otherwise whitish; auricular and postocular regions sooty grayish brown; suborbital and malar regions, chin, throat, chest, and median portion of breast and abdomen white (usually dull or more or less tinged with brownish); sides and flanks (broadly) and under tailcoverts plain very dark sooty brown or sooty black; feathers along 
edge of wing broadly margined with pale grayish brown or dull brownish white; bill black; iris dark brown; feet dull livid pinkish. Adult male.-Length (skins), 138-152 (147); wing, 131-148 (145); tail, 53.5-63.5 (57.5); exposed culmen, 5-6.5 (5.9); tarsus, 9.5-11 (10.2); middle toe, $6.5-8$ (7.6) ${ }^{a}$

Adult female.-Length (skins), 136-152 (145); wing, 135.5-149 (142.5); tail, 52.5-61.5 (57); exposed culmen, 6-6.5 (6.2); tarsus, 10-11 (10.3); middle toe, $7-8$ (7.3). ${ }^{b}$

Young.-Similar to adults, but white of under parts duller (more or less grayish or sooty) and blackish of sides duller, especially anteriorly, where more sooty grayish and less strongly contrasted with whitish of throat, etc.

Western United States and southward to Guatemala; north to Washington (Lake Chelan), southern Montana (Belt River), and southwestern Alberta (Henry House), east to western South Dakota (Sturgis; Bad Lands), western Nebraska, Wyoming (Hanton's ranch; between Cheyenne and Fort Laramie), Colorado, New Mexico, and western Texas (Chisos Mountains), south to Lower California (San Pedro Martir Mountains; Coronados Islands; Guadalupe Island), and through Mexico (Senoyita, etc., Sonora; Chico, Hidalgo; Miquihuana, Nuevo León; mountains near Orizaba, Vera Cruz ?), to highlands of Guatemala (gorge of Rio Guacalate, near Dueñas); apparently breeding throughout its range.

?Acanthylis saxatilis Woophouse, Rep. Sitgreaves' Expl. Zuñi and Col. R., 1853, 64 (Inscription Rock, New Mexico).c-Cassin, Illustr. Birds Cal., Tex., etc., 1855, 252.-Coues, Ibis, 1865, 356, in text.

[Panyptila] saxatilis Coues, Key N. Am. Birds, 1872, 182.

\begin{tabular}{|c|c|c|c|c|c|}
\hline$a$ Fourteen specimens. & $b$ Ten & specir & mens. & & \\
\hline Locality. & Wing. & Tail. & $\begin{array}{c}\text { Ex- } \\
\text { posed } \\
\text { culmen. }\end{array}$ & Tarsus. & $\begin{array}{c}\text { Middle } \\
\text { toe. }\end{array}$ \\
\hline \multicolumn{6}{|l|}{ MALES. } \\
\hline Ten adult males from Rocky Mountain district, United States. & 140.9 & 58 & 6 & 10.3 & 7.8 \\
\hline Three adult males from California............................. & 139.5 & 55 & 5.5 & 9.8 & 7 \\
\hline 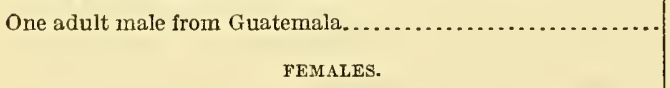 & 148 & 60 & 5.5 & 9.5 & 7 \\
\hline 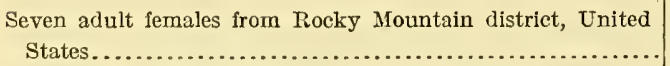 & 142.3 & 57.6 & 6.2 & 10.2 & 7.4 \\
\hline One adult female from California........................... & 141 & 54.5 & 6 & 10 & 6.5 \\
\hline One adult female from Nuevo Leon (Miquihuana)............ & 144.5 & 54 & ....... & 11 & 7.5 \\
\hline 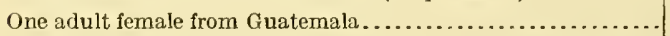 & 143.5 & 59 & 6.5 & 10.5 & 7.5 \\
\hline
\end{tabular}

$c$ No specimens obtained, and, although there can be no doubt that this is the species seen, the description is not entirely applicable. See Baird, Rep. Pacific R. R. Surv., ix, 1858, 143. 
Panyptila saxatilis Coues, Check List, 1873, no. 269; 2d ed., 1882, no. 403; Birds Northwest, 1874, 265.-Ridgway, Bull. Essex Inst., 1875, 20, 21 (Toyabe and East Humboldt Mts., Nevada); Orn. 40th Parallel, 1877, 564 (Salt Lake City, Utah, etc.; habits).-Henshaw, Rep. Orn. Spec. Wheeler's Surv., 1874, 129 (Ft. Wingate, New Mexico; habits); Zool. Expl. W. 100th Merid., 1875, 370 (Inscription Rock and Ft. Wingate, New Mexico).-Mrnot, Bull. Nutt. Orn. Club, v, 1880, 231 (Manitou, Colorado; breeding).

$P[$ anyptila $]$ saxatilis Coues, Key N. Am. Birds, 2 d ed., 1884, 456.

Panyptila saxitilus Yarrow and Henshaw, Rep. Orn. Spec. Wheeler's Surv., 1874, 23 (between Grass Valley and Gunnison, Utah).

Cypselus saxatilis Ridgway, Proc. U. S. Nat. Mus., iii, March 27, 1880, 6, 188; Nom. N. Am. Birds, 1881, no. 349.-Williams, Bull. Nutt. Orn. Club, vii, 1882, 123 (Belt R., Montana).--Belding, Proc. U. S. Nat. Mus., v, 1883, 547 (San José del Cabo, Lower California, May 17).-Allen and Brewster, Bull. Nutt. Orn. Club, viii, 1883, 196 (Colorado Springs, Garden of the Gods, Cheyenne Canyon and Williams Canyon, Colorado).-Drew, Auk, ii, 1885, 17 (Colorado, breeding at 6,000-12,500 ft.).

Micropus saxatilis Stejneger, Auk, i, July, 1884, 230.

Cypselus melanoleucus Barrd, Proc. Ac. Nat. Sci. Phila., vii, June, 1854, 118 (San Francisco Mt., Arizona; coll. U. S. Nat. Mus.).-Cassin, Illustr. Birds Cal., Tex., etc., 1855, 248.-Kennerly, Rep. Pacific R. R. Surv., iv, pt. vi, 1856, 16 ("Camp 123").

[Cypselus] melanoleucus Gray, Hand-list, i, 1869, 64, no. 738.

Panyptila melanoleuca BAIRD, Rep. Pacific R. R. Surv., ix, 1858, 141; ed. 1860 (Birds N. Am.), 141, pl. 18, fig. 1.-Heermann, Rep. Pacific R. R. Surv., x, no. 1, 1859, 10 (San Fernando Pass and Palm Spring, California; Tucsón, Arizona; "Texas"); pt. iv, no. 2, 1859, 35.-Kennerly, Rep. Pacific R. R. Surv., x, pt. iv, no. 3, 1859, 23, pl. 18, fig. 1 (Bill Williams Fork, Arizona).Sclater and Salvin, Ibis, 1859, 125 (Dueñas, Guatemala; habits).-Cooper, Proc. Cal. Ac. Sci., 1861, 122 (Cajón Pass, Califormia); Orn. Cal., 1870, 347.Sclater, Proc. Zool. Soc. Lond., 1865, 607 (Dueñas); Journ. für Orn., 1867, 128.-Coues, Proc. Ac. Nat. Sci. Phila., 1866, 57 (Inscription Rock, New Mexico; habits).-Sumichrast, Mem. Bost. Soc. N. H., i, 1869, 562 (mts. near Orizaba, Vera Cruz?).-Aluen, Bull. Mus. Comp. Zool., iii, 1872, 151, 180 (Colorado; habits).-Arken, Proc. Bost. Soc. N. H., xv, I872, 206 (Colorado).-Salvin, Ibis, 1873, 428 (Guatemala).-RIdgway, Bull. Essex Inst., v, 1873, 173, 185 (Salt Lake City, Utah; Colorado).-BAIrd, Brewer, and Ridgway, Hist. N. Am. Birds, ii, 1874, 424, pl. 45, fig. 5; iii, 1874, 521 (Santa Ana and San Buenaventura, California).

[Panypila] melanoleuca Sclater and Salvin, Nom. Av. Neotr., 1873, 94.

Panyplela melanoleuca Allen, Am. Nat., vi, 1872, 350 (Garden of the Gods, Colorado).

Micropus melanoleucus RIDGway, Auk, i, Juiy, 1884, 230, footnote--AMErican Ornithologists' Union, Check List, 1886, no. 425.-Evermann, Auk, iii, 1886, 180 (Santa Paula Creek, Ventura Co., California).-Sсотт, Auk, iii, 1886, 430 (Santa Catalina Mts. and near Tucson, Arizona).-Bryant (IV. E.), Bull. Cal. Ac. Sci., ii, 1887, 291 (Guadalupe Island; habits).-Shufeldt, Ibis, 1887, 151, pl. 5 (bet. Cheyenne and Laramie, Wyoming; Ft. Wingate, New Mexico; habits).-Mearns, Auk, vii, 1890, 255 (Ft. Verde and San Francisco Mt., Arizona).-Lowe, Auk, xi, 1894, 268 (Wet M[ts., Colorado, $10,000 \mathrm{ft}$.).

M[icropus] melanoleucus Ridgway, Man. N. Am. Birds, ]887, 303.

$$
\text { S1255 - Bull. 50-11- } 14
$$


Aëronautes melanoleucus Hartert, Cat. Birds Brit. Mus., xvi, 1892, 459.Salvin and Godman, Biol. Centr.-Am., Aves, ii, 1892, 368.-Anthony, Zoë, iv, 1893, 237 (San Pedro Martir Mts., etc., and Coronados Islands, Lower California); Auk, xii, 1895, 139 (San Fernando, Lower California; breeding).-American Ornithologists' Union Committee, Auk, x, 1893, 62; Check List, 2d ed., 1895, no. 425; 3d ed., 1910, 201.-Bendire, Life Hist. N. Am. Birds, ii, 1895, 185.-DAwson, Wilson Bull., no. 10, 1896, 4 (Columbia R. gorge, Okanogan Co., Washington); Auk, xiv, 1897, 175 (Okanogan Co., Washington).-Grinnell, Pub. 1, Pasadena Ac. Sci., 1897, 9 (San Nicolas I., California), 15 (San Clemente I., breeding); Pub. 2, 1898, 27 (Los Angeles Co., resident).-Cooke, Bull. Col. Agr. Coll., no. 37, 1897, 86 (Colorado, breeding from 6,000 to at least $12,000 \mathrm{ft}$.).-Merriam, North Am. Fauna, no. 16, 1899, 117 (Mt. Shasta, California).-CARY, Auk, xviii, 1901, 234 (Black Hills, Wyoming, breeding).-ОвеRHoLser, Auk, xix, 1902, 300 (Chisos, Guadalupe, and Davis mountains, w. Texas).-BaILEy (Florence M.), Handb. Birds W. U. S., 1902, 232; Condor, ix, 1907, 169-172 (Capistrano, San Jacinto Mts., s. California; breeding habits).-Brewster, Bull. Mus. Comp. Zool., xli, 1902, 112 (Sierra de la Laguna, Lower California; crit., etc.).-Swarth, Pacific Coast Avif., no. 4, 1904, 16 (Huachuca Mits., Arizona; habits).-Richardson, Condor, vi, 1904, 135 (Piute Mts., Calif.).-MontGomery, Auk, xxii, 1905, 14 (Green Gulch, Brewster Co., Texas).-Kaeding, Condor, vii, 1905, 134 (Guadalupe Island, flock, March 25).-SHarp, Condor, ix, 1907, 88 (San Diego Co., California, breeding).-Preble, North Am. Fauna, no. 27, 1908, 390 (15 m. s. of Henry House, s. w. Alberta, 1 spec., July).-Richardson, Condor, x, 1908, 66 (Santa Catalina Is., California).Linton, Condor, x, 1908, 84 (San Clemente I.), 127 (Santa Cruz I., Dec.).Bowles, Condor, $\mathrm{x}, 1908$, 192 (Lake Chelan, Washington, breeding).Hanna, Condor, xi, 1909, 77-81 (breeding habits, etc.; descr. nest and eggs).-Wright, Condor, xi, 1909, 100 (Coronados Islands, Lower California).-Brooks, Auk, xxvi, 1909, 62 (Vaseux Lake, Okanogan Distr., Brit. Columbia).-Visher, Auk, xxvi, 1909, 148 (badlands of w. South Dakota).-Kermode, Prov. Mus. Vict., 1909, 51 (Keremos and Okanogan, Brit. Columbia).

A[eronautes] melanoleucus Ridgwax, Man. N. Am. Birds, 2d ed., 1896, 303.-

Hartert, Das Tierreich, Podarg., Caprim., Macropt., 1897, 83

[Aëronautes] melanoleucus SHARPE, Hand-list, ii, 1900, 94.

\section{Genus PANYPTILA Cabanis.}

Panyptila a Cabanis, Wiegm. Archiv für Naturg., xiii, 1847, I, 345. (Type, Hirundo cayanensis Gmelin.)

Pseudoprocne Streubel, Isis, 1848, 357. (Type, Hirundo cayanensis Gmelin.)

Similar to Aëronautes, but with tail much more deeply forked (for at least half its length), the lateral rectrices attenuated, toes more densely feathered, and plumage of pileum and under parts soft and blended.

Outermost (tenth) primary acuminate, shorter than ninth but longer than eighth; tail about half as long as wing, forked for half its length or more, the lateral rectrices attenuated terminally; tarsus much longer than anterior toes, very stout; middle and inner toes

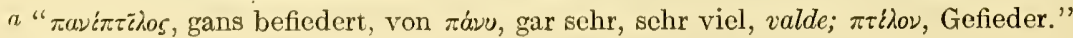
(Cabanis.) 
equal in length, the outer slightly but decidedly shorter; hallux very short; all the toes, together with their claws, very strong, and, together with tarsus, rather densely feathered.

Coloration.-Glossy blue-black, relieved by a small white spot on each side of forehead, a white area covering chin, throat, upper chest, and sides of neck (extending across hindneck as a narrow band), and a white patch on each side of rump; secondaries and distal primaries grayish toward tip and margined terminally with white. Sexes alike.

Nidification.-Nest a long tubular structure, open at lower end and attached at the more or less enlarged upper end to the under surface of an overhanging rock or base of a branch of large tree, composed of downy plant seeds, plant down, bits of bark or lichens, etc., glued together by the bird's salivary excretion. Eggs placed in a lateral pocket within the enlarged upper portion of the tube.

KEY TO THE SPECIES OF PANYPTILA.

a. Smaller (wing 116-120). (Nicaragua to Brazil and Ecquador.)

Panyptila cayanensis (p. 691). a. Larger (wing 180-195). (Guatemala.) ...... Panyptila sancti-hieronymi (p. 692).

\section{PANYPTLA CAYANENSIS (Gmelin).}

CAYENNE SWIFT

Adults (sexes atite).--General color uniform velvety black with a faint bluish gloss; inner webs of primaries and terminal portion of secondaries mostly, or in part, dark grayish brown, the former narrowly edged, the latter terminally margined with white; a patch on each side of rump, a supraloral spot or broad streak, chin, throat, upper chest, and sides of neck white, the latter confluent with a band or collar of grayish white or pale brownish gray across hindneck; outer web of outermost pair of rectrices dull white or pale grayish basally; bill black; iris dark brown; feet (where not feathered) grayish brown or dusky, claws pale grayish brown or grayish white.

Adult male.-Length (skins), 118-121 (119.5); wing, 118-120 (119); tail, 55.5-60 (57.7); exposed culmen, 5-6.5 (5.7); tarsus, 8.5; middle toe, $6-7(6.5) .^{a}$

Adult female.--Length (skins), 119-123 (121); wing, 116.5-117.5 (117); tail, 54-58 (56); exposed culmen, 5.5-6 (5.7); tarsus, 8; middle toe, $5.5-6(5.7) .^{a}$

Southeastern Nicaragua (Rio Escondido) and southward through eastern Costa Rica, ${ }^{b}$ eastern Panamá (Rio Chagres) through Colombia (Bogotá; Antioquía), Venezuela, the Guianas, and Amazon

$a^{*}$ Two specimens.

$b$ The species has not yet been recorded from Costa Rica, however, so far as I am aware. 
Valley to western Ecuadór (Guayaquíl), southeastern Brazil (Bahia), and Trinidád.

[Hirundo] cayanensis Gmeurn, Syst. Nat., ii, 1789, 1024 (based on Le Martinet à collier blane Buffon, Hist. Nat. Ois., vi, 671; Martinet à collier de Cayenne Daubenton, Pl. Enl., pl. 725, fig. 2).-Latham, Index Orn., ii, 1790, 583.

Cypselus cayanensis StepHens, Shaw's Gen. Zool,; x, 1817, 75.-LÉotaud, Ois. Trinidad, 1866, 81.

[Cypselus] cayanensis Bonaparte, Consp. Av., i, 1850, 66.-Gray, Hand-list, i. 1869,64 , no. 737 .

Panyptila cayanensis Burmeister, Syst. Ueb. Th. Bras,, ii, 1856, 369.-Sclater, Proc. Zool. Soc. Lond., 1865, 606 (monogr.; Cayenne; Bahia).-PelzelN, Orn. Bras., iv, Abth., 1870, 401.-Barrd, Brewer, and Ridgway, Hist. N. Am. Birds, ii, 1874, 424, footnotes.-Sclater and Salvin, Proc. Zool. Soc. Lond., 1879, 531 (Antioquía and Bogotá, Colombia).-Hartert, Cat. Birds Brit. Mus., xvi, 1892, 461 (Merumé Mts., Brit. Guiana; Venezuela; Bogotá and Antioquía, Colombia; Veneznela; Bahia, Pará, and Santarém, Brazil; Samiria, upper Amazon).-Richmond, Proc. U. S. Nat. Mus., xvi, 1893, 515 (Rio Escondido).-Chapman, Bull. Am. Mus. N. H., vi, 1894, 58 (Trinidád).Goeldi, Bolet. Mus. Paraense, ii, no. 4, 1898, 430, pl., figs. 1-4 (nest).

[Panyptila] cayanensis Sclater and Salvin, Nom. Av. Neotr., 1873, 94.-Sharpe, Hand-list, ii, 1900, 95.

P[anyptila] cayanensis Hartert, Das Tierreich, Podarg., Caprim., Macropt., 1897, 83.

[Panyptila cayanensis] var. cayanensis BAIRD, Brewer, and RIDGWAY, Hist. N. Am. Birds, ii, 1874, 424.

Hirundo cayenensis Vieillot, Nouv. Dict. d'Hist. Nat., xiv, 1817, 513.

Panyptila cayenensis Rrchmond, Auk, x, 1893, 84 (Rio Escondido, Nicaragua; descr. nest).

Panyptila cayennensis Cabanis, Wiegmann's Archiv für Naturg., xiii, 1847, pt. i, 345.-Sclater, Proc. Zool. Soc. Lond., 1865, 606 (Cayenne; Bahia); Journ. für Orn., 1867, 128; Ibis. 1897, 262 (Leguan, Essequibo R., Brit. Guiana; descr. nest).-LaYard, Ibis, 1873, 389 (Pará, lower Amazon).Berlepsch and Taczanowshi, Proc. Zool. Soc. Lond., 1883, 569 (Guayaquíl, w. Ecuador).--Salvin, Ibis, 1885, 436 (Merumé Mits., Brit. Guiana).Sclater (W. L.), Ibis, 1885, 318 (Guiana).-Salvin and Godman, Biol. Centr.-Am., Aves, ii, 1892, 370 (Rio Chagres, Panamá; etc.).-Richmond, Auk, xv, 1898, 7-10, pl. 1 (habits, notes, descr. nest, etc.; colored plate of bird and nest).-Berlepsch, Novit. Zool., xv, 1908, 268 (Cayenne).

\section{PANYPTILA SANCTI-HIERONYMI Salvin.}

\section{SAN GERÓNIMO SWIFT.}

Precisely like $P$. cayanensis in coloration but about twice as large. Adult (sex not determined).-Length (skins), 181-198 (188.5); wing, 185.5-190.5 (188); tail, 86.5-88 (87.2); ${ }^{a}$ exposed culmen, 8; tarsus, 13 ; middle toe, $9.5 .^{b}$

Highlands of Guatemala (San Gerónimo and Pיebla Vieja, Vera Paz; Volcán de Fuego; near Antigua).

I'anyptila suncti-jeromæ SAlvrn, Ibis, 1863, 239, in text (nomen nudum); Proc. Zool. Soc. Lond., 1863, pl. 23. 
anyptila sancti-hieronymi Salvin, Proc.Zool. Soc. Lond., 1863, 190 (San Gerónimo, Vera Paz, Guatemala; coll. Salvin and Godman).-Sclater, Proc. Zool. Soc. Lond., 1865, 607 (monogr.); Journ. für Orn., 1867, 128.-SAlviN, Ibis, 1866, 195 (Guatemala; habits); 1874, 188 (breeding habits, etc.).-BAIRD, BrEwEr, and Ridgway, Hist. N. Am. Birds, ii, 1874, 424, footnote.-Salvin and GodMan, Biol. Centr.-Am., Aves, ii, 1892, 371 (San Gerónimo, Volcán de Fuego, and vicinity of Antigua).

anyptila] sancti-hieronymi Sclater and Salvin, Nom. Av. Neotr., 1873, 94.-

Sharpe, Hand-list, ii, 1900, 95.

[Cypselus] sancti hieronymi Gray, Hand-list, i, 1869, 64, no. 739.

Panyptila sanctihieronymi Hartert, Cat. Birds Brit. Mus., xvi, 1892, 462.

P[anyptila] sanctihieronymi Hartert, Das Tierreich, Podarg., Caprim., Macropt., 1897, 83.

[Panyptila cayanensis] var. sancti-hieronymi BAIRD, BrEwer, and Ridgway, Hist. N. Am. Birds, ii, 1874, 424.

\section{Genus TACHORNIS Gosse.}

Tachornis Gosse, Birds Jamaica, 1847, 58. (Type, T. phonicobia Gosse.)

Small Micropodidæ (length about 90-100 mm.) with outer and middle toes inclined outward, inner toe freely reversible, toes naked, and tail forked for much less than half its length, the outermost rectrices not attenuated terminally.

Outermost (tenth) primary equal to or shorter than eighth, the ninth longest, the tenth short-acuminate terminally; tail less than half as long as wing, forked for much less than half its length, the lateral rectrices not attenuated terminally; tarsus much longer than anterior toes, rather stout, feathered in front; middle toe very slightly longer than lateral toes, the inner toe freely reversible; toes naked. (Unique among Micropodinæ in character of sternum. ${ }^{a}$ )

Coloration (of American species).-Above sooty blackish, lighter on head and neck; a white patch on each side of rump; throat and abdomen dull whitish, rest of under parts sooty.

Nidification.-Nest placed within a hollow spathe or attached to under side of a frond of a palm tree, composed of feathers and plantdown or other soft vegetable fiber (usually down of the Bombax or silk-cotton tree), firmly glued to its support by salivary secretion, the materials of the inner portion also densely felted together with the same substance.

\section{KEY TO THE SUBSPECIES OF TACHORNIS PHENICOBIA.}

a. Back black, decidedly darker than pileum; sides nearly black, abruptly contrasted with white of abdomen; tail less deeply forked. (Jamaica; Haiti.)

Tachornis phœnicobia phœnicobia (p. 694). aa. Back dark sooty brown, little darker than pileum; sides dark sooty brown, fading gradually into (or at least not abruptly contrasted with) white of abdomen; tail more deeply forked. (Cuba.)......... Tachornis phœnicobia yradii (p. 695).

$a$ So far as known, all Micropodinæ except Tachornis have the metasternum and carina sterni entire; but (according to Gosse, Birds of Jamaica, p. 59) Tachomis phonicobia has not only two large metasternal foramina, but also has an opening through the anterior portion of the keel. 


\section{TACHORNIS PHENICOBIA PHCENICOBIA GosSe.}

JAMAICAN PALM SWIFT.

Adults (sexes alike).-Pileum and hindneck deep or dark sooty brown (sepia to nearly clove brown); back, scapulars, median portion of upper rump, upper tail-coverts, and tail black or sooty black; rump (except median upper portion) white; wings sooty blackish, the inner webs of primaries paler, especially toward edges, the secondaries narrowly margined terminally with paler; a blackish space immediately in front of eye, with a less distinct (sometimes nearly obsolete) dull whitish space immediately beneath it; anterior portion of loral region, suborbital region, auricular region, and sides of neck grayish brown (broccoli brown or hair brown); chin, throat, and chest dull white (the first sometimes more or less extensively grayish brown), the feathers grayish brown basally; sides dark sooty brown, this extending across upper breast as a more or less continuous narrow band; abdomen and lower median portion of breast dull white; under tail-coverts very dark sooty brown or sooty black; bill dull black; iris dark brown; feet dusky.

Young.-Not essentially different from adults, but white of under parts duller, especially that of abdominal area, and brown of sides and under tail-coverts paler.

Adult male.-Length (skins), 94-96 (95); wing, 100.5-102.5 (101.7); tail, 39-40 (39.3); exposed culmen, 4-4.5 (4.3); tarsus, 7-7.5 (7.2); middle toe, $4-5$ (4.5). ${ }^{a}$

Adult female.-Length (skins), 94-100 (98); wing, 97-102 (100.7); tail, 38.5-44.5 (41.5); exposed culmen, 4-4.5 (4.4); tarsus, 7 ; middle toe, $4.5 .^{b}$

Islands of Jamaica (Spanishtown; Kingston; St. Andrews; Hope Garden) and Haiti (near Jacmél; Santo Domingo).

Tachornis phonicobia Gosse, Birds Jamaica, 1847, 58; Illustr. Birds Jamaica, 1849, pl. 9.-Albrecht, Journ. für Orn., 1862, 194 (Jamaica).-Мarch, Proc. Ac. Nat. Sci. Phila., 1863, 287 (Jamaica).

T[achornis] phonicobia Newton (E. and A.), Handb. Jam., 1881, 108.

T[achornis] phoenicobius Hartent, Das Tierreich, Podarg., Caprim., Macropt., 1897, 82, part (Jamaica; Haiti).

[Tachornis] phœenicobius SHARpe, Hand-list, ii, 1900, 94, part (Jamaica; Haiti).

[Cypselus] phaenicobia Bonaparte, Consp. Av., i, 1850, 66, part.

Cypselus phœnicobius Sclater, Proc. Zool. Soc. Lond., 1865, 604, part (Jamaica); Journ. für Orn., 1867, 125, part (Jamaica; monogr.).-Cory, Bull. Nutt. Orn. Club, vi, 1881, 153 (Haiti); Birds Haiti and San Dom., 1855, 87, pl. (22), fig. 12; Auk, iii, 1886, 344, part (Jamaica; Haiti); Birds West Ind., 1889, 139, part (Jamaica; Haiti).-Scotт, Auk, ix, 1892, 276 (Jamaica).-Field, Auk, xi, 1894, 125 (Port Henderson, Jamaica).

a Three specimens, from Jamaica.

$b$ Five specimens, but measurements of tarsus and middle toe from only one.

Three specimens from Haiti, but with sex undetermined, measure as follows: Wing, 99-103.5 (101.7); tail, 39-40 (39.5); exposed culmen, 4; tarsus, 7; middle toe, 4.5. 
[Cypselus] phonicobius Gray, Hand-list, i, 1869, 64, no. 733, part (Jamaica).Sclater and Salvin, Nom. Av. Neotr., 1873, 94, part (Jamaica).-Cory, List Birds West Ind., 1885, 17, part (Jamaica; Haiti).

Tachornis phonicobius CoRr, Cat. West Ind. Birds, 1892, 12, 43, part (Jamaica; Haiti).

Cypselus cayennensis? (not Hirundo cayanensis Gmelin) Sallé, Proc. Zool. Soc. Lond., 1857, 232 (Santo Domingo).

Cypselus cayanensis? Bryant, Proc. Bost. Soc. N. H., xi, 1867, 95 (Santo Domingo).

\section{TACHORNIS PHENICOBIA YRADII (Lembeye).}

\section{CUBAN PAIM SWIFT.}

Similar to T. p. phonicobia, but tail more deeply forked, back averaging much more sooty (less black), color of sides averaging decidedly paler, and sides of head more extensively grayish brown; averaging larger.

Adult male.-Length (skins), 96-107 (102); wing, 94.5-106 (100.6); tail, 38-47 (42.5); exposed culmen, 4-5 (4.4); tarsus, 6.5-7 (6.8); middle toe, $4-4.5(4.3){ }^{a}$

Adult female.-Length (skins), 102-113 (108); wing, 98.5-110 (106); tail, 41-48 (45.9); exposed culmen, 4.5-5 (4.6); tarsus, 6.5-7.5 (7); middle toe, $4-4.5(4.2){ }^{a}$

Island of Cuba (Monte Verde; Pinár del Rio; Guánajay; Batabano; Holquín; San Pablo: Trinidád).

Cypselus yradii Lembeye, Aves de la Isla de Cuba, 1850, 50, pl. 7, fig. 4.

Tachornis iradii GuNDLACH, Journ. für Orn., 1860, 268; 1874, 116 (habits); Repert. Fisico-Nat. Cuba, 1866, 95.-Albrecht, Journ. für Orn., 1861, 208.

[Tachornis] iradii GuNDLACH, Journ. für Orn., 1861, 330.

Tachornis gradii (typographical error) BrEwer, Proc. Bost. Soc. N. H., vii, $1860,306$.

Tachornis phoenicobius (not T. phonicobia Gosse) CABANIs, Journ. für Orn., 1856, 5.-Gundlach, Journ. für Orn., 1861, 411.-Corr, Cat. West Ind. Birds, 1892, 12, 43, part (Cuba).

[Tachornis] phonicobius Sharpe, Hand-list, ii, 1900, 94, part.

T[achornis] phoenicobius Hartert, Das Tierreich, Podarg., Caprim., Macropt., 1897, 82, part (Cuba).

Cypselus phonicobius Sclater, Proc. Zool. Soc. Lond., 1865, 604, part (Cuba); Journ. für Orn., 1867, 125, part (Cuba; monogr.).-Conx, Auk, iii, 1886, 344, part (Cuba); viii, 1891, 294 (Cuba); Birds West Ind., 1889, 139, part (Cuba).

[Cypselus] phœnicobius GraY, Hand-list, i, 1869, 64, no. 733, part (Cuba).Sclater and Salvin, Nom. Av. Neotr., 1873, 94, part (Cuba).-Cory, List Birds West Ind., 1885, 17, part (Cuba).

Tachornis phonicobia Chapman, Bull. Am. Mus. N. H., iv, 1892, 302 (Sau Pablo, s. Cuba).

[Cypselus] phaenicobia Bonaparte, Consp. Av., i, 1850, 66, part.

Cypselus phænicobius Menegaux, Rev. Franç. d'Orn., no. 2, 1909, 26 (Guantanamo and San Carlos, Cuba).

Tachornis phoernicobius GunduAcr, Orn. Cubana, ed. 1895, 98. 


\section{Genus STREPTOPROCNE Oberholser.}

Streptoprocne a Oberholser, Proc. Biol. Soc. Wash., xix, May 1, 1906, 69, in text. (Type, Hirundo zonaris Shaw.)

Very large Chæturine Swifts (wing 180-235 mm.) with the hallux more than half as long as inner toe, tarsus longer than middle toe with claw, lateral toes scarcely shorter than middle toe, shafts of rectrices very rigid and more or less produced terminally, the coloration plain blackish or sooty with a white collar, at least across hindneck.

Nostrils elliptical, nearly parallel, for the greater part (sometimes wholly) anterior to the latero-frontal antia; distance from tips of longest secondaries to that of longest primary a little less than two-thirds the total length of wing; tenth (outermost) primary longest; tail about one-third as long as wing, emarginate (S. zonaris) or truncate (S. semicollaris), the rectrices firm, with very rigid and more or less extruded shafts; tarsus longer than middle toe with claw; middle and outer toes equal in length, the inner toe very slightly shorter; hallux (without claw) more than half as long as inner toe (without claw). ${ }^{b}$

Coloration.-Plain blackish or sooty, the adults with a white collar, at least across hindneck.

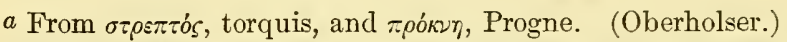

$b$ A peculiarity in the myology of Streptoprocne is thus described by Dr. F. A. Lucas in The Auk, xvi, 1899, 97:

It might be supposed that the anatomical possibilities of so small a group as the Swifts had been exhausted, but that this is not the case is shown by an examination of Hemiprocne zonaris, for which I am indebted to Mr. C. B. Taylor, of Jamaica. The cranium is typically cypseline, so are the wing muscles, although the deltoid is small, as in the majority of the true Swifts, there being an apparent tendency to reduction in the number of wing muscles in birds which fly, so to speak, by main strength and in which the humerus is reduced in length. The leg muscles are curious first by the absence of the peroneus longus, a muscle which runs from the head of the tibia to the upper end of the tarsus in Passeres, and second by the great simplification of the deep plantar tendons. In the Passeres, as we all know, one tendon flexes the first digit of the foot, while another with three branches flexes the three front toes. In the Tree Swifts, Macropterygidæ, the tendon of the hind toe is attached by a short slip to the branch running to the fourth digit. In the other Swifts so far examined the two main tendons are completely fused for some distance although worked by two muscles. Now in Hemiprocne [i. e., Streptoprocne] while the muscle which ordinarily works the front toes, the flexor perforans, is present, it has no separate tendon, but is attached to the muscle of the first digit, flexor longus hallucis, and is diverted to the work of pulling on its tendon, which as usual runs up over the outer side of the belly of the muscle. Below this single tendon sends off four slips, one to each digit, thus presenting the simplest condition possible and literally realizing Gadow's statement that the flexor longus hallucis is really a common flexor of all digits. If a good generic character is needed for Hemiprocne [Streptoprocne], here it is. 
Nidification.-Nest in cavities of rocks, composed of mud and moss. ${ }^{a}$ Range.-Southern Mexico to southern Brazil, Bolivia, and Peru; Cuba; Haiti; Jamaica; Grenada. (Three species.)

KEY TO THE SPECIES AND SUBSPECIES OF STREPTOPROCNE.

a. Tail emarginate; under parts with more or less of white; smaller (wing not more than $204 \mathrm{~mm}$.).

b. Under parts black with a white band across chest. (Adults.)

c. White collar continuous around neck. (Streptoprocne zonaris.)

$d$. Forehead sooty black, scarcely if at all different from color of cromn.

$e$. General color less intensely black (more sooty); larger (wing $214 \mathrm{~mm}$.).

(Southern Brazil and northern Argentina.)

Streptoprocne zonaris zonaris (extralimital). $b$

$e e$. General color deep or intense black; smaller (wing 18s-207 mm.). (Northern South America to Costa Rica.)

Streptoprocne zonaris albicincta (p. 697).

$d d$. Forehead always sooty gray or grayish brown, distinctly different from black of crown.

$e$. No white line on sides of forehead. (Southern Mexico to Guatemala and British Honduras.) .... Streptoprocne zonaris mexicana, adults (p. 700). ee. A narrow white line along side of forehead. (Jamaica; Cuba.)

Streptoprocne zonaris pallidifrons, aclults (p. 701).

$c c$. White collar interrupted on sides of neck (confined to hindneck and chest).

(Southeastern Brazil.)............ Streptoprocne biscutata (extralinital).c $b b$. Under parts sooty with whitish terminal margins to feathers.

Streptoprocne zonaris mexicana, young (p. 700). aa. Tail even; under parts without any white (uniform sooty); larger (wing 228-233 mm.). (Mexico.)..................... Streptoprocne semicollaris (p. 702).

\section{STREPTOPROCNE ZONARIS ALBICINCTA (Cabanis).}

\section{COLOMBIAN COLLARED SWIFT.}

Similar to S. z. zonaris, of Brazil, but decidedly smaller and coloration much blacker.

Adults (sexes alike).-Pileum black, usually slightly (but rarely distinctly, never conspicuously) more sooty on forehead; sides of

a Salmon, Proc. Zool. Soc. Lond., 1879, 531.

b Hirundo zonaris Shaw, in Miller's Cimel. Phys., 1796, 100, pl. 55 (type locality not stated, but is assumed to be Brazil).- II [emiprocne] zonaris Cabanis and Heine, Mus. Ilein., ii, 1860, S3 (Brazil).-Chætura zonaris Sclater, Cat. Am. Birds, 1862, 282, part (s. Brazil).-Hirundo albicollis Vieillot, Nouv. Dict. d'Hist. Nat., xiv, 1817, 524 (Brazil).-Hirundo collaris Maximilian, Reise Bras, i, 1820, 75 (Tio de Janeiro, Brazil).-Cypsclus collaris Temminck, Pl. Col., 33d livr., Jan., 1821, pl. 195; Maximilian, Beitr. Nat. Bras., iii, 1830, 344.-Acanthylis collaris Burmeister, Syst. Ueb. Th. Bras., i, pt. ii, 1856, 364.-Ch[actura] zonaris (typica) Hartert, Das Tierreich, Podarg., Caprim., Macropt., 1897, 74, part.-Streptoprocne zonaris zonaris Oberholser, Proc. Biol. Soc. Wash., xix, May 1, 1906, 69, part.

c Chxtura biseutata Sclater, Proc. Zool. Soc. Lond., 1865, 609, pl. 34 (Ypanema, \&. e. Brazil; coll. P. L. Sclater; ex Cypselus biscutata Natterer, manuscript); Hartert, Cat. Birds Brit. Mus., xvi, 1892, 479.-[Hemiprocnc] biseutata Sclater and Salvin, Nom. Av. Neotr., 1873, 95.-Streptoprocne biscutata Oberholser, Proc. Biol. Soc. Wash., May 1, 1906, 69. 
head, chin, and throat plain sooty black or very dark sooty; a conspicuous white collar completely encircling neck, this broadest below, where usually encroaching slightly on median portion of lower throat, the feathers all sooty blackish or dark sooty basally; rest of plumage black, the back, scapulars, rump, and upper tail-coverts slightly glossed with bluish, the wings and tail more grayish black, paler (more grayish sooty) on inner webs of remiges and rectrices; bill and feet black; iris dark brown.

Adult male.-Length (skins), 185-200 (188.3); wing, 188-205 (196.5); tail, 62.5-72 (67.5); exposed culmen, 9-10 (9.5); tarsus, 19-22 (20.9); middle toe, $13.5-15.5$ (14.6). ${ }^{a}$

Adult female.-Length (skins), 180-194 (189); wing, 185.5-207 (197.6); tail, 63-75 (69.4); exposed culmen, 9-10.5 (9.9); tarsus, 19.5-22 (21.1); middle toe, $14.5-15.5$ (14.9). ${ }^{b}$

Costa Rica (Peralta; Tucurríqui; San Pedro; Volcán de Irazú; La Palma de San José; Escazú; Boruca; Paso Reál de Térraba) and southward through Panamá (Chitra; Calovévora), Colombia (Bogotá; Sierra Nevada de Santa Marta; La Concepción, Santa Marta; Antioquía; Ambalema; Bucaramanga) and Ecuadór (Guayaquíl; Quijos; Chimbo; Chaupi; Paramo del Illiniza; Volcán de Pichincha, 13,00014,000 feet) to Peru (Lima; Cuzco; Cosnipata; Chyavetas; Chanchamayo; Huallaga; La Mercéd; Santa Ana; Huaynapata), Trinidád, Grenada, and British Guiana (Roraima).

Hemiprocne albicincta CABANIs, Journ. für Orn., 1862, 165, part (Guiana).

Acanthylis collaris (not Hirundo collaris Maximilian) Cabanis, in Schomburgk's

Reise Brit. Guiana, iii, 1848, 709.-LÉotaud, Ois. Trinidad, 1866, 83.

Hemiprocne collaris Chapuan, Bull. Am. Mus. N. H., vi, 1894, 58 (Trinidád).

$a$ Ten specimens. $\quad b$ Eight specimens.

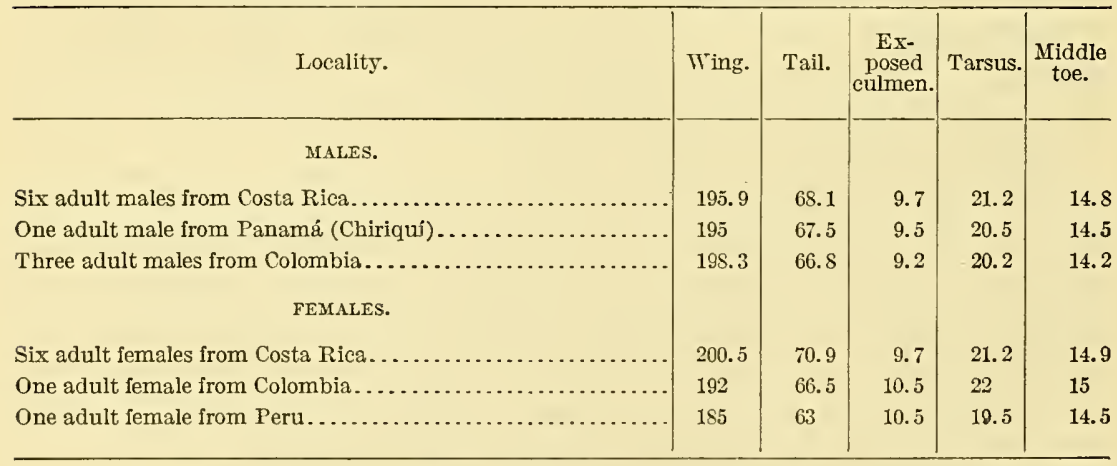

I have not seen specimens from the type locality of Hemiprocne albicincta Cabanis (Guiana) or contiguous territory, and the form here characterized as Streptoprocne zonaris albicincta may possibly not be the same. In this case the name Streptoprocne zonaris minor would have to be used instead, the type locality of Hemiprocne minor Lawrence being central Colombia (Bogotá). 
[Chætura] albicincta Sharpe, Hand-list, ii, 1900, 91.

Hemiprocne zonaris var. albicincta Pelzeln, Ibis, 1875, 330 ("Spanish Guiana;" crit.).

Chætura zonaris (Shaw), $\alpha$. albicincta (Cab.) HARtert, Cat. Birds Brit. Mus., xvi, 1892, p. xiv.

[Chæiura zonaris] Subsp. $\alpha$. Chætura albicincta Hartert, Cat. Birds Brit. Mus., xvi, 1892, 478 (Guiana).

Ch[aetura]zonaris albicincta Hartent, Das Tierreich, Podarg., Caprim., Macropt., 1897, 74 .

Chaetura zonaris albicincia Hellmayr., Novit. Zool., xiii, 1906, 36 (Chaguanas, Trinidád; crit.).-Berdepsch, Novit. Zool., xv, 1908, 268, footnote (Brit. Guiana).

Streptoprocne zonaris albicincta Oberholser, Proc. Biol. Soc. Wash., xix, May 1, $1906,69$.

S[treptoprocne] $z$ [onaris] albicincta Ridgway, Proc. Biol. Soc. Wash., xxiii, 1910, 53 , in text.

Acanthylis albicollis (not Hirundo albicollis Vieillot) Sclater, Proc. Zool. Soc. Lond., 1854, 110 (Quijos, Ecuadór); 1858, 60 (e. Ecuadór).

Hemiprocne zonaris (not Hirundo zonaris Shaw) CABANIS, Journ. für Orn., IS62, 165 (Costa Rica; crit.).-Sclater and Salvis, Proc. Zool. Soc. Lond., 1879, 531 (Antioquía, Colombia; descr. nest and eggs).-Berlepsch and TACZAnowski, Proc. Zool. Soc. Lond., 1883, 569 (Guayaquíl and Chimbo, w. Ecuadór).-Taczanowski, Orn. du Pérou, i, 1884, 231.-Zeledón, Anal. Mus. Nac. Costa Rica, i, 1887, 120 (La Palma de San José).-Wells, Proc. U. S. Nat. Mus., ix, 1S87, 620 (Grenada).-BerLepsch and StolzManx, Proc. Zool. Soc. Lond., 1892, 398 (Lima, Peru).-Bangs, Proc. Biol. Soc. Wash., xii, 1898, 158 (Pueblo Viejo, Santa Marta, Colombia).-Stone, Proc. Ac. Nat. Sci. Phila., 1899, 305 (near Ambalema, Colombia).-Salvadori and Festa, Boll. Mus. Zool., etc., Torino, xv, 1900, 12 (Chaupi, Paramos del Illiniza, etc., centr. Ecuadór; crit.).-CLark, Proc. Bost. Soc. N. H., xxxii, 1905, 273 (Grenada).

[Hemiprocne] zonaris Sclater and Salvin, Nom. Av. Neotr., 1873, 95, part.

Hemiprocne zonaris? Boucard, Proc. Zool. Soc. Lond., 1878, 67 (Tolcán de Irazú, Costa Rica).

Chrtura zonaris Salvin, Proc. Zool. Soc. Lond., 1870, 201 (Chitra and Calovévora, Panamá); Ibis, 1885, 436 (Roraima, 3,500 ft., Brit. Guiana).-Sclater and Salvin, Proc. Zool. Soc. Lond., 1867, 752 (Huallaga, e. Peru); 1873, 186 (Cosnipata, Peru), 289 (Chyavetas, e. Peru).-Berlepsch, Journ. für Orn., 1884, 313 (Bucaramanga, Colombia; crit.).-Salvin and Godman, Biol. Centr.-Am., Aves, ii, 1S93, 373, part (Costa Rican, Panaman and Colombian localities and references; Grenada).-Hantert, Novit. Zool., v, 1S98, 496 (Volcín de Pichincha, 13,000-14,000 ft., n. w. Ecuadór).-Berlepsch and Stolzmann, Proc. Zool. Soc. Lond., 1902, 29 (La Mercéd, centr. Peru); Ornis, 1906, 96 (Santa Ana, Peru), 122 (Huaynapata, Cuzco, Peru).-Goodfellow, Ibis, 1902, 208 (eastern Andes of Ecuadór, 10,000-15,000 ft.; habits).

Ch[actura] zonaris (iypica) Hantert, Das Tierreich, Podarg., Caprim., Macropt., 1897,74 , part.

[Chxtura] zonaris SHAnpe, Hand-list, ii, 1900, 91, part.

Streptoprocne zonaris zonaris OBerholser, Proc. Biol. Soc. Wash., xix, May 1, 1906, 69, part.-Bangs, Auk, xxiv, 1907, 295 (Pozo del Rio Grande, s. w. Costa Rica).-Carrmer, Ann. Camegie Mus., vi, 1910, 506 (Costa Rica; habits).

Hemiprocne minor Lawrence, Ann. N. Y. Acad. Sci., ii, 1882, 11 (Bogotá, Colombia; coll. G. N. Lawrence).-Reichenow and Schalow, Joum. für Orn., 1884, 382 (reprint of orig. descr.). 


\section{STREPTOPROCNE ZONARIS MEXICANA Ridgway.}

\section{MEXICAN COLLARED SWIFT.}

Similar to S. z. albicincta, but averaging decidedly larger, general color much duller (less bluish) black, and forehead always distinctly grayish sooty; similar also to $S . z$. zonaris, ${ }^{a}$ but averaging smaller and coloration less uniform, the forehead and chin always distinctly paler than rest of head.

Adults (sexes alike).-General color plain black or sooty black above, slightly more sooty below and decidedly more so on forehead, chin, and throat, interrupted by a conspicuous collar of white (this broadest on chest), the feathers of this white collar dark sooty brown or dusky basally; bill black; iris dark brown; legs and feet dusky (more or less livid in life?).

Immature.-Similar to adults, but white collar more or less broken by larger dusky central areas to feathers (especially on chest), and (in younger specimens) feathers of chin and upper throat streaked, those of lower throat tipped with whitish, and those of breast and abdomen and marginal under wing-coverts terminally margined with whitish.

Young.-Much duller in color than adults, the under parts grayish sooty anteriorly, dark sooty posteriorly; white collar developed only on hindneck (where feathers are rather narrowly tipped with white), the feathers of chest very narrowly margined terminally with white; otherwise like the immature stage, described above.

Adult male.-Length (skins), 183-225 (206.5); wing, 200-215 (206.4); tail, 66.5-81.5 (75.6); exposed culmen, 8.5-10.5 (9.6); tarsus, 20.5-24 (22.3); middle toe, 14.5-16.5 (15.2). ${ }^{a}$

Adult female.--Length (skins), 187-222 (207); wing, 194.5-206.5 (200.5); tail, 62-79 (72); exposed culmen, 9-10.5 (9.8); tarsus, 20.5-24 (22); middle toe, $14-16(15){ }^{b}$

$a$ Of southern Brazil and Argentina; see p. 697.

$b$ Fourteen specimens.

\begin{tabular}{|c|c|c|c|c|c|}
\hline Locality. & Wing. & Tail. & $\begin{array}{c}\text { Ex- } \\
\text { posed } \\
\text { culmen. }\end{array}$ & Tarsus. & $\begin{array}{c}\text { Middle } \\
\text { toe. }\end{array}$ \\
\hline \multicolumn{6}{|l|}{ MALES. } \\
\hline Ten adult males from Mexico............ & 205.5 & 75.6 & 9.5 & 22.5 & 15.2 \\
\hline Two adult males from Guatemala......... & 211.7 & 79 & 10 & 23 & 15.2 \\
\hline Two adult males from British Honduras............... & 205.5 & 72.2 & 9.7 & 22 & 15.2 \\
\hline \multicolumn{6}{|l|}{ FEMALES. } \\
\hline 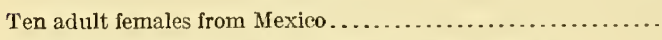 & 200.3 & 73.1 & 9.7 & 22.8 & 15.2 \\
\hline Three adult females from Guatemala (2) and Chiapas (1)...... & 202.5 & 71.5 & 10 & 21.5 & 14.7 \\
\hline One adult female from British Honduras.................. & 194.5 & 62 & 10 & 20.5 & 15 \\
\hline
\end{tabular}


Southern Mexico, in States of Vera Cruz (Córdova; Rio Seco, near Córdova; Miradór: Uvero; Téxolo; Túxtepec), Guerrero (Papayo), Oaxaca (Villa Alta; Cacoprieto; Santa Efigénia), and Chiapas (Chicharras), and southward through highlands of Guatemala (Dueñas; Tecpám; Retalhuleu; Patzicia; Calderas; San José; Los Amates, etc.) to British Honduras (Toledo District).

Hemiprocne zonaris (not Hirundo zonaris Shaw) Sclater and Salvin, Ibis, 1859, 125 (Guatemala).-Salvin and Sclater, Ibis, 1860, 37 (Dueñas, Guatemala; crit.).

Chætura zonaris Sclater, Proc. Zool. Soc. Lond., 1863, 99, part (monogr.; Guatemala); 1865, 609, part (Guatemala; monogr.).-Suмichrast, Mem. Bost. Soc. N. H., i, 1869, 562 (highlands of Vera Cruz). -Salvis and Godmax, Biol. Centr.-Am., Aves, ii, 1893, 373, part (Uvero, Córdova, and Miradór, Tera Cruz; Villa Alta, Santa Efigénia, and Cacoprieto, Oaxaca; Retalhuleu, Patzicia, Calderas, Dueñas, and San José, Guatemala).

[Chætura] zonaris Sharpe, Hand-list, ii, 1900, 91, part (Mexico).

[Hemiprocnc zonaris] Sclater and Salvin, Nom. Av. Neotr., 1873, 95, part (Mexico).-Heine and Reichenow, Nom. Mus. Hein. Orn., 1890, 90, part (Mexico).

Streptoprocne zonaris zonaris Uberholser, Proc. Biol. Soc. Wash., xix, May 1, 1906,69 , part.

Streptoprocne zonarns Dearbonn, Pub. 125 Field Mus. N. H., 1907, 95 (Los Amates, bet. Lake Atitlán and Tecpám, and above Tecpám, Guatemala; descr. nesting place).

Ch[aetura] zonaris (typica) Hartert, Das Tierreich, Podarg., Caprim., Macropt., 1897,74 , part.

Streptoprome zonaris mexicana Ridgwax, Proc. Biol. Soc. Wash., xxiii, Apr. 19, 1910, 53 (Rio Seco, near Córdova, Yera Cruz, e. Mexico; coll. U. S. Nat Mus.).

STREPTOPROCNE ZONARIS PALLIDIFRONS (Hartert).

\section{ANTILLEAN COLLARED SWIFT.}

Similar to S.z. mexicana, but smaller, the forehead and chin (sometimes throat also) paler, and with a more or less conspicuous narrow supraloral streak of whitish.

Adult male.-Length (skins), 178-195 (186); wing, 194-212 (201.6); tail, 64.5-74 (70.4); exposed culmen, 8.5-10 (9.2); tarsus, 18.5-20 (19.2); middle toe, $13-15$ (14) ${ }^{a}$

Adult female.-Length (skin), 190; wing, 195-196.5 (195.7); tail, 68.5-71 (69.7); exposed culmen, 10; tarsus, 19-19.5 (19.2); middle toe, $13.5-14(13.7) .^{b}$

Islands of Jamaica, Haiti, and Cuba, Greater Antilles. Jamaica: Belle Vista, St. Andrews; Moneague; Cinchona. Cuba: Monte Verde; San Juan; Nueva Gerona, Isle of Pines.

Acanthylis collaris? (not Hirundo collaris Maximilian) Gosse, Birds Jamaica, 1847, 51; Illustr. Birds Jamaica, 1849, pl. 8.

Chrtura collaris Brewer, Proc. Bost. Soc. N. H., vii, 1860, 306 (Cuba).-MLırch. Proc. Ac. Nat. Sci. Phila., 1862, 286 (Jamaica). 
Cypcelus collaris AlbRecht, Journ. für Orn., 1861, 206 (Cuba).

Nephocaetes collaris Gundlach, Journ. für Orn., 1861, 330 (Cuba); 1862, 177 (Cuba); 1874, 114 (Cuba; habits); Contr. Orn. Cuba, 1876, 83.

Chætura zonaris (not Hirundo zonaris Shaw) Sclater, Proc. Zool. Soc. Lond., 1861, 79 (Jamaica; crit.); 1863, 99, part (monogr.; Jamaica; Haiti); 1865, 609, part (monogr.).—AגBRECHT, Journ. für Orn., 1862, 201 (Jamaica).-CoRY, Auk, xii, 1895, 279 (Santo Domingo).-Cherrie, Contr. Orn. San Dom., 1896, 18 (Santo Domingo City).-Salvin and Godman, Biol. Centr.-Am., Aves, ii, 1893, 373, part (Greater Antilles).-Menegaux, Rev. Franç. d'Orn., no. 2, 1909, 26 (Guantanamo and San Carlos, Cuba).

Hemiprocne zonaris Corr, Auk, iii, 1886, 346; Birds West Ind., 1889, 141.Chapman, Bull. Am. Mus. N. H., iv, 1892, 302 (San Juan, s. Cuba).-Scotr, Auk, ix, 1892, 276 (Jamaica; habits).-Field, Auk, xi, 1894, 125 (Port Henderson, Jamaica).

A[canthylis] zonaris Newton (E. and A.), Handb. Jamaica, 1881, 108.

Chatura zonaris pallidifrons HARTERT, Ibis, July, 1896, 368 (Jamaica; coll. Tring Mus.).

Ch[ætura] zonaris pallidifrons Hartent, Das Tierreich, Podarg., Caprim., Macropt., 1897, 74.

Hemiprogne zonarta GuNdLACH, Orn. Cubana, ed. 1895, 97.

[Chætura] pallidifrons SHARPE, Hand-list, ii, 1900, 91 (Jamaica; Haiti).

Hemiprocna zonaris pallidifrons BANGS and ZAPPEY, Am. Nat., xxxix, April, 1905, 203 (Nueva Gerona, Isle of Pines).

Streptoprocne zonaris pallidifrons OBerholser, Proc. Biol. Soc. Wash., xix, May $1,1906,69$.

\section{STREPTOPROCNE SEMICOLLARIS (SausSure).}

\section{WHITE-NAPED SWIFT.}

Aault male.-Head, neck, and chest dark grayish sooty, slightly paler on forehead and chin (especially the former), the feathers of chin and throat with darker shafts; a white band across hindneck, the feathers of which are abruptly dark sooty basally; rest of plumage plain very dark grayish sooty, the back, scapulars, rump, and upper tail-coverts more blackish and faintly glossed with bronze-greenish; bill brownish black; iris dark brown; toes brownish black, the tarsi more brownish (in dried skin); length (skin), 238; wing, 228; tail, 73; exposed culmen, 12 ; tarsus, 27 ; middle toe, $19.5 .^{a}$

South-central Mexico, in States of Mexico (San Joaquín, near City of Mexico) and Hidalgo (Irolo)

Acanthylis semicollaris De Saussure, Rev. et Mag. de Zool., iii, March, 1859, 117 (San Joaquín, near City of Mexico).

Chatura semicollaris Sclater, Cat. Am. Birds, 1862, 282; Proc. Zool. Soc. Lond., 1863, 99 (monogr.); 1865, 609 (monogr.); Journ. für Orn., 1867, 130.-Sclater and Salvin, Exotic Orn., pt. vii, 1866, 103, pl. 52.-Sumichrast, Mem. Bost. Soc. N. H., i, 1869, 562.-Herrera, La Naturaleza, (2), i, 1888 (Apunt. de Orn., p. 15).-Hartert, Cat. Birds Brit. Mus., xvi, 1892, 479.-Salvin and Godman, Biol. Centr.-Am., Aves, ii, 1893, 374.

[Chætura] semicollaris Gray, Hand-list, i, 1869, 69, no. 781.-Sharpe, Hand-list, ii, $1900,92$. 
Ch[ætura] semicollaris Hartert, Das Tierreich, Podarg., Caprim., Macropt., $1897,74$.

[Hemiprocne] semicollaris Sclater and Salvin, Nom. Av. Neotr., 1873, 95.Hetne and Reichenow, Nom. Mus. Hein. Orn., 1890, 190.

Hemiprocne semicollaris Sumichrast, La Naturaleza, v, 1881, 250.

Streptoprocne semicollaris Oberholser, Proc. Biol. Soc. Wash., xix, May 1, 1906,69 .

\section{Genus NEPHCECETES Baird.}

Nephocaetes Batrd, Rep. Pacific R. R. Surv., ix, 1858, 142. (Type, Hirundo nigra Gmelin.)

Nephoecetes (emendation) Barrd, Rep. Pacific R. R. Surv., ix, 1858, pp. xxix, 922.

Nephocetes (emendation) Sclater, Proc. Zool. Soc. Lond., 1859, 236.

Medium-sized Chæturine Swifts (length about 135-168 mm.) with tarsus longer than middle toe with claw, hallux more than half as long as inner toe, and tail decidedly to deeply emarginate, with rectrices soft and with normal shafts.

Nostrils elliptical or narrowly oval, nearly parallel, for the greater part posterior to the latero-frontal antiæ; distance from tips of longest secondaries to that of longest primary decidedly less than two-thirds the total length of wing; tenth (outermost) primary longest; tail nearly two-fifths as long as wing, decidedly emarginate, the rectrices rather soft, with shafts normal (not rigid, nor with extruded tip); tarsus longer than middle toe with claw; outer toe as long as middle toe, the inner slightly shorter; hallux (without claw) more than half as long as inner toe (without claw); feet relatively rather weak or slender. ${ }^{a}$

Coloration.-Mostly plain dark sooty, the sides of forehead more or less hoary or whitish; adult females with feathers of posterior under parts more or less distinctly tipped with whitish.

Nidification.-Nest in recesses among rocks ${ }^{b}$ or about buildings, composed of straw, feathers, leaves, bits of paper, etc., loosely put together and not held together by salivary secretion. ${ }^{c}$

Range.-British Columbia and Montana to Costa Rica; West Indies (Cuba, Haiti, Jamaica, Guadeloupe, Martinique, and St. Vincent); British Guiana. (Monotypic.)

a Nephocetes differs from all other North American genera of Swifts, at least, in having seven (instead of six) pairs of complete ribs and in having the vomer not expanded distally. (See Lucas, Auk, x, 1893, 365, 366.)

$b$ See Vrooman, Condor, vii, 1905, 176, 177, where the eggs are stated to be laid on bare earth behind a tussock of grass, on a shelf or pocket of a cliff overhanging the sea. Doubts have, however, been expressed as to correct identification in this case. That $N$. niger borealis does nest among rocks, however, I have reason to believe from having seen a large colony at a cliff facing the Carson River near Fort Churchill, Nevada, in June, 1868. (See Orn. 40th Parallel, 1877, 565, 566.)

c See Gormley, Auk, v, 1888, 424, 425. 
KEY TO THE SUBSPECIES OF NEPHECETES NIGER.

a. General color decidedly grayish. (Haiti; Cuba?) Nephœcetes niger niger (p. 704). aa. General color distinctly blackish or dark snoty.

b. Smaller (wing averaging 154.5 in male, 150 in female) but tail longer (averaging 66 in male, 58.5 in female); female with white tips to feathers of posterior under parts much less distinct. (Jamaica; Porto Rico?; Dominica?; Guadeloupe?; St. Vincent?; Martinique?; British Guiana?)

Nephœcetes niger jamaicensis (p. 705).

6b. Larger (wing averaging 159 or more in male, more than 157 in female) but tail shorter (averaging not more than 61 in male, less than 52 in female).

c. Larger (wing averaging 165.8 in male, 162 in female), coloration slightly paler; female with white tips to feathers of posterior under parts averaging narrower. (British Columbia to southern Mexico.)

Nephœcetes niger borealis (p. 707).

$c c$. Smaller (wing averaging 159 in male, 157.1 in female); coloration slightly darker; female with white tips to feathers of posterior under parts averaging broader. (Costa Rica.)........... Nephœcetes niger costaricensis (p. 710).

NEPHCEETES NIGER NIGER (Gmelin).

BLACK SWIFT.

Adult male. ${ }^{a-P i l e u m}$ and hindneck deep grayish brown or sooty, passing into sooty blackish on back and other upper parts (the wings and tail very faintly glossed with bluish); chin and throat much lighter grayish brown passing into much darker sooty on under parts of body and under tail-coverts (the color slightly darker than that of pileum); feathers of forehead and crown narrowly margined at tip with grayish white, these whitish tips much broader on sides of forehead, blending on edge into a distinct whitish area bordering the upper edge of the velvety black lores; marginal under wingcoverts very narrowly margined terminally with pale grayish; bill black; iris dark brown; legs and feet dusky (in dried skin); length (skins), 155-158 (156.5); wing, 151-156 (153.5); tail, 62-63 (62.5) (forked for 12); exposed culmen, 6-7 (6.5); tarsus, 12; middle toe, $8.5-9(8.7) .^{b}$

Adult female.-Similar to the adult male but tail less emarginate (nearly truncate), under parts paler, especially under parts of body and under tail-coverts, which are nearly concolor with the throat, the general color of the under parts being a clear sooty brownish gray or grayish brown; in some specimens, the feathers of lower abdomen indistinctly tipped with whitish; length (skins), 138-156

a Described from a Cuban specimen, no adult male from Santo Domingo or Haiti being available. This Cuban specimen is much paler in coloration than even adult females of the Jamaican form, and, though slightly darker (especially on the under parts) than adult females from Santo Domingo I believe will be found referable to the same form.

b Two specimens. 
(149); wing, 149-157.5 (152.4); tail, 53-58.5 (56.6); exposed culmen, 6-6.5 (6.1); tarsus, $12-13$ (12.6); middle toe, 9-9.5 (9.1). ${ }^{a}$

Islands of Haiti and Cuba, Greater Antilles. ${ }^{b}$

[Hirundo] nigra Gueurn, Syst. Nat., i, pt. ii, 1789, 1025 (based on Martinet de Saint-Domingue, Hirundo apus dominicensis Brisson, Orn., ii, 514, pl. 46, fig. 2; Le petit Martinet noir Buffon, Hist. Nat. Ois., vi, 668.)-Lathan, Index Orn., i, 1790, 577.

[Cypselus] nigra Bonaparte, Consp. Av., i, 1850, 66, part.

Cypselus niger (not of Gosse) Gundlach and Lawrence, Ann. Lyc. N. Y., vi, 1858, 268 (Cuba).-Brewer, Proc. Bost. Soc. N. H., vii, 1860, 306 (Cuba).Albrecht, Journ. für Orn., 1861, 207 (Cuba).

Nephocaetes niger Barrd, Rep. Pacific R. R. Surv., ix, 1858, 142, part (Cuba).GundLach, Journ. für Orn., 1862, 177 (Cuba); 1874, 115 (Cuba).

Nephocetes niger Baird, Brewer, and Ridgway, Hist. N. Am. Birds, ii, 1874, 429, part (Cuba).-Cory, Birds Haiti and San Dom., 1885, 88, pl. (22), fig. 11.-Christy, Ibis, 1897, 329 (La Vega, Santo Domingo; habits).

[Nephocaetes] niger GundLach, Journ. für Orn., 1861, 330 (Cuba).

[Nephoecetes] niger Cory, List Birds West Ind., 1885, 17, part.

[Chætura] niger GrAY, Hand-list, i, 1869, 68, no. 784, part (Cuba).

Nechopætes (typographical error) niger GundLach, Repert. Fisico-Nat. Cuba, i, 1866, 281.

Cypseloides niger Sclater, Proc. Zool. Soc. Lond., 1865, 615, part (Cuba; monogr.); Journ. für Orn., 1867, 138.-Cory, Auk, iii, 1886, 345, part (Santo Domingo); Birds West Ind., 1889, 140, part (Santo Domingo); Cat. West Ind. Birds, 1892, 105, part (Cuba; Haiti).-Chapiran, Bull. Am. Mus. N. H., iv, 1892; 301 (San Juan, s. Cuba).- - Hartert, Cat. Birds Brit. Mus., xvi, 1892, 494, part (San Cristobal, Cuba; La Vega, Santo Domingo).-SAlvin and GooMan, Biol. Centr.-Am., Aves, ii, 1893, 379, part (in synonymy).-GundLAch, Orn. Cubana, ed. 1895, 98.-Menegaux, Rev. Franç. d'Orn., no. 2, 1909, 26 (Figuabas, e. Cuba).

C[ypseloides] niger (typicus) Ha Rtert, Das Tierreich, Podarg., Caprim., Macropt., 1897, 79, part.

[Cypseloides] niger Sharpe, Hand-list, ii, 1900, 93, part.

C[ypseloides] n[iger] niger Rrogway, Proc. Biol. Soc. Wash., xxiii, April 19, 1910, 53 , in text.

Cypseloides niger niger Auerican Ornithologists' Union, Check-list, 1910, 200 -extralimital).

\section{NEPHÆCETES NIGER JAMAICENSIS (Ridgway).}

\section{JAIIAICAN BLACK SWIFT.}

Similar to $N . n$. niger, but much darker, the upper and under parts sooty black, more or less distinctly (but not conspicuously) paler or more grayish sooty on chin, throat, and chest.

$a$ Five specimens, from Santo Domingo.

$b$ Haiti: La Vega, Santo Domingo. Cuba; San Juan; San Cristóbal.

$81255^{\circ}-13411.50-11-45$ 
Adult male.-Length (skins), 142-166 (153); wing, 148-161 (154.5); tail, 58.5-69.5 (66); exposed culmen, 5.5-7 (6.5); tarsus, 12-13 (12.5); middle toe, $9-10(9.5) .^{a}$

Adult female.-Length (skins), 136-146 (140); wing, 149.5-150.5 (150); tail, 53-64.5 (58.5); exposed culmen, 5.5-6 (5.8); tarsus, 11.5-12 (11.8); middle toe, $9-9.5(9.2){ }^{b}$

Island of Jamaica (Mayfield; St. Andrews; Passage Fort; Cinchona). Porto Rico? Dominica (Roseau)? Guadeloupe? St. Vincent? Martinique? British Guiana (Merumé Mountains)??

Cypselus niger (not Hirundo nigra Gmelin) Gosse, Birds Jamaica, 1847, 63; Illustr. Birds Jam., 1849, pl. 10.-ALbREChт, Journ. für Orn., 1862, 194 (Jamaica).-March, Proc. Ac. Nat. Sci. Phila., 1863, 287 (Jamaica).

[Cypselus] nigra Bona Parte, Consp. Av., i, 1850, 66, part.

Nephocetes niger Sclater, Cat. Am. Birds, 1862, 283, part (Jamaica).-Baird,

Brewer, and Ridgway, Hist. N. Am. Birds, ii, 1874, 429, part (Jamaica).

Nephocætes niger Gundlach, Journ. für Orn., 1878, 159, 172 (Porto Rico).

[Nephocetes] niger CoRy, List Birds West Ind., 1885, 17, part (Jamaica).

[Chætura] niger GRAY, Hand-list, i, 1869, 68, no. 784.

Cypseloides niger Sclater, Proc. Zool. Soc. Lond., 1865, 615, part (Jamaica; monogr.); Journ. für Orn., 1867, 138; Ibis, 1880, 74 (St. Vincent).-LAwRence, Proc. U. S. Nat. Mus., i, 1878, 459, 487 (Guadeloupe).-Lister, Ibis, 1880, 41 (St. Vincent).-Cory, Auk, iii, 1886, 358, part (Jamaica. Porto Rico; Guadeloupe); viii, 1891, 48 (Guadeloupe); Birds West Ind; 1889, 140, part (Jamaica; Porto Rico; Guadeloupe); Cat. West Ind. Birds, 1892, 105, part (Jamaica; Porto Rico; Guadeloupe; St. Vincent).-Scotr, Auk, ix, 1892, 276 (Jamaica).-Verrilu (G. E.), Trans. Conn. Ac. Arts and Sci., viii, 1892, 330 (Dominica).-Hartert, Cat. Birds Brit. Mus., xvi, 1892, 494, part (Guadeloupe; Martinique; St. Vincent; Merumé Mts., Brit. Guiana).-Clark, Proc. Bost. Soc. N. H., xxxii, 1905, 272 (St. Vincent).Bowdish, Auk, xix, 1902, 366 (Porto Rico).

$a$ Six specimens, from Jamaica.

$b$ Three specimens, from Jamaica.

\begin{tabular}{|c|c|c|c|c|c|}
\hline Locality. & Wing. & Tail. & $\begin{array}{c}\text { Ex- } \\
\text { posed } \\
\text { culmen. }\end{array}$ & Tarsus. & $\begin{array}{c}\text { Middle } \\
\text { toe. }\end{array}$ \\
\hline MALES. & & & & & \\
\hline 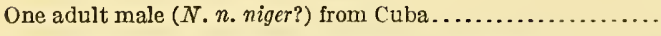 & 151 & 63 & 6 & 12 & 9 \\
\hline One adult male ( $N . n$. nigerl) from Santo Domingo............ & 156 & 62 & 7 & 12 & 8. 5 \\
\hline Six adult males ( $N . n$. jamaicensis) from Jamaica........... & 154.5 & 66 & 6.5 & 12.5 & 9.5 \\
\hline Four adult males ( $N . n$. jamaicensis?) from Guadeloupe...... & 150. 7 & 65.9 & 6 & 12.6 & 9.1 \\
\hline $\begin{array}{l}\text { One adult male ( } N . n \text {.jamaicensis?) from Dominica......... } \\
\text { FEMALES. }\end{array}$ & 155.5 & 68 & 6 & 13 & 9 \\
\hline Five adult females ( $N$. n. niger) from Santo Domingo..... & 152.4 & 56.6 & 6.1 & 12.6 & 9.1 \\
\hline Three adult females ( $N . n$. jamaicensis) from Jaınaica......... & 150 & 58.5 & 5.8 & 11.8 & 9.2 \\
\hline Two adult females (N.n. jamaicensis?) from Guadeloupe...... & 145. 8 & 57.7 & 5.7 & 12 & 8.5 \\
\hline
\end{tabular}

Specimens from Dominica and Guadeloupe are not quite so dark as those from Jamaica, and may be different, but the series examined is much too small to settle the question. I have not seen specimens from Porto Rico, St. Vincent, Martinique, or British Guiana. Possibly the last are referable to the Costa Rican form. 
[Cypseloides] niger Sclater and Salvin, Nom. Av. Neotr., 1873, 95 (Jamaica).SHARPE, Hand-list, ii, 1900, 93, part.

C[ypseloides] niger Newton, Handb. Jamaica, 1881, 108.

C[ypseloides] niger (typicus) Hartent, Das Tierreich, Podarg., Caprim., Macropt., 1897, 79, part.

[Nephocetes niger var. borealis] a. niger Coues, Birds Northwest, 1874, 268, footnote, part (synonymy).

Cypseloides niger jamaicensis Rrdgway, Proc. Biol. Soc. Wash., xxiii, Apr. 19, 1910, 53 (Mayfield, St. Andrews, Jamaica; coll. U. S. Nat. Mus.).

\section{NEPHCECTES NIGER BOREALIS (Kennerly).}

\section{NORTHERN BLACK SWIFT.}

Adult male probably similar to that of $N$. n. niger (from Cuba), ${ }^{a}$ but larger; adult female similar to that of $N$. n. jamaicensis, but with feathers of abdomen and under tail-coverts much more distinctly tipped with white, these white tips often extending over whole of under parts posterior to chest.

$a$ I have not been able to examine an adult male of $N . n$. niger from the type locality (Santo Domingo).

$b$ Supposed changes of plumage in this subspecies according to age are thus described by Mr. Frank M. Drew, in Bull. Nutt. Orn. Club, vii, 1882, 182, 183:

"An examination of ten birds of this species, taken at Howardsville, Colorado, in 1880 and 1881, leads me to believe that four years are necessary for them to acquire their complete plumage. A young male of the year, taken September 17, was marked as follows. General color dull black, every feather tipped with white, scarcely appreciable on npper back and throat, broader on upper tail coverts and rump. Crissum almost pure white. In birds of the second year the general plumage has a brownish cast; feathers of back tipped with brown, the head whitish, belly feathers yet broadly tipped with white. The third year the color is black, with a very faint edging of white on under tail coverts. In the fourth year pure black, forehead hoary, neck with a brownish wash. Feather's bordering the black loral crescent whitish."

$\mathrm{Mr}$. Drew is undoubtedly mistaken, however, in assuming that the sexes are alike in coloration, for all the sexed specimens examined by me, from whatever locality, show that all those with white-tipped feathers on posterior under parts are females and all those without these white-tipped feathers are males. This is true of all the subspecies, except that in the West Indian forms these white tips are much less distiuct, sometimes nearly obsolete. 
Adult male.-Length (skins), 139-168 (155); wing, 157.5-175 (165.8); tail, 53-66 (61); exposed culmen, 6-7.5 (6.8); tarsus, 12-13.5 (12.9); middle toe, $10-10.5$ (10.2). ${ }^{a}$

Adult female.-Length (skins), 137-160 (147); wing, 156-164 (160); tail, 47-58.5 (52.5); exposed culmen, 6.5-7 (6.9); tarsus, 12-13 (12.5); middle toe, $9-10.5(9.6) .^{b}$

Western North America and southward to southern Mexico (to Guatemala ?); north to British Columbia (Victoria; New Westminster; Asheroft; Sumas; Kamloops; Vernon; Lake La. Hache; Comox; Okanogan; Clinton; Caribou District; Chilliwack; Lula Island) and southern Alaska (Revillagigedo Island; Boca de Quadra), eastward to Colorado and New Mexico, southward to Lower California (San Quintín; San Carlos Landing; San Telmo; San Pedro Martir Mountains), and southern Mexico, in States of Vera Cruz (Orizaba; Jalapa; Jico), Tlaxcala (Laguna del Rosário), Mexico (Rio Seco near Córdova), Puebla (San Miguél Molino), Durango (Huasamota), and Oaxaca (Guichicovi) and Territory of Tepíc (Sierra Madre; Santa Teresa) to highlands of Guatemala (Raxché; Cobán; Dueñas; Alotenango) and Honduras. ${ }^{c}$

Cypselus borealis Kennerly, Proc. Ac. Nat. Sci. Phila., ix, 1857, 202 (Simiahmoo Bay, Washington; coll. U. S. Nat. Mus.).

Nephoecetes borealis Sclater, Proc. Zool. Soc. Lond., 1859, 236 (Vancouver Island). Cypseloides borealis Sclater, Proc. Zool. Soc. Lond., 1865, 615 (Puget Sound; monogr.); Journ. für Orn., 1867, 138.

[Chætura] borealis Gray, Hand-list, i, 1869, 68, no. 785 .

Nephocetes niger borealis Ridgway, Bull. Essex Inst., vii, Jan., 1875, 17, 38

(Pyramid Lake Reservation, Nevada).-Coues, Check-list, 2d ed., 1882, no. 404.

N[ephocetes] niger borealis Coues, Key N. Am. Birds, $2 d$ ed., 1884, 457.

[Nephocetes] niger var. borealis Coues, Key N. Am. Birds, 1872, 183.

a Ten specimens.

$b$ Nine specimens.

\begin{tabular}{|c|c|c|c|c|c|}
\hline Locality. & Wing. & Tail. & $\begin{array}{c}\text { Ex- } \\
\text { posed } \\
\text { culmen. }\end{array}$ & Tarsus. & $\begin{array}{l}\text { Middle } \\
\text { toe. }\end{array}$ \\
\hline MALES. & & & & & \\
\hline 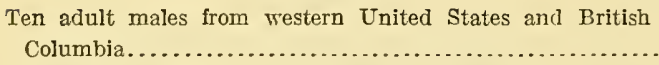 & 165.8 & 61 & 6.8 & 12.9 & 10.2 \\
\hline $\begin{array}{l}\text { Five adult males }(N . n . \text { costaricensis }) \text { from Costa Rica.......... } \\
\text { FEMales. }\end{array}$ & 159 & 58.6 & 6.6 & 12.4 & 9.5 \\
\hline $\begin{array}{r}\text { Four adult females from western United States and British } \\
\text { Columbia } . . . . \ldots \ldots \ldots \ldots \ldots \ldots \ldots \ldots \ldots \ldots \ldots \ldots \ldots \ldots \ldots\end{array}$ & 162 & 51.2 & 6.8 & 13 & 9.8 \\
\hline Five adult females from Mexico $\ldots \ldots \ldots \ldots \ldots \ldots \ldots \ldots$ & 158.4 & 53.5 & 7 & 12.3 & 9.3 \\
\hline Four adult females $(N, n$. costaricensis) from Costa Rica..... & 157.1 & 51.9 & 6 & 12.3 & 9.5 \\
\hline
\end{tabular}

c I have not seen specimens from Guatemala or Honduras, and therefore can not be sure that they are referable to this northern form. 
Nephocetes niger, var. borealis Coues, Check-list, 1873, no. 270.-RIDGway, Bull. Essex Inst., vii, 1875, 17 (Pyramid Lake Reservation).

[Nephocetes niger var. borealis] b. borealis Coues, Birds Northwest, 1874, 269.

Nephocetes niger, $\beta$. borealis Ridgway, Orn. 40th Parallel, 1877, 565 (Pyramid Lake Reservation and near Fort Churchill, Nevada).

Cypseloides niger borealis Ridgway, Proc. U. S. Nat. Mus., iii, Aug. 24, 1880, 188; Nom. N. Am. Birds, 1881, no. 350.-Drew, Bull. Nutt. Orn. Club, vii, 1882, 182 (Howardsville, Colorado, up to 13,000 ft., breeding up to $11,000 \mathrm{ft}$.; measurements; desçr. young; remarks on plumages, etc.); Auk, ii, 1885, 17 (vertical range in Colorado).-Henshaw, Auk, iii, 1886, 78 (upper Pecos R., New Mexico, migrant).-Gormiex, Auk, v, 1888, 424 (Seattle, Washington; descr. nest and eggs).-AMerican Ornithologists' Union, Auk, xiv, 1897, 126; xvi, 1899, 111; Check-list, 3d ed., 1910, 200.-DAwson, Auk, xiv, 1897, 175 (Okanogan Co., Washington.)-Cooke, Bull. Col. Agr. Coll., no. 37, 1897, 86 (Colorado; breeds from 10,000-12,000 ft., and ranges much above 13,000 ft.); Auk, xxvi, 1909, 413 (Denver, Colorado, June).-Grinneld (J.), Pub. 2, Pasadena Acad. Sci., 1898, 27 (Los Angeles Co., California, rare migrant), Pacific Coast Avifauna, no. 3, 1902, 40 (California range); Univ. Cal. Pub. Zool., v, 1908, 69 (San Bernardino Mts., s. California, July).-ChapMan, Bull. Am. Mus. N. H., x, 1898, 34 (Jalapa; Vera Cruz).-Baney (Florence M.), Handb. Birds W. U. S., 1902, 229.-Vrooman, Auk, xviii, 1901, 394 (near Santa Cruz, California, breeding; descr. nest and eggs); Condor, vii, 1905, 176 (breeding on cliffs of seashore, near Santa Cruz, California; descr. nest and eggs).-Rathbun, Auk, xix, 1902, 135 (Seattle, Washington, summer res.; habits).-Dowles, Auk, xxiii, 1906, 144 (Tacoma, Washington).Kernode, Prov. Mus. Victoria, 1909, 51 (Victoria, Chilliwack, Okanogan, and Comox, Brit. Columbia).-Swarth, Univ. Calif. Pub. Zool., vii, 1911, 71 (Revillagigedo. I. and Boca de Quadra, s. Alaska; crit.; habits).

C[ypseloides] niger borealis Hartert, Das Tierreich, Podarg., Caprim., Macropt., 1897, 79.

[Cypseloides niger.] Subsp: $\alpha$. Cypseloides borealis KAartert, Cat. Birds Brit. Mus., xvi, 1892, 495 (Brit. Columbia; San Miguél Molino, Puebla; Sierra Madre, Tepíc, etc.).

[Cypseloides niger] $\alpha$. borealis Hartent, Cat. Birds Brit. Mus., xvi, 1892, p. xiv.

[Cypseloides] borealis SHARpe, Hand-list, ii, 1900, 93, part.

Nephocaetes niger (not Hirundo nigra Gmelin) BaIRD, Rep. Pacific R. R. Surv., ix, 1858, 142, part.-Elliot, Illustr. N. Am. Birds, i, 1869, pl. 20.

Nephoecetes niger BaIRD, Rep. Pacific R. R. Surv., ix, 1858, pp. xxix, 922, part; Cat. N. Am. Birds, 1859, no. 108.

Nephoctes niger Sumichrast, Mem. Bost. Soc. N. H., i, 1869, 562 (Vera Cruz, breeding).

Nephocetes niger Cooper, Orn. Calif., 1870, 349.-Baird, Brewer, and Ridgway, Hist. N. Am. Birds, ii, 1874, 429, part, pl. 45, fig. 4; iii, 1874, 521 (San Francisco, California).

Cypseloides niger American Ornithologists' Union, Check-list, 1886, no. 422.Bryant (W. E.), Proc. Calif. Ac. Sci., ser. 2, 1889, 288 (San Quintín and San Carlos Landing, Lower California; migrant).-FAnNIx, Check-list Birds Brit. Col., 1891, 29 (Victoria, B. C.).-Rhodds, Proc. Ac. Nat. Sci. Phila., 1893, 43 (Lula Island, Clinton, Lake La Hache, Ashcroft, Kamloops, and Vernon, Brit. Columbia; habits).-Fisher (A. K.), North Am. Fauna, no. 7, 1893, 54 (Owens Lake, near Keeler, Independence, etc., s. e. Califormia, May, June).-Anthony, Zoë, iv, 1893, 236 (San Telmo and San Pedro Martir Mts., Lower California); Auk, xii, 1895, 139 (San Fermando, Lower California, May).-Salvin and Godman, Biol. Centr.-Am., Aves, ii, 1894, 
379, part (Brit. Columbia; w. United States; Rio Seco, near Córdova; Valley of Mexico; Puebla; Laguna del Rosário, Tlaxcala; Guichicovi, Oaxaca; Raxché, Cobán, Dueñas, Alotenango, etc., Guatemala?; Honduras?).Brooks, Auk, xx, 1903, 282 (Caribou distr., Brit. Columbia).-Bendire, Life Hist. N. Am. Birds, ii, 1895, 175.-DAwson, Wilson Bull., no. 10, 1896, 4 (Okanogan Co., e. Washington; habits).

C[ypseloides] niger RidGway, Man. N. Am. Birds, 1887, 302, part.

\section{NEPH@CETES NIGER COSTARICENSIS (Ridgway).}

\section{COSTA RICAN BLACK SWIFT.}

Similar to N.n. borealis, but decidedly darker, the adult female with feathers of abdomen and flanks more broadly tipped with white, and averaging slightly smaller; adult male similar to that of $N$. n. jamaicensis, but wing averaging longer and tail decidedly shorter, and general color of head and neck decidedly more grayish.

Adult male.-Length (skins), 135-152 (146); wing, 154-165. . (159); tail, 57.5-63.5 (58.6); exposed culmen, 6.5-7 (6.6); tarsus, 12-13 (12.4); middle toe, $9-10(9.5){ }^{a}$

Adult female.-Length (skins), 134-145 (139); wing, 152.5-162 (157.1); tail, 50.5-53.5 (51.9); exposed culmen, 6; tarsus, 12-12.5 (12.3); middle toe, $9.5 .^{b}$

Highlands of Costa Rica (San José; San Pedro; Buenos Aires).

Cypseloides niger (not Hirundo nigra Gmelin) Zeuedón, Anal. Mus. Nac. Costa Rica, i, 1887, 120 (San José, Costa Rica).-Cherrie, Auk, vii, 1890, 333 (San José); ix, 1892, 324 (San José).-Salvin and Godman, Biol. Centr.-Am., Aves, ii, 1894, 379, part (Costa Rica).

C[ypseloides] niger RIDGwaY, Man. N. Am. Birds, 1887, 302, part (Costa Rica).

[Cypseloides niger] Subsp. $\alpha$. Cypseloides borealis Hartert, Cat. Birds Brit. Mus., xvi, 1892, 495, part.

[Cypseloides] borealis Sharpe, Hand-list, ii, 1900, 93, part (Costa Rica).

Cypseloides niger borealis CarrIker, Ann. Carnegie Mus., vi, 1910, 509 (highlands of Costa Rica).

Cypseloides niger costaricensis Ridgway, Proc. Biol. Soc. Wash., xxiii, Apr. 10, 1910, 53 (San José, Costa Rica; coll. U. S. Nat. Mus.).

\section{Genus CYPSELOIDES Streubel.}

Cypseloides Streuber, Isis, 1848, 366. (Type, Hemiprocne fumigata Streubel.) Aerornis c Bertoni, Aves Nuevas del Paraguay, 1901, 66. (Type, A. niveifrons Bertoni $=$ Cypselus senex Temminck.)

Rather small Chæturine Swifts (wing about 119-123 mm.) resembling and closely related to Nephocetes but differing in truncate or very slightly emarginate or double-rounded tail, with rigid shafts to rectrices.

Nostrils rather broadly oval, nearly parallel, for the greater part posterior to the latero-frontal antix; distance from tip of longest secondary to that of longest primary decidedly less than two-thirds the total length of wing; tenth (outermost) primary longest in $C$. cherriei, decidedly shorter than ninth in C. brunneitorques (in the 
latter more acuminate terminally); tail about one-third as long as wing (in C.brunneitorques) to nearly two-fifths as long (in C.cherriei), slightly emarginate (C. brunneitorques) or truncate (C. cherriei), the rectrices with rigid and slightly extended (protruded) shafts; tarsus decidedly longer than middle toe with claw; outer toe very nearly if not quite as long as middle toe, the inner nearly as long in C.brunneitorques, decidedly shorter in $C$. cherriei; hallux (without claw) more than half as long as inner toe (without claw).

Coloration.-Plain dark sooty or blackish; one species with a white spot on each side of forehead (in both sexes?), two with a rufous collar in adult male.

Nidification.-Nest (of C. brunneitorques) composed of moss, shallow and compact, placed in dark culverts, near water (probably in rocky banks or cliffs also). ${ }^{a}$

Range.-Southern Mexico to Brazil and Peru. (Five species.)

KEY TO THE SPECIES OF CYPSELOIDES.

a. A rufous collar round neck.

b. Chin and throat rufous. (Guiana and Trinidád.)

bb. Chin and throat dark sooty. (Southern Mexico to Peru.)

Cypseloides rutilus (extralimital). $b$

c. Coloration darker (back, etc., sooty black, under parts deep sooty grayish brown). (Southeastern Mexico to Peru.)

Cypseloides brunneitorques brunneitorques (p. 712).

cc. Coloration paler (back, etc., sooty brown, under parts sooty grayish. (Western Mexico.)................ Cypseloides brunneitorques griseifrons (p. 714).

aa. No rufous on neck.

$b$. No white on head.

c. Smaller (wing less than $150 \mathrm{~mm}$.).

d. Smaller (wing less than $135 \mathrm{~mm}$.).

Cypseloides brunneitorques brunneitorques, adult female (p. 712).

$d d$. Larger (wing more than $145 \mathrm{~mm}$.). (Brazil, Peru, and Ecuadór.)

Cypseloides fumigatus (extralimital).c

$c c$. Larger (wing $175 \mathrm{~mm}$.). (Brazil.)......... Cypseloides senex (extralimital). $d$ bb. A white spot on each side of forehead. (Costa Rica.)

Cypseloides cherriei (p. 714$)$.

a Orton, Am. Nat., iv, 1871, 713.

b Hirundo rutila Vieillot, Nouv. Dict. d'Hist. Nat., xiv, 1817, 528.-Chætura rutila Sclater, Proc. Zool. Soc. Lond., 1863, 100, part.-Cypseloides rutilus Hartert, Cat. Birds Brit. Mus., xvi, 1892, 493; Das Tierreich, Podarg., Caprim., Macropt., 1897, 79.-Hirundo robini Lesson, Traité d'Orn., 1830, 270.

c Hemiprocne fumigata Streubel, Isis, 1848, 366.-Cypseloides fumigatus Sclater, Proc. Zool. Soc. Lond., 1865, 615; Hartert, Cat. Birds Brit. Mus., xvi, 1892, 496; Das Tierreich, Podarg., Caprim., Macropt., 1897, 80.-Nephocætes fumigatus Pelzeln, Orn. Bras., i Abth., 1868, 16.-[Chrtura] fumigatus Gray, Hand-list, i, 1869, 68.

dCypselus senex Temminck, Pl. Col., 1826, 397.-Acanthylis senex Bonaparte, Consp. Av., i, 1849, 65.-Cypseloides senex Sclater, Proc. Zool. Soc. Lond., 1865, 614; Hartert, Cat. Birds Brit. Mus., xvi, 1892, 496; Das Tierreich, Podarg., Caprim., Macropt., 1897, 80.-Chrtura senex Pelzeln, Orn. Bras., i Abth., 1868, 16.-Hemiprocne temminckii seu temminckiana Streubel, Isis, 1848, 368.- Chxtura major Bertoni, Revista de Agronomía, ii, 1900, 58.-Aërornis niveifrons Bertoni, Aves Nuevas del Paraguay, 1901, 66. 


\section{CYPSELOIDES BRUNNEITORQUES BRUNNEITORQUES (Lafresnaye).}

CHESTNUT-COLLARED SWIFT.

Adult male.-Pileum sooty black, the feathers along each side, immediately above the lores, narrowly margined or edged with whitish; lores deep black posteriorly, more sooty anteriorly; chin, throat, and malar region dark sooty grayish brown; a broad collar round neck deep cinnamon-rufous or chestnut-rufous, sharply defined and clearer in color on hindneck, usually more or less broken on foreneck by dusky center to feathers; remainder of upper parts sooty black, of under parts deep sooty grayish brown; bill black; iris dark brown; feet grayish brown or dusky (in dried skins); length (skins), 112-131 (122); wing, 120-133 (126.7); tail, 40.5-51 (45.3); exposed culmen, 5.5-6.5 (5.8); tarsus, 11-13 (11.9); middle toe, $7-8.5(8) .^{a}$

Adult female.-Similar to the adult male but without the rufous collar ${ }^{b}$ which is entirely replaced by the general dark sooty color; length (skins), 103-127 (116); wing, 121-130 (125.1); tail, 40-48 (43.4); exposed culmen, 5.5-6.5 (5.9); tarsus, 11-12.5 (11.8); middle toe, $7.5-8.5(7.8) .^{c}$

Young.-Similar to the adult female but texture of the plumage different (softer) and general coloration somewhat paler, especially on under parts, where, at least on flanks, abdomen, and under tail-

$a$ Seventeen specimens.

$b$ Among the seventeen specimens examinec whose sex was determined as female by their respective collectors are five which have the rufous collar, exactly as in adult males. Whether these indicate that the female eventually attains the coloration of the adult male, or that the sex was erroneously determined is a question; but I incline to the latter view.

$c$ Twelve specimens.

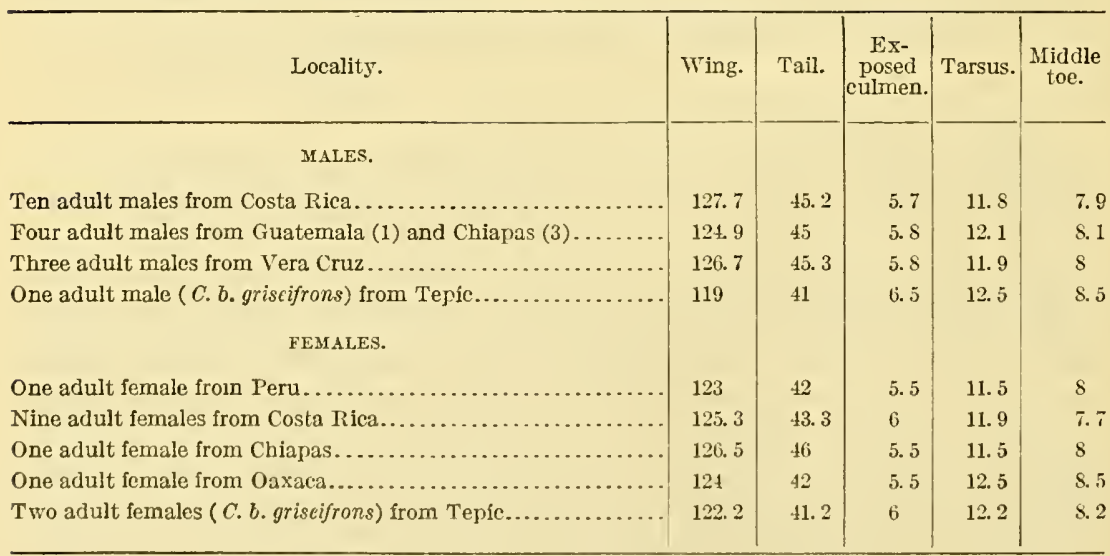

I am not able to discern any color differences between specimens from the different localities (except in case of those from Tepic). 
coverts, the feathers have more or less distinctly paler terminal margins; young males (sometimes, at least) with feathers of neck tinged or narrowly tipped with rusty.

Southeastern Mexico, in States of Vera Cruz (Orizaba; Jico; Tuxpango), Puebla (San Miguél Molino), Mexico (near City of Mexico), Oaxaca (Mount Zempoáltepec) and Chiapas (Chicharras); highlands of Guatemala (Dueñas); highlands of Costa Rica (Volcán de Irazú; San Pedro; San José; El Generál; Pozo Reál de Térraba) and southward through Panamá (Calovévora), Colombia (Retiro, Antioquía) and Ecuadór (Quito Valley; Mapoto; Gualaquiza) to Peru (La Glória; La Mercéd; Santa Ana; Amable Maria; Idma).

Chætura brunneitorques Lafressaye, Rev. Zool., 1844, 81 (Colombia; coll. Lafresnaye).-Salvin and Godman, Ibis, 1882, 83 (Mexico; Guatemala; Panamá; Colombia; Ecuadór; synonymy); Biol. Centr.-Am., Aves, ii, 1894, 378 (Tuxpango and Orizaba, Vera Cruz; San Miguél Molino, Puebla; near Dueñas, Guatemala; San José, Costa Rica; Chiriquí and Calovevora, Panamá; Colombia; Ecuadór).-Taczanowski and Berlepsch, Proc. Zool. Soc. Lond., 1885, 105 (Mapoto, Ecuadór).-Zeledón, Anal. Mus. Nac. Costa Rica, i, 1887, 120 (San José, Costa Rica).-Ridgway, Proc. U. S. Nat. Mus., xi, 1888, 542 (San José, Costa Rica; crit.).-Salvadori and Festa, Boll. Mus. Zool., etc., Torino, xv, 1900, 12 (Gualaquiza, e. Ecuadór).-Cherrie, Auk, ix, 1892, 324 (San José, Costa Rica).

C[hætura brunneitorques RidGway, Man. N. Am. Birds, 1887, 303.

[Acanthylis] brunneitorques Bonaparte, Consp. Av., i, 1850, 64.

Cypseloides brunneitorques Hartert, Cat. Birds Brit. Mus., xvi, 1892, 493 (Retiro, Colombia; etc.).-Berlepsch and Stolzmann, Proc. Zool. Soc. Lond., 1902, 29 (La Glória and La Mercéd, centr. Peru; crit.); Ornis, 1906, 96 (Santa Ana and Idma, Peru).

C[ypseloides] brunneitorques Hartert, Das Tierreich, Podarg., Caprim., Macropt., 1897, 79.

[Cypseloides] brunneitorques Sharpe, Hand-list, ii, 1900, 93.

Cypseloides brunneitorques brunneitorques Carriker, Ann. Carnegie Mus., vi, 1910, 509 (Costa Rica).

Acanthylis rutila (not Hirundo rutila Vieillot) ScLater, Proc. Zool. Soc. Lond., $1855,135$.

Chxtura rutila Salvin and Sclater, Ibis, 1860, 37, pl. 3 (Dueñas, Guatemala; crit.).-Sclater and Salvin, Proc. Zool. Soc. Lond., 1869, 363 (near City of Mexico); 1879, 531 (Retiro, Antioquía, Colombia).-Sclater, Cat. Am. Birds, 1862, 283 (Dueñas, Guatemala); Proc. Zool. Soc. Lond., 1863, 100, part (Dlieñas; monogr.); 1865, 613 (Dueñas; monogr.); Journ. für Orn., 1867, 135, part.-Sunichrast, Mem. Bost. Soc. N. H., i, 1869, 562 (highlands of Vera Cruz); La Naturaleza, v, 1881, 250 (Tuxpango, near Orizaba, Vera Cruz).-Orton, Am. Nat., iv, 1871, 713 (Quito Valley, Ecuadór; descr. nest).-Taczanowski, Proc. Zool. Soc. Lond., 1874, 545 (Amable Maria, centr. Peru).

[Chxtura] rutila Gray, Hand-list, i, 1869, 66, no. 764, part (Guatemala).-SCLAter and Salvin, Nom. Av. Neotr., 1873, 95, part (Mexico to Ecuador). 


\section{CYPSELOIDES BRUNNEITORQUES GRISEIFRONS (NelsOn).}

TEPIC SWIFT.

Similar to $C . b$. brunneitorques, but coloration paler (the back, etc., deep sooty instead of nearly black, the under parts of body grayish sooty), and feathers of forehead (in both sexes) margined with pale grayish, these margins becoming broader and whitish on sides of forehead, along upper margin of loral region.

Adult male.-Length (skin), 127.5; wing, 119 (primaries much worn at tip); tail, 41 (worn at tip); exposed culmen, 6.5 ; tarsus, 12.5; middle toe, 8.5. ${ }^{a}$

Adult female.--Length (skins), 125-127 (126); wing, 121.5-123 (122.2); tail, 40-42.5 (41.2); exposed culmen, 6; tarsus, 12-12.5 (12.2); middle toe, $8-8.5(8.2){ }^{b}$

Western Mexico, in Territory of Tepíc (Santa Teresa); also (according to Nelson) Sierra Madre of Jalisco, western Zacatecas, and southern Durango.

Cypselus brunneitorques griseifrons Nelson, Auk, xvii, July, 1900, 262 (Santa Teresa, Tepíc, w. Mexico; coll. U. S. Nat. Mus.).

\section{CYPSELOIDES CHERRIEI Ridgway.}

\section{CHERRIE'S SWIFT.}

Adult (male?).-Uniform deep, dark sooty, very slightly paler below (the chin sooty grayish), the remiges and rectrices very slightly darker (almost sooty black); lores sooty black; a conspicuous white spot on each side of forehead and a smaller postocular spot or streak of white; bill black; iris dark brown; legs and feet dusky (in dried skin); length (skin), 129.5; wing, 127; tail, 4.7; exposed culmen, 6 ; tarsus, 13 ; middle toe, $9 .{ }^{c}$

Adult female?-Similar to the adult male(?), as described above, but white spots on forehead slightly smaller, postocular white spot or streak wanting, and feathers of abdomen and flanks tipped, narrowly, with white; length (skin), 118; wing, 123; tail, 46.5; exposed culmen, 6 ; tarsus, 13 ; middle toe, $9 .^{c}$

High mountains of Costa Rica (Volcán de Irazú).

Cypseloides cherriei Ringway, Proc. U. S. Nat. Mus., xvi, no. 923, June 13, 1893, 44 (Volcan de Irazú, Costa Rica; coll. U. S. Nat. Mus.).-Salvin and Godman, Biol. Centr.-Am., Aves, ii, 1892, 380.-Carriker, Ann. Carnegie Mus., vi, 1910, 510 (Costa Rica).

C[ypseloides] cherriei Hartert, Das Tierreich, Podarg., Caprim., Macropt., 1897, 80. [Cypseloides] cherriei SHARPe, Hand-list, ii, 1900, 94.

\section{Genus CH $A$ ET URA Stephens.}

Chætura Stephens, Shaw's Gen. Zool., xiii, pt. ii, 1825, 76. (Type, Hirundo pelagica Linnæus.)

Acanthylis BoIE, Isis, 1826, 971. (Type, Hirundo spinicauda Temminck.)

Acanthyllis (emendation) Newron ( $\Lambda$. and E.), Handb. Jamaica, 1881, 108.Hartert, Cat. Birds Brit. Mus., xvi, 1892, 470, footnote. 
Rhaphidura OAtes, Birds Burmah, ii, 1883, 6. (Type, Acanthylis leucopygialis Blyth.)

Acanthura a Gullding, Zool. Journ., iii, 1827, 407. (Type, Hirundo acuta "Stephens" i. e. Gmelin.)

Small Chæturine Swifts (wing about 100-130 mm.) resembling Cypseloides but with the hallux relatively much smaller (less than half as long as inner toe) and with shafts of the rectrices more rigid, usually conspicuously extruded terminally.

Nostrils elliptical, nearly parallel, for the most part anterior to the latero-frontal antix; distance from tip of longest secondary to that of longest primary about two-thirds the total length of wing; tenth and ninth primaries longest, usually nearly or quite equal in length, but sometimes one or the other a little shorter, the tenth (outermost) more or less narrowed (sometimes subacuminate) terminally; tail (to base of spines) less than two-ninths to more than one-third as long as wing, truncate or slightly rounded, very firm, the shafts very rigid and, usually, conspicuously extruded terminally, forming spine-like tips; tarsus equal to or longer than middle toe with claw, entirely naked, nonscutellate; outer toe slightly shorter, the inner toe slightly to decidedly shorter, than middle toe; hallux very small and weak, less than half as long as inner toe. ${ }^{b}$

Coloration.-Plain sooty or blackish, sometimes with a gray or whitish rump-patch or band, one species with the rump, tail-coverts, and tail light gray in contrast with rest of plumage.

Nidification.-Nest in form of a half saucer or shallow cup, composed of dried twigs glued together by salivary excretion and attached by same substance to the inner wall of a hollow tree, chimney, or similar place.

\section{KEY TO THE SPECIES AND SUBSPECIES OF CHETURA.}

a. Under parts of body and under tail-coverts gray or sooty, concolor with or paler than tail.

b. Rump brownish gray or grayish brown, concolor with tail and not conspicuously lighter than back; tail relatively shorter (only two-sevenths as long as wing).

c. Under parts and rump darker brownish gray or grayish brown.

d. Larger (wing 122-133 mm.); pileum and back not blackish. (Eastern North America, south to eastern Mexico in winter.)

Chætura pelagica (p. 717).

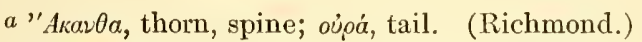

$b$ According to Lucas (Auk, xiii, 1896, 82) Chxtura (C. pelagica at least) is peculiar among the North American genera of Swifts in lacking the deltoid muscle. This muscle is present not only in other North American genera but also in Tachornis, Streptoprocne, Collocalia, and Macropteryx (double in the last, single in the rest). It is not known, however, whether it is present or absent in Panyptila, Claudia, Micropus, or Cypscloides, or other species of Chxtura than C. pelagica. (Seo Auk, xvi, 1899,77 , as to deltoid muscle in Streptoprocne.) 
dd. Smaller (wing 105-116.5 mm.); pileum and back blackish.

e. Darker; rectrices with conspicuous spiny tips; wing averaging 111.2, tail 36.2 , in male, wing 111.8, tail 37.1, in female. (Eastern Mexico to Costa Rica.)........................... Chætura richmondi (p. 719).

$e e$. Paler, especially under parts; rectrices without distinct (if any) spiny tips (except in very fresh plumage); wing averaging 105.5, tail 27.7, in male, wing 105.2, tail 30.1, in female. (Yucatan.)

Chætura gaumeri (p. 721).

cc. Under parts and rump much paler brownish gray. (Western North America, south in winter to Guatemala.)................. Chætura vauxii (p. 722).

b6. Rump clearer gray, ash gray, or pale buffy gray, contrasting with the black or blackish tail as well as with black or dark sooty of back; tail relatively longer (one-third or more as long as tail).

$\therefore$ Pileum and back dark sooty.

d. Rump deep brownish gray or sooty gray, shading gradually into the darker color of upper tail-coverts. (Dominica, Guadeloupe, and Santa Lucia, Lesser Antilles.) ............................ Chætura acuta (p. 724).

$d d$. Rump pale buffy gray, forming a broad and sharply defined band, abruptly contrasted with dark sooty or sooty blackish of back and upper tail-coverts. (Guianas and Trinidád to eastern Brazil.)

Chætura spinicauda (extralimital). ${ }^{a}$

cc. Pileum and back glossy black. (Chrtura cinereiventris. ${ }^{b}$ )

d. Upper tail-coverts black or blackish, in contrast with pale gray of rump. e. Under parts of body paler; slightly smaller (wing $110 \mathrm{~mm}$.). (Eastern Brazil.) .......... Chætura cinereiventris cinereiventris (extralimital). $c$ $e e$. Under parts of body darker; slightly larger (wing $111.1 \mathrm{~mm}$.). (Pacific coast district from Costa Rica to northern Colombia.)

Chætura cinereiventris fumosa (p. 725).

a Hirundo spinicauda [Temminck?] Catal. Naamlyst Vog. Johan. Sonnenberg Galant, 1810, 13 (based on l'Hirondelle acutipenne Buffon, Hist. Nat. Ois., vi, 701; Hirondelle à queue pointue de Cayenne Daubenton, Pl. Enl., 726, fig. 1); Kuhl, Buff. et Daub. Fig. Av. Col. Nom. Syst., 1820, 13 (credits name to Temminck).Cypselus spinicaudus Temminck, Tabl. Méth., 1839, 78.-Acanthylis spinicauda Boie, Isis, 1826, 971; 1844, 167.-Chætura spinicauda Sclater, Cat. Am. Birds, 1862, 283; Hartert, Cat. Birds Brit. Mus., xvi, 1892, 483; Das Tierreich, Podarg., Caprimulg., Macropt., 1897, 75.-Chrtura spinicauda spinicauda Hellmayr, Verh. Orn. Gesellsch. Bayern, viii, 1908, 158 (range; synonymy; descr.).

$b$ The following forms, referred to this species, as subspecies, by Hellmayr, I have not seen:

(1) [Chætura cinereiventris] Subsp. a. Chætura guianensis Hartert, Cat. Birds Brit. Mus., xvi, 1892, 486.-Chætura cinereiventris guianensis Hellmayr, Verh. Orn. Gesellsch. Bayern, viii, 1908, 155.

(2) Chxtura sclateri Pelzeln, Orn. Bras., 1868, 15, 56.-Chætura cinereiventris sclateri Hellmayr, Verh. Orn. Gesellsch. Bayern, viii, 1908, 157.

(3) Chrtura sclateri occidentalis Berlepsch and Taczanowski, Proc. Zool. Soc. Lond., 1883, 569.-Chxtura cinereiventris occidentalis Hellmayr, Verh. Orn. Gesellsch. Bayern, viii, 1908, 158.

c Chrtura cinereiventris Sclater, Cat. Am. Birds, 1862, 283; Hartert, Cat. Birds Brit. Mus., xvi, 1892, 485.-Ch[ætura] cinereiventris (typica) Hartert, Das Tierreich, Podarg., Caprim., Macropt., 1897, 76.-Chaetura cinereiventris cinerciventris Hellmayr, Verh. Orn. Gesellsch. Bayern, viii, 1908, 153 (e. Brazil; synonymy; descr.).Cypselus acutus (not Hirundo acuta Vieillot) Maximilian, Beitr., iii, pt. i, 1830, 351 (Brazil; coll. Am. Mus. N. H.). 
$d d$. Upper tail-coverts gray, or mostly so, like rump.

e. Upper tail-coverts partly blackish; under parts of body paler (as in C. c. cinereiventris). (Grenada, Tobago, Trinidád, and Margarita Island, Venezuela.)............... Chætura cinereiventris lawrencei (p. 727). ee. Upper tail-coverts entirely gray, like rump; under parts of body darker (as in C. c.fumosa). (Caribbean slope, Nicaragua and Costa Rica.)

Chætura cinereiventris phæopygos (p. 727). aa. Under parts of body black, or sooty black, conspicuously darker than color of tail and tail-coverts. (St. Vincent and Grenada, Lesser Antilles; Tobago, and Trinidád to Venezuela, eastern Peru, and northern Brazil.)

Chætura brachyura (p. 728).

I am fully aware of the unsatisfactory character of the above "key" so far as it relates to the group containing C. spinicauda and $C$. cinereiventris. This results mainly from paucity of material, only two specimens of each of the forms designated and only three examples of $C$. cinereiventris lawrencei being available for comparison. Of $C$. cinereiventris phxopygos and what purports to be $C$. fumosa (from western Costa Rica) there are, however, extensive series; and in the case of the latter I am convinced that if the birds so identified really represent $C$. fumosa the latter is not a form of C. spinicauda, but, on the other hand, is very closely related to and almost certainly only subspecifically distinct from $C$. cinereiventris. Indeed I am able to separate it from C.c. cinereiventris (from Brazil) only by the much darker color of the under parts, which, however, are colored precisely as in C.c. phxopygos, the rump and upper tailcoverts being colored exactly as in $C$. c. cinereiventris, whereas $C$. spinicauda has a very definite pale buffy gray band across the rump (instead of a large area of purer or less yellowish gray), very abruptly defined against the black of upper tail-coverts, the color of the back and pileum being, moreover, sooty blackish instead of glossy bluish or greenish black.

\section{CHATURA PELAGICA (Linnæus)。}

CHIMNEY SWIFT.

Adults (sexes alike).-Above plain dark sooty olive, passing into paler grayish brown (deep hair brown) on rump, upper tail-coverts, and tail, the plumage slightly glossy, the feathers of pileum darker centrally, producing an indistinctly squamate effect, those of the rump and the upper tail-coverts sometimes very narrowly and indistinctly tipped with paler; rigid shafts of rectrices black; wings slightly glossy sooty blackish, the inner webs of remiges passing into grayish brown toward edges; loral region blackish, the feathers along projecting edges of forehead and crown (especially the superciliary portion) narrowly (sometimes very indistinctly or obsoletely) margined with whitish; sides of head otherwise, sides of neck, and under parts plain grayish brown (nearest dark hair brown, but more grayish), fading into a much paler tint (sometimes very pale dull gray or almost 
grayish white on throat, chin, and malar region; bill black; iris brown; legs and feet brownish or dusky (more or less livid in life).

Young.-Not essentially if at all different in coloration from adults. Adult male.-Length (skins), 116-132 (124); wing, 126-133 (129.2); tail, 39.5-44 (42.3); exposed culmen, 5-6 (5.7); tarsus, 11.5-12.5 (12); middle toe, 8-9 (8.3). ${ }^{a}$

Adult female.-Length (skins), 112-134 (117); wing, 122.5-133.5 (129.7); tail, 40-45.5 (42); exposed culmen, 5.5-6 (5.6); tarsus, 11-12.5 (11.7); middle toe, 8-8.5 (8.2). ${ }^{b}$

Eastern North America; north to New Brunswick (Fort Fairfield; Grand Falls), Nova Scotia (Cape Breton Island), Province of Quebec (Point de Monts), southern Labrador, ${ }^{c}$ northern Ontario (Lake Muskoka), Manitoba (Winnipeg), and Alberta (Edmonton)-accidentally to southern Greenland (Sukkertoppen)-west to western border of Great Plains (Miles City, Montana, Black Hills, South Dakota) and (accidentally?) New Mexico (Rinconada, March 1); breeding southward to southern Florida (Tarpon Springs) and thence westward along Gulf coast to southeastern Texas; during migration southward to Vera Cruz (Jalapa) and Yucatan (Cozumél Island)-also to Guatemala ?; ${ }^{d}$ occasional straggler to the Bermudas.

[Hirundo] pelagica Linswus, Syst. Nat., ed. 10, i, 1758, 192 (based on Hirundo, cauda aculeata, americana Catesby, Nat. Hist. Carolina, iii, 8, pl. 8).

Chrtura pelagica Baird, Breter, and Ridgway, Hist. N. Am. Birds, ii, 1874, 432, pl. 45, fig. 7.-Coues, Birds Northwest, 1874, 267 (Bijou Hills, South Dakota); Bull. U. S. Geog. and Geol. Surv. Terr., iv, 1878, 614 (Pembina and Souris R., North Dakota).-Reid, Bull. U. S. Nat. Mus., no. 25, 1884, 209 (Bermuda, straggler).-Ridgway, Proc. U. S. Nat. Mus., iii, 1880, 188; Orn. Illinois, i, 1889; 364.-Hofrman, Proc. Bost. Soc. N. H., 1882, 401 (Fort Berthold, North Dakota, breeding).-SEron, Auk, iii, 1886, 156 (w. Manitoba, summer res.).-American Ornithologists' Union, Check List, 1886, no. 423; 3d ed., 1910, 200.-Sсотт, Auk, vi, 1889, 252 (Tarpon Springs, Florida, breeding).-Salvin, Ibis, 1889, 367 (Cozumél I., Yucatan; crit.).-Thonpson, Proc. U. S. Nat. Mus., xiii, 1890, 556 (Winnipeg, etc., Manitoba).Hartert, Cat. Birds Brit. Mus., xvi, 1892, 480 (Jalapa, Vera Cruz; Cozumél I., etc.).-Salvin and Godman, Biol. Centr.-Am., Aves, ii, 1894, 374 (Jalapa; Cozumél; Guatemala?).-Bendire, Life Hist. N. Am. Birds, ii, 1895, 177, pl. 1, fig. 25 (egg).-Beyer, Proc. Louisiana Soc. N. H. for 1897-99 (1900), 103 (Louisiana, breeding).-Bailey (Florence M.), Handb. Birds W. U. S., 1902, 230.-Williams, Auk, xxi, 1904, 456 (Leon Co., Florida; summer res.).Townsend (C. W.), Auk, xxiii, 1906, 174 (Cape Breton I., Nova Scotia; descr. nest, etc.).-Swales and Taverner, Wilson Bull., no. 55, 1906, 65 (Lake Muskoka, n. Ontario, common).-Hunt, Wilson Bull., no. 58, 1907, 18 (Lake Sebago, Maine).-Preble, North Am. Fauna, no. 27, 1908, 390 (Edmonton, Alberta, May 17).-Visher, Auk, xxvi, 1909, 148 (Black Hills, w. South Dakota).

a Ten specimens.

$b$ Eight specimens.

c Perhaps doubtful.

$\boldsymbol{d}$ See Salvin and Godman, Biol. Centr.-Am., Aves, ii, 1894, 375. 
C[hætura] pelagica Ridgway, Man. N. Am. Birds, 1887, 303.

Ch[aetura] pelagica Hartert, Das Tierreich, Podarg., Caprim., Macropt., 1897, 74.

[Chxtura] pelagica Sharpe, Hand-list, ii, 1900, 92 ("Mexico to Costa Rica" in winter).

[Chætura pelagica] var. pelagica BaIRd, Brewer, and RIdgway, Hist. N. Am. Birds, ii, 1874, 431.

[Hirundo] pelasgia Linneus, Syst. Nat., ed. 12, i, 1766, 345.-Gmelrn, Syst. Nat., i, pt. ii, 1789, 1023.--LathaM, Index Orn., ii, 1790, 581.

Hirundo pelasgia Vienlot, Ois. Am. Sept., i, 1807, 63, pl. 33; Nouv. Dict. d'Hist. Nat., xiv, 1817, 512.--Tеммлскк, Cat. Syst., 1807, 135.-Wilson, Am. Orn., v, 1812, 48, pl. 39, fig. 1.-Stephens, Shaw's Gen. Zool., x, 1817, 129.

Cypselus pelasgius Bonaparte, Synop. Birds U. S., 1828, 63.-Nuttall, Man. Orn. U. S. and Can., i, 1832, 609.-Audubon, Orn. Biog., ii, 1834, 329, pl. 158; $\mathrm{v}, 1839,419$.

C[ypselus] pelasgius Maxidillian, Journ. für Orn., 1858, 99.

Hemiprocne pelasgia Streubel, Isis, 1848, 363.

[Acanthylis] pelasgia Bonaparte, Consp. Av., i, 1850, 64.-Woodhouse, in Rep. Sitgreaves' Expl. Zuñi and Col. R., 1853, 63, part(Indian Territory; Texas).Cassin, Illustr. Birds Col., Tex., etc., 1855, 249.-Brewer, North Am. Oology, 1857, 108.

Chrtura pelasgia Stephens, Shaw's Gen. Zool., xiii, pt. ii, 1S25, 76.-Bonaparte, Geog. and Comp. List, 1838, 8.-Auduron, Synopsis, 1839, 33; Birds Am., oct. ed., i, 1840, 164, pl. 44.-Hurdis, Jardine's Contr. Orn., 1850, 35 (Bermudas, straggler).-BAIRd, Rep. Pacific R. R. Surv., ix, 1858, 144; Cat. N. Am. Birds, 1859, no. 109.-Martens, Journ. für Orn., 1859, 216 (Bermudas).-Willis, An. Rep. Smithson. Inst., 1859, 287 (Bermudas).-Sclater, Cat. Am. Birds, 1862, 282; Proc. Zool. Soc. Lond., 1863, 100 (monogr.); 1865, 610 (monogr.); Journ. für Orn., 1867, 132.-TrIppe, Proc. Essex Inst., vi, 1871, 114 (Minnesota).-Coues, Check List, 1873, no. 271.-Allen, Proc. Bost. Soc. N. H., xvii, 1874, 62 (Fort Rice, Dakota; Yellowstone R. near mo. of Tongue R., Montana).-Newton, Man. N. H. Greenland, 1875, 97 (near Sukkertoppen, Greenland, 1 spec., 1863).

[Chætura] pelasgia Gray, Hand-list, i, 1869, 66, no. 760.-Coues, Key N. Am. Birds, 1872, 183.-Sclater and Salvin, Nom. Av. Neotr., 1873, 95.

Chxtura pelasgica Ridgwar, Nom. N. Am. Birds, 18s1, no. 351.-Coues, Check List, 2d ed., 1882, no. 405.-Batchelder, Bull. Nutt. Orn. Club, vii, 1882, 150 (Fort Fairfield and Grand Falls, New Brunswick, common).-Nenrling, Bull. Nutt. Orn. Club, vii, 1882, 169 (s. e. Texas, breeding).-Merriald, Bull. Nutt. Orn. Club, vii, 1882, 236 (Point de Monts, Quebec).-Bicknell, Auk, ii, 1885, 257 (notes).-Cantwell, Orn. and Ool., xv, 1890, 133 (Minnesota).

C[hætura] pelasgica Couss, Key N. Am. Birds, 2d ed., 1884, 457.

(?) Cypselus poliourus Temurvck, Tabl. Méth., 1839, 7S (based on Hirondelle d queue pointue, de la Louisiane Daubenton, Pl. Enl., pl. 726, fig. 2; see Hellmayr, Novit. Zool., xiii, 1906, 37, in text).

\section{CHETURA RICHMONDI Ridgway.}

\section{RICHMOND'S SWIFT.}

Similar to $C$. gaumeri, but larger and coloration darker (the pileum and back more nearly black), and rectrices with conspicuous spiny tips.

Adults (sexes alike).-Lores velvety black; pileum, hindneck, back, and scapulars uniform sooty black, faintly glossed with greenish; 
rump and upper tail-coverts plain grayish brown (deep hair brown), the feathers (especially longer upper tail-coverts) sometimes narrowly and indistinctly margined at tip with paler; tail slightly darker grayish brown, the rigid shafts of rectrices black; wings black, slightly glossed with greenish blue; under parts plain grayish brown (like color of rump and upper tail-coverts), fading on throat and chin into much paler gray (sometimes almost grayish white), the feathers dusky grayish brown basally; bill black; iris brown; legs and feet grayish brown (more or less livid in life).

Young.-Not noticeably if at all different in coloration from adults.

Adult male. - Length (skins), 91-106 (99); wing, 104.5-116.5 (111.2); tail, 34-38 (36.2); culmen, 4.5-6 (5); tarsus, 10-11 (10.3); middle toe, $7-8(7.5) .^{a}$

Adult female.-Length (skins), 95-110 (104); wing, 107-115 (111.8); tail, 35.5-38.5 (37.1); culmen, 4.5-5.5 (4.9); tarsus, 10-11 (10.5); middle toe, $7-8(7.6){ }^{b}$

Southeastern Mexico, in States of Tamaulipas (Carricitos; Guiaves), Vera Cruz (Motzorongo; San Andres Túxtla; Volcán de Túxtla) and Oaxaca (Guichicovi; Santo Domingo) and southward through Guatemala (Gualán; Dueñas, Los Amates, Ysabál), Nicaragua (Rio Escondido) and Costa Rica (La Hondura; Volcán de Irazú; Carrillo; Cariblanco de Sarapiquí; El Generál; Coliblanco; Guayabo; Juan Viñas; Laguária, Copéy, Las Vueltas, and Santa Maria, Dota) to western Panamá (Chiriquí).

Chætura gaumeri (not of Lawrence) Rrdaway, Proc. U. S. Nat. Mus., vi, 1883, 415 (Costa Rica).-Salvin, Ibis, 1889, 367, part (Chiriquí, Panamá; crit.).Hartert, Cat. Birds Brit. Mus., xvi, 1892, 482, part (Costa Rica).-RichMond, Proc. U. S. Nat. Mus., xvi, 1893, 516 (Rio Escondido, Nicaragua).Salvin and Godman, Biol. Centr.-Am., Aves, ii, 1894, 376, part (Rio Escon-

a Fourteen specimens.

$b$ Fifteen specimens.

\begin{tabular}{|c|c|c|c|c|c|}
\hline Locality. & Wing. & Tail. & 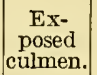 & Tarsus. & $\begin{array}{c}\text { Middle } \\
\text { toe. }\end{array}$ \\
\hline \multicolumn{6}{|l|}{ MALES. } \\
\hline Two adult males ( $C$. gaumcri) from Yucatan.... & 105. 5 & 27.7 & 5 & 11 & 7.5 \\
\hline Two adult males ( $C$. richmondi) from Vera Cruz... & 115. 2 & 36.2 & 5.2 & 10.5 & 7.5 \\
\hline Two adult males ( $C$. richmondi) from Nicaragua.......... & 110 & 35.2 & 5.7 & 10.7 & 7.5 \\
\hline Ten adult males ( C. richmondi) from Costa Rlca... & 110.6 & 36.3 & 4.9 & 10.2 & 7.6 \\
\hline \multicolumn{6}{|l|}{ FEMALES. } \\
\hline Four adult females ( $C$. gaumcri) from Yucatan............. & 105. 2 & 30.1 & 4. 6 & 10.2 & 7.3 \\
\hline Three adult females ( $C$. richmondi) from Vera Cruz (1) and & & & & & \\
\hline 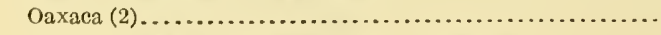 & 113. 2 & 36.8 & 5.2 & 10.5 & 7.5 \\
\hline One adult female ( $C$. richmondi) from Guatemala.... & 113.5 & 38.5 & …. & 10 & 7.5 \\
\hline One adult female ( $C$. richmondi) from Nicaragua...... & 110 & 36 & 5.5 & 10.5 & 8 \\
\hline Ten adult females ( $C$. richmondi) from Costa Rlca... & 111.5 & 37.1 & 4.8 & 10. 6 & 7.5 \\
\hline
\end{tabular}


dido; Costa Rica; Chiriquí).--Dearborn, Pub. 125, Field Mus. N. H., 1907, 96 (Los Amates, e. Guatemala, Jan.).-Carriker, Ann. Carnegie Mus., vi, 1910, 507 (Costa Rica).-Ferry, Pub. 146, Field Mus. N. H., orn. ser., i, no. 6, 1910, 264 (Guayabo, Costa Rica).

C[hætura] gaumeri RIdgway, Man. N. Am. Birds, 1887, 303, part (Costa Rica).

Ch[ætura] gaumeri Hartert, Das Tierreich, Podarg., Caprim., Macropt., 1897, 75, part (Nicaragua; Costa Rica).

[Chrtura] gaumeri SharPe, Hand-list, ii, 1900, 92, part (Nicaragua; Costa Rica). Chxtura vauxii (not Cypcelus vauxii Townsend) LAwrence, Bull. U. S. Nat. Mus., no. 4, 1876, 32 (Guichicovi, Oaxaca).

Chxtura vauxi Salvin and Godman, Biol. Centr.-Am., Aves, ii, 1894, 375, part (Guichicovi, Oaxaca; Rio Escondido, Nicaragua; Costa Rica; Honduras?).Carriker, Ann. Carnegie Mus., vi, 1910, 507 (Costa Rica).

Chætura richmondi Ridgway, Proc. Biol. Soc. Wash., xxiii, Apr. 19, 1910, 53 (Guayabo, e. Costa Rica; coll. U. S. Nat. Mus.).-Phillıs, Auk, xxviii, 1911, 77 (Carricitos and Guiaves, Tamaulipas).

\section{CHASTURA GAUMERI Lawrence.}

GAUMER'S SWIFT.

Similar to C. richmondi, but decidedly smaller (except bill and feet), paler, especially the rump, upper tail-coverts, and under parts, and rectrices without distinct (if any) projecting tip to shaft of rectrices (except, sometimes, in very fresh plumage).

Adults (sexes alike).-Lores velvety black; pileum, hindneck, back, and scapulars uniform very dark sooty brown or blackish brown, faintly glossed with greenish, the wings similar but more nearly black and with the gloss more bluish green; rump and upper tailcoverts grayish brown (hair brown, decidedly lighter than in $C$. richmondi), the feathers usually (?) narrowly and indistinctly tipped with paler; tail slightly darker grayish brown, the shafts of rectrices black; under parts grayish brown (hair brown), gradually becoming slightly paler on chest, where fading into much paler gray (sometimes almost grayish white) on chin and upper throat; bill black; iris brown; legs and feet dusky (more or less livid in life).

Young.-Not materially, if at all, different in coloration from adults. Adult male.-Length (skins), 109; wing, 105-106 (105.5); tail, 2629.5 (27.7); culmen, 5 ; tarsus, 11 ; middle toe, $7.5 .^{a}$

Adult female.-Length (skins), 95.5-99.5 (97) : wing, 99-111 (105.2); tail, 28-31.5 (30.1); culmen, 4.5-5 (4.6); tarsus, 10-10.5 (10.2); middle toe, $7-7.5(7.3) .^{b}$

Yucatan (Mérida; Chichen-Itza; Temax; La Vega; Silám; Tunkas; Ticúl; Cozumél Island).

a Two specimens.

$b$ Four specimens.

Although the series examined of this form is a very large one, most of the specimens have not the sex determined.

$81255^{\circ}-$ Bull. 50-11- 46 
Chrtura vauxii (not Cypcelus vauxii Townsend) Lawrence, Ann. Lyc. N. Y., ix, 1869, 204 (Mérida, Yucatan).

Chætura gaumeri Lawrence, Ann. N. Y. Ac. Sci., ii, no. 8, March, 1882, 245

(Yucatan; coll. G. N. Lawrence); iii, 1883, 273; iv, 1884, 273 (crit.).-BouCARD, Proc. Zool. Soc. Lond., 1883, 451 (Yucatan).-Reichenow and SchaLow, Journ. für Orn., 1884, 381 (reprint of orig. descr.).-SALvin, Ibis, 1889, 367, part (Cozumél I., Yucatan; crit.).-Hartent, Cat. Birds Brit. Mus., xvi, 1892, 482, part (Temax and Cozumél I., Yucatan).-Salvin and GodMaN, Biol. Centr.-Am., Aves, ii, 1894, 376, part (Mérida, Silám, Temáx, Tunkas, Ticúl, and Cozumél I., Yucatan).-Cose, Bull. Mus. Comp. Zool., 1, 1906, 127 (Chichen-Itza).

Chrtura gaumeri? Stone, Proc. Ac. Nat. Sci. Phila., 1890, 206 (Tunkas and Ticúl, Yucatan).

C[hætura] gaumeri Ridgwax, Man. N. Am. Birds, 1887, 303, part (Yucatan).

Ch[ætura] gaumeri Hartert, Das Tierreich, Podarg., Caprim., Macropt., 1897, 75 , part (Yucatan).

[Chætura] gaumeri SHARPE, Hand-list, ii, 1900, 92, part (Yucatan).

Chrtura yucatanica Lawrence, Ann. N. Y. Ac. Sci., iii, no. 5, Jan. 5, 1885, 156 (Silam, Yucatan; coll. G. N. Lawrence;=young).

Chætura peregrinator Lawrence, Ann. N. Y. Ac. Sci., iii, no. 9, Dec., 1885, 273 (Temáx, Yucatan; coll. G. N. Lawrence;=young full-grown).

\section{CHETURA VAUXII (Townsend).}

VAUX'S SWIFT.

Similar to $C$. pelagica, but decidedly smaller, and with color of rump, upper tail-coverts, and under parts (especially the latter) decidedly paler.

Adults (sexes alike).-Pileum, hindneck, back, and scapulars plain dark sooty olive, very faintly glossed with bronzy olive, the feathers of pileum (especially the forehead) with more or less distinct paler margins, producing a squamate effect; rump and upper tail-coverts rather light grayish brown (hair brown), the feathers sometimes arrowly margined terminally with paler: tail darker grayish brown, with rigid shafts of rectrices black; wings sooty blackish, becoming grayish brown on inner secondaries and toward edges of inner webs of primaries; loral region black posteriorly, dark grayish brown anteriorly; feathers of projecting edge of forehead and crown (especially above black ante-orbital area) narrowly margined with whitish; auricular region, sides of neck, and under parts light grayish brown (pale hair brown), passing into grayish white on chest, throat, chin, and malar region and into deeper grayish brown (hair brown) on under tailcoverts: bill black; iris brown; feet brownish or dusky (more or less livid in life).

Young.-Not essentially if at all difierent from adults.

Adult male.-Length (skins), 101-117 (110); wing, 107-115 (112.8); tail, 34-37.5 (36.2); exposed culmen, 5-5.5 (5.3); tar'sus, 10-11.5 (10.9); middle toe, $7-8(7.6){ }^{a}$ 
Adult female.-Length (skins), 105-119 (112); wing, 107-117 (111.9); tail, 36-39.5 (37.1); exposed culmen, 4.5-5.5 (5.1); tarsus, 10-11.5 (10.8); middle toe, $7-8$ (7.5). ${ }^{a}$

Western United States, British Columbia (Nisqually; Goldstream; Lake La Hache; New Westminster; Vancouver Island; Sicamous) and southern Alaska (Revillagigedo Island; Boca de Quadra; Chickamin River; Broadfield Canal; Thomas Bay), east to Montana (Silver, Missoula County), western Nevada (Pyramid Lake Reservation), and New Mexico (?); south to Lower California (San José del Cabo; San Pedro Martir Mountains; between San Rafaél and San Pedro Martir Mountains; Tia Juana; Salton River), and through Mexico, in States of Morelos (Cuernavaca), Jalisco (San Sebastián), Tlaxcala (Laguna del Rosário), Mexico (Valley of Mexico), Puebla, Vera Cruz (Rio Seco, near Córdova; Motzorongo), and Oaxaca (Guichicovi) to highlands of Guatemala (Mazatenango; Alotenango; Cobán; Dueñas; Raxché) and Honduras. ${ }^{b}$

Cypcelus vauxii Townsend, Journ. Ac. Nat. Sci. Phila., viii, 1839, 148 (Ft. Vancouver, Columbia River).

Cypcelus vauxii Townsend, Narrative, 1839, 348.

Chætura vauxii De KAx, Zool. N. Y., ii, 1844, 36.-BaIRd, Rep. Pacific R. R. Surv., ix, 1858, 145; ed. 1860 (Birds N. Am.), 145, pl. 18; Cat. N. Am. Birds, 1859, no. 110.-Kennerly, Rep. Pacific R. R. Surv., x, pt. iv, 1859, pl. 18, fig. 2 (no text).-Cooper and Suckley, Rep. Pacific R. R. Surv., xii, pt. ii, 1860, 165 (Straits of Fuca, Washington).-Sclater, Cat. Am. Birds, 1862, 282; Proc. Zool. Soc. Lond., 1863, 100 (monogr.); 1865, 611 (monogr.; crit.); Journ. für Orn., 1867, 133.-Cooper, Orn. Calif., 1870, 351 (Coast Range, near Santa Clara, California); Auk, iv, 1887, 92 (Ventura Co., California).-HeNshaw, Rep. Orn. Spec. Wheeler's Surv., 1876, 256 (Tejón Mits., California).Ridgway, Proc. U. S. Nat. Mus., iii, 1880, 188; ix, 1886, 158 (Laguna del Rosário, Tlaxcala; crit.); Nom. N. Am. Birds, 1881, no. 352.-Sumichrast, La Naturaleza, v, 1881, 250 (Rio Seco, near Córdova, Valley of Mexico).Ferrari-Perez, Proc. U. S. Nat. Mus., ix, I886, 158 (Laguna del Rosario, Tlaxcala).-Scotr, Auk, iii, 1886, 429 (Santa Catalina Mis., 3,000-4,000 ft., Arizona, Oct.).-Anerican Ornithologists' Union, Check List, 1886, no. 424.-Bryant (W. E.), Proc. Calif. Ac. Sci., ser. 2, 1889, 288 (bet. San Rafaél and San Pedro Martir, Lower California).-FAnNin, Check List Birds Brit. Col., 1891, 30 (e. and w. of Cascade Range on mainland).Rroads, Proc. Ac. Nat. Sci. Phila., 1893, 44 (Nisqually, Goldstream, and Lake La Hache, Brit. Columbia).-Fisher (A. K.), North Am. Fauna, no. 7, 1893, 55 (Olancha, Owens Lake, Yosemite Valley, Three Rivers, and Visalia, California).-Antronx, Zoë, iv, 1893, 236 (Tia Juana, etc., San Pedro Martir Mts., Lower California).-Bendre, Life Hist. N. Am. Birds, ii, 1895, 183, pl. 1, fig. 26 (egg).-DAwson, Wilson Bull., no. 10, 1896, 4 (Lake Chelan, Okanogan Co., e. Washington, breeding); Auk, xiv, 1897, 175 (Okanogan Co.,

$a$ Ten specimens.

$b$ Salvin and Godman, Biol. Centr.-Am., Aves, ii, 1894, 376. Possibly the specimen from Honduras and some of those from Guatemala referred to C. vauxii by the authors of the "Biologia" are C. richmondi, as are most certainly those from Nicaragua and Costa Rica. 
Washington).-Merrilu (J. H.), Auk, xiv, 1897, 354 (Ft. Sherman, Idaho).Grinnelu (J.), Pub. 2, Pasadena Ac. Sci., 1898, 27 (Los Angeles Co., California, migrant).-Brewster, Bull. Mus. Comp. Zool., xli, 1902, 111 (San José del Cabo, Lower California, Sept., Nov.).-Ratriun, Auk, xix, 1902, 135 (Seattle, Washington, summer res.).-Bailey (Florence M.), Handb. Birds W. U. S., 1902, 231.-Bowles, Auk, xxiii, 1906, 144 (Puyallup Valley, Washington, breeding).-Dearborn, Pub. 125, Field Mus. N. H., 1907, 96 (Mazatenango, Guatemala, March).-Kenmode, Prov. Mus. Victoria, 1909, 51 (Vancouver I., Sicamous, etc.).

[Chætura] vauxii Gray, Hand-list, i, 1869, 66, no. 761.-Coues, Key N. Am. Birds, 1872, 183.

C[hætura] vauxii Ridgway, Man. N. Am. Birds, 1887, 303.

[Chætura] vauxi Sclater and Salvin, Nom. Av. Neotr., 1873, 95.-Sharpe, Hand-list, ii, 1900, 92.

Chrtura vauxi Brown, Ibis, 1868, 421 (Vancouver I.).-BAIRD, BrEwER, and Ridgway, Hist. N. Am. Birds, ii, 1874, pl. 45, fig. 8; iii, 1874, 521 (near San Buenaventura and San Diego, California).-RIDGway, Bull. Essex Inst., vii, 1875, 15, 17 (Pyramid Lake Reservation, Nevada); Orn. 40th Parallel, 1877, 565 (Pyramid Lake Reservation).-Allen (C. A.), Bull. Nutt. Orn. Club, v, 1880, 55 (Nicásio, California; habits).-Coues, Check List, 2d ed., 1882, nо. 406.-ANтноNy, Auk, iii, 1886, 165 (Washington Co., Oregon, summer res.).-Merrilu, Auk, v, 1888, 256 (Ft. Klamath, Oregon, summer res.; habits).-Hartert, Cat. Birds Brit. Mus., xvi, 1892, 481.-Salvin and Godman, Biol. Centr.-Am., Aves, ii, 1894, 375 (Rio Seco, near Córdova, Vera Cruz; Valley of Mexico; Puebla; Laguna del Rosário, Tlaxcala; Raxché, Cobán, Dueñas, Alotenango, etc., Guatemala; "Honduras").-SwArtH, Pacific Coast Avifauna, no. 4, 1904, 16 (Huachuca Mts., Arizona, May); Univ. Calif. Pub. Zool., vii, 1911, 73 (Revillagigedo I., Boca de Quadra, Chickamin R., Broadfield Canal, and Thomas Bay, s. Alaska; crit.; habits).TAYlor, Condor, vii, 1905, 177 (Humboldt Co., California, breeding; descr. nest and eggs).-American Ornithologists' Union, Check List, 3d ed., 1910, 201.

C[hætura] vauxi Coues, Key N. Am. Birds, 2d ed., 1884, 458.

Ch[æetura] vauxi Hartert, Das Tierreich, Podarg., Caprim., Macropt., 1897, 75.

[Acanthylis] vauxi Bonaparte, Consp. Av., i, 1850, 64.

[Chætura pelagica] var. vauxi BAIRD, Brewer, and RIdGway, Hist. N. Am. Birds, ii, 1874, 431.

Chætura (pelagica var?) vauxi BaIrd, Brewer, and Ridgway, Hist. N. Am. Birds, ii, 1874, 435 .

Chrtura - S Salvin and Sclater, Ibis, 1860, 37 (Cobán, Guatemala; Mexico; diagn.; crit.).

Acanthylis pelasgia (not Firundo pelagica Linnæus) Woonнouse, Rep. Sitgreaves Expl. Zữ̃i and Col. R., 1853, 63, part (New Mexico?; California).

\section{CHETURA ACUTA (Gmelin).}

\section{MARTINIQUE SWIFT.}

Adults (sexes alike).-Above, including tail, sooty black, faintly glossed with bluish green; rump brownish gray or grayish brown (grayer and rather lighter than hair brown), the upper tail-coverts much darker, the longer ones approaching sooty black; under parts deep sooty brown, darker on under tail-coverts, much paler on throat and chin, where feathers are dusky basally; bill black; iris brown; legs and feet grayish brown or dusky (in dried skins). 
Adult male.-Length (skins), 105; wing, 106.5-111 (108.7); tail 37.5-39.5 (38.5); exposed culmen, 4; tarsus, 9 ; middle toe, $7 .^{a}$

Adult female.-Length (skins), 107-111 (109); wing, 111-113 (112); tail, 37.5-39.5 (38.5); exposed culmen, 4.5 ; tarsus, 9.5 ; middle toe, $7 .{ }^{a}$ Islands of Guadeloupe, Dominica, Martinique, ${ }^{b}$ St. Vincent, and Santa Lucia, Lesser Antilles.

[Hirundo] acuta Gmeun, Syst. Nat., i, pt. ii, 1789, 1023 (based on Hirondelle acutipenne, de la Martinique Buffon, Hist. Nat. Ois., vi, 702; Hirondelle de la Martinique Daubenton, Pl. Col., pl. 544, fig. 1).-Latham, Index Orn., ii, 1790, 581 (Martinique).

Hirundo acuta Stephens, Shaw's Gen. Zool., x, 1817, 131.

[Chætura] acuta GraY, Hand-list, i, 1869, 66, no. 768.-Sharpe, Hand-list, ii, 1900, 92.

Chætura acuta Hartert, Cat. Birds Brit. Mus., xvi, 1892, 486 (Dominica; Santa Lucia).-Cory, Cat. West Ind. Birds, 1892, 12, 106, 143 (Dominica; Guadeloupe; Santa Lucia; St. Vincent).-Clark, Proc. Bost. Soc. N. H., xxxii, 1905, 273 (St. Vincent).

Ch[ætura] acuta Hartert, Das Tierreich, Podarg., Caprim., Macropt., 1897, 76. Chætura poliura (not Cypselus poliourus Temminck) Lawrence, Proc. U. S. Nat. Mus., i, 1878, 62 (Dominica).

Chætura dominicana Lawrence, Ann. N. Y. Ac. Sci., i, no. 8, Dec., 1878, 255 (Dominica; coll. U. S. Nat. Mus.); Proc. U. S. Nat. Mus., i, 1878, 487 (Dominica).-Lister, Ibis, 1880, 42 (St. Vincent).-Sclater, Ibis, 1880, 75 (Santa Lucia; crit.).-Corx, Auk, iii, 1886, 346; viii, 1891, 48 (Guadeloupe); Birds West Ind., 1889, 141.--AlLen, Bull. Nutt. Orn. Club, vi, 1881, 128 (Santa Lucia).-Verrilu (G. E.), Trans. Conn. Ac. Arts and Sci., viii, 1892, 330 (Dominica; habits; crit.).

[Chrtura] dominicana Cony, List Birds West Ind., 1885, 17.

Chætura dominica Sclater, Proc. Zool. Soc. Lond., 1889, 327 (Dominica).

Chætura dominicana colardeaui Lawrence, Auk, viii, Jan., 1891, 59 (Guadeloupe; coll. Am. Mus. N. H.).

\section{CHETURA CINEREIVENTRIS FUMOSA (Salvin.)}

\section{SMOKY SWIFT.}

Adults (sexes alike).--Pileum, hindneck, lores, back, scapulars, wings, and tail glossy bluish black (the remiges and rectrices with a very narrow terminal margin of whitish in fresh plumage); rump pale buffy gray, the feathers narrowly tipped with whitish; upper tail-coverts grayish black, the inner webs edged with light grayish; chin and upper throat very pale gray or grayish white (the feathers deep sooty gray basally) passing gradually into deep mouse gray on auricular region and chest, this deepening into blackish slate on under parts of body, the under tail-coverts slate-black; bill black;

a Two specimens, from Dominica.

An adult male from Guadeloupe (type of $C$. dominica colardeaui Lawrence) measures: Wing, 107; tail, 39. Eight adults of undetermined sex from Santa Lucía measure as follows: Wing, 103-108 (105.2); tail, 36-40.5 (38.4); exposed culmen, 4-4.5 (4.3); tarsus, 9 ; middle toe, $6.5-7$ (6.9).

$b$ Not recorded, however, from Martinique (the type locality) since Buffon. 
iris dark brown; legs and feet brownish (in dried skins) the toes darker terminally.

Adult male.-Length (skins), 97-107 (102); wing, 108.5-116.5 (111.1); tail, 37-41.5 (39.2); exposed culmen, 4.5-6 (5.2); tarsus, 9.5-10.5 (10.1); middle toe, 7-7.5 (7.3). ${ }^{a}$

Adult female.-Length (skins), 97-106 (101); wing, 108.5-116 (110.9); tail, 39-42 (40.3); exposed culmen, 4.5-5.5 (4.9); tarsus, 10-10.5 (10.2); middle toe, $7-7.5(7.4) .^{b}$

Southwestern Costa Rica (Pozo Azúl de Pirrís; El Generál) and southward through Panamá (Bugaba, Chiriquí; Volcán de Chiriquí) to northern Colombia (Cacagualita, Santa Marta; Naranjo, west of Bucaramanga). (Also said to occur at Pará and Santarém on the lower Amazon; ${ }^{c}$ but until the birds of this group can be carefully revised with the aid of ample material I have doubts as to the correct identification of specimens from the localities mentioned.)

Chrtura fumosa Salvin, Proc. Zool. Soc. Lond., Aug. 1, 1870, 204 (Bugaba, Chiriquí, Panamá; coll. Salvin and Godman).-Wratt, Ibis, 1871, 375 (Naranjo, 2,500 ft., Colombia).-Hartert, Cat. Birds Grit. Mus., xvi, 1892, 483 (Bugaba, Panamá;? Santarém and Pará, lower Amazon).-Salvin and Godman, Biol. Centr.-Am., Aves, ii, 1894, 377, part (Bugaba; Volcan de Chiriquí; Colombia;? Santarém;? Pará).

[Chrtura] fumosa Sclater and Salvin, Nom. Av. Neotr., 1873, 95.-Sharpe, Hand-list, ii, 1900, 92.

Ch[ætura] fumosa Hartert, Das Tierreich, Podarg., Caprim., Macropt., 1897, 75. Chætura spinicauda fumosa Bangs, Proc. New Engl. Zool. Club, iv, March 19, 1908, 25, 26 (Pozo Azúl de Pirrís, w. Costa Rica; crit.).-Hellarayr, Verh. Orn. Gesellsch. Bayern, viii, 1908, 160 (synonymy; descr.).-Carriker, Ann. Carnegie Mus., vi, 1910, 508 (Pacific lowlands of Costa Rica).

(?) Chætura spinicauda (not Cypselus spinicaudus Temminck) LAYARD, Ibis, 1873, 389 (Pará).

$a$ Nine specimens, from Costa Rica.

$b$ Ten specimens, from Costa Rica.

\begin{tabular}{|c|c|c|c|c|c|}
\hline Locality. & Wing. & Tail. & $\begin{array}{c}\text { Ex- } \\
\text { posed } \\
\text { culmen. }\end{array}$ & Tarsus. & $\begin{array}{l}\text { Middle } \\
\text { toe. }\end{array}$ \\
\hline MALES AND SEX UNDETERMINED. & & & & & \\
\hline Nine adult males of $C . c$. fumosa from w. Costa Rica.... & 111.1 & 39.2 & 5.2 & 10.1 & 7.3 \\
\hline Six adult males of C.c. phropygos from e. Costa Rica..... & 107.1 & 39 & 5 & 9.9 & 7.2 \\
\hline $\begin{array}{l}\text { One adult male of } C . c . \text { lawrencei from Margarita Is., Venezuela.. } \\
\text { Two adults (sex not determined) of } C . c \text {. cinereiventris from }\end{array}$ & 101 & 40 & 5 & 11 & 7 \\
\hline Brazil................... & 110 & 42 & 4. 7 & 11.5 & 7 \\
\hline $\begin{array}{l}\text { One adult (sex not determined) of C. spinicauda from Cayenne. } \\
\text { FEMALES. }\end{array}$ & 108.5 & 40.5 & 4 & 10.5 & 5 \\
\hline Ten adult females o & 110.9 & 40.3 & 4.9 & 10.2 & 7.4 \\
\hline Three adult females of $C . c$. phropygos from e. Costa Rica... & 105. 7 & 38.8 & 4. 8 & 10.2 & 7.2 \\
\hline One adult female of C. c. lawrencei from Grenada...... & 106.5 & 42.5 & 4 & 10.5 & 6.5 \\
\hline One adult female of $C$. spinicauda from British Guiana. & 101 & 38.5 & & 10 & 7.5 \\
\hline
\end{tabular}

c According to Hartert, Cat. Birds Brit. Mus., xvi, 1892, 483. 


\section{CH ÆTURA CINEREIVENTRIS LAWRENCEI RidgWay.}

I.A.WENCE'S SWIFT.

Similar to C. c. phxopygos, but upper tail-coverts darker (nearly black on outer webs) and color of under parts lighter (under parts of body slate color) with dusky bases to feathers of throat broader, more exposed.

Adult male.-Length (skin), 105.5; wing, 104; tail, 40; exposed culmen, 5 ; tarsus, 11 ; middle toe, $7 .^{a}$

Adult female.-Length (skin), 108.5; wing, 106.5; tail, 42.5; exposed culmen, 4 ; tarsus, 10.5 ; middle toe, $6.5 .^{6}$

Islands of Grenada, Tobago, and Trinidád; Margarita Island, Venezuela.

(?) Acanthylis oxyura (not Hirundo oxyura Vieillot) LÉotaud, Ois. Trinidad, $1866,84$.

Chxtura cinereiventris (not of Sclater) Wells, Proc. U. S. Nat. Mus., ix, 1886, 620 (Grenada, W. I.; habits).-Cony, Auk, v, 1888, 158 (Grenada); Birds West Ind., 1889, 294 (Grenada).

[Chætura cinereiventris.] Subsp. $\alpha$. Chætura guianensis Hartert, Cat. Birds Brit. Mus., xvi, 1892, 486, part (Grenada).

Chxtura cinereiventris guianensis CoRx, Cat. West Ind. Birds, 1892, 106 (Grenada).-Clark, Proc. Bost. Soc. N. H., xxxii, 1905, 273 (Grenada).

Ch[ætura] cinereiventris guianensis Hartert, Das Tierreich, Podarg., Caprim., Macropt., 1897, 76, part.

Chætura lawrencei Ridgway, Proc. U. S. Nat. Mius., xvi, no. 923, June 13, 1893, 43 (Grenada, Lesser Antilles; coll. U. S. Nat. Mus.).

C[hætura] cinereiventris lawrencei RIdG way, Proc. U. S. Nat. Mus., xvi, 1893, 44.

Chxtura cinereiventris lawrencei Ridgway, Proc. U. S. Nat. Mus., xvi, June 13, 1893, 43 (Grenada; Tobago; Trinidád).-Chapman, Bull. Am. Mus. N. H., vi, 1894, 58 (Trinidád).-Robinson, Proc. U. S. Nat. Mus., xviii, 1896, 668 (Margarita I., Venezuela).-Hellaayr, Novit. Zool., xiii, 1906, 37 (Trinidád; crit.); Verh. Orn. Gesellsch. Bayern, viii, 1908, 154 (synonymy; descr.).

Chrtura guyanensis (not C. cinereiventris guianensis Hartert) Dacmas, Bull. Soc. Zool. France, xiii, 1900, 143 (Tobago).

[Chrtura] guianensis Sharpe, Hand-list, ii, 1900, 92, part (Trinidád; "Lesser Antilles").

(?) Chxtura fumosa (not of Salvin ?) Cherrie, Brookl. Inst. Arts and Sci., Science Bull., i, no. 8, 1906, 192 (Heights of Aripo, Trinidád).

\section{CHETURA CINEREIVENTRIS PHAOPYGOS Helimayr.}

GRAY-RUMPED CHIMNEY SWIFT.

Similar to C. c. lawrencei, but upper tail-coverts clear ash gray, like rump, and under parts of body much darker, less strongly contrasting with blackish of under tail-coverts. Similar also to $C$. $c$. fumosa, but rump darker and less buffy gray, the upper tail-coverts concolor with the rump; wing averaging shorter.

Adults (sexes alike).-Pileum, hindneck, lores, back, scapulars, wings, and tail deep, slightly glossy, bluish or greenish black; rump

$b$ One specimen (type of the subspecies) from Grenada. 
and upper tail-coverts clear slate-gray, the feathers (except in worn plumage) narrowly tipped with whitish, the outer webs of tail-coverts rather darker gray; chin and upper throat pale gray (the feathers dusky or dark sooty basally), gradually passing into deep mouse gray on auricular region and chest, this passing, through dark slate or blackish slate on under parts of body, into slate-black on under tail-coverts; bill black; iris dark brown; legs and feet dusky.

Adult male.-Length (skins), 100-104 (102); wing, 104-110.5 (107.1); tail, 36-41 (39); exposed culmen, 4.5-5.5 (5) ; tarsus, 9.510.5 (9.9); middle toe, 7-7.5 (7.2). ${ }^{a}$

Adult female.-Length (skins), 100-102 (101); wing, 104.5-107.5 (105.7); tail, 37-41 (38.8); exposed culmen, 4.5-5 (4.8); tarsus, 9.5-10.5 (10.2); middle toe, 7-7.5 (7.2). ${ }^{b}$

Eastern Nicaragua (Rio Escondido) and Costa Rica (Rio Frio; Carrillo; Juan Viñas; Jiménez).

Chætura cinereiventris guianensis (not of Hartert) RIDGway, Proc. U. S. Nat. Mus., xvi, 1893, 43, part (Rio Escondido, Nicaragua).-Richmond, Proc.

U. S. Nat. Mus., xvi, 1893, 516 (Rio Escondido; Rio Frio, Costa Rica).

C[hætura] cinereiventris guianensis RIDGWay, Proc. U. S. Nat. Mus., xvi, 1893, 44, part (Rio Escondido, Nicaragua).

Ch[ætura $]$ cinereiventris guianensis Hartert, Das Tierreich, Podarg., Caprim., Macropt., 1897, 76. part.

[Chætura] guianensis SHARPE, Hand-list, ii, 1900, 92, part (Costa Rica; Nicaragua). Chrtura fumosa (not of Salvin) Salvin and Godman, Biol. Centr.-Am., Aves, ii, 1894, 377, part (Rio Escondido; Rio Frio).

Chætura cinereiventris phæopygos Helumayr, Bull. Brit. Orn. Club, xvi, no. cxxiv, May 8, 1906, 83 (Carrillo, e. Costa Rica; coll. Tring Mus.); Verh. Orn. Gesellsch. Bayern, viii, 1908, 156 (synonymy; descr.).-Bangs, Proc. New Engl. Zool. Club, iv, 1908, 25, 26 (Carrillo and Juan Viñas, Costa Rica; crit.).Carriker, Ann. Carnegie Mus., vi, 1910, 508 (Caribbean lowlands of Costa Rica).

CHETURA BRACHYURA (Jardine).

\section{SHORT-TAILED SWIFT.}

Adults (sexes alike).-Head, neck, upper back, scapulars, wings, and under parts plain black, more or less distinctly glossed with bluish or greenish (especially on wings), the chest and throat more sooty, the chin still paler (sooty grayish); rump, tail-coverts (upper and lower), and tail light brownish gray or drab-gray (the tailcoverts narrowly tipped with whitish in fresh plumage), the gray darker on upper rump, where shading into grayish black or sooty on lower back; shafts of rectrices black; bill black; iris dark brown; legs and feet dusky.

Adult male.-Length (skins), 96-102 (99); wing, 120-122.5 (121); tail, 29.5-31 (30.3); exposed culmen, 4.5-5 (4.8); tarsus, 10.5-11 (10.7); middle toe, $7.5-8(7.7){ }^{c}$

\footnotetext{
$a$ Six specimens. $\quad b$ Three specimens. $\quad c$ Three specimens from St. Vincent.
} 
Adult female.-Length (skins), 91-97 (95); wing, 117.5-125.5 (121.1); tail, 26-32 (29.4); exposed culmen, 4.5-5 (4.6); tarsus, 10-10.5 (10.2); middle toe, 7.5-8 (7.7).$^{a}$

Islands of St. Vincent and Grenada, Lesser Antilles; also Tobago and Trinidád, and continental portion of South America, from British Guiana to eastern Ecuadór and Peru and southern Brazil.

[Acanthylis] poliourus (not Cypselus poliourus Temminck) Bonaparte, Consp. Av., i, 1850, 64.-LÉotaud, Ois. Trinidad, 1866, 86, part.

Chxtura polioura Chapman, Bull. Am. Mus. N. H., vi, 1894, 58 (Trinidád).

Chætura poliura Sclater, Cat. Am. Birds, 1862, 283; Proc. Zool. Soc. Lond., 1863, 101 (monogr.); 1865, 611 (monogr.); 1870, 329 (diagn.); Journ. für Orn., 1867, 133.-Pelzeln, Orn. Bras., i, Abth., 1868, 16.-Frnsch, Proc. Zool. Soc. Lond., 1870, 558 (Trinidád; crit.).-LaYard, Ibis, 1873, 389 (Pará, lower Amazon; habits).-Sclater and Salvin, Proc. Zool. Soc. Lond., 1873, 289 (Xeberos and Chamicuros, e. Peru).-Taczanowskr, Orn. du Pérou, i, 1884, 229.-Cory, Ibis, 1886, 473 (St. Vincent, W. I.); Cat. West Ind. Birds, 1892, 106, 143 (St. Vincent; Grenada).-Hartert, Cat. Birds Brit. Mus., xvi, 1892, 484 (St. Vincent; Tobago; Cayenne; Aunai, Brit. Guiana; Pará; Xeberos and Chamicuros, e. Peru; Ecuadór).-KoenigsWald, Journ. für Orn., 1896, 372 (Sao Paulo, s. Brazil).-Clank, Proc. Bost. Soc. N. II., xxxii, 1905, 273 (St. Vincent; Grenada).

[Chrtura] poliura Gray, Hand-list, i, 1869, 66, no. 762.-Pelzeln, Orn. Bras., iv Abth., 1870, 401.-Sclater and Salvin, Nom. Av. Neotr., 1873, 95.Sharpe, Hand-list, ii, 1900, 92 (n. Brazil; e. Peru; e. Ecuadór; Guiana; Trinidád; "Lesser Antilles".).

Ch[ætura $]$ poliura Hartert, Das Tierreich, Podarg., Caprim., Macropt., 1897, 76 .

[Chrtura pelagica] var. poliura Batrd, Brewer, and Ridgway, Hist. N. Am. Birds, ii, 1874, 431.

Acanthylis brachyura Jardine, Ann. and Mag. N. H., ser. 1, xviii, 1846, 120 (Tobago; coll. Sir W. Jardine).

Chætura brachyura CoRy, Auk, v, 1888, 158 (St. Vincent); Birds West Ind., 1889, 294 (St. Vincent; Grenada).-HeLlmaYr, Novit. Zool., xiii, 1906, 37 (Trinidád; crit. nomencl.); Verh. Orn. Gesellsch. Bayern, viii, 1908, 148 (range; synonymy; descr.).-BerLepsch, Novit. Zool., xv, 1908, 268 (Roche Maria, Cayenne).-Lowe, Ibis, 1909, 310 (St. Vincent; crit.).

Chrtura brachycerca Sclater and Salvin, Proc. Zool. Soc. Lond., 1867, 758, pl. 34 (Xeberos, e. Peru; coll. Sir W. Jardine b).-Sclater, Proc. Zool. Soc. Lond., 1870, 329 (crit.).

[Chætura] brachycerca GraY, Hand-list; i, 1869, 66, no. 765.

\section{Suborder HETERODACTYLE.}

\section{HETERODACTYLE CORACIFORMES.}

$=$ Heterodactyles Blainvilie, Bull. Soc. Philomat., 1816, 110.

= Coccyges heterodactylæ Sclater and Salvin, Nom. Av. Neotr., 1873, pp. vi, 103.-Salvin and Godman, Biol. Centr.-Am., Aves, ii, 1895, 480.

$=$ Heterodactyli Sеввонм, Ibis, Jan., 1890, 37 .

$a$ Four specimens from St. Vincent.

An adult of undetermined sex from Tobago measures as follows: Wing, 121.5; tail, 35.5; exposed culmen, 4.5 ; tarsus, 11.5 ; middle toe, 8 .

$b$ Now in coll. Brit. Mus.; see Sclater, Cat. Birds Brit. Mus., xvi, 1892, 485. 
=Heterodactylæa Sclater, Ibis, Oct., 1880, 401, in text.-Dubois, Mém. Soc. Zool. France, 1891, 115.

$=$ Trogoninæ A. Mulne-Edwards, Ois. Foss., ii, 1867-1871.

=Trogonoidex Stejneger, Stand. Nat. Hist., iv, 1885, 433, in text.

=Trogonoidei Cope, Am. Nat., xxiii, Oct., 1889, 872, 873.

= Trogones American Ornithologists' Union, Check List, 1886, 208.-FuerBringer, Unters. Morph. Syst. Vög., 1888, 1567.-Seевонм, Classif. Birds, 1890, pp. vii, xi, 8.--SHarpe, Rev. Classif. Birds, 1891, 92; Hand-list, ii, 1900, 146.-GADow, in Bronn's Thier-Reich., Vög., ii, 1893, 254, 301; Classif. Vertebr., 1898, pp. xv, 37.-Beddand, Struct. and Classif. Birds, 1898, 202.-Knowlton, Birds of the World, 1909, 50.

Zygodactylous but heterodactylous and heteropelmous coraciiform birds with myological formula AX and with the dorsal pteryla simple (not forked) between shoulders.

Palate schizognathous; nasals holorhinal; basipterygoid processes present; vomer present; metasternum 4-notched; spina interna absent, spina externa present (long and bifid); coracoids touching but not connected; hypotarsus complex; cervical vertebræ 15; complete ribs, 4-5 pairs; syrinx tracheo-bronchial; only the left carotid artery developed; cæca present (but short); intestinal convolutions of type VI; flexor tendons of type VIII; femoro-caudal and semitendinosus muscles present, the accessory femoro-caudal absent; pterylosis passerine, the spinal pteryla well defined from nape to oil-gland, not forked; wing-coverts coraciine (middle coverts absent); oil-gland nude; aftershaft of contour feathers very large; no adult downs; rectrices 12 ; tenth (outermost) primary very short; secondaries quintocubital; young gymnopædic.

The Heterodactylæ are a strongly characterized group of Coraciiform birds which combine the cranial characters of the Caprimulgi, the myological formula of the Alcedinidæ (=Anisodactylæ, part), and an oscinine pterylosis with an entirely unique arrangement of the toes and the deep plantar tendons. Like the Pici and Cuculiformes, they have the toes in pairs (two in front and two behind), and are therefore to that extent zygodactylous; but they differ from these two groups and from all other birds in having the second digit (the inner front toe of anisodactyle birds) reversed, instead of the outer toe; in other words, the hallux is the outer of the two hind toes, whereas in all other zygodactyle birds it is the inner one. This unique arrangement of the toes is correlated with a unique arrangement of the deep plantar tendons, the front one of which (the flexor perforans) is split into two, leading, respectively, to the two front (third and fourth) toes, while the hinder one (the flexor hallucis) is also divided, the two branches leading, respectively, to the two posterior (first and second) toes-an arrangement in strong contrast with those of the other zygodactyle groups, in which the front plantar leads to the third digit only in the Pici, while the hind plantar leads to the first digit (hallux) only in the Cuculiformes. 


\section{Family TROGONID无.}

THE TROGONS.

=Trogonid $x$ Swainson, Fauna Bor.-Am., ii, 1831, 326.-Cabanis, in Wiegmann's Archiv für Naturg., 1847, pt. i, 347.-Bonaparte, Consp. Av., i, 1850, 148.Cabanis and Heine, Mus. Heine, iv, 1863, 154.-Carus, Handb. Zool., i, 1868-75, 231.-Stejneger, Stand. Nat. Hist., iv, 1885, 433.-Fuerbringer, Unters. Morph. Syst. Vög., 1888, 1331. (And of authors generally.)

=Trogoninæ Sundevall, Av. Disp. Tent., ii, 1873, 84 (and of Bonaparte, Cabanis, and Cabanis and Heine, as cited above).

$=$ Trogontidæ (emendation) OberHolser, Outl. Classif. N. Am. Birds, Sept., $1905,3$.

The following characters are additional to those given under Suborder Heterodactylæ:

Bill short (much shorter than head), broad basally (triangular in vertical profile), the culmen strongly decurved and terminally more or less distinctly (but not conspicuously) uncinate; maxillary tomium usually more or less serrate subterminally (smooth in one American genus, Pharomachrus, and in most of the Old World forms); base of bill concealed by well-developed, curved, antrorse latero-frontal, pre-malar, and mental bristle-tipped feathers; feet weak, the tarsus much shorter than longest anterior toe, chiefly (sometimes entirely) feathered; anterior toes united for about the basal half; wing short, rounded, very concave beneath; primaries more or less falcate or subfalcate terminally, the tenth (outermost) decidedly shortest; secondaries short; tail longer than wing, composed of twelve broad and nearly truncate rectrices; plumage dense and soft, easily detached; colors bright, brilliantly metallic (green, golden, coppery, blue, or violet above) in adult males, the under parts of body pure red, orange, or yellow; young usually spotted and without bright colors; nest in holes of trees, stumps, etc.; eggs plain white or pale bluish.

The Trogons are a well-marked group of Picarian birds, differing from all others in the conformation of the feet, the inner toe being reversed, or turned backward, instead of the outer, as is the case with all other birds which have the toes in pairs.

They are forest birds, and therefore arboreal, passing their entire life among the trees, where they nest in natural cavities or those abandoned by parrots or the larger woodpeckers. They feed chiefly on fruits and insects, both of which they take while flying. As a group the Trogons are celebrated for their beanty of plumage, some of the species being among the most beautiful of birds, the magnificent Quetzál (Pharomachrus mocinno), of Guatemala, excelling even the famed Birds of Paradise in the gorgeous beauty of its plumage and exquisite grace of form. 
Like the Barbets, the Trogons are found in the Tropics of both hemispheres; but, unlike them, they are most numerous in America, where eight genera and about thirty-two speciesoccur. Two peculiar genera, with a single species each, occur in Cuba and Haiti, respectively.

\section{KEY TO THE GENERA OF TROGONIDE.}

a. Tomia without serrations (only the subterminal notch being present); nostril narrow, longitudinal, overhung by a broad operculum; adult males with upper tailcoverts distinctly outlined, the longest much more than half as long as tail (sometimes greatly exceeding the tail in length); middle wing-coverts very large, distinctly outlined, sometimes elongated.

$b$. Culmen elevated basally, the depth of the bill at nostrils equal to or greater than its width at same point; loral feathers closely appressed, antrorse anteriorly; middle wing-coverts elongated, more or less pointed; adult males with longer upper tail-coverts reaching to or beyond tip of tail, distinctly narrowed terminally ...................................

$b b$. Culmen depressed basally, the depth of bill at nostrils less than its width at same point; loral feathers retrorse, not closely appressed; feathers on sides of occiput elongated, very slender, forming a filamentous tuft; middle wingcoverts broadly rounded, not elongated; adult male with longer upper tailcoverts falling far short of tip of tail, more broadly rounded terminally.

Leptuas (p. 740).

aa. Tomia distinctly serrated, especially on mandible; nostril roundish, nonoperculate; adult males with upper tail-coverts blended, the longest less than half as long as tail; wing-coverts small, or at least not elongated nor conspicuously large.

b. Auricular feathers normal; eyelids naked, forming a conspicuous orbital ring (brightly colored in life); sexes very different in color, the adult females without metallic hues; anterior toes united for more than basal phalanx.

c. Larger and more stoutly built, with larger and heavier bill; tarsus decidedly shorter than longest anterior toe, the feet much stronger.

d. Anterior toes united for first and second phalanges; tail less strongly graduated, the rectrices more rounded at tip, the lateral rectrices without white, or else with only narrow bars of that color, never tipped with white; abdomen and under tail-coverts red; adult males with chest and upper parts metallic bronze-green to bluish green, the wing-coverts and secondaries vermiculated; adult females with chest and upper parts slate color; young conspicuously spotted, very different from adults.

Curueujus (p. 742)

$d d$. Anterior toes united for first phalanx and only part of second phalanx; tail more strongly graduated, the rectrices broader and more truncated at tip, the lateral rectrices with much white (outermost ones sometimes wholly white); abdomen and under tail-coverts yellow or reddish orange; adult males with head black or slate color (the pileum sometimes metallic violet-blue), back, etc., metallic green, blue, or violet-blue, wing-coverts and secondaries uniform black or slate color; adult females with head, neck, chest, and upper parts slate color; young essentially like adult female in coloration........................... Trogon (p. 750).

$c c$. Smaller and more slightly built, with relatively smaller and weaker bill; tarsus as long as longest anterior toe, the feet much weaker. (Tail always with more or less white, the lateral rectrices broadly tipped aud usually barred with that color; abdomen and under tail-coverts red, orange, or yellow; 
adult males with chest and upper parts metallic bronze, green, or blue, the wing-coverts and secondaries always vermiculated; adult females with chest and upper parts brown or slate color.)

d. Tarsus feathered for not more than upper half; tail decidedly longer than wing; plumage of young conspicuously spotted, very different from that of adults ................................... Trogonurus (p. 761).

$d d$. Tarsus feathered for at least greater part; tail little if any longer than wing; plumage of young similar to that of adults........ Chrysotrogon (p. 784).

$b b$. Auricular feathers slender, filamentous, curving outward terminally; eyelids feathered; sexes alike (or nearly so) in color, the adult females with back, etc., metallic green; anterior toes united for basal phalanx only.

$c$. Rectrices normal in shape; sexes slightly different in coloration, the wingcoverts plain bronzy blackish in male, barred with white in female.

Temnotrogon (p. 790).

$c c$. Rectrices unique in shape, the longer ones deeply concavely incised at tip, where the lateral portions are prolonged into falcate points; sexes exactly alike in color................................ Priotelus (p. 793).

\section{Genus PHAROMACHRUS De la Llave.}

Pharomachrus De la Llave, Registro Trimestre, i, num. 1, Jan., 1832, 48. (Type, P. mocinno De la Llave.)

Pharomacrus (emendation) Sclater, Proc. Zool. Soc. Lond., 1858, 60.

Calurus Swainson, Classif. Birds, ii, 1837, 337. (Type, Trogon resplendens Gould = Pharomachrus mocinno De la Llave.)

Antisianus Fitzinger, Sitz. k. Akad. Wiss. (Math.-Nat. Classe) [Wien], xxi, Heft. 2, July, 1856, 294. (Type, Trogon antisianus D'Orbigny, 1837=T. antisiensis D’Orbigny, 1835.)

Cosmurus Reichenbach, Av. Syst. Nat., Aug. 1, 1850, pl. 88. (Type, Trogon antisiensis D'Orbigny.)

Tanypeplus a Cabanis and Heine, Mus. Hein., iv, March, 1863, 205. (Type, Trogon pavoninus Spix.)

Large Trogons with smooth (nonserrate) tomia, pileum more or less crested, middle wing-coverts elongated and decumbent, and upper tail-coverts much developed.

Bill moderate in size (distance from tip to nostril considerably less than from latter to anterior angle of eye), the culmen rather strongly arched, not depressed basally, rounded (not ridged), the tomia smooth (unserrated) but with a distinct subterminal notch on both maxilla and mandible, the tip of the latter forming a distinct ascending point; gonys about half as long as mandibular rami, the latter widely divergent, the distance across basal portion of interramal space about equal to length of rami; nostril narrow, longitudinal, overhung by a broad operculum; rictal bristles minute or obsolete, but chin with conspicuous antrorse, recurred bristles, the post-nasal feathers also with antrorse bristles; feathers of lores appressed, vertical, antrorse anteriorly, sometimes so much developed as to cover nostrils and forming a conspicuous, compressed, frontal duplex crest, which in

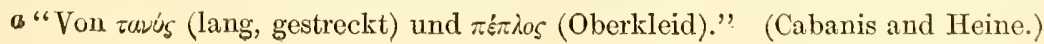


adult males of some species extends backward to or beyond middle of crown, the feathers of the latter, together with those of the occiput, in one species (P. mocinno) much elongated, semidecomposed, forming a bushy crest; middle wing-coverts enlarged, more or less narrowed terminally, in the males of some species much elongated, decurved, and subacuminate; sixth primary longest, the seventh a little shorter, the tenth less than half to slightly more than half as long as sixth; tail slightly shorter to slightly longer than wing, strongly graduated (sometimes for more than one-third its length), the rectrices firm, tapering terminally, the tip not truncated; upper tail-coverts enlarged and elongated, the longer ones reaching to much beyond middle of tail, in adult males of one species ( $P$. mocinno) several times as long as tail, forming streamer-like, pendant plumes; tarsus decidedly shorter than longest toe (without claw), the upper portion feathered.

Coloration.-Upper parts (including wing-coverts), throat, and chest, brilliant metallic green (the head sometimes golden or bronzy); remiges and at least four middle rectrices black, the three outer pairs of the latter usually mostly white; under parts posterior to chest rich bright red $a$ (sometimes darker next to green of chest); adult females duller in color, with red of under parts more restricted anteriorly, the lower chest, at least, sometimes breast, sides, and abdomen, brownish or grayish.

Range.-Highlands of Chiapas to mountains of Peru, Bolivia, and Venezuela. (Five or six species.)

\section{KEY TO THE SPECIES AND SUBSPECIES OF PHAROMACHRUS.}

a. Under parts metallic green anteriorly, red posteriorly (no brown or gray). (Adult males.)

$b$. Loral and latero-frontal plumes greatly developed, antrorse and erect, forming a closely appressed bilateral crest, which anteriorly covers basal half or more of maxilla; lateral rectrices white.

c. Crest grealy developed, involving whole of pileum; distal upper tail-coverts greatly elongated, several times longer than tail. (Pharomachrus mocinno.)

d. Larger (wing averaging 206.6, tail 206.3) with supracaudal plumes much broader, averaging much longer $(822.1 \mathrm{~mm}$., sometimes more than 950 $\mathrm{mm}$. ), and more golden in color. (Southern Mexico to Honduras.)

Pharomachrus mocinno mocinno, adult male (p. 736).

$d d$. Smaller (wing averaging 199, tail 187.4), with supracaudal plumes much narrower, averaging much shorter $(660.5 \mathrm{~mm}$., never more than $825 \mathrm{~mm}$.), less golden in color. (Costa Rica and western Panamá; Nicaragua?)

Pharomachrus mocinno costaricensis, adult male (p. 739).

$a$ In one supposed species (possibly a color-variety of $P$. auriceps) the abdomen, etc., are orange-yellow. This is Pharomacrus xanthogaster Turati and Salvadori, Proc. Zool. Soc. Lond., 1874, 652 (Bogotá, Colombia; coll. Count Turati); Oustalet, Nouv. Archiv. Mus. Paris, (3), vii, 1895, 229, pl. 8. 
cc. Crest moderately developed, involving only forehead and lores; distal upper tail-coverts but little, if any, longer than tail. (Colombia to Ecuadór, Bolivia, and Venezuela.)

Pharomachrus antisiensis, adult male (extralimital) ${ }^{a}$

bb. Loral and latero-frontal feathers much less developed, not forming a crest, and covering much less than basal half of maxilla; lateral rectrices wholly black or else only partly white for distal portion.

c. Lateral rectrices partly white distally; latero-frontal plumes more developed. (Sierra Nevada de Santa Marta, Colombia.)

Pharomachrus festatus, adult male (extralimital). $b$

cc. Lateral rectrićes entirely black; latero-frontal plumes less developed.

d. Bill yellow. (Colombia to Venezuela and Peru.)

Pharomachrus auriceps, adult male (extralimital).c dd. Bill red. (Basins of Upper Amazona nd Rio Negro.)

Pharomachrus pavoninus, adult male (extralimital). ${ }^{d}$

$a$ a. Under parts with brown or gray separating the green or bronze of chest from red of under tail-coverts, etc. (Adult females.)

a Trogon antisiensis D’Orbigny, Voy. Amér. Mérid., Ois., 1835-1844, 381, pI. 66, fig. 1 (Yungas, Bolivia).-Pharomacrus antisiensis Sclater, Proc. Zool. Soc. Lond., 1858, 60; Grant, Cat. Birds Brit. Mus., xvii, 1892, 433.-[Trogon] antisianus D'Orbigny, Mag. de Zool., an 7, 1837, cl. ii, p1. 85.-C[alumus] antisianus Gray, Gen. Birds, i, 1845, 71.-Pharomacrus antisianus Gould, Mon. Trog., ed. 2, 1858, pl. 2 and text.-Trogon pulchellus Gould, Mon. Trog., ed. 1, 1838, pl. 22 and text.-Trogon (Calurus) pulchellus Gould, Mon. Trog., ed. 1, List of Plates, sp. 22.-Calurus pulchellus Gould, Mon. Trog., ed. 1, 1838, Synop. Sp. Calurus, sp. 9.-[Pharomachrus] pulchellus Bonaparte, Consp. Voluc. Zygod., 1854, 14.-Trogon peruvianus Gould, Mon. Trog., ed. 2, 1858, in text to pl. 2.-Trogon fulgidus Gould, Mon. Trog., ed. 1, 1838, pl. 24 and text (=immature male).-Trogon (Calurus) fulgidus Gould, Mon. Trog., ed. 1, 1838, List of Plates, sp. 24.-C[alurus] fulgidus Gray, Gen. Birds, i, 1845, 71.-[Cosmurus] fulgidus Bonaparte, Consp. Voluc. Zygod., 1854, 14.-Pharomacmus fulgidus Gould, Mon. Trog., ed. 2, 1858, pl. 3, and text.-T[anypeplus] fulgidus Cabanis and Heine, Mus. Hein., iv, 1863, 20 s.

b Pharomachrus festatus Bangs, Proc. Biol. Soc. Wash., xiii, Nov. 11, 1899, 92 (Chirua, Santa Marta, Colombia, 7,000 ft.; coll. E. A. and O. Bangs).

c Trogon (Calurus) auriceps Gould, Ann. and Mag. N. H., ix, 1842, 238 (Quito, Ecuadór; coll. J. Gould).-Calurus auriceps IIartlanb, Verz. Mus. Bremen, 1844, 12.-[Cosmurus] auriceps Bonaparte, Consp. Voluc. Zygod., 1854, 14.-Pharomacrus aurceps Gould, Mon. Trog., ed. 2, 1858, pl. 4 and text; Grant, Cat. Birds Brit. Mus., xvii, 1892, 434 (erroneous descr. of adult male!).-T[anypeplus] auriceps Cabanis and Heine, Mus. Hein., iv, 1863, 207.-T[anypeplus] hcliactin Cabanis and Heine, Mus. Hein., iv, Feb., 1863, 207 (Nanegál and Pallatanga, e. Ecuadór; coll. Heine Mus.).Pharomacrus auriceps heliactin Berlepsch and Taczanowski, Proc. Zool. Soc. Lond., 1884, 308 (Cayandeléd, w. Ecuadór; crit.).-(?)Pharomacrus xanthogaster Turati and Salvadori, Proc. Zool. Soc. Lond., 1874 (pub. April, 1875), 652 (Colombia; coll. Count Turati).-Trogon (Calurus) hargitti Oustalet, Le Nat., ann. 13, sér. 2, v, no. 112, Nov. 1, 1891, 261 (int. Venezuela; coll. Paris Mus.).

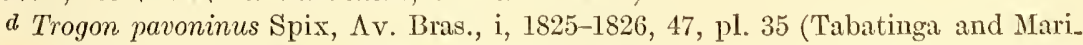
batanas, Brazil; coll. Munich Mus.); Gould, Mon. Trog., ed. 1, 1838, p1. 23 and text.-Calurus pavoninus Swainson, Classif. Birds, ii, 1837, 338.-T[anypeplus] pavoninus Cabanis and Heine, Mus. Hein., iv, 1863, 205.-Pharomacmes pavonimus Sclater and Salvin, Proc. Zool. Soc. Lond., 1867, 583; Gould, Mon. Trog., ed, 2 , 1869, pl. 5 and text; Grant, Cat. Birds Brit. Mus., xvii, 1892, 436. 
b. Feathers cf orown and occiput elongated.

Pharomachrus mocinno costaricensis, adult female (p. 739.) ${ }^{a}$

$b b$. Feathers of crown and occiput not elongated.

c. Head brown...........Pharomachrus antisiensis, adult female (extralimital.) $c c$. Head metallic green or bronze (at least on pileum).

d. Abdomen red, like under tail-coverts, etc.

e. Lateral rectrices extensively white terminally.

Pharomachrus festatus, adult female (extralimital.)

$e e$. Lateral rectrices wholly black or else with only a small terminal area of white........... Pharomachrus auriceps, adult female (extralimital).

$d d$. Abdomen (except extreme lower portion) brown, like breast.

Pharomachrus pavoninus, adult female (extralimital).

\section{PHAROMACHRUS MOCINNO MOCINNO De la Llave.}

\section{QUETZĀL. $b$}

Adult male.-Upper parts, head, neck, and chest brilliant metallic green or golden green (the head and long supracaudal plumes more golden), changing to bluish green or even greenish blue in certain lights, the elongated greater wing-coverts with basal portion (partly exposed) abruptly black; greater and primary wing-coverts, alula, and six middle rectrices uniform black; three lateral rectrices (on each side) white with black shaft, the basal portion (concealed) grayish black or slate color; under parts, posterior to chest, intense geranium red, darkening into crimson or burnt carmine on upper breast; tibial and tarsal feathers black, the lower ones glossed with metallic green; bill yellow; iris dark brown; feet dusky (in dried skins); length (skins), to end of rectrices, 355-390 (371); wing, 200.5-218 (206.6) ; tail, 197-217.5 (205.3); longest upper tail-coverts, 650-957 (811); culmen, 20-21.5 (21); tarsus, 18-21.5 (19.2); inner anterior toe, $19-21.5(20.4) .^{c}$

Adult female. ${ }^{\text {- }}$-Pileum and sides of head metallic bronze-green (the color much less bright than in adult male), the loral and laterofrontal feathers much less developed; back, scapulars, wing-coverts, rump, and upper tail-coverts bright metallic golden green, as in

$a$ I have not seen the female of $P . m$. mocinno, which, however, undoubtedly agrees with that of $P . m$. costaricensis in this character.

$b$ Not Quet'zal, as given in the dictionaries! The Central American native pronunciation is uniformly and distinctly kā-tzál, or kā-zál.

$c$ Fifteen specimens.

$d$ The descriptions of the adult female and young stages are taken from specimens of $P . m$. costaricensis (which probably do not differ materially from the same plumages of $P . m$. mocinno), in order to preserve uniformity of treatment of composite species, there being no specimens of $P . m$. mocinno other than adult males in the series which I have been able to examine. The nestling described is the specimen recorded by Mr. Lawrence in his catalogue of Costa Rican birds as Nyctibius jamaicensis (no. 51269, coll. U. S. Nat. Mus., "San Jose"=Volcan de Irazú?, Costa Rica, Jan. 15, 1867; José C. Zeledón). 
adult male, but the longer upper tail-coverts not reaching much, if any, beyond tip of tail (often falling short of tip); remiges black, the primaries broadly edged with buff; tail black, the three lateral rectrices on each side broadly white distally and on outer web (except basally), the white portion barred with dusky; chin and throat grayish brown; foreneck and chest metallic green; breast, sides, and abdomen (except extreme lower portion of the latter) plain grayish brown (nearly hair brown); extreme lower abdomen, hinder flanks, anal region, and under tail-coverts pure geranium red; thighs sooty blackish, the lower feathers glossed with metallic green; bill blackish; feet dusky (in dried skins).

Immature male.-Similar to the adult female, but metallic green of head, etc., brighter, bill yellow, breast, abdomen, and sides gray instead of grayish brown, and distal portion of rectrices with more white (the white portion with much fewer dusky bars).

Young (nestling, sex not determined).--Pileum, hindneck, back, scapulars, rump, and upper tail-coverts plain dark sooty brown (nearly seal brown), some of the longer upper tail-coverts with a narrow mesial terminal streak of dull tawny, the scapulars with large but not well defined spots of tawny-buff; wings darker sooty brown, the coverts (except primary coverts and alula) with very large spots cf tawny-buff, the remiges broadly edged with the same; four middle rectrices wholly blackish brown, the lateral rectrices (as far as developed) white; throat naked, the chin thinly covered with loose-webbed feathers of dull tawny mixed with dusky; chest dull tawny-ochraceous or clay color, rather broadly barred with dark sooty brown, these bars indistinct anteriorly but very distinct near posterior margin of chest, where the ochraceous area has a very definite convex outline; rest of under parts white suffused with buffy, especially on sides and flanks, which are rather broadly but indistinctly barred with grayish dusky; bill and feet brownish (in dried skin).

High mountains of Guatemala (San Martín, Quezaltenango; Pié de la Cuesta, San Marcos; Cerro Zuníl and Calderas, Volcán de Fuego; Volcán de Agua; Chiacamán, Chinantla Mountains; near Cobán; Raxché, Chilasco, etc., Vera Paz; mountains of Santa Cruz), Honduras (south and east of Comayágua), and Chiapas; northern Nicaragua (San Rafaél del Norte) ? a

Trogon pavoninus (not of Spix) Temminck, Pl. Col., iii, 1825, pl. 372.-Lesson, Traité d'Orn., 1830, 120.-Wirson, Illustr. Zool., 1831, pl. 6.-Dubois, Orn. Gal., i, 1839, 79, pl. 49.

Trogon pavonius Gloger, Hand-u. Hilfsb. Nat. 1842, 201.

$a$ Nicaraguan specimens, which I have not seen, may possibly be referable to P. m. costaricensis.

S1255 - Bull. $50-11-47$ 
Pharomachrus mocinno De la Llave, Registro Trimestre, i, num. 1, Jan., 1832, 48 (Guatemala; Chiapas); Rev. et Mag. de Zool., xiii, 1861, 23-33; La Naturaleza, ii, 1874, 17, 18.-RIdgway, Man. N. Am. Birds, 1887, 275, footnote.

P[haromachrus] mocinno Gray, Gen. Birds, iii, 1849, App., p. 30a.

Pharomacrus mocinno Brewer, Proc. Bost. Soc. N. H., xv, 1872, 152 (Guatemala).-Gould, Mon. Trog., ed. 2, 1875, pl. 1 and text.-Grant, Cat. Birds Brit. Mus., xvii, 1892, 431, part ("Mexico"; San Martín, Quezaltenango, Pié de la Cuesta, San Marcos, Cobán, Raxché, Volcán de Fuego, Volcán de Agua, and Chilasco, Guatemala).--Salvin and Godman, Biol. Centr.-Am., ii, 1896, 481, part (localities in Guatemala; San Rafaél del Norte, Nicaragua? ${ }^{a}$ ).-Nelson, Auk, xv, 1898, 156 (near Tumbalá and east of Tuxtla, e. Chiapas).

Pharomachrus mociño WÜrTTEMBerg, Naumannia, 1852, 51, in text.

P[haromacrus] mocinno Cabanis and Heine. Mus. Hein.. iv, 1863, 211 (Volcán de Fuego).

[Pharomacrus] mocinno Heine and Reichenow, Nom. Mus. Hein. Orn., 1890, 210 (Volcán de Fuego).-Sharpe, Hand-list, ii, 1900, 146, part (Guatemala).

[Pharomacrus] mocinna GraY, Hand-list, i, 1869, 85, no. 1002.

Pharomacrus mocina Boucard, Liste Ois.-1écol. Guat., 1878, 25; The Hum. Bird, i, 1891, 6, 7 (Guatemala; s. Mexico; descr.; habits).

Pharomacrus mosinno CuBAs, Cuadro Geograf., 1S84, 176 (Chiapas).

[Calurus] mocinno Bonaparte, Consp. Av., i, 1850, 152.

Trogon resplendens Gould, Proc. Zool. Soc. Lond., 1835, 29 (s. Mexico); 1836, 12; Isis, Bd. xxxi, 1838, 172; Mon. Trog., ed. 1, 1838, pl. 21 and text.-BonAParte, Proc. Zool. Soc. Lond., 1837, 101.

Trogon (Calurus) resplendens Gould, Mon. Trog., ed. 1, 1838, List of Plates, sp. 21.

Calurus resplendens Swainson, Classif. Birds, ii, 1837, 338.-Gould, Mon. Trog., ed. 1, 1838, Synop. Sp. Gen. Calurus, sp. 1.-Gray, Cat. Fissir. Birds Brit. Mus., 1848, 45.--Burmeister, Syst. Ueb. Th. Bras., ii, 1856, 273, footnote. C[alurus] resplendens Gray, Gen. Birds, i, 1845, 71.

[Trogon] paradiseus Bonaparte, Proc. Zool. Soc. Lond., 1837 (pub. 1838), b 101, in text (Vera Paz, Guatemala); in Charlesw. Mag. N. H., ii, 1838, 229-231.

Calurus paradiseus Hartlaub, Verz. Mus. Brem., 1844, 12.-Württemberg, Naumannia, 1852, 51 .

Pharomacrus paradiseus Sclater and Salvin, Ibis, 1859, 132 (Calderas, Cobán, and Quezaltenango, Guatemala, above 6,000 ft.).-Moore, Proc. Zool. Soc. Lond., 1859, 52 (Quezaltenango).-TAYLOR, Ibis, 1860, 118 (mts. near Comayágua, Honduras).-Salvin, Proc. Zool. Soc. Lond., 1860, 374 (mts. of Santa Cruz, Guatemala; habits; descr. nest and eggs); Ibis, 1861, 138 (Vera Paz, Guatemala; habits).--Owen, Ibis, 1861, 66, pl. 2, fig. 1, egg (mts. of Santa Cruz; descr. nest and eggs).-Sclater, Cat. Am. Birds, 1862, 277 (Raxchẻ and Cobán, Guatemala).-Nenrkorn, Journ. für Orn., 1889, 286 (Honduras; descr. eggs).-Hartert, Kat. Vogelsamml. Mus. Senckenb., 1891, 135 (Mexico).

[Pharomacrus] paradiseus Sclater and Salvin, Nom. Av. Neotr., 1873, 104, part (Guatemala).

a Nicaraguan specimens (which I have not seen) may be referable to P.m. costaricensis.

$b$ Bonaparte here claims that he so named the species in 1826 , but I have not been able to find the reference. 


\section{PHAROMACHRUS MOCINNO COSTARICENSIS (Cabanis).}

\section{COSTA RICAN QUETZÂL.}

Similar to $P . m$. mocinno, but smaller, and the adult male with elongated supracaudal plumes much narrower and averaging decidedly shorter, their color usually much less golden green.

Adult male.-Length to tip of rectrices (skins), 330-375 (350); wing, 189-206 (199); tail, 179.5-195.5 (187.4); longest upper tailcoverts, 480-825 (660.5); culmen, 20.5-24 (21.6); tarsus, 18-20 (18.5); inner anterior toe, 18-21.5 (19.9). ${ }^{a}$

Adult female.-Length (skins), 345-378 (356); wing, 193-208 (198.4); tail, 184-216 (196.8); culmen, 21-24.5 (22.4); tarsus, 18-20.5 (18.7); inner anterior toe, 18-22 (19.7). ${ }^{b}$

Higher mountains of Costa Rica (Volcán de Irazí; Volcán de Turrialba; Coliblanco; Volcán de Poás; Cerro de la Candelária; "Cartago;" Naranjo de Cartago; "San José;" La Palma de San José; El Zarcero de Alajuela; Rancho Redondo; Quebrada Honda; Cervantes; Navarro) and western Panamá (Boquete; Calovévora; Calobre; Davíd; Volcán de Chiriquí).

Pharomacrus mocinno (not Pharomachrus $m$. De la Llave) Sclater, Proc. Zool. Soc. Lond., 1856, 139 (Davíd, Chiriquí, Panamá).-Salvin, Proc. Zool. Soc. Lond., 1867, 151 (Boquete, Chiriquí); 1870, 202 (Calobre, Calovévora, and Volcán de Chiriquí; crit.).-Salvadori, Atti Torino, 1868, 183 (Costa Rica).Grant, Cat. Birds Brit. Mus., xvii, 1892, 431, part ("Sau José," Costa Rica; Volcán de Chiriquí and Calovévora, w. Panamá).-Salvin and Godman, Biol. Centr.-Am., Aves, ii, 1896, 481, part (localities in Costa Rica and western Panamá; San Rafaél del Norte, Nicaragua?).c-SALvadori and Festa, Boll. Mus. Zool., etc., Torino, xiv, 1899, no. 339, 8 (Chiriquí).

$a$ Seventeen specimens. The longest supracaudal plume in a series of one hundred adult males from Costa Rica examined at one time measured $774.5 \mathrm{~mm}$., while the longest in another series of seventy-seven adult males measured $787 \mathrm{~mm}$. In none of the entire lot of nearly two hundred adult males examined were these plumes nearly as wide as in the average of Guatemalan examples, usually not more than about half as wide.

$b$ Thirteen specimens.

\begin{tabular}{|c|c|c|c|c|c|c|}
\hline Locality. & Wing. & Tail. & $\begin{array}{l}\text { Longest } \\
\text { upper } \\
\text { tail- } \\
\text { coverts. }\end{array}$ & $\begin{array}{l}\text { Cul- } \\
\text { men. }\end{array}$ & $\begin{array}{l}\text { Tar- } \\
\text { sus. }\end{array}$ & $\begin{array}{l}\text { Inner } \\
\text { an- } \\
\text { terior } \\
\text { toe. }\end{array}$ \\
\hline \multicolumn{7}{|l|}{ MALES. } \\
\hline Seven adult males from Costa Rica................... & 201.8 & 189.5 & 647.1 & 21.1 & 18.3 & 19.5 \\
\hline Ten adult males from western Panamá............. & 196.9 & 185.9 & 668.6 & 21.8 & 18. 7 & 20.2 \\
\hline Two adult males ( $P . m$. mocinno) from Honduras.... & 206 & 200.5 & 650 & ...... & .... & -.... \\
\hline $\begin{array}{l}\text { Fifteon adult males }(P . m . \text { mocinno }) \text { from Guatemala. } \\
\text { FEMALEs. }\end{array}$ & 206. 6 & 206.3 & 822.1 & 20.8 & 19.2 & 20.4 \\
\hline Seven adult females from Costa Rica................ & 199.1 & 198.1 & ........ & 22.5 & 18.8 & 19.8 \\
\hline 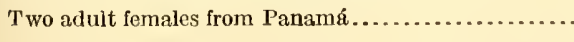 & 195.2 & 189. 2 & ......... & 21.5 & 18.5 & 19 \\
\hline
\end{tabular}

c I have not seen Nicaraguan specimens, which may be referable to $P$. m. mocinno. 
[Pharomacrus] mocinno Sharpe, Hand-list, ii, 1900, 146, part (Panamá).

Pharomacrus mo-cinno Lawrence, Ann. Lyc. N. Y., ix, 1868, 120 (Costa Rica).Frantzius, Journ. für Orn., 1869, 313 (Turrialba, Cervantes, and Volcán de Irazú, Costa Rica).

Ph[aromacrus] costaricensis CABAnIs, Journ. für Orn., 1869, 313, footnote, in text (Costa Rica).

Pharomacrus costaricensis Gould, Mon. Trog., ed. 2, 1875, in text to pl. 1.Boucard, Rowley's Orn. Misc., iii, 1877, 21.-Zeledón, Proc. U. S. Nat. Mus., viii, 1885, 109 (Costa Rica); Anal. Mus. Nac. Costa Rica, i, 1887, 120 (El Zarcero de Alajuela, La Palma de San José, and Faldas de Irazú, Costa Rica).

[Pharomacrus] costaricensis Heine and Reichenow, Nom. Mus. Hein. Orn., 1890 210 (Chiriquí).

Pharomacrus mocinno, var. costaricensis Boucard, Proc. Zool. Soc. Lond., 1878, 48 (Volcán de Irazú, Navarro, Candelária, and Naranjo de Cartago, Costa Rica; habits).

Pharomacrus mocina, ... var. costaricensis Boucard, Rowley's Orn. Misc., iii, 1877 21; The Hum. Bird, i, 1891, 6, 7 (Costa Rica; Verágua), 18 (descr. female).

Pharomacrus mocinno costaricensis Ridgway, Proc. U. S. Nat. Mus., v, Feb. 28, 1883, 497 (Volcán de Irazú; crit.), 501 (mts. near San José).-Bangs, Proc. New Engl. Zool. Club, iii, 1902, 31 (Boquete and Volcán de Chiriquí, 4,0007,000 ft.).-Alfaro, Paginas Illustradas, i, 1904, 531, in text.-Carriker, Ann. Carnegie Mus., vi, 1910, 556 (highlands of Costa Rica; habits).-FERRY, Pub. 146, Field Mus. N. H., orn. ser., i, no. 6, 1910, 264 (Coliblanco, Costa Rica; habits).

Pharomacrus paradiseus (not Trogon paradiseus Bonaparte) Cabanis, Journ. für Orn., 1862, 175 (Costa Rica).

Nyctibius jamaicensis? [!] Lawrence, Ann. Lyc. N. Y., ix, 1868, 120 (San José, Costa Rica;=nestling!)

\section{Genus LEPTUAS Cabanis and Heine.}

Euptilotis a (not Euptilotus Reichenbach, 1850 b) Govld, Mon. Trog., ed. 2, pt. 1 1858, text to pl. 6. (Type, Trogon neoxenus Gould.)

Euptllotis (typographical error) Sclater and Salvin, Nom. Av. Neotr., 1873, 104. Leptuas c Cabanis and Heine, Mus. Hein., iv, Heft. 1, Feb., 1863, 185, 206. (Type, Trogon neoxenus Gould.)

Septuas (typographical error) Gould, Mon. Trog., ed. 2, Introd., 1875.

Large Trogons related to Pharomachrus, but bill more slender, depressed basally, with gonys relatively much longer and interramal space shorter and narrower; loral feathers retrorse (instead of antrorse or erect); feathers on sides of occiput elongated, very slender, forming filamentous tufts; middle wing-coverts broadly rounded, not elongated, and adult male with longer upper tail-coverts falling far short of tip of tail.

Bill rather small, the moderately arched culmen much depressed and broadly rounded basally; tomia smooth (nonserrate), but with a distinct subterminal notch on both maxilla and mandible, the tip of

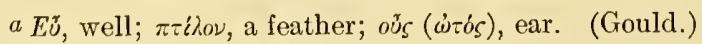

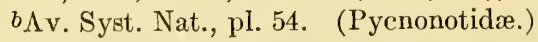

c"Von $\lambda \varepsilon \pi \tau o ́ s$ (zart, fein) und oús (Ohr)." (Cabanis and Heine.) 
latter forming a distinct ascending point; gonys much more than half as long as mandibular rami, the distal width of the interramal space about equal to its length. Nostril oval (narrower anteriorly), longitudinal, overhung by a broad operculum. Rictal bristles minute or obsolete, but feathers of loral, malar, and mental antiæ with distinct antrorse bristly tips, those of the chin more slender and strongly recurved; loral feathers normal; feathers on sides of occiput (supraauricular region) elongated, very slender, forming a narrow, filamentous tuft; middle wing-coverts very large, very broadly rounded; upper tail-coverts elongated, distinctly outlined, those of the adult male reaching to beyond middle of tail, broadly rounded terminally. Seventh primary longest, the sixth a little shorter, the tenth less than half as long as seventh. Tail shorter than wing, graduated for more than one-third its length, the rectrices rounded at tip, the lateral ones perceptibly narrowing terminally; tarsus decidedly shorter than longest toe, feathered for upper portion.

Coloration.-Chest and upper parts, including wing-coverts, metallic green, the middle rectrices glossy blue-black, the remiges slaty; lateral rectrices broadly tipped with white; breast, abdomen, and under tail-coverts red; adult female similar, but with head and chest slate-grayish.

Range.--Mountains of northwestern Mexico. (Monotypic.)

\section{LEPTUAS NEOXENUS (Gould).}

EARED TROGON.

Adult male.-Pileum dark metallic bronze-green or greenish bronze; rest of head, including chin and throat, dull black, faintly glossed (except on lores) with bluish; back, scapulars, and broad tips to wing-coverts bright metallic green to greenish bronze, passing into bright bluish green on rump and upper tail-coverts; six middle rectrices and basal portion of lateral rectrices dark metallic blue, the three lateral pairs of rectrices broadly tipped with white, this occupying the terminal third (approximately) on outermost rectrix; remiges and greater and primary wing-coverts slate-blackish, the greater coverts and secondaries (especially the former) more or less distinctly margined (narrowly) with metallic green, the outer webs of primaries (except innermost) more grayish, passing into grayish white basally; middle and lesser wing-coverts abruptly slate-blackish basally, this largely exposed; chest bright metallic bronze-green, passing into a more bluish hue toward blackish of throat; rest of under parts bright, pure red (geranium red), the thighs dark slate color; bill bluish gray for basal half or more, blackish terminally; feet horn color or dusky (in dried skins); length (skins), 320-351 (332); wing, 181-200 (191.6); tail, 161-179.5 (171.2); culmen, 
17-19.5 (18.4); tarsus, 15.5-17.5 (16.4); inner anterior toe, 17.519.5 (18.4). ${ }^{a}$

Adult female.-Upper parts and tail as in adult male, but pileum and remiges slate color; sides of head, chin, and throat brownish slate-gray or mouse gray, passing into light grayish brown on chest and upper breast, the red of posterior under parts less intense than in adult male; bill and feet as in adult male; length (skins), 307-350 (327); wing, 183.5-198.5 (192.5); tail, 157-177 (165); culmen, 1719.5 (18.1); tarsus, $14.5-17$ (16.2); inner anterior toe, $17.5-20$ (18.8). ${ }^{b}$

Mountains of northwestern Mexico, in States of Chihuáhua (near Colonia Garcia; Sierra Madre near Guadalupe y Calvo; Durasno; Pacheco; La Pinita; Mound Valley), Zacatecas (Plateado; Sierra Madre; Sierra de Valparaiso), and Michoacán (Patambán; Mount Tancítaro), and Territory of Tepíc (Santa Teresa; Sierra de Nayarít, 8,000 feet).

Trogon neoxenus GouLd, Mon. Trog., ed. 1, 1838, pl. 25 and text (Mexico; coll. J. Gould).

Trogon (Calurus) neoxenus Gould, Mon. Trog., ed. 1, 1838, List of Plates, sp. 25.

Calurus neoxenus Gould, Mon. Trog., ed. 1, 1838, Synop. Genus Calurus, sp. 5.Gray, Cat. Fissir. Birds Brit. Mus., 1848, 46.-Bonaparte, Consp. Av., i, 1850, 152.-Burmeister, Syst. Ueb. Th. Bras., ii, 1856, 273.

C[alurus] neoxenus Gray, Gen. Birds, i, 1845, 71.

[Cosmurus] neoxenus Bonaparte, Consp. Voluc. Zygod., 1854, 14.

Euptilotis neoxenus Gould, Mon. Trog., ed. 2, 1858, pl. 6 and text.-Grant, Cat.

Birds Brit. Mus., xvii, 1892, 437 (Sierra de Valparaiso, Zacatecas; Sierra de Nayarít, 8,000 ft., Tepíc).-Alten, Bull. Am. Mus. N. H., v, 1893, 34 (La Pinita, n. Chihuáhua).-Salvin and Godman, Biol. Centr.-Am., Aves, ii, $1896,485$.

[Euptilotis] neoxenus SHARPE, Hand-list, ii, 1900, 147.

[Euptllotis] neoxenus Sclater and Salvin, Nom. Av. Neotr., 1873, 104.

L[eptuas] neoxenus Cabanis and Heine, Mus. Hein., iv, Feb., 1863, 206.

[Pharomacrus] neoxenus Gray, Hand-list, i, 1869, 85, no. 1008.

\section{Genus CURUCUJUS Bonaparte.}

Curucujus Bonaparte, Atti Italiano, no. 8, May, 1854 (Consp. Voluc. Zygod., 1854, p. 14). (Type, as fixed by Gray, 1855, “Trogon curucui Linn[æus]"i. e. T. melanurus Swainson.)

Troctes $c$ (not of Burmeister) Cabanis and Heine, Mus. Hein., iv, Feb., 1863, 201. (To replace Curucujus Bonaparte, on grounds of purism.)

Eutroctes d (not of Zimmerman) Heine, Journ. für Orn., xi, Sept., 1863, 358, in text. (To replace Troctes Cabanis and Heine, preoccupied.)

Large, strongly-built Trogons with heavy, strongly serrate bill, vermiculated wing-coverts and secondaries, and with the lateral rectrices uniform dusky or else (in one species) narrowly barred (not tipped) with white.

a Ten specimens.

$b$ Nine specimens.

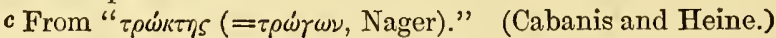

$d$ "Von $\varepsilon \tilde{u}$, wohl, schön und $\tau \rho \dot{\omega} \kappa \tau \eta s(=\tau \rho \dot{\gamma} \gamma \omega \nu) . "$ (Heine.) 
Bill very large and strong, as deep as broad at base, the culmen strongly arched, not distinctly if at all ridged; gonys shorter than mandibular rami, strongly ascending terminally; interramal space as broad, distally, as long, broadly rounded anteriorly; tomia distinctly serrate for anterior half, the notches and tooth-like points deeper on mandible than on maxilla, the tip of the mandible forming a distinct ascending point. Nostril rounded, nonoperculate, concealed by an antrorse tuft of bristly plumes. Feathers of chin and malar apex bristly, antrorse, the former strongly recurved. Feathering of head normal; seventh, eighth, or seventh and sixth primaries longest, the tenth (outermost) less than half as long as the longest; tail slightly shorter to decidedly longer than wing, graduated for one-fourth its length or slightly more, the lateral rectrices not truncate at tip nor distinctly if at all tapering terminally, the terminal outline of inner web strongly oblique, the middle rectrices subtruncate. Tarsus decidedly shorter than longest toe, naked for more than lower half; toes very strong, the two anterior ones united for more than half their length.

Coloration.-Adult males with head, neck, chest, and upper parts metallic bronze-green to bluish green (sometimes blue on rump, upper tail-coverts and middle rectrices), the wing-coverts and secondaries finely vermiculated with black and grayish white, the three outermost rectrices (on each side) plain blackish or slaty (in one species) with narrow white bars; under parts, posterior to chest, bright red; adult females with upper parts slate-color, the anterior under parts slate-gray. Young very different from adults (conspicuously spotted).

Range.-Southern Mexico to Amazon Valley. (Four species.)

KEY TO THE SPECIES AND SUBSPECIES OF CURUCUJUS.

a. Upper parts (except wings) and chest metallic green (sometimes bluish on rump and upper tail-coverts); maxilla yellow or orange. (Adult males.)

b. Lateral rectrices uniform blackish slate (the outer web minutely freckled with pale grayish basally).

c. No white on upper breast. (Southeastern Mexico to eastern Panamá.)

Curucujus massena, adult male (p. 744).

cc. A white band across upper breast (next to green of chest). (Curucujus melanurus.)

d. Smaller (wing 147-165, averaging 155.3; tail 143-175, averaging 160.1). (Colombia to western Ecuadór, Amazon Valley, and Cayenne.)

Curucujus melanurus melanurus, adult male (extralimital). ${ }^{a}$

a Trogon melanurus Swainson, Anim. in Menag., pt. iii, Jan. 1, 1838, 329 (Demerara, Brit. Guiana); Gould, Mon. Trog., ed. 1, 1838, text to pl. 18; ed. 2, 1875, pl. 29 and text; Grant, Cat. Birds Brit. Mus., xvii, 1892, 472.-[Cumicujus] melanurus Bonaparte, Consp. Voluc. Zygod., 1854, 14.-T[roctes] melanurus Cabanis and Heine, Mus. Hein., iv, 1863, 201.-Trogon nigricaudata Gould, Mon. Trog., ed. 1, pl. 18.$T$ roctes] mesurus Cabanis and Heine, Mus. Hein., iv, Feb., 1863, 202 (Babahoyo, w. Ecuadór; coll. Heine Mus.). 
$d d$. Larger (wing 157-167, averaging 162.7; tail 165.5-181.5, averaging 171.3). (Eastern Panamá and northern Colombia.)

Curucujus melanurus macrourus, adult male (p. 747). $b b$. Lateral rectrices narrowly barred with white. (Costa Rica and western Panamá.).................... Curucujus clathratus, adult male (p. 749). aa. Upper parts and chest slate color or slate-gray; maxilla black. (Adult females.)

b. Lateral rectrices plain blackish slate; breast slate-gray.

c. Larger (wing 165-185, tail 163-186).

Curucujus massena, adult female (p. 744). cc. Smaller (wing 148.5-160.5, tail 154-164.5). (Curucujus melanurus.)

d. Smaller (wing 148.5-155, averaging 154, tail 154-159.5, averaging 156.4).

Curucujus melanurus melanurus, adult female (extralimital). $d d$. Larger (wing 155.5-157.5, averaging 156, tail 161.5-164.5, averaging 163).

Curucujus melanurus macrourus, adult female (p. 748). bb. Lateral rectrices narrowly barred with white; breast brown.

Curucujus clathratus, adult female (p. 749).

\section{CURUCUJUS MASSENA (Gould).}

MASSENA TROGON.

Adult male.-Above bright metallic green, usually golden green on back, scapulars, and upper rump, sometimes more bluish green, or even intermixed with blue or violet-blue on lower rump and upper tail-coverts; four middle rectrices metallic green or bronze-green, broadly, but not sharply, tipped with black, the inner webs of second and third (from middle) and both webs of lateral rectrices uniform black, the outer web of fourth glossed with bronze-green basally, that of outermost rectrix and edges of next two toward base usually freckled or sprinkled with pale grayish, the under surface of the tail slate color, the rectrices tipped with black; wingcoverts (except anterior portion of lesser covert area) and secondaries delicately vermiculated with black and white; alula, primary coverts, and primaries dull black or slate-black, the longer quills edged with pale grayish or grayish white proximally; loral, orbital, auricular and malar regions, chin, and throat, dull black; chest bright metallic green or bronze-green; remaining under parts pure geranium red, the thighs sooty blackish; bill deep orange or orangeyellow; iris dark yellow; ${ }^{a}$ naked eyelids sky blue; ${ }^{b}$ feet (in dried skins), brownish or horn color; length (skins), 298-349 (319); wing, 163-181 (173.2); tail, 161-186 (170.8); culmen, 23-27 (24.5); tarsus, 15.5-18 (16.4); inner anterior toe, 15.5-19.5 (17.6). ${ }^{c}$

Adult female.-Head, neck, back, scapulars, rump, upper tailcoverts, chest, and breast plain slate color, darker on loral, orbital, auricular, and malar regions, chin, and throat, paler on lower breast, where sometimes indistinctly barred; rest of under parts pure geranium red, the thighs blackish; tail slate-black, sometimes faintly darker than color of back, etc., the under surface of rectrices slate- 
glossed with violaceous, the middle rectrices more slaty but much color tipped with black; wings blackish slate or sooty slate, the coverts and secondaries minutely freckled with paler, the longer primaries edged with white basally; maxilla black, with extreme basal lower portion, together with mandible, orange; feet as in adult male; length (skins), 294-353 (319); wing, 165-185.5 (174.1); tail, 160.5186 (171.9); culmen, 23-25.5 (24.2); tarsus, 15-17.5 (16.2); inner anterior toe, $16.5-19(17.5) .^{a}$

Immature male.-Similar to the adult male, but lateral rectrices tipped with white and narrowly barred on at least distal portion of outer web and, usually, on distal portion of inner web (except on third from outside) with white, middle rectrices much duller metallic bronze-green and without black tip, secondaries (at least distal ones) spotted or mottled with dull white or buffy white along edges, and bill more brownish orange or yellowish.

Immature female.-Similar to the adult female, but lateral rectrices and secondaries marked with white, as in immature male.

Young (nestling). ${ }^{b}$ - Above plain tawny-brown (near to tawnyolive), slightly darker on pileum, passing into tawny on upper tailcoverts; general color of wings dull black, except on corerts and proximal secondaries, where the prevailing color is buff, broken by irregular bars of black, the buff forming rery large roundish spots on proximal greater coverts and terminal portion of proximal seconda-

a Twenty-four specimens.

\begin{tabular}{|c|c|c|c|c|c|}
\hline Locallty. & Wing. & Tail. & $\begin{array}{l}\text { Cul- } \\
\text { men. }\end{array}$ & Tarsus. & $\begin{array}{c}\text { Inner } \\
\text { ante- } \\
\text { rior toe. }\end{array}$ \\
\hline MALES. & & & & & \\
\hline Two adult males from vera Cruz..... & 175.7 & 174.7 & 27 & 16.5 & 1s. \\
\hline $\begin{array}{l}\text { Five adult males from Chiapas (2), Guatemata (2), and Hon- } \\
\text { duras (1) }\end{array}$ & 179.4 & 176.7 & 25.5 & 16.5 & \\
\hline 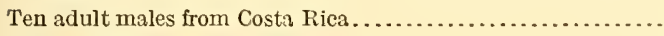 & 172.5 & 169.9 & 24.3 & 16.6 & 17.7 \\
\hline Eleven adult males from Panamá........................... & 170.6 & 165.9 & 24. 1 & 16.1 & 17.3 \\
\hline FEMALES. & & & & & \\
\hline $\begin{array}{l}\text { Four adult females from Vera Cruz (2), Oaxaca (1), and Cam- } \\
\text { peche }(1) \ldots \ldots \ldots\end{array}$ & 181.6 & $17 \pi .2$ & 25.2 & 17 & 17 \\
\hline Three adult females from Guatemala (2) and Honduras (1)..... & 179.7 & 179.2 & 24.7 & 16.3 & 17.5 \\
\hline Ten adult females from Costa Rica... & 172.9 & 170.4 & 23.9 & 16. 3 & 17.3 \\
\hline Seven adult females from Panamá... & 169.2 & 167.5 & 23.9 & 15.7 & 17.6 \\
\hline
\end{tabular}

Specimens from eastern Panamá are smaller than those from Verágua and Chiriquí, a male and female from Colón being the smallest in the entire series, their measurements being as follows: Adult male: Wing, 163; tail, 165; culmen, 23; tarsus, 17; inner anterior toe, 17. Adult female: Wing, 165; tail, 175; culmen, 24; tarsus, 16.5; inner anterior toe, $\mathbf{1 7 . 5}$.

b Described from no. 155132, coll. U. S. Nat. Mus. (Biol. Surv. Coll.), mountains near Santo Domingo, Oaxaca, June 16, 1895; Nelson and Goldman. 
ries (tertials); malar region, chin, throat, and chest plain wood brown or isabella color, the remaining under parts white, heavily clouded or spotted on breast and upper abdomen, with darker brown, the under tail-coverts tinged with buff; primaries as in adults, the rectrices (very slightly developed) apparently as in immature female (as described above).

Southeastern Mexico, in States of Vera Cruz (Playa Vicente; Uvero; Motzorongo; Achotál; Buena Vista), Oaxaca (mountains near Santo Domingo; Chimalapa), Tabasco (Teapa), Campeche (Apazote), and Chiapas (Palenque), and southward through Guatemala (Chiséc; Choctúm; Raxché; Telemán; Los Amates, Yzabál), British Honduras (Western District; San Felipe; Cayo), Honduras (La Cumbre; Chasníguas; Omoa; San Pedro; Rio Segóvia), Nicaragua (Greytown; Los Sábalos; Chontales; Rio Escondido; San Carlos; Rana; Virgin Bay), Costa Rica (San Carlos; La Palma de Nicoya; Bebedero; Volcán de Miravalles; Pigres; Pozo Azúl de Pirrís; Boruca; Pozo del Rio Grande; La Vijágua; Lagarto; Bonilla; Guayabo; Turrialba; Jiménez; Carrillo; Tucurríqui; La Balsa; San José; Naranjo de Cartago; Angostura; Rio Sícsola, Talamanca; Talamanca; Rio Frio) to Panamá (Divala; Volcán de Chiriquí; Cordillera de Tolé; Santiago de Verágua; Bugaba; Panamá; Lion Hill; Colón).

Trogon massena Gould, Mon. Trog., ed. 1, 1838, pl. 16 and text (Guatemala; coll. J. Gould).-Gray, Cat. Fissir. Birds Brit. Mus., 1848, 40 (Mexico; Honduras).-Sclater, Proc. Zool. Soc. Lond., 1859, 387 (Playa Vicente, Vera Cruz); Cat. Am. Birds, 1862, 277 (Guatemala).-Sclater and Salvin, Ibis, 1859, 132 (Honduras); Proc. Zool. Soc. Lond., 1864, 364 (Lion Hill, Panamá).-Moore, Proc. Zool. Soc. Lond., 1859, 53 (Omoa and San Pedro, Honduras).-(?)CAssin, Proc. Ac. Nat. Sci. Phila., 1860, 135 (Rio Truando and delta of Rio Atrato, n. w. Colombia).-Salvin, Ibis, 1861, 146 (Honduras); 1872, 321 (Chontales, Nicaragua); Proc. Zool. Soc. Lond., 1867, 151 (Cordillera de Tolé and Santiago de Verágua, Panamá); 1870, 202 (Bugaba and Volcán de Chiriquí, Panamá).-Cabanis, Journ. für Orn., 1862, 174 (Costa Rica; crit.).-LAwRence, Ann. Lyc. N. Y., vii, 1862, 290 (Lion Hill, Panamá); viii, 1865, 183 (Greytown, Nicaragua); ix, 1868, 119 (Angostura and Tucurriqui, Costa Rica).-Frantzius, Journ. iür Orn., 1869, 313 (Costa Rica).-Boucard, Proc. Zool. Soc. Lond., 1878, 48 (San Carlos, Costa Rica); Liste Ois. récol. Guat., 1878, 26.-Sumichrast, La Naturaleza, v, 1881, 239 (Uvero, Vera Cruz).-Nutring, Proc. U. S. Nat. Mus., v, 1882, 400 (La Palma de Nicoya, Costa Rica; habits); vi, 1883, 407 (Los Sábalos, Nicaragua).-Zeuedón, Proc. U. S. Nat. Mus., viii, 1885, 109 (Costa Rica); Anal. Mus. Nac. Costa Iica, i, 1887, 120 (Pozo Azúl de Pirrís, Jiménez, and Naranjo de Cartago, Costa Rica).-Ridgwax, Proc. U. S. Nat. Mus., x, 1887, 591 (Rio Segóvia, Honduras); xiv, 1891, 476 (Pacuare and Jiménez, Costa Rica; crit.).-RichMond, Proc. U. S. Nat. Mus., xvi, 1893, 514 (Rio Escondido, Nicaragua; habits).-Grant, Cat. Birds Brit. Mus., xvii, 1892, 474.-Cherrie, Expl. Zool. Merid. Costa Rica, 1893, 47 (Lagarto and Boruca, Costa Rica).-SALvin and Godman, Biol. Centr.-Am., Aves, ii, 1896, 503.-Underwood, Ibis, 1896, 444 (Volcán de Miravalles, Costa Rica).-Dearborn, Pub. 125, Field Mus. N. H., 
1907, 88 (Los Amates, Guatemala).-Bangs, Proc. New Engl. Zool. Club, ii, 1900, 19 (Loma del León, Panamá); Auk, xxiv, 1907, 294 (Boruca and Pozo del Rio Grande, Costa Rica).-Carriker, Ann. Carnegie Mus., vi, 1910, 562 (Costa Rica; crit.; habits).-Ferry, Pub. 146, Field Mus. N. H., orn. ser., i, no. 6, 1910, 265 (Guayabo, Costa Rica; crit.).

T[rogon] massena Gray, Gen. Birds, i, 1845, 70.-Bonaparte, Consp. Av., i, $1850,149$.

[Trogon] massena Gray, Hand-list, i, 1869, 81, no. 951.-Sumichrast, Mem. Bost. Soc. N. H., i, 1869, 560 (hot region of Vera Cruz).-Sclater and Salvin, Nom. Av. Neotr., 1873, 104.-Sharpe, Hand-list, ii, 1900, 149.

Trogon massenæ Sclater, Proc. Zool. Soc. Lond., 1858, 96 (s. Mexico).

[Curucujus] massena Bonaparte, Consp. Voluc. Zygod., 1854, 14.

T[roctes] massenae Cabanis and Heine, Mus. Hein., iv, March, 1863, 204 (Mexico). Troctes massenæ Gould, Mon. Trog., ed. 2, 1869, pl. 31 and text (Guatemala).

E[utroctes] massenae HeIne, Journ. für Orn., xi, Sept., 1863, 358.

[Eutroctes] massenae Heine and Reichenow, Nom. Mus. Hein. Orn., 1890, 210 (Mexico).

T[roctes] hoffmanni Cabanis and Heine, Mus. Hein., iv, March, 1863, 204, footnote (in text) (Costa Rica; coll. Berlin Mus.).

E[utroctes] hoffmanni Heıne, Journ. für Orn., xi, Sept., 1863, 358.

[Trogon] hoffmanni GRAY, Hand-list, i, 1869, 81, no. 954.

Trogon erythronotus Müller, Reis. in Mex., i, 1864, 229 (Mexico); iii, 1865, 562.

[Trogon] erythronotus Gray, Hand-list, i, 1869, 83, no. 979.

\section{CURUCUJUS MELANURUS MACROURUS (Gould).}

\section{LARGE-TAIIED TROGON.}

Similar to $C$. massena, but smaller, with relatively much longer tail, the adult male with a narrow white band between the metallic green of chest and red of breast; quite similar in coloration to C.m. melanurus, ${ }^{a}$ but averaging decidedly larger.

Adult male.-Above bright metallic green, more or less golden green on back, scapulars, and upper rump, more bluish green (sometimes greenish blue) on lower rump and upper tail-coverts; middle pair of rectrices dark metallic bluish green or greenish blue rather broadly (but not sharply) tipped with black, the second and third pairs black, with outer portion of outer web (more or less broadly) dark metallic green tipped with black; remaining rectrices black, their outer webs finely freckled or sprinkled along edge, especially toward base, with pale grayish or dull grayish white; anterior lesser wing-coverts bright metallic green or golden green, the remaining coverts, together with secondaries, delicately vermiculated with black and white; rest of wing dull black or slate-black, the longer primaries edged wich white (except terminally); loral, orbital, auricular, and malar regions, chin, and upper throat black; lower throat and chest bright metallic green or golden green, margined posteriorly by a band or line of white across upper breast, this white band sometimes narrowly barred with blackish; rest of under parts pure geranium red, the thighs slate-black or blackish slate; bill yellow (orange in 
life ?); naked orbital ring yellowish (orange in life ?); feet dusky horn color (in dried skins); length (skins), 294-317 (305); wing, 157-167 (162.6); tail, 165.5-181.5 (172.6); culmen, 22-24.5 (23.1); tarsus, 15-17 (15.7); inner anterior toe, $16.5-17.5(17) .^{a}$

Adult female. ${ }^{b}$ - Above plain slate color, the tail darker and more brownish slate, the larger wing-coverts and secondaries usually minutely freckled or vermiculated with paler, the primaries more brownish slate or dull blackish slate, their outer web broadly edged with white passing into gray terminally; sides of head, chin, and throat dull brownish slate, darker on lores and anterior margin of chin; chest slate-gray passing into paler gray (nearly no. 7 gray) on breast and sides, the lower portion of breast more or less distinctly barred or vermiculated; rest of under parts geranium red, paler on under tail-coverts; thighs blackish slate; under surface of tail brownish slate, the rectrices narrowly tipped with darker; maxilla black, with lower basal portion, together with mandible yellow (orange in life?); feet dusky horn color (in dried skins); length (skins), 293; wing, 155.5-175.5 (156.5); tail, 161.5-174.5 (163); culmen, 20-23.5 (21.8); tarsus, 14-15.5 (14.7); inner anterior toe, 15-15.5 (15.2). ${ }^{c}$

Eastern Panamá (Darién; Panamá; Lion Hill; Paraiso; Rio Cianati) and northern Colombia (Rio Truando; delta of Rio Atrato; Cartagena; Cauca Valley; Remédios and Nechi, Antioquía).

Trogon macroura Gould, Mon. Trog., ed. 1, 1838, pl. 17 and text ("Mexique;" Carácas, Venezuela).-Gray, List Fissir. Birds Brit. Mus., 1848, 41.Lawrence, Ann. Lyc. N. Y., vii, 1862, 290 (Lion Hill, Panamá).

Trogon] macrourus GraY, Gen. Birds, i, 1845, 70.

Trogon macrourus Cassin, Proc. Ac. Nat. Sci. Phila., 1860, 135, footnote (Rio Truando and delta of Rio Atrato, n. w. Colombia).

Trogon] macrurus Bonaparte, Consp. Av., i, 1850, 150 ("Mexico").

Trogon macrurus Sclater and Salvin, Proc. Zool. Soc. Lond., 1864, 364 (Lion Hill, Panamá); 1879, 535 (Remédios and Nechi, Antioquía, Colombia).Gould, Mon. Trog., ed. 2, 1875, pl. 30 and text.-Grant, Cat. Birds Brit. Mus., xvii, 1892, 474 (Panamá and Paraiso Station, Panamá; Remédios and Nechi, Colombia).-Salvin and Godman, Biol. Centr.-Am., Aves, ii, 1896, 502.-Salvadori and Festa, Boll. Mus. Zool., etc., Torino, xiv, 1899, no. 339, 8 (Rio Cianati, Panamá).

¿Trogon] macrurus Gray, Hand-list, i, 1869, 81, no. 950.-Sclater and Salvin, Nom. Av. Neotr., 1873, 104.-Sharpe, Hand-list, ii, 1900, 149.

Trogon melanurus macrurus Bangs, Proc. New Engl. Zool. Club, ii, Sept. 20, 1900, 19 (Loma del León, Panamá).

[Curucujus] macrurus Bonaparte, Consp. Volucr. Zygod., 1854, 14.

T[roctes] macrurus Cabanis and Heine, Mus. Hein., iv, 1863, 203 (Cartagena, Colombia).

$a$ Seven specimens.

$b$ I am able to distinguish females of this species from those of $C$. massena (both occurring together on the Isthmus of Panamá) only by its smaller and relatively narrower bill. The coloration seems to be precisely the same except this, the bill is more yellow (less orange).

c Three specimens. 
E[utroctes] macrurus HeINe, Journ. für Orn., xi, Sept., 1863, 358.

[Eutroctes] macrurus Heine and Reichenow, Nom. Mus. Hein. Orn., 1890, 210 (Cartagena).

\section{CURUCUJUS CLATHRATUS (Salvin).}

\section{LATTICE-TAILED TROGON.}

Much like C. massena, but smaller, lateral rectrices crossed by narrow lines of white, and adult female with lower breast light brown instead of gray.

Adult male.-Above nearly uniform metallic green or golden or bronzy green, the upper tail-coverts rarely more bluish, but middle pair of rectrices usually more bluish green (sometimes greenish blue), rather broadly, but not sharply, tipped with black; inner web of second and third pairs of rectrices (from middle) black, the outer web metallic green, bluish green, or greenish blue, tipped with black; remaining rectrices black, crossed on outer web and distal portion of inner web with narrow lines of white, the outermost rectrix with greater portion of inner web thus barred; anterior lesser wing-coverts metallic green or bronze-green, the remaining coverts and the secondaries delicately vermiculated with black and white; remainder of wing dull black or blackish slate, the longer primaries edged with grayish white, this broken into minute freckling on distal portion; loral, orbital, auricular, and malar regions, chin and throat black; chest metallic green or golden-green; remaining under parts pure geranium red, the thighs black or dark sooty slate, the longer feathers sometimes narrowly tipped with pinkish; bill yellow (orange in life?); iris brown; ${ }^{a}$ feet brownish or horn color (in dried skins); length (skins), 285-302 (295) ; ${ }^{b}$ wing, 152-165 (159); tail, 148.5-160 (153.5); culmen, 20-21.5 (20.8); tarsus, 14.5-15.5 (15.1); inner anterior toe, $14.5-17.5(15.5){ }^{c}$

Adult female.--Pileum blackish slate; remaining upper parts slate color, the middle rectrices darker and more brownish slate, narrowly and rather indistinctly tipped with blackish; rest of tail as in adult male; wings dull blackish slate, the wing-coverts and secondaries minutely and rather indistinctly vermiculated with pale grayish, the longer primaries edged with white; loral, orbital, auricular, and malar regions, chin, and throat dark sooty; chest slate color, passing, through dull slate-gray, into light raw umber or wood brown, the posterior portion sometimes faintly barred; rest of under parts geranium red, the thighs blackish or sooty; maxilla blackish, with lower basal portion, together with mandible dull yellow; feet as in adult male; length (skins), 27S-285 (282); wing, 151-165 (15S.7);

\footnotetext{
$a$ Heyde and Lux, manuscript.

$b$ Three specimens.

c Nine specimens,
} 
tail, 152-154 (153.2); culmen, 19-20.5 (19.8); tarsus, 15.5-16 (15.7); inner anterior toe, $15.5-16$ (15.8) ${ }^{a}$

Costa Rica (Guápiles; Angostura; Carrillo; Bonilla; La Vijágua) and Panamá (Santa Fé de Verágua; Santiago de Verágua; Minerál de Verágua; Calovévora; Cordillera de Tolé; Cascajál, Coclé; Panamá).

Trogon clathratus Salvin, Proc. Zool. Soc. Lond., 1866, 75 (Santa Fé de Verágua, Panamá; coll. Salvin and Godman); 1867, 151 (Santa Fé, Santiago, and Cordillera de Tolé, Verágua; descr. adult female); 1870, 202, (Calovévora, Veragua); Ibis, 1874, 329 (Minerál de Verágua, Panamá).-(?)Frantzius, Journ. für Orn., 1869, 313 (Costa Rica).-Gould, Mon. Trog., ed. 2, 1875, pl. 28 and text.-Zeledón, Proc. U. S. Nat. Mus., viii, 1885, 109 (Costa Rica); Anal. Míus. Nac. Costa Rica, i, 1887, 120 (Costa Rica).-Grant, Cat. Birds Brit. Mus., xvii, 1892, 476 (Angostura, Costa Rica; Calovévora, Cordillera de Tolé, and Santa Fé de Verágua, Panamá).-Salvin and Godman, Biol. Centr.-Am., Aves, ii, 1896, 504.-Carriker, Ann. Carnegie Mus., vi, 1910, 562 (Costa Rica; crit.).

[Trogon] clathratus Sclater and Salvin, Nom. Av. Neotr., 1873, 104.-Sharpe, Hand-list, ii, 1900, 149.

T[rogon] clathratus RIDGWay, Condor, vii, 1905, 156, in text (Bonilla, e. Costa Rica).

[Trogon] calthratus Gray, Hand-list, i, 1869, 81, no. 952.

\section{Genus TROGON Brisson.}

Trogon Brisson, Orn., i, 1760, 42; iv, 1760, 164, pl. 16, fig. 1. (Type, as fixed by Stone, Auk, xxiv, 1907, 192,b Trogon viridis Linnæus=T. strigilatus Linnæus.)

Aganus c Cabanis and Heine, Mus. Hein., iv, Feb., 1863, 184. (Type, by original designation, Trogon viridis Linnæus. $d$ )

Rather large Trogons, most like Curucujus in structure but differing in smaller size, more strongly graduated tail, with rectrices more truncated at tip, much white on lateral rectrices, and under parts yellow or (in one species only) reddish orange.

$a$ Three specimens.

\begin{tabular}{|c|c|c|c|c|c|}
\hline Locality. & Wing. & Tail. & $\begin{array}{l}\text { Cul- } \\
\text { men. }\end{array}$ & Tarsus. & $\begin{array}{c}\text { Inner } \\
\text { ante- } \\
\text { rior toe. }\end{array}$ \\
\hline MALES. & & & & & \\
\hline Three adult males from Costa Rica.. & 158.2 & 153.8 & 20.8 & 15.3 & 16.3 \\
\hline Six adult males from Panamá.. & 159.4 & 153:4 & 20.8 & 15 & 15.1 \\
\hline
\end{tabular}

$b$ "Type remains the same," i. e., as given in the American Ornithologists' Union's "Check List of North American Birds," second and revised edition (1895).

c "Von diravós (freundlich, angenehm)." (Cabanis and Heine.)

$d$ Not Aganus braccatus Cabanis and Heine, as given in Cat. Birds Brit. Mus. (xvii, 440 ), since the authors expressly say that the most typical species ("deren typischter Arten") is T. viridis.

To what group the generic name Harpaleus Cabanis and Heine (Mus. Hein., iv, 1863 , 185, footnote) was intended to apply can not be determined, no species being mentioned nor character given. In other words, the name is a nomen nudum. 
Bill strong, as deep as broad at nostrils, the culmen strongly curved, sometimes distinctly ridged, sometimes rounded; gonys shorter than mandibular rami, more or less convex, ascending terminally; anterior half of mandibular tomia strongly but irregularly serrate, the maxillary rami less strongly so; tip of mandible produced into a distinct ascending point. Nostril rounded, nonoperculate, mostly concealed by strong, antrorse, decurved bristles. Feathering of head normal; feathers of chin and malar apex antrorse, bristle-like, the former strongly recurved; seventh, sixth, or seventh and sixth primaries longest, the tenth (outermost) less than half as long as the longest; tail equal to or slightly longer than wing, graduated for more than one-third its length, the middle rectrices truncate, the lateral ones subtruncate, at tip. Tarsus decidedly shorter than longest anterior toe, feathered for upper half or more; anterior toes united for basal and part of second phalanx.

Coloration.--Adult males with upper parts (except wings and, sometimes, head), metallic green or blue, the middle rectrices tipped with black; wings black or blackish slate; chest slate-blackish or glossed with metallic bluish green, blue, or violet, the remaining under parts orange-yellow or (in T. bairdii) reddish orange or orangered; lateral rectrices extensively white terminally and on outer web or very broadly tipped with white. Adult females with head, neck, chest, and upper parts plain slate color, the wing-coverts sometimes narrowly barred with white.

Range.-Western Mexico to Peru and eastern Brazil. (Five species.)

KEY TO THE SPECIES AND SUBSPECIES OF TROGON.

a. Back, scapulars, rump, upper tail-coverts, and middle rectrices brightly metallic green or blue. (Adult males.)

b. Pileum and chest glossed, more or less, with metallic blue or violet.

c. Posterior under parts reddish orange or orange-red. (Southwestern Costa Rica and western Panamá.)........... Trogon bairdii, adult male (p. 752). cc. Posterior under parts orange-yellow. (Trogon strigilatus.)

$d$. Lateral rectrices less extensively white (the basal black on outermost pair extending much beyond the under tail-coverts. (Caribbean slope of Colombia to Cayenne, upper Amazons, and southeastern Brazil.)

Trogon strigilatus strigilatus (and other South American subspecies), adult male (extralimital). ${ }^{a}$

a [Trogon] strigilatus Linnæus, Syst. Nat., ed. 12, i, 1766, 167, no.1 (=adult female; based on Trogon cayanensis cinereus Brisson, Orn., iv, 165, pl. 16, fig. 1).-Trogon strigilatus Stephens, Shaw's Gen. Zool., ix, ]815, 10.-[Trogon] viridis Linnæus, Syst. Nat., ed. 12, i, 1766, 167, no. 3 (=) adult male; based on Trogon cayanensis riridis Brisson, Orn., iv, 168, pl. 17, fig. 1).-Trogon viridis Stephens, Shaw's Gen. Zool., ix, 1815, 11, pl. 4; Gould, Mon. Trog., ed. 2, 1869, pl. 21 and text; Grant, Cat. Birds Brit. Mus., xvii, 1892, 458.-A[ganus] viridis Cabanis and Heine, Mus. Hein., iv, Feb., 1863, 196.-Trogon leverianus Shaw, Mus. Lever., 1792, 175, with plate (Cayenne; coll. Leverian Mus.).-T[rogon] albiventer Cuvièr, Règne Anin., i, IS29, 459 (based on Levaillant, Couroucous, pl. 5).-Trogon melanoptcrus Swainson, 
$d d$. Lateral rectrices more extensively white (the basal black on outermost pair restricted to a small area entirely concealed by under tail-coverts). (Panamá to western Ecuadór.)

Trogon strigilatus chionurus, adult male (p. 754).

$b b$. Pileum and chest "dead" slate-black or slate color, without trace of metallic gloss (except, sometimes, very faintly, on occiput and hindneck).

c. Outermost pair of rectrices with much less than terminal third white. (Trogon melanocephalus.)

d. Head, neck, and chest slate-black to blackish slate. (Eastern Mexico to northeastern Costa Rica.)

Trogon melanocephalus melanocephalus, adult male (p. 756).

$d d$. Head, neck, and chest slate color to slate-gray. (Pacific coast district of Costa Rica and Nicaragua.)

Trogon melanocephalus illætabilis, adult male (p. 759).

$c c$. Outermost pair of rectrices with terminal half, or more, white. (Western Mexico.)

Trogon citreolus, adult male (p. 759).

aa. Back, scapulars, rump, upper tail-coverts, and middle rectrices blackish slate to slate-gray, like head, neck, and chest. (Adult females.)

$b$. Wing-coverts and secondaries narrowly barred with white or pale gray; lateral rectrices barred with white.

c. Posterior under parts reddish orange or orange-red.

cc. Posterior under parts orange-yellow. (Trogon strigilatus.)

Trogon bairdii, adult female (p. 753).

$d$. Lateral rectrices with white much less extended.

Trogon strigilatus strigilatus, adult female (extralimital).

$d d$. Lateral rectrices with much more white.

Trogon strigilatus chionurus, adult female (p. 755).

$b b$. Wing-coverts and secondaries plain blackish slate or slate color; lateral rectrices not distinctly (if at all) barred with white.

c. White tip to lateral rectrices much shorter, with anterior outline more directly

transverse. (Trogon melanocephalus.)

d. Head, neck, and chest darker (slate-blackish).

Trogon melanocephalus melanocephalus, adult female (p. 757).

$d d$. Head, neck, and chest more grayish (slate color to slate-gray).

Trogon melanocephalus illætabilis, adult female (p. 759).

$c c$. White tip to lateral rectrices much longer, with lateral outlines strongly oblique.

Trogon citreolus, adult female (p. 760).

\section{TROGON BAIRDII Lawrence.}

\section{BAIRD'S TROGON.}

Similar to T. strigilatus chionurus, but posterior under parts bright orange or orange-red instead of orange-yellow.

Adult male.-Pileum and hindneck black, usually more or less glossed with violet-blue; back, scapulars, anterior lesser wing-coverts,

Anim. in Menag., pt. iii, Jan. 1, 1838, 332 (Brazil; coll. W. Swainson); Gould, Mon. Trog., ed. 1, 1838, pls. 10, 11, and text.-A[ganus] venustus Cabanis and Heine, Mus. Hein., iv, Feb., 1863, 194 (Colombia; coll. Heine Mus.).-T[rogon] cyanurus Finsch, Proc. Zool. Soc. Lond., Nov., 1870, 559, in text (Cayenne; coll. Bremen Mus.; ex Hartlaub, manuscript).

Like many other of the South American Trogons, this species unquestionably requires subdivision. The specimens from southeastern Brazil, for example, are very different from those from Cayenne, etc. 
and upper rump bright metallic green or bluish green, usually intermixed with violet-blue, passing into rich violet-blue or bluish violet on upper margin of back and on lower rump and upper tail-coverts; middle rectrices rather dark metallic bluish green to violet-blue, abruptly tipped with black, the inner web of second and third rectrices (from middle) wholly black; lateral rectrices extensively white terminally, the white on third (from outside) occupying about terminal third to terminal half (the white area usually smaller on inner than on outer web), the outermost rectrix with whole of the exposed portion white, the black being confined to a small area, concealed by under tail-coverts; wings (except anterior lesser coverts) uniform black, the longer primaries edged with white basally; sides of head, chin, throat, chest, and upper breast dull black or sooty black, the lower chest and upper breast usually glossed, more or less, with violet-blue, especially laterally; rest of under parts bright pure reddish orange or orange-red (flame scarlet to between flame scarlet and saturn red), the tibial and tarsal feathers sooty black; bill (in dried skins) pale grayish yellow or glaucous-whitish, sometimes darker (grayish) on mandible and lower basal portion of maxilla; feet horn color (in dried skins); length (skins), 263-298 (282); wing, 142-153 (146.5); tail, 147-172.5 (155.9); culmen, 21.5-25 (23.4); tarsus, 12.5-15 (14.2); inner anterior toe, 13-16 (14.4). ${ }^{a}$

Adult female.-Above plain slate color or dark slate-gray, the four middle rectrices darker (blackish slate or sooty slate), narrowly tipped with black; wings black, the wing-coverts and secondaries very narrowly barred with white (these narrow white transverse lines many times narrower than the black interspaces), the longer primaries edged with white basally and, usually, specked or dotted with white distally or subterminally; lateral rectrices black, tipped with white (the white tip from about $2-9 \mathrm{~mm}$. wide), the remaining portion narrowly barred with white (white bars several times narrower than the black interspaces) for distal portion and on greater part of outer web; lores and orbital region blackish; sides of head and neck, chin, throat, chest, whole breast, sides, and flanks uniform slate-gray or grayish slate, gradually darkening into the color of pileum, etc., somewhat paler along posterior margin, where sometimes faintly barred with still paler grayish and tipped with orange-pinkish; abdomen, anal region, and under tail-coverts reddish orange (clear orange-chrome to saturn red or light flame scarlet), the flanks more or less strongly tinged or intermixed with the same, the feathers of tibia and tarsus dark sooty slate; maxilla black, with lower basal portion, together with mandible, grayish (in dried skins); feet as in 
adult male; length (skins), 258-304 (286); wing, 143-153.5 (146); tail, 148-170 (157.8); culmen, 21-23 (22); tarsus, 13.5-15.5 (14.2); inner anterior toe, $13.5-15$ (14.2). ${ }^{a}$

Young male (nestling).- Similar to the adult female, but abdomen, sides, and flanks grayish sooty passing into pale fulvous or buffy on anal region, the under tail-coverts dull white and pale buffy with basal portion dark sooty.

Southwestern Costa Rica (San Mateo; Las Trojas; Pigres; Pozo Azúl de Pirrís; Pozo del Rio Grande; El Pozo de Térraba; Boruca; El Generál; Palmár) and western Panamá (Divala; Bugaba; Bibaláz; Verágua; Chiriquí).

Trogon bairdii Lawrence, Ann. Lyc. Nat. Hist. N. Y., ix, 1870 (extras issued April, 1868), 119, 120 (San Mateo, w. Costa Rica; coll. U. S. Nat. Mus.).Frantzius, Journ. für Orn., 1869, 313 (Costa Rica).-Zeledón, Proc. U. S. Nat. Mus., viii, 1885, 109 (Costa Rica); Anal. Mus. Nac. Costa Rica, i, 1887, 120 (Pozo Azúl de Pirrís and Las Trojas, s. w. Costa Rica).-Cherrie, Expl. Zool. Merid. C. R., 1893, 47 (Palmár and Boruca, s. w. Costa Rica).-RIDGWAY, Condor, vii, 1905, 155, in text (near Pigres, w. Costa Rica).

Trogon bairdi SaLvin, Ibis, 1869, 316; Proc. Zool. Soc. Lond., 1870, 202 (Bugaba, Panamá; descr. adult female).-Gould, Mon. Trog., ed. 2, 1875, pl. 23 and text.-Grant, Cat. Birds Brit. Mus., xvii, 1892, 461 (Bugaba and Bibaláz, Panamá).-Salvin and Godman, Biol. Centr.-Am., Aves, ii, 1896, 496.Bangs, Auk, xxiv, 1907, 294 (Boruca and Pozo del Rio Grande, s. w. Costa Rica).-Carriker, Ann. Carnegie Mus., vi, 1910, 560 (s. w. Costa Rica; habits).

[Trogon] bairdi Sclater and Salvin, Nom. Av. Neotr., 1873, 104.-Sharpe, Hand-list, ii, 1900, 148.

Trogon clathratus (not of Salvin) Lawrence, Ann. Lyc. N. Y., ix, 1868, 119 (San Mateo, Costa Rica; descr. supposed female).-(?) Frantzius, Journ. für Orn., 1869, 313 (Costa Rica).

\section{TROGON STRIGILATUS CHIONURUS (Sclater and Salvin).}

\section{WHITE-TAILED TROGON.}

Adult male.-Head, neck, and upper chest black glossed with violet, the lower chest and sides of breast dark metallic bluish violet or violetblue; back, scapulars, and upper rump brilliant metallic green, passing into violet-blue on upper margin of back, lower rump, and upper tail-

a Thirteen specimens.

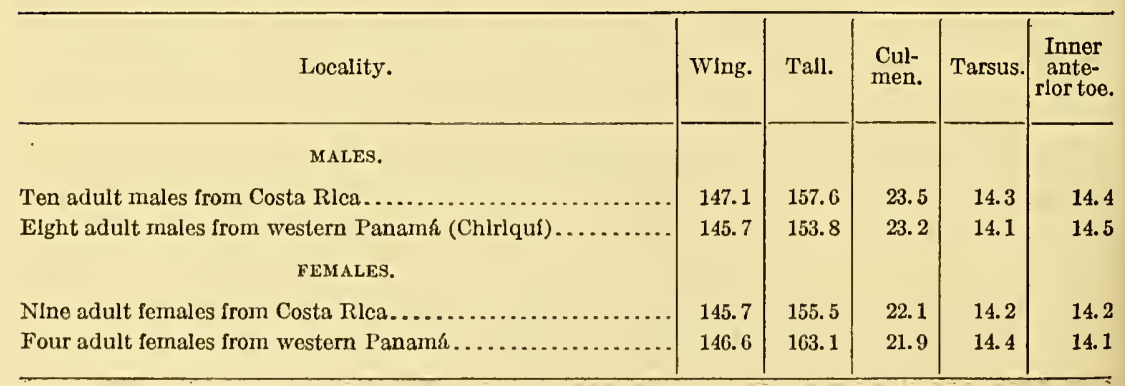


coverts; middle pair of rectrices metallic bluish green or greenish blue, abruptly tipped with black, the next two pairs similar on outer web, but inner web wholly black; fourth rectrix (from middle) black, with about terminal half of outer web white, the inner web with much less white, with base of the area forming an acute angle next to shaft; fifth rectrix with the white occupying approximately terminal twothirds of outer web and terminal half of inner web; outermost rectrix with only the extreme base of outer web and basal third, or less, of inner web black, sometimes with the black reduced to a small spot; wings black, the primaries (except shorter proximal ones) edged basally with white; median portion of breast, abdomen, flanks, and under tail-coverts rich orange-yellow (cadmium yellow); sides dark slaty or blackish slate; thighs slate-black; bill (in dried skins) light grayish yellow; feet dusky or horn color (in dried skins); length (skins), 250-274 (265); wing, 129-144 (136); tail, 137-151 (145.2); culmen, 21-23 (22); tarsus, 12-14.5 (13.3); inner anterior toe, 13$14.5(13.9) .^{a}$

Adult female.-Above uniform blackish slate, the rectrices without black tip; wings rather darker (slate-black), the coverts and secondaries very narrowly barred with white, the primaries edged with white basally and with small spots of white along edge for terminal half or more; three lateral rectrices (on each side) with much less white than in adult male, this broken (except for broad terminal portion) with broad bars confluent with the slate-black basal area; sides of head and neck, chin, tliroat, chest, and breast plain blackish slate (very slightly less blackish than upper parts), slightly paler (nore grayish slate) posteriorly and on sides and outer portion of flanks; rest of underparts orange-yellow (less intense than in adult male), the thighs blackish slate; maxilla mostly blackish or dusky horn color, the mandible paler (dull grayish yellowish), at least terminally; feet as in adult male; length (skins), 267-270 (268); wing, 136-140 (137.5); tail, 144-150.5 (146.1); culmen, 19-21 (20.1); tarsus, 13-15 (13.5); inner anterior toe, $12.5-13.5$ (13). ${ }^{b}$

Immature male.-Similar to the adult male, but lateral rectrices as in adult temale (the white more extended, however, and the broad black bars not reaching to shaft on inner web), wing-coverts and

$b$ Four specimens.

\begin{tabular}{|c|c|c|c|c|c|}
\hline Locality. & Wing. & Tail. & $\begin{array}{l}\text { Cul- } \\
\text { men. }\end{array}$ & Tarsus. & $\begin{array}{l}\text { Inner } \\
\text { ante- } \\
\text { rior toe. }\end{array}$ \\
\hline MALES. & & & & & \\
\hline Ten adılt males from Panamá.... & 136.3 & 144.9 & 21.7 & 13.1 & 13.7 \\
\hline Four adult males from Colombla.... & 134.7 & 144.2 & 22.2 & 13.6 & 14.1 \\
\hline One adult male from western Ecuadór (Guayaquíl)............ & 139 & $15 \mathrm{t}$ & 23.5 & 14 & 14.5 \\
\hline
\end{tabular}


proximal secondaries very narrowly barred with light gray, distal secondaries with small spots of white along edge of outer web, and anterior underparts (in younger specimens) intermixed with dull blackish slate.

Eastern Panamá (Panamá; Lion Hill; Cascajál, Coclé), northwestern Colombia (Rio Truando; valley of Rio Magdalena; Patúria; Remédios, Medellín, and Nechi, Antioquía; Carmen; near Jiménez; 20 miles from Honda, Tolima, 2,000 feet), and western Ecuadór (Guayaquíl; Balzár Mountains; Cachaví, 500 feet; Foreste del Rio Peripa).

Trogon melanopterus (not of Swainson) Cassin, Proc. Ac. Nat. Sci. Phila., 1860, 136 (Rio Truando, n. w. Colombia).

Trogon viridis (not of Linnæus) La Wrence, Ann. Lyc. N. Y., vii, 1862, 290 (Lion Hill, Panamá).-Sclater and Salvin, Proc. Zool. Soc. Lond., 1864, 364 (Lion Hill).

Trogon chionurus Sclater and Salvin, Proc. Zool. Soc. Lond., 1870, 843 (Lion Hill, Panamá; coll. Salvin and Godman); 1871, 374 (crit.); 1879, 535, 549 (Remédios and Nechi, Antioquía, Colombia).-Wyatт, Ibis, 1871, 130 (Magdalena Valley, Colombia), 374 (Patúria, Colombia).-Berlepsch, Journ. für Orn., 1884, 318 (Patúria).-Grant, Cat. Birds Brit. Mus., xvii, 1892, 460 (Verágua, Panamá; Remédios and Medellín, Colombia; Balzár Mts., w. Ecuadór).--Salvin and Godman, Biol. Centr.-Am., Aves, ii, 1896, 495.Hartert, Novit. Zool., v, 1898, 499 (Cachaví, 500 ft., n. w. Ecuadór).-SALvadori and Festa, Boll. Mus. Zool., etc., Torino, xv, 1900, 17 (Foreste del Rio Peripa, w. Ecuadór)._Bangs, Proc. New Engl. Zool. Club, ii, 1900, 19 (Lion Hill).

[Trogon] chionurus Sclater and Salvin, Nom. Av. Neotr., 1873, 104.-Sharpe, Hand-list, ii, 1900, 148.

Trogon eximius Lawrence, Ann. Lyc. Nat. Hist. N. Y., x, 1874 (pub. March, 1871), 11, 13 (Panamá; coll. G. N. Lawrence).

\section{TROGON MELANOCEPHALUS MELANOCEPHALUS Gould.}

\section{BLACK-HEADED TROGON.}

Adult male.-Head, neck, and chest uniform black or slate-black, the occiput and hindneck sometimes faintly glossed with metallic bluish; back, scapulars, anterior lesser wing-coverts, and upper rump bright metallic bluish green to golden green, usually more bluish next to black of hindneck and sometimes intermixed with violet-blue; lower rump and upper tail-coverts rich metallic blue, violet-blue, or bluish violet; four middle rectrices metallic bronze-green to bluish green (rarely blue or violet-blue), abruptly tipped with black, the inner web of second and third rectrices (from middle) wholly black; three lateral pairs of rectrices black, broadly tipped with white (this about 15-30 mm. wide); wings (except anterior portion of lesser covert area) slatc-black, the longer primaries edged basally with white; sides and flanks blackish slate or sooty slate, the latter more or less tinged or intermixed with orange-yellow; rest of underparts rich orange-yellow (cadmium or deep chrome), fading into yellowish 
white anteriorly, where forming a more or less well-defined band against blackish of chest, the feathers of tibia and tarsus sooty blackish; bill (in dried skins) pale grayish yellow or yellowish gray; iris brown; naked eyclids sky blue or light azure blue; feet dusky horn color (in dried skins); length (skins), 256-303 (272); wing, 130-146.5 (137.9); tail, 136-165 (148.2); culmen, 18-21.5 (19.7); tarsus, 13-15 (13.9); inner anterior toe, $13-15$ (14.1). ${ }^{a}$

Adult female.-Similar to the adult male but metallic coloring of upper parts replaced by slate color or blackish slate; maxilla black, except lower basal portion; length (skins), 250-285 (267); wing, 133-141.5 (136.4); tail, 138-155 (147); culmen, 17-21.5 (19.1); tarsus, 13-14.5 (13.9); inner anterior toe, $13-15(13.7) .^{b}$

Immature male.-Similar to the adult male but middle rectrices mostly dull black (the metallic coloring mostly confined to basal two-thirds of outer web of middle pair and basal outer edge of next two), lateral rectrices narrower at tip and with two or three white spots or bars on subterminal portion of outer web, and outer webs of secondaries and greater wing-coverts spotted and edged with white.

Immature female.- Similar to the adult female but middle rectrices without distinct black tip, lateral rectrices narrower at tip and with outer web more or less spotted or barred with white, and secondaries edged with white.

Eastern Mexico, from States of southern Tamaulipas (Tampico; Alta Mira), Vera Cruz (Catemán; Orizaba; Jalapa; Playa Vicente; Uvero; Achotál; Misantla; Laguna Verde; Tlalcotalpám; Minatitlán; Coatzocoalcos; Otatitlán; Motzorongo; Rivera; Santo Domingo; Pasa Nueva), Puebla (Rinconada), Mexico ("City of Mexico"), eastern Oaxaca (Túxtepec), Tabasco (Teapa), Chiapas (Palenque), Cam-

\begin{tabular}{|c|c|c|c|c|c|}
\hline a Twenty-nine specimens. & $b$ Eigh & een $\mathrm{s}$ & ecimer & & \\
\hline Looality. & Wing. & Tail. & $\begin{array}{l}\text { Cul- } \\
\text { men. }\end{array}$ & Tarsus. & $\begin{array}{c}\text { Inner } \\
\text { ante- } \\
\text { rior toe. }\end{array}$ \\
\hline \multicolumn{6}{|l|}{ MALES. } \\
\hline Nine adult males from Tamaulipas (2) and Vera Cruz (7). & 140.5 & 155.7 & 20.1 & 14.2 & 14.4 \\
\hline Ten adult males from Yucatán.......................... & 136.7 & 147.5 & 19.3 & 13.8 & 14.1 \\
\hline Ten adult males from Chiapas (1), Guatemala (2), British & & & & & \\
\hline Honduras (1), Honduras (5), and eastern Nicaragua (1)..... & 136.8 & 144.2 & 19.6 & 13.6 & 13.8 \\
\hline Seven adult males ( $T . m$. illætabilis) from western Nicaragua.. & 141.1 & 148.9 & 21 & 14.4 & 14.4 \\
\hline Ten adult males ( $T, m$. illætabilis) from western Costa Riea... & 145.6 & 153.9 & 21.3 & 14.5 & 14.6 \\
\hline \multicolumn{6}{|l|}{ FEMALES. } \\
\hline 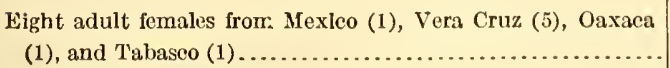 & 136.4 & 148.5 & 19.3 & 13.9 & 14.1 \\
\hline Nine adult females from Yucatán..................... & 136.9 & 146.7 & 19.1 & 13.8 & 13.5 \\
\hline One adult female from British Honduras............. & 133 & 138 & 17 & . & ..... \\
\hline Ten aduit females ( $T . m$. illatabilis) from western Costa Rica.. & 144.3 & 148. 8 & 20.5 & 14.2 & 14.6 \\
\hline
\end{tabular}


peche (Apazote), and Yucatán (Mérida; Silám; La Vega; Temáx; Izamál; Calotmúl; Cuxtún; Buctzotz; Peto; Meco; San Felipe; Chichen-Itza; Yak-Zonat; Chem-Zonat; Meco Island), southward through British Honduras (Belize; Corosál; Orange Walk; San Antonio; Cayo; San Felipe), Guatemala (Choctúm; Rio Managua; Gualán, Zacapa; Los Amates, Yzabál; Santo Tomas), Salvadór (La Unión; Volcán de San Miguél), Honduras (Omoa; Medina; San Pedro; Chasníguas; Truxillo; Boca de Rio Román; Céiba; Taulevi; Tigre Island) and eastern Nicaragua (Greytown; Los Sábalos; La Libertád, Chontales) to northeastern Costa Rica (Rio Frio).

Trogon melanocephala Goutd, Mon. Trog., ed. 1, 1838, pl. 12 (Tamaulipas, Mexico; coll. J. Gould).

Trogon] melanocephalus Gray, Gen. Birds, i, 1845, 70.-Bonaparte, Consp. Av., i, 1850, 149.-Ridgway, Man. N. Am. Birds, 1887, 277.

Trogon melanocephalus Gray, List Fissir. Birds Brit. Mus., 1848, 42 (Mexico; Honduras).-Sclater, Proc. Zool. Soc. Lond., 1857, 227 (Catemán, Vera Cruz); 1858, 357 (Tigre I., Honduras); 1859, 367 (Jalapa, Vera Cruz), 387 (Playa Vicente, Vera Cruz); Cat. Am. Birds, 1862, 276 (Guatemala).Govld, Mon. Trog., ed. 2, 1858, pl. 27 and text (Mexico; Honduras).Sclater and Salvin, Ibis, 1859, 132 (Guatemala; Honduras); Proc. Zool. Soc. Lond., 1870, 837 (Medina and San Pedro, Honduras).-Moore, Proc. Zool. Soc. Lond., 1859, 53 (Omoa, Honduras).-TAYLor, Ibis, 1860, 117 (Tigre I. and Taulevi, Honduras).-Salvin, Ibis, 1870, 115 (Costa Rica); 1872, 322 (Chontales, Nicaragua); 1889, 371 (Meco I., Yucatan; range); 1890, 88 (Meco I., etc.).-Lawrence, Ann. Lyc. N. Y., viii, 1867, 183 (Greytown, Nicaragua).-Sumichrast, La Naturaleza, v, 1881, 239 (Uvero, Vera Cruz).-Boucard, Proc. Zool. Soc. Lond., 1883, 454 (Yak-Zonat and Chem-Zonat, Yucatan).-Zeledón, Proc. U. S. Nat. Mus., viii, 1885, 109 (Costa Rica); Anal. Mus. Nac. Costa Rica, i, 1887, 120.-Ridgway, Proc. U. S. Nat. Mus., x, 1887, 581 (Truxillo, Honduras).-Grant, Cat. Birds Brit. Mus., xvii, 1892, 462, part (Tampico, Tamaulipas; Playa Vicente, Misantla, and Laguna Verde, Vera Cruz; Teapa, Tabasco; Meco I., Buctzotz, Mérida, and Peto, Yucatan; etc.).-Richmond, Proc. U. S. Nat. Mus., xvi, 1893, 515 (Rio Escondido, Nicaragua; habits); xviii, 1896, 629 (Alta Mira, Tamaulipas).-Salvin and Godman, Biol. Centr.-Am., Aves, ii, 1896, 498, part.-Lantz, Trans. Kansas Ac. Sci. for 1896-97 (1899), 220 (Rinconada, Puebla; Santo Tomas, Guatemala).-Bangs, Bull. Mus. Comp. Zool., xxxix, 1903, 144 (Céiba, Honduras).-Coxe, Bull. Mus. Comp. Zool., 1, 1906, 129 (Chichen-Itza, Yucatan; crit.).-Dearborn, Pub. 125, Field Mus. N. H., 1907, 88 (Los Amates and Gualán, Guatemala).

[Trogon] melanocephalus Gray, Hand-list, i, 1869, 82, no. 958.-Sumichrast, Mem. Bost. Soc. N. H., i, 1869, 560 (hot region Vera Cruz).-Sclater and Sadvin, Nom. Av. Neotr., 1873, 104.-Sharpe, Hand-list, ii, 1900, 148.

Trogon melanocephalus melanocephalus Bangs, Proc. Biol. Soc. Wash., xxii, March 10, 1909, 31, in text (crit.).

[Trogonurus] melanocephalus Bonaparte, Consp. Voluc. Zygod., 1854, 14.

A[ganus] melanocephalus Cabanis and Heine, Mus. Hein., iv, March, 1863, 197 (Mexico).

[Aganus] melanocephalus Heine and Reichenow, Nom. Mus. Hein. Orn., 1890, 209 (Mexico). 


\section{TROGON MELANOCEPHALUS ILLETABILIS Bangs.}

\section{SLATY-HEADED TROGON.}

Similar to T.m. melanocephalus, but head, neck, and chest more slaty, the chest often slate-gray in adult female; slightly larger.

Adult male.-Length (skins), 260-288 (268); wing, 132.5-148.5 (143.8); tail, 143.5-158.5 (151.9); culmen, 19.5-23.5 (21.2); tarsus, 13.5-15 (14.5); inner anterior toe, $14-15$ (14.5) ${ }^{a}$

Adult female.-Length (skins), 255-267 (259); wing, 140-150.5 (144.3); tail, 142.5-156 (148.8); culmen, 19.5-22 (20.5); tarsus, 13.5-15 (14.2); middle toe, $14-15.5$ (14.6). ${ }^{6}$

Western Costa Rica (Bolsón; Bebedero; Barranca de Punta Arenas; Tenório; Volcán de Miravalles) and western Nicaragua (Sucuyá; Realejo; Manágua; Omotepe; San Gerónimo, Chinandega ; Grenada).

Trogon melanocephalus (not of Gould) Nutring, Proc. U. S. Nat. Mus., v, 1882, 400 (La Palma de Nicoya, w. Costa Rica; habits); vi, 1883, 376, 387, 395 (San Juan del Sur, Sucuyá, and Omotepe, Nicaragua).-Grant, Cat. Birds Brit. Mus., xvii, 1892, 462, part (Virgin Bay and Volcán de Chinandega, w. Nicaragua; Costa Rica?).-Salvin and Godman, Biol. Centr.-Am., Aves, ii, 1896, 498, part (San Juan del Sur, Sucuyá, Omotepe, Virgin Bay, and Volcán de Chinandega, w. Nicaragua; La Palma de Nicoya, w. Costa Rica).Underwood, Ibis, 1896, 444 (Volcán de Miravalles and Bagaces, n. w. Costa Rica).-(?)Alfaro, Paginas Illustradas, i, 1904, 530, 531 (Costa Rica; nesting habits; fig. of nest).-BANGs, Auk, xxiv, 1907, 294 (Barranca de Punta Arenas, w. Costa Rica).

(?) T[rogon] melano-cephalus Lawrence, Ann. Lyc. N. Y., ix, 1868, 120, in text (Costa Rica).

Trogon melanocephalus illaetabilis Bangs, Proc. Biol. Soc. Wash., xxii, March 10, 1909, 30 (Bolsón, w. Costa Rica; coll. E. A. and O. Bangs).-Carriker, Ann. Carnegie Mus., vi, 1910, 560 (Nicoya peninsula and s. Guanacaste, w. Costa Rica.

\section{TROGON CITREOLUS Gould.}

\section{CITREOLINE TROGON.}

Adult male.-Pileum, hindneck, and sides of head and neck blackish slate, passing gradually into slate color on chin, throat, and chest; back and scapulars metallic golden green, passing into metallic bluish green or greenish blue (sometimes tinged with violet-blue) on rump and upper tail-coverts, the extreme upper portion of back sometimes bluish green; middle pair of rectrices metallic green or bronze-green, abruptly and rather narrowly tipped with black, the outer web of next two pairs similar but inner web wholly black; three outer pairs black basally, extensively white terminally, the white on outermost rectrix occupying about half of inner web and all but basal portion of outer web, that on the third (from outside) about terminal third of outer and fourth of inner web; wing-coverts 
and secondaries plain slate color, the anterior lesser coverts broadly tipped with metallic green or golden green; primaries blackish slate, broadly edged with white, except the shorter proximal and outermost quills; upper breast white or yellowish white, passing into yellow (deep chrome or light orange-yellow) on rest of under parts, the thighs slate color; bill pale grayish yellowish (bluish gray in life) $;^{a}$ naked eyelids ultramarine blue or violet-blue; ${ }^{a}$ iris yellow; ${ }^{a}$ feet dusky horn color (bluish gray or cinereous in life); ${ }^{a}$ length (skins), 255-287 (269); wing, 130.5-145.5 (137); tail, 139-158 (147.8); culmen, 18.5-21 (19.8); tarsus, 13-14.5 (13.6); inner anterior toe, $13-15(14){ }^{b}$

Adult female.-Similar to the adult male, but back, scapulars, rump, and upper tail-coverts uniform slate color (or between slate color and slate-gray), middle rectrices dark slate color (the middle pair less dark and narrowly tipped with black, white of lateral rectrices much less extensive (that on outer web broken proximally into bars or spots, that on inner web with the proximal margin much less sharply defined, sometimes broken into irregular spotting or marbling), anterior under parts paler (slate-gray instead of slate color), yellow of other under parts averaging paler, and maxilla blackish, except for lower basal (rictal) portion; length (skins), 249-282 (264); wing, 130.5-141 (136.6); tail, 140.5-160 (148); culmen, 17-20 (18.7); tarsus, 12.5-15 (13.8); inner anterior toe, $13-15$ (14). ${ }^{c}$

Immature male.-Similar to the adult male, but outer web of greater wing-coverts and secondaries conspicuously edged with white, metallic color of middle rectrices duller, white of breast more extended, and yellow of posterior under parts paler.

Immature female.-Similar to the adult female, but greater wingcoverts and secondaries conspicuously edged with white, the proximal secondaries (tertials) mottled with the same, middle rectrices lighter and more brownish slate and without black tip, and posterior under parts yellowish white.

Pacific slope of Mexico, in States of Sinaloa (Mazatlán; Presídio de Mazatlán; La Palma; Los Coyotes; Escuinapa), Michoacán (La Salada), Colima (Manzanillo; Culata near Manzanillo; Colima; Rio de la Armería; Sierra Madre), Guerrero (Acapulco; Rincón), Oaxaca (Tehuántepec; Tapántepec; Tapana; Huilótepec; Santa Efigénia; Chimalapa; Chihuitán; Tequistlán; Ianhuitlán; Ventosa; Cacoprieto), and Chiapas (Tonalá), and Territory of Tepíc (San Blas; Santiago; Rancho El Colomo, Compostella).

Trogon citreolus Gould, Proc. Zool. Soc. Lond., 1835, 30 (locality unknown; coll. J. Gould); Mon. Trog., ed. 1, 1838, pl. 13 and text; ed. 2, 1875, pl. 26 and text.-Sclater and Salvin, Ibis, 1859, 132 ("Yucatan;" error).-Finsch, Abh. Nat. Mus. Bremen, 1870, 327 (Mazatlán, Sinaloa).-Lawrence, Mem. 
Bost. Soc. N. H., ii, 1874, 290 (Mazatlán; crit.); Bull. U. S. Nat. Mus., no. 4, 1876, 31 (Chihuitán, Ventosa, Tapana, and Santa Efigénia, Oaxaca).Sumichrast, La Naturaleza, v, 1881, 239.-Ferrari-Perez, Proc. U. S. Nat. Mus., ix, 1886, 162 (Oaxaca).-Grant, Cat. Birds Brit. Mus., xvii, 1892, 461 (Mazatlán; Santiago and San Blas, Tepíc; Culata and Colima, Colima; Acapulco and Rincón, Guerrero; Tehuántepec and Chimalapa, Oaxaca; Tonalá, Chiapas).-Salvin and Godman, Biol. Centr.-Am., Aves, ii, 1896, 497.-Miller (W. De W.), Bull. Am. Mus. N. H., xxi, 1905, 350 (Escuinapa, etc., s. Sinaloa; habits; crit.).-BAntex (H. H.), Auk, xxiii, 1906, 388 (San Blas, Tepíc).

T[rogon] citreolus Gray, Gen. Birds, i, 1845, 69.-Bonaparte, Consp. Av., i, 1850, 149.-Ridgway, Man. N. Am. Birds, 1887, 277.

[Trogon] citreolus Gray, Hand-list, i, 1869, 82, no. 967.-Sclater and SAlviN, Nom. Av. Neotr., 1873, 104.-Sharpe, Hand-list, ii, 1900, 148.

A[ganus] citreolus Cabanis and Heine, Mus. Hein., iv, 1863, 197, footnote ("Guatemala;" Mexico).

[Aganus] citreolus Heine and Reichenow, Nom. Mus. Hein. Orn., 1890, 209 (Mazatlán).

(?)Trogon capistratum a Lesson, Rev. Zool., 1842, 136 (Realejo, Nicaragua; error?).

(?)T[rogon] capistratus a Gray, Gen. Birds, iii, 1849, App., p. 4.-Bonaparte, Compt. Rend., xlii, 1856,-.

(?)[Trogonurus] capistratus a Bonaparte, Consp. Voluc. Zygod., 1854, 14.

\section{Genus TROGONURUS Bonaparte.}

Trogonurus Bonaparte, Ann. Sci. Nat. (Zool.), 4 sér., i, 1854, 130 (nomen nudum); Ateneo Italiano, no. 8, May, 1854, - (Consp. Voluc. Zygod., 1854, 14). Type, as fixed by Gray, 1855, Trogon collaris Vieillot.)

Pothinus $b$ Cabanis and Heine, Mus. Hein., iv, Feb., 1863, 180. (Type, Trogon atricollis Vieillot.)

Hapalophorus c CaBanis and IErne, Mus. Hein., iv, Feb., 1863, 199. (Type, Trogon surucura Vieillot.)

Rather small and delicately-built Trogons with serrated tomia, relatively small and weak bill, lateral rectrices always broadly tipped (usually also barred) with white, the auricular feathers not clongated, slender, nor filamentous, and the adult female without metallic colors.

Bill relatively small (not more than half as long as head), the culmen rather strongly arched, usually distinctly ridged, not depressed basally; tomia distinctly serrate; gonys about half as long as mindibular rami or a little less, distinctly convex, strongly ascending terminally, the tip of mandible forming a distinct ascending point; interramal space about as broad basally as long. Nostril roundish, nonoperculate, mostly hidden by distinct antrorse, decurved bristles; feathers of chin and malar apex also antrorse and bristle-like, the former strongly recurved. Seventh, or seventh and sixth, primaries

a Possibly T. melanocephalus illatabilis Bangs, in which case the name of this bird would be Trogon melanocephalus capistratus (Lesson).

b"Von $\pi 00 \varepsilon \iota \nu o_{S}$ (erwünscht, ersehnt)." (Cabanis and Heine.)

c"Von ázaגoфópos (weiche Kleider, zartes Gefieder tragend)." (Cabanis and Heine.) 
longest, the tenth (outermost) very variable, sometimes not more than half as long as ninth, sometimes more than half as long as seventh (longest); tail decidedly (sometimes much) longer than wing, all the rectrices (except, sometimes, outermost pair) truncate or subtruncate at tip, the outermost pair more or less strongly bowed basally. Tarsus about as long as longest anterior toe, naked for about lower half; inner anterior toe united to outer toe for whole of its first and half or more of its second phalanx.

Coloration.-Adult males with chest and upper parts (except wings) metallic green, bronze, or blue (head sometimes black), the wingcoverts and secondaries narrowly barred or vermiculated with white and blackish, the middle rectrices broadly tipped with black; under parts (posterior to chest) bright red, orange, or orange-yellow, this usually separated from metallic green, bronze, or blue of chest by a band of white; adult females with chest and upper parts brown or slate color.

Range.-Rio Grande Valley and southern Arizona to eastern Peru, Bolivia, Paraguay, Uruguay, Cayenne, and Trinidád. (About fifteen species.)

KEY TO THE SPECIES AND SUBSPECIES OF TROGONURUS.

a. Back, chest, etc., bright metallic green, golden green, or golden bronze. (Adult males.)

b. Lateral rectrices uniform black, except the broad terminal area of white; outer web of primaries not edged with white. (Highlands of Mexico and Guatemala.)

Trogonurus mexicanus, adult male (p. 765).

bb. Lateral rectrices barred or vermiculated with white; outer web of primaries (except outermost) edged with white.

c. Under parts, posterior to chest, red or orange.

d. Lateral rectrices (three pairs) very broadly tipped with white. (Under parts red, rarely orange.)

$e$. Lateral rectrices white, finely vermiculated or narrowly barred with black (except the very broad terminal immaculate area); forehead (sometimes crown also) black.

$f$. Lateral rectrices vermiculated; middle rectrices golden or coppery; tail shorter (152.5-171). (Trogonurus ambiguus.)

$g$. Above more golden or bronzy, the middle rectrices frequently coppery bronze; tail averaging longer (165.6 mm.). (Highlands of Mexico to southern Arizona and Rio Grande Valley in Texas.)

Trogonurus ambiguus ambiguus, adult male (p. 768).

gg. Above more greenish, the middle rectrices bronze-green to greenish bronze (never coppery); tail averaging shorter $(155.8 \mathrm{~mm}$.). (Tres Marias Islands, western Mexico.)

Trogonurus ambiguus goldmani, adult male (p. 772).

ff. Lateral rectrices narrowly and regularly barred; middle rectrices green or golden green; tail longer (161.5-180.5 mm.). (Pacific slope, from Guatemala to Costa Rica.). . Trogonurus elegans, adult male (p. 773). 
$e e$. Lateral rectrices (except the broad white tip) black, regularly barred with white; forehead (except extreme anterior portion) and crown metallic green.

f. Lateral rectrices broadly barred with white; wing-coverts and secondaries more coarsely vermiculated or barred. (Colombia to Venezuela, Ecuadór, eastern Peru, etc.)

Trogonurus collaris, adult male (extralimital). $a$

ff. Lateral rectrices very narrowly barred with white; wing coverts and secondaries finely vermiculated. (Colombia to British Guiana, Ecuadór, Bolivia, etc.)

Trogonurus personatus, adult male (extralimital). $b$

dd. Lateral rectrices narrowly tipped with white (the remaining portion, for most part, narrowly barred with white).

e. Under parts pure geranium red. (Southern Mexico to western Panamá.) Trogonurus puella, adult male (p. 775).

ee. Under parts orange or orange-red. (Trogonurus aurantiiventris.)

$f$. Under parts orange (between cadmium orange and saturn red). (Mountains of western Panamá to central Costa Rica.)

Trogonurus aurantiiventris aurantiiventris, adult male (p. 778).

$f f$. Under parts orange-red (flame scarlet to salmon-pink). (Mountains of northwestern Costa Rica.)

Trogonurus aurantiiventris underwoodi, adult male (p. 780).

cc. Under parts yellow. (Trogonurus curucui.)

a Trogon collaris Vieillot, Nouv. Dict. d'Hist. Nat., viii, 1817, 320 ("Cayenne"); Gould, Mon. Trog., ed. 1, 1838, pl. 5 and text; Grant, Cat. Birds Brit. Mus., xvii, 1892, 448.-[Trogonurus] collaris Bonaparte, Consp. Voluc. Zygod., 1854, 14.-Trogon castaneus Spix, Av. Bras., i, 1824, 48, pl. 47 (=female).-Trogon rosalba Cuvier, Règne Anim., i, 1829, 459.-Trogon auratus Swainson, Anim. in Menag., pt. iii, Jan. 1, 1838, 329 (new name for T. collaris Vieillot); Birds Brazil, Mex., etc., 1841?, pls. 61, 62.?Trogon eytoni Fraser, Proc. Zool. Soc. Lond., 1856 (pub. May 8, 1857), 368, in text (Rio de Janeiro, Brazil).-T[rogon] exoptatus Cabanis and Heine, Mus. Hein., iv, Feb., 1863, 179 (Puerto Cabello, Venezuela; coll. Meine Mus.).-Trogon curucui (not of Linnæus) Hahn, Vög. As., Afr., Am., etc., Lief. vii, 1820, pl. 3.-T[rogon] curucui Cabanis and Heine, Mus. Hein., iv, 1863, 176; Hellmayr, Abh. der K. Bayer. Akad. der Wiss., ii, K1. xxii, Bd. iii, 1906, 596.-? T[rogon] virginalis Cabanis and Heine, Mus. Hein., iv, Jan., 1863, 173 (Pallatanga, w. Ecuadór; coll. Heine Mus.).

b Trogon personata Gould, Ann. and Mag. N. II., ix, 1842, 237 (Peru; coll. J. Gould).-T[rogon] personatus Gray, Gen. Birds, i, 1845, 70.-Trogon personatus Gould, Mon. Trog., ed. ii, 1875, pl. 10 and text; Grant, Cat. Birds Brit. Mus., xvii, 1892, 446.-[Trogonurus] personatus Bonaparte, Consp. Voluc. Zygod., 1S54, 14.Trogon heliothrix Tschudi, in Wiegm. Archiv für Naturg., 1844, 300; Fauna Peruana, 1845-1846, 41, 257.-Trogon personatus heliothrix Taczanowski, Orn. du Pérou, iii, 1886, 167.-Trogon assimilis Gould, Proc. Zool. Soc. Lond., Oct., 1846, 67; Ann. and Mag. N. H., xviii, 1846, 349 (Peru; coll. J. Gould).-[Trogonurus] assimilis Bonaparte, Consp. Voluc. Zygod., 1854, 14.-T[rogon] propinquus Cabanis and Heine, Mus. Hein., iv, Jan., 1863, 175 (Puellaro, Ecuadór; coll. Heine Mus.).-Trogon personatus propinquus Berlepsch and Taczanowski, Proc. Zool. Soc. Lond., 1884, 307 (Cayandeled and Chaguarpata, Ecuadór; crit.).

These two species undoubtedly require subdivision, some of the names given in the synonymy without doubt representing more or less well-defined subspecies; but I have neither the material nor time required for the satisfactory working out of the question. 
d. Middle rectrices bronze-green or greenish bronze. (Tropical South America.) Trogonurus curucui curucui, and other subspecies (extralimital). ${ }^{a}$ $d d$. Middle rectrices metallic pure green, bluish green, or greenish blue; lateral rectrices more broadly barred. (Southern Honduras to Panamá.)

Trogonurus curucui tenellus, adult male (p. 781).

aa. Head, chest, and upper parts brownish (without metallic coloring), the middle pair of rectrices more rufescent. (Adult females.)

b. A conspicuous auricular spot of dull white; lower breast white.

c. Lateral rectrices very irregularly barred or mottled with grayish dusky. (Trogonurus ambiguus.)

d. Darker and browner above and on chest, the middle rectrices cinnamonrufous or light chestnut; red of posterior under parts deeper.

Trogonurus ambiguus ambiguus, adult female (p. 768).

$d d$. Paler and grayer above and on chest, the middle rectrices cinnamon; red of posterior under parts paler.

Trogonurus ambiguus goldmani, adult female (p. 772).

cc. Lateral rectrices regularly barred with grayish black.

Trogonurus elegans, adult female (p. 773).

bb. No white auricular spot; lower breast not white.

c. Posterior under parts red or orange.

d. Posterior under parts red.

$e$. Breast brown (paler and sometimes more grayish posteriorly), with an imperfectly developed white band across anterior margin; lateral rectrices broadly barred with white on outer web.

Trogonurus mexicanus, adult female (p. 765).

$e e$. Breast red (like abdomen, etc.) bordered anteriorly by a conspicuous band of white.

$a$ There are, apparently, at least four definable South American forms of this species; but as both material and time are lacking for properly working them out, I can here only cite the various names which are applicable to them as a whole: [Trogon] curucui Linnæus, Syst. Nat., ed. 12, i, 1766, 167 (based essentially on Yellow-bellied Green Cuckow Edwards, Gleanings Nat. Hist., iii, 256, pl. 331).-[ Trogon curucui] r. Gmelin, Syst. Nat., i, pt. 1, 1788, 403.-[Trogon] rufus Gmelin, Syst. Nat., i, pt. 1, 1788, 404 (Cayenne; based on Couroucou à queue rousse de Cayenne Buffon, Hist. Nat. Ois., vi, 293; Pl. Enl., pl. 736; = adult female).-Trogon atricollis Vieillot, Nouv. Dict. d'Hist. Nat., viii, 1817, 318 (Guiana; Surinám; etc.); Gal. Ois., i, 1825, 17, pl. 31; Gould, Mon. Trog., ed. 1, 1838, pl. 8, and text; ed. 2, 1875, pl. 14 and text; Grant, Cat. Birds Brit. Mus., xvii, 1892, 455, part.-P[othinus] atricollis Cabanis and Heine, Mus. Hein., iv, Feb., 1863, 180 (Brazil).-Trogon lepturus Swainson, Anim. in Menag., pt. iii, Jan. 1, 1838, 331 (Cayenne).-Trogon sulphureus Spix, Av. Bras., i, 1824-1826, 48, pl. 38, figs. 1, 2 (Tabatinga, Brazil).-Trogon chrysochloros Pelzeln, Sitz. Ak. Wien, $\mathrm{xx}, 1856,496,505$ (Ypanema Brazil).-Trogon atricollis chrysochlorus Berlepsch and Ihering, Zeitschr. Orn., 1885, 160.-? A[ganus] devillei Cabanis and Heine, Mus. Hein., v, Feb., 1863, 191, footnote (Santa Maria, upper Amazon).

In adopting as the earliest name for this species Trogon curucui Linnæus, I am conscious of the fact that Mr. Hellmayr, for whose determinations $I$ have the greatest respect, has reached a different conclusion by identifying the name in question with $T$. collaris Vieillot. It is true that Linnæus's $T$. curucui, a composite species, includes $T$. collaris as well as the present species, and that the majority of the references cited belong to $T$. collaris; but the diagnosis is evidently based solely on the Yellow-bellied Green Cuckow of Edwards, which is unquestionably the species generally known as Trogon atricollis Vieillot, the phrase "subtus fulvus," instead of being an erroneous translation, being, to my mind, intended to describe the color as represented on Edwards's plate, or, possibly, a slip or misprint for "subtus flavus." 
f. Loral, orbital, auricular, and malar regions, chin, and throat, black; lateral rectrices regularly barred with black and white; maxilla yellow, like mandible.

Trogonurus personatus, adult female (extralimital).

ff. Loral, orbital, auricular, and malar regions, chin, and throat, dull brownish or dusky grayish; lateral rectrices without regular bars; maxilla mostly black.

g. Loral, orbital, and auricular regions, etc., dusky grayish; white tip to lateral rectrices narrow..Trogonurus puella, adult female (p. 776).

gg. Loral, orbital, and auricular regions, etc., dull brownish; white tip to lateral rectrices broad.

Trogonurus collaris, adult female (extralimital).

d. Posterior under parts orange, orange-red, or salmon-pinkish. (Trogonurus aurantiiventris.)

e. Posterior under parts light reddish orange.

Trogonurus aurantiiventris aurantiiventris, adult female (p. 779). $e e$. Posterior under parts salmon-pink.

Trogonurus aurantiiventris underwoodi, adult female (p. 780). cc. Posterior under parts yellow..Trogon curucui tenellus, adult female (p. 781).

\section{TROGONURUS MEXICANUS (Swainson).}

\section{MEXICAN TROGON.}

Adult male.-A bove bright metallic green, bronze-green, or bronze, the middle pair of rectrices metallic green or bluish green, abruptly tipped with black; wings dark slaty or slate-blackish, the wingcoverts and secondaries finely vermiculated with grayish white; tail (except middle pair of rectrices) black, the three outer pairs of rectrices broadly and abruptly tipped with white; loral, orbital, auricular, and malar regions, chin, and throat dull black or slateblack; chest metallic green or bronze-green, bordered posteriorly by a broad bar or band of white across upper breast; rest of under parts pure red (geranium red), the thighs slate-black; bill yellow; feet brownish (in dried skins); length (skins), 275-313 (292); wing, 138.5-152 (145.6); tail, 165.5-190 (179.9); culmen, 15.5-17.5 (16.5); tarsus, 15-16 (15.3); inner anterior toe, $14-15$ (14.3) ${ }^{a}$

Adult female.-General color of upper parts brown (nearly raw umber to more grayish brown-rarely hair brown), the middle pair of rectrices mars brown or nearly russet, abruptly tipped with black (more narrowly than in adult male), sometimes with a narrow subterminal band of paler brown, cinnamomeous, or buffy; wing-coverts and secondaries vermiculated with pale brown, or dull buffy, and dusky; outer webs of primaries broadly edged with dull white, the innermost with outer web wholly white (abruptly) basally; rectrices (except middle pair) dull black, the three outer pairs broadly tipped with white and with terminal half (more or less) of outer web white, broadly barred with blackish, the terminal white on inner web 
forming a narrow wedge running along inner side, next to shaft, the edge of inner web of these rectrices also notched with white; a white orbital ring (interrupted immediately above and below eye) the sides of head otherwise more dusky than the general color, especially on loral and suborbital regions; chin, throat, and chest brown, like upper parts; breast paler brown, with a more or less distinct band of white across upper portion, the brown passing gradually into, or at least not abruptly contrasted with, the geranium red or deep geranium pink of remaining under parts; ${ }^{a}$ maxilla blackish, sometimes paler at tip; mandible yellowish brown or brownish; feet brownish; length (skin), 285-310 (302); wing, 136-157.5 (142.8); tail, 175-200 (184.5); culmen, 14.5-17 (15.9); tarsus, 14-16 (15.2); inner anterior toe, $13-15$ (14.2). ${ }^{b}$

Immature male.-Similar to the adult male, but with white tailmarkings as in adult female, the middle pair of rectrices metallic green, narrowly tipped, or mottled at tip, with pale buffy brown or cinnamon. $c$

Immature female.-Similar to the adult female, but middle pair of rectrices narrowly tipped with buff or whitish (instead of black), and proximal greater wing-coverts and secondaries (tertials) more or less (sometimes conspicuously) spotted with pale buff.

Young (first plumage).-Head, neck, chest, back, and scapulars plain tawny-brown or raw umber, the suborbital region dusky; rump and upper tail-coverts lighter and more rufescent brown (nearly cinnamon) the feathers narrowly and indistinctly tipped with dusky; under parts, posterior to chest, brownish buff or clay color, barred or transversely spotted with brown; wing-coverts and tertials each with a very large roundish spot of pale buff, margined with blackish; primaries and rectrices as in the immature female.

$a$ Sometimes the brown feathers of the breast are narrowly tipped with paler, producing an indistinctly barred appearance.

$b$ Fourteen specimens.

\begin{tabular}{|c|c|c|c|c|c|}
\hline Locality. & Wing. & Tail. & $\begin{array}{l}\text { Cul- } \\
\text { men. }\end{array}$ & Tarsus. & $\begin{array}{c}\text { Inner } \\
\text { ante- } \\
\text { rior toe. }\end{array}$ \\
\hline MALES. & & & & & \\
\hline Eleven adult males from Mexico.... & 147.6 & 181.5 & 16.6 & 15.3 & 14.3 \\
\hline Five adult males from Guatemala... & 141.1 & 176. 4 & 16.3 & 15.3 & 14.1 \\
\hline FEMALES. & & & & & \\
\hline Ten adult females from Mexico.. & 145.4 & 186.8 & 15.8 & 15.1 & 14.3 \\
\hline Four adult females from Guatemala. & 139 & 178.6 & 15.9 & 15.5 & 14.1 \\
\hline
\end{tabular}

c In still younger specimens the proximal greater coverts and secondaries (tertials) have terminal spots of buff or whitish and the upper breast partly light brownish (sometimes narrowly barred). 
Mexico, in States of Tamaulipas (Rampahuila; Galindo; Guiaves; Rio Santo; Montelunga; Alta Mira; Realito), Chihuáhua (Sierra Madre near Guadalupe y Calvo; Jesús Maria; Sierra Madre, 65 miles east of Batópilas), Zacatecas (Sierra de Valparaiso), Jalisco (Sierra Nevada de Colima; San Sebastián; Bolaños; Sierra de Bolaños), Colima, Michoacán (Coapa; Patzcuaro; Mount Tancítaro), Guerrero (Omilteme), Mexico (Ajusco; Rio Frio, Ixtaccihuátl; Popocatépetl; Tenango; Chimalpa; Temascáltepec; Valley of Mexico; Tenango del Valle), Hidalgo (Reál del Monte), Puebla (Huanchinango), Vera Cruz (Orizaba; Jalapa; Jico; Cofre de Perote; Coátepec), Oaxaca (La Parada; Cinco Señores; Reyes; 15 miles west of Oaxaca City; Mount Zempoáltepec; Villa Alta; Reál Arriba), and Chiapas (Pinabete; San Cristóbal) and Territory of Tepíc (Sierra de Nayarít) and highlands of Guatemala (Sierra de Santa Cruz; San Gerónimo; Chuacus and Calderas, Volcán de Fuego; Todos Santos; Sierra Santa Elena; Tecpám; Uspantán, Quitché; Volcán de Santa Maria, San Martín, and Cuipaché, Quezaltenango; Baja Vera Paz).

Trogon mexicanus Swarnson, Philos. Mag., n. s., i, 1827, 440 (Temascáltepec, Mexico;=adult female); Zool. Illustr., ser. 2, 1831-1833, pls. 82 (immature male), 107 (adult female); Classif. Birds, ii, 1837, 337.-WAGLer, Isis, 1831, 523.-Bonaparte, Proc. Zool. Soc. Lond., 1837, 109 (Mexico).-Gould, Mon. Trog., ed. 1, 1838, pls. 1, 2, and text; ed. 2, 1875, pl. 7, and text.Hartlaub, Verz. Mus. Brem., 1844, 11 (Mexico; Guatemala).-Grax, Cat. Fissir. Birds Brit. Mus., 1848, 41 (Mexico).-Sclater, Proc. Zool. Soc. Lond., 1859, 367 (Jalapa, Vera Cruz), 387 (Cinco Señores, Oaxaca); Cat. Am. Birds, 1862, 276 (San Gerónimo, Guatemala).-Sclater and SAlvin, Ibis, 1859, 132 (Guatemala).-Salvin and Sclater, Ibis, 1860, 41 (Volcán de Fuego, Guatemala; color of eyelids).-Sumichrast, Mem. Bost. Soc. N. H., i, 1869, 562 (alpine region Vera Cruz); La Naturaleza, v, 1881, 239 (alpine region of Orizaba, Vera Cruz).-Ferrari-Perez, Proc. U. S. Nat. Mus., ix, 1S86, 161 (Cerro de San Mateo, Puebla; Jalapa).-Grant, Cat. Birds Brit. Mus., xvii, 1892, 444 (Sierra de Nayarít, Sierra de Bolaños, and Santa Ana, Jalisco; Sierra Nevada, Colima; Chimalpa, Coapa, Tenango del Valle, near City of Mexico, and Rio Frio, Ixtaccihuátl, Mexico; Coátepec and Cofre de Perote, Vera Cruz; Villa Alta and Juchatengo, Oaxaca; Omilteme, Guerrero; Santa Cruz Mts., San Gerónimo, Volcán de Fuego, Santa Maria, San Martín, and Cuipaché, near Quezaltenango, Guatemala).-Salvin and Godman, Biol. Centr.-Am., Aves, ii, 1896, 487.-Dearbonn, Pub. 125, Field Mus. N. H., 1907, 87 (above Tecpám, Guatemala, 9,500 ft.).-Phillıps, Auk., xxviii, 1911, 76 (Rampahuila, Montelunga, Alta Mira, Rio Santo, Galindo, Guiaves, and Realito, Tamaulipas).

T[rogon] mexicanus Gray, Gen. Birds, i, 1845, 70.-Bonaparte, Consp. Av., i, 1850, 150.-Cabanis and Heine, Mus. Hein., iv, 1S63, 137 (Mexico).Ridgway, Man. N. Am. Birds, 1887, 276.

[Trogon] mexicanus Gray, Hand-list, i, 1869, 82, no. 969.-Sclater and Salvin, Nom. Av. Neotr., 1873, 103.-Sharpe, Hand-list, ii, 1900, 147.

[Trogonurus] mexicanus Bonaparte, Consp. Voluc. Zygod., 1854, 14.

Trogon glocitans Lichtenstein, Preis-Verz. Mex. Thierw., 1830, 1; Journ. für Orn., 1863, 55 .

"Trogon morgani Swains"[on] Gould, Mon. Trog., ed. 1, 1838, in text to pl. 1. 
TROGONURUS AMBIGUUS AMBIGUUS (Gould).

COPPERY-TAILED TROGON.

Adult male.-Forehead (sometimes part, occasionally whole, of crown also) black; occiput (usually more or less of crown), hindneck, back, scapulars, and anterior portion of lesser wing-covert region bright metallic green, bronze-green, or golden bronze, passing into metallic pure green or bronze-green on rump and upper tail-coverts; middle pair of rectrices bright bronze or copper-bronze, changing to a greenish hue in some lights (the color sometimes more greenish basally), broadly and abruptly tipped with black or bluish black, the next pair of rectrices similarly colored on outer web, but inner web darker and more purplish bronze passing into blackish basally, the terminal black area broader and less sharply defined; remaining rectrices very broadly tipped with white (this white terminal area margined basally by a narrow, usually more or less interrupted, narrow bar of black), the subterminal portion and greater part of outer web white, irregularly vermiculated or finely flecked with blackish (except sometimes on basal portion of outer web of outermost rectrix), the basal portion of inner web uniform blackish; wing-coverts (except anterior portion of lesser covert area) delicately vermiculated with black and white; primaries slate-black, the outer webs mostly pale gray or grayish white; loral, suborbital, auricular, and malar regions, chin, and throat uniform black or slate-black; chest bright metallic bronze-green, bronze, or copper-bronze, succeeded by a crescentic band of pure white, the remaining under parts pure geranium red; thighs slate-black or blackish slate, the longer feather broadly tipped with pink or pinkish white; bill yellow; naked eyelids red or orange; iris dark brown; feet brownish; length (skins), 255-295 (278); wing, 127-136 (130.8); tail, 153.5-171 (165.6); culmen, 17-19 (18.2); tarsus, 14.5-16 (15); inner anterior toe, 14-16.5 (14.9). ${ }^{a}$

Adult female.-Forehead and at least anterior portion of crown slate color or brownish slate, passing into plain brown (between isabella color and raw umber) on occiput, hindneck, back, and scapulars, the rump and upper tail-coverts similar but (especially the latter) paler; wing-coverts similar in color to rump and upper tailcoverts but (on very close inspection) minutely vermiculated with darker, the outer webs of secondaries similar but paler; primaries slate color or blackish slate, the outer web (except of outermost) broadly edged with white or grayish white; middle pair of rectrices vandyke brown to chocolate brown (sometimes lightening into russet or cinnamon-brown distally), broadly and abruptly tipped with black; next pair blackish brown or brownish black, the outer web more or less broadly edged (except terminally) with lighter brown; remaining rectrices extensively white terminally and (except on third 
rectrix) on greater part of outer web, a broad terminal area immaculate, the remainder of white portion, except middle portion of outer web of outermost rectrix, more or less broadly and irregularly barred with blackish or dark slaty, the basal portion of these rectrices uniformly of the latter color; loral and suborbital regions dark slaty or blackish; auricular region crossed obliquely by a broad bar of pale brownish buff or brownish white and tipped by an oblique bar of black; a broad brownish white orbital ring, interrupted on upper and lower eyelids; malar region, chin, and throat brownish slate to grayish brown (hair brown), passing into brown (like color of back) on chest; breast much paler brown, fading posteriorly into brownish white, and crossed anteriorly (immediately behind brown jugular area) by a crescentic band of brownish white or pale brownish buff; lower abdomen, flanks, anal region, and under tail-coverts light geranium red; thighs slate color, the longer feathers broadly tipped with whitish; bill yellow (duller than in adult male), the maxilla sometimes tinged with brownish; iris and feet as in adult male; length (skins), 275-302 (290); wing, 124-137 (132); tail, 165-185 (176.5); culmen, 16.5-18 (17.2); tarsus, 14.5-15.5 (15.1); inner anterior toe, $14-15.5(14.7){ }^{a}$

Immature male.-Similar to the adult male, but tail (except middle rectrices) as in adult female, the middle rectrices greenish bronze or bronze-green, passing into light russet-brown or cinnamon at tip. (Younger individuals have the breast, below the white post-jugular band, pale buffy grayish narrowly barred or vermiculated with darker, passing into buffy white posteriorly, and secondaries with a terminal spot of whitish.)

a Thirteen specimens.

\begin{tabular}{|c|c|c|c|c|c|}
\hline Locality. & Wing. & Tail. & $\begin{array}{l}\text { Cul- } \\
\text { men. }\end{array}$ & Tarsus. & $\begin{array}{l}\text { Inner } \\
\text { ante- } \\
\text { rior toe. }\end{array}$ \\
\hline MALES. & & & & & \\
\hline $\begin{array}{l}\text { Six adult males from Tamaulipas (1), Nuevo León (3), Chi- } \\
\text { huahua (1), and Durango (1)....................... }\end{array}$ & 131.3 & 167.7 & 17.7 & 15.3 & 15 \\
\hline Seven adult males from Jalisco $(5)$ and Teple $(2) \ldots \ldots \ldots \ldots \ldots$ & 130.4 & 163.4 & 18.6 & 14.8 & 14.9 \\
\hline Five adult males of $T, a$. goldmani from Tres Marias Islands.. & 129.9 & 155.8 & 18.3 & 15.9 & 15.3 \\
\hline FEMALES. & & & & & \\
\hline $\begin{array}{l}\text { Six adult females from Tamaulipas (2), Nuevo Leon (1), Chi- } \\
\text { huahua (1), San Luís Potosí (1), and Durango (1)......... }\end{array}$ & 134.3 & 178.8 & 16.9 & 15.1 & 14.6 \\
\hline Seven adult females from Sinaloa (1), Tepíc (2), and Jalisco (4). & 130 & 174.5 & 17.4 & 15.2 & 14.7 \\
\hline Four adult females of $T, a . g o l d m a n i$ from Tres Marias Islands. & 133 & 175.1 & 18 & 16.2 & 15.4 \\
\hline
\end{tabular}

The variation in color of the back, etc., from nearly pure metallic green to golden bronze and in the hue of the middle rectrices occurs in both series of the mainland birds, the extremes sometimes being shown in specimens from one locality.

$81255^{\circ}-$ Bull. $50-11-49$ 
Immature female.-Similar to the adult female, but middle rectrices narrowly tipped with blackish, wing-coverts and secondaries more or less (according to age) spotted with pale buff or buffy whitish, and red of under parts replaced (at least in part) by white.

Young male. - - Head dull brownish gray, darker above, paler beneath, more tinged with olive-brownish posteriorly; lores and suborbital region blackish gray; a small spot on malar apex, a conspicuous orbital ring (interrupted on middle portion of upper eyelid and on anterior half or more of lower lid) and broad bar crossing obliquely the middle portion of auricular region pure white; back and scapulars grayish brown (interspersed with a few metallic bronzegreen feathers of the adult plumage); rump and upper tail-coverts dull cinnamon-brown, mixed with a few feathers of pure metallic green (of adult livery); middle rectrices dusky, passing into dull cinnamon-brown on edges and toward tips (the latter narrowly black at extremity) and glossed with coppery bronze; next two pairs of rectrices uniform black; two outer rectrices with outer webs pure white (except basally), barred with black, the inner webs chiefly black, but passing into pure white terminally and on edges, the white portion barred with black; lesser and middle wing-coverts buffy white or very pale buff, margined with black, producing conspicuous large spots; greater coverts and tertials pale grayish buffy, minutely freckled with dusky, and each terminated by a large spot of buffy white (nearly pure white on tertials); secondaries dusky, edged with freckled pale grayish buffy; primaries blackish dusky, edged with pure white; breast, belly, sides, flanks, anal region, and lower tailcoverts dull white or grayish white, marked with rather broad but more or less irregular transverse bars of grayish brown, this nearly uniform on sides of breast, the flanks, anal region, and crissum nearly immaculate whitish; bill bright yellow; feet pale brownish gray (in dried skin).

Young female (nestling).-Pileum dull grayish brown (between hair brown and sepia) the feathers narrowly tipped with blackish; hindneck, back, scapulars, rump, and upper tail-coverts plain brown (between bister and sepia); wing-coverts (except distal greater coverts) and proximal secondaries (tertials) with a very large subterminal roundish spot of pale buff margined with black, the basal portion of the feathers vermiculated or freckled with grayish brown and pale grayish buffy, the distal greater coverts and secondaries light buffy grayish brown finely vermiculated with dusky, the former rather narrowly tipped with pale buffy; alula, primary coverts, and primaries dull blackish slate edged with paler, the edgings broader

$a$ Described from no. 109523, coll. U. S. Nat. Mus., Huachuca Mts., Arizona, Aug. 24, 1885; Lieut. H. C. Benson, U. S. A. 
and more whitish on longer primaries; middle pair of rectrices deep bronzy or coppery brown, the distal portion cinnamon-brown narrowly tipped with black; next three pairs black, the two lateral pairs mostly white barred, except for a large terminal area, with black; loral and suborbital regions dusky; an incomplete white orbital ring, and an oblique patch of dull white across auricular region, the terminal portion of the latter blackish; malar region, chin, throat, and chest grayish brown, the lower chest with feathers narrowly and indistinctly tipped with dusky; a rather broad white band (sharply defined on both sides) across upper breast; rest of under parts buffy white broadly barred with grayish brown, the bars more faint posteriorly, but anteriorly broader and coalescing into a definite band next to the white band across upper breast.

From southern Arizona (Huachuca, Santa Catalina, and eastern side of San Luís Mountains; mountains near Tombstone) and extreme southern Texas (Fort Brown) southward over greater part of Mexico, in States of Sonora (Ālamos; Ysleta), Chihuáhua (Batópilas; Durasno; Rio San Juan; Piños Altos; Bravo; Barranca de Cobre), Nuevo León (Boquillo; Cerro de la Silla; Monteréy; Montemorelos; Bacaro; Rio Camacho; Villa Grande, Hacienda de la Cruz), Tamaulipas (Sierra Madre above Ciudád Victoria; Soto la Marina; Tautina; Tampico; Alta Mira; Xicotencatl; Rio Corono; Rio Pilón; San Augustín; Santa Leonora; Rio Martinez; Galindo; Guiaves; Montelunga; Rio de la Cruz; Realito), San Luís Potosí (Villár; Vallés; Sierra de San Luís Potosí), Durango (Chacalá; Arroyo del Buéy), Zacatecas (Sierra de Valparaiso), Jalisco (Bolaños; Zapotlán; Sierra Madre; Angostura; Barranca Ibarra; Las Palmas; Ixtapa; Guadalajara; Ameca; Hacienda San Marcos; Hacienda San Felipe de Hijar; Plantanár), Sinaloa (Mazatlán; Presídio de Mazatlán; Rio Acoparuta; Escuinapa; Rio Juana Gomez; Mount Juan Lisiarraga; Arroyo de Los Pieles; Los Limones), Michoacán (Mount Tancítaro), Mexico (Coajimalpa), Puebla (Chietla; Chachapa), Vera Cruz (Orizaba), Oaxaca (Talea; Xacáutepec; Juchatengo), and Guerrero (Amula; Omilteme) and Territory of Tepíc (San Blas; Santiago; Mesccatitlán; Rancho El Colomo, Compostella; Sicrra de Nayarít).

Trogon ambiguus Gould, Proc. Zool. Soc. Lond., 1835, 30 (northern Mexico); Mon. Trog., ed. 1, 1838, pl. 4 and text; ed. 2, 1858, pl. 8 and text.-Sclater, Proc. Zool. Soc. Lond., 1859, 387 (Talea, Oaxaca).-Sumichrast, Mem. Bost. Soc. N. H., i, 1869, 562 (alpine region Vera Cruz); La Naturaleza, v, 1881, 239 (alpine region of Orizaba, Vera Cruz).-Finsch, Abh. Nat. Mus. Brem., 1870, 326 (Mazatlán, Sinaloa).-Merrilu, Proc. U. S. Nat. Mus., i, 1878, 118, footnote (Ft. Brown, Texas).-RIDGwax, Proc. U. S. Nat. Mus., iii, 1880, 6, 190, 229; ix, 1886, 161 (descr. adult male; crit.); x, 1887, 147 (Huachuca Mts., Arizona, etc.; crit.); Nom. N. Am. Birds, 1881, no. 384; Auk, iv, 1887, 161 (Huachuca Mts.).-Coues, Check List, 2d ed., 1882, no. 
422.-American Ornithologists' Union, Check List, 1886, no. 389; 3d ed., 1910, 183.-Ferrari-Perez, Proc. U. S. Nat. Mus., ix, 1886, 161 (Chietla, Puebla).-Grant, Cat. Birds Brit. Mus., xvii, 1892, 451 (Sierra Madre, Zapotlán, etc., Jalisco; San Blas, Tepíc; Amula and Omilteme, Guerrero; Oaxaca; etc.).-Joux, Proc. U. S. Nat. Mus., xvi, 1893, 785 (Angostura and Barranca Ibarra, Jalisco).-Salvin and Godman, Biol. Centr.-Am., Aves, ii, 1896, 490.-Richmond, Proc. U. S. Nat. Mus., xviii, 1895, 629 (Alta Mira, Tamaulipas).-Bendire, Life Hist. N. Am. Birds, ii, 1895, 32.-Swarth, Pacific Coast Avifauna, no. 4, 1904, 10 (Huachuca Mts.).-Miller (W. DeW.), Bull. Am. Mus. N. H., xxi, 1905, 350 (Escuinapa, etc., Sinaloa; habits); xxii, 1906, 164 (Arroyo del Buéy, Durango).-Phillips, Auk, xxviii, 1911, 76 (Santa Leonora, Rio Martinez, Galindo, Guiaves, Montelunga, Rio de la Cruz, and Realito, Tamaulipas).

Trogon] ambiguus Gray, Gen. Birds, i, 1845, 69.-Bonaparte, Consp. Av., i, 1850, 149.-Cabanis and Heine, Mus. Hein., iv, 1863, 169.-Coues, Key N. Am. Birds, 2d ed., 1884, 468.-Ridgwax, Man. N. Am. Birds, 1887, 276.

[Trogon] ambigurus Grax, Hand-list, i, 1869, 82, no. 971.-Sclater and Salvin, Nom. Av. Neotr., 1873, 103.-SharPe, Hand-list, ii, 1900, 148.

[Trogonurus] ambiguus Bonaparte, Consp. Voluc. Zygod., 1854, 14.

Trogon mexicanus (not of Swainson) BaIRd, Rep. Pacific R. R. Surv., ix, 1858, 69 (Boquillo, Nuevo León); ed. 1860 (Birds N. Am.), 69, atlas, pl. 40, fig. 1; Rep. U. S. and Mex. Bound. Surv., ii, pt. 2, 1859, pl. 2 (Boquillo); Cat. N. Am. Birds, 1859, no. 65.-OrTon, Am. Nat., iv, 1871, 711 ("Texas;" spec. in Mus. Vassar College).-Coues, Check List, 1873, no. 284.

[Trogon] mexicanus? Couss, Key N. Am. Birds, 1872, 186.

Trogon —— ScotT, Auk, iii, 1886, 425 (Santa Catalina Mts., Arizona).

(?)Trogon puella (not of Gould?) DugÉs, La Naturaleza, i, 1873, 139 (Guanajuato and Guadalajara).

\section{TROGONURUS AMBIGUUS GOLDMANI (Nelson),}

GOLDMAN'S TROGON.

Similar to T. a. ambiguus, but adult males greener above, never(?) distinctly bronzy, the middle rectrices bronze-green to greenish bronze, never(?) coppery; adult females much paler and grayer above and on chest (the general color hair brown, becoming mouse gray on pileum and cinnamon on middle rectrices), with red of under parts paler, breast with less of brown (sometimes mostly whitish).

Adult male.-Length (skins), 266-280 (271) ; wing, 126-133 (129.9); tail, 152.5-159.5 (155.8); culmen, 17-19 (18.3); tarsus, 15.5-16.5 (15.9); inner anterior toe, 14.5-16 (15.3). ${ }^{a}$

Adult female.-Length (skins), 283-295 (288); wing, 130.5-136 (133); tail, 167-183.5 (175.1); culmen, 17.5-18.5 (18); tarsus, 15-17 (16.2); inner anterior toe, $14.5-16(15.4) .^{b}$ 
Tres Marias Islands (Maria Madre Island), western Mexico.

Trogon ambiguus (not of Gould) Grayson, Proc. Bost. Soc. N. H., xiv, 1871, $272^{\circ}$ (Tres Marias Islands; habits, notes, etc.).-Lawrence, Mem. Bost. Soc. N. H., ii, 1874, 290, part (Tres Marias).

Trogon ambiguus goldmani Nelson, Proc. Biol. Soc. Wash., xii, Jan. 27, 1898, 8 (Maria Madre I., Tres Marias group, w. Mexico; coll. U. S. Nat. Mus.); N. Am. Fauna, no. 14, 1899, 42 (Tres Marias; habits).

[Trogon] goldmanni SHARPE, Hand-list, ii, 1900, 148.

\section{TROGONURUS ELEGANS (Gould).}

ELEGANT TROGON.

Similar to T. ambiguus, but tail decidedly longer, adult male with lateral rectrices regularly though narrowly barred (instead of vermiculated) with black, and wing-coverts and secondaries more coarsely vermiculated, the adult female with black tip to middle rectrices much narrower and lateral rectrices regularly and more broadly barred with black.

Adult male.-Forehead (more or less broadly), loral, orbital, auricular and malar regions, chin, and throat dull black; rest of head and neck, chest, back, scapulars, anterior lesser wing-coverts, rump, and upper tail-coverts bright metallic green or golden green, the rump and upper tail-coverts sometimes purer (less golden) green; middle pair of rectrices bluish golden green, broadly and abruptly tipped with black, the outer web of next two pairs similar, but inner web brownish black or blackish brown, tipped with black; three lateral pairs of rectrices with exposed portion (in closed tail) white, immaculate for a large terminal area (about $14-23 \mathrm{~mm}$. long-longest on third rectrix from outside), the remainder narrowly and regularly barred with black, the black bars slightly narrower than the white interspaces and averaging about $1.5 \mathrm{~mm}$. wide; wing-coverts (except anterior portion of lesser covert area) finely vermiculated or undulated with blackish slate and white; rest of wing blackish slate, the longer primaries broadly edged with white; a broad white band across upper breast (next to metallic green of chest); rest of under parts pure geranium red, the thighs blackish slate; bill yellow; naked eyelids orange; ${ }^{a}$ iris dark brown; ${ }^{a}$ feet (in dried skins), horn color; length (skins), 283-293 (288); wing, 12S-139 (134.2); tail, 161.5-180.5 (172); culmen, 17.5-19.5 (18.3); tarsus, 14-15 (14.6); inner anterior toe, $14.5-15.5(15) .^{b}$

Adult female.-Forehead brownish gray (nearly mouse gray), passing into hair brown on occiput, this into broccoli brown on hindneck, back, scapulars, and lesser wing-coverts, the rump (lower portion) and 
upper tail-coverts paler and more buffy brown (wood brown or isabella color), the coverts sometimes narrowly tipped with paler: middle pair of rectrices clear chestnut or deep cinnamon-rufous, sharply tipped with black, the next two pairs blackish brown, passing (more or less broadly) into chestnut or chestnut-brown on edge of outer web; three lateral rectrices, on each side, broadly tipped with white, the remaining portion white distally and on more or less of outer web, brownish black or slate-black basally, the white portion regularly and rather broadly barred with slate-black; middle and greater wing-coverts and secondaries light buffy brown, very minutely freckled or vermiculated with dusky; alula, primary coverts, and primaries dull blackish slate or slate-blackish, the primaries more brownish terminally, the longer ones broadly edged with white; loral and suborbital regions dull slate-blackish, relieved by a conspicuous white orbital ring (interrupted on lower eyelid) and a broad white bar across subterminal portion of auricular region, the terminal portion of the latter black; malar region, chin, and throat brownish gray or grayish brown, passing into broccoli brown or isabella color on chest; a broad band of white across upper breast, passing laterally into pale buffy brownish, the lower breast pale buffy brown or buffy grayish, passing into white posteriorly and on median portion of abdomen (the brownish portion indistinctly barred with paler); flanks and sides of abdomen pure geranium red, the under tail-coverts similar but somewhat paler and usually tipped with pinkish white; thighs grayish dusky, the feathers tipped with light grayish brown; bill dull yellow; feet brownish or horn color (in dried skins); length (skins), 267-287 (275); wing, 125-134.5 (131.3); tail, 160.5-185.5 171.3); culmen, 16-19 (17.3); tarsus, 13-15.5 (14.1); inner anterior toe, $13.5-15.5(14.6) .^{a}$

Immature male.-Similar to the adult male, but middle rectrices grayish brown basally, dull metallic bronze-green in middle portion, cinnamon brown or russet terminally; next two pairs brownish black on inner web and terminal portion of outer web, the outer web mostly dark sepia brown; lateral rectrices with pattern as in adult female, but bars usually less regular; rermiculated wing-coverts and secondaries tinged or stained with pale buffy brown; chest mostly grayish brown; breast as in adult female, but intermixed laterally with bright geranium red; maxilla yellowish horn color. (In younger individuals the proximal greater wing-coverts and secondaries have large terminal spots of buffy white, the ground color of the coverts and secondaries more buffy, the chest wholly brown, breast without any red, posterior under parts pink or whitish, and with a white auricular patch and incomplete orbital ring, as in adult female.) 
Pacific slope of Central America, from Guatemala (El Rancho), through Salvadór (La Libertád; Volcán de San Miguél), Honduras (Plains of Comayágua), Nicaragua (Grenada; Chinandega; Volcán de Chinandega; León; Matagalpa; Lake Nicaragua; Chontales; Virgin Bay; boundary between Nicaragua and Honduras, 180 miles from Pacific coast) to Costa Rica (Bebedero; Bagaces; San Lucas Island, Gulf of Nicoya).

Trogon elegans Gould, Proc. Zool. Soc. Lond., ii, 1834, 26 (Guatemala or Mexico; coll. J. Gould); Isis, Bd. xxviii, 1835, 1025; Mon. Trog., ed. 1, 1838, pl. 3 and text; ed. 2, 1869, pl. 9 and text (Honduras).-Swainson, Classif. Birds, ii, 1837, 337.-Gray, Cat. Fissir. Birds Brit. Mus., 1848, 43 (Guatemala; Mexico).--Sclater, Proc. Zool. Soc. Lond., 1858, 357 (Plain of Comayágua, Honduras).-T TAYLor, Ibis, 1860, 117 (Plain of Comayágua).-SALvin, Ibis, 1866, 194 (Guatemala; "Mexico;" Nicaragua); 1872, 313, 322 (Lake Nicaragua and Chontales, Nicaragua).-Cherrie, Proc. U. S: Nat. Mus., xiv, 1891, 536 (San Lucas I., Gulf of Nicoya, Costa Rica).-Grant, Cat. Birds Brit. Mus., xvii, 1892, 449 (Virgin Bay, Chontales, and Volcán de Chinandega, Nicaragua; Comayágua, Honduras; La Libertád and Volcán de San Miguél, Salvadór).Salvin and Godman, Biol. Centr.-Am., Aves, ii, 1896, 489.--Underwood, Ibis, 1896, 443 (Bagaces, n. w. Costa Rica).-Dearborn, Pub. 125, Field Mus. N. H., 1907, 88 (El Rancho, Guatemala).-Carriker, Ann. Carnegie Mus., vi, 1910, 557 (shores of Gulf of Nicoya, w. Costa Rica).

T[rogon] elegans Gray, Gen. Birds, i, 1845, 69.-Bonaparte, Consp. Av., i, 1850, 149.-Cabanis and Herne, Mus. Hein., iv, 1863, 170 (Guatemala; "Mexico").--Ridgway, Man. N. Am. Birds, 1887, 276.-Hartert, Kat. Vogelsamml. Mus. Senckenb., 1891, 135 ("Tamaulipas").

[Trogon] elegans Gray, Hand-list, i, 1869, 82, no. 970.-Sclater and Salvin, Nom. Av. Neotr., 1873, 103.-Sharpe, Hand-list, ii, 1900, 147.

[Trogonurus] elegans Bonaparte, Consp., Voluc. Zygod., 1854, 14.

Trogon] personatus (not of Gould) Hartlaub, Verz. Mus. Brem., 1844, 12 (Guatemala).

C[alurus] auriceps (not of Gould) Hartlaub, Verz. Mus. Brem., 1844, 12 (Guatemala; supposed female).

TROGONURUS PUELLA (Gould).

JALAPA TROGON.

Adult male.-Upper parts (except wings) metallic golden green, occasionally varying to metallic grass green or (as the other extreme) almost golden bronze, the middle rectrices abruptly tipped with black; second and third pairs of rectrices with outer web metallic green, tipped with black (like middle pair), but inner web wholly black; three outer pairs black, tipped with white (the white tip varying from 1.5 to, rarely, $9 \mathrm{~mm}$. in width), ${ }^{a}$ the remainder black, narrowly barred with white (the white bars much less than half as

$a$ Very rarely the white terminal bar is narrowly margined terminally with black. 
wide as the black interspaces), the white bars wanting from greater part of inner web of third rectrix (from outside); wings black, the lesser wing-coverts (except anterior portion of the area) narrowly and irregularly barred with white, the greater coverts and secondaries finely vermiculated with the same, the longer primaries edged with white, especially toward base; loral, orbital, auricular, and malar regions, chin, and throat black; chest metallic green or golden green, like upper parts; a broad white bar or band across upper breast (next to metallic green jugular area); rest of under parts pure deep geranium red, the thighs slate-black; bill yellow; naked eyelids brown; ${ }^{a}$ iris dark brown; ${ }^{a}$ feet brownish or horn color (in dried skins); length (skins), 226-272 (252); wing, 115-138 (126.6); tail, 127.5-160 (142.6); culmen, 16-18 (16.9); tarsus, 12-16 (14.4); inner anterior toe, $11.5-15$ (13.4). ${ }^{b}$

Adult female.-Above plain brown, the color darker (between prouts brown and raw umber) on pileum, more tawny or rufescent (nearly tawny-olive or russet) on lower rump and upper tail-coverts, the middle pair of rectrices chestnut, sharply tipped with black; outer web of next two rectrices chestnut tipped with black, but inner web wholly brownish black; three outer pairs of rectrices mostly black on upper surface, grayish on under surface, rather narrowly tipped with white and crossed by a subterminal narrow band or bar of black, preceding which the general grayish color is paler distally and next to the subterminal black bar more or less vermiculated with darker, the outer web whitish gray, with or without minute vermiculations or freckles, growing darker basally; wing-coverts brown (paler and more grayish than color of back) minutely vermiculated or freckled with dusky, the secondaries similar but with ground color sometimes slightly paler; primaries slate-black or blackish slate conspicuously edged with white, except on shorter proximal and outermost quills; a white orbital ring, broadly interrupted on upper and lower eyelids; orbital region otherwise, together with loral, auricular, and malar regions, dusky, or dull blackish slate, the chin and throat somewhat lighter dull slaty; chest uniform brown, like color of back; rest of under parts as in adult male; maxilla blackish, the lower basal portion pale yellowish horn color or dull yellowish, the mandible dull yellowish (olive-yellow in life) $;^{c}$ naked eyelids dusky; ${ }^{c}$ iris umber brown; ${ }^{c}$ feet brownish or dusky (light horn color in life) $;^{c}$ length (skins), 233-270 (248); wing, 120-136.5 (127.1); tail, 132.5-159

$a$ Dearborn.

$b$ Thirty-five specimens.

$c$ Fresh colors of specimens shot by the writer in Costa Rica. 
(144.9) ; culmen, 16-17 (16.3) ; tarsus, 13.5-15.5 (14.4) inner anterior toe, $12-14(12.9) .^{a}$

Southeastern Mexico, in States of Vera Cruz (Jalapa; Orizaba; Buena Vista; Cofre de Perote; Coátepec; Vega de Casadero; Misantla; Córdova; Uvero; Atoyác; Playa Vicente), Puebla (Metlaltoyuca), Mexico ("near City of Mexico"), Oaxaca (Chimalapa; Guichicovi), Tabasco (Teapa), Chiapas (Chicharras; Tumbalá), Campeche (Apazote), Yucatán (Tizimín; Izamál; Chichen-Itza), and southward through Guatemala (Pié de la Cuesta; Santa Maria, Quezaltenango; Retalhuleu; Tolimán; Telemán; Médio Monte; Alotenango; Dueñas; Choctúm; Escuintla; Chiriquya, near Cobán; Yaxcamnál; Patulúl, Sololá), British Honduras (Western District), Honduras, Nicaragua (San Rafaél del Norte; Matagalpa), and Costa Rica (Volcán de Irazú; Azahár, Navarro, Naranjo, and Birrís, Cartago; Turrialba; Angostura; San Juan; San Carlos; Juan Viñas; Bonilla; Guayabo; Coliblanco; Cedrál de Escazú; Escazú; Cerro de la Candelária; San Mateo; Barranca; Copéy; Dota; Santa Maria de Dota) to western Panamá (Volcán de Chiriquí; Boquete; Davíd; Calovévora; Castillo; Santa Fé de Verágua; Cordillera de Tolé).

Trogon puella Gould, Proc. Zool. Soc. Lond., xiii, 1845 (pub. April, 1845), 18 (Escuintla, "S. Am.," i. e., w. Guatemala; coll. J. Gould); Mon. Trog., ed. 2, 1858, pl. 11 and text.-Sclater, Proc. Zool. Soc. Lond., 1856, 286 (Córdova, Vera Cruz); 1859, 367 (Jalapa, Vera Cruz), 387 (Playa Vicente, Vera Cruz); Cat. Am. Birds, 1862, 276 (Guatemala).-Sclater and Salvin, Ibis, 1859, 132 (Pacific slope of Guatemala).-Cabanis, Journ. für Orn., 1862 173 (Costa Rica).-Lawrence, Ann. Lyc. N. Y., ix, 1868, 118 (Dota, Turrialba, Birrís, and San Juan, Costa Rica); Bull. U. S. Nat. Mus., no. 4, 1876, 31 (Guichicovi and Chimalapa, Oaxaca).-Salvadori, Atti Torino, iv, 1868, 181 (Costa Rica).-Frantzıus, Journ. für Orn., 1869, 312 (Costa Rica).-

$a$ Seventeen specimens.

\begin{tabular}{|c|c|c|c|c|c|}
\hline Locality. & Wing. & Tail. & $\begin{array}{l}\text { Cul- } \\
\text { men. }\end{array}$ & Tarsus. & $\begin{array}{l}\text { Inner } \\
\text { ante- } \\
\text { rior toe. }\end{array}$ \\
\hline MALES. & & & & & \\
\hline 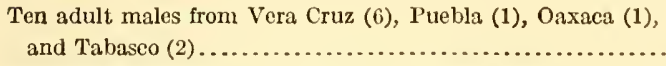 & 129.3 & 145. 2 & 17.1 & 14.7 & 14.1 \\
\hline Five adult males from Campeche (1) and Yucatan (4)........ & 119.5 & 134.2 & 16.3 & 13.6 & 12.9 \\
\hline $\begin{array}{l}\text { Six adult males from Chiapas (2), Guatemala (3), and Flon- } \\
\text { duras (1) } \ldots \ldots \ldots \ldots \ldots \ldots \ldots \ldots \ldots \ldots \ldots \ldots \ldots \ldots \ldots \ldots \ldots \ldots \ldots \ldots \ldots \ldots \ldots\end{array}$ & 127.5 & $143 . S$ & 16.9 & 14.5 & 13 \\
\hline 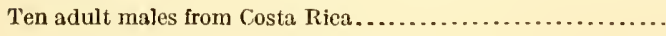 & 127.6 & 143.8 & 16.0 & 14.8 & 13.4 \\
\hline 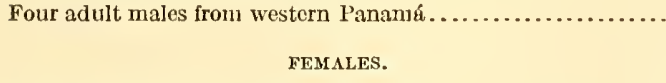 & 125.2 & 141.5 & 16.6 & 13.9 & 12.7 \\
\hline Threo adult females from Vera Cruz..... & 134 & 155.3 & 16 & 15.2 & 13.7 \\
\hline Two adult females from Yueatan.......... & 122 & 136.2 & 16 & 13.7 & 12.7 \\
\hline Ono adult female from Guatemala................... & 123.5 & 132.5 & 16 & 14.5 & 13.5 \\
\hline Nlne adult females from Costa Rlea............. & 125.4 & 145.2 & 16.4 & 14.1 & 12.8 \\
\hline Two adult females from western I'anamá................. & 131 & 152. 7 & 17 & 14 & 12.7 \\
\hline
\end{tabular}


Sumichrast, Mem. Bost. Soc. N. H., i, 1869, 560 (hot region, Vera Cruz); La Naturaleza, v, 1881, 239 (Uvero, Vera Cruz).-Salvin, Proc. Zool. Soc. Lond., 1870, 202 (Volcán de Chiriquí, Panamá).-Boucard, Proc. Zool. Soc. Lond., 1878, 48 (Cerro de la Candelária and Navarro de Cartago, Costa Rica); 1883, 454 (Izamál and Tizimín, Yucatan); Liste Ois. récol. Guat., 1878, 25.Zeledón, Proc. U. S. Nat. Mus., viii, 1885, 109 (Costa Rica); Anal. Mus. Nac. Costa Rica, i, 1887, 120 (Turrialba and Navarro de Cartago, Costa Rica).-Grant, Cat. Birds Brit. Mus., xvii, 1892, 452.-Salvin and Godman, Biol. Centr.-Am., Aves, ii, 1896, 491.-Chapman, Bull. Am. Mus. N. H., x, 1898, 34 (Jalapa).-Bangs, Proc. New Engl. Zool. Club, iii, 1902, 31 (Boquete, Panamá, 4,000-7,000 ft.).-Cole, Bull. Mus. Comp. Zool., I, 1906, 128 (Chichen-Itza, Yucatan).-Dearborn, Pub. 125, Field Mus. N. H., 1907, 88 (Patulúl, Guatemala).-Carriker, Ann. Carnegie Mus., vi, 1910, 557 (Costa Rican range).-Ferry, Pub. 146, Field Mus. N. H., orn. ser., i, no. 6, 1910, 265 (Guayabo, Costa Rica; habits).

Trogon] puella Gray, Gen. Birds, i, 1845, 70.-Bonaparte, Consp. Av., i, 1850, 149.-Cabanis and Heine, Mus. Hein., iv, 1863, 172 (Jalapa).-Sclater, Proc. Zool. Soc. Lond., 1864, 176 (near City of Mexico).-Ridgway, Man. N. Am. Birds, 1887, 277.

[Trogon] puella Gray, Hand-list, i, 1869, 82, no. 972.--Sclater and Salvin, Nom. Av. Neotr., 1873, 104.-Sharpe, Hand-list, ii, 1900, 148, part (includes

T. aurantiventris and T. a. underwoodi).

[Trogonurus] puella Bonaparte, Consp. Voluc. Zygod., 1854, 14.

Trogon xalapensis Du Bus, Esquiss. Orn., i, 1845, pl. 2 (Jalapa, Vera Cruz).LAFResnaye, Rev. Zool., x, 1847, 180.

T[rogon] xalapensis Gray, Gen. Birds, iii, 1849, App., p. 4.-Bonaparte, Consp. Av., i, 1850, 150.

[Trogonurus] xalapensis Bonaparte, Consp. Voluc. Zygod., 1854, 14.

Trogon luciani “'Less[on] ex Bonap[arte]' Bonaparte, Compt. Rend., xlii, 1856, 955 , footnote. (Nomen nudum?)

\section{TROGONURUS AURANTIVENTRIS AURANTIIVENTRIS (Gould).}

\section{ORANGE-BELLIED TROGON.}

Similar to T. puella but color of under parts orange (between cadmium orange and saturn red).

Above bright metallic green or golden green, including middle rectrices, which are abruptly tipped with black, the second and third pairs with the inner web wholly black; remaining rectrices black, rather narrowly tipped with white (the white terminal bar about $2-5 \mathrm{~mm}$. wide), the remaining portion narrowly barred with white, the white bars several times narrower than the black interspaces; on inner web of third rectrix (from outside) the bars confined to subterminal portion, except along edge, on that of second rectrix confined to about terminal half and edge; anterior lesșer wing-coverts bright metallic green, like back, etc., the rest black narrowly barred with white; greater coverts and secondaries black finely vermiculated with white; primaries black, edged with white on outer web, except on shorter proximal and outermost quills; loral, orbital, auricular, and malar regions, chin, and throat, black; chest bright metallic green or golden green, margined posteriorly by a band of white across upper breast; rest of under parts pure orange (between cadmium orange and saturn red, 
but nearest the former), more or less paler on under tail-coverts, the thighs black; bill yellow; feet brownish or horn color (in dried skins); length (skins), 248-267 (256); wing, 122.5-128 (125.6); tail, 132.5-157.5 (142.4); culmen, 15.5-18 (16.8); tarsus, 14-15 (14.4); inner anterior toe, $12.5-13.5(13) .^{a}$

Adult female.-Above plain brown (nearest raw umber or between that and mummy brown), darker (nearly prouts brown or mummy brown) on pileum, slightly paler and more tawny brown on lower rump and upper tail-coverts; middle rectrices clear chestnut, narrowly and sharply tipped with black, the inner web of second and third pairs (from middle) wholly dark brown (nearly seal brown); anterior lesser wing-coverts plain brown, like pileum, the remaining coverts and secondaries paler brown finely vermiculated or freckled with blackish; primaries dull slate-blackish, the longer conspicuously edged on outer web with white, the shorter proximal quills with exterior portion of outer web pale brownish minutely freckled with dusky; loral and postocular regions dusky; a white orbital ring, broadest behind eye, broadly interrupted on both upper and lower eyelids; suborbital, auricular, and malar regions, chin, and throat dusky brown; chest tawny brown, like color of back, etc.; rest of under parts as in adult male, but the orange averaging paler; maxilla blackish or dusky, the lower basal portion, together with mandible, yellowish; feet as in adult male; length (skins), 247-256 (251); wing, 120-124 (122.7); tail, 135-144 (138.2); culmen, 15.5-16.5 (16); tarsus, 14-14.5 (14.3); inner anterior toe, $12-12.5(12.2) .^{b}$

Western Panamá (near Davíd, Chiriquí; Santa Fé de Verágua; Calovévora; Castillo; Cordillera de Tolé; Boquete, 3,000-6,000 feet) and southern and central Costa Rica (Dota; Cartago; Volcán de Irazú).

Trogon aurantiiventris Gould, Proc. Zool. Soc. Lond., xxiv, 1856, 107 (near Davíd, Verágua, w. Panamá; coll. J. Gould); Ann. and Mag. N. H., 2d ser., xix 1857, 110; Mon. Trog., ed. 2, 1858, pl. 12, and text.-Sclater, Proc. Zool. Soc. Lond., 1856, 139 (above Davíd).-Salvin, Proc. Zool. Soc. Lond., 1867, 151 (Santa Fé, and Cordillera de Tolé, Verágua; Davíd); 1870, 202 (Calovévora and Castillo, Verágua).-Ripgway, Proc. U. S. Nat. Mus., xiv, 1891, 478 (Volcán de Irazú and Cartago, Costa Rica; crit.).-Bangs, Proc. New Engl. Zool. Club, iii, 1902, 31 (Boquete, Chiriquí, Panamá, 3,000-6,000 ft.; crit.).

[Trogon] aurantiiventris Gray, Hand-list, ii, 1869, 83, no. 984, part (Verígua).Sclater and Salvin, Nom. Av. Neotr., 1873, 104, part (Verágua).

Trogon auranteiventris Grant, Cat. Birds Brit. Mus., xvii, 1892, 454, part (Chiriquí; Calovévora, Santa Fé, and Cordillera de Tolé, Verágua).

$P$ [othinus] aurantiiventer Cabanrs and Herne, Mus. Hein., iv, 1S63, 182, part (Davíd, Chiriquí).

Trogon puella (not of Gould) Salvin and Gomman, Biol. Centr.-Am., Aves, ii, 1896, 491 (orange-bellied specimens from Panamá).

[Trogon] puella Sharpe, Hand-list, ii, 1900, 148, part (Panamá). 


\section{TROGONURUS AURANTIIVENTRIS UNDERWOODI (BangS).}

\section{UNDERWOOD'S TROGON.}

Similar to T. a. aurantiiventris and T. puella but posterior under parts orange-red (flame scarlet to salmon-pink) instead of orange (aurantiiventris) or geranium red ( $T$. puella).

Adult male.-Length (skins), 226-255 (239); wing, 122.5-131 (127.1); tail, 130-144 (136.9); culmen, 17-18 (17.4); tarsus, 14-16 (15); inner anterior toe, $12-14(13.1){ }^{a}$

Adult female.-Length (skin), $242 ;^{b}$ wing, 126-133 (128.7); tail, 135-143 (138.9); culmen, 16-17.5 (16.5); tarsus, 14-15 (14.4) inner anterior toe, $11.5-13(12.5) .^{c}$

Northwestern Costa Rica (Barranca; Cerro Santa Maria; Tenório; La Hondura; Volcán de Miravalles). (Possibly also northward to Vera Cruz, Mexico; see references in synonymy.)

(?)Trogon sallæi Bonaparte, Compt. Rend., xlii, 1856, 955 (Orizaba, Vera Cruz).

(?)P[othinus] sallaei Cabanis and Heine, Mus. Hein., iv, 1863, 183 (Mexico; crit.).

(?) Trogon aurantiiventris (not of Gould) Sclater, Proc. Zool. Soc. Lond., 1856, 286 (Córdova, Vera Cruz).-SAlvin, Ibis, 1866, 194 (Choctúm, Vera Paz, Guatemala).

(?)Trogon auranteiventris Grant, Cat. Birds Brit. Mus., xvii, 1892, 454, part (Choctúm).

(?)[Trogon] aurantiiventris Gray, Hand-list, i, 1869, 83, no. 984, part (Mexico).Sclater and Salvin, Nom. Av. Neotr., 1873, 104, part (Mexico).

(?)P[othinus] aurantiiventris CABanis and Heine, Mus. Hein., iv, 1863, 182, part (Córdova).

Trogon aurantiiventris (not of Gould) Lawrence, Ann. Lyc. N. Y., ix, 1868, 118 (Barranca, n. w. Costa Rica).-Frantzıus, Journ. für Orn., 1869, 312 (Costa Rica).-Zeledón, Proc. U. S. Nat. Mus., viii, 1885, 109 (Costa Rica); Anal. Mus. Nac. Costa Rica, i, 1887, 120 (Barranca).-Underwood, Ibis, 1896, 444 (Volcán de Miravalles, Costa Rica).

[Trogon] aurantiiventris Sclater and Salvin, Nom. Av. Neotr., 1873, 104, part. Trogon auranteiventris Grant, Cat. Birds Brit. Mus., xvii, 1892, 454, part (Barranca).

Trogon puella (not of Gould) Salvin and Godman, Biol. Centr.-Am., Aves, ii, 1896, 491, part (Barranca).

[Trogon] puella Sharpe, Hand-list, ii, 1900, 148, part.

Trogon underwoodi Bangs, Proc. New Engl. Zool. Club, iv, March 19, 1908, 24 (Volcán de Miravalles, n. w. Costa Rica; coll. E. A. and O. Bangs); Proc. Biol. Soc. Wash., xxii, 1909, 30 (Tenório and Cerro Santa Maria, n. w. Costa Rica; crit.).

Trogon aurantiiventris underwoodi CARriker, Ann. Carnegie Mus., vi, "August $29 "=$ Sept. 7, 1910, 558 (highlands of n. w. Costa Rica; crit.). 


\section{TROGONURUS CURUCUI TENELLUS (Cabanis).}

GRACEFUL TROGON.

Adult male.-Pileum, hindneck, back, scapulars, lesser wingcoverts, rump, upper tail-coverts, and chest bright metallic green, the back, etc., usually slightly more golden green, the upper tailcoverts usually slightly more bluish green; loral, orbital, auricular, and malar regions, chin, and throat black; middle pair of rectrices metallic bluish green or greenish blue, broadly and abruptly tipped with black, the two adjoining pairs with outer webs similar, but inner webs blackish; three lateral pairs of rectrices black broadly tipped with white, the subterminal portion of inner web and greater part of outer web broadly barred with white; middle and greater wingcoverts and outer webs of secondaries finely vermiculated with black and white; primaries black, edged (except outermost and shorter proximal quills) with white, this somewhat broken on terminal portion; under parts posterior to chest pure orange-yellow (between cadmium and chrome yellow), the anterior margin paler or somewhat intermixed with white, forming an indistinct band next to green of chest; thighs sooty blackish; bill dull yellowish or yellowish gray in dried skins, light apple green ${ }^{a}$ or chromium green ${ }^{b}$ in life; naked eyelids glaucous ${ }^{a}$ or blue; ${ }^{b}$ iris dark brown; feet gray $^{b}$ or plumbeous; $^{b}$ length (skins), 213-254 (224); wing, 105-117.5 (110.4); tail, 124-144 (134.1); culmen, 16-17.5 (16.5); tarsus, 12-14.5 (12.7); inner anterior toe, $12-14.5$ (12.8). ${ }^{c}$

Adult female.-Pileum, auricular region, hindneck, back, scapulars, lesser wing-coverts, rump, and upper tail-coverts plain brown (nearly raw umber), the color slightly deeper (nearly mummy brown or prouts brown) on pileum, paler and grayer (nearly isabella color) on rump and upper tail-coverts, the longer of the latter sometimes more rufescent; middle pair of rectrices deep cinnamon-rufous or chestnut, rather narrowly tipped with black, this preceded by an indistinct subterminal narrow band of cinnamon-buffy; next two pairs with outer web similar but inner web blackish brown; three lateral pairs extensively white terminally and on greater part of outer web, black basally, the white portion (except an immaculate terminal area) broadly barred with black; middle and greater wingcoverts and secondaries much paler brown than back, etc., finely vermiculated with dusky; a white orbital ring, interrupted on lower eyelid, broadest behind eye, where margined posteriorly by a black bar; suborbital region and posterior portion of lores grayish dusky;

$a$ Fresh colors of specimens shot by the writer in Costa Rica.

$b$ Nutting.

c Twenty-one specimens. 
malar region, chin, throat, and chest plain brown (like color of rump); rest of underparts as in adult male, but the yellow usually less intense, and sides of breast washed or intermixed with brownish gray; maxilla blackish, the lower basal portion and mandible light grayish yellowish (in dried skins), the whole maxilla also sometimes yellowish; length (skins), 227-263 (242); wing, 105.5-115.5 (111.6); tail, 129.5-152 (138.4); culmen, 15.5-17.5 (17.2); tarsus, 12-14 (12.8); inner anterior toe, $12-14$ (13.2). ${ }^{a}$

Immature male.-Intermediate in coloration between the adult male and adult female, the pileum, back, rump, upper tail-coverts, etc., being bright metallic golden green, as in the former, but sides of head, throat, and chest, together with larger wing-coverts and secondaries, brown, as in the latter; tail as in adult female but six middle rectrices partly metallic green basally, the middle pair without distinct black tip. (Older specimens have more or less of metallic green on chest, chin and throat black, and wing-coverts and secondaries as in adult male.)

Young male (nestling).-Pileum, hindneck, back, and scapulars warm cinnamon or russet, passing on rump and upper tail-coverts, into cinnamon-rufous, the middle rectrices chestnut abruptly tipped with black; wing-coverts and secondaries light buffy brown or wood brown, vermiculated with grayish dusky, most of the feathers with a very large roundish or subcordate spet of buff, deeper buff on lesser coverts, paler on tertials, these spots margined with a dusky line; remiges, primary coverts, alula, and lateral rectrices as in adult female; an interrupted white orbital ring, lores grayish dusky; chin, throat, and chest uniform cinnamon-brown or russet; rest of underparts light tawny, deeper on breast, paler posteriorly and on upper margin of breast (where somewhat intermixed with whitish tawny).

Panamá (Lion Hill; Chepo; Panamá; Chitra; Calovévora; Bugaba; Divala; Santiago de Verágua; Santa Fé de Verágua; Cordillera de

$a$ Nineteen specimens.

\begin{tabular}{|c|c|c|c|c|c|}
\hline Locality. & Wing. & Tail. & $\begin{array}{l}\text { Cul- } \\
\text { men. }\end{array}$ & Tarsus. & $\begin{array}{c}\text { Inner } \\
\text { ante- } \\
\text { rior toe. }\end{array}$ \\
\hline MALES. & & & & & \\
\hline Ten adult males from Panamá.. & 107.9 & 131.5 & 16. 6 & 12.8 & 12. 7 \\
\hline Ten adult males from Costa Rica... & 112.7 & 136.5 & 16.4 & 12.7 & 12.9 \\
\hline One adult male from Nicaragua................. & 111.5 & 136 & 16.5 & 12.5 & 13 \\
\hline FEMALES. & & & & & \\
\hline Six adult females from Panamá.. & 110.3 & 139.7 & 16.5 & 12.6 & 12.9 \\
\hline Ten adult females from Costa Rlca.... & 112.3 & 137.7 & 16.6 & 13 & 13.2 \\
\hline Three adult females from Nicaragua (2) and Honduras (1)... & 111.8 & 138 & 17.2 & 12.7 & 13. 7 \\
\hline
\end{tabular}


Tolé; Volcán de Chiriquí) and northward through Costa Rica (Angostura; Guaitíl; Pacuare; Barranca; Las Trojas; Pozo del Rio Grande; Pozo Azúl de Pirrís; Paso Reál; Boruca; Tenório; Bebedero; Lagarto; Guayabál; Bonilla; Juan Viñas; Rio Sícsola, Talamanca; Talamanca; Orosí; La Vijágua) and Nicaragua (Greytown; Rio Escondido; San Emilis, Lake Nicaragua; La Libertád and Santo Domingo, Chontales) to southeastern Honduras (Rio Segóvia).

Trogon aurantiiventris (not of Gould) Lawrence, Ann. Lyc. N. Y., vii, 1862, 290 (Lion Hill, Panamá).

Trogon tenellus Cabanis, Journ. für Orn., May, 1862, 173 (Costa Rica; coll. Berlin Mus.).-Lawrence, Ann. Lyc. N. Y., viii, 1863, 481 (Lion Hill); ix, 1868, 119 (Angostura, Guaitíl, Pacuare, and Barranca, Costa Rica).-Frantzius, Journ. für Orn., 1869, 312 (Costa Rica).-Salvin, Ibis, 1872, 321.-Gould, Mon. Trog., ed. 2, 1875, pl. 15 and text.

[Trogon] tenellus Gray, Hand-list, i, 1869, 83, no. 983.

P[othinus] tenellus Cabanis and Heine, Mus. Hein., iv, 1863, 181 (Costa Rica; crit.).

[Trogon atricollis] Race B. (Trogon tenellus) Grant, Cat. Birds Brit. Mus., xvii, 1892, 456, 458 (Chontales, Nicaragua; Barranca and Angostura, Costa Rica; Bugaba, Cordillera de Tolé, Santiago, Santa Fé de Verágua, Chitra, Calovévora, Panamá, and Chepo, Panamá).

Trogon atricollis tenellus Richmond, Proc. U. S. Nat. Mus., xvi, 1893, 513 (Rio Escondido, Nicaragua).-Bangs, Auk, xviii, 1901, 360 (Divala, Panamá); xxiv, 1907, 294 (Boruca and Pozo del Rio Grande, Costa Rica; descr. young).Carriker, Ann. Carnegie Mus., vi, 1910, 559 (Costa Rica; habits; descr. nest and eggs).

Trogon atricollis tenuellus Bangs, Proc. New Engl. Zool. Club, ii, 1900, 19 (Loma del León, i. e. Lion Hill, Panamá).

Trogon atricollis (not of Vieillot) Sclater and Salvin, Proc. Zool. Soc. Lond., 1864, 364 (Lion Hill, Panamá).-Salvin, Proc. Zool. Soc. Lond., 1867, 151 (Cordillera de Tolé, Santiago, and Santa Fé de Verágua, Panamá; crit.); 1870, 202 (Volcán de Chiriquí, Bugaba, Chitra, and Calovévora, Panamá); Ibis, 1872, 313, 321 (Chontales, Nicaragua; crit.).-Zeledón, Proc. U. S. Nat. Mus., viii, 1885, 109 (Costa Rica); Anal. Mus. Nac. Costa Rica, i, 1887, 120 (Las Trojas, Angostura, and Pacuare, Costa Rica).--Ridgway, Proc. U. S. Nat. Mus., x, 1887, 591 (Rio Segóvia, s. e. Honduras).-Cherrie, Expl. Zool. Merid. Costa Rica, 1893, 47 (Lagarto and Boruca, Costa Rica).-SALvin and Godman, Biol. Centr.-Am., Aves, ii, 1896, 493, part (Central American localities and references).-Underwood, Ibis, ]896, 444 (Volcán de Miravalles, Costa Rica).

[Trogon] atricollis Sclater and Salvin, Nom. Av. Neotr., 1873, 104, part (Central America).-Sharpe, Hand-list, ii, 1900, 148, part (Honduras; Nicaragua; Costa Rica; Panamá).

(?) Trogon chrysomelas a Richuond, Proć. U. S. Nat. Mus., xvi, no. 947, Oct. 4,

$a$ Description of the type (and only known specimen):

Adult male.-Pileum, sides of head, chin, and throat uniform sooty black, the chest similar but more sooty; back, scapulars, lesser wing-coverts, rump, upper tail-coverts, and middle rectrices sooty grayish brown (nearly clove brown), the last broadly and sharply tipped with black; three lateral pairs of rectrices broadly tipped with white, the remaining portion very regularly barred with black and white (the black and white bars of nearly equal width and about $2-3 \mathrm{~mm}$. wide), except basal (concealed) 
1893, 513 (Rio Escondido, Nicaragua; coll. U. S. Nat. Mus.; = abnormally colored adult male?).--Salvin and Godman, Biol. Centr.-Am., Aves, ii, 1896, 501.

[Trogon] chrysomelas Sharpe, Hand-list, ii, 1900, 149.

\section{Genus CHRYSOTROGON Ridgway. ${ }^{a}$}

Microtrogon (not of Bertoni, 1901 b) Goeldi, Bol. Mus. Goeldi, v, no. 1, Feb., 1908, 92, 93, 94, 95. (Type, Trogon ramoniana Deville and Des Murs.).Snethlage, Bol. Mus. Goeldi, v, no. 1, Feb., 1908, 62, in text.c

Small Trogons, resembling Trogonurus, but differing in having the tarsus densely feathered to base of toes, tail relatively shorter, and nestling resembling adults in coloration.

Bill stout, its depth at nostrils equal to its width at same point, the culmen strongly arched, indistinctly ridged; gonys about as long as mandibular rami, slightly to moderately convex, strongly ascending terminally; interramal space broader at base than long; tomia distinctly serrate, especially on mandible, the tip of which forms a short ascending point. Nostril roundish, margined above and behind by membrane, mostly concealed by strong, antrorse, decurved laterofrontal bristles. Eyelids naked, forming a rather broad orbital ring. Feathers of malar apex and chin bristly, antrorse, the latter strongly recurved; seventh and sixth primaries longest, the eighth a little shorter, the tenth (outermost) about half as long as ninth; tail about as long as wing (sometimes shorter), graduated for a little more than one-third its length, the rectrices truncate (the lateral ones obliquely so) at tip, the outermost moderately bowed basally. Tarsus about

portion of inner web of outermost rectrix and basal half or more of inner web of next two; middle and greater wing-coverts and secondaries delicately vermiculated with black and white; rest of wing slate-blackish, the longer primaries edged with white; under parts, posterior to chest, rich, pure orange-yellow (between lemon and cadmium, but nearer to latter), margined anteriorly by a band of white across upper breast (next to sooty color of chest), the feathers of tibia and upper portion of tarsus sooty black, tipped with yellowish white; bill (in dried skin) grayish horn color, with tomia and terminal half of culmen dull yellowish; feet horn color, in dried skin; length (skin), 238; wing, 110.5; tail, 140; culmen, 17; tarsus, 13; inner anterior toe, 14 . (No. 127338, coll. U. S. Nat. Mus., Rio Escondido, Nicaragua, September 23, 1892; Charles W. Richmond.)

This bird agrees so perfectly in measurements, pattern of coloration of lateral rectrices, and color of under parts (posterior to the chest), that, in spite of the utter absence of metallic coloring, I am now disposed to consider it an abnormal adult male of $T$. curucui tenellus. The adult female described by Dr. Richmond as that of T. chrysomelas is unquestionably referable to Chrysotrogon caligatus.

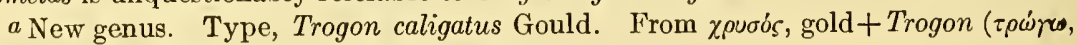
I gnaw, I eat).

$b$ Aves Nueves del Paraguay, 1901, 41. (Type, M. fulvescens Bertoni=Bucco [Nonnula] rubecula Spix.

$c$ Has anteriority over publication of same name by Goeldi, but not intended as new. 
as long as middle toe, densely feathered for entire length; anterior toes united for basal and part of second phalanx.

Coloration.-Adult males with head and neck black, chest metallic bluish green to violet-blue, back bright metallic green, upper tailcoverts and middle rectrices metallic bluish green or greenish blue (the latter broadly tipped with black), lateral rectrices barred with black and white (except a terminal area of immaculate white), wingcoverts and secondaries minutely vermiculated with black and white, and under parts posterior to chest rich orange-yellow; adult females with slate color replacing all the metallic colors, as well as the black of head and neck, the wing-coverts and secondaries narrowly barred with white, and inner web of lateral rectrices wholly blackish except the narrow white tip; young male similar to the adult male, but chest, back, and middle rectrices dark sooty brown or sooty slate; young female similar to the adult female, but the slate color darker and more sooty.

Range.-Southern Mexico to Ecuadór, Amazon Valley, Guiana, and Trinidád. (Three or four species. ${ }^{a}$ )

\section{KEY TO THE SPECIES AND SUBSPECIES OF CHRYSOTROGON.}

a. Back, scapulars, rump, upper tail-coverts and middle rectrices bright metallic green and blue or greenish blue; no white orbital ring; wing-coverts and secondaries minutely vermiculated or freckled with white or gray, or else uniform slate-black. (Adult males.)

b. Lower part of tarsus naked; bill broader basally, the interramal space relatively larger and broader; pileum (except forehead) metallic blue or violet.

c. Culmen rounded, or at least not distinctly ridged; wing-coverts distinctly (though minutely) freckled with pale gray. (Cayenne and Trinidád to Caribbean slope of Colombia.)

Chrysotrogon violaceus, adult male (extralimital). $b$ cc. Culmen distinctly ridged; wing-coverts not distinctly if at all freckled with gray. (Chrysotrogon ramonianus.)

a Although Trogon meridionalis Swainson and T. ramoniana Deville and Des Murs differ from the type of Chrysotrogon in having the extreme lower part of the tarsus bare, and the plumage of their young is unknown, the adults resemble $C$. caligatus so closcly in coloration that I have little doubt they belong in the same genus.

$b$ [Trogon] violaceus Gmelin, Syst. Nat., i, pt. 1, 17S8, 404 (based on Lanius capite, etc., Koelreuter, Nov. Act. Petrop., ii, 436, pl. 16, fig. S; Couroucou à chaperon violet Buffon, Hist. Nat. Ois., vi, 294; Violet-headed Curucui Latham, Synopsis Birds, i, pt. 2, 491).-T[rogon] violaceus Hellmayr, Abh. K. Bayer. Akad. Wiss. München, ii, Kl., xxii, Bd. iii, 1906, 596 (crit.).-A[ganus] violaceus Cabanis and Heine, Mus. Hein., iv, Feb., 1S63, 190 (Cayenne; Guiana; Trinidád).-Trogon meridionalis Swainson, Anim. in Menag., pt. iii, Jan. 1, 1838, 332 ("Bahamas and other neighboring islands;" coll. W. Swainson); Gould, Mon. Trog., ed. 1, 183S, pl. 9 and text; ed. 2, 1875, pl. 17 and text; Grant, Cat. Birds Brit. Mus., xvii, 1892, 467.-A[ganus] caligatus (not Trogon caligatus Gould) Cabanis and Heine, Mus. Hein., iv, Feb., 1863, 189 (Cartagena, Colombia). 
d. Wing-coverts and secondaries uniform black or with very minute freckling showing on very close examination; bill larger, with culmen less sharply ridged. (Eastern Ecuadór and Peru.)

Chrysotrogon ramonianus ramonianus, adult male (extralimital) ${ }^{a}$

$d d$. Wing-coverts and secondaries obviously (though minutely) vermiculated or freckled with grayish; bill smaller, with culmen compressed and sharply ridged. (Lower Amazon Valley; Bahia?)

Chrysotrogon ramonianus crissalis?, adult male (extralimital). $b$

bb. Lower part of tarsus feathered (to base of toes); bill narrower basally, the interramal space smaller and narrower; pileum black (only the hindneck glossed with blue or violet). (Southern Mexico to western Ecuadór.)

Chrysotrogon caligatus, adult male (p. 786).

aa. Back, scapulars, rump, upper tail-coverts, middle rectrices, and chest plain slate color or blackish slate (like head and neck); interrupted orbital ring and narrow cross-lines on wing-coverts and secondaries white. (Adult females.)

$b$. Lower portion of tarsus naked.

c. Bill larger, the culmen not distinctly ridged.

Chrysotrogon violaceus, adult female (extralimital). $c$ cc. Bill smaller, the culmen sharply ridged.

Chrysotrogon ramonianus crissalis?, adult female (extralimital). $c$

$b b$. Lower part of tarsus feathered (to base of toes).

Chrysotrogon caligatus, adult female (p. 787).

\section{CHRYSOTROGON CALIGATUS (Gould).}

\section{GARTERED TROGON.}

Adult male.-Head and neck black, sometimes passing into metallic blue or violet-blue on lower hindneck; ${ }^{d}$ back, scapulars, upper rump, and anterior lesser wing-coverts bright metallic green or golden green, passing into pure metallic green, bluish green, or nearly greenish blue on lower rump, upper tail-coverts, and middle pair of rectrices, the latter abruptly tipped with black, the next two pairs of rectrices with outer web similar but inner web wholly uniform black; three lateral pairs of rectrices broadly tipped with white, the remaining

a Trogon ramoniana Deville and Des Murs, Rev. Zool., 1849, 331 (Sarayacu, e. Ecuadór); Des Murs, in Castelnau's Expéd. l'Amér. du Sud, Ois., 1855, 33, pl. 11, fig. 2.- Trogon ramonianus Bonaparte, Compt. Rend., xlii, 1856, 955, note 1; Gould, Mon. Trog., ed. 2, 1858, pl. 18 and text; Grant, Cat. Birds Brit. Mus., xvii, 1892, 468.-A[ganus] ramonianus Cabanis and Heine, Mus. Hein., iv, Feb., 1863, 194 (Sarayacu and Pampas del Sacramento).

$b(?) A[$ ganus $]$ crissalis Cabanis and Heine, Mus. Hein., iv, Feb., 1863, 190 (Bahia, c. Brazil; coll. Heine Mus.).-Trogon ramonianus (not T. ramoniana Deville and Des Murs) Goeldi, Bol. Mus. Goeldi, v, 1908, 92 (Pará, etc., Lọer Amazon).

I have not seen a specimen from Bahia, and assume that the bird from that district may be the same as the Lower Amazon form. It certainly can not be either true ramonianus or $C$. violaceus. But the Bahia bird may be a different form, in which case I propose for the Pará bird the name Chrysotrogon ramonianus goeldii. (Type, no. 105,232, coll. U. S. Nat. Mus., Pará, Brazil, March 6, 1881; E. M. Brigham.)

$c$ With only one specimen of the Lower Amazon form, and none of C.ramonianus ramonianus, I am not able to more satisfactorily characterize the females of these two forms and $C$. violaceus.

d More rarely this metallic coloring extends over greater part of the hindneck. 
portion black, for the most part barred with white, the outermost rectrix with the outer web barred for whole length (but basally the white bars not reaching to shaft), the inner web also barred for greater part, but the white bars becoming gradually narrower and shorter (from edge of web) proximally, the third rectrix (from outside) with outer web barred for more than half its length but the inner web with not more than one or two complete bars (often with none at all) - the white bars continuous (involving the shaft) on the subterminal portion of two outer rectrices and there nearly (sometimes quite) equal in width to the black interspaces; wing-coverts and secondaries minutely vermiculated with black and white; primaries dull black, the longer ones edged with white for basal half or more; chest metallic bluish green, blue, or violet-blue, rarely black, glossed, more or less, with metallic bluish green or blue; rest of under parts rich pure orange-yellow or yellowish orange (cadmium yellow to orange), ${ }^{a}$ paler, sometimes slightly intermixed with whitish, along anterior margin (next to metallic blue of chest), the outer portion of sides and flanks gray, tinged or washed with orange-yellow, the thighs and tarsal feathers black; bill pale yellowish or grayish in dried skins, pale olive-gray or dull glaucous ${ }^{b}$ or ashy blue ${ }^{c}$ in life; naked orbital ring orange-yellow, ${ }^{b}$ like color of abdomen; iris dark brown $;^{b}$ feet gray ${ }^{b}$ or plumbeous $;^{c}$ length (skins), 214-254 (229); wing, 110-134 (121.1); tail, 112-135 (122.6); culmen, 15-18.5 (16.6); tarsus, $12.5-15$ (13.4); inner anterior toe, $12-15$ (13.5). ${ }^{d}$

Adult female.-Upper parts (except wings) plain slate color, darker (blackish slate) on pileum, the middle rectrices abruptly and rather broadly tipped with black; a broad white orbital ring, interrupted on upper and lower eyelids; wings black, or slate-black, the wingcoverts and secondaries narrowly barred with white transverse lines (these several times narrower than the broad black interspaces), the longer primaries edged with white; three lateral rectrices with inner web black tipped with white, the latter extending, wedge-like, for a greater or less distance next to shaft, the outer web broadly barred with white (for nearly entire length of outermost, for about one-third the length of third rectrix); sides of head and neck, chin, throat, and chest plain slate color or blackish slate; outer portion of sides and flanks lighter slate color or slatc-gray, tinged with orange-yellow; tibial and tarsal feathers black; rest of under parts orange-yellow, paler (usually somewhat intermixed with white) along anterior margin; bill light grayish or buffy in dried skins, the maxilla sometimes partly blackish; iris dark brown; feet dusky horn color or brownish in dried skins, grayish in life; length (skins), 213-247 (231);

$a$ Of the author's "Nomenclature of Colors."

$b$ Fresh colors of specimens shot by the writer in Costa Rica.

$c$ Acording to Sumichrast.

$d$ Fifty-three specimens. 
wing, 113-130.5 (121.5); tail, 114.5-135.5 (126.1); culmen, 15-17.5 (16.7); tarsus, $12.5-15.5$ (13.6); inner anterior toe, $12-14$ (13.2). ${ }^{a}$

Immature male. - Similar to the adult male but lateral rectrices less regularly barred (the pattern essentially intermediate between that of the adult male and that of adult female), wing-coverts more coarsely vermiculated, and chest with greater or less intermixture of dull slate color.

Young male (nestling).-Similar to the adult female, but the general slate color darker and more sooty, pileum black, and with wing-coverts and secondaries more irregularly barred with white.

Southeastern Mexico, in States of Tamaulipas (Tampico), Vera Cruz (Córdova; Orizaba; Jalapa; Omealca; Uvero; Motzorongo; Colipa; Misantla; Los Cerillos; Atoyác; Playa Vicente; Valle Reál; Pasa Nueva), Puebla (Metlaltoyuca), Mexico ("near City of Mexico"), Oaxaça (Guichicovi; Choapám; Cacoprieto; Chimalapa; Santa Efigénia), Tabasco (Teapa), Chiapas (Huehuetán; Palenque; Tapachula), Canıpeche (Yohaltán) and Yucatan (La Vega; Slıkolak; Peto; Izamál; Calotmúl; Tunkas; Chichen-Itza) and southward through Guatemala (Choctúm; Yaxcamnál; Chiséc; Telemán; Tolimán; Dueñas; Volcán de Fuego; Alotenango; Retalhuleu; Mazatenango; Santo Tomas; Gualán, Zacapa; Patulúl, Sololá; Naranjo), Salvadór (Volcán de San Miguél), Honduras (Omoa; Yaruca; Copán), Nicaragua (Matagalpa; San Rafaél del Norte; Volcán de Chinandega; San Carlos; León; La Libertád, Chontales; Sucuyá; Rio Escondido), Costa Rica (La Palma de Nicoya; San Mateo; Turrialba; Birrís de Cartago; Naranjo de Cartago; Cartago; San Juán; Alajuela; Las Trojas; Jiménez; Guaitíl; San José; Angostura; Turrialba; Juan Vinas; Bonilla; Guayabo; Pigres; Boruca; Barranca de Boruca;

a Thirty-seven specimens.

\begin{tabular}{|c|c|c|c|c|c|}
\hline Locality. & Wing. & Tail. & $\begin{array}{l}\text { Cul- } \\
\text { men. }\end{array}$ & Tarsus. & $\begin{array}{l}\text { Inner } \\
\text { ante- } \\
\text { rior toe. }\end{array}$ \\
\hline \multicolumn{6}{|l|}{ MALES. } \\
\hline Six adult males from Vera Cruz (5) and Puebla (1)...... & 126.4 & 129.7 & !6. 8 & 14.1 & 14.1 \\
\hline Five adult males froin Oaxaca (4) and Tabaseo (1).... & 123.7 & 125.1 & 16.8 & 13.5 & 13.5 \\
\hline Nine adult males from Yueatán. . . . . . . . . . . . . . . & 124.3 & 124. 8 & 16.7 & 13.6 & 13.6 \\
\hline Five adult males fronı Chiapas (2) and Guatemala (3).. & 122.2 & 123.6 & 16.4 & 13.7 & 13.5 \\
\hline Four adult males from Honduras...................... & 124.2 & 125.5 & 16 & 14 & 13.9 \\
\hline Ten adult males from Costa Rica .................. & 119.2 & 119 & 16.5 & 13.4 & 13.7 \\
\hline Ten adult males from Panamá.............. & 115.7 & 118.3 & 16.6 & 12.9 & 13 \\
\hline 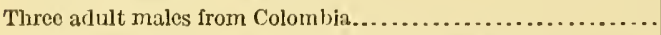 & 115.7 & 123.2 & 16. 3 & 12.2 & 12.7 \\
\hline Ono adult male from western Eeıadór (Guayaquil)........ & 118 & 118 & 16 & 13 & 12 \\
\hline \multicolumn{6}{|l|}{ FEMALES. } \\
\hline Fivo adult femalos from Vera Cruz......... & 125.1 & 130.6 & 16.4 & 13.8 & 13.5 \\
\hline Three adult females from Oaxaca............. & 124.3 & 125.7 & 16.5 & 13.7 & 13.3 \\
\hline 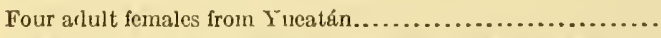 & 123.9 & 131.7 & 15.9 & 13.7 & 13.7 \\
\hline Seven adult females from Chlapas (1) and Guatemala (6)....... & 123.9 & 127.3 & 16.1 & 14.2 & 13.1 \\
\hline 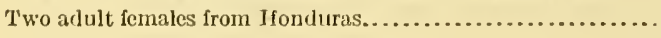 & 128.2 & 131.7 & 16.7 & 14.2 & 13.7 \\
\hline Ten adult females from Costa Rica..................... & 119.9 & 123.7 & 16.3 & 13.4 & 13 \\
\hline Five adult females from eastern Janamá.............. & 114.6 & 120.1 & 16 & 12.6 & 12.6 \\
\hline One adult female froin w estern Eenador (Guayaruíl)........ & 117 & 120 & 15.5 & 12.5 & 13 \\
\hline
\end{tabular}


Barranca de Punta Arenas; Lagarto; Bolsón; Tenório; Volcán de Miravalles; Guápiles; Guácimo), Panamá (Calovévora; Castillo; Santiago de Verágua; Santa Fé; Divala; Lion Hill; San Pablo; Paraiso; Panamá; Sabana de Panamá; Punta de Sabana), Colombia (20 miles from Honda, Tolima; Minca and Cacagualito, Santa Marta; Naranjo; Popayán), and western Ecuadór (Guayaquíl; Babahoyo; Balzár Mountains; Chimbo) to northwestern Peru (Tumbez; Lechugál). ${ }^{a}$

Trogon caligatus Gould, Mon. Trog., ed. 1, 1838, pl. 7 and text (locality unknown; coll. J. Gould); ed. 2, 1858, pl. 16 and text.-GRAY, Cat. Fissir. Birds Brit. Mus., 1848, 43 (Mexico).-Pelzeln, Sitz. Ak. Wien, xx, 1856, 495 (Mexico).Sclater, Proc. Zool. Soc. Lond., 1856, 286 (Córdova, Vera Cruz); 1859, 367 (Jalapa, Vera Cruz), 387 (Playa Vicente, Vera Cruz); 1860, 284 (Babahoyo, w. Ecuadór); 1864, 176 (near City of Mexico); Cat. Am. Birds, 1862, 276 (Guatemala).-Moore, Proc. Zool. Soc. Lond., 1859, 53 (Omoa, Honduras).-Sclater and Salvin, Ibis, 1859, 132 (Pacific coast Guatemala), Proc. Zool. Soc. Lond., 1864, 364 (Panamá).-Lawrence, Ann. Lyc. N. Y., vii, 1862, 290 (Panamá); ix, 1868, 118 (San Mateo, Turrialba, Birrís, and San Juan, Costa Rica).-Salvin, Proc. Zool. Soc. Lond., 1S67, 151 (Santa Fé de Verágua, Panamá); 1870, 202 (Calovévora and Castillo, Panamá); Ibis, 1872, 322 (Chontales, Nicaragua).-Wyatт, Ibis, 1871, 374 (Naranjo, Colombia).-Frantzius, Journ, für Orn., 1869, 312 (Costa Rica).-Taczanowski, Proc. Zool. Soc. Lond., 1877, 32 S (Lechugál, n. Peru); Orn. du Pérou, iii, 1886, 173 (Tumbez, n. Peru).-Boucard, Liste Ois. récol. Guat., 1878, 25; Proc. Zool. Soc. Lond., 1883, 458 (Yucatan; habits).-SALvin and Godman, Ibis, 1880, 174 (Minca, Santa Marta, Colombia, 2,000 ft.); Biol. Centr.-Am., Aves, ii, 1896, 500.-Sunichrast, La Naturaleza, v, 1S81, 239 (Omealca and Uvero, Vera Cruz).-Nutting, Proc. U. S. Nat. Mus., v, 1882, 400 (La Palma de Nicoya, Costa Rica); vi, 18s3, 387 (Sucuyá, Nicaragua).-Zeledón, Proc. U. S. Nat. Mus., viii, 1885, 109 (Costa Rica); Anal. Mus. Nac. Costa Rica, i, 1887, 120 (Birrís de Cartago, Naranjo de Cartago, Alajuela, Las Trojas, Jiménez, aud San José, Costa Rica).-Stone, Proc. Ac. Nat. Sci. Phila., 1890, 206 (Tunkas, Yucatan).-Grant, Cat. Birds Brit. Mus., xvii, 1892, 464, 465 (Balzár Mts. and Babahoyo, w. Ecuadór; Popayán, s. w. Colombia; etc.).-Richmond, Proc. U. S. Nat. Mus., xvi, 1893, 513 (Rio Escondido, Nicaragua).-Cherrie, Expl. Zool. Merid. Costa Rica, 1893, 47 (Lagarto and Boruca, Costa Rica).-UNDERwood, Ibis, 1896, 444 (Volcán de Miravalles, Costa Rica).-Hartert, Novil. Zool., v, 1898, 499 (Chimbo, n. w. Ecuadór, 1,000 ft.).-Salvadori and Festa, Boll. Mus. Zool., elc., Torino, xiv, 1899, no. 339, \& (Punta de Sabana, Panamá).LAntz, Trans. Kansas Ac. Sci. for 1896-97 (1899), 220 (Naranjo, Guatemala).-Allen, Bull. Am. Mus. N. H., xiii, 1900, 135 (Cacagualito and Minca, Sauta Marta, Colombia).-Bangs, Proc. New Eugl. Zool. Club, ii, 1900, 19 (Loma del León, Panamá); Auk, xviii, 1901, 360 (Divala, Panamá).Srinner, Coudor, iii, 1901, 77, 78 (Tapachula, Chiapas; habits; descr. nest and eggs).-Alfaro, Pagiuas Illustradas, i, 1904, 531 (Costa Rica; habits! descr. nest and eggs).-Cole, Bull. Mus. Comp. Zool., 1, 1906, 129 (Chichen, Itza, Yucatan).-Dearborn, Pub. 125, Field Mus. N. H., 1907, Ss (Gualán, Mazatenango, and Patulúl, Guatemala; crit.).-Ferry, Pub. 146, Field Mus. N. H., oru. ser., i, no. 6, 1910, 265 (Guayabo, Costa Rica).

a I have not seen specimeus from northern Peru and very few from westeru Ecuadór. It is possible that these are separable from true $C$. caligatus. 
Trogon] caligatus Gray, Gen. Birds, i, 1845, 70.-Bonaparte, Consp. Av., i, $1850,149$.

[Trogon] caligatus Grax, Hand-list, i, 1869, 81, no. 955.-Sumichrast, Mem. Bost. Soc. N. H., i, 1869, 562 (hot region Vera Cruz).-Sclater and SalviN, Nom. Av. Neotr., 1873, 104.-Berlepsch, Journ. für Orn., 1884, 318 (Naranjo, Colombia); Proc. Zool. Soc. Lond., 1885, 118 (Babahoyo, w. Ecuadór).-Sharpe, Hand-list, ii, 1900, 148.

Trogon caligatus caligatus Bangs, Bull. Mus. Comp. Zool., xxxix, July, 1903, 144 (Yaruca, Honduras; crit.); Auk, xxiv, 1907 (Boruca, Barranca, and Barranca de Punta Arenas, Costa Rica).-Carriker, Ann. Carnegie Mus., vi, 1910, 561 (Costa Rica; crit.; habits).

Trogon concinnus Lawrence, Ann. Lyc. Nat. Hist. N. Y., vii, Feb., 1862, 463 (Lion Hill, Panamá; coll. G. N. Lawrence); ix, 1868, 119 (San Juan, Costa Rica).-Frantzius, Journ. für Orn., 1869, 312 (Costa Rica).

[Trogon] concinnus Gray, Hand-list, i, 1869, 82, no. 965.

Trogon caligatus concinnus Bangs, Bull. Mus. Comp. Zool., xxxix, July, 1903, 145, in text.-Thayer and Bangs, Bull. Mus. Comp. Zool., xlvi, 1906, 216 (Sabana de Panamá).

A[ganus] concinnus Cabanis and Heine, Mus. Hein., iv, Feb., 1863, 188, footnote (Panamá; crit.).

A[ganus] lepidus Cabanis and Heine, Mus. Hein., iv, Feb., 1863, 187 (Babahoyo, w. Ecuadór; coll. Heine Mus.).

[Trogon] lepidus Gray, Hand-list, i, 1869, 82, no. 961.

A[ganus] braccatus Cabanis and Heine, Mus. Hein., iv, Feb., 1863, 184 (Mexico; coll. Heine Mus.).

[Aganus] braccatus Heine and Reichenow, Nom. Mus. Hein. Orn., 1890, 209 (Mexico).

[Trogon] braccatus GraY, Hand-list, i, 1869, 82, no. 959.

Trogon braccatus Lawrence, Bull. U. S. Nat. Mus., no. 4, 1876, 31 (Guichicovi, Oaxaca).-Sumichrast, La Naturaleza, v, 1881, 239.

Trogon chrysomelas, supposed female, Richмомd, Proc. U. S. Nat. Mus., xvi, 1893, 512 (Rio Escondido, Nicaragua; description).

\section{Genus TEMNOTROGON Bonaparte.}

Temnotrogon Bonaparte, Consp. Voluc. Zygod., 1854, 14 (estr. dall' Atteneo Italiano, no. 8, May, 1854). (Type, Trogon roseigaster Vieillot.)

Tmetotrogon a (emendation) Cabanis and Heine, Mus. Hein., iv, Heft i, Jan., $1863,166$.

Rather small Trogons, resembling Trogonurus but auricular feathers elongated, slender (filamentous), curving outward terminally, anterior toes united for basal phalanx only, the adult female with upper parts metallic-colored.

Bill rather stout, the culmen strongly arched, rounded (not ridged), not depressed basally; gonys slightly shorter than mandibular rami, distinctly convex, strongly ascending, the tip of mandible forming a distinct ascending point; basal width of interramal space equal to or greater than its length; tomia distinctly serrate, the subterminal notch deep. Nostril roundish, non-opereulate, mostly covered by

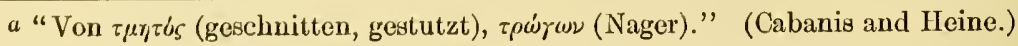


slender, decurved, antrorse bristles; feathers of chin and malar apex antrorse, forming slender bristles, the former strongly recurved; auricular feathers with elongated filamentous tips, curved outward terminally; sixth primary longest, the seventh slightly shorter, the tenth (outermost) much less than half as long as eighth; tail much longer than wing, the middle rectrices truncate, the lateral ones subtruncate at tip, the outermost pair strongly bowed basally. Tarsus about as long as longest anterior toe (without claw), the lower half naked; anterior toes united for basal phalanx only.

Coloration.-Adult male with upper parts, including wing-coverts, metallic green, the middle rectrices, with outer web, metallic greenish blue, inner web grayish bronze, the throat, chest, and breast slategray, the abdomen and under tail-coverts red, the lateral rectrices broadly tipped with white; adult female similar, but wing-coverts and secondaries blackish, narrowly barred with white.

Range.-Island of Haiti, Greater Antilles. (Monotypic.)

\section{TEMNOTROGON ROSEIGASTER (Vieillot).}

HAITIAN TROGON.

Adult male.-Pileum rather dull metallic bronze-green or greenish bronze; back, scapulars, anterior lesser wing-coverts, and upper rump brighter bronze-green, passing into pure metallic green or slightly bluish green on lower rump and upper tail-coverts; outer web of middle pair of rectrices dark metallic blue or greenish blue, except a small subterminal (usually triangular) area of grayish bronze or olive bronze, the inner web grayish bronze, bronze-gray, or bronzy olive, broadly tipped with dark metallic blue; next two pairs of rectrices wholly dark metallic blue or greenish blue, the three outer pairs similar but extensively white terminally, the white area occupying a much greater portion of outer web (most of outer web on outermost pair), which has a subterminal spot of dark metallic blue or blue-black; under surface of inner web of three lateral rectrices (on each side) with an area (more or less well defined) of metallic grayish between the basal dark metallic blue and a subterminal spot of dark metallic blue or blue-black; posterior lesser, middle, greater and primary wing-coverts, alula, and secondlaries blackish, more or less glossed with bronze-greenish (at least on coverts) and narrowly but very regularly barred with white; primaries black, their outer web marked with quadrate spots of white, except proximal portion of longer quills, which are more or less continuously white or edged with white; lores dusky, passing into slate color on orbital, auricular, and malar regions, chin, and upper throat, the lower throat and chest slate-gray, more or less strongly glossed (especially on chest) with bronze-green or greenish bronze: breast, upper abdomen, and ante- 
rior portion of sides clear gray, slightly paler posteriorly; rest of under parts intense pure geranium red, darker along anterior margin, where the line of demarkation between the red and gray is very sharply defined and very regularly transverse; thighs slate-gray or slate color, the feathers of upper portion of tarsus darker; bill yellow; feet dusky horn color (in dried skins); length (dried skins), 262-294 (284); wing, 132.5-145 (138.4); tail, 154-170.5 (160.7); culmen, 16.5-19 (17.4); tarsus, 16-17.5 (16.7); inner anterior toe, 15.5-17 (16.3). ${ }^{a}$

Adult female.-Similar to the adult male, but wing-coverts and secondaries without white bars, the former grayish olive margined terminally with metallic bronze-green or bronze, the latter plain slategray; primaries without quadrate white spots on outer web, which is grayish distally, white proximally; length (skins), 267-285 (276); wing, 133.5-141 (136.2); tail, 149.5-187.5 (163); culmen, 16.5-17.5 (17); tarsus, 16-17 (16.7); inner anterior toe, 14.5-16.5 (15.7). ${ }^{b}$

Island of Haiti, Greater Antilles (Port au Prince, Haiti; Aguacate, La Vega, and mountains above Harabajoa, Santo Domingo).

Trogon roseigaster VieiLlot, Nouv. Dict. d'Hist. Nat., viii, 1817, 314 (Santo Domingo; "Mexico"); Tabl. Enc. Méth., iii, 1823, 1358.-Gould, Mon. Trog., ed. 1, 1838, pl. 20 and text; ed. 2, 1858, pl. 32 and text.-SAllÉ, Proc. Zool. Soc. Lond., 1857, 235 (Santo Domingo; habits).-Bryant, Proc. Bost. Soc. N. H., xi, 1867, 95 (Santo Domingo).

T[rogon] roseigaster Gray, Gen. Birds, i, 1845, 69.-Bonaparte, Consp. Av., i, 1850, 149.

[Trogon] roseigaster Gray, Hand-list, i, 1869, 83, no. 987.

Temnurus roseigaster Gould, Mon. Trog., ed. 1, 1838, Synop. Species of Temnurus, sp. 2.

Trogon (Temnurus?) roseigaster Gould, Mon. Trog., ed. 1, 1838, List of Plates, sp. 20.

[Temnotrogon] roseigaster Bonaparte, Consp. Voluc. Zygod., 1854, 14.-Cory, List Birds West Ind., 1885, 18.

Temnotrogon roseigaster CoRY, Birds of Haiti and San Domingo, 1885, 95; Auk, iii, 1886, 360; xii, 1895, 279 (Santo Domingo); Birds West Ind., 1889, 155; Cat. West Ind. Birds, 1892, 11, 103, 131, 142.-Cherrie, Contr. Orn. San Dom., 1896, 19 (Aguacate, Santo Domingo).-Cirristr, Ibis, 1897, 330 (mts. above Harabajoa, Santo Domingo).

T[emnotrogon] roseigaster Cory, Birds Haiti and San Domingo, 1885, pl. (13).

Tmetotrogon roseigaster Gould, Mon. Trog., ed. 2, 1875, Synopsis of Species, p. xix. Trogon rhodogaster Temminck, Pl. Col., iii, livr. 63, May, 1825, gen. Couroucou, sp. 14 (based on Levaillant, Courouc., pl. 13, p. 18; Caleçon rouge Buffon).

$T$ [metotrogon] rhodogaster Cabanis and Heine, Mlus. Hein., iv, Feb., 1863, 166 (Haiti).

Tmetotrogon rhodogaster Grant, Cat. Birds Brit. Mus., xvii, 1892, 438.

[Tmetotrogon] rhodogaster Sharpe, Hand-list, ii, 1900, 147.

[Temnotrogon] rhodogaster Sclater and Salvin, Nom. Av. Neotr., 1873, 103.

Trogon domicellus Cuvier, Règne Anim., ed. 2, i, 1829, 459. 


\section{Genus PRIOTELUS Gray.}

Temnurus $a$ (not of Lesson, 1831) Swainson, Classif. Birds, ii, July, 1837, 337. (Type, T. albicollis Swainson=Trogon temnurus Temminck.)

Priotelus Gray, List. Gen. Birds, 1840, 10. (Type, Trogon temnurus Temminck.)

Prionotelus (emendation) Reichenbach, Av. Syst. Nat., 1850, pl. 88.-Cabanis and Heine, Mus. Hein., iv, 1863, 164.

Prionoteles (emendation) Sclater and Salvin, Nom. Av. Neotr., 1873, 103.

Rather small Trogons agreeing with Temnotrogon in filamentous auricular feathers, slight extent of cohesion of anterior toes, and similarity of sexes in coloration, but differing conspicuously in form of middle rectrices (which are concavely incised and laterally pointed terminally) and in conspicuous white subterminal spots on outer webs of secondaries.

Bill rather stout but broader than deep basally, the culmen moderately arched, rounded (not ridged), the gonys about as long as mandibular rami, distinctly convex, strongly ascending terminally, the tip of mandible forming a distinct but small ascending point; basal width of interramal space about equal to its length; tomia distinctly serrate. Nostril roundish, non-operculate, concealed, or nearly so, by antrorse, decurved bristles. Feathering of head normal, except auricular feathers, which have elongated, filamentous tips, curved outward; feathers of chin and malar apex bristle-like, antrorse, the former strongly recurved; seventh, or seventh and sixth primaries longest, the tenth (outermost) less than half as long as eighth; tail longer than wing, the eight middle rectrices with tip strongly concavely incised, with web on each side of the excision expanded and prolonged into sub-falcate points, the two lateral pairs with tip obliquely truncate or subtruncate, with inner web longest and usually (at least in adult males) forming a blunt or rounded point. Tarsus longer than longest anterior toe (without claw), naked for lower half or more; anterior toes united for basal phalanx only.

Coloration.-Pileum dark metallic violet-blue to greenish blue, passing into black on sides of head; rest of upper parts except remiges and lateral rectrices metallic green, more bluish on rump and upper tail-coverts; remiges spotted with white, the lateral rectrices extensively white terminally; anterior under parts, as far backward as middle of abdomen, light gray (the throat more whitish), posterior under parts red. (Sexes alike.)

Range.-Island of Cuba, Greater Antilles. (Monotypic.)

KEY TO THE SUBSPECIES OF PRIOTELUS TEMNURUS.

a. Larger (male averaging: Wing 123.6, tail 116.4, tarsus 16.8, inner anterior toe, 15.3, female averaging: Wing 121.8, tail 114.4, tarsus 17, inner anterior toe 15.2); bill relatively smaller and narrower; red of under parts deeper. (Island of Cuba.)

Priotelus temnurus temnurus (p. 794). 
aa. Smaller (male averaging: Wing 117.8, tail 112.8, tarsus 16, inner anterior toe 14.4; female averaging: Wing 117.6, tail 113.6, tarsus 16.4, inner anterior toe 14.4); bill relatively larger and broader; red of under parts lighter. (Isle of Pines, south of Cuba.)................. Priotelus temnurus vescus (p. 795).

\section{PRIOTELUS TEMNURUS TEMNURUS (Temminck).}

CUBAN TROGON.

Adult male.-Pileum dark metallic blue, more violaceous on occiput; loral, suborbital, and auricular regions black; back, scapulars, and rump metallic green or slightly bronzy green, passing into more bluish green on hindneck and upper tail-coverts; six middle rectrices glossy blue-black or dark violaceous blue, the middle pair with outer webs brighter and less violaceous blue, passing into dark violet-blue terminally, their inner webs bronze-green or greenish bronze, passing, through blue, into dark violet-blue terminally; three outer rectrices (on each side) extensively white terminally, blue-black basally, the outer web of second and third with one to three white spots on black portion of outer web, the inner web sometimes with one or two transverse spots of white; lesser and middle wing-coverts dark metallic green, broadly margined with much brighter green; greater coverts very dark bluish green narrowly edged with brighter bluish green, the outer web with a very large terminal subquadrate spot of white; alula and primary coverts black, the former with three white spots on outer web, the latter with a subterminal spot of white; proximal secondaries (tertials) dark metallic bluish green; other secondaries black, edged with metallic bluish green and with a very large subterminal quadrate spot of white on outer web; primaries black, the terminal half (more or less) of outer web with quadrate spots of white, the basal portion continuously white, except the two outermost, which are spotted to the base; chin, throat, and malar region white, passing into clear gray (no. 7) on chest, breast, and upper abdomen and sides, the remaining under parts pure geranium red, the line of demarkation between the red and the gray forming a very sharp transverse line; thighs grayish white, the feathers dark grayish basally; maxilla brownish black, except rictal portion, which, together with the mandible, is clull vermilion red; iris carmine red; ${ }^{a}$ feet dark brownish (in dried skins); length (skins), 247-260 (255); wing, 117-128 (123.6); tail, 105.5-124.5 (116.4); culmen, 16.5-18 (16.8); tarsus, $16-18$ (16.8); inner anterior toe, 15-16.5 (15.3). ${ }^{b}$

Adult female.-Precisely like the adult male, but averaging slightly smaller; length (skins), 248-25s (251); wing, 118-125 (121.8); tail, 106-120 (114.4); culmen, 16-18 (17.2); tarsus, 16.5-17.5 (17); inner anterior toe, $14-16$ (15.2). ${ }^{c}$

a Palmer and Riley.

$b$ Ten specimens.

$c$ Six specimens. 
Island of Cuba (Havana; Cabañas; El Guamá; Guamá; Guantánamo; Baracoa; San Diego de los Baños; near Trinidád; San Cristóbal; Holquín; Remédios; Figuabas; Santiago de Cuba).

Trogon temnurus Temminck, Pl. Col., iii, livr. 55, Feb., 1825, pl. 326 and text (Havana, Cuba).-Vigors, Zool. Journ., iii, 1827, 443.-Lesson, Traité d'Orn., 1831, 120.-Gould, Mon. Trog., ed. 1, 1838, pl. 19 and text.D'Orbigny, in La Sagrás Hist. Nat. Cuba, Ois., 1840, 165, atlas, pl. 26.Gundeach, Journ. Bost. Soc. N. H., vi, 1857, 319.

Trogon temnura Clark, Proc. Zool. Soc. Lond., 1841, 53.

P[riotelus] temnurus Gray, List Gen. Birds, 1840, 10; Gen. Birds, i, 1845, 70.

Priotelus temnurus Gray, List Fissir. Birds Brit. Mus., 1848, 43.-Cabanis, Journ. für Orn., 1856, 106 (habits).—GundLACH, Journ. für Orn., 1859, 348; 1874, 165 (habits); Repert. Fisico-Nat. Cub., i, 1866, 298; Orn. Cubana, ed. 1895, 153.-Cory, Auk, iii, 1886, 360; Birds West Ind., 1889, 155; Cat. West Ind. Birds, 1892, 11, 103, 128, 142.-HARTERT, Kat. Vogelsamml. Mus. Senckenb., 1891, 135.-Chapman, Bull. Am. Mus. N. H., iv, 1892, 299 (near Trinidád, s. Cuba; habits).

[Priotelus] temnurus Bonaparte, Consp. Av., i, 1850, 150.-Gray, Hand-list, i, 1869, 83, no. 988.-Gundlach, Journ. für Orn., 1861, 336.-Sharpe, Handlist, ii, 1900, 147.

P[rionotelus] temnurus Cabanis and Heine, Mus. Hein., iv, 1863, 164, footnote. Prionotelus temnurus Gould, Mon. Trog., ed. 2, 1875, pl. 33 and text.-Grant, Cat. Birds Brit. Mus., xvii, 1892, 439 (San Cristóbal and Remédios, Cuba).Menegaux, Rev. Franç. d'Orn., no. 2, 1909, 23 (Figuabas, e. Cuba).

Prionoteles temnurus Gould, Mon. Trog., ed. 2, 1875, List of Plates, sp. 33.

[Prionoteles] temnurus Sclater and Salvin, Nom. Av. Neotr., 1873, 103.Cory, List Birds West Ind., 1885, 18.

Temnurus albicollis Swainson, Classif. Birds, ii, July, 1837, 337.

Trogon (Temnurus) albicollis Gould, Mon. Trog., ed. 1, 1838, List of Plates, sp. 19.

Trogon silens Würtтenberg, Erste Reise Nordlische Amerika, 1835, 68, 74, footnote, in text (Cuba).

Temnurus silens Hartuadb, Naumannia, 1852, 51.

\section{PRIOTELUS TEMNURUS VESCUS Bangs and Zappey.}

\section{ISLE OF PINES TROGON.}

Similar to P. t. temnurus, but with decidedly shorter wing, tail, and middle toe, and relatively larger and broader bill, and with red of under parts appreciably lighter.

Adult male.-Length (skins), 232-243 (239); wing, 116.5-119 (117.8); tail, 108-122 (112.8); culmen, 17-18.(17.5); tarsus, 15.516.5 (16); inner anterior toe, $14-15.5$ (14.7). ${ }^{a}$

Adult female.-Length (skins), 234-238 (236); wing, 116-120 (117.6); tail, 111.5-116 (113.6); culmen, 16.5-17.5 (17); tarsus, 16-17 (16.4); inner anterior toe, $13.5-15$ (14.4) ${ }^{a}$

Isle of Pines, near Cuba (Almacigos; Nueva Gerona; Callebonita; Puebla Nueva; Pasadita).

Prionotelus temnurus vescus BAngs and ZAPPEy, Am. Nat, xxxix, no. 460, April, 1905, 204 (Almacigos, Isle of Pines, Cuba; coll. E. A. and O. Bangs). 



\section{INDEX.}

A.

Abalius.

$$
\text { bridgesi }
$$

Abeillea abeillei

abeillei, Abeillea

Abeillia....................... 51

Abelleia....................... 518

Adelomya.................... 518

Basilinna....................... 517 r. Baucis.............. 517

Baucis..................... 517,518

Daucis....................... 518

Mellisuga..................... 517

Ornismya................... 516,517

Ramphomicron ............... 517

Trochilus.................... 515

Abeilleia abeillei....................... 518

Abeille's Humming Bird................. 515

Abeillia.

abeillei

306,516

typica..........................516, 515

abnormis, Ametrornis.................. 314

Acanthura ......................... . 277,715

Acanthurus........................... 277

microrhynchus........... $2 \pi 7,279$

Acanthylis........................... 714

albicollis.................... 699

brachyura................... 729

brunneitorques................. 713

collaris................... 697,698, 701

lencopygialis.................. 715

oxyura................... 727

pelasgia................. 719,724

poliourus................... 729

rutila...................... 713

saxatilis.................... 688

semicollaris.................. 702

senex..................... 711

spinicauda.................. 716

vauxi...................... 724

zonaris...................... 702

Acanthyllis.......................... 714

acedesta, Dendrocincla homochroa. 2S8, 293, 294, 295

Acontistes............................ 84

Acrorchilus........................ 161, 188, 184

antisiensis.................. 184

erythrops.................... 184

crythrops.......... 184, 185

griseigularis......... 184, 185

rufigenis........... 184, 186

hellmayri.................. 184

pallida........................ 184

acuta, Chrtura................... 716, 724,725

Hirundo.................... $715,716,725$

acutus, Cypselus
Page.

Adelomya abelliei..................... 518

guimeti.................... 515

Adelomyia? castaneiventris............... 503

Admirable Humming Bird ............... . 568

adolphi, Eremita....................... 325

Phæthornis .............. 326, 327, 329

Phothornis .................. 316, 326

adolphi.... 316,324, 325, 326

Pygmornis .................... 325

Pygornis ...................... 325

adorabilis, Dialia ...................... 676

Lophormis...... . . 669,670,671,675,676

Adorable Coquette..................... 675

ænea, Glaucis......................... 334, 335

hirsuta............... 330,334

æneicauda, Chalybura................... 390

Hypuroptila.................. 390

æneicaudus, Polytmus.................. $\quad 390$

æneoriridis, Riccordia.................... 545

ricordii .... $542,543,544,545$

æneus, Glaucis...................... 334, 335

hirsuta................. 335

hirsutus, var.............. 335

æquatorialis, Dendrornis................. 241

erythropygia..... $\quad 241$

Gouldia conversi............ $6 \$ 1$

Popelairea................. 681 conversi............ 681

Popelairia conversi........... 681

conversii........678,679

Sittasomus............... 279

Thamnistes................ 22

Aëronautes..................... $6 \$ 5,687,690$

melanoleucus............... 687,690

Aërornis............................. 710

niveifrons.................... 710,711

æthiops, Thamnophilus ............... 12, 48

Ethurus............................. 338

polytmus taylori............... 341

affinis, Dacryophorus ................... 263

Deudrocolaptes............. 262,263, 267

Dysithamnus.................. 54,55,57 affinis.............. 54

Glaucis......................... 334 hirsuta............ 330,333,334 hirsutus, rar............ 334

Lepidocolaptes.................... 263

Picolaptes........... 259, 262, 263, 264, 267 affinis.............259, 261,263

Polytmus..................... 334

Thamnophilus................ 39,42, 44 doliatus.......... 44

Thripobrotus.................... 263

Xenops....................... 172 


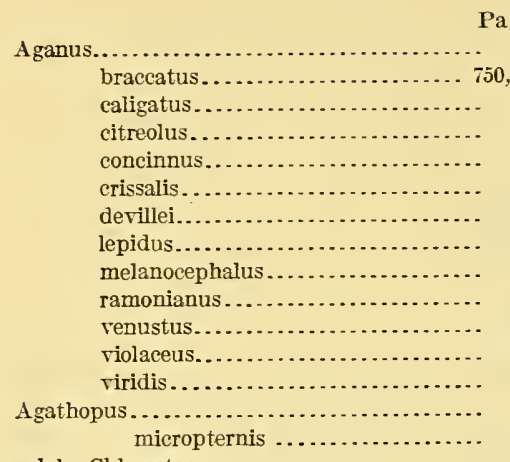

aglala, Chlorestes ....................... r. Saucerottia ............

aglaiæ, Amazilius .......................

Ariana riefferi, var................

Hemithylaca....................

Polytmus.......................

Trochilutas.

Agyrtria........... $305,406,430,431,435,522,537$ amabilis...................... 525 amabilis................ 525

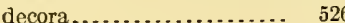

boucardi........................ 541

buffonii........................ 390

caeruleigularis................... 540 candida................. 431, 432,433,434 o. Chalybura.................... 386 buffonii............. 390 cæruleiventris........ 357 goudoti ............. 538 viridis .............. 473

chionopectus.................... 431 typica .............. 431

chionura......................... 403 chlorocephala................... 528 cyanocephala................ 423, 426 o. Cyanochloris caeruleigularis ...... 540 decora........................ 526 faustinæ..................... $\quad 427$ goudotii........................ 538 linnæi......................... 432 luciæ....................... 431,434 maculata ...................... 431 maculicauda..................... 406 malvinæ....................... 431 margaritacea..................... 434 microrhyncha................... 429 niveipectus..................... 431 quadricolor..................... 423 rosenbergi...................... 523 salvini........................ 430 tenebrosa...................... 528 tephrocephala................... 406 tobaci......................... 432 в. Uranomitra cyanocephala ...... 426 quadricolor ........ 423 viridipallens.................... 510 viridis........................ 473 viridissima................... 431 Aithurus.................... 301,303,838, 627 fuliginosus.................... 341 polytmus............ $3399,340,341,342$
Page.

Aithurus scitulus ................. 339, 341,342 taylori ....................... 341

Aiturus polytmus..................... 341

Alaudidæ............................. 2, 158 albescens, Synallaxis ................ 187, 188, 195 albescens........... 188, 195

albicans, Thamnophilus................. 38 radiatus.......... 38,139

albicapilla, Siptornis....................... 161

albiceps, Siptornis....................... 161

albicincta, Chætura....................... 699

zonaris, $a . \ldots \ldots \ldots \ldots .699$

Hemiprocne................. 698 zonaris............ 699

Streptoprocne zonaris. . $\mathbf{6 9 7}, 698,699,700$

albicollis, Acanthylis. .................... 699

Dendrocopus.................. 235, 238

Hirundo....................... 697,699

Temnurus..................... 793,795

Xiphocolaptes................ 236, 238

albicoronata, Microchera................... 582

albicrissa, Anthoscenus.................. 345

Floricola ...................... 345

longirostris............ 345

Heliomaster................... 345

Heliomastes.................. 345

albifrons, Pipra......................... $\quad 16$

albigula, Myrmotherula .................. $\quad 70$

albigularis, Dendocolaptes................. 159

Sclerurus................... 164, 166

albigularis........... 164

Synallaxis.................... 188

albescens...... 188, 194, 195

albiventer, Trogon..................... 751

albiventris, Drymophila.................. 105

Myrmeciza longipes ............ 105

Thamnophilus nævius.......... 49

albocoronata, Chrysolampis................ 582

Topaza.................. 582

albo-coronata, Mellisuga ............... 580,582

Microchera............. 581,582

albogularis, Sclerurus ................. 164, 166

albolineatus, Picolaptes.................. 258

albus, Trochilus......................... 461

Alcedines............................. 296

Alcedinidæ............................. 730

alexandrei, Trochilus .................... 636

alexandri, Archilochus............. $628,633,636$ Mellisuga................... 636

Ornismra.................. 636

Selasphorus................. 636

Trochilus............... 627,634,630

alfaroana, Amazilia..................... 441

Amizilis..................... 441

Saucerottea.................. 441

Saucerottia................ 437,411

cyanifrons........... 441

Alfaro's Humming Bird.................. 441

aliciæ, Amazilia...................... 438

Amizilis tobaci................. 438

Saucerottea tobaci................ 438

Saucerottia tobaci................ 433

alineius, Heliothrix barroti............... 564

Heliothryx barroti............... 562

alleni, Selasphorus $596,597,607,608, \mathbf{6 0 9}, 611,612,616$ 
Allied Emerald

Woodhewer...................... $\mathbf{2} 61$

alticincta, Formicirora................. 83

Microrhopias grisea............. $\pi ;, 81$

amabilis, Agyrtria....................... 525 amabilis............... 525

Coeligena........................ 524 ค. Damophila.......... 524

Damophila............. 524,525,526

Juliamyia.................... 524

Polyerata................ 5 $\$ 23,525,526$

Trochilus.................... 522, 524

Amalasia.......................... 647

elizæ........................ 651

enicura...................... 649

henicura.................... 649

Amalusia........................... 647

elizæ......................... 651

enicura...................... 649

Amathusia.......................... $64^{-1}$

(Doricha) elizæ............. 651

(Egolia) evelynæ............. 643

enicura.......................... 619

(Manilia) pulchra............. 656

amazili, Ornismya..................... $\quad 412$

Amazilia............................ 405

alfaroana........................ 441

aliciæ........................ 438

arsinoe...................... 418,450

berilina ....................... 450

beryllina........ . . . . . . . . . . . . 450, 451

cervineiventris.................. 415

cervinisentris............... $413,414,410$

cervinisentris........ $₫ 14$

chalconota......... 415

typica............. $\quad 414$

chalconota................... $\$ 15$

cinnamomea................. 415,419 saturata............ 419

corallirostris .................... 419

cupreicauda.................... $43 \mathrm{~S}$

cyanifrons...................... 436

cyanocephala.................. 426,428

guatemalensis....... 425

typica............. $42 \pi$

cyanura................... $415,446,447$

devillei..................... 418

devillii........................ 448

dubusi ...................... 412

dumerillii.................... 448

edwardi........................ 445

edwardii....................... 445

erythronota.................. 437

eximia......................... 395

feliciæ...................... 438

forreri........................ 416

fuscicaudata.................. $\quad 410$

dubusl............. 412

fuscicaudata......... $\$ 11$

jucunda............ 407

typica............. $\$ 12$

fuscocaudata................... $\$ 11$

graysoni.................... 420

guatemalensis................. 428

guerrerensis.................. 422
Page.

Amazilia iodura ........................ 438

latirostris................... 372

maria...................... 448

mariæ.................... 448, 450

niveirentris.................... 443

niveorenter........... ......... 443

ocai........................ 435, 452

(Pyrrhophæna) graysoni......... 420

riefferi..................... $\quad 111$

jucunda................ 407

salvini....................... 430

saturata................... $\quad 419$

saucerottii................... 436

sophiæ....................... 141

sumichrosti................... 451

tobaci........................ 137

tzacatl..................... $\quad \$ 10$

dubusi............... $\quad 412$

verticalis................... 423

tioliceps..................... 425

viridifrons................... 422

viridigaster.................. 138

viridiventris..... ............. \pm 38

फarszewiczi....... . . ......... 436

warszewiezi.................... 436

xantusii....................... 383

yucatanensis................ $413,414,415$

yucatanensis........ 414

amazilia, Orthorhynchus............. 405,406

Amazilicus . . . . . . . . . . . . . . . . . ....... 405

Amazilina........................... 405

Amazilis................................ 105

cervinitentris .................. 414

cinnamomea.................. 418

cinnamomeus................... 415

saturatus.......... 419

fuscicaudatus............... $\$ 10$

graysoni..................... 420

tzacat1....................... $\quad 110$

Amazilius........................ . 405

aglaiæ...................... $\quad 112$

arsinoe....................... 450

cerviniventris................... 414

corallirostris.................. 418.419

derillei...................... 445

dubusi...................... 412

edward........................ 444

erythrorhynchus............... $41 \mathrm{~s}$

haematorhynchus.............. $41 \mathrm{~s}$

latirostris ..................... $3 \pi 2$

ocai......................... 452

riefferi.................... $\quad 411$

sophiæ...................... 410

Amazillia............................ 405

cinnamomea.................. $41 \mathrm{~s}$

corallirostris.................. 418,419

riefferi ....................... 411

amaura, Phaëthornis.................... 328

Pygmornis .................... 328

amazonicus, Thamnophilus ............. 51

amazonus, Sittasomus ...................... 279

olivaceus............. $\quad 279$

ambiguus, Thamnophilus................ 48

Trogon ....................

Trogonurus........... $762,764,772,773$ ambiguus......... 762 ,

$764,765,772$ 


\begin{tabular}{|c|c|}
\hline amethystina, Delattria... & $\begin{array}{r}\text { Page. } \\
\text { Anabates cervinigularis....... }\end{array}$ \\
\hline methystinus, Lampornis................ 454, & erythrocephalus................ 1 \\
\hline $494,495,496,497,498,499$ & ferruginolentus... \\
\hline amethystinus.... 495, & eucophthalmus.................. \\
\hline $496,497,498$ & lineaticeps...... \\
\hline Trochilus. & montanus...... \\
\hline Ametrornis. & nigropectus..... \\
\hline (n................ & ochrolæmus..................... \\
\hline Amila cerviniventris . . . . . . . . . & rufifrons......................... \\
\hline amizili, Ornismya..................... 405 & rubiginosus................ 214, \\
\hline Orthorhynchus................. & squamigera................... \\
\hline Amizilis ..................... $305,405,406,435$ & striaticollis..................... \\
\hline alfaroana........................ 441 & subalaris................... 207,2 \\
\hline bangsi...................... 407,420 & superciliaris................... 2 \\
\hline 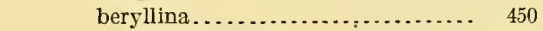 & temporalis....................... \\
\hline
\end{tabular}

beryllina ...................... 450 viola................. 451

beryllinus....................... 450 cerviniventris .................... 414 cerviniventris........ 414 chalconota.......... 415

cinnamomea.................... 418 cinnamomea......... 418 saturata............. 419 cyanocephala.................... 408 cyanocephala... 408, 425,427 guatemalensis.. 408, $\mathbf{4 2 7}, 428$ cyanura....................... 446 devillii....................... 448 edward....................... 444 edwardi........................ 445 forreri.................... 407, 416 fuscicaudata................... 411 graysoni.............. 407, 417, $\mathbf{4 1 9 , 4 2 0}$ latirostris..................... 405 microrhyncha............... 408,428 ocai.......................... 452 rutila....................... 405,407 corallirostris........... 407, 417, $\mathbf{4 1 9}$ rutila.......... 407,416,419,420 salvini..................... 408,429 sophiæ....................... 441 sumichrasti..................... 452 tobaci......................... 437 alicix................... 438 erythronota............. 437 feliciæ.................. 438 tzacatl..................... 407, 410 dubusi................. 412 jucunda.............. 407, 409 tzacatl............... 407,408 verticalis................... 408, 122 violiceps................... 408,424 viridifrons................... 408, 421 warszewiezi.................. 436 yucatanensis................... 413 cerviniventris...... 407,414 chalconota........ 407,415 yucatanensis...... 407,412

Amizillis ........................... 405

fuscicaudata................ 410

tzacati........................ $\quad \mathbf{4 1 0}$

Anabasitta. .......................... 177

Anabates........................... 186 airicapillus.................. 201,203 auritus...................... 197 boissonneautii............. 196, 197, 198
Anabatidæ......................... 1, 157 anabatina, Dendrocincla.... . . 286, 287, 289, 290, 291 anabatina... 287, $\mathbf{2 8 8 , 2 9 0}$

Anabatinæ.......................... 157

anabatinus, Dendrocops................ . .290

Dendromanes. . . . . . . . . . .... 290, 291

Thamnistes............... 21, 23, 24 anabatinus........ 2:, 23

Anabatoides........................... 162

Anabazenops......................... 162 lineatus................... 211 mentalis................... 207 striaticollis................ 207 subalaris .............. 207,211 lineatus............ 211

temporalis................ 207 variegaticeps............... 209

Anabaztenops rariegaticeps ............... 209 anais, Ornismya................ 4\$0, 481, 483,485 Petasophora..................... 481

Ramphodon..................... 481

Rhamphodon.................... $4 \$ 3$

Trocbilus........................ 483 analis, Formicarius ................ 117, 119,124 analis............... 117

Merulaxis....................... 5

Myothera................ 115,117,119,124

Myrmornis..................... 117

Ancistrops.......................... 162

andrei, Dysitbamnus affinis.............. $\quad 54$

mentalis......... 54, 55,57

Anecorbamphus...................... 170

anguina, Dendrocincla olivacea............ 288

angustipennis, Chlorostilbon.............. 559

Chrysomirus.............. 559

Trocbilus................ 547,559

Anisodactylæ................... 296, 297,730

$\Lambda$ nisoterus............................. $\quad 314$

anna, Atthis......................... $\quad 622$

Calliope......................... 622

Calliphlox...................... 621

Calypte................... 596,597, $616,618,619,621,622,628,636$

Crochilus....................... 621

Mellisuga..................... 621

Oruismya......................618,621

Selasphorus..................... 621

Sclosphorus..................... 621

Trochilus.......................... 621

0. Atthis................. 621

Anna Humming Bird ................ 619 
annæ, Calipte

Calypte.

Zephyritis.

Anomalogonatæ.

Anoplops.

bicolor.

cristata

griseiventris.................. 131

hofimannsi.................. 131

leucaspis..................... 131

lunulata...................... 131

melanosticta................. 131

olivascens.................... 131,132

pallidus...................... 131

ruficeps ..................... 131

rufigula.................... 130,131

salvini....................... 131

Antbird, Bare-crowned.................. $\quad 99$

Bare-fronted................... 101

Bicolored.................... 132

Black Tyrannine............... 91

Cassin's........................ 110

Cherrie's....................... 113

Costa Rican Bare-crowned........ 101

Dusky Tyrannine ............... 95

Olive-sided .................. 132

Salvin's..................... 109

Sclater's...................... 111

Spotted...................... 128

Tyrannine.................... 93

White-bellied................... 107

Zeledón's...................... 114

Antbirds............................ 2,8

Anthocephala eastaneiventris........ 504,506, 507 anthoides, Asthenes..................... 161

anthophilus, Phaëthornis................ 316

Phoethornis................ 316 anthophilus ..... 316

Trochilus................ 316

Anthoscaenus ....................... 344

Anthoscenus...................... 304, $\mathbf{3 4 4}$

albicrissa.................. 345

constanti................... 352

constantii................... 345

constantii..... $345,350,351$

leocadiæ... 345, 350, 351, 352

leocadiæ .................. 352

longirostris............... 345, 348

longirostris....... $345, \mathbf{3 4 6}$ pallidiceps..... $345,346,349$

superbus pallidiceps........... 349

Anthracothorax................... 305,454 aurulentus.... $455,457, \mathbf{4 6 9}, 470,472$ chlorolaimus............ 477 dominicus............... 455, $456,457, \mathbf{4 6 8}, 469,470$ $\beta$. Floresia porphyrurus ..... $\quad 459$ gramineus............. 456,457 holosericeus.............. 476

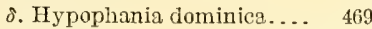
mango.......... 455,457,462,617 nigricollis............... 455, 462 irideseens... . 456,457, 460 nigricollis......... 456, $457,459,462$

porphyrurus ...... 459
Anthracothorax prevosti gracilirostris Page. hendersoni......... 466 prevosti.......465, 466 prevostii ............. 465, 467 gracilirostris...... 456, $457,463, \mathbf{4 6 5}$ hendersoni........ 456, $457,463, \mathbf{4 6 6}$ prevostii. $456,457, \mathbf{4 6 3}, 465$ r. Sericotes .............. 473 chlorolaimus .... 477 holosericeus..... 476 veraguensis ..... 467 veraguensis ........ 456, $\mathbf{4 5 7 , \mathbf { 4 6 7 }}$ violicaudus iridescens ..... 456 viridis ........... 455, 457,472

Antillean Collared Swift............... 701

antiqua, Erythronota................... 437

Antisianus............................. 733

antisianus, Calurus.................... 735

Pharomacrus............... 735

Trogon................... 733,735

antisiensis, Acrorchilus.................. 184

Pharomachrus............. 735,736

Pharomacrus................ 735

Siptornis .................... 184

Synallaxis................... 184

Trogon .................... 733.735

antoniæ; Trochilus.................... 336

Antpitta. Costa Rican.................. $\quad 149$

Dives....................... 154

Guatemalan.................. 148

Lawrence's .................. 155

Lizano's...................... 156

Mexican...................... 150

Michler's................... 141

Nelson's...................... 151

Talamanca.................. 156

Zeledón's...................... 142

Antshrike, Barred-crested................ $\quad \mathbf{4 5}$

Black-crested.................. 37

Bridges's....................

Colombian Crested.............. 33

Fasciated................... 19

Gorgona Island ............... 5

Holland's.................. $\mathbf{2 8}$

Mexican................. $\$ 4$

Pacific...................... 43

Russet. . . . . . . . . . . 23

Slaty ...................... 49

Tawny...................... $\mathbf{\Omega}$

Turbo..................... $\$ 6$

Yueatan.................. 14

Antthrush, Black-headed................ 118

Hoffmann's................ 123

Intermediate.............. 121

McLeannan's................. 135

Mexican ..................... 119

Nicaraguan................ 120

Panama.................... 1:3

Richardson's................ 139

Rufous-breasted.............. 195

Yueatan................... 121

Antvireo, Northern..................... 55

Spotted-crowned.............. 58

Streaked-crowned.............. 59 


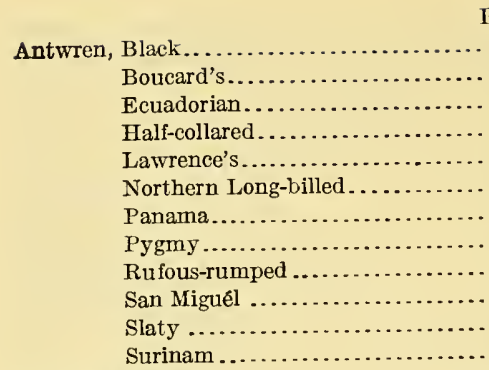

Anumbius striaticollis................... anxius, Xenicopsis.................... 206, 20 Aphantochroa......................... 363 cirrhochloris............... 365 cuvieri................... 364 cuvierii saturatior.......... 365 roberti.................. 366

apicalis, Trochilus...................... 316 Apodinæ............................. 683, 685 approximans, Xenops.................. 172 Apus................................ 685 apus, Hirundo ......................... 685 aquila, Eutoxeres.................... 311,313 aquila................. 311

Trochilus.................... 310,311,313 Archilochus.......... 308, 309, 595, 618, 627, 628, 636 alexandri.............. 628, $\mathbf{6 3 3}, 636$ colubris........... . 432,628, 629, 633 violajugulum............. 628,636 ardens, Selasphorus...... 596, 597, 604, 605, 606, 607 ardesiaca, Myiothera.................... 10 ardesiacus, Dysithamnus................ 48,53 arechavaletæ, Stipituropsis............... 14

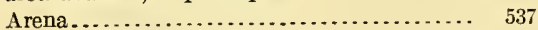
boucardi..................... 537,541 arequipæ, Siptornis.................... 161 argentifrons, Scytalopus................. 7 argentinus, Xiphocolaptes................ 236 argyobronchus, Xenops................. 172 Ariana.............................. 435 cyanifrons...................... 436 cyanura........................ 446 erythronota.................... 437 feliciæ........................ 437 niveiventris.................... 443 riefferi....................... 411 var. aglaiæ................ 412 var. jucunda.............. 407 var. suavis............... 412 sancerottei. sophiæ. 440,441 viridigaster ..................... 438 warszwiczi..................... 436

Arinia............................. 537

boucardi...................... 537,541 'arsennii, Ornismya..................... 381 arsinoe, Amazilia.................... 448, 450 $\Delta$ mazilius..................... 450 Ornismya.................... 448, 450 Polytmus................... 450

Aspasta.............................. 570

lcadbeateri.................. 572

otero......................... 572 splendens.

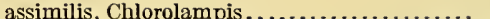

Chlorostilbon............ 549,558, 559

Hylocharis .................... . 559

Myrmotherula.................. 61

Trogon...................... 763

Trogonurus................... 763

Asthenes ............. 161

anthoides..................... 161

humicola.................... 161

modesta...................... 161

striaticeps. .................... 161

atala, Chlorestes....................... 560

Chlorostilbon..................... 560

Chrysomirus..................... 560

Hylocharis.................... 560

Ornismya......................... 560

Prasitis......................... 560

Saucerottia...................... 560

atra, Pyriglena......................... 14

atricapillus, Anabates ................. 201,203

Philydor.................. 202,203

Trochilus.................... 463

atricollis, Pothinus...................... 764

Trogon................ 761, 764,783

atrimentalis, Phæthornis ................ 317

striigularis ........ $\quad 317$

atrinucha, Erionotus punctatus..........49,52

Thamnophilus.............. 51,52 nævius........... 52

atripes, Picolaptes..................... 261

atrirustris, Dendrocincla................. 292

Dendrocops................... 292

Dendromanes................. 292

atrogularis, Myrmotherula................ 62

atrothorax, Myrmoderas................... $\quad 15$

Atthis.................... 308,587,591, 621 anna............................ 622

calliope......................... 591

costæ............................. 625

ellioti......................... 594,595

eloisœ......................... 594

helenæ..................... 627

heloisa........................ 594 ellioti..................... 594 heloisa.............. 592, 594,595 morcomi.................. 595

heloisæ..................... 593, 594

morcomi.......................... 595

Augasma............................ 526

bicolor................... $\quad 530$ smaragdineum ............... 526, 528

Augasmus........................... 526

auranteiventris, Trogon............... 779,780 aurantiiventer, Pothinus................ 779

aurantiiventris, Pothinus ............... 780

Trogon............. 779, 780, 783

Trogonurus......... 763, 765, 780 aurantiiventris.. 763

765,778 auratus, Trochilus . . . . ............... 479, 480 (Culampis)........... 479

Trogon........................ 763 aureigaster, Trochilus ................. 633 aureigula, Trochilus .................. 633 aureigularis, Trochilus ................. 633 auriceps, Calurus.................. 735, 775 
auriceps, Chlorolampis.

Chlorostilbon $548,549,551,552$

Cosmurus...................... 735

Hylocharis.................. 552

Pharomachrus............. 734,735, 736

Pharomacrus................ 735

Sporadinus................... 552

Tanypeplus.................... 735

Trochilus.................... 547,552

Trogon (Calurus) .............. 735

aurigularis, Trochilus.................... 633

Aurinia .............................. $\quad 310$

auritus, Anabates..................... 197

Trochilus...................... 561

aurulenta, Lampornis.................... 469

Margarochrysis............... 469

aurulentus, Anthracothorax........ 455,470, 472

Eulampis.................. 469

Lampornis............... 470, 471

Polytmus.................. 469

Trochilus.............. 454,469, 471 (Lampornis) ......... 471

Automoleæ.......................... 162

Automolis............................. 211

Automolus.............. 162,211, 213, 222,223

Buff-throated ................ 217

cervinigularis................. 212,

$213,217,218,219,220,222$ cervinigularis. $213, \mathbf{2 1} \mathbf{j}, 219$ exsertus........... 222 hypophæus... 213,218, 219

Chiriqul.................... $\quad \mathbf{2 2 1}$

Dark-breasted.................. $\quad 219$

exsertus..................... 221

ferruginolentus............... 223

fumosus................ 213,216,217

guerrerensis............. 212,213,216

Guerrero................... $\mathbf{2 1 6}$

holostictus................. 223

ignobilis................... 222,223

leucophthalmus.............. 212

ochrolæmus.................. 212

Pale-throated................ $\quad \mathbf{2 8 0}$

pallidigularis...... $212,213,219,220,221$ exsertus ........ 213,221 pallidigularis. $213,220,221$

pectoralis................... 216 rubiginosus....... 212, 213, 214,215, 216

Ruddy..................... 214

rufescens..................... 204

rufipectus.................. 212,213

rufo-brunneus................ 224

Sooty...................... $\quad 216$

stictoptilus................... 223

Streaked...................

striaticeps................... 223

subulatus................... 223

Tawny..................... 215

umbrinus................. 212,215

veræpacis............... 212,213,215

umbrinus..........213,215

veræpacis....... 213, 214,215

Vera Paz................... 214

virgatus..................... 201

A vis gutture rubro ..................... 630

mellivora........................ 630
Page.

A $v$ is mellivora minor, cristata............ 663 ventre albo............... $\quad 578$

minor.......................... 630

axillaris, Formicivora................ 67,69

Myrmopagis.................. 67

Myrmophila.................. 67

Myrmothera.............65,67,69

Myrmotherula................67,69

axillaris.................... 67

Ayturus polytmus..................... 341

Azure-crown, Black-billed................ $\quad 422$

Guatemalan............... 427

Red-billed................. 425

Salvin's ................. 499

Small-billed............... 428

B.

Bahama Wood-Star ................... 641

Bahaman Emerald.................... 54t

bahamensis, Trochilus................... 643

bairdi, Trogon........................... 754

bairdii, Trogon ................. . 751, 752, 754

Baird's Trogon....................... 752

bancrofti, Trochilus .................... 480

Bangs's Hermit....................... $\quad 317$

Humming Bird................. 420

bangsi, Amizilis. . . . . ................ 407.420

Barbets........................... 732

Bare-crowned Antbird............... .99

-fronted Antbird................. 101

Barnesia............................. 187

Baroness de Lafresnaje's Plumeleteer...... 391

baroni, Eutoxeres..................... $\quad 312$

Barred-erested Antshrike................ 45

Woodhewer.................. $\mathbf{9 2 9}$

barroti, Heliothrix.................. 563,564

Heliothryx................... 562,563

Ormismya.................... 563

Trochilus...................... 563

barrotii, Heliothrix.................... 564

Barrot's Fairy....................... $\mathbf{5 6 2}$

Basilina........................... 377

Basilinna...................... 304,377, $37 \mathrm{~s}$

abeillei.................... 517

r. Baucis abeillei ............. 517

guimeti $\ldots \ldots \ldots \ldots \ldots \ldots \ldots \ldots . .515$

$\beta$. Klais .................... 513

guimeti.............. 515

leucotis............. $37 \mathrm{~s}, 380,381,382$ leucotis..............378, 381 pygmæa......... 37s, 381, 3s2

xanthusi................... 383

xantusi................. $378,3 \$ 3$

xantusii..................... $38 \mathrm{~s}$

Batara............................ 10

Baucis............................ 516

abeillei........................ 517,518

Beautiful Humming Bird............... 655

Béfroi............................ 18

behni, Myrmotherula................... 62

Bellatrix........................... 669

Bellona................................ 656 cristata..........661, 662, 663,664, 665 cristata................. 665

emigrans............... 664

exilis.................. 660 


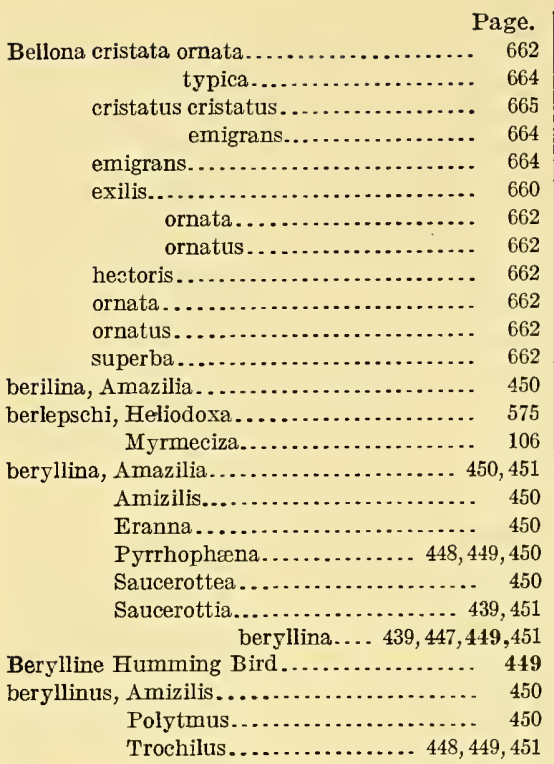

Biastes............................... 12

Biatas ................................ 12

bicolor, Anoplops................. 130, 131, 132

Augasma....................... 530

Chlorostilbon.................... 530

Cyanophaia.................. 527,529

Gmelinius........................ 530

Gymnopithys................. 132,134

Hylocharis. . . ................ 530

Hylocharis, $\beta$. Cyanophaia......... 530

Microrhopias..................... 75

Ornismya...................... 530

Pithys ........................ 132,133

Polytmus...................... 530

Thalurania..................... 530

Timolia........................ 530

Trochilus.................. 526,527,530

Bicolored Antbird..................... 132

biscutata, Chætura...................... 697

Cypselus....................... 697

Hemiprocne................. 697

Streptoprocne.................. 697

bivittatus, Dendrocolaptes............... $\quad 257$

Black and blue Humming Bird............ 480

Black Antwren ........................ 68

-bellied Green Humming Bird......... 475

Humming Bird............. 400

-billed Azure-crown................. 422

Streamer-tail................ 341

-breasted Humming Bird............ 456

-chinned Humming Bird............ $\quad 633$

-crested Antshrike................. $\quad 37$

-headed Antthrush................. 118

Trogon.................... 756

-striped Woodhewer.............. 242

Swift......................... 70

-Costa Rican.................. 710

Jamaican.................... 705

Northern................... 707

-tbroated Mango.................. 459
Black Tyrannine Antbird................

Blue-crested Humming Bird............. $\quad \mathbf{6 6 2}$

-crest, Grenada.................... 664

St. Vincent................... 661

-tailed Humming Bird................. $\quad \mathbf{4 4 5}$

-throated Humming Bird.............. 492

bogotensis, Dendrornis triangularis.......... 241

boissonneaui, Otipne..................... 197

boissoneauti, Pseudocolaptes............. 197, 198

boissonneautii, Anabates............ 196, 197, 198

Philydor................. 197

Pseudocolaptes............. 197

boliviana, Myrmotherula................. 62, 67

boothi, Orthorhynchus.................. 627

borealis, Campylorhamphus............. 270,272

pusillus........ 273

Chætura...................... 708

Cypseloides............... 708, 709,710

niger............... 709,710

Subsp. a........ 710

Cypselus....................... 708

Nephøcetes................... 708

niger .............. 703,

$\mathbf{7 0 4 , 7 0 7 , 7 0 8 , 7 0 9 , 7 1 0}$

$\operatorname{var} \ldots . . . .708,709$

Boruca Woodhewer.................... 232

boucardi, Agyrtria......................... 541

Arena..................... 537,541

Arinia..................... 537,541

Drymophila................. 79, 105

Formicivora ................ $79,80,81$

Lepidopyga.............. 538,539,541

Microrhopias................. 75,76

boucardi....... $76,78,79$

Myrmeciza........... 104, 105, 106, 109 boucardi........... 105, 107

Polyerata.................... 541

Sapphironia.................. 541

boucardii, Formicivora................. 79, 80

Boucard's Antwren....................... 78

Hermit..................... 324

Humming Bird................ 541

bourcieri, Trochilus. ..................... 314

braccata, Hemithylaca................. 437

Saucerottea warscewiczi........... 437

Saucerottia sophiæ............. 437

braccatus, Aganus.................... 750,790

Trogon....................... 790

bracei, Riccordia ricordii................ 544

Sporadinus.................... 544,545

brachycerca, Chætura.................. 729

Brachypus........................... 685

brachyura, Acanthylis................... 729

Chætura..........664, 717, 728, 729

Synallaxis.................. 192

brasiliensis, Trochilus................... $\quad 332$

brevicauda, Formicarius.................. 18

Formicivora................ 10,65

Myrmotherula................ 62

brevicaudus, Turdus.................... $\quad 15$

brevirostris, Delattria henrica............ 498 Lampornis amethystinus. $495,497,498$ Ornismya................. 430

briantæ, Doricha ....................... 646

Bridges' $\Lambda$ ntshrike..................... 25

brldgesi, Abalius..................... 25 
Page.

bridgesi, Thamnophilus

24,27

bridgesii, Nasica..

Broad-billed Humming Bird

-tailed Humming Bird

Bronzy Hermit.

Brown-crowned Humming-bird

Dendrocincla.................... 291

Violet-ear ..................... $\quad 486$

browni, Conopophaga................... 144

brunneicauda, Margarornis................ 183

Premnoplex brunnescens.. 181, 183

brunneicaudalis, Synallaxis.............. 192

brunneitorques, Acanthylis.............. 713

Chætura................ 713

Cypseloides......... 710,711,713

brunneitorques.. 711 ,

$\mathbf{7 1 2}, \mathbf{7 1 3}, \mathbf{7 1 4}$

brunnescens, Margarornis

$150,181,182$

Premnoplex........... 181, 182,183

brunnescens.... 181, 182

Sittasomus ............... 182

brunneus, Sclerurus................... 165

caudacutus........... 165

bryantæ, Calliphlox ................... 646

Calothorax ................... 646

Doricha ..................... 646

Dorycha..................... 646

Nesophlox ........... 640,641,645,646

Philodice...................... 646

bryanthae, Dorycha................... 646

Bucco rubecula.......................... 784

Bucerotes.......................... 296, 297

Buff-bellied Humming Bird.............. 415

-throated Automolus................ $\quad \mathbf{2 1 7}$

buffoni, Chalybura.................... 390

(Lampornis) .......... 390

Hypuroptila.................... $\quad 390$

Lampornis..................... 389

Trochilus..................... 386

buffonii, Agyrtria.................... $\quad 390$

o. Chalybura........... 390

Chalybura.............. 387,388, 390

Polytmus.................... 389

Trochilus................... $\quad 389$

Buffon's Plumeleteer................... $\quad 388$

Buphagidæ.......................... 295

C.

cabanidis, Colibri ...................... 486

cyanotus............... 486

Petasophora.................. 486

cyanotis........... 486

cyanotus........... 486

Polytmus................... $4 S 6$

cabanisi, Petasophora cyanotis............ 486

cabanisii, Petasophora................... $\quad 480$

Cæligena hemileuca..................... $50 s$

viridipallens.................. 510

cæruleiceps, Elvira.................... 405

caruleigaster, Lampornis . . . . . . . . . . . .... 387

eæruleigularis, Cyanophaia.............. 540

Hylocharis.............. 540

Lepidopyga.............. 540

Sapphironia .............. 540

cæruleiventris, Agyrtria, $\delta$. Chalybura ..... 387 Chalybura............. 386,387
Page.

cæruleiventris, Hylocharis, $o$. Chalybura.... 387

Hypuroptila............. 387

cæruleogaster, Chalybura.............. 387, 388

Hypuroptila............. 387

Trochilus (Glaucis?)....... 386, 387

cæruleogularis, Lepidopyga............5 538, 539

Polytmus................ 540

Sapphironia............. 540

Trochilus................ 539

cæruleo-lavata, Cyanophaia............... 528

Eucephala............... 528

Thalurania............... 528

cærulescens, Hylocharis, $\beta$. Cyanophaia..... 540

Myrmothera................. 90

Thamnophilus...........47,48, 51

cæsius, Lanius......................... 14

Calecon rouge ......................... 792

caligata, Chlorestes.................... 441

$r$. Saucerottia.......... 441

Hemithylaca............... 437,441

caligatus, Aganus...................... 785

Chrysotrogon ......... 784, 785, 786, 789

Saucerottia.................. 441

Trochilus................... 437,441

Trogon.............. 7\$4,785, 789,790

caligatus.............. 790

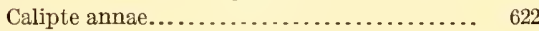

callinota, Formicivora.................. 84

Terenura..................... 83,84

Calliope anna........................ 622

Humming Bird.................. 588

calliope, Atthis...................... 591

Calothorax................ 589, 590

Lucifer...................... 590

o. Calothorax ............ 590

Selasphorus................. 591

Stellula.................588,590, 591

Trochilus.................. 587,591

(Calothorax)........... 589

Zephyritis (Stellula).............. 591

Callipharus .......................... 304, 399

nigriventris.............. 400, 401

Calliphlox......................... 309, 640

anna....................... 621

bryantæ.................... 646

$\beta$ Doricha................... 647

henicura........... 649

evelynæ................... 643

henicura..................... 649

lyrura........................ 645

mitchelli.................... 658

rufa....................... 616

Callithorax.......................... 651

lucifer..................... 654

pulcher...................... 656

Callothorax........................... 651

evillinæ.................... 643

Calobamon............................ 140

Calobathris ........................... 146

macularia.................. 153

calolæma, Oreopyra............. 504,505, 506

castaneiventris......... 506

eastaneoventris .. 502, 504, 506

calolæmus, Trochilus................. 506

Calothorax.....................309,647,651, 652

bryanta................... 646 


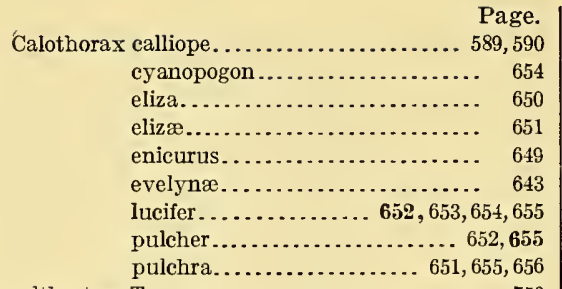

calthratus, Trogon........................ 750

Calurus. ............................... 733

antisianus........................ 735

auriceps ....................... 735, 775

fulgidus......................... 735

mocinno...................... 738

neoxenus.......................... 742

paradiseus..................... 738

pavoninus.. .................... 735

pulchellus......................... 735

resplendens..................... 738

Calypte.................... $308,309,595,618$ anna.... 596, 597, 616, 618, $\mathbf{6 1 9}, 622,628,636$ annæ...................... 621, 622 costæ.............. 618,619,623, 624,625 costai.......................... 625

floresi.......................... 618

floresii...................... 618

helenæ. . . . . . . ... 618,619,625, 626, 627 campyloptera, Pampa ................. 353, 355 Campylopterus............ 304,356, 357, 358, 363 clemenciæ................. 494 cuvieri.................... 364 cuvierii................... 364 delattre.................. 360 delattrei................... 360 delattrie.................. 360 delattrii................. 360 ensipennis................. 357 hemileucurus ........ 357,358,360 mellitus...... 360

hyperythrus............ 356, 357 largipennis.............. 357 lazulus................... 357 obseurus.................. 357 pampa............... 354, 356 var. curvipennis..... 356

roberti.................. 366 rufus. ....... $356,357,358,361,362$ villavicencio................ 357

Campylorhamphus.............. 227,268, 269 borealis............. 270, 272 chapmani............. 270 dorso-immaculatus..... 269 falcularius............. 270 lafresnayeanus.......... 269 longirostris............ 268 procurvoides............ 270 procurvus............ 270 pusillus............. 268, 270 borealis........ 273

rufodorsalis............ 269

thoracicus............ 269

trochilirostris........... 269

major....... 269 trochilirostris 269

venezuelensis. $268,270,271,272$ canadensis, Hypolophus Page. Lanius..................... 32

canaveti, Chlorolampis................. 555 candida, Agyrtria............... 431,432, 433, 434 Leucolia...................... 434

Leucollia...................... 434

candidus, Polytmus..................... 433

Thaumantias................. 433

Thaumatias................... 433

Trochilus..................... 433

canlceps, Dendroma.................. 201,202

canigularis, Sclerurus................ 164, 165, 166

canivete, Chlorostilbon................. 555

caniveti, Chloauges.................... 555

Chloristilbon................... 555

Chlorolampis.............. 555, 556, 557

Chlorostilbon.......... 553, 555, 556, 557

Sporadinus................... 555

Thaumatias........... 555,622,628,636

canivetii, Chlorestes.................... $\quad 555$

o. Riccordia........... 555

Chlorostilbon................ 549, 556 canivetii...... 549,553, 556

Hylocharis................... 555

Ornismia...................... 555

Ornismya............ 553, 555, 556, 557

Xenops..................... 203

Canivet's Emerald...................... 55

cano-fumosus, Formicivora............... $\quad 77$

cantator, Formicarius.................. 15

Hypocnemis................... 127

capistratum, Trogon................... 761

capistratus, Thamnophilus radiatus........ $\quad 38$

Trogon...................... 761 melanocephalus........ 761

Trogonurus................. 761 capitalis, Thamnophilus ................. 48

capitoides, Dendrexetastes................ $\quad 226$

Capitones........................... 296, 297

capnitis, Hypocnemis nævioides............ 130

Caprimulgi ........................ 296,297, 730

Caprimulgidæ......................... 298

Carbuncle Humming-bird.................. 669

carbunculus, Chrysolampis............... 669

Trochilus.................. 669

caribæus, Chlorostilbon............ 559, 560, 561

Chrysomiras atala, var.......... 561

caribbæa, Chlorostilbon ................ 561

caribbæus, Chlorostilbon ................ 549,561

Caribbean Emerald................... $\quad 559$

caribbeus, Chlorostilbon .................. 561

caribeus, Chlorostilbon................... 561

Carib, Darker Green.................. $\quad \mathbf{4 7 6}$ Green........................ 474

Purple........................ $\quad \mathbf{4 7 8}$

carnioli, Chalybura....................... 393

Carriker's Dendrocincla................. $\quad \mathbf{2 9 0}$

Cartago Woodhewer.................... $\quad \mathbf{8 3 9}$

cassini, Myrmeciza............. 106, 107, 110,111

Myrmelastes.................... 111

Cassin's Antbird....................... 110

castaneiceps, Formicarius .............. 125, 126

castaneiventris, $A$ delomyia?............. 503

Anthocephala? .......... 504, 506

Metallura................ 503

Oreopyra............. 504, 506 
castaneiventris, Oreopyra castaneiventris Page. Trochilus? .............. 503 eastaneocauda, Heliopædica.............. 383 castaneoventris, Oreopyra............... 501 castaneoventris ... 502, 504,506

Trochilus? $501,503,506$

castaneus, Trogon...................... 763

Xiphocolaptes............... 236

castelnaudi, Glyphorynchus.............. 275 cuneatus...... 275

catharinæ, Mellisuga.................. 584, 586 Ornismia.................... 587

caudacutus, Sclerurus............. 165, 168, 170 caudacutus.......... 165

Thamnophilus........... 165, 168, 170 cayanensis, Cypselus.................. 692,695 Formicarius............... 115, 117 Hirundo .............. 690, 692,695 Myrmornis ................. 117 Panyptila..............684,691,692 cayanensis, var...... 692

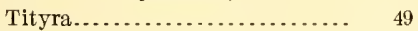

cayenensis, Hirundo................... 692

Panyptila................. 692

Cayenne Swift.......................... 691

cayennensis, Cypselus .................. 695 Panyptila.................. 692

Cazique, Gnatemalan................. 498

Humming Bird................ 496

Margaret's.................... 499

Pringle's...................... 50

Short-billed................. 497

cephala, Ptyonornis................... 322

cephalater, Polytmus................... 341

cephalatra, Ornismya.................. 341

Polytmus.................. 341

cephale, Phaëtornis.................... 321,323

cephalus, Phaethornis................. 321,322

Phaetornis.............. 321,322,323

Phœthornis longirostris.... 316,321, 320

Ptyonornis................... 322

Trochilus................... 321,322

Cercomacra........................ 14,90,91 crepera................... 97 maculicauda.................. 93 maculicaudis................ 93 maculosa.................... 93 nigricans................91,92,93 tyrannina...........91,94,95,96,97 crepera......... 91,95, 97 tyrannina..... 91, 93, 95,97

Certhia.......................... 226 cinnamomea.................... 186 prasinoptera.................... 480

certhla, Dendrocolaptes................. 228,229 Picus.......................... 227

Certhiaxis............................ 186

Certhijdæ.................... 2, 158,225,295 cervineiventris, $\Lambda$ mazilia.............. 415 cervinicauda, Threnetes................ 336 cervinigularis, Anabates...... 217, 218, 219, 220, 222 Automolus.............. 212, $213,217,218,219,220,222$ cervinigularis..... 213, $\mathbf{2 1 7 , 2 1 9}$ cervinigularis, Ipoborus .......... Page.

Philydor................. 219

cerviniventris, Amazilia........... 413,414,415 cerviniventris...... 414

Amazilis................ 414

Amazilius................. $\quad 414$

Amila.................... 414

Amizilis................. 414

cerviniventris ...... 414

yucatanensis...... 407, $\mathbf{4 1 4}$

Eranna................. 41

Polytmus................ 414

Pyrrhophæna . . ........... 413,414

ceterus, Myrmelastes. . ................. 99, 101

Chætura...............6 6\$4, 6\$5, 686, 714, 715 acuta................ $716, \mathbf{7 2 4}, 725$ albicincta.................... 699 biscutata..................... 697 borealis....................... 708 brachycerca................... 729 brachyura...........684,717, 728, 729 brunneitorques.................. 713 cinereiventris............ $716,717,727$ cinereiventris . . $716,717,726$ fumosa.... $716,717,725,726$ guianensis....... 727,728 lawrencei.... 717,726, 727 occidentalis......... $\quad 716$ phæopygos......... 717 726. 727,728 sclateri............ 716 typica............. 716 Subsp. Chrtura guianensis......... 716, 727

colardeaui.................... 725

collaris........................ 701

dominica..................... $\quad 725$

dominicana................... 725

colardeaui.................... $\quad 725$

fumigatus................... $\quad 711$

fumosa.............. 717,726,727,728

gaumeri.......... 716, 719,720, 721, 722

guianensis.............. $716,727,728$

guyanensis................... 727

lawrencei................... $\quad 727$

major........................ 711

niger..................... 705,706

nudipes..................... 686

pallidifrons.................... 702

pelagica........... $684, \mathbf{7 1 5}, \mathbf{7 1 7}, \mathbf{7 1 8}, 719$

var. pelagica........... 719 poliura.............. 729

vanxi............... 72

pelasgia....................... 719

pelasgica................. 719,722

peregrinator................... 722

picina...................... 686

polioura....................... 729

poliura..................... 725,729

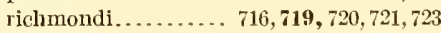

rutila..................... 711,713

sclateri...................... 716

occidentalis............. 716

semicollaris................ 702,703

senex....................... 711

spinicauda............. $716,717,720$ 
Chætura spincauda fumosa $\quad$ Page. spinicauda............. 716 vauxi..................... 721,724 vauxii............ 716,721, 722, 723,724 yucantanica. zonaris. $697,699,701,702$ albicincta................ 699 a. albicincta............. 699 pallidifrons.............. 702 typica.............6 697,699, 701

Chæturinæ.................... 682,683, 684, 686 Chæturine Swifts............... 696, 703, 710,715 chalconota, Amazilia................... 415 cerviniventris ........ $\mathbf{4 1 5}$

Amizilis yucatanensis......... 407,415

Chalybura....................... 304,386, 387 æneicauda . .................. 390 buffoni...................... 390 buffonii................ 387,388, 390 cæruleiventris.............. 386, 387 cæruleogaster ............... 387, 388 carnioli....................... 393 intermedia.................. 388 isauræ............. 387, 388, 391, 392 (Lampornis) buffoni........... 390 cœruleiventris...... 387 viridis ............. 473

melanorrhoa ............. 388,392, 393 urochrysa............... 387, 388, 390 urochrysea.................... 391 urochrysia.................... 391 viridis......................... 473

Chamæbates............................ 146

rufiventris ................. 146

Chamæza............................. 15,116

guatimalensis................... 149

meruloides....................... 15

Chamæzosa.............................. 15

chapadensis, Sittasomus.................. 279

sylviellus.......... 279

chapmani, Campylorhamphus............. 270

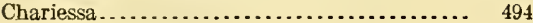

henrici...................... 497

viridipallens................... 510

Charming Humming Bird................ 525

cheiroleuca, Gymnocichla................ 103

Cherrie's Antbird ...................... 113

Deconychura ................... 285

Swift ........................ $\mathbf{7 1 4}$

Chestnut-collared Swift................. $\mathbf{7 1 2}$

chianura, Elvira....................... 403

Chimney Swift........................ $\quad \mathbf{6 1 7}$

Gray-rumped............. 727

chionogaster, Trochilus.................. 305

chionopectus, $\Lambda$ gyrtria................. 431

Leucolia................... 431

Polytmus................. 431

Thaumatias............... 431

chionura, $\Lambda$ gyrtria................... 403 Elvira........... 401,402, 403, 404, 405

Eupherusa................ 403,404

Trochilus ('Thaumatias) .......44, 401 403

chionurus, Leucippus................... 403

Polytmus................... 404

Thaumantias................. 403

Thaumatias.................. 403
Pagè. strigilatus............ 752,754

chiriquensis, Eugenes spectabilis .......... $\quad 570$

Chiriqui Automolus.................... $\quad 221$

Mountain Gem................ 502

chiroleuca, Gymnocichla............ 99, 101, 103

Chloauges............................. 547 caniveti.................... 555 salvini...................... 557

Chlorestes aglaiæ....................... $\quad 412$

atala......................... 560

caligata..................... 441

canivetii..................... 555

cyanifrons.................... 436

edwardsii...................... 444

elegans....................... 546

erythronota................... 437

feliciæ...................... 437

fuscicauda................... 411

gertrudis.................... 551

hæberlini .................... 547

jodura...................... 438

malvina..................... 431

mariæ........................ 450

niveiventris.................. 442

raimondii..................... . 544

o. Riccordia ................... 542

canjvetij........... 555

elegans............. 546

raimondii........... 544

ricordii...................... 544

r. Saucerottia aglaiæ........... 412

caligata.......... 441

cyanifrons........ 436

edwardsii......... 444

eximia........... 395

feliciæ........... 437

fuscicauda........ 411

iodura........... 438

niveiventer....... 442

sophiæ........... 440

viridipectus........ 431

viridiventris....... 438

B. Smaragditis mariæ........... 450

sophiæ..................... 440

typica...................... 436

viridiventris................. 438

chlorocephala, Agyrtria................... 528

Cyanophaia............... 528

Eucephala................ 528

Saucerottea............... 528

Thalurania............... 528

chlorocephalus, Hylocharis.............. 528

chlorocercus, Thaumatias................. 305

chlorolæma, Lampornis.................... 476

chlorolæmus, Eulampis.............. 476, 477

Polytmus................. 477

Sericotes................. 477 holosericeus........ $\quad \mathbf{4 7 6}$

chlorolaimus, $\Lambda$ nthracothorax........... 477 $\gamma$. Sericotes.... 477

Chlorolampis........................ 547 assimilis.................. 559 aurlecps................... 552 caniveti.............. 555,556,557 forficata................ 553 


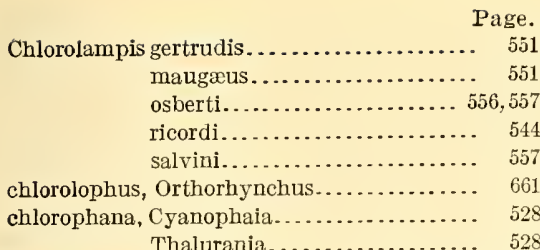

Chlorostilbon............... 307,542,547, 548 angustipennis.............. 559 assimilis. . . . . . . . . . . 549,558, 559 atala.................... 560 auriceps..........548,549,551,552 bicolor................... 530 canivete................... 555 caniveti. . . ......... 553,555,556,557 osberti............. 556 salvini............. 557 var. osberti......... 556 salvini......... 557 typicus............. 555 canivetii................. 549,556 canivetii....... 549, 553, 556 osberti......... 549, 556, 557 salvini........ 549,557, 558 caribæus............. 559560,561 nanus............. 561 caribbæa.................... 561 caribbæus................ 549,561 caribbeus................... 561 lessoni............... 561 caribeus.................. 561 forficatus............ 549,552, 553 maugæi ................. 549,550 osberti................... 556,557 osbertii.................... 556 panamensis............... 559 prasinus.................... 5418 salvini.................... 557 chrysochloros, Trogon . . . . . . . . . . . ...... 764 atricollis........... 764 chrysogaster, Trochilus.................. 547 Chrysolampis................... 310,657, 66.

albocoronata.............. 582 carbunculus................. 669

elatus.................... 669

(Emilia) goudoti........... 538 infumatus................ 669

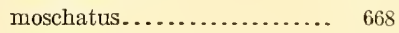

moschita................. 668

moschitus................. 668

mosquita.................. 668

mosquitus...............666, 668

reichenbachi............... 669

chrysomelas, Trogon .............. 783,784.790

Chrysomiras atala, var. caribæus........... 501

Chrysomirus........................ 547

angustipennis.............. 559

atala.................... 560

Chrysotrogon.................... 733, 784, 785 ealigatus.......... $784,785, \mathbf{7 8 6 ,} 789$ ramonianus............... 785 crissalis......... 786 goeldii.......... 786 ramonianus...... 786

violaceus............... 785,786
Chrysurisca eliciæ...................... Page.

Chrysuronia elicia..................... 385 eliciæ.................... 385, 386

Cianomyia quadricolor.................. 423 violiceps .................... 425

Cichlocolaptes........................ 211

cinctus, Cyphorinus (Microcereulus) ........ 13 cinerascens, Synallaxis................. 191 cinereicauda, Oreopyra................. 506,507 leucaspis.......... 507

cinereicaudus, Trochilus................. 507

cinereiceps, Thamnophilus............... 48

cinereiventris, Chætura........... 716, 717,727 cinereiventris... $716,717,726$

Microbates............... 89

Myrmotherula ............ 61

Rhamphoexnus........... 90

einereo-niger, Thamnophilus............... 48

cinereus, Thamnophilus................. 10

Trogon cayanensis............... 751

cinnamomea, Amazilia................. 418, 419

Amazilis................. 418

Amazillia................... 418

Amizilis................... 418

cinnamomea........ 418

Certhia................... 186

Eranna..................... 418

Myrmoderas................ $\quad 15$

Ornismia.................. 405

Ornismya.............4 406,417,419

Polytmus................ 418

Pyrrhophæna.............. 418

Cinnamomeous Humming Bird.......... 416

cinnamomeus, Amazilis.................. 418

Ornismya................ 417

Xiphocolaptes............ 236

Cipselus............................... 685

Circe............................... $\quad 369$

doubledayi...................... 377

doubledeayi...................... 377

latirostris...................... 372,374

magica.......................... 373

circe, Hylocharis....................... 373

Sapphironia.................... 373

cirrhatus, Hypolophus................... 32

Turdus..................... 32

cirrhochloris, A phantochroa............. 365

Trochilus.................. 365

Cistothorus........................... 158

Citreoline Trogon...................... 759

citreolus, Aganus........................ 761

Trogon................ 752, 759, 760,761

Cladoscopus......................... 226

Clais.............................. 513

guimeti........................... 515

merretil......................... 516

clarissæ, Ornismia...................... 405

clathratus, Curucujus................. $744,7 \mathbf{7 9}$

Trogon.................. 750,754

Claudia............................ 686, 715

clemencia, Lampornis.................. 494

clemeneiæ, Campylopterus.............. 49.4 Coligena............... 365, 493,494 r. Coeligeua............. 493 Cyanolæmus............... 492, 494 Delattria .................... 494 
Page.

clemenciæ, Mellisuga Ornismya...

Ornismyia

clementiæ, Cœligena. .

Clotho...

Clytolæma fulgens.

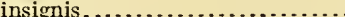

jacula

jamesoni......................

leadbeateri...

var. otero............

rhami.........................

Coccyges heterodactylæ..................

Coccygomorphæ.

coelestis, Ornismya

Cœligena.

amabilis.

clemenciæ................ 365, 493, 494

clementiæ.

r. Coeligena clemenciæ

columbica.

B. Damophila

amabilis...........

fulgens.

hemileuca

henrica. ................. 497, 499

margarethæ. .......... 500

pringlei ................ 501

typica............... 497,499

henrici. ................ 497, 498, 499

henricii...................... 497

jacula....................... 571

juliæ.......................... 520

§. Leadbeatera jacula........... 571

jamersoni........ 571

sagitta........... 572

typica........... 572

leucotis...................... 381

margarethæ................... 500

margaritæ..................... 500

ourissia..................... 551

pringlei..................... 501

puella......................... 534

sagitta...................... 572

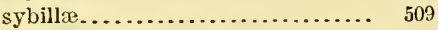

a. Thalurania columbica .......... 534

puella............. 534

venusta........... 535

wagleri $-\cdots,-530$

venusta...................... 535

viridipallens................. 510

wagleri...................... 530

xanthusi..................... 383

cœlina, Lepidopyga................. 538,539

Thalurania.................... 538

coruleigularis, $\Lambda$ gyriria . .............. $\quad 540$

o. Cyanochloris..... 540

Lepidopyga............... 540

(Cyanophaia).... 540

Sapphironia............. 5.10

coruleiventris, Chalybura (Lampornis)..... 387

Lampornis ............... $\quad 387$

corulescens, IIy locharis................ 540

cohuat1, Trochilus.................... 655
Page.

Coiba Island Humming Bird. ............ $\mathbf{3 6 5}$

Colaptes.............................. $\quad 226$

colardeaui, Chætura dominicana.......... 725

Colibri ............................... 306,480

à cravate verte................... 456

à gorge verte de Cayenne .......... 456

à queue violette de Cayenne........ 461

bleu........................... 480

cabanidis....................... 486

crispus....................... 480

cyanotis......................... 485

cyanotus .................. 481, 484,485 cabanidis............... 486

delphinæ $\ldots \ldots \ldots \ldots \ldots \ldots \ldots .481,486,488$

de St. Domingue................. 469

iolotus......................... 481

serrirostris.................... 481

thalassinus.............. 481, 482, 483, 484

violet........................... 479

Colibris cyanotus....................... 485

thalassina...................... 483

Colies ........... 298

Colii................................. 296, 298

Coliidæ............................... 298

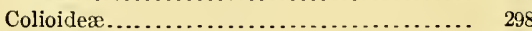

Colioidei............................... 298

Coliomorphæ........................ 298

Colius............................... 298

Collared Swift, Antillean................ 701

Colombian................ 697

Mexican............... $\mathbf{7 0 0}$

collaris, Acanthylis.............. 697,698, 701 Chætura....................... 701

Cypcelus....................... 702

Cypselus...................... 697

Hemiprocne.................... 698

Hirundo. . . . . . . . . . . ..... 697, 698, 701

Microbates.................... 88,89

Nephocætes.................... 702

Rhamphocænus.................. 10,88

Trochilus...................... 616

Trogon..................... 763,764

Trogonurus................... 763,765

Collocalia.......................... 684,715

Colma, de Cayenne...................... 117

colma, Formicarius.................... 115,117

Myiothera....................... 117

Myrmothera..................... 117

Turdus....................... 115, 117

Colombian Collared Swift............... $\quad 697$

Crested Antshrike..............

Wood-Nymph................

colombica, Ornismya................ 534,535

Thalurania............. 532, 534,535 colombica ........ 532,534

coloratus, Premnoplex................ 181 brunnesceus....... 181, 182

Colubris............................. 627 rubens....................... 627

colubris, Archilochus .......... 432, $628,6 \mathbf{6 2 9}, 633$ Cynanthus.................... 63.3 Mfclisuga.................... 633

Mcllisuga..................... 633 Ormismya.................6.632,633

Orthorluynchus................. 633

Trochilus...............627,630,632 
colubris, Trochillus

Page.

Columbæ.

columbiana, Glaucis.

columbianus, Philydor.

columbica, Coeligena.

534

Thalurania.

columbicus, Polytmus.................... 534

communis, Orthocolaptes................. 227

compressirostris, Xiphocolaptes............ 236

compressus Picolaptes............... 265, 266, 267

compressus......... 266

lineaticeps..... 259, $\mathbf{2 6 5}, 266$

Thripobrotus........... 265, 266, 267

concinnus, Aganus...................... 790

Trogon...................... 790

caligatus.............. 790

condamini, Eutoxeres................... 312

confinis, Dendrornis nana............... 253

Xiphorhynchus nanus....... 241, 252, $\mathbf{2 5 3}$

Conopophaga browni.................... 144

nævioides .............. 126, 129

Conopophagidæ.................... 1,2,3,4,8

Conopophaginæ...................... 4

consobrina, Drymophila................ 81

Formicivora................ 81

Microrhopias................. 75

boucardi..... $76,79,80$

constanti, Anthoscenus................... 352

Floricola................ 351,352,353

constanti.............. 352

Heliomaster.................. 351, 353

Heliomastes ................... 351

Ornismya................... 353

Trochilus .................... 351

cosstantii, Anthoscenus.................. 345

constantii.... $345,350,351$

Heliomaster................... 353

Heliomastes................... 351

Ornismya.................. 351

Selasphorus.................. 351

r. Hellomaster...... 351

Constant's Star-throat.................. $\quad \mathbf{3 5 0}$ conversi, Gouldia................... 678,681

Mellisuga.................... 678

Popelairea...............6.678,681 conversi.............. 681

Popelairia.................... 678,681

Primnacantlia................ 681

Prymnacantha..............678,681

cony̧ersii, Popelairia.................. 680 conversii ..........6 678,679

Trochilus .................. 678,681

Coppery-headed Emerald................ $\mathbf{4 0 1}$

-tailed Trogon................. 768

Coquette, Adorable.................... 675

De Lattré's.................. 671

Princess Helena's............... 673

Coraciadæ........................... 298

Coraciae........................... 296, 298

Coraciidæ.......................... 296, 298

Coraciuformes................... $\mathbf{8 9 5 , 2 9 6 , 2 9 7}$

Heterodactyle............ $\mathbf{7 2 9}$

Coraciine Birds........................ $\$ \mathbf{9 9 5}$

Coracoider............................ 296

Coracornithes........................... 296
Pagc.

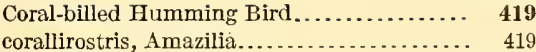

Amazilius................ 418,419

Amazillia................ 418,419

Amizilis rutila......... 407,417,419

Pyrrhophæna .............. 419

Trochilus................418,419

corruscus, Trochilus..................... 654

coruscus, Phaëthornis guy ................ 319

Phothornis guyi............. 316,317

Corvidæ............................ 295,297

corvinus, Myrmelastes................... 99, 100

Thamnophilus............... 100

Cosmurus......................... 733

auriceps..................... 735

fulgidus...................... 735

neoxenus................... 742

costæ, Atthis.......................... 625

Calypte............ 618, 619, $\mathbf{6 2 8}, 624,625$

Leucaria....................... 625

Mellisuga........................ 624

Ornismya..................... 618,624

Selasphorus ...................... 624

Selosphorus.................... 624

Trochilus....................... 624

o Atthis................ 624

Zephyritis...................... 625

costai, Calypte......................... 625

Costa Rican Antpitta.................. 149

Bare-crowned Antbird......... 101

Black Swift................. $\quad 710$

Grallarieula................. $\quad \mathbf{1 4 5}$

Gray-breasted Synallaxis...... $\mathbf{1 9 4}$

Margarornis................ 178

Mountain Gem............... $\mathbf{5 0 1}$

Premnoplex................. 181

Quetzál.................... $\quad \mathbf{7 3 9}$

Ruddy Dendrocincla.......... $\quad \mathbf{2 9 4}$

Sickle-Bill................. 972

Snow-Cap................. 582

Woodhewer................. $\quad \mathbf{2 8 3}$

Wood-Nymph............... 534

Wood-Star................. $\mathbf{6 4 5}$

costaricensis, Cypseloides uiger........... 710

Dendrocolaptes validus . 229, 233, 235

Dendrornis lawrencei ........ 253

lawrencii........ 253

nana............. 253

Grallaricula............. 144, 145 flavirostris ....... 146

Nephœeetes niger...... 704, 708, 710

Pharomachrus mocinno....... 734,

$736,737,738,739$

Pharomacrus.............. 740

mocina, var..... 740

mocinno........ 740

var..... 740

Pseudocolaptes.............. 199

Xiphocolaptes emigrans..... 236, 239

Fiphorhyuchus nanus... 241,252,253

Costa's Humming Bird................. $\quad 623$

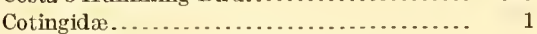

Couroucou à chaperon violet............. 785

à queue rousse de Cayenue...... 764

Cozumel Emerald....................... $55 \%$

Cranioleuca ............................. 161 


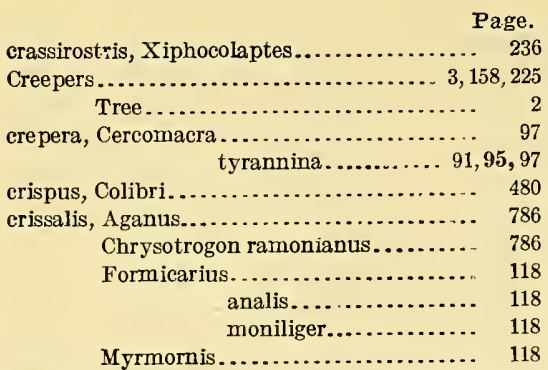

cristata, Anoplops...................... 131

Bellona........... 661,662, 663, 664, 665 cristata.................. 665

Mellisuga...................... 663

Mellivora rubra................... 669

Ornismya.....................661,662

cristatellus, Trochilus................... 661

cristatus, Bellona cristatus................ 665

Orthorhynchus............ 662,663,664

Orthorhyncus................ 657,661 cristatus.. $657, \mathbf{6 6 2}, 663,664$

Trochilus..........6656,661, 662, 663,664

Crochilus anna ........................ 621

Cuban Palm Swift.......................

Trogon

Cuckow, Green Yellow-bellied............. 764

Cuculi................................ 296

Cuculidæ.............................. 296

Cuculiformes......................... 295, 730

Cuculinæ calopteræ...................... 296

cuculliger, Trochilus....................... 381

Culampis.............................. 477 cuneatus, Dendrocolaptes............. 274, 275, 277

Glyphorhincus................ 277

Glyphorhynchus.............. 275,277

cuneatus........ 275

Glyphorynchus................. 275 cuneatus...... 275, 276

cupreicauda, Amazilia................... $\quad 438$

Saucerottea................. 438

Saucerottia................. 438

cupreiceps, Elvira............ 401,402,404, 405

Eupherusa................. 401,405

Lawrencius.................... 405

Polytmus..................... 405

Thaumatias................... 405

curucui, Trogon................. 742,763,764

Trogonurus..................... 763

curucui............... 764

Curucui, violet-headed................... 785

Curucujus...................... 732, 742, 750

clathratus................... $744, \mathbf{7 1 9}$

macrurus..................... 748

massena........... 743, 744, 747, 748, 749

melanurus................. 743,744

macrourus.......... 744, 747

melanurus.......... 743,744

cururuvi, Synallaxis.................... 187

Curve-winged Saber-wing................... 35.5

curvipennis, Campylopterus pampa, var.... 356

I'ampa.................... 356 pampa......... 354,355, 356

Polytmus................... 356

Sphenoproctus.............. $\quad 356$ curvipennis, Trochilus.

Campylopterus................. 364

Phæochroa............. 363, 364, 365, 366

Polytmus........................ 365

Trochilus....................... 362, 366

cuvierii, Campylopterus................... 364

Phæochroa.... 365

cuvierii.............363, 365

Trochilus........................ 364

Cuvier's Humming Bird.................. $\mathbf{3 6 3}$

cyaneifrons, Pyrrhophæna................. 436

cyaneotincta, Polyerata.................. 523

cyaneus, Trochilus ...................... 480

cyanifrons, Amazilia...................... 436

Ariana...................... 436

Chlorestes.................... 436

r. Saucerottia......... 436

Eratopis..................... 436

Hemithylaca.................. 436

Polytmus..................... 436

Saucerottea.................. 436

Saucerottia................... 436

Thalurania................. 436

Trochilus.................. 435, 436

cyanocephala, Agyrtria................... 426 B. Uranomitra....... 426

Amazilia................ 426, 428

Amizilis................... 408 cyanocephala. $408,125,427$

Cyanomya.............. 426, 427 (Leucolia)........ 426

Cyanomyia.............. 426, 427

Leucolia................... 426

Ornismya.................. 426

Uranomitra............... 426, 428

cyanocephalus, Ornismya................. $\quad 426$

Ornismyia................ 427

Polytmus.................. 426

Trochilus...$\ldots \ldots$

Cyanochloris......................... 386,540

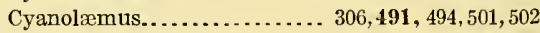

clemenciæ................. 492, 494

cyanomelas, Trochilus.................. 480

Cyanomia guatemalensis.................. $\quad 428$

viridifrons................... 422

Cyanomya............................ 430

cyanocephala.............. 426, 427 var. faustinæ....... 427 guatemalensis................. 428

(Leucolia) cyanocephala.......... 426 quadricolor .......... 424

microrhyncha................. 429

quadricolor................... 423

violiceps ....................... 425

viridifrons.................... 422

Cyanomyia........................ 406, 430 cyanocephala.............. 426, 427 ellioti....................... 424 guatemalensis................ 428 guerrercnsis............... 421, 422 (Leucolia) violiceps............. 425 microrhyncha................ 429 quadricolor................... 423 salvini.................... 430 sordida................... 366,368 
Cyanomyia verticalis ......

violiceps.................424,425 viridifrons................ 421,422

Cyanophaia........................ 307,526 bicolor................... 527, $5 \mathrm{6} z 9$ cæruleigularis ................ 540 cæruleo-lavata............... 528 chlorocephala............... 528 chlorophana................. 528 goudoti................... 538 lerchi...................... 528 Iuminosa................. 538 scapulata.................... 528 smaragdinea................. 528

Cyanopogon.......................... 651

cyanopogon, Calothorax................ 654

Lucifer...................... 654

Ornismya.................. 654

(Lucifer) $\ldots \ldots \ldots \ldots .654$

Trochilus................... 654

cyanota, Petasophora................... 486

cyanotis, Colibri....................... 485 Petasophora................... 485 r. Praxilla.......... 485 cyanotus, Colibri............... 481,484,485 Colibris....................... 485 Petasophora.................. 485

Trochilus..................... 485 cyanura, Amazilia................. 445, 446, 447 Amizilis....................... 446

Ariana...................... 446

Eratina....................... 446

Hemithylaca................... 446

Pyrrhophæna................. 446 Saucerottea................. 446, 447 Saucerottia............... 439,446,448 cyanura....... 439, $\mathbf{4 5 5 , 4 4 6}$

cyanurus, Polytmus..................... 446

Trogon....................... 752

Cymbilaimus....................... 10,18

lineatus.................. 19,20

fasciatus........... 19

lineatus........... 19, 20

C 7 mbilanius............................ 18 lineatus................ 19,21,27

fasciatus............ 21

lineatus............ 19

Cymbolæmus......................... 18

Cynanthus................ 304,367, 368,369, 627 colubris ........................ 633

doubledayi............... 370,375

latirostris . $368,369,370,372,373,374,375$ magicus............. 371

lawrencei ...........370,371,373,375

lucifer.................. 651,653

maugerii...................... 551

thalassinus................. 483

Cynanthus ? tricolor ..................... 601

Cypcelus.............................. 685

collaris....................... 702

vauxii................ $721,722,723$

Cyphorinus (Microcereulus) cinctus........ 13

Cypseli.............................. 298, 681

Cypselidæ.......................... 681,683

Cypseliformes......................... 298

Cypselinœ.......................681,685,687
Cypseloides................. 686, 710,711,715

borealis.............. 708, 709,710

brunneitorques........ 710,711,713

brunneitorques.. 711 ,

712, 713,714

griseifrons ...... 711

712,714

cherriei

$710,711,714$

fumigatus................682,711

niger.......... $705,706,707,709,710$

borealis............. 709,710

costaricensis............. 710

jamaicensis.............. 707

niger.................. 705

typicus............... 705,707

rutilus.................... 711

senex..................... 711

Cypselomorphæ...................... 298

Cypselus.................................. 68.5

acutus..................... 716

biscutata................... 697

borealis........................ 708

cayanensis.................... 692,695

cayennensis.................. 695

collaris...................... 697

giganteus. . ................... 686

gradii........................ 695

longipennis................... 683

melanoleucus.................. 687,689

niger................... 705,706

nigra...................... 705, 706

pelasgius..................... 719

phænicobia................. 694,695

phænicobius.................... 695

phœenicobius.................. 694,695

poliourus............... $719,725,729$

sancti hieronymi................ 693

saxatilis ..................... 689

senex.................... 710,711

spinicaudus................. 716,726

squamatus................... 686

D.

Dacryophorus........................ 257

affinis..................... 263

Damophila..................... 306,518, 524

amabilis................ 524,525,526

feliciana ................... 518

juliæ................... 519,520

feliciana........... 519,520,521

juliæ................. 519

julie feliciana................ 519 panamensis............... 522

typica.................. 520

panamensis ............. 519, 521, 522

typica...................... 520

Dark-breasted Automolus................ $\quad \mathbf{2 1 9}$

Darker Green Carib..................... 476

Dasyptilops............................ 16

Dasythamnus.......................... 52

mentalis.................. 54

Daucis abeillei...................... 518

Deconychura .................... 227,283, 284

Cherrie's................. $\mathbf{2 8 5}$

longicauda................. 284

secunda................... 285 
Page.

stictolæmus ............. typica............ 283, 284, 285, 286

decora, Agyrtria...................... 526 amabilis................. 526

Polyerata................... 523,525, 526 delatrei, Mfellisuga...................... 360 delattre, Campylopterus................... $\quad 360$

delattrei, Campylopterus................ 360 Lophornis...............670,671,672 Ornysmia (Lophorinus) . . . . . . . 669,672 Ornismyia................... 360

Telamon...................... 672

Trochilus..................... 672

De Lattre's Coquette ................... $\quad \mathbf{6 7 1}$

Sabre-wing.................. $\quad 358$

Delattria.......................... 494,502 amethystina.................. 497 clemenciæ...................... 494

fulgens......................... 567

hemileuca................... 508

henrica..................... 497 brevirostris.............. 498 henrica.............. 497 salvini.................. 499 henrici.................. 497,498, 499 margarethæ.................. 500 margaritæ.................... 500 pringlei....................... 501 rhami........................ 490,491 sybillæ..................... 502,509 sybille....................... 509 viridipallens.................. 510

delattrie, Campylopterus.................. 360 delattrii, Campylopterus.................. 360

Lophornis.................... 672 delphinæ, Colibri................ 481, $\mathbf{4 8 6 , 4 8 8}$ Ornismya.................... 480, 488 Petasophora.................. 488 ß. Telesiella .......... 488 Polytmus..................... 488

Telesiella.................... 488

Telesilla...................... 488

Delphinella............................ 480

deluzæ, Formicivora...................... $\quad 77$

Dendrexetastes........................ 226

capitoides ................. 226

Dendrocalaptes...................... 227,229 Dendrochelidonidæ.............. 682,683,684,686 Dendrocincla.................. 227,284, 286, 287 anabatina..... 286,287,289,290,291 anabatina.... 287, $\mathbf{2 8 8 , 2 9 0}$ saturata. . 287,289, 290,291 typhla....... 287, 289,290 atrirostris.................. 292 Brown................... $\quad 291$ Carriker's.................. $\mathbf{9 9 0}$ Costa Rican Ruddy.......... $\mathbf{2 9 4}$ fuliginosa............... 257 fumigata................. 292 homochroa........ 287, 288, 294, 295 acedesta. $285,293,294,295$ homochroa. . 288, 293, 294 ruficeps.. $288,293,294,295$

lafresnayei...............287,288 lafresnayei........ 288

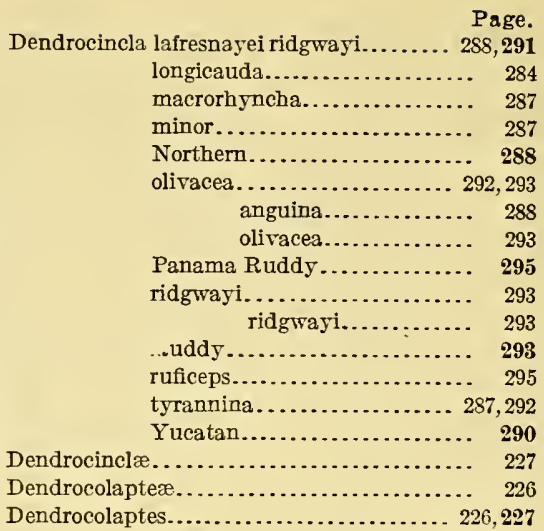

affinis............... 262,263,267

albigularis ................ 159

bivittatus................ 257

certhia................ 228, 229 sancti-thomæ....... 231

cuneatus............ 274,275, 277

eburneirostris.............. 247

emigrans.................. 238

erithacus............... 277, 279

erythropygius.............. 255

fumigatus.................. 292

guttatus................... 251

lacrymiger............... 257

lacrymosus................. 243

lafresnayanus............. 272

mentalis................. 248

multistrigatus........ 229, 233, 235

nanus.................... 251

obsoletus................. 229

perrotii.................... 226

picumnus............... 227, 229

platyrostris.............. 227

procurvus............ 265, 269, 270

puncticollis....... 229, $232,233,235$

radiolatus............... 229

sanctithomæ.......... 229, 231, 232

sancti-thomæ hesperius..... 229,

231,232

sancti-thomæ. 229 ,

231,232

squamatus............... 257

superciliosus.............. 162

susurrans.............. 251, 253

sylviellus................. 277

temminckii................ 226

tenuirostris.............. 257,265

triangularis.......... 241, 255, 257

trochilirostris......... 269, 270,272

turdinus................. 286

validus........... 228, 229, 233, 235 costaricensis.. 229, 233,235 validus ......... 229, 233

Dendrocolaptidx ........ 1, 2, 3, 4, 158, 224, 225, 226,

$228,235,239,257,268,274,278,283,286$

Dendrocolaptinæ................ 1, 158, 224, 226

Dendrocops .......................... 227

anabatinus.................. 290

atrirostris................. 292 


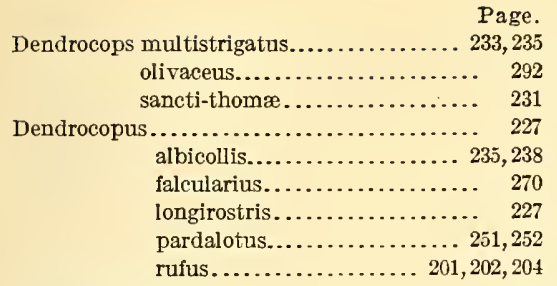

Dendrodramus........................ 159

Dendroma............................. 201

caniceps................... 201,202

Dendromanes........................ 286

anabatinus............... 290,291

atrirostris................. 292

homochrous................. 294

Dendroœcia.......................... 14

erythroptera................ 14

Dendroplex......................... 226

Dendrornis..................... 226, 239, 243

æquatorialis................ 241

eburneirostris......... 246,247,248, 249

erythropygia........... 255, 256, 257 æquatorialis...... 241

flavigaster............. 246, 248, 249 megarhynchus....... 248 mentalis............ 247

flavigastra................... 246

guttatus..................... 251

lachrimosa................... 244

lachrymosa................ 243,244

eximia.......... 243, 244

lachrymosa........ 243

lachrymosus............... 243,244

lawrencei.................. 251

costaricensis......... 253

lawrenceii costaricensis......... 253

lawrencii costaricensis.......... 253

megarhyncha................ 248

mentalis.................... 247

nana ................. 251, 252,253

confinis................ 253

costaricensis............. 253

nana ................. 251

pardalotus.................. 251,252

punctigula................... 257

striatigularis.................. 250

susurrans................ 239, 251,253

tenuirostris................... 265

triangularis............. 241, 255,257

bogotensis......... 241

erythropygia....... 255

De Oca's Humming Bird................. 452

devillei, Amazilia......................... 448

Amazilius....................... 448

Eranna........................ 448

Polytmus....................... 448

Pyrrhophæna.................... 448

Saucerottea.................... 448

Saucerottia................... 447

Trochilus...................... 448

Deville's Humming Bird .................... 447

devilli, Amazilia...................... 448

Amizilis......................... 448

Pyrrhophæna.................... 448

Saucerottea.................... 448
Page.

devillil, Saucerottla.................... 448

Dialia............................... 669

adorabilis....................... 676

Diallactes............................ 27

granadensis................... 32

melanocrissus................. 31

melanurus..................... 31

transandeanus................. 31

Dichrozona............................ 13

zononota.................. 13

difficilis, Thamnophilus radiatus.......... 38

dignissima, Grallaria................... 10

Diphlogœna leueaspis................... 504

Dippers............................. 9

Disithamnus semicinereus............... 57

Disythamnus rufiventris ................. . 95

Dives Antpitta....................... 154

dives, Grallaria......................... 154

Hylopezus................ 152, 153, 154

Dnophera........................... 336

Dolerisca............................. 305

Doleromya sordida..................... 368

var. zonura........... 368

Doleromyia....................... 305, 367

doliatus, Lanius............. $34,36,39,42,43,44$

Thamnophilus................ 36 ,

$37,38,39,40,41,42,43,44$ doliatus............ 36

Dolicha................................ 647

domicella, Lanius...................... 14

domicellus, Trogon...................... 792

dominica, Anthracothorax, $\delta$. Hypophania,... 469

Chætura.................... 725

dominicana, Chætura.................... 725

dominicensis, Poljtmus................... 4469

dominicus, Anthracothorax............ 455, 456, $457, \mathbf{4 6 8}, 469,470$

Lampornis................. 469, 472

Polytmus.................. 456

Trochilus........ 332, 45 $4,456,469,472$

Doricha.......................... 309,639,647

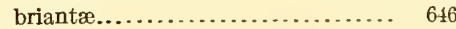

bryantæ...................... 616

elisæ.......................... 651

eliza.................. 647,618,650

enicura...............6 647,648, 649,655

evelynæ...................... 643

henicura..................... 649

lyrura......................... 645

Dorifera........................... 342

ludoviciæ..................... 341

reraguensis.................... 344

dorso-immaculatus, Campylorhamphus...... $\quad 269$

Dorycha bryantæ..................... 646

bryanthæ..................... 646

evelynæ....................... 643

lyrura....................... 615

Doryfera.......................... 342

ludovicia...................... 34

veraguensis................... 344

Dorsphera ludoriciæ.................. 344

Doryphora.......................... 342

veraguensis................. 344

doubledayi, Circe....................... 377

Cynanthus.................. 370.375

Hylocharis................ 373,377 


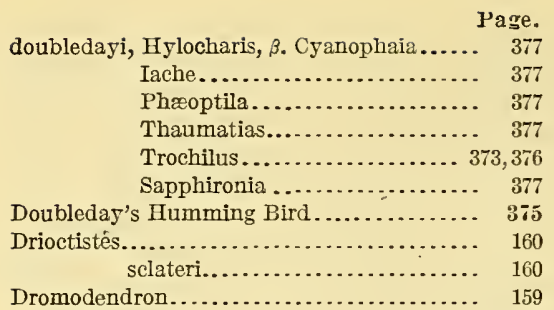

Drymophila........................ 13, 14, 105

albiventris................. 105

boucardi.................. 79,105 consobrina.................. 81

grisea...................... 77

margaritensis........... 77

tobagensis.............. 77

intermedia................. 77,83

læmosticta................ 110

stictoptera................. 110

swainsoni.................... 109

variegata.................. 14

virgata..................... 80

Drymornis ............................ 227

Drymornithes......................... $\quad 227$

Dryocopus............................ 286

eburneirostris................ 246,248

flavigaster..................... 246

dubusi, Amazilia ........................... 412

fuscicaudata............ 412

tzacatl................. 412

Amazilius...................... 412

Amizilis tzacatl .................. 412

Eranna........................ 412

Pyrrhophæna................. 412

Trochilus....................... 412

duchassaingi, Sapphironia............... 540 duchassaini, Trochilus..................... 540

duchassainii, Hylocharis................. $\quad 540$

ß. Cyanophaia..... 540

Duchassain's Humming Bird............. 559

dumerili, Ornismya..................... 448

dumerillii, Amazilia...................... 448

duponti, Mellisuga...................... 639

Ornismya..................... 639

Thaumastura.................. 639

Tilmatura...................... 639

Triphæna..................... 639

Trochilus..................... 639

dupontii, Ornismya................... 637,638

Tilmatura................... 638

Tryphæna.................... 639

Dupont's Humming Bird ................. 638

Dusky Hermit........................ 326

Humming Bird .................. 367

Plumeleteer..................... 392

Sclerurus...................... 168

Tyrannine Antbird............... 95

-winged Philydor .................. 204

Dyrinia............................. 583

Dysithamnus...................... 12, 48,52

affinis................ 54,55,57

affinis............... 54

andrei............... $\quad \mathbf{5 4}$

spodionotus........... 55

ardesiacus................. 48,53
Dysithamnus flemingi

leucostictus...

mentalis............... $53,54,55$

andrei......... 54, 55,57

mentalis........ 54,55,57

oberi.............5 54,57

semicinereus..... 54,55,57

septentrionalis.... $54, \overline{55}, 58$ spodionotus ..... 54,55,57

olivaceus.................. 54 semicinereus........ 58

plumbea.................. 48

plumbeus................... 53

puncticeps.............. 55, 58,59

schistaceus................ 57

semicinereus............... 54,53

spodionotus................ 54,55

striaticeps.., ,............ 55, 59, 60

subplumbeus.............. 48, 53

tambillanus................ 53

unicolor................... 48,53

xanthopterus............... 53

\section{E.}

Eared Trogon . ..................

eburneirostris, Dendrocolaptes............ 247

Dendrornis......... 246, 247, 248, 249

Dryocopus.............. 246, 248

Premnocopus............. 247

Xiphorhynchus flavigaster... 247

Ecuadorian Antwren.................... $\quad 80$

edward, Amazilius. . ..................... 444

Amizilis....................... 444

Polytmus...................... 444

Saucerottea .................... 445

Saucerottia..................... 444

Thaumantias................... 444

Trochilus..................... 435, 444

edwardi, Amazilia..................... 445

Amizilis...................... 445

Eratina....................... 444

Erythronota.................. 444

Hemithylaca................... 444

Leucodora..................... 444,445

Saucerottea...................... 444

Saucerottia........4 439, 441,443, 444, 445

edwardii, Amazilia..................... 445

edwardsii, Chlorestes..................... 444

Chlorestes, $r$. Saucerottia........ 444

Polytmus................... 444

Egolia.................................. 639

egregia, Eupherusa ................. 394,396, 397

Egregious Ifumming Bird . . . . . . . . . . . . . . . . 396

egregius, Polytmus..................... 397

elatus, Chrysolampis.................... 669

Trochilus....................... 669

elegans, Chlorestes..................... 546

o. Riccordia.............. 546

Chlorolampis.................. 547

Erythronota.................435,547

Hylocharis................... 546

Lampornis .................. 546

Ricordia.................... 547

Sporadicus..................... 547

Sporadinus.................... 546 
elegans, Trochilus...................

Trogon........................ 775

Trogonurus............ 762,764,773,775

Elegant Trogon .......................

elenæ, Lophornis ..................... 675

elicia, Chrysuronia..................... 385

eliciæ, Chrysurisca ....................... 386

Chrysuronia................... 385, 386

Hylocharis.................... 384, 386

Polytmus....................... 385

Trochilus...................... 385

Elicia's Golden-tail...................... 384

Elisa................................ 647

elisa, Lucifer .......................... 650

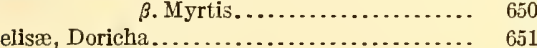

Taumastura..................... 651

eliza, Calothorax..................... 650

Doricha................... 647,648,650

Trochilus......................6 647,650

elizæ, Amalasia ....................... 651

Amalusia....................... 651

Amathusia (Doricha).............. 651

Calothorax.................... 651

Thaumastura................... 650

ellioti, Atthis...................... 594,595

heloisa................. 594

Cyanomyia.................... 424

Lampornis..................... 471

Trochilus....................... 595

Uranomitra.................... 424

Elliot's Humming Bird................. 594

Ellipura............................ 14, 83 grisea........................ 77

eloisœ, Atthis........................ 594

Elvira........................ 304,399, 401 cæruleiceps.................... 405

chianura....................... 403

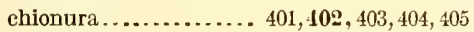
cupreiceps .............. 401,402,401,405 nigriventris..................... 401

elviræ, Zephyrites (Calypte)............. 627

Emerald, Allied...................... 558

Bahaman.................... 514

Canivet's..................... 553

Caribbean ................... $\quad 559$

Coppery-headed............... 404

Cozumel...................... 552

Golden-crowned............... 551

Guatemalan.................. 556

Haitian.................... 546

Lucy's..................... 434

Porto Rican................... $\quad 550$

Ricord's.................... $5 \mathbf{5 4 3}$

Salvin's.................... 557

White-bellied.................. 432

tailed................... 402

emigrans, Bellona.................... 664 cristata............... 664

cristatus............... 664

Dendrocolaptes................ 238

Orthorhynchus................ 664

Orthorhyncus cristatus........657,664

Xiphocolaptes........... 236,238,239 emlgrans $236, \mathbf{2 3 7}, 238,239$
537

goudoti....................... 538

luminosa...................... 538

emiliæ, Phaëthornis................... 316, 319

guy $\ldots \ldots \ldots \ldots \ldots \ldots . \quad 316$

guyi................ 319

Phaetornis guyi, var ............. 316

Phœthornis guyi............ 316,317,318

Toxateuches................... 319

Toxoteuches..................... 316

Trochilus...................... 316,319

Endoxa............................ 454

mango........................ 459

porphyrura................... $\quad 459$

enicura, Amalasia...................... 649

Amalusia...................... 649

Amathusia.................... 649

Doricha.............647,648, 649, 655

Myrtis....................... 649

Thaumastura................... 649

enicurus, Calothorax..................... 649

Lucifer....................... 649

Trochilus................ 647,649,655

ensipennis, Campylopterus............... 357

Eranna............................ 406

beryllina...................... 450

cerviniventris................... 414

cinnamomea.................. 418

devillei....................... 448

dubusi.......................... 412

fuscicaudata.................. 411

graysoni...................... 420

jucunda....................... 407

marix........................ 448

rlefferi ....................... 411

suavis........................ 412

yucatanensis.................. 413

Erasmia............................. 435

Eratina........................... 435

cyanura..................... 446

edwardi........................ 444

iodura...................... 438

viridiventris.................. 435

Eratopis............................. 435

cyanifrons..................... 436

Eremita.......................... 314

adolphi........................ 325

striigularis .................... 325

Eriodora intermedia.................. $\quad 77$

Eriodoridæ......................... 8

Erionotus .................... 12, $\mathbf{7 7}, 48,53$ nævius.................... 49 punctatus...................... 27,51

atrinucha ..........49, 52

gorgonx............ 49,58

punctatus............49,50

erithacus, Dendrocolaptes............. 277,279

Sittasomus.................. 279

erratilis, Gymnocichla nudiceps..... 9s, 99,100, 101

ery thacus, Sittasomus................. 279

ery throcephalus, Anabates.............. 160

erythrocercus, Philydor................ 201,202

Erythronota........................ 435

antiqua.................. 437

edwardi.................... 444

$81255^{\circ}-$ Bull. $50-11-52$ 
Page.

Erythronota elegans.................. 435,547

feliciæ............... 437

niveiventris ................ 442

saucerottei................. 436

sophiæ.................... 440

typica..................... 436

erythronota, Amazilia.................. 437

Amizilis tobaci............... 437

Ariana................... 437

Chlorestes.................. 437

Hemithylaca................ 437

Myrmotherula.............. 62

Ornismya................. 435

Saucerottea tobaci............ 437

Saucerottia.................. 437

tobaci............ 437

erythronotos, Ornismya ................ 437

Polytmus.................. 437

erythronotus, Phyllobates................ 83

Polytmus.................. 437

Trochilus.................. 437

Trogon..................... 747

erythrops, Acrorchilus .................... 184 erythrops.......... 184, 185

Siptornis. . . . . . . . . . . . . . . . . 184, 186

Synallaxis. . . . . . . . . . . . . . 183,184,186 erythroptera, Dendroœcia................. 14 erythropterus, Formicarius............... 135 erythropygia, Dendrornis.............. 255, 256,257 triangularis...... 255

erythropygius, Dendrocolaptes........... 255

Xiphorhynchus...... 241,254,255

erythrorhynchus, Amazilius............... 418 erythrothorax, Synallaxis . . . 187, 158, 189, 190, 191 erythrura, Myrmotherula................... 62 erytrothorax, Synallaxis.................. 191

Eucephala cæruleo-lavata................ 528

chlorocephala................ 528

lerchi...................... 528

scapulata..................... 528

smaragdinea.................. 528

smaragdo-cærulea.............. 528

euchloris, Smaragditis.................. 547

Eugenes ........................ 308, 564, 565

fulgens ................... 56.5, 567,568 spectabilis ............. 565, 568, 569, 570 chiriquensis........... 570

viridiceps..................... $56 \mathrm{~S}$

Eulampes jugularis..................... 479 Eulampis......................... 305, 473,477 aurulentus.................. 469 chlorolæmus. . . . . . . . . . . .... 476, 477 holosericeus.............. . 475, 476, 477 jugularis .................. 478, 479 eximius.............. 480 longirostris ................... 477 Eupherusa ............ 304,398, 394, 399, 401, 402 chionura................. 403, 404 cupreiceps................ 401,405 egregia .................. 394,396, 397 eximia............. 394, 395, 396, 397 eximia ..............391, 396 nelsoni ............. 394,396

nigriventris................ 399,401 niveicauda.................. 404 poliocerca.......... 394, 397, 398, 399
Page.

Euphrerusa eximia ..................... 396

poliocerea.................. 399

Euptilotis............................ $\quad 740$

neoxenus.................... 742

Euptllotis............................ 740 neoxenus..................... 742

Eurylaimi............................ 296

eurynome, Trochilus................... 314

Eutoxeres........................... 303,310

aquila....................... 311,313

heterura.......... 311, 312,313 typicus................. 311 salvini................ 311,310

var. heterura........... 311

var. salvini............. 313

baroni...................... $\quad 312$

condaminei gracilis............ 312

condamini..................... 312

heterura................... 311,313

salvini...................... 313

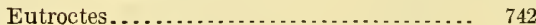

hofimanni.................. 747

macrurus..................... 749

massenæ...................... 747

evelynæ, Amathusia (Egolia)............... 643

Calliphlox................... 643

Calothorax..................... 643

Doricha..................... 643

Dorycha..................... 643

Lucifer........................ 643

o. Calotinorax ............. 643

Nesophlox ................641, 643

Philodice....................... 643

Thaumastura.................. 643

Trochilus............... 639,643, 645

evillinæ, Callothorax..................... 643

exilis Bellona........................... 660

cristata...................... 660

Mellisuga....................... 660

Microlyssa....................... 660

Orthorhynchus.............. 660,664,665

Orthorhyncus ..................... 657 exilis.......... $657,658,661$

Trochilus................... . 656,660, 664, 665 (Orthorhynchus) .......... 660

eximia, Amazilia....................... 395

Chlorestes, $\psi$. Saucerottia ......... 395

Dendrornis lacrymosa . .......... 243, 244

Eupherusa.............. 394,395,396, 397 eximia............ 394, 396

Euphrerusa.................... 396

Ornismia....................... 405

Ornismya.............. 393, 395, 396, 397

Saucerottia..................... 395

eximius, Eulampis jugularis.............. $\quad 480$

Polytmus...................... 396

Trogon.......................... 756

Xiphorhynchus lachrymosus. $241,243,244$

exoptatus, Trogon...................... 763

exsertus, Automolus.................... 221

cervinigularis......... 222 pallidigularis......... 213, $\mathbf{2 1}$

exsul, Myrmeciza............... 106, 107,1i1,112 exsul ................. 111

Myrmelastes..................... 111

exsul .................. 112

eytoni, Trogon ........................ 763 
Fairy, Barrot's

falcinellus, Picolaptes.

falcularius, Campylorhamphus

Xiphorhynchus.

Xiphornis

Falculia.

fallax, Leucippus.

$$
\text { Trochilus. }
$$

Fasciated Antshrike.

fasciatus, Cymbilaimus lineatus

Cymbilanius lineatus . . . .

Trochilus......................

faustinæ, Agyrtria. Cyanomya cyanocephala, var .... .

Uranomitra....................

Fawn-breasted Humming Bird.

felicim Amazilia

Amizilis tobaci.

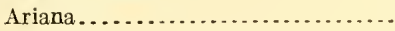

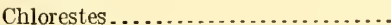

Erythronota....................

Hemithylaca....................

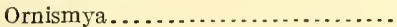

Polytmus.

Saucerottea tobaci................

Saucerottia.

Chlorestes, $. \ldots \ldots \ldots \ldots . \quad 437$

tobaci............... 437

eliciana, Damophila juliæ................ 519 julie .......... 5 519,520,521

Ornismya.................... 438

fernandensis, Sephanoides............... 417

ferruginatus, Lanius..................... 36

ferruginea, Myiothera................. 14

Myrmeciza.................. 100

ferrugineipectus, Grallaria................ 144 Grallaricula.............. 144

ferrugineus, Lanius. .................... $\quad 36$

Trochilus................... 332

ferruginolentus, Anabates............... 211

Automolus.............. 223

festatus, Pharomachrus................ 735, 736

fimbriata, Topaza.................... 579

fimbriatus, Trochilus................... 579

flabellifera, Florisuga ................ 579,580 mellivora, var....... 580

Topaza.................... 579

flabelliferus, Florisuga................... 579

Trochilus ................ 579

flammula, Selasphorus ... 596, 597,601, 602, 603, 604 flammula........... 602 platycercus, var ..... 602

Trochilus................... 602

flammulata, Holocnemis................ 16

flammulatus, Sittasomus .................. 275

flavescens, Pseudocolaptes.............. 197 Thamnophilus (Silvestrius)..... 52

flavigaster, Dendrornis . ............ 246, 248, 249 Dryocopus .................. 246

Nasica.................... 240

Xiphorliynclius.... 239, 241, 246, 248, 249 flavigaster ...... 241,

$214,246,247$

flavigastra, Dendrornis . . . . . . . . . . . . . . . 246

flavirostris, Grallaria.............. 143, 144, 146

Grallaricula................ 144, 146
Page.

flemingi, Dysithamnus................. $\quad 53$

Flicker ................................ 226

Floresia.......................... 454,459

floresi, Calypte....................... 618

Lampornis..................... 459

floresii, Calypte......................... 618

Selasphorus ........ 596, 597,616, 617,618

Trochilus .................. 459,617,618

(Selasphorus) ........... 618

Floresi's Humming Bird............... 616

Floricola............................. 344

albicrissa.................... 345

constanti..................... 351,353

constanti............. 352

leocadiæ.............. 352

typica................ 352

leocadiæ...................... 352

longirostris................... 349

albicrissa............ 345

pallidiceps........... 349

stuartæ............. $34 \mathrm{~S}$

palhidiceps.................... 349

superba ...................... 348

pallidiceps............. 348,349

stewartæ.............. 348

superba.................. 348

typica.................... 348

Florisuga ....................... 308, $5 \mathbf{5}$

flabellifera.................. 579,580

flabelliferus................... 559

guianensis.................. 550

mellivora ...........5 576,578,579,580

mellirora............ 579

tobagensis.......... 577, 578

var. flabellifera......... 580

mellivorus.................... 558

perusiana................... 580

sallæi....................... 580

sallei....................... 580

forficata, Chlorolampis................ 553

forficatus, Chlorostilbon . .......... 549, 552, 553

Trochilus................... 341

Formicarieæ....................... 15

Formicariidæ........................ 1,2,

$3,4,8,9,10,18,21,24,27,32,34,47,52,60$

Formicariinæ..................... $\$, 10$

Formicarius . . . . . . . . . . . . . . . . . . 15, 115

analis............... 117,119, 124

analis............... 117

crissalis............... 118

nigricapillus ..... 117, 118, 119

saturatus ............. 118

brevicauda................. 18

cantator..................... 15

castaneiceps ................ 125, 126

cayanensis................ 115, 117

colma................... 115,117

nigrifrons............ 117

erissalis................... 118

erythropterus............... 135

hoftimani................. 123

hofimauni............. 123, 124, 125

hoffmanni......... 124

saturatus ........... 118

moliniger................. 121

moniliger.............. 120, 122, 123 


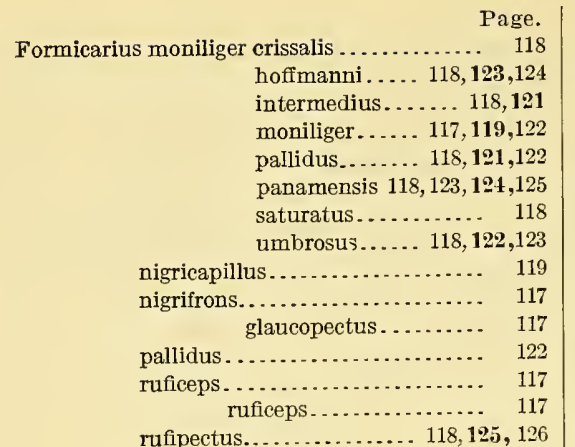

saturatus.................... 118

thoracicus. . ................. 118

torquatus. . ................ 138, 139

trivittatus................... 135

umbretta..................... 164

umbrosus. . ................. 123

varius. . ................... 10, 146

Formicaroideæ........................ 1

Formicaroidei......................... 1,3

Formicivora $\ldots \ldots \ldots \ldots \ldots \ldots \ldots \ldots \ldots . \ldots \ldots$ 13, 14, 83

alticincta................... 83

axillaris. . . . . . . . . . . . . 67,69

boucardi. ................. $79,80,81$

virgata............ 80

boucardii.................. 79,80

brevicauda.................. 10,65

callinota.................... 84

cano-fumosus............... $\quad 77$

consobrina.................. 81

deluzæ..................... 77

genei...................... 14

grisea..................... 77

intermedia .............. $76,77,83$

melæna................... 69

menetriesi.................. 67,72

nigricollis.................. 77

orenocensis................. $\quad 77$

ornata....................... 74

pygmæa..................... 65

quixensis.................. 80,81

schisticolor.................. 72

speciosa.................... 13

tobagensis.................. 77

virgata..................... 80

formicivora, Myrmothera................ 139

Rhopoterpe ................ 139

Formicivoræ......................... 12

Formicivorus......................... 14, 138

palikour.................. 138, 139

formicivorus, Turdus.................. 138, 139

forreri, Amazilia........................ 416

Amizilis..................... 407, 416

Forrer's Iumming Bird.................. $4 \mathbf{4 1 6}$

fortis, Xiphocolaptes................... 236

Fourmillier.......................... 138 de Cayenne................. 139

huppé...................... 34

francix, Trochilus.................... $\quad 430$

fraterculus, Thamnophilus doliatus......... 41,43

fulgens, Clytolæma.................... 568

Coligena....................... 567
Page.

Delattria....................... 567

Eugenes.................... 565, 567, 568

Mellisuga....................... 567

Trochilus.................... 564,567

fulgidus, Calurus....................... 735

Cosmurus...................... 735

Pharomacrus................. 735

Tanypeplus.................... 735

Trogon......................... 735

(Calurus) . . . . . . . . . . . . 735

fuliginosa, Dendrocincla................. 287

Myiothera................... 67

fuliginosus, Aithurus ................... 341

fulvescens, Microtrogon.................. 784

fulviventris, Myrmetherula................. 74

Myrmopagis................ 67, 73

Myrmotherula................ 74

fumigata, Dendrocincla................... 292

Hemiprocne................. 710,711

fumigatus, Chætura................... 711

Cypseloides................6 682,711

Dendrocolaptes............... 292

Nephocætes................. 711

fumosa, Chætura............. 717,726, 727,728

cinereiventris... $716,717, \mathbf{7 2 5}, 726$

spinicauda .............. 726

fumosus, Automolus.............. 213, 216, 217

funebris, Lanius. . . . . . . . . ................ 10

furcata, Ornismya.................... 341

furcatus, Trochilus................... 341, 530

Furnariidæ........... 1, 3, 4, 157, 158, 224, 225, 226

Furnariinæ......................... 157, 159

Furnarius pallidus. . ................... 122

fusca, Sitta......................... 162

fuscicapilla, Myrmothera ................ 117

fuscicapillus, Picolaptes................. 258

fuscicauda, Chlorestes.................... 411

r. Saucerottia........ 411

fuscicaudata, Amazilia................... 410 fuscicaudata......... 411

Amizilis.................... 411

Amizillis................... 410

Eranna................... 411

fuscicaudatus, Amazilis................. 410

Hylocharis ................. 410

Trochilus................ 405, 410

fusciceps, Thripophaga................. 160

fuscipennis, Philydor . . ...... 201, 202, 203, 204, 205

fuscocaudata, Amazilia................. 411

fuscus, Sclerurus....................... 165

Scytalopus...................... 5

Tinactor.................... 163, 164, 165

Trochilus...................... 308

G.

Galbulæ............................ 296

Garnet-throated Humming Bird ........ 479,489

Gartered Trogon..................... 786

gaumeri, Chætura ........... 716, 719, 720, 721, 722

Gaumer's Swift....................... $7 \mathbf{7 2 1}$

genci, Formicivora . . . . . . . .............. 14

genibarbis, Xenops................. 170, 172, 175

genibarbis......... 172, 174

Gcoøcia............................ 163 orryetera.................... 163 


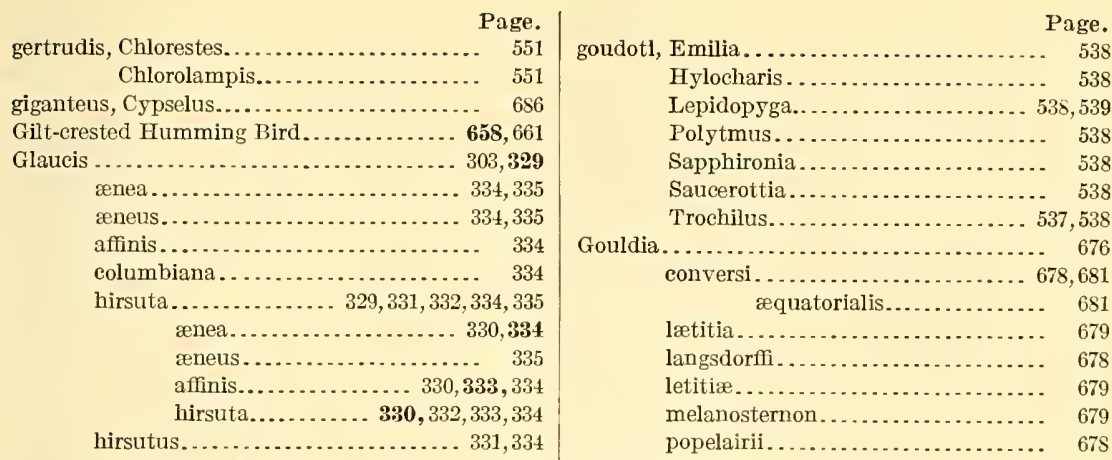

Gouldomyia.......................... 676,678

Graceful Trogon ...................... 781 gracilirostris, Anthracothorax prevostii..... 456,

lanceolata.

mazeppa...................... 333

melanura..................... 334

ruckeri........................ 337

glaucopectus, Formicarius nigrifrons........ 117

Glaucopes........................... 531

Glaucopis........................... 531

glaucopis, Trochilus.................... 531

glocitans, Trogon . . . . . . . . . . . . . . ........ 767

Glow-throated Humming Bird............ $\quad 604$

Glyphorhincus cuneatus................. 277

Glyphorhyncheæ...................... 227

Glyphorhynchinæ................... 226,227

Glyphorhynchus................. 226,227,274 cuneatus............... 275,277 castelnaudi...... 275 cuneatus........ 275 major................. 277 pectoralis............... 277

Glyphorynchus..................... 274,284 castelnaudi.............. 275 cuneatus................ 275 cuneatus...... 275,276 pectoralis......... $\mathbf{2 7 5}$ major.................. 277 ruficaudus............. 274, 275

Gmelinius..................... 527 bicolor...................... 530

goeldii, Chrysotrogon ramonianus........ 786

Golden-crowned Emerald ................ 551

-tail, Elicia's...................... 384

-tailed Plumeleteer................. $\quad \mathbf{8 9 0}$

goldmani, Trogon..................... 773 ambiguus.............. 773

Trogonurus ambiguus.. 762, 764, 769, 772 Goldmania .................... 305, 338, 452 violiceps . . . . . . . . . . . 452,453, 454 Goldman's Humming Bird............... $\$$ Trogon................... 779 Gorgona Island Antshrike............... 52 gorgonæ, Erionotus punetatus........... 49,52 Thamnophilus................. 4s, 52 goudoti, $A$ gyrtria...................... 538 $\delta$. Clialybura ............ 538 Chrysolampis (Emilia) .......... 538 Cyanophaia.................. 538

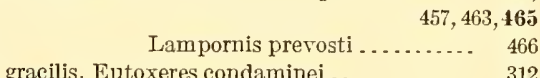

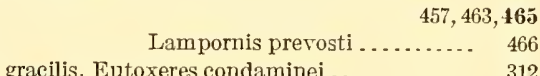

$\begin{array}{rr}\text { gracilis, Eutoxeres condaminei ............... } & 312 \\ \text { Picolaptes........................... } & 266\end{array}$

Graculidæ............................ 295

gradii, Tachornis......................... 695

Grallaria ........................ 10,17, 146

dignissima................... 10

dives.............................. 154

ferrugineipectus................. 144

flavirostris................. 143, 144, 146

guatemalensis.............. 149, 150,151

princeps.......... 150

guatimalensis............ 147, 149, 151 guatimalensis .. $147, \mathbf{1 4 8 , 1 5 0}$ mexicana......... 148, 150 ochraceiventris..... 148, 151 princeps......... 148, 149

intermedia .................. 156, 157

lizanoi ....................... 156

macularia..................... 153

mexicana.................... 151, 152

ochraceiventris................ 152

perspicillata............ 152, 155, 156, 157

princeps. . . . . . . . ............. 149, 150

ruficapilla..................... Is

ruficeps....................... 18

rufula....................... 18

squamigera.................. 147

grallaria, Myiothera ..................... 146

Grallaricula......................... 17, 143

Costa Rican................ 145

costaricensis................ 144, 145

ferrugineipectus.............. 144

flavirostris................. 144, 146

costaricensis........ 146

vegata.................... 146

Grallariinæ.......................... 17

Grallina.............................. 146

gramineus, Anthracothorax .......... 456, 457

Lampornis.................. 456

Polytmus................... 456

Trochilus................... 456

granadensis, Diallactes.................. 32

Tliamnophilus transandeanus.. 30,32

granatimus, Trochilus................... 480

grandis, Xiphorhynchus................. 273
Grallariæ............................... 17 
grata. Leadbeatera.................. $\begin{array}{r}\text { Page. } \\ 570,572\end{array}$

grayi, Hylocharis....................... 384

Gray-rumped Chimney Swilt............. 727

-tailed Mountain Gem............... 506

-throated Sclerurus................. $\quad 166$

graysoni, Amazilia...................... 420

(Pyrrhophæna)........ 420

Amazilis................... 420

Amizilis............. 407, 417,419,420

Eranna....................... 420

Polytmus.................... 420

Pyrrhophæna................. 420

Grayson's Humming Bird................ 419

Woodhewer.................. $\quad \mathbf{2 4 7}$

Green Carib.......................... 474

Cuckow, Yellow-bellied............. 764

-fronted Humming Bird............. 421

Mango........................... 472

-throated Humming Bird. .......... 456

Mountain Gem............ 509

Grenada Blue-erest.................... 661

grisea, Drymophila $. . . \ldots \ldots \ldots \ldots \ldots \ldots \ldots . .67$

Ellipura....................... 77

Formicivora................... 77

Microrhopias................... 75,76

grisea............... 77

griseifrons, Cypseloides brunneitorques $711,712, \mathbf{7 1 4}$

griseigularis, Acrorehilus erythrops ........ 184, 185 griseipectus, Myrmeciza boueardi......... 105, 106 griseiventris, Anoplops................. 131

griseus, Sittasomus..................... $\quad 279$

Thamnophilus................. 77

Turdus......................... 76,77

Grisin de Cayenne ................... 77

Gryphus salvini....................... 313

Guatemala Woodhewer.................

guatemalæ, Saucerottea cyanura........... 447 Saucerottia cyanura.......... 439,416

Guatemalan Antpitta.................. $14 \dot{8}$

Azure-crown............... 427

Blue-tailed Humming Bird..... 446

Cazique.................... 498

Emerald................... 556

Hermit................... $\quad \mathbf{3 1 9}$

Selerurus.................. 169

guatemalensis, Amazilia............... $42 S$ cyanocephala....... 428 Amizilis cyanocephala. $405, \mathbf{4 2 7}, 428$ Cyanomia................ 428 Cyanomya................ 428 Grallaria............ 149,150,151 Myiotriehas................ 151 Polytmus................. 428 Selerurus............ 165, 169, 170 Tinaetor................. 170 Uranomitra............... 428 cyanoeephala.... 428

guatimalensis, Chamreza.................. 149

Grallaria............. 147,149,151 guatimalcnsis. $147,148,150$

Selerurus................. 170

guayabambx, Myrmotherula............ 62

guerrerensis, Amazilia................. 422

A utomolus............ 212,213,216

Cyanonıia ............... 421,422

Uranomitra............... 422
Page.

Guerrero Automolus.................... $\quad 216$

Hermit....................... 323

Woodhewer..................... 239

Guiana Humming-bird.................. 669

guianensis, Chætura............... 716,727,728

cinereiventris ........ 727,728

Florisuga.................. 580

Motacilla.................. 186

Trochilus.................. 669

Guimetia.......................... 513

guimeti, Adelomya................... 515

Basilinna....................... 515

ß. Klais .............. 515

Clais........................ 515

Hylocharis................... 515

Klais....................... 514

Myiabellia.................... 515

Trochilus.................... 513,515

Guimet's Humming Bird................ 514

gujanensis, Trochilus................... 669

gularis, Myrmotherula.................... 74

Thamnophilus.................. 13,74

guttata, Margarornis................... 160

Myrmothera................... 13

Myrmotherula................. 13,62

guttatus, Dendrocolaptes............... 251

Dendrornis ................... 251

Leptorhynchus................ 10

Sylviaxis..................... 5

Thamnophilus.................... 10

guttulatus, Dysithamnus............... $\quad 53$

Lanius....................... 52

guttuligera, Thripophaga................. 161

gutturalis, Myrmopagis . ................ 67

guyanensis, Chætura................... $\quad 727$

guy, Phaëthornis ......................... 315

Toxoteuches ..................... $\quad 315$

Trochilus......................... 315

guyi, Phœthornis....................... 315

guyi.................. 315

Trochilus...................... 314

Guyornis........................... 314

typus......................... 315

Gymnociehla.................. 15,97,98

cheiroleuea................ 103

chiroleuca............ 99,101,103

nudieeps......... 98, 99,100,101,103 erratilis..... 98, 99, 100,101 nudiceps....... 98.99, 100 sancta-martæ....... 99,100

Gymnopithys........................ 130

bicolor ................. 132,134

olivascens........... 134

leueaspis ................. 131

olivascens.................. 134

ruficeps.................... 131

rufigula................... 131

gymnops, Rhegmatorhina.............. 16

H.

hæberlini, Chlorestes.................... $\quad 547$

Hxlioprdica melanotis................... 381

hamatonota, I Iyrmotherula.............. 62

hæmatorhynehus, $A$ mazilius............. 418

Hairy Hermit....................... $\quad \mathbf{3 3 0}$

Haitlan Emerald..................... 546 
Page.

Trogon

Vervain Humming Bird ........... 586

Halcyones......................... 296

Half-collared Antwren................. 89

Hapalophorus............................ 761

hargitti, Trogon (Calurus)............... $\quad 735$

Harpaleus.......................... 750

hauxwelli, Myrmotherula................ 62

hectoris, Bellona...................... 662

helena, Lophornis...................... 675

helenæ, Atthis . . . . . . . . . . . . ......... 627

Calypte ..........6 615, 619,625, 626,627

Lophornis.............670,671,678, 674

Mellisuga....................... 674

Ornismya................... 669,674

Orthorhynchus................ 626

Paphiosa...................... 675

Paphosia....................... 675

Trochilus................... 627,675

Helena's Humming Bird . . . . . . . . . . . . . . . . 695

heliactin, Pharomacrus auriceps .......... 735

Tanypeplus.................... 735

Heliobletus.............. . . . . . . . . . . 160, 162

Heliodoxa ....................... 308,570, 571

berlepschi.................. 575

henrica................... 497

henrici.................... 575

henryi..................... 574,575

jacula.............. 570,571, 572,574

henryi........ 572,573, 574, 575 jacula............ 571, 572,573

jamersoni............ 571,572

jamesoni.............. 571 typica................. 571

jamesoni..................... 571

o. Lamprolaima............... 489 henrica . . . . . . . 497

rhami........ 491

leadbeateri.................. 572

leadbeateri......... 572

parvula............ 572

typica............ 572

otero...................... 572

sagitta..................... 572

splendens.................... 572

xanthogenys................. 570

Heliomaster constanti. . . . . . . . . . . . . 351, 353

leocadia.................... 352

leocadiæ.................. 352

longirostris................ 347,349

var. sclateri........ 348

stuartæ....... 345

pallidiceps................ 348, 349

pinicola.................... 353

sclateri................... 348

spectabilis................. 569

stuartæ.................... 348

Heliomastes. ......................... 344

albicrissa.................. 345

constantii................. 351, 353

Ileliopædica......................... 377

castaneocauda............... 383

(Coeligena) leucotis........... 381

xanthusi......... 383

leucotis................... 381
Page.

xanthusi.

xantusi................... 383

Heliopedica........................ 377

melanotis.................. 381

Heliopøedica xantusi. . . . . . . . . . . . . . ... 383

Heliothrix........................... 561

barroti.................... 563,564

alincius............... 564

var. purpureiceps........ 564

violifrons.......... 564

barrotii..................... 564

purpureiceps.................. 564

violifrons...................... 564

heliothrix, Trogon..................... 763

personatus............ 763

Heliothrys........................... 561

Heliothryx.......................... 307, 561

barroti.................. 562, 563

alincius............... 562

Heliotrix........................ 561

Heliotrope-throated Humming Bird........ 602 hellmayri, Acrorchilus.................... 184

Hellopædica xanthusi.................. 383

heloisa, Atthis......................... 594 heloisa............. 592, 594, 595

Mellisuga...................... 593

Ornismya................... 591, 594

Ornysmia...................... 593

Selasphorus................... 593

Trochilus....................... 593

o. Athis............... 593

Tryphæna..................... 593

heloisæ, Atthis..................... 593, 594

Selasphorus................. 593,594

Tryphæna.................... 593

Heloise's Humming Bird............... $\mathbf{5 9 2}$

hemileuca, Cæligena................... 508

Coeligena .................... 508

Delattria ................. 508

Oreopyra ........... 501,502,507,508

hemileucurus, Campylopterus ....... 357,358, 360

Polytinus ................ 360

Sxpiopterus .............. $\quad 360$

Trochilus ................ 359

hemileueus, Trochilus................. 50 s

hemimelæna, Mfyrmeciza................ 15

Hemiprocna zonaris pallidifrons ........... 702

Hemiprocne....................... 683,696 albicincta................... 698

biscutata................... 697

collaris..................... 698

fumigata.................. 711

fumigatus.................. 710

minor....................6 698, 699

pelasgia..................... 719

semicollaris.................... 703

temminckiana.............. 711

temminekii................. 711

zonaris..........6.6. $696,697,699,701,702$ var. albicincta......... 699

Hemiproenidæ......................... 683

Hemiprogne zonarta .................... 702

Hemistephania ..................... 303,349

ludoviciæ veraguensls ....... 344 veraguensis ............ 343,344 


\begin{tabular}{|c|c|}
\hline \multirow{2}{*}{ Hemistilbon $\ldots \ldots \ldots \ldots \ldots \ldots \ldots \ldots \ldots \ldots, \quad 435$} & Page. \\
\hline & Heterocnemis............. \\
\hline ocai. & Heterodactylæ .............. \\
\hline Hemithylaca.... & Heterodactyle Coraciiformes ............. \\
\hline aglaiæ. & Heterodactyles. . . . . . . . . . . . . . . . . . . . \\
\hline braccata..................... & Heterodactyli.......................... \\
\hline caligata .................. 437,441 & 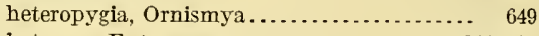 \\
\hline cyanifrons................. $\quad 436$ & heterura, Eutoxeres.................... 311,313 \\
\hline cyanura................. & aquila........... $311,312,313$ \\
\hline edwardi..................... & var........... \\
\hline erythronota........... & heterurus, Xenops....................... \\
\hline feliciæ................ & rutilus.......... 172,175, 176 \\
\hline hoffmannii. . & (n) \\
\hline iodura ....... & Hirondelle acutipenne, de la Martinique..... \\
\hline niveiventris............. 442,443 & Hirondelle à queue pointue, de la Louisiane. . \\
\hline saucerottel................. 436 & hirsuta, Glaucis........... $329,331,332,334,335$ \\
\hline sophiæ.................... & hirsuta ........ 330, 332, 333, 334 \\
\hline viridiventris . . . . . . . . . . & hirsutus, Glancis.................... 331,334 \\
\hline warscewiczi .............. & Phæthornis.................... 332 \\
\hline viczi $\ldots \ldots \ldots \ldots \ldots \ldots$ & Polytmus.............. 332 \\
\hline hendersoni, Anthracothorax prevosti........ & Trochilus................... 329, 331 \\
\hline prevostii...... 456, & Hirundapus................. \\
\hline $466,457,463$ & Hirundimapus.......................... \\
\hline Lampornis................. 466 & 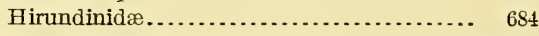 \\
\hline prevosti........... & Hirundo acuta.................... $715,716,725$ \\
\hline Henderson's Mango . . . . . . . . . . . . . . . . . . 466 & albicollis..................... 697,699 \\
\hline henicura, Amalasia..................... & apus............................. \\
\hline Calliphlox............................... & dominicensis............... \\
\hline$\beta$. Doricha............. & cauda aculeata................ 718 \\
\hline 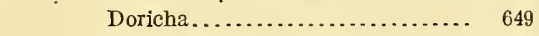 & cayanensis................ $690,692,695$ \\
\hline Thanmastura.................. & cayenensis....................... \\
\hline lenrica, Cæligena................... 497, 499 & collaris................. $697,698,701$ \\
\hline Cœligena. . . . . . . . . . . . . . . . . 497 & nigra. . . . . . . . $703,705,706,709,710$ \\
\hline Delattria..................... & oxyura.................... 727 \\
\hline henrica............... & pelagica.................. $714,718,724$ \\
\hline Heliodoxa....................... & pelasgia......................... \\
\hline o. Lamprolaima......... & robini............................. \\
\hline Ornismya................... 454,494 & rutila..................... 711,713 \\
\hline Ornismyia.................. 497,498 & spinicanda............... 714,716 \\
\hline Topaza..................... 497 & zonaris.............696, 697, 701,702 \\
\hline
\end{tabular}

henrici, Chariessa..................... 497

Coeligena.................. 497,49\$, 499

Delattria.................. 497,498,499

Heliodoxa.................... 575

Lampornis.................... 497

henricii, Cœligena..................... 497

henrri, Heliodoxa................... 574,575

jacula $\ldots \ldots \ldots .572,578,574,575$

Trochilus...................... 574

Henry's Humming Bird................. 578

henshawi, Selasphorus................. 616

Hermit, Bangs'....................... $\quad 317$

Boucard's..................... 324

Bronzy...................... 334

Dusky...................... $\quad 326$

Guatemalan.................. $\mathbf{3 1 9}$

Guerrero..................... 328

Ilairy.................... $\quad \mathbf{3} 30$

Island .......................... 32.4

Lesser Hairy . . . . . . . . . ........ \$3;3)

Nicaraguan.................... 321

Rucker's......................

Stripe-throated................ 327

Vera Cruz..................... 323

IIerpsilochmus......................... 14

hesperius, Dendrocolaptes sanctl-thomit..... 229,

hoffmani, Formicarius................. 123

hoffmanni, Eutroctes.................... 747

Formicarius........... 123, 124, 125

hoffmanni........ 124

moniliger.... 118, 123, 124

Myrmornis............... 123,124

Saucerottia.................. 441

Troctes...................... 747

Trogon.................... 747

hoffmannii, Hemithylaca................ 441

IIoffmann's Antthrush .................. 19:3

hoffmannsi, Anoplops................. 131

hollandi, Thamnophilus................ $\quad 31$

JIolland's Antshrike.................... 28

Holocnemis.......................... $\quad 16$

flamnulata................. 16

holosericeus, Anthracothorax........... 476 r. Sericotes... 476

Eulampis............. 475,476,477

Lampornis................ 476

Polytmus.................. 475

Sericotes................ 476,477 holosericeus...... 474,476

Trochilus................ 473, 475 (Lamporuis)........ 476

holostictus, Automolus................ 223

Homalogonatx.......................... 297 
Page.

homochroa, Dendrocinela........ 257,288,294, 295 homochroa. 28s, 298,294

homochrous, Dendromanes.............. 294

Honduras Wood-Nymph ................ 5896

Honeysucker, Ruffed................... 613

humicola, Asthenes.................... 161

humila, Mellisuga...................... 585

humilis, Mellisuga...................... 585

Siptornis...................... 161

Humming Bird ...................... 630

Humming Birds and Swifts............. $\quad \mathbf{2 9 8}$

Humming Birds, The .................. 8300

Humming Bird, A beillê's ................. 51

Admirable.............. $\mathbf{5 6 8}$

Alfaro's................. $\mathbf{4 4 1}$

Allen's................. 609

Anna................. $\quad 619$

Bangs's................ $\quad \mathbf{4 2 0}$

Beautiful............... 655

Berylline............... $\mathbf{4 9}$

Black and Blue........... 480

Black-bellied............ 400

Black-bellied Green....... 475

Black-breasted........... 456

Black-chinned............ 633

Blue-crested............. 662

Blue-tailed............... 445

Blue-throated............ $\quad \mathbf{4 9 2}$

Boucard's............... 541

Broad-billed............. $\quad \mathbf{3 7 0}$

-tailed............ $\mathbf{5 9 7}$

Brown-crowned........... 669

Buff-bellied.............. $\quad \mathbf{4 1 5}$

Calliope................ $\mathbf{5 8 8}$

Carbuncle................ 669

Cazique................ 496

Charming............. 525

Cinnamomeous........... $\mathbf{4 1 6}$

Coiba Island............. $\quad \mathbf{3 6 5}$

Coral-billed............. $\quad \mathbf{4 1 9}$

Costa's................ 6283

Cuvier's................. $\quad \mathbf{3 0}$

De Oca's............... 452

Deville's................ 147

Doubleday's............. 375

Duchassain's............ $\mathbf{5 3 9}$

Dupont's............... 6838

Dusky................. $\mathbf{3 6 7}$

Egregious............... $\quad 396$

Elliot's................ $5 \mathbf{5 4}$

Fawn-breasted............ $\mathbf{4 1 4}$

Floresi's................ $\quad 616$

Forrer's................ $4 \mathbf{4 1 6}$

Garnet-throated......... 479,489

Gilt-crested............. . 658, 661

Glow-throated. . . . . . . . . . 604

Goldman's.............. $\mathbf{4 5}$

Grayson's............... $\quad \mathbf{4 1 9}$

Green-fronted............ 421 -throated............ 456

Guatemalan Blue-tailed... $\quad \mathbf{4 6}$

Guiana................. 669

Guimet's............... 514

Iraitiau Vervain.......... 586

IIeleua's ................ $\mathbf{6 2 5}$

Heliotrope-throated........ 602
Humming Bird, Heloise's................ 592

Henry's............... $\quad \mathbf{5 8 3}$

Irazú.................. $\quad \mathbf{5 1 0}$

Jacobin ............... $\quad 5 \mathbf{5 6}$

Lawrence's.............. $\mathbf{3 7 3}$

Least.................. 585

Lesser Broad-tailed........ 601

White-eared........ 381

Little Brown............. 616

Long-tailed Black-cap..... $\quad 340$

Lovely ................... $\quad \mathbf{5 8 3}$

Lucifer................... 652

Mango.................. $\quad \mathbf{4 5 7}$

Horcom's............... $\mathbf{5 9 5}$

Nelson's................ $\mathbf{3 9 6}$

Owen's................. $\quad \mathbf{3 6 5}$

Panama.................. 521

Red-throated............. $\quad 630$

Rieffer's................ 408

Rivoli.................. $\mathbf{5 6 5}$

Ruby-and-Topaz.......... $\quad \mathbf{6 6 6}$

Ruff-necked.............. 613

Rufous................. 612

Sapphire and Emerald..... $\quad 530$

Scintillant.............. $\quad \mathbf{6 0 7}$

Simon's................ $\quad 606$

Small Green and Crimson.. 669

Snowy-breasted........... $\mathbf{4 4 1}$

Sophia's............... $\quad 439$

Streamer-tailed........... $\quad 339$

Stripe-tailed............. 394

Sumichrast's............ 451

Tobago............... 437

Vervain................ 584

Violaceous.............. $\mathbf{4 5 1}$

Violet-crowned........... 424 -throated............ 636

White-bellied............ 578 -eared.............. 378 -tailed............ 397

Wilson's............... 443

Xantus's.............. $\quad \mathbf{3 8 2}$

Yucatan.............. 412

hyalinus, Phaëthornis .................. 324

Phœthornis anthophilus ....... 316,324

Hylexetastes ........................... 226

Hylocharis......................... 377, 304,384

amabilis.................... 525

assimilis................... $\quad 559$

atala..................... 560

auriceps................... 552

bicolor..................... 530

cæruleigularis ............... 540

canivetii .................... 555

§. Chalybura cæruleiventris ...... 387

ehlorocephalus............... 528

ciree...................... 373

coerulescens................ 540

$\delta$. Cyanochloris............. 386

B. Cyanophaia ................ 526

bicolor.......... 530

caerulescens...... 540

doubledayi....... $\quad 377$

duchassainii ..... 540

lazula ........... 373

doubledayi ............... 373,377 


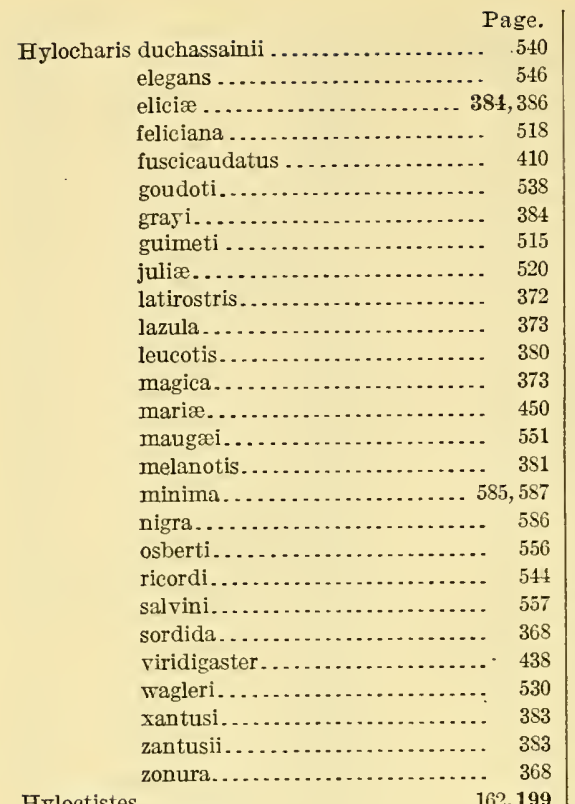

Hyloctistes.......................... 162,199 Striped..................... $\mathbf{2 0 0}$ virgatus .................. $\mathbf{2 0 0 , 2 0 1}$

Hylopezus............................. 18, dives................. 152, 153,154 intermedius............ 153,156, 157 lizanoi....................... 153, 156 macularius . . . . . . . . . . . . . . . 152, 153 perspicillatus............... 152, 153 lizanoi.......... 153,156 perspicillatus..... 153, 15.

Hylophylax ................... 16, 126, 128 nævioides................. 128, 130 hyperythrus, Campylopterus............ 356, 357 Hypocnemididæ....................... 8

Hypoenemis........................ 15, 127 cantator.................. 127 lepidonota............... 127 leucophrys................ 127 lugubris................... 127 melanopogon............... 14 melanura................. 14 myiotherina............... 127 nævia.................. 127 nævioides............ 127, 128, 129 capuitis.......... 130 nævoides................. 130 poecilonota................. 127 schistacea................... 14, 95

IIypodaleus............................ 10 hypolcuca, Synallaxis albescens...... 159, 195, 196 IIypolia............................. 570 leadbeateri................... 572 otero........................ 572 splendens...................... 572

IIypolophus........................ 12,32 canadonsis................. 32 pulchellus ......... 33

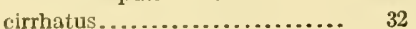
$\begin{array}{rr}\text { Hypolophus melanonotus . . . . . . . . . . . . . } & 32 \\ \text { pulchellus..................... } & 34\end{array}$ hypophæus, Automolus cervinigularis. $213,218,219$ Trochilus .................. 669 Hypophania....................... 454,469 Hypsibemon........................... 18

Hypuroptila......................... 386 æueicauda.................. 390 buffoni.................... 390 cæruleiventr s............. 387 cæruleogaster ............... 387 intermedia................. 388 isauræ.................... 391 (Lampornis) isauræ. ........... 392 melanorrhoa...... 393 melanorrhoa................. 393 urochrysa................... 391 urochrysia................. 391

\section{I.}

Iache.............................. 369

doubledayi...................... 377

latirostris..................... 372,373

lawrencei...................... 375

lawrencii........................ 375

magica........................ 373

nitida......................... 377

icterocephalus, Trochilus.................. 622

idaliæ, Trochilus ........................ 314

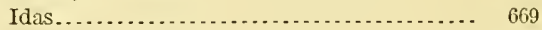

ignobilis, Automolus.................... 222, 223

Rhopoctites.................. 223

ignotus, Xiphocolaptes.................... 236

illætabilis, Trogon melanocephalus........ 752,

$757,759,761$

immaculata, Myrmeciza......... 106, 107, 112, 115

immaculatus, Mfyrinelastes............... 115

Thamnophilus........ 106,112, 115

impatiens, Saucerottea cyanura........... 446

Saucerottia cyanura............ 446

Inagua Wood-Star..................... $\quad 613$

incertus, Sporadinus................... 547

infumatus, Chrysolampis . . . ............... 669

inornata, Myrmotherula .................. 62

inornatus, Thamnophilus ............... 48

insignis, Clytolæma....................... 513

Panterpe............ 506,510,512,513

Picolaptes..................... 267 lineaticeps..... 259,265, 266,267

Trochilus..................... 513

insolitus, Xiphorhyuchus punctigulus..... 242,:357

intermedia, Chalybura ................... $38 s$

Drymophila................ 77,83

Eriodora.................... 77

Formicivora ............. $76,77,83$

Grallaria................. 156, 157

Hypuroptila............... $38 s$

Microrhopias................ 75 grisea......... $77,81,82$

Myrmeciza............. 112, 113,114

Intermediate Antthrush ............... 121

intermedius, Formicarius moniliger ....... 11s, 121

IIylopezus . . . . . . . . . . 153, 156, 157

Myrmelastes.............. 112,114 occidentalis...... 112

Thamnophilus .............. 43

Trochilus................. 314 
Page.

iodura, Amazilia........................ 438

Chlorestes..................... 438

r. Saucerottia ......... 438

Eratina....................... 438

Hemithylaca.................. 438

Pyrrhophæna.................... 438

Saucerottia................... 438

iodurus, Trochilus........................ 435

iolota, Petasophora.................. 480,481

iolotus, Colibri........................ 481

Ipoborus........................... 211

cervinigularis.................. 219

montanus................... 207

iradii, Tachornis . ...................... 695

Irazú Humming Bird. . . . . . . . . . . . . . 510

iridescens, Anthracothorax nigricollis. . 456, 457, 460 violicaudus...... 456

Lampornis................ 456

Irrisoridæ............................ 297

isabella, Xiphorhynchus................ 272

isauræ, Chalybura ............. . 387,388, 391, 392

Hypuroptila................... . . . 391

(Lampornis) ......... 392

Lampornis..................... 392

Polytmus. . . . . . . . . . . . . . . . . . 392

Island Hermit. . . . . . . . . . . . . . . . . . . . . . $\quad 324$

Isle of Pines Trogon ................... 795

\section{J.}

Jache latirostris

nitida.

Jacobin Hutmming

Cœligena. . .................... 571

ऽ. Leadbeatera.......... 571

Heliodoxa.............. 570,571,572,574 jactula . . . . . . . . . 571, 572,573

Leadbeatera.................... 571

Trochilus .......................... 571

Jalapa Trogon......................... $\quad 775$

jaliscensis, Sittasomus .................. $\quad 2 S 3$ sylvioides . ..... 279, 281, 288

Jalisco Sittasomus. . . . . . . . . . . . . . . . . . . . . 283

Jamaican Black Swift.................... $\quad \mathbf{7 0 5}$

Palm Swift.................... 694

jamaicensis, Cypseloides niger........... 707 Nephocetes niger... 704, 705,707, 710 Nyctibius................ . 736, 740

jamersoni, Coeligena, $\delta$. Leadbeatera....... 571

Heliodoxa jacula. . . . . . . . . . . 5 571, 572

Trochilus...................... 571

jamesoni, Clytolæma.................... 571

Heliodoxa. . . . . . . . . . . . . 571

jacula.............. 571

Leadbeatera................. 571

jucunda, Amazilia fuscicaudata........... 407 riefferi.................. 407

Amizilis tzacatl............. 407, 409

Ariana riefferi, var . ............. 407

Eranna......................... 407

jugularis, Eulampes.................... 479

Eulampis ................ 478,479

Polytmus................... 479

Trochilus............... 477,479

julia, Coeligena, $\beta$. Damophila ........... 520

julix, Damophila.............. 519, 520,522 julix

519,521
Page.

juliæ, Hylocharis..................... 520

Ornismya.................. 518,520,522

Juliamya feliciana..................... 518

typica.................. 520,521,522

Juliamyia.......................... 518

amabilis ..................... 524

panamensis .................. 522

typiea...................... 518

julie, Ornismya...................... 520

Julie's Humming Bird . . . . . . . . . . . . . ... 519

K.

Klais.......................... 306, 513

guimeti ....................... 514

merritti ................. 516

var. merritti............. 516

merritti .......... 516

I.

labrador, Lucifer..................................... 655

Ormismya.................... 654

lachrimosa, Dendrornis.................. 244

lachrymosa, Dendrornis.............. 243,244

lachrymosa ....... 243

lachrymosus, Dendrornis............... 243,244

Xiphorhynchus............ 239

lachrymosus .. 241,

242, 243

lacrymiger, Dendrocolaptes................ 257

lacrymosus, Dendrocolaptes................ 243

Xiphorhynchus lacrymosus..... 243

læmosticta, Drymophila.................. 110 Myrmeciza .......... 104, 106, 109, 110

laetitia, Gouldia ....................... 679

lætitiæ, Prymnacantha.................. 679

lafresnayanus, Xiphorhynchus............. 272

lafresnayeana, Myrmotherula .............. 62

lafresnayeanus, Campylorhamphus......... 269

lafresnayei, Dendrocincla ............. 287,288

lafresnayei....... 288

Lampornis................. 306, 494, 495, 501, 502 amethystinus................ 454,

$494,495,496,497,498,499$ amethystinus... 495, $496,497,498$ brevirostris...... 495 ,

$\mathbf{4 9 7}, 498$ salvini ....... 495, 498

aurulenta................. 469

aurulentus................ 470,471 var. virginalis....... 471

buffoni..................... 389

cæruleigaster............... 387

chlorolaema................ 476

-elemeucia.................... 494

coervleiventris............... 387

dominicus................. 469,472

elegans.................... 540

ellioti.................... 471

floresi ..................... 459

gramiueus.................. 456

hendersoni................. 466

henrici..................... 497

holosericeus. ............... 476

iridescens.................. 456

isauræ..................... 392

n1ango............... 458, 462,465 


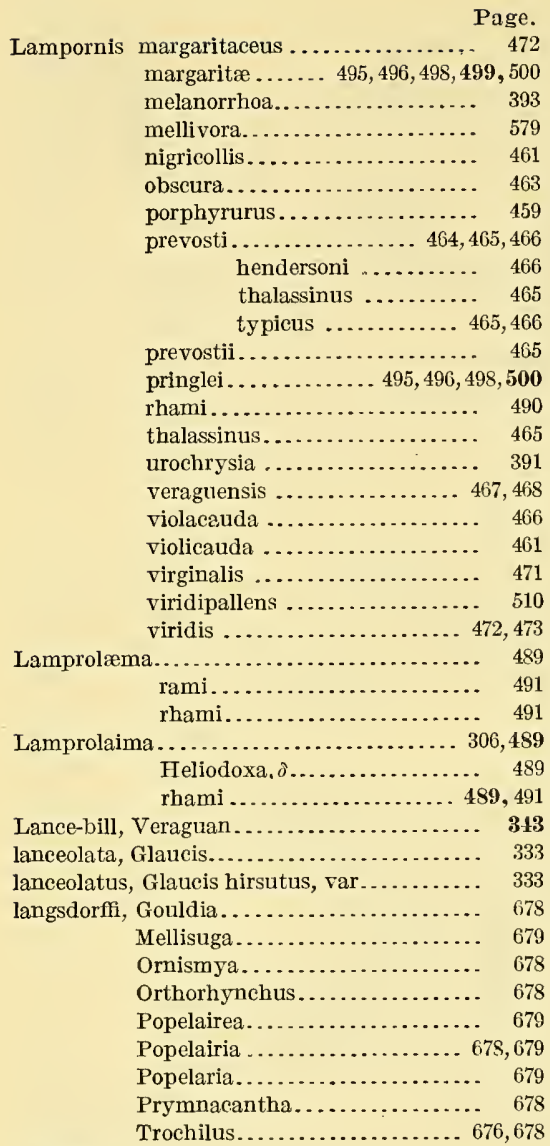

Laniidæ............................. 2

Lanius cæsius......................... 14 canadensis...................... 32 cayanensis striatus................. 36 doliatus............. 34, 36, $39,42,43,44$ domicella...................... 14

ferruginatus................... 36 ferrugineus...................... 36

funebris....................... 10

guttulatus....................... 52 lineatus...................... 18, 19,21

luctuosus........................ 12

nævius ....................... 49,51 punctatus..................... 27, 49

rubiginosus...................... 36

severus....................... 11

turdus.......................... 34

Iarge-billed Woodhewer................. 248

-tailed Trogon .................. 747

largipennis, Campylopterus............... 357

Trochilus.................. 356

latirostris, Amazilia ................... 372

Amazilius................... 372

Circe...................... 372,374

Cynanthus :............... 368 , $369,370,372,373,374,375$

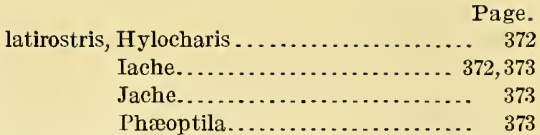

latitabunda, Synaliaxis albescens....... 188, 194, 195

Lattice-tailed Trogon.................. $\mathbf{7 4 9}$

lawrencei, Chætura ..................... 727 cinereiventris . . . 717,726, 727

Cynanthus .......... 370, 371, 373, 375

Dendrornis.................... 251

Iache....................... $\quad 375$

Myrmelastes.................. 103

Phæoptila...................... 375

Pseudocolaptes.................. 199

Sclerurus....................... 165

Lawrence's Antpitta .................... 155

Antwren................... 73

Humming Bird............. $\quad 373$

Pseudocolaptes................ 197

Spinetail.................... 184

Swift..................... 727

woodhewer................. $\mathbf{2 5 0}$

Lawrencia............................. 401

lawrencii, Iache......................... 375

Myrmelastes............. 100,102, 103

Pseudocolaptes ............. 197, 198

Lawrencius............................... 401

cupreiceps.................. 405

lazula, Hylocharis...................... 373 B. Cyanophaia.......... 373

lazulus, Campylopterus ................. 357

Trochilus ..................... 356

leachii, Thamnophilus.................. 11

Leadbeatera.......................... $\quad 570$

grata.................. 570, 572 jacula..................... 571

jamesoni................... 571

otero....................... 572

splendens.................. 572

leadbeateri, Aspasta.................... 572

Clytolæma................. 572

Heliodoxa................... 572

leadbeateri......... 572

Hypolia................... 572

Trochilus................. 570,572

Least Humming Bird.................... 585

Le Colma, de Cayenne................. $\quad 117$

Le grisin de Cayenne.................... 77

leocadia, IIeliomastes.................... 352

leocadiæ, $\Lambda$ nthoscenus.................. 352 constantii.......... 345

$350,351,352$

Floricola constanti.............. 352

Heliomaster................... 352

Heliomastes..................... 352

Trochilus................... 352

Lo Manikup de Cayenue................. 16 lepida, Tilmatura.................. 637,639

Lepidocolaptes....................... 257 affinis.................... 263

lepidonota, Iypocnenis................ 127

Lepidopyga ....................... 307,537 boueardi............. 538, 539,541 crumleigularis ............. 540 ceruleogularis............. 538,539 
Page.

Lepidopyga colina................... 538,539 (Cyanophaia) cœruleigularis.... 540 luminosa......... 538

goudoti ................... 538, 539 luminosa..................... 538

lepidus, Aganus....................... 790

Trogon...................... 790

Le petit Martinet noir................. 705

Le plus beau des becfleurs................ 381

Leptasthenura........................ 158

Leptorhynchus guttatus.................. 10

Leptosomati.......................... 298

Leptosomatidæ...................... 298

Leptoxyura........................... $\quad 186$

Leptuas. . . . . . . . . . . . . . . . . . . . . 732,740

neoxenus ................. 741,742

lepturus, Trogon ........................ 764

lerchi, Cyanophaia..................... 528

Eucephala..................... 528

Thalurania...................... 528

Timolia........................... 528

lerdi, Thaumatias..................... 452

Lesser Broad-tailed Humming Bird........ 601

Hairy Hermit. .................... 333

Violet-ear...................... 484

White-eared Humming Bird ......... 381

lessoni, Chlorostilbon caribbeus ........... 561

Pampa....................... 355

Uranomitra....................... 427

lessonii, Ornysmia...................... 373

Le Tachet............................ 49

Tetêma de Cayenne.................. 117

letitiæ, Gouldia....................... 679

Mellisuga...................... 679

Mythinia........................ 679

Mytinia...................... 679

Popelairea........................ 679

Popelairia...................... 679

Prymnacantha.................. 679

Trochilus.................. 677,679

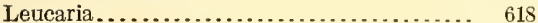

costæ........................ 625

leucaspis, Anoplops ................... 131

Diphlogoena ................... 504

Gymnopithys................... 131

Myrmeciza ............. 131, 132,133

Oreopyra.................... 501,504

Pithys ..................... 131, 132

Trochilus.................... 504

Ieucauchen, Thamnophilus.............. 34

Leucippus.......................... 305, 367

chionurus................. 403

fallax...................... 305

pallidus...................... 305

viridicauda................. 305

Leucochloris linnæi.................... 432

Leucodora......................... 430, 435

edwardi.................. 444,445

niveiventris................... 443

leucogaster, Picolaptes.............. . 259,260, 261

Thripobrotus............... 261

Xiphorhynchus............... 260

Leucolia.............................. $\quad 430$

candida.................... 434

chionopectus................... 431

cyanocephala.
Leucolia nireipectus.

quadricolor

424

sordida........................ 368

violiceps..................... 425

viridifrons...................... 422

Ieuconotus, Thamnophilus............... 12, 105

leucophrys, Hypocnemis ................ 127 Pithys...................... 14

leucophthalmus, Anabates.............. 211

Automolus.............. 212

leucops, Pithys........................ 16

leucoptera, Pyriglena..................... 14

leucopterus, Turdus.................... 14

leucopygialis, Acanthylis............... 715

leucostictus, Dysithamnus.............. 48, 53

leucotis, Basilinna.............. 378, 380,381, 382

leucotis............. 378,381

Basillina....................... 381

Cœligena...................... 381

Heliopædica.................... 381

(Coligena) ........... 381

Hylocharis.................. 380

Thaumatias................... 380

Trochilus................. 377,380,382

leucurus, Trochilus................... 336

leverianus, Trogon . . . . . . . . . . . . ........ 751

levis, Sittasomus ........................ 283 sylvioides......... 279, 281, 282

lichtensteini, Philydor . . . . . . . . . ....... 201,202

Lineated Xenicopsis..................... $\quad \mathbf{2 0 9}$

lineaticeps, Anabates.................. 162

Picolaptes........... 259, 264, 266, 267

lineaticeps..... 259, 264,265

lineatus, Anabazenops................ 211 subalaris........... 211

Cymbilaimus.................... 19,20 lineatus.......... 19,20

Cymbilanius................ 19,21,27 lineatus........... 19

Lanius................... 18, 19,21

Thamnophilus................. 19

Jenicopsis subalaris ........ 207,209, 211

Xenops....................... 211

linnæi, Agyrtria....................... 432

Leucochloris................... 432

Polytmus..................... 432

Thaumatias.................... 432

Lisoria.............................. 435

Little Brown Humming Bird............. 616

littoralis, Xenops.................... 171,172 genibarbis............ 172

lizanoi, Grallaria ....................... 156

Hylopezus . ................... 153,156

perspicillatus........ 153, 156

Lizano's Antpitta ..................... 156

Lochites............................... 11

Long-billed Star-throat.................. $\quad 346$

-tailed Black-cap Humming Bird...... 340

longicauda, Deconsehura.................. 284

Dendrocincla................. 284

Myrmotherula ............... 62

longipennis, Cypselus................... 683

Myrmotherula.............. 62

longipes, Myrmeciza.................. 105, 10 S

Myrmothera............... 103, 105, 108

longirostris, Anthoscenus............... 345 


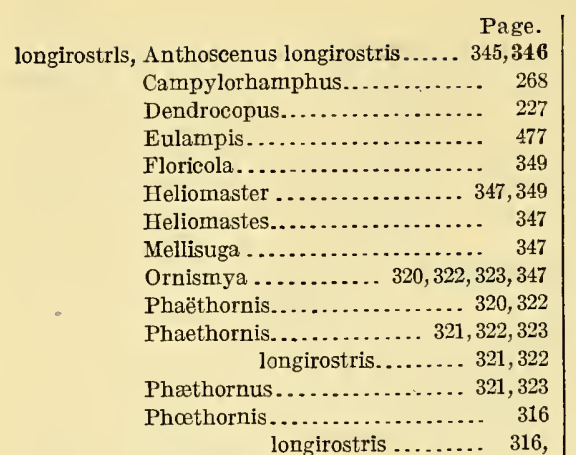

$319,320,321,323$

Polytmus.................. 477

Selasphorus $\gamma$. Heliomaster-.... 347

Sericotcs................... 477

Trochilus................. 344, 347

longuemareus, Trochilus.................. 314

Lophomyia........................... 669

Lophorhina........................... 669

Lophorhinus ........................... 669

(Ornysmia) delattrei......... 672

Lophornis......................... 310,669 adorabilis......... $669,670,671, \mathbf{6 7 5}, 676$ delattrei................670,671, 672

delattrii..................... 672

elenæ......................... 675

helena...................... 675

helenæ............670,671,673,674

Lophornithinæ....................... $\quad 310$

loricata, Myiothera..................... 15

louise, Trochilus (Doryfera) .............. 342

Lovely Humming Bird................. 523

Loxopterus............................ 356

luciæ, Agyrtria...................... 431, $\mathbf{4 3 4}$

Polytmus......................... 434

luciani, Trogon ...................... $\quad 778$

lucida, Mellisuga......................... 381

Sapphironia..................... 381

lucidus, Trochilus...................... 381

Lucifer.................................. 651

calliope........................ 590

o. Calothorax calliope............. 590 evelynæ.............. 643

tendali.............. 654

cyanopogon..................... 654

elisa........................... 650

enicurus........................ 649

evelynæ...................... 643

IIumming Bird................... 652

labrador......................... 655

B. Myrtis elisa................... 650

lucifer, Callithorax..................... 654

Calothorax...............6. (65).653,654,655

Cynanthus....................651,653

Trochilus ....................... 654

Juctuosus, Lanius...................... 12

Thamnophilus............... 12

Lucy's Emerald........................ 4ist

Judovicia, Doryfera...................... 344

Judovicix, Dorifcra..................... 344

Doryphera................... 34

'Trochilus.................... 342
Page.

lugubris, Hypocnemis .................. 127

Myrmoborus................... 14

lumachella, Ornismia..................... 405

luminosa, Cyanophaia.................... 538

Emilia....................... 538

Lepidopyga................... 538

Lepidopyga (Cyanophaia)....... 538

Sapphironia.................. 538

lunulata, Anoplops...................... 131

lyrura, Calliphlox...................... 645

Doricha............................ 645

Dorycha....................... 645

Nesophlox................. 641,643,645

Philodice........................ 645

\section{M.}

macleannani, Phlegopsis............... 136, 137

Phlogopsis ............... 134

Macrochires................. 296, 297, $298,299,300$

Macropterygidæ................ 299, 682, 683,696

Macropteryginæ....................... 683

Macropteryx......................... $\quad 715$

macrorhyncha, Dendrocincla............. $\quad 287$

macroura, Trogon...................... 748

macrourus, Curucujus melanurus........ 744,747

Trogon..................... 748

macrurus, Curucujus.................... 748

Eutroctes..................... 749

Troctes....................... 748

Trogon........................ 748

melanurus.............. 748

macularia, Calobathris ................... 153

Grallaria..................... 153

Pitta....................... 153

macularius, Hylopezus............... 152, 153

maculata, Agyrtria..................... 431

Myiothera................... 10,83

maculatus, Trochilus.................. 431, 456

maculicauda, Agyrtria.................. 406

Cercomacra................ 93

maculifer, Myrmeciza................... 106

Myrmelastes.................. 106

exsul.............. 106

maculipennis, Thamnophilus............. 11

maculosa, Cercomacra.................. 93

magellanica, Motacilla.................. 5

magica, Circe............................ 373

Hylocharis..................... 373

Iache ........................ 373

magicus, Cynanthus latirostris............ 371

magnificus, Trochilus.................... 669

major, Campylorhamphus trochilirostris..... 269

Chætura........................ 711

Glyphorhynchus.................. 277

Glyphorynchus.................. 277

Thamnophilus................... 27

Xiphocolaptes................... 236

Xiphorhynchus.................. 277

Makrochires............................ 298

malvina, Chlcrestes................... 431

malvinæ, $\Lambda$ gyrtria................... 431

Mango, Black-throated................. 459

Green...................... 479

Henderson's ..................... $\mathbf{1 6 6}$

llumming bird................. 457

Porto Rican.................... $\mathbf{4 7 0}$ 
Mango, Prevost's....... Page.

Slender-billed................... 465

Veraguan ........................ 467

mango, Anthracothorax.......... 455,45i,462,617

Endoxa..................... 459

Lampornis................ 458,462,455

Polytmus...................... 462

Trochilus............... 454, 458, 462,465

Manikup............................... 16

de Cayenne..................... 10

Manilia................................... 651

pulchra........................ 656

margarethæ, Coeligena................. 500

henrica............ 500

Delattria................ 500

Margaret's Cazique....................... 499

margaritacea, Agyrtria.................. 434

margaritaceus, Lampornis................. 472

Poly tmus ................. 469

Trochilus.............. 434,469

margaritæ, Cœeligena..................... 500

Delattria................... 500

Lampornis....... 495, 496, 498, $\mathbf{4 9 9 , 5 0 0}$ margaritata, Myrmeciza.................. 11

margaritensis, Drymophila grisea.......... $\quad 77$

Microrhopias grisea......... 77, 82

Margarochrysis......................... 454 aurulenta................ 469

Margarornis ................... 158, 159, 177,226 brunneicauda................ 183 brunnescens............. 180, 181, 182 Costa Rican............... 17s guttata..................... 160 rubiginosa ............... 17s, 179 squamigera ................. 178

maria, Amazilia.

Saucerotia...................... 450

Trochilus....................... 341

mariæ, Amazilia..................... 448, 450

Chlorestes....................... 450

ß. Smaragditis .......... 450

Eranna.......................... 448

Hylocharis...................... 450

Panychlora..................... 450

Trochilus ...................... 448, 450

Marsh Wrens........................... 158

Marsyas............................ 547

Martinet de Saint Domingue............. 705

Martinique Swift..................... $\quad \mathbf{7 2 4}$

Massena Trogon....................... $\quad \mathbf{7 4 4}$

massena, Curucujus ........ $743, \mathbf{7 4 4}, \mathbf{7 4 7}, 748,749$

Trogon...................... 746,747

massenæ, Eutroctes.................... $\quad 747$

Trogon.......................... 747

maugæi, Chlorostilbon .................. 549,550

Hylocharis................... 551

Ornismya.................... 550

Riccordia.................... 542,548

Ricordia.................... 551

Sporadinus.................... 551

(Marsyas)............ 551

maugæus, ChIorolampis................ 551

Ricordia..................... 551

Sporadinus................... 550

Trochilus.................. 547,550

maugei, Ricordia. maugei, Sporadinus $\quad$ Page.

Trochilus..................... 550

maugerii, Cynanthus.................... 551

maugeus, Sporadinus.................... 550

maximiliani, Synallaxis................. 186

mazeppa, Glaucis ...................... 333

hirsutus............... 333

Phaethornis.................. 333

Polytmus ..................... 333

Trochilus.................... 333

MeLeannan's Antthrush ................. 135

mcleannani, Phænostictus ................ 137

mcleannani. . . 135, 136

Phlogopsis................. 136

Mearnsia.......................... 686

megarhyncha, Dendrornis............... 248

megarhynchus, Dendrornis flavigaster....... 248

Xiphorhynchus flavigaster.241, $\mathbf{2 4 8}$

Magastictus.......................... 11

melæna, Formicivora.................. 69

Myrmopagis..................6.67,68

Myrmophila.................. 70

Myrmotherula................ 69, 70

melanocephala, Trogou.................. 758

melanocephalus, Aganus ................. $\quad 758$

Trogon........... 752,758,759 melanocephalus. $752,756,758$

Trogonurus .............. 758

Xenops................. 203

melanochrous, Thamnophilus ............. 12,48

melanocrissus, Diallactes................. 31

Thamnophilus........... 31

melanoleuca, Panyptela.................. 689

Panyptila................. 689

melanoleucus, Aëronautes ............. 687, 690

Cypselus................ 687,689

Micropus................. 689

melanonotus, Hypolophus............... $\quad 32$

Melanopareia........................ 186

melanopogon, Hypocnemis ............... 14

melanopterus, Trogon.................. 751, 756

melanorrhoa, Chalybura ........... 35s, 392, 393

Hypuroptila............... 393

(Lampornis) . . . . 393

Lampornis................. 393

melanorrhous, Polytmus................. 393

melanosternon, Gouldia.................. 679

Trochilus................. 679

melanosticta, Anoplops................. 131

melanotis, Hæliopædica ................. 381

Heliopredica.................. 381

Heliopedica.................... 381

Hylocharis................... 381

Trochilus................ 377,381

Melanotrochilus...................... 308

melanura, Glaucis ... . . . . . . . . ........... 334

hirsutus var........... 334

Hypocnemis................. 14

Polytmus ................... 334

melanurus, Curucujus . ................. 743, 744

melanurus ......... 743,744

Diallactes................. 31

Ramphocænus............... $\$ 4$

Thamnophilus............... 31

Troctes..................... 743

Trogon................. 742,743 
Melisuga colubris .................... 633 Mellisuga................... 308,583,5\$4, 627

abeillei. ........ 517

albo-coronata............... 580,582

alexandri.................... 636

anna........................... 621

avis minima................ 585

catharinæ.................. 584,586

cayanensis, ventre griseo........ 668

cayennensis gutture nævia....... 579

clemenciæ................... 494

colubris...................... 633

conversi..................... 678

costæ....................... 624

eristata....................... 663

delatrei..................... 360

de lattrei.................... 672

duponti...................... 639

exilis......................... 660

fulgens..................... 567

helenæ....................... 674

heloisa...................... 593

humila..................... 585

humilis...................... 585

langsdorffi.................... 679

letitiæ....................... 679

longirostris .................. 347

lucida........................ 381

mellivora................... 579

merrettii..................... 516

minima ............ 584, 585, 586, 587

minimus.................. 585, 587

moschita..................... 667

platycercus................... 599

rhami....................... 490

surinamensis . . ............... 579,616

mellisugus, Trochilus.................. 586

mellitus, Campylopterus hemileucurus..... 360

Mellivora avis maxima.................. 458

cristata rubra............... 669

mango........................ 458

mellivora, Avis...................... 630

Florisuga $\ldots \ldots \ldots \ldots \ldots .5 \mathbf{5 7 6 , 5 7 8 , 5 7 9 , 5 8 0}$ mellivora............ 579

Lampornis.................. 579

Mellisuga..................... 579

Ornismya.................. 578

Topaza..................... 579

mellivorus, Florisuga................... 578

Trochilus.............. 575, 578, 579

menetriesi, Formicivora...............67,72

Myrmophila.................. 67

Myrmotherula............67, 72,73

menetriesii, Myrmopagis............6 67,70,71

Myrmothera...........6 67,70,72

Myrmotherula............... 72,73

mentalis, Anabazenops.................. 207

Dasythamnus................ 54

Dendrocolaptes................. 248

Dendrornis................... 247

flavigaster.......... 247

Dysithamnus.............. 53, 54,55 mentalis........ 54,55,57

Myothera................ 52,54

Xiphorhynchus flavigaster . 241,247,248 meridionalis, Trogon.................. 785

Merion. . . . . . . . . . . . . . .

Meropes............................... 296

Meropidæ........................... 296

merretti, Clais ......................... 516

merrettii, Mellisuga. . . . . . . . . . . . . ........ 516

merritti, Klais....................... 516 guimeti .................. $\quad 516$

var $\ldots \ldots \ldots \ldots \ldots . .516$

Merulaxis analis....................... 5

meruloides, Chamæza.................. 15

Mesomyodi............................ 1,2

Tracheophone............... 1,2

Mesomyodian Passeres................... 1,2

Mesophila.......................... 314

mesurus, Troctes........................ 743

Metallura castaneiventris................. 503

Methon............................. $\quad 386$

Mexican Antpitta..................... 150

Antshrike.................... 40

Antthrush................... 119

Collared Swift................. $\quad \mathbf{7 0 0}$

Sclerurus....................... 166

Shear-tail................... 650

Sittasomus................... 280

Trogon.......................

Violet-ear.................... 482

Wood-Nymph................ $5 \mathbf{5 3 7}$

Xenops........................ 172

mexicana, Grallaria................... 151,152 guatimalensis. $148,149,150,151$

mexicanus, Phœthornis................. 323

longirostus $316,320, \mathbf{3 2 3}, 324$

Selerurus........ 163, 165, 167, 168, 170 mexicanus..... 165, 166, 168

Scleurus.................... 170

Streptoprocne zonaris.... 697, 700,701

Thamnophilus doliatus......... 36 , $40,42,43,44,45$

Trogon................... 767,772

Trogonurus......... 762,764, 765,767

Xenops................... 174, 175

genibarbis......... 172, 175

michleri, Pittasoma................... 140,142 michleri............. 141

Pittisoma....................... 142

Michler's Antpitta.................... 141

Mricrobates....................... 10,14,88

cinerciventris............... 89 semitorquatus..... 89

collaris................... 88,89

torquatus................... 88

Microchera...................... 308,580, 581

albicoronata................ 582

albo-coronata............... 581,582

parvirostris............. 581, 582,583

Microlyssa......................... 656 exilis......................... 660

Micropodidæ ................ 682, 683, 685,693 Micropodii .......... 297, 29S, 299, 300,681, 682, 683 Micropodin $x \ldots \ldots \ldots \ldots \ldots \ldots \ldots \ldots . \ldots 65,686,693$ Micropodoidea....................... 682 Micropodoidex........................ 298,682 Micropodoidei........................ 298 
micropterus, Agathopus.................. $\quad$ 5

Micropus...........................685,715 melanoleucus................. 689 saxatilis..................... 689 Microrhopias .................. 13, 14, 75, 76, 83 bicolor.................... 75 boucardi.................75,76 boucardi .......76,78,79 consobrina.......76,79, 80 virgata $\ldots \ldots \ldots 76,78, \mathbf{7 9}, 80$ consobrina.................. 75 grisea.................... 75,76

alticincta............ 77,81 grisea............... 77 intermedia......... 77,81, 82 margaritensis.......... 77,82 tobagensis............. 77,82 intermedia................. 75 quixensis.................. 75 rufatra..................... 75

microrhyncha, Agyrtria................. 449

Amizilis.............. 408,428 Cyanomya................ 429 Cyanomyia............... 429

Uranomitra............... 429 microrhynchus, Acanthurus............ 277,279 Microtrogon......................... 784 fulvescens................ 784

Milornis .............................. 314 minima, Hylocharis . . . . . . . . . . . . . . . . 585,587 Mellisuga .............584, 585, 586, 587 avis.................. 585 Ornismya................. 585, 587 Zephyritis (Dyrinia).......... 5 $\$ 55,587$ minimus, Mellisuga . . . . . . . . . . . . . . . ... 585, 587 Trochilus............. 583,585,586,587 minor, Avis. Dendrocincla................... 287

Hemiprocne.................. 698,699

Streptoprocne zonaris............. 698 minutulus, Trochilus.................... 585 minutus, Trochilus.................... 585 mitchelli, Calliphlox.................... 656 Trochilus................. 309,656 modesta, Asthenes................... 161 Myrmotherula................ 72 mocina, Pharomacrus.................. 738 mocinna, Pharomacrus................. 738 mocinno, Calurus..................... 738 Pharomachrus...... 731,733,734, 738, 739 mocinno.... 734, 736, 739

Pharomacrus............. 738, 739,740 mociño, Pharomachrus................... 738 moliniger, Formicarius.................... 121

Momoti............................ 296

Momus............................. 314

moniliger, Formicarius............. 120,122, 123 moniliger..... 117, 119, 122

Myrmornis.................. 121 montana, Trochilus..................... 601 montanus, Anabates................... 207

Ipoborus..................... 207

Philydor.................... 207

Trochilus...................... 601

morcomi, Atthis. heloisa.
Morcom's Tumming Bird

.

morgani, Trogon...................... $\quad 767$

moschatus, Chrysolampis ................ 668

moschita, Chrysolampis ................. 668

Mellisuga.................... 667

Ornismya.................... 667

moschitus, Chrysolampis................ 668

Trochilus.................... 667

mosinno, Pharomacrus.................. 738

mosquita, Chrysolampis................. 668

mosquitus, Chrysolampis ..............666, 668

Trochilus................. 665,667

Motacilla guianensis................... 186 magellanica................... 5

Motacillidæ..........................

Mountain Gem, Chiriqui................ 50 ?

Costa Rican............. 504

Gras-tailed ............. 506

Green-throated........... 509

Sybil's.................. 508

White-bellied ............ 507

multistriatus, Thamnophilus .......... $36,45,46$ multistrigatus, Dendrocolaptes....... 229,233, 235

Dendrocops............. 233, 235

murinus, Thamnophilus................. 48

Muscicapa pygmæa..................... 60,65

Musophagidæ........................ 298

Myiabeillia typica.................... 518

Myiabellia............................ 516

guimeti................... 515

Myiaetinia........................... 310

Myiothera ardesiaca .................... 10

colma...................... 117

ferruginea.................. 14

fuliginosa................... 67

grallaria.................... 146

loricata..................... 15

maculata.................... 10, 83

nudiceps.................97, 100, 101

pileata..................... 14

poliocephala.................. 54

pusilla........................ 64

rufimarginata................ 14

squamata................... 14

strigilata................... 13

superciliaris................. $\quad \mathbf{7 7}$

tetema..................... 117

umbretta................. 163, 164

Myiotheridx....................... 8

myiotherina, IIy pocnemis.............. 127

m5iotherinus, Mfrmoborus.............. 14

My iotrichas......................... 146

guatemalensis............... 151

Myioturdus........................ 146

pallkour.................. 139

tetema.................... 117

umbretta................. 164

Myletes........................... 406

Myocincla ............................ 115

Myothera........................... 115

analis.............. 115, 117, 119, 124

mentalis..................... 52,54

nigromaculata............. 17,135

pectoralis..................... 131

Myotthera runceps.................... 115, 117 
Page.

Myrmeciza

106

boucardi. boucardi........... 105, 107 griseipectus . ........ 105, 106 panamensis - 105, 106, 107, 109 swainsoni....... 105, 107, 108 cassini ............. 106, 107,110, 111 exsul....................... 111, 112 exsul . . . . . .......... 106, 107,111 occidentalis......... 106, 107, 113 ferruginea................... 100 hemimelæna.................. 15 immaculata........... 106, 107, 112, 115 intermedia............... 112, 113, 114 læmosticta .......... 104, 106, 109, 110 leucaspis..................... 131 longipes.................... 105, 108 albiventris............. 105 maculifer.................. 106 margaritata................... 11 occidentalis.................. 114 pelzelni...................... 15 plumbea...................... 104 stictoptera ................ 109, 110 swainsoni................. 105, 108 zeledoni............. 106, 107,114,115

Myrmecophaga........................ 115

Myrmelastes..................... 15, 103,105 cassini..................... 111 ceterus................... 99,101 corvinus................ 99, 100 exsul ....................... 111 exsul.................. 112 maculifer.............. 106 occidentalis............ 113,114 immaculatus............... 115 intermedius................. 112, 114 lawrencei................... 103 lawrencii............ 100,102,103 maculifer.................. 106 occidentalis................ 114 intermedius................ 112 plumbeus..................... 103

Myrmetherula fulviventris................ 74 Myrmoborus.......................... 14,128 lugubris.................... 14 myiotherinus................ 14

Myrmochanes.......................... 10

Myrmoderas............................. 15

atrothorax................. 15

cinnamomea............... 15 ruficauda................... 15 squamosa................. 15

Myrmonax ......................... 103 Myrmopagis....................... 13,65,67 axillaris........................ 67 fulviventris.............. 67,73 gutturalis.................... 67 melæna................... 67,68 menetriesi ..............67,70,71 ornata........................... 67 schisticolor..............67,68, 70

Myrmophila....................... 10,65 axillaris . . . . melæna. 70
Myrmorchilus. ...

Myrmornis analis ........................ $\quad 117$

cayanensis.................. 117

crissalis....................... 118

hoffmanni................ 123, 124

moniliger.................. 121

pallidus..................... 122

Myrmothera........................ 18,115

axillaris................ 65,67,69

cærulescens................. 90

colma...................... 117

formicivora $\ldots \ldots \ldots \ldots \ldots \ldots . . .6139$

fuscicapilla.................. 117

guttata................... 13

longipes................ 103, 105, 108

menetriesii.............. 67,70,72

pectoralis................... 131

Mfyrmotherium...................... 60 surinamense............. 64

Myrmotherula ................. 13,60,62,66,84 albigula.................. 70 assimilis................... 61 atrogularis................ 62 axillaris................... 67,69 axillaris.......... 67

behni.................... 62 boliviana................. 62,67

brevicauda................. 62

cinereiventris.............. 61

erythronota................ 62

erythrura................. 62

fulviventris............... 74

hæmatonota. ........... 62

hauxwelli.................. 62

inornata................. 62

lafresnayeana.............. 62

longicauda................ 62

longipennis............... 62 melæna................... 69,70

menetriesi ............. 67,72,73 schisticolor....... 72

menetriesii................. 72,73

modesta................. 72

nigrorufa ................ 72

ornata.................... 74

guayabambæ.............. 62

gularis.................... 74

guttata................... 13,62

pygmæa............61,62,64, 65

pyrrhonota................ 62

sanctæmartæ.............. 62

schisticolor................ 72

sororia..................... 62

spodionota............... 62 surinamensis.... $61,62,63,64,65,84$ surinamensis... 64 typica......... 64

unicolor................... 62

urosticta.................. 62

viduata................... 62

Myrtls enlcura......................... 649

Mythinia.............................. 677 letitix....................... 679

Mytinia............................ 677

letitiæ....................... 679 
$\begin{array}{cr}\text { N. } & \text { Page. } \\ \text { nævia, Hypocnemis.................... } & 127,128\end{array}$

Mellisuga cayennensis gutture ...... 579

Sitta.......................... 10,16

nævioides, Conopophaga ................ 126, 129

Hylophylax ............... 128,130

Hypocnemis........... 127, 128, 129

nævius, Erionotus

Lanius ........................ 49,51

Thamnophilus ............. 48, 49, 51 nævius............ 49

nævoides, Hypocnemis ................. 130

nana, Dendrornis ................ 251, 252, 253 nana.................. 251

nanus, Chlorostilbon caribæus............. 561

Dendrocolaptes.................. 251

Xiphorhynchus.................. 241 nanus. $241,250,251,252,253$

nasalis, Nasica...................... 227

Nasica............................. 227

bridgesii...................... 227

flavigaster..................... 246

nasalis........................ 227

triangularis..................... 241

Nechopætes niger.................... 705 neglectus, Picolaptes affinis ....... 259, 262, 263, 264

Nelson's Antpitta ..................... 151

Humming Bird................ 396

nelsoni, Eupherusa eximia ............. 394,396

Neoctantes.......................... 10

Neops............................. 170

ruficaudus...................... 170, 172

neoxenus, Calurus.................... 742

Cosmurus.................... 742

Euptilotis................... 742

Euptllotis.................... 742

Leptuas .................. 741, 742

Pharomacrus................ 742

Trogon.................... 740,742

(Calurus) $\ldots \ldots \ldots \ldots \ldots \ldots .742$

Nephocætes....................... 703

collaris.................... 702

fumigatus.................. 711

niger................. $705,706,709$

Nephœcetes . . . . . . . . . . . . . . 686, 703, 710

borealis.................... 708

niger............. 704, 705,706,709 borealis.... 703, 704, 707,708, 710 ß. borealis............. 709 costaricensis........ 704,708, 710 jamaicensis .... 704, 705, 707, 710 niger............ 704,705, 707 var. borealis....... $707,708,709$ nesiotis, Synallaxis albescens . . . . . . . . . . 188, 195 Nesophlox ................. 309,637,639,640 bryantæ ...........640,641,645,646 evelynæ...............6.641,643 lyrura $\ldots \ldots \ldots \ldots \ldots \ldots 6.641,643,645$

Nicaraguan Antthrush .................. 122

Hermit ................... 321

nlger, Chætura ..................... 705, 706

Cypseloides........... 705, 706, 707, 709, 710 niger................ 705

Cypselus...................... 705, 706

Nechopætes.................... 705

Nephocætes................ 705, 706, 709

Nephocetes............. 704, 705, 706, 709
Page.

niger, Nephœcetes niger........... 704, 705, 707

Nephœctes....................... 709

Ornismya........................ 586

Trochilus...................... $\quad 586$

Xenops.......................... 10

nigra, Cypselus...................... 705, 706

Hirundo............ 703, 705, 706, 709, 710

Hylocharis .................... 586

nigricans, Cercomacra .............. 91, 92, 93

nigricapillus, Formicarius ................ 119

analis .... 117, 118, 119

nigricaudata, Trogon................... 743

nigriceps, Thamnophilus ................ $\quad 36$

virgatus......... 36

nigricollis, Anthracothorax............ 455, 462 nigricollis....... 456, $457, \mathbf{1 5 9}, 462$

Formicivora............... 77

Lampornis.................... 461

Trochilus.................. 454, 461

nigricristatus, Thamnophilus...... 21, 27, 38, 39, 44 doliatus...... $\quad 39$ nigricristatus.. $\quad 39$ radiatus ... 35, 37,39

nigrifrons, Formicarius................. 117 colma............ 117

nigrifumosa, Synallaxis................. 193 pudica....... 188, 189, 192

nigriventris, Callipharus .............400, 401

Elvira..................... 401

Eupherusa............... 399, 401

Polytmus.................. 401

Thaumatias................ 401

nigrofumosa, Synallaxis................. 193

nigromaculata, Myothera................ 17, 135

nigropectus, Anabates................. 12

nigrorufa, Myrmotherula............... 72

Nisius............................... 11

nitida, Tache....................... $\quad 377$

Jache.......................... 377

Phæoptila..................... 377

nitidus, Trochilus..................... 461

niveicauda, Eupherusa................. 404

niveifrons, Aërornis................. 710,711

niveipectus, Agyrtria................. 431

Leucolia..................... 431

niveiventer, Chlorestes, $\gamma$. Saucerottia....... 442

Tliaumatias................ 442

niveiventris, Amazilia................... 443

Ariana.................... 443

Chlorestes.................. 442

Erythronota.............. 442

Hemithylaca............. 442,443

Leucodora.................. $\quad 443$

Polytmus................... 443

Saucerottea................ 443

Saucerottia................. 443

niveoventer, Amazllia................... 443

Saucerottea............... 443

Saucerottia............439,441, 443

Trochilus............. 434, 435,442

norrisii, Trochilus.................... 430

Northern Antvireo.................... 55

Black Swift................. 707

Dendrocincla.................. $\mathbf{q S S}$

Long-billed Antwren............ 85 
Northern Streaked-headed Woodhewer..... 26 Wedgebill ...................... 275 nudiceps, Gymnocichla....... 98, 99, 100, 101, 103 nudiceps ...... 98,99,100 Myiothera................ 97, 100,101 Pyriglena................... 100 nuđipes, Chætura...................... 686 nunezi, Saucerottia.................... 438 Nuthatch, Surinam.................... 63 Nyctibius jamaicensis . ................. 736,740 Nycticoraciæ........................ 297,298 Nyctiharpages........................ 298

\section{O.}

oberi, Dysithamnus mentalis............. 54,57

obscura, Trochllus..................... 463

obscuras, Pygmornis..................... 314

obscurus, Campylopterus ................ $\quad 357$

obsoletus, Dendrocolaptes................. 229

obtectus, Picolaptes..................... 258

ocai, Amazilia....................... 435,452

Amazilius.......................... 452

Amizilis.......................... 452

Hemistilbon...................... 452

Polytmus........................ 452

Pyrrhophæna..................... 452

Saucerottea...................... 452

Saucerottia.................... 439,452

occidentalis, Chætura cinereiventris........ 716 sclateri............. 716

Myrmeciza................. 114

exsul ........ 106, 107,113

intermedia........ 113

Myrmelastes.................. 114

ochraceiventris, Grallaria................. 152

guatimalensis... 148, 151

Ochraceous Philydor................... 208

ochrolæmus, Anabates................... 220

Automolus................. 212

Ocyptilinæ........................... 682

Oiseau-Mouche Pourpre................. 616

aे ventre gris............. 586, 587

oleagineus, Xenicopsis.................... 206

Oligomyodi............................. 1

olivacea, Dendrocincla................. 292, 293 olivacea........... 293

olivaceus, Dendrocops................... 292

Dysithamnus................. 54

Gymnopithys bicolor ............ 134

Sittasomus.................. 279,282

Sittosomus..................... 282

Thamnophilus................. 54

ollvascens, Anoplops .................. 131, 132 Gymnopithys................ 134 bicolor........... 134

Pithys bicolor................. 134 Sclerurus....................... 165

Olive-slded Antbird .................... 132 omiltemensis, Xiphocolaptes emigrans.... 236, 239 Oplsthocomidæ ...................... 298 Oplsthocomus......................... 295 Orange-belled Trogon................... $\quad \mathbf{7 7 8}$ orbignli, Siptornis...................... 161 orenocensis, Formleivora................ $\quad 77$ Oreopyra ......................... 306, 501,502 calolæma................ 504,505,506
Page.

typica................ 506

castanciventris................ 504,506 castaneiventris . . . ... 504

castaneoventris................. 502

3 calolæma ... 502,504,506 castaneoventris..... 502,

504,506

cinereicauda ............. 502,506,507

hemileuca ........... 501,502,507,508

leucaspis.................... 501,504 cinereicauda.......... 507 typica................. 504

pectoralis.................... 506

salolæma..................... 506

sybillæ.................. 501,502,508

venusta....................... 506

viridipallens .............. 501, 502, 509

Oriolidæ............................. 295

Oriolus picus.......................... 226

ornata, Bellona......................... 662

cristata.................. 662

exilis .................... 662

Formicivora.................... 74

Myrmopagis......................... 67

Myrmotherula................... 74

ornatus, Bellona........................ 662

exilis................... 662

Orthorhynchus................ 661,662

Orthorhyncus................. 658,662

exilis .......... 657,661

Trochilus.................... 662,669

Ornismia............................ 627

canivetii...................... 555

catharinæ................... 587

cinnamomea................... 405

clarissæ......................... 405

eximia........................ 405

lumachella................... 405

rufula........................ 405

Ornismya........................... 627

abeillei................... 516,517

alexandri.................... 636

amazili...................... 412

amizili..................... 405

anais.................... 480, 483, 485

anna...................... 618,621

arsennii..................... 381

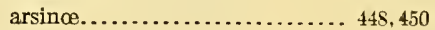

atala........................ 560

barroti........................ 563

bicolor....................... 530

brevirostris................. 430

canivetii............. 553,555, 5506, 557

cephalatra.................. 341

cinnamomea............. 406, 417,419

cinnamomeus................ 417,419

elemenclæ................... 365, 493

coelestls..................... 639

colombica................... 534,535

colubris ................... 632,633

constanti................... 353

constantii.................... 351

costæ..................... 618, 624

cristata..................6.661,663

cyanocephala.................. $\quad 426$ 
Ornismya cyanocephalus................. $\quad 426$ cyanopogon................... 654 delphinæ.................. 480,488 dumerili....................... 448

duponti..................... 639 dupontil.................. 637,638 erythronota.................. 435 erythronotos................... 437 eximia............... 393, 395, 396, 397 feliciæ......................... 437 feliciana.................. 438, 518

furcata.................... 341

helenæ.................... 669,674

heloisa..................... 591, 594

henrica...................... 454, 494

heteropygia................... 649

juliæ.................. 518,520,522

julie...................... 520

labrador....................... 654

langsdorffi. .................... 678

Iongirostris............ $320,322,323,347$ (Lophorinus) delattrei .......... 669

(Lucifer) cyanopogon .............. 654

maugæ1...................... 550

mellivora...................... 578

minima.................... 585,587

montana...................... 601

moschita..................... 667

niger........................ 586

pampa ................ 353,354,356

parzudhakl................... 544

prasina...................... 547

rhami..................... 489,490

ricordii.................... 544,545

rivolii..................... 568

rutila...................... 418

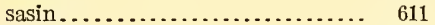

superba..................... 348

swalnsonii................. 547,649

tricolor....................... 601

viridissima................... 431

wagleri.................... $\quad 530$

zémès......................... 639

Ornismyia clemencix................... 491

cyanocephala................ 423

cyanocephalus............... 427

de lattrei.................... 360

henrica................... 497,498

senex...................... 434

Ornysmia heloisa...................... 593

lessonil....................... 373

(Lophorinus) delattrei.......... 672

rhami...................... 490

Oropezus ............................. 18

Orthocolaptes.......................... $\quad 227$

communis.............. 227

Orthorhynchus...................... 656 amazilla............... 405, 406 amizili................ 405 boothi.................. 627 chlorolophus............. 661 colubris................. 633 cristatus............ 662,663,664 emigrans................. 664 exilis............. 660,664,665 helenæ.
Orthorhynchus langsdorffi................ $\quad 678$ ornatus ................ 661,662 ricordi................... 544

Orthorhyncus .................... 310,656, 657 cristatus................ 657,661 cristatus.. $657,662,663,664$ emigrans.......657,664 exilis................... 657 exilis ......... 657, 658, 661 ornatus............ 657,661 ornatus..................6 658,662

Orthornis........................... 314 osberti, Chlorolampis................. 556,557

Chlorostilbon ................. 556,557 caniveti............. 556 var......... 556 canivetii ...... 549, 556, 557

Hylocharis................... 556 osbertii, Chlorostilbon ..................... 556 otero, Aspasta......................... 572

Clytolæma leadbeateri, var.......... 572

Heliodoxa...................... 572

Hypolia.......................... $\quad 572$

Leadbeatera.................... 572

Trochilus........................ 572

Othello............................... 12

Otipne............................. 196

boissonneaui..................... 197

ourissia, Cæligena..................... 551

Thaumatias.................... 551

Oven Birds ........................... 157

Owen's Humming Bird.................... $\quad \mathbf{3 6 5}$

Oxypiga............................. 163

Oxypyga............................. 163 scansor..................... 163, 164

Oxyruncidæ......................... 224

oxyura, Acanthylis....................... 727

Hirundo..................... 727

P.

Pacific Antshrike.................... 48 pacificus, Thamnophilus doliatus..... 36, 41,43, 44 Pale-crowned Star-throat............... 349

throated Automolus................. $\mathbf{2 2 0}$ palikour, Formicivorus................ 138, 139 Myioturdus.................. 139

Pallene............................. 686 pallida, Acrorchilus....................... 184 pallidiceps, Anthoscenus longirostris .. $345,346, \mathbf{3 4 9}$ superbus.......... 349

Floricola ................... 349 longirostris . . .......... 349 superba........... 348, 349

Feliomaster................. 348, 349

Heliomastes................. 349

pallidifrons, Chætura................... 702 zonaris............. 702

IIemiprocne zonaris.......... 702

Streptoprocne zonaris.... 697, 701,702 pallidigularis, Automolus...... 212, 213, 219, 220, 221 pallidigularis...... 213,

220, 221

Philydor................... 221

pallidus, Anoplops................... 131

Formicarius.................. 122 moniliger......118, 121, 122 


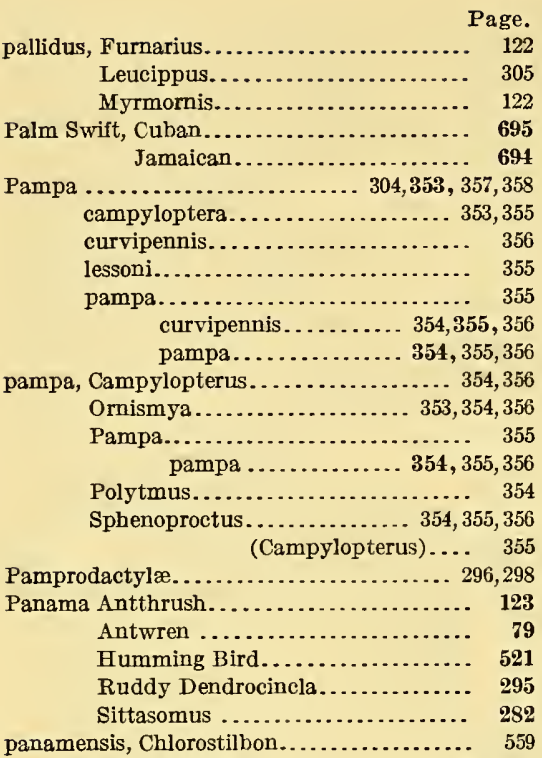

Damophila............. 519,521, 522

Formicarius moniliger........ 118,

$123,124,125$

Myrmeciza boucardi.. 105, 106, 107,109

Phæthornis ................ 322

panerythrus, Philydor ............ 202,203, 204

rufus................ 204

Panterpe ............................ 306, 511

insignis ............. 506, $510,512,513$

Panychlora ........................... 547,548

mariæ.................... 450

parvirostris................. 583

Panyptila ...................... 685, 690, 691, 715

cayanensis ..............684, 691, 692 var. cayanensis....... 692 var. sancti-hieronymi.. 693

cayenensis.................... 692

cayennensis.................. 692

melanoleuca................... 689

sancti-hieronymi .......684,691,692,693 sancti-jeromæ................ 692 saxatilis...................... 688,689

saxitilus..................... 689

papantzin, Trochilus.................... 568

Paphiosa.................................. 669

helenæ....................... 675

Paphosia............................... 669

helenæ........................ 675

Paradiseidæ............................. 295

paradiseus, Calurus .................... 738

Pharomacrus................ 738, 740

Trogon ...................... 738,740

pardalotus, Dendrocopus............... 251, 252 Dendrornis................ 251,252

Parulus............................. 186

ruficeps........................ 186

parvirostris, Mlcrochera............ 581, 582, 583 Panychlora................. 583

Picolaptes..................... 258

Topaza.................... 583
Page.

parvula, Heliodoxa leadbeateri............. 572

parzudhaki, Ornismya.................. 544

Passeres, Mesomyodian................... 2

Tracheophone.................... 2

Passeriformes .......................... 296, 297

pavoninus, Calurus ....................... 735

Pharomachrus............... 735, 736

Pharomacrus.................. $\quad 735$

Tanypeplus.................. 735

Trogon.................. 733, 735, 737

pavonius, Trogon ...................... 737

pectinicaudus, Sittasomus................ 282

Sittosomus................ 282

pectoralis, Automolus .................. 216

Glyphorhynchus.............. 277

cuneatus....... $\mathbf{2 7 5}$

Myothera..................... 131

Myrmothera................. $\quad 131$

Oreopyra....................... 506

calolæma ............ 506

Trochilus .................... $\quad 456$

Turdus......................... 131

pegasus, Trochilus....................... 668

pelagica, Chætura.......... 684, 715, 717,718,719

Hirundo................. 714, 718, 724

pelasgia, Acanthylis................... 719,724

Chætura..................... 719

Hemiprocne..................... 719

Hirundo...................... 719

pelasgica, Chætura...................... 719,722

pelasgius, Cypselus...................... 719

pelzelni, Myrmeciza...................... 15

Xenops genibarbis................ 172

percnopterus, Xenicopsis................. 206

Percnostola............................ 10

peregrinator, Chætura...................... 722

perrotii, Dendrocolaptes.................. $\quad 226$

personata, Trogon ....................... 763

personatus, Trogon...................... 763,775

Trogonurus ................ 763,765

perspicillata, Grallaria............ 152, 155, 156, 157

perspicillatus, Hylopezus............... 152,153

perspicillatus.... 153,155

peruviana, Florisuga . ................... 580

peruvianus, Trogon........................ 735

Petasophora........................... 480

anais....................... 481

cabanidis.................... 486

cabanisii .................... 486

cyanota................... $\quad 486$

cyanotis................... 485

cabanidis............ 486

cabanisi.............. 486

cyanotus................... 485

cabanidis............ 486

delphinæ................. 489

jolota.................... 480

r. Praxilla cyanotis ......... 485

thalassina .......... 483

ß. Teleslella delphinæ......... 488 thalassina................. 483,486

Petasophorus....................... 480

Petit Gobe-mouche tachet 6 de Cayenne..... 65

merle brun a gorge rousse de Cayenne.. 131

Phacellodomus........................ 161

Phacellodromus....................... 161 
Phacelodomus

Page.

Phaceloscenus.

161

phænicobia, Cypselus................... 694,695

phænicobius, Cypselus.................. 695

Phænostictus........................ 17, 134

macleannani mcleannani. 135,136, 137 saturatus..... 136, 137

Phæochroa $304, \mathbf{3 6 2}, 363$ cuvleri. . ............. 363, 364, 365, 366 cuvierii .................... 365 cuvierii............ 363,365 saturatior........... $363, \mathbf{3 6 5}$ roberti ................ $363, \mathbf{3 6 5}, 366$

Phæoptila............................. 304,366 doubledayi.................. 377 latirostris..................... 373 lawrencei.................... 375 nitida.................... 377 sordida .................. $\mathbf{3 6 7}, 368$ zonura.................... 368

phæopygos, Chætura cinereiventris ....... 717, $726,727,728$

Phæthornis . adolphi............... 326, 327,329 amaura..................... 328 anthophilus................ 316 atrimentalis............... 317 cephalus................... 321,322 emiliæ..................... 316,319 guy...................... 315 coruscus................ 319 emiliæ................ 316,319 typicus................. 315 hirsutus.................. 332 hyalinus.................... 324 longirostris. ........ $320,321,322,323$ longirostris.......321,322 veræcrucis........ 323

mazeppa................... 333 mexicanus .................. 323 panamensis................. 322 striigularis................. 328 yaruqui................... 319

Phæthornus......................... 314 longirostris.............. 321, 323

Phætornis............................ 314 cephale ..................... 321, 323 cephalus................ 321,322,323 guyi, var. emiliæ ............. 316 longirostris................ 322

Pharomachrus............. 731, 732, 733, 734, 740 antisiensis............. 735, 736 auriceps............. 734, 735, 736 festatus................ 735,736 mocinno...... 731, 733, 734, 738, 739 costaricensis ....... 734 , $736,737,738,739$ mocinno .... 734, 736, 739

mociño.................. 738 pavoninus............. 735, 736 pulchellus................ 735

Pharomacrus........................ 733 antisianus.................. 735 antisiensis................... 735 auriceps................... 735 heliactin............. 735
Pharomacrus costaricensis Page.

fulgidus................... 735

mocina................... 738 var. costaricensis...... 740

mocinna.................. 738

mocinno.............. $738,739,740$ costaricensis......... 740 var. costaricensis..... $\quad 740$

mosinno.................. 738

neoxenus................... 742

paradiseus................ 738,740

pavoninus................. 735

xanthogaster.............. 734,735

Philodice........................... 309

bryantæ..................... 646

evelynæ ...................... 643

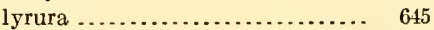

Philydor...................... 162, 201, 202 atricapillus................... 202, 203

boissonneautii................ 197

cervinigularis.................. 219

columbianus................... 202

Dusky-winged.................. $\quad \mathbf{2 0 4}$

erythrocercus................ 201, 202

fuscipennis ......... 201, 202, 203, 204, 205

lichtensteini................. 201, 202

montanus.................... 207

Ochraceous................... 208

pallidigularis.................... 221

panerythrus .............. 202, 203, 204 rufescens............ 204 rufus.............. 204

pyrrhodes .................. 201,202 rubiginosus.................... 214

rufescens...................... 204

ruficollis..................... 202 rufo-brunneus............. 222, 223, 224 rufus...................... 201, 202 panerythrus............... 20. semirufus..................... 204 striaticollis.................... 207 superciliaris.................. 203 virgatus................... 199, 200, 201

Philydorinæ.......................... 158

Phlegopsis......................... 17, 135 macleannani................ 136, 137 saturata..................... 137

Phlogopsis........................... 17 macleannani.................. 136, 137 meleanuani................... 134, 136 saturata..................... 137 phœnicobia, Tachornis............. 686, 69.4, 695 phonicobia ... 693, 694, 695

phœnicobius, Cypselus................ 694, 695 Tachornis................694,695

phœernicobius, Tachornis............... 695

Phothornis .................... 303, 314,315 adolphỉ.................. 316,326 adolphi..... 316,324, 325,326 saturatus . . . .... 316,326, 327 anthophilus................. 316 anthophilus....... 316 hyalinus....... 316,324

guyi....................... 315 coruscus............. 316,317 emiliæ............ 316, 317, 318 


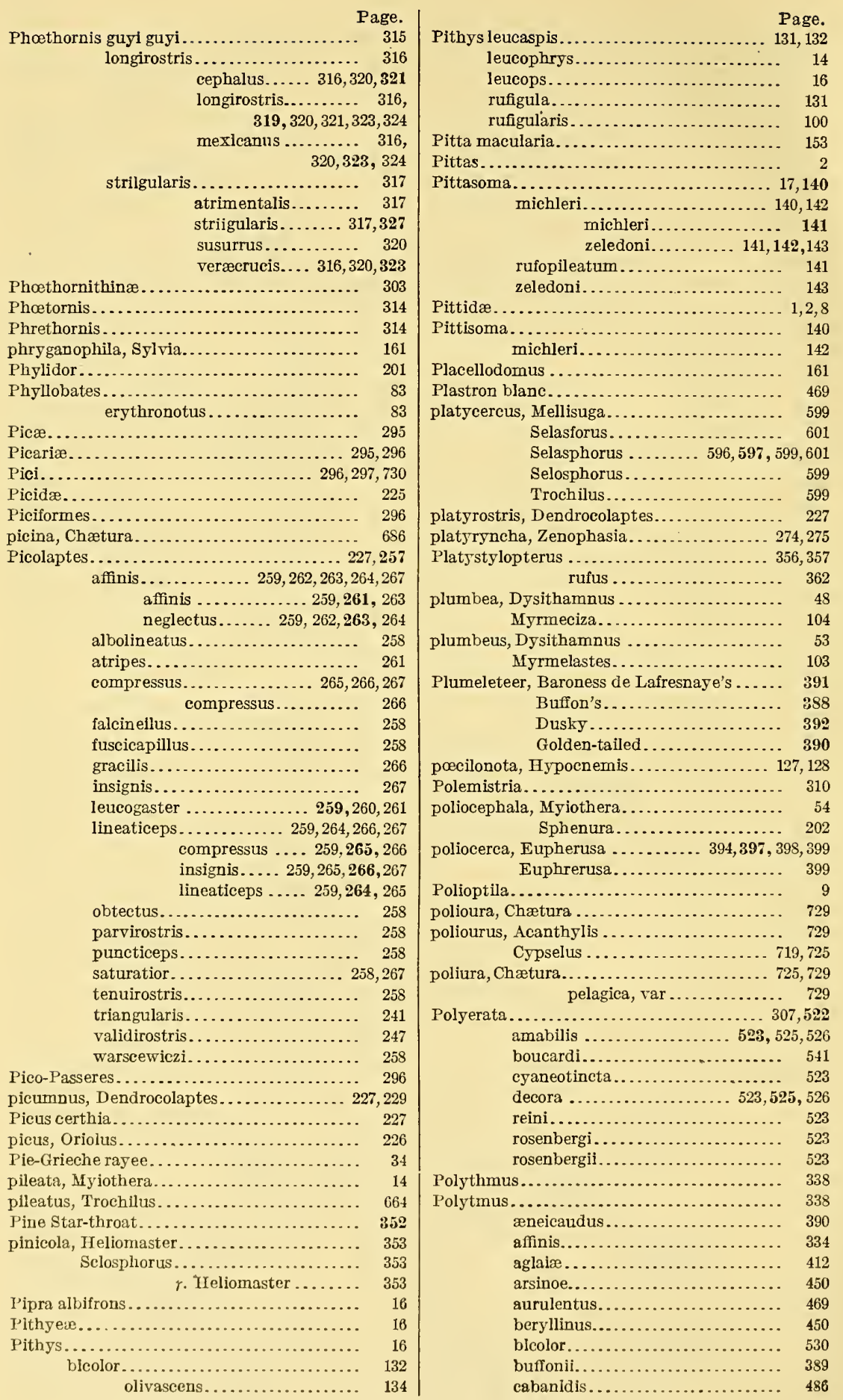


Polytmus cæruleogularis

candidus.....................

cayennensis violaceus............

cephalater.....................

cephalatra.....................

cerviniventris..................

chionopectus...................

chionurus......................

chlorolæmus..................

cinnamomea..................

columbicus....................

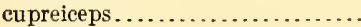

curvipennis....................

cuvieri..........................

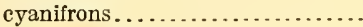

cyanocephalus..................

cyanurus.......................

delphinæ....................

devillei........................

dominicensis...................

dominicus....................

edward...

edwardsii.

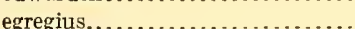

eliciæ........................

erythronotos.

erythronotus....................

eximius.......................

feliciæ.........................

goudoti.......................

gramineus....................

graysoni.......................

guatemalensis ..................

hemileucurus.................

hirsutus......................

holosericeus .................

isauræ.

jugularis.

linnæi...........................

longirostris.

luciæ

mango ...........................

margaritaceus

mazeppa. .

melanorrhous .

mexicanus cyaneus

minimus variegatus.............

nigriventris ..................

niveiventris...................

ocai..........................

pampa........................

porphyrurus

prevostii......................

quadricolor....................

riefferi...................... 411

roberti...................... 366

ruckeri....................... 337

rufus....................... 362,616

sophiæ...................... 440

suavis...................... 412

thalassinus .................. 483

urochryseus ................. 391

venustus.................... 535

veraguensis................... 468

rerticalis.................... 427
Page.

virginalis................... 471

viridans.................... 340, 341

viridigaster................. 438

viridipallens................. 510

viridis....................... 473

warsewizi.................. 436

yucatanensis................. 413

polytmus, Aithurus ........... $339,340,341,342$

Aiturus.................... 341

Ayturus.................... 341

Trochilus................ 338,340,627

Popelairea........................... 676

æquatorialis................. 681

conversi..................678,681

æquatorialis .......... 681

conversi .............. 681

typica .............6 678,681

langsdorffi................... 679

letitiæ..................... 679

popelairei................... 678

popelairei, Popelairea................... 678

Prymnacantha................. 678

Tricholopha................. 678

popelairi, Popelairia................... 677

Popelairia.......................... 310.676

conversi .................... 678

conversi ............. 681

æquatorialis ........... 681

conversii ................... 680

æquatorialis . . . . . . . . 678, 679

conversii ..........6 678,679

salvini ................ 680

langsdorfif. ................678, 679

letitiæ...................... 679

popelairi..................... 677

popelairii.............677,678,679

tricholopha...............676,678

popelairii, Gouldia..................... 678

Popelairia............ 677,678,679

Trochilus................ 676,678

Popelaria langsdorffi................... 679

tricholopha................. 678

porphyrura, Endoxa ................... 459

Lampornis . . . . . . . . . . . . . . 459

porphyrurus, Anthracothorax ........... 459

B. Floresia.... 459

Lampornis................ $\quad 459$

Polytmus............... 459

Trochilus................ 454,459

Porto Rican Emerald. . . . . . . . . . . . . . . . 550

Mango................... $\quad 470$

Pothinus.......................... 761

atricollis..................... 704

aurantliventer................ $\quad 779$

aurantiiventris................ $7 \mathrm{s0}$

sallæi..................... 750

tenellus..................... $7 \mathrm{S3}$

prasina, Ornismya .................. $\quad 517$

prasinoptera, Certhia.................. 480

prasinus, Chlorostilbou .................... 548

Prasitis............................. 547

atala....................... 560

Praxilla............................ 480

Premuocopus........................ 227

eburueirostris ............. 247 
Page.

Premnoplex

brunnescens brunneicauda brunnescens $158,160,180$ $181,182,183$ 181,182 coloratus $\ldots .181,182$

coloratus................... 181

Costa Rican................ 181 stictonota................... 180

Premnornis........................... 160

pretrii, Trochilus........................ 314 prevosti, Anthracothorax prevosti......... 465 Lampornis................ 464,465, 466 prevosti............. 466

prevostii Anthracothorax ............... 465,467 prevostii. $456,457, \mathbf{4 6 3}, 465$

Lampornis................... 465

Polytmus....................... 464

Trochilus.................... 464,465

Prevost's Mango . . . . . . . . . . . . . . . ........ $\quad \mathbf{4 6 3}$

Primnacantha.......................... 676 conversi.................. 681

princeps, Grallaria.................... 149, 150 guatemalensis ......... 150 guatimalensis......... 148, 149

Princess Helena's Coquette............... 673

pringlei, Coeligena..................... 501 henrica............... 501

Delattria..................... 501

Lampornis............ 495, 496, $498, \tilde{5} 00$

Pringle's Cazique...................... $\quad 500$

Prionoteles.............................. 793

temnurus . . . . . . . . . . . .

Prionotelus.......................... 793

temnurus.................... 795

Priotelus........................... 733, 793

temnurus ..................... 793,795 temnurus......... 793, $\mathbf{7 9 4 , 7 9 5}$

vescus.............. 794,795

procurvoides, Campylorhamphus........... 270

Xiphorhynchus............. 270

procurvus, Campylorhamphus ........... 270

Dendrocolaptes.......... 268, 269,270

promeropirhynchus, Xiphocolaptes......... 236

propinquus, Sclerurus albigularis............ 164

Trogon.................... 763

personatus............. 763

Prymnacantha......................... 676 conversi ................6678,681

lætitiæ................. 679

langsdorffi................ 678

letitiæ.................. 679

popelairei.................. 678

Pseudocolapteæ........................ 162

Pseudocolaptes ................... 162,196, 197 boissoneauti............. 197, 198 boissonneautii............ 197 costaricensis............... 199 flavescens............... 197 lawrencei................. 199 lawrencii............... 197, 198 Lawrence's............... 197 semicinnamomeus........ 196, 197

Pseudoprocne .......................... 690

Psilorhamphus.......................... 10, 83

Pteroptochidæ $\ldots \ldots \ldots \ldots \ldots \ldots \ldots \ldots . \ldots \ldots, 2,3,4,5,8$
Page.

cephala.

cephalus...................... 322

pudibunda, Siptornis . . . . . . . . . . . ........ 161 pudica, Synallaxis......... 187, 188, 191, 192, 193, 194 pudica ....... 188, 191, 192,193

puella, Cœligena.......................... 534 a. Thalurania ............. 534

Thalurania ..................... 534

Trogon............ 772,777, 778, 779, 780

Trogonurus......... 763, 765, 775, 778, 780

pulchellus, Calurus...................... 735

Hypolophus................. 34

canadensis ......... $\mathbf{3 3}$

Pharomachrus............... 735

Thamnophilus............... 34

Trogon....................... 735

(Calurus).............. 735

pulcher, Callithorax ................... 656

Calothorax................... 652,655

Trochilus ........................ 656

pulchra, Amathusia (Manilia)............. 656

Calothorax .............. 651,655,656

Manilia ... . . . . . . . 656

pullus, Sclerurus mexicanus............. 165,168

punctatus, Erionotus................. 27,51

punctatus........... 49,50

Lanius.................... 27, 49

Thamnophilus.............. 24,27

punctatus....... 49

Trochilus .................... 461

puneticeps, Dysithamnus. ............. 55, 58,59

Picolaptes................... 258

puncticollis, Dendrocolaptes...... 229, 232, 233,235

punctigula, Dendrornis.................... 257

Xiphorhynchus............... 257

punctigulus, Xiphorhynchus......... 241,242,257

punctigulus ... 242,

255, 257

punctulatus, Trochilus.................. 461

puniceus, Trochilus........................ 664

Purple Carib........................... $\quad \mathbf{4 7 8}$

purpureiceps, Heliothrix................. 564

barroti, var......... 564

pusilla, Myiothera...................... 64

pusillus, Campylorhamphus . . . . . . . . ... 268, 270

Xiphorhynchus .............. 270,273

Xiphornis .................... 273

Pygarrhicus ..................... 4, 158, 159,226

Pygiptila............................. 11

pygmæa, Basilinna leucotis ............ 378,381, 382

Formicivora ................... 65

Muscicapa...................6,60,65

Mymotherula............61, 62,64,65

pygmæum, Myrmophila ................. 65

pygmæus, Trochilus .................... 314, 585

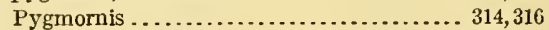

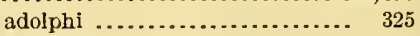

amaura .................... 328

obscura $\ldots \ldots \ldots . .314$

striigularis .................. 328

Pygmy Antwren ...................... 64

Pygoptila............................... 11

Pygornis............................. 314

adolphi..................... 325 
Pyriglena, ......................... Page.

atra.......................... 14

leucoptera................... 14

nudiceps................... 100

tyrannina................. 94,96

pyrrhodes, Phiiydor................... 201,202

pyrrhonota, Myrmotherula................ 62

Pyrrhophæna........................ 406

beryliina............. 448, 449, 450

cerviniventris............ 413, 414

cinnamomea............... 418

coraliirostris............... 419

cyaneifrons............... 436

cyanura.................. 446

deviliei................... 448

devillii................... 448

dubusi................... 412

graysoni................. 420

lodura.................. 438

ocal...................... 452

riefferi.................... 411

saucerottei................ 436

suavis.................... 412

viridigaster............... 438

viridiventris.............. 438

yucatanensis............... 413

Q.

quadricolor, Agyrtria............ 493

B. Uranomitra........ 423

Clanomyia................. 423

Cyanomya.................. 423

(Leucolia).......... 424

Cyanomyia................ 423

Leucolia.................... 424

Polytmus.................. 424

Trochilus.......... 356, 406, 423, 462

Uranomitra............ $356,423,424$

Quetzál............................ 731, 738

Costa Rican................... 739

quixensis, Formiclvora................. 80,81

Microrhopias.................. 75

Thamnophilus............ $75,80,81$

R.

radiatus, Thamnophílus............ $36,37,39,41$ radiatus........... 37,38

radiolatus, Dendrocolaptes............... 229

raimondii, Chlorestes..................... 544

o. Riccordia.......... 544

rami, Lamproiæma..................... 491

ramondit, Riccordia..................... 542

ramoniana, Trogon................ $784,785,786$

ramonianus, Aganus.................. 786

Chrysotrogon................ 785

ramonianus..... 786

Trogon...................... 786

Ramphastides.......................... 296

Ramphocænus.................. 14,83,84, 88 melanurus............... 84 rufiventris............... 87 rufiventris....... 85

semitorquatus............. 89,90

Ramphocœnus....................... 84

Ramphodon anais..................... 481
Page.

Red-bilied Azure-crown . ....... 517

throated Humming Bird ............ 630

reichenbachi, Chrysolampis.............. 669

reini, Polyerata...................... 523

resplendens, CaIurus.................... 738

Trogon ................... 733,738

(Calurus).............. 738

rhami, Ciytolæma...................... 491

Delattria.................... 490,491

Heliodoxa, $\delta$. Lamprolaima .......... 491

Lampornis....................... 490

Lamprolæma..................... 491

Lamprolaima.................. 459, 491

Mellisuga....................... 490

Ornismya.................... 489,490

Ornysmia....................... 490

Trochilus...................... 491

Rhamphocænus...................... 83,84

cinereiventris............. 90

collaris................. 10,88

rufiventer.............. 87

rufiventris............... 87

semitorquatus............ 90

Rhamphocenus rufiventris.............. $\quad 87$

Rhamphodon anais................... 483

Rhaphidura......................... 715

Rhegmatorhina...................... 16

gymnops................ 16

Rhinomydeæ ....................... 4

rhodogaster, Tmetotrogon................ 792

Trogon.................... 792

Rhopias.............................. 13

Rhopochares......................... 12

Rhopoctites....................... 162,222

ignobilis................... 223

rufobrunneus.............. 223, 224

Rhoporchilus....................... 13

Rhopornis......................... 10

Rhopoterpe...................... 17, 138

formicivora................ 139

stictoptera................ 139, 140

torquata.................. 139

Rhopoterpeæ........................ 17

Riccordia.................... 307,542, 548

æneoviridis.................. 545 maugæi.................... 542,548 ramondii.................... 542

ricordii. .................. 542,544 æneoviridis..... 542, $543, \mathbf{5} 11,545$

bracei................. 544

ricordii.............5 542,513

swainsonii.............. 542,543,546

Richardson's Autthrush................ 139

richmondi, Chætura........ 716, 719, 720,721, 723

Richmond's Swift..................... $\quad 719$

Ricordia........................... 542

elegans....................... 547

maugæi....................... 551

maugæus...................... 551

maugei....................... 551

ricordi....................... 54 54,545

ricordi, Chlorolampis................... 544

Hylocharis...................... 544

Orthorhynchus................. 544 


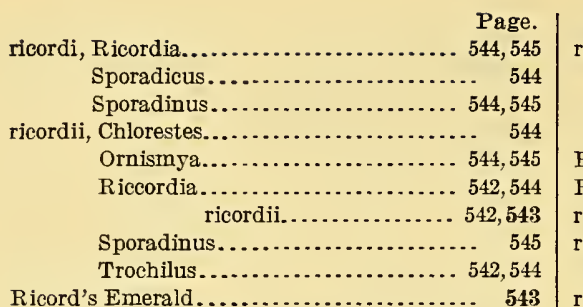

ridgwayi, Dendrocincla................... lafresnayei....... 288, 291 ridgwayi............ 293

Thalurania................ 532,537

riefferi, Amazilia....................... 411

Amazilius........................ 411

Amazillia......................... 411

Ariana......................... 411

Eranna......................... 411

Polytmus........................ 411

Pyrrhophæna.................. 411

Trochilus....................... 411

Rieffer's Humming Bird ................. 408

Rivoli Humming Bird................... $\quad 565$

rivolii, Ornismya..................... 568

Trochilus....................... 568

roberti, Aphantochroa.................... 366

Campylopterus.................... 366

Phæochroa................ 363,365, 366

Polytmus...................... 366

robini, Hirundo....................... 711

rohdei, Thamnophilus................... 28

Roi des Fourmilliers...................... 146

rosalba, Trogon........................... 763

roseigaster, Temnotrogon............. 791, 792

Temnurus...................... 792

Tmetotrogon................. 792

Trogon................... 790, 792 (Temnurus?).......... 792

rosenbergi, Agyrtria................... 523

Polyerata................... 523

Rouge-queue de la Guiane................ $\quad 186$

rubecula, Bucco..................... 784

rubens, Colubris....................... 627

ruber, Selasphorus...................... 616

Trochilus....................... 616

rubiginosa, Margarornis............... 178, 179

rubiginosus, Anabates................. 214, 215

Automolus....... 212, 213, 214, 215, 216

Lanius.................... 36

Philydor.................. 214

Sittasomus................ 179

rubromitratus, Selasphorus.............. 618

Trochilus............... 618

Ruby-and-Topaz Humming Bird........... $\quad 666$

ruckeri, Glaucis ..................... 337

Polytmus...................... 337

Threnetes.................. 336, 338

Trochilus..................... 337

Rucker's Hermit....................... $\quad 386$

Ruddy $\Lambda$ utomolus.................... $\mathbf{2 1 4}$

Dendrocincla.................... $\mathbf{2 9 3}$

rufa, Calliphlox....................... 616

rufater, Thamnophilus.................. 76

rufatra, Microrhopias................... $\quad 75$
Page.

rufescens, Automolus..................... 204

Philydor..................... 204

panerythrus............ 204

Thamnistes.................... 22

Ruffed Honeysucker..................... 613

Ruff-necked Humming Bird................ 613

ruffus, Trochilus........................ 616

ruficapilla, Grallaria.................... 18

Synallaxis ............. 186, 187,188

ruficauda, Myrmoderas................. $\quad 15$

ruficaudus, Glyphorynchus.............. 274, 275

Neops................... 170, 172

ruficeps, Anoplops...................... 131

Dendrocincla................... 295 homochroa. 288, 293, 294, 295

Formicarius................... 117 ruficeps............. 117

Grallaria...................... 18

Gymnopithys.................. 131

Myotthera................... 115, 117

Parulus....................... 186

ruficollis, Philydor..................... 202

Sclerurus..................... 167

rufifrons, Anabates...................... 161

Xenops........................ 202

rufigaster, Trochilus.................... 314

rufigenis, Acrorchilus erythrops........... 181, 186

Slptornis..................... 186

Synallaxis................... 186

rufigula, Anoplops.................... 130,131

Gymnopithys................ 131

Pithys...................... 131

Turdus................... 100, 130, 131

rufigularis, Pithys....................... 100

Sclerurus.................... 168

Tinactor...................... 168

rufimarginata, Myiothera................. 14

rufpectus, Automolus.................. 212,213

Fomicarius.............. 118, 125, 126

rufiventer, Rhamphocænus.............. 87

rufiventris, Chamæbates.................. 146

Disythamnus.................. 95

Ramphocænus................ 87

rufiventris....... 85

Rhamphocænus.............. 87

Rhamphocenus............... 87

Scolopacinus.................. 84, 87

rufo-brunneus, Automolus................ 224

Phylidor............ 222,223,224

Rhopoctites............ 223, 224

rufodorsalis, Campylorhamphus............ 269

Xiphorhynchus................ 269

Xiphornis................. 269

rufopileatum, Pittasoma.................. 141

rufo-superciliatus, Xenops.............205, 206

Rufous-breasted $A$ ntthrush............... 125

Synallaxls.................. 189

Humming Bird................. 612

-rumped Antwren................. 84

Sabre-wing...................... 361

rufula, Ornismla....................... 405

Grallarla........................ 18

rufus, Campylopterus ........ 356,357,358, 361, 362

Dendrocopus.................. 201, 202, 204

Philydor...................... 201,202 
Page.

rufus, Philydor panerythrus

Platystylopterus.................. 362

Polytmus...................... 362,616

Sæpiopterus.................... 362

Selasphorus..................... 596,

$597,608,609,611,612,614,615$

rufus, var.............. 615

Selatophorus.................... 615

Trochilus.................. 595,613,616

(Selasphorus).............. 614

Trogon.......................... 764

Rupicolidæ.

Russet Antshrike...................... $\quad 23$

rutila, Acanthylis........................... 713

Amizilis.................... 405, 407 rutila............ 407, $\mathbf{4 1 6 , 4 1 9 , 4 2 0}$

Chætura...................... 711, 713

Hlrundo..................... 711, 713

Ornismya....................... 418

rutiians, Xenops..................... 172, 176

rutilus, Cypseloides.................... 711

Thamnophilus................... 42

Xenops.................... 172, 176, 177 rutiius................. 172, 176

S

Saber-wing, Curve-winged.

De Lattre's.................. 358

Rufous...................... $\mathbf{3 6 1}$

Wedge-tailed................. $\mathbf{3 5 4}$

Sæpiopterus...................... 356,357 hemileucurus................ 360 rufus........................ 362

sagitta, Cœligena...................... $\quad 572$

o Leadbeatera............ 572

Heliodoxa...................... 572

saliæi, Florisuga..................... $\quad 580$

Pothinus........................ 780

Trogon .......................... 780

sailei, Fiorisuga....................... $\quad 580$

saloiæma, Oreopyra .................... 506

saivini, Agyrtria....................... 1330

Amazilia..................... 430

Amiziiis........................ 408,429

Anoplops ....................... 131

Chlorauges..................... 557

Chlorolampis................... 557

Chiorostiibon.................... 557

caniveti............ 557

var........... 557

canivetii........ 549,55 $\mathbf{5}, 558$

Cynomyia..................... 430

Delattria henrica................. 499

Eutoxeres ........................ 313

aquila .............. 311, $\mathbf{3 1 2}$

var............... 313

Gryphus....................... 313

Hyiocharis.................. 557

Lampornis amethystinus......... 495,498

Popelairia conversii.............. 680

Uranomitra.................... 430

Salvin's Antbird...................... 109

Azure-crown.................. 429

Emeraid...................... 557

Slckle-bill..................... 812

Thorn-tail..................... $6 \mathbf{6 7 9}$ sancta-martæ, Gymnocichla nudiceps...... 99, 100

sanctæmartæ, Myrmotherula.............. 62

sancti-hieronymi, Cypselus............... 693

Panyptila...... 681,691, 692,693 cayanensis, var. 693

sancti-jeromæ, Panyptila................. 692

sancti-thomæ, Dendrocolaptes........ 229, 231,232 certhia...... 231 sancti-thomæ. $\mathbf{2 2 9}$,

231,232

San Gerónimo Swift.................. 692

San Miguêl Antwren..................... 81

saphirinus, Trochilus.................... 384

Sapphire and Emerald Humming bird ...... 530

sapphirinus, Trochilus .................... 384

Sapphironia........................ 384

boucardi .................... 541

cæruleigularis................ 540

cæruleogularis.............. 540

circe...................... 373

doubledayi................. 377

duchassaingi............... 540

goudoti..................... 538

iucida..................... 381

iuminosa................. 538

Sarcorhamphi........................ 296

sasin, Ornismya ..................... 612

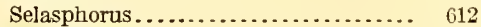

saturata, Amazilia ..................... 419

cinnamomea.......... 419

Amizilis cinnamomea............ 419

Dendrocincla anabatina. $287,289, \mathbf{2 9 0}, 291$

Phlegopsis................... 137

Phlogopsis................... 137

saturatior, Aphantochroa cuvierii........... 365

Phæochroa euvierii ............ . 363,365

Picolaptes ................. 258,267

saturatus, Amazilis cinnamomeus .......... 419

Formicarius................. 118

analis.............. 118

hoffmanni.......... 118

moniliger........... 118

Phænostictus mcleannani. . .... 136, 137

Phothornis adolphi....... 316,326,327

Thamnistes anabatinus......... $\mathbf{2 8 , 2 4}$

Xiphocolaptes................ 236

Saucerothia sophiæ..................... 440

Saucerotia sophiæ...................... 440

Saucerottea ........................ 434

alfaroana.................... 441

beryllina................... 450

chiorocephala............... 528

cupreicauda................. $\quad 438$

cyanifrons................... 436

cyanura.................. 446, 447

guatemalæ........... 447

impatiens............ 446

devillei..................... 448

devillii...................... 448

edward.................... 445

edwardi.................... 444

niveiventris................ 443

nlveoventer................ 443

ocai....................... 452

sophiæ..................... 440

sumichrasti ................ $\$ 52$ 


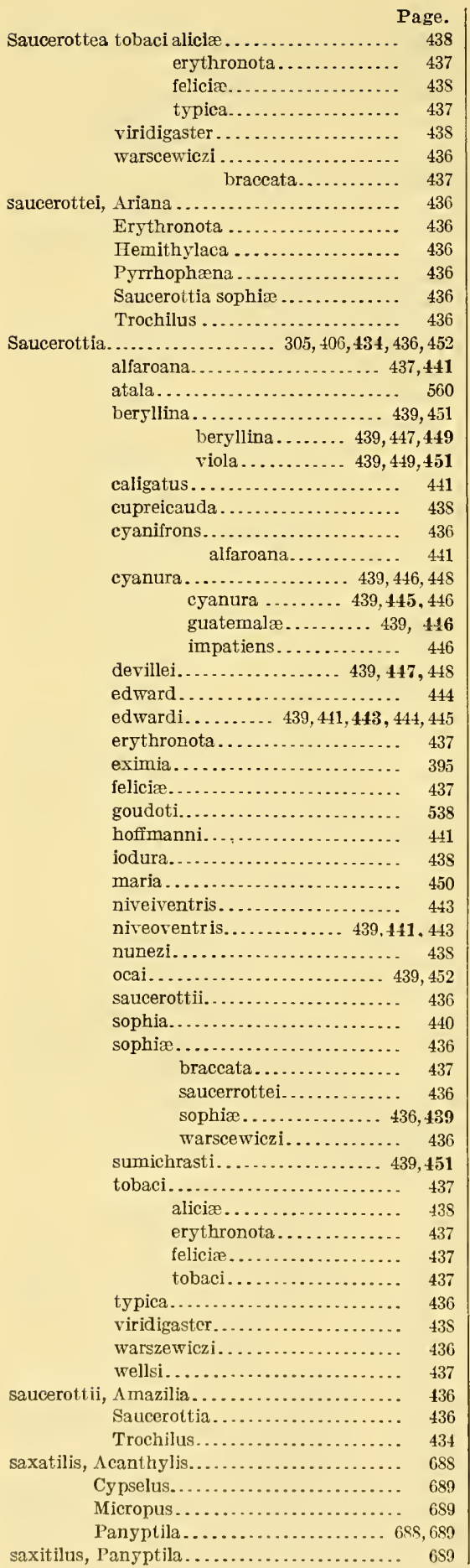

Scaly-throated Xenicopsis. 
secunda, Deconychura.

Selasforus

platycercus. rufus

595

601

615

Selaspherus 595

Selasphorus $309,591,595,596$ alexandri................... 636 alleni. $596,597,607,608,609,611,612,616$ anna...................... 621 B. Archilochus ............... 627 alexandri..... 636 ardens . . .... 596, 597, 604, 605, 606, 607 calliope.................... 591 constantii................... 351 costæ.................... 624 flammula.... 596, 597, 601, $602,603,604$ flammula.......... 602 torridus............. 604 floresii.........596, 597,616,617,618
$\gamma$. Heliomaster constantii...... 351 longirostris..... 347 pinicola........ 353

heloisa...................... 593

heloisæ.................... 593, 594 henshawi................. 616 pinicola..................... 353 platycercus ........ 596, 597, 599, 601 var. flammula...... 602 (platycercus, var.?) flammula... 602 platycercus, var. platycercus.... 601 ruber........................ 616 rubromitratus................ 618 rufus................... 596, 597, $608,609,611,612,614,615,616$ var. rufus.............. 615 scintilla............ 609 (rufus, var.?) scintilla.......... 609 sasin.................... 611 scintilla........... 597,605,607, 009 simoni.............. 597,606,607 torridus........... 596,597,602,604 underwoodi................607,609

Selatophorus......................... 595 rufus...................... 615

Selosphorus........................ 595 anna........................ 621 costæ.................... 624 platycercus................ 599 ruter....................... 616 semicinereus, Disithamnus............... 57 Dysithamnus............. 54,57 mentalis........ 54,55 olivaceus....... 5s semicinnamomeus, Pseudocolaptes....... 196, 197 semicollaris, Acanthylis................... 702 Chætura................. 702,703

Hemiprocne................ 703 Streptoprocne...... 696,697.702,703 semirufus, Philydor.................. 204 semitorquatus, Microbates cinereiventris..... $\quad 89$ Ramphocænus........... 89.90 Rhamphocænus........... 90 senex, Acanthylis .................... 711 Chæutura ....................... 711 Cypseloides....................... 711 Cypselus....................... 710,711 Ornismyfa..................... 434
Sephanoides fernandensis................. $\quad 417$ septentrionalis, Dysithamnus mentalís... $54, \mathbf{5 5}, 58$ Septuas............................. 740 Sericotes........................... 305,473 chlorolæmus.................. 477 holosericeus................. 476,477 chlorolæmus ......... 476 holoserIcens....... $\mathbf{4 7 4 , 4 7 6}$

longirostris..................... 477 serrirostris, Colibri....................... 481 Trochilus.................... 480

severus, Lanius........................ 11

Shear-tail, Mexican. ................... 650

Slender..................... $\mathbf{6 4 8}$

Short-billed Cazique.................. $\quad 497$

tailed Swift........................ 728

Sickle-bill, Costa Rican.................. 272

Salvin's..................... 312

Venezuelan................... $\mathbf{2 7 1}$

silens, Temnurus........................ 795

Trogon......................... 795

Silvery-fronted Scytalopus................

Silvestrius........................... 52

simoni, Selasphorus............... 597,606, 607

Simon's Humming Bird................. 606

simplex, Thamnophilus................. 48

Trochilus..................... 654

Siptornis........................ 160,161,184

albleapilla.................. 161

albiceps ....................... 161

antisiensis..................... 18

arequipæ................... 161

erythrops................. 18t, 186

humilis ...................... 161

orbignii........................ 161

pudibunda ................... 161

rufigenis....................... 186

sitkensis, Trochilus..................... 616

Sittacilla............................ 274

Sitta fusca........................... 162

nævia......................... 10,16

surinamensis..................... 63

Sittasomæ............................ 227

Sittasomus................... 227, 277, 279,281

æquatorialis............... 279

amazonus................... 279

brunnescens.................. 182

chapadensis................. 279

erthacus.................... $\quad 279$

erythacus.................. 279

flammulatus................ 275

griseus..................... 279

jaliscensis.................. 283

Jalisco...................... $\quad \mathbf{2 8}$

levis........................ 283

Mexican................... 250

olfvaceus.................... 2\%9, 882

amazonus.......... 279

Panama.................. 282

pectinicaudus................. 282

rubiginosus.................. 179

stictolæmus.................. $2 \$ 5$

sylviellus................... 279

chapadensls......... 279

sylvlellus. . . . . . . . .... 279

sylvioldes........... 279,2\$1,2\$2, $2 \& 3$ 
Page.

Sittasomus sylvioides jaliscensis...... 279, 281,283 levis.........279, 281, 282 sylvtoides .......... 279, $280,281,282,283$

Sittidæ............................... 295

Sittosomus........................... 277

olivaceus...................... 282

pectinicaudus................. 282

stictolæmus.................... 285

Slaty. Antshrike........................ 49

Antwren ......................... 70

-headed Trogon.................... $\quad \mathbf{7 5 9}$

Synallaxis........................ 191

Slender-billed Mango..................... $\quad \mathbf{4 6 5}$

Shear-tail ...................... 648

Small-billed Azure-crown................. 428

Small Green and Crimson Humming-bird... 669

smaragdinea, Cyanophaia.................. $\quad 528$

Eucephala.................. 528

Thalurania................. 528

Timolla................... 528

smaragdineum, Augasma................ 526,528

Smaragditis............................ 454

euchloris.................... 547

smaragdo-cærulea, Eucephala............. $\quad 528$

Smoky Swift.......................... $\quad 725$

Snow-cap, Costa Rican................... 582

Veraguan.................... $\mathbf{5 8 1}$

Snowy-breasted Humming Bird........... 441

Sooty Automolus...................... $\mathbf{2 1 6}$

Synallaxis....................... 192

sophia, Saucerottia ...................... $\quad 440$

sophiæ, Amazilia........................ 441

Amazilius...................... 440

Amizilis........................ 441

Ariana...................... 440,441

Chlorestes....................... 440

r. Saucerottia.......... 440

Erythronota.................... 440

Hemithylaca................... 440

Polytmus........................ 440

Saucerothia.................... 440

Saucerotia.................... 440

Saucerottea.................... 440

Saucerottia.................. 436, 440 sophiæ............. 436, $\mathbf{4 3 9}$

Trochilus....................... 440

Sophia's Humming Bird................ 439

sordida, Cyanomyia (?)............... 366, 368

Doleromya.................... 368

Hylocharis..................... 368

Leucolia...................... 368

Phæoptila.................. 367,368

Synallaxis.................... 161

Uranomitra................... 368

sororia, Myrmotherula ................... 62

Souimangap rasinoptére................. 480

Southern Allied Woodhewer.............. $\mathbf{2 6 3}$

speciosa, Formicivora.................... 13

spectabilis, Eugenes .......... 56.5, 568, 569, 570

Heliomaster................ 569

Trochilus................... 569

Sphenoproctus........................ 353 (Campylopterus) pampa..... 355 curvipennis................ 350 pampa............. 354, 355, 356
Sphenorhynchus. Page.

Sphenura poliocephala.......................

striolata...................... 161

sulphurascens .................. 211

superciliaris.................. 201, 203

Spinetail, Lawrence's..................... 184

spinicauda, Acanthylis................... 716

Chætura.............. 716,717,726

spinicauda ........... 716

Hirundo................. 714,716

spinicaudus, Cypselus................. 716,726

spixi, Synallaxis........................ 186

splendens, Aspasta...................... $\quad 572$

Heliodoxa.................... 572

Hypolia................... $\quad 572$

Leadbeatera.................... 572

spodionota, Myrmotherula............... 62

spodionotus, Dysithamnus.............. 54,55

affinis......... 55

mentalis..... $54,55,57$

Sporadicus.......................... 542

elegans...................... 547

ricordi...................... 544

Sporadinus........................... 542

auriceps...................... 552

bracei..................... 544,545

caniveti..................... 555

elegans...................... 546

incertus..................... 547

(Marsyas) maugæi............ 551

maugæi..................... 551

maugæus.................... 550

maugei................... 550,551

mangeus................... 550

riccordi...................... 544,545

riccordii..................... 545

ricordi...................... 544,545

Spotted Antbird....................... 128

-crowned Antvireo............... 58

-necked Woodhewer.............. 232

-throated Woodhewer............... 255

Woodhewer..................... 254

squalidus, Trochilus...................... 314

squamata, Myiothera...................... $\quad 14$

squamatus, Cypselus..................... 686

Dendrocolaptes............... 257

squamigera, Anabates.................. 177

Grallaria.................... 147

Margarornis.................. 178

squamosa, Myrmoderas................... 15

Star-throat, Constant's.................. $\quad \mathbf{3 5 0}$

Long-billed.................. $\quad \mathbf{3 4 6}$

Pale-crowned................ $\quad 349$

Pine........................ 352

Steatornithidæ......................... 298

stellaris, Thamnophilus.................. 48

Stellula ............................ 308, 587 calliope ................ 588, 590, 591

Stellura............................ 587

stewartæ, Floricola superba............... 348

stlctolæma, Deconychura................ 285

stictolæmus, Deconychura............... 285

Sittasomus.................. 285

Sittosomus.................. 285

stictonota, Premnoplex................. 180

stictoptera, Drymophila................. $\quad 110$ 
Page.

stictoptera, Myrmeciza. Rhopoterpe.

109,110

139,140

stictoptilus, Automolus. 223

Stipituropsis arechavaletæ

Streaked Automolus. -crowned Antvireo.

-headed Woodhewer

Xenops...

Streamer-tail, Black-billed Streptoprocne

-tailed Humming Bird ............

.........686, 696, 697, 715

biscutata.................. 697 semicollaris.......666,697, 702, 703 zonaris................ 697,701 albicincta.... 697, 698, 699, 700 mexicana....... 697, 700, 701 minor.............. 698 pallidifrons......697, 701, 702 zonaris......6 697, 699, 700, 701

striata, Vanga......................... 10 striaticeps, Asthenes..................... 161

Automolus................... 223

Dysithamnus............. 55, 59, 60 striaticollis, Anabates................... 207

Anabazenops................. 207

Anumbius ................... 160

Pbilydor................... 207

Synallaxis................... 160

Xenicopsis................ 207, 206

striatigularis, Dendrornis ............... 250

Xiphorhynchus........ 241, 249, 250

striatus, Trochilus...................... 669 Striges........................ 295, 296, 297 strigilata, Myiothera.................... 13 strigilatus, Thamnophilus................. 162 Trogon................. 750,751,752 strigilatus........... 751,752

strigularis, Eremita................... 328

Phæthornis .................. 328

Phœthornis ................. 317 strligularis....... $317, \mathbf{8 2 7}$

Pygmornis ................. 328

striolata, Sphenura...................... 161

Thripophaga.................. 161

Striped-bellied Woodhewer................. 243

Hyloctistes.................... 200

-tailed Humming Bird .............. 394

-throated Woodhewer .............. $\mathbf{2 4 9}$

Stripe-throated Hermit................... $\mathbf{3 2 7}$

Strisores.......................... 296, 298 stuartæ, Floricola longirostris ............. 348 Heliomaster................... 348 longlrostris, var....... 348

St. Vincent Blue-crest.................. 661

suavis, Ariana riefferi, var................. 412

Eranna....................... 412

Polytmus......................... 412

subalaris, Anabates.................. 207, 211

Anabazenops................ 207, 211

Xenicopsis..............206, 207, 211

subalaris ........ 207,209,210

subplumbeus, Dysithamnus............. 48,53

subprocurvus, Xiphorhynchus............ 270

Xiphornis................. 270

subradiatus, Thanmophilus radiatus....... 38
Page.

subulatus, Automolus................... 223

sulphurascens, Sphenura................. 211

sulphureus, Trogon...................... 764

sumichrasti, Amazilia................... 451

Amizilis.................... 452

Saucerottea................ 452

Saucerottia................. 439,451

Sumichrast's Humming Bird............. 451

superba, Bellona....................... 662

Floricola...................... 348

superba.............. 348

Ornismya..................... 348

superbus, Trochilus..................... 348

superciliaris, Anabates................... 203

Myiothera.................. 77

Philydor................... 203

Sphenura................. 201, 203

superciliosus, Dendrocolaptes.............. 162

Trochilus................ 314, 332

Surinam Antwren ..................... 62

Nuthatch.................... 63

surinamense, Myrmotherium............. 64

surinamensis, Mellisuga................ 579, 616

Myrmotherula... 61, 62,63, 64, 65, 84 surinamensis... 64

Sitta ...................... 63

surucura, Trogon....................... 761

Suspensi........................... 300

susurrans, Dendrocolaptes.............. 251, 253

Dendrornis............... 239, 251, 253

susurrus, Phœthornis longirostris ......... 320

swainsoni, Drymophila................... 109

Myrmeciza................... 105, 108 boucardi....... 105, 107,108

swainsonii, Ornismya................. 649,547

Riccordia............... 542,543.546

Trochilus.................... 547

Swainson's Woodhewer ................ 244

Swift, Antillean Collared................. $\quad \sigma_{01}$

Black........................ 704

Cayenne........................ 691

Cherrie's....................... $\mathbf{7 1 4}$

Chestnut-collared................. 712

Chimney...................... $\mathbf{7 1 7}$

Colombian Collared............... 697

Cuban Palm..................... 695

Gaumer's....................... 721

Gray-rumped Chimney............

Jamaican Black..................

Lawrence's....................... 728

Martinique...................... 724

Mexican Collared.................. $\quad 700$

Northern Black................. 707

Richmond's..................... $\quad \mathbf{7 1 9}$

San Geronimo.................. 692

Short-tailed...................... 728

Smoky ....................... 725

Tepic.......................... $\mathbf{7 1 4}$

Vaux's....................... 722

White-naped..................... 702 -throated................... 687

Swifts, The.......................... 681

Chæturine.............696,703, 710,715

Humming Birds and.............. 298

Tree........................... 696

True........................683

$$
81255^{\circ}-\text { Bull. } 50-11-54
$$


Page.

yblllæ, Coeligena ...................... 509

Delattria..................... 502

Oreopyra ................501,502, 508

sybille, Delattria ..................... 509

Sybil's Mountain Gem................... 508

Sylosella............................. 277

Sylvia phryganophila.................... 161

Sylviaxis............................. 5

guttatus............... 5

sylviellus, Dendrocolaptes............... 277

Sittasomus.................. 279

sylviellus........... 279

sylvioides, Sittasomus............ 279, 281, 282, 283

sylvioides.......... 279, $280,281,282,283$

Synallaxeæ........................... 160

Synallaxinæ........................... 158

Synallaxis .................... 13,161, 186, 188

albescens................ 187, 188, 195

albescens........... 188, 195

albigularis....... 188, 194, 195

hypoleuca ....... 189, 195, 196

latitabunda ..... 188, 194, 195

nesiotis........... 188, 195

albigularis.................... 188

antisiensis................... 184

brachyura................... 192

brunneicaudalis................ 192

cinerascens..................... 191

Costa Rican Gray-breasted....... 194

cururuvi...................... 187

erythrops................ 183, 184, 186

erythrothorax ..... 187, 188, 189, 190, 191

erytrothorax.................. 191

maximiliani................... 186

nigrifumosa.................. 193

nigrofumosa................. 193

pudica........ 187, 188, 191, 192, 193, 194

nigrifumosa....... 188, 189, 192

pudica ....... 188, 191, 192, 193

ruficapilla ............... 186, 187, 189

rufigenis..................... 186

Rufous-breasted............... 189

Slaty...................... 191

Sooty..................... $\mathbf{1 9 2}$

sordida..................... 161

spixi....................... 186

striaticollis.................... 160

White-breasted................ 195

Syndactyla.......................... 205

Syndactylus.

\section{T.}

Tabara......

Tachornis............... 682, 683,686,693, 715 gradil........................ 695

Iradli......................... 695

phœenlcobla...........686,693,694, 695 phcenicobla..... 683, 694, 695 yradil............683,695

phoenlcoblus................. 694, 695

phœrnlcoblus................. 695

Talamanca Antpitta.................. 156

Talaphorus........................ 305

Talapiot............................ 227 tambllanus, Dysithamnus................ Page.

Tamnophilus........................ 34

Tanypeplus........................... 733

auriceps...................... 735

fulgidus................... 735

heliactin.................... 735

pavoninus................... 735

Tapaculos, The...................... 4

Taraba............................. 11,27

transandeana transandeana......... 28

Taumastura elisæ..................... 651

Tawny Antshrlke...................... 22

Automolus...................... 215

taylori, Aithurus ...................... 341

polytmus............... 341

Telamon........................... 669

delattrei....................... 672

Telesiella................................ 480

delphinæ..................... 488

Telesilla.............................. 480 delphinæ..................... 488

temminckii, Dendrocolaptes.............. $\quad 226$

Hemiprocne................ 711

Temnotrogon.................... 733, 790, 793 roseigaster.............. 791, 792

temnura, Trogon....................... 795

Temnurus........................... 793

albicollis................... 793,795

roseigaster................... 792

silens.......................... 795

temnurus, Prionoteles.................... 795

Prionotelus .................. 795

Priotelus .................... 793,795

temnurus....... 793, 794, 795

Trogon .................. 793,795

temporalis, Anabates.................... 207

Anabazenops................ 207

Xenicopsis................ 207,206

tendali, Lucifer, $\delta$. Calothorax.............. 654

tenebrosa, Agyrtria.................... 528

tenellus, Pothinus....................... 783

Trogon....................... 783

atricollis................ 783

Trogonus curucui....... 764,765, 781, 784

tenuelius, Trogon atricollis................ 783

tenuifasciatus, Thamnophilus............. 46

tenuirostris, Dendrocolaptes............ 257, 265

Dendrornis................ 265

Picolaptes.................. 258

Xenops...................... 171

tephrocephala, Agyrtria................... 406

Teple Swift......................... $\mathbf{7 1 4}$

Terenura.......................... 10,83, 84

callinota...................... 83,84

Tetema de Cayenne.................... 117

tetema, Mylothera..................... 117

thalassina, Colibrls...................... 483

Petasophora............. 483,486

7. Praxilla ......... 483

thalassinus, Collbri............ 481, 482, 483,484

Cynanthus................... 483

Lampornis . .

prevostl............ 465

Polytmus $\ldots . . . . . . . . . . .4483$

Trochilus ................. 483, 486

Thaluranla.................... 307, 530, 542 
Thalurania bicolor

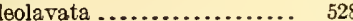

chlorocephala ................ 528

chlorophana................. 528

coelina ....................... 538

colombica .............. 532, 534,535

colombica..............532,534

venusta ......... 532, 533, 534, 5535

columbica ................. 534,535

typica.................. 534

venusta .................. 535

var. venusta.................. 535

cyanifrons................... 436

lerchi..................... 527,528

puella ....................... 534

ridgwayi $\ldots \ldots \ldots \ldots \ldots \ldots \ldots \ldots . \ldots \ldots 32,587$

scapulata................... 528

smaragdinea.................. 528

townsendi.................. 532, อี36

venusta $\ldots . . . \ldots \ldots \ldots \ldots \ldots \ldots . .6535$

wagleri .................... 530

Thaluronia......................... 531

Thamnarchus........................... 10

Thamnistes.......................... 11, 21

æquatorialis................ 22

anabatinus................ 21, 23, 24

anabatinus.......22, 23

saturatus......... 23, 24

rufescens...................... 22

Thamnocharis........................ $\quad 10$

Thamnomanes....................... 14

Thamnophilus ............ 12,27,34, $35,47,48,53$

æthiops................ 12,48

affinis................ $39,42,44$

albicans.................. 38

amazonicus.............. 51

ambiguus................ 48

atrinucha............... 51,52

bridgesi.................. 24, 27

cærulescens............ 47,48,51

capitalis................... 48

caudacutus........... 165, 168, 170

cinereiceps................ 48

cinereo-niger.............. 48

cinereus................... 10

corvinus................ 100

doliatus ... $36,37,38,39,40,42,43,44$ affinis............. 44 doliatus........ $36,40,41$ fraterculus.........41, 43 mexicanus .......... 36 , $40,42,43,44,45$

nigricristatus....... 39 pacificus...... $36, \mathbf{4 1}, \mathbf{4 3}, \mathbf{4 4}$ yucatanensis. $36,41, \mathbf{4 4}, 45$

gorgonx................ 48,52

griseus.................. 77

gularis................. 13,74

guttatus.................. 10

hollandl.................. 31

immaculatus......... 106, 112, 115

inornatus................ 48

intermedius............... 43

leachii................... 11

levequchen................ 34

leuconotus............. 12, 105
Page.

Thamnophilus lineatus.................. $\quad 19$

luctuosus.................. 12

maculipennis.............. 11

major.................... 27

melanochrous.............. 12.48

melanocrissus.............. 31

melanurus................. 31

multistriatus. ........... . $36, \mathbf{4 5}, 46$

murinus.................. 48

nævius................... 49

albiventris......... 49

atrinucha.......... 52

nævius........... 49,51

nigriceps................. 36

nigricristatus......... 21, 27, 39,44

nigricristatus... $\quad 39$

olivaceus................. 54

pulchellus................. 34

punctatus................ 24, 27 punctatus........ 49

quixensis............. $75,80,81$

radiatus.............. $36,37,39,44$ albicans........... 38, 39 capistratus......... 38 difficilis........... 38 nigricristatus. $\mathbf{3 5}, \mathbf{3 7}, 38,39$ radiatus........... $3 \pi, 38$ subradiatus......... 38

rohdei.................... 28

rufater.................... 76

rutilus................... 42

schistaceus................ 48

(Silvestrius) flavescens....... 52

simplex................ 48

stellaris................... 48

strigilatus................ 162

tenuifasciatus.............. 46

tenuipunctatus.............. 46

torquatus............... 12

transandeanus............ 30, 34 granadensis... 30,32

tristis.................. 45

tschudii................... 12, 49 virgatus................ $34,36,47$ nigriceps.......... 36 virgatus........... $36, \mathbf{4 6}$

Thaumantias candidus.................. 433

chionura.................. 403

chionurus................. 403

edward..................... 44

riridipallens................ 510

Thaumastura duponti.................. 639

elizæ...................... 650

enicura..................... 649

erelynæ.................. 643

henicura................. 649

Thanmatias candidus................... 433

canireti.................. 555

chionopectus................ +31

chionurus................. 403

chlorocercus................. 305

cupreiceps................... 405

doubledayi.................. $3 \pi$

lerdl................... 452

leucotis..................... 38 .

linnæi................... 432 


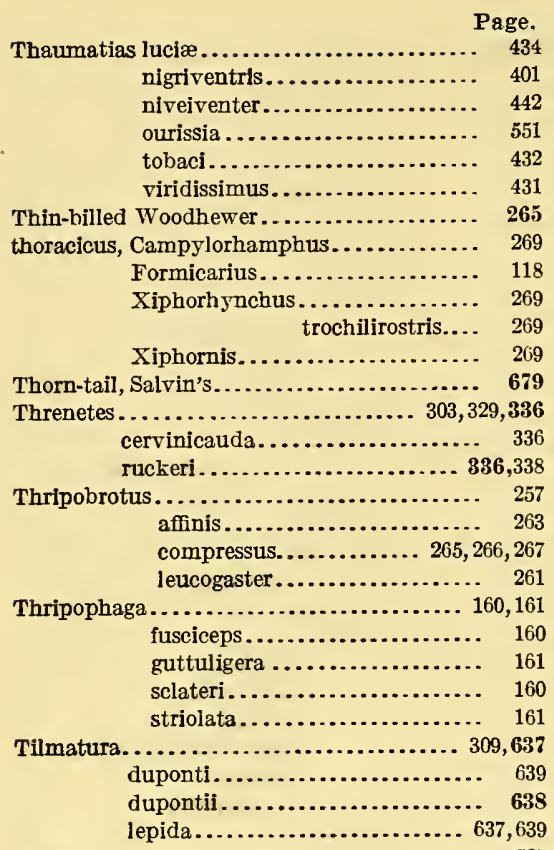

Timolia............................. $\quad 527$

bicolor........................ 530

lerchi........................ 528

smaragdinea.................... 528

Tinactor............................. 163

fuscus................... 163, 164, 165

guatemalensis.................. 170

rufigularis..................... 168

tintinnabulatus, Turdus................. $\quad 15$

tipica, Myiabeillia....................... 518

Tityra cayanensis....................... $\quad 49$

Tmetotrogon.......................... $\quad 790$

rhodogaster................ 792

roseigaster................. 792

tobaci, Agyrtria....................... 432

Amazilia....................... 437

Amizilis....................... 437

Saucerottia...................... 437

tobaci.................. 437

Thaumatias..................... 432

Trochilus..................... 432, 437

tobagensis, Drymophila grisea............. 77

Florisuga mellivora......... 577, 578

Formicivora................. 77

Microrhopias grisea............ 77,82

Tobago Humming-bird................ 437

Todi................................. 296

Todidæ............................... 296

Topaza albocoronata................... $\quad 582$ fimbriata...................... 579

flabellifera..................... 579

henrica........................ 497 mellivora....................... 579 parvirostris...................... 583

viridipallens................... 510

topiltzin, Trochllus...................... 494

torquata, Rhopoterpe................... 139 torquatus, Formicarius................ 138, 139

Microbates................... 88

Thamnophilus................ 12

torridus, Selasphorus........... 596, 597,602,604

flammula .......... 604

townsendi, Thalurania................ 532,586

Toxateuches emiliæ.................... 319

Toxoteuches.......................... 314

emiliæ..................... $\quad 316$

guy ...................... 315

Tracheophonæ....................... 1,2,3

Tracheophone Mesomyodi.............. 1,2

Passeres................... 2

Tracheophones........................ 1

transandeana, Taraba transandeana........ $\quad 28$

transandeanus, Diallactes................ 31

Thamnophilus............ 30,31

Tree Swifts......................... 696

triangularis, Dendrocolaptes......... 241, 255, 257

Dendrornis ........... 241,255, 257

Nasica..................... 241

Picolaptes................... 241

Xiphorhynchus............... 241

triangularis.... 241

Tricholopha........................... 676

popelairel................... 678

tricholopha, Popelairia.................676,678

tricolor, Cynanthus....................... 601

Ornismya........................ 601

Triphæna duponti....................... 639

tristis, Thamnophilus.................... 48

trivittatus, Formicarius................. 135

Trochili........................ 297,299,300

Trochilidæ....... 296, 300, 301, 303, 357,362,639, 647

Trochilinæ.......................... 303,342

trochilirostris, Campylorhamphus.......... 269

Dendrocolaptes........ 269, 270,272

Xiphorhynchus....... 269,270,272

Xiphornis................. 269

Trochillus colubris..................... 632

Trochilus................................ 627

abeillei....................... 518

aglaiæ...................... 412

albus.......................... 461

aiexandrei.................... 636

alexandri.............. 627,634,636

alleni........................ 611

amabilis................... 522,524

amethystinus................. 309

anais.......................... 483

augustipennis................. 547,559

anna.......................... 621

anthophilus.................... 316

antoniæ........................ 336

apicalis....................... 316

aquila.................... 310,311,313

atricaplllus.................... 463

8. Atthis ....................... 591

anna.................. 621

costæ................... 624

heloisa ................ 593

auratus...................... 479,480

aureigaster..................... 633

aureiguia...................... 633

aureigularis................... 633

auriceps.................. 547,552 
Trochilus aurigularis.

Page. auritus........................ 561 aurulentus...............4454,469,471 bahamensis................... 643 bancroftl..................... 480 barroti......................... 503 beryllinus ................. 448, 449,451 bicolor................. 526,527,530 bourcieri........................ 314 brasiliensis................... 332 buffoni.......................... 386 buffonii........................ 389 cæruleogularis .................. $\quad 539$ caligatus.................... 437,441 calliope..................... 587,591 calolæmus.................... 506 (Calothorax) calliope............ $\quad 589$ candidus...................... 433 carbunculus...................... 669 castaneiventris................. 503 castaneoventris........ 501,503, 506, 507 cephalus.................... 321, 322 chionogaster.................. 305 chrysogaster................... 547 cinereicaudus.................. 507 cirrhochloris................... 365 cohuati....................... 655 collaris...................... 616 colubris.................627,630, 632 constant1...................... 351 conversii ....................6 678,681 corallirostris................. 418,419 corruscus...................... 654 costæ.......................... 624 cristatellus..................... 661 cristatus..........656,661,662,663,664 cuculliger.................... 381

(Culampls) auratus............ 479 violaceus............ 480 curvipennis.................... 356 cuvieri....................... 362, 366 cuvieril....................... 364 cyaneus........................ 480 cyanifrons.................... 435, 436 cyanocephalus................. 426 cyanomelas..................... 480 cyanopogon.................... 654 cyanotus....................... 485 delattrei...................... 672 devillei..................... 448 dominicus........ 332, 454, $456,469,472$ (Doryfera) louise............... 342 doubledayi................... 373,376 dubusl........................ 412 duchassainl................... $\quad 540$ dupontl........................ 639 edward.................. 435,444,650 elatus........................ 669 elegans........................ 546 ellelæ......................... 385 ellza......................... 647 ellioti........................ 595 emiliæ....................... 316,319 enicurus................. 647,649,655 erythronotus................... 437 eurynorne...................... 314
Page.

Trochilus evelynæ..................6 639,643,645 exilis................ 656,660,664,665 fallax......................... 305

fasciatus....................... 461

ferrugineus.................... 332

fimbriatus...................... $\quad 579$

flabelliferus.................... 579

flammula..................... 602 floresii.................. 459,617,618

forficatus..................... 341

franciæ...................... 430

fulgens..................... 564,567

furcatus..................... 341,530

fuscicaudatus................ 405, 410

fuscus........................ 308

(Glaucis?) cæruleogaster......... 386, 387

glaucopis . . . . . . ............ 531

goudoti...................... 537

gramineus..................... 456

granatinus.................... 480

guianensis...................... 669

guimeti..................... 513,515

gujanensis..................... 669

guy......................... $\quad 315$

guyi............................ 314

helenæ................... 627,675

heloisa......................... 593

hemileucurus................... 359

hemileucus.................... 508

henryi...................... 574

hirsutus................... 329, 331

holosericeus.................. 473,475

hypophæus................... 669

jeterocephalus................... 622

idaliæ......................... 314

insignis ...................... 513

intermedius.................... 314

iodurus..................... 435, 438

jacula........................ 571

jamersoni.................... 571

jugularis.................. 477, 479

(Lampornis) aurulentus.......... 471 holosericeus......... 476

langsdorffi................... 676,678

largipennis................... 356

lazulus..................... 356

leadbeateri. . . . . . . ...........5 570,572

leocadiæ.................... 352,353

letitiæ..................... 677,679

leucaspis.................... 504

leucotis................ $377,380,382$

leucurus..................... 336

longirostris................... 344,347

longuemareus................... 314

lucidus........................ 381

lucifer...................... 654

ludoviciæ...................... 342

maculatus................... 431, 456

magnificus.................... 669 mango.............. 454,458,462,465 margaritaceus................ 434,469

maria....................... 341

mariæ....................... 448, 450

maugæus...................... 547,550

maugei....................... 550

mazeppa..................... 333 


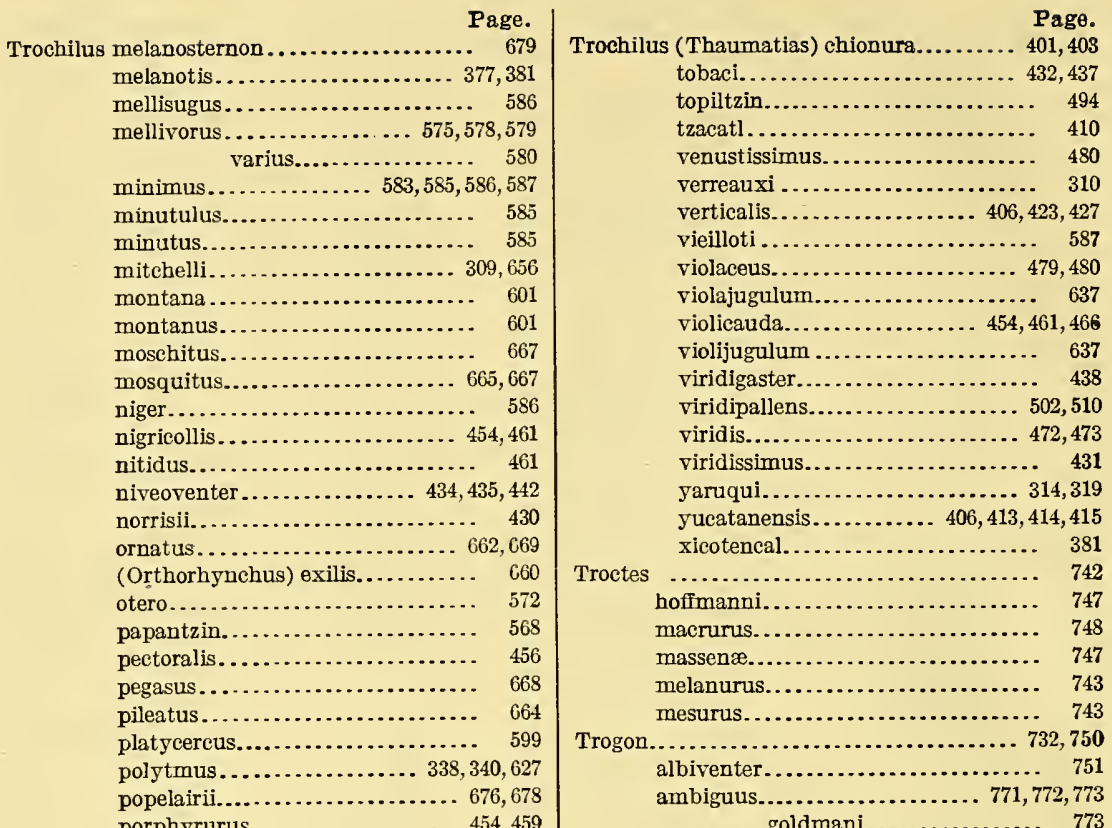

pretrii........................... 314

prevostii.................. 464,465, 466

pulcher......................... 656

punctatus...................... 461

punctulatus................... 461

puniceus...................... 664

pygmæus..................... 314,585

quadricolor........... 356,406,423,462

rhami......................... 491

ricordii..................... 542,544

riefferi........................ 411

rivolii......................... 568

ruber.......................... 616

rubromitratus................. 618

ruckeri........................ 337

ruffus......................... 616

rufigaster .................... 314

rufus $\ldots \ldots \ldots \ldots \ldots \ldots \ldots \ldots . \ldots 59,613,616$

saphirinus ................... 384

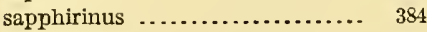

saucerrottel................... 436

saucerottii.................... 434

scintilla...................... 609

(Selasphorus) floresii............ 618

(Selosphorus) scintilla.......... 609

serrirostris.................... 480

simplex..................... 654

sitkensis..................... 616

sophix...................... 440

spectabilis...................... 569

squalidus..................... 314

striatus...................... $\quad 869$

superbus...................... 348

supereiliosus............... 314, 332

swainsonii................... 547

thalassinus................... 483, 486

(Thalurania) venusta........... 535

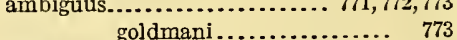

antisianus.................... 733,735

antisiensis.................... 733,735

assimilis........................ 763

atricollis................... 761,764,783 chrysochloros............. 764 tenellus ................. 783

auranteiventris................. 779,780 aurantiiventris............. 779,780,783

underwoodi......... 780

auratus......................... 763

bairdi........................... 754

bairdii .................... 751, 752,754

Baird's........................ 752

Black-headed................... 756

braccatus........................ 790

caligatus............... 784, 785, 789, 790 caligatus................. 790

concinnus............... 790

calthratus...................... $\quad 750$

(Calurus) auriceps................ 735

fulgidus................ 735

hargitti................ 735

neoxenus.............. 742

pulchellus............... 735

resplendens.............. 738

capistratum .................... 761

capistratus..................... 761

castaneus......................... 763

cayanensis cinereus............... 751 viridis................. 751

chionurus........................ 756

chrysochloros.................... 764

chrysomelas................ 783,784, 790

Citrooline...................... 759

citreolus ............... 752, 759, 760,761

clathratus................... 750,754

collaris....................... 763,764 
Trogon concinnus ........ Coppery-tailed.................. 768

Cuban.......................... 79 curucui.................... 742,763,764 cyanurus........................ 752

domicellus....................... 792

Eared.......................... 741

elegans........................... 775

Elegant....................... 773

erythronotus..................... 747

eximius......................... 756

exoptatus...................... 763

eytoni............................ 763

fulgidus......................... 735

Gartered........................ $\quad \mathbf{7 8 6}$

glocitans........................ $\quad 767$

goldmani......................... 773

Goldman's...................... 778

Graceful......................... 781

Haitian......................... $\quad 791$

heliothrix...................... 763

hoffmannl........................ 747

Isle of Pines..................... $\quad \mathbf{7 0 5}$

Jalapa........................... 775

Large-tailed...................... 747

Lattice-tailed...................... $\quad \mathbf{7 \pm 9}$

lepidus............................ $\quad 790$

lepturus.......................... 764

leverianus......................... 751

luciani........................... $\quad 778$

macroura....................... 748

macrourus........................ 748

macrurus ........................ 748

Massena......................... 74

massena...................... 746, 747

massenæ...................... 747

melanocephala .................... 758

melanocephalus................ 752,758

capistratus......... 761

Illætabilis .......... 752 ,

$757,759,761$

melanocephalus .... 752,

$\mathbf{7 5 6 , 7 5 8 , 7 5 9}$

melanopterus ................. 751,756

melanurus..................... 742,743

$\begin{array}{rr}\text { macrurus................ } & 748 \\ \text { meridionalís....................... } & 785\end{array}$

Mexican........................ $\mathbf{7 6 5}$

mexicanus...................... 767,772

morgani......................... 767

neoxenus.................... 740,742

nigricaudata..................... 743

Orange-bellied.................... 778

paradiseus..................... 738,740

pavoninus................. 733,735,737

pavonius......................... 737

personata.......................... 763

personatus..................... 763,775

heliothrix............ 763

propinquus............. 763

peruvianus........................ 735

propinquus....................... 763 puella............. $772,777,778,779,780$

pulchellus....................... 735

ramoniana................. $784,785,786$

ramonianus.

786
Progen resplendens. rhodogaster........................ 792

rosalba......................... 763

roseigaster.................... 790,792

rufus........................... 764

sallæi........................... 780

silens............................ 795

Slaty-headed.................... 759

strigilatus................. $750,751,752$

chlonurus............ 752,754

strigilatus........... 751,752

sulphureus...................... 764

surucura......................... 761

temnura........................ 795

temnurus................... 793,795

(Temnurus?) roselgaster.......... 792

tenellus........................ 783

underwoodi..................... $\quad 780$

Underwood's..................... 780

violaceus........................ 785

virginalis....................... 763

viridis..................... 750,751,756

White-tailed...................... 754

xalapensis....................... 778

Trogones........................... 296, 730

Trogonidæ ......................... 731, 732

Trogoninæ ........................ 730,731

Trogonoideæ.......................... $\quad 730$

Trogonoidei.............................. $\quad 730$

Trogons, The ................. 731, 732, 733, 761

Trogontidæ.......................... 731

Trogonurus ...................... 733, 761, 762

ambiguus.............. $762,764,773$

ambiguus.. $762,764,768,772$

goldmani .. $762,764,769,772$

assimilis................... 763 aurantilventris......... $763,765,780$ aurantiiventris.. 763 ,

765,778

underwoodi ..... 763 ,

765,780

capistratus................. 761

collaris.................... 763,765

curucui...................... 763

curucui............. 764

tenellus .... $764,765,781,784$

elegans........... 762, 764,773,775

melanocephlus............. 758,759

mexicanus........... 762,764,765,767

personatus................. 763,765

puella......... 763, 765, 775, 778, 780

xalapensis................. 778

Truando Woodhewer................. $\$$

True Swifts........................ 6 683

Tryphæna........................... 637

dupontii...................... 639

heloisa....................... 593

heloisæ...................... 593

tschudl, Thamnophilus.................... 12,48

Tucurriqui Woodhewer................. $\mathbf{2 5 2}$

Turbo Antshrike....................... 46

Turdidæ............................. 2

turdinus. Dendrocolaptes................. 286

Turdus brevicaudus..................... $\quad 15$

cirrhatus....................... 32

colma....................... 115, 117 
Page.

Turdus formicivorus

138,139 griseus........................ 76, 77 leucopterus....................... 14 pectoralis....................... 131 rufigula................... 100,130,131 tintinnabulatus.................. 15

turdus, Lanius.......................... 34

Turqul de Baxo.......................... 462 typhla, Dendrocincla anabatina. ..... 287,289, 290 typlca, Abeillia . .................... 516,518 Agytria chionopectus............. 431 Amazilia cerviniventris............. 414 cranocephala............ 427 fuscicaudata............. 412

Bellona cristata.................. 664 Chætura cinereiventris............. $\quad \mathbf{7 1 6}$ zonaris ............. 697,699, 701

Chlorestes..................... 436 Coligena henrica............... 497, 499 o. Leadbeatera........... 572

Damopbila .................... 520 julie................ 520

Deconychura.......... 283, 284, 285, 286

Erythronota..................... 436

Floricola constanti............... 352 superba................ 348

Heliodoxa jacula................. 571 leadbeateri.............. 572

Juliamya...................... $\quad 520$

Juliamyia. . . .............. 518,521, 522 Ifyiabeillia..................... $\quad 518$

Myrmotherula surinamensis......... 64

Oreopyra calolaema.............. 506 leucaspis................ 50

Popelairea conversi............... 678

Popelairia conversi.............. 681

Saucerottea tobaci................. 437

Saucerottia..................... 436

Thalurania columbica............. 534 typicus, Chlorostilbon caniveti............. 5555

Cypseloides niger............. 705, 707

Eutoxeres aquila................ 311

Lampornis prevosti . ............ 465,466

Phaethornis guy .............. 315

typus, Guyornis...................... 315

Tyrannidæ............................ 1 tyrannina, Cercomacra........... 91, 94, 95, 96, 97 tyrannina.... 91,93, 95,97 Dendrocincla................ 287,292 Pyriglena..................... 94, 96

Tyrannine Antbird . .................... 93

tzacatl, Amazilia....................... 410

Amazilis....................... 410

Amizilis......................... 407 tzacatl..............407,408

Amizillis...................... $\quad 410$

U.

umbretta, Formicarius.................. 164

Mylothera.................... 163, 164

Myioturdus.................... 164

Sclerurus ..................... 164 caudacutus........... 164

umbrinus, Automolus................. 212, 215 veræpacls........ 213,215 umbrosus, Formicarius. ................ 123 monlliger ..... 118, 122, 123
Page.

urderwoodi, Selasphorus............... 607,609
Trogon.................... 780

aurantiirentris........ 780

Trogonurus aurantïventris.... 763 ,

765,780

Underwood's Trogon ................... $\quad 780$

unicolor, Dysithamnus................... 48, 53

Myrmotherula................... 62

Upupæ.............................. 296,297

Upupidæ ............................. 297

Upupinæ............................. 297

Upupoideæ.......................... 297

Uranomitra................... 406, 426,430

Agyrtria, $\beta . . . . . . . . . . . . . . .430$

cyanocephala............... 426,428

guatemalensis..... $42 S$

ellioti...................... 424

faustinæ.................... 427

guatemalensis................. 428

guerrerensis................... 422

lessoni..................... 427

microrhyncha................ 429

quadricolor................. 356, 423

salvini..................... 430

sordida.................... 368

violiceps..................406, 425 viridifrons........... 422

riridifrons................ 406,422

urochrysa, Chalybura................ $387,38 s, 390$

Hypuroptila................ 391

urochrysea, Chalybura................... 391

urochryseus, Polytmus.................... 391

urochrysia, Chalybura................... 391

Hypuroptila.................. 391

Lampornis................... 391

Urocolius.............................. 298

urosticta, Myrmotherula.................. 62

Urotomus............................ 138

\section{$\boldsymbol{\nabla}$.}

validirostris, Picolaptes.................. 247

validus, Dendrocolaptes.......... 228, 229, 233, 235 validus.......... 229, 233

Vanga striata........................... 10

variegata, Drymophila.................. 14

variegaticeps, Anabazenops............... 209

Anabaztenops................ 209

Xenicopsis...........206, 207,209

Xenops.................... 209

variegatus, Polytmus minimas............ 585

varius, Formicarius...................... 10, 146

Trochilus mellivorus............... 580

vauxi, Acanthylis....................... 724

Chætura..................... 721,724

pelagica.................. 724

vauxii, Chætura........... 716, 721, 722, 723, 724

Cypcelus.................. 721,722,723

Vвux's Swift.........................

vegata, Grallaricula..................... 146

Venezuelan Sickle-bill................... 271

venezuelensis, Campylorhamphus. $268,270,271,272$

Xiphorhynchus............. $2 \pi 2$

Xiphornis................. 272

venusta, Coeligena....................... $\quad 535$

a. Thalurania.......... 535

Oreopyra...................... 506 
venusta, Thalurania.................... $\quad \begin{array}{r}\text { Page. } \\ 535\end{array}$ colombica.... 532, 533, 534, 535 columbica............ 535 var........ 535

Trochilus (Thalurania)........... $\quad 535$ venustissimus, Trochilus................. 480 venustus, Aganus....................... $\quad 752$ Polytmus..................... 535 Vera Cruz Hermit....................... 323 veræcrucis, Phæthornis longirostris......... 323 Phœthornis longirostris... 316, 320,323

veræpacis, Automolus............... 212,213, 215 reræpacis..... 213,214,215

Veraguan Lance-bill..................... $3 \mathbf{3 4 3}$

Mango....................... 467

Snow-cap...................... 581

veraguensis, Anthracothorax........ 456,457, 16 i r. Sericotes.... 467

Dorifera.................... 344

Doryfera.................... 344

Doryphora.................. 344

Hemistephania............. 343,344 ludoviciæ...... 344

Lampornis............... 467,468 Polytmus.................... 468

Vera Paz Automolus.................... $\quad \mathbf{2 1 4}$

verreauxi, Trochilus.................... $\quad 310$

verticalis, Amizilis................. 408, 422

Polytmus..................... 427

Trochilus................... 406, 427

Vervain Humming Bird.................. 5S4

vescus, Priotelus temnurus.............. 794, 795

viduata, Myrmotherula................... 62

vielloti, Trochilus...................... $\quad 557$

villavicencio, Campylopterus.............. 357

viola, Amizilis beryllina................. 451

Saucerottia bersllina............ 439, 449,451

violacauda, Lampornis.................... 466

Violaceous Humming Bird.............. $\$ 51$

violaceus, Aganus....................... 785

Chrysotrogon................. $7 \$ 5,7 \$ 6$

Polytmus cayennensis.......... 479

Trochilus.................... 479,450 (Culampis).......... 480

Trogon...................... 785 violajugulum, Archilochus............. 628,636 Trochilus.................. 637

Violet-crowned Humming Bird............ -ear, Brown ..................... 486

Lesser....................... 484

Mexican..................... 482

-headed Curucui................... 785

-throated Iumming Bird.............. $\quad .636$

violicauda, Lampornis ................... 461 Trochilus................ 454, 461, 466

violiceps, Amazllia .................... $\quad 425$

Amizilis...................4 408,484

Clanomyia.................... 425

Cyanomya..................... 425

Cyanomyia.................. 424,425

(Leucolla)............. 425

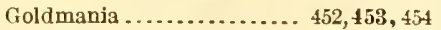

Polytmus.................... 425

Uranomitra................. 406, 425

vilifions, Hellothrlx..................... 564 barroti, var. 564

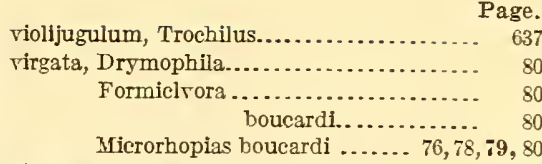

virgatus, Automolus...................... 201

Hyloctistes.................... $\mathbf{2 0 0}$

Philydor................. 199, 200,201

Thamnophilus................ 34, 36, 47 virgatus.......... $36, \mathbf{4 6}$

Xiphocolaptes................. 230 virginalis, Lampornis.................... $4 i 1$ aurulentus, var....... $\quad 471$

Polytmus..................... $4 i 1$

Trogon..................... 763

viridans, Polytmus. . . . . . . . . . . . . . . . 340,341

viridicauda, Leucippus.................. $\quad 305$

viridiceps, Eugenes...................... $56 \mathrm{~S}$

riridifrons, Amazilia ................... $\quad 422$

Amizilis................... 408, 421

Cyanomia................... 422

Cуanomra................... 422

Cranomyia................ 421, 422

Leucolia.................... 422

Uranomitra ............... 406, 422 violiceps............ 422

viridigaster, Amazilia................... 435

Ariana........................... 435

Hylocharis................. 438

Polytmus................... $43 \mathrm{~s}$

Psrrhophæna.............. 438

Saucerottea................. 438

Saucerrottia................. 438

Trochilus................... 435

viridipallens, Agyrtria................... 510

Cæligena................... 510

Chariessa................. 510

Cœligena.................. 510

Delattria.................. 510

Lampornis ............... 510

Oreopyra ............ 501,502, 509

Polytmus................. 510

Thaumantias.............. 510

Topaza................... 510

Trochilus................ 502,510

viridipectus, Chlorestes, $\beta$. Saucerottia...... 431

riridis, Aganus........................ $\quad 751$

Agyrtria....................... 473

d. Chalybura............. 473

Anthracothorax............. 455,45i, 47:

Chalrbura........................ 473

(Lampornis) ........... 473

Lampornis................... 472,473

Polytmus........................ 473

Trochilus .................... 472, 473

Trogon.................... $750,751,756$ cayenensis ............... 751

riridissima, Agyrtria.................... 431

Ormismya................. 431

Thaumatias................. 431

Trochilus.................... 431

riridiventris, Amazilia.................. 438 Chlorestes.................. 438 T. Saucerottia...... 438

Eratina................... 435

Hemithylaca............... 438

Pyrrhophæna.............. 435 
W.

wagleri, Cœligena.

Hylocharis.

a. Thalurania.

Ornismya.

Thalurania

Wagler's Wood Nymph.

warscewiczl, Hemithylaca.

Picolaptes. .

Saucerottea

Saucerottia sophiæ.

Polytmus.

warszewiczi, Amazilia.

Hemithylaca.

Saucerottia.

warszewiezi, Amazilla

Amizllis.

warszwiczi, Ariana ......................

Wedgebill, Northern.

Wedge-tailed Sabre-wing

wellsi, Sancerottia .....

White-bellied Antbird

Humming Bird.

Mountain Gem

-breasted Synallaxis................

-eared Humming Bird.

-naped Swift

-striped Woodhewer.

-tailed Emerald.

Humming Bird

-throated Swift.

Wilson's Humming Bird.

Woodhewer, Allied.

Barred.......................

Black-striped.

Boruca...2.

Cartago ...........................

Costa Rican..................

Grayson's.

Guatemala....................

Guerrero.....................

Large-billed....................

Lawrence's. . . . . . . . . . . . . . . .

Northern Streaked-headed.....

Sclater's......................

Southern Allied.

Spotted .....................

-necked..............

-throated.............

Streaked-headed . ...............

Stripod-bellied. .

-throated..............

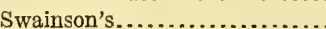

Thin-billed.................

Truando.....................

Tucurriqui...................

White-striped.................

-throated.............. 25

Yucatan.................. 248

Woodhewers......................... 224, 225

Wood-Nymph, Colomblan............... 582

Costa Rlean.............. 534

Ironduras................ $\quad \mathbf{5 3 B}$

Mexican.................. 587

Waglor's................. 529
Woodpeckers.

Page.

Wood-Star, Bahama................... 641

Costa Rican.................. $\quad 645$

Inagua...................... 618

\section{$\mathbf{x}$.}

xalapensis, Trogon...................... 778

Trogonurus.................. 778

xanthogaster, Pharomacrus........... 734,735

Xanthogenys.......................... 570

xanthogenys, Heliodora................. 570

Xanthogenyx...................... 570

xanthopterus, Dysithamnus............... 53

xanthusi, Basilinna..................... 383

Cœligena..................... 383

Heliopædica.................... 383

(Cœligena)......... 383

Hellopædlca................. 383

xantusi, Basilinna..................... 378, 383

Heliopædica.................... 383

Heliopœdica.................... 383

Hylocharis . .................... 383

xantusii, Amazilia....................... 353

Basilinna..................... 382

Xantus's Humming Bird.................. 382

Xenicidæ.............................

Xenicopsis..................... 162, 205, 206

anxius.................... 207, 206

Lineated..................... 209

oleagineus.................... 206

percnopterus.................. 206

Scaly-throated................ 207

striaticollis.................. 207,206

subalaris................ 207,206, 211

lineatus...... 207, 209, 211

subalaris........ 207, 209,210

temporalis.................206, 207

variegaticeps............ 206, 207, 209

Xenops......................... 159,170

affinis......................... 172

approximans..................... 172

argyobronchus................... 172

canivetii........................ 203 genibarbis................ 170, 172, 175 genibarbis.......... 172, 174 littoralis............... 172 mexicanus .......... 172, 175 pelzelni................ 172

heterurus..................... 177

lineatus....................... 211

littoralis...................... 171, 172

melanocephalus................. 203

Mexican......................... 172

mexicanus................... 174, 175

niger........................... 10

rufifrons......................... 202

rufo-superciliatus............... 205, 206

rutilans . .................... 172,176

rutilus..................... 172, 176, 177

heterurus........... 172,175, 176

rutilus................. 172, 170

Streaked...................... 175

tonuirostris....................... 171

varlegaticeps..................... 208

xicotencal, Trochilus..................... 381

Xiphocolaptex........................ 226 
Page.

Xiphocolaptes.

albicollis................. 236, 238

argentinus.................. 236

castaneus................... 236

cinnamomeus.............. 236

compressirostris............ 236

crassirostris................. 236

emigrans............ 236, 238, 239

costaricensis...... 236, 239

emigrans.. 236, $237,238,239$ omiltemensis...... 236, 289 sclateri...... 236, $\mathbf{2 8 8 , 2 3 9}$

fortis.................... 236

lgnotus.................... 236

major.................... 236

promeropirhynchus......... 236

saturatus................. 236

sclateri.................... 238

virgatus.................. 236

Xlphorhynchus................ 226, $\mathbf{2 3 9 , 2 4 0 , 2 6 8}$

erythropygius....... 241, 254, 255

falcularius................ $\quad 270$

flavigaster.... 239, 241, 246, 248, 249

eburneirostris.... 247

flavigaster..... 241,

$244,246,247$

megarhynchus. $241, \mathbf{2 4 8}$

mentalis... 241, 247,248

yucatanensis... 241, 248

grandis................. 273

isabella.................. 272

lachrymosus............... 239

eximius..... 241, 243

lachrymosus... 241,

242, 243

lacrymosus eximius...... 243,244

lacrymosus..... 243

lafresnayanus............. 272

leucogaster................ 260

major..................... 277

nanus.................... 241

confinis......2 241, 252, 253

costaricensis... . 241, 252, 253

costiricensis......... 253

nanus . 241, 250, 251,252, 253

procurvoldes.............. 270

punctigula................ 257

punctigulus.......... 241, 242, 257

insolitus..... 242,257

punctigulus.... 242,

255,257

pusillus................. 270,273

rufodorsalis ............... 269

striatigularls ........ 241, $\mathbf{2 4 9 , 2 5 0}$

subprocurvus............. 270

thoracicus................. 269

triangularis............... 241

bogotensis...... 241

triangularis..... 241

trochilirostris........ 269, 270, 272

venezuelensis............. 272
Page.

Xiphornis............................ 268

falcularius................... 270

pusillus........................ 273

rufodorsalis................... 269

subprocurvus................. 270

thoracicus..................... 269

trochilirostris.................... 269

venezuelensis................... 272

Xiphorynchus......................... 268

\section{Y.}

yaruqui, Phaethornis................. 319

Trochilus..................... 314,319

Yeliow-bellied Green Cuckow.............. 764

yradil, Cypselus........................ 695

Tachornis phœnicobia........... 693,695

Yucatan Antshrike..................... $\quad 44$

Antthrush.................... 121

Dendrocincla................... $\quad \mathbf{2 9 0}$

Humming Bird. . . . . . . . . . . . . . . 412

Woodhewer.................... $\quad 218$

yucatanensis, Amazilia.............. 413, 414, 415 yucatanensis......... 414

Amizilis .................. 407,413 yucatanensis....... 407, 412

Eranna.................. 413

Polytmus................. 413

Pyrrhophæna.............. 341

Thamnophilus doliatus. $36,41,44,45$

Trochilus......... 406, 413,414,415

Xiphorhynchus flavigaster . $241, \mathbf{2 4 8}$

yucatanica, Chætura.................. 722

\section{Z.}

zantusii, Hylocharis. .................. 383

zeledoni, Myrmeciza............ 106, 107,114, 115

Pittasoma ..................... 143 michleri........ 141,148, 1.13

Zeledon's Antbird..................... 114

Antpitta..................... 112

zémès, Ornismya....................... 639

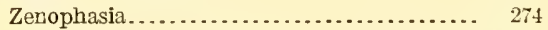

platyryncha............... 274, 275

Zephyritis............................ 618

annæ...................... 622

(Calypte) elviræ.............. 627

costæ....................... 625

(Dyrinia) minima............ 585, 587

(Stellula) calliope.............. 591

Ziphorhynchus........................ 208

zonaris, Acanthylis.................... 702

Chætura..............697,699, 701,702

Hemiprocne......... 696,697,699, 701,702

Hirundo.............. 696, 697,701,702

Streptoprocne................. 697,701 zonaris.... $697,699,700,701$

zonarta, Hemiprogne ................... 702

zononota, Dichrozona ................... 13

zonura, Doleromya sordida, var............. 368

Hylocharis.................... 368

Phæoptila...................... $3 \mathrm{~s} \mathrm{~s}$

Zygodactylæ........................ 297 



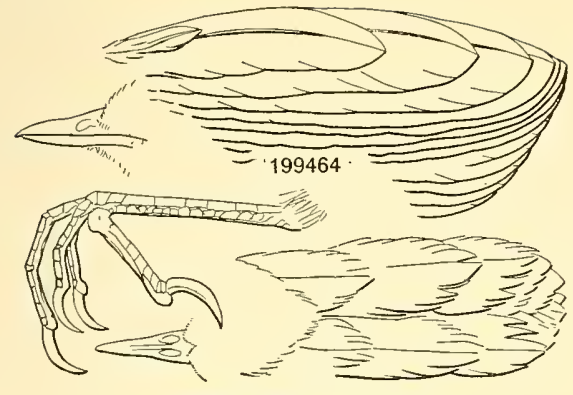

I. SCYTALOPUS argentifrons.

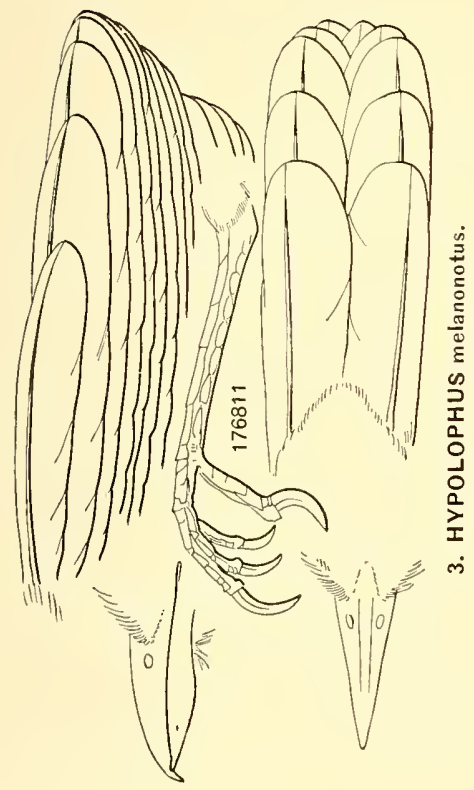

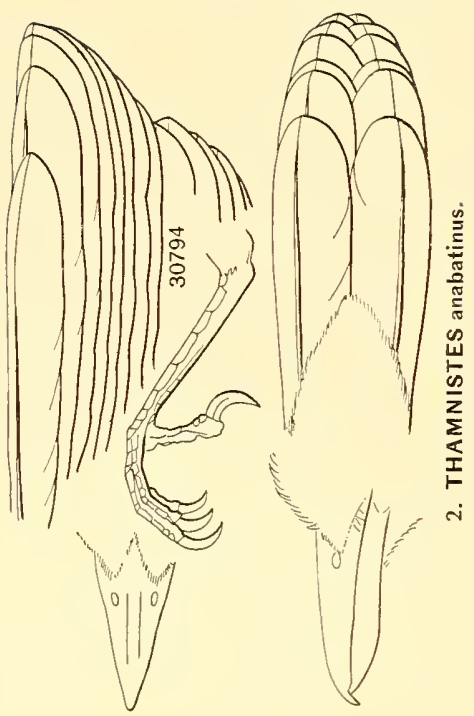

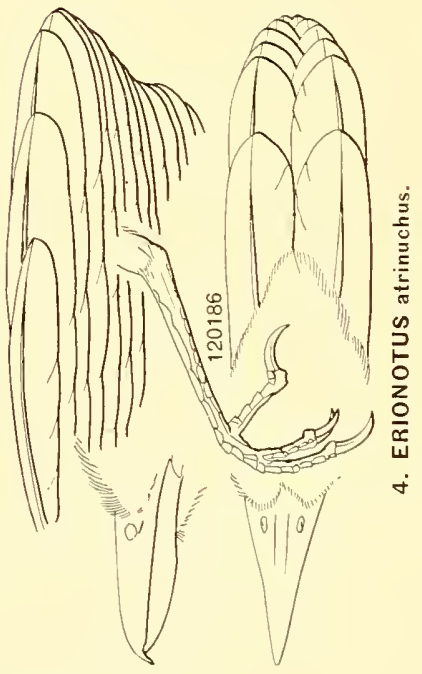

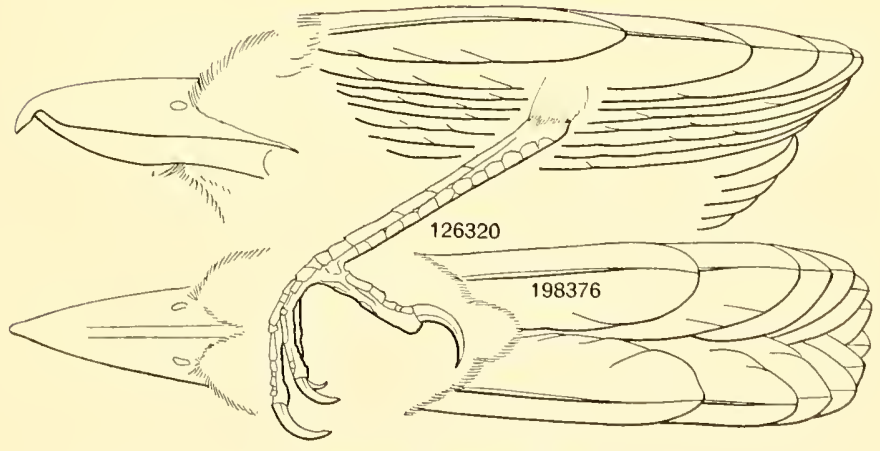

5. CYMBILAIMUS fasciatus. 



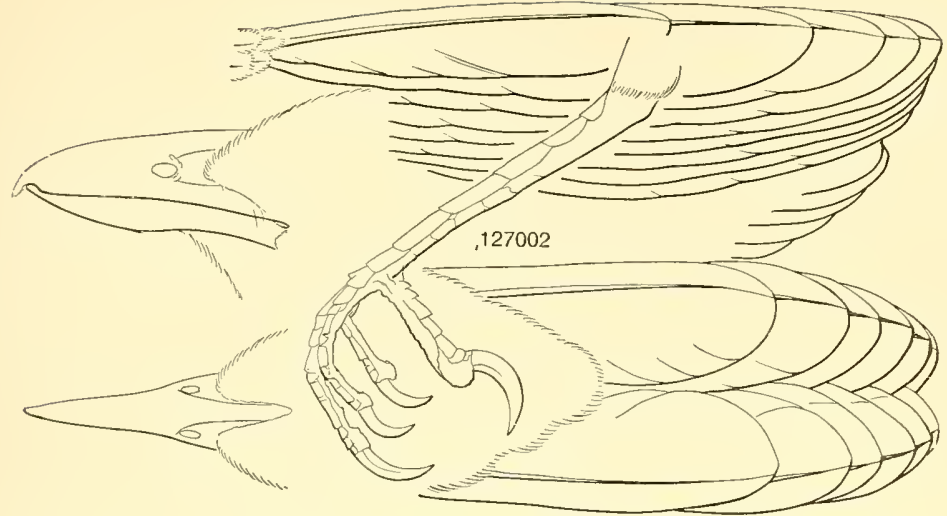

I. TARABA transandeara.
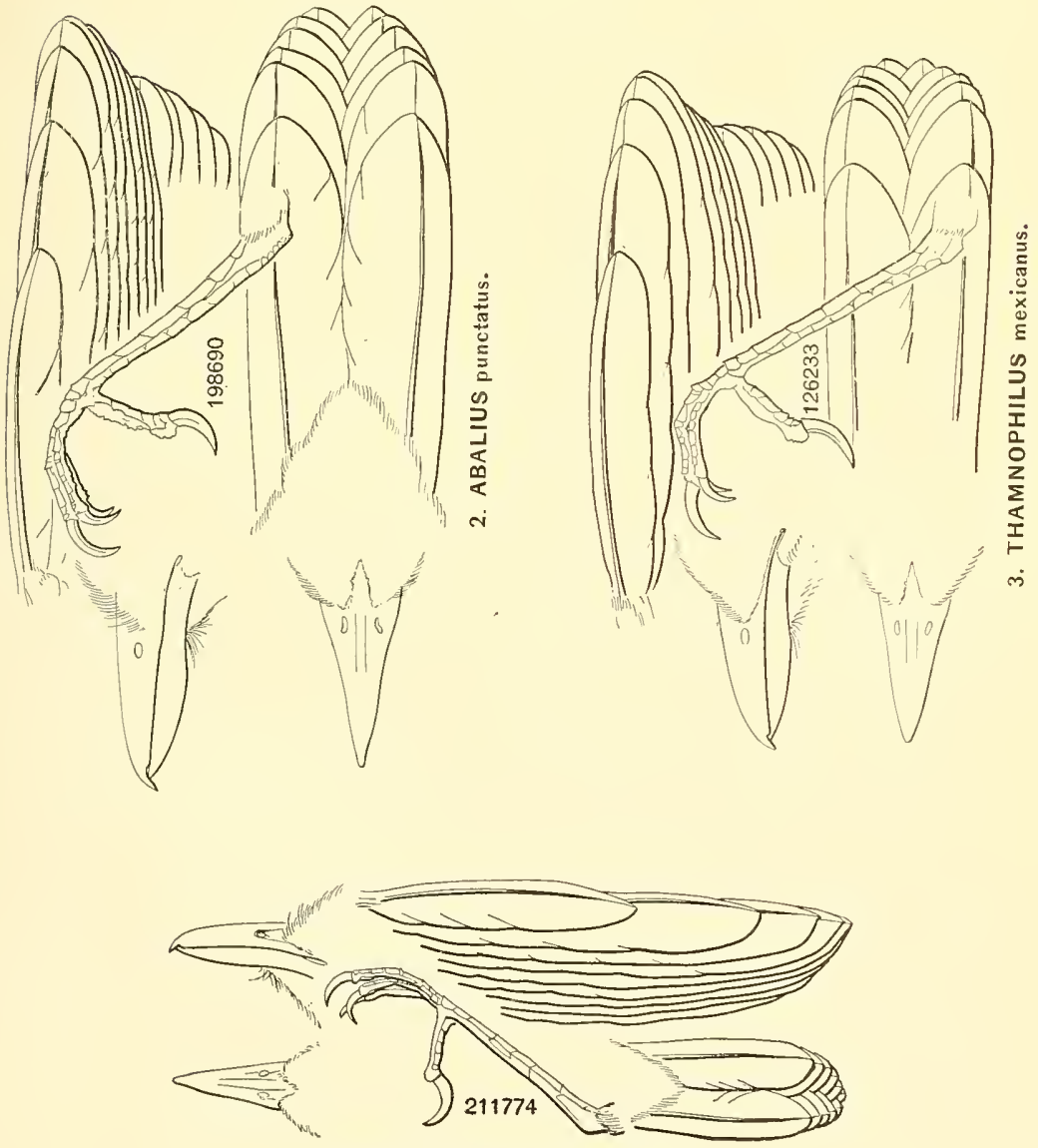

4. DVSITHAMNUS septentrionalis. 


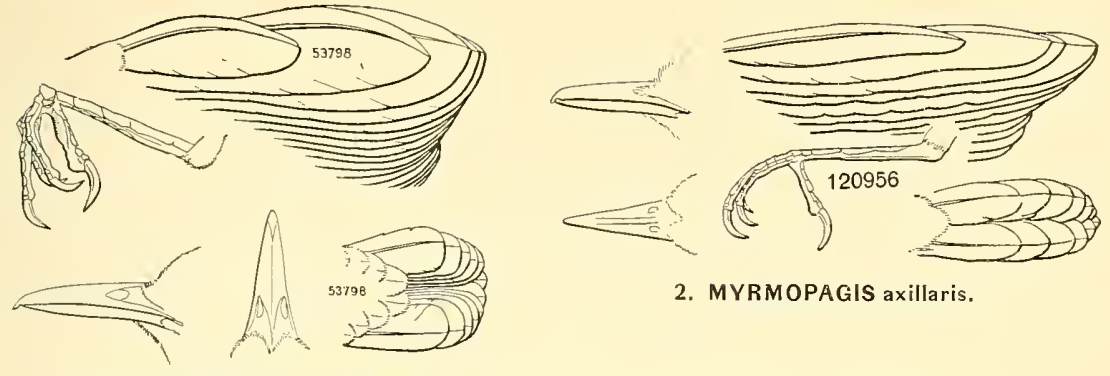

2. MYRMOPAGIS axillaris.

I. MYRMOTHERULA surinamensis.
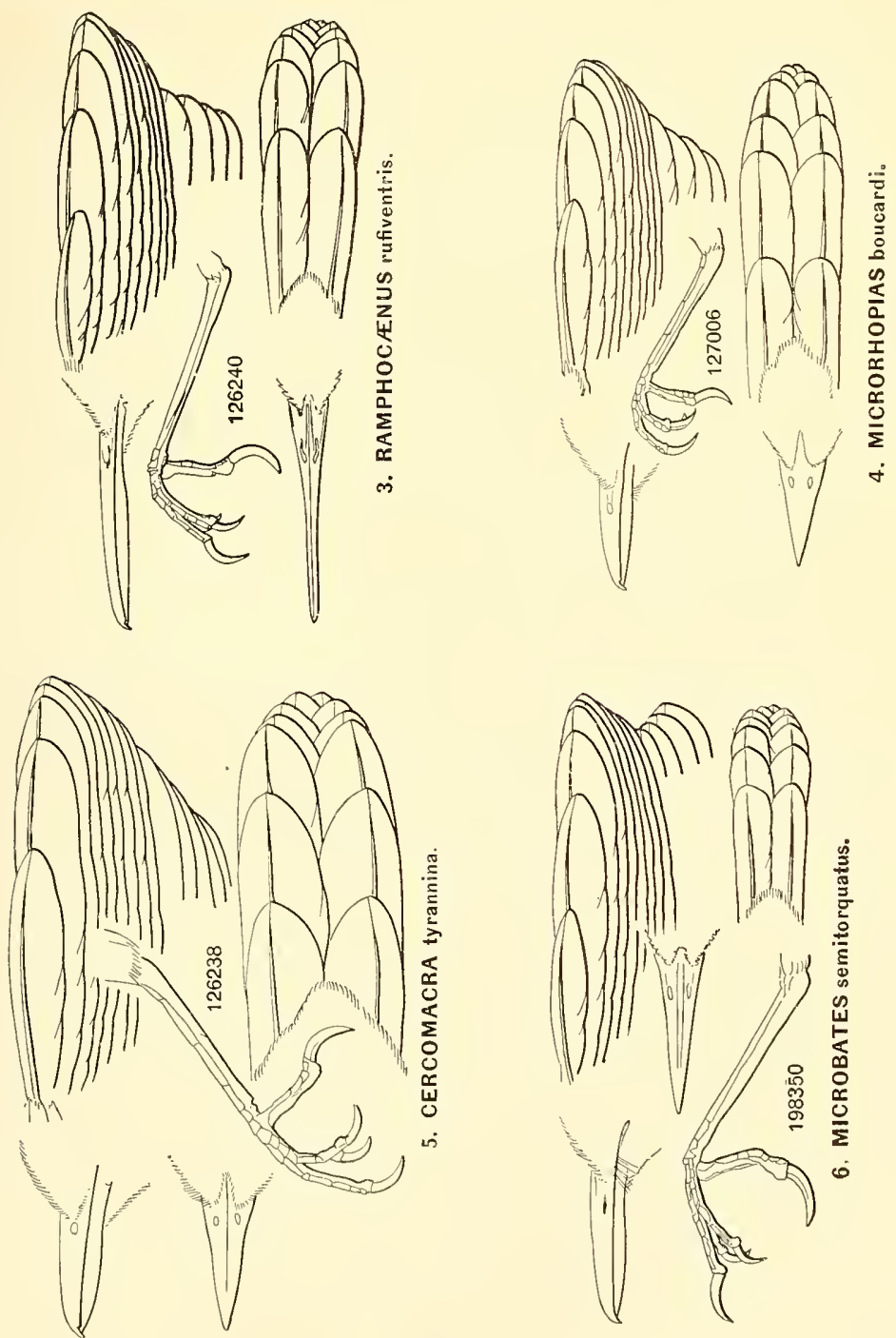



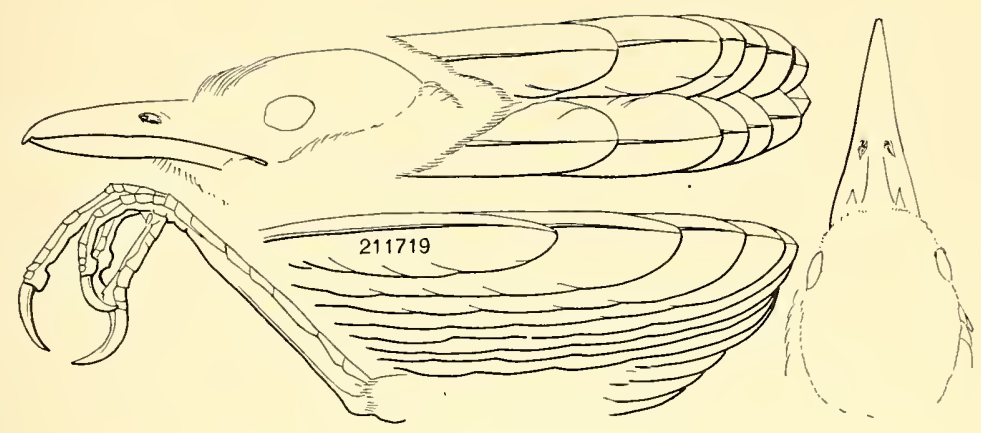

I. GYMNOCICHLA erratilis.

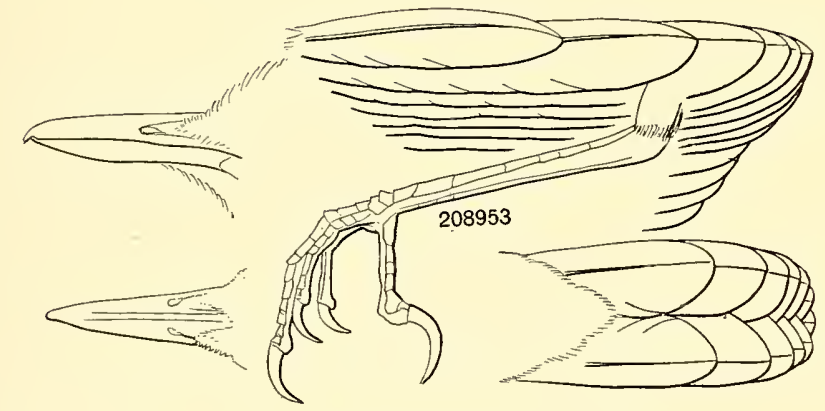

2. MYRMECIZA exsul.

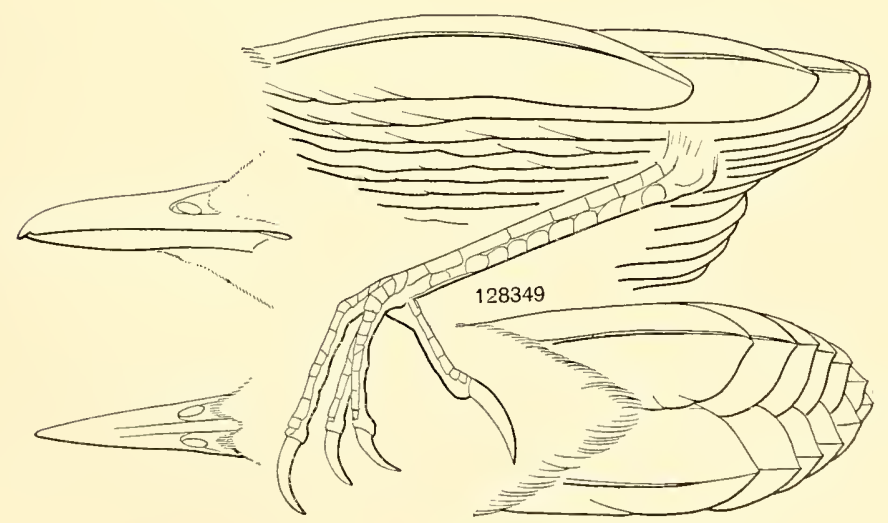

3. FORMICARIUS umbrosus. 



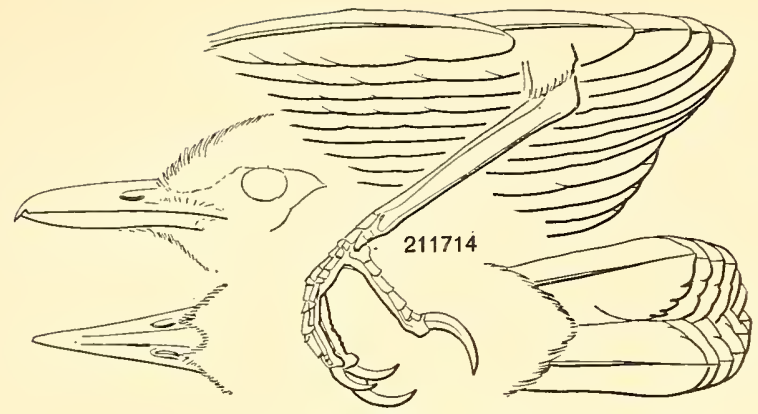

I. ANOPLOPS olivascens.

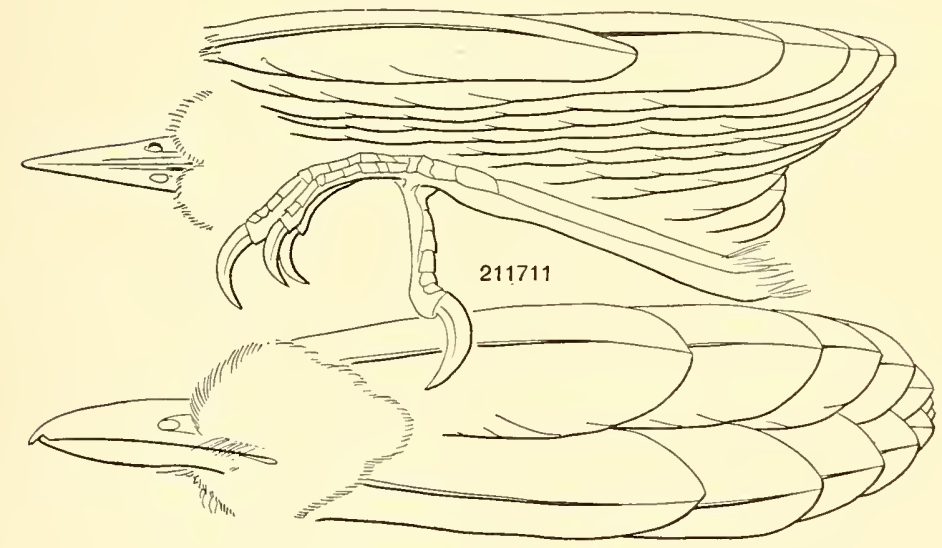

2. PHÆNOSTICTUS saturatus.

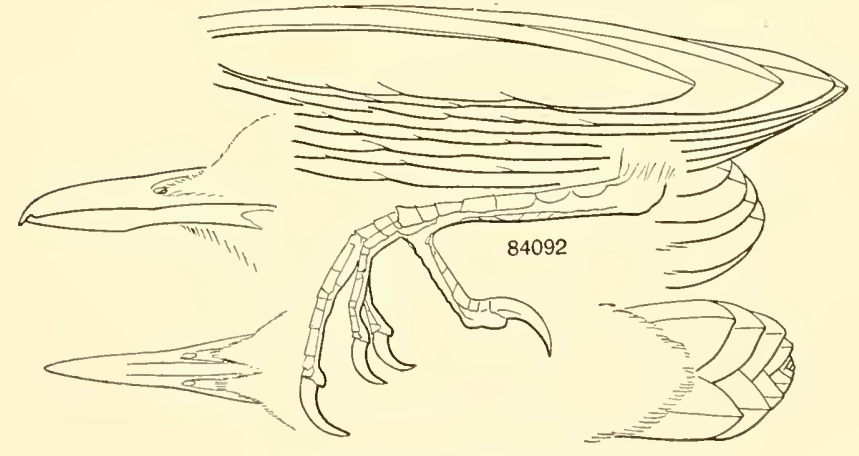

3. RHOPOTERPE torquata. 



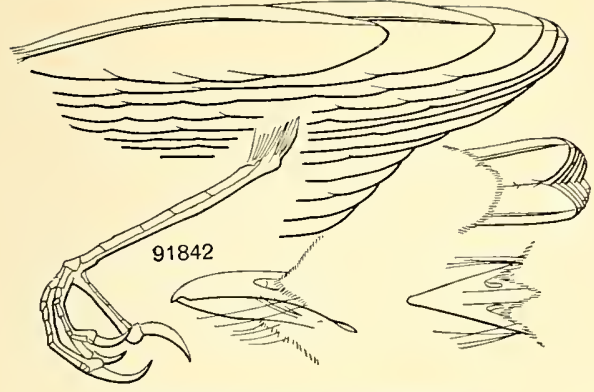

I. GRALLARICULA costaricensis.
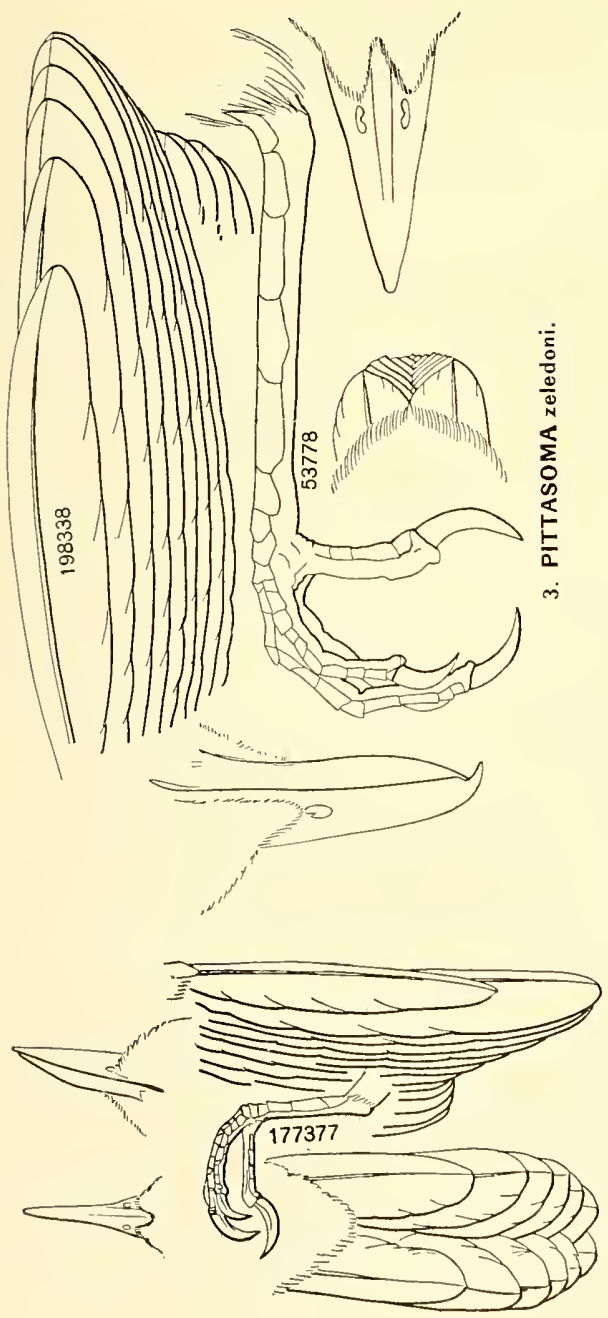

5. XENOPS mexicanus.
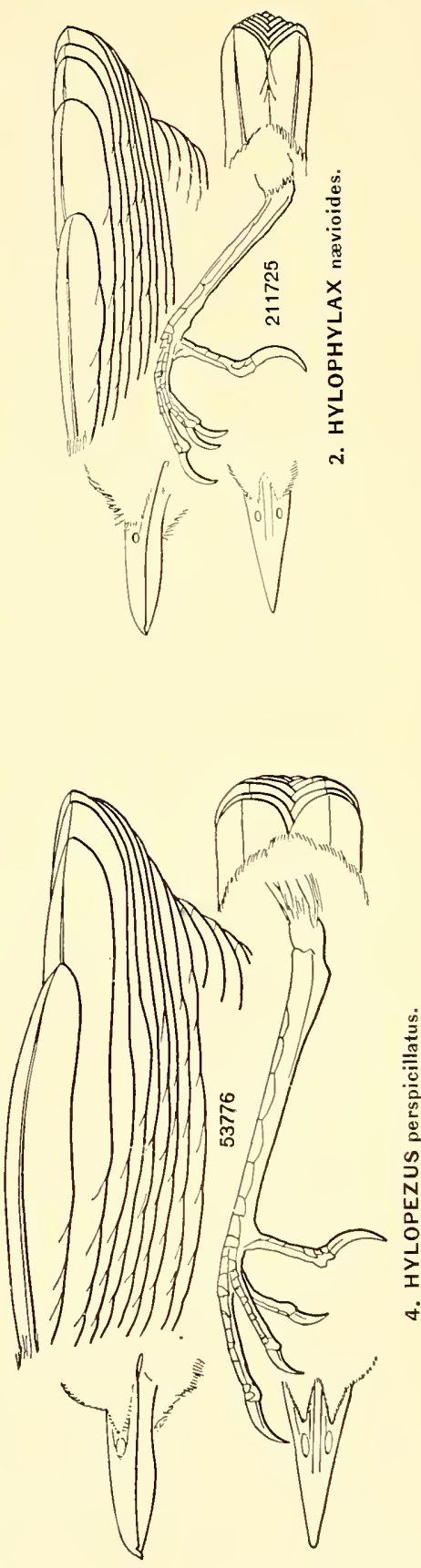



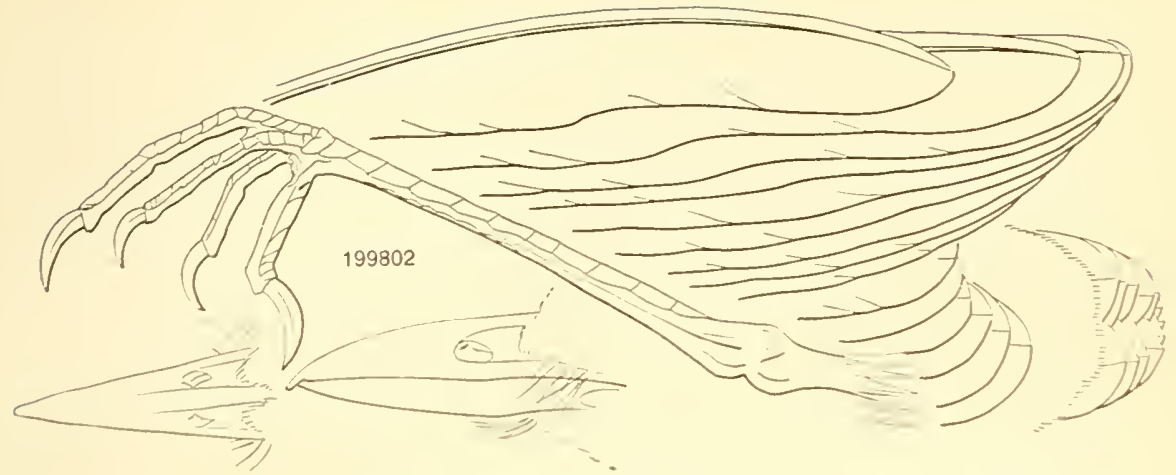

I. GRALLARIA princeps.

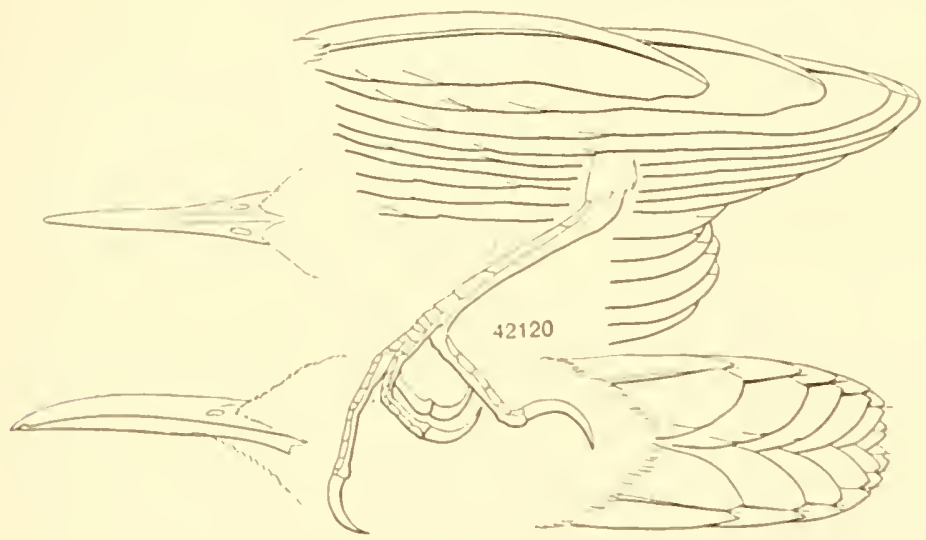

2. SCLERURUS mexicanus.

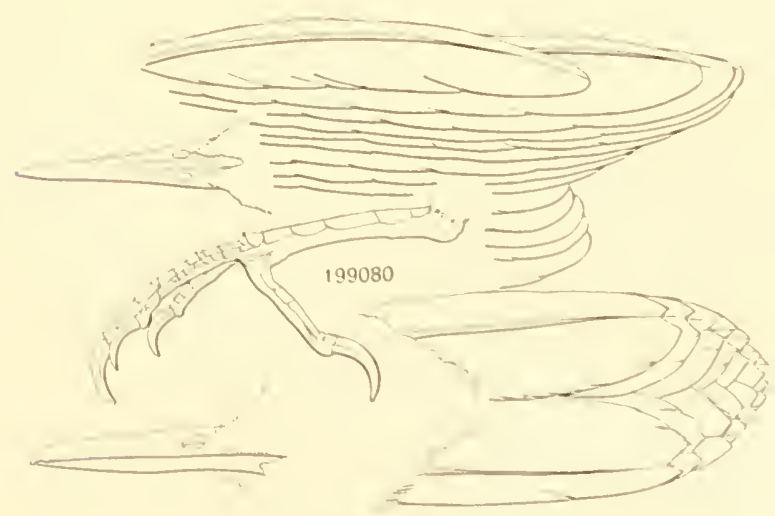

3. SCLERURUS guatemalensis. 



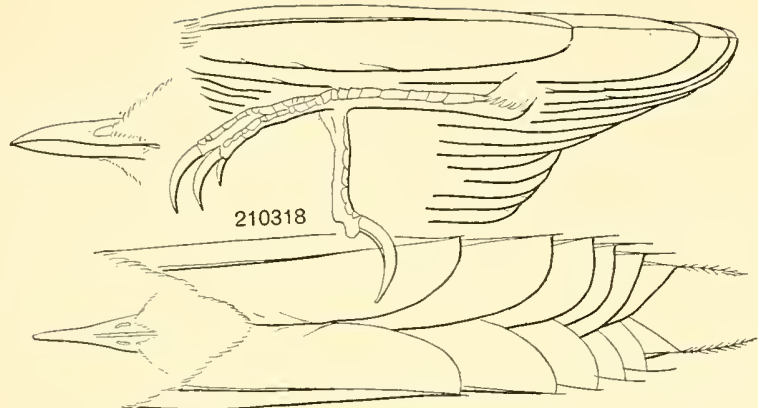

I. MARGARORNIS rubiginosa.

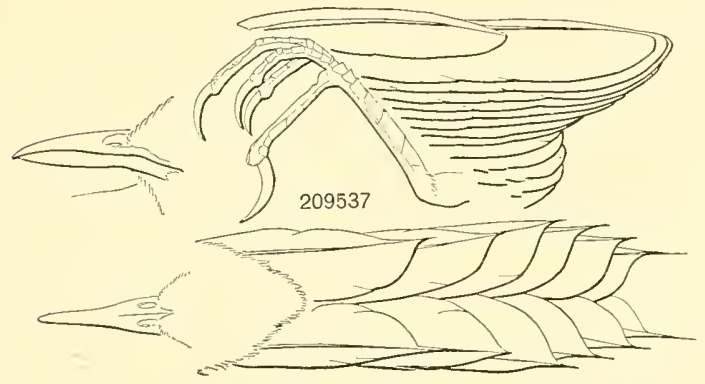

2. PREMNOPLEX brunneicauda.

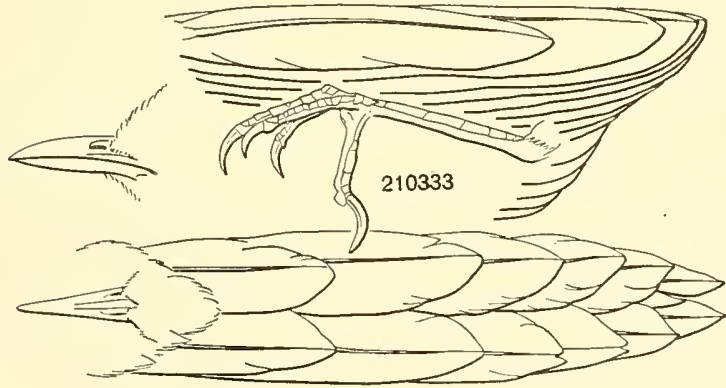

3. ACRORCHILUS rufigenis.

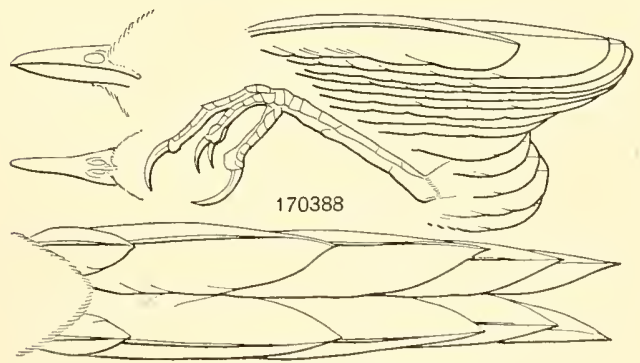

4. SYNALLAXIS albigularis. 


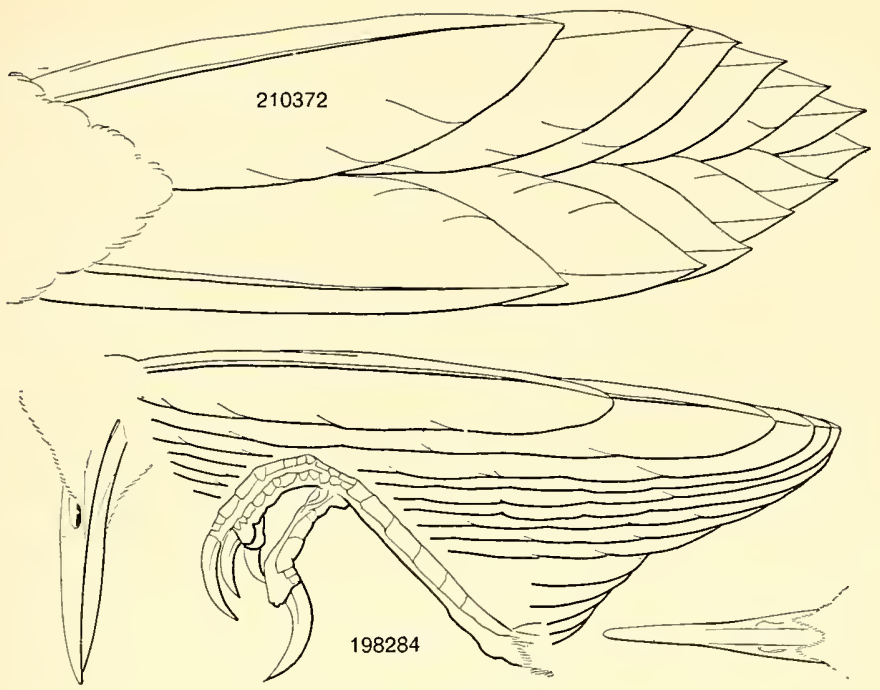

I. PSEUDOCOLAPTES lawrencii.

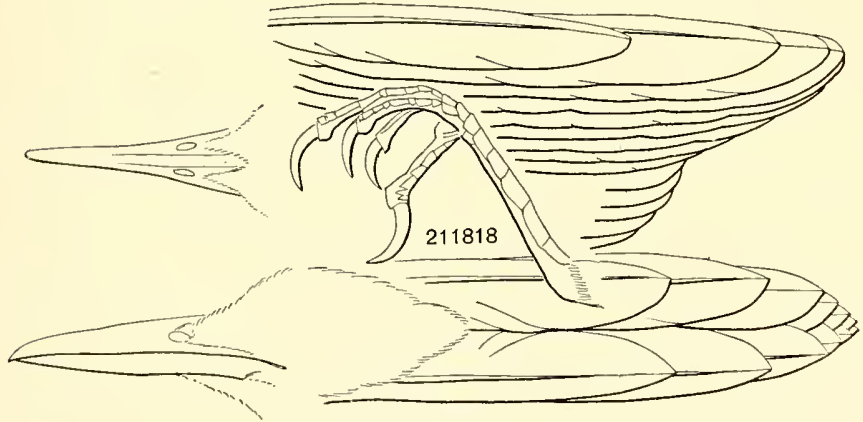

2. HVLOCTISTES virgatus.

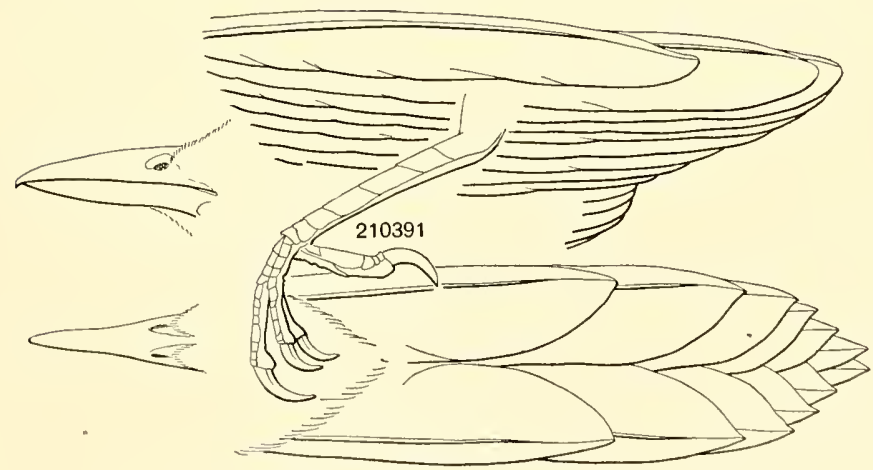

3. PHILYDOR panerythrus. 



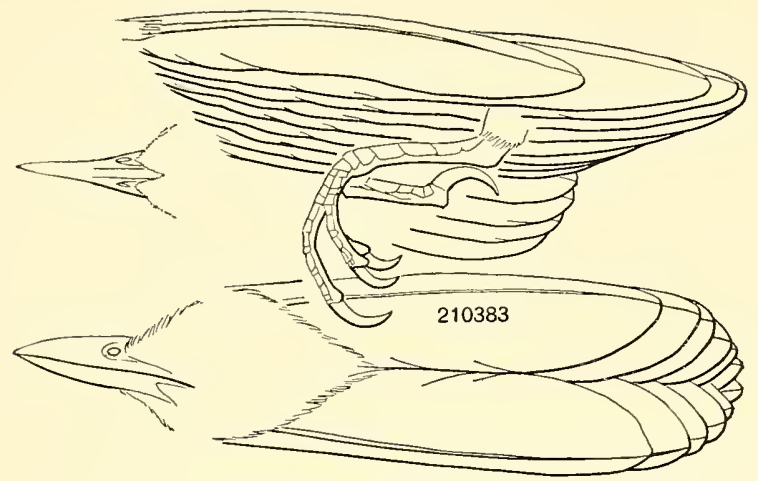

I. XENICOPSIS variegaticeps.

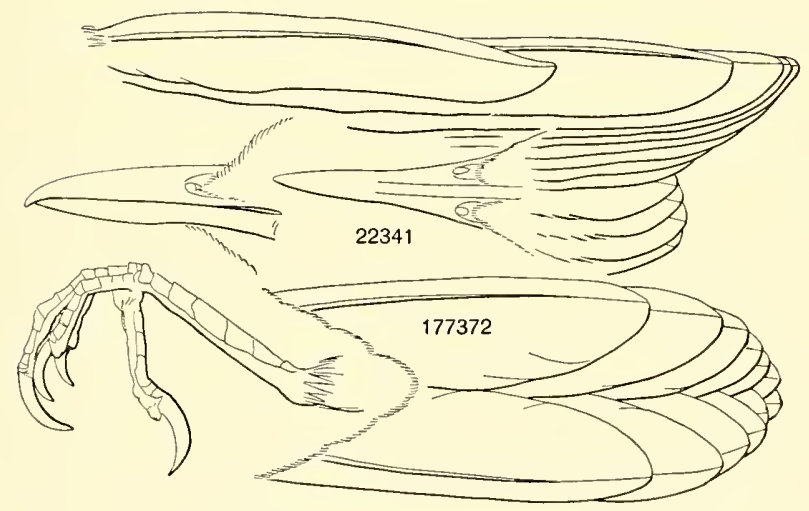

2. AUTOMOLUS cervinigularis.

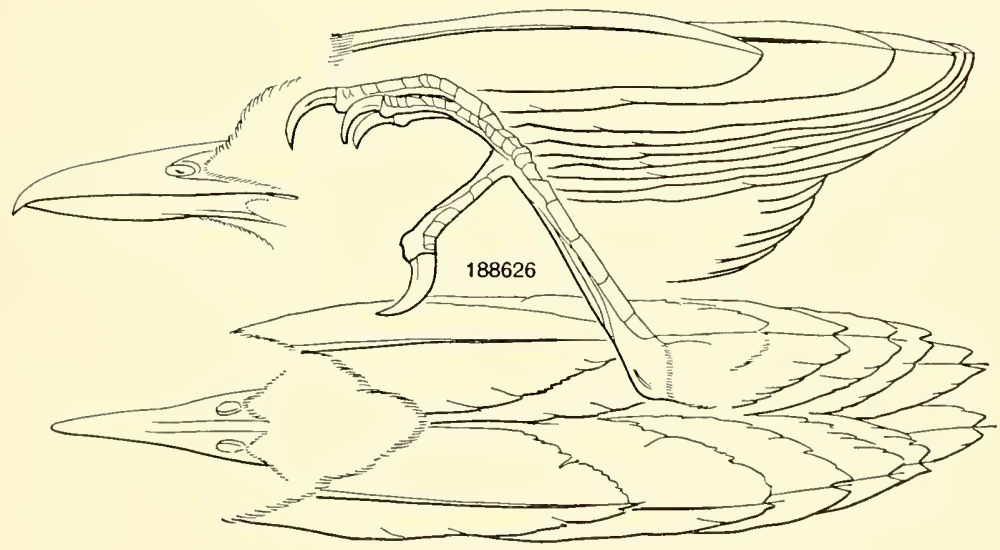

3. RHOPOCTITES rufo-brunneus. 



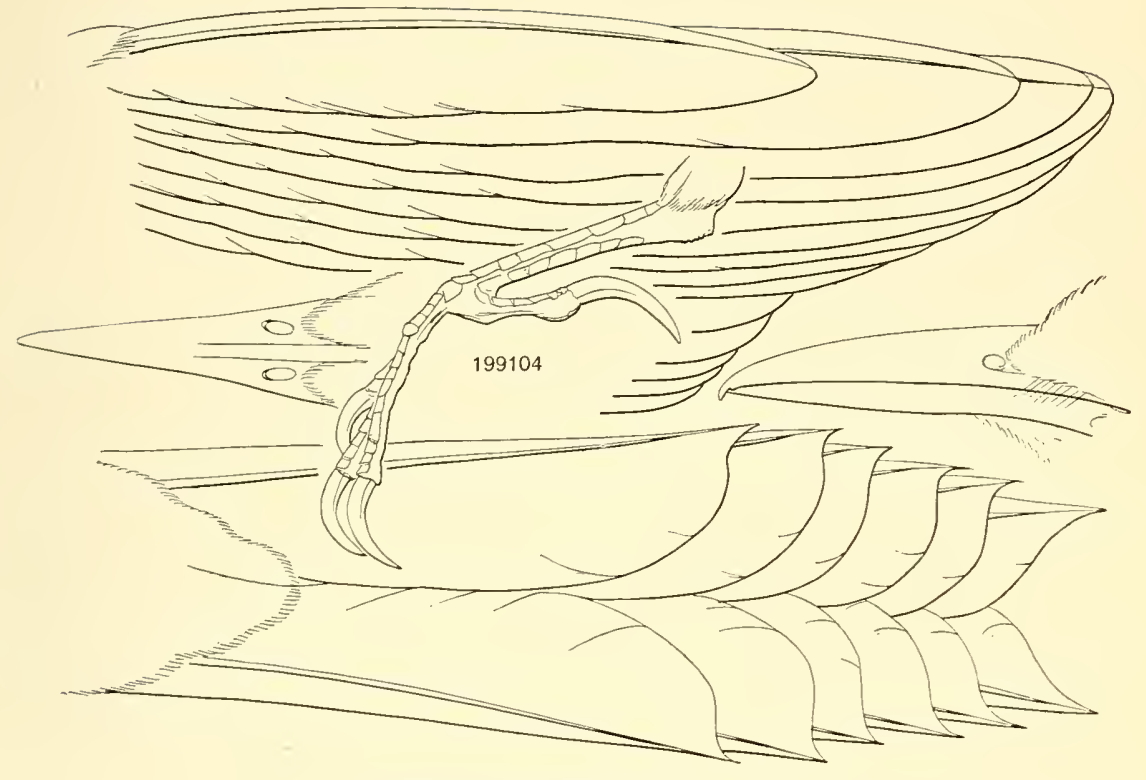

I. DENDROCOLAPTES sancti-thoma.
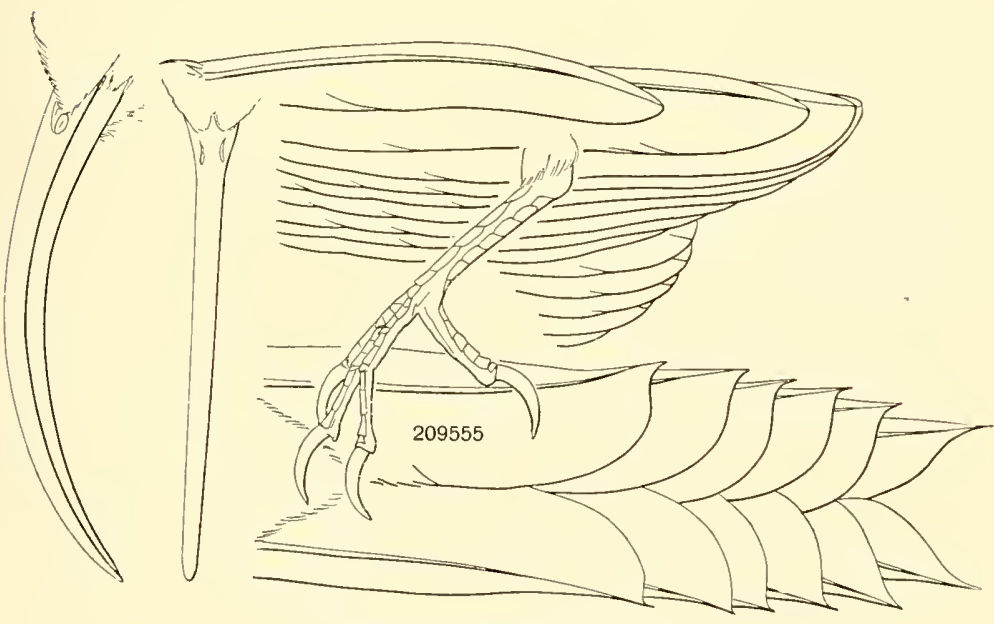

2. CAMPYLORHAMPHUS borealis. 



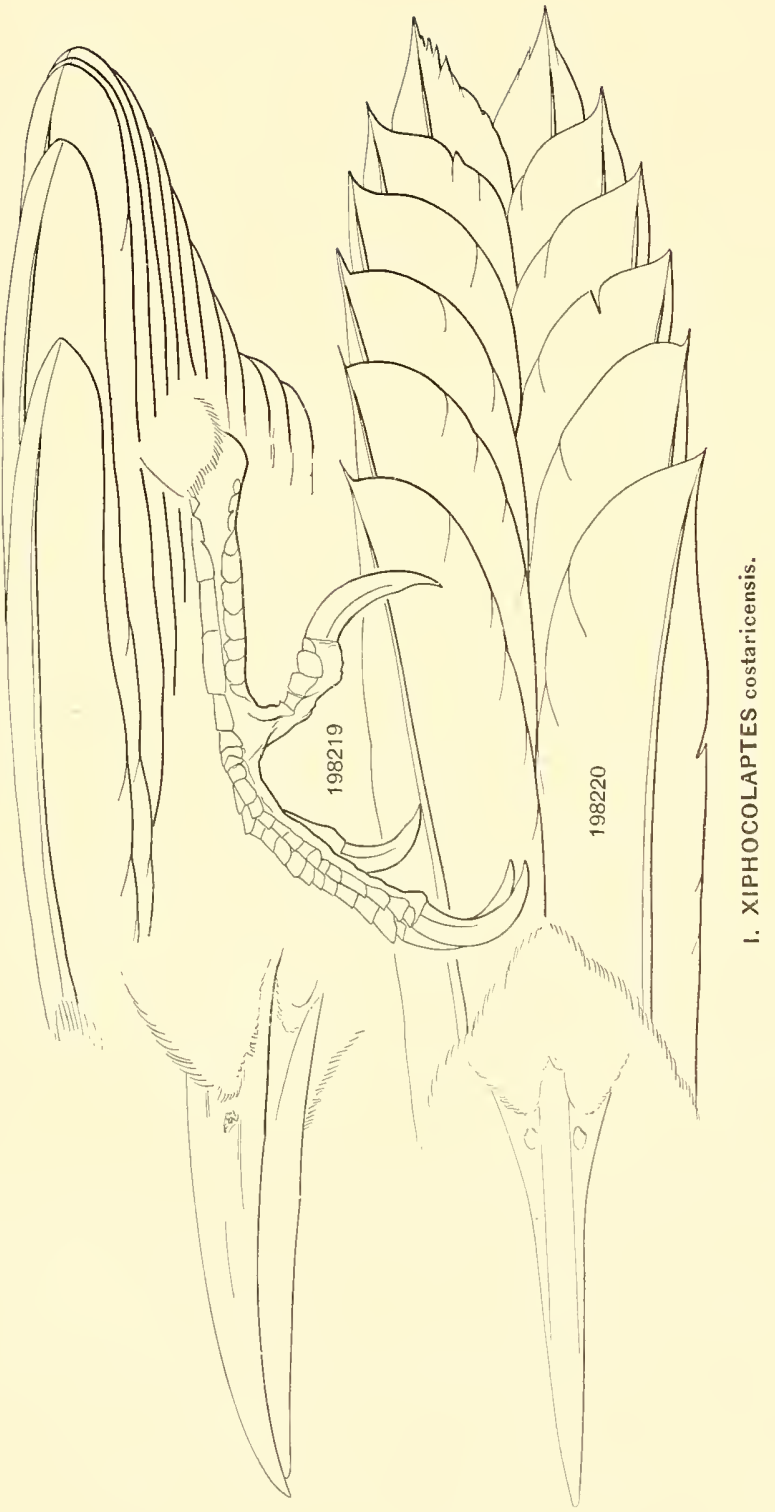





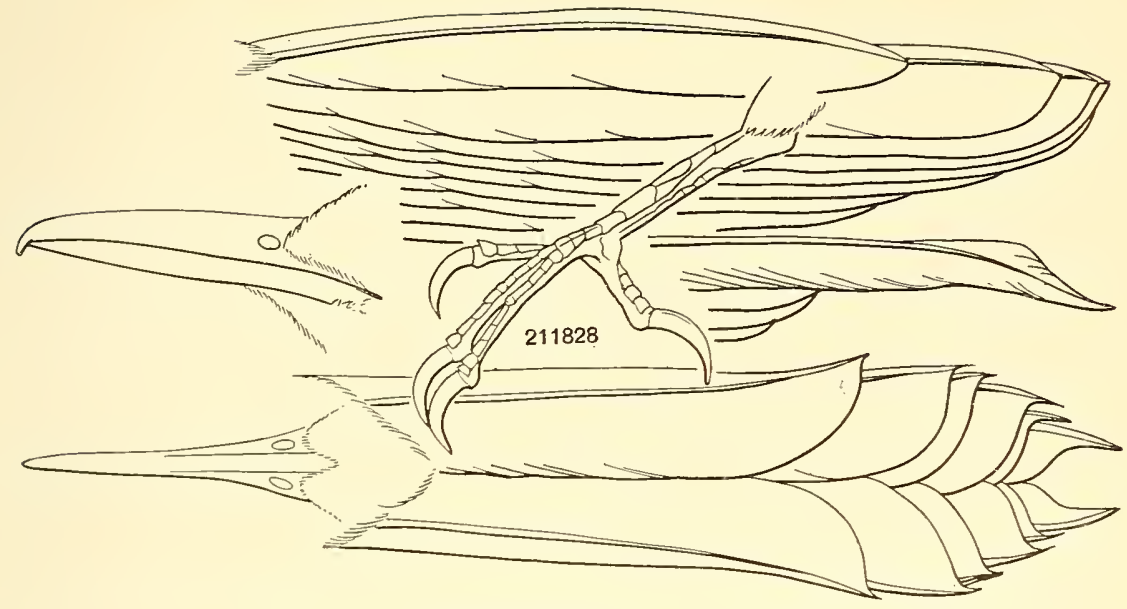

1. XIPHORHYNCHUS punctigulus.

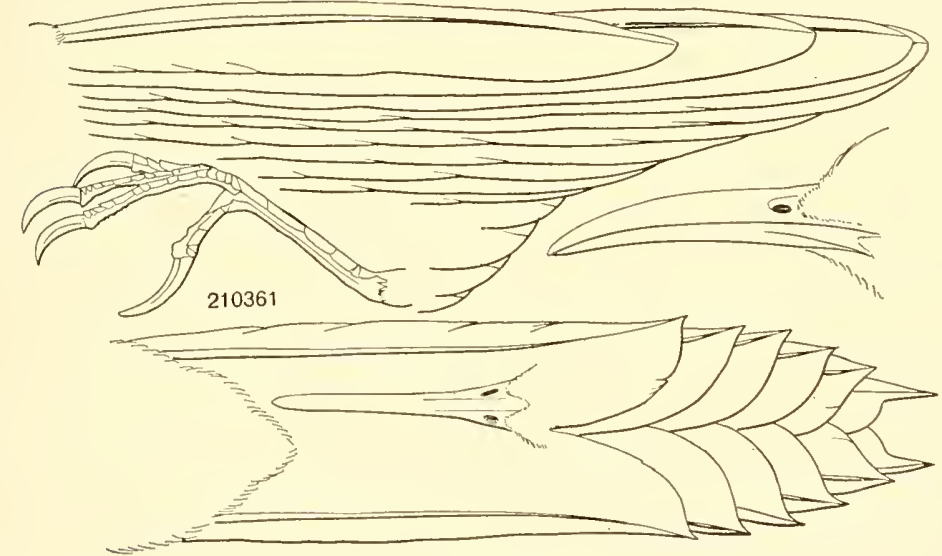

2. PICOLAPTES affinis.

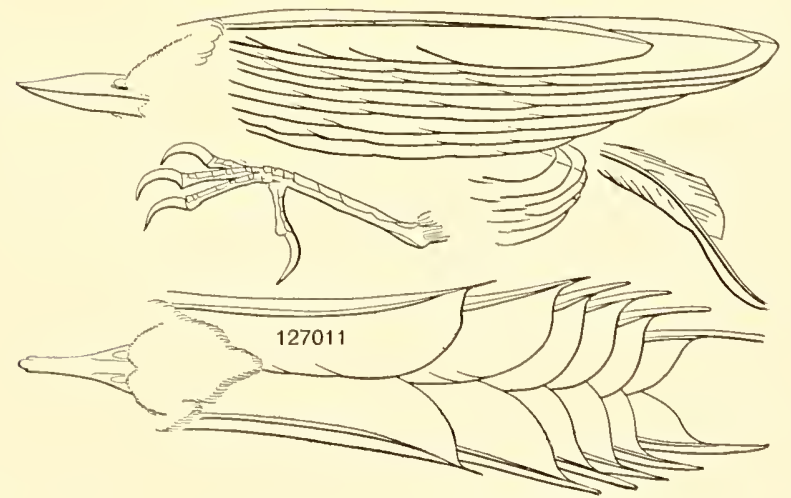

3. GLYPHORHYNCHUS pectoralis. 



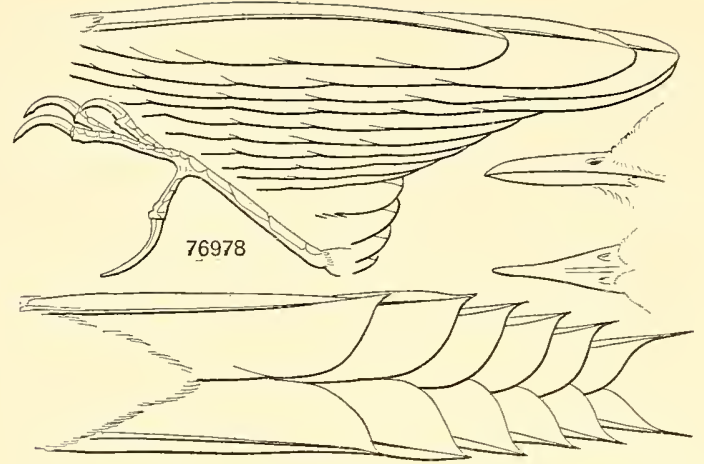

I. SITTASOMUS sylvioides.

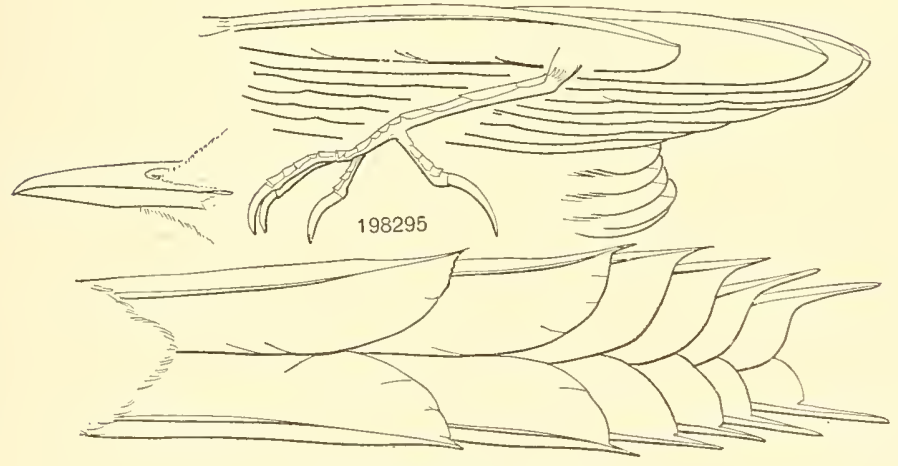

2. DECONYCHURA typica.

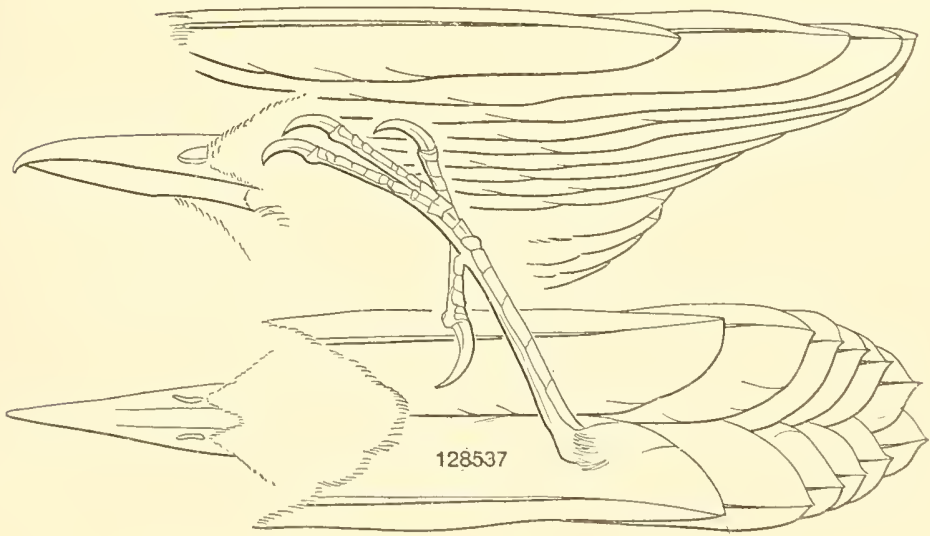

3. DENDROCINCLA anabatina, 


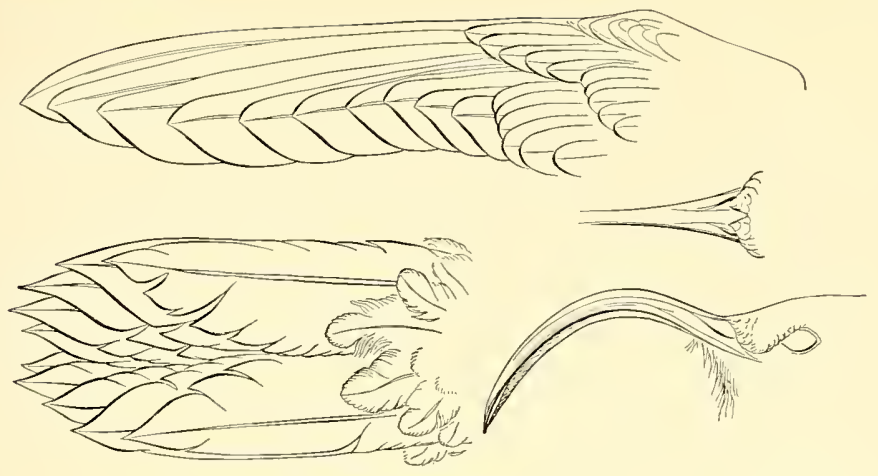

1. EUTOXERES aquila.

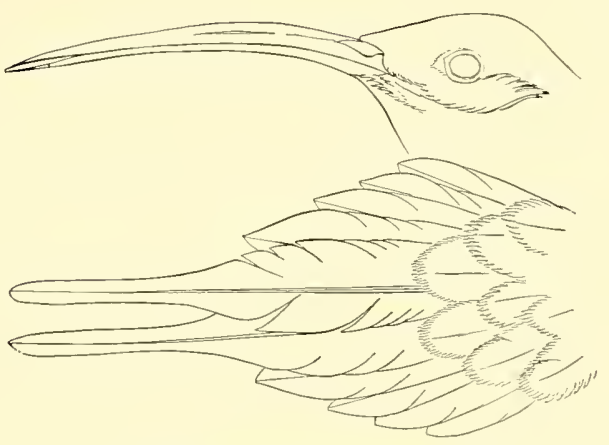

2. PHETHORNIS superciliosus.
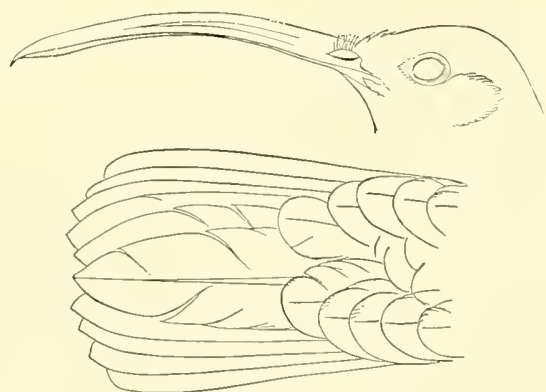

3. GLAUCIS hirsuta.

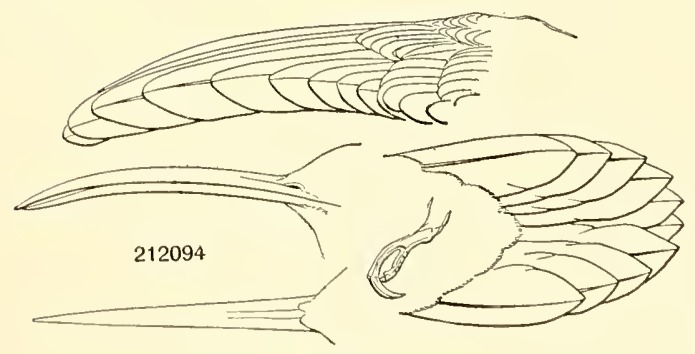

4. THRENETES ruckeri. 



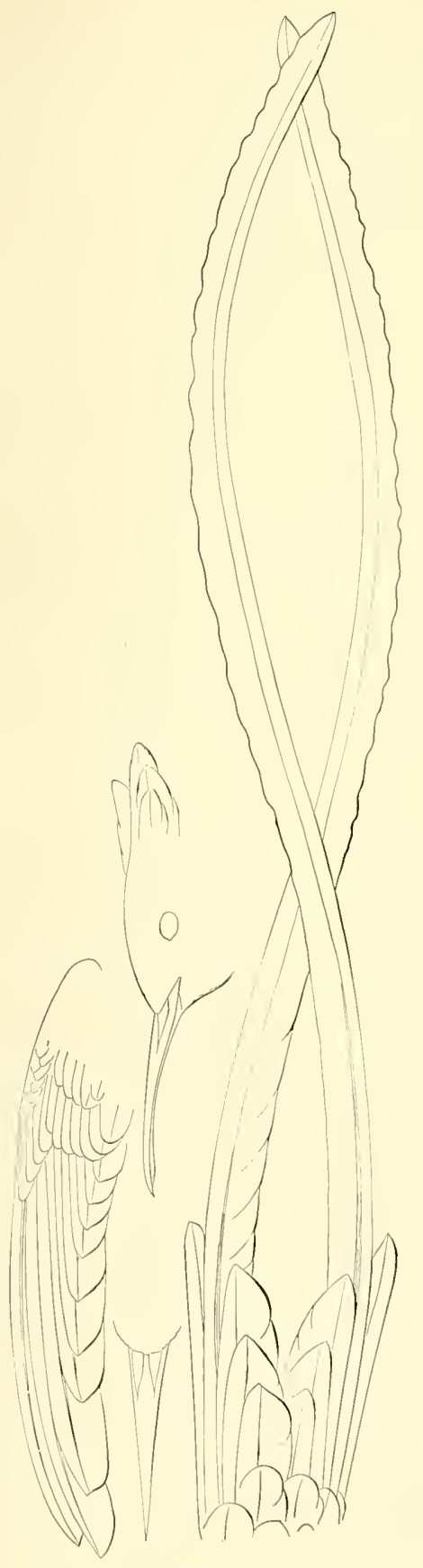

I. AITHURUS polytmus.

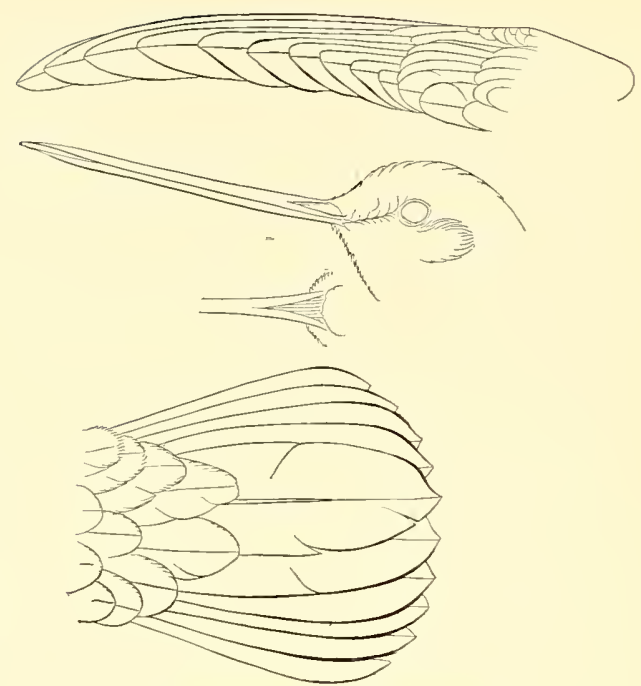

2. HEMISTEPHANIA ludoviciæ.

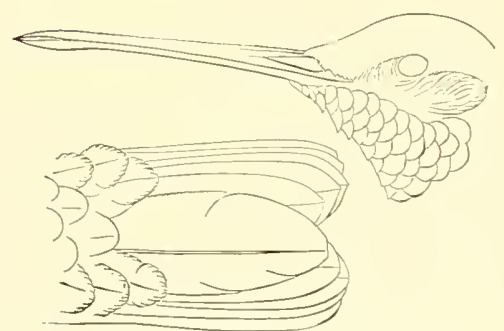

3. ANTHOSCENUS longirostris.
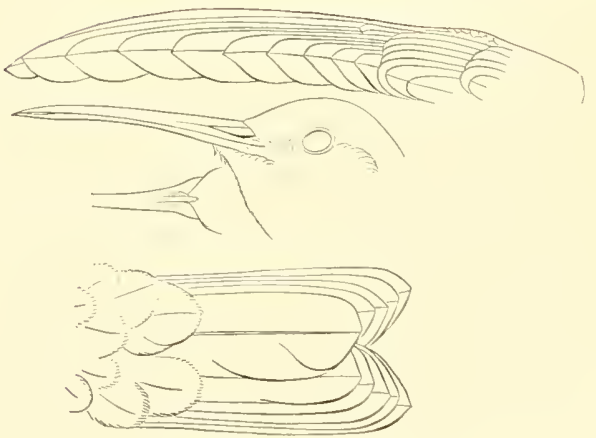

4. PH/EOPTILA sordida. 



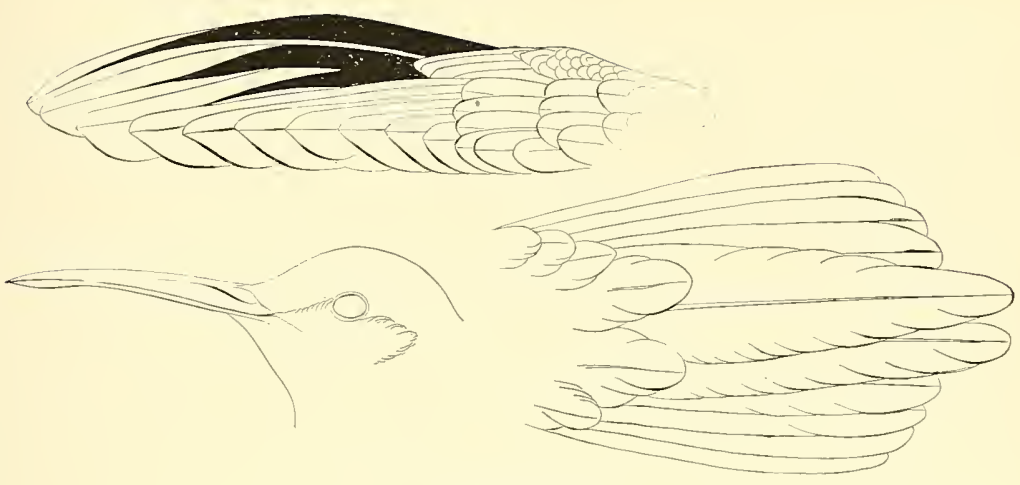

I. PAMPA pampa.

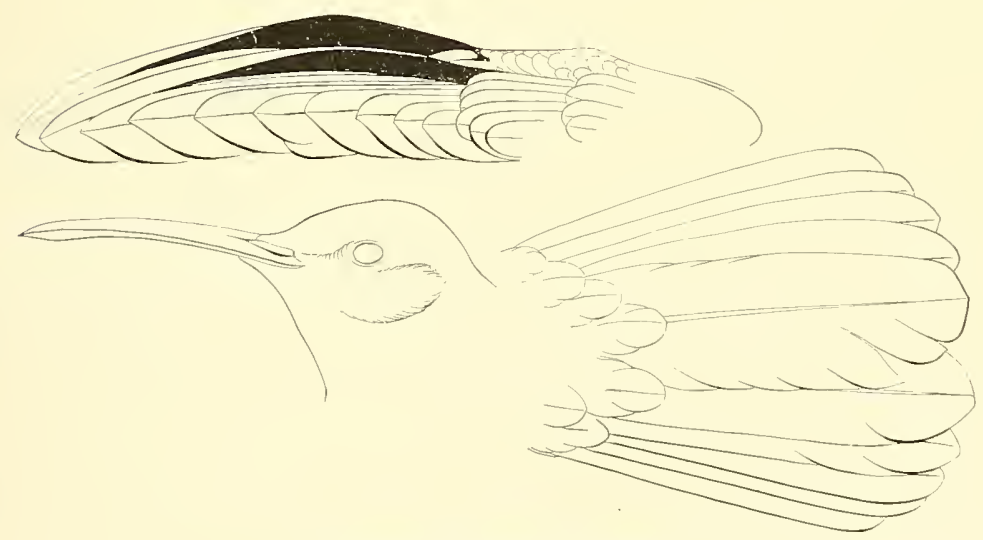

2. CAMPYLOPTERUS ensipennis.

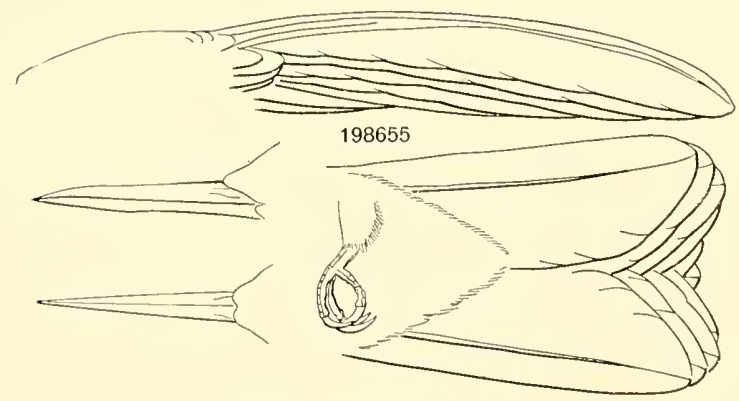

3. PHÆOCHROA cuvieri. 



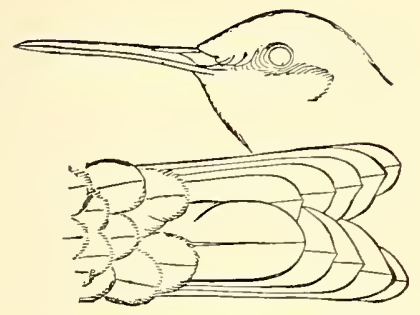

I. CYNANTHUS latirostris, $\pi$.

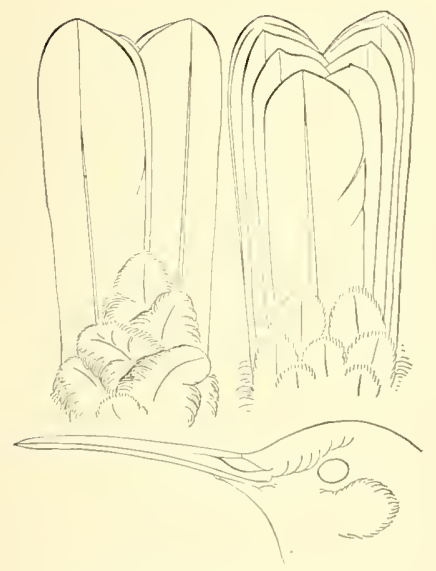

3. CHALVBURA buffoni, $\pi$
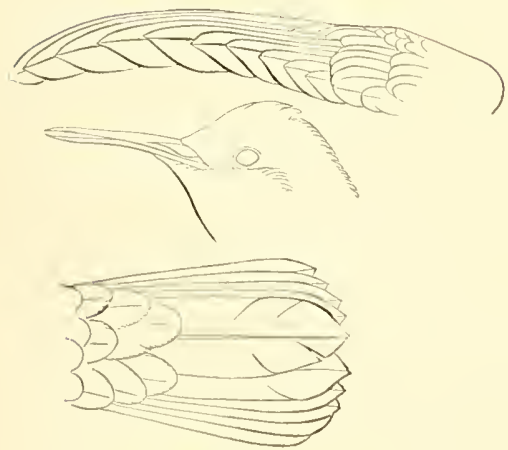

6. CALLIPHARUS nigriventris, $\pi$.

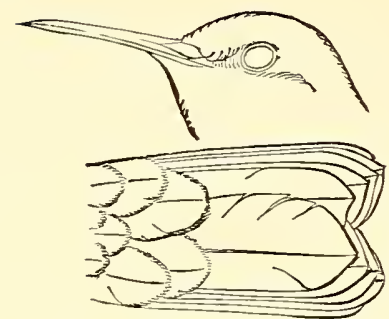

2. BASILINNA leucotis, $0^{\pi}$.
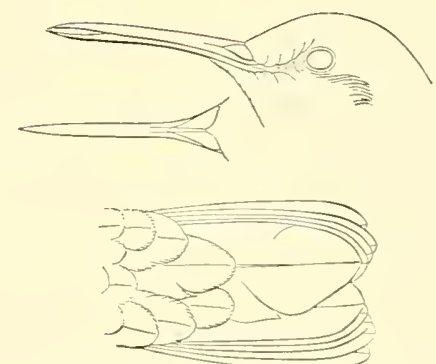

4. HYLOCHARIS sapphirina, d.
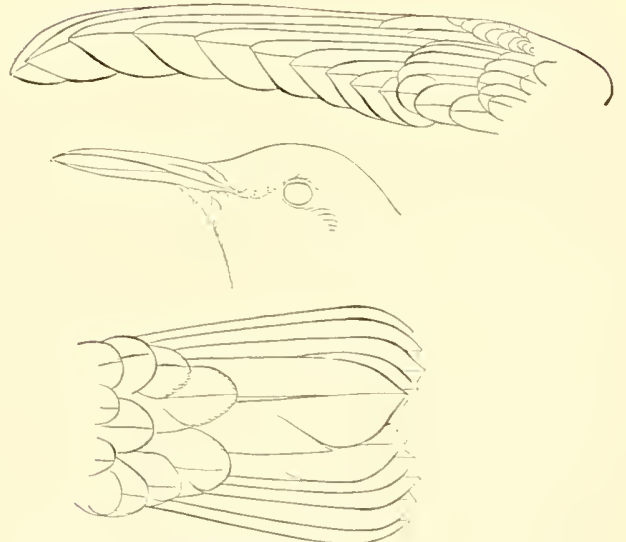

5. EUPHERUSA eximia. *

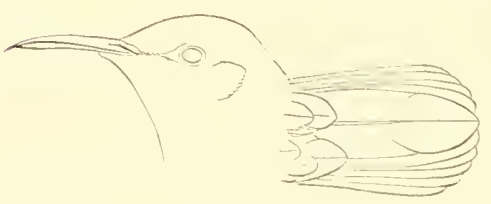

7. ELVIRA cupreiceps, 8 . 


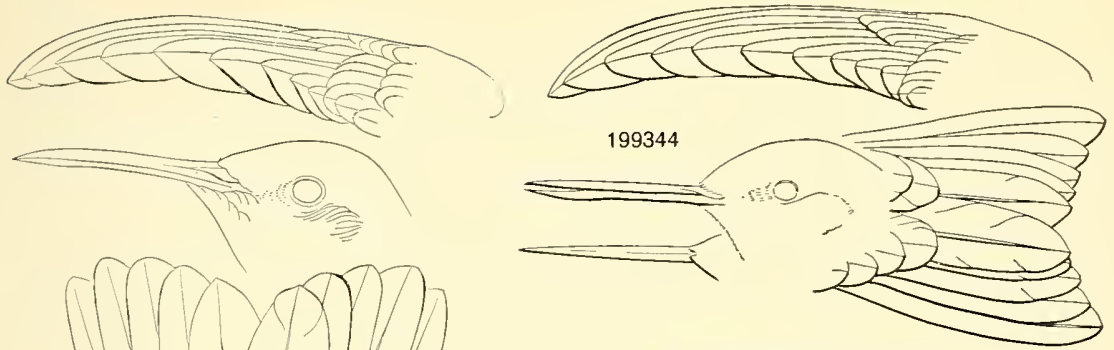

2. SAUCEROTTIA sophia.

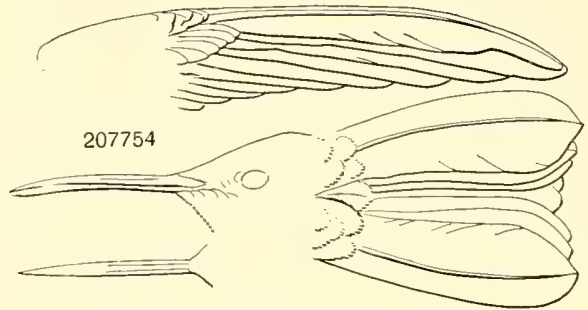

3. GOLDMANIA violiceps.
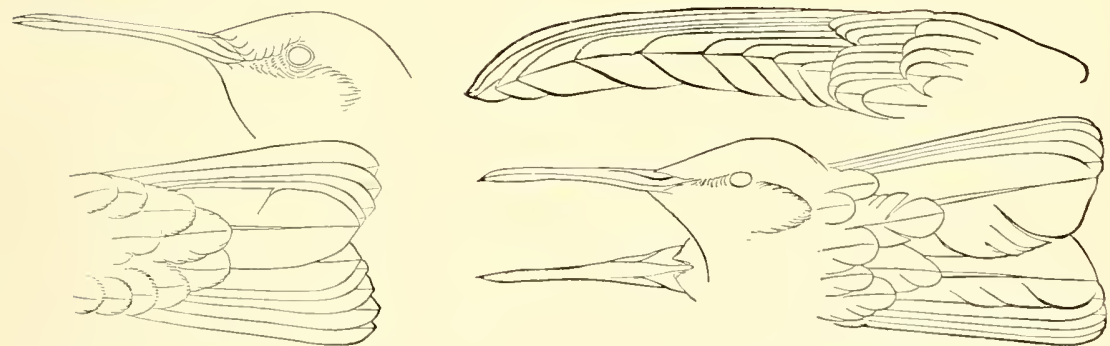

4. AMIZILIS cyanocephala.

5. AMIZILIS amazilia, ${ }^{*}$.

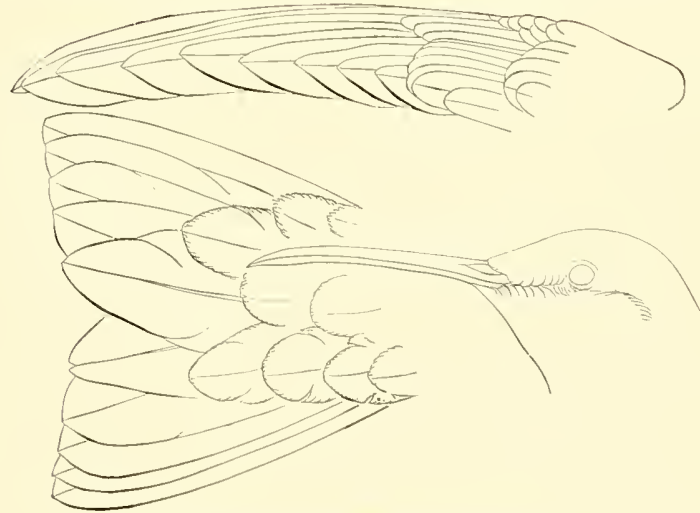

6. ANTHRACOTHORAX nigricollis, $\pi$. 


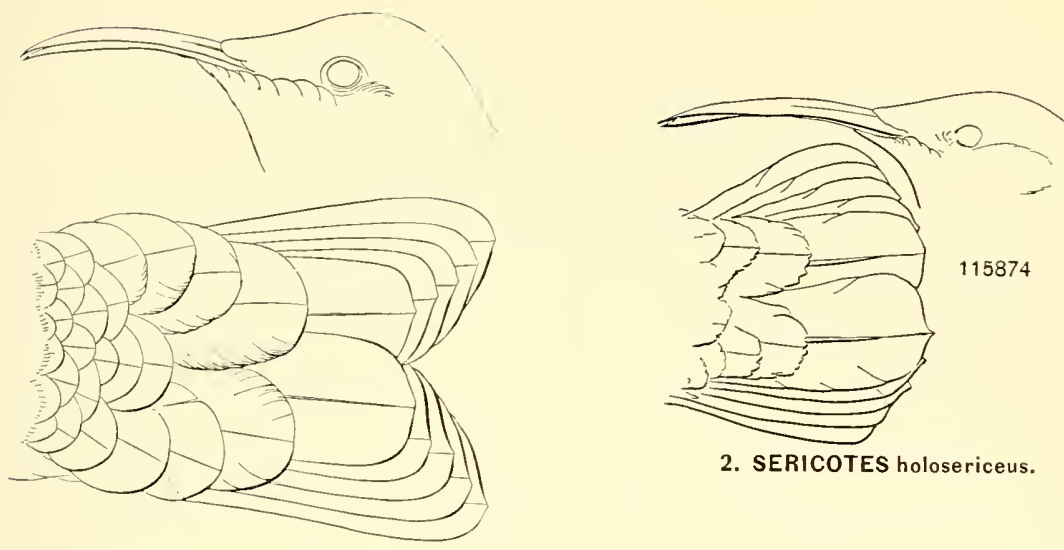

1. EULAMPIS jugularis.

\section{SERICOTES holosericeus.}

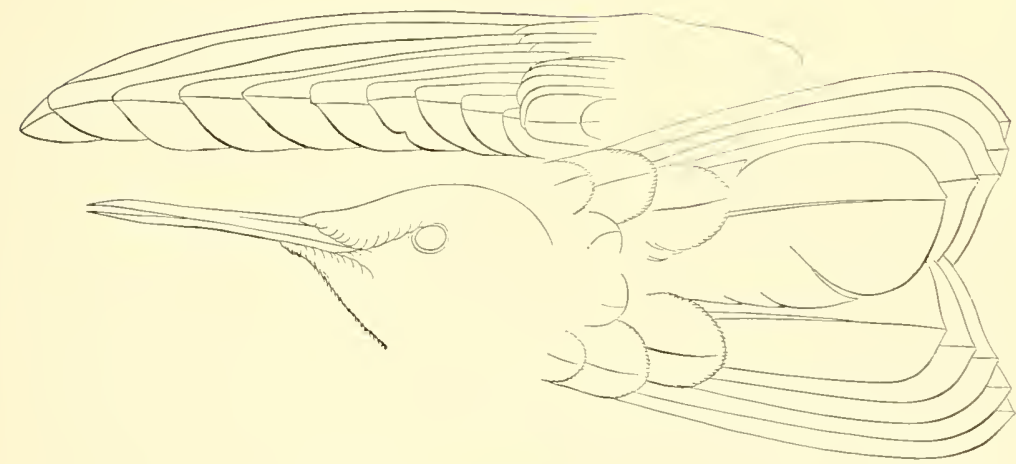

3. COLIBRI iolotus.

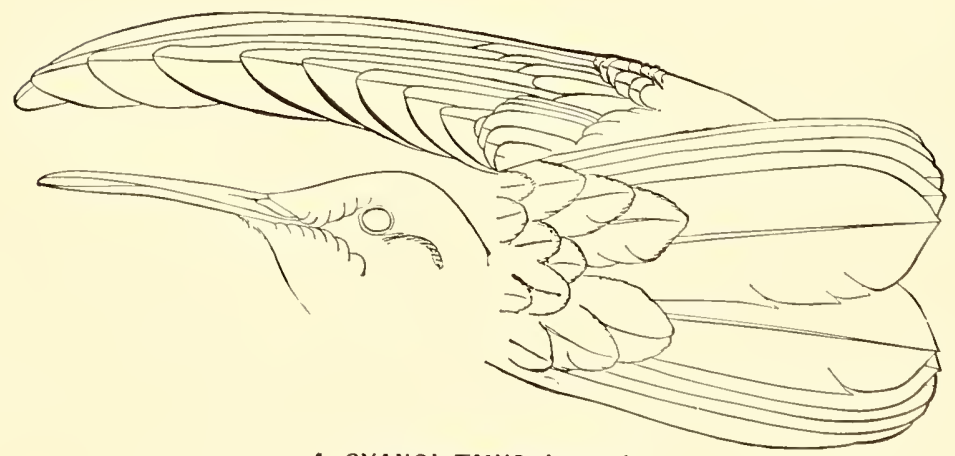

4. CYANOLÆMUS clemenciæ. 


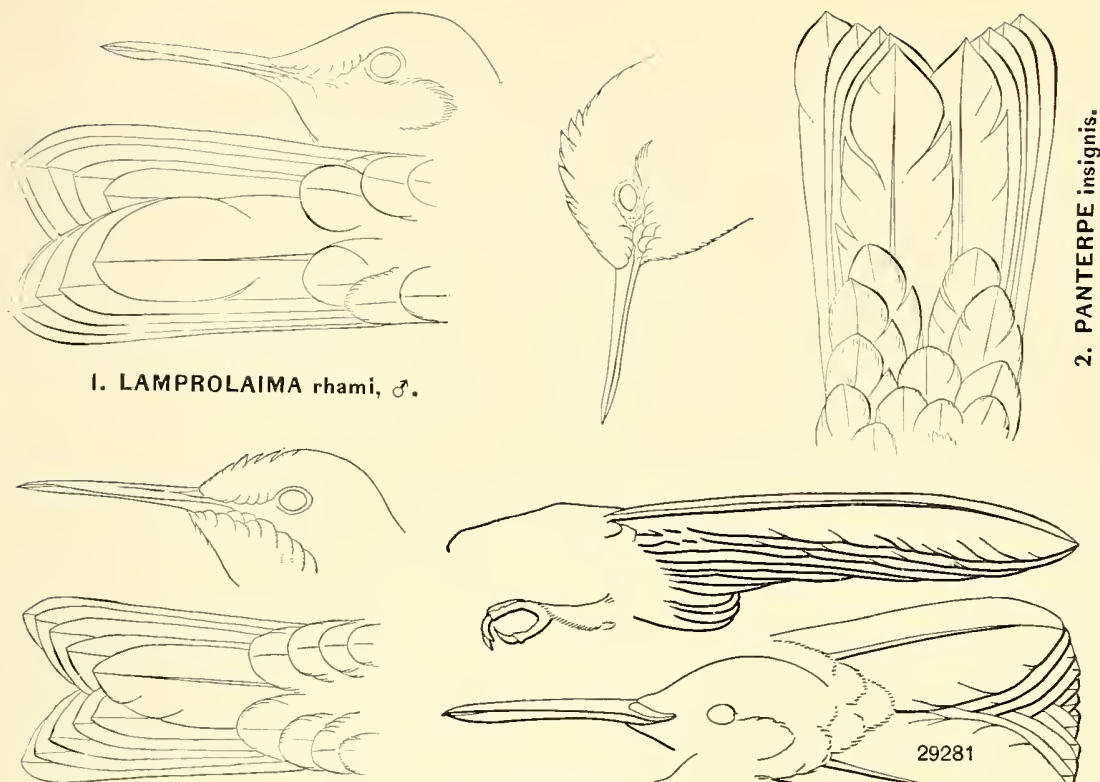

3. OREOPYRA calolæma, ${ }^{*}$.

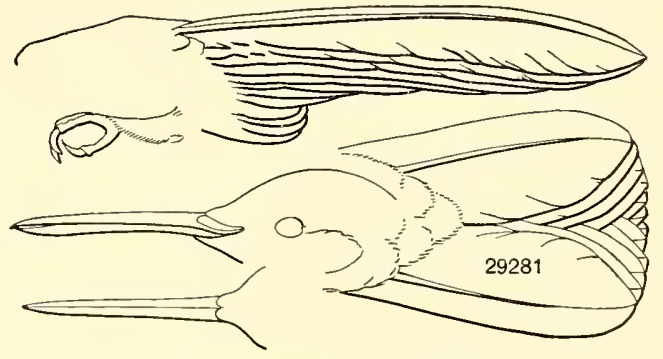

4. LAMPORNIS amethystinus.

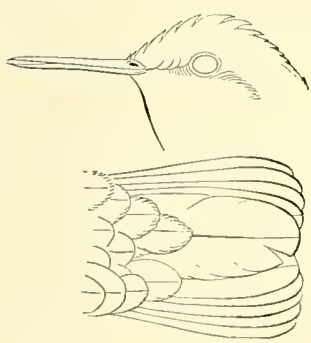

5. KLAIS guimeti, 8 .

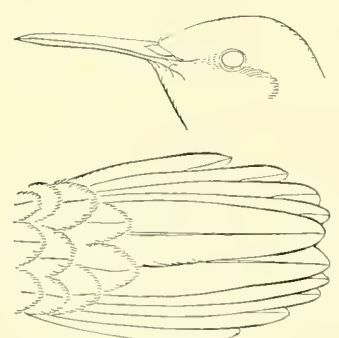

6. DAMOPHILA juliæ, \&.

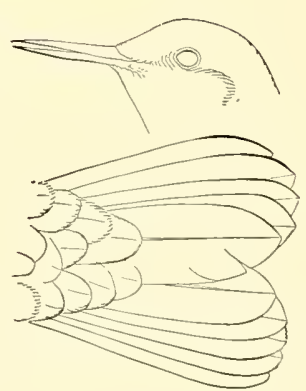

7. ABEILLIA abeillei, $\sigma^{7}$.

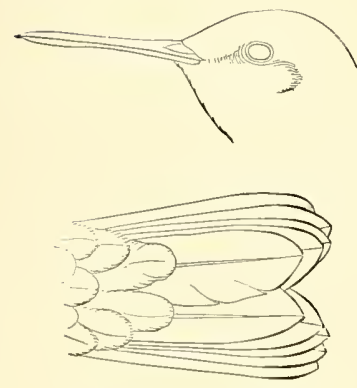

8. POLYERATA amabilis.

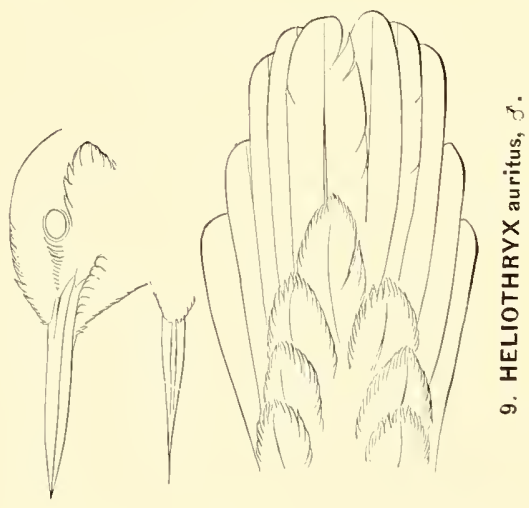




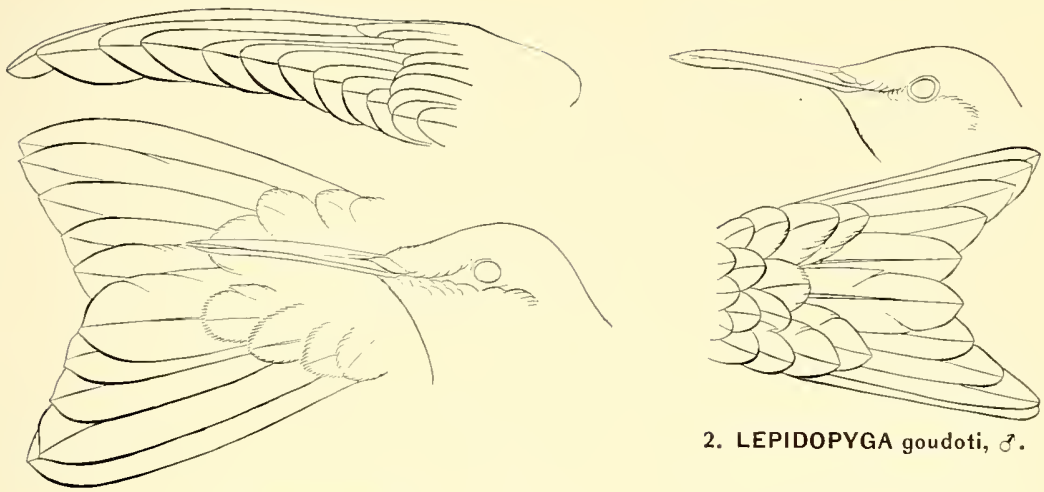

2. LEPIDOPYGA goudoti, 8 .

I. CYANOPHAIA.

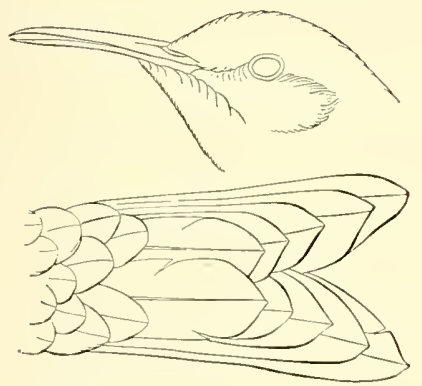

3. THALURANIA glaucopis, ?
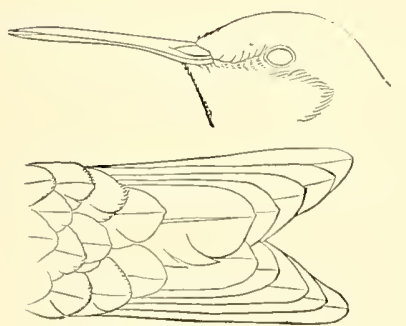

5. CHLOROSTILBON

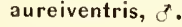
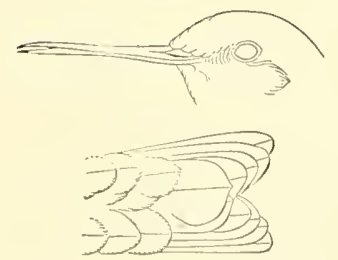

6. CHLOROSTILBON

(Panychlora) aliciæ.

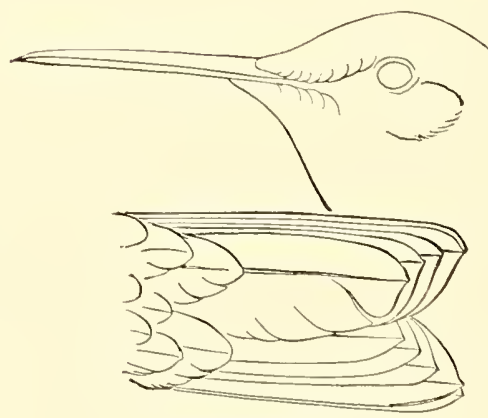

7. EUGENES fulgens, $\pi$.

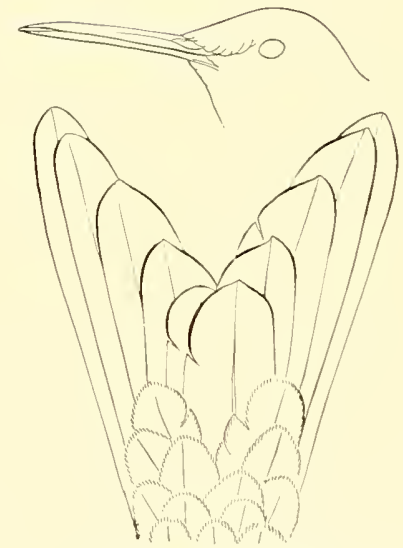

4. RICCORDIA swainsoni, ${ }^{7}$. 

U. S. NATIONAL MUSEUM

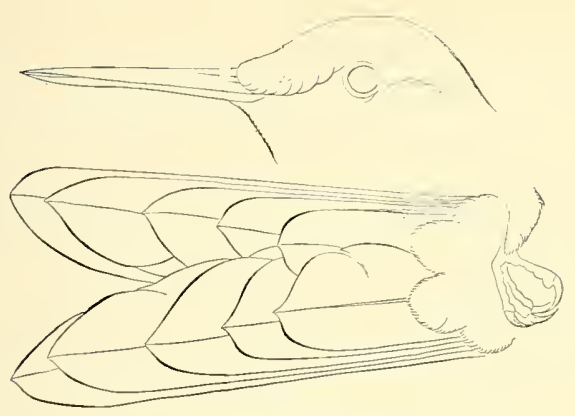

I. HELIODOXA jacula, $₫$.

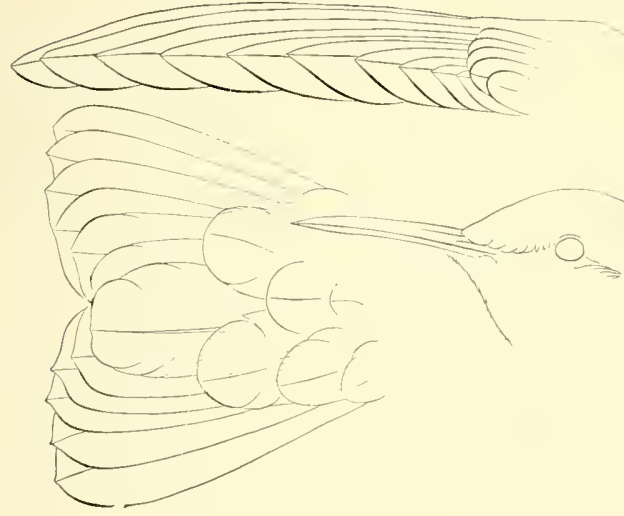

3. FLORISUGA mellivora, $\uparrow$.

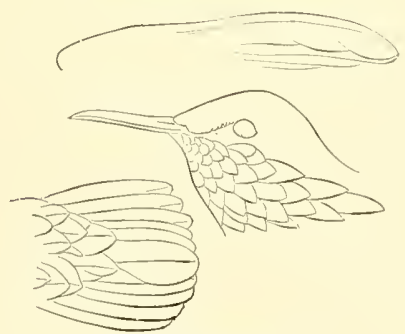

5. ATTHIS ellioti, ?.

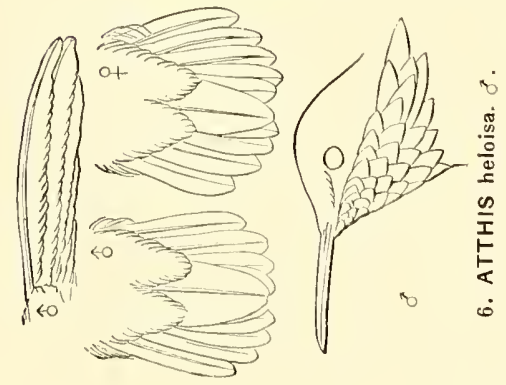

BULLETIN NO. 50, PART 5, PL. XXIII
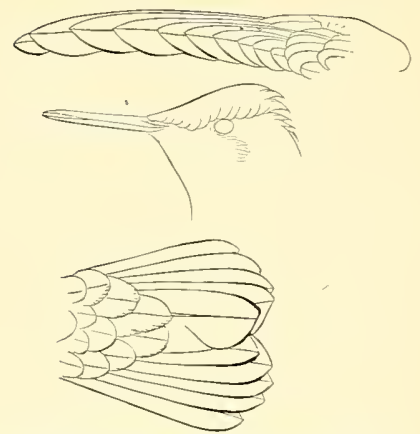

2. MICROCHERA albo-coronata,

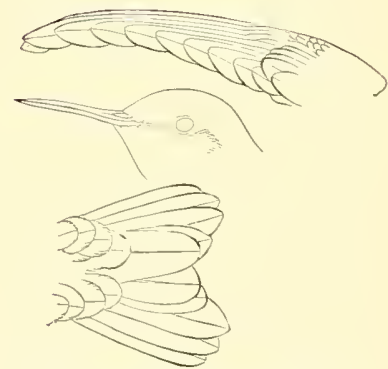

4. MELLISUGA minima, 8"
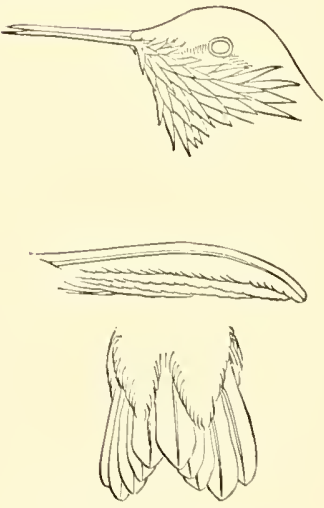

7. STELLULA calliope, 8 . 



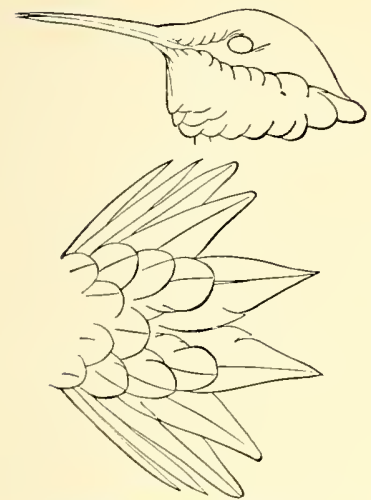

I. SELASPHORUS alleni, 8 .

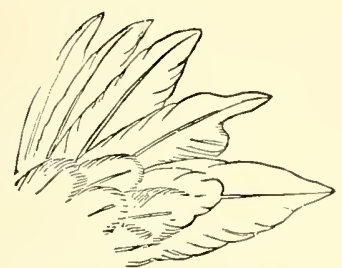

4. SELASPHORUS rufus, 7 .

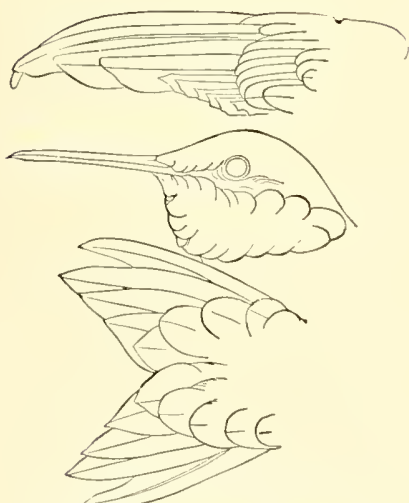

5. ARCHILOCHUS colubrls, *

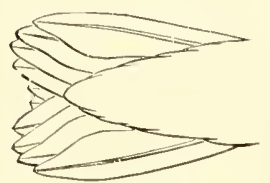

6. ARCHILOCHUS colubris, $q$.

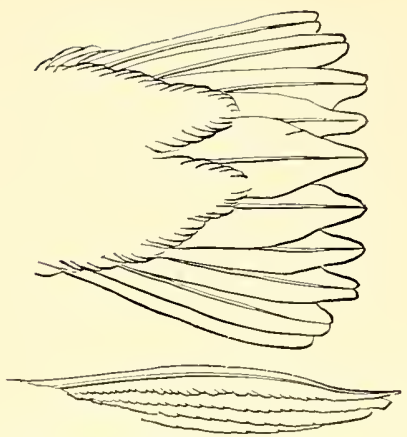

2. SELASPHORUS piatycercus, $₫$.

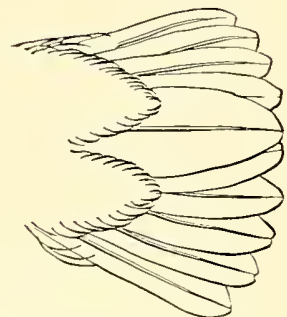

3. S. platycercus, .
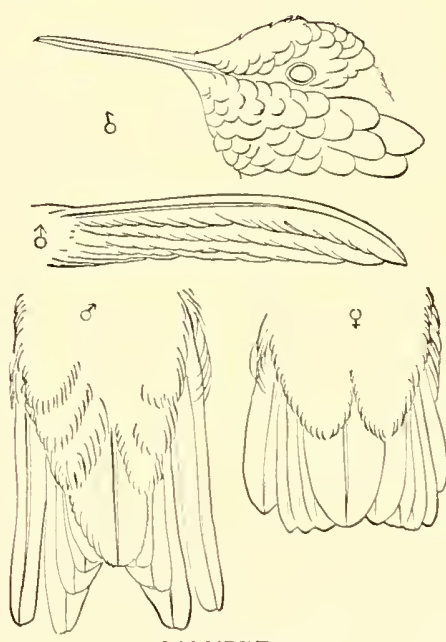

7. CALYPTE anna.

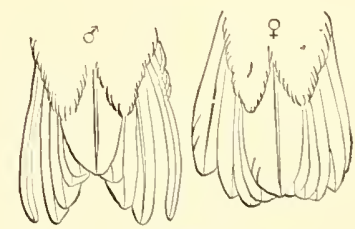

8. CALYPTE costæ.

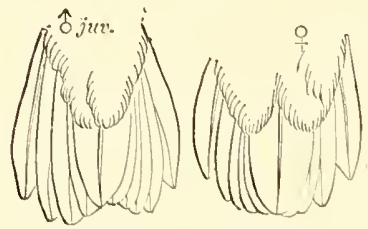

3. ARCHILOCHUS alexandri. 



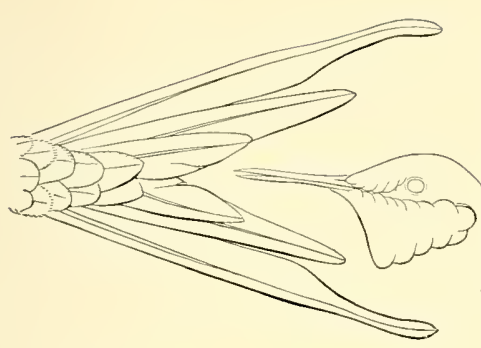

I. TILMATURA duponti,

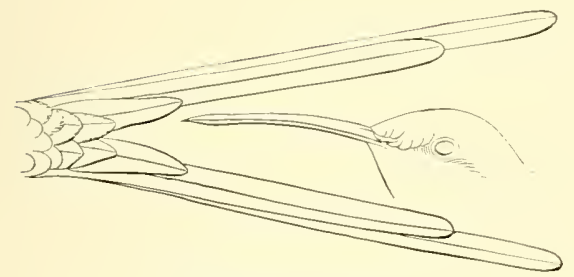

3. DORICHA enicura, 8 .
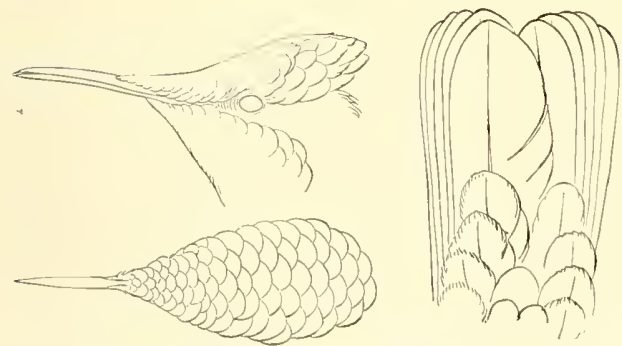

5. CHRYSOLAMPIS mosquitus,

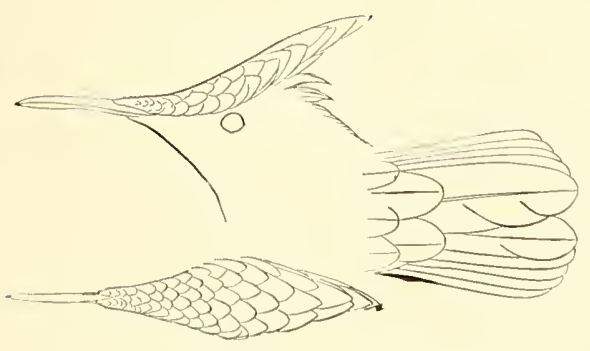

6. ORTHORHYNCUS cristatus, 8 .
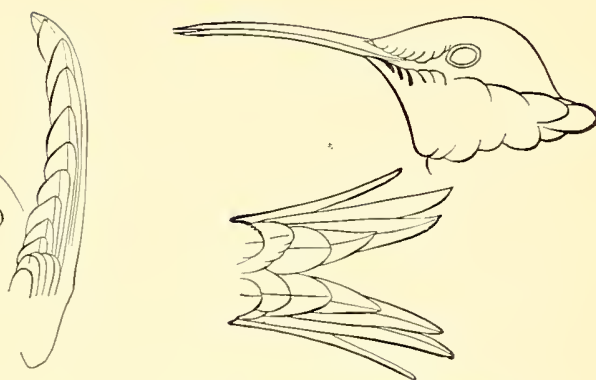

2. CALOTHORAX lucifer, $₫$.
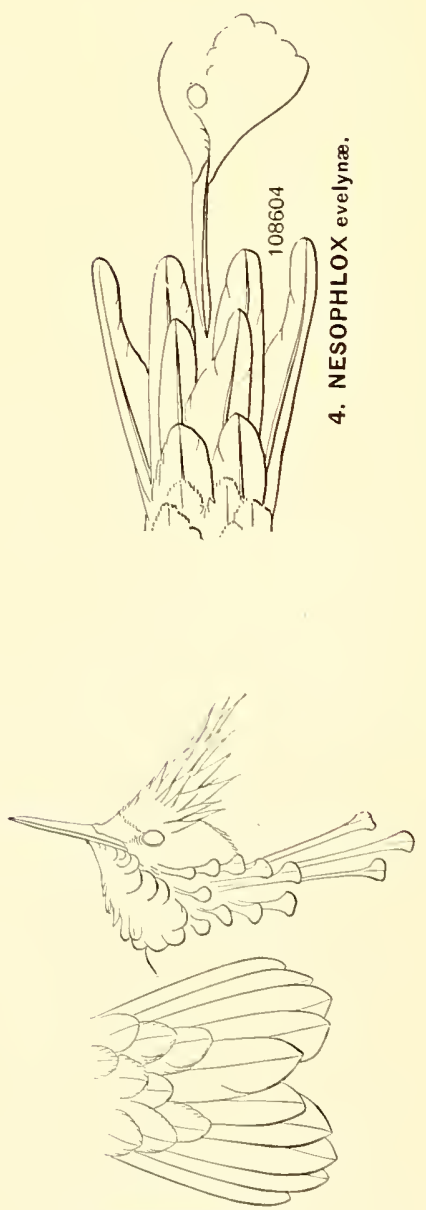

7. LOPHORNIS ornatus, of. 


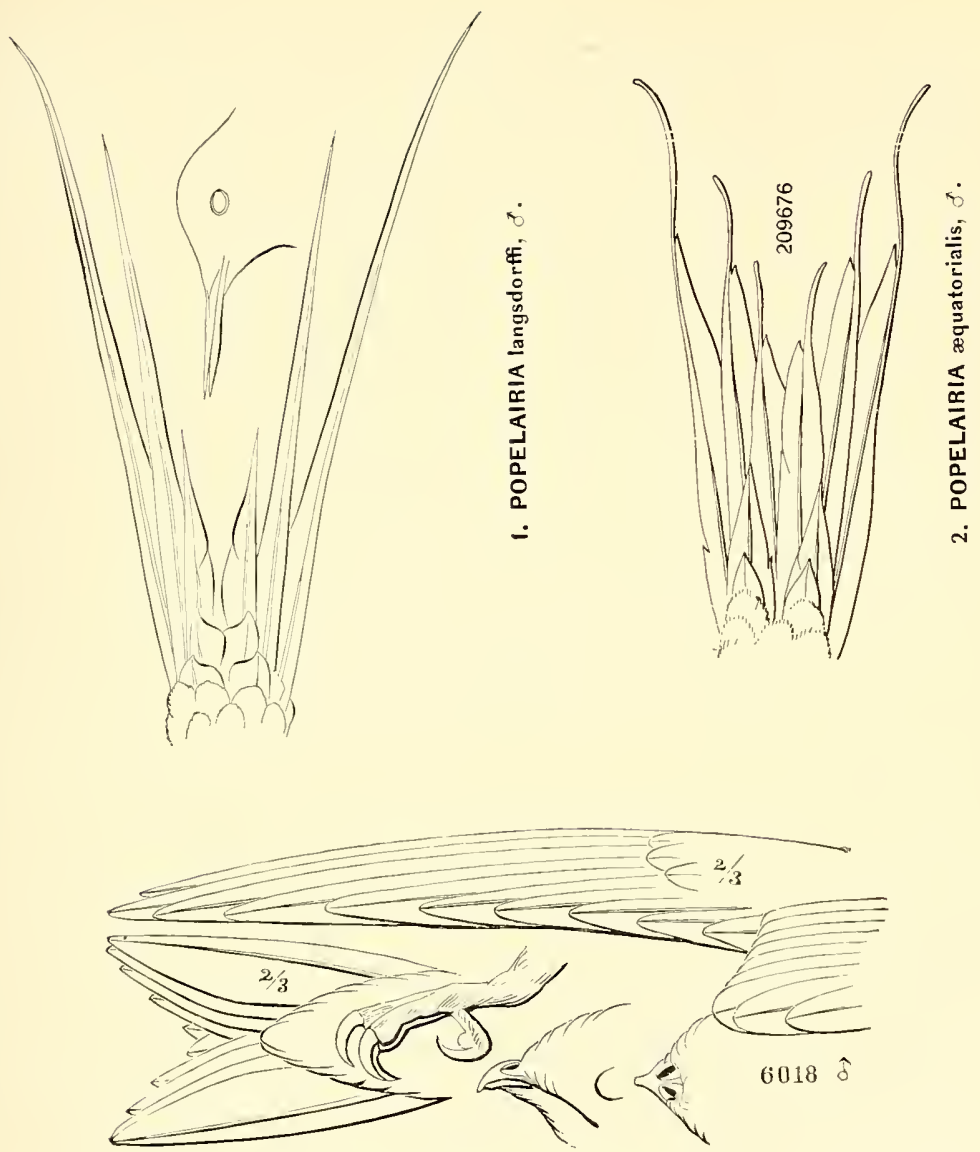

3. AËRONAUTES melanoleucus.

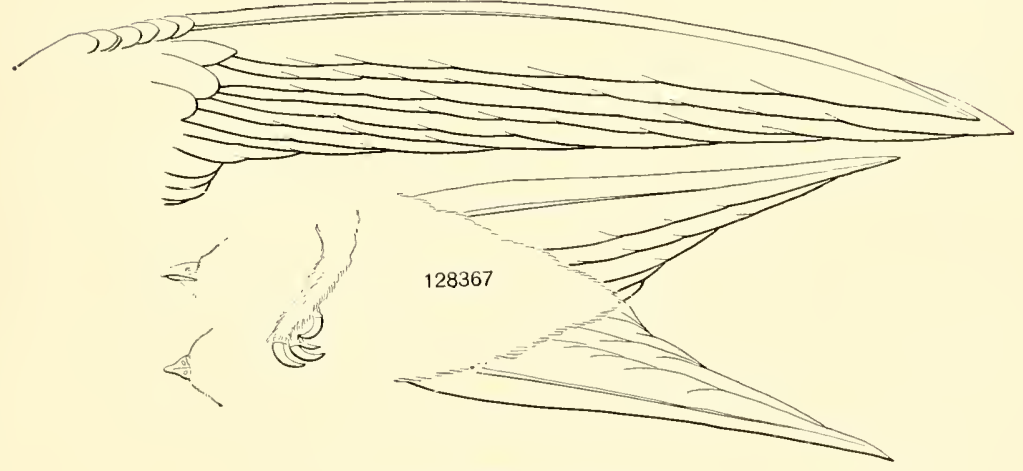

4. PANYPTILA cayanensis. 



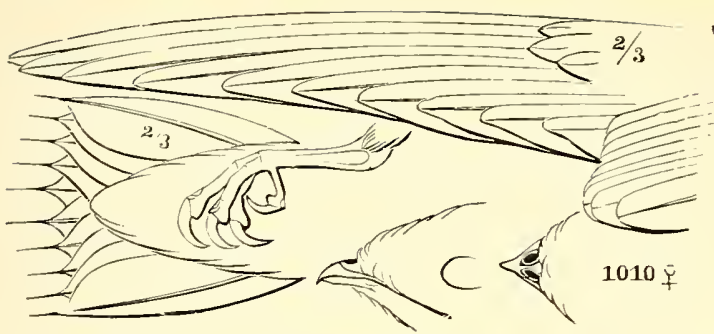

I. CHÆTURA pelagica.

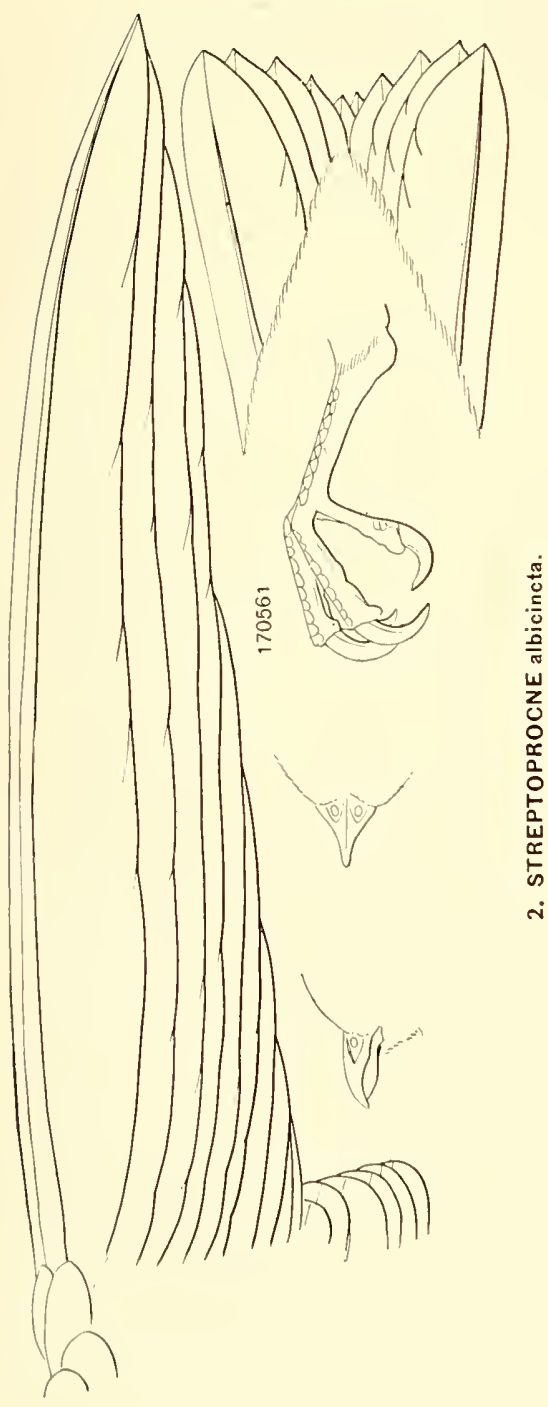

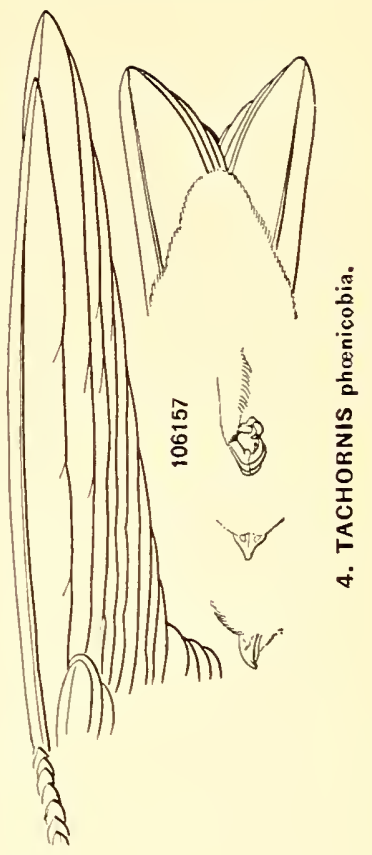

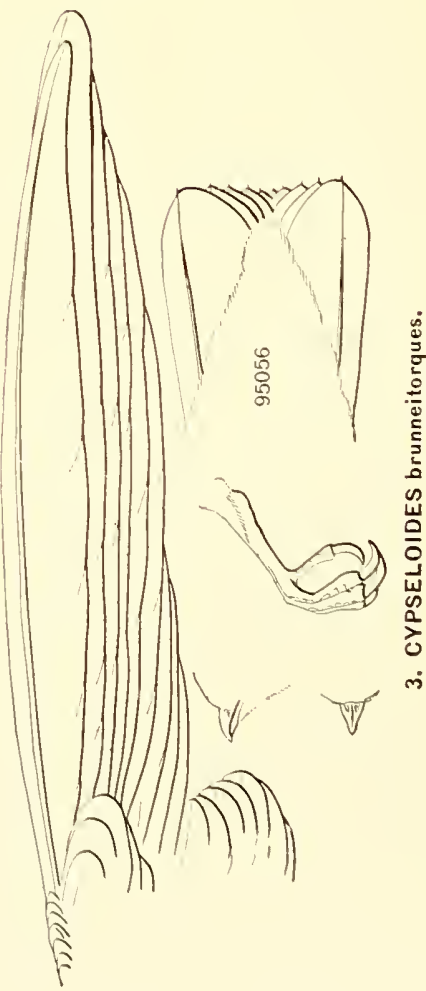




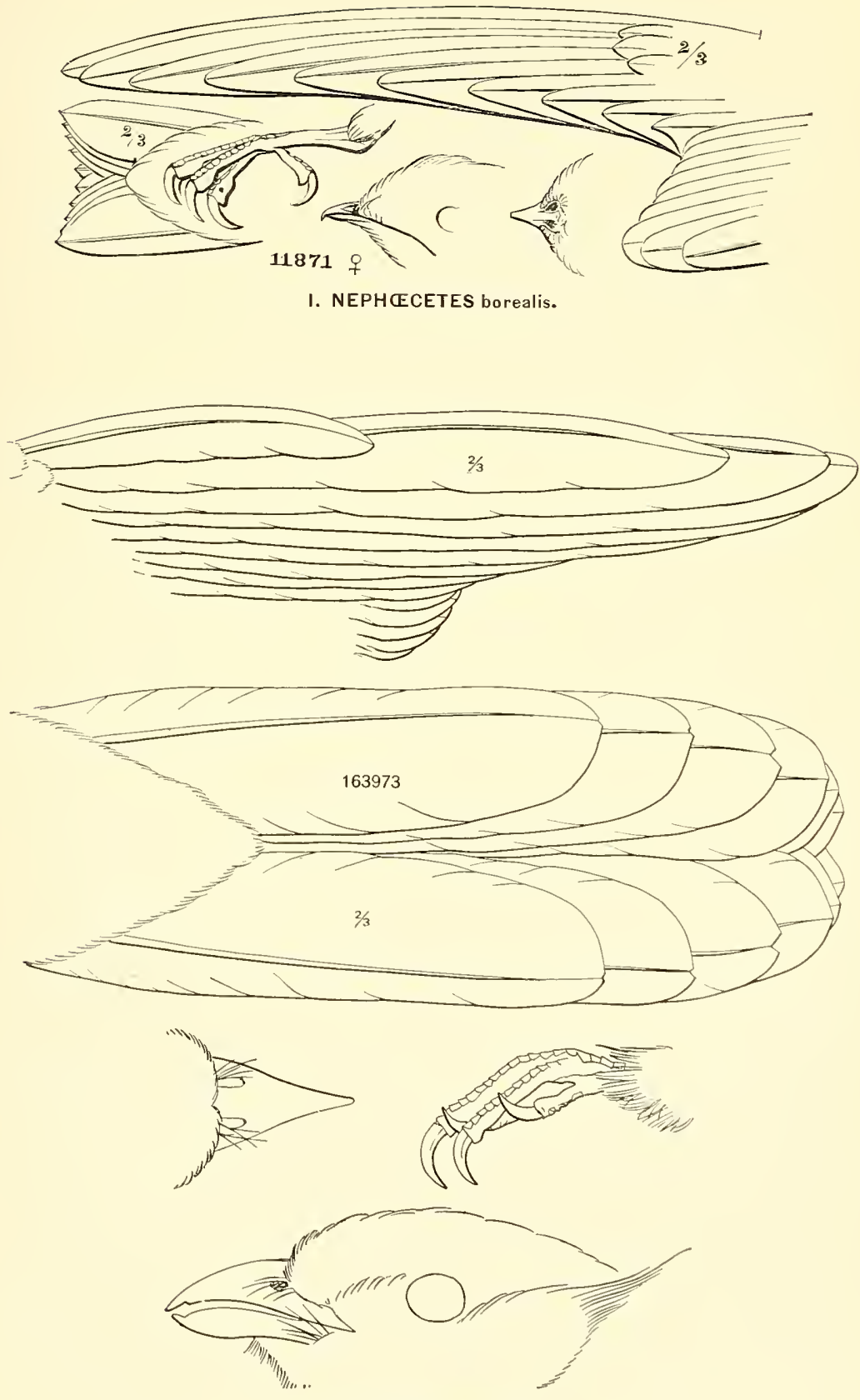

2. LEPTUAS neoxenus. 



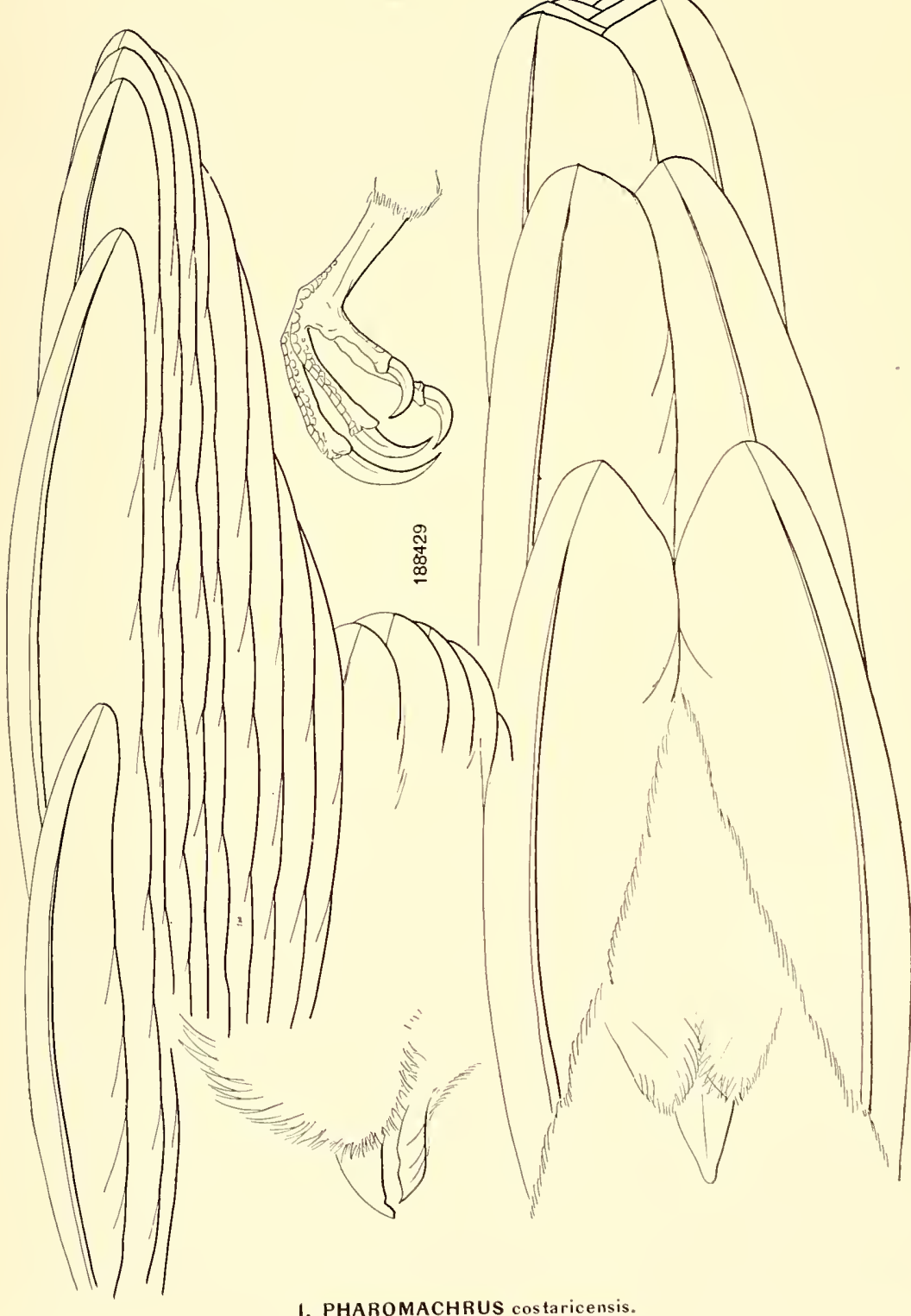

I. PHAROMACHRUS costaricensis. 


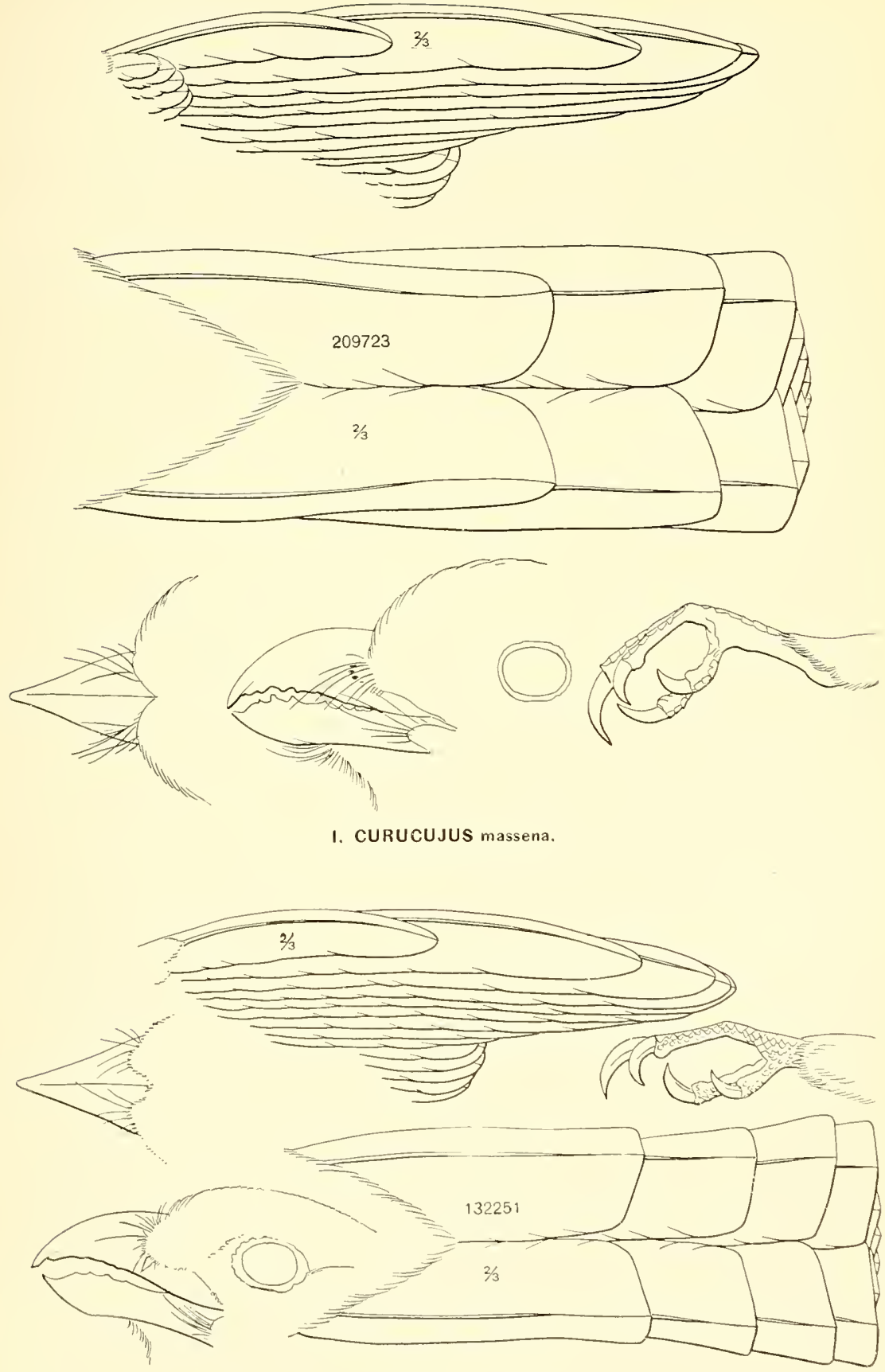

2. TROGON melanocephalus. 



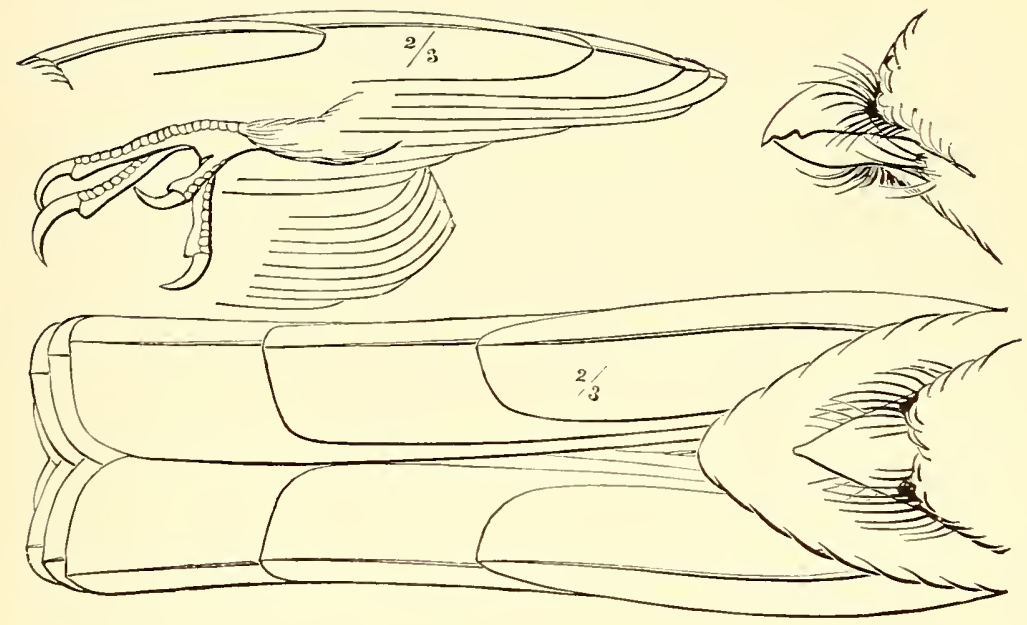

I. TROGONURUS ambiguus.
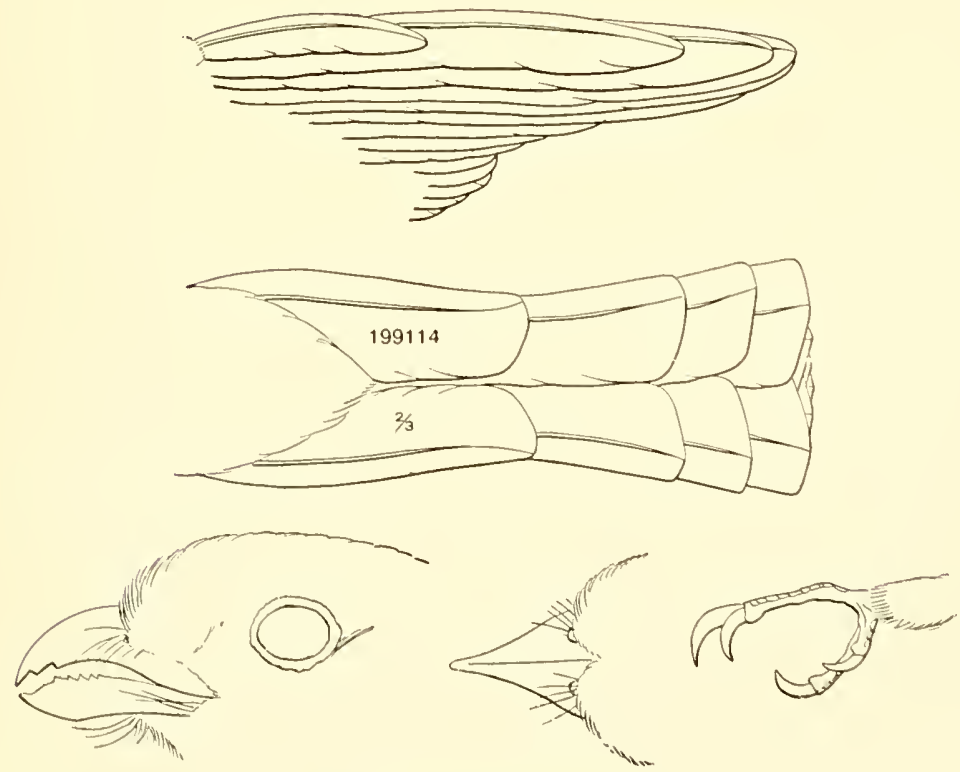

2. CHRYSOTROGON caligatus. 



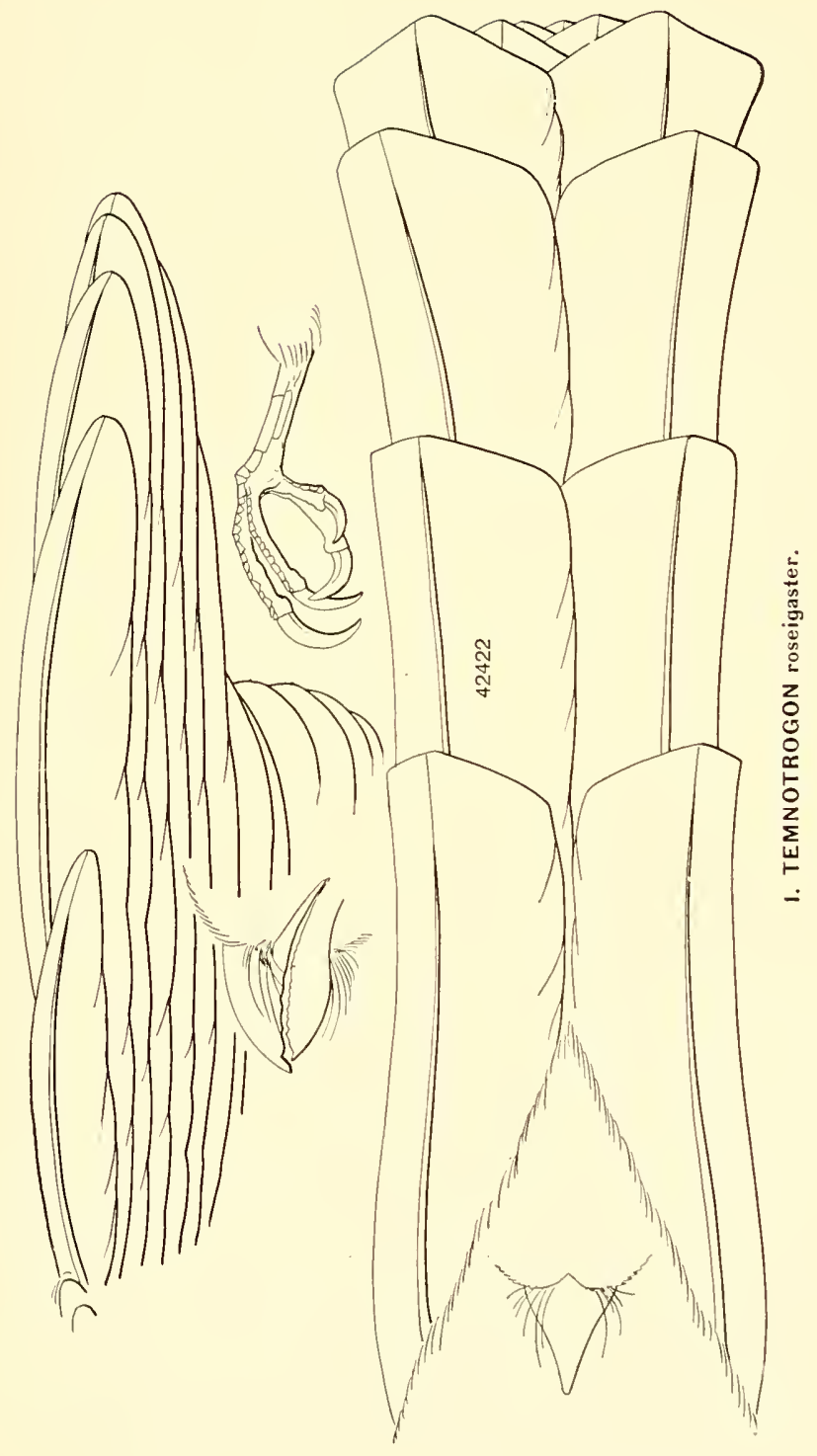





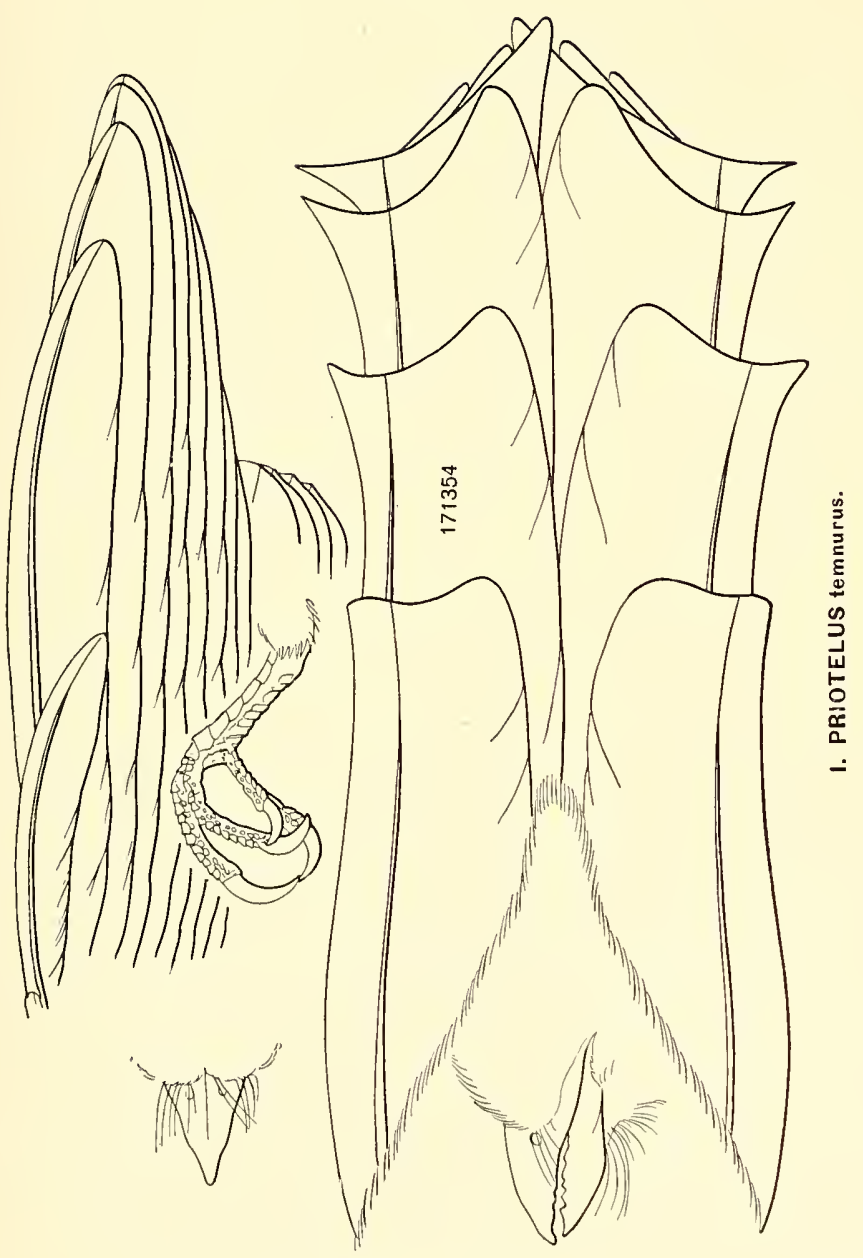









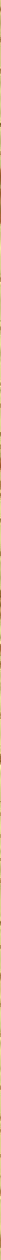


